\title{
Balancing trade and health in the SPS Agreement: the development dimension
}

Citation for published version (APA):

Prevost, D. (2009). Balancing trade and health in the SPS Agreement: the development dimension.

[Doctoral Thesis, Maastricht University]. Wolf Legal Publishers. https://doi.org/10.26481/dis.20090507dp

Document status and date:

Published: 01/01/2009

DOI:

10.26481/dis.20090507dp

Document Version:

Publisher's PDF, also known as Version of record

\section{Please check the document version of this publication:}

- A submitted manuscript is the version of the article upon submission and before peer-review. There can be important differences between the submitted version and the official published version of record.

People interested in the research are advised to contact the author for the final version of the publication, or visit the DOI to the publisher's website.

- The final author version and the galley proof are versions of the publication after peer review.

- The final published version features the final layout of the paper including the volume, issue and page numbers.

Link to publication

\footnotetext{
General rights rights.

- You may freely distribute the URL identifying the publication in the public portal. please follow below link for the End User Agreement:

www.umlib.nl/taverne-license

Take down policy

If you believe that this document breaches copyright please contact us at:

repository@maastrichtuniversity.nl

providing details and we will investigate your claim.
}

Copyright and moral rights for the publications made accessible in the public portal are retained by the authors and/or other copyright owners and it is a condition of accessing publications that users recognise and abide by the legal requirements associated with these

- Users may download and print one copy of any publication from the public portal for the purpose of private study or research.

- You may not further distribute the material or use it for any profit-making activity or commercial gain

If the publication is distributed under the terms of Article $25 \mathrm{fa}$ of the Dutch Copyright Act, indicated by the "Taverne" license above, 
Balancing Trade and Health in the SPS Agreement:

The Development Dimension 
Balancing Trade and Health in the SPS Agreement: The Development Dimension Denise Prévost

ISBN: 978-90-5850-419-7

No part of this book may be reproduced in any form, by print, photocopy, microfilm or any other means, without the written permission of the author.

This edition has been published by:

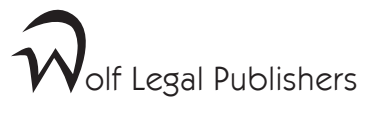

PO Box 31051

6503 CB Nijmegen

The Netherlands

www.wlp.biz

\section{(c) Denise Prévost 2009}

Layout and cover design: Michelle Verwey, Seesaw Design

Cover photograph: iStockphoto 


\section{Balancing Trade and Health in the SPS Agreement: \\ The Development Dimension}

DISSERTATION

to obtain the degree of doctor at Maastricht University, on the authority of the Rector Magnificus,

Prof. dr. G.P.M.F. Mols,

in accordance with the decision of the Board of Deans,

to be defended in public on Thursday

the 7 th of May 2009 , at 16:00 hours

by

Marie Denise Prévost 


\section{Supervisor:}

Prof. dr. P.L.H. Van den Bossche

\section{Assessment Committee:}

Prof. dr. E.I.L. Vos (Chairperson)

Prof. dr. C. Flinterman

Prof. dr. P.J. Kuijper (University of Amsterdam)

This doctoral research benefitted from financial assistance from the VerLoren Van Themaat grant of the Utrecht Universiteitsfonds, as well as additional financing from the School of Law of Utrecht University. The publication of this book was financed by the Maastricht Fund for Education and Research in International Economic Law (MUFERIEL). 


\section{Acknowledgements}

This book has been a lengthy project, and many people have contributed to its completion in a variety of ways. To them I owe my heartfelt thanks.

In particular, I would like to express my gratitude to Peter Van den Bossche, my thesis supervisor, whose unflagging support all these years has made the completion of this book possible. His willingness to provide thoughtful input and his exceptional depth of knowledge of WTO law have made this a challenging and rewarding project. My sincere thanks are also due to the members of my doctoral assessment committee, Ellen Vos (Chair), Pieter Jan Kuijper and Cees Flinterman for reading and commenting on the manuscript.

I am also grateful to Hildegard Schneider, at whose initiative the process was started that led to the position of Ph.D candidate being offered to me by the Board of Maastricht University. Further, I would like to express my appreciation to Sacha Prechal and my other former colleagues at Utrecht University, who gave me much support in my efforts to find time for my thesis research. Most particularly, I am thankful for the friendship and encouragement extended to me by Ige Dekker. During the period in which I worked at Utrecht University, my doctoral research was facilitated by financial assistance from the School of Law of Utrecht University and the VerLoren Van Themaat grant of the U-Fonds, for which I am grateful. I would also like to thank the Law Faculty of Maastricht University for granting me a six-month sabbatical to complete this book and my current colleagues for their understanding of my limited availability in this period. I gratefully acknowledge the financial contribution of the Maastricht Fund for Education and Research in International Economic Law (MUFERIEL) towards the publication of this book.

I have been fortunate to benefit from the experience and insights of many people in the process of writing this book, who found the time in their busy schedules either to meet with me or to send me useful information. In particular, I would like to thank Gretchen Stanton, Christiane Wolff and Michael Roberts (Agriculture and Commodities Division of the WTO Secretariat), Erik Wijkstrom (Environment Division of the WTO Secretariat), Shyam Kumar Gujadhur (International Trade Centre), Shishir Priyardashi (formerly at the South Centre in Geneva, now at the Economic Research Division of the WTO Secretariat), Jörgen Schlundt (WHO), Attie Swart (formerly the South African representative to, and Chairman of, the SPS Committee), Alex Thierman (US representative in Brussels, formerly Chairman of the SPS Committee), John Wilson (World Bank), Spencer Henson (University of Reading), Koen De Feyter (formerly at Maastricht University, now at the University of Antwerp), Gideon Brückner (Dept. of Agriculture of the Western Cape, South Africa), Mike Holtzhausen (Directorate of Plant Health and Quality, National Dept. of Agriculture, South Africa), Alice Baxter (Directorate of Plant Health and Quality, National Dept of Agriculture, South Africa), Cheryl French (APHIS, USDA, Pretoria office), Verna Carolissen-Mackay (Deputy Director, Food Control, National Dept. of Health, South Africa), Engela Schlemmer (UNISA), Rosalind Thomas (SADC), Jürgen Hoffmann (Meat Board of Namibia), Urs Thomas (University of Geneva), Simonetta Zarilli (UNCTAD). Their input has been invaluable to me. Of course, they bear no responsibility for the opinions expressed in this book, and any errors are mine alone. 
During my research towards this book I was privileged to intern at the Legal Affairs Division of the WTO Secretariat. This experience provided me with valuable insights into the practical application of WTO law and the day-to-day work of this organisation. I would like to express my sincere gratitude to Pieter Jan Kuijper and Gabrielle Marceau for the confidence they showed in me by giving me challenging projects to work on during my internship. I have learnt a lot from them both.

I have benefited over the years from lively and stimulating discussions with a variety of participants at capacity-building courses and workshops I have given, organised by UNCTAD, the Asser Institute, the Clingendael Institute and the Trade Law Centre for Southern Africa. Through these workshops I have been able to hear developing-country participants' first-hand experiences in dealing with WTO rules and in addressing SPS trade barriers. I am deeply grateful to them for sharing their insights with me.

The proofreading, editing, layout and cover design of this book were very skilfully done by my sister, Michelle Verwey. Her high standard of professionalism and care have contributed greatly to the result you see before you. She has worked assiduously though many pages of text and graphs to present them in a clear, uncluttered and orderly manner. I am very grateful for the numerous hours of painstaking work she cheerfully invested in this task. I could not have done this without her.

Thanks is also due to my untiring student assistants, who have, over the years, been a great help in indexing countless articles, copying piles of literature, and carrying out a variety of other thankless tasks. They have done so with enthusiasm and diligence. In particular, I would like to thank Karla Vanessa Araujo, Jurga Stanciute, Isabel Puig Palermo, Eline Post, Matilda Troost, Lorin van Nuland, Bas Megens, Willemijn Noordhoek, Siavash Shamskho and Ilaria Vianello. In the last months of my research I also benefited from the willing and committed research assistance of Ana Maria Daza Vargas. I am grateful to Wies Rayar for quickly and professionally translating the summary of this book into Dutch for me. All these people have made my work significantly easier.

Indispensable to the completion of this book have been my incomparable friends. For their friendship and support, beyond measure, I would like to thank Esther Engelhard, Eva Rieter, Ilse Van den Driessche, Mathilda Berglin, Raffaella Lombardi, Annette Hoffmann, Joanna Sudajtis, Ruth Prinsloo, Ida Wendt, Mariëlle Matthee, Andrea Ott, Constance Johnson and Belinda Ormond. If I were to thank them individually for all the many ways in which they have been there for me, the result would have more pages than this book. I am exceptionally fortunate to have them in my life. Particular thanks are due to my two 'paranimfs', Esther Engelhard and Ilse van den Driessche, for their enthusiastic assistance and thoughtful advice.

I owe a very special thanks to my partner, Paul Byrne, for his endless patience in the face of my constant working weekends and nights. His cheerful forbearance and helpfulness have made the load infinitely lighter. With his optimism and humour he has brought happiness to my life. I would not have been able to finish this book without him. I look forward to our 'post-thesis' life together.

Last, but most importantly, I would like to express my boundless gratitude for the love and support of my family, throughout this long process. I especially thank my mother, for 
her unshakeable belief in the success of this project and her constant loving encouragement. This book is dedicated to her. The love, wisdom and unconditional support of my sisters, Delmence and Michelle, have been a source of strength and inspiration to me. They are my pillars. My father has passed on to me the love of reading and intellectual pursuits that made this research possible. My nieces, Lucia, Milene and Halo, my nephew Ryan and my new sister Alexandra have brought me much joy. I am truly blessed.

The manuscript of this book was completed on the $31^{\text {st }}$ of August 2008. Consequently, later developments, including the report of the Appellate Body in the Canada/US Continued Suspension disputes, have not been taken into account in this analysis. They will be the subject of future work.

Maastricht, 20 January 2009 


\section{Table of Contents}

Introduction 1

1. The balance between trade and health and its development dimension 2

2. The development dimension of the SPS Agreement: policy spaces and special treatment 6

3. Structure of the discussion 8

\section{Part I - Background to the SPS Agreement:}

On the interface between globalised trade and globalised health 15

Introduction to Part I 16

Chapter 1 - The globalisation of trade: Developing countries in the world trading system 17

1.1 The normative framework: The right to development and its relevance for the world trading system 18

1.2 The definition of 'developing countries' 27

1.3 Developing countries in the early years of the GATT 1947

1.4 The 1965 Protocol Adding Part IV to the GATT 1947

1.5 The Tokyo Round: The Enabling Clause and the Codes 42

1.6 The Uruguay Round negotiations 49

1.7 From the Uruguay Round to the Seattle Ministerial Conference 55

1.8 The Doha Development Agenda 59

1.9 Conclusion $\quad 75$

Chapter 2 - The globalisation of health: Addressing transboundary health risks 78

2.1 The origins of international attention to the tension between trade and health in the mid-nineteenth century 78

2.2 The science paradigm in the globalisation of health 79

2.3 The re-nationalisation of health issues in developed countries in the first half of the twentieth century $\quad 80$

2.4 Return to the international approach: The globalisation of health 81

2.5 The new approach to globalised health risks at the turn of the century:
International and national strategies

2.6 Conclusion 87

Chapter 3 - The interface between globalised trade and globalised health:

Health regulations and standards and their impact on developing countries 89

3.1 The importance of the agriculture and food sector for development 89

3.2 Problems with developing country trade in agriculture and food products 92

3.3 The proliferation of health regulations and standards in developed countries $\quad 100$

3.4 Impact of health regulations and standards on health and trade in

Conclusion to Part I 111

Part II - National and international SPS regulation and standard setting 113

Introduction to Part II

Chapter 1 - General aspects of national SPS regulation and standard setting 116

1.1 Normative framework for national sanitary and phytosanitary protection 116 
1.2 Reasons for sanitary and phytosanitary regulation

1.3 Nature of national sanitary and phytosanitary measures 134

1.4 Costs and benefits of sanitary and phytosanitary regulation 143

1.4.1 Benefits of SPS regulation 143

1.4.2 Costs of SPS regulation 146

1.4.3 Cost/benefit analysis 150

1.5 Role of scientific analysis in national SPS regulation 152

Chapter 2 - National SPS systems in selected developed-and developing-country Members 162

2.1 Choice of WTO Members 162

2.2 Choice of information provided 164

2.3 Sources of information $\quad 169$

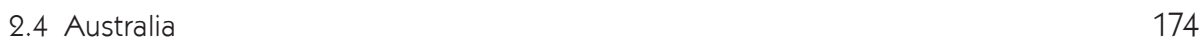

2.4.1 Factual background $\quad 174$

2.4.2 Australia's SPS system 188

2.4.3 Overall assessment of the SPS system of Australia 226

2.5 Mauritius 228

2.5.1 Factual background 228

2.5.2 Mauritius's SPS system 241

2.5.3 Overall assessment of the SPS system of Mauritius 251

2.6 Jamaica 252

2.6.1 Factual background 252

2.6.2 Jamaica's SPS system 264

2.6.3 Overall assessment of the SPS System of Jamaica 287

2.7 Bangladesh 290

2.7.1 Factual background $\quad 290$

2.7.2 Bangladesh's SPS system 300

2.7.3 Overall assessment of the SPS system of Bangladesh 309

2.8 Conclusion: The differences between SPS regulatory systems at different levels of development $\quad 310$

Chapter 3 - International SPS standard-setting 313

3.1 General aspects of international standard setting 317

3.1.1 Reasons for harmonisation of SPS regulation around international standards 317

3.1.2 Failings of harmonisation 318

3.2 International standard setting process 322

3.2.1 Codex Alimentarius Commission 326

3.2.2 International Office of Epizootics/World Organisation for Animal Health $\quad 375$

3.2.3 The Secretariat of the International Plant Protection Convention and the
Commission on Phytosanitary Measures

$\begin{array}{ll}3.3 \text { Conclusion } & 437\end{array}$

Conclusion to Part II $\quad 442$

Part III - The rules balancing trade and health in the SPS Agreement 445

Introduction to Part III 446

Chapter 1 - History of the SPS Agreement 451

1.1 Rules on SPS measures before the entry into force of the SPS Agreement 451 
1.1.1 The GATT 1947, Articles III, XI and XX(b)

1.1.2 The Tokyo Round Standards Code

1.1.3 Insufficiency of the GATT 1947 and the Standards Code 473

1.2 The Uruguay Round negotiations on the SPS Agreement 481

1.2.1 Background to the negotiations 481

1.2.2 Positions of the developed-country participants and the Cairns Group 488

1.2.3 Positions of the developing-country participants 505

1.3 Conclusion $\quad 512$

Chapter 2 - Scope of application of the SPS Agreement 515

2.1 Substantive scope of application 516

2.1.1 The concept of an SPS measure 516

2.1.2 Effect on international trade 533

2.2 Personal scope of application $\quad 534$

2.3 Temporal scope of application 559

2.4 Relationship with other WTO agreements $\quad 560$

$\begin{array}{ll}\text { 2.4.1 The TBT Agreement } & 561\end{array}$

2.4.2 The GATT $1994 \quad 564$

2.4.3 The Agreement on Agriculture $\quad 570$

2.5 Conclusion $\quad 571$

Chapter 3 - Basic principles 576

3.1 Right to impose SPS measures 576

3.2 Basic limits to the exercise of the right to impose SPS measures 577

$\begin{array}{ll}3.2 .1 \text { Necessity } & 577\end{array}$

3.2.2 Prohibition on arbitrary or unjustifiable discrimination or disguised
restrictions on trade

$\begin{array}{ll}\text { 3.2.3 Basic scientific disciplines } & 587\end{array}$

$\begin{array}{ll}3.3 \text { Conclusion } & 600\end{array}$

$\begin{array}{ll}\text { Chapter } 4 \text { - Disciplines promoting harmonisation } & 603\end{array}$

4.1 International standards, guidelines or recommendations 604

$\begin{array}{ll}\text { 4.1.1 Appropriate standards of other relevant organisations } & 604\end{array}$

4.1.2 Nature of the relevant international norms 609

4.2 Obligations with regard to international standards 614

4.2.1 Measures based on international standards 616

4.2.2 Measures conforming to international standards 621

4.2.3 Measures providing a higher level of protection than international standards 623

4.2.4 Measures providing a lower level of protection than international standards 626

$\begin{array}{ll}4.3 \text { Conclusion } & 629\end{array}$

Chapter 5 - Disciplines regarding risk analysis 633

$\begin{array}{ll}5.1 \text { Risk assessment } & 636\end{array}$

$\begin{array}{ll}\text { 5.1.1 Definition of a risk assessment } & 637\end{array}$

5.1.2 Risk assessment as appropriate to the circumstances 654

5.1.3 Taking into account the risk assessment techniques developed by the relevant international organisations $\quad 657$

$\begin{array}{ll}\text { 5.1.4 Relevant factors to be considered in assessing risk } & 660\end{array}$

5.1.5 Requirement that SPS measures be based on a risk assessment 665

5.2 Risk management 678 
5.2.1 Concept of an appropriate level of protection

5.2.2 The objective of minimising negative trade effects 680

5.2.3 Avoidance of arbitrary or unjustifiable distinctions in appropriate levels of protection

5.2.4 Least-trade-restrictive measure 697

5.2.5 Rules on provisional measures 709

$\begin{array}{ll}5.3 \text { Conclusion } & 733\end{array}$

Conclusion to Part III 738

Part IV - Procedural and institutional mechanisms under the SPS Agreement 747

$\begin{array}{ll}\text { Introduction to Part IV } & 748\end{array}$

Chapter 1 - Institutional and procedural obligations on Members 750

$\begin{array}{ll}1.1 \text { Recognition of equivalence } & 750\end{array}$

1.1.1 Acceptance of equivalence 753

1.1.2 Agreements on recognition of equivalence 754

$\begin{array}{ll}\text { 1.1.3 Procedure } & 755\end{array}$

1.1.4 Examples $\quad 757$

1.1.5 Problems with implementation $\quad 759$

1.1.6 The Equivalence Decision 761

1.1.7 International guidelines on equivalence 766

$\begin{array}{ll}1.2 \text { Regionalisation } & 769\end{array}$

1.2.1 Adaptation to resional conditions 770

1.2.2 Recognition of pest- or disease-free areas or areas of low pest or disease prevalence 771

$\begin{array}{ll}\text { 1.2.3 Procedure } & 772\end{array}$

1.2.4 Examples $\quad 772$

1.2.5 Problems with implementation $\quad 775$

1.2.6 Regionalisation Decision $\quad 778$

1.2.7 International guidelines on regionalisation 783

1.3 Transparency obligations $\quad 785$

$\begin{array}{ll}\text { 1.3.1 Publication obligation } & 787\end{array}$

1.3.2 Notification obligation 793

1.3.3 Explanation of reasons for SPS measures 800

1.3.4 Infrastructure for transparency 803

1.3.5 Implementation of transparency obligations by selected Members 806

1.3.6 Problems with implementation 811

1.3.7 Work on improving the implementation of the transparency provisions 817

1.4 Rules regarding control, inspection and approval procedures 822

1.4.1 Scope of application 824

1.4.2 Systems of prior approval and tolerance determination 825

1.4.3 Undue delay 830

1.4.4 Less favourable treatment 831

1.4.5 Operation of procedures 833

1.4.6 Information requirements 836

1.4.7 Requirements on individual specimens 837

$\begin{array}{ll}\text { 1.4.8 Remaining obligations } & 837\end{array}$ 
Chapter 2 - Institutional and procedural arrangements for administration and enforcement 842

2.1 The SPS Committee

2.1.1 Furtherance of the implementation of the SPS Agreement

2.1.2 Forum for consultations

2.1.3 Monitoring and promotion of international harmonisation 863

2.1.4 Periodic review of the SPS Agreement 869

2.2 Dispute settlement procedures $\quad 871$

2.2.1 Overview of the WTO dispute settlement system 873

2.2.2 Burden of proof 877

2.2.3 Standard of review 884

2.2.4 Role of international law in interpretation 897

2.2.5 Expertise of panellists and the use of panel experts 907

2.2.6 Resort to other dispute resolution mechanisms 918

2.2.7 Use of the dispute settlement mechanism 920

2.3 Conclusion 932

Conclusion to Part IV 938

Part V - Special provisions for developing countries in the SPS Agreement 941 Introduction to Part $V \quad 942$

Chapter 1 - Special and differential treatment of developing-country Members 946

1.1 Consideration of the special needs of developing-country Members 946

1.2 Longer time frames for compliance for developing-country Members 953

1.3 Reasonable adaptation period 956

1.4 Delayed compliance with the SPS Agreement 959

1.5 Time-limited exemptions from specific oblizations 960

1.6 Special provisions in the notification obligations 962

1.7 Work on improving implementation of SDT provisions 963

1.8 Transparency in the provision of SDT 972

1.9 Conclusion 976

Chapter 2 - Technical assistance for developing countries 978

2.1 Technical assistance needs of developing-country Members 979

2.2 Facilitation of provision of technical assistance 985

2.3 Technical assistance for compliance with SPS measures 986

2.4 Technical assistance for participation in international standard-setting 987

2.5 Provision of technical assistance 989

2.5.1 Bilateral provision of technical assistance 990

2.5.2 Multilateral provision of technical assistance 993

2.6 Problems with the implementation of technical assistance 1010

2.7 Efforts to improve the implementation of technical assistance 1014

2.8 Conclusion 1021

Conclusion to Part $\vee \quad 1023$

$\begin{array}{ll}\text { Conclusion } & 1025\end{array}$

1. The SPS Agreement as a product of historical developments forming its background 1026 
2. The factual context of national and international SPS systems within which the SPS Agreement operates

3. The relevance of the history of the SPS Agreement

4. The limits of the coverage of the SPS Agreement

5. The delicate trade/health balance in the regulatory disciplines

6. The underestimated benefits of the procedural and institutional arrangements

7. The limits of special and differential treatment for developing-country Members in the SPS Agreement

8. The need to turn technical assistance into capacity building

9. Concluding remarks

\section{Summary}

1. The SPS Agreement on the interface between globalised trade and globalised health

2. National and international SPS regulation and standard setting

3. The rules balancing trade and health in the SPS Agreement

4. Procedural and institutional mechanisms under the SPS Agreement

5. Special provisions for developing countries in the SPS Agreement

\section{Samenvatting}

1. De SPS Overeenkomst op het snijvlak van geglobaliseerde handel en gezondheid

2. Nationale en internationale SPS regulering en normstelling

3. Regels in de SPS Overeenkomst die evenwicht aanbrengen tussen handel en gezondheid

4. Procedurele en institutionele mechanismen op grond van de SPS Overeenkomst

5. Bijzondere bepalingen voor ontwikkelingslanden in de SPS Overeenkomst

Appendix: Table of Disputes initiated under the SPS Agreement xxvi

List of Abbreviations

xxxiii

Table of Cases

xxxviii

\section{Bibliography}

Curriculum Vitae

cli

Index

clii 


\section{List of Tables, Figures and Graphs}

\section{Tables}

Table 1: Selected WTO Members across geographic regions and income levels

Table 2: Summary table of relevant indicators per selected Members

\section{Figures}

Figure 1: Institutional Structure of the Codex Alimentarius Commission

Figure 2: Institutional Structure of the World Organisation for Animal Health

Figure 3: Institutional Structure of the Commission on Phytosanitary Measures

\section{Graphs}

Graph 1: Members of the Codex Alimentarius Commission that are WTO Members, by Income Level, 2007

Graph 2: Codex Alimentarius Commission Thirtieth Session: Attendance by WTO Members by Income Level, 2007

Graph 3: Codex Alimentarius Commission Thirtieth Session: Delegates of WTO Members by Income Level, 2007

Graph 4: Codex Alimentarius Commission Thirtieth Session: Average Number of Delegates per WTO Member by Income Level, 2007

Graph 5: Codex Alimentarius Commission:

Participation of WTO Members by Income Level, 1999-2007

Graph 6: Codex Alimentarius Commission: Participation in Drafting Groups for New Standards of WTO Members by Income Level, 2001-2007

Graph 7: Codex Alimentarius Commission: Leadership of Drafting Group for New Standards of WTO Members by Income Level, 2001-2007

Graph 8: Codex General Subject Committees:

Attendance by WTO Members by Income Level, 2007

Graph 9: Codex Commodity Committees: Attendance by WTO Members by Income Level, 2006-2007

Graph 10: Codex General Subject Committees: Attendance by WTO Members by Income Level, 2007

Graph 11: Codex Commodity Committees: Attendance by Delegates of WTO Members by Income Level, 2006-2007

Graph 12: Codex Regional Committees:

Attendance by WTO Members by Income Level, 2006-2007

Graph 13: Codex Regional Committees: Attendance by Delegates of WTO Members by Income Level, 2006-2007

Graph 14: Codex Committee on General Principles: Participation of WTO Members by Income Level, 1999-2007

Graph 15: Codex Committee on Pesticides Residues:

Participation of WTO Members by Income Level, 1999-2007

Graph 16: Codex Committee on Fish and Fishery Products: Participation of WTO Members by Income Level, 1999-2007 
Graph 17: Codex Committee on Fresh Fruits and Vegetables: Participation of WTO Members by Income Level, 1999-2007

Graph 18: JECFA: WTO Members in Rosters of Experts by Income Level, 2007-2011

Graph 19: JMPR: WTO Members in Roster of Experts by Income Level, 2004-2010

Graph 20: JECFA Meetings: Attendance by Experts from WTO Members by Income Level, 2006-2007

Graph 21: JMPR Meetings: Attendance by Experts from WTO Members by Income Level, 2006-2007

Graph 22: JMRA Meetings: Attendance by Experts from WTO Members by ncome Level, 2006

Graph 23: Members of the OIE that are WTO Members by Income Level, 2007

Graph 24: OIE Administrative Commission: Administrative Commission Members that are WTO Members by Income Level, 2008

Graph 25: OIE Specialist Commission Members that are WTO Members by Income Level, 2007

Graph 26: OIE Ad Hoc Groups: Ad Hoc Group Members that are WTO Members by Income Level, 2008

Graph 27: OIE Working Groups: Working Group Members that are WTO Members by Income Level, 2007-2008

Graph 28: Contracting Parties to the IPPC that are Members of the WTO by ncome Level, 2007

Graph 29: Commission on Phytosanitary Measures, Second Session: Attendance by WTO Members by Income Level, 2007

Graph 30: Commission on Phytosanitary Measures, Second Session: Delegates of WTO Members by Income Level, 2007

Graph 31: Commission on Phytosanitary Measures, Second Session: Average Number of Delegates per WTO Member by Income Level, 2007

Graph 32: IPPC Informal Working Group on Strategic Planning and Technical Assistance: Attendance by WTO Members by Income Level, 2003-2007

Graph 33: Graph 33: IPPC Standards Committee: Standards Committee Members that are WTO Members by Income Level, 2007

Graph 34: IPPC Standards Committee: Attendance by Standards Committee Members that are WTO Members by Income Level, 2007

Graph 35: IPPC Expert Working Groups: EWG Members that are WTO Members by Income Level, 2007

Graph 36: IPPC Expert Working Groups: Attendance by EWG Members that are WTO Members by Income Level, 2005-2008

Graph 37: IPPC Expert Working Groups: Stewards that are from WTO Members by Income Level, 2007

Graph 38: IPPC Technical Panels: Membership of WTO Members by Income Level, 2007

Graph 39: IPPC: Proposals for New or Amended Standards Submitted by WTO Members by Income Level, 2003 and 2007

Graph 40: Specific Trade Concerns: Participation by WTO Members by Income Level, 1995-2007

Graph 41: Resolved Specific Trade Concerns Raised by WTO Members by Income 
Level, 1995-2007

860

Graph 42: Status of Specific Trade Concerns Raised by WTO Members by Income Level, 1995-2007

Graph 43: Participation in Initiating SPS-related Dispute Settlement Proceedings: WTO Members by Income Level, 1995-2008

Graph 44: Participation in SPS-related Dispute Settlement Proceedings in which a Panel was Established: WTO Members by Income Level, 1995-2008 
Introduction 


\section{The balance between trade and health and its development dimension}

The link between free trade and measures for the protection of health ${ }^{1}$ is not a new phenomenon. It has been recognised since the commencement of trading activities between newly emerged city-states in the fourteenth century. ${ }^{2}$ Today, however, the proliferation of health measures on the one hand and the great advancements in trade liberalisation on the other mean that the interaction between these two policy areas has assumed critical importance.

Both trade liberalisation and health protection measures pursue important societal aims, which are, respectively, economic growth ${ }^{3}$ through the earning of foreign revenue ${ }^{4}$ and the protection of the life and health of humans, plants and animals. However, these two societal objectives are often in conflict with each other. ${ }^{5}$ On the one hand, traded products, particularly in the food and agricultural sector, can introduce risks to human, animal or plant life or health into the importing region. Examples of such risks are the spread of insect pests hosted by imported fruit or vegetables, the transfer of infectious animal

${ }^{1}$ Unless otherwise indicated, the word 'health' in this book will be used to refer to human, animal or plant life or health. Similarly, the term 'health measures' refers to measures for the protection of human, animal or plant life or health.

${ }^{2}$ As noted in Chapter 2 below, Fidler reports various examples of measures taken by Italian city-states to reduce health risks from traded products. See David P. Fidler, 'Microbialpolitik: Infectious Diseases and International Relations', American University International Law Review 14, 1998, 1-52, 8.

${ }^{3}$ The idea that free trade promotes economic growth was postulated in 1776 by Adam Smith, in his seminal work, The Wealth of Nations and refined in 1817 by David Ricardo who advanced the theory of comparative advantage. Reliance on this theory by proponents of free trade has been criticised on the grounds that the prerequisite for its validity, namely perfect market conditions, does not exist in practice. See for example Joel R. Paul, 'Do International Trade Institutions Contribute to Economic Growth and Development?' Virginia Journal of International Law 44 (1), 2003, 284-340. It is beyond the ambit of this book to examine the arguments for and against free trade in general. Instead, this book will limit itself to the generally-accepted proposition that increased market access for exports of food and agricultural products from developing countries contributes to their foreign revenue earnings and thus to their economic growth. See further on this point below, Part I, Chapter 1, Section 1.1.

${ }^{4}$ It is important to note that free trade is not an aim in itself, but rather a tool to achieve important societal objectives. This fact is reflected in the first recital in the Preamble to the Marrakesh Agreement Establishing the World Trade Organization, which recognises that, '...[Members'] relations in the field of trade and economic endeavour should be conducted with a view to raising the standards of living, ensuring full employment and a large and steadily growing volume of real income and effective demand, and expanding the production of and trade in goods and services, while allowing for the optimal use of the world's resources in accordance with the objective of sustainable development, seeking both to protect and preserve the environment and to enhance the means for doing so in a manner consistent with their respective needs and concerns at different levels of economic development'. See 'Marrakesh Agreement Establishing the World Trade Organization', in The Results of the Uruguay Round of Multilateral Trade Negotiations: The Legal Texts (World Trade Organization, Geneva), 1994, 6-18.

${ }^{5}$ In a speech given in 2004, then EU Trade Commissioner Pascal Lamy noted that a community's 'collective preferences', as reflected in regulatory standards, are a reflection of societal values and may clash with the 'collective preferences' of trading partners. He thus stated, 'Trade is the natural point of intersection for different systems of collective preferences.' He argued that, '...the trading system....brings two legitimate demands into conflict with each other: the demand that commitments given to the WTO be honoured on the one hand and the demand to exercise legitimate social choices on the other.' Pascal Lamy, 'The Emergence of Collective Preferences in International Trade: Implications for Regulating Globalisation', presented at the Conference on Collective Preferences and Global Governance: What Future for the Multilateral Trading System? (European Commission, Brussels) 15 September 2004, 3 and 5, available at: http://ec.europa.eu/archives/commission_1999_2004/lamy/speeches_articles/spla242_en.htm, visited on 7 June 2008. 
diseases carried by imported animals or animal products and food-safety risks from inadequate hygienic standards in the production or transportation of the exported food. ${ }^{6}$ On the other hand, the measures taken by importing states to protect health in their territories against such risks, whether real or perceived, are likely to act as barriers to market access for the exporting country, thereby reducing its export earnings.

These health measures can focus on human or animal life or health (sanitary measures) or on plant life or health (phytosanitary measures). Together, they are termed sanitary and phytosanitary (SPS) measures and can take many forms. One can think of examples such as regulations setting maximum residue levels for toxins or contaminants in food, ${ }^{7}$ approval procedures for additives, quarantine requirements to minimise the spread of pests and diseases, labelling requirements to notify consumers of potentially harmful foodstuffs (such as allergen-containing products), regulations imposing hygiene requirements on the process or production method whereby the product is made, inspection and certification requirements, or outright bans on hazardous products. ${ }^{8}$ All these measures, when applied to imports, may restrict trade.

The exponential increase in the speed and volume of trade and in the diversity of traded products in the last fifty years, and the accompanying proliferation of health risks and SPS measures, has meant that the international trade regime, currently embodied in the rules of the World Trade Organisation (WTO), has had to find new ways of mediating the conflict between free trade and health protection. Acting on the interface of globalised trade and globalised health risks, is the WTO's Agreement on the Application of Sanitary and Phytosanitary Measures ${ }^{9}$ (SPS Agreement). It reflects a negotiated balance between the competing goals of the liberalisation of trade in the food and agricultural sector and the protection of health by national governments. ${ }^{10}$

Developing-country Members of the WTO have a significant interest in the way in which these two competing societal aims are balanced in the SPS Agreement. On one side, as agricultural products often form an important part of the merchandise export trade of several developing-country Members, ${ }^{11}$ they are concerned with gaining market access

${ }^{6}$ A less obvious example is the outbreak of the Ebola virus and hemorrhagic fever due to international trade in wild primates captured for scientific research, as recounted in David P. Fidler, 'Return of the Fourth Horseman: Emerging Infectious Diseases and International Law', Minnesota Law Review 81, 1997, 771-868, note 138.

7 The EC's maximum residue levels for aflatoxins are an example of such an SPS measure.

${ }^{8}$ For example, many countries banned beef imports from the European Union in response to the outbreak of foot-and-mouth disease in 2001.

9 'Agreement on the Application of Sanitary and Phytosanitary Measures', in The Results of the Uruguay Round of Multilateral Trade Negotiations: The Legal Texts (World Trade Organization, Geneva), 1994, 69-84.

${ }^{10}$ It is important to recognise that the SPS Agreement, like other WTO agreements, is not simply a set of rules promoting free markets in accordance with economic principles. Instead, it reflects particular policy choices about the way in which economic globalisation should be harnessed to balance free trade with other societal objectives. As stated by Joel Paul: 'The WTO is more than a mechanical application of principles of market rationality. The WTO has inscribed a wide range of policy choices onto its member states, even in ways that distort market forces. ... [International trade] institutions should acknowledge their political character and accept responsibility for the human consequences of globalization.' Joel R. Paul, 'Do International Trade Institutions Contribute to Economic Growth and Development?' Virginia Journal of International Law 44 (1), 2003, 284-340, 339-340. It is on the basis of such recognition that this book examines the consequences of the political balance struck in the SPS Agreement for developing countries.

${ }^{11}$ A 2003 study at the initiative of the Danish Association for International Cooperation indicates that developing countries are often heavily dependent on income from agricultural exports. This amounts to $16 \%$ of export 
in this sector in order to earn the foreign revenue necessary to meet their development needs. ${ }^{12}$ It is important not to lose sight of the consequences in human terms of lost revenue due to market barriers in this sector. ${ }^{13}$ The agricultural sector provides a livelihood for the majority of the population in many developing countries, particularly the poorer and less powerful population groups in society. ${ }^{14}$ Access to foreign markets for

income (excluding oil) for least-developed countries in general and 50\%-90\% for 15 countries among them. Also, these exports are often limited to a few products, making developing countries particularly vulnerable to barriers to market access for the products of export interest to them. Over $90 \%$ of Africa's agricultural export revenue comes from only cocoa, coffee, cotton, tobacco, sugar, tea, palm oil, rubber, bananas and groundnuts. The remaining 10\% derives from special products important for particular countries such as cashew nuts in Tanzania and Mozambique, vanilla in Madagascar, sisal in Madagascar and Tanzania etc. See Christian Friis Bach et al., Free Trade Is Not Enough: A New Vision for the World's Poorest Farmers (Mellemfolkeligt Samvirke, Copenhagen, Denmark), October 2003, 7. The significance of the agricultural sector for exports differs across income levels of countries. According to the World Development Indicators of 2008, the share of agricultural exports in total exports of goods and services in 2008 is $18 \%$ in low-income countries; $15.1 \%$ in lower-middle-income countries; $12.7 \%$ in upper-middle-income countries; and $2 \%$ in high income countries. The importance of agricultural exports also varies across countries and regions. The countries of Sub-Saharan Africa and South Asia have the highest share of world agricultural exports at 27 and 21 percent, respectively. Roumeen Islam and Gianni Zanini, World Trade Indicators 2008: Benchmarking Policy and Performance (World Bank, Washington D.C.), 2008, xxiii, available at: http://info.worldbank.org/etools/wti2008/docs/ mainpaper.pdf, visited on 7 June 2008 .

12 The United Nations General Assembly has adopted a resolution calling on the Secretary-General of UNCTAD to designate a group of eminent persons to examine and report on commodity issues, including the impact of volatile commodity prices and declining terms of trade on the development efforts of developing countries (General Assembly Resolution 57/236 of 20 December 2002, para. 11). The report of this meeting of eminent persons indicates that they attach the highest priority to enhanced, equitable and predictable market access for commodities of key importance for developing countries and emphasises the need for urgent progress on issues such as the removal of barriers to market access for these products and problems relating to sanitary and phytosanitary measures. See General Assembly, Report of the Meeting of Eminent Persons on Commodity Issues: Note by the Secretary General, A/58/402 (United Nations, 2 October 2003, paras 5-6, available at: www.un.org/ga/58/documentation/list4.html, visited on 25 June 2008. A subsequent UNCTAD report on commodity dependence in Africa notes that although Africa has witnessed a growth in trade relative to GDP in the past decade, its share in world exports has declined. According to this report, '[t]his phenomenon has as much to do with the structure of international trade as with the composition of Africa's merchandise trade, the trade policies applied on the continent in the past 20 years, market access and agricultural policies in industrial countries.' In examining recent developments on commodity markets, the report notes that, '... the determining factor in market entry is the capacity to upgrade and produce according to specific requirements relating to quality, health and environmental standards as well as consumer preferences and tastes. The major challenges are how to identify market opportunities and meet the specific requirements for each market... [T] echnical assistance may be required if African countries are to meet quality and health requirements, particularly in consonance with the WTO Agreement on Sanitary and Phytosanitary Measures.' United Nations Conference on Trade and Development, Economic Development in Africa: Trade Performance and Commodity Dependence, UNCTAD/GDS/AFRICA/2003/1 (United Nations, Geneva), 2003, 1 and 28, available at: http://www.unctad. org/en/docs/gdsafrica20031_en.pdf, visited on 20 June 2008. In addition, the UN Special Rapporteur on the Right to Food has, in a recent report, expressed his concerns regarding the impact of protectionism in developed country agricultural markets on food security in developing countries and stated 'Today, agricultural trade is far from being free, and even further from being fair.' See Jean Ziegler, Report Submitted by the Special Rapporteur on the Right to Food, E/CN.4/2004/10 (United Nations Commission on Human Rights, Geneva), 9 February 2004, 7, available at: www.unhchr.ch/huridocda/huridoca.nsf/(symbol)/E.CN.4.2004.10. En?opendocument, visited on 6 June 2008.

${ }^{13}$ In his opening statement at a recent conference in Kampala, Ugandan president Yoweri Museveni pointed to the link between hunger and malnourishment in Africa and market barriers to African agricultural exports. See Maria Gutiérrez et al., Summary Report of the Conference on Assuring Food and Nutrition Security in Africa by 2020: 1-3 April 2004, circulated on 5 April 2004.

${ }^{14}$ The World Development Report of 2008 notes that 3 of every 4 poor people in developing countries live in 
their agricultural products can contribute to higher income levels and improved standards of living for these people. ${ }^{15}$ However, hard-won achievements in liberalising trade in agricultural products ${ }^{16}$ can easily be undermined by the misuse of SPS measures for protectionist purposes. ${ }^{17}$ Developing-country Members thus depend on effective disciplines in international trade rules to limit the trade-restrictive effect of SPS measures on their export markets and to prevent them being used as disguised means to protect agricultural and food industries in the importing countries.

On the other side, one should not forget the fact that developing-country Members are also important importers of food and agricultural products, ${ }^{18}$ and face sanitary and phytosanitary risks from imported products. In this respect, they have an interest in being allowed sufficient flexibility by international trade rules to enact SPS regulations appropriate to their needs and capabilities. It is therefore important to recognise that the interests balanced in the SPS Agreement are those of conflicting societal goals of importance to both developed and developing-country Members, rather than competing developed and developing country interests. ${ }^{19}$ Nevertheless, the mechanisms used to achieve this balance

rural areas, and most of these depend on agriculture for their livelihoods. World Bank, World Development Report 2008: Agriculture for Development (World Bank, Washington D.C.), 2008, 1, available at: http://siteresources.worldbank.org/INTWDR2008/Resources/WDR_00_book.pdf, visited on 27 June 2008. For this reason, the abovementioned Danish study has noted that development and growth in the agricultural sector 'can become the dynamo to create economic growth and development throughout the entire society.' See Christian Friis Bach et al., Free Trade Is Not Enough: A New Vision for the World's Poorest Farmers (Mellemfolkeligt Samvirke, Copenhagen, Denmark), October 2003, 6.

${ }^{15}$ The other side of the coin should not be forgotten: developing countries may also benefit from reducing their own barriers to trade in the food and agricultural sector, as this can contribute to food security. Murphy notes: Murphy notes: 'Experience shows that securing food from international markets offers important benefits to countries, including the possibility of cheaper, more varied food and an effective way to stabilize supplies in times of domestic shortfall. Bangladesh, for example, was able to use private imports of rice to make up a shortfall caused by floods that destroyed about 10 per cent of the annual rice crop in 1998. These imports were only possible because the government had liberalized its trade policies shortly before, creating the opportunity for the private sector to import and meet demand. There are all too many examples of countries whose governments have let their people to starve behind closed borders, including Mengistu's Ethiopia and successive governments in North Korea, to give two extreme examples.' See Sophia Murphy, Securing Enough to Eat (International Institute for Sustainable Development, Winnipeg), January 2005, 11, available at: http://www. iisd.org/pdf/2005/trade_securing_enough_to_eat.pdf.

${ }^{16}$ These achievements are reflected in the Agreement on Agriculture, one of the products of the Uruguay Round of trade negotiations. 'Agreement on Agriculture', in The Results of the Uruguay Round of Multilateral Trade Negotiations: The Legal Texts (World Trade Organization, Geneva), 1994, 39-68.

${ }^{17}$ UN Millennium Project, Investing in Development: A Practical Plan to Achieve the Millennium Development Goals (United Nations Development Programme, New York), 2005, 216-217, available at: http://www.unmillenniumproject.org/reports/ fullreport.htm, visited on 7 January 2008. See also WTO Secretariat, World Trade Report 2005: Exploring the Links between Trade, Standards and the WTO (World Trade Organization, Geneva), 30 June 2005, available at: http://www.wto.org/english/res_e/booksp_e/anrep_e/world_trade_ report05_e.pdf, visited on 4 June 2007.

18 In fact, developing countries as a group have shifted from being net exporters of food and agricultural products in the 1960s to being net importers of these products in the1990s and early 2000s. See Food and Agriculture Organization, The State of Agricultural Commodity Markets (United Nations, Rome), 2004, 14, available at: ftp://ftp.fao.org/docrep/fao/007/y5419e/y5419e00.pdf.

19 Sometimes the mistaken impression is created that developing country interests in the SPS Agreement lie only with gaining market access for their agricultural and food exports, whereas developed countries' only concern is with maintaining sufficient flexibility in the disciplines of the SPS Agreement to allow them to impose high standards for imports in their SPS regulations. Instead, both groups of countries have an interest in both market access and health protection. It is the relative weight of these interests in domestic policy and 
in the SPS Agreement may have a disparate impact on Members at different levels of development.

This book explores the balance between free trade and health protection reflected in the SPS Agreement, with a particular focus on its development dimension. More specifically, it addresses the question whether the SPS Agreement improves the opportunities of Members at lower levels of development to gain market access for their food and agricultural exports by means of effective disciplines ${ }^{20}$ on the use of trade-restrictive SPS measures, while at the same time sufficiently respects the right of these, and all, WTO Members to protect health in their territories in a way that takes account of varying regulatory and institutional capacity and policy choices at different levels of development. It is in this sense that the core question addressed in this book, namely whether the SPS Agreement achieves an 'appropriate' balance between liberalising trade in the food and agricultural sector and allowing sufficient scope for health protection measures, should be understood.

\section{The development dimension of the SPS Agreement: policy spaces and special treatment ${ }^{21}$}

The central question examined in this book, as set out in Section 1 above, is the appropriateness of the trade/health balance achieved by the SPS Agreement for Members at different levels of development. This question addresses what can be called the 'development dimension' of the balancing act conducted by the SPS Agreement. The 'development dimension' of this Agreement can be seen as composed of two distinct, but interrelated elements, which are determinative for the impact of the SPS Agreement on the trade and health interests of Members at different levels of development. When examining the balance achieved by the SPS Agreement in this book, therefore, these two complementary elements are dealt with, namely: (1) the limits of policy space; and (2) special treatment for developing-country Members.

The issue of the limits of policy space refers to the manner in which the general rights and obligations of SPS Agreement discipline Members' ability to regulate to give effect

the capacity to use certain mechanisms to achieve a balance between these competing interests that varies between developed and developing countries.

${ }^{20}$ In this book, the term 'disciplines' is often used to refer to WTO rules. Although every effort has been made to avoid WTO jargon in this work, this particular instance of 'GATT-ese' is retained due to its aptness for describing the impact of the rules discussed on government action. Alternative terms such as 'rules' or 'obligations' do not capture the essence of the SPS Agreement provisions - which allow but discipline government health regulation - as fittingly.

${ }^{21}$ This title has been adapted from the title given to a proposal by Venezuela in the preparations for the Seattle Ministerial Conference. In that proposal, however, the 'spaces for policies' element referred to the recognition in WTO rules of the legitimacy of the use of market-oriented supply-policy instruments by developing countries to meet development objectives. General Council, Preparations for the 1999 Ministerial Conference. Special and Differential Treatment and the Spaces for Policies in WTO: Two Elements of the Development Dimension in the Multilateral Trading System, WT/GC/W/279, circulated on 29 July 1999. Here, however, a different type of policy is at issue, namely health policy, and the policy spaces refer to the limits of the scope to enact SPS measures to protect health within the rules of the SPS Agreement. It is in these limits that the balance between the protection of health and the liberalisation of trade in the SPS Agreement can be found. 
to their SPS policies. These rights and obligations give effect to the underlying balance which is the objective of the Agreement. The question is whether the balance achieved is equally appropriate for Members at different levels of development. Therefore, the examination of the impact of the SPS Agreement in this book focuses on the way the balance is struck and the tools or mechanisms used to achieve this balance. In other words, if the SPS Agreement is seen as a scale on which the two competing interests are balanced, the question is whether the scale is an effective and workable instrument for all Members.

The balance reflected in the disciplines on policy space in the SPS Agreement cannot be divorced from the question of special treatment for developing-country Members. Even if an appropriate balance between trade and health is achieved in the disciplines of the SPS Agreement, the reality of the great disparity in the situations of Members at different levels of development necessitates special rules to address this. The issue of special treatment for developing countries thus refers to the special rules in favour of developing-country Members in the SPS Agreement, contained in its provisions on special and differential treatment and its rules on technical assistance. These two categories of provisions aim to address developing-country Members' capacity constraints. If the SPS Agreement is to be an effective balancing instrument also for the less-developed Members, it is essential to assist these Members to comply with the rules of the SPS Agreement and with the sanitary and phytosanitary requirements of their trading partners and to enforce their rights under this Agreement. ${ }^{22}$ The question arises whether the current provisions are effective and whether there is a need for differentiation between developing-country Members in the implementation of these provisions. If effective and operational rules on special treatment of developing-country Members are included in the SPS Agreement, it can be ensured that these Members can use this Agreement to obtain access to markets for their food and agricultural products without paying an inordinate price through the diversion of their scarce resources to upgrading their SPS regimes. However, this objective has to be balanced against the need to ensure that it does not come at the cost of health protection in importing Members.

These two interrelated elements of the central research question form the basis of the analysis of the 'development dimension' of the provisions of the SPS Agreement conducted in this book.

\footnotetext{
22 This need for assistance has been recognised in authoritative reports. In its report on how to achieve the Millennium Development Goals, the UN Millennium Project points to the problem of market access barriers in the form of 'ever more and ever higher OECD standards' and states that two things are essential for developing countries in this regard: (1) Assistance to make effective use of the SPS (and TBT) Agreement to ensure that standards are not abused for protectionist purposes; and (2) Assistance in creating the infrastructure and institutions necessary to comply with legitimate standards. In addition, the need for assistance to ensure substantive involvement in standard-setting activities in mentioned. UN Millennium Project, Investing in Development: A Practical Plan to Achieve the Millennium Development Goals (United Nations Development Programme, New York), 2005, 217, available at: http://www.unmillenniumproject.org/reports/fullreport.htm, visited on 7 January 2008. Further, the Report of the Eminent Persons on Commodity Issues notes that, in order to drastically reduce poverty, and achieve diversification in productive capacity, access to markets in a necessary condition but not a sufficient one. Supply-side capacity must be developed in order for developing countries to be able to take advantage of increased market access, which necessitates financial and technical assistance. General Assembly, Report of the Meeting of Eminent Persons on Commodity Issues: Note by the Secretary General, A/58/402 (United Nations, Geneva), 2 October 2003, para. 27, available at: www.un.org/ ga/58/documentation/list4.html, visited on 25 June 2008.
} 


\section{Structure of the discussion}

The first component of the research question examined in this book is whether the disciplines on Members' ability to regulate in the areas of human, animal and plant life and health contained in the SPS Agreement, as interpreted by panels and the Appellate Body, strike an 'appropriate balance' between the need for increased market access and the protection of health.

This question is best understood against the factual background of two parallel processes of globalisation, namely the globalisation of trade and the globalisation of health. It is on the interface of these processes that the SPS Agreement is situated. Consequently, Part I of this book sketches this factual background. In particular, in Chapter 1 it looks at the historical development in the international trading system from a 'gentlemen's club' arrangement between a small group of countries to an almost global system encompassing practically all the world's trading nations. Associated to this development was the gradual realisation of the need to address the special position of developing countries in the rules of the international trade regime. The progressive steps towards the integration of developing countries into the world trading system are set out to establish the background for the examination of the 'development dimension' of the SPS Agreement. This background is set against the normative framework provided by the emergent recognition of the existence of a 'right to development'.

The second element of the factual background described in Part I is the process of the globalisation of health, addressed in Chapter 2. This refers to the increasing realisation of the inability of national governments acting alone to prevent health risks on their territories, due to the growth in cross-border movements of food products, plants and animals. The historical developments that have led to increasing international cooperation to deal with health risks from traded products and then later to a partial 're-nationalisation' of strategies to address these risks are examined. This description aims to create an understanding of the factual background of the complex multi-level systems of health governance against which the SPS Agreement operates.

The delicate position of the SPS Agreement on the border of the interaction between these twin aspects of the globalisation process is established in Chapter 3 of Part I. This Chapter examines the importance of trade in agricultural and food products for many developingcountry Members of the WTO, and the potential of trade liberalisation in this sector to contribute to economic growth and poverty reduction. This potential is set against the trade restrictive effect of the proliferation of SPS measures and standards in developedcountry Members and its consequences for developing-country exporters. This discussion aims to establish the need for effective disciplines to distinguish legitimate health protection from disguised protectionism. It is in this respect that the role of SPS Agreement is of crucial importance.

Part II of this book turns to examine the regulatory context within which the SPS Agreement operates. In order to understand the practical implications of the balance struck between trade and health in the SPS Agreement it is necessary to examine national and international regimes for the protection of health, and their trade implications. 
Chapter 1 of Part II discusses national SPS regulation against the normative context of the duty of governments to protect life, ensure adequate food and protect public health in their territories. This normative analysis informs the later discussion on the limitations on regulatory autonomy in this area in the form of the disciplines of the SPS Agreement. This Chapter continues by looking at national SPS regulation from a law-and-economics perspective. This clarifies the role of private-interest influence in determining regulatory choices of government and the need for international disciplines in order to guard against this. Further this analysis elucidates the wide differences in the costs and benefits of SPS regulation for Members at different levels of development. This serves the purpose of establishing an understanding of the reasons for the different regulatory choices of Members situated at different places along the development spectrum.

The heterogeneity of WTO Members has important implications for the disparate impact of the rules of the SPS Agreement on Members at different levels of development. This impact does not vary only between developed- and developing-country Members, but also within the highly divergent group of 'developing-country Members'. The range of different policy priorities and SPS regulatory regimes cannot be understood in the abstract. Consequently, in Chapter 2 of Part II four WTO Members, selected across different income levels and geographical regions, are used as illustrative examples. Thereby, this Chapter aims to afford some insight into the different ways in which Members, at different levels of development, regulate for the protection of health and thus to provide the context against which the subject matter of the disciplines of the SPS Agreement can be understood.

Also of importance to understanding the context of the SPS Agreement is an examination of international systems for the elaboration of SPS standards, discussed in Chapter 3 of Part II. These international standard-setting systems aim to facilitate trade by reducing the divergence in national SPS regulation, while promoting a minimum level of SPS protection reflected in their science-based standards. Chapter 3 starts by briefly examining the reasons for international harmonisation initiatives and the problems inherent in the standard setting process. Against this background it turns to a concrete examination of the main international bodies responsible for setting standards in the areas of human, plant and animal health and scrutinizes their objectives, membership, institutional structure and decision-making processes. Particular attention is given to the role played by developingcountry Members within these standard-setting bodies. The aim of this discussion is to provide the background for understanding the implications of those disciplines of the SPS Agreement that encourage harmonisation of SPS measures on the basis of the SPS standards set by these international bodies.

Subsequently, in Parts III to V, the focus of this book is on the SPS Agreement itself and the effect of its rules on Members at different levels of development. The analysis of the SPS Agreement is not limited to the provisions in the SPS Agreement themselves, but it also examines the way in which panels and the Appellate Body have interpreted these provisions. ${ }^{23}$ In each of these Parts, working through the SPS Agreement

${ }^{23}$ In the context of the negotiations regarding the reform of the Dispute Settlement Understanding (DSU) the Least Developed Country (LDC) group has stated: 'A careful reading of the accumulated jurisprudence of the DS system thus far reveals that the interests and perspectives of developing countries have not been 
provision-by-provision, two questions are addressed. First, do the disciplines of the SPS Agreement leave sufficient 'policy space' within which Members at different levels of development can pursue their legitimate SPS policies? Second, do these disciplines effectively enable Members at different levels of development to gain access to export markets by creating workable limits on policy space so as to prevent disguised protectionist measures? Throughout this analysis the importance of the trade/health balance which is the objective of the SPS Agreement is emphasised. Disturbing this balance cannot be of benefit to Members, whatever their level of development. Instead, the purpose of the analysis is to examine whether the tools used to achieve this balance in the SPS Agreement are useful instruments in the hands of developing-country Members.

Part III starts in Chapter 1 by setting the scene. It looks into the historical background to the SPS Agreement, by examining the trade rules in place before its coming into force and its negotiation history. This Chapter aims to clarify why the particular disciplines found in the SPS Agreement take the form that they do. Chapter 2 subsequently examines the scope of application of the SPS Agreement in order to demarcate from the outset the limited range of situations to which the Agreement applies, and the strong presence of the trade/health conflict in these situations. Particular attention is paid to the problem of private-sector SPS standards in this discussion.

Chapters 3 to 5 of Part III analyse those substantive rules of the SPS Agreement that set the limits of the policy space available to Members for SPS regulation. They examine the way in which these rules incorporate and elaborate upon the relevant rules of the General Agreement on Tariffs and Trade (GATT) 1947, and supplement them with new disciplines, namely, the promotion of harmonisation of SPS measures around international standards and the new science-based rules. The discussion deals, in particular, with the differences in the way in which these disciplines address two distinct stages of the regulatory process: risk assessment and risk management. While strict scientific obligations are in place to discipline the risk assessment stage, the policy choices of Members that characterise the risk management stage of regulation are left largely untouched. This analysis is useful in delimiting the policy space left to Members by the relevant substantive disciplines of the SPS Agreement in their efforts to distinguish health protection from trade protectionism.

adequately taken into account. The panels and the Appellate Body have displayed an excessively sanitized concern with legalisms, often to the detriment of the evolution of a development-friendly jurisprudence. ...' Dispute Settlement Body Special Session, Negotiations on the Dispute Settlement Understanding. Proposal by the LDC Group, TN/DS/W/17, circulated on 9 October 2002, para. 5. Similarly, the African Group has stated: 'In their interpretation and application of the provisions, the panels and the Appellate Body have in several instances exceeded their mandate and fundamentally prejudiced the interests and rights of developing-country Members as enshrined in the WTO Agreement; The panel and Appellate Body composition and operation have not been conducive to ensuring the achievement of the development objectives of the WTO and of equity in geographical distribution;...' Dispute Settlement Body Special Session, Negotiations on the Dispute Settlement Understanding. Proposal by the African Group, TN/DS/W/15, circulated on 25 September 2002, para. 2. In this regard Qureshi points out that these claims made in the context of the Doha negotiations on the reform of the DSU are made on a political level and have not been accompanied by sufficient evidence substantiating these sweeping statements. However, he notes that this does not necessarily mean the claims are without merit, and argues that perceptions as to whether WTO jurisprudence facilitates the development objective are as important as the actual record. Asif H. Qureshi, 'Interpreting World Trade Organization Agreements for the Development Objective', Journal of World Trade 37 (5), 2003, 847-882, 864. 
Part IV continues by looking at the institutional and procedural arrangements in place under the SPS Agreement. The institutional and procedural provisions contained in the SPS Agreement and those developed by the SPS Committee to operationalise certain substantive obligations in the Agreement have an important impact on the effectiveness of the SPS Agreement in achieving its goals. They aim to reduce as much as possible the trade restrictive effect of legitimate SPS measures, while not diminishing the right of Members to decide for themselves the level of SPS protection they deem appropriate in their own territories. As such, while often underestimated, these institutions and procedures have the potential to achieve much in the way of trade liberalisation, while not threatening the protection of health by Members. The examination of these provisions aims to determine the extent to which they are effective tools for exporting Members at lower levels of development to gain market access without endangering the ability of importing Members to protect health in their territories.

As noted in Section 1 above, the second aspect of the development dimension of the SPS Agreement relates to the special rules in place to address the particular constraints faced by developing country Members. It has been noted that '[o]ne size does not fit all', ${ }^{24}$ both with regard to disciplines in SPS Agreement that require substantial investments for implementation (such as infrastructure for transparency) and with regard to disciplines on national regulatory measures (risk assessment etc). Therefore the provisions of the SPS Agreement that aim to address the special position of developing-country Members receive attention in Part V of this book. First, in Chapter 1, the special and differential treatment (SDT) provisions of the SPS Agreement providing additional flexibility for developing-country Members are examined. This flexibility relates to both the regulatory disciplines of the SPS Agreement and to compliance with the SPS requirements of their trading partners. The aim of this Chapter is to determine whether this additional 'elbow room' for developing countries sufficiently takes account of their resource constraints and

${ }^{24}$ The fact that 'one size does not fit all' with regard to special and differential treatment of developing countries is emphasised in Bernard Hoekman et al., More Favorable Differential Treatment of Developing Countries: Towards a New Approach in the WTO, World Bank Policy Research Working Paper 3107 (World Bank, Washington D.C.), August 2003, 6-7, available at: www.econ.worldbank.org/files/28991_wps3107.pdf, visited on 11 November 2004. A recent study under the auspices of the Danish Association for International Cooperation proposing a new vision for agricultural development of the world's poorest countries, points out that improved market access is not sufficient but must go hand-in-hand with the development of institutions, including those for monitoring and implementing SPS standards, but emphasises the fact that 'this is not a case where one size fits all' as institutions need to be adapted to the surroundings and the development of the country. See Christian Friis Bach et al., Free Trade Is Not Enough: A New Vision for the World's Poorest Farmers (Mellemfolkeligt Samvirke, Copenhagen, Denmark), October 2003, 19. Similarly, the report of the Group of Eminent Persons convened by UNCTAD to study commodity issues noted that as problems with regard to commodity trade differ between countries due to differences in size and institutional capacity, 'there were no solutions that would fit all cases.' General Assembly, Report of the Meeting of Eminent Persons on Commodity Issues: Note by the Secretary General, A/58/402 (United Nations, 2 October 2003, para. 45, available at: www.un.org/ga/58/documentation/list4.html, visited on 25 June 2008. Finally, a recent paper published by the Institute for Global Dialogue notes that, with regard to WTO agreements with domestic regulatory content (including the SPS Agreement), there are limits to the one-size-fits-all approach which 'ignores the fact that policies and institutions differ according to differences in circumstance, not least comparative costs which vary with levels of development'. See Razeen Sally, Whither the World Trading System? Trade Policy Reform, the WTO and Prospects for the New Round, IGD Occasional Paper No. 36 (Institute for Global Dialogue, Braamfontein,), January 2003, 26, available at: www.idgd.org.za/pub/OP/OP36.rtf, visited on 6 November 2003. 
thereby avoids unreasonable limitations to their policy space in the area of health regulation. The possibilities to operationalise SDT provisions in the SPS Agreement through effective treaty interpretation by panels and the Appellate Body and through ongoing work in the SPS Committee to improve the implementation of SDT are discussed. The limits of these possibilities are examined.

In Chapter 2 of Part V, the provisions of the SPS Agreement that deal with technical assistance to developing-country Members are addressed, as is their operation in practice. It is important to recognise that barriers to market access in the form of unjustified SPS measures are not the only constraints that developing countries face with regard to their exports of food and agricultural products. Another major constraint is the lack of supplyside capacity, including the inability to meet strict, but legitimate, SPS requirements and the high costs faced by firms in developing countries due to the lack of the necessary infrastructure for compliance. ${ }^{25}$ Technical and financial assistance can play a useful role in building institutional and trade capacity. ${ }^{26}$ For this reason, a brief examination of selected technical assistance initiatives, both at bilateral and at multilateral level, is undertaken to determine whether enough is being done to address developing country needs in this regard.

In examining both the rules on SDT and the provision of SPS-related technical assistance, an overarching question is whether there is a need for differentiation between developingcountry Members, in line with the current discussion on this issue with regard to WTO rules in general. ${ }^{27}$ In accordance with the basic premise in this book that any serious effort to address the needs of developing-country Members must take account of the reality of

\footnotetext{
${ }^{25}$ In its report regarding the types of problems that producers face in accessing the EU market, the Secretariat of the Common Market for Southern Africa noted that, 'These problems can be placed into two main categories, these being capacity constraints (such as lack of market information, lack of laboratory equipment and technical staff, lack of infrastructure, etc) and market access constraints. There is sometimes no clear defining line between the two...' See COMESA Secretariat, Market Access Constraints (Common Market for Southern Africa, Lusaka), 2003, para. 32, available at: www.comesa.int/trade/multilateral/epa/ Market $\% 20$ Access $\% 20$ Constraints/en, visited on 10 January 2008.

${ }^{26}$ In the context of the WTO Work Programme on Small Economies, a group of landlocked developing countries submitted a series of proposals, including that technical assistance be given to small economies to obtain the knowledge and technical infrastructure necessary to comply with SPS requirements on their export markets. See Committee on Trade and Development, Proposals Submitted by the Landlocked Developing Countries Work Programme on Small Economies: Communication by Paraguay on Behalf of the Delegations of Bolivia, Mongolia, and Paraguay, WT/COMTD/SE/W/10, circulated on 27 April 2004, para. 4. Similarly, recently, the trade ministers of the least-developed countries, meeting in Dakar, adopted the Dakar Declaration regarding their position on the Doha Round of multilateral trade negotiations, in which they call for WTO Members to exercise restraint in applying SPS measures to products from LDCs and for technical and financial assistance to be provided to assist these countries in developing facilities and systems for compliance with SPS export requirements. See Third LDC Trade Ministers' Meeting, Dakar Declaration, Dakar, Senegal), 4-5 May 2004, para. 6(b), available at: www.enda.sn/english/dakardec.htm, visited on 25 June 2007.

${ }^{27}$ In a post-Cancun analysis of the implications of the failure of the Ministerial Conference, Hoekman suggests that the concept of SDT must be revisited, requiring, at a minimum, greater differentiation between countries in determining the scope and content of SDT. Hoekman believes that a new framework for SDT 'could do much to move the market access agenda forward, and could also facilitate movement on domestic regulatory policies where members agree cooperation is beneficial'. See Bernard Hoekman, Cancún: Crisis or Catharsis? (World Bank, Washington D.C.), 20 September 2003, 4, available at: http://siteresources.worldbank.org/ INTRANETTRADE/Resources/Hoekman-CancunCatharsis-092003.pdf, visited on 5 December 2003.
} 
the wide divergence within the heterogeneous group of developing-country Members, the question arises whether this reality must be given effect through differentiated rules. This issue is touched upon in Part V.

Finally, this book draws upon the discussions in Parts I to V to reach conclusions regarding the development dimension of the SPS Agreement. In its Conclusion it evaluates whether the disciplines on policy space contained in the relevant substantive rules of the SPS Agreement together with the procedural arrangements under the Agreement achieve a balance between trade and health that is workable for Members at different levels of development. The balance achieved is evaluated in the light of the previous discussion of the differences in national SPS regimes, and in participation in international standard setting, of Members at different levels of development. On the basis of this evaluation, the question is addressed whether changes are necessary to reflect developing-country Members' constraints and priorities in the rules of the SPS Agreement and in their interpretation by panels and the Appellate Body. Further, the Conclusion examines whether the difficulties faced by developing-country Members in fully benefiting from the SPS Agreement should rather be redressed through its special provisions for developing-country Members, in the form of SDT and technical assistance. Finally, suggestions are made with regard to the need for strengthening and operationalising the technical assistance provisions in the SPS Agreement in order to make the trade/health balance achieved in the Agreement workable for developing-country Members. In this respect, the need for further research in this area is identified. 


\section{Part I}

Background to the SPS Agreement:

On the interface between

globalised trade and globalised health 


\section{Introduction to Part I}

Part I of this book provides the background necessary for a full understanding of the research problem, and the development focus adopted therein. In particular, it examines the parallel processes of globalisation ${ }^{1}$ in the area of trade and in the area of health, in order to situate the SPS Agreement in this context.

It does so firstly by examining, in Chapter 1, the role of developing countries in the world trading system to determine why an examination of the development dimension of international trade rules, and more specifically on the SPS Agreement, is urgently needed. The progressive integration of developing countries into the trading system is referred to as the globalisation of trade for purposes of this book.

Secondly, Chapter 2 sketches the historical developments relating to the recognition of the globalisation of health in the face of transboundary health risks and the initiatives for international cooperation in this regard. It examines the role of scientific developments in this process, and the impact thereof on developing countries.

These dual aspects of the process of globalisation are brought together, and related to the core theme of this research, in Chapter 3 by means of an examination of the importance of regulations and standards imposed to address globalised health risks for developing country trade.

The Conclusion to Part I situates the SPS Agreement on the interface between globalised trade and globalised health.

\footnotetext{
${ }^{1}$ For purposes of this book, the term 'globalisation' will be used to refer to the process by which national borders become less important due to global forces (such as trade liberalisation and cross-border movement of unsafe food, pests and diseases), and national governments' ability to exercise their sovereignty consequently diminishes.
} 


\section{CHAPTER 1 \\ The globalisation of trade: \\ Developing countries in the world trading system}

Since the end of the colonial period and the accompanying emergence of new sovereign nations, the development of these nations and their integration into the international economy has been the focus of increasing international attention. ${ }^{1}$ In examining the development dimension of the SPS Agreement, both the evolving understanding of what 'development' entails and the changing manner in which the world trading system has addressed the need to integrate developing countries deserve attention.

The concept of development has been subject to different interpretations in different periods. Zalaquette identifies these as ranging from the notion, in the 50s, that development means mere economic growth through the idea, in the $70 \mathrm{~s}$, that development requires a 'New International Economic Order', self-reliance, or the satisfaction of basic needs, to the current understanding that development entails the realisation of all human rights. ${ }^{2}$ It is within this current understanding of development that the discussion of the impact of the rules of the international trade regime on development takes place. Therefore, this Chapter starts by examining the normative framework created by the emergent right to development and its relevance for the world trading system.

Any attempt to provide suggestions for reform of world trade rules to make them more supportive of development occurs against the background of previous such initiatives. It should therefore be based on an understanding of the effect of previous attempts to give special treatment to developing countries in trade rules on their position in the world trading system.

The position of and role played by developing countries in the international trading system has evolved over time. This Chapter traces this development in order to demonstrate the increasing significance of world trade rules for developing countries and the changing role played by these countries in the creation and implementation of these rules. It is in this evolving context that the process of globalisation of trade must be understood to elucidate the disparate effects of this process on developed and developing countries. ${ }^{3}$ This highlights the fact that globalisation of trade implies neither equally effective participation in trade nor equal costs and benefits of trade across the globe. In fact, recent studies

\footnotetext{
${ }^{1}$ Although the term development only became widely used during decolonisation, the idea that international cooperation for development was needed was already present in the Charter of the United Nations, where members undertook to promote 'higher standards of living, full employment and conditions of economic and social progress and development'. Charter of the United Nations, 26 June 1945, Article 55(a).

2 José Zalaquette, 'The Relationship between Development and Human Rights', in Food and Human Rights, Asbjorn Eide, et al. (eds.) (The United Nations University, Tokyo), 1984, 141-151, 145.

${ }^{3}$ A 2003 IMF working paper has shown, using an econometric model of economic analysis, that although the GATT and later the WTO have had a powerful and positive impact on trade, this impact has been uneven. The increase in trade has been mostly in developed countries and has had little impact on sectors subject to high protection on developed countries, such as agriculture and textiles. Arvind Subramanian and Wei ShangJin, The WTO Promotes Trade, Strongly but Unevenly, WP/03/185 (International Monetary Fund), September 2003, 20-21, available at: www.inf.org/external/pubs/cat/longres.cfm?sk=16822.0, visited on 26 November 2003.
} 
show that, with the exception of East Asian and Central American countries, developing countries' share in world exports of goods has hardly increased in the last 20 years. ${ }^{4}$ South American, African and Central and Eastern European countries now actually have smaller shares in total world exports of goods than they had in $1960 .^{5}$

Previous attempts to address these uneven effects by means of providing special and differential treatment (SDT) ${ }^{6}$ to developing countries must be examined in order to learn from the successes and mistakes of the past. This discussion establishes the background for this study and makes clear why the position of developing countries merits special attention in the context of the SPS Agreement. It aims to provide the framework for evaluating the current rules with regard to their development dimension.

The following discussion attempts to sketch this context in broad lines, focusing on the main developments both under the GATT 1947 regime and under the WTO, that have had an impact on the role of developing countries in the world trading system. It does not pretend to offer an exhaustive analysis of this topic (something that has been extensively and very ably done by others), ${ }^{7}$ but limits itself to providing the basic understanding necessary for purposes of the thesis developed in this book.

\subsection{The normative framework: The right to development and its relevance for the world trading system}

The law of the international trading system is not an isolated system, but is part of public international law. ${ }^{8}$ There is widespread recognition of the need to ensure coherence

\footnotetext{
${ }^{4}$ In the period 1980-2002, developing countries' exports of goods grew by $7.6 \%$. However, in that same period, their share of world exports of goods increased by only $2.3 \%$. United Nations Conference on Trade and Development, Development and Globalisation: Facts and Figures (United Nations, Geneva and New York), 2004, 49, available at: www.unctad.org/Templates/WebFlyer.asp?intItemID=3096\&lang=1, visited on 21 June 2008 .

${ }^{5}$ The share in world merchandise exports of African countries decreased from $7.6 \%$ in 1960 to $5.4 \%$ in 2002 , that of South American countries from 5.6\% to 2.1\% and that of Central European countries from $10.6 \%$ to $4.9 \%$. Ibid., 51.

${ }^{6}$ Special and differential treatment for developing countries encompasses preferential market access, non-reciprocity in trade negotiations and greater freedom to use trade policies than would otherwise be allowed under world trade rules. Bernard Hoekman et al., More Favorable Differential Treatment of Developing Countries: Towards a New Approach in the WTO, World Bank Policy Research Working Paper 3107 (World Bank, Washington D.C.), August 2003, available at: www.econ.worldbank.org/files/28991_wps3107.pdf, visited on 11 November 2004.

7 See for example: E.A. Aghatise, GATT and Developing Countries: The Tokyo Round and After, (Benin, 1980) (manuscript on file with author); Muchkund Dubey, An Unequal Treaty - World Trading Order after GATT (New Age International, India), 1996; Sidney Golt, Developing Countries in the GATT System (Trade Policy Research Centre, London), 1978; Robert E. Hudec, Developing Countries in the GATT Legal System (Gower, London), 1987; Sheila Page et al., The GATT Uruguay Round: Effects on Developing Countries, 2 ed. (Chameleon Press, London), 1992; Chakravarthi Raghavan, Recolonization - GATT, the Uruguay Round and the Third World (Third World Network, Penang), 1990; T.N. Srinivasan, Developing Countries and the Multilateral Trading System - from GATT to the Uruguay Round and the Future (Westview, Boulder, Colorado), 1998; Diana Tussie, The Less Developed Countries and the World Trading System - a Challenge to the GATT (Pinter, London), 1987.

${ }^{8}$ As noted by Joost Pauwelyn, 'WTO law is not a secluded island but part of the territorial domain of international law. The WTO, important as it may be, must thus be put in perspective. For public international law at
} 
between the various functional areas of international law. ${ }^{9}$ This is also true for the relationship between international trade law and international human rights law. ${ }^{10}$ Consequently, a discussion of the impact of the rules of the international trading system on development necessarily occurs in the normative framework created by human rights law, and in particular the emerging recognition of a 'right to development'. As Ernst-Ulrich Petersmann aptly states:

Even though WTO law nowhere explicitly refers to human rights, it serves manifold "human rights functions" across frontiers. Given the widespread bias among human rights lawyers vis-à-vis economics and WTO law, and the agnostic attitude of many trade specialists vis-à-vis human rights, it is an important task of academics to promote more dialogue and a better understanding among these different communities of trade specialists and human rights lawyers so as to render both human rights law and WTO law more effective in dealing with worldwide poverty, health and human rights problems. ${ }^{11}$

Discussion regarding the concept of a 'right to development' started in the $70 \mathrm{~s} .{ }^{12}$ This right was later explicitly recognised in the United Nations Declaration on the Right to

large, this approach pleads for the unity of international law, not its fragmentation.' Joost Pauwelyn, Conflict of Norms in Public International Law: The Example of the World Trade Organization: Internal Hierarchy and How WTO Law Relates to Other Rules of International Law, Doctoral Thesis, Faculté de Droit (Université de Neuchâtel, Neuchâtel), 2001, 2. The fact that WTO agreements should not be read 'in clinical isolation from public international law’ was recognised in Appellate Body Report, US - Gasoline, 16.

${ }^{9}$ This recognition gave rise to the initiative of the International Law Commission in 2000 to address in its work programme the issue of the risks ensuing from the fragmentation of international law. In 2002, it created a Study Group on this issue, which prepared the following report: International Law Commission, Fragmentation of International Law: Difficulties Arising from the Diversification and Expansion of International Law. Report of the Study Group of the International Law Commission, A/CN.4/L.682 (United Nations General Assembly, Geneva), 13 April 2006. On the issue of fragmentation of international law, and the possibility of using crossregime linkages to address this problem, see Oren Perez, 'Multiple Regimes, Issue Linkage, and International Cooperation: Exploring the Role of the WTO', University of Pennsylvania Journal of International Economic Law 26 (4), 2005, 735-778.

${ }^{10}$ Ernst-Ulrich Petersmann argues that: 'the universal recognition of human rights as part of general international law requires a human rights framework for all areas of international law and international organisations so as to render human rights more effective and promote better coherence of national and international law and policies. The state centred tradition of treating individuals as mere objects of international law, and the contradictory behaviour of governments paying lip service to human rights in UN bodies but advocating "realpolitik" without regard to human rights in "specialized" international organizations, are inconsistent with the legal primacy and constitutional functions of human rights.' Ernest-Ulrich Petersmann, 'Time for a United Nations" "Global Compact” For Integrating Human Rights into the Law of Worldwide Organizations: Lessons from European Integration Law for Global Integration Law', in Trade and Human Health and Safety, George A. Bermann and Petros C. Mavroidis (eds.), Columbia Studies in WTO Law and Policy (Cambridge University Press, Cambridge), 2006, 271-326, 275. Pauwelyn argues that human rights norms have an 'integral' character and 'have a standing that is, in many respects, higher than norms establishing mere reciprocal or concessionary obligations' such as those of the international trade regime. Joost Pauwelyn, Conflict of Norms in Public International Law: The Example of the World Trade Organization: Internal Hierarchy and How WTO Law Relates to Other Rules of International Law, Doctoral Thesis, Falculté de Droit (Université de Neuchâtel, Neuchâtel), 2001, 16.

${ }^{11}$ Ernest-Ulrich Petersmann, 'Time for a United Nations' "Global Compact” For Integrating Human Rights into the Law of Worldwide Organizations: Lessons from European Integration Law for Global Integration Law', in Trade and Human Health and Safety, George A. Bermann and Petros C. Mavroidis (eds.), Columbia Studies in WTO Law and Policy (Cambridge University Press, Cambridge), 2006, 271-326, 313.

12 This was seen as a third generation right, a category referring to 'solidarity rights' belonging to peoples 
Development in $1986,{ }^{13}$ which stated that the right to development is 'an inalienable human right by virtue of which every human person and all peoples are entitled to participate in, contribute to, and enjoy economic, social, cultural and political development, in which all human rights and fundamental freedoms can be fully realised. ${ }^{14}$ An emerging international consensus ${ }^{15}$ on the existence of a right to development was evinced in the Vienna Declaration and Programme of Action of the Second World Conference on Human Rights in 1993, which 'reaffirm[ed] the right to development, as established in the Declaration on the Right to Development, as a universal and inalienable right and an integral part of fundamental human rights. ${ }^{16}$ In addition, the UN High Commissioner for Human Rights has been expressly mandated to play an important role in the realisation of the right to development, ${ }^{17}$ and both an open-ended working group and an independent expert on the right to development have been appointed. ${ }^{18}$

The right to development is understood to entail the progressive realisation of all civil, political, economic, social and cultural rights. The right to development encompasses the right of persons to both the improved realisation of the various human rights (i.e. an out-

and covering global concerns. Stephen Marks, 'The Human Right to Development: Between Rhetoric and Reality', Harvard Human Rights Journal 17, 2004, 137-168, 138, available at: http:/www.law.harvard.edu/ students/orgs/hrj/current/marks.shtml\#Heading160, visited on 3 June 2005. Solidarity rights have a plurality of beneficiaries and subjects of the right (interview with Koen de Feyter, Maastricht University, 2 December 2003).

${ }^{13}$ This Declaration was adopted by a UN General Assembly resolution and is thus not legally binding, as is confirmed by the hortatory language in its provisions. See General Assembly, Declaration on the Right to Development, G.A. Resolution 41/128 U.N. GAOR, 41st Sess., Supp. No. 53, at 186, U.N. Doc. A/41/53 (United Nations, Geneva), 4 December 1986, available at: www.unhchr.ch/html/menu3/b/74.htm, visited on 25 June 2007. It was adopted by a majority of 146 countries in favour, with the US voting against and 8 countries abstaining (Australia, Austria, Belgium, Ireland, Japan, Norway and the UK).

${ }^{14}$ Ibid., Article 1.1.

${ }^{15}$ For an interesting analysis on the US position in relation to this emerging consensus, see Stephen Marks, 'The Human Right to Development: Between Rhetoric and Reality', Harvard Human Rights Journal 17, 2004, 137-168, available at: http://www.law.harvard.edu/students/orgs/hrj/current/marks.shtml\#Heading160, visited on 3 June 2005. Marks discusses various reasons for the US opposition to most instruments recognising the right to development as an international human right, including where such instruments acknowledge economic, social and cultural rights and duties, where they propose regulation of state behaviour, or where they challenge the neoliberal approach of the US. However, Marks notes that US practice in development assistance, while refraining from reference to the right to development, does reflect some principles of this right. Ibid. 151-152.

${ }^{16}$ World Conference on Human Rights, Vienna Declaration and Programme of Action, UN Doc. A/CONF.157/23, Vienna), 25 June 1993, para. 10. This Declaration and Programme of Action was adopted unanimously by international consensus of the representatives of 171 countries, indicating that the US had dropped its opposition to the emergence of a right to development. It was endorsed by the UN General Assembly in Resolution 48/141 of 1993. See G.A. Res. 48/141, U.N. GAOR, 48th Sess., Supp. No. 49, at 261, U.N. Doc. A/48/141 (1993).

${ }^{17}$ UN General Assembly Resolution 48/141, U.N. GAOR, $48^{\text {th }}$ Sess., Supp. No. 49, at 261, UN Doc. A/48/141 (1993).

${ }^{18}$ UN Commission on Human Rights, Resolution 72 U.N. ESCOR, 44 ${ }^{\text {th }}$ Sess., Supp. No. 3, at 229, UN Doc. E/ CN.4/1998/177 (1998). This resolution recommended that the Economic and Social Council establish these two organs. The Open-Ended Working Group on the right to development is intended to monitor and review the progress of the Independent Expert and to report back to the Commission on Human Rights. The Independent Expert was mandated to present a study on the state of progress in the implementation of the right to development to each session of the Open-Ended Working Group, as a basis for focused discussion. Dr Arjun Sengupta was appointed as the Independent Expert and wrote 6 reports on the right to development. 
come) and to the process of realising this outcome..$^{19}$ The role of international cooperation in promoting development ${ }^{20}$ and the responsibility of states for the creation of favourable international conditions for the realization of the right to development ${ }^{21}$ are recognised. It is, however, generally accepted that the primary responsibility for promoting development within its territory lies with the developing state itself. ${ }^{22}$

The status of the right to development is not yet definitively established, and its content has not yet fully crystallised. It is thus not possible to derive from it a binding obligation on states or international organisations to contribute to development in specific ways. ${ }^{23}$

${ }^{19}$ Arjun Sengupta, Review of Progress and Obstacles in the Promotion, Implementation, Operationalization, and Enjoyment of the Right to Development. Consideration of the Sixth Report of the Independent Expert on the Right to Development: Implementing the Right to Development in the Current Global Context, UN Doc. E/CN.4/2004/WG.18/2 (UN Commission on Human Rights, Geneva), 17 February 2004, para. 3. This report clarifies that both the ends and the means of the process are to be treated as a right.

${ }^{20}$ The role of the international community in promoting development has been recognised in several key documents. The Declaration on the Right to Development notes, in Article 4.1 that 'States have the duty to take steps, individually and collectively, to formulate international development policies with a view to facilitating the full realisation of the right to development' and in Article 4.2 that '[a]s a complement to the efforts of developing countries, effective international co-operation is essential in providing these countries with appropriate means and facilities to foster their comprehensive development.' General Assembly, Declaration on the Right to Development, G.A. Resolution 41/128 U.N. GAOR, 41st Sess., Supp. No. 53, at 186, U.N. Doc. A/41/53 (United Nations, Geneva), 4 December 1986, Article 4, available at: www.unhchr.ch/html/menu3/b/74.htm, visited 15 June 2007. The Vienna Declaration of the World Conference on Human Rights provides that '... The international community should promote an effective international cooperation for the realisation of the right to development and the elimination of obstacles to development.' World Conference on Human Rights, Vienna Declaration and Programme of Action, UN Doc. A/CONF.157/23, Vienna), 25 June 1993, para.10. The Agenda for Development, presented by the then UN Secretary-General Boutros-Gali in 1994, which seeks to set out a vision of development for the central UN bodies and organs, also refers to the role of the 'international climate' for the realisation of development. Boutros Boutros-Ghali, An Agenda for Development, UN Doc. A/48/935 (United Nations, 6 May 1994, para. 46, available at: www.un.org/Docs/SG/agdev.html, visited 25 June 2007. The Independent Expert on the Right to Development noted in 2004 that while the primary responsibility for translating the potential of the market to contribute to the realisation of the right to development lies with the state, 'there is a definite and significant role for international development cooperation.' Arjun Sengupta, Review of Progress and Obstacles in the Promotion, Implementation, Operationalization, and Enjoyment of the Right to Development. Consideration of the Sixth Report of the Independent Expert on the Right to Development: Implementing the Right to Development in the Current Global Context, UN Doc. E/CN.4/2004/WG.18/2 (UN Commission on Human Rights, Geneva), 17 February 2004, 2.

${ }^{21}$ Article 3.1 of the Declaration provides for the responsibility of states for the creation of 'international conditions favourable to the realization of the right to development' General Assembly, Declaration on the Right to Development, G.A. Resolution 41/128 U.N. GAOR, 41st Sess., Supp. No. 53, at 186, U.N. Doc. A/41/53 (United Nations, Geneva), 4 December 1986, Article 3.1, available at: www.unhchr.ch/html/menu3/b/74. htm, visited 25 June 2007. This Article also refers to the responsibility for the creation of such conditions on national level. The Vienna Declaration of the World Conference on Human Rights notes that "[1]asting progress towards the implementation of the right to development requires...equitable economic relations and a favourable economic environment at the international level.' World Conference on Human Rights, Vienna Declaration and Programme of Action, UN Doc. A/CONF.157/23, Vienna), 25 June 1993, para.10.

${ }^{22}$ The Declaration on the Right to Development provides in Article 2.3 that 'States have the right and duty to formulate appropriate national development policies...' and in Article 8.1 that 'States should undertake, at the national level, all necessary measures for the realisation of the right to development...' and gives a non-exhaustive list of what this entails. General Assembly, Declaration on the Right to Development, G.A. Resolution 41/128 U.N. GAOR, 41st Sess., Supp. No. 53, at 186, U.N. Doc. A/41/53 (United Nations, Geneva), 4 December 1986, Articles 2.3 and 8.1, available at: www.unhchr.ch $/ \mathrm{html} / \mathrm{menu} / \mathrm{b} / 74 . h t m$, visited 25 June 2007. See also Koen De Feyter, World Development Law: Sharing Responsibility for Development (Intersentia, Antwerp), 2001, 23 and 26.

${ }^{23}$ In 2003, the UN Commission on Human Rights requested the Sub-Commission on the Promotion and 
The value of the Declaration on the Right to Development lies, instead, with the establishment of a link between development and human rights. ${ }^{24}$ The subsequent Vienna Declaration and Programme of Action builds upon this recognition. The alleviation of poverty was therein, for the first time, recognised as a human rights goal, ${ }^{25}$ and the fact that development and respect for human rights are interdependent and mutually reinforcing was expressly acknowledged. ${ }^{26}$ Development can no longer be seen purely from an economic growth perspective, but must take into account the impact of development strategies, including in the area of trade liberalisation, on human rights. ${ }^{27}$ With regard to the link between trade liberalisation, development and human rights, the then UN High Commissioner for Human Rights, Mary Robinson noted:

Despite the lack of data, the links between trade, development, and human rights are increasingly plain to see - from the impact of open markets on jobs in developed countries to the implementation of labour and environmental standards in developing countries, from the question of trade-restrictive barriers to protect public health to barriers to full participation by developing countries in the international economic system. These are just some difficult issues that must be addressed if we are to ensure that the global economy contributes to the realization of all human rights for all people... It should be recognized that human rights norms and standards are as relevant to the fields of international trade, finance and investment as to any other area of human activity. The pursuit of equitable development and fair trade are legitimate human rights concerns. ${ }^{28}$

Protection of Human Rights to prepare a draft document with options for the implementation of the right to development, including a binding international standard. This resolution was adopted with 47 countries in favour, 3 against (the US, Australia and Japan) and three abstentions (Canada, Korea and Sweden). Commission on Human Rights, Resolution 2003/83, UN Doc. E/CN.4/RES/2003/83 (2003). The Sub-Commission on the Promotion and Protection of Human Rights delegated the task of preparing a working paper on this issue to one of its members, who submitted this paper in 2005. This report states: 'It can be argued that the right to development is inextricably linked to both civil and political rights and economic, social and cultural rights and requires national implementation of those legally binding obligations that are already set out in the two International Covenants on Human Rights.' However, it notes that there are 'strong differences of opinion among legal luminaries as to whether the right to development can be placed within a legally binding framework.' United Nations Commission on Human Rights, Concept Document on the Right to Development. Working Paper Submitted by Florizelle O'Connor, E/CN.4/Sub.2/2005/23 (Sub-Commission on the Promotion and Protection of Human Rights, Geneva), 24 June 2005, paras 13 and 14.

${ }^{24}$ Interview with Koen de Feyter, 2 December 2003.

${ }^{25}$ World Conference on Human Rights, Vienna Declaration and Programme of Action, UN Doc. A/CONF.157/23, Vienna), 25 June 1993, paras 14 and 25. See also Manfred Nowak, Introduction to the International Human Rights Regime, vol. 14 (Martinus Nijhoff Publishers, Leiden/Boston), 2003, 150.

26 World Conference on Human Rights, Vienna Declaration and Programme of Action, UN Doc. A/ CONF.157/23, Vienna), 25 June 1993, para. 74. This paragraph states in relevant part: '...Actors in the field of development cooperation should bear in mind the mutually reinforcing interrelationship between development, democracy and human rights...'

${ }^{27}$ As stated by Florizelle O'Connor: 'There is a tendency to focus on things that are easier to measure, like economic growth statistics. This type of measurement can be very misleading from a human rights perspective. There is a need to find genuine, effective indicators of true development progress from a human rights perspective.'United Nations Commission on Human Rights, Concept Document on the Right to Development. Working Paper Submitted by Florizelle O'Connor, E/CN.4/Sub.2/2005/23 (Sub-Commission on the Promotion and Protection of Human Rights, Geneva), 24 June 2005, para. 33.

${ }^{28}$ M. Robinson, 'Making the Global Economy Work for Human Rights', in Gary P. Sampson, ed., The Role of the WTO in Global Governance (United Nations University Press, 2001). 
The relevance of the right to development for the world trading system therefore lies in the fact that a state or an organisation whose activities have an impact on development must take full account of the human rights implications of its actions. ${ }^{29}$ This is also true for the states and organisations that form part of the international trading system. ${ }^{30}$ For this reason, while the economic growth achievements of international rules on trade liberalisation are important to promote development, they cannot come at the cost of other rights, such as human life, health and access to safe food. ${ }^{31}$ Instead, mechanisms must be found to appropriately balance these competing goals. The SPS Agreement may be seen as an attempt to achieve such a balance.

It is important to bear in mind that the goals of trade liberalisation and health are not always competing, but can also be mutually reinforcing. In his book Development as Freedom, Amartya Sen, Nobel laureate for economics, emphasised the link between development and various rights or freedoms and the interaction between social and economic freedoms as follows:

Development requires the removal of major sources of unfreedom: poverty as well as tyranny, poor economic opportunities as well as systematic social deprivation, neglect of public facilities as well as intolerance or overactivity of repressive states. Despite unprecedented increases in overall opulence, the contemporary world denies elementary freedoms to vast numbers--perhaps the majority--of people. . . Freedoms are not only the primary ends of development, they are also among its principal means. In addition to acknowledging, foundationally, the evaluative importance of freedom, we also have to understand the remarkable empirical connection that links freedoms of different kinds with one another. Political freedoms (in the form of free speech and elections) help to promote economic security. Social opportunities (in the form of education and health facilities) facilitate economic participation. Economic facilities (in the form of opportunities for participation in trade and production) can help generate personal abundance as well as public resources for social facilities. Freedoms of different kinds can strengthen one another. ${ }^{32}$

Economic growth has been called the 'engine of development as a whole' in the Agenda for Development presented in 1994 by the then UN Secretary-General Boutros Boutros-

\footnotetext{
${ }^{29}$ Nowak notes that the new awareness of the correlation between poverty, development and human rights, as reflected in the results of the second World Conference on Human Rights and the first World Social Summit in Copenhagen on 6-12 March 1995, led the World Bank and the International Monetary Fund to introduce their 'poverty reduction strategy papers', which make poverty reduction and debt relief the main focus of their new and comprehensive development framework. Manfred Nowak, Introduction to the International Human Rights Regime, vol. 14 (Martinus Nijhoff Publishers, Leiden/Boston), 2003, 151.

${ }^{30}$ Fox states: 'A world trade organization of the twenty-first century must be sufficiently copious or porous to take account of the values on which it treads - or on which critical masses believe it treads. Isolation of trade from its impacts is not an appropriate option for the world.' Eleanor M. Fox, 'The Prospective Role of Economic and Social Human Rights in the Law of International Trade Liberalization and Economic Integration: Globalization and Human Rights: Looking out for the Welfare of the Worst Off', NYU Journal of International Law and Politics 35, 2002, 201-220, 210.

${ }^{31}$ The right to health and the right to food are discussed below, Part II, Section 1.1.

32 Amartya Sen, Development as Freedom, 1st ed. (Knopf, New York), 1999, 3-4, 10-11 (emphasis added).
} 
Ghali. ${ }^{33}$ Further, he expressly recognised that the "expansion of international trade is essential to economic growth and is an integral part of the economic dimension of development. ${ }^{34}$ This is a generally accepted proposition. ${ }^{35}$ In order for developing countries to secure the resources necessary for their development needs, they need access to the markets of their trading partners. ${ }^{36}$ Opening up their own markets to imports can also promote growth in developing countries, ${ }^{37}$ providing access to cheaper products and attracting foreign investment. Thus, free trade is not an end in itself, but an instrument for the attainment of economic growth and development. ${ }^{38}$ As noted by Martin Wolf:

${ }^{33}$ Boutros Boutros-Ghali, An Agenda for Development, UN Doc. A/48/935 (United Nations, 6 May 1994, 41, available at: www.un.org/Docs/SG/agdev.html, visited 25 June 2007.

${ }^{34}$ Ibid., 53.

${ }^{35}$ In a background note for UNCTAD XI, the UNCTAD Secretariat states, 'International trade is recognized as an important engine of growth in the world economy...Increasing and predictable earnings from trade can substantially relieve foreign exchange constraints facing developing countries, reduce dependence on foreign aid, and lessen external debt burdens. Improved trade performance can contribute to higher levels of domestic and foreign investment, strengthening and diversifying the economic base and enhancing efficiency in resource allocation through greater competition...By increasing productive employment, trade can create new opportunities for the poor and expand the prospects for more beneficial participation by women in economic activities. Trade can ensure access for the poor to food, essential medicines and basic social services.' United Nations Conference on Trade and Development, Development and Globalisation: Facts and Figures (United Nations, Geneva and New York), 2004, para. 1, available at: www.unctad.org/Templates/WebFlyer. asp?intItemID=3096\&lang=1, visted 21 June 2008 .

${ }^{36}$ Fox argues that if WTO Members were to adopt only one human welfare measure, it should be the elimination of artificial barriers to the trade of developing countries (which according to Oxfam reports, cost developing countries over US\$100 billion per year). This would help the poor to help themselves. See Eleanor M. Fox, 'The Prospective Role of Economic and Social Human Rights in the Law of International Trade Liberalization and Economic Integration: Globalization and Human Rights: Looking out for the Welfare of the Worst Off', NYU Journal of International Law and Politics 35, 2002, 201-220, 211. The UNCTAD 2004 Least Developed Countries report notes, 'International trade can play a powerful role in poverty reduction in the LDCs. It is important because exports and imports facilitate a process of sustained economic growth, the development of productive capacities and expansion of employment opportunities and sustainable livelihoods. For most LDCs, the primary sector, particularly agriculture, dominates production and employment in the economy, and productive capacities are weakly developed. In this situation, exports enable the acquisition, through importation, of goods which are necessary for economic growth and poverty reduction, but which are not produced domestically. These include food, manufactured consumer goods, fuel and raw materials, machinery and equipment and means of transport, and intermediate inputs and spare parts. Through exports it is possible to transform underutilized natural resources and surplus labour into imports which support economic growth.' United Nations Conference on Trade and Development, The Least Developed Countries Report 2004: Linking International Trade with Poverty Reduction, UNCTAD/LDC/2004 (UNCTAD, Geneva), 27 May 2004, 4-5, available at: http://www.unctad.org/en/docs/ldc2004_en.pdf, visited on 7 June 2008.

${ }^{37}$ Although this proposition holds true in perfect market conditions, it is disputed whether in reality, where these conditions are usually not present, trade liberalisation actually benefits developing countries. Empirical studies examining to what extent developing countries have shared in the economic benefits of free trade, show conflicting results. Some show increased inequality in growth between developed and developing countries, whereas others, on the contrary, indicate a narrowing of the income gap. Much of the disparity in results can be ascribed to choices made in the methodology for measuring inequality, which choices embody value judgements about distributive justice. This issue is discussed in an enlightening paper by Ravallion, a World Bank economist. See Martin Ravallion, Competing Concepts of Inequality in the Globalization Debate, Working Paper 3243 (World Bank, Washington D.C.), March 2004. Generally, on the different methodologies for measurement of inequality, see Joel R. Paul, 'Do International Trade Institutions Contribute to Economic Growth and Development?' Virginia Journal of International Law 44 (1), 2003, 284-340, 308-313.

${ }^{38}$ Free trade is a tool for reaching important objectives in the area of economic development, which are mentioned in the preamble to the WTO Agreement, such as raising standards of living, ensuring full employment and an increasing volume of real income and effective demand, allowing for the optimal use of the 
Globalisation does not make countries poor; it helps make them rich. ... But one thing, above all, is clear: if the world is to become less unequal through raising the bottom, rather than collapsing the top, and still more if mass poverty is to be eliminated, it can only be via successful integration, not its opposite. ${ }^{39}$

Nevertheless, it should be emphasised that although free trade is a necessary requirement for economic growth and thus for development ${ }^{40}$ it is not sufficient by itself to reduce poverty $^{41}$ or to achieve full development. ${ }^{42}$ It must go hand in hand with appropriate domestic policies and international assistance to address the costs and fairly distribute the gains of trade liberalisation and to enable developing countries to take advantage of increased market access by addressing supply-side constraints. ${ }^{43}$ As noted by Florizelle O'Connor, member of the Sub-Commission on the Promotion and Protection of Human Rights:

world's resources in accordance with the objective of sustainable development, etc. 'Marrakesh Agreement Establishing the World Trade Organization', in The Results of the Uruguay Round of Multilateral Trade Negotiations: The Legal Texts (World Trade Organization, Geneva), 1994, 6-18, 1st recital.

${ }^{39}$ Martin Wolf, 'Growth Makes the Poor Richer', Financial Times, 24 January 2001.

${ }^{40}$ One of the five dimensions of development, identified by Boutros-Ghali in his Agenda for Development, is economic growth. However, although it is considered necessary for development, economic growth is not regarded as sufficient in itself to achieve development. Boutros Boutros-Ghali, An Agenda for Development, UN Doc. A/48/935 (United Nations, 6 May 1994, 41-43, available at: www.un.org/Docs/SG/agdev.html, visited 25 June 2007. The other four dimensions of development identified in this document are peace, the environment, social justice and democracy.

${ }^{41}$ Ravallion discusses the issue of 'pro-poor growth', examining different definitions of this concept and suggesting factors that make growth more pro-poor. He argues that growth is typically pro-poor in the sense that poor people benefit in absolute terms (absolute poverty measures fall with growth), since studies have shown that growth tends to be 'distribution neutral' on average. He notes, however, that the same rate of growth can bring very different rates of poverty reduction in different countries. This is due to two main factors. First, the differences in initial inequality (for example with regard to access to private assets and public goods) within the populations of different countries affect the extent to which growth benefits the poor. Second, differences between countries with regard to changing income distribution (for example through changes to the trade regime, tax reforms and welfare-policy reforms) affect the pro-poor impact of growth. Ravallion points to the concentration of poor people in certain regions or sectors, such as rural areas and the agricultural sector, and notes that high growth in several developing countries has not been accompanied by growth in poor areas but has rather led to widening inequalities. Therefore it is important that public policies address distributional aspects to ensure that economic growth benefits the poor. See Martin Ravallion, Pro-Poor Growth: A Primer, Working Paper 3242 (World Bank, Washington D.C.), March 2004.

${ }^{42}$ The report regarding how to meet the Millennium Development Goals, issued in 2005 by the UN Millennium Project (an advisory body to UN Secretary-General Kofi Annan) emphasises that while trade liberalisation is indispensable for economic development and thus poverty reduction, it is not a 'magic bullet'. Instead, trade liberalisation must go hand-in-hand with complementary national and international development policies. It notes that international trade policy should focus on two issues: improving market access and terms of trade for the poorest countries; and improving supply-side competitiveness of poor countries' exports by means of investments in infrastructure. See UN Millennium Project, Investing in Development: A Practical Plan to Achieve the Millennium Development Goals (United Nations Development Programme, New York), 2005, 211, available at: http://www.unmillenniumproject.org/reports/fullreport.htm, visited on 7 January 2008. See also Sally, who points out that careful qualification is needed 'in order not to oversell the case for external liberalisation and convey the impression that it is a panacea.' Razeen Sally, Whither the World Trading System? Trade Policy Reform, the WTO and Prospects for the New Round, No. 76 (Timbro, Stockholm), 2002, 10, available at: http://www.timbro.se/pdf/whither.pdf, visited on 28 January 2008.

${ }^{43}$ The Havana Programme of Action, adopted by the G-77 and China at the first South Summit on 12-14 April 2000 and circulated as a document of the UN Millennium Summit, expressly calls for:'[w] the effective integration of all countries into the international trading system including improving supplyside capabilities of developing countries especially the least developed among them...' General Assembly, 
Concrete funding commitments from rich donor countries and international organizations are absolutely essential for meaningful progress to be achieved in the right to development. Admittedly, this is a controversial topic ... We must avoid duplication of work, but constructive ways must be explored of bringing the entire international family of Governments and organizations together to promote the right to development for all peoples. This is not somebody else's problem - this is everyone's problem - more so in the context of a globalized world. ${ }^{44}$

Equally importantly, free trade must be achieved by disciplines that are appropriate to the particular situation of developing countries and are thus supportive of development. ${ }^{45}$ This necessitates the recognition of the special position developing countries occupy in the world trading system. ${ }^{46}$

The special position of developing countries is already recognised in the preamble to the WTO Agreement ${ }^{47}$ It has come to the forefront of attention with the launching of the

Fifty-Fifth Session of the General Assembly. Letter Dated 5 May 2000 from the Permanent Representative of Nigeria to the United Nations Addressed to the President of the General Assembly, A/55/74 (United Nations, New York), 12 May 2000, Annex II para. V(1) 12th bullet point available at: www.G77.org/main/docs/summitfinaldocs_english.pdf, visited on 28 January 2008. Similarly, it is noted in the UNCTAD LDC Report 2004 that international assistance to address supply-side constraints (together with better national development strategies and improvements to the international trade regime) is essential if international trade is to become a more effective instrument of poverty reduction. See United Nations Conference on Trade and Development, The Least Developed Countries Report 2004: Linking International Trade with Poverty Reduction, UNCTAD/ LDC/2004 (UNCTAD, Geneva), 27 May 2004, 21, available at: http:/www.unctad.org/en/docs/ldc2004 en.pdf, visited on 7 June 2008.

${ }^{44}$ United Nations Commission on Human Rights, Concept Document on the Right to Development. Working Paper Submitted by Florizelle O'Connor, E/CN.4/Sub.2/2005/23 (Sub-Commission on the Promotion and Protection of Human Rights, Geneva), 24 June 2005, para. 49.

${ }^{45}$ It is important to move away from the idea that prevailed in the 70 s that economic growth is synonymous with development. Instead, development should be seen as a multidimensional concept, and progress made in one dimension, for example economic growth through trade liberalisation, should not be at the expense of another dimension. See Koen De Feyter, World Development Law: Sharing Responsibility for Development (Intersentia, Antwerp), 2001, 16. In this regard, it is interesting to note that the report of the Consultative Board on The Future of the WTO states that if the poorest Members of the WTO do not receive real benefits from membership, 'the moral case for the WTO as a source of good is diminished.' See Peter Sutherland et al., The Future of the WTO: Addressing Institutional Challenges in the New Millennium. Report by the Consultative Board to the Director-General Supachai Panitchpakdi (World Trade Organization, Geneva), 2004, para.48, available at: http://www.wto.org/english/thewto_e/10anniv_e/future_wto_e.pdf, visited on 25 June 2008 .

${ }^{46}$ The Declaration of the South Summit of the G-77 and China, adopted on 14 April 2000 and circulated as a document of the UN Millennium Summit, underlines the 'urgent need to redress the imbalances in the present WTO Agreements, and in particular, with regard to the right of developing countries to promote their exports...' and calls for, inter alia, negotiation with the objective of incorporating the agricultural sector within normal WTO rules. General Assembly, Fifty-Fifth Session of the General Assembly. Letter Dated 5 May 2000 from the Permanent Representative of Nigeria to the United Nations Addressed to the President of the General Assembly, A/55/74 (United Nations, New York), 12 May 2000, Annex I para. 20, available at: www.G77.org/ main/docs/summitfinaldocs_english.pdf, visited on 28 January 2008.

${ }^{47}$ The Preamble recognizes 'that there is need for positive efforts designed to ensure that developing countries, and especially the least developed among them, secure a share in the growth in international trade commensurate with the needs of their economic development.' 'Marrakesh Agreement Establishing the World Trade Organization', in The Results of the Uruguay Round of Multilateral Trade Negotiations: The Legal Texts (World Trade Organization, Geneva), 1994, 6-18, 2nd recital. 
Doha Round of trade negotiations in November 2001. The explicit commitment in the Ministerial Declaration setting the agenda for negotiations in the Doha Round, known as the Doha Development Agenda, to 'seek to place developing country needs and interests at the heart of the Work Programme adopted in [that] Declaration', ${ }^{48}$ reflects a new-found international consensus regarding the urgency of the need to integrate developing countries into the world trading system. It is important that this commitment not remain at the level of rhetoric, but be given content in the negotiations themselves. It is here that research can contribute. As pointed out by World Bank economists Finger and Schuler:

In upcoming trade negotiations, more imaginative thinking will be needed to examine reforms in the WTO in ways that make sense from a development perspective....Trade ministers at Doha (implicitly) called attention to the need for such thinking; the research community should interpret this as a challenge to provide it. ${ }^{49}$

\subsection{The definition of 'developing countries'}

It is first necessary to establish what is meant by 'developing countries' for purposes of the world trading system. Initially, the GATT 1947 did not contain special provisions for developing countries and thus there was no need to determine which countries could be considered as developing. With time, provisions were added to take into account the special position of developing countries. First, in an early review of the GATT 1947 (discussed below), the application of certain parts of Article XVIII, regarding the protection of infant industries and additional flexibility for balance-of-payments restrictions, was limited to 'a contracting party the economy of which can only support low standards of living and is in the early stages of development'.$^{50}$ Later, provisions were added to the GATT 1947 that distinguished between 'developed' and 'less-developed' countries. However, no definitions of these two terms existed under the GATT 1947. Instead, a system of self-selection applied, meaning that GATT Contracting Parties were free to decide for themselves whether they were developed or less-developed countries.

Currently the WTO agreements contain numerous provisions in favour of 'developing countries', ${ }^{11}$ and 'least-developed countries'. The system of self-selection still applies in

${ }^{48}$ Ministerial Conference, Doha Ministerial Declaration. Adopted on 14 November 2001, WT/MIN(01)/DEC/1, circulated on 20 November 2001, para. 2.

${ }^{49}$ J. Michael Finger and Philip Schuler, 'Implementation of WTO Commitments. The Development Challenge', in Development, Trade and the WTO: A Handbook, Philip English, et al. (eds.) (World Bank), 2002, 493-503, 501, available at: http://publications.worldbank.org/catalog/product-detail?product_id=1525978\&, visited on 5 June 2003.

${ }^{50}$ Article XVIII:4(a) of the GATT 1947. The terms 'can only support low standards of living' and 'in the early stages of development' are clarified in an interpretative note to Article XVIII. According to this interpretative note, the determination of whether an economy 'can only support low standards of living' must take into account the normal position of that economy and not be based on exceptional circumstances such as temporarily favourable conditions for the staple exports of the relevant country. The term 'in the early stages of development' is broadly defined to include not only countries that have just started their economic development, but also those undergoing industrialisation to correct an excessive dependence on primary production.

${ }^{51}$ Although the GATT 1947 used the term 'less-developed countries' to refer to this group of countries, the new WTO Agreements negotiated in the Uruguay Round use the term 'developing countries'. However, the term 
the WTO regime with regard to the category of 'developing countries'. ${ }^{52}$ However, the decision of a WTO Member to make use of the special provisions in WTO Agreements available only to developing countries can be challenged by other Members. ${ }^{53}$ In contrast, least-developed countries (LDCs) are defined for WTO purposes according to the UN classification. ${ }^{54}$

It is important to remember that developing countries are not a homogenous group. ${ }^{55}$ There are significant differences between these countries, inter alia, with regard to gross domestic product (GDP), share in world trade, level of industrialisation, export diversification, infrastructure and participation in international negotiations on trade issues. ${ }^{56}$

'less-developed countries' is still used in the GATT 1994, as it incorporates by reference the provisions of the GATT 1947. In this book, the term 'developing countries' will be used throughout.

${ }^{52}$ It is interesting to note that it is possible for a Member to be a 'developing-country Member' for purposes of one WTO agreement while not being so for purposes of another. China is an example of this.

53 This happens mainly in diplomatic or political exchanges, often outside the context of formal meetings.

54 The UN currently classifies a group of 49 countries (originally 24) as least developed countries (LDCs). These are: Afghanistan, Angola, Bangladesh, Benin, Bhutan, Burkina Faso, Burundi, Cambodia, the Central African Republic, Chad, the Comoros, the Democratic Republic of the Congo, Djibouti, Equatorial Guinea, Eritrea, Ethiopia, Gambia, Guinea, Guinea-Bissau, Haiti, Kiribati, the Lao People's Democratic Republic, Lesotho, Liberia, Madagascar, Malawi, Maldives, Mali, Mauritania, Mozambique, Myanmar, Nepal, Niger, Rwanda, Samoa, Sao Tome and Principe, Senegal, Sierra Leone, Solomon Islands, Somalia, Sudan, Timor-Leste (as of December 2003), Togo, Tuvalu, Uganda, the United Republic of Tanzania, Vanuatu, Yemen and Zambia. United Nations Conference on Trade and Development, The Least Developed Countries Report 2007: Knowledge, Technological Learning and Innovation for Development, UNCTAD/LDC/2007 (UNCTAD, Geneva), 2007, available at: http://www.unctad.org/en/docs/ldc2007_en.pdf, visited on 7 June 2008. To be classified as an LDC, countries must fall below certain thresholds established regarding income, economic diversification and social development. The current criteria are: low national income (per capita GDP under $\$ 745$ for inclusion in, and above US $\$ 900$ for graduation from, the list), weak human resources (a composite index based on health, nutrition and education indicators) and high economic vulnerability (a composite index based on indicators of instability of agricultural production and exports, inadequate diversification and economic smallness). Different thresholds are used for addition to, and graduation from, the list of LDCs. A country qualifies for addition to the list if it meets inclusion thresholds on all three criteria, and if its population does not exceed 75 million. To graduate from the list a country must reach threshold levels for graduation for at least two of the three criteria in two consecutive triennial reviews or its GNI per capita must exceed at least twice the threshold level, and there must be a high degree of likelihood that the level of GNI per capita is sustainable. On 1 June 2008, 32 of these 49 LDCs were WTO Members, namely Angola, Bangladesh, Benin, Burkina Faso, Burundi, Cambodia, Central African Republic, Chad, Democratic Republic of the Congo, Djibouti, Gambia, Guinea, Guinea Bissau, Haiti, Lesotho, Madagascar, Malawi, Maldives, Mali, Mauritania, Mozambique, Myanmar, Nepal, Niger, Rwanda, Senegal, Sierra Leone, Solomon Islands, Tanzania, Togo, Uganda and Zambia. Although Cape Verde was an LDC at the time of its accession to the WTO in December 2007, it graduated from LDC status at the end of 2007. See UN Office of the High Representative for the Least Developed Countries, Landlocked Developing Countries and Small Island Developing States, 'No more an LDC, Cape Verde looks to build on economic gains', 19 February 2008, available at: http://www.unohrlls.org/ en/orphan/590/, visited on 8 June 2008. Nine other LDCs are in the process of accession to the WTO, namely Afghanistan, Bhutan, Ethiopia, Laos, Samoa, Sao Tome \& Principe, Sudan, Vanuatu and Yemen. Vanuatu has completed accession negotiations but has yet to ratify its accession protocol. This list of least-developed-country WTO Members and accession candidates is available at: http://www.wto.org/english/thewto_e/whatis_e/ tif e/org7 e.htm, visited on 1 June 2008.

${ }^{55}$ Patrick Low notes that despite the misleading assumption by some authors on developing country matters in the WTO context that developing countries are a homogenous group, the diversity of interests and priorities among developing-country Members is increasingly obvious. Patrick Low, 'Is the WTO Doing Enough for Developing Countries?' in WTO Law and Developing Countries, George A. Bermann and Petros C. Mavroidis (eds.) (Cambridge University Press, Cambridge), 2007, 324-358, 324.

${ }^{56}$ Further, within many large countries (such as Russia and China) there are also often large internal differences in level of development. In this regard, Picker proposes that, for purposes of special treatment of developing 
There are also considerable differences with regard to levels of human development, including poverty incidence and health status. Despite these distinctions, there is no differentiation within the WTO system between different groups of developing countries, aside from the category of least-developed countries. Even in the context of the various work programmes of the WTO Committee on Trade and Development, ${ }^{57}$ for example the work programme on 'small economies' and on 'small island developing states' under the Doha Development Round mandate, ${ }^{58}$ it is expressly stated that the aim of this work is not to create sub-categories of WTO Members, but 'to frame responses to the trade-related issues identified for the fuller integration of small, vulnerable economies into the multilateral trading system.' ${ }^{59}$

Outside the WTO context, various efforts have been made to sub-divide the category of developing countries. ${ }^{60}$ Aside from the group of least-developed countries, the UN has recognised the categories of landlocked developing countries, ${ }^{61}$ small island develop-

countries under WTO rules, geographic differentiation within a country between less- and more-developed regions be made. In this way, special treatment could be limited to developing regions rather than whole countries. See Colin B. Picker, 'Neither Here nor There - Countries That Are Neither Developing nor Developed in the WTO: Geographic Differentiation as Applied to Russia and the WTO', George Washington International Law Review 36, 2004, 147-171. However, the practical difficulty of implementing such a proposal should not be underestimated.

57 The mandate for work in this area was delegated by the General Council to dedicated sessions of the Committee on Trade and Development at its meeting on 1 March 2002. See World Trade Organization.

${ }^{58}$ Ministerial Conference, Doha Ministerial Declaration. Adopted on 14 November 2001, WT/MIN(01)/DEC/1, circulated on 20 November 2001, para. 35.

59 Ibid.

${ }^{60}$ For example, in the Second Joint WTO/OECD Report on Trade-Related Technical Assistance and Capacity Building (TRTA/CB), developing countries are categorised as follows: Least Developed Countries; Other Low Income Countries, include all non-LDC with per capita GNI below US\$ 760 in 1998 (World Bank Atlas basis); Lower Middle Income Countries, include all countries with per capita GNI between US\$ 761 and US\$ 3030 in 1998; Upper Middle Income Countries, include all countries with per capita GNI between US\$ 3031 and US\$ 9360 in 1998; High Income Countries, include developing countries with per capita GNI above US\$ 9360 in 1998; Central and Eastern European Countries / New Independent States (of the former Soviet Union) excluding those considered as developing countries; and More Advanced Developing Countries and Territories.

${ }^{61}$ Landlocked developing countries are defined in the UN Convention on the Law of the Sea as a country that has no sea coast. There are 31 such countries, 16 of which are also least developed countries. In its 2004 Report on Development and Globalization, UNCTAD notes that such countries face many development constraints, such as small domestic markets, great vulnerability to economic shocks and natural disasters and little human resources. In addition, their remoteness from world markets and fact that they export mainly low-value bulk commodities make transport costs particularly burdensome and diminish the possibilities for exportled growth. See United Nations Conference on Trade and Development, Development and Globalisation: Facts and Figures (United Nations, Geneva and New York), 2004, 4, available at: www.unctad.org/Templates/ WebFlyer.asp?intItemID=3096\&lang=1, visited on 21 June 2008. 
ing states ${ }^{62}$ and African countries, ${ }^{63}$ based on the common problems and constraints of countries within those groups. The World Bank and the International Monetary Fund differentiate between categories of developing countries on the basis of per capita income, for purposes of determining eligibility for financial assistance. ${ }^{64}$ The United Nations Development Programme (UNDP) distinguishes between countries with high, medium and low human development, as reflected in its Human Development Index. ${ }^{65}$ In addition, UNCTAD uses a system of classification of countries into 'main economic areas' ${ }^{66}$ Some of these divisions are based purely on economic criteria such as GNP or per capita income; whereas others take into account other factors such as geographic conditions or human development criteria. While the appropriate sub-division is open to debate, ${ }^{67}$ it is

${ }^{62}$ No official criteria have been established by the UN for inclusion in the category of small island developing states. Instead, reference is usually had to membership in the Alliance of Small Island States. UNCTAD undertakes extensive studies on the impact of trade liberalisation on small island developing states. The World Bank Group has a small island exception in its eligibility policy regarding international development association concessionary treatment. In the WTO work programme on small economies, some proposals have been made with regard to small island developing countries. Small island developing countries, as noted by UNCTAD, face greater risks of marginalisation from the world economy due to their remoteness from large markets, high transport costs, small size, high environmental vulnerability and exposure to natural disasters. See United Nations Conference on Trade and Development, The Least Developed Countries Report 2004: Linking International Trade with Poverty Reduction, UNCTAD/LDC/2004 (UNCTAD, Geneva), 27 May 2004, 6, available at: http://www.unctad.org/en/docs/ldc2004_en.pdf, visited on 7 June 2008.

${ }^{63}$ African countries can be divided into North Africa and Sub-Saharan Africa. These countries evince slow and erratic economic growth and an average decline in real per capita GDP in the 1990s. They are heavily dependent on commodity trade, but face declining market share in this sector. UNCTAD has conducted studies on Africa's economic performance. This information is provided in Ibid., 8.

${ }^{64}$ The International Development Association (IDA) is the part of the World Bank that lends money to the lowincome countries on concessional terms (i.e. interest free and with repayments over 35-40 years). Eligibility for IDA loans is principally based on a country's relative poverty, defined as GNI per capita below a certain threshold (in fiscal year 2008 this is US\$1,065). Middle-income countries (defined as having a per capita income of between US\$1,066 and US\$10,000) and low-income countries that are creditworthy are eligible to lend money from the International Bank for Reconstruction and Development (IBRD). This information is taken from the website of the World Bank, available at: http://go.worldbank.org/YX2261GMX0, visited on 8 June 2008. Eligibility for funding from the International Monetary Fund's Poverty Reduction and Growth Facility is also mainly based on a country's per capita income as well as its eligibility under the IDA of the World Bank. This information is taken from the website of the IMF, available at: http://www.imf.org/external/ $\mathrm{np} / \mathrm{sec} / \mathrm{nb} / 2000 / \mathrm{nb} 0081 . \mathrm{htm}$, visited on 8 June 2008

${ }^{65}$ The criteria used as the basis for this index are discussed in below, Part II, Section 2.2.

${ }^{66}$ UNCTAD's country classification (developed for purposes of statistical convenience) according to main economic areas is as follows: Developed market economy countries: Australia, Canada, the European Union (Austria, Belgium, Denmark, Finland, France, Germany, Greece, Ireland, Italy, Luxembourg, the Netherlands, Portugal, Spain, Sweden and the UK), Faeroe Islands, Gibraltar, Iceland, Israel, Japan, New Zealand, Norway, South Africa, Switzerland and the United States. Countries in Eastern Europe: Albania, Belarus, Bulgaria, the Czech Republic, Estonia, Hungary, Latvia, Lithuania, Poland, the Republic of Moldova, Romania, the Russian Federation, Slovakia and Ukraine. Developing countries and territories: All other countries, territories and areas in Africa, Asia, America, Europe and Oceania not specified above. United Nations Conference on Trade and Development, The Least Developed Countries Report 2002: Escaping the Poverty Trap, UNCTAD/ LDC/2002 (UNCTAD, Geneva), 18 June 2002, available at: http://www.unctad.org/en/docs/ldc2002_en.pdf, visited on 7 June 2008.

${ }^{67}$ Picker goes even further and argues that the division should not be between countries but within countries. He points to the problem that some countries are difficult to classify as developed or developing, due to huge economic disparities within these countries. He mentions the examples of China, Russia and India. He notes that these countries are too large and their impact on world trade is too great for WTO Members to be willing to grant them developing country status when deciding on preferential regimes and in the conduct of accession negotiations (as the examples of WTO accession negotiations with China and currently Russia illustrate). 
indubitable that the differences between developing countries have a significant impact on their ability to participate in the negotiation of world trade rules, to implement these rules and to benefit fully from them. This is particularly the case for rules that have implications for behind-the-border regulatory systems and require substantial investments for their implementation, ${ }^{68}$ such as those in the SPS Agreement.

There is clearly a need to take such differences into account in WTO rules, in particular in those rules that make provision for SDT and technical assistance for developing countries. Such recognition may also increase the willingness of developed countries to agree to more meaningful SDT provisions and implement such rules ${ }^{69}$ Currently, many SDT provisions are only 'best-endeavour' obligations and are poorly implemented, reflecting a reluctance of Members to undertake binding obligations to provide special treatment to all self-declared developing-country Members, including those more-developed developing countries that are effective competitors on the world market. However, there has been strong opposition from developing countries themselves, especially the more developed among them, to any suggestion of differentiation between developing countries (other than for least-developed countries) in the WTO context. ${ }^{70}$

\subsection{Developing countries in the early years of the GATT 1947}

Despite the fact that 11 of the 23 countries that negotiated the GATT $1947^{71}$ were countries that are now regarded as developing, ${ }^{72}$ the GATT, in its original form, did not make

Nevertheless, regions within these countries, especially in rural areas, are characterised by abject poverty. See Colin B. Picker, 'Neither Here nor There - Countries That Are Neither Developing nor Developed in the WTO: Geographic Differentiation as Applied to Russia and the WTO', George Washington International Law Review 36, 2004, 147-171.

${ }^{68}$ As Hoekman et al. aptly put it, 'One size does not fit all' when it comes to WTO rules on domestic regulation or that require substantial investments to be implemented.' Bernard Hoekman et al., More Favorable Differential Treatment of Developing Countries: Towards a New Approach in the WTO, World Bank Policy Research Working Paper 3107 (World Bank, Washington D.C.), August 2003, 3, available at: www.econ. worldbank.org/files/28991_wps3107.pdf, visited on 11 November 2004.

69 A New Approach to Special and Differential Treatment, IPC position paper (International Food and Agricultural Trade Policy Council, Washington D.C.), 15 September 2004, 2, available at: www.agritrade.org/ Publications/Position\%20Papers/13\%20SND.pdf, visited on 25 June 2007.

${ }^{70}$ Low argues that the refusal of developing-country Members to engage in any discussion on differentiation or graduation is due to an 'analytical deficit' in SDT proposals. He notes that developing countries have tended to view SDT 'as a political right rather than a development imperative.' He notes that this analysis-free thinking has facilitated the dismissal by developed Members of the underlying case for SDT. Patrick Low, 'Is the WTO Doing Enough for Developing Countries?' in WTO Law and Developing Countries, George A. Bermann and Petros C. Mavroidis (eds.) (Cambridge University Press, Cambridge), 2007, 324-358, 334.

71 The negotiation of the GATT 1947 was concluded in October 1947, but it was intended to go hand-in-hand with the establishment of an International Trade Organization (ITO). As the negotiations towards the ITO were intended to be completed only in 1948 and there was some urgency in bringing the negotiated GATT disciplines into effect, the GATT provisions came into force provisionally through the Protocol of Provisional Application (PPA) (55 UNTS 308 (1947)), pending the completion of negotiations on the ITO. It was understood that the GATT 1947 would be submitted to national legislatures for definitive application together with the ITO Charter. As the ITO never came into existence, the GATT 1947 itself never came into force but its provisions continued to apply through the PPA. See John H. Jackson, The World Trading System: Law and Policy of International Economic Relations, Second ed. (MIT Press, Cambridge), 1997, 39-40.

${ }^{72}$ These 11 developing countries were Brazil, Burma (Myanmar), China, Ceylon (Sri Lanka), Chile, Cuba, 
special provision for developing countries. This can be explained by the historical context of the GATT negotiations. The relations between the developed and developing regions of the world were largely governed by colonialism and there was not yet a significant break between developed and developing countries. ${ }^{73}$

The GATT 1947 emphasised the fundamental principle of non-discrimination. ${ }^{74}$ Article I of the GATT embodies the principle of most-favoured-nation (MFN) treatment, which requires that any benefit or advantage accorded by a GATT Contracting Party to the products originating in or destined for any other country must be immediately and unconditionally granted to the like product originating in or destined for all other GATT Contracting Parties. As a result, no preferential treatment could be granted to products from any developing country, as the same preference would have to be immediately granted to all GATT Contracting Parties. The underlying idea was that discrimination in favour of a particular country was welfare-decreasing and resulted in a misallocation of the scarce resources of the world. The drafters of the GATT believed that all countries stood to benefit from the trade liberalisation rules contained therein, by adopting outward oriented policies and exploiting their comparative advantage.

As a result of its non-discrimination focus, the GATT disciplines, as negotiated in 1947, applied uniformly to all its Contracting Parties. Article XII of the GATT, which provided an exception to the general prohibition on quantitative restrictions to trade for restrictions to safeguard balance of payments, ${ }^{75}$ was equally available to all Contracting Parties. However, some of its requirements were thought to be too restrictive to take into account the fact that developing countries often tend to face chronic balance of payments problems. Even the addition, by means of an amendment in 1948, of Article XVIII entitled 'Government Assistance to Economic Development and Reconstruction'76 which made provision for the Contracting Parties ${ }^{77}$ to give permission for a Contracting Party to

India, Lebanon, Pakistan, Southern Rhodesia (Zimbabwe) and Syria.

${ }^{73}$ Koen De Feyter, World Development Law: Sharing Responsibility for Development (Intersentia, Antwerp), 2001,71 .

${ }^{74}$ The Preamble to the GATT 1947 indicated in its third recital that its objectives would be achieved by 'entering into reciprocal and mutually advantageous arrangements directed to the substantial reduction of tariffs and other barriers to trade and to the elimination of discriminatory treatment in international commerce'.

75 This exception was agreed upon by the United States and Britain as early as 1943. It aimed to take into account the fact that post-war reconstruction, domestic employment or social policies could result in an increased demand for imports, thus threatening the balance of payments in countries. See John H. Jackson, World Trade and the Law of GATT: A Legal Analysis of the General Agreement on Tariffs and Trade (Bobbs Merrill, Indianapolis), 1969, 678.

76 This provision was negotiated as Article 13 of the ITO Charter, which was intended to establish the 'International Trade Organization' (ITO), the organisation under which the GATT 1947 would operate. The ITO Charter was not approved by the US Congress and as a result the ITO never came into being since countries did not want to be part of an international trade organisation which did not include the US. Certain provisions of the ITO Charter were subsequently, mutatis mutandis, carried over into the GATT 1947 by amendment. See Havana Charter for an International Trade Organization, UN Doc. E/Conf.2/78, United Nations Conference on Trade and Employment, 28 March 1948.

77 As the GATT 1947 was intended to be a treaty on the reduction of tariffs and other trade barriers, not a treaty establishing an international organisation, multilateral decisions taken there under were taken by the Contracting Parties, acting jointly, rather than by any organ or body. The designation 'Contracting ParTies' is therefore, according to Article XXV of the GATT, a reference to the Contracting Parties acting jointly, in other words the collective decision-making forum under the GATT 1947. Later, a large number of subordinate bodies such as committees, working parties and panels were established to carry out the tasks under the GATT, 
use protective measures that would otherwise be in conflict with GATT disciplines in order to promote the establishment, development or reconstruction of a particular industry or branch of agriculture, applied equally to developing and developed countries. It was aimed at post-World War II reconstruction in developed countries rather than at the promotion of development. ${ }^{78}$ Developing countries raised concerns regarding the focus on the development of a particular industry and the requirement of prior permission in this article. ${ }^{79}$

The above illustrates the fact that although the negotiated rules were equally applicable to all Contracting Parties, this does not mean that they had the same impact on developed and developing countries ${ }^{80}$ Instead, loopholes and flexibilities in the trade rules were negotiated in areas most useful to developed countries. ${ }^{81}$ As noted by John Jackson:

The issues at Geneva in 1947 did not, viewed from the perspective of the present day, seem to be free trade versus protectionism, or internationalism versus national sovereignty. Each of the groups in the debate desired international control of some things and not of others. Both sides desired to use certain types of trade protective measures but wanted to limit or restrict others. The controversy seemed to be over which trade restrictions would be subjected to international control and which not. From the point of view of the less-developed country, the wealthy countries wanted freedom to use those restrictions that only they were most able to use effectively while banning those restrictions that less-developed countries felt they were most able to use. ${ }^{82}$

and the meetings of the Contracting Parties were reduced to yearly sessions of a few days each. See John H. Jackson, The World Trading System: Law and Policy of International Economic Relations, Second ed. (MIT Press, Cambridge), 1997, 38 and 63.

${ }^{78}$ De Feyter points out that the main priority after World War II was reconstruction, not development. Koen De Feyter, World Development Law: Sharing Responsibility for Development (Intersentia, Antwerp), $2001,71$.

79 John H. Jackson, World Trade and the Law of GATT: A Legal Analysis of the General Agreement on Tariffs and Trade (Bobbs Merrill, Indianapolis), 1969, 687.

${ }^{80}$ In examining whether GATT 1947 rules, in practice, discriminated against developing countries Jackson points to the distinction made in GATT between primary and industrial products. For example, he notes the exemption of primary products from the disciplines on antidumping and countervailing duties in Article VI:7, the exception in Article XI:2(c) from the prohibition on quantitative restrictions for quotas on any agricultural or fisheries product in certain circumstances, and the exclusion of primary products from the prohibition on export subsidies in Article XVI:4. In addition Jackson notes the argument that GATT applies more stringent disciplines on those types of trade barriers commonly used by developing countries, namely quantitative restrictions, than those used by developed countries, such as subsidies. Ibid., 665.

${ }^{81}$ This point was recently made in the report of the UN Millennium Project, which notes, 'Developing countries, sometimes by their own decision and other times by explicit exclusion dictated by richer countries, have not been influential in the [trading ] system's design. Moreover, most of today's multilateral rules have emulated to a great extent the policies, the practices, and most important, the laws and regulations of only a few developed countries.' UN Millennium Project, Investing in Development: A Practical Plan to Achieve the Millennium Development Goals (United Nations Development Programme, New York), 2005, 212, available at: http://www.unmillenniumproject.org/reports/fullreport.htm, visited on 7 January 2008.

82 John H. Jackson, World Trade and the Law of GATT: A Legal Analysis of the General Agreement on Tariffs and Trade (Bobbs Merrill, Indianapolis), 1969, 637-638. Jackson goes on to point out, however, that in practice developing countries were usually able to make use of the balance-of-payments exceptions in the GATT in order to apply quantitative restrictions to trade with much freedom. 
Due to the relative strength of the positions of the negotiating countries, developed and developing, developed country interests came to be reflected in the negotiated rules.

The GATT 1947 was reviewed in 1954-1955 ${ }^{83}$ and on the insistence of developing country Contracting Parties, this Review Session recognised for the first time the need for additional flexibility in GATT disciplines for developing countries, thus introducing the concept of differential treatment of developing countries into the GATT. This 'differential treatment' took the form of exempting developing countries from certain GATT disciplines. In the Review Session, Article XVIII (discussed above) was amended, limiting the application of parts $\mathrm{A}, \mathrm{B}$ and $\mathrm{C}$ thereof to 'a contracting party the economy of which can only support low standards of living and is in the early stages of development'. ${ }^{84}$ Thus, developed countries were excluded from making use of the exemption provided in these paragraphs of Article XVIII. ${ }^{85}$ Parts A, C and D of Article XVIII allow for the protection of infant industries in order to raise the standard of living or promote economic development by means of measures that deviate from GATT rules, for example by imposing tariffs above the bound level ${ }^{86}$ or applying quotas or other non-tariff measures. ${ }^{87}$ The new Article XVIII: B recognises the structural nature of developing countries' balance-ofpayments problems and thus allows the countries falling within its scope of application

\footnotetext{
${ }^{83}$ As it had become apparent by the 1950s that no ITO would be established and that the GATT was developing into the main international organisation for trade, the Contracting Parties saw the necessity of reviewing and amending the GATT. Thus the $9^{\text {th }}$ regular session of the Contracting PARTIEs was designated a 'review session' and resulted in protocols to amend the GATT. See John H. Jackson, The World Trading System: Law and Policy of International Economic Relations, Second ed. (MIT Press, Cambridge), 1997, 42.

${ }^{84}$ Article XVIII:4(a) of the GATT 1947. The terms 'can only support low standards of living' and 'in the early stages of development' are clarified in an interpretative note to Article VIII. According to this interpretative note, the determination of whether an economy 'can only support low standards of living' must take into account the normal position of that economy and not be based on exceptional circumstances such as temporarily favourable conditions for the staple exports of the relevant country. The term 'in the early stages of development' is broadly defined to include not only countries that have just started their economic development, but also those undergoing industrialisation to correct an excessive dependence on primary production.

${ }^{85}$ However, Article XVIII:4(b) does allow recourse to Section D of this article by 'a contracting party, the economy of which is in the process of development' but which does not fall within the scope of Subparagraph (a). This is generally accepted to mean countries whose economies can support a high standard of living but are dependent on exports of primary commodities. See John H. Jackson, World Trade and the Law of GATT: A Legal Analysis of the General Agreement on Tariffs and Trade (Bobbs Merrill, Indianapolis), 1969, 656.

${ }^{86}$ The amended Article XVIII:A allows those countries falling within its scope of application to protect infant industries by raising their tariffs on those products they want to produce and thus renegotiating the tariff bindings to which they have agreed in their schedules of concessions. This gives developing countries an additional avenue for the renegotiation of schedules, over that provided in Article XXVIII of the GATT.

${ }^{87}$ Article XVIII:C allows a country falling within its scope of application to use a measure which deviates from other GATT articles, except Articles I, II and XIII, which is necessary to promote the establishment of a particular industry, with a view to raising the standard of living of its people. In the amended version, the requirement of prior approval was relaxed to some extent. The new Article XVIII:D provides the possibility for a country with an economy in the process of development but whose economy does not fall within the category of those that 'can only support low standards of living', to apply to the ConTRACTING PARTIEs for permission to deviate from GATT rules, except Articles I, II and XIII, in order to promote the establishment of a particular industry, in the interest of the development of its economy.
} 
more flexibility in using restrictions on the quantity or value of imports ${ }^{88}$ to address balance of payments problems than apply to other Contracting Parties under Article XII. ${ }^{89}$

The Review Session also introduced the new Article XXVIII(bis), which made provision for periodic rounds of multilateral tariff negotiations. Paragraph 3(b) of this article provided that these negotiations shall take into account the needs of less-developed countries for a more flexible use of tariff protection to assist their economic development as well as their special needs to maintain tariffs for revenue purposes.

Finally, the Review Session amended Article XVI of the GATT to add Paragraphs 2-5 as Part B, ${ }^{90}$ imposing stricter disciplines on export subsidies. Paragraph 3 of this article provides that Contracting Parties 'should seek to avoid' export subsidies on primary products, while Paragraph 4 contains a prohibition on export subsidies on non-primary products. ${ }^{91}$ Many developing countries objected to the different treatment of primary and manufactured products in the amended Article XVI and consequently did not accept the new Paragraph 4 resulting from this amendment. ${ }^{92}$ Consequently, these disciplines did not apply to them.

Despite these developments, many developing countries remained dissatisfied with GATT rules and refrained from becoming Contracting Parties to the GATT 1947 for

${ }^{88}$ This seems to imply that only quantitative restrictions may be taken to address balance of payments problems. However, in the Tokyo Round, the Contracting PARTIES adopted a Declaration regarding articles XII and XVIII:B noting that restrictive import measures other than quantitative restrictions can be used for balanceof-payment purposes and agreeing that the procedures of Articles XII and XVIII shall apply to all restrictive import measures taken for this purpose. See Declaration on Trade Measures Taken for Balance-of-Payment Purposes, BISD 26S/205 (1980), L/4904, Decision of the GATT ConTracting Parties, 28 November 1979, para. 1. One of the outcomes of the Uruguay Round, the Understanding on Balance-of-Payments Provisions of the GATT 1994, now clarifies the issue of which measures may be taken for balance-of-payments problems. It provides that Members will give preference to price-based measures, which may be applied in excess of a Member's tariff bindings in its schedule of commitments, in derogation of Article II. Only if price-based measures are not feasible due to a critical balance-of-payments situation, a Member may apply quantitative restrictions but must provide a justification as to the reasons why priced-based measures are not an adequate instrument to deal with the situation. This Understanding is an integral part of the GATT 1994, in terms of Paragraph 1(c)(iii) of the language incorporating the GATT 1994 into the WTO Agreement.

${ }^{89}$ In the amendment of Article XVIII, the obligation on developing countries maintaining balance-of-payments restrictions to hold annual consultations was reduced to once in two years (See Article XVIII:12(b)). In addition, the conditions for introducing measures for balance-of-payments problems were more relaxed than those that applied under Article XII.

${ }^{90}$ The drafting of the new Part B in the Review Session drew upon Articles 26-28 of the ITO Charter.

${ }^{91}$ An interpretative note to this article defines primary products as products of farm, forest or fishery.

${ }^{92}$ The new Paragraph 4 of Article XVI does not itself specify a date of entry into force, but provides that 'as from 1 January 1958 or the earliest practicable date thereafter,' Contracting Parties have certain obligations with regard to export subsidies on non-primary products. It contains a standstill provision prohibiting the extension of export subsidies beyond 1955 levels until 31 December 1957, by which time it was expected that Contracting Parties would have reached agreement on the prohibition of all export subsidies in non-primary products. As this deadline was not met, the standstill provision was extended by declarations annually until 1960. In 1960, the Contracting Parties were able to reach agreement on the Declaration Giving Effect to the Provisions of Article XVI:4, 19 November 1960, BISD 9S/32 (1961). In terms of this declaration, Article XVI:4 entered into force on 14 November 1962 for those seventeen countries that accepted the declaration. These were all developed countries except for Southern Rhodesia (Zimbabwe). John H. Jackson, World Trade and the Law of GATT: A Legal Analysis of the General Agreement on Tariffs and Trade (Bobbs Merrill, Indianapolis), 1969, 372-374. See also Edwini Kwame Kessie, 'Developing Countries and the World Trade Organization: What Has Changed?’ World Competition 22 (2), 1999, 83-110, 87. 
several years. Further, few of those developing countries that were GATT Contracting Parties had permanent representatives in Geneva to deal with GATT matters both as a consequence of their limited resources and the fact that active participation in the GATT system was not seen as a priority by these countries. The tide began to turn in the $60 \mathrm{~s}$, with the political independence of several developing countries in Asia and Africa and their accession to the GATT $1947 .{ }^{93}$ According to Article XXVI:5(c), newly independent countries could become Contracting Parties to the GATT through the 'sponsorship' of the previous colonial power, if that colonial power was a GATT Contracting Party and had applied the GATT to its dependent territory. ${ }^{94}$ The 'sponsorship' entailed that the colonial power made a declaration that the territory had acquired full autonomy in the conduct of their external commercial relations and other matters covered by the GATT. ${ }^{95}$ The usual requirements ${ }^{96}$ of negotiation of terms of accession, which in practice entailed negotiated tariff commitments recorded in a schedule of concessions, and of a two-thirds majority vote in favour of the accession by the GATT Contracting PARTIES, did not apply in such a case. Instead, if the colonial power had previously negotiated a tariff schedule on behalf of the relevant territory, it became the schedule of the newly independent country. ${ }^{97}$ Often these schedules contained very few commitments and in some cases there were no tariff schedules at all, which meant that these countries had no tariff commitments under the GATT. ${ }^{98}$ Sixty-three developing countries became GATT Contracting Parties in this way, ${ }^{99}$ thirty-two of which in the 50 s and 60 s. Even those developing countries

${ }^{93}$ During the 1960s, approximately 35 developing countries became Contracting Parties to the GATT 1947.

${ }^{94}$ A simplified procedure for the acquisition of Contracting Party status under Article XXVI:5(c) was adopted by the GATT Council in 1963, providing for certification by the GATT Executive Secretary that the conditions under this article had been met and advising that the relevant country had become a Contracting Party to the GATT (see C/M/15, 7).

${ }^{95}$ John H. Jackson et al., Legal Problems of International Economic Relations: Cases, Materials and Text on the National and International Regulation of Transnational Economic Relations, Fourth ed., American Casebook Series (West Group, St. Paul), 2002, 232; Koen De Feyter, World Development Law: Sharing Responsibility for Development (Intersentia, Antwerp), 2001, 79.

${ }_{96}$ These requirements for accession to the GATT 1947 are laid down in Article XXXIII. This article has now been replaced by the rules for accession to the WTO, provided for in Article XII of the WTO Agreement.

${ }_{97}$ Where a schedule of concessions existed for the relevant territory, a new schedule for the newly independent country comprising these concessions was established by means of the procedure of certification of changes to the GATT. Under para. 5 of the Decision on Procedures for Modification and Rectification of Schedules of Tariff Concessions of 26 March 1980, the certification procedure under that decision could be applied for establishing schedules under Article XXVI:5(c) where all changes were modifications or rectifications of a purely formal character (See Decision on Procedures for Modification and Rectification of Schedules of Tariff Concessions L/4962, 26 March 1980, BISD 27S/26, 26).

${ }^{98}$ John H. Jackson et al., Legal Problems of International Economic Relations: Cases, Materials and Text on the National and International Regulation of Transnational Economic Relations, Fourth ed., American Casebook Series (West Group, St. Paul), 2002, 233.

${ }^{99}$ Indonesia was the first country to become a Contracting Party in this way in 1950, followed by Ghana and Malaysia (1957); Nigeria (1960); Sierra Leone and Tanzania (1961); Trinidad and Tobago and Uganda (1962); Benin, Burkina Faso, Cameroon, Central African Republic, Chad, Congo, Côte d'Ivoire, Cyprus, Gabon, Jamaica, Kuwait, Madagascar, Mauritania, Niger and Senegal (1963); Kenya, Malawi, Malta and Togo (1964); Burundi and Gambia (1965); Guyana and Rwanda (1966); Barbados (1967); Mauritius (1970); Singapore (1973); Suriname (1978); Zambia (1982); Belize and Maldives (1983); Hong Kong (1986); Antigua and Barbuda and Botswana (1987); Lesotho (1988); Macau (1991); Mozambique and Namibia (1992); Dominica, Mali, Swaziland, St. Lucia, St Vincent and the Grenadines, Fiji, Brunei, Darussalam and Bahrain (1993); and Angola, Djibouti, Grenada, Guinea-Bissau, Republic of Guinea, Lichtenstein, Papua New Guinea, Qatar, St Christopher and Nevis, Solomon Islands, United Arab Emirates (1994). See Analytical Index: Guide to GATT 
which acceded to the GATT 1947 by means of the usual accession procedure and had to record tariff concessions in their schedules of commitments, usually made insignificant concessions on a limited range of products. Developed countries did not have strong interests in developing country markets at that time and therefore did not push for drastic tariff reductions as a condition for accession. As a result, the hurdle to becoming a GATT Contracting Party was low and several developing countries made use of the opportunity to join the GATT regime.

The rapid increase in developing country Contracting Parties in this period affected the balance of power in the trading system. ${ }^{100}$ These developing countries were aware of the importance of moving away from economies based on the production of primary products, ${ }^{101}$ towards industrialised economies. They expected to achieve this aim by using GATT rules to gain market access and earn the foreign revenue necessary for their development needs, including the diversification of their economies. ${ }^{102}$ At the same time, they were reluctant to reduce their own trade barriers, believing the prevailing economic wisdom of the time, which urged developing countries to protect their domestic markets from competition from imported products and pursue import substitution policies as the best path to speedy industrialisation. ${ }^{103}$ Developing countries believed that GATT rules had been largely drafted by developed countries in their own interests and contained disciplines that made it impossible for developing countries to diversify their economies. They thus called for differential treatment for developing countries by means of exemptions from GATT rules. ${ }^{104}$

In response to developing country concerns with the existing trade rules, in 1957 the Ministerial Session of GATT Contracting Parties established a panel of experts, headed by Professor Gottfried Haberler, to examine the effect of world trade rules on developing countries and, in particular, "the failure of the trade of less-developed countries to develop as rapidly as that of industrialised countries, excessive short-term fluctuations in prices of primary products, and widespread resort to agricultural protectionism.' ${ }^{105}$ The expert panel issued its report, commonly known as the Haberler Report, in 1958, in

Law and Practice Vol. 2 Appendix D (Geneva: WTO, 1995) 1145.

${ }^{100}$ Edwini Kwame Kessie, 'Developing Countries and the World Trade Organization: What Has Changed?' World Competition 22 (2), 1999, 83-110, 88.

${ }^{101}$ This was due to the fact that the market for primary products is notoriously unstable and the prices of primary products are very low compared to those of manufactured products.

102 Edwini Kwame Kessie, 'Developing Countries and the World Trade Organization: What Has Changed?' World Competition 22 (2), 1999, 83-110, 86.

${ }^{103} \mathrm{Ibid}$. Kessie points out that many prominent development economists were proponents of this approach and that the economic literature in those days emphasised 'elasticity pessimism', in other words the concern that developing countries' export surpluses would result in lower prices and worsening terms of trade for their products. Thus developing countries were encouraged to divert resources from export sectors and insulate their domestic markets.

${ }^{104}$ De Feyter notes that the effect of decolonisation was to shift the focus of international economic and social cooperation from reconstruction to development. He points out that developing countries in this period challenged free market principles, believing that they contributed to inequality and that market forces needed to be regulated to restore equilibrium in the world economy. Koen De Feyter, World Development Law: Sharing Responsibility for Development (Intersentia, Antwerp), 2001, 80.

${ }^{105}$ For a detailed discussion of the background to the Haberler Report and a summary of its conclusions, see John H. Jackson, World Trade and the Law of GATT: A Legal Analysis of the General Agreement on Tariffs and Trade (Bobbs Merrill, Indianapolis), 1969, 640-643. 
which it concluded that 'there is some substance in the feeling of disquiet among primary producing countries that the present rules and conventions about commercial policies are relatively unfavourable to them.' ${ }^{106}$ On the basis of this report, the Thirteenth Session of the GATT Contracting Parties in 1958 established an Action Program ${ }^{107}$ to address the possibility of further tariff reductions, the problems of non-tariff barriers and income support in the agricultural sector, and other obstacles to the expansion of trade with particular reference to developing countries.

The GATT Ministerial Meeting of 1963 recognised the need for an 'adequate legal and institutional framework to enable the CONTRACTING PARTIEs to discharge their responsibilities in connexion with the work of expanding the trade of less-developed countries' ${ }^{108}$ and authorised the establishment of a working group to examine proposals on preferential treatment for developing country exports. ${ }^{109}$ The Committee on the Legal and Institutional Framework of GATT in Relation to Less-Developed Countries was established to address this need. ${ }^{110}$

Attention to developing country concerns in the multilateral trade regime increased further following the establishment of the United Nations Conference on Trade and Development (UNCTAD) in 1964. ${ }^{111}$ UNCTAD was perceived as an alternative international forum for pursuing trade interests, ${ }^{112}$ and one that focused on developing country concerns. ${ }^{113}$ During the late $60 \mathrm{~s}$ and the $70 \mathrm{~s}$, developing countries devoted their attention to UNCTAD rather than the GATT as the main instrument through which to further their trade interests. ${ }^{114}$ In order to secure developing countries' participation in the GATT system, thereby

${ }^{106}$ GATT, Trends in International Trade, (Geneva: 1958), Sales No. GATT/1958-3.

${ }^{107}$ BISD 7S/28 (1959).

108 BISD 12S/45 (1964)

${ }^{109}$ At this Ministerial Meeting it was also agreed that, 'in the trade negotiations every effort shall be made to reduce barriers to exports of the less-developed countries, but that the developed countries cannot expect to receive reciprocity from the less-developed countries.' Reported in WTO Development Division, Developing Countries and the Multilateral Trading System: Past and Present. Background Document for the High Level Symposium on Trade and Development (World Trade Organization, Geneva), 17-18 March 1999, 13, available at: http://www.wto.org/english/tratop_e/devel_e/tr_dvbadoc_e.doc, visited on 25 June 2007.

${ }^{110}$ In 1964 this Committee drafted a chapter on Trade and Development, for inclusion in the GATT (discussed in Part I, Section 1.4). John H. Jackson, World Trade and the Law of GATT: A Legal Analysis of the General Agreement on Tariffs and Trade (Bobbs Merrill, Indianapolis), 1969, 644-645.

111 The creation of UNCTAD followed from the launching of the first UN Trade and Development Decade in 1961.

112 UNCTAD was created as a forum to discuss international trade from a development perspective, not as a body where countries could negotiate binding obligations. As such, it did not offer a true alternative to the GATT system for developing countries. It did however promote coalition building between developing countries and the Group of 77 had its origins in the UNCTAD system. In addition, several significant initiatives for developing countries originated in UNCTAD and were transformed into legal obligations in other fora, for example the establishment of the Generalised System of Preferences, the recognition of the need for special treatment of least-developed countries and the creation of commodity agreements. See Koen De Feyter, World Development Law: Sharing Responsibility for Development (Intersentia, Antwerp), $2001,85$.

${ }^{113}$ Edwini Kwame Kessie, 'Developing Countries and the World Trade Organization: What Has Changed?' World Competition 22 (2), 1999, 83-110, 88. Kessie points out that UNCTAD's strategy was to challenge the multilateral trade regime under the GATT 1947 and to push for a new framework that would take developing country interests into account and would equitably distribute the world's resources and opportunities among countries.

114 Constantine Michalopolous, 'The Developing Countries in the WTO', The World Economy 22, $1999,117-$ $143,117$. 
protecting its position as the main international organisation for trade, developed countries were forced to comply with the demands of developing countries for special treatment. ${ }^{115}$ These demands were based on the contention that equal treatment of unequal trading partners is inherently unfair. The tendency of developing countries to act collectively at that time ${ }^{116}$ together with the rivalry from UNCTAD ${ }^{117}$ meant that developed Contracting Parties could not afford to ignore the demands of developing countries. ${ }^{118}$

\subsection{The 1965 Protocol Adding Part IV to the GATT 1947}

Developing countries in the 60 s began to realise that the special and differential treatment in the form of derogations from GATT rules allowing them, under certain conditions, to use trade barriers to protect their markets from competition was not sufficient to secure the economic growth they needed for their development aims. ${ }^{119}$ Instead, they pushed for explicit recognition in the GATT of their special situation and of the need for positive measures by developed countries to increase their market access. ${ }^{120}$ These positive measures were seen to include preferential treatment of developing country exports, non-reciprocity in trade negotiations and the provision of technical and financial

115 Edwini Kwame Kessie, 'Developing Countries and the World Trade Organization: What Has Changed?' World Competition 22 (2), 1999, 83-110, 88.

${ }^{116}$ At the end of first session of UNCTAD, on 15 June 1964, an important coalition of developing countries was formed, known as the Group of 77 (G-77), by means of the Joint Declaration of the Seventy-Seven Countries. The G-77 originated in the merging of List A (African and Asian developing countries and Yugoslavia) and List C (Latin American developing countries) of UNCTAD's Trade and Development Board. This group has been active also outside the context of UNCTAD. See Koen De Feyter, World Development Law: Sharing Responsibility for Development (Intersentia, Antwerp), 2001, 97.

117 Jackson notes that developments with regard to the establishment of UNCTAD 'are generally conceded to have had a psychological impact on national representatives to GATT, particularly the delegates from industrialized nations. Perhaps it was realized that developing countries had some moral force behind their position, even though they had little economic force.' John H. Jackson, World Trade and the Law of GATT: A Legal Analysis of the General Agreement on Tariffs and Trade (Bobbs Merrill, Indianapolis), 1969, 645.

118 Edwini Kwame Kessie, 'Developing Countries and the World Trade Organization: What Has Changed?' World Competition 22 (2), 1999, 83-110, 88. The response of the GATT contacting parties to the emergence of UNCTAD in the form of the addition of Part IV of the GATT (discussed below, Part I, Section 1.4), is noted in Third World Network, The Multilateral Trading System: A Development Perspective (United Nations Development Programme, New York), December 2001, 27.

119 Edwini Kwame Kessie, 'Developing Countries and the World Trade Organization: What Has Changed?' World Competition 22 (2), 1999, 83-110, 88. Raoul Prebisch and Hans Singer established the theoretical foundation for special and differential treatment, pointing out that developing countries' exports were mainly commodities with volatile prices and declining terms of trade. They argued for import-substitution policies, protection of infant industries and preferential market access for developing country products. World Bank, Global Economic Prospects 2004: Realizing the Development Promise of the Doha Agenda, 0-8213-5582-1 (World Bank, Washington D.C.), 2003, 207, available at: http://www.worldbank.org/prospects/gep2004/full. pdf, visited on 30 June 2008.

${ }^{120}$ De Feyter points to the fact that in the 60 s and 70 s pleas were heard for a 'duality of norms' applying to developed and developing countries, including the concepts of preferential treatment and non-reciprocity as well as assistance from developed states. He also notes the existence of a more radical view, calling for disengagement from the world trading system and the organisation of a form of collective autonomy by developing states (something which never materialized despite ongoing efforts at South-South co-operation). See Koen De Feyter, 'Contracting for Human Development: International Law and Development Revisited', Asia Pacific Law Review 10 (1), 2002, 49-74, 54. 
assistance to developing countries. ${ }^{121}$ As a result of developing country initiatives, ${ }^{122}$ a chapter entitled 'Trade and Development' was drafted by the Committee on Legal and Institutional Framework of GATT in Relation to Less Developed Countries, and finalised in a Special Session of the Contracting PARTiEs which took place from 17 November 1964 to 8 February 1965 . This chapter was added by an amending protocol as Part IV of the GATT, ${ }^{123}$ consisting of Articles XXXVI, XXXVII and XXXVIII. It represented an evolution in the concept of special and differential treatment of developing countries, away from the idea that additional flexibility in GATT rules for trade restrictive measures by developing countries was sufficient, towards recognition of the need for developed countries to play an active part by granting preferential treatment to developing country exports. However, Part IV is mostly hortatory, setting out principles and objectives and best-endeavour commitments.

The new Part IV recognizes, inter alia, that 'the export earnings of less-developed contracting parties can play a vital part in their economic development'. ${ }^{124}$ Thus, the Contracting Parties agree on various necessary steps including the 'need for a rapid and sustained expansion of the export earnings of the less-developed contracting parties' 125 and 'the need for positive efforts designed to ensure that less-developed contracting parties secure a share in the growth in international trade commensurate with the needs of their economic development.' ${ }^{126}$ To achieve this, a number of best-endeavour commitments are laid down for developed countries, to which they must give effect 'to the fullest extent possible'. ${ }^{127}$ These include according high priority to the reduction and elimination of barriers to products currently or potentially of particular interest to developing countries $^{128}$ and refraining from introducing or increasing tariffs or non-tariff barriers to trade in these products. ${ }^{129}$ In addition, developed countries must 'give active consideration' to

${ }^{121}$ De Feyter draws attention to the fact that the UN set a non-binding target for official development assistance (ODA), namely $0.7 \%$ of the GNP of developed countries. See UN General Assembly Resolution 2626 (XXV), 24 December 1970. He notes that the call for the recognition of entitlements to aid for developing countries was based either on the recognition of a duty to contribute to international solidarity or on the need for reparation for past injustices committed by developed countries during colonialism. Ibid.

122 John H. Jackson et al., Legal Problems of International Economic Relations: Cases, Materials and Text on the National and International Regulation of Transnational Economic Relations, Fourth ed., American Casebook Series (West Group, St. Paul), 2002, 1170.

123 BISD 13S/1 (1965). The addition of Part IV was the last amendment ever made to the GATT. Part IV came into effect, de facto, on 8 February 1965 and finally on 27 June 1966 for those countries that had accepted it. WTO Development Division, Developing Countries and the Multilateral Trading System: Past and Present. Background Document for the High Level Symposium on Trade and Development (World Trade Organization, Geneva), 17-18 March 1999, 13, available at: http://www.wto.org/english/tratop_e/devel_e/ tr_dvbadoc_e.doc, visited on 25 June 2007; John H. Jackson, World Trade and the Law of GATT: A Legal Analysis of the General Agreement on Tariffs and Trade (Bobbs Merrill, Indianapolis), 1969, 646.

${ }_{124}$ Part IV, Article XXXVI:1(b) of the GATT 1947.

${ }^{125}$ Part IV, Article XXXVI:2 of the GATT 1947.

${ }^{126}$ Part IV, Article XXXVI:3 of the GATT 1947.

${ }^{127}$ According to Article XXXVII:1, this means 'except when compelling reasons, which may include legal reasons, make it impossible'. Other qualifying phrases soften Paragraph 3 of Article XXXVII:3, which obliges developed Contracting Parties to 'make every effort', 'give active consideration', and 'have special regard' rather than to actually do something.

${ }_{128}$ This explicitly includes barriers that unreasonably differentiate between primary and processed products.

${ }^{129}$ Part IV, Article XXXVII:1(a) and (b) of the GATT 1947. Article XXXVII:2 makes provision for reporting non-compliance with Paragraph 1 of this Article to the Contracting Parties, which should consult with the interested Contracting Parties with respect to the matter with a view to reaching a solution satisfactory to all 
developing measures to increase the scope for the development of imports from developing countries. ${ }^{130}$ However, all these commitments are couched in non-mandatory language and thus do not create binding or enforceable obligations for developed countries.

The Contracting Parties are also obliged to collaborate to further the objectives of Part IV, as appropriate. ${ }^{131}$ In particular, joint action by the CONTRACTING PARTIES is envisaged, inter alia, through international agreements to improve market access for primary products of particular interest to developing countries and to devise measures to stabilise and improve conditions on world markets for such products. ${ }^{132}$ Further, the Contracting ParTies are obliged to establish institutional arrangements necessary to further the objectives of Part IV. In terms of this provision, the Committee on Trade and Development was established in $1964,{ }^{133}$ with the mandate to review the application of Part IV of the GATT, formulate proposals to further its provisions and consider changes or additions to Part IV. In addition, it had the task of considering any question regarding the eligibility of a GATT Contracting Party to be considered as less developed. In the same year, the International Trade Centre ${ }^{134}$ was created with the objective of promoting developing country trade.

In addition, and perhaps most significantly, Part IV provides a GATT legal basis for the concept of non-reciprocity in trade negotiations between developed and developing countries, ${ }^{135}$ a concept that was already recognised in practice since $1963 .{ }^{136}$ According to an interpretative note to this provision, it meant that, in the course of trade negotiations, developing countries should not be expected to make contributions inconsistent with their individual development, financial and trade needs. ${ }^{137}$ The actions of developing countries

Contracting Parties concerned.

${ }^{130}$ An interpretative note provides that these other measures 'might include steps to promote domestic structural changes, to encourage the consumption of particular products, or to introduce measures of trade promotion.'

131 Article XXXVIII:1 of the GATT 1947.

${ }^{132}$ Article XXXVIII:2(a) of the GATT 1947.

133 BISD 13S/75 (1965).

${ }^{134}$ BISD 12S/138 (1964). The International Trade Centre (ITC) was established under the GATT in 1964 and became a joint agency of the GATT and UNCTAD in 1968. The ITC works with developing countries and economies in transition to set up effective trade promotion programmes for expanding their exports and improving their import operations. It is an executing agency of the UNDP and implements UNDP-financed projects relating to trade promotion in developing countries and economies in transition. See WTO Development Division, Developing Countries and the Multilateral Trading System: Past and Present. Background Document for the High Level Symposium on Trade and Development (World Trade Organization, Geneva), 17-18 March 1999, 14, available at: http://www.wto.org/english/tratop_e/devel_e/tr_dvbadoc_e.doc, visited on 25 June 2007. For more information on the ITC, see its website available at: http://www.intracen.org/index.htm, visited on 30 June 2007.

${ }^{135}$ Part IV, Article XXXVI:8 of the GATT. This Paragraph provides, 'The developed contracting parties do not expect reciprocity for commitments made by them in trade negotiations to reduce or remove tariffs and other barriers to the trade of less-developed contracting parties.'

${ }^{136}$ WTO Development Division, Developing Countries and the Multilateral Trading System: Past and Present. Background Document for the High Level Symposium on Trade and Development (World Trade Organization, Geneva), 17-18 March 1999, 13, available at: http://www.wto.org/english/tratop_e/devel_e/tr_dvbadoc_e. doc, visited on 25 June 2007.

${ }^{137}$ This provision was further interpreted in the Kennedy Round as follows: 'There will, therefore, be no balancing of concessions granted on products of interest to developing countries by developed participants on the one hand and the contribution which developing participants would make to the objective of trade liberalization on the other and which it is agreed should be considered in the light of the development, financial and trade needs of developing countries themselves. It is, therefore, recognized that the developing countries themselves must decide what contributions they can make' (See COM.TD/W/37, 9, as reported in Ibid., 13). 
in subsequent trade negotiations were guided by this concept, particularly in the Tokyo Round. ${ }^{138}$ Developing countries therefore did not actively engage in the negotiations, as they saw no need to offer concessions but were content to simply benefit from the concessions negotiated between developed countries, which would be extended to them on an MFN basis under GATT rules. This, however, also meant that developing countries could not direct negotiations to areas of importance to them or seek meaningful tariff reductions from their trading partners for products of interest to them, since it is in the nature of negotiations that in order to gain significant concessions, countries have to offer concessions in return.

Despite these developments, no fundamental changes to GATT rules were achieved. At the same time, the first two sessions of $\mathrm{UNCTAD}^{139}$ achieved international recognition of the need for a generalized system of non-reciprocal trade preferences for developing countries, resulting in the establishment of the Generalized System of Preferences in 1968. ${ }^{140}$ Further, the Committee on Trade and Development drafted a report, adopted by the Contracting Parties in 1966, recognising the important contribution that the establishment of preferences between developing countries can make to the attainment of the GATT objectives. However, no agreement could be reached between GATT Contracting Parties regarding whether the new Part IV of the GATT 1947 allowed the introduction of such preferences. Consequently, preferential schemes introduced by developed countries under the Generalized System of Preferences and preferential agreements between developing countries had to be authorised for purposes of the GATT regime by means of waivers from the MFN obligation. ${ }^{141}$ Part IV of the GATT continued to be viewed as simply a set of guidelines that did not change the rights and obligations under GATT. ${ }^{142}$

\subsection{The Tokyo Round: The Enabling Clause and the Codes}

As mentioned above, the 1970s saw calls for the establishment of a New International Economic Order (NIEO), reflecting social justice in international economic relations. In addition, demands for special treatment of developing countries in international econom-

${ }^{138}$ Edwini Kwame Kessie, 'Developing Countries and the World Trade Organization: What Has Changed?' World Competition 22 (2), 1999, 83-110, 98. The Tokyo Round negotiations are discussed in Part I, Section 1.5 , below.

139 In 1964 and 1968.

140 The adoption of UNCTAD Resolution 21 (II) embodied 'unanimous agreement in favour of the early establishment of a mutually acceptable system of generalized, non-reciprocal and non-discriminatory preferences which would be beneficial to the developing countries.'

${ }^{141}$ Article XXV:5 of the GATT 1947 made provision for the granting of waivers. The GATT waiver for the Generalized System of Preferences (GSP) was adopted on 25 June 1971 and expired on 25 June 1981 (BISD 18S/24 (1972)). It was not renewed in view of the fact that the 1979 Enabling Clause, discussed below, authorised preferential tariff treatment by developed countries to developing country products in accordance with the GSP. The waiver for the Protocol Relating to Trade Negotiations among Developing Countries was adopted on 26 November 1971 without a specified time limit (BISD 18S/26). It is currently applied in terms of Paragraph 2(c) of the Enabling Clause. See BISD 27S/172.

${ }^{142}$ De Feyter notes that Part IV of the GATT was only raised 4 times in disputes and never successfully. Koen De Feyter, World Development Law: Sharing Responsibility for Development (Intersentia, Antwerp), 2001, 83 . 
ic relations increased, focussing on the need for trade preferences for developing country exports and non-reciprocity in trade negotiations.

These developments formed the background for the launch of a new Round of multilateral trade negotiations in Tokyo in 1973, which was aimed at disciplining the use of non-tariff barriers to trade, building on the attempts made in this area in the Kennedy Round. The special position of developing countries was recognised in the Tokyo Round negotiations. The Declaration launching the Tokyo Round stated, with regard to developing countries:

The Ministers recognize the need for special measures to be taken in the negotiations to assist the developing countries in their efforts to increase their export earnings and promote their economic development and, where appropriate, for priority attention to be given to products or areas of interest to developing countries. They also recognize the importance of maintaining and improving the Generalized System of Preferences. They further recognize the importance of the application of differential measures to developing countries in ways which will provide special and more favourable treatment for them in areas of the negotiation where this is feasible and appropriate. ${ }^{143}$

It also indicated that the negotiations must aim to:

...secure additional benefits for the international trade of developing countries so as to achieve a substantial increase in their foreign exchange earnings, the diversification of their exports, the acceleration of the rate of growth of their trade, taking into account their development needs, an improvement in the possibilities for these countries to participate in the expansion of world trade and a better balance as between developed and developing countries in the sharing of the advantages resulting from this expansion, through, in the largest possible measure, a substantial improvement in the conditions of access for the products of interest to the developing countries... ${ }^{144}$

Sixty-eight developing countries participated in the Tokyo Round of trade negotiations. ${ }^{145}$ One of the results of this Round, ${ }^{146}$ concluded in 1979, was the Decision on Differential and More Favourable Treatment, Reciprocity and Fuller Participation of Developing Countries ${ }^{147}$ commonly known as the 'Enabling Clause'. This clause went further than

${ }^{143}$ Ministerial Meeting, 20S/19 (1974), MIN(73)1, Declaration of Ministers approved at Tokyo, 14 September 1974, para.5.

144 Ibid., para. 2.

145 WTO Development Division, Developing Countries and the Multilateral Trading System: Past and Present. Background Document for the High Level Symposium on Trade and Development (World Trade Organization, Geneva), 17-18 March 1999, 5, available at: http://www.wto.org/english/tratop_e/devel_e/tr_dvbadoc_e.doc, visited on 25 June 2007.

146 The principal aim of the Tokyo Round was to create disciplines on the use of non-tariff barriers to trade and it resulted, inter alia, in the first Agreement on Technical Barriers to Trade, commonly known as the Standards Code. See Agreement on Technical Barriers to Trade, 26S/154, 1186 UNTS 276, LT/TR/A/5, 12 April 1979.

${ }^{147}$ Differential and More Favourable Treatment, Reciprocity and Fuller Participation of Developing Countries, BISD 26S/203 (1980), L/4903, LT/TR/D/1, Decision of the GATT Contracting Parties, 28 November 1979. The legal nature of the Enabling Clause under the GATT 1947 is rather murky. It was not based on Article 
Part IV of the GATT by formalising the concepts of SDT ${ }^{148}$ for developing countries and non-reciprocity in trade negotiations and by establishing them as an integral part of the multilateral trading system. Recently, the Appellate Body in EC-Tariff Preferences clarified the reasons behind the Enabling Clause as follows:

...between the entry into force of the GATT and the adoption of the Enabling Clause, the Contracting Parties determined that the MFN obligation failed to secure adequate market access for developing countries so as to stimulate their economic development. Overcoming this required recognition by the multilateral trading system that certain obligations, applied to all Contracting Parties, could impede rather than facilitate the objective of ensuring that developing countries secure a share in the growth of world trade. This recognition came through an authorization for GSP schemes in the 1971 Waiver Decision and then in the broader authorization for preferential treatment for developing countries in the Enabling Clause. ${ }^{149}$

One of the most important elements of the Enabling Clause is the express provision for deviation from the principle of Most-Favoured-Nation treatment in Article I of the GATT, in order to allow for preferential treatment of developing countries. It provides:

Notwithstanding the provisions of Article I of the General Agreement, contracting parties may accord differential and more favourable treatment to developing countries, without according such treatment to other contracting parties. ${ }^{150}$

According to the Appellate Body in EC-Tariff Preferences, the Enabling Clause constitutes an exception to Article I: 1 of the GATT 1994. ${ }^{151}$ However, due to its fundamental role in the WTO system as a means of stimulating economic growth and development, ${ }^{152}$ the Appellate Body held that it is not a typical exception, which normally the responding party is responsible for raising as a defence against a claim of violation. ${ }^{153}$ As a result, it is not sufficient for a complainant challenging a measure taken under the Enabling

XXV:5 of the GATT 1947, which made provision for time-limited waivers of GATT obligations. Neither was it explicitly based on Article XXX which allowed for amendments to the GATT 1947. It would seem to embody a tacit amendment of Article I of the GATT 1947, which contains the obligation of Most-FavouredNation treatment. Whatever its legal nature under the GATT 1947, it is now part of the GATT 1994 within the meaning of Article 1(b)(iv) of the language of Annex 1A incorporating the GATT 1994 into the WTO Agreement, which provides that the GATT 1994 shall consist of, inter alia, 'other decisions of the ConTRACTING PARTIES to the GATT 1947'. The fact that the Enabling Clause is now an integral part of the GATT 1994 was recently confirmed by the Appellate Body. See Appellate Body Report, EC - Tariff Preferences, para. 90.

148 At the time, the term used was 'differential and more favourable treatment'. Later the term 'special and differential treatment' became common usage to describe the same concept. In this book, the term 'special and differential treatment' will be used.

${ }^{149}$ Appellate Body Report, EC-Tariff Preferences, para. 109.

${ }^{150}$ Differential and More Favourable Treatment, Reciprocity and Fuller Participation of Developing Countries, BISD 26S/203 (1980), L/4903, LT/TR/D/1, Decision of the GATT Contracting Parties, 28 November 1979, para.1(footnote omitted).

151 Appellate Body Report, EC - Tariff Preferences, para. 99.

${ }^{152}$ After examining the history and objective of the Enabling Clause, the Appellate Body held that, unlike the case with other exceptions in WTO law, 'Members are encouraged to deviate from Article I in the pursuit of “differential and more favourable treatment” for developing countries.' Ibid., para. 111.

${ }^{153}$ Ibid., para. 106 
Clause to merely claim a violation of Article I: 1 . Instead it must also identify the specific provisions of the Enabling Clause that the preference scheme of the responding Member allegedly violates. ${ }^{154}$ However, the burden of establishing the facts necessary to prove inconsistency with the relevant provisions of the Enabling Clause does not lie with the complainant, but rather the respondent bears the burden of proof to show that the relevant provisions are complied with. ${ }^{155}$ This rather awkward construction may be seen as reflecting the recognition by the Appellate Body of the importance of giving effect to the purpose of the Enabling Clause, namely the promotion of more favourable treatment of developing countries.

In the Enabling Clause, a list is provided of the types of differential and more favourable treatment envisaged there under. These are preferential tariffs accorded by developed countries to developing country products, in accordance with the Generalized System of Preferences; ${ }^{156}$ differential and more favourable treatment regarding GATT rules on non-tariff measures; regional or global arrangements among developing countries with regard to the elimination or reduction of tariffs or non-tariff measures on products from one another; and special treatment of least-developed countries. ${ }^{157}$

Interestingly, the Enabling Clause seems to make some provision for the 'graduation' of developing countries. ${ }^{158}$ It provides in Paragraph 3(c) that SDT under the Enabling Clause 'shall in the case of such treatment accorded by developed contracting parties to developing countries be designed and, if necessary, modified, to respond positively to the development, financial and trade needs of developing countries.' Further, the Enabling Clause provides in Paragraph 7 that as the economies of developing countries progressively develop and their trade situation improves, they would 'expect that their capacity to make contributions or negotiated concessions or take other mutually agreed action under the General Agreement would improve' and 'would accordingly expect to participate more fully in the framework of rights and obligations' under the GATT. ${ }^{159}$ During the review of the Enabling Clause conducted at the fifty-eighth session of the Committee on Trade and Development, one delegate noted that the Enabling Clause provided a useful mechanism

${ }^{154}$ Ibid., para. 113. This is in order to avoid subjecting preference schemes to open-ended challenges, which, according to the Appellate Body, "would be inconsistent ... with the intention of Members, as reflected in the Enabling Clause, to "encourage" the adoption of preferential treatment for developing countries and to provide a practical means for doing so within the legal framework of the covered agreements.' Appellate Body Report, EC-Tariff Preferences, para. 114.

155 Appellate Body Report, EC-Tariff Preferences, para. 115.

156 As noted above, previously the GSP was authorised in terms of a 10-year waiver, granted in 1971 under Article XXV:5 of the GATT, from the most favoured nation obligation in Article I of the GATT (BISD 18S/24 (1972)). When this waiver expired in 1981, it was not necessary to extend it as preferential treatment under the GSP was then possible under the Enabling Clause.

${ }^{157}$ Differential and More Favourable Treatment, Reciprocity and Fuller Participation of Developing Countries, BISD 26S/203 (1980), L/4903, LT/TR/D/1, Decision of the GATT ConTracting Parties, 28 November 1979, para. 2

${ }^{158}$ This issue should be distinguished from the issue of differentiation between developing countries on the basis of considerations other than their stage of development. The latter type of differentiation was at issue in EC-Tariff Preferences, where the EC's preference scheme provided for special preferences under arrangements to combat drug production and trafficking in 12 predetermined countries.

${ }^{159}$ Differential and More Favourable Treatment, Reciprocity and Fuller Participation of Developing Countries, BISD 26S/203 (1980), L/4903, LT/TR/D/1, Decision of the GATT Contracting PARTIES, 28 November 1979, para. 7 . 
for permitting temporary deviation from the MFN principle but that SDT there under must be gradually phased out under the guidelines in Paragraph 3(c). This delegate further pointed out that Paragraph 7 requires differentiation between developing countries, beyond that envisaged for the least developed countries, with regard to SDT and the degree of reciprocity required in negotiations. ${ }^{160}$ Several other delegates disagreed, noting that Paragraph 7 does not provide a basis for differentiation among developing countries and that the decision to participate more fully in the GATT system was an autonomous decision to be taken by a developing country in terms of its own judgement of its development, financial and trade needs. ${ }^{161}$

In EC-Tariff Preferences, the Panel addressed the question whether the Enabling Clause permits differentiation between beneficiaries. ${ }^{162}$ It found:

...that the requirement of non-discrimination, as a general principle formally set out in [UNCTAD] Resolution 21 (II) and later carried over into the 1971 Waiver Decision and then into the Enabling Clause, obliges preference giving countries to provide the SP benefits to all developing countries without differentiation, except for the implementation of a priori limitations in GSP schemes. ${ }^{163}$

The Panel found that explicit authorisation is necessary for preferential treatment granted to 'less than all developing countries', which authorisation is only provided for the benefit of least-developed countries in Paragraph 2(d) of the Enabling Clause and for the implementation of a priori limitations as set out in the Agreed Conclusions. ${ }^{164}$ On appeal, the Appellate Body reversed this finding of the Panel and held that:

...the participants in this case agree that developing countries may have "development, financial and trade needs" that are subject to change and that certain development needs may be common to only a certain number of developing countries. We see no reason to disagree. Indeed, paragraph 3(c) contemplates that "differential and more favourable treatment" accorded by developed to developing countries may need to be "modified" in order to "respond positively" to the needs of developing countries. Paragraph 7 of the Enabling Clause supports this view by recording the expectation of "less-developed contracting parties" that their capacity to make contributions or concessions under the

${ }^{160}$ Committee on Trade and Development, Report Presented to the Contracting Parties, BISD 32S/21 L/5913, circulated on 28 November 1985, para. 34.

161 Ibid., para. 36.

162 The issue in this case was not the graduation of developing countries from the EC's GSP scheme due to improvements in their degree of development, but rather the granting of special preferences to 12 specific designated countries by the EC to combat drug production and trafficking. However, to the extent that the case deals with the issue of the permissibility of differentiation between developing countries with regard to preferences under the Enabling Clause, it is relevant to the issue of graduation. Further, several references were made by the Appellate Body to the effect of differences in development needs.

${ }^{163}$ Panel Report, EC - Tariff Preferences, para. 7.144.

${ }^{164}$ Ibid., para. 7.151. The Agreed Conclusions of 26 March 1968 are the result of negotiations in the Special Committee on Preferences, established by Resolution 21(II) of the Second Session of UNCTAD with the mandate to develop agreed detailed arrangements for the GSP. The Agreed Conclusions permit a priori limitations, which are exceptional measures setting import ceilings so as to exclude certain imports from individual developing countries, where the products at issue reach a certain competitive level in the market of the preference-giving country. 
GATT will "improve with the progressive development of their economies and improvement in their trade situation". Moreover, the very purpose of the special and differential treatment permitted under the Enabling Clause is to foster economic development of developing countries. It is simply unrealistic to assume that such development will be in a lockstep for all developing countries at once, now and for the future. ${ }^{165}$

The Appellate Body also pointed out that the Preamble to the WTO Agreement, which informs all the covered agreements, recognizes the 'need for positive efforts designed to ensure that developing countries, and especially the least-developed among them, secure a share in the growth in international trade commensurate with the needs of their economic development.' According to the Appellate Body, the word 'commensurate' leaves open the possibility that 'developing countries may have different needs according to their levels of development and particular circumstances. ${ }^{\text {'166 }}$ Thus, the Appellate Body held that a GSP scheme might be 'non-discriminatory' even if identical tariff preferences are not granted to all GSP beneficiaries. ${ }^{167}$ However, an objective standard must be applied in assessing the existence of 'development, financial and trade needs' under Paragraph 3(c) and the relevant tariff preferences must be made available to all beneficiaries that share that need. ${ }^{168}$ While this ruling seems to leave open the door for differentiation, on an objective basis, between developing countries with regard to preference schemes, the issue of graduation of developing countries from special and differential treatment schemes remains a difficult and controversial one.

Special and differential treatment of developing countries was further embodied in the results of the Tokyo Round by means of specific provisions in the various Codes negotiated to address particular non-tariff barriers to trade and trade remedies. ${ }^{169}$ These Codes established disciplines beyond those of the GATT, limiting the regulatory freedom of those Contracting Parties that were signatories thereof in several areas. For example, Codes were agreed to dealing with government procurement, ${ }^{170}$ import licensing, ${ }^{171}$ customs valuation, ${ }^{172}$ anti-dumping measures, ${ }^{173}$ subsidies and countervailing measures ${ }^{174}$

\footnotetext{
${ }^{165}$ Appellate Body Report, EC - Tariff Preferences, para. 160 (footnotes omitted).

166 Ibid., 161. The Appellate Body further noted that the Preamble to the WTO Agreement recognizes that Members' 'respective needs and concerns at different levels of development' may differ according to the different stages of development of different Members.

${ }^{167}$ Ibid., 165.

168 Ibid., 163 and 165.

${ }^{169}$ One of these Codes, that dealing with antidumping measures, built upon work already done in the preceding Kennedy Round (1964-1967) in this regard.

${ }^{170}$ Agreement on Government Procurement, LT/TR/PLURI/2, dated 12 April 1979, BISD 26S/33.

171 Agreement on Import Licensing Procedures, LT/TR/A/4, dated 12 April 1979, BISD 26S/154.

172 Agreement on Implementation of Article VII of the General Agreement on Tariffs and Trade, LT/TR/A/2, dated 12 April 1979, BISD 26S/116.

${ }^{173}$ Agreement on Implementation of Article VI of the General Agreement on Tariffs and Trade, LT/TR/A/1, dated 12 April 1979, BISD 26S/171. This agreement replaces the 1967 Agreement on Implementation of Article $V I$ of the General Agreement (BISD 15S/24), which was negotiated in the Kennedy Round of multilateral trade negotiations and entered into force on 1 July 1968.

${ }^{174}$ Agreement on Interpretation and Application of Articles VI, XVI and XXIII of the General Agreement on Tariffs and Trade, LT/TR/A/3, dated 12 April 1979, BISD 26S/56.
} 
and, most relevant for this study, technical barriers to trade. ${ }^{175}$ Participation in the various Tokyo Round Codes was voluntary, and their provisions therefore only bound those Contracting Parties that decided to become signatories of the particular Code. ${ }^{176}$

Developing countries' participation in the negotiation of the Tokyo Round Codes was limited to the last stages, where they demanded the inclusion of special and differential treatment provisions in their favour. ${ }^{177}$ Thus the general disciplines in the Codes themselves do not reflect developing country concerns. Instead, the special constraints faced by developing countries in complying with these new rules were to some extent recognized by means of the special and differential treatment provisions in these Codes. However, the nature of these provisions varies from Code to Code, some providing clear exemptions from their obligations for developing countries, and others being limited to hortatory provisions. ${ }^{178}$ In spite of these provisions, the far-reaching commitments entailed by the new agreements prompted many developing countries to opt not to become signatories of the various Tokyo Round Codes. For example, only 24 developing countries became signatories of the Tokyo Round Agreement on Technical Barriers to Trade. ${ }^{179}$ In addition, developing countries were able to negotiate decisions in the Tokyo Round relaxing the rules applicable to developing countries with regard to balance of payments restrictions and the protection and promotion of infant industries. ${ }^{180}$

In 1982, UNCTAD conducted an assessment of the results of the Tokyo Round, which concluded that they were 'modest and wanting in many specific respects.' In particular, the assessment criticised the fact that developing country proposals for concrete application of the concepts of differential and more favourable treatment were not fully realised. It found that although general provisions on differential treatment had been included in some Tokyo Round instruments, specific measures for their application were either lacking, or vague and inadequate. Further, it noted that the institutionalisation of the concepts of conditionality and graduation have far-reaching consequences for developing countries and could lead to arbitrary discrimination. ${ }^{181}$

175 Agreement on Technical Barriers to Trade, 26S/154, 1186 UNTS 276, LT/TR/A/5, 12 April 1979. This

Standards Code is discussed further below, Part III, Sections 1.1.2 and 1.1.3.

176 The relationship between the Tokyo Round Codes and the GATT 1947 was addressed in a decision by the GatT Contracting Parties at the conclusion of the Tokyo Round. It stated: 'The Contracting Parties also note that existing rights and benefits under the GATT of contracting parties not being parties to these Agreements, including those derived from Article I, are not affected by these Agreements...' Action by the Contracting Parties, on the Multilateral Trade Negotiations. Decision of 28 November 1979, L/4905, circulated on 3 December 1979. It was thus possible for GATT Contracting Parties to choose whether or not to become signatories to the agreements which were negotiated in the Tokyo Round to supplement the GATT disciplines. It was only in the Uruguay Round that all WTO Members undertook to be bound to all the multilateral Agreements as part of a 'single undertaking'.

177 Edwini Kwame Kessie, 'Developing Countries and the World Trade Organization: What Has Changed?' World Competition 22 (2), 1999, 83-110, 91.

${ }^{178}$ Ibid.

${ }^{179}$ Patrick Low, 'Is the WTO Doing Enough for Developing Countries?' in WTO Law and Developing Countries, George A. Bermann and Petros C. Mavroidis (eds.) (Cambridge University Press, Cambridge), 2007, $324-$ 358, Table 12.11.

${ }^{180}$ Declaration on Trade Measures taken for Balance of Payment Purposes, LT/TR/DEC/1, L/4897, decision of 28 November 1979, BISD 26S/209 and Decision on Safeguard Action for Development Purposes, LT/ TR/D/2, L/4904, decision of 28 November 1979, BISD 26S/205.

181 Report by the Secretary-General of UNCTAD, Assessment of the Results of the Multilateral Trade 


\subsection{The Uruguay Round negotiations}

The Uruguay Round of trade negotiations, which lasted from 1986 to 1994, saw a marked change in the attitude of developing countries. This can be partly attributed to the end of the Cold War and the fall of communism during the course of the Round. Demands for a New International Economic Order faded and state intervention in the national economy was no longer seen as the best way to achieve development. As a result, developing countries evinced a new readiness to engage in trade liberalisation. ${ }^{182} \mathrm{~A}$ record number of 76 developing countries participated in the Uruguay Round, ${ }^{183}$ and some of these countries played an active role in the negotiations. ${ }^{184} \mathrm{~A}$ new resolve to become effective participants in the multilateral trade regime ${ }^{185}$ was evident in their willingness to make reciprocal concessions and undertake to comply with the negotiated disciplines.

Continuing the work initiated in the two previous rounds, ${ }^{186}$ the Uruguay Round involved not only the negotiation of tariff reductions but also new substantive disciplines on nontariff barriers to trade, involving behind-the-border policy areas. ${ }^{187}$ For the first time, such new disciplines formed part of a 'single undertaking' that all countries wishing to be WTO Members had to sign on to. ${ }^{188}$ Therefore, the new involvement of developing coun-

Negotiations, UNCTAD Doc. T/B/778/Rev.1 (1982) 29, as quoted in John H. Jackson et al., Legal Problems of International Economic Relations: Cases, Materials and Text on the National and International Regulation of Transnational Economic Relations, Fourth ed., American Casebook Series (West Group, St. Paul), 2002, 1172 .

${ }^{182}$ De Feyter notes that '[t]oday, 'developing countries' wear the emperor's clothes of 'emerging markets'.' Koen De Feyter, 'Contracting for Human Development: International Law and Development Revisited', Asia Pacific Law Review 10 (1), 2002, 49-74, 49.

${ }^{183}$ WTO Development Division, Developing Countries and the Multilateral Trading System: Past and Present. Background Document for the High Level Symposium on Trade and Development (World Trade Organization, Geneva), 17-18 March 1999, 5, available at: http://www.wto.org/english/tratop_e/devel_e/tr_dvbadoc_e.doc, visited on 25 June 2007.

${ }^{184}$ This more active role of developing countries has been ascribed by Ostry to the transformation in the economic policy paradigm following the debt crisis of the $1980 \mathrm{~s}$, and thus the increased role of the IMF and World Bank, and the fall of the Berlin wall. Sylvia Ostry, 'The Uruguay Round North-South Grand Bargain: Implications for Future Negotiations', in The Political Economy of International Trade Law. Essays in Honor of Robert E. Hudec, Daniel L. M. Kennedy and James D. Southwick (eds.) (Cambridge University Press, Cambridge), 2002, 285-310, 286.

${ }^{185}$ Edwini Kwame Kessie, 'Developing Countries and the World Trade Organization: What Has Changed?' World Competition 22 (2), 1999, 83-110, 84. Kessie notes that developing countries hoped that by undertaking extensive commitments, they would 'send a positive signal to the international community that they were serious about economic reform.'

${ }^{186}$ Attention to non-tariff barriers to trade began during the Kennedy Round. The Tokyo Round codes went further in addressing non-tariff barriers to trade. However, unlike in the Uruguay Round where the single undertaking approach was followed, the Tokyo Round codes were only binding on those countries that accepted them. Most developing countries, therefore, did not incur obligations thereunder.

${ }^{187}$ United Nations Conference on Trade and Development, Assuring Development Gains from the International Trading System and Trade Negotiations. Background Note by the UNCTAD Secretariat for the 11th Session, 13-18 June 2004, TD/397 (United Nations, São Paulo), 4 May 2004, para. 5.

${ }^{188}$ The Punta Del Este Declaration launching the Uruguay Round negotiations stated: 'The launching, the conduct and the implementation of the outcome of the negotiations shall be treated as parts of a single undertaking.' Special Session of the GATT Contracting Parties, Ministerial Declaration on the Uruguay Round of 20 September 1986, GATT MIN.DEC, BISD 33S/19, circulated on 25 September 1986, Pat I:B(ii). As noted by Marceau and Trachtman, this embodies two separate concepts, the single political undertaking, which means that in the negotiations the approach was that 'nothing is agreed until everything is agreed' and the single legal undertaking, which means that the outcome of the negotiations would be a single package to be 
tries meant that they took on extensive obligations, ${ }^{189}$ not only to reduce tariffs but also to limit non-tariff barriers to trade, including in the area of domestic regulation, ${ }^{190}$ and to reform trade procedures. ${ }^{191}$

The new commitment to the integration of developing countries in the world economy was reflected in the rhetoric of the results of the Uruguay Round negotiations. The preamble to the Marrakesh Agreement Establishing the World Trade Organization ${ }^{192}$ (WTO Agreement), the agreement that together with its Annexes embodies the results of the Uruguay Round negotiations, recognises:

...that there is need for positive efforts designed to ensure that developing countries, and especially the least developed among them, secure a share in the growth in international trade commensurate with the needs of their economic development. ${ }^{193}$

While this preambular language does not create binding obligations on Members, it is not without significance. ${ }^{194}$ The relevance of the preamble to the WTO Agreement was clarified by the Appellate Body in US - Shrimp, where it stated: 195

...As this preambular language reflects the intentions of negotiators of the WTO Agreement, we believe it must add colour, texture and shading to our interpretation of the agreements annexed to the WTO Agreement... ${ }^{196}$

Nevertheless, despite the good intentions reflected in the preamble, it appears that the gains for developing countries from the results of the Uruguay Round have been meagre. It has been argued that both the agreements themselves and their interpretation by the dispute settlement organs of the WTO have evinced little understanding for developing countries' constraints and capacities and have, as such, not sufficiently led to the attain-

implemented as a single treaty. Gabrielle Marceau and Joel P. Trachtman, 'GATT, TBT and SPS: A Map of WTO Law of Domestic Regulation of Goods', in The WTO Dispute Settlement System 1995-2003, F. Ortino and Ernst-Ulrich Petersmann (eds.) (Kluwer Law International, Deventer), 2004, 275-340, footnote 5.

${ }^{189}$ Ostry notes, with respect to the Uruguay Round results: 'The degree of intrusiveness into domestic sovereignty bears little resemblance to the shallow integration of the GATT model of negative regulation - what governments must not do - to positive regulations, or what governments must do.' Sylvia Ostry, 'The Uruguay Round North South Grand Bargain: Implications for Future Negotiations,' presented at the Conference on the Political Economy of International Trade Law, Minneapolis, University of Minnesota Law School, 15-16 September 2000, 6 .

190 Examples are technical regulations and standards, sanitary and phytosanitary measures, and intellectual property protection.

${ }^{191}$ For example, import licensing procedures and customs valuation.

192 'Marrakesh Agreement Establishing the World Trade Organization', in The Results of the Uruguay Round of Multilateral Trade Negotiations: The Legal Texts (World Trade Organization, Geneva), 1994, 6-18.

${ }^{193}$ Ibid., 2nd recital. This recognition was absent from the preamble of the GATT 1947.

${ }^{194}$ In fact, the Appellate Body in EC-Tariff Preferences referred to this particular recital of the Preamble when establishing the object and purpose of the WTO Agreement and the Enabling Clause, in order to determine whether the Enabling Clause was intended to operate as an exception to Article I:1 of the GATT 1994. See Appellate Body Report, EC-Tariff Preferences, paras 91-92.

${ }^{195}$ In this case, the Appellate Body was dealing with the preambular recital that refers to the optimal use of the world's resources in accordance with the objective of sustainable development. However, its finding on the role of preambular language applies more generally to all recitals in the preamble of the WTO Agreement.

${ }^{196}$ Appellate Body Report, US - Shrimp, para. 153. 
ment of the objective of integration of developing countries into the world economy by securing them a share in the growth of international trade commensurate with their development needs. ${ }^{197}$

The 'single undertaking' approach followed in the Uruguay Round meant that countries were obliged to sign on to all the multilateral agreements resulting from the round, or not at all. They could not pick and choose among them, as had been the practice in previous rounds. ${ }^{198}$ As aptly put by Sylvia Ostry with regard to the single undertaking:

The deal was pretty much take it or leave it for the Southern countries. So they took it but, it is safe to say, without a full comprehension of the profoundly transformative implication of this new trading system. ${ }^{199}$

The Uruguay Round resulted in high costs for developing countries. Those developing countries that had no schedules of tariff concessions were obliged to negotiate such schedules in order to become original WTO Members. ${ }^{200}$ Due to the increased willingness of developing countries to engage actively in the Uruguay Round negotiations and to make reciprocal concessions in order to gain market access concessions in areas of interest to them, this has led to considerable tariff reductions in these countries, ${ }^{201}$ as compared

${ }^{197}$ Asif Qureshi notes that the development dimension 'has hitherto neither been sufficiently articulated nor coherently structured in the architecture of international trade agreements.' He also reports the dissatisfaction of developing-country Members with the record of WTO jurisprudence in interpreting WTO agreements in a way that advances the development objective. In this respect, Qureshi refers to three submissions of developing-country Members in the context of the negotiations on the reform of the WTO dispute settlement system, namely those contained in TN/DS/W/15 (Kenya, on behalf of the African Group), TN/ DS/W/17 (Zambia, on behalf of the LDC Group) and TN/DS/W/18 (India, on behalf of Cuba, Honduras, India, Malaysia, Pakistan, Sri Lanka, Tanzania and Zimbabwe). Asif H. Qureshi, 'Interpreting World Trade Organization Agreements for the Development Objective', Journal of World Trade 37 (5), 2003, 847-882, 848. Similarly, Mary Footer notes the concern of developing-country Members that they are 'witnessing a trend towards stricter interpretation' of SDT provisions in WTO agreements. In this respect Footer refers to a communication by Egypt to the General Council and the Committee on Trade and Development on SDT, contained in WT/GC/W/109 and WT/COMTD/W/49. Mary E. Footer, 'Developing Country Practice in the Matter of WTO Dispute Settlement', Journal of World Trade 35 (1), 2001, 55-98, 84.

198 There were only four plurilateral agreements that did not form part of the 'single undertaking', namely those on civil aircraft, government procurement, dairy and bovine meat.

199 Sylvia Ostry, 'The Uruguay Round North-South Grand Bargain: Implications for Future Negotiations', in The Political Economy of International Trade Law. Essays in Honor of Robert E. Hudec, Daniel L. M. Kennedy and James D. Southwick (eds.) (Cambridge University Press, Cambridge), 2002, 285-310, 287. Finger, an economist (previously with the World Bank) who is renowned for his work on trade and development issues, agrees with this evaluation. See J. Michael Finger, 'The Uruguay Round North-South Bargain: Will the WTO Get over It?' in The Political Economy of International Trade Law. Essays in Honor of Robert E. Hudec, Daniel L. M. Kennedy and James D. Southwick (eds.) (Cambridge University Press, Cambridge), 2002, 301-310, 308.

${ }^{200}$ Article XI of the WTO Agreement provides that Contracting Parties to the GATT 1947 that accept the WTO Agreement and the Multilateral Trade Agreements, and for which schedules of concessions and commitments are annexed to the GATT and the GATS, shall become original Members of the WTO. Special provision is made in para. 2 of this Article for LDCs, which are only 'required to undertake commitments and concessions to the extent consistent with their individual development, financial and trade needs or their administrative and institutional capabilities.' Countries that accede to the WTO in terms of Article XII of the WTO Agreement are obliged to accede to the WTO Agreement and all the multilateral trade agreements and to negotiate terms of accession that include schedules of tariff commitments.

${ }^{201}$ Finger has pointed out that developing country tariff reductions in the Uruguay Round covered as large a share of their imports as did those of developed countries $(30 \%)$, while their tariff cuts (measured according 
to the negligible tariff concessions made by developing countries in previous rounds. As tariffs form a significant source of revenue for many developing countries, this has meant a reduction in the resources available for their development needs. In exchange, developing countries pushed for the opening of markets, especially in OECD countries, for agricultural products and labour-intensive manufactured products, particularly textiles and clothing. However, while implementation of tariff reduction commitments by developing countries has been timely, ${ }^{202}$ the expected opening by developed countries of their agricultural and textile markets has occurred at a slower pace or more limited extent than envisaged by developing countries. ${ }^{203}$

Although, for the first time, agriculture took centre stage in the negotiations, the resulting Agreement on Agriculture ${ }^{204}$ made only limited progress in liberalising the agricultural sector, with the commitment to continue liberalisation in $2000 .{ }^{205}$ With regard to textiles and clothing, transitional arrangements were put into place for a 10 -year period ending in 2005, after which the Multi-Fibre Agreements were terminated and the textiles and clothing sector fully integrated into the GATT. ${ }^{206}$ However, Members held out until the last minute to make the necessary reforms in their textiles and clothing sectors. With regard to tariff reductions, significant tariff peaks remain with regard to manufactured or processed goods from developing countries, making it difficult for them to diversify their economies away from a reliance on the export of primary products. The results of the Uruguay

to how they will affect importers' costs) were actually deeper than those of developed countries. J. Michael Finger, 'The Uruguay Round North-South Bargain: Will the WTO Get over It?' in The Political Economy of International Trade Law. Essays in Honor of Robert E. Hudec, Daniel L. M. Kennedy and James D. Southwick (eds.) (Cambridge University Press, Cambridge), 2002, 301-310, 302.

202 Finger notes that there was full implementation of tariff commitments by developing countries by the January 2000 deadline despite the fact that developing countries made substantial commitments in this regard, and there was no problem with implementation of the GATS. J. Michael Finger, The Doha Agenda and Development: A View from the Uruguay Round (Asian Development Bank, Manila), August 2002, 9-10, available at: http://www.adb.org/Economics/pdf/doha/J_Michael_Finger.pdf, visited on 29 June 2008.

${ }^{203}$ As noted by Finger and Nogués, the wording of the Ūruguay Round Agreement on Textiles and Clothing, which requires the integration of all textile and clothing products into the GATT regime in 4 stages, allowed developed countries to delay much of the liberalisation of this sector until 2005. The authors report that although the first two phases should notionally lead to the liberalisation of 33\% of textile and clothing imports, Members tended to 'liberalise' those clothing imports that were not subject to restraints to begin with. As a result, the US had by the end of the second stage eliminated only $1 \%$ of its restrictions under the Multi-Fibre Agreements, the EC only 7\% and Canada only 14\%. The liberalisation of the agricultural sector has been even more problematic. While Members were obliged to replace their non-tariff barriers to trade with tariffs (known as tariffication), many developed-country Members applied tariffs that only slightly reduced, or in some cases increased, the level of protection. In addition, reductions of export subsidies and domestic support in the agricultural sector were limited. J. Michael Finger and Julio J. Nogués, The Unbalanced Uruguay Round Outcome: The New Areas in Future WTO Negotiations, December 2001, 3-4.

204 'Agreement on Agriculture', in The Results of the Uruguay Round of Multilateral Trade Negotiations: The Legal Texts (World Trade Organization, Geneva), 1994, 39-68.

${ }^{205}$ Article 20 of the Agreement on Agriculture.

206 Article 9 of the Agreement on Textiles and Clothing. See 'Agreement on Textiles and Clothing', in The Results of the Uruguay Round of Multilateral Trade Negotiations: The Legal Texts (World Trade Organization, Geneva), 1994, 85-137. 
Round have thus, not without reason, been called a 'lopsided bargain' ${ }^{207}$ Developing countries have lost more than they gained in real economic terms. ${ }^{208}$

Further, the implementation of the obligations contained in the Uruguay Round agreements has been costly for developing countries. ${ }^{209}$ The new agreements encompass disciplines to tackle a broad range of behind-the-border regulatory measures, going beyond the non-discrimination requirements of the GATT ${ }^{210}$ and laying down substantive disciplines for regulatory barriers to trade. ${ }^{211}$ This requires new or reformed laws and regulations and the institutional capacity to administer new regulatory systems. ${ }^{212}$ While developing countries, just as developed countries, potentially benefit from the increased market access that these new disciplines bring, they bear much higher costs in the implementation of the new rules. The new rules can be said to embody the 'best practice' in respect of regulatory regimes in developed countries and, as such, compliance requires significant technical, financial and administrative resources from developing countries. ${ }^{213}$ These

${ }^{207}$ Sylvia Ostry, 'The Uruguay Round North-South Grand Bargain: Implications for Future Negotiations', in The Political Economy of International Trade Law. Essays in Honor of Robert E. Hudec, Daniel L. M. Kennedy and James D. Southwick (eds.) (Cambridge University Press, Cambridge), 2002, 285-310, 288.

${ }^{208}$ Finger evaluates the North-South bargain of the Uruguay Round as follows: ' ...the North's mercantilist sacrifice on tariffs and quotas is, in real economics, a gain for them... The South's concessions, however, involve real costs to the South - significant costs to implement the policy changes, negative impacts in many cases of the changes themselves... North concessions...did not equal those by the developing countries. As for South concessions in the WTO New Areas - as mercantilism they are unrequited, as real economics they are overly costly.' J. Michael Finger, 'The Uruguay Round North-South Bargain: Will the WTO Get over It?' in The Political Economy of International Trade Law. Essays in Honor of Robert E. Hudec, Daniel L. M. Kennedy and James D. Southwick (eds.) (Cambridge University Press, Cambridge), 2002, 301-310, 304.

${ }^{209}$ A World Bank study in 2000 found that, 'the costs of implementing WTO agreements can easily exceed the entire development budget of a least-developed country' and noted that, 'It is not at all clear from a development perspective that the resources required for implementation of some WTO agreements, whatever the amount might be, would not be better used to build schools or improve infrastructure.' Rajesh Chadha et al., 'Developing Countries and the Next Round of WTO Negotiations', The World Economy 23 (4), 2000, 431-436, 433.

${ }^{210}$ Article III:4 of the GATT lays down the National Treatment obligation with regard to regulatory treatment of like domestic and imported products, prohibiting less favourable treatment of imports. Likewise, the requirement of Most-Favoured-Nation treatment in Article I of the GATT extends also to domestic regulation, prohibiting discrimination between imported products from different countries. Any advantage or privilege granted by a Contracting Party (now a WTO Member) to any product from another country must be accorded to the like product from all other Contracting Parties.

${ }^{211}$ As noted by the UNCTAD Secretariat, "the creation of the WTO in 1995 marked a paradigm shift by encompassing 'within-the-borders' policy issues in the context of a single undertaking.' United Nations Conference on Trade and Development, UNCTAD XI - the Spirit of Sao Paulo, TD/L.382 (United Nations, Sao Paulo), 17 June 2004, 5, available at: www.unctad.org/en/docs/TDL382_en/pdf, visited on 1 June 2005.

${ }^{212}$ J. Michael Finger, 'The Uruguay Round North-South Bargain: Will the WTO Get over It?' in The Political Economy of International Trade Law. Essays in Honor of Robert E. Hudec, Daniel L. M. Kennedy and James D. Southwick (eds.) (Cambridge University Press, Cambridge), 2002, 301-310, 304. See further on this point below, Part I, Section 1.7.

213 The intrusion of WTO rules into regulatory areas has been criticised by Jagdish Bhagwati as 'backdoor intrusionism, an attempt to iron out the asymmetries in other countries' domestic institutions and raise their costs out of line with comparative advantages.'. See Jagdish Bhagwati, Free Trade Today, (Princeton NJ: Princeton University Press, 2002): 67 as referred to by Sally. Sally points out that comparative advantage is undermined by what he calls 'standards harmonisation' as it 'ignores the fact that policies and institutions differ according to differences in circumstance, not least comparative costs which vary with levels of development.' Razeen Sally, Whither the World Trading System? Trade Policy Reform, the WTO and Prospects for the New Round, No. 76 (Timbro, Stockholm), 2002, 25-26, available at: http://www.timbro.se/pdf/whither.pdf, visited on 28 January 2008. 
costs are particularly high for developing countries whose domestic regulatory systems are still rudimentary in many areas. Implementation of these rules may divert resources from areas of higher priority for their development objectives, such as the provision of food, water and basic sanitation.

Unlike in past negotiating rounds, developing countries did not insist on special and differential treatment in the form of broad exemptions from negotiated disciplines but agreed to comply with these rules, in exchange for increased market access in areas of importance for them, such as agriculture. Calls for special and differential treatment were limited to longer timeframes for implementation of their obligations, consideration for their special position and improved technical assistance, instead of demands for developing country cut-outs from negotiated rules. ${ }^{214}$ However, expectations with regard to special and differential treatment and technical assistance have not been met. ${ }^{215}$ As noted by Finger and Schuler:

$[\mathrm{T}]$ he developing countries have taken on bound commitments to implement in exchange for unbound commitments of assistance. ${ }^{216}$

The lack of implementation of provisions on special treatment of developing countries has been a factor limiting the benefits that developing countries might have reaped from the market access gains resulting from the Uruguay Round, due to the fact that developing countries face supply-side constraints. These constraints mean that developing countries cannot take full advantage of increases in market access opportunities as they lack the capacity to respond to these opportunities. ${ }^{217}$ For this reason, increased market access does not necessarily translate into increased exports from developing countries. In order for trade liberalisation to result in real economic growth for developing countries, increased market access must therefore go hand-in-hand with technical assistance and capacity building to ensure that developing countries have the means to take advantage of market access gains. ${ }^{218}$ However, the references to technical assistance in the Uruguay

${ }^{214}$ Edwini Kwame Kessie, 'Developing Countries and the World Trade Organization: What Has Changed?' World Competition 22 (2), 1999, 83-110, 84.

${ }^{215}$ As stated by the UNCTAD Secretariat, 'Since the integration into the [international trading system] of developing countries has increasingly involved aligning their policies and standards with those of developed countries, there a number of expectations have been implicit in the participation of developing countries in the ITS: (a) that their development, financial and trade needs and circumstances would be fully 'integrated' into the framework of rights and obligations; (b) that adequate international support and assistance, technical and financial, would be readily available, as structural and adjustment support; (c) that their own liberalization and structural adjustment would be reciprocated, especially by developed-country partners; (d) that international markets would be less imperfect and distorted and would allow developing-country enterprises to compete fairly and make best use of efficiencies generated by economic reform; (e) that enhanced and stable preferential market access in areas of developing countries' inherent and emerging comparative advantage in commodities, manufactures and services would be realized in their major markets; and (f) that their vulnerabilities and inadequacy of bargaining power would be redressed.' United Nations Conference on Trade and Development, UNCTAD XI - the Spirit of Sao Paulo, TD/L.382 (United Nations, Sao Paulo), 17 June 2004, para. 6, available at: www.unctad.org/en/docs/TDL382_en/pdf, visited on 1 June 2005.

${ }^{216}$ Michael J. Finger and Philip Schuler, 'Implementation of Uruguay Round Commitments: The Development Challenge’, The World Economy 23 (4), 2000, 511-525, 514.

${ }^{217}$ De Feyter points out that sub-Saharan African countries 'struggle with the inadequate domestic supply response to existing market opportunities'. Koen De Feyter, World Development Law: Sharing Responsibility for Development (Intersentia, Antwerp), 2001, 97.

${ }^{218}$ The UNCTAD Secretariat, in its background note to UNCTAD XI, notes, 'In the context of limited resources, 
Round agreements are couched in hortatory terms and have fallen short of addressing supply-side constraints. ${ }^{219}$

That is not to say that developing countries have not benefited at all from the results of the Uruguay Round. Most significantly, the creation of the World Trade Organization and its dispute settlement system through the Uruguay Round negotiations, holds important benefits for developing countries. The increased judicial nature of the world trading system has increased the certainty and predictability of the trading environment. ${ }^{220}$ The creation of a strong system of enforcement of its rules through a quasi-judicial dispute settlement system means that developing countries are no longer at the mercy of more powerful trading partners. ${ }^{221}$

\subsection{From the Uruguay Round to the Seattle Ministerial Conference}

Since the coming into existence of the WTO, a large number of developing countries, and two least-developed countries, ${ }^{222}$ have negotiated membership in this organisation. Developing countries currently represent four-fifths of WTO Members. This, together with the increasing assertiveness of developing country Members, has led to a change in the dynamics of the organisation.

On the basis of their experience with the results of the Uruguay Round and the implementation problems arising from those agreements, developing countries raised concerns regarding the asymmetry of the benefits and costs of the world trading system. ${ }^{223}$ There

developing countries have difficulty giving priority to the resources required for trade success when some pressing development priorities (e.g. combating widespread poverty, illiteracy, hunger and malnutrition and pandemics) legitimately claim a large part of their institutional attention and budgetary allocation. Unless adequate support and phase in are provided for integration into the [international trading system], the costs of integration may far outweigh the benefits.' United Nations Conference on Trade and Development, Assuring Development Gains from the International Trading System and Trade Negotiations. Background Note by the UNCTAD Secretariat for the 11th Session, 13-18 June 2004, TD/397 (United Nations, São Paulo), 4 May 2004, para. 22.

${ }^{219}$ In his recommendations for the Doha Round negotiations on the basis of the Uruguay Round experience with technical assistance, Finger advises, 'Do not trust trade ministers when they talk about money, they do not have any.' He refers to the fact that trade ministers and ministries do not have authority or even influence within their governments to dispose of the necessary sums of money for technical assistance. J. Michael Finger, The Doha Agenda and Development: A View from the Uruguay Round (Asian Development Bank, Manila), August 2002, 38, available at: http://www.adb.org/Economics/pdf/doha/J_Michael_Finger.pdf, visited on 29 June 2008.

${ }^{220}$ Low notes that even if developing countries cannot influence the behaviour of their trading partners through participation in the WTO, they nevertheless benefit from membership in the WTO. He points to the inherent benefit in the fact that their trading partners are required to subscribe to a set of rules that increase certainty and reduce the arbitrariness of their trade policy behaviour. Patrick Low, 'Is the WTO Doing Enough for Developing Countries?' in WTO Law and Developing Countries, George A. Bermann and Petros C. Mavroidis (eds.) (Cambridge University Press, Cambridge), 2007, 324-358, 327.

${ }^{221}$ The WTO dispute settlement system is briefly described below, Part IV, Section 2.2.1.

${ }^{222}$ Nepal was the first LDC to accede to the WTO, in April 2004, followed by Cambodia in October of the same year.

${ }^{223}$ The UNCTAD Secretariat has noted, 'Significant gains were anticipated and promised, including from the 'grand bargain' that was struck from the most ambitious round of multilateral trade negotiations, the Uruguay Round, which led to the creation of the WTO. ... From the perspective of developing countries, which constitute the majority of the WTO membership, the unfinished business of the Uruguay Round needs to 
were calls for the 'rebalancing' of the Uruguay Round results before any new negotiations could be launched. ${ }^{224}$ In addition, developing countries strongly opposed the negotiation of new WTO rules requiring the development or reform of national regulatory regimes, such as rules on competition and investment, the so-called 'new issues' in the run up to the Seattle Session of the Ministerial Conference. They also opposed increased recognition of societal concerns such as labour standards, environment and health in WTO rules by means of additional flexibility for trade restrictions in these areas. ${ }^{225}$ This can be ascribed to their concern with benefiting fully from trade liberalisation and limiting the costs of membership in the WTO. ${ }^{226}$

In the run-up to the Seattle Session of the Ministerial Conference, the proactive role of developing countries was striking. A positive agenda was put forward by these countries, and they submitted more than half of the 250 specific proposals for the Ministerial Conference. ${ }^{227}$ These proposals demonstrated the heterogeneity of developing countries, with larger developing countries and agricultural exporting nations focusing on market access issues while smaller developing countries and LDCs prioritised implementation issues and the need for effective technical assistance and special and differential treatment. ${ }^{228}$ A notable factor that contributed to the new proactive stance of developing countries was the growing awareness of the importance of trade issues among the business community and non-governmental organisations in developing countries. These new actors in the policy arena have contributed to the development of positive negotiating positions in developing countries. In addition, UNCTAD played a role in assisting developing countries to formulate their own agenda and become demandeurs in the negotiations. ${ }^{229}$

These developments led to an emphasis on implementation issues as an attempt to 'rebalance' the Uruguay Round results. ${ }^{230}$ Although the idea of implementation issues originally

be completed, the Agreements fully implemented, and its gains to materialize. Many developing countries have drawn attention to the urgent need to address specific development provisions and mandates of the Doha Declaration, and to correct the asymmetries in the MTS.' United Nations Conference on Trade and Development, UNCTAD XI - the Spirit of Sao Paulo, TD/L.382 (United Nations, Sao Paulo), 17 June 2004, para.7, available at: www.unctad.org/en/docs/TDL382_en/pdf, visited on 1 June 2005.

${ }^{224}$ Sylvia Ostry, 'The Uruguay Round North-South Grand Bargain: Implications for Future Negotiations', in The Political Economy of International Trade Law. Essays in Honor of Robert E. Hudec, Daniel L. M. Kennedy and James D. Southwick (eds.) (Cambridge University Press, Cambridge), 2002, 285-310, 289.

225 Allowing a wide margin of flexibility for trade restrictions to protect health, environment and labour standards in WTO rules forces developing countries to implement the social standards maintained by developed countries and erodes the comparative advantage that developing countries have in certain areas due to their lower production costs resulting from lower social standards.

${ }^{226}$ Koen De Feyter, World Development Law: Sharing Responsibility for Development (Intersentia, Antwerp), 2001,99 .

227 See WTO Secretariat, Preparations for the 1999 Ministerial Conference. Compilation of Proposals Submitted in Phase 2 of the Preparatory Process. Informal Note by the Secretariat. Revision, JOB(99)/4797/ Rev.3, circulated on 18 November 1999.

${ }^{228}$ Sylvia Ostry, 'The Uruguay Round North-South Grand Bargain: Implications for Future Negotiations', in The Political Economy of International Trade Law. Essays in Honor of Robert E. Hudec, Daniel L. M. Kennedy and James D. Southwick (eds.) (Cambridge University Press, Cambridge), 2002, 285-310, 289.

${ }^{229}$ Ostry notes that the Secretary-General of UNCTAD, Rubens Ricupero, stated that the role of UNCTAD is to assist developing countries to develop a positive agenda. Ibid., 292.

${ }^{230}$ Ibid. Finger notes that the implementation debate at the WTO does not reflect a movement towards the appropriate economics. Developed countries argue that 'a deal is a deal' with regard to developing country obligations in the new areas covered by the Uruguay Round agreements. Developing countries' response is 
referred to problems of compliance with negotiated obligations, in the preparatory process for the Seattle Session of the Ministerial Conference this idea was used to refer more broadly to imbalances in the Uruguay Round results. ${ }^{231}$ In other words, implementation issues covered not only actual non-implementation of the legally-binding obligations in the Uruguay Round agreements, but also the fact that, due to flexibilities in certain provisions in the agreements ${ }^{232}$ and the interpretation of these provisions by some countries in a way that runs counter to the interests of developing countries, the expected benefits for developing countries had failed to materialise. At the Geneva Session of the Ministerial Conference in 1998, it was agreed that implementation issues were an important part of the future work of the WTO. The Ministerial Declaration provided:

Full and faithful implementation of the WTO Agreement and Ministerial Decisions is imperative for the credibility of the multilateral trading system and indispensable for maintaining the momentum for expanding global trade, fostering job creation and raising standards of living in all parts of the world. When we meet at the Third Session we shall further pursue our evaluation of the implementation of individual agreements and the realization of their objectives. Such evaluation would cover, inter alia, the problems encountered in implementation and the consequent impact on the trade and development prospects of Members. We reaffirm our commitment to respect the existing schedules for reviews, negotiations and other work to which we have already agreed.

.... we decide that a process will be established under the direction of the General Council to ensure full and faithful implementation of existing agreements, and to prepare for the Third Session of the Ministerial Conference. This process shall enable the General Council to submit recommendations regarding the WTO's

equally traditional, making suggestions based on the mercantilist concept of SDT, namely that developing countries be exempted from some obligations and be granted longer implementation periods. Finger claims that legitimate questions can be raised about the economic rationality of some countries implementing certain of their Uruguay Round obligations. J. Michael Finger, 'The Uruguay Round North-South Bargain: Will the WTO Get over It?' in The Political Economy of International Trade Law. Essays in Honor of Robert E. Hudec, Daniel L. M. Kennedy and James D. Southwick (eds.) (Cambridge University Press, Cambridge), 2002, 301-310, 306-307.

${ }^{231}$ Doha Round Briefing Series. Cancun Update: Implementation-Related Issues and Concerns, Vol. 2 No. 1 (The International Centre for Trade and Sustainable Development and the International Institute for Sustainable Development, Geneva), August 2003. See also Patrick Low, 'Is the WTO Doing Enough for Developing Countries?' in WTO Law and Developing Countries, George A. Bermann and Petros C. Mavroidis (eds.) (Cambridge University Press, Cambridge), 2007, 324-358, 333.

${ }^{232}$ For example, some of the provisions at issue are hortatory, such as Article 10.2 of the SPS Agreement, which provides that longer time-frames for compliance should be granted on products of interest to developing countries, where the appropriate level of SPS protection allows. Other provisions at issue are quite flexible in allowing for different interpretations, such as Article 4.1 of the SPS Agreement which obliges Members to accept the SPS measures of other Members as equivalent, if they are objectively demonstrated to meet the appropriate level of protection of the importing Member and Article 15 of the Antidumping Agreement which obliges developed countries to have 'special regard' for the situation of developing countries when considering the imposition of anti-dumping measures. Although it would be difficult to prove that these provisions have been violated, developing countries believe that they have not been faithfully implemented according to the spirit of the agreements, and thus that a asymmetry has resulted in the results of the Uruguay Round for developed and developing countries. 
work programme, including further liberalization sufficiently broad-based to respond to the range of interests and concerns of all Members, within the WTO framework, that will enable us to take decisions at the Third Session of the Ministerial Conference. ... ${ }^{233}$

Implementation was probably the most discussed issue in the period leading up to the Seattle Ministerial Conference. Over 150 implementation concerns were identified by developing countries and presented to the General Council before the Seattle Ministerial meeting. ${ }^{234}$ As is common knowledge, the Seattle Ministerial Conference ended in failure, with disagreement between the United States (US) and European Communities (EC) $)^{235}$ on crucial issues, the walkout of most non-OECD countries, amidst non-governmental organisation protests and street riots. As noted by Sylvia Ostry after the failed Seattle Ministerial Conference:

The bicycle theory of trade liberalisation - combat protectionist pressures by means of regular negotiations - is a metaphor based on the past. The cyclist was the US and, perhaps, a bicycle built for two could accommodate the EU on the back seat. The WTO today is like a crowded bus full of noisy passengers who cannot (or will not) agree on the instructions for the poor, beleaguered driver. Yet...it would not be impossible to arrange for a reasoned discussion on the road to take to reach an agreed destination. ${ }^{236}$

Following the fiasco in Seattle, there was a new realisation among developed countries of the need to take developing country concerns seriously in order to get the international consensus necessary to relaunch the negotiating round. Developing countries gained in confidence and continued to push for recognition of the need to address the problems of the existing Uruguay Round agreements, particularly with regard to implementation, before new negotiations could be started. In April 2000, the Group of 77 and China ${ }^{237}$ adopted the Havana Programme of Action ${ }^{238}$ at the South Summit, in which they committed themselves, inter alia, to:

${ }^{233}$ Ministerial Conference, Second Session, Ministerial Declaration, WT/MIN(98)/DEC/1, (Geneva: World Trade Organization, adopted 20 May 1998): paras 8-9.

234 These issues were divided into two categories (i) issues to be decided before the Seattle Ministerial Conference and (ii) issues to be agreed within one year thereof.

${ }^{235}$ The European Communities, not the European Community or the European Union, is a Member of the WTO. Its membership is provided for in Article XI of the WTO Agreement. Hereafter in this book the abbreviation 'EC' will be used to refer to the European Communities, unless otherwise indicated.

${ }^{236}$ Sylvia Ostry, 'The Uruguay Round North-South Grand Bargain: Implications for Future Negotiations', in The Political Economy of International Trade Law. Essays in Honor of Robert E. Hudec, Daniel L. M. Kennedy and James D. Southwick (eds.) (Cambridge University Press, Cambridge), 2002, 285-310, 300.

${ }^{237}$ See note 116. The G-77 currently has 135 members but the original name has been kept due to its historic significance. When China acts together with this group, it is known as the Group of 77 and China (G-77+ China).

${ }^{238}$ The Havana Programme of Action was intended to further the objectives of the Declaration of the South Summit, which noted with concern that developing countries '...have not been able to share in the benefits of globalization on an equal footing with developed countries...', and that: '[a]symmteries and imbalances have intensified in international economic relations...'. See the text of this document, contained in: General Assembly, Fifty-Fifth Session of the General Assembly. Letter Dated 5 May 2000 from the Permanent Representative of Nigeria to the United Nations Addressed to the President of the General Assembly, A/55/74 (United Nations, New York), 12 May 2000, Annex I para. 11, available at: www.G77.org/main/docs/ 
Intensify efforts to review and reform the WTO regime with a view to promoting a multilateral trading system that is fair, equitable and rule-based, and that operates in a non-discriminatory, inclusive and transparent manner, in a way which provides benefits for all countries, especially developing countries. This will involve among other things, improving market access for goods and services of particular interest to developing countries, resolving issues relating to the implementation of WTO Agreements, fully implementing special and differential treatment, facilitating access to the WTO, and providing technical assistance. ${ }^{239}$

The Declaration of the South Summit also called upon developed countries to fully implement SDT for developing countries and stated that future multilateral trade negotiations should be based on a positive agenda and should take full consideration of the development dimension of trade and of the specific needs and concerns of developing countries. ${ }^{240}$

\subsection{The Doha Development Agenda}

In order to address the problems leading to the failure of the Seattle Session of the Ministerial Conference, a new surge in efforts to integrate developing countries interests into future trade negotiations emerged in the run-up to the Doha Session of the Ministerial Conference. Confidence-building initiatives to encourage developing countries to agree to launch new round of negotiations abounded. ${ }^{241}$ More funding was made available for trade-related technical assistance and capacity building. ${ }^{242}$

In addition, discussions were held on the implementation concerns of developing countries. As already mentioned, these implementation concerns relate, on the one hand, to the difficulties encountered by developing countries in implementing their obligations under the Uruguay Round agreements, ${ }^{243}$ and on the other, to the failure of developed countries to fully and faithfully implement the Uruguay Round agreements, including those provisions on special and differential treatment for developing countries. The implementation discussion continued to centre on the 'rebalancing' of the Uruguay Round agreements,

summitfinaldocs_english.pdf, visited on 28 January 2008.

${ }^{239}$ Ibid., Annex II para. V(1) 2nd bullet point.

${ }^{240} \mathrm{Ibid}$., Annex I para. 21.

${ }^{241}$ One delegate relabelled these initiatives as 'confidence shattering', due to their limited nature. Sylvia Ostry, 'The Uruguay Round North-South Grand Bargain: Implications for Future Negotiations', in The Political Economy of International Trade Law. Essays in Honor of Robert E. Hudec, Daniel L. M. Kennedy and James D. Southwick (eds.) (Cambridge University Press, Cambridge), 2002, 285-310, 295.

${ }^{242}$ For example, the Integrated Framework for Trade Related Technical Assistance to Least-Developed Countries was established by means of cooperation between the WTO, World Bank, IMF, ITC, UNCTAD and UNDP. Sub-Committee on Least-Developed Countries, Report on the Seminar by the Integrated Framework Core Agencies, WT/LDC/SWG/IF/15/Rev.1, circulated on 17 April 2001.

${ }^{243}$ Finger notes that most implementation problems, in this sense, relate to agreements creating disciplines for national regulatory systems, such as the SPS Agreement, the TBT Agreement, and TRIPS. Developing countries, in contrast, implemented their significant tariff reduction commitments within the negotiated deadline of January 2000, and there were no problems with the implementation of the GATS. J. Michael Finger, The Doha Agenda and Development: A View from the Uruguay Round (Asian Development Bank, Manila), August 2002, 9-10, available at: http://www.adb.org/Economics/pdf/doha/J_Michael_Finger.pdf, visited on 29 June 2008. 
to address the asymmetry in the results obtained. Shortly before the Doha Ministerial Conference in 2001, the Group of 77 (G-77) and China adopted a Declaration ${ }^{244}$ noting that:

...the benefits of the existing multilateral trading system continue to elude developing countries. Progress towards full liberalisation in sectors of particular interest to them is lagging behind, and significant imbalances between rights and obligations exist in multilateral trade agreements (MTAs), as well as in conditions of market access. ... Addressing these asymmetries and the development deficit should receive primacy in all future work programmes in the WTO... ${ }^{245}$

Developing countries raised 104 implementation concerns in the course of the new implementation discussions. They argued that these concerns should be addressed before the launching of a new negotiating round, as they should not have to 'pay' again, by means of trade-offs in other areas during a new round of negotiations, for proper implementation of the Uruguay Round results. ${ }^{246}$ In May 2000, the General Council established an Implementation Review Mechanism, consisting of Special Sessions of the General Council to address implementation issues. ${ }^{247}$ In December 2000, a decision was taken by the General Council in which seven minor implementation issues were resolved and the objective expressed to complete the process no later than the Fourth WTO Ministerial Conference, to be held in Doha in November $2001 .{ }^{248}$ However, many developing countries were dissatisfied with the progress made in the preparatory phase of the Doha Session of the Ministerial Conference. The abovementioned Declaration of the G-77 and China expressed:

...deep disappointment on the lack of any meaningful progress on implementation issues, despite a clear consensual decision in May and December 2000 by

\footnotetext{
${ }^{244}$ Group of 77 and China, Declaration by the Group of 77 and China on the Fourth WTO Ministerial Conference at Doha, Qatar, 22 October 2001.

245 Ibid., para. 4.

${ }^{246}$ Doha Round Briefing Series. Developments since the Fourth WTO Ministerial Conference: ImplementationRelated Issues and Concerns, Vol. 1 No.1 (The International Centre for Trade and Sustainable Development and the International Institute for Sustainable Growth, Geneva), February 2003, 1, available at: www.ictsd. org/pubs/dohabriefings/doha1-implement.pdf, visited 25 June 2007. Developed country Members, by contrast, are of the opinion that strengthening the provisions of the WTO agreements with which there are implementation concerns amounts to changing the rights and obligations negotiated in the Uruguay Round, and that trade-offs should therefore be made.

${ }^{247}$ At the first Special Session on Implementation of the General Council on 22 June - 3 July 2000, a work programme on implementation issues was agreed upon. The Special Session held on 18 October 2000 referred certain implementation issues to the relevant WTO bodies dealing with these areas. General Council Special Session on Implementation, Minutes of Meeting - Held in the Centre William Rappard on 18 October 2000, WT/GC/M/59, circulated on 13 November 2000. Special Sessions of the General Council met again on implementation issues on 15 December 2000 and on 27 April and 3 October 2001.

${ }_{248}$ Taking into account the reports from the WTO bodies to which implementation issues were referred, the Third Special Session of the General Council, on 15 December 2000, took a series of modest decisions on seven implementation issues which mostly dealt with clarifications regarding subsidies rules. It was further decided that the General Council would address the outstanding implementation issues with a view to completing the process no later than the Fourth Session of the Ministerial Conference. General Council, Implementation-Related Issues and Concerns - Decision of 15 December 2000, WT/L/384, circulated on 19 December 2000, para. 7 .
} 
the WTO General Council to address and adopt decisions no later than the $4^{\text {th }}$ Ministerial Meeting. ${ }^{249}$

The discussions on implementation issues in Special Sessions of the General Council continued and finally resulted in the drafting of the Decision on Implementation Related Issues and Concerns (the Implementation Decision), which was adopted at the Doha Ministerial Conference on 14 November 2001. ${ }^{250}$ This decision has been described as the quid pro quo for developing countries agreement to the launching of a new round of trade negotiations at the Doha Ministerial Conference. It aims to meet developing countries' demands that their implementation concerns regarding the Uruguay Round agreements be addressed before they could agree to new negotiations. However, the achievements of the Implementation Decision are limited. Although it embodies decisions on over 50 implementation issues under various agreements for immediate delivery, these decisions mainly reaffirm existing provisions or their accepted interpretation, ${ }^{251}$ urge Members to implement them fully, ${ }^{252}$ approve recommendations developed in other bodies ${ }^{253}$ or direct certain WTO bodies to undertake work in particular areas. ${ }^{254}$ In fact, it has been argued

${ }^{249}$ Group of 77 and China, Declaration by the Group of 77 and China on the Fourth WTO Ministerial Conference at Doha, Qatar, 22 October 2001, para. 5.

${ }^{250}$ Ministerial Conference, Implementation-Related Issues and Concerns. Decision of 14 November 2001, WT/ $\operatorname{MIN}(01) / 17$, circulated on 20 November 2001.

${ }^{251}$ For example, inter alia, it is reaffirmed: that Article XVIII of the GATT 1994 is a SDT provision for developing countries and that recourse to it should be less onerous than to Article XII of the GATT 1994; that least-developed country members are exempt from the prohibition on export subsidies in Article 3.1(a) of the Agreement on Subsidies and Countervailing Measures; that the provisions of Article 66.2 of the TRIPS Agreement are mandatory; and that preferences granted to developing countries pursuant to the Enabling Clause should be generalised, non-reciprocal and non-discriminatory. See Ibid., paras 10.15, 11.12, and 12.12 respectively.

${ }^{252}$ For example, inter alia, Members are urged to fully implement the provisions on technical assistance in the SPS Agreement and the TBT Agreement; and it is agreed that the provisions of the Agreement on Textiles and Clothing relating to the early integration of products and the elimination of quota restrictions should be effectively utilised. See Ibid., paras 3.6, 5.4 and 4.1 respectively.

${ }^{253}$ For example, inter alia:, (1) the report of the Committee on Agriculture on the implementation of the Decision on Measures Concerning the Possible Negative Effects of the Reform Programme on Least-Developed and Net Food-Importing Developing Countries, on the implementation of Article 10.2 of the Agreement on Agriculture, as well as on the administration of tariff rate quotas and the submission by Members of addenda to their notifications is noted and the recommendations or decisions of this Committee are approved; (2) the SPS Committee's Decision on Equivalence is noted; and (3) the approach to technical assistance developed by the TBT Committee reflecting the results of the triennial review is confirmed. See Ibid., paras 2.2, 2.3, $2.4,3.3$ and 5.1 respectively.

${ }^{254}$ For example, inter alia: (1) the Council for Trade in Goods is directed to examine proposals with regard to the calculation of quotas under the Agreement on Textiles and Clothing and make recommendations to the General Council; (2) the Director-General is urged to continue cooperative efforts with international standard-setting organisations under the SPS and TBT Agreements to ensure the effective participation of developing, and in particular least-developed countries; (3) the SPS Committee is instructed to expeditiously develop a specific programme for the implementation of Article 4 of the SPS Agreement; (4) the Committee on Antidumping practices is directed to study the issue of time-frames in establishing the volume of dumped imports and to make recommendations is this regard; (5) the TRIPS Council is directed to continue its examination of the scope and modalities for complaints of the types provided for under Subparagraphs 1(b) and 1(c) of Article XXIII of GATT 1994 and make recommendations; and (6) the Committee on Trade and Development is instructed to identify the SDT provisions that are mandatory and those that are not, to consider the implications of making the latter mandatory and to examine additional ways to make SDT provisions more effective. Ibid., paras 4.4, 4.5, 3.5, 5.3, 3.3, 7.2, 11.11 and 12.11 respectively. 
that only five 'mandatory and concrete' decisions are embodied in the Implementation Decision. ${ }^{255}$ With regard to outstanding implementation issues, the Implementation Decision refers to paragraph 12 of the Doha Ministerial Declaration, which notes the utmost importance of these issues and sets out a two-track work programme for addressing them. ${ }^{256}$ On some issues, a negotiating mandate was agreed, whereas on others the issue was referred to the appropriate WTO body, which was obliged to take it up as a matter of priority and report to the Trade Negotiations Committee by the end of 2002 for appropriate action. Also subject to the same deadline, a separate declaration, the Doha Declaration on TRIPS and Public Health, adopted at the Doha Ministerial Conference, instructs the Council for TRIPS to find an expeditious solution to the problem of access to essential medicines created by requirements set by the TRIPS Agreement provision allowing compulsory licensing of patents. ${ }^{257}$ However, continuing lack of consensus meant that this deadline was missed in both cases.

Concern with the integration of developing countries into the multilateral trading system is also reflected in the Ministerial Declaration on the launching of a new round of trade negotiations, adopted by the Ministerial Conference in Doha on 14 November 2001. Establishing what has become known as the 'Doha Development Agenda' for trade negotiations, the Doha Ministerial Declaration provides:

International trade can play a major role in the promotion of economic development and the alleviation of poverty. We recognize the need for all our peoples to benefit from the increased opportunities and welfare gains that the multilateral trading system generates. The majority of WTO members are developing countries. We seek to place their needs at the heart of the Work Programme adopted in this declaration. Recalling the Preamble to the Marrakesh Agreement, we shall continue to make positive efforts designed to ensure that developing countries, and especially the least developed among them, secure a share in the growth of world trade commensurate with the needs of their economic development. In this context, enhanced market access, balanced rules, and well-targeted, sustainably

${ }^{255}$ Doha Round Briefing Series. Developments since the Fourth WTO Ministerial Conference: ImplementationRelated Issues and Concerns, Vol. 1 No.1 (The International Centre for Trade and Sustainable Development and the International Institute for Sustainable Growth, Geneva), February 2003, 3, available at: www.ictsd. org/pubs/dohabriefings/doha1-implement.pdf, visited 25 June 2007. These are the decisions specifying the longer time frames for compliance with SPS measures by developing countries under the SPS Agreement as normally not less than six months; specifying the reasonable interval for adaptation to new SPS and TBT measures under the SPS and TBT Agreements as normally not less than six months; and decisions under the Agreement on Subsidies and Countervailing Measures with regard to the extension of transition periods for subsidy programs under Article 27.4. Ministerial Conference, Implementation-Related Issues and Concerns. Decision of 14 November 2001, WT/MIN(01)/17, circulated on 20 November 2001, paras 3.1, 3.2, 5.2, 10.11 and 10.14 respectively.

256 Ministerial Conference, Doha Ministerial Declaration. Adopted on 14 November 2001, WT/MIN(01)/ DEC/1, circulated on 20 November 2001, para. 12(a) and (b).

${ }^{257}$ Article 31 of the TRIPS Agreement allows the granting of compulsory licences to patented medicines in cases of national emergency or extreme urgency. However, this right is limited by the requirement, in paragraph (f), that the compulsory licences be granted 'predominantly for the supply of the domestic market'. Members that lack sufficient manufacturing capacity in pharmaceuticals therefore could not make use of this provision. This was a serious problem for many developing-country Members and they successfully pushed for the inclusion of this issue in the Doha Round negotiations. 
financed technical assistance and capacity building programmes have important roles to play. ${ }^{258}$ (Emphasis added)

A development round of the kind envisaged in the Doha Development Agenda would be in line with the Monterrey Consensus, unanimously adopted in 2002 at the UN-hosted International Conference on Financing for Development. ${ }^{259}$ The Monterrey Consensus, while acknowledging the primary responsibility each state has for its own development, emphasises the need for domestic efforts to be supported by an 'enabling international economic environment'. As a result, the heads of state and government at Monterrey committed themselves, inter alia, to 'promoting international trade as an engine for development' and 'increasing international financial and technical cooperation for development'. ${ }^{260}$ The UN World Economic and Social Survey 2003 suggests that the Doha Ministerial Conference and the Monterrey International Conference on Financing for Development, together with the World Summit on Sustainable Development, ${ }^{261}$ 'collectively defined a new global partnership for development between developed and developing countries' the overriding objective of which is 'to accelerate development through shared responsibilities and mutual commitment' ${ }^{262}$

In addition to its focus on market access and balanced rules for developing countries, the Doha Declaration recognises the importance of SDT provisions, noting that they are 'an integral part of the WTO Agreements' and mandating a review of these provisions with a view to 'strengthening them and making them more precise, effective and operational'. ${ }^{263}$ According to the Doha Declaration, modalities for further commitments, including SDT provisions, had to be established by 31 March 2003.264

The UNCTAD Secretariat notes that a key element of development-oriented SDT is 'adequate flexibility and space for developing countries regarding within-the-borders issues and resource-intensive agreements...' ${ }^{265}$ In other words, the issue of adequate policy space for developing countries forms an integral part of discussions on SDT. ${ }^{266}$ However,

258 Ministerial Conference, Doha Ministerial Declaration. Adopted on 14 November 2001, WT/MIN(01)/ DEC/1, circulated on 20 November 2001, para. 2.

${ }^{259}$ Report of the International Conference on Financing for Development, UN Doc. A/CONF.198/11 (United Nations, Monterrey), 18-22 March 2002, Chapter VI, available at: www.un.org/esa/ffd/aconf198-11.pdf, visited on 25 June 2007.

${ }^{260}$ Ibid., Chapter I, paras 4 and 6.

${ }^{261}$ Held in Johannesburg, South Africa, in August-September 2002.

${ }^{262}$ UN Department of Economic and Social Affairs, UN World Economic and Social Survey (United Nations, December 2003, 15, available at: www.un.org/esa/analysis/wess/wess2003chap1.pdf, visited on 25 June 2007. This survey argues that meaningful progress on the Doha negotiations will require governments to take a more flexible approach to the negotiations 'and, above all, to see them not as trade negotiations but as part of the new partnership to foster development'.

263 Ministerial Conference, Doha Ministerial Declaration. Adopted on 14 November 2001, WT/MIN(01)/ DEC/1, circulated on 20 November 2001, para. 44.

${ }^{264}$ Ibid., para. 12.

${ }^{265}$ United Nations Conference on Trade and Development, Assuring Development Gains from the International Trading System and Trade Negotiations. Background Note by the UNCTAD Secretariat for the 11th Session, 13-18 June 2004, TD/397 (United Nations, São Paulo), 4 May 2004, para. 25.

${ }^{266}$ A summary of the discussions on SDT under the Doha mandate can be found in the ICTSD/IISD Doha Round Briefing Series, and the Cancun Update of this series. See Doha Round Briefing Series. Developments since the Fourth WTO Ministerial Conference: Special and Differential Treatment, Vol. 1 No. 13 (International 
the negotiations on SDT provisions in the period leading up to the Cancun Session of the Ministerial Conference in 2003 only led to tentative agreement on 28 proposals, none of which are regarded as being of much value.

The Cancun Ministerial Conference, held on 10-14 September 2003, aimed to provide a mid-term review of the progress of the Doha Round negotiations, and to allow for certain decisions to be made necessary to the further progress of the negotiating round. However, the fact that most of the deadlines for decisions set out in the Doha Ministerial Declaration had not been met meant that the agenda for the Cancun Ministerial Conference was overloaded.

In the weeks leading up to the Cancun Ministerial Conference, a new alliance of developing countries, dubbed the Group of 20 (G-20), ${ }^{267}$ emerged. ${ }^{268}$ It took a strong stance in favour of agricultural liberalisation and against the launching of negotiations on the so-called Singapore issues of competition, investment, trade facilitation and transparency in government procurement. ${ }^{269}$ The G-20 negotiated as a bloc, putting forward its own positive negotiating positions. This was in marked contrast to the role of previous

Centre for Trade and Sustainable Development and International Institute for Sustainable Development, Geneva), February 2003, available at: www.ictsd.org/pubs/dohabriefings/doha13-s-and-d.pdf, visited on 25 June 2007; Doha Round Briefing Series. Cancun Update: Special and Differential Treatment, Vol. 2 No. 13 (The International Centre for Trade and Sustainable Development and the International Institute for Sustainable Development, Geneva), August 2003.

${ }^{267}$ This moniker resulted from the fact that the number of members of the coalition before Cancun was initially 20 (the coalition brought together Argentina, Bolivia, Brazil, Chile, China, Colombia, Costa Rica, Cuba, Ecuador, El Salvador, Guatemala, India, Mexico, Pakistan, Paraguay, Peru, the Philippines, South Africa, Thailand and Venezuela, and was led by Brazil and India). Its membership changed several times during and after the Cancun Ministerial Conference, resulting in it sometimes being referred to as the G-20+. In Cancun, Egypt, Indonesia and Nigeria joined whereas El Salvador withdrew. With China on board, the coalition represents approximately $51 \%$ of the world's population, $63 \%$ of the world's farmers and $20 \%$ of agricultural production. After the Cancun Ministerial, the G-20 has lost more members namely, Colombia, Costa Rica, Guatemala, Ecuador, Peru and Thailand. Some of these countries decided to pursue bilateral or regional trade agreements with the US. For slightly differing listings of the varying compositions of the G-20 alliance, see International Development Committee - House of Commons, Trade and Development at the WTO: Learning the Lessons of Cancún to Revive a Genuine Development Round. First Report of Session 2003-04, HC92-I (House of Commons, London), 4 December 2003, 48, available at: www.publications.parliament.uk/pa/cm200304/cmselect/cmintdev/92/92.pdf, visited on 10 June 2008; Bernard Hoekman, Cancún: Crisis or Catharsis? (World Bank, Washington D.C.), 20 September 2003, note 2, available at: http://siteresources.worldbank.org/INTRANETTRADE/Resources/Hoekman-CancunCatharsis-092003.pdf, visited on 5 December 2003.

${ }^{268}$ The then-EU Trade Commissioner Pascal Lamy repeatedly voiced the opinion that the G-20 had 'an agricultural mother and a geopolitical father'. In other words, he claimed that this alliance arose due to, on the one hand, concerns by its members regarding limited agricultural liberalisation by developed countries and, on the other hand, the desire of its members to show that they can stand up to rich and powerful countries and play a stronger role in the world arena. Pascal Lamy, 'The EU, Cancun and the Future of the Doha Development Agenda', presented at the Annual Lecture of the Journal for Common Market Studies, London) 28 October 2003, available at: http://europa.eu.int/comm/commissioners/lamy/speeches_articles/spla195 en.htm, visited on 6 December 2008; Pascal Lamy, 'Result of the WTO Ministerial Conference in Cancun', presented at the Plenary Session of the European Parliament, Strasbourg) 24 September 2003, available at: http://europa.eu.int/comm/commissioners/lamy/speeches_articles/spla192_en.htm.

269 Hoekman notes that there were active efforts to divide the G-20 group through specific offers targeted at individual countries. Bernard Hoekman, Cancún: Crisis or Catharsis? (World Bank, Washington D.C.), 20 September 2003, 2, available at: http://siteresources.worldbank.org/INTRANETTRADE/Resources/ Hoekman-CancunCatharsis-092003.pdf, visited on 5 December 2003. 
developing country coalitions in WTO negotiations, which was mostly limited to agenda setting or blocking consensus. ${ }^{270}$ Another developing country grouping active at the Cancun Ministerial was the Group of 90 (G-90), which brought together the members of the African Union, the African, Caribbean and Pacific countries and the least-developed countries. ${ }^{271}$ This coalition also opposed negotiations on the Singapore issues and advocated the protection of preferential access for its members to developed country markets. In addition, four West-African countries ${ }^{272}$ formed an alliance around a proposal for the abolition of subsidies for cotton producers in the EU, US and China. This initiative represented the first time African countries came forward with a specific demand in WTO negotiations. ${ }^{273}$ These developing country coalitions were particularly active in the negotiations on agriculture, pushing for increased market access and removal of tradedistorting measures. ${ }^{274}$ In addition, they succeeded in obtaining agreement, in principle, on 28 agreement-specific proposals regarding the strengthening of SDT provisions in various WTO agreements. ${ }^{275}$

The Cancun Session of the Ministerial Conference failed, as developed and developing countries could not reach agreement on the key issues of agricultural reform and the launching of negotiations on the Singapore issues. ${ }^{276}$ A contributing factor to the

270 Ibid.

${ }^{271}$ At Cancun, this group represented 90 countries, 60 of which are WTO Members. International Development Committee - House of Commons, Trade and Development at the WTO: Learning the Lessons of Cancún to Revive a Genuine Development Round. First Report of Session 2003-04, HC92-I (House of Commons, London), 4 December 2003, 48, available at: www.publications.parliament.uk/pa/cm200304/cmselect/cmintdev/92/92.pdf, visited on 10 June 2008.

272 Benin, Burkina Faso, Chad and Niger.

273 Bernard Hoekman, Cancún: Crisis or Catharsis? (World Bank, Washington D.C.), 20 September 2003, 2, available at: http://siteresources.worldbank.org/INTRANETTRADE/Resources/HoekmanCancunCatharsis-092003.pdf.

${ }^{274}$ For a good synopsis of the ongoing agriculture negotiations and the positions of developing country coalitions therein, see the quarterly reports of the International Centre for Trade and Sustainable Development on Agriculture Negotiations at the WTO, available at: http://www.agtradepolicy.org/page/ictsd/resource. htm\#reports, visited on 25 June 2007.

${ }^{275}$ These agreed provisions were circulated as Annex C of document JOB(03)/150/Rev.2. However, due to the failure of the Cancun Session of the Ministerial Conference, they were never finally adopted.

276 The talks on the final day of the Ministerial Conference deadlocked on the question whether to launch negotiations on the Singapore issues. During the 'green room' consultations on the Singapore issues, the EC offered to drop investment, competition and, according to some sources, transparency in government procurement from the negotiations. Participants were then given just one hour to consult with the countries they represented. Thereafter, the G-90, represented by Botswana, indicated that it could not agree to a deal which included any of the Singapore issues, whereas Korea supported by Japan stated that they could not agree to a deal that excluded any of the four Singapore issues. The Chairperson, Mr Derbez, reported back to the Heads of Delegation and at 18.00 he declared that there was no prospect of reaching consensus and the Ministerial Meeting was therefore closed. Many delegations regarded this closure as unexpected and premature, since Ministerial Conferences are often extended to allow for last-minute agreement to be reached. On the evening of 14 September at Cancun, a trade minister of one of the leading G-20 members said to Patricia Hewitt, UK Secretary of State for Trade and Industry, that if there had just been six hours of serious discussions on agriculture, it would have been possible to reach agreement on a framework of negotiations to move things forward. Reported in International Development Committee - House of Commons, Trade and Development at the WTO: Learning the Lessons of Cancun to Revive a Genuine Development Round. First Report of Session 2003-04, HC92-I (House of Commons, London), 4 December 2003, paras 8, 13 and 19, available at: www. publications.parliament.uk/pa/cm200304/cmselect/cmintdev/92/92.pdf, visited on 10 June 2008. 
failure of the negotiations was the overloaded negotiating agenda. As noted by the Directorate-General for Trade of the European Commission:

...the sheer volume and substantive importance of the mass of issues on the agenda made it difficult for any, except the largest and best organised of the delegations, to analyse and position themselves as the situation changed over the last few hours. ${ }^{277}$

The only outcome of this meeting was a Ministerial Statement reaffirming commitment to the implementation of the Doha Declarations and Decisions and calling for a General Council meeting at Senior Official level to be convened no later than 15 December 2003, to take the action necessary to enable Members to move towards a timely and successful conclusion of the negotiations. ${ }^{278}$

There have been diverging views regarding whether the failure of the Ministerial Conference in Cancun was good or bad for developing countries. Some developing countries and non-governmental organisations have asserted that the failure of this Ministerial Conference session was to the advantage of developing countries as it demonstrated to developed countries that developing country concerns need to be taken seriously. The proponents of this view are of the opinion that no deal is better than a bad deal. ${ }^{279} \mathrm{On}$ the contrary, others including the EC and the WTO Director-General saw the collapse of the negotiations at Cancun as bad news for developing countries, representing a missed opportunity. ${ }^{280}$ A recent report by the International Development Committee of the United Kingdom House of Commons correctly points out that what the breakdown of talks at Cancun will mean for developing countries depends to a large extent on 'what happens next'. ${ }^{281}$ This report states:

277 European Commission Directorate-General for Trade, The Doha Development Agenda after Cancun (European Union, Brussels), 25 September 2003, 7, available at: http://www.ictsd.org/ministerial/cancun/ docs/COMMISSION-Cancun-and-Beyond-Sept-03.pdf, visited on 3 December 2003.

278 Ministerial Conference Fifth Session, Ministerial Statement. Adopted on 14 September 2003, WT/ MIN(03)/20, circulated on 23 September 2003, paras 4 and 6.

${ }^{279}$ International Development Committee - House of Commons, Trade and Development at the WTO: Learning the Lessons of Cancún to Revive a Genuine Development Round. First Report of Session 2003-04, HC92-I (House of Commons, London), 4 December 2003, para. 12, available at: www.publications.parliament.uk/ pa/cm200304/cmselect/cmintdev/92/92.pdf, visited on 10 June 2008. See also Sheila Page, 'Making Doha a Better Deal for Poor Countries', Financial Times, 26 July 2004. Page, a research fellow at the Overseas Development Institute, points out that while gains to the G-90 countries from the Doha Round are difficult to identify (as most of these countries already have preferential market access to the EU and US and regional trade agreements with neighbouring countries), but some face clear losses from preference erosion and additional rules.

${ }^{280}$ International Development Committee - House of Commons, Trade and Development at the WTO: Learning the Lessons of Cancún to Revive a Genuine Development Round. First Report of Session 2003-04, HC92-I (House of Commons, London), 4 December 2003, para. 12, available at: www.publications.parliament.uk/pa/ $\mathrm{cm} 200304 / \mathrm{cmselect} / \mathrm{cmintdev} / 92 / 92$.pdf, visited on 10 June 2008.

${ }^{281}$ In a similar vein, Hoekman states, 'The question confronting the international community is whether Cancún represents a crisis that will derail multilateral cooperation on trade for some time to come, or whether it represents an opportunity for policymakers to identify a more balanced negotiating set that is feasible to pursue.' Bernard Hoekman, Cancún: Crisis or Catharsis? (World Bank, Washington D.C.), 20 September 2003, 1, available at: http://siteresources.worldbank.org/INTRANETTRADE/Resources/HoekmanCancunCatharsis-092003.pdf, visited on 5 December 2003. 
If there is a shift to prioritise bilateral trade negotiations... and if the promise of a 'Development Round' evaporates, then the collapse of Cancún will have been a disaster. What happens next depends on how well the lessons of Cancún are learned; this in turn depends on how well the reasons for the collapse of Cancún are understood. ${ }^{282}$

After the breakdown of talks in Cancun, the major trading nations initially refused to take the lead in reviving the stalled negotiations. ${ }^{283}$ Instead, their attitude towards the demands of developing countries, and particularly the G-20 nations, hardened. ${ }^{284}$ The developing countries repeatedly called for renewed attempts to get the negotiations back on track, and softened their stance on many issues in an effort to prevent the disengagement of developed countries. ${ }^{285}$ At the meeting of the G-20 on 11-12 December 2003, these

${ }^{282}$ International Development Committee - House of Commons, Trade and Development at the WTO: Learning the Lessons of Cancún to Revive a Genuine Development Round. First Report of Session 2003-04, HC92-I (House of Commons, London), 4 December 2003, para.14, available at: www.publications.parliament.uk/pa/ $\mathrm{cm} 200304 / \mathrm{cmselect} / \mathrm{cmintdev} / 92 / 92$.pdf, visited on 10 June 2008.

${ }^{283}$ The US indicated that it would focus on bilateral trade agreements with what it regards as the 'will-do' or 'can-do' countries, and the EU said that it was in 'listening mode' or 'reflection mode'. After a period of reflection and consultation, the European Commission released a Communication setting out its proposed strategy for reviving the Doha Round negotiations. See Commission of the European Communities, Communication from the Commission to the Council, to the European Parliament, and to the Economic and Social Committee: Reviving the DDA Negotiations - the EU Perspective (European Union, Brussels), 26 November 2003, available at: hrrp://trade-info.cec.eu.int/doclib/html/114259.htm; Robert Zoelink, 'America Will Not Wait', in Where Next for the WTO? After Cancún: Views, Ideas and Proposals by Trade Ministers (Federal Trust for Education and Research and Commonwealth Business Council, London), 2003, 47-48.

${ }^{284}$ Gaur reports that Malaysian Prime Minister Dr. Mahathir expressed his apprehension of a backlash by developed countries against those developing countries blamed for the collapse of the trade negotiations at Cancun. Gaur notes the comment of US Senator Grassley, Chairman of the Senate Finance Committee that approves US trade agreements, pointing out that he would take note of those nations that played a constructive role in Cancun and those that did not and questioning whether certain G-20 members had sufficient commitment to free trade to be rewarded with special access to the US market. See Sema Gaur, Politics of Cancun Failure: US Stance Hardens Towards G-20+ Nations (Institute of South East Asian Studies, Singapore), 6 October 2003, available at: ww.iseas.edu.sg/viewpoint/sg6Oct03.pdf.

285 For example, on 13-14 November 2003, a meeting of trade ministers and representatives from Benin, Botswana, Burkina Faso, Chad, Kenya, Lesotho, Mali, Mauritius, Nigeria, Senegal, South Africa and Egypt as well as the Director-General of the WTO and the Trade Commissioner of the Economic and Monetary Union of West Africa was held in Cairo. The Ministers at this meeting called on WTO Members and especially the major trading nations to return to the negotiating table as soon as possible. They noted that issues of interest to LDCs must be addressed 'in a spirit of realism' and agreed to the use of the Derbez Text as a starting point for future discussions. The G-20 met on 2 and 10 October 2003 and called for a quick relaunch of trade negotiations and adopted a more conciliatory tone than before, when it had taken a tough stance against the joint EC/US proposal on agriculture. The coalition lost some of its members which pursued bilateral trade negotiations with the US. It is reported that after the Cancun Ministerial Conference, US Senator Chuck Grassley, chair of the powerful Senate Finance Committee, warned countries that he would not support any bilateral trade agreements with G-20 members. Bridges Weekly Trade News Digest 7(33), 8 October 2003 and 7(34), 15 October 2003. In addition, the Asia Pacific Economic Cooperation (APEC) countries (which include both developed and developing countries representing $47 \%$ of world trade, namely, Australia, Brunei, Canada, Chile, China, Hong Kong, Indonesia, Japan, Malaysia, Mexico, New Zealand, Papua New Guinea, Peru, the Philippines, Russia, Singapore, South Korea, Taiwan, Thailand, the US and Vietnam) at their $15^{\text {th }}$ Ministerial Meeting on 17-18 October 2003, called on all WTO Members to 'quickly re-energize the negotiation process by building on Chairman Derbez's text of 13 September 2003, recognizing that flexibility and political will from all are urgently needed.' The Joint Statement of APEC ministers is available at: http://www.apecsec.org.sg/apec/ministerial_statements/annual_ministerial/2003_15th_apec_ministerial. 
countries discussed with the then-EU trade commissioner Pascal Lamy how to move forward with the Doha Round. A joint communiqué was issued noting the general agreement on the need to intensify negotiations in early 2004. In this communiqué, the G-20 reiterated its disposition to 'move into a negotiation mode' in early $2004 .{ }^{286}$ WTO officials, in the period after Cancun, emphasised that developing countries stand to lose the most if talks are not resumed. ${ }^{287}$

An improvement of the relationship between developed and developing-country Members was achieved with the successful adoption, on 30 August 2003, of a decision of the General Council on the issue of access to essential medicines. This decision waives the requirement of Article 31(f) of the TRIPS Agreement thereby allowing Members to grant compulsory licences to produce patented medicines for export to Members with insufficient manufacturing capacity. ${ }^{288}$

Post-Cancun the positions of developing-country Members on some issues softened, but their emphasis on the need to ensure that the rules of the world trading system are supportive of development has not abated. The focus of UNCTAD XI, ${ }^{289}$ held on 13-18 June 2004 in São Paulo, was on enhancing the coherence between national development strategies and global economic processes towards economic growth and development, including specific attention to the rules of the WTO. ${ }^{290}$ In the resulting São Paulo Conclusions, the following elements deserve to be highlighted.

html\#15AMM_Statement, visited on 20 June 2008.

${ }^{286}$ Joint Press Communiqué of the Meeting between the G-20 Ministers and the EU Trade Commissioner Pascal Lamy, Brasilia), 12 December 2003, available at: http://europa.eu.int/comm/trade/issues/newround/doha_da/ jpc121203_en.htm, visited on 30 June 2008.

${ }^{287}$ As pointe $\bar{d}$ out by the then-WTO Deputy Director-General Dr. Kipkorir Aly Azad Rana to the Second East African Business Summit, held in Nanyuki, Kenya on 18-21 September 2003: 'Experience tells us that on a bilateral basis, your negotiation leverage dwindles and you will find it much harder to advance the issues of real concern to your countries than in a multilateral environment.' With respect to the impression created by some commentators that the failure of the Cancun meeting was good news for developing countries, he noted: 'I find this attitude very wrong-headed, betraying a lack of understanding of what the multilateral trading system does and how it works. Stalemate in the field of international trade relations simply translates into foregone opportunities - opportunities to create a more vibrant and relevant trading system at the service of all nations. For us in Africa, this means fewer development opportunities.' See WTO Press release of 19 September 2003, available at: http://www.wto.org/english/news_e/news03_e/speech_rana_19sep03_e.htm, visited on 25 June 2007. WTO Director-General Supachai Panitchpakdi, in an article in the International Herald Tribune, pointed out along similar lines: 'Sadly, those that will suffer the most for their inability to compromise are the poorest countries among us. A more open and equitable trading system would provide them with an important tool in alleviating poverty and raising their levels of economic development.' See International Herald Tribune, 18 September 2003.

${ }^{288}$ General Council, Implementation of Paragraph 6 of the Doha Declaration on the TRIPS Agreement and Public Health. Decision of the General Council of 30 August 2003, WT/L/540 and Corr.1, circulated on 1 September 2003. As all waiver decisions under Article IX of the WTO Agreement, this waiver is temporary in nature. On 6 December 2005, the General Council adopted a decision to amend the TRIPS Agreement to resolve this matter permanently. When the amendment decision comes into force (upon ratification by twothirds of WTO Members) a new Article 31 bis and a new Annex will be added to the TRIPS Agreement, incorporating the content of the waiver decision. General Council, Amendment of the TRIPS Agreement. Decision of the General Council of 6 December 2005, WT/L/641, circulated on 8 December 2005.

${ }^{289}$ UNCTAD XI is the $11^{\text {th }}$ of the four-yearly UNCTAD ministerial conferences where priorities and guidelines are set and debates are held on key economic and development issues.

${ }^{290}$ See the preparatory document TD(XI)/PC/1. The substantive agenda item for UNCTAD XI mentioned specifically: (i) development strategies in a globalising world economy; (ii) building productive capacity and 
First, the São Paulo Consensus stresses the importance of agriculture in the Doha negotiations and the need to ensure that these negotiations 'deliver an outcome that is consistent with the ambition set out in the Doha mandate. ${ }^{291}$ While this refers to the disciplines under the Agreement on Agriculture regarding market access, export subsidies and domestic support, rather than to the disciplines of the SPS Agreement, it does reflect the centrality of agriculture to the development focus of the Doha negotiations. It should be remembered that gains in liberalising the agricultural sector could be undermined by trade barriers in the form of SPS measures. ${ }^{292}$ Thus, it is argued here that it is necessary to address developing country concerns with regard to the SPS Agreement in order to ensure that the expected gains from agricultural liberalisation are reaped.

Second, the São Paulo Consensus refers expressly to the need to ensure that the limits placed by trade rules on national 'policy space' are not counter to the development needs of developing countries. ${ }^{293}$ One lesson that could be fruitfully learnt from Cancun, as identified by Hoekman, is that a successful negotiation necessitates an agenda that is seen to contain potential benefits for all Members. ${ }^{294}$ Negotiations on new regulatory disciplines on behind-the-border issues that limit spaces for regulatory policies, such as competition and investment, do not meet this requirement as they entail significant implementation costs for developing countries and hold few benefits in terms of increased market access in key sectors. This was evinced by the experience with Uruguay Round agreements on regulatory areas, such as the SPS Agreement. Instead, of negotiating new

international competitiveness; (iii) assuring development gains from the international trading system and trade negotiations; and (iv) partnership for development. See UNCTAD website for the $11^{\text {th }}$ ministerial meeting, available at http://www.unctadxi.org/templates/Page__145.aspx, visited 4 April 2004.

${ }^{291}$ United Nations Conference on Trade and Development, Eleventh Session, 13-18 June 2004. Draft São Paulo Consensus, TD/L.380 (United Nations, Sao Paulo), 16 June 2004, para. 75, available at: www.unctad.org/en/ docs/td1380_en.pdf, visited 21 June 200.

${ }^{292}$ This point is made in Section 1 of the Introduction, above. It has been explicitly recognized in the report of the UN Millennium Project in 2005, which warns against erosion of hard-won gains in the area of market access by other policies, including SPS requirements. It calls for assistance for developing countries to make effective use of the SPS (and TBT) Agreement to ensure that standards are not abused for protectionist purposes; assistance for developing countries to develop the infrastructure and institutional frameworks necessary to meet legitimate standards; and assistance for developing countries to participate fully in international standard-setting processes. UN Millennium Project, Investing in Development: A Practical Plan to Achieve the Millennium Development Goals (United Nations Development Programme, New York), 2005, 216-217, available at: http://www.unmillenniumproject.org/reports/fullreport.htm, visited on 7 January 2008.

293 United Nations Conference on Trade and Development, Eleventh Session, 13-18 June 2004. Draft São Paulo Consensus, TD/L.380 (United Nations, Sao Paulo), 16 June 2004, para. 8, available at: www.unctad. org/en/docs/tdl380_en.pdf, visited on 21 June 2007. This Consensus refers to the limitations on space for national economic policy resulting from rules-based regimes for international economic relations. It notes the importance for developing countries 'that all countries take into account the need for appropriate balance between national policy space and international disciplines and commitments.' While specific reference was made only to economic policies in the areas of trade, investment and industrial development, similar considerations apply in the area of health policies. Similarly, The Spirit of São Paulo, also adopted at UNCTAD XI, specifically states that, "countries should use the ability to explore options and maintain the necessary space for policy in order to arrive at the best possible balance between different approaches in their national development strategies'. United Nations Conference on Trade and Development, UNCTAD XI - the Spirit of Sao Paulo, TD/L.382 (United Nations, Sao Paulo), 17 June 2004, para. 11, available at: www.unctad.org/en/ docs/TDL382_en/pdf, visited on 1 June 2005.

294 Bernard Hoekman, Cancún: Crisis or Catharsis? (World Bank, Washington D.C.), 20 September 2003, 3, available at: http://siteresources.worldbank.org/INTRANETTRADE/Resources/HoekmanCancunCatharsis-092003.pdf, visited on 5 December 2003. 
such agreements, real efforts must be made to address the outstanding implementation issues under existing agreements, ${ }^{295}$ including by means of 'rebalancing' the existing rules in order to ensure that developing countries get a fair share of the benefits of trade liberalisation. With regard to the SPS Agreement, this means that it is necessary to examine whether its rules are workable for developing countries, taking account of their special constraints. Not only should the rules make it possible for developing countries to challenge effectively protectionist measures in the guise of SPS regulations, but they should also leave sufficient policy space for developing countries to adopt SPS regulations suited to their needs.

Third, the São Paulo Consensus emphasises the need to review the SDT provisions to make them 'more precise, effective and operational. ${ }^{296}$ It is important that the new concept of SDT be strengthened, rather than that there be a return to the old reliance on SDT in the form of exemptions for developing countries. ${ }^{297}$ In order to secure benefits from the outcome of negotiations, developing countries have to continue to be prepared to put offers on the table and engage in reciprocal bargaining, rather than insist of exemptions from the rules. However, this willingness to engage must be met by a corresponding willingness on the part of developed countries to undertake real and binding commitments to respond in a constructive way to the special position of developing countries. In particular, it must be acknowledged that trade rules, especially those dealing with behindthe-border regulatory issues such as the SPS Agreement, carry progressively heavier implementation costs, the less developed a Member is. ${ }^{298}$

In this regard, the development of criteria for differentiation between developing-country Members for purposes of SDT may be useful. ${ }^{299}$ This would decrease the reluctance of developed country Members to agree to binding obligations in the area of SDT and

295 The São Paulo Consensus also makes explicit reference to the 'utmost importance' of addressing the outstanding implementation issues in a manner consistent with the Doha Work Programme. United Nations Conference on Trade and Development, Eleventh Session, 13-18 June 2004. Draft São Paulo Consensus, TD/L.380 (United Nations, Sao Paulo), 16 June 2004, para. 81, available at: www.unctad.org/en/docs/ tdl380_en.pdf, visited on 21 June 2007.

${ }^{296}$ Ibid., para. 82.

297 Bernard Hoekman, Cancún: Crisis or Catharsis? (World Bank, Washington D.C.), 20 September 2003, 4, available at: http://siteresources.worldbank.org/INTRANETTRADE/Resources/HoekmanCancunCatharsis-092003.pdf. See also UN Millennium Project, Investing in Development: A Practical Plan to Achieve the Millennium Development Goals (United Nations Development Programme, New York), 2005, 219, available at: http://www.unmillenniumproject.org/reports/fullreport.htm, visited on 7 January 2008. The latter report notes that there 'is no compelling case for exemption for rules on traditional trade policies' but calls for cost-benefit analysis of the effect of rules on domestic regulations requiring investment of resources in order to determine what types of SDT should be granted and to which countries.

298 Bernard Hoekman, Cancún: Crisis or Catharsis? (World Bank, Washington D.C.), 20 September 2003, 4, available at: http://siteresources.worldbank.org/INTRANETTRADE/Resources/HoekmanCancunCatharsis-092003.pdf.

299 A different but related proposal, made by Page, is that a compensation fund be created for those countries that actually lose out due to trade liberalisation (for example due to preference erosion), with enforceable guarantees of compensation built into the WTO agreements. She refers to the IMF's suggestion of a calculation method for establishing losses from liberalisation (developed for purposes of granting loans), in order to establish which countries would be eligible for compensation. This proposal would allow for differentiation between developing countries for purposes of financial assistance, but is limited to addressing the costs of the results of the new Round. See Sheila Page, 'Making Doha a Better Deal for Poor Countries', Financial Times, 26 July 2004. 
may be a step towards operationalising these provisions. In fact, some developed country Members have expressed the opinion that the absence of a mechanism to differentiate between more and less advanced non-LDC developing countries is the main obstacle to strengthening the SDT provisions. ${ }^{300}$ However, the issue of differentiation is an important point of contention in the review of SDT provisions. ${ }^{301}$

Wording that might have left room for differentiation between developing-country Members originally in the framework text for a revised Doha Work Programme adopted by the General Council on 1 August 2004, was removed at the insistence of larger, more advanced developing country Members. ${ }^{302}$ The framework text, often referred to as the

300 'Work on Development Sees Limited Progress at WTO', Bridges Weekly Trade News Digest, 3 August 2004. See also on this point Patrick Low, 'Is the WTO Doing Enough for Developing Countries?' in WTO Law and Developing Countries, George A. Bermann and Petros C. Mavroidis (eds.) (Cambridge University Press, Cambridge), 2007, 324-358, 334.

${ }^{301}$ This is illustrated by the discussion on the proposal for a mechanism to implement and monitor SDT introduced by the African Group in 2000 (TN/CTD/W/3/Rev2 and TN/CTD/W/23). Disagreement arose when subsequent submissions by the EC and Switzerland (TN/CTD/W/13, 20 and 26 and TN/CTD/W/14) proposed the use of such a mechanism to determine when a developing country could graduate from eligibility for SDT. Several middle-income developing country Members thereafter refused to discuss the monitoring mechanism due to the perception that it was tied to differentiation and graduation, which they strongly oppose. It took three years before developing-country Members stated that they were once again open to discussions on proposals for a monitoring mechanism for SDT. "WTO Members "Open" to Talks on S\&D Monitoring Mechanism’ Bridges Weekly Trade News Digest, 12 April 2006.

${ }^{302}$ It is interesting to note that the draft framework text circulated by the WTO Director General and the Chair of the General Council in July 2004 provided that, 'The specific concerns of preference dependent, commodity dependent countries and net food-importing developing countries shall be appropriately addressed, in the context of the multilateral liberalization commitments undertaken in the Doha Round. In addition, the concerns of small, vulnerable developing economies shall be taken into account...' However, the provision was explicitly added that this would be 'without creating a sub-category of Members.' Supachai Panitchpakdi and Shotaro Oshima, Doha Work Programme. Draft General Council Decision of [...] July 2004, JOB(04)/96, circulated on 16 July 2004, para. 1(d). Despite the added proviso, there was strong opposition to the text by certain larger developing countries (particularly advanced Latin American and East Asian developing countries), on the grounds that a differentiation between developing countries would result. They feared the institutionalization of preferential market access. A compromise was worked out by Brazil, Colombia, Costa Rica, India, Jamaica, Kenya, Nigeria, Thailand and Uruguay. The revised draft of the framework text, issued on 30 July 2004, simply referred to the trade and development related needs of developing countries, including capacity constraints, and stated, 'These particular concerns of developing countries, including relating to food security, rural development, livelihood, preferences, commodities and net food imports, as well as prior unilateral liberalisation, should be taken into consideration, as appropriate, in the course of the Agriculture and NAMA negotiations. The trade-related issues identified for the fuller integration of small, vulnerable economies into the multilateral trading system, should also be addressed, without creating a sub-category of Members, as part of a work programme, as mandated in Paragraph 35 of the Doha Ministerial Declaration.' See Supachai Panitchpakdi and Shotaro Oshima, Doha Work Programme. Draft General Council Decision of [...] July 2004. Revision, JOB(04)/96/Rev.1, circulated on 30 July 2004, para. 1(d). This revised wording was kept in the final text adopted by the General Council on 1 August 2004. General Council, Doha Work Programme. Decision Adopted by the General Council on 1 August 2004, WT/L/579, circulated on 2 August 2004, para. 1(d). This formulation is much weaker, replacing the mandatory instructions that developing country concerns 'shall be appropriately addressed' and 'shall be taken into account' with the hortatory words 'should be taken into consideration, as appropriate' and 'should also be addressed'. In addition, instead of being applicable to all 'multilateral liberalization commitments undertaken in the Doha Round' this attention for developing country concerns has been limited to only 'the Agriculture and NAMA negotiations'. Furthermore, to avoid any indication of differentiation between developing countries, the reference to preference dependent, commodity dependent countries and net food-importing countries has been omitted from the revised draft. Instead preferences, commodities and net food imports have been added to the list of particular concerns of developing countries. Also, language was added to the beginning of this section referring 
'July Package', aimed to breathe new life into the stalled Doha Round negotiations. It called on Members to 'redouble their efforts towards the conclusion of a balanced overall outcome of the Doha Development Agenda'. ${ }^{303}$ The July Package focused on pushing ahead the talks in five areas, namely agriculture, non-agricultural market access (NAMA), development issues, trade facilitation and services. ${ }^{304}$ In other areas of the Doha mandate, the July Package affirmed the ongoing negotiations. The main breakthrough of the July Package was the adoption of a framework for future agriculture negotiations, included as a separate Annex to the Decision. ${ }^{305}$ With regard to development issues, in the July Package the General Council 'rededicates and recommits Members to fulfilling the development dimension of the Doha Development Agenda.' ${ }^{306}$ WTO bodies entrusted with work on SDT are instructed to 'expeditiously complete' this work and report to the General Council with clear recommendations for a decision no later than July 2005. ${ }^{307}$ While recognising the progress made since the Doha Ministerial Conference in expanding trade related technical assistance (TRTA) to developing countries, the decision states that: 'such countries, and in particular least-developed countries, should be provided with enhanced TRTA and capacity building, to increase their effective participation in the negotiations, to facilitate their implementation of WTO rules, and to enable them to adjust and diversify their economies. ${ }^{308}$ Further WTO bodies dealing with implementation issues are instructed 'to redouble their efforts to find appropriate solutions as a priority.' ${ }^{309}$

Discussions in the Special Session of the Committee on Trade and Development under the Doha mandate regarding how to make SDT more precise, effective and operational have not made much progress. Negotiations deadlocked around the issue whether to focus on the 88 agreement-specific proposals on SDT (an approach favoured by developing countries, led by the Africa group), or to first address cross-cutting issues, such as the principles and objectives of SDT, differentiation between developing-country Members and graduation from eligibility for SDT (the approach supported by certain developed countries including the US). As a compromise to move negotiations forward on both tracks simultaneously, Chair Faizel Ismail proposed, in February 2005, that negotiators cluster agreement-specific proposals on the basis of the underlying principles involved. ${ }^{310}$

explicitly to 'the fundamental principles of the WTO and the relevant provisions of GATT 1994' in order to ensure that the WTO principle of most favoured nation treatment qualifies the special attention to developing country concerns in the negotiations mandated by this Paragraph. See 'Work on Development Sees Limited Progress at WTO’, Bridges Weekly Trade News Digest, 3 August 2004.

${ }^{303}$ General Council, Doha Work Programme. Decision Adopted by the General Council on 1 August 2004, WT/L/579, circulated on 2 August 2004, para. 3. This decision extends the negotiations beyond the time frame set at the Doha Ministerial Conference, to continue in the period leading up to the Sixth Session of the Ministerial Conference in Hong Kong in 2005.

${ }^{304}$ An important aspect of the July Package is the agreement not to start negotiations on three of the 'Singapore issues' (investment, competition, transparency in government procurement and trade facilitation). The remaining Singapore issue, trade facilitation, formed part of the new work programme set out in the July Package.

${ }^{305}$ General Council, Doha Work Programme. Decision Adopted by the General Council on 1 August 2004, WT/L/579, circulated on 2 August 2004, Annex A.

306 Ibid., para. 1(d).

307 Ibid.

308 Ibid.

309 Ibid.

310 This approach was termed the 'situational flexibility' methodology and aims to allow developing countries to benefit from enhanced flexibilities in WTO rules to respond to their development needs, while continuing 
These he identified as being effective market access, enhanced flexibility in WTO rules, consistency with a multilateral rules-based system and enhanced capacity-building programmes. $^{311}$

Members agreed to treat the Chair's approach as a reference point for the negotiations, although concerns were raised by larger developing countries that this approach would introduce differentiation between developing countries. At the Special Session of the Committee on Trade and Development on 6 April 2005, the Chair developed his approach further by classifying proposals regarding both agreement-specific issues and cross-cutting issues into two categories: flexibility and capacity building. He suggested that the remainder of the two-day meeting be spent on flexibility proposals, the first day on agreement-specific proposals in this category an the second on cross-cutting proposals, This meeting deadlocked, however, due to concerns by several developing countries that this approach would shift the focus towards cross-cutting rather than agreementspecific issues. ${ }^{312}$

Members have made 88 proposals with regard to agreement-specific SDT issues. These have informally been divided into three categories: Category I is composed of those proposals on which agreement is likely in the short-term, including those 28 proposals which were agreed upon in principle before the Cancun Ministerial; Category II consists of those 38 proposals that were forwarded to those WTO bodies that deal with the specific agreements involved for further work; and Category III refers to the most controversial proposals on which negotiations have not yet been conducted. Five proposals have been made containing 12 specific recommendations that relate to the provisions on SDT and technical assistance of the SPS Agreement. ${ }^{313}$ Work on specific issue areas, including SPS issues, continues to take place in the relevant WTO bodies and in Special Sessions of the Committee on Trade and Development. ${ }^{314}$

In the run-up to the Hong Kong Ministerial Conference in 2005, a mini-Ministerial meeting was held in China, in which SDT received more attention than has been the case in this type of meeting to date. After this meeting, on 19-27 July 2005, intensive negotiations in the Special Session of the Committee on Trade and Development were initiated by its Chairperson. Reportedly, a strong sense prevailed among delegations that there was a need to reach agreement on five SDT proposals of least-developed-country Members in order to demonstrate a commitment to resolving the concerns of the WTO's poorest

to act consistently with the fundamental principles of the multilateral trade regime. 'WTO Members Move Forward on S\&D Negotiations', Bridges Weekly Trade News Digest, 9 February 2005.

311 The Chair said he would circulate a text detailing his proposed approach, which is expected to call for the clustering of proposals around the four principles he identified, and to possibly suggest working groups on each thematic cluster. Ibid.

${ }^{312}$ These countries noted that the July Package (WT/L/579) required concrete recommendations on agreementspecific proposals by the July 2005 deadline, whereas only a report to the General Council at an unspecified date regarding crosscutting issues was mandated. Thus they proposed that the Special Sessions of the Committee on Trade and Development should focus on agreement-specific issues. Several developed countries, on the contrary, argued that crosscutting issues are central to the negotiations and must be addressed before or simultaneously to agreement-specific issues. 'S\&D Talk Adjourn Early Amidst Disagreement', Bridges Weekly Trade News Digest, 13 April 2004.

${ }^{313}$ These proposals are discussed below in Part V, Section 1.7.

314 'WTO Members Move Forward on S\&D Negotiations', Bridges Weekly Trade News Digest, 9 February 2005. 
Members. ${ }^{315}$ However, on 27 July the Chairperson reported that 'several issues remain unresolved' on SDT, making it 'impossible... to make specific recommendations' to the General Council meeting at the end of that week. This lack of progress reflected both the divergence in positions on SDT and the stalled negotiations in other key areas.

At the Hong Kong Session of the Ministerial Conference in December 2005, however, agreement was reached on the five SDT proposals of least-developed-country Members. ${ }^{316}$ The Hong Kong Ministerial Declaration instructs the Committee on Trade and Development and the relevant WTO bodies to expeditiously complete their work on the remaining agreement-specific proposals and to report back to the General Council by December 2006. ${ }^{317}$ In addition the Committee on Trade and Development is mandated to 'resume work on all other outstanding issues, including on the cross-cutting issues, the monitoring mechanism, and the incorporation of S\&D into the architecture of WTO rules, and report on a regular basis to the General Council. ${ }^{318}$ An important achievement was made with regard to agricultural trade in the Hong Kong Ministerial Declaration, namely the agreement on the progressive elimination of all agricultural export subsidies by $2013 .{ }^{319}$ A new deadline was set for other issues on the agenda, namely July 2006.

This deadline was not met, and due to the wide gaps remaining between Members and the absence of significant movement in negotiators' positions, the WTO Director-General decided to suspend the whole round of negotiations to provide a period for 'serious and sober reflection' by participants. ${ }^{320}$ Negotiations were relaunched in February 2007, following the 'increasing level of political engagement and clear signals of renewed commitment to a successful conclusion of the Round'. ${ }^{321}$ By July 2008, the momentum had increased and the Director-General reported to an informal meeting of the Trade Negotiations Committee on 27 June 2008 that there was a 'clear political determination to conclude the Round by the end of 2008. ${ }^{322}$ The intensified negotiations have focused on obtaining agreement on modalities for the commitments on agriculture and non-agricultural market access. The G-20 has criticised the diminished ambition of the revised draft modalities circulated by the Chairperson of the Special Session of the Committee on Trade in Agriculture, particularly in the areas of domestic support and market access. Emphasising the development dimension of the Doha Round negotiations and the importance of agriculture to developing-country Members' economies, the G-20 called for

315 'No Results on S\&D Despite Marathon Negotiations', Bridges Weekly Trade News Digest, 27 July 2005. The five proposals at issue were: proposal 23 (on an understanding in respect of waivers of obligations), proposal 36 (on duty- and quota-free market access for LDCs), proposal 38 (on coherence of International Monetary Fund, World Bank and WTO measures), proposal 84 (on exemption from the Agreement on TradeRelated Investment Measures), and proposal 88 (on measures in favour of LDCs).

316 Ministerial Conference, Doha Work Programme. Ministerial Declaration Adopted on 18 December 2005, WT/MIN(05)/DEC, circulated on 22 December 2005, para. 36 and Annex F.

317 Ibid., paras 36-37.

318 Ibid., para. 38.

319 Ibid., para. 6.

320 'Talks Suspended: Today there are Ony Losers', WTO News Item, 24 July 2006, available at: http://www. wto.org/english/news_e/news06_e/mod06_summary_24july_e.htm, visited on 6 June 2008 .

321 'Lamy: "We have resumed negotiations fully across the board"' WTO News Item, 7 February 2007, available at: http://www.wto.org/english/news_e/news07_e/gc_dg_stat_7feb07_e.htm, visited on 8 June 2008.

322 'Lamy Urges "Maximum Effort” for July Meeting of Ministers', WTO News Item, 27 June 2008, available at: http://www.wto.org/english/news_e/news08_e/tnc_dg_stat_june08_e.htm, visited on 29 June 2008. 
a better balance between the ambitious level of commitments sought in the area of non agricultural market access and the watered-down commitments on agricultural liberalisation. It remains to be seen if this call will be heard.

\subsection{Conclusion}

The relevance of the examination of the 'development dimension' of the SPS Agreement can best be understood against the background of increasing developing country participation in the international trading system, and the implications of this increased participation for the rules of the system.

This background cannot be divorced from the normative framework established by international human rights law, and in particular the emerging recognition of the right to development. While not yet fully crystallised as creating particular obligations on states, the right to development is important in that it emphasises the interdependence between development and human rights. It is no longer possible to see development purely from an economic growth perspective. Instead, development strategies, also in the form of trade liberalisation must take account of their impact on human rights, including the rights to life, health and safe food. The WTO, as an organisation whose activities have an impact on development, must ensure that the economic growth achieved by its rules does not come at the cost of the protection of human rights. Therefore, in respect of the SPS Agreement, this means that the objective of liberalisation of trade in food and agricultural products must be balanced against that of health protection. In addition, while the importance of trade as an engine for growth and poverty alleviation is crucial to development, in order to be truly supportive of development trade liberalisation must be achieved by rules that are appropriate to the special position of developing countries. This requires not only flexibilities, where possible, in recognition of developing country constraints, but also provision for assistance from the international community to build capacity in developing countries.Against this background, an examination of the historical developments towards the integration of developing countries in the international trading system reveals significant problems but also some progress. In particular, the changing approach to the recognition of developing country constraints is instructive.

While the initial approach of the GATT 1947 was to emphasise the fundamental principle of non-discrimination and thus apply its rules equally to developed and developing Contracting Parties, it is clear that the impact of these rules was not the same for all Contracting Parties. The flexibilities negotiated into the rules, while available to all, were in areas most useful to developed countries. The change initiated in the Review Session of 1954-1955, with the introduction of the concept of differential treatment of developing countries, and the calls for broad derogations from GATT rules for these countries, was insufficient to secure the gains in economic growth needed by developing countries. The recognition by developing countries of the need for positive action by developed countries to increase their market access led to the introduction of a new Part IV on 'Trade and Development' into the GATT setting out a number of actions for developed countries to ensure that a self-selected group of less-developed Contracting Parties secured a share in the growth of trade commensurate with their development needs. However, these actions 
were expressed in purely hortatory terms or as best-endeavour commitments. The concept of 'special and differential treatment' was formalised in the Tokyo Round Enabling Clause, formally allowing deviation from the principle of most-favoured-nation treatment to accord preferential treatment to developing countries. In addition SDT provisions were included in the Tokyo Round Codes, which addressed various types of non-tariff barriers to trade. These SDT provisions were criticised as insufficient due to the vague wording of SDT provisions, lacking specification of measures necessary for their application. This despite the fact that these Codes entailed far-reaching commitments with regard to behind-the-border areas of regulatory policy. As a result, most developing countries chose not to become parties to the Codes.

It is elucidating to bear in mind the new approach of developing countries in the Uruguay Round negotiations that led, inter alia, to the adoption of the SPS Agreement. In these negotiations developing countries evinced a new willingness to engage actively in the negotiations and make reciprocal concessions in order to gain concessions in areas of particular interest to them, including agriculture and textiles. Developing countries undertook to bind themselves, as part of a 'single undertaking' to broad-ranging disciplines, encompassing rules not only on traditional trade barriers but also on non-tariff barriers to trade in the form of regulatory measures, an example of which are SPS measures. The implementation of these new disciplines entails progressively higher compliance costs, in the form of legislative reform and the creation of the necessary institutional infrastructure, the less developed a country is. Instead of negotiating exemptions from these rules, developing countries called for a new form of SDT, in the form of longer transition periods, consideration for their special position and the provision of technical assistance. These provisions can be found in the SPS Agreement. However, in the SPS Agreement as in the other Uruguay Round agreements, the SDT provisions are either non-binding or are framed in such open terms as to be practically unenforceable. Developing-country Members regard SDT as the quid pro quo for the extensive obligations they undertook in the Uruguay Round, and therefore regard the inadequate implementation thereof as cause for concern. Consequently, the lack of implementation of SDT provisions by developedcountry Members and the high compliance costs for developing-country Members of implementing the disciplines of these agreements led to growing dissatisfaction with the asymmetrical costs and benefits of the multilateral trading system as reflected in the outcome of the Uruguay Round.

These implementation concerns were the focus of attention in the run-up to the Seattle Ministerial Conference, which was supposed to launch a new 'Millennium Round' of trade negotiations. The failure of this Ministerial Conference led to a realisation of the need to take seriously the concerns of developing-country Members. This is reflected in the renewed focus on developing country concerns at the Doha Ministerial Conference in 2001. The Implementation Decision adopted at this Ministerial Conference contains decisions (of rather limited impact) on certain implementation issues, and, more importantly, sets out a work programme on SDT. The Doha Ministerial Conference also successfully launched the 'Doha Development Round' of trade negotiations, which seeks to place developing country needs at the heart of its work programme. The Doha Ministerial Declaration, adopted at the same time as the Implementation Decision, recognises that SDT provisions are an integral part of the WTO agreements and mandates the review of 
SDT provisions in order to strengthen and operationalise them. However, negotiations on this issue have become mired in disagreement and have borne little fruit thus far. The polarisation in the discussion reflects the unrealistic and rigid positions taken on both sides.

It is clear that progress on resolving the implementation concerns of developing countries, both with regard to the high compliance costs they face in implementing new regulatory disciplines and with regard to the lack of faithful implementation of the special provisions negotiated to take account of their constraints, is urgently needed. It seems that an agreement-specific focus contains more prospects for success than a cross-cutting approach. Implementation problems are agreement-specific and addressing them in this way allows the discussion to move from the political level to a concrete technical level where the solutions are most likely to be found. However, both developed and developing-country Members will have to show a willingness to move from their current rigid positions and to look for constructive solutions. To facilitate this movement, in-depth research is needed to identify where the problems lie in each agreement, and what the possibilities are for improvement. 


\section{CHAPTER 2}

\section{The globalisation of health: Addressing transboundary health risks}

Hand-in-hand with the globalisation of trade, and the progressive integration of developing countries into the world trading system, there has been a development towards the globalisation of health. The impetus for this development lies in the growth in the movement of food, plants and animals across borders and the SPS risks this entails. Consequently, countries became aware of the need for international cooperation to address these risks.

However, this process has not been a smooth one. Instead, it is characterised by changes and even reversals that reflect the widely held view that the protection of health is a national issue and choices in this regard are the prerogative of sovereign governments. The developments in this area are closely linked to advances in science and its ability to provide a commonly accepted framework for regulatory decisions. This Chapter aims to sketch the process of the globalisation of health concerns in broad strokes.

\subsection{The origins of international attention to the tension between trade and health in the mid-nineteenth century}

As mentioned above, ${ }^{1}$ from its earliest beginnings, international trade has had an impact on national health and, conversely, national health measures have affected trade between states. However, national sanitary measures only became an international issue in the mid-nineteenth century. Two principal factors contributed to this development. First, the outbreak of cholera epidemics in Europe between 1830 and 1847 led to a realisation that current national responses to health threats from other countries, which mainly took the form of quarantine measures, were insufficient to address the growing risks from imported infectious diseases due to the increase in both the volume and speed of travel and trade. ${ }^{2}$ Second, due to the growing share of trade earnings in their GDP, developed countries became increasingly concerned about the trade-restrictive effects of health measures, such as quarantine requirements, on their export markets and serious trade conflicts arose.

Consequently, states (mostly European) began international efforts to coordinate their sanitary measures, and the first International Sanitary Conference was held in $1851 .^{3} \mathrm{~A}$ series of sixteen international sanitary conferences and thirteen international sanitary conventions followed between 1851 and $1944 .{ }^{4}$ As noted by Brigit Toebes, '[t]he major purpose of the conferences was not to improve global health, but rather to protect the European States against alien diseases... ${ }^{5}$ In addition, some international health

\footnotetext{
${ }^{1}$ See above, Part I, Section 1.1.

2 David P. Fidler, 'Microbialpolitik: Infectious Diseases and International Relations', American University International Law Review 14, 1998, 1-52, 18-19. Fidler's analysis is limited to the area of sanitary measures imposed in response to threats from infectious diseases, but similar considerations apply to sanitary and phytosanitary threats in general.

${ }^{3}$ Ibid., 18.

4 David P. Fidler, 'Return of the Fourth Horseman: Emerging Infectious Diseases and International Law', Minnesota Law Review 81, 1997, 771-868, 834.

${ }^{5}$ Brigit Toebes, The Right to Health as a Human Right in International Law (Intersentia-Hart, Groningen),
} 
organisations were created to administer these international and regional sanitary rules. ${ }^{6}$ Despite this new attention to threats to human health on international level, the international regime with regard to the control of the spread of infectious diseases was haphazard and incomplete. The early sanitary conventions were products of political compromise and irrational fears, lacking a scientific basis. The manifold of sanitary conventions sometimes overlapped, important trading nations were not party to some or all the conventions, and the treaty-making process was too cumbersome to allow the rules to adapt to developments in scientific knowledge. ${ }^{7}$

Developments were made in the late nineteenth century in the scientific understanding of the causes of diseases and the discovery of more effective methods to address these risks. These initially facilitated international efforts towards cooperation in this area.

\subsection{The science paradigm in the globalisation of health}

The great advances made in scientific knowledge and research techniques in the late nineteenth century, ${ }^{8}$ were instrumental in facilitating the international cooperation in the area of health protection mentioned above. Previously, the lack of a common understanding of the causes of health risks and the most effective ways to deal with them was an obstacle to the efforts to coordinate national responses to international risks. As science and scientific techniques developed, it became possible to detect toxins or contaminants in food, identify plant and animal diseases and evaluate the risks arising from them. The new scientific understanding of the causes of infections and other diseases created a more objective basis for regulatory decisions in the area of health and enabled trading nations to reach agreement on ways to coordinate their health measures internationally in order to minimise their trade-restrictive effects. Science replaced politics and narrow self-interest as the basis for agreement on international health issues. ${ }^{9}$

This emerging scientific consensus on health issues also made it possible to establish international harmonised standards for food safety and plant and animal health. These standards were not only driven by health concerns but were also often linked to trade facilitation initiatives. For example, in 1903, the International Dairy Federation developed international standards for milk and milk products, in order to diminish the

1999, 12.

${ }^{6}$ For example, the Office International d'Hygiéne Publique (1907), the League of Nations Health Organisation (1945) and the Health Division of the UN Relief and Rehabilitation Administration on international level, and the Pan American Sanitary Bureau and the Egyptian Sanitary Maritime and Quarantine Board. See 'Forum Interview with Szeming Sze, WHO: From Small Beginnings,' World Health Forum 9 (1988) 29-43 at 30.

7 David P. Fidler, 'Return of the Fourth Horseman: Emerging Infectious Diseases and International Law', Minnesota Law Review 81, 1997, 771-868, 835.

${ }^{8}$ Fidler notes that the absence of proper scientific understanding of microbes constituted an important obstacle to international cooperation through much of the second half of the nineteenth century. He mentions the scientific validation of the 'germ theory' as instrumental in enabling international cooperative efforts to achieve concrete results, in the form of treaties and international health bodies. David P. Fidler, 'Microbialpolitik: Infectious Diseases and International Relations', American University International Law Review 14, 1998, $1-52,19$.

${ }^{9}$ This is reflected in the fact that increasingly negotiations regarding international health issues were carried out by health experts rather than ambassadors and other political representatives. 
trade-restrictive effects of diverse national regulations with respect to dairy products. Similarly, other commodity groups lobbied for international harmonisation of health regulations that affected their sector. ${ }^{10}$ The idea that science provided a neutral, universally accepted foundation for health measures made agreement on these harmonised standards possible. Thus, science was the scale on which the competing interests of health and trade were balanced.

However, the benefits of scientific advances and international cooperation on health issues did not extend to developing regions of the world, where infectious diseases remained prevalent. Lack of resources, adequate health infrastructure and know-how meant that the advent of scientific tools in the area of health, such as antimicrobial drugs, had a limited impact on health in developing countries. ${ }^{11}$ Further, developing countries played a very limited role, if any, in international negotiations on health issues, due to lack of human and financial resources and ineadequate scientific capacity. As a result, the international strategies developed to break the grip of infectious diseases on developing countries were often inappropriate and misguided.

\subsection{The re-nationalisation of health issues in developed countries in the first half of the twentieth century}

Paradoxically, developments in science eventually led to the re-nationalisation of health issues in developed countries in the first half of the twentieth century. ${ }^{12}$

As domestic health infrastructure improved and powerful drugs and treatments were developed to deal with bacteria, parasites and viruses, countries grew more confident of their abilities to address imported health risks by means of national measures. ${ }^{13}$ Many infectious diseases and parasites were practically eradicated in much of the developed world. With the establishment of good sanitation systems, science-based food safety regulations and accurate control and testing procedures, the frequency and costs of disease outbreaks were greatly reduced.

\footnotetext{
${ }^{10}$ Peter W.B. Phillips, 'Food Safety, Trade Policy and International Institutions', in Governing Food: Science, Safety and Trade, Peter W.B Phillips and Robert Wolfe (eds.) (McGill-Queen's University Press, Montreal), 2001, 27-48, 29.

11 David P. Fidler, 'Return of the Fourth Horseman: Emerging Infectious Diseases and International Law', Minnesota Law Review 81, 1997, 771-868. Fidler points to the fact that the misuse of international availability of antimicrobial drugs in developing countries has led to antimicrobial resistance in diseases such as malaria and tuberculosis.

${ }^{12}$ Fidler points to advances in epidemiology and antimicrobial pharmaceuticals as the cause of the re-nationalisation of public health in the developed world. See David P. Fidler, 'The Globalization of Public Health: Emerging Infectious Diseases and International Relations', Indiana Journal of Global Legal Studies 5 (2), 1997, 27, available at: http://www.law.indiana.edu/glsj/vol5/no1/fidler.html, visited on 25 June 2007.

${ }^{13}$ As noted by Fidler, in 1969 the advances made in the fight against infectious diseases, including through the use of vaccines and antibiotics, prompted the United States' Surgeon General to report to the US Congress that it was time to 'close the book' on infectious diseases.' David P. Fidler et al., 'Emerging and Re-Emerging Infectious Diseases: Challenges for International, National, and State Law', The International Lawyer 31, 1997, 773-813, 773.
} 
Health experts claimed that developed countries had passed through the 'health transition,' from a situation where infectious diseases were the leading cause of death to a situation where chronic or non-communicable illnesses such as heart disease, obesity, cancer and respiratory problems, were the greatest health problem. ${ }^{14}$ Developed countries thus no longer had a strong national interest in promoting international cooperation in the area of health and international initiatives lost impetus.

As discussed above, international efforts in the late nineteenth century had failed to bring about a health transition in the developing world. The continued prevalence of pests and infectious diseases in the developing world was, however, not perceived as a threat by developed countries, but was seen as a problem for developing countries only. ${ }^{15}$ Science was regarded as providing effective tools to deal with any imported health risks on national level. As a result, international cooperation was no longer seen as essential as developed countries 'regained sovereign control over public health.' ${ }^{16}$

\subsection{Return to the international approach: The globalisation of health}

The unprecedented increase in the speed, volume and scope of trade in the second half of the twentieth century prompted a rethinking of the complacent attitude that had developed with regard to health risks from imported products. A significant new factor that played a role in the re-evaluation of countries' ability to deal with health risks on a purely national level was the rapid expansion of trade between developed and developing countries, following the decolonisation process after World War II. ${ }^{17}$ As noted above, there was a rapid increase in the number of developing countries that joined the international trade regime in the $50 \mathrm{~s}$ and $60 \mathrm{~s}$. For the first time, trade was truly global in reach.

In addition, the international trade rules imposed strict disciplines on countries' ability to adopt trade-restrictive measures for the protection of health. ${ }^{18}$ Thus, increasingly, developed countries were exposed to threats from imported products sourced in countries where parasites, pests and microbiological contaminants were endemic. ${ }^{19}$ National strategies to deal with these risks were no longer sufficient as the volume of trade made effective screening of imports an impossible task. This can be referred to as the phenomenon

${ }^{14}$ David P. Fidler, 'Symposium on Globalization at the Margins: Perspectives on Globalization from Developing States: Neither Science nor Shamans: Globalization of Markets and Health in the Developing World', Indiana Journal of Global Legal Studies 7, 1999, 191-224, 194.

15 David P. Fidler, 'The Globalization of Public Health: Emerging Infectious Diseases and International Relations', Indiana Journal of Global Legal Studies 5 (2), 1997, 29, available at: http://www.law.indiana.edu/ glsj/vol5/no1/fidler.html, visited on 25 June 2007.

16 Ibid.

17 Ibid., 31.

${ }^{18}$ The provisions of the GATT 1947 prohibited discriminatory regulatory treatment of domestic and imported products (Article III:4) and quantitative restrictions, including bans (Article XI:1), but contained a limited exception to these rules for measures necessary for the protection of human, animal or plant life or health (Article XX(b)). Contracting Parties to the GATT 1947 had to comply with strict requirements in order for their health measures to pass scrutiny under this agreement. These GATT rules are discussed below, Part III, Section 1.1.1.

${ }^{19}$ Fidler notes the example of the outbreak of cyclospora parasite in the U.S. in 1996, which was believed to have originated in Latin American strawberries or raspberries. 
of the globalisation of health, meaning the situation where states are losing the ability to protect health in their territories by means of purely national measures. ${ }^{20}$

The impetus for renewed attention to international health cooperation therefore came from developed countries, due to concerns regarding exposure to health threats from the developing world. It differed from the efforts at international cooperation undertaken in the mid-nineteenth century in that it relied greatly on science as a tool to achieve agreement on a common approach to global health risks. It attempted to combine the early efforts at harmonisation of national health measures in response to global health risks, with the development of international institutions and rules to promote common action.

Some of the global initiatives to foster international cooperation against sanitary and phytosanitary risks are the creation of the International Office for Epizootics in 1921, to prevent the spread of diseases in animals and animal products through international trade; the establishment of the Codex Alimentarius Commission in 1961 to administer the Joint FAO/WHO Food Standards Programme; and the adoption by the FAO of the International Plant Protection Convention (IPPC) in 1951 to formalise international cooperation in the area of plant protection. These initiatives were based on cooperative efforts, at the level of experts, to elaborate voluntary guidelines to minimise SPS risks, while causing as little disruption as possible to the flow of international trade. ${ }^{21}$

In 1948, the World Health Organisation (WHO) was established, ${ }^{22}$ with the objective of ensuring the 'attainment by all peoples of the highest possible level of health. ${ }^{23}$ The WHO's constitution defines health as 'a state of complete physical, mental and social well-being and not merely the absence of disease or infirmity. ${ }^{24}$ Its mandate thus goes beyond the control of infectious diseases to the promotion of health in general.

Under the auspices of the WHO, ${ }^{25}$ the International Sanitary Regulations were adopted in 1951. These were revised and renamed the International Health Regulations ${ }^{26}$ (IHR)

${ }^{20}$ This term is adapted from the concept of the 'globalization of public health', referred to by Fidler in connection with the loss of states' ability to protect their publics against threats from diseases. This concept can be extended to all health threats, not only those to human beings from infectious diseases and thus the term 'globalisation of health' would be more appropriate in this context. See David P. Fidler, 'Symposium on Globalization at the Margins: Perspectives on Globalization from Developing States: Neither Science nor Shamans: Globalization of Markets and Health in the Developing World', Indiana Journal of Global Legal Studies 7, 1999, 191-224, 196-197. See further on the challenges for health protection caused by cross-border movement of food, F.K. Kaferstein et al., 'Foodborne Disease Control: A Transnational Challenge', Emerging Infectious Diseases 3 (4), 1997, 503-510.

${ }^{21}$ For a detailed discussion of these three initiatives, see Part II, Sections 3.2.1-3.2.3.

${ }^{22}$ The WHO was the first specialised agency of the UN. Article 55 of the UN Charter provides that one of the tasks of the UN shall be to promote solutions to international health problems (David P. Fidler, 'Return of the Fourth Horseman: Emerging Infectious Diseases and International Law’, Minnesota Law Review 81, 1997, 771-868, 836 and note 320).

${ }^{23}$ Article 1 of the Constitution of the World Health Organization as adopted by the International Health Conference, New York, 19-22 June, 1946; signed on 22 July 1946 by the representatives of 61 States (Official Records of the World Health Organization, no. 2, p. 100) and entered into force on 7 April 1948.

${ }^{24}$ Preamble to the Constitution of the World Health Organization.

${ }^{25}$ Fidler points out that Article 21 of the WHO Constitution provided the authority for the WHO to adopt binding sanitary and quarantine regulations and other procedures to prevent the international spread of disease. See David P. Fidler, 'Return of the Fourth Horseman: Emerging Infectious Diseases and International Law', Minnesota Law Review 81, 1997, 771-868, 835.

${ }^{26}$ World Health Organization, International Health Regulations, adopted by the $22^{\text {nd }}$ World Health Assembly 
in $1969 .{ }^{27}$ The objective of the IHR is 'to ensure the maximum security against the international spread of diseases with a minimum interference with world traffic. ${ }^{28}$ The IHR aim to achieve this dual objective by, on the one hand, creating an international system of notification and surveillance of specified diseases, ${ }^{29}$ requiring certain health facilities at ports and harbours, setting out particular obligations with regard to notifiable diseases and, on the other hand, by establishing the maximum measures applicable to international traffic that member countries may take to protect their territories from diseases subject to the IHR. ${ }^{30}$ Member countries were obliged to notify the WHO of all measures they apply to imports from infected areas and could not require additional health documentation beyond that provided for in the IHR. ${ }^{31}$ It therefore appears that, once again, international efforts to deal with increasingly globalised risks to health attempted to balance health protection with trade concerns.

However, despite its binding disciplines, the IHR failed to achieve their dual objective. The IHR were ineffective in preventing the international spread of the notifiable infectious diseases, such as cholera, and limited member countries' ability to respond to other equally important diseases not covered by its provisions. In addition, the IHR did not succeed in achieving 'minimum interference with world traffic' as member countries largely ignored the prohibition on measures more restrictive than those provided for in the IHR. ${ }^{32}$

In 1983, a WHO/FAO Joint Expert Committee on Food Safety found that food contamination, both by microbes ${ }^{33}$ and by chemicals and toxins, ${ }^{34}$ was a considerable and widespread health problem in the world and had an important economic impact. ${ }^{35}$ Similarly,

(1969) and amended in 1973 and 1981 (3 $3^{\text {rd }}$ annotated ed.) Geneva 1983, available at, http://policy.who.int/cgibin/om_isapi.dll?infobase=Ihreg\&softpage=Browse_Frame_Pg42, visited on 25 June 2007.

27 The IHR are binding on WHO member countries, but opt outs and reservations are possible.

${ }^{28}$ Foreword to the IHR.

29 The initial objective of the IHR was to monitor and control the spread of six infectious diseases, namely cholera, plague, yellow fever, smallpox, relapsing fever and typhus. However, under the IHR of 1969, only cholera, plague and yellow fever were notifiable diseases. See the website on of the World Health Organization, the information on the International Health Regulations, available at: http://www.who.int/csr/ihr/en/, visited on 5 September 2005.

${ }^{30}$ Article 23 IHR, which prohibits countries from imposing stricter health measures than those laid down in the IHR.

${ }^{31}$ See David P. Fidler, 'Return of the Fourth Horseman: Emerging Infectious Diseases and International Law', Minnesota Law Review 81, 1997, 771-868, 843-847. The IHR are currently in the process of revision in order to make them more effective and responsive to contemporary threats from emerging infectious diseases.

${ }^{32}$ Ibid. As discussed below, in Part I, Section 2.5, the IHR have been recently revised in order to make them more effective and responsive to contemporary threats.

${ }^{33}$ Microbes or parasites in food can cause acute illness, for example diarrhoeal diseases, botulism, cholera (typhoid), salmonellosis, or hepatitis A; or chronic illnesses, such as tuberculosis, trichinosis or tapeworm.

34 These chemicals or toxins may take the form of pesticide or herbicide residues, drugs and hormones administered in animal husbandry, toxins naturally occurring in plants, marine biotoxins and mycotoxins. They can cause cancer, antibiotic resistance, ergotism, alimentary toxic aleukia, and haemolytic anaemia, among other diseases. Joint FAO/WHO Expert Committee on Food Safety, The Role of Food Safety in Health and Development, WHO Technical Report Series 705, (Geneva: World Health Organization, 1984) at 18-20.

35 Joint FAO/WHO Expert Committee on Food Safety, The Role of Food Safety in Health and Development, WHO Technical Report Series 705, (Geneva: World Health Organization, 1984) at 12-21. The magnitude of the health problem and its accompanying economic impact was found to be difficult to establish accurately, due to the poor records kept by countries in this regard. Ibid at 13 and 21. 
the spread of animal and plant pests and diseases continued to form a significant threat to agricultural production across the world.

\subsection{The new approach to globalised health risks at the turn of the century: International and national strategies}

One response to the failure of international efforts to check the spread of SPS risks in an increasingly globalised world was to strengthen international regulation. In fact, the impact of rapidly increasing trade on health was one of the factors ${ }^{36}$ that led to the process of revision of the WHO's International Health Regulations, from 1995 to 2005 . The revision, ${ }^{37}$ referred to as the International Health Regulations $2005^{38}$ (IHR 2005) has expanded the scope of parties' obligations to assess and notify a public health event to include not only specified infectious diseases (as was previously the case) but also all 'events potentially constituting a public health emergency of international concern.' ${ }^{39}$ The 'decision instrument' provided to assist governments in determining whether such an event exists lists, as one of the indicative factors, ${ }^{40}$ 'a significant risk of international travel or trade restrictions'. ${ }^{41}$

The IHR 2005 oblige States Parties to develop and maintain certain minimum core capacities for surveillance of and response to public health events, ${ }^{42}$ including the capacity to provide specialised staff, laboratory analysis of samples (on national level or through collaborating centres), and logistical assistance; and the capacity to establish and implement a response plan to events that may constitute a public health emergency of international concern. ${ }^{43}$ Further, minimum requirements apply with regard to designated ports, airports and ground border crossings, such as the provision of trained inspectors; the application of measures, when appropriate, to disinfect, decontaminate, eliminate rats or insects, or otherwise treat cargo and goods. ${ }^{44}$

\footnotetext{
${ }^{36}$ Other relevant factors were emerging infections diseases, such as the SARS outbreak in 2003; interspecies transfer of animal diseases, such as BSE and avian influenza, to humans; the threat of bioterrorism; and increased movement of people across borders. See Gerald S. Schatz, International Health Regulations: New Mandate for Scientific Cooperation, circulated on 2 August 2005.

37 The revision was adopted on 23 May 2005 and came into force two years from that date as binding on those States Parties that had not rejected them or tried to make impermissible reservations by that time. See Revision of the International Health Regulations, WHA58.3, Fifty-Eighth World Health Assembly, 23 May 2005, Article 59.

${ }^{38}$ Ibid., Preamble, recital 1.

${ }^{39}$ Ibid., Article 6.1.

${ }^{40}$ All four factors listed are: (1) that the public health event is serious; (2) that the public health event is unusual or unexpected; (3) that there is a risk of international spread; and (4) that there is a significant risk of international travel or trade restrictions. If at least two of the four factors is present, the event must be notified to the WHO.

${ }^{41}$ Revision of the International Health Regulations, WHA58.3, Fifty-Eighth World Health Assembly, 23 May 2005, Annex 2.

${ }^{42}$ States Parties have five years from the entry into force of the IHR 2005 to develop the required capabilities. See Ibid., Articles 5 and 13.

${ }^{43}$ Ibid., Annex 1A para. 6.

${ }^{44}$ Ibid., Annex 1B.
} 
Many countries do not have the required capacities and lack the resources to develop them. The IHR 2005 do not establish a funding mechanism to assist States Parties in this regard, but oblige the WHO to collaborate with them to mobilise funding to support developing countries in building and maintaining these capacities. ${ }^{45}$ Further, the IHR 2005 oblige States Parties to collaborate with each other, to the extent possible, in detecting, assessing and responding to public health events covered by it; providing or facilitating technical and logistical assistance in developing and maintaining the required core capacities; and drafting implementing legislation and procedures. ${ }^{46}$ It remains to be seen to what extent the necessary assistance will be provided.

In order to avoid unnecessary interference with international traffic and trade, ${ }^{47}$ the IHR 2005 impose limits on the ability of States Parties to take health measures. If the Director General of the WHO determines that a public health emergency of international concern exists, ${ }^{48}$ he or she must issue temporary recommendations of appropriate measures. ${ }^{49}$ With regard to ongoing public health risks, standing recommendations may be issued to prevent or reduce the international spread of disease and avoid unnecessary interference with international traffic and trade..$^{50}$ Temporary and standing recommendations may be seen as attempts to harmonise responses to public health events around internationally established standards. ${ }^{51}$ Deviation from recommended measures is subject to a list of requirements. Members may apply health measures that achieve the same or a higher level of protection than the WHO recommendations, provided that such measures are not more restrictive of international traffic than reasonably available alternatives that achieve the appropriate level of health protection. Further, States Parties must base their decisions to take other measures than those recommended on scientific principles; available scientific evidence of risk, or if such evidence is insufficient, on available information including from the WHO and other relevant international bodies; and any available specific guidance or advice from the WHO. ${ }^{52}$ If such measures significantly interfere with international traffic, the State Party implementing the measure must notify the WHO and submit to it the public health rational for the measure and supporting scientific information. ${ }^{53}$ The WHO circulates this information to other States Parties and may ask the relevant State Party to reconsider the measure. States Parties affected by the measure may request consultations with the implementing party to clarify the scientific information and public health rationale for the measure and try to find a mutually acceptable solution.

\footnotetext{
${ }^{45}$ Ibid., Article 44.

${ }^{46}$ Ibid., Article 44.

${ }^{47}$ As mentioned above, the IHR have a dual objective, namely to prevent the international spread of disease and avoid unnecessary interference with international traffic and trade. This dual objective is maintained in the IHR 2005. See Ibid., Article 2.

${ }^{48}$ This determination is made according to the rules laid down in the IHR 2005. Ibid., Article 12.

49 Ibid., Article 15.

${ }^{50}$ Ibid., Article 16.

${ }^{51}$ Recommendations must take into account scientific principles and available scientific evidence, relevant international standards, activities of other intergovernmental organisations and international bodies, the advice of the Emergency Committee or Review Committee (committees of experts established under the IHR 2005), the views of the States Parties involved and other appropriate information. Ibid., Article 17.

${ }_{52}$ Such measures must also be reviewed within 3 months on the basis of the same three criteria. Ibid., Article 43.

${ }^{53}$ Significant interference is defined as the refusal of entry or departure of inter alia cargo or goods, or their delay for more than 24 hours. Ibid.
} 
Despite these efforts to strengthen the international regulatory approach, the inability of such an approach to deal with differences in national health conditions and implementation capacities has led to a rethinking of the strategy needed to address the threat to health from the globalisation process. This rethinking has further been spurred by recognition of the weak commitment of the 'international society' to comply with their commitments in the area of disease control. ${ }^{54} \mathrm{~A}$ new strategy has developed, which can be captured in the phrase: 'think globally, act locally' ${ }^{55}$ It reflects the awareness that international cooperation is a necessary, but not sufficient, response to the global spread of health risks.

In particular, current thinking acknowledges the danger in dealing with the globalisation of health risks by means of 'one-size-fits-all' harmonised measures. Instead, it is important to allow for policy choices to be made on the basis of national circumstances and institutional capacity. ${ }^{56}$ London School of Economics economist Razeen Sally disagrees with the view of Mark Malloch Brown, administrator of the UNDP, that the nation state is in retreat thus necessitating global solutions to provide global public goods. ${ }^{57}$ While Sally does not deny the importance of international cooperation where national level action is inadequate, he points out that national governance co-exists with international economic integration and that globalisation continues to depend on law-governed nation-states. ${ }^{58}$

The current approach to coping with the challenges that globalisation poses for health is a multifaceted one. It continues to rely on international cooperation, based on scientific

\footnotetext{
${ }^{54}$ Fidler notes that unlike the participants at the international sanitary conferences in the late nineteenth century, today we are aware of the inability of international harmonisation of quarantine measures to deal with the international movement of microbes. Further, unlike the 'dedicated servants in the halcyon days of international health organizations' today we recognise the limits of reliance on notions of the international society. David P. Fidler, 'Microbialpolitik: Infectious Diseases and International Relations', American University International Law Review 14, 1998, 1-52, 40.

55 David P. Fidler et al., 'Emerging and Re-Emerging Infectious Diseases: Challenges for International, National, and State Law', The International Lawyer 31, 1997, 773-813, 778.

${ }^{56}$ This point is made by Dani Roderik, a reputable Harvard economist and referred to by Razeen Sally. Razeen Sally, Whither the World Trading System? Trade Policy Reform, the WTO and Prospects for the New Round, No. 76 (Timbro, Stockholm), 2002, 6, available at: http://www.timbro.se/pdf/whither.pdf, visited on 28 January 2008.

${ }^{57}$ Malloch-Brown argues that certain issues 'simply cannot be handled on a national level' but 'require a global response'. He advocates a 'real paradigm shift' entailing a 'much more vigorous vision of how to manage the global economy and global society'. As, in his view, national governments are unable to deal with global problems, including health issues, he proposes global solutions. Global governance, in his opinion, should take the form of 'the right kinds of partnerships between different levels of government in the world', and 'partnerships with non-government players, both the private sector, civil society, and others.' Mark Malloch-Brown, 'Human Security and Human Development in the 21st Century: A Post-September 11 Agenda', presented at the London School of Economics, Centre for the Study of Global Governance, London) 25 October 2001, available at: www.lse.ac.uk/collections/globalDimensions/lectures/humanSecurityAndHumanDevelopment/, visited on 5 November 2001. Sally adopts a classical liberal critique of Malloch-Brown's vision, arguing that: '...this is a profoundly illiberal vision, whose distrust of markets and faith in government intervention (now at the global level) would, if put into practice, undermine the freedom of contract and restrict competition. Needless to say, this has implications for economic efficiency, but one should not forget that these prescriptions erode the freedom of choice: they threaten individual liberty itself.' Razeen Sally, Whither the World Trading System? Trade Policy Reform, the WTO and Prospects for the New Round, No. 76 (Timbro, Stockholm), 2002, 6 (footnote omitted) available at: http://www.timbro.se/pdf/whither.pdf, visited on 28 January 2008.

${ }^{58}$ Razeen Sally, Whither the World Trading System? Trade Policy Reform, the WTO and Prospects for the New Round, No. 76 (Timbro, Stockholm), 2002, 12, available at: http://www.timbro.se/pdf/whither.pdf, visited on 28 January 2008.
} 
research and the sharing of information by experts and technocrats, to develop harmonised standards and guidelines for the management of risks. However, these standards are voluntary, and it is up to states to adopt them in national regulations, according to their own needs and capacities. The emphasis is therefore on national sovereignty in policy decisions regarding protection from SPS risks, within a framework of cooperative efforts at international level, involving the sharing of information and best practices regarding minimum levels of health protection, to limit the trade restrictive effect of national measures.

A further development has occurred in governance of health risks in the past decade. This is development away from central government regulation, towards local, transnational and private governance structures in the area of SPS protection. Increasingly local governments, transnational networks of regulators and private entities such as retail conglomerates are active in addressing SPS risks. These new governance structures have emerged due to the crisis of confidence in the ability of central governments to effectively protect their citizens from health risks, in the aftermath of health scares such as avian influenza and bovine spongiform encephalopathy (BSE).

This complex arrangement of multi-level governance currently defines the strategy for dealing with globalised health risks.

\subsection{Conclusion}

The impetus for international cooperation in the area of health protection in the mid-nineteenth century has its origins in developed country concerns. First, developed countries became aware of the inadequacy of national measures to address the increased exposure to sanitary and phytosanitary risks from imported food, plant and animal products in the face of growing trade. Second, the increased share of trade earnings in the GDP of developed countries spurred them to efforts to diminish the impact of national SPS measures on trade by means of harmonisation. These countries therefore turned to international cooperation to achieve their health and trade objectives.

Developments in science in the late nineteenth century facilitated international cooperation, by providing a seemingly neutral and universally valid basis for agreement on harmonised health measures. Science provided a useful tool for balancing competing trade and health objectives in developing international strategies. However, the lack of scientific capacity in developing countries meant that they were unable to play an effective part in the international negotiations leading to harmonised health standards.

By the mid-twentieth century, national capacity in developed countries to deal with health risks, including those from imported products had greatly improved due to scientific advances. This led to the re-nationalisation of strategies to deal with health risks and an attendant loss of momentum in international cooperative efforts. However, by the end of that century developed countries had rethought their complacent positions. This turnaround was brought about by the unprecedented increase in the speed, volume and scope of trade, and in particular the growing participation in trade by developing countries, where SPS risks were still wide-spread. As national SPS regimes were unable to deal 
with the proliferation of risks in this new setting, international efforts redoubled, with the creation of international institutions and frameworks for common action.

The international approach failed in its objective to address globalised health risks in a manner that facilitates trade, due to its neglect of the differences in national health priorities and implementation capacities and its inability to enforce compliance. The current strategy to address SPS risks takes account of the limitations of international cooperation by adopting a multifaceted approach. This entails continuing efforts within institutional frameworks for international cooperation to set harmonised SPS standards, based on scientific research and information sharing at a technical level, in order to minimise the trade restrictive effect of SPS measures. However, the resulting standards are voluntary and countries are free to adopt them or not, depending on their national needs and capacities. In addition, more recently, particularly in developed countries, national regulation to address SPS risks is increasingly supplemented by actions at the level of decentralised government, transnational networks and private sector bodies.

This shift in thinking with regard to the manner in which to deal with the globalisation of health arising from increased trade forms an important part of the background to understanding the SPS Agreement. As a product of the late twentieth century, the SPS Agreement embodies the multifaceted approach to risk regulation prevailing at that time. As discussed in Part III of this book, ${ }^{59}$ the SPS Agreement incorporates both the reliance on international cooperative efforts to establish science-based harmonised SPS standards in order to facilitate trade, and the recognition of the need to allow for policy choices based on national priorities and capacities. Reflecting the then-prevailing view of science as objective and universally valid, the SPS Agreement makes use of scientific justification as a neutral arbiter between legitimate health measures and disguised protectionist measures. $^{60}$

The background sketched in this Chapter is therefore useful to bear in mind when discussing the manner in which the SPS Agreement tries to achieve a balance between trade and health.

\footnotetext{
59 See below, Part III, Chapter 4.

${ }^{60}$ See below, Part III, Chapter 5.
} 


\section{CHAPTER 3 \\ The interface between globalised trade and globalised health: Health regulations and standards and their impact on developing countries}

The globalisation of trade, in the sense of the full integration of developing countries into the international trading system, is affected by measures to deal with globalised health risks, in the form of both national and international SPS regulations and standards. This is due to the importance of agricultural and food exports for the foreign revenue earnings of many developing countries, and the effect of the proliferation of SPS regulations and standards on such exports.

This Chapter therefore proceeds to examine the role of agri-food exports in the economies of developing countries. It then discusses the problems developing countries face with regard to trade in agri-food products. In this context, it sets out some of the reasons for the exponential increase, in recent years, of SPS measures, particularly in developed countries. The effect of such measures on developing country exports is subsequently discussed. In this way, this section aims to bring together the foregoing discussions of globalised trade and of globalised health by drawing attention to the interface between these two processes. It is on this interface that the SPS Agreement comes into play.

\subsection{The importance of the agriculture and food sector for development}

Agriculture forms an important sector in the economies of many developing countries, in terms of both income generation (GDP) and employment. ${ }^{1}$ The Declaration of the South Summit of the G-77 and China, adopted in April 2000, points to the fact that, for most developing countries, agriculture remains the mainstay of their economies. ${ }^{2}$ This fact is reaffirmed by the WTO's World Trade Report 2004, ${ }^{3}$ and the 2004 report of the UN Food and Agricultural Organization (FAO) entitled The State of Agricultural Commodity Markets. ${ }^{4}$ A 2003 report by the World Bank notes that agriculture accounts for about 25 percent of GDP in low-income countries and 15 percent in middle-income countries.

\footnotetext{
${ }^{1}$ United Nations Conference on Trade and Development, Development and Globalisation: Facts and Figures (United Nations, Geneva and New York), 2004, para. 28, available at: www.unctad.org/Templates/ WebFlyer. asp?intItemID $=3096 \&$ lang $=1$, visited on 25 June 2007.

${ }^{2}$ General Assembly, Fifty-Fifth Session of the General Assembly. Letter Dated 5 May 2000 from the Permanent Representative of Nigeria to the United Nations Addressed to the President of the General Assembly, A/55/74 (United Nations, New York), 12 May 2000, Annex I para. 11, available at: www.G77.org/main/docs/summitfinaldocs_english.pdf, visited on 28 Janurary 2008.

3 This report notes: 'In recent years (1999-2001) agricultural exports accounted for more than one quarter of total merchandise exports in more than 55 countries (developed and developing). For 32 countries, agricultural exports exceeded one half of their merchandise exports' WTO Secretariat, World Trade Report 2004: Exploring the Linkage between the Domestic Policy Environment and International Trade (World Trade Organization, Geneva), 11 June 2004, 15, available at: www.wto.org/english/news_e/pres04_e/press378_annex_e.pdf, visited on 26 June 2008.

${ }^{4}$ Food and Agriculture Organization, The State of Agricultural Commodity Markets (United Nations, Rome), 2004, 6, available at: ftp://ftp.fao.org/docrep/fao/007/y5419e/y5419e00.pdf, visited on 27 June 2008.
} 
Together with agro-related industries and food-related services, the share goes up to 25 to 40 percent of GDP. ${ }^{5}$ This report further points out that agriculture is the largest employer in developing countries, employing 60 percent of the labour force in low-income countries and 25 percent in middle-income countries. ${ }^{6}$ Further, the importance of the agricultural sector in effective poverty alleviation is emphasised in the 2008 World Development Report of the World Bank. ${ }^{7}$

In addition, it is widely recognised that the agricultural sector is particularly important for the livelihoods of the poorest people in developing countries. The fact that 73 percent of the poor ${ }^{8}$ in developing countries live in rural areas means that improvements in the agricultural sector are significant for the alleviation of poverty. ${ }^{9}$ The agricultural sector thus has a disproportionate impact on development. The pivotal importance of the agricultural sector for least-developed countries was recognised in the Programme of Action adopted at the Third UN Conference on Least Developed Countries in May 2001, ${ }^{10}$ which noted that this sector underpins food security, industrial and rural development and employment generation.

Agriculture also plays an important role in the generation of export revenue for developing countries. ${ }^{11}$ Agricultural exports account for over 50 percent of all exports of several

5 Global Economic Prospects 2004: Realizing the Development Promise of the Doha Agenda (World Bank, Washington D.C.), 2003, 103.

${ }^{6}$ Ibid.

7 The World Development Report of 2008 notes: 'Cross-country estimates show that GDP growth originating in agriculture is at least twice as effective in reducing poverty as GDP growth originating outside agriculture.' World Bank, World Development Report 2008: Agriculture for Development (World Bank, Washington D.C.), 2008, 6, available at: http://siteresources.worldbank.org/INTWDR2008/Resources/WDR_00_book.pdf, visited on 27 June 2008.

${ }^{8}$ The generally accepted measure of poverty as living with $\$ 1$ a day or less is used here. Global Economic Prospects 2004: Realizing the Development Promise of the Doha Agenda (World Bank, Washington D.C.), 2003, 105.

${ }^{9}$ The FAO reports that 2.5 billion people in the developing world depend on agriculture for their livelihoods. See Food and Agriculture Organization, The State of Agricultural Commodity Markets (United Nations, Rome), 2004, 6, available at: ftp:/ftp.fao.org/docrep/fao/007/y5419e/y5419e00.pdf, visited on 27 June 2008. In addition, the Secretariat background note for UNCTAD XI notes that, both with regard to income and with regard to expenditure, there is a disproportionately high dependence of the world's poorest people on food products. Thus, 'negotiations on agriculture are closely related to poverty'. United Nations Conference on Trade and Development, Development and Globalisation: Facts and Figures (United Nations, Geneva and New York), 2004, para. 28, available at: www.unctad.org/Templates/ WebFlyer.asp?intItemID=3096\&lang=1, visited on 21 June 2008. Along the same lines, the 2005 Human Development Report notes, 'More than twothirds of all people surviving on less than $\$ 1$ a day live and work in rural areas, either as smallholder farmers or as agricultural labourers. Unfair trade practices systematically undermine the livelihoods of these people, hampering progress towards the [Millennium Development Goals] in the process.' United Nations Development Programme, Human Development Report 2005. International Cooperation at a Crossroads: Aid, Trade and Security in an Unequal World (United Nations, New York), 2005, 129, available at: http://hdr.undp.org/en/ media/hdr05_complete.pdf, visited on 2 January 2008.

10 Third UN Conference on Least-Developed Countries, Programme of Action for the Least-Developed Countries, A/CONF.191/11 (United Nations, 14-20 May 2001) para. 57.

11 The World Development Report of 2008 points out, with regard to the importance of agriculture for development and poverty reduction, referring particularly to Sub-Saharan Africa, that 'the comparative advantage in the tradeable subsectors will still lie in primary activities (agriculture and mining) and agroprocessing for many years, because of resource endowments and the difficult climate for investment for manufactures.' World Bank, World Development Report 2008: Agriculture for Development (World Bank, Washington D.C.), 2008, 7, available at: http://siteresources. worldbank.org/INTWDR2008/Resources/WDR_00_book.pdf, 
developing countries. ${ }^{12}$ According to the World Bank, despite the fact that most agricultural production is absorbed by the domestic market, agricultural exports can produce faster growth than can demand on the local market. This is because the international market provides opportunities for growth without the constraint, which exists on the domestic market, that increased production would lead to sharply lower prices. ${ }^{13}$ However, although developing countries have almost doubled their share of world trade in manufactured products since 1980, their share in agricultural trade has stagnated at 30 percent. ${ }^{14}$ Growth in developing country agricultural trade was accounted for by 56 percent by sales to other developing countries. ${ }^{15}$ Middle-income developing countries have managed to increase their share in the agricultural market by exporting to other developing countries and by diversifying to non-traditional exports such as seafood, cut flowers and processed foods. ${ }^{16}$ Low-income countries have, instead, experienced a decline in their share of world agricultural trade. ${ }^{17}$

The importance of the agricultural sector for poverty reduction through trade was emphasised by the UNCTAD LDC Report 2004. It notes that:

...a form of economic growth in which expansion is localized within a small geographical and sectoral enclave is becoming a problem in some LDCs whose major exports are manufactures and mining. With this form of economic growth, there are weak links between the rapidly growing export enclave and the agricultural sector where the majority of the population and the majority of the poor have their livelihoods. In these circumstances, it is possible to have very high rates of export growth but no change in the incidence of poverty. ${ }^{18}$

Many opportunities for economic growth and poverty reduction through export trade exist in the agri-food sector. ${ }^{19}$ Due to population increases, mainly in developing countries,

visited 25 June 2007.

${ }^{12}$ United Nations Conference on Trade and Development, Development and Globalisation: Facts and Figures (United Nations, Geneva and New York), 2004, para. 28, available at: www.unctad.org/Templates/WebFlyer. asp? intItemID=3096\&lang=1, visited 21 June 2008.

13 Global Economic Prospects 2004: Realizing the Development Promise of the Doha Agenda (World Bank, Washington D.C.), 2003, 109.

${ }^{14}$ Ibid., 104 and 110.

${ }_{15}$ Agricultural exports of developing countries to other developing countries increased from $31 \%$ to $43 \%$ of their total agricultural exports in the period 1990-2002. Agricultural imports of developing countries from other developing countries increased from $37 \%$ to $47 \%$ in the same period. See WTO Secretariat, World Trade Report 2004: Exploring the Linkage between the Domestic Policy Environment and International Trade (World Trade Organization, Geneva), 11 June 2004, 15, available at: www.wto.org/english/news_e/pres04_e/ press378 annex e.pdf, visited on 26 June 2008.

${ }_{16}$ Global Economic Prospects 2004: Realizing the Development Promise of the Doha Agenda (World Bank, Washington D.C.), 2003, 104. This report points out that growth in non-traditional exports has exceeded growth in traditional commodities by $3: 1$.

17 Ibid.

${ }^{18}$ United Nations Conference on Trade and Development, The Least Developed Countries Report 2004: Linking International Trade with Poverty Reduction, UNCTAD/LDC/2004 (UNCTAD, Geneva), 27 May 2004, 1920, available at: http://www.unctad.org/en/docs/ldc2004_en.pdf, visited on 7 June 2008.

19 The following three factors are noted in a recent World Bank study. Poverty Reduction \& Economic Management Trade Unit and Agriculture and Rural Development Department, Food Safety and Agricultural Health Standards: Challenges and Opportunities for Developing Country Exports, Report no. 31207 (World Bank, Washington D.C.), 10 January 2005, 3, available at: http://siteresources.worldbank.org/ 
demand for food is increasing significantly thus fuelling trade between developing countries. In addition, the progressive liberalisation of agricultural trade achieved under the auspices of the WTO will reduce traditional trade barriers in this sector. Finally, increased affluence of consumers in developed, but also increasingly developing, countries drives demand for diverse and high-value agri-food products, such as fresh fruit and vegetables and processed foods. ${ }^{20}$ Diversification of developing country exports to high-value fresh and processed products would have the advantage of reducing vulnerability to price volatility, as prices for such products are much more stable. Therefore, the agri-food sector has the potential to be a catalyst for growth in developing countries, if they can overcome the problems they face with their trade in this area.

\subsection{Problems with developing country trade in agriculture and food products}

In order to reach the Millennium Development Goals ${ }^{21}$ relating to poverty reduction, it is crucial to address the problems ${ }^{22}$ that many developing countries face with regard to their trade in primary commodities, ${ }^{23}$ in particular agricultural products. ${ }^{24} \mathrm{~A}$ report by a group of eminent persons appointed by UNCTAD to examine commodity issues found that problems regarding trade in the commodity sector impact on the development efforts of commodity-dependent developing countries, increasing their vulnerability and

INTRANETTRADE/Resources/Topics/Standards/ standards_challenges_synthesisreport.pdf, visited on 27 June 2008

${ }^{20}$ Food and Agriculture Organization, The State of Agricultural Commodity Markets (United Nations, Rome), 2004, 15, available at: ftp://ftp.fao.org/docrep/fao/007/y5419e/y5419e00.pdf, visited on 27 June 2008.

${ }^{21}$ These goals include halving the proportion of people living below the poverty level (i.e. people who live on less than 1 \$ per day) and the proportion of people who suffer from hunger between 1990 and 2015. The Millennium Development Goals (MDG) were recognised by the UN General Assembly as part of the road map for the implementation of the UN Millennium Declaration (General Assembly resolution 55/2). See General Assembly, Road Map Towards the Implementation of the United Nations Millennium Declaration, A/56/326, (United Nations, 6 September 2001): Annex. The MDG recognise that 'in order to significantly reduce poverty and promote development, it is essential to achieve sustained and broad-based economic growth.' They thus expressly refer to 'improved market access for exports from developing countries' as one of the commitments made by developed countries in order to achieve these goals. Ibid., para 80.

${ }^{22}$ The primary commodity sector is characterised by price volatility and declining terms of trade. In addition, market access for agricultural commodities is limited as this sector is traditionally subject to a large degree of protectionism.

${ }^{23}$ Primary commodities consist of both minerals and agricultural commodities. For purposes of this book, the focus will be on agricultural commodities. It is also this category of commodities that has been subject to the most dramatic decline in prices between 1980 and 2000, with the prices of coffee, cocoa, sugar and palm oil declining by nearly $70 \%$ and that of cotton and vegetable oils by nearly $50 \%$. See Committee on Trade and Development, Non-Paper on the Need for Urgent Action in WTO to Deal with the Crisis Situation Created by the Long-Term Trend Towards Decline in Prices of Primary Commodities to the Trade and Development of Developing Countries Which Are Heavily Dependant on Their Exports. Communication from Kenya, Uganda and Tanzania, WT/COMTD/W/113, circulated on 19 May 2003, para. 2.

${ }^{24}$ It should however be noted that this book does not make the claim that free trade will automatically feed the hungry or eliminate poverty. Instead the claim made is much more modest, namely that increased market access for developing country exports in the food and agricultural sector can play a significant role in generating the revenue needed for developing countries to achieve their development goals, provided that measures are in place to address supply-side constraints in order to ensure that developing countries are able to take advantage of increased market access. Domestic policies must be in place to ensure that the gains from trade are used in a way that is supportive of development. 
undermining their attempts to fight poverty. ${ }^{25}$ The report emphasises the urgent need to give equitable and enhanced market access for primary commodities of key importance to developing countries. Agriculture and food products are such commodities. ${ }^{26}$

The Programme of Action adopted at the Third UN Conference on Least Developed Countries in May 2001, ${ }^{27}$ called for, inter alia, increased trade liberalisation in the area of agriculture and for coherent action by the UN and other international organisations to transform trade into a powerful engine for growth and poverty eradication in LDCs. ${ }^{28}$ Aggravating the vulnerability of developing countries to problems with regard to trade in agricultural commodities is the fact that many of these countries rely on a limited range of commodities for their export earnings. ${ }^{29}$ It has been reported that '[o]ver the past decade, commodity export dependence and export concentration have not decreased significantly. ${ }^{\prime 30}$ Developing countries are thus particularly vulnerable to market barriers in respect of those agricultural products in which they trade.

Traditionally, such market barriers take the form of high tariffs on some agri-food products, tariff escalation with regard to high-value and processed products, domestic support for the agricultural industry and export subsidies. The World Bank report entitled Global Economic Prospects 2004: Realising the Development Promise of the Doha Agenda, notes that despite the disciplines negotiated with regard to agricultural trade in the Uruguay Round, reforms in industrial countries have been modest, resulting in over-production and price declines for agricultural commodities. ${ }^{31}$ This has had the result

${ }^{25}$ General Assembly, Report of the Meeting of Eminent Persons on Commodity Issues: Note by the Secretary General, A/58/402 (United Nations, 2 October 2003, para. 31, available at: www.un.org/ga/58/documentation/list4.html, visited on 25 June 2008. See also UNCTAD 'World Commodity Trends and Prospects' 10 October 2002, noting the sharp decline in primary commodity prices, including with respect to agricultural commodities, and its major impact on third world producers. At the CTD meeting of 16 and 23 October 2003, commodities of particular importance to developing countries were discussed. Kenya suggested that a special session of the CTD, also involving other relevant WTO bodies, be mandated to examine the problems of exporters of primary commodities in depth. However, this received a cool response from developed countries. See 'UN Assembly and WTO Discuss Primary Commodities' Bridges Biores vol. 3 no 19, 31 October 2003.

${ }^{26}$ Primary commodities are composed of food products, raw agricultural products, fuels and minerals and ores.

27 Third UN Conference on Least-Developed Countries, Programme of Action for the Least-Developed Countries, A/CONF.191/11 (United Nations, 14-20 May 2001).

${ }^{28}$ Ibid., paras 62 and 65.

29 According to a recent FAO report, more than 50 developing countries, including most LDCs, depend on three or fewer commodities for more than half their exports. Food and Agriculture Organization, The State of Agricultural Commodity Markets (United Nations, Rome), 2004, 6, available at: ftp://ftp.fao.org/docrep/ fao/007/y5419e/y5419e00.pdf, visited on 27 June 2008. This point was also made in a non-paper by Kenya, Uganda and Tanzania circulated by the Committee on Trade and Development in 2003. See Committee on Trade and Development, Non-Paper on the Need for Urgent Action in WTO to Deal with the Crisis Situation Created by the Long-Term Trend Towards Decline in Prices of Primary Commodities to the Trade and Development of Developing Countries Which Are Heavily Dependant on Their Exports. Communication from Kenya, Uganda and Tanzania, WT/COMTD/W/113, circulated on 19 May 2003, para. 3.

${ }^{30}$ United Nations Conference on Trade and Development, Development and Globalisation: Facts and Figures (United Nations, Geneva and New York), 2004, para. 40, available at: www.unctad.org/Templates/WebFlyer. asp?intItemID $=3096 \&$ lang $=1$, visited on 21 June 2008 .

31 The World Development Indicators of 2008 points to the fact that the achievements in the liberalisation of trade in goods are concentrated in the manufacturing sector. It notes: 'Less has been done in agriculture. Across all regions and income groups, agricultural imports face much higher trade restrictions than manufacturing and mining imports. Countries tend to protect domestic farmers relative to manufacturing and mining. ... [H]igh-income OECD countries are more protective than any of the other developing regions...' Roumeen 
of 'reducing opportunities for many developing countries to expand exports and penalizing the world's poor.' 32 A 2004 UNCTAD report notes that a complete removal of trade barriers in the area of agriculture would, according to some estimates, result in global welfare gains of $\$ 165$ billion per year, about a quarter of which would fall to developing countries. ${ }^{33}$ Negotiations on liberalising the agricultural sector form an important, and controversial, part of the WTO's current Doha Round of trade negotiations.

Diversification of developing country food and agricultural exports from traditional agricultural commodities (such as grains, coffee, tea and cocoa) to high-value perishable products (horticultural products, meat and diary) and processed agri-food products holds potential for great gains in trade earnings. ${ }^{34}$ This is due to the fact that these products are less vulnerable to price volatility and are rapidly gaining market share. ${ }^{35}$ The expanding demand for high-value and processed food goes hand-in-hand with growing incomes in developed (and now some developing) countries, year-round demand for fresh produce, and the increasing prevalence of small households and of women's participation in the workforce. $^{36}$

The importance of processed products for trade in agricultural products was confirmed by the WTO's World Trade Report of 2004, which found that exports of processed agricultural products increased significantly faster than exports of unprocessed or semiprocessed agricultural products in the period 1990-2002. ${ }^{37}$ Currently, developed countries

Islam and Gianni Zanini, World Trade Indicators 2008: Benchmarking Policy and Performance (World Bank, Washington D.C.), 2008, 13, available at: http://info.worldbank.org/etools/wti2008/docs/mainpaper.pdf, visited on 7 June 2008.

${ }^{32}$ Global Economic Prospects 2004: Realizing the Development Promise of the Doha Agenda (World Bank, Washington D.C.), 2003, 103.

${ }^{33}$ United Nations Conference on Trade and Development, Development and Globalisation: Facts and Figures (United Nations, Geneva and New York), 2004, para. 29, available at: www.unctad.org/Templates/WebFlyer. asp?intItemID $=3096 \&$ lang=1, visited on 21 June 2007.

${ }^{34}$ Murphy notes: 'Profits from international agricultural trade are increasingly in processed and higher valueadded products. Exports from fisheries in developing to developed countries are now often worth more than the combined value of net exports of coffee, tea, cocoa, bananas and sugar.' Sophia Murphy, Securing Enough to Eat (International Institute for Sustainable Development, Winnipeg), January 2005, 6, available at: http:// www.iisd.org/pdf/2005/ trade_securing_enough_to_eat.pdf, visited on 6 February 2005.

${ }^{35}$ A report of the Economic Research Service of the USDA notes that global trade in high-value foods (including horticultural products and processed foods) increased from 48\% of world agricultural trade in 1976 to $75 \%$ in 1994. However, due to market access problems (discussed further below) this growth has slowed down, reaching only $79 \%$ of world agricultural trade in 2002. Anita Regmi et al., Market Access for HighValue Foods, Agricultural Economic Report No. 840 (United States Department of Agriculture, Washington D.C.), February 2005, 1, available at: http://www.ers.usda.gov/publications/aer840/aer840.pdf, visited on 30 June 2008.

${ }^{36}$ These factors are noted in the World Trade Report 2004. This report also attributes the growth of trade in processed agricultural goods to the fact that processed goods have more possibilities for intra-industry trade and for product differentiation. For example, while two countries that produce cocoa beans are unlikely to trade this product between each other, if they produce chocolate bars of different types, they could trade these products to cater for different consumer tastes. WTO Secretariat, World Trade Report 2004: Exploring the Linkage between the Domestic Policy Environment and International Trade (World Trade Organization, Geneva), 11 June 2004, 16-17, available at: www.wto.org/english/news_e/pres04_e/press378_annex_e.pdf, visited on 26 June 2008.

${ }^{37}$ According to this report, processed agricultural products accounted for $42 \%$ of global agricultural trade in 1990, and 48\% in 2001-2. Ibid., 16. 
have captured the greatest part of trade in this rapidly expanding sector. ${ }^{38}$ Particularly the 14 largest agricultural exporters evinced a strong shift towards processed agricultural products. ${ }^{39}$ Similarly, agricultural trade is shifting away from traditional bulk products such as dried gains and pulses towards high-value, perishable products such as fresh fruit and vegetables, meat, diary and fish. ${ }^{40}$ While most of this trade is accounted for by developed countries, the more advanced and prosperous developing countries have been able to take advantage of this trend by shifting production to these sectors. ${ }^{41}$

However, diversification of developing country agricultural exports to high-value and processed food products brings with it not only increased prosperity but also new risks. ${ }^{42}$ These products face high levels of trade barriers. Traditionally, one such barrier that affects processed products is high tariffs, arising from tariff peaks and tariff escalation. ${ }^{43}$ Although the average incidence of tariffs on agricultural exports from developing coun-

${ }^{38}$ Food and Agriculture Organization, The State of Agricultural Commodity Markets (United Nations, Rome), 2004, 26, available at: ftp://ftp.fao.org/docrep/fao/007/y5419e/y5419e00.pdf, visited on 26 June 2008. This report notes that developing country shares in world exports of processed agricultural products actually decreased from $27 \%$ in $1981-1990$ to $25 \%$ in $1991-2000$, and for LDCs this decrease was from $0.7 \%$ to $0.3 \%$ in the same period.

39 These are countries whose agricultural exports were in excess of $\$ 6$ billion in 2002, except for Brazil and Chile. However, while no overall link was found between income levels of countries and their share of processed agricultural products, the 'World Trade Report 2004' found that all countries that have a low share of processed goods are low or lower-middle income countries. These countries' share of processed goods in their agricultural exports is less than 15\%. Examples are Sri Lanka, Cameroon, Pakistan and Zimbabwe. WTO Secretariat, World Trade Report 2004: Exploring the Linkage between the Domestic Policy Environment and International Trade (World Trade Organization, Geneva), 11 June 2004, 17, available at: www.wto.org/english/news_e/pres04_e/press378_annex_e.pdf, visited on 26 June 2008.

${ }^{40}$ A 2005 World Bank study notes that $\overline{5} 0 \%$ of agri-food exports of developing countries is made up of highvalue products (fresh and processed fruits and vegetables, fish, meat, nuts and spices), while traditional agri-food exports (coffee, tea, cocoa, sugar, cotton and tobacco) continue to decline. Poverty Reduction \& Economic Management Trade Unit and Agriculture and Rural Development Department, Food Safety and Agricultural Health Standards: Challenges and Opportunities for Developing Country Exports, Report no. 31207 (World Bank, Washington D.C.), 10 January 2005, 1, available at: http://siteresources.worldbank.org/ INTRANETTRADE/Resources/Topics/Standards/standards_challenges_synthesisreport.pdf, visited 27 June 2008. See also Global Economic Prospects 2004: Realizing the Development Promise of the Doha Agenda (World Bank, Washington D.C.), 2003, 115

${ }^{41}$ The FAO notes that developing countries other than the LDCs have more than doubled the share of horticultural, meat and diary products in their exports, while reducing reliance on tea, coffee, cocoa and raw materials from over 55\% to 30\% between 1960 and 2000. However, the dependence of LDCs on traditional products has actually increased from $59 \%$ to $72 \%$ in the same period. Food and Agriculture Organization, The State of Agricultural Commodity Markets (United Nations, Rome), 2004, 11, available at: ftp://ftp.fao.org/docrep/ fao/007/y5419e/y5419e00.pdf, visited on 26 June 2008.

42 This point is made by Murphy. See Sophia Murphy, Securing Enough to Eat (International Institute for Sustainable Development, Winnipeg), January 2005, 6, available at: http://www.iisd.org/pdf/2005/trade_securing_enough_to_eat.pdf, visited on 6 February 2005.

${ }^{43}$ The abovementioned FAO report notes in this regard: 'Tariff escalation, in particular, constitutes a major barrier to market access for most of the processed agricultural exports of developing countries' Food and Agriculture Organization, The State of Agricultural Commodity Markets (United Nations, Rome), 2004, 27, available at: ftp://ftp.fao.org/docrep/fao/007/y5419e/y5419e00.pdf, visited on 26 June 2008. A recent World Bank report notes, with reference to trade barriers in the agricultural sector: 'High-income countries have higher nontariff barriers, greater tariff escalation and dispersion, and much higher maximum tariffs than lowincome countries; that is, they protect certain sectors much more than others. Many of these protected sectors and goods are of special interest to developing-country exporters.' Roumeen Islam and Gianni Zanini, World Trade Indicators 2008: Benchmarking Policy and Performance (World Bank, Washington D.C.), 2008, xix, available at: http://info.worldbank.org/etools/wti2008/docs/mainpaper.pdf, visited on 7 June 2008. 
tries is low, 'tariff peaks' which are significantly higher than the average are applied to certain commodities of importance to developing countries. For example, horticultural products and poultry products (both examples of high-value perishable products) are subject to tariff peaks. ${ }^{44}$ The term 'tariff escalation' refers to the levying of higher tariffs on goods at more advanced stages of processing. The tariffs applied by many countries increase greatly by level of processing of agricultural products, resulting in limited market access for processed foods..$^{45}$ A 2003 World Bank study notes that 'the protection rates for food processing in industrial countries are extremely high - far above those of any manufacturing subsector.' ${ }^{46}$ It argues that tariff escalation with regard to semi- and fullyprocessed agricultural products is 'strikingly antidevelopment ${ }^{\text {' }}$ ' as it penalises investors in developing countries who seek to add value to production for export. This high level of protection for processed food and agricultural products is regarded as explaining many developing countries' failure to diversify their exports towards processed products and to penetrate developed country markets in this area. ${ }^{48}$

${ }^{44}$ Food and Agriculture Organization, The State of Agricultural Commodity Markets (United Nations, Rome), 2004, 22, available at: ftp://ftp.fao.org/docrep/fao/007/y5419e/y5419e00.pdf, visited on 26 June 2008.

${ }^{5}$ Global Economic Prospects 2004: Realizing the Development Promise of the Doha Agenda (World Bank, Washington D.C.), 2003, 104. The problem of tariff escalation as a hurdle to developing countries increasing the degree of processing of key agricultural products, has also been noted in a recent UNCTAD report. See United Nations Conference on Trade and Development, Development and Globalisation: Facts and Figures (United Nations, Geneva and New York), 2004, 76, available at: www.unctad.org/Templates/ WebFlyer.asp?intItemID=3096\&lang=1, visited on 21 June 2008. It is also referred to in the 2005 report of the Economic research Service of the USDA as a significant problem for agricultural trade. This report illustrates the issue of tariff escalation with reference to the example of cocoa and cocoa products. While the major importers of agricultural products (Australia, Canada, the EU, Japan and the US) have tariffs of 0-1\% on cocoa beans, their tariffs on chocolate and other cocoa products is $15-57 \%$. As a result, developing country trade shares range from $96 \%$ for cocoa beans to only $8 \%$ for chocolate. Anita Regmi et al., Market Access for High-Value Foods, Agricultural Economic Report No. 840 (United States Department of Agriculture, Washington D.C.), February 2005, 5-9, available at: http://www.ers.usda.gov/publications/aer840/aer840.pdf, visited on 30 June 2008.

${ }^{46}$ Global Economic Prospects 2004: Realizing the Development Promise of the Doha Agenda (World Bank, Washington D.C.), 2003, 111.

${ }^{47}$ Ibid., 123.

${ }^{48}$ United Nations Conference on Trade and Development, Development and Globalisation: Facts and Figures (United Nations, Geneva and New York), 2004, 76, available at: www.unctad.org/Templates/WebFlyer. asp? intItemID $=3096$ \&lang=1, visited on 21 June 2008. This point is also made by the Economic Research Service of the USDA. Anita Regmi et al., Market Access for High-Value Foods, Agricultural Economic Report No. 840 (United States Department of Agriculture, Washington D.C.), February 2005, 5, available at: http:// www.ers.usda.gov/publications/aer840/aer840.pdf, visited on 30 June 2008. This limited access to global markets for high-value and processed products is despite the fact that, for domestic consumption, the shift to processed and high-value products is reported to be broad based, across regions and among a large majority of developing countries. WTO Secretariat, World Trade Report 2004: Exploring the Linkage between the Domestic Policy Environment and International Trade (World Trade Organization, Geneva), 11 June 2004, 18, available at: www.wto.org/english/news_e/pres04_e/press378_annex_e.pdf, visited on 26 June 2008. In fact, the domestic markets for high-value agricultural products are among the fastest growing in most developing countries, led by livestock products and horticulture. World Bank, World Development Report 2008. Agriculture for Development (World Bank, Washington D.C.), 2008, 12, available at: http://siteresources worldbank.org/INTWDR2008/Resources/WDR_00_book.pdf. 
Traditional trade barriers in the agricultural sector, including tariff escalation, ${ }^{49}$ are currently being addressed in the context of the agriculture negotiations in the Doha Round..$^{50}$ However, another significant trade barrier affecting agri-food products, especially highvalue and processed products, is SPS regulation. ${ }^{51}$ In fact, a survey conducted in 2004 indicates that many developing countries consider SPS measures the most important barrier to their agricultural exports to the EU, exceeding in importance traditional market barriers such as tariffs and quantitative restrictions. ${ }^{52}$ The importance of SPS measures as market barriers can be partly ascribed to the lack of resources, ${ }^{53}$ both technical and financial, in many developing countries to address sanitary and phytosanitary risks, even on a basic level (such as by prevention of filth and decomposition). ${ }^{54}$ These problems are even

49 In the context of the Doha negotiations on agricultural trade, the text adopted by the General Council on 1 August 2004 (commonly referred to as the 'July Package') proposes that 'tariff escalation be addressed through a formula to be agreed.' General Council, Doha Work Programme. Decision Adopted by the General Council on 1 August 2004, WT/L/579, circulated on 2 August 2004, Annex A para. 36.

${ }^{50}$ The Doha Ministerial Declaration calls for 'substantial improvements in market access' for agricultural products. Ministerial Conference, Doha Ministerial Declaration. Adopted on 14 November 2001, WT/MIN(01)/ DEC/1, circulated on 20 November 2001, para 13. The July Package reaffirms the commitment to substantial improvements by providing: 'Substantial overall tariff reductions will be achieved as a final result from negotiations.' While allowing the designation of specific sensitive products, the July Package provides that: '[t]he principle of substantial improvement' will apply to each product. General Council, Doha Work Programme. Decision Adopted by the General Council on 1 August 2004, WT/L/579, circulated on 2 August 2004, paras 28, 29 and 32. The latest revision of the draft modalities for agriculture circulated by the Chairperson of the Special Session of the Committee on Trade in Agriculture on 19 May 2008 contains a three-tiered formula for tariff reductions, requiring greater percentage of reductions in higher levels of tariffs, thereby aiming to reduce tariff peaks. In addition, it requires additional tariff reductions for listed 'tariff escalation products' and 'tropical and diversification products'. Committee on Trade in Agriculture, Special Session, Revised Draft Modalities for Agriculture, TN/AG/W/4/Rev.2, circulated on 19 May 2008, paras 3, 79-85, 134-135, and Annexes D and G.

${ }^{51}$ Murphy notes: 'Standards for the export of such perishable goods (especially seafood and horticulture) are high and one incidence of disease can lead to the whole crop being rejected. Without a strong system of support, technical advice and insurance, the shift to higher-value agricultural exports can leave farmers vulnerable to expensive failures.' See Sophia Murphy, Securing Enough to Eat (International Institute for Sustainable Development, Winnipeg), January 2005, 6, available at: http://www.iisd.org/pdf/2005/trade_securing_enough_to_eat.pdf, visited on 6 February 2005. The impact of SPS requirements on developing country trade is discussed further below, Part I, Section 3.4.

${ }^{52}$ This study involved a survey of all countries classified as low- and middle-income countries by the World Bank that were Members of the WTO and/or the Codex Alimentarius Commission in March 1999. The results are based on a $72 \%$ response rate. See Spencer Henson et al., 'How Developing Countries View the Impact of Sanitary and Phytosanitary Measures on Agricultural Exports', in Agriculture and the New Trade Agenda: Creating a New Global Trading Environment for Development, M.D. Ingco and L.A. Winters (eds.) (Cambridge University Press, Cambridge), 2004, 359-375, 361-362. Henson et al. report that other technical requirements (such as labelling and compositional requirements) were also regarded as important but that tariffs and quantitative restrictions were seen as less important. A possible reason for this suggested by the authors is the fact that many developing countries benefit from preferential market access to EU markets, thus decreasing the relevance of traditional market barriers.

${ }^{53}$ For example, with regard to African countries, the Blair Commission for Africa report notes, 'Health standards such as sanitary and phyto-sanitary (SPS) standards can be serious barriers to trade... It is not unwillingness to meet these standards that is the problem, nor disagreement with their rationale. The problem is that poor countries in Africa are not equipped to meet these standards.' Blair Commission for Africa, Our Common Interest, March 2005, 278, available at: http://213.225.140.43/english/report/thereport/cfafullreport.pdf, visited 30 November 2005.

${ }^{54}$ Information on US border inspections shows that the main reasons for the rejection of products from Africa, Asia, Latin America and the Caribbean are microbiological contamination, filth and decomposition This information is referred to by Henson et al. who point out that only the US systematically collects this type of 
greater with regard to high-value and processed agri-food products. ${ }^{55}$ Processed food products destined for sale directly to consumers are subject to stricter sanitary requirements than those food exports destined for further processing. ${ }^{56}$ Similarly, high-value perishable products are more strictly regulated than traditional agricultural exports, as they are more vulnerable to infection by pathogens than traditional bulk products. ${ }^{57}$ Many concerns have been raised regarding the legitimacy of these strict requirements. ${ }^{58}$ Those developing countries that lack the capacity to meet these stricter SPS requirements may be hindered in their diversification efforts.

Another factor aggravating the problem of compliance with SPS requirements, identified in a non-paper ${ }^{59}$ by Kenya, Uganda and Tanzania on commodity issues circulated to the WTO Committee on Trade and Development in 2003, is the abolition of marketing

information and makes it publicly available. Spencer Henson et al., 'How Developing Countries View the Impact of Sanitary and Phytosanitary Measures on Agricultural Exports', in Agriculture and the New Trade Agenda: Creating a New Global Trading Environment for Development, M.D. Ingco and L.A. Winters (eds.) (Cambridge University Press, Cambridge), 2004, 359-375, 361. The WHO Regional Office for Africa reports that a large part of rejections of African exports by the U.S. are due to 'lack of basic food hygiene'. Of reasons for import detentions, microbiological contamination accounts for $41.3 \%$, filth for $17.8 \%$ and mould for $6.3 \%$. See WHO Regional Office for Africa, 'Developing and Maintaining Food Safety Control Systems for Africa - Current Status and Prospects for Change', presented at the FAO/WHO Second Global Forum of Food Safety Regulators, Conference Room Document 32 (Food and Agriculture Organization and World Health Organization, Bangkok, Thailand) 12-14 October 2004, Table 1, available at: ftp://ftp.fao.org/docrep/ fao/meeting/008/ae144e/ae144e00.pdf visited on 24 June 2008.

${ }_{55}$ The USDA Economic Research Service reports that SPS requirements are stricter with regard to high-value (including processed) products than with regard to traditional bulk products. This is ascribed to their readyto-eat and perishable nature and the fact that they require specialised handling, packaging and shipping. For this reason, and due to the diversity in such SPS requirements, suppliers may prefer to manufacture high-value food locally rather than engage in export trade in these products, thereby affecting trade. Anita Regmi et al., Market Access for High-Value Foods, Agricultural Economic Report No. 840 (United States Department of Agriculture, Washington D.C.), February 2005, 3, available at: http://www.ers.usda.gov/publications/aer840/ aer840.pdf, visited on 30 June 2008.

${ }^{56}$ The UNCTAD Secretariat reports that, 'issues such as tariff escalation and sanitary and phytosanitary regulations make it difficult for developing countries to increase their export income.' United Nations Conference on Trade and Development, Assuring Development Gains from the International Trading System and Trade Negotiations. Background Note by the UNCTAD Secretariat for the 11th Session, 13-18 June 2004, TD/397 (United Nations, São Paulo), 4 May 2004, para. 28.

${ }^{57}$ It is interesting to note that since the entry into force of the SPS Agreement the largest number of notifications of SPS measures thereunder relate to live animals, meat and animal products (63\%). This figure increases to $74 \%$ if notifications of measures applying to fish and seafood, dairy products and eggs are included. The next largest category of notifications relate to horticultural products, namely fresh fruit and vegetables (12\%). Bulk agricultural products account for only $7 \%$ of notifications, most of which relate to restrictions on genetically modified products. Anita Regmi et al., Market Access for High-Value Foods, Agricultural Economic Report No. 840 (United States Department of Agriculture, Washington D.C.), February 2005, 10-11, available at: http://www.ers.usda.gov/publications/aer840/ aer840.pdf, visited on 30 June 2008.

${ }^{58}$ These SPS requirements make up by far the largest part of specific trade concerns raised before the SPS Committee to date. SPS measures affecting fully-processed products account for $50 \%$ of all trade concerns raised, measures on semi-processed products for $37 \%$ and measures on horticultural products for $11 \%$. By contrast, measures on primary products account for a mere $2 \%$ of trade concerns raised. Ibid., 12.

${ }^{59}$ Committee on Trade and Development, Non-Paper on the Need for Urgent Action in WTO to Deal with the Crisis Situation Created by the Long-Term Trend Towards Decline in Prices of Primary Commodities to the Trade and Development of Developing Countries Which Are Heavily Dependant on Their Exports. Communication from Kenya, Uganda and Tanzania, WT/COMTD/W/113, circulated on 19 May 2003, paras 11-12. 
boards in developing countries ${ }^{60}$ on the insistence of the International Monetary Fund and the World Bank under their structural adjustment programmes. These boards, while often subject to problems of corruption or maladministration, provided valuable services to farmers by undertaking quality control and assisting them to meet quality and safety standards. ${ }^{61}$ Now farmers in developing countries, who often farm on a small-scale and therefore have little capital to invest, are faced with the difficult task of keeping track of SPS requirements on their export markets and taking the necessary steps to meet them. In addition, they must be able to prove compliance to the satisfaction of the importing country. Without a system of quality control in place, as was previously provided by the marketing boards, it is difficult for farmers to provide convincing assurance of compliance.

Market access problems caused by SPS requirements are exacerbated due to the differences in SPS requirements and regulatory regimes in countries across different levels of development. ${ }^{62}$ Faced with more pressing health concerns ${ }^{63}$ and other competing development priorities ${ }^{64}$ many developing countries often do not prioritise SPS regulation as an area of government spending. ${ }^{65}$ Developed countries, on the other hand, tend to maintain high levels of SPS protection, in keeping with their technological and financial capabilities as well as the demands of their consumers and agricultural industries. The proliferation of SPS regulations and standards in developed countries in recent decades is a reflection of these differences.

${ }^{60}$ A2004 UNCTAD report refers generally to the abolition of government-supported marketing and distribution systems in many developing countries as a factor contributing to the decline in the share of developing countries in the world commodities market. This is particularly the case in Africa, whereas Asian countries that have maintained the provision of technical support to farmers have managed to promote commodity exports. See United Nations Conference on Trade and Development, Development and Globalisation: Facts and Figures (United Nations, Geneva and New York), 2004, 78, available at: www.unctad.org/Templates/ WebFlyer.asp?intItemID=3096\&lang=1, visited 21 June 2008.

${ }^{61}$ Murphy, with reference to the experiences of several African countries, makes the additional point that agricultural marketing boards used to provide services to the country as a whole, including remote regions. Now farmers in remote areas find themselves unable to pay for the services they need, and unable to interest a private investor in providing the necessary funding. Sophia Murphy, Securing Enough to Eat (International Institute for Sustainable Development, Winnipeg), January 2005, 7, available at: http://www.iisd.org/ pdf/2005/trade_securing_enough to_eat.pdf, visited on 6 February 2005.

${ }_{62}$ These differences are illustrated by means of case studies below, Part II, Sections 2.4-2.7.

${ }^{63}$ Examples of more immediate health issues faced by many developing countries are the need for clean drinking water, good medical care, the fight against AIDS etc.

${ }^{64}$ Non-health related development priorities include, for example, education and housing.

${ }^{65}$ The WHO Regional Office for Africa has noted that many countries in Africa 'do not have adequate food security, so having effective food control systems appear not to be a priority, resulting in little or no attention to food legislation, its administration and enforcement. This has often resulted in the importation of substandard food items as well as trade rejections of food exports.' See WHO Regional Office for Africa, 'Developing and Maintaining Food Safety Control Systems for Africa - Current Status and Prospects for Change', presented at the FAO/WHO Second Global Forum of Food Safety Regulators, Conference Room Document 32 (Food and Agriculture Organization and World Health Organization, Bangkok, Thailand) 12-14 October 2004, 1, available at: ftp://ftp.fao.org/docrep/fao/meeting/ 008/ae144e/ae144e00.pdf, visited on 25 June 2007. 


\subsection{The proliferation of health regulations and standards in developed countries}

The nature of trade in food and agricultural products is changing. This has led to a proliferation of health regulations and standards with which exporters have to comply in order to gain access to foreign markets. The number of SPS notifications to the WTO increased four-fold between 1995 and 2002, ${ }^{66}$ and continues to rise. ${ }^{67}$ This increase is concentrated in developed-country Members. ${ }^{68}$ In addition, private sector SPS standards are on the increase, with supermarkets competing for consumers on the basis of high levels of safety and quality of food products.

Four main factors can be identified as creating an impetus for the rise in number of SPS requirements. First, there is an increase in the number and variety of potential risks contained in food and agricultural products. This is can be partly ascribed to changes in the nature of traded products. As already mentioned, there is growing demand for processed food products, and thus more possibilities for contamination at various stages of the processing chain. Risks are compounded by increasing use of new technologies in agriculture and food processing, such as pesticides, additives and genetic modification. In addition, as discussed above, trade in high-value perishable products is on the increase, and these products are more vulnerable to infection by pathogens than traditional bulk products such as dried grains and pulses.

Changes in the sources of traded products also play a role in the increased risk of importation of unsafe food, pests or diseases. ${ }^{69}$ Consumer tastes, especially in developed countries, increasingly international so that demand for foreign food products is growing and seasonal fruits and vegetables must be provided all year round. There has consequently been growth in imports from developing countries whose domestic SPS infrastructures are often inadequate to address sanitary and phytosanitary risks. As a result of these developments, there has been a proliferation of SPS regulations and private standards to deal with the increase in volume, variety, sources and technical sophistication of food and agricultural products being traded.

${ }^{66}$ John S. Wilson and Tsunehiro Otsuki, Food Safety in Food Security and Food Trade: Balancing Risk Reduction and Benefits from Trade in Setting Standards (International Food Policy Research Institute, Washington D.C.), September 2003.

${ }^{67}$ WTO Members are required to notify new, or modifications to existing, SPS measures which are not substantially the same as international standards and may have a significant effect on international trade. The notification obligation is discussed below, Part IV, Section 1.3.2. From the entry into force of the SPS Agreement on 1 January 1995 until 8 October 1996, 396 notifications were submitted. This number rose to 610 in the period 1 January to 30 September 2001. In the period 1 January to 31 August 2007, 1,157 notifications of SPS measures were submitted, resulting in a total of 8,217 notifications since the entry into force of the SPS Agreement. Committee on Sanitary and Phytosanitary Measures, Workshop on Transparency Held on 15 - 16 October 2007. Note by the Secretariat, G/SPS/R/47, circulated on 8 January 2008, para. 15.

${ }^{68}$ Currently, although developed-country Members account for about a quarter of WTO Members, they are responsible for $58 \%$ of the notifications of new or revised SPS measures. The US alone has notified 1082 SPS measures, far ahead of the EC which has submitted 207 notifications.

${ }^{69}$ W.C.K. Hammer, 'Food Trade and Implementation of the SPS and TBT Agreements: Current Status of Food Trade, Including Food Quality and Safety Problems', presented at the Conference on International Food Trade Beyond 2000: Science-Based Decisions, Harmonization, Equivalence and Mutual Recognition (Food and Agriculture Organization of the United Nations, Melbourne Australia) 11-15 October 1999, 1, available at: www.fao.org/docrep/meeting/X2636e.htm, visited on 28 June 2008. 
Second, regulators and economic operators in the agri-food sector have to respond to the elevation in consumer expectations and demands with regard to food standards in developed countries. Due to increased affluence in these countries, consumers are willing to pay more for a higher level of health protection. Consumer awareness of food-related risks is also on the rise, particularly in developed countries where education levels are high and consumer advocacy groups have the resources to identify and publicise health risks. Increased consumer concerns, especially in developed countries, with regard to food safety, quality, environmental impact and animal welfare have also led to progressively stricter and more comprehensive government regulation and more demanding private requirements by supermarket chains. In addition, as life expectancy has greatly increased in many developed countries, the long-term health effects of chemicals and contaminants in food are more significant, prompting higher consumer demands in this area. The emergence of precautionary approaches to risk regulation can be seen as a response by governments to elevated consumer demands.

Third, regulators are faced with pressure from the agriculture and food industry lobbies in the face of increased competition due to progress in agricultural liberalisation. The first hard-won steps towards liberalising this traditionally protected sector were taken in the Uruguay Round negotiations, resulting in the Agreement on Agriculture. ${ }^{70}$ The subsequent ongoing agricultural trade liberalisation mandated by the Agreement on Agriculture, ${ }^{71}$ and now the subject of torturous negotiations in the context of the Doha Round of trade negotiations ${ }^{72}$ aims to dismantle the wall of traditional protectionist measures (tariffs, export subsidies and domestic support) shielding domestic producers from competition. The agricultural industry therefore seeks to convince governments to put in place non-tariff barriers to trade in the form of SPS regulations. In many countries the domestic industry provides significant input into the regulatory process, resulting in SPS regulations that favour domestic producers or reflect their best practices.

Fourth, advances in science and technology have contributed to the creation of comprehensive regulatory systems and control mechanisms. Great strides have been made in scientific knowledge of the causes of risks, particularly with regard to microbiological contaminants in food and plant and animal pests and diseases. This has made it possible to regulate effectively against an increasing array of identified risk factors. The substantial progress made in technological capacity to test for the presence of risk-causing elements, such as bacteria, chemicals and metabolites, have made it possible to lay down extremely strict requirements and to control that these are being met through ever-stricter conformity assessment mechanisms.

\footnotetext{
70 'Agreement on Agriculture', in The Results of the Uruguay Round of Multilateral Trade Negotiations: The Legal Texts (World Trade Organization, Geneva), 1994, 39-68.

${ }^{71}$ Ibid., Art. 20.

${ }^{72}$ Ministerial Conference, Doha Ministerial Declaration. Adopted on 14 November 2001, WT/MIN(01)/DEC/1, circulated on 20 November 2001, paras 13-14. The work programme set out in the Ministerial Declaration with regard to agriculture aims at substantial improvements in market access; reductions, with a view to phasing out, of export subsidies; and substantial reductions in trade-distorting domestic support.
} 
As a result of these developments, the number and stringency of SPS regulations adopted is steadily increasing and market access for food and agricultural products is greatly reduced. ${ }^{73}$

\subsection{Impact of health regulations and standards on health and trade in developing countries}

It is clear that SPS requirements (in the form of both government regulations and private standards) impact on trade, particularly that of countries at lower levels of development. On the one hand, SPS requirements may be an important market access barrier for food and agricultural products, ${ }^{74}$ thereby reducing export earnings and affecting rural livelihoods. On the other, they may create opportunities for those market operators able to meet the requirements to increase their market share and improve their competitive position.

It is important to bear in mind that SPS requirements have distributional implications. The consequences (both negative and positive) of SPS requirements may differ, even with respect to the same product, across countries and across producers within countries. In many cases, the initial conditions prevailing in a country, industry or firm will affect the distribution of costs and benefits arising from SPS requirements. ${ }^{75}$

${ }^{73}$ Extensive studies have been conducted into the impact of SPS measures and technical barriers to trade in general on trade. Some have focused on the impact on developing country exports. Although precise quantification of the effect of these measures has proved difficult due to the complexity of the impact of standards on supply and demand, econometric studies show clear indications of significant negative effects on trade flows (see for example Tsunehiro Otsuki et al., 'Measuring the Effect of Food Safety Standards on African Exports to Europe', in The Economics of Quarantine and the SPS Agreement, Kim Anderson, et al. (eds.) (Centre for International Economic Studies, Adelaide), 2001; T. Ademola Oyejide et al., 'Quantifying the Trade Impact of Sanitary and Phytosanitary Standards: What Is Known and Issues of Importance for Sub-Saharan Africa', presented at the Workshop on Quantifying the Trade Effect of Standards and Regulatory Barriers: Is it possible? (World Bank, Washington D.C.) 27 April 2000, available at: http://www.worldbank.org/research/trade/ conference/oyeyide1.pdf, visited on 25 October 2000; John S. Wilson et al., Agriculture in the WTO - the Role of Product Attributes in the Agricultural Negotiations, Commissioned paper no. 17 (The International Agricultural Trade Research Consortium, Washington DC), 2001, available at: www1.worldbank.org/wbiep/ trade/Standards/Product_Attributes.pdf, visited on 10 November 2001; Keith E. Maskus and John S. Wilson, 'Quantifying the Impact of Technical Barriers to Trade: A Review of Past Attempts and the New Policy Context', presented at the World Bank Workshop on Quantifying the trade effect of standards and technical barriers: Is it possible? (World Bank, Washington D.C.) 27 April 2000, available at: http://www.worldbank.org/research/trade/conference/maskus.pdf, visited on 25 October 2000; Spencer Henson and Rupert Loader, 'Barriers to Agricultural Exports from Developing Countries: The Role of Sanitary and Phytosanitary Requirements', World Development 29 (1), 2001, 85-102.

${ }^{74}$ The importance of regulatory requirements and standards for trade is reflected by the fact that the theme of the WTO's 2005 World Trade Report is the link between trade, standards and the WTO. WTO Secretariat, World Trade Report 2005: Exploring the Links between Trade, Standards and the WTO (World Trade Organization, Geneva), 30 June 2005, available at: http://www.wto.org/english/res_e/booksp_e/anrep_e/world_trade_ report05 e.pdf, visited on 4 June 2007.

75 This point is made in a World Bank study. This study further notes that the particular strategies and policies adopted to deal with SPS requirements will further influence the degree of impact of these requirements. Poverty Reduction \& Economic Management Trade Unit and Agriculture and Rural Development Department, Food Safety and Agricultural Health Standards: Challenges and Opportunities for Developing Country Exports, Report no. 31207 (World Bank, Washington D.C.), 10 January 2005, 109, available at: http://siteresources.worldbank.org/INTRANETTRADE/Resources/Topics/Standards/standards_challenges synthesisreport.pdf, visited 27 June 2008. 
The different market access effects of SPS requirements on countries at different levels of development are clear. The capacity of a particular country (both in terms of the necessary public infrastructure and in terms of private industry resources) to meet the relevant SPS requirements on its export markets will be determinative for its access to those markets. In addition, the reputation that an exporting country has established in respect of compliance, quality management and effective regulation, will play an important role in ensuring the confidence of the importing country in its ability to meet SPS requirements. ${ }^{76}$ Thus, the initial conditions from which countries operate are crucial; the better the existing regulatory infrastructure, public certification and control systems and private industry leadership, the less additional costs in meeting SPS requirements. While certain, more affluent, developing countries have succeeded in adjusting to the SPS requirements they face, sometimes with the help of technical assistance programmes, many countries at lower levels of development have encountered serious difficulties in doing so. ${ }^{77}$

The diversity of SPS requirements across different markets aggravates this situation. When one bears in mind the vast array of SPS regulations and standards that exist in different countries, reflecting their national priorities, stage of economic development and consumer preferences, it becomes clear that the possibilities exporters have for exploiting economies of scale on the international market are greatly reduced. This is particularly so for countries at lower levels of development due to the vast differences between domestic SPS requirements and those on export markets in developed countries. The high costs of meeting the stricter health requirements means that exporters are forced to charge higher prices for their products on their export markets or are even completely excluded from these markets. ${ }^{78}$

${ }^{76}$ A 2008 World Bank paper notes, with regard to the effectiveness of negotiations to address SPS trade barriers, that: "countries or industries that are known or perceived as having their "house in order" are much more effective in carrying out SPS-related diplomacy than countries/industries known for problematic systems and past deficiencies in compliance.' Luz B Diaz Rios and Steven Jaffee, Barrier, Catalyst, or Distraction? Standards, Competitiveness, and Africa's Groundnut Exports to Europe, Agriculture and Rural Development Discussion Paper 39 (World Bank, Washington D.C.), January 2008, 69, available at: http://siteresources.worldbank.org/ INTARD/825826-1111055015956/21663468/ARDDiscussionPaper39.pdf, visited on 5 March 2008.

77 The abovementioned 2005 World Bank study draws the 'tentative conclusion' that developing countries as a group are not suffering from the tightening of SPS requirements, yet there may be significant redistribution of welfare across countries due to differences in capacity for compliance and in approaches to deal with SPS challenges. The fragmentary nature of the evidence on this issue from developing countries and the methodological problems in attributing distributional effects to standards make it difficult to draw firm conclusions. Poverty Reduction \& Economic Management Trade Unit and Agriculture and Rural Development Department, Food Safety and Agricultural Health Standards: Challenges and Opportunities for Developing Country Exports, Report no. 31207 (World Bank, Washington D.C.), 10 January 2005, 112, available at: http://siteresources.worldbank.org/INTRANETTRADE/Resources/Topics/Standards/standards_challenges_ synthesisreport.pdf, visited 27 June 2008.

${ }^{78}$ A study on the total impact of SPS standards on US exports of agricultural products in 1996, estimated that effect at US\$4.4 billion. Suzanne Thornsbury, Sanitary and Phytosanitary Issues: Where Does the WTO Go from Here?, Working Paper (Center for International Business Education and Research, Gainesville, Florida), 2000, 10 and note 17. Thornsbury refers to a USDA study conducted in 1996 with regard to measures that actually or potentially decreased US exports of agricultural products to certain markets and appeared to violate a WTO agreement. $86 \%$ of these measures seemed to violate the SPS Agreement and a further 5\% appeared to fall under multiple WTO agreements. The total effect of the 302 measures identified was US\$4.9 billion, and those falling under the SPS Agreement, alone or together with other WTO agreements, accounted for $90 \%$ of this amount. 
The important impact of SPS requirements on developing countries has been recognised both in the context of the WTO Doha Round negotiations on agriculture ${ }^{79}$ and in other fora. For example, in a paper submitted by the World Bank and IMF to the WTO Working Group on Trade, Debt and Finance, it is reported that technical standards, including SPS requirements, have become a key concern for developing countries with regard to market access. ${ }^{80}$ Similarly, in the São Paulo Conclusions of UNCTAD XI, express reference was made to the difficulties developing countries face in meeting standards and requirements on the markets of developed countries. ${ }^{81}$ In the 2005 report of the Blair Commission for Africa, it was noted that the greatest concern of African countries with regard to trade is the need to meet product standards. ${ }^{82}$ In addition, several World Bank studies have been conducted which show the difficulties which SPS requirements create for developing country exports to developed countries. ${ }^{83}$

There are various reasons for the particularly great impact of SPS requirements on developing country exports of food and agricultural products. ${ }^{84}$ As discussed above, many

${ }^{79}$ For example, in the overview of the negotiations on agriculture provided by the Chairman of the Special Session of the Committee on Agriculture, reference is made to specific proposals relating to SPS issues, including the need for technical and financial assistance for developing countries in the area of SPS. Committee on Agriculture Special Session, Negotiations on Agriculture. Overview, TN/AG/6, circulated on 18 December 2002, para. 28.

${ }^{80}$ Debt and Finance Working Group on Trade, Market Access for Developing Country Exports -Selected Issues. Paper Prepared Jointly by the Staff of the International Monetary Fund and the World Bank, WT/ WGTDF/W/14 (World Trade Organization, Geneva), 18 October 2002, para. 19. This report notes that, 'SPS and other technical requirements have been viewed by developing country trade officials as a greater constraint on their ability to export than tariffs and quantitative restrictions...

${ }^{81}$ United Nations Conference on Trade and Development, Eleventh Session, 13-18 June 2004. Draft São Paulo Consensus, TD/L.380 (United Nations, Sao Paulo), 16 June 2004, para. 64, available at: www.unctad.org/en/ docs/td1380_en.pdf, visited on 21 June 2007. These conclusions identified SPS measures as one of the issues of particular concern to developing countries, and called for them to be 'developed transparently and applied non-discriminatorily' and for the provision of technical assistance and capacity-building to assist developing countries to meet these standards effectively. Ibid., paras 68 and 79.

${ }^{82}$ Blair Commission for Africa, Our Common Interest, March 2005, 268, available at: http://213.225.140.43/ english/report/thereport/cfafullreport.pdf, visited 30 November 2005.

83 John S. Wilson, The Post-Seattle Agenda of the World Trade Organization in Standards and Technical Barriers to Trade: Issues for Developing Countries (World Bank, Washington D.C.), 1999, available at: http://www1.worldbank.org/wbiep/trade/Standards/Position_TBT_SPS.pdf, visited on 25 October 2000; Tsunehiro Otsuki et al., Saving Two in a Billion: A Case Study to Quantify the Trade Effect of European Food Safety Standards on African Exports (World Bank Development Research Group, Washington D.C.), 2000, available at: http://www1.worldbank.org/wbiep/trade/Standards/aflatoxins.pdf, visited on 5 April 2001; John S. Wilson, International Trade: Standards, Technical Regulations, and Global Reform (World Bank, Economic Development Institute, Washington D.C.), 1997, available at: http://www1.worldbank.org/wbiep/ trade/Standards/diplomacy.pdf, visited on 24 June 2000; Tsunehiro Otsuki et al., A Race to the Top? A CaseStudy of Food Safety Standards and African Exports, Report No. 2563 (World Bank, Washington D.C.), 2000, available at: http://econ.worldbank.org/files/1424_wps2563.pdf, visited on 15 April 2001; Steven Jaffee et al., Food Safety and Agricultural Health Standards: Challenges and Opportunities for Developing Country Exports, 31207 (World Bank, Poverty Reduction \& Economic Management Trade Unit and Agriculture and Rural Development Department, Washington D.C.), 10 January 2005, available at: http://www-wds. worldbank.org/external/default/WDSContentServer/WDSP/IB/2005/01/25/000160016_20050125093841/ Rendered/PDF/31207.pdf, visited on 18 May 2008; Steven Jaffee and Spencer Henson, Standards and AgroFood Exports from Developing Countries: Rebalancing the Debate, 3348 (World Bank, Geneva), June 2004, available at: http://econ.worldbank.org/external/default/main?pagePK=64165259\&theSitePK=469382\&piP $\mathrm{K}=64165421 \&$ menuPK=64166093\&entityID=000112742_20040722152604, visited on 28 June 2008.

${ }^{84}$ This, of course, does not mean that the dollar value of the affected trade is greater in the case of developing 
developing countries largely depend on the agricultural sector (and often a limited range of products) for their export revenue and are particularly vulnerable to market barriers in this area. In addition, SPS requirements are particularly burdensome for many developing countries due to their lack of technical and financial capacity and regulatory infrastructure to comply with many of these requirements. ${ }^{85}$ This has important implications for developing countries' trade, and thus for their generation of export revenue as well as for the livelihoods of small domestic producers and rural populations. ${ }^{86}$ Similarly, the WHO Regional Office for Africa has noted that the losses from the rejection of food exports 'not only rob countries of critical revenues but also of credibility as reliable trading partners. ${ }^{87}$ The importance of effectively dealing with this market access problem for developing countries cannot be overstated.

The societal aspects of the distributional impact of SPS requirements within developing countries should not be ignored. Even in those developing countries where the export sector has succeeded in maintaining its market share by complying with the relevant SPS requirements, there have often been societal costs involved related to distributional problems ${ }^{88}$ In particular, it has been the large companies that have been able to benefit from compliance with SPS requirements to exploit market possibilities. Such companies have easier access to credit facilities, better access to information, established reputations with foreign buyers and inspectors and benefit from economies of scale. They are therefore better able to bear the costs of adjusting to new SPS requirements. In addition, powerful supermarket chains, which now dominate food retailing, tend to work with incumbent 'preferred suppliers' that have the capacity to meet their requirements in terms of volume,

countries, but rather that the impact of the trade barriers on export revenues is greater due to the importance of agricultural exports in total trade from developing countries.

${ }^{85}$ Otsuki et al. point to the fact that developing countries are more vulnerable to SPS regulatory changes than developed countries due to the scarcity of public funding in the former to finance compliance with new SPS requirements. Tsunehiro Otsuki et al., 'Saving Two in a Billion: Quantifying the Trade Effect of European Food Safety Standards on African Exports', Food Policy 26, 2001, 495-514, 503, available at: www.elsevier. com/locate/foodpol, visited on 25 June 2007.

${ }^{86}$ In March 2004, the Food and Agriculture Organization (FAO) reported that one third of global meat exports was being affected by measures to address the outbreaks of avian flu and mad cow disease. It noted that 'the impact of import bans on export-dependent countries, such as Thailand, ... will increase the income vulnerability of small producers as local prices drop sharply.' The affected volume of meat amounted to six million tons. According to the FAO, the losses in export revenue could rise to US\$10 billion in 2004 if the import bans on meat and poultry were not lifted. In that year, international trade in meat and live animals was valued at US\$33 billion (excluding intra-EU trade). See Animal Disease Outbreaks Hit Global Meat Exports (Food and Agriculture Organization, Rome), 2 March 2004, available at: http:/www.fao.org/newsroom/en/ news/2004/37967/index.html, visited on 25 June 2007.

87 See WHO Regional Office for Africa, 'Developing and Maintaining Food Safety Control Systems for Africa - Current Status and Prospects for Change', presented at the FAO/WHO Second Global Forum of Food Safety Regulators, Conference Room Document 32 (Food and Agriculture Organization and World Health Organization, Bangkok, Thailand) 12-14 October 2004, 2, available at: ftp://ftp.fao.org/docrep/fao/ meeting/008/ae144e/ae144e00.pdf, visited on 24 June 2008.

${ }^{88}$ A World Bank study notes that changes in SPS standards in international trade 'inevitably have distributional impacts that reflect the nature of these standards themselves and the strategies employed to achieve compliance.' Poverty Reduction \& Economic Management Trade Unit and Agriculture and Rural Development Department, Food Safety and Agricultural Health Standards: Challenges and Opportunities for Developing Country Exports, Report no. 31207 (World Bank, Washington D.C.), 10 January 2005, 97, available at: http:// siteresources.worldbank.org/INTRANETTRADE/Resources/Topics/Standards/standards_challenges_synthesisreport.pdf, visited 27 June 2008. 
safety and quality of the products. They often provide technical information and assistance to these suppliers to ensure that they meet their SPS requirements. As a result, the share of small farmers in export trade may be dramatically reduced ${ }^{89}$ unless they operate in areas with adequate infrastructure, benefit from long-term relationships with buyers and have effective producer organisations. ${ }^{90}$ The resulting bias towards large companies may have important implications for rural livelihoods in developing countries. ${ }^{91}$

In some cases, these negative consequences for rural populations may be offset by new employment opportunities resulting from stricter SPS requirements. For example, offfarm employment may be created in the private sector with regard to packaging, cleaning, handling, processing and SPS controls..$^{92}$ Public sector employment may result from the need for inspectors, veterinary officers, certification authorities and qualified laboratory staff. There may therefore be a net benefit in the long term for society as a whole. However, it should be borne in mind that these new jobs typically require skilled or semi-skilled workers who are often sourced from urban centres, rather than from the rural population. In some cases this has led to conflicts with the local inhabitants. ${ }^{93}$

A 2003 study by the World Bank mentions an illustrative example of the trade barrier effect of SPS requirements on developing countries. It describes the situation of a Mauritanian dairy processor who developed a technology to produce pate molle cheese from camel milk, obtained from poor nomads. In return the processor gave the nomads access to credit and vaccinated their animals to ensure a healthy supply of milk. The camel-milk cheese won a prize at a trade fair and was stocked in elite stores in Europe, such as Harrods and Fauchon. However, due to concerns regarding the spread of footand-mouth disease, the EU decided to ban camel-milk cheese imports from Mauritania,

\footnotetext{
${ }^{89}$ This point is made in the report of the Blair Commission for Africa, which notes that private supermarket standards may be more exacting than official SPS requirements and lead to the exclusion of small farmers by concentrating business in the hands of large companies. Blair Commission for Africa, Our Common Interest, March 2005, 266, available at: http://213.225.140.43/english/report/thereport/cfafullreport.pdf, visited 30 November 2005.

${ }_{90}$ The aforementioned World Bank study notes that smallholders in such situations may be able to reap benefits from participation in evolving supply chains. See Poverty Reduction \& Economic Management Trade Unit and Agriculture and Rural Development Department, Food Safety and Agricultural Health Standards: Challenges and Opportunities for Developing Country Exports, Report no. 31207 (World Bank, Washington D.C.), 10 January 2005, 112, available at: http://siteresources.worldbank.org/INTRANETTRADE/Resources/ Topics/Standards/standards_challenges_synthesisreport.pdf, visited 27 June 2008.

${ }^{91}$ See in this regard the example of the Bangladeshi shrimp industry discussed below, Part II, Section 2.7.2.1.

92 Poverty Reduction \& Economic Management Trade Unit and Agriculture and Rural Development Department, Food Safety and Agricultural Health Standards: Challenges and Opportunities for Developing Country Exports, Report no. 31207 (World Bank, Washington D.C.), 10 January 2005, 113, available at: http://siteresources.worldbank.org/INTRANETTRADE/Resources/Topics/Standards/standards_challenges synthesisreport.pdf, visited 27 June 2008.

${ }_{93}$ Alauddin and Hamid note the conflicts that have arisen with the growth of commercial shrimp farming in Bangladesh. These displace small-scale operations as only large farmers have the resources needed to make the investments demanded by the new SPS requirements. They note that large commercial shrimp farmers are commonly 'outsiders', based in urban centres and they tend to hire labourers from outside the area, rather than absorb surplus rural labour. Mohammad Alauddin and M. Akhter Hamid, 'Shrimp Culture in Bangladesh with Emphasis on Social and Economic Aspects', in Towards Sustainable Shrimp Culture in Thailand and the Region: Proceedings of a Workshop, Paul Smith (ed.) (Australian Centre for International Agricultural Research, Canberra), 1999, 53-62, 59, available at: http://www.aciar.gov.au/web.nsf/doc/JFRN-5J473M/\$file/ PR90\%20Chapter\%2009.pdf, visited 13 May 2000. See further below, Part II, Section 2.7.2.1.
} 
despite the absence of evidence that camels can spread this disease. Later the EU replaced its ban with the requirement that mechanical methods be used to obtain the camel milk used in the cheese. This requirement was impossible to meet for the low-income nomad milk producers, who were located far away from major ports where the mechanical facilities were available. Mauritania did not bring a WTO dispute on this matter, as the significant costs involved could not be justified for exports of \$3-5 million of camel-milk cheese per year. ${ }^{94}$

Aside from studies such as the one above providing anecdotal evidence of the effects of particular SPS trade barriers, ${ }^{95}$ other studies have been conducted to attempt to quantify the impact of SPS standards on developing country trade. ${ }^{96}$ Quantification has proved difficult due to the paucity of available data and the difficulty in ascertaining and measuring these effects. ${ }^{97}$ Nevertheless, some estimates have been made with the use of econometric models, ${ }^{98}$ and have come to the conclusion that the strict SPS requirements of developed

${ }^{94}$ Global Economic Prospects 2004: Realizing the Development Promise of the Doha Agenda (World Bank, Washington D.C.), 2003, 116.

95 See for example also Charles J. Kithu, 'Issues on SPS and Environmental Standards for India', presented at the Workshop on a New WTO Round on Agriculture, SPS, and the Environment: Capturing the Benefits for South Asia (World Bank, UNCTAD, SAARC Secretariat, New Delhi, India) 11-13 January 2001, available at: http://R0.unctad.org/trade_env/test1/meetings/standards/charles.doc, visited on 27 June 2008; Tika Karki, 'Issues on SPS and Food Standards for Nepal', presented at the Workshop on a New WTO Round on Agriculture, SPS, and the Environment: Capturing the Benefits for South Asia (World Bank, UNCTAD, SAARC Secretariat, New Delhi, India) 11-13 January 2001, available at: http://r0.unctad.org/trade_env/ test1/meetings/standards/nepal.doc, visited 28 June 2008; Anura Herath, 'Cost of Compliance of Sanitary and Phytosanitary Requirements in Beverages and Spices in Sri Lanka', presented at the Workshop on a new WTO Round on Agriculture, SPS and the Environment: Capturing the Benefits for South Asia (World Bank, UNCTAD, SAARC Secretariat, New Delhi, India) 11-13 January 2001, available at: http://r0.unctad.org/ trade_env/test $1 /$ meetings/standards/anura $\% 20$ herath.doc. Some such anecdotal information will be discussed in Part II below, with reference to the particular WTO Members used as illustrative examples in this book.

${ }^{96}$ An assessment of the various methodologies employed for the measurement of the effect of non-tariff barriers to trade in the food and agricultural sectors was conducted under the auspices of the OECD in 2001. See OECD Food Agriculture and Fisheries Directorate, Measurement of Sanitary, Phytosanitary and Technical Barriers to Trade, 17-18 September 2001, available at: www.oecd.org/dataoecd/1/36/1816774.pdf, visited on 22 June 2008.

${ }^{97}$ MacLaren mentions two difficulties in economic analysis of technical barriers to trade in the agri-food sector. These are, first, that the use of these measures may lead to more, rather than less, efficient market outcomes. The second is that 'the time dimension introduced by the spread and effects of imported diseases cannot be ignored...[T]he time profiles of costs and benefits are different and ...the future stream of costs (and benefits) is uncertain and perhaps irreversible.' Donald Maclaren, Some Issues in the Economic Analysis of Technical Barriers to International Trade in Agri-Food Products, Research Paper Number 663 (University of Melbourne, Department of Economics, Melbourne), December 1998, 2. Similarly, in a study quantifying the effect of Japan's phytosanitary trade barrier to apple imports from the US, Calvin and Krissoff note that, 'While measuring [the technical barrier's] tariff-rate equivalents and determining the welfare impacts of removing barriers are simple concepts, the empirical application is complex and the results are highly dependent on a number of simplifying assumptions.' Linda Calvin and Barry Krissof, 'Technical Barriers to Trade: A Case Study of Phytosanitary Barriers and U.S.-Japanese Apple Trade', Journal of Agricultural and Resource Economics 23 (2), 1998, 351-366, 364.

${ }^{98}$ For example, Otsuki, Wilson and Miravat have estimated the effect of European food safety requirements for exports from African countries. Tsunehiro Otsuki et al., 'Measuring the Effect of Food Safety Standards on African Exports to Europe', in The Economics of Quarantine and the SPS Agreement, Kim Anderson, et al. (eds.) (Centre for International Economic Studies, Adelaide), 2001. For discussions on the quantification of the effects of standards see also Keith E. Maskus et al., Quantifying the Impact of Technical Barriers to Trade: A Framework for Analysis, Report No. 2512 (World Bank, Washington D.C.), December 2000, available at: http://econ.worldbank.org/files/1324_wps2512.pdf, visited on 5 April 2001. See further the following 
countries have proved very costly for countries at lower levels of development. These costs are generated both by the losses suffered due to rejection of products and their subsequent destruction or diversion to less lucrative markets and by investments made to meet the relevant SPS requirements. ${ }^{99}$

When discussing the trade effects of SPS requirements on developing countries, care should be taken to avoid broad generalisations. The heterogeneity of developing countries must be remembered, as it impacts on the ability of these countries to overcome the traderestrictive effects of SPS requirements by adapting to new requirements and securing their market share. A 2005 World Bank report notes that some developing countries have been able to meet the challenge posed by higher standards on export markets. ${ }^{100}$ It points to the example of Kenya, whose food industry has responded to the food safety standards in Europe by accelerating the adoption of modern supply-management techniques and engaging in collaboration with the public sector. As a result, Kenya is able to supply fresh vegetables and salad greens to major European supermarket chains. ${ }^{101}$

Despite the potential negative trade effect of SPS requirements on developing countries, the question arises whether there might be positive secondary effects on health, in terms of both of food safety and agricultural productivity. If efforts to meet the SPS requirements of their trading partners lead to higher levels of protection of human, animal and plant health in developing countries, gains might be reaped in the area of health. It is interesting to note that the WHO Regional Office for Africa has reported that food borne diseases currently pose a significant health threat in Africa, particularly those from micro-

conference papers Niel Gandal, 'Quantifying the Trade Impact of Compatibility Standards and Barriers - an Industrial Organization Perspective', presented at the Workshop on Quantifying the Trade Effect of Standards and Regulatory Barriers: Is it possible? (World Bank, Washington D.C.) 27 April 2000, available at: http:// www.worldbank.org/research/trade/conference/gandal.pdf, visited on 25 October 2000; T. Ademola Oyejide et al., 'Quantifying the Trade Impact of Sanitary and Phytosanitary Standards: What Is Known and Issues of Importance for Sub-Saharan Africa', presented at the Workshop on Quantifying the Trade Effect of Standards and Regulatory Barriers: Is it possible? (World Bank, Washington D.C.), 27 April 2000, available at: http:// www.worldbank.org/research/trade/conference/oyeyide1.pdf, visited on 25 October 2000; Mattias Ganslandt and James R. Markusen, 'Standards and Related Regulations in International Trade: A Modeling Approach', presented at the Workshop on Quantifying the Trade Effect of Standards and Regulatory Barriers: Is it possible? (World Bank, Washington D.C.), 27 April 2000, available at: http://www.worldbank.org/research/trade/ conference/markusen.pdf, visited on 25 October 2000; Keith E. Maskus and John S. Wilson, 'Quantifying the Impact of Technical Barriers to Trade: A Review of Past Attempts and the New Policy Context', presented at the World Bank Workshop on Quantifying the trade effect of standards and technical barriers: Is it possible? (World Bank, Washington D.C.) 27 April 2000, available at: http://www.worldbank.org/research/trade/conference/maskus.pdf, visited on 25 October 2000.

${ }^{99}$ Horton mentions the various costs for developing countries from rejection of products at the border. She notes that these costs are not limited to value of product but include transportation and other export costs. In addition, costs of compliance with SPS requirements are also significant for developing countries and include the costs of upgrading production systems, quality control and certification systems. See Linda R. Horton, 'Food from Developing Countries: Steps to Improve Compliance', Food and Drug Law Journal 53, 1998, 139-171.

100 Poverty Reduction \& Economic Management Trade Unit and Agriculture and Rural Development Department, Food Safety and Agricultural Health Standards: Challenges and Opportunities for Developing Country Exports, Report no. 31207 (World Bank, Washington D.C.), 10 January 2005, 86-88, available at: http://siteresources.worldbank.org/INTRANETTRADE/Resources/Topics/Standards/standards_challenges_ synthesisreport.pdf, visited 27 June 2008.

${ }_{101}$ Global Economic Prospects 2004: Realizing the Development Promise of the Doha Agenda (World Bank, Washington D.C.), 2003, 115. 
bial pathogens, chemical contaminants and biotoxins. ${ }^{102}$ It has pointed out that studies by international organisations in the African region have established that common problems exist with regard to food-safety legislation and its implementation, surveillance and inspection systems, and laboratory services. ${ }^{103}$ Such problems are not limited to the African region, but are common to many developing countries. ${ }^{104}$ In addition, similar problems exist in the area of animal and plant health in several of these countries.

Improvements in this situation would doubtless be beneficial. However, such improvements do not necessarily flow from the imposition of strict SPS requirements by importing countries. Instead, the lack of financial resources and skilled manpower to establish and maintain effective SPS systems in many developing countries are an obstacle to meeting SPS requirements. Thus, far from promoting improvements in the SPS situation in developing countries, strict SPS requirements on their export products may have the opposite effect by reducing the export revenue available to finance the necessary reforms in legislative SPS regimes and infrastructure. Where resources, either domestic or from foreign assistance projects, are available to make the SPS improvements necessary to access foreign markets, often these are limited and thus applied only to specific products destined for the export market and do not filter through to the domestic consumer. ${ }^{105}$

In this regard, also, the heterogeneity of developing countries should be borne in mind. There is a clear distinction to be made between the situation of middle-income countries and that of low-income and least developed countries. While the improving standard of living and corresponding increasing consumer demands in middle-income countries mean that improvements in food safety standards also benefit the domestic population and correspond with domestic priorities, the same cannot be said of poorer countries. Gains in the area of health from compliance with strict SPS regulations in these countries are not significant, since the main health risks facing their populations are from infectious diseases and lack of hygienic conditions, for example impure drinking water. In addition, consumers in these conditions often have a higher degree of immunity to risks

${ }^{102}$ WHO Regional Office for Africa, 'Developing and Maintaining Food Safety Control Systems for Africa - Current Status and Prospects for Change', presented at the FAO/WHO Second Global Forum of Food Safety Regulators, Conference Room Document 32 (Food and Agriculture Organization and World Health Organization, Bangkok, Thailand) 12-14 October 2004, 1, available at: ftp://ftp.fao.org/docrep/fao/meeting/008/ae144e/ae144e00.pdf, visited on 24 June 2008.

103 Ibid.

${ }^{104}$ For example, the Instituto Panamericano de Protección de Alimentos y Zoonosis notes that one of the biggest concerns in the Americas is the lack of laboratory-based surveillance of food-borne disease and the scarcity of reliable data on disease outbreaks and food contaminants. See Instituto Panamericano De Proteccion De Alimentos y Zoonosis, 'International Cooperation on Food Contamination Monitoring and Foodborne Disease Surveillance. A Case Study in the Amro Region', presented at the FAO/WHO Second Global Forum of Food Safety Regulators, Conference Room Document 66 (Food and Agriculture Organization and World Health Organization, Bangkok, Thailand) 12-14 October 2004, 1, available at: ftp://ftp.fao.org/docrep/fao/ meeting/008/ae196e.pdf, visited on 26 June 2008.

105 The FAO/WHO Secretariat points out that while it may be appealing to concentrate food-safety controls on the export field while neglecting the domestic market, this system of 'dual safety standards' for exported and domestically-consumed products is not desirable as it penalises national consumers. See FAO/WHO Secretariat, 'Strengthening Official Food Safety Control Services', presented at the FAO/WHO Second Global Forum of Food Safety Regulators, GF 02/3 (Food and Agriculture Organization and World Health Organization, Bangkok, Thailand) 12-14 October 2004, 11, available at: ftp://ftp.fao.org/docrep/fao/meeting/008/j2951e.pdf, visited on 26 June 2008. 
from contaminated food than do consumers in countries where high hygienic standards are maintained. Due to the low life expectancy in poor countries, threats from carcinogens or the long-term health effects of pesticide residues are not significant. The population is correspondingly less willing to pay for reduced risk in food. Instead, the loss of food trade impacts on these countries' ability to earn income to pay for improvements in their domestic health situation. Thus high SPS standards do not reflect the priorities of the poor. ${ }^{106}$

Aside from those SPS measures that are based on legitimate health concerns, many SPS measures exist with more questionable bases. Clearly governments, under the influence of domestic industry pressure groups, may misuse SPS measures as disguised trade barriers for protectionist purposes. There is a need for effective disciplines to draw the line between protection and protectionism in this area. It is here that the SPS Agreement acts.

As one of the WTO agreements negotiated in the Uruguay Round, ${ }^{107}$ the SPS Agreement aims to discipline trade restrictive regulatory measures that could undermine the steps towards liberalisation of the agricultural sector achieved in that Round. At the same time, it reflects a new recognition, absent in GATT rules, of the right of governments to regulate to protect against SPS risks in traded products. ${ }^{108}$ In doing so, the SPS Agreement attempts to achieve an appropriate balance between the liberalisation of agri-food trade and the protection of health.

The manner in which the SPS Agreement seeks to attain its balancing objective can best be understood when the historical developments leading to the globalisation of trade and the globalisation of health are considered in the light of the importance of liberalisation of agri-food trade for development.

106 Michiel Keyzer and Max Merbis, 'SPS-Standards and Developing Countries: The Need for Differentiation', presented at the Capaciteitsopbouw in Ontwikkelingslanden in verband met Niet-Tarifaire Handelsbelemmeringen (SPS) (Dutch Ministry of Agriculture and Ministry of Foreign Affairs (DGIS), The Hague) 20 June 2001, 3.

107 The negotiation history of the SPS Agreement is discussed below, Part III, Section 1.2.

108 The recognition in the SPS Agreement of the right of Members to adopt the SPS measures necessary to protect human, animal or plant life of health, is discussed below, Part III, Section 3.1. 


\section{Conclusion to Part I}

Understanding the impact of the disciplines used in the SPS Agreement to achieve a balance between trade and health objectives on Members at different levels of development necessitates a grasp of the context within which the Agreement functions. This context encompasses the twin processes of the globalisation of trade and the globalisation of health.

The progressive integration of developing countries into the world trading system has to be seen in the normative context provided by the emerging recognition of the right to development. This serves to establish, on the one hand, the importance of trade as an engine for economic growth in the service of development and the responsibility of the international community to create favourable conditions to facilitate this growth. On the other hand, the right to development clarifies that development is more than economic growth. Instead, development entails the progressive realisation of all human rights. This means that mechanisms to promote development, including through trade liberalisation, may not come at the cost of other human rights such as the right to life, health and safe food. Consequently, the SPS Agreement, which plays an important role in liberalising agricultural trade, cannot achieve its trade objectives through disciplines that would undermine the ability of Members to protect life and health in their territories.

The increasing participation of developing countries in the international trade system has resulted in a new awareness of the need to take their interests into account in the shaping of the rules that govern this system. This has taken a variety of forms, ranging from broad exemptions for developing countries to purely hortatory statements encouraging consideration of their constraints. The new engagement of developing countries evinced in the Uruguay Round negotiations and their willingness to take on the full obligations of membership has meant that they both benefit from greater influence in the multilateral trading system and bear the burden of greater compliance obligations. With the negotiation of new agreements creating detailed disciplines for behind-the-border regulatory areas, such as the SPS Agreement, this has resulted in significant implementation costs. If the globalisation of trade, through the integration of developing countries, is to have a positive impact on their economic growth, it needs to deliver on its promise of increased market access. For countries at lower levels of development this means not only effective trade rules in areas of interest to them, including the food and agricultural sector, but also mechanisms to assist them in using these rules to their full advantage, and in making the necessary adjustments for compliance themselves. This necessitates concerted efforts to address implementation issues, including those relating to the provision of technical assistance and special and differential treatment.

This background is useful to consider when assessing the SPS Agreement. The approach taken in the SPS Agreement is characteristic of the new Uruguay Round agreements aimed at addressing non-tariff barriers to trade through disciplines on regulatory areas. Despite the high implementation costs entailed by these disciplines, the SPS Agreement contains weak provisions on SDT and technical assistance for developing countries. ${ }^{1}$ In analysing

${ }^{1}$ The rules in the SPS Agreement to address the special position of developing-country Members are discussed in Part V of this book. 
the development dimension of the SPS Agreement it is therefore important to assess both the appropriateness of its disciplines for Members at lower levels of development and the effectiveness of its special provisions for developing-country Members.

The globalisation of trade has brought with it the international spread of threats to human, animal and plant life and health. The evolution in the strategies to deal with this problem has been determined to some extent by developments in scientific understandings of risk. Science has formed the basis both for common understandings that support international cooperation, and for national strategies to mitigate risk. The failure of purely national approaches as well as international regulatory approaches to provide an effective strategy in the face of globalised risk, has led to a new, multifaceted approach to risk management. This involves both national and international initiatives in both public and private arenas. These complex governance structures for the protection against SPS risk form the backdrop for the operation of the SPS Agreement. Acknowledging the achievements made on international level in setting voluntary harmonised standards, it incorporates these standards into its rules, while allowing for deviation. ${ }^{2}$ It reflects the focus on science as a neutral and universally valid benchmark for SPS regulation that prevailed at the time of its negotiation, and requires scientific justification for non-harmonised measures. ${ }^{3}$

The proliferation of SPS requirements to mitigate risks from traded products has important implications for trade in the agri-food sector, particularly for countries at lower levels of development. These countries are often primarily dependant on agricultural exports for their foreign revenue earnings. Hard-won gains in the liberalisation of agricultural trade achieved through rules on traditional trade barriers can be undermined by the trade restrictive effects of SPS measures. As these measures predominate in the areas of highvalue fresh produce and processed food products, the possibilities for developing countries to diversify their exports to these lucrative markets are restricted. While many SPS measures are legitimate efforts to address health risks, they may be more trade restrictive than is necessary to achieve their objectives. In addition, the danger exists that SPS measures may be misused for protectionist purposes.

The SPS Agreement acts to address this problem. Situated on the interface of globalised trade and globalised health, this Agreement aims to balance the often conflicting goals of trade liberalisation and health protection. The mechanisms it uses to do so are a reflection of the historical developments outlined above.

\footnotetext{
2 The harmonisation disciplines of the SPS Agreement are examined in Chapter 4 of Part III, below.

3 The obligations of the SPS Agreement requiring that SPS measures be based on scientific principles and not be maintained without sufficient evidence, and its obligations relating to risk assessments, are discussed in Chapters 3 and 5 of Part III below.
} 


\section{Part II}

National and international SPS regulation and standard setting 


\section{Introduction to Part II}

The SPS Agreement has an impact on both the market access and the policy space of WTO Members, which differs at different levels of development. In order to have a proper grasp of this impact, an understanding of both national and international systems for SPS regulation and standard setting is indispensable. It is through these national and international systems that countries give effect to their national priorities with regard to health and trade. Therefore, Part II of this book aims to sketch these two systems broadly, to provide the basic understanding needed for purposes of the subsequent analysis of the development dimension of the SPS Agreement in Parts III to V.

Chapter 1 of Part II examines general aspects of national SPS regulation and standard setting. These include the normative context for government action to protect against SPS risks and a law-and-economics analysis of the reasons why regulation is often necessary to give effect to government obligations in this regard. In order to focus the discussion on the role that the level of development of a country plays in this respect, the different benefits and costs that regulatory action in the area of SPS risks entails for countries at different levels of development is examined. A brief overview is then given of different types of SPS measures. Finally, Chapter 1 sketches the role and limits of science in the regulatory process.

The disparate impact of the SPS Agreement on the ability of governments, at different levels of development, to regulate in the area of SPS risks and to secure market access for their agri-food products, can best be appreciated if one looks in more detail at particular national SPS regulatory systems. Chapter 2 therefore proceeds to a more specific analysis of the difference in SPS regulatory systems of Members at different levels of development.

For this purpose, illustrative examples are provided of the SPS systems of four selected WTO Members at different levels of development. These are the developed-country Member Australia and the developing-country Members Mauritius, Jamaica, and Bangladesh. As will become apparent from the discussion in Parts III to V of this book, ${ }^{1}$ the disciplines of the SPS Agreement can be seen as reflecting 'best practice' standards in the area of SPS regulation. The question of how appropriate and workable these disciplines are for Members at different levels of development cannot be answered in the abstract. Instead, in keeping with the recognition in this book of the fact that one cannot speak generally of 'developing-country Members' but must take into account that they are a diverse group, concrete examples are used in Chapter 2 to illustrate the differences in SPS systems across levels of development. These illustrative examples aim to provide the factual background needed to facilitate the understanding of the practical effect of the disciplines of the SPS Agreement analysed in Parts III to V of this book.

Part II of this book turns, in Chapter 3, to look at international standard-setting systems in the area of SPS risk. The globalisation of health risks, as discussed in Part I of this book,

\footnotetext{
${ }^{1}$ Part III of this book deals with the those substantive disciplines of the SPS Agreement that balance trade liberalisation and health protection, Part IV examines the procedural and institutional mechanisms under the SPS Agreement and Part V discusses the rules in the SPS Agreement that address the special position of developing countries.
} 
has led to international SPS standard setting. The SPS Agreement incorporates developments in this regard by making express reference to the standards, guidelines and recommendations developed by the main international standard-setting bodies working in the field of sanitary or phytosanitary risks. Such standards, guidelines and recommendations form the basis of the rules on harmonisation of SPS measures in the SPS Agreement. Chapter 3 therefore starts by looking in general at the reasons behind initiatives to harmonise SPS requirements at international level and the link between such initiatives and trade liberalisation. The discussion is then directed to the benefits and pitfalls of harmonisation of SPS requirements for countries at different levels of development, thereby focusing on the role played by the development level of a country in the impact that harmonisation initiatives are likely to have on that country.

Clearly, to appreciate the way in which the SPS Agreement's use of these international standards in its disciplines affects Members at different levels of development, one must have a basic understanding of the way in which the relevant international bodies set standards, and the extent to which Members at different levels of development can participate effectively in international standard-setting systems. For this reason, Chapter 3 turns to an examination of these systems and the extent of participation therein of Members at different levels of development.

Finally, the Conclusion to Part II highlights the main aspects of the national and international SPS regulatory systems which are essential to keep in mind throughout the analysis of the provisions of the SPS Agreement in Parts III to V of this book, in order to perceive fully the disparate impact of the provisions discussed therein on Members at different levels of development. 


\section{CHAPTER 1 \\ General aspects of national SPS regulation and standard setting}

The disciplines of the SPS Agreement affect the ability of governments to adopt, maintain and apply SPS regulations. In order to appreciate fully this impact, and its differing effect on countries at different levels of development, it is necessary to have a basic understanding of national SPS regulatory systems.

It is useful to start with a general examination of national regulatory systems for dealing with SPS risks, before turning to look at specific examples in selected Members. First, this general discussion identifies the reasons why governments regulate in the area of sanitary and phytosanitary protection, both from a normative and from a law-and-economics perspective. This serves to highlight the public interest function of SPS regulation and the need to provide sufficient policy space for governments to meet the public interest goal of health protection. The role of private interests in determining regulatory outcomes is also noted in order to establish the need for disciplines on the regulatory freedom of governments in this area.

Second, Chapter 1 proceeds to a brief discussion of the various types of SPS measures that can be adopted by governments and private economic operators. This serves to establish the scope of regulatory action covered by the WTO rules addressed in this book, and to determine which SPS requirements lie outside this scope.

A third section of the general analysis in Chapter 1 sets out, in broad terms, the benefits and costs that are entailed in SPS regulation. Emphasis is placed on the effect of the level of development of a country on these costs and benefits. The extent to which governments carry out cost/benefit analyses in regulatory decision-making receives attention here.

Finally, Chapter 1 concludes this general discussion of SPS regulatory systems by examining the role of science in SPS regulation and the way in which scientific uncertainty is dealt with by scientists and regulators.

This chapter aims to create a theoretical framework within which to understand the factual descriptions of various SPS systems that are set out in Chapter 2 of Part II.

\subsection{Normative framework for national sanitary and phytosanitary protection}

The idea that the protection of public health against sanitary and phytosanitary risks is one of the tasks of rulers and governments has been recognised throughout history. Examples mentioned in the literature include references to food labelling in Egyptian scrolls, purity control of beer and wine in ancient Athens, the Roman state food-control system for consumer protection against health risks from produce, and the quality and safety laws promulgated in several European countries in the Middle Ages with regard to eggs, sausages, bread, cheese, wine and beer. ${ }^{1}$ Early examples of the application of such

\footnotetext{
${ }^{1}$ These examples are listed by Phillips. See Peter W.B. Phillips, 'Food Safety, Trade Policy and International Institutions', in Governing Food: Science, Safety and Trade, Peter W.B Phillips and Robert Wolfe (eds.)
} 
SPS protection measures to traded products are the SPS controls applied to maritime and overland commerce by Italian city-states in the fourteenth century. ${ }^{2}$ Today, all sovereign states take measures to protect against risks to human, animal and plant life or health in their territories, including those arising from imported food and agricultural products.

Such government measures have an underlying normative rationale. It is currently widely recognised in international human rights law that ensuring adequate food and human health are among the fundamental duties ${ }^{3}$ of governments, and an integral part of both the right to life and the right to development. The normative framework for SPS protection provided by international human rights law informs the discussion of the limitations on regulatory autonomy in this area arising from international trade rules. ${ }^{4} \mathrm{~A}$ brief look will therefore be taken at the relevant human rights and their interpretation by human rights bodies and scholars.

The right to life is enshrined in Article 3 of the Universal Declaration on Human Rights ${ }^{5}$ and Article 6 of the International Covenant on Civil and Political Rights (ICCPR) ${ }^{6}$ as well as in many other human rights instruments. ${ }^{7}$ In its General Comment on the Right to Life, ${ }^{8}$

(McGill-Queen's University Press, Montreal), 2001, 27-48, 235-236.

2 See above, Part I, Section 2.1. Fidler mentions the establishment of the first boards of health in Venice and Florence in 1348 and the first isolation of shipping in the Italian Adriatic colony of Ragusa in 1377, followed by the subsequent development of quarantine practices with regard to suspect maritime trade. In addition, overland commerce was subject to controls and bans in Milan and Mantua in 1374. David P. Fidler, 'Microbialpolitik: Infectious Diseases and International Relations', American University International Law Review 14, 1998, 1-52, 8.

3 The right to food and the right to health fall within the category of economic, social and cultural rights. Governments' obligations with respect to economic, social and cultural rights have been defined by treaty bodies as well as scholars as the obligation to respect, protect and fulfil the relevant right. The obligation to respect is a negative obligation, meaning that governments must not do anything to violate that right (for example, a government may not eliminate food-safety regulations without an adequate replacement if the health risk still exists). The obligation to protect entails positive action to prevent violation of the right by others (for example a government must impose regulatory requirements on producers and importers of food products to ensure that only safe food is marketed on its territory). The obligation to fulfil means that a government must provide an enabling environment for the fulfilment of the right and, as a last resort, itself take action to fulfil the right (for example, a government may have to operate inspection facilities for imported food at points of entry). The fact that no international body exists before which these rights can be adjudicated does not detract from the fact that they create binding obligations on states parties to the relevant treaties.

${ }^{4}$ Robert Howse and Ruti Teitel have noted that: '[t]here is an absence today of a plausible, agreed normative economic framework that can inform debates about globalisation as well as related domestic reforms. This provides a window of opportunity for international human rights law to supply an alternative normative structure for such a debate.' Robert Howse and Ruti G. Teitel, Beyond the Divide: The Covenant on Economic, Social and Cultural Rights and the World Trade Organization, Occasional Paper No.30 (Friedrich Ebert Stiftung, Geneva), April 2007, 6, available at: http://library.fes.de/pdf-files/iez/global/04572.pdf, visited on 15 June 2008.

${ }^{5}$ Universal Declaration on Human Rights, General Assembly Resolution 217A (III), UN Doc. A/810 (1848), adopted 10 December 1948.

${ }^{6}$ International Covenant on Civil and Political Rights, General Assembly Resolution 2200A (XXI), UN Doc. A/6316 (1966), adopted 16 December 1966, entry into force: 23 March 1976.

${ }^{7}$ Art. 4 of the American Convention on Human Rights, OAS Treaty Series No. 36, adopted 22 November 1969, entry into force 18 July 1978; Art. 2 of the Convention for the Protection of Human Rights and Fundamental Freedoms, ETS No. 5 (Protocol 11, ETS No. 155), adopted 4 November 1950, entry into force 3 September 1953 (as amended, in force 1 November 1998); Art. 4 African Charter on Human and People's Rights, 1520 UNTS 363, adopted 27 June 1981, entry into force 21 October 1986.

8 Human Rights Committee, ICCPR General Comment No. 6 on Article 6 (the Right to Life) (United 
the Human Rights Committee characterised the right to life as a 'supreme right' without which other human rights are devoid of meaning. No derogations from this right are permitted, even in times of public emergencies that threaten the life of the nation, under Article 4 of the ICCPR. According to this General Comment, the right to life entails not only a prohibition on the deprivation of life by states, ${ }^{9}$ but also a requirement that states take positive action to increase life expectancy. ${ }^{10}$ The link between health, safe food and the right to life was recognised by Okechukwu Ibeanu, the UN Special Rapporteur on the Adverse Effects of the Illicit Movement and Dumping of Toxic and Dangerous Products and Wastes on the Enjoyment of Human Rights in a thematic report in 2006. ${ }^{11}$ This report focuses on the human rights impact of exposure of individuals to toxic chemicals in food and everyday household goods. It affirms that toxic products constitute a serious threat to the right to life and that other human rights such as the rights to health and food can be affected. ${ }^{12}$ It stresses the obligation of states to take steps to regulate in order to prevent a level of exposure to hazardous chemicals, such as pesticides, that could result in violations of these human rights. ${ }^{13}$

The rights to health and food are enshrined in the International Covenant on Economic, Social and Cultural Rights (ICESCR) of $1966 .{ }^{14}$ The obligations of a state with regard to these rights are set out in Article 2 of the ICESCR, which obliges a state:

... to take steps, individually and through international assistance and cooperation, especially economic and technical, to the maximum of its available resources, with a view to achieving progressively the full realization of the rights recognized in the present Covenant by all appropriate means, including particularly the adoption of legislative measures.

The meaning of this obligation has received the attention of international scholars. In 1986, a group of distinguished international experts unanimously agreed on a set of principles, known as the 'Limburg Principles', which in their view reflected the state of international law regarding states' obligations under the ICESCR. ${ }^{15}$ The Limburg Principles state, inter alia, that the obligation of progressive realisation of rights in Article 2 of the ICESCR requires States to 'move as expeditiously as possible towards the realization of

Nations, Geneva), 30 April 1982, para. 1, available at: http://www.unhcr.org/cgi-bin/texis/vtx/refworld/ rwmain?docid $=45388400$ a, visited on 3 January 2008.

9 Ibid., para. 3.

${ }^{10}$ Ibid., para 5. The General Comment refers to the duty to take measures to reduce infant mortality and to increase life expectancy, especially in adopting measures to eliminate malnutrition and epidemics. However, it seems logical that measures to prevent food safety risks would be included under this duty since they also increase life expectancy.

${ }^{11}$ Okechukwu Ibeanu, Report of the Special Rapporteur on the Adverse Effects of the Illicit Movement and Dumping of Toxic and Dangerous Products and Wastes on the Enjoyment of Human Rights, UN Doc. E/ CN.4/2006/42 (UN Commission on Human Rights, Geneva), 20 February 2006.

12 Ibid., para. 17.

13 Ibid., para. 45.

14 The right to adequate food and the right to health are recognised in Arts 11 and 12 respectively of the International Covenant on Economic, Social and Cultural Rights (ICESCR), UN Doc. A/6316, 1966, adopted within the UN framework. The ICESCR came into force on 3 January 1976.

15 The Limburg Principles on the Implementation of the International Covenant on Economic, Social and Cultural Rights, UN Doc. E/CN.4/1987/17 (International Commission of Jurists, the Urban Morgan Institute on Human Rights and the Centre for Human Rights of Limburg University, Maastricht), 6 June 1986. 
the rights' and that this shall not be interpreted to imply that states have the right to defer indefinitely their efforts to ensure full realisation of the rights involved. ${ }^{16}$ According to the Limburg Principles, 'the obligation of progressive achievement exists independently of the increase in resources; it requires effective use of resources available. ${ }^{17}$

These principles were elaborated on ten years later with regard to the nature and scope of violations of economic, social and cultural rights and appropriate responses and remedies, in order to reflect the evolution of international law in this area and to make more concrete the obligations entailed by these rights. This elaboration is contained in the Maastricht Guidelines on Violations of Economic, Social and Cultural Rights (referred to as the Maastricht Guidelines). ${ }^{18}$ The Maastricht Guidelines specify that violations of economic, social and cultural rights can occur through acts of commission or omission by states, and they provide examples of such acts. Examples of violations through acts of commission include the formal removal or suspension of legislation necessary for the continued enjoyment of a right under the ICESCR that is currently enjoyed; and the active support for measures adopted by third parties which are inconsistent with ICESCR rights. ${ }^{19}$ Examples of violations through an act of omission are the failure to amend or repeal legislation that is manifestly inconsistent with an obligation of the ICESCR; the failure to enforce legislation or put into effect policies to implement provisions of the ICESCR; and the failure to regulate activities of individuals or groups in order to prevent them from violating rights under the ICESCR. ${ }^{20}$

It is widely agreed that the obligation of Article 2 of the ICESCR means that states must guarantee, under any circumstances and regardless of their available resources, the 'core content' of social, economic and cultural rights and to 'progressively' realise other aspects of these rights. ${ }^{21}$ There have thus been attempts to clarify what the 'core content' of each right is. ${ }^{22}$ The precise substance of those rights is, however, still in the process of crystallisation.

\footnotetext{
${ }^{16}$ Ibid., para. 21.

${ }^{17}$ Ibid., para. 23.

${ }^{18}$ The Maastricht Guidelines on Violations of Economic, Social and Cultural Rights (International Commission of Jurists, the Urban Morgan Institute on Human Rights and the Centre for Human Rights of Maastricht University, Maastricht), 26 January 1997. The legal developments since the drafting of the Limburg Principles referred to in the Maastricht Guidelines were the emerging jurisprudence of the Committee on Economic, Social and Cultural Rights and the adoption of instruments, such as the revised European Social Charter of 1996 and the Additional Protocol to the European Charter Providing for a System of Collective Complaints, and the San Salvador Protocol to the American Convention on Human Rights in the Area of Economic, Social and Cultural Rights of 1988. Further, the commitments of governments in the framework of seven UN World Summits conferences (1992-1996) and the proposed Optional Protocols to the International Covenant on Economic, Social and Cultural Rights and the Convention on the Elimination of All Forms of Discrimination Against Women were mentioned.

${ }^{19}$ Ibid., para. 14(a) and (c).

${ }^{20}$ Ibid., para. 15(b), (c) and (d).

${ }^{21}$ Committee on Economic Social and Cultural Rights, General Comment No. 3 on the Nature of States Parties' Obligations, UN Doc. E/1991/23 (United Nations, Geneva), 14 December 1990, para. 10. More recent documents of human rights bodies have confirmed this approach, for example Office of the United Nations High Commissioner for Human Rights, Human Rights and Poverty Reduction: A Conceptual Framework, HR/ PUB/04/1 (UN Office of the United Nations High Commissioner for Human Rights, Geneva), 2004, 26-27.

${ }^{22}$ Brigit Toebes, 'The Right to Health', in Economic, Social and Cultural Rights: A Textbook, Asbjorn Eide, et al. (eds.) (Martinius Nijhoff, Dordrecht, Boston, London), 2001, 169-190, 176.
} 
The right to adequate food is part of the right to an adequate standard of living, laid down in Article 25 of the Universal Declaration on Human Rights. It is also provided for in Article 11 of the ICESCR. ${ }^{23}$ An authoritative interpretation of the right to adequate food has been developed by the UN Committee supervising the ICESCR, namely the Committee on Economic, Social and Cultural Rights, in a General Comment. ${ }^{24}$ According to this interpretation, what is 'adequate' depends on the prevailing social, economic, cultural, climatic, ecological and other conditions. The core content of this right, according to this General Comment, includes the availability of food 'free from adverse substances' ${ }^{25}$ In addition, the UN Special Rapporteur on the Right to Food, Jean Ziegler, has conducted further work on defining the right to food. He argues that: '[t] he right to food implies access to proper food, that it be healthy food, free of any harmful substance and free of harmful consequences for the development of the human body and the reproduction of its vital forces. ${ }^{26}$ Ziegler has also stated that the obligation to protect the right to food means that governments must protect their citizens against violations by other actors, for example by instituting regulations on food safety. ${ }^{27}$

In June 2002, the declaration of the World Food Summit: Five Years Later invited the Council of the Food and Agriculture Organization to establish an intergovernmental working group to develop voluntary guidelines on the progressive realisation of the right to adequate food. This working group was established in November 2002 and the voluntary guidelines it drafted were adopted by the FAO Council in November $2004 .^{28}$ These guidelines comprise the first attempt by governments to interpret the content of an economic, social and cultural right and give practical guidance to states for their implemen-

\footnotetext{
${ }^{23}$ The right to food is also reflected, to different extents (sometimes encompassed by the generic right to an adequate standard of living), in the following international instruments: Arts 11-14 of the Convention on the Elimination of All Forms of Discrimination against Women of 1979, 1249 UNTS 14, adopted 18 December 1979, entry into force 3 September 1981; Arts 24 and 27 of the Convention on the Rights of the Child of 1989, General Assembly Resolution A/RES/44/25, 1577 UNTS 44, adopted 20 November 1989, entry into force 2 September 1990; Art. 12(1) of the Additional Protocol to the American Convention on Human Rights in the Area of Economic, Social and Cultural Rights of 1988, AG/RES.907 (XVIII-0/88), OAS, Treaty Series No. 69, adopted 17 November 1988, entry into force 16 November 1999; Art. 4(1) of the European Social Charter of 1961, Strasbourg, adopted on 18 October 1961, entry into force on 26 February 1965; and The Final Declaration of the World Food Summit: Five Years Later of 2002, contained in the Report of the World Food Summit: Five Years Later. International Alliance Against Hunger, Rome 10-13 June 2002, Appendix.

${ }^{24}$ Committee on Economic Social and Cultural Rights, General Comment No. 12 on the Right to Adequate Food, UN Doc. E/2000/22 (United Nations, Geneva), 2000.

25 Ibid., para. 8.

${ }^{26}$ Jean Ziegler, Report Submitted by the Special Rapporteur on the Right to Food, UN Doc. E/CN.4/2001/53 (United Nations Commission on Human Rights, Geneva), 7 February 2001, para. 73.

27 Jean Ziegler, Report Submitted by the Special Rapporteur on the Right to Food, UN Doc. E/CN.4/2003/54 (United Nations Commission on Human Rights, Geneva), 10 January 2003, para. 18. An interesting discussion on the right to food in international law can be found in Asbjorn Eide et al., 'Food Security and the Right to Food in International Law and Development', Transnational Law and Contemporary Problems 1, 1991, 415-467.

${ }^{28}$ Economic and Social Council, Voluntary Guidelines to Support the Progressive Realization of the Right to Adequate Food in the Context of National Food Security, adopted by the 127th Session of the FAO General Council in November 2004, UN Doc. E/CN.4/2005/131 (United Nations Commission on Human Rights, Geneva), 28 February 2005. The Human Rights Council recently reaffirmed the value of these guidelines. Human Rights Council, Mandate of the Special Rapporteur on the Right to Food, UN Doc. A/HRCRES/6/2 (United Nations, Geneva), 27 September 2007, para.6.
} 
tation of the progressive realisation of the right. ${ }^{29}$ Guideline 9 of this document provides that 'States should take measures to ensure that all food, whether locally produced or imported ... is safe and consistent with national food safety standards. ${ }^{30}$ Further, it provides that states should put into place comprehensive and rational food control systems, using risk analysis and supervisory mechanisms to reduce food-borne risks in the entire food chain. ${ }^{31}$ Science-based food safety standards are encouraged, as are improvements in institutional and regulatory frameworks for food safety. ${ }^{32}$ Where necessary, the guidelines provide that states should assist farmers and processors to follow good agricultural practices and good manufacturing practices. ${ }^{33}$ The guidelines recognise that capacity constraints may limit the ability of a state to implement them. Thus, to assist developing countries, developed and more advanced developing countries are encouraged to provide technical assistance through credits, grants for capacity building, advice, or training in food safety. ${ }^{34}$ The guidelines refer expressly to the SPS Agreement and provide that measures taken by states should be in conformity therewith. ${ }^{35}$

In 2006, the Office of the UN High Commissioner for Human Rights published the Principles and Guidelines for Human Rights Approach to Poverty Reduction Strategies, setting out a human-rights based approach to the poverty reduction. These principles emphasise the crucial role played by the right to adequate food in poverty reduction, ${ }^{36}$ and note that adequate food encompasses, inter alia, food safety. ${ }^{37}$ One of the strategies identified for realising the right to adequate food is the establishment of regulatory mechanisms 'to ensure that the suppliers and distributors of food maintain minimum acceptable standards of health safety. ${ }^{38}$

The right to health is reflected, among others, in Article 25(1) of the Universal Declaration of Human Rights and in Article 12 of the ICESCR. ${ }^{39}$ The Committee on Economic, Social

29 Economic and Social Council, Voluntary Guidelines to Support the Progressive Realization of the Right to Adequate Food in the Context of National Food Security, adopted by the 127th Session of the FAO General Council in November 2004, UN Doc. E/CN.4/2005/131 (United Nations Commission on Human Rights, Geneva), 28 February 2005, iii.

${ }^{30}$ Ibid., para. 9.1.

31 Ibid., para. 9.2.

32 Ibid., para. 9.3.

33 Ibid., para. 9.5 .

${ }^{34}$ Ibid., para. 9.8 .

${ }^{35} \mathrm{Ibid}$., paras 9.3 and 9.7. In the former provision, reference is made to the need to take account of international standards in accordance with the SPS Agreement and in the latter the guidelines state that measures to protect consumers should be in conformity with the WTO agreements, in particular the SPS Agreement and TBT Agreement.

${ }^{36}$ Office of the United Nations High Commissioner for Human Rights, Principles and Guidelines for the Human Rights Approach to Poverty Reduction Strategies, HR/PUB/06/12 (United Nations, Geneva), 2006, para. 136.

${ }^{37}$ According to these principles: '[f]ood safety implies that food should be free from adverse substances, whether from adulteration, poor environmental hygiene or other causes.' Ibid., para. 136.

38 Ibid., para. 149.

39 Universal Declaration on Human Rights, General Assembly Resolution 217A (III), UN Doc. A/810 (1848), adopted 10 December 1948; and International Covenant on Economic, Social and Cultural Rights, General Assembly Resolution 2200A (XXI, UN Doc. A/6316 (1966), adopted 16 December 1966, entry into force 3 January 1976. Various formulations of the right to health can also be found in, for example, Art. 24 of the Convention on the Rights of the Child, General Assembly Resolution A/RES/44/25, 1577 UNTS 44, adopted 20 November 1989, entry into force 2 September 1990; Art. 12 of the Convention on the Elimination of All Forms of Discrimination against Women, 1249 UNTS 14, adopted 18 December 1979, entry into force 3 
and Cultural Rights interpreted the right to the highest attainable standard of health in a General Comment. ${ }^{40}$ According to this authoritative interpretation, the right to health, is 'an inclusive right extending not only to timely and appropriate health care but also to the underlying determinants of health, such as ... an adequate supply of safe food, nutrition and housing, ... and access to health-related education and information... ${ }^{41}$ According to the Committee, one of the core obligations arising from the right to health is 'To ensure access to the minimum essential food which is nutritionally adequate and safe...'. ${ }^{42}$ The UN Special Rapporteur on the Right to Health, Paul Hunt, has undertaken further work in respect of elaborating the right to health. ${ }^{43}$ In addition, authors have addressed the content of this right. Brigit Toebes identifies two aspects of the right to health: health care and the underlying preconditions for health. She argues that the latter includes adequate nutritious food, given the interrelationship between food and health. She notes that malnutrition results not only from the insufficient quantity but also from insufficient quality of food. In particular, she refers to the food-related diseases and disorders that arise from poor quality food. ${ }^{44}$ Howse and Teitel note that in the current era of globalisation, threats to health in the form of diseases spread through trade in goods are significant. Mentioning

September 1981; Art. 16 of the African Charter on Human and Peoples' Rights, 1520 UNTS 363, adopted 27 June 1981, entry into force 21 October 1986; Art. 11 of the European Social Charter, Strasbourg, adopted on 18 October 1961, entry into force on 26 February 1965; and Art. 10 of the Additional Protocol to the American Convention on Human Rights in the Area of Economic, Social and Cultural Rights, AG/RES.907 (XVIII-0/88), OAS, Treaty Series No. 69, adopted 17 November 1988, entry into force 16 November 1999. The recognition that the enjoyment of the highest attainable standard of health is one of the fundamental rights of every human being is already found in the Constitution of the World Health Organisation, International Health Conference, New York, Off. Rec. Wld Hlth Org., 2,100, adopted 22 July 1946, entry into force 7 April 1948.

${ }^{40}$ Committee on Economic Social and Cultural Rights, General Comment No. 14 on the Right to the Highest Attainable Standard of Health, UN Doc. E/C.12/2000/4 (United Nations, Geneva), 11 August 2000. See also Office of the United Nations High Commissioner for Human Rights, Principles and Guidelines for the Human Rights Approach to Poverty Reduction Strategies, HR/PUB/06/12 (United Nations, Geneva), 2006, para. 175.

${ }^{41}$ Committee on Economic Social and Cultural Rights, General Comment No. 14 on the Right to the Highest Attainable Standard of Health, UN Doc. E/C.12/2000/4 (United Nations, Geneva), 11 August 2000, para. 11.

${ }^{42}$ Ibid., para. 43(b).

${ }^{43}$ Paul Hunt, Report Submitted by the Special Rapporteur on the Right of Everyone to the Enjoyment of the Highest Attainable Standard of Physical and Mental Health, UN Doc. E/CN.4/2003/58 (United Nations Commission on Human Rights, Geneva), 13 February 2003. This Special Rapporteur was appointed by the Commission on Human Rights in 2002 for an initial three year term, extended by another three years in 2005. The work of the Commission of Human Rights was concluded by a resolution on the UN General Assembly in 2006 (Resolution 60/251 of 15 March 2006) and the Human Rights Council was created. The latter extended all the mandates of the former Commission on Human Rights, including that of the Special Rapporteur. It is interesting to note that the Special Rapporteur undertook a mission to the WTO in 2003 in order to address the impact of WTO agreements on the right to health. Due to constraints on the length of his report, he did not address all the relevant agreements, but noted that he hoped that the omitted agreements (including the SPS Agreement) would be subject, in future, to detailed analysis 'through the prism of the right to health.' Paul Hunt, Report of the Special Rapporteur on the Right of Everyone to the Enjoyment of the Highest Attainable Standard of Physical and Mental Health. Mission to the World Trade Organization, UN Doc. E/CN.4/2004/49/ Add.1 (United Nations Commission on Human Rights, Geneva), 1 March 2004, para. 6.

${ }^{44}$ Brigit Toebes, The Right to Health as a Human Right in International Law (Intersentia-Hart, Groningen), 1999, 256. Toebes further provides an enlightening discussion of the content and status of the right to health in international law. A general discussion on the implications of the right to health for WTO law can be found in Mohammed Hussain, 'World Trade Organisation and the Right to Health: An Overview', Indian Journal of International Law 43 (2), 2003, 279-313. 
the examples of avian flu and BSE, they stress that a fundamental aspect of the right to health is the duty of a state to protect against such risks. ${ }^{45}$

The right to health encompasses more than this, however. The Principles and Guidelines for Human Approach to Poverty Reduction Strategies published by Office of the UN High Commissioner for Human Rights in 2006 refer to the centrality of good health in poverty alleviation. ${ }^{46}$ These principles set out key strategies for realising the right to health, including through promoting policies in other sectors that have a positive impact on the underlying determinants of health, especially for the poor, for example by 'supporting agricultural policies that have positive health outcomes for the poor ... and by generally promoting their income-generating activities. ${ }^{47}$ In this regard one may think of the need for states with poor rural populations to take action to prevent the introduction and spread of pests and diseases that affect crops and livestock, and to provide agricultural support services to protect the livelihoods of small-holder farmers.

The right to development is also of relevance here. ${ }^{48}$ The then Independent Expert on the Right to Development of the UN Commission on Human Rights, Arjun K. Sengupta, defined the right to development as the right to a process through which all human rights and fundamental freedoms can be fully realised. He has suggested a concrete programme for the realisation of the right to development, which focuses on the achievement of three basic rights: the rights to food, health and primary education. ${ }^{49}$ An improvement in the realisation of the right to development requires the improvement in the realisation of at least some human rights, while the realisation of no other human right deteriorates. ${ }^{50}$ This concept has been further developed in subsequent reports of the Independent Expert as well as in reports of the Open-Ended Working Group on the Right to Development, set up by the UN Economic and Social Council in 1998 as a follow-up mechanism with regard to the realisation of the right to development. ${ }^{51}$ In his Sixth Report on the Right to Development in 2004, Sengupta dealt with the impact of globalisation on development. ${ }^{52}$ While recognising the positive impact of openness to trade on economic growth in de-

\footnotetext{
${ }^{45}$ Robert Howse and Ruti G. Teitel, Beyond the Divide: The Covenant on Economic, Social and Cultural Rights and the World Trade Organization, Occasional Paper No.30 (Friedrich Ebert Stiftung, Geneva), April 2007, 20, available at: http://library.fes.de/pdf-files/iez/global/04572.pdf, visited 15 June 2008.

46 Office of the United Nations High Commissioner for Human Rights, Principles and Guidelines for the Human Rights Approach to Poverty Reduction Strategies, HR/PUB/06/12 (United Nations, Geneva), 2006, paras 171-172. The link between the right to health and poverty alleviation is discussed in detail in World Health Organization, Human Rights, Health and Poverty Reduction Strategies, WHO/ETH/HDP/05.1 (World Health Organization, April 2005.

${ }^{47}$ Office of the United Nations High Commissioner for Human Rights, Principles and Guidelines for the Human Rights Approach to Poverty Reduction Strategies, HR/PUB/06/12 (United Nations, Geneva), 2006, para. 182.

48 The right to development is discussed in more detail above, Part I, Section 1.1.

49 Sengupta, however, notes that countries may choose to focus on other rights first.

50 \{Sengupta, 2000 \#2606\} Arjun Sengupta, The Right to Development. Report of the Independent Expert on the Right to Development, UN Doc. E/CN.4/2000/WG.18/CRP.1 (UN Commission on Human Rights, Geneva), 11 September 2000, para. 15-19, 25 and 64-66. In 2004, Sengupta became the Independent Expert on Human Rights and Extreme Poverty of the UN Commission on Human Rights (now the Human Rights Council)..

${ }^{51}$ See for example the Open-Ended Working Group on the Right to Development, The Right to Development, UN Doc. E/CN.4/2001/26 (United Nations Commission on Human Rights, Geneva), 20 March 2001.

${ }_{52}$ Arjun Sengupta, Report of the Independent Expert UN Doc. E/CN.4/2006/43 (UN Commission on Human Rights, Geneva), 2 March 2006.
} 
veloping countries, ${ }^{53}$ he noted the loss of autonomy in policy making that arises from economic globalisation and WTO obligations. ${ }^{54}$ This loss of autonomy due to WTO obligations includes the disciplines on SPS regulation under the SPS Agreement. Sengupta stressed the need for 'managed globalisation' in order to deliver a desired process of development. ${ }^{55}$ In this connection he noted that the process of globalisation 'tends to favour those with better endowments and greater command over resources, and hence with favourable initial conditions, as against those that are at a disadvantage on these counts and are "latecomers" in the process of development." ${ }^{56}$ As will be seen in the following discussion, this is certainly the case with regard to agreements such as the SPS Agreement that require a certain level of regulatory capacity. Sengupta noted that the complexity of the international trade agreements requires countries to have specific capacities, knowledge bases and negotiating skills 'to articulate and successfully address their concerns in the relevant international forums. ${ }^{57}$ Referring to the general recognition that developing countries often lack these capacities, he emphasised the need for technical and development assistance by the international community in this regard. ${ }^{58}$ According to the Sengupta, international cooperation is as important as national policies in the realisation of the right to development. ${ }^{59}$ Without such assistance, economic growth through trade liberalisation could come at the cost of effective regulation to ensure the rights to life, health and safe food.

As Allan Rosas has pointed out, the specific impact of the rights and obligations flowing from the right to development on the policies of states and international institutions has yet to crystallise. ${ }^{60}$ He proposes that the right to development be seen as 'an umbrella concept and programme rather than a specific human right. ${ }^{61}$ In that way, it serves as an indicator of the human rights dimension of programmes and policies related to development, 'rather than function as a legal mechanism per se. ${ }^{62}$ The elaboration of the right to development makes clear that efforts to promote development through economic growth, including through trade liberalisation, must not be at the cost of other rights, such as the rights to life, adequate food and the highest attainable standard of health.

Not only the protection of human health, but also the prevention of risks to the agricultural sector is a concern from a human rights perspective. The UN Independent Expert on Human Rights and International Solidarity, Rudi Muhammad Rizki, in his 2005 report to the Human Rights Council addressed collective responsibilities of states in the context of globalisation. ${ }^{63}$ In this context, Rizki noted the importance of preventing the spread of ag-

${ }^{53}$ Ibid., para. 10.

${ }^{54}$ Ibid., para. 27.

55 Ibid., para. 31.

${ }^{56}$ Ibid.

${ }^{57}$ Ibid., para. 28.

58 Ibid.

${ }^{59}$ Ibid., para. 34.

${ }^{60}$ Alan Rosas, 'The Right to Development', in Economic, Social and Cultural Rights: A Textbook, Asbjorn Eide, et al. (eds.) (Martinius Nijhoff publishers, Dordrecht, Boston, London), 2001, 119-130, 129.

${ }^{61}$ Ibid.

${ }^{62}$ Ibid.

${ }^{63}$ Rudi Muhammad Rizki, Report of the Independent Expert on Human Rights and International Solidarity. Note by the United Nations High Commissioner for Human Rights, A/HRC/4/8 (UN Human Rights Council, Geneva), 7 February 2007. 
ricultural pests and diseases. He emphasised the fact that the spread of such pests and diseases not only poses a threat to human health in cases where the disease is transmissible to humans (for example avian influenza), but also threatens the livelihoods of millions of poor farmers and smallholders. ${ }^{64}$ Rizki noted the fact that agricultural pests are one of the main causes of disruptions in the agricultural sector, which can lead to social unrest, food shortages and unemployment and threaten sustainable development. ${ }^{65}$ The particular vulnerability of developing countries to these threats is noted. ${ }^{66}$ According to Rizki, 'a strategic and integrated approach encompassing policy and regulation for the analysis and management of risk' covering food safety and animal and plant health is needed ${ }^{67} \mathrm{He}$ proposes that states consider the need for 'international solidarity in helping developing countries to develop an analytical capacity and the necessary scientific, administrative and infrastructure capacity in agriculture' as well as strengthening agricultural support services. ${ }^{68}$

A human rights perspective clearly provides a normative framework for the discussion of SPS protection and, therefore, also of international rules that limit the ability of governments to regulate in this area. It determines the link between health and safe food and the right to life, a right that is supreme in nature. It further establishes why a government has an obligation to take steps, 'to the maximum of its available resources', to progressively realise the human rights to adequate food and the highest attainable standard of health, and to address threats to the agricultural sector in the form of pests and diseases. Further, this approach makes it clear that assistance from the international community in this regard is essential. The important role of trade as an engine for growth and development is tempered by the recognition, in the understanding of the right to development, that economic growth may not be achieved at the cost of other rights, such as the right to life, adequate food and the highest attainable standard of health. In addition, this normative framework is useful because it incorporates into the discussion considerations inherent to the human rights system, such as the importance of non-discrimination and equitable access to safe food, and the need to protect vulnerable groups such as poor rural farmers.

The relevance of the human rights approach as a normative framework for the following discussion in this book lies in insights it provides with regard to the human aspect of the international trade regime. It has been argued that in the context of increasing globalisation, not only states, but also multilateral institutions must act in accordance with international human rights, or at least not undermine the protection of human rights by states. ${ }^{6}$

${ }^{64}$ Ibid., para. 29

${ }^{65}$ Ibid., paras 33-34.

${ }^{66}$ Ibid., para. 34.

${ }^{67}$ Ibid., para. 35. Rizki calls this approach 'biosecurity'.

${ }^{68}$ Ibid., para. 40.

${ }^{69}$ Jean Ziegler, Interim Report of the Special Rapporteur on the Right to Food. Note by the Secretary General, A/60/350 (UN General Assembly, Geneva), 12 September 2005, paras 35-53. Ziegler argues that the human rights, including the right to food, must be respected not only by states, but also by international organisations that affect domestic policy making, such as the WTO. He argues that the right to food, as part of customary international law, binds international organisations such as the IMF, the WTO and the World Bank. Despite the 'member-driven' character of the WTO, Ziegler notes that it operates through its own organs (for example the dispute settlement organs that interpret its agreements and the WTO Secretariat that conducts technical assistance projects) and should therefore be bound by international human rights. Similarly, Ernst-Ulrich Petersmann argues that the protection of human rights is not only the task of national and international human 
It is no longer possible for a state or an organisation whose activities impact on development to ignore the human rights implications of its actions..$^{70}$ This is also true for the states and organisations that form part of the international trading system. ${ }^{71}$ For this reason, while the economic growth achievements of international rules on trade liberalisation are important to promote development, they cannot come at the cost of other rights, such as the right to health and safe food. Instead, mechanisms must be found to appropriately balance these competing goals in a way that does not undermine human rights. It needs to be seen whether the SPS Agreement achieves such a balance.

The human rights perspective, as has been seen above, recognises that the obligations of states in respect of the rights to life, health and food include the obligation to take positive action, sometimes in the form of regulation, to protect these rights even if this restricts trade and thereby limits economic growth. However, in order to understand why, to fulfil their obligations under this normative framework, regulation is very often necessary when sanitary and phytosanitary risks are at stake, it is useful to turn to a law-andeconomics analysis. This serves to elucidate the role of the SPS Agreement in disciplining SPS regulation.

\subsection{Reasons for sanitary and phytosanitary regulation}

Why is government regulation often necessary for protection from sanitary and phytosanitary risks? Left to their own devices, would suppliers of food and agricultural products not be spurred by market forces, namely the demand for products free from SPS risks and

rights law, and of specialised human rights bodies, but also of the law of global and regional organisations such as the WTO and the EU. He advocates a 'Global Compact' committing all international organisations to respect for human rights, rule of law, democracy and good governance in their 'collective exercise of government powers'. Ernest-Ulrich Petersmann, 'Time for a United Nations' "Global Compact” For Integrating Human Rights into the Law of Worldwide Organizations: Lessons from European Integration Law for Global Integration Law', in Trade and Human Health and Safety, George A. Bermann and Petros C. Mavroidis (eds.), Columbia Studies in WTO Law and Policy (Cambridge University Press, Cambridge), 2006, 271-326, 308309. Robert Howse and Ruti Teitel, instead, take a narrower approach to the need for consistency between the rights in the ICESCR and WTO law. They focus on the notion that 'one treaty regime should not undermine the existing effectiveness of the other.' Robert Howse and Ruti G. Teitel, Beyond the Divide: The Covenant on Economic, Social and Cultural Rights and the World Trade Organization, Occasional Paper No.30 (Friedrich Ebert Stiftung, Geneva), April 2007, 9, available at: http://library.fes.de/pdf-files/iez/global/04572.pdf, visited 15 June 2008. However, they do leave open the possibility that in the long run it may be desirable to examine the way in which the WTO regime could be made to enhance the capacity of states to respect, protect and fulfil the rights under the ICESCR.

${ }^{70}$ Manfred Nowak notes that the new awareness of the correlation between poverty, development and human rights, as reflected in the results of the second World Conference on Human Rights and the first World Social Summit in Copenhagen on 6-12 March 1995, led the World Bank and the International Monetary Fund to introduce their 'poverty reduction strategy papers', which make poverty reduction and debt relief the main focus of their new and comprehensive development framework. Manfred Nowak, Introduction to the International Human Rights Regime, vol. 14 (Martinus Nijhoff Publishers, Leiden/Boston), 2003, 151.

${ }^{71}$ Eleanor Fox states: 'A world trade organization of the twenty-first century must be sufficiently copious or porous to take account of the values on which it treads - or on which critical masses believe it treads. Isolation of trade from its impacts is not an appropriate option for the world.' Eleanor M. Fox, 'The Prospective Role of Economic and Social Human Rights in the Law of International Trade Liberalization and Economic Integration: Globalization and Human Rights: Looking out for the Welfare of the Worst Off', NYU Journal of International Law and Politics 35, 2002, 201-220, 210. 
consumers' willingness to pay a premium for such products, to take risk reduction measures? Similarly, would a liability regime which, ex post facto, holds suppliers responsible for harmful consequences arising from the products they supply not be sufficient to ensure that they take appropriate measures against SPS risks? Although there are several perspectives from which these questions can be answered, ${ }^{72}$ it is beyond the scope of this book provide a comprehensive analysis of the various theories of risk regulation, something that has been skilfully done by others. ${ }^{73}$ Instead, the discussion here will limit itself to sketching, in broad lines, one such approach in order to create the basic understanding necessary to follow the subsequent discussion. The law-and-economics approach provides a particularly enlightening explanation of the reasons for government regulation of risk, which can usefully be applied to the area of SPS risks. ${ }^{74}$ This approach allows us to examine the costs and benefits of SPS regulation, which differ across development levels, and thus to understand the different regulatory choices made by countries across the development spectrum.

Seen from a law-and-economics perspective, risk regulation by governments can be regarded as a response to market failure. ${ }^{75}$ Governments need to act to pursue collective goals where these goals are unlikely to be met by an unregulated market. ${ }^{76}$ SPS regulation, like other types of social regulation, aims to correct two types of market failure, namely (1) inadequate information of consumers; and (2) spillover effects creating harm or benefits for individuals not involved in the relevant market transaction (known as negative and positive externalities, respectively). ${ }^{77}$ One result of these market failures is that the collective goal of the protection of human, plant and animal health is not achieved if left to market forces.

\footnotetext{
${ }^{72}$ Ortwin Renn provides a classification of various approaches to risk regulation. He distinguishes the technical, economic, psychological, sociological and cultural perspectives on risk. He argues that policies with regard to risk regulation should not be solely based on technical and economic approaches but should include social science approaches. Ortwin Renn, 'Concepts of Risk: A Classification', in Social Theories of Risk, S. Krimsky and D. Golding (eds.) (Praeger, Westport), 1992, 412. While it is not necessary for purposes of this book to go into the debate on this issue, it is nevertheless important to be aware that a diversity of approaches to risk regulation exists, of which the economic approach is only one.

73 For a detailed analysis of why governments regulate against risks, see Christopher Hood et al., The Government of Risk: Understanding Risk Regulation Regimes (Oxford University Press, Oxford), 2001.

74 The WTO's World Trade Report of 2005, which focuses on trade and standards, also relies on a law-andeconomics perspective for its analysis of the impact of standards on trade and welfare. See WTO Secretariat, World Trade Report 2005: Exploring the Links between Trade, Standards and the WTO (World Trade Organization, Geneva), 30 June 2005, Part II, available at: http://www.wto.org/english/res_e/booksp_e/ anrep_e/world_trade_report05_e.pdf, visited on 4 June 2007.

${ }^{75}$ For a comprehensive and eminently readable account of the economic theory of regulation, see Anthony Ogus, Regulation: Legal Form and Economic Theory (Clarendon Press, Oxford), 1994. Much of the discussion in this section is drawn from this source.

${ }^{76} \mathrm{Ibid} ., 3$. This is known as the public interest theory of regulation.

77 The WTO's World Trade Report of 2005 identifies three types of market situations where government intervention would be desirable, namely imperfect information, negative externalities and network externalities. WTO Secretariat, World Trade Report 2005: Exploring the Links between Trade, Standards and the WTO (World Trade Organization, Geneva), 30 June 2005, 35-51, available at: http://www.wto.org/english/res_e/ booksp_e/anrep_e/world_trade_report05_e.pdf, visited on 4 June 2007. The latter category deals with technical compatibility of products and is not relevant here. The other two categories are discussed further below, and additional attention is given to positive externalities. In this regard, see Anthony Ogus, Regulation: Legal Form and Economic Theory (Clarendon Press, Oxford), 1994, 4.
} 
The two types of market failure mentioned above can be explained as follows. In a perfect world, consumers would have complete information regarding the SPS risks of the products on the market and would act rationally on the basis of this information. They would therefore be willing to pay more for safe products, and would sue for damages caused by unsafe products, providing an incentive for producers to invest in measures to reduce SPS risks in their products. ${ }^{78}$ However, in reality, consumers are often not aware of the risks of certain products, since the safety level is not readily observable. ${ }^{79}$ For example, they may not be aware that the milk they drink was produced by cows treated with the recombinant bovine somatotrophin (rBST) hormone, ${ }^{80}$ or that the fruit they buy has a high level of pesticide residues. ${ }^{81}$ Further, even when possessed of adequate information, consumers do not always make rational choices. ${ }^{82}$ They tend to overvalue certain low-probability risks and undervalue other high-probability risks, even when they have been informed as to the actual probability of the risk occurring. For example, consumers may attach a high value $^{83}$ to the avoidance of the risk of cancer from aflatoxins in nuts and spices although the probability of the risk occurring has been shown to be one in a billion, whereas they may not attach much value to avoiding the much more probable risk of heart disease or obesity from eating fast food. Thus, when left to market forces, this 'probability neglect' ${ }^{84}$

78 As pointed out by Kathleen Segerson, firms will supply safe products without the need for government regulation if the benefits to the firm (higher prices paid by consumers) plus the decrease in damages the firm would be liable for due to supplying unsafe products, outweigh the costs to the firm in ensuring safe products. Kathleen Segerson, 'Mandatory vs. Voluntary Approaches to Food Safety', Agribusiness 15 (1), 1999, 53-70.

${ }^{79}$ Lorraine Mitchell points out that consumers cannot know that food is contaminated before purchasing and consuming it. An additional complication is that, even if consumers become ill after eating the food, it is often difficult to trace the cause of the illness to a particular food product out of the various consumed. Lorraine Mitchell, 'Economic Theory and Conceptual Relationships between Food Safety and International Trade', in International Trade and Food Safety: Economic Theory and Case Studies, Jean C. Buzby (ed.), Agricultural Economic Report No. 828 (USDA Economic Research Service, Washington D.C.), 2003, 10-27, 12, available at: http://ers.usda.gov/publications/aer828.pdf, visited 4 January 2007.

${ }^{80}$ Recombinant bovine somatotropin (rBST) is a hormone produced by genetic engineering to increase milk production in cows. The hormone bovine somatotropin (BST) occurs naturally in cows, but the long term effects of rBST on human health are not yet known.

${ }^{81}$ In this respect, economists classify goods into three categories: search goods (whose quality can be determined by consumers before purchase), experience goods (whose quality is ascertained by use after purchase through consumption and use) and credence goods (whose quality is usually not ascertainable even after consumption). Food and agricultural products are typically experience goods. See the explanation of these concepts in WTO Secretariat, World Trade Report 2005: Exploring the Links between Trade, Standards and the WTO (World Trade Organization, Geneva), 30 June 2005, 43, available at: http://www.wto.org/english/ res_e/booksp_e/anrep_e/world_trade_report05_e.pdf, visited on 4 June 2007. This report points out that liability legislation may be inadequate to spur producers to supply safe goods in cases where the impact of the product defect is difficult or impossible to compensate (e.g. severe illness or death). With regard to food products as 'experience' or 'credence' goods, see Spencer Henson, 'Consumer Perceptions of Food Safety: Survey Research in Economics and Social Psychology', in Governing Food: Science, Safety and Trade, Peter W.B Phillips and Robert Wolfe (eds.) (McGill-Queen's University Press, Montreal), 2001, 91-111, 101. See also Anthony Ogus, Regulation: Legal Form and Economic Theory (Clarendon Press, Oxford), 1994, 190.

${ }^{82}$ Economists thus accept that consumers act with 'bounded rationality'. Consumers' capacity to receive, store and process information is limited. Anthony Ogus, Regulation: Legal Form and Economic Theory (Clarendon Press, Oxford), 1994, 41.

${ }^{83}$ Since the value of non-marketable assets, such as health, is difficult to measure, a 'willingness to pay' test has emerged, determining the value of such assets to be the sum which individuals would be willing to pay to avoid the risk to the asset if fully informed of the magnitude of the risk. Ibid., 157.

${ }^{84}$ This term was coined by Cass Sunstein. See Cass R. Sunstein, 'Probability Neglect: Emotions, Worst Cases, and Law', Yale Law Journal 112, 2002, 61-107, 84 and 103. There is some disagreement about the appropriate 
by consumers would result in a misallocation of resources to avoiding low-probability risks. These resources could be more efficiently spent to address more probable risks.

The second reason for market failure mentioned above, relates to externalities. The problem of negative externalities arises due to the fact that a particular transaction may cause harm to persons other than the parties to the transaction. For example, an exporter may supply tomatoes to supermarkets in a foreign country. However, these tomatoes may be infested with a pest that poses a threat to tomato producers in the importing country. If the exporter does not have to cover the costs incurred by producers in the importing country due to the introduction and spread of the pest, these costs will not be reflected in the export price of the tomatoes. In other words, the external costs have not been internalised by the exporter and the price does not reflect the true social cost of production. ${ }^{85}$ Demand for these tomatoes is consequently artificially high in the importing country and there is a misallocation of resources to the production and importation of these tomatoes. ${ }^{86}$ Private law instruments, such as liability rules, may be inadequate to correct negative externalities particularly when the harm is dispersed among a large group, is spread out over time, or is difficult to trace back to the causer of the harm. ${ }^{87}$ In our example, a tomato producer in the importing country may not be aware that the pest destroying his crop was introduced by the relevant exporter of pest-infested tomatoes and could thus not sue the exporter for damages. ${ }^{88}$

Positive externalities may also lead to market failure. A third party may benefit from a producer's activity without having to pay for it. ${ }^{89}$ This is particularly the case with re-

response to this phenomenon. See, for example, Howard F. Chang, Risk Regulation, Endogenous Public Concerns, and the Hormones Dispute: Nothing to Fear but Fear Itself?, Research Paper 03-25 (University of Pennsylvania Law School, Institute for Law and Economics, Pennsylvania), August 2003, available at: http:// ssrn.com/abstract_id=432220, visited 12 June 2006.

${ }^{85}$ Anthony Ogus, Regulation: Legal Form and Economic Theory (Clarendon Press, Oxford), 1994, 19.

${ }^{86}$ Ogus points out that, in theory, the misallocation of resources could be corrected through utility maximizing contracts with all third parties affected. In our example, the foreign tomato producers may offer to pay the tomato exporter to exterminate the pests before exporting tomatoes. If the price they are willing to pay exceeds the costs to the exporter of taking measures to exterminate the pests, an agreement will be reached. If not, no agreement will be reached, showing that the value to tomato producers of eliminating risks from pests in imported tomatoes is less than the costs of pest extermination. In either case, there is no misallocation of resources. However, Ogus notes that this theoretical solution rarely works in practice as the transaction costs of bargaining among large numbers are very high and the harmful effects for third parties are dispersed. Ibid.

${ }^{87}$ For example, with bulk imports of agricultural products from various producers it may be difficult to identify the particular producer that supplied the infested or contaminated product. Likewise, an unsafe food product may have passed through the hands of several firms in the processing chain and it may be difficult to determine at which point in the chain the contamination occurred in order to assign responsibility. See in this regard Lorraine Mitchell, 'Economic Theory and Conceptual Relationships between Food Safety and International Trade', in International Trade and Food Safety: Economic Theory and Case Studies, Jean C. Buzby (ed.), Agricultural Economic Report No. 828 (USDA Economic Research Service, Washington D.C.), 2003, 10-27, 13-14, available at: http://ers.usda.gov/publications/aer828.pdf, visited 4 January 2004.

${ }^{88}$ Similarly, in the area of food safety, Mitchell points out that consumers do not take into account the full social costs of their food purchases. This reduces incentives for producers to invest in ensuring that they supply safe food. For example, aside from the costs illness causes to a consumer of unsafe food, social costs also arise in the form of the use of health care resources, the lost working days for employers etc. These costs are not borne by consumers and are therefore not reflected in the price consumers are willing to pay for a food product. Ibid., 12.

${ }^{89}$ Anthony Ogus, Regulation: Legal Form and Economic Theory (Clarendon Press, Oxford), 1994, 21. 
spect to 'public goods', ${ }^{90}$ which are commodities which benefit the public as a whole, or a group within it, and from which it is impossible to exclude a member of that group. ${ }^{91}$ The health of humans, plants and animals could be regarded as an 'impure' public good..$^{92}$ While measures taken by suppliers to ensure that the products they place on the market do not pose SPS risks primarily benefit the consumers of those products, which benefit is reflected in the price of the product, they also benefit the public as a whole. For example, safe food ensures a healthy population and thus reduces losses in the form of diminished productivity and costs to the public health system from food-related illnesses. Similarly, measures to ensure pest- or disease-free plant or animal products often do not primarily benefit consumers of those products (since pests or diseases that affect plants or animals are only very rarely transmissible to humans) but rather benefit the agricultural sector as a whole and the environment, as the spread of these pests and diseases to farms and natural fauna and flora is thereby prevented. If left to market forces, the price that suppliers would obtain for their products would not reflect the public-good aspects thereof and thus the true social value of the product. A misallocation of resources would result and there would be underproduction of SPS risk-free products. ${ }^{93}$

Thus, governments need to act to correct these deficiencies in the market system in meeting collective goals. Governments may have to turn to regulatory instruments, such as the imposition of SPS measures, to address market failures. This would constitute the publicinterest justification for regulation in the area of SPS protection.

Regulation may also serve distributional or 'paternalistic' goals. ${ }^{94}$ For example, governments may need to regulate in the SPS area because not all consumers are able to pay a

${ }^{90}$ For an interesting discussion of the public goods nature of the WTO itself, see Joost Pauwelyn, 'WTO Dispute Settlement: Of Sovereign Interests, Private Rights and Public Goods', in International Public Goods and Transfer of Technology under a Globalized Intellectual Property Regime, Keith E. Maskus (ed.) (Cambridge University Press, Cambridge), 2005, 817-830. Pauwelyn notes that two types of public goods may come into conflict in the WTO, namely the public good of freer trade and the public goods of environmental protection, respect for human rights and other such societal objectives.

${ }^{91}$ Public goods are characterised by two qualities: non-excludability and non-rivalry in consumption. Simply put, this means that it is impossible or too expensive for a supplier to exclude those that do not pay for the benefit, and that consumption by one individual does not diminish the availability of the good. Anthony Ogus, Regulation: Legal Form and Economic Theory (Clarendon Press, Oxford), 1994, 33; Peter Drahos, 'The Regulation of Public Goods', Journal of International Economic Law 7 (2), 2004, 321-339, 321.

${ }^{92}$ Gregory Shaffer notes that the 'publicness' of a good lies along a continuum so that goods may combine public and private attributes. Economists often refer to goods that do not fully meet the two criteria, but have significant public attributes, as 'impure' public goods. Gregory Shaffer, 'Recognising Public Goods in WTO Dispute Settlement: Who Participates? Who Decides? The Case of TRIPS and Pharmaceutical Patent Protection', Journal of International Economic Law 7 (2), 2004, 459-482, 461. Ogus illustrates impure public goods using the examples of education and training. Anthony Ogus, Regulation: Legal Form and Economic Theory (Clarendon Press, Oxford), 1994, 34.

${ }^{93}$ Peter Drahos points out that although public goods could be supplied through voluntary arrangements, the importance of self-interest as a factor motivating individuals limits the extent to which voluntary arrangements can be relied upon to correct market failure in this regard. Peter Drahos, 'The Regulation of Public Goods', Journal of International Economic Law 7 (2), 2004, 321-339, 325.

${ }^{94}$ Regulators may take distributional considerations into account in conducting a cost-benefit analysis by giving a heavier weighting to the interests of more vulnerable groups (for example children or poor people). Due to the difficulty in choosing the appropriate weighting, Ogus notes that it is possible that distributional considerations may be left out of cost-benefit analysis but nevertheless be taken into account in making regulatory decisions as regulators may only want to adopt measures that correspond to their conceptions of distributional justice or that are politically acceptable from a distributional perspective. Anthony Ogus, Regulation: Legal 
premium for safe food. If left to market forces these poorer consumers would be exposed to unsafe food. In addition, less-informed or uneducated consumers may be ill equipped to make choices in their own best interests regarding which products to buy. Such outcomes would be contrary to the obligation of governments, derived from international human rights law, to ensure access to safe food for all on a non-discriminatory basis. Further, a so-called 'paternalistic' argument ${ }^{95}$ for regulation in the area of SPS risks can be made on the basis of the assertion that, in respect of health risks, scientific and regulatory experts may know better than the individual what serves the latter's interests and should be allowed to make appropriate choices on behalf of the individual. ${ }^{96}$ Behavioural economics has shown that even 'highly-competent, well-functioning people' make certain decision-making errors in particular situations. ${ }^{97}$ This is, for instance, the case due to probability neglect in individual decision-making with regard to risks, as mentioned above..$^{98}$ The imposition of regulatory choices is thus justified on the grounds that the decision-making abilities of the individual are inadequate to make correct choices in the face of the complex scientific and factual circumstances that surround SPS risks.

The public-interest theory of regulation, described above, is not the only way to explain why governments regulate. Due to scepticism regarding the public-interest motivation of legislators and the prevalence of regulatory failure, an alternative theory has been posited, namely, the private-interest theory of regulation..$^{99}$ This theory had its origin in the notion of 'regulatory capture' that arose in the 70s, according to which regulators are vulnerable to capture or influence by interest groups affected by the relevant regulation. ${ }^{100}$ This idea

Form and Economic Theory (Clarendon Press, Oxford), 1994, 160.

${ }_{95}$ Ogus mentions paternalism as one of the types of non-economic goals pursued by regulation in terms of public-interest theory. He calls this particular embodiment of paternalism anti-individualist, as opposed to the liberal idea of paternalism as the situation where individuals rationally delegate choices to others in areas where they realise they may make unwise choices. According to the liberal approach, regulation embodies that to which individuals would have consented if they had been able to perceive what was in their own best interests. Ibid., 52.

${ }^{96}$ Ogus describes this argument in general terms. Ibid., 53.

${ }^{97}$ Colin Camerer et al., 'Regulation for Conservatives: Behavioral Economics and the Case for 'Asymmetric Paternalism'.' University of Pennsylvania Law Review 151, 2003, 101-144, 104. In this article, Camerer et al discuss the arguments for paternalistic regulation in certain predictable situations where people's bounded rationality results in them failing to act in their own best interests. According to the authors, this is to be distinguished from the situation where people make rational choices, accurately reflecting their true preferences, but based on considerations other than maximising their profits. In the latter case, there is no need for paternalistic regulation. The authors propose a new, more nuanced way of assessing the costs and benefits of regulatory options, in line with their idea of 'asymmetric paternalism'. A regulation is defined as asymmetrically paternalistic by the authors 'if it creates large benefits for those who make errors, while imposing little or no harm on those who are fully rational. Colin Camerer et al., 'Regulation for Conservatives: Behavioral Economics and the Case for 'Asymmetric Paternalism'.' University of Pennsylvania Law Review 151, 2003, 101-144, 102.

${ }^{98}$ See above, Part II, Section 1.2. Paul Slovic et al note that variation in the probability of a risk occurring is disregarded by individuals especially in cases where the affective meaning of the consequences of the risk is strong. An example of such a case is the risk of cancer. The authors point out that individuals' concerns about nuclear power and exposure to very low levels of toxic chemicals do not decrease in the light of information regarding the extremely low probabilities of the feared consequences of these risks. Paul Slovic et al., 'Risk as Analysis and Risk as Feelings: Some Thoughts About Affect, Reason, Risk and Rationality', presented at the Workshop on Conceptualizing and Measuring Risk Perceptions (National Cancer Institute, Washington D.C.) 13-14 February 2003, 15.

${ }_{99}$ Anthony Ogus, Regulation: Legal Form and Economic Theory (Clarendon Press, Oxford), 1994, 4.

${ }^{100} \mathrm{Ibid}$., 57-58. Ogus mentions various ways in which a regulatory agency could be influenced by the regulated industry, namely where the information required by the regulator is available only from the regulated 
led to the development of a general economic theory to explain how private interests affect public institutions, known as the 'public-choice' theory. ${ }^{101}$

According to public-choice theory, the political arena may be likened to the market, where 'legislation is a product which is supplied by politicians in response to the demand of private interests. ${ }^{\prime 02}$ Demand is expressed by means of voting, both through the election of legislatures by the electorate and through decision making by legislatures on legislative proposals. In addition, private interests make themselves felt through pressure from interest groups (for example by lobbying of legislators) and through bureaucracies that help formulate legislative proposals. ${ }^{103}$ Private interest groups, such as industries, engage in what is known as 'rent-seeking behaviour' 104 in an effort to maximise profits, for example by pushing for regulation that protects them from competition. ${ }^{105}$

An example of rent-seeking behaviour is the following. Cut flower producers in a certain country may lobby for legislation requiring that imported cut flowers be subjected to fumigation treatment before importation in order to reduce the risk of importation of

industries, where the regulatory agency recruits its officers from the regulated industry due to lack of expertise in the subject-matter, and where the regulated industries threaten the regulator with costly and timeconsuming appeals.

${ }^{101}$ Ibid., 58-59. A critical overview of early literature on public choice theory is provided in Daniel A. Farber and Philip P. Frickey, 'The Jurisprudence of Public Choice', Texas Law Review 65 (5), 1987, 873-928. The authors note that until around the $70 \mathrm{~s}$, economists naively assumed that politicians were only interested in furthering the public interest. Later, economic models embodied a revised view of legislative behaviour, namely that legislators are motivated by self-interest (in re-election) and legislation is thus a product of the influence of special interest groups. They point out that this theory is most closely associated with George Stigler and other members of the Chicago school.

${ }^{102}$ Anthony Ogus, Regulation: Legal Form and Economic Theory (Clarendon Press, Oxford), 1994, 63. See also Michael G. Faure, 'Environmental Regulation', in Encyclopedia of Law and Economics. Vol. II: Civil Law and Economics, Boudewijn Bouckaert and Gerrit De Geest (eds.), vol. 2 (Edward Elgar, Cheltenham), 2000, 443-519, 472-474, available at: www.allserv.rug.ac.be/ gdegeest/2300book.pdf, visited on 25 June 2007. Although Faure discusses the private interest theory with respect to environmental regulation, many of the same observations can be made with regard to SPS regulation.

${ }^{103}$ Anthony Ogus, Regulation: Legal Form and Economic Theory (Clarendon Press, Oxford), 1994, 63.

104 Ogus points out that 'rent' in this context means the difference between production cost and the revenue earned from the good produced. Competition eliminates rent whereas the protection from competition enables producers to acquire rents. Wealth is consequently transferred to them from consumers. Ibid., 73. Faure notes that rent-seeking behaviour will be particularly successful in cases where the transaction costs of bringing together interested parties are relatively small and the information costs for the public to find out about the rent-seeking are relatively high. Michael G. Faure, 'Environmental Regulation', in Encyclopedia of Law and Economics. Vol. II: Civil Law and Economics, Boudewijn Bouckaert and Gerrit De Geest (eds.), vol. 2 (Edward Elgar, Cheltenham), 2000, 443-519, 473, available at: www.allserv.rug.ac.be/ gdegeest/2300book. pdf, visited on 25 June 2007.

105 Kenneth Schepsle describes prevailing public choice theory's characterisation of legislation as follows: 'Interest groups and legislators enter into a relationship, the terms of which are determined by forces in the political marketplace. Interest groups demand specific sections of bills, and legislators supply them in exchange for various forms of political support (campaign contributions, endorsements...etc.).' Kenneth A. Schepsle, 'Congress Is A "They," Not An "It": Legislative Intent as an Oxymoron', International Review of Law and Economics 12 (2), 1992, 239-256, 240. Schepsle goes on to criticise this asymmetric focus on the demand-side of the legislative process and points out that, as a legislator who 'supplies' the legislation is not an individual but a group, complex factors play a role in determining legislative outcomes. He draws conclusions regarding the futility of a search for legislative intent in interpreting legislation. As this part of his discussion is not relevant for purposes of this book, it will not be looked at further here. Nevertheless, the fact that the 'supply-side' of the market for regulation is more complex than it appears from the discussion here should be borne in mind. 
aphids (plant lice). Such a requirement may effectively eliminate competition from foreign producers if it is overly costly or results in damage to the flowers due to the treatment itself or the delay in getting the flowers onto the market. Such private interests can have a significant impact on regulation, to the extent that more general preferences expressed through the democratic process may be overridden, ${ }^{106}$ leading to inefficient outcomes. ${ }^{107}$

Another form of private interest that influences regulatory outcomes in the SPS area is that of the politicians and bureaucracies ${ }^{108}$ responsible for ensuring human, plant or animal health. The quest for increased power and prestige may motivate these actors to act swiftly and decisively to address risks, particularly those receiving extensive media attention. Since food safety is a politically sensitive issue and is highly valued by the electorate, it is in this area that SPS regulation may be most affected by this form of private interest. This may lead to over-regulation in the form of stricter requirements than are justified by public interest goals. ${ }^{109}$

When one examines the SPS regulations that are promulgated in various countries, it becomes clear that both public interest and public choice theory provide an explanatory basis for these regulations. ${ }^{110}$ Governments are motivated by a wide range of factors in

${ }^{106}$ Charles K. Rowley et al., eds., The Political Economy of Rent Seeking (Kluwer, Dordrecht), 1988, as referred to by Ogus in this regard. Anthony Ogus, Regulation: Legal Form and Economic Theory (Clarendon Press, Oxford), 1994, 70.

${ }^{107}$ Ogus notes that legislation that results from democratic processes and thus reflects a broad range of economic interests is likely to be efficient in Kaldor-Hicks terms (i.e. although there may be some winners and some losers, the aggregate gains would exceed the aggregate losses so that those who gain could potentially fully compensate all the losers and still remain better off). However, if private interest groups frustrate the democratic process, their minority interests will prevail over the economic interests of the majority and the result will be Kaldor-Hicks inefficient. Anthony Ogus, Regulation: Legal Form and Economic Theory (Clarendon Press, Oxford), 1994, 24 and 72-73. This issue is also dealt with by Daniel Farber and Philip Frickey, who note that: 'the activities of special interest groups undermine the democratic ethos. The successful functioning of a democracy requires voters, and sometimes government officials, to act in economically irrational ways. Because these behaviours are not reinforced by economic incentives, they depend on a somewhat fragile public adherence to a social code. Special interest groups create the impression that government is simply an arena of self interest and thus foster an atmosphere of cynicism that is incompatible with a healthy democracy.' Daniel A. Farber and Philip P. Frickey, 'The Jurisprudence of Public Choice', Texas Law Review 65 (5), 1987, 873-928, 889.

108 Ogus discusses theories regarding the influence of bureaucracies on regulation. See Anthony Ogus, Regulation: Legal Form and Economic Theory (Clarendon Press, Oxford), 1994, 68-69.

${ }^{109}$ Ibid., 191. Laura Loppacher and William Kerr term this phenomenon 'political precaution' and refer to it as an illegitimate reason for the imposition of SPS measures. They state that: "[p]olitical precaution arises when politicians are being pressured to "do something", or feel the need to be "seen to be doing something" in the face of strongly expressed concerns by members of civil society even where risks are very low or largely speculative. ... Politicians fearing an adverse voter reaction... are driven to imposing border measures even in the absence of any group seeking economic protection.' Loppacher and Kerr name as examples the EU ban on hormone treated beef, and restrictions with regard to genetically modified organisms. Laura J. Loppacher and William A. Kerr, 'The Efficacy of World Trade Organization Rules on Sanitary Barriers: Bovine Spongiform Encephalopathy in North America', Journal of World Trade 39 (3), 2005, 427-443, 434-435.

${ }^{110}$ Farber and Frickey criticise the view that legislation is purely a product of private interests, noting that this is unsupported by empirical evidence. Neither do they subscribe to the view that only public interest motivates legislators. Instead, they claim that: '[o]ur best picture of the political process, then, is a mixed model in which constituent interest, special interest groups and ideology all influence legislative conduct.' Daniel A. Farber and Philip P. Frickey, 'The Jurisprudence of Public Choice', Texas Law Review 65 (5), $1987,873-928,889$ and 903 . Faure, with respect to environmental regulation, also argues for a combination of the public interest and private interest approaches to understand the regulatory process. Michael G. Faure, 
deciding whether to regulate and what form a regulation should take. Governments have to engage in a balancing process between different and possibly conflicting public goods, such as free trade and health. ${ }^{111}$ In addition, they have to decide on the allocation of scarce public resources among competing regulatory goals. Further, not only the goal of ensuring the protection of health against SPS risks but also political considerations, including industry interests, play a role in regulatory decisions. One should therefore take care, in examining the reasons for SPS regulation, not to rely on easy generalisations. Instead, the economic approaches described above should be seen as useful tools, to be used with caution, to explain the forces at work in the regulatory process.

\subsection{Nature of national sanitary and phytosanitary measures}

A wide range of regulatory instruments is available to governments to address SPS risks. At one end of the spectrum are low-impact measures such as information requirements (for example mandatory labelling rules or certification of compliance with voluntary standards) and at the other end are high-impact measures such as outright bans and the requirement of prior approval before a product can be imported or marketed. ${ }^{112}$ Between the two ends of the spectrum are the majority of regulatory instruments, which impose SPS requirements backed by criminal sanctions on suppliers. ${ }^{113}$ For example, maximum residue levels may be laid down for harmful pesticides or veterinary drugs and fumigation or heat-treatment requirements may be imposed for agricultural products that are known to host pests of quarantine significance.

The wide range of SPS measures that may be taken can be classified in different ways. A brief look is taken below at the following three categorisations: product requirements versus process requirements; country-wide measures versus regionalised measures; and mandatory government regulations versus non-binding private sector standards.

Regulations to address SPS risks may lay down either product or process requirements. Product requirements relate to the characteristics of the product itself. Examples of product requirements are prohibitions on the presence of unauthorised additives or contaminants, maximum residue levels for veterinary drugs, pesticides or herbicides, and

'Environmental Regulation', in Encyclopedia of Law and Economics. Vol. II: Civil Law and Economics, Boudewijn Bouckaert and Gerrit De Geest (eds.), vol. 2 (Edward Elgar, Cheltenham), 2000, 443-519, 476, available at: www.allserv.rug.ac.be/ gdegeest/2300book.pdf, visited on 25 June 2007.

${ }^{111}$ In the context of a discussion on the TRIPS Agreement, Shaffer notes that both free trade and public health are impure public goods. Free trade has public good characteristics in that everyone benefits from free trade policies due to the resulting availability of a greater variety of products at lower prices. Similarly, everyone benefits from policies that eradicate risks to health. The fact that these public goods may conflict, complicates decision making by governments. Gregory Shaffer, 'Recognising Public Goods in WTO Dispute Settlement: Who Participates? Who Decides? The Case of TRIPS and Pharmaceutical Patent Protection', Journal of International Economic Law 7 (2), 2004, 459-482, 462-463.

112 Anthony Ogus, Regulation: Legal Form and Economic Theory (Clarendon Press, Oxford), 1994, 5. Ogus calls these low and high intervention instruments, respectively, due to the level of state intervention required.

${ }^{113} \mathrm{Ibid}$. Ogus calls such requirements 'standards'. However, the word 'standards' in this book is used to refer to voluntary SPS requirements in order to distinguish them from mandatory SPS requirements laid down in regulations. Thus, in this book the word 'requirements' will be used to refer to what Ogus calls 'standards', which covers both the mandatory and the voluntary variety. 
labelling and packaging requirements directly related to SPS risks such as sell-by dates or pest-control requirements on wood packaging materials. Product requirements are relatively simple to police through border interventions, ${ }^{114}$ and are therefore well suited to countries with limited regulatory and scientific infrastructure. They also facilitate compliance as the method of achieving conformity is left up to the producer or exporter. Process requirements, instead, relate to the process or production method by which the product was produced, packaged, transported, stored or marketed. They are increasingly applied in the area of food safety due to the fact that risks in food are often caused by pathogens or contaminants that can enter at various stages of the production process. ${ }^{115}$ For example, rules may be laid down regarding hygiene requirements in meat and fish processing and packaging plants, refrigeration requirements during transportation of perishable foodstuffs and rules regarding the segregation of genetically-modified and conventional grain in storage facilities. ${ }^{116}$ Process requirements are fairly rigid, as they regulate the production process and therefore do not allow for different methods to achieve the same level of risk reduction. Thus they do not take into account the different conditions prevailing in different countries of production. ${ }^{117}$ A rigorous approach to process standards is embodied in the Hazard Analysis and Critical Control Point (HACCP) system. HACCP is a system used to ensure food safety by analysing potential hazards, identifying the points in the production process where they can be controlled and setting up process parameters and their critical limits to achieve this control, as well as follow-up procedures. ${ }^{118}$ It aims at the

114 Donna Roberts, David Orden and Tim Josling point out that product requirements set out observable or testable attributes of end products. Therefore the assessment of conformity of the product with the applicable SPS requirements is straight forward. Donna Roberts et al., 'Sanitary and Phytosanitary Barriers to Agricultural Trade: Progress, Prospects and Implications for Developing Countries', in Agriculture and the New Trade Agenda - Creating a Global Trading Environment for Development, M.D. Ingco and L.A.Winters (eds.) (Cambridge University Press, Cambridge), 2004, 329-358, 337.

115 Roberts, Orden and Josling note that process standards have been established to be 'generally an inefficient means of achieving regulatory goals' in the area of environmental regulation, but that the unique nature of food hazards 'requires regulating production processes to avoid repeated, expensive tests of conformity with product standards'. Ibid.

${ }^{116}$ In its 2003 report identifying US barriers to trade and investment from the EU, the European Commission pointed to an example of a process requirement, namely the 'non-comminglement' requirement applied by the US in respect of meat products. According to this requirement, establishments exporting meat or meat products to the US may not handle meat or meat products from other countries that are not recognised as being free from diseases of concern to the US. Although the EU-US Agreement on the Application of the Third Country Meat Directive allows an establishment to handle both categories of meat provided a certain period of time elapses between handling each, the US has not been willing to apply this provision of the agreement. See European Commission, Report on United States Barriers to Trade and Investment (European Commission, Brussels), December 2003, 34, available at: http://trade-info.cec.eu.int/doclib/docs/2003/december/tradoc_115383.pdf, visited on 3 January 2004.

${ }^{117}$ Roberts, Orden and Josling provide the example of process standards in the beef industry that were introduced after the outbreaks of bovine spongiform encephalitis. They report that these process requirements increased costs for exporters in countries where BSE had never been detected, such as Brazil. Donna Roberts et al., 'Sanitary and Phytosanitary Barriers to Agricultural Trade: Progress, Prospects and Implications for Developing Countries', in Agriculture and the New Trade Agenda - Creating a Global Trading Environment for Development, M.D. Ingco and L.A.Winters (eds.) (Cambridge University Press, Cambridge), 2004, 329$358,339$.

${ }^{118}$ The HACCP method was first used by the US National Aeronautics and Space Administration (NASA) to ensure the safety of food taken into space. Food Safety Unit of the Programme of Food Safety and Food Aid, HACCP: Introducing the Hazard Analysis and Critical Control Point System, WHO/FSF/FOS/97.2 (World Health Organization, Geneva), 1997, 1. 
prevention of the introduction of food-safety risks by setting up controls throughout the entire production process from primary producer to final consumer (commonly known as a 'farm-to-fork' approach to food safety), in contrast to the classic approach of relying on general hygiene requirements and the analysis of samples of the final product to identify food-safety risks. The HACCP system was adopted generally as a food-safety tool by the EC and the US in the 1980s, and its use subsequently spread to other developed countries with regard to high-risk food products that are particularly vulnerable to contamination, such as fish and seafood. ${ }^{119}$ According to a report of the Commodities and Trade Division of the Food and Agriculture Organization, all developed countries except Japan now use HACCP based systems to ensure the safety of fish and fish products. ${ }^{120}$ From the fisheries sector, the use of the HACCP system in several developed countries has been extended to the meat and dairy sectors, poultry and other food sectors. ${ }^{121}$ Since they impose HACCP requirements also on imported products, this means that many developing countries have also had to implement HACCP systems. ${ }^{122}$ The HACCP system requires a fundamental change in food production, involving responsible actors throughout the chain of production and documented by means of thorough records. The confidence of importers in the proper implementation of the HACCP system in the production of exported products depends on credible government assessment. ${ }^{123}$ Therefore, it entails significant costs both for private operators and for government agencies. ${ }^{124}$ Consequently, access to the markets

119 The Commodities and Trade Division of the Food and Agriculture Organization explains the role of HACCP in the fishery sector as follows: 'By the end of the 1980s many countries arrived at the conclusion that classic fish (and food) inspection based on the analysis of samples of the final product and on generic hygiene measures was not enough to provide the necessary level of protection to consumers. A preventive system called "Hazard Analysis and Critical Control Point" (HACCP) was adopted and governments started to shift their regulations to HACCP-based systems. If one word has to be chosen to explain HACCP, it is prevention.' FAO Commodities and Trade Division, Commodity Market Review 1999-2000 (Food and Agriculture Organization, Rome), 2000, Box 9.

${ }^{120}$ This FAO report states that: '[a]pproximately 65 percent of the total international fish trade is performed under HACCP-based regulations. The large exception is the Japanese market. Japan, which accounts for about 32 percent of the total fish market (demand) has no HACCP regulations yet.' Ibid. From December 1997, all fish and fishery products produced in and imported to the US have been required to comply with HACCP requirements. See International Trade Centre, Export Quality -an Introduction to HACCP, Bulletin No. 71 (UNCTAD and WTO, December 2002, 11.

${ }^{121}$ For example, HACCP systems are included in the UK's Food Safety Act of 1990 and its Food Hygiene Inspection Codes of Practice; Canada's Food safety Enhancement Programme encourages the establishment of HACCP-based procedures in the agricultural and food processing sectors; the Australian Quarantine and Inspection Service (AQIS) has developed a new inspection system called the Food Hazard Control System, based on HACCP principles; the FDA revised its Food Code in 1993 to make it compatible with HACCP principles. In the US, HACCP requirements apply in the fishery sector, the low-acid canned food industry, the juice industry and the meat and poultry industry. The FDA is considering developing HACCP regulations in other areas of the food industry; the EU in Council Directive No. 93/43/EEC on Hygiene of Foodstuffs of 14 June 1993 requires that food business operators develop HACCP-based systems for food safety, and allows Member States to develop codes of practice for specific food sectors. The European Commission Decision 94/356/EC of 20 May 1994 includes a system of 'own checks' for the production and sale of fishery products which contains HACCP requirements. See Ibid., 11-12.

${ }^{122}$ For illustrative examples of problems faced by two of the selected countries discussed in this Chapter with regard to the implementation of HACCP process requirements, see below, Part II, Sections 2.6.2.1 and 2.7.2.1.

${ }^{123}$ For example, the US requires importers to obtain HACCP plans from exporters and submit them to the FDA for verification. The EU requires that HACCP plans prepared by EU producers or by exporters into the EU must be verified by an authority designated by the EU. International Trade Centre, Export Quality - an Introduction to HACCP, Bulletin No. 71 (UNCTAD and WTO, December 2002, 11.

124 The World Health Organization has written guidelines to help government agencies in this task. See for 
of developed Members in sectors subject to HACCP requirements has been considerably reduced. ${ }^{125}$

Most SPS measures taken by governments with regard to imported products are applied to entire exporting countries. This despite the fact that many SPS risks, especially those from plant and animal pests and diseases, are not determined by national borders. On the one hand, the prevalence of pests and diseases can differ widely within a country, for example due to geographic and climatic variations within its borders. On the other, a pest or disease may be pervasive in an area that extends across national boundaries. ${ }^{126}$ However, since regulatory responsibility is circumscribed by national borders, countries are often treated as single entities for purposes of SPS measures. This may be justified where the SPS regulatory authorities or infrastructure in a particular country are inadequate to monitor, contain or provide safeguards against SPS risks, or when significant differences exist in the risk management choices made at national level by different countries. ${ }^{127}$ However, in many other cases, the application of country-wide SPS measures has no justification beyond administrative ease of implementation for the importing country. Nevertheless, SPS measures that distinguish between areas of high and low prevalence of pests or diseases are few and far between.

SPS regulations are usually accompanied by rules regarding conformity assessment procedures, which are control mechanisms to check compliance with the relevant requirements. These may take various forms, such as certification systems, random sampling and testing procedures and pre-shipment inspections. They may be imposed on products within the domestic market, for example requirements regarding veterinary inspections of cattle within the national territory, or on products crossing borders, either at the time of importation or exportation. ${ }^{128}$ For example, customs officials in the importing country

example, Food Safety Unit of the Programme of Food Safety and Food Aid, Guidance on Regulatory Assessment of HACCP. Report of a Joint FAO/WHO Consultation on the Role of Government Agencies in Assessing HACCP, WHO/FSF/FOS/98.5 (World Health Organization and Food and Agriculture Organization, Geneva), 2-6 June 1998.

${ }^{125}$ For example, Roberts, Orden and Josling note that of the (then) 140 WTO Members, only 15 were permitted to export fresh, chilled or frozen poultry meat to the EC, only 2 to the US, only 1 to Canada, and none at all to Australia. Donna Roberts et al., 'Sanitary and Phytosanitary Barriers to Agricultural Trade: Progress, Prospects and Implications for Developing Countries', in Agriculture and the New Trade Agenda - Creating a Global Trading Environment for Development, M.D. Ingco and L.A.Winters (eds.) (Cambridge University Press, Cambridge), 2004, 329-358, 338.

${ }^{126}$ Loppacher and Kerr note that: '[i]n the science of animal disease control, international boundaries are artificial constructs - mere lines on a map that have no bearing on the dynamics of a disease in an animal population.' Laura J. Loppacher and William A. Kerr, 'The Efficacy of World Trade Organization Rules on Sanitary Barriers: Bovine Spongiform Encephalopathy in North America', Journal of World Trade 39 (3), 2005, 427-443, 433.

${ }^{127}$ Loppacher and Kerr state that: ' ...border measures, while sub-optimal from an animal management strategy, may provide the best line of defence when faced with an incompetent foreign regulatory regime.' Further, they note that in the absence of agreement between countries on the best risk management strategy, countrywide border measures are justified. However, examining the SPS measures imposed against Canada and the US in response to BSE, they argue that neither of these two justifications exists as Canadian and US veterinary services are well regarded worldwide, and the existence of a chapter on BSE management in the World Organisation for Animal Health's Code reflects international consensus in this area. See Ibid., 436.

${ }^{128}$ One example of conformity assessment at the time of exportation is the requirement by the importing country of export certificates. Horton notes that export certificates serve to show that a supplier meets certain requirements and are based on the expectation that the certifying body (either a government authority or officially 
may be required to detain imported fruit shipments for purposes of point-of-entry sampling and testing for levels of pesticide residues, or certification requirements may be laid down according to which competent officials in the exporting country may verify that hygiene requirements were met by the abattoirs where the exported meat was processed.

Aside from mandatory SPS regulations, laid down by central or local governmental bodies or by agencies authorised by them, ${ }^{129}$ SPS requirements may be set by non-governmental bodies without regulatory authority. ${ }^{130}$ Such requirements (commonly known as 'private sector standards') have no binding force. Nevertheless, they may have an important impact on suppliers of food and agricultural products. For example, certain SPS standards for food products may be set by supermarket chains as a precondition for the acceptability of products from suppliers. ${ }^{131}$ Importers in certain sectors may establish Codes of Practice setting out standards which exporters must comply with before the importers will purchase their products. ${ }^{132}$ Industry organisations may also self-regulate in

recognised non-governmental organisation) will conduct inspections or tests to substantiate the accuracy of the information on the certificate. Linda R. Horton, 'Food from Developing Countries: Steps to Improve Compliance', Food and Drug Law Journal 53, 1998, 139-171, 147.

129 Note that while certain agencies established by governments to develop standards (e.g. national bureaus of standards, which are in some countries public bodies) may establish non-mandatory standards, when these standards relate to food safety issues or to animal or plant health, governments typically take these standards up in national legislation and make them mandatory.

130 Another source of non-binding standards are those set at international level by the relevant international standard-setting bodies. Such standards form the subject of Chapter 3 of Part II. Here, in Chapter 2, the discussion is limited to national SPS regulations and standards.

${ }^{131}$ For general discussions on the effect of supermarket standards on developing country suppliers of food and agricultural products see Julio A. Berdeguë et al., Food Safety in Food Security and Food Trade: Case Study: Supermarkets and Quality and Safety Standards for Produce in Latin America (International Food Policy Research Institute, Washington D.C.), September 2003, available at: http://www.ifpri.org/2020/focus/focus10/focus10_12.pdf, visited on 23 January 2008; Food and Agriculture Organization, Rise of Supermarkets across Africa Threatens Small Farmers: Opportunities and Challenges in a Changing Market (FAO, Rome), 8 October 2003, available at: http://www.fao.org/english/newsroom/news/2003/23060-en.html, visited on 23 January 2008. Catherine Dolan and John Humphrey see the relationship between large retailers in developed countries and suppliers in developing countries as a form of 'governance', where retailers exercise close control over the supply chain. They provide an interesting analysis of the consequences of the control exercised by UK supermarkets over trade in fresh vegetables for the inclusion or exclusion of different types of producers and exporters as well as for the long-term prospects for the fresh vegetables industry in Kenya and Zimbabwe. Catherine Dolan and John Humphrey, Governance and Trade in Fresh Vegetables: The Impact of UK Supermarkets on the African Horticulture Industry (World Bank, Washington DC), available at: http:// www.colorado.edu/geography/class_homepages/geog_3662_s06/uk.pdf, visited on 23 January 2008. A 2003 study reports that consolidation in the EU retail sector has increased the power of large retail chains over developing country suppliers. Such retailers prefer to deal with large production units in developing countries, rather than small producers, because the former can more easily undertake compliance measures. This results in the exclusion of small farmers or producers from export markets. See Technical Centre for Agricultural and Rural Cooperation ACP-EU, Study of the Consequences of the Application of Sanitary and Phytosanitary (SPS) Measures on ACP Countries (CTA, Wageningen), May 2003, 14-15, available at: http://www.tcd.ie/ iiis/policycoherence/index.php/iiis/content/download/371/1446/file/CTA\%20Impact\%20of\%20SPS\%20 Measures\%20on\%20ACP\%20countries.pdf., visited on 23 January 2008. The 2005 Human Development Report of the UNDP also identifies, as one of the main problems affecting developing country trade, the role of supermarkets as 'the main gatekeeper to developed country markets for agricultural produce.' The same problems mentioned above are highlighted in this report. See United Nations Development Programme, Human Development Report 2005. International Cooperation at a Crossroads: Aid, Trade and Security in an Unequal World (United Nations, New York), 2005, 142-143, available at: http://hdr.undp.org/en/media/ hdr05_complete.pdf, visited on 2 January 2008.

${ }^{132}$ There has been a proliferation of Codes of Practice (COPs) in various sectors in the EU, setting standards for 
order to create consumer confidence in the products they supply and avoid the need for government regulation. ${ }^{133}$ Voluntary safety-labelling schemes may be used by suppliers to provide a competitive advantage to their products. ${ }^{134}$ In addition, systems of certification of compliance with voluntary safety standards administered by national standards bodies, whether public or private, serve to provide guarantees to buyers of certain safety levels, beyond those required by regulations.

Until the 1990s, voluntary requirements and labelling and certification schemes administered by national (public or private) standard-setting bodies were typically limited to technical and quality standards, rather than health standards. When voluntary standards set by national standards bureaus or actors in the private sector dealt with safety issues, governments often converted the standard into a regulatory requirement and took over responsibility for ensuring compliance. Voluntary, primarily private sector, SPS standards did exist in a few circumstances, particularly in countries where government regulation was inadequate to provide the level of food-safety that some consumers demanded. This was, and still is, the case in some developing countries with weak SPS regulatory regimes where private sector standards fill the gap by providing consumers with the choice to buy safer products at a price premium. ${ }^{135}$ Distributional problems arise, however, as safety

all aspects of the food chain (such as growing, processing, transportation etc.). Although these COPs are not mandatory, importing firms will only source their imports from exporters that meet the standards of the Code of Practice. The best known COP is the EUREPGAP, which is the Good Agricultural Practices standard of the European Retailer Produce Working Group. EUREP also has a standard for Good Warehouse Practice for fruit and vegetables. Note that in September 2007, EUREPGAP was rebranded as the Global Partnership for Good Agricultural Practice (GLOBALGAP). Similarly, the British Retail Consortium has a global standard on food safety and quality, a standard for food packaging materials, and for non-genetically modified food ingredients. The Grain and Feed Association (GAFTA) has a COP for shipping and transport of grain, and over 80 standard contract forms for trade verification, examination and quality control in transit. The European Spice Association sets minimum standards for imported spices and herbs, dealing with EU requirements regarding pesticide residues, aflatoxins, trace metals and microbiological contamination. Technical Centre for Agricultural and Rural Cooperation ACP-EU, Study of the Consequences of the Application of Sanitary and Phytosanitary (SPS) Measures on ACP Countries (CTA, Wageningen), May 2003, 13, available at: http:// www.tcd.ie/iiis/policycoherence/index.php/iiis/content/download/371/1446/file/CTA\%20Impact\%20of\%20 SPS\%20Measures\%20on\%20ACP\%20countries.pdf., visited on 23 January 2008.

${ }^{133}$ An interesting example of self-regulation by an industry group in order to build consumer confidence, is that of the 'stewardship' programmes developed and implemented by the Crop Protection Institute of Canada, a trade association representing the 'life-science' industry (i.e. the industry producing pesticides and genetically modified crops). Lorne H. Hepworth, 'Industry Stewardship as a Response to Food Safety Concerns', in Governing Food: Science, Safety and Trade, Peter W.B Phillips and Robert Wolfe (eds.) (McGill-Queen's University Press, Montreal), 2001, 63-74.

${ }^{134}$ Berdeguë et al. mention the example of a safety-labelling scheme in use in Guatemala. The Agricultural and Environmental Integral Protection Program, a public-private entity with experience in meeting export standards, has created the 'Safety Certification Seal' to address local and regional certification requirements for safety labelling. Although this is a voluntary system, some producers that supply the largest supermarket chain in Guatemala are upgrading their production systems in line with this new programme. Julio A. Berdegue et al., Food Safety in Food Security and Food Trade: Case Study: Supermarkets and Quality and Safety Standards for Produce in Latin America (International Food Policy Research Institute, Washington D.C.), September 2003, available at: http://www.ifpri.org/2020/focus/focus10/focus10_12.pdf, visited on 23 January 2008.

${ }^{135}$ Elizabeth Farina et al discuss the example of the Argentinean milk industry where by the early 2000s, consensus was growing that public sanitary regulations were inadequate, being weaker than both international standards and the private standards of domestic processors. As a result, private industry has taken over the development of milk standards and monitoring their implementation. Elizabeth M.M.Q. Farina et al., 'Private and Public Milk Standards in Argentina and Brazil', Food Policy 30, 2005, 302 - 315, 312-313. Similarly, 
becomes the prerogative of wealthier and more educated consumers who can take advantage of the choice offered by these schemes.

The 1990s saw the introduction of private sector food-safety standards also in certain developed countries, where the concern of some consumers with food-safety risks is such that they are willing to pay more for the assurance of very high safety standards, exceeding regulatory requirements. Examples of the latter are low residue levels for pesticides and labelling and certification schemes for organic fruit and vegetables. Since their introduction in the 1990s, there has been an explosion in the number and variety of private standards in the area of food safety and good agricultural practice, for example, the EuroRetailer Produce Working Group's Good Agricultural Practice Standards (EUREPGAP) and the Global Food Safety Initiative (GFSI). ${ }^{136}$ These standards have proliferated in response to factors such as the decline in consumer confidence in national SPS regulation following food-safety scares; the increased liability of retailers for the safety of the products they sell; the growing use of food safety and quality claims by retailers for firm and product differentiation; ${ }^{137}$ and growing consumer demands for food characteristics not typically addressed in regulations, such as organic production or biotech-free food. ${ }^{138}$

While, due to the impetus created by these factors, private sector standards are rapidly increasing in the area of food safety, the same cannot be said for the areas of animal and

Berdegué et al, on the basis of case studies in Costa Rica, Guatemala, El Salvador, Honduras and Nicaragua report that the rise of the use of private standards by Latin American supermarket chains occurs in the context of the near-absence of public food safety standards and the lack of effective implementation of such standards where they do exist. Julio A. Berdegué et al., 'Central America Supermarkets' Private Standards of Quality and Safety in Procurement of Fresh Fruits and Vegetables', Food Policy 30, 2005, 254 - 269, 154. In this regard, see also Spencer Henson and Thomas Reardon, 'Private Agri-Food Standards: Implications for Food Policy and the Agri-Food System', Food Policy 30, 2005, 241 - 253, 245.

136 Digby Gascoine et al., Private Voluntary Standards within the WTO Multilateral Framework (United Kingdom Department for International Development, London), March 2006, Annex 1, 40. The GFSI was created in 2000 at the request of Chief Executive Officers of food industries to promote continuous improvement in food safty and improve cost efficiency in the food supply chain. It also promotes concvergence of food safety standards through benchmarking of private sector food standards. Committee on Sanitary and Phytosanitary Measures, Report of the STDF Information Session on Private Standards (26 June 2008). Note by the Secretariat, G/SPS/50, circulated on 24 July 2008, para. 7.

${ }^{137}$ Henson explains that retail firms use private sector standards in an attempt to differentiate their products from those of other retailers to protect and increase their market share. Leadings firms, to avoid the supermarket 'price wars', compete instead in the area of safety and quality standards. Henson states: 'private standards have arguably become a critical element of strategies to differentiate products and firms, that requires the consistent supply of food safety and quality attributes supported by branding and certification.' Spencer Henson, 'The Role of Public and Private Standards in Regulating International Food Markets', presented at the IATRC Summer Symposium on Food Regulation and Trade: Institutional Framework, Concepts of Analysis and Empirical Evidence, Bonn) May 28-30 2006, 13, available at: http://www.ilr1.uni-bonn.de/ iatrc/iatrc_program/Session\%204/Henson.pdf, visited on 27 May 2008.

${ }^{138}$ A 2005 World Bank study identifies these and other factors and refers to them as the 'carrot' and the 'stick' behind greater involvement of economic actors in the food supply chain. It notes that some of these private responses are stimulated by regulatory measures while others fill gaps in governance responding to consumer concerns. Poverty Reduction \& Economic Management Trade Unit and Agriculture and Rural Development Department, Food Safety and Agricultural Health Standards: Challenges and Opportunities for Developing Country Exports, Report no. 31207 (World Bank, Washington D.C.), 10 January 2005, 26, available at: http:// siteresources.worldbank.org/INTRANETTRADE/Resources/Topics/Standards/standards_challenges_synthesisreport.pdf, visited on 27 June 2008. See also Digby Gascoine et al., Private Voluntary Standards within the WTO Multilateral Framework (United Kingdom Department for International Development, London), March 2006, Annex 1, 40. 
plant health. ${ }^{139}$ As the driving force for stricter animal or plant health requirements comes from domestic producers, rather than consumers, there is no price premium to be gained by private action in this area. Neither do the same liability issues arise for importers of products that may introduce risks for plant or animal health. Regulatory requirements thus continue to predominate in these areas as there is no incentive for private sector action. ${ }^{140}$

While private sector standards have the potential to stimulate improvements in production practices and provide a competitive advantage to producers that comply with these standards, ${ }^{141}$ they can also be extremely burdensome for suppliers in less developed countries, and in particular for small-scale producers. ${ }^{142}$ Despite the fact that compliance with private sector standards is voluntary, these standards have an important impact on international trade. This is due to the fact that compliance with particular private sector standards is required by large supermarket chains which control the greatest share of the market, ${ }^{143}$ making the standards de facto mandatory for producers, especially of high-value food and agricultural products, wishing to export their products. ${ }^{144}$ Thus, the distinction between mandatory SPS requirements laid down in regulations and voluntary SPS standards demanded by private parties is losing much of its relevance for economic operators in the food and agricultural industries.

139 Poverty Reduction \& Economic Management Trade Unit and Agriculture and Rural Development Department, Food Safety and Agricultural Health Standards: Challenges and Opportunities for Developing Country Exports, 31207 (World Bank, Washington D.C.), 2005, 4-5 and 30, available at: http://www-wds. worldbank.org/external/default/WDSContentServer/WDSP/IB/2005/01/25/000160016_20050125093841/ Rendered/PDF/31207.pdf, visited on 18 May 2008.

${ }^{140}$ An exception to this is, of course, where human health risks may flow from pests or diseases of plants or animals. In such cases, consumer demands and liability regimes do create incentives for stricter private standards. An example of this is the refusal of retailers to stock British beef in the aftermath of the BSE crisis.

${ }^{141}$ Jaffee and Masakure provide an example of the successful, though costly, adjustment of the leading suppliers in the Kenyan vegetable industry to meet stringent private sector standards. The impetus for this strategic reorientation of the relevant industry is ascribed to the realisation of Kenyan suppliers of the need to gain a competitive advantage in the face of increased competition from North and West African suppliers. The large investments undertaken in implementing a range of food safety and quality systems to achieve compliance with private sector standards have resulted in the forms involved gaining the status of preferred suppliers to European retailers. Steve Jaffee and Oliver Masakure, 'Strategic Use of Private Standards to Enhance International Competitiveness: Vegetable Exports from Kenya and Elsewhere', Food Policy 30, 2005,316 -333 .

142 Digby Gascoine et al., Private Voluntary Standards within the WTO Multilateral Framework (United Kingdom Department for International Development, London), March 2006, Executive Summary para. 2. With regard to the exclusionary effect of private sector standards on small holders in OECD countries, see Linda Fulponi, Final Report on Private Standards and the Shaping of the Agro-Food System, AGR/CA/ $\operatorname{APM}(2006) 9 /$ FINAL (Organisation for Economic Co-operation and Development, Paris), 31 July 2006, para. 76, available at: http://www.olis.oecd.org/olis/2006doc.nsf/43bb6130e5e86e5fc12569fa005d004c/4e3a2945 ffec37eec12571bc00590ce3/\$FILE/JT03212398.PDF, visited on 27 May 2008.

${ }^{143}$ The high level of concentration within food retailing, so that in many industrialised countries five firms control over $50 \%$ of the food retail market, is the main driving factor for buyer-driven supply chains. These firms are often multinationals, and source their products globally, making use of vertical integration or exclusive contracts with preferred suppliers. Spencer Henson, 'The Role of Public and Private Standards in Regulating International Food Markets', presented at the IATRC Summer Symposium on Food Regulation and Trade: Institutional Framework, Concepts of Analysis and Empirical Evidence, Bonn) May 28-30 2006, 10-11, available at: http://www.ilr1.uni-bonn.de/iatrc/iatrc_program/Session\%204/Henson.pdf, visited on 27 May 2008. This situation raises concerns from a competition perspective, as such firms are able to impose their requirements on suppliers which are obliged to comply or will be excluded from the market.

144 Digby Gascoine et al., Private Voluntary Standards within the WTO Multilateral Framework (United Kingdom Department for International Development, London), March 2006, Annex 1, 40. 
However, the distinction retains its importance when one bears in mind the role of the SPS Agreement in disciplining government, not private, action. ${ }^{145}$ As the SPS Agreement was negotiated before private sector standards became widespread in the SPS area, it was not intended to extend to these standards. Instead, the SPS Agreement is based on the traditional view of the role of government regulation in the area of sanitary and phytosanitary risks, as discussed above. In this view, self-regulation, voluntary schemes and purchaser requirements can be regarded as market instruments used by economic operators to ensure that the supply of risk-free food and agricultural products meets the demand for these products in a way that maximises profits. ${ }^{146}$ This is normal, and acceptable, market behaviour. However, due to market failure, operators are not induced to take into account the interests of all affected actors. ${ }^{147}$ The unregulated market therefore fails to provide an optimal level of safe food and agricultural products or leads to distributional problems. ${ }^{148}$ Therefore, governments step in to oblige operators on the market to act in a way that will result in an optimal safety level, equally accessible to all. The vulnerability of government regulators to private interest pressures, however, may result in sub-optimal or protectionist regulations. It is therefore government intervention in the market that needs to be disciplined. The SPS Agreement was negotiated to meet this need. ${ }^{149}$

${ }^{145}$ As discussed below, Part III, Section 2.2, the SPS Agreement does not apply directly to SPS requirements laid down by private operators, although Article 13 does require Members to take reasonable measures to ensure that non-governmental entities in their territories comply with the relevant rules of the SPS Agreement. Note that at the SPS Committee meeting of 29-30 June 2005 the issue of private sector standards was raised for the first time by St. Vincent and the Grenadines (supported by Jamaica, Peru, Ecuador and Argentina), who complained about EUREPGAP standards that are stricter than government standards. Some Members called for a clarification of Article 13 of the SPS Agreement. The discussion on whether private standards should be caught by the disciplines of the SPS Agreement is still ongoing in the SPS Committee. See further on this point below, Part III, Section 2.2, regarding the scope of application of the SPS Agreement.

${ }^{146}$ Although the profit motive is not the basis for voluntary standards set by non-governmental organisations, these standards usually reflect concerns such as fair trade, environmental protection and animal welfare, rather than concerns with SPS risks, and therefore fall outside the scope of this discussion.

${ }^{147}$ As noted in the WTO's World Trade Report of 2005: 'The distinction between public and private standards will depend not so much on whether standards are public law, but rather on whose interests are taken into account when a standard is set and enforced. In the case of public standards, it is assumed that the interests of all actors in an economy are taken into account when the standard is set. This implies that the effect on the profits of all companies and the wellbeing of all consumers has been considered. Externalities like those related to the environment or to public health are also factored into the decision-making of the government. Private standards, on the other hand, are assumed to take account only of the profits of firms. Depending on the situation, individual firms will decide if they are willing to cooperate in standard-setting activities. Private standards may implicitly take consumer interests into account, but only if these interests correspond to their own interests.' WTO Secretariat, World Trade Report 2005: Exploring the Links between Trade, Standards and the WTO (World Trade Organization, Geneva), 30 June 2005, 32-33, available at: http://www.wto.org/ english/res_e/booksp_e/anrep_e/world_trade_report05_e.pdf, visited on 4 June 2007.

148 This issue is discussed above, Part II, $\overline{\text { Section }} 1.2$.

149 Whether this approach is still appropriate in the light of the proliferation of private sector standards in the SPS area is open to question. This issue is discussed in the analysis of the personal scope of application of the SPS Agreement, below, Part III, Section 2.2. 


\subsection{Costs and benefits of sanitary and phytosanitary regulation}

Government regulations to address SPS risks entail both costs and benefits. However, these costs and benefits vary across countries depending on their level of development. ${ }^{150}$ The relative significance of SPS risks (and thus the benefit of risk regulation) for a country differs according to several factors, including the average income level, the population's diet, the importance of the food and agricultural sector for the economy, the level of industrialisation, climatic conditions, availability of health services and the prevalence of other threats to health. Similarly, the costs of regulation vary depending on the existence and adequacy of regulatory infrastructure, the capacity of producers, processors and retailers to meet regulatory requirements and climatic conditions, among other factors. These divergences in costs and benefits are reflected in the differences in regulatory decisions governments make with regard to similar health risks. Although many governments do not undertake explicit cost/benefit analysis as part of the regulatory decision-making process, these considerations often underlie the different tradeoffs governments at different levels of development make between various priorities.

\subsubsection{Benefits of SPS regulation}

The benefits from SPS regulation seem obvious. Improved food safety leads to better health of the domestic population and improved quality of life. Better health, in turn, has economic benefits due to increased productivity ${ }^{151}$ and a diminished burden on public health services and the welfare system. However, in countries with poor sanitation and impure drinking water, the significance of these benefits may be decreased. In such countries, national health priorities may focus on the provision of basic services such as clean water, sanitation and primary health care. Reduction in factors causing adverse health effects in the long-term may be less important in a country where life expectancy is low.

The regulation of SPS risks not only has the benefit of reducing health risks but also has the benefit of increasing the confidence of consumers and (domestic and foreign) retailers in the safety of the food and agricultural products subject to the regulation. The more effective and rigorous the regulatory system, the more consumers and retailers will trust in the system and be willing to buy the products which meet regulatory requirements and are thus allowed on the market. ${ }^{152}$ In the absence of regulation, the distrust of consum-

${ }^{150}$ Wilson and Otsuki emphasise the increasing importance of developing new ways to measure the costs and benefits of changes in SPS requirements so that public policy decisions can be informed by empirical evidence regarding the trade effect of different SPS requirements. John S. Wilson and Tsunehiro Otsuki, Food Safety in Food Security and Food Trade: Balancing Risk Reduction and Benefits from Trade in Setting Standards (International Food Policy Research Institute, Washington D.C.), September 2003.

${ }^{151}$ A 2005 UNCTAD report notes that effective implementation of consumer protection policies has an important impact on development. In particular, it notes that poor quality food not only leads to health risks for consumers but also to 'reduced and more variable (and, therefore, less reliable) labour force participation through sickness.' Philippe Brusick et al., Strengthening Institutions and Capacities in the Area of Competition and Consumer Protection Policies in Latin America: Cases of Bolivia, Costa Rica, El Salvador, Honduras, Guatemala, Nicaragua and Peru, UNCTAD/DITC/CPL/2004/3 (United Nations Conference on Trade and Development, New York and Geneva), 2005, xv, available at: http://www.unctad.org/en/docs/ditcclp20043_en.pdf, visited on 7 June 2008.

${ }^{152}$ The COMESA Secretariat, in its report on market access constraints on the EU market notes that SPS measures may facilitate and enhance trade by increasing consumer confidence in imported products by reducing 
ers, retailers and importing companies may lead to avoidance of certain products and distortions in consumption patterns. ${ }^{153}$ Consumers and retailers are often willing to pay a premium for products certified as being of a particular safety level by an authority they trust. For example, consumers may be prepared to buy higher-priced fruit that is certified as organically grown by a reputable body. Similarly, a foreign retailer wishing to provide food free from genetic modification may source its fresh produce from countries that have a good regulatory system in place to ensure segregation of genetically-modified and conventional crops. In this way, SPS regulation may improve profits and export potential.

These benefits may, however, be more significant in countries where affluent consumers are able to pay higher prices for high-quality products (or countries able to export to such affluent markets) than in countries where such products would be financially out-of-reach for the majority of consumers. In addition, in countries with large urban populations, where the chain of supply from the farm to the table is longer and more complex, and food products are highly processed, consumers rely greatly on regulatory systems to ensure the safety of food products as they are not in a position to be able to identify and control risks themselves. In contrast, in many countries with large rural populations, consumers buy fresh food products directly from farmers or local fresh produce markets and are able to exercise more direct control due to their experience with the product and their familiarity with their regular suppliers. This reduces the benefits of SPS regulation.

Further, it has been argued that the benefits of increased confidence or reduced fear due to SPS regulation exist even when fears are ungrounded. ${ }^{154}$ If fear of exposure to risk is viewed as a real social cost in the sense that it diminishes consumer welfare, then the 'reduction of even a baseless fear is a social good'. ${ }^{155}$ Consumers may be willing to pay to reduce fears, even if those fears are irrational or out of proportion to the probability of a risk occurring. Often, government action in the form of informing or educating the public is not effective in eliminating groundless fears. ${ }^{156}$ In such cases, SPS regulation may

risks of unsafe food. COMESA Secretariat, Market Access Constraints (Common Market for Southern Africa, Lusaka), 2003, para. 51, available at: www.comesa.int/trade/multilateral/epa/Market $\% 20$ Access $\% 20$ Constraints/en, visited on 10 January 2008.

${ }^{153}$ Howard F. Chang, Risk Regulation, Endogenous Public Concerns, and the Hormones Dispute: Nothing to Fear but Fear Itself?, Research Paper 03-25 (University of Pennsylvania Law School, Institute for Law and Economics, Pennsylvania), August 2003, 8, available at: http://ssrn.com/abstract_id=432220, visited on 12 June 2006. Chang gives the example that European consumers who have concerns regarding eating hormonetreated beef may avoid eating beef altogether in the absence of regulation dealing with this risk. Although a ban on hormone-treated beef entails costs for consumers, these costs may be smaller than the costs from distortions in consumption patterns that would result from consumer anxieties in the absence of regulation.

154 Robert Howse argues that: 'the utility from regulation comes not only from the reduced likelihood of an event that one disvalues, but also from the psychological security that results from one's belief about the protection one is receiving.' Robert Howse, 'Democracy, Science, and Free Trade: Risk Regulation on Trial at the World Trade Organization', Michigan Law Review 98, 2000, 2329-2357, 2350.

${ }^{155}$ Cass R. Sunstein, 'Probability Neglect: Emotions, Worst Cases, and Law', Yale Law Journal 112, 2002, 61107,104 . Sunstein points out that there are enormous ripple effects associated with fear, as widespread fear leads to a host of additional problems, for example making people reluctant to engage in certain activities.

${ }^{156}$ Howard Chang claims that 'there may be little reason to believe that efforts to explain risk would be as effective in reducing fear as a regulatory response would be.' Howard F. Chang, Risk Regulation, Endogenous Public Concerns, and the Hormones Dispute: Nothing to Fear but Fear Itself?, Research Paper 03-25 (University of Pennsylvania Law School, Institute for Law and Economics, Pennsylvania), August 2003, 11, available at: http://ssrn.com/abstract_id=432220, visited on 12 June 2006. 
create social benefits in the form of fear reduction. ${ }^{157}$ How highly fear reduction with regard to SPS risks is valued in a particular country depends on many factors, including the risk-averseness of a particular society, the relative importance of SPS risks as compared to other health risks and the scarcity of resources available to pay for such risk reduction. Thus these benefits may be greater in affluent countries than in countries at lower levels of development.

Regulations laying down information requirements have the benefit of correcting market failures that arise due to information asymmetries between suppliers and purchasers. ${ }^{158}$ Examples of this type of regulation are the requirements that products containing chemical additives be labelled as such, or that the presence of known allergens, such as nuts, in processed foods be clearly indicated on the label. Such regulation should eliminate the losses that arise when demand for a product is artificially high due to a lack of information regarding the risks on that product, leading to a misallocation of resources towards supplying larger quantities of that product than are efficient. However, the ability of consumers to read and understand information provided depends on their literacy, level of education and awareness of the health effects of the labelled ingredients. Such regulations may not create much benefit in countries where the level of education is low or consumer awareness of risks is lacking. ${ }^{159}$

Regulations to prevent the introduction and spread of plant and animal pests and diseases create benefits in the form of a healthier agricultural industry. Additional production costs for farmers in the form of veterinary services and herbicide and pesticide outlay are minimised and losses resulting from reductions in herds and harvest outputs due to pests or diseases are avoided if the regulatory systems in place are effective in addressing SPS risks. Farmers may also be able to access markets for higher quality crops and animal products. In addition, the export potential of the plant or animal products may increase due to their greater acceptability on foreign markets. Once again, the benefits of these regulations depend on the prevailing animal and plant health status in the national territory and the existence of demand for high-quality products at higher prices. Where droughts, poor soil conditions, inadequate animal feed and harsh climatic conditions are significant factors affecting animal and plant health, SPS regulations may bring limited benefits.

It appears, therefore, that while there are many benefits to be reaped from regulations to protect against SPS risks, the magnitude of these benefits is dependent on factors relating to the initial conditions in the relevant country, which in turn is linked to its level of development.

\footnotetext{
${ }^{157}$ Chang argues that it is important to distinguish between fears that have an objective source and fears that are artificially generated in this regard. Some fears are generated by publicity and media sensationalism and promoted by private interests that would benefit from regulation. To regulate in such cases would provide an incentive to private interest groups to generate fears to trigger regulation. Regulation could also lend credibility to baseless fears and sustain them, whereas they might otherwise have dissipated with time. Ibid., 19-24.

158 Anthony Ogus, Regulation: Legal Form and Economic Theory (Clarendon Press, Oxford), 1994, 152.

159 Ogus notes that 'information regulation tends to discriminate against those with poor educational attainment'. Ibid., 153.
} 


\subsubsection{Costs of SPS regulation}

SPS regulations also entail costs. These costs may be borne by domestic private producers and processors, by the domestic public sector, or by foreign producers or governments with export interests in the domestic market.

In the first place, SPS regulations lead to compliance costs. Compliance costs are those additional costs necessarily incurred in order to meet an SPS requirement, beyond the costs that would have been incurred in the absence of the SPS requirement. ${ }^{160}$ Economic operators in the private sector bear many of these compliance costs. The costs for producers of complying with the requirements laid down in SPS regulations may be high. For example, farmers may have to invest in better pest-control systems, modern harvesting equipment, segregated storage bins, etc. There may also be significant costs for processors, for example in achieving better sanitary levels in processing plants, training staff with regard to hygiene and cleanliness, investing in refrigeration facilities and implementing new risk management systems such as HACCP. ${ }^{161}$ Aside from these compliance costs that often entail substantial investments, recurring compliance costs also exist in the form of higher production costs flowing from the SPS requirements. ${ }^{162}$

The impact of these compliance costs varies greatly depending on the size of the affected enterprise or economic operator and the availability of supporting infrastructure. Smallscale enterprises are less able to absorb the costs of adjustment to SPS requirements than are large-scale enterprises whose costs are reduced by economies of scale. In addition, small-scale producers often lack access to credit and have large fixed costs. As farmers are often unable to influence the price of their products and can therefore not pass on additional costs to the buyer, their ability to bear the additional costs is determinative of their survival on the market. ${ }^{163}$ Particularly in countries at lower levels of development

160 Poverty Reduction \& Economic Management Trade Unit and Agriculture and Rural Development Department, Food Safety and Agricultural Health Standards: Challenges and Opportunities for Developing Country Exports, Report no. 31207 (World Bank, Washington D.C.), 10 January 2005, 67, available at: http:// siteresources.worldbank.org/INTRANETTRADE/Resources/Topics/Standards/standards_challenges_synthesisreport.pdf, visited on 27 June 2008.

${ }^{161}$ For a brief discussion of the HACCP system, see above, Part II, Section 1.3.

162 The abovementioned World Bank report emphasises the distinction between recurring and non-recurring costs and notes that there may be significant economies of scale for non-recurring costs, high recurring costs can reduce competitiveness by increasing the production cost per unit. Poverty Reduction \& Economic Management Trade Unit and Agriculture and Rural Development Department, Food Safety and Agricultural Health Standards: Challenges and Opportunities for Developing Country Exports, Report no. 31207 (World Bank, Washington D.C.), 10 January 2005, 68, available at: http://siteresources.worldbank.org/ INTRANETTRADE/Resources/Topics/Standards/standards_challenges_synthesisreport.pdf, visited on 27 June 2008 .

${ }^{163}$ For example, a case study in Latin America has shown that supermarkets there do not pay a premium for good quality produce but set a price and buy the produce that meets their safety/quality requirements at that price. Thus the producer is responsible for meeting the requirements and bears the costs for this, without being able to pass them on to the supermarkets. This results in changes to the structure of production in the food and agricultural sector. In Latin America the vast majority of fresh fruit and vegetables bought by supermarkets are produced by medium to large enterprises who can afford the additional costs. Small-scale enterprises are thus pushed out of the market. Julio A. Berdeguë et al., Food Safety in Food Security and Food Trade: Case Study: Supermarkets and Quality and Safety Standards for Produce in Latin America (International Food Policy Research Institute, Washington D.C.), September 2003, available at: http://www.ifpri.org/2020/ focus/focus10/focus10_12.pdf, visited on 23 January 2008. 
where agricultural production is often largely in the hands of smallholders, these compliance costs may have a significant impact on small-scale enterprises and may put them out of business. ${ }^{164}$

The costs of SPS regulation for producers and suppliers of food and agricultural products relate not only to compliance with the requirements set in the relevant regulations, but also to being able to demonstrate such compliance. This necessitates the existence of an infrastructure for monitoring, testing and certification of compliance. The authority assessing and certifying conformity must be recognised and trusted. In developed countries where such infrastructure exists on public level and enjoys the confidence of both domestic and foreign buyers, producers bear little cost in respect of demonstrating compliance with SPS requirements. In countries with less-developed SPS systems, however, this infrastructure is often lacking, or its ability to ensure compliance is not trusted. This means that producers and suppliers in such countries may face rejection of their products both by domestic buyers and, more often, on foreign markets, not due to the fact that they are unsafe, but rather because compliance with SPS requirements cannot be reliably proven. ${ }^{165}$ Private systems of conformity assessment and certification are very costly and difficult to implement. ${ }^{166}$ Particularly with respect to foreign markets, recognition of the competence of such private certification bodies is hard to achieve.

An additional, but related, cost of SPS regulation for producers or suppliers is what could be termed 'non-compliance' costs. This refers to the costs resulting from the rejection of products that do not meet the applicable SPS requirements. Sometimes such products are impounded and destroyed by the relevant authorities, resulting in complete loss to the economic operators. In other cases they may be released to the relevant operator who may divert the products to another market where SPS requirements are less strict. This most often means that a reduction in price on the alternative market must be accepted and, in

164 This point was made by the COMESA Secretariat in its report on market access barriers in the EU. COMESA Secretariat, Market Access Constraints (Common Market for Southern Africa, Lusaka), 2003, para. 52, available at: www.comesa.int/trade/multilateral/epa/Market $\% 20$ Access $\% 20$ Constraints/en, visited on 10 January 2008.

${ }^{165}$ The COMESA Secretariat notes that Eastern and Southern African countries: 'face difficulties in entering the EU food market not necessarily because their products are unsafe but often because the ESA country lacks the monitoring, testing and certification infrastructure that would make it possible for them to demonstrate compliance with import requirements.' It gives the example of the EU rules with regard to import of live animals or animal products, which require that the competent national authority demonstrate that it has a competent management structure, is independent of outside pressures, has sufficient resources and staff, conducts training programmes, has enforcements powers, has properly sourced laboratory services, maintains effective import controls, has an effective detection and notification system for animal diseases, and applies appropriate food safety controls. Import approval will not be considered if any of these requirements is not met. Ibid., para. 53 .

${ }^{166}$ Such private certification is more often found with respect to quality requirements than with respect to safety requirements and occurs mainly within large multinational food enterprises that source their products in developing countries for sale on developed country markets. However, private food-safety certification schemes do exist, one example of which is the third-party certification of food safety used by a major food supplier in Guatemala, Honduras and Nicaragua, as reported in Julio A. Berdeguë et al., Food Safety in Food Security and Food Trade: Case Study: Supermarkets and Quality and Safety Standards for Produce in Latin America (International Food Policy Research Institute, Washington D.C.), September 2003, available at: http://www. ifpri.org/2020/focus/focus10/focus10_12.pdf, visited on 23 January 2008. 
the case of perishables, that additional losses are incurred from spoilage due to the delay in getting the products onto a market.

The extent to which a country has a well-functioning administration also affects the level of costs from SPS regulation. In countries where administrative procedures for the implementation and enforcement of SPS regulations are untransparent, inappropriate or inadequate or where bureaucratic corruption is rife, SPS regulation may create additional costs for producers. A recent UNCTAD report has noted that these costs can take the form of 'bureaucratic harassment of the public sector and a more uncertain business climate' and thus counteract the positive effects of SPS regulation on development. ${ }^{167}$

Aside from costs to private enterprises in the food and agricultural sector, public costs are generated by SPS regulation. The enactment, implementation and enforcement of domestic SPS regulations, and the determination and certification of compliance with foreign SPS requirements, by regulatory agencies and government departments entail public expenditure. For example, scientifically trained and technically skilled officials are needed to identify SPS risks and draft appropriate regulations to address such risks. Trained staff is required to undertake inspections of processing plants, storage facilities and products and to conduct sampling and testing activities to monitor compliance with (domestic and foreign) SPS requirements and administer certification schemes. Public infrastructure is also necessary to enforce SPS regulations; for example, well-equipped laboratories staffed by trained personnel are required for testing for chemical residues and microbiological contamination; and quarantine facilities are necessary at entry points to contain infested imports and prevent the entry of pests. In countries with a large tax base and sufficient public revenue, these costs may be easier to bear and therefore these countries often have well-established and effectively functioning SPS regimes in place. The enactment and enforcement of new SPS regulations and the determination of compliance with new foreign SPS requirements consequently do not entail significant additional costs. ${ }^{168}$ Developed countries also tend to prioritise SPS issues as an area of government spending. In many developing countries, however, scarce public resources may be directed towards more pressing social needs which reflect the development priorities of the relevant country. As a result, the necessary public infrastructure and expertise to deal with SPS risks is weak or lacking. This means that the enactment and enforcement of SPS

${ }^{167}$ Philippe Brusick et al., Strengthening Institutions and Capacities in the Area of Competition and Consumer Protection Policies in Latin America: Cases of Bolivia, Costa Rica, El Salvador, Honduras, Guatemala, Nicaragua and Peru, UNCTAD/DITC/CPL/2004/3 (United Nations Conference on Trade and Development, New York and Geneva), 2005, xv, available at: http://www.unctad.org/en/docs/ditcclp20043 en.pdf, visited on 14 September 2006. This report deals with consumer protection in general, including with regard to foodsafety issues.

${ }_{168}$ As referred to above, a World Bank study notes that recurring and non-recurring costs should be distinguished. Non-recurring costs (such as upgrading SPS infrastructure and implementing new risk management systems) entail one-off or time-limited investments. Recurring investments (such as the costs of regular surveillance and testing) instead, are on-going. Poverty Reduction \& Economic Management Trade Unit and Agriculture and Rural Development Department, Food Safety and Agricultural Health Standards: Challenges and Opportunities for Developing Country Exports, Report no. 31207 (World Bank, Washington D.C.), 10 January 2005, 68, available at: http://siteresources.worldbank.org/INTRANETTRADE/Resources/Topics/ Standards/standards_challenges_synthesisreport.pdf, visited on 27 June 2008. Here it is argued that where the non-recurring public costs of setting up an effective SPS regime have already been borne by the relevant country, the additional costs of maintaining and adapting that system will most often be relatively small. 
regulations, and ensuring compliance with foreign SPS requirements, in such countries will require substantial investments.

Indirect economic and social costs may also arise from SPS regulation. ${ }^{169}$ To the extent that regulation may serve to lend credibility to baseless or disproportionate fears of health risks, it may impose social costs ex post, in the form of distortions in behaviour and consumer demands that the needless regulation remain in place. ${ }^{170}$ Without such regulation, it is likely that many groundless fears, particularly those that are created artificially by publicity and media attention, may dissipate with time and increased familiarity with the product. ${ }^{171}$ Also, regulation may indirectly generate ex ante costs in the form of incentives for special interest groups that stand to benefit from the relevant regulation, to generate public fears in order to induce regulation. ${ }^{172}$

In addition, if SPS regulation results from pressure from interest groups, for example from an industry that stands to gain from the regulation through protection from competition it would otherwise have faced, it gives rise to costs in the form of welfare loss due to the elimination of competition. The industry gains rents as they can charge higher prices than they could in the presence of competition. ${ }^{173}$ Thus wealth is transferred from consumers to the industry. ${ }^{174}$

${ }^{169}$ Ogus notes that indirect costs are: 'the generally unintended, and sometimes perverse, consequences of regulation.' However, he points out in footnote that these costs 'may, of course, be intended by those who benefit from them!' Anthony Ogus, Regulation: Legal Form and Economic Theory (Clarendon Press, Oxford), 1994, 155 and note 124 .

${ }^{170}$ Howard F. Chang, Risk Regulation, Endogenous Public Concerns, and the Hormones Dispute: Nothing to Fear but Fear Itself?, Research Paper 03-25 (University of Pennsylvania Law School, Institute for Law and Economics, Pennsylvania), August 2003, 21, available at: http://ssrn.com/abstract_id=432220, visited on 12 June 2006. Chang notes that this is especially the case if the relevant regulations prevent consumers from gaining experience with the supposedly risky product. This point is also made by Sunstein, who notes that '[i]f government attempts to reduce fear by regulating the activity that produces it, it may well intensify that very fear, simply by suggesting that the activity is worth regulating.' He points to the example of a labelling requirement for genetically modified food, which may suggest a danger that (arguably) does not exist. Cass R. Sunstein, 'Probability Neglect: Emotions, Worst Cases, and Law', Yale Law Journal 112, 2002, 61-107, 104.

171 Sunstein notes that: '[s]ometimes the fear that accompanies probability neglect diminishes over time, as experience moves the activity or process from the cognitive category of "unsafe" to "safe". A regulatory approach might prevent this process (salutary when the risk is really low) from occurring.' Cass R. Sunstein, 'Probability Neglect: Emotions, Worst Cases, and Law', Yale Law Journal 112, 2002, 61-107, 104-105.

172 Howard F. Chang, Risk Regulation, Endogenous Public Concerns, and the Hormones Dispute: Nothing to Fear but Fear Itself?, Research Paper 03-25 (University of Pennsylvania Law School, Institute for Law and Economics, Pennsylvania), August 2003, 22, available at: http://ssrn.com/abstract_id=432220, visited 12 June 2006. For example, with regard to the regulatory response to consumer fears following the BSE outbreak, Loppacher and Kerr note that 'most regretfully, certain groups with vested interests have actively worked to fuel those fears for their own benefit. Politicians have recognised this consumer fear and want to ensure that they are seen as doing something to protect their citizens.' Laura J. Loppacher and William A. Kerr, 'The Efficacy of World Trade Organization Rules on Sanitary Barriers: Bovine Spongiform Encephalopathy in North America', Journal of World Trade 39 (3), 2005, 427-443, 429.

${ }^{173}$ For an explanation of 'rents', see note 104 above.

174 Ogus notes that: 'such wealth transfer can be condemned on distributional grounds' but that there are also narrower economic grounds to condemn rent-seeking behaviour, namely 'the waste engendered by devoting resources to capturing the wealth transfers, an activity which from society's point of view, is entirely unproductive.' Anthony Ogus, Regulation: Legal Form and Economic Theory (Clarendon Press, Oxford), $1994,73$. 
Other indirect costs may arise from SPS regulation. For example, SPS regulations laying down requirements regarding processes and production methods may stifle innovation. ${ }^{175}$ These costs are often difficult to quantify and to trace back to the regulatory action. Nevertheless, in some cases they may be quite substantial.

\subsubsection{Cost/benefit analysis}

As has been mentioned above, SPS regulation aims to address the failure of the market to achieve the public goal of health protection, due to problems of lack of information and externalities. However, as we have seen, regulation brings not only benefits but may entail substantial costs. Thus, in order to ensure that SPS regulation is welfare enhancing and leads to the most efficient allocation of resources, regulators should determine whether the benefits of the proposed regulation exceed its costs.

In economic terms, the Kaldor-Hicks criterion is the most appropriate to test the allocative efficiency of regulation. ${ }^{176}$ According to this test, a policy is efficient if the aggregate gains there from exceed the aggregate losses, so that those who stand to gain from the policy could, theoretically, compensate the losers. ${ }^{177}$ It is this test that forms the conceptual base for standard cost-benefit analysis of regulation. ${ }^{178}$

Ideally, according to the law-and-economics approach, each country would undertake such a cost/benefit analysis prior to taking a decision on whether to regulate in a particular situation, and if so, what level of protection to secure and what SPS measure to adopt to achieve this level of protection. However, this is very often not the case. Frequently, regulators lack the necessary information to undertake adequate cost/benefit analyses in order to determine the most welfare-enhancing regulatory outcomes. ${ }^{179}$ In many cases the relevant information is very costly or difficult to obtain. In addition, the value of certain costs and benefits may be very difficult to quantify. ${ }^{180}$ The uncertainty that commonly exists with regard to the effects of regulation aggravates this situation. ${ }^{181}$

${ }^{175}$ Ogus calls this type of requirement a 'specification standard' and notes that as a specification standard prescribes inputs in the production process and prohibits other inputs, it 'induces technological rigidity, since it inhibits firms from innovating in general, and from developing other, cheaper means of meeting regulatory targets in particular.' Ibid., 169.

176 The Pareto test of efficiency requires that at least one individual gains and no-one loses by the action. SPS regulation will almost never be Pareto-efficient as some individuals will unavoidably bear the costs of such regulation and thus be 'losers'. Ibid., 24.

${ }_{177}$ Ogus notes, however, that this test does not require that the winners actually compensate the losers. Ibid., 24-25.

178 This point is made by Ogus. Ibid., 25 .

179 Howard F. Chang, Risk Regulation, Endogenous Public Concerns, and the Hormones Dispute: Nothing to Fear but Fear Itself?, Research Paper 03-25 (University of Pennsylvania Law School, Institute for Law and Economics, Pennsylvania), August 2003, 23, available at: http://ssrn.com/abstract_id=432220, visited on 12 June 2006.

${ }^{180}$ According to Ogus, the benefits of regulation are more difficult to quantify that the costs. He attributes this to four reasons. First, the many benefits of regulation are diffuse and removed in time and space from the regulated activity. Second, establishing causality between the regulation and the benefit may be difficult. Third, often the benefits are non-marketed assets (such as life and health) which are difficult to convert to units of currency. Fourth, benefits may arise over long periods of time, necessitating the use of a discounting method to establish current value. Anthony Ogus, Regulation: Legal Form and Economic Theory (Clarendon Press, Oxford), 1994, 156.

${ }^{181}$ One alternative to cost-benefit analysis, in response to the difficulties of obtaining the necessary information 
In addition, private-interest influence means that government regulation may not always reflect the optimal or most efficient balance between costs and benefits. Instead, certain pressure groups such as domestic industry may be the beneficiaries of regulatory interventions, leading to sub-optimal results and thus regulatory failure. ${ }^{182}$ This is particularly the case when the competitors prejudiced by the regulation are foreign businesses, as they have insufficient influence with the regulating government to counteract the pressure from domestic interest groups. ${ }^{183}$ Thus, the danger exists that regulators may undervalue the costs of regulation for foreign competitors. ${ }^{184}$ The resulting regulations may therefore serve as protectionist tools for the benefit of domestic industry. ${ }^{185}$ Another form of privateinterest influence, as discussed above, is that of politicians and bureaucracies responsible for SPS regulation. Their wish to be seen to respond decisively to health risks may mean that those risks that are receiving most media attention are overvalued.

A mechanism is necessary to prevent such inefficient outcomes and to establish disciplines on governments' regulatory actions. The difficulty of conducting accurate cost/ benefit analyses of regulatory initiatives means that this type of evaluation is not used to discipline government action in the area of SPS risks. Increasingly, countries have turned to science as the basis on which to establish such disciplines and use it as the touchstone against which SPS regulations can be judged. ${ }^{186}$ Chang argues that science serves as a 'proxy' for the circumstances justifying regulation. As it may be too costly or otherwise impossible to gather all the relevant information on the costs and benefits of regulation, science can be used as an indicator or a 'proxy' for the variables that would ideally be

that is described by Ogus is that of 'cost-effectiveness analysis'. According to this second-best approach, a policy-maker may first establish a goal (for example a $10 \%$ reduction in the risk of microbiological contamination of meat) and the regulator must formulate requirements so as to achieve that goal at the lowest possible cost. Alternatively, the policy-maker may specify the cost (for example a budgetary limit of US\$500 000 ) and the regulator must then formulate requirements so as to maximise the benefits from the use of those resources. Ibid., 161.

182 Ogus points out that when regulation results from democratic processes it broadly reflects the range of economic interests in society and there is 'a good chance that it will be Kaldor-Hicks efficient, the aggregate gains from the measure exceeding the aggregate losses.' However, if the democratic process is frustrated by private interest groups, 'concentrated, minority economic interests prevail over the more widespread, majority economic interests; and the Kaldor-Hicks test of efficiency is not satisfied'. Ibid., 72-73.

${ }^{183}$ Howard F. Chang, Risk Regulation, Endogenous Public Concerns, and the Hormones Dispute: Nothing to Fear but Fear Itself?, Research Paper 03-25 (University of Pennsylvania Law School, Institute for Law and Economics, Pennsylvania), August 2003, 25, available at: http://ssrn.com/abstract_id=432220, visited on 12 June 2006.

${ }^{184}$ Joanne Scott refers to Robert Keohane in this regard. Joanne Scott, European Regulation of GMOs: Thinking About 'Judicial Review' in the WTO, Jean Monnet Working Paper 04/04 (Jean Monnet Program, New York), 2004, 13, available at: www.jeanmonnetprogram.org/papers/04/040401.pdf, visited on 24 November 2007. Keohane argues that since the impact of regulation extends beyond the domestic jurisdiction, a problem of 'external accountability' arises (i.e. accountability of the decision-making body to the people outside its jurisdiction who are affected by its decisions). Keohane sees the WTO as promoting external accountability through its transparency requirements and possibilities for sanctions on the decision-maker. Robert Keohane, 'Global Governance and Democratic Accountability', in Taming Globalization: Frontiers of Governance, David Held and Mathias Koenig-Archibugi (ed.) (Polity Press, Cambridge), 2003, 130-159, 150-151.

185 Howse argues that: 'especially with respect to trade regulations, 'democratic' outcomes typically reflect capture of the regulatory process by concentrated interests'. Robert Howse, 'Democracy, Science, and Free Trade: Risk Regulation on Trial at the World Trade Organization', Michigan Law Review 98, 2000, 2329 2357, 2333.

${ }^{186}$ Howse believes that 'hand-tying of the political process by international rules, or by an apolitical authority such as 'science,' actually may enhance domestic welfare.' Ibid. 
considered. The use of a simple proxy is less costly and results in regulatory outcomes that are more predictable. ${ }^{187}$ It is useful to examine, therefore, the use of science in the national regulatory process. This will assist in the understanding of the science-based disciplines on national SPS regulation contained in the SPS Agreement, discussed in Part III of this book.

\subsection{Role of scientific analysis in national SPS regulation}

National health regulation is normally purported to be based on scientific findings. Without such basis, regulatory measures would be subject to criticism at national level. In fact, it has been argued that science is used 'as a screening device to rationalise priorities in risk regulation and, in particular, to ensure that government resources and authority are directed toward substantial risks as opposed to small or trivial ones.' ${ }^{188}$

Regulations gain authoritative validity through recourse to scientific justifications. This has been termed the 'meta-legal' authority of science. ${ }^{189}$ Since the early 1970s, in developed countries national legislation governing the enactment of regulations by agencies began explicitly to set scientific justification requirements against which the validity of these regulations can be tested. Scientific committees were created to provide the input into the regulatory process necessary for rational decision making. Currently, scientific assessments of risks to human, animal or plant life or health determine areas in which regulatory action is necessary, and science is also used to evaluate the efficacy of the various possible measures in order to design an appropriate regulation. ${ }^{190}$ Thus, it is clear that at national level, particularly in developed countries, science plays an important role in the regulatory process.

However, that is not the whole story. In practice, regulatory design is more than just a scientific discipline. Public health measures also reflect social policy choices. One must bear in mind that regulators do not operate in a vacuum. Instead, regulations are drafted in a particular economic, social and political context. They reflect societal values and preferences regarding acceptable levels of risk, economic judgements regarding the feasibility of alternative SPS measures and their costs to society when compared to the benefits to be achieved by the regulation concerned, political pressures brought to bear upon regulators by powerful lobby groups and other such non-scientific factors. As a result, disparate regulatory measures are taken across national boundaries even where the scientific rationale

${ }^{187}$ Howard F. Chang, Risk Regulation, Endogenous Public Concerns, and the Hormones Dispute: Nothing to Fear but Fear Itself?, Research Paper 03-25 (University of Pennsylvania Law School, Institute for Law and Economics, Pennsylvania), August 2003, 24-25, available at: http://ssrn.com/abstract_id=432220, visited on 12 June 2006.

188 David A. Wirth, 'International Trade Agreements: Vehicles for Regulatory Reform?' The University of Chicago Legal Forum, 1997, 331-373, 335.

189 Christian Joerges, 'Scientific Expertise in Social Regulation and the European Court of Justice: Legal Frameworks for Denationalized Governance Structures', in Integrating Scientific Expertise into Regulatory Decision-Making: National Traditions and European Innovations, Christian Joerges, et al. (eds.) (Nomos, Baden-Baden), 1997, 295-323, 320.

190 Jeffery Atik, 'Symposium - Institutions for International Economic Integration: Science and International Regulatory Convergence', Journal of International Law and Business 17, 1997, 736-758, 736. 
for the measures is the same. Science does inform the process, but is not decisive in determining the regulatory outcome.

To reflect this, a conceptual distinction has been drawn between three principal aspects of the regulatory process: risk assessment, risk management and risk communication. Together, these three aspects form what is known as risk analysis. Risk assessment is the scientific process of evaluating a risk, i.e. identifying the hazard or harm at issue, establishing the probability that the harm will materialise and determining the magnitude of such harm. ${ }^{191}$ Risk management is the process of evaluating the available options with regard to the levels of protection from risk and the measures that can be applied to achieve these levels of protection, and choosing among these options. ${ }^{192}$ This is a policy decisionmaking process and involves not only a consideration of scientific evidence but also the making of value judgements based on political, social and economic considerations. Risk communication is the interactive exchange of information concerning risks, risk-related factors and risk perceptions among all interested parties (such as risk assessors, risk managers, consumers and industry). The idea behind drawing this distinction is to identify and delimit the aspects of the regulatory process that are subject to non-science influences.

A simplified illustration of this three-tier process would be the following, using the example of the contaminant acrylamide which is inadvertently produced by certain types of cooking of food at high temperatures (generally above $120^{\circ} \mathrm{C}$ ) and is inter alia found in foods (such as crisps, cookies and coffee) produced in commercial processing plants. Due to concerns regarding the carcinogenic potential of acrylamide (the hazard), the Joint FAO/WHO Expert Committee on Food Additives (JECFA) reviewed all available scientific data on toxicity and intake levels of acrylamide. ${ }^{193}$ JECFA used a risk assessment approach known as the Margin of Exposure (MOE) ${ }^{194}$ It came to the conclusion that the MOE for acrylamide is 300 for the general population and 75 for high consumers (compared to MOEs of 25000 and 20000 for polycyclic aromatic hydrocarbons and ethyl carbonate respectively, both also shown to cause cancer in animal studies). This risk assessment therefore indicates a human health concern. The risk assessment results were communicated to national food safety authorities by the International Food Safety Authorities Network.

It is conceivable that country A, on the basis of this risk assessment and its own policy considerations (such as the high demands for health protection by citizens), decides to opt for a conservative level of protection. To achieve this level of protection it may impose a regulation prohibiting the marketing and importation of products such as crisps, cookies and coffee that have concentrations of acrylamide above a certain level (for example, 2 parts per billion). These are risk management decisions by national regulatory

191 Vern R. Walker, 'Keeping the WTO from Becoming The "World Trans-Science Organization": Scientific Uncertainty, Science Policy, and Factfinding in the Growth Hormones Dispute', Cornell International Law Journal 31, 1998, 251-320, 263-267 for an in-depth discussion of the main elements of a risk assessment.

192 Ibid.

${ }^{193}$ International Food Safety Authorities Network, Acrylamide in Food Is a Potential Health Hazard, INFOSAN Information Note No. 2/2005 (FAO and WHO, Geneva), 1 March 2005, available at: http://www.who.int/ foodsafety/fs_management/en/No_02_Acrylamide_Mar05_en.pdf, visited 27 June 2008.

194 The MOE is calculated by dividing the toxicity estimate from animal experiments by the estimated intake from food. Therefore, the lower the MOE the greater the public health concern. Ibid., 2. 
authorities. Country B may have different priorities (such as promoting the development of its emerging processed food sector) and, after considering the same JECFA risk assessment, may instead decide to choose a less-strict level of protection. It may therefore merely encourage food industries to develop new food preparation methodologies that significantly reduce the concentration of acrylamide in food, while not obliging them to meet specific requirements regarding acrylamide levels in products. Both these options are the outcome of risk-management decisions based on different value judgments and policy considerations.

During this whole process, information would be exchanged between risk assessors, risk managers, consumers and industry regarding risk and risk-perception. For example, in country A, a consumer group that is particularly concerned with children's health, could lobby the regulating agency to take strict measures to prevent harm to children who are typically large consumers of crisps and cookies. In country B, the food industry that would bear high costs if maximum acrylamide levels were imposed, could apply contrary pressure on its own regulators to allow the industry to develop acrylamide-reducing processing methods in its own time. The relevant regulator in each country would later explain the basis of its risk management decision to the public at large. All these information exchanges are part of the risk communication aspect of risk analysis.

The usefulness of the risk assessment/risk management/risk communication distinction lies in its identification of the limits of the role of science as part of the national regulatory process. Whereas previously regulatory agencies were seen as engaged in purely scientific decision-making, involving no discretion and thus free from political influence, and their decisions were thus not subject to democratic control, today suspicion of the actions of regulators and their claims of scientific expertise dominates the regulatory process. This has led to a transformation in agency decision-making processes, based on new requirements of openness, transparency, public participation and judicial review, in order to take account of the political aspects inherent in the regulatory process. ${ }^{195}$ Part of this transformation has been, particularly in developed countries, the formal separation of the bodies charged with risk assessment and those charged with risk management functions and the improvement of transparency in the risk communication process.

However, this separation should not create the impression that risk assessment is a purely objective, scientific process. Even in the risk assessment part of the regulatory process, the reliance on the neutrality of science should be approached with caution. The traditionally uncritical view taken of science by the law is no longer generally accepted. Starting in the 1950s, a new understanding of the limitations of science has gradually replaced the initial authoritative view of its claims to objective validity. There is currently a more critical understanding of scientific processes, and general recognition of the fact that science is not absolute but is characterised by gaps in knowledge and uncertainties. ${ }^{196}$ This

${ }^{195}$ Martin Shapiro, 'The Frontiers of Science Doctrine: American Experiences with the Judicial Control of Science-Based Decision-Making', in Integrating Scientific Expertise into Regulatory Decision-Making: National Traditions and European Innovations, Christian Joerges, et al. (eds.) (Nomos, Baden-Baden), 1997, $325-342,326$. Shapiro provides an interesting discussion of the changes in the perception of science in the US and how this affects the evaluation of regulations.

196 Walker identifies three main categories of uncertainty in risk assessment, namely measurement uncertainty, uncertainty associated with the use of scientific models and gaps in data. Vern R. Walker, 'Keeping the 
is particularly so in the field of health and the environment, due to the complexity of the human body and the ecology. ${ }^{197}$ Further, the exponential growth in scientific knowledge has made it clear that science is inherently evolving and what is regarded as valid today may be substantially disproved tomorrow. Scientists deal with these realities by making use of basic assumptions, models, rules of thumb and extrapolations of conclusions from empirical data to similar areas for which insufficient data is available. ${ }^{198}$ The choice of assumptions and models used to fill gaps in scientific knowledge involves subjective judgement which is based on the values ${ }^{199}$ and the dominant paradigms and ideologies of the scientific community of which the scientist is part. ${ }^{200}$ These discretionary elements of the risk assessment process are known as 'science policy' and are widely recognised in scientific discourse. ${ }^{201}$ It is thus often the case that more than one scientifically valid conclusion can be drawn from the same data. ${ }^{202}$ This is commonly known as the problem

WTO from Becoming The "World Trans-Science Organization": Scientific Uncertainty, Science Policy, and Factfinding in the Growth Hormones Dispute', Cornell International Law Journal 31, 1998, 251-320, 258.

${ }^{197}$ Atik states: 'In general, the science which underlies regulation, including SPS regulation, is science applied to immense complexity. The human body, the ecology of a particular locale and the interplay of social factors are all enormously complex systems, about which strong scientific assertion breaks down. Heuristics (rules-of-thumb) replace direct observation and synthesis in guiding the formation of scientific consensus and introduce the possibility of multiple outcomes.' Jeffery Atik, 'Symposium - Institutions for International Economic Integration: Science and International Regulatory Convergence', Journal of International Law and Business 17, 1997, 736-758, 747-748. Stark notes that while risk assessment was first developed by the insurance industry to determine life expectancies, it has developed into a highly sophisticated technique for establishing risks from chemicals in food and the environment. However, it is much less developed when it comes to assessing biological hazards, such as risks of the spread of exotic insect species. John D. Stark, 'An Overview of Risk Assessment', in Incorporating Science, Economics, and Sociology in Developing Sanitary and Phytosanitary Standards in International Trade: Proceedings of a Conference, National Research Council Board on Agriculture and Natural Resources (ed.) (National Academy Press, Washington D.C.), 2000, 51-64, available at: www.nap.edu/openbook/0309070902/html/199.html, visited on 25 June 2007.

${ }^{198}$ Peter W.B. Phillips, 'Food Safety, Trade Policy and International Institutions', in Governing Food: Science, Safety and Trade, Peter W.B Phillips and Robert Wolfe (eds.) (McGill-Queen's University Press, Montreal), 2001, 27-48, 5; George G. Khachatourians, 'How Well Understood Is The "Science" Of Food Safety?' in Governing Food: Science, Safety and Trade, Peter W.B Phillips and Robert Wolfe (eds.) (McGill-Queen's University Press, Montreal), 2001, 13-23. The tools used to infer risks from data that is incomplete are termed 'inference options' and provide flexibility in the risk assessment process. Doaa Abdel Motaal, 'Is the World Trade Organization Anti-Precaution?' Journal of World Trade 39 (3), 2005, 483-501, 495.

199 The fact that science incorporates cultural and social biases is demonstrated by the disparate scientific consensuses that exist across countries. Jeffery Atik, 'Symposium - Institutions for International Economic Integration: Science and International Regulatory Convergence', Journal of International Law and Business 17, 1997, 736-758, 739 and note 711.

${ }^{200}$ For an enlightening discussion of the cultural theory of risk analysis, which posits that the principles inherent in a particular institution or organisation determines how risks are perceived, defined and managed, see Steve Rayner, 'Cultural Theory and Risk Analysis', in Social Theories of Risk, S. Krimsky and D. Golding (eds.) (Praeger, Westport), 1992, 412.

${ }^{201}$ Vern Walker notes that science policies are the guidance followed by risk assessors in their choices on how to proceed when they are faced with specific types of scientific uncertainty. Vern R. Walker, 'The Myth of Science as A "Neutral Arbiter" For Triggering Precautions', International \& Comparative Law Quarterly 26, 2003, 197-228, 211-216; Vern R. Walker, 'Keeping the WTO from Becoming The "World Trans-Science Organization”: Scientific Uncertainty, Science Policy, and Factfinding in the Growth Hormones Dispute', Cornell International Law Journal 31, 1998, 251-320, 304.

${ }^{202}$ Harry Otway refers to a comparison of ten studies regarding risks to people living in proximity to liquefied natural gas terminals carried out in Germany, the UK, The Netherlands and the US. Although the technical facilities in the studies were alike, the risks established by these studies varied over a factor of 100 million, due to the assumptions and methods used by the analysts in making their quantitative assessments. Harry 
of 'duelling science'. ${ }^{203}$ It is accordingly crucial to recognise that an element of subjectivity is present in most risk assessments. Aside from the uncertainty arising from these problems of insufficient evidence, measurement error, imperfect models and subjective evaluation, which Rosie Cooney and Andrew Lang refer to as 'epistemic uncertainty', in areas involving complex systems, there is also what these authors call 'ontological uncertainty' ${ }^{204}$ This type of uncertainty is a result of the variability and unpredictability of the system under analysis. ${ }^{205}$ Unlike epistemic uncertainty, ontological uncertainty is inherent and persistent - it cannot be eliminated or reduced by additional research. ${ }^{206}$ It requires new approaches to risk management that take into account unpredictability and are responsive to systems-wide effects and interactions. ${ }^{207}$

This situation is further complicated by the effect of research funding on scientific results. Since science can be used strategically to benefit certain political or economic interests due to its influence on public action, there is competition for dominance of the scientific process. ${ }^{208}$ Actors seek to promote the 'vision of the world' most suited to their interests. ${ }^{209}$ This is often achieved through the provision of funding to particular areas of scientific research, which has the effect of directing the enquiry towards the thesis

Otway, 'Public Wisdom, Expert Flexibility: Toward a Contextual Theory of Risk', in Social Theories of Risk, S. Krimsky and D. Golding (eds.) (Praeger, Westport), 1992, 412.

${ }^{203}$ Carolyn Raffensperger and Joel Tickner note that: '[a] typical risk assessment relies on at least 50 different assumptions about exposure, dose-response, and relationships between humans and animals. The modelling of uncertainty also depends on assumptions. Two risk assessments conducted on the same problem can vary widely in results.' Carolyn Raffensperger and Joel Tickner, 'To Foresee and to Forestall', in Protecting Public Health and the Environment: Implementing the Precautionary Principle, Carolyn Raffensperger and Joel Tickner (eds.) (Island Press, Washington D.C.), 1999, 1-12, 2.

${ }^{204}$ Rosie Cooney and Andrew T.F. Lang, 'Taking Uncertainty Seriously: Adaptive Governance and International Trade', European Journal of International Law 18 (3), 2007, 523-551, 529-530.

${ }^{205}$ Ibid., 530.

206 Ibid.

${ }^{207}$ In this respect, Cooney and Lang refer to the approach called 'post-normal science'. Ibid. See further Silvio O. Funtowicz and Jerome R. Ravetz, 'Science for the Post-Normal Age', Futures 25 (7), 1993, 739-755; Silvio O. Funtowicz and Jerome R. Ravetz, 'Three Types of Risk Assessment and the Emergence of PostNormal Science', in Social Theories of Risk, S. Krimsky and D. Golding (eds.) (Praeger, Westport), 1992, 412. These authors argue that a new conception of science is emerging to address prevailing circumstances where traditional scientific methodologies are ineffective. These are circumstances of high levels of uncertainty or high 'decision stakes' (referring to the costs, benefits and value commitments involved in the issue through various stakeholders). In such situations, the traditional methods of science of managing uncertainties automatically and leaving values unspoken, is inappropriate. In terms of the new methodology of science, 'uncertainty is not banished but is managed, and values are not presupposed but are made explicit.' Ibid. 740 .

${ }^{208}$ Shiela Jasanoff notes the move in the US towards greater government-sponsored research to supply regulatory agencies (such as the Environmental Protection Agency) with the needed scientific information to fulfil their expanded mandates. The resultant distrust of the 'regulatory science' generated in this way led to calls for peer review and for greater demarcation of the line between 'science' and 'policy'. Sheila Jasanoff, The Fifth Branch: The Science Advisers as Policymakers (Harvard University Press, Cambridge and London), 1990, 40-43 and 59.

209 Olivier Godard, 'Social Decision-Making under Conditions of Scientific Controversy, Expertise and the Precautionary Principle', in Integrating Scientific Expertise into Regulatory Decision-Making: National Traditions and European Innovations, Christian Joerges, et al. (eds.) (Nomos, Baden-Baden), 1997, 39-73, 46. Godard (at 45) states that in cases where there is a feeling of urgency in society to take action for which there is still insufficient scientific basis, this pressure: 'opens up the Pandora's box of temptations of manipulating science for the benefit of political and economic interests. Concerned social actors and big corporations significantly involved in R \& D activities are spreading their strategic field of action and competition to the scientific representations of the world...' 
proposed by the commissioning actor. ${ }^{210}$ The consequence of this 'commodification' of science is that the result of scientific analysis cannot be viewed as an objective, empirically based truth, but instead is partially a reflection of the interests of economically powerful groups or institutions in society. ${ }^{211}$ As the generation of scientific evidence is costly and difficult, the requirement of scientific justification for SPS regulation results in a bias towards those with the resources necessary to produce scientific support for their initiatives. Thus science is not the objective, universally valid, neutral standard it appears to be. Any evaluation of regulation involving scientific justifications must thus take this important limitation into account.

This fundamental change in thinking extends to the appreciation of the use of science in regulation as a tool to depoliticise regulatory decisions. ${ }^{212}$ A substantial debate exists today, for the reasons set out above, concerning the limitations of use of science in law, particularly as regards the uncritical use of risk assessment as a criterion for regulatory validity. These limitations of science, however, do not imply that it is not still a useful tool in promoting greater rationality in decision-making in the regulatory process and reducing the risks of protectionism due to private interest capture of the regulatory process. Requiring scientific justification from regulators at least improves the transparency of the regulatory process and forces regulators to produce the factual evidence on which they base their decisions. ${ }^{213}$ Instead, account is increasingly taken of the limitations of science by means of a more realistic and nuanced approach to its justificatory capacity. ${ }^{214}$

A further, but related, limitation to the use of science as a basis for the evaluation of SPS regulation lies in the problem of scientific uncertainty. Rigorous evidentiary requirements may limit the possibilities for governments to act in situations where science has not yet provided a definite answer regarding the existence or magnitude of a risk. Increasing awareness of the limitations in the ability of science to accurately predict SPS risks, and

210 Jeffery Atik, 'Symposium - Institutions for International Economic Integration: Science and International Regulatory Convergence', Journal of International Law and Business 17, 1997, 736-758, 750. Atik contends that a system that requires scientific justifications for self-interested positions is likely to find them. Ibid. 758 .

${ }^{211}$ A constructivist approach to science has emerged, according to which it should be recognised that science is a social construct and may be contaminated by particular interests. It should therefore be viewed with scepticism. Ian Holland and Aynsley Kellow, 'Trade and Risk Management: Exploring the Issues', in Globalization and the Environment. Risk Assessment and the WTO, David Robertson and Aynsley Kellow (eds.) (Edward Elgar, Cheltenham), 2001, 229-248, 235-239 and 241.

${ }^{212}$ For an interesting discussion on the attempts to use of science and scientific committees to 'take the politics out of policy making' and thereby to legitimate regulation in the US, see Sheila Jasanoff, The Fifth Branch: The Science Advisers as Policymakers (Harvard University Press, Cambridge and London), 1990. Jasanoff argues that: ' $[\mathrm{t}]$ he notion that the scientific component of decision making can be separated from the political and entrusted to independent experts has effectively been dismantled by recent contributions to the political and social studies of science. With the accumulation of evidence that "truth" in science is inseparable from power, the idea that scientists can speak truth to power in a value-free manner has emerged as a myth without correlates in reality.' Ibid., 16-17.

${ }^{213}$ Andrew Green and Tracey Epps, 'The WTO, Science, and the Environment: Moving Towards Consistency', Journal of International Economic Law 10 (2), 2007, 285-316, 303.

${ }^{214}$ The extent to which national administrative or judicial review of national regulations on the basis of scientific requirements has been tempered by this new realisation of the limits of science has been discussed elsewhere and it is not necessary to go into this issue for purposes of this book. Instead, the implications of this realisation for the use of science in international disciplines on SPS regulation, embodied in the SPS Agreement, is discussed below, Part III, Sections 5.1.5.1 and 5.1.5.2. 
to do so early enough to allow for effective action to prevent the risk, ${ }^{215}$ have led to a shift in approach 'in favour of a bias towards safety or caution. ${ }^{216}$ Particularly in developed countries where high levels of health protection have been achieved, resulting in longer life spans and greater attention health risks that may only materialise in the long-term, regulators are under pressure to err on the side of caution in decision making in situations of scientific uncertainty. Another development reinforcing this trend is growing use of new technologies in agricultural and food production, ${ }^{217}$ such as the use of hormones in beef and milk production, the genetic modification of crops, the use of meat and bone meal additives in cattle feed, the great increase in highly processed consumer-ready food and the concomitant increase in consumer fears regarding the safety of these products. Following highly publicised health risks, such as the BSE outbreaks in Europe or the dioxin scandal in Belgium, citizens demand regulatory action to protect them from possible risks from new technologies, even in those cases where there is no definitive proof of risk yet, as is the case with the use of rBST to increase milk production in cows..$^{218}$

The precautionary principle, or precautionary approach, ${ }^{219}$ emerged in response to the concerns regarding scientific uncertainty in environmental regulation. ${ }^{220}$ It can be seen as complementary to the preventive principle, ${ }^{221}$ which is reflected in the idea that established

215 Owen McIntyre and Thomas Mosedale, 'The Precautionary Principle as a Norm of Customary International Law', Journal of Environmental Law 9 (2), 1997, 221-241, 222.

${ }^{216}$ David Freestone, 'The Road to Rio: International Environmental Law after the Earth Summit', Journal of Environmental Law 6, 1994, 193-218, 211.

${ }^{217}$ Neville Craddock, 'Risk, Precaution, and the Food Business', in Governing Food: Science, Safety and Trade, Peter W.B. Phillips and Robert Wolfe (eds.) (McGill-Queen's University Press, Montreal), 2001, 75-88, 82.

${ }^{218}$ George G. Khachatourians, 'How Well Understood Is The "Science” Of Food Safety?' in Governing Food: Science, Safety and Trade, Peter W.B Phillips and Robert Wolfe (eds.) (McGill-Queen's University Press, Montreal), 2001, 13-23, 17. Khachatourians points out that rBST is banned in both Canada and the EC, following expert advice that approval of a licence for the use of this hormone not be granted until the long term effects of rBST were studied.

219 There is considerable debate on the nature of this concept between the EC which sees it as a 'precautionary principle' and the US which instead regards it as a 'precautionary approach'. Nevertheless, both these Members, and many others, typically act with precaution when faced with serious, but uncertain, health risks. Catherine Button notes that; '[w]hile the US has not embraced the precautionary principle in the WTO, it would be wrong to assume that its domestic regulations are necessarily less protective than those of the EU.' She recommends moving beyond the caricature of Europeans as 'paranoid Luddites opposed to science and innovation' and of the US as 'forward-looking and risk-taking', to a recognition that in both jurisdictions the approach taken depends on the particular health risk at stake. Catherine Button, The Power to Protect. Trade, Health and Uncertainty in the WTO (Hart Publishing, Oxford and Portland, Oregon), 2004, 126.

${ }^{220}$ It is generally accepted that the origins of the precautionary principle lie in the principle of precautionary action established in German environmental law in the 1970s and 1980s ('Vorsorgeprinzip'). Konrad Von Moltke, 'The Relationship between Policy, Science, Technology, Economics and Law in the Implementation of the Precautionary Principle', in The Precautionary Principle and International Law: The Challenge of Implementation, David Freestone and Ellen Hey (eds.) (Kluwer Law International), 1996, 97-108, 102. See also Owen McIntyre and Thomas Mosedale, 'The Precautionary Principle as a Norm of Customary International Law', Journal of Environmental Law 9 (2), 1997, 221-241, 221. McIntyre and Mosedale cite the following: S. Boehmer-Christiansen, 'The Precautionary Principle in Germany - Enabling Government' in T. O'Riordan and J. Cameron (eds), Interpreting the Precautionary Principle (Cameron May: London), 1994, 31-60; and K von Moltke, The Vorzorgeprinzip in West German Environmental Policy, $12^{\text {th }}$ Report, (Royal Commission on Environmental Policy: London) 1998, Appendix 3.

221 This point has been made by Alessandra Arcuri. Alessandra Arcuri, The Case for a Procedural Version of the Precautionary Principle Erring on the Side of Environmental Preservation, Global Law Working Paper 09/04 (Hauser Global Law School, New York), 2004, 16, available at: www.nyulawglobal.org/workingpapers/documents/GLWP0904Arcuri.pdf, visited 12 May 2005. Arcuri further notes that the prevention 
hazards should be prevented before they occur. The precautionary principle goes beyond this, by dealing with the situation where there is a lack of scientific certainty regarding the risk that a hazard may occur or its magnitude. As explained by De Sadeleer:

The distinction between the preventive principle and the precautionary principle rests on a difference of degree in the understanding of risk. Prevention is based on certainties: it rests on cumulative experience concerning the degree of risk posed by an activity (Russian roulette, for example, involves a predictable onein-six chance of death). Therefore, prevention presupposes science, technical control, and the notion of an objective assessment of risks in order to reduce the probability of their occurrence. Preventive measures are thus intended to avert risks for which the cause-and-effect relationship is already known .... Precaution, in contrast, comes into play when the probability of a suspected risk cannot be irrefutably demonstrated. The distinction between the two principles is thus the degree of uncertainty surrounding the probability of risk. The lower the margin of uncertainty, the greater the justification for intervention as a means of prevention, rather than in the name of precaution. By contrast, precaution is used when scientific research has not yet reached a stage that allows the veil of uncertainty to be lifted.222

The precautionary principle has gained wide acceptance on the international level, ${ }^{223}$ particularly in the area of environmental protection, ${ }^{224}$ in response to the increasing realisation

principle is tempered by the proportionality principle. Requiring that all risks be prevented would mean that most industrial activities (which are otherwise beneficial to society) should be banned. The proportionality principle, instead, brings in an element of cost-benefit analysis and trade-off which are part of a rational regulatory process.

${ }^{222}$ N. De Sadeleer, Environmental Principles: From Political Slogans to Legal Rules, (Oxford University Press, Oxford), 2002, 74 .

${ }^{223}$ The precautionary principle is recognised in the following international instruments amongst others: the Treaty on the European Community, as amended by the Treaty on the European Union 1992 (Article 174, previously Article 130r, with regard to environmental protection), the Framework Convention on Climate Change (1992 31 I.L.M. 849 in Article 3.3), Agenda 21 of the United Nations Conference on the Environment and Development (1992, in para. 17.21), the Rio Declaration on Environment and Development (1992 31 I.L.M. 876 in Principle 15) and the Cartagena Protocol on Biosafety, UNP/157, adopted 29 January 2000, entry into force 11 September 2003, in Article 10.5).

224 There is an extensive body of literature on the precautionary principle in environmental law, only a few examples of which are mentioned here for further information on this issue. James Cameron, 'The Precautionary Principle', in Trade, Environment, and the Millennium, Gary P. Sampson and W. Bradnee Chambers (eds.) (United Nations University Press, Tokyo), 1999, 239-269; James Cameron and Juli Abouchar, 'The Precautionary Principle: A Fundamental Principle of Law and Policy for the Protection of the Global Environment', Boston College International and Comparative Law Review 14 (1), 1991, 1-27; James Cameron and Juli Abouchar, 'The Status of the Precautionary Principle in International Law', in The Precautionary Principle and International Law: The Challenge of Implementation, David Freestone and Ellen Hey (eds.) (Kluwer Law International), 1996, 29-52; Nicole Coutrelis, Le Principe De Precaution: Aspects Juridiques, 16 May 2000; Frank B. Cross, 'Paradoxical Perils of the Precautionary Principle', Wash \& Lee Law Review 53 (3), 1996, 1; Elizabeth Fisher, 'Precaution, Precaution Everywhere: Developing a Common Understanding of the Precautionary Principle in the European Community', Maastricht Journal of European and Comparative Law 9 (1), 2002, 7-28; David Freestone and Ellen Hey, 'Implementing the Precautionary Principle: Challenges and Opportunities', in The Precautionary Principle and International Law: The Challenge of Implementation, David Freestone and Ellen Hey (eds.) (Kluwer Law International), 1996, 249-268; Ellen Hey, 'The Precautionary Concept in Environmental Policy and Law: Institutionalizing Caution', Georgetown International Environmental Law Review 4, 1992, 303-318; 
of the prevalence of uncertainty in science. ${ }^{225}$ Although there is still debate regarding whether the precautionary principle as gained the status of a principle of customary international law and no generally accepted definition of the precautionary principle has yet emerged, ${ }^{226}$ one can outline its 'core content' in broad terms. It comes down to the idea that a government may legitimately regulate against possible risks in situations where conclusive scientific evidence as to the existence or extent of the risk is still lacking. Thus, there are three components to this principle: (1) scientific uncertainty; (2) threat of harm; and (3) precautionary action. ${ }^{227}$ Typically, certain thresholds or conditions are applied as limits to the possibility to rely on this principle, in order to prevent its misuse, but these vary in different formulations of the principle. According to one formulation, reliance on the precautionary principle is limited to situations where there are threats of serious or irreversible damage. ${ }^{228}$ Other possible limits are the requirement that the threat of harm be based on 'reasonable grounds for concern, rather than mere conjecture', ${ }^{229}$ and that precautionary action be effective and proportional to the risk involved. ${ }^{230}$

While in the area of SPS risk the status and content of the precautionary principle remain controversial, it is not debated that precautionary approaches are embedded in the regulatory processes of many countries and are particularly prevalent in those where SPS risks are a regulatory priority. ${ }^{231}$ It is beyond the scope of this book to engage in an analysis of

${ }^{225}$ For a law-and-economics analysis of the precautionary principle, based on a broad interpretation of scientific uncertainty that includes not only situations where the probability of a risk cannot be ascertained but also situations of ambiguity and ignorance in risk appraisals, see Muhamad Ramdan Andri Gunawan Wibisana, Law and Economics Analysis of the Precautionary Principle, Doctoral Thesis, Maastricht University, Faculty of Law (Universitaire Pers, Maastricht), 2008. Andri Wibisana notes: 'By recognizing the intrinsically subjective and political nature of risk regulations, the precautionary principle has a potential to reveal assumptions and reasons behind a particular policy or technological choice.' Ibid., 295.

${ }^{226}$ In the field of environmental protection, a convincing argument has been made by Trouwborst that the precautionary principle has evolved into a principle of customary international law, and he has conducted a thorough study into the content of the principle in this field. See Arie Trouwborst, Evolution and Status of the Precautionary Principle in International Law (Kluwer Law International: The Hague/Boston/London), 2002 and Arie Trouwborst, Precautionary Rights and Duties of States, Doctoral Thesis, Utrecht University, Faculty of Law (Martinus Nijhoff Publishers, Leiden/Boston), 2006.

${ }^{227}$ Pauline Barrieu and Bernard Sinclair-Desgagne, The Paradox of Precaution (CIRANO, Montreal), October 2003, 5, available at: www.cirano.qc.ca/pdf/publication/2003s-63.pdf, visited 15 June 2004. These three elements are elaborated on in detail in Arie Trouwborst, Precautionary Rights and Duties of States, Doctoral Thesis, Utrecht University, Faculty of Law (Martinus Nijhoff Publishers, Leiden/Boston), 2006.

${ }^{228}$ This limitation is found in the formulation used in the Rio Declaration.

229 This implies more than a theoretical possibility of harm, but does not go as far as to require proof of the existence and magnitude of the risk. See Arie Trouwborst, Precautionary Rights and Duties of States, Doctoral Thesis, Utrecht University, Faculty of Law (Martinus Nijhoff Publishers, Leiden/Boston), 2006, 115-117.

${ }^{230}$ See Ibid., 147-153.

${ }^{231}$ Although it is often believed that 'precaution is for Europeans' and that the US takes a more rational, cost/ benefit approach to risk regulation, due to certain widely publicised controversies regarding US' criticism of precautionary European regulations, studies have shown that both the EC and the US have highly precautionary regulatory regimes. Where they differ is on the question of which risks to prioritise as significant enough for precautionary action, and this has often led to transatlantic tensions. See Jonathan B. Wiener, 'Whose Precaution after All? A Comment on the Comparison of Civil Justice Systems', Duke Journal of Comparative and International Law 13, 2003, 45; M. D. Rogers and Jonathan B. Wiener, 'Comparing Precaution in the United States and Europe', Journal of Risk Research 5 (4), 2002, 317-349. An example of a precautionary approach in US food regulation can be found in its statutes on pesticide residues, food additives, colorants and veterinary drug residues. The US takes the approach that all these substances are unsafe unless proven safe and consequently applies a pre-marketing approval requirement. To obtain such approval, convincing 
the status and content of the precautionary principle in the area of SPS risk. Instead, brief reference is made to this principle to draw attention to the fact that SPS regulatory regimes currently take account of the fact that regulators may need to act to protect against harm in situations of scientific uncertainty. Precaution thus tempers the reliance on science as the final arbiter of the legitimacy of SPS regulation. ${ }^{232}$ One example of a precautionary approach in the area of SPS regulation is the requirement of prior approval for the importation of a potentially risky product whose safety has not yet been determined, as is the case with the EC regime for genetically modified organisms or the Australian regime for novel foods. Such a system relies on an a priori ban on certain category of products, pending a scientific determination of their safety. ${ }^{233}$

Both the use of science as a tool, albeit an inherently limited one, to discipline and legitimate regulatory action and the attendant emergence of precautionary approaches to deal with situations of scientific uncertainty are developments rooted in advances in regulatory regimes in the developed world. They entail a high level of human and financial resources devoted to risk regulation and reflect best practices in dealing with the complexities of SPS risks. It should be borne in mind that these best practices do not present an accurate picture of the regulatory systems with regard to SPS risks in countries at lower levels of development. As will become apparent from the discussion in the following sections, while the SPS regimes in developed countries embody the abovementioned risk analysis practices in a variety of forms, many other countries at lower levels of development lack the capacity to staff and operate the scientific committees and regulatory agencies necessary to enact SPS regulations in a manner that conforms with these best practices.

evidence must be presented to the US Food and Drug Administration that no harm will result from the intended use of the product. Vern R. Walker, "The Myth of Science as A "Neutral Arbiter" For Triggering Precautions', International \& Comparative Law Quarterly 26, 2003, 197-228, 217-218. For a discussion of the application of the precautionary principle in the area of food and agricultural policy to avoid SPS risks, see Calum G. Turvey and Eliza M. Mojduszka, 'The Precautionary Principle and the Law of Unintended Consequences', Food Policy 30, 2005, 145 - 161.

${ }^{232}$ This issue is discussed further with the analysis of the scope for precautionary action under the provisions of the SPS Agreement. See below, Part III, Sections 3.2.3.2 and 5.2.5.

${ }^{233}$ An example of the use of precaution (partly) in the area of SPS risk at international level is the Cartagena Protocol on Biosafety to the Convention on Biological Diversity, UNP/157, adopted 29 January 2000, entry into force 11 September 2003. Article 10.6 of the Cartagena Protocol provides:' Lack of scientific certainty due to insufficient relevant scientific information and knowledge regarding the extent of the potential adverse effects of a living modified organism on the conservation and sustainable use of biological diversity in the party of import, taking also into account risks to human health, shall not prevent that Party from taking a decision, as appropriate, with regard to the import of the living modified organism in question ... to avoid or minimize such potential adverse effects.' (Emphasis added). 


\title{
CHAPTER 2 \\ National SPS systems in selected \\ developed- and developing-country Members
}

\begin{abstract}
A specific examination of SPS regulatory systems across regions and economic levels is useful in providing practical insights into the differences in the ways Members at different levels of development regulate to protect human, plant and animal life and health. These differences have important implications for the impact of the SPS Agreement on the regulatory capacity of the relevant Members. ${ }^{1}$ They also play a significant role in determining the ability of exporters from various Members across different levels of development to access foreign markets for their food and agricultural products, by meeting the SPS requirements of their trading partners. An understanding of these differences therefore forms the context for the examination of rules of the SPS Agreement in later chapters of this book.
\end{abstract}

\subsection{Choice of WTO Members}

The WTO Members examined in this section are selected across a range of levels of economic development and geographical regions, in order to ensure that a broad spectrum of SPS regimes is covered. The relevant regions covered in this study are Africa, the Americas and the Asia/Pacific region. The Members from the European region are not selected as examples in this section. This is because SPS protection in the developedcountry Members that are Member States of the European Union (EU) is achieved by a combination of national regulation at national level and supra-national regulation at EU level, making these countries a-typical with respect to SPS regulatory systems. The countries in transition in Eastern Europe (such as Croatia, Turkey, the Former Yugoslav Republic of Macedonia) are also not useful as illustrative examples as they evince elements of both developing and developed countries, and are in the special position of receiving extensive assistance, both financial and technical, to strengthen their regulatory systems through the various aid programmes of the EU.

The selection of countries also attempts to ensure a spread across levels of economic development. For the sake of convenience, the World Bank classification ${ }^{2}$ of countries by income is used as indicator of level of economic development. Income is calculat-

\footnotetext{
${ }^{1}$ In its report regarding how to meet the Millennium Development Goals, the UN Millennium Project points out that the assessment of the costs and benefits of WTO rules on domestic regulations (such as the SPS Agreement) will vary according to the level of development of the country. The report then links this fact to the issue of special and differential treatment (SDT), through the suggestion that an assessment of costs and benefits should guide what SDT to grant and to which countries. UN Millennium Project, Investing in Development: A Practical Plan to Achieve the Millennium Development Goals (United Nations Development Programme, New York), 2005, 219, available at: http://www.unmillenniumproject.org/reports/fullreport.htm, visited on 7 January 2008.

2 See the World Bank classification, as at 1 July 2007, available at: http://siteresources.worldbank.org/ DATASTATISTICS/Resources/CLASS.XLS, visited on 18 December 2007.
} 
ed as Gross National Income per capita (GNI), ${ }^{3}$ converted into US dollars according to the World Bank Atlas method. ${ }^{4}$ This classification divides countries into low-income countries (GNI of US\$905 or less), lower-middle-income countries (GNI of US\$906 US\$3,595), upper-middle-income countries (GNI of US\$3,596 - US\$11,115) and highincome countries (GNI of US\$11,116 or more). Although low-income and (lower- and upper-) middle-income countries are, for the sake of convenience, sometimes referred to as developing countries, this income classification does not necessarily fully reflect the level of development of the relevant countries. ${ }^{5}$ Nevertheless, it provides a useful tool for the selection of countries of varying capacity in the area of SPS regulation, as there is a logical correlation between the resources available in a country and the possibility to prioritise SPS regulation as an area of government.

The specific countries to be examined within these geographic and income categories are chosen by means of a purposeful sampling strategy rather than probability sampling. It is not the intention, as would be the case with probability sampling, to derive generalisations from the sample country with regard to SPS regimes that would be applicable to the relevant category of countries. Such an exercise would be futile in an area as diverse and complex as SPS regulation, where broad generalisations are not possible or useful. In this area, it is not only difficult but also misleading to draw conclusions from the experiences of one country for another, even at the same economic level. Instead, purposeful sampling calls for the selection of examples of cases where there is sufficient information for in-depth study. ${ }^{6}$ The aim of such a sampling strategy is to provide 'insights and in-depth understandings rather than empirical generalizations' ${ }^{7}$ For this reason, the availability of

\footnotetext{
${ }^{3}$ GNI per capita is defined as follows by the World Bank: 'the gross national income (GNI) in current U.S. dollars as divided by the mid-year population. GNI measures the total domestic and foreign income claimed by the residents of the economy. It comprises GDP plus net factor income from abroad, which is the income residents receive from abroad for factor services (labour and capital) less similar payments made to non-residents who contributed to the domestic production. GNI in U.S. dollars is calculated according to the World Bank Atlas method of conversion from national currency to U.S. dollar terms.' See the technical notes accompanying the World Bank country statistics available at: http://www.worldbank.org/data/countrydata/aag.htm, visited 25 June 2007.

${ }^{4}$ Conversion according to the Atlas method aims to reduce the impact of exchange rate fluctuations in the crosscountry comparison of national incomes. It is explained as follows by the World Bank: The Atlas conversion factor for any year is the average of the country's exchange rate for that year and those for the two preceding years, adjusted for differences in relative inflation between the country and the G-5 countries (France, Germany, Japan, the UK, and the US). From 2001 onwards, these countries include the Euro Zone, Japan, the UK, and the US. A country's inflation rate is measured by the change in its GDP deflator. This three-year average smoothes fluctuations in prices and exchange rates for each country. See the technical notes accompanying the World Bank country statistics available at: http://go.worldbank.org/8MH1UTJVK0, visited on 18 December 2007.

${ }^{5}$ For example, although Saudi Arabia has a GNI per capita of US\$12,510 and is classified as a high-income economy by the World Bank, it is ranked only $61^{\text {st }}$ in the Human Development Index of 2007, below countries such as Tonga (a lower-middle-income economy) and Bulgaria (a upper-middle-income economy) which have much lower income levels (GNI per capita of US\$2,170 and US\$3,990 respectively).

${ }^{6}$ Patton notes that: '[t] he logic and power of purposeful sampling lie in selecting information-rich cases for study in depth.' See Michael Quinn Patton, Qualitative Research and Evaluation Methods, 3rd ed. (Sage, Thousand Oaks), 2002, 230. This statement by Patton was quoted in Diahanna L. Post, 'The Diffusion of International Food Safety Policies: What's the Motivation?' presented at the 2003 Annual Convention of the International Studies Association, Portland, Oregon) 25 February - 1 March 2003, 8.

${ }^{7}$ Michael Quinn Patton, Qualitative Research and Evaluation Methods, 3rd ed. (Sage, Thousand Oaks), 2002, 230 .
} 
data, in the form of case studies and reports from reputable and authoritative sources has been a guiding criterion in the selection of countries. The following table illustrates the geographic and income spread of the WTO Members studied in this chapter.

\section{Table 1: Selected WTO Members across geographic regions and income levels}

\begin{tabular}{|l|c|c|c|}
\hline \multirow{2}{*}{ Income Classification } & \multicolumn{3}{|c|}{ Geographic Region } \\
\cline { 2 - 4 } & Africa & Americas & Asia/Pacific \\
\hline High income & & & Australia \\
\hline Upper-middle income & Mauritius & & \\
\hline Lower-middle income & & Jamaica & \\
\hline Low income & & & Bangladesh \\
\hline
\end{tabular}

\subsection{Choice of information provided}

Sections 4 to 7 of Chapter 2 describe the SPS systems of one developed-country Member of the WTO (Australia) and three developing-country Members of the WTO (Mauritius, Jamaica, and Bangladesh). The information selected from the various sources relied upon, set out below, is aimed at providing a factual context for the analysis of the SPS Agreement and its impact on WTO Members across different levels of development that follows in Parts III to V of this book.

As explained in the Introduction to this book, the underlying assumption guiding the discussion of the SPS Agreement is that 'level of development matters' when it comes to WTO disciplines on regulatory regimes that go beyond non-discrimination obligations. This is of course a broad statement. What conclusions one can draw from it for WTO disciplines on SPS regulation depend in part on what the impact of level of development is on the ability of a Member to use the relevant disciplines to its benefit in gaining market access for its exports as well as on the capacity of that Member to comply with the disciplines at issue. In order to test whether the proposition that 'one size does not fit all' is true when it comes to WTO rules affecting the regulatory autonomy of Members, due to the differing initial positions of Members, it is necessary to have some understanding of what these initial positions might be.

Therefore the selection of information provided is guided by three considerations: (1) the need to position each Member discussed along the development continuum, by reference to various indicators of economic and human development that are directly or indirectly relevant to its SPS system; (2) the need to establish the relative importance of SPS issues for the health and trade priorities, particularly in the area of food and agriculture, of each 
of the described Members; and (3) the need to describe, as accurately as possible, the institutional and legislative regime in place in each selected Member to address SPS risks.

To meet these objectives, for each selected WTO Member the following information is provided. The description in each case starts by setting out relevant factual background information with regard to the Member at issue. A first subsection in this factual background section provides certain economic and human development indicators. In each case, the indicators relate to most recent year for which data is available for all four selected Members. This information includes economic data regarding not only GNI per capita, but also GDP at purchasing power parity and GDP per capita at purchasing power parity. ${ }^{8}$ In this way the strength of the economies of the selected countries can be compared. Selected data reflecting the level of human development is also provided in these

\footnotetext{
${ }^{8}$ The GDP of a country can be thought of as the sum of the prices multiplied by their quantities, for all products and services consumed in the relevant year. GDP is the primary basis used for comparing the relative sizes of various economies. GDP is also indicated on a per capita basis to represent the flow of goods and services available to countries to contribute to their economic well-being. GDP is indicated at purchasing power parity to deal with the problem of comparing economies across national boundaries since national GDP levels must be converted to a common currency to enable comparisons to be made. The purchasing power parity between two countries is the rate at which the currency of one country needs to be converted into that of a second country to represent the same volume of goods and services in both countries. A commonly known example of purchasing power parity is the 'Big Mac Index' compiled and published by The Economist. It is based on a single consumption item and compares the cost of a 'Big Mac' in different countries to its cost in the US. However, as price differences vary for different products and in different economic sectors, purchasing power parities are usually prepared using relative prices for a very large number of comparable goods and services. The International Comparison Program, initiated in 1968 as a joint venture of the UN and the University of Pennsylvania, with contributions from the Ford Foundation and the World Bank, generates purchasing power parities based on actual price data collected for over 1,000 items on a periodic basis in the currently 147 participating countries. International Comparison Program, ICP 2003-2006 Handbook, available at: http:// go.worldbank.org/MW520NNFK0, visited on 7 January 2008. Since the most recent year for which GDP and GDP per capita at purchasing power parity is available for all selected Members is 2005, the 2005 data will be provided across all selected Members. This 2005 economic data is also used as one of the indicators to generate the Human Development Index of 2007 of the UNDP, discussed below.
} 
background sections. Data is provided regarding population size, poverty levels, ${ }^{9}$ and ranking on the UNDP's Human Development Index (HDI) of 2007. ${ }^{10}$

The data set out in this background section of the description of each Member is of interest for several reasons. In keeping with the understanding underlying the analysis in this book that 'development' is more than economic growth but also entails the realisation of all human rights, ${ }^{11}$ the development level of a Member can only be established fully by looking at other indicators of human development. The composite HDI ranking based on key development indicators is therefore provided. In line with the recognition that development occurs along a continuum, the background data provided serves to outline various social and economic factors that play a role in situating a Member along this continuum. Specifically, it refers to factors that directly or indirectly influence the regulatory capacity

${ }^{9}$ Poverty is normally defined as the lack of minimum income, or consumption level, to meet basic needs. This minimum varies across countries. To make comparisons of poverty across countries, an international poverty measure is necessary. Using an absolute poverty line (i.e. one with fixed purchasing power across countries) rather than a relative poverty line is useful for comparative analysis. For this reason, in this book, the World Bank's international poverty measures will be used, as published in the 2005 World Development Indicators (WDI), available at: http://devdata.worldbank.org/wdi2005/index2.htm, visited on 17 January 2008. The UNDP's Human Development Index for 2007 makes use of the World Bank data for 2005 in this regard. The Millennium Development Goals with respect to poverty are also monitored on the basis of the World Bank's annual WDI. The World Bank measures poverty as the percentage of people living below the international poverty lines of either US\$1 per day or US\$2 per day, measured in 1985 international prices and adjusted to local currency using purchasing power parities. According to the 2005 WDI report, 'Poverty measures based on an international poverty line attempt to hold the real value of the poverty line constant across countries, as is done when making comparisons over time.' In this book, the international poverty measure of US\$2 per day will be referred to as an indicator of the incidence of poverty in the countries studied. This is preferred to the US\$1 per day measure as the latter is a measure of extreme poverty, and is commonly used when analysing poverty in least-developed countries. The US\$2 per day measure is commonly used in comparisons involving not only low-income but also middle-income countries, as is the case in this book. However, for the sake of completeness, and because the Millennium Development Goals make reference to it, the poverty incidence based in the US\$1 per day measure will be indicated in footnote. Note that as the poverty measures based on the international poverty line of US $\$ 2$ per day were designed to compare low- or middle-income countries. They do not differentiate well between high-income countries. For these countries an alternative index, that of US\$4 per day may better facilitate comparisons of the level of poverty that still exists, and it is used in the UNDP's Human Development Index as one of the indicators of 'human poverty' for OECD countries, Central and Eastern Europe and the Commonwealth of Independent States. However, as this book does not compare high-income countries with each other, but only compares one high-income country with three middle- and low- income countries, the US\$2 per day poverty line will be used throughout United Nations Development Programme, Human Development Report 2007/2008. Fighting Climate Change: Human Solidarity in a Divided World (Palgrave Macmillan, New York), 2007, 227 and Table 224, available at: http://hdr.undp.org/ en/media/hdr_20072008_en_complete.pdf, visited on 10 December 2007.

${ }^{10}$ See the Human Development Index (HDI) for 2007, Ibid., 229-232.. The HDI was developed in 1990 by Nobel Laureate Amartya Sen and economist Mahbub ul Haq (assisted by Gustav Ranis of Yale University and Lord Meghad Desai of the London School of Economics). The Human Development Report of the UNDP is based on this index. The UN Human Development Index measures countries' achievements in terms of three indicators: (1) a long and healthy life as measured by life expectancy at birth; (2) knowledge, as measured by the adult literacy rate and the combined primary, secondary and tertiary gross educational enrolment ratio; and (3) a decent standard of living measured by GDP per capita. It can be regarded as an alternative measure of a country's level of development, going beyond categorisations on purely economic terms. Information on the meaning of terms, the calculations and the data sources underlying this index is available in United Nations Development Programme, Human Development Report 2007/2008. Fighting Climate Change: Human Solidarity in a Divided World (Palgrave Macmillan, New York), 2007, 221-227 and 355-373, available at: http://hdr.undp.org/en/media/hdr_20072008_en_complete.pdf, visited on 10 December 2007.

${ }^{11}$ See the discussion of the concept of development, above, Part I, Section 1.1. 
of the relevant country and its ability to deal with SPS market barriers. For purposes of this book it is assumed that a country that ranks higher on the HDI is more likely to be able to deal with the social consequences of stricter SPS measures, the resultant concentration of export capacity in a few large firms, and concomitant decrease in traditional smallholder participation in trade.

In a second subsection of the background description of each selected Member, its health and sanitation levels are discussed. ${ }^{12}$ These are selected for specific attention from among the various indicators of human development provided in the Human Development Report of 2007, due to their relevance to the subject of this book. Further information regarding the Member's health status and areas of policy focus is obtained, where available, from government strategy papers. This information on health status, including access to health care, clean water and sanitation, provides an indication of the priorities for public spending in the area of health in the selected Members. It helps to establish the likely effect on public health that diversion of resources towards building SPS regulatory capacity would have in Members with different health concerns. It also provides a context for understanding the impact of the disciplines of the SPS Agreement on the regulatory choices of the relevant Member in the area of health.

The third subsection of the factual background description addresses the trade priorities of each selected Member. The importance of trade to that Member's GDP and the extent of its participation in the multilateral trading system are discussed. In particular, the areas of focus of its trade policy are highlighted.

Fourth, in the following subsection the importance of the food and agricultural industry for the relevant Member is established, with special attention to the contribution of this sector to GDP and employment, its share in export revenue earnings and its degree of diversification. This aims to determine the effect that trade barriers in the form of SPS measures could have on that Member's economy and more particularly on poverty alleviation and the promotion of development in the sense used in this book. It is assumed that a Member in which trade in food and agricultural products makes a significant contribution to GDP, export earnings or employment will be more vulnerable to market access barriers in this sector. The bearing of such barriers on poverty in a Member is expected to be linked to the incidence of rural poverty and the contribution made by the agricultural sector, including in the food-processing industry, to employment and livelihoods. Similarly, it is assumed that a Member with a greater diversification in export products will suffer less from the impact of an SPS market barrier than one whose export trade is heavily dependent on a single agricultural product or a small number of such products.

A final subsection provides a brief overview of the relevance of the factual background set out with regard to each Member for the discussion of its SPS system.

The description then turns, in a second section, to each Member's SPS regime, with respect to human, animal and plant health regulation, and examines the impact of the SPS

12 This information is drawn from the statistical tables contained in United Nations Development Programme, Human Development Report 2007/2008. Fighting Climate Change: Human Solidarity in a Divided World (Palgrave Macmillan, New York), 2007, available at: http://hdr.undp.org/en/media/hdr_20072008_en_complete.pdf, visited on 10 December 2007. 
regulations of other Members on its exports. Separate subsections address the Member's food-safety system, its system for the protection of animal health and its system for the protection of plant health. Deficiencies in the Member's SPS regime are highlighted. Where available, information is provided on specific SPS trade barriers faced by the Member at issue, in order to provide practical illustrations of the impact of SPS measures on exports. In addition, where the SPS measures of the Member at issue have led to reported market access concerns raised by other Members, information is provided on the matter.

Although part of the SPS system of a Member, the participation of the Member in international standard-setting activities and the use made of the disciplines of the SPS Agreement to address its trade-related SPS concerns are only briefly touched upon. The experiences of the selected Members with regard to participation in international standard setting are set out where relevant in Chapter 3 of Part II, where the international standard setting systems are examined in detail. The use made by the selected Members of the disciplines of the SPS Agreement and their implementation of these disciplines are set out in Parts III to $\mathrm{V}$ of this book, where the provisions of the SPS Agreement are discussed.

It is essential to bear in mind the purpose of the following descriptions. They do not attempt to provide detailed and comprehensive descriptions of the selected Members and their SPS regimes, something which is neither necessary for purposes of the discussion in this book, nor possible bearing in mind the difficulty in obtaining reliable information in this area. Neither, do these descriptions pretend to provide the basis for generalisations regarding the SPS regimes of countries at similar levels of economic and human development. As stated above, such generalisations would be imprudent in an area as complex and varied as that of SPS regulation. Instead, the factual descriptions undertaken below have a more modest objective. They provide a practical context within which to situate the theoretical discussion that follows in Parts III to V of this book where the disciplines of the SPS Agreement are analysed and their disparate impact on Members at different levels of development is highlighted. Their objective is to give illustrative examples across a range of regions and income levels in order to give the reader a foothold when considering legal disciplines on SPS regulation. 
Table 2: Summary table of relevant indicators per selected Members

\begin{tabular}{|c|c|c|c|c|c|c|c|}
\hline $\begin{array}{l}\overline{\bar{\nu}} \\
\text { है } \\
\text { है }\end{array}$ & 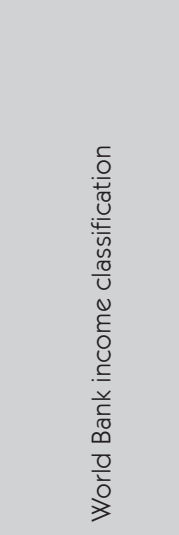 & 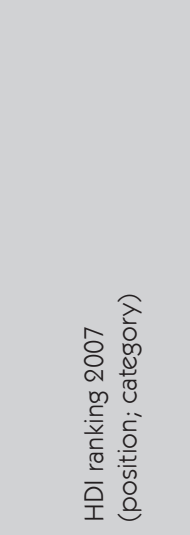 & 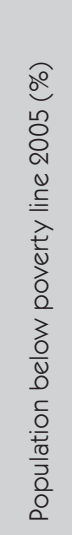 & 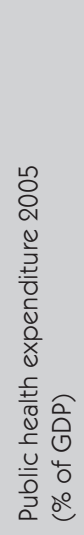 & 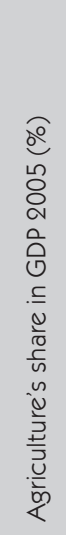 & 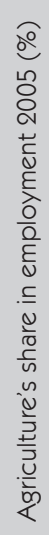 & 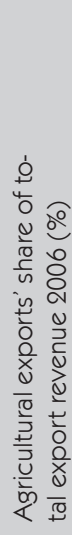 \\
\hline Australia & High income & 3rd; High & $\begin{array}{l}\text { No } \\
\text { data }\end{array}$ & 6.5 & 3.1 & 3.5 & 18.0 \\
\hline Bangladesh & $\begin{array}{l}\text { Low income } \\
\text { (LDC) }\end{array}$ & 140th; Medium & 84 & 0.9 & 19.6 & 52 & 7.2 \\
\hline Jamaica & $\begin{array}{l}\text { Lower-middle } \\
\text { income }\end{array}$ & 101st; Medium & 14.4 & 2.8 & 5.9 & 18 & 15.5 \\
\hline Mauritius & $\begin{array}{l}\text { Upper-middle } \\
\text { income }\end{array}$ & 65th; High & $\begin{array}{l}\text { No } \\
\text { data }\end{array}$ & 2.4 & 5.6 & 10 & 30.2 \\
\hline
\end{tabular}

\subsection{Sources of information}

In order to provide an overview of the SPS systems of the selected developed- and developing-country Members of the WTO, this Chapter makes use of several sources of information, chosen for their authoritative nature, reliability and, in some cases, depth of analysis.

Economic indicators, human development indicators and trade statistics with regard to each selected WTO Member are taken from the data provided on the websites of the World Bank, the WTO, the International Trade Centre of the WTO and UNCTAD, and the UNDP. In each case the most recent year for which data is available for all selected Members is used, to facilitate comparison.

Extensive use is made of the information provided in the reports drawn up by the WTO Secretariat in the context of the most recent trade policy reviews of the selected Members. ${ }^{13}$ Such periodic reviews are required under paragraph C(ii) of the Trade Policy

13 Trade Policy Review Body, Trade Policy Review: Mauritius - Report by the Secretariat, WT/TPR/S/90, circulated on 5 October 2001; Trade Policy Review Body, Trade Policy Review: Jamaica - Report by the Secretariat. Revision, WT/TPR/S/139/Rev.1, circulated on 9 March 2005; Trade Policy Review Body, Trade 
Review Mechanism, which is Annex 3 to the WTO Agreement. ${ }^{14}$ The Secretariat report is usually extensive and can be regarded as an authoritative source of information on the trade policy of a country, including its agricultural policy and SPS regime, particularly where its findings are supported or not contradicted in the brief report submitted as part of the review process by the Member under review. Where relevant, the information obtained from the Secretariat report has been supplemented by information in the Member's corresponding report. ${ }^{15}$

In the case of the developed-country Member, Australia, as is the case with most developed-country Members, detailed and easily accessible information can be found on the official website of the relevant government Ministries and departments.

In particular, policy papers and annual reports of the Australian Government Department of Health and Aging, the Australian Government Department of Agriculture, Fisheries and Forestry, and the Australian Government Department of Foreign Affairs and Trade, available on their websites, are drawn from extensively..$^{16}$ The particular divisions and agencies responsible for various aspects of Australia's SPS regime provide detailed information that was used in setting out the complex regulatory system in place in Australia. Recent examples of policy developments and practical implementation of Australia's SPS system are taken from the Annual Report for 2007 of the Department of Agriculture, Fisheries and Forestry. In addition, data compiled by the Australian Bureau of Statistics is relied upon for statistical data with regard to health, trade and agriculture in Australia. ${ }^{17}$ Further, several papers of the Australian Bureau of Agricultural and Resource Economics (ABARE) containing research and analysis with regard to various sectors of the Australian agricultural industry, are used. ABARE is an Australian government economic research agency noted for its professionally independent research and analysis. ${ }^{18}$

Policy Review: Bangladesh - Report by the Secretariat, WT/TPR/S/168, circulated on 9 August 2006; Trade Policy Review Body, Trade Policy Review: Australia - Report by the Secretariat, WT/TPR/S/178, circulated on 29 January 2007.

14 See 'Trade Policy Review Mechanism', in The Results of the Uruguay Round of Multilateral Trade Negotiations: The Legal Texts (World Trade Organization, Geneva), 1994, 434-437.

${ }^{15}$ Trade Policy Review Body, Trade Policy Review: Australia - Report by the Government, WT/TPR/G/178, circulated on 29 January 2007; Trade Policy Review Body, Trade Policy Review: Mauritius - Report by the Government, WT/TPR/G/90, circulated on 5 October 2001; Trade Policy Review Body, Trade Policy Review: Jamaica - Report by the Government, WT/TPR/G/139, circulated on 15 December 2004; Trade Policy Review Body, Trade Policy Review: Bangladesh - Report by the Government, WT/TPR/G/168, circulated on 9 August 2006.

16 The website of the Australian Government Department of Health and Aging is available at: http://www. health.gov.au, visited on 18 January 2008; the website of the Australian Government Department of Foreign Affairs and Trade is available at: http://www.dfat.gov.au, visited on 18 January 2008; the website of the Australian Government Department of Agriculture, Fisheries and Forestry is available at: http://www.daff. gov.au, visited on 18 January 2008.

17 Australian Bureau of Statistics, 2007 Year Book Australia: A Comprehensive Source of Information About Australia, ABS Catalogue No. 1301.0 (Commonwealth of Australia, Canberra), 2007, 273, available at: http://www.ausstats.abs.gov.au/Ausstats/subscriber.nsf/0/D6C6B02D31617DA4CA25726D000467A6/\$Fi 1e/13010_2007.pdf, visited on 12 January 2008.

${ }^{18} \mathrm{ABARE}$ also produces regular quarterly forecasts for the full range of export commodities, so that industries can plan their future better, based on sound research. ABARE employs around 150 staff comprising economists, statisticians, modellers, mathematicians and support staff. For further information on ABARE, see its website, available at: htttp://www.abareconomics.com, visited on 18 January 2008. 
In addition, as Australia is an active participant in the SPS Committee, and has raised the trade concerns it has regarding the SPS measures of other Members in this forum, it was possible to draw interesting information in this regard from the yearly compilation of SPS trade raised at SPS Committee meetings concerns maintained by the WTO Secretariat. ${ }^{19}$ The information provided in the Secretariat summary is supplemented by other official WTO documents related to the specific issue, where available.

Unlike in the case of developed-country Members of the WTO, information on the SPS systems of developing-country Members is often limited in scope, difficult to obtain, of varying accuracy and sometimes contradictory. To overcome these limitations, this Chapter examines the SPS systems of certain developing-country Members for which authoritative and reliable sources of information exist.

These sources of information are the following. First, this section relies to a large extent on the results of a project, jointly funded by the Commonwealth Secretariat and International Trade Centre of UNCTAD and the WTO, aiming to identify technical assistance needs of developing countries in the area of TBT and SPS requirements. In particular this project focused on the need to overcome problems of effective participation in international standard setting, meeting technical requirements on export markets and building capacity to derive full benefits from the WTO's SPS Agreement and TBT Agreement. This was done on the basis of case studies in six developing countries, namely Malaysia, Jamaica, Kenya, Mauritius, Uganda and Namibia. The results of this project were compiled in a two-volume report. ${ }^{20}$ Both the final report, and papers compiled in the context of the project are drawn from. ${ }^{21}$

Second, where available, regard is had to country papers submitted in the context of the original and second Global Forum of Food Safety Regulators, convened by FAO and WHO in 2002. ${ }^{22}$ This forum was intended to provide an opportunity for food safety

19 Committee on Sanitary and Phytosanitary Measures, Specific Trade Concerns. Note by the Secretariat. Revision, G/SPS/GEN/204/Rev.7, circulated on 6 February 2007.

${ }^{20}$ Vinod Rege et al., Influencing and Meeting International Standards: Challenges for Developing Countries. Volume I: Background Information, Findings from Case Studies and Technical Assistance Needs (International Trade Centre UNCTAD/WTO and Commonwealth Secretariat, Geneva), 2003; Vinod Rege et al., Influencing and Meeting International Standards: Challenges for Developing Countries. Volume II: Procedures Followed by Selected International Standard-Setting Organisations and Country Reports on TBT and SPS (International Trade Centre UNCTAD/WTO and Commonwealth Secretariat, Geneva), 2004.

${ }^{21}$ For example. Spencer Henson and Steve Jaffee, Jamaica's Trade in Ethnic Foods and Other Niche Products: The Impact of Food Safety and Plant Health Standards, Agriculture and Rural Development Discussion Paper (World Bank, Washington D.C.), 2005, available at: http://siteresources.worldbank.org/INTARD/Resources/ JamaicaStandardsF_final.pdf, visited on 7 January 2008.

${ }^{22}$ Australia New Zealand Food Safety Authority, 'The Development and Implementation of the New Australian Food Safety Standards', presented at the FAO/WHO Global Forum of Food Safety Regulators (Food and Agriculture Organization and World Health Organization, Marrakesh) 28-30 January 2002, available at: www. foodsafetyforum.org/global/, visited on 6 November 2002; Australian Government Department of Health and Ageing and Food Standards Australia New Zealand, 'Enhancing Surveillance of Foodborne Diseases in Australia to Control Disease and Improve Food Safety', presented at the FAO/WHO Second Global Forum of Food Safety Regulators, Conference Room Document 6 (Food and Agriculture Organization and World Health Organization, Bangkok, Thailand) 12-14 October 2004, available at: ftp://ftp.fao.org/docrep/fao/meeting/008/ae019e.pdf, visited on 22 January 2008; Australian Government Department of Health and Ageing and Food Standards Australia New Zealand, 'Emerging Chemical and Microbiological Issues - Importance of Surveillance and International Cooperation and Information Sharing', presented at the FAO/WHO Second 
regulators from all countries of the world to come together and share experiences on food safety issues. In this context, several countries prepared papers briefly describing their food safety regulatory system or certain aspects thereof.

Third, the 2005 report of a World Bank study on the impact of SPS measures on developing country exports is relied upon. ${ }^{23}$ This report is based on a series of case studies regarding selected commodities (fish, horticulture, livestock products, nuts and spices) across nine low- and middle-income countries. This study aimed to improve the understanding of emerging policy and commercial issues in the SPS area, and to guide World Bank activities in this area.

Fourth, use is made of reports, scoping papers and conference papers drafted in the context of a technical cooperation project implemented by the United Nations Conference on Trade and Development (UNCTAD), with the support of the International Development Research Centre (IDRC) in Canada, in 2001-2002. ${ }^{24}$ This project, entitled 'Standards and Trade, Strengthening Developing Countries' Capacity to Respond to Health, Sanitary and Environmental Requirements' aimed to identify policies addressing developing country constraints in meeting SPS requirements on their export markets. It encompassed case studies in three developing regions, namely South Asia, Eastern and Southern Africa and Central America. ${ }^{25}$ The outcome of this project was published in book form in $2006 .{ }^{26}$

Fifth, some use is made of a study commissioned in 2003 by the Technical Centre for Agricultural and Rural Cooperation ACP-EU, regarding the consequences of SPS measures taken by the EC on African, Caribbean and Pacific (ACP) countries. ${ }^{27}$ This study examined EC SPS legislation and assessed its impact on the exports and infrastructure of ACP countries as well as on individual firms in ACP countries. It was based on existing reports and supplemented by discussions with organisations that play an important role in SPS issues between the EC and ACP countries, ${ }^{28}$ and contacts with importers, standardsetters and others.

Global Forum of Food Safety Regulators, Conference Room Document 8 (Food and Agriculture Organization and World Health Organization, Bangkok, Thailand) 12-14 October 2004, available at: ftp://ftp.fao.org/docrep/fao/meeting/008/ae081e.pdf, visited on 22 January 2008.

23 Poverty Reduction \& Economic Management Trade Unit and Agriculture and Rural Development Department, Food Safety and Agricultural Health Standards: Challenges and Opportunities for Developing Country Exports, Report no. 31207 (World Bank, Washington D.C.), 10 January 2005, available at: http:// siteresources.worldbank.org/INTRANETTRADE/Resources/Topics/Standards/standards_challenges_synthesisreport.pdf, visited on 27 June 2008.

${ }^{24}$ UNCTAD project number INT/99/A64, with a budget of US\$122 171. IDRC project code 100124, with a budget of CAN\$233 500 .

25 The case study reports were presented in regional workshops in 2001 . The project culminated in a workshop in Geneva in 2002 where the results of the project were presented. This project was coordinated with activities in the same area by the International Trade Centre of UNCTAD and the WTO, the Commonwealth Secretariat, the World Bank and the OECD, and some of the workshops were co-organised with certain of these organizations.

${ }^{26}$ Veena Jha, ed., Environmental Regulation and Food Safety: Studies of Protection and Protectionism (Edward Elgar and International Development Research Centre, Ottawa), 2005.

27 Technical Centre for Agricultural and Rural Cooperation ACP-EU, Study of the Consequences of the Application of Sanitary and Phytosanitary (SPS) Measures on ACP Countries (CTA, Wageningen), May 2003, available at: http://www.tcd.ie/iiis/policycoherence/index.php/iiis/content/download/371/1446/file/CTA\%20 Impact $\% 20$ of $\% 20$ SPS $\% 20$ Measures\%20on\%20ACP\%20countries.pdf., visited on 23 January 2008.

${ }_{28}$ These include the Food and Agriculture Organisation, the Codex Alimentarius Commission, the Centre for 
Finally, where articles, news reports or briefs are available touching upon SPS issues in the Members discussed, the relevant information is incorporated where appropriate. ${ }^{29}$ Again, as with the previous section, it should be borne in mind that the objective of this section is not to provide a comprehensive study of the SPS regulatory regimes in the selected countries, but only to provide a context for the discussion in Parts III to V of this book by means of concrete illustrations.

the Development of Enterprise, the Comite de Liason Europe-Afrique-Caraibes-Pacifique and the Centre for Imports from Developing Countries. Ibid., 1.

${ }^{29}$ For example, for Mauritius, regard is had to Southern African Development Community, SADC SPS and Food Safety Issues: An Agenda for Action (SADC Consultative Forum on SPS/Food Safety, Windhoek, Namibia), 20-22 November 2000, available at: www1.worldbank.org/wbiep/trade/Stds_Africa/SADC_SPS. pdf, visited on 1 February 2001. With respect to Jamaica, information is taken from Eurostep et al., New ACP-EU Trade Arrangements: New Barriers to Eradicating Poverty? (Eurostep, Brussels), March 2004, available at: www.eurostep.org/pubs/trade_study.pdf, visited 25 June 2007. A consultancy study produced for the Inter-American Institute for Cooperation on Agriculture (IICA) by Janice Reid, on the readiness of Jamaican institutions to comply with the SPS Agreement is also relied upon. Janice Reid, Needs Analysis of the Readiness of Jamaican Institutions for WTO-SPS: Executive Summary (Inter-American Institute for Cooperation on Agriculture, Kingston), April 2000, available at: www.agroinfo.org/caribbean/iicacarc/jamaica/summary.pdf, visited on 7 January 2008. With regard to Bangladesh, , the published outcome of the technical cooperation project carried out by UNCTAD with the support of the IDRC is relied upon. Veena Jha, ed., Environmental Regulation and Food Safety: Studies of Protection and Protectionism (Edward Elgar and International Development Research Centre, Ottawa), 2005. Extensive use is made of the specific scoping paper drawn up for this project. Sahadad M. Hussain and S.M. Khalilur Rahman, 'Sanitary and Phytosanitary Measures and Environmental Management in Bangladesh', presented at the Workshop on a New WTO Round on Agriculture, SPS, and the Environment: Capturing the Benefits for South Asia (World Bank, UNCTAD and SAARC Secretariat, New Delhi, India) 11-13 January 2001, available at: http://r0.unctad.org/trade_env/ test $1 /$ meetings/standards/BARC.doc, visited on 7 July 2001. Further, several reports and conference papers of studies done regarding the shrimp industry in Bangladesh have been used. James C. Cato and S. Subasinge, Food Safety in Food Security and Food Trade: Case Study: The Shrimp Export Industry in Bangladesh (International Food Policy Research Institute, Washington D.C.), September 2003, ; Mustafizur Rahman, 'EU Ban on Shrimp Imports from Bangladesh: A Case Study on Market Access Problems Faced by LDCs', presented at the Workshop on a New WTO Round on Agriculture, SPS, and the Environment: Capturing the Benefits for South Asia (World Bank, UNCTAD and SAARC Secretariat, New Delhi, India) 11-13 January 2001, available at: http://r0.unctad.org/trade_env/test1/meetings/standards/mustafizur.doc, visited on 6 March 2001; Mohammad Alauddin and M. Akhter Hamid, 'Shrimp Culture in Bangladesh with Emphasis on Social and Economic Aspects', in Towards Sustainable Shrimp Culture in Thailand and the Region: Proceedings of a Workshop, Paul Smith (ed.) (Australian Centre for International Agricultural Research, Canberra), 1999, 53-62, available at: http://www.aciar.gov.au/web.nsf/doc/JFRN-5J473M/\$file/PR90\%20Chapter\%2009.pdf, visited on 13 May 2000; James C. Cato and C.A. Lima Dos Santos, 'Costs to Upgrade the Bangladesh Frozen Shrimp Processing Sector to Adequate Technical and Sanitary Standards and to Maintain a HACCP Program', presented at the Conference on the Economics of HACCP: New Studies of Costs and Benefits, Washington D.C.) 15-16 June 1998, available at: www.umass.edu/ne165/haccp1998/cato.html, visited 25 June 2007; Mustafa K. Mujeri, Rural Development Priorities for Poverty Reduction in Bangladesh (Bangladesh Resident Mission of the Asian Development Bank, Dhaka), November 2001, available at: www.adb.org/documents/ epps/ban/rural_development/rural_development.pdf, visited 6 December 2002; Nazneen Ahmed, Ad Hoc Expert Meeting in Preparation for the Mid-Term Review of the Programme of Action for the Least Developed Countries for the Decade 2001-2010: Case Study on Bangladesh UNCTAD/LDC/MISC/2006/4 (United Nations Conference on Trade and Development, May 2006; Greater Access to Trade Expansion Project, $A$ Pro-Poor Analysis of the Shrimp Sector in Bangladesh (United States Agency for International Development Arlington), February 2006, available at: http://www.usaid.gov/our_work/cross-cutting_programs/wid/pubs/ Bangladesh_Shrimp_Value_Chain_Feb_2006.pdf, visited 13 January 2008. 


\subsection{Australia}

\subsubsection{Factual background}

Australia is a country in the Southern hemisphere, between the Indian and Pacific Oceans. It is the world's largest island and smallest continent. ${ }^{30}$ The Commonwealth of Australia was formed in 1901, with the federation of six former British colonies. The Federation is now composed of six States and three Territories. ${ }^{31}$ In order to situate Australia along the continuum of levels of development, it is useful to look at selected indicators of economic and human development.

\subsubsection{Development indicators}

Australia falls, in terms of the World Bank's classification of countries by income, within the category of high-income countries. ${ }^{32}$ Its GNI per capita in 2006 was US\$35,990. ${ }^{33}$ Australia is a Member of the Organisation for Economic Cooperation and Development (OECD). ${ }^{34}$ The GDP of Australia was US\$768.2 billion in $2006 .{ }^{35}$ Its GDP at purchasing power parity was US $\$ 646.3$ billion and its GDP per capita at purchasing power parity was US\$31,794 in 2005. ${ }^{36}$

Australia is ranked third by the UN Human Development Index of 2007, and falls into the category of high-human-development countries. ${ }^{37}$ In 2006, the population of Australia amounted to 20.5 million people. ${ }^{38}$ There is no data available on the percentage of people

${ }^{30}$ Australia has an area of 7.69 million square $\mathrm{km}$.

31 Six States federated to form the Commonwealth of Australia, under the Commonwealth Government. However, they retain legislative power over matters not under the authority of the Commonwealth (Sec. 51 of the Australian Constitution). Territories are areas within Australia's borders that are not claimed by one of the six States. They can be governed by the Commonwealth Government, or they can be granted a right of self-government, which allows them to establish a government in a similar manner to a state. Three of the ten Australian Territories have limited self-government; the others fall under the Commonwealth Government. This information is provided on the website of the Australian Government, available at: http://www.australia. gov.au/State_and_Territory_Government, visited on 17 January 2008.

${ }^{32}$ See the World Bank classification of economies by income of July 2007 available at: http://siteresources. worldbank.org/DATASTATISTICS/Resources/CLASS.XLS, visited on 8 January 2008.

${ }^{33}$ World Bank, Key Development Data and Statistics, available at: http://go.worldbank.org/1SF48T40L0, visited on 12 January 2008.

${ }^{34}$ The OECD is the successor of the Organisation for European Economic Co-operation (OEEC), which was established to administer aid from the US and Canada under the Marshall Plan for the reconstruction of Europe after the Second World War. Since the OECD replaced the OEEC in 1961, its membership has expanded to 30 countries (Australia, Austria, Belgium, Canada, Czech Republic, Denmark, Finland, France, Germany, Greece, Hungary, Iceland, Ireland, Italy, Japan, Korea, Luxembourg, Mexico, Netherlands, New Zealand, Norway, Poland, Portugal, Slovak Republic, Spain, Sweden, Switzerland, Turkey, the UK and the US). There are no formal membership criteria other than a commitment to a market economy and a pluralistic democracy. This information is provided on the website of the OECD, available at: www.oecd.org, visited on 12 January 2008 .

35 United Nations Development Programme, Human Development Report 2007/2008. Fighting Climate Change: Human Solidarity in a Divided World (Palgrave Macmillan, New York), 2007, 1, available at: http:// hdr.undp.org/en/media/hdr_20072008_en_complete.pdf, visited on 10 December 2007.

${ }^{36}$ Ibid., 277.

${ }^{37}$ UN Human Development Index for 2007, contained in Ibid., 8.

38 See the World Bank webpage on Key Development Data \& Statistics of 2006 available at: http://web. 
in Australia living below the absolute poverty line for OECD countries of US\$4 per day in 2000-2004. ${ }^{39}$ However, for purposes of comparison with the middle- and low-income Members selected in this Chapter, it seems safe to assume that there is no incidence of poverty below US\$2 per day in Australia. This does not mean, of course, that there is no poverty in relative terms in Australia. According to the alternative measure of relative income poverty in developed countries, namely the share of the population living on less than 50 percent of the median adjusted disposable household income, 12.2 percent of the Australian population fell below this relative poverty line in $2000-2004 .^{40}$

\subsubsection{Health priorities}

Australia's public health priorities provide an indication of the relative importance of SPS regulation as an area of public spending and policy focus. They also provide the context within which the impact of the disciplines of the SPS Agreement on health regulation in Australia can be understood. Australia's priorities in the area of public health can be seen from the following factual background.

In Australia, government spending on public health accounted for 6.5 percent of GDP, or US $\$ 3,123$ per capita at purchasing power parity. ${ }^{41}$ Life expectancy at birth is high, at 80.9 years. ${ }^{42}$ This high life expectancy has significant implications for government spending in public health.

Death rates in Australia from all causes are reported by the Australian government to be among the lowest in the world, ${ }^{43}$ which is consistent with Australia's relatively high life expectancy. The infant mortality rate in Australia is only 5 per 1000 births. ${ }^{44}$ These achievements are due, in part, to the high levels of health care and sanitation in Australia.

worldbank.org/WBSITE/EXTERNAL/DATASTATISTICS/0,,contentMDK:20535285 menuPK:1192694 p agePK:64133150 piPK:64133175 theSitePK:239419,00.html, visited on 9 January 2008.

${ }^{39}$ The absolute poverty lines of US $\$ 1$ and US $\$ 2$ per days were established for purposes of comparison between middle- and low-income countries, but are not useful in comparing high income countries since little or no differences will be found at these low levels. As a result, the Human Development Report does not provide data using these poverty measures for OECD countries, Central and Eastern Europe and the Commonwealth of Independent States. Instead, data is provided with regard to the percentage of population living below US $\$ 4$ and US\$11 per day. In addition data on the percentage of the population living below $50 \%$ of the median income is provided, as a measure of relative poverty in a particular country.

40 United Nations Development Programme, Human Development Report 2007/2008. Fighting Climate Change: Human Solidarity in a Divided World (Palgrave Macmillan, New York), 2007, 241, available at: http://hdr.undp.org/en/media/hdr_20072008_en_complete.pdf, visited on 10 December 2007.

${ }^{41}$ Ibid., 247.

${ }^{42}$ See the UNDP Human Development Index for 2007, contained in Ibid., 229.

${ }^{43}$ Australian Bureau of Statistics, 2007 Year Book Australia: A Comprehensive Source of Information About Australia, ABS Catalogue No. 1301.0 (Commonwealth of Australia, Canberra), 2007, 247, available at: http://www.ausstats.abs.gov.au/Ausstats/subscriber.nsf/0/D6C6B02D31617DA4CA25726D000467A6/\$Fi le/13010_2007.pdf, visited on 12 January 2008.

44 United Nations Development Programme, Human Development Report 2007/2008. Fighting Climate Change: Human Solidarity in a Divided World (Palgrave Macmillan, New York), 2007, 261, available at: http://hdr.undp.org/en/media/hdr_20072008_en_complete.pdf, visited on 10 December 2007. 
One hundred percent of the Australian population has sustainable access to clean water and sanitation. ${ }^{1}$ There are 247 physicians in Australia per 100000 people. $^{2}$

Australia made the health transition, in the middle of the twentieth century, from a situation where infectious diseases were the primary cause of death, to the situation where the leading causes of death became non-communicable diseases. In 2004, communicable diseases accounted for only 4 percent of all deaths in Australia, largely due to influenza and pneumonia. ${ }^{3}$ Diseases such as diphtheria, whooping cough and polio have either been eradicated or are negligible as causes of death, due to effective child immunisation programs. ${ }^{4}$ The prevalence of tuberculosis in Australia is only 6 cases per 100,000 people. ${ }^{5}$ However, food-borne infectious diseases (such as those caused by Salmonella and E. Coli) are still a considerable burden on the Australian economy. On average, 5.4 million cases of food-borne infection occur each year, costing about A\$1.2 billion. ${ }^{6}$ Although most cases are not serious enough to require medical attention, the high number of affected people that have to take leave from work to recover or to care for affected family members account for 60 percent of the costs involved.?

The leading causes of death in Australia are currently non-communicable diseases. In particular, cardiovascular disease (primarily strokes and heart attacks) and cancer, account for almost two-thirds of all deaths. ${ }^{8}$ Although significant reductions in death rates from cancer and cardiovascular diseases have been achieved in the last ten years, they are still a health challenge in Australia. ${ }^{9}$ Important risk factors contributing to the incidence of non-communicable diseases in Australia are lifestyle related, including example the

\footnotetext{
${ }^{1}$ United Nations Development Programme, Human Development Report 2005. International Cooperation at a Crossroads: Aid, Trade and Security in an Unequal World (United Nations, New York), 2005, 242, available at: http://hdr.undp.org/en/media/hdr05_complete.pdf, visited on 2 January 2008.

2 United Nations Development Programme, Human Development Report 2007/2008. Fighting Climate Change: Human Solidarity in a Divided World (Palgrave Macmillan, New York), 2007, 247, available at: http://hdr.undp.org/en/media/hdr_20072008_en_complete.pdf, visited on 10 December 2007.

${ }^{3}$ Of the 5,305 deaths due to communicable diseases in 2004, 3,381 or 64\% were caused by influenza or pneumonia. Australian Bureau of Statistics, 2007 Year Book Australia: A Comprehensive Source of Information About Australia, ABS Catalogue No. 1301.0 (Commonwealth of Australia, Canberra), 2007, 273, available at: http://www.ausstats.abs.gov.au/Ausstats/subscriber.nsf/0/D6C6B02D31617DA4CA25726D000467A6/\$Fi le/13010_2007.pdf, visited on 12 January 2008.

4 Ibid., $27 \overline{6}$.

${ }^{5}$ United Nations Development Programme, Human Development Report 2007/2008. Fighting Climate Change: Human Solidarity in a Divided World (Palgrave Macmillan, New York), 2007, 257, available at: http://hdr undp.org/en/media/hdr_20072008_en_complete.pdf, visited on 10 December 2007.

${ }^{6}$ OzFoodNet Working Group, Burden and Causes of Foodborne Disease in Australia: Annual Report of the OzFoodNet Network, 2005 (Commonwealth of Australia, Canberra), 2006, 278, available at: http://www. health.gov.au/internet/wcms/Publishing.nsf/Content/cda-cdi3003-pdf-cnt.htm/\$FILE/cdi3003b.pdf, visited on 14 January 2008.

${ }^{7}$ Ibid.

${ }^{8}$ Australian Bureau of Statistics, 2007 Year Book Australia: A Comprehensive Source of Information About Australia, ABS Catalogue No. 1301.0 (Commonwealth of Australia, Canberra), 2007, 246, available at: http://www.ausstats.abs.gov.au/Ausstats/subscriber.nsf/0/D6C6B02D31617DA4CA25726D000467A6/\$Fi le/13010 2007.pdf, visited on 12 January 2008.

9 From 1994 to 2004, the death rate for malignant neoplasms (cancer) decreased by 14\%, while the rate for circulatory diseases decreased by $39 \%$. Ibid.
} 
high prevalence of smoking, obesity, alcohol abuse, insufficient exercise and low levels of consumption of fruit and vegetables. ${ }^{10}$

Chronic disease, such a diabetes, arthritis, Alzheimer's, asthma, cancer and heart disease, is an increasing burden on the public health system in Australia as the population ages and lifestyle-related health risks play a larger role. ${ }^{11}$ In 2004-2005, over three-quarters of people living in private dwellings (as opposed to institutions) had at least one chronic health condition. ${ }^{12}$ This proportion increased with age, from 41 percent of children under 15 years to almost 100 percent of people aged 65 years and over. ${ }^{13}$

Due to the growing burden of chronic disease in Australia, a key policy objective of the Australian government and the governments of all its states is the prevention and effective management of chronic disease. This is evinced by the fact that the Australian National Health Priority Action Council under the Government Department of Health and Aging has adopted a National Chronic Disease Strategy as a public health priority. ${ }^{14}$ Chronic illnesses are often lifestyle-related, and an important element hereof is diet. The focus in Australia's health strategy on the prevention of chronic disease therefore indicates that factors with long-term health effects, such as food-safety risks, have increased importance as regulatory priorities.

Already in 2000, the Council of Australian Governments established a single regulatory framework for the development of all national food-safety requirements covering the entire food chain, through an inter-governmental agreement on food-safety regulation, the Food Regulation Agreement of 2000, which was revised in 2002. ${ }^{15}$ Several additional steps, which are discussed below, ${ }^{16}$ have been taken to strengthen the food-safety system throughout the Commonwealth. In view of the fact that Australia imports a large amount of food, ${ }^{17}$ this system has to include effective controls on imports to ensure that they meet the same safety levels as domestic products. The large share of processed foods in the food imports of Australia ${ }^{18}$ increases the importance of a farm-to-fork approach to

10 The outcome of a 2004 National Health Survey in Australia indicated that $23 \%$ of adults smoked, $13 \%$ of adults consumed alcohol at levels constituting a high risk to their health in the long term, $70 \%$ of adults had low exercise levels, $52 \%$ of adults were classified as overweight or obese based, and $86 \%$ did not consume the recommended daily intake of vegetables per day. Ibid., 265.

${ }^{11}$ Ibid., 263.

12 Ibid., 255.

13 Ibid.

14 National Health Priority Action Council, National Chronic Disease Strategy (Department of Health and Aging of the Commonwealth of Australia, Canberra), 2006 available at: http://www.health.gov.au/internet/ wcms/publishing.nsf/Content/7E7E9140A3D3A3BCCA257140007AB32B/\$File/stratal3.pdf, visited on 12 January 2008.

15 The Food Regulation Agreement, between the Commonwealth of Australia and its States and Territories, adopted on 6 December 2002, available at: http://www.coag.gov.au/ig_agreements/food_regulation_agreement_2002.htm, visited on 12 January 2008.

${ }^{16}$ See below, Part II, Section 2.4.2.2.

17 Although Australia is a net food exporter, it does import significant quantities of food products (amounting to A\$6.8 billion in 2005-2006). Australian Government Department of Agriculture Fisheries and Forestry, Australian Food Statistics 2006 (Commonwealth of Australia, Canberra), 2007, 11, available at: http://www. abareconomics.com/publications_html/crops/crops_07/fstats_main.pdf, visited on 15 January 2008.

${ }^{18}$ Ninety-five percent of the value of food imports is accounted for by processed food. Australia's main food imports are processed vegetables, fruit and nuts; processed dairy products; processed meat, bakery products and beverages. Ibid. 
food-safety requirements, in order to prevent the introduction of contaminants, such as carcinogens, or other risks in the production process.

\subsubsection{Trade priorities}

Australia was one of the original 23 Contracting Parties to the GATT 1947. When the Marrakesh Agreement Establishing the World Trade Organization (the WTO Agreement ${ }^{19}$ was adopted on 14 April 1994, Australia became one of the original Members of the WTO.

Australia is an active participant in world trade. In 2006-07, its foreign revenue earnings from exports of goods and services amounted to A $\$ 216$ billion, an increase of 10 percent from the previous year, ${ }^{20}$ and made up 20.6 percent of its GDP. ${ }^{21}$ The ratio of trade to GDP in Australia in 2004 - 2006 was 39.8. ${ }^{22}$ In the same period, total merchandise exports increased by 10 per cent to $\$ 168$ billion. Australia's main merchandise export products are coal, iron ore, gold and crude petroleum..$^{23}$ In 2006-2007, fuel and mineral exports, including gold, made up 50.1 percent of total merchandise exports. ${ }^{24}$ Food and agricultural products made up another 16.1 percent in that period. ${ }^{25}$

Due to the important share of agricultural products in Australia's non-mineral exports, ${ }^{26}$ liberalisation of agricultural trade is a priority for Australia. Australia is a founding member of the Cairns Group, a coalition of countries that are important exporters of agricultural

19 'Marrakesh Agreement Establishing the World Trade Organization', in The Results of the Uruguay Round of Multilateral Trade Negotiations: The Legal Texts (World Trade Organization, Geneva), 1994, 6-18.

${ }^{20}$ Australian Government Department of Foreign Affairs and Trade, Composition of Trade Australia: $2006-07$ (Commonwealth of Australia, Canberra), November 2007, 1, available at: http://www.dfat.gov.au/publications/stats-pubs/downloads/COT_FY2007.pdf, visited on 12 January 2008.

${ }^{21}$ Australian Government Department of Foreign Affairs and Trade, Trade Topics: A Quarterly Review of Australia's International Trade. Spring 2007 (Commonwealth of Australia, Canberra), September 2007, 31, available at: http://www.dfat.gov.au/publications/stats-pubs/downloads/trade_topics_spring_07.pdf, visited on 12 January 2008.

${ }^{22}$ WTO Secretariat, Trade Profiles 2007 (World Trade Organization, Geneva), October 2007, 10, available at: http://www.wto.org/english/res_e/booksp_e/anrep_e/trade_profiles07_e.pdf, visited on 8 January 2008. The ratio of trade to GDP is a useful indicator of the significance of international trade to a country's economy. It is calculated by dividing an economy's total trade in goods and services (exports + imports) by its GDP, on the basis of data for the three latest years available. GDP is measured in nominal terms and with market exchange rates.

${ }^{23}$ Australian Government Department of Foreign Affairs and Trade, Composition of Trade Australia: 2006-07 (Commonwealth of Australia, Canberra), November 2007, 1, available at: http://www.dfat.gov.au/publications/stats-pubs/downloads/COT_FY2007.pdf, visited on 12 January 2008. Of Australia's A \$216 billion in export earnings in 2007-2007, coal accounted for A \$21.9 billion, iron ore for A \$15.5 billion, gold for A \$10.7 billion and crude petroleum for A $\$ 7.6$ billion.

${ }^{24}$ Australian Government Department of Foreign Affairs and Trade, Exports of Primary and Manufactured Products Australia: 2006-07 (Commonwealth of Australia, Canberra), December 2007, 16, available at: http://www.dfat.gov.au/publications/stats-pubs/downloads/pmp_2006_07.pdf, visited on 12 January 2008.

25 This information is provided on the website of the Australian Government Department of Foreign Affairs and Trade, available at: http://www.dfat.gov.au/trade/negotiations/trade_in_agriculture.html, visited on 12 January 2008. In 2006 alone, the share of agriculture (including processed agricultural products) in Australia's export earnings was 18\%. WTO Secretariat, Trade Profiles 2007 (World Trade Organization, Geneva), October 2007, 11, available at: http:/www.wto.org/english/res_e/booksp_e/anrep_e/trade_profiles07_e.pdf, visited on 8 January 2008.

${ }^{26}$ The share of food and agricultural products in Australia's merchandise exports, excluding fuels and minerals, was over $30 \%$ in $2006-2007$. 
products, which aims to promote the liberalisation of agricultural trade. ${ }^{27}$ Australia chairs this coalition. One of Australia's main priorities with regard to the Doha Development Round of trade negotiations is to improve market access for agricultural products and reduce domestic support in agriculture. ${ }^{28}$ In addition, it aims to increase market access for services and non-agricultural products, and to improve WTO disciplines on regional trade agreements. ${ }^{29}$

Australia actively defends its interests in the WTO regime, ${ }^{30}$ including through the use of the dispute settlement system. It has been a complainant in seven disputes, five of which proceeded to adjudication by WTO panels and, in some cases, also by the Appellate Body. ${ }^{31}$ Notably, most of these disputes had to do with agricultural products, although none of them was brought under the SPS Agreement. It has been a third party to disputes brought by other WTO Members in 45 cases, ${ }^{32} 20$ of which involved agricultural products and six of which were decided under the SPS Agreement. ${ }^{33}$ Australia joined consultations initiated by other WTO Members in a further 18 cases, nine of which dealt with measures affecting agricultural products and one of which involved claims under the SPS Agreement. ${ }^{34}$ Australia has also had disputes brought against it in ten cases, six of which were brought under the SPS Agreement. ${ }^{35}$ Two of these disputes, one of which involved

27 The Cairns Group is a coalition of agriculture exporting countries, formed in 1986. It is composed of the main exporters of agricultural products, including developed and developing countries, across the world (Argentina, Australia, Bolivia, Brazil, Canada, Chile, Colombia, Costa Rica, Guatemala, Indonesia, Malaysia, New Zealand, Pakistan, Paraguay, Philippines, South Africa, Thailand, Uruguay). Its members account for over $25 \%$ of world trade in agricultural products. It is influential in the negotiations on the reform of agricultural trade. See the website of the Cairns Group, available at: http://www.cairnsgroup.org/, visited on 8 January 2008.

${ }_{28}$ Trade Policy Review Body, Trade Policy Review: Australia - Report by the Secretariat. Revision, WT/ TPR/S/178/Rev.1, circulated on 1 May 2007, Section II para. 14.

${ }^{29}$ Ibid., Section II para. 14-16.

${ }^{30}$ A WTO Trade Law Branch of the DFAT was created in 2001 to provide Australia with legal expertise and trade policy advice with regard to the WTO agreements. Ibid., Section II para. 17 note 22.

${ }^{31}$ This information is taken from the page on Australia on the WTO website, available at: http://www.wto.org/ english/thewto_e/countries_e/australia_e.htm, visited on 23 January 2008.

${ }^{32}$ This information is taken from the page on Australia on the WTO website, available at: http://www.wto.org/ english/thewto_e/countries_e/australia_e.htm, visited on 23 January 2008. However, this number excludes

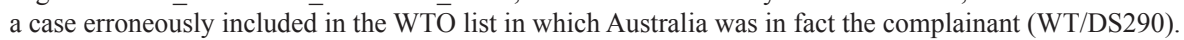

33 Australia was a third party in the following 6 disputes regarding three different matters that were decided under the SPS Agreement: European Communities Measures Concerning Meat Products (Hormones), Complaint by the United States, WT/DS26; EC Measures Concerning Meat and Meat Products (Hormones), Complaint by Canada, WT/DS48; Japan - Measures Affecting the Importation of Apples, WT/DS245; European Communities - Measures Affecting the Approval and Marketing of Biotech Products, WT/DS291, WT/DS292, and WT/DS293; United States - Continued Suspension of Obligations in the EC - Hormones Dispute, WT/DS320; Canada - Continued Suspension of Obligations in the EC - Hormones Dispute, WT/ DS321.

${ }^{34}$ India - Quantitative Restrictions on Imports of Agricultural, Textile and Industrial Products - Request to Join Consultations, WT/DS96/5, circulated on 5 August 1997.

${ }^{35}$ These are Australia - Measures Affecting the Importation of Salmon, Complaint by Canada (WT/DS18); Australia - Measures Affecting the Importation of Salmonids, Complaint by the United States (WT/DS21); Australia - Certain Measures Affecting the Importation of Fresh Fruit and Vegetables, Complaint by the Philippines (WT/DS270); Australia - Certain Measures Affecting the Importation of Fresh Pineapple, Complaint by the Philippines (WT/DS271); Australia - Quarantine Regime for Imports, Complaint by the European Communities (WT/DS287); and Australia - Measures Affecting the Importation of Apples from New Zealand, Complaint by New Zealand (WT/DS367). 
a challenge under the SPS Agreement, have been adjudicated..$^{36}$ One dispute, brought by New Zealand against Australia under the SPS Agreement is currently before a Panel. ${ }^{37}$ With regard to a further two disputes under the SPS Agreement, a panel has been established but not composed. ${ }^{38}$

Australia and New Zealand have greatly integrated economies, on the basis of the AustraliaNew Zealand Closer Economic Relations Trade Agreement of 1983 (ANZCERTA), which is the longest-standing preferential trade agreement to which Australia is party. It provides duty-free market access between the parties. This agreement is complemented by a range of bilateral agreements on specific issues, such as government procurement, movement of persons and mutual recognition of standards. In addition, an agreement on food-safety requirements was reached between Australia and New Zealand in 2002, creating a common regulatory authority. ${ }^{39} \mathrm{New}$ Zealand is currently Australia's 5th largest trading partner, accounting for 5.9 percent of its exports of goods and services. ${ }^{40}$

Australia also participates in other several preferential trade arrangements. It grants unilateral preferences to goods from least-developed and developing countries through the Australian System of Tariff Preferences (ASTP). In addition, since 1 July 2003, all 50 least-developed countries are given duty-free, quota-free market access. Unilateral preferences are also granted to Forum Island countries under the South Pacific Region Trade and Economic Cooperation Agreement (SPARTECA) and to Papua New Guinea under the Papua New Guinea and Australia Trade and Commercial Relations Agreement. Other regional arrangements and bilateral trade agreements in which Australia participates include: the Asia Pacific Economic Cooperation (APEC), the Association of Southeast Asian Nations (ASEAN), the Singapore-Australia Free Trade Agreement of 2003 (SAFTA), the Thailand-Australia Free Trade Agreement of 2005 (TAFTA), and the Australia-United States Free Trade Agreement of 2005 (AUSFTA). ${ }^{41}$

Australia is also an active participant in specific bilateral arrangements with its trading partners, including with regard to agriculture-related issues. Examples of these are

${ }^{36}$ The following SPS dispute in which Australia was the respondent proceeded to adjudication by a panel, and on appeal by the Appellate Body: Australia - Measures Affecting Importation of Salmon, WT/DS18. In addition, a compliance panel established under Article 21.5 of the Dispute Settlement Understanding decided a dispute concerning Australia's implementation of the recommendations and rulings of the Dispute Settlement Body in this case.

${ }^{37}$ On 21 January 2008, a Panel was established to hear New Zealand's challenge to Australia's phytosanitary requirements to prevent the introduction of fire blight from the importation of New Zealand apples. Dispute Settlement Body, Australia - Measures Affecting the Importation of Apples from New Zealand. Request for the Establishment of a Panel by New Zealand, WT/DS367/5, circulated on 7 December 2007. The Panel was composed on 12 March 2008 and issued a preliminary ruling on 6 June 2008.

${ }^{38}$ In two parallel disputes concerning Australia's quarantine regime, initiated by the Philippines (WT/DS270) and the EC (WT/DS287), panels were established in August and November 2003 respectively. However, these panels have never been composed. A mutually agreed solution to the latter dispute was reported in March 2007. Dispute Settlement Body, Australia - Quarantine Regime for Imports. Notification of Mutually Agreed Solution, WT/DS287/8, G/L/618/Add.1, G/SPS/GEN/384/Add.1, circulated on 13 March 2007.

${ }^{39}$ This bilateral regulatory authority is discussed further below, Part II, Section 2.4.2.2.

${ }^{40}$ Australian Government Department of Foreign Affairs and Trade, Composition of Trade Australia: 2006-07 (Commonwealth of Australia, Canberra), November 2007, 23, available at: http://www.dfat.gov.au/publications/stats-pubs/downloads/COT_FY2007.pdf, visited on 12 January 2008.

${ }^{41}$ Trade Policy Review Body, Träde Policy Review: Australia - Report by the Secretariat. Revision, WT/ TPR/S/178/Rev.1, circulated on 1 May 2007, Section II paras 21-31. 
memoranda of understanding with regard to quarantine controls and other SPS measures and technical cooperation in the agricultural sector. ${ }^{42}$ Through these arrangements, Australia seeks both to facilitate market access for its agricultural products by means of harmonised SPS requirements or mutual recognition of SPS controls and to ensure the safety of the agricultural products imported into its territory. These initiatives reflect the importance given to agricultural trade by the Australian government. The role of this sector in the Australian economy, and more specifically in its export trade, deserves further attention.

\subsubsection{Significance of agricultural sector}

The agricultural industry accounted for only 3.1 percent of GDP in Australia in 2005$2006 .{ }^{43}$ This share has decreased from 4.4 percent in 2001-2002, partly due to widespread drought which has affected the productivity of farms. ${ }^{44}$ In addition, the share of agricultural industry in employment has dropped from 4.9 percent in 2001-2002 to 3.5 percent in $2005-2006 .{ }^{45}$

However, despite its relatively small share in Australia's economy, agriculture plays a significant role in Australia's export trade as noted above. ${ }^{46}$ Australia is very competitive in agricultural production and exports approximately two thirds of total production. ${ }^{47}$ As mentioned above, in 2006, 18 percent of merchandise exports from Australia were agricultural products, including processed food and beverages. ${ }^{48}$ The last decade has seen Australia's exports in this sector grow, and they currently account for 2.3 percent of all agricultural exports worldwide. ${ }^{49}$

${ }^{42}$ Ibid., Section IV para. 8 and note 9.

${ }^{43}$ Ibid., Section IV para. 6. The main contributor to GDP in Australia is the services industry, which accounted for $68.9 \%$ of GDP in 2005-2006.

44 Ibid. Australian Bureau of Agricultural and Resource Economics, Australian Farm Survey Results 2004-05 to 2006-07 (Commonwealth of Australia, Canberra), March 2007, 2, available at: http:/www.abareconomics. com/publications_html/economy/economy_07/fsr_07.pdf, visited on 13 January 2008.

45 Trade Policy Review Body, Trade Policy Review: Australia - Report by the Secretariat. Revision, WT/ TPR/S/178/Rev.1, circulated on 1 May 2007, Section IV para. 6. In 2005-2006, total employment in the food and beverage manufacturing sector fell by more than 13,000 to 181,775 persons. In agricultural production, employment figures also dropped from 313,275 persons in 2004-2005 to 305,800 persons in 2005-2006. In commercial fishing, the reduction in the same period was from 16,000 persons to 13,650 . Australian Government Department of Agriculture Fisheries and Forestry, Australian Food Statistics 2006 (Commonwealth of Australia, Canberra), 2007, 2, available at: http://www.abareconomics.com/publications html/crops/crops_07/fstats_main.pdf, visited on 15 January 2008.

${ }^{46}$ Trade Policy Review Body, Trade Policy Review: Australia - Report by the Secretariat. Revision, WT/ TPR/S/178/Rev.1, circulated on 1 May 2007, Section IV para. 6.

47 This makes it the second most export-oriented industry in Australia, after mining. Currently $95 \%$ of wool production, $65 \%-75 \%$ of beef sugar and wheat production and $50 \%-60 \%$ of sheep meat, wine and dairy products are exported. Ibid., Section IV para. 6 and note 8.

${ }^{48}$ WTO Secretariat, Trade Profiles 2007 (World Trade Organization, Geneva), October 2007, 10, available at: http://www.wto.org/english/res_e/booksp_e/anrep_e/trade_profiles07_e.pdf, visited on 8 January 2008.

49 This information is provided on the website of the Australian Government Department of Foreign Affairs and Trade, available at: http://www.dfat.gov.au/trade/negotiations/trade_in_agriculture.html, visited on 12 January 2008. 
Australia's main agricultural export is bovine meat, ranking eighth in value among Australia's export products in 2006-2007. ${ }^{50}$ It accounted for 3 percent of total merchandise exports in 2006-2007. ${ }^{51}$ Bovine meat exports are destined mainly for Japan and the US, with other important importers being the Republic of Korea, Taiwan and Indonesia. ${ }^{52}$ Other important agricultural exports are wool, wheat, meat other than bovine meat, milk and cream and live animals. ${ }^{53}$ The success of the live cattle industry of Australia in meeting the growing demand in South East Asian countries has been attributed in part to the disease-free status of Australian cattle, which gives it an advantage over potential competitors such as Brazil or India. ${ }^{54}$

The importance of the horticultural sector ${ }^{55}$ in Australia is growing and has doubled in value over the 1990 s to around $\$ 680$ million in $2000-01 .{ }^{56}$ In particular, grapes, potatoes, apples, bananas and niche fruits and vegetables such as nashi pears, lychees, olives and herbs are important horticultural products in Australia. As over 60,000 of the persons employed in the horticultural industry are located in rural areas and outlying regions, this industry makes a significant contribution to rural and regional economies. Horticultural products make up approximately five per cent of the value of Australia's food exports. As Australia is located in the southern hemisphere, the horticulture industry can supply counter-seasonal fresh produce to many northern hemisphere markets. The main importers of Australia's horticultural products are Hong Kong, Singapore, Japan and the US.

${ }^{50}$ Australian Government Department of Agriculture Fisheries and Forestry, Australian Food Statistics 2006 (Commonwealth of Australia, Canberra), 2007, 34, available at: http://www.abareconomics.com/publications_html/crops/crops_07/fstats_main.pdf, visited on 15 January 2008.

${ }^{51}$ Australian Government Department of Foreign Affairs and Trade, Composition of Trade Australia: 2006-07 (Commonwealth of Australia, Canberra), November 2007, 6, available at: http://www.dfat.gov.au/publications/stats-pubs/downloads/COT_FY2007.pdf, visited on 12 January 2008. Export earnings from bovine meat came to A\$4.9 billion in 2006-2007. Each year since 2001-2002, bovine meat export earnings increased by an average of $4 \%$.

${ }^{52}$ These importers generated the following export earnings: Japan (\$2.1 billion), US (\$1.2 billion), Republic of Korea (\$894 million), Taiwan (\$140 million) and Indonesia (\$73 million). Ibid.

${ }_{53}$ Ibid., 36. In 2006-2007, wool ranked $15^{\text {th }}$ in contribution to merchandise export revenue and earned A $\$ 2.7$ billion (exported mainly to China and Italy). Wheat ranked $17^{\text {th }}$ and generated A $\$ 2.6$ billion (destined mainly for Indonesia, India and Japan). Meat other than bovine meat ranked $18^{\text {th }}$ in contribution to merchandise export earnings and generated A $\$ 2.1$ billion (destined mainly for the US and Japan). Milk and cream ranked $22^{\text {nd }}$ and earned A \$1.3 billion in export revenue (destined mainly for Malaysia and Singapore), and live animals ranked $24^{\text {th }}$, earning A $\$ 953$ million. Exports of crustaceans earned A $\$ 793$ million (ranked $30^{\text {th }}$ ) and fish A\$259 million (ranked $72^{\text {nd }}$ ) in that year.

${ }^{54}$ Peter Martin et al., Australian Beef. Live Cattle Export Trade: Importance to Northern and Southern Australian Beef Industries ABARE 07.1 (Australian Bureau of Agricultural and Resource Economics, February 2007, 4-5, available at: http://www.abareconomics.com/publications_html/livestock/livestock_07/Beef07.pdf, visited on 16 January 2008. This study reports that the improved management systems initiated as part of the campaign to eradicate tuberculosis and brucellosis in cattle in the $1980 \mathrm{~s}$, led to expansion in cattle trade.

${ }^{55}$ The term 'horticulture' which means the art of gardening or plant growing, is often used to refer to the smaller scale cultivation of a wide variety of crops, including fruit trees, in contrast to agronomy which refers to the cultivation of field crops such as cereals and fodder, forestry, which refers to the cultivation of trees or agriculture, which refers to the practice of large scale farming.

${ }^{56}$ Australian Government Department of Agriculture Fisheries and Forestry, National Food Industry Strategy: An Action Agenda for the Australian Food Industry (Commonwealth of Australia, Canberra), June 2002, 9 , available at: http://www.daff.gov.au/_data/assets/pdf_file/0017/183320/strategy_statement_final.pdf, visited on 13 January 2008. 
The fishery sector in Australia (comprised mainly of rock lobster, prawns, abalone and tuna) is the fifth most viable rural industry. ${ }^{57}$ It makes a significant contribution to the Australian economy. Fisheries employ approximately 21,000 people for catching and harvesting activities, 6,000 in aquaculture and a further 4,000 in processing. ${ }^{58}$ Around 9,000 commercial fishing vessels operate in Australia. ${ }^{59}$ Although fisheries production decreased by 13 percent in volume from $1999-2000$ to $2005-2006,{ }^{60}$ it increased in value by one percent and now accounts for A $\$ 2.13$ billion. ${ }^{61}$ The Australian government has made a significant investment, through its Securing our Fishing Future package, to promote the profitability and sustainability of Australian fisheries. ${ }^{62}$ The Australian fishery industry contributes to export earnings. Exports fell by 36 percent in volume in 2005-2006, ${ }^{63}$ but increased in value by $\mathrm{A} \$ 5.3$ million that period to A $\$ 1.55$ billion. ${ }^{64}$ Australia's edible fishery production is exported primarily to Hong Kong and Japan. ${ }^{65}$ About 80 percent of export earnings come from edible fishery products. ${ }^{66}$ Australia's main fisheries export product is rock lobster, followed by pearls, abalone, tuna and prawns. The Australian government is active in promoting fisheries exports. In order to ensure that market access issues with regard to Australian fishery exports are dealt with effectively and in a coordinated fashion by the Australian and State governments and the industry itself, the Fisheries Market Access and Trade Program was launched in March 2001. ${ }^{67}$ In addition,

57 This information is drawn from the fisheries page of the website of the Australian Government Department of Agriculture, Fisheries and Forestry, available at: http://www.daff.gov.au/fisheries, visited on 13 January 2008. According to this Department, the fishery industry ranks after beef, wool, wheat and dairy as most viable rural industry. The Department sees the challenge in this sector as how to develop the industry while ensuring the sustainability of Australia's marine ecosystem.

58 Trade Policy Review Body, Trade Policy Review: Australia - Report by the Secretariat, WT/TPR/S/178, circulated on 29 January 2007, Section IV para. 32.

59 Ibid.

${ }^{60}$ Causes of reduced production include increased fuel prices and reduction in allowable catches to prevent over-fishing. Wildcatch fishery production fell by 13 percent in volume, although aquaculture production increased by 16 percent in volume, in this period. Roslyn Wood et al., Australian Fisheries Statistics 2006 (Australian Bureau of Agricultural and Resource Economics, Canberra), June 2007, 3, available at: http:// www.abareconomics.com/publications_html/fisheries/fisheries_07/07_fishstats.pdf, visited on 13 January 2008.

${ }^{61}$ This was due to an $18 \%$ increase in the value of aquaculture production (driven by higher prices for Tasmanian salmonids and increased production of South Australian southern bluefin tuna), which compensated for the loss of volume. Ibid.

62 This A\$220 million package, announced in November 2005, aims to ensure profitable and sustainable Commonwealth fisheries for the future. It is reported to be the largest financial contribution ever made by the Australian Government to the fishery sector. This information is found on the Securing our Future page of the website of the Australian Government Department of Agriculture, Fisheries and Forestry, available at: http:// www.daff.gov.au/fisheries/domestic/fishingfuture, visited on 14 January 2008.

${ }^{63}$ Roslyn Wood et al., Australian Fisheries Statistics 2006 (Australian Bureau of Agricultural and Resource Economics, Canberra), June 2007, available at: http://www.abareconomics.com/publications_html/fisheries/ fisheries_07/07_fishstats.pdf, visited on 13 January 2008.

${ }^{64}$ Ibid., 9 .

65 Ibid., 10.

${ }^{66}$ The main edible fishery exports in 2005-06 (and their export earnings) were rock lobster (A $\$ 489$ million), abalone (A $\$ 246$ million), tuna (A $\$ 177$ million) and prawns (A $\$ 134$ million). The non-food component of fisheries exports is made up of peals, fish meal and marine fats and oils. Ibid., 3.

67 This program, inter alia, aims to improve coordination and cooperation between the Australian fisheries industry and the Commonwealth, State and Territory governments in dealing with market access issues. See the website of the Fisheries Market Access and Trade Program, available at: http:/www.daff.gov.au/fisheries/ marketaccess/about, visited on 13 January 2008. 
a wide range of services, grants and programs are provided by the Australian government to assist exporters of fishery products. ${ }^{68}$

Exports of processed food make up a greater share of the merchandise exports of Australia than unprocessed food products. In 2006-2007, processed food accounted for 9.2 percent of merchandise export earnings, while unprocessed food exports contributed 4.1 percent to these earnings. ${ }^{69}$ The food and beverage industry is the largest manufacturing industry, ${ }^{70}$ and one of the fastest growing manufacturing sectors in Australia. ${ }^{71}$ This has been attributed in large part to the growth in exports and the development of more sophisticated processed food products. ${ }^{72}$ Around 22 percent of processed food produced in Australia is exported..$^{73}$

Australia's agricultural sector is greatly liberalised. Australia provides very little domestic support to the agricultural sector compared to other OECD countries. ${ }^{74}$ In addition its

${ }^{68}$ These are set out in detail in The FishBook, drawn up under the auspices of the DAFF. This publication lists both the programs in place for the fisheries industry in general, and, in a separate section, those that are aimed at exporters of fishery products. Jim Fitzgerald and Shelley Kowalski, The FishBook II: A Guide to Australian Government Programs, Grants and Services for the Australian Seafood Industry (Department of Agriculture, Fisheries and Forestry of the Government of Australia, Canberra), 2006, 37, available at: http://www.daff.gov. au/_data/assets/pdf_file/0019/6049/fishbook_2.pdf, visited on 13 January 2008. Two examples of services listed in this book are the following: ANIMEX, a database maintained by the Australian Quarantine and Inspection Service (AQIS) of export requirements for live animals (including fish) and reproductive material; and publications issued to demystify the requirements for market access in various trading partners, for example $A \$ 40$ billion reasons to access the EU seafood market and $A \$ 34$ billion reasons to access the US seafood market. Additional programs and services are mentioned in the discussion of the animal health system of Australia, below Part II, Section 2.4.2.3.

${ }^{69}$ Exports of processed food earned A\$ 15,523 million in 2006-2007 (up from A\$14,738 million in 2001-2002). Exports of unprocessed food generated A \$ 6,948 million in the same period (down from A\$11.039 in 20012002). Australian Government Department of Foreign Affairs and Trade, Composition of Trade Australia: 2006-07 (Commonwealth of Australia, Canberra), November 2007, 25, available at: http://www.dfat.gov.au/ publications/stats-pubs/downloads/COT_FY2007.pdf, visited on 12 January 2008.

${ }^{70}$ Australian Government Department of Agriculture Fisheries and Forestry, Australian Food Statistics 2006 (Commonwealth of Australia, Canberra), 2007, 3, available at: http://www.abareconomics.com/publications html/crops/crops_07/fstats_main.pdf, visited on 15 January 2008. This sector provided over $17 \%$ of employment in the manufacturing sector, and $21 \%$ of sales and service income (A\$68.8 billion) in 2004-2005.

${ }^{71}$ Australian Government Department of Agriculture Fisheries and Forestry, National Food Industry Strategy: An Action Agenda for the Australian Food Industry (Commonwealth of Australia, Canberra), June 2002, 8, available at: http://www.daff.gov.au/_data/assets/pdf_file/0017/183320/strategy_statement_final.pdf, visited on 13 January 2008.

${ }^{72}$ Ibid.

${ }^{73}$ Ibid. To promote the contribution of food processing to rural employment, the Australian government created the Food Processing in Regional Australia Programme. This is a four-year programme initiated in 2004 to provide grants to small- and medium-sized food processors in rural and regional areas to assist them to add value to food produce and establish regional networks and market contacts. Australian Government Department of Agriculture Fisheries and Forestry, Annual Report 2004-05 (Commonwealth of Australia, Canberra), October 2005, available at: http://www.daff.gov.au/_data/assets/word_doc/0016/5704/2004-05_annual_report_exc_ fin_statements.doc, visited on 17 January 2008.

${ }^{74}$ Australia spends A $\$ 980$ million, or $0.11 \%$ of its GDP, on assistance to the agricultural sector. Trade Policy Review Body, Trade Policy Review: Australia - Report by the Secretariat. Revision, WT/TPR/S/178/Rev.1, circulated on 1 May 2007, Section IV Table IV.1. Australia's domestic support to agriculture amounts to just $4 \%$ of farm income, compared to $33 \%$ in the EC, $18 \%$ in the US and $56 \%$ in Japan. This data is provided in the 'Trade Fact Sheet' page on the website of the Australian Government Department of Foreign Affairs and Trade, available at: http://www.dfat.gov.au/trade/fs/wto_agriculture.html, visited on 22 January 2008. 
tariffs on agricultural products are low (with a few exceptions) ${ }^{75}$ averaging 1.4 percent $\mathrm{ad}$ valorem in $2006 .{ }^{76}$ However, a significant barrier to market access for agricultural products is the very strict SPS regime in place in Australia, as will be discussed further below.

The Australian Government Department of Agriculture, Fisheries and Forestry (DAFF) has recognised that the continued competitiveness, future earnings and long-term viability of the Australian agricultural and food industry will be influenced by developments on international food markets and will depend on Australia's ability to harness global opportunities. ${ }^{77}$ As stated by the Minister for Agriculture, Fisheries and Forestry, Warren Truss, when introducing the National Food Industry Strategy in $2002,{ }^{78}$ ' $[\mathrm{h}]$ istorical advantages and approaches will not be sufficient to ensure success in the global food industry of the future. Industry and Government must work in partnership to capture the opportunities and meet the challenges arising from this global trend. ${ }^{.79}$

The DAFF has identified new market opportunities resulting from greater demand for agricultural raw materials and inputs for food production in growing developing countries such as China ${ }^{80}$ In addition, it has noted that improved living standards in some developing countries, such as India, with the concomitant change in consumer choice and demands, provide new markets for high quality food products.$^{81}$ In developed-country markets across the world, consumers are becoming increasingly affluent, sophisticated and discerning, leading to high consumer expectations regarding food-safety, nutritional value, variety and convenience of food products. ${ }^{82}$ The National Food Industry Strategy therefore notes the importance of Australian producers and exporters responding to these changing consumer expectations. It recommends that producers and exporters take advantage of the niche market opportunities created by this changed demand by capitalising on Australia's reputation for producing safe food from a clean environment. ${ }^{83}$ This repu-

${ }^{75}$ Certain non-ad valorem duties conceal tariff peaks, including the specific rate of A $\$ 1.22 / \mathrm{kg}$ for cheese and curd (amounting to an ad valorem equivalent of $23.8 \%$ and the alternate rate of $5 \%$ or A $\$ 0.45 / \mathrm{kg}$ for fruit juices. Ibid., Section IV para. 16.

${ }^{76}$ Ibid., Section IV para. 7.

77 Australian Government Department of Agriculture Fisheries and Forestry, Australian Food Statistics 2006 (Commonwealth of Australia, Canberra), 2007, 23, available at: http://www.abareconomics.com/publications_html/crops/crops_07/fstats_main.pdf, visited on 15 January 2008.

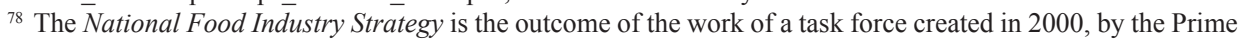
Minister's Supermarket to Asia Council, to analyse the issues that are likely to have an impact on the Australian food industry. The new global structure of food processing and retailing, involving a high degree of concentration and vertical integration, was identified as the key factor creating both opportunities and challenges for the Australian food industry. Australian Government Department of Agriculture Fisheries and Forestry, National Food Industry Strategy: An Action Agenda for the Australian Food Industry (Commonwealth of Australia, Canberra), June 2002, 34, available at: http://www.daff.gov.au/__data/assets/pdf_file/0017/183320/ strategy_statement_final.pdf, visited on 13 January 2008.

${ }^{79}$ Ibid., 5 .

${ }^{80}$ Australian Government Department of Agriculture Fisheries and Forestry, Australian Food Statistics 2006 (Commonwealth of Australia, Canberra), 2007, 24, available at: http://www.abareconomics.com/publications_html/crops/crops_07/fstats_main.pdf, visited on 15 January 2008.

${ }^{81}$ Ibid., 23-24.

${ }^{82}$ Australian Government Department of Agriculture Fisheries and Forestry, National Food Industry Strategy: An Action Agenda for the Australian Food Industry (Commonwealth of Australia, Canberra), June 2002, 11, available at: http://www.daff.gov.au/_data/assets/pdf_file/0017/183320/strategy_statement_final.pdf, visited on 13 January 2008.

83 Ibid. 
tation can be marketed to consumers through, for example, organic certification, GMfree certification or eco-labelling. This in turn requires effective supply-chain management, ensuring traceability, product integrity and segregation. ${ }^{84}$ This is an area in which Australian producers are weak. ${ }^{85}$

Certain challenges to the agricultural and food industry have been pointed out by the DAFF. One of these is the challenge arising from SPS risks. For example, the adverse impact of outbreaks of animal diseases, such as BSE and avian influenza, on global food trade has been noted. ${ }^{86}$ As a result, the National Food Industry Strategy sees a strategic role for the government in supporting food trade through maintaining and refining its effective SPS controls to minimise incursions of pests and diseases into Australia, as well as to ensure that Australian food exports meet the SPS requirements of importing countries. ${ }^{87}$ The DAFF has noted the need for the food and agricultural industry to adapt to the new regulatory environment to address SPS risks. ${ }^{8}$ In addition, the National Food Industry Strategy sees an important role for government addressing SPS barriers to trade. It therefore includes in its strategy the continuation and expansion of the Technical Market Access Program, which comprises agricultural and veterinary counsellors on located in the importing countries as well as technical experts based in Canberra. This program aims at early intervention, on technical level, in case of SPS market barriers in order to 'avert the occurrence of seriously disruptive decisions and actions by import agencies. ${ }^{, 89}$

In addition, the National Food Industry Strategy points to the challenges arising from the increasing concentration of world food trade and retailing. Currently, just a few multinational firms, are responsible for about one third of processed food trade through via intra-firm transfers. ${ }^{90}$ These firms are vertically integrated with producers and distributors, for example through joint ventures. In addition, some global processing companies use established supply-chain networks to source their agricultural inputs from producers, anywhere in the world. ${ }^{91}$ Producers are chosen that can provide a reliable supply of high-

\footnotetext{
${ }^{84}$ Ibid.

${ }^{85}$ Ibid.

${ }^{86}$ Australian Government Department of Agriculture Fisheries and Forestry, Australian Food Statistics 2006 (Commonwealth of Australia, Canberra), 2007, 24, available at: http://www.abareconomics.com/publications html/crops/crops 07/fstats main.pdf, visited on 15 January 2008. Although demand in Asian countries for Australian meat increased in the wake of the BSE outbreaks in Europe and the US, this report points out that such health scares benefit no-one in the long run since consumer perceptions of the relevant product are negatively affected and demand is thereby reduced.

${ }^{87}$ Australian Government Department of Agriculture Fisheries and Forestry, National Food Industry Strategy: An Action Agenda for the Australian Food Industry (Commonwealth of Australia, Canberra), June 2002, 17, available at: http://www.daff.gov.au/_data/assets/pdf_file/0017/183320/strategy_statement_final.pdf, visited on 13 January 2008.

${ }^{88}$ Australian Government Department of Agriculture Fisheries and Forestry, Australian Food Statistics 2006 (Commonwealth of Australia, Canberra), 2007, 24, available at: http://www.abareconomics.com/publications_html/crops/crops_07/fstats_main.pdf, visited on 15 January 2008 . This regulatory environment will be sketched below, Part II, Section 2.4.2.

${ }^{89}$ Australian Government Department of Agriculture Fisheries and Forestry, National Food Industry Strategy: An Action Agenda for the Australian Food Industry (Commonwealth of Australia, Canberra), June 2002, 25, available at: http://www.daff.gov.au/_data/assets/pdf_file/0017/183320/strategy_statement_final.pdf, visited on 13 January 2008.

${ }^{90}$ Ibid., 13.

${ }^{91}$ Ibid.
} 
quality, safe, agricultural products at competitive prices. Similarly, there is a high level of concentration in food retailing. ${ }^{1}$ The major international retailers, such as Wal-Mart, Carrefour and Ahold, are also sourcing their products through long-term global supplychain relationships with a few selected suppliers. ${ }^{2}$ These retailers impose their own systems-wide food safety and quality requirements, commonly known as 'supermarket standards', which are generally much stricter than the SPS requirements set by the countries in which they will market their products. ${ }^{3}$ They discourage the 'sharing' of suppliers, making these exclusive supply agreements 'a form of vertical integration'. ${ }^{4}$ Currently, Australian food suppliers do not participate fully in these supply-chain relationships due to the 'overall lack of a supply chain ethos in Australia's food industry'. ${ }^{5}$ This means that product integrity and traceability is not guaranteed. The National Food Industry Strategy emphasises the importance for Australian suppliers of tapping into the global supplychain networks by forming strategic relationships with global food processors and retailers. ${ }^{6}$ Australia is well placed to take advantage of the possibilities and to capture the benefits of participation in these global networks as its agricultural products are of a high quality and safety level, are competitive in price, and benefit from the ability to supply counter-seasonal fresh produce for countries in the Northern hemisphere.

To achieve the objectives of its National Food Industry Strategy, the Australian government committed A \$102.4 million over five years, as of 1 July 2002, to specific initiatives. ${ }^{7}$ One of these initiatives is focused on providing the infrastructure and capabilities needed to enhance product integrity and supply-chain management of Australian products for international markets, to which A $\$ 15.6$ million has been allocated. ${ }^{8}$ National Food Industry Council, composed of industry leaders and key Commonwealth Ministers, has been established to oversee the implementation of this strategy. ${ }^{9}$ This Council reports to the Minister for Agriculture, Fisheries and Forestry.

\subsubsection{Summary of factual background}

The factual background set out above aims to provide a context for the following discussion of Australia's SPS system. It focuses on the health and trade priorities of Australia, to facilitate the understanding of the SPS system it has in place. Thereby it also forms

\footnotetext{
${ }^{1}$ Ibid., 14. This strategy paper notes that six retail chains control around $80 \%$ of food retail outlets in the UK, and two retail chains are responsible for over $70 \%$ of sales in Australia. The 10 largest global retailers operate in at least 7 countries and in some cases in up to 28 countries.

${ }^{2}$ This maximizes profits due to improvements in efficiencies throughout the supply chain. Ibid.

${ }^{3}$ For a discussion on private SPS standards and reasons why processors and retailers impose these strict requirements, see above, Part II, Section 1.3.

${ }^{4}$ Australian Government Department of Agriculture Fisheries and Forestry, National Food Industry Strategy: An Action Agenda for the Australian Food Industry (Commonwealth of Australia, Canberra), June 2002, 14, available at: http://www.daff.gov.au/_data/assets/pdf_file/0017/183320/strategy_statement_final.pdf, visited on 13 January 2008.

${ }^{5}$ Ibid., 12.

${ }^{6}$ Ibid., 14.

${ }^{7}$ Ibid., 31 .

${ }^{8}$ Ibid.

9 The National Food Industry Council replaces the Prime Minister's Supermarket to Asia Council. It has a global focus and covers all the issues that have an on the competitiveness of the Australian food industry. Ibid., 22.
} 
a background against which the impact of the SPS Agreement on Australia's health and trade objectives and their implementation can be appreciated.

As has been seen above, Australia has a high level of health care and one of the lowest death rates in the world. It has long passed the stage where infectious diseases are a primary health concern, and instead the main health burden it faces comes from noncommunicable, chronic diseases. Many of these diseases are life-style and diet related, and they require a preventative approach that addresses long term-causal factors, including unsafe food. In addition, some short-term health risks related to food safety remain a concern, namely those from pathogens such as Salmonella. Consequently, Australia has reformed its food-safety system to ensure effective control throughout the food chain. This food-safety system, however, must also avert risks from imported food products in order to meet the challenge of disease prevention. It is here that the disciplines of the SPS Agreement come into play.

While the agricultural industry does not contribute a large share to the Australian economy, it is nevertheless an important sector in export earnings. In addition, it plays a significant role in the rural economy. As a result, the Australian government sees the maintenance of this industry as a viable sector of the economy as a priority, as evinced by its active role in promoting liberalisation of agricultural trade and its significant investments in projects and services to assist agricultural producers and exporters.

The recognition by the Australian government of the need for the food industry to adjust to international developments, and its commitment to assist this industry in this task, is reflected in its National Food Industry Strategy. In order to remain competitive, Australia must take advantage of the opportunities and respond to the challenges of the global market. A key challenge in this respect is the significant concentration of food-processing and retailing, which makes use of established supply-chain relationships with trusted suppliers. These suppliers are required to comply with private SPS standards set by the global processors and retailers. To participate effectively in international food trade, Australian producers must therefore engage in these strategic supply-chain relationships. It is important, for this purpose, that Australian agricultural and food products maintain their reputation for providing a high level of safety and quality, in keeping with the demanding private standards set by processing and retailing conglomerates. In addition, supply-chain management in Australia must be improved to ensure the product traceability and integrity required by the major food processors and retailers that currently dominate food trade.

An examination of the SPS system in place in Australia provides an indication of the extent to which Australia is in a position to meet the challenges posed by the global environment both in the area of protecting the health of its citizens and with respect to promoting its trade in food and agricultural products.

\subsubsection{Australia's SPS system}

In order to ensure the consistency and effectiveness of its SPS system, Australia has a general framework of quarantine controls in place, applicable to humans, plants and animals and associated products, including food. ${ }^{10}$ It also has specific systems in place under

${ }^{10}$ Trade Policy Review Body, Trade Policy Review: Australia - Report by the Secretariat. Revision, WT/ 
this framework to address food-safety, animal health and plant health. This rigorous and complex SPS system is outlined below.

\subsubsection{General framework}

Australia has a very stringent SPS system in place. It has characterised its SPS system as 'providing a high level of sanitary and phytosanitary protection aimed at reducing risk to a very low level, but not to zero', ${ }^{11}$ in accordance with the expectations of its citizens. Australia justifies this very strict level of protection with reference to the particular vulnerability of its unique and diverse indigenous fauna and flora, and the fact that Australia is currently free from most pests and diseases of quarantine significance. ${ }^{12}$ In addition, the importance of the agricultural sector for Australia is referred to in this regard. ${ }^{13}$

The SPS system of Australia is complex, involving three levels of authority. First, at the level of the Commonwealth government, responsibility for human health, including in the area of food-safety, lies in the final instance with the Australian Government Department of Health and Aging. Overall responsibility for animal and plant health in Australia is in the hands of the Australian Government Department of Agriculture, Fisheries and Forestry. Second, the various States and Territories of Australia play a key role in SPS regulation, ${ }^{14}$ particularly with regard to differences in pest and disease status within Australia. ${ }^{15}$ Implementation of national SPS policies and inspection to check compliance with SPS requirements is largely in the hands of the States and Territories. Third, in the area of food safety, an additional level of governance has been established under a cooperation agreement between Australia and New Zealand. This agreement creates a regu-

TPR/S/178/Rev.1, circulated on 1 May 2007, Section III para. 50.

${ }^{11}$ Australian Government Department of Agriculture Fisheries and Forestry, Import Risk Analysis Handbook 2007 (Commonwealth of Australia, Canberra), September 2007, 8, available at: http://www.daff.gov.au/biosecuritycoordination/import_risk_analysis_handbook_2007, visited on 15 January 2008. This was also quoted in Trade Policy Review Body, Trade Policy Review: Australia - Report by the Secretariat. Revision, WT/ TPR/S/178/Rev.1, circulated on 1 May 2007, Section III para. 48.

12 Australian Government Department of Agriculture Fisheries and Forestry, Import Risk Analysis Handbook 2007 (Commonwealth of Australia, Canberra), September 2007, 8, available at: http://www.daff.gov.au/biosecuritycoordination/import_risk_analysis_handbook_2007, visited on 15 January 2008; Trade Policy Review Body, Trade Policy Review: Australia - Report by the Secretariat. Revision, WT/TPR/S/178/Rev.1, circulated on 1 May 2007, Section III para. 48.

13 Australian Government Department of Agriculture Fisheries and Forestry, Import Risk Analysis Handbook 2007 (Commonwealth of Australia, Canberra), September 2007, 8, available at: http://www.daff.gov.au/biosecuritycoordination/import_risk_analysis_handbook_2007, visited on 15 January 2008; Trade Policy Review Body, Trade Policy Review: Australia - Report by the Secretariat. Revision, WT/TPR/S/178/Rev.1, circulated on 1 May 2007, Section III para. 48.

${ }^{14}$ In terms of the Australian Constitution, the Commonwealth Government does not have exclusive authority to legislate in the area of quarantine policy. Therefore State and Territory legislation also exists in this area.

15 Trade Policy Review Body, Trade Policy Review: Australia - Report by the Secretariat. Revision, WT/ TPR/S/178/Rev.1, circulated on 1 May 2007, Section III para. 50 and note 78. For example, in northern Australia, quarantine is crucial due to the proximity of this region to Southeast Asia and the Pacific, areas of prevalence of many pests and diseases of which Australia is currently free. The Northern Australia Quarantine Service is responsible for quarantine control of border movements through the Torres Strait and conducts pest and disease surveillance in coastal northern Australia and in Papua New Guinea, Indonesia and East Timor. This information is provided on the website of the Australian Quarantine and Inspection Service, available at: http://www.daff.gov.au/aqis/about/reports-pubs/at-a-glance, visited on 17 January 2008. 
latory body called Food Standards Australia New Zealand (FSANZ), ${ }^{16}$ responsible for developing and enforcing the Australia New Zealand Food Standards Code. Aside from these three levels of mandatory SPS regulation by central and local government and regional bodies, voluntary SPS standards in Australia are set by Standards Australia, a nongovernmental body. ${ }^{17}$ Almost a third of the standards developed by Standards Australia are taken up in a Commonwealth, State or Territory law, and thereby become mandatory. ${ }^{18}$

The SPS system of Australia is characterised by a high level of transparency and stakeholder participation. Key elements of the regulatory process are the publication of 'issues papers' ${ }^{19}$ risk assessments and draft SPS measures and the invitation of comments from all interested parties at various stages of the risk analysis process. As highlighted in the 1996 Nairn Review, which led to the reform of Australia's quarantine system, '[t]he effectiveness of consultation and communication will ultimately be judged by the credibility and ownership of quarantine policies, programs and decisions. ${ }^{20}$

The general quarantine (or SPS) control framework at the Commonwealth level is based on the Quarantine Act of 1908 as amended in $2007,{ }^{21}$ as supplemented by the Quarantine Regulations of $2000^{22}$ and three Quarantine Proclamations. ${ }^{23}$ This framework rests on a prior-approval system, which entails that only those products whose safety has been established through risk analysis, and which have accordingly been granted an import

${ }^{16}$ The FSANZ is discussed further below, Part II, Section 2.4.2.2.

17 Standards Australia was established in 1922. It is the main non-governmental standard-setting body in Australia, recognised through a Memorandum of Understanding with the Commonwealth Government. It is a limited company with 72 members representing groups interested in the development and application of standards and related products and services. The standards developed by Standards Australia are not limited to food safety standards, but include industrial standards, occupational health and safety standards, environmental standards etc. See the website of Standards Australia, available at: http://www.standards.org.au/default.asp, visited on 17 January 2008.

${ }^{18}$ See the 'The Legal Status of Australian Standards' on the website of Standards Australia, available at: http:// www.standards.org.au/cat.asp?catid=7, visited on 17 January 2008.

${ }^{19}$ Issues papers are published for each IRA, providing background information, identifying the hazard at issue, and outlining the further steps in the IRA process. All stakeholders are invited to comment on issue papers.

${ }^{20}$ M.E. Nairn et al., Australian Quarantine: A Shared Responsibility (Australian Quarantine Review Secretariat, Canberra), 1996, 46, available at: http://www.daff.gov.au/_data/assets/pdf_file/0009/111969/nairn_report. pdf, visited on 24 January 2008.

${ }^{21}$ Australian Government Department of the Attorney General, Quarantine Act of 1908, Act No. 3 of 1908, as Amended (Commonwealth of Australia, Canberra), 4 October 2007, available at: http://www.comlaw. gov.au/ComLaw/Legislation/ActCompilation1.nsf/0/71DD1F7D48D8CEA8CA25736E001978EC/\$file/ Quarantine 1908 WD02.doc, visited on 25 January 2008.

22 Australian Government Department of the Attorney General, Quarantine Regulations of 2000, Statutory Rules No. 129 of 2000, as Amended, Made under the Quarantine Act 1908 (Commonwealth of Australia, Canberra), 15 December 2007, available at: http://www.comlaw.gov.au/ComLaw/legislation/legislativeinstrumentcompilation1.nsf/0/3DE4AB6D94856101CA2573AA00197491/\$file/QuarantineRegs2000.doc, visited on 25 January 2008.

${ }^{23}$ These are the Quarantine Proclamation of 1998, the Quarantine Proclamation (Cocos Island) of 2004 and the Quarantine Proclamation (Christmas Island) of 2004. These laws are available at: www.aqis.gov.au/ law/index.htm, visited on 24 January 2008. Trade Policy Review Body, Trade Policy Review: Australia Report by the Secretariat. Revision, WT/TPR/S/178/Rev.1, circulated on 1 May 2007, Section III note 79; Australian Government Department of Agriculture Fisheries and Forestry, Import Risk Analysis Handbook 2007 (Commonwealth of Australia, Canberra), September 2007, 10, available at: http://www.daff.gov.au/biosecuritycoordination/import_risk_analysis_handbook_2007, visited on 15 January 2008. 
permit, may be imported. ${ }^{24}$ Quarantine controls are applied to humans, plants and plant products, animals and animal products, and processed food at three stages: pre-border, border and post-border. ${ }^{25}$

At the pre-border stage, assessment of risks to human health from food products and the formulation of risk management strategies is the responsibility of the FSANZ, which falls under the portfolio of the Department of Health and Aging. With respect to plant and animal health, Biosecurity Australia is responsible for conducting risk assessments and making risk management recommendations. Biosecurity Australia was created in 2000 to improve the SPS system of Australia. In 2004, this body became independent of both the Australian Quarantine and Inspection Service (AQIS) and the Department of Foreign Affairs and Trade of the Government of Australia. ${ }^{26}$ Its task is to provide sciencebased quarantine risk analyses, known as import risk analyses (IRAs). In the IRA process, stakeholders are invited to submit their comments. ${ }^{27}$ In cases of significant differences in scientific opinion or where the harm that could result from importation is significant, an expanded IRA will be carried out. ${ }^{28}$ IRAs involve risk assessments which are required to identify the pests or diseases of quarantine concern that may be carried by the product involved; assess the likelihood that the identified pest or disease would enter, establish or spread, and assess the possible extent of the harm that would result. ${ }^{29}$ On the basis of these risk assessments, Biosecurity Australia provides policy advice with regard to imports of animals and plants. ${ }^{30}$ If Biosecurity Australia finds that the assessed risk exceeds

${ }^{24}$ Sec. 64(2) and 65(2) of the Quarantine Proclamation of 1998, as amended, prohibits the importation by a person into Australia of animals, plants or their products, or any material that may introduce a risk (such wood packaging material) unless a Director of Quarantine has granted the person a permit to import it into Australia. Australian Government Department of the Attorney General, Quarantine Proclamation of 1998, as Amended, Made under Section 13 of the Quarantine Act of 1908 (Commonwealth of Australia, Canberra), 1 November 2007, available at: http:/www.comlaw.gov.au/ComLaw/Legislation/LegislativeInstrumentCompilation1.nsf/ all/search/AA0B4452ED7BBD44CA25737F00157097, visited on 24 January 2008.

${ }^{25}$ The idea of quarantine control as a continuum comprised of pre-border, border and post-border stages was introduced by the Nairn Review of Australia's quarantine system in 1996. This report was critical of the previous focus on border measures only. M.E. Nairn et al., Australian Quarantine: A Shared Responsibility (Australian Quarantine Review Secretariat, Canberra), 1996, 7, available at: http://www.daff.gov.au/_data/ assets/pdf_file/0009/111969/nairn_report.pdf, visited on 24 January 2008. The three stages of quarantine control are currently an integral part of the SPS system of Australia, as recognised in Australian Government Department of Agriculture Fisheries and Forestry, Import Risk Analysis Handbook 2007 (Commonwealth of Australia, Canberra), September 2007, 8-9, available at: http://www.daff.gov.au/biosecuritycoordination/import_risk_analysis_handbook_2007, visited on 15 January 2008. See also the Secretariat's report in the context of the latest trade policy review of Australia. Trade Policy Review Body, Trade Policy Review: Australia - Report by the Secretariat. Revision, WT/TPR/S/178/Rev.1, circulated on 1 May 2007, Section III para. 50.

${ }^{26}$ Trade Policy Review Body, Trade Policy Review: Australia - Report by the Secretariat. Revision, WT/ TPR/S/178/Rev.1, circulated on 1 May 2007, Section IV para. 10. See also Australian Government Department of Agriculture Fisheries and Forestry, Annual Report 2004-05 (Commonwealth of Australia, Canberra), October 2005, available at: http://www.daff.gov.au/_data/assets/word_doc/0016/5704/2004-05_annual_report_exc_fin_statements.doc, visited on 17 January 2008 .

${ }^{27}$ Biosecurity Australia publishes the draft IRA and notifies it to the WTO. It then invites comments and allows up to 60 days for written submissions (this period may be extended once). Australian Government Department of Agriculture Fisheries and Forestry, Import Risk Analysis Handbook 2007 (Commonwealth of Australia, Canberra), September 2007, 18-19, available at: http://www.daff.gov.au/biosecuritycoordination/import risk_analysis_handbook_2007, visited on 15 January 2008.

${ }^{28}$ Ibid., 14.

29 Ibid., 11.

${ }^{30}$ Trade Policy Review Body, Trade Policy Review: Australia - Report by the Secretariat. Revision, WT/ 
the level of protection chosen by Australia, it will examine whether risk management options are available to reduce the risk to the relevant level of protection. If so, the product will be granted an import permit subject to the condition that specified risk management requirements are met; if not, the product will be banned. ${ }^{31}$ If an expanded IRA was carried out, it must be reviewed by an independent body called the Eminent Scientists Group before its publication..$^{32}$ Biosecurity Australia then prepares a final IRA report and recommendations, ${ }^{33}$ which are submitted to the Director of Animal and Plant Quarantine for a determination. ${ }^{34}$ The determination is published and notified to the WTO and to stakeholders. A problem that has been raised as a concern by several WTO Members is the length of time taken in conducting the import risk analyses (IRAs) required before import approval is granted by Australia. ${ }^{35}$ In response, Australia has recently announced reforms to increase the transparency, efficiency, timeliness and predictability of the IRA procedures. ${ }^{36}$ These reforms are contained in the revision to the Quarantine Regulations of 2000, which came into force on 25 June $2008 .{ }^{37}$ Currently a standard IRA must be completed within 24 months, and an expanded IRA within 30 months. $^{38}$

At the border stage, on the advice of Biosecurity Australia (for risks to animal or plant health) or the FSANZ (for food-safety), the AQIS implements quarantine policies. AQIS has a staff of 3300. Its activities include issuing import permits and export certificates, ${ }^{39}$

TPR/S/178/Rev.1, circulated on 1 May 2007, Section IV para. 10.

${ }^{31}$ Australian Government Department of Agriculture Fisheries and Forestry, Import Risk Analysis Handbook 2007 (Commonwealth of Australia, Canberra), September 2007, 11, available at: http://www.daff.gov.au/biosecuritycoordination/import_risk_analysis_handbook_2007, visited on 15 January 2008.

32 Ibid., 19.

${ }^{33}$ A limited administrative appeal possibility exists in case of a significant deviation from the IRA process that adversely affects the rights of a stakeholder. Ibid., 20.

${ }^{34}$ A determination is an administrative decision on the basis of the IRA and its recommendations, the report of the Eminent Scientists Group (if any), the outcome of any appeals, Australia's international rights and obligations and any other relevant information. It provides a policy framework on the basis of which decisions regarding the issuing of import permits and the conditions attached to such permits are made. Ibid., 21.

${ }^{35}$ These concerns are reported in the WTO Secretariat's overview of trade concerns raised at SPS Committee meetings. Committee on Sanitary and Phytosanitary Measures, Specific Trade Concerns. Note by the Secretariat. Addendum: Issues Not Considered in 2006, G/SPS/GEN/204/Rev.7/Add.2, circulated on 7 February 2007, items 50 and 155.

${ }^{36}$ Trade Policy Review Body, Trade Policy Review: Australia - Report by the Secretariat. Revision, WT/ TPR/S/178/Rev.1, circulated on 1 May 2007, Section IV para. 10.

${ }^{37}$ Sec. 69E of the revised Quarantine Regulations of 2000. Australian Government Department of the Attorney General, Quarantine Regulations of 2000, Statutory Rules No. 129 of 2000, as Amended on 15 December 2007, Made under the Quarantine Act 1908 (Commonwealth of Australia, Canberra), in force on 25 June 2008, available at: http://www.comlaw.gov.au/ComLaw/legislation/legislativeinstrumentcompilation1.ns f/0/3DE4AB6D94856101CA2573AA00197491/\$file/QuarantineRegs2000.doc, visited on 29 June 2008. Australian Government Department of the Attorney General, Quarantine Regulations of 2000, Statutory Rules No. 129 of 2000, as Amended, Made under the Quarantine Act 1908 (Commonwealth of Australia, Canberra), 15 December 2007, available at: http://www.comlaw.gov.au/ComLaw/legislation/legislativeinstrumentcompilation1.nsf/0/3DE4AB6D94856101CA2573AA00197491/\$file/QuarantineRegs2000.doc, visited on 25 January 2008.

${ }^{38}$ Ibid. See also Australian Government Department of Agriculture Fisheries and Forestry, Import Risk Analysis Handbook 2007 (Commonwealth of Australia, Canberra), September 2007, 14, available at: http://www.daff. gov.au/biosecuritycoordination/import_risk_analysis_handbook_2007, visited on 15 January 2008.

${ }^{39}$ To facilitate the export certification process, AQIS implements an Export Documentation System (EXDOC) for the electronic preparation of export documentation for meat, dairy, fish, grain, horticulture, wool and skins, and hide exports. It is an integral part of AQIS certification system, which aims to ensure that products comply 
and carrying out border inspections. A high level of border inspections is maintained. Government policy sets the level of inspection at 100 percent for all foreign air or sea vessels and their containers (externally) and for international mail consignments. ${ }^{40}$ Increased funding has been provided to AQIS to enhance surveillance in order to diminish the risk of entry of highly pathogenic avian influenza (bird flu). ${ }^{41}$ The tasks of AQIS with respect to export inspection and certification are carried out under the Export Control Act of 1982.

Post-border SPS matters are dealt with by the Product Integrity, Animal and Plant Health Division of the DAFF, in cooperation with the governments of the States and Territories. This Division manages risks to animal health (and welfare), plant health and human health from pests, diseases and food (including residues of agricultural and veterinary chemicals). It aims to strengthen the national SPS framework in place to address these risks. ${ }^{42}$

As noted above, aside from government regulations, also non-governmental standards, developed by Standards Australia, form part of the SPS system of Australia. These standards are not legally binding, but may become so if they are taken up in legislation by a State or Territory or by the Commonwealth. Standards Australia's policy is to develop standards that are based on international standards 'to the maximum extent possible'. ${ }^{43}$ In terms of the Memorandum of Understanding between Standards Australia and the Commonwealth Government, Standards Australia must ensure that its practices comply with the Code of Good Practice for the Preparation, Adoption and Application of Standards contained in Annex 3 of the WTO Agreement on Technical Barriers to Trade. ${ }^{44}$

with Australian and importing country SPS requirements. Jim Fitzgerald and Shelley Kowalski, The FishBook II: A Guide to Australian Government Programs, Grants and Services for the Australian Seafood Industry (Department of Agriculture, Fisheries and Forestry of the Government of Australia, Canberra), 2006, 27, available at: http://www.daff.gov.au/_data/assets/pdf_file/0019/6049/fishbook_2.pdf, visited on 13 January 2008.

${ }^{40}$ The quarantine inspection target for air passengers is lower, at $81 \%$, in order to permit efficient processing of passengers at peak arrival times. Australian Government Department of Agriculture Fisheries and Forestry, Annual Report 2006-07: Growing Australia through Sustainable, Innovative and Profitable Agriculture, Fisheries and Forestry (Commonwealth of Australia, Canberra), September 2007, 253, available at: http:// www.daff.gov.au/_data/assets/pdf_file/0005/439493/2_AR_06-07_ROP_WEB.pdf, visited on 17 January 2008 .

${ }^{41}$ Ibid., 144. According to this report, an additional A $\$ 32.2$ million over 3 years was provided for increased surveillance, additional staff at airports and seaports, community awareness campaigns and increased intervention of risk material (poultry, feathers and eggs).

42 Ibid., 119.

43 Article 3.4 of the Memorandum of Understanding between the Commonwealth of Australia and Standards Australia International Limited, 2003, available at: http://www.pc.gov.au/__data/assets/pdf_file/0016/13516/ sai1.pdf, visited on 17 January 2008.

44 This Memorandum of Understanding sets out the agreement between the Commonwealth Government and Standards Australia, with respect to Australian standardisation. Among the main elements of this agreement are that no Australian Standard will contravene the requirement in the TBT Agreement that national standards may not be used as non-tariff barriers to trade; and that no new Australian Standard will be developed where an acceptable international standard already exists. See further on the TBT Agreement's Code of Good Practice, below, Part III, Section 2.4.1. 


\subsubsection{Food-safety system}

Until 1990, food regulation was the responsibility of States and Territories in Australia, with the assistance of a small national advisory committee. ${ }^{45}$ However, the result of this division of competence was fragmentation and inefficiency in food controls. A National Food Authority was created in 1991 to improve matters by drafting national food standards (excluding food-safety standards) and coordinating the surveillance of their implementation. In 1996 the National Food Authority was replaced by the Australia New Zealand Food Authority (ANZFA), the first bi-national food regulator. ${ }^{46}$ However, foodsafety standards were left outside the scope of its mandate. ${ }^{47}$ This changed when, in 1995, an outbreak of E. Coli from contaminated mettwurst affected 170 people. In response to public outcry, ANZFA was then given the task of drafting a new Model Food Act to ensure uniform food-safety standards across Australia.

A review of the Australian food regulatory system, known as the Blair Review, was initiated in 1996, to examine ways to reduce the regulatory burden on industry. The Blair Review report, issued in August 1998, included recommendations for reform, leading to the establishment of a body called FSANZ on 1 July 2002, in terms of the Food Standards Australia New Zealand Act of $1991 .^{48}$ The FSANZ operates under the authority of the Australia New Zealand Food Regulation Ministerial Council, composed of health Ministers, and Ministers with related portfolios, from the governments New Zealand and Australia, as well as from all Australian States and Territories. The FSANZ has 142 staff members. Its task is to develop food standards and joint codes of practice with the food industry, for food marketed in Australia and New Zealand. ${ }^{49}$ In addition, for Australia

\footnotetext{
${ }^{45}$ Australia New Zealand Food Authority, 'The Development and Implementation of the New Australian Food Safety Standards', presented at the FAO/WHO Global Forum of Food Safety Regulators (Food and Agriculture Organization and World Health Organization, Marrakesh) 28-30 January 2002, 1, available at: ftp://ftp.fao. org/docrep/fao/meeting/004/y2003e.pdf, visited on 22 January 2008.

${ }^{46}$ The Australia New Zealand Food Authority (ANZFA) was created on 5 July 1996, pursuant to the Agreement between the Government of Australia and the Government of New Zealand Establishing a System for the Development of Joint Food Standards, 5 December 1995, available at: http://www.foodstandards.gov.au/ srcfiles/NZ_Treaty.pdf, visited on 28 January 2008. This agreement aims to establish joint Australia New Zealand Food Standards Code. This information can be found on Food Standards Australia New Zealand, A Short History of NFA/ANZFA/FSANZ (Commonwealth of Australia, Canberra), available at: http://www. foodstandards.gov.au/aboutfsanz/historyoffsanz.cfm, visited on 17 January 2008.

${ }^{47}$ Australia New Zealand Food Authority, 'The Development and Implementation of the New Australian Food Safety Standards', presented at the FAO/WHO Global Forum of Food Safety Regulators (Food and Agriculture Organization and World Health Organization, Marrakesh) 28-30 January 2002, 2, available at: ftp://ftp.fao. $\mathrm{org} / \mathrm{docrep} /$ fao/meeting/004/y2003e.pdf, visited on 22 January 2008.

${ }^{48}$ This information can be found on Food Standards Australia New Zealand, A Short History of NFA/ANZFA/ FSANZ (Commonwealth of Australia, Canberra), available at: http://www.foodstandards.gov.au/aboutfsanz/ historyoffsanz.cfm, visited on 17 January 2008. See also Australian Government Department of the Attorney General, Food Standards Australia New Zealand Act No. 118 of 1991, as Amended (Commonwealth of Australia, Canberra), 1991, available at: http://www.comlaw.gov.au/ComLaw/Legislation/ActCompilation1. nsf/0/FE55337FDCFAA567CA25735B0001D93D/\$file/FoodStandAusNZ1991.pdf, visited on 20 January 2008.

${ }^{49}$ In addition, Sec. 13 of the Food Standards Australia New Zealand Act of 1991 sets out a range of other functions of the FSANZ, such as facilitating the harmonisation of State and Territory food legislation, coordinating national food monitoring, surveillance and recall systems, conducting research, developing policies for risk assessment of imported food, working with other national food agencies and international agencies, reviewing existing Standards, and developing codes of practice with industry.
} 
only, FSANZ develops food-safety standards, including maximum residue limits for agricultural and veterinary drug residues. All these standards are contained in the Australia New Zealand Food Standards Code (the Food Standards Code). ${ }^{50}$ Another review, the Bansemer Review of 2004, led to the restructuring of the FSANZ to create separate risk assessment and risk management sections. ${ }^{51}$ Changes to the Food Standards Australia New Zealand Act of 1991, which were proposed in 2006 and came into force on 1 October 2007, aim to improve the assessment procedures for new and amended food standards and make the regulatory process more efficient. ${ }^{52}$

The standard-setting process is set out in the Food Standards Australia New Zealand Act of $1991 .{ }^{53}$ The FSANZ may develop standards on its own initiative, or on application by any person or body. In developing standards, it is required to have regard to the following,: the need for standards to be based on risk analysis, using the best available scientific evidence; the promotion of consistency between domestic and international food standards; the desirability of an efficient and internationally competitive food industry; the promotion of fair trade in food; and any policy guidelines of the Australia New Zealand Food Regulation Ministerial Council notified to it. ${ }^{54}$ However, provision is made for cases where the FSANZ considers that the best available scientific evidence is insufficient. ${ }^{55} \mathrm{In}$ such situations, it may provisionally adopt SPS measures on the basis of available pertinent scientific information. It must then take all reasonable steps to obtain the information necessary for a more objective risk assessment and a review of the SPS measures, to be undertaken within a reasonable period of time. ${ }^{56}$

${ }^{50}$ Food Standards Australia New Zealand, Australia New Zealand Food Standards Code (Commonwealth of Australia, Canberra), available at: http:/www.foodstandards.gov.au/thecode/foodstandardscode.cfm, visited on 17 January 2008. The Food Standards Code is a compilation of the food standards developed by the FSANZ, subdivided into 4 Chapters. Chapter 1 contains generally applicable food standards, while Chapter 2 contains standards for particular types of food. Chapter 3 contains food-safety standards and Chapter 4 contains primary production and processing standards. The latter two Chapters apply to Australia only (New Zealand has its own national standards in these areas).

${ }^{51}$ This information can be found on Food Standards Australia New Zealand, A Short History of NFA/ANZFA/ FSANZ (Commonwealth of Australia, Canberra), available at: http://www.foodstandards.gov.au/aboutfsanz/ historyoffsanz.cfm, visited on 17 January 2008.

52 These change was introduced to address the backlogs in applications for amendments to food standards that had arisen because the same procedure was applied to all applications, regardless of the scope of the proposed change. The amendment introduces three different procedures for applications that would take 3 months, 9 months or 12 months depending on whether the application relates to a minor amendment to a food regulatory measure, a new food regulatory measure or a major amendment to an existing measure, or is an urgent application. This information is provided on the website of FSANZ available at: http:/www.foodstandards.gov.au/ newsroom/factsheets/factsheets2007/changestothefsanzact3731.cfm, visited on 17 January 2008.

${ }^{53}$ Sections 21-45 set out the procedure for standards developed on application by a person or body, and Sections 54-87 set out the procedure for standards developed at the initiative of the FSANZ itself. In case of urgent applications and proposals, Sections 95-105 set out an expedited procedure.

${ }^{54}$ Sec. 18(2) of the Food Standards Australia New Zealand Act of 1991, as amended. For example, the Australia New Zealand Food Regulation Ministerial Council has notified policy guidelines on primary production and processing standards, on novel foods, on the addition of caffeine to foods and on food safety management in Australia. These are found on the Ministerial Council Policy Guidelines page of the FSANZ website, available at: http://www.foodstandards.gov.au/standardsdevelopment/ministerialcouncilpo1603.cfm, visited on 22 January 2008.

${ }_{55}$ Sec. 18(4) of the Food Standards Australia New Zealand Act of 1991, as amended.

${ }^{56}$ Sec. 18(4) of the Food Standards Australia New Zealand Act of 1991, as amended. 
A ten-step procedure is outlined for the development of standards by the FSANZ. ${ }^{57}$ In broad lines, the procedure is as follows. The FSANZ prepares a proposal for a new or amended standard itself or an application is made by another body or person for a new or amended standard. In the case of applications, the FSANZ decides whether to accept or reject the application and notifies the applicant. Thereafter, public notice is given of the proposal. The FSANZ then assesses the proposal taking into account its costs and benefits, ${ }^{58}$ and may decide to abandon it, or proceed with it. If the proposal is not abandoned, a call for public submissions is issued in order to obtain the views of all stakeholders (such as the affected industry and consumer groups) on the issues raised by the draft standard and the impacts of the regulatory options. ${ }^{59}$ Having regard to any received submissions, the FSANZ prepares a draft regulatory measure or an amendment to an existing measure.

In drafting the food-safety measure or amendment, the FSANZ must take into account the abovementioned considerations, ${ }^{60}$ including the need to base the measure on the best available scientific evidence, and to promote consistency between national and international standards. ${ }^{61}$ Risk analysis forms the basis for any food safety measure drafted by the FSANZ. A risk assessment is prepared as part of this process. To undertake its risk assessments, FSANZ draws upon a broad range of in-house scientific expertise from its staff experts in fields including toxicology, nutrition, microbiology and biotechnology. ${ }^{62}$ For proposals involving areas of expertise beyond its own capacities, FSANZ makes use of external scientific experts from government as well as from non-governmental organisations. ${ }^{63}$ To assist in developing specific standards, Standards Development Committees (SDCs) are established, composed of persons from government and industry bodies and consumer groups in Australia and New Zealand. SDCs give expert advice regarding

${ }^{57}$ Sec. 21 of the Food Standards Australia New Zealand Act of 1991, as amended.

${ }^{58}$ In addition to the considerations that must be had regard to under Sec. 18 of the Food Standards Australia New Zealand Act, Sec. 29(2) and 59(2) oblige the FSANZ to have regard to whether the costs from the proposed measure outweigh the direct and indirect benefits to the community, government and industry that would arise from it, and whether there are more cost-effective measures than that proposed. The FSANZ must prepare a report which includes an analysis of potential social and economic costs and benefits of the regulatory options available, as part of its assessment (known as the Regulatory Impact Statement (RIS)). Food Standards Australia New Zealand, Application Handbook, Issue 1 (Commonwealth of Australia, Canberra), October 2007, 15, available at: http://www.foodstandards.gov.au/_srcfiles/Application\%20Handbook\%20 as\%20at\%201\%20Oct\%2007.pdf, visited on 21 January 2008.

${ }^{59}$ Ibid., 2.

${ }^{60}$ These considerations are set out in Sec 18(2) of the Food Standards Australia New Zealand Act of 1991, as amended.

${ }^{61}$ Food Standards Australia New Zealand, Application Handbook, Issue 1 (Commonwealth of Australia, Canberra), October 2007, 2, available at: http://www.foodstandards.gov.au/_srcfiles/Application\%20 Handbook\%20as\%20at\%201\%20Oct\%2007.pdf, visited on 21 January 2008.

${ }^{62}$ This information is provided on the 'FSANZ Science Strategy' page of the FSANZ website, available at: http://www.foodstandards.gov.au/aboutfsanz/scientificcapabilities/, visited on 22 January 2008. In addition, FSANZ has a few staff members with expertise in immunology, chemistry, mathematical modelling, epidemiology and qualitative and quantitative research. Ibid.

${ }^{63}$ Ibid. These experts work in fields such as nutrition, social science and statistics. To supplement the scientific and other professional advice available to it, the FSANZ has also established a network of FSANZ Fellows, appointed for 3-year terms and selected on the basis of their expertise in the relevant fields (such as risk modelling, microbiology, food science etc.). In addition, a Science Network has been created between scientists in Australia and New Zealand to promote increased understanding and consensus on scientific issues relating to food regulation. 
scientific, technical and policy issues of relevance to the standard being established or amended. ${ }^{64}$ The FSANZ follows the guidelines of the Codex Alimentarius Commission with respect to the risk assessment process. On the basis of the risk assessment, and other mandated considerations including a cost/benefit analysis, a risk management plan, to determine the best regulatory options available, is developed. In order to ensure full transparency in risk communication, the FSANZ publishes the scientific reports relating to food safety underlying its regulatory measures. ${ }^{65}$

Public submissions are then called for on the draft measure. Taking into account any submissions received, the FSANZ subsequently decides whether to approve or reject the standard and prepares a report, setting out the reasoning for its decision particularly in cases where scientific views conflict. ${ }^{66}$ If the measure is approved, it is notified to the Australia New Zealand Food Regulation Ministerial Council. Finally, this Council considers the standard or amendment and may request the FSANZ to review it. If the Council approves the standard or amendment, the FSANZ is obliged to publish it, after which it comes into force.

The FSANZ adopts a precautionary approach to food safety, based on a system of prior approval of novel foods. ${ }^{67}$ This entails that food or food ingredients that do not have an established history of safe use by humans in Australia or New Zealand (known as 'nontraditional foods'), and which have features that raise safety concerns, are prohibited, unless expressly permitted. ${ }^{68}$ Standard 1.5 .1 of the Food Standards Code applies to all novel foods, which are those 'non-traditional foods' for which there is insufficient knowledge in the broad community to enable safe use in the form or context in which it is presented. This Standard prohibits the sale of 'novel foods' ${ }^{69}$ unless they are listed in the Table attached to that Standard, and meet any special conditions set out in that Table (for example, composition or purity requirements, the requirement of preparation or cooking instructions, or warning statements). The FSANZ assesses the safety for human consumption of each novel food before it is included in the Table. Likewise, pre-marketing

${ }^{64}$ SDCs have been created with respect to issues including mandatory fortification of foods with folic acid and iodine, nutrition, and primary production and processing standards. Ibid.

${ }^{65}$ These scientific reports are published in the Technical Report Series on the FSANZ website, available at: http://www.foodstandards.gov.au/mediareleasespublications/technicalreportserie1338.cfm, visited on 22 January 2008. Another aspect of risk communication is the, already mentioned, incorporation of public comments into the regulatory process by making provision for notifications and calls for comments at two stages of the standard drafting procedure.

${ }^{66}$ Food Standards Australia New Zealand, Application Handbook, Issue 1 (Commonwealth of Australia, Canberra), October 2007, 2, available at: http://www.foodstandards.gov.au/_srcfiles/Application $\% 20$ Handbook\%20as\%20at\%201\%20Oct\%2007.pdf, visited on 21 January 2008.

${ }_{67}$ This approach follows that of the ANZFSA, the predecessor of the FSANZ. Ad Hoc Group on Food Safety, Compendium of National Food Safety Systems and Activities, SG/ADHOC/FS(2000)5/ANN/FINAL (Organisation for Economic Co-operation and Development, Paris), 12 May 2000, 6, available at: http://www. olis.oecd.org/olis/2000doc.nsf/LinkTo/sg-adhoc-fs(2000)5-ann-final, visited on 12 January 2008.

68 Ibid.

${ }^{69}$ A revision has been made to Standard 1.5.1 regarding the approach for determining whether a food is 'novel'. An Advisory Committee on Novel Foods will be established by FSANZ (expected in February 2008) composed of representatives of Australian State and Territory jurisdictions, AQIS and the New Zealand Food Safety Authority. See the page on the 'Review of Novel Foods' of the FSANZ website available at: http:// www.foodstandards.gov.au/foodmatters/novelfoods/regulationofnovelfoo3024.cfm, visited on 20 January 208. 
approval is required for genetically modified foods and irradiated foods, in Standards 1.5.2 and 1.5.3 of the Food Standards Code, subject to a risk assessment. Similarly, a precautionary approach is taken towards contaminants in food, in the form of agricultural and veterinary chemical residues. Those contaminants, for which safety levels, in the form of scientifically established maximum residue levels, have not been determined, are prohibited. Standard 1.4.2 of the Food Standards Code provides a list, in Schedule 1 thereto, of all of the permissible maximum residue levels (MRLs) for agricultural and veterinary chemicals in particular foods. ${ }^{70}$ If an MRL for a chemical in a particular food is not listed in Schedule 1, no detectable residues of that chemical in that food are permitted. Also, if an agricultural or veterinary chemical is not listed in Schedule 1 at all, no detectable residues of that chemical (or its metabolites) in any food is allowed. In practice, the maximum residue level for such contaminants is set at the 'limit of determination' (LOD), i.e. the lowest level at which it is analytically possible to detect any residue. A different approach is followed in Standard 1.4.1 with regard to other contaminants. This standard sets certain maximum levels of specified metal and non-metal contaminants (such as mercury and aflatoxins) and natural toxicants (for example, quinine) in particular foods. Maximum levels are only established if this serves an effective risk management function and only for foods that contribute significantly to the total dietary exposure. However, whether or not a maximum level has been set, this Standard provides that the levels of contaminants and natural toxicants in all foods should be kept 'as low as reasonably achievable' (commonly known as the ALARA principle in risk management).

Australia applies a systems-wide (or 'farm-to-fork') approach with regard to food-safety risks, rather than just imposing end-product requirements. ${ }^{71}$ This is reflected in Standard 3.2.1 of the Food Standards Code, ${ }^{72}$ which lays down HACCP requirements for all food production firms in Australia that fall within a priority classification determined by the relevant authority. ${ }^{73}$ In addition, the systems-wide approach is given further effect by the initiation by the Australian government, in May 2003, of the development of new 'primary production and processing standards' by the FSANZ. ${ }^{74}$ These standards, contained in Chapter 4 of the Food Standards Code which is applicable only to Australia, require that operators in specific food industries identify potential food safety hazards and implement controls that are commensurate with the risk. This therefore extends the HACCP approach, applied in Standard 3.2.1 to food manufacturing and retailing, to cover also primary production and processing of food. The objectives of this new approach were stated to be the need to strengthen food-safety in Australia, in order to lower the incidence of food-borne diseases; and the need to assure foreign markets of consistent levels of food-safety in Australian exports, in order to promote export trade. Domestic food-safety

\footnotetext{
70 This Standard applies only in Australia.

${ }^{71}$ On the difference between a systems-wide (or farm-to-fork) approach and a product-based approach to SPS regulation, see above, Part II, Section 1.3.

${ }^{72}$ This standard, like all standards contained in Chapters 3 (food safety) and 4 (primary production and processing) of the Standards Code, as mentioned above, apply only to Australia.

${ }^{73}$ For an explanation of the HACCP approach, see above, Part II, Section 1.3.

74 The Australian government provided a total of A \$2.8 million over four years to develop these standards and to inform the food industry. This information is provided on FSANZ News Room, Food Standards Australia New Zealand, Fact Sheet 2003: Imported Food. The Imported Food Inspection Scheme in Australia (Commonwealth of Australia, Canberra), May 2003, available at: http://www.foodstandards.gov.au/newsroom/factsheets/factsheets2003/importedfoodinspecti1985.cfm, visited on 20 January 2008.
} 
requirements in this integrated system are harmonised with the requirements for food exports applied by AQIS. In addition, like all standards contained in the Food Standards Code, these production and processing requirements apply to imported products. The first production and processing standard developed by FSANZ was for the seafood industry, ${ }^{75}$ an industry particularly vulnerable to pathogen contamination. ${ }^{76}$ There are now similar standards for poultry, meat, diary and cheeses industries. ${ }^{77}$

Implementation of the standards developed by the FSANZ is the responsibility of the government of New Zealand and the States and Territories of Australia, which are obliged to give these standards legal effect in their jurisdictions. ${ }^{78}$ The standards in the Food Standards Code are published in the government gazettes of Australia and New Zealand throughout the year, as they are approved. They are then adopted by reference and without amendment into the food legislation of New Zealand and the States and Territories of Australia and into the Commonwealth Imported Food Control Act of 1992. States and Territories may deviate from these standards only in limited cases of emergency situations creating risks for public health or safety, or due to exceptional conditions not presenting a public health or safety risk. ${ }^{79}$ It is a criminal offence in Australia to supply food that does not comply with the standards set out in the Food Standards Code. ${ }^{80}$

As mentioned above, illness from food-borne pathogens remains a concern in Australia. A national program, called OzFoodNet, was established by the DHA in 2000 as a collaborative initiative between Commonwealth and State governments to improve surveillance of food-borne diseases from pathogens such as Salmonella and E. coli. ${ }^{81}$ It aims, inter alia, to determine the causes of food-borne diseases and to coordinate investigations of foodborne disease outbreaks. Investigations increasingly relate to imported food products. ${ }^{82}$

\footnotetext{
${ }^{75}$ Standard 4.2.1 of the Food Standards Code.

76 The majority of food-bone disease outbreaks in Australia are traced back to pathogens in fishery products, followed by poultry. OzFoodNet Working Group, Burden and Causes of Foodborne Disease in Australia: Annual Report of the OzFoodNet Network, 2005 (Commonwealth of Australia, Canberra), 2006, 278, available at: http://www.health.gov.au/internet/wcms/Publishing.nsf/Content/cda-cdi3003-pdf-cnt.htm/\$FILE/ cdi3003b.pdf, visited on 14 January 2008.

77 Standards 4.2.2 to 4.2.4 of the Food Standards Code.

78 This information is provided in Food Standards Australia New Zealand, Australia New Zealand Food Standards Code. Commentary (Commonwealth of Australia, Canberra), Issue 88, available at: http://www. foodstandards.gov.au/_srcfiles/Commentary_v95.pdf, visited on 18 January 2008.

79 Ad Hoc Group on Food Safety, Compendium of National Food Safety Systems and Activities, SG/ADHOC/ FS(2000)5/ANN/FINAL (Organisation for Economic Co-operation and Development, Paris), 12 May 2000, 6, available at: http://www.olis.oecd.org/olis/2000doc.nsf/LinkTo/sg-adhoc-fs(2000)5-ann-final, visited on 12 January 2008.

${ }^{80}$ Sec. 11 of the Food Standards Australia New Zealand Act of 1991, as amended.

${ }^{81}$ OzFoodNet is under the authority of the Communicable Diseases Network Australia, and gets technical assistance from the National Centre for Epidemiology and Population Health at the Australian National University, Food Standards Australia New Zealand and the Public Health Laboratory Network. This information is taken from the website of OzFoodNet, available at: http://www.ozfoodnet.org.au, visited on 13 January 2008.

82 Australian Government Department of Health and Ageing and Food Standards Australia New Zealand, 'Enhancing Surveillance of Foodborne Diseases in Australia to Control Disease and Improve Food Safety', presented at the FAO/WHO Second Global Forum of Food Safety Regulators, Conference Room Document 6 (Food and Agriculture Organization and World Health Organization, Bangkok, Thailand) 12-14 October 2004, available at: ftp://ftp.fao.org/docrep/fao/meeting/008/ae019e.pdf, visited on 22 January 2008.
} 
In order to ensure that imported food meets Australia's food-safety requirements, Australia has the Imported Foods Inspection Scheme in place, jointly run by FSANZ and AQIS. FSANZ is responsible for risk assessment policy for food products and AQIS undertakes the inspection and sampling, in terms of the Imported Food Control Act of 1992. The requirements against which imports are tested are those of the Food Standards Code, as mentioned above. ${ }^{83}$

The frequency with which imported food is inspected by AQIS officials depends on the inspection category it is placed in by FSANZ, on the basis of its risk assessments. The three categories are: risk, active surveillance and random surveillance. ${ }^{84}$ Food is placed in the 'risk' category if it could pose high or medium risk to public health. The inspection rate applied to food in the 'risk' category is 100 percent. ${ }^{85}$ In addition to inspection, these foods are subject to a pre-determined range of tests for risks such as microbiological contamination and pesticide residues. ${ }^{86}$ Before the results of these analyses are known, the imported food in this category may not be marketed in Australia. ${ }^{87}$ Foods in the 'active surveillance' category are subject to much lower levels of inspection. Only ten percent of shipments from each exporting country are referred to AQIS for inspection, and are permitted to be marketed after they have been sampled. ${ }^{88}$ FSANZ periodically analyses the results of tests on these samples to review the appropriate inspection category of the food product. All food products not placed in the 'risk' or 'active surveillance' categories, fall into the 'random surveillance' category. ${ }^{89}$ Only five percent of these products are referred to AQIS for inspection, and are released after sampling. ${ }^{90}$ If a food product in the active

${ }^{83}$ This information is provided on FSANZ News Room, Food Standards Australia New Zealand, Fact Sheet 2003: Imported Food. The Imported Food Inspection Scheme in Australia (Commonwealth of Australia, Canberra), May 2003, available at: http://www.foodstandards.gov.au/newsroom/factsheets/factsheets2003/ importedfoodinspecti1985.cfm, visited on 20 January 2008.

${ }^{84}$ The categorisation of imported food into these inspection categories is regularly reviewed by FSANZ. Ibid.

${ }^{85}$ Sec. 14(1) of the Imported Food Control Regulations. Australian Government Department of the Attorney General, Imported Food Control Regulations, Statutory Rules No. 100 of 1993, as Amended (Commonwealth of Australia, Canberra), 1 July 2005, available at: http://www.comlaw.gov.au/ComLaw/Legislation/ LegislativeInstrumentCompilation1.nsf/0/50F611D12A8F4B2CCA25702E007DFC1E?OpenDocument, visited on 29 January 2008. In practice this means that the Australian customs service refers all shipments of these food products to AQIS for inspection and testing. However, not all food shipments in this category are actually inspected. Foods in the 'risk' category are subject to a 'performance-based approach' according to which imported food products from producers with a consistent history of compliance with the Food Standards Code are inspected less frequently than products from new suppliers or those with a history of non-compliance with the Food Standards Code. Sec. 15 of the Imported Food Control Regulations set out the performance-based inspection levels as follows: (1) The first 5 shipments of a food product from a particular producer are inspected - if 5 shipments are consecutively cleared, the inspection level decreases to the next level; (2) One in every 4 shipments is then inspected - if 20 of the inspected shipments are in compliance and if importation follows a steady pattern, the inspection level decreases to the next level; (3) One in every 20 shipments is then inspected.

${ }^{86}$ Sec. 29 of the Imported Food Control Regulations.

${ }^{87}$ Food Standards Australia New Zealand, Fact Sheet 2003: Imported Food. The Imported Food Inspection Scheme in Australia (Commonwealth of Australia, Canberra), May 2003, available at: http://www.foodstandards.gov.au/newsroom/factsheets/factsheets2003/importedfoodinspecti1985.cfm, visited on 20 January 2008.

${ }^{88}$ Sec. 14(2) of the Imported Food Control Regulations. See also ibid.

${ }^{89}$ Sec. 11 of the Imported Food Control Regulations.

${ }^{90}$ Sec. 14(3) of the Imported Food Control Regulations. See also Food Standards Australia New Zealand, Fact Sheet 2003: Imported Food. The Imported Food Inspection Scheme in Australia (Commonwealth of Australia, Canberra), May 2003, available at: http:/www.foodstandards.gov.au/newsroom/factsheets/factsheets2003/ importedfoodinspecti1985.cfm, visited on 20 January 2008. 
or random surveillance categories is found not to comply with the Food Standards Code, the inspection category of the product from the foreign supplier involved is raised to 'risk' level..$^{91}$ All shipments are then automatically detained for inspection and testing until five consecutive shipments are determined to be in compliance. Thereafter the product reverts to its prior inspection category. ${ }^{92}$

Australia is well-aware of the difficulty of averting food-safety risks from imported products purely by means of national measures. At the Second FAO/WHO Forum of Food Safety Regulators, the representatives of the Australian regulators emphasised the importance of international cooperation in this regard. ${ }^{93}$ They noted that early detection, identification and tracing of risky imported products depend on effective communication with the authorities of the exporting country. ${ }^{94}$ The current inadequacy of communication channels between food-safety authorities in different countries weakens food-safety controls. Information sharing with regard to disease outbreaks or the incidence of contaminants in food is therefore considered vital by Australia, and it supports initiatives in this regard, such as the International Food Safety Authorities Network (INFOSAN) and the Food Safety Emergency Network of the World Health Organization, that facilitate information exchange and thereby improve food-safety control. ${ }^{95}$

The international aspect of Australia's food-safety system extends beyond efforts, through national controls and international cooperation, to ensure the safety of food imports. Australia's sanitary regime also plays key role in promoting market access for its food and agricultural exports. As discussed above, the high level of food safety characterising Australian products due to the rigour of Australia's SPS system facilitates their acceptance on import markets. In addition, to assist its food and agricultural export industries to meet foreign SPS requirements, Australia issues publications containing detailed technical information regarding food-safety and other requirements on foreign markets. ${ }^{96}$ Further, it has various financial programs to reduce the costs of SPS compliance. ${ }^{97}$ However, often

91 Ibid.

92 Ibid.

93 Australian Government Department of Health and Ageing and Food Standards Australia New Zealand, 'Emerging Chemical and Microbiological Issues - Importance of Surveillance and International Cooperation and Information Sharing', presented at the FAO/WHO Second Global Forum of Food Safety Regulators, Conference Room Document 8 (Food and Agriculture Organization and World Health Organization, Bangkok, Thailand) 12-14 October 2004, available at: ftp://ftp.fao.org/docrep/fao/meeting/008/ae081e.pdf, visited on 22 January 2008.

94 Ibid.

95 Ibid.

${ }^{96}$ For example, the NFIS publishes a range of 'toolkits' to assist its food exporters gain market access to various countries. They include summaries of the relevant food-safety standards applicable in the relevant countries. Currently, the following publications exist: 8 Steps to Dubai, 8 Steps to India, and 8 Steps to the UK, available at: http://www.nfis.com.au/index.html, visited on 22 January 2008. In addition, guides for meeting requirements for fisheries exports in various countries have been issued by the DAFF in cooperation with the Australian Seafood Industry Council, for example, Jim Fitzgerald, A\$34 Billion Reasons to Access the US Seafood Market: A Guide to Exporting Australia's Fisheries Products to the United States (Department of Agriculture, Fisheries and Forestry of the Government of Australia and Australian Seafood Industry Council, Canberra), November 2002, available at: http://www.daff.gov.au/_data/assets/pdf_file/0017/6047/34billion. pdf, visited on 22 January. Similar guides exist for Hong Kong and the EC.

${ }_{97}$ For example, the Export Market Development Scheme provides $\$ 450$ million over three years to assist smaller firms in the Australian food industry to develop an export capacity. In addition, a $40 \%$ reduction in the service fees of AQIS is granted to small businesses falling within its seven commodity programs. Australian 
the ability of an exporter to demonstrate convincingly the conformity of its products with the applicable SPS requirements (whether public or private) is as important as the conformity itself. As a result, the Australian Government provides high-quality services in the area of export inspection and certification to its food and agricultural industries. The Export Control Act of 1982 governs the export of all products categorised as 'prescribed goods', such as meat, fish and processed food products. Export certificates issued by AQIS are based on inspection and auditing, to ensure that exports of food and agricultural products meet the SPS requirements of importing countries. ${ }^{98}$ This service greatly facilitates Australian exports, and is carried out in consultation with industry consultative committees. $^{99}$

Australia is also pro-active in dealing promptly with any food-safety issues that may arise, through technical consultations between officials of the International Food and Agriculture Service (IFAS) and the regulatory authorities of the importing country before a sanitary barrier to Australian exports is imposed. For example, when Australian food processing establishments started to use recycled potable water on food and food contact surfaces when water restrictions were imposed due to the drought, AQIS prepared a detailed protocol to enable such use. This protocol was used by IFSAS to obtain acceptance by the United States Food Safety Inspection Service of the safety of this practice, thus enabling exports from Australian establishments to continue unhindered. ${ }^{100}$ This pro-active strategy avoids the costs that its industry would suffer from loss of market access if the relevant sanitary measure were imposed. ${ }^{101}$ Australia also makes use of the mechanism

Government Department of Agriculture Fisheries and Forestry, National Food Industry Strategy: An Action Agenda for the Australian Food Industry (Commonwealth of Australia, Canberra), June 2002, 25, available at: http://www.daff.gov.au/_data/assets/pdf_file/0017/183320/strategy_statement_final.pdf, visited on 13 January 2008.

98 AQIS commodity inspectors in the regional offices provide assistance to food exporters in various areas, including the registration of food export establishments; the approval of HACCP-based systems; the auditing of export-registered establishments in accordance with both Australian and foreign requirements; the provision of export documentation; and general information. Jim Fitzgerald and Shelley Kowalski, The FishBook II: A Guide to Australian Government Programs, Grants and Services for the Australian Seafood Industry (Department of Agriculture, Fisheries and Forestry of the Government of Australia, Canberra), 2006, 31, available at: http://www.daff.gov.au/_data/assets/pdf_file/0019/6049/fishbook_2.pdf, visited on 13 January 2008.

99 Trade Policy Review Body, Trade Policy Review: Australia - Report by the Secretariat. Revision, WT/ TPR/S/178/Rev.1, circulated on 1 May 2007, Section III para. 51.

${ }^{100}$ Australian Government Department of Agriculture Fisheries and Forestry, Annual Report 2006-07: Growing Australia through Sustainable, Innovative and Profitable Agriculture, Fisheries and Forestry (Commonwealth of Australia, Canberra), September 2007, 108 and 151, available at: http://www.daff.gov.au/ data/assets/ pdf file/0005/439493/2 AR 06-07 ROP WEB.pdf, visited on 17 January 2008. The report notes that this has been a major achievement for the Australian meat and food processing industry as they use a large amount of water and are faced with water restrictions aimed at sustainable water use in Australia.

${ }^{101}$ As noted above, as part of the efforts to promote the food industry outlined in the National Food Industry Strategy, the Technical Market Access Program will be continued and expanded. This program aims to address SPS issues on existing or potential new markets for Australian products through early intervention by technical experts to avoid the imposition of market access barriers to Australian products by agencies in importing countries. It involves both Australian agricultural and veterinary experts located in the importing countries and a team of capital-based technical specialists. Australian Government Department of Agriculture Fisheries and Forestry, National Food Industry Strategy: An Action Agenda for the Australian Food Industry (Commonwealth of Australia, Canberra), June 2002, 25, available at: http://www.daff.gov.au/_ data/assets/ pdf_file/0017/183320/strategy_statement_final.pdf, visited on 13 January 2008. 
provided by the SPS Committee for the raising of trade concerns with regard to the SPS measures of other WTO Members, in order to resolve issues if bilateral discussions are unsuccessful. ${ }^{102}$

In addition, the Australian government works towards concluding agreements with its trading partners regarding the recognition of the equivalence of the sanitary controls of the countries involved. In 2006, Australia reached agreement with New Zealand on the recognition of the equivalence of the two countries' sanitary systems for dairy exports. As a result, the certification requirement for soft cheese exports to New Zealand has been lifted. ${ }^{103}$ Australia also has an equivalence agreement with Japan regarding exports of organic produce, which was been extended until 2009. ${ }^{104}$ The EC recognises the equivalence of Australia's laboratory testing system with regard to testing of crustaceans for cadmium residues. ${ }^{105}$

It is useful to examine the implications of Australia's food-safety system for its trade, by looking at practical examples. One of these examples demonstrates the extent to which Australia's sophisticated and well-resourced food-safety system can promote market access for Australian exports by enabling it to deal effectively with potential SPS barriers to trade. The other example illustrates the impact of this highly protective food-safety system on exports from other Members.

\subsection{Example of a food-safety measure affecting Australian exports}

A good illustration of Australia's efforts to facilitate its exports through pursuing the recognition of the equivalence of its food-safety controls is provided by the example of the introduction of HACCP in the meat sector. ${ }^{106}$

Australia's main agricultural export, as previously mentioned, is bovine meat. After Japan, the US is its main export market. The US also has an important meat export industry and the two countries compete on the same markets. ${ }^{107}$ However, their systems for inspection and certification of meat exports differ considerably. In the US, this system is centralized in the hands of the United States Department of Agriculture (USDA) whereas in Australia inspection authority remains with the governments of the States and Territories. In response to complaints regarding the complexity of this inspection and certification system by US importers of Australian meat, and following the recommendations of a

\footnotetext{
102 Australia has raised 9 trade concerns regarding the SPS measures of other WTO Members to date, and has joined the concerns raised by other Members in 18 cases. The trade concerns mechanism of the SPS Committee will be discussed further below, Part IV, Section 2.1.2.

103 Australian Government Department of Agriculture Fisheries and Forestry, Annual Report 2006-07: Growing Australia through Sustainable, Innovative and Profitable Agriculture, Fisheries and Forestry (Commonwealth of Australia, Canberra), September 2007, 151, available at: http://www.daff.gov.au/_data/ assets/pdf_file/0005/439493/2_AR_06-07_ROP_WEB.pdf, visited on 17 January 2008.

104 Ibid.

${ }^{105}$ Ibid. Interestingly, the DAFF reports that Australia managed to keep its access to the EC market for prawns despite the fact that the natural levels of cadmium in Australian prawns sometimes exceed the MRL set by the EC.

${ }^{106}$ This example is taken from J.J. Kastner and R. K. Pawsey, 'Harmonising Sanitary Measures and Resolving Trade Disputes through the WTO-SPS Framework. Part II. A Case Study of the USA-Australia Determination of Equivalence in Meat Inspection', Food Control 13, 2002, 57-60.

${ }^{107}$ Ibid., 57.
} 
1996 review of Australia's quarantine system, ${ }^{108}$ AQIS gained increased influence over the meat inspection programmes of the States and Territories.

In 1996, Australia moved away from the traditional product-based system for the control of meat safety and replaced this with a HACCP-based system, first for domestic production and then for export production. ${ }^{109}$ Meat processing establishments were required to adopt HACCP systems and much of the control responsibilities shifted from AQIS inspectors to the establishments themselves. Regulatory oversight by the government took the form of periodic audits and the provision of one in-plant veterinarian. ${ }^{110}$ Already during the process of implementing this changed sanitary system, due to the importance of the US market for its meat exports, Australia requested the US to recognise the equivalence of the new system with its own sanitary requirements for meat. A technical committee was established between the USDA and the Australian Food Safety Inspection Service to examine this issue. Although this committee found that the new system provided adequate safety assurance, in November 2007 the US rejected the request for recognition of equivalence. ${ }^{111}$ According to the USDA, the new system resulted in an unacceptable reduction in government oversight and would lead to inadequate verification of food safety. ${ }^{112}$ However the USDA offered to consider a revised proposal, if the level of federal oversight was equivalent to that provided in the US inspection system. In collaboration with the USDA, AQIS drew up an amended proposal for the recognition of equivalence of its meat safety system, increasing government oversight of the production process and adding another inspector to the processing line. In 1999, the USDA agreed to accept the equivalence of the revised system, on the basis that it ensured American consumers the same level of food-safety and provided by USDA domestic inspection. ${ }^{113}$

The willingness of Australia and the US to collaborate constructively on this issue has been ascribed to the importance of their trade relationship in the meat sector. ${ }^{114}$

\footnotetext{
108 The report of the Nairn Review recommended that a nationally coordinated, consistent and transparent quarantine system be established. M.E. Nairn et al., Australian Quarantine: A Shared Responsibility (Australian Quarantine Review Secretariat, Canberra), 1996, available at: http:/www.daff.gov.au/_data/assets/pdf file/0009/111969/nairn_report.pdf, visited on 24 January 2008.

109 J.J. Kastner and R. K. Pawsey, 'Harmonising Sanitary Measures and Resolving Trade Disputes through the WTO-SPS Framework. Part II. A Case Study of the USA-Australia Determination of Equivalence in Meat Inspection', Food Control 13, 2002, 57-60, 58.

${ }^{110}$ Ibid.

111 Ibid.

${ }^{112}$ It is interesting to note that, at the time when the USDA turned down Australia's equivalence request, it was itself considering a new HACCP-based inspection system reducing reliance on government inspectors. It therefore used the opportunity to coordinate the changes in its meat safety system with those of Australia, by setting out 5 conditions that AQIS would have to meet to have its new system considered equivalent. Due to concerns of the US inspectors union that the US HACCP system would result in the transfer of most inspection tasks from government inspectors to company employees, as was the case in Australia, one of the US conditions for the recognition of equivalence related to the increase of government oversight. Ibid., 59.

113 Ibid.

${ }^{114}$ Ibid., 60. In 1997, Australian meat exports to the US amounted to US\$344 million.
} 


\subsection{Example of a food-safety measure affecting imports into Australia ${ }^{115}$}

The Philippines exports sauces containing benzoic acid, ${ }^{116}$ and wished to gain market access to Australia for these products. However, since 1996 Australia had maintained an import prohibition on sauces containing benzoic acid. In September 1998, the Philippines raised a trade concern on this issue at a meeting of the SPS Committee. ${ }^{117}$

In particular, the Philippines argued that Australia's import prohibition on Philippine sauces containing benzoic acid were discriminatory, as imports of sauces from New Zealand were permitted regardless of their benzoic acid content.

Australia showed readiness to address this matter with the Philippines, but at the SPS Committee meeting held in November 1998, the Philippines reported that bilateral discussions had been unsuccessful. ${ }^{118}$ The lack of an international standard for benzoic acid in sauces was pointed out. Australia explained that its new joint food code with New Zealand was being developed and that it expected the final standard for food additives to be finalised in the first half of 1999. It pointed out that the reason why New Zealand sauces were granted import permission stemmed from the Australian-New Zealand Agreement for the Development of a Joint Food Standard System, and was only transitional. ${ }^{119}$

When the Philippines raised the matter again at the SPS Committee in July 1999, Australia confirmed that the new Food Standards Code would include benzoic acid as a permissible additive. ${ }^{120}$ An update provided by Australia in June 2000 indicated that as of that month, the prohibition on benzoic acid would be lifted. Instead, a tolerance level of 1000 milligrams per kilogram would apply for benzoates in all sauces, whether domestically produced or imported. ${ }^{121}$

${ }^{115}$ This example is taken from the summary of trade concerns raised at SPS Committee meetings, maintained by the WTO Secretariat. Committee on Sanitary and Phytosanitary Measures, Specific Trade Concerns. Note by the Secretariat. Addendum: Resolved Issues, G/SPS/GEN/204/Rev.7/Add.3, circulated on 7 February 2007, item 49.

${ }^{116}$ Benzoic acid is an anti-microbial preservative used in sauces, particularly those intended for export which thus require a shelf-life of 6 to 12 months. Committee on Sanitary and Phytosanitary Measures, Procedure to Monitor the Process of International Harmonization: First Annual Report Adopted by the Committee on 8 July 1999, G/SPS/13, circulated on 12 July 1999, para. 23.

${ }^{117}$ Committee on Sanitary and Phytosanitary Measures, Review of the Operation and Implementation of the Agreement on the Application of Sanitary and Phytosanitary Measures: Report of the Committee, G/SPS/12, circulated on 11 March 1999, paras 83-85

118 Committee on Sanitary and Phytosanitary Measures, Summary of the Meeting Held on 10-11 November 1998: Note by the Secretariat, G/SPS/R/13, circulated on 15 January 1999, paras 24-25. See also Committee on Sanitary and Phytosanitary Measures, Australian Import on Sauces Containing Benzoic Acid: Statement by Philippines at the Meeting of 11-12 November 1998, G/SPS/GEN/106, circulated on 23 November 1998.

119 Under this agreement, a mutual recognition arrangement was in place whereby Australia permitted the imports of food products from New Zealand that met the requirements either of the Australian Food Standards or of the New Zealand Food Regulations. Benzoic acid in sauces was permitted by the New Zealand Food Regulations. Committee on Sanitary and Phytosanitary Measures, Summary of the Meeting Held on 10-11 November 1998: Note by the Secretariat, G/SPS/R/13, circulated on 15 January 1999, para. 21.

${ }^{120}$ Committee on Sanitary and Phytosanitary Measures, Summary of the Meeting Held on 7-8 July 1999: Note by the Secretariat, G/SPS/R/15, circulated on 20 September 1999, para. 68.

${ }^{121}$ Committee on Sanitary and Phytosanitary Measures, Summary of the Meeting Held on 21-22 June 2000: Note by the Secretariat, G/SPS/R/19, circulated on 1 August 2000, para. 21. 
At the SPS Committee meeting in October 2001, the Philippines confirmed that this change had occurred and that Philippine sauces were no longer being detained in Australia due to benzoic acid. ${ }^{122}$

\subsubsection{Animal health system}

Australia has a rigorous animal health system in place that successfully maintains a high level of protection. Australia is currently free of most major animal diseases, including avian influenza, foot-and-mouth disease and bovine spongiform encephalitis. In order to prevent the introduction of these and other exotic pests and diseases, Australia applies a prior approval system to imports of animals or animal products, based on a through risk analysis process.

Public provision of animal health services in Australia is in the hands of the Commonwealth Government, the governments of the States and Territories, ${ }^{123}$ and local government. ${ }^{124}$ In order to ensure that these services are provided in a coherent manner, a range of consultative committees have been established. ${ }^{125}$ The Primary Industries Ministerial Council is the highest body responsible of agricultural policy making at national level. ${ }^{126}$ It is composed of ministerial-level representatives of the Commonwealth Government, States and Territories. It is supported by the Primary Industries Standing Committee. ${ }^{127}$ This Committee is advised by the Animal Health Committee (AHC), composed of the Chief Veterinary Officers of the Commonwealth, States, Territories and New Zealand, as well as representatives of Biosecurity Australia, Animal Health Australia and the Commonwealth Scientific and Industrial Research Organisation (CSIRO). ${ }^{128}$ The AHC's task is to develop a coherent national policy on animal health that is science-based. ${ }^{129}$

At the Commonwealth Government level, animal health services are provided by the Office of the Chief Veterinary Officer (OCVO), AQIS and CSIRO. ${ }^{130}$ It is responsible

122 Committee on Sanitary and Phytosanitary Measures, Summary of the Meeting Held on 31 October-1 November 2001. Note by the Secretariat, G/SPS/R/25, circulated on 18 January 2002, para.36.

${ }_{123}$ The States and Territories are responsible for control and eradication of animal diseases within their territories. This information is taken from the 'Australia's Animal Health System' page of the DAFF website, available at: http://www.daff.gov.au/animal-plant-health/animal/system, visited on 23 January 2008.

124 States and Territories are subdivided into veterinary regions under the control of a veterinary officer. Ibid.

125 There are a range of consultative committees, including scientific committees focused on animal health and a ministerial-level committee working, in part, on animal health issues which require high-level policy endorsement. This information is available on the 'Committees that Deal with Animal Health' page of the DAFF website, available at: http://www.daff.gov.au/animal-plant-health/animal/committees, visited on 22 January 2008.

${ }^{126}$ This information is available on the 'Committees that Deal with Animal Health' page of the DAFF website, available at: http://www.daff.gov.au/animal-plant-health/animal/committees, visited on 22 January 2008.

127 This Committee is composed of the Chief Executive Officers of the Commonwealth Government, States and Territories in the relevant policy areas. This information is available on the 'Committees that Deal with Animal Health' page of the DAFF website, available at: http://www.daff.gov.au/animal-plant-health/animal/ committees, visited on 22 January 2008.

${ }^{128}$ This information is taken from the 'Animal Health Committee' page of the website of the DAFF, available at: http://www.daff.gov.au/animal-plant-health/animal/committees/ahc, visited on 22 January 2008.

129 Ibid.

130 The largest employer of veterinarians in Australia is the Commonwealth Government, due to the large number needed for meat inspection services. This enables it to provide an important reserve force to the States and Territories in case of any major outbreak of an exotic animal disease. This information is taken 
for the formulation of national policies and strategies with regard to animal health in Australia. ${ }^{131}$ The OCVO has around 30 staff members whose tasks include risk assessments, surveillance of animal diseases, laboratory diagnostics, veterinary epidemiology, and policy development. ${ }^{132}$ It is also the main agency representing Australia internationally with regard to animal health matters, including in international standard-setting. ${ }^{133}$

Risk analysis in the area of animal health is the responsibility of Animal Biosecurity, a division of Biosecurity Australia. It has a staff of scientists and veterinarians whose task it is to assess the risks of the introduction and spread of exotic pests and diseases from imports of live animals (including aquatic animals), animal products and genetic material. ${ }^{134}$ These import risk assessments underlie the quarantine policies developed by Animal Biosecurity for the protection of animal health in Australia. ${ }^{135}$ Animal Biosecurity also participates in international standard-setting in the area of animal health and is actively involved in technical discussions with Australia's trading partners to promote market access for Australian animals and animal products. ${ }^{136}$

CSIRO has the task of carrying out research with regard to animal health. It is responsible for the operation of the Australian Animal Health Laboratory (AAHL), which is among the world's leading laboratories for safe handling and containment of animal diseases. ${ }^{137}$ This laboratory not only provides a high-security facility for emergency research and diagnosis on animal diseases but is also used to provide training in animal disease emergencies to Australian and foreign veterinary and laboratory personnel. ${ }^{138}$ The AAHL has the capacity to provide sensitive, accurate and fast diagnostic tests. The DAFF maintains a high level of funding of the AAHL, which ensures that its facilities can be regularly upgraded and continually improved. The budget of the AAHL was increased in May 2007 by $\mathrm{A} \$ 16.8$ million over the next four years. ${ }^{139}$ In addition to the AAHL, a network of an-

from the 'Australian Government responsibilities' page on the DAFF website, available at: http://www.daff. gov.au/animal-plant-health/animal/system/gvnt, visited on 22 January 2008.

131 OCVO acts as the coordinator of national activities with regard to the emergency terrestrial and aquatic animal disease response contingency plans, known as AUSVETPLAN and AQUAVETPLAN. Australian Government Department of Agriculture Fisheries and Forestry, The OCVO - Who We Are and What We Do (Commonwealth of Australia, Canberra), available at: http://www.daff.gov.au/_data/assets/pdf file/0020/361541/about-ocvo.pdf, visited on 22 January 2008.

132 Ibid.

133 Ibid.

134 This information is provided on the 'Animal Biosecurity' page of the DAFF website, available at: http:// www.daff.gov.au/ba/about/animal, visited on 23 January 2008.

135 Ibid.

136 Ibid.

137 The AAHL was established in 1985 and cost over A $\$ 150$ million to set up. It is able to handle the most infectious and pathogenic animal diseases. This information is taken from the AAHL website available at: http://www.csiro.au/places/aahl.html, visited on 22 January 2008.

${ }^{138}$ This information is published on the 'Australian Government responsibilities' page on the DAFF website, available at: http://www.daff.gov.au/animal-plant-health/animal/system/gvnt, visited on 22 January 2008.

The AAHL is designated by the World Organization for Animal Health as a Collaborating Centre for New and Emerging Diseases and as a reference laboratory for bluetongue, avian influenza, Newcastle disease, Hendra and Nipah virus diseases, yellowhead disease, epizootic haematopoietic necrosis, brucellosis and rabies. This information on the AAHL is provided on its website, available at: http://www.csiro.au/places/aahl.html, visited on 22 January 2008.

139 This information is taken from the AAHL website available at: http:/www.csiro.au/places/aahl.html, visited on 22 January 2008. 
imal health laboratories exists at the State and Territory level, including public, private and university laboratories. ${ }^{140}$ All government laboratories in Australia must be accredited to international standards. The National Association of Testing Authorities (NATA) conducts accreditation for veterinary laboratories to ISO/IEC 17025:2005 standards (General Requirements for the Competence of Testing and Calibration Laboratories). ${ }^{141}$ Accreditation is important for the recognition of competent testing services, which facilitates the acceptance of Australian animal products on foreign markets.

The implementation of appropriate risk management measures is the responsibility of AQIS. The role of AQIS in the animal health system is to provide quarantine services as well as import inspection and export certification services with regard to animals and animal products. While it retains ultimate responsibility for these tasks, it may delegate some functions to AQIS-accredited veterinary officers of the States or Territories. ${ }^{142}$ As in the area of food safety, with regard to animal health AQIS makes a considerable contribution to assisting the export of Australian livestock and fishery products through its reputable inspection and certification services and its provision of information to exporters. ${ }^{143}$ It also facilitates audits by foreign inspectors of Australia's animal health system to check conformity with requirements in the importing country. For example, in July to August 2006, AQIS assisted the US Food and Drug Administration's review of the export dairy system in Australia. This review established the conformity of the Australian system with US requirements for dairy imports. ${ }^{144}$ Subsequently, an AQIS submission in support of a request for simplification of the application procedure for import permits for Australian cream and milk was accepted by the US. ${ }^{145}$

\footnotetext{
${ }^{140}$ The laboratory network consists of 11 Commonwealth Government animal health laboratories, 6 central State or Territory government laboratories, 5 regional government laboratories, a private laboratory contracted by the Victorian government to undertake additional diagnostic and investigative work, an associated veterinary diagnostic laboratory in each of Australia's six veterinary schools, and a number of private veterinary laboratories in five States. This information is provided on the 'Australia's Animal Health Laboratories Network' page of the DAFF website, available at: http://www.daff.gov.au/animal-plant-health/animal/system/lab-network, visited on 22 January 2008.

${ }^{141} \mathrm{Ibid}$. NATA also represents Australia in the International Laboratory Accreditation Cooperation (ILAC).

${ }^{142} \mathrm{Ibid}$. The OCVO is active in the World Organization for Animal Health in contributing to the development of international animal health standards.

${ }^{143}$ For example, AQIS maintains ANIMEX, which is a database of export requirements for live animals and reproductive material, available at: http://www.aqis.gov.au/animex/asp/search.asp, visited on 23 January 2008. The AQIS Fish Exports Program provides the seafood export industry with operational, policy and technical advice to assist it in obtaining and maintaining market access. The AQIS Export Facilitation Program, which works in cooperation with industry, promotes trade in agricultural products (including seafood) by providing information and advice to Australian exporters with regard to SPS requirements. It also provides an initial contact point for agricultural exporters facing SPS barriers t trade. Jim Fitzgerald and Shelley Kowalski, The FishBook II: A Guide to Australian Government Programs, Grants and Services for the Australian Seafood Industry (Department of Agriculture, Fisheries and Forestry of the Government of Australia, Canberra), 2006, 28-29, available at: http://www.daff.gov.au/_data/assets/pdf_file/0019/6049/fishbook_2.pdf, visited on 13 January 2008.

144 Australian Government Department of Agriculture Fisheries and Forestry, Annual Report 2006-07: Growing Australia through Sustainable, Innovative and Profitable Agriculture, Fisheries and Forestry (Commonwealth of Australia, Canberra), September 2007, 151, available at: http://www.daff.gov.au/_data/ assets/pdf_file/0005/439493/2_AR_06-07_ROP_WEB.pdf, visited on 17 January 2008.

145 Ibid.
} 
The DAFF Division of Product Integrity, Animal (Including Aquatic Animal) and Plant Health (PIAPH) is, inter alia, responsible for post-border management of risks to terrestrial and aquatic animal health and welfare from pests, diseases and veterinary chemicals. It leads responses to animal disease incidents, and provides technical assistance to farmers in that regard. In 2006-2007, these incidents included anthrax outbreaks in Victoria and New South Wales, the detection of Asian honey bees in Cairns, and die-off events of abalone in wild fisheries. ${ }^{1}$ The PIAPH takes a pro-active approach to prevention and preparedness for outbreaks of animal diseases of which Australia is currently free. It develops contingency plans, coordinates national responses and conducts training and simulation exercises. For example, in order to develop a strategy to prevent and respond to outbreaks of highly pathogenic avian influenza, it has involved the poultry industry, State and Territory authorities and the Australian Animal Health Laboratory. ${ }^{2}$ The Avian Influenza Programme has established a national 'whole-of-government' policy for preparedness and response to avian influenza, including through surveillance and vaccination programmes. ${ }^{3}$

The Australian Pesticides and Veterinary Medicine Authority is responsible for regulating the use of veterinary drugs in livestock farming. A list of specific products to be included in a national registration scheme for agricultural and veterinary chemicals is being considered by the Primary Industries Standing Committee, which will make recommendations in this regard. ${ }^{4}$ A National Residue Survey has undertaken random monitoring of animal products to assist the industry to gain access to national and foreign markets. ${ }^{5}$

In order to improve traceability of livestock, Australia has implemented a National Livestock Identification Scheme for cattle, and extending it to sheep and goats. ${ }^{6}$ This scheme aims to create a nationally integrated system to trace livestock in case of animal disease emergencies or food-safety risks. ${ }^{7}$

The governments of the Australian States and Territories play an important role in animal disease control. In partnership with Animal Biosecurity and the PIAPH, they develop strategies to address regional differences in pest and disease prevalence, and adopt measures to maintain pest- or disease-free areas. ${ }^{8}$

One of the objectives of Australia's strict animal health system is to secure market access for its exports of animals and animal products. However, this same system has the effect of restricting market access for the products of other countries. It is useful to look at examples of both of these situations.

${ }^{1}$ Ibid., 123.

2 Ibid., 125.

${ }^{3}$ Ibid., 119 and 123. In 2005, a national simulation of an avian influenza outbreak was conducted. The simulation model was used to determine the potential spread of the disease and assess the effectiveness of various surveillance strategies. Most of the recommendations that were drawn from this exercise have now been implemented. A performance audit is currently being carried out by the Australian National Audit Office.

${ }^{4}$ Ibid., 122.

5 Ibid., 123.

${ }^{6}$ Ibid., 122.

${ }^{7}$ Ibid. The Australian government has made A $\$ 20$ million available for this project over 4 years.

${ }^{8}$ Australian Government Department of Agriculture Fisheries and Forestry, Import Risk Analysis Handbook 2007 (Commonwealth of Australia, Canberra), September 2007, 9, available at: http://www.daff.gov.au/biosecuritycoordination/import_risk_analysis_handbook_2007, visited on 15 January 2008. 


\subsection{Example of an animal health measure restricting Australian exports}

As previously mentioned, Australia maintains its territory free of most major animal diseases through its comprehensive system of animal health controls. However, it has been confronted with the problem of lack of recognition of its disease free status by importing countries. These countries impose generally-applicable restrictions without taking into account the disease-free status of Australia.

Australia has raised its trade concerns with regard to two such measures, taken by the EC. In 1997, Australia expressed its concerns with regard to a marketing ban imposed by the $\mathrm{EC}$ on cosmetics containing certain bovine, ovine and caprine tissues and fluids from the brain, spinal cord, or eyes. ${ }^{9}$ due to the risks of transmission to humans of transmissible spongiform encephalitis from tissues infected with BSE. ${ }^{10}$ Australia pointed out that it was free of BSE but that the EC measure did not take into account the animal health status of the supplying countries. The EC responded that in light of the fact that global surveillance of BSE was still being developed and that the long incubation period of BSE made its detection difficult, its was not prepared to recognise any country as BSE free. ${ }^{11}$

In 2003, Australia complained about the EC's notification regarding a measure to address blue tongue. ${ }^{12}$ It argued that it had been free of blue tongue for over a decade, as recognized by several including the US, Canada, Mexico, New Zealand and Japan. Australia noted that it had repeatedly submitted scientific evidence to the EC. It pointed out that the EC measure would affect its alpaca exports to the EC. ${ }^{13}$ The EC indicated that its measure did not address Australia's situation, and that it would address the matter bilaterally with Australia. ${ }^{14}$ No solution to this issue has been reported, but the issue was not raised again in 2006 or 2007, which may indicate that it was resolved bilaterally. ${ }^{15}$

\footnotetext{
9 European Commission, 20th Commission Directive 97/1/EC of 10 January 1997 Adapting to Technical Progress Annexes II, III, VI and VII of Council Directive 76/768/EEC on the Approximation of the Laws of the Member States Relating to Cosmetic Products, 97/1/EC (European Community, Brussels), 10 January 1997, available at: http://eur-lex.europa.eu/LexUriServ/LexUriServ.do?uri=CELEX:31997L0001:EN:HTML, visited on 28 January 2008. See also Committee on Sanitary and Phytosanitary Measures, Notification, G/SPS/N/ EEC/43, circulated on 7 March 1997.

${ }^{10}$ Committee on Sanitary and Phytosanitary Measures, Specific Trade Concerns. Note by the Secretariat. Addendum: Issues Not Considered in 2006, G/SPS/GEN/204/Rev.7/Add.2, circulated on 7 February 2007, item 17.

${ }^{11}$ Committee on Sanitary and Phytosanitary Measures, Summary of the Meeting Held on 19-20 March 1997: Note by the Secretariat, G/SPS/R/7, circulated on 29 April 1997, 61-62. No solution to this issue has been reported, but it was last raised at an SPS Committee meeting in 1997, which may indicate that it has been resolved bilaterally. Committee on Sanitary and Phytosanitary Measures, Specific Trade Concerns. Note by the Secretariat. Addendum: Issues Not Considered in 2006, G/SPS/GEN/204/Rev.7/Add.2, circulated on 7 February 2007, item 17.

${ }^{12}$ Committee on Sanitary and Phytosanitary Measures, Summary of the Meeting Held on 24-25 June 2003: Note by the Secretariat, G/SPS/R/30, circulated on 4 September 2003, 68-69.

13 Committee on Sanitary and Phytosanitary Measures, Specific Trade Concerns. Note by the Secretariat. Addendum: Issues Not Considered in 2006, G/SPS/GEN/204/Rev.7/Add.2, circulated on 7 February 2007, item 170.

${ }^{14}$ Committee on Sanitary and Phytosanitary Measures, Summary of the Meeting Held on 24-25 June 2003: Note by the Secretariat, G/SPS/R/30, circulated on 4 September 2003, 68-69.

15 Committee on Sanitary and Phytosanitary Measures, Specific Trade Concerns. Note by the Secretariat. Addendum. Issues Not Considered in 2007, G/SPS/GEN/204/Rev.8/Add.2, circulated on 27 March 2008, item 170 .
} 


\subsection{Examples of animal health measure restricting imports to Australia}

An illustration of the effect on exporting countries of Australia's strict system of prior approval of animal imports on the basis of IRAs, is provided by the example of shrimp exports from Vietnam. In 2000, Australia notified WTO Members of its draft IRA for prawn and prawn products from Asian countries, requiring risk management measures for white spot syndrome virus and yellowhead virus. ${ }^{16}$ Before the comment period provided for in its notification had elapsed, Australia imposed interim quarantine requirements for whole or unpeeled headless green prawns. ${ }^{17}$ These were motivated by Australia's concerns regarding the illegal use in its territory of uncooked prawns a fishing bait, which was occurring frequently and had resulted in an outbreak of White Spot Virus.

On behalf of ASEAN, Thailand raised concerns on this matter at an SPS Committee meeting in 2001, arguing that domestic illegal practices may not be taken into account as a major element in a risk analysis. ${ }^{18}$ It urged Australia to complete the IRA and terminate the interim measure. Throughout 2001, 2002 and 2003, Thailand continued to raise this matter at SPS Committee meetings, complaining of the delay in completing the IRA and the continued imposition of the interim measure.

The revised draft IRA was finally made available for comments in $2007 .{ }^{19}$ It found that five pathogens had to be controlled: Taura Syndrome Virus, Infectious Hypodermal and Haematopoietic Necrosis Virus, Necrotising Hepatopancreatis Bacterium, White Spot Syndrome Virus and Yellowhead Virus. It indicated its intention to test 100 percent of prawn shipments for Yellowhead Virus and White Spot Syndrome Virus.

At the SPS Committee meeting in June 2007, Vietnam raised its concerns with regard to the revised IRA, pointing to the crucial economic importance of prawn industry to its economy ${ }^{20}$ as well as the general acceptance by its trading partners of the good safety level of its prawns. ${ }^{21}$ It claimed that only two of the five pathogens (White Spot Syndrome

${ }^{16}$ Committee on Sanitary and Phytosanitary Measures, Notification by Australia, G/SPS/N/AUS/124, circulated on 23 November 2000.

${ }^{17}$ Committee on Sanitary and Phytosanitary Measures, Notification by Australia, G/SPS/N/AUS/126, circulated on 19 February 2001.

${ }^{18}$ Committee on Sanitary and Phytosanitary Measures, Specific Trade Concerns. Note by the Secretariat. Addendum: Issues Not Considered in 2006, G/SPS/GEN/204/Rev.7/Add.2, circulated on 7 February 2007, item 85 .

19 The DAFF Annual Report 2006-07 states that a revised draft IRA report on prawns was made available for public comment for a 90 day period ending in February 2007, resulting in over 50 submissions which were considered in the light of possible stricter measures. Australian Government Department of Agriculture Fisheries and Forestry, Annual Report 2006-07: Growing Australia through Sustainable, Innovative and Profitable Agriculture, Fisheries and Forestry (Commonwealth of Australia, Canberra), September 2007, 192, available at: http://www.daff.gov.au/_data/assets/pdf_file/0005/439493/2_AR_06-07_ROP_WEB.pdf, visited on 17 January 2008.

${ }^{20}$ Vietnam reported that the fishery industry employs 4 million persons in Vietnam, $50 \%$ of whom are in the prawn sector (manufacturing feed for prawn, prawn culture, processing and other related logistics services). Committee on Sanitary and Phytosanitary Measures, Australia's Revised Import Risk Analysis and Measures on Prawns and Prawn Products. Statement by Vietnam at the Meeting of 27-28 June 2007, G/SPS/GEN/791, circulated on 4 July 2007.

${ }^{21}$ According to Vietnam, its prawns, particularly black tiger prawns are of high quality due to its well-organized system of aquatic animal disease control. It reported that in 2006, Vietnam exported prawn products to over 90 countries, including those with a strict food safety and disease control requirements (for example the EC, Japan and the US). Ibid. 
Virus and Yellowhead Virus) had been found to occur in Vietnam and argued that Australia should conduct individual risk assessments for each country.

In addition, Vietnam pointed to the fact that despite the long history of importation by Australia of prawns from Asian countries where White Spot Syndrome Virus and Yellowhead are prevalent, these viruses have not occurred in Australia for the last six years. This was due to the effective operation of the quarantine measures in place in Australia since 2001, ${ }^{22}$ according to Vietnam. Therefore, it argued that Australia should maintain the current quarantine measures and address the threat from illegal use as bait by tightening its domestic controls post-arrival. Thailand, Indonesia, the Philippines and China also raised concerns on this issue and urged the Australian authorities to consider the comments. ${ }^{23}$

In response, Australia pointed out that the comment period on the revised draft IRA, which had provided the opportunity for all interested parties to submit new scientific information that might not have been taken into account before Australia imposed the interim measures, had expired on 21 February 2007. Australia pointed out that it had reviewed the many submissions received. It reported that further consideration was required before the Director of Quarantine decided whether the interim measures had to be strengthened to achieve Australia's appropriate level of protection. Thereafter, the IRA would be reviewed by the Eminent Scientists' Group and then be finalised. ${ }^{24}$ Thailand and Australia undertook further technical discussions through the ASEAN SPS group and bilaterally. In September 2007, Australia accepted Thailand's proposal on alternative cooking parameters for prawns and indicated its willingness to consider similar proposals from other exporting countries, and to discuss equivalent measures as well as zoning and compartmentalisation. ${ }^{25}$ On 1 October 2007, Australia's revised interim measures for prawns and prawn products came into force. ${ }^{26}$

Another example of an animal health measure affecting imports into Australia, and one which is discussed in detail in Part III of this book, is the measure for the protection of Australian fish stocks against imported fish diseases, that was at issue in the Australia - Salmon dispute. ${ }^{27}$ This measure, under Australia's Quarantine Proclamation of 1975,

${ }^{22}$ The quarantine measures in place since 2001 required imported prawns to be larger than $15 \mathrm{gr} / \mathrm{piece}$, and required certificates issued by the competent authority of the exporting country certifying that the prawns were not 'early harvest' prawns and that there were no clinical signs of White Spot Syndrome Virus or Yellowhead Virus. Ibid.

${ }^{23}$ Committee on Sanitary and Phytosanitary Measures, Summary of the Meeting of 27-28 June 2007. Note by the Secretariat, G/SPS/R/45, circulated on 12 September 2007, paras 33-36.

${ }^{24}$ Ibid., para. 37.

${ }^{25}$ Committee on Sanitary and Phytosanitary Measures, Specific Trade Concerns. Note by the Secretariat. Addendum. Issues Considered in 2007, G/SPS/GEN/204/Rev.8/Add.1, circulated on 27 March 2008, item 85.

26 These revised interim measures were notified in Committee on Sanitary and Phytosanitary Measures, Notification. Addendum, G/SPS/N/AUS/204/Add.1, circulated on 2 August 2007.

27 These measures were also at issue in the parallel dispute brought by the US. Dispute Settlement Body, Australia - Measures Affecting the Important of Salmonids. Request for Consultations by the United States, WT/DS21/1, G/L/39, G/SPS/W/40, circulated on 23 November 1995. A Panel was established to hear this dispute in June 1999 and composed in August 1999. However, in view of the ongoing consultations, the Panel was requested to suspend its work. A mutually agreed solution was achieved between Australia and the US in November 2000 on the basis of the revision of the Australian measures notified in G/SPS/N/AUS/117. Dispute Settlement Body, Australia - Measures Affecting the Importation of Salmonids. Notification of Mutually 
amounted to a prohibition on the importation of dead salmon except if prior to importation the salmon had been treated in a manner that in the opinion of the Director of Quarantine was 'likely to prevent the introduction of any infections or contagious disease, or disease or pest affecting persons, animals or plants'. In accordance with this mandate, the Director of Quarantine permitted importation of commercial quantities of heat-treated salmon products for human consumption and non-commercial quantities of other salmon (mainly for scientific research) under specific conditions. Canada was therefore denied market access for untreated fresh, chilled or frozen salmon. Canada expressed the view that this measure was contrary to the SPS Agreement and the GATT 1994, and requested consultations with Australia under the WTO dispute settlement system to resolve this dispute. ${ }^{28}$ These were unsuccessful.

Subsequently, in December 1996, on the basis of an import risk analysis for uncooked, wild, adult, ocean-caught Pacific salmon conducted by AQIS in 1995 and finalised in $1996,{ }^{29}$ which identified 24 disease agents of concern in Canadian salmon, ${ }^{30}$ the Australian Director of Quarantine decided to ban Canadian fresh, chilled or frozen salmon. In March 1997, Canada requested that a panel be established to hear this dispute, under various provisions of the SPS Agreement and the GATT. Broadly speaking, Canada alleged inter alia that the Australian measure was not based on a proper assessment of risks to salmonid life or health as required by the SPS Agreement; that it amounted to arbitrary and unjustifiable discrimination by Australia in the levels of protection it deemed appropriate in comparable situations since no similar restrictions were applied to imports of herring and live finfish; and that the measure was more trade restrictive than required to achieve Australia's appropriate level of sanitary protection. A Panel was accordingly established in April 1997 and it circulated its report in June 1998, finding a violation of various provisions of Articles 2 and 5 of the SPS Agreement. ${ }^{31}$ Both parties appealed certain legal findings and interpretations of the Panel.

The Appellate Body issued its report in October 1998, reversing the Panel's findings. ${ }^{32}$ The Panel Report and Appellate Body Report were adopted by the Dispute Settlement

Agreed Solution, WT/DS21/10, G/L/39/Add.1, G/SPS/W/40/Add.1, circulated on 1 November 2000.

${ }^{28}$ Dispute Settlement Body, Australia - Measures Affecting Importation of Salmon. Request for Consultations by Canada, WT/DS18/1, G/L/28, G/SPS/W/29, circulated on 11 October 1995. Consultations were held on 23-24 November 1995.

${ }^{29}$ The import risk analysis, as agreed with Canada and the US, was limited to wild, ocean-caught Pacific salmon in the first instance due to the complexity of the task of evaluating all the quarantine issues arising from importation of uncooked salmon. Panel Report, Australia - Salmon, para. 2.27.

${ }^{30}$ The 1996 Final Report of the Import Risk Analysis noted the possibility that up to 24 disease agents exotic to Australia might be present in Pacific salmon products. While the probability of establishment of the relevant diseases was low, the Report noted that the diseases would be ineradicable and the economic impacts of their establishment would be major, seriously threatening the viability of aquaculture and recreational fishing in Australia. It recommended that the present quarantine policies for uncooked salmon products remain in place. AQIS, Salmon Import Risk Analysis: An Assessment by the Australian Government of Quarantine Controls on Uncooked, Wild, Ocean-Caught Pacific Salmonid Products Sourced from the United States of America and Canada, Final Report, December 1996, 70.

${ }^{31}$ Panel Report, Australia - Salmon, para. 9.1. In particular, a violation of Articles 5.1, 5.5 and 5.6, and on that ground also Articles 2.2 and 2.3, were found. These findings are discussed where relevant in Part III of this book.

32 Appellate Body Report, Australia - Salmon, para. 279. These findings are discussed in detail in Part III of this book. 
Body (DSB) on 6 November 1998, recommending that Australia bring its measures into conformity with the SPS Agreement. On 15 July 1999, after the reasonable period of time for implementation of the recommendations and rulings of the Dispute Settlement Body had expired, ${ }^{33}$ Canada indicated that it would request authorisation to suspend the application to Australia of tariff concessions and other GATT obligations, in retaliation for Australia's non-compliance. ${ }^{34}$

On 28 July 1999, Australia informed the DSB that an AQIS decision had been taken on 19 July 1999 on the basis of a new import risk analysis, allowing the importation into Australia of fresh, chilled or frozen salmon products from Canada that were either 'consumer-ready' (inter alia eviscerated, headless, pan-size fish; skinless, de-boned fillets of any weight; or skin-on, de-boned fillets of less than 450 grams in weight) or processed into a consumer-ready state at an AQIS approved plant before release from quarantine. Further, Australia stated that it had taken similar measures regarding imports of herring and finfish. According to Australia, this brought its measure into conformity with the SPS Agreement. Canada disagreed and a Panel was established under Article 21.5 of the DSU to hear this compliance dispute. ${ }^{35}$ Also at issue before the compliance Panel was a newly imposed measure by the Government of Tasmania, an Australian State, banning the importation of fresh, chilled or frozen salmon unless it is derived from fish grown in an area free of six specified diseases. As Canada was not free of all these diseases, the measure amounted to an import prohibition on Canadian fresh, chilled or frozen salmon. The compliance Panel found that Australia's new measure as well as the Tasmanian ban were in violation of various provisions of the SPS Agreement. ${ }^{36}$ This report was adopted by the DSB on 20 March 2000. In May 2000, Canada and Australia reported to the SPS Committee that a mutually agreed solution had been found to this dispute. ${ }^{37}$

\subsubsection{Plant health system}

Australia has a favourable plant health status, being free of most major plant pests and diseases. This provides its plant products with a competitive advantage on export markets. Australia makes concerted efforts to maintain this health status as its plant industry (mainly in horticulture, grains and forestry) depends to a large extent on exports for its profitability. ${ }^{38}$

\footnotetext{
${ }^{33}$ The reasonable period of time was established by an Arbitrator, under Article 21.3(c) of the DSU, to be eight months from the adoption of the Panel and Appellate Body Reports, which period would expire on 6 July 1999. Award of the Arbitrator, Australia - Salmon (Article 21.3(c)), para. 39.

${ }^{34}$ Australia referred the matter of the level of suspension of concessions to arbitration under Article 22.6 of the DSU. Canada and Australia agreed that the arbitration proceedings would be held in abeyance until the Panel deciding the compliance dispute under Article 21.5 had circulated its report.

${ }^{35}$ The Article 21.5 dispute was referred to the original Panel, which issued its report on 18 February 2000.

${ }^{36}$ Panel Report, Australia - Salmon (Article 21.5 - Canada), para. 8.1. The findings of the compliance Panel are discussed, where relevant, in Part III of this book.

${ }^{37}$ Committee on Sanitary and Phytosanitary Measures, Specific Trade Concerns. Note by the Secretariat. Addendum. Resolved Issues, G/SPS/GEN/204/Rev.8/Add.3, circulated on 27 March 2008, item 8. This solution has not been formally notified to the DSB.

${ }^{38}$ This information is drawn from the 'Plant Health' page of the DAFF website, available at: http://www.daff. gov.au/animal-plant-health/plant, visited on 24 January 2008.
} 
Australia's phytosanitary system is currently regarded as one of the strictest in the world. In order to prevent the introduction of plant pests and diseases through imported products, this phytosanitary system relies on a prior-approval requirement. Only those plants or plant products that have been established through risk analysis to be safe are granted an import permit. The Quarantine Proclamation of 1998 states that the importation into Australia of a fresh fruit or vegetable, plant or plant part is prohibited unless the Director of Quarantine has granted the person a permit to import it into Australia. ${ }^{39}$ The Australian government asserts that its strict phytosanitary system is based on scientific import risk assessments and maintains a high level of protection, independently of economic concerns on the domestic market. ${ }^{40}$

Responsibility for plant health is shared between the Commonwealth Government and the governments of the States and Territories. The Commonwealth Government regulates the movement of plants and their products into and out of Australia, while the State and Territory governments have primary responsibility for plant health controls within Australia both inter-state and intra-state. Similarly to the situation in the animal health system, coherence is ensured by the Primary Industries Ministerial Council, the highest national policy-making body, with the support of the Primary Industries Standing Committee. ${ }^{41}$ This Committee is advised by the Plant Health Committee (PHC), composed of the Chief Plant Protection Officer of the DAFF, the departments of primary industries and agriculture of the States and Territories, as well as representatives of Biosecurity Australia, Plant Health Australia and the CSIRO. ${ }^{42}$ The PHC's task is to facilitate a consistent and science-based approach to plant health at national level. ${ }^{43}$

As in the area of animal health, at Commonwealth level, pre-border risk analysis is conducted by Biosecurity Australia (specifically, by its Plant Biosecurity division) and research in the area of plant health is in the hands of CSIRO. Border inspection and certification is the responsibility of AQIS. Post border responsibility for plant health is in the hands of the Office of the Chief Plant Protection Officer (OCPPO) within the DAFF. ${ }^{44}$ As

39 Sec. 64(2) and 65(2) of the Quarantine Proclamation of 1998. Australian Government Department of the Attorney General, Quarantine Proclamation of 1998, as Amended, Made under Section 13 of the Quarantine Act of 1908 (Commonwealth of Australia, Canberra), 1 November 2007, available at: http://www.comlaw.gov.au/ComLaw/Legislation/LegislativeInstrumentCompilation1.nsf/all/search/ AA0B4452ED7BBD44CA25737F00157097, visited on 24 January 2008.

${ }^{40}$ Trade Policy Review Body, Trade Policy Review: Australia - Report by the Secretariat. Revision, WT/ TPR/S/178/Rev.1, circulated on 1 May 2007, Section IV para. 49.

${ }^{41}$ Committee is composed of the Chief Executive Officers of the Commonwealth Government, States and Territories in the relevant policy areas. This information is available on the 'Plant Health Committee' page of the DAFF website, available at: http:/www.daff.gov.au/animal-plant-health/plant/committees/phc, visited on 25 January 2008.

${ }^{42}$ This information is taken from the 'Plant Health Committee' page of the website of the DAFF, available at: http://www.daff.gov.au/animal-plant-health/plant/committees/phc, visited on 25 January 2008.

43 Ibid.

44 The creation of the OCPPO was one of the recommendations of the Nairn review of Australia's quarantine system in 1996. This review was critical of the imbalance between the regulatory attention given to the animal health sector as compared to the plant health sector, which it blamed for the fact that over the previous 25 years incursions of plant pests and diseases had exceeded ten times incursions of animal pests and diseases. M.E. Nairn et al., Australian Quarantine: A Shared Responsibility (Australian Quarantine Review Secretariat, Canberra), 1996, 5, available at: http://www.daff.gov.au/_data/assets/pdf_file/0009/111969/nairn_report.pdf, visited on 24 January 2008. 
the arrangements in this regard are substantially the same as in the area of animal health, they will not be repeated here. Instead, aspects specifically relevant to Australia's phytosanitary system will be expanded upon. These relate to the IRA process that supports Australia's prior-approval system. ${ }^{45}$

An IRA must be carried out by Plant Biosecurity when an import permit is requested that requires a significant variation in established policy. This is the case, for example, if it relates to a product not previously imported and therefore one for which no IRA exists, or if there has been a considerable change in the phytosanitary situation with regard to that product. A routine IRA is sufficient if the change is less complex or entails a review of established policy. However, if the risk analysis required is likely to be extensive and complex, a non-routine IRA is carried out. ${ }^{46}$

In conducting the necessary risk assessments, Plant Biosecurity follows international risk assessment guidelines developed under the International Plant Protection Convention, ${ }^{47}$ as well as the requirements of the SPS Agreement. ${ }^{48}$ In accordance with these guidelines, Australia's pest risk assessments entail: the identification and categorisation of a pest; the determination of the probability of its entry, establishment or spread in Australia; and the assessment of the potential consequences thereof. ${ }^{49}$ Pest categorisation refers to the determination whether a pest has quarantine significance for Australia. ${ }^{50}$ The probability of entry, establishment or spread of a pest is expressed qualitatively, rather than quantitatively, to avoid unrealistically precise determinations..$^{51}$ Both direct and indirect biological and economic consequences of the risk occurring are assessed.

The risk management aspect of an IRA conducted by Plant Biosecurity entails the process of identifying and implementing measures to manage the identified risks so as to achieve

${ }^{45}$ The IRA process has been set out above, Part II, Section 2.4.2.1. The following description therefore only highlights particular aspects relevant to plant health IRAs.

${ }^{46}$ The IRA process for plant pests is set out in an introductory section of the draft and final IRAs published by Biosecurity Australia. The information provided here is drawn from Biosecurity Australia, Importation of Fresh Bananas from the Philippines: Revised Draft IRA Report (Commonwealth of Australia, Canberra), February 2004, 25, available at: http://www.daff.gov.au/_data/assets/pdf_file/0006/22866/banana_rev_draft. pdf, visited on 28 January 2008.

${ }^{47}$ International Plant Protection Convention, Pest Risk Analysis for Quarantine Pests including Analysis of Environmental Risks, ISPM 11.

${ }^{48}$ An IRA refers directly to the requirements of the SPS Agreement and indicates the steps taken in accordance with these requirements. Of course this does not necessarily mean that the IRA in fact complies with the rules of the SPS Agreement applicable to risk analysis (discussed in Part III of this book), but rather indicates detailed awareness by Biosecurity Australia of the relevant rules and its active efforts towards compliance.

49 Biosecurity Australia, Importation of Fresh Bananas from the Philippines: Revised Draft IRA Report (Commonwealth of Australia, Canberra), February 2004, 47-48, available at: http://www.daff.gov.au/_data/ assets/pdf_file/0006/22866/banana_rev_draft.pdf, visited on 28 January 2008.

${ }^{50}$ ISPM 11 defines a pest of quarantine significance as 'a pest of potential economic importance to the area endangered thereby and not yet present there, or present but not widely distributed and being officially controlled.'

${ }^{51}$ Likelihood is divided into six incremental categories, each assigned a broad probability range. Events considered virtually certain to occur are assigned a likelihood of 1 . The parameters for the six qualitative expressions of likelihood are then: High $0.7 \rightarrow 1$, Moderate $0.3 \rightarrow 0.7$, Low $0.05 \rightarrow 0.3$, Very low $0.001 \rightarrow 0.05$, Extremely low 10-6 $\rightarrow$ 0.001, Negligible $0 \rightarrow$ 10-6. Biosecurity Australia, Importation of Fresh Bananas from the Philippines: Revised Draft IRA Report (Commonwealth of Australia, Canberra), February 2004, 51, available at: http://www.daff.gov.au/_data/assets/pdf_file/0006/22866/banana_rev_draft.pdf, visited on 28 January 2008 . 
Australia's chosen (or 'appropriate') level of protection, which, as set out above, has been determined to be 'a high level of sanitary and phytosanitary protection aimed at reducing risk to a very low level, but not to zero. ${ }^{52}$ Consequently, if the risk from importation of the product without additional phytosanitary measures (called the 'unrestricted risk') is either 'negligible' or 'very low' it is considered to meet Australia's appropriate level of protection and no risk management measures are necessary. ${ }^{53}$ Risks in any other category must be addressed by means of risk management measures that will achieve Australia's 'low' risk level of protection. The IRA must therefore assess the possible risk according to the various measures that could be taken to mitigate it. If effective measures are available to achieve a ' low' risk level, the IRA would recommend that an import permit be granted, subject to the condition that the identified measures be taken. If no risk management measure is available that would achieve Australia's level of protection, the IRA will recommend that no import permit be granted.

As stated above, IRAs are published in draft form and revised on the basis of comments by stakeholders. The revision may again be made available for comments, and revised a second time. A final IRA is reviewed by the Eminent Scientists Group before a decision is taken by the Director of Animal and Plant Quarantine. This process is extremely lengthy and complex, and has led to long delays in responding to import permit requests. Some of these delays have led to serious problems for other WTO Members. The DAFF reports that several high-profile IRAs relating to phytosanitary concerns have now been finalized, including those for apples from New Zealand, Tahitian limes from New Caledonia and table grapes from Chile. ${ }^{54}$ It also reports good progress on the three "remaining "legacy" IRAs' inter alia with regard to Philippine bananas, discussed further below. ${ }^{55}$

Australia has a high level of success in establishing and maintaining pest-free regions within its territory. It expends considerable effort on this task in order to ensure that exports from regions free of quarantine pests are able to have access to the markets of its trading partners, despite the prevalence of the relevant pests elsewhere in Australia. It also takes an active role in promoting the recognition of pest-free areas by importing countries. ${ }^{56}$

52 Australian Government Department of Agriculture Fisheries and Forestry, Import Risk Analysis Handbook 2007 (Commonwealth of Australia, Canberra), September 2007, 8, available at: http://www.daff.gov.au/biosecuritycoordination/import_risk_analysis_handbook_2007, visited on 15 January 2008.

53 Biosecurity Australia, Importation of Fresh Bananas from the Philippines: Revised Draft IRA Report (Commonwealth of Australia, Canberra), February 2004, 89, available at: http://www.daff.gov.au/_data/assets/pdf_file/0006/22866/banana_rev_draft.pdf, visited on 28 January 2008.

${ }^{54}$ This report states that the IRA process for New Zealand apples has been completed and a final determination was made by the Director of Animal and Plant Quarantine on 26 March 2007. AQIS is now processing the work plan in this regard. With regard to table grapes from California, the review of the conditions imposed for import has been completed. The final determination made concerning Tahitian limes from New Caledonian permits their importation. In addition to these high-profile cases, 15 other IRAs were completed in 2006-2007. Australian Government Department of Agriculture Fisheries and Forestry, Annual Report 200607: Growing Australia through Sustainable, Innovative and Profitable Agriculture, Fisheries and Forestry (Commonwealth of Australia, Canberra), September 2007, 192, available at: http://www.daff.gov.au/_data/ assets/pdf_file/0005/439493/2_AR_06-07_ROP_WEB.pdf, visited on 17 January 2008.

${ }_{55} \mathrm{Ibid}$. The Annual Report 2006-07 states that a revised draft IRA with regard to Philippine bananas was made available for public comment by June 2007. The other two 'legacy' IRAs related to animal products (prawns and chicken meat). Aside from these high profile cases, progress was made on 59 risk analyses.

${ }^{56}$ Aside from bilateral initiatives with trading partners in this regard, Australia was a strong proponent for the 
As is the case in the area of animal health, also in the area of plant health Australia is active in addressing barriers to market access for its exports. It does so by ensuring that its exporters have up-to-date detailed information on the phytosanitary requirements on foreign markets, ${ }^{57}$ as well as by pro-actively addressing potential phytosanitary barriers through technical discussions. Australia is also very active in promoting its interests in this area in international fora.

\subsection{Example of a phytosanitary measure affecting Australian exports}

A useful recent illustration of the successful use by Australia of discussions at the technical level with regulatory authorities in importing countries to resolve SPS problems affecting its exports is reported in the DAFF Annual Report 2006-07. ${ }^{58}$ It relates to Indonesian measures against fruit flies on fresh fruit and vegetables. This example also highlights the benefits of Australia's efforts to maintain pest- and disease-free areas within its territories.

In March 2006, new quarantine measures were imposed by Indonesia requiring fumigation or cold treatment of imports of certain fruit and vegetables that are known hosts of fruit fly. These requirements had a considerable impact on the Australian fruit industry, particularly in respect of table grapes and citrus, which together earn A \$22 million a year in the Indonesian market. The additional costs imposed by the new requirement would reduce the profits of Australian fruit exporters, who were already burdened by drought and increasingly stringent import requirements.

To resolve this problem, the DAFF responded promptly, as soon as the measure was announced, by working together with the States and industry involved to make a convincing case to Indonesia regarding the effectiveness of the systems in place to control fruit fly in Australia. High-level representations were held, involving the Minister of Agriculture, Fisheries and Forestry of Australia and the Minister of Agriculture of Indonesia and detailed technical information was provided with regard to the fruit-fly free regions in Australia. Technical experts from both countries conducted inspections of the relevant regions. In December 2006, Indonesia recognised the status of the districts of Riverina, Riverland and Sunraysia and the State of Tasmania as fruit-fly-free regions. According to Paul Morris of the International Division of the DAFF, this 'confirmed Australia's standing as a world leader in establishing and maintaining areas free of major pests. ${ }^{, 59}$

establishment of guidelines in the SPS Committee for the recognition of pest- and disease-free areas, in line with work done on this issue in the international standard-setting bodies. See further below, Part IV, Section 1.2.6.

${ }^{57}$ AQIS maintains an Export Conditions Database, known as PHYTO, for plant and plant products including fruit, vegetables, seeds, grains, cut flowers and timber, available at: http://www.aqis.gov.au/phyto/asp/ ex_home.asp, visited on 25 January 2008.

58 This example is set out in detail in a case study reported in the Australian Government Department of Agriculture Fisheries and Forestry, Annual Report 2006-07: Growing Australia through Sustainable, Innovative and Profitable Agriculture, Fisheries and Forestry (Commonwealth of Australia, Canberra), September 2007, 109, available at: http://www.daff.gov.au/_data/assets/pdf_file/0005/439493/2_AR_0607_ROP_WEB.pdf, visited on 17 January 2008.

${ }^{59}$ Ibid. 


\subsection{Examples of phytosanitary measures affecting imports to Australia}

The impact of the Australia's strict phytosanitary system on import products is illustrated by the example of its restrictions on Philippine fresh fruit and vegetables, particularly bananas. ${ }^{60}$ The Philippines has an important economic interest in banana exports. ${ }^{61}$ Its banana exports are accepted in Members that have high phytosanitary standards, such as Japan. ${ }^{62}$ It is broadly estimated that access to the Australian market would add between five and 19 percent to Philippine banana exports amounting to between US\$14 million and US\$63 million. ${ }^{63}$

As mentioned above, Australia's SPS system, including in the area of phytosanitary protection, relies on the requirement of prior approval of food and agricultural products, based on IRAs and administered through import permits. In 1994 and 1995, under this system Australian importers applied for import permits with regard to papaya, plantain and bananas from the Philippines. ${ }^{64}$ In January 1995, the Philippines provided AQIS with a list of pests and diseases of bananas. ${ }^{65}$ At that time, Australia prohibited imports of fresh bananas from all countries as it had not yet conducted an IRA for this product. ${ }^{66}$

Between 1996 and 2000, the Philippines engaged in discussions on the issue, both bilaterally and in various fora, ${ }^{67}$ including at meetings of the SPS Committee. ${ }^{68}$ In the latter setting, the Philippines reported that its exports of fresh tropical fruit faced phytosanitary

${ }^{60}$ This example is taken from Josyline Javelosa and Andrew Schmitz, 'Costs and Benefits of a WTO Dispute: Philippine Bananas and the Australian Market', The Estey Centre Journal of International Law and Trade Policy 7 (1), 2006, 58-83.

${ }^{61}$ Banana production and packaging employs about 45,000 workers in the Philippines. Almost half of the banana production of the Philippines is exported. By contrast, 95\% of Australian banana production is for domestic consumption. Biosecurity Australia, Importation of Fresh Bananas from the Philippines: Revised Draft IRA Report (Commonwealth of Australia, Canberra), February 2004, 33-35, available at: http://www.daff.gov. $\mathrm{au} /$ data/assets/pdf_file/0006/22866/banana_rev_draft.pdf, visited on 28 January 2008.

62 Josyline Javelosa and Andrew Schmitz, 'Costs and Benefits of a WTO Dispute: Philippine Bananas and the Australian Market', The Estey Centre Journal of International Law and Trade Policy 7 (1), 2006, 58-83, 64. Javelosa and Schmitz note that most of Japan's banana imports come from the Philippines, and these imports must comply with the strict requirements of Japan's Plant Protection Law and Food Sanitation Law.

${ }^{63}$ This range reflects calculations made on the basis of different supply elasticities (0.5 to 3.57). Ibid., 70 .

${ }^{64}$ This is reported in Dispute Settlement Body, Australia - Certain Measures Affecting the Importation of Fresh Fruit and Vegetables - Request for the Establishment of a Panel by the Philippines - Revision, WT/DS270/5/ Rev.1, circulated on 11 July 2003.

${ }^{65}$ Biosecurity Australia, Import Risk Analysis (IRA) on Fresh Banana Fruit from the Philippines: Issues Paper (Commonwealth of Australia, Canberra), 2 May 2001, available at: http://www.daff.gov.au/_data/assets/ word_doc/0018/22941/2001-10a.doc, visited on 25 January 2008.

${ }^{66}$ An IRA for Ecuadorian bananas had been initiated in 1991, but was suspended due to the withdrawal of the application by the prospective importer. Ibid., 20.

${ }^{67}$ The matter was discussed in the Joint Philippine - Australian Bilateral Committee and in the Association of South East Asian Nations (ASEAN) - Australian dialogue. Josyline Javelosa and Andrew Schmitz, 'Costs and Benefits of a WTO Dispute: Philippine Bananas and the Australian Market', The Estey Centre Journal of International Law and Trade Policy 7 (1), 2006, 58-83, 61.

68 The Philippines first raised a trade concern on this issue at the SPS Committee meeting in March 2000. Several other Members, namely Thailand, Brazil, Malaysia. Korea, India the EC and the US, supported the Philippine complaint and pointed to similar problems with delays in the granting of import permits for their fresh fruit exports to Australia. Committee on Sanitary and Phytosanitary Measures, Specific Trade Concerns. Note by the Secretariat. Addendum: Issues Not Considered in 2006, G/SPS/GEN/204/Rev.7/Add.2, circulated on 7 February 2007, item 74. 
barriers to market access in Australia, for which no risk assessment existed. ${ }^{69}$ Australia responded that it conducted a risk analysis process that was transparent and consultative to prevent the introduction of diseases. It mentioned that, due to scarce resources to conduct the necessary risk analyses, it was obliged to prioritise among the various import permit requests. $^{70}$

To date, no IRAs have been initiated for papaya or plantain, despite the fact that over a decade has passed since the permit request. An IRA with respect to Philippine bananas was initiated in $2000 .^{71}$ The report of the first round of consultations with stakeholders on this issue stated that a non-routine IRA process would be followed, based on the consideration that an assessment of potentially significant quarantine risks that had not previously been studied by AQIS would be required, and that the analysis was likely to be large and technically complex. The IRA was expected to take 18 to 24 months. ${ }^{72}$ A risk analysis panel was established, with the support of three technical working groups, to carry out the IRA. ${ }^{73}$ A series of technical workshops, meetings with stakeholders and a meeting between Biosecurity Australia officials and their counterparts and industry technical experts in the Philippines followed in 2001 and early 2002. ${ }^{74}$ In addition, written exchanges of questions and answers were conducted on technical level.

A draft IRA report was published in July 2002 and made available for comments. ${ }^{75}$ Of the 80 banana pests identified in the draft IRA, 22 were categorised as pests of quarantine concern and subject to individual risk assessments. ${ }^{76}$ One issue of concern with regard to banana imports was the possible spread of black Sigatoka disease, a disease of quarantine significance for Australia due to the fact that its presence in specific regions of Australia (the Torres Strait and far northern Queensland) is being strictly controlled to mitigate the risk of the disease spreading to production areas. ${ }^{77}$ Other pests whose "unrestricted

${ }^{69}$ Ibid., item 74 para. 29.

70 Ibid., item 74 para. 30. The issues paper published for the bananas IRA reports that in June 1996, the Philippines Bureau of Plant Industry and AQIS agreed that mango was the Philippines first priority, and therefore that it's IRA would be carried out first and those for bananas and pineapples would be conducted in due course. Biosecurity Australia, Import Risk Analysis (IRA) on Fresh Banana Fruit from the Philippines: Issues Paper (Commonwealth of Australia, Canberra), 2 May 2001, available at: http://www.daff.gov.au/_data/assets/word_doc/0018/22941/2001-10a.doc, visited on 25 January 2008.

${ }^{71}$ All documents related to the IRA for bananas from the Philippines are available at: http://www.daff.gov. au/ data/assets/word doc/0015/14082/2003-30.doc, visited on 25 January 2008.

72 Biosecurity Australia, Plant Biosecurity Policy Memorandum, 2000/22 (Commonwealth of Australia, Canberra), 17 October 2000, available at: http://www.daff.gov.au/_data/assets/word_doc/0017/22904/200022.doc, visited on 25 January 2008. The non-routine process was outlined in the IRA Handbook of 1998.

${ }^{73}$ The panel's membership was finalised in January 2001. Biosecurity Australia, Import Risk Analysis (IRA) on Fresh Banana Fruit from the Philippines: Issues Paper (Commonwealth of Australia, Canberra), 2 May 2001, available at: http://www.daff.gov.au/_data/assets/word_doc/0018/22941/2001-10a.doc, visited on 25 January 2008.

${ }^{74}$ Biosecurity Australia, Plant Biosecurity Policy Memorandum 2002/08, Canberra), 4 March 2002, available at: http://www.daff.gov.au/ data/assets/word doc/0003/18930/2002-08.doc, visited on 25 January 2008.

${ }^{75}$ Biosecurity Australia, Importation of Fresh Bananas from the Philippines: Draft IRA Report (Commonwealth of Australia, Canberra), June 2002, available at: http://www.daff.gov.au/__data/assets/pdf_file/0012/164001/ draft-ira.pdf, visited on 25 January 2008.

${ }^{76}$ The categorization of pests was based on their presence or absence in Australia, their association with banana fruit, their potential to become established in Australia, and the potential consequences of establishment. Ibid., 13 .

${ }^{77}$ Biosecurity Australia, Import Risk Analysis (IRA) on Fresh Banana Fruit from the Philippines: Issues Paper 
risk $^{78}$ of entry, establishment or spread in Australia was evaluated to be too high to meet Australia's appropriate level of protection were Moko, freckle and mealybugs. ${ }^{79}$ While appropriate risk management measures were identified to reduce the risks from Black Saratoga, freckle and mealybugs to 'very low' which would meet Australia's appropriate level of protection, no such measure could be found for Moko. ${ }^{80}$ As a result, the draft IRA recommended that imports of Philippine bananas be prohibited. ${ }^{81}$

The Philippines initiated WTO dispute settlement proceedings against Australia in October 2002, ${ }^{82}$ with the support of the Advisory Centre for WTO Law. ${ }^{83}$ The driving force behind bringing this formal dispute is reported to be the Philippine Banana Growers and Exporters Association, which consists of the largest banana companies which are mostly affiliated with multinationals such as Dole, Del Monte and Chiquita. ${ }^{84}$ On its side, Australia had to deal with pressure from the Australian Banana Growers Council, a powerful industry lobby organisation, which opposed changes to Australia's restrictive quarantine policy. ${ }^{85}$

Consultations between Australia and the Philippines failed to resolve the matter. Therefore, in 2003, the Philippines requested the establishment of a panel to hear the dispute. ${ }^{86}$ It alleged that Australia's SPS system entailed an a priori prohibition on im-

(Commonwealth of Australia, Canberra), 2 May 2001, 21, available at: http://www.daff.gov.au/ data/assets/ word_doc/0018/22941/2001-10a.doc, visited on 25 January 2008.

${ }^{78}$ The term 'unrestricted risk' is used in Australia's IRAs to mean the risk associated with imports in the absence of specific risk management measures (in this case bananas 'produced to the standard achieved through normal practices of production, quality control, packing, transport and shipment from the specified areas, as described in documentation provided by the Philippines'). Biosecurity Australia, Importation of Fresh Bananas from the Philippines: Draft IRA Report (Commonwealth of Australia, Canberra), June 2002, 13, available at: http://www.daff.gov.au/ data/assets/pdf file/0012/164001/draft-ira.pdf, visited on 25 January 2008.

${ }^{79} \mathrm{Ibid}$. For all other identified pests, the risks were determined to be low enough to meet Australia's appropriate level of protection.

${ }^{80}$ Ibid., 14.

81 Ibid., 15.

82 Dispute Settlement Body, Australia - Certain Measures Affecting the Importation of Fresh Fruit and Vegetables. Request for Consultations by the Philippines, WT/DS270/1, G/L/575, G/SPS/GEN/345, G/ LIC/D/34, circulated on 23 October 2002. This complaint listed the measures at issue as being Sec. 64 of the Quarantine Proclamation of 1998 (which establishes the prior-approval system for imports of fresh fruit and vegetables), the regulations, requirements and procedures issued there under, any amendments to these measures and their application. The complaint was brought not only in terms of the SPS Agreement but also the GATT 1994 and the Agreement on Import Licensing Procedures.

${ }^{83}$ The Advisory Centre on WTO Law is an intergovernmental organisation established in 2001 to provide legal advice on WTO legal issues at greatly reduced rates to developing countries. The Philippines is a member of the Advisory Centre on WTO Law, and pays a low legal fee of CHF 324 per hour. This information is provided on the website of the Advisory Centre on WTO Law, available at: http://www.acwl.ch/, visited on 24 January 2008.

${ }^{84}$ Josyline Javelosa and Andrew Schmitz, 'Costs and Benefits of a WTO Dispute: Philippine Bananas and the Australian Market', The Estey Centre Journal of International Law and Trade Policy 7 (1), 2006, 58-83, 66. This paper also reports that at the time of initiation of the WTO dispute, the Secretary of the Department of Agriculture of the Philippines was the former chair of the Philippine Banana Growers and Exporters Association.

${ }^{85} \mathrm{Ibid}$., 66-67. Javelosa and Schnitz report that the Australian Banana Growers Council represents 1,900 banana growers. It has a full-time national secretariat in Brisbane.

86 Dispute Settlement Body, Australia - Certain Measures Affecting the Importation of Fresh Fruit and Vegetables. Request for the Establishment of a Panel by the Philippines. Revision, WT/DS270/5/Rev. 1, circulated on 11 July 2003. The Philippines challenges Australian regime for the importation of fresh fruits and 
ports of fresh fruit and vegetables, which subverts the fundamental principles of the SPS Agreement. ${ }^{87}$ The Australian government characterised the Philippines's challenge as 'a broad systemic challenge to Australia's quarantine regime that strikes at the fundamental right of WTO Members to have a quarantine system. ${ }^{\text {88 }}$ It asserted that many WTO Members have similar prior-approval systems in place. A panel was established to hear the dispute on 29 August $2003,{ }^{89}$ but was never composed.

In 2003, Australia's draft IRA was considerably revised in response to the substantial nature of the submissions and the technical information received, including research results submitted by the Philippines regarding the Moko bacterium..$^{0}$ The revised draft IRA was published for comments in February 2004. It recommends allowing the importation of Philippine bananas under strict conditions, including that bananas may only be sourced from plantations that can demonstrate that the prevalence of Moko and freckle diseases is below the level acceptable to Australia, ${ }^{91}$ and from plants that have been inspected weekly and found free from symptoms of moko and freckle; that all bananas be treated with chlorine in the packing station and be inspected by quality assurance staff to reduce the risk of mealybugs to a very low level and that additional practical measures be taken with regard to packing materials, packing and transport procedures to reduce the risk of contaminants

vegetables, as centred on Section 64 of the Quarantine Proclamation of 1998 (containing the a priori prohibition on importation of fresh fruit and vegetables), in its request for the establishment of a panel. This document states the products of concern to be all fresh fruit and vegetables for which a Director of Quarantine has not yet made a decision whether or not to grant a permit for their importation into Australia. It challenges Australia's measures under the GATT 1994, the Import Licensing Agreement, and the SPS Agreement.

${ }^{87}$ Dispute Settlement Body, Minutes of Meeting Held in Centre William Rappard on 29 August 2003, WT/ DSB/M/155, circulated on 7 November 2003, para. 24.

${ }^{88}$ Ibid., para. 25.

${ }^{89}$ Ibid., paras 26-27. The first panel request was made in July 2003, but the establishment of the panel was blocked by Australia, as is possible under Art. 6 of the Dispute Settlement Understanding (DSU). The second request, which cannot be blocked under DSU rules, was made in November 2003 and a panel was then established. China, the EC, Ecuador, India, Thailand and the US reserved their third party rights in this dispute. The EC brought a parallel complaint (WT/DS287) against Australia's quarantine regime (for imports of animals, animal parts, meat and meat products, dairy products, plants and plant products, fresh fruit and vegetables, seeds and bee products), and a panel was established in November 2003. The latter panel was however also never composed. A mutually agreed solution to the latter dispute was notified in March 2007. The agreed solution reportedly 'includes enhanced transparency of the quarantine regime of Australia, principles of treatment for market access applications from the European Communities, and continued expert discussions on scientific aspects associated with trade in pig meat and chicken meat.' Dispute Settlement Body, Australia Quarantine Regime for Imports. Notification of Mutually Agreed Solution, WT/DS287/8, G/L/618/Add.1, G/ SPS/GEN/384/Add.1, circulated on 13 March 2007.

${ }^{90}$ Biosecurity Australia, Plant Biosecurity Memorandum, 2003/30 (Commonwealth of Australia, Canberra), 22 October 2003, available at: http://www.daff.gov.au/_data/assets/word_doc/0015/14082/2003-30.doc, visited on 25 January 2008.

${ }^{91}$ This acceptable prevalence level is extremely low (in the case of Moko, no more than one in 6,800 infected plants per year are permissible). It must be proven by weekly surveys over a minimum period of 2 years immediately preceding harvest of bananas intended for export to Australia. If the low prevalence level is exceeded, the affected area would be suspended from exporting to Australia for a minimum period of 2 years. 
such as leaf trash, weed seeds and frogs. ${ }^{92}$ These conditions were strengthened by the addition of further requirements in June 2004. ${ }^{93}$

In December 2004, the Australian government announced that as Biosecurity Australia had been restructured, it would have to review all the IRAs in progress, including that for Philippine bananas. A second revised draft IRA was finally issued for comment on 1 March 2007. ${ }^{94}$ This second revision identifies additional pests of quarantine concern. ${ }^{95}$ It finds that no individual measure can effectively manage the risks. It therefore recommends an integrated 'systems-approach' composed of a combination of measures for each disease. Mandatory pre-clearance arrangements are required. It requires that AQIS officials be involved in all risk management measures in the Philippines and that the Philippine certification system be audited. The panel that conducted the IRA for Biosecurity Australia recognised that some of the measures required would be difficult to achieve, but considered them feasible and therefore to be included in the IRA. One dissenting panel member was of the view that the risk management measures recommended for Moko were inappropriate, inter alia because areas of low pest prevalence 'cannot be defined, implemented, maintained and verified in the Philippines, where Moko is widespread' and there was, in his view, 'insufficient evidence to conclude that any measurable effect would result from visual inspection and corrective action. ${ }^{96}$ However, Biosecurity Australia chose to adopt the majority view. ${ }^{97}$

On the basis of the 21 comments received on its second revised draft IRA, Biosecurity Australia will draft a final IRA for review by the Eminent Scientists Group, after which

92 These measures are on top of the risk management measures proposed by the Philippines proposed for the production, processing, packaging and transportation of bananas to Australia. Biosecurity Australia, Importation of Fresh Bananas from the Philippines: Revised Draft IRA Report (Commonwealth of Australia, Canberra), February 2004, available at: http:/www.daff.gov.au/_data/assets/pdf_file/0006/22866/banana rev_draft.pdf, visited on 28 January 2008.Note however, that no risk management measures are required for Black Sigatoka, as the revised draft IRA established that the unrestricted risk associated with black Sigatoka was actually acceptable as it is a leaf pathogen not a fruit pathogen and the risks that banana leaves would be accidentally imported was very small.

${ }^{93}$ Biosecurity Australia, Importation of Fresh Bananas from the Philippines: Addendum to Revised Draft IRA Report of February 2004 (Commonwealth of Australia, Canberra), June 2004, available at: http://www.daff. gov.au/_data/assets/pdf_file/0003/22881/ban_add.pdf, visited on 25 January 2008. This change is due to an error in transcription in a cell of a spreadsheet used to estimate the risk in the IRA. This error had an impact of the risk assessment. The new requirements are the application of a more stringent ' area of low pest prevalence' regime for Moko, the additional requirement of insecticidal treatment for mealybugs, and the inclusion of quarantine conditions for banana bract mosaic virus.

${ }^{94}$ Biosecurity Australia, Revised Draft Import Risk Analysis Report for the Importation of Cavendish Bananas from the Philippines (Commonwealth of Australia, Canberra), February 2007, available at: http://www. daff.gov.au/_data/assets/pdf_file/0005/157964/2007-06a.pdf, visited on 25 January 2008. The comment period was initially open until 30 May 2007, but was extended by another 30 days (until 29 June 2007) to give stakeholders sufficient opportunity to engage appropriate expertise and to comment on the substantial material contained in the report. Biosecurity Australia, Plant Biosecurity Memorandum, 2007/12 (Commonwealth of Australia, Canberra), 16 May 2007, available at: http://www.daff.gov.au/_data/assets/ word_doc/0010/243982/2007_12.doc, visited on 25 January 2008. 19 submissions were received.

95 The pests and diseases of quarantine concern identified in the second revised draft are Moko, black Sigatoka, freckle, mealybugs, armoured scales, spider mites, and banana rust thrips.

${ }^{96}$ Biosecurity Australia, Revised Draft Import Risk Analysis Report for the Importation of Cavendish Bananas from the Philippines (Commonwealth of Australia, Canberra), February 2007, 19, available at: http://www. daff.gov.au/_data/assets/pdf_file/0005/157964/2007-06a.pdf, visited on 25 January 2008.

${ }^{97}$ Comments on the minority view were received from stakeholders and from the Philippine government. 
the final IRA will be issued. On this basis, the Director of Animal and Plant Quarantine will make a decision, which will determine whether an import permit will be granted and if so under what conditions. The status report in May 2008 indicates that submissions are being considered but no further progress has been made..$^{98}$ Not only has this process lasted over 12 years, but the resulting import permit is likely to be subject to quarantine requirements well beyond the capacity of the Philippines to meet.

The Australian government asserts that the fact that its phytosanitary system is strictly science-based is illustrated by the fact that its ban on Philippine bananas was kept in place despite the fact that the droughts in 2002-2003 and in 2006 and the tropical cyclone in early 2006 wreaked havoc with Australia's banana crop and led to significant price increases. ${ }^{99}$ Therefore, the Australian government argues that its strict SPS system is applied consistently, regardless of domestic market considerations, such as the effect of natural disasters on domestic production, or consumer prices. ${ }^{100}$

Another example of an Australian phytosanitary measure is that applied to imports of apples from New Zealand, in order to prevent the introduction of fire blight. This measure is currently before a WTO Panel. ${ }^{101}$ The background to this dispute is as follows. Since 1986, New Zealand has been seeking market access to Australia for apples, which are its second biggest horticultural export after kiwi fruit. In 1999 New Zealand applied for the fourth time for market access, but by 2005 the Australian authorities had only circulated two draft IRAs followed by comment periods. New Zealand considered this six year delay unacceptable and raised a concern regarding this matter at the SPS Committee meeting of June 2005. ${ }^{102}$

Chile, the EC and the US supported New Zealand in this matter. The EC and the US encouraged Australia in reviewing its 2004 risk assessment, to do so in the light of the findings of the Panel in Japan - Apples that stringent control measures are not justified on the basis of available scientific evidence showing that mature symptomless apple fruit do not pose a risk of transmission of fire blight. ${ }^{103}$ The representative of Australia reminded

98 Biosecurity Australia, Import Risk Analysis for Bananas from the Philippines - Status Report, Advice 2008/13, available at: http://www.daff.gov.au/_data/assets/word_doc/0020/661403/2008-13.doc, visited on 28 June 2008. The stakeholder comment period on the revised draft import risk analysis during which twenty one stakeholder submissions were received, closed on 29 June 2007. Regular meetings were held by the expert IRA team to consider the submissions. The May 2008 status report indicates that '[a] draft final IRA report will soon be forwarded to the independent Eminent Scientists Group for review.'

99 Trade Policy Review Body, Trade Policy Review: Australia - Report by the Secretariat. Revision, WT/ TPR/S/178/Rev.1, circulated on 1 May 2007, Section IV para. 49 and note 77.

100 This argument is not very convincing. Australia's policy could also be explained on the grounds that Australia prioritises the protection of its banana producers above the interests of its consumers in access to cheaper bananas.

${ }^{101}$ Dispute Settlement Body, Australia - Measures Affecting the Importation of Apples from New Zealand. Request for the Establishment of a Panel by New Zealand, WT/DS367/5, circulated on 7 December 2007.

${ }_{102}$ Committee on Sanitary and Phytosanitary Measures, Specific Trade Concerns. Note by the Secretariat. Addendum. Issues Considered in 2007, G/SPS/GEN/204/Rev.8/Add.1, circulated on 27 March 2008, item 217. See also Committee on Sanitary and Phytosanitary Measures, Summary of the Meeting Held on 29 and 30 June 2005. Note by the Secretariat. Corrigendum, G/SPS/R/37/Rev.1 para. 13.

103 The findings in the Japan - Apples dispute are discussed in Part III of this book. In this dispute, the Panel found that the 10 cumulative requirements applied by Japan to apple imports from the US, in order to prevent the introduction of fire blight were disproportional to the negligible risk of transmission of fire blight by mature symptomless apple fruit. See further below, Part III, Section 3.2.3.1. 
the SPS Committee that recent changes to Biosecurity Australia had led to delays in completion of a number of risk analyses, but that Australia was committed to providing a science-based risk assessment for New Zealand apples as soon as possible. It noted that its ongoing risk analysis addressed a number of quarantine concerns about pests and diseases in addition to fire blight. ${ }^{104}$

In December 2005, Australia issued a third revised draft IRA for New Zealand apples, permitting importation subject to certain conditions including determination of the fire blight free status of orchards by Australian inspectors and chlorine treatment of apples prior to export. In addition, due to concerns with apple scab disease, the importation of New Zealand apples into Western Australia was prohibited. New Zealand argued that the requirements with regard to fire blight were not justified in the light of scientific evidence. Further, New Zealand pointed out that an outbreak of apple scab disease had been reported in Western Australia at the time of the revised draft IRA. In addition, the IRA process conducted in Australia, comprising successive cycles of draft IRAs and consultations, was criticised by New Zealand as causing undue delays and a disguised restriction on trade. Australia countered that all relevant scientific information, including that considered in the Japan - Apples case, had been taken into account in its revised draft IRA. It stated that fire blight was only one of several pests and diseases dealt with in the revised draft IRA. It also claimed that the variations in phytosanitary status of different regions within Australia had been appropriately taken into account. Its revised draft IRA was open for comments until March 2006.

New Zealand and the US provided comprehensive submissions to Biosecurity Australia on the revised draft IRA. Overall, 40 submissions were received from stakeholders and technical discussions were conducted in 2006. In June 2006 the consideration of submissions was completed and on 1 August 2006 the final draft report was referred to the Eminent Scientific Group for its recommendations. This group completed its review within the required 60-day period and transmitted its report to the Director of Animal and Plant Quarantine. Australia reported that Biosecurity Australia would take into account the recommendations of the Eminent Scientific Group and produce the final IRA by the end of 2006.

In February 2007, New Zealand raised the matter again at the SPS Committee meeting, noting that while some progress had been made, the IRA process had not been completed by the end of 2006 as expected. The final IRA had been issued, but subject to an appeal process open until January 2007. ${ }^{105}$ New Zealand argued that the extensive conditions applied for the importation of New Zealand apples meant that it was doubtful whether commercially meaningful trade would be possible. The strict requirements relating to fire blight, were argued to be contrary to the conclusions in the Japan - Apples case, on the grounds that there was no scientific or legal justification for their imposition. New Zealand also expressed concerns regarding proposed measures relating to other pests, such as the requirement that Australian inspectors be present in orchards. ${ }^{106}$ The US made

${ }^{104}$ Committee on Sanitary and Phytosanitary Measures, Summary of the Meeting Held on 29 and 30 June 2005. Note by the Secretariat. Corrigendum, G/SPS/R/37/Rev.1 paras 14-15.

${ }^{105}$ It should be recalled that the appeal process only covers procedural issues, not the scientific basis for the measure in the IRA report. Three appeals were heard and dismissed on this issue.

106 Committee on Sanitary and Phytosanitary Measures, Summary of the Meeting of 28 February - 1 March 
similar remarks. The EC further noted that 'undue delays appeared to be a regular, most troublesome, feature of the Australian IRA process.' ${ }^{107}$

On 27 March 2007, the Australian Director of Animal and Plant Quarantine determined a policy for the importation of apples from New Zealand, stating that the importation of apples could be permitted subject to the Quarantine Act of 1908, and the application of the phytosanitary measures specified in the November 2006 Final Report of the IRA for apples from New Zealand. In June 2007, New Zealand reported that it was closely engaged with Australian authorities in negotiating standard operating procedures to implement the Australian requirements, but that it still considered them unjustified and would keep its options open for further action. On 31 August 2007 New Zealand initiated dispute settlement proceedings against Australia on this matter. ${ }^{108}$ Consultations failed to resolve the matter and the dispute is currently before a Panel. ${ }^{109}$

\subsubsection{Overall assessment of the SPS system of Australia}

Australia's SPS system is renowned for being one of the most stringent in the world, reflecting Australia's vulnerable island ecosystem, its concerns with protecting its unique fauna and flora, and the importance of its agricultural industry. Australia has undertaken several reforms to its SPS system to further improve its effective functioning, inter alia by introducing HACCP requirements, by extending these requirements to the primary production and processing stage for key industries, and by separating the risk assessment and risk management tasks of the FSANZ.

However, the strictness of Australia's SPS system has given rise to concerns by other WTO Members, which are faced with market access barriers in the form of Australia's SPS measures. In particular, the prior-approval requirement for food and agricultural imports, coupled with the very lengthy IRA process, have been repeatedly criticised by other Members. Australia has taken some steps to address these concerns. Some concerns are resolved through bilateral discussions. For example, a long-running concern of the EC regarding Australia's quarantine regime, in particular its measures on truss tomatoes, citrus, cured hams and poultry from the $\mathrm{EC}$, was resolved in bilateral discussions in 2007. ${ }^{110}$ Australia now allows imports of these products from the EC. ${ }^{111}$ Other concerns have been addressed through changes to Australia's SPS system. For example, as mentioned above, in response to the various complaints regarding the undue delays in issuing IRAs, the Australian government has announced reforms to increase the transparency, efficiency,

2007. Note by the Secretariat, G/SPS/R/44, circulated on 30 May 2007. paras 21-24.

107 Ibid., para. 23.

108 Dispute Settlement Body, Australia - Measures Affecting the Importation of Apples from New Zealand. Request for Consultations by New Zealand, WT/DS367/1, G/L/825, G/SPS/GEN/796, circulated on 4 September 2007.

109 Dispute Settlement Body, Australia - Measures Affecting the Importation of Apples from New Zealand. Request for the Establishment of a Panel by New Zealand, WT/DS367/5, circulated on 7 December 2007.

110 Dispute Settlement Body, Australia - Quarantine Regime for Imports. Notification of Mutually Agreed Solution, WT/DS287/8, G/L/618/Add.1, G/SPS/GEN/384/Add.1, circulated on 13 March 2007.

111 Australian Government Department of Agriculture Fisheries and Forestry, Annual Report 2006-07: Growing Australia through Sustainable, Innovative and Profitable Agriculture, Fisheries and Forestry (Commonwealth of Australia, Canberra), September 2007, 104, available at: http://www.daff.gov.au/_data/ assets/pdf_file/0005/439493/2_AR_06-07_ROP_WEB.pdf, visited on 17 January 2008. 
timeliness and predictability of the IRA procedures. Nevertheless, several concerns remain, particularly with regard to the prior-approval nature of Australia's quarantine system as illustrated by the Philippine banana and the New Zealand apple disputes.

Australia also makes concerted efforts to address SPS market access barriers to its exports of food and agricultural products. It follows an effective three-pronged strategy in this regard. First, it provides extensive support to its food and agricultural industry to assist them in complying with the SPS requirements imposed by their trading partners, and in demonstrating such compliance. This support takes various forms, including the provision of high quality export inspection and certification services, the publication of clear and easily accessible information to the food and agricultural export industry with regard to SPS requirements on foreign markets, and various financial programs to reduce the costs of SPS compliance.

Second, Australia engages actively with its trading partners to resolve SPS issues affecting its exports. Australia engages on a technical level, with the regulatory authorities of its trading partners to resolve SPS issues before trade restrictive measures are imposed. In its Annual Report 2006-07, the DAFF notes that this work made measurable differences for Australian exporters of horticultural and animal products in particular. ${ }^{112}$ Good examples in this respect are that with regard to Indonesia's recognition of Australia's fruit fly-free areas, and that with regard to the US recognition of the equivalence of Australia's sanitary system for meat exports, described above. ${ }^{113}$ If its efforts to resolve SPS issues through bilateral technical discussions are unsuccessful, Australia raises trade concerns at WTO level, through the mechanism provided by the SPS Committee, discussed below. ${ }^{114}$

Third, Australia vigorously promotes its export interests at the international level, by monitoring and influencing the debate in international bodies on SPS issues. Australia is an active participant in the international standard-setting bodies referred to by the SPS Agreement, through the International Food and Agriculture Service of the DAFF. As part of its food market entry strategy, it has allocated budgetary resources to improving its capacity to pursue its objectives in international standard-setting bodies. ${ }^{115}$ Australia effectively promotes its industry interests in the negotiations whereby these international bodies draft standards. For example, the DAFF Annual Report 2004-05 states that a fruit juice standard favourable to trade in Australian fruit juices was negotiated by the DAFF at the Codex Alimentarius Commission, saving the industry an estimated A $\$ 9$ million per year. ${ }^{116}$ In addition, at discussions in the SPS Committee with regard to making specific

112 Ibid., 108.

113 See above, Part II, Section 2.4.2.2.

${ }^{114}$ Australia has raised 8 trade concerns regarding the SPS measures of other WTO Members to date, and has joined the concerns raised by other Members in 21 cases. These will be discussed further below, Part IV, Section 2.1.2.

${ }^{115}$ Australia has committed A $\$ 2.5$ million, as part of the budget from the implementation of the National Food Industry Strategy to increase Australia's capacity further its interests in the international standard-setting bodies. Australian Government Department of Agriculture Fisheries and Forestry, National Food Industry Strategy: An Action Agenda for the Australian Food Industry (Commonwealth of Australia, Canberra), June 2002, 31, available at: http://www.daff.gov.au/_data/assets/pdf_file/0017/183320/strategy_statement_final. pdf, visited on 13 January 2008.

116 Australian Government Department of Agriculture Fisheries and Forestry, Annual Report 2004-05 (Commonwealth of Australia, Canberra), October 2005, available at: http://www.daff.gov.au/_data/assets/ 
provisions of the SPS Agreement more effective and operational, Australia ensures that its voice is heard. ${ }^{117}$ For example, it worked together with like-minded WTO Members in the informal discussions on the recognition of pest- and disease-free areas, an issue of particular relevance to Australia. ${ }^{118}$ It also participated in the discussions on improving the transparency of special and differential treatment for developing counties, to ensure that this initiative does not undermine the right of each WTO Member to determine for itself the level of SPS protection it will ensure on their territories. ${ }^{119}$

Overall, Australia's SPS system can be characterised as extremely effective both in protecting Australia from SPS risks and in securing market access for its food and agricultural exports. However, it creates significant, and often insurmountable, difficulties for other Members, at all levels of development, who wish to gain market access to Australia for their food and agricultural exports.

\subsection{Mauritius}

\subsubsection{Factual background}

Mauritius is an African country, situated in the Indian Ocean. It is among the 'small-island developing states' (SIDS) of the world. ${ }^{120}$ Mauritius became independent of British rule in 1968. The following indicators provide a picture of the development level of Mauritius both in economic and in human terms.

\subsubsection{Development indicators}

According to the World Bank classification of countries by income, Mauritius graduated in 1991 from being a lower-middle-income economy ${ }^{121}$ to being an upper-middle-income

word_doc/0016/5704/2004-05_annual_report_exc_fin_statements.doc, visited on 17 January 2008.

${ }^{117}$ Australia's delegation to SPS Committee meetings includes representatives of the International Division of the DAFF.

118 These discussions address Article 6 of the SPS Agreement, discussed below, Part IV, Section 1.2. Australia's objective in this regard is the development of guidelines on the recognition of pest- or disease-free areas that complement the work done in this area by the relevant three international standard setting bodies. Australian Government Department of Agriculture Fisheries and Forestry, Annual Report 2006-07: Growing Australia through Sustainable, Innovative and Profitable Agriculture, Fisheries and Forestry (Commonwealth of Australia, Canberra), September 2007, 107, available at: http:/www.daff.gov.au/_data/assets/pdf_ file/0005/439493/2_AR_06-07_ROP_WEB.pdf, visited on 17 January 2008.

119 Ibid., 108.

${ }^{120}$ The UN has recognised the particular problems of 'small-island developing states' (SIDS) since 1994. They are considered to be at greater risk of marginalization from the global economy than many other developing countries due to their small size, remoteness from large markets and high vulnerability to economic and natural shocks. However, the UN has never established criteria to draw up an official list of SIDS. UNCTAD uses an unofficial list of 29 SIDS for purposes of establishing statistics for analysis. Mauritius is among these 29 SIDS. See the UNCTAD website's page on SIDS, available at: http://www.unctad.org/Templates/Page. asp? intItemID=3620\&lang=1, visited on 9 January 2008.

${ }^{121}$ See the World Bank's table on Analytical Classifications, (Country Analytical History), available at: http:// siteresources.worldbank.org/DATASTATISTICS/Resources/OGHIST.xls, visited on 8 January 2008. 
economy. ${ }^{122}$ Its GNI per capita in 2006 was US\$ 5,450. ${ }^{123}$ Mauritius had a GDP of US\$ 15.8 billion at purchasing power parity and GDP per capita of US\$12,715 at purchasing power parity in $2005 .^{124}$

Mauritius is ranked $65^{\text {th }}$ in the world in the UN Human Development Index of 2007, and falls into the category of high-human-development countries. ${ }^{125}$ Its population was 1.3 million in $2006 .{ }^{126}$ In 2001/2002, only 1.5 percent of the Mauritian population lived below the poverty line of US\$2 per day. ${ }^{127}$

\subsubsection{Health priorities}

The health status of Mauritius provides an indication of is priorities in the area of public health spending and therefore also of the relative importance of guarding against SPS risks in its territory. Public health expenditure in Mauritius accounts for 2.4 percent of GDP, or US\$516 at purchasing power parity per capita. ${ }^{128}$

Life expectancy at birth in Mauritius has increased from 63 to 72 years, over the last 30 -year period. ${ }^{129}$ There has been a transition in the health state of Mauritius from a situation where communicable diseases were a primary concern, to a situation where noncommunicable lifestyle-related diseases are the principal problem. ${ }^{130}$ The prevalence of tuberculosis in Mauritius has decreased to 132 per 100,000 people. ${ }^{131}$ Other communicable diseases have been virtually eradicated. ${ }^{132}$ The main causes of death in Mauritius are

${ }^{122}$ See the World Bank classification of economies of July 2007 available at: http://siteresources.worldbank.org/ DATASTATISTICS/Resources/CLASS.XLS, visited on 8 January 2008.

${ }^{123}$ See the World Bank webpage on Key Development Data \& Statistics of 2006, available at: http://web.worldbank.org/WBSITE/EXTERNAL/DATASTATISTICS/0,,contentMDK:20535285 menuPK:1192694 pageP K:64133150 piPK:64133175 theSitePK:239419,00.html, visited on 8 January 2008

124 United Nations Development Programme, Human Development Report 2007/2008. Fighting Climate Change: Human Solidarity in a Divided World (Palgrave Macmillan, New York), 2007, 278, available at: http://hdr.undp.org/en/media/hdr_20072008_en_complete.pdf, visited on 10 December 2007.

125 Ibid., 230.

${ }^{126}$ See the World Bank webpage on Key Development Data \& Statistics of 2006, available at: http://web.worldbank.org/WBSITE/EXTERNAL/DATASTATISTICS/0,,contentMDK:20535285 menuPK:1192694 pageP K:64133150 piPK:64133175 theSitePK:239419,00.html, visited on 8 January 2008.

${ }^{127}$ In the Human Development Report 2007/2008 of the UNDP, there is no data available on the income poverty level of Mauritius. Neither is this data available in the World Bank's webpage on Key Development Data and Statistics of 2006. The latest data available on this issue is that provided for $2001 / 2002$ by the Central Statistic Office of the Republic of Mauritius, available at: http://www.gov.mu/portal/site/cso/menuitem.dee2 25f644ffe2aa338852f8a0208a0c/?content_id=6dda3f48c654c010VgnVCM1000000a04a8c0RCRD, visited on 8 January 2008. If one measures poverty as the percentage of people living on less than US\$1 per day, it is estimated that less than 1\% of Mauritius' population lives below the poverty line (2001-2002).

128 United Nations Development Programme, Human Development Report 2007/2008. Fighting Climate Change: Human Solidarity in a Divided World (Palgrave Macmillan, New York), 2007, 248, available at: http://hdr.undp.org/en/media/hdr_20072008_en_complete.pdf, visited on 10 December 2007.

${ }^{129}$ Ibid., 262.

${ }^{130}$ Ministry of Quality of Life and Health of Mauritius, Non-Communicable Diseases Survey 2004, July 2006, available at: http://www.gov.mu/portal/goc/moh/file/ncd/yr2004m.pdf, visited on 10 January 2008.

131 United Nations Development Programme, Human Development Report 2007/2008. Fighting Climate Change: Human Solidarity in a Divided World (Palgrave Macmillan, New York), 2007, 258, available at: http://hdr.undp.org/en/media/hdr_20072008_en_complete.pdf, visited on 10 December 2007.

132 Major infectious diseases of significance in Mauritius in the past (malaria, polio, diphtheria, typhoid and cholera) which are still prevalent many African countries have almost been eradicated. Mauritius is also one of the most successful African countries in containing the spread of HIV/AIDS $(0.08 \%$ of the adult 
now heart disease and diabetes. ${ }^{133}$ Other important health problems are related to smoking and obesity, such as cancer, hypertension and strokes. ${ }^{134}$ This epidemiological transition is a result of improvements in living standards, health care and sanitation.

There are 106 physicians per 100,000 people in Mauritius. ${ }^{135}$ Access to sanitation and clean water is enjoyed by 94 and 100 percent of the population in 2004, respectively. ${ }^{136}$ Infant mortality in Mauritius is at a rate of 13 per 1000 births, in $2005,,^{137}$ down from 64 deaths per 1000 births in $1970 \mathrm{~s} .{ }^{138}$ The percentage of children under five who die due to diarrhoeal diseases was 1 percent in 2000-2003. ${ }^{139}$ Only 5 percent of the population is undernourished. ${ }^{140}$

The new pattern of health concerns, arising from lifestyle-related illness, creates a growing burden on the health services of Mauritius, including through complications that require heart surgery, haemodialysis and transplants. ${ }^{141}$ To address these needs, Mauritius has invested in a range of new high technology diagnostic facilities such as CT scan and MRI. There have also been developments in sophisticated treatments such as a major expansion in heart surgeries, the provision of haemodialysis in four regions of Mauritius, the availability of radiotherapy for cancers and the modernisation of equipment for operation theatres and intensive care units. ${ }^{142}$

population was infected in 2002. Ministry of Health and Quality of Life, Republic of Mauritius, White Paper on Health Sector Development and Reform, December 2002, 26, available at: http://www.gov.mu/portal/goc/ moh/file/whitepap.doc, visited on 10 January 2008.

133 These two causes of death accounted for 1,921 (22.8\%) and 1,778 (21.1\%) deaths respectively in 2005. See the website of the Ministry of Health \& Quality of Life of Jamaica, Health Statistics Annual 2005: An Analysis of the Health Situation available at: http://www.gov.mu/portal/goc/moh/file/statsm05/analys05.pdf, visited on 10 January 2008.

${ }^{134}$ In 2004, 35.9\% of men and 5.1\% of women (aged 20-74 years) were smokers. In 2004, the prevalence of obesity in adults aged 20-74 years was 5.6\% among men and $13.7 \%$ among women. The prevalence of overweight in the same year was $25.1 \%$ among men and $25.7 \%$ among women. Taken together, $35.7 \%$ of the Mauritian population aged 20-74 years are either obese or overweight. See Ministry of Quality of Life and Health of Mauritius, Non-Communicable Diseases Survey 2004, July 2006, available at: http://www.gov.mu/ portal/goc/moh/file/ncd/yr2004m.pdf, visited on 10 January 2008.

135 United Nations Development Programme, Human Development Report 2007/2008. Fighting Climate Change: Human Solidarity in a Divided World (Palgrave Macmillan, New York), 2007, 230, available at: http://hdr.undp.org/en/media/hdr_20072008_en_complete.pdf, visited on 10 December 2007.

${ }^{136}$ Ibid., 252.

${ }^{137}$ Ibid., 262.

${ }^{138}$ Ministry of Health and Quality of Life, Republic of Mauritius, White Paper on Health Sector Development and Reform, December 2002, 8, available at: http:/www.gov.mu/portal/goc/moh/file/whitepap.doc, visited on 10 January 2008.

${ }^{139}$ See World Health Organization, Mortality Country Fact Sheet of 2006, diarrhoeal disease available at: http:// www.who.int/whosis/mort/profiles/mort afro mus mauritius.pdf, visited on 8 January 2008. This information is included to provide some indication of the incidence of diarrhoea in children in Mauritius, as no data on treatment of children with diarrhoea is available in the Human Development Report 2007/2008 of the UNDP.

140 United Nations Development Programme, Human Development Report 2007/2008. Fighting Climate Change: Human Solidarity in a Divided World (Palgrave Macmillan, New York), 2007, 252, available at: http://hdr.undp.org/en/media/hdr_20072008_en_complete.pdf, visited on 10 December 2007.

${ }^{141}$ Ministry of Health and Quality of Life, Republic of Mauritius, White Paper on Health Sector Development and Reform, December 2002, 9, available at: http:/www.gov.mu/portal/goc/moh/file/whitepap.doc, visited on 10 January 2008.

${ }^{142}$ Ministry of Health and Quality of Life, Republic of Mauritius, White Paper on Health Sector Development and Reform, December 2002, 6, available at: http:/www.gov.mu/portal/goc/moh/file/whitepap.doc, visited 
As a result of the new health issues confronting Mauritius, its health priorities, as noted in the White Paper on Health Sector Development and Reform of the Ministry of Health and Quality of Life of Mauritius, now focus on health promotion and preventive medicine. ${ }^{143}$ The new Action Plan for Health aims to increase capacity to reduce deaths from kidney failure, by expanding provision of kidney dialysis and transplant services, to improve preventative care for those with hypertension and diabetes to reduce the risks of complications. Health promotion will aim at improvements in lifestyle, for example through the reduction of smoking and alcohol abuse, increasing exercise and improvements to diet. ${ }^{144}$

This current focus on preventative health care and on the long-term health benefits of diet increases the importance of preventing food-safety risks, such as from the presence of contaminants and carcinogens, as a priority of public spending. Therefore, the Action Plan for Health presented in the White Paper notes the importance of good hygienic sanitary conditions in commercial and industrial establishments. It includes as a priority for future action the strict enforcement of food-safety legislation in Mauritius. ${ }^{145}$

However, despite Mauritius's good record of achievements in the area of health, it lacks the financial and human capacity to keep pace with the needs both in primary health care and in high technology facilities. As a result, many hospitals are old and poorly maintained and equipment is in need of replacement. ${ }^{146}$ Therefore, the Action Plan for Health set out by the White Paper notes the need for resources, beyond those drawn from general taxation, to implement its proposals. ${ }^{147}$

\subsubsection{Trade priorities}

Mauritius became a contracting party to the GATT 1947 in 1970, under the special provision for newly independent states in GATT Article XXVI:5(c), ${ }^{148}$ after having applied the GATT on a de facto basis since its independence $1968 .{ }^{149}$ It has been an original Member of the WTO since 1 January 1995. Mauritius participates actively in the multilateral trading system. It is regarded as a 'small vulnerable economy' and 'small-island developing state' for purposes of the WTO work programmes on these issues.

on 10 January 2008.

${ }^{143}$ Ibid.

144 Ibid., 7.

145 Ibid., 56.

${ }^{146}$ Ibid.

${ }^{147}$ Ibid., 77. This White Paper estimates that the Action Plan for Health, if fully implemented by 2008/2009, will require a 75\% increase in health expenditure (Rs4-5 billion in capital expenditure). In addition, Rs200 million per year is needed for maintenance and upkeep of the present buildings and equipment. The largest part of the additional resources is needed for developing services to meet the growing epidemic of non-communicable diseases. The White Paper notes that the additional funding required is beyond the limits likely to be provided from existing budgetary sources.

${ }^{148}$ This special procedure was discussed above, Part I, Section 1.3.

149 Mauritius was under colonial rule for centuries, first by the Dutch (1598), then the French (1710) and finally the British (1810). 
Exports of goods and services amounted to 24.5 percent of GDP in Mauritius in 2006. ${ }^{150}$ The ratio trade to GDP in Mauritius in 2004 - 2006 was 125.9. ${ }^{151}$ In the context of the WTO negotiations on agricultural liberalisation, Mauritius has pointed to the multifunctional role of agriculture in SIDS, particularly with regard to food security. ${ }^{152}$ In a joint communication with other SIDS, Mauritius has pointed to the inherent structural difficulties that prevent SIDS for achieving the level of competitiveness needed for effective participation in agricultural trade, including diseconomies of scale and high costs of transport and input factors due to their remoteness, smallness, vulnerability to natural disasters and scarcity of resources. ${ }^{153}$ The consequent dependence of SIDS on a limited range of agricultural products for their export earnings and the fact that these exports are made possible through non-reciprocal preferential trading arrangements was pointed out to highlight the threat to SIDS from the rapid erosion of preferential tariff margins due to multilateral tariff reduction. ${ }^{154}$ In addition, this communication pointed to the fact that the agricultural exports of these countries face stringent SPS requirements that are 'invariably beyond the administrative and technical capacity of SIDS'. ${ }^{155}$

In the context of the Doha Development Round of trade negotiations at the WTO, Mauritius is active in promoting the interests of developing countries, particularly 'small vulnerable economies' (SVES). It has stressed the importance of addressing supply-side constraints alongside improving market access. In particular, it regards as critical issues such as the need to ensure 'balanced rules that provide developing countries the policy space to pursue development policies, enhanced market access for products and services of interest to them, capacity-building programmes and technical assistance (including supply-side capacity, institution building, and human resource development), and adjustment support measures.' ${ }^{156}$ Mauritius regards the role of the international community as

${ }^{150}$ See the statistics in the World Bank's country profile for Mauritius, available at: http://devdata.worldbank. org/external/CPProfile.asp?PTYPE=CP\&CCODE=MUS, visited on 14 January 2008. According to the World Bank, in this calculation 'Exports of goods and services represent the value of all goods and other market services provided to the rest of the world. They include the value of merchandise, freight, insurance, transport, travel, royalties, license fees, and other services, such as communication, construction, financial, information, business, personal, and government services. They exclude labour and property income (formerly called factor services) as well as transfer payments.'

${ }^{151}$ WTO Secretariat, Trade Profiles 2007 (World Trade Organization, Geneva), October 2007, 111, available at: http://www.wto.org/english/res_e/booksp_e/anrep_e/trade_profiles07_e.pdf, visited on 8 January 2008. As noted above, the trade-to-GDP ratio reflects the significance of trade for a country's economy. It is calculated by dividing an economy's total trade in goods and services (exports + imports) by its GDP, on the basis of data for the three latest years available. GDP is measured in nominal terms and with market exchange rates.

${ }^{152}$ Mauritius, Multifunctional Role of Agriculture in Small Island Developing States, AIE/51, dated 10 March 1999, cited in Committee on Agriculture, Non-Trade Concerns - Issues Raised by Members in AIE Papers and Pre-Seattle Submissions, G/AG/NG/S/17, circulated on 16 October 2000.

${ }^{153}$ Committee on Agriculture, WTO Negotiations on Agriculture: Proposals by Small Island Developing States (SIDS): Communication from Barbados, Cuba, Dominica, Jamaica, Mauritius, St. Kitts and Nevis, St. Lucia, St. Vincent and the Grenadines, and Trinidad and Tobago, G/AG/NG/W/97 and Corr.1, circulated on 29 December 2000, paras 3-4.

${ }^{154}$ Ibid., paras 5-6.

${ }^{155} \mathrm{Ibid}$., para. 6. This communication proposes, inter alia, that non-reciprocal preferential tariffs for SIDS be improved and bound under the Agreement on Agriculture and that a framework be created for the provision of technical assistance for meeting the costs of compliance with SPS measures in the international market.

${ }_{156}$ Trade Policy Review Body, Trade Policy Review: Mauritius - Report by the Secretariat WT/TPR/S/198, circulated on 19 March 2008, Part II para. 26. See also Sixth Session of the Ministerial Conference, Mauritius: Statement of the Honourable Madan Murlidhar Dulloo Minister of Foreign Affairs, International Trade and 
key in supporting developing countries to address the problem of supply capacity, competitiveness, and upgrading product standards to meet SPS and technical requirements in their export markets. ${ }^{157}$

Like many other more-developed developing countries, Mauritius has diversified its economy to some extent, moving away from the agriculture-based economy it had at independence, to an economy based on growing services and industrial sectors. ${ }^{158}$ However, due to its narrow resource base and small domestic market, the diversification of the economy of Mauritius is still rather limited and its production and exports are largely concentrated on a relatively narrow range of products and services. ${ }^{159}$

In particular, Mauritius relies on textiles, sugar and tourism ${ }^{160}$ and financial services ${ }^{161}$ for its foreign revenue earnings. Textiles dominate the manufacturing industry of Mauritius and accounted for 49 percent of the merchandise exports of Mauritius in 2006. ${ }^{162}$ However, they are currently subject to increased competition since the termination of the special regime under the WTO Agreement on Textiles and Clothing on 1 January 2005, and their resultant full integration into the multilateral trading system. ${ }^{163}$ This competition will be even greater when the possibility for special safeguard measures against Chinese textiles is terminated at the end of 2008. ${ }^{164}$

Sugar made up 16 percent of the foreign revenue earnings from the merchandise trade of Mauritius in 2006. ${ }^{165}$ The sugar exports of Mauritius, until recently, benefited from the

Cooperation, WT/MIN(05)/ST/120, circulated on 16 December 2005.

157 Trade Policy Review Body, Trade Policy Review: Mauritius - Report by the Secretariat WT/TPR/S/198, circulated on 19 March 2008, Part II para. 26. See also Fifth Session of the Ministerial Conference, Mauritius: Statement Circulated by the Honourable Jaya Krishna Cuttaree Minister of Industry and International Trade, $\mathrm{WT} / \mathrm{MIN}(03) / \mathrm{ST} / 70$, circulated on 12 September 2003.

158 Technical Centre for Agricultural and Rural Cooperation ACP-EU, Study of the Consequences of the Application of Sanitary and Phytosanitary (SPS) Measures on ACP Countries (CTA, Wageningen), May 2003, 25, available at: http://www.tcd.ie/iiis/policycoherence/index.php/iiis/content/download/371/1446/ file/CTA $\% 20$ Impact $\% 20$ of $\% 20$ SPS $\% 20$ Measures $\% 20$ on $\% 20$ ACP $\% 20$ countries.pdf., visited on 23 January 2008 .

${ }^{159}$ See Trade Policy Review Body, Trade Policy Review: Mauritius - Report by the Government, WT/TPR/G/90, circulated on 5 October 2001.

${ }^{160}$ Tourism accounted for 7,9\% of GDP and for $25 \%$ of Mauritius's total export earnings in 2006, thus overtaking sugar as the largest source of foreign revenue in Mauritius. Trade Policy Review Body, Trade Policy Review: Mauritius - Report by the Secretariat WT/TPR/S/198, circulated on 19 March 2008, Part IV para. 143.

${ }^{161}$ Financial services contributed $9,9 \%$ to GDP in 2005. Ibid., Patr IV para. 91.

${ }^{162}$ In 2006, textile exports accounted for 5.8\% of GDP in Mauritius. Ibid., Part IV para. 80. The value of textile exports from Mauritius in 2005 was US\$738.6 million. This data is provided by the International Trade Centre of UNCTAD/WTO, Trade Competitiveness Map, Exports of Mauritius, 2005, available at: http:// www.intracen.org/appli1/TradeCom/TP_EP_CI.aspx?RP=480\&YR=2005, visited on 11 January 2008.

${ }^{163}$ This agreement is one of the outcomes of the Uruguay Round negotiations and is contained in Annex $1 \mathrm{~A}$ to the Marrakesh Agreement Establishing the World Trade Organization. This agreement provided a 10-year phase out period for textile quotas, and terminated on 1 January 2005. 'Agreement on Textiles and Clothing', in The Results of the Uruguay Round of Multilateral Trade Negotiations: The Legal Texts (World Trade Organization, Geneva), 1994, 85-137.

${ }^{164}$ A special safeguards regime, applicable to Chinese textiles and clothing, was established in para. 242 of the Report of the Working Party on the Accession of China. This regime is applicable until 31 December 2008. It is part of the terms and conditions for China's accession and therefore considered part of China's Protocol of Accession to the WTO.

165 Trade Policy Review Body, Trade Policy Review: Mauritius - Report by the Secretariat WT/TPR/S/198, 
guaranteed high prices provided under the Sugar Protocol to the Cotonou Agreement with the EC. ${ }^{166}$ Mauritius is a member of the group of ACP countries with which the EC had this non-reciprocal preferential trade agreement. The Sugar Protocol to this agreement guarantees prices significantly higher than the world market price for fixed quantities of sugar from specific ACP countries, including Mauritius. However, the EC is in the process of reforming its sugar regime, and has already cut prices by 36 percent, with significant consequences for Mauritian export revenue. ${ }^{167}$ In addition, a Decision of the EC Council of Ministers has terminated the Sugar Protocol with effect as of 1 October 2009. ${ }^{168}$ As the WTO waiver for the preferential arrangements under the Cotonou Agreement expired on 31 December 2007, the EC has negotiated new (comprehensive or interim) Economic Partnership Agreements (EPAs) with six different groups of ACP countries. ${ }^{169}$ One of these groups is Eastern and Southern Africa, of which Mauritius is part. The interim EPA with Eastern and Southern African countries, initialled by Mauritius in December 2007, does not provide for guaranteed sugar prices, but only provide tariff-free access to sugar within specified quota limits during a transitional period. ${ }^{170}$

circulated on 19 March 2008, Part IV para. 19.

${ }^{166}$ Partnership Agreement between the Members of the African, Caribbean and Pacific Group of States of the One Part and the European Community and Its Member States, of the Other Part, signed in Cotonou, Benin, on 23 June 2000 (the Cotonou Agreement). The Cotonou Agreement, which replaced the successive Lomé Conventions between the EU and the ACP states, provides zero customs duties to almost all industrial products and lower than normal customs duties to agricultural products from ACP countries (Art. 1 of Annex V). Special regimes for bananas and sugar are established in the Banana Protocol and Sugar Protocol to the Cotonou Agreement.

${ }^{167}$ This price reduction, it is reported, will lead to a shortfall in export earnings for Mauritius of $€ 782$ million in the 2006-2015 period. Ministry of Agro-Industry and Fisheries of the Republic of Mauritius, Multi-Annual Adaptation Strategy Sugar Sector Action Plan 2006-2015: Safeguarding the Future through Consensus (Republic of Mauritius, Port Louis), 2006, 1, available at: http://www.gov.mu/portal/sites/moasite/download/ Multi\%20Annual\%20Adaption\%20Strategy.pdf, visited on 10 January 2008.

${ }^{168}$ Council Decision 2007/627/EC of 28 September 2007 denouncing on behalf of the Community Protocol 3 on ACP sugar appearing in the ACP-EEC Convention of Lomé and the corresponding declarations annexed to that Convention, contained in Protocol 3 attached to Annex V to the ACP-EC Partnership Agreement, with respect to Barbados, Belize, the Republic of Congo, the Republic of Cote d'Ivoire, the Republic of the Fiji Islands, the Republic of Guyana, Jamaica, the Republic of Kenya, the Republic of Madagascar, the Republic of Malawi, the Republic of Mauritius, the Republic of Mozambique, the Federation of Saint Kitts and Nevis, the Republic of Suriname, the Kingdom of Swaziland, the United Republic of Tanzania, the Republic of Trinidad and Tobago, the Republic of Uganda, the Republic of Zambia and the Republic of Zimbabwe OJ L $255,29.9 .2007$, p. 38 .

${ }^{169}$ While the CARIFORUM group of ACP countries initialled a comprehensive EPA with the EC, members of the other five groups of ACP countries (Central Africa, West Africa, the Pacific Group, the Southern African Development Community (SADC) and Eastern and Southern African countries) initialled only interim EPAs, which cover only trade in goods but are the first step towards comprehensive EPAs (note that not all members of these groups have initialled the interim EPAs to date). Mauritius initialled the interim EPA between Eastern and Southern African countries and the EC on 4 December 2007.

${ }^{170}$ The new arrangements under the EPA agreements are given effect to in Council Regulation applying the arrangements for products originating in certain states which are part of the African, Caribbean and Pacific (ACP) Group of States provided for in agreements establishing, or leading to the establishment of, Economic Partnership Agreements, 14970/1/07 REV 1, Brussels, 18 December 2007, available at: http://www.mcci. org/photos/news/EPARegulation.pdf, visited on 10 January 2008. Duty-free, quota-free market access for most products, excluding arms, but are subject to transitional periods and arrangements for certain sensitive products. Sugar is one of the sensitive products, and is subject to a tariff rate, under Art. 7(1) of the Regulation, during a transitional period from 1 October 2008 to 30 September 2009. From 1 October 2009 to 30 September 2012 a transitional safeguard mechanism applies under Art. 9 of the Regulation if sugar imports from ACP countries exceed specified limits. 
Mauritius's participation in WTO dispute settlement, although very limited, reflects its particular focus on sugar exports as well as on preferential arrangements with the EC. ${ }^{171}$ Mauritius has never initiated a WTO dispute, nor has it had a dispute brought against it. The five cases in which it has participated as a third party involve the EC's GSP system, the EC's sugar regime, and Mexico's anti-dumping investigation against high-fructose corn syrup from the US, which Mauritius considered to have an impact on market access to the US for its own sugar exports. ${ }^{172}$

The loss of export earnings due to the changes mentioned above in the textiles and sugar sectors, both of which are important sources of employment, pose great challenges to the economy of Mauritius, and to its development situation. Mauritius has recognized the need to diversify its exports.

As one of its policy objectives to diminish its dependence on preferential arrangements for the export of primary products, Mauritius has identified the aim of becoming an agroprocessing hub in the region by importing agricultural products from other countries in the region and taking advantage of its technology, infrastructure and communications facilities to process and re-export these products. ${ }^{173}$ This will make domestic agro-processing industries more competitive and better able to exploit export opportunities.

\subsubsection{Significance of the agricultural sector}

The importance of the SPS Agreement for Mauritius depends on the role played by its food and agricultural industry in economic growth and poverty alleviation.

The share of the agricultural industry in the GDP of Mauritius has declined from 6.9 percent in 2001 to 5.6 percent in 2006. ${ }^{174}$ Production capacity in Mauritius is low due to its geographical isolation and size, as is the case with many small-island developing states. Other challenges to the agricultural industry are climatic uncertainties, rising costs of

171 These disputes are listed on the page for Mauritius on the WTO website, available at: http://www.wto.org/ english/thewto_e/countries_e/mauritius_e.htm, visited on 18 January 2008.

${ }^{172}$ Mauritius and Jamaica made a joint oral statement before the Panel emphasising the potential impact of the Mexico - Corn Syrup dispute on market access for sugar from Jamaica and Mauritius to the US. They argued that the dispute at issue was only one facet of a much broader disagreement over sweetener trade between these Mexico and the US. In particular they expressed concern that as market access for Mexican sugar to the US increased, market access for sugar from traditional suppliers was reduced correspondingly. Panel Report, Mexico - Corn Syrup, paras 5.654-5.660.

${ }^{173}$ Committee on Sanitary and Phytosanitary Measures, The Mauritian Experience with the SPS Agreement from the Indian Ocean Perspective, G/SPS/GEN/526, circulated on 25 October 2004, para. 12. See also Ministry of Agro-Industry and Fisheries of the Republic of Mauritius, Strategic Options in Crop Diversification and Livestock Sector 2007-2015 (Consultative Draft) (Republic of Mauritius, Port Louis), August 2007, 122, available at: http://www.areu.mu/files/pub/areunssp.pdf, visited on 10 January 2008. This policy document notes that neighbouring countries such as Madagascar and Mozambique have abundant unexploited land resources, very cheap labour resources and climactic conditions conducive to year-round crop cultivation. In addition, some crops (e.g. potatoes) that cannot be grown in Mauritius in specific periods can be grown in these same periods in these countries, thus ensuring a regular supply.

174 Ministry of Agro-Industry and Fisheries of the Republic of Mauritius, Strategic Options in Crop Diversification and Livestock Sector 2007-2015 (Consultative Draft) (Republic of Mauritius, Port Louis), August 2007, 1, available at: http://www.areu.mu/files/pub/areunssp.pdf, visited on 10 January 2008. See also the World Bank, Countries at a Glance table for Mauritius, available at: http://devdata.worldbank.org/ AAG/mus_aag.pdf, visited on 11 January 2008. 
imported inputs, tougher competition from other countries, increased exposure to pests and increasingly rigorous sanitary and phytosanitary requirements on export markets. ${ }^{175}$ In addition, the agricultural industry has remained mostly traditional and has not kept pace with the modernisation achieved in the other sectors of the economy. Therefore, the competitiveness of Mauritian agricultural products on the world market is weak, and Mauritius is highly dependent on imports for its food security. ${ }^{176}$

However, agriculture and food exports still account for a considerable share of Mauritius's merchandise export earnings. In 2006, this share amounted to 30.2 percent. ${ }^{177}$ In addition, as the agricultural industry, excluding fisheries, still provided direct employment to 10 percent of the labour force of Mauritius in 2005 its socio-economic importance is still significant. ${ }^{178}$ The government of Mauritius considers that agriculture plays a crucial multifunctional role. Not only does it provide income to industries and their employees, but it also increases food procurement capacity, reduces dependency on imported oil, promotes the development and stability of the rural areas, and ensures the protection of the environment against erosion. ${ }^{179}$

Mauritius's agricultural exports are dominated by sugar. ${ }^{180}$ As mentioned above, sugar accounts for 16 percent of Mauritius's merchandise export earnings and 10 percent of its to-

175 These challenges were identified in Ministry of Agriculture Food Technology \& Natural Resources of the Republic of Mauritius, A Sustained Programme for Agricultural Diversification: A Non-Sugar Sector Strategic Plan 2003-2007 (Republic of Mauritius, Port Louis), 2003, ii, available at: http://www.gov.mu/ portal/sites/moasite/download/nsssplan.pdf, visited on 11 January 2008.

${ }^{176}$ Ministry of Agro-Industry and Fisheries of the Republic of Mauritius, Strategic Options in Crop Diversification and Livestock Sector 2007-2015 (Consultative Draft) (Republic of Mauritius, Port Louis), August 2007, 2 , available at: http://www.areu.mu/files/pub/areunssp.pdf, visited on 10 January 2008. This consultative document notes that domestic production accounts for only $23 \%$ of food consumption in Mauritius. In 2005, imports of agricultural and food products amounted to Rs 15,492 million (17\% of total imports) which represents an increase of $50 \%$ since 2000 , and that the food import bill keeps increasing every year.

177 WTO Secretariat, Trade Profiles 2007 (World Trade Organization, Geneva), October 2007, 111, available at: http://www.wto.org/english/res_e/booksp_e/anrep_e/trade_profiles07_e.pdf, visited on 8 January 2008.

178 United Nations Development Programme, Human Development Report 2007/2008. Fighting Climate Change: Human Solidarity in a Divided World (Palgrave Macmillan, New York), 2007, 235-236, available at: http://hdr.undp.org/en/media/hdr_20072008_en_complete.pdf, visited on 10 December 2007. See also Ministry of Agriculture Food Technology \& Natural Resources of the Republic of Mauritius, A Sustained Programme for Agricultural Diversification: A Non-Sugar Sector Strategic Plan 2003-2007 (Republic of Mauritius, Port Louis), 2003, available at: http://www.gov.mu/portal/sites/moasite/download/nsssplan.pdf, visited on 11 January 2008.

179 Ministry of Agro-Industry and Fisheries of the Republic of Mauritius, Multi-Annual Adaptation Strategy Sugar Sector Action Plan 2006-2015: Safeguarding the Future through Consensus (Republic of Mauritius, Port Louis), 2006, 2, available at: http://www.gov.mu/portal/sites/moasite/download/Multi\%20Annual\%20 Adaption\%20Strategy.pdf, visited on 10 January 2008.

${ }^{180}$ In 2001, sugar exports accounted for US\$ 279 million in export earnings for Mauritius and amounted to $3.5 \%$ of world trade in sugar. Mauritian sugar was exported mainly to the UK (81\%) and Portugal $(9 \%)$. This information is reported in the country market-analysis profile of Mauritius provided by the International Trade Centre, see www.intracen.org/menus/countries.htm, visited on 25 June 2007. According to World Bank estimates, in 2002, Mauritius's export earnings from sugar had increased to US\$ 283 million. (see http:// www.worldbank.org/data/countrydata/aag/mus_aag.pdf, visited on 25 June 2007). Sugar is likely to remain the main component of the agricultural sector in Mauritius in the near future, according to the Mauritian government. Trade Policy Review Body, Trade Policy Review: Mauritius - Report by the Government, WT/ TPR/G/90, circulated on 5 October 2001. See also Ministry of Agro-Industry and Fisheries of the Republic of Mauritius, Multi-Annual Adaptation Strategy Sugar Sector Action Plan 2006-2015: Safeguarding the Future through Consensus (Republic of Mauritius, Port Louis), 2006, available at: http:/www.gov.mu/portal/sites/ 
tal foreign exchange earnings, amounting to US\$ 350 million in $2006 .{ }^{181}$ The main market for Mauritian sugar is the EC, ${ }^{182}$ and in particular the UK. These exports previously took place under the Sugar Protocol to the Cotonou Agreement, as mentioned above. However, Mauritius has had to deal with the impact of the reform of the EC's sugar regime as well as the erosion of its preferential access to the EU market. ${ }^{183}$ This sector will be the worst affected by preference erosion as production costs of sugar in Mauritius are twice as high as in the rest of the world. ${ }^{184}$ Mauritius has developed a Sugar Sector Action Plan to make the sugar industry competitive and sustainable in the long term, so that it can continue to fulfil its multifunctional role. ${ }^{185}$ However, the need to develop the non-sugarcane sector has been recognized by Mauritius since the 1960s. ${ }^{186}$

The non-sugarcane sector, which comprises horticulture, livestock, and food processing, is a sector which the Mauritian government wants to develop. ${ }^{187}$ However, it faces prob-

moasite/download/Multi\%20Annual\%20Adaption\%20Strategy.pdf, visited on 10 January 2008.

181 Trade Policy Review Body, Trade Policy Review: Mauritius - Report by the Secretariat WT/TPR/S/198, circulated on 19 March 2008, Part IV para. 19. See also International Trade Centre of UNCTAD/WTO, Trade Competitiveness Map, Exports of Mauritius, 2005, available at: http://www.intracen.org/appli1/TradeCom/ TP_EP_CI.aspx?RP=480\&YR=2005, visited on 11 January 2008.

${ }_{182}$ Mauritius enjoyed a duty-free quota of 507, 000 tons for sugar exports to the EC under the Sugar Protocol to the Cotonou Agreement, mentioned above. Another 16,000 tonnes had preferential access under the Special Preferential Sugar Agreement. The latter agreement was replaced by the Complementary Quantity (CQ) system on 1 July 2006. In 2006/07, Mauritius exported 487,000 tonnes under the Sugar Protocol, which applied a guaranteed price of $€ 523.70$ per tonne till 30 June 2006. This price is scheduled to decrease to $€ 496.80$ ( 1 July 2006 - 30 September 2008); €434 (1 October 2008 - 30 September 2009); and €335 (as of 1 October 2009). In addition, a small proportion of sugar exports (12, 000 tons) enter the US market under the US Tariff Rate Quota Arrangements. See Ibid., Part IV paras 20-21. See also Trade Policy Review Body, Trade Policy Review: Mauritius - Report by the Government, WT/TPR/G/90, circulated on 5 October 2001, paras 12-14; Trade Policy Review Body, Trade Policy Review: Mauritius - Report by the Secretariat, WT/TPR/S/90, circulated on 5 October 2001, para. 52.

${ }^{183}$ This erosion of preferences is due to the 'Everything But Arms' initiative of the EC in the context of its Generalised System of Preferences for developing countries. Under this initiative, the EC grants duty-free market access to essentially all products, except arms, from LDCs. This duty-free access came into effect in March 2001, except for three products, including sugar for which duty-free access was delayed until 2009. Low production costs in LDCs mean that importers are very likely to source their sugar from these countries which can provide it at lower prices than Mauritius. Trade Policy Review Body, Trade Policy Review: Mauritius - Report by the Government, WT/TPR/G/90, circulated on 5 October 2001, paras 121-125.

${ }^{184}$ Trade Policy Review Body, Trade Policy Review: Mauritius - Report by the Secretariat WT/TPR/S/198, circulated on 19 March 2008, para. 23.

${ }^{185}$ Ministry of Agro-Industry and Fisheries of the Republic of Mauritius, Multi-Annual Adaptation Strategy Sugar Sector Action Plan 2006-2015: Safeguarding the Future through Consensus (Republic of Mauritius, Port Louis), 2006, available at: http://www.gov.mu/portal/sites/moasite/download/Multi\%20Annual\%20 Adaption\%20Strategy.pdf, visited on 10 January 2008.

${ }^{186}$ Ministry of Agriculture Food Technology \& Natural Resources of the Republic of Mauritius, A Sustained Programme for Agricultural Diversification: A Non-Sugar Sector Strategic Plan 2003-2007 (Republic of Mauritius, Port Louis), 2003, 3, available at: http://www.gov.mu/portal/sites/moasite/download/nsssplan. pdf, visited on 11 January 2008. The COMESA Secretariat reported in 2003 that non-sugar exports from Mauritius remained marginal, representing less than $3 \%$ of total agricultural exports. Nevertheless, it expressed the belief that export potential exists for processed vegetables and food, game meat, spices and fresh organic fruits and vegetables. COMESA Secretariat, Market Access Constraints (Common Market for Southern Africa, Lusaka), 2003, para. 84, available at: www.comesa.int/trade/multilateral/epa/Market $\% 20$ Access\%20Constraints/en, visited on 10 January 2008.

${ }^{187}$ In 2001, food crops accounted for around $17 \%$ and livestock for $12 \%$ of the share of agriculture in GDP while flowers, fruits and forestry accounted for the remaining $4 \%$. The share of tea and tobacco to GDP are negligible. Ministry of Agriculture Food Technology \& Natural Resources of the Republic of Mauritius, 
lems at production and institutional levels. Crop production in Mauritius largely in the hands of small-holder farmers. ${ }^{188} \mathrm{~A}$ wide range of crops are cultivated including potatoes, onions, tomatoes, chillies, crucifers, garlic, and ginger. The main constraints for increasing crop production are the lack of suitable land and labour, the insufficiency of irrigation facilities, the increasing cost of energy and the need for pest and disease control. ${ }^{189}$ Institutional problems identified in the non-sugarcane sector are the lack of coordination in information dissemination, the weakness in providing support services to farmers and food processors and the inadequate response to the needs and requirements in the agricultural supply chain. ${ }^{190}$

Mauritius has a small but successful export trade in flowers, particularly anthuriums, destined for the European, Japanese and Australian markets. ${ }^{191}$ It also exports some wheat or meslin flour, mainly to Madagascar. ${ }^{192}$ However, overall the contribution of food crops, aside from sugar, to export earnings is negligible. ${ }^{193}$

Animal husbandry does not make up a significant part of Mauritian agriculture. Although Mauritius is self-sufficient with regard to eggs and poultry meat, it imports large quantities of other meat, fish, and dairy products. The livestock sector faces many constraints, including the small number of commercial farmers, the deficient husbandry skills of livestock farmers and the insufficiency of lands allocated to livestock farming. ${ }^{194}$

A Sustained Programme for Agricultural Diversification: A Non-Sugar Sector Strategic Plan 2003-2007 (Republic of Mauritius, Port Louis), 2003, 2, available at: http:/www.gov.mu/portal/sites/moasite/download/ nsssplan.pdf, visited on 11 January 2008.

${ }^{188}$ The average agricultural holding is of 0.25 ha. There are only a few large farms bigger than 10 ha. Ministry of Agro-Industry and Fisheries of the Republic of Mauritius, Strategic Options in Crop Diversification and Livestock Sector 2007-2015 (Consultative Draft) (Republic of Mauritius, Port Louis), August 2007, 2, available at: http://www.areu.mu/files/pub/areunssp.pdf, visited on 10 January 2008. See also Trade Policy Review Body, Trade Policy Review: Mauritius - Report by the Secretariat WT/TPR/S/198, circulated on 19 March 2008, Part IV para. 44.

189 Ministry of Agro-Industry and Fisheries of the Republic of Mauritius, Strategic Options in Crop Diversification and Livestock Sector 2007-2015 (Consultative Draft) (Republic of Mauritius, Port Louis), August 2007, 2, available at: http://www.areu.mu/files/pub/areunssp.pdf, visited on 10 January 2008.

190 Ibid., 3.

191 In 2001, exports of flowers and foliage amounted to $2 \%$ of total agricultural exports. Anthurium exports have been the second largest export earning product in the agricultural sector, after sugar, since the late 1980s. Currently Mauritius is the second anthurium exporter in the world, after the Netherlands. Ministry of Agriculture Food Technology \& Natural Resources of the Republic of Mauritius, A Sustained Programme for Agricultural Diversification: A Non-Sugar Sector Strategic Plan 2003-2007 (Republic of Mauritius, Port Louis), 2003, 2-3, available at: http://www.gov.mu/portal/sites/moasite/download/nsssplan.pdf, visited on 11 January 2008. In 2006, Mauritius exported MUR 96 million worth of anthurium. Trade Policy Review Body, Trade Policy Review: Mauritius - Report by the Secretariat WT/TPR/S/198, circulated on 19 March 2008, Part IV para. 6.

${ }^{192}$ Wheat or meslin flour earned Mauritius US\$7 million in foreign revenue in 2001, and was exported mainly to Madagascar $(66 \%)$. However, Mauritius imported US\$18 million worth of wheat or meslin flour in the same year. This information is reported in the country market analysis profile of Mauritius provided by the International Trade Centre, see www.intracen.org/menus/countries.htm, visited on 25 June 2007.

${ }^{193}$ Ministry of Agriculture Food Technology \& Natural Resources of the Republic of Mauritius, A Sustained Programme for Agricultural Diversification: A Non-Sugar Sector Strategic Plan 2003-2007 (Republic of Mauritius, Port Louis), 2003, 2, available at: http://www.gov.mu/portal/sites/moasite/download/nsssplan.pdf, visited on 11 January 2008.

194 Ibid., 67. 
Consequently Mauritius is dependent on imports of milk and meat (other than poultry). ${ }^{195}$ As the prices of milk and meat products are increasing, the government of Mauritius is concerned that there will be insufficient supply of these food products on the domestic market and believes that there is an urgent need to address the decline in domestic production of milk and meat. ${ }^{196}$

Food processing is fast becoming one of Mauritius's most promising industries. A few large processing establishments have emerged especially in the sectors of edible oil refining, animal feed compounding, wheat flour milling, and tuna canning. ${ }^{197}$ Also, a few firms now import fruits and vegetables for processing and some smaller-scale businesses have started food crop processing and preservation using exotic recipes. Although these industries initially targeted the domestic market, they have started to expand to export markets, regionally and internationally, through their variety of exotic niche products. ${ }^{198}$ As noted above, Mauritius's strategy for agricultural diversification aims to develop the country's potential to become an agro-processing hub in the region, by importing agricultural products from neighbouring countries and processing them for export. ${ }^{199}$ It has particular attributes giving it an advantage in this area, such as the fact that it has existing know-how and technology in agro-processing, that some of its agro-processing firms are already producing under international franchises, that it has modern infrastructure at ports and airports (warehouses, cold rooms and processing centres). ${ }^{200}$ However, as mentioned above, processed food products are subject to stricter SPS requirements on export markets than bulk primary products such as sugar. Therefore, the success of the export diversification of Mauritius to the processed food sector depends on its ability to meet the SPS requirements of its trading partners. This is recognised by the strategy paper, which notes that a serious constraint to exploiting the possibilities to become a regional agro-processing hub is the poor sanitary and phytosanitary conditions in the region. ${ }^{201}$ The strategy paper emphasises the importance of establishing and vigorously enforcing international norms in Mauritius and in countries in the region where Mauritian agro-processors will source their inputs, are essential prerequisites for achieving success in this initiative. ${ }^{202}$

Similarly, Mauritius is trying to develop its fishery sector, which employs around 12,000 persons. ${ }^{203}$ As it does not have a large continental shelf, its fisheries are concentrated in the lagoon, off-lagoon and banks. Although local fish production does not contribute significantly to GDP, ${ }^{204}$ Mauritius is also actively engaged as a landing and processing site

\footnotetext{
195 The Ministry of Agro-Industry and Fisheries reports that Mauritius's dependency on imported meat and milk has been increasing over the last 5 years. In 2005, the Mauritian meat production (excluding poultry) satisfied only $6 \%$ of its consumption. Ministry of Agro-Industry and Fisheries of the Republic of Mauritius, Strategic Options in Crop Diversification and Livestock Sector 2007-2015 (Consultative Draft) (Republic of Mauritius, Port Louis), August 2007, 67, available at: http://www.areu.mu/files/pub/areunssp.pdf, visited on 10 January 2008.

196 Ibid.

${ }^{197}$ Ibid., 116.

198 Ibid.

199 Ibid., 123.

${ }^{200}$ Ibid., 177.

${ }^{201}$ Ibid., 122.

${ }^{202}$ Ibid., 123.

203 This figure includes fishers as well as persons involved in processing, distribution and marketing of fish.

${ }^{204}$ The fishery sector, excluding processing, contributed 1\% to GDP in 2007. Trade Policy Review Body, Trade
} 
for fishery products and 40 percent of its fishery exports in 2006 were in fact re-exports of landed fish. ${ }^{205}$ The economic contribution of these 'seafood hub' activities to the economy of Mauritius was reported by the Minister of Agro-Industry and Fisheries Arvin Boolell to be US\$250 million in 2006. ${ }^{206}$ Mauritius intends to expand its capacity to act as a seafood hub. However, it will have to upgrade its inspection and certification capacity to meet the sanitary requirements of the EC, which is the main importer of Mauritian fish and fishery products. $^{207}$

\subsubsection{Summary of factual background}

This factual background sketch aims to provide an indication of the trade and health priorities in Mauritius as the context within which the relevance of the SPS Agreement for this Member can be understood.

The significant developments have taken place in the health status of Mauritius, in particular its transition from a situation where life expectancy was low and infectious diseases were a primary concern, to the current situation where most infectious diseases have been eradicated and the main challenges in the area of health are lifestyle and diet related. With this transition comes a new emphasis on the prevention of health risks and the importance of food-safety controls. However, financial and human resource constraints still play a role and make it difficult for Mauritius to maintain its high level of health achievements without additional resources being made available.

The trade concerns of Mauritius have also undergone changes. The share of agricultural exports in GDP is declining, being overtaken by the textile and tourism sectors. In addition, export earnings from sugar are facing serious challenges due to the reform of the EC sugar regime and the erosion of tariff preferences. However, the agricultural sector still plays an important socio-economic role in ensuring food security, generating employment and providing rural livelihoods. Therefore steps are urgently needed to revitalise the sector. The new agricultural strategy of Mauritius focuses on diversification to new horticultural products as well as to exploiting its comparative advantage in the region as a hub for processing and re-exporting imported agricultural and fisheries products. To meet its objectives in this regard, however, Mauritius must have a well-functioning SPS system in place.

The SPS system of Mauritius is now examined. On the one hand, this examination will help to establish its ability to enact and enforce regulations to protect against SPS risks

Policy Review: Mauritius - Report by the Secretariat WT/TPR/S/198, circulated on 19 March 2008, Part IV para. 58 .

${ }^{205}$ About $90 \%$ of imports of fish and fish products consist of frozen tuna for processing by the canning industry. Most fishery exports of Mauritius are canned tuna and loins. Fishery exports accounted for MUR 7 billion in export earnings in 2006. Ibid.

206 The Minister reported that while domestic fish production generated 700 million rupees in 2006, fishing vessels calling in the port produced 3.5 billion rupees. The fish processing sector generated a further 6 billion rupees. In total this amounts to US\$250 million, which is a significant amount compared to other sectors of the economy. Speech by Dr. the Hon. Arvin Boolell, Minister of Agro Industry and Fisheries, to the National Assembly on 13 November 2007, presenting the Fisheries \& Marine Resources Bill (Second Reading), available at: http://www.gov.mu/portal/site/moa?content_id=fc3eda1ef2f36110VgnVCM1000000a04a8c0RC RD, visited on 10 January 2008.

${ }^{207}$ Ibid. 
to human, animal and plant life or health in its territory, and thereby to achieve its public health objectives as well as its priorities with regard to the protection of its agricultural industry. On the other hand, the discussion will address the ability of Mauritius to meet the SPS requirements of its trading partners, in order for it to take advantage of new export possibilities, for example in the horticultural and food-processing sectors. This section will therefore proceed to give an overview of the SPS system currently in place in Mauritius.

\subsubsection{Mauritius's SPS system}

\subsubsection{Food-safety system}

Food-safety is gaining importance in Mauritius, due to improvements in the health awareness of its population and the rapid rise in non-transmissible diseases that are linked to poor eating habits. ${ }^{208}$ Therefore there is a new focus on the need to incorporate food-safety measures into the strategy for development of the agro-food industry. ${ }^{209}$ In addition, order to make certain that this emerging industry gains access for its products on foreign markets, the importance of ensuring conformity with international food safety standards has been recognised. ${ }^{210}$

Food safety is primarily the responsibility of the Preventive Branch of the Ministry of Health and Quality of Life of Mauritius, both with regard to imported and domestically produced food. ${ }^{211}$ However, not only the Ministry of Health, but also other ministries are involved in the enforcement of different aspects of food control, leading to overlaps, duplication and gaps in enforcement, as reported by the WHO Regional Office for Africa. ${ }^{212}$

Food safety activities are currently carried out in terms of the Food Act of 1998, ${ }^{213}$ the Food Regulations of 1999 and the Ministry of Health and Quality of Life Guidelines of

${ }^{208}$ In its most recent strategy paper, the Ministry of Agro-Industry and Fisheries has noted the very high rate of lifestyle-related diseases, such as diabetes, hypertension and cardiovascular diseases in Mauritius, which are all, to some extent, linked to eating habits. The need to address the presence of toxins and chemical residues and the fat content in food has been stressed. Ministry of Agro-Industry and Fisheries of the Republic of Mauritius, Strategic Options in Crop Diversification and Livestock Sector 2007-2015 (Consultative Draft) (Republic of Mauritius, Port Louis), August 2007, 115, available at: http://www.areu.mu/files/pub/areunssp. pdf, visited on 10 January 2008.

209 Ibid.

210 Ibid.

${ }^{211}$ In its report regarding the second trade policy review of Mauritius, the WTO Secretariat noted that foodsafety legislation in Mauritius applies equally to imports and locally-produced food. See Trade Policy Review Body, Trade Policy Review: Mauritius - Report by the Secretariat, WT/TPR/S/90, circulated on 5 October 2001, Part III para. 84.

${ }^{212}$ WHO Regional Office for Africa, 'Developing and Maintaining Food Safety Control Systems for Africa - Current Status and Prospects for Change', presented at the FAO/WHO Second Global Forum of Food Safety Regulators, Conference Room Document 32 (Food and Agriculture Organization and World Health Organization, Bangkok, Thailand) 12-14 October 2004, 3, available at: ftp://ftp.fao.org/docrep/fao/meeting/008/ae144e/ae144e00.pdf, visited on 24 June 2008.

213 Trade Policy Review Body, Trade Policy Review: Mauritius - Report by the Secretariat, WT/TPR/S/90, circulated on 5 October 2001, Part III para. 84. See also Southern African Development Community, SADC SPS and Food Safety Issues: An Agenda for Action (SADC Consultative Forum on SPS/Food Safety, Windhoek, Namibia), 20-22 November 2000, 15, available at: www1.worldbank.org/wbiep/trade/Stds_Africa/SADC_ SPS.pdf, visited on 1 February 2001. 
2006. The Food Act of 1998 was passed to update the Food and Drugs Act of 1940 and related legislation, in response to the rapid growth of tourism. Under this new Act, 428 regulations, the Food Regulations of 1999, were promulgated, based on the standards of the Codex Alimentarius Commission. ${ }^{214}$ Both the Food Act of 1998 and the Food Regulations of 1999 came into effect on 1 January 2000. The Health Inspectorate Division of the Ministry of Health has been reinforced and has established more than 494 violations under this legislation over the past two years. ${ }^{215}$

However, as reported by the WHO Regional Office for Africa, the food industry has strongly criticised the new Food Act, arguing that it is too modern for the Mauritian situation, did not involve industry in its drafting and did not allow enough time for compliance. Also, the food industry argues that it introduces requirements that deviate from international standards, making importation of some food products difficult. As a result, a joint committee was established to review and amend the Food Act. ${ }^{216}$ These problems illustrate the difficulties that arise when new food safety requirements, imposed to meet trade needs (either with regard to tourism services or with regard to exports of food products) no longer accord with the capacity of producers on the domestic market.

Mauritius is a net food-importing country. It therefore has a particular interest in the safety of imports of food products. Prior approval by the Ministry of Health is required for the importation of new food and beverage products, and certain chemicals. ${ }^{217} \mathrm{~A}$ permit is issued if it is established that new food products meet Mauritian sanitary requirements.

Food-safety standards are developed by the Mauritius Standards Bureau (MSB), which was established in 1975 under the authority of the Standards Council. Its task is to provide services to the manufacturing and services sectors in the areas of metrology, standards, testing and quality assurance. ${ }^{218}$ Voluntary technical standards are developed by nine Standards Committees, one of which deals with food and agriculture standards (both with regard to food safety and food quality). ${ }^{219}$ When the relevant committee reaches agreement on a draft standard, it is published for public comment. ${ }^{220}$ After comments are

214 The Codex Alimentarius Commission is an international standard setting body in the area of food safety and quality. It is discussed below, Part II, Section 3.2.

${ }^{215}$ Ministry of Health and Quality of Life, Republic of Mauritius, White Paper on Health Sector Development and Reform, December 2002, 56, available at: http://www.gov.mu/portal/goc/moh/file/whitepap.doc, visited on 10 January 2008.

${ }^{216}$ WHO Regional Office for Africa, 'Developing and Maintaining Food Safety Control Systems for Africa - Current Status and Prospects for Change', presented at the FAO/WHO Second Global Forum of Food Safety Regulators, Conference Room Document 32 (Food and Agriculture Organization and World Health Organization, Bangkok, Thailand) 12-14 October 2004, 3, available at: ftp://ftp.fao.org/docrep/fao/meeting/008/ae144e/ae144e00.pdf, visited on 24 June 2008.

217 Trade Policy Review Body, Trade Policy Review: Mauritius - Report by the Secretariat, WT/TPR/S/90, circulated on 5 October 2001, Part III para. 80

218 The Mauritius Standards Bureau is currently a corporate body administered by the Standards Council in terms of the Mauritius Standards Bureau Act of 1993, as amended in 1999. For further information on the MSB see its website, available at: http://msb.intnet.mu/MSB/MSBHome.nsf?Open, visited on 12 January 2008.

${ }^{219}$ See the MSB website, available at: http://msb.intnet.mu/MSB/MSBHome.nsf?Open, visited on 12 January 2008.

220 The period allocated for public comments on draft standards, proposed amendments, withdrawals or revisions of standards was increased from one month to 60 days by the 1999 amendment to the Mauritius Standards Bureau Act of 1993, in Section 18. Trade Policy Review Body, Trade Policy Review: Mauritius 
considered, the draft is submitted for approval to the Standards Council. The standards of the MSB can become mandatory upon publication of a notice to that effect by the Minister of Agro-Industry and Fisheries. ${ }^{221}$

The food-safety requirements of Mauritius are based on the international standards set by the Codex Alimentarius Commission, whenever possible. ${ }^{222}$ Mauritius has very little capacity for carrying out its own risk assessments, as this would require substantial empirical data and scientific expertise. ${ }^{223}$

Inspection of food products for food-safety risks is carried out by officials of the Ministry of Health's Health Inspectorate Division. ${ }^{224}$ These officials must establish whether food products conform to the relevant food-safety requirements. The evaluation of hundreds of new products every year creates a substantial workload for the laboratories of the Ministry of Health. ${ }^{225}$ Food processing establishments are also regularly inspected by the Health Inspectorate Division. ${ }^{226}$

Food-labelling requirements for pre-packaged foods are in place in Mauritius, including the obligation to indicate ingredients, sell-by date and, where necessary, instructions for storage and use. ${ }^{227}$ Food containing preservatives must be labelled as such. ${ }^{228}$ In an effort to curb the high incidence of heart disease in its population, Mauritius applies restrictions to the saturated fatty acid content of animal and vegetable fats and oils. ${ }^{229}$ A certificate

- Report by the Secretariat, WT/TPR/S/90, circulated on 5 October 2001, Section III note 36.

221 Ibid., Section III para. 74.

${ }^{222}$ Vinod Rege et al., Influencing and Meeting International Standards: Challenges for Developing Countries. Volume II: Procedures Followed by Selected International Standard-Setting Organisations and Country Reports on TBT and SPS (International Trade Centre UNCTAD/WTO and Commonwealth Secretariat, Geneva), 2004, 148.

223 Ibid.

${ }^{224}$ Inspection of food products where animal and plant health issues are at stake is carried out by officials of the Ministry of Agriculture. Meat and fish imports are inspected by the Division of Veterinary Services of the Ministry of Agriculture. Ibid.

${ }^{225}$ Doubts have been expressed about the adequacy of this prior approval system to address risks associated with a branded product (such as low-acid canned food) in situations where products marketed under the same brand may be safe when sourced from a particular factory yet unsafe when sourced from another factory. Ibid.

${ }^{226}$ Over the last 2 years, around 43,000 food premises and 10,000 containers of imported foodstuffs have been inspected and about $379,000 \mathrm{~kg}$ of food (such as meat, fish, vegetables, fruits and canned food) have been seized, condemned and destroyed. Ministry of Health and Quality of Life, Republic of Mauritius, White Paper on Health Sector Development and Reform, December 2002, 56, available at: http://www.gov.mu/ portal/goc/moh/file/whitepap.doc, visited on 10 January 2008. See also Southern African Development Community, SADC SPS and Food Safety Issues: An Agenda for Action (SADC Consultative Forum on SPS/ Food Safety, Windhoek, Namibia), 20-22 November 2000, 14, available at: www1.worldbank.org/wbiep/ trade/Stds_Africa/SADC_SPS.pdf, visited on 1 February 2001.

${ }^{227}$ Mauritian Standard MS 30-1984 on the Labelling of Prepackaged Foods, General Notice No. 1058 of 1983.

228 This information is provided in the report of the WTO Secretariat during the second trade policy review of Mauritius in 2001. See Trade Policy Review Body, Trade Policy Review: Mauritius - Report by the Secretariat, WT/TPR/S/90, circulated on 5 October 2001, Part III para. 87.

229 Trade Policy Review Body, Trade Policy Review: Mauritius - Report by the Secretariat WT/TPR/S/198, circulated on 19 March 2008, Part III Table III.7. For example, margarine rich in polyunsaturates (HS 15.17) must contain not less than $45 \%$ of polyunsaturated fats and not more than $25 \%$ of saturated fats on the fat weight basis; and edible mixtures or preparations of animal or vegetable fats or oil or of fractions of different fats or oil (HS 15.17 and 15.18 ) must contain not more than $23 \%$ of saturated fatty acids and not more than $25 \%$ of palm oils. 
of analyses by a recognised authority of the exporting country is required for imports of animal and vegetable fats. ${ }^{230}$

In order to ensure acceptance of its food exports on the markets of its trading partners, Mauritius maintains an export certification system. An exporter must obtain an export permit from the Ministry of Health, which is issued once Ministry officials are satisfied that all requirements of the importing country with regard to the production, processing, packing, labelling and storage of the product have been met. ${ }^{231}$ If an export is subject to SPS requirements, the exporter is obliged to submit a certificate of sanitary and phytosanitary health to the Ministry of Industry, Commerce and International Trade, before the shipment may leave Mauritius. ${ }^{232}$

\subsection{Example of a food-safety measure affecting Mauritian exports - pesticide residue levels}

A weakness of the Mauritian food-safety regime has been the lack of adequate laboratory facilities for the analysis of pesticide residues. ${ }^{233}$ This makes it difficult to establish whether the relevant maximum residue levels for pesticide residues imposed on Mauritian export markets have been met.

This problem is significant in view of the increasingly strict maximum residue limits for pesticides are being imposed, particularly on the EC market which is the main importer of Mauritian fresh produce. ${ }^{234}$ The proposed EC limitation on pesticide residue levels for as many as 100 chemical ingredients at the lowest level of determination has caused much concern. ${ }^{235}$ This would require substantial laboratory capacity in Mauritius, in order to be able to test for all relevant residues at this extremely low level.

Currently, misuse of pesticides is rife among Mauritian farmers. As a result, tropical fruit exports are expected to be dramatically affected, as are processed food products using domestic inputs. ${ }^{236}$

${ }^{230}$ Ibid., Part III para. 70.

231 Southern African Development Community, SADC SPS and Food Safety Issues: An Agenda for Action (SADC Consultative Forum on SPS/Food Safety, Windhoek, Namibia), 20-22 November 2000, 14, available at: www1.worldbank.org/wbiep/trade/Stds_Africa/SADC_SPS.pdf, visited on 1 February 2001.

${ }^{232}$ Ibid.

${ }^{233}$ Ibid., 15. See also Ministry of Agro-Industry and Fisheries of the Republic of Mauritius, Strategic Options in Crop Diversification and Livestock Sector 2007-2015 (Consultative Draft) (Republic of Mauritius, Port Louis), August 2007, 107, available at: http://www.areu.mu/files/pub/areunssp.pdf, visited on 10 January 2008. This report notes that facilities for analysis of food to assess conformity with sanitary requirements in Mauritius 'are almost non-existent' creating significant difficulties for the agro-processing industry. Analyses are currently carried out in foreign laboratories, leading to great expense and delays.

234 Ministry of Agro-Industry and Fisheries of the Republic of Mauritius, Strategic Options in Crop Diversification and Livestock Sector 2007-2015 (Consultative Draft) (Republic of Mauritius, Port Louis), August 2007, 107, available at: http://www.areu.mu/files/pub/areunssp.pdf, visited on 10 January 2008.

${ }_{235}$ Committee on Sanitary and Phytosanitary Measures, The Mauritian Experience with the SPS Agreement from the Indian Ocean Perspective, G/SPS/GEN/526, circulated on 25 October 2004, para. 2.

236 Ministry of Agro-Industry and Fisheries of the Republic of Mauritius, Strategic Options in Crop Diversification and Livestock Sector 2007-2015 (Consultative Draft) (Republic of Mauritius, Port Louis), August 2007, 107, available at: http://www.areu.mu/files/pub/areunssp.pdf, visited on 10 January 2008. 
The Mauritian government has recognized the crucial importance of making sure that the necessary legal framework, analytical capacity and enforcement mechanisms are in place to ensure that food production and processing complies with the requirements of its trading partners. ${ }^{237}$ As existing laboratory facilities under the Ministry of AgroIndustries and Fisheries were inadequate, the Mauritian government has established the Food Technology Laboratory that will be accredited for quality control of agricultural produce. ${ }^{238}$ These and other efforts to help Mauritius to comply with the new pesticide levels are being made with the support of the EC, previously within the context of the Cotonou Agreement. ${ }^{239}$

\subsubsection{Animal health system}

Livestock health is the responsibility of the Ministry of Agro-Industries and Fisheries' Division of Veterinary Services, which has only 21 officers. ${ }^{240}$ Livestock health is still regulated by the Animal Disease Act of 1925 although an amendment to this Act has been in preparation for over ten years. ${ }^{241}$ Fish health falls under the responsibility of the Ministry of Agro-Industries and Fisheries in terms of the Fisheries and Marine Resources Act of 1998.

Animal diseases such as tuberculosis and brucellosis in cattle, Marek's disease in poultry and infectious bursal disease are present in Mauritius but at low incidence levels. A weakness of the current animal health regime is the inadequate flow of information to stakeholders following the outbreak of diseases at local or national level. ${ }^{242}$ This makes disease control more difficult.

Mauritius adopts animal health measures following the guidelines and standards set by the World Health Organisation (OIE) to protect human and animal health in its territory

\footnotetext{
237 Ibid.

${ }^{238}$ Committee on Sanitary and Phytosanitary Measures, The Mauritian Experience with the SPS Agreement from the Indian Ocean Perspective, G/SPS/GEN/526, circulated on 25 October 2004, para. 3. This laboratory tests products destined for both exportation and domestic consumption. It aims to help agro-processors and food exporters to ensure compliance with food-safety export requirements and international standards in a timely manner. It also aims to ensure the safety of food imports into Mauritius. Ministry of Agro-Industry and Fisheries of the Republic of Mauritius, Strategic Options in Crop Diversification and Livestock Sector 2007-2015 (Consultative Draft) (Republic of Mauritius, Port Louis), August 2007, 107, available at: http:// www.areu.mu/files/pub/areunssp.pdf, visited on 10 January 2008.

239 The EC Directorate General for Development has mandated the Liaison Committee Europe-AfricaCaribbean-Pacific (COLEACP) to implement urgently the Pesticide Initiative Programme. An information centre has been created in Brussels and databases developed on existing residue limits and pesticide usage. In addition, the list of chemical ingredients whose tolerance level may be set at the level of determination has been reduced from 450 to 100. Vinod Rege et al., Influencing and Meeting International Standards: Challenges for Developing Countries. Volume II: Procedures Followed by Selected International StandardSetting Organisations and Country Reports on TBT and SPS (International Trade Centre UNCTAD/WTO and Commonwealth Secretariat, Geneva), 2004, 150.

${ }^{240}$ Ibid., 148.

${ }^{241}$ The Veterinary Services (Duties and Powers) Bill has been adopted by Parliament and is awaiting official decree to enter into force. Ibid. See also Trade Policy Review Body, Trade Policy Review: Mauritius - Report by the Secretariat WT/TPR/S/198, circulated on 19 March 2008, Part III para. 66.

${ }^{242}$ Southern African Development Community, SADC SPS and Food Safety Issues: An Agenda for Action (SADC Consultative Forum on SPS/Food Safety, Windhoek, Namibia), 20-22 November 2000, 15, available at: www1.worldbank.org/wbiep/trade/Stds_Africa/SADC_SPS.pdf, visited on 1 February 2001.
} 
from risks in imported animal products. ${ }^{243}$ Live animals, meat, fish and products thereof may only be imported if authorised by an import permit once compliance with OIE standards (where relevant) has been established. ${ }^{244}$ Certification by the relevant authority in the exporting country of compliance with the conditions of the import permit is required. ${ }^{245}$ Quarantine regulations are in place with regard to the importation of live animals. Mauritius bans the importation of animals from countries where diseases of great economic or zoonotic importance prevail. ${ }^{246}$ Currently, Mauritius does not publish the specific standards it adopts in the area of animal health. ${ }^{247}$

As mentioned above, Mauritius relies on a system of import and export permits and certification for the implementation of its SPS regime. This is also the case for animal products. The MSB has conformity assessment procedures in place in terms of which it provides export certification services for producers, including in the area of sanitary and phytosanitary requirements. This assists exporters to prove compliance with SPS requirements on their import markets. The MSB will seek to have all its testing laboratories accredited with the Mauritius Accreditation Service (MAURITAS), the accreditation body for Mauritius. ${ }^{248}$ With regard to imports, Mauritius accepts accreditations and certifications issued under the auspices of the mutual recognition agreements of the International Laboratory Accreditation Cooperation and the International Accreditation Forum.

The main exports of Mauritius in the animal and fishery sector are canned tuna ${ }^{249}$ and live primates $^{250}$ for laboratory use. It also exports small quantities of chicken, smoked marlin and venison. Mauritius applies an export certification system to exports of animals and animal products, which for the most part does not create significant problems..$^{251}$

\footnotetext{
243 Ibid., 14.

244 Trade Policy Review Body, Trade Policy Review: Mauritius - Report by the Secretariat WT/TPR/S/198, circulated on 19 March 2008, Part III para. 70.

245 Ibid.

${ }^{246}$ For example, a ban on the importation of dogs from Africa, Madagascar, Latin America and Asia is in place due to the prevalence of rabies in those areas. See Trade Policy Review Body, Trade Policy Review: Mauritius - Report by the Secretariat, WT/TPR/S/90, circulated on 5 October 2001, Part III para. 82.

${ }^{247}$ Vinod Rege et al., Influencing and Meeting International Standards: Challenges for Developing Countries. Volume II: Procedures Followed by Selected International Standard-Setting Organisations and Country Reports on TBT and SPS (International Trade Centre UNCTAD/WTO and Commonwealth Secretariat, Geneva), 2004, 149.

248 MAURITAS was established in 1998 and is an associate member of the International Laboratory Accreditation Cooperation and a member of the International Accreditation Forum. See Trade Policy Review Body, Trade Policy Review: Mauritius - Report by the Secretariat, WT/TPR/S/90, circulated on 5 October 2001, Part III para. 77.

249 The exports of Mauritius of preserved and prepared fish in 2001 amounted to US\$ 62 million in 2001. This information is reported in the country market analysis profile of Mauritius provided by the International Trade Centre, see www.intracen.org/menus/countries.htm, visited on 25 June 2007.

${ }^{250}$ Export earnings from live animals in 2001 amounted to US\$ 10 million, which accounted for a $2.2 \%$ share of world trade. These animals were destined mainly for the US (34\%) and France (26\%). This information is reported in the country market analysis profile of Mauritius provided by the International Trade Centre, see www.intracen.org/menus/countries.htm, visited on 25 June 2007.

${ }^{251}$ An exception is the case of canned tuna exports to South Africa, discussed below.
} 


\subsection{Examples of animal health measures affecting exports}

Mauritius faces trade barriers in the form of sanitary requirements with regard to its exports of animal and fishery products, some of which have been addressed by bilateral discussions or with the help of technical assistance. ${ }^{252}$ For example, South Africa does not accept the current conformity assessment procedures applied in Mauritius with regard to canned tuna. ${ }^{253}$ Further, the possibility of exporting small quantities of venison and valueadded poultry products to the island of Reunion is prevented by the fact that Reunion applies French law and thus the SPS requirements of the EC. Mauritius is unable to meet $\mathrm{EC}$ requirements with regard to abattoirs and meat processing plants and is thus denied access to the Reunion market. Mauritius also lacks a fish processing plant that is eligible to export smoked marlin to the EU.

To address some of these problems, the Division of Veterinary Services of the Ministry of Agro-Industries and Fisheries, which is the 'competent authority' for issuing export permits in respect of meat and fishery products, has been assisted by two consultants, appointed to help the Division to upgrade its capacity. ${ }^{254}$ The Division is now in a position to submit to the EC new processing establishments for accreditation. As mentioned above, Mauritius also has a new Food Technology Laboratory and is working towards its accreditation. The support from this laboratory is essential for the certification of fish and fish products. ${ }^{255}$ The laboratory monitors fish processing plants for HACCP compliance. ${ }^{256}$ The Minister for Agro-Industry and Fisheries reported recently that three new establishments will soon be in a position to export fish and fish products to the EC. ${ }^{257}$

${ }^{252}$ A ban on day-old chicks from Mauritius was imposed recently by Kenya, due to concerns regarding avian encephalomyelitis. According to Mauritius, Kenya had not conducted a risk assessment, no testing had been done and Kenya had not notified its measure to the WTO. Mauritius requested advice from the Secretariat of the International Office of Epizootics as to the status of avian encephalomyelitis. Although Mauritius considered raising the issue at the following SPS Committee meeting, it did not do so and the matter was resolved bilaterally, with Kenya withdrawing its measure. In addition, canned tuna from Mauritius was denied entry into the South African market due to non-compliance with the food safety standards sets by the South African Bureau of Standards (SABS). The International Trade Centre organised an inspection visit to the Mauritian company involved, to determine whether it could meet the relevant standards and to assist in the negotiation of a technical agreement between the SABS and the corresponding regulatory authority in Mauritius. These examples were reported in Vinod Rege et al., Influencing and Meeting International Standards: Challenges for Developing Countries. Volume II: Procedures Followed by Selected International StandardSetting Organisations and Country Reports on TBT and SPS (International Trade Centre UNCTAD/WTO and Commonwealth Secretariat, Geneva), 2004, 151 and 153.

${ }^{253}$ The technical agreement reached between Mauritius and South Africa with regard to canned tuna specifies that in the short term, South Africa would agree to accept Mauritian canned tuna on the condition that each shipment be inspected and, in the medium term, the Mauritian Department of Veterinary Services would have to be accredited as an inspection body and the food laboratory of the Mauritian Standards Bureau would have to be accredited as a testing laboratory.

${ }^{254}$ Speech by Dr. the Hon. Arvin Boolell, Minister of Agro Industry and Fisheries, to the National Assembly on 13 November 2007, presenting the Fisheries \& Marine Resources Bill (Second Reading), available at: http:// www.gov.mu/portal/site/moa?content_id=fc3eda1ef2f36110VgnVCM1000000a04a8c0RCRD, visited on 10 January 2008.

255 Ibid.

${ }^{256}$ See the page on the Food Technology Laboratory on the website of the Ministry for Agro-Industry and Fisheries, available at: http:/www.gov.mu/portal/site/agroind/menuitem.1a1e1e9713e711c26a7a98ada0208 a0c/?content_id=7fe4cafc3a9dc010VgnVCM1000000a04a8c0RCRD, visited on 12 January 2008.

${ }^{257}$ Speech by Dr. the Hon. Arvin Boolell, Minister of Agro Industry and Fisheries, to the National Assembly on 13 November 2007, presenting the Fisheries \& Marine Resources Bill (Second Reading), available at: http:// 


\subsubsection{Plant health system}

Plant health was the responsibility of the Division of Plant Pathology and Quarantine ${ }^{258}$ of the Ministry of Agro-Industry and Fisheries of Mauritius, under the Plants Act of 1976.259 In order to update this legislation, and to take account of new requirements under the SPS Agreement, ${ }^{260}$ a new Plants Protection Act was adopted in 2006, to replace the dated Plants Act. ${ }^{261}$ The new legislation also confers investigative powers on certain officials, to deal with issues of organic farming and makes provision for plant variety rights. The Plant Protection Act creates a National Plant Protection Office, with responsibility for phytosanitary control in Mauritius. This Act creates the legal and administrative framework necessary to meet Mauritius's international obligations under the IPPC. The NPPO is responsible for issuing phytosanitary export certificates, and may lay down phytosanitary import requirements. ${ }^{262}$ In addition, a new legislative proposal regarding seed quality control, marketing, export and import and the necessary institutional framework is being prepared. $^{263}$

Mauritius applies a well-developed system of border controls to protect plant health in its territory against phytosanitary risks from imported products. ${ }^{264}$ Prior to the importation of plant and plant products, a permit is required from the NPPO ${ }^{265}$ Imports must be accompanied by a certificate by the relevant authority in the country of origin, attesting conformity with the conditions on the import permit. ${ }^{266}$

These controls are supported by facilities such as glasshouses for post-entry plant quarantine. Its border control system for the prevention of entry of exotic pests and diseases at its

www.gov.mu/portal/site/moa?content_id=fc3eda1ef2f36110VgnVCM1000000a04a8c0RCRD, visited on 10 January 2008.

${ }^{258}$ This division has 53 staff members.

259 Vinod Rege et al., Influencing and Meeting International Standards: Challenges for Developing Countries. Volume II: Procedures Followed by Selected International Standard-Setting Organisations and Country Reports on TBT and SPS (International Trade Centre UNCTAD/WTO and Commonwealth Secretariat, Geneva), 2004, 148. See also Trade Policy Review Body, Trade Policy Review: Mauritius - Report by the Secretariat, WT/TPR/S/90, circulated on 5 October 2001, Part III para 84.

${ }^{260}$ These requirements are discussed in detail in Parts III-IV of this book.

261 Trade Policy Review Body, Trade Policy Review: Mauritius - Report by the Secretariat WT/TPR/S/198, circulated on 19 March 2008, Part III para. 66.

${ }^{262}$ Ibid., Part III para. 67.] Plant products that do not comply with phytosanitary requirements or are infested with pests may be seized or destroyed.

${ }^{263}$ These developments are reported in Vinod Rege et al., Influencing and Meeting International Standards: Challenges for Developing Countries. Volume II: Procedures Followed by Selected International StandardSetting Organisations and Country Reports on TBT and SPS (International Trade Centre UNCTAD/WTO and Commonwealth Secretariat, Geneva), 2004, 148. See also Trade Policy Review Body, Trade Policy Review: Mauritius - Report by the Secretariat WT/TPR/S/198, circulated on 19 March 2008, Part III para. 66.

${ }^{264}$ Vinod Rege et al., Influencing and Meeting International Standards: Challenges for Developing Countries. Volume II: Procedures Followed by Selected International Standard-Setting Organisations and Country Reports on TBT and SPS (International Trade Centre UNCTAD/WTO and Commonwealth Secretariat, Geneva), 2004, 149.

265 Trade Policy Review Body, Trade Policy Review: Mauritius - Report by the Secretariat WT/TPR/S/198, circulated on 19 March 2008, Part III para. 68.

${ }^{266}$ Such certificate must be issued, after inspection of the products, not more than 14 days before dispatch of the shipment. See the report of the WTO Secretariat during the second trade policy review of Mauritius in 2001. Ibid. 
port and airport is well developed and adequately resourced. ${ }^{267}$ Imported seeds are tested by means of germination under quarantine control. All ships that arrive in Mauritius are inspected for quarantine pests. In addition, ship containers that contain plant or animal products are examined by inspectors at the port, responsible for both animal and plant health inspections. ${ }^{268}$ Adequate facilities for post-arrival fumigation of consignments with phosphine gas or methyl bromide exist. ${ }^{269}$ Quarantine procedures are also carried out at the airport, including the spraying of cargo holds of incoming aircraft. An incinerator for quarantine waste is available at the airport. In exceptional cases, luggage is X-rayed on arrival to detect quarantine risk materials. A light-trapping device near the airport exists in order to detect exotic pests that may have come in with incoming aircraft. ${ }^{270}$

Mauritius follows the international phytosanitary standards set by the IPPC where possible. However, few international standards exist in the areas of plant health that are of relevance to Mauritius. ${ }^{271}$ In addition the specific phytosanitary controls appropriate in a particular situation depend on the pest and disease status of the exporting and importing country and the conditions prevailing in each. ${ }^{272}$ As a result, Mauritian phytosanitary measures are often not in conformity with international standards. Mauritius lacks the capacity to undertake detailed scientific risk assessments to support each of its phytosanitary measures, as a result of which Mauritian phytosanitary measures are largely vulnerable to challenge under the rules of the SPS Agreement. ${ }^{273}$

As mentioned above, the Mauritian economy is heavily dependant on sugar exports. The phytosanitary regime of Mauritius therefore focuses on protecting sugar cane against pests and diseases. Special protocols exist aimed at reducing the risk of entry of sugar cane white grub to extremely low levels. For example, during the season when the sugar cane grub is in its moth stage (November-January), ships from Reunion may not enter a Mauritian port unless it left Reunion during the daytime, when its lights would not have attracted the moths. The decks of such ships may be treated with insecticides if deemed necessary. All yachts from Reunion are subjected to quarantine inspection during the flight season of the sugar cane white grub. ${ }^{274}$

\footnotetext{
${ }^{267}$ Vinod Rege et al., Influencing and Meeting International Standards: Challenges for Developing Countries. Volume II: Procedures Followed by Selected International Standard-Setting Organisations and Country Reports on TBT and SPS (International Trade Centre UNCTAD/WTO and Commonwealth Secretariat, Geneva), 2004, 149.

${ }^{268}$ Ibid., 150.

269 Ibid.

270 Ibid.

271 Ibid., 149.

272 Ibid.

273 The rules of the SPS Agreement requiring that SPS measures that do not conform to international standards be based on a risk assessment are discussed below, Part III, Section 4.2.3. Note, however, that to date no challenges have been made to Mauritius's SPS measures, whether in formal dispute settlement procedures or through raising trade concerns at meetings of the SPS Committee.

${ }^{274}$ Vinod Rege et al., Influencing and Meeting International Standards: Challenges for Developing Countries. Volume II: Procedures Followed by Selected International Standard-Setting Organisations and Country Reports on TBT and SPS (International Trade Centre UNCTAD/WTO and Commonwealth Secretariat, Geneva), 2004, 149.
} 
Despite the well-developed system of phytosanitary controls in Mauritius, there have been some cases of entry and establishment of plant pests and diseases. ${ }^{275}$ For example, the Peach fruit fly (Bactrocera zonata) was detected in 1987 and is now established and a serious pest in Mauritius. Another fruit fly (Carpomya vesuviana) was detected in 1986 and is now established. In 1996, an infestation of Oriental fruit fly (Bactrocera dorsalis) was detected, which was presumably caused by some kind of quarantine failure. ${ }^{276}$ It was successfully eradicated at very high cost in 1999. To avoid its reintroduction, in 2003 Mauritius imposed an emergency measure temporarily banning the importation of fruits and vegetables from Kenya, following information of a detection of fruit fly on the Kenyan coastal region. ${ }^{277}$ Recently, two species of white fly have become established in Mauritius. $^{278}$

With regard to its current exports of plants and plant products, Mauritius has a well-functioning export certification system in place to assess conformity with the phytosanitary requirements on its export markets. ${ }^{279}$ This certification system is generally accepted by its trading partners. However, it still faces certain barriers to its exports in the form of phytosanitary requirements.

\subsection{Examples of phytosanitary measures affecting exports}

Mauritian horticultural exports are occasionally rejected due to the detection of plant pests, or are subject to burdensome phytosanitary measures. For example, Japan requires that flowers from Mauritius be fumigated and Reunion bans chillies from Mauritius due to concerns regarding Oriental fruit fly, despite the fact that this pest has already been eradicated in Mauritius. ${ }^{280}$

Another phytosanitary issue of concern to Mauritian exporters is the IPPC's international standard ISPM 15, which lays down guidelines for regulating wood packaging material in international trade, in order to avoid the risk of introduction of pests through wood packaging. Mauritius does not have the capacity to set up the required heat-treatment plant for wood packaging material. The methyl bromide quarantine treatment currently in use in Mauritius is unable to deal with the large volumes of wood materials and pallets used

${ }^{275}$ These examples were reported in the ITC/Commonwealth Secretariat report cited above. Ibid., 150.

${ }^{276}$ Ibid., 149.

277 Committee on Sanitary and Phytosanitary Measures, Notification of Emergency Measures, G/SPS/N/ MUS/11, circulated on 3 December 2003.

278 Vinod Rege et al., Influencing and Meeting International Standards: Challenges for Developing Countries. Volume II: Procedures Followed by Selected International Standard-Setting Organisations and Country Reports on TBT and SPS (International Trade Centre UNCTAD/WTO and Commonwealth Secretariat, Geneva), 2004, 149.

${ }^{279}$ For example, anthurium growers and exporters are expected to register their nurseries with the NPPO so that the phytosanitary status of their nurseries may be regularly monitored in conformity with agreements made with the phytosanitary authority of the importing countries regarding phytosanitary certification of cut flowers. See the website of the National Plant Protection Office, available at: http:/www.gov.mu/portal/site/ agroind/menuitem.1a1e1e9713e711c26a7a98ada0208a0c/?content_id=2d5a5533c1adc010VgnVCM100000 0a04a8c0RCRD, visited on 12 January 2008.

${ }^{280}$ Vinod Rege et al., Influencing and Meeting International Standards: Challenges for Developing Countries. Volume II: Procedures Followed by Selected International Standard-Setting Organisations and Country Reports on TBT and SPS (International Trade Centre UNCTAD/WTO and Commonwealth Secretariat, Geneva), 2004, 150. 
to package exported products. Mauritius has raised concerns in the SPS Committee that pressure from ISPM-compliant countries threatens its export market. ${ }^{281}$ It has therefore recently sought, through the WTO Secretariat, the granting to it by the IPPC secretariat of a four-year moratorium for the implementation of ISPM 15. Mauritius has already taken steps towards setting up a heat-treatment facility, but proposes to use phosphine fumigation in the meantime, recognised by the IPPC as a possible alternative to heat treatment. ${ }^{282}$

\subsubsection{Overall assessment of the SPS system of Mauritius}

As noted above, Mauritius would like to diversify its agricultural export trade to fruit, vegetables and other horticultural products, thereby reducing its dependence on sugar for export earnings. This would require the development of its phytosanitary regime to enable it to manage risks from the manifold of pests and diseases that form a potential threat to this sector, while avoiding heavy use of pesticides that would affect the acceptability of its products on export markets. Mauritian authorities would have to draw up an adequate plant pest list based on sufficient data from monitoring and surveillance and extend the export certification system to this broad range of products. This is currently not within the capabilities of Mauritius. ${ }^{283}$ Currently, misuse of pesticides and inadequate sanitary controls are restricting the ability of Mauritius to achieve its ambition to become a food and fish processing hub and in the region. For this reason, it is important that the new Food Technology Laboratory of Mauritius have the capacity to test for a wide range of contaminants and for pesticide residues at very low levels. In addition, effective monitoring of HACCP implementation and other SPS requirements on export markets is essential.

Some shortcomings identified with regard to Mauritian SPS controls are the absence of an incinerator for quarantine risk material at the port, the inadequate coordination of the light-trapping device at the airport and the absence of such a device at the port. ${ }^{284}$ In addition, Mauritius does not conduct detailed and comprehensive risk assessments to support its phytosanitary measures where no international standards exist. ${ }^{285}$

The government of Mauritius has recognized the vital importance of developing good tools for diagnosis of phytosanitary pests and diseases, to make early action possible. ${ }^{286}$ The NPPO aims to upgrade its inspection system protocol and to develop a manual for officers enforcing phytosanitary measures at ports of entry. Additionally, it intends to review its list of quarantine pests and diseases and to draft regulations necessary to imple-

281 Committee on Sanitary and Phytosanitary Measures, Implementation of International Standards. Communication by Mauritius, G/SPS/GEN/547, circulated on 2 March 2005.

282 Ibid., para. 3.

${ }^{283}$ Vinod Rege et al., Influencing and Meeting International Standards: Challenges for Developing Countries. Volume II: Procedures Followed by Selected International Standard-Setting Organisations and Country Reports on TBT and SPS (International Trade Centre UNCTAD/WTO and Commonwealth Secretariat, Geneva), 2004, 150.

${ }^{284}$ Ibid.

${ }^{285}$ Ibid., 149.

${ }^{286}$ Ministry of Agriculture Food Technology \& Natural Resources of the Republic of Mauritius, A Sustained Programme for Agricultural Diversification: A Non-Sugar Sector Strategic Plan 2003-2007 (Republic of Mauritius, Port Louis), 2003, 58, available at: http://www.gov.mu/portal/sites/moasite/download/nsssplan. pdf, visited on 11 January 2008. 
ment the Plant Protection Act of $2006 .{ }^{287}$ In addition, Mauritius has recognised the need to establish an independent food-safety authority with greater capacity for sanitary control. ${ }^{288}$ Also, in light of its strategy to overcome its own constraints in the production of agricultural products by sourcing inputs from countries in the region and focusing on developing its comparative advantage as a processing hub for fish and agricultural products, Mauritius must promote regional cooperation on SPS matters. ${ }^{289}$ Such cooperation would ensure that the inputs it uses in its processing activities meet the SPS requirements of its export markets.

In general, Mauritius has very little capacity to conduct risk analyses with respect to the SPS measures it adopts in the absence of relevant international standards. It lacks the substantial empirical data necessary to undertake such analyses and the requisite professional expertise. For this reason, it is of particular importance to Mauritius that international SPS standards be set in areas of relevance to it and that such standards reflect its capabilities and concerns.

\subsection{Jamaica}

\subsubsection{Factual background}

Jamaica is a 'small-island developing state' in the Caribbean Sea, south of Cuba. ${ }^{290}$ It gained independence from the UK in 1962. The following indicators are useful in situating Jamaica within the spectrum of levels of human and economic development.

\subsubsection{Development indicators}

Jamaica's GNI per capita in 2006 was US $\$ 3,480 .{ }^{291}$ It is therefore classified by the World Bank as a lower-middle-income economy. ${ }^{292}$ Jamaica had a GDP of US\$10.5 billion in $2006 .{ }^{293}$ Its GDP in 2005 at purchasing power parity was US\$11.4 billion and its per capita GDP at purchasing power parity in that year was US\$4,291.294

${ }^{287} \mathrm{Ibid}$.

${ }^{288}$ Ibid., 121.

${ }^{289} \mathrm{Ibid}$. Areas of cooperation mentioned in this paper are capacity building, and the harmonisation of standards and procedures.

${ }^{290}$ For more information on the UN classification of 'small-island developing states and territories', see above, Part II, Section 2.5.1, note 407.

${ }^{291}$ See the World Bank webpage on Key Development Data \& Statistics of 2006 available at:, http://web.worldbank.org/WBSITE/EXTERNAL/DATASTATISTICS/0,,contentMDK:20535285 menuPK:1192694 pageP K:64133150 piPK:64133175 theSitePK:239419,00.html visited on 9 January 2008.

${ }^{292}$ See the World Bank classification of economies by income of July 2007 available at: http://siteresources. worldbank.org/DATASTATISTICS/Resources/CLASS.XLS, visited on 9 January 2008.

${ }^{293}$ See the World Bank webpage on Key Development Data \& Statistics of 2006 available at:, http://web.worldbank.org/WBSITE/EXTERNAL/DATASTATISTICS/0,,contentMDK:20535285 menuPK:1192694 pageP K:64133150 piPK:64133175 theSitePK:239419,00.html visited on 9 January 2008.

${ }^{294}$ United Nations Development Programme, Human Development Report 2007/2008. Fighting Climate Change: Human Solidarity in a Divided World (Palgrave Macmillan, New York), 2007, 278, available at: http://hdr.undp.org/en/media/hdr_20072008_en_complete.pdf, visited on 10 December 2007. 
Jamaica is ranked $101^{\text {st }}$ in the UN Human Development Index of 2007, and falls into the category of medium-human-development countries. ${ }^{295}$ Jamaica's population was 2.7 million in $2006,{ }^{296} 14.4$ percent of which lives below the US $\$ 2$ per day poverty line. ${ }^{297}$ While Jamaica made significant advances in poverty alleviation between 1988 and 2002, rural poverty remains a serious problem. ${ }^{298}$

\subsubsection{Health priorities}

Jamaica's public health priorities, and therefore the relative importance of SPS regulation as an area of public spending can be understood against the following factual background. Jamaica spends 2.8 percent of its GDP on public health, which amounts to US\$223 per capita at purchasing power parity. ${ }^{299}$ Life expectancy at birth is 72 years, ${ }^{300}$ reduced from 75 years due to problems of violence and HIV/AIDS. ${ }^{301}$ The prevalence of tuberculosis in Jamaica is 10 cases per 100,000 people. ${ }^{302}$ The infant mortality rate in Jamaica is 17 per 1000 births. ${ }^{303}$ Merely twenty-one percent of children under five with diarrhoea receive oral hydration and continued feeding. ${ }^{304}$ Jamaica has only 85 physicians per 100000 people. ${ }^{305}$

In Jamaica 80 percent of the population has sustainable access to improved sanitation and 93 percent to clean water. ${ }^{306}$ Nine percent of the population is undernourished..$^{307}$

295 Ibid., 262.

${ }^{296}$ See the World Bank webpage on Key Development Data \& Statistics of 2006 available at: http://web.worldbank.org/WBSITE/EXTERNAL/DATASTATISTICS/0,,contentMDK:20535285 menuPK:1192694 pageP K:64133150 piPK:64133175 theSitePK:239419,00.html visited on 9 January 2008.

297 United Nations Development Programme, Human Development Report 2007/2008. Fighting Climate Change: Human Solidarity in a Divided World (Palgrave Macmillan, New York), 2007, 239, available at: http://hdr.undp.org/en/media/hdr_20072008_en_complete.pdf, visited on 10 December 2007. If one measures poverty as the percentage of people living on less than US\$1 per day, less than $2 \%$ of Jamaica's population lives below the poverty line.

298 Spencer Henson and Steve Jaffee, Jamaica's Trade in Ethnic Foods and Other Niche Products: The Impact of Food Safety and Plant Health Standards, Agriculture and Rural Development Discussion Paper (World Bank, Washington D.C.), 2005, 4, available at: http://siteresources.worldbank.org/INTARD/Resources/ JamaicaStandardsF_final.pdf, visited on 7 January 2008. This report notes that the poverty headcount declined from $30.5 \%$ in 1988 to $19.9 \%$ in 1997 and by 2002 had stabilized in the upper teens. However, in rural areas poverty was still at $24.1 \%$ (in 2001), with high and persistent rates of extreme poverty.

299 United Nations Development Programme, Human Development Report 2007/2008. Fighting Climate Change: Human Solidarity in a Divided World (Palgrave Macmillan, New York), 2007, 248, available at: http://hdr.undp.org/en/media/hdr_20072008_en_complete.pdf, visited on 10 December 2007.

${ }^{300}$ Ibid., 262.

301 The Minister of Health of Jamaica stated in 2006 that the total number of AIDS cases reported in Jamaica since the start of the epidemic in 1982 was 9,682, and the total number of AIDS deaths was 6,032. An estimated 25,000 HIV infected persons live in Jamaica. HIV/AIDS is the second leading cause of death in the 30-34 year age group. This was stated in the policy speech by the Jamaican Minister of Health in September 2006, during the Sectoral Debate session, available at: http://www.moh.gov.jm/Sectoral_Debate_20061.pdf, visited on 28 December 2007.

302 United Nations Development Programme, Human Development Report 2007/2008. Fighting Climate Change: Human Solidarity in a Divided World (Palgrave Macmillan, New York), 2007, 258, available at: http://hdr.undp.org/en/media/hdr_20072008_en_complete.pdf, visited on 10 December 2007.

${ }^{303}$ Ibid., 262.

${ }^{304}$ Ibid., 248.

305 Ibid.

${ }^{306}$ Ibid., 252.

${ }^{307}$ Ibid. 
The public health strategy, outlined in the National Strategic Plan for 2006-2010, ${ }^{308}$ aims at refocusing on primary health care, particularly with regard to maternal and child health, and addressing the challenges posed by violence and HIV/AIDS.$^{309}$ An additional priority is the implementation of the Healthy Lifestyle Policy, promulgated in 2004, to control the incidences of life-style related, chronic, non-communicable diseases (such as diabetes). ${ }^{310}$

\subsubsection{Trade priorities}

Jamaica became a GATT Contracting Party in 1963, before which it applied the GATT de facto as a territory of the UK. It became an original Member of the WTO on 9 March 1995. Jamaica bound all its tariff lines in the Uruguay Round negotiations and made commitments in various service sectors.

It is useful to look at Jamaica's trade interests to determine the importance of exports for its economy. Exports of goods and services accounted for 43.6 percent of GDP in Jamaica in 2006. ${ }^{311}$ The trade-to-GDP ration in Jamaica in $2004-2006$ was 105.4. ${ }^{312}$ The service sector, especially the tourism industry, is the main foreign revenue earner in Jamaica and continues to increase in importance. ${ }^{313}$ In recent years Jamaica has seen a decline in its exports of goods overall. However, in 2006, exports of primary products have risen to 90.2 percent of its total merchandise exports ( 75.7 percent is made up of mining products and the remaining 15.5 percent is made up of agricultural products) thus making Jamaica even more dependent on primary commodities for foreign revenue earnings in the merchandise sector. ${ }^{314}$

Much of Jamaica's trade occurs in the context of preferential trade arrangements. Jamaica is a member of the group of ACP countries with which the EU had, until 31 December

308 The Ministry of Health of Jamaica has a five year strategic planning cycle. The National Strategic Plan for 2006-2010 took effect in April 2006. This information can be found on the Ministry of Health's website, available at: http://www.moh.gov.jm, visited on 28 December 2007.

309 These priorities were identified in the policy speech by the Minister of Health in September 2006, available at: http://www.moh.gov.jm/Sectoral_Debate_20061.pdf, visited on 28 December 2007.

310 Ibid.

311 See the statistics in the World Bank's country profile for Jamaica, available at: http://www.worldbank.org/ data/countrydata/countrydata.html, visited on 28 December 2007. According to the World Bank, in this calculation 'Exports of goods and services represent the value of all goods and other market services provided to the rest of the world. They include the value of merchandise, freight, insurance, transport, travel, royalties, license fees, and other services, such as communication, construction, financial, information, business, personal, and government services. They exclude labour and property income (formerly called factor services) as well as transfer payments.'

${ }^{312}$ WTO Secretariat, Trade Profiles 2007 (World Trade Organization, Geneva), October 2007, 88, available at: http://www.wto.org/english/res_e/booksp_e/anrep_e/trade_profiles07_e.pdf, visited on 8 January 2008. This indicates the significance of trade to Jamaica's economy.

${ }^{313}$ Tourism alone accounts for as much in foreign exchange earnings as do all merchandise exports combined. The service industry employs about three quarters of Jamaica's labour force. Trade Policy Review Body, Trade Policy Review: Jamaica - Report by the Secretariat. Revision, WT/TPR/S/139/Rev.1, circulated on 9 March 2005, Table I.5 and Section IV para. 75.

314 WTO Secretariat, Trade Profiles 2007 (World Trade Organization, Geneva), October 2007, 88, available at: http://www.wto.org/english/res_e/booksp_e/anrep_e/trade_profiles07_e.pdf, visited on 8 January 2008. Exports of manufactured goods have decreased significantly (from $23.7 \%$ in 1998 to $9.8 \%$ in 2002) mainly due to a sharp decrease in exports of clothing to the US. Trade Policy Review Body, Trade Policy Review: Jamaica - Report by the Secretariat. Revision, WT/TPR/S/139/Rev.1, circulated on 9 March 2005, Section I paras 3 and 37. 
2007, a non-reciprocal preferential trade agreement, the Cotonou Agreement. ${ }^{315}$ Jamaica relied upon the preferential treatment provided under the Cotonou Agreement for much of its agricultural trade, as set out below. As noted above, due to the expiry of the WTO waiver for this preferential arrangement on 31 December 2007, negotiations have been undertaken to replace the Cotonou Agreement with EPAs between the EC and six different groups of ACP countries. ${ }^{316}$ One of those EPAs is the EPA between the EC and a group of 15 Caribbean countries including Jamaica. ${ }^{317}$ Under this EPA, Jamaica still benefits from duty-free and quota-free market access for most of its exports to the EU, including bananas and other agricultural products. However, sugar is subject to a special transitional regime which only provides tariff-free access to sugar within specified quota limits during a transitional period ending in 2009 , after which a safeguard mechanism is in effect until 2012. ${ }^{318}$ Preferential access to the US market is enjoyed by Jamaica under the Caribbean Basin Initiative. In addition, under the Caribbean - Canada Trade Agreement (CARIBCAN) programme, Jamaica has preferential access to the Canadian market (together with other Commonwealth Caribbean countries). The largest market for Jamaican exports is currently the EU, followed by the US and Canada. ${ }^{319}$ Jamaica, as a member of

315 Partnership Agreement between the Members of the African, Caribbean and Pacific Group of States of the One Part and the European Community and Its Member States, of the Other Part, signed in Cotonou, Benin, on 23 June 2000 (the Cotonou Agreement). The Cotonou Agreement, which replaced the successive Lomé Conventions between the EU and the ACP states, provides zero customs duties to almost all industrial products and lower than normal customs duties to agricultural products from ACP countries (Art. 1 of Annex V). Special regimes for bananas and sugar are established in the Banana Protocol and Sugar Protocol to the Cotonou Agreement.

${ }^{316}$ For more details on the EPAs and the reform of the EC sugar regime, see above, Part II, Section 2.5.1.3.

317 On 16 December 2007 the European Commission initialled the Economic Partnership Agreement with the 15 'Cariforum' countries, i.e. the forum of Caribbean ACP states, bringing together the CARICOM member states except Montserrat (Antigua and Barbuda, Bahamas, Barbados, Belize, Dominica, Grenada, Guyana, Haiti, Jamaica, Saint Lucia, Saint Vincent and the Grenadines, Saint Kitts and Nevis, Surinam, and Trinidad and Tobago) and the Dominican Republic. This was the only comprehensive EPA initialled to date (i.e. unlike the interim EPAs initialled with the other groups of ACP countries, which cover only trade in goods, this comprehensive EPA covers a broad range of areas, including trade in services, investment, government procurement and intellectual property protection). Agricultural and processed agricultural products are excluded from liberalisation obligations of the Cariforum countries under this EPA. The EPA contains provisions regarding the regional harmonisation of SPS regulations. See European Commission, Directorate General for Trade, 'Update: Interim Economic Partnership Agreements', Trade Policy in Practice, 19 December 2007, available at: http://rade.ec.europa.eu/doclib/docs/2007/november/tradoc 136959.pdf, visited on 21 December 2007. See also European Commission, Directorate General for Trade, Note on the State of Play in the EPAs Negotiations, Brussels, 20 December 2007, available at: http://trade.ec.europa.eu/doclib/docs/2007/ december/tradoc_137364.pdf, visited on 22 December 2007.

318 European Commission, Directorate General for Trade, Economic Partnership Agreements: Questions and Answers, Brussels, 2 October 2007, available at: http://trade.ec.europa.eu/doclib/docs/2007/october/tradoc_136230.pdf, visited on 21 December 2007.

319 The EU absorbed around $32.6 \%$ of Jamaican exports, the US $28.2 \%$ and Canada $14.1 \%$ in 2002 . Trade with Latin America, China and Japan is on the increase. Trade Policy Review Body, Trade Policy Review: Jamaica - Report by the Secretariat. Revision, WT/TPR/S/139/Rev.1, circulated on 9 March 2005, Chart I.2. See also Eurostep et al., New ACP-EU Trade Arrangements: New Barriers to Eradicating Poverty? (Eurostep, Brussels), March 2004, 19, available at: www.eurostep.org/pubs/trade_study.pdf, visited on 25 June 2007. 
the Caribbean Community (CARICOM), also enjoys preferential access to the markets of the other 14 members. ${ }^{320}$ However, trade with CARICOM countries remains limited. ${ }^{321}$

As discussed further below, the erosion of trade preferences, particularly with regard to sugar and bananas, due to progressive liberalisation of trade at the multilateral level and due to reforms in the EU trade and support regimes for sugar and bananas, is creating challenges for Jamaica, since these Jamaican products are not competitive on the world market. ${ }^{322}$

The fact that much of its trade occurs under preferential agreements, is reflected in the nature of Jamaica's participation in the multilateral trading system. It has made several negotiating proposals in the Doha Development Round, including in the area of agriculture, focusing on its concerns regarding preference erosion following tariff reductions with regard to agricultural products, and on securing exemptions from tariff reductions for a percentage of developing country export commodities. ${ }^{323}$ In the negotiating proposal of the CARICOM countries, the fact that the majority of agricultural exports, employment and investment resources are oriented towards the production of agricultural products benefiting from preferential arrangements is highlighted, to indicate the problems from preference erosion. ${ }^{324}$ At the same time, it is noted that, while significantly smaller, the proportion of exports of value-added and processed agricultural products is growing rapidly. Such trade occurs on non-preferential terms and is therefore not directly affected by preference erosion. ${ }^{325}$ Jamaica is an active advocate of special and differential treatment for developing countries at the WTO and has proposed that special status be granted to small-island developing countries within the WTO regime on SDT. ${ }^{326}$ In addition, the

320 The Treaty Establishing the Caribbean Community (CARICOM) was signed in Chaguaramas, on 4 July 1973. The Caribbean Community comprises a customs union between 15 Caribbean countries, namely Antigua and Barbuda, Bahamas, Barbados, Belize, Dominica, Grenada, Guyana, Haiti, Jamaica, Montserrat, Saint Kitts and Nevis, Saint Lucia, Saint Vincent and the Grenadines, Suriname, and Trinidad and Tobago. In 2002, the Revised Treaty of Chaguaramas Establishing the Caribbean Community, Including the CARICOM Single Market and Economy was signed, establishing the CARICOM Single Market and Economy, according to which most trade restrictions between member countries were to be removed by 2005. CARICOM has 15 members,. See Trade Policy Review Body, Trade Policy Review: Jamaica - Report by the Secretariat. Revision, WT/TPR/S/139/Rev.1, circulated on 9 March 2005, Section II para.56. See also the website of CARICOM, available at www.caricom.org, visited on 8 January 2008.

${ }^{321}$ Ibid., Section 1 para. 42.

322 Trade Policy Review Body, Trade Policy Review: Jamaica - Report by the Secretariat, WT/TPR/S/139, circulated on 11 October 2004, Section II para. 5; Vinod Rege et al., Influencing and Meeting International Standards: Challenges for Developing Countries. Volume II: Procedures Followed by Selected International Standard-Setting Organisations and Country Reports on TBT and SPS (International Trade Centre UNCTAD/ WTO and Commonwealth Secretariat, Geneva), 2004, 110. The latter report notes that Jamaican banana exports declined by $34 \%$ between 1996 and 2000 .

${ }^{323}$ See WTO documents TN/AG/R/6, circulated on 21 February 2003, TN/AG/R/8, circulated on 18 July 2003, and TN/AG/9, circulated on 25 August 2003. According to Jamaica, an essential element of special and differential provisions for developing countries must be the creation of a special safeguard mechanism for developing countries, in view of their food security and genuine non-trade concerns. See General Council, Preparations for the 1999 Ministerial Conference - Agreement on Agriculture, WT/GC/W/370, circulated on 13 October 1999.

${ }^{324}$ Committee on Agriculture, WTO Negotiations on Agriculture - Market Access. Negotiating Proposal on Behalf of Members of the Caribbean Community (CARICOM), G/AG/NG/W/100, circulated on 15 January 2001.

325 Ibid.

${ }^{326}$ FAO Commodities and Trade Division, Agriculture, Trade and Food Security: Issues and Options in the 
preservation of policy space to pursue development objectives has been identified by Jamaica as one of its goals in the Doha Development Round negotiations. ${ }^{327}$ In particular, it has noted that as trade rules increasingly encompass behind-the-border measures, it seeks to ensure that sufficient room is provided for developing countries to pursue their development goals. ${ }^{328}$

Jamaica has never initiated a WTO dispute, nor has it been challenged in WTO dispute settlement proceedings. It has, however, acted as a third party in eight disputes, which mainly concerned measures affecting its preferential access to agricultural markets. ${ }^{329}$ In addition, it joined consultations between other WTO Members in one further dispute that did not proceed to a panel. ${ }^{330}$ In the context of the Doha Development Round negotiations on the reform of the dispute settlement system, Jamaica has made proposals on SDT for developing countries. ${ }^{331}$

\subsubsection{Significance of agricultural sector}

The role played by the food and agricultural sector in Jamaica's economy provides an indication of the importance of the SPS Agreement in improving market access for its exports in this sector.

Agriculture is an important sector of the Jamaican economy, but has been overtaken in significance by the services industry. ${ }^{332}$ Agriculture accounted for only 5.9 percent of GDP in $2006^{333}$ (or 13.8 percent if processed agricultural products are included). ${ }^{334}$ However,

WTO Negotiations from the Perspective of Developing Countries. Volume II: Country Case Studies (Food and Agriculture Organization, Geneva), 2000, Chapter 1, Section 4, available at: www.fao.org/docrep/003/ X8731e/X8731e00.htm, visited on 7 January 2008.

327 Trade Policy Review Body, Trade Policy Review: Jamaica - Report by the Government, WT/TPR/G/139, circulated on 15 December 2004, 37.

${ }^{328}$ Trade Policy Review Body, para. 6.2.

329 The list of disputes in which Jamaica was a third party is found on the page for Jamaica on the WTO website, available at: http://www.wto.org/english/thewto_e/countries_e/jamaica_e.htm, visited on 25 January 2008. One of these is the previously mentioned Mexico - Corn Syrup dispute, where Jamaica made a joint statement with Mauritius expressing their concerns regarding the impact of the outcome of this dispute on their sugar trade. See further above, Part II, Section 2.5.1.3.

${ }^{330}$ United States - Section 306 of the Trade Act of 1974 and Amendments Thereto. Request to Join Consultations, WT/DS200/3, circulated on 22 June 2000.

${ }^{331}$ See Jamaica's proposal on SDT contained in WTO document TN/DS/W/21, circulated on 10 October 2002; as well as the joint proposal in which Jamaica participated, contained in WTO document TN/DS/W/47, circulated on 11 February 2003. Jamaica also made a proposal concerning the right of a Member to determine the composition of its delegation in dispute settlement proceedings in WTO document TN/DS/W/44, circulated on 11 February 2003.

${ }^{332}$ The service industry is currently the largest employer in Jamaica, employing $60 \%$ of the economically active population. Technical Centre for Agricultural and Rural Cooperation ACP-EU, Study of the Consequences of the Application of Sanitary and Phytosanitary (SPS) Measures on ACP Countries (CTA, Wageningen), May 2003, 26, available at: http://www.tcd.ie/iiis/policycoherence/index.php/iiis/content/download/371/1446/ file/CTA $\% 20$ Impact $\% 20$ of $\% 20$ SPS $\% 20$ Measures $\% 20$ on $\% 20$ ACP $\% 20$ countries.pdf., visited on 23 January 2008.

${ }^{333}$ See the World Bank, Countries at a Glance table for Jamaica, available at: http://devdata.worldbank.org/ AAG/jam_aag.pdf, visited on 9 January 2008.

334 Trade Policy Review Body, Trade Policy Review: Jamaica - Report by the Secretariat. Revision, WT/ TPR/S/139/Rev.1, circulated on 9 March 2005, Section IV para. 9. The contribution of agriculture to GDP here is calculated in terms of figures for 2003 and takes into account also forestry and fishery products. See 
this sector still employs 18 percent of the labour force ${ }^{335}$ and supports 150000 rural families. In addition, as 72 percent of the poor in Jamaica live in rural areas, ${ }^{336}$ the agricultural sector is crucial for the alleviation of poverty and rural development. ${ }^{337}$

In a Special Session of the WTO Committee on Agriculture in 2000, Jamaica noted the importance of the agricultural sector for its socio-economic development and pointed to the difficulties of small-island economies that are dependent on a limited number or crops and face difficulties in diversifying. ${ }^{338}$ Jamaica participated in the joint communication of SIDS, mentioned above, ${ }^{339}$ pointing to the inherent structural problems (like remoteness, smallness and vulnerability to natural disasters) preventing SIDS from becoming competitive in agricultural trade, and resulting in dependence on non-reciprocal preferences. ${ }^{340}$ The additional constraints caused by stringent SPS requirements that are beyond the capabilities of SIDS were also noted with concern. ${ }^{341}$

The main agricultural products of Jamaica are sugarcane, fruits and vegetables, roots and tubers, meat, fish and molluscs. ${ }^{342}$ Agricultural production is primarily oriented towards the domestic market and is largely produced by smallholders. ${ }^{343}$ However, some agri-

also the World Fact Book, US Central Intelligence Agency, 2003, available at: http:/www.odci.gov/cia/publications/factbook/geos/jm.html, visited on 25 June 2007.

335 United Nations Development Programme, Human Development Report 2007/2008. Fighting Climate Change: Human Solidarity in a Divided World (Palgrave Macmillan, New York), 2007, 300, available at: http://hdr.undp.org/en/media/hdr_20072008_en_complete.pdf, visited on 10 December 2007.

${ }^{336}$ FAO Commodities and Trade Division, Agriculture, Trade and Food Security: Issues and Options in the WTO Negotiations from the Perspective of Developing Countries. Volume II: Country Case Studies (Food and Agriculture Organization, Geneva), 2000, Chapter 7, Section 1, available at: www.fao.org/docrep/003/ X8731e/X8731e00.htm, visited on 7 January 2008.

337 Spencer Henson and Steve Jaffee, Jamaica's Trade in Ethnic Foods and Other Niche Products: The Impact of Food Safety and Plant Health Standards, Agriculture and Rural Development Discussion Paper (World Bank, Washington D.C.), 2005, 4, available at: http://siteresources.worldbank.org/INTARD/Resources/ JamaicaStandardsF_final.pdf, visited on 7 January 2008.

${ }^{338}$ Committee on Agriculture, Fourth Special Session of the Committee on Agriculture. Statement by Jamaica, G/AG/NG/W/86, circulated on 6 December 2000. This statement was made in the context of the discussion on non-trade concerns in agriculture, and Jamaica indicated that it shared the non-trade concern of the threat to social and political stability due to major negative changes in the agricultural sector. It proposed flexibility for developing countries in the rules on agricultural liberalisation to allow for the promotion of rural development.

339 See above, Part II, Section 2.5.1.3.

${ }^{340}$ Committee on Agriculture, WTO Negotiations on Agriculture: Proposals by Small Island Developing States (SIDS): Communication from Barbados, Cuba, Dominica, Jamaica, Mauritius, St. Kitts and Nevis, St. Lucia, St. Vincent and the Grenadines, and Trinidad and Tobago, G/AG/NG/W/97 and Corr.1, circulated on 29 December 2000, paras 3-6.

${ }^{341} \mathrm{Ibid}$., para. 6. As noted above, this joint communication proposes the binding of non-reciprocal preferential tariffs for agricultural products from SIDS under the Agreement on Agriculture and the creation of a framework for the provision of technical assistance for compliance with SPS measures in the international market.

${ }^{342}$ See FAO Statistical Yearbook, Country Profile of Jamaica, available at: http://www.fao.org/es/ess/yearbook/ vol_1_2/pdf/Jamaica.pdf, visited on 9 January 2008.

343 These smallholders comprise about $77 \%$ of Jamaican farmers and have farms of 2.02 ha or less. Trade Policy Review Body, Trade Policy Review: Jamaica - Report by the Secretariat. Revision, WT/TPR/S/139/ Rev.1, circulated on 9 March 2005, Section IV para. 10. The fragmented nature of agricultural production in Jamaica has been noted to be of questionable viability. Spencer Henson and Steve Jaffee, Jamaica's Trade in Ethnic Foods and Other Niche Products: The Impact of Food Safety and Plant Health Standards, Agriculture and Rural Development Discussion Paper (World Bank, Washington D.C.), 2005, 4, available at: http:// siteresources.worldbank.org/INTARD/Resources/JamaicaStandardsF_final.pdf, visited on 7 January 2008. 
culture and food products do constitute major exports for Jamaica. In 2006, agricultural exports, including processed food, amounted to 15.5 percent of all exports of goods in Jamaica. ${ }^{344}$ Most of Jamaica's agricultural exports are food products. ${ }^{345}$ Historically, these exports have been dominated by traditional products, produced mainly by large-scale farmers. ${ }^{346}$ The most important traditional export crops are sugar, bananas and coffee, ${ }^{347}$ which together make up almost 50 percent of Jamaica's agricultural exports and 9.4 percent of total merchandise export earnings. ${ }^{348}$ Food processing in Jamaica occurs mostly with regard to animal feed, sugar, poultry, flour and beverages ${ }^{349}$ and is one of Jamaica's most important industries. ${ }^{350}$

Sugar is Jamaica's main export crop, its second largest employer ${ }^{351}$ and third largest earner of foreign revenue. ${ }^{352}$ The most important export market for Jamaican sugar is the EU. ${ }^{353}$ The sugar industry in Jamaica faces high production costs, ${ }^{354}$ therefore preferential access for sugar is regarded by Jamaica as essential for its economy. Until 31 December 2007, Jamaica's sugar exports benefited from the preferential regime of the Sugar Protocol to the Cotonou Agreement, allowing Jamaica to sell its raw sugar above world market prices. ${ }^{355}$ As noted above, however, the regime for sugar under the new EPA, allows tariff

344 WTO Secretariat, Trade Profiles 2007 (World Trade Organization, Geneva), October 2007, 88, available at: http://www.wto.org/english/res_e/booksp_e/anrep_e/trade_profiles07_e.pdf, visited on 8 January 2008.

345 Jamaica exports both unprocessed and processed agricultural products. The processed agricultural product sector (comprising food, beverages and tobacco) is the largest manufacturing sector in Jamaica, accounting for 23.2\% of GDP in 2003. Trade Policy Review Body, Trade Policy Review: Jamaica - Report by the Secretariat. Revision, WT/TPR/S/139/Rev.1, circulated on 9 March 2005, Chart IV.3.

${ }^{346}$ These large-scale farmers represent less than $1 \%$ of all Jamaican farmers and use about $39 \%$ of arable land. Ibid., Section IV para. 10.

347 Ibid.

348 Together with other traditional exports (such as rum), these products constituted $72 \%$ of Jamaica's agricultural and food exports in 2000. Vinod Rege et al., Influencing and Meeting International Standards: Challenges for Developing Countries. Volume II: Procedures Followed by Selected International StandardSetting Organisations and Country Reports on TBT and SPS (International Trade Centre UNCTAD/WTO and Commonwealth Secretariat, Geneva), 2004, 109.

349 Trade Policy Review Body, Trade Policy Review: Jamaica - Report by the Secretariat. Revision, WT/ TPR/S/139/Rev.1, circulated on 9 March 2005, Section IV para. 10.

${ }^{350}$ See the World Fact Book, US Central Intelligence Agency, 2003, available at: http://www.odci.gov/cia/publications/factbook/geos/jm.html\#Intro, visited on 25 June 2007.

351 The sugar industry employs 41,000 people during cropping season and 28,000 during the rest of the year. Trade Policy Review Body, Trade Policy Review: Jamaica - Report by the Secretariat. Revision, WT/ TPR/S/139/Rev.1, circulated on 9 March 2005, Section IV para. 13.

${ }^{352}$ The first two export earners are bauxite and tourism. Ibid.

${ }^{353}$ Although Jamaica also has a quota for sugar exports to the US, in 2000-2002 no sugar was shipped to the US due to lack of demand, and in 2003 Jamaica was unable to produce enough sugar to meet its US quota requirement. Ibid., Section IV para. 14.

${ }^{354}$ It is reported that the average production cost for sugar in Jamaica is US\$ $0.24 / \mathrm{lb}$, which is about three times the world market price and double the sugar price expected in the EU after the current reform process is completed. Spencer Henson and Steve Jaffee, Jamaica's Trade in Ethnic Foods and Other Niche Products: The Impact of Food Safety and Plant Health Standards, Agriculture and Rural Development Discussion Paper (World Bank, Washington D.C.), 2005, 4, available at: http://siteresources.worldbank.org/INTARD/ Resources/JamaicaStandardsF_final.pdf, visited on 7 January 2008.

355 The Sugar Protocol to the Cotonou Agreement provided for specific quantities of sugar from 18 ACP countries to be imported into the EU at a guaranteed price. However, on 29 September 2007, the European Council of Ministers unilaterally renounced the Sugar Protocol, in the context of reforms to the EU sugar regime to bring it more into line with world market prices, following successful challenges by Brazil and Australia in WTO dispute settlement. The abolition of the existing sugar regime is set to take effect in October 2009. 
free quotas only until 2009, and establishes an import surveillance system and special safeguard mechanism thereafter, until 2012.. ${ }^{356}$

Coffee is Jamaica's second largest export crop, and is destined mainly for the Japanese market, where it commands premium prices. ${ }^{357}$ Bananas are the third most important agricultural export. ${ }^{358}$ Bananas are almost exclusively exported to the EU (mainly to the UK) ${ }^{359}$ previously under the Cotonou Agreement. ${ }^{360}$ The new EPA, initialled on 16 December 2007, includes tariff free treatment for bananas. Like sugar, bananas produced in Jamaica are not competitive on the world market due to low productivity and high costs, and exports are only possible through non-reciprocal preferential arrangements, especially those with the EU. ${ }^{361}$ In addition, export revenues from bananas are decreasing due to the inability of farmers to meet stricter standards on their export markets. ${ }^{362}$

As preferences are being phased out, a sharp contraction in Jamaica's sugar and banana exports has resulted. ${ }^{363}$ Non-traditional exports in the agricultural sector (i.e. exports other than sugar, bananas, and coffee) are therefore increasing in importance. ${ }^{364}$ An emergent but uneven trend of exports has been reported with regard to three categories of non-

356 The regime under the Cotonou Agreement, as noted above, will be replaced by the EPA between the EU and the Cariforum countries (initialled on 16 December 2007) as the WTO waiver for the preferential system expired on 31 December 2007.

357 The coffee industry employs about 25,000 people directly and 150,000 indirectly. Trade Policy Review Body, Trade Policy Review: Jamaica - Report by the Secretariat. Revision, WT/TPR/S/139/Rev.1, circulated on 9 March 2005, Section IV para. 15.

358 The banana industry accounts for 6,000 jobs in Jamaica. Ibid.

359 FAO Commodities and Trade Division, Agriculture, Trade and Food Security: Issues and Options in the WTO Negotiations from the Perspective of Developing Countries. Volume II: Country Case Studies (Food and Agriculture Organization, Geneva), 2000, Chapter 7 Section 3.1, available at: www.fao.org/docrep/003/ X8731e/X8731e00.htm, visited on 7 January 2008.

${ }^{360}$ Jamaica benefited from the Cotonou Agreement's quota regime for banana imports from ACP countries. After this regime was found to be WTO incompatible, it was replaced in January 2006 by a tariff only regime. This was also found to be inconsistent with the terms of the relevant waiver. Trade Policy Review Body, Trade Policy Review: Jamaica - Report by the Secretariat. Revision, WT/TPR/S/139/Rev.1, circulated on 9 March 2005, Section IV para. 15.

${ }^{361}$ Spencer Henson and Steve Jaffee, Jamaica's Trade in Ethnic Foods and Other Niche Products: The Impact of Food Safety and Plant Health Standards, Agriculture and Rural Development Discussion Paper (World Bank, Washington D.C.), 2005, 4, available at: http://siteresources.worldbank.org/INTARD/Resources/ JamaicaStandardsF_final.pdf, visited on 7 January 2008.

362 Trade Policy Review Body, Trade Policy Review: Jamaica - Report by the Secretariat. Revision, WT/ TPR/S/139/Rev.1, circulated on 9 March 2005, Section IV para. 12.

${ }^{363}$ Henson and Jaffee report that Jamaica's banana exports declined by half and its sugar exports declined by $33 \%$ between 1997 and 2003, and that further major contraction is expected in the coming years. Spencer Henson and Steve Jaffee, Jamaica's Trade in Ethnic Foods and Other Niche Products: The Impact of Food Safety and Plant Health Standards, Agriculture and Rural Development Discussion Paper (World Bank, Washington D.C.), 2005, 4, available at: http://siteresources.worldbank.org/INTARD/Resources/JamaicaStandardsF_final.pdf, visited on 7 January 2008 .

${ }^{364}$ Henson and Jaffee note that while the Jamaican government is relying on growth in the tourism industry to reduce the growing trade deficit, "there is some hope and expectation that the country can increase its exports in a broadly diversified range of fruits and vegetables, fishery products and processed foods'. Ibid. Non-traditional products made up $27 \%$ of agricultural and food exports from Jamaica in 2000. They are mainly exported to the US, followed by the UK and Canada. See Vinod Rege et al., Influencing and Meeting International Standards: Challenges for Developing Countries. Volume II: Procedures Followed by Selected International Standard-Setting Organisations and Country Reports on TBT and SPS (International Trade Centre UNCTAD/WTO and Commonwealth Secretariat, Geneva), 2004, 109. 
traditional products, namely (1) a broad range of fruit and vegetables; (2) fishery products; and (3) processed foods. ${ }^{365}$ The non-traditional fruit and vegetable exports mainly take the form of staples in the Jamaican diet (such as yam, ${ }^{366}$ papaya, ${ }^{367}$ ackee, ${ }^{368}$ sweet potato and hot pepper) and have been destined mostly for Africa, Asian and Caribbean immigrant communities in Canada, the UK and the US or for exports to other Caribbean countries. ${ }^{369}$ This is part of the growing phenomenon of trade in 'ethnic foods' stimulated by migration of developing country nationals as well as by travel and demand for variety by developed country nationals. ${ }^{370}$ Jamaica's non-traditional exports of fishery products, which grew strongly through the $1990 \mathrm{~s},{ }^{371}$ are mainly concentrated in conch, tilapia and lobster. As these non-traditional products are mostly produced by small-holder farmers or artisanal fishers in Jamaica, ${ }^{372}$ the expansion of this trade holds much potential for poverty reduction in rural areas. ${ }^{373}$ However, it is precisely with regard to this type of exotic, high-value food products that demanding SPS measures in import markets are rife. In order for Jamaica to be able to diversify into this lucrative niche market, it needs to en-

365 Spencer Henson and Steve Jaffee, Jamaica's Trade in Ethnic Foods and Other Niche Products: The Impact of Food Safety and Plant Health Standards, Agriculture and Rural Development Discussion Paper (World Bank, Washington D.C.), 2005, 4, available at: http://siteresources.worldbank.org/INTARD/Resources/ JamaicaStandardsF_final.pdf, visited on 7 January 2008. Henson and Jaffee report that Jamaica's trade in non-traditional products rose rapidly in the early 1990s (from US\$45 million in 1990 to US\$75 million in 1994) and is now between US\$70-85 million per year, although the export revenues from specific nontraditional products have varied widely due, in part, to difficulties meeting SPS requirements of trading partners. Spencer Henson and Steve Jaffee, Jamaica's Trade in Ethnic Foods and Other Niche Products: The Impact of Food Safety and Plant Health Standards, Agriculture and Rural Development Discussion Paper (World Bank, Washington D.C.), 2005, 8, available at: http://siteresources.worldbank.org/INTARD/ Resources/JamaicaStandardsF_final.pdf, visited on 7 January 2008.

${ }^{366}$ Jamaica accounts for $50 \%$ of world exports of yams. It produces about 150,000 tons of yams, of which 10,0012,000 tons are exported. Spencer Henson and Steve Jaffee, Jamaica's Trade in Ethnic Foods and Other Niche Products: The Impact of Food Safety and Plant Health Standards, Agriculture and Rural Development Discussion Paper (World Bank, Washington D.C.), 2005, 41, available at: http://siteresources.worldbank.org/ INTARD/Resources/JamaicaStandardsF_final.pdf, visited on 7 January 2008.

${ }^{367}$ The papaya sector is the most integrated of the indigenous food sectors in Jamaica. Three producers (a subsidiary of a US company and two farmers contracted to it) dominate export trade in this product. Ibid., 44.

${ }^{368}$ Exports of ackee accounted for US\$7.2 million in export revenue in 2002, up from US\$5.6 million in 2001. The livelihood of around 50,0000 Jamaicans comes from ackee production and a further 3,700 are employed in the ackee processing and canning sectors. Ibid., 45.

${ }^{369}$ Ibid., 4. These three markets accounted for $95 \%$ of Jamaica's exports of non-traditional agricultural products in 2000. Vinod Rege et al., Influencing and Meeting International Standards: Challenges for Developing Countries. Volume II: Procedures Followed by Selected International Standard-Setting Organisations and Country Reports on TBT and SPS (International Trade Centre UNCTAD/WTO and Commonwealth Secretariat, Geneva), 2004, 109.

${ }^{370}$ Spencer Henson and Steve Jaffee, Jamaica's Trade in Ethnic Foods and Other Niche Products: The Impact of Food Safety and Plant Health Standards, Agriculture and Rural Development Discussion Paper (World Bank, Washington D.C.), 2005, 4-5, available at: http://siteresources.worldbank.org/INTARD/Resources/ JamaicaStandardsF_final.pdf, visited on 7 January 2008.

${ }^{371} \mathrm{Ibid}$., 34. In the late 1990s, fishery products accounted for US\$16-19 million of foreign revenue earnings for Jamaica, and amounted to $1.2 \%$ of total merchandise exports. Jamaica is an important exporter of conch, destined mainly for the EU French Caribbean territories of Martinique and Guadalupe. Smaller amounts are exported to the US and other parts of the EU.

372 Ibid., 5.

${ }^{373}$ Supply of non-traditional products takes place by between 3, 500 and 4, 000 producers. These small producers also supply the domestic market. Exports are usually channelled through intermediaries, who sometimes source a product from over 100 farmers. Due to limited irrigation, many farmers rely on rainfall, making supply unreliable. Ibid., 9. 
sure that it can meet the SPS requirements of its trading partners. For this, Jamaica must develop public and private sector capacity. However, as the trade volume of each of these non-traditional products on its own is still small, it is difficult to create incentives for the investment in the public and private infrastructure needed for this purpose. ${ }^{374}$

The Ministry of Foreign Affairs and Trade of Jamaica is responsible setting international trade policy, ${ }^{375}$ including policy with regard to trade-related SPS issues. Within this Ministry, a Trade Coordination and Policy Committee was established in 1992, with the aim of coordinating trade matters and promoting public/private cooperation. ${ }^{376}$ In addition, the Jamaica Trade Adjustment Team, composed of representatives of industry and civil society and officials of ministries and departments active in the area of trade, establishes a consultative forum that informs the trade policy formulation process. ${ }^{377}$

Jamaica's trade and development policy aims are elaborated in the National Industrial Policy 1996-2010, which has as its objectives the improvement of quality of life in Jamaica and the efficiency of the Jamaican economy by promoting growth in GDP and increasing the value of exports. Among the economic areas targeted by this policy is agriprocessing. The National Industrial Policy was supplemented by the New Trade Policy developed by the Ministry of Foreign Affairs and Trade in 2001. One of the main objectives of the New Trade Policy is to move away from the previous focus on preserving preferential trade arrangements and to promote the expansion and diversification of trade. ${ }^{378}$ It therefore aims to enhance Jamaica's export capacity by, inter alia, building human and physical resources, broadening its export base, negotiate for the removal of tariff and non-tariff barriers and engaging in sector- or issue-specific negotiations to address supply side constraints. ${ }^{379}$ From these policy documents it is evident that in order to meet its trade and development objectives, Jamaica will need market access for its agricultural and food products, particularly for non-traditional products, and assistance in addressing supply-side constraints in this sector.

The Jamaican government's Agricultural Policy Framework aims at food security and poverty alleviation. ${ }^{380}$ To achieve these aims, inter alia, the following tools are mentioned: enhanced efficiency and productivity in the various subsectors (including traditional and non-traditional crops); increased exports of traditional and non-traditional agricultural products; provision of support services such as research, development and training; re-

\footnotetext{
${ }^{374}$ Henson and Jaffee state that aside from yam, which exceeds US\$10 million per year in export value, non-traditional agricultural exports only earn a few million dollars of export revenue each per year. It is therefore difficult to mobilise sufficient resources or to achieve economies of scale to address SPS challenges. Ibid., 8-9.

375 Trade Policy Review Body, Trade Policy Review: Jamaica - Report by the Government, WT/TPR/G/139, circulated on 15 December 2004, para. 38.

376 Vinod Rege et al., Influencing and Meeting International Standards: Challenges for Developing Countries. Volume II: Procedures Followed by Selected International Standard-Setting Organisations and Country Reports on TBT and SPS (International Trade Centre UNCTAD/WTO and Commonwealth Secretariat, Geneva), 2004, 116.

377 Trade Policy Review Body, Trade Policy Review: Jamaica - Report by the Government, WT/TPR/G/139, circulated on 15 December 2004, 39.

378 Trade Policy Review Body, Trade Policy Review: Jamaica - Report by the Secretariat. Revision, WT/ TPR/S/139/Rev.1, circulated on 9 March 2005, Section II paras 15-16.

${ }^{379}$ Ibid., Section II para. 17.

${ }^{380}$ Ibid., Section IV para.19.
} 
habilitation of infrastructure and improving agri-processing. ${ }^{381}$ Some agricultural support services provided by the Jamaican government are livestock research and improvement, crop research and plant protection, advisory services and veterinary services (including artificial insemination, laboratory services and training). ${ }^{382}$ In order to promote the development of the food processing industry, increase rural incomes and earn foreign exchange through exports, the government of Jamaica has used funding from the US to implement a fruit tree crop project. It provides for developing and producing commercial orchards of indigenous fruit tree crops. ${ }^{383}$ Another project to support the agricultural industry is the Eastern Jamaica Agricultural Support Project. This project was implemented from 2000 to 2004, giving support to small-scale farmers to increase production of non-traditional agricultural products with a competitive advantage on export markets. ${ }^{384}$ In addition, the Jamaican government supports its agricultural industry through imposing high tariffs on imports of agricultural products that compete with local farmers. ${ }^{385}$

\subsubsection{Summary of factual background}

This factual background aims to provide an indication of the health and trade priorities in Jamaica as the context within which the relevance of the SPS Agreement for its health and trade objectives can be understood. As a net importer of food and agricultural products, Jamaica has an important interest in the safety of imported food and agricultural products. However, SPS protection is unlikely to be one of Jamaica's highest priorities in the area of health spending. More pressing health priorities are primary health care, the prevention of violence and the fight against HIV/AIDS.

It appears that while Jamaica's main source of export revenue is not agricultural products but rather tourism services, agriculture plays an important role in poverty alleviation as a major source of employment and domestic food production. However, the main traditional export crops in Jamaica are uncompetitive and thus dependent on preferential market access. Preference erosion and stricter product standards threaten the viability of this export industry.

In addition, burgeoning export trade in non-traditional agricultural products, which are mainly produced by small-scale farmers and thus important for poverty alleviation in Jamaica is constrained by SPS barriers. Therefore strengthening the non-traditional agricultural export industry, particularly by improving the ability of exporters to meet the legitimate SPS requirements on their export markets, or ensuring that Jamaica can effectively challenge those requirements that are not legitimate, is essential to Jamaica's development.

It is now necessary to examine Jamaica's SPS regime in order to establish its ability to meet these challenges. This section will therefore proceed to give an overview of the SPS

381 Ibid.

${ }^{382}$ These agricultural support measures cost US\$9.3 million in 1999-2000 and US\$13.9 million in 2002-2003. Ibid., Section IV para. 32.

383 The J\$100 million needed for this project was covered by funds made available under the United States' Agricultural Trade Development and Assistance Act. Ibid., Section IV para. 36 and Table IV.34.

384 The EU funded $€ 6$ million of the costs of this project and the remaining $€ 1.1$ million was funded by the Jamaican government. Ibid., Section IV para. 37 and Table IV.34.

385 Ibid., Section IV para. 22. 
regime currently in place in Jamaica, and will provide examples of some problems, both with regard to SPS measures applied by Jamaica and with regard to Jamaica's ability to comply with the SPS measures of its trading partners.

\subsubsection{Jamaica's SPS system}

\subsubsection{Food-safety system}

Responsibility for different aspects of food safety in Jamaica is divided between the Ministry of Health, ${ }^{386}$ the Ministry of Agriculture and Lands and the Ministry of Commerce, Science and Technology. In addition, the Bureau of Standards of Jamaica (BSJ) plays an important role in the food safety system. This fragmented system is sketched below.

The Ministry of Health has three divisions, the Standards and Regulation Division, the Health Promotion and Public Health Division, and the Planning and Integration Division. The Health Promotion and Protection Division is in charge of food safety policy, also with regard to zoonoses. ${ }^{387}$ Enforcement is decentralised into four regional authorities, which are responsible for health services in their regions, such as food safety inspections and veterinary public health inspections. ${ }^{388}$ The regional authorities have 150 food safety inspectors and 14 veterinary inspectors. ${ }^{389}$ The Health Promotion and Inspection Division of the Ministry of Health has an Environmental Health Unit, which cooperates with regional inspectors with regard to training, planning and setting priorities. However, this Unit has only one food safety officer and one veterinary public health officer. ${ }^{390}$

The Ministry of Commerce, Science and Technology bears responsibility for preventing contamination and infestation of both domestic and imported food and feed, in particular through its Food Storage and Prevention of Infestation Division (FSPID). ${ }^{391}$ The FSPID aims to control pests, contaminants and residues in food and may condemn and destroy infested or contaminated food. There are 15 FSPID inspectors. ${ }^{392}$

The Ministry of Agriculture and Lands, through its Veterinary Services Division, is responsible for food-safety certification of meat and fishery products for export. ${ }^{393}$ However, it has no authority to inspect meat or fish processing establishments, as this competence lies

${ }^{386}$ The competences of the Ministry of Health with regard to food safety are set out in the Public Health Act of 1985 and the Food and Drugs Act of 1974. Vinod Rege et al., Influencing and Meeting International Standards: Challenges for Developing Countries. Volume II: Procedures Followed by Selected International Standard-Setting Organisations and Country Reports on TBT and SPS (International Trade Centre UNCTAD/ WTO and Commonwealth Secretariat, Geneva), 2004, 110.

387 Ibid. Zoonoses are animal diseases that can be transmitted to humans, for example Bovine Spongiform Encephalopathy that can cause Creutzfeldt-Jakob disease in humans.

${ }^{388}$ Ibid.

389 Ibid.

390 Ibid.

391 Ibid. The FSPID operates under the Food Storage and Prevention of Infestation Act of 1958 and its Regulations of 1973.

392 Ibid.

${ }^{393}$ Spencer Henson and Steve Jaffee, Jamaica's Trade in Ethnic Foods and Other Niche Products: The Impact of Food Safety and Plant Health Standards, Agriculture and Rural Development Discussion Paper (World Bank, Washington D.C.), 2005, 11, available at: http://siteresources.worldbank.org/INTARD/Resources/ JamaicaStandardsF_final.pdf, visited on 7 January 2008. 
with the Ministry of Health and the BSJ. This lack of coherence in the allocation of competences created problems for Jamaica's fishery exports to the EC, as discussed below. A Memorandum of Understanding had to be signed between the Ministry of Agriculture and Lands and the Ministry of Health in terms of which inspections by officials of the Ministry of Health are recognised for export certification purposes by the Ministry of Agriculture and Lands. ${ }^{394}$

Food-safety standards (as well as other technical standards) are set by the BSJ, under the authority of the Ministry of Commerce, Science and Technology. ${ }^{395}$ The mission of the BSJ is 'to promote the international competitiveness of Jamaican products, facilitate trade and protect consumers'. ${ }^{396}$ Mandatory requirements are established in terms of the Processed Food Act of 1959 and voluntary standards in terms of the Standards Act of $1968 .{ }^{397}$ The Standards Council ${ }^{398}$ is set up to give general policy and administrative guidance to the work of the BSJ. ${ }^{399}$ The standard-setting procedure is as follows. ${ }^{400}$ The Standards Council authorises the commencement of work on new or amended (sanitary or technical) standards, upon initiative of BSJ staff, BSJ committees or national organisations. ${ }^{401}$ Once authorised, the work is referred to one of the 36 standing technical committees, or if none exists for the relevant issue, a new committee is formed. ${ }^{402}$ The actual standard-setting work is carried out by these committees, in which consumer and industry interests and the public sector are represented. ${ }^{403}$ Very little use is made of international

394 Ibid.

395 The BSJ was established in 1969 by the Standards Act of 1963, under Art. 3. It also sets standards and specifications in non-food-related areas. For further information on the work of the BSJ, see its website, available at: www.jbs.org.jm, visited on 8 January 2008.

${ }^{396}$ Mission Statement of the BSJ, in its Citizens' Charter, available online at: http://www.jbs.org.jm/charter.htm, visited on 8 January 2008.

397 Vinod Rege et al., Influencing and Meeting International Standards: Challenges for Developing Countries. Volume II: Procedures Followed by Selected International Standard-Setting Organisations and Country Reports on TBT and SPS (International Trade Centre UNCTAD/WTO and Commonwealth Secretariat, Geneva), 2004, 110. The Standards Act of 1968 is available at: http://www.jbs.org.jm/regulations/standards act.pdf, visited on 8 January 2008 and the Processed Food Act of 1959 is available at: http://www.jbs.org.jm/ regulations/processed_food.pdf, visited on 8 January 2008.

398 The Standards Council is composed of the Director of Standards and 13 other members, namely, one former senior civil servant, one representative of the interests of the agricultural producers, three representatives of manufacturers, wholesalers and retailers, three representatives of consumer interests, and four persons in government service. See The Standards Act, Act 58 of 1968 (the Standards Act), in force on 15 July 1969, Second Schedule, Art.1.

399 The Standards Act, Art. 4(1).

400 This procedure is detailed in the foreword to the Catalogue of Jamaican Standards of the BSJ (as updated in 2001), available at: http://www.jbs.org.jm/standards/section_one(sectional_list_of_jamaican_standards) (part1).pdf, visited on 8 January 2008.

401 The possibility for initiatives from the private sector was introduced in 2001, during the restructuring of the BSJ. This was done in order to increase participation by industry and consumer groups and public sector experts.

402 Trade Policy Review Body, Trade Policy Review: Jamaica - Report by the Secretariat. Revision, WT/ TPR/S/139/Rev.1, circulated on 9 March 2005, Section III para. 82. These committees are composed of, inter alia, representatives of consumer interests, the public and manufacturing sectors.

${ }^{403}$ Before July 2001, standards were drafted by committees of volunteers set up by the BSJ and approved by the Standards Council. As these committees were sometimes not representative of the industry for which the standard was drafted, implementation of standards was often problematic. Since the 2001 restructuring of the BSJ, new technical committees are set up by the industry stakeholders with regard to the standard being set, and approved by the Standards Council. These technical committees evaluate the need for a new standard and 
guidelines for risk analysis. ${ }^{404}$ It has been reported that, due to the limited availability of scientific information, an ad hoc approach is followed with regard to risk assessments for fresh produce. ${ }^{405}$ The resulting draft standard is approved by the Standards Council and forwarded to the Minister of Commerce, Science and Technology, to obtain approval of any other Minister in whose portfolio the standard falls. Thereafter, the draft standard is made available for public comment. ${ }^{406}$ Comments received are considered by the relevant technical committee and a final standard is drafted. The Standards Council then recommends the standard to the Minister for approval. The Council may recommend that a particular standard be made compulsory (i.e. be promulgated as a sanitary or technical regulation). Where it appears to him necessary to do so in the public interest, the Minister may declare a standard to be compulsory. ${ }^{407}$ Approved standards and regulations are published in the Government Gazette and copies made available for sale.

By 2001, the BSJ had established 66 food-related standards, ${ }^{408}$ for example standards for frozen foods, fruit juices, meat products and sauces. The BSJ policy is to make effort to adopt international food-safety standards, particularly those of the Codex Alimentarius Commission and those of CARICOM. ${ }^{409}$ If this is not possible, it uses international standards in the development of national standards. ${ }^{410}$ In practice BSJ food standards are largely based on Codex standards although sometimes adjusted according to local requirements. ${ }^{411}$ In 2002, the CARICOM Regional Organisation for Standards and Quality (CROSQ) was established in response to the need for more formal standard-setting to improve the competitiveness of Caribbean goods. ${ }^{412}$ The primary objective of the CROSQ is to develop and harmonise regional standards to facilitate trade and improve consumer protection. ${ }^{413}$ However, as noted by the Executive Secretary of the CROSQ, Kenneth Mullin, there is growing recognition in the region that most new standards are being

draft the standard if necessary. This aims to create 'ownership' of resulting standards by the industry. The BSJ acts as facilitator in the standard-setting process. See the standards development section on the BSJ website, available at: http://www.jbs.org.jm/standardization.htm, visited on 8 January 2008.

404 Janice Reid, Needs Analysis of the Readiness of Jamaican Institutions for WTO-SPS: Executive Summary (Inter-American Institute for Cooperation on Agriculture, Kingston), April 2000, 7, available at: www.agroinfo.org/caribbean/iicacarc/jamaica/summary.pdf, visited on 7 January 2008.

405 Ibid.

${ }^{406}$ A notification is placed in the press inviting all interested parties to comment. In addition, copies of the standard or regulation are sent to those known to be interested in the subject of the standard.

407 The Standards Act, Art. 7(7).

408 The most recent version of the Catalogue of Jamaican Standards that is available on the website of the BSJ is that published in 2001, available at: http://www.jbs.org.jm/standards.htm, visited on 28 December 2007.

${ }^{409}$ International standard setting by the Codex Alimentarius Commission is discussed below, Part II, Section 3.2.1.

${ }^{410}$ See the standards development section on the BSJ website, available at: http://www.jbs.org.jm/standardization.htm, visited on 20 December 2007.

411 Vinod Rege et al., Influencing and Meeting International Standards: Challenges for Developing Countries. Volume II: Procedures Followed by Selected International Standard-Setting Organisations and Country Reports on TBT and SPS (International Trade Centre UNCTAD/WTO and Commonwealth Secretariat, Geneva), 2004, 115.

412 The Agreement establishing the CARICOM Regional Organisation for Standards and Quality (CROSQ) signed at Belize City on 4 February 2002. The CROSQ replaces the Caribbean Common Market Standards Council, an informal grouping of national standard-setting organization, which had no own staff, and thus established few standards (27 food standards by 2001). See Ibid., 121-122. See also the website of CROSQ, available at: http://www.crosq.org, visited on 8 January 2008.

${ }^{413}$ Art. 4(1) of the Agreement establishing the CARICOM Regional Organisation for Standards and Quality. 
developed at the international level and that it is more important for the region to participate effectively in international standard setting than to set its own standards. ${ }^{414}$ The CROSQ is therefore not very active in regional standard setting. ${ }^{415}$ Instead its priority is to assist regulatory bodies and the private sector in the region to implement international standards and to coordinate regional positions for participation in international standard setting. ${ }^{416}$

Jamaica has experienced great problems with regard to the acceptance of its standards on export markets, particularly where these are not based on international standards. The absence of standards with respect to many products of export interest to Jamaica is therefore clearly problematic. Interestingly, the BSJ sometimes takes over the SPS requirements of its trading partners, namely those of the US and the UK, in its own standard setting.

Food safety regulations may also be made by the Minister of Health consistent with the terms of the Processed Food Act in order to carry out its purposes, including regulations prescribing standards of purity, composition or other quality of food destined for domestic consumption of exportation; ${ }^{417}$ and regulations with regard to processes or production methods for food to protect consumer health. ${ }^{418}$ The Processed Food Act of 1959 lays down guidelines for the preparation and packaging of processed foods, including those intended for export. ${ }^{419}$ It requires the registration and inspection of any establishment where food for which standards have been prescribed is produced or processed for domestic sale or for export. ${ }^{420}$ This inspection is carried out be the BSJ which bears responsibility for approving establishments. However, the Ministry of Health is responsible for sanitary requirements for milk and dairy products produced in establishments approved by the BSJ, leading to overlapping regulatory responsibilities. ${ }^{421}$ The Act also lays down penalties (fines or imprisonment) for contravention of its provisions or for the offering to, or acceptance by, inspectors of bribes in connection with matters under the Act. ${ }^{422}$

The BSJ undertakes conformity assessment of imports and domestic products with regard to SPS requirements. For this purpose it carries out inspections at factories and points of entry and conducts random inspections and testing at retail level. ${ }^{423}$ The BSJ

\footnotetext{
${ }^{414}$ Message from the Executive Secretary, The CROSQ Standard 1(2), 2007, 1.

${ }^{415}$ Although a list of standards in development is provided by the CROSQ, including 16 standards for food products, there is neither any information on the stage of development of these standards, nor any publication of finalized standards available on the CROSQ website. See the website of CROSQ, available at: http://www. crosq.org, visited on 8 January 2008.

416 Ibid.

${ }^{417}$ The Processed Food Act, Art. 13(1)(c).

418 The Processed Food Act, Art. 13(1)(d).

419 The Processed Food Act of 15 October 1959. This Act is supplemented by the Processed Food (General) Regulations of 1959, the Processed Food (Inspection and Sampling) Regulations of 1959, the Processed Food (Establishments) Regulations of 1959 and the Processed Food (Prepared Syrups) Regulations of 1974. See Trade Policy Review Body, Trade Policy Review: Jamaica - Report by the Secretariat. Revision, WT/ TPR/S/139/Rev.1, circulated on 9 March 2005, Section III para. 80 and note 40.

420 The Processed Food Act, Arts 3 and 4.

421 Vinod Rege et al., Influencing and Meeting International Standards: Challenges for Developing Countries. Volume II: Procedures Followed by Selected International Standard-Setting Organisations and Country Reports on TBT and SPS (International Trade Centre UNCTAD/WTO and Commonwealth Secretariat, Geneva), 2004, 110.

${ }^{422}$ The Processed Food Act, Art. 15.

${ }^{423}$ Trade Policy Review Body, Trade Policy Review: Jamaica - Report by the Secretariat. Revision, WT/
} 
also administers a system for certification of compliance with requirements of its trading partners. Certification by the BSJ is in certain cases accepted by importing countries under informal arrangements. ${ }^{424}$ Finally, note that the BSJ functions as Jamaica's Codex Contact Point.

Pesticide residues in food can create food-safety risks. Responsibility for control of pesticides in Jamaica lies with the Pesticides Control Authority, an agency of the Ministry of Health. This Unit consists of four technical staff members. ${ }^{425}$ Its duties include registration and approval of pesticides, control of domestic pesticide use and of pesticides in imported food and agricultural products, and analysis of pesticide residues. ${ }^{426}$ Pesticide approval in Jamaica does not occur on a crop-by-crop basis but instead is for use in agricultural production in general. No national maximum residue levels for pesticides are set in Jamaica - instead it uses the residue levels set by the Codex Alimentarius Commission, as necessary. ${ }^{427}$ However, for many of the non-traditional fruit and vegetables exported by Jamaica, no Codex MRLs have been established. ${ }^{428}$ In addition, in many cases Jamaica's trading partners do not establish specific MRLs for these products. Due to the lack of scientifically established MRLs, the residue limit applied at point-of-entry inspections is the LOD, i.e. the level at which analytical instruments can detect any residue. ${ }^{429}$ These very strict limits are imposed for purely practical purposes in the absence of specific MRLs rather than due to the identification of particularly serious risks from pesticide residues on the relevant products. However, their implications for Jamaican exports are severe since the detection levels of the sophisticated testing equipment available in Jamaica's trading partners are extremely low. The problem of these strict requirements for pesticide residues is greatly exacerbated by the fact that, due to limited resources in Jamaica, the controls in place on pesticide use and residue levels are weak. This leads to widespread misuse of pesticides by producers, including by application at the wrong concentration, frequency and/or interval before harvest. ${ }^{430}$ This misuse has partly been attributed to producers'

TPR/S/139/Rev.1, circulated on 9 March 2005, Section III para. 86.

${ }^{424}$ Vinod Rege et al., Influencing and Meeting International Standards: Challenges for Developing Countries. Volume II: Procedures Followed by Selected International Standard-Setting Organisations and Country Reports on TBT and SPS (International Trade Centre UNCTAD/WTO and Commonwealth Secretariat, Geneva), 2004, 115 .

${ }^{425}$ Ibid., 111.

426 Ibid.

${ }^{427}$ Ibid.

${ }^{428}$ Spencer Henson and Steve Jaffee, Jamaica's Trade in Ethnic Foods and Other Niche Products: The Impact of Food Safety and Plant Health Standards, Agriculture and Rural Development Discussion Paper (World Bank, Washington D.C.), 2005, 40, available at: http://siteresources.worldbank.org/INTARD/Resources/ JamaicaStandardsF_final.pdf, visited on 7 January 2008.

${ }^{429} \mathrm{Ibid} ., 41$. Henson and Jaffee note that the small volume of production and trade in non-traditional agricultural products means that there is no incentive for agro-chemical companies to supply the data necessary for establishing an MRL for each of these products. Similar disincentives can be supposed to exist for importing countries to invest in the necessary analyses to establish the relevant MRLs for products traded in such small volumes. The application of a limit set at the level of determination avoids any risk in the absence of specific MRLs.

${ }^{430}$ Vinod Rege et al., Influencing and Meeting International Standards: Challenges for Developing Countries. Volume II: Procedures Followed by Selected International Standard-Setting Organisations and Country Reports on TBT and SPS (International Trade Centre UNCTAD/WTO and Commonwealth Secretariat, Geneva), 2004, 118. Henson and Jaffee note that non-traditional agricultural products are produced by smallholder farmers who lack awareness and training in the proper use of pesticides. Resource limitations have 
attempts to avoid rejection of their products by the US, which applies a 'zero tolerance' policy with regard to pests. ${ }^{431}$ Small farmers are reportedly resistant to changing these practices. ${ }^{432}$ Due to the inadequacy of the laboratories in Jamaica to handle large volumes of samples, discussed below, routine residue testing of fresh produce is not carried out. ${ }^{433}$

National food safety legislation in Jamaica is, in many cases, outdated, or poorly implemented. Efforts have been made to modernise national regulations where necessary to meet requirements on Jamaica's export markets, to comply with international standards and to facilitate enforcement. ${ }^{434}$ In some cases new food-safety legislation was drafted but left unadopted until demand arose from potential export markets. For example, before Jamaica was confronted with the need to meet EC requirements on fish and fishery products in order to gain market access, it had no legislation in force in this area. In 1991, as discussed below, the Aquaculture, Inland and Marine Products and By-Products (Inspection, Licensing and Export) Act was drafted based on the relevant EC Directives, ${ }^{435}$ imposing hygiene requirements for fish and fishery products broadly equivalent to those of the EC. ${ }^{436}$ As the new EC requirements were not fully implemented until the late 1990s, the draft Jamaican legislation was left unadopted until 1999 when it was necessitated by the imposition of the relevant EC hygiene requirements. ${ }^{437}$ Similarly updated legislation in the meat sector aims at facilitating exports to the US and EC..$^{438}$

Laboratory facilities in Jamaica have the capacity to conduct a wide range of tests but significant problems remain particularly in the light of the new tests and increased sensitivity of analysis currently required in Jamaica's export markets. ${ }^{439}$ The National Public Health Laboratory undertakes laboratory testing for food safety purposes. ${ }^{440}$ It is responsible for microbiological testing and surveillance of meat, fish and dairy products. While its

restricted government initiatives to provide training to farmers. Instead training is provided by agro-chemical companies, focusing on how to address a pest using their pesticides rather than on how to reduce pesticide use.

431 Ibid.

432 Ibid., 119.

${ }^{433}$ Ibid., 118.

${ }^{434}$ Ibid., 112.

${ }^{435}$ EC Directives 91/492/EC and 91/493/EC.

436 Spencer Henson and Steve Jaffee, Jamaica's Trade in Ethnic Foods and Other Niche Products: The Impact of Food Safety and Plant Health Standards, Agriculture and Rural Development Discussion Paper (World Bank, Washington D.C.), 2005, 35, available at: http://siteresources.worldbank.org/INTARD/Resources/ JamaicaStandardsF_final.pdf, visited on 7 January 2008.

437 Ibid.

${ }^{438}$ Vinod Rege et al., Influencing and Meeting International Standards: Challenges for Developing Countries. Volume II: Procedures Followed by Selected International Standard-Setting Organisations and Country Reports on TBT and SPS (International Trade Centre UNCTAD/WTO and Commonwealth Secretariat, Geneva), 2004, 112. This report notes that although this legislation was drafted in 1991, it was only implemented to meet demands on the export market.

439 Spencer Henson and Steve Jaffee, Jamaica's Trade in Ethnic Foods and Other Niche Products: The Impact of Food Safety and Plant Health Standards, Agriculture and Rural Development Discussion Paper (World Bank, Washington D.C.), 2005, 15, available at: http://siteresources.worldbank.org/INTARD/Resources/ JamaicaStandardsF_final.pdf, visited on 7 January 2008.

${ }^{440}$ Vinod Rege et al., Influencing and Meeting International Standards: Challenges for Developing Countries. Volume II: Procedures Followed by Selected International Standard-Setting Organisations and Country Reports on TBT and SPS (International Trade Centre UNCTAD/WTO and Commonwealth Secretariat, Geneva), 2004, 111. 
facilities are relatively up-to-date and capable of carrying out many, albeit not all, of the analyses required by Jamaica's trading partners, it is not adequate for high-volume quick turnaround analyses. ${ }^{441}$ Facilities need to be upgraded and staff must be retrained. ${ }^{442}$ Five additional laboratories, none of which are internationally accredited, are run by the FSPID of the Ministry of Industry, Commerce and Technology. These laboratories are responsible for testing with regard to entomology, microbiology, pesticide residues, mycotoxins and post-harvest technology, but are staffed by only three persons. ${ }^{443}$ The chemical residue laboratory can test for most residues except heavy metals. ${ }^{444}$ The mycotoxin laboratory is only able to conduct semi-quantitative tests so that samples in which mycotoxins are detected must be sent elsewhere for quantitative testing. In addition resource constraints have led to shortages in solvents and other chemicals as a result of which the equipment is operating at only 40 to 50 percent of its capacity. ${ }^{445}$ Testing backlogs occur when there is a surge in samples due to the limited capacity of the equipment. ${ }^{446}$ The FSPID is struggling with the cost of maintenance of laboratory equipment. For example, equipment software must be updated every three years to incorporate new chemical residues. Further, there is only one engineer in the region able to service the chemical residue equipment and he must be flown it at great cost for maintenance work. ${ }^{447}$ The fragmentation of laboratory capacity means that economies of scale cannot be exploited to reduce costs.

Another area where human capacity is important is in the implementation of HACCP requirements. HACCP implementation is still in its early stages in Jamaica, although the 30 inspectors of the Veterinary Services Department of the Ministry of Agriculture and Lands are fully trained in the HACCP system. ${ }^{448}$ The fish processing industry is fully HACCP compliant. However, capacity with regard to HACCP system implementation needs to be developed further. ${ }^{449}$ Funding has been received from the Canadian Food Inspection Agency to train staff of the Food Storage and Prevention of Infestation Division of the Ministry of Industry, Commerce and Technology in this area. ${ }^{450}$

While no trade concerns have been raised at the SPS Committee with regard to sanitary measures taken by Jamaica, some such concerns have been discussed at the meeting of the Trade Policy Review Body in 2005, in the context of the trade policy review of Jamaica. At this meeting, the US inquired about the scientific basis for the application by Jamaica of the same SPS requirements for processed, packaged, dry products that contain minor amounts of dairy content as for fresh dairy products, whereas the former pose a different level of risk than the latter. ${ }^{451}$ Jamaica clarified that all processed animal products, including milk-based products, in Jamaica are required to be certified by the official regulatory agency as being wholesome, safe and fit for human consumption. Such certification

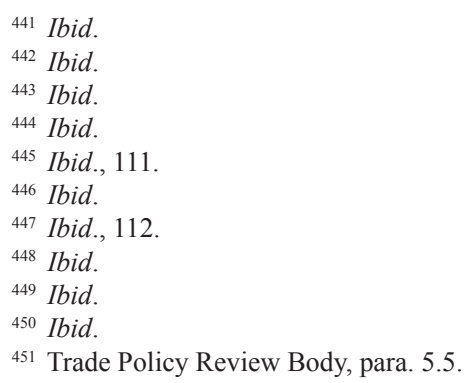


addresses the process or production method of the product, for example pasteurisation or ultra-heat treatment of milk in order to render it safe to use in milk-based products. Jamaica pointed out that when animal products that are allergen producing, such as dairy, are contained in a processed product, the amount of that ingredient is irrelevant to the allergenic response. ${ }^{452}$

A well-functioning sanitary regime is not only important for Jamaica's public health objectives but also to its trade objectives. Market access for food products depends on the ability of Jamaican exporters to meet the food-safety requirements of its trading partners. Particularly in view of Jamaica's attempts to diversify its agricultural exports into highvalue, non-traditional food products, it is important to ensure that its trading partners have confidence in the capacity of its exporters to guarantee high levels of food safety. Where the sanitary requirements set in national legislation in Jamaica are not as strict as those set by its trading partners, private investment in meeting these requirements and demonstrating compliance is necessary. This is made difficult by the greatly fragmented nature of production and export in the non-traditional agricultural sector (except in the case of more integrated sectors such as papaya and fish processing). ${ }^{453}$ Investments to comply with SPS requirements beyond those necessary on the domestic market are not economically viable for small producers or exporters. ${ }^{454}$ As a result there is little or no food-safety control capacity in the private sector. No collective efforts are made in the private sector to develop such capacity, for example by drafting industry codes of practice. ${ }^{455} \mathrm{In}$ addition, traceability through the supply chain is almost entirely lacking, ${ }^{456}$ making it difficult to document compliance particularly with regard to farm-to-fork process standards such as HACCP. For this reason, government action is essential to assist exporters in gaining market access abroad, for example by updating food-safety legislation to reflect export standards, effective compliance control, and proactive efforts to find solutions in consultation with trading partners.

It is elucidating to examine the extent to which Jamaica has been able to assist its food exporters that face problems due to sanitary trade barriers. Some examples are those of fishery exports and of indigenous food products to the EU and US that were restricted by food-safety requirements. It is interesting to look at these SPS restrictions in more detail and to examine whether, and if so how, they have been addressed.

452 Ibid.

${ }^{453}$ Spencer Henson and Steve Jaffee, Jamaica's Trade in Ethnic Foods and Other Niche Products: The Impact of Food Safety and Plant Health Standards, Agriculture and Rural Development Discussion Paper (World Bank, Washington D.C.), 2005, 15, available at: http://siteresources.worldbank.org/INTARD/Resources/ JamaicaStandardsF_final.pdf, visited on 7 January 2008.

${ }^{454}$ As mentioned above, Henson and Jaffee report that almost all non-traditional agricultural exports are sourced from hundreds of smallholder farmers or artisanal fishers. Their production is not dedicated to export but also supplies the domestic market. Thus there are diseconomies of scale in investing to meet demanding SPS requirements on export markets. Also export is fragmented with some 35 active firms, each with a turnover of only a few million dollars a year. This is different in the case of papaya, where 3 major producer-exporters dominate trade. Ibid., 9.

${ }^{455}$ Ibid., 15.Henson and Jaffee note that although the Jamaica Exporters' Association has been created as part of private sector efforts to promote exports of non-traditional food and agricultural products, it is not active in creating food-safety capacity. Instead it focuses on providing capital, lobbying and trade show administration.

${ }^{456}$ Ibid., 9. 


\subsection{Examples of food-safety measures affecting Jamaican exports}

As mentioned above, Jamaica has developed a small but profitable export industry in fish and fishery products in the early 1990s. The fishery industry is in the hands of artisanal fishers and employs 20,000 fishers along 184 landing beaches. ${ }^{457}$ It is traditionally unregulated to a large extent. The Veterinary Services Division is responsible for checking compliance with food safety requirements but it lacks inspection capacity and the legislative authority to inspect and certify products for export. ${ }^{458}$ In 1991, new hygiene requirements for fisheries were set by the EC in new Directives, ${ }^{459}$ but the deadline for implementation of at least equivalent hygiene controls for marine gastropods, ${ }^{460}$ bivalve molluscs, tunicates and echinoderms was only 31 June $1998 .{ }^{461}$ Therefore, although Jamaica drafted the Aquaculture, Inland and Marine Products and By-Products (Inspection, Licensing and Export) Act in 1991, it left it unadopted. Jamaica's failure to meet the implementation deadline for the EC's new hygiene requirements led to a ban on Jamaican exports of conch. Other Jamaican exports of fish and fishery products were provisionally permitted. As noted above, this led to the adoption of the new legislation, the Aquaculture, Inland and Marine Products and By-Products (Inspection, Licensing and Export) Act in 1999, incorporating EU requirements. ${ }^{462}$ However, this legislation was poorly implemented and control of the production process was inadequate. ${ }^{463}$ In 1999, an inspection visit of the Food and Veterinary Office of the European Commission to Jamaica discovered discrepancies in Jamaica's sanitary regime for fish and fishery products, leading to food-safety concerns. ${ }^{464}$ The inadequate implementation and monitoring of the relevant requirements was noted. The processing plants were found not to comply with EU requirements regarding water control, pest and vermin control and maintenance and production conditions. ${ }^{465}$ The implementation of HACCP was still in its early stages, with critical control points having been identified but not yet monitored or verified. ${ }^{466}$ In addition, laboratory

457 Ibid., 34.

458 Ibid., 35.

459 The relevant EC legislation was EC Directives 91/492/EC and 91/493/EC.

${ }^{460}$ Conch is regarded in the EU as a marine gastropod, which are shellfish that feed off plankton and small organisms. Where they live in contaminated water, the contamination is ingested. Spencer Henson and Steve Jaffee, Jamaica's Trade in Ethnic Foods and Other Niche Products: The Impact of Food Safety and Plant Health Standards, Agriculture and Rural Development Discussion Paper (World Bank, Washington D.C.), 2005, note 13, 35, available at: http://siteresources.worldbank.org/INTARD/Resources/JamaicaStandardsF final.pdf, visited on 7 January 2008.

${ }^{461}$ Ibid., 35.

${ }^{462}$ Ibid. The Act appointed the Veterinary Services Division as the 'competent authority'

${ }^{463}$ Vinod Rege et al., Influencing and Meeting International Standards: Challenges for Developing Countries. Volume II: Procedures Followed by Selected International Standard-Setting Organisations and Country Reports on TBT and SPS (International Trade Centre UNCTAD/WTO and Commonwealth Secretariat, Geneva), 2004, 119.

${ }^{464}$ Ibid. Spencer Henson and Steve Jaffee, Jamaica's Trade in Ethnic Foods and Other Niche Products: The Impact of Food Safety and Plant Health Standards, Agriculture and Rural Development Discussion Paper (World Bank, Washington D.C.), 2005, 35, available at: http://siteresources.worldbank.org/INTARD/ Resources/JamaicaStandardsF_final.pdf, visited on 7 January 2008.

${ }^{465}$ Vinod Rege et al., Influencing and Meeting International Standards: Challenges for Developing Countries. Volume II: Procedures Followed by Selected International Standard-Setting Organisations and Country Reports on TBT and SPS (International Trade Centre UNCTAD/WTO and Commonwealth Secretariat, Geneva), 2004, 119.

${ }^{466}$ Ibid. 
facilities for microbiological and residue testing were regarded as inadequate. ${ }^{467}$ Jamaica undertook considerable efforts to rectify the problems with its sanitary regime for fish and fishery products, resulting in only a few remaining discrepancies being identified in a second inspection visit in April 2000. ${ }^{468}$ After written assurances had been provided by the Jamaican government that also these problems had been remedied, the EU, in December 2000, established special conditions for imports from Jamaica and added Jamaica to its list of approved countries for the export of fish, fishery products and marine gastropods to its market. ${ }^{469}$ Among these conditions was the identification of the area from which conch exports to the EU could be sourced, namely Pedro Bank, and requirements regarding record-keeping, water monitoring, microbiological and contaminant analyses, and upgrading of vessels. ${ }^{470}$ It is reported that six plants and six freezer vessels were approved for export to the EU by $2004 .{ }^{471}$

Jamaica has doubts as to the appropriateness of the EU requirements for its fisheries. In particular, the EU's maximum levels and monitoring requirements for coliforms and biotoxins are argued by Jamaica to be more appropriate for the areas where marine gastropods, tunicates, echinoderms and bivalve molluscs are typically produced in Europe, namely shallower, in-shore waters, than for the deep water fishery of Pedro Bank in Jamaica. ${ }^{472}$ These concerns, however, have not been officially communicated to the EU. ${ }^{473}$

The delayed fashion in which Jamaica responded to the EU's sanitary requirements for fisheries has been attributed, in part, to the considerable investments required. ${ }^{474}$ Jamaica had to create mechanisms for the approval of processing plants, the issuance of health certificates and the monitoring of water and fish for contaminants. There were insufficient Veterinary Service Division inspectors for these tasks, and an understanding had to be reached with the Ministry of Health to use their inspectors. ${ }^{475}$ Laboratories had to be upgraded to carry out the required analyses. ${ }^{476}$ Private investments by fish processors were

\footnotetext{
${ }^{467}$ Ibid.

${ }^{468} \mathrm{Ibid}$. See the relevant report, official document number DG (SANCO)/1166/2000-MR Final.

${ }^{469}$ Ibid. Spencer Henson and Steve Jaffee, Jamaica's Trade in Ethnic Foods and Other Niche Products: The Impact of Food Safety and Plant Health Standards, Agriculture and Rural Development Discussion Paper (World Bank, Washington D.C.), 2005, 36, available at: http://siteresources.worldbank.org/INTARD/ Resources/JamaicaStandardsF final.pdf, visited on 7 January 2008.

${ }^{470}$ Spencer Henson and Steve Jaffee, Jamaica's Trade in Ethnic Foods and Other Niche Products: The Impact of Food Safety and Plant Health Standards, Agriculture and Rural Development Discussion Paper (World Bank, Washington D.C.), 2005, 36 and Box 33, available at: http://siteresources.worldbank.org/INTARD/ Resources/JamaicaStandardsF_final.pdf, visited on 7 January 2008. Upgrading of vessels includes requirements that stainless steel storage containers be installed, toilet facilities be provided on-board depending on the number of crew members and a freezing system. These requirements have led to the exclusion of many artisanal fishers from supplying exporters to the EU.

471 Ibid., 36.

472 Ibid., 36-37.

473 This is reported by Henson and Jaffee. Ibid., 36.

${ }^{474} \mathrm{Ibid}$. These investments are estimated at US\$1.25 million and were borne by the Jamaican government.

475 Ibid.

${ }^{476}$ Ibid.
} 
also undertaken. ${ }^{477}$ Additional ongoing public investments are needed to operate this new sanitary system and to upgrade its capacity. ${ }^{478}$

As noted above, Jamaica has been trying to develop its export industry with respect to indigenous agricultural and food products. These indigenous products such as callaloo, yam, hot peppers and ackee, provide a living for approximately 50000 Jamaicans. As noted above, the US, together with the UK and Canada, constitutes Jamaica's whole export market for these indigenous products. An important impediment to trade in these products is the problem of compliance with strict MRLs for chemicals in fresh produce.

Some indigenous food products that reportedly face problems meeting food-safety requirements when exported to the US market are yams and callaloo (a spinach-like vegetable). These problems are due to fungicide and pesticide residues. In the case of yams, the fungicide commonly used in Jamaica to prevent the growth of blue mould on cut ends of yams during sea shipment is not registered by the US Food and Drug Administration (FDA). ${ }^{479}$ Consequently the MRL is set at the analytical limit of determination. ${ }^{480}$ Periodic spot checks by the FDA in 2000 detected residues of this fungicide leading to the loss of shipments by several large exporters. Although the US did not impose a ban on Jamaican yams, it only granted them provisional entry subject to the requirement that the next five shipments were certified as residue free by an approved laboratory. ${ }^{481}$ Jamaica created the Yam Task Force to address this problem. It applied for permission from the FDA to use two other fungicides that were already approved for sweet potato and for which specific MRLs were established. ${ }^{482}$ In the meantime it advised yam producers to use calcium

$477 \mathrm{Ibid}$. As hygiene controls were absent in processing plants, the cost of changes amounted to US\$740,000 per plant or US\$4.5 million industry-wide. Plants still depend on public capacity (e.g. public laboratories) to meet EU requirements.

${ }^{478}$ Spencer Henson and Steve Jaffee, Jamaica's Trade in Ethnic Foods and Other Niche Products: The Impact of Food Safety and Plant Health Standards, Agriculture and Rural Development Discussion Paper (World Bank, Washington D.C.), 2005, available at: http://siteresources.worldbank.org/INTARD/Resources/ JamaicaStandardsF_final.pdf, visited on 7 January 2008. Henson and Jaffee point out that current capacity is only the minimum of what is required. Laboratory testing capacity must be improved to test for dioxins and steroids and to do quantitative analyses of antibiotic residues. Further, the laboratory must be accredited. Expenses to maintain the current capacity are expected to be high. Fees charged for laboratory tests recover only $50 \%$ of the costs and it is considered politically unacceptable to charge fees for processing plant inspections.

479 Vinod Rege et al., Influencing and Meeting International Standards: Challenges for Developing Countries. Volume II: Procedures Followed by Selected International Standard-Setting Organisations and Country Reports on TBT and SPS (International Trade Centre UNCTAD/WTO and Commonwealth Secretariat, Geneva), 2004, 118 .

${ }^{480}$ Spencer Henson and Steve Jaffee, Jamaica's Trade in Ethnic Foods and Other Niche Products: The Impact of Food Safety and Plant Health Standards, Agriculture and Rural Development Discussion Paper (World Bank, Washington D.C.), 2005, 44, available at: http://siteresources.worldbank.org/INTARD/Resources/ JamaicaStandardsF_final.pdf, visited on 7 January 2008.

${ }^{481}$ Vinod Rege et al., Influencing and Meeting International Standards: Challenges for Developing Countries. Volume II: Procedures Followed by Selected International Standard-Setting Organisations and Country Reports on TBT and SPS (International Trade Centre UNCTAD/WTO and Commonwealth Secretariat, Geneva), 2004, 118.

482 These two fungicides are Deccosol and Botran. However, the manufacturer of Deccosol has not provided the information necessary for approval of that product in Jamaica. As a result, the Ministry of Agriculture and Lands has approved only Botran and calcium hypochloride for use as fungicides on yams for export. Spencer Henson and Steve Jaffee, Jamaica's Trade in Ethnic Foods and Other Niche Products: The Impact of Food Safety and Plant Health Standards, Agriculture and Rural Development Discussion Paper (World 
hypochlorite and to grow a smaller variety of yams that does not require cutting before export. ${ }^{483}$ The FDA approved the alternative fungicides. However, as the alternative treatments are less effective in abating mould growth, it is suspected that Imazilil is still extensively used. ${ }^{484}$

With regard to callaloo, there have been recurring detections of pesticides exceeding US MRLs at US ports of entry. ${ }^{485}$ Consequently, all shipments from the same exporter are automatically detained until a pattern of compliance with US requirements for pesticide residues has been re-established. ${ }^{486}$ This problem is caused by the inadequacy of controls on pesticide use discussed further below. ${ }^{487}$

Many crops indigenous to Jamaica are also being restricted from market access to the EU due to pesticide residues. As mentioned above, this problem is exacerbated by the EU's latter's policy of setting MRLs for pesticides on tropical fruits and vegetables (such as yams and callaloo) at the LOD, due to the absence of commercial support to conduct the experimental trials that are necessary to establish specific MRLs on these products. ${ }^{488}$ The EU has acknowledged the serious implications of this policy for many ACP countries. It has therefore implemented the Pesticides Initiative Programme through the Committee for Liaison for Europe and the African Caribbean and Pacific countries (COLEACP) to assist the producers in these countries to respond to this issue. ${ }^{489}$ This programme aims to collect information on pesticide use in ACP countries and to support the establishment of MRLs for crops of interest to these countries. ${ }^{490}$ Jamaica has been involved with the Pesticides Initiative Programme since 2000. An area under discussion is the application of the same MRL that is used for sweet potato to yams. These discussions reportedly had not borne fruit by $2004 .{ }^{491}$

Bank, Washington D.C.), 2005, 43, available at: http://siteresources.worldbank.org/INTARD/Resources/ JamaicaStandardsF_final.pdf, visited on 7 January 2008.

483 Ibid.

484 Ibid.

${ }^{485}$ Ibid., 25.

${ }^{486}$ Vinod Rege et al., Influencing and Meeting International Standards: Challenges for Developing Countries. Volume II: Procedures Followed by Selected International Standard-Setting Organisations and Country Reports on TBT and SPS (International Trade Centre UNCTAD/WTO and Commonwealth Secretariat, Geneva), 2004, 118.

487 See below, Part II, Section 2.6.2.3.

488 Janice Reid, Needs Analysis of the Readiness of Jamaican Institutions for WTO-SPS: Executive Summary (Inter-American Institute for Cooperation on Agriculture, Kingston), April 2000, 6, available at: www.agroinfo.org/caribbean/iicacarc/jamaica/summary.pdf, visited on 7 January 2008.

489 This example is set out in the Proposal for the Coordination of the Activities of Agricultural Health and Food Safety Agencies in Jamaica, dated May 2005, included with the Memorandum of Understanding signed by the Ministry of Health, the Ministry of Agriculture and Lands and the Ministry of Industry, Commerce and Technology of Jamaica setting up a single Food Safety Authority for Jamaica, as mentioned below, Part II, Section 2.6.3. This document is available at http://www.mct.gov.jm/FINAL\%20CO-ORDINATION\%20 PROPOSAL\%20-Signed1.pdf, visited on 27 December 2007.

${ }^{490}$ Spencer Henson and Steve Jaffee, Jamaica's Trade in Ethnic Foods and Other Niche Products: The Impact of Food Safety and Plant Health Standards, Agriculture and Rural Development Discussion Paper (World Bank, Washington D.C.), 2005, 41, available at: http://siteresources.worldbank.org/INTARD/Resources/ JamaicaStandardsF_final.pdf, visited on 7 January 2008.

491 Ibid. 
Another SPS problem limiting diversification to non-traditional exports relates to farmto-fork food safety requirements for processed foods. Jamaica is developing an export industry in processed foods such as pepper sauces, soups, sauces and tinned products. While these were initially destined for Caribbean immigrants in the UK, US and Canada, the growing demand for ethnic foods among wider populations of developed countries has increased the market base. ${ }^{492}$ Processed foods typically are subject to more stringent SPS requirements than fresh produce. Developed countries have HACCP requirements in place in many processed-food sectors to ensure a systems-wide approach to the prevention of food-safety risks. In 1973, due to the presence of the toxin hypoglycin in unripe ackee, the US placed an import alert on canned ackee. This was extended to all ackee exports to the US in 1993, effectively amounting to an import ban on Jamaican exports of this product ${ }^{493}$ Due to the importance of the US market for this product, Jamaica had a strong incentive to resolve the SPS problems to regain market access to the US. It took an active approach, engaging in bilateral discussions with US authorities to identify the problems and take the necessary action, with the support of financing from the US. These steps were (1) the implementation of a US-approved system of prior approval and regulation of ackee processors, including the requirement to implement a HACCP system in this sector, in terms of which four processors had been approved by 2001; and (2) the operation of a pre-clearance programme for fresh produce exports to the US (initially funded by USAID and now funded through a box levy on exports). ${ }^{494}$ Jamaica developed a national standard for canned ackee in brine. ${ }^{495}$ It has now implemented HACCP requirements with regard to canned ackee. ${ }^{496}$ Exports of canned ackee to the US restarted in 2001. 497

Other examples of processed food requirements affecting Jamaican exports are the US requirement that the details of the production process be filed with the FDA before market access is granted. ${ }^{498}$ Prior approval of the production process is also required for acidified

\footnotetext{
492 Ibid., 45.

${ }^{493}$ Vinod Rege et al., Influencing and Meeting International Standards: Challenges for Developing Countries. Volume II: Procedures Followed by Selected International Standard-Setting Organisations and Country Reports on TBT and SPS (International Trade Centre UNCTAD/WTO and Commonwealth Secretariat, Geneva), 2004, 117. See also Spencer Henson and Steve Jaffee, Jamaica's Trade in Ethnic Foods and Other Niche Products: The Impact of Food Safety and Plant Health Standards, Agriculture and Rural Development Discussion Paper (World Bank, Washington D.C.), 2005, 45, available at: http://siteresources.worldbank.org/ INTARD/Resources/JamaicaStandardsF_final.pdf, visited on 7 January 2008.

494 The steps taken are identified in Shyam K. Gujadhur, 'Technical Assistance for SPS Measures: Protect Health, Not Trade', International Trade Forum (3), 2002, 31-35, available at: http://www.tradeforum.org/ news/fullstory.php/aid/460/Technical_Assistance_for_SPS_Measures:_Protect_Health,_Not_Trade.html, visted on 28 June 2003.

495 Spencer Henson and Steve Jaffee, Jamaica's Trade in Ethnic Foods and Other Niche Products: The Impact of Food Safety and Plant Health Standards, Agriculture and Rural Development Discussion Paper (World Bank, Washington D.C.), 2005, 45, available at: http://siteresources.worldbank.org/INTARD/Resources/ JamaicaStandardsF_final.pdf, visited on 7 January 2008.

${ }^{496}$ Trade Policy Review Body, Trade Policy Review: Jamaica - Report by the Secretariat. Revision, WT/ TPR/S/139/Rev.1, circulated on 9 March 2005, Appendix Table AIII.1.

${ }^{497}$ Spencer Henson and Steve Jaffee, Jamaica's Trade in Ethnic Foods and Other Niche Products: The Impact of Food Safety and Plant Health Standards, Agriculture and Rural Development Discussion Paper (World Bank, Washington D.C.), 2005, 45, available at: http://siteresources.worldbank.org/INTARD/Resources/ JamaicaStandardsF_final.pdf, visited on 7 January 2008.

${ }^{498}$ Ibid., 46.
} 
canned foods. ${ }^{499}$ Jamaican processed foods have sometimes been rejected by the US due to the use of unapproved additives and colorants. ${ }^{500}$ Compliance with process requirements requires a coordinated systems-wide approach, rather than ad hoc initiatives to deal with specific trade restrictions as they arise. More training of producers and processors is needed, particularly with regard to HACCP requirements.

\subsubsection{Animal health system}

Animal health is the responsibility of the Veterinary Services Department of the Ministry of Agriculture and Lands, with a staff of 55 persons, 48 of whom are technical staff. ${ }^{501}$ The Veterinary Services Department is in charge of monitoring the incidence of animal diseases and setting and enforcing quarantine requirements. It operates a quarantine facility for this purpose. ${ }^{502}$ This Department is additionally responsible for issuing import and export permits for meat and fishery products. Control of slaughtering and processing plants for export products is also in the hands of the Veterinary Services Department. However, control of slaughtering and processing plants for products intended for domestic consumption is the responsibility of the Ministry of Health. ${ }^{503}$

The World Organisation for Animal Health (OIE) ${ }^{504}$ which maintains lists of countries recognised as free of particular animal diseases, lists Jamaica as free of 'List A' diseases, except for Newcastle disease. ${ }^{505}$ Jamaica has, however, been free of Newcastle disease since $1969,{ }^{506}$ and is in the process of requesting recognition of its status as Newcastle disease free from the OIE. Screwworm and leptospirosis are endemic, however, and present problems for Jamaica's trade in animal products. ${ }^{507}$ With respect to several animal diseases, such as bovine tuberculosis, bovine brucellosis, classical swine fever and Newcastle disease, Jamaica conducts routine surveillance. ${ }^{508}$

Jamaica has implemented some projects to address animal health concerns in its territory. For example, in order to eradicate screwworms, and prevent re-infestation, a project was implemented from 1998 to 2001 and then extended until 2005, using government and do-

\footnotetext{
499 Ibid.

500 Ibid.

501 Vinod Rege et al., Influencing and Meeting International Standards: Challenges for Developing Countries. Volume II: Procedures Followed by Selected International Standard-Setting Organisations and Country Reports on TBT and SPS (International Trade Centre UNCTAD/WTO and Commonwealth Secretariat, Geneva), 2004, 113.

502 Ibid.

${ }^{503}$ Ibid., 111.

${ }^{504}$ For a discussion of this international standard-setting organisation, see below, Part II, Section 3.2.2.

505 List A diseases are the transmissible animal diseases that have the potential for very serious and rapid spread, irrespective of national borders (e.g. Foot-and-Mouth Disease, Newcastle Disease, Rinderpest, Rift Valley Fever). See Section 2.1.1 of the Terrestrial Animal Health Code (16 $6^{\text {th }}$ ed. May 2007) of the World Organisation for Animal Health.

${ }^{506}$ The last incidence of Newcastle disease in Jamaica according to the OIE database was in 1969 and the disease is under general surveillance.

${ }^{507}$ Vinod Rege et al., Influencing and Meeting International Standards: Challenges for Developing Countries. Volume II: Procedures Followed by Selected International Standard-Setting Organisations and Country Reports on TBT and SPS (International Trade Centre UNCTAD/WTO and Commonwealth Secretariat, Geneva), 2004, 113.

${ }^{508}$ Ibid.
} 
nor funding. ${ }^{509}$ In addition, Jamaica has made significant efforts to upgrade the capacity of the Veterinary Services Department, inter alia as noted above, to facilitate exports of fish and fishery products to the EU. ${ }^{510}$ Once again, these efforts have been reactive, coming only after market access had been denied due to sanitary problems. While these efforts have proved sufficient to obtain the approval of Jamaica to export fish, fishery products and marine gastropods to the EU, further investment is required. ${ }^{511}$

Much of the animal health legislation in Jamaica is outdated, for example the Animal Diseases and Importation Act 1943 and the Pets Import Regulations of $1943 .{ }^{512}$ Improvements in the area of animal health controls are driven by Jamaica's trade, rather than health, priorities. In response to sanitary requirements on its export markets, as noted above, Jamaica has enacted and implemented new legislation in this area, namely the Meat and Meat Products (Inspection and Export) Act of 1998 and the Aquaculture, Inland and Marine Products and By-Products (Inspection, Licensing and Export) Act of 1999. ${ }^{513}$

Meat and meat products are tested for veterinary drug and pesticide residues by a laboratory of the Veterinary Services Department. This laboratory has the capacity to test for most micro-organisms and some residues of antibiotics and pesticides. ${ }^{514}$ Jamaica would like to achieve accreditation of this laboratory for biotoxin and residue testing to perform analyses at regional level. The laboratory was upgraded at an expense of J\$10 million but still requires further investment. ${ }^{515}$ Human resource constraints are also a significant difficulty - there is a shortage of skilled staff and a high turnover rate. ${ }^{516}$ A reported example of this problem is the fact that a high-performance liquid chromatograph was

509 The Jamaican government spent US\$9.9 million from funds made available under the United States Agricultural Trade Development Act and also received funding from USAID and IAEA for this project. Trade Policy Review Body, Trade Policy Review: Jamaica - Report by the Secretariat. Revision, WT/TPR/S/139/ Rev.1, circulated on 9 March 2005, Section IV, Table IV.4.

510 See above, Part II, Section 2.6.2.1.

511 Vinod Rege et al., Influencing and Meeting International Standards: Challenges for Developing Countries. Volume II: Procedures Followed by Selected International Standard-Setting Organisations and Country Reports on TBT and SPS (International Trade Centre UNCTAD/WTO and Commonwealth Secretariat, Geneva), 2004, 113. Henson and Jaffee point out that investments to upgrade sanitary controls in the fishery sector in order to gain access to the EU market were driven by the public sector. Fishery firms depend for their continued compliance with EU requirements on laboratory testing services provided by the Ministry of Agriculture and Lands, as they are unable to make investments in this type of facilities themselves. Spencer Henson and Steve Jaffee, Jamaica's Trade in Ethnic Foods and Other Niche Products: The Impact of Food Safety and Plant Health Standards, Agriculture and Rural Development Discussion Paper (World Bank, Washington D.C.), 2005, 39, available at: http://siteresources.worldbank.org/INTARD/Resources/ JamaicaStandardsF_final.pdf, visited on 7 January 2008.

512 Vinod Rege et al., Influencing and Meeting International Standards: Challenges for Developing Countries. Volume II: Procedures Followed by Selected International Standard-Setting Organisations and Country Reports on TBT and SPS (International Trade Centre UNCTAD/WTO and Commonwealth Secretariat, Geneva), 2004, 113

513 Trade Policy Review Body, Trade Policy Review: Jamaica - Report by the Government, WT/TPR/G/139, circulated on 15 December 2004, 68.

${ }^{514}$ Vinod Rege et al., Influencing and Meeting International Standards: Challenges for Developing Countries. Volume II: Procedures Followed by Selected International Standard-Setting Organisations and Country Reports on TBT and SPS (International Trade Centre UNCTAD/WTO and Commonwealth Secretariat, Geneva), 2004, 112.

515 Ibid.

${ }^{516}$ Ibid. 
acquired by the laboratory for US $\$ 80,000$ but could not be used due to lack of the necessary expertise. ${ }^{517}$

To guard against the introduction of animal pests or diseases through imported products, Jamaica's procedures for the importation of live animals or animal products require the consideration of relevant factors including the reported animal disease status of the exporting country; the implementation of the official regulatory agency's management or monitoring systems during production, slaughtering and processing; and the risk that importation, use and waste disposal of the animal products or their by-products may pose to Jamaica's human or animal population. ${ }^{518}$

In the discussions in the context of the latest trade policy review of Jamaica, the US noted that Jamaica has banned all US pork products due to the presence of Aujesky's disease (pseudorabies) in certain states. As there have been no reported cases of Aujesky's disease in the US since March 2003, the US asked Jamaica when it planned to remove its import ban. ${ }^{519}$ Jamaica responded that its Veterinary Services Division will always respond to a request from the competent authority or an exporting country for an evaluation of that country's disease status and the implementation of its sanitary programme with respect to the production and processing of the relevant product. ${ }^{520}$

\subsubsection{Plant health system}

The responsibility for protecting plant health against harm from plant pests and diseases rests with the Plant Quarantine/Produce Inspection Unit of the Marketing Division of the Ministry of Agriculture and Lands. This unit is responsible for inspection of domestic controls and inspections as well as inspection of imports and exports. ${ }^{521}$ It has 23 inspectors and three regional offices. The unit carries out its functions in cooperation with other government agencies, specifically the Rural Agricultural Development Authority, the Plant Protection Division of the Ministry of Agriculture and Lands and the Food Storage and Prevention of Infestation Division of the Ministry of Commerce, Industry and Technology. ${ }^{522}$

In an effort to improve plant protection in its territory, Jamaica has upgraded its Plant Quarantine Act of 1993 and Agricultural Produce Act of $1926 .{ }^{523}$ It has also undertaken projects to deal with phytosanitary problems, for example, the Citrus Tristeza Virus, which is of concern to Jamaica's citrus sector. A project has been implemented with government funding, loans and grants to increase production through the use of planting

517 Ibid.

518 Trade Policy Review Body, Trade Policy Review: Jamaica - Minutes of Meeting. Addendum, WT/ TPR/M/139/Add.1, circulated on 2 March 2005, para. 5.6.

519 Ibid.

${ }^{520}$ Ibid., para 5.6.

521 Vinod Rege et al., Influencing and Meeting International Standards: Challenges for Developing Countries. Volume II: Procedures Followed by Selected International Standard-Setting Organisations and Country Reports on TBT and SPS (International Trade Centre UNCTAD/WTO and Commonwealth Secretariat, Geneva), 2004, 111.

522 Ibid.

${ }_{523}$ Trade Policy Review Body, Trade Policy Review: Jamaica - Report by the Government, WT/TPR/G/139, circulated on 15 December 2004, 68. 
material free of Citrus Tristeza Virus. It involves public education, technical services (certification, research and implementation management) and credit services. ${ }^{524}$

Jamaica has implemented several phytosanitary measures to protect its crops from imported plant pests and diseases. Jamaica has in place an import prohibition on coffee berries, bananas, citrus fruits and plants and raw honey, which according to the authorities is due to the high risk of introduction of exotic pests and diseases carried by such products. ${ }^{525}$ Similarly, the importation of fruits that are known hosts of pests that are not known to exist in Jamaica is banned. ${ }^{526}$ To avoid the introduction of plant pests through soil or wooden pallets used in transportation, Jamaica has banned soil imports and prohibited the entry of wooden pallets from India, Thailand and Indonesia unless they are treated in accordance with the relevant standard developed by the International Plant Protection Convention, to address the risk from plant pests in wooden packaging material, ISMP 15.527

The Plant Quarantine/Produce Inspection Unit is subject, however, to considerable resource constraints. Due to under-resourcing, this Unit has difficulty maintaining an adequate level of import inspection. ${ }^{528}$ It has only three cold storage facilities to inspect imports and despite the significant increase in imports since the 1990s, it has no additional dedicated import inspection facilities at its disposal. ${ }^{529}$ Information on rejections of imported produce is imprecise, recording is sporadic and often contradictory. ${ }^{530}$ Due to lack of coordination between customs officials and the Plant Quarantine/Produce Inspection Unit, shipments have been released before they have been examined. ${ }^{531}$

The situation for exports is better. Two well-functioning export complexes, one at each international airport, exist for inspection and certification of exports. ${ }^{532}$ Both have fumigation facilities but only one, at Kingston airport, has cold storage facilities available. ${ }^{533}$

524 The Jamaican government and DBJ spent US\$5.69 million on this project and a US\$ 9.9 million loan and US\$0.26 million grant was obtained from the CBD. The remaining US\$4.6 million was funded from other sources. Trade Policy Review Body, Trade Policy Review: Jamaica - Report by the Secretariat. Revision, WT/TPR/S/139/Rev.1, circulated on 9 March 2005, Section IV para. 34 and Table IV.34.

${ }^{525}$ Ibid., Section IV para. 27.

526 Ibid.

527 Committee on Sanitary and Phytosanitary Measures, Notification of Emergency Measures, G/SPS/N/ JAM/10, circulated on 12 October 2007 ; Committee on Sanitary and Phytosanitary Measures, Notification of Emergency Measures G/SPS/N/JAM/11, circulated on 12 October 2007; Committee on Sanitary and Phytosanitary Measures, Notification of Emergency Measures, G/SPS/N/JAM/9, circulated on 12 October 2007.

${ }^{528}$ Vinod Rege et al., Influencing and Meeting International Standards: Challenges for Developing Countries. Volume II: Procedures Followed by Selected International Standard-Setting Organisations and Country Reports on TBT and SPS (International Trade Centre UNCTAD/WTO and Commonwealth Secretariat, Geneva), 2004, 113.

529 Ibid.

530 Janice Reid, Needs Analysis of the Readiness of Jamaican Institutions for WTO-SPS: Executive Summary (Inter-American Institute for Cooperation on Agriculture, Kingston), April 2000, 8, available at: www.agroinfo.org/caribbean/iicacarc/jamaica/summary.pdf, visited on 7 January 2008.

${ }^{531}$ Ibid.

${ }^{532}$ Vinod Rege et al., Influencing and Meeting International Standards: Challenges for Developing Countries. Volume II: Procedures Followed by Selected International Standard-Setting Organisations and Country Reports on TBT and SPS (International Trade Centre UNCTAD/WTO and Commonwealth Secretariat, Geneva), 2004, 113

${ }^{533} \mathrm{Ibid}$. See also Spencer Henson and Steve Jaffee, Jamaica's Trade in Ethnic Foods and Other Niche Products: The Impact of Food Safety and Plant Health Standards, Agriculture and Rural Development Discussion 
The Kingston facility was developed by means of a loan from the World Bank in 1989 and significantly upgraded in the late 1990 s with a government investment of J\$30 million. ${ }^{534}$ Exporters are required to have a pack house meeting particular requirements, which is inspected and approved by plant quarantine inspectors. ${ }^{535}$ For exports to the US, ${ }^{536}$ preclearance is conducted by inspectors of the Plant Quarantine/Produce Inspection Unit under the oversight of an official of the US Animal and Plant Health Inspection Service (APHIS), based in Jamaica. ${ }^{537}$ There are considerable benefits to Jamaica from the operation of a pre-clearance system. Exporters can be confident that pre-cleared shipment will gain market access to the US as border officials will conduct only periodic checks. This eliminates the high costs of rejections at the border, allowing exporters to divert their products to other destinations if they do not pass pre-clearance. ${ }^{538}$ Sixty-four different products from about 80 percent of exporters destined for export to the US are approved for pre-clearance in Jamaica. Rejections are, in more than 80 percent of cases, due to arthropod pests ${ }^{539}$ and are highest for callaloo, peppers and papaya. ${ }^{540}$ To avoid undermining the integrity of the pre-clearance program in the eyes of APHIS, Jamaica has responded quickly and rigorously to phytosanitary problems. ${ }^{541}$ In some cases it has even voluntarily removed a product subject to repeated pest detections from the program. ${ }^{542}$ However,

Paper (World Bank, Washington D.C.), 2005, 16, available at: http://siteresources.worldbank.org/INTARD/ Resources/JamaicaStandardsF_final.pdf, visited on 7 January 2008.

${ }_{534}$ Spencer Henson and Steve Jaffee, Jamaica's Trade in Ethnic Foods and Other Niche Products: The Impact of Food Safety and Plant Health Standards, Agriculture and Rural Development Discussion Paper (World Bank, Washington D.C.), 2005, 26, available at: http://siteresources.worldbank.org/INTARD/Resources/ JamaicaStandardsF_final.pdf, visited on 7 January 2008.

${ }^{535}$ Vinod Rege et al., Influencing and Meeting International Standards: Challenges for Developing Countries. Volume II: Procedures Followed by Selected International Standard-Setting Organisations and Country Reports on TBT and SPS (International Trade Centre UNCTAD/WTO and Commonwealth Secretariat, Geneva), 2004, 113.

${ }^{536}$ Exports destined for other markets are inspected and certified separately from the US pre-clearance program.

${ }^{537}$ Vinod Rege et al., Influencing and Meeting International Standards: Challenges for Developing Countries. Volume II: Procedures Followed by Selected International Standard-Setting Organisations and Country Reports on TBT and SPS (International Trade Centre UNCTAD/WTO and Commonwealth Secretariat, Geneva), 2004, 113.

${ }^{538}$ If products are not taken through pre-clearance and are rejected at the US border, they not only unnecessarily bear the high costs of transportation, but also lose the possibility of diversion to another destination due to the fact that the US destroys rejected products automatically. Spencer Henson and Steve Jaffee, Jamaica's Trade in Ethnic Foods and Other Niche Products: The Impact of Food Safety and Plant Health Standards, Agriculture and Rural Development Discussion Paper (World Bank, Washington D.C.), 2005, 29, available at: http://siteresources.worldbank.org/INTARD/Resources/JamaicaStandardsF_final.pdf, visited on 7 January 2008.

539 The pests at issue are mainly Homoptera and Lepidoptera. Janice Reid, Needs Analysis of the Readiness of Jamaican Institutions for WTO-SPS: Executive Summary (Inter-American Institute for Cooperation on Agriculture, Kingston), April 2000, 7, available at: www.agroinfo.org/caribbean/iicacarc/jamaica/summary. pdf, visited on 7 January 2008.

540 Ibid.

${ }^{541}$ Although APHIS requires only a 2\% level of inspection of produce, Jamaica conducts a $10 \%$ level to avoid detections leading to loss of confidence in the system by the US. Spencer Henson and Steve Jaffee, Jamaica's Trade in Ethnic Foods and Other Niche Products: The Impact of Food Safety and Plant Health Standards, Agriculture and Rural Development Discussion Paper (World Bank, Washington D.C.), 2005, 27, available at: http://siteresources.worldbank.org/INTARD/Resources/JamaicaStandardsF_final.pdf, visited on 7 January 2008.

${ }^{542} \mathrm{Ibid}$. Henson and Jaffee give the example of the voluntary withdrawal by Jamaica of callaloo from the preclearance program to prevent devaluation of the program and the introduction of fumigation requirements 
the pre-clearance system is costly to operate, despite the cost-recovery fee imposed, and it reportedly absorbs a quarter or the budget of the Plant Quarantine/Produce Inspection Unit. ${ }^{543}$ Some exporters have chosen to avoid the fee for pre-clearance and take their chances with possible detentions at US ports of entry. ${ }^{544}$

Jamaica is free of most plant pests and diseases of significance to international trade. ${ }^{545}$ It has surveillance programmes in place to control plant pests and diseases in domestic production. The Rural Agricultural Development Authority has 60 extension officers, stationed across Jamaica in offices with a computer linked to centrally stored data, responsible for conducting the necessary surveillance. Surveillance is carried out for fruit fly, scale insects, papaya ring spot virus, papaya mealy bug (of which Jamaica is free), pink mealy bug and hot pepper gall midge. ${ }^{546}$ The Rural Agricultural Development Authority is notified of rejected export shipments and is supposed to investigate the matter. However, financial constraints have lead to poor implementation of this inspection system. ${ }^{547}$ In addition, as Jamaica lacks sufficient capacity to undertake pest risk assessments, its status as being free from certain pests and diseases is not confirmed. ${ }^{548}$ There are insufficient inspectors for proper surveillance of plant pests and diseases. ${ }^{549}$ In addition, the weakness of Jamaica's diagnostic laboratory capacity with regard to plant pathology and pest identification and its lack of expertise in this area has made it difficult for Jamaica to defend its export interests when faced with phytosanitary barriers imposed by its trading partners. ${ }^{550}$

With regard to the plant pests that are present in Jamaica, for example fruit flies, Jamaica faces significant problems. As is the case in many developing countries, Jamaica's diversification into exports of high-value horticultural products has been plagued by the problem of how to eliminate harmful pests from shipments while keeping to the maximum residue levels for pesticides required by its trading partners. ${ }^{551}$ Horticultural products are vulnerable to infestation by many pests, and the incidence of pests, particularly exotic or

by the US.

${ }^{543}$ Ibid., 27. Henson and Jaffee report that the pre-clearance system was initially funded by USAID but since 1996 it has had to be self supporting. Until 2001 the system was operated by the Jamaican Exporters' Association, and since then it is run by the Ministry of Agriculture, funded by a $20 \%$ cost recovery fee. The fee has proved insufficient and the system has run into arrears. The cost of the system is US\$390,000 per year, much of which goes to the resident APHIS official (US\$150,000 per year). Jamaica would like to save on these costs by operating the pre-clearance system itself, seeing as its inspectors already conduct most of the inspections and the APHIS official only provides oversight. However, the US is unlikely to agree.

${ }^{544}$ Unlike in other countries where export associations have made the use of pre-clearance systems mandatory, in Jamaica exporters may choose to take their products through the pre-clearance program or not. Ibid., note $8,27$.

${ }^{545}$ Vinod Rege et al., Influencing and Meeting International Standards: Challenges for Developing Countries. Volume II: Procedures Followed by Selected International Standard-Setting Organisations and Country Reports on TBT and SPS (International Trade Centre UNCTAD/WTO and Commonwealth Secretariat, Geneva), 2004, 113

546 Ibid.

${ }^{547}$ Ibid.

548 Ibid.

${ }^{549}$ Ibid., 113-114.

${ }^{550}$ Ibid., 114.

${ }^{551}$ George W. Norton et al., Food Safety in Food Security and Food Trade: Case Study: Reducing Pesticide Residues on Horticultural Crops, in 2020 Vision for Food, Agriculture and the Environment (International Food Policy Research Institute, Washington D.C.), September 2003, 1, 1. 
invasive ones, are a significant cause of shipment detentions at posts of entry. ${ }^{552}$ Since horticultural exports from developing countries are often non-traditional, pre-inspection protocols may not exist, rendering these exports especially likely to be detained for inspection or fumigation. The discovery of a pest in even one shipment may lead to an exporting country being placed on a quarantine list, resulting in denial of market access. As a result, heavy pesticide use occurs. ${ }^{553}$ However, exceeding pesticide residue limits is also an important cause of shipment detentions, and repeated violations may lead to the automatic detention of all shipments from that country. ${ }^{554}$

\subsection{Examples of phytosanitary measures affecting Jamaican exports}

The problem caused by plant pests is illustrated by the example of exports of hot peppers from Jamaica. Hot peppers are identified as a priority crop by the Jamaican government, as it helps small farmers increase their income. ${ }^{555}$ This product is exported to Canada, the UK and the US, reaching high export levels in the mid-1990s but experiencing a decline in exports since then, largely explained by phytosanitary problems with exports to the US. ${ }^{556}$ In 1997 on its arrival in US ports a hot pepper shipment was found to be infested with gall midge, a pest not normally associated with peppers, and not a quarantine pest under international standards. ${ }^{557}$ The APHIS imposed a mandatory requirement of fumigation with methyl bromide on all peppers from Jamaica (including bell peppers and chilli peppers) leading to a three quarter reduction in hot pepper exports from Jamaica due to the added costs and reduced quality resulting from fumigation. ${ }^{558}$ To address this set-

552 Ibid.

${ }^{553}$ With regard to Jamaica's food-safety controls of pesticides, see the discussion in the food safety subsection above.

${ }^{554}$ George W. Norton et al., Food Safety in Food Security and Food Trade: Case Study: Reducing Pesticide Residues on Horticultural Crops, in 2020 Vision for Food, Agriculture and the Environment (International Food Policy Research Institute, Washington D.C.), September 2003, 1, 1.

${ }_{555}$ Spencer Henson and Steve Jaffee, Jamaica's Trade in Ethnic Foods and Other Niche Products: The Impact of Food Safety and Plant Health Standards, Agriculture and Rural Development Discussion Paper (World Bank, Washington D.C.), 2005, 30, available at: http://siteresources.worldbank.org/INTARD/Resources/ JamaicaStandardsF_final.pdf, visited on 7 January 2008. Henson and Jaffee report that in 2000 a plot of only 0.005 hectares, which can support about 1,000 plants, could produce an estimated weekly income of J\$10,000.

${ }_{556}$ Ibid., 31. Other obstacles to exports noted by Henson and Jaffee are production problems caused by variable rainfall and poor quality seed, and the fact that the demand for and price of hot peppers on the domestic market are good. As a result of these factors and the phytosanitary problems with exports to the US, exports accounted for only $5 \%$ of total production in the late $1990 \mathrm{~s}$.

${ }^{557}$ More than 100 shipments in 1998 were found to be infested with gall midge. George W. Norton et al., Food Safety in Food Security and Food Trade: Case Study: Reducing Pesticide Residues on Horticultural Crops, in 2020 Vision for Food, Agriculture and the Environment (International Food Policy Research Institute, Washington D.C.), September 2003, 2, 2.; Spencer Henson and Steve Jaffee, Jamaica's Trade in Ethnic Foods and Other Niche Products: The Impact of Food Safety and Plant Health Standards, Agriculture and Rural Development Discussion Paper (World Bank, Washington D.C.), 2005, 31, available at: http:// siteresources.worldbank.org/INTARD/Resources/JamaicaStandardsF_final.pdf, visited on 7 January 2008. Henson and Jaffee point out that gall midge is also found in Florida.

${ }_{558}$ George W. Norton et al., Food Safety in Food Security and Food Trade: Case Study: Reducing Pesticide Residues on Horticultural Crops, in 2020 Vision for Food, Agriculture and the Environment (International Food Policy Research Institute, Washington D.C.), September 2003, 2, 2. Hot pepper exports fell from over 200 tons in 1997 to only 25 tons in 2002 and 2003. According to Henson and Jaffee, the cost of fumigation is estimated to be $8 \%$ of the FOB value of hot peppers, making it difficult for Jamaican peppers to compete with 
back, the Jamaican government established a National Pepper Task Force to identify and correct the problem. Inspections revealed a high incidence of gall midge on hot peppers in the rainy months. ${ }^{559}$ However, as gall midge is not a pest of quarantine significance under international protocols, and is present in the US already (in Florida), Jamaica questioned the justification for the US measure and requested documentary evidence of risk. Despite repeated such requests, no justification has been provided. ${ }^{560}$

Instead, a collaborative effort was undertaken by the Jamaican government and the US Agency for International Development (USAID) under the latter's Integrated Pest Management Collaborative Research Support Program (IPM CRSP). ${ }^{561}$ IPM systems use biological, cultural and less chemically intensive pest management approaches. ${ }^{562}$ The IPM strategy used in this case involved a ten-point protocol, including the establishment of a pre-clearance system under which approved peppers would be allowed market access without fumigation, the reduction of pesticide use and the improvement of cultivation practices; replacing methyl bromide with a less costly and environmentally friendly fumigant where fumigation was still needed for clearance; establishing a traceability system for growers; monitoring of gall midge progression in the field; and training officers and farmers. ${ }^{563}$ The system was based on sourcing hot peppers from gall midge-free areas and on rigorous controls throughout the supply chain. ${ }^{564}$ If the rejection rate due to detection of any quarantine pests reaches 15 percent, however, all peppers will again require fumigation. This initiative is reported, in a study by the ITC and Commonwealth Secretariat, to have led to a 90 percent reduction in infested shipments and subsequently to the lifting

those of other Caribbean producers which are not subject to fumigation requirements. It is reported that fumigated peppers, due to their reduced quality, can only be sold for processing rather than on the fresh produce market. Fumigated peppers lose their sheen and have limited shelf-life. Vinod Rege et al., Influencing and Meeting International Standards: Challenges for Developing Countries. Volume II: Procedures Followed by Selected International Standard-Setting Organisations and Country Reports on TBT and SPS (International Trade Centre UNCTAD/WTO and Commonwealth Secretariat, Geneva), 2004, 118. Spencer Henson and Steve Jaffee, Jamaica's Trade in Ethnic Foods and Other Niche Products: The Impact of Food Safety and Plant Health Standards, Agriculture and Rural Development Discussion Paper (World Bank, Washington D.C.), 2005, 31, available at: http://siteresources.worldbank.org/INTARD/Resources/JamaicaStandardsF_final.pdf, visited on 7 January 2008.

559 Spencer Henson and Steve Jaffee, Jamaica's Trade in Ethnic Foods and Other Niche Products: The Impact of Food Safety and Plant Health Standards, Agriculture and Rural Development Discussion Paper (World Bank, Washington D.C.), 2005, available at: http://siteresources.worldbank.org/INTARD/Resources/ JamaicaStandardsF_final.pdf, visited on 7 January 2008. Henson and Jaffee note that over $70 \%$ of shipments are infested with gall midge in the rainy months.

${ }^{560}$ Ibid.

${ }^{561}$ George W. Norton et al., Food Safety in Food Security and Food Trade: Case Study: Reducing Pesticide Residues on Horticultural Crops, in 2020 Vision for Food, Agriculture and the Environment (International Food Policy Research Institute, Washington D.C.), September 2003, 2, 2.

${ }^{562}$ Ibid., 1,1 .

${ }_{563}$ Ibid., 2, 2. The ten elements of the protocol are set out by Henson and Jaffee.Spencer Henson and Steve Jaffee, Jamaica's Trade in Ethnic Foods and Other Niche Products: The Impact of Food Safety and Plant Health Standards, Agriculture and Rural Development Discussion Paper (World Bank, Washington D.C.), 2005, 33, Box 32, available at: http://siteresources.worldbank.org/INTARD/Resources/JamaicaStandardsF_ final.pdf, visited on 7 January 2008.

${ }^{564}$ Spencer Henson and Steve Jaffee, Jamaica's Trade in Ethnic Foods and Other Niche Products: The Impact of Food Safety and Plant Health Standards, Agriculture and Rural Development Discussion Paper (World Bank, Washington D.C.), 2005, 32, available at: http://siteresources.worldbank.org/INTARD/Resources/ JamaicaStandardsF_final.pdf, visited on 7 January 2008. 
of the fumigation requirement in 2002 subject to the requirements that growers had to participate in the IPM field control program and those with shipments rejected once due to gall midge would be removed from the program. ${ }^{565}$ More than 400 farmers were assigned traceability numbers under this program in $2003 .{ }^{566}$

Fumigation requirements are also imposed by the US on yam exports from Jamaica, since the 1940 s, to eliminate a weevil found in Jamaica. ${ }^{567}$ Although Jamaica claims that a survey by the Ministry of Agriculture and Lands has identified pest-free areas in Jamaica and has requested that APHIS undertake a pest risk assessment in order to lift the requirement for yam exports from pest-free areas ${ }^{568}$ no solution to this problem has yet been reported. ${ }^{569}$

Another significant, and to date unresolved, problem with a phytosanitary trade barrier affecting Jamaican non-traditional exports has been the US measure to prevent the introduction of West Indian and Caribbean fruit flies through mango imports from Jamaica. ${ }^{570}$ The US requires hot water treatment of mangoes before it will allow importation. However, Jamaica lacks the facilities to provide this treatment and has thus been unable to obtain approval for its mango exports to the US. ${ }^{571}$ The costs of creating the necessary facility, which would be able to treat 1,000 tons of mangoes per month, have been estimated at

${ }^{565}$ George W. Norton et al., Food Safety in Food Security and Food Trade: Case Study: Reducing Pesticide Residues on Horticultural Crops, in 2020 Vision for Food, Agriculture and the Environment (International Food Policy Research Institute, Washington D.C.), September 2003, 2, 2. Note however, that, to the contrary, Henson and Jaffee report that the ten-point protocol had not been implemented by the Jamaican government at the date of the writing of their report (2004) and that all hot pepper shipments remained subject to compulsory fumigation. They note that no economically significant areas in Jamaica could be identified that would be able to produce peppers with a level of infestation that could be controlled at pack houses. They note further the problems for traceability caused by the fragmented supply chains. In addition they point out that the required changes are not regarded as cost effective by exporters, particularly in view of high risk of re-imposition of the fumigation requirements if pest detection reaches $15 \%$, which would render their investment worthless. They also recall the fact that the domestic market for hot peppers, where these phytosanitary requirements do not apply, remains lucrative. Spencer Henson and Steve Jaffee, Jamaica's Trade in Ethnic Foods and Other Niche Products: The Impact of Food Safety and Plant Health Standards, Agriculture and Rural Development Discussion Paper (World Bank, Washington D.C.), 2005, 33-34, available at: http:// siteresources.worldbank.org/INTARD/Resources/JamaicaStandardsF_final.pdf, visited on 7 January 2008.

${ }^{566}$ George W. Norton et al., Food Safety in Food Security and Food Trade: Case Study: Reducing Pesticide Residues on Horticultural Crops, in 2020 Vision for Food, Agriculture and the Environment (International Food Policy Research Institute, Washington D.C.), September 2003, 2, 2.

${ }^{567}$ Spencer Henson and Steve Jaffee, Jamaica's Trade in Ethnic Foods and Other Niche Products: The Impact of Food Safety and Plant Health Standards, Agriculture and Rural Development Discussion Paper (World Bank, Washington D.C.), 2005, 42, available at: http://siteresources.worldbank.org/INTARD/Resources/ JamaicaStandardsF_final.pdf, visited on 7 January 2008.

568 This example is reported in Vinod Rege et al., Influencing and Meeting International Standards: Challenges for Developing Countries. Volume II: Procedures Followed by Selected International Standard-Setting Organisations and Country Reports on TBT and SPS (International Trade Centre UNCTAD/WTO and Commonwealth Secretariat, Geneva), 2004, 118.

${ }^{569}$ Spencer Henson and Steve Jaffee, Jamaica's Trade in Ethnic Foods and Other Niche Products: The Impact of Food Safety and Plant Health Standards, Agriculture and Rural Development Discussion Paper (World Bank, Washington D.C.), 2005, 43, available at: http://siteresources.worldbank.org/INTARD/Resources/ JamaicaStandardsF_final.pdf, visited on 7 January 2008.

${ }^{570}$ Ibid., 27.

${ }^{571}$ Vinod Rege et al., Influencing and Meeting International Standards: Challenges for Developing Countries. Volume I: Background Information, Findings from Case Studies and Technical Assistance Needs (International Trade Centre UNCTAD/WTO and Commonwealth Secretariat, Geneva), 2003, 58. 
US\$175, 000..$^{572}$ Neither the production in Jamaica of export-quality mangoes nor the demand in the US for such mangoes is sufficient to support even one such facility. Therefore no investment has been made to deal with this problem. ${ }^{573}$

A further problem faced by Jamaica with regard to its exports of fresh fruit and vegetables relates to private standards. In particular, the requirement imposed by UK supermarkets that fresh produce imports be certified for compliance with EUREPGAP standards, many of which are SPS requirements, is problematic for Jamaican exporters. ${ }^{574}$ In 2005 , Jamaica supported a trade concern raised by Saint Vincent and the Grenadines at the SPS Committee in this regard. ${ }^{575}$ This concern related to the significant cost implications of these private standards, which are typically much more demanding than government standards, for small farmers in vulnerable economies. ${ }^{576}$

A report of an UNCTAD study has pointed out that the EUREPGAP protocol requires a high level of investment and expertise for its implementation. ${ }^{577}$ According to this study, the EUREPGAP protocol is best suited to large producers that have the necessary human and financial resources. In addition, due to the lack of local certification bodies for EUREPGAP, exporters are forced to use the services of multinational companies, at high costs. $^{578}$

The EC representative pointed out that EUREPGAP was not an EC body, but instead a private sector consortium representing the interests of major retailers. Therefore

${ }^{572}$ Spencer Henson and Steve Jaffee, Jamaica's Trade in Ethnic Foods and Other Niche Products: The Impact of Food Safety and Plant Health Standards, Agriculture and Rural Development Discussion Paper (World Bank, Washington D.C.), 2005, 26, available at: http://siteresources.worldbank.org/INTARD/Resources/ JamaicaStandardsF_final.pdf, visited on 7 January 2008. Henson and Jaffee note that the cost would rise to US $\$ 250,000$ if a new building were to be constructed to house the necessary facilities.

${ }^{573} \mathrm{Ibid}$. Notable additional reasons given by Henson and Jaffee for the lack of investment in creating this facility are the fact that Jamaican mango producers still have access to the UK and Canadian markets; the fact that Jamaica does not benefit from a seasonal niche in the US market; and the fact that there is strong competition from Brazil, Haiti and Mexico where extensive investments have been made in hot water treatment facilities and economies of scale exist. Investment in such facilities in Jamaica would therefore only be worthwhile if there were parallel investments in improving mango production.

${ }^{574}$ As explained above, EUREPGAP requirements are standards for 'good agricultural practices' (GAP) laid down by the Euro-Retailer Produce Working Group (EUREP), a consortium representing major retailers. This consortium was rebranded as GLOBALGAP in September 2007, to indicate that its standards are open to producers worldwide. See further above, Part II, Section 1.3.

575 Committee on Sanitary and Phytosanitary Measures, Summary of the Meeting Held on 29-30 June 2005. Note by the Secretariat. Revision, G/SPS/R/37/Rev.1, circulated on 18 August 2005, para. 17. See further Committee on Sanitary and Phytosanitary Measures, Specific Trade Concerns. Note by the Secretariat. Addendum: Issues Considered in 2006, G/SPS/GEN/204/Rev.7/Add.1, circulated on 6 February 2007, item 219. This complaint was supported not only by Jamaica but also by Argentina, Belize, Cuba, Dominica, Ecuador, Egypt, Indonesia, Kenya, Mexico, Peru and South Africa. See also Committee on Sanitary and Phytosanitary Measures, Private Industry Standards. Communication from Saint Vincent and the Grenadines, G/SPS/GEN/766, circulated on 28 February 2007

${ }^{576}$ Committee on Sanitary and Phytosanitary Measures, Summary of the Meeting of 11-12 October 2006. Note by the Secretariat, G/SPS/R/43, circulated on 3 January 2007, para. 41.

577 Committee on Sanitary and Phytosanitary Measures, Executive Summary of a Study on Agri-Food Safety and SPS Compliance in Guinea Conakry, Mozambique and Tanzania. Communication from UNCTAD, G/SPS/ GEN/567, circulated on 17 June 2005, para. 43.

${ }^{578} \mathrm{Ibid}$., para. 51. In order to be allowed to certify compliance with EUREPGAP, a certification body must be accredited by Food PLUS, the legal owner of the EUREPGAP protocol. A prerequisite for such accreditation is accreditation to ISO $65 / \mathrm{EN} 45011$ standards. 
EUREPGAP standards could not be regarded as EC requirements. In addition, the EC stated that such standards did not violate EC legislation and therefore the EC was not in a position to object to them, even if they were stricter than the SPS requirements of the EC. The EC advised WTO Members that had concerns with EUREPGAP requirements, especially LDCs, to discuss the matter with consumer-interest non-governmental organisations, since in many cases EUREPGAP standards reflect consumer concerns. ${ }^{579}$

Arising from this discussion, and the interest expressed by several Members in this issue, informal sessions of the SPS Committee were held in October 2006 and February 2007 to discuss private standards. These discussions were not limited to EUREPGAP standards, but addressed the over- 400 private standard schemes that are in operation. ${ }^{580}$

\subsubsection{Overall assessment of the SPS System of Jamaica}

As has been seen from the above discussion, while Jamaica has the basic framework of laws and institutions needed for a well-functioning SPS system, the great degree of fragmentation in responsibility evinced by the many public agencies and plethora of laws and regulations making up this system undermine its effectiveness. ${ }^{581}$ This leads to problems of overlapping regulatory competence, duplication of tasks, ${ }^{582}$ waste of scarce resources and lack of coordination. ${ }^{583}$ This fragmentation has been criticised as compromising Jamaica's ability to identify and respond to emerging SPS problems effectively. ${ }^{584}$

579 Committee on Sanitary and Phytosanitary Measures, Summary of the Meeting Held on 29-30 June 2005.

Note by the Secretariat. Revision, G/SPS/R/37/Rev.1, circulated on 18 August 2005, para. 18.

${ }^{580}$ Committee on Sanitary and Phytosanitary Measures, Summary of the Meeting of 11-12 October 2006. Note by the Secretariat, G/SPS/R/43, circulated on 3 January 2007, para. 40.

${ }^{581}$ This criticism has also been made in Vinod Rege et al., Influencing and Meeting International Standards: Challenges for Developing Countries. Volume II: Procedures Followed by Selected International StandardSetting Organisations and Country Reports on TBT and SPS (International Trade Centre UNCTAD/WTO and Commonwealth Secretariat, Geneva), 2004, 110.

582 For example, the monitoring of imported products to avoid the introduction of SPS risks is carried out by a variety of officials from the Ministry of Health, the BSJ, the Veterinary Services Division, the Plant Quarantine/Produce Inspection Unit and the FSPID. Further, the control of pesticides is carried out by the Pesticide Control Authority (PCA) under the Pesticides Act, but the FSPID also has tasks relating to aspects of pesticide control. These overlaps have been the subject of negotiations between PCA and the FSPID over many years. These problems of overlap are mentioned in the Proposal for the Coordination of the Activities of Agricultural Health and Food Safety Agencies in Jamaica, dated May 2005, included with the Memorandum of Understanding signed by the Ministry of Health, the Ministry of Agriculture and Lands and the Ministry of Industry, Commerce and Technology of Jamaica setting up a single Food Safety Authority for Jamaica, available at http://www.mct.gov.jm/FINAL\%20CO-ORDINATION\%20PROPOSAL\%20-Signed1.pdf, visited on 27 December 2007.

583 Spencer Henson and Steve Jaffee, Jamaica's Trade in Ethnic Foods and Other Niche Products: The Impact of Food Safety and Plant Health Standards, Agriculture and Rural Development Discussion Paper (World Bank, Washington D.C.), 2005, 10, available at: http://siteresources.worldbank.org/INTARD/Resources/ JamaicaStandardsF_final.pdf, visited on 7 January 2008. Henson and Jaffee point to the examples of the overlapping responsibility for licensing of pest control operators by both the PCA of the Ministry of Health and the FSPID of the Ministry of Industry, Commerce and Technology; and the responsibility for inspection and approval of food processing establishments by both the BSJ and the Ministry of Health.

${ }^{584}$ Vinod Rege et al., Influencing and Meeting International Standards: Challenges for Developing Countries. Volume II: Procedures Followed by Selected International Standard-Setting Organisations and Country Reports on TBT and SPS (International Trade Centre UNCTAD/WTO and Commonwealth Secretariat, Geneva), 2004, 116. This also limits Jamaica's ability to use the SPS Agreement to challenge the SPS measures of its trading partners. 
Consequently, Jamaica's approach to SPS trade barriers, as has been seen above, has been characterised as 'reactive'. In other words, although the Jamaican government has demonstrated its ability and willingness to address SPS problems vigorously through cooperation with its trading partners, it develops strategies and makes changes only once these SPS problems have led to a loss of market access. ${ }^{585}$ This creates uncertainty among producers and exporters and is a disincentive to investment in export production. In addition, while Jamaica has identified SPS trade restrictions on its exports that seem to be unjustified, it has not strongly pursued the avenue of challenging the legitimacy of such restrictions.

Human resources are an important constraint reducing the capacity of Jamaica to respond effectively to SPS problems. Across the various agencies with responsibility in the area of food safety, there are limited skills and experience in risk analysis and equivalence issues. ${ }^{586}$ In addition, capacity to implement HACCP systems needs to be increased. ${ }^{587}$

SPS legislation in Jamaica is in many cases outdated and poorly implemented. Changes are driven by demands on export markets and are therefore sector specific, leading to greater incoherence in the SPS system. There is a need to consolidate legislation and make SPS requirements clearer to producers. In addition, legislative authority to set MRLs for pesticides is needed. ${ }^{58}$

The limited capacity of Jamaican laboratories is also a problem, as it undermines regulatory initiatives to control pesticide residues and other contaminants. The lack of accreditation of these laboratories weakens the credibility of their test results in the eyes of trading partners.

Lack of adequate controls on the use of pesticides and veterinary drugs is a significant concern. There is a pressing need to develop guidelines for good pest management practice based on international standards and to strengthen programmes relating to integrated pest management. ${ }^{589}$ Good Agricultural Practice (GAP) standards must be implemented and compliance therewith documented to ensure acceptability of produce by means of the demonstration of successful control of pests. ${ }^{590}$

\footnotetext{
585 Spencer Henson and Steve Jaffee, Jamaica's Trade in Ethnic Foods and Other Niche Products: The Impact of Food Safety and Plant Health Standards, Agriculture and Rural Development Discussion Paper (World Bank, Washington D.C.), 2005, 1, available at: http://siteresources.worldbank.org/INTARD/Resources/ JamaicaStandardsF_final.pdf, visited on 7 January 2008.

${ }^{586}$ Vinod Rege et al., Influencing and Meeting International Standards: Challenges for Developing Countries. Volume II: Procedures Followed by Selected International Standard-Setting Organisations and Country Reports on TBT and SPS (International Trade Centre UNCTAD/WTO and Commonwealth Secretariat, Geneva), 2004, 112.

${ }^{587}$ Ibid.

${ }^{588}$ Spencer Henson and Steve Jaffee, Jamaica's Trade in Ethnic Foods and Other Niche Products: The Impact of Food Safety and Plant Health Standards, Agriculture and Rural Development Discussion Paper (World Bank, Washington D.C.), 2005, 15, available at: http://siteresources.worldbank.org/INTARD/Resources/ JamaicaStandardsF_final.pdf, visited on 7 January 2008.

589 This need is identified in Janice Reid, Needs Analysis of the Readiness of Jamaican Institutions for WTOSPS: Executive Summary (Inter-American Institute for Cooperation on Agriculture, Kingston), April 2000, 10, available at: www.agroinfo.org/caribbean/iicacarc/jamaica/summary.pdf, visited on 7 January 2008.

${ }^{590}$ Ibid.
} 
In order to improve the reception of its agricultural and food products on its export markets, Jamaica has taken steps to improve its SPS regime, including through implementing new legislation that incorporates the SPS requirements of its export markets, creating 'one-stop' export pre-clearance centres at its two international airports, establishing a residue-testing laboratory at the Ministry of Agriculture and Lands, and increasing participation in international standard-setting bodies. ${ }^{591}$

In addition, to reduce fragmentation and improve coordination of responsibilities, Jamaica established a National Agricultural Health and Food Safety Coordinating Committee (NAHFSCC) on which 23 agencies and departments are represented. ${ }^{592}$ In May 2005 a memorandum of understanding was signed between the Ministry of Health, the Ministry of Agriculture and Lands and the Ministry of Industry, Commerce and Technology in collaboration with the NAHFSCC in order to create a single food-safety authority. ${ }^{593}$ In addition, in 2006, the Ministry of Agriculture and Lands started preliminary work towards a Comprehensive Agricultural Policy, requesting technical assistance from the FAO in this regard. The new policy aims to create a comprehensive framework for rural and agricultural development, to promote investment, job creation and rural prosperity. ${ }^{594}$ Currently several policies are in the process of being developed by the Ministry of Agriculture and Lands. With regard to animal and plant health, the intention to create new policies has been notified to the Cabinet and concept papers are being drafted. ${ }^{595}$ Inter alia, these policies aim to satisfy requirements in international trade. ${ }^{596}$

591 FAO Commodities and Trade Division, Agriculture, Trade and Food Security: Issues and Options in the WTO Negotiations from the Perspective of Developing Countries. Volume II: Country Case Studies (Food and Agriculture Organization, Geneva), 2000, Chapter 1, Section 2.4, available at: www.fao.org/docrep/003/ X8731e/X8731e00.htm, visited on 7 January 2008.

${ }^{592}$ Spencer Henson and Steve Jaffee, Jamaica's Trade in Ethnic Foods and Other Niche Products: The Impact of Food Safety and Plant Health Standards, Agriculture and Rural Development Discussion Paper (World Bank, Washington D.C.), 2005, 10, available at: http://siteresources.worldbank.org/INTARD/Resources/ JamaicaStandardsF_final.pdf, visited on 7 January 2008. The National Agricultural Health and Food Safety Coordinating Committee is mandated: 'to establish and maintain a rational and integrated farm-to-table agricultural health and food safety system in Jamaica that harmonizes inter-agency conflict and overlap, and ensures the protection of public health in a manner consistent with WTO and other international standards.' The NAHFSCC is composed of senior technical officers from the three ministries, representatives from Scientific Research Council, the BSJ, the University of the West Indies, the Caribbean Food and Nutrition Institute, the FAO, IICA, Consumer Affairs Commission and the Jamaica Exporters Association among others. The chair of this committee is rotated annually between the three ministries and the Agricultural Support Services Project (ASSP) hosts the secretariat.

${ }^{593}$ This development took place under the auspices of the Agricultural Support Services Project (ASSP). Ministry of Development, 'MOU Signed for Creation of Single Food Safety Agency' Jamaica Information Service, Kingston, 25 May 2005, available at: http:/www.jis.gov.jm/development/html, visited on 27 December 2007. Note that already in 2001 the National Quality Policy for Jamaica approved by the Cabinet included the establishment of a single Food Safety Agency. A MOU to this effect was finally agreed in 2002, but it was only signed in 2005. Henson and Jaffee attribute the delay in signing to the large degree of inertia and resistance to change within the SPS administration of Jamaica and the political sensitivities linked to the reforms. Ibid., 10-11.

594 This information is provided on the 'Agricultural Planning and Policy' page of the website of the Ministry of Agriculture and Lands of Jamaica, available at: http://www.moa.gov.jm/agripp/pol/index.php, visited on 28 December 2007.

${ }^{595}$ Ministry of Agriculture and Lands, Policies Being Developed for the Financial Year 2006/2007, Synopsis Table, available at: http://www.moa.gov.jm/agripp/pol/index.php, visited on 28 December 2007.

${ }^{596}$ Ibid. 
However much more needs to be done if Jamaica is to be able to exploit the potential to diversify its agricultural exports to high-value, non-traditional products, thereby reducing its dependence on preferential trade regimes and making an important contribution to the alleviation of rural poverty. Aside from ad hoc initiatives to address specific SPS issues, such as those outlined above, Jamaica has received limited assistance in upgrading its SPS regime to achieve these objectives. ${ }^{597}$

\subsection{Bangladesh}

\subsubsection{Factual background}

Bangladesh is a South Asian country, bordering Burma, India and the Bay of Bengal. It gained independence from West Pakistan in $1971 .{ }^{598}$ It is useful to examine selected economic and human development indicators in order to determine the position of Bangladesh along the continuum of levels of development.

\subsubsection{Development indicators}

Bangladesh's GNI per capita in 2006 was US\$480..$^{59}$ It is therefore classified as a lowincome economy, according to the World Bank classification of countries according to income. ${ }^{600}$ Its GDP in the same year amounted to US\$62 billion. ${ }^{601}$ The GDP of Bangladesh at purchasing power parity in 2005 was US\$291.2 billion and the GDP per capita at purchasing power parity in the same year was US\$2,053. ${ }^{602}$ Bangladesh is designated as a LDC by the United Nations Conference on Trade and Development. ${ }^{603}$

${ }^{597}$ FAO Commodities and Trade Division, Agriculture, Trade and Food Security: Issues and Options in the WTO Negotiations from the Perspective of Developing Countries. Volume II: Country Case Studies (Food and Agriculture Organization, Geneva), 2000, Chapter 1, Section 2.4, available at: www.fao.org/docrep/003/ X8731e/X8731e00.htm, visited on 7 January 2008.

598 'West Pakistan' was the common name (and official name in 1955-1970) of the western wing of Pakistan until 1971. The eastern wing, previously known as 'East Pakistan', became independent as Bangladesh in 1971.

599 See the World Bank Key Development Data and Statistics page for Bangladesh, available at: http:// go.worldbank.org/1SF48T40L0, visited on 9 January 2008.

${ }^{600}$ See the World Bank classification of economies by income of July 2007, available at: http://siteresources. worldbank.org/DATASTATISTICS/Resources/CLASS.XLS, visited on 9 January 2008.

${ }^{601}$ See the World Bank webpage on Key Development Data \& Statistics of 2006 available at: http://web.worldbank.org/WBSITE/EXTERNAL/DATASTATISTICS/0, contentMDK:20535285 menuPK:1192694 pageP K:64133150 piPK:64133175 theSitePK:239419,00.html, visited on 9 January 2008.

602 United Nations Development Programme, Human Development Report 2007/2008. Fighting Climate Change: Human Solidarity in a Divided World (Palgrave Macmillan, New York), 2007, 279, available at: http://hdr.undp.org/en/media/hdr_20072008_en_complete.pdf, visited on 10 December 2007.

${ }^{603}$ UNCTAD maintains a list of least-developed countries, classified as such according to specified criteria. The current criteria are: low national income (per capita GDP under US\$750 for countries now joining the list, US\$900 for graduation), weak human assets (a composite index based on health, nutrition and education indicators) and high economic vulnerability (a composite index based on indicators of instability of agricultural production and exports, inadequate diversification and economic smallness). Different thresholds are used for addition to, and graduation from, the list of LDCs. A country qualifies for addition to the list if it meets inclusion thresholds on all three criteria, and if its population does not exceed 75 million. See Least Developed Countries at a Glance, Press Release TAD/INF/PR/LDC02, (UNCTAD) 18 June 2002, available at: http:// www.unctad.org/Templates/webflyer.asp?docid=2929\&intItemID=1634\&lang=1, visited on 25 June 2007. 
In 2005, the population of Bangladesh was 153.3 million, ${ }^{604}$ making it one of the most densely populated countries in the world. ${ }^{605}$ Poverty rates in Bangladesh are high with 84 percent of the population living below the US\$2 per day poverty line. ${ }^{606}$

Despite still being dreadfully poor, Bangladesh has experienced 'some of the developing world's most rapid advances in basic human development indicators' ${ }^{607}$ It graduated in 2003 from being classified as a low-human development country to being classified as a medium-human development country. ${ }^{608}$ It is now ranked $140^{\text {th }}$ in the world by the UNDP's Human Development Index of 2007. ${ }^{609}$

\subsubsection{Health priorities}

The relatively low importance of public health as an area of government spending in Bangladesh is illustrated by the following. Bangladesh only spends 0.9 percent of its GDP on public health, which amounts to US\$64 per capita at purchasing power parity. ${ }^{610}$ Despite increased attention to the health sector leading to some improvements in recent years, serious challenges remain.

Life expectancy at birth is low, at 63.1 years. ${ }^{611}$ The prevalence of tuberculosis in Bangladesh is 406 per 100,000 people. ${ }^{612}$ The infant mortality rate is 54 per 1000 births. $^{613}$

See also The Least Developed Countries Report 2002: Escaping the Poverty Trap, UNCTAD/LDC/2002, (UNCTAD) 18 June 2002) available at: http://www.unctad.org/Templates/webflyer.asp?docid=2026\&intIte $\mathrm{mID}=1397 \&$ lang=1\&mode=toc, visited on 18 December 2007.

604 United Nations Development Programme, Human Development Report 2007/2008. Fighting Climate Change: Human Solidarity in a Divided World (Palgrave Macmillan, New York), 2007, 245, available at: http://hdr.undp.org/en/media/hdr_20072008_en_complete.pdf, visited on 10 December 2007.

${ }^{605}$ The population density in Bangladesh is 872 persons per square kilometre, which is three times the density of India, five times that of Pakistan and eight times that of Indonesia. Trade Policy Review Body, Trade Policy Review: Bangladesh - Report by the Secretariat, WT/TPR/S/168, circulated on 9 August 2006, note 22.

606 United Nations Development Programme, Human Development Report 2007/2008. Fighting Climate Change: Human Solidarity in a Divided World (Palgrave Macmillan, New York), 2007, 239, available at: http://hdr.undp.org/en/media/hdr_20072008_en_complete.pdf, visited on 10 December 2007. If one measures poverty as the percentage of people living on less than US\$1 per day, $41.3 \%$ of Bangladesh's population lives below the poverty line.

${ }^{607}$ United Nations Development Programme, Human Development Report 2005. International Cooperation at a Crossroads: Aid, Trade and Security in an Unequal World (United Nations, New York), 2005, Box 1.7, available at: http://hdr.undp.org/en/media/hdr05_complete.pdf, visited on 2 January 2008. This report notes that child and infant mortality rates in Bangladesh have been falling at over $5 \%$ per year, malnutrition among mothers decreased from $52 \%$ in 1996 to $42 \%$ in 2002, primary school enrolment rose from $72 \%$ to $90 \%$ since 1990. This was achieved through strong state action and civic activism, rather than by significant income growth.

608 United Nations Development Programme, Human Development Report 2007/2008. Fighting Climate Change: Human Solidarity in a Divided World (Palgrave Macmillan, New York), 2007, 231, available at: http://hdr.undp.org/en/media/hdr_20072008_en_complete.pdf, visited on 10 December 2007.

609 Ibid.

${ }^{610}$ Ibid., 249.

${ }^{611}$ Ibid., 231.

${ }^{612}$ Ibid., 259.

${ }^{613}$ Ibid., 263. Maternal mortality is also high, at 320 deaths per 100,000 births (and double that rate among adolescent mothers). Ninety percent of births occur at home, with skilled health personnel are present only at 13 percent of all births. United Nations Population Fund, Draft Country Programme Document for Bangladesh, DP/FPA/DCP/BGD/7 (United Nations, New York), 7 April 2005, paras 2-3, available at: http://www.unfpa. org/exbrd/2005/annualsession/bangladesh-final-draft.doc, visited on 9 January 2008. 
Improvements with regard to child mortality have been attributed to an expanded immunization programme, covering 81 percent of children aged between 12 to 23 months in 2004. ${ }^{614}$ However, significant health concerns remain. Communicable diseases, including respiratory infections, diarrhoeal diseases, malaria, and tuberculosis remain prevalent, and HIV/AIDS rates are increasing. ${ }^{615}$ Of children under five with diarrhoea, only 35 percent receive oral hydration and continued feeding. Bangladesh has only 29 physicians per 100000 people. ${ }^{616}$

In Bangladesh, a mere 38 percent of the population has sustainable access to improved sanitation, ${ }^{617}$ although an improved water source is accessible to 72 percent. ${ }^{618}$ Undernourishment prevails in 30 percent of the population. ${ }^{619}$ Health case service in Bangladesh is inadequate, and the government's recent Health Nutrition Population Strategic Investment Plan 2003-2010 indicates that the priority area is pro-poor health service provision. ${ }^{620}$ An area that receives particular attention is reproductive health, due to the high incidence of infant and maternal mortality and the particularly vulnerable position of women in society.

${ }^{614}$ Nazneen Ahmed, Ad Hoc Expert Meeting in Preparation for the Mid-Term Review of the Programme of Action for the Least Developed Countries for the Decade 2001-2010: Case Study on Bangladesh UNCTAD/ LDC/MISC/2006/4 (United Nations Conference on Trade and Development, May 2006, 13. Ahmed reports that child mortality (under 5 years) decreased from 109 per 1000 in 1999 to 88 per 1000 in 2004.

${ }^{615}$ This has been reported by the World Bank. See World Bank Trade Research, Bangladesh: World Bank Supports the Health, Nutrition, and Population Sector, 28 April 2005, available at http://econ.worldbank.org/ WBSITE/EXTERNAL/EXTDEC/EXTRESEARCH/EXTPROGRAMS/EXTTRADERESEARCH/0,,conte ntMDK:20470386 menuPK:51441535 pagePK:210083 piPK:152538 theSitePK:544849,00.html, visited on 10 January 2008.

${ }^{616}$ United Nations Development Programme, Human Development Report 2007/2008. Fighting Climate Change: Human Solidarity in a Divided World (Palgrave Macmillan, New York), 2007, 249, available at: http://hdr.undp.org/en/media/hdr_20072008_en_complete.pdf, visited on 10 December 2007.

${ }^{617}$ A significant problem in the area of sanitation is insufficient access to sanitary toilets, partly due to rapid urbanization. Only $14 \%$ of slum dwellers have access to sealed toilets. Nazneen Ahmed, Ad Hoc Expert Meeting in Preparation for the Mid-Term Review of the Programme of Action for the Least Developed Countries for the Decade 2001-2010: Case Study on Bangladesh UNCTAD/LDC/MISC/2006/4 (United Nations Conference on Trade and Development, May 2006, 14.

${ }^{618}$ United Nations Development Programme, Human Development Report 2007/2008. Fighting Climate Change: Human Solidarity in a Divided World (Palgrave Macmillan, New York), 2007, 253, available at: http://hdr.undp.org/en/media/hdr_20072008_en_complete.pdf, visited on 10 December 2007. Although $96.3 \%$ of the population has access to pathogen-free water, arsenic contamination of water is still a problem, especially in rural areas. Nazneen Ahmed, Ad Hoc Expert Meeting in Preparation for the Mid-Term Review of the Programme of Action for the Least Developed Countries for the Decade 2001-2010: Case Study on Bangladesh UNCTAD/LDC/MISC/2006/4 (United Nations Conference on Trade and Development, May 2006, 14.

${ }^{619}$ United Nations Development Programme, Human Development Report 2007/2008. Fighting Climate Change: Human Solidarity in a Divided World (Palgrave Macmillan, New York), 2007, 242, available at: http://hdr.undp.org/en/media/hdr_20072008_en_complete.pdf, visited on 10 December 2007.

${ }^{620}$ Nazneen Ahmed, Ad Hoc Expert Meeting in Preparation for the Mid-Term Review of the Programme of Action for the Least Developed Countries for the Decade 2001-2010: Case Study on Bangladesh UNCTAD/ LDC/MISC/2006/4 (United Nations Conference on Trade and Development, May 2006, 14. The World Bank approved the granting of US\$300 million credit to help the government of Bangladesh to implement this plan. World Bank Trade Research, Bangladesh: World Bank Supports the Health, Nutrition, and Population Sector, 28 April 2005, available at http://econ.worldbank.org/WBSITE/EXTERNAL/EXTDEC/EXTRESEARCH/ EXTPROGRAMS/EXTTRADERESEARCH/0,,contentMDK:20470386 menuPK:51441535 pagePK:210 083 piPK:152538 theSitePK:544849,00.html, visited on 10 January 2008. 
With these critical health concerns in mind, it seems unlikely that regulation against SPS risks is a priority for public health spending in Bangladesh.

\subsubsection{Trade priorities}

The importance of trade as an engine for growth and poverty alleviation in Bangladesh can be evaluated by examining its participation in the multilateral trading system. Bangladesh became a contracting party to the GATT 1947 in 1972 and is an original Member of the WTO.

Since the mid-1980s, Bangladesh abandoned its inward-looking growth strategy and embraced trade liberalisation. Although, as a least-developed country Member, it was entitled to longer transition periods for the implementation of the Uruguay Round agreements, it decided not to postpone implementation. Instead, it adopted a phased programme, to gradually develop and strengthen the capacity of its ministries, departments and agencies to derive full benefits from the WTO regime and to conform to its rules. ${ }^{621}$ Bangladesh participates actively in WTO negotiations. On behalf of LDC, Bangladesh is an active advocate for SDT in favour of least-developed-country Members. ${ }^{622}$ In the context of the Doha Development Round, Bangladesh has voiced LDC interests in various negotiating groups ${ }^{623}$ It is interesting to note that Bangladesh has twice participated in the early stages of dispute settlement proceedings in the WTO, once by requesting consultations (being the first LDC to do so $)^{624}$ and once by joining consultations between other Members. ${ }^{625}$

In 2006, exports of goods and services contributed 17.8 percent $^{626}$ to the GDP of Bangladesh, ${ }^{627}$ from which it earned US\$8.6 billion. ${ }^{628}$ The ratio of trade to GDP in

${ }^{621}$ A statement to this effect in a report by the Ministry of Commerce of Bangladesh in 1998 is quoted in Trade Policy Review Body, Trade Policy Review: Bangladesh - Report by the Secretariat, WT/TPR/S/68, circulated on 3 April 2000, Part II para. 23.

${ }^{622}$ For example, Bangladesh acted as spokesman for the LDCs during the Uruguay Round negotiations. Further, Bangladesh communicated the outcome of the Second LDC Trade Ministers' Meeting to the WTO DirectorGeneral, on behalf of the LDC Group in the WTO. At this meeting, a common strategy for LDCs for the Doha Development Round was drawn up. See World Trade Organization, Second LDC Trade Ministers' Meeting, Dhaka, Bangladesh. Communication from Bangladesh, WT/L/521, circulated on 26 June 2003.

${ }^{623}$ For example, Bangladesh participated in the joint communication on the Doha Work Programme on Special and Differential Treatment and Outstanding Implementation Issues. It has been involved in negotiations at the Special Session of the Committee on Agriculture with regard to food aid, exemption of LDCs from tariff reduction commitments, quota free access for LDCs and phasing out of export-subsidies. In the Negotiating Group on Rules, Bangladesh participated in a joint communication on anti-dumping actions on textiles and clothing.

${ }^{624}$ India - Anti-dumping Measure on Batteries from Bangladesh. Request for Consultations by Bangladesh, WT/DS306/1, circulated on 2 February 2004. The EC joined the consultations and in 2006 a mutually agreed solution was reported as the measure had been terminated in January 2005.

625 United States - Rules of Origin for Textiles and Apparel Products. Request to Join Consultations. Communication from Bangladesh, WT/DS243/2, circulated 5 February 2002. When a panel was established in this case, Bangladesh reserved its third party rights but did not make a written submission or present its views orally before the Panel.

${ }^{626}$ It is typical of LDCs that trade accounts for only a small share (usually between $9 \%$ and $16 \%$ ) of their GDP. See High-Level Meeting on Integrated Initiatives for Least-Developed Countries' Trade Development, Market Access for Least Developed Countries, WT/LDC/HL/14, circulated on 23 October 1997, para. 8.

${ }^{627}$ See the statistics in the World Bank's data profile for Bangladesh, available at: http://devdata.worldbank.org/ external/CPProfile.asp?PTYPE=CP\&CCODE=BGD, visited on 9 January 2008.

${ }^{628}$ Trade Policy Review Body, Trade Policy Review: Bangladesh - Report by the Secretariat, WT/TPR/S/168, 
Bangladesh in 2004 - 2006 was 42.1. ${ }^{629}$ The official trade figures for Bangladesh, however, do not reflect the significant amount of unofficial trade taking place along the border with India, which was estimated at 13 percent of total trade in $2000 .^{630}$

As is often the case with LDCs, Bangladesh's exports are concentrated in a few commodities and a few markets. ${ }^{631}$ Bangladesh's major export product is clothing, which makes up 76.6 percent of its exports, and to a lesser extent textiles, which account for a further 6.7 percent. ${ }^{632}$ These products are currently subject to strong competition after the phasing out of textile quotas under the WTO Agreement on Textiles and Clothing. ${ }^{633}$ This competition will increase further when special safeguard measures against Chinese textiles are terminated at the end of 2008. ${ }^{634}$ Therefore, the future trade performance of Bangladesh's depends on its success in diversifying to new products and gaining access to new markets.

The main export markets of Bangladesh are those of the EC and the US, ${ }^{635}$ with which Bangladesh enjoys preferential market access under GSP schemes. ${ }^{636}$ Under the 'Everything But Arms' initiative on the EC's GSP regime, most products from LDCs such

circulated on 9 August 2006, Section I Table 1.

${ }^{629}$ WTO Secretariat, Trade Profiles 2007 (World Trade Organization, Geneva), October 2007, 15, available at: http://www.wto.org/english/res_e/booksp_e/anrep_e/trade_profiles07_e.pdf, visited on 8 January 2008. This indicator reflects the relative importance of trade to the economy of Bangladesh.

${ }^{630}$ The main items smuggled into Bangladesh are food, agricultural products and livestock, making up over $70 \%$ of smuggled imports. Incentives for smuggling include high tariffs, quantitative restrictions and import bans. See Trade Policy Review Body, Trade Policy Review: Bangladesh - Report by the Secretariat, WT/ TPR/S/68, circulated on 3 April 2000, Part I para. 31 and Part III para. 26. This was reiterated in Trade Policy Review Body, Trade Policy Review: Bangladesh - Report by the Secretariat, WT/TPR/S/168, circulated on 9 August 2006, Section I para. 36.

${ }^{631}$ See High-Level Meeting on Integrated Initiatives for Least-Developed Countries' Trade Development, Country-Specific Round Tables: Documentation - Bangladesh: Addendum, WT/LDC/HL/12/Add.1, circulated on 24 October 1997, 3. Typically, the top three export products of an LDC account for over $70 \%$ of its total exports, as is the case for Bangladesh. This makes such countries particularly vulnerable to fluctuations in demand for and prices of these products, as well as to market barriers affecting them. However, it should be noted that, relative to other LDCs, Bangladesh (like Haiti, Laos, Madagascar and Myanmar) has a significantly more diversified export structure. See High-Level Meeting on Integrated Initiatives for LeastDeveloped Countries' Trade Development, Market Access for Least Developed Countries, WT/LDC/HL/14, circulated on 23 October 1997, para. 11.

${ }^{632}$ Trade Policy Review Body, Trade Policy Review: Bangladesh - Report by the Secretariat, WT/TPR/S/168, circulated on 9 August 2006, Section I Chart I.3.

${ }^{633}$ This agreement is one of the outcomes of the Uruguay Round negotiations and is contained in Annex 1A to the Marrakesh Agreement Establishing the World Trade Organization. This agreement provided a 10-year phase out period for textile quotas, and terminated on 1 January 2005. 'Agreement on Textiles and Clothing', in The Results of the Uruguay Round of Multilateral Trade Negotiations: The Legal Texts (World Trade Organization, Geneva), 1994, 85-137.

${ }^{634}$ Nazneen Ahmed, Ad Hoc Expert Meeting in Preparation for the Mid-Term Review of the Programme of Action for the Least Developed Countries for the Decade 2001-2010: Case Study on Bangladesh UNCTAD/ LDC/MISC/2006/4 (United Nations Conference on Trade and Development, May 2006, 18.A special safeguards regime, applicable to Chinese textiles and clothing, was established in para. 242 of the Report of the Working Party on the Accession of China. This regime is applicable until 31 December 2008. It is part of the terms and conditions for China's accession and therefore considered part of China's Protocol of Accession to the WTO.

${ }^{635}$ In 2003/2004, the EC accounted for 58.4\% of Bangladeshi exports and the US for 25.6. Trade Policy Review Body, Trade Policy Review: Bangladesh - Report by the Secretariat, WT/TPR/S/168, circulated on 9 August 2006, Section I Chart I.4.

${ }^{636}$ Bangladesh benefits from the EU's Everything But Arms initiative for least developed countries, providing duty and quota-free market access for most products under its GSP scheme. 
as Bangladesh, including textiles, agriculture and fishery products, benefit from dutyfree, quota-free access to the EC market. ${ }^{637}$ Under the GSP system of the US, Bangladesh is the second largest LDC exporter. ${ }^{638}$ The GSP system of the US excludes 20 clothing items from preferential treatment, thereby reducing the share of the US market in exports from Bangladesh. ${ }^{639}$ Bangladesh benefits from GSP treatment from several other WTO Members, including Japan and Canada. ${ }^{640}$

\subsubsection{Significance of agricultural sector}

The importance of the SPS Agreement for Bangladeshi trade must be seen in the light of the role played by agriculture in its economy. The share of agriculture in the GDP of Bangladesh has declined in the last 6 years, whereas the share of manufacturing and services has increased. ${ }^{641}$ Agriculture, including livestock and fisheries, now accounts for 19.6 percent of Bangladesh's GDP. ${ }^{642}$ Agricultural exports in 2006 amounted to 7.2 per cent of overall merchandise exports of Bangladesh. ${ }^{643}$ The low level of mechanisation and fragmentation in land holdings, together with the frequency of natural disasters, have been identified as causes for the low productivity of the agricultural sector. ${ }^{644}$

637 The new GSP scheme that came into force in January 2006 extends the coverage of preferential treatment to a greater number of LDC products, particularly agriculture and fishery products. It has been reported, however, that the benefits to Bangladesh under this scheme are diminished due to the strict rules of origin that apply for products to receive these preferences. Bangladesh has not yet taken advantage of the offer by the $\mathrm{EC}$ of regional cumulation and relaxation of value-added requirements. As Bangladeshi export industries are heavily dependent on imported inputs, and add little value, the products will often not qualify as originating in Bangladesh under these rules. Bangladesh does not qualify for 'GSP plus' treatment as it does not meet the requirement of ratification and application of 27 human rights treaties and the conditions regarding labour standards, environmental protection and good governance. Nazneen Ahmed, Ad Hoc Expert Meeting in Preparation for the Mid-Term Review of the Programme of Action for the Least Developed Countries for the Decade 2001-2010: Case Study on Bangladesh UNCTAD/LDC/MISC/2006/4 (United Nations Conference on Trade and Development, May 2006, 18.

${ }^{638}$ Bangladesh accounted for $33 \%$ of all LDC exports to the US in 2001, and its products made up $1 \%$ of both products eligible for GSP treatment and those receiving such treatment. Trade Policy Review Body, Trade Policy Review: Bangladesh - Report by the Secretariat, WT/TPR/S/168, circulated on 9 August 2006, Section II para. 41.

${ }^{639}$ Ibid. The US Trade and Development Act of 2000 excluded, as of 2001, 20 clothing items from its GSP scheme. Bangladesh has been the LDC most affected by this exclusion.

${ }^{640}$ As from 31 December 2002, Bangladesh benefits from duty-free, quota-free treatment of its exports under Canada's Least-Developed Country Market Access Initiative, leading to a $40 \%$ increase in its total exports to Canada.

${ }^{641}$ The share of agriculture, including livestock and fisheries fell from $25.3 \%$ in $1998 / 1999$ to $19.2 \%$ in 2004/2005. Manufacturing increased its share in GDP slightly from $14.9 \%$ in $1998 / 1999$ to $16.58 \%$ in 2004/2005. In the same period, services increased their share in GDP from $46.9 \%$ to $50.7 \%$, and are the fastest growing component of GDP in this period. Trade Policy Review Body, Trade Policy Review: Bangladesh - Report by the Secretariat, WT/TPR/S/168, circulated on 9 August 2006, Section IV paras 8, 48 and 62.

${ }^{642}$ See the World Bank, Countries at a Glance table for Bangladesh, available at: http://devdata.worldbank.org/ AAG/bgd_aag.pdf visited on 23 January 2008. Nazneen Ahmed points out that another 36\% of GDP is generated by the rural non-farm sector. This sector is dependent on the agricultural industry for its existence, thus increasing the indirect impact of agriculture on the economy. Nazneen Ahmed, Ad Hoc Expert Meeting in Preparation for the Mid-Term Review of the Programme of Action for the Least Developed Countries for the Decade 2001-2010: Case Study on Bangladesh UNCTAD/LDC/MISC/2006/4 (United Nations Conference on Trade and Development, May 2006, 27.

${ }^{643}$ WTO Secretariat, Trade Profiles 2007 (World Trade Organization, Geneva), October 2007, 15, available at: http://www.wto.org/english/res_e/booksp_e/anrep_e/trade_profiles07_e.pdf, visited on 8 January 2008.

${ }^{644}$ Trade Policy Review Body, Trade Policy Review: Bangladesh-Report by the Secretariat, WT/TPR/S/168, 
However, as 52 percent of the work force of Bangladesh is employed in the agricultural sector, ${ }^{645}$ this sector is of crucial importance for poverty alleviation in Bangladesh. ${ }^{646}$ Three-quarters of the population of Bangladesh, and 85 percent of the poor, live in rural areas and their livelihoods depend on the agricultural industry, not only through formal employment but also through informal work. ${ }^{647}$ As a result, the government of Bangladesh has identified agriculture and rural development as its main priorities in respect of poverty reduction. ${ }^{648}$

Crop production dominates the agricultural industry, and is followed by fisheries and then livestock. ${ }^{649}$ Rice is the most important agricultural product in Bangladesh, ${ }^{650}$ followed by

circulated on 9 August 2006, Section IV para. 8.

${ }^{645}$ This data relates to 2005. United Nations Development Programme, Human Development Report 2007/2008. Fighting Climate Change: Human Solidarity in a Divided World (Palgrave Macmillan, New York), 2007, 300, available at: http://hdr.undp.org/en/media/hdr_20072008_en_complete.pdf, visited on 10 December 2007.. In 2003, Ahmed notes that the agricultural industry employed 51.7\% of the 44.3 million labour force of Bangladesh, whereas the manufacturing industry employed only 9.7\%. Nazneen Ahmed, Ad Hoc Expert Meeting in Preparation for the Mid-Term Review of the Programme of Action for the Least Developed Countries for the Decade 2001-2010: Case Study on Bangladesh UNCTAD/LDC/MISC/2006/4 (United Nations Conference on Trade and Development, May 2006, 6.

${ }^{646}$ In a study carried out in the context of the Partnership Agreement on Poverty Reduction between Bangladesh and the Asian Development Bank, it is noted: 'In Bangladesh, agriculture assumes a considerably important role in stimulating growth and creating a growth structure leading to alleviation of poverty. The impact of agricultural growth on rural wages is an important element in the process since a major share of income of the poor originates from wage labour in agricultural and non-agricultural activities. A high agricultural growth creates synergies for diversification of the rural economy and development of the rural non-farm sector with greater poverty-reduction impact.' Mustafa K. Mujeri, Rural Development Priorities for Poverty Reduction in Bangladesh (Bangladesh Resident Mission of the Asian Development Bank, Dhaka), November 2001, 1, available at: www.adb.org/documents/epps/ban/rural_development/rural_development.pdf, visited on 6 December 2006.

${ }^{647}$ Nazneen Ahmed, Ad Hoc Expert Meeting in Preparation for the Mid-Term Review of the Programme of Action for the Least Developed Countries for the Decade 2001-2010: Case Study on Bangladesh UNCTAD/ LDC/MISC/2006/4 (United Nations Conference on Trade and Development, May 2006, 27. This point is also made in C.A.F. Dowlah, 'Agriculture and the New WTO Round - Economic Analysis of Interests and Options for Bangladesh', presented at the Workshop on a New WTO Round on Agriculture, SPS, and the Environment: Capturing the Benefits for South Asia (World Bank, UNCTAD and SAARC Secretariat, New Delhi, India) 31 December 2000, 4, available at: http://r0.unctad.org/trade_env/test1/meetings/standards/NewDelhi.doc, visited on 7 July 2001. In Bangladesh the informal sector of the economy dominates employment, accounting for an estimated $80 \%$ to $90 \%$ of the labour force. It is characterised by unregistered, small-scale, labourintensive activities, carried out mainly by family labour. Trade Policy Review Body, Trade Policy Review: Bangladesh - Report by the Secretariat, WT/TPR/S/168, circulated on 9 August 2006, Section I para. 11.

${ }^{648}$ Nazneen Ahmed, Ad Hoc Expert Meeting in Preparation for the Mid-Term Review of the Programme of Action for the Least Developed Countries for the Decade 2001-2010: Case Study on Bangladesh UNCTAD/ LDC/MISC/2006/4 (United Nations Conference on Trade and Development, May 2006, 27.

${ }^{649}$ In 2002/2003 in the agricultural sector, crops accounted for $11.5 \%$ of GDP, livestock for $2.4 \%$ and fisheries for 4.4\%. Trade Policy Review Body, Trade Policy Review: Bangladesh - Report by the Secretariat, WT/ TPR/S/168, circulated on 9 August 2006, Section IV para. 14.

${ }^{650}$ Ibid., Section IV para. 8. 
jute, ${ }^{651}$ tea, wheat, sugarcane, and potatoes. ${ }^{652}$ Livestock and fisheries production is growing. ${ }^{653}$ The government of Bangladesh supports the agricultural industry through various forms of subsidy, including through the distribution of low-cost seeds, the provision of subsidies for production of non-urea fertilisers and for the electricity costs of irrigation, and the government purchase of food grains from domestic producers at pre-announced prices for distribution through the Public Food Distribution System. ${ }^{654}$

Frequent cyclones and floods are an important impediment to the growth of the agricultural sector, ${ }^{655}$ and contribute to food insecurity. Bangladesh is heavily dependent on imports of food as well as food aid. ${ }^{656}$ Agricultural imports are mainly edible oils, dairy products, fruit, vegetables and sugar. In addition, considerable amounts of food-grain (rice and wheat) are imported to meet the country's food requirements. ${ }^{657}$

Agricultural exports are mainly primary products, ${ }^{658}$ such as fish and shrimp, raw jute, tea and vegetables. Exports of processed agricultural products are negligible. ${ }^{659}$ The Bangladeshi government is trying to promote export-oriented agricultural industries by providing export incentives and facilities to farms of at least five acres for the production of fruit, vegetables, fresh flowers etc. for export. ${ }^{660}$ Direct cash subsidies are given for

${ }^{651}$ Bangladesh is the world's largest jute producer. Jute is either sold raw or in the form of manufactured goods (burlap, sacks, rope, mats, twine and carpet backing). Although jute is a major earner of export revenue for Bangladesh, it is subject to vast price fluctuations (of 30 major internationally-traded commodities, only 6 are subject to as much price and supply instability as jute). See the Country Study of the Federal research Division of the US Library of Congress for Bangladesh, available at: http://countrystudies.us/bangladesh/71. htm, visited on 25 June 2007.

${ }^{652}$ See the World Fact Book, US Central Intelligence Agency, 2007, available at: https://www.cia.gov/library/ publications/the-world-factbook/geos/bg.html\#Intro, visited on 10 January 2008.

${ }^{653}$ In 1992/1993 crops made up 64\% of agricultural production, while livestock, fishery and forestry accounted for the remaining 36\%. In 1998-1999 this was 58\% and 42\%respectively. Trade Policy Review Body, Trade Policy Review: Bangladesh - Report by the Secretariat, WT/TPR/S/68, circulated on 3 April 2000, Part IV para. 7 and Chart IV.3. Currently, fish account for over $80 \%$ of consumption of animal protein of Bangladeshis.

${ }^{654}$ Trade Policy Review Body, Trade Policy Review: Bangladesh - Report by the Secretariat, WT/TPR/S/168, circulated on 9 August 2006, Section IV paras 18-28. In 2005/2006, the budget allocation for subsidies for crops was Tk 11 billion.

${ }_{655}$ The Government of Bangladesh notes that growth in per capita GDP would have been higher were it not for the devastating floods of 1987, 1988 and 1998 and the catastrophic cyclone of 1991. See Trade Policy Review Body, Trade Policy Review: Bangladesh - Report by the Government, WT/TPR/G/68, circulated on 3 April 2000, para. 10.

${ }^{656}$ Food security is a major policy goal of the Bangladeshi government. A substantial portion of the foreign aid received by Bangladesh entails food. See Trade Policy Review Body, Trade Policy Review: Bangladesh Report by the Secretariat, WT/TPR/S/68, circulated on 3 April 2000, Part I paras 3 and 28.

${ }^{657}$ Food-grain imports are covered by foreign aid and government and commercial imports. See Ibid., Part IV paras 8 and 17.

${ }^{658}$ C.A.F. Dowlah, 'Agriculture and the New WTO Round - Economic Analysis of Interests and Options for Bangladesh', presented at the Workshop on a New WTO Round on Agriculture, SPS, and the Environment: Capturing the Benefits for South Asia (World Bank, UNCTAD and SAARC Secretariat, New Delhi, India) 31 December 2000, 13 and 15, available at: http://r0.unctad.org/trade_env/test1/meetings/standards/NewDelhi. doc, visited on 7 July 2001.

${ }^{659}$ Important reasons for this are the poor rural infrastructure and financial services, weak functioning of public institutions in rural areas, lack of electrification and communication facilities and the lack of marketing networks to reduce price variability. See World Bank, Bangladesh. A Proposed Rural Development Strategy (World Bank, Dhaka), 1999, 26-27.

${ }^{660}$ Export Policy, 1997-2002. Trade Policy Review Body, Trade Policy Review: Bangladesh - Report by the Secretariat, WT/TPR/S/68, circulated on 3 April 2000, Box III.2. 
agricultural exports. ${ }^{661}$ Agricultural exports, especially processed agricultural products, are, however, decreasing. ${ }^{62}$

An increasingly important export of Bangladesh in the area of fisheries is shrimp. Bangladesh is uniquely situated to cultivate and harvest shrimp, due to its location at the confluence of several rivers. ${ }^{663}$ From being negligible in the early 1970 s, shrimp exports grew to be one of the main exports ${ }^{664}$ of primary products in Bangladesh. ${ }^{665}$ After clothing, shrimp ranks second with regard to ability to earn foreign exchange. ${ }^{666}$ The shrimp sector is also important to rural livelihoods. About 1.2 million Bangladeshis are directly engaged in activities relating to shrimp production, such as harvesting, culture, processing and exporting, while an additional 4.8 million household members are supported by

${ }^{661}$ Trade Policy Review Body, Trade Policy Review: Bangladesh - Report by the Secretariat, WT/TPR/S/168, circulated on 9 August 2006, Section IV para. 15. These subsidies were notified to the WTO (G/AG/N/ BGD/1, dated 15 July 2002) with the indication that the Bangladesh government does not consider them to be subject to reduction commitments.

${ }^{662}$ This is even more the case for exports of processed agricultural products, which evinced and even steeper decline than primary agricultural products. See C.A.F. Dowlah, 'Agriculture and the New WTO Round Economic Analysis of Interests and Options for Bangladesh', presented at the Workshop on a New WTO Round on Agriculture, SPS, and the Environment: Capturing the Benefits for South Asia (World Bank, UNCTAD and SAARC Secretariat, New Delhi, India) 31 December 2000, 15, available at: http://r0.unctad. org/trade_env/test1/meetings/standards/NewDelhi.doc, visited 7 on 7 July 2001.

${ }^{663}$ Greater Access to Trade Expansion Project, A Pro-Poor Analysis of the Shrimp Sector in Bangladesh (United States Agency for International Development Arlington), February 2006, 22, available at: http://www.usaid. gov/our_work/cross-cutting_programs/wid/pubs/Bangladesh_Shrimp_Value_Chain_Feb_2006.pdf, visited 13 January 2008. Bangladesh occupies the delta of the Ganges, Jamuna and Brahmaputra rivers.

${ }^{664}$ James C. Cato and S. Subasinge, Food Safety in Food Security and Food Trade: Case Study: The Shrimp Export Industry in Bangladesh (International Food Policy Research Institute, Washington D.C.), September 2003, 1. Shrimp accounted for less than 1\% of exports from Bangladesh in the early 1970s but increased to $4.9 \%$ of exports in 2004. Greater Access to Trade Expansion Project, A Pro-Poor Analysis of the Shrimp Sector in Bangladesh (United States Agency for International Development Arlington), February 2006, 22 23, available at: http://www.usaid.gov/our_work/cross-cutting_programs/wid/pubs/Bangladesh_Shrimp_ Value_Chain_Feb_2006.pdf, visited 13 January 2008.

${ }^{665}$ Shrimp is the primary commodity exhibiting the most spectacular growth in post-independence Bangladesh. Mohammad Alauddin and M. Akhter Hamid, 'Shrimp Culture in Bangladesh with Emphasis on Social and Economic Aspects', in Towards Sustainable Shrimp Culture in Thailand and the Region: Proceedings of a Workshop, Paul Smith (ed.) (Australian Centre for International Agricultural Research, Canberra), 1999, 5362, 53, available at: http://www.aciar.gov.au/web.nsf/doc/JFRN-5J473M/\$file/PR90\%20Chapter\%2009.pdf, visited on 12 May 2000. In 2000 shrimp exports exceeded exports of raw jute and jute products, accounting for about a quarter of exports (excluding ready-made garments) from Bangladesh. See Mustafizur Rahman, 'EU Ban on Shrimp Imports from Bangladesh: A Case Study on Market Access Problems Faced by LDCs', presented at the Workshop on a New WTO Round on Agriculture, SPS, and the Environment: Capturing the Benefits for South Asia (World Bank, UNCTAD and SAARC Secretariat, New Delhi, India) 11-13 January 2001, 2, available at: http://r0.unctad.org/trade_env/test1/meetings/standards/mustafizur.doc, visited on 6 March 2001.

${ }^{666}$ Greater Access to Trade Expansion Project, A Pro-Poor Analysis of the Shrimp Sector in Bangladesh (United States Agency for International Development Arlington), February 2006, 9, available at: http://www.usaid. gov/our_work/cross-cutting_programs/wid/pubs/Bangladesh_Shrimp_Value_Chain_Feb_2006.pdf, visited 13 January 2008. Shrimp earns over US\$360 million in export revenue per year. 
the industry. ${ }^{667}$ Shrimp production by aquaculture is carried out solely for export purposes, producing five percent of global shrimp production. ${ }^{668}$

Nevertheless, shrimp culture remains rather unsophisticated, ${ }^{669}$ which results in relatively low productivity and rejections of exports due to food-safety concerns, such as salmonella, bacterial and antibiotic contamination and residues of urea ${ }^{670}$ As a result, the global shrimp market is currently dominated by Thailand, Indonesia, China and Ecuador, countries that have successfully implemented innovations in production and processing. ${ }^{671} \mathrm{~A}$ recent study by USAID in Bangladesh notes the urgent need to raise productivity and improve production methods in the shrimp sector. ${ }^{672}$

\subsubsection{Summary of factual background}

The above outline of factual background aims to provide an indication of the trade and health priorities in Bangladesh as the context within which the relevance of the SPS Agreement for its trade and health objectives can be understood.

While Bangladesh, despite its low level of economic resources, has managed to improve its human development situation, also with respect to health, significant challenges remain. These challenges relate to basic issues, including sanitation, malnutrition, primary health care and communicable diseases. Investment in the legislation and infrastructure necessary for effective food-safety regulation is not among the main priorities for public health spending in Bangladesh.

${ }^{667}$ Ibid. See also Mustafizur Rahman, 'EU Ban on Shrimp Imports from Bangladesh: A Case Study on Market Access Problems Faced by LDCs', presented at the Workshop on a New WTO Round on Agriculture, SPS, and the Environment: Capturing the Benefits for South Asia (World Bank, UNCTAD and SAARC Secretariat, New Delhi, India) 11-13 January 2001, 2, available at: http://r0.unctad.org/trade_env/test1/meetings/standards/mustafizur.doc, visited on 6 March 2001.

${ }^{668}$ Shrimp aquaculture occurs in 9000 farms and produces 30000 tons per year. Mustafizur Rahman, 'EU Ban on Shrimp Imports from Bangladesh: A Case Study on Market Access Problems Faced by LDCs', presented at the Workshop on a New WTO Round on Agriculture, SPS, and the Environment: Capturing the Benefits for South Asia (World Bank, UNCTAD and SAARC Secretariat, New Delhi, India) 11-13 January 2001, 2, available at: http://r0.unctad.org/trade_env/test1/meetings/standards/mustafizur.doc, visited on 6 March 2001.

${ }_{669}$ Shrimp farmers have to rely on wild shrimp stock as there are only nine hatcheries in Bangladesh with limited capacity for producing fry. In addition, the shortage of artificial shrimp feed means that farmers mostly rely on natural feed with lower productivity. Most shrimp farmers use an improved version of traditional extensive shrimp farming, applying only a few elements of farming technologies. Only $1 \%$ of shrimp farms use a semi-intensive method of shrimp farming, involving a high density nursery phase before fry are transferred to shrimp fields. Intensive farming, requiring heavy feeding, removal of waste, water exchange and an aeration system, is very uncommon in Bangladesh. See Mohammad Alauddin and M. Akhter Hamid, 'Shrimp Culture in Bangladesh with Emphasis on Social and Economic Aspects', in Towards Sustainable Shrimp Culture in Thailand and the Region: Proceedings of a Workshop, Paul Smith (ed.) (Australian Centre for International Agricultural Research, Canberra), 1999, 53-62, 54-56, available at: http://www.aciar.gov.au/ web.nsf/doc/JFRN-5J473M/\$file/PR90\%20Chapter\%2009.pdf, visited on 13 May 2000.

${ }^{670}$ Greater Access to Trade Expansion Project, A Pro-Poor Analysis of the Shrimp Sector in Bangladesh (United States Agency for International Development Arlington), February 2006, 17, available at: http://www.usaid. gov/our_work/cross-cutting_programs/wid/pubs/Bangladesh_Shrimp_Value_Chain_Feb_2006.pdf, visited 13 January 2008. Urea is an organic waste product used to accelerate shell-shedding by shrimp and to hasten their growth.

671 Ibid.

${ }^{672}$ Ibid., 14. 
As a least-developed-country Member, Bangladesh's exports are concentrated in a small number of products. In particular, Bangladesh is highly dependent on clothing exports for its foreign revenue earnings. However, this sector is being subject to increasing competition since the integration of textiles and clothing into the multilateral free trade regime. The benefits that Bangladesh derives under the GSP schemes of various Members are threatened with erosion through progressive tariff reductions. It is therefore important that Bangladesh branches out into new export industries.

The growing shrimp industry is very important to Bangladesh's efforts to diversify away from its dependence on clothing exports, and to reduce the incidence of rural poverty. Shrimp are a high-value product with great potential for export earnings. Japan, the US and the EC are the main markets for shrimp, absorbing 90 percent of shrimp exports worldwide ${ }^{673}$ However, as fishery products are typically high-risk products from a foodsafety perspective, these Members apply strict sanitary requirements to prevent such risks. The success of the budding shrimp export industry in Bangladesh is thus highly dependent on the ability of exporters to meet these requirements.

This is recognised by the Bangladeshi government, which has identified as the main market access problems that Bangladesh encounters, non-tariff barriers and in particular stringent quality and standards requirements, ${ }^{674}$ both in the context of its trade policy review and during the technical needs assessment carried out in the context of the Integrated Framework for Trade Related Technical Assistance to Least Developed Countries. ${ }^{675}$

It is useful to examine Bangladesh's SPS system in order to establish its ability, on the one hand, to enact and enforce regulations to protect against SPS risks to human, animal and plant life or health in its territory, and, on the other, to meet or challenge the SPS requirements of its trading partners. This section will therefore proceed to give an overview of the SPS system currently in place in Bangladesh.

\subsubsection{Bangladesh's SPS system}

\subsubsection{Food-safety system}

Responsibility for food safety in Bangladesh rests with particular bodies within the Ministry of Health, the Ministry of Local Government and Rural Development and the Ministry of Industries. ${ }^{676}$

The Ministry of Health has a Department of Public Health and Extension, which carries out food-safety responsibilities. Food safety in Bangladesh is still governed by the Pure

\footnotetext{
${ }^{673}$ Ibid., 22.

${ }^{674}$ See Trade Policy Review Body, Trade Policy Review: Bangladesh - Report by the Government, WT/ TPR/G/68, circulated on 3 April 2000, para. 26.

${ }^{675}$ The Integrated Framework is a collaborative effort of 6 core agencies, the IMF, ITC, UNCTAD, UNDP, the World Bank and the WTO. In this context, Bangladesh prepared an assessment of its trade-related technical assistance needs in 1997. A summary is provided in Trade Policy Review Body, Trade Policy Review: Bangladesh - Report by the Secretariat, WT/TPR/S/68, circulated on 3 April 2000, Annex II.1.

${ }^{676}$ Trade Policy Review Body, Trade Policy Review: Bangladesh-Report by the Secretariat, WT/TPR/S/168, circulated on 9 August 2006, Section III para. 86.
} 
Food Ordinance of 1959. However, this law was revised by the Food Safety Ordinance of 1994 to take account of Codex standards and guidelines. ${ }^{677}$

Bangladesh also imposes certain sanitary requirements to ensure the safety of food imports, as set out in the restricted list of the Import Policy Order. ${ }^{678}$ These requirements may relate to certificates, prior permission or clearance from the relevant authorities or may relate to conditions that have to be met by the products themselves.

An example of certification requirements is, in case of importation of baby food, milk food and non-fat dried milk, Bangladesh requires a certificate from the competent authority of the exporting country, declaring that the food is fit for human consumption. ${ }^{679}$ Similarly, a clearance certificate from the Bangladesh Atomic Energy Commission is required for imports of food, certifying that radioactivity does not exceed permissible levels. ${ }^{680}$ Foreign certifications of radioactivity levels are also accepted. ${ }^{681}$

An example of a product requirement is the fact that imports of palm oil must pass a purity test conducted by the Bangladesh Council of Scientific and Industrial Research to be allowed on the market in Bangladesh. ${ }^{62}$ In addition, imports of all food and beverages must clearly mention the date of manufacture and of expiry on each package or container, ${ }^{683}$ and milk food products must indicate their ingredients, composition and expiry date. ${ }^{64}$

National standards for all products (except pharmaceuticals), including food and agricultural products, are set by the Bangladesh Standards and Testing Institute (BSTI), under the responsibility of the Ministry of Industries. It is the only national testing and certification body in Bangladesh. ${ }^{655}$ This body also enforces compliance with standards and certifies the quality of products for import, export and domestic consumption. ${ }^{686}$ The same testing and certification procedures apply to imports and domestic products. ${ }^{67}$ The harmonisation of national requirements with international standards is one of the main policy

${ }^{677}$ FAO Commodities and Trade Division, Agriculture, Trade and Food Security: Issues and Options in the WTO Negotiations from the Perspective of Developing Countries. Volume I: Issues and Options (Food and Agriculture Organization, Geneva), 2000, Chapter1, Section 2.4, available at: www.fao.org/docrep/003/ X4829e/X4829e00.htm, visited on 29 June 2008.

${ }^{678}$ Import Policy Order 2003-2006. Under the Import Policy Order, some items are banned, while others may be imported subject to certain conditions. Banned items relate to religious and social practices in Bangladesh rather than to sanitary concerns. For example, pork and pork products and poppy seeds are banned. Restricted items may relate to health concerns. Trade Policy Review Body, Trade Policy Review: Bangladesh - Report by the Secretariat, WT/TPR/S/168, circulated on 9 August 2006, Section III paras 63-65.

679 Import Policy Order 1997-2002, para. 26(2). See Trade Policy Review Body, Trade Policy Review: Bangladesh - Report by the Secretariat, WT/TPR/S/68, circulated on 3 April 2000, Table III.1.

${ }^{680}$ Import Policy Order 2003-2006, Section 26.2. Acceptable limits of radioactivity for milk products are set at $95 \mathrm{bq}$ of CS-137 per kg, and for other food items at 50bq of CS-137 per kg. Alcoholic beverages, spices and concentrated essences are exempt from radioactivity testing. See Trade Policy Review Body, Trade Policy Review: Bangladesh - Report by the Secretariat, WT/TPR/S/168, circulated on 9 August 2006, Table AIII.4.

${ }^{681}$ Ibid., Section III para. 87.

${ }^{682}$ Import Policy Order 2003-2006, Section 24.7. Ibid., Table AIII.4.

683 Ibid.

${ }^{684}$ Ibid.

${ }^{685}$ Trade Policy Review Body, Trade Policy Review: Bangladesh - Report by the Government, WT/TPR/G/68, circulated on 3 April 2000, para. 19.

${ }^{686}$ Trade Policy Review Body, Trade Policy Review: Bangladesh - Report by the Secretariat, WT/TPR/S/168, circulated on 9 August 2006, Section III para. 81.

${ }^{687}$ Ibid., Section III para. 79. 
objectives in the area of standards ${ }^{688}$ However, the government of Bangladesh has noted that the adoption of international standards is difficult for Bangladesh, due to the lack of domestic expertise and institutional structures for the adoption of these standards and due to the additional financial burden these standards place on its exporters. ${ }^{689}$

Despite the existence of its food-safety measures, Bangladesh has had negative experiences with unsafe food imports. These have been ascribed to inadequate regulation and inspection systems and to delays in updating national food-safety legislation. ${ }^{600}$ In addition, the urgent need for training of government officials and the food industry in all aspects of food safety has been reported. ${ }^{691}$

The government of Bangladesh has raised its concern that, in view of the LDC status of Bangladesh and the associated stigma of lower SPS conditions, more stringent SPS measures may be applied to Bangladeshi agricultural exports than to those of other countries. ${ }^{692}$ However, no information was provided of instances where this concern actually materialised. It seems likely that the same SPS product requirements would be applied by importing countries to products from Bangladesh as to those of other countries, but that the conformity assessment and testing requirements would be more rigorous, reflecting the lack of confidence in the SPS regime of Bangladesh. This is particularly the case in the absence of accreditation.

At the time of its previous Trade Policy Review in 2000, Bangladesh faced the problem that it lacked a laboratory accreditation scheme, with the result that no Bangladeshi laboratories were accredited. ${ }^{693}$ In the absence of accredited laboratories, Bangladesh accepted the accreditation certificates issued by some multinationals operating in Bangladesh. In 2002, Bangladesh formed a committee to work on the establishment of a national accreditation body. ${ }^{694}$ This body will be involved in the accreditation of laboratories, certification bodies and assessors. ${ }^{695}$ In February 2006, Bangladesh notified the WTO Secretariat that the Accreditation Act of 2006 was being finalised. ${ }^{696}$

${ }^{688}$ Ibid., Section III para. 80.

${ }^{689}$ Trade Policy Review Body, Trade Policy Review: Bangladesh - Report by the Government, WT/TPR/G/68, circulated on 3 April 2000, para. 19.

${ }^{690}$ FAO Commodities and Trade Division, Agriculture, Trade and Food Security: Issues and Options in the WTO Negotiations from the Perspective of Developing Countries. Volume II: Country Case Studies (Food and Agriculture Organization, Geneva), 2000, Chapter 1, Section 2.4, available at: www.fao.org/docrep/003/ $\mathrm{X} 8731 \mathrm{e} / \mathrm{X} 8731 \mathrm{e} 00 . \mathrm{htm}$, visited on 7 January 2008. The urgent need to update national food-safety legislation, on the basis of the Model Food Law of the FAO and WHO, Codex standards and guidelines, and expert consultations, has been emphasised in this report.

${ }^{691}$ Ibid., Chapter 1, Section 4.

${ }^{692}$ Trade Policy Review Body, Trade Policy Review: Bangladesh-Report by the Government, WT/TPR/G/68, circulated on 3 April 2000, para. 20.

${ }^{693}$ The importance of improving national accreditation and certification schemes in order to boost the confidence of importers in the safety of Bangladeshi products was noted in FAO Commodities and Trade Division, Agriculture, Trade and Food Security: Issues and Options in the WTO Negotiations from the Perspective of Developing Countries. Volume II: Country Case Studies (Food and Agriculture Organization, Geneva), 2000, Chapter 1, Section 4, available at: www.fao.org/docrep/003/X8731e/X8731e00.htm, visited on 7 January 2008.

${ }^{694}$ Trade Policy Review Body, Trade Policy Review: Bangladesh-Report by the Secretariat, WT/TPR/S/168, circulated on 9 August 2006, Part III para. 82.

${ }^{695}$ Ibid.

${ }^{696}$ Ibid. 
Particular problems with food-safety requirements identified by Bangladesh are requirements relating to the HACCP system for frozen foods imports into the US and the quality and standards requirements in the EU ${ }^{697}$ Bangladesh has also indicated its concern that its exports of frozen food, dried fish, tea, vegetables and other traditional products may be affected by SPS measures. ${ }^{698}$

No mutual recognition agreements yet exist between Bangladesh and its trading partners with regard to standards, testing or certification. However, the government is currently pursuing such possibilities with the South Asian Association for Regional Cooperation (SAARC) countries as well as with India. ${ }^{699}$

An illustration of the effect of food-safety measures on Bangladeshi exports is provided by the case of the EU's import ban on frozen shrimp from Bangladesh in 1997, due to non-compliance with sanitary standards.

\subsection{Food-safety measure affecting shrimp exports from Bangladesh}

Sanitary facilities and training have lagged behind the rapid expansion of the shrimp industry, as a result of which Bangladesh has a reputation for poor-quality shrimp exports, not meeting international standards as set by the Codex Alimentarius Commission. ${ }^{700}$ Like many other LDCs, Bangladesh experiences difficulties in meeting sanitary requirements. ${ }^{701}$ In order to help Bangladesh address these problems of safety and quality in the shrimp sector so as to enable it to fully exploit its potential in this area, the FAO has conducted technical assistance programmes in Bangladesh since the early $1980 \mathrm{~s}^{702}$ However, despite these initiatives, sanitary problems in the shrimp industry continued.

${ }^{697}$ See Trade Policy Review Body, Trade Policy Review: Bangladesh - Report by the Government, WT/ TPR/G/68, circulated on 3 April 2000, para. 26.

${ }^{698}$ C.A.F. Dowlah, 'Agriculture and the New WTO Round - Economic Analysis of Interests and Options for Bangladesh', presented at the Workshop on a New WTO Round on Agriculture, SPS, and the Environment: Capturing the Benefits for South Asia (World Bank, UNCTAD and SAARC Secretariat, New Delhi, India) 31 December 2000, 20, available at: http://r0.unctad.org/trade_env/test1/meetings/standards/NewDelhi.doc, visited on 7 July 2001.

699 Trade Policy Review Body, Trade Policy Review: Bangladesh - Report by the Secretariat, WT/TPR/S/68, circulated on 3 April 2000, Part III para. 72.

${ }^{700}$ Due to this negative reputation and Bangladesh's small share of the world shrimp market, it is a price-taker rather than price-setter, and its frozen shrimp obtain lower-than-average prices for the Asian region. See James C. Cato and S. Subasinge, Food Safety in Food Security and Food Trade: Case Study: The Shrimp Export Industry in Bangladesh (International Food Policy Research Institute, Washington D.C.), September 2003, 1 .

${ }^{701}$ It is reported that these difficulties start at the pre-processing phase (harvesting, sorting, peeling) where conditions and facilities are inadequate to ensure hygienic handling of raw shrimp. At the processing stage, the lack of high quality water, weak infrastructure, poor transport facilities and irregular supply of electricity hinder the application of modern sanitary practices. Mustafizur Rahman, 'EU Ban on Shrimp Imports from Bangladesh: A Case Study on Market Access Problems Faced by LDCs', presented at the Workshop on a New WTO Round on Agriculture, SPS, and the Environment: Capturing the Benefits for South Asia (World Bank, UNCTAD and SAARC Secretariat, New Delhi, India) 11-13 January 2001, 3, available at: http://r0.unctad. org/trade_env/test1/meetings/standards/mustafizur.doc, visited on 6 March 2001.

${ }^{702}$ In the early 1980s, the FAO assisted Bangladesh in the development of product standards, regulations and fish inspection schemes. Consequently Bangladesh promulgated the Fish and Fish Product Ordinance (Inspection and Quality Control) of 1983 and upgraded the laboratory for fish inspection and its staff in 1985. In 1996, the FAO implemented a project to help Bangladesh implement the HACCP system in fish and shrimp plants, by providing training to the public and private sector on HACCP procedures and informing 
Bangladesh's shrimp export markets are primarily the EU and US, ${ }^{703}$ both of which have strict sanitary requirements for shrimp imports. Following a determination in 1995 that Bangladesh's shrimp exports to the US do not meet US hygiene standards, these exports currently undergo automatic detention and examination by USDA authorities. ${ }^{704}$ In the same year, an EU inspection of Bangladesh shrimp processing plants also found the hygiene levels to be below EU standards and that the water used in these plants was not chlorine free. ${ }^{705}$ In 1997, a team of inspectors determined that very few processing plants met the HACCP requirements set by the EU. Not only were there concerns regarding infrastructure and hygiene in the processing plants, but also a lack of confidence in the quality controls carried out by the competent authority, the Department of Fisheries, in Bangladesh. ${ }^{706}$

Consequently an EU ban was imposed on shrimp exports from Bangladesh. ${ }^{707}$ The ban had a serious impact on the shrimp industry. In the five months that the ban remained in place, it has been estimated that Bangladesh suffered losses of US\$14.7 million. ${ }^{708}$ This

the government about requirements on major import markets. Finally, the Intergovernmental Organization for Marketing Information and Technical Advisory Services for Fishery Products in the Asia Pacific Region (INFOFISH), conducted a parallel Common Fund For Commodities/FAO project to promote the export of value added products, including training of industry and development of export opportunities. James C. Cato and S. Subasinge, Food Safety in Food Security and Food Trade: Case Study: The Shrimp Export Industry in Bangladesh (International Food Policy Research Institute, Washington D.C.), September 2003, 1.

${ }^{703}$ In 2000, the EU absorbed 38.7\% and the US 38.3\% of shrimp exports from Bangladesh, and Japan followed with 11.2\%. Mustafizur Rahman, 'EU Ban on Shrimp Imports from Bangladesh: A Case Study on Market Access Problems Faced by LDCs', presented at the Workshop on a New WTO Round on Agriculture, SPS, and the Environment: Capturing the Benefits for South Asia (World Bank, UNCTAD and SAARC Secretariat, New Delhi, India) 11-13 January 2001, 2, available at: http://r0.unctad.org/trade_env/test1/meetings/standards/mustafizur.doc, visited on 6 March 2001.

${ }^{704}$ In 1997 alone, 143 shrimp shipments from Bangladesh were automatically detained. James C. Cato and C.A. Lima Dos Santos, 'Costs to Upgrade the Bangladesh Frozen Shrimp Processing Sector to Adequate Technical and Sanitary Standards and to Maintain a HACCP Program', presented at the Conference on the Economics of HACCP: New Studies of Costs and Benefits, Washington D.C.) 15-16 June 1998, 1, available at: www.umass. edu/ne165/haccp1998/cato.html, visited on 25 June 2007.

${ }^{705}$ Mohammad Alauddin and M. Akhter Hamid, 'Shrimp Culture in Bangladesh with Emphasis on Social and Economic Aspects', in Towards Sustainable Shrimp Culture in Thailand and the Region: Proceedings of a Workshop, Paul Smith (ed.) (Australian Centre for International Agricultural Research, Canberra), 1999, 5362, 55, available at: http://www.aciar.gov.au/web.nsf/doc/JFRN-5J473M/\$file/PR90\%20Chapter\%2009.pdf, visited on 13 May 2000.

${ }^{706}$ James C. Cato and S. Subasinge, Food Safety in Food Security and Food Trade: Case Study: The Shrimp Export Industry in Bangladesh (International Food Policy Research Institute, Washington D.C.), September 2003, 1. See also Mustafizur Rahman, 'EU Ban on Shrimp Imports from Bangladesh: A Case Study on Market Access Problems Faced by LDCs', presented at the Workshop on a New WTO Round on Agriculture, SPS, and the Environment: Capturing the Benefits for South Asia (World Bank, UNCTAD and SAARC Secretariat, New Delhi, India) 11-13 January 2001, 2-3, available at: http://r0.unctad.org/trade_env/test1/ meetings/standards/mustafizur.doc, visited on 6 March 2001.

707 The ban was imposed on 30 July 1997.

708 Mustafizur Rahman, 'EU Ban on Shrimp Imports from Bangladesh: A Case Study on Market Access Problems Faced by LDCs', presented at the Workshop on a New WTO Round on Agriculture, SPS, and the Environment: Capturing the Benefits for South Asia (World Bank, UNCTAD and SAARC Secretariat, New Delhi, India) 11-13 January 2001, 4, available at: http://r0.unctad.org/trade_env/test1/meetings/standards/ mustafizur.doc, visited on 6 March 2001. Rahman points to the result of a study by Cato and Lima dos Santos, which estimated the losses from the ban at US\$65.1 million. However, as Bangladesh was able to divert a large part of shrimp exports to the US and Japan, these potential losses were reduced to US\$17.7 million. J.C. Cato and C.A. Lima Dos Santos, 'European Union 1997 Seafood Safety Ban: The Economic Impact on 
figure does not take into account the long-term losses due to loss of market share following market diversions, erosion in the price offered to exporters and loss of momentum of the shrimp industry. ${ }^{709}$

In response to the ban, concerted efforts were made to improve the quality and safety of shrimp exports. ${ }^{710}$ In 1997 the Fish Inspection and Quality Control Rules were drafted on the basis of the relevant EC Directives. ${ }^{711}$ Both the government of Bangladesh and the shrimp industry invested significant sums in order to ensure compliance with HACCP requirements for shrimp exports. In addition, special credit programmes were established and support was sought from international organisations. ${ }^{712}$ Investments included repair and upgrading of plant infrastructure, new equipment and laboratories, recruitment and training of staff and sanitation audits. ${ }^{713}$ The cost of these improvements is estimated at US $\$ 18$ million. ${ }^{714}$ Maintaining the HACCP system costs an additional US\$2.4 million annually, ${ }^{715}$ which represents 0.31 to 0.85 percent of the export earnings of the shrimp sector in $1997 .{ }^{716}$

Bangladesh Shrimp Processing', Marine Resource Economics 13 (3), 1998, 215-227. See also Veena Jha, 'South Asia', in Environmental Regulation and Food Safety: Studies of Protection and Protectionism, Veena Jha (ed.) (Edward Elgar and International Development Research Centre, Ottawa), 2005, 39-69, 44, available at: http://www.idrc.ca/openebooks/185-X/, visited on 5 January 2006.

709 Mustafizur Rahman, 'EU Ban on Shrimp Imports from Bangladesh: A Case Study on Market Access Problems Faced by LDCs', presented at the Workshop on a New WTO Round on Agriculture, SPS, and the Environment: Capturing the Benefits for South Asia (World Bank, UNCTAD and SAARC Secretariat, New Delhi, India) 11-13 January 2001, 4, available at: http://r0.unctad.org/trade_env/test1/meetings/standards/ mustafizur.doc, visited on 6 March 2001.

710 James C. Cato and S. Subasinge, Food Safety in Food Security and Food Trade: Case Study: The Shrimp Export Industry in Bangladesh (International Food Policy Research Institute, Washington D.C.), September 2003, 1 .

711 Committee on Sanitary and Phytosanitary Measures, Implementation of the SPS Agreement. Information for the Workshop on 31 March 2006. Communication from Bangladesh, G/SPS/GEN/676, circulated on 31 March 2006.

712 Mustafizur Rahman, 'EU Ban on Shrimp Imports from Bangladesh: A Case Study on Market Access Problems Faced by LDCs', presented at the Workshop on a New WTO Round on Agriculture, SPS, and the Environment: Capturing the Benefits for South Asia (World Bank, UNCTAD and SAARC Secretariat, New Delhi, India) 11-13 January 2001, 4, available at: http://r0.unctad.org/trade_env/test1/meetings/standards/ mustafizur.doc, visited on 6 March 2001.

713 James C. Cato and S. Subasinge, Food Safety in Food Security and Food Trade: Case Study: The Shrimp Export Industry in Bangladesh (International Food Policy Research Institute, Washington D.C.), September 2003, 1 .

${ }^{714}$ This calculation is based on a survey of 19 shrimp processing plants in Bangladesh. Industry investment in upgrading of plants was calculated as US\$17.6 million and government investments in improving facilities such as laboratories and training personnel was calculated as US\$382 000. See James C. Cato and C.A. Lima Dos Santos, 'Costs to Upgrade the Bangladesh Frozen Shrimp Processing Sector to Adequate Technical and Sanitary Standards and to Maintain a HACCP Program', presented at the Conference on the Economics of HACCP: New Studies of Costs and Benefits, Washington D.C.) 15-16 June 1998, 1, available at: www.umass. edu/ne165/haccp1998/cato.html, visited on 25 June 2007.

715 These costs are made up of US\$2.2 million in industry expenditures and US\$225 in government costs in connection with the monitoring of HACCP implementation. See Ibid.

${ }^{716}$ It is interesting to note that that this cost represents US $\$ 0.015$ to US\$0.04 per pound of shrimp, as compared to the cost for HACCP plans in US shrimp plants of US\$0.0009 per pound. Predictably, HACCP implementation in developing countries costs much more than in developed countries. Ibid. 
Following these improvements, the EU ban was gradually lifted, as particular processing plants were judged to meet EU requirements. ${ }^{717}$ Fishery and aquaculture exports to the EC from Bangladesh were required to come from the approved plants and to be accompanied by a prescribed health certificate from the competent authority in Bangladesh, designated to be the Department of Fisheries - Fish Inspection and Quality Control. ${ }^{718}$ Shrimp exports from Bangladesh began to recover and, in 2000, were well on their way to reaching pre-ban levels. ${ }^{719}$ However, it has been noted that the lost momentum of the shrimp industry has not yet been regained. ${ }^{720}$

Additionally, it is important to bear in mind the social consequences of strict sanitary requirements in the shrimp sector. They reinforce the bias that exists in favour of large shrimp farmers as opposed to single or household operations, ${ }^{721}$ as only large farmers have the resources needed to make the investments demanded by the new requirements. Large commercial shrimp farmers are commonly 'outsiders', based in urban centres, who are influential with government bureaucracies and insensitive to local problems. ${ }^{722}$ Unlike local farmers, they are not concerned with the social and environmental impact ${ }^{723}$ of their activities on the local area. Many small farmers are forced to leave their land and receive very low rent from the large farmers. ${ }^{724}$ In addition, large farmers tend to hire labourers from outside the area, rather than absorb surplus rural labour. ${ }^{725}$ The economic benefits for local rural communities from shrimp farming have consequently become minimal

${ }^{717}$ The EU ban was conditionally lifted with regard to six processing plants from 1 January 1998. This increased to 11 plants in July 1998 and by 2002, 48 of the 65 plants licensed by the Bangladesh government to export shrimp, had received EU approval. James C. Cato and S. Subasinge, Food Safety in Food Security and Food Trade: Case Study: The Shrimp Export Industry in Bangladesh (International Food Policy Research Institute, Washington D.C.), September 2003, 2.

718 These requirements were set out in a Commission Decision, which also listed the approved plants and provided the required certificate in Annex. Under the certificate, the health official must certify that the exports meet the requirements of EC Directives 91/493/EEC and 92/48/EEC, with regard to hygienic catching, handling, preparation, processing, freezing, thawing and storage; health controls; microbiological, parasitological, chemical and organoleptic checks; and that they do not come from species that are toxic or contain biotoxins. See European Commission, Commission Decision of 13 February 1998 Laying Down Special Conditions Governing Imports of Fishery and Aquaculture Products Originating in Bangladesh, (EC) 98/147/EC (European Commission, Brussels), 13 February 1998.

${ }^{719}$ Before the ban, in 1997, shrimp exports to the EU amounted to US\$128.9 million. This fell to US\$48.2 million in 1998 following the ban. In 1999, exports climbed to US\$89.3 million and reached US\$124.9 million in 2000. Mustafizur Rahman, 'EU Ban on Shrimp Imports from Bangladesh: A Case Study on Market Access Problems Faced by LDCs', presented at the Workshop on a New WTO Round on Agriculture, SPS, and the Environment: Capturing the Benefits for South Asia (World Bank, UNCTAD and SAARC Secretariat, New Delhi, India) 11-13 January 2001, 4, available at: http://r0.unctad.org/trade_env/test1/meetings/standards/ mustafizur.doc, visited 6 March 2001.

${ }^{720}$ Ibid.

${ }^{721}$ Alauddin and Hamid point out that commercial shrimp farming arose in response to international demands and shrimp are currently grown primarily for the export market. Mohammad Alauddin and M. Akhter Hamid, 'Shrimp Culture in Bangladesh with Emphasis on Social and Economic Aspects', in Towards Sustainable Shrimp Culture in Thailand and the Region: Proceedings of a Workshop, Paul Smith (ed.) (Australian Centre for International Agricultural Research, Canberra), 1999, 53-62, 54-55, available at: http://www.aciar.gov.au/ web.nsf/doc/JFRN-5J473M/\$file/PR90\%20Chapter\%2009.pdf, visited on 13 May 2000.

${ }^{722}$ Ibid., 57-58.

${ }^{723}$ Shrimp farming brings with it high environmental costs, including reduction in crop production (particularly rice), decrease in vegetation and destruction of mangrove forests. Ibid., 53.

${ }^{724}$ Ibid., 58 .

${ }^{725}$ Ibid., 59. 
as profits flow to urban centres. As a result, conflicts have arisen between outsiders and locals.

\subsubsection{Animal health system}

Livestock and fisheries are growing sectors of agricultural production in Bangladesh, as mentioned above. Regulation of this sector is not limited to addressing food-safety risks, but involves also the protection of the health of aquatic and terrestrial animals. Responsibility for ensuring animal health in Bangladesh rests with the Ministry of Livestock and Fisheries, and the Livestock Directorate and Department of Fisheries under its authority.

All imports of chicks, hatching eggs and deep frozen semen of cattle must be accompanied by a sanitary certificate issued by the Livestock Directorate or the competent authority in the exporting country that the product is free from contagious diseases. ${ }^{726}$ Deep frozen semen of oxen is banned. ${ }^{727}$ In addition, imports of eggs or larvae of shrimps and prawns are banned in Bangladesh. New regulations on hatcheries and fish feed are being drafted. ${ }^{728}$ The animal health measures imposed by Bangladesh are undermined by the prevalence of smuggling across the border with India.

Bangladesh also aims to ensure that its exports of livestock and fishery products meet sanitary requirements on their export markets, in order to avoid facing barriers to market access in the form of sanitary measures. For this reason, quality control licences from the BSTI are required prior to exportation of certain products. ${ }^{729}$ In addition, health and quarantine certificates are required, respectively, for exports of frozen fish and exports of plant products. ${ }^{730}$

The government is taking steps to improve compliance with sanitary requirements, including by increasing awareness of exporters of such requirements by means of seminars and by modernising the BSTI. Nevertheless, failure to meet internationally acceptable standards has led to restrictions in market access for Bangladeshi products. Lack of facilities to ensure product quality is a significant obstacle faced by exporters. ${ }^{731}$

\subsubsection{Plant health system}

As mentioned above, crop production is the most important area of agricultural activity in Bangladesh, and significant for purposes of food security. Major crops, namely

\footnotetext{
${ }^{726}$ Import Policy Order, 2003-2006, control list. Trade Policy Review Body, Trade Policy Review: Bangladesh - Report by the Secretariat, WT/TPR/S/168, circulated on 9 August 2006, Table AIII.4.

${ }^{727}$ Import Policy Order, 2003-2006, control list. Ibid.

${ }^{728}$ Committee on Sanitary and Phytosanitary Measures, Implementation of the SPS Agreement. Information for the Workshop on 31 March 2006. Communication from Bangladesh, G/SPS/GEN/676, circulated on 31 March 2006.

${ }^{729}$ Further details on the products subject to this licensing requirement and the conditions applicable are not available. See Trade Policy Review Body, Trade Policy Review: Bangladesh-Report by the Secretariat, WT/ TPR/S/68, circulated on 3 April 2000, Part III para. 95.

${ }^{730}$ Ibid., Table III.11.

${ }^{731}$ Ibid., Part III para. 96.
} 
rice, wheat, jute, potato and sugarcane, are classified as 'notified crops' and their varietal development, multiplication and quality control remains in the hands of public bodies. ${ }^{732}$

The Plant Protection Directorate, under the Ministry of Agriculture and Lands, is in charge of ensuring phytosanitary protection and implementing existing plant quarantine legislation. ${ }^{733}$ Phytosanitary protection is still governed by the Destructive Insects and Pests Act of 1914 and the Destructive Insects and Pests Rules of 1966 (as amended in July 1989), promulgated there under. ${ }^{734}$ All imported products of plant origin are required to obtain a quarantine certificate from the Plant Protection Directorate, in terms of the Quarantine Ordinance. ${ }^{735}$ In addition, seed imports of the five notified crops are subject to additional restrictions. ${ }^{736}$

Sixteen plant quarantine stations are currently operational at entry points (airports, sea ports and land borders) into Bangladesh. ${ }^{737}$ While these are mostly poorly to moderately

${ }^{732}$ C.A.F. Dowlah, 'Agriculture and the New WTO Round - Economic Analysis of Interests and Options for Bangladesh', presented at the Workshop on a New WTO Round on Agriculture, SPS, and the Environment: Capturing the Benefits for South Asia (World Bank, UNCTAD and SAARC Secretariat, New Delhi, India) 31 December 2000, 7, available at: http://r0.unctad.org/trade_env/test1/meetings/standards/NewDelhi.doc, visited 13 May 2000.

${ }^{733}$ Sahadad M. Hussain and S.M. Khalilur Rahman, 'Sanitary and Phytosanitary Measures and Environmental Management in Bangladesh', presented at the Workshop on a New WTO Round on Agriculture, SPS, and the Environment: Capturing the Benefits for South Asia (World Bank, UNCTAD and SAARC Secretariat, New Delhi, India) 11-13 January 2001, 2, available at: http://r0.unctad.org/trade_env/test1/meetings/standards/BARC.doc, visited on 7 July 2001. The Plant Protection Directorate consists of 5 sections: plant quarantine, pesticide administration and quality control, operation, surveillance and forecasting, and integrated pest management. See also Veena Jha, 'South Asia', in Environmental Regulation and Food Safety: Studies of Protection and Protectionism, Veena Jha (ed.) (Edward Elgar and International Development Research Centre, Ottawa), 2005, 39-69, 63, available at: http://www.idrc.ca/openebooks/185-X/, visited on 5 January 2006.

${ }^{734}$ Sahadad M. Hussain and S.M. Khalilur Rahman, 'Sanitary and Phytosanitary Measures and Environmental Management in Bangladesh', presented at the Workshop on a New WTO Round on Agriculture, SPS, and the Environment: Capturing the Benefits for South Asia (World Bank, UNCTAD and SAARC Secretariat, New Delhi, India) 11-13 January 2001, 1, available at: http://r0.unctad.org/trade_env/test1/meetings/standards/ BARC.doc, 7 July 2001.

735 Trade Policy Review Body, Trade Policy Review: Bangladesh - Report by the Secretariat, WT/TPR/S/68, circulated on 3 April 2000, Table III.1.

${ }^{736}$ The private sector may only import seeds of notified crops for trials. If the seeds are then judged suitable, the variety may be multiplied and the seeds sold. See C.A.F. Dowlah, 'Agriculture and the New WTO Round - Economic Analysis of Interests and Options for Bangladesh', presented at the Workshop on a New WTO Round on Agriculture, SPS, and the Environment: Capturing the Benefits for South Asia (World Bank, UNCTAD and SAARC Secretariat, New Delhi, India) 31 December 2000, 7, available at: http://r0.unctad. org/trade_env/test1/meetings/standards/NewDelhi.doc, visited 13 May 2000.

737 Veena Jha, 'South Asia', in Environmental Regulation and Food Safety: Studies of Protection and Protectionism, Veena Jha (ed.) (Edward Elgar and International Development Research Centre, Ottawa), 2005, 39-69, 63, available at: http:/www.idrc.ca/openebooks/185-X/, visited on 5 January 2006. In 1978, Bangladesh signed a Memorandum of Understanding with India, according to which fifteen land border check-posts between the two countries were surveyed and agreement was reached to establish new plant quarantine stations to prevent the introduction of destructive exotic pests. Sahadad M. Hussain and S.M. Khalilur Rahman, 'Sanitary and Phytosanitary Measures and Environmental Management in Bangladesh', presented at the Workshop on a New WTO Round on Agriculture, SPS, and the Environment: Capturing the Benefits for South Asia (World Bank, UNCTAD and SAARC Secretariat, New Delhi, India) 11-13 January 2001, 3, available at: http://r0.unctad.org/trade_env/test1/meetings/standards/BARC.doc, visited on 7 July 2001. 
equipped, two have been upgraded. ${ }^{738}$ Nevertheless, the large amount of unofficial trade that takes place across the long border between Bangladesh and India means that the phytosanitary restrictions of Bangladesh are often bypassed, resulting in threats to plant health.

Bangladesh's main exports of plant products, namely tea, jute and jute products, have to date never been subject to phytosanitary barriers to trade. However, concerns have been raised that stricter EC measures may have adverse effects on Bangladeshi exports. ${ }^{739}$

\subsubsection{Overall assessment of the SPS system of Bangladesh}

The SPS system of Bangladesh has been categorised as extremely weak by a recent World Bank study. ${ }^{740}$ Both the human resources and the technical capacity to deal with increasingly strict SPS requirements on the markets of its trading partners are inadequate. ${ }^{741}$

In addition, it has been noted that the current plant inspection and quarantine rules in Bangladesh are outdated and should be completely revised. In addition, Bangladesh should establish a list of important plant pests and diseases in its territory, something which is often required by importing countries. Finally, the necessity for cooperation and exchange of information between plant quarantine services in Bangladesh and neighbouring countries has been emphasised. ${ }^{742}$ These improvements will require financial and technical assistance. Lack of information of Bangladeshi exporters of agricultural products (such as tea, jute, shrimps and frozen food and vegetables) regarding the SPS measures of importing countries has been identified as a problem in accessing the markets of industrialised countries. ${ }^{743}$ Further, the government has observed that the lack of knowledge of WTO rules by exporters in Bangladesh prevents them from approaching the government in cases where their exports face market barriers in violation of the rules of the SPS Agreement. ${ }^{744}$

\footnotetext{
${ }^{738}$ These are the Chittagong sea port and the Benapole land border check-post.

${ }^{739}$ Sahadad M. Hussain and S.M. Khalilur Rahman, 'Sanitary and Phytosanitary Measures and Environmental Management in Bangladesh', presented at the Workshop on a New WTO Round on Agriculture, SPS, and the Environment: Capturing the Benefits for South Asia (World Bank, UNCTAD and SAARC Secretariat, New Delhi, India) 11-13 January 2001, available at: http://r0.unctad.org/trade_env/test1/meetings/standards/ BARC.doc, visited on 7 July 2001. Which EC measures these concerns relate to was not specified.

${ }^{740}$ Poverty Reduction and Economic Management Sector Unit, South Asia Region, Bangladesh - Growth and Export Competitiveness, Report No. 31394-BD (World Bank, Washington D.C.) 4 May 2005. This report is cited in Trade Policy Review Body, Trade Policy Review: Bangladesh - Report by the Secretariat, WT/ TPR/S/168, circulated on 9 August 2006, Section III para. 88.

741 Ibid.

${ }^{742}$ Sahadad M. Hussain and S.M. Khalilur Rahman, 'Sanitary and Phytosanitary Measures and Environmental Management in Bangladesh', presented at the Workshop on a New WTO Round on Agriculture, SPS, and the Environment: Capturing the Benefits for South Asia (World Bank, UNCTAD and SAARC Secretariat, New Delhi, India) 11-13 January 2001, 10, available at: http://r0.unctad.org/trade_env/test1/meetings/standards/ BARC.doc, visited on 7 July 2001.

${ }^{743}$ Trade Policy Review Body, Trade Policy Review: Bangladesh - Report by the Secretariat, WT/TPR/S/68, circulated on 3 April 2000, Part III para. 144.

${ }^{744}$ Trade Policy Review Body, Trade Policy Review: Bangladesh-Report by the Government, WT/TPR/G/68, circulated on 3 April 2000, para. 21.
} 


\subsection{Conclusion: The differences between SPS regulatory systems at different levels of development}

The above discussion has illustrated the significant differences that exist between WTO Members with regard to SPS regulatory systems. These differences reflect the different levels of development of the relevant Members - there are clearly vast differences between the developed-country Member and the developing-country Members studied. However, it is important to note that these differences also exist between developingcountry Members at different levels of development, as reflected by their GDP, level of human development, and export diversification. Clearly, some developing countries have been more successful than others have in upgrading their SPS systems and securing access to the markets of their trading partners.

In addition, it has been shown that differences are also prevalent between different sectors within certain countries. Some sectors are operating at high levels of SPS safety, while others remain underdeveloped in this regard. This reflects national priorities with regard to export promotion as well as technical and financial assistance received in a particular area. Most of the countries studied have in place relatively strong SPS controls over the most important SPS risks they face. ${ }^{745}$ There is therefore clearly a need for a more nuanced understanding of the SPS problematique than to see it merely in terms of a developed country versus developing country issue.

Nevertheless, two general conclusions can be drawn regarding differences in SPS regimes according to level of development. First, the level of SPS protection exhibits marked differences, being substantially higher in more developed countries due to better technological capacity, higher consumer demands, and more developed regulatory infrastructure. Second, the regulatory focus differs. Less developed countries tend to rely on product requirements, which are enforced by means of testing and inspections by government authorities at the point of exit or entry. Product requirements are easier to comply with as they leave the means of compliance up to the producer and are based on objective, testable properties that can readily be ascertained. By contrast, developed countries are increasingly, especially in the area of food safety, moving towards process requirements, such as HACCP ${ }^{746}$ which require the producers themselves to take responsibility for ensuring that the entire chain, 'from farm to fork' meets certain standards of hygiene and safety. These process requirements entail a systems-wide approach to SPS issues, which necessitates significant technical expertise, supporting infrastructure and control systems.

These differences in SPS regimes have notable consequences for the impact both of SPS measures themselves and of the SPS Agreement on countries at different levels of development. First, various problems faced by developing countries with compliance with

\footnotetext{
745 The report of the case studies of six developing countries carried out by the ITC and Commonwealth Secretariat has also come to this conclusion. See Vinod Rege et al., Influencing and Meeting International Standards: Challenges for Developing Countries. Volume I: Background Information, Findings from Case Studies and Technical Assistance Needs (International Trade Centre UNCTAD/WTO and Commonwealth Secretariat, Geneva), 2003, 84. This report notes that it would be too simplistic to merely state that developing countries cannot meet SPS requirements. Instead 'where SPS or TBT requirements threaten their economic interests, the countries are willing and able to take action.' Ibid.

${ }^{746}$ The HACCP system is explained above, Part II, Section 1.3.
} 
SPS measures in developed country markets have been identified in the country case studies above, by means of illustrative examples. These problems reflect the fact that the difficulty and costs of compliance are directly related to the extent of the gap between the existing domestic SPS regime and the SPS requirements in foreign markets. Several factors play a role here, such as weak domestic SPS regulation, inadequate public infrastructure, unreliable compliance assessment and certification, insufficient dissemination of information on SPS requirements abroad, and poor laboratory equipment and staff.

Second, the differences between countries at different stages of development have bearing on the way in which the SPS Agreement impacts on them. As will be seen in the discussion in subsequent chapters, the disciplines of this Agreement reflect 'best practices' in developed countries with regard to SPS regulation. The case studies above show that the reality in many developing countries is different. Thus compliance with the requirements in the SPS Agreement for SPS regulation, in terms of both scientific basis and procedural transparency, is more difficult and costly for less developed countries. In addition, institutional and scientific deficiencies affect the possibilities that less developed countries have to use the substantive rules and procedural mechanisms of the SPS Agreement to gain access to foreign markets.

The discussion of the international aspect of Australia's SPS system has shown that it has a highly effective and pro-active system in place to address potential SPS market barriers faced by its producers. Australia is therefore able to resolve SPS issues promptly, in many cases before they result in the imposition of SPS measures, thus avoiding economic harm to Australian operators. Such a system is absent in the middle- and low-income WTO Members discussed in this Chapter, and their approach to SPS barriers tends to be more reactive. As a result, their exporters bear heavy financial losses from product rejections while the SPS measure remains in place. Examples discussed in this Chapter that illustrate this point are the inability of Mauritian abattoirs to meet EC requirements for poultry and venison, resulting in a loss of market access to Reunion; and Jamaica's lack of resources to create a hot water treatment facility to eliminate fruit flies on mangoes, as required by the US, leading to a ban on its mango exports to the US. Even when adjustments are successfully made by the exporting Member to address the SPS problem, its industry may not always recover its original position on the market, as illustrated by the situation of the Bangladeshi shrimp industry discussed above.

However, it would be an over-generalisation to state that middle- and low-income Members are entirely incapable of meeting SPS requirements on their export markets, or of upgrading their SPS systems to protect their territories from SPS risks. A recent study, conducted by the International Trade Centre and the Commonwealth Secretariat in six developing countries, has indicated that both in areas where SPS requirements threaten their key economic interests and in areas where important SPS risks to their territories are at stake, developing countries have demonstrated a willingness and ability to take action. ${ }^{747}$

747 Vinod Rege et al., Influencing and Meeting International Standards: Challenges for Developing Countries. Volume I: Background Information, Findings from Case Studies and Technical Assistance Needs (International Trade Centre UNCTAD/WTO and Commonwealth Secretariat, Geneva), 2003. The report is discussed by Guyadhur, a Senior Adviser on Export Quality Management at the ITC. See Shyam K. Gujadhur, 'Technical Assistance for SPS Measures: Protect Health, Not Trade', International Trade Forum (3), 2002, 31-35, available at: http://www.tradeforum.org/news/fullstory.php/aid/460/ 
For example, as discussed in this Chapter, in order to ensure access for its canned ackee to the US market, one of its most important markets, Jamaica has undertaken an innovative implementation of a pre-clearance system. Mauritius has taken measures to keep sugarcane pests out of its territory, as this pest would entail significant phytosanitary risks for a crop crucial to the economy of this Member. Bangladesh has largely restructured its shrimp industry to meet EU food-safety requirements. These three Members have made concerted, and effective, efforts to resolve the SPS issues of particular export or import importance to them.

It is, nevertheless, important to note the central role played by technical and financial support from the importing Member in some of these initiatives. ${ }^{748}$ It is unlikely that, without the necessary support, the exporting Member would have been able to resolve the SPS problems facing its industry. This puts those Members that face capacity constraints in the area of SPS regulation in a very dependent position. As bilateral technical assistance tends to be donor driven, and based on the trade interests of the donor country, this may lead to situations where the development priorities of the recipient country are disregarded. While certainly valuable in assisting exporting Members to overcome specific difficulties they face in the SPS area, such ad hoc technical assistance should not be seen as the magic bullet solution to the differences in SPS capacity, and the concomitant disparity in SPS requirements, of WTO Members at different levels of development. Instead, as will be discussed in Part V of this book, a new, integrated, predictable and coherent approach to technical assistance is needed, to ensure that it is successful in strengthening the SPS regime of the beneficiary Member in accordance with its particular needs and priorities. ${ }^{749}$

Technical_Assistance_for_SPS_Measures:_Protect_Health,_Not_Trade.html, visited on 28 June 2003.

${ }^{748}$ Ibid.

${ }^{749}$ See further below, Part V, Section 2.8 . 


\section{CHAPTER 3 \\ International SPS standard-setting}

Vast differences exist in national SPS regulatory systems, as seen from the discussion in Chapter 2. These differences can be ascribed to the divergent economic, ecological, institutional, cultural, social and legal contexts in which they occur. For example, a Member with a unique and vulnerable ecology and a largely pest-free status may have sophisticated quarantine requirements in place, whereas a Member whose territory is already teeming with pests may not regard this as a priority. Similarly, a Member with affluent, risk-averse citizens may choose to impose process requirements for food products, whereas a Member whose citizens face food shortages or risks from infectious diseases may focus its resources rather on poverty alleviation and basic sanitation. Diverging SPS requirements are thus a reflection of the diversity in both capacity and policy priorities that exists in different Members and can be seen as a natural outcome of the exercise of sovereign regulatory authority by their governments.

However, regulatory diversity has long been recognised to constitute a significant trade barrier. Differing SPS measures can act as non-tariff barriers to trade by subjecting producers to additional requirements on their export markets, beyond those that they have to meet in the country of production. When producers are further faced with a multiplicity of SPS requirements in the different export markets, meeting all these requirements will be even more burdensome and costly, thus reducing efficiency gains and preventing the realisation of economies of scale. ${ }^{1}$ The promotion of harmonisation of SPS requirements aims to address this problem. ${ }^{2}$

Harmonisation initiatives in the area of SPS regulation have a long history. Hand-inhand with the expansion of trade in food and agricultural products came the increasing awareness of the trade restrictive effect of divergent national SPS requirements and of the need to promote their harmonisation. Already in 1903, the International Dairy Federation

\footnotetext{
${ }^{1}$ Economies of scale refer to the phenomenon where increases in the scale of production (for example due to access to foreign markets) typically lead to a corresponding decrease in the costs of production per unit, since fixed costs are shared over a larger number of units. This is particularly the case when there are high fixed costs of production and small marginal costs. Where the product has to be adapted to different requirements on the various export markets, these economies of scale are reduced or lost.

2 Some commentators distinguish two types of harmonisation, namely international standard setting and the recognition of the equivalence of domestic and foreign standards. See, for example, Public Citizen, Harmonization Handbook: Accountable Governance in the Era of Globalization: The WTO, NAFTA, and International Harmonization of Standards (Public Citizen, Washington D.C.), 2000, 3. However, it is argued here that the recognition of the equivalence of different standards is a way to diminish the trade-restrictive effect of divergent SPS requirements by preventing these divergences from constituting reasons to restrict importation, while not harmonising them. The technique of equivalence, unlike harmonisation, does not lead to the application of uniform regulatory standards. Instead, members of the free trade regime are obliged, under certain conditions, to accept the regulations of other members as equivalent to their own even if they differ in content, provided that they achieve the same regulatory objectives. Thus members cannot prohibit or restrict imports based on differences in regulatory standards. The following discussion will accordingly limit itself to those uniform standards drafted on international level. Therefore, equivalence agreements and mutual recognition agreements will not be discussed in here, but instead in Part IV, Section 1.1 below. This accords with the typology used in the SPS Agreement, where the term 'harmonization' is used to refer only to the first category of initiatives, while the second type falls under the heading of 'equivalence'.
} 
drew up standards for international trade in milk and milk products. ${ }^{3}$ Other commodity organisations took similar initiatives. In the 1930s, under the auspices of the International Institute for Agriculture, several conventions establishing uniform rules for particular commodities were adopted. ${ }^{4}$ This trend has grown beyond efforts by specific commodity interest groups. After the Second World War, regional initiatives to harmonise food regulations were launched, such as the development of a Latin American Food Code and the Codex Alimentarius Europeaus. ${ }^{5}$ Currently, free trade regimes, such as the European Community, ${ }^{6}$ North American Free Trade Agreement (NAFTA) and the WTO, promote harmonisation as part of their trade liberalisation disciplines.

Harmonisation of SPS regulation within free trade regimes relies upon international standard setting to generate norms. International standard setting refers to the process of establishment of a single regulatory standard to be applied by all members of the particular free trade system. This harmonised standard can be set by the decision-making bodies of the free trade organisation itself, as in the case of the EC. Alternatively, the standard can be set by existing international standard-setting organisations that are independent of the trade regime but expressly referred to by the relevant rules thereof, as in the case of the WTO and NAFTA.

The harmonisation of SPS requirements around international standards has good reasons behind it. However, it also has significant failings which give cause for concern. It is useful to address both aspects of this issue, in order to be able to evaluate the reference

${ }^{3}$ Peter W.B. Phillips, 'Food Safety, Trade Policy and International Institutions', in Governing Food: Science, Safety and Trade, Peter W.B Phillips and Robert Wolfe (eds.) (McGill-Queen's University Press, Montreal), 2001, 27-48, 29.

${ }^{4}$ The International Institute for Agriculture (IIA) was the forerunner of the UN Food and Agriculture Organization (FAO). Mariëlle Masson-Matthee, The Codex Alimentarius Commission and Its Standards, Doctoral Thesis, Maastricht University, Faculty of Law (T.M.C. Asser Press, Maastricht), 2007, 14. Mariëlle Masson-Matthee mentions the following examples of conventions adopted under the IIA: the Brussels Convention for the Marking of Eggs, adopted 10 December 1931 and the Rome Convention on the Unification of Sampling and Analysis Methods for Cheese, adopted 26 April 1934. She also notes that proposals on the initiative of the International Dairy Federation with regard to various milk products were presented for adoption in 1939 but their adoption was hindered by the outbreak of the Second World War.

5 Ibid., 15. Masson-Matthee notes that the Codex Alimentarius Europeaus was based on the earlier Codex Alimentarius Austriacus, the 1897 food code of the Austro-Hungarian empire. In 1958, an initiative of the International Commission on Agricultural Industries and the Permanent Bureau of Analytical Chemistry led to the creation of the Council of the Codex Alimentarius Europeaus with the mandate to establish a European food code. This Council later proposed that, in order to expand participation, the FAO should take over its work. This eventually led to the proposal by the FAO in 1961 for the establishment of the Codex Alimentarius Commission, discussed further below, Part II, Section 3.2.1.

${ }^{6}$ The success of the harmonisation of regulations in promoting free trade is evinced by the experience of the European Community, where the promulgation of common standards applicable to all Member States in various areas of consumer and environmental protection, together with the mutual recognition of standards among Member States, have facilitated the free movement of goods and thus the creation of the Single Market in Europe. Product safety regulation at European Community level provides a good example of this strategy. The European Community replaced national regulations setting product safety standards with sophisticated regulatory frameworks at European Community level, 'which have now reached the point of almost comprehensively covering the whole range of technical goods and other products'. Christian Joerges, 'Scientific Expertise in Social Regulation and the European Court of Justice: Legal Frameworks for Denationalized Governance Structures', in Integrating Scientific Expertise into Regulatory Decision-Making: National Traditions and European Innovations, Christian Joerges, et al. (eds.) (Nomos, Baden-Baden), 1997, 295-323, 298. 
to harmonisation around international standards in the SPS Agreement ${ }^{7}$ and its effect on Members at different levels of development. This chapter therefore starts, in a first general section, by examining the reasons behind the promotion of harmonisation of SPS regulation around international standards. This is addressed from a law-and-economics perspective, as was done when examining the reasons for national SPS regulation in Chapter 2. Thereafter, the failings of harmonisation are discussed, with a particular focus on the procedural problems inherent in international standard setting. This general section aims to provide the conceptual background for the more concrete discussion in the section that follows.

The following section of this Chapter comprises a more specific discussion of international standard setting in practice, by examining the three international standard setting bodies referred to in the SPS Agreement. This provides a necessary factual context for the discussion of the harmonisation provisions of the SPS Agreement in Part III of this book. WTO Members are obliged, under Article 3.4 of the SPS Agreement, to participate in the work of the relevant international standard-setting organisations, to the extent that their resources permit, and to promote the development and periodic review of the SPS standards set in these organisations. However, this provision itself recognises that resources are a limiting factor regarding the participation of Members in international standardsetting organisations. The extent to which resource constraints impact on the ability of WTO Members to influence the development and adoption of the international standards that will be used as benchmarks under the disciplines of the SPS Agreement, can best be understood by looking in some detail at the structure and functioning of the standard setting bodies involved.

Therefore, each of three international standard setting bodies expressly referred to in the SPS Agreement are addressed in turn in this section. ${ }^{8}$ In particular, in a first subsection, the mandate of each of these bodies is set out to establish its scope of activities. Second, the institutional structure of the relevant body is explained, with reference to the tasks and composition of the various organs involved. The rules on membership and observer status of each of the standard-setting body at issue are set out in a third subsection in order to determine the scope for participation by the relevant actors, including countries at different levels of development, and various interest groups. The current composition of the membership of the relevant standard-setting body is noted here, with reference to WTO Members at different levels of development. In keeping with the approach taken elsewhere in this book, income level is used as a convenient indicator of level of economic development in order to be able to systematise and present the information available. ${ }^{9}$

\footnotetext{
7 This reference is discussed in detail below, Part III, Chapter 4.

${ }^{8}$ Note that the SPS Agreement provides the possibility, in Annex A.3(d), in respect of 'matters not covered' by the three international standard-setting bodies expressly mentioned in the Agreement, for the SPS Committee to identify appropriate standards promulgated by other organisations open for membership to all WTO Members. However, the SPS Committee has not yet done so. As a result, the discussion of standard setting in this Chapter is limited to those three organisations currently of relevance under the SPS Agreement. On Annex A.3(d), see below, Part III, Section 4.1.1.

${ }^{9}$ Income level is indicated, as done elsewhere in this book, on the basis of the 2007 World Bank classification of countries by income level. See the World Bank classification, as at 1 July 2007, available at: http://siteresources.worldbank.org/DATASTATISTICS/Resources/CLASS.XLS, visited on 18 December 2007.
} 
However, this does not imply the view that the level of income or economic development of a country is fully indicative of its position on the development continuum. ${ }^{10}$

A fourth subsection explains the standard setting procedures of the international standardsetting body at issue. This is done with a view to making clear the problems that Members at lower levels of development may face in participating effectively in these procedures. Where available, information is provided on evaluations of standard-setting procedures carried out for the relevant body, identifying problematic aspects of these procedures. Initiatives to reform the standard-setting procedures are also identified where they exist.

The actual attendance and active participation of WTO Members at different levels of economic development in the standard-setting process in the international standard-setting body at issue is examined in a fifth subsection. Once again, the 2007 World Bank classification of countries by income level is used as an indicator of level of development. ${ }^{11}$ The data examined in this regard is limited specifically to WTO Members rather than to all members of the international standard-setting body at issue. This is because the purpose of this Chapter is to establish the context for the discussion of the implications of the disciplines on harmonisation in the SPS Agreement for WTO Members at different levels of development. It is for these countries that the international standards set by the relevant standard-setting bodies have taken on new importance as benchmark standards under the SPS Agreement.

In most cases, to establish the levels of attendance of WTO Members at different income levels, the lists of participants at the most recent meetings of the various committees, expert groups and other bodies involved in the standard-setting process and for which data is available, are relied upon. Some indication of trends in the level of active participation of WTO Members by income level is derived from an examination of the number of their interventions in meetings of specific committees, where this information is available. Where publicly available, information on the extent to which WTO Members at different income levels have proposed new standards for elaboration by the relevant bodies is provided. All these statistics aim to sketch a picture of the current situation with regard to the participation of WTO Members at different levels of development in international standard setting.

While a serious attempt has been made to collect and systematise the data available, this section does not pretend to offer a precise calculation of the exact levels of attendance and active participation of WTO Members by income level. Such an endeavour is made impossible by the many gaps in the publicly available data, and the lack of statistical expertise of the author. Instead, this section only provides an indication of the approximate levels of attendance and participation of WTO Members.

The Chapter concludes by evaluating the current state of the international standard-setting procedures and the extent of developing country participation therein.

\footnotetext{
${ }^{10}$ As discussed in above in Chapter 2, and recognised in the UNDP's Human Development Index, various indicators of economic and social development must be taken into account in establishing the level of development of a country. See above, Part II, Section 2.2.

${ }^{11}$ Note that the 2007 classification is used throughout, even where data provided relates to a number of years. As a result, the limited number of cases where a Member may have moved from one income classification to another during the periods examined, is not taken into account in the presentation of data in this book.
} 


\subsection{General aspects of international standard setting}

\subsubsection{Reasons for harmonisation of SPS regulation around international standards}

Harmonisation may be seen as an attempt to address the difficulties that arise from the globalisation of trade in food and agricultural products, and the concomitant globalisation of health risks.

In law-and-economics terms, harmonisation may be regarded as a response to the problem of global public goods. As discussed in Chapter 2, public goods are characterised by 'non-rivalry in consumption and non-excludability. ${ }^{12}$ When the externality effects of provision of the public good extend beyond national borders, it can be regarded as a global public good. This is the case, for example, for the public good of liberalised markets, which benefits not only the national economy, but also provides opportunities to foreign producers to expand their markets. It is likewise the case for the public good of safe products, which prevents risks both to domestic consumers and, if the product is traded, also to consumers in the importing country.

Regulations for SPS protection have externality effects on both trade and health beyond the national borders. They typically affect not only domestic producers and consumers but also foreign competitors and consumers. ${ }^{13}$ The trade restrictive effect of the diversity of national SPS regulations has a significant impact on exporters of food and agricultural products. At the same time, the increasing globalisation of SPS health concerns has arisen from the growth in movement of food and agricultural products across borders, leading to risks from unsafe food imports and from the introduction and spread of pests and diseases by imported plants, animals or their products.

Despite the fact that they are affected by the externality effects of SPS regulation, foreign stakeholders have insufficient influence on the regulating government to counteract the influence of domestic interest groups. As a result regulators may undervalue the costs or benefits to foreign operators. ${ }^{14}$ This results in inefficient provision of global public goods. ${ }^{15}$

12 Peter Drahos, 'The Regulation of Public Goods', Journal of International Economic Law 7 (2), 2004, 321339,321 . More simply put, this means that consumption of the good by one person does not leave less available for other persons to consume, and it is impossible or too costly to exclude those who do not pay from the benefit of the good. See further on public goods the discussion above, Part II, Section 1.2.

13 Alessandra Casella notes that 'standards may be linked to public goods that are defined not in physical space, but in economic space: the standards we consume my depend more on the products we buy than on the place where we live.' Alessandra Casella, 'Free Trade and Evolving Standards', in Fair Trade and Harmonisation: Prerequisites for Free Trade?, Jagdish N. Bhagwati and Robert E. Hudec (eds.), vol. 1 (MIT Press, Cambridge), 1997, 119-156, 136.

${ }^{14}$ Robert Keohane, 'Global Governance and Democratic Accountability', in Taming Globalization: Frontiers of Governance, David Held and Mathias Koenig-Archibugi (ed.) (Polity Press, Cambridge), 2003, 130-159, $150-151$.

15 This point was also made above, Part II, Section 1.2. See Howard F. Chang, Risk Regulation, Endogenous Public Concerns, and the Hormones Dispute: Nothing to Fear but Fear Itself?, Research Paper 03-25 (University of Pennsylvania Law School, Institute for Law and Economics, Pennsylvania), August 2003, 25, available at: http://ssrn.com/abstract_id=432220, visited 12 June 2006. See also Robert Keohane, 'Global Governance and Democratic Accountability’, in Taming Globalization: Frontiers of Governance, David Held 
Therefore, the efficient supply of global public goods may necessitate international cooperation in the area of SPS regulation. Such cooperation, embodied in negotiations between national governments to elaborate international SPS standards, aims to ensure that the regulatory outcome takes account of costs and benefits at the global level and therefore leads to welfare maximisation globally.

\subsubsection{Failings of harmonisation}

The benefits aimed at by harmonisation of SPS requirements through international standard-setting are often not achieved. This failing may be ascribed to problems inherent in international standard-setting procedures. As noted by Razeen Sally:

...the global governance catchphrase - "global solutions for global problems" assumes, wrongly, that most or all problem-solutions are global, to be dealt with by (often unaccountable and unrepresentative) members of the "international community". It is this unconditional embrace of global governance that is both glib and illiberal. ${ }^{16}$

One important problem with international harmonisation of regulatory standards, not only in the SPS area but also more broadly, is the fact that the standards on which such harmonisation is based cannot truly reflect global public choice. This is because of 'the nature of global regulatory standard-setting processes. ${ }^{17}$ It is useful to look at these processes and the interests that underlie them in more detail.

There is no global government provider of global public goods that weighs up costs and benefits to all stakeholders. Instead, as Peter Drahos points out, harmonised standards are developed by imperfect international institutions, whose standard-setting procedures involve "contests of principles between complex alliances of state and non-state actors with different mechanisms at their disposal. ${ }^{18}$ As at national level, power plays a role in this process, and international regulators are subject to capture by interest groups. ${ }^{19}$ There is much political power of multinational food and agrochemical companies behind the drive towards international harmonisation of standards. This power is used to influence the positions of states in the standard-setting process, in order to achieve outcomes of benefit to such companies. Global public goods may consequently be underprovided due to the fact that the relative power of actors within international institutions shapes their provision and distribution. Actors such as countries at lower levels of development and consumer interest groups are often underrepresented in international standard-setting bodies, or lack

and Mathias Koenig-Archibugi (ed.) (Polity Press, Cambridge), 2003, 130-159, 150-151.

${ }^{16}$ Razeen Sally, Whither the World Trading System? Trade Policy Reform, the WTO and Prospects for the New Round, No. 76 (Timbro, Stockholm), 2002, 14, available at: http://www.timbro.se/pdf/whither.pdf, visited on 28 January 2008.

${ }^{17}$ Peter Drahos, 'The Regulation of Public Goods', Journal of International Economic Law 7 (2), 2004, 321 339,338 .

18 Ibid.

${ }^{19}$ Donna Roberts et al., 'Sanitary and Phytosanitary Barriers to Agricultural Trade: Progress, Prospects and Implications for Developing Countries', in Agriculture and the New Trade Agenda - Creating a Global Trading Environment for Development, M.D. Ingco and L.A.Winters (eds.) (Cambridge University Press, Cambridge), 2004, 329-358, 341. 
the resources to effectively promote their interests. ${ }^{20}$ Those countries and industry interest groups that do have the financial, technical and human resources to participate effectively in the glut of committees where the standard-setting work is done, "end up defining the level of public goods' ${ }^{21}$ provided by harmonised standards. High-income WTO Members have become adept at using the international standard setting process to pursue their industry interests. ${ }^{22}$ It has been noted that in industrialised countries 'international standards have followed rather than shaped national standards' ${ }^{23}$ This is often due, in large part, to the strength of their existing regulatory systems. ${ }^{24}$

In fact, much critical attention has been focused on the standard-setting process in the international standard-setting bodies and the problems that WTO Members at lower levels of development face with regard to effective participation therein. ${ }^{25}$ The constraints that limit the ability of these Members to promote their interests in the international standard-setting process are manifold. ${ }^{26}$ First, lack of resources often leads to inadequate at-

20 This comment was made by India in the run up to the Seattle Ministerial Conference meeting in 1999. General Council, Preparations for the 1999 Ministerial Conference. Proposals Regarding the Agreement on Sanitary and Phytosanitary Measures in Terms of Paragraph 9(a)(I) of the Geneva Ministerial Declaration. Communication from India, WT/GC/W/202, circulated on 14 June 1999, para. 1.

${ }^{21}$ Peter Drahos, 'The Regulation of Public Goods', Journal of International Economic Law 7 (2), 2004, 321339,338 . Drahos notes that this is one reason why big business is such an influential actor in food standards regulation, inter alia. In addition, Drahos points to the fact that some states and businesses can draw upon mechanisms of economic coercion not available to other actors. Here one can think of the threat of withdrawal of financial or technical assistance to developing countries that do not support the donor state's position in standard-setting bodies.

${ }^{22}$ Mattli and Büthe cite the following early statement of the US Federal Trade Commission with regard to international standards and the power struggles that underlie them: '[A]lthough the considerations of the standard tend to be expressed in rather technical language, behind this façade of engineering jargon, what is actually happening is an economic fight, often of the most savage type imaginable because the states are so high.' US Federal Trade Commission, Standards and Certification: Proposed Rules and Staff Report (Washington D.C.) 1978, 94, cited in Walter Mattli and Tim Büthe, 'Setting International Standards: Technological Rationality or Primacy of Power', World Politics 56 (1), 2003, 1-42, 1.

23 David G. Victor, 'Risk Management and the World Trading System: Regulating International Trade Distortions Caused by National Sanitary and Phytosanitary Policies', in Incorporating Science, Economics, and Sociology in Developing Sanitary and Phytosanitary Standards in International Trade: Proceedings of a Conference, National Research Council Board on Agriculture and Natural Resources (ed.) (National Academy Press, Washington D.C.), 2000, 118-169, 133, available at: www.nap.edu/openbook/0309070902/html/199. html, visited on 25 June 2007. David Victor makes this point specifically with regard to the standards of the Codex Alimentarius Commission, but it can be extended generally to international standards. A useful example is provided by the discussion by Sara Poli of the way in which the EC defends its interests within the international standard-setting process of the Codex Alimentarius Commission. Sara Poli, 'The European Community and the Adoption of International Food Safety Standards within the Codex Alimentarius Commission', European Law Journal 10 (5), 2004, 613-630.

${ }^{24}$ Walter Mattli and Tim Büthe posit (with reference to technical standards set by the International Organization for Standardization and the International Electro-technical Commission) that historical institutional legacies in national systems 'play a critical though largely accidental role' determining who sets the international standards agenda (the 'first-movers') and who bears the cost of switching to the international standards (the 'second movers'). Walter Mattli and Tim Büthe, 'Setting International Standards: Technological Rationality or Primacy of Power', World Politics 56 (1), 2003, 1-42, 4.

${ }_{25}$ The issue of effective participation should be distinguished from that of membership in the international standard-setting organisations. In fact, a large majority of WTO Members, including most developing countries, are members of Codex, the OIE and the IPPC. The WTO Secretariat has compiled a list in this regard. See Committee on Sanitary and Phytosanitary Measures, Membership in WTO and International StandardSetting Bodies, G/SPS/GEN/49/Rev.7, circulated on 26 July 2006.

${ }^{26}$ For a discussion of these constraints as they relate specifically to the CAC, see Mariëlle Masson-Matthee, The 
tendance by WTO Members at lower levels of development of meetings of the standard setting bodies, particularly of the subsidiary committees where the real standard-setting work is done. As a result the opportunities for these Members to influence the standardsetting process are limited. Second, even when delegates are sent to the relevant meetings, the lack of mechanisms for coordination between government departments and for consultation with stakeholders at national level means that positions of these Members at meetings of the standard setting bodies are often ill-informed. Third, the lack of regulatory experience and infrastructure of some of these Members may make it difficult for their delegates to evaluate the implications of the standards being discussed. Fourth, in many Members at lower levels of development, weak SPS capacity makes is difficult to collect the scientific data necessary to provide adequate input into the standard-setting process. As a result, the standards that are set may not reflect the specific conditions in these Members, including dietary practices, pest status, disease prevalence etc.

This pitfall of harmonisation is reflected in the outcome of international standard setting procedures. International standards often do not take account of developing country preferences and resource constraints. ${ }^{27}$ Instead, the harmonisation process can be described as a best-practices approach whereby developed country regulatory practices 'are compared and debated at organization meetings, after which the most attractive ones are selected and then recommended to regulators throughout the globe. ${ }^{28}$

While this has the positive result of allowing developing countries to benefit from the regulatory experience and scientific expertise of developed countries, and of spreading high-quality standards across the world, it has a down side as well. The deficient participation and influence of developing countries in elaborating the harmonised standards often means that the resulting standards are inappropriate for their situations, technically or financially unachievable for them or absent in areas most useful for them. ${ }^{29}$ Examples of areas of particular interest to certain developing countries where standards are lacking

Codex Alimentarius Commission and Its Standards, Doctoral Thesis, Maastricht University, Faculty of Law (T.M.C. Asser Press, Maastricht), 2007, 244.

${ }^{27}$ In this regard, David Leebron calls harmonisation a 'Procrustean response' to international trade, making an apt analogy with the myth of Procrustes. Procrustes tied all travellers to his bed: if they were shorter than the bed, he stretched their limbs to make them fit; if they were longer than the bed he lopped off the excess length of their limbs. David W. Leebron, 'Lying Down with Procrustes: An Analysis of Harmonization Claims', in Fair Trade and Harmonization: Prerequisites for Free Trade?, Jagdish N. Bhagwati and Robert E. Hudec (eds.), vol. 1 (MIT Press, Cambridge), 1997, 41-117, 41 note 41.

28 David Zaring, Informal Procedure, Hard and Soft, in International Administration, IILJ Working Paper 2004/6 (Institute for International Law and Justice, New York University School of Law, New York), 2004, 4, available at: http://www.iilj.org/publications/documents/2004.6\%20Zaring.pdf, visited on 28 January 2008. Zaring makes this observation in the context of international harmonization in the area of financial regulation. However, it holds true more broadly, including in the SPS area. Sally has stated that harmonization initiatives at the WTO are, at worse, 'tantamount to an OECD standards harmonisation agenda.' Razeen Sally, Whither the World Trading System? Trade Policy Reform, the WTO and Prospects for the New Round, No. 76 (Timbro, Stockholm), 2002, 29, available at: http://www.timbro.se/pdf/whither.pdf, visited on 28 January 2008.

29 Jonathan Macey criticizes this proselytisation achievement as being nakedly imperialistic. See Jonathan Macey, 'Regulatory Globalization as a Response to Regulatory Competition,' Emory Law Journal 52, no. 3, (2003),1353-1379:1353-1354, as referred to by Zaring, David Zaring, Informal Procedure, Hard and Soft, in International Administration, IILJ Working Paper 2004/6 (Institute for International Law and Justice, New York University School of Law, New York), 2004, 4, available at: http://www.iilj.org/publications/documents/2004.6\%20Zaring.pdf, visited on 28 January 2008. 
are spices and exotic fruits. Critics have noted that international standard setting tends to focus on income-sensitive products, such as energy drinks, and that the risk management solutions reflected in the standards are resource-intensive. ${ }^{30}$ Harmonisation, it is argued, has been harnessed by industry interests in developed countries to generate 'complex, rigid and costly standards ... to realise their protectionist aims. ${ }^{31}$

Such international standards are of little use to Members at lower levels of development. This is ironic when one bears in mind that one of the objectives of international harmonisation was to provide those developing countries that lack the capacity to develop their own SPS regulations with standards they can usefully draw upon. Spencer Henson notes that: '[d]eveloping countries regard international standards as a resource-efficient approach to establishing technical regulations at the national level, which reflect current scientific knowledge and facilitate international trade. ${ }^{32}$ He therefore emphasises the serious consequences of the inability of developing countries to participate effectively in international standard setting for the appropriateness of the resultant standards for developing countries. ${ }^{33}$ This problem has led to limited use of international standards by the very countries for which harmonisation was expected to hold the most benefits. As stated in the WTO's 2005 World Trade Report:

Contrary to expectations, countries with scarce resources and limited capacity do not necessarily have the largest share of adopted international standards. In fact, resource constraints seem to restrict poor countries' integration into the international standardization system as much if not more than they restrict their own standardization activities. ${ }^{34}$

Aside from the failings of harmonisation that arise from the process of international standard setting, other concerns have been raised that are inherent to the nature of harmonisation itself. It is noted that the 'one-size-fits-all' approach inherent in harmonisation ignores the fact that regulatory policies and institutions differ for good reasons. They

\footnotetext{
${ }^{30}$ Donna Roberts et al., 'Sanitary and Phytosanitary Barriers to Agricultural Trade: Progress, Prospects and Implications for Developing Countries', in Agriculture and the New Trade Agenda - Creating a Global Trading Environment for Development, M.D. Ingco and L.A.Winters (eds.) (Cambridge University Press, Cambridge), 2004, 329-358, note 29.

${ }^{31}$ Razeen Sally, Whither the World Trading System? Trade Policy Reform, the WTO and Prospects for the New Round, No. 76 (Timbro, Stockholm), 2002, 28, available at: http://www.timbro.se/pdf/whither.pdf, visited on 28 January 2008. Sally sees this as 'an attempt to iron out asymmetries in other countries' domestic institutions and raise their costs out of line with comparative advantages', which has an effect the same as classic protectionism.

32 Spencer Henson et al., Review of Developing Country Needs and Involvement in International Standards Setting Bodies (Centre for Food Economics Research, Department of Agricultural and Food Economics, University of Reading, 2001, para. 37, available at: http:/www.dfid.gov.uk/pubs/files/issb.pdf, visited on 12 May 2008.

33 Ibid.

${ }^{34}$ WTO Secretariat, World Trade Report 2005: Exploring the Links between Trade, Standards and the WTO (World Trade Organization, Geneva), 30 June 2005, 87, available at: http://www.wto.org/english/res_e/ booksp_e/anrep_e/world_trade_report05_e.pdf, visited on 4 June 2007. This report points out that due to the costly nature of effective participation in the international standard-setting process, as well as of setting up the necessary infrastructure, it may be less resource intensive for a developing WTO Member to develop its own national standards in isolation, or to simply adopt the standards of its main trading partner. An example given is that of Namibia, where the manufacturing sector relies upon South African standards.
} 
reflect varying circumstances, including comparative costs which differ with level of development. ${ }^{35}$ They also reflect legitimate differences in local conditions and consumer preferences. Sally argues that harmonisation 'pollutes' the international trading system by intruding too far into regulatory competence. ${ }^{36}$ Similarly, Mayeda regards international harmonisation as 'largely an ineffective tool for dealing with development issues' due to its failure to recognise the need for countries to adapt their legislation and institutions to their own domestic situations. ${ }^{37}$

Despite these flaws, harmonisation of standards is growing in importance and will 'require developing countries to rethink the ways in which they regulate for the provision of public goods. ${ }^{38}$ There are new limits on the regulatory choices available to developing countries. This is particularly the case for SPS regulation now that the disciplines of the SPS Agreement provide a strong incentive for WTO Members, particularly those at lower levels of development, to align their requirements with international standards. ${ }^{39}$ This calls for an examination of the international standard-setting processes generating such standards and the extent of the influence of WTO Members at different levels of development therein.

\subsection{International standard setting process}

In several respects, the WTO's SPS Agreement draws on the experience of the EC in the area of harmonisation of standards. Like in the EC, harmonisation under the SPS Agreement is achieved by relying on the scientific expertise of technical commissions. ${ }^{40}$

${ }^{35}$ Razeen Sally, Whither the World Trading System? Trade Policy Reform, the WTO and Prospects for the New Round, No. 76 (Timbro, Stockholm), 2002, 29, available at: http://www.timbro.se/pdf/whither.pdf, visited on 28 January 2008. Sally argues that harmonisation 'slams the door on healthy, competitive, bottom-up national experiments with policies and institutions tailored to differing circumstances.' Ibid.

${ }^{36}$ Ibid.

${ }^{37}$ Graham Mayeda, 'Developing Disharmony? The SPS and TBT Agreements and the Impact of Harmonization on Developing Countries', Journal of International Economic Law 7 (4), 2004, 737-764, 740. It is useful to note here that the harmonisation disciplines of the SPS Agreement do not oblige Members always to adopt international standards, but instead they provide a possibility for deviation from international standards under specific conditions. These disciplines are discussed below, Part III, Section 4.2.

38 Peter Drahos, 'The Regulation of Public Goods', Journal of International Economic Law 7 (2), 2004, 321339, 337. Drahos makes this point with regard to harmonized standards for excludability in the context of intellectual property protection under the TRIPS. However, it holds true also for SPS standards since the coming into force of the SPS Agreement.

${ }^{39}$ David Vogel claims that the SPS and TBT Agreements 'reflect the political strength of internationally oriented firms, who increasingly favor international standards.' David Vogel, 'Food Safety and International Trade', in Trading Up: Consumer and Environmental Regulation in a Global Economy (Harvard University Press, Cambridge/London), 1995, 150-195, 190.

${ }^{40}$ Ibid., 189. Vogel likens the Codex Alimentarius Commission, to which the SPS Agreement refers for standard setting in the area of food safety, with the EC's Scientific Commission on Foodstuffs. David Vogel, 'Food Safety and International Trade', in Trading Up: Consumer and Environmental Regulation in a Global Economy (Harvard University Press, Cambridge/London), 1995, 150-195, 190. However, it should be remembered that while the Scientific Commission on Foodstuffs is an EC body, the Codex is an independent organisation, over which the WTO has no say. Unlike in the EC where scientific advice from its advisory committees is considered by EC decision-making organs and could result in binding legislative action taken by these organs creating common standards, the results of activities of Codex committees are embodied in voluntary standards adopted by the Codex Commission, independently of WTO decision-making processes. 
In addition, both the SPS Agreement and the EC Treaty allow countries to set standards higher than the harmonised ones, ${ }^{41}$ but they subject this right to international scrutiny in terms of certain criteria, in order to prevent abuse. ${ }^{42}$

However, there are significant differences in the way in which the standards underlying harmonisation attempts at EC and WTO level are set. The most obvious of these is due to the EC's ability, as a body with supranational powers conferred on it by its Member States, to promulgate binding rules. It is thus able, using the normal decision-making processes available to Community institutions, to harmonise national measures in certain areas, including that of SPS, and to bind Member States to follow these common standards. ${ }^{43}$ On the contrary, the WTO has no such supranational regulatory authority. Further, it lacks the institutional capacity, including the existence of scientific committees, to draw up SPS standards. An additional difficulty is that decisions in the WTO are taken by all its Members, almost always by consensus. While it is theoretically possible for the Members to make decisions containing binding harmonised standards under the auspices of the WTO, the likelihood of reaching consensus on such decisions between countries with interests as diverse as have the Members of the WTO in the areas of agriculture and health, is extremely remote. ${ }^{44}$ Even were this unlikely scenario to materialise, the cumbersome

Although the WTO SPS Committee has a mandate to maintain close contact with the relevant international organisations, in particular the Codex Alimentarius Commission, the International Office of Epizootics and the International Plant Protection Convention, in order to obtain the best technical and scientific advice (Article 12.2 of the SPS Agreement) and may ask these organisations to examine specific matters regarding a standard, guideline or recommendation (Article 12.6 of the SPS Agreement), it has no control over the workings of these standard-setting bodies.

${ }^{41}$ See Article 3.3 of the SPS Agreement and Article 153(5) of the EC Treaty. David Vogel, 'Food Safety and International Trade', in Trading Up: Consumer and Environmental Regulation in a Global Economy (Harvard University Press, Cambridge/London), 1995, 150-195, 189.

${ }^{42}$ Under the SPS Agreement, these criteria are exclusively scientific and come down to the requirement of a risk assessment to justify the divergent measure. Under EC law, in cases where harmonisation is non-exhaustive (setting minimum standards only), stricter measures can be justified in terms of Article 30 of the EC Treaty or the mandatory requirement exception (developed in the case law), both of which require the proportionality of the measure to its health objective. One element of this proportionality test is the requirement of support from international scientific research (see for example Case 178/84 Commission v Germany (Reinheitsgebot) [1987] ECR 1227 at 1274). In cases of exhaustive harmonisation, recourse to Article 30 and the mandatory requirement exception is no longer possible. For an in-depth study of the use of scientific disciplines in the EC, see Christian Joerges, 'Scientific Expertise in Social Regulation and the European Court of Justice: Legal Frameworks for Denationalized Governance Structures', in Integrating Scientific Expertise into Regulatory Decision-Making: National Traditions and European Innovations, Christian Joerges, et al. (eds.) (Nomos, Baden-Baden), 1997, 295-323.

${ }^{43}$ It can do this in two ways as provided in the EC Treaty. Firstly, in terms of Article 95(1) of the EC Treaty, it may adopt harmonisation measures in the context of the completion of the internal market. Secondly, under Article 153(3)(b) it can take specific action to support and supplement Member States' policies in respect of the protection of health, safety and economic interests of consumers or to provide them with adequate information. The Amsterdam Treaty amended the title on Public Health in the EC Treaty to include the power in Article 152(4)(b) to use the co-decision procedure for the adoption of measures in the veterinary and phytosanitary areas which have as their direct objective the protection of public health. Both the former types of measures are also adopted using the co-decision procedure, which entails qualified majority voting in the Council and an equal say for the European Parliament in the decision-making process. Under the title on Agriculture, Article 37 gives the EC the power to harmonise legislation in respect of animal and plant health, as well as zootechnical and botanical legislation (as decided in ECJ Case 68/86 United Kingdom v. Council [1988] ECR 855).

${ }^{44}$ This should not create the impression that the lack of institutional scientific capacity and the consensus practice mean that the WTO is incapable of making decisions on SPS issues. Such decisions can be, and are, taken 
process of achieving consensus for decision making in the WTO would mean that standards would soon become outdated and prompt response to new health concerns would be impossible. $^{45}$

For these reasons, the WTO looks to other international bodies to set the harmonised standards that are used as benchmarks in the provisions of the relevant agreements. The SPS Agreement specifically references three international standard-setting bodies, ${ }^{46}$ namely, in the area of food safety, the Codex Alimentarius Commission (CAC); in the area of animal health, the International Office of Epizootics (OIE), now called the World Organisation for Animal Health; ${ }^{47}$ and in the area of plant health, the Secretariat of the International Plant Protection Convention (IPPC).$^{48}$ These three bodies are recognised as the three leading international bodies for the drafting of SPS standards and the coordination of information on SPS matters. ${ }^{49}$

The CAC, OIE and IPPC (also known as 'the three sisters'), were established in an era where regulatory cooperation in the area of SPS risks was seen as a technical, rather than politically-charged, exercise. As a result, the procedural rules for standard setting were flexible and broad, reflecting the informal, cooperative nature of the standard-setting process. The secretariats of these bodies were small and their budgets minimal. In

in the SPS Committee by delegates of WTO Members with technical expertise regarding SPS matters, as is discussed further below, Part IV, Section 2.1. However, the constraints mentioned have the effect of making the SPS Committee poorly suited, in practice, for setting harmonised SPS standards.

${ }^{45}$ The same problem of adaptation to rapidly changing SPS risks would arise if an attempt was made to negotiate a WTO agreement containing harmonised SPS standards, similar to the TRIPS Agreement which lays down harmonised standards of intellectual property protection by WTO Members, incorporating and supplementing existing standards drawn up by the World Intellectual Property Organisation. An additional problem is that, unlike the TRIPS Agreement, which contains positive obligations for minimum standards of protection, an agreement harmonising SPS requirements within the context of trade liberalisation would have to contain maximum standards of protection. This would entail an unacceptable limitation on the regulatory autonomy of Members in choosing the level of SPS protection that they will ensure on their territories.

${ }^{46}$ These three international bodies are expressly named in Annex A.3(a)-(c) of the SPS Agreement, under the definition of "international standards, guidelines and recommendations". They are the only three standard-setting bodies mentioned by name in the SPS Agreement. Annex A3(d) refers, for matters not covered by the three mentioned organisations, to 'appropriate standards, guidelines and recommendations promulgated by other relevant international organizations open for membership to all Members, as identified by the Committee.' Various provisions in the SPS Agreement refer to 'relevant international organizations' which can be assumed to include the Codex, OIE and IPPC. Although the SPS Agreement calls them 'international organizations', strictly speaking only the OIE is an international organization in the legal sense of the word. The CAC is merely the body established jointly by the FAO and WHO to administer their Food Standards Programme. The IPPC Secretariat is the executive body responsible for the administration of the IPPC, a multilateral treaty. For this reason, the term 'international standard-setting bodies', rather than 'international organisations' will be used in this book to refer collectively to the CAC, OIE, IPPC Secretariat and other relevant international standard-setting bodies.

${ }^{47}$ As this organization is based in Paris, it was mostly referred to by its French name Office International des Epizooties. Thus its acronym is OIE. This acronym has been maintained despite the fact that the organisation has recently changed its name to the World Organisation for Animal Health.

${ }^{48}$ Although standard setting in the area of plant health is carried out by the bodies set up under the auspices of the Secretariat of the IPPC, in cooperation with regional plant protection organisations operating within the framework of the IPPC, the acronym IPPC is commonly used to refer to these bodies.

49 Terence P. Stewart and David S. Johanson, 'The SPS Agreement of the World Trade Organization and International Organizations: The Roles of the Codex Alimentarius Commission, the International Plant Protection Convention, and the International Office of Epizootics', Syracuse Journal of International Law and Commerce 26, 1998, 27-53, 28 and fn 24. 
addition, the national delegates participating in the standard-setting bodies were generally government-employed scientists or technocrats, rather than diplomats or private sector representatives.

The CAC, OIE and IPPC consequently operated in relative obscurity and their decisions were not the subject of much political concern. ${ }^{50}$ This was primarily due to the fact that adoption of the standards they set was purely voluntary. Now, the SPS Agreement has given added significance to the international standards set by the CAC, OIE and IPPC. Although still not making them formally binding, ${ }^{51}$ it has increased the stakes of WTO Members in these standards. ${ }^{52}$ The promotion of the adoption of the harmonised standards by the SPS Agreement has increased the importance and visibility of these international standard-setting bodies. ${ }^{53} \mathrm{New}$ attention is being focused on international standard setting by states, industry and consumer groups and the result has been a politicisation of their activities. These bodies are now adjusting to their new role vis-à-vis the international trading system, resulting in significant changes in their policies and functioning. ${ }^{54}$

While relying on the standards set by the relevant international bodies, the SPS Agreement does not lay down any procedural requirements for the setting of such standards. The standard-setting bodies referred to in the SPS Agreement have widely differing membership, decision-making structures and rules about public participation and transparency. In addition, they set a range of different kinds of norms, ranging from detailed technical product standards to process guidelines and codes of practice. However, the standards set in these bodies are given equal status, as benchmarks against which Members' SPS requirements are assessed, by the rules of the SPS Agreement. The sole criterion is whether

\footnotetext{
50 Ibid., 28.

${ }^{51}$ Reinhard Quick and Andreas Blüthner, 'Has the Appellate Body Erred? An Appraisal and Criticism of the Ruling in the WTO Hormones Case', Journal of International Economic Law 2 (4), 1999, 603-639, 613.Quick and Blüthner criticise the view of some authors that voluntary international standards have become binding on states due to the provisions of the SPS Agreement, thus changing their status retroactively. They argue that these standards remain mere recommendations without legal consequences of their own. International standards merely inform and further define the relevant provisions of the SPS Agreement. Quick and Blüthner also deny that the relevant standards now have de facto or indirect legal effect, submitting that only the provisions of the SPS Agreement themselves give rise to any obligations for Members. However, this does not mean that it can be denied that the SPS Agreement has given a new significance to international standards set by the relevant bodies. There is new pressure to adopt harmonised standards, which did not exist previously. The standards themselves remain formally non-binding, but the rules contained in the SPS Agreement which refer to these standards are binding and encourage (while not mandating) their adoption, as discussed below, Part III, Section 4.2. The consequences of deviating from international standards are significant. Contra, see Mariëlle Masson-Matthee, The Codex Alimentarius Commission and Its Standards, Doctoral Thesis, Maastricht University, Faculty of Law (T.M.C. Asser Press, Maastricht), 2007, 159-164. Masson-Matthee argues convincingly that international standards set by the bodies referred to in the SPS Agreement have become de facto binding.

${ }^{52}$ The disciplines regarding harmonisation of SPS measures around international standards are contained in Article 3 of the SPS Agreement and are discussed below, Part III, Section 4.2.

${ }^{53}$ On the effects of the SPS Agreement on the Codex Alimentarius Commission, see H. Micheal Wehr, 'Update on Issues before the Codex Alimentarius', Food and Drug Law Journal 52, 1997, 531-536.

${ }_{54}$ Terence P. Stewart and David S. Johanson, 'The SPS Agreement of the World Trade Organization and International Organizations: The Roles of the Codex Alimentarius Commission, the International Plant Protection Convention, and the International Office of Epizootics', Syracuse Journal of International Law and Commerce 26, 1998, 27-53, 29.
} 
the relevant standard was set by an international standard-setting body referenced in the SPS Agreement or identified as relevant by the SPS Committee.

A closer look is now taken at the structure and functioning of these three standard-setting bodies, in order to provide the context within which to evaluate the effect of the SPS Agreement's reference to their standards on market access and health protection in WTO Members.

\subsubsection{Codex Alimentarius Commission}

In the area of food safety, the SPS Agreement refers to the standards, guidelines and recommendations 'established by the Codex Alimentarius Commission relating to food additives, veterinary drug and pesticide residues, contaminants, methods of analysis and sampling, and codes and guidelines of hygienic practice'. ${ }^{55}$ As its standards relate to food safety and quality and thus to human health, a subject of great political and public concern, the CAC is the most controversial of the three international standard-setting bodies referred to in the SPS Agreement.

The origins of the CAC lie in an initiative of the FAO to address the need for internationally accepted food standards in order to protect both consumers and producers across the world.$^{56}$ Based on its recognition of the important role of the World Health Organization in the health aspects of work on food standards, the FAO proposed that a mechanism for cooperation between the FAO and WHO in the area of food standards be established ${ }^{57} \mathrm{~A}$ Joint FAO/WHO Conference on Food Standards was held in 1962 to discuss this proposal. It resulted in the establishment of the Joint FAO/WHO Food Standards Programme, to be administered by a Joint FAO/WHO Codex Alimentarius Commission. ${ }^{58}$ The CAC was formally established by a resolution of the FAO in $1961^{59}$ and of the World Health Assembly of the WHO in $1963 .^{60}$ These two UN Specialised Agencies also adopted the statutes and rules of procedure of the CAC. ${ }^{61}$ It is therefore not an independent interna-

\footnotetext{
${ }^{55}$ Annex A.3(a) of the SPS Agreement.

56 Sami Shubber, 'The Codex Alimentarius Commission under International Law', International and Comparative Law Quarterly 21, 1972, 631-655, 631.

${ }^{57}$ Ibid.

${ }^{58}$ Report of the Joint FAO/WHO Conference on Food Standards, ALINORM 62/8, Geneva, 1-5 October 1962, para. g. See also Mariëlle Mason-Matthee, The Codex Alimentarius Commission and Its Standards, Doctoral Thesis, Maastricht University, Faculty of Law (T.M.C. Asser Press, Maastricht), 2007, 15-16.

59 FAO Conference, Resolution No. 12/61, adopted at the11th Session of the FAO Conference, 4-24 November1961, para. 263. The FAO was established in 1945, and is the main UN agency for agriculture, forestry, fisheries and rural development.

${ }^{60}$ World Health Assembly, Resolution 16.42, adopted at the 16th Session World Health Assembly, Geneva, 7-23 May 1963, Off. Rec. World Health Organization 124, 74. The WHO was established in 1948, and is the directing and coordinating authority for health within the UN system.

${ }^{61}$ Food and Agriculture Organization and World Health Organization, Understanding the Codex Alimentarius (United Nations, Rome), 2005, 9, available at: http:/www.fao.org/docrep/008/y7867e/y7867e00.HTM, visited on 28 July 2006. The Statutes of the Codex Alimentarius Commission form the legal basis of the work of the CAC and provide its mandate or terms of reference. The Rules of Procedure set out the formal working procedures of the CAC. The Statutes of the Codex Alimentarius Commission were revised in 1966 and 2006. The Rules of Procedure have been amended several times, most recently in 2006.
} 
tional organisation, but instead a joint inter-governmental body of the FAO and WHO. ${ }^{62}$ The CAC headquarters are located in Rome, at the offices of the FAO.

\subsubsection{Mandate}

According to its statutes, the $\mathrm{CAC}$ is responsible for making proposals to the DirectorsGeneral of the FAO and the WHO on all matters pertaining to the implementation of the Joint FAO/WHO Food Standards Programme.$^{63}$ The latter's purpose is defined to include the dual function of 'protecting the health of the consumers and ensuring fair practices in the food trade. ${ }^{\prime 64}$ In addition, the CAC has the objectives of coordinating international work on food standards, and of initiating, elaborating, finalising and amending food standards. ${ }^{65}$ In order to achieve its aims, the CAC is specifically mandated to develop food standards as well as multilateral good practice standards on issues such as labelling, the composition of food products, additives, and inspections.

To date, the CAC has set 278 standards, 65 guidelines and related texts and 63 codes of practice. ${ }^{66}$ These range from maximum residue levels for specific pesticides and veterinary drugs in food, ${ }^{67}$ to codes of practice on various products ${ }^{68}$ and guidelines on inspection and certification systems. ${ }^{69}$ This collection of standards, codes of practice, guidelines and other related texts is known as the Codex Alimentarius (Food Code). As stated in the General Principles of the Codex Alimentarius:

The Codex Alimentarius is a collection of internationally adopted food standards presented in a uniform manner. These food standards aim at protecting consumers' health and ensuring fair practices in the food trade. The Codex Alimentarius also includes provisions of an advisory nature in the form of codes of practice, guidelines and other recommended measures intended to assist in achieving the purposes of the Codex Alimentarius. The publication of the Codex Alimentarius is intended to guide and promote the elaboration and establishment of definitions and requirements for foods to assist in their harmonization and in doing so to facilitate international trade..$^{70}$

\footnotetext{
${ }^{62}$ See further on this point Mariëlle Mason-Matthee, The Codex Alimentarius Commission and Its Standards, Doctoral Thesis, Maastricht University, Faculty of Law (T.M.C. Asser Press, Maastricht), 2007, 18-21.

${ }^{63}$ Article 1of the Statutes of the Codex Alimentarius Commission published in Joint FAO/WHO Food Standards Programme, Codex Alimentarius Commission: Procedural Manual (Food and Agriculture Organization and World Health Organization, Rome), 2006, available at: ftp:/ftp.fao.org/codex/Publications/ProcManuals/ Manual_16e.pdf, visited on 21 February 2008.

${ }^{64}$ Article 1 (a) of the Statutes of the Codex Alimentarius Commission.

${ }^{65}$ Article 1(b)-(e) of the Statutes of the Codex Alimentarius Commission.

${ }^{66}$ See Committee on Sanitary and Phytosanitary Measures, List of Codex Alimentarius Commission Standards, Guidelines, Codes of Practice and Other Texts in Force as of 4 March 2008, G/SPS/GEN/828, circulated on 19 March 2008.

${ }^{67}$ Maximum Residue Limits for Veterinary Drugs in Food, CAC/MRL 2-2006, and the Maximum Residue Limits (MRLs) for Pesticides, CAC/MRL 1-2001.

${ }^{68}$ For example the Code of Hygienic Practice for Refrigerated Packaged Foods with Extended Shelf-Life, CAC/ RCP 46-1999 and Recommended International Code of Practice for the Processing and Handling of Quick Frozen Foods, CAC/RCP 8-1976.

${ }^{69}$ For example the Principles for Food Import and Export Certification and Inspection, CAC/GL 20-1995 and Guideline Procedures for the Visual Inspection of Lots of Canned Foods, CAC/GL 17-1993.

${ }^{70}$ Principle 1 of the General Principles of the Codex Alimentarius, published in Joint FAO/WHO Food Standards
} 
The competing mandates in the areas of trade and consumer health of the Food Standards Programme have been criticised as making the CAC poorly suited to setting global foodsafety standards. ${ }^{71}$ Unlike national health administrations, the CAC has no over-arching objective of public health protection. Instead, it constantly balances its public health objectives with the need to promote international trade. The CAC is best seen as an intergovernmental body promoting trade in food products by setting minimum health and quality standards which countries, especially developing countries, can use to facilitate the acceptance of their products on international markets. Many developed countries routinely set higher standards. ${ }^{72}$

\subsubsection{Institutional structure}

The Codex Alimentarius Commission has a complex institutional structure, due to its nature as a subsidiary body of the FAO and WHO jointly. These two international organisations are responsible for the creation of an institutional framework for the conduct of their Joint Food Standards Programme. The framework they have established consists of the CAC and its subsidiary bodies which function under the responsibility of the CAC. In addition, the FAO and WHO have assigned tasks to joint FAO/WHO bodies that are independent of the CAC but fall under the direct authority of the FAO and WHO. These are the joint $\mathrm{FAO} / \mathrm{WHO}$ scientific expert bodies and expert meetings.

Programme, Codex Alimentarius Commission: Procedural Manual (Food and Agriculture Organization and World Health Organization, Rome), 2006, 30, available at: ftp://ftp.fao.org/codex/Publications/ProcManuals/ Manual_16e.pdf, visited on 21 June 2008. The General Principles of the Codex Alimentarius define the scope and purpose of CAC standards.

${ }^{71}$ See Lucinda Sikes, 'FDA's Consideration of Codex Alimentarius Standards in Light of International Trade Agreements', Food and Drug Law Journal 53, 1998, 327-335, 328.

${ }^{72}$ According to Vogel, both the US and the EC have recognised that the CAC cannot be relied upon to set safety standards for the protection of consumers. David Vogel, 'Food Safety and International Trade', in Trading Up: Consumer and Environmental Regulation in a Global Economy (Harvard University Press, Cambridge/ London), 1995, 150-195, 191. 
Figure 1: Institutional Structure of the Codex Alimentarius Commission

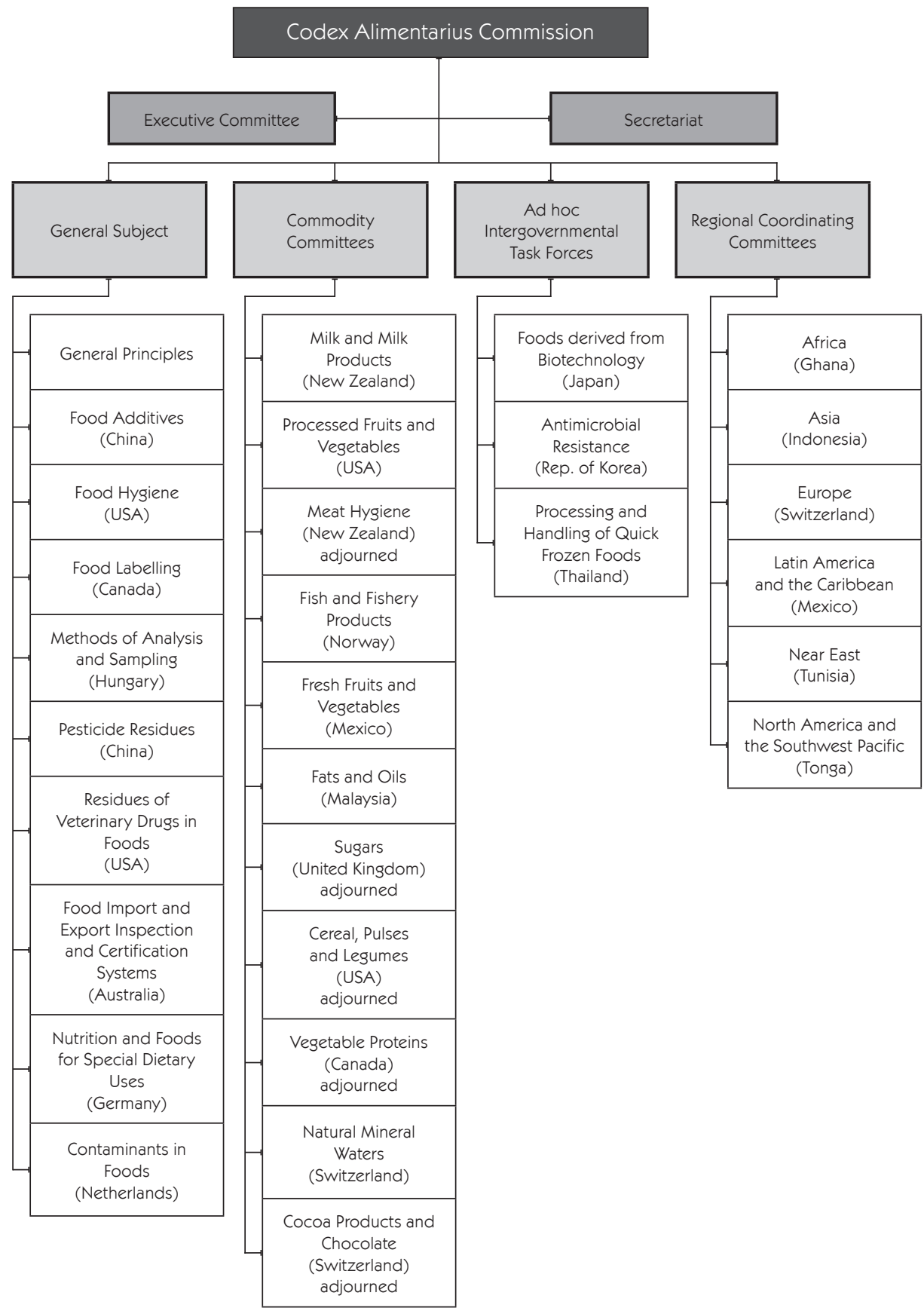

Source: Codex Alimentarius Commission, Procedural Manual, 17th ed., 2007, updated in accordance with Codex Alimentarius Commission, Report of the Thirtieth Session, 2-7 July 2007, ALINORM 07/30/REP (Food and Agriculture Organization and World Health Organization, Rome). 
The Codex Alimentarius Commission is the main decision-making organ of the Joint FAO/WHO Food Standards Programme. It is the plenary body, and meets in regular annual sessions lasting about a week, and in additional sessions as the need arises. ${ }^{73}$ As a subsidiary body of the FAO and $\mathrm{WHO}$, the CAC depends on these two organisations for the delegation of competences to it. ${ }^{74}$ According to the competences it has been given, the CAC decides on the initiation of work on the elaboration of a standard, and adopts draft and final standards. It also adopts and amends its own rules of procedure. ${ }^{75}$

The executive organ of the CAC between sessions of the plenary Commission is the Executive Committee. ${ }^{76}$ It is composed of the Chairperson and three Vice-Chairpersons of the Commission, the Coordinators of the six regional Coordinating Committees and seven additional members elected by the Commission from among its members, one each coming from Africa, Asia, Europe, Latin America and the Caribbean, Near East, and North America and the South-West Pacific ${ }^{77}$ The task of the Executive Committee is to make proposals to the Commission regarding general orientation, strategic planning, and programming of its work, to study special problems that may arise and to assist in the management of the Commission's programme of standards development, namely by conducting a critical review of proposals to undertake work and monitoring the progress of standards development. ${ }^{78}$

The CAC is given the discretion to establish subsidiary bodies as the need arises. ${ }^{79}$ Currently, there are 27 different Codex committees that carry out the risk management aspects of the preparation of standards. ${ }^{80}$ These fall into three categories: General Subject Committees, ${ }^{81}$ regional Coordinating Committees, ${ }^{82}$ and Commodity Committees. ${ }^{83}$ In

\footnotetext{
${ }^{73}$ Rule VI.1 of the Rules of Procedure.

${ }^{74}$ The FAO and WHO have delegated competences to the CAC by means of their adoption of the Statutes of the Codex Alimentarius Commission and the Rules of Procedure, which expressly set out the powers of the CAC with regard to the implementation of the Joint FAO/WHO Food Standards Programme. Codex Alimentarius Commission, Procedural Manual, Seventeenth Edition (Joint FAO/WHO Food Standards Programme, Rome), 2007, available at: ftp://ftp.fao.org/codex/Publications/ProcManuals/Manual_17e.pdf, visited on 21 February 2008.

${ }^{75}$ Rule XII.1 of the Rules of Procedure. This competence has been given to the CAC and is not subject to the approval of the FAO and WHO.

${ }^{76}$ Article 6 of the Statutes of the Codex Alimentarius Commission provide for the establishment of an Executive Committee whose composition 'should ensure an adequate representation of the various geographical areas of the world to which the Members of the Commission belong.'

${ }^{77}$ Rule V.1 of the Rules of Procedure. It is interesting to note that, due to the increasing number of delegates brought by some Executive Committee members to meetings of this organ, in 1989 the Commission adopted an understanding to Rule V (then Rule IV) of the Rules of Procedure, limiting the number of advisors that may accompany a delegate to the Executive Committee to no more than two. Codex Alimentarius Commission, Report of the Eighteenth Session, 3-12 July 1998, ALINORM 89/40, para. 183. See also Mariëlle MassonMatthee, The Codex Alimentarius Commission and Its Standards, Doctoral Thesis, Maastricht University, Faculty of Law (T.M.C. Asser Press, Maastricht), 2007, 32-33.

${ }^{78}$ Rule V.2 of the Rules of Procedure.

${ }^{79}$ Article 7 of the Statutes of the Codex Alimentarius Commission and Rule XI.1 of the Rules of Procedure.

${ }^{80}$ Although there are 27 subsidiary committees at present, only 22 of these are currently active. Others have been adjourned sine die. Codex Alimentarius Commission, Report of the Thirtieth Session, ALINORM 07/30/ REP (Joint FAO/WHO Food Standards Programme, Rome), 2 - 7 July 2007, Appendix X, available at: http:// www.codexalimentarius.net/web/archives.jsp?year=07, visited on 8 February 2008.

${ }^{81}$ The General Subject committees are established under Rule XI.1(b)(i) of the Rules of Procedure.

${ }^{82}$ The six regional Coordinating Committees are established under Rule XI.1(b)(ii) of the Rules of Procedure.

${ }^{83}$ The Commodity Committees are established under Rule XI.1(b)(i) of the Rules of Procedure.
} 
addition, to increase flexibility and enable the CAC to respond to the demand for standards across an increasing range of subjects, in 1999 the CAC decided to create a new kind of subsidiary body, namely ad hoc Intergovernmental Task Forces. ${ }^{84}$

The General Subject Committees work on issue-related subjects, such as food additives, contaminants, food hygiene, food labelling, pesticide residues, general principles, residues of veterinary drugs in food, food import and export inspection and certification systems etc. These committees are also called horizontal committees because their work applies across the board to various commodities and regions.$^{85}$ They are open to all Codex members and observers. There are currently ten General Subject Committees.

The Commodity Committees are divided according to food product categories, such as meat hygiene, milk and milk products, tropical fresh fruits and vegetables etc. Commodity Committees convene as necessary, and may go into recess or even be abolished when the $\mathrm{CAC}$ decides that their work has been completed. New commodity committees may be created as the need arises. Commodity Committees are open for participation by all Codex members and observers. As of July 2007, there are six Commodity Committees that meet regularly, and another five work through correspondence or have been adjourned. ${ }^{86}$

The six regional Coordinating Committees comprise Africa, Asia, Europe, Latin America and the Caribbean, Near East and North America and the Southwest Pacific. They work, inter alia, at ensuring that the work of the $\mathrm{CAC}$ is responsive to regional interests and to the concerns of developing countries. Regional Coordinating Committees are open for participation by all Codex members that are part of the relevant region. Normally they meet every two years. They have the mandate to develop regional standards for food products 'moving exclusively or almost exclusively in intra-regional trade. ${ }^{87}$

Ad hoc Intergovernmental Task Forces have very limited terms of reference and are established for a fixed time period. ${ }^{88}$ As of July 2007, five ad hoc Intergovernmental Task Forces have been established, dealing with animal feeding, fruit and vegetable juices, foods derived from biotechnology, antimicrobial resistance and the handling and processing of quick frozen foods. Of these only the last three are currently active. Like other Codex bodies aside from the Executive Committee, ad hoc Intergovernmental Task Forces are open for participation to all Codex members and observers.

\footnotetext{
${ }^{84}$ Ad hoc Intergovernmental Task Forces are established under Rule XI.1(a) of the Rules of Procedure.

${ }^{85}$ Food and Agriculture Organization and World Health Organization, Understanding the Codex Alimentarius (United Nations, Rome), 2005, 17, available at: http://www.fao.org/docrep/008/y7867e/y7867e00.HTM, visited on 28 July 2006.

${ }^{86}$ Ibid., 18.

${ }^{87}$ See paragraph (d) of the Terms of Reference of each of the various regional Coordinating Committees. Codex Alimentarius Commission, Procedural Manual, Seventeenth Edition (Joint FAO/WHO Food Standards Programme, Rome), 2007, 181-181, available at: ftp://ftp.fao.org/codex/Publications/ProcManuals/ Manual_17e.pdf, visited on 21 February 2008. Currently there is only one regional standard, the European standard on chantarelle (Codex Stan 40-1981). All other regional standards have been deleted or converted into worldwide standards.

${ }^{88}$ Joint FAO/WHO Food Standards Programme, Codex Alimentarius Commission: Procedural Manual (Food and Agriculture Organization and World Health Organization, Rome), 2006, 146-151, available at: ftp://ftp. fao.org/codex/Publications/ProcManuals/Manual_16e.pdf, visited on 21 February 2008.
} 
These committees and task forces meet as many times as is necessary to prepare and update standards. There may be as many as 20 committee meetings in one year. Each committee and task force has a designated host country, ${ }^{89}$ which is responsible for the costs of servicing, maintaining and administering the committee and for providing its chairperson. ${ }^{90}$ Due to many developing countries' lack of resources to bear these costs, host countries are overwhelmingly developed countries. ${ }^{91}$ This is of relevance because committees and task forces generally meet in the designated host country. ${ }^{92}$

The CAC and its subsidiary bodies are serviced by a Secretariat that is seriously understaffed. ${ }^{93}$ Although the Codex Secretariat is formally part of the FAO and is located at the FAO headquarters in Rome, its staff is currently dedicated only to work on CAC matters. ${ }^{94}$ They prepare and attend all CAC and Codex committee meetings.

${ }^{89}$ The regional Coordinating Committees have no permanent host country but are hosted ad hoc by different countries in the region appointed as coordinators by the Commission.

${ }^{90}$ In respect of each committee, the CAC designates a host country which has indicated its willingness to accept financial and all other responsibility for the relevant committee, including appointing its chairperson from among its own nationals, and providing a secretariat and all other conference services (translation, interpretation, document reproduction etc.). Host countries for each committee are designated or confirmed at each regular session of the CAC. See the Guidelines to Host Governments of Codex Committees and Ad Hoc Intergovernmental Task Forces in Joint FAO/WHO Food Standards Programme, Codex Alimentarius Commission: Procedural Manual, 15th ed. (Food and Agriculture Organization and World Health Organization, Rome), 2005, Section II.

${ }^{91}$ Seven of the 10 General Subject Committees are hosted by high-income countries, as are 9 of the 11 Commodity Committees and two of the three Intergovernmental Task Forces. As mentioned above, the hosts of the Regional Coordinating Committees vary for each meeting. Three of the remaining committees are hosted by upper-middle-income countries, namely Hungary (Codex Committee on Methods of Analysis and Sampling), Malaysia (Codex Committee on Fats and Oils) and Mexico (Codex Committee on Fresh Fruit and Vegetables). The remaining CAC committees are task force hosted by lower-middle-income countries, namely China (Codex Committee on Food Additives and Codex Committee on Pesticide Residues), and Thailand (Intergovernmental Task Force on Processing and Handling of Quick Frozen Foods). No low-income countries host Codex committees or task forces. Codex Alimentarius Commission, Report of the Thirtieth Session, ALINORM 07/30/REP (Joint FAO/WHO Food Standards Programme, Rome), 2 - 7 July 2007, Appendix X, available at: http://www.codexalimentarius.net/web/archives.jsp?year=07, visited on 8 February 2008.

It is interesting to note that in its $29^{\text {th }}$ Session, the CAC decided to divide the work of the Codex Committee on Food Additives and Contaminants (previously hosted by the Netherlands) among two new committees, the Codex Committee on Food Additives and the Codex Committee on Contaminants in Food. China was designated as the host country for the former committee. Both Brazil and the Netherlands indicated their interest in hosting the latter committee. The CAC took the decision, by secret ballot, to designate the Netherlands as host country. In response, Brazil commented in the meeting on the fact that the majority of CAC committees are still hosted by developed countries and that a better geographic balance should be achieved in the future. See Codex Alimentarius Commission, Report of the Twenty-Ninth Session ALINORM 06/29/41 (Joint FAO/WHO Food Standards Programme, Geneva), 3-7 July 2006, paras 229-232.

${ }_{92}$ The host country is consulted by the FAO and WHO Directors-General before they determine where and when a session of that committee will be convened. In practice, sessions are held in the host country itself. With regard to a proposal to introduce a system of co-hosting of committee meetings so that some meetings are held in developing countries, see below, Part II, Section 3.2.1.5.

${ }_{93}$ The Codex Secretariat is composed of the Secretary and 10 other staff members (mostly food standards officers). The Secretariat has no legal officers.

${ }_{94}$ The Codex Secretariat was established under Rule III.5 of the Rules of Procedure. It is formally part of the Food and Nutrition Division of the Economic and Social Department of the FAO. Its staff is therefore appointed by the FAO and fall under its responsibility. Previously this meant that the Codex Secretariat not only worked on CAC matters but also had tasks in relation to the FAO. Currently the Secretariat staff works only on CAC matters. Mariëlle Masson-Matthee, The Codex Alimentarius Commission and Its Standards, Doctoral Thesis, Maastricht University, Faculty of Law (T.M.C. Asser Press, Maastricht), 2007, 33-34. See 
As noted above, the institutional framework relevant to the work of CAC includes joint FAO/WHO bodies that operate under the responsibility of the parent organisations, independently of the CAC. The most important of these are the joint FAO/WHO expert committees and ad hoc expert consultations, which provide input on technical and scientific matters to the Codex committees. These bodies include formally established expert bodies with a scheduled programme of work, namely the Joint FAO/WHO Meetings on Pesticide Residues (JMPR) ${ }^{95}$ and JECFA, ${ }^{96}$ both of which have for many years generated internationally acclaimed data widely used by governments, industries and research facilities. Also included are regularly convened expert meetings on a particular topic, such as the Joint FAO/WHO Expert Meetings on Microbiological Risk Assessment (JEMRA). ${ }^{97}$ Finally, ad hoc expert consultations may be convened to address a specific topic, for example foods derived from biotechnology. These expert bodies or meetings are completely independent of the $\mathrm{CAC}$, in accordance with the principle of ensuring independence of scientific risk analysis from the practical realities of risk management decisions. They are composed of prominent scientists acting in an independent capacity. ${ }^{98}$ These scientists are drawn from rosters of experts. The expert bodies that meet regularly maintain their own rosters of experts, which apply for a specified number of years after which a new call for experts is issued. ${ }^{99}$ For other expert meetings and $a d$ hoc consultations, short-term rosters of experts are developed for the specific meeting. Experts are selected for inclusion on the rosters by a selection panel of FAO and WHO representatives and two external experts. All experts responding to a call for experts that meet the specific requirements (expertise, experience, availability, etc) in the call for experts and that agree to sign a declaration of interests to ensure independence and objectivity, are placed on the relevant roster of experts subject to the approval of the FAO and WHO. ${ }^{100}$

The work of the joint FAO/WHO expert bodies is financed through the regular programme budgets of the FAO and WHO as well as by extra-budgetary resources. The FAO and WHO bear the costs of convening meetings, the travel and subsistence of experts, ${ }^{101}$

also Codex Alimentarius Commission, Conclusions and Recommendations of the Joint FAO/WHO Evaluation of the Codex Alimentarius and Other FAO and WHO Work on Food Standards, ALINORM 03/25/3 (Joint FAO/WHO Food Standards Programme, Rome), December 2002, paras 101-104.

${ }^{95}$ The JMPR was established in 1963 to assess pesticide residues in food. Its members are internationally recognised specialists. FAO/WHO Framework for the Provision of Scientific Advice on Food Safety and Nutrition (to Codex and Member Countries) (Food and Agriculture Organization and World Health Organization, Rome/Geneva), 2007, 7, available at: http://www.fao.org/ag/agn/agns/files/Final_Draft_EnglishFramework. pdf, visited on 1 February 2008.

96 The JECFA was established in 1956, originally to assess the safety of food additives but its mandate has been extended to include contaminants, toxins and residues of veterinary drugs in food. The membership of its meetings varies depending on the subject matter. Ibid.

97 JEMRA was established in 2000 to assess microbiological hazards in food. It comprises a series of regular meetings. Ibid.

98 Other sources of scientific input into the Codex process are international organisations, such as the Organisation for Animal Health (OIE) and the International Atomic Energy Agency (IAEA), which provide scientific advice.

${ }^{99}$ For example, the JECFA roster of experts applies for a 5-year period.

100 FAO/WHO Framework for the Provision of Scientific Advice on Food Safety and Nutrition (to Codex and Member Countries) (Food and Agriculture Organization and World Health Organization, Rome/Geneva), 2007, 16-17, available at: http://www.fao.org/ag/agn/agns/files/Final_Draft_EnglishFramework.pdf, visited on 1 February 2008.

${ }^{101}$ Experts are not remunerated for their work. 
the preparation of working papers and the publication of the results. ${ }^{102}$ Extra-budgetary contributions by donor governments are usually linked to specific activities. Difficulties have been experienced due to increasing demand for scientific advice, which necessitates additional resources in order to continue to fully respond in a timely manner with high quality scientific advice. However, the FAO and WHO face decreasing regular budget resources and extra-budgetary contributions. In 2003, the FAO and WHO agreed to convene a 'consultative process' to review the provision of scientific advice to the CAC and member countries, to improve the quality, quantity and timeliness of this advice. ${ }^{103} \mathrm{As}$ one of the outcomes of this consultative process, at the Thirtieth Session of the CAC in July 2007, the FAO and WHO launched the Global Initiative for Food-Related Scientific Advice (GIFSA). ${ }^{104}$ This initiative is a response to the growing demand for scientific advice as challenges in the fields of food safety and nutrition continue to emerge. It aims to ensure the sustainable funding of the FAO/WHO programme on the provision of scientific advice to the $\mathrm{CAC}$ and its member countries by establishing a mechanism to facilitate the provision of extra-budgetary resources for scientific advice activities. Contributions will be accepted from governments, organisations and foundations in accordance with FAO and WHO rules. ${ }^{105}$

\subsubsection{Members and observers}

Only States and regional economic integration organisations (REIOs) ${ }^{106}$ can be members of the CAC. Membership is open to all FAO and WHO members and associate members

${ }^{102}$ FAO/WHO Framework for the Provision of Scientific Advice on Food Safety and Nutrition (to Codex and Member Countries) (Food and Agriculture Organization and World Health Organization, Rome/Geneva), 2007, 9, available at: http://www.fao.org/ag/agn/agns/files/Final_Draft_EnglishFramework.pdf, visited on 1 February 2008.

${ }^{103}$ This decision was taken on the basis of the general review of Codex procedures discussed at the Twenty-Fifth (Extraordinary) Session of the CAC in 2003. Codex Alimentarius Commission, Report of the Twenty-Fifth (Extraordinary) Session, ALINORM 03/25/5 (Joint FAO/WHO Food Standards Programme, Rome), 13-15 February 2003.

${ }^{104}$ This launch occurred at a side-event of the Thirtieth Session of the CAC. Codex Alimentarius Commission, Report of the Thirtieth Session, ALINORM 07/30/REP (Joint FAO/WHO Food Standards Programme, Rome), 2 - 7 July 2007, para. 126, available at: http://www.codexalimentarius.net/web/archives.jsp?year=07, visited on 8 February 2008.

105 The WHO and FAO will maintain two separate accounts. A committee will be created to manage the GIFSA, and procedures developed to ensure the independent and transparent allocation of GIFSA resources, taking into consideration the criteria for prioritisation of activities already agreed by Codex, FAO and WHO and the specific needs of FAO and WHO member countries. Conclusions of the Consultative Process on the Provision of Scientific Advice and Global Initiative for Food-Related Scientific Advice (GIFSA), (Food and Agriculture Organization and World Health Organization, Rome) 6 July 2007, Annex 2, available at: http:// www.fao.org/ag/agn/agns/files/GIFSA_SideEvent_July2007.pdf, visited on 12 June 2008.

106 REIO membership was made possible following a change to the CAC Procedural Manual adopted in 2003 by the $26^{\text {th }}$ Session of the CAC. Codex Alimentarius Commission, Report of the Twenty-Sixth Session, ALINORM 03/41 (Joint FAO/WHO Food Standards Programme, Rome), 30 June - 7 July 2003, paras 22-24. Rule I(3) provides that membership of the CAC shall also comprise REIOs members of either the FAO or WHO that notify the Director General of either of these two organisations of their desire to be considered Members of the CAC. According to Rule II.1 of the Rules of Procedure, a REIO member shall exercise its membership rights alternately with its Member States, according to their respective competences. Rule II(5) requires that the division of competences between the REIO and its Member States be made known in writing before any meeting of the $\mathrm{CAC}$ or its subsidiary bodies, with regard to any specific question to be considered in the meeting. Joint FAO/WHO Food Standards Programme, Codex Alimentarius Commission: Procedural 
(including REIOs) that have notified the Director-General of the FAO or WHO of their desire to be considered Members of the CAC. ${ }^{107}$ Currently the only REIO that is a member of the $\mathrm{CAC}$ is the European Community.

\section{Graph 1: Members of the Codex Alimentarius Commission that are WTO Members, by Income Level, 2007}

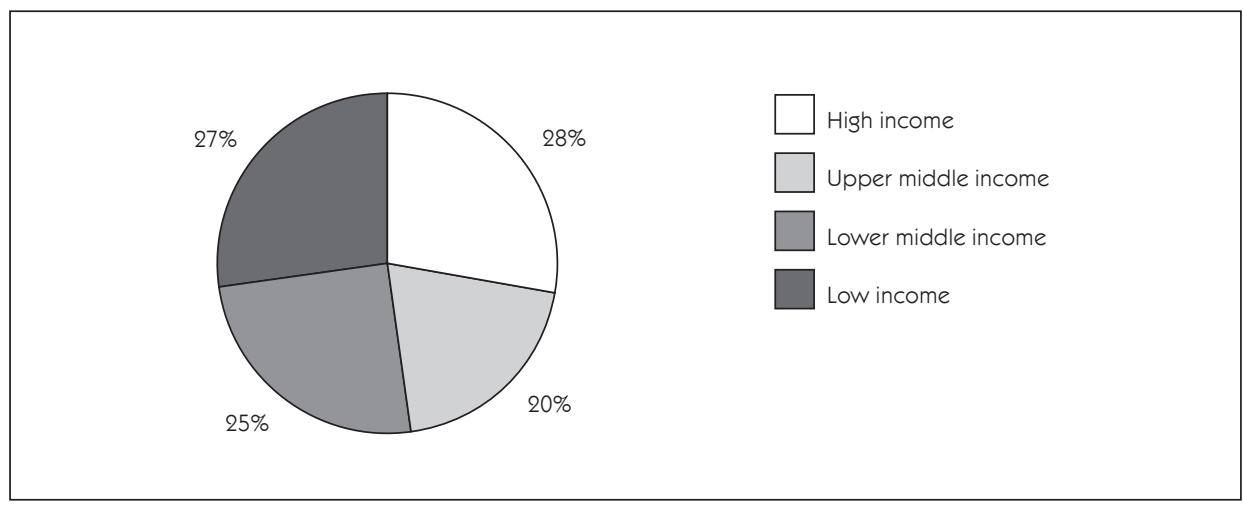

By the end of 2007, the CAC had 176 members, ${ }^{108}$ of which 145 were are also Members of the WTO. ${ }^{109}$ Of these, 28 percent (41) are high-income Members, 20 percent (29) are upper-middle-income Members, 24 percent (38) are lower-middle-income Members and 28 percent (39) are low-income Members.

Manual (Food and Agriculture Organization and World Health Organization, Rome), 2006, available at: ftp:// ftp.fao.org/codex/Publications/ProcManuals/Manual_16e.pdf, visited on 21 February 2008.

107 Rule I of the Rules of Procedure. Codex Alimentarius Commission, Procedural Manual, Seventeenth Edition (Joint FAO/WHO Food Standards Programme, Rome), 2007, 6, available at: ftp://ftp.fao.org/codex/ Publications/ProcManuals/Manual_17e.pdf, visited on 21 February 2008.

108 Note that this number includes the European Communities as a Member Organization. Committee on Sanitary and Phytosanitary Measures, Membership in WTO and International Standard - Setting Bodies: Note by the Secretariat, G/SPS/GEN/49/Rev.8, circulated on 9 October 2007. The data from this document has been updated to include Bosnia Herzegovina which subsequently became a member of the CAC. Cape Verde and Ukraine (both lower-middle-income countries), which acceded to the WTO in 2008, are also CAC members. However, as the data presented here relates to 2007, they are not taken into account.

${ }^{109}$ Note that three WTO Members are not States but are customs territories (Hong Kong, China; Macao, China; and Chinese Taipei). These WTO Members are not members of the CAC in their own right. Instead, China, which includes both mainland China and these separate customs territories, participates in CAC activities. Aside from these three customs territories, the only other WTO Members that are not members of the CAC are Djibouti, Liechtenstein and the Maldives. 
In addition, non-member States, international non-governmental organisations, ${ }^{110}$ and international or regional governmental organisations ${ }^{111}$ may be granted observer status to participate in meetings of the CAC and its subsidiary committees. ${ }^{112}$ They may deliver position papers and make presentations, but they may not vote or participate in decision making. In practice, many observers are active and often influential participants at meetings. A wide range of observers are currently recognised at the CAC. ${ }^{113}$ International inter-governmental observers include the WTO, the OECD, ASEAN and the Caribbean Community as well as a number of UN bodies such as UNCTAD, the UNDP and UNEP. International non-governmental organisations with observer status include primary producer organisations (such as the International Peanut Forum), processor organisations (for example the International Dairy Federation and the International Bottled Water Association), standards organisations (for example, the International Organization for Standardization and the Comisión Panamericana de Normas Técnicas), and consumer interest groups (such as Consumers International and Greenpeace International). Currently no states that are not CAC members have observer status.

There are two exceptions to the participation of observers in Codex meetings, namely with regard to meetings of the Codex Executive Committee and meetings of the FAO/ WHO scientific committees on whose reports the standard-setting process is based. Such

110 According to para. 3 of the Principles Concerning the Participation of International Non-Governmental Organizations in the Work of the Codex Alimentarius Commission, International non-governmental organizations are eligible for observer status if (i) they have consultative status, specialized consultative status or liaison status with the FAO; (ii)they have official relations with the WHO; or (iii) they are international in structure and scope of activity; representative of the specialized field of interest in which they operate; concerned with matters covering a part or all of the field of activity of the CAC; have aims and purposes in conformity with the Statutes of the CAC; have a permanent directing body and Secretariat, authorized representatives and systematic procedures and machinery for communicating with its membership in various countries; and have been established at least three years before they apply for observer status. Codex Alimentarius Commission, Procedural Manual, Seventeenth Edition (Joint FAO/WHO Food Standards Programme, Rome), 2007, 34, available at: ftp://ftp.fao.org/codex/Publications/ProcManuals/Manual_17e.pdf, visited on 21 February 2008.

111 The observer status of international intergovernmental organisations is the responsibility of the FAO and WHO and is governed by the relevant provisions of the Constitutions of FAO or WHO, as well as by the applicable regulations of FAO or WHO on relations with intergovernmental organizations. Rule IX:5 of the Rules of Procedure.

112 The Directors General of the FAO or WHO may invite international non-governmental organisations to participate as observers, in terms of Rule IX:4 of the Rules of Procedure. The role of non-governmental organisations and international governmental organisations in the activities of the CAC is governed by the Guidelines on Cooperation between the Codex Alimentarius Commission and International Intergovernmental Organizations in the Elaboration of Standards and Related Texts and the Principles Concerning the Participation of International Non-Governmental Organizations in the Work of the Codex Alimentarius Commission. See Joint FAO/WHO Food Standards Programme, Codex Alimentarius Commission: Procedural Manual, 12th ed. (Food and Agriculture Organization and World Health Organization, Rome), $2001,32-$ 34 and 35-41. Observers may put forward their views at any stage of a meeting except the final decision. Food and Agriculture Organization and World Health Organization, Understanding the Codex Alimentarius (United Nations, Rome), 2005, 15, available at: http://www.fao.org/docrep/008/y7867e/y7867e00.HTM, visited on 28 July 2006.

113 The CAC has recognised 219 observers, including 62 international intergovernmental organisations and 157 international non-governmental organisations. Currently there are no CAC observers that are states. The list of observers is published on the CAC website, available at: http://www.codexalimentarius.net/web/ organizations.jsp, visited on 28 January 2008. See also Mariëlle Mason-Matthee, The Codex Alimentarius Commission and Its Standards, Doctoral Thesis, Maastricht University, Faculty of Law (T.M.C. Asser Press, Maastricht), 2007, 27. 
meetings are closed to non-members. Furthermore, the CAC makes certain decisions in closed sessions by secret ballot. ${ }^{114}$

\subsubsection{Standard-setting procedures}

The Codex Alimentarius Commission meets annually, ${ }^{115}$ either in Rome or Geneva, in regular session, ${ }^{116}$ inter alia to establish whether there is a need for a new or revised standard and to arrange for it to be drafted.

The right of initiative to propose that a new standard be drafted or an existing standard be revised is not set out in the CAC Procedural Manual. In practice, such initiatives may come from a CAC member country or a Codex committee, or in some cases from an international nongovernmental organisation. ${ }^{117}$

A uniform 8-step procedure, set out in the Procedures for the Elaboration of Codex Standards and Related Texts, is followed for the elaboration of all Codex texts, including standards, codes of practice, guidelines and related texts. ${ }^{118}$ During this procedure, the standards or other texts are elaborated by Codex committees on the advice of the independent scientific expert committees and reviewed twice by members and other interested parties at the regular sessions of the CAC.

At step 1 of this procedure, the CAC decides (after considering the outcome of the critical review of the proposal for a new standard by the Executive Committee against CAC priorities and criteria) to undertake the development of a new standard or the review of an existing standard. ${ }^{119}$ It also decides what subsidiary body must undertake the work.

${ }^{114}$ Sikes refers to the example of the decision on MRLs for hormones, taken by secret ballot in the 1995 meeting of the CAC. See Lucinda Sikes, 'FDA's Consideration of Codex Alimentarius Standards in Light of International Trade Agreements', Food and Drug Law Journal 53, 1998, 327-335, 329. See also Consumers International. Position of Consumers International for the Twenty-Second Session of the Codex Alimentarius Commission Re: Involvement of Non-Governmental Organizations in the Work of the Codex Alimentarius Commission June 1997 (position paper).

115 Until 2003, the CAC regular sessions were biannual. However, due to the increased workload since the coming into force of the SPS Agreement, the frequency of the regular sessions has been increased to yearly, with the possibility of additional (extraordinary) sessions as may be considered necessary by the Directors-General of the FAO and WHO, in consultation with the Chairperson of the Executive Committee of the CAC. See Rule VI of the Rules of Procedure in Joint FAO/WHO Food Standards Programme, Codex Alimentarius Commission: Procedural Manual, 15th ed. (Food and Agriculture Organization and World Health Organization, Rome), 2005, 10.

${ }^{116}$ From its founding until December 2007, the CAC has held 30 regular sessions and one extraordinary session. The latter was for purposes of the discussion of the results of the evaluation process, which is discussed further below, Part II, Section 3.2.1.5.

117 Mariëlle Masson-Matthee, The Codex Alimentarius Commission and Its Standards, Doctoral Thesis, Maastricht University, Faculty of Law (T.M.C. Asser Press, Maastricht), 2007, 249.

${ }^{118}$ The Procedures for the Elaboration of Codex Standards and Related Texts are contained in the Procedural Manual. Previously different procedures were in place for different types of standards. These procedures were comprehensively revised in 1993 to provide a uniform procedure for the elaboration of all Codex texts. The new procedure was revised again in 2004 to introduce the strategic planning process and critical review. Joint FAO/WHO Food Standards Programme, Codex Alimentarius Commission: Procedural Manual, 15th ed. (Food and Agriculture Organization and World Health Organization, Rome), 2005, 23-25. For a thorough analysis of the legitimacy of the CAC standard-setting procedure, see Mariëlle Masson-Matthee, The Codex Alimentarius Commission and Its Standards, Doctoral Thesis, Maastricht University, Faculty of Law (T.M.C. Asser Press, Maastricht), 2007, 228-260.

119 A decision to elaborate a standard may also be made by a subsidiary body of the CAC (after taking into 
Step 2 of this procedure is where the Codex Secretariat arranges for the preparation of the draft proposed standard. Although not explicitly stated in the Procedures Manual, in practice this task is usually assigned to an individual CAC member or observer (usually the member or observer that initiated the standard). ${ }^{120}$ The draft is prepared taking into account the input from the FAO/WHO expert committees. At step 3, the draft is sent by the Codex Secretariat to all CAC members and interested parties for comment. Step 4 involves the review by the relevant committee of all the comments received and, if necessary, the preparation of a new draft. The proposed draft standard is submitted to both the Executive Committee and the regular session of the CAC at step 5 for adoption as a draft standard, in which case it may go through to finalisation. In taking a decision at this step, the CAC will take into account the outcome of the critical review of the Executive Committee. At step 6 the standard is again sent to all members and interested parties for comments. The subsidiary committee finalises the draft standard on the basis of the comments received at step 7. At step 8 , the finalised standard is again submitted to both the Executive Committee and the regular session of the CAC. After a final round of comments, and taking into account the critical review of the Executive Committee, the CAC decides whether to adopt the draft as a final Codex standard. If so, it is published by the Codex Secretariat as part of the Codex Alimentarius. It is also possible for the CAC to identify standards to be elaborated by means of an accelerated procedure. In such cases a 5-step process is followed, with the standards being submitted to the regular session of the CAC for adoption at step 5, instead of at step $8 .{ }^{121}$

Previously, the 8-step procedure made specific provision for substantive comments and amendments to be submitted with regard to a standard at step 8, and set out guidelines for how such comments should be dealt with. ${ }^{122}$ This aimed to allow all CAC members, including those that had not participated in earlier stages of the standard-setting process, to participate fully in the development of each standard. However, this enabled members to limit their participation to the late stages of the standard setting process and to delay the adoption of a standard through their late interventions. In 2006, the CAC decided to delete these guidelines. ${ }^{123}$ Currently, if substantive comments are submitted at a late stage,

account the outcome of the critical review), subject to subsequent approval by the Commission at the earliest possible opportunity. Where regional standards are at issue, the Commission must base its decision on the proposal of the majority of members of the region involved. Part III of the Procedures for the Elaboration of Codex Standards and Related Texts.

120 Mariëlle Masson-Matthee, The Codex Alimentarius Commission and Its Standards, Doctoral Thesis, Maastricht University, Faculty of Law (T.M.C. Asser Press, Maastricht), 2007, 76.

${ }^{121}$ This accelerated procedure is set out in the Procedures for the Elaboration of Codex Standards and Related Texts, Joint FAO/WHO Food Standards Programme, Codex Alimentarius Commission: Procedural Manual, 15th ed. (Food and Agriculture Organization and World Health Organization, Rome), 2005, 25-26.

${ }_{122}$ According to this guideline, amendments proposed at step 8 could only be adopted immediately by the Commission if they were only editorial in nature. Substantive amendments had to be referred back to the committee level. Submission of proposals for significant amendments had to be made in writing sufficiently in advance of the Committee meeting to give all members time to consider the amendments. These procedures were contained in the Guide to the Consideration of Standards at Step 8 of the Procedure for the Elaboration of Codex Standards including Consideration of any Statements Relating to Economic Impact, in the $14^{\text {th }}$ edition of the Procedural Manual 2004, 27. See Mariëlle Masson-Matthee, The Codex Alimentarius Commission and Its Standards, Doctoral Thesis, Maastricht University, Faculty of Law (T.M.C. Asser Press, Maastricht), 2007, 237-238.

${ }^{123}$ Codex Alimentarius Commission, Report of the Twenty-Ninth Session ALINORM 06/29/41 (Joint FAO/ WHO Food Standards Programme, Geneva), 3-7 July 2006, para. 23. 
the standard is nevertheless adopted at step 8 as it is, and a decision is taken to revise the standard immediately. ${ }^{124}$ A standard will only be referred back to step 6 for reconsideration by the relevant committee if there is a failure to reach consensus. ${ }^{125}$

The standards elaborated through this 8-step process are science-based. This was expressly stated in the Statements of Principle relating to the Role of Food Safety Risk Assessment, adopted in 1997. ${ }^{126}$ The latter provide, inter alia, that Codex food safety standards should be based on a risk assessment, as appropriate to the circumstances, ${ }^{127}$ and that such risk assessment should be soundly based on science, ${ }^{128}$ should be documented in a transparent manner, ${ }^{129}$ and should use available quantitative information to the greatest extent possible. ${ }^{130}$ In addition, the Statements of Principle provide that there should be a functional separation of risk assessment and risk management. ${ }^{131}$ In 2003, the CAC adopted a comprehensive statement of Working Principles for Risk Analysis for Application in the Framework of the Codex Alimentarius, which was incorporated into the Procedural Manual. ${ }^{132}$ According to these Working Principles, the responsibility for risk management lies with the CAC and its subsidiary bodies, while the responsibility for risk assessment lies with the joint FAO/WHO expert bodies and consultations.

The joint FAO/WHO expert bodies, including JECFA, JMRA and JMPR, as well as ad hoc expert consultations provide scientific input to Codex committees in response to specific requests for information. ${ }^{133}$ They are governed by the general rules and procedures adopted by the governing bodies of the FAO and WHO, ${ }^{134}$ and by more specific terms

124 Mariëlle Masson-Matthee, The Codex Alimentarius Commission and Its Standards, Doctoral Thesis, Maastricht University, Faculty of Law (T.M.C. Asser Press, Maastricht), 2007, 240.

${ }^{125}$ On the problematic nature of consensus decision making by the Commission, see further below in this Section. See also ibid., 230-241.

126 The Statements of Principle relating to the Role of Food Safety Risk Assessment were adopted by the CAC in 1997 at its 22 ${ }^{\text {nd }}$ Session (ALINORM 97/37) and were incorporated into the Procedural Manual in the Appendix on General Decisions of the Commission. Codex Alimentarius Commission, Procedural Manual, Seventeenth Edition (Joint FAO/WHO Food Standards Programme, Rome), 2007, 196, available at: ftp://ftp. fao.org/codex/Publications/ProcManuals/Manual_17e.pdf, visited on 21 February 2008.

${ }^{127}$ Principle 1 of the Statements of Principle relating to the Role of Food Safety Risk Assessment.

${ }_{128}$ Principle 2 of the Statements of Principle relating to the Role of Food Safety Risk Assessment.

129 Principle 2 of the Statements of Principle relating to the Role of Food Safety Risk Assessment. This principle further provides that risk assessments should incorporate the four steps of the risk assessment process.

${ }^{130}$ Principle 4 of the Statements of Principle relating to the Role of Food Safety Risk Assessment.

${ }^{131}$ Principle 3 of the Statements of Principle relating to the Role of Food Safety Risk Assessment. This Principle further recognises, however, that some interactions between risk assessment and risk management are essential for a pragmatic approach. On the concepts of risk assessment and risk management see further above, Part II, Section 1.5 and below, Part III, Chapter 5 (introductory paragraphs).

${ }^{132}$ The Working Principles for Risk Analysis for Application in the Framework of the Codex Alimentarius was adopted by the CAC at its $26^{\text {th }}$ Session in 2003 (ALINORM 03/41) and is to be found in Section III of the Procedural Manual. Codex Alimentarius Commission, Procedural Manual, Seventeenth Edition (Joint FAO/ WHO Food Standards Programme, Rome), 2007, 112-118, available at: ftp://ftp.fao.org/codex/Publications/ ProcManuals/Manual 17e.pdf, visited on 21 February 2008.

${ }^{133}$ It is useful to note that the FAO/WHO expert bodies also have the task of providing scientific advice, upon request, to members of the FAO or WHO. However, a large part of their work is dedicated to Codex activities.

${ }^{134}$ Article VI of the FAO Constitution provides the authority to establish committees and working parties on matters pertaining to the FAO's purpose. It has further developed the Principles and Procedures which should Govern Conventions and Agreements Concluded under Articles XIV and XV of the Constitution and Commissions and Committees established under Article VI of the Constitution, 1967. Similarly Article 38 of the WHO's Constitution gives the WHO Executive Board the competence to establish committees to serve 
of reference and rules of procedure adopted for each body. ${ }^{135}$ These differ from expert body to expert body. However, there are some common elements to their basic working principles. In particular, in 2004 six core principles for the provision of scientific advice were agreed by the FAO and WHO. ${ }^{136}$ These are (1) the soundness or scientific excellence of both the experts and the scientific process; (2) the responsibility or accountability of experts for their views; (3) the objectivity of the experts and advice provided; (4) the fairness of the scientific process; (5) the transparency of the process whereby advice is formulated; and (6) the inclusiveness of the process through regard to minority scientific opinion and maintenance of geographical and socioeconomic balance, but not to the extent that scientific integrity is compromised.

Requests for scientific advice are prioritised in consultation with the CAC, member countries and other international organisations in order to make the best use of the available resources and expertise. Requests from the CAC are prioritised on the basis of the following four criteria: the objectives defined in the CAC Strategic Plan; the clear definition of the scope and objective of the request; the significance of urgency of the request to CAC standard-setting work, taking into account the health and/or trade relevance of the issue and the needs of developing countries; and the availability of scientific knowledge or data to conduct the risk assessment. ${ }^{137}$ The latter criterion has been criticised by some members, referring to the difficulties experienced by developing countries in obtaining or producing data to carry out risk assessments. In this respect, the Executive Committee pointed out that the criterion was meant to reflect the fact that in the absence of sufficient data it would be difficult for FAO and WHO to organise expert meetings to conduct the risk assessment. ${ }^{138}$

The joint FAO/WHO expert bodies conduct risk assessments on the basis of the risk assessment policies issued to them by the relevant Codex committee and the best available scientific data, which is sought by means of a 'call for data' for a particular expert meeting. This data is taken from a variety of sources, including government agencies, national and regional research institutes and the industries producing food, additives, pesticides, veterinary drugs, chemicals and pharmaceuticals. The data may take the form of peer reviews publications or unpublished proprietary data submitted to the FAO/WHO

purposes within the competence of the WHO. It has established Regulations for Expert Advisory Panels and Committees.

${ }^{135}$ For a full list of the various documents containing the guidelines, terms of reference and rules of procedure of the expert bodies, see FAO/WHO Framework for the Provision of Scientific Advice on Food Safety and Nutrition (to Codex and Member Countries) (Food and Agriculture Organization and World Health Organization, Rome/Geneva), 2007, Annex B, available at: http://www.fao.org/ag/agn/agns/files/Final_ Draft_EnglishFramework.pdf, visited on 1 February 2008.

${ }^{136}$ Report of the Joint FAO/WHO Workshop on the Provision of Scientific Advice to Codex and Member Countries, Held on 27-29 January 2004 (Food and Agriculture Organization and World Health Organization, Geneva), 2004, available at: http://www.who.int/foodsafety/codex/en/workshop_report.pdf, visited on 20 June 2008.

137 These criteria were agreed in 2005 by the Executive Committee of the CAC, and adopted in 2005 by the CAC. Codex Alimentarius Commission, Report of the Twenty-Eighth Session, ALINORM 05/28/41 (Joint FAO/WHO Food Standards Programme, Rome), 4 - 9 July 2005, para. 75, available at: http:/www.codexalimentarius.net/web/archives.jsp?year=05, visited on 14 May 2008.

${ }^{138}$ Executive Committee of the Codex Alimentarius Commission, Report of the Fifty-Fifth Session, ALINORM 05/28/3, (Joint FAO/WHO Food Standards Programme, Rome), 9-11 February 2005, para. 72. 
Secretariat. Efforts are made to ensure that the data reflects the current state of scientific knowledge and is of high quality. The data is collected and reviewed by the expert body involved to generate a risk assessment. Where the quality and quantity of data does not permit a risk assessment, an expert evaluation of the available scientific data forms the basis of the scientific advice provided. ${ }^{139}$ Limitations in data and assumptions made in the scientific advice must be clearly described in the final report. ${ }^{140}$ The scientific advice issued by an expert body reflects the conclusions of all the experts present at a particular meeting, In exceptional cases where experts cannot reach agreement on the conclusions, the dissenting opinions and the reasons there for are recorded in the report. ${ }^{141}$

As mentioned above, in 2001, the Twenty-Fourth Session of the CAC requested a review of the status and procedures of the joint FAO/WHO expert bodies. ${ }^{142}$ This led, in 2003, to the initiation of a 'consultative process' to consider ways to improve the transparency, timeliness, efficiency, integrity and sustainability of the provision of scientific advice by FAO/WHO scientific committees. One of the outcomes of this process was a framework document setting out the current practices and procedures in the provision of scientific advice by the FAO and WHO, published in 2007. ${ }^{143}$ This aims to make more transparent the current procedures.

Another of the outcomes of the consultative process is the definition of new approaches to enhance the participation of experts and the use of data from developing countries in the elaboration of international scientific advice. ${ }^{144}$ The FAO and WHO are currently reviewing recommendations to further strengthen the global nature of scientific advice. The three priority areas identified are: greater inclusion of data from developing countries; enhancement of the potential for experts from developing countries to be selected as members and have an effective participation in these meetings; and means to enhance the enabling environment at national, regional and international levels.

On the basis of the risk assessment and risk management process described above, standards are elaborated for adoption by the CAC. There are three types of standards: commodity standards, which define what qualifies as a particular commodity; residue standards, which set acceptable maximum residue levels for pesticides, veterinary drugs and additives; and codes of conduct, guidelines and other recommended measures including good

139 FAO/WHO Framework for the Provision of Scientific Advice on Food Safety and Nutrition (to Codex and Member Countries) (Food and Agriculture Organization and World Health Organization, Rome/Geneva), 2007, 5, available at: http://www.fao.org/ag/agn/agns/files/Final_Draft_EnglishFramework.pdf, visited on 1 February 2008.

140 Ibid., 21.

141 Ibid., 4.

${ }^{142}$ Codex Alimentarius Commission, Report of the Twenty-Fourth Session, ALINORM 01/41 (Joint FAO/WHO Food Standards Programme, Geneva), 2-7 July 2001, para. 61.

${ }^{143}$ Food Quality and Standards Service of the FAO and Zoonoses and Foodborne Diseases and International Programme on Chemical Safety of the WHO Department of Food Safety, FAO/WHO Framework for the Provision of Scientific Advice on Food Safety and Nutrition (to Codex and Member Countries) (Food and Agriculture Organization and World Health Organization, Rome/Geneva), 2007, available at: http://www.fao. org/ag/agn/agns/files/Final_Draft_EnglishFramework.pdf, visited on 1 February 2008.

${ }^{144}$ Enhancing Developing Country Participation in FAO/WHO Scientific Advice Activities. Report of a Joint FAO/WHO Meeting, FAO Food and Nutrition Paper 88 (Food and Agriculture Organization and World Health Organization, Rome), December 2006, available at: ftp://ftp.fao.org/docrep/fao/meeting/010/j7630e.pdf, visited on 4 October 2006. 
practice standards for issues such as risk assessment and the use of veterinary drugs. ${ }^{145}$ Once the standards, guidelines or recommendations have been adopted by the CAC, they form part of what is known as the Codex Alimentarius (Food Code). ${ }^{146}$ The adopted standards constitute voluntary standards. ${ }^{147}$

The coming into force of the SPS Agreement has given these standards a new status, not envisaged when CAC structures and procedures were designed. While the standards are still not binding, deviation from them makes national measures susceptible to challenge in terms of the SPS Agreement's science-based disciplines. ${ }^{148}$ They thus constitute a benchmark against which SPS measures are judged. Measures meeting this benchmark are presumptively WTO consistent. As a result, increased attention has been focused on CAC standards and the procedures by which they are set.

One question that has arisen regards the extent to which the different nature of CAC standards, guidelines and other recommendations would be taken into account under the SPS Agreement. In 1997, the CAC Secretariat was asked by members to submit a written request for clarification from the chair of the SPS Committee on this point. ${ }^{149}$ The Chair of the SPS Committee, after informal consultations, drafted a response with was adopted, after revision, ${ }^{150}$ by the SPS Committee in April 1998 and sent to the CAC. ${ }^{151}$ This response, after indicating that the SPS Committee cannot formally interpret the SPS

145 This categorisation is made by Victor, in David G. Victor, 'The Sanitary and Phytosanitary Agreement of the World Trade Organization: An Assessment after Five Years', Journal of International Law and Politics 32 (4), 2000, 865-938, 886.

146 The Codex Alimentarius is defined as 'a collection of internationally adopted food standards presented in a uniform manner' which 'aim at protecting consumers' health and ensuring fair practices in the food trade.' General Principles of the Codex Alimentarius, para. 1, in Joint FAO/WHO Food Standards Programme, Codex Alimentarius Commission: Procedural Manual, 15th ed. (Food and Agriculture Organization and World Health Organization, Rome), 2005, 31. These General Principles were drafted by the Codex Committee on General Principles, adopted by the 3rd Session of the CAC in 1965, and amended by the 6th Session of the CAC in 1969. Codex Alimentarius Commission, Report of the Sixth Session (Joint FAO/WHO Food Standards Programme, Geneva), 4 - 14 March 1969, para. 16 and Appendix IV, available at: http:// www.fao.org/docrep/meeting/005/87246e/87246e00.htm, visited on 14 May 2008.

${ }^{147}$ Originally, an acceptance procedure was set out in the General Principles of the Codex Alimentarius, paras 4.A and 5.A, according to which CAC members could indicate their intention to be bound by a particular standard (full acceptance), to be bound with some reservations regarding the operative date (target acceptance), to be bound with some qualifications (acceptance with minor deviations). Members could also refuse to accept the standard in its entirety, as provided for in General Principles of the Codex Alimentarius, paras 4.B and 5.B. Sami Shubber, 'The Codex Alimentarius Commission under International Law', International and Comparative Law Quarterly 21, 1972, 631-655, 649. The acceptance procedure was abolished by the $28^{\text {th }}$ Session of the CAC. Codex Alimentarius Commission, Report of the Twenty-Eighth Session, ALINORM 05/28/41 (Joint FAO/WHO Food Standards Programme, Rome), 4 - 9 July 2005, para. 36, available at: http:/ www.codexalimentarius.net/web/archives.jsp?year=05, visited on 14 May 2008.

${ }_{148}$ The harmonisation disciplines of the SPS Agreement are discussed below, Part III, Chapter 4.

149 Codex Alimentarius Commission, Report of the Twenty-Second Session (Joint FAO/WHO Food Standards Programme, Geneva), 23-28 June 1997, para. 172. The letter from the CAC to the SPS Committee was circulated as Committee on Sanitary and Phytosanitary Measures, Clarification of References to Codex Texts - Request from the Codex Alimentarius Commission, G/SPS/W/84, circulated on 8 October 1997.

${ }_{150}$ Committee on Sanitary and Phytosanitary Measures, Clarification of References to Codex Texts: Draft Response to the Codex Alimentarius Commission. Note by the Chairman. Revision, G/SPS/W/86/Rev.1, circulated on 13 March 1998.

${ }^{151}$ Committee on Sanitary and Phytosanitary Measures, Summary of the Meeting Held on 12-13 March 1998, G/SPS/R/10, circulated on 30 April 1998, para. 50. 
Agreement, noted that the SPS Agreement does not differentiate between different categories of CAC norms such as standards, guidelines and recommendations. It further indicated that WTO Members are under no legal obligation to apply CAC standards, guidelines or recommendations. In addition, it noted that the substantive content of a text rather than its category would determine how it would be applied and how a Member could show that its measure was based thereon. ${ }^{152}$ Finally, with regard to the question of the status of regional standards under the SPS Agreement, the SPS Committee stated that regional CAC standards were not included in the definition of 'international standards' in the SPS Agreement. It noted that such standards were meant to apply only within a given geographic region. ${ }^{153}$ However, the fact that scientifically sound regional standards could become the foundation for the creation of international standards was recognised.

In 1998, referring to this response of the SPS Committee, the Executive Committee of the CAC agreed that: 'the work of Codex should move forward without concern arising from misunderstandings or misinterpretations as to how Codex standards and related texts might be used. ${ }^{154}$ However, it suggested that the Committee on General Principles should examine the possibility of developing a set of 'appropriate preambular statements' to explain the intent of different categories of Codex texts. ${ }^{155}$

The standards developed by the CAC subsidiary committees are based on scientific risk assessments obtained from the FAO/WHO expert bodies as described above. However, as all risk management decisions, the standards elaborated by the CAC committees are not purely based on risk assessment but reflect also the policy choices of the participating members. This has become a problematic issue since the coming into force of the SPS Agreement and has led to members fighting out their trade conflicts in the standard setting process. The politicisation of standard setting in the CAC is illustrated by the events surrounding the setting of safety standards for hormone-residues, at issue in $E C$ - Hormones. ${ }^{156}$ In June 1987, the JECFA determined Acceptable Daily Intake (ADI) and MRLs for Zeranol and Trenbolone (two synthetic hormones) in beef and found that it was unnecessary to do the same for endogenous hormones as the residues from the use thereof as growth promoters in accordance with good veterinary practice 'are unlikely to pose a hazard to human health.' ${ }^{157}$ The Codex Committee on Residues of Veterinary Drugs in Food (CRVDF) agreed with the recommendations of the JECFA and proceeded to advance the adoption of the relevant MRLs through the normal 8-step procedure followed in the CAC. ${ }^{158}$ At the following meeting of the CAC in July 1991, the question of

${ }^{152}$ For example, the SPS Committee noted that specific numeric value of an MRL provides a higher degree of precision than a guideline or other Codex text.

${ }^{153}$ Codex Alimentarius Commission, Report of the Twenty-Second Session (Joint FAO/WHO Food Standards Programme, Geneva), 23-28 June 1997, para. 168.

154 Executive Committee, Report of the Forty-Fifth Session, ALINORM 99/3, 3-5 June 1998 (Codex Alimentarius Commission, Rome) para. 44.

155 Executive Committee, Report of the Forty-Fifth Session, ALINORM 99/3, 3-5 June 1998 (Codex Alimentarius Commission, Rome) para. 44.

${ }^{156}$ These events are outlined in Dale E. McNiel, 'The First Case under the WTO's Sanitary and Phytosanitary Agreement: The European Union's Hormone Ban', Virginia Journal of International Law 39, 1998, 89-134, 108-109.

${ }^{157}$ FAO/WHO Joint Expert Committee on Food Additives. Summary and Conclusions: Thirty-Second Meeting, Rome, 15-23 June 1987.

${ }^{158}$ Committee on Residues of Veterinary Drugs in Food, Session of 1990 where the CRVDF agreed to advance 
the adoption of these MRLs for the relevant five hormones was fiercely debated. The EC argued that factors other than science are to be taken into account when setting health standards. The CAC decided to ignore the advice of its own scientific committee and a vote was taken not to adopt the MRLs.

In 1995, the question of adoption of the MRLs for hormones was again at issue, only seven months after the coming into force of the SPS Agreement. ${ }^{159}$ Following intense discussion, the US proposed that a secret vote be held on these standards. This proposal was approved and the MRLs were adopted by a vote of 33 to 29 , with 7 abstentions. ${ }^{160}$ However, the International Observer from the EC criticised the decision to take a secret vote as this deviated from the goal of transparency in CAC procedures and brought into question the validity of Codex standards. ${ }^{161}$ It became clear that the added importance of Codex standards were leading to increased politicisation of its standard-setting process. The adopted standards no longer represented a broad consensus on the safety of the relevant products but were controversial results of the struggle of interests within the CAC.

In 1995, in reaction to the politicised voting on the standards for the hormones at issue in the dispute between the EC and the US, ${ }^{162}$ the CAC developed the Statements of Principle Concerning the Role of Science in the Codex Decision-Making Process and the Extent to which Other Factors are Taken into Account. ${ }^{163}$ These Statements of Principle state:

these MRLs at the CAC meeting in July 1991.

159 These events are described in Terence P. Stewart and David S. Johanson, 'The SPS Agreement of the World Trade Organization and International Organizations: The Roles of the Codex Alimentarius Commission, the International Plant Protection Convention, and the International Office of Epizootics', Syracuse Journal of International Law and Commerce 26, 1998, 27-53, 42.

${ }^{160}$ Codex Alimentarius Commission, Report of the Twenty-First Session, ALINORM 95/37 (Joint FAO/WHO Food Standards Programme, Rome), 3 - 8 July 1995, 45, available at: http://www.fao.org/docrep/meeting/005/v7950e/v7950e00.htm, visited on 13 May 2008.

${ }^{161}$ Ibid., 46. The EC Observer also stated that the EC might reconsider its participation in the CAC, but the delegations of the Netherlands, the UK, Sweden, Spain and Finland dissociated themselves from parts or all of these remarks.

${ }^{162}$ The first attempt to adopt standards for the relevant hormones, as recommended by the Codex Committee on Residues of Veterinary Drugs in Food on the basis of scientific analysis carried out by the JECFA, was opposed by the EC. According to the EC, factors other than science must be taken into account in setting standards. A vote was taken, the outcome of which was 12 in favour of adoption; 27 against adoption; and 9 abstentions. This vote resulted in the non-adoption of the relevant standards. Codex Alimentarius Commission, Report of the Nineteenth Session, ALINORM 91/40 (Joint FAO/WHO Food Standards Programme, Rome), 1-10 July 1991, paras 161-162, available at: http://www.fao.org/docrep/meeting/005/t0490e/t0490e00.htm, visited on 13 May 2008. The role of CAC standards in the EC-Hormones dispute is discussed further below, Part III, Sections 4.1.2 and 4.2.

${ }^{163}$ These Statements of Principle were adopted by the $21^{\text {st }}$ Session of the CAC in 1995 and were incorporated into the Procedural Manual, in the Appendix on General Decisions of the Commission. Codex Alimentarius Commission, Procedural Manual, Seventeenth Edition (Joint FAO/WHO Food Standards Programme, Rome), 2007, 194-195, available at: ftp://ftp.fao.org/codex/Publications/ProcManuals/Manual_17e.pdf, visited on 21 February 2008. As discussed by Donna Roberts, in the debate leading to this text, the EC and US both sought to establish criteria that favoured their industry interests. The US (and its allies) supported the view that standards should be based only on science. In contrast the EC (and its allies) proposed a 'need' criterion for new technologies (such as growth hormones). The result was compromise language stating that standards shall be based on principle of sound science but where appropriate CAC will consider other legitimate factors. Donna Roberts et al., 'Sanitary and Phytosanitary Barriers to Agricultural Trade: Progress, Prospects and Implications for Developing Countries', in Agriculture and the New Trade Agenda - Creating a Global Trading Environment for Development, M.D. Ingco and L.A.Winters (eds.) (Cambridge University Press, Cambridge), 2004, 329-358, 341-342. 
1. The food standards, guidelines and other recommendations of Codex Alimentarius shall be based on the principle of sound scientific analysis and evidence, involving a thorough review of all relevant information, in order that the standards assure the quality and safety of the food supply.

2. When elaborating and deciding upon food standards Codex Alimentarius will have regard, where appropriate, to other legitimate factors relevant for the health protection of consumers and for the promotion of fair practices in food trade.

3. In this regard it is noted that food labelling plays an important role in furthering both of these objectives.

4. When the situation arises that members of Codex agree on the necessary level of protection of public health but hold differing views about other considerations, members may abstain from acceptance of the relevant standard without necessarily preventing the decision by Codex. ${ }^{164}$ (emphasis added).

In order to ensure that the consideration of 'other factors' does not affect the scientific basis of a risk assessment, these Statements of Principle further call for respect of the functional separation of risk assessment from risk management. As the other relevant factors referred to in the Statements of Principle were not defined, a call was made for the elaboration and clarification of the phrase 'other legitimate factors relevant for the health protection of consumers ${ }^{165}$ This question was addressed in Thirteenth Session of Codex Committee on General Principles and the results of this discussion were adopted by the CAC in 2001, ${ }^{166}$ and are included as an appendix to the Procedural Manual. ${ }^{167}$ According to the criteria laid down in this decision, any 'other relevant factors' which have worldwide relevance are potentially legitimate in setting Codex standards, but they should be clearly identified and should not affect the scientific basis for the standard. In addition, 'other relevant factors' which are explicitly mentioned in these criteria are the constraints of production and processing methods and transport and storage, especially in developing countries, which can affect the feasibility of different risk management options. A notable aspect of the principles laid down in this decision is the fact that provision is made for the adoption of standards where agreement cannot be reached on the non-scientific considerations. Clearly, the greater the recognition of the role of policy considerations in standard setting, the more openly governments can openly base their different views regarding the appropriate standard on non-science factors. This makes agreement between CAC members even more difficult than when differences had to be argued on the basis of scientific

${ }^{164}$ Codex Alimentarius Commission, Report of the Twenty-First Session, ALINORM 95/37 (Joint FAO/WHO Food Standards Programme, Rome), 3 - 8 July 1995, Appendix II, available at: http:/www.fao.org/docrep/ meeting/005/v7950e/v7950e00.htm, visited on 13 May 2008. These were incorporated into the Procedural Manual in the Appendix on General Decisions of the Commission. Codex Alimentarius Commission, Procedural Manual, Seventeenth Edition (Joint FAO/WHO Food Standards Programme, Rome), 2007, 194, available at: ftp://ftp.fao.org/codex/Publications/ProcManuals/Manual_17e.pdf, visited on 21 February 2008.

${ }^{165}$ Codex Alimentarius Commission, The Application of Risk Analysis Principles in Codex, ALINORM 97/7 (Joint FAO/WHO Food Standards Programme, 16 May 1997.

${ }^{166}$ Codex Alimentarius Commission, Report of the Twenty-Fourth Session, ALINORM 01/41 (Joint FAO/WHO Food Standards Programme, Geneva), 2-7 July 2001, 98.

167 Joint FAO/WHO Food Standards Programme, Codex Alimentarius Commission: Procedural Manual, 15th ed. (Food and Agriculture Organization and World Health Organization, Rome), 2005, Appendix. 
findings alone. Thus the possibility is created that a member may abstain, while allowing the standard to be adopted nevertheless. While this might be a sensible solution to the reality of the differing policy objectives of members in a situation where the standards are merely voluntary norms, the new role of CAC standards following the coming into force of the SPS Agreement makes this rule of questionable wisdom. Its effect will be to create standards on the basis of certain members' value-based choices, which will set the norm against which all WTO Members' measures will be judged for presumptive validity.

Other concerns raised after the coming into force of the SPS Agreement regard the appropriateness of the procedures for standard setting in the CAC, and the legitimacy of the resulting standards. ${ }^{168}$ One contentious element of CAC procedures for standard setting relates to decision making. Most decisions of the CAC and its subsidiary committees are taken by consensus. If consensus cannot be reached, the decision can be taken by majority vote, ${ }^{169}$ though this rarely happens at committee level. During meetings of the CAC, however, decisions were previously occasionally taken by majority vote when consensus was lacking, and this situation occurred more frequently after the coming into force of the SPS Agreement. ${ }^{170}$ Two well-known examples of this are the controversial standards for bottled mineral waters and maximum residue levels of hormones in beef. The hormone standards was hard-fought due to their relevance in the EC - Hormones dispute between the US and EC. The decision that no maximum residue level was necessary in this case because hormone residues in beef are safe, when hormones are administered in accordance with good veterinary practice, was adopted by 33 votes in favour with 29 votes against and 9 abstentions. The revised standard for mineral waters, which reflected the traditional European method of ensuring water purity, ${ }^{171}$ was adopted by 33 votes in favour, with 31 against and 10 abstentions. ${ }^{172}$ All EC Member States and most other

${ }^{168}$ It has been pointed out that the commitment of developed countries embodied in Article 10.4 of the SPS Agreement, to encourage and facilitate the participation by developing countries in international standardsetting organisations has turned out to be hollow. Kevin C. Kennedy, 'Resolving International Sanitary and Phytosanitary Disputes in the WTO: Lessons and Future Directions', Food and Drug Law Journal 55 (1), 2000, 81-104. See further on Article 10.4 of the SPS Agreement below, Part V, Section 2.4.

${ }^{169}$ Rule XII(2) of the Rules of Procedure. Joint FAO/WHO Food Standards Programme, Codex Alimentarius Commission: Procedural Manual, 15th ed. (Food and Agriculture Organization and World Health Organization, Rome), 2005. See also Natalie Avery et al., Cracking the Codex; an Analysis of Who Sets World Food Standards (National Food Alliance, London), 1993, 7.

170 Since the adoption of the SPS Agreement, the Codex has been subject to increasing politicisation of its decision-making processes as its members try to capture the setting of standards to reflect their own health or trade priorities. This has had the initial consequence of increasing the number of non-consensus decisions as member countries were unwilling to back down and agree to standards which have implications for the disciplines their SPS measures are exposed to under the multilateral trade regime. Codex members thus tried to use the Codex processes to attain their national economic goals, rather than to establish minimum safety standards. Stewart and Johanson noted in 1998 that the number of non-consensus decisions had increased since the adoption of the SPS Agreement. Terence P. Stewart and David S. Johanson, 'The SPS Agreement of the World Trade Organization and International Organizations: The Roles of the Codex Alimentarius Commission, the International Plant Protection Convention, and the International Office of Epizootics', Syracuse Journal of International Law and Commerce 26, 1998, 27-53, 45.

171 Traditionally, European mineral water producers ensure its purity by bottling it at the source. On the other hand, other countries such as the US and Japan use antimicrobial agents, a procedure prohibited by the proposed standard. Ibid., 44

${ }_{172}$ Codex Alimentarius Commission, Report of the Twenty - Second Session, ALINORM 97/3 (Joint FAO/WHO Food Standards Programme, Geneva), 23 - 28 June 1997, paras 89-90, available at: http://www.codexalimentarius.net/web/archives.jsp?year=97, visited on 14 May 2008. 
European countries voted in favour, leading to suspicions regarding the influence of the EC on the voting behaviour of countries then seeking admission to the EC. ${ }^{173}$ Following the vote, several delegations expressed concerns about the safety of this standard ${ }^{174}$ and emphasised that the CAC should try to reach important decisions by consensus of its members. ${ }^{175}$ However, this appeal had little effect and the number of non-consensus decisions in the CAC increased.

As a result of the controversy following these standards, the adoption of standards by means of voting led to criticism and to a re-evaluation of the standard-setting procedure. The CAC has now committed itself to make every effort to adopt standards by consensus rather than voting. ${ }^{176}$ However, reaching consensus, particularly on sensitive issues, has become increasingly difficult due to the current awareness of the trade implications of CAC standards. To address this problem, the CAC adopted a decision, at its $26^{\text {th }}$ Session in 2003, recommending measures to facilitate consensus. ${ }^{177}$

A problematic aspect of the process of standard setting by the CAC, especially relevant to the study in this book, is the great divergence in the extent to which countries at different levels of development participate in the various stages of this process. As is the case for risk regulation on national level, the standard-setting process in the CAC includes risk assessment, risk management and risk communication aspects. ${ }^{178}$ These elements of risk analysis are subject to the same inherently subjective elements and policy choices on

173 Japan requested that the vote be taken by secret ballot, but this proposal was rejected by a show of hands. Terence P. Stewart and David S. Johanson, 'The SPS Agreement of the World Trade Organization and International Organizations: The Roles of the Codex Alimentarius Commission, the International Plant Protection Convention, and the International Office of Epizootics', Syracuse Journal of International Law and Commerce 26, 1998, 27-53, 45.

${ }^{174}$ For example, Japan pointed to the fact that certain conditions, presumably including water quality, vary throughout the world. It is thus possible that the European method would not necessarily guarantee the safety of mineral water bottled elsewhere. The adoption of the European method, reflected in the Codex standard, by other countries may thus give cause for concern.

175 Codex Alimentarius Commission, Report of the Twenty - Second Session, ALINORM 97/3 (Joint FAO/ WHO Food Standards Programme, Geneva), 23 - 28 June 1997, paras. 45 and 93, available at: http://www. codexalimentarius.net/web/archives.jsp?year=97, visited on 14 May 2008. The issue of non-consensus decision making in the CAC when adopting the standard for hormones was raised by the EC before the Panels in EC-Hormones. See further below, Part III, Section 4.1.2.

${ }^{176}$ At the $23^{\text {rd }}$ Session of the CAC, the decision-making procedure for the adoption and amendment of standards (then Rule X of the Rules of Procedure) was amended to stress the need for consensus in the adoption of standards and related texts, stating that voting may only be resorted to if every effort to reach consensus has failed. See Codex Alimentarius Commission, Report of the Twenty-Third Session, ALINORM 99/37 (Joint FAO/ WHO Food Standards Programme, Rome), 28 June - 3 July 1999. Now this rule is contained in Article XII.2 of the Rules of Procedure. Joint FAO/WHO Food Standards Programme, Codex Alimentarius Commission: Procedural Manual (Food and Agriculture Organization and World Health Organization, Rome), 2006, 16, available at: ftp://ftp.fao.org/codex/Publications/ProcManuals/Manual_16e.pdf, visited on 21 February 2008.

177 These recommended measures are now included in the Appendix to the Procedural Manual containing general decisions of the CAC. Joint FAO/WHO Food Standards Programme, Codex Alimentarius Commission: Procedural Manual (Food and Agriculture Organization and World Health Organization, Rome), 2006, 167, available at: ftp://ftp.fao.org/codex/Publications/ProcManuals/Manual_16e.pdf, visited on 21 February 2008.

${ }^{178}$ That these three 'distinct but closely linked' components of risk analysis are an integral part of the overall risk analysis to be conducted by the CAC is recognised in the Working Principles for Risk Analysis for Application in the Framework of the Codex Alimentarius at para. 5. See Joint FAO/WHO Food Standards Programme, Codex Alimentarius Commission: Procedural Manual, 15th ed. (Food and Agriculture Organization and World Health Organization, Rome), 2005, 101. 
international level as are present on national level. ${ }^{179}$ These subjective elements are given content by the actors in the risk assessment and risk management stages so that the resulting standards reflect their interests. It is therefore worthwhile to examine in more detail the degree of participation of WTO Members at different levels of development in the risk analysis process at the CAC.

\subsubsection{Participation in standard setting}

In theory, all CAC members can participate in CAC activities and send delegations to any Codex committee in which they want to take part. However, in practice, the multiplicity of committees and meetings, together with the fact that they are most often held in developed host countries, makes it costly to be actively involved in their standard setting activities. As a result, the most active participation in the plethora of Codex committees is by developed country members. Countries at lower levels of development face constraints with regard to the financial resources and the technical expertise needed to participate in all the numerous Codex committees. ${ }^{180}$ They thus often restrict their participation to the annual regular sessions of the CAC and possibly certain committees of particular relevance to their export products. This means that, in the majority of CAC standards, the input of countries at lower levels of development is lacking. As noted in the 2002 report of the $\mathrm{FAO} / \mathrm{WHO}$ evaluation of the CAC:

$[\mathrm{P}]$ oorer countries and, to a lesser extent, those with limited importance for trade, have too little involvement and influence. Many countries outside of North America, Australasia and the European Union feel that it is difficult to make their voices hear in Codex. Governments in low-income countries do not always consider attendance at Codex meetings a high enough priority among many pressing demands for resources. ${ }^{181}$

Most developing-country WTO Members that do attend CAC meetings give highest priority to attending the regular sessions of the CAC, where decisions are taken on the initiation of work on standards, the adoption of draft standards which can proceed to finalisation and the adoption of final standards. ${ }^{182}$ These Members cannot effectively ensure that their interests are reflected in Codex standards since, at these stages, fundamental changes are not easy to make. Nevertheless, an examination of attendance of meetings of various Codex bodies by WTO Members at different income levels shows that the CAC regular sessions are best attended by middle- and low-income Members.

\footnotetext{
179 See the discussion on risk analysis, below, Part III, Chapter 5.

${ }^{180}$ In fact, developing countries indicated in the context of the FAO/WHO evaluation of the CAC in 2002, that their limited financial resources are 'overwhelmingly' the most important hindrance to their full participation in CAC activities. Codex Alimentarius Commission, Conclusions and Recommendations of the Joint FAO/ WHO Evaluation of the Codex Alimentarius and Other FAO and WHO Work on Food Standards, ALINORM 03/25/3 (Joint FAO/WHO Food Standards Programme, Rome), December 2002, para 139.

${ }^{181}$ Ibid., para. 138

182 Stuart A. Slorach, Enquiry Concerning the FAO/WHO Project and Trust Fund for Enhanced Participation in Codex ("Codex Trust Fund") (Swedish International Development Cooperation Agency, Stockholm), 12 October 2007, 11, available at: http://www.who.int/foodsafety/codex/Slorach_report.pdf, visited on 10 June 2008 .
} 


\section{Graph 2: Codex Alimentarius Commission Thirtieth Session: Attendance by WTO Members by Income Level, 2007}

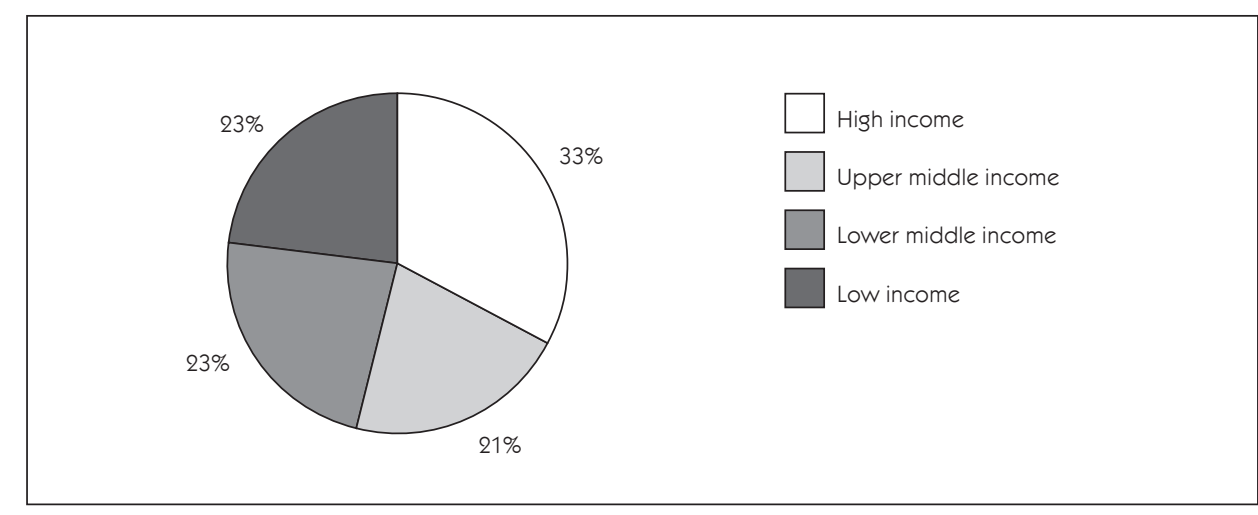

The spread across income levels of WTO Members that attended the Commission's regular session in 2007 closely resembles that of the membership of the CAC. ${ }^{183}$ This session was attended by $108 \mathrm{CAC}$ members that are also WTO Members. Of these WTO Members, 33 percent were high-income Members, 21 percent were upper-middle-income Members, 23 percent were lower-middle-income Members and 21 percent were lowincome Members. ${ }^{184}$

However, mere representation at the meeting cannot give a full picture of the extent to which the interests of Members at different income levels are promoted at the meeting. One factor that must be taken into account is the size of Members' delegations. National delegations to the CAC usually comprise senior government officials with expertise in the area of food trade, ${ }^{185}$ assisted by representatives of industry and sometimes consumer organisations or academics.

\footnotetext{
${ }^{183}$ See above, Part II, Section 3.2.1.3, Graph 1.

184 These numbers are based on the list of delegates contained in the Report of the Thirtieth Session of the CAC in 2007. Only those CAC members that are also WTO Members are taken into account in this calculation. For purposes of the categorisation of WTO Members by income level, the 2007 World Bank classification of economies used throughout this book is relied upon. According to the Report of the Thirtieth Session, 35 high-income Members, 23 upper-middle-income Members, 25 lower-middle-income Members and 25 lowincome Members attended the meeting. Codex Alimentarius Commission, Report of the Thirtieth Session, ALINORM 07/30/REP (Joint FAO/WHO Food Standards Programme, Rome), 2 - 7 July 2007, Appendix I, available at: http://www.codexalimentarius.net/web/archives.jsp?year=07, visited on 8 February 2008.

${ }^{185}$ National delegates to Codex committees should, as far as possible, serve in a continuing capacity and be specialists in the respective fields of the committees, as stated in Rule XI.4 of the Rules of Procedure. See Codex Alimentarius Commission, Procedural Manual, Seventeenth Edition (Joint FAO/WHO Food Standards Programme, Rome), 2007, 15, available at: ftp://ftp.fao.org/codex/Publications/ProcManuals/Manual_17e. pdf, visited on 21 February 2008.
} 


\section{Graph 3: Codex Alimentarius Commission Thirtieth Session: Delegates of WTO Members by Income Level, 2007}
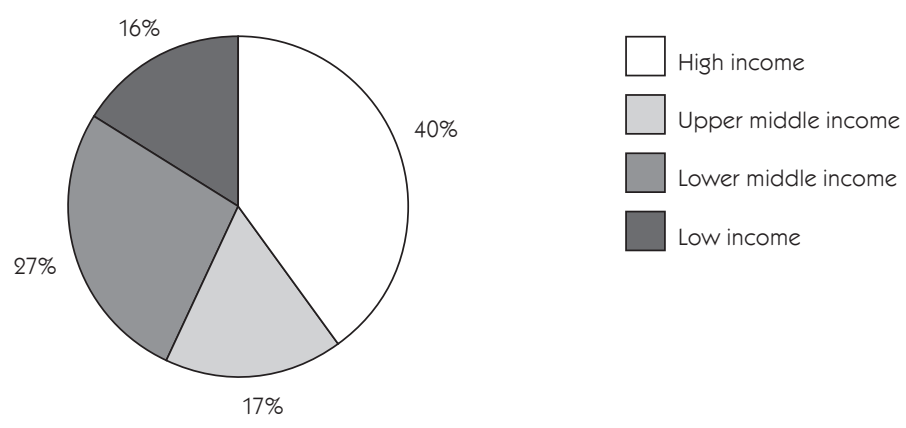

The size of delegations that WTO Members send to CAC sessions vary widely across income levels. Of the 427 delegates of WTO Members present at the regular session of the $\mathrm{CAC}$ in 2007, 40 percent were on the delegations of high-income Members, 17 percent were on delegations of upper-middle-income Members, 27 percent were on delegations of lower-middle-income Members and 16 percent were on delegations of low-income Members. ${ }^{186}$

\section{Graph 4: Codex Alimentarius Commission Thirtieth Session: Average Number of Delegates per WTO Member by Income Level, 2007}
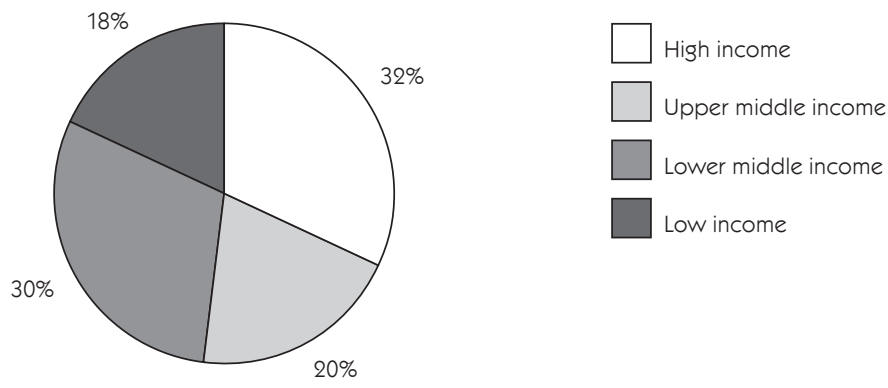

Examining the size of delegations against the number of WTO Members attending the meeting, it is possible to determine the average number of delegates per Member by income level. The average number of delegates per WTO Member represented at the 2007

${ }^{186}$ Of all the delegates of WTO Members attending the $30^{\text {th }}$ Session of the CAC, 171 were delegates of highincome Members, 27 were delegates of upper-middle-income Members, 115 were delegates of lower-middle-income Members (of which 22 were on the Chinese delegation), and 69 were delegates of low-income Members. Codex Alimentarius Commission, Report of the Thirtieth Session, ALINORM 07/30/REP (Joint FAO/WHO Food Standards Programme, Rome), 2 - 7 July 2007, Appendix I, available at: http://www.codexalimentarius.net/web/archives.jsp?year=07, visited on 8 February 2008. 
session of the CAC was 4.88 for high-income Members, 3.1 for upper-middle-income Members 4.6 for lower-middle-income Members, and 2.76 for low-income Members. ${ }^{187}$ The surprisingly high average number of delegates for lower-middle-income Members is partly due to the fact that China sent 22 delegates to this meeting. Without China, the average number of delegates sent by lower-middle-income Members to this meeting would be 3.87 .

Attendance of meetings cannot be equated with active participation. Not all WTO Members represented at the regular sessions of the CAC voice their views on the matters under discussion. It is therefore elucidating to examine the degree to which Members at different levels of development actually participate in the discussions at CAC sessions.

\section{Graph 5: Codex Alimentarius Commission: Participation of WTO Members by Income Level, 1999-2007}

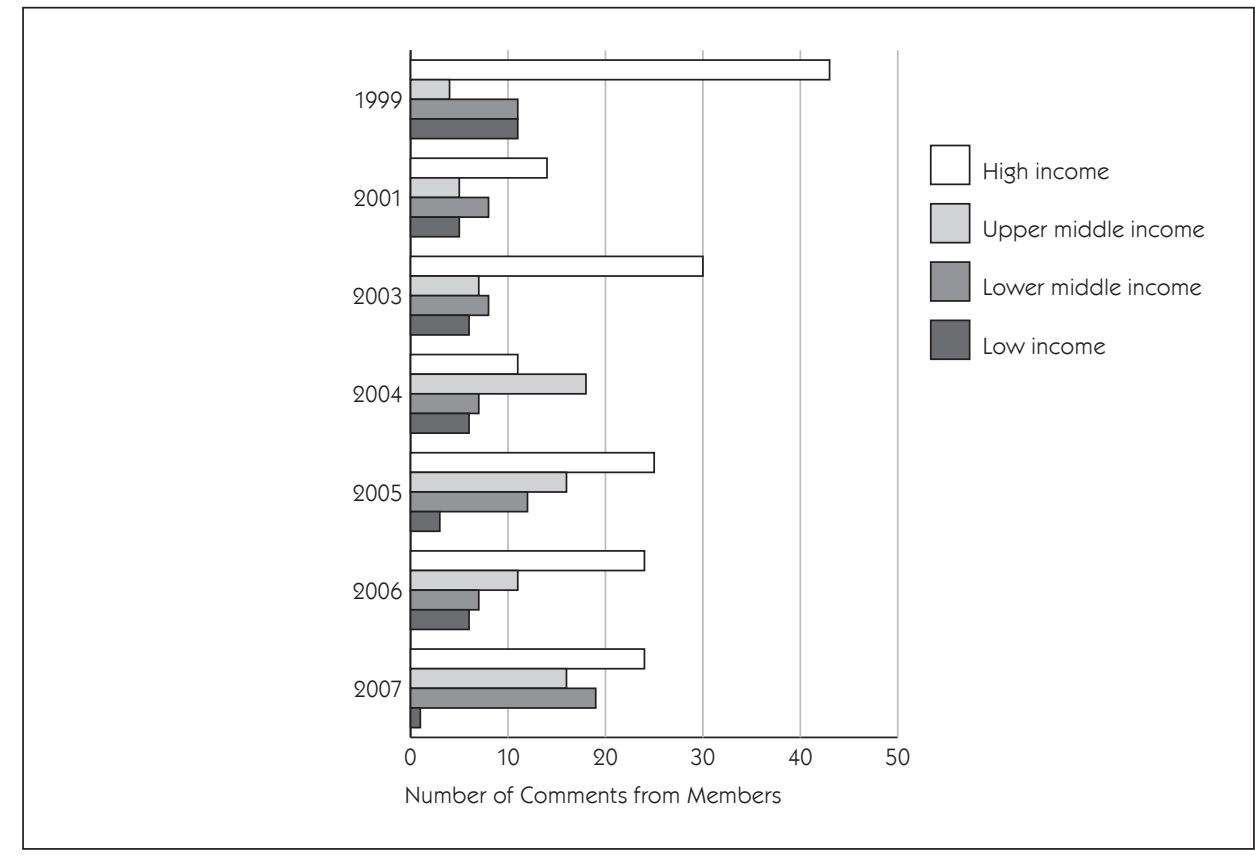

An examination of the comments made during CAC sessions from 1999 to 2007 shows that traditionally, high-income WTO Members have been more active participants than middle- and low-income Members. However, this situation has been improving over the years. In 2007 the participation by upper- and lower- middle income Members has almost equalled that of high-income Members. ${ }^{188}$ The participation by low-income Members is still poor.

${ }^{187}$ This calculation is made on the basis of the attendance list. Codex Alimentarius Commission, Report of the Thirtieth Session, ALINORM 07/30/REP (Joint FAO/WHO Food Standards Programme, Rome), 2 - 7 July 2007, Appendix I, available at: http://www.codexalimentarius.net/web/archives.jsp?year=07, visited on 8 February 2008.

188 Of course, bearing in mind that there are many more upper- and lower-middle income Members than 
As has become clear from the discussion of the standard-setting procedures in the CAC, participation in the regular sessions of the CAC is by far not enough to ensure effective input into the standard-setting process. Instead, much more influence can be exerted if a Member participates actively in the initial stages of the elaboration of a standard. The initial preparation of proposed draft standards is increasingly assigned to individual CAC members or working groups, most often composed of the members or observers that submitted the proposal to elaborate the relevant standard. These are largely developedcountry CAC members and industry associations. As noted by Diahanna Post:

Once a carefully tailored draft reaches the full committee for discussion, it is in theory open for discussion, but in fact the working group members are often extremely reluctant to reopen the debate on the draft. They argue that the draft reflects a well-thought-out consensus on the part of the working group members. In part this reflects the difficulty of trying to negotiate international standards by committee. But regardless of whether the intention is to exclude opinions, the result is that a handful of countries, usually those that can afford to devote staff time to drafting Codex standards in between committee meetings, dominate the framing of the standard. ${ }^{189}$

It is therefore elucidating to examine the origin of proposals for new standards and the assignment of the task of drafting proposed standards in more detail.

\section{Graph 6: Codex Alimentarius Commission: Participation in Drafting Groups for New Standards of WTO Members by Income Level, 2001-2007}

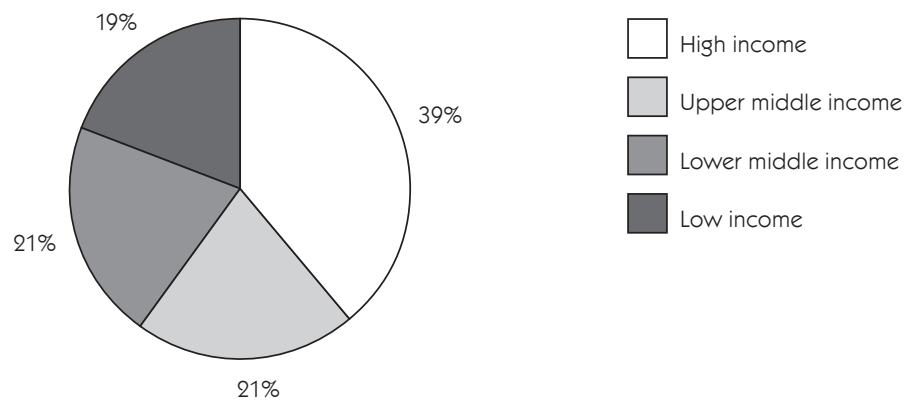

Between 2001 and 2007, an estimated 41 proposals for new standards within the framework of the Codex Alimentarius were presented by WTO Members. ${ }^{190}$ Of these propos-

high-income Members that are CAC members, this improvement does not mean translate to an almost equal level of participation in relative terms.

189 Diahanna L. Post, 'Standards and Regulatory Capitalism: The Diffusion of Food Safety Standards in Developing Countries', The ANNALS of the American Academy of Political and Social Science (598), 2005, 168-183, 171, available at: http://ann.sagepub.com/cgi/reprint/598/1/168, visited on 12 June 2008

190 The number of proposals for new standards has been calculated using the information provided in the documents referred to in the agendas of Codex Alimentarius Commission meetings, under the agenda item 'List of proposals for the elaboration of new Standards and Related Texts'. However, the agendas of the meetings 
als, 24 were proposed and prepared by WTO Members individually and 17 proposals were either proposed by one WTO Member and further developed and drafted by

held in 2003 and 2004 are not available on the CAC website. Therefore proposals that may have been made in those years are not taken into account in this calculation. To identify the WTO Members involved in proposing or drafting the proposed standards, regard was had to the various Codex committee documents referred to in the document containing the 'List of Proposals'. Among the CAC members to whom the initial drafting of the proposed standard has been assigned, the country that originally proposed the new standard is not always indicated in the relevant committee reports. It is therefore only possible to divide by income level the WTO Members that were involved in the group of countries assigned the task to draft the initial version of the standard. The documents used are the following: Codex Alimentarius Commission, Consideration of Codex Standards and Related Texts. Part III: Proposals to Elaborate New Standards and/or Related Texts, ALINORM 01/21, Part III (Joint FAO/WHO Food Standards Programme, Geneva), 2 - 7 July 2001, available at: ftp://ftp.fao.org/codex/ALINORM01/a10121ce.pdf, visited on 20 February 2008., Codex Committee on Food Hygiene, Report of the Thirty-Third Session, ALINORM 01/13A (Joint FAO/WHO Food Standards Programme, Washington), 23 - 28 October 2000, available at: http://www.codexalimentarius.net/web/archives.jsp?year=01, visited on 1 April 2008., Codex Committee on Food Import and Export Inspection and Certification Systems, Report of the Ninth Session, ALINORM 01/30A (Joint FAO/WHO Food Standards Programme, Perth), 11-15 December 2000, available at: http://www.codexalimentarius.net/web/archives. jsp?year=01, visited on 1 April 2008., Codex Committee on Processed Fruits and Vegetables, Report of the Twentieth Session, ALINORM 01/27 (Joint FAO/WHO Food Standards Programme, Washington), 1115 September 2000, available at: http://www.codexalimentarius.net/web/archives.jsp?year=01, visited on 2 April 2008., Codex Alimentarius Commission, List of Proposals for the Elaboration for the New Standards and the Related Texts and for the Discontinuation of Work, ALINORM 05/28/8 (Joint FAO/WHO Food Standards Programme, Rome), 4 - 9 July 2005, available at: ftp://ftp.fao.org/codex/cac/cac28/al28_08e. pdf, visited on 20 February 2008., FAO/WHO Coordinating Committee for Asia, Report of the Fourteenth Session, ALINORM 05/28/15 (Joint FAO/WHO Food Standards Programme, Jeju-Do), 7-10 September 2004, available at: http://www.codexalimentarius.net/web/archives.jsp?year=05, visited on 1 April 2008. Codex Ad Hoc Intergovernmental Task Force on Foods Derived from Biotechnology, Report of the Fifth Session, ALINORM 06/29/34 (Joint FAO/WHO Food Standards Programme, Chiba), 19-23 September 2005, available at: http:/www.codexalimentarius.net/web/archives.jsp?year=06, visited on 1 April 2008., Codex Committee on Fresh Fruits and Vegetables, Report of the Twelfth Session, ALINORM 05/28/35 (Joint FAO/ WHO Food Standards Programme, Mexico City), 16-20 May 2005, available at: http://www.codexalimentarius.net/web/archives.jsp?year=05, visited on 1 April 2008., Codex Committee on Fats and Oils, Report of the Nineteenth Session, ALINORM 05/28/17 (Joint FAO/WHO Standards Food Programme, London), 21-25 February 2005, available at: http://www.codexalimentarius.net/web/archives.jsp?year=05, visited on 1 April 2008., Codex Committee on Fish and Fishery Products, Report of the Seventy-Seventh Session, ALINORM 05/28/18 (Joint FAO/WHO Food Standards Programme, Cape Town), 28 February - 4 March 2005, available at: http://www.codexalimentarius.net/web/archives.jsp?year=05, visited on 1 April 2008., Codex Committee on Food Additives and Contaminants, Report of the Thirty-Seventh Session, ALINORM 05/28/12 (Joint FAO/WHO Food Standards Programme, The Hague), 25-29 April 2005, available at: http://www.codexalimentarius.net/web/archives.jsp?year=05, visited on 1 April 2008., Codex Alimentarius Commission, List of Proposals for the Elaboration of New Standards and Related Texts (Including Project Documents Submitted) and for the Discontinuation of Work, ALINORM 06/29/8 (Joint FAO/WHO Food Standards Programme, Geneva), 3 - 7 July 2006, available at: ftp://ftp.fao.org/codex/CAC/CAC29/al29 08e.pdf, visited on 20 February 2008., Codex Committee on Food Additives and Contaminants, Report of the Thirty-Eighth Session, ALINORM 06/29/12 (Joint FAO/WHO Food Standards Programme, The Hague), 24-28 April 2006, available at: http://www.codexalimentarius.net/web/archives.jsp?year=06, visited on 1 April 2008., Codex Committee on Food Labelling, Report of the Thirty-Fourth Session, ALINORM 06/29/22 (Joint FAO/WHO Food Standards Programme, Ottawa), 1-5 May 2006, available at: http://www.codexalimentarius.net/web/ archives.jsp?year=06, visited on 1 April 2008., Codex Committee on Methods of Analysis and Sampling, Report of the Twenty-Seventh Session, ALINORM 06/29/23 (Joint FAO/WHO Food Standards Programme, Budapest), 15-19 May 2006, available at: http://www.codexalimentarius.net/web/archives.jsp?year=06, visited on 1 April 2008., Codex Alimentarius Commission, List of Proposals for the Elaboration of New Standards and Related Texts (Including Project Documents Submitted) and for the Discontinuation of Work, ALINORM 07/30/8 (Joint FAO/WHO Food Standards Programme, Rome), 2 -7 July 2007, available at: ftp:// ftp.fao.org/codex/CAC/CAC30/al30_08e.pdf, visited on 20 February 2008. 
a group of Members or proposed and drafted by a group of Members. In total, 53 WTO Members participated in making proposals for new standards, either jointly or individually. ${ }^{191}$ Of these, 39 percent (21) were high-income WTO Members, 21 percent (11) were upper-middle-income WTO Members, 21 percent (11) were lower-middle-income WTO Members and 19 percent (10) were low-income WTO Members. ${ }^{192}$

\section{Graph 7: Codex Alimentarius Commission: Leadership of Drafting Group for New Standards of WTO Members by Income Level, 2001-2007}
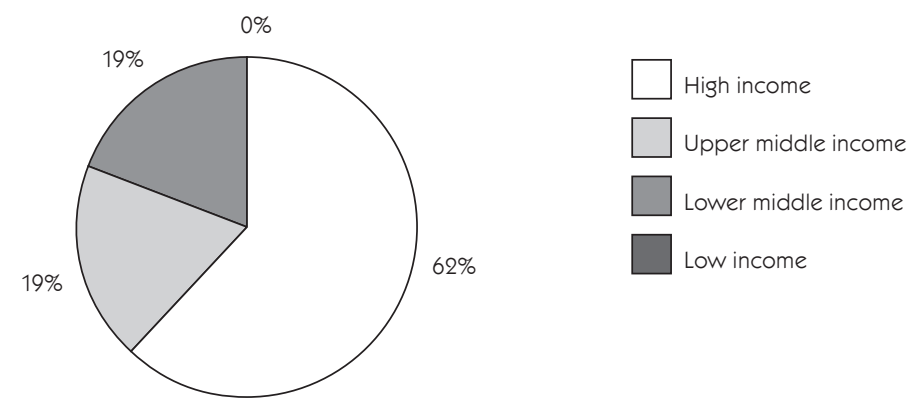

An analysis of the assignment of leadership of the group tasked with drafting the proposed standards between 2001 and 2007 shows that 62 percent of the proposed draft standards and have been drawn up under the authority of a high-income WTO Member. ${ }^{193}$ Uppermiddle-income and lower-middle-income WTO Members have each been assigned leadership roles in only 19 percent of the cases. ${ }^{194}$ No leadership roles have been assigned to

191 Several of these WTO Members participated in drafting more than one proposed standard. The only nonWTO Member that has participated in drafting groups for new standards in the period studied is Iran.

${ }^{192}$ WTO Members participating in the proposal and draft of new standards were: Angola, Argentina, Australia, Austria, Belgium, Brazil, Canada, Chile, China, Costa Rica, Cuba, Denmark, Egypt, the European Communities, Fiji, Finland, France, Gabon, The Gambia, Georgia, Germany, Ghana, India, Indonesia, Ireland, Italy, Jamaica, Japan, Kenya, the Republic of Korea, Madagascar, Malaysia, Mexico, Mongolia, The Netherlands, New Zealand, Norway, Pakistan, Panama, Philippines, Poland, South Africa, Spain, Sweden, Switzerland, Tanzania, Thailand, Tonga, Turkey, Uganda, the UK, the US and Vietnam.

${ }^{193}$ Masson-Matthee drew a similar conclusion from an examination of the assignment of the task of drafting in 2000 and 2002. Mariëlle Masson-Matthee, The Codex Alimentarius Commission and Its Standards, Doctoral Thesis, Maastricht University, Faculty of Law (T.M.C. Asser Press, Maastricht), 2007, 245.

194 This information has been drawn from the following documents: Codex Alimentarius Commission, Consideration of Codex Standards and Related Texts. Part III: Proposals to Elaborate New Standards and/or Related Texts, ALINORM 01/21, Part III (Joint FAO/WHO Food Standards Programme, Geneva), 2 - 7 July 2001, available at: ftp://ftp.fao.org/codex/ALINORM01/al0121ce.pdf, visited on 20 February 2008., Codex Committee on Food Hygiene, Report of the Thirty-Third Session, ALINORM 01/13A (Joint FAO/WHO Food Standards Programme, Washington), 23 - 28 October 2000, available at: http://www.codexalimentarius.net/ web/archives.jsp?year=01, visited on 1 April 2008., Codex Committee on Food Import and Export Inspection and Certification Systems, Report of the Ninth Session, ALINORM 01/30A (Joint FAO/WHO Food Standards Programme, Perth), 11-15 December 2000, available at: http://www.codexalimentarius.net/web/archives. jsp?year=01, visited on 1 April 2008., Codex Committee on Processed Fruits and Vegetables, Report of the Twentieth Session, ALINORM 01/27 (Joint FAO/WHO Food Standards Programme, Washington), 1115 September 2000, available at: http://www.codexalimentarius.net/web/archives.jsp?year=01, visited on 2 April 2008., Codex Alimentarius Commission, List of Proposals for the Elaboration for the New Standards 
low-income Members. In 1999, a recommendation was adopted by the CAC to appoint a developing-country member as co-author of position papers of which the main author is a developed-country CAC member. ${ }^{195}$ However, this recommendation does not seem to have been put into practice.

At the level of subsidiary committees, where the technical discussion on a draft proposed standard takes place and thus participation can be effective, participation of middle- and low-income Members has typically been low. ${ }^{196}$ This is problematic, since it is at these committees that risk management decisions are made, taking into account scientific evaluations of risk as well as policy considerations, to develop a particular standard which will be forwarded to the CAC. Value judgments and policy choices form an acknowl-

and the Related Texts and for the Discontinuation of Work, ALINORM 05/28/8 (Joint FAO/WHO Food Standards Programme, Rome), 4 - 9 July 2005, available at: ftp://ftp.fao.org/codex/cac/cac28/al28_08e. pdf, visited on 20 February 2008., FAO/WHO Coordinating Committee for Asia, Report of the Fourteenth Session, ALINORM 05/28/15 (Joint FAO/WHO Food Standards Programme, Jeju-Do), 7-10 September 2004, available at: http://www.codexalimentarius.net/web/archives.jsp?year=05, visited on 1 April 2008. Codex Ad Hoc Intergovernmental Task Force on Foods Derived from Biotechnology, Report of the Fifth Session, ALINORM 06/29/34 (Joint FAO/WHO Food Standards Programme, Chiba), 19-23 September 2005, available at: http:/www.codexalimentarius.net/web/archives.jsp?year=06, visited on 1 April 2008., Codex Committee on Fresh Fruits and Vegetables, Report of the Twelfth Session, ALINORM 05/28/35 (Joint FAO/ WHO Food Standards Programme, Mexico City), 16-20 May 2005, available at: http://www.codexalimentarius.net/web/archives.jsp?year=05, visited on 1 April 2008., Codex Committee on Fats and Oils, Report of the Nineteenth Session, ALINORM 05/28/17 (Joint FAO/WHO Standards Food Programme, London), 21-25 February 2005, available at: http://www.codexalimentarius.net/web/archives.jsp?year=05, visited on 1 April 2008., Codex Committee on Fish and Fishery Products, Report of the Seventy-Seventh Session, ALINORM 05/28/18 (Joint FAO/WHO Food Standards Programme, Cape Town), 28 February - 4 March 2005, available at: http://www.codexalimentarius.net/web/archives.jsp?year=05, visited on 1 April 2008., Codex Committee on Food Additives and Contaminants, Report of the Thirty-Seventh Session, ALINORM 05/28/12 (Joint FAO/WHO Food Standards Programme, The Hague), 25-29 April 2005, available at: http://www.codexalimentarius.net/web/archives.jsp?year=05, visited on 1 April 2008., Codex Alimentarius Commission, List of Proposals for the Elaboration of New Standards and Related Texts (Including Project Documents Submitted) and for the Discontinuation of Work, ALINORM 06/29/8 (Joint FAO/WHO Food Standards Programme, Geneva), 3 - 7 July 2006, available at: ftp://ftp.fao.org/codex/CAC/CAC29/al29_08e.pdf, visited on 20 February 2008., Codex Committee on Food Additives and Contaminants, Report of the Thirty-Eighth Session, ALINORM 06/29/12 (Joint FAO/WHO Food Standards Programme, The Hague), 24-28 April 2006, available at: http://www.codexalimentarius.net/web/archives.jsp?year=06, visited on 1 April 2008., Codex Committee on Food Labelling, Report of the Thirty-Fourth Session, ALINORM 06/29/22 (Joint FAO/WHO Food Standards Programme, Ottawa), 1-5 May 2006, available at: http://www.codexalimentarius.net/web/ archives.jsp?year=06, visited on 1 April 2008., Codex Committee on Methods of Analysis and Sampling, Report of the Twenty-Seventh Session, ALINORM 06/29/23 (Joint FAO/WHO Food Standards Programme, Budapest), 15-19 May 2006, available at: http://www.codexalimentarius.net/web/archives.jsp?year=06, visited on 1 April 2008., Codex Alimentarius Commission, List of Proposals for the Elaboration of New Standards and Related Texts (Including Project Documents Submitted) and for the Discontinuation of Work, ALINORM 07/30/8 (Joint FAO/WHO Food Standards Programme, Rome), 2 -7 July 2007, available at: ftp:// ftp.fao.org/codex/CAC/CAC30/al30_08e.pdf, visited on 20 February 2008.

195 Codex Alimentarius Commission, Report of the 23 $3^{\text {rd }}$ Session, 28 June-3 July 1989 (FAO/WHO, Rome) ALINORM 99/37, para. 56(f).

${ }^{196}$ In a very thorough study conducted in 1993 by the National Food Alliance, a UK non-governmental organisation, of participation in the $19^{\text {th }}$ session of the CAC, it was found that $55 \%$ of committee participants on national delegations came from Western Europe and North America, outnumbering the aggregate of participants from Africa, Asia, Latin America, Eastern and Central Europe, the South West Pacific and the Caribbean (see Natalie Avery et al., Cracking the Codex; an Analysis of Who Sets World Food Standards (National Food Alliance, London), 1993, 1. The situation today can be illustrated by an analysis of participation at the most recent meetings of the five currently active Codex Commodity Committees. 
edged and necessary part of risk management decisions. They result in the chosen levels of protection embodied in the standards elaborated in Codex committees and adopted by the CAC. On national level, risk management decisions are taken after balancing competing interests on national level and result in standards reflecting national preferences and economic realities. On the contrary, as explained above, ${ }^{197}$ risk management decisions on international level do not reflect truly global preferences. Instead, they are based on the preferences and policy choices of those members participating effectively in the relevant Codex committee.

Attendance of committee meetings is overwhelmingly by developed country Members. A 2007 study with regard to funding requests to attend Codex meetings has shown that where developing-country members wish to attend committee meetings, they tend to prioritise specific committees, particularly the General Subject committees where general principles are developed for use across commodities. ${ }^{198}$ The greatest attendance by members at lower levels of development is at meetings of the General Subject Committees on General Principles, Food Hygiene and Food Labelling. Some of these members also prioritise the General Subject committees in Pesticide Residues, Food Additives and Contaminants and Nutrition and Foods for Special Dietary Uses. This study notes that the priority given to the Committee on General Principles by developing-country members is difficult to understand, as it deals mainly with procedural questions. ${ }^{199}$

A look at attendance of the most recent meetings of the General Subject Committees by WTO Members is useful.

${ }^{197}$ With regard to the role of power in generating global public goods, see above, Part II, Section 1.2.

198 Stuart A. Slorach, Enquiry Concerning the FAO/WHO Project and Trust Fund for Enhanced Participation in Codex ("Codex Trust Fund") (Swedish International Development Cooperation Agency, Stockholm), 12 October 2007, available at: http://www.who.int/foodsafety/codex/Slorach_report.pdf, visited on 10 June 2008. This study evaluates the Codex Trust Fund for Enhanced Participation in Codex, and therefore focuses on requests for funding from this Trust Fund, submitted by Codex members who need support to attend Codex meetings.

199 Ibid., 12. The study speculates that reasons for the particular interest in attendance of the Committee on General Principles could be the fact that it provides the best opportunity to meet delegates from many other CAC members. In addition, the fact that recent meetings of this Committee have discussed the Codex Code of Ethics for Food Trade might have played a role, as this Code is important to developing-country members with poor import control systems which risk being used to dump low quality or unsafe food from developedcountry members. 
Graph 8: Codex General Subject Committees: Attendance by WTO Members by Income Level, 2007

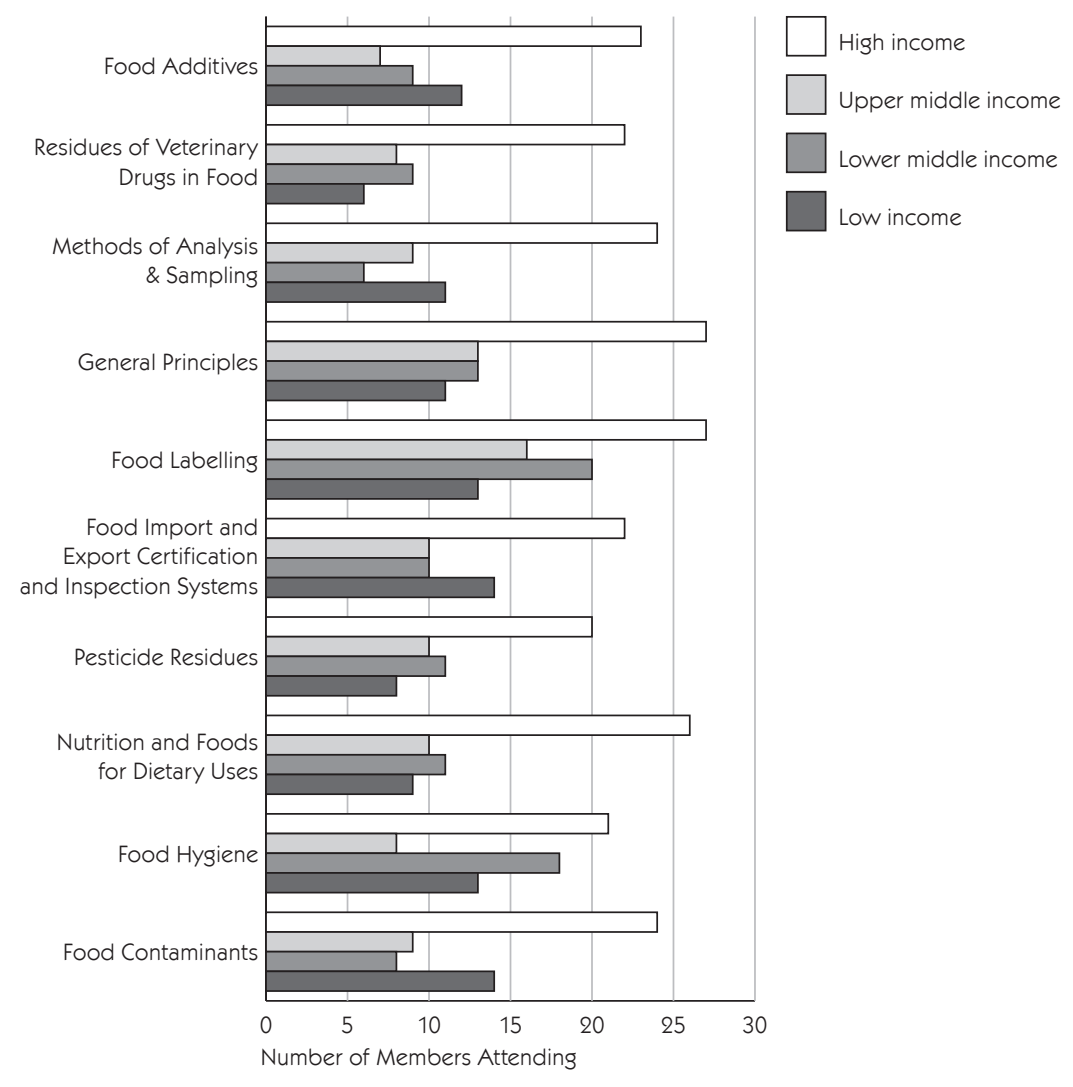

At these most recent meetings of the General Subject Committees, 42 percent of WTO Members attending were high-income Members. Upper-middle-income Members made up 18 percent and lower-middle-income Members 20 percent of the Members attending. Low-income Members made up another 20 percent of the Members attending. ${ }^{200}$ Greatest

200 These figures were drawn from an examination of the lists of participants at the most recent Codex General Subject Committee meetings as of 8 February 2008. At the $39^{\text {th }}$ Session of the Codex Committee on Food Additives held on 24-28 April 2007, 23 high-income, 7 upper-middle-income, 9 lower-middle-income and 12 low-income WTO Members were present. Codex Committee on Food Additives, Report of the Thirty-Ninth Session, ALINORM 07/30/12 Rev. (Joint FAO/WHO Food Standards Programme, Beijing), 24-28 April 2007, available at: http://www.codexalimentarius.net/web/archives.jsp?year=07, visited on 8 February 2008. At the $17^{\text {th }}$ Session of the Codex Committee on Residues of Veterinary Drugs in Food held on 3-7 September 2007, 22 high-income, 8 upper-middle-income, 9 lower-middle-income and 6 low-income WTO Members were present. Codex Committee on Residues of Veterinary Drugs in Foods, Report of the Seventeenth Session, ALINORM 08/31/31 (Joint FAO/WHO Food Standards Programme, Breckenridge, Colorado), 3-7 September 2007, available at: http://www.codexalimentarius.net/web/archives.jsp?year=08, visited on 8 February 2008. At the $27^{\text {th }}$ Session of the Codex Committee on Methods of Analysis and Sampling held on 5-9 March 2007, 24 high-income, 9 upper-middle-income, 6 lower-middle-income and 11 low-income WTO 
attendance by non-high-income Members was at the Committees on Food Labelling, Food Hygiene and General Principles.

The 2007 study mentioned above notes that there is relatively little interest by developing-country members in attendance of Commodity Committee meetings where standards for specific commodities are developed. An exception to this is the Committee on Fish and Fishery Products. ${ }^{201}$ The current situation is illustrated by an examination of participation by WTO Members at the most recent meeting of each of the Codex Commodity Committees.

Members were present. Codex Committee on Methods of Analysis and Sampling, Report of the TwentyEighth Session, ALINORM 07/30/23 (Joint FAO/WHO Food Standards Programme, Budapest), 5-9 March 2007, available at: http://www.codexalimentarius.net/web/archives.jsp?year=07, visited on 8 February 2008. At the 24 ${ }^{\text {th }}$ Session of the Codex Committee on General Principles held on 2 -6 April 2007, 27 high-income, 13 upper-middle-income, 13 lower-middle-income and 11 low-income WTO Members were present. Codex Committee on General Principles, Report of the Twenty-Fourth Session, ALINORM 07/30/33 (Joint FAO/WHO Food Standards Programme, Paris), 2-6 April 2007, available at: http://www.codexalimentarius. net/web/archives.jsp?year $=07$, visited on 8 February 2008. At the $39^{\text {th }}$ Session of the Codex Committee on Pesticide Residues held on 7- 12 May 2007, 20 high-income, 10 upper-middle-income, 11 lower-middleincome and 8 low-income WTO Members were present. Codex Committee on Pesticide Residues, Report of the Thirty-Ninth Session, ALINORM 07/30/24 - Rev. 1 (Joint FAO/WHO Food Standards Programme, Beijing), 7 - 12 May 2007, available at: http://www.codexalimentarius.net/web/archives.jsp?year=07, visited on 8 February 2008. At the $16^{\text {th }}$ Session of the Codex Committee on Food Import and Export Inspection and Certification Systems, held on 26 - 30 November 2007, 22 high-income, 10 upper-middle-income, 10 lower-middle-income and 14 low-income WTO Members were present. Codex Committee on Food Import and Export Inspection and Certification Systems, Report of the Sixteenth Session ALINORM 08/31/30 (Joint FAO/WHO Food Standards Programme, Surfers Paradise, Queensland), 26 -30 November 2007, available at: http://www.codexalimentarius.net/web/archives.jsp?year $=08$, visited on 8 February 2008. At the $39^{\text {th }}$ Session of the Codex Committee on Food Hygiene, held on 30 October - 4 November 2007, 21 high-income, 8 upper-middle-income, 18 lower-middle-income and 13 low-income WTO Members were present. Codex Committee on Food Hygiene, Report of the Thirty-Ninth Session, ALINORM 08/31/13 (Joint FAO/WHO Food Standards Programme, New Delhi), 30 October - 4 November 2007, available at: http://www.codexalimentarius.net/web/archives.jsp?year $=08$, visited on 8 February 2008. At the $29^{\text {th }}$ Session of the Codex Committee on Nutrition and Foods for Special Dietary Uses, held on 12- 16 November 2007, 26 high-income, 10 upper-middle-income, 11 lower-middle-income and 9 low-income WTO Members attended. Codex Committee on Nutrition and Foods for Special Dietary Uses, Report of the Twenty-Ninth Session, ALINORM 08/31/26 (Joint FAO/WHO Food Standards Programme, Bad Neuenahr-Ahrweiler), 12 - 16 November 2007, available at: http://www.codexalimentarius.net/web/archives.jsp?year=08, visited on 8 February 2008. At the $35^{\text {th }}$ Session of the Codex Committee on Food Labelling, held on 30 April - 4 May 2007, 27 high-income, 16 upper-middle-income, 20 lower-middle-income and 13 low-income WTO Members were present. Codex Committee on Food Labelling, Report of the Thirty-Fifth Session, ALINORM 07/30/22 (Joint FAO/WHO Food Standards Programme, Ottawa), 30 April-4 May 2007, available at: http://www.codexalimentarius. net/web/archives.jsp?year=07, visited on 8 February 2008. At the $1^{\text {st }}$ Session of the Codex Committee on Contaminants in Food, held on 16-20 April 2007, 24 high-income, 9 upper-middle-income, 8 lower-middleincome and 14 low-income WTO Members were present. Codex Committee on Contaminants in Foods, Report of the First Session, ALINORM 07/30/41 (Joint FAO/WHO Food Standards Programme, Beijing), 16-20 April 2007, available at: http://www.codexalimentarius.net/web/archives.jsp?year=07, visited on 8 February 2008.

${ }^{201}$ Stuart A. Slorach, Enquiry Concerning the FAO/WHO Project and Trust Fund for Enhanced Participation in Codex ("Codex Trust Fund") (Swedish International Development Cooperation Agency, Stockholm), 12 October 2007, 12, available at: http://www.who.int/foodsafety/codex/Slorach_report.pdf, visited on 10 June 2008. 


\section{Graph 9: Codex Commodity Committees: Attendance by WTO Members by Income Level, 2006-2007}

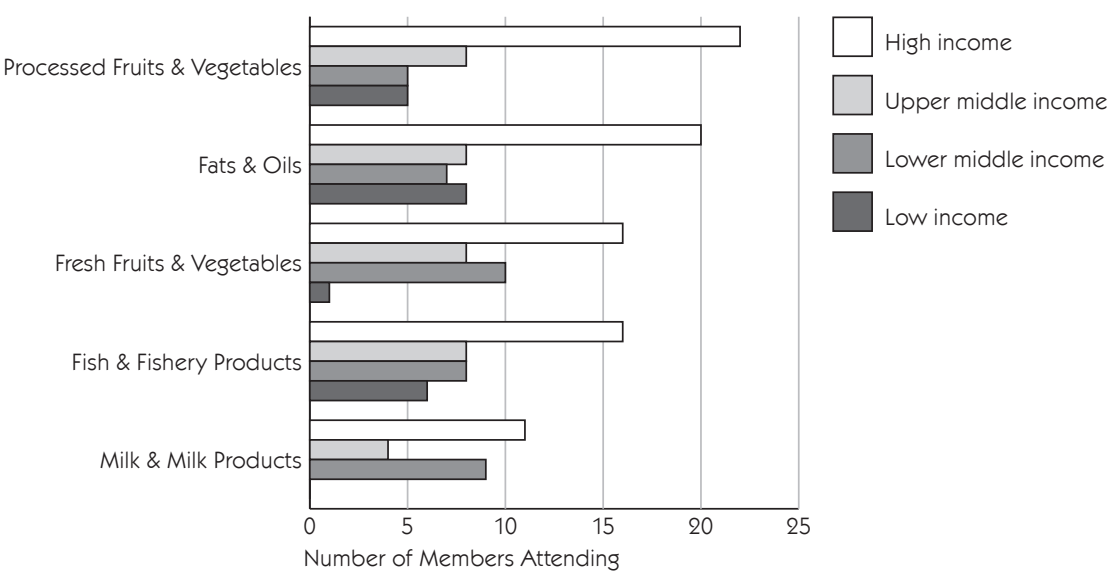

Although middle- and low-income WTO Members make up 71.7 percent of the membership of the CAC, only 52.8 percent of the Members represented at the Commodity Committee meetings were middle- and low-income Members. ${ }^{202}$ By contrast, high-income Members accounted for 47.2 percent of WTO Members represented at the Commodity Committee meetings. ${ }^{203}$ The greatest attendance of non-high-income Members was at the

202 Of the middle- and low-income WTO Members attending Commodity Committee meetings, 20\% were upper-middle-income Members, 21,7\% were lower-middle-income Members and 11,1\% were lower-income country Members.

${ }^{203}$ These figures were drawn from an examination of the lists of participants at the most recent Codex Commodity Committee meetings as of 8 February 2007. Participation of Members at different income levels varies at the different Commodity Committees depending on the importance of the commodity, and the standards on the agenda, for the trade of the countries involved. At the $7^{\text {th }}$ Session of the Codex Committee on Milk and Milk Products, held on 27 March - 1 April 2006, 22 high-income, 8 upper-middle-income, 5 lower-middleincome and 5 low-income WTO Members attended. Codex Committee on Milk and Milk Products, Report of the Seventh Session, ALINORM 06/29/11 (Joint FAO/WHO Food Standards Programme, Queenstown), 27 March-1 April 2006, available at: http://www.codexalimentarius.net/web/archives.jsp?year=06, visited on 8 February 2008.. At the $28^{\text {th }}$ Session of the Codex Committee on Fish and Fishery Products held on $18-22$ September 2006, 20 high-income, 8 upper-middle-income, 7 lower-middle-income and 8 low-income WTO Members were represented. Codex Committee on Fish and Fishery Products, Report of the Twenty-Eighth Session, ALINORM 07/30/18 (Joint FAO/WHO Food Standards Programme, Beijing), 18 - 20 September 2006, available at: http://www.codexalimentarius.net/web/archives.jsp?year=07, visited on 8 February 2008. At the $12^{\text {th }}$ Session of the Codex Committee on Fresh Fruits and Vegetables held on 25 -29 September 2006, 16 high-income, 8 upper-middle-income, 10 lower-middle-income and 1 low-income WTO Members were represented. Codex Committee on Fresh Fruits and Vegetables, Report of the Thirteenth Session, ALINORM 07/30/35 (Joint FAO/WHO Foods Standards Programme, Mexico City), 25-29 September 2006, available at: http:/www.codexalimentarius.net/web/archives.jsp?year=07, visited on 8 February 2008. At the $19^{\text {th }}$ Session of the Codex Committee on Fats and Oils, held on 19-23 February 2007, 16 high-income, 8 upper-middle-income, 8 lower-middle-income and 6 low-income WTO Members were represented. Codex Committee on Fats and Oils, Report of the Twentieth Session, ALINORM 07/30/17 (Joint FAO/WHO Food Standards Programme, London), 19-23 February 2007, available at: http://www.codexalimentarius.net/web/ archives.jsp?year $=07$, visited on 8 February 2008. Finally, at the $23^{\text {rd }}$ Session of the Codex Committee on Processed Fruits and Vegetables, held on 16-21 October 2006, 11 high-income, 4 upper-middle-income, 9 
Committee on Fish and Fishery Products. While a correlation between the Codex meetings attended and the food trade interests of members has been identified, this is not the case for all members. The correlation is the strongest in those members who rely on food exports for their economic development. ${ }^{204}$

The size and make-up of national delegations sent to Codex meetings deserves further attention. Member governments may send delegations of any size to Codex meetings, ${ }^{205}$ but only one member of a delegation is designated the 'official delegate' and has the sole right to vote. ${ }^{206}$ The rest of the delegation acts as advisors to the official delegate..$^{207}$ National delegations of WTO Members that are at higher levels of development are typically large and include a significant number of representatives from the agricultural, food and pharmaceutical sectors, as well as a few consumer and food-safety interest groups. ${ }^{208}$ Thus the positions taken by the official delegate of these Members within the CAC are well-informed with regard to their industry interests and can therefore effectively promote these interests in the standard-setting process.

lower-middle-income and 0 low-income WTO Members were represented. Codex Committee on Processed Fruits and Vegetables, Report of the Twenty-Third Session, ALINORM 07/30/27 (Joint FAO/WHO Food Standards Programme, Arlington, Washington D.C.), 16-21 October 2006, available at: http://www.codexalimentarius.net/web/archives.jsp?year=07, visited on 8 February 2008.

${ }^{204}$ Stuart A. Slorach, Enquiry Concerning the FAO/WHO Project and Trust Fund for Enhanced Participation in Codex ("Codex Trust Fund") (Swedish International Development Cooperation Agency, Stockholm), 12 October 2007, 17-18, available at: http:/www.who.int/foodsafety/codex/Slorach_report.pdf, visited on 10 June 2008.

205 The membership of these delegations is not restricted and can consist of government officials, academics, and representatives of corporations, industry groups, consumer organisations or professional organisations.

206 Rule VI of the Rules of Procedure. Codex Alimentarius Commission, Procedural Manual, Seventeenth Edition (Joint FAO/WHO Food Standards Programme, Rome), 2007, 10-11, available at: ftp://ftp.fao.org/ codex/Publications/ProcManuals/Manual 17e.pdf, visited on 21 February 2008.

207 Natalie Avery et al., Cracking the Codex; an Analysis of Who Sets World Food Standards (National Food Alliance, London), 1993, 7.

${ }^{208}$ Ibid., 10. The National Food Alliance study of the $19^{\text {th }}$ session of the CAC revealed that of the 2019 persons participating in government delegations, 445 represented industry and only 8 represented public interest groups. Further, the top food companies, such as Nestle and Philip Morris and top agrochemical corporations, such as Monsanto and Bayer, "sent more representatives to Codex meetings than any nation sent government representatives." Natalie Avery et al., Cracking the Codex; an Analysis of Who Sets World Food Standards (National Food Alliance, London), 1993, 17. 
Graph 10: Codex General Subject Committees: Attendance by WTO Members by Income Level, 2007

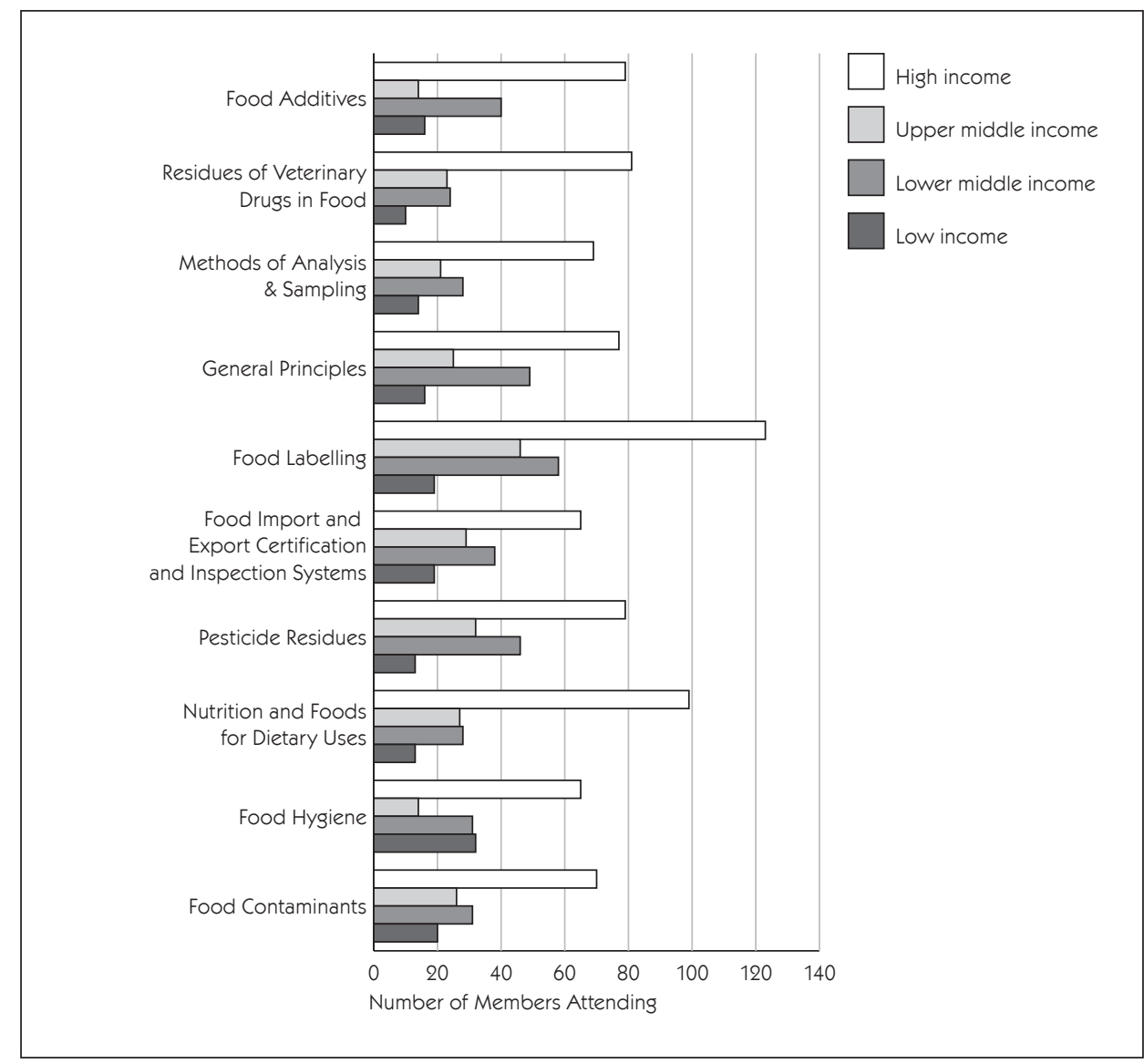

At the most recent General Subject Committees, 50 percent of the delegates attending the meetings were representatives of high-income Members, 16 percent of upper-middle-income Members, 23 percent of lower-middle-income Members and 11 percent of low-income Members. ${ }^{209}$ Most delegates of non-high-income Members attended the Committee

${ }^{209}$ At the $39^{\text {th }}$ Session of the Codex Committee on Food Additives held on 24-28 April 2007, of the 149 delegates of WTO Members attending the meeting, 53\% (79) were on high-income Members' delegations, 9,4\% (14) were on upper-middle-income Members' delegations, 26,8\% (40) were on lower-middle income Members' delegations (of which 35\% (14) were delegates of China) and 10,7\% (16) were on low-income Members' delegations. Codex Committee on Food Additives, Report of the Thirty-Ninth Session, ALINORM 07/30/12 Rev. (Joint FAO/WHO Food Standards Programme, Beijing), 24-28 April 2007, available at: http:// www.codexalimentarius.net/web/archives.jsp?year=07, visited on 8 February 2008. At the $17^{\text {th }}$ Session of the Codex Committee on Residues of Veterinary Drugs in Food held on 3-7 September 2007, of the 138 delegates of WTO Members attending the meeting 58,7\% (81) were on high-income Members' delegations, $16,7 \%$ (23) were on upper-middle-income Members' delegations, 17,4\% (24) were on lower-middle income Members' delegations and 7,2\% (10) were on low-income Members' delegations. Codex Committee on Residues of Veterinary Drugs in Foods, Report of the Seventeenth Session, ALINORM 08/31/31 (Joint FAO/ WHO Food Standards Programme, Breckenridge, Colorado), 3-7 September 2007, available at: http://www. 
on Food Labelling, followed by the Committee on Pesticide residues and the Committee on General Principles.

codexalimentarius.net/web/archives.jsp?year=08, visited on 8 February 2008. At the $27^{\text {th }}$ Session of the Codex Committee on Methods of Analysis and Sampling held on 5-9 March 2007, of the 132 delegates of WTO Members attending the meeting, 52,3\% (69) were on high-income Members' delegations, 15,9\% (21) were on upper-middle-income Members' delegations, 21,2\% (28) were on lower-middle income Members' delegations and 10,6\% (14) were on low-income Members' delegations. Codex Committee on Methods of Analysis and Sampling, Report of the Twenty-Eighth Session, ALINORM 07/30/23 (Joint FAO/WHO Food Standards Programme, Budapest), 5-9 March 2007, available at: http://www.codexalimentarius.net/web/archives. jsp?year $=07$, visited on 8 February 2008. At the $24^{\text {th }}$ Session of the Codex Committee on General Principles held on 2 -6 April 2007, of the 167 delegates of WTO Members, attending the meeting, 46,1,3\% (77) were on high-income Members' delegations, 15\% (25) were on upper-middle-income Members' delegations, 29,3\% (49) were on lower-middle income Members' delegations and 9,6\% (16) were on low-income Members' delegations. Codex Committee on General Principles, Report of the Twenty-Fourth Session, ALINORM 07/30/33 (Joint FAO/WHO Food Standards Programme, Paris), 2-6 April 2007, available at: http://www.codexalimentarius.net/web/archives.jsp?year=07, visited on 8 February 2008. At the $39^{\text {th }}$ Session of the Codex Committee on Pesticide Residues held on 7- 12 May 2007, of the 170 delegates of WTO Members present, 46,5\% (79) were on high-income Members' delegations, 18,8\% (32) were on upper-middle-income Members' delegations, 27,1\% (46) were on lower-middle income Members' delegations and 7,6\% (13) were on lowincome Members' delegations. Codex Committee on Pesticide Residues, Report of the Thirty-Ninth Session, ALINORM 07/30/24 - Rev. 1 (Joint FAO/WHO Food Standards Programme, Beijing), 7 - 12 May 2007, available at: http://www.codexalimentarius.net/web/archives.jsp?year=07, visited on 8 February 2008. At the $16^{\text {th }}$ Session of the Codex Committee on Food Import and Export Inspection and Certification Systems, held on 26 - 30 November 2007, of the 154 delegates of WTO Members present, 44,2\% (68) were on high-income Members' delegations, 18,8\% (29) were on upper-middle-income Members' delegations, 24,7\% (38) were on lower-middle income Members' delegations and 12,3\% (19) were on low-income Members' delegations. Codex Committee on Food Import and Export Inspection and Certification Systems, Report of the Sixteenth Session ALINORM 08/31/30 (Joint FAO/WHO Food Standards Programme, Surfers Paradise, Queensland), 26 -30 November 2007, available at: http://www.codexalimentarius.net/web/archives.jsp?year=08, visited on 8 February 2008. At the $39^{\text {th }}$ Session of the Codex Committee on Food Hygiene, held on 30 October -4 November 2007, of the 142 delegates of WTO Members present 45,8\% (65) were on high-income Members' delegations, 9,9\% (14) were on upper-middle-income Members' delegations, 21,8\% (31) were on lowermiddle income Members' delegations and 22,5\% (32) were on low-income Members' delegations. Codex Committee on Food Hygiene, Report of the Thirty-Ninth Session, ALINORM 08/31/13 (Joint FAO/WHO Food Standards Programme, New Delhi), 30 October - 4 November 2007, available at: http://www.codexalimentarius.net/web/archives.jsp?year=08, visited on 8 February 2008 . At the $29^{\text {th }}$ Session of the Codex Committee on Nutrition and Foods for Special Dietary Uses, held on 12- 16 November 2007, of the 167 delegates of WTO Members present 59,3\% (99) were on high-income Members' delegations, 16,2\% (27) were on upper-middle-income Members' delegations, $16,8 \%$ (28) were on lower-middle income Members' delegations and 7,8\% (13) were on low-income Members' delegations. Codex Committee on Nutrition and Foods for Special Dietary Uses, Report of the Twenty-Ninth Session, ALINORM 08/31/26 (Joint FAO/ WHO Food Standards Programme, Bad Neuenahr-Ahrweiler), 12 - 16 November 2007, available at: http:// www.codexalimentarius.net/web/archives.jsp?year $=08$, visited on 8 February 2008. At the $35^{\text {th }}$ Session of the Codex Committee on Food Labelling, held on 30 April - 4 May 2007, of the 246 delegates of WTO Members present, 50\% (123) were on high-income Members' delegations, 18,7\% (46) were on upper-middleincome Members' delegations, 23,6\% (58) were on lower-middle income Members' delegations and 7,7\% (19) were on low-income Members' delegations. Codex Committee on Food Labelling, Report of the ThirtyFifth Session, ALINORM 07/30/22 (Joint FAO/WHO Food Standards Programme, Ottawa), 30 April-4 May 2007, available at: http://www.codexalimentarius.net/web/archives.jsp?year=07, visited on 8 February 2008. At the $1^{\text {st }}$ Session of the Codex Committee on Contaminants in Food, held on 16 - 20 April 2007, of the 147 delegates of WTO Members present, 47,6\% (70) were on high-income Members' delegations, 17,7\% (26) were on upper-middle-income Members' delegations, 21,1\% (31) were on lower-middle income Members' delegations and 13,6\% (20) were on low-income Members' delegations. Codex Committee on Contaminants in Foods, Report of the First Session, ALINORM 07/30/41 (Joint FAO/WHO Food Standards Programme, Beijing), 16-20 April 2007, available at: http://www.codexalimentarius.net/web/archives.jsp?year=07, visited on 8 February 2008. 


\section{Graph 11: Codex Commodity Committees: Attendance by Delegates of WTO Members by Income Level, 2006-2007}

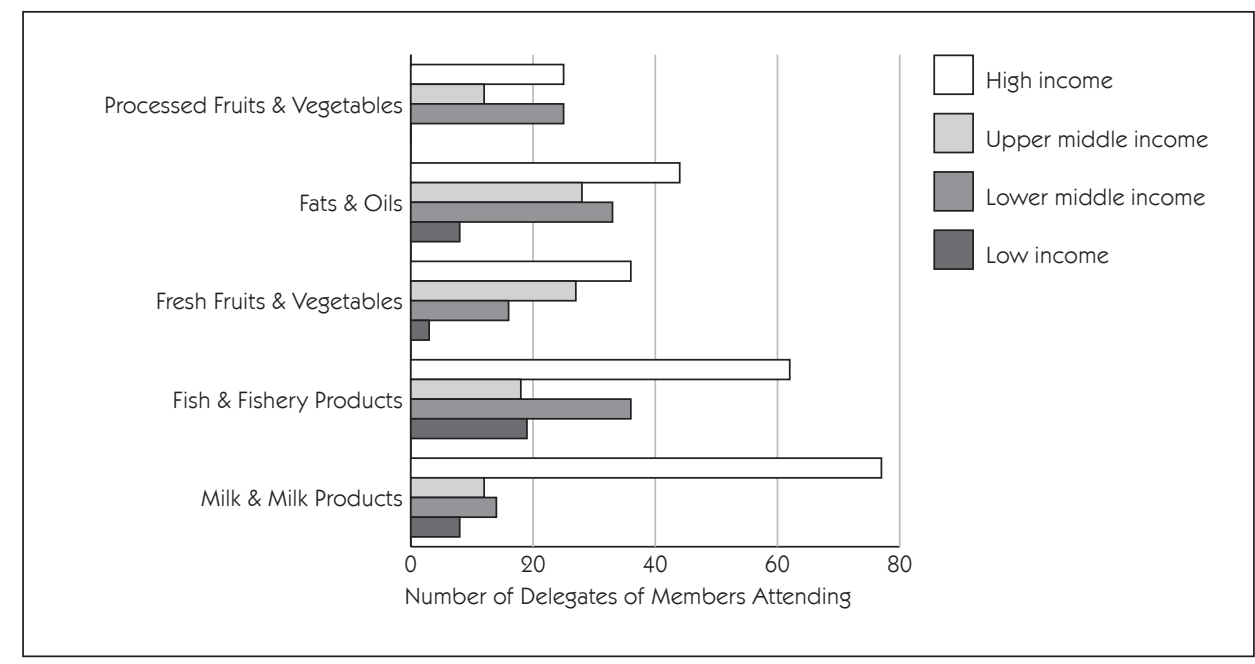

At the most recent Codex Commodity Committee meetings, the delegates of high-income Members accounted for 49 percent of the delegates of WTO Members attending. The delegates of upper-middle-income Members and lower-middle income Members made up only 19 percent and 25 percent, respectively, of the delegates of WTO Members at these meetings. The remaining 7 percent were delegates from low-income Members. Most non-high-income WTO Member delegates attended the Committee on Fish and Fishery Products. ${ }^{210}$

210 This data is drawn from the lists of participants at the most recent Codex Commodity Committee meetings as of 8 February 2007. Of the total of 111 delegates of WTO Members that attended the 7th Session of the Codex Committee on Milk and Milk Products, held on 27 March - 1 April 2006, 69,4\% (77) were on high-income Members' delegations, $10,8 \%$ (12) on upper-middle-income Members' delegations, 12,6\% (14) on lower-middle-income Members' delegations and 7,2\% (8) on low-income Members' delegations. Codex Committee on Milk and Milk Products, Report of the Seventh Session, ALINORM 06/29/11 (Joint FAO/WHO Food Standards Programme, Queenstown), 27 March-1 April 2006, available at: http://www. codexalimentarius.net/web/archives.jsp?year=06, visited on 8 February 2008. Of the total of 135 delegates at the 28th Session of the Codex Committee on Fish and Fishery Products held on 18- 22 September 2006, $45,9 \%$ (62) were on the delegations of high-income Members, 13,3\% (18) on delegations of upper-middleincome Members, 26,7\% (36) on delegations of lower-middle-income Members delegations, and 14,1\% (19) on delegations of low-income Members. Codex Committee on Fish and Fishery Products, Report of the Twenty-Eighth Session, ALINORM 07/30/18 (Joint FAO/WHO Food Standards Programme, Beijing), 18 20 September 2006, available at: http:/www.codexalimentarius.net/web/archives.jsp?year=07, visited on 8 February 2008. Of the 82 delegates of WTO Members present at the 12th Session of the Codex Committee on Fresh Fruits and Vegetables held on 25 -29 September 2006, 43,9\% (36) were on the delegations of highincome Members, 32,6\% (27) were on the delegations of upper-middle-income Members, 19,5\% (16) were on the delegations of lower-middle-income Members and 3,7\% (3) were on the delegations of low-income Members. Codex Committee on Fresh Fruits and Vegetables, Report of the Thirteenth Session, ALINORM 07/30/35 (Joint FAO/WHO Foods Standards Programme, Mexico City), 25-29 September 2006, available at: http://www.codexalimentarius.net/web/archives.jsp?year=07, visited on 8 February 2008. Of the 113 delegates of WTO Members present at the 19th Session of the Codex Committee on Fats and Oils, held on 19-23 February 2007, 38,9\% (44) were on the delegations of high-income Members, 24,8\% (28) were on the delegations of upper-middle-income Members, 29,2\% (33) were on the delegations of lower-middle-income 
One reason for the limited attendance of Codex subsidiary committee meetings by Members at lower levels of development is the fact that committee meetings are most often held in the country that is the host of that committee. Since the host country bears the costs and carries the administrative tasks corresponding to the committees work, hosts tend to be developed country members of the CAC. A proposal was made in 2001, to introduce a system of co-hosting committees by pairing developed and developing countries as hosts. ${ }^{211}$ This proposal has not been adopted, but instead the Procedural Manual has been amended by the addition of the hortatory statement that the host country 'should consider arrangements for holding Codex sessions in developing countries. ${ }^{212}$ The advantage of doing so is that while the developed country host member bears the costs of the committee meeting, the location of the meeting is moved to a developing country thereby facilitating participation by other developing country members in that region. ${ }^{213}$ In addition, by providing the developing country member involved with hands-on experience in hosting a committee meeting, capacity is built in that member, which facilitates its more active participation in future committee meetings. To date six host countries (The Netherlands, the US, Canada, Norway, Australia and Germany) have held committee meetings in developing countries, with respect to sixteen sessions of nine committees, some of which took place before the amendment. ${ }^{214}$ This initiative is likely to have

Members and 7,1\% (8) were on the delegations of low-income Members. Codex Committee on Fats and Oils, Report of the Twentieth Session, ALINORM 07/30/17 (Joint FAO/WHO Food Standards Programme, London), 19-23 February 2007, available at: http://www.codexalimentarius.net/web/archives.jsp?year=07, visited on 8 February 2008. Finally, of the 62 delegates of WTO Members present at the 23rd Session of the Codex Committee on Processed Fruits and Vegetables, held on 16 - 21 October 2006, 40,3\% (25) were on the delegations of high-income Members, 19,4\% (12) were on the delegations of upper-middle-income Members, 40,3\% (25) were on the delegations of lower-middle-income Members and logically none were on the delegations of low-income Members. Codex Committee on Processed Fruits and Vegetables, Report of the Twenty-Third Session, ALINORM 07/30/27 (Joint FAO/WHO Food Standards Programme, Arlington, Washington D.C.), 16-21 October 2006, available at: http://www.codexalimentarius.net/web/archives. jsp?year=07, visited on 8 February 2008.

211 This proposal was made at the $24^{\text {th }}$ Session of the CAC. Codex Alimentarius Commission, Report of the Twenty-Fourth Session, ALINORM 01/41 (Joint FAO/WHO Food Standards Programme, Geneva), 2-7 July 2001, para. 63 .

212 See the Guidelines to Host Governments of Codex Committees and Ad Hoc Intergovernmental Task Forces in Joint FAO/WHO Food Standards Programme, Codex Alimentarius Commission: Procedural Manual (Food and Agriculture Organization and World Health Organization, Rome), 2006, 49, available at: ftp://ftp.fao.org/ codex/Publications/ProcManuals/Manual 16e.pdf, visited on 21 February 2008.

${ }^{213}$ However, participation by developing countries from other regions is made more difficult by this arrangement due to the weaker transportation infrastructure that reduces accessibility. Mariëlle Masson-Matthee, The Codex Alimentarius Commission and Its Standards, Doctoral Thesis, Maastricht University, Faculty of Law (T.M.C. Asser Press, Maastricht), 2007, 246.

214 The Netherlands held the $28^{\text {th }}$ session of the Codex Committee on Food Additives and Contaminants in Manila, the Philippines, in 1996, its $32^{\text {nd }}$ session in Beijing, China in 2000, and its $35^{\text {th }}$ session in Arusha, Tanzania in 2003. In 2007, after this committee had been split into the Codex Committee on Food Additives (hosted by China) and the Codex Committee on Contaminants in Food (hosted by the Netherlands), the Netherlands held the 1st session of the latter committee in Beijing, China. The Netherlands, which hosted the Codex Committee on Pesticide Residues until China became the host in 2005, held the $25^{\text {th }}$ session of this committee in Havana, Cuba in 1993, the $36^{\text {th }}$ session of this committee in New Delhi, India in 2004 and the $38^{\text {th }}$ in Fortaleza, Brazil in 2006. The US has held the $34^{\text {th }}$ session of the Codex Committee on Food Hygiene in Bangkok, Thailand in 2001, its $37^{\text {th }}$ session in Buenos Aires, Argentina, in 2005 and its $39^{\text {th }}$ Session in New Delhi, India in 2007. In 1996, the US held the $10^{\text {th }}$ session of the Codex Committee on Residues of Veterinary Drugs in Foods in San Jose, Costa Rica and its $16^{\text {th }}$ Session in Cancún, Mexico in 2006. Canada held the $33^{\text {rd }}$ session of the Codex Committee on Food Labelling in Kota Kinabalu, Malaysia in 2005. In 2005, Norway 
contributed to the fact that China is now the official host of two Codex committees, the Codex Committee on Food Additives and the Codex Committee on Pesticide Residues.

Attendance of meetings of the regional Coordinating Committees by low- and middleincome WTO Members is relatively higher than at meetings of the CAC itself. ${ }^{215}$ This

held the $27^{\text {th }}$ session of the Codex Committee on Fish and Fishery Products in Cape Town, South Africa and the $28^{\text {th }}$ Session of this Committee in Beijing, China in 2006. Australia, which hosts the Codex Committee on Food Import and Export Certification and Inspection Systems, held the $15^{\text {th }}$ Session of this Committee in Mar del Plata, Argentina in 2006. Germany, which costs the Codex Committee on Nutrition and Foods for Special Dietary Uses, held the 28th Session of this Committee in Chiang Mai, Thailand in 2006.

${ }^{215}$ The FAO/WHO Coordinating Committee for North America and the South West Pacific has 13 members of which 8 are also WTO Members. At the $9^{\text {th }}$ Session of the FAO/WHO Coordinating Committee for North America and the South West Pacific on 10-13 October 2006, 4 high-income, 0 upper-middle-income, 2 lowermiddle-income and 2 low-income WTO Members were present. They were represented by 13 delegates of which $61,5 \%$ (8) were on high-income Members' delegations, logically none were on upper-middle-income Members' delegations, 23,1\% (3) were on lower-middle income Members' delegations and 15,4\% (2) were on low-income Members' delegations FAO/WHO Coordinating Committee for North America and South West Pacific, Report of the Ninth Session, ALINORM 07/30/32 (Joint FAO/WHO Food Standards Programme, Apia), 10-13 October 2006, available at: http://www.codexalimentarius.net/web/archives.jsp?year=07, visited on 8 February 2008. The FAO/WHO Coordinating Committee for Latin America and the Caribbean has 33 members of which 32 are also WTO Members. At the $15^{\text {th }}$ Session of the FAO/WHO Coordinating Committee for Latin America and the Caribbean on 13-17 November 2006, 2 high-income, 9 upper-middleincome, 9 lower-middle-income and 1 low-income WTO Members were present.. They were represented by 66 delegates of which 3\% (2) were delegates of high-income Members, 66,7\% (44) were delegates of upper-middle-income Members, (of which 54,5\% (24) were on the delegation of Argentina, which hosted the meeting) $28,8 \%$ (19) were delegates of lower-middle-income Members and 1,5\% (1) were delegates of low-income Members. FAO/WHO Coordinating Committee for Latin America and the Caribbean, Report of the Fifteenth Session, ALINORM 07/30/36 (Joint FAO/WHO Food Standards Programme, Mar del Plata), 13 - 17 November 2006, available at: http://www.codexalimentarius.net/web/archives.jsp?year=07, visited on 8 February 2008. The FAO/WHO Coordinating Committee for Asia has 22 members of which 19 are also WTO Members. At the $15^{\text {th }}$ Session of the FAO/WHO Coordinating Committee for Asia on 21-24 November 2006, 3 high-income, 1 upper-middle-income, 5 lower-middle-income and 8 low-income WTO Members were present. They were represented by 69 delegates of which 43,5\% (30) were delegates of high-income Members, 4,3\% (3) were delegates of upper-middle-income Members, 33,3\% (23) were delegates of lowermiddle-income Members and 18,8\% (13) were delegates of low-income Members. FAO/WHO Coordinating Committee for Asia, Report of the Fifteenth Session, ALINORM 07/30/15 (Joint FAO/WHO Food Standards Programme, Seoul), 21 - 24 November 2006, available at: http://www.codexalimentarius.net/web/archives. jsp?year=07, visited on 8 February 2008. The FAO/WHO Coordinating Committee for Europe has 46 members of which 40 are also WTO Members (one is a member organization, the EC). At the $25^{\text {th }}$ Session of the FAO/WHO Coordinating Committee for Europe on 15 -18 January 2007, 20 high-income, 8 upper-middleincome, and no lower-middle-income or low-income WTO Members were present. They were represented by 44 delegates of which 72,7\% (32) were delegates of high-income Members, 27,3\% (12) were delegates of upper-middle-income Members, none were delegates of lower-middle-income or low-income Members. FAO/WHO Coordinating Committee for Europe, Report of the Twenty-Fifth Session, ALINORM 07/30/19 (Joint FAO/WHO Food Standards Programme Vilnius), 15-18 January 2007, available at: http://www.codexalimentarius.net/web/archives.jsp?year=07, visited on 1 March 2008. The FAO/WHO Coordinating Committee for Africa has 44 members of which 38 are also WTO Members. At the $17^{\text {th }}$ Session of the FAO/WHO Coordinating Committee for Africa on 23 -29 January 2007, no high-income, 3 upper-middleincome, 6 lower-middle-income and 24 low-income WTO Members were present. They were represented by 75 delegates of which, logically, none were delegates of high-income Members, 6,7\% (5) were delegates of upper-middle-income Members, 32\% (24) were delegates of lower-middle-income Members and 61,3\% (46) were delegates of low-income Members. FAO/WHO Coordinating Committee for Africa, Report of the Seventeenth Session, ALINORM 07/30/28 (Joint FAO/WHO Food Standards Programme, Rabat), 2326 January 2007, available at: http://www.codexalimentarius.net/web/archives.jsp?year=07, visited on 8 February. The FAO/WHO Coordinating Committee for the Near East Region has 17 members of which 9 are also WTO Members. At the $4^{\text {th }}$ Session of the FAO/WHO Coordinating Committee for the Near East Region 
is particularly the case for the Regional Committee for Africa, where some low-income Members participate in Codex meetings only at the regional level. ${ }^{216}$

\section{Graph 12: Codex Regional Committees:} Attendance by WTO Members by Income Level, 2006-2007

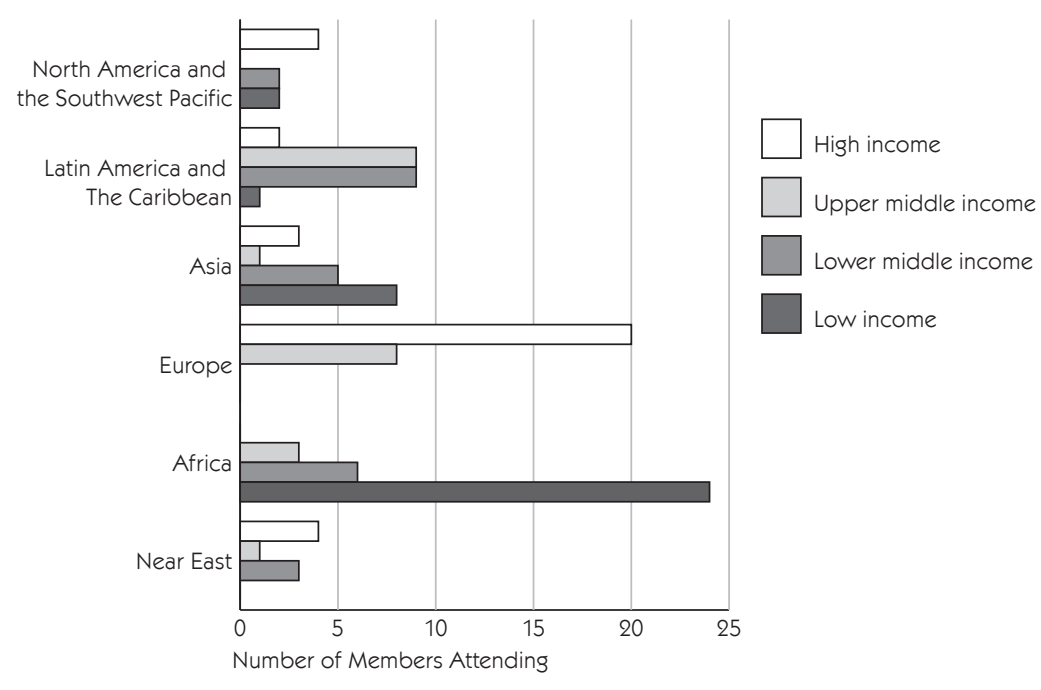

The number of delegates of WTO Members attending the regional Coordinating Committees also shows the priority given to the regional Coordinating Committee for Africa by low-income African Members. The same is true for other non high-income Members in various regions.

on 26 February -1 March 2007, 4 high-income, 1 upper-middle-income, 3 lower-middle-income and 0 lowincome WTO Members were present. They were represented by 24 delegates of which 45,8\% (11) were delegates of high-income Members, 4,2\% (1) were delegates of upper-middle-income Members, 50\%(12) were delegates of lower-middle-income Members and 0 were delegates of low-income Members. FAO/WHO Coordinating Committee for the near East Region, Report of the Fourth Session, ALINORM 07/30/40 (Joint FAO/WHO Food Standards Programme, Amman), 26 February - 1 March 2007, available at: http://www. codexalimentarius.net/web/archives.jsp?year=07, visited on 8 February 2008.

216 This was concluded in the report of the evaluation of the CAC and other FAO/WHO food standards work that was conducted in 2002 by an independent team and independent expert panel. See Report of the Evaluation of the Codex Alimentarius and Other FAO and WHO Food Standards Work (Food and Agriculture Organization and World Health Organization, Rome), 15 November 2002, para. 111, available at: http://www.fao.org/ docrep/meeting/005/y7871e/y7871e00.htm, visited on 4 August 2006. 


\section{Graph 13: Codex Regional Committees: Attendance by Delegates of WTO Members by Income Level, 2006-2007}

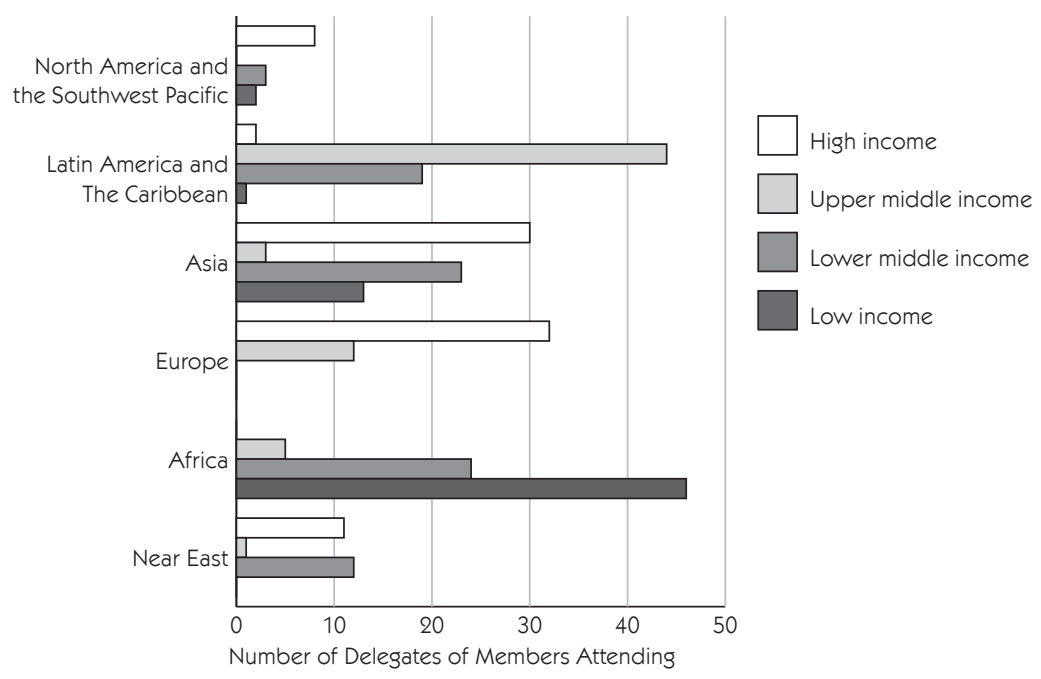

In general, due to lower travel costs within regions, more delegates are sent to regional Coordinating Committee meetings. However, although regional Coordinating Committees could fulfil a useful role in developing standards for products of interest for intra-regional trade, their standards are of less importance as they are not used as benchmark standards under the SPS Agreement. ${ }^{217}$ In fact, currently no regional standards are being developed and almost all existing regional standards have been revoked or converted into worldwide standards. ${ }^{218}$ The work of the regional Coordinating Committees is currently focused on recommending to the $\mathrm{CAC}$ the development of worldwide standards for products of interest to the region, and fulfilling a coordinating role among their members. In addition, these committees facilitate capacity building activities in the region. ${ }^{219}$

However, in practice the regional Coordinating Committees are not very effective. Concerns have been raised that some of the regions are too large and too diverse to

217 The 2002 report of the FAO/WHO evaluation of the CAC notes that regional standards have become less relevant since the coming into force of the SPS Agreement. Codex Alimentarius Commission, Conclusions and Recommendations of the Joint FAO/WHO Evaluation of the Codex Alimentarius and Other FAO and WHO Work on Food Standards, ALINORM 03/25/3 (Joint FAO/WHO Food Standards Programme, Rome), December 2002, para. 112.

${ }^{218}$ One proposal for a regional standard is under discussion, namely a ginseng standard for the Asian region. However, there is some opposition to the idea by members who point out that ginseng is also grown outside Asia and that a worldwide standard covering all varieties is therefore more appropriate. This example is described in Mariëlle Masson-Matthee, The Codex Alimentarius Commission and Its Standards, Doctoral Thesis, Maastricht University, Faculty of Law (T.M.C. Asser Press, Maastricht), 2007, 57.

219 This fact is noted in Codex Alimentarius Commission, Conclusions and Recommendations of the Joint FAO/ WHO Evaluation of the Codex Alimentarius and Other FAO and WHO Work on Food Standards, ALINORM 03/25/3 (Joint FAO/WHO Food Standards Programme, Rome), December 2002, para. 113. 
permit effective cooperation. ${ }^{220}$ In addition, insufficient resources are allocated to regional Coordinating Committees to allow regional representatives and coordinators to work between sessions of these committees. Further, initiatives elaborated in regional Coordinating Committees do not receive sufficient support in CAC sessions. ${ }^{221}$ In view of the potential created by the higher participation of middle- and low-income members in regional Coordinating Committees than in other Codex committees, the report of the $2002 \mathrm{FAO} / \mathrm{WHO}$ evaluation of the CAC recommends a review of their mandate, structure and work. ${ }^{222}$ In particular, it is suggested that sub-regional groupings be created, on the basis of economically and geographically coherent groups; that a regional coordinator represent each region at meetings of the CAC Executive Committee and that his participation and coordination activities be funded if he is from a developing country; that, in developing regions, capacity-building be systematically discussed at meetings and that seminars and workshops be combined with regional meetings. ${ }^{223}$

As noted before, an examination of attendance of meetings does not provide the full picture with regard to the degree of effective participation of countries. It is also necessary to examine the extent to which Members at different levels of development participate in discussions in some of the various committees. A precondition for active participation particularly in committees where commodity standards are being developed, is sufficient technical expertise to assess the standards being discussed and evaluate their potential impact at national level. It is also important to build a national position through consultations with national stakeholders. Often this capacity is lacking in Members at lower levels of development.

An illustration of the trends in the extent of participation by Members is provided by looking in detail at the reports of the meetings of a sample of four Codex committees in the period 1999-2007. Two General Subject Committees and two Commodity Committees have been selected for this purpose. The chosen committees include those in both categories that are most frequently prioritised for attendance by developing-country Members.

\footnotetext{
${ }^{220}$ Ibid., para. 114.

221 Ibid.

${ }^{222}$ Ibid., Recommendation 17.

${ }^{223}$ Ibid., para. 115.
} 
Graph 14: Codex Committee on General Principles:

Participation of WTO Members by Income Level, 1999-2007

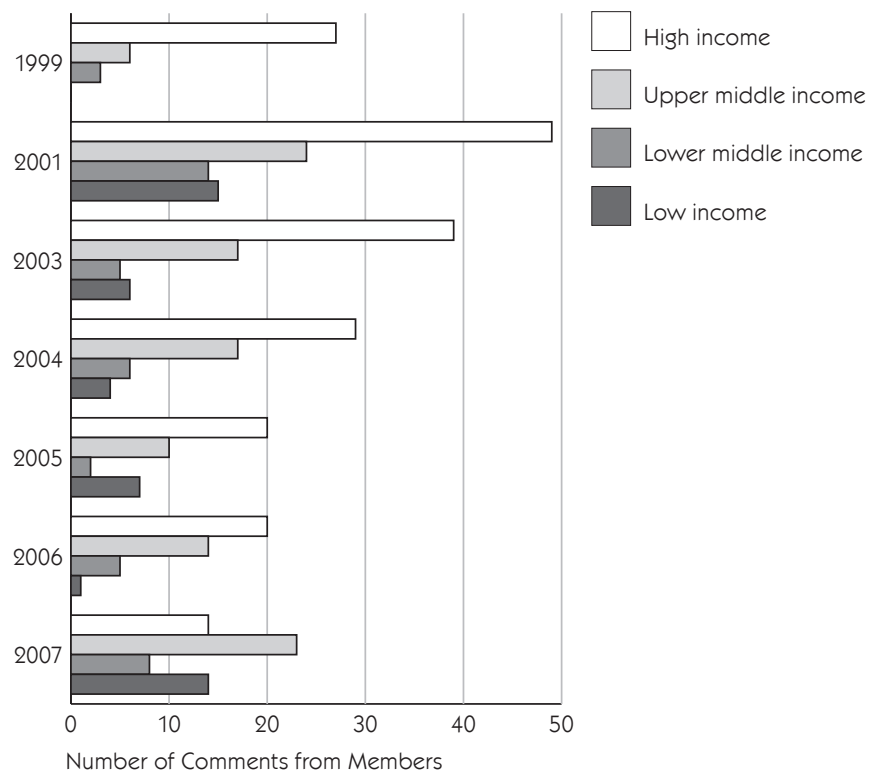

Graph 15: Codex Committee on Pesticides Residues:

Participation of WTO Members by Income Level, 1999-2007

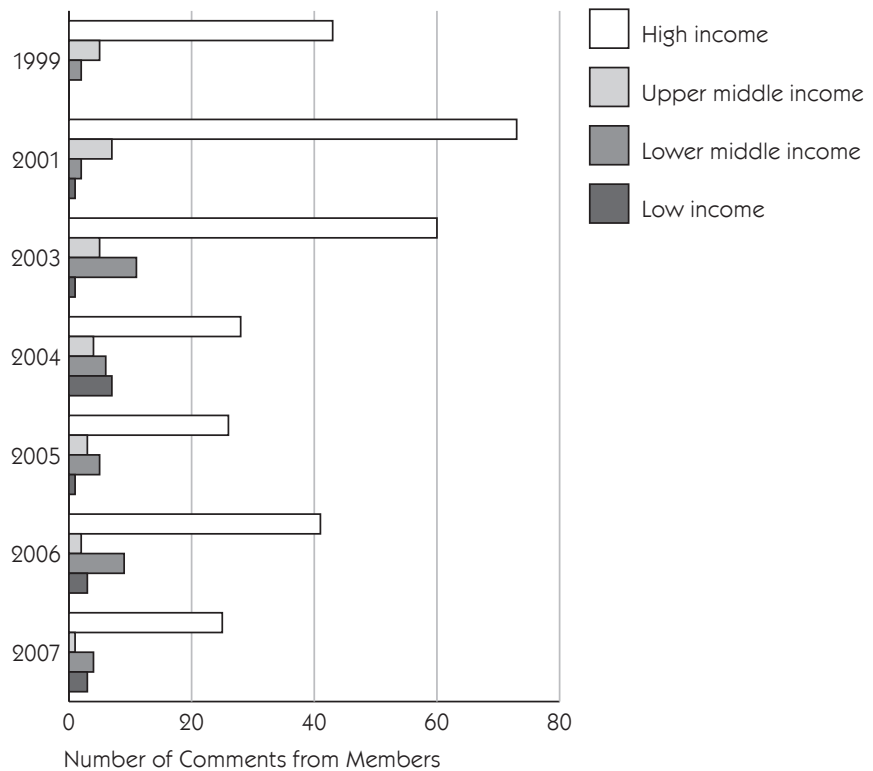




\section{Graph 16: Codex Committee on Fish and Fishery Products: Participation of WTO Members by Income Level, 1999-2007}

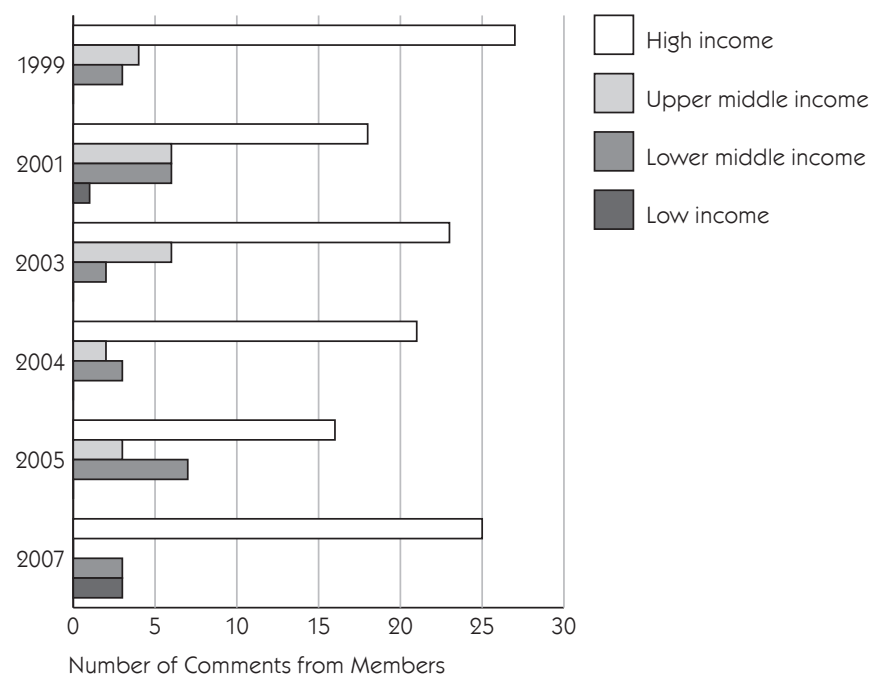

Graph 17: Codex Committee on Fresh Fruits and Vegetables: Participation of WTO Members by Income Level, 1999-2007

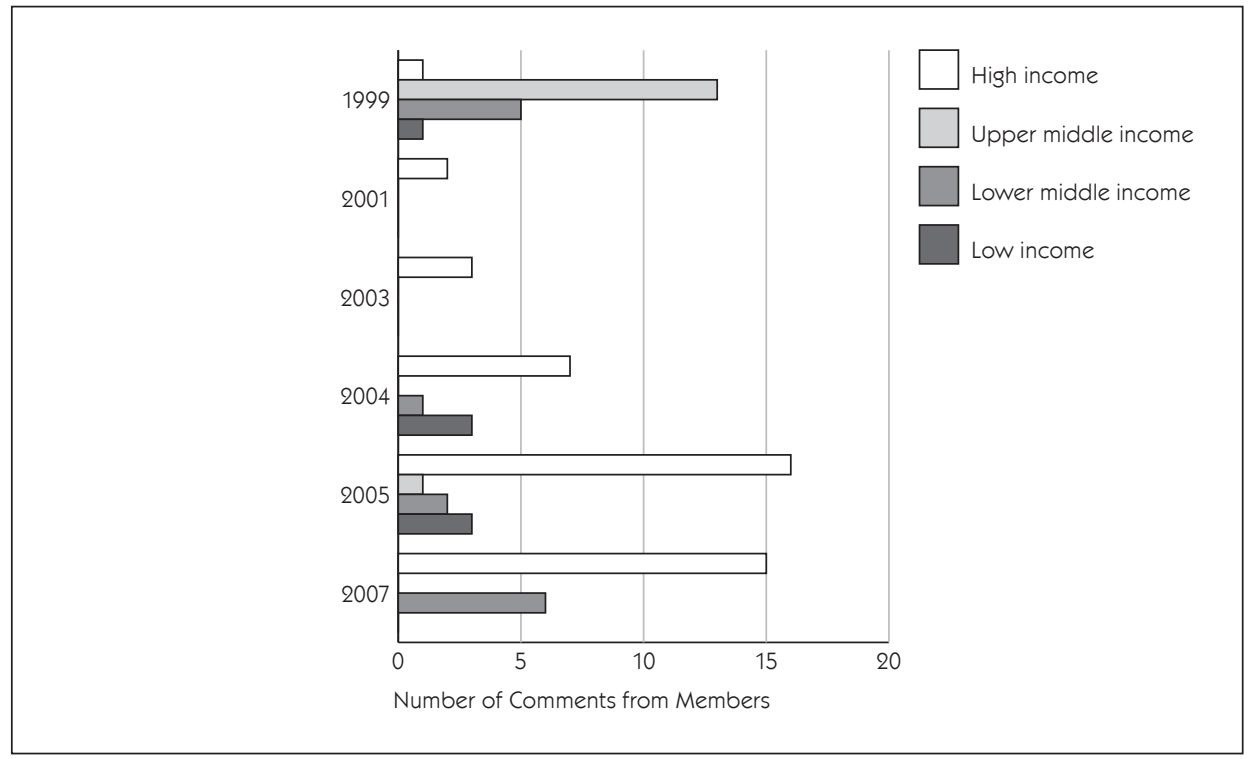

This analysis shows the very low level of active participation by WTO Members at lower income levels relative to high-income Members, in the work of the selected Codex Committees. The 2002 report of the FAO/WHO evaluation of the CAC has pointed out in 
this respect that possibly more important than facilitating attendance of meetings by developing country members is facilitating the enhancement of national capacity. ${ }^{224}$ Without improved national capacity, increased attendance is unlikely to lead to effective and active participation by Members at lower levels of development.

In an effort to promote developing country participation on Codex standard-setting work, the FAO and WHO developed training package in 2005. ${ }^{225}$ In February 2006, the FAO and WHO issued an information guide for first-time delegates to Codex meetings. ${ }^{226}$ This guide aims to assist delegates by referring them to the rules of procedure, providing information on how to obtain the relevant documents for a meeting, explaining the format of meetings and how interventions should be made, and setting out the procedure whereby the report of the meeting is drawn up and adopted. While it is too soon to tell how effective these initiatives will be, there does seem to be an improvement in the active participation of middle- and low-income Members in 2007 in the Committee on General Principles and of upper-middle income Members in the Committee on Fresh Fruits and Vegetables.

As stated above, the scientific input for the standards developed by Codex committees is provided by the joint FAO/WHO expert committees and expert meetings. Logically, as is the case for risk assessments on national level, the conclusions reached by risk assessments carried out by the FAO/WHO expert committees advising the Codex committees, are neither universally valid nor free of subjective elements. Instead, they incorporate assumptions and choices reflecting science policy. ${ }^{227}$ The selection of experts to participate in these expert committees therefore has consequences for the approach taken in science policy decisions. While experts act in their individual capacities and not as representatives of their governments in FAO/WHO committees, they bring with them their particular national experiences and attitudes to risk, which affect their approach to science policy decisions. Since the coming into force of the SPS Agreement, increasing care is taken in the selection of experts in order to ensure the credibility and acceptability of their conclusions and recommendations. ${ }^{228}$ As noted above, the experts participating in the various JECFA and JMPR expert meetings are drawn from rosters of experts maintained by the FAO and $\mathrm{WHO}^{229} \mathrm{~A}$ look is therefore now taken at the composition of these rosters.

${ }^{224}$ Ibid., para. 140.

225 Food and Agriculture Organization and World Health Organization, Enhancing Participation in Codex Activities. An FAO/WHO Training Package, 2005, available at: ftp://ftp.fao.org/docrep/fao/008/y5884e/ y5884e00.pdf, visited on 16 April 2008.

${ }_{226}$ Codex Alimentarius Commission, Information Guide for First-Time Delegates to a Codex Session (Joint FAO/WHO Food Standards Programme, Geneva), February 2006, available at: ftp://ftp.fao.org/codex/ Information_for_delegates/Info_leaflet_en.pdf, visited on 25 July 2006.

${ }^{227}$ For further information regarding the concept of science policy, see the discussion above, Part II, Section 1.5.

${ }^{228}$ In 1999, the criticism was made that the FAO/WHO scientific committees were predominantly staffed by US and Canadian regulatory officials and industry consultants with no expertise in public health issues. See Samuel S. Epstein, Codex Alimentarius Decided to Support Rbgh Moratorium (Cancer Prevention Coalition, 18 August 1999, available at: www.psrast.org/bghcodex.htm, visited on 28 January 2008. Efforts have been taken by the FAO and WHO to address these concerns by laying down guidelines for the selection of experts. The members of the expert committees must be pre-eminent in their specialty, command the highest respect of their scientific peers, and be impartial and objective. They are appointed in their individual capacities rather than as representatives of governments or organisations.

${ }^{229}$ The selection procedures vary slightly for each specific scientific body, but they have key elements in common. A public 'call for experts' is issued by the FAO and WHO and widely disseminated (through their 


\section{Graph 18: JECFA: WTO Members in Rosters of Experts by Income Level, 2007-2011}

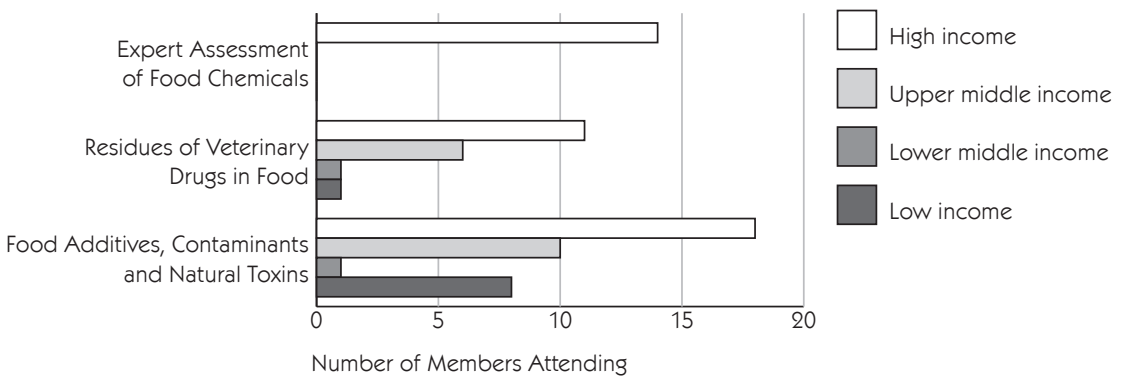

\section{Graph 19: JMPR: WTO Members in Roster of Experts by Income Level, 2004-2010}
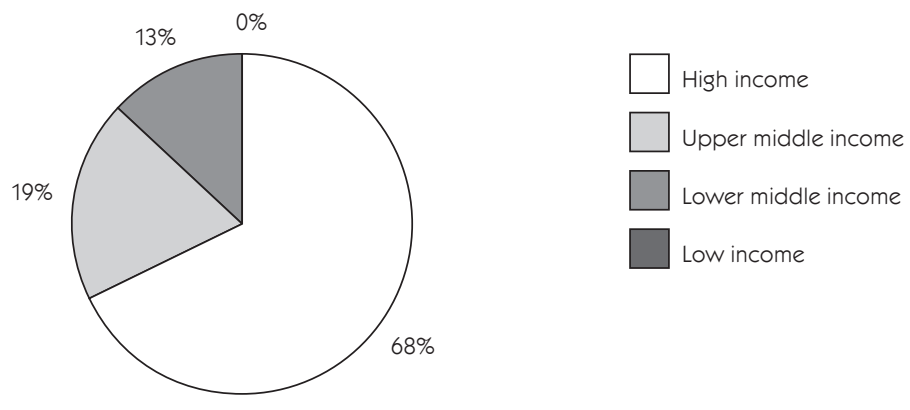

websites, various scientific journals, electronic mailing lists etc.) to invite experts from all over the world and in a wide range of disciplines to be considered in the selection process. The applications are reviewed by a selection panel of independent experts and the secretariat of the relevant scientific body to determine if they meet the essential requirements and selection criteria outlined in the call for experts (for example, the selection criteria for the JEMRA relate to technical expertise and professional recognition; publications in the relevant area; and the ability to participate in group discussions and draft clear and concise reports). The Directors-General of the FAO and WHO review and approve the proposed lists of experts and a roster of qualified experts is published on the FAO and WHO websites. Experts are appointed by the FAO and WHO from these rosters to participate in expert meetings, consultations etc. In order to ensure the independence of scientific advice, selected experts must submit a declaration of interests which is scrutinized by the Joint FAO/WHO Secretariats of the scientific bodies to determine if the declared interest could constitute a conflict with regard to the issues being considered. They inform the Chairperson of the meeting of their conclusions and a joint decision is taken regarding whether the particular expert should participate in the discussion and decision-making on the relevant agenda item. See Food and Agriculture Organization and World Health Organization, Understanding the Codex Alimentarius (United Nations, Rome), 2005, 21-24, available at: http://www.fao.org/docrep/008/y7867e/y7867e00.HTM, visited on 28 July 2006; Codex Alimentarius Commission, Scientific Advice to Codex and FAO/WHO Member Countries (Submitted by FAO and WHO). Selection of Experts and Working Procedures of the Expert Committees and Expert Consultations: $2002-$ 2003, CAC/26 INF/4 (Food and Agriculture Organization and World Health Organization, Rome), 30 June - 7 July 2003. 
The most recent rosters of experts of the JECFA and JMPR are overwhelmingly composed of experts from high-income WTO Members. ${ }^{230}$ This has been attributed in part to the fact that the calls for experts are not always successful in reaching sufficient experts from developing countries. The study conducted in the context of the 'consultative process' on this issue has recommended that better use be made of national and regional sources of information on available experts. ${ }^{231}$

While the WHO and FAO bear the costs of experts' attendance of meetings and efforts are made to select experts reflecting geographical diversity, in practice the majority of experts serving in expert meetings or consultations tend to be from high-income countries. ${ }^{232}$ This can be seen from an examination attendance by experts from WTO Members of two selected meetings, in 2006 and 2007, of the following joint FAO/WHO expert bodies.

\section{Graph 20: JECFA Meetings: Attendance by Experts from WTO Members by Income Level, 2006-2007}

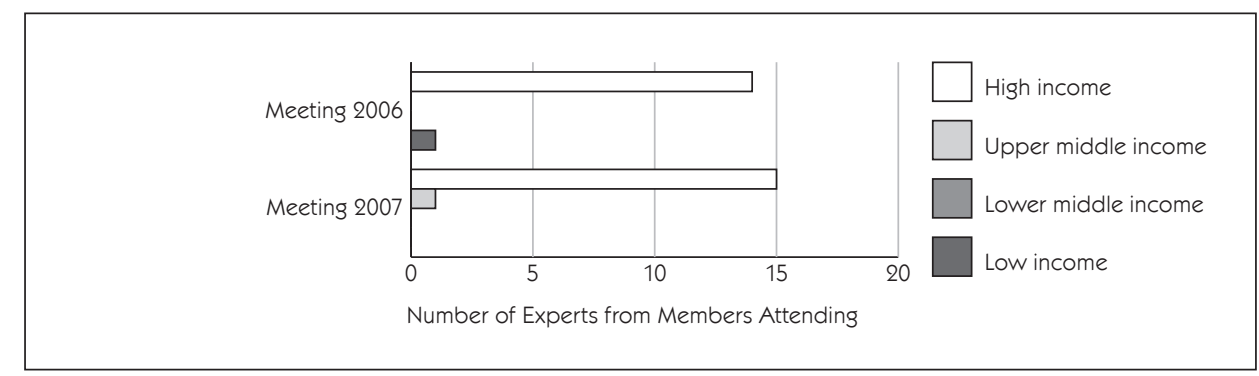

${ }^{230}$ The roster of experts for the JEMRA is not available online, so no data on this roster could be included here.

${ }^{231}$ Enhancing Developing Country Participation in FAO/WHO Scientific Advice Activities. Report of a Joint FAO/WHO Meeting, FAO Food and Nutrition Paper 88 (Food and Agriculture Organization and World Health Organization, Rome), December 2006, 11, available at: ftp://ftp.fao.org/docrep/fao/meeting/010/j7630e.pdf, visited on 4 October 2006.

${ }^{232}$ For the 2007-2011 period, the three FAO rosters of experts (on food additives contaminants and natural toxicants, exposure assessment of food chemicals, and residues of veterinary drugs in food) from which participants for JECFA meetings on those topics are drawn, contain a total of 74 experts, of which 70 come from WTO Members. Of these, 48 come from high-income Members, 16 from upper-middle-income Members, 2 from lower-middle-income Members and 4 from low-income Members. The 2004-2010 FAO roster from which experts for JMPR meetings are drawn contains 16 experts, of which 11 are from high-income Members, 3 are from upper-middle-income Members and 2 are from lower-middle-income Members. Note that although the data presented here regarding the JMPR roster of experts comprises the whole period of 2004-2010, JMPR experts participate in one of two overlapping periods, either 2004-2008 or 2006-2010. 


\section{Graph 21: JMPR Meetings: Attendance by Experts from WTO Members by Income Level, 2006-2007}

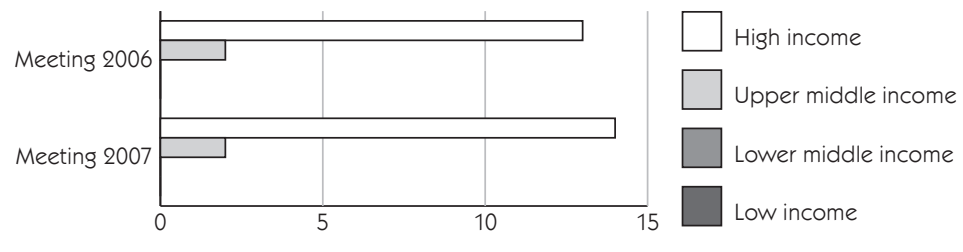

Number of Experts from Members Attending

\section{Graph 22: JMRA Meetings: Attendance by Experts from WTO Members by Income Level, 2006}

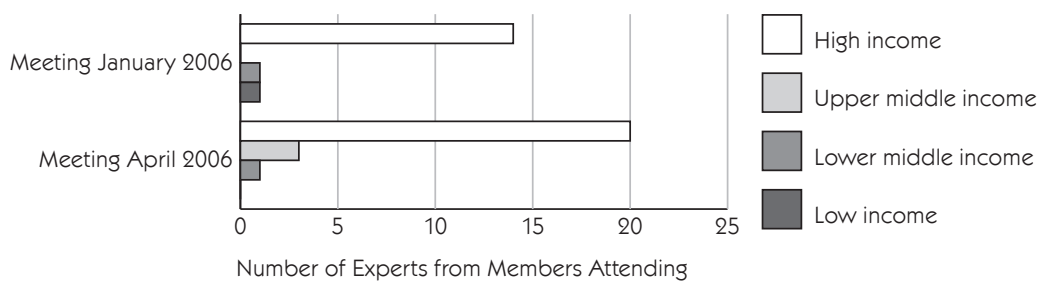

In addition, the fact that the meetings of these committees and expert consultations are closed is a cause for concern. It leads to a lack of transparency regarding the science policy choices and assumptions made in the risk assessment process.

Insufficient developing country participation and lack of transparency were among the main concerns raised in the context of the review of the status and procedures of the FAO/WHO expert bodies in the 'consultative process' mentioned above. ${ }^{233}$ As already mentioned, one outcome of this process was a study, published in 2006, assessing the constraints faced by developing countries in participating in the scientific process underlying the standard-setting procedure and setting out recommendations for new approaches and mechanisms to enhance developing country participation in FAO/WHO scientific advice activities. ${ }^{234}$ Some of the problems faced by developing countries identified in this study are a lack of understanding of the need to provide data in response to FAO/WHO calls for data, and of the types of data required; deficiencies in the infrastructure and

${ }^{233}$ One of the elements of the consultative process initiated to respond to this request was a joint FAO/WHO workshop. For the report of this workshop and its recommendations, see Report of the Joint FAO/WHO Workshop on the Provision of Scientific Advice to Codex and Member Countries, Held on 27-29 January 2004 (Food and Agriculture Organization and World Health Organization, Geneva), 2004, available at: http:// www.who.int/foodsafety/codex/en/workshop_report.pdf, visited on 20 June 2008.

${ }^{234}$ Enhancing Developing Country Participation in FAO/WHO Scientific Advice Activities. Report of a Joint FAO/WHO Meeting, FAO Food and Nutrition Paper 88 (Food and Agriculture Organization and World Health Organization, Rome), December 2006, available at: ftp://ftp.fao.org/docrep/fao/meeting/010/j7630e.pdf, visited on 4 October 2006. 
mechanisms in developing countries to generate and collate the required data; and limited facilities, personnel and operating funds. ${ }^{235}$ It was recommended that capacity building programmes be initiated to strengthen the capacities of national experts to participate in expert meetings. In addition 'twinning' agreements between and experienced country and a less experienced country on an official level were proposed to familiarise developing country scientists with the work of the expert bodies and to share knowledge on data collection, proper sampling, methods of analysis and quality assurance. ${ }^{236}$ The FAO and WHO are currently reviewing these recommendations.

The implications of the inadequate participation of less developed Members in CAC standard-setting procedures should not be underestimated. As noted by Diahanna Post:

[R] egulatory capitalism in the form of Codex standards is not a disinterested, objective form of regulation. Rather, it is shaped by powerful countries and actors. ... The role of politics and power in forming highly technical standards often goes unnoticed. Yet how and by whom the standards are shaped - and for what purposes - has ethical and distributive consequences. ${ }^{237}$

\subsubsection{International Office of Epizootics/World Organisation for Animal Health}

For animal health and zoonoses, ${ }^{238}$ the SPS Agreement refers to the standards, guidelines and recommendations 'developed under the auspices of the International Office of Epizootics'.239

The International Office of Epizootics (OIE), now called the World Organisation for Animal Health is an international intergovernmental organisation, created by the International Agreement for the Creation of an Office International des Epizooties of 25 January $1924 .{ }^{240}$ Its original objective was to prevent the spread of diseases in animals and animal products through international trade. The impetus for its creation lay in the incursions of rinderpest into Europe in the $1920 \mathrm{~s} .{ }^{241}$

235 Ibid., 7.

${ }^{236}$ Ibid., 16-17.

237 Diahanna L. Post, 'Standards and Regulatory Capitalism: The Diffusion of Food Safety Standards in Developing Countries', The ANNALS of the American Academy of Political and Social Science (598), 2005, 168-183, 180, available at: http://ann.sagepub.com/cgi/reprint/598/1/168, visited on 12 June 2008.

${ }^{238}$ The word zoonosis means any disease or infection that is naturally transmissible from animals to humans.

239 See Annex 3A.3(b) of the SPS Agreement.

${ }^{240}$ Due to its historical origins, the majority (19 out of a total of 28) of the signatories to the International Agreement for the Creation of an Office International des Epizooties, signed in Paris on 25 January 1924, were European countries. The 28 original signatories were the Argentine Republic, Belgium, Brazil, Bulgaria, Denmark, Egypt, Spain, Finland, France, Great Britain, Greece, Guatemala, Hungary, Italy, Luxemburg, Morocco, Mexico, the Principality of Monaco, the Netherlands, Peru, Poland, Portugal, Romania, Siam, Sweden, Switzerland, the Czechoslovak Republic, and Tunisia.

${ }^{241}$ In particular, the spread of Rinderpest in Belgium in 1920 created the impetus for this initiative. This information is drawn from the page entitled 'A short history of the International Office des Epizooties' on the OIE website, available at: http://www.oie.int/eng/oie/en_histoire.htm, visited on 5 February 2008. Rinderpest is a highly fatal viral disease of domestic cattle, buffaloes and yaks, and may also affect sheep, goats and some breeds of pigs and a large variety of wildlife species. Historically the virus was widely distributed throughout Europe, Africa, Asia and West Asia, but never became established in either the Americas or Australia/New Zealand. 
The OIE is headquartered in Paris. Unlike the CAC and the IPPC, the OIE does not fall under the auspices of the FAO and it is not part of the UN system. ${ }^{242}$ However, it does cooperate with the FAO and WHO on animal health issues that relate to their respective mandates..$^{243}$

\subsubsection{Mandate}

The OIE is the world's oldest animal health organisation and has extensive experience with setting voluntary international animal health standards. ${ }^{244}$ Its mandate covers the promotion of the transparency of animal disease status world-wide; the collection, analysis and dissemination of veterinary scientific information; the strengthening of international coordination and cooperation in the control of animal diseases; the promotion of safety of world trade by developing sanitary standards for international trade in animals and animal products; and the improvement of the legal framework and resources of Veterinary Services. $^{245}$

In fulfilment of its standard-setting mandate, the OIE has developed standards and guidelines, which are to be found in the International Terrestrial Animal Health Code ${ }^{246}$ and the International Aquatic Animal Health Code ${ }^{247}$ (the Health Codes). These are regularly revised. Strictly speaking, the standards and guidelines laid down in each Code are only applicable with regard to the diseases listed therein. ${ }^{248}$ Standards regarding diagnostic tests and vaccines are also adopted by the OIE, for both terrestrial and aquatic animals and are incorporated into the Manual of Diagnostic Tests and Vaccines for Terrestrial Animals and the Manual of Diagnostic Tests for Aquatic Animals (the Diagnostic Manuals). ${ }^{249}$

${ }^{242}$ After the UN established the FAO (in 1946) and WHO (in 1948), the question arose whether the continued existence of the OIE was justified, in view of the overlapping mandates of the UN specialized agencies with those of the OIE. The possibility of dissolving the OIE was discussed in 1946 and 1951, but due to the opposition of many OIE member countries this was never done. The OIE signed an official agreement with the FAO in 1952 and with the WHO in 1960. . This information is drawn from the page entitled 'A short history of the International Office des Epizooties' on the OIE website, available at: http://www.oie.int/eng/oie/en_histoire. htm, visited on 5 February 2008.

${ }^{243}$ Alberto Alemanno, Trade in Food: Regulatory and Judicial Approaches in the EC and WTO (Cameron May, London), 2007, 272.

${ }^{244}$ Terence P. Stewart and David S. Johanson, 'The SPS Agreement of the World Trade Organization and International Organizations: The Roles of the Codex Alimentarius Commission, the International Plant Protection Convention, and the International Office of Epizootics', Syracuse Journal of International Law and Commerce 26, 1998, 27-53, 49.

${ }^{245}$ Committee on Sanitary and Phytosanitary Measures, Implementing the Standards of the OIE. Communication from the OIE, G/SPS/GEN/437, circulated on 28 October 2003, para. 4.

${ }^{246}$ OIE, Terrestrial Animal Health Code, , $16^{\text {th }}$ edition (2007) available at: http://www.oie.int/eng/normes/ mcode/en_sommaire.htm, visited on 25 June 2007. This code applies to mammals, birds and bees, according to Article 1.1.1.1 thereof.

${ }^{247}$ OIE, Aquatic Animal Health Code, $10^{\text {th }}$ edition (2007) available at: http://www.oie.int/eng/normes/fcode/ en_sommaire.htm, visited on 25 June 2007. This code applies to fish, molluscs and crustaceans originating from aquaculture establishments or removed from the wild, for farming purposes, for release into the aquatic environment or for human consumption, according to Article 1.1.1.1 thereof.

248 David G. Victor, 'The Sanitary and Phytosanitary Agreement of the World Trade Organization: An Assessment after Five Years', Journal of International Law and Politics 32 (4), 2000, 865-938, 893.

249 OIE, Manual of Diagnostic Tests and Vaccines for Terrestrial Animals, $5^{\text {th }}$ edition (2004) available at: http:// www.oie.int/eng/normes/mmanual/A_summry.htm visited on 12 June 2008; and OIE, Manual of Diagnostic Tests for Aquatic Animals, $5^{\text {th }}$ edition (2006) available at: http://www.oie.int/eng/normes/fmanual/A_summry.htm, visited on 12 June 2008. 
In 2001, the mandate of the OIE was extended to include animal welfare and food safety risks arising from animals. ${ }^{250}$ The OIE was given the new name World Organisation for Animal Health in 2003, in view of its now-extended mandate, beyond the prevention and control of epizootic diseases, to cover all animal health issues and their public health implications that need to be addressed on a regional or global scale. ${ }^{251}$ However, the original name is still often used and the official acronym for this organisation remains OIE.

In view of the potential for overlap between the new food-safety mandate of the OIE and the work of the CAC, the OIE has established an effective mechanism, which includes participation of WHO and CAC representatives, responsible for coordination of OIE activities with those of the CAC. ${ }^{252}$

\subsubsection{Institutional structure}

The OIE is an international intergovernmental organisation, with its own established institutional structure. Most of the bodies of the OIE have limited membership.

${ }^{250}$ These two new areas of work for the OIE were identified as priorities in the OIE's 2001-2005 Strategic Plan. An Ad hoc Group of Experts was convened by the OIE Director General for each of these areas, which made recommendations defining the role of the OIE in these two new areas, for discussion by the International Committee. The International Committee adopted resolutions based on these recommendations. Resolution XIV, Animal Welfare Mandate of the OIE and Resolution XV, Food Safety Mandate of the OIE, adopted by the International Committee of the OIE at its 70th General Session on 29-30 May 2002. See Bernard Vallat, The New Mandates of the OIE (International Office of Epizootics, Paris), November 2002, available at: http://www.oie.int/eng/Edito/en_edito_nov02.htm, visited on 5 February 2008. Vallat has been the DirectorGeneral of the OIE since 2001.

${ }^{251}$ This was done in 2003, when the International Committee of the OIE adopted Resolution XVI authorising the OIE Director General and statutory bodies to use, in all circumstances, alongside the official name of the OIE, the common name 'World Organisation for Animal Health'. See Resolution XVI, Use of a Common Name for the Office International des Epizooties, adopted by the International Committee of the OIE on 23 May 2003. This resolution is contained in: International Committee of the OIE, Final Report of the 71st General Session, 71/GS/FR (OIE, Paris), 18-23 May 2003, available at: ftp://ftp.oie.int/A_RFinal_2003\%20 wp.pdf, visited on 24 August 2006.

${ }^{252}$ More specifically, as noted by Scott, the OIE has created a Working Group on Animal Production Food Safety, in which CAC and WHO representatives participate. This Working Group has set out a work programme for OIE standards on food-safety issues relating to animal production focused on the farm level (i.e. pre-slaughter issues and those relating to issues before the first transformation of animal products) and has prioritised the development of procedures for common or linked CAC and OIE standards. Joanne Scott, The WTO Agreement on Sanitary and Phytosanitary Measures: A Commentary, Oxford Commentaries on the GATT/WTO Agreements (Oxford University Press, Oxford), 2007, 250. 


\section{Figure 2: Institutional Structure of the World Organisation for Animal Health}

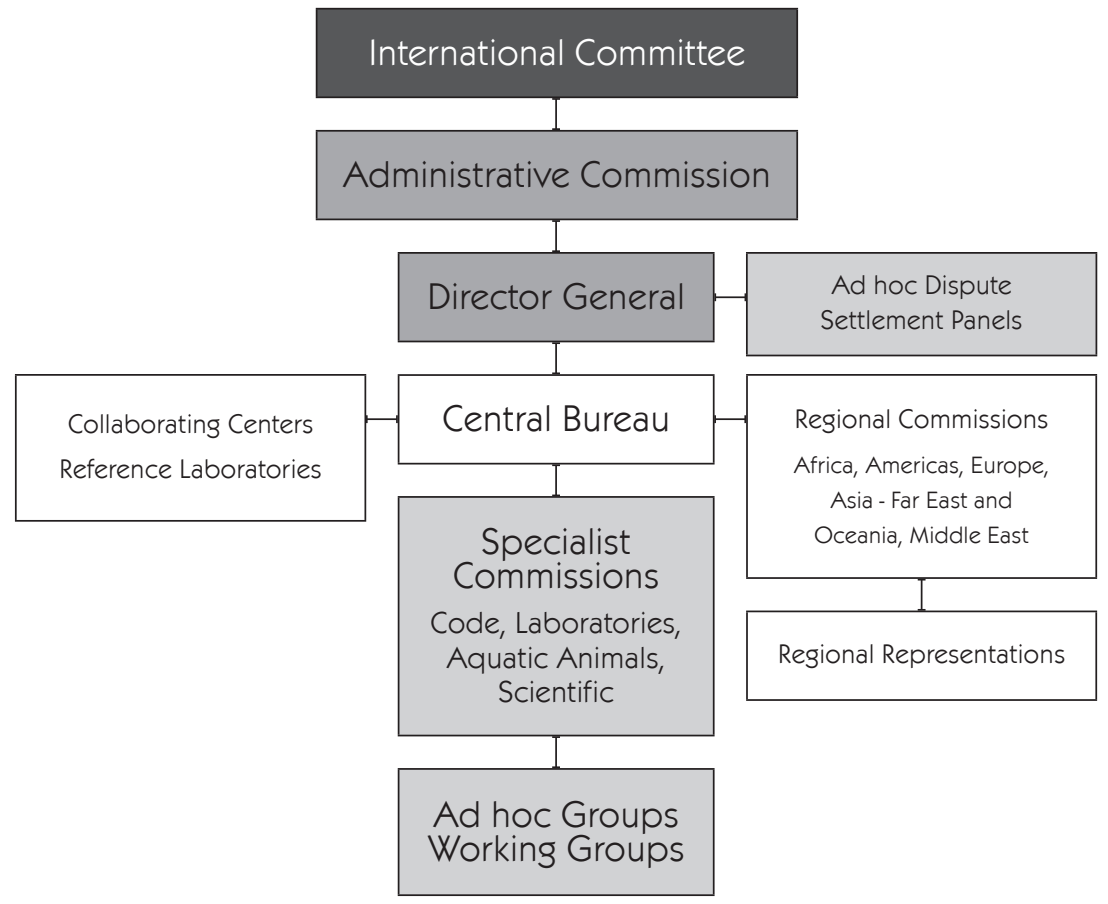

Source: OIE website, available at: http://www.oie.int/eng/OIE/organisation/en_structure.htm?eld1,visited on 5 February 2008.

The highest authority of the OIE is the International Committee (IC), which is composed of the permanent delegate ${ }^{253}$ representing all member countries. It meets in Paris in May of each year in a General Session lasting five days. ${ }^{254}$ The primary tasks of the IC are the adoption of international standards in the field of animal health, especially for international trade and the adoption of resolutions on the control of the major animal diseases. ${ }^{255}$ Almost all delegates to the General Session are veterinarians. They are required by the OIE to be technically competent to discuss and adopt decisions within the area of activity of the OIE. Decisions may be taken on the basis of a simple majority if a quorum of more than half the delegates is present ${ }^{256}$ and voting follows the principle of 'one country one

\footnotetext{
${ }^{253}$ Delegates may be accompanied by one alternate and one or several observers and rapporteurs, according to Article 2 of the General Rules of the OIE.

${ }^{254}$ Articles 2 and 45 of the General Rules of the OIE.

${ }^{255}$ See the homepage of the IC of the OIE available at http://www.oie.int/eng/OIE/organisation/en_CI.htm, visited on 6 February 2008. The International Committee also has the tasks of the election of the members of the governing bodies of the OIE ((President and Vice-President of the IC, Members of the Administrative Commission, Regional and Specialist Commissions), the appointment of the Director General as well as the examination and approval of the annual report of activities and the financial report of the Director General and the annual budget of the OIE.

${ }^{256}$ Article 6 of the General Rules of the OIE.
} 
vote'. ${ }^{257}$ In practice, the adoption of animal health standards forwarded to the IC by the Specialist Commissions are adopted unless more than ten members are opposed. ${ }^{258}$

The OIE also has an Administrative Commission, which is composed of nine delegates, ${ }^{259}$ namely the President of the IC, its Vice-President, the immediate Past-President, two Auditors and four representatives of OIE member countries elected by the IC. In electing the members of the Administrative Commission, the IC must take into account the need for even geographical representation and each of the regional groups must necessarily be represented. The Administrative Commission is chaired by the President of the IC. It meets twice a year in Paris to discuss technical and administrative matters (particularly the budget and the work programme of the OIE) and to prepare the work of the IC. ${ }^{260}$ In the intervals between the General Sessions, it represents the IC.

Five Regional Commissions have been established Commissions for Africa; the Americas; Asia, the Far East and Oceania; Europe and the Middle East. ${ }^{261}$ These aim to promote cooperation and study specific problems on a regional level. Each Commission organises a regional conference (usually biannually) in one of the countries in the region to address technical issues and coordinate regional cooperation regarding the control of animal diseases. ${ }^{262}$ Regional Commissions prepare and submit reports and recommendations to the IC. ${ }^{263}$ In addition, the OIE maintains regional representations in Africa, the Americas, Asia-Pacific, Eastern Europe and the Middle East. These Representations aim to provide regionally adapted services to members in order to strengthen the surveillance and control of animal diseases in the region. ${ }^{264}$

The IC also has the authority to establish Specialist Commissions, ${ }^{265}$ ad hoc, in order to examine problems of epidemiology and control of animal diseases and issues of harmo-

${ }^{257}$ International organisations with which the OIE has concluded agreements are invited to participate in the scientific and technical sessions of the International Committee and their representatives may take the floor during sessions but have no voting rights. Article 2 of the General Rules of the OIE.

258 Joanne Scott, The WTO Agreement on Sanitary and Phytosanitary Measures: A Commentary, Oxford Commentaries on the GATT/WTO Agreements (Oxford University Press, Oxford), 2007, 249.

${ }^{259}$ All candidates for elective office in the Administrative Commission must be proposed by two members of the IC. Articles 8 and 9 of the General Rules of the OIE.

260 See V. Welte, 'Introduction to the Office International Des Epizooties (OIE)', in Multilateral Trade Negotiations on Agriculture: A Resource Manual. Agreement on the Application of Sanitary and Phytosanitary Measures (SPS) and Agreements on Technical Barriers to Trade (TBT), Food and Agriculture Organization (ed.), vol. III (Food and Agriculture Organization, Rome), 2000, 13, available at: www.fao.org/docrep/003/ $\mathrm{x} 7354 \mathrm{e} / \mathrm{X} 7354 \mathrm{e} 01 . \mathrm{htm}$, visited on 27 June 2001.

${ }^{261}$ These Commissions have been established under the power granted to the IC to do so with the aim of furthering any of the objectives of the OIE in one or more of the regions of the world. Article 12 of the General Rules of the OIE.

${ }^{262}$ Article 16 of the General Rules of the OIE.

${ }^{263}$ Article 14 of the General Rules of the OIE. See further V. Welte, 'Introduction to the Office International Des Epizooties (OIE)', in Multilateral Trade Negotiations on Agriculture: A Resource Manual. Agreement on the Application of Sanitary and Phytosanitary Measures (SPS) and Agreements on Technical Barriers to Trade (TBT), Food and Agriculture Organization (ed.), vol. III (Food and Agriculture Organization, Rome), 2000, 13, available at: www.fao.org/docrep/003/x7354e/X7354e01.htm, visited on 27 June 2001.

${ }^{264}$ This information is found on the page for 'Regional Representations' on the OIE website, available at: http:// www.oie.int/eng/OIE/organisation/en_CR.htm, visited on 12 June 2008.

${ }^{265}$ Under the power granted to the IC under Article 18 of the General Rules of the OIE, four Specialist Commissions were established in 2003 to replace the previously existing Specialist Commissions (while ensuring continuity in their operation). This decision was motivated by the 'need for a general redefinition 
nisation of international regulations in this area. ${ }^{266}$ Currently, the following Specialist Commissions are in existence: the Terrestrial Animal Health Standards Commission (Code Commission), ${ }^{267}$ the Biological Standards Commission (Laboratories Commission), ${ }^{268}$ the Aquatic Animal Health Standards Commission (Aquatic Animals Commission), ${ }^{269}$

of the purpose and mode of operation of the Specialist Commissions, to take into account the evolution and the extension of the missions of the OIE and the necessary changes in the conditions under which it acts.' See Resolution XVII, New Terms of Reference for the Specialist Commissions of the Office International des Epizooties, adopted by the International Committee of the OIE on 22 May 2003. This Resolution is contained in: International Committee of the OIE, Final Report of the 71st General Session, 71/GS/FR (OIE, Paris), 18-23 May 2003, available at: ftp://ftp.oie.int/A_RFinal_2003\%20wp.pdf, visited on 24 August 2006.

${ }^{266}$ According to Article 19 of the General Rules of the OIE, these Commissions are limited in time to the period necessary to address the specific problem. However, as the current four Specialist Commissions are responsible for revising and updating the Health Codes and Diagnostic Manuals and for evaluating the pest or disease free status of member countries, their mandates are not time-limited.

${ }^{267}$ The Code Commission replaces the Animal Health Code Commission, founded in 1960. It is responsible for seeing to it that the Terrestrial Code reflects the current state of scientific knowledge. It is composed of six members, who must be veterinarians with a broad knowledge of the major animal diseases, experience and expertise in the animal health aspects of international trade in animals and animal products, and an understanding and practical experience of the relevant international trading rules. They are elected by the International Committee and are drawn from all OIE regions (as on September 2007, the members came from France, Germany, New Zealand, Brazil, Zimbabwe and Sudan). The Code Commission meets several times a year to draft new articles of the Terrestrial Code, or revise existing articles in the light of scientific advances. It works with internationally renowned specialists and seeks the views of members' delegates through the circulation of draft and revised texts. The new or revised articles it elaborates are forwarded to the OIE General Session for adoption, after which they are incorporated into the Terrestrial Code. See the Terms of Reference, Internal Rules and Qualifications of Members of the Terrestrial Animal Health Code Commission, adopted by the OIE International Committee by Resolution No. XVII of 22 May 2003, available at: http://www.oie. int/tahsc/eng/en_tahsc.htm.

268 The Laboratories Commission replaces the Foot and Mouth Disease and other Epizootics Commission, which was founded in 1949. It is composed of five members (increased from 3 members by Resolution XIX adopted by the International Committee on 26 May 2006 due to the increased workload). The members are elected by the International Committee taking account of the need for geographically balanced representation (as of January 2007, the members came from the UK, US, Morocco, India and Russia). Members must be recognised specialists in the field of infectious terrestrial animal diseases diagnosis and/or prevention, particularly in laboratory methods and operations. They must have international experience and specialized training in the area of laboratory diagnosis and/or immunological prevention of infectious animal diseases. The Laboratories Commission establishes or approves methods for diagnosing diseases of mammals, birds and bees and for testing biological products, such as vaccines, used for control purposes. It oversees the production of the Manual of Diagnostic Tests for Aquatic Animals. Furthermore, it selects OIE Reference Laboratories for terrestrial animal diseases, and promotes the preparation and distribution of standard reagents for diagnostic testing. See the Terms of Reference, Internal Rules and Qualifications of Members of the Biological Standards Commission, adopted by the OIE International Committee by Resolution No. XVII of 22 May 2003, available at: http://www.oie.int/bsc/eng/en bsc.htm, visited 25 June 2007.

269 The Aquatic Animals Commission replaces the Fish Diseases Commission, which was founded in 1960. It is composed of five members, drawn from all OIE regions (as of October 2007, the members come from Australia, UK, Chile, Italy and Uganda). The members are elected by the International Committee. They must be internationally recognised specialists in the fields of methods for surveillance, diagnosis and prevention of infectious aquatic animal diseases and have extensive international experience, at the regional or global level, of aquatic animal infectious disease surveillance, diagnosis, control and disease prevention methods. The Aquatic Animals Commission is responsible for ensuring that both the Aquatic Animal Health Code and the Diagnostic Manual for Aquatic Animal Diseases reflect the current state of scientific knowledge, by proposing revisions and additions to these standards. It meets at least one a year, and consults with other OIE Specialist Commissions as well as relevant experts in the elaboration of new or revised texts. See the Terms of Reference, Internal Rules and Qualifications of Members of the Aquatic Animal Health Standards Commission, adopted by the OIE International Committee by Resolution No. XVII of 22 May 
and the Scientific Commission for Animal Diseases (Scientific Commission). ${ }^{270}$ These Specialist Commissions are composed of five or six expert members, elected by the IC taking into account the need for fair geographical representation. During the discussion on the terms of reference of these Commissions, concerns raised by developing countries regarding the requirements that the expert members of these Commissions be 'international specialists' in the relevant field and have 'specialised training.' It was argued that these requirements could have the effect of excluding developing country scientists who may have the necessary expertise but might not be internationally recognised or have received specialised training. However, it was also emphasised that there is a need for Specialist Commission members to be experts with the necessary scientific competence so that the results of their deliberations will be recognised by the international community. Consequently, the requirements were modified to replace the term 'specialised training' with 'appropriate experience' and the Director General clarified that an 'international specialist' would be understood to include scientists with experience in more than one country or in a region or scientists with relevant international publications. ${ }^{271}$

The elaboration of standards, in the form of new or revised articles or chapters in the Health Codes or Diagnostic Manuals, takes place in the Specialist Commissions. They meet at least once a year and may periodically hold a conference of specialists to evaluate scientific developments, or hold a meeting composed of delegates of members and specialists to examine urgent problems arising from the occurrence and spread of a particular disease or diseases. ${ }^{272}$

Aside from the above-mentioned bodies, there are also three permanent Working Groups, ${ }^{273}$ which are established by the Director-General for an indefinite period and meet to review progress in their field and take steps to ensure that all members quickly benefit from this progress. ${ }^{274} \mathrm{Ad}$ hoc groups can also be established to address specific

2003, available at: http://www.oie.int/aac/eng/en_fdc.htm, visited on 25 June 2007.

270 The Scientific Commission replaces the Standards Commission which was founded in 1946. It is composed of five specialised members, elected by the International Committee, with due regard to geographical representation (as of January 2007 the members come from Italy, Argentina, Denmark, Japan, and Tunisia). Members must be veterinarians with post-graduate training and practical experience in a field relevant to the control of infectious diseases of animals, who have a publication record appropriate to an international specialist in the field. The Scientific Commission is responsible for identifying the most appropriate strategies and measures for disease prevention and control. It also examines member countries' submissions regarding their animal health status for those countries that wish to be included on the OIE list of countries 'free' of certain diseases. See the Terms of Reference, Internal Rules and Qualifications of Members of the Scientific Commission for Animal Diseases adopted by the OIE International Committee by Resolution No. XVII of 22 May 2003, available at: http://www.oie.int/scad/eng/en_scad.htm, visited 25 June 2007.

${ }^{271}$ International Committee of the OIE, Final Report of the 71st General Session, 71/GS/FR (OIE, Paris), 18-23 May 2003, para. 371, available at: ftp://ftp.oie.int/A_RFinal_2003\%20wp.pdf, visited on 24 August 2006.

${ }^{272}$ Approval of the Committee or, in cases of emergency, of the Administrative Commission is required for these conferences or meetings (see Article 25 of the General Rules of the OIE).

${ }^{273}$ Currently there are Working Groups on Wildlife Diseases, Animal Welfare and Animal Production Food Safety. These Working Groups have six members, who are specialists, recognised at international level and selected for their competence (Article 4 of the Mandates and Internal Rules for Working Groups and Ad Hoc Groups, Reference Laboratories, Collaboration Centres, adopted by the OIE International Committee on 28 May 1993 (Resolution No. XII of 28 May 1993).

274 Para. I of the First Part of the Mandates and Internal Rules for Working Groups and Ad Hoc Groups, Reference Laboratories, Collaboration Centres, adopted by the OIE International Committee on 28 May 1993 (Resolution No. XII of 28 May 1993). 
issues. The members of both these types of groups should reflect broad regional representation and scientific diversity.

In addition, the OIE has Reference Laboratories and Collaboration Centres, both of which provide members with scientific and technical advice and assistance on issues of disease surveillance and control. ${ }^{275}$ In particular, a Reference Laboratory functions as a centre of expertise and standardisation of diagnostic techniques for the particular disease assigned to it. ${ }^{276}$ Each laboratory has an expert, responsible to the OIE and its members, who is a leading and active researcher. The expert helps the Reference Laboratory to provide scientific and technical assistance and expert advice on the surveillance and control of the disease for which the Reference Laboratory is responsible. Collaborating Centres are centres of expertise in a particular area of competence relating to the management of general questions on animal health issues (for example epidemiology, risk analysis, etc.). ${ }^{277}$ In their designated field of competence, they must provide their expertise internationally. ${ }^{278}$ The OIE has a global network of 171 Reference Laboratories with 146 experts covering 93 diseases/topics in 30 countries, and 24 Collaborating Centres covering 22 topics in 14 countries. ${ }^{279}$

The OIE is serviced by a Central Bureau, headed by its Director-General, which has the task of providing the secretariat for the annual General Session of the IC, meetings of the Commissions and technical meetings organised at the OIE. It also assists the secretariats of regional and specialised conferences. In addition, the Central Bureau implements and coordinates information, technical cooperation and scientific activities, which the International Committee has decided upon. ${ }^{280}$

275 See V. Welte, 'Introduction to the Office International Des Epizooties (OIE)', in Multilateral Trade Negotiations on Agriculture: A Resource Manual. Agreement on the Application of Sanitary and Phytosanitary Measures (SPS) and Agreements on Technical Barriers to Trade (TBT), Food and Agriculture Organization (ed.), vol. III (Food and Agriculture Organization, Rome), 2000, 13, available at: www.fao.org/docrep/003/ $\mathrm{x} 7354 \mathrm{e} / \mathrm{X} 7354 \mathrm{e} 01 . \mathrm{htm}$ visited on 21 June 2001.

276 Applications for the title of Reference Laboratory of the OIE must be submitted to the Director General by the delegate of the member country to which the laboratory belongs or by the corresponding Regional Commission. The Director General forwards the applications to the administrative Commission which makes its selection solely on the basis of the scientific and technical competence of the candidate establishment. The applications of laboratories selected by the Administrative Commission are sent to the IC for approval. See Articles 1-3 of the Internal Rules, contained in the Mandates and Internal Rules for Working Groups and Ad Hoc Groups, Reference Laboratories, Collaboration Centres, adopted by the OIE International Committee on 28 May 1993 (Resolution No. XII of 28 May 1993). Australia operates an OIE Reference Laboratory.

277 Para. I of the Second and Third Parts of the Mandates and Internal Rules for Working Groups and Ad Hoc Groups, Reference Laboratories, Collaboration Centres, adopted by the OIE International Committee on 28 May 1993 (Resolution No. XII of 28 May 1993).

${ }^{278}$ The information on OIE Collaborating Centres is found on the 'Collaborating Centres' page of the OIE website available at: http://www.oie.int/eng/OIE/organisation/en_CC.htm?e1d8, visited on 12 June 2008.

279 This information is available on the page for 'Reference Laboratories' on the OIE website, available at: http://www.oie.int/eng/OIE/organisation/en_LR.htm?e1d8, visited on 12 June 2008.

${ }^{280}$ This information is provided on the 'Central Bureau' page of the OIE website, available at: http://www.oie. int/eng/OIE/organisation/en_BC.htm, visited on 6 February 2008. 


\subsubsection{Members and observers}

\section{Graph 23: Members of the OIE that are WTO Members by Income Level, 2007}
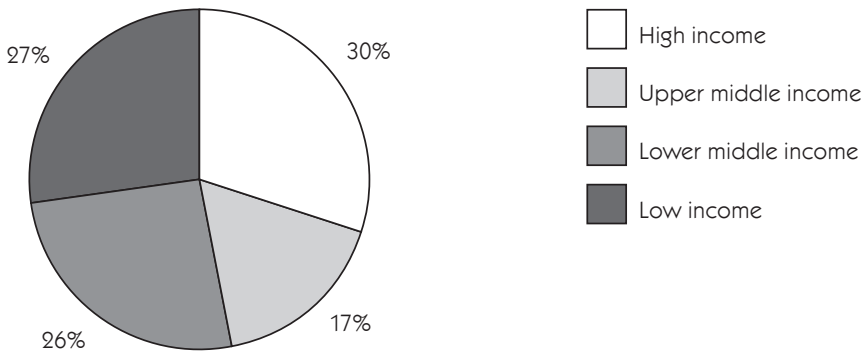

In December 2007 OIE had 172 members, ${ }^{281}$ of which 139 were also WTO Members. ${ }^{282}$ Of these, 29 percent (41) are high-income Members, 17 percent (24) are upper-middleincome Members, 27 percent (37) are lower-middle-income Members and 27 percent (37) are low-income Members. Membership of the OIE is not limited to sovereign states, but includes also members from non-sovereign regions, such as Chinese Taipei. ${ }^{283}$ The European Community is not a member of the OIE in its own right. However, all of its 27 Member States are OIE members.

The OIE maintains permanent relationships with 35 regional and international organisations. International organisations with which the OIE has concluded agreements are invited to participate in the scientific and technical sessions of the International Committee. Their representatives may take the floor during sessions but have no voting rights. ${ }^{284}$ Each of these international organisations may make a presentation at an IC session every two years, except the CAC, WTO, FAO, WHO, World Bank and World Veterinary Organisation, which may make yearly presentations. Regional organisations may only make presentations in the OIE Regional Commissions.

${ }^{281}$ See OIE Members, available at: http://www.oie.int/eng/OIE/PM/en_PM.htm?e1d1, visited on 14 February 2008.

${ }^{282}$ Committee on Sanitary and Phytosanitary Measures, Membership in WTO and International StandardSetting Bodies. Note by the Secretariat. Revision, G/SPS/GEN/49/Rev.8, circulated on 9 October 2007. The data from this document has been updated to include Liechtenstein, Montenegro and the Maldives.

${ }^{283}$ Both China and Chinese Taipei are OIE members. When China's right and obligations as a sovereign state member of the OIE were restored in 2007, the continued participation of Chinese Taipei as a non-sovereign regional member was affirmed. Resolution No. XX: Restoration of the Exercise of the Legal Rights and Obligations of the People's Republic of China to the Word Organisation for Animal Health, contained in World Organisation for Animal Health, Final Report of the $75^{\text {th }}$ General Session, 75 GS-FR, 20-25 May 2007, (OIE, Paris), 134.

${ }^{284}$ Article 2 of the General Rules of the OIE. 


\subsubsection{Standard-setting procedure}

The standard setting procedure of the OIE is characterised by its flexibility. Proposals for new or revised standards for inclusion in the Health Codes or Diagnostic Manuals can come from a variety of sources, including OIE bodies, OIE members, individual experts and international organisations. If the OIE decides to undertake work on the proposed standard, the Director-General decides which Specialist Commission will be entrusted with this task. A member may offer to develop an initial draft of a new or revised standard on the grounds of work done by its national experts on the relevant disease or procedure.

The Director-General determines the membership and terms of reference of the ad hoc group or permanent Working Group that will carry out the technical work. The DirectorGeneral aims to ensure broad regional representation and a diversity of expertise in the ad hoc groups or Working Groups he sets up. As a basis for the work of these groups, the Director-General may commission a supporting document to be drafted by an expert with the latest scientific information. Once the relevant ad hoc group or Working Group has developed a draft standard, it is reviewed by the responsible Specialist Commission.

Thereafter, comments are solicited from OIE member delegates through the circulation of draft texts. One of the problems facing the four Specialist Commissions was the lack of comments from members on draft standards other than those being proposed for immediate adoption. In order to improve this aspect of the standard-setting process, in the context of the implementation of its new Strategic Plan, the OIE has taken steps to facilitate the provision of comments by members' delegates and other interested parties. To do so, it has revised the timetable for meetings of both the Code Commission and the Aquatic Animals Commission to provide additional time for the examination of their proposals by members and interested organisations. ${ }^{285}$ Under the new time table, each of these Commissions would meet each year in August/September and again in March. ${ }^{286}$ Except in urgent cases, the process for adoption of proposals will take two years, instead of one year as was previously the case. ${ }^{287}$

285 The revised timetable provides that each of these two Specialist Commissions will meet each year once in August/September and another time in March. At the August/September meeting the relevant Commission will examine the comments of members and organizations received and take them into account in the elaboration of proposals for new or revised Code chapters and appendices. The reports of these meetings will contain, aside from the reports of working groups and ad hoc expert groups that formed the basis of the proposed standards, two types of texts for comments by members: the proposals being submitted for adoption at the next General Session of the IC; and drafts of ongoing work which may be submitted for adoption at a later General Session of the IC. These meeting reports will be circulated to members and posted on the OIE website in the three official languages. At the following meeting in March, the relevant Commission will review the comments received on the reports and may amend some of the proposals so that they can be put forward for adoption at the IC General Session in May. Other proposals may be discussed and held over for further work. The reports of these meetings will once again be circulated to members and posted on the OIE website. At the General Session of the IC, delegates of members may make comments and suggest improvements to the proposals at the time they are proposed for adoption. International Office of Epizootics, Widening Consultation Mechanisms in the Development of OIE Standards. Press Release 3 October 2005, available at: http://www.oie.int/eng/press/en_051003.htm, 'visited on' 24 August 2006.

${ }^{286}$ OIE, The OIE International Standards (World Organisation for Animal Health, Paris), 2007, available at: http://www.oie.int/eng/normes/guide\%20to\%20OIE\%20intl\%20standards\%20v6.pdf, visited on 1 June 2008.

${ }^{287}$ International Office of Epizootics, Widening Consultation Mechanisms in the Development of OIE Standards. Press Release 3 October 2005, available at: http://www.oie.int/eng/press/en_051003.htm, 'visited on' 24 
Also, in 2005, as part of the implementation of its Fourth Strategic Plan, the OIE took some initiatives to improve the transparency of the standard-setting process in order to ensure that standards have the best possible scientific basis and widest possible support. ${ }^{288}$ While the OIE does not solicit comments other than from delegates of members, the increased transparency in its work has attracted comments from organisations with an interest in the work of the OIE. ${ }^{289}$ The OIE does not refuse such comments as they may be a valuable source of information, but continues to give the greatest weight to the comments of members' delegates. The comments received are reviewed by the Working Group or ad hoc group experts and the Specialist Commissions at their biannual meetings. ${ }^{290}$ They amend the proposal as appropriate and circulate the new draft to OIE members for comments. ${ }^{291}$ If the comments indicate widespread support for the draft standard, the Specialist Commission will submit it to the IC for adoption. If not, a further round of technical work followed by comments is undertaken.

Each OIE member has an official delegate, normally the Chief Veterinary Officer, who is responsible for coordinating that member's participation in the OIE. Industry groups, organisations and experts who want to participate in the OIE standard-setting process are encouraged to do so through the official delegate. ${ }^{292}$ It is the delegates, acting as members of the IC in its General Session, who take the final decisions regarding adoption of the proposed texts. As noted above, standards are adopted in practice by consensus or in the absence of consensus a standard may be adopted if not more than ten members are opposed. ${ }^{293}$

Once adopted by the IC, the standards and guidelines are voluntary and are primarily to be found in the two Health Codes. Both these Health Codes currently refer explicitly to the SPS Agreement. ${ }^{294}$ They provide risk assessment guidelines for countries, requiring them to conduct transparent risk assessments, based on the best available scientific infor-

August 2006.

${ }^{288}$ The OIE now publishes all documents of the Specialist Commissions on its website, and includes as appendices the accepted reports from the relevant working groups or ad hoc groups.

${ }^{289}$ While it accepts the comments of non-members, the OIE encourages them to submit their comments through their respective member delegate in order to ensure that they receive full consideration. The OIE also encourages member delegates to consult the relevant stakeholders and non-governmental organisations in their countries in the process of formulating their comments on proposed OIE texts. However, the OIE recognizes the difficulties that international non-governmental organisations face when trying to channel their comments through multiple OIE member delegates. World Organisation for Animal Health, Transparency in the OIE Standard-Setting Process (OIE, Paris), 2005, available at: http://www.oie.int/eng/oie/transparency\%20_eng. pdf, visited on 5 February 2008.

${ }^{290}$ Reports of the Specialist Commissions normally incorporate the Working Group reports in their entirety, and explain how the various comments were taken into account. These reports are published on the OIE website.

291 OIE, The OIE International Standards (World Organisation for Animal Health, Paris), 2007, available at: http://www.oie.int/eng/normes/guide\%20to\%20OIE\%20intl\%20standards\%20v6.pdf, visited on 1 June 2008.

${ }^{292}$ However, there is no prohibition on submission of information directly to the OIE. Ibid., 4.

293 Joanne Scott, The WTO Agreement on Sanitary and Phytosanitary Measures: A Commentary, Oxford Commentaries on the GATT/WTO Agreements (Oxford University Press, Oxford), 2007, 249.

${ }^{294}$ See Article 1.3.1.2 of the International Animal Health Code, and Article 1.4.1.2 of the International Aquatic Animal Health Code. 
mation and current scientific thinking. They recommend the adoption of OIE standards as risk management measures. ${ }^{295}$

The Health Codes contain disease-specific chapters, setting out the optimal measures to prevent the introduction of the relevant disease into the importing country. ${ }^{296}$ These are set out according to categories of notifiable diseases. In the International Animal Health Code, these are designated as List A diseases and List B diseases, ${ }^{297}$ both of which are considered of socio-economic or public health importance and are significant for international trade in animals. List A diseases have more serious public health or socio-economic importance and have the potential for very serious and rapid spread. ${ }^{298}$ For each disease, criteria are laid down according to which a country be regarded free of the disease or have a region in its territory regarded free of the disease. In certain cases, ${ }^{299}$ countries must submit evidence to the OIE that the criteria are met, on approval of which they will be included in the list of disease-free countries with regard to the particular disease. For each disease, standards are laid down regarding what an importing country should require when importing from countries considered free of the particular disease, as well as when importing from countries regarded as infected by the disease. In addition, various guidelines and standards are set out regarding aspects of trade in animals such as requirements for the transportation of animals, the management of quarantine stations at border posts, border inspections, certification procedures etc.

Unlike the case with the IPPC, discussed below, radical revision of the OIE was not necessitated by the coming into force of the SPS Agreement. ${ }^{300}$ Prior to the Uruguay Round, the OIE was already active in the setting of voluntary international standards and was

${ }^{295}$ Forexample, withregard toriskmanagement, theOIEInternationalAquatic AnimalHealth Codestatesas follows: 1. Risk management is the process of deciding upon and implementing measures to achieve the Member Country's appropriate level of protection, whilst at the same time ensuring that negative effects on trade are minimised. The objective is to manage risk appropriately to ensure that a balance is achieved between a country's desire to minimise the likelihood or frequency of disease incursions and their consequences and its desire to import commodities and fulfil its obligations under international trade agreements. 2. The international standards of the OIE are the preferred choice of sanitary measures for risk management. The application of these sanitary measures should be in accordance with the intentions of the standards or other recommendations of the SPS Agreement. See Article 1.4.2.5 of the International Aquatic Animal Health Code. There is an almost identical provision in Article 1.3.2.5 of the OIE International Animal Health Code.

296 These chapters set out in general for each disease: a description of the disease; a list of commodities that do not require disease-specific measures; a list of commodities that do require the measures set out in the chapter, with the inference that no additional measures are required; a list of the f actors that should be considered in assessing the risk presented by the exporting country for that disease; a list of requirements to be met by a country or region to achieve a specified disease status (e.g. disease-free status with vaccination, moderate risk etc); and recommended health measures for commonly traded commodities.

297 This distinction is not made in the International Aquatic Animal Health Code which refers only to notifiable diseases, which are considered to be of socio-economic and/or public health importance within countries and that are significant in the international trade in aquatic animals and aquatic animal products and "other significant diseases" which are not required to be notified (Article 1.1.1.1 of the International Aquatic Animal Health Code).

${ }^{298}$ Article 1.1.1.1 of the International Animal Health Code.

${ }^{299}$ For example, with regard to foot and mouth disease.

300 Terence P. Stewart and David S. Johanson, 'The SPS Agreement of the World Trade Organization and International Organizations: The Roles of the Codex Alimentarius Commission, the International Plant Protection Convention, and the International Office of Epizootics', Syracuse Journal of International Law and Commerce 26, 1998, 27-53, 50. 
institutionally capable of fulfilling its added role under the SPS Agreement. The OIE did take account of the coming into force of the SPS Agreement by means of an agreement ${ }^{301}$ formalising its relationship with the WTO, whereby the two organisations undertook to consult on issues of mutual interest, to regularly exchange relevant information, to be invited to and participate in relevant meetings held by one another and to co-operate in the provision of technical assistance to developing countries. ${ }^{302}$

In contrast to the situation with the CAC, the increased status of the OIE due to the establishment of its standards as benchmarks under the SPS Agreement initially did not lead to much controversy or public attention. This can be ascribed to the fact that the standards set by the OIE relate to animal health, a much less politically sensitive issue than the human health standards set by the CAC. ${ }^{303}$ However, by 2005, due to the increasing pressure to comply with OIE standards as a prerequisite for market access, OIE member countries felt the need to address the trade significance of these standards. In addition, animal health measures came to the fore as the main subject of challenges at SPS Committee meetings. In 2005, the SPS Committee reported that 40 percent $^{304}$ of all specific trade concerns raised by WTO Members at meetings of the SPS Committee related to areas covered by the OIE, namely animal health issues and zoonoses (animal diseases that can be transmitted to humans). ${ }^{305}$

As a result of these developments, the OIE is now addressing the implications of its standards for trade. It circulated a questionnaire among its member countries in order to evaluate, on the basis of their perceptions and experiences in applying both the OIE Health Codes and the SPS Agreement, whether these rules facilitate or hinder trade in animal products. ${ }^{306}$ Developing countries have expressed concerns with regard to the costs of implementation of OIE standards. In addition, sixty-six percent of respondents to the questionnaire indicated their belief that OIE standards favour industrialised countries.

301 This agreement is embodied in an exchange of letters (see Committee on Sanitary and Phytosanitary Measures, Draft Agreement between the World Trade Organization and the Office International Des Epizooties, G/SPS/W/61, circulated on 22 May 1996.). It was approved by the International Committee of the OIE in May 1997 and by the General Council of the WTO in October 1997.

302 Terence P. Stewart and David S. Johanson, 'The SPS Agreement of the World Trade Organization and International Organizations: The Roles of the Codex Alimentarius Commission, the International Plant Protection Convention, and the International Office of Epizootics', Syracuse Journal of International Law and Commerce 26, 1998, 27-53, 50.

303 Ibid.

${ }^{304}$ This figure was established by the WTO Secretariat, which maintains statistics on these issues. It was published in the report of the SPS Committee's second review of the operation of the SPS Agreement, discussed further below, Part IV, Section 2.1.4. See Committee on Sanitary and Phytosanitary Measures, Review of the Operation and Implementation of the Agreement on the Application of Sanitary and Phytosanitary Measures. Report Adopted by the Committee on 30 June 2005, G/SPS/36, circulated on 11 July 2005, para. 84.

305 For example, Bovine Spongiform Encephalopathy (commonly known as 'mad-cow disease'), which may cause Creutzfeldt-Jakob disease in humans.

306 See the report on the outcome of this questionnaire, which received 106 responses, in Gideon Brückner, Implementation of OIE Standards in the Framework of the SPS Agreement, 73 SG/9 (World Organization for Animal Health, Paris), 22-27 May 2005, available at: http://www.oie.int/downld/SG/2005/A_73\%20SG_9. pdf, visited 12 September 2005. Brückner notes that some responses differed depending on the status of the relevant country as exporting/importing, developed/developing and industrialised/non-industrialised. He recommended that these differences in response be considered and incorporated into the OIE Strategic Plan where necessary. 
On 26 May 2005, following a report on the outcome of the questionnaire survey, ${ }^{307}$ the IC adopted a resolution entitled Implementation of OIE Standards in the Framework of the SPS Agreement. ${ }^{308}$ In this resolution, the IC addresses the challenges and opportunities with regard to participation in international trade for developing countries that adopt OIE standards. The resolution calls on the OIE to facilitate capacity building and training of animal health officials to actively participate in the development and implementation of OIE standards. ${ }^{309}$ Further, the OIE Director General is instructed to request the Code Commission to take developing country needs and circumstances into account in the development of standards, and to establish a uniform format for standards to facilitate their implementation and make them more understandable. ${ }^{310}$ The Director General must further instruct the relevant OIE Commissions to include in the standards, where possible, descriptions of risk mitigation procedures to make animal products safe for trade, and to list which products can be traded without restriction for each specific disease. ${ }^{311}$ Further, the OIE is instructed to request the WTO to grant observer status before the SPS Committee to regional organisations in order to ensure some form of representation of countries lacking the capacity or expertise to ensure continuity of representation in SPS Committee meetings. ${ }^{312}$ In addition, the OIE is mandated to work with the WTO on examining how OIE animal welfare standards can be taken into account. The outcome of the latter examination will be reported to the International Committee for further discussion. ${ }^{313}$ Finally, the OIE is called upon to consider, in collaboration with relevant partners, methods to support the evaluation of veterinary services and an independent audit system for such services, functioning under the auspices of the OIE, to assist members in evaluating their national veterinary services in order to identify problems of compliance with OIE standards as well as areas where investments are needed. ${ }^{314}$

\subsubsection{Participation in standard-setting}

The OIE takes efforts to ensure the participation of all members in its activities. It does so by funding the participation of Chief Veterinary officers of all members at meetings of the IC. As over two thirds of the 172 OIE members are developing countries, the OIE gives

\footnotetext{
307 See ibid.

${ }^{308}$ Resolution XXVII adopted by the International Committee on 26 May 2005. It is contained in International Committee of the OIE, Final Report of the 73rd General Session, 73/GS/FR (OIE, Paris), 22-27 May 2005, 179-180, available at: http://www.oie.int/downld/SG/2005/A_RF_2005.pdf, visited on 5 February 2008.

${ }^{309}$ Ibid., Resolution No. XXVII, point 1.

${ }^{310}$ Ibid., Resolution No. XXVII, points 2 and 3.

311 Ibid., Resolution No. XXVII, point 4.

${ }^{312}$ Ibid., Resolution No. XXVII, point 5.

${ }^{313} \mathrm{Ibid}$., Resolution No. XXVII point 6. The proviso that the result of the discussions would be remitted to the IC for its assessment was added due to Australia's comment, during the discussions on this resolution, that it opposed any attempt to bring animal welfare issues under the SPS Agreement. Australia correctly pointed out that such issues fall outside the scope of this Agreement. See the report of this discussion in International Committee of the OIE, Final Report of the 73rd General Session, 73/GS/FR (OIE, Paris), 22-27 May 2005, para. 50, available at: http://www.oie.int/downld/SG/2005/A_RF_2005.pdf, visited on 5 February 2008. See further on the substantive scope of application of the SPS Agreement below, Part III, Section 2.1.

${ }^{314}$ International Committee of the OIE, Final Report of the 73rd General Session, 73/GS/FR (OIE, Paris), $22-$ 27 May 2005, Resolution No. XXVII point 7, available at: http://www.oie.int/downld/SG/2005/A_RF_2005. pdf, visited on 5 February 2008.
} 
significant attention to capacity building to help its members implement OIE standards. ${ }^{315}$ The capacity building work of the OIE includes conferences and workshops at national, regional and global level.

The Seventy-Fifth General Session of the International Committee of the OIE was attended by 159 members. In addition, observers from five non-member countries and 47 international or regional organisations, institutions or federations attended the meeting. ${ }^{316}$ As there is no list of participants to the meetings of the IC, it is not possible to determine how many Members at different levels of economic development sent delegates to recent meetings, and what the relative size of the delegations were.

The nine-member Administrative Commission of the OIE is required to reflect geographical representation and to necessarily include a representative of each of the regional groups of the OIE. In 2008, the Members of the Scientific Commission that are WTO Members were predominantly from high-income and upper-middle-income Members. ${ }^{317}$

\section{Graph 24: OIE Administrative Commission: Administrative Commission Members that are WTO Members by Income Level, 2008}
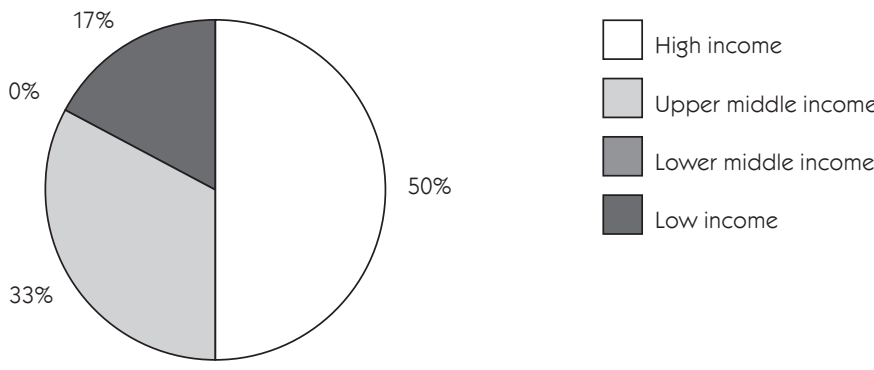

The four Specialist Commissions of the OIE are composed of limited groups of delegates of members, as set out above. The division of the members of these Specialist Commissions that are WTO Members by income level in 2007 shows a predominance of high-income Members in these Commissions. ${ }^{318}$

\footnotetext{
${ }^{315}$ Committee on Sanitary and Phytosanitary Measures, Capacity-Building Tools and Activities. Communication from the World Organization for Animal Health (OIE), G/SPS/GEN/830, circulated on 27 March 2008, para. 3.

${ }^{316}$ International Committee of the OIE, Final Report of the Seventy-Fifth General Session, 75/GS/FR (World Organisation for Animal Health, Paris), 20-25 May 2007, paras 2-3.

317 The three lower-middle-income members of the Administrative Commission in 2008 were all from non-WTO Members. These were the members from Bhutan, Algeria and Syria. The members of the Administrative Commission are provided on the page for the Administrative Commission of the OIE website, available at: http://www.oie.int/eng/OIE/organisation/en_CA.htm, visited on 28 June 2008.

318 The members of the four specialist Commissions are listed on the pages for each Specialist Commission on the OIE website, available at: http:/www.oie.int/eng/OIE/organisation/en_CS.htm, visited on 29 June 2008.
} 


\section{Graph 25: OIE Specialist Commission Members that are WTO Members by Income Level, 2007}

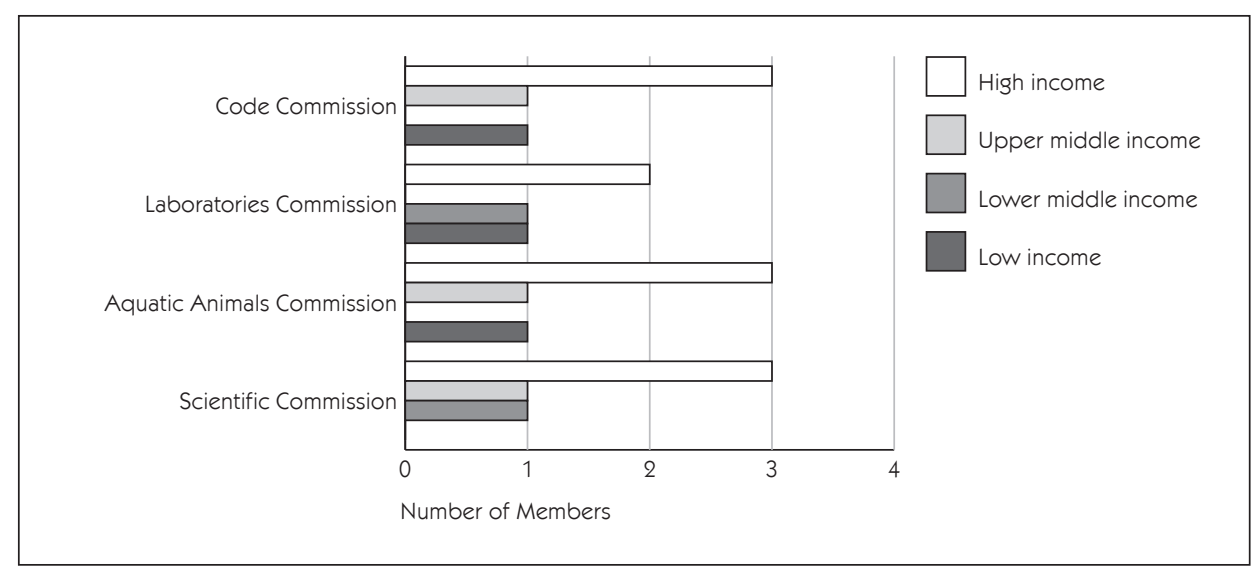

As stated above, the composition of the three Working Groups and several ad hoc groups is determined by the Director-General, and endorsed annually by the IC, on the basis of broad regional representation and scientific diversity. Nevertheless, the primary consideration in selection of members is the level scientific excellence of the experts. 


\section{Graph 26: OlE Ad Hoc Groups: Ad Hoc Group Members that are WTO Members by Income Level, 2008}

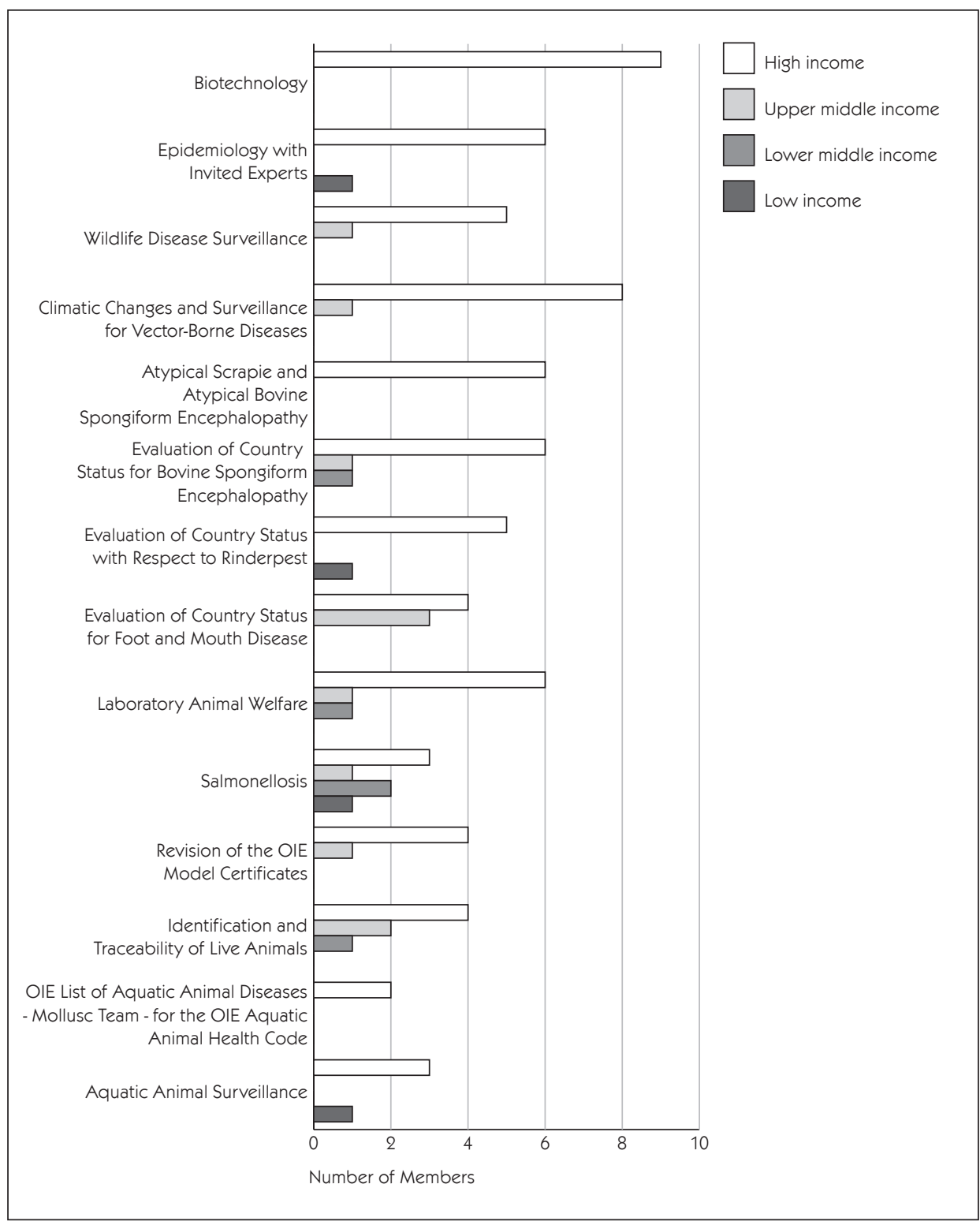




\section{Graph 27: OIE Working Groups: Working Group Members that are WTO Members by Income Level, 2007-2008}

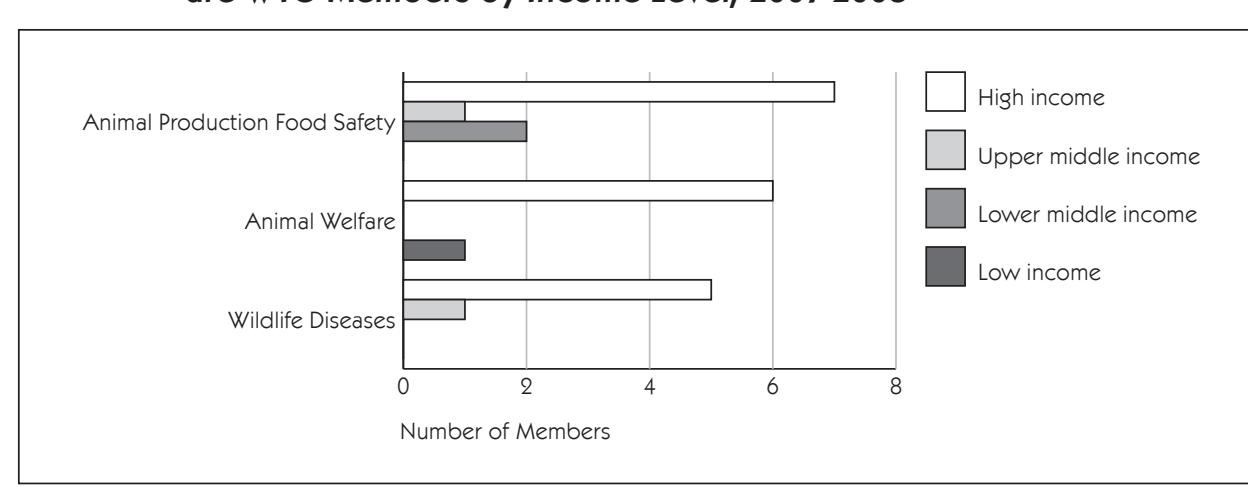

An examination of the most recent meetings of these technical expert groups evinces that by far most of their Members that are WTO Members are from high-income countries. ${ }^{319}$

\subsubsection{The Secretariat of the International Plant Protection Convention and the Commission on Phytosanitary Measures}

In the area of plant health, the SPS Agreement refers to the standards, guidelines and recommendations 'developed under the auspices of the Secretariat of the International Plant Protection Convention in cooperation with regional organisations operating within the framework of the International Plant Protection Convention'. 320

The IPPC is the only one of the 'three sisters' that is in fact an international convention rather than a standard-setting body in the legal sense. This is why the SPS Agreement refers to its Secretariat and the regional organisations operating within its framework for the development of standards. ${ }^{321}$ The origins of the IPPC can be traced back to the Phylloxera

${ }^{319}$ The information on membership of the OIE Working Groups is taken from the most recent reports of the meetings of each Working Group. OIE Working Group on Animal Production Food Safety, Report of the Seventh Meeting, 76 SG/12/CS1 B (World Organisation for Animal Health, Paris), 6-8 November 2007;OIE Working Group on Animal Welfare, Report of the Sixth Meeting, (World Organisation for Animal Health, Paris), 5-7 September 2007; and OIE Working Group on Wildlife Diseases, Report to 76th General Session of the International Committee, 76 SG/13/GT (World Organisation for Animal Health, Paris), 28-31 January 2008. The information on membership of the OIE ad hoc groups is taken from the lists of participants in OIE ad hoc groups provided in the most recent reports of the four Scientific Commissions. Aquatic Animal Health Standards Commission, Report of the Meeting, 76 SG/12/CS4 B (World Organization for Animal Health, Paris), 3-7 March 2008; Biological Standards Commission, Report of the Meeting, 76 SG/12/CS2 B (World Organization for Animal Health, Paris), 22-24 January 2008; Scientific Commission for Animal Diseases, Report of the Meeting, 76 SG/12/CS3 C (World Organization for Animal Health, Paris), 19-21 February 2008; Terrestrial Animal Health Standards Commission, Report of the Meeting, 76 SG/12/CS1 B (World Organization for Animal Health, Paris), 10-14 March 2008.

${ }^{320}$ See Annex A.3(b) of the SPS Agreement.

${ }^{321}$ Although the SPS Agreement refers to the Secretariat of the IPPC, the institutional structure of the IPPC has developed considerably since the coming into force of the SPS Agreement, as discussed below. In this book, in keeping with the current practice at the SPS Committee the abbreviation 'IPPC' will be used to refer to the international standard-setting body that currently adopts phytosanitary standards. However, it should be born in mind that at present, standards adopted under the auspices of the IPPC are in fact adopted by the Commission on Phytosanitary Measures (CPM). 
Convention of $1881,{ }^{322}$ where 12 countries agreed on regulatory measures for grapevines. This was the first initiative to formalise international cooperation in the area of plant protection, and led to the recognition of the need to extend this cooperation to address other plant pests and to include all countries. ${ }^{323}$

Such broader cooperation was embodied in the International Convention for the Protection of Plants, ${ }^{324}$ which never came into force but was later superseded by the IPPC, ${ }^{325}$ adopted by the FAO at its Sixth Session in $1951 .{ }^{326}$ It came into force in April 1952, after ratification by three signatories. ${ }^{327}$ The IPPC was amended in $1979 .{ }^{328} \mathrm{~A} \mathrm{sec}-$ ond, wide-ranging amendment was undertaken to 'deal with the new reality of the formation of the WTO, and the adoption of the Agreement on the Application of Sanitary and Phytosanitary Measures. ${ }^{329}$ This amendment is embodied in the International Plant Protection Convention, New Revised Text (commonly known as the New Revised Text of 1997), which was approved by the FAO Conference in 1997 and came into force in October $2005 .^{330}$

322 International Convention respecting Measures to be taken against the Phylloxera Vastatrix signed on 3 November 1881, and the additional Convention signed at Berne on 15 April 1889.

${ }^{323}$ IPPC Secretariat, A Summary of the IPPC (International Plant Protection Convention, Rome), 30 June 2006, 1, available at: https://www.ippc.int/servlet/BinaryDownloaderServlet/14258_IPPC_History_Member_. doc?filename $=1152100003077$ Handout00_IPPC_History_Member_-610767244.doc\& $\overline{r e f I D}=14258$, visited on 28 July 2006.

${ }^{324}$ The International Convention for the Protection of Plants was drafted in 1929 at the International Conference for Plant Protection, held in Rome. The consideration of the draft text of this convention was delayed considerably due to the Second World War. In 1947, it was brought to the attention of governments meeting in the then-recently created UN Food and Agriculture Organization (FAO). This led to the drafting of the International Plant Protection Convention.

${ }^{325}$ International Plant Protection Convention (IPPC), 6 December 1951, 150 U.N.T.S. 67. According to Article 10 thereof, the IPPC superseded all previous international agreements for the protection of plants, namely the Phylloxera Convention of 1881, the Berne Convention of 1889 and the draft International Convention for the Protection of Plants of 1929.

326 The IPPC was deposited with the Director-General of the FAO.

327 The first three signatories were Ceylon, Spain and Chile. IPPC Secretariat, A Summary of the IPPC (International Plant Protection Convention, Rome), 30 June 2006, 1, available at: https://www.ippc.int/servlet/BinaryDownloaderServlet/14258_IPPC_History_Member_doc?filename=1152100003077_Handout00 IPPC_History_Member_-610767244.doc\&refID=14258, visited on 28 July 2006.

${ }^{328}$ This amendment came into force with respect to all contracting parties on 4 April 1991, after ratification by two-thirds of the contracting parties according to Article 13.4 of the IPPC.

329 This statement was made by the Assistant Director-General of the FAO at the first session of the Commission for Phytosanitary Measures in April 2006. See International Plant Protection Convention, Report of the First Session of the Commission on Phytosanitary Measures, CPM-1 (2006)/Report (Food and Agriculture Organization, Rome), 3-7 April 2006, 2, available at: https://www.ippc.int/servlet/ BinaryDownloaderServlet/133571_CPM_1_report_2006.pdf?filename=1151505665852_CPM_1_report. pdf\&refID=133571, visited on 28 July 2006. Note also that the preamble to the New Revised Text of 1997 expressly states that the contracting parties note 'the agreements concluded as a result of the Uruguay Round of Multilateral trade Negotiations, including the Agreement on the Application of Sanitary and Phytosanitary Measures'.

${ }^{330}$ International Plant Protection Convention, New Revised Text, approved by the FAO Conference at its 29th Session, November 1997. This amendment came into force on 2 October 2005, 30 days after ratification by two thirds of the contracting parties according to Article XII.4 of the IPPC. At the $7^{\text {th }}$ Session of the ICPM, it was noted that entry into force of the New Revised Text of 1997 would apply to all contracting parties, including those that had not accepted the New Revised Text at the time of entry into force. 


\subsubsection{Mandate}

The primary aim of the IPPC to secure common and effective action to prevent the introduction and spread of plant pests and diseases, ${ }^{331}$ and to promote appropriate measures for their control. ${ }^{332}$ According to the preamble of New Revised Text of the IPPC, the contracting parties:

[recognise] the necessity of international cooperation in controlling pests of plants and plant products and in preventing their spread, and especially their introduction into endangered areas; ... [desire] to ensure close coordination of measures directed to these ends; [desire] to provide a framework for the development and application of harmonized phytosanitary measures and the elaboration of international standards to that effect; ${ }^{333}$

More concretely, Article I.1 of the New Revised Text provides that the contracting parties agree to adopt the legislative, technical or administrative measures set out in the New Revised Text of the IPPC and supplementary agreements. ${ }^{334}$ Article X of the New Revised Text states that contracting parties agree to cooperate in the development of international standards, according to the procedures adopted by the Commission on Phytosanitary Measures. Contracting parties are only permitted to impose phytosanitary measures in respect of quarantine pests and regulated non-quarantine pests ${ }^{335}$ as defined in the New Revised Text - measures in respect of other pests, known as 'non-regulated pests', are prohibited. ${ }^{336}$

In 2007, the Commission on Phytosanitary Measures, which is the governing body of the IPPC formulated its Mission Statement as:

Cooperation between nations in protecting the world's cultivated and natural plant resources from the spread and introduction of pests of plants, while minimizing interference with the international movement of goods and people. ${ }^{337}$

International co-operation for the protection of plants remains the main objective of the IPPC and its coverage therefore extends beyond cultivated plants to include natural or

331 Plant pests are defined in Article II.1 of the New Revised Text of 1997 as including pathogenic agents, and thus plant diseases are covered as well.

${ }^{332}$ Article I.1 of the New Revised Text of 1997.

${ }^{333}$ Preamble to the New Revised Text of 1997 of the IPPC. The preamble of the IPPC of 1979 was practically identical, except that it used the word 'usefulness' instead of 'necessity' and referred to 'introduction across national boundaries' instead of 'introduction into endangered areas'.

334 Supplementary agreements are agreements concluded, in accordance with the principles and provisions of the IPPC, for the purpose of addressing special problems of plant protection. They may, for example, be applicable to specific regions, specific pests, specific plants or specific means of transportation (see Article XVI of the New Revised Text of 1997, previously Article 3 of the IPPC of 1979).

${ }_{335}$ Regulated non-quarantine pests are defined in Article II.2 of the New Revised Text as non-quarantine pests 'whose presence in plants for planting affects the intended use of those plants with an economically unacceptable impact' and which are therefore regulated within the territory of the importing contracting party.

${ }^{336}$ Article VI.2 of the New Revised Text.

${ }^{337}$ Commission on Phytosanitary Measures, Business Plan 2007-2011 (International Plant Protection Convention, Rome), 29 March 2007, 12, available at: https://www.ippc.int/servlet/BinaryDownloaderServlet/184265 CPMBusinessPlan.pdf?filename $=1180093785157$ Latest_Business_Plan Revised-1196537010. pdf\&refID=184265, visited on 2 April 2008. 
wild flora. However, the main use of phytosanitary measures in most countries has been in the protection of agriculture, horticulture and forestry from the introduction and spread of pests and diseases. Thus the work of the IPPC is mainly focused on quarantine pests relevant to international trade. ${ }^{338}$ Nevertheless, it has been recognised that IPPC principles are equally valid for the protection of wild flora and biodiversity, and mechanisms to address environmental issues, such as invasive alien species, have been developed. ${ }^{339}$ The role of the IPPC in relation to the protection of marine plants remains to be clarified.

The IPPC has seven 'medium term goals', identified as part of the Business Plan adopted by its governing body, the Commission on Phytosanitary Measures (CPM), in 2007. ${ }^{340}$ These are: the development, adoption and implementation of international standards for phytosanitary measures (ISPMs); information exchange; the provision of dispute settlement mechanisms; the development of the phytosanitary capacity of contracting parties through promoting the provision of technical assistance; the maintenance of an effective and efficient administrative framework; the promotion of the IPPC and cooperation with relevant international organisations; and the review of the status of plant protection in the world.

Much of the activity of the IPPC bodies centres on the first medium-term goal, namely standard setting. In November 1993, the first ISPM was adopted by the newly-created IPPC Secretariat. Currently, Article X of the New Revised Text provides for the adoption of international standards by the CPM. As of 1 June 2007, 29 ISPMs have been adopted and a further six are under consultation. While early ISPMs dealt with general

${ }^{338}$ Quarantine pests are defined in Article II.1 of the New Revised Text as pests 'of potential economic importance to the area endangered thereby and not yet present there, or present but not widely distributed and being officially controlled.'

339 The issue of invasive alien species is also addressed by the Convention on Biological Diversity (CBD). Therefore the importance of strong cooperation between the IPPC and the CBD has been explicitly recognised. International Plant Protection Convention, Report of the First Session of the Commission on Phytosanitary Measures, CPM-1 (2006)/Report (Food and Agriculture Organization, Rome), 3-7 April 2006, Appendix XVI, available at: https://www.ippc.int/servlet/BinaryDownloaderServlet/133571_CPM_1_report_2006. pdf?filename $=1151505665852$ CPM_1_report.pdf\&refID $=133571$, visited on 28 July 2006 . The 2007 report of the independent evaluation team established to evaluate the operation and institutions of the IPPC notes that in evaluation interviews, issues related to the interface between the IPPC and the Convention on Biological Diversity were mentioned as areas where the IPPC should focus more attention in standard setting. Risks associated with movement of articles capable of vectoring plant pests of environmental concern were argued to be areas where IPPC standards are needed. FAO Programme Committee, Independent Evaluation of the Working of the International Plant Protection Convention and Its Institutional Arrangements (Food and Agriculture Organization, Rome), 17-21 September 2007, paras 32-33, available at: https:/www.ippc. int/servlet/BinaryDownloaderServlet/184229_IPPC_Evaluation_Repo.doc?filename=1180006371650_1 IPPC_Final_Evaluation_Report.doc\&refID=18̄4229, visited on $10 \overline{0}$ March 2008.

340 International Plant Protection Convention, Report of the Second Session of the Commission on Phytosanitary Measures, CPM-2 (2007)/Report (Food and Agriculture Organization, Rome), 26-30 March 2007, available at: https://www.ippc.int/servlet/BinaryDownloaderServlet/184215_CPM_2_report. pdf?filename $=1179929463410 \_C P M \_2$ report.pdf\&refID $=184215$, visited on 20 February 2008 . The seven 'medium term goals' incorporate the six 'strategic directions' identified by the CPM as part of its Strategic Plan adopted at its First Session in 2006 but add one item, namely the review of the status of plant protection in the world. The six 'strategic directions' are contained in International Plant Protection Convention, Report of the First Session of the Commission on Phytosanitary Measures, CPM-1 (2006)/Report (Food and Agriculture Organization, Rome), 3-7 April 2006, Appendix XVI, available at: https:/www.ippc.int/servlet/ BinaryDownloaderServlet/133571_CPM_1_report_2006.pdf?filename=1151505665852_CPM_1_report. pdf\&refID=133571, visited on 28 July 2006. 
or cross-cutting phytosanitary issues such as pest risk analysis, ${ }^{341}$ the establishment of pest-free areas, ${ }^{342}$ pest eradication guidelines ${ }^{343}$ and a glossary of phytosanitary terms, ${ }^{344}$ recent ISPMs are more specific to particular phytosanitary problems, such as modes of transmission of risks (e.g. wood packaging material), ${ }^{345}$ pests (e.g. fruit flies), ${ }^{346}$ risk mitigation measures (e.g. irradiation) $)^{347}$ and diagnostic protocols for regulated pests. ${ }^{348}$ The New Revised Text is a legally binding agreement for all its contracting parties, but the standards and guidelines set by the CPM are not legally binding. Article X of the New Revised Text provides that contracting parties 'should' take these standards into account when undertaking activities related to the IPPC.

The second medium term goal, namely information exchange, is achieved through the provision by contracting parties of the information required in the New Revised Text, ${ }^{349}$ and the maintenance by the IPPC Secretariat of an internet portal, known as the International Phytosanitary Portal (IPP), to enhance the accessibility of phytosanitary information. ${ }^{350}$

${ }^{341}$ Framework of Pest Risk Analysis, ISPM 2 (1995), revised in 2007.

${ }^{342}$ Requirements for the Establishment of Pest Free Areas, ISPM 4 (1995).

${ }^{343}$ Guidelines for Pest Eradication Programmes, ISPM 9 (1998).

344 Glossary of Phytosanitary Terms, ISPM 5 (1996), updated regularly.

${ }^{345}$ Guidelines for Regulating Wood Packaging Material in International Trade, ISPM 15 (2002), modified in 2006 (Annex 1).

${ }^{346}$ Establishment of Pest Free Areas for Fruit Flies (Tephritidae), ISPM 26 (2006).

${ }^{347}$ Guidelines for the Use of Irradiation as a Phytosanitary Measure, ISPM 18 (2003).

${ }^{348}$ Diagnostic Protocols for Regulated Pests, ISPM 27 (2006). This development from cross-cutting to specific phytosanitary standards is discussed in the 2007 report of the independent evaluation team established to evaluate the operation and institutions of the IPPC. The report notes that the increasing movement towards specific standards, which apply to specific crops, plants and ecological zones, will require particular attention to the relevance of the specific standards to salient phytosanitary issues and trade demands in a manner that is equitable to the contracting parties. FAO Programme Committee, Independent Evaluation of the Working of the International Plant Protection Convention and Its Institutional Arrangements (Food and Agriculture Organization, Rome), 17-21 September 2007, paras 26 and 29-30, available at: https:/www.ippc.int/servlet/ BinaryDownloaderServlet/184229_IPPC_Evaluation_Repo.doc?filename=1180006371650_1_IPPC_Final_ Evaluation_Report.doc\&refID=184229, visited on 10 March 2008.

${ }^{349}$ Contracting parties are required to provide pest reports (Articles IV.2(b) and VIII.1(a) of the New Revised Text), information on their phytosanitary restrictions, prohibitions and requirements (Article VII.2(b) of the New Revised Text), information on emergency actions (Article VII.6 of the New Revised Text), their lists of regulated pests (Article VII.2(i) of the New Revised Text), a description of their NPPOs (Article IV.4 of the New Revised Text), and the contact details of their official IPPC Contact Points (Article VIII.2 of the New Revised Text).

${ }^{350}$ The IPP, established through a decision of the Third Session of the ICPM in 2001, is the official website of the IPPC. The IPP facilitates information exchange by providing a single forum where contracting parties can comply with their reporting obligations under the New Revised Text.. Officially nominated persons (known as 'editors') from NPPOs, RPPOs and the IPPC Secretariat are responsible for entering information onto and maintaining the IPP. Ten IPP training workshops had been conducted by June 2007, resulting in the training of 288 NPPO editors from 135 contracting parties and 18 RPPO editors. This has led to a significant increase in the amount of information available on the IPP. An IPP Support Group was created in 2001 by the ICPM to provide guidance to the IPPC Secretariat in the implementation and maintenance of the IPP. International Plant Protection Convention, Procedural Manual (Food and Agriculture Organization, Rome), 1 June 2007, 87, available at: https:/www.ippc.int/servlet/BinaryDownloaderServlet/159931_Procedural manual_20.pdf?filename=1188388585480_ProceduralManual2007.pdf\&refID=159931, visited on $10 \mathrm{March}$ 2008. Committee on Sanitary and Phytosanitary Measures, Summary of the Work of the International Plant Protection Convention (IPPC) October 2007-February 2008. Communication from the IPPC Secretariat, G/SPS/GEN/833, circulated on 26 March 2008, para. 10.The IPP is available at: www.ippc.int, visited on 8 March 2008. 
Another of the medium term goals of the IPPC mentioned above is building the phytosanitary capacity of its contracting parties. Under Article XX of the IPPC, contracting parties agree to promote the provision of technical assistance to other contracting parties, especially to those that are developing contracting parties so as to build capacity for the implementation of the IPPC. Capacity building programmes to date have focused on the implementation of the obligations under the IPPC and of ISPMs. The IPPC Secretariat has administered the delivery of technical assistance to developing contracting parties of the IPPC to the amount of approximately US\$ 20 million over five years through the FAO Technical Cooperation Programme and US\$ 2 million through trust funds. ${ }^{351}$ Further, expertise has been made available by the IPPC Secretariat and NPPO volunteers to assist in implementation. An important achievement in the area of capacity building has been the establishment and use of the Phytosanitary Capacity Evaluation (PCE) tool. This tool has made a significant contribution to determining the needs of NPPOs with regard to national phytosanitary systems and national strategic plans, and has been useful in the formulation of donor funded projects including unilateral trust funds and in the delivery of technical assistance to developing countries. ${ }^{352}$

The medium term goal of the review of the state of plant protection in the world has not yet been the subject of work under the IPPC. ${ }^{353}$ Unlike the OIE (in the area of animal health), the bodies of the IPPC do not undertake any action with regard to collecting and compiling information on the incidence and spread of plant pests and diseases. This has been criticised in the report of the independent evaluation of the IPPC in 2007, noting that the IPPC is a unique forum for the evaluation of phytosanitary issues at the global level. ${ }^{354}$

\subsubsection{Institutional structure}

While originally, the IPPC was administered only by a Secretariat and was implemented by Regional Plant Protection Organisations, the administrative framework of the IPPC has since evolved to accommodate the new increased workload and the change in the status of its standards following the coming into force of the SPS Agreement. Several administrative bodies have been created to carry out the functions under the IPPC, under the authority of the governing body known as the Commission on Phytosanitary Measures.

\footnotetext{
${ }^{351}$ Commission on Phytosanitary Measures, Business Plan 2007-2011 (International Plant Protection Convention, Rome), 29 March 2007, 9, available at: https://www.ippc.int/servlet/BinaryDownloaderServlet/184265 CPMBusinessPlan.pdf? filename $=1180093785157$ Latest_Business_Plan__Revised-1196537010. pdf\&refID=184265, visited on 2 April 2008.

352 Ibid.

353 This function is expressly provided in Article XI.2(a) of the New Revised Text.

${ }^{354}$ FAO Programme Committee, Independent Evaluation of the Working of the International Plant Protection Convention and Its Institutional Arrangements (Food and Agriculture Organization, Rome), 17-21 September 2007, para. 145, available at: https://www.ippc.int/servlet/BinaryDownloaderServlet/184229_IPPC Evaluation_Repo.doc?filename $=1180006371650 \_1$ _IPPC_Final_Evaluation_Report.doc\&refID $=184229$, visited on 10 March 2008.
} 


\section{Figure 3: Institutional Structure of the Commission on Phytosanitary Measures}

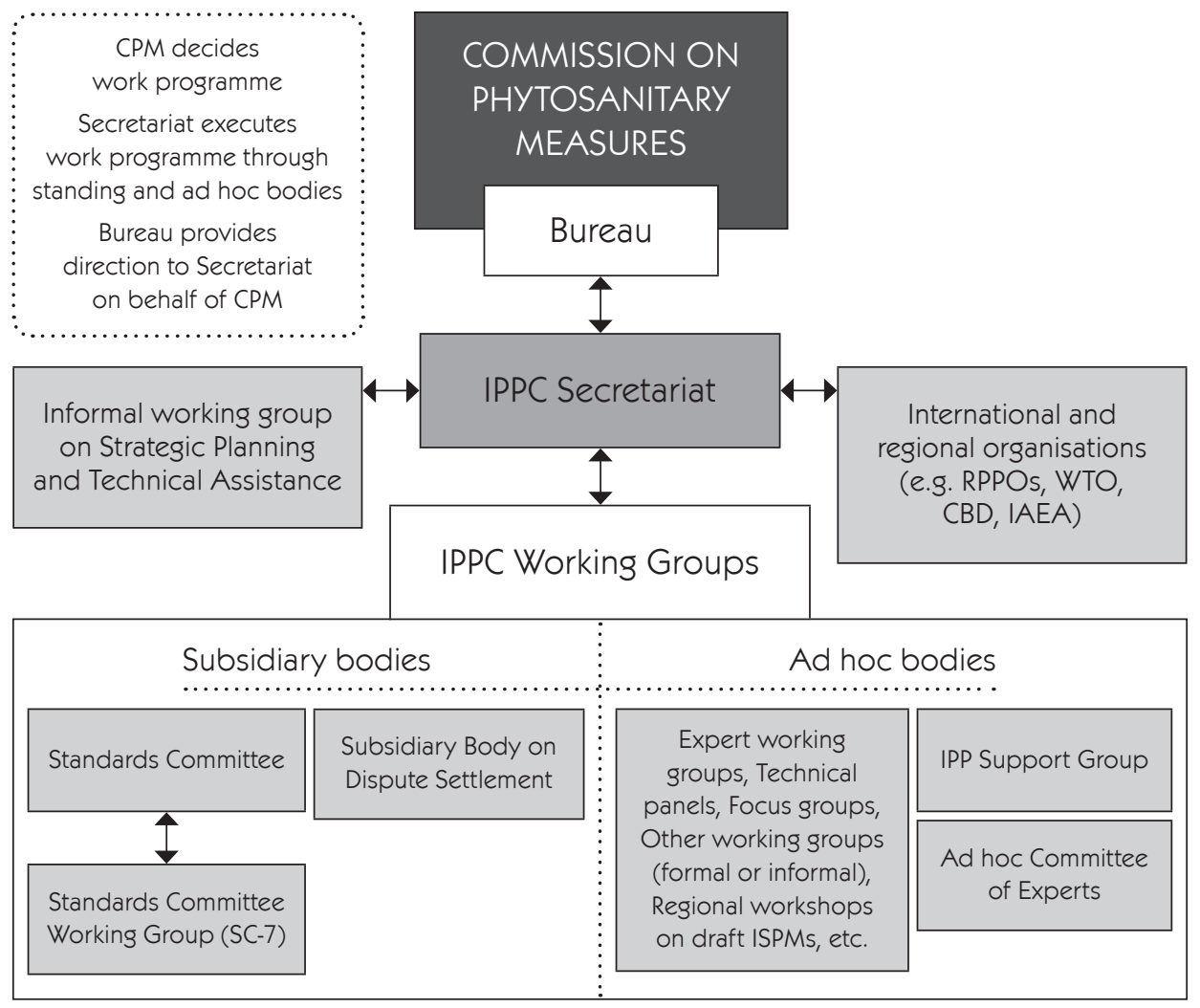

Source: International Plant Protection Convention, Procedural Manual, Food and Agriculture Organization, Rome, 1 June 2007, Annex $7 .^{355}$

In 1992, as a result of its then-expected new standard-setting role under the SPS Agreement, the IPPC was provided with its own secretariat by the FAO, ${ }^{356}$ within the FAO Plant Protection Service. ${ }^{357}$ While it is no longer the case that the administration of the IPPC is entirely in the hands of its Secretariat, the IPPC Secretariat continues to

355 International Plant Protection Convention, Procedural Manual (Food and Agriculture Organization, Rome), 1 June 2007, Annex 7, available at: https://www.ippc.int/servlet/BinaryDownloaderServlet/159931 Procedural_manual_20.pdf?filename=1188388585480_ProceduralManual2007.pdf\&refID=159931, visited on 10 March 2008.

356 The IPPC Secretariat is still appointed by the FAO's Director-General through the FAO selection and recruitment procedures. The Secretary of the IPPC Secretariat is also the chief of the FAO Plant Protection Service and only devotes $20 \%$ of his time to the IPPC. FAO Programme Committee, Independent Evaluation of the Working of the International Plant Protection Convention and Its Institutional Arrangements (Food and Agriculture Organization, Rome), 17-21 September 2007, para. 163, available at: https://www.ippc.int/servlet/BinaryDownloaderServlet/184229_IPPC_Evaluation_Repo.doc?filename=1180006371650_1_IPPC_ Final_Evaluation_Report.doc\&refID=184229, visited on 10 March 2008.

${ }^{357}$ Until 1992, the IPPC was administered directly by the FAO and implemented through the co-operation of national member governments and Regional Plant Protection Organisations. 
play an important role. The IPPC Secretariat has a broad mandate. It implements the policies and activities of the CPM and co-ordinates the work-programme, in particular the elaboration of international phytosanitary standards. ${ }^{358}$ Unlike the Secretariats of the CAC and the OIE, the IPPC Secretariat plays a substantive role in standard-setting. ${ }^{359}$ Further it facilitates the provision of technical assistance (whether provided through the FAO Secretariat, bilaterally or through appropriate international organisations). ${ }^{360} \mathrm{~A}$ third task of the Secretariat is the dissemination of information required by the IPPC and the facilitation of information exchange between contracting parties. The IPPC Secretariat is funded by the FAO and located at the FAO headquarters in Rome. It is composed of 11 persons, a Secretary, a Coordinator and nine professional officers. It is supported by two administrative staff members. ${ }^{361}$ Contracting parties supplement the permanent staff of the Secretariat by providing staff through the Visiting Scientist and Associate Professional Officer (APO) programmes. ${ }^{362}$

A concern has been raised in the reviews of the IPPC with regard to the inadequate size of the IPPC Secretariat. In view of its substantive role in standard-setting, the fact that the IPPC Secretariat is short-staffed is particularly problematic. ${ }^{363}$ The secondment of staff by contracting parties to the Secretariat does not solve this problem, and leads to a bias in the composition of this influential body towards high-income contracting parties, that are in

358 This information is provided on the page on the IPPC Secretariat on the IPPC website, available at: https://www.ippc.int/servlet/CDSServlet?status=ND0xMzMzMiY2PWVuJjMzPSomMzc9a29z, visited on 26 March 2008.

${ }^{359}$ In short, the IPPC Secretariat can initiate a new ISPM, it collaborates with the steward in drafting standard specifications, it consults with the Chair of the SC before a draft standard is submitted for consultation, and in the case of standards in the fast-track procedure, it resolves issues raised by comments on the standards before the draft and comments are submitted to the SC. The role of the IPPC Secretariat in standard setting is set out in more detail below, Part II, Section 3.2.3.4.

${ }^{360}$ Article XII of the New Revised Text of 1997.

361 The composition of the IPPC Secretariat as of 1 June 2007 is set out in International Plant Protection Convention, Procedural Manual (Food and Agriculture Organization, Rome), 1 June 2007, Annex 10, available at: https://www.ippc.int/servlet/BinaryDownloaderServlet/159931_Procedural_manual_20. pdf?filename=1188388585480_ProceduralManual2007.pdf\&refID=159931, visited on 10 March 2008.

${ }^{362}$ The 2007 report of the IPPC Secretariat notes that the US supplied two APOs (for standard setting and information exchange), Japan supplied one APO and Canada supplied one visiting scientist to supplement its staff. However, the Secretariat reported that the areas of information exchange and improved phytosanitary capacity were still under-staffed and that problems could be experienced in those areas in fulfilling the requirements of the IPPC Operational Plan. Commission on Phytosanitary Measures, Report by the Secretariat, CPM 2007/21 (Food and Agriculture Organization, Rome), 26 - 30 March 2007, para. 43, available at: https://www.ippc.int/ servlet/BinaryDownloaderServlet/177435_CPM2007_21.pdf?filename=1169452364803_CPM2007_21r. pdf\&refID $=177435$, visited on 27 March 2008 .

${ }^{363}$ At the second session of the CPM, the Chairperson Mr Kedera noted that the lack of staff in the IPPC Secretariat and uncertainties about future improvements to this situation were becoming chronic problems. International Plant Protection Convention, Report of the Second Session of the Commission on Phytosanitary Measures, CPM-2 (2007)/Report (Food and Agriculture Organization, Rome), 26-30 March 2007, para. 14, available at: https://www.ippc.int/servlet/BinaryDownloaderServlet/184215_CPM_2_report.pdf?filename $=1179929463410 \_C P M \_2$ report.pdf\&refID $=184215$, visited on 20 February 2008 . The extraordinarily heavy workload of the IPPC Secretariat was noted with concern in the report of the independent evaluation of the IPPC in 2007. FAO Programme Committee, Independent Evaluation of the Working of the International Plant Protection Convention and Its Institutional Arrangements (Food and Agriculture Organization, Rome), 17-21 September 2007, para. 162, available at: https://www.ippc.int/servlet/BinaryDownloaderServlet/184229_IPPC_Evaluation_Repo.doc?filename=1180006371650_1_IPPC_ Final_Evaluation_Report.doc\&refID=184229, visited on 10 March 2008. 
a position to make such secondments. It has been proposed that the position of Secretary of the IPPC become a full time position and that the permanent professional staff of the Secretariat be increased from 1.5 person years to 6 (or alternatively 4) person years. ${ }^{364}$

As noted above, several new bodies have been established to carry out the functions laid down in the IPPC. The New Revised Text provides for the establishment of a CPM within the framework of the FAO, ${ }^{365}$ which is the new governing body of the IPPC. ${ }^{366}$ It is composed of all the contracting parties to the IPPC. Contracting parties are represented in the Commission by delegates, selected by their governments. ${ }^{367}$ The CPM meets in annual sessions to implement the objectives of the IPPC, in particular to set the priorities for the adoption of international phytosanitary standards and to adopt such standards. ${ }^{368}$ It is assisted by the IPPC Secretariat. ${ }^{369}$ The contracting parties in the CPM are required to make every effort to reach agreement on all matters by consensus, although voting is possible as a last resort. ${ }^{370}$ In such cases, decisions are taken by a two-thirds majority of the contracting parties present and voting. ${ }^{371}$ Since October 2005, when the New Revised Text entered into force, the CPM has met twice, once in 2006 and once in 2007. ${ }^{372}$ At its First Session, the CPM elected Mr Kedera (Kenya) as its Chairperson. ${ }^{373}$

${ }^{364}$ FAO Programme Committee, Independent Evaluation of the Working of the International Plant Protection Convention and Its Institutional Arrangements (Food and Agriculture Organization, Rome), 17-21 September 2007, 167, available at: https://www.ippc.int/servlet/BinaryDownloaderServlet/184229_IPPC Evaluation_Repo.doc?filename $=1180006371650$ 1_IPPC_Final_Evaluation_Report.doc\&refID $=\overline{184229}$, visited on $\overline{10}$ March 2008. The Independent Evaluation proposed 4 person years, whereas in its analysis of the recommendations of the Independent Evaluation, the SPTA proposed 6 person years as its assumed that less work would be done on a voluntary basis, contrary to the assumption of the Independent Evaluation. International Plant Protection Convention, Report of the Second Meeting of the CPM Informal Working Group on Strategic Planning and Technical Assistance (SPTA) (Food and Agriculture Organization, Rome), 1-5 October 2007, para. 28, available at: https://www.ippc.int/servlet/BinaryDownloaderServlet/190812_9 th_SPTA_Report_2007.pdf?filename=1196340302166_9th_SPTA_Report_2007.pdf\&refID $=190812$, visited on $2 \overline{7}$ March 2008 .

365 Article XI of the New Revised Text of 1997.

${ }^{366}$ Pending the coming into force of the New Revised Text, the FAO established an Interim Commission on Phytosanitary Measures (ICPM), which met in four sessions (First Session, 3-6 November 1998; Second Session, 4-8 October 1999; Third Session, 2-6 April 2001; Fourth Session, 11-15 March 2002). All sessions were held in Rome. In 1999 the ICPM adopted new standard-setting procedures.

${ }^{367}$ According to Article XI.4 of the New Revised Text of 1997, each party may be represented by a single delegate. An alternate as well as experts and advisers may accompany the delegate and take part in the proceedings but may not vote (unless the alternate is authorised to replace the delegate).

${ }^{368}$ The Commission may also be convened in Special Sessions.

369 Articles XI.2(a) and (b) and XII.3 of the New Revised Text of 1997. The CPM and IPPC Secretariat have additional tasks that are listed in Articles XI and XII.

${ }^{370}$ Article XI.5 of the New Revised Text of 1997.

371 Article XI.5 of the New Revised Text of 1997.

372 International Plant Protection Convention, Report of the First Session of the Commission on Phytosanitary Measures, CPM-1 (2006)/Report (Food and Agriculture Organization, Rome), 3-7 April 2006, available at: https://www.ippc.int/servlet/BinaryDownloaderServlet/133571 CPM 1 report 2006. pdf?filename $=1151505665852 \_$CPM_1_report.pdf\&refID=133571, visited on 28 July 2006; International Plant Protection Convention, Report of the Second Session of the Commission on Phytosanitary Measures, CPM-2 (2007)/Report (Food and Agriculture Organization, Rome), 26-30 March 2007, available at: https:// www.ippc.int/servlet/BinaryDownloaderServlet/184215_CPM_2_report.pdf?filename=1179929463410_ CPM_2_report.pdf\&refID=184215, visited on 20 February 2008.

${ }^{373}$ International Plant Protection Convention, Report of the First Session of the Commission on Phytosanitary Measures, CPM-1 (2006)/Report (Food and Agriculture Organization, Rome), 3-7 April 2006, para. 189, available at: https://www.ippc.int/servlet/BinaryDownloaderServlet/133571_CPM_1_report_2006. 
The CPM is headed by a Bureau, which has the task of working with the IPPC Secretariat throughout the year in executing the CPM's work programme. The Bureau chairs CPM Sessions and decides, together with the IPPC Secretariat and Standards Committee, on the selection of experts to participate in Expert Working Groups (EWG) and Technical Panels (TP). It also attends working group meetings and extraordinary meetings of the Standards Committee. The Bureau is currently composed of three persons, namely the Chairperson and two Vice-Chairpersons of the CPM. However, some contracting parties raised concerns with regard to the fact that such a small group of persons is authorised to take such important decisions for the CPM. ${ }^{374}$ As a result, in 2007, the CPM adopted an amendment to its rules of procedures, to expand the membership of the Bureau to seven persons. The CPM, at its next session in 2008, must therefore elect a Chairperson and not more than two Vice-Chairpersons and four other persons from among the delegates to form a Bureau of seven persons, so that each FAO region is represented. ${ }^{375}$ The term of office would be for two years and the main purpose would be to provide guidance to the CPM on the strategic direction and financial and operational management of its activities. $^{376}$

In 2001, an informal working group was created to formulate recommendations on topics and priorities, including changes in the existing priorities and on procedures for identifying topics and priorities. ${ }^{377}$ This body became known the Informal Working Group on Strategic Planning and Technical Assistance (SPTA). ${ }^{378}$ The SPTA meets at least

pdf?filename=1151505665852_CPM_1_report.pdf\&refID=133571, visited on 28 July 2006. Mr Kedera was previously the Chairperson of the ICPM until its replacement by the CPM.

${ }^{374}$ FAO Programme Committee, Independent Evaluation of the Working of the International Plant Protection Convention and Its Institutional Arrangements (Food and Agriculture Organization, Rome), 17-21 September 2007, para. 148, available at: https:/www.ippc.int/servlet/BinaryDownloaderServlet/184229 IPPC Evaluation_Repo.doc?filename $=1180006371650 \_1$ IPPC_Final_Evaluation_Report.doc\&refID $=\overline{184229}$, visited on $\overline{10}$ March 2008.

375 The phrase 'from among the delegates' is understood to mean that the members of the Bureau have to be present at the CPM session where the election takes place in order to be elected. This is because members of the Bureau should be familiar with the discussions and decisions made at the annual sessions of the CPM. This first election of a 7 member Bureau will take place at the Third Session of the CPM in April 2008.

376 These items were introduced into Rule II.1 of the Rules of Procedure of the CPM. The meetings of the Bureau will not be open-ended and the Bureau will set its own rules of procedure.

377 Third Interim Commission on Phytosanitary Measures, Report of the Third Interim Commission on Phytosanitary Measures, ICPM 01/REPORT (Food and Agriculture Organization, Rome), 2-6 April 2001, para. 4, available at: https://www.ippc.int/servlet/BinaryDownloaderServlet/14320_ICPM Report_2001_E.PDF?filename=1079019159579_ICPM3e.PDF\&refID=14320, visited on 2 April $200 \overline{8}$ This body is the successor to the Technical Consultation on Strategic Planning, which was created in 1999 as an informal working group of interested contracting parties to develop a strategic plan for the ICPM. It met in 2000 and 2001. Interim Commission on Phytosanitary Measures, Report of the Second Interim Commission on Phytosanitary Measures, ICPM-2(1999)/Report (Food and Agriculture Organization, Rome), 4-8 October 1999, available at: https://www.ippc.int/servlet/BinaryDownloaderServlet/13804_ICPM_Report_1999_E. PDF?filename $=/$ publications/13804.Report_of_the_Second_Meeting_of_the_ICPM_1999.2001-3-27. PDF\&refID=13804, visited on 10 March 2008.

${ }^{378}$ The first meeting of the SPTA under its new name was in 2002. In 2004, the ICPM recognised concerns that this important body had no rules of procedure and that its composition tended to be unbalanced. In 2005, the ICPM adopted interim terms of reference for the SPTA, setting out its functions. The final Terms of Reference and Rules of Procedure for the CPM Informal Working Group on Strategic Planning and Technical Assistance (SPTA) were adopted in 2007. International Plant Protection Convention, Report of the Second Session of the Commission on Phytosanitary Measures, CPM-2 (2007)/Report (Food and Agriculture Organization, Rome), 26-30 March 2007, Appendix 9, available at: https://www.ippc.int/ 
once a year, at least 4 months before the CPM session. Its composition is open-ended, comprising a core group of the Bureau of the CPM, ${ }^{379}$ the chairpersons of the Standards Committee and the Subsidiary Body on Dispute Settlement and other interested persons from contracting parties. ${ }^{380}$ The SPTA undertakes specific tasks related to planning and prioritising the work programme of the CPM and making recommendations to the CPM or its subsidiary bodies in this regard. These tasks include planning and prioritising work with regard to topics for new ISPMs, technical assistance, information exchange, funding issues and liaising with international organisations. The SPTA strives for consensus on all issues regarding its advice or recommendations to the CPM or subsidiary bodies. If consensus cannot be reached, the CPM or subsidiary body is informed of the situation. ${ }^{381}$ While formally speaking the SPTA is only an advisory body, it is widely recognised that it has been very influential in the IPPC, including in decision making by the CPM. ${ }^{382}$ Due to its informal nature, there are concerns regarding lack of transparency in the work of the SPTA. ${ }^{383}$ Also, the relationship between the SPTA and the new expanded Bureau is not clear. As a result, proposals have been made with regard to turning the SPTA into a formal body or combining the functions of the SPTA and the Bureau in a single body. However, it has been agreed to keep the SPTA as an informal body until the effectiveness of the new Bureau can be evaluated. ${ }^{384}$

servlet/BinaryDownloaderServlet/184215_CPM_2_report.pdf?filename=1179929463410_CPM_2_report. pdf\&refID $=184215$, visited on 20 February 2008 .

${ }^{379}$ In 2006, the CPM decided that the composition of the SPTA should be formalised, to consist of a core group composed of the enlarged 7-person Bureau (i.e. the Chairperson and two Vice-Chairpersons of the CPM and a representative from each of the remaining 4 FAO regions); the Chairpersons of the SBDS and $\mathrm{SC}$ and other interested persons from the contracting parties. International Plant Protection Convention, Report of the First Session of the Commission on Phytosanitary Measures, CPM-1 (2006)/Report (Food and Agriculture Organization, Rome), 3-7 April 2006, para. 105, available at: https:/www.ippc.int/servlet/ BinaryDownloaderServlet/133571_CPM_1_report_2006.pdf?filename=1151505665852_CPM_1_report. pdf\&refID=133571, visited on 28 July $200 \overline{6} .$. In 2007 , the CPM decided that the SPTA should remain informal and its membership remain open-ended so that all IPPC contracting parties could participate in its work on an equal basis. It was agreed that the composition of the SPTA in 2007 should be the same as in 2006, namely the core group of 7 members made up of the expanded Bureau, the chairpersons of the subsidiary bodies (SBDS and SC) and other interested persons from the contracting parties. International Plant Protection Convention, Report of the Second Session of the Commission on Phytosanitary Measures, CPM-2 (2007)/Report (Food and Agriculture Organization, Rome), 26-30 March 2007, paras 103-104, available at: https://www.ippc.int/ servlet/BinaryDownloaderServlet/184215 CPM 2 report.pdf?filename=1179929463410 CPM 2 report. pdf\&refID=184215, visited on 20 February 2008 .

${ }^{380}$ Paragraph 3 of the Terms of Reference of the SPTA. The Standards Committee and the Subsidiary Body on Dispute Settlement are discussed below, in this same Section.

${ }^{381}$ Rule 4 of the Rules of Procedure for the SPTA.

382 FAO Programme Committee, Independent Evaluation of the Working of the International Plant Protection Convention and Its Institutional Arrangements (Food and Agriculture Organization, Rome), 17-21 September 2007, para. 151, available at: https://www.ippc.int/servlet/BinaryDownloaderServlet/184229_IPPC Evaluation_Repo.doc?filename $=1180006371650$ _1_IPPC_Final_Evaluation_Report.doc\&refID $=184229$, visited on 10 March 2008.

383 Ibid.

384 The SPTA itself discussed proposals from the Bureau regarding whether the SPTA should remain openended and whether it should become a formal body. It was agreed that the working group should be kept informal until such a time that the effectiveness of the enlarged Bureau could be evaluated. In order to maintain the open-ended nature of the SPTA it was recommended that its membership include the Bureau, the Chairpersons of the two subsidiary bodies and other interested persons from the contracting parties. No observers would be allowed and all representatives would have equal status. 
Aside from these policy-oriented bodies, the IPPC has a variety of expert bodies of limited membership. These are responsible for carrying out the more technical tasks set out in the IPPC. The members of such bodies act in their capacity as experts rather than as representatives of contracting parties. To ensure the technical integrity and impartiality of the work carried out within the framework of the IPPC, the members of these bodies are required declare any interests that could constitute a real, potential or apparent conflict of interest. ${ }^{385}$ Acting as a representative of a national government does not, however, constitute a conflict of interest.

The CPM has established two standing subsidiary bodies, namely the Subsidiary Body on Dispute Settlement and the Standards Committee. ${ }^{386}$ The Subsidiary Body on Dispute Settlement (SBDS), was created to administer the IPPC dispute settlement procedures. ${ }^{387}$ The SBDS has 7 members, from each of the FAO regions. The members must have experience in phytosanitary systems, be familiar with the IPPC and its standards, have experience with legislation and regulations, and preferably have some form of dispute settlement or conflict resolution experience or knowledge. These members serve 2-year terms, renewable twice. Under the authority of the SBDS, the FAO Director-General may establish ad hoc committees of experts, upon request by the parties to a dispute, to examine the issue in dispute. ${ }^{388}$

The second subsidiary body of the CPM, the Standards Committee (SC), oversees and manages the standard-setting process of the IPPC, but does not itself draft standards. ${ }^{389}$

385 The Declaration of Interests for Experts within the Framework of the IPPC is contained in International Plant Protection Convention, Report of the Second Session of the Commission on Phytosanitary Measures, CPM-2 (2007)/Report (Food and Agriculture Organization, Rome), 26-30 March 2007, Appendix 12, available at: https://www.ippc.int/servlet/BinaryDownloaderServlet/184215_CPM_2_report. pdf?filename=1179929463410_CPM_2_report.pdf\&refID=184215, visited on 20 February 2008 .

${ }_{386}$ Rule IX of the Rules of Procedure of the CPM provides that the CPM may establish such subsidiary bodies as it deems necessary for the fulfilment of its functions and shall determine their terms of reference.

387 The Terms of Reference and Rules of Procedure for the Subsidiary Body on Dispute Settlement are to be found in International Plant Protection Convention, Report of the First Session of the Commission on Phytosanitary Measures, CPM-1 (2006)/Report (Food and Agriculture Organization, Rome), 3-7 April 2006, Appendix V, available at: https:/www.ippc.int/servlet/BinaryDownloaderServlet/133571_CPM_1_report_2006.pdf?filename $=1151505665852 \_C P M \_1 \_$report.pdf\&refID=133571, visited on 28 July $200 \overline{6}$. The SBDS replaces the interim Subsidiary Body on Dispute Settlement that was in place pending the entry into force of the New Revised Text.

${ }^{388}$ On the dispute settlement procedures administered by the SBDS and the practice to date, see below, Part IV, Section 2.2.6.

${ }^{389}$ In 1993, prior to the establishment of the Standards Committee, the Committee of Experts on Phytosanitary Measures (CEPM) was formed and interim standard-setting procedures were adopted. In 2000, the CEPM was replaced by the Interim Standards Committee (ISC), composed of phytosanitary experts from around the world. In yearly meetings, it examined and provided its views on the documents prepared by the Secretariat. In 2002, Standards Committee (SC) was created as the standard setting body of the Interim Commission on Phytosanitary Measures (pending the entry into force of the New Revised Text). Thereafter, at its first session in April 2006, the CPM took over the SC as its standard-setting body, and adopted its terms of reference and rules of procedure. R. Griffin, 'Introduction to the International Plant Protection Convention (IPPC)', in Multilateral Trade Negotiations on Agriculture: A Resource Manual. Agreement on the Application of Sanitary and Phytosanitary Measures (SPS) and Agreements on Technical Barriers to Trade (TBT), Food and Agriculture Organization (ed.), vol. III (Food and Agriculture Organization, Rome), 2000, 28, available at: www.fao.org/docrep/003/x7354e/X7354e01.htm visited on 21 June 2001. See also International Plant Protection Convention, Report of the First Session of the Commission on Phytosanitary Measures, CPM-1 (2006)/Report (Food and Agriculture Organization, Rome), 3-7 April 2006, para. 
Its main objective is to expeditiously prepare draft ISPMs that have been identified by the $\mathrm{CPM}$ as priority standards, for adoption by the CPM. ${ }^{390} \mathrm{It}$ is also responsible for selecting members of EWG and TP as well as stewards. ${ }^{391}$ The SC meets at least once a year. ${ }^{392}$ The $\mathrm{SC}$ is composed of 25 members drawn from each of the seven FAO regions, ${ }^{393}$ in order to ensure that it includes a 'diversity of global views' on any subject it deals with. ${ }^{394}$ The choice of experts on a regional basis is founded on the pragmatic consideration that a range of views can best produce internationally acceptable standards. ${ }^{395}$ Members of the SC act as individual experts, not as country representatives, but their views are expected to be characteristic of the region they come from. They should be senior officials of NPPOs, designated by contracting parties. In addition they should have qualifications in a scientific biological discipline (or equivalent) in plant protection, and have experience and skills in the practical operation and administration of a national or international phytosanitary system and the application of phytosanitary measures related to international trade. ${ }^{396}$ In addition, SC members must be able to dedicate the time necessary to participate in SC meetings in a regular and systematic way. However, in practice, the existing rules are not

189, available at: https://www.ippc.int/servlet/BinaryDownloaderServlet/133571_CPM_1_report_2006. pdf?filename=1151505665852_CPM_1_report.pdf\&refID=133571, visited on 28 July 2006.

${ }^{390}$ Paragraph 2 of the Terms of Reference for the Standards Committee. The SC, in particular, ensures that draft standards fulfil the specification for the standard, fall within the scope of the IPPC's mandate, are technically based, have scientific integrity, follow the principles and policy of the CPM, are presented in the required format for standards and are witten in clear, simple and precise language. See para. 2 of the Guidelines on the Duties of Members of the Standards Committee, approved by the Standards Committee in November 2006.

${ }^{391}$ Expert Working Groups, Technical Panels and stewards are discussed below, in this same Section.

392 Rule 5 of the Rules of Procedure of the Standards Committee. Depending on the workload and available resources, the SC or the IPPC Secretariat, in consultation with the Bureau, may request additional meetings of the SC. In practice, normally the SC meets biannually, in May and November of each year.

${ }^{393}$ The distribution for each region will be Africa (4), Asia (4), Europe (4), Latin America and the Caribbean (4), Near East (4), North America (2), and Southwest Pacific (3). Each FAO region may lay down its own procedures for selecting its members of the SC. The selected members are confirmed by the CPM. Members of the SC serve for terms of three years and may not serve more than two terms, unless a region requests the CPM for an exemption. Rules 1 and 3 of the Rules of Procedure of the Standards Committee contained in International Plant Protection Convention, Terms of Reference and Rules of Procedure for the Standards Committee, CPM-1 (2006)/Report (Food and Agriculture Organization, Rome), 2006, Appendix III, available at: https://www.ippc.int/servlet/BinaryDownloaderServlet/142427_TORs_ROPs SC.doc?filename=1155309920830_CPM_1_Terms_of_reference_and_R-221799051.doc\& $\overline{\text { refID }}=\overline{142427}$, visited on 10 March 2008. Note that the process for selection of SC members was criticised as being insufficiently transparent and rigorous by the independent evaluation team established to evaluate the operation and institutional arrangements of the IPPC. FAO Programme Committee, Independent Evaluation of the Working of the International Plant Protection Convention and Its Institutional Arrangements (Food and Agriculture Organization, Rome), 17-21 September 2007, para. 52, available at: https:/www.ippc.int/servlet/ BinaryDownloaderServlet/184229_IPPC_Evaluation_Repo.doc?filename=1180006371650_1_IPPC_Final_ Evaluation Report.doc\&refID=184229, visited on 10 March 2008.

${ }^{394}$ Para. 2 of the Guidelines on the Duties of Members of the Standards Committee, approved by the Standards Committee in November 2006. This provision states that the views of SC members encompass the views of different geographic regions of the world, developed and developing countries, tropical and temperate regions, continental and island nations, highly and sparsely populated countries, countries with intensive agricultural or forestry interests etc.

395 See para. 2 of the Guidelines on the Duties of Members of the Standards Committee, approved by the Standards Committee in November 2006.

${ }^{396}$ Rule 1 of the Rules of Procedure of the Standards Committee contained in Terms of Reference and Rules of Procedure for the Standards Committee, CPM-1 (2006)/Report, Appendix III, available at: https://www.ippc. int/servlet/BinaryDownloaderServlet/142427_TORs_ROPs_SC.doc?filename=1155309920830_CPM_1_ Terms_of_reference_and_R-221799051.doc\&refID=142427, visited on 10 March 2008. 
rigorously applied in selecting SC members. ${ }^{397}$ As a result, the members of the SC often do not have sufficient technical knowledge. ${ }^{398}$ The SC met twice in 2006, sending five draft ISPMs and several proposed amendments to the Glossary of Phytosanitary Terms for country consultation, during which over 2300 comments were received. ${ }^{399}$

Aside from the standing subsidiary bodies, the CPM is assisted by ad hoc working groups established by the SC. The SC has the competence to establish temporary or permanent working groups and drafting groups, as required, whose members are selected by the SC from among its own members. ${ }^{400}$ One of these working groups, composed of 7 members and called the SC-7, has been given a key role in the standard-setting process. The seven members of the SC-7 are selected by the SC members from each FAO region, and they, in turn, select their own chair. ${ }^{401}$ No observers are permitted at SC-7 meetings. ${ }^{402}$ However, the stewards of the draft ISPMs to be discussed at an SC-7 meeting are invited to attend. ${ }^{403}$ The SC-7 meets to review and discuss country comments on draft ISPMs and prepare revised drafts to be considered by the $\mathrm{SC}$.

The SC has also established EWGs and TPs to undertake the drafting of standards. An EWG is and ad hoc expert drafting body established to draft a particular standard, whereas a Technical Panel is a standing expert drafting body, established to work in a particular area. An EWG should have six to ten members, which represent a wide geographic area and include proportional developing country representation. Regardless of the composition of the EWG, it should allow a delegate from the host country to participate and should have a member from the SC, normally the steward assigned for that standard.

397 This criticism was made by the independent evaluation team tasked with the evaluation of the operation and institutions of the IPPC in 2006 to 2007. It recommended that the RPPOs be given a greater role in the identification of appropriate candidates for SC membership. FAO Programme Committee, Independent Evaluation of the Working of the International Plant Protection Convention and Its Institutional Arrangements (Food and Agriculture Organization, Rome), 17-21 September 2007, para. 52, available at: https:/www.ippc.int/servlet/ BinaryDownloaderServlet/184229_IPPC_Evaluation_Repo.doc?filename=1180006371650_1_IPPC_Final_ Evaluation_Report.doc\&refID $=18 \overline{4} 229$, visited on 10 March 2008.

398 Ibid.

${ }^{399}$ International Plant Protection Convention, Report of the Second Session of the Commission on Phytosanitary Measures, CPM-2 (2007)/Report (Food and Agriculture Organization, Rome), 26-30 March 2007, para. 20, available at: https://www.ippc.int/servlet/BinaryDownloaderServlet/184215_CPM_2_report. pdf?filename=1179929463410_CPM_2_report.pdf\&refID=184215, visited on 20 February 2008.

${ }^{400}$ Para. 3 of the Terms of Reference for the Standards Committee.

${ }^{401}$ In 2006, the SC agreed that if a member of the SC-7 is unable to attend a meeting of the SC-7, he/she can be replaced by another SC member from the same region, chosen through consultation between the original SC-7 member and the other SC members from that region. Standards Committee, Report of the Standards Committee (Food and Agriculture Organization, Rome), May 2006, para. 64, available at: https://www. ippc.int/servlet/BinaryDownloaderServlet/137751_SC_report_May_2006.pdf?filename=1153319150093 Report_SC_2006_May_FINAL_with_ISPMs.pdf\&refID $=1377 \overline{5} 1$, visited on 27 March 2008.

${ }^{402}$ In $200 \overline{7}$, the SPTA discussed the issue of allowing observers to the SC-7. At this meeting the IPPC Secretariat indicated that it was unable to fund observers, and that therefore opening the SC-7 to observers would mean that only countries with sufficient resources would be able to participate as observers, thereby possibly biasing the meetings. In addition, the IPPC Secretariat noted that the presence of observers would make the SC-7 meeting, which is intended to be small, much larger. International Plant Protection Convention, Report of the Second Meeting of the CPM Informal Working Group on Strategic Planning and Technical Assistance (SPTA) (Food and Agriculture Organization, Rome), 1-5 October 2007, para. 93, available at: https://www.ippc. int/servlet/BinaryDownloaderServlet/190812_9th_SPTA_Report_2007.pdf?filename=1196340302166_9th SPTA_Report_2007.pdf\&refID=190812, visited on 27 March 2008.

${ }^{403}$ The role of stewards is discussed below, in this same Section. 
EWG members should have the necessary qualifications (including scientific expertise or phytosanitary risk management experience) and be able to participate in and contribute to the EWG proceedings. ${ }^{404}$ Nominations for EWG members by NPPOs, RPPOs or contracting party governments are requested when the work programme or specifications for the relevant standard are adopted by the CPM. ${ }^{405}$ The SC selects the EWG members and submits a list to the CPM Bureau and IPPC Secretariat for confirmation. ${ }^{406}$ The participation of those EWG members that are from developed countries should be funded, wherever possible, by their governments or employers. ${ }^{407}$ Any member of the CPM Bureau may attend the EWG meeting. While industry representatives or others may be invited to provide expertise, they may not participate as members and no observers should be allowed. ${ }^{408}$

Technical Panels, as stated above, are standing bodies that may be established by the SC and operate under its authority. They work in specific areas to assist in the standard-setting work of the SC, in particular with regard to drafting standards under the 'fast-track' or 'special' procedure discussed below, ${ }^{409}$ and providing advice on the request of the SC within their areas of expertise. ${ }^{410}$ There are currently five Technical Panels, on diagnostic protocols for specific pests, pest free areas and systems approaches for fruit flies, phytosanitary treatments, forest quarantine and the Glossary of Phytosanitary Terms. The advantage of Technical Panels over EWGs is that the former provide for continuity in the members involved in drafting a series of related standards. The membership of Technical Panels follows the same rules as for Expert Working Groups. They have six to ten members, representing a wide geographic area, including the proportional representation of developing countries. Technical Panel members may also be representatives of other organisations, including RPPOs. ${ }^{411}$ Members of Technical Panels should have the necessary expertise and experience in the subject matter of the relevant panel, and should be able to participate in and contribute to the proceedings. ${ }^{412}$ They serve for an undefined peri-

${ }^{404}$ Para. 2 of the Guidelines for the Composition and Organization of Expert Working Groups, contained in Interim Commission on Phytosanitary Measures, Report of the Fifth Interim Commission on Phytosanitary Measures, ICPM-5(2003)/Report (Food and Agriculture Organization, Rome), 7-11 April 2003, Appendix $\mathrm{XV}$, available at: https:/www.ippc.int/servlet/BinaryDownloaderServlet/21899_ICPM5_2003_en.pdf. pdf?filename=1053957860772_ICPM5Report_final_en.pdf\&refID=21899, visited on 10 March 2008.

${ }^{405}$ Para. 3 of the Guidelines for the Composition and Organization of Expert Working Groups.

406 Ibid.

${ }^{407}$ Para. 4 of the Guidelines for the Composition and Organization of Expert Working Groups.

${ }^{408}$ Rule 10 of the Rules of Procedure for Technical Panels, approved by the Standards Committee in November 2006.

409 See below, Part II, Section 3.2.3.4.

${ }^{410}$ Para. 3 of the Terms of Reference for Technical Panels, approved by the Standards Committee in November 2006.

411 For example, the Technical Panel on Forest Quarantine has a member from the International Forestry Quarantine Research Group, and the Technical Panel on Pest Free Areas and Systems Approaches for Fruit Flies has members from the FAO/IAEA Joint Division and from the North American Plant Protection Organization (NAPPO), and Technical Panel for the Glossary has a member from the Comite de Sanidad Vegetal del Cono Sur (COSAVE), one of the RPPOs. See further on RPPOs, below, Part II, Section 3.2.3.4.

${ }^{412}$ Rule 1 of the Rules of Procedure for Technical Panels. 
od. ${ }^{413}$ The SC may agree to invite experts to provide support to a Technical Panel, where necessary. ${ }^{414}$

Due to the need to establish stronger links between the SC and expert drafting groups (i.e., EWGs and Technical Panels), some of the duties involved in the preparation of standards have been entrusted to 'stewards' by the SC. These stewards are, if possible, members of the SC itself. They should be senior plant health officials or scientists who are familiar with the IPPC standard-setting procedures. ${ }^{415}$ In the case of standards developed in the subject area of the Technical Panel, the Chair of the Technical Panel acts as the steward for the standards. ${ }^{416}$ For standards not developed by Technical Panels, but rather by EWGs, the SC assigns a steward from among its members, if possible. The functions of a steward are described in detail in the Guidelines for the role of a steward of an ISPM. In brief, the role of a steward is to oversee the work of a Technical Panel or to assist with the development of a standard from the time of drafting of the standard specification to the adoption of the standard by the CPM. ${ }^{417}$ The steward participates in the selection of experts for the expert drafting group, explains the standard-setting process and the specifications for the standard to the expert drafting group, assists in the development of discussion papers, assists the IPPC Secretariat in the organisation and running of the meeting, assists the IPPC Secretariat to complete the draft standard and prepare the meeting report, explains the main points of the draft standard to the SC and answers questions and assists the SC in analysing country comments on the draft standard. ${ }^{418}$ Although the extent of involvement of a steward in the preparation of a standard varies with the com-

413 Rule 3 of the Rules of Procedure for Technical Panels. The SC should regularly review and may change the membership of Technical Panels (for example due to changes in the scientific expertise needed or in the professional duties of experts) and may 'disestablish' a Technical Panel when it has completed the specific work assigned to it (see para. 7 of the Terms of Reference for Technical Panels).

${ }^{414}$ For example, in May 2007, the SC agreed that an expert with expertise in the trapping of the Bactrocera species of fruit fly be invited to participate in the next meeting of the Technical Panel on Pest Free Areas and Systems Approaches for Fruit Flies, as this Technical Panel had identified a lack of expertise on this issue among its members. Standards Committee, Report of the Standards Committee (Food and Agriculture Organization, Rome), 30 April - 4 May 2007, paras 36-37, available at: https:/www.ippc.int/servlet/CDSSer vlet?status=ND0xMzQwMiY2PWVuJjMzPSomMzc9a29z, visited on 1 April 2008.

415 Para. 2 of the Guidelines on the Role of a Steward of an ISPM, approved by the Standards Committee in November 2006. Standards Committee, Report of the Standards Committee (Food and Agriculture Organization, Rome), November 2006, Appendix 20, available at: https://www.ippc.int/servlet/ BinaryDownloaderServlet/174127_SC_report_Nov_2006.pdf?filename=1164985290005_Report_SC_ November_2006_FINAL_with_ISPMs.pdf\&refID=174127, visited on 27 March 2008.

416 Provision of the establishment of Technical Panels was made at the Sixth Session of the ICPM in 2004. Interim Commission on Phytosanitary Measures, Report of the Sixth Interim Commission on Phytosanitary Measures, ICPM-6 (2004)/Report (Food and Agriculture Organization, Rome), 29 March - 2 April 2004, Appendix IX, available at: https://www.ippc.int/servlet/BinaryDownloaderServlet/34062_ICPM6_2004_ en.pdf?filename=1085664580297_ICPM6_Report_final.pdf\&refID=34062, visited on 26 March 2008.. In November 2006, the SC adopted the Terms of Reference and Rules of Procedure for Technical Panels. Standards Committee, Report of the Standards Committee (Food and Agriculture Organization, Rome), November 2006, Appendix 2, available at: https://www.ippc.int/servlet/BinaryDownloaderServlet/174127 SC_report_Nov_2006.pdf?filename=1164985290005_Report_SC_November_2006_FINAL_with_ISPMs. pdf\&refID $=174 \overline{1} 27$, visited on 27 March 2008.

${ }^{417}$ Para. 3 of the Guidelines on the Role of a Steward of an ISPM.

418 Ibid. 
plexity of the standard, it is estimated that a steward needs to invest at least eight weeks of time in a single standard. ${ }^{419}$

The CPM and IPPC Secretariat are assisted in their work by Regional Plant Protection Organizations (RPPOs). RPPOs are intergovernmental organisations that function as coordinating bodies within their regions with regard to the areas covered by the IPPC. ${ }^{420}$ They, inter alia, elaborate regional standards, encourage their members to cooperate in the preparation of: proposals for new or revised ISPMs, comments on specifications for new or revised ISPMs and comments on draft ISPMs received for consultation. ${ }^{421}$ They also assist the CPM and IPPC Secretariat in elaborating international standards, for example by identifying regional standards that could be proposed as ISPMs, nominating experts for IPPC expert working groups and technical panels, acting as collaborators or hosts of standard-setting meetings. ${ }^{422}$ In addition, technical consultations between the various RPPOs are held to promote the development and use of ISPMs and to encourage inter-regional cooperation in promoting harmonised phytosanitary measures. ${ }^{423}$ There are currently nine RPPOs. ${ }^{424}$ Regional workshops are held to assist contracting parties to have a better understanding of draft ISPMs.

419 Para. 4 of the Guidelines on the Role of a Steward of an ISPM.

${ }^{420}$ Article IX of the New Revised Text.

421 In 1999, the ICPM adopted recommendations laying down these tasks as part of the role of RPPOs in standard-setting. Interim Commission on Phytosanitary Measures, Report of the Second Interim Commission on Phytosanitary Measures, ICPM-2(1999)/Report (Food and Agriculture Organization, Rome), 4-8 October 1999, Appendix VII, available at: https://www.ippc.int/servlet/BinaryDownloaderServlet/13804 ICPM_Report_1999_E.PDF?filename=/publications/13804.Report_of_the_Second_Meeting_of_the_ ICPM_1999.2001-3-27.PDF\&refID=13804, visited on 10 March.

${ }^{422}$ These tasks are specified in Interim Commission on Phytosanitary Measures, Report of the Seventh Interim Commission on Phytosanitary Measures, ICPM-7(2005)/Report (Food and Agriculture Organization, Rome), 4-7 April 2005, Appendix XIX, available at: https://www.ippc.int/servlet/BinaryDownloaderServlet/75067 Report_ICPM7_E.pdf?filename=1132938412531_ICPM7_Report_En_REV_list_part.pdf\&refID $=75067$, visited on 10 March 2008.

${ }^{423}$ Article IX.4 of the New Revised Text. Note that before the establishment of the ICPM, the mechanism of technical consultation of RPPOs was the only international forum for discussion on phytosanitary matters, and led to the development of the early ISPMs. Currently, the role and functions of the technical consultation are limited to those set out in Article IX.4, set out above, but its importance remains significant as it is the only opportunity for RPPOs to consult as a group and to exchange information. Developing-country RPPOs have stressed the importance of this opportunity. Interim Commission on Phytosanitary Measures, Report of the Fifth Interim Commission on Phytosanitary Measures, ICPM-5(2003)/Report (Food and Agriculture Organization, Rome), 7-11 April 2003, Appendix XVII, available at: https://www.ippc.int/servlet/BinaryDownloaderServlet/21899_ICPM5_2003_en.pdf.pdf?filename=1053957860772_ICPM5Report_ final_en.pdf\&refID=21899, visited on 10 March 2008 .

${ }^{424}$ As of 20 February 2008, there are nine RPPOs: the Asia and Pacific Plant Protection Commission which has 24 members, of which 22 are also WTO Members, the Caribbean Plant Protection Commission which has 22 members representing 30 countries (i.e. France represents Guadeloupe, French Guiana, Martinique, the Netherlands represents Aruba, and Netherlands Antilles, the UK represents British Virgin Islands, and the US represents United States Virgin Islands and Puerto Rico), of which 22 are WTO Members, the Comite de Sanidad Vegetal del Cono Sur which has 6 member countries, all of them WTO Members, the Comunidad Andina which has 4 member countries, all them WTO Members, the European and Mediterranean Plant Protection Organization which has 49 member countries, of which 39 are WTO Members, the Inter-African Phytosanitary Council which has 53 member countries of which 40 are also WTO Members, the North American Plant Protection Organization which has 3 member countries, all of them WTO Members, the Organismo Internacional Regional de Sanidad Agropecuaria which has 9 member countries, all of which are WTO Members, and the Pacific Plant Protection Organization which has 26 members, including 22 Pacific Island Countries and Territories and 4 founding members (Australia, France, New Zealand, and the 


\subsubsection{Contracting parties and observers}

\section{Graph 28: Contracting Parties to the IPPC that are Members of the WTO by Income Level, 2007}
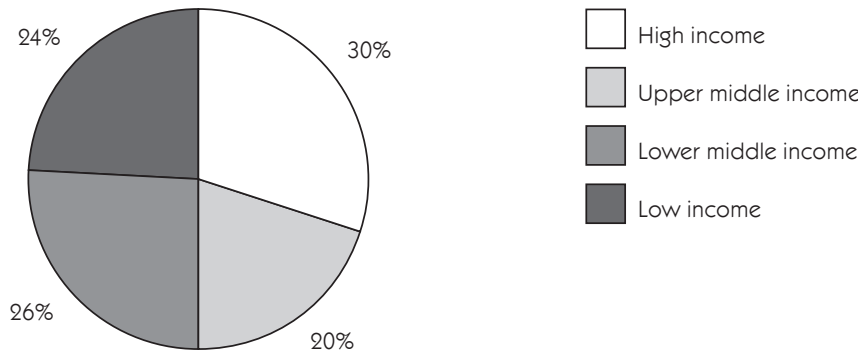

As an international convention, rather than an international organisation, the IPPC has contracting parties rather than members. The IPPC was open for signature by all states until 1 May 1952, and thereafter it was open for adherence by non-signatory states and member organisations of the FAO, such as the European Community. ${ }^{425}$

As of December 2007, the IPPC had 166 contracting parties, ${ }^{426}$ of which 134 are also WTO Members. ${ }^{427}$ Of these, 28 percent (40) are high-income Members, 20 percent (29)

US), of which 8 are also WTO Members. Not all IPPC contracting parties are members of RPPOs, nor are all RPPO members contracting parties to the IPPC. Furthermore, certain IPPC contracting parties belong to more than one RPPO. See the RPPO page of the International Phytosanitary Portal, the official website of the International Plant Protection Convention, available at: https:/www.ippc.int/servlet/CDSServlet?st atus=ND0xMzMxMCY2PWVuJjMzPSomMzc9a29z, visited on 20 February 2008. See further R. Griffin, 'Introduction to the International Plant Protection Convention (IPPC)', in Multilateral Trade Negotiations on Agriculture: A Resource Manual. Agreement on the Application of Sanitary and Phytosanitary Measures (SPS) and Agreements on Technical Barriers to Trade (TBT), Food and Agriculture Organization (ed.), vol. III (Food and Agriculture Organization, Rome), 2000, 28, available at: www.fao.org/docrep/003/x7354e/ X7354e01.htm, visited on 27 June 2001.

${ }^{425}$ According to Article XVII.2 of the New Revised Text, adherence is achieved by the deposit of an instrument of adherence with the FAO Director-General. Where a member organisation of the FAO becomes a contracting party to the IPPC, it must submit such modifications or clarifications to its declaration of competence submitted under the FAO Constitution, as may be necessary under the IPPC. In addition, Article XVII.3 provides that a member organisation must, upon request by any contracting party, provide information regarding which, as between the organisation and its member states, is responsible for implementation of any matter covered by the IPPC.

${ }^{426}$ As on 6 March 2008, see the list of contracting parties on the International Phytosanitary Portal (IPP), the official website of the International Plant Protection Convention, available at: http://www.fao.org/Legal/ TREATIES/004s-e.htm, visited 6 March 2008.

${ }^{427}$ Committee on Sanitary and Phytosanitary Measures, Membership in WTO and International Standard Setting Bodies: Note by the Secretariat, G/SPS/GEN/49/Rev.8, circulated on 9 October 2007. The data in this document was updated to include Guinea Bissau, which adhered to the IPPC on 24 October 2007. Djibouti, Gabon and Mozambique adhered to the IPPC only in 2008 and are therefore not included in this number. Likewise, the two 2008 accessions to the WTO (Cape Verde and Ukraine) are not taken into account here. Another revision made here to the data in the WTO Secretariat document relates to Macao. Although the Secretariat document counts Macao as a contracting party to the IPPC since Macao is a WTO Member in its 
are upper-middle-income Members, 25 percent (36) are lower-middle-income Members and 27 percent (38) are low-income Members. The European Community is a contracting party to the IPPC. It adhered to the IPPC on 6 October 2005 as a 'member organisation'.

Although observers are not mentioned in the New Revised Text of the IPPC, the Rules of Procedure of the CPM makes provision for them. Any country that is not an IPPC contracting party but is a member of the FAO as well as of the UN or any of its specialised agencies, or of the International Atomic Energy Agency, may attend meetings of the CPM and its subsidiary bodies as an observer, upon request to the FAO Director-General. ${ }^{428}$ In addition, representatives of the RPPOs shall be invited to attend all sessions of the CPM and its subsidiary bodies as observers. ${ }^{429}$ The Director General of the FAO, under the guidance of the CPM, may invite international intergovernmental and non-governmental organisations to attend CPM sessions as observers. ${ }^{430}$ Further, any IPPC contracting party may attend meetings of subsidiary bodies as an observer upon request to the IPPC Secretary. ${ }^{431}$ Observers may submit memoranda and may participate in discussions but may not vote.

At the first Session of the CPM in 2006, observers attended from 15 international intergovernmental organisations (including RPPOs, the FAO and UN specialised agencies), 2 non-governmental organisations and 8 non-contracting party countries. ${ }^{432}$ At the Second Session in 2007, observers attended from 16 international intergovernmental organisations (including the FAO and UN specialised agencies), one international non-governmental organisation and 8 non-contracting party countries. ${ }^{433}$

own right and the IPPC applies to it by virtue of a decision of the People's Republic of China under the Basic Law of the Macao Special Administrative Region of the PRC, in fact Macao is not officially a contracting party to the IPPC. As a result, the data presented here has been adjusted accordingly. The same problem does not arise with regard to the WTO Member Hong Kong, China since in accordance with the Basic Law of the Hong Kong Special Administrative Region of the PRC, the PRC has decided that the IPPC does not apply to the Hong Kong Special Administrative Region of the PRC.

${ }^{428}$ Rule VII.1 of the Rules of Procedure of the CPM.

${ }^{429}$ Rule VII. 2 of the Rules of Procedure of the CPM.

${ }^{430}$ Rule VII.3 of the Rules of Procedure of the CPM. Rule VII.4 of the Rules of Procedure of the CPM further provides that the FAO Constitution and other pertinent Basic Texts of the FAO govern the participation of international organisations in the work of the CPM.

${ }^{431}$ Rule VII. 5 of the Rules of Procedure of the CPM.

${ }^{432}$ International Plant Protection Convention, Report of the First Session of the Commission on Phytosanitary Measures, CPM-1 (2006)/Report (Food and Agriculture Organization, Rome), 3-7 April 2006, Appendix XX, available at: https://www.ippc.int/servlet/BinaryDownloaderServlet/133571_CPM_1_report_2006. pdf?filename $=1151505665852 \_C P M \_1$ _eport.pdf\&refID $=133571$, visited on 28 July 2006. The non-contracting party attendees were from Angola, Armenia, Gabon, Madagascar, Myanmar, Qatar, Singapore, and Uganda.

${ }^{433}$ International Plant Protection Convention, Report of the Second Session of the Commission on Phytosanitary Measures, CPM-2 (2007)/Report (Food and Agriculture Organization, Rome), 26-30 March 2007, Appendix 21, available at: https://www.ippc.int/servlet/BinaryDownloaderServlet/184215_CPM_2_report. pdf?filename=1179929463410_CPM_2_report.pdf\&refID=184215, visited on 20 February 2008. The noncontracting party attendees were from Angola, the Democratic Republic of Congo, Gabon, Mozambique, San Marino, Singapore, Uganda and Zimbabwe. 


\subsubsection{Standard-setting procedure}

The standard-setting procedure of the IPPC is composed of four stages, divided into eight steps. ${ }^{434}$ The first stage is that of determination of topics and priorities (steps 1 and 2), the second that of drafting (steps 3 and 4), the third that of consultation (steps 5 and 6) and the fourth and final stage is that of adoption and publication of the standard (steps 7 and 8). Aside from the regular standard-setting procedure a 'fast track' or 'special' procedure is available for less complex situations. ${ }^{435}$ Both procedures are currently at the final stages of the process of revision, and it is expected that the revised procedures will be adopted by the CPM at its Third Session in $2008 .{ }^{436}$ Therefore, the discussion below sets out the new procedures, with reference to the current procedures where necessary.

At step 1, the IPPC Secretariat issues a biennial call for topics for new work on ISPMs. ${ }^{437}$ Submissions for new topics for standards may be made by National Plant Protection

${ }^{434}$ Annex 1 of the Rules of Procedure of the CPM, adopted by the Second Session of the ICPM in 1999.

${ }^{435}$ The special procedure, known as the 'fast-track' procedure was adopted in 2004 by the Sixth Session of the ICPM in response to concerns with the slow pace of standard setting. It is intended to be used in highly technical situations, such as where the technical material or resources needed for a standard are available or simple to develop; where technical standards of potential global interest are available that have been approved by RPPOs or other organisations; where technical annexes to existing standards are needed; where minor revisions to standards are needed that are not of a conceptual nature; and where specifically authorised by the CPM. Interim Commission on Phytosanitary Measures, Report of the Sixth Interim Commission on Phytosanitary Measures, ICPM-6 (2004)/Report (Food and Agriculture Organization, Rome), 29 March - 2 April 2004, Appendix X, available at: https://www.ippc.int/servlet/BinaryDownloaderServlet/34062_ICPM6_2004_ en.pdf?filename=1085664580297_ICPM6_Report_final.pdf\&refID=34062, visited on 26 March 2008.. The SPTA recommended in 2007 that the name be changed to 'special procedure' due to the fact that the procedure is different, but not really faster, than the normal procedure. The change of name was adopted in 2008. The special procedure was initiated for the first time for the revision of Annex 1 of ISPM 15 (on wood packaging materials) but the resulting standard was eventually adopted through the normal standard setting procedure. Since then, work on annexes to two ISPMs (annexes dealing with particular pests, to ISPM 27 on diagnostic protocols for regulated pests; and annexes dealing with irradiation treatment for specific pests, to ISPM 28 on phytosanitary treatments for regulated pests) has been initiated under the special procedure. FAO Programme Committee, Independent Evaluation of the Working of the International Plant Protection Convention and Its Institutional Arrangements (Food and Agriculture Organization, Rome), 17-21 September 2007, para. 61 and footnote 10, available at: https://www.ippc.int/servlet/BinaryDownloaderServlet/184229_IPPC_Evaluation Repo.doc?filename $=1180006371650$ 1_IPPC_Final_Evaluation_Report.doc\&refID $=18 \overline{4229}$, visited on 10 March 2008. See also Commission on Phytosanitary Measures, Report of the Second Session of the CPM: Standard Setting Work Programme, CPM 2007/24 (International Plant Protection Convention, Rome), 2630 March 2007, Annex 1, available at: https://www.ippc.int/servlet/BinaryDownloaderServlet/177411 CPM2007_24.pdf?filename=1169219668797_CPM2007_24.pdf\&refID=177411, visited on 11 April 2008.

${ }^{436}$ At the Second Session of the CPM, a Focus Group was established to review the procedures and criteria for identifying topics for inclusion on the IPPC work programme, the IPPC standard-setting procedure, the terms of reference and rules of procedure of Technical Panels and the issue of transparency in the standard-setting process. It proposed changes which were then reviewed and amended by the SPTA. After discussion by the SC in November 2007, these revisions have been forwarded for adoption to the Third Session of the CPM to be held in April 2008. Standards Committee, Report of the Standards Committee (Food and Agriculture Organization, Rome), 5-9 November 2007, Appendices 5 and 7, available at: https://www.ippc.int/servlet/ BinaryDownloaderServlet/191801_Report_SC_Nov_2007.doc?filename=1197908679365_Report_SC_ Nov_2007_FINAL_with_ISPMs.doc\&refID=191801, visited on 2 April 2008.

${ }^{437}$ This call is issued to contracting parties, NPPOs, RPPOs and the 'Secretary' of the SPS Committee of the WTO (which seems to refer to the member of the WTO Secretariat's Agriculture and Commodities Division that services the SPS Committee). It is also posted on the International Phytosanitary Portal (IPP), which is the website maintained by the IPPC. Submissions must be made on a prescribed form available on the IPP, and should address the applicable criteria for justification of new work. These criteria are currently under 
Organisations (NPPOs), RPPOs, the IPPC Secretariat, and the WTO SPS Committee. At step 2, a summary of submissions is compiled by the IPPC Secretariat and posted on the IPP, as well as presented to the SPTA. ${ }^{438}$ The SPTA reviews the submissions and identifies strategic priorities on the basis of the agreed criteria for justification of proposed topics. ${ }^{439}$ These criteria are currently under revision. ${ }^{440}$ Both the current and the proposed new list of criteria include as a criterion the 'relevance and utility of a standard to developing countries'. The SC, taking into account the SPTA strategic priorities and the criteria for justification, ${ }^{441}$ reviews the existing work programme and the new submissions and proposes a revised work programme. ${ }^{442}$ The CPM reviews this proposal, adjusts it if necessary, and adopts the revised standard-setting work programme. ${ }^{443}$

revision.

${ }^{438}$ Although the current procedure still refers to the presentation of the summary of proposals to the ICPM, in practice since the establishment of the SPTA, this body determines the strategic priorities and makes a proposal to the CPM on this matter.

439 For example, at its meeting in October 2007, the SPTA reviewed the submissions from the call for topics and identified as strategic priorities for the Standards Committee: pathways for spread of pests (conveyances, plants for planting, grain, cut flowers, international garbage) and certification systems (including accreditation/authorization) with the view to filling some of the gaps in the framework for standards. International Plant Protection Convention, Report of the Second Meeting of the CPM Informal Working Group on Strategic Planning and Technical Assistance (SPTA) (Food and Agriculture Organization, Rome), 1-5 October 2007, para. 135, available at: https://www.ippc.int/servlet/BinaryDownloaderServlet/190812 9th_SPTA_Report_2007.pdf?filename $=1196340302166$ 9th_SPTA_Report_2007.pdf\&refID $=190812$, visited on 27 March 2008 .

${ }^{440}$ As noted above a Focus Group was set up in 2007 to review, inter alia, the procedure and criteria for identifying new topics for inclusion on the IPPC work programme. The recommendations of the Focus Group in this regard are discussed below, in this same Section.

${ }^{441}$ Pending the decision of the CPM on the new criteria for justification and prioritisation of new topics, the SC evaluates the submissions according to the existing Procedures for Identifying Topics and Priorities for Standards, which was adopted in 2002 by the ICPM.

${ }^{442}$ The SC can add, delete or modify topics and gives each topic a recommended priority level (high or normal), identifying those topics that may be elaborated under the special standard-setting procedure. For example, in November 2007, the SC selected 9 submissions to recommend to the CPM for inclusion in the standardsetting work programme, of which four were identified as 'high priority'. The IPPC Secretariat noted that although the work programme already includes a long list of topics, continuing to add to this list ensures that work can proceed steadily and that when resources become available for new work, the Secretariat will be in a position to utilise them. Standards Committee, Report of the Standards Committee (Food and Agriculture Organization, Rome), 5-9 November 2007, paras 41 and 46, available at: https:/www.ippc.int/ servlet/BinaryDownloaderServlet/191801_Report_SC_Nov_2007.doc?filename=1197908679365_Report_ SC_Nov_2007_FINAL_with_ISPMs.doc\&refID=191801, visited on 2 April 2008.

443 This work programme is attached as an appendix to the CPM meeting report. Note that additions to the work programme of topics for technical standards falling under the scope of work of any of the Technical Panels do not require CPM adoption. It is assumed that CPM approval has been given by the establishment of the Technical Panel by the CPM. The Technical Panels are under the authority of the SC, whose approval must be sought for the addition of topics to their work programme. The existing standard-setting procedures, including the assignment of stewards and the prior development of specifications apply. However, these technical standards will be developed under the fast-track process, unless the SC decides otherwise. For purposes of transparency, all new topics for technical standards under each Technical Panel is added to the standard-setting work programme presented to the CPM, indicating that their addition was approved by the SC. Standards Committee, Report of the Standards Committee (Food and Agriculture Organization, Rome), November 2006, para. 23, available at: https://www.ippc.int/servlet/BinaryDownloaderServlet/174127 SC_report_Nov_2006.pdf?filename $=1164985290005$ Report_SC_November_2006_FINAL_with_ISPMs. pdf\&refID $=174 \overline{1} 27$, visited on 27 March 2008. 
At step 3, the SC appoints a steward, usually a member of the SC, for each topic (or Technical Panel). The steward, in collaboration with the IPPC Secretariat, is responsible for drafting a specification for a standard, taking into account the proposal for the topic. ${ }^{444}$ As a result, the steward plays a key role in the initial formulation of the basis of the standard. The draft specification is reviewed by the SC, and may be amended and/or adopted. Thereafter the adopted specification is made available on the IPP for a 60-day consultation period. ${ }^{445}$ The IPPC Secretariat compiles the comments received, posts them on the IPP and submits them to the steward and the SC. The specification is amended as necessary on the basis of the comments received, and adopted by the SC. Thereafter it is published on the IPP.

At step 4, in accordance with the relevant specification, a standard is drafted (or revised) by an expert drafting group, which may be an Expert Working Group or a standing Technical Panel designated by the SC. Expert Working Groups are established to draft standards under the normal procedure. Technical Panels are designated only where a standard is to be developed under the fast-track procedure. ${ }^{446}$ As noted above, there are currently five Technical Panels each working in a specific area. The resulting draft standard is forwarded via the Secretariat to the SC. If the normal procedure is being followed, either the SC or, in most cases, the SC-7 holds a meeting to review the draft. ${ }^{447}$ It decides whether to approve the draft and send it on to the consultation phase (step 5), to return it to the steward or expert drafting group for further work, or to put it on hold. If the special procedure is being followed, the SC takes its decision by email, if possible.

At step 5 draft standards approved by the SC are distributed by the IPPC Secretariat to contracting parties, RPPOs, NPPOs and relevant international organisations for consultation. The draft is also posted on the IPP. The consultation period lasts 100 days. ${ }^{448}$ Written submissions are compiled by the IPPC Secretariat and, in the normal procedure, submitted to the steward and SC for consideration. ${ }^{449}$ In the special procedure the Secretariat

\footnotetext{
${ }^{444}$ The current procedure in Annex 1 to the Rules of Procedure for the ICPM (now CPM) states that specifications are drafted by the IPPC Secretariat only, but the current procedural manual notes that a steward is assigned to each topic added to the IPPC work programme. International Plant Protection Convention, Procedural Manual (Food and Agriculture Organization, Rome), 1 June 2007, para. 9.4.1, available at: https://www. ippc.int/servlet/BinaryDownloaderServlet/159931_Procedural_manual_20.pdf?filename=1188388585480_ ProceduralManual2007.pdf\&refID=159931, visited on 10 March 2008.

${ }^{445}$ The current procedures were amended in 2004 to no longer state only that the specification is made available to contracting parties and RPPOs for the 60-day consultation period, but instead to provide that the IPPC Secretariat is requested to post drafts on the IPP and to continue to send hard copies to NPPOs.

${ }^{446}$ Previously, Technical Panels had a broader mandate, but in 2004 the ICPM limited the role of Technical Panels to the fast-track procedure. Interim Commission on Phytosanitary Measures, Report of the Sixth Interim Commission on Phytosanitary Measures, ICPM-6 (2004)/Report (Food and Agriculture Organization, Rome), 29 March - 2 April 2004, para. 77, available at: https://www.ippc.int/servlet/ BinaryDownloaderServlet/34062_ICPM6_2004_en.pdf?filename=1085664580297_ICPM6_Report_final. pdf\&refID=34062, visited on 26 March 2008 .

${ }_{447}$ If only the SC-7 meets, comments by any other SC member will also be taken into account.

448 The original 120 day consultation period was shortened to 100 days in 2004, to allow the SC and IPPC Secretariat enough time to review the comments. Interim Commission on Phytosanitary Measures, Report of the Sixth Interim Commission on Phytosanitary Measures, ICPM-6 (2004)/Report (Food and Agriculture Organization, Rome), 29 March - 2 April 2004, para.77, available at: https://www.ippc.int/servlet/ BinaryDownloaderServlet/34062_ICPM6_2004_en.pdf?filename=1085664580297_ICPM6_Report_final. pdf\&refID=34062, visited on 26 March 2008 .

${ }_{449}$ Compiled comments are also posted on the IPP.
} 
submits the compilation of comments, to the Technical Panel and SC for consideration, by email if possible.

At step 6 the SC-7 and the SC take the comments into account and revise the draft standard. In the normal procedure, the SC then decides whether to forward the revised draft to the CPM for adoption, to return it to the steward or expert drafting group, to put it on hold, or to submit it for another round of consultations. In the report of the SC meeting, a summary of the discussion and of the SC reactions to substantive comments not incorporated into the standard is provided. ${ }^{450}$ In the special procedure, the IPPC Secretariat tries to resolve the issues raised in comments with the countries involved. If the draft is not changed after resolution of the issues raised in comments, it is sent directly to the CPM for adoption. If comments resulted in changes to the draft, the draft is submitted to the $\mathrm{SC}$, which examines the draft in consultation with the Technical Panel and if appropriate modifies it. ${ }^{451}$ The SC then decides (by email if possible) whether to forward the revised draft to the CPM for adoption. Draft ISPMs are posted on the IPP at least six weeks before the next CPM Session.

At step 7, the draft standard following approval of the SC, is put on the agenda of the CPM for adoption. Comments on draft standards must be sent to the IPPC Secretariat at least 14 days before the CPM meeting. In the normal procedure, comments are discussed at the CPM meeting and the CPM decides whether to adopt the ISPM. The CPM must make every effort to reach consensus - only if 'all efforts to reach consensus have been exhausted and no agreement has been reached' may a decision, as a last resort, be taken by a two-thirds majority of CPM members present and voting. ${ }^{452}$ An exception applies if the proposed ISPM is being introduced before the CPM for the first time. In such cases, if consensus is not reached on adoption of the ISPM, it must be referred back to the appropriate subsidiary body, together with the comments of the CPM thereon, for further consideration. ${ }^{453}$ In the special procedure, if no formal objection is received up to 14 days before the CPM meeting, the ISPM is adopted without discussion. If comments are received, the draft is sent back to the SC to decide how to proceed. ${ }^{454}$ At step 8 , the

450 This summary of SC reactions to unincorporated comments was included in the standard-setting procedure in response to particular concerns raised in discussions that contracting parties should receive proper feedback on how their comments on draft ISPMs were taken into account. For the first time in November 2007, the stewards, SC-7 and SC made an attempt to draft such summaries for each standard, and these were included with each standard in the SC report. Standards Committee, Report of the Standards Committee (Food and Agriculture Organization, Rome), 5-9 November 2007, available at: https:/www.ippc.int/servlet/BinaryDownloaderServlet/191801_Report_SC_Nov_2007.doc?filename=1197908679365_Report_SC_ Nov 2007 FINAL with ISPMs.doc\&refID=191801, visited on 2 April 2008.

${ }^{451}$ Originally, the special procedure provided that if a draft was changed due to comments, it would be sent to the CPM for discussion. However, as noted by the SPTA, the CPM is not an appropriate forum for technical discussion as the necessary experts are unlikely to attend. Therefore the SPTA amended the procedure to refer the draft back to the SC. International Plant Protection Convention, Report of the Second Meeting of the CPM Informal Working Group on Strategic Planning and Technical Assistance (SPTA) (Food and Agriculture Organization, Rome), 1-5 October 2007, para. 99, available at: https://www.ippc.int/servlet/BinaryDownl oaderServlet/190812_9th_SPTA_Report_2007.pdf?filename=1196340302166_9th_SPTA_Report_2007. pdf\&refID=190812, visited on 27 March 2008.

${ }^{452}$ Rule VI.2 of the Rules of Procedure of the CPM.

${ }^{453}$ Rule X.2 of the Rules of Procedure of the CPM.

${ }^{454}$ The SC decides, if possible via email, how to proceed, including the possibility for submitting the draft to the CPM for adoption through the normal procedure. 
adopted ISPM is appended to the report of the CPM Session and published by the IPPC Secretariat, which also posts the ISPM on the IPP.

The standard-setting procedure of the IPPC is less resource intensive than that of the CAC. This is due to the fact that, since most IPPC bodies have limited membership, contracting parties need to attend a much smaller number of meetings. However, this also reduces the possibilities for a contracting party to influence the outcome of the standardsetting process. As a result, aside from increasing the importance of a balanced selection of members of the relevant bodies, as discussed above, this situation makes it even more crucial that, at those stages in the process that are open to all contracting parties, effective participation at different levels of development be ensured.

The procedure of standard setting at the IPPC has been subject to review by the external team on the Independent Evaluation of the Workings of the IPPC and its Institutional Arrangements (the Independent Evaluation team), ${ }^{455}$ as well as by the IPPC Focus Group on the Review of the IPPC Standard Setting Procedures (the Focus Group) ${ }^{456}$ in 2007. Some of the concerns identified in those reviews deserve to be mentioned here as they are of relevance to the effective participation of contracting parties at different levels of development.

One of these concerns relates to the procedure and criteria for identifying new topics for inclusion in the IPPC standard-setting work programme and for the prioritisation of these topics. As mentioned above, while submissions for new topics may be made by all NPPOs and RPPOs, as well as by the IPPC Secretariat and the WTO SPS Committee, the decision by the CPM on which new topics will be added to the work programme is based on the SC proposal taking into account a list of agreed criteria. The Independent Evaluation team viewed the existing criteria as useful and as a good basis for prioritisation, but noted that there are many criteria and it is not clear how they are used in the process of approving and prioritising new topics for the standard-setting work programme ${ }^{457}$ It proposed that a

455 The Independent Evaluation of the Workings of the IPPC and its Institutional Arrangements is a result of the request by the Seventh Session of the ICPM for input on the future policy, strategy and management of the IPPC, and for analysis of the current management of the IPPC. The report of the team conducting this independent evaluation was presented to the FAO Programme Committee in its $98^{\text {th }}$ Session in 2007. FAO Programme Committee, Independent Evaluation of the Working of the International Plant Protection Convention and Its Institutional Arrangements (Food and Agriculture Organization, Rome), 17-21 September 2007, available at: https:/www.ippc.int/servlet/BinaryDownloaderServlet/184229_IPPC_Evaluation_Repo. doc?filename $=1180006371650$ 1_IPPC_Final_Evaluation_Report.doc\&refID $=18 \overline{42} 29$, visited on $10 \overline{\mathrm{March}}$ 2008.

${ }^{456}$ The Second Session of the CPM in 2007 decided to convene a Focus Group on the Review of the IPPC Standard Setting Procedures. The report of the Focus Group was submitted in July 2007. Focus Group on the Review of IPPC Standard Setting Procedures, Report of the Focus Group (International Plant Protection Organization, Rome), 16-20 July 2007, available at: https://www.ippc.int/servlet/BinaryDownloaderServlet/189350 Report_FG_2007.pdf?filename=1193215805220_Report_2007_FG_on_standard_set-1163088563. pdf\&refID $=189350$, visited on 9 April 2008. It was agreed that the findings of the Focus Group would be analysed by the SPTA and the outcome considered by the SC and then by the CPM at its Third Session in 2008.

${ }^{457}$ FAO Programme Committee, Independent Evaluation of the Working of the International Plant Protection Convention and Its Institutional Arrangements (Food and Agriculture Organization, Rome), 17-21 September 2007, para.62, available at: https:/www.ippc.int/servlet/BinaryDownloaderServlet/184229_IPPC Evaluation_Repo.doc?filename $=1180006371650 \_1$ _IPPC_Final_Evaluation_Report.doc\&refID $=\overline{184229}$, visited on 10 March 2008. 
ranking or weighting of criteria be devised to facilitate prioritisation. ${ }^{458}$ The Focus Group recommended three core criteria that all submissions for new standards should meet, namely the contribution of the standard to the purpose of the IPPC; the feasibility of implementation at global level (including technical complexity, relevance for more than one region and the capacity of NPPOs to implement the standard); and the clear identification of problems that need to be resolved through the development of the standard. In addition, 19 supporting criteria were recommended, subdivided into technical, practical, economic, environmental and strategic criteria. ${ }^{459}$ One of the strategic criteria is the relevance and utility of the standard for developing countries. The proposed list of criteria was reviewed by the SPTA and by the SC and forwarded to the CPM for adoption in its 2008 Session. ${ }^{460}$ The implementation of the new criteria is intended to result in greater transparency in the selection of new topics and a clearer basis for this selection. It should, inter alia, lead to a work programme that systematically takes into account developing country priorities and technical capacities.

A second concern is that the short time frame for standard setting in the IPPC results in insufficient time for consideration and incorporation of comments of contracting parties, which has a negative impact on the quality of the standards. It also diminishes the possibilities for effective participation by those contracting parties that do not have the resources to respond quickly to requests for comments. In the current procedure, draft standards approved by the SC are posted on the IPP in January and the CPM session where the standards are to be adopted takes place in March or April of the same year. Contracting parties must submit their comments 14 days before the CPM session and these comments are distributed in the CPM meeting in the language in which they were submitted. As a result, contracting parties (especially those with resource constraints)

${ }^{458}$ Ibid., para.63. The Independent Evaluation team pointed out that the lack of clarity regarding the use of the current criteria for prioritisation has led to a disproportionate number of high priority topics for standards on the current work programme. In 2007, 77 of the total of 86 items on the work programme had been given high priority status. On the work programme for 2008, 5 of the 7 new topics are characterised as high priority. As noted by the Independent Evaluation team, the fact that the number of high priority standards on the work programme exceeds the number of standards that are adopted each year is an indication that the current designation of priority topics is not realistic.

${ }^{459}$ Focus Group on the Review of IPPC Standard Setting Procedures, Report of the Focus Group (International Plant Protection Organization, Rome), 16-20 July 2007, Annex 4, available at: https:/www.ippc.int/servlet/ BinaryDownloaderServlet/189350_Report_FG_2007.pdf?filename=1193215805220_Report_2007_FG_ on_standard_set-1163088563.pdf\&refID $=189350$, visited on 9 April 2008. The technical criterion is the availability of information, or possibility to collect information, in support of the standard. Practical criteria are, for example, the feasibility of adopting the standard within a reasonable time frame and the availability of the necessary expertise. Economic criteria include the value of trade affected by the proposed standard and the value of new trade opportunities provided by the proposed standard. Environmental criteria are, for example, the contribution of the standard to the protection of the environment. Strategic criteria other than the relevance and utility of the standard for developing countries, include the urgent need for the standard and the extent of support for the proposal.

${ }^{460}$ CPM Informal Working Group on Strategic Planning and Technical Assistance, Report of the Second Meeting (International Plant Protection Convention, Rome), 1-5 October 2007, para. 16, available at: https://www.ippc. int/servlet/BinaryDownloaderServlet/190812_9th_SPTA_Report 2007.pdf?filename=1196340302166_9th SPTA_Report_2007.pdf\&refID=190812, visited on 1 April 2008. Standards Committee, Report of the Standärds Committee (Food and Agriculture Organization, Rome), 5-9 November 2007, paras 52-54, available at: https://www.ippc.int/servlet/BinaryDownloaderServlet/191801_Report_SC_Nov_2007. doc?filename $=1197908679365$ Report_SC_Nov_2007_FINAL_with_ISPMs.doc\& $\bar{r}$ _fID $=191801$, visited on 2 April 2008. 
have insufficient time to review the comments before they are discussed at the CPM session. ${ }^{461}$ Both the reports of the Focus Group and of the Independent Evaluation team, contain proposals for an extended time schedule for the regular standard-setting process, adding at least one year to the current time-frame. ${ }^{462}$ These proposals aim to improve the quality of the ISPMs and enable contracting parties to participate more effectively in the standard-setting process.

A third, but related, concern has been raised with regard to the overloaded agenda of the annual CPM sessions. Due to the lack of time for the consideration of comments on draft standards prior to CPM sessions in the current standard setting process, there is no possibility for consensus building in advance of the CPM session. Therefore much of the CPM session is devoted to detailed discussion of contracting parties' views on the draft standards. ${ }^{463}$ However, the agendas of CPM Sessions cover not only the adoption of ISPMs but all six 'strategic directions' of the IPPC. ${ }^{464}$ Between 20 and 30 agenda items are covered in each Session, among which is the adoption of international standards. The full agenda means that delegates have a heavy workload in preparing their country positions if they are to participate effectively in decision making in the CPM. In the report of the Independent Evaluation team, it is noted that stakeholders find the agenda too detailed. ${ }^{465}$ This makes it difficult to devote the necessary time to the discussion of important agenda items. Further, it is not easy to ensure that all the views on draft standards expressed at CPM meetings are properly addressed in building a consensus for the

${ }^{461}$ FAO Programme Committee, Independent Evaluation of the Working of the International Plant Protection Convention and Its Institutional Arrangements (Food and Agriculture Organization, Rome), 17-21 September 2007, para. 63, available at: https:/www.ippc.int/servlet/BinaryDownloaderServlet/184229_IPPC Evaluation_Repo.doc?filename $=1180006371650$ _1_IPPC_Final_Evaluation_Report.doc\&refID $=184229$, visited on 10 March 2008.

${ }^{462}$ In its review of the recommendations of the Focus Group, the SPTA noted that this proposal does not require a formal amendment to the standard-setting procedure, as the SC is currently free to decide when to submit a draft ISPM to the CPM for adoption. The SC will now start using this possibility to extend the schedule for review of comments on draft ISPMs sent out for consultation, so that drafts may be presented to the CPM for adoption two years after the consultation period. Both the Focus Group and the SPTA noted the need for flexibility so that urgently needed standards, or those on which few comments were received, could be adopted within the current time frame. International Plant Protection Convention, Report of the Second Meeting of the CPM Informal Working Group on Strategic Planning and Technical Assistance (SPTA) (Food and Agriculture Organization, Rome), 1-5 October 2007, para. 115, available at: https:/www.ippc.int/servlet/BinaryDown loaderServlet/190812_9th_SPTA_Report_2007.pdf?filename=1196340302166_9th_SPTA_Report_2007. pdf\&refID=190812, visite $\overline{\text { on }} 27 \overline{\text { March }} 2008$.

${ }^{463}$ FAO Programme Committee, Independent Evaluation of the Working of the International Plant Protection Convention and Its Institutional Arrangements (Food and Agriculture Organization, Rome), 17-21 September 2007, para. 64, available at: https:/www.ippc.int/servlet/BinaryDownloaderServlet/184229_IPPC Evaluation_Repo.doc?filename $=1180006371650 \_1$ IPPC_Final_Evaluation_Report.doc\&refID $=184229$, visited on 10 March 2008.

${ }^{464}$ The 'strategic directions' of the IPPC are mentioned above, Part II, Section 2.3.2.1, note 340. Since the end of 2007, the six 'strategic directions' have been replaced by the seven 'medium term goals' of the IPPC, also set out above, Part II, Section 3.2.3.1.

${ }^{465}$ FAO Programme Committee, Independent Evaluation of the Working of the International Plant Protection Convention and Its Institutional Arrangements (Food and Agriculture Organization, Rome), 17-21 September 2007, para. 143, available at: https:/www.ippc.int/servlet/BinaryDownloaderServlet/184229_IPPC Evaluation_Repo.doc?filename $=1180006371650 \_1$ _IPPC_Final_Evaluation_Report.doc\&refID $=\overline{184229}$, visited on 10 March 2008. 
adoption of the standard. ${ }^{466}$ This lack of time may lead to rushed changes to draft ISPMs at the CPM session. ${ }^{467}$

A fourth concern that has been raised relates to the issue of transparency in IPPC standard-setting procedures. Although some decisions to improve transparency were taken in 2004, these have not been fully implemented. ${ }^{468}$ Currently access to documents containing input to and output of the SC, for example reports from Technical Panels and EWGs, is restricted. ${ }^{469}$ This means that contracting parties that do not have members in these bodies, are uninformed as to the content of these documents. The Focus Group was asked to review a paper submitted by Brazil, Chile and Paraguay on this issue, which suggested broader dissemination, preferably through the IPP, of all documents exchanged and produced in the standard-setting process. ${ }^{470}$ This paper noted that all contracting parties should be fully engaged in the standard-setting process, rather than only consulted at the comments stage of the process. Making available all documents, including the comments of other contracting parties and the reactions of the SC to comments received, promptly to all contracting parties would ensure that views could be enriched by the comments of others. It would also enhance the understanding of why comments are rejected or incorporated into draft standards. It would also reduce the last minute influx of comments on draft standards in the 14-day period before the CPM Session in which the draft standard is up for adoption. ${ }^{471}$ In response to the proposal of Brazil, Chile and Paraguay, the Focus Group noted that documents for Technical Panels or EWGs are often drafts, and may contain personal or proprietary information, or unpublished scientific information. Making these publicly available would discourage the provision of information and could mislead the public. ${ }^{472}$ The Focus Group considered, instead, that a level of transparency appropri-

${ }^{466}$ Ibid.

${ }^{467}$ Ibid., para. 54.

${ }^{468}$ Interim Commission on Phytosanitary Measures, Report of the Sixth Interim Commission on Phytosanitary Measures, ICPM-6 (2004)/Report (Food and Agriculture Organization, Rome), 29 March - 2 April 2004, Appendix 9, paras 6-7, available at: https://www.ippc.int/servlet/BinaryDownloaderServlet/34062 ICPM6 2004 en.pdf?filename=1085664580297 ICPM6 Report final.pdf\&refID=34062, visited on $2 \overline{6}$ March 2008 . It was decided then that all country comments should be published on the IPP, that the IPPC Secretariat should produce and make accessible a generic summary of SC reactions to these comments and that the SC members should report back to the countries in their regions. In addition, it was recommended that modern telecommunication, such as email and teleconferencing, be used to advance discussion on standards. However, it was provided that email communication be used to supplement, but not replace, face-to-face expert meetings.

${ }^{469}$ These documents are posted on the IPP, but in a restricted area access to which requires a password. The SC decides who may have access to particular documents. In some cases only members of the expert drafting group involved, or SC members, have access.

${ }^{470}$ Commission on Phytosanitary Measures, Improvement of Transparency in the Development of International Standards for Phytosanitary Measures. Proposal of Brazil, Chile and Paraguay, CPM 2007/31 (International Plant Protection Convention, Rome), 23-30 March 2007, available at: https://www.ippc.int/ servlet/BinaryDownloaderServlet/182254_CPM2007_31.pdf?filename=1173975771673_CPM_2007_31. pdf\&refID=182254, visited on 11 April 2008 .

${ }^{471}$ Ibid.

${ }^{472}$ It was noted that scientists may be reluctant to publicly share information before they have published their scientific papers. In addition, the concern was raised that a policy of posting all documents on the IPP could result in the withholding of information, verbal rather than documented reporting at meetings, or sending documents directly to participants, bypassing the IPPC Secretariat. Also, the fact that documents in the early stages of drafting might be misleading to the general public was noted. Focus Group on the Review of IPPC Standard Setting Procedures, Report of the Focus Group (International Plant Protection Organization, Rome), 
ate for the standard-setting process would be ensured if the following documents would be made available to all contracting parties on the IPP: all documents approved at an SC meeting; all reports of Technical Panels and EWGs; the compilation of country comments made by the IPPC Secretariat; the agenda and list of participants of the SC; the revised draft ISPMs and draft specifications presented to the SC; and the list of SC documents. ${ }^{473}$ Another recommendation, made by the Independent Evaluation team, is that the reports of meetings of the SC, EWGs and Technical Panels should contain sufficient detail on the discussion that took place on key issues related to the draft standards and that these reports should be available before the consultation period. ${ }^{474}$ This would allow for more informed discussion, raise the level of the comments submitted in the consultation period and result in better quality standards. The SPTA has agreed with this recommendation and recommended that the IPPC Secretariat remind the relevant IPPC bodies of the need for detailed reports of their meetings. ${ }^{475}$ One can expect that, if these recommendations are adopted, the resulting improved transparency will enable contracting parties, particularly those with limited resources, to be better informed and therefore to make more successful use of the opportunities available to influence the standard-setting process.

\subsubsection{Participation in standard setting}

The only IPPC body of which all contracting parties are members is the CPM, previously the ICPM. This body is not only responsible for making decisions on matters of policy under the IPPC, but also decides on new topics for standard setting and adopts new standards. While provision is made in its Rules of Procedure for adoption of standards by a two-thirds majority vote if consensus cannot be achieved, to date all ISPMs have been adopted by consensus. ${ }^{476}$ Attendance of CPM meetings is important if a WTO Member wants to ensure that its interests are reflected in key decisions. Since the institutional reforms following the coming into force of the SPS Agreement, attendance of the (I)CPM has been steadily increasing, from 82 contracting parties in 1998 at the first meeting of the ICPM, to 129 contracting parties at the second meeting of the CPM in 2007. Attendance

16-20 July 2007, para. 96, available at: https://www.ippc.int/servlet/BinaryDownloaderServlet/189350 Report_FG_2007.pdf?filename=1193215805220_Report_2007_FG_on_standard_set-1163088563. pdf\&refID $=\overline{1} 89350$, visited on 9 April 2008.

${ }^{473}$ Ibid., para. 99. In addition the Focus Group suggested that, on request of an SC member or a contracting party's contact point, any other document could be made available on the IPP if the SC and the author of the document (if applicable) agree.

${ }^{474}$ FAO Programme Committee, Independent Evaluation of the Working of the International Plant Protection Convention and Its Institutional Arrangements (Food and Agriculture Organization, Rome), 17-21 September 2007, 54, available at: https://www.ippc.int/servlet/BinaryDownloaderServlet/184229 IPPC_Evaluation Repo.doc?filename $=1180006371650 \_1$ IPPC_Final_Evaluation_Report.doc\&refID $=18 \overline{4229}$, visited on 10 March 2008.

${ }^{475}$ CPM Informal Working Group on Strategic Planning and Technical Assistance, Report of the Second Meeting (International Plant Protection Convention, Rome), 1-5 October 2007, para. 25, available at: https://www.ippc. int/servlet/BinaryDownloaderServlet/190812_9th_SPTA_Report_2007.pdf?filename=1196340302166_9th_ SPTA_Report_2007.pdf\&refID=190812, visited on 1 April 2008.

476 Interim Commission on Phytosanitary Measures, Developing Country Participation in IPPC StandardSetting and Listing of Experts for IPPC Working Groups 2000-2002, ICPM 03/INF/2 (International Plant Protection Convention, Rome), 7-11 April 2003, para. 11, available at: https://www.ippc.int/ servlet/BinaryDownloaderServlet/21133_English.pdf?filename=1051088293796_ICPM03_INF2. pdf\&refID=21133, visited on 18 April 2008. On decision making in the CPM, see above, Part II, Section 3.2.3.2. 
by middle- and low-income contracting parties is growing commensurately. ${ }^{477}$ In particular, attendance of African contracting parties rose sharply between the fourth and fifth meetings of the ICPM in 2002 and 2003, due to support from the Special Trust Fund for the IPPC (discussed below). ${ }^{478}$

\section{Graph 29: Commission on Phytosanitary Measures, Second Session: Attendance by WTO Members by Income Level, 2007}
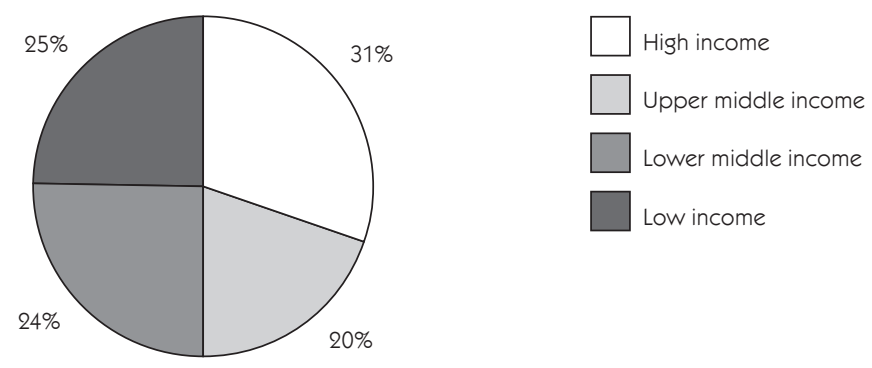

At the Second Session of the Commission on Phytosanitary Measures in 2007, ${ }^{479}$ participation closely reflected the membership of the IPPC. Of the 166 contracting parties, 129 were represented, of which 103 were WTO Members. Of these, 31 percent were high-income Members, 20 percent were upper-middle-income Members; 24 percent were lower-middle-income Members and 25 percent were low-income Members.

However, the strength of the representation of different WTO Members, as reflected in the size of their delegations, also deserves attention.

477 At the first two sessions of the ICPM in 1998 and 1999, middle- and low-income contracting parties accounted for $80 \%$ of those represented at the sessions. At the most recent session of the CPM in 2007, they accounted for $95 \%$. For the data on the 1998 and 1999 ICPM sessions, see ibid., para. 10.

${ }^{478}$ FAO Programme Committee, Independent Evaluation of the Working of the International Plant Protection Convention and Its Institutional Arrangements (Food and Agriculture Organization, Rome), 17-21 September 2007, para. 142, available at: https://www.ippc.int/servlet/BinaryDownloaderServlet/184229_IPPC Evaluation_Repo.doc?filename $=1180006371650$ _1_IPPC_Final_Evaluation_Report.doc\&refID=184229, visited on 10 March 2008. This report notes that the number of African contracting parties attending ICPM meetings almost doubled, from 15 in 2002 to 29 in 2003. The Special Trust Fund of the IPPC is discussed further below, in this same Section.

${ }^{479}$ At this meeting, 31 high-income WTO Members, 21 upper-middle-income WTO Members, 24 lower-middleincome WTO Members and 27 low-income WTO Members were represented. International Plant Protection Convention, Report of the Second Session of the Commission on Phytosanitary Measures, CPM-2 (2007)/ Report (Food and Agriculture Organization, Rome), 26-30 March 2007, available at: https://www.ippc.int/ servlet/BinaryDownloaderServlet/184215_CPM_2_report.pdf?filename=1179929463410_CPM_2_report. pdf\&refID=184215, visited on 20 February 2008. 
Graph 30: Commission on Phytosanitary Measures, Second Session: Delegates of WTO Members by Income Level, 2007
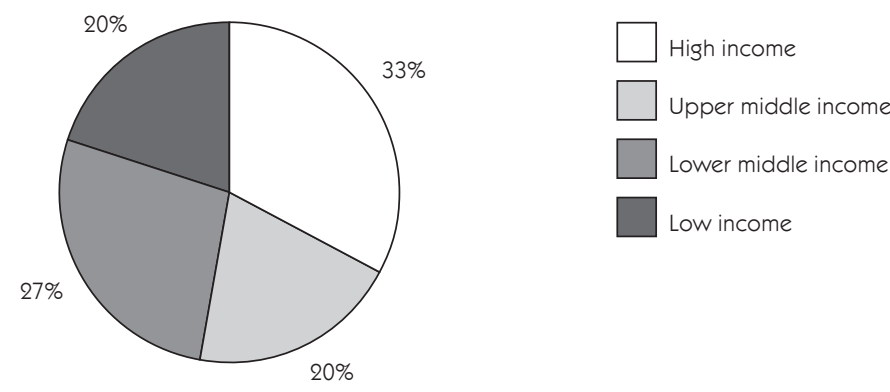

In total 33 percent of the participants from WTO Members at the Second Session of the CPM were delegates of high-income WTO Members, 20 percent were delegates of uppermiddle-income Members, 27 percent were delegates of lower-middle-income Members and 20 percent were delegates of low-income Members. ${ }^{480}$

\section{Graph 31: Commission on Phytosanitary Measures, Second Session: Average Number of Delegates per WTO Member by Income Level, 2007}
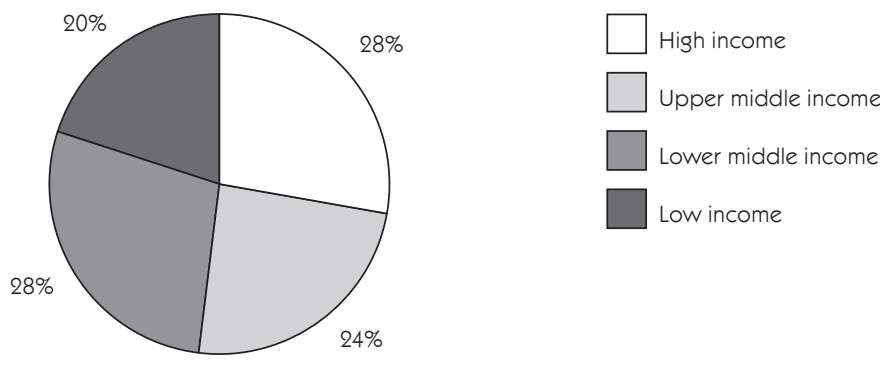

The average number of delegates per WTO Member represented at the Second Session of the CPM by income level was 2,54 for high-income Members, 2,19 for lower-middle-income Members, 2,52 for upper-middle income Members and 1,76 for low-income Members.

${ }^{480}$ In total 234 delegates of WTO Members were present. These were 79 delegates of high-income Members, 46 delegates of upper-middle-income Members, 63 delegates of lower-middle-income Members and 46 delegates of low-income Members. These numbers are based on the list of delegates provided in the report of the second session of the CPM. See Ibid., Appendix 21. 
As noted above, the SPTA is an open-ended working group in that, aside from its core members (the enlarged Bureau of the $\mathrm{CPM},{ }^{481}$ and the chairpersons of the SC and the SBDS), it is open for membership to interested persons from any contracting party. This has made it possible for the SPTA to benefit from the efforts of a relatively small group of persons with extensive IPPC experience. ${ }^{482}$ Members of the SPTA, where possible, fund their own travel and subsistence for the attendance of meetings. However, SPTA members that are members of the Bureau or Chairpersons of the two subsidiary bodies may request financial assistance from the $\mathrm{FAO}$ for meeting attendance. If financial assistance is available, priority will be given to developing-country participants. ${ }^{483}$

\section{Graph 32: IPPC Informal Working Group on Strategic Planning and Technical Assistance: Attendance by WTO Members by Income Level, 2003-2007}

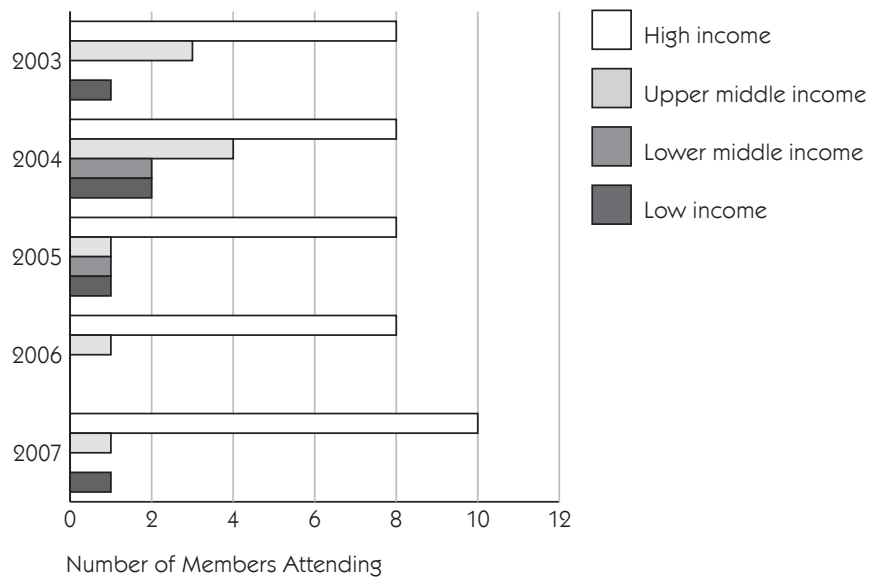

In practice, an examination of participants' lists of SPTA meetings ${ }^{484}$ shows that the composition of the SPTA in most years has been unbalanced, in favour of high-income WTO

481 The Bureau which heads the CPM is currently composed of the Chairperson and two Vice-Chairpersons of the CPM. These are Chagema J Kedera (Kenya), Reinouw Bast-Tjeerde (Canada) and Ralf Lopian (Finland). As discussed above, a decision was taken by the CPM in 2007 to expand the Bureau to 7 members but this will only take effect once the new members have been elected at the Third Session of the CPM in 2008. In the meantime, in addition to the existing Bureau, the core members of the SPTA include representatives from the 7 FAO regions. Ibid., Appendix 21.

${ }^{482}$ FAO Programme Committee, Independent Evaluation of the Working of the International Plant Protection Convention and Its Institutional Arrangements (Food and Agriculture Organization, Rome), 17-21 September 2007, para. 151, available at: https://www.ippc.int/servlet/BinaryDownloaderServlet/184229_IPPC Evaluation_Repo.doc?filename $=1180006371650$ _1_IPPC_Final_Evaluation_Report.doc\&refID $=184229$, visited on 10 March 2008.

${ }^{483}$ Article 3 of the Terms of Reference for the SPTA.

${ }^{484}$ The data presented here was obtained from the participants' lists included in the SPTA meeting reports of 2003 to 2007. While the SPTA meeting report of 2002 is available, it does not include a list of participants and therefore data for that year cannot be included. As done elsewhere in this chapter, when presenting the data regard is had only to WTO Members that are contracting parties to the IPPC (consequently, the attendance 
Members. ${ }^{485}$ In the period 2003-2007, of the total of 60 participants in SPTA meetings, 70 percent (42) were from high-income WTO Members, 17 percent (10) were from upper-middle-income WTO Members, 5 percent (3) were from lower-middle-income WTO Members and 8 percent (5) were from low-income WTO Members. ${ }^{486}$ In addition, the report of the Independent Evaluation team notes that it has proved difficult to ensure continuity of membership of developing country attendees. ${ }^{487}$

The unbalanced composition of the SPTA is a matter of concern when seen in the light of the significant role of this body in the governance of the IPPC. To address this problem, in 2004 a recommendation was adopted by the ICPM that the IPPC Secretariat seek to facilitate the participation of two developing country representatives per FAO region, for the 2005 SPTA meeting. ${ }^{488}$ This decision applied only for that meeting and, even then,

of Lebanon in 2003, 2004 and 2005, and of Samoa in 2005 is not reflected in the data). Further, the data presented here does not take into account the participants that are part of the core group of the SPTA (the Bureau and representatives of the remaining FAO regions) or the Chairpersons of the SBDS or SC. In addition, participants from the IPPC Secretariat and observers from the FAO have been omitted. All of the omitted participants, aside from the non-WTO Members, do not represent particular contracting parties and therefore cannot be classified by income level.

${ }^{485}$ A similar calculation to that presented here, but taking into account SPTA core group members (i.e. the Bureau and the representatives of the 7 FAO regions), is contained in the 2007 report of the independent evaluation of the IPPC. This report notes that the attendance of developed and developing country participants in SPTA meetings between 2003 and 2006 was as follows: 2003: 8 developed and 6 developing country participants; 2004: 8 developed and 11 developing country participants, 2005: 9 developed and 7 developing country participants and 2006: 11 developed and 5 developing country participants. FAO Programme Committee, Independent Evaluation of the Working of the International Plant Protection Convention and Its Institutional Arrangements (Food and Agriculture Organization, Rome), 17-21 September 2007, para.149, available at: https://www.ippc.int/servlet/BinaryDownloaderServlet/184229_IPPC_Evaluation_Repo. doc?filename $=1180006371650$ 1_IPPC_Final_Evaluation_Report.doc\&refID $=18 \overline{4} 229$, visited on $10 \overline{\mathrm{March}}$ 2008.

${ }^{486}$ ICPM Informal Working Group on Strategic Planning and Technical Assistance, Final Report of the Fifth Meeting (International Plant Protection Convention, Rome), 13-17 October 2003, available at: https:// www.ippc.int/servlet/BinaryDownloaderServlet/30461_SPTA2003_report.pdf?filename=1073570691417 FINAL_REPORT_SPTA.pdf\&refID $=30461$, visited on 1 April 2008; ICPM Informal Working Group on Strategic Planning and Technical Assistance, Report of the Sixth Meeting (International Plant Protection Convention, Rome), 11-15 October 2004, available at: https:/www.ippc.int/servlet/ BinaryDownloaderServlet/41717_Report_SPTA2004.pdf?filename=1107531893932_SPTA2004_Final_ Report.pdf\&refID=41717, visited on 1 April 2008; ICPM Informal Working Group on Strategic Planning and Technical Assistance, Report of the Seventh Meeting, Rome), 11-14 October 2005, available at: https://www. ippc.int/servlet/BinaryDownloaderServlet/116839_Report_SPTA_2005.pdf?filename=1141372703272_ SPTA_report_2005.pdf\&refID=116839, visited on 1 April 2008; CPM Informal Working Group on Strategic Planning and Technical Assistance, Report of the First Meeting (International Plant Protection Convention, Rome), 2-6 October 2006, available at: https://www.ippc.int/servlet/BinaryDownloaderServlet/176987 SPTA_Report_2006.pdf?filename $=1168261796553$ SPTA_2006_Final_Report.pdf\&refID $=176987$, visited on 1 April 2008; CPM Informal Working Group on Strategic Planning and Technical Assistance, Report of the Second Meeting (International Plant Protection Convention, Rome), 1-5 October 2007, available at: https://www.ippc.int/servlet/BinaryDownloaderServlet/190812_9th_SPTA_Report_2007. pdf?filename=1196340302166_9th_SPTA_Report_2007.pdf\&refID=190812, visited on 1 April 2008.

${ }^{487}$ FAO Programme Committee, Independent Evaluation of the Working of the International Plant Protection Convention and Its Institutional Arrangements (Food and Agriculture Organization, Rome), 17-21 September 2007, para. 149, available at: https:/www.ippc.int/servlet/BinaryDownloaderServlet/184229_IPPC Evaluation_Repo.doc?filename $=1180006371650$ _1_IPPC_Final_Evaluation_Report.doc\&refID $=184229$, visited on $\overline{10}$ March 2008.

${ }^{488}$ Interim Commission on Phytosanitary Measures, Report of the Sixth Interim Commission on Phytosanitary Measures, ICPM-6 (2004)/Report (Food and Agriculture Organization, Rome), 29 March - 2 April 2004, 
its implementation is not reflected in the data on participants. ${ }^{489}$ In that and other SPTA meetings, the balance of participants has remained skewed towards high-income WTO Members.

As noted above, the permanent and ad hoc subsidiary bodies of the IPPC, unlike the CPM, have limited membership. This membership reflects the seven FAO regions, or, in the case of EWGs and Technical Panels, represents 'a wide geographic area', including the proportional representation of developing countries. Although members of the IPPC subsidiary bodies participate in their capacity as experts, rather than as representatives of particular contracting parties, it is envisioned that through their participation, the standard-setting bodies incorporate a diversity of views in order to contribute to the drafting of internationally acceptable standards. ${ }^{490}$ This diversity should not only be regional, but should also reflect a range of levels of development, phytosanitary and climatic conditions, etc. ${ }^{41}$ However, a major problem that has been identified with regard to the selection of members of IPPC bodies is the limited availability and readiness of individuals to participate, given the workload at their current institutions and the inadequate resources to fund their travel and time. ${ }^{492}$ As a result, compromises have to be made to achieve 'a working set of members' ${ }^{493}$ These compromises may result in an over-representation of contracting parties at higher levels of development.

It is therefore useful to examine the membership and attendance of WTO Members at different income levels in the various IPPC bodies in order to determine the extent to which the 'diversity of views' currently reflected incorporates the views of WTO Members at different levels of economic development.

As already mentioned, the Standards Committee is the body charged with overseeing the standard-setting process at the IPPC, and plays a critical role in this process. It is responsible for the advancement of standards at two stages in the standard-setting process. ${ }^{494}$ It members are selected by each FAO region, and are confirmed by the CPM. An examination of the membership of the Standards Committee by WTO Members across income levels is useful in determining the level of influence of WTO Members at different levels of economic development in the elaboration of IPPC standards.

para. 84, available at: https://www.ippc.int/servlet/BinaryDownloaderServlet/34062_ICPM6_2004_ en.pdf?filename=1085664580297_ICPM6_Report_final.pdf\&refID=34062, visited on 26 March 2008.

${ }^{489}$ Even taking into account the non-WTO Member participants and the participant from the Bureau, the number of middle- and low-income country participants in the 2005 meeting was only 7.

${ }^{490}$ See for example para. 2 of the Guidelines on the Duties of the Members of the Standards Committee, discussed above, Part II, Section 3.2.3.2.

491 Ibid.

${ }^{492}$ FAO Programme Committee, Independent Evaluation of the Working of the International Plant Protection Convention and Its Institutional Arrangements (Food and Agriculture Organization, Rome), 17-21 September 2007, para. 57, available at: https:/www.ippc.int/servlet/BinaryDownloaderServlet/184229_IPPC Evaluation_Repo.doc?filename $=1180006371650$ _1_IPPC_Final_Evaluation_Report.doc\&refID=184229, visited on 10 March 2008.

${ }^{493} \mathrm{Ibid}$. Note, however, that in the case of the Standards Committee, discussed below, the attendance of meetings by its members is funded by the IPPC Secretariat.

${ }^{494}$ As explained above, the SC reviews and approves draft ISPMs before they are made available for comments in the consultation phase, and it also reviews comments received, amends draft ISPMs and decides whether to submit them to the CPM for adoption. 


\section{Graph 33: Graph 33: IPPC Standards Committee: Standards Committee Members that are WTO Members by Income Level, 2007}
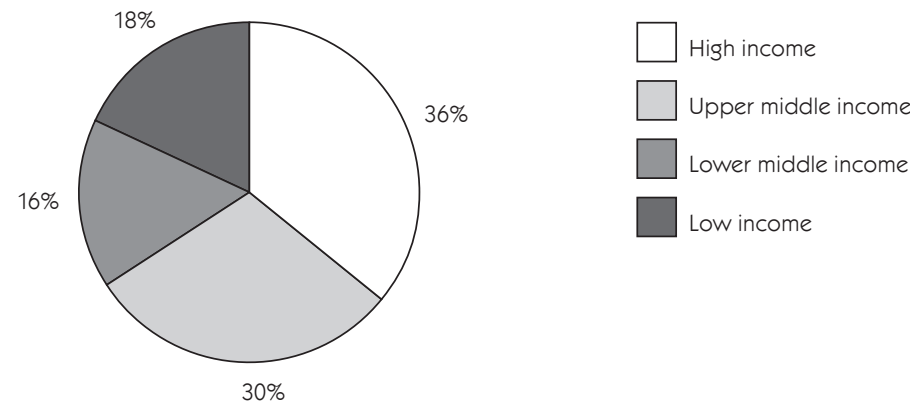

The examination of the membership of the Standards Committee in May and November 2007 indicates that this influential body was dominated by members from high-income and upper-middle-income WTO Members, respectively accounting overall for 36 percent and 30 percent of the WTO Members that were members of this body in 2007. ${ }^{495}$ Lowermiddle-income and low-income WTO Members respectively accounted for only 16 percent and 18 percent of the SC members that were WTO Members in that year.

Attendance of SC meetings is funded by the IPPC Secretariat, ${ }^{496}$ except where the government of the member involved voluntarily waives funding. Nevertheless, not all SC members are able to attend all meetings. In fact, one concern raised with regard to SC members is the fact that some of them are not released from their normal duties by their governments or employers in order to allow them to attend SC meetings. ${ }^{497}$

495 To facilitate comparison with the data on attendance of SC meetings in 2007, the membership of the SC in 2007 is presented here, rather than that in 2008. In 2007, all but three members of the SC were from contracting parties that were WTO Members. The SC members in May 2007 were from Australia, Argentina, Brazil, Canada, China, Costa Rica, the European Community, Germany, India, Israel, Japan, Jordan, Latvia, Malaysia, New Zealand, Nigeria, South Africa, Sudan, Syria, Tonga, Uganda, the US, Uruguay, Yemen, and Zambia. In November 2007, a member from Indonesia replaced the member from Malaysia. Of all these SC members, Sudan, Syria and Yemen are not WTO Members. The membership of the SC changed again in 2008. In its current composition, the SC includes a member from Denmark (instead of the member from the European Community), a member from Turkey instead of the member from Syria and has a different member from Canada - the remaining members are the same as in the previous composition. Standards Committee, Report of the Standards Committee (Food and Agriculture Organization, Rome), 30 April - 4 May 2007, Appendix 19, available at: https://www.ippc.int/servlet/CDSServlet?status=ND0xMzQwMiY2PWVuJjMzP SomMzc9a29z, visited on 1 April 2008; International Plant Protection Convention, Standards Committee Membership (International Plant Protection Convention, Rome), 23 January 2008, available at: https://www. ippc.int/servlet/BinaryDownloaderServlet/179715_SC_members_contact_i.doc?filename=1201075805403 SC members contact info 200801 23.doc\&refID $=\overline{179715}$, visited on 10 March 2008.

496 This funding comes from the regular programme budget of the FAO. Interim Commission on Phytosanitary Measures, Developing Country Participation in IPPC Standard-Setting and Listing of Experts for IPPC Working Groups 2000-2002, ICPM 03/INF/2 (International Plant Protection Convention, Rome), 7-11 April 2003, para. 4, available at: https://www.ippc.int/servlet/BinaryDownloaderServlet/21133_English. pdf?filename=1051088293796_ICPM03_INF2.pdf\&refID=21133, visited on 18 April 2008.

${ }_{497}$ This concern was raised by the independent evaluation team tasked with the evaluation of the operation and institutions of the IPPC in 2006 to 2007. FAO Programme Committee, Independent Evaluation of the 


\section{Graph 34: IPPC Standards Committee: Attendance by Standards Committee Members that are WTO Members by Income Level, 2007}

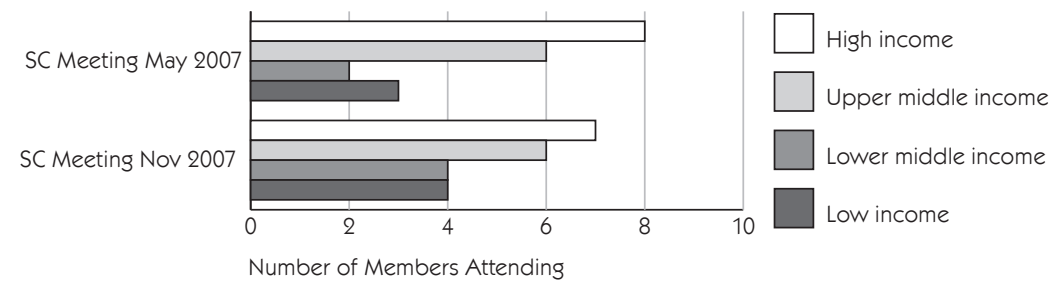

In 2007, of the SC members that were WTO Members attending the meetings, 38 percent (15) were from high-income WTO Members, 30 percent (12) were from upper-middleincome WTO Members, 15 percent (6) were from lower-middle-income WTO Members and 17 percent (7) were from low-income WTO Members. ${ }^{498}$ The SC members from India, South Africa and Tonga were unable to attend the meeting of the SC held in May 2007, and that of Australia was unable to attend the meeting held in November 2007. ${ }^{499}$

Membership of the SC-7 is even more unbalanced than that of the SC. In 2007, the members of the SC-7 were from Canada, China, Costa Rica, Germany, Jordan, New Zealand and South Africa, all WTO Members. ${ }^{500}$ Of these countries, 42 percent (3) are high-income WTO Members, 29 percent (2) are upper-middle-income WTO Members, 29 percent (2) are lower-middle-income WTO Members, and none are low-income WTO Members.

The scientific expertise on which the ISPMs are based is derived from the EWGs and Technical Panels that elaborate the draft standards under the supervision of the relevant steward. The EWGs and Technical Panels have limited membership. While members participate in their capacity as experts rather than as country representatives, they are selected to represent a wide geographic area. In addition, the proportional representation of developing countries is aimed at. This reflects recognition of the fact that scientific viewpoints are influenced by the background of the expert involved. ${ }^{501}$ It is useful to exam-

Working of the International Plant Protection Convention and Its Institutional Arrangements (Food and Agriculture Organization, Rome), 17-21 September 2007, para. 52, available at: https:/www.ippc.int/servlet/ BinaryDownloaderServlet/184229_IPPC_Evaluation_Repo.doc?filename=1180006371650_1_IPPC_Final_ Evaluation_Report.doc\&refID=184229, visited on 10 March 2008.

${ }^{498}$ As elsewhere in this chapter, the information on attendance takes into account only WTO Members. The nonWTO Members that attended the SC meeting of May 2007 are Sudan, Syria and Yemen. Sudan and Yemen also attended the SC Meeting of November 2007.

${ }^{499}$ In addition, the SC member from Syria (not a WTO Member) was unable to attend the meeting of November 2007.

500 The participants' list for the SC-7 in 2007 can be found on the page on the SC-7 meeting of 2007 of the IPP, available at: https://www.ippc.int/servlet/CDSServlet?status=ND0xMzI5Mi4xMjc0OTkmNj1lbiYzMz 1ldmVudHMmMzc9aW5mbw , visited on 26 March 2008. The composition of the SC-7 in 2006 was the same, except that there was a member from Brazil (also an upper-middle-income WTO Member) instead of the Costa Rican member of the SC in 2007. The participants' list for the SC-7 in 2006 is available at: https:// www.ippc.int/servlet/CDSServlet?status=ND0xMzM1NS40MzExMSY2PWVuJjMzPWV2ZW50cyYzNz1 pbmZv, visited on 26 March 2008.

${ }^{501}$ For a discussion of the value-laden nature of scientific expertise, and the myth of universal or objective science, see above, Part II, Section 1.5. 
ine the membership and participation in these expert drafting groups by WTO Members across different income levels to determine to what extent the scientific perspectives of Members at different levels of development are incorporated in ISPMs.

\section{Graph 35: IPPC Expert Working Groups: EWG Members that are WTO Members by Income Level, 2007}

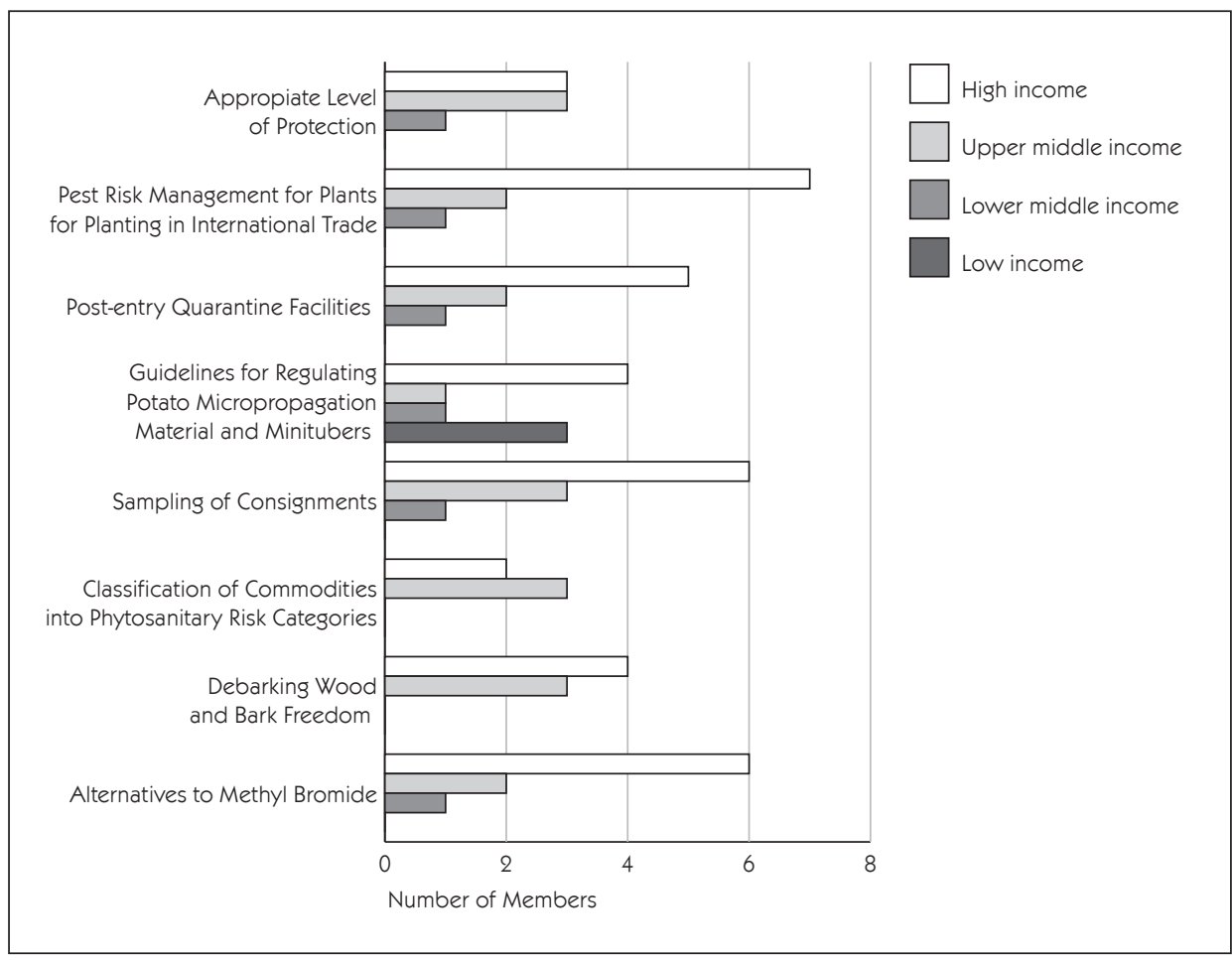

An indication of the membership of EWGs drafting ISPMs is provided by an examination of nine EWGs that were working on standards that were part of the IPPC standardsetting work programme in 2007. ${ }^{502}$ All but two of the 65 members of these EWGs were experts from WTO Members. ${ }^{503}$ Of the total number of members of the relevant EWGs

${ }^{502}$ Another indication of the membership of EWGs is provided by the review in 2007 of the drafting of a sample of ten ISPMs, carried out in the context of the independent evaluation of the IPPC. This review indicates that the majority (48\%) of participants in the EWGs drafting the selected ten standards were from developed countries, with developing countries accounting for $30 \%$ and the remaining $10 \%$ being made up of RPPO participants (which include developing countries) and the IPPC Secretariat. FAO Programme Committee, Independent Evaluation of the Working of the International Plant Protection Convention and Its Institutional Arrangements (Food and Agriculture Organization, Rome), 17-21 September 2007, para. 57, available at: https:/www.ippc.int/servlet/BinaryDownloaderServlet/184229_IPPC_Evaluation_Repo. doc?filename=1180006371650_1_IPPC_Final_Evaluation_Report.doc\&refID $=18 \overline{4} 229$, visited on 10 March 2008.

${ }^{503}$ The two EWG members that were not experts from a WTO Member were the member of the EWG on Alternatives to Methyl Bromide that was from the UNDP, Montreal Protocol, Regional Office for Latin American and the Caribbean, and the member of the EWG on Appropriate Level of Protection that was from the WTO Secretariat. 
that were WTO Members, 57 percent (37) were from high-income WTO Members, 29 percent (19) were from upper-middle-income WTO Members, 9 percent (6) were from lower-middle-income WTO Members and 5 percent (3) were from low-income WTO Members. ${ }^{504}$ The surprisingly high membership of low-income Members, who are otherwise completely absent from the EWGs examined here, in the EWG on Guidelines for Potato Micropropagation Material and Minitubers is explained by the importance of the topic for India and the South Pacific islands. ${ }^{505}$

${ }^{504}$ This data was drawn from the lists of participants and absent members in the EWG meeting reports of all EWGs elaborating standards that were on the IPPC standard-setting work programme in 2007. However, many of the relevant EWGs did not meet in 2007. Nevertheless, they were considered in generating this data as their work was ongoing in the year under consideration. The reports relied upon are the following: Expert Working Group on Alternatives to Methyl Bromide, Report of the Expert Working Group on Alternatives to Methyl Bromide (International Plant Protection Convention, Orlando), 30 October - 3 November 2006, available at: https://www.ippc.int/servlet/BinaryDownloaderServlet/183954_Report_EWG_Methyl_ br.doc?filename $=1178634989508$ EWG_report_Methyl_bromide_FINAL.doc\&refID $=183954$, visited on 9 April 2008; Expert Working Group on Debarking of Wood and Bark Freedom, Report of the Expert Working Group on Debarking of Wood and Bark Freedom (International Plant Protection Convention, Aas), 6-10 June 2005, available at: https://www.ippc.int/servlet/BinaryDownloaderServlet/124443_EWG_report Debarking.doc? filename $=1146746850877$ Report_EWG_DEBARKED_AND_BARK_F-1150223015. doc\&refID $=124443$, visited on 9 April 2008; Expert Working Group on Classification of Commodities into Phytosanitary Risk Categories, Report of the Expert Working Group on Classification of Commodities into Phytosanitary Risk Categories (International Plant Protection Convention, Kleinmachnow), 18-22 September 2006, available at: https://www.ippc.int/servlet/BinaryDownloaderServlet/183948_Report_EWG_Classific. doc?filename $=1178634754538$ Report_EWG_Classification_of_c-390496381.doc\&refID $=183948$, visited on 9 April 2008; Expert Working Group on Sampling of Consignments, Report of the Expert Working Group on Sampling of Consignments (International Plant Protection Convention, Ottawa), 18-22 July 2005, available at: https://www.ippc.int/servlet/BinaryDownloaderServlet/183951_Report_EWG_Sampling. doc?filename $=1178634852520$ EWG_report_Sampling_of_consignments_FINAL.doc\&refID $=183951$, visited on 9 April 2008; Expert Working Group on Guidelines for Regulating Potato Micropropagation, Report of the Expert Working Group on Guidelines for Regulating Potato Micropropagation (International Plant Protection Convention, Edinburgh), 12-16 September 2005, available at: https://www.ippc.int/ servlet/BinaryDownloaderServlet/107323_Report.doc.doc?filename=1135789491954_Potatoes_EWG_ Report.doc\&refID $=107323$, visited on 9 April 2008; Expert Working Group on Post-Entry Quarantine Facilities, Report on Expert Working Group on Post-Entry Quarantine Facilities (International Plant Protection Convention, Clermont Ferrand), 23-27 May 2005, available at: https://www.ippc.int/servlet/BinaryDownloaderServlet/107175_quarantine.doc.doc?filename=1135691355617_EWG_Report_ post_entry_quarantine.doc\&refID $=107175$, visited on 9 April 2008; Expert Working Group on Pest Risk Management for Plants for Planting in International Trade, Report of the Second Meeting of the Expert Working Group on Pest Risk Management for Plants for Planting in International Trade (International Plant Protection Convention, Vancouver), 26 February - 2 March 2007, available at: https://www.ippc. int/servlet/BinaryDownloaderServlet/201554_2007_Report_Pest_ris.doc?filename $=1207143261816$ _ REPORT_EWG_Pest_risk_managemen1364784651.doc\&refID=201554, visited on 9 April 2008; Expert Working Group on Appropriate Level of Protection, Report of the Expert Working Group on Appropriate Level of Protection (International Plant Protection Convention, Ottawa), 23 August - 1 September 2006, available at: https://www.ippc.int/servlet/BinaryDownloaderServlet/184106_Report_EWG_ALOP. doc?filename=1179214789083_Report_EWG_ALOP_2007_04_24_final.doc\&refID $=184106$, visited on 9 April 2008.

${ }^{505}$ The topic of the EWG relates to the development of guidance on measures to reduce the risks from regulated pests associated with potato micropropagation material and minitubers in international trade. Internationally, large numbers of pests are associated with potato propagative material. According to the Regional Potato and Sweet potato Improvement Network in Eastern and Central Africa (PRAPACE), the single most important constraint for potato production is the shortage of clean planting material. Micropropagation or propagation in vitro offers a solution to the problem, provided that the propagation material is pathogen free. As micropropagation material and potato minitubers are intended for use in vegetative propagation, if this material or tubers are infected, there is a great risk of spreading pests or diseases. Various trade-restrictive measures are 


\section{Graph 36: IPPC Expert Working Groups: Attendance by EWG Members that are WTO Members by Income Level, 2005-2008}

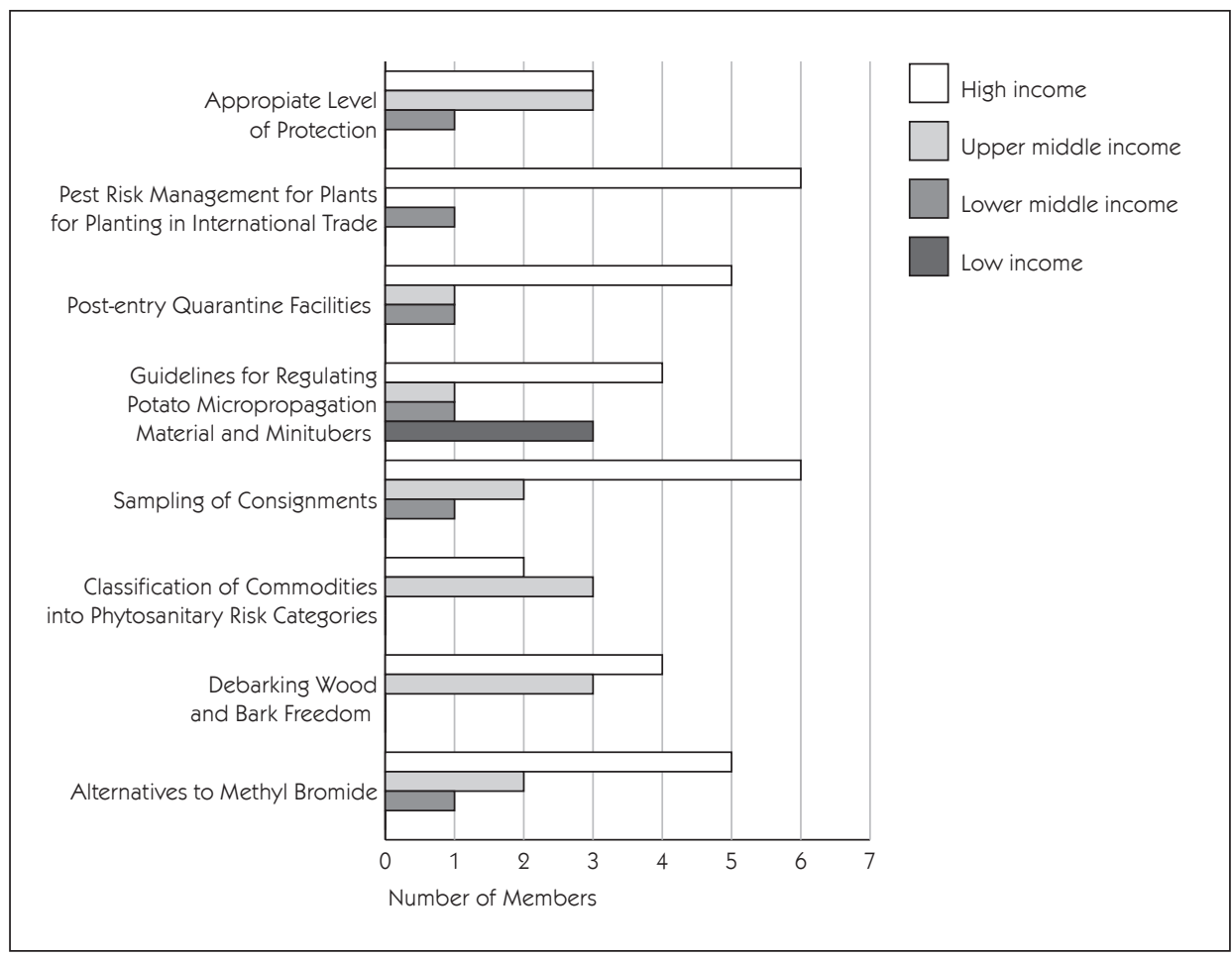

Not all EWG members attend the meetings of the relevant EWG. Of the 60 members of the relevant EWGs that actually attended the meetings, all but one were experts from

taken by importing countries to address this risk. The EWG was established to elaborate guidelines for such phytosanitary measures. In some South East Asian and South Pacific countries, including India, Thailand and Papua New Guinea (all members of this EWG), micropropagation has been promoted as a way to improve agricultural production. Transfer of technology, dissemination and adoption of micropropagation techniques from developed countries have been very successful in Thailand and India, resulting in the establishment of around 30 semi-commercial plant tissue culture companies in Thailand and more than 50 commercial laboratories, with a total capacity of 210 million plants per annum, in India. Similarly, micropropagation has been successfully introduced into South Pacific Island countries in order to diminish reliance on the extremely fragile ecosystems and limited natural resources of these countries. It was first introduced into the region through the tissue culture laboratory established by the South Pacific Commission (SPC), Plant Protection Service to increase the number of varieties of the main root and tuber crops available in the Pacific island countries, and to facilitate their trade by ensuring their pathogen-tested status. The importance of this topic for South East Asian and South Pacific countries explains the fact that both the steward and one other EWG member are from India (the latter from the Central Potato Research Institute, in Shimla, India), and another two members are from Thailand and Papua New Guinea. Edgar J. DaSilva and Mary Taylor, 'Island Communities and Biotechnology ', Electronic Journal of Biotechnology 1 (1), 1998, 1-10, available at: http://www.ejbiotechnology.info/content/vol1/issue1/full/1/1.pdf, visited on 14 April 2008; J. Prakash, 'Plant Tissue Culture: Concept to Commercialisation in South East Asia', International Society for Horticultural Science Acta Horticulturae 560 (IV), 2001, 571-574, available at: http://www.actahort.org/ books/560/560_117.htm, visited on 15 April 2008. 
WTO Members. ${ }^{506}$ Of these, 58 percent (35) were from high-income WTO Members, 25 percent (15) were from upper-middle-income WTO Members, 10 percent (6) were from lower-middle-income WTO Members and 5 percent (3) were from low-income WTO Members. ${ }^{507}$

As mentioned above, each topic for a new ISPM is assigned a steward by the SC, usually from among the SC members. The steward is a full member of the EWG or Technical Panel drafting the ISPM and plays a key role in its development. ${ }^{508}$ It is therefore important to determine the extent to which WTO Members at different levels of development are selected as stewards.

\section{Graph 37: IPPC Expert Working Groups: Stewards that are from WTO Members by Income Level, 2007}
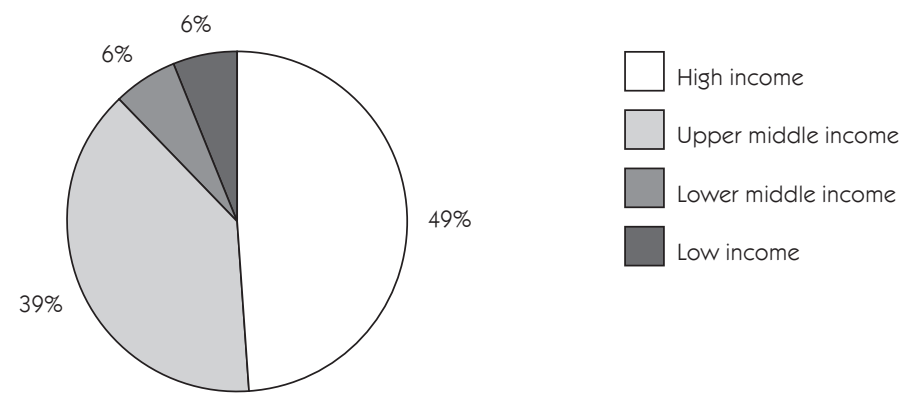

An examination of the stewards assigned to the 34 draft ISPMs on the IPPC standardsetting work programme in 2007 shows that 33 of the draft ISPMs had a steward from a WTO Member. ${ }^{509}$ The remaining ISPM had a steward from the International Atomic

506 The single EWG member attending the EWG meeting that was not from a WTO Member was the member from the UNDP, Montreal Protocol, Regional Office for Latin American and the Caribbean, who participated in the EWG on Alternatives to Methyl Bromide.

507 This data covers only EWGs working on standards that were part of the IPPC standard-setting work programme in 2007. Some of these EWGs met in 2007, but several met in previous years. The data is taken from the reports of the EWGs that are available in IPPC website. It therefore does not consider EWGs which have not yet met, or for which a report is not yet publicly available. Stewards, chairs and hosts have been considered as part of the EWG, as have members of EWGs that are RPPOs (in casu, the member from the European and Mediterranean Plant Protection Organization, based in France). Members representing international organisations (in casu, the member from the UNDP, Montreal Protocol, Regional Office for Latin American and the Caribbean) are full members of EWGs but were not taken into account in the data presented here as they do not represent countries and cannot be assigned an income level. Rapporteurs, members of the IPPC Secretariat and members of the CPM Bureau participating in EWG meetings are not members of the EWG and are therefore not considered.

${ }^{508}$ On the role of the steward in the standard-setting process, see above, Part II, Section 3.2.3.2.

${ }^{509}$ Note that the same person is often steward of more than one draft ISPM. For example, Greg Wolff (Canada) was assigned 5 ISPMs, Mike Holtzhausen (South Africa) was assigned 4 ISPMs, David Porritt (Australia) and Odilson Ribeiro e Silva (Brazil) were assigned 3 ISPMs each, and Julie Aliaga (USA), Mohammad Katbeh Bader (Jordan), John Hedley (New Zealand), Magda Gonzalez (Costa Rica) and Robert Karyeija (Uganda) were assigned 2 ISPMs each. The remaining stewards were assigned one ISPM each. 
Energy Agency (IAEA) and later from the North American Plant Protection Organization (NAPPO)..$^{510}$ Of the 33 ISPMs with stewards from WTO Members, 49 percent (16) had stewards from high-income WTO Members, 39 percent (13) from upper-middle-income WTO Members, 6 percent (2) from lower-middle-income WTO Members and 6 percent (2) from low-income WTO Members. ${ }^{511}$ There is therefore clearly an overwhelming representation of high-income and upper-middle-income WTO Members among the stewards.

\section{Graph 38: IPPC Technical Panels: Membership of WTO Members by Income Level, 2007}

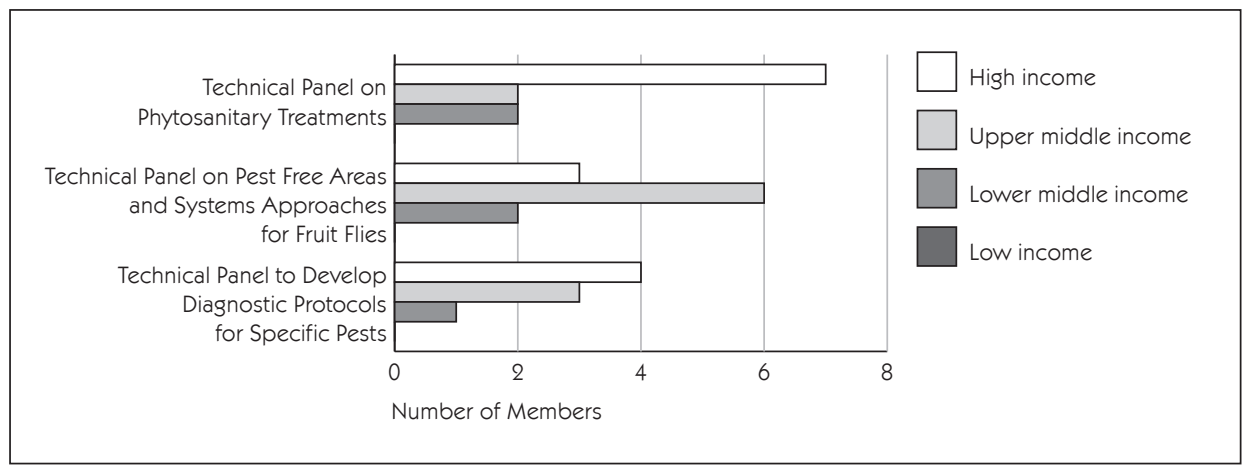

As stated above, some ISPMs are elaborated by standing Technical Panels. The 43 experts that made up the membership of the five Technical Panels in 2007, were all from WTO Members. Again, these experts were predominantly from high-income and, to a lesser extent, from upper-middle-income WTO Members. ${ }^{512}$ More specifically, 54 percent

510 The steward assigned to this ISPM was Walther Enkerlin, who was originally from the IAEA. However, in the course of 2007, he moved to the NAPPO, resulting in a change in his affiliation.

511 Standards Committee, Report of the Standards Committee (Food and Agriculture Organization, Rome), 30 April - 4 May 2007, Appendix 2, available at: https://www.ippc.int/servlet/CDSServlet?status=ND0xMzQw MiY2PWVuJjMzPSomMzc9a29z, visited on 1 April 2008.

512 Note that the data considered this chart does not take into account international organisation members of the Technical Panels, as these do not bring in the perspective of a specific country or region, but rather that of the international organisation from which they come. The data does, however, take into account stewards of the Technical Panels and RPPO members. Stewards and RPPO members are full members of Technical Panels. Neither stewards nor other Technical Panel members represent the interests of particular Members in the standard-setting process. Instead they act in their capacity as experts. Nevertheless, they are expected to bring in the perspective and experience of the country or region from which they come. International Plant Protection Convention, Technical Panel to Develop Diagnostic Protocols for Specific Pests (TPDP) (Food and Agriculture Organization, Rome), 2007, available at: https://www.ippc. int/servlet/BinaryDownloaderServlet/186512_08.do.doc?filename=1186745673624_Members_TPDP contact_info_2007_08.doc\&refID=186512, visited on 10 March 2008; International Plant Protection Convention, Technical Panel on Forest Quarantine (TPFQ) (Food and Agriculture Organization, Rome), 2007, available at: https:/www.ippc.int/servlet/BinaryDownloaderServlet/184132_TPFQ_membership. doc?filename $=1179394878295$ _Members_TPFQ_contact_info_2007_05.doc\&refID $=184132$, visited on 10 March 2008; International Plant Protection Convention, Technical Panel on Pest Free Areas and Systems Approaches for Fruit Flies (TPFF) (Food and Agriculture Organization, Rome), 2007, available at: https://www. ippc.int/servlet/BinaryDownloaderServlet/184135_TPFF_membership.doc? filename $=1198056074829$ Members_TPFF_contact_info_2007_12.doc\&refID $=18413 \overline{5}$, visited on 10 March 2008; International 
(23) of the members of the Technical Panels were from high-income WTO Members, 30 percent (13) were from upper-middle-income WTO Members, 16 percent (7) were from lower-middle-income WTO Members and none were from low-income WTO Members. The greatest number of non-high-income Members is to be found in the Technical Panel on Pest Free Areas and Systems Approaches for Fruit Flies, which may be a reflection of the importance of this issue for developing country fruit exporters. ${ }^{513}$ The distribution of stewards of Technical Panels is even more skewed. All the stewards of the Technical Panels are from high-income WTO Members, except for one (the steward of the Technical Panel on Pest Free Areas and Systems Approaches for Fruit Flies), who is from an uppermiddle-income WTO Member. ${ }^{514}$

Unlike the case with regard to the CAC, it is not possible to determine the extent of active participation of WTO Members at different income levels in the various IPPC bodies, by examining the frequency with which they participate in the discussions in these bodies, as meeting reports do not specify the contracting parties responsible for comments made. It is, however, possible to get some indication of the degree of active participation of WTO Members at different income levels in standard-setting work under the IPPC by examining the origin of proposals for new standards. The first time that a call was issued inviting contracting parties to propose topics for new standards (ISPMs) was in 2003. ${ }^{515}$ Thereafter, the call was issued biennially. In 2003 and again in 2007, a list was published

Plant Protection Convention, Technical Panel for the Glossary (TPG) (Food and Agriculture Organization, Rome), 2007, available at: https://www.ippc.int/servlet/BinaryDownloaderServlet/184138_TPG_membership.doc?filename $=1179394983426 \_$Members_TPG_contact_info_09_2006.doc\&refID $=184138$, visited on 10 March 2008; International Plant Protection Convention, Technical Panel on Phytosanitary Treatments (TPPT) (Food and Agriculture Organization, Rome), 2007, available at: https:/www.ippc.int/servlet/ BinaryDownloaderServlet/184141_TPPT_membership.doc?filename=1195228322930_Members_TPPT_ contact_info_2007_11_16.doc\&refID=184141, visited on 10 March 2008.

${ }^{513}$ An examination of the agreed priorities for fruit fly treatments developed by this Technical Panel reveals that the Caribbean, Mediterranean and Oriental varieties of fruit fly are addressed most often, and that the hosts of fruit flies are frequently tropical fruits such as lychee, mango, papaya, carambola (star fruit) and longan. It therefore makes sense that this Technical Panel includes experts from countries such as Brazil, Mexico, Chile, Malaysia, Surinam and Jordan.

514 The following Technical Panels have stewards from high-income WTO Members: Technical Panel to Develop Diagnostic Protocols for Specific Pests (Germany); Technical Panel on Forest Quarantine (Canada); Technical Panel for the Glossary (New Zealand); Technical Panel on Phytosanitary Treatments (Australia). The only Technical Panel with a steward from an upper-middle-income WTO Member is the Technical Panel on Pest Free Areas and Systems Approaches for Fruit Flies, which has a member from Brazil as its steward.

515 The SPTA at its meetings in 2001 and 2002 and the ICPM at its 2002 session recognised that the lack of phytosanitary standards is a severe impediment to the full implementation of the IPPC and impacts negatively on the facilitation of safe trade. The SPTA suggested that the Chair of the ICPM request proposals for new topics from contracting parties prior to the next meeting of the ICPM. The Chair of the ICPM sent out a letter in November 2002 requesting that national and regional plant protection organizations indicate their priority needs for standards, in order for them to be considered during the Fifth Session of the ICPM. In response 143 proposals were received. Interim Commission on Phytosanitary Measures, Fifth Session: Topics and Priorities for Standards, ICPM 03/14, (Food and Agriculture Organization, Rome), 7-11 April 2003, paras 1-3. In 2005, the Seventh Session of the ICPM decided that a call for proposals would be issued biennially in future. Interim Commission on Phytosanitary Measures, Report of the Seventh Interim Commission on Phytosanitary Measures, ICPM-7(2005)/Report (Food and Agriculture Organization, Rome), 4-7 April 2005, para. 93, available at: https://www.ippc.int/servlet/BinaryDownloaderServlet/75067_Report_ICPM7_E. pdf?filename=1132938412531_ICPM7_Report_En_REV_list_part.pdf\&refID=75067, visited on 10 March 2008 . 
containing all new proposals for topics for new or amended ISPMs, including an indication of the source of the proposal. ${ }^{516}$

\section{Graph 39: IPPC: Proposals for New or Amended Standards Submitted by WTO Members by Income Level, 2003 and 2007}

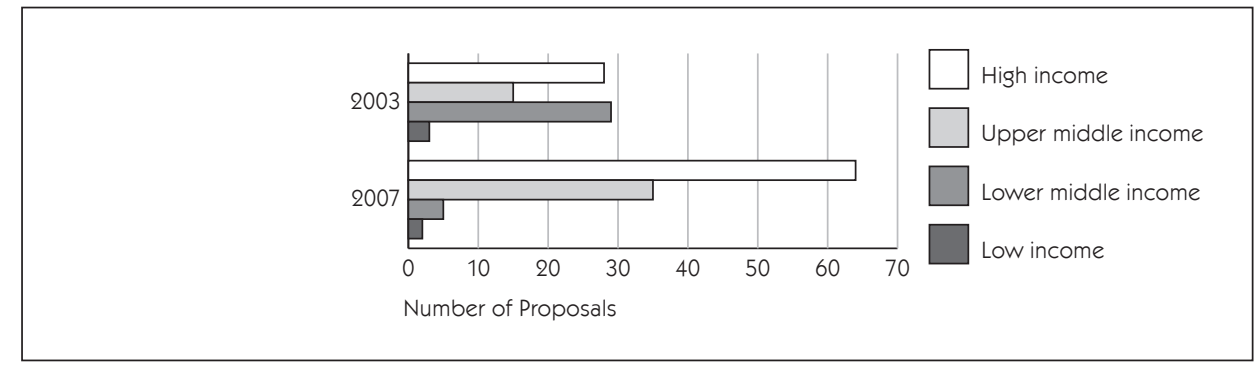

In response to the first call for proposals of November 2002, 143 new proposals were received by the IPPC Secretariat. These were submitted by 26 different contracting parties ( 25 of which were WTO Members), and 3 RPPOs (EPPO, NAPPO and COSAVE). ${ }^{517}$ The call for proposals of June $2007^{518}$ resulted in the submission of 36 proposals. These came from 45 different contracting parties (all of which were WTO Members), ${ }^{519}$ one member organisation (the European Community) and one RPPO (COSAVE). ${ }^{520}$ Of the WTO Members that submitted proposals in 2003 and 2007, taken together, 66 percent were high-income WTO Members, 19 percent were upper-middle-income WTO Members, 13 percent were lower-middle-income WTO Members and 2 percent were low-income WTO Members. The unexpectedly high percentage of proposals from lower-middle-income Members is largely due to the fact that Peru made 21 proposals in 2003 . Of the 36 proposals submitted in 2007, nine were selected by the SC to recommend to the SC for inclusion

516 In the years between 2003 and 2008, no such list was made publicly available. Therefore the data provided here is necessarily limited to the proposals made in response to the calls for proposals of 2003 and 2007.

517 Interim Commission on Phytosanitary Measures, Topics and Priorities for Standards, ICPM 03/14 (International Plant Protection Convention, Rome), 7-11 April 2003, Appendix, available at: https://www. ippc.int/servlet/BinaryDownloaderServlet/21165_English.pdf?filename=1079446899123_ICPM03_14_ with_appendix.pdf\&refID $=21165$, visited on 14 May 2008. In the list of proposals of $200 \overline{3}$ is stated that six proposals were submitted by the 'Council of the European Union'. As the EC had not yet adhered to the IPPC in 2003, these proposals are counted here as having been made by the then-15 Member States of the European Community.

518 As the call for proposals takes place on a biennial basis, the next call for proposals will be in 2009.

519 Note that the number of proposals made by contracting parties that were WTO Members does not correspond to the number of WTO Members making proposals since many proposals were made jointly by several Members, and many Members submitted more than one proposal. In 2003, the US submitted the greatest number of proposals, and was responsible (individually) for 26 of the 143 proposals made. It was followed, surprisingly, by Peru, which made 21 individual proposals. The US again submitted the greatest number of proposals in 2007 (individually), accounting for 12 of the 36 proposals made. Canada followed with 5 proposals. Peru made no proposals in 2007.

${ }_{520}$ Standards Committee, Report of the Standards Committee (Food and Agriculture Organization, Rome), 5-9 November 2007, Appendix 3, available at: https:/www.ippc.int/servlet/BinaryDownloaderServlet/191801_ Report_SC_Nov_2007.doc?filename=1197908679365_Report_SC_Nov_2007_FINAL_with_ISPMs. doc\&refID $=19180 \overline{1}$, visited on 2 April 2008. This document states that the 2007 proposals were made by 18 different contracting parties. However, as the list of proposals for 2007 reports that one proposal was made by the EC and its Member States, these are counted as separate contracting parties here. 
in the work programme. ${ }^{521}$ The selected proposals were submitted by 24 high-income WTO Members, 13 upper-middle-income WTO Members, one lower-middle-income WTO Members and no low-income WTO Members. ${ }^{522}$

In order to improve the attendance and participation of developing countries in standard setting under the IPPC, a Special Trust Fund was established in $2003 .{ }^{523}$ It facilitated the attendance of developing country delegates to the ICPM and CPM sessions, ${ }^{524}$ to regional workshops on draft ISPMs and to various other meetings. ${ }^{525}$ Financial regulations for the Special Trust Fund were adopted in $2005 .{ }^{526}$ This Special Trust Fund is to be financed by voluntary contributions by members of the CPM, non-members and other sources. ${ }^{527} \mathrm{In}$

521 Standards Committee, Report of the Standards Committee (Food and Agriculture Organization, Rome), 30 April - 4 May 2007, para. 46, available at: https://www.ippc.int/servlet/CDSServlet?status=ND0xMzQwM iY2PWVuJjMzPSomMzc9a29z, visited on 1 April 2008. These 9 new topics adopted for the development of ISPMs were: guidelines for the use of permits as import authorisation; accreditation systems for phytosanitary programmes; international movement of cut flowers and foliage; international movement of grain; minimising pest movement by sea containers and conveyances; minimising pest movement by air containers and aircrafts; handling and disposal of international garbage; a diagnostic protocol for Striga spp.; and wood products and handicrafts made from raw wood. The latter two topics were assigned to the Technical Panel on Forest Quarantine and the Technical Panel to Develop Diagnostic Protocols for Specific Pests, respectively.

${ }^{522}$ No selection of topics for new standards was carried out in 2003 , as this was the first time a call had formally been made for new topics and a procedure for prioritisation of proposed topics for inclusion in the standardsetting work programme had not yet been developed, although some general prioritisation criteria had been adopted by the ICPM in 2002. At the Fifth Session of the ICPM in 2003, several contracting parties suggested that the ICPM develop a procedure for prioritisation of topics for new standards considering the large number of specific standards proposed by Members in response to the first call for topics. Interim Commission on Phytosanitary Measures, Report of the Fifth Interim Commission on Phytosanitary Measures, ICPM-5(2003)/ Report (Food and Agriculture Organization, Rome), 7-11 April 2003, para. 76, available at: https://www. ippc.int/servlet/BinaryDownloaderServlet/21899_ICPM5_2003_en.pdf.pdf?filename $=1053957860772$ ICPM5Report final en.pdf\&refID=21899, visited on 10 March 2008 .

${ }^{523}$ Ibid., para. 86.

${ }^{524}$ Prior to the establishment of the Special Trust Fund, the IPPC Secretariat made a distinction in respect of funding between persons participating as experts in the standard-setting work of the IPPC, and persons participating as government representatives in the ICPM. While funding was provided by the IPPC Secretariat for developing country participation in expert drafting groups and committees associated with the standardsetting work of the IPPC, developing country attendance of (I)CPM meetings was not funded. Governments were expected to fund their own delegates. Interim Commission on Phytosanitary Measures, Developing Country Participation in IPPC Standard-Setting and Listing of Experts for IPPC Working Groups 20002002, ICPM 03/INF/2 (International Plant Protection Convention, Rome), 7-11 April 2003, para. 3, available at: https://www.ippc.int/servlet/BinaryDownloaderServlet/21133 English.pdf?filename=1051088293796 ICPM03_INF2.pdf\&refID=21133, visited on 18 April 2008.

${ }^{525}$ FAO Programme Committee, Independent Evaluation of the Working of the International Plant Protection Convention and Its Institutional Arrangements (Food and Agriculture Organization, Rome), 17-21 September 2007, para. 175, available at: https://www.ippc.int/servlet/BinaryDownloaderServlet/184229 IPPC Evaluation_Repo.doc?filename $=1180006371650$ 1_IPPC_Final_Evaluation_Report.doc\&refID $=\overline{184229}$, visited on 10 March 2008.

${ }^{526}$ Interim Commission on Phytosanitary Measures, Report of the Seventh Interim Commission on Phytosanitary Measures, ICPM-7(2005)/Report (Food and Agriculture Organization, Rome), 4-7 April 2005, Appendix XVI, available at: https://www.ippc.int/servlet/BinaryDownloaderServlet/75067_Report_ICPM7_E. pdf?filename=1132938412531_ICPM7_Report_En_REV_list_part.pdf\&refID=75067, visited on 10 March 2008.

527 Paragraph 5.1 of the Financial Guidelines for the Trust Fund for the International Plant Protection Convention. Since its inception, the Special Trust Fund has received contributions from three donors (New Zealand, Canada and the US) amounting to US\$860 000 (as of February 2007). It has been used to fund the attendance of 60 representatives from developing countries to meetings of IPPC bodies. FAO Programme Committee, Independent Evaluation of the Working of the International Plant Protection Convention and 
June 2008, however, the IPPC Secretariat reported that it had not received any indication by the contracting parties of an intention to contribute to the Trust Fund in $2008 .{ }^{528}$ In addition to the Trust Fund, new funding guidelines were implemented in 2007, whereby the IPPC Secretariat provides support for attendance of IPPC meetings. The World Bank classification of countries by income level is relied upon in the allocation of financial support - participants from lower-middle-income and low-income contracting parties have their airfare paid and are given a daily subsistence allowance, whereas participants from upper-middle-income contracting parties have their airfare paid only. ${ }^{529}$ High-income contracting parties are expected to pay their own participants' costs.

Financial support for attendance of meetings of IPPC bodies is, however, not sufficient to ensure full participation of IPPC contracting parties at different levels of development. In addition, the phytosanitary capacity of those contracting parties that face constraints in this area must be strengthened. Without improved phytosanitary capacity, representatives of, and experts from, some of these contracting parties will not be in a position to influence the standard-setting process in a way that takes account of the interests and situations of their respective countries. For this reason, the technical assistance supported by the IPPC Secretariat and financed by the FAO Technical Cooperation Programme (TCP), ${ }^{530}$ is not limited to that related to the IPPC's core activities, but extends to strengthening of national phytosanitary capacity. ${ }^{531}$ In 2007 , a proposal was made by the Evaluation Team that conducted the Independent Evaluation of the IPPC to the effect that technical as-

Its Institutional Arrangements (Food and Agriculture Organization, Rome), 17-21 September 2007, para. 175, available at: https://www.ippc.int/servlet/BinaryDownloaderServlet/184229_IPPC_Evaluation_Repo. doc?filename=1180006371650_1_IPPC_Final_Evaluation_Report.doc\&refID $=18 \overline{4} 229$, visited on $10 \overline{\mathrm{March}}$ 2008.

${ }^{528}$ Committee on Sanitary and Phytosanitary Measures, Decisions from the Third Session of the Commission on Phytosanitary Measures (Rome, 7-11 April 2008). Submission from the International Plant Protection Convention, G/SPS/GEN/849, circulated on 18 June 2008, para. 31. The independent evaluation of the IPPC urged the IPPC Secretariat to formulate a strategy for funding mobilisation. This work is in its initial stages. Ibid., para. 35 .

${ }^{529}$ Standards Committee, Report of the Standards Committee (Food and Agriculture Organization, Rome), 30 April - 4 May 2007, para. 3, available at: https:/www.ippc.int/servlet/CDSServlet?status=ND0xMzQwMiY 2PWVuJjMzPSomMzc9a29z, visited on 1 April 2008.

${ }_{530}$ The FAO Technical Cooperation Programme is part of the regular programme budget of the FAO. Between 2001 and 2008, this facility funded 48 projects for a total value of US\$ 10.8 million. FAO Programme Committee, Independent Evaluation of the Working of the International Plant Protection Convention and Its Institutional Arrangements (Food and Agriculture Organization, Rome), 17-21 September 2007, para. 113, available at: https://www.ippc.int/servlet/BinaryDownloaderServlet/184229_IPPC_Evaluation_Repo. doc?filename $=1180006371650$ 1_IPPC_Final_Evaluation_Report.doc\&refID $=18 \overline{4} 229$, visited on $10 \overline{\mathrm{March}}$ 2008.

531 Technical assistance related to the IPPC's core activities includes financial support for the attendance at IPPC meetings and workshops on draft standards, as well as training on the development and use of the IPP. Technical assistance towards strengthening phytosanitary capacity covers a wide range of activities such as the modernisation of plant quarantine facilities and laboratories, the training of staff, the drafting of phytosanitary legislation and the establishment of systems for the surveillance, management and establishment of pest-free areas and pest risk analysis. Informal Working Group on Technical Assistance and Phytosanitary Capacity Evaluation, Draft Report of the Informal Working Group on Technical Assistance and Phytosanitary Capacity Evaluation (International Plant Protection Organization, Nairobi), 29 July - 3 August 2007, Appendix 3 para. 3, available at: https:/www.ippc.int/servlet/BinaryDownloaderServlet/188573_Draft Report_IWG_TA_doc?filename $=1191582430687$ TA_PCE_IWG_Draft_report_v4.doc\&refID $=\overline{188573}$, visited on 21 April 2008. 
sistance carried out directly under the IPPC should be limited to its core business. ${ }^{532}$ The Evaluation Team regarded the FAO as better placed than the IPPC Secretariat to coordinate global support for strengthening national phytosanitary capacity, and suggested that this be done outside the IPPC context. ${ }^{533}$ This suggestion was rejected by both the SPTA ${ }^{534}$ and by the Informal Working Group on Technical Assistance and Phytosanitary Capacity Evaluation. ${ }^{535}$ Both these bodies stressed the particular expertise of the IPPC Secretariat in this area, ${ }^{536}$ while acknowledging the constraints it faces due to limited resources and lack of donor funding for strengthening national capacities. The importance of increasing the resources available to the IPPC Secretariat, both from donors and from other agencies, was recognised. However, it was noted that technical assistance in the area of capacity building must be based on the needs and priorities of the beneficiary countries, rather than on the interests of the donor countries.

${ }^{532}$ FAO Programme Committee, Independent Evaluation of the Working of the International Plant Protection Convention and Its Institutional Arrangements (Food and Agriculture Organization, Rome), 17-21 September 2007, para. 131, available at: https://www.ippc.int/servlet/BinaryDownloaderServlet/184229 IPPC Evaluation_Repo.doc?filename $=1180006371650$ 1_IPPC_Final_Evaluation_Report.doc\&refID=184229, visited on 10 March 2008. While the Evaluation Team recognised the tremendous need for technical assistance to strengthen phytosanitary capacity of developing country contracting parties, it did not see the IPPC as an appropriate provider as such assistance. Instead, it argued that this task would be best undertaken by international organisations such as the FAO that have the experience and capacity to raise funds and to implement projects.

${ }^{533}$ The Independent Evaluation Team noted that few donors support IPPC-related technical assistance activities through the FAO. It noted that due to the fact that funding for this type of technical assistance comes almost entirely from the FAO regular budget, the projects are small and catalytic, with limited long-term effects and sustainability. It recommended the development of formal links to other technical assistance agencies and more attention to the interests and priorities of donor countries in planning technical assistance activities. Ibid., paras 117-125.

${ }^{534}$ CPM Informal Working Group on Strategic Planning and Technical Assistance, Report of the Second Meeting (International Plant Protection Convention, Rome), 1-5 October 2007, paras 39-43, available at: https://www.ippc.int/servlet/BinaryDownloaderServlet/190812_9th_SPTA_Report_2007. pdf?filename=1196340302166_9th_SPTA_Report_2007.pdf\&refID=190812, visited on 1 April 2008. The SPTA regarded the IPPC Secretariat as best placed to undertake this task, and recommended the development of a phytosanitary capacity building strategy to address implementation, funding and linkage to FAO financing and resources.

${ }^{535}$ Informal Working Group on Technical Assistance and Phytosanitary Capacity Evaluation, Draft Report of the Informal Working Group on Technical Assistance and Phytosanitary Capacity Evaluation (International Plant Protection Organization, Nairobi), 29 July - 3 August 2007, Appendix 3 paras 3 and 21, available at: https:/www.ippc.int/servlet/BinaryDownloaderServlet/188573_Draft_Report_IWG_TA_. doc?filename $=1191582430687$ TA PCE IWG Draft report v4.doc\&refID $=188573$, visited on 21 April 2008. The Informal Working Group on Technical Assistance and Phytosanitary Capacity Evaluation noted that the IPPC Secretariat has the relevant knowledge of the phytosanitary needs of the IPPC contracting parties. It argued, however, that donors and agencies should be engaged to provide more resources to the IPPC Secretariat to enable it to accomplish more.

${ }^{536}$ The SPTA noted that the delegates to the CPM are the world leaders in phytosanitary issues and that the IPPC Secretariat is staffed with some of the leading experts worldwide in this field. It viewed the recommendation of the Independent Evaluation Team as having the effect of relegating phytosanitary issues to a 'lower level' by addressing them within the wider FAO system instead of within the specialised IPPC system. CPM Informal Working Group on Strategic Planning and Technical Assistance, Report of the Second Meeting (International Plant Protection Convention, Rome), 1-5 October 2007, Appendix 1 item 3, available at: https://www.ippc. int/servlet/BinaryDownloaderServlet/190812_9th_SPTA_Report_2007.pdf?filename=1196340302166_9th_ SPTA_Report_2007.pdf\&refID=190812, visited on 1 April 2008. 


\subsection{Conclusion}

The increasing globalisation of health concerns arising from the growth in movement of persons and products across borders has resulted in SPS regulation on international level. Such regulation reflects the realisation of governments that SPS risk cannot be effectively addressed without international cooperation, and their concern with ensuring that obstacles to trade are minimised as far as possible by the promotion of uniformity of SPS requirements across national boundaries. Consequently, international bodies have been established with the objective of drafting SPS standards on which national governments can base their SPS regulations.

Harmonisation of national SPS requirements around internationally established standards has many benefits. Conceptually, harmonisation can be seen as a tool to address the externality effects of SPS-regulation, due to the 'global public goods' nature of both free trade and safe products. The efficient supply of these global public goods may necessitate international cooperation in the area of SPS regulation. Such cooperation, embodied in negotiations between national governments to elaborate international SPS standards, aims to ensure that the regulatory outcome takes account of costs and benefits at the global level and therefore leads to welfare maximisation globally. On a more practical level, harmonisation provides a scientifically justified basis for regulation which is particularly useful for countries where the necessary expertise to conduct risk analyses is lacking. It also contributes to the legitimacy of SPS regulations based thereon and diminishes disputes between countries on the appropriateness of the requirements they set. Last, but certainly not least, it facilitates the movement of products across borders by reducing the diversity of requirements that exporters have to meet in order to have access to foreign markets.

At the same time, harmonisation has its fair share of pitfalls. Internationally-set standards cannot mirror the diversity of circumstances in countries around the world. Instead, they reflect a compromise position accepted by the delegates of the countries present and active in the standard-setting process, according to the procedures of the relevant standardising body. Such a compromise raises concerns regarding the appropriateness of the resulting standard for application across the globe. Not only do the demands of civil society (consumers as well as industry) differ widely across countries, but also the ability of governments to ensure implementation of SPS standards diverges. Many of these differences correspond to the differences in levels of development of the countries involved. Regulators must respond to national development priorities and therefore, it could be argued, should not be constrained by harmonisation obligations around internationallyestablished standards.

As aptly put by Keyser and Merbis, of the Centre for World Food Studies in Amsterdam:

...basic economic intuition tells us that consumers demand different product qualities at different levels of income. Food standards should reflect this. Clearly, as all men are born equal and have remarkably similar food as well as sanitary needs, it often is tempting to assert that food safety norms should be standardised and applied universally. Whomever expresses a different view is easily accused of violating basic ethical principles. Yet the flaw in such rights-based reasoning is that the poor only would suffer from its application unless they are given the 
means to reach the stated standards without having to sacrifice more fundamental ones, such as survival. ${ }^{537}$

This reality was recognised in the procedures of the international standard-setting bodies and the legal status of the standards they adopt. Until recently, the standard setting procedures were rather informal and based on technical discussions among experts and the adoption of standards was uncontroversial. Many developing countries did not attend, or did not effectively participate in the international standard-setting process. This did not create many problems as the resulting adopted standards were voluntary in nature and states were free to implement them in their national regulations or diverge from them, as they saw fit. In addition, the international standard-setting bodies focused more on the adoption of guidelines and recommendations with respect to approaches to risk assessment and risk management, than on setting specific standards. ${ }^{538}$ These guidelines were useful in disseminating information on best practices in these areas, and thereby leading to a natural convergence in resulting national SPS requirements. ${ }^{539}$

However, a change in this situation has been brought about by the use of these standards as benchmarks by the WTO's SPS Agreement, as will be set out in Part III of this book. ${ }^{540}$ While not making international standards binding, the SPS Agreement has increased their relevance by creating a set of obligations for countries deviating from them, thereby problematising the informal and technocratic standard-setting procedures. It has also neglected to take into account the differences in the types of norms generated by international setting bodies. The legitimacy and appropriateness of international standards has therefore come to the forefront of discussions at the standard-setting bodies, and their procedures have become politicised. These bodies are now fora for fighting out traderelated concerns, often leading to a paralysis of the standard-setting process, particularly in sensitive areas of particular economic concern to industry groups.

In this context, this Chapter examined the institutional and procedural arrangements of the three international standard-setting bodies referenced in the SPS Agreement to identify possible constraints to the participation of WTO Members at different levels of development. To provide factual illustrations of the problems of participation, data on membership, attendance and active participation of WTO Members was collected to the extent available, and systematised according to the World Bank's classification of countries by income. No absolute figures accurately quantifying the extent and effectiveness of participation were generated due to problems of data and difficulty in reducing the available information into precise figures. Instead, only some indications or trends in participation

537 Michiel Keyzer and Max Merbis, 'SPS-Standards and Developing Countries: The Need for Differentiation', presented at the Capaciteitsopbouw in Ontwikkelingslanden in verband met Niet-Tarifaire Handelsbelemmeringen (SPS) (Dutch Ministry of Agriculture and Ministry of Foreign Affairs (DGIS), The Hague) 20 June 2001, 11.

${ }^{538}$ Donna Roberts et al., 'Sanitary and Phytosanitary Barriers to Agricultural Trade: Progress, Prospects and Implications for Developing Countries', in Agriculture and the New Trade Agenda - Creating a Global Trading Environment for Development, M.D. Ingco and L.A.Winters (eds.) (Cambridge University Press, Cambridge), 2004, 329-358, 341.

539 Roberts, Orden and Josling note that knowledge gaps and chance events are 'bad' reasons for divergent national standards, and emphasis the positive impact of international guidelines on analytical techniques and mitigation technologies in reducing these divergences. Ibid.

${ }^{540}$ See below, Part III, Chapter 4. 
can be derived from the data. More research is needed into the extent and effectiveness of participation in the international standard-setting processes by Members at different levels of development and the reasons for this. This research should be multidisciplinary, examining the economic and political factors that play a role. An examination of that nature could form the basis for more directed efforts at addressing the problems that affect the participation of some Members. However, such research goes beyond the scope of this book, which is focused on the legal aspects of international standard setting (i.e. the institutional framework and procedures in place). The analysis of data conducted here serves only to provide a factual illustration of the identified institutional and procedural problems. These limitations in mind, the analysis conducted in this Chapter permits the following conclusions. ${ }^{541}$

In recent years, due to their awareness of the increased importance of international standards under the SPS Agreement, the participation of developing countries in the standardsetting organisations has increased. Their level of attendance has improved and they have become more vocal in ensuring their viewpoints are taken into account in plenary sessions where standards are decided upon. However, their participation in technical committees where scientific evidence is discussed and standards are prepared often leaves much to be desired. This is often due to the lack of human and financial resources necessary to ensure attendance of the plethora of committee meetings by well-prepared specialists in the areas in which standards are set. In addition, the lack of effective national infrastructures for the evaluation of draft standards and the formulation of positions has been identified as a problem. ${ }^{542}$ The weakness of the participation of many middle- and low-income WTO Members in the international standard-setting bodies, coupled with the fact that the products in respect of which they face SPS barriers are frequently insignificant in terms of world trade, ${ }^{543}$ means that it is unlikely that international standards will be developed in areas of interest to them. This fact is illustrated by the lack of standards for traditional vegetables from Jamaica, such as ackee, yam and callaloo, despite the fact that Jamaican exports of these products are severely restricted by the SPS measures of its trading partners.

${ }^{541}$ Some of the results from the analysis of data presented here seem counterintuitive, showing higher than expected participation of Members at lower income levels in particular areas of international standard-setting. Some possible reasons for this are, first, the fact that the level of development of a Member is not fully reflected in income level, as explained in Chapter 2. While income level was used here as a shorthand for economic development, in order to be able to categorise Members, the results of the data presented here must be relativised. The complexity of the issue of development and of the various indicators of development level that play a role in SPS capacity means that income level is not determinative. Second, it is important to take into account that that national priorities may differ. It is likely that differences in participation in different committees of the standard-setting bodies are due to the varying importance of the standards set in those committees for specific Members. Third, in some cases the unexpected level of attendance by delegates of Members at lower income levels may indicate that some initiatives to improve developing-country participation may be having results, at least in terms of presence if not quality of participation.

${ }^{542}$ Committee on Sanitary and Phytosanitary Measures, Note on Developing Country Participation in Codex Bodies. Submission by the FAO/WHO Codex Alimentarius Commission, G/SPS/GEN/236, circulated on 9 March 2001.

${ }^{543}$ Vinod Rege et al., Influencing and Meeting International Standards: Challenges for Developing Countries. Volume I: Background Information, Findings from Case Studies and Technical Assistance Needs (International Trade Centre UNCTAD/WTO and Commonwealth Secretariat, Geneva), 2003, 86. 
One result of the new situation in which international standard setting-bodies now find themselves has been the 're-nationalisation' and sometimes the privatisation of SPS regulation. ${ }^{544}$ Developed-country Members that do not succeed in influencing international standard setting sufficiently to obtain standards that reflect their health and trade concerns have tended to adopt national SPS measures that deviate from international standards. They have done so on the basis that existing international standards do not achieve the level of protection they have deemed appropriate for their territories. Members at lower levels of development have also shown a tendency to adopt SPS measures that are not based on international standards, often due to the lack of international standards in areas of interest to them, but also due to the inappropriateness of existing standards for their particular situations. A parallel development has been the proliferation of private standards, typically much stricter than international standards, set by global consortia of processors or retailers. These private standards reflect the high level of consumer demands to which global supermarket chains currently cater, and which are not met by international standards.

The three standard-setting bodies referenced in the SPS Agreement have had to re-examine their rules of procedure and functional mandates in order to adapt to the new reality in which they find themselves since the coming into force of the SPS Agreement. These reform initiatives seem to have been successful to a greater or lesser extent and work is ongoing to improve developing country participation. ${ }^{545}$ Also outside the 'three sisters' there have been concerted efforts to address the problems that developing countries face with regard to effective participation in standard-setting organisations. ${ }^{546}$ The DirectorsGeneral of the FAO, WHO, OIE, WTO and the President of the World Bank issued a statement at the Doha Ministerial Conference in which they affirmed their commitment to strengthening the capacity of developing countries to participate fully in international standard-setting. ${ }^{547}$ However, much remains to be done if the reference to the international standards as a benchmark for justifying national SPS measures under the SPS Agreement is to be 'development friendly'. This remaining work lies not only in simplifying and improving the standard-setting procedures of the relevant bodies, but also in efforts to

${ }^{544}$ Peter W.B. Phillips, 'Food Safety, Trade Policy and International Institutions', in Governing Food: Science, Safety and Trade, Peter W.B Phillips and Robert Wolfe (eds.) (McGill-Queen's University Press, Montreal), 2001, 27-48, 44.

${ }^{545}$ In this respect it should be noted that a review of the Codex (and other FAO and WHO work on food standards) has been launched to provide input into decision making on future policies and management. This review will include an evaluation of the particular interests of developing countries as regards their participation in the standard-setting process. World Health Organization and Food and Agriculture Organization, Joint FAO/WHO Evaluation of the Codex Alimentarius and other FAO and WHO Work on Food Standards (WHO/FAO, Rome/Geneva), 16 April 2002, para. 8(iv). See also Steve Suppan and Rod Leonard, Comments Submitted to the Independent Evaluation of the Codex Alimentarius and Other FAO-WHO Work on Food Standards, available at: http://www.tradeobservatory.org/library/uploadedfiles/Comments_Submitted_to_ the_Independent_Evaluati.htm, visited 24 June 2007.

${ }^{546}$ See for example the initiatives described in Committee on Sanitary and Phytosanitary Measures, Summary Report of the Workshop on the International Standard-Setting Organizations: Process and Participation, G/ SPS/GEN/250, circulated on 14 May 2001.

${ }^{547}$ Ministerial Conference, Participation of Developing Countries in the Development and Application of International Standards, Guidelines and Recommendations on Food Safety, Animal and Plant Health, WT/ $\mathrm{MIN}(01) / \mathrm{ST} / 97$, circulated on 11 November 2001. 
build the capacity of Members at lower levels of development to participate effectively in these procedures. 


\section{Conclusion to Part II}

The descriptions of national and international systems for setting SPS regulations and standards conducted in Part II of this book form the necessary factual background to the analysis of the provisions of the SPS Agreement that is found in Parts III to V. Only with this concrete understanding of the context within which the Agreement functions can its aim of balancing trade and health objectives and the disparate impact of its provisions on Members at different levels of development be fully understood.

In particular, the normative framework for national SPS regulation, reflected in international human rights law, is instrumental in establishing why the promotion of trade through regulatory disciplines in the SPS Agreement cannot be pursued in disregard of the ability of Members to protect health on their territories. While the economic growth achievements of liberalisation of agricultural trade are important to promote development, they cannot come at the cost of other rights, such as the right to life, health and safe food. Instead, international trade rules must appropriately balance these competing goals in a way that does not undermine human rights. In examining the provisions of the SPS Agreement the importance of this balance must constantly be borne in mind.

As stated in Part I, the SPS Agreement mediates the conflict between trade and health objectives by imposing regulatory disciplines on Members. The specific impact of these disciplines on a particular Member is largely a factor of its SPS capacity, as reflected in its regulatory system. It is important to keep in mind the great variety in the SPS regulatory systems of WTO Members, reflecting their levels of development and their specific health and trade priorities, when examining the SPS Agreement. While all Members have a normative duty to regulate against SPS risks on their territories, the manner in which they do so and the level of protection they seek to achieve varies in relation to their level of development. This is due to the fact that the costs and benefits of SPS regulation differ with factors such as the health status of the country, the existing SPS infrastructure, the dietary practices of its citizens, the economic importance of its agricultural industry, and its scientific capacity, among others. As a result, Members have in place greatly differing SPS regulatory systems.

The illustrative examples of four WTO Members across various regions and income levels, and with different trade and health priorities, give concrete form to these general conclusions. They show the range of regulatory responses in place to address the need for SPS protection. These vary not only in the level of protection sought but also in the manner in which the protection is achieved. For example, more developed Members with established and well-functioning SPS systems increasingly choose for a systems-wide approach to food-safety risks, as illustrated by Australia's farm-to-fork approach, whereas Members with more rudimentary SPS systems and limited capacity choose for regulation focused on product characteristics, as shown by Bangladesh's requirements regarding palm oil purity. In addition, the extent to which SPS regulation is supported by a rigorous risk analysis process, encompassing scientific risk assessment, policy based-risk management and risk communication to stakeholders, is determined by the capacity and priorities of the Member involved. The regulatory system in place in Australia, which is characterised by a separation of risk assessment and risk management tasks and a strong 
consultative process for the involvement of stakeholders is a good example of a sophisticated system. By contrast, lacking the capacity for its own risk assessments, Jamaica sometimes takes over the SPS requirements of its trading partners. These differences in SPS systems have logical implications for the extent to which Members can comply with the prescriptive rules of the SPS Agreement, which as will be seen in Parts III and IV of this book embody best practices in SPS regulation.

Weakness of SPS regulatory systems affects not only the ability of Members to implement their obligations under the SPS Agreement. It also has significant consequences for their capacity to comply with the SPS requirements of their trading partners, or to challenge such requirements in terms of the rules of the SPS Agreement.

In view of these regulatory divergences and the impact they have both on health and on trade, efforts have been made to promote harmonisation of SPS requirements around international standards. As international standard-setting processes are based on the scientific assessment of risks, harmonisation around international standards provides a scientifically justified basis for regulation. This is particularly useful for countries that lack the necessary expertise to conduct risk analyses. Harmonisation also diminishes the trade restrictive effect of SPS regulation by reducing the diversity of requirements that exporters have to meet in order to have access to foreign markets. For this reason, the SPS Agreement uses international standards as benchmark standards for the SPS measures of WTO Members.

However, for the promotion of harmonisation to be truly 'development-friendly' it is important for the procedures by which international standards are set to facilitate the full participation of countries at all levels of development. Without such participation, the standards set by the international standard-setting bodies are of doubtful legitimacy as the basis for the promotion of harmonisation at WTO level. Standards set without full and effective participation of all Members may be technically unfeasible for some developingcountry Members. In addition, standards may be lacking in areas of particular interest to such Members. Consequently, there is currently much attention to the need to ensure effective participation of developing countries in the work of the standard-setting bodies.

An examination of the institutional structure and procedures of the three international standard-setting bodies referenced in the SPS Agreement indicates that various problems exist that act as hindrances to full participation by WTO Members at lower levels of development. These differ from international standard-setting body to international standard-setting body. In some cases, the plethora of committees in which attendance is needed exceeds the financial and human capacity of some Members. The location of committee meetings in developed countries may also contribute to attendance costs. In other cases, the relevant committees are of limited membership, and as members are selected on the basis of scientific expertise, this means that they are most often dominated by developedcountry experts. The insufficient participation of developing-country Members is illustrated by an examination of actual attendance of, and active contribution to discussions in, the organs of the international standard-setting bodies. While the data is incomplete and therefore not conclusive, it does provide an indication of the persistent inadequacy of participation by Members at lower levels of development across all three bodies. 
As will be seen in the analysis of the harmonisation provisions in Part III of this book, the ability of a WTO Member to push forward its interests in the international standard-setting process has a significant effect on the impact of the SPS Agreement on that Member. This impact is particularly important for Members at lower levels of development that lack the capacity to conduct the necessary scientific analysis as a basis for their national SPS requirements. Many efforts are being made within the CAC, OIE and IPPC to enhance developing country attendance of meetings. However, this is not enough. In order to promote effective participation of developing-country Members, serious efforts at capacity building are necessary, to ensure that these Members can build strong and wellfounded national positions and defend them effectively in the standard-setting process. ${ }^{1}$

\footnotetext{
${ }^{1}$ The issue of capacity building is addressed in Chapter 2 of Part V of this book.
} 


\section{Part III}

The rules balancing trade and health in the SPS Agreement 


\section{Introduction to Part III}

Having established, in Part II of this book, the factual context against which the impact of the SPS Agreement on WTO Members at different levels of development can be understood, Parts III to V turn to scrutinize the SPS Agreement itself. Part III begins this analysis by examining the regulatory disciplines of the SPS Agreement that give effect to its objective of balancing trade liberalisation with health protection. It does so against the historical background to the SPS Agreement and with specific reference to its scope of application. Part IV turns to look at the institutional and procedural mechanisms under the SPS Agreement. Part V follows by dealing with those provisions of the SPS Agreement that address the special position of developing-country Members.

The development impact of the SPS Agreement is clearly not limited to the provisions discussed in Part V of this book. ${ }^{1}$ Instead, all the provisions of the SPS Agreement have an effect on developing-country Members of the WTO. This effect can be seen both in the extent to which the Agreement facilitates the lowering of market access barriers to food and agricultural products from developing-country Members, and in the restrictions the Agreement places on the ability of these Members to regulate against SPS risks. Clearly, as seen from the factual background set out in Part II, developing-country Members are not a homogeneous group when it comes to trade and health priorities and SPS regulatory capacity. Therefore the effect of the SPS Agreement is not the same for all developingcountry Members. The discussion in Parts III and IV of this book highlights the disparate impact of the SPS Agreement on Members at different levels of development.

The analysis takes a critical look at the appropriateness of the general provisions of the SPS Agreement for Members at lower levels of development. In doing so, it recognises that technical assistance cannot be seen as a magic bullet solution to all developingcountry concerns with the SPS Agreement. Technical assistance certainly does not obviate the need for a rigorous analysis of the substantive rules and procedural arrangements to ensure that they are appropriate for all Members as tools to achieve the balancing objectives of the SPS Agreement.

The examination of the provisions of the SPS Agreement carried out in this book is conducted in the light of the interpretation given to the relevant provisions in adopted panel and the Appellate Body reports, since such interpretation, despite the absence of a formal precedent system in WTO adjudication, is in practice followed by panels and the Appellate Body in subsequent disputes. ${ }^{2}$ The rulings of the WTO adjudicatory bodies

\footnotetext{
${ }^{1}$ As noted by Joanne Scott, the development dimension of the SPS Agreement pervades all its provisions. Joanne Scott, The WTO Agreement on Sanitary and Phytosanitary Measures: A Commentary, Oxford Commentaries on the GATT/WTO Agreements (Oxford University Press, Oxford), 2007, 280.

2 On the status of adopted panel reports, the Appellate Body in Japan - Alcoholic Beverages II found as follows: 'Adopted panel reports are an important part of the GATT aquis. They are often considered by subsequent panels. They create legitimate expectations among WTO Members, and, therefore, should be taken into account where they are relevant to any dispute. However, they are not binding, except with respect to resolving the particular dispute between the parties to that dispute. In short, their character and their legal status have not been changed by the coming into force of the WTO Agreement.' Appellate Body Report, Japan - Alcoholic Beverages II, 14. The Appellate Body clarified in US - Shrimp (Article 21.5 - Malaysia) that this reasoning equally applies to adopted Appellate Body reports. Appellate Body Report, US - Shrimp (Article 21.5 - Malaysia), para.109. According to the Appellate Body in US - Stainless Steel (Mexico): '[T]he legal
} 
can therefore be regarded as clarifying the provisions of the WTO agreements, fleshing them out. Five disputes under the SPS Agreement have been the subject of adjudication thus far. These are: the complaints of the US and Canada with regard to the EC's ban on hormone-treated beef (EC - Hormones $){ }^{3}$ the complaint of Canada with regard to Australia's requirements for the importation of salmon (Australia - Salmon), ${ }^{4}$ the complaint of the US regarding Japan's varietal testing requirement for the importation of certain fruits (Japan - Agricultural Products II) $;^{5}$ the complaint of the US regarding Japan's quarantine requirements on imports of US apples (Japan-Apples), ${ }^{6}$ and the complaints of the US, Canada and Argentina with regard to the EC's general de facto moratorium on the approval of biotech products for marketing in the EC, its measures regarding the approval of specific biotech products and the safeguard measures of certain EU Member States on biotech products already approved at EC level (EC-Approval and Marketing of Biotech Products). ${ }^{7}$ In addition, two disputes brought by the EC against the continued suspension by the US and Canada of concessions against it, due to its perceived continued non-compliance with the recommendations and rulings of the Dispute Settlement Body in EC - Hormones, were decided under the provisions of the Dispute Settlement Understanding but involved an analysis of several provisions of the SPS Agreement (US

interpretation embodied in adopted panel and Appellate Body reports becomes part and parcel of the acquis of the WTO dispute settlement system. Ensuring "security and predictability" in the dispute settlement system, as contemplated in Article 3.2 of the DSU, implies that, absent cogent reasons, an adjudicatory body will resolve the same legal question in the same way in a subsequent case. Clarification, as envisaged in Article 3.2 of the DSU, elucidates the scope and meaning of the provisions of the covered agreements in accordance with customary rules of interpretation of public international law. ... While the application of a provision may be regarded as confined to the context in which it takes place, the relevance of clarification contained in adopted Appellate Body reports is not limited to the application of a particular provision in a specific case. Appellate Body Report, US - Stainless Steel (Mexico), paras 160-161.

${ }^{3}$ Appellate Body Report, EC Measures Concerning Meat and Meat Products (Hormones) (EC - Hormones), WT/DS26/AB/R, WT/DS48/AB/R, adopted 13 February 1998, DSR 1998:I, 135; Panel Report, EC Measures Concerning Meat and Meat Products (Hormones), Complaint by the United States (EC - Hormones (US)), WT/DS26/R/USA, adopted 13 February 1998, as modified by Appellate Body Report, WT/DS26/AB/R, WT/DS48/AB/R, DSR 1998:III, 699; Panel Report, EC Measures Concerning Meat and Meat Products (Hormones), Complaint by Canada (EC - Hormones (Canada)), WT/DS48/R/CAN, adopted 13 February 1998, as modified by Appellate Body Report, WT/DS26/AB/R, WT/DS48/AB/R, DSR 1998:II, 235.

${ }^{4}$ Appellate Body Report, Australia - Measures Affecting Importation of Salmon (Australia - Salmon), WT/ DS18/AB/R, adopted on 6 November 1998, DSR 1998:VIII, 332; Panel Report, Australia-Measures Affecting Importation of Salmon (Australia - Salmon), WT/DS/18/R and Corr.1, adopted on 6 November 1998, as modified by Appellate Body Report, WT/DS18/AB/R, DSR 1998:VIII, 3407.

${ }_{5}^{5}$ Appellate Body Report, Japan - Measures Affecting Agricultural Products (Japan - Agricultural Products II), WT/DS76/AB/R, adopted 19 March 1999, DSR 1999:I, 277; Panel Report, Japan - Measures Affecting Agricultural Products (Japan - Agricultural Products II), WT/DS76/R, adopted 19 March 1999, as modified by Appellate Body Report, WT/DS76/AB/R, DSR 1999:I, 315.

${ }^{6}$ Appellate Body Report, Japan - Measures Affecting the Importation of Apples (Japan - Apples), WT/DS245/ AB/R, adopted 10 December 2003, DSR 2003:IX, 4391; Panel Report, Japan - Measures Affecting the Importation of Apples (Japan-Apples), WT/DS245/R, adopted 10 December 2003, upheld by Appellate Body Report, WT/DS245/AB/R, DSR 2003:IX, 4291.

${ }^{7}$ Panel Reports, European Communities - Measures Affecting the Approval and Marketing of Biotech Products (EC-Approval and Marketing of Biotech Products), WT/DS291/R, WT/DS292/R, WT/DS293/R, Corr.1 and Add.1, 2, 3, 4, 5, 6, 7, 8 and 9, adopted on 21 November 2006. A single Panel was established on 29 August 2003 to hear the three complaints by the US, Argentina and Canada against the EC, and the Panel issued its three reports in a single document, comprising some common parts and some parts specific to each report. The final reports were issued to the Parties on 10 May 2006, and circulated on 29 September 2006. The Panel reports were not appealed, and were adopted by the Dispute Settlement Body on 21 November 2006. 
- Continued Suspension and Canada-Continued Suspension). ${ }^{8}$ The findings in all these cases are discussed where relevant to the analysis of the provisions of the SPS Agreement.

Chapter 1 of Part III addresses the history of the SPS Agreement. This examination is useful in elucidating the reasons behind the provisions chosen by the drafters of the SPS Agreement to discipline the enactment and application of SPS measures by WTO Members. In particular, the impetus for the new approach of the SPS Agreement in balancing the competing goals of trade and health is set out. A brief examination of the trade rules of relevance to measures for the protection of human, animal and plant life or health that were in place before the coming into force of the SPS Agreement aims to identify the gaps in the legal framework that led negotiators to agree on the need for new disciplines for SPS measures. It also shows the aspects of the existing provisions, or their interpretation, that were considered effective and later incorporated into the disciplines of the SPS Agreement. This is followed by a discussion of the negotiating history of the SPS Agreement, including an identification of the main actors in the negotiation process, and their positions. In particular, the SPS Agreement's encouragement of harmonisation around international standards, its focus on scientific risk assessment as the basis for SPS regulation, its respect for national regulatory decisions regarding the level of SPS protection and its emphasis on transparency and consultation, are seen against this background. No official record of the Uruguay Round negotiations that led to the adoption of the SPS Agreement exists. However, negotiation position papers and other official documents as well as the published recollections of some Uruguay Round negotiators may fruitfully be relied upon to obtain a picture of the positions of various actors in the negotiation process. ${ }^{9}$

In Chapter 2 of Part III, the scope of application of the SPS Agreement is determined, in order to establish the range of measures that will be subject to the disciplines discussed in the rest of this book. The provisions of the SPS Agreement that set out its scope of application embody particular policy choices, either consciously or inadvertently made by the drafters, with regard to the limits of the Agreement. These provisions are intended to determine which particular types of market access barriers are caught by the rules contained in the SPS Agreement. However, as noted above, the text of the relevant provisions cannot be seen in isolation of its interpretation by WTO panels and the Appellate Body. This interpretation has, in some cases, resulted in a surprising reach of the disciplines of the SPS Agreement, as is discussed in this Chapter. Further, in this Chapter some attention is given to the vexed issue of private sector SPS standards and the question whether they fall within the disciplines of the SPS Agreement. Finally, in discussing the scope of application of the SPS Agreement, the extent to which certain measures falling within its

\footnotetext{
${ }^{8}$ Panel Report, Canada - Continued Suspension of Obligations in the EC - Hormones Dispute (CanadaContinued Suspension), WT/DS321/R, (at time of writing not yet adopted, pending appeal); Panel Report, United States - Continued Suspension of Obligations in the EC - Hormones Dispute (US - Continued Suspension), WT/DS320/R, (at time of writing not yet adopted, pending appeal).

${ }^{9}$ In this section of Chapter 1, reliance is had on Terence P. Stewart, ed., The GATT Uruguay Round. A Negotiating History (1986-1992), vol. I - IV (Kluwer Law and Taxation Publishers, Deventer), 1993. This book, in four volumes, compiles information on the Uruguay Round negotiations obtained from official documents as well as many interviews with Uruguay Round negotiations and GATT Secretariat officials over a three year period. The author of the section of this book that deals with the agriculture negotiations, including on SPS issues, is John Breen.
} 
ambit may also fall within the scope of application of other WTO agreements deserves some attention. This Chapter therefore briefly looks at the relationship between the SPS Agreement and other WTO agreements, in particular the GATT 1994, the TBT Agreement and the Agreement on Agriculture.

In Chapters 3 to 5 of Part III, certain substantive rules of the SPS Agreement that embody its trade/health balance are examined to determine the way in which they discipline WTO Members' ability to enact and apply SPS measures. As stated above, the adjudicatory bodies of the WTO play an important role in clarifying the meaning of the provisions of WTO agreements. A detailed analysis of the relevant substantive rules of the SPS Agreement as interpreted in the case law is therefore necessary in order to provide a clear understanding of the precise disciplines they impose on WTO Members.

In particular, Chapter 3 of Part III addresses the basic principles laid down in Article 2 of the SPS Agreement. This Article embodies the underlying aim of the SPS Agreement, namely to balance the legitimate right of sovereign governments to take health protection measures, with the goal of promoting free trade and preventing protectionism. Chapter 4 turns to examine the rules, contained in Article 3 of the SPS Agreement, that aim to promote harmonisation of SPS measures around international standards. The disciplines that govern risk analysis, in Article 5 of the SPS Agreement, are discussed in Chapter 5.

It is the thesis of this book that the impact on WTO Members of the tools used in the SPS Agreement to balance trade and health varies at different levels of development. To illustrate this, the legal analysis of the relevant provisions of the SPS Agreement in Chapters 3 to 5 goes hand-in-hand with references to their effect in practice. In some cases, this is done in the light of practical examples of situations where WTO Members at lower levels of development have faced market access barriers that might have been addressed using the disciplines of the SPS Agreement, or where these Members have had difficulty in complying with the relevant provisions of the SPS Agreement themselves.

The aim of the legal analysis, and factual illustrations, conducted in Chapters 3 to 5 is twofold. First, by examining how effective the existing rules are in disciplining the use of SPS measures as non-tariff barriers to trade to avoid misuse for protectionist purposes, these Chapters aim to establish in how far the rules are useful in securing market access for food and agricultural exports. However, WTO Members are also importers of food and agricultural products. Therefore, a second objective of the discussion of the substantive rules in these Chapters is to assess whether the relevant substantive disciplines in the SPS Agreement sufficiently respect the right of Member governments to take measures to protect human, animal and plant life and health in their territories. This analysis therefore sketches the contours of the fragile balance struck by certain disciplines of the SPS Agreement between the right of Members to regulate against SPS risks and the competing goal of liberalisation of trade in the agri-food sector.

The conclusion to Part III therefore attempts to evaluate the balance struck by the relevant substantive provisions of the SPS Agreement, with specific regard to its development implications. The criteria used for this evaluation are those set out in the Introduction to this book, namely whether the SPS Agreement effectively increases market access opportunities for WTO Members at lower levels of development; and whether it leaves these Members sufficient policy space for SPS regulation. 
Once again, as elsewhere in this book, it must be recalled that developing-country Members are not a homogenous group. Instead, there are large differences between the SPS capabilities and financial and human resources of WTO Members at different positions along the development continuum. The capacities of different developing-country Members to meet their obligations and enforce their rights under the SPS Agreement vary greatly. In addition, an SPS measure that one Member experiences as a trade barrier may be, for another, a competitive opportunity. The illustrative examples provided in this Part with regard to experiences of particular developing-country Members with the SPS disciplines discussed are therefore only intended as indications of the possible impact of these disciplines in a specific factual context. No generally applicable conclusions can be drawn from the experiences of one developing-country Member for the entire group of developing-country Members of the WTO. 


\section{CHAPTER 1 \\ History of the SPS Agreement}

\subsection{Rules on SPS measures before the entry into force of the SPS Agreement}

The idea that trade rules should address non-tariff barriers to trade, such as national SPS measures, is not new. From the outset, the trade disciplines in the GATT 1947 covered the use of non-tariff measures, including SPS regulations, as trade barriers and tried to limit the possibilities for their misuse for protectionist purposes. However, with the proliferation of non-tariff barriers to trade, it became increasingly clear that new, more effective, disciplines were necessary. This led to the drafting of four 'Codes' in the Tokyo Round dealing with different types of non-tariff barriers to trade. One of these was the Agreement on Technical Barriers to Trade of 1979, commonly known as the Standards Code. The Standards Code covered technical regulations and standards, including but not limited to those imposed to address SPS risks.

The relevant provisions of the GATT 1947 and the Standards Code are discussed briefly below. This aims to establish the manner in which these rules disciplined SPS barriers to trade. Thereafter, some of the inadequacies of these disciplines are pointed out in order to explain the need for a new agreement dealing specifically with SPS measures.

\subsubsection{The GATT 1947, Articles III, XI and XX(b)}

The most important provisions in the GATT 1947 of relevance to measures for the protection of human, animal or plant life or health are Articles III:4, XI and XX(b). ${ }^{10}$ These Articles of the GATT 1947, now incorporated by reference into the GATT 1994, ${ }^{11}$ contained provisions that were (and still are) applicable to health regulations and standards, to the extent that they discriminate against imports or amount to quantitative restrictions to trade. ${ }^{12}$

In order to understand the disciplines imposed by these provisions, a brief look at their interpretation in the case law is necessary. This case law has continued to evolve after the conclusion of the Uruguay Round and the incorporation of the provisions of the GATT 1947 into the GATT 1994. So as to provide a clear picture of the GATT disciplines relevant to SPS measures, the discussion is not limited to GATT panel reports, but includes more recent WTO panel and Appellate Body reports. However, it should be borne in mind that at the time of the Uruguay Round negotiations the case law on the relevant provisions was at a more rudimentary stage, as reflected in the findings of the GATT panels

\footnotetext{
${ }^{10}$ Article I of the GATT, which sets out the most favoured nation treatment obligation, is of course also relevant to SPS measures. However, it will not be discussed here as it adds little to our understanding of the GATT disciplines applicable to SPS measures.

${ }_{11}$ The language of Paragraph 1(a) of the GATT 1994, incorporates the GATT 1947 by reference.

${ }^{12}$ On the current relationship between the SPS Agreement and the GATT 1994, see below, Part III, Section 2.4.2.
} 
mentioned below. In fact, some of the more recent interpretations of Article XX(b) of the GATT rely to a large extent on the case law that developed under the SPS Agreement. ${ }^{13}$

Article III contains what is commonly called the national treatment provision, which prohibits discriminatory tax and regulatory treatment of imported products from WTO Members once they have crossed the border. ${ }^{14}$ According to Article III:4, Members must provide to imported products of other Members treatment 'no less favourable' than that granted to 'like' domestic products in respect of all laws, regulations and requirements affecting their sale, purchase, distribution, transportation or use.

The word 'affecting' was broadly interpreted by GATT panels to cover not only laws, regulations and requirements directly governing the conditions of internal sale or use of products, but also any laws, regulations or requirements that may adversely modify the conditions of competition between domestic and imported products on the domestic market. ${ }^{15}$ In addition, 'affecting' was found to cover not only laws and regulations setting out substantive requirements but also those laying down procedural conditions. ${ }^{16}$ As a result,

\footnotetext{
${ }^{13}$ An example of where regard has been had to findings made in disputes under the SPS Agreement in the interpretation of Article $\mathrm{XX}(\mathrm{b})$ is the $E C-$ Asbestos dispute. Here the Appellate Body, referring to its finding in EC-Hormones under the SPS Agreement, held that '[i]n justifying a measure under Article $\mathrm{XX}(\mathrm{b})$ of the GATT 1994, a Member may also rely, in good faith, on scientific sources which, at that time, may represent a divergent, but qualified and respected, opinion. A Member is not obliged, in setting health policy, automatically to follow what, at a given time, may constitute a majority scientific opinion.' Appellate Body Report, $E C$ - Asbestos, para.178. The Appellate Body also referred to its findings in $E C$-Hormones to hold: 'as with the SPS Agreement, there is no requirement under Article XX(b) of the GATT 1994 to quantify, as such, the risk to human life or health. A risk may be evaluated either in quantitative or qualitative terms.' Appellate Body Report, EC-Asbestos, para. 167. In addition, the Appellate Body noted, and the parties did not dispute, that WTO Members have the right to determine the level of protection of health that they consider appropriate in a given situation. While not expressly referring to the SPS Agreement and its case law, this finding mirrors the approach taken in the case law under the SPS Agreement to the discretion of a Member to choose its own level of protection. Appellate Body Report, EC - Asbestos, para. 168. Gabrielle Marceau and Joel Trachtman note that this 'horizontal cross-fertilization' may be based on either the requirement of 'effective' interpretation of the WTO Agreement or efforts in the jurisprudence to maintain coherence in WTO law. Gabrielle Marceau and Joel Trachtman, 'GATT, TBT and SPS: A Map of WTO Law of Domestic Regulation of Goods', in The WTO Dispute Settlement System 1995-2003, F. Ortino and E-U Petersmann (eds.), vol. 18 (Kluwer Law International, Deventer), 2004, 275-340, 277.

${ }^{14}$ For a detailed analysis of the national treatment obligation, see Michael J. Trebilcock and Shiva K. Giri, 'The National Treatment Principle in International Trade Law', in Handbook of International Trade, Choi E. Kwan (ed.) (Blackwell, Malden MA), 2005, 185-238.. For an analysis of the interpretation of this obligation in dispute settlement, and its implications for the regulatory autonomy of Members, see Gaëtan Verhoosel, National Treatment and WTO Dispute Settlement: Adjudicating the Boundaries of the Regulatory Autonomy (Hart Publishing, Oxford), 2002.

${ }^{15}$ GATT Panel Report, Italy - Agricultural Machinery, para. 12. More recently, the Appellate Body in US - FSC (Article 21.5-EC) has confirmed this broad interpretation, but stressed that the word 'affecting' defines the scope of application of Article III:4 by limiting the laws, regulations and requirements covered to those which affect the sale, purchase, transportation, distribution or use of the products. Appellate Body Report, US - FSC (Article 21.5-EC), paras 208-210.

${ }^{16}$ GATT Panel Report, US - Section 337, para. 5.10.
} 
the coverage of Article III:4 extended to a rather broad range of measures. ${ }^{17}$ This broad interpretation has been continued in WTO case law. ${ }^{18}$

However, the non-discrimination obligation of Article III:4 applies only to 'like products'. ${ }^{19}$ As noted by the GATT Panel in EEC - Animal Feed Proteins, the concept of 'like products', used in various GATT provisions, is not defined in the GATT. ${ }^{20}$ Instead, GATT panels developed certain criteria as tools to establish likeness, including the characteristics of the products, their end use, consumer tastes and habits and the tariff regimes of other Contracting Parties. ${ }^{21}$ In addition, initially a line of case law developed according to which an examination of the 'aim and effects' of the measure at issue was necessary to the determination of 'like products', in order to establish whether the regulatory distinction was made 'so as to afford protection to domestic production'. ${ }^{22}$ However, the 'aim and effect' approach to the determination of 'like products' has since been definitively rejected by WTO panels and the Appellate Body. ${ }^{23}$ As a result, the fact that the discrimi-

${ }^{17}$ Examples of measures found by GATT panels to fall under the scope of application of Article III:4 are additional marking or labelling requirements (Working Party Report, Certificates of Origin, Marks of Origin, Consular Formalities, para. 13); an advertising ban on cigarettes (GATT Panel Report, Thailand-Cigarettes, para. 77); a restriction on wholesale distribution of imported beer and wine to in-State distributors (GATT Panel Report, US - Malt Beverages, para, 5.32); additional packaging requirements for sale authorisation and minimum price requirements (GATT Panel Report, Canada - Provincial Liquor Boards (US), paras 5.4 and 5.30); minimum price requirements (GATT Panel Report, Canada - Provincial Liquor Boards (EEC), para. 4.26); and trade-related investment measures requiring investors to submit undertakings to purchase domestic goods or to use domestic suppliers (GATT Panel Report, Canada-FIRA, para. 6.1).

${ }^{18}$ For examples of this broad interpretation, see Appellate Body Report, EC-Bananas III, para. 211; Panel Report, Canada - Autos, paras 10.80-10.84; Panel Report, Dominican Republic - Import and Sale of Cigarettes, paras 7.170-7.171; Panel Reports, Canada - Wheat Exports and Grain Imports, paras 6.3316.332, 6.165 and 6.262; Panel Report, EC - Trademarks and Geographical Indications (Australia), para. 7.263; Panel Report, Mexico - Taxes on Soft Drinks, para. 8.113 and Panel Report, Brazil - Retreaded Tyres, paras 7.419 and 7.433 .

${ }_{19}$ The non-discrimination obligations of Articles I and III:2, first sentence, of the GATT also apply to 'like' products. However, the concept of like products has been held to have different meanings in the different provisions in which it is found. Appellate Body Report, Japan-Alcoholic Beverages II, 21.

${ }^{20}$ GATT Panel Report, EEC - Animal Feed Proteins, paras 4.1-4.2. In this case the Panel relied on the different duty rates and tariff bindings, varying protein contents and differing origin (animal, vegetable and synthetic) of the protein products before it, to find that they were not 'like products'.

${ }^{21}$ GATT Panel Report, Spain - Unroasted Coffee, paras 4.6-4.9; GATT Panel Report, US - Malt Beverages, para. 5.23; Working Party Report, Australian Subsidy on Ammonium Sulphate, para. 8; GATT Panel Report, Canada/Japan - Tariff on Imports of Spruce, Pine, Fir (SPF), paras 5.13-5.14. Some of these GATT panel reports dealt with 'like products' under Article I or Article III:2 of the GATT. While the nature and extent of the competitive relationship between products that is required for a finding of likeness varies between the different GATT provisions in which the term 'like products' is found, the criteria used as tools to determine such a competitive relationship are the same.

${ }^{22}$ GATT Panel Report, US - Taxes on Automobiles, paras 5.4-5.16, 5.23-5.32 and 5.33-5.37 (not adopted); and GATT Panel Report, US-Malt Beverages, paras. 5.71-5.74. The phrase 'so as to afford protection to domestic production' is found in Article III: 1 of the GATT and, as an indication of the purpose of Article III, was used in the interpretation of Article III:2 and III:4.

${ }^{23}$ Already in US - Gasoline, the Panel did not have regard to the regulatory intent behind the different treatment of imported and domestic gasoline (Panel Report, US - Gasoline, para. 6.9). In Japan - Alcoholic Beverages $I I$, the Panel explicitly rejected the aim and effect test for likeness (under Article III:2), noting that regulatory aims are sometimes difficult or impossible to ascertain and that incorporating an examination of regulatory objectives into the test for 'like products' would render the exceptions of Article XX of the GATT redundant or useless (Panel Report, Japan - Alcoholic Beverages II, paras 6.16-6.17). The Appellate Body implicitly affirmed this finding of the Panel (Appellate Body Report, Japan-Alcoholic Beverages II, 115). For a detailed discussion of this issue, see Robert E. Hudec, 'GATT/WTO Constraints on National Regulation: Requiem for 
natory treatment in a regulatory measure was designed to address an SPS risk rather than to protect the domestic industry is irrelevant to the determination of whether the products at issue are 'like'. Thus, such measures are not exempt from the disciplines of Article III:4 and, if found in violation, the imposing Member will have to justify them under the exception contained in Article XX(b).

As clarified in more recent case law, likeness is determined with reference to the nature and extent of the competitive relationship between the products involved. ${ }^{24}$ Four general criteria are commonly used by panels and the Appellate Body as tools to establish this relationship, namely (i) the properties, nature and quality of the products; (ii) the end-uses of the products; (iii) consumers' tastes and habits in respect of the products; and (iv) the tariff classification of the products. ${ }^{25}$ However, all relevant evidence must be examined in the determination of likeness. ${ }^{26}$ Whether in a particular case the nature and extent of the competitive relationship between the products involved is sufficient for them to be 'like' for purposes of Article III:4 cannot be determined in the abstract, but depends on the circumstances of the case. ${ }^{27} \mathrm{~A}$ controversial issue that has arisen in this regard is whether differences in the process and production method (PPM) whereby products are made can be taken into account in the determination of likeness. Where such PPMs affect the physical characteristics of the resulting product, for example where the absence of adequate sanitation in fishing vessels results in bacterial contamination of the fish, this factor is taken into account in the normal 'like products' analysis and does not give rise to problems. However, in many cases governments regulate PPMs that are not reflected in the physical characteristics of the final product (known as 'non-product-related PPMs'). Here one can think of environmental and labour standard requirements in the production process, such as sustainable harvesting requirements for tropical timber. The GATT Panel in US - Tuna (Mexico), evaluating the US Marine Mammals Protection Act which banned tuna imports from countries that could not show that their tuna harvesting methods met US standards regarding minimising the incidental killing of dolphins, held:

Article III:4 calls for a comparison of the treatment of imported tuna as a product with that of domestic tuna as a product. Regulations governing the taking of dolphins incidental to the taking of tuna could not possibly affect tuna as a

An "Aim and Effects" Test', in Essays on the Nature of International Trade Law (Cameron May, London), 1999, 359-393; Frieder Roesseler, 'Beyond the Ostensible. A Tribute to Professor Robert Hudec's Insights on the Determination of the Likeness of Products under the National Treatment Provisions of the General Agreement on Tariffs and Trade', Journal of World Trade 27 (4), 2003, 771-781; Donald H. Regan, 'Further Thoughts on the Role of Regulatory Purpose under Article III of the General Agreement on Tariffs and Trade. A Tribute to Bob Hudec', Journal of World Trade 27 (4), 2003, 737-760; Amelia Porges and Joel Trachtman, 'Robert Hudec and Domestic Regulation: The Resurrection of Aim and Effects', Journal of World Trade 27 (4), 2003, 783-799.

${ }^{24}$ Appellate Body Report, EC-Asbestos, para. 99.

${ }^{25}$ These criteria have been developed in the case law to 'assist in the task of sorting and examining the relevant evidence' but are, as emphasised by the Appellate Body, 'neither a treaty-mandated nor a closed list of criteria that will determine the legal characterisation of products.' Appellate Body Report, EC-Asbestos, para. 102.

${ }^{26}$ Appellate Body Report, EC-Asbestos, para. 113.

27 The Appellate Body in EC-Asbestos, while not ruling on the precise scope of the 'like' products concept in Article III:4, held that the scope of this concept in Article III:4 is broader than that in Article III:2, first sentence, but not broader than the combined scope of 'like products' and 'directly competitive or substitutable products' under the first and second sentences of Article III:2. Appellate Body Report, EC - Asbestos, paras 99-100. 
product. Article III:4 therefore obliges the United States to accord treatment to Mexican tuna no less favourable than that accorded to United States tuna, whether or not the incidental taking of dolphins by Mexican vessels corresponded to that of United States vessels. ${ }^{28}$

This report was never adopted, and there is still much debate as to whether non-productrelated PPMs can be had regard to in order to determine that the relevant products are not 'like' and can therefore be treated differently without violating Article III:4. ${ }^{29}$ The prevailing opinion is that non-product-related PPMs are not relevant to the 'like product' analysis. ${ }^{30}$ However, the more recent findings of the Appellate Body in EC-Asbestos add nuance to this matter. ${ }^{31}$

In $E C$ - Asbestos, the Appellate Body considered the health risks associated with chrysotile asbestos fibres as pertinent in the examination of likeness, under the criteria of physical properties and consumer tastes and habits. ${ }^{32}$ It is clear, that the SPS risk inherent in a particular product would be a relevant consideration to be taken into account by a panel or the Appellate Body when determining the likeness of the products involved, even if this risk arises from PPMs, where it is reflected in the product characteristics (for example, an increased level of toxins). However, also non-product-related PPMs can have an impact on consumer preferences to the extent that they weaken the competitive relationship between the products involved. Although it is not often the case, in practice, that consumers are guided in their purchasing behaviour by ethical considerations rather than price and

${ }^{28}$ GATT Panel Report, US - Tuna (Mexico) (unadopted), para. 5.15. See also GATT Panel Report, US - Tuna (EEC), (unadopted), paras 5.8-5.9.

${ }_{29}$ See for example Robert E. Hudec, 'The Product-Process Doctrine in GATT/WTO Jurisprudence', in New Directions in International Economic Law. Essays in Honour of John H. Jackson, M. Bronckers and R. Quick (eds.) (Kluwer Law International, The Hague), 2000, 187-217; John H. Jackson, 'Comments on Shrimp/Turtle and the Product/Process Distinction', European Journal of International Law 11 (2), 2000, 303-307; Christian Tietje, 'Process-Related Measures and Global Environmental Governance', in Multilevel Governance of Global Environmental Change: Perspectives from Science, Sociology and the Law, Gerd Winter (ed.) (Cambridge University Press, Cambridge), 2006, 254-274; Robert Howse and Donald Regan, 'The Product/ Process Distinction - an Illusory Basis for Disciplining Unilateralism in Trade Policy', European Journal of International Law 11 (2), 2000, 249-289.

${ }^{30}$ Peter Van den Bossche, The Law and Policy of the World Trade Organization: Text, Cases and Materials, $2^{\text {nd }}$ ed. (Cambridge University Press, Cambridge), 2008, 381 and Mitsuo Matsushita et al., The World Trade Organization: Law, Practice, and Policy 1st ed. (Oxford University Press, Oxford), 2003, 162. Contra see Jason Potts, The Legality of the PPMs under the GATT: Challenges and Opportunities for Sustainable Trade Policy (International Institute for Sustainable Development, Manitoba), 2008, available at: http://www.iisd. org/pdf/2008/ppms_gatt.pdf, visited on 9 April 2008.

${ }^{31}$ Peter Van den Bossche, The Law and Policy of the World Trade Organization Text, Cases and Materials, $2^{\text {nd }}$ ed. (Cambridge University Press, Cambridge), 2008, 378 and 381.

${ }^{32}$ Appellate Body Report, EC - Asbestos, para. 113. However, according to one Appellate Body Member who wrote a separate concurring opinion, the extent of the scientific evidence showing that chrysotile asbestos fibres are carcinogenic means that even in the absence of evidence regarding end-uses and consumer tastes and habits, cement-based products containing chrysotile asbestos fibres can be characterised as not 'like' cement-based products containing PCG fibres. This Appellate Body Member rejected the decisive nature of the test of the competitive relationship of the products on the market, stating: 'the necessity or appropriateness of adopting a "fundamentally" economic interpretation of the "likeness" of products under Article III:4 of the GATT 1994 does not appear to me to be free from substantial doubts.' Appellate Body Report, EC-Asbestos, para. 154. 
quality, this may be changing. ${ }^{33}$ In some situations, a difference in SPS risk, even if not reflected in the final product, depending on the circumstances of the case, could be an indication that the products involved are not 'like' for purposes of Article III:4, if this difference would affect the nature and extent of the competitive relationship between the products to a sufficient degree. One example would be the preference of consumers in many European countries for non-genetically modified food, even where the genetically modified product is substantially equivalent to its non-genetically modified counterpart. In many cases, while genetic modification is part of the production process (for example, a GM additive is used in processed food, or GM feed is given to beef cattle), the final product bears little or no trace of the modified genes. Still, concerns with the long-term environmental effects of genetic modification may prompt consumers to avoid such products, weakening their competitive relationship with non-GM products to the extent that they may no longer be considered 'like'. ${ }^{34}$

It is useful to note, however, that although a difference in SPS risk may mean that seemingly like products are in fact not 'like', a similarity in the SPS risk contained in two products does not make them 'like' for purposes of Article III:4 of the GATT, since it cannot create, by itself, a competitive relationship between different products. For example, the fact that both ostriches and canaries may be carriers of avian influenza, does not mean that ostriches and canaries are 'like' products and should be subject to the same regulatory treatment under Article III:4, since these products clearly do not compete with each other on the market. Consequently, the non-discrimination discipline in Article III:4 of the GATT does not serve to eliminate arbitrary distinctions in regulatory treatment of different products that contain comparable risks. ${ }^{35}$

Article III:4 requires that the treatment of imported products be 'no less favourable' than that given to 'like' domestic products. It is important to note that treatment that is different is not per se 'less favourable'. ${ }^{36}$ Neither is identical treatment necessarily equally favourable to domestic and imported products. ${ }^{37}$ Instead, as held by the GATT Panel in $U S$ - Section 337, the words 'no less favourable treatment' require 'effective equality of competitive opportunities' for the imported products as compared to the 'like' domestic

\footnotetext{
${ }^{33}$ See on this issue R. Howse, P. van Bork and C. Hedebrand, 'WTO Disciplines and Biofuels, Opportunities and Constraints in the Creation of a Global Marketplace', IPC Discussion Paper, October 2006; M. Araya, 'WTO Negotiations on Environmental Goods and Services: Maximizing Opportunities', Global Environmental and Trade Study, Yale Center for Environmental Law and Policy, June 2003, 1-2. cited in Peter Van den Bossche, The Law and Policy of the World Trade Organization Text, Cases and Materials, $2^{\text {nd }}$ ed. (Cambridge University Press, Cambridge), 2008, 381.

${ }^{34}$ In this respect, Peter Van den Bossche notes a Zogby poll which showed that $80.7 \%$ of US consumers would be willing to pay more for eggs from hens treated humanely, as would $87 \%$ of consumers in the UK. A.B. Thiermann and S. Babcock, 'Animal Welfare and International Trade', Revue Scientifique et Technique Office International des Epizooties, 2005, 751, cited in Peter Van den Bossche, The Law and Policy of the World Trade Organization Text, Cases and Materials, $2^{\text {nd }}$ ed. (Cambridge University Press, Cambridge), $2008,381$.

${ }^{35}$ As such a discipline with regard to the level of protection against SPS risks chosen by Members was deemed necessary by the Uruguay Round negotiators, it was included in Article 5.5 of the SPS Agreement. See below, Part III, Section 5.2.3.

${ }^{36}$ GATT Panel Report, US - Section 337, para. 5.11 and GATT Panel Report, EEC - Animal Feed Proteins, para. 4.12 .

${ }^{37}$ GATT Panel Report, US - Section 337, para. 5.11. For a more recent confirmation of this interpretation, see Appellate Body Report, Korea - Various Measures on Beef, para. 137.
} 
products. ${ }^{38}$ If the regulatory requirements impose an additional burden on imported products that is not borne by domestic products, they will be regarded as adversely affecting the conditions of competition to the detriment of the imported products, even if they are applied in a formally identical manner to imports and domestic products. ${ }^{39}$

However, in the Dominican Republic - Import and Sale of Cigarettes case, the Appellate Body has held that if the detrimental effect on imported products that results from a measure 'is explained by factors or circumstances unrelated to the foreign origin of the product' the measure will not be held to accord 'less favourable treatment' to the imported product. ${ }^{40}$ This ruling was followed by the Panel in EC-Approval and Marketing of Biotech Products, ${ }^{41}$ in rejecting Argentina's claim that the EC had violated Article III:4 of the GATT by its alleged suspension of consideration, or failure to consider, eight applications for approval of biotech products, resulting in less favourable treatment of the relevant biotech products than was given to 'like' non-biotech products. The Panel noted that Argentina had not alleged that the manner of processing applications under the relevant EC Regulation had differed depending on the origin of the products (i.e. that it differed between domestic biotech products and imported biotech products), neither was it self-evident that the alleged less favourable treatment of imported biotech maize was explained by its foreign origin. Instead the Panel considered that, 'for instance, a perceived difference between biotech products and non-biotech products in terms of their safety, etc.' could explain the different treatment. ${ }^{42}$

It would seem from this recent case law that any SPS measure that has a detrimental effect on imports, such as one laying down maximum residue levels for particular pesticides used by foreign producers or setting out pre-shipment inspection requirements to avoid the introduction of plant pests with imported products, could be regarded as applied so as to provide 'no less favourable treatment' to imports than to 'like' domestic products

${ }^{38}$ GATT Panel Report, US - Section 337, para. 5.11; GATT Panel Report, Canada-Provincial Liquor Boards (US), para. 5.5; GATT Panel Report, US - Malt Beverages, para. 5.30.

${ }^{39}$ GATT Panel Report, US - Section 337, para. 5.11 and GATT Panel Report, Canada - Provincial Liquor Boards (US), para. 5.14. More recently, in Dominican Republic - Import and Sale of Cigarettes, the Panel held that a stamp tax applied in a formally identical manner to domestic and imported cigarettes imposed additional processes and costs on imported cigarettes and was thus 'less favourable' treatment. Panel Report, Dominican Republic - Import and Sale of Cigarettes, para. 7.196.

${ }^{40}$ Appellate Body Report, Dominican Republic - Import and Sale of Cigarettes, para. 96. This finding related to a bond requirement imposed by the Dominican Republic on importers and domestic producers of cigarettes, which had a greater detrimental effect on imported cigarettes because the resulting per-unit cost of this requirement was higher for imported cigarettes. As the higher per-unit cost was due to the smaller market share of the importer of Honduran cigarettes, rather than due to the foreign origin of the imported cigarettes, the Appellate Body agreed with the Panel that no less favourable treatment had been established. In contrast, see the Panel's finding in the earlier case, Canada - Wheat Exports and Grain Imports, where the Panel held that while there may be legitimate reasons for Canada to treat domestic grain differently from 'like' imported grain (for example because imported grain was not subject to the Canadian quality assurance system), it did not see how these arguments could support the conclusion that the measure treated imported grain 'no less favourably' than like domestic grain. Panel Reports, Canada - Wheat Exports and Grain Imports, paras 6.209-6.214.

${ }^{41}$ This Panel Report was adopted (unappealed) on 21 November 2006.

42 Panel Report, EC - Approval and Marketing of Biotech Products, para. 7.2514. The Panel followed almost identical reasoning to reject Argentina's claim of violation of the second clause of Annex C.1(a)of the SPS Agreement which contains a national treatment provision with respect to procedures to check compliance with SPS requirements, as discussed below, Part IV, Section 1.4.4. Panel Report, EC-Approval and Marketing of Biotech Products, para. 7.2411. 
under Article III:4 of the GATT, as the detrimental effect results from the SPS risk, or even a perceived SPS risk, contained in the imported product rather than from the foreign origin of the product. As with the old 'aim and effect' test for likeness, this incorporation of an examination of the reasons for the adverse effects on the conditions of competition into the 'no less favourable' treatment analysis seems misplaced. It allows measures that impose a greater burden on imports than on domestic products to slip through the national treatment provision, if the adverse effect on the competitive relationship can be explained by circumstances unrelated to the fact that the product originates abroad, without subjecting such measures to the disciplines of Article XX. More worryingly, it allows even 'perceived' differences between products to justify different treatment that aversely affects competitive conditions. It would seem preferable to begin the enquiry by determining whether the products (in casu biotech products and their non-biotech equivalents) are in fact 'like', taking account of real differences in product characteristics, including safety levels, and having regard to perceived differences only to the extent that they do, in practice, affect the market behaviour of consumers and thereby the nature and extent of the competitive relationship between the products. The reasons for the different treatment of the 'like' products should then be assessed for justifiability under Article XX.

Article XI of the GATT, in contrast to Article III:4, focuses on quantitative restrictions in relation to importation or exportation, rather than on internal regulations. ${ }^{43}$ In terms of the Note $A d$ Article III, regulations that apply to both imported and domestic products but are enforced at the border, nevertheless fall under Article III:4. Article XI:1 prohibits prohibitions or restrictions, whether in the form of bans, quotas or other measures, on imports from or exports to Members, except in very limited cases ${ }^{44}$ As noted by the GATT Panel in Japan - Trade in Semi-Conductors, the wording of Article XI:1 is comprehensive. ${ }^{45}$ The prohibition in Article XI extends to both de jure and de facto quantitative restrictions. ${ }^{46}$ Examples of SPS measures that would be caught by Article XI are regulations prohibiting the importation of genetically-modified organisms (GMOs) or banning imports of poultry products from Members in which avian influenza outbreaks have been reported. Not only outright bans but also other types of import restrictions, such as quotas and import or export licensing schemes, ${ }^{47}$ are subject to the prohibition of Article XI. For example, a licensing system for plant imports that are hosts of pests of quarantine

${ }^{43}$ These measures are not limited to border measures, as held by the Panel in India - Autos. Instead, the key criterion is the nature of the measure as a restriction in relation to importation or exportation. Whether a measure falls under Article III or Article XI depends on the manner in which it affects the competitive opportunities of imports - if it affects competitive opportunities on the domestic market, it falls under Article III:4 whereas if it affects the opportunities for entering the market, i.e. importation itself, if falls under Article XI:1. Different aspects of a measure may fall under each of the two provisions. Panel Report, India - Autos, paras 7.261 and 7.224 .

44 These limited exceptions are contained in Article XI:2, and include temporary export restrictions to relieve critical food shortages. In addition, the general exceptions of Article XX of the GATT apply.

${ }^{45}$ GATT Panel Report, Japan - Trade in Semi-Conductors, para. 117. According to the Panel, the use of the word 'measures' instead of only laws and regulations, indicated that the legal status of the measure involved was not decisive in determining whether or not it fell under Article XI:1. Therefore a non-mandatory measure restricting exports below cost price was regarded as caught by Article XI:1.

${ }^{46}$ Panel Report, Argentina - Hides and Leather, para. 11.17.

${ }^{47}$ Note that automatic licensing systems (i.e. those where the licence is automatically granted) do not constitute a restriction of the type prohibited under Article XI:1. GATT Panel Report, EEC-Minimum Import Prices, para. 4.1. 
significance, which conditions the granting of a licence on the requirement that the pestfree status of plant imports be certified by competent officials, would fall under Article XI. Unlike Article III, the prohibition of Article XI is not tempered by any conditions aimed at identifying protectionism.

It is clear that in some cases regulations that discriminate against imports or constitute quantitative restrictions on imported products are a justifiable exercise of the sovereign duty of a government to protect certain societal values on its territory. For this reason, the GATT provides, in Article XX, for certain qualified exceptions from its rules for measures aimed at particular policy objectives. ${ }^{48}$ One of these exceptions, contained in Article $\mathrm{XX}(\mathrm{b})$, is that for measures necessary to protect the life or health of humans, animals and plants. Such measures are allowed, provided they are not applied in a manner constituting arbitrary or unjustified discrimination between countries where the same conditions prevail, or a disguised restriction on international trade, in terms of the chapeau (headnote) of Article XX. Since Article XX provides an exception from the trade rules of the GATT, is for the responding party to prove that its measure falls within the exception provided in Article XX(b) and is applied in a manner that meets the requirements of the chapeau. ${ }^{49}$ This means that, under the GATT, SPS measures that fall foul of the disciplines of Articles III:4 or XI are only permitted if the regulating country can show that they meet the requirements of paragraph (b) and the chapeau of Article XX.

Two requirements must be met in order to justify a measure under Article XX(b), namely:

(1) that the policy objective pursued by the measure falls within the range of policies designed to protect human, animal or plant life or health; and

(2) that the inconsistent measure for which the exception is being invoked was necessary to fulfil that policy objective..$^{50}$

The first step in an analysis of whether a measure falls under Article XX(b) is thus to determine whether the policy objective of the measure is the protection of human, animal or plant life or health. In Thailand - Cigarettes, the GATT Panel accepted that smoking constitutes a serious health risk and that measures designed to reduce smoking are therefore within the scope of Article XX(b) ${ }^{51}$ Once it is established that the measure aims at such a

${ }^{48}$ The GATT Panel in US - Section 337 noted that Article XX provides a limited and conditional exception from other GATT provisions. GATT Panel Report, US - Section 337, para. 5.9. In US - Tuna (Mexico) the GATT Panel recalled this finding. GATT Panel Report, US - Tuna (Mexico), para. 5.22.

${ }^{49}$ For findings of GATT panels allocating the burden of proof under Article XX to the responding party, see GATT Panel Report, Canada - FIRA, para. 5.20; and GATT Panel Report, US - Section 337, para. 5.27. This allocation of the burden of proof was confirmed by the Appellate Body in US - Gasoline and the Panel in EC - Asbestos. Appellate Body Report, US - Gasoline, 22; and Panel Report, EC - Asbestos, paras 8.177-8.178. Note that although the GATT Panel in US - Tuna (Mexico) held that the practice of GATT panels had been to interpret Article XX narrowly due to its nature as a conditional exception, the Appellate Body has not followed this approach. Instead, the Appellate Body tries to balance the objective of trade liberalisation reflected in the normal GATT rules with the societal policy objectives reflected in the exceptions of Article XX. Appellate Body Report, US - Gasoline, 16-17; and Appellate Body Report, US - Shrimp, para. 121.

${ }^{50}$ Panel Report, US - Gasoline, 6.20. This two step test was reiterated in Panel Report, EC-Asbestos, 8.169.

${ }^{51}$ GATT Panel Report, Thailand-Cigarettes, para. 73. In later WTO cases, such as EC-Asbestos and Brazil - Retreaded Tyres, the Panels have also accepted that the measure at issue aims at a policy objective that falls under Article XX(b). Panel Report, US - Gasoline, para. 6.21; Panel Report, EC-Asbestos, para. 8.194 and Panel Report Brazil - Retreaded Tyres, para. 7.102. In EC - Tariff Preferences the Panel held that not only 
policy, the country involved is free to set the standard of protection it chooses. The GATT Panel in US - Tuna (Mexico) stressed that Article XX(b) 'allows each contracting party to set its own human, animal or plant life or health standards ${ }^{52}$ and that the conditions in Article XX(b) and the chapeau which limit resort to the exception, refer to the trade measure at issue and not to the life or health standard chosen by the Contracting Party.

WTO case law on Article XX(b) of the GATT 1994, has further fleshed out this requirement by requiring sufficient scientific evidence of risk. In $E C$-Asbestos, the Panel found that the determination that the policy aimed at by the measure fell within the scope of policies 'designed to protect human, plant or animal life or health' required a finding of a health risk..$^{53}$ It held:

[W]e consider that, inasmuch as they include the notion of "protection", the words "policies designed to protect human life or health" imply the existence of a health risk. We must therefore determine, on the basis of the relevant rules of evidence, whether chrysotile-asbestos, in the various forms we have considered so far, poses a risk to human life or health. ${ }^{54}$

The Panel then went on to state that it would determine whether there was sufficient scientific evidence of a risk, on the basis of the scientific evidence presented by the parties and the comments of the experts consulted by the Panel, ${ }^{55}$ while not setting itself up as an arbiter of scientific opinions. ${ }^{56}$ After doing so, it concluded that the evidence tended to show that asbestos and asbestos products constituted a risk to human health, rather than the opposite. ${ }^{57}$

Whether the policy objective of the protection of human, animal or plant life or health in Article $\mathrm{XX}(\mathrm{b})$ is subject to a territorial limitation is still an open question. Article $\mathrm{XX}$ of the GATT does not expressly state whether it can be relied upon to justify measures for the protection of the societal values listed in that Article outside the territory of the Member imposing the measure. In the unadopted GATT Panel report in US - Tuna (Mexico), the GATT Panel found that the exception contained in Article XX(b) of GATT 1947 only

the express provisions of the measure at issue but also its design, architecture and structure is relevant in determining whether it is a measure designed to achieve the stated health objectives. Panel Report, EC-Tariff Preferences, para. 7.200. In that case, the Panel found that the policy reflected in the Drug Arrangements of the EC's Generalised System of Preferences was not one designed for the purpose of protecting human life or health in the EC, and therefore did not fall under Article XX(b) of the GATT. Panel Report, EC - Tariff Preferences, para. 7.210.

${ }^{52}$ GATT Panel Report, US - Tuna (Mexico) (unadopted), para. 5.27. This was reiterated by the Appellate Body in EC-Asbestos, Appellate Body Report, EC-Asbestos, para. 168.

${ }^{53}$ The Panel stopped short, however, of requiring a 'risk assessment' within the meaning of the term in the SPS Agreement. For a discussion of the risk assessment requirement of the SPS Agreement, see below, Part III, Section 5.1.

${ }^{54}$ Panel Report, EC-Asbestos, para. 8.170.

${ }^{55}$ Ibid., para. 8.182.

56 The Panel stated: 'In this context, in relation to the scientific information submitted by the parties and the experts, the Panel feels bound to point out that it is not its function to settle a scientific debate, not being composed of experts in the field of the possible human health risks posed by asbestos. Consequently, the Panel does not intend to set itself up as an arbiter of the opinions expressed by the scientific community.' Ibid., para. 8.181 .

${ }^{57}$ Ibid., paras 8.193-194. The Appellate Body upheld the Panel's finding on this point. Appellate Body Report, EC-Asbestos, para. 163. 
applies to measures to protect life or health within the jurisdiction of the Contracting Party imposing the measures. ${ }^{58}$ However, in US - Tuna (EEC), a later case regarding the same facts, the GATT Panel held that as Article XX(b) of GATT 1947 did not specify any limitation on the location of the living things to be protected, and neither the other provisions of the GATT nor international law in general proscribe extra-territorial application of regulations in principle, the US measures could fall under Article XX(b). Nevertheless, the Panel held that measures taken so as to force other countries to change their policies within their own jurisdictions could not fall under Article XX(b) as this would impair the objectives of the GATT. ${ }^{59}$

The Appellate Body has not yet ruled on this question. In US - Shrimp, in which a US ban on imports of shrimp harvested in a manner leading to incidental killing of turtles was challenged, the Appellate Body used the fact that turtles migrate and thus cross US territorial waters to avoid ruling on whether there was an implied territorial limitation in Article XX. ${ }^{60}$ In EC - Tariff Preferences, however, the Panel held that the policy reflected in the 'Drug Arrangements' that formed part of the EC's Generalised System of Preferences was not one designed to protect human life or health in the EC and the Drug Arrangements were therefore not a measure falling under Article XX(b) of the GATT. ${ }^{61}$ Whether the Appellate Body will follow the approach of this Panel remains to be seen. This issue has implications for the controversial question of whether regulations imposing requirements on the PPM of an imported product can be justified under Article XX, if such PPM is not reflected in the characteristics of the product itself and therefore cannot affect the attainment of a particular policy objective, such as SPS protection, within the territory of the importing Member. For example, a regulation requiring that abattoirs in the exporting Member which process meat for export comply with specific hygiene requirements is a PPM requirement that bears upon the sanitary characteristics of the exported product. It therefore aims to protect health in the importing Member and would fall under the policy objective of Article XX(b). By contrast, a requirement that proper protective equipment be provided to agricultural workers administering toxic pesticides in the exporting Member in order to protect their health addresses a PPM that does not affect the final product and has no implications for health protection in the importing Member. ${ }^{62}$ Instead, such a measure seeks to protect policy interests outside the territory of the importing Member. It is not clear, as stated above, whether such a measure could be justified under Article XX(b), but it seems doubtful.

The second element of the Article XX(b) test is the 'necessity' requirement. The GATT Panel in Thailand-Cigarettes, noted that Article XX(b) 'clearly allowed contracting parties to give priority to human health over trade liberalization'. ${ }^{63}$ However, it pointed out

\footnotetext{
${ }^{58}$ GATT Panel Report, US - Tuna (Mexico) (unadopted), paras 5.24-5.29.

${ }^{59}$ GATT Panel Report, US - Tuna (EEC) (unadopted), paras 5.31-5.33.

${ }^{60}$ Appellate Body Report, US - Shrimp, para. 133. The Appellate Body was dealing with Article XX $(\mathrm{g})$ in this dispute. However, the same question arises with regard to other paragraphs of Article XX, including paragraph (b).

${ }^{61}$ Panel Report, EC - Tariff Preferences, para. 7.210.

${ }^{62}$ Note that this would be different if the regulation at issue addressed permissible pesticide residues on the imported product. The latter regulation would regulate a PPM that is reflected in the product characteristics and has health implications for the importing Member.

${ }^{63}$ GATT Panel Report, Thailand-Cigarettes, para. 73.
} 
that to be covered by Article XX(b), the measure had to be 'necessary'. ${ }^{64}$ According to the Panel, a measure can be considered 'necessary' only if there is no alternative measure consistent with the GATT, or less inconsistent with it, that the respondent could reasonably be expected to use to achieve its health policy objectives. ${ }^{65}$ Applying this 'least GATT-inconsistent' test, the Panel found that Thailand's measures were not 'necessary' as its health policy goals could be achieved by measures reasonably available to it and consistent or less inconsistent with the GATT. ${ }^{66}$ This test has more recently been formulated by the Appellate Body as the 'least-trade-restrictive' test, which requires that the measure least restrictive of trade be applied, to the extent that it is reasonably available. ${ }^{67}$

It should be noted that neither any panel nor the Appellate Body has ever questioned the necessity of the policy objective embodied in a measure under Article XX(b), but they have limited their enquiries to whether the measure applied to achieve the policy goal complied with the requirements of Article XX(b).$^{68}$ This was confirmed by the Panel in EC-Asbestos, which stated:

[W]e note that the panel in United States - Gasoline also made clear that it did not have to examine the necessity of the policy goal. ${ }^{69}$ In other words, we do not have to assess the choice made by France to protect its population against certain risks, nor the level of protection of public health that France wishes to achieve. We must simply determine if the French policy of prohibiting the use of chrysotile-asbestos falls within the range of policies designed to protect human life or health. ${ }^{70}$

Thus the policy itself is only examined to determine whether it is a policy which falls within the ambit of one of the Article XX exceptions, in casu Article XX(b). In US Gasoline the Panel and the parties accepted that:

${ }^{64}$ Ibid. para. 74.

${ }^{65} \mathrm{Ibid}$., para. 75.

${ }^{66}$ For example, the Panel saw non-discriminatory labelling and ingredient disclosure rules, advertising bans on both domestic and imported cigarettes and non-discriminatory supply control through the government tobacco monopoly as reasonable alternatives.

${ }^{67}$ Appellate Body Report, EC - Asbestos, para. 172; and Appellate Body Report, Brazil - Retreaded Tyres, para. 178.

${ }^{68}$ With regard to the environmental exception, the GATT Panel in US - Tuna (Mexico) held that "the conditions set out in Article XX $(\mathrm{g})$... refer to the trade measure requiring justification under Article XX(g), not however to the conservation policies adopted by the contracting party.' GATT Panel Report, US - Tuna (Mexico) (unadopted). Similarly the Panel in US - Gasoline has found that 'it was not its task to examine generally the desirability or necessity of the environmental objectives of the Clean Air Act or the Gasoline Rule. ... Under the General Agreement, WTO Members were free to set their own environmental objectives, but they were bound to implement these objectives through measures consistent with its provisions...' Panel Report, US Gasoline, para. 7.1. This was confirmed by the Appellate Body in the latter case, stating that 'WTO Members have a large measure of autonomy to determine their own policies on the environment (including its relationship to trade), their environmental objectives and the environmental legislation they enact and implement. So far as concerns the WTO, that autonomy is circumscribed only by the need to respect the requirements of the General Agreement and the other covered agreements.' Appellate Body Report, US - Gasoline, 30.

${ }^{69}$ In a footnote here the panel referred to Panel Report, US - Gasoline, para. 6.22; as well as GATT Panel Report, US - Section 337, para. 5.26; and GATT Panel Report, Thailand-Cigarettes, para. 74.

${ }^{70}$ Panel Report, EC-Asbestos, para. 8.171. 
.... policy to reduce air pollution resulting from the consumption of gasoline was a policy within the range of those concerning the protection of human, animal and plant life or health mentioned in Article XX(b). ${ }^{71}$

The question of which alternative measures are to be considered 'reasonably available' is clearly important to the 'necessary' test. ${ }^{72}$ In Thailand - Cigarettes, in which Thailand's ban on cigarette imports was challenged, the GATT Panel examined whether alternative measures were 'reasonably available' by looking at whether other GATT-consistent or less GATT-inconsistent measures might be used to meet Thailand's health objectives (reducing the quantity and ensuring the quality of cigarettes sold in Thailand). As confirmed in WTO case law, in order for an alternative measure to be reasonably available, it must achieve the chosen level of protection of the importing Member. This can be seen as a 'weak proportionality' requirement in that it implicitly allows the consideration of whether a measure is disproportionate because a less trade-restrictive measure is available that would achieve the same health policy objective. ${ }^{73}$ The health policy objective itself is not open to challenge under this type of proportionality testing. In $E C$-Asbestos, the Appellate Body noted that:

... it is undisputed that WTO Members have the right to determine the level of protection of health that they consider appropriate in a given situation. ${ }^{74}$

According to the Appellate Body in that case, it follows that a Member cannot reasonably be expected to employ any alternative measure that would not achieve its chosen level of health protection. ${ }^{75}$

However, there is more to the 'reasonably available' test than an identification of less trade-restrictive alternative measures that achieve the policy objectives, including the level of protection, aimed at by the importing Member. The Panel in Thailand-Cigarettes did not seem to take into account the question whether the alternative measures identified, such as labelling and ingredient-disclosure regulations, or a ban on harmful additives in cigarettes, which are administratively more burdensome than a simple import ban, were technically and economically feasible for Thailand. In US - Gasoline the Panel did not view the administrative difficulties presented by an alternative measure as sufficient to

${ }^{71}$ Panel Report, US - Gasoline, para. 6.21.

72 The question of which party bears the burden of proof with regard to the existence of a reasonably available alternative measure was addressed by the Appellate Body in Brazil-Retreaded Tyres. It found that the complaining Member must identify possible alternatives to the measure at issue that the responding Member could have taken. The responding Member then bears the burden of showing that the proposed alternatives are not, in fact, reasonable available to it. Appellate Body Report, Brazil-Retreaded Tyres, para. 156, referring to Appellate Body Report, US - Gambling, para. 307.

${ }^{73}$ Catherine Button, The Power to Protect. Trade, Health and Uncertainty in the WTO (Hart Publishing, Oxford and Portland, Oregon), 2004, 29.

${ }^{74}$ Appellate Body Report, EC-Asbestos, para. 168.

75 Appellate Body Report, EC - Asbestos, para. 174. The Appellate Body here held that France could not reasonably be expected to adopt any alternative measure that would involve a continuation of the very risk that its chosen measure sought to halt, namely the spread of asbestos-related diseases. As scientific evidence suggested that the alternative measure of 'controlled use' of asbestos products could still lead to a significant residual risk of asbestos-related diseases, it could not be regarded as achieving France's chosen level of health protection and was thus not a 'reasonably available' alternative measure. This approach was reiterated in Appellate Body Report, Brazil - Retreaded Tyres, para. 156. 
show that it was not reasonably available. ${ }^{76}$ This question was not appealed in that case. In EC - Asbestos, however, the Panel considered that the economic and administrative capacity of a country to implement alternative measures was relevant, holding that:

$\ldots$ in order to determine whether a measure is necessary it is important to assess whether consistent or less inconsistent measures are reasonably available. The term "reasonably" has not been defined as such by the panels that have referred to it in the context of Article XX. It suggests, however, that the availability of a measure should not be examined theoretically or in absolute terms. Nevertheless, in the light of the reasoning of these panels, we find the word "reasonably" should not be interpreted loosely either. The fact that, administratively, one measure may be easier to implement than another does not mean that the other measure is not reasonably available. ${ }^{77}$ We consider that the existence of a reasonably available measure must be assessed in the light of the economic and administrative realities facing the Member concerned but also by taking into account the fact that the State must provide itself with the means of implementing its policies. Thus, the Panel considers that it is legitimate to expect a country such as France with advanced labour legislation and specialized administrative services to deploy administrative resources proportionate to its public health objectives and to be prepared to incur the necessary expenditure. ${ }^{78}$

In Brazil - Retreaded Tyres, the Appellate Body held that in the evaluation of whether an alternative measure is reasonably available, 'the capacity of a country to implement remedial measures that would be particularly costly, or would require advanced technologies' may be relevant. ${ }^{79}$

There would thus clearly be a difference in the requirements of this 'least trade-restrictive measure reasonably available' test when applied to Members at different levels of development. The additional flexibility provided could be applied in order to take account of the financial and technical constraints faced by developing countries which may affect their ability to implement alternative SPS measures that are technically complex or resource intensive. ${ }^{80}$

\footnotetext{
${ }^{76}$ Panel Report, US - Gasoline, 6.26 and 26.28.

${ }^{77}$ Here the Panel referred to US - Gasoline, paras 6.26 to 6.28.

${ }^{78}$ Panel Report, EC-Asbestos, para. 8.207.

${ }^{79}$ Appellate Body Report, Brazil - Retreaded Tyres, para. 156. The Appellate Body here cited its finding in $U S$ - Gambling (with respect to the necessity requirement in Article XIV(a) of the GATS) that an alternative measure 'may be found not to be 'reasonably available' ... where it is merely theoretical in nature, for instance, where the responding Member is not capable of taking it, or where the measure imposes an undue burden on that Member, such as prohibitive costs or substantial technical difficulties.' Appellate Body Report, US - Gambling, para. 308.

${ }^{80}$ In Korea - Various Measures on Beef, with regard to the necessity test in Article XX(d), the Appellate Body found that the alternative GATT-consistent measures at issue would be able to achieve Korea's chosen level of enforcement, if Korea would devote more resources to this enforcement mechanism. It found Korea's argument regarding its lack of resources to do so insufficiently persuasive. Appellate However, the Appellate Body did recognise that the alternative measures would entail higher costs for the national budget, as these costs could no longer be shifted to imported goods and retailers of imported products. Appellate Body Report, Korea-Various Measures on Beef, para. 181.
} 
Further, in respect of the question whether there is a 'reasonably available' alternative, the Appellate Body in Korea - Various Measures on Beef elaborated a weighing and balancing test, involving a consideration of various factors. It regarded this test as part of the determination of whether the GATT-consistent or less GATT-inconsistent alternative measure is 'reasonably available'. ${ }^{81}$ In respect of the factors to be weighed, it held:

It seems to us that a treaty interpreter ... may, in appropriate cases, take into account the relative importance of the common interests or values that the law or regulation to be enforced is intended to protect. The more vital or important those common interests or values are, the easier it would be to accept as "necessary" a measure designed as an enforcement instrument.

There are other aspects of the enforcement measure to be considered in evaluating that measure as "necessary". One is the extent to which the measure contributes to the realization of the end pursued, .... The greater the contribution, the more easily a measure might be considered to be "necessary". Another aspect is the extent to which the compliance measure produces restrictive effects on international commerce, that is, in respect of a measure inconsistent with Article III:4, restrictive effects on imported goods. A measure with a relatively slight impact upon imported products might more easily be considered as "necessary" than a measure with intense or broader restrictive effects.

In sum, determination of whether a measure, which is not "indispensable", may nevertheless be "necessary" within the contemplation of Article XX(d), involves in every case a process of weighing and balancing a series of factors which prominently include the contribution made by the compliance measure to the enforcement of the law or regulation at issue, the importance of the common interests or values protected by that law or regulation, and the accompanying impact of the law or regulation on imports or exports. ${ }^{82}$

This weighing and balancing approach was reiterated by the Appellate Body in $E C$ Asbestos, and applied to the specific case of measures for the protection of human health. Referring to the Korea - Various Measures on Beef decision, it stated:

... we observed, in that case, that "[t]he more vital or important [the] common interests or values" pursued, the easier it would be to accept as "necessary" measures designed to achieve those ends. In this case, the objective pursued by the measure is the preservation of human life and health through the elimination, or reduction, of the well-known, and life-threatening, health risks posed by asbestos fibres. The value pursued is both vital and important in the highest degree. The remaining question, then, is whether there is an alternative measure that would achieve the same end and that is less restrictive of trade than a prohibition. ${ }^{83}$

\footnotetext{
${ }^{81}$ Ibid., para. 166.

${ }^{82}$ Ibid., paras 162-164.

${ }^{83}$ Appellate Body Report, EC-Asbestos, para. 172.
} 
It appears that the 'weighing and balancing' approach to the requirement of necessity adds an element of 'strong proportionality' testing ${ }^{84}$ that was not present in the old GATT case law. ${ }^{85}$ The examination of necessity now includes an examination of the relationship between the importance of the values protected and the nature of the measure (specifically its trade-restrictiveness and its suitability as reflected in its contribution to the objective pursued) ${ }^{86}$ In other words, this test seems not to be limited to assessing the means used to achieve the chosen objective (termed 'weak proportionality') but instead seems to allow the calling into question of the objective itself by balancing its importance or value against the trade restrictiveness and suitability of the measure. ${ }^{87}$ The latter is commonly called a 'strong proportionality' test. ${ }^{88}$

In Brazil-Retreaded Tyres, the Appellate Body set out the necessity test, as developed in the case law, concisely as follows:

...in order to determine whether a measure is "necessary" within the meaning of Article XX(b) of the GATT 1994, a panel must consider the relevant factors, particularly the importance of the interests or values at stake, the extent of the contribution to the achievement of the measure's objective, and its trade restrictiveness. If this analysis yields a preliminary conclusion that the measure is necessary, this result must be confirmed by comparing the measure with possible

\footnotetext{
${ }^{84}$ For support for the view that the weighing and balancing test suggests a strong proportionality requirement, see Jan Neumann and Elisabeth Türk, 'Necessity Revisited: Proportionality in World Trade Organization Law after Korea--Beef, EC-Asbestos and EC-Sardines', Journal of World Trade 37 (1), 2003, 199-233, 199-200; Catherine Button, The Power to Protect. Trade, Health and Uncertainty in the WTO (Hart Publishing, Oxford and Portland, Oregon), 2004, 36-37. Contra see Peter Van den Bossche, 'Looking for Proportionality in WTO Law', Legal Issues of Economic Integration 35 (3), 2008, 283-294, 289.

${ }^{85}$ On the general agreement among authors that the early case law of GATT panels on the 'necessary' requirement did not include a proportionality test, see Peter Van den Bossche, 'Looking for Proportionality in WTO Law', Legal Issues of Economic Integration 35 (3), 2008, 283-294, 288, footnote 218.

${ }^{86}$ This proportionality aspect can be found in the following statements of the Appellate Body in Korea - Various Measures on Beef: 'The more vital or important those common interests or values are, the easier it would be to accept as "necessary" a measure designed as an enforcement instrument'; '[ $\mathrm{t}]$ he greater the contribution [of the measure to the realization of the end pursued], the more easily a measure might be considered to be "necessary"; and '[a] measure with a relatively slight impact upon imported products might more easily be considered as "necessary" than a measure with intense or broader restrictive effects.' Appellate Body Report, Korea-Various Measures on Beef, paras 162-163. Catherine Button criticises the importation of a strong proportionality test into the 'necessary' criterion, arguing that it alters the balance of authority between Members and the WTO, 'so that Members are no longer free to take severe steps to combat what panels or complaining Members might not regard as significant risks.' Catherine Button, The Power to Protect. Trade, Health and Uncertainty in the WTO (Hart Publishing, Oxford and Portland, Oregon), 2004, 36.

${ }^{87}$ For this distinction between the concepts of strong and weak proportionality, see Joanne Scott, The WTO Agreement on Sanitary and Phytosanitary Measures: A Commentary, Oxford Commentaries on the GATT/ WTO Agreements (Oxford University Press, Oxford), 2007, 157 footnote 168.

${ }^{88}$ Contra see Peter Van den Bossche, 'Looking for Proportionality in WTO Law', Legal Issues of Economic Integration 35 (3), 2008, 283-294, 289. Peter Van den Bossche distinguishes between three elements of the proportionality principle as applied in the EC legal order and in WTO law, namely (1) an assessment of the suitability of the measure to achieve the ends pursued; (2) the determination of the availability of a less-trade restrictive alternative that is at least equally effective in achieving the ends pursued; and (3) an assessment of whether the effects of the measure are disproportionate or excessive in relation to the interests involved. The third element he terms 'proportionality strictu sensu'. Ibid., 285. Van den Bossche argues that since the weighing and balancing of factors conducted in Korea - Various Measures on Beef was explicitly comprehended in the determination of the availability of a less WTO-inconsistent alternative, it is part of the second element of the proportionality test rather than an indication of an assessment of proportionality strictu sensu. Ibid., 289.
} 
alternatives, which may be less trade restrictive while providing an equivalent contribution to the achievement of the objective. This comparison should be carried out in the light of the importance of the interests or values at stake. It is through this process that a panel determines whether a measure is necessary. ${ }^{89}$

This 'weighing and balancing' of the three relevant factors seems to reflect the proportionality test established in the previous case law. However, the Appellate Body went further to note that:

Another key element of the analysis of the necessity of a measure under Article $\mathrm{XX}(\mathrm{b})$ is the contribution it brings to the achievement of its objective. A contribution exists when there is a genuine relationship of ends and means between the objective pursued and the measure at issue. To be characterized as necessary, a measure does not have to be indispensable. However, its contribution to the achievement of the objective must be material, not merely marginal or insignificant, especially if the measure at issue is as trade restrictive as an import ban. ${ }^{90}$

By setting a threshold for the degree of contribution of a measure to the achievement of its objective, this finding appears to go even further in allowing a 'strong proportionality' test into the necessity requirement of Article XX(b) of the GATT 1994. ${ }^{91}$

Despite the Appellate Body's assertion of the 'undisputed' right of WTO Members to determine the level of protection that they consider appropriate in a given context, ${ }^{92}$ which has also been called 'the fundamental principle' by the Appellate Body, the proportionality test seems to undermine this right. ${ }^{93}$ The level of protection chosen by a Member is not sacrosanct in the weighing and balancing interpretation of the 'necessary' requirement. Instead, not only is the measure at issue scrutinised with respect to its trade-restrictiveness and suitability to meet its objective, but also the importance or value of the objective pursued is assessed and weighed against the effect of the measure chosen to achieve it. In so doing, the possibility is created that a panel might find that the trade-restrictive effect of the chosen measure is excessive in relation to the importance of the objective it pursues. However, the importance which a Member attaches to a particular health objective

\footnotetext{
${ }^{89}$ Appellate Body Report, Brazil - Retreaded Tyres, para. 178.

${ }^{90}$ Appellate Body Report, Brazil-Retreaded Tyres, para. 210.

${ }^{91}$ Van den Bossche states: 'In these last sentences, the Appellate Body seems to suggest that the determination of 'necessity' under Article XX(b) of the GATT 1994 ...goes beyond determining whether there is a less trade restrictive measure which is reasonably available. If the contribution of the measure at issue to the policy objective is marginal or insignificant, this measure cannot, according to the Appellate Body in Brazil-Retreaded Tyres, be justified under Article XX(b) even when there would be no less trade restrictive alternative measure to achieve the policy objective the Member concerned pursues and the level of protection it has set. Further, when the Appellate Body stated that 'the contribution of the measure has to be weighed against its trade restrictiveness, taking into account the importance of the interests or the values underlying the objective pursued by it', it seems to introduce a proportionality strictu sensu assessment.' Peter Van den Bossche, 'Looking for Proportionality in WTO Law’, Legal Issues of Economic Integration 35 (3), 2008, 283-294, 294. However, Van den Bossche doubts whether the Appellate Body intended to introduce such a strict proportionality test into the necessity test. Ibid.

92 Appellate Body Report, EC-Asbestos, para. 168.

${ }^{93}$ Appellate Body Report, Brazil - Retreaded Tyres, para. 210.
} 
is reflected in the level of protection it chooses as appropriate and the measure it imposes to achieve this level. Subjecting the importance of the health objective to review thus undercuts the policy space of a Member in this regard.

Once a measure has been shown to meet the requirements of Article XX(b), it must be determined whether it complies with the disciplines of the chapeau of Article XX. The chapeau provides that measures, provisionally justified under one of the paragraphs of Article XX, must not be applied in a manner that would constitute arbitrary or unjustifiable discrimination or a disguised restriction on trade. The chapeau of Article XX was seen by the drafters of the GATT 1947 as a means to see to it that the exceptions of Article XX are not abused for protectionist purposes. ${ }^{94}$ This role of the chapeau has been confirmed in GATT and WTO case law. ${ }^{95}$ As held by the Appellate Body in US - Shrimp, the task of interpreting and applying the chapeau is 'the delicate one of locating and marking out a line of equilibrium between the right of a Member to invoke an exception under Article XX and the rights of other Members under varying substantive provisions ... of the GATT 1994.'96

As noted by the GATT Panel in US - Spring Assemblies, it is the application of a measure and not the measure itself that must be examined under the chapeau. ${ }^{97}$ To determine whether the application of a measure amounts to arbitrary or unjustifiable discrimination, the Appellate Body has had regard to various considerations, such as the fact that the discrimination resulting from the measure was not inadvertent but could have been foreseen; ${ }^{98}$ the failure of the measure to take account of the different conditions prevailing in the exporting countries, by imposing the rigid requirement that exporting Members adopt the same regulatory programme as the importing Member; ${ }^{99}$ and the failure of the importing Member to adequately explore a multilateral or bilateral solution to the problem before applying a unilateral measure. ${ }^{100}$ In Brazil - Retreaded Tyres, the Appellate Body referred to its previous case law and noted that:

\footnotetext{
${ }^{94}$ In the discussions regarding the relationship between Article XX(b) and the chapeau in the Geneva Session of the Preparatory Committee (the committee established to elaborate a draft Charter for an International Trade Organisation, which work eventually resulted in the GATT 1947), it was noted that the protection for exporting countries against abuse of the exception 'is afforded one by the headnote to the Article.' After agreeing to delete a clarification in Article XX(b) specifying the requirement that domestic safeguards under similar conditions exist in the importing country, it was stated: 'In view of the misuses which have been made in the past of sanitary regulations, and of damages caused in this way to exporting countries, it would be regrettable if we were to renounce any clarification of the provisions of sub-paragraph (b). However, the discussion which was raised here shows clearly that this Committee is against any possibility of this provision being used as a measure of protection in disguise.' EPCT/A/PV/30, 13, cited in WTO Secretariat, Analytical Index: Guide to GATT Law and Practice, 6th ed., vol. 1 (World Trade Organization, Geneva), 1995, 565.

${ }_{95}$ GATT Panel Report, US - Spring Assemblies, para. 56; GATT Panel Report, US - Section 337, para. 5.9; Appellate Body Report, US - Gasoline, 20-21; and Appellate Body Report, US - Shrimp, para. 156.

${ }^{96}$ Appellate Body Report, US - Shrimp, para. 159.

97 This was confirmed in Appellate Body Report, US - Gasoline, 20.

98 Appellate Body Report, US-Gasoline, 27.

${ }_{99}$ Appellate Body Report, US - Shrimp, para. 177. In US - Shrimp (Article 21.5 - Malaysia), the Appellate Body noted that there is an important difference between conditioning market access on the adoption of essentially the same regulatory programme, and on the adoption of a programme comparable in effectiveness. The latter gives the exporting Member sufficient latitude to adopt a regulatory programme suitable to its domestic conditions, and thus avoids 'arbitrary and unjustifiable discrimination'. Appellate Body Report, US - Shrimp (Article 21.5 - Malaysia), para. 144.

${ }^{100}$ Appellate Body Report, US - Shrimp, paras 116 and 172; and Appellate Body Report, US - Shrimp (Article
} 
[a]nalysing whether discrimination is arbitrary or unjustifiable usually involves an analysis that relates primarily to the cause or the rationale of the discrimination. ${ }^{101}$

It explained that even discrimination that results from a rational decision may be 'arbitrary or unjustifiable' if it is explained by a rationale that bears no relation to the objective of a measure provisionally justified under one of the subparagraphs of Article XX, or goes against that objective.

The determination of whether a measure is applied so as to constitute a disguised restriction on trade is made on the basis of the same type of considerations as are taken into account to determine whether there is arbitrary or unjustifiable discrimination. ${ }^{102}$ While the GATT Panel in US - Tuna (Canada) found that the US import ban at issue could not be considered as a disguised restriction on trade as it had been 'taken as a trade measure and publicly announced as such', ${ }^{103}$ the Appellate Body held in US - Gasoline that 'concealed or unannounced restriction' does not exhaust the meaning of 'disguised restriction'. ${ }^{104}$ Rather, 'disguised restriction' encompasses measures amounting to arbitrary or unjustifiable discrimination that are taken 'under the guise of a measure formally within the terms of an exception listed in Article XX.' ${ }^{105}$ Similarly, the Panel in EC-Asbestos found that a measure which complies with the requirements of Article XX(b) will be a disguised trade restriction 'if such compliance is in fact only a disguise to conceal the pursuit of traderestrictive objectives.' ${ }^{106}$ As it is difficult to determine the objective of a measure, it has been held that the protective application of a measure 'can most often be discerned from its design, architecture and revealing structure.' ${ }^{107}$

This brief examination of the provisions of the GATT of particular relevance to SPS measures, and the clarification that has been provided to their rather rudimentary terms in the GATT and WTO case law, serves two purposes in establishing the background to the SPS Agreement. First, it indicates the ambit of the GATT provisions and their limitations in disciplining SPS regulation by striking an appropriate balance between trade and health objectives. This elucidates the reasons why new disciplines were considered necessary. Second, it serves to illustrate the background to some of the specific provisions of the SPS Agreement, which in many cases reflect the developments in the case law giving content to the relevant GATT provisions.

21.5 - Malaysia), paras 115-134.

${ }^{101}$ Appellate Body Report, Brazil-Retreaded Tyres, para. 225.

${ }^{102}$ Appellate Body Report, US - Gasoline, 23.

${ }^{103}$ GATT Panel Report, US - Tuna (Canada), para. 4.8.

${ }^{104}$ Appellate Body Report, US - Gasoline, 23.

105 Appellate Body Report, US - Gasoline, 23.

106 Panel Report, EC - Asbestos, para, 8.236. This approach was also taken in Panel Report, US - Shrimp (Article 21.5 - Malaysia), paras 5.138-5.144.

107 Panel Report, EC-Asbestos, para. 8.236.The Panel here referred to the finding of the Appellate Body in Japan-Alcoholic Beverages II in respect of Article III:4 of the GATT 1994, and stated that it saw no reason why this approach should not be applicable in other circumstances where it is necessary to establish whether a measure is being applied for protective purposes. 


\subsubsection{The Tokyo Round Standards Code}

The early negotiating rounds under the auspices of the GATT 1947 focused on tariff negotiations, and were quite successful in reducing tariff levels. As a result, the relative importance of standards and regulations as trade barriers increased. At the same time, growing consumer awareness of health and environmental issues was leading to a proliferation of regulations and standards in these areas, particularly in developed countries. ${ }^{108}$ A new awareness of the importance of non-tariff barriers to trade arose. After the Kennedy Round, a notification exercise was carried out which confirmed the increasing multiplicity of national standards. ${ }^{109}$ Basic data on the incidence of SPS regulation was collected and updated through counter-notifications by Contracting Parties that considered themselves to be adversely affected. ${ }^{110}$ This data highlighted the importance of SPS measures as trade barriers.

Working Group 4 of the Agriculture Committee, in the run-up to the Tokyo Round, began work on examining possible approaches to non-tariff barriers to agricultural trade that take the form of SPS regulations. ${ }^{111}$ This work was taken up by the Agriculture Committee

${ }^{108}$ A few instances in which SPS issues arose between GATT Contracting Parties are mentioned in the background note drafted by the GATT Secretariat in the context of the Uruguay Round negotiations on SPS issues. These are a 1959 consultation with Australia on its agricultural policies, including its strict SPS regime (GATT Secretariat, Expansion of Trade-Agricultural Policy-Report of Committee II on the Consultation with Australia, L/1055, circulated on 7 October 1959, para.40); Uruguay's recourse to Article XXIII:2 of the GATT against 15 Contracting Parties with regard to their sanitary measures on meat, which ended without a panel ruling (Twentieth Session of the CONTRACTING PARTIES, Report of the Panel on Uruguayan Recourse to Article XXIII, L/1923 and Corr.1 and 2, circulated on 15 November 1962, Annex I); a 1962 discussion in the Group on Meat on the discriminatory effects of phytosanitary restrictions (CG/3); a 1969 French notification arguing that its restrictions on animal semen and live plants were in conformity with Article XX(b) of the GATT (GATT Secretariat, Notifications of Import Restrictions Applied Inconsistently with the Provisions of GATT and Not Covered by Waivers - Addendum - France, L/3212/Add.12, circulated on 22 August 1969, 2); and a 1980 recourse to Article XXIII:2 of the GATT by the US regarding the UK's implementation of EEC Directives on poultry imports, claiming, inter alia, a violation of Article XX(b) of the GATT (GATT Secretariat, EEC - Imports of Poultry from the United States - Recourse to Article XXIII:2 by the United States, L/5033, circulated on 29 September 1980. This complaint was withdrawn without a panel being established). See further Negotiating Group on Agriculture, Sanitary and Phytosanitary Regulations Affecting Trade in Agriculture. Background Note by the Secretariat, MTN.GNG/NG5/W/41, circulated on 2 February 1988, paras 3-4, available at: http://www.wto.org/gatt_docs/English/SULPDF/92030210.pdf, visited on 11 May 2008.

${ }^{109}$ Committee on Trade in Industrial Products, Examination of Part 3 of the Inventory of Non-Tariff Barriers (Spec(69)51) - Standards Involving Imports and Domestic Goods - Note by the Secretariat, COM.IND/W/13, circulated on 19 October 1969; Committee on Trade in Industrial Products, Working Group 5, Examination of the Inventory of Non-Tariff Barriers - Supplemental and Replacement Cards, COM.IND/W/20, circulated on 9 January, 20 March and 9 November 1970; Committee on Trade in Industrial Products, Report to the Council, L/3496 circulated on 10 February 1971; Committee on Trade in Industrial Products, Report to the Council, L/3756, circulated on 24 October 1972. These are referred to in Gabrielle Marceau and Joel Trachtman, 'GATT, TBT and SPS: A Map of WTO Law of Domestic Regulation of Goods', in The WTO Dispute Settlement System 1995-2003, F. Ortino and E-U Petersmann (eds.), vol. 18 (Kluwer Law International, Deventer), 2004, 275-340, 278.

${ }^{110}$ A compilation of such counter-notifications was maintained by the GATT Secretariat under GATT document series COM.AG/W/68/Add.4/*. See Negotiating Group on Agriculture, Sanitary and Phytosanitary Regulations Affecting Trade in Agriculture. Background Note by the Secretariat, MTN.GNG/NG5/W/41, circulated on 2 February 1988, para. 7, available at: http://www.wto.org/gatt_docs/English/SULPDF/92030210. pdf, visited on 11 May 2008.

111 Agriculture Committee, Report to the Council, L/3472, circulated on 18 December 1970, Annex IV. This 
itself, and by the Working Group on Techniques and Modalities. ${ }^{112}$ The proposed approaches elaborated through this work focused on the establishment of a code of conduct for good practices in SPS regulation; the creation of procedures for notification of SPS measures and consultations thereon; arrangements for negotiations on specific SPS regulations; and the elaboration of the disciplines of Article XX(b) of the GATT. ${ }^{113}$ No consensus was achieved on these issues, but there was general agreement that the proposed approaches were not necessarily mutually exclusive. ${ }^{114}$

In view of the general agreement on the need to address this issue, in the Tokyo Round of trade negotiations there was a shift in focus towards tackling non-tariff barriers to trade, including SPS regulations. ${ }^{115}$ Four Codes on this form of trade barrier were adopted. One of these was the Agreement on Technical Barriers to Trade, ${ }^{116}$ commonly known as the 'Standards Code'. The negotiating group which had been tasked by the Trade Negotiating Committee with continuing work on SPS regulation in the Tokyo Round, focused its work on examining the applicability of the then-draft Standards Code to SPS measures. ${ }^{117}$ The result of these negotiations was that the Standards Code was made applicable to both industrial and agricultural products. ${ }^{118}$

As was the case with the other Tokyo Round Codes, the Standards Code was not binding on all GATT Contracting Parties but only on those Contracting Parties that were Parties to it. ${ }^{119}$ Originally 23 GATT Contracting Parties were Parties to the Standards Code. ${ }^{120}$

document is referred to in Negotiating Group on Agriculture, Sanitary and Phytosanitary Regulations Affecting Trade in Agriculture. Background Note by the Secretariat, MTN.GNG/NG5/W/41, circulated on 2 February 1988, para. 8, available at: http://www.wto.org/gatt_docs/English/SULPDF/92030210.pdf, visited on 11 May 2008.

112 Agriculture Committee, Report to the Council, L/3472, circulated on 18 December 1970, paras. 45 - 52. See also Agriculture Committee, Working Group on Techniques and Modalities. Report to the Agriculture Committee, COM.AG/W/88, circulated on 4 August 1972, paras 136 - 147. These documents are referred to in Negotiating Group on Agriculture, Sanitary and Phytosanitary Regulations Affecting Trade in Agriculture. Background Note by the Secretariat, MTN.GNG/NG5/W/41, circulated on 2 February 1988, para. 8, available at: http://www.wto.org/gatt_docs/English/SULPDF/92030210.pdf, visited on 11 May 2008.

${ }^{113}$ Negotiating Group on Agriculture, Sanitary and Phytosanitary Regulations Affecting Trade in Agriculture. Background Note by the Secretariat, MTN.GNG/NG5/W/41, circulated on 2 February 1988, para. 9, available at: http://www.wto.org/gatt_docs/English/SULPDF/92030210.pdf, visited on 11 May 2008.

114 Ibid., para. 10.

115 These negotiations lasted from 1973 to 1979.

${ }^{116}$ Agreement on Technical Barriers to Trade, 26S/154, 1186 UNTS 276, LT/TR/A/5, 12 April 1979.

117 This group, later called 'Group Agriculture' first examined various alternatives for negotiating rules on SPS measures, including strengthening Article XX(b) of the GATT; drawing up a Code of Conduct to reduce the adverse trade effects of SPS measures; examining the possibility of arbitral procedures; and examining the possible applicability of the draft Standards Code to SPS measures. In the later stages of the Round, Group Agriculture focused its work on the last option, as part of the more general issue of the applicability of the Standards Code to agriculture. The outcome of this work is that the Standards Code was made applicable to both industrial and agricultural products. Negotiating Group on Agriculture, Sanitary and Phytosanitary Regulations Affecting Trade in Agriculture. Background Note by the Secretariat, MTN.GNG/ NG5/W/41, circulated on 2 February 1988, paras 13-16, available at: http:/www.wto.org/gatt_docs/English/ SULPDF/92030210.pdf, visited on 11 May 2008.

118 Article 1.3 of the Standards Code.

119 The relationship between the Tokyo Round Codes and the GATT 1947 was discussed above, Part I, Section 1.5 , note 176 .

${ }^{120}$ By February 1982, the number of signatories to the Standards Code had increased to 36 and by December 1995 to 44. Of the signatories by 1982, 15 were developing-country Contracting Parties and of those in 1995, 
The Standards Code did not focus specifically on measures for the protection of human, plant or animal life or health, but was aimed broadly at all technical regulations, standards and conformity assessment procedures, as is currently the Uruguay Round Agreement on Technical Barriers to Trade (TBT Agreement). The Standards Code was primarily intended to discipline industrial regulations and standards, such as those relating to quality and performance levels of products. However, as many SPS measures take the form of technical regulations or standards on agricultural or industrial products (e.g. processed food), they fell within the scope of application of the Standards Code.

The Standards Code reiterated the GATT obligation of national treatment of like imported products. ${ }^{121}$ However, unlike the GATT, it applied also to non-discriminatory measures, laying down disciplines for the elaboration and application of standards and regulations, also where they applied indistinctly to domestic and imported products. Under the Standards Code, signatories agreed to adopt only standards and regulations that were necessary to achieve a legitimate aim, such as the protection of public health, and not to apply these measures in a manner that would constitute a disguised restriction on trade or create unnecessary obstacles to trade. ${ }^{122}$ More importantly, the Code required signatories to apply relevant international standards where they existed, unless these were deemed inappropriate to meet the goal aimed at, ${ }^{123}$ thus introducing the first reference to harmonised standards in the international trade regime. In addition (and perhaps the main achievement of the Standards Code) it introduced transparency requirements for the adoption of regulations and standards that were not 'substantially the same' as international standards. ${ }^{124}$

The Standards Code did not directly apply to PPMs that were not reflected in the product itself. The definition in the Standards Code of a measure that would fall under its disciplines was: 'A specification contained in a document which lays down the characteristics of a product such as levels of quality, performance, safety or dimensions'. ${ }^{125}$ This

24 were developing-country Contracting Parties. WTO Secretariat, World Trade Report 2007: Six Decades of Multilateral Trade Cooperation: What Have We Learnt? (World Trade Organization, Geneva), 2007, 235, available at: http://www.wto.org/english/res_e/booksp_e/anrep_e/wtr07-2d_e.pdf, visited on 7 June 2008.

${ }^{121}$ Article 2.1 of the Standards Code provided, in relevant part: 'products imported from the territory of any Party shall be accorded treatment no less favourable than that accorded to like products of national origin and to like products originating in any other country in relation to such technical regulations or standards.'

${ }^{122}$ This is reflected in the $6^{\text {th }}$ paragraph of the Preamble to the Standards Code. Article 2.1 provides in relevant part: 'Parties shall ensure that technical regulations and standards are not prepared, adopted or applied with a view to creating obstacles to international trade. .... They shall likewise ensure that neither technical regulations nor standards themselves nor their application have the effect of creating unnecessary obstacles to international trade.'

${ }^{123}$ Article 2.2 of the Standards Code provided: 'Where technical regulations or standards are required and relevant international standards exist or their completion is imminent, Parties shall use them, or the relevant parts of them, as a basis for the technical regulations or standards except where, as duly explained upon request, such international standards or relevant parts are inappropriate for the Parties concerned, for inter alia such reasons as national security requirements; the prevention of deceptive practices; protection for human health or safety, animal or plant life or health, or the environment; fundamental climatic or other geographical factors; fundamental technological problems.'

${ }^{124}$ Articles 2.5 to 2.8 of the Standards Code contained detailed publication and notification obligations, including the requirement to notify draft measures in advance, in order to allow interested parties to become acquainted with them and to provide comments.

${ }_{125}$ Annex 1, paragraph 1 of the Standards Code. This paragraph contains the definition of a technical specification which is the basis for both the definitions of technical regulations and technical standards in paragraphs 2 and 3 of Annex 1. 
implicitly excludes process and production requirements to the extent that they are not reflected in the product characteristics themselves. However, under Article 14.25 of the Standards Code, a signatory could challenge a PPM-related measure under the Standards Code where it considered that the requirements had been drafted in the form of regulations on PPMs in order to avoid the Standards Code's disciplines.

The Standards Code included a dispute-settlement mechanism, which a Party could resort to if it believed that 'any benefit accruing to it, directly or indirectly, under [the Standards Code] [was] being nullified or impaired, or that the attainment of any objective of this Agreement [was] being impeded, by another Party or Parties, and that its trade interests [were] significantly affected. ${ }^{126}$ This process commenced with consultations between the parties to the dispute. If no solution could be reached through consultations, the Committee on Technical Barriers to Trade could be requested by either party to meet to facilitate the achievement of a mutually satisfactory solution. ${ }^{127}$ If no solution was achieved within three months, any party that considered that the issues under dispute involved questions of a technical nature could request the Committee on Technical Barriers to Trade to establish a technical expert group to examine the matter. ${ }^{128}$ This established a possibility for review of technical regulations, standards or conformity assessment procedures that could have 'the effect of creating unnecessary obstacles to international trade'. Thus, a Party could challenge the regulations or standards of another signatory on the grounds that they violated a provision of the Standards Code. Despite the fact that no formal disputesettlement proceeding was ever conducted under the Code, it did assist in the resolution of a few trade disputes involving industrial standards. ${ }^{129}$

\subsubsection{Insufficiency of the GATT 1947 and the Standards Code}

The rules of the GATT 1947 were inadequate in several respects to address the problem of the increasing use of SPS measures in ways that restricted trade in agricultural and food products. At the same time, these rules insufficiently recognised the right of governments to regulate against SPS risks. This made the GATT 1947 an inappropriate tool to achieve an acceptable balance between the often competing objectives of the liberalisation of food and agricultural trade on the one hand and the protection of human, animal or plant life or health on the other.

These shortcomings are due to the following aspects of the applicable GATT rules. Firstly, as set out above, GATT disciplines on national regulations focus on prohibiting discrimination between domestic and 'like' imported products. Thus, the rules do not catch non-discriminatory SPS measures that have trade-restrictive effects. Typically, however, most SPS regulations apply to all products containing a particular SPS risk, both imports and domestic products. For this reason, SPS regulations often escape the

\footnotetext{
${ }^{126}$ Article 14.2 of the Standards Code.

${ }^{127}$ Article 14.4 of the Standards Code.

128 Article 14.9 of the Standards Code.

${ }^{129}$ David Vogel discusses a few cases where agreement was reached in bilateral consultations following a challenge on the basis of the Standards Code. David Vogel, 'Food Safety and International Trade', in Trading Up: Consumer and Environmental Regulation in a Global Economy (Harvard University Press, Cambridge/ London), 1995, 150-195, 152-153.
} 
GATT non-discrimination disciplines. Since the Appellate Body's decision in Dominican Republic - Import and Sale of Cigarettes, another loophole in the Article III:4 discipline exists. As held in that case, discriminatory regulations will not fall foul of Article III:4 where the detrimental effect of the regulation on the competitive opportunities of the imported product is explained by factors other than the foreign origin of the product. ${ }^{130}$ As a result, measures whose detrimental effect is due to the SPS risk, or even perceived SPS risk, contained in the imported product, will escape Article III:4. SPS regulations that amount to prohibitions or restrictions on importation (i.e. that affect the competitive opportunities of imports to enter the market) would be caught by the prohibition on quantitative restrictions in Article XI:1 of the GATT. However, most SPS measures take the form of internal regulations that apply both to domestic and to imported products, even if they are sometimes enforced at the border. As a result, they would often fall outside the scope of Article XI.

Secondly, the exception provided in Article XX(b) of the GATT from the usual GATT rules for measures necessary to protect human, animal or plant life or health does not contain detailed rules disciplining the adoption or use of such measures. While panels and the Appellate Body have gradually developed a complex set of disciplines through their interpretation of the 'necessary' requirement of Article XX(b) and their clarification of the meaning of the chapeau of Article XX, as set out above, these provisions were not particularly crafted with SPS regulation in mind and they therefore fail to establish adequate controls for the avoidance of protectionism. For example, no risk assessment is required as a basis for the relevant measure, ${ }^{131}$ nor are Members required to avoid arbitrary distinctions in the levels of protection they choose in comparable situations. In addition, particular procedural disciplines, such as the requirement that Members publish their draft measures in advance to allow for comments or that they allow an adaptation period for exporting industries to adjust to the new requirements, are absent. ${ }^{132}$ As such, the exception of Article XX(b) is rather a blunt tool when it comes to disciplining measures as complex as those used in SPS regulation.

Lastly, but by no means least importantly, there is no recognition in the GATT of the right of governments to enact regulations for the protection of human, animal and plant life or health in their territories. Instead, health measures that either amount to restrictions or prohibitions on importation under Article XI or discriminate against imports under Article III:4 are prohibited in principle, but are seen as potentially justified under a 'limited and conditional' 133 exception to the usual GATT disciplines. Thus the Member

${ }^{130}$ Appellate Body Report, Dominican Republic - Import and Sale of Cigarettes, para. 96, followed in Panel Reports, EC-Approval and Marketing of Biotech Products, para. 7.2514.

${ }^{131}$ It should be recalled, as discussed above, that while the Appellate Body in EC-Asbestos, has read an obligation to scientifically establish a health risk into Article XX(b) of the GATT 1994, it stopped short of requiring a 'risk assessment' within the meaning of the term in the SPS Agreement.

${ }^{132}$ It should be noted that notification obligations of relevance to SPS measures are present in the GATT. Article $\mathrm{X}$ of the GATT requires prompt publication of, inter alia, laws, regulations and administrative rulings pertaining to restrictions or prohibitions on imports or exports or affecting their sale, distribution, processing or other use. However, this obligation does not extend to prior notification of draft measures in order to allow other Members to provide comments, nor does it require an adaptation period to be granted, where possible, to allow adjustment to the new requirements.

${ }^{133}$ GATT Panel Report, US - Section 337, para 5.9. Although this case dealt with Article XX(d), the principle that exceptions under Article XX of the GATT are limited to those listed in paragraphs (a) to (j) of this Article 
imposing the measure bears the burden of proving that it falls within the scope of the exception provided in Article XX(b) of the GATT 1994 and meets the requirements of the chapeau of this Article. This rule-exception relationship and its concomitant allocation of the burden of proof on the respondent Member have important implications for the regulatory autonomy of Members. It is doubtful whether this bias towards trade liberalisation is appropriate in the case of measures aiming at protection against SPS risks, particularly when those risks include risks to human life or health.

The Standards Code also had certain inherent shortcomings, which limited its effectiveness in disciplining the use of regulations for the protection of human, animal and plant life or health as barriers to trade. First, it was only binding on its parties, which meant that most GATT Contracting Parties did not have to comply with its rules. ${ }^{134}$ Second, as it did not directly apply to measures addressing PPMs that were not reflected in the product itself, regulations on how a specific product was produced fell outside its scope and were dealt with in terms of the usual GATT disciplines. Third, its disciplines were not regarded as effective in promoting harmonisation around international standards, as they did not specify in what cases an international standard could be seen as 'inappropriate' for a party, thereby leaving considerable room for divergent measures. Fourth, the dispute settlement mechanism created in the Standards Code, like that in the GATT 1947, required consensus among its parties for the establishment of a panel or technical expert group to review a complaint. It was thus possible for a party whose regulation was being challenged to block the establishment of such a panel or review group. Further, even if review of the measure was not blocked, the findings of the relevant panel or review group had to be adopted by consensus of the parties to the Standards Code in the Committee on Technical Barriers to Trade in order to become binding. This created a second possibility for a signatory to block the dispute settlement process. Finally, no enforcement mechanism existed to ensure compliance with adopted dispute settlement reports, and thus compliance depended on the good faith of the party involved and the shaming effect of the ruling.

The recognition of the need to improve the disciplines applicable to SPS measures is evinced by the recommendation of the Contracting Parties in the Committee on Trade in Agriculture, in 1984, that:

Sanitary and phytosanitary regulations ...., including related administrative requirements, are brought within the ambit of improved procedures aimed at minimizing the adverse effects that those measures have on trade in agriculture. ${ }^{135}$

and are subject to the conditions contained in those paragraphs and the chapeau of Article XX, applies to all the Article XX exceptions.

134 As noted above, the Standards Code originally had only 23 parties, increasing to 44 by December 1994. All developed countries except Australia, Iceland and Israel were parties. It is interesting to note that none of the developing-country Members selected as illustrations in this book (namely Mauritius, Jamaica and Bangladesh) were parties to the Standards Code.

135 Fortieth Session of the GATT Contracting Parties, Trade in Agriculture. Action Taken on 30 November 1984, L/5753, circulated on 20 December 1984. This document contains the set of recommendations relating to trade in agriculture adopted at this Session. 
The weakness of the trade disciplines that existed prior to the SPS Agreement is illustrated by the fact that by 1986, the year the Uruguay Round negotiations were launched, almost 90 percent of food imports into the US were affected by non-tariff barriers to trade. In 1966, this had been only 56 percent. ${ }^{136}$ This sharp escalation in the use of non-tariff barriers in this sector resulted in an awareness of the urgent need for new rules.

The inability of the existing rules to effectively address SPS barriers to trade was further highlighted and brought to the forefront of attention of Uruguay Round negotiators by the history of the well-known dispute regarding the EC's ban on hormone-treated beef. ${ }^{137}$ This dispute arose in the 1980s between the US and the EC. In response to public outcry following premature sexual development in Italian schoolchildren, in 1977, ${ }^{138}$ and Italian babies, in 1980, which had respectively been fed school lunches and baby food containing veal and milk from hormone-treated cows, the EC had imposed a ban on the use of two hormonal substances in cattle. ${ }^{139}$ A scientific investigation was initiated into the safety of five additional growth hormones (three natural hormones and two synthetic hormones), which found that the hormones were not harmful to human health, when administered in accordance with good veterinary practice and within maximum dose limits. ${ }^{140}$ Nevertheless, in 1985, due to strong political pressure from consumers, ${ }^{141}$

136 These figures are reported in David Vogel, Trading up, Consumer and Environmental Regulation in the Global Economy (Harvard University Press, Cambridge/London), 1995, 150.

${ }^{137}$ A detailed account of the origins and development of the hormones dispute is provided in David Vogel, 'Food Safety and International Trade', in Trading Up: Consumer and Environmental Regulation in a Global Economy (Harvard University Press, Cambridge/London), 1995, 150-195, 154-171.This is used as the basis for the summary provided here.

${ }^{138}$ Sara Pardo Quintillán, 'Free Trade, Public Health Protection and Consumer Information in the European and WTO Context: Hormone Treated Beef and Genetically Modified Organisms', Journal of World Trade 33 (6), 1999, 147-197, footnote 43.

139 The original ban in 1981 covered thyrostatics and stilbenes, including dimethyl stilbenes (DES) which were the hormones used in dairy production that had been found in Italian baby food. Although the link between this hormone and the premature development in Italian babies was never conclusively shown, as dimethyl stilbene is considered a carcinogen, its use had been banned in most dairy producing countries including the US. David Vogel, 'Food Safety and International Trade', in Trading Up: Consumer and Environmental Regulation in a Global Economy (Harvard University Press, Cambridge/London), 1995, 150-195, 154.

${ }^{140}$ The investigation, carried out by the Scientific Working Group on Anabolic Agents in Animal Production, established by the European Commission, examined the safety of three natural hormones and two synthetic hormones. For the natural hormones, it concluded that the natural hormones presented no danger to human health when administered in conditions of good animal husbandry and maximum dose limits. There was insufficient scientific evidence for a conclusion to be drawn with regard to the safety of the two artificial hormones. However, a subsequent enquiry in 1984 and 1985 established that also the two artificial hormones were safe. The final report of the Working Group was never issued, however, as European Commission put a stop to its work following a resolution by the European Parliament rejecting a proposal to authorise the three natural hormones, and endorsing a ban on the two synthetic hormones. Dale E. McNiel, 'The First Case under the WTO's Sanitary and Phytosanitary Agreement: The European Union's Hormone Ban', Virginia Journal of International Law 39, 1998, 89-134, 104. See also David Vogel, 'Food Safety and International Trade', in Trading Up: Consumer and Environmental Regulation in a Global Economy (Harvard University Press, Cambridge/London), 1995, 150-195, 155.

141 Vogel reports that a 'vigorous campaign' was waged by consumer- and environmental-interest groups in the EC in the first half of the 1980s, the focal point of which was the European Parliament. As a result, the European Parliament opposed a Commission proposal to allow, under strict conditions, the use of the three natural hormones. It also opposed a compromise that would have allowed Member States to keep their national regulations in place for some of the hormones at issue. David Vogel, 'Food Safety and International Trade', in Trading Up: Consumer and Environmental Regulation in a Global Economy (Harvard University Press, Cambridge/London), 1995, 150-195, 156-157. 
as well as the need to prevent the distortions in intra-Community trade caused by divergent Member State regulations in this area, ${ }^{142}$ the Council of Ministers of the EC voted to adopt a Directive extending its ban to the five additional hormones when used for growthpromotion purposes in livestock farming, and on imports of hormone-treated beef. ${ }^{143} \mathrm{An}$ exception was made for the use of the three natural hormones for therapeutic or zootechnical purposes. The ban was originally planned to come into force on 1 January 1987, but was delayed by two years by the granting of transition periods. ${ }^{144}$

In the US, all five of the hormones banned by the EC were permitted to be used in beef production, ${ }^{145}$ and were crucial to the US beef industry, enabling beef cattle raised in feedlots to reach their ideal weight faster and produce leaner beef. ${ }^{146}$ The US Food and Drug Administration had found that the natural hormones left no residue differentiable from naturally-occurring hormones in cows. They had set rather conservative maximum residue levels for both the natural and the synthetic hormones. ${ }^{147}$ In the mid-1980s, the US

${ }^{142}$ In the absence of harmonised EC regulation on growth hormones, Member States could decide for themselves how to regulate their use. Vogel notes that half of the Member States banned all five hormones at issue, while the other half authorized at least one of them. The border controls necessitated by this difference in regulatory approach undermined the creation of a single European Market. Ibid., 155-156. See also Grace Skogstad, 'The WTO and Food Safety Regulatory Policy Innovation in the European Union', Journal of Common Market Studies 39 (3), 2001, 485-505, 491-492.

${ }^{143}$ Council of Ministers, Council Directive 85/649 Prohibiting the Use in Livestock Farming of Certain Substances Having a Hormonal Action of 31 December 1985, O.J. (L.382) 228. The ban was successfully challenged before the European Court of Justice and annulled on procedural grounds. The ban was again proposed by the Commission and adopted by the Council of Ministers in 1988 (Council Directives 88/146 and 88/299). It was further strengthened in 1996 with the adoption of Council Directive 96/22, replacing the two Directives of 1988. For details of the various EC Directives and proposals on this issue as well as this history of this dispute, see Dale E. McNiel, 'The First Case under the WTO's Sanitary and Phytosanitary Agreement: The European Union's Hormone Ban', Virginia Journal of International Law 39, 1998, 89-134, 99-107; Sara Pardo Quintillán, 'Free Trade, Public Health Protection and Consumer Information in the European and WTO Context: Hormone Treated Beef and Genetically Modified Organisms', Journal of World Trade 33 (6), 1999, 147-197, 156-159; David Vogel, 'Food Safety and International Trade', in Trading Up: Consumer and Environmental Regulation in a Global Economy (Harvard University Press, Cambridge/London), 1995, 150-195, 154-161.

${ }^{144}$ First, a one year transitional period was provided to allow the sale of stocks of hormone-treated beef already in the EC, and to conduct additional negotiations with the US. Another year's grace was provided only for non-EC producers following protests in December 1987. David Vogel, 'Food Safety and International Trade', in Trading Up: Consumer and Environmental Regulation in a Global Economy (Harvard University Press, Cambridge/London), 1995, 150-195, 161.

${ }^{145}$ Dale McNiel notes that the approval of growth hormones in the US beef industry began in the 1950s with the approval of the use of DES in cattle. In the late 1970s, DES was found to be carcinogenic and banned. In 1956, implants of estradiol benzoate and progesterone were approved, and in 1977 melengestrol acetate (MGA), a synthetic hormone, was allowed as a feed additive. Subsequently a range of other hormones, including Zeranol, Trenbolone acetate (both synthetic hormones) and estradiol $17 \beta$ were approved for implants in calves for growth-promotion purposes. Dale E. McNiel, 'The First Case under the WTO's Sanitary and Phytosanitary Agreement: The European Union's Hormone Ban', Virginia Journal of International Law 39, 1998, 89-134, 99-100.

146 The US Department of Agriculture has estimated that: 'the increased production efficiency combined with the high lean meat percentage gave the farmer an economic benefit of $\$ 80$ per head.' Vogel notes that this would be an estimated benefit of $\$ 650$ million per year. David Vogel, 'Food Safety and International Trade', in Trading Up: Consumer and Environmental Regulation in a Global Economy (Harvard University Press, Cambridge/London), 1995, 150-195, 160.

${ }^{147}$ Vogel points out that the maximum residue level set, namely $1 \%$ of daily production of the relevant hormone, was conservative as humans actually only absorb $10 \%$ of hormones they ingest. Ibid., 159 . 
was the largest beef exporter to the EC. Of the US beef exports to the EC, less than ten percent were produced without hormones. In addition, US beef exports to the EC centred mainly on 'varietal' meats, such as kidneys, hearts, tongues and livers, in which hormone levels tend to be relatively high. ${ }^{148}$ As a result, the EC ban on hormone-treated beef had the effect of sharply reducing, by almost 80 percent, US beef exports to the EC. ${ }^{149}$

The US turned to international fora to address this problem. Towards the end of 1986, it raised the issue at the CAC. The FAO/WHO Joint Expert Committee on Food Additives (JECFA) established maximum residue levels and acceptable daily intake levels for the two synthetic hormones and found that no such levels needed to be set for the natural hormones since these were 'unlikely to pose a hazard to human health' when used in accordance with good veterinary and animal husbandry practice. ${ }^{150}$ Both the Codex Committee on Residues of Veterinary Drugs in Food and the Codex Committee of Food Additives and Contaminants agreed there was no scientific basis to the EC's ban, and approved the JECFA recommendations. However in July 1991, the CAC, after much debate, voted not to adopt the proposed maximum residue levels. ${ }^{151}$

148 These varietal meats, as reported by Vogel, were used to produce European specialties such as blood pudding, pate, kidney pies etc. as their tenderness was prized by European consumers, and their standard size was useful for producers to standardise their production processes. It was not economically feasible for US producers to adapt to the EC requirements as varietal meats form only a small part of the meat of each cow (about \$25 worth) and the varietal meat prices in the EC were not high enough to justify the investment needed to produce hormone-free meat. Ibid., 160.

${ }^{149}$ As noted by Vogel, other trading partners of the EC which authorized the use of hormones in beef production, such as Brazil, Australia and Canada, also formally opposed the ban. However, the economic consequences of the ban for these countries were limited. Brazil had authorized the use of only one hormone, so adaptation to the new EC requirements was not difficult. Australia had authorized all five hormones, but as most of Australian cattle were raised on grassland without the use of hormones, and the Australian government had an effective system in place to monitor and certify hormone-free beef, producers were hardly affected by the EC requirements. In addition Australia's beef exports to the EC were modest. Canada also exported very limited amount of beef to the EC (less than $0.02 \%$ of its total beef production) and was therefore not greatly affected by the ban.

150 Joint FAO/WHO Expert Committee on Food Additives, Summary and Conclusions of the Thirty Second Meeting (Food and Agriculture Organization and World Health Organization, Rome), 15 - 23 June 1987.

151 The vote was called by the Netherlands. The outcome of the vote was 12 in favour of adoption; 27 against adoption; and 9 abstentions. Codex Alimentarius Commission, Report of the Nineteenth Session, ALINORM 91/40 (Joint FAO/WHO Food Standards Programme, Rome), 1-10 July 1991, paras 161-162, available at: http://www.fao.org/docrep/meeting/005/t0490e/t0490e00.htm, visited on 13 May 2008. Vogel ascribes the refusal to adopt the proposed MRLs to the reluctance of the CAC to become embroiled in the conflict between the EC and the US. David Vogel, 'Food Safety and International Trade', in Trading Up: Consumer and Environmental Regulation in a Global Economy (Harvard University Press, Cambridge/London), 1995, $150-195,165$. The vote taken by the CAC on this issue was seen as politically motivated, and resulted in work on 'proposals to base Codex standards and other recommendations on scientific principles and the extent to which other factors needed to be taken into account'. Codex Alimentarius Commission, Report of the Nineteenth Session, ALINORM 91/40 (Joint FAO/WHO Food Standards Programme, Rome), 1-10 July 1991, para. 403, available at: http:/www.fao.org/docrep/meeting/005/t0490e/t0490e00.htm, visited on 13 May 2008. This work led to the development of a set of statements of principle, for the establishment of Codex food safety standards by the CAC Executive Committee. Codex Alimentarius Commission, Report of the Twenty-First Session, ALINORM 95/37 (Joint FAO/WHO Food Standards Programme, Rome), 3-8 July 1995, Appendix 2, available at: http://www.fao.org/docrep/meeting/005/v7950e/v7950e00.htm, visited on 13 May 2008. These are discussed above, Part II, Section 3.2.1.4. See also Dale E. McNiel, 'The First Case under the WTO's Sanitary and Phytosanitary Agreement: The European Union's Hormone Ban', Virginia Journal of International Law 39, 1998, 89-134, 108. 
In 1987, consultations on this dispute were held between the US and the EC under the Standards Code, and lasted six months. ${ }^{152}$ Some of the issues on which there was disagreement were the following. Firstly, the EC regarded its ban as outside the scope of the Standards Code since a ban on the use of hormones in beef production amounted to a regulation on a PPM rather than a product characteristic. ${ }^{153}$ According to the US, the EC was attempting to circumvent the Standards Code by framing its measure as a regulation on PPMs, when its real purpose was to ensure that only hormone-free beef was marketed in the EC. ${ }^{154}$ Secondly, the EC argued that the US had to show that its ban was adopted 'with a view to creating obstacles to international trade' ${ }^{155}$ in order for it to violate the Standards Code. As the hormone ban was neither discriminatory on its face nor intended to restrict imports, it did not violate the Standards Code, according to the EC. The US, on the contrary, noted that the Standards Code caught not only discriminatory measures, but all measures that have the effect of creating unnecessary obstacles to international trade. ${ }^{156}$ Thirdly, the EC and US disputed whether the hormones ban could be regarded as an 'unnecessary' obstacle to international trade, contrary to the obligations of the Standards Code. ${ }^{157}$ According to the US, the absence of scientific evidence that US beef production methods resulted in unsafe beef indicated that the EC ban was not 'necessary' to protect human life or health. The EC's counter-argument was that in the absence of conclusive scientific proof that hormone-treated beef was safe, the ban was justified as 'necessary'.

As the consultations were unsuccessful in resolving the dispute, the US requested that the matter be referred to a technical expert group under the Standards Code. As noted above, such a decision had to be taken by consensus in the Committee on Technical Barriers to Trade. The EC used the possibility provided by this consensus requirement to block the establishment of this expert group. Therefore the conflict remained unresolved. On 1 January 1989, the EC ban came into effect and the US responded by increasing tariffs by 100 percent on a range of EC exports to the US. ${ }^{158}$ This ongoing dispute served to highlight the insufficiency of the existing rules with respect to the use of measures for the protection of human, animal or plant life or health in ways that restrict international trade. David Vogel notes that:

152 These consultations were requested in January 1987, which was when the hormones ban was originally supposed to come into force. David Vogel, 'Food Safety and International Trade', in Trading Up: Consumer and Environmental Regulation in a Global Economy (Harvard University Press, Cambridge/London), 1995, $150-195,165$.

${ }^{153}$ As pointed out by Vogel, the wording of the Directive at issue specifies that its prohibition applies to the use of hormones for growth promotion purposes. The Directive does not prohibit the sale or importation of meat containing hormone residues. Its focus is therefore the production process rather than the characteristics of the product. Ibid.

${ }^{154}$ Ibid., 165-166.

${ }^{155}$ Article 2.1 of the Standards Code provides in its first sentence: 'Parties shall ensure that technical regulations and standards are not prepared, adopted or applied with a view to creating obstacles to international trade.'

${ }^{156}$ Article 2.1 of the Standards Code, in its last sentence, requires Parties to: 'ensure that neither technical regulations nor standards themselves nor their application have the effect of creating unnecessary obstacles to international trade.'

${ }^{157}$ As noted above, Article 2.1 of the Standards Code prohibited measures that had the effect of creating 'unnecessary obstacles to international trade.'

${ }^{158}$ The US action was taken under Section 301 of the Trade Act of 1974. The EC threatened to counter-retaliate but an escalation of the dispute was prevented by an 'interim' agreement reached between the EC and the US according to which the EC allowed some US beef exports to the EC (beef intended for pet food as well as beef certified as hormone-free) while the US reduced its retaliation measures correspondingly. 
[i]t was in large measure the frustration of the United States over the inability of the Standards Code to resolve its complaint against the EC that led the United States to propose a strengthening of the GATT's discipline over sanitary and phytosanitary Standards in the Uruguay Round. ${ }^{159}$

Although the intractable hormones dispute is the best known SPS dispute predating the SPS Agreement, it was certainly not the only dispute of its kind. In the 1990s, the EC was faced with barriers to its French and Italian wine exports in the form of a US ban. ${ }^{160}$ This ban resulted from the fact that these wines contained residues of procymidone, a fungicide used on about 20 percent of French grapes and 10 percent of Italian grapes. The ban was imposed under US legislation which prohibits chemicals in food for which safe maximum residue levels have not been established. As procymidone was not used in the US, no tolerance levels had been determined for its residues. While procymidone in high doses produces cancer in rodents, no scientific evidence had established a health risk from the low residue levels found in wine. However, pressure from US consumer and environmentalist groups led the US Environmental Protection Agency to keep the ban in place, ${ }^{161}$ against vigorous protests from the EC wine industry. ${ }^{162}$ The conflict was defused the following year when the Environmental Protection Agency set an interim tolerance level for procymidone in grapes grown before 1990 for the next four years. ${ }^{163}$ Another such SPS dispute concerned Japan's import prohibition on US apples, due to concerns with the introduction of harmful pests from the US. Japan justified this measure with reference to the fact that as an island country it has to implement stricter quarantine requirements than other countries, to avoid introducing previously unknown pests that would threaten its agricultural production. Apple producers in Washington State had spent over ten years adapting 3,500 acres of orchards to Japanese requirements by 1993, but Japan maintained its import ban. After producers lobbied the US government to apply trade sanctions against Japan, the latter agreed to allow importation of US apples. This commenced in $1995 .{ }^{164}$ A third SPS trade conflict concerned Chilean grape exports to the

${ }^{159}$ David Vogel, 'Food Safety and International Trade', in Trading Up: Consumer and Environmental Regulation in a Global Economy (Harvard University Press, Cambridge/London), 1995, 150-195, 153.

${ }^{160}$ This example is discussed by David Vogel and Marsha Echols. Ibid., 174-175; Marsha A. Echols, 'Sanitary and Phytosanitary Measures', in The World Trade Organization: The Multilateral Trade Framework for the 21st Century and U.S. Implementing Legislation, Terence P. Stewart (ed.) (American Bar Association, Washington, D.C.), 1996, 191-222, 197. The summary of this dispute presented here is based on these discussions.

${ }^{161}$ Some of these pressure groups relied on the 'Delaney Clause', a 1958 amendment to the Federal Food, Drug and Cosmetic Act that establishes a zero tolerance policy for all carcinogens in food.

${ }_{162}$ Vogel reports that the CAC established a maximum residue level for procymidone of 5 parts per million, which is over ten times higher than the highest residue level found in EC wines. This CAC standard was adopted in the course of the Uruguay Round negotiations and it prompted the EC to support stronger harmonization disciplines in the SPS Agreement. David Vogel, 'Food Safety and International Trade', in Trading Up: Consumer and Environmental Regulation in a Global Economy (Harvard University Press, Cambridge/ London), 1995, 150-195, 174.

163 The interim tolerance level was 7 parts per million. According to the EPA administrator at the time, as cited by Vogel, the available data indicated that the level of procymidone residues found in wine 'should not pose a serious risk to consumers.' Ibid., 175.

164 This dispute reared its head again in 2000 when the strict quarantine requirements applied by Japan to prevent the introduction of fire blight from US apple imports were challenged by the US under the SPS Agreement. The findings in this dispute are discussed as relevant to the interpretation of the provisions of the 
US. A food-safety scare broke out when cyanide was found in two Chilean grapes at the port in Philadelphia. This led to the impounding of Chilean grape imports at all US points of entry, a marketing recall, and an official consumer warning regarding all fruit from Chile. In addition an import ban on Chilean grapes was imposed for 11 days. ${ }^{165}$ These and other similar disputes ${ }^{166}$ evinced the lack of adequate trade disciplines to resolve conflicts involving the sensitive issues around SPS risk and agricultural trade. They formed the impetus for including the issue on the agenda for the Uruguay Round negotiations.

\subsection{The Uruguay Round negotiations on the SPS Agreement}

\subsubsection{Background to the negotiations}

The Uruguay Round of trade negotiations, which lasted from 1986 to 1994, was marked by a new readiness on the part of developing countries to engage in trade liberalisation. ${ }^{167}$ A record number of 76 developing countries participated in the Uruguay Round, ${ }^{168}$ and some of these countries played an active role in the negotiations. A new resolve to become effective participants in the multilateral trade regime was evident in their willingness to make reciprocal concessions and undertake to comply with all the negotiated disciplines. ${ }^{169}$

One very important aim of the Uruguay Round negotiations was the liberalisation of the agricultural sector. This sector had remained subject to much protectionism, despite the existing GATT rules. ${ }^{170}$ The need to take steps to ensure the liberalisation of trade in agriculture was one of the main driving forces behind the launching of the Uruguay

SPS Agreement below, in Part III.

${ }^{165}$ Chilean exporters and US importers unsuccessfully brought a civil suit and the Chilean government tried to get the matter resolved through arbitration. Marsha A. Echols, 'Sanitary and Phytosanitary Measures', in The World Trade Organization: The Multilateral Trade Framework for the 21st Century and U.S. Implementing Legislation, Terence P. Stewart (ed.) (American Bar Association, Washington, D.C.), 1996, 191-222, footnote 35. Marsha Echols notes that this episode is currently regarded as an example of government overreaction to risk.

${ }^{166}$ Other examples of SPS disputes are those between the EC and the US with regard to the EC's ban on bovine somatotrophin (BST), a hormone used in milk production, and with regard to the EC's allegedly discriminatory application of a directive on the processing of poultry meat. In these disputes the EC argued that the Standards Code was not applicable to PPMs.

${ }^{167}$ See the discussion above, Part I, Section 1.6.

${ }^{168}$ WTO Development Division, Developing Countries and the Multilateral Trading System: Past and Present. Background Document for the High Level Symposium on Trade and Development (World Trade Organization, Geneva), 17-18 March 1999, 5, available at: http://www.wto.org/english/tratop_e/devel_e/tr_dvbadoc_e.doc, visited on 25 June 2007.

169 Edwini Kwame Kessie, 'Developing Countries and the World Trade Organization: What Has Changed?' World Competition 22 (2), 1999, 83-110, 84. Kessie notes that developing countries hoped that by undertaking extensive commitments, they would 'send a positive signal to the international community that they were serious about economic reform.'

${ }^{170}$ As noted by Breen, agriculture was seen as a 'special case' in GATT rules. In some cases GATT rules were drafted in accordance with agricultural policies prevailing in the major Contracting Parties, in others waivers, reservations in accession agreements or informal 'grandfather' agreements protected agricultural policies from the full bite of GATT rules. John M. Breen, 'Agriculture', in The GATT Uruguay Round: A Negotiating History (1986-1992), Terence P. Stewart (ed.), vol. I: Commentary (Kluwer, Deventer), 1993, 125-254, 134. 
Round of trade negotiations in September 1986. The agenda for these negotiations was set out in the Punta Del Este Declaration. ${ }^{171}$ The Declaration called for the liberalisation of trade in agricultural products and for bringing '...all measures affecting import access....under strengthened and more operationally active GATT rules and disciplines' by, inter alia, 'minimising the adverse effects that sanitary and phytosanitary regulations and barriers can have on trade in agriculture, taking into account the relevant international agreements.' $^{172}$

During the Uruguay Round negotiations on agricultural trade liberalisation and on what would eventually become the Agreement on Agriculture, negotiators were very aware of the possibility that the progress achieved towards lowering trade barriers in the agricultural sector, could be made ineffective by the increased use of SPS measures for protectionist purposes. The growing number of disputes involving market access barriers to agricultural products in the form of SPS measures made these concerns concrete. Thus special disciplines for SPS measures were seen as crucial and inherently linked to the attempts to liberalise the agricultural sector. ${ }^{173}$ The main impetus for the negotiations on strengthened disciplines for SPS measures came from the US. ${ }^{174}$ It was strongly supported in this by other agriculture exporting nations, including both developed and developing countries. As noted by Gretchen Stanton, 'Agricultural exporters were the principal champions of the SPS negotiations.' ${ }^{175}$ At the same time, she notes, these same negotiators were well aware of the need to recognise the right of countries to legitimately regulate for the protection against SPS risk. Consumer groups, environmental groups and those domestic industries whose marketing strategies involved claims of a high level of health protection formed an effective lobby in this regard. ${ }^{176}$

Originally, the idea was to negotiate strengthened provisions in Article XX(b) of the GATT and/or the Standards Code with respect to SPS measures, in order to address the

${ }^{171}$ Special Session of the GATT CONTRACTING PARTIES, Ministerial Declaration on the Uruguay Round of 20 September 1986, GATT MIN.DEC, BISD 33S/19, circulated on 25 September 1986.

172 Ibid., 6.

${ }^{173}$ This link was recognised in the Punta Del Este Declaration (as set out above) and is also reflected in Article 14 of the Agreement on Agriculture, which provides: 'Members agree to give effect to the Agreement on the Application of Sanitary and Phytosanitary Measures'. This provision is in fact redundant, since all WTO Members are bound to all the multilateral agreements reached in the Uruguay Round. It only serves to emphasise the perceived threat to agricultural liberalisation by SPS measures and to the role of the SPS Agreement in addressing this threat.

${ }^{174}$ In 1988, the US submitted a communication to the Negotiating Group on Agriculture, proposing the establishment of a separate Working Group on SPS issues, which it argued were not well suited to multilateral negotiation due to their technical nature. Negotiating Group on Agriculture, Communication from the United States on a Health and Sanitary Working Group, MTN.GNG/NG5/77, circulated on 13 September 1988. The task of the Working Group, according to the US proposal, would be to strengthen the disciplines of Article XX(b) of the GATT by developing parameters for acceptable SPS measures, the degree of equivalency or mutual recognition to be accorded to SPS regulations, the role of international standard-setting organisations in drafting science-based guidelines for the harmonisation of national SPS requirements, and the framework for notification and consultation procedures. John M. Breen, 'Agriculture', in The GATT Uruguay Round: A Negotiating History (1986-1992), Terence P. Stewart (ed.), vol. I: Commentary (Kluwer, Deventer), 1993, 125-254, 176.

${ }^{175}$ Gretchen Stanton, Food Safety and the SPS Agreement (Standards and Trade Development Facility, Geneva), 2000, 1, available at: www.standardsfacility.org/files/foodsafety\&sps.pdf, visited on 13 December 2000.

${ }^{176}$ Ibid. 
inadequacies of these agreements. ${ }^{177}$ However, as negotiations progressed, the issue of SPS measures was seen as meriting special attention, apart from the larger genus of technical standards. Reasons that have been suggested for this view are the close link between agricultural trade and SPS standards, the importance of the beef hormone dispute and the fact that SPS measures were thought to raise problems different from those linked to other technical standards, for example the greater importance of scientific risk assessment, the greater divergence in national approaches to SPS regulation and the regulatory autonomy of national authorities in deciding on the need for regulation and the measures to be taken. ${ }^{178}$ In the course of discussions on SPS issues in the Committee on Trade in Agriculture, several participants pointed out that the scope for improved disciplines to minimise the adverse trade effects of SPS measures would be conditioned by factors specific to this area, such as the technical nature of the issues involved; the differences in the geographic, climatic and production conditions prevailing in different countries; and the fact that the assessment of the existence of a threat to human, plant or animal health as well as the determination of preventive measures considered necessary, were matters within the competence of national regulatory authorities. ${ }^{179}$ Despite these constraints, it was felt that SPS measures should be brought under appropriate procedures relating to notification, transparency, consultation and dispute settlement. ${ }^{180}$ The importance of ensuring an appropriate level of technical expertise in any procedures for review, consultation and dispute settlement was noted. ${ }^{181}$ It was suggested that a counter-notification process, whereby particularly trade-disruptive SPS measures could be identified by the countries

${ }^{177}$ At the first meeting of the Working Group on Sanitary and Phytosanitary Regulations and Barriers, much of the discussion centred on the need to reinforce GATT rules, particularly Article XX(b), to discipline SPS measures effectively. However, some participants expressed the view that the possibilities for providing greater clarity and precision to this Article were limited. Negotiating Group on Agriculture, Working Group on Sanitary and Phytosanitary Regulations and Barriers, Summary of Main Points Raised at the First Meeting of the Working Group on Sanitary and Phytosanitary Regulations and Barriers: Note by the Secretariat, MTN.GNG/NG5/WGSP/W/1, circulated on 28 October 1988, para. 8. At the second meeting of the Working Group, the Chairman raised the question whether the negotiations with regard to SPS measures would result in improvements to the Standards Code or in a separate agreement. Participants expressed the view that the Standards Code was relevant to the work on SPS measures, but that it had proven unsatisfactory in addressing SPS barriers to trade. Therefore strengthened rules were needed. Negotiating Group on Agriculture, Working Group on Sanitary and Phytosanitary Regulations and Barriers, Summary of Main Points Raised at the Second Meeting of the Working Group on Sanitary and Phytosanitary Regulations and Barriers: Note by the Secretariat, MTN.GNG/NG5/WGSP/W/2, circulated on 14 November 1988, paras 11-12. Work proceeded on this basis. See for example, the Nordic Group's submission addressing the deficiencies of the Standards Code and possible ways of strengthening this Code. Negotiating Group on Agriculture, Working Group on Sanitary and Phytosanitary Regulations and Barriers, Applicability of the Agreement on Technical Barriers to Trade to Sanitary and Phytosanitary Regulations and Barriers: Note Submitted by the Nordic Delegations, MTN.GNG/NG5/WGSP/W/5, circulated on 22 May 1989.

${ }^{178}$ David A. Wirth, 'Symposium: The Role of Science in the Uruguay Round and NAFTA Trade Disciplines', Cornell International Law Journal 27, 1994, 817-859, 824. See also Eliza Patterson, 'International Efforts to Minimize the Adverse Trade Effects of National Sanitary and Phytosanitary Regulations', Journal of World Trade 24 (2), 1990, 91-102, 95.

${ }^{179}$ Committee on Trade in Agriculture, Summary of Points Raised at the Meeting of the Committee Held on 2 - 3 April 1985. Note by the Secretariat, AG/W/13, circulated on 4 September 1985, para. 2.

${ }^{180} \mathrm{Ibid}$. See also Negotiating Group on Agriculture, Working Group on Sanitary and Phytosanitary Regulations and Barriers, Summary of Main Points Raised at the First Meeting of the Working Group on Sanitary and Phytosanitary Regulations and Barriers: Note by the Secretariat, MTN.GNG/NG5/WGSP/W/1, circulated on 28 October 1988, para. 11.

181 Ibid., para. 7. 
adversely affected by them, and reviewed, would be useful, and that the Committee itself might provide a permanent forum for periodic review of these measures. ${ }^{182}$

By the mid-term review of the Uruguay Round in December 1988, five areas of priority had been agreed upon for SPS disciplines, namely harmonisation of SPS measures around standards set by international organisations; the establishment of an effective notification procedure for SPS measures to improve transparency; the creation of a consultative mechanism for resolving disputes bilaterally; the improvement of the multilateral dispute settlement system; and the creation of a possibility of obtaining scientific input and expertise, relying on the international organisations. ${ }^{183}$ A separate Working Group on Sanitary and Phytosanitary Regulations and Barriers was created in 1988, under the Negotiating Group on Agriculture, which was open to all 124 governments which participated in the Uruguay Round negotiations. ${ }^{184}$ Due to the technical nature of SPS issues, negotiators in this Working Group included representatives from agricultural and trade ministries as well as SPS regulatory agencies. ${ }^{185}$ In addition, in order to better understand the operation of the CAC, OIE and IPPC, representatives from these bodies/treaty were invited to participate as observers in the Working Group meetings. ${ }^{186}$ Negotiations in the Working Group proceeded on the basis of the agreed priorities.

The Working Group on Sanitary and Phytosanitary Regulations and Barriers drew up a draft text of the SPS Agreement in November 1990. ${ }^{187}$ The most important points of

${ }^{182} \mathrm{Ibid}$. It is interesting to note the similarity between this early proposal and the current system of raising 'specific trade concerns' with notified SPS measures before the SPS Committee, for discussion. This is discussed below, Part IV, Section 2.1.2.

${ }^{183}$ Trade Negotiations Committee, Mid-Term Meeting, MTN.TNC/11, circulated on 21 April 1989, 9. See also Simonetta Zarrilli, The SPS Agreement and the Developing Countries (World Bank, Washington D.C.), 2003.

184 WTO Secretariat, Understanding the World Trade Organization Agreement on Sanitary and Phytosanitary Measures (SPS). Revision 1, Export Quality Bulletin no. 46 Rev. 1, International Trade Centre, November 1996, 12, available at: www.intracen.org/eqm/eqb/eq46eng.pdf, visited on 5 April 1999.

185 Donna Roberts, 'Sanitary and Phytosanitary Risk Management in the Post-Uruguay Round Era: An Economic Perspective', in Incorporating Science, Economics, and Sociology in Developing Sanitary and Phytosanitary Standards in International Trade: Proceedings of a Conference, National Research Council Board on Agriculture and Natural Resources (ed.) (National Academy Press, Washington D.C.), 2000, 33-50, 36, available at: www.nap.edu/openbook/0309070902/html/199.html, visited on 25 June 2007.

${ }^{186}$ Negotiating Group on Agriculture, Working Group on Sanitary and Phytosanitary Regulations and Barriers, Summary of Main Points Raised at the First Meeting of the Working Group on Sanitary and Phytosanitary Regulations and Barriers: Note by the Secretariat, MTN.GNG/NG5/WGSP/W/1, circulated on 28 October 1988, para. 19. These bodies submitted written statements in the course of the negotiations. Negotiating Group on Agriculture, Working Group on Sanitary and Phytosanitary Regulations and Barriers, Statement by the Representative of the Codex Alimentarius Commission at the Second Meeting of the Working Group (3 November 1988), MTN.GNG/NG5/WGSP/W/3, circulated on 30 November 1988; Negotiating Group on Agriculture, Working Group on Sanitary and Phytosanitary Regulations and Barriers, Statement by the Representative of the International Plant Protection Convention at the Second Meeting of the Working Group (3 November 1988), MTN.GNG/NG5/WGSP/W/4, circulated on 30 November 1988; Negotiating Group on Agriculture, Working Group on Sanitary and Phytosanitary Regulations and Barriers, Comments by the International Office of Epizootics (OIE): Meeting of 2-3 April 1990, MTN.GNG/NG5/WGSP/W/19, circulated on 4 May 1990.

187 Working Group on Sanitary and Phytosanitary Regulations and Barriers, Draft Text on Sanitary and Phytosanitary Measures, MTN.GNG/NG5/WGSP/7, circulated on 20 November 1990. Breen notes that this Working Group was the only one among the agriculture Working Groups to succeed in producing a draft text in November 1990. John M. Breen, 'Agriculture', in The GATT Uruguay Round: A Negotiating History (1986-1992), Terence P. Stewart (ed.), vol. I: Commentary (Kluwer, Deventer), 1993, 125-254, 200. 
agreement in this 1990 draft were that: (1) SPS measures should be non-discriminatory and should not constitute disguised barriers to trade; (2) SPS measures should be harmonised in accordance with generally accepted scientific principles; (3) developing-country constraints in meeting SPS requirements should be given special consideration; (4) procedures for transparency in setting SPS regulations and in resolving disputes concerning such measures were needed; and (5) an international committee should be created as a forum for consultations on SPS measures. ${ }^{188}$ Significant areas of disagreement still remained, however. In particular, these dealt with: ${ }^{189}$ (1) whether, and if so, under what conditions, Parties could impose measures stricter than international standards; ${ }^{190}(2)$ whether 'other economic considerations and genuine consumer concerns' were factors that could be taken into account in a risk assessment; ${ }^{191}$ and (3) what disciplines should be imposed on control, inspection and approval systems. ${ }^{192}$

In the last months of 1990, however, the Uruguay Round negotiations as a whole faltered and the Brussels Meeting in December 1990 at which the Round should have been completed ended in deadlock. The deadlock was largely due to disagreement on issues relating to the liberalisation of agricultural trade. To break the deadlock, the then Director-General of the GATT tabled in December 1991 what is now known as the Dunkel Draft, ${ }^{193}$ embodying an overall compromise position. With respect to the SPS Agreement the Dunkel Draft closely followed the text of the December 1990 draft prepared by the Working Group on Sanitary and Phytosanitary Regulations and Barriers, ${ }^{194}$ and this formed the basis for the final text of the SPS Agreement. ${ }^{195}$

188 This summary is provided in John M. Breen, 'Agriculture', in The GATT Uruguay Round: A Negotiating History (1986-1992), Terence P. Stewart (ed.), vol. I: Commentary (Kluwer, Deventer), 1993, 125-254, 200-201.

189 This list of points is provided ibid., 201.

190 The EC and the US supported flexibility in the harmonisation provision, allowing Members to apply stricter measures than those embodied in international standards. The Cairns group opposed such flexibility as undermining the harmonisation effort. Ibid.

191 This issue was controversial due to the ongoing disputes regarding the EC's bans on hormones in beef and dairy production, discussed above. These bans were seen as contrary to the weight of scientific evidence, and motivated by consumer fears and market surpluses in the EC. Ibid., footnote 381 .

192 The issue of disciplines on systems for prior approval of food additives, and for control and inspection of products and PPMs to assess conformity with SPS requirements was extremely controversial, as reflected in the fact that the draft text provided four different options, one of which was the complete omission of the provision on this issue. Ibid., 201.

193 Trade Negotiations Committee, Draft Final Act Embodying the Results of the Uruguay Round of Multilateral Trade Negotiations, MTN.TNC/W/FA, circulated on 20 December 1991.

194 John M. Breen, 'Agriculture', in The GATT Uruguay Round: A Negotiating History (1986-1992), Terence P. Stewart (ed.), vol. I: Commentary (Kluwer, Deventer), 1993, 125-254, 213. Breen points out that negotiations on SPS measures continued to make faster progress than those on other sectors within the agriculture negotiations.

${ }^{195}$ Some significant differences between the Dunkel Draft and the final version of the SPS Agreement were: (1) the addition of a footnote clarifying what is meant by the 'scientific justification' required when an SPS measure deviates from an international standard; (2) the change in the initial requirement in Article 5.6 that SPS measures be least restrictive to trade, to specify that they must be no more trade restrictive than required to achieve a Member's appropriate level of protection; (3) the indication in Article 5.3 that the requirement that account be taken of economic factors in a risk assessment does not extend to situations of risk to human health; and (4) the extension of the transitional period for the implementation of the SPS Agreement from two to five years for least-developed-country Members. John M. Breen, 'Agriculture', in The GATT Uruguay Round: A Negotiating History (1986-1992), Terence P. Stewart (ed.), vol. IV: The End Game (Kluwer, The Hague/London/Boston), 1999, 41-45, Annex 2. 
As a result of the distinct mandate of the Working Group on Sanitary and Phytosanitary Regulations and Barriers, two separate agreements on technical barriers to trade emerged from in the Uruguay Round: firstly, the Agreement on Technical Barriers to Trade ${ }^{196}$ (TBT Agreement), applicable to technical regulations, standards and conformity assessment procedures other than SPS measures; and, secondly, the Agreement on the Application of Sanitary and Phytosanitary Measures ${ }^{197}$ (SPS Agreement), applicable only to SPS measures. ${ }^{198}$

It is interesting to examine in more detail the main actors in the negotiation of the SPS Agreement and the positions they took. This provides some background to understanding the concerns that different countries had in the negotiation process and casts some light on the way in which the provisions of the Agreement were framed. In particular, it goes some way towards explaining why the disciplines in the SPS Agreement applicable to the SPS regulatory process so closely resemble the regulatory regimes in developed countries.

In the negotiations that led to the conclusion of the SPS Agreement the leading role was taken by the US, ${ }^{199}$ the EC, ${ }^{200}$ the Nordic countries (Norway, Sweden, Iceland and Finland) ${ }^{201}$

196 'Agreement on Technical Barriers to Trade', in The Results of the Uruguay Round of Multilateral Trade Negotiations: The Legal Texts (World Trade Organization, Geneva), 1994, 138-162, 6-18. This Agreement elaborated on and replaces the Tokyo Round Standards Code of 1979. The TBT Agreement goes further than the Standards Code in that it applies to both mandatory standards and recommendations and extends not only to products but also related processes and production methods.

197 'Agreement on the Application of Sanitary and Phytosanitary Measures', in The Results of the Uruguay Round of Multilateral Trade Negotiations: The Legal Texts (World Trade Organization, Geneva), 1994, 69-84.

${ }^{198}$ The scope of application of the SPS Agreement and its relationship to the TBT Agreement are discussed below, Part III, Section 2.4.1.

199 Negotiating Group on Agriculture, Submission of the United States on Comprehensive Long-Term Agricultural Reform, MTN.GNG/NG5/W/118, circulated on 25 October 1989; Negotiating Group on Agriculture, Working Group on Sanitary and Phytosanitary Regulations and Barriers, Communication from the United States Regarding the International Office of Epizootics, MTN.GNG/NG5/WGSP/W/12, circulated on 16 February 1990.

200 Negotiating Group on Agriculture, Communication from the European Communities. Working Paper: Drafting of an Appropriate Framework of Rules for Sanitary and Phytosanitary Regulations, MTN.GNG/ NG5/W/56, circulated on 20 April 1988; Negotiating Group on Agriculture, Submission of the European Communities on Sanitary and Phytosanitary Regulations and Measures, MTN.GNG/NG5/W/146, circulated on 20 December 1989.

201 The Nordic countries were particularly proactive in the negotiations, submitting detailed proposals for the text of a new Agreement, originally based on the text of the Standards Code. Negotiating Group on Agriculture, Working Group on Sanitary and Phytosanitary Regulations and Barriers, Applicability of the Agreement on Technical Barriers to Trade to Sanitary and Phytosanitary Regulations and Barriers: Note Submitted by the Nordic Delegations, MTN.GNG/NG5/WGSP/W/5, circulated on 22 May 1989; Negotiating Group on Agriculture, Working Group on Sanitary and Phytosanitary Regulations and Barriers, Note Submitted by the Nordic Delegations with Respect to Some Elements of the Work Programme, MTN.GNG/ NG5/WGSP/W/7, circulated on 31 October 1989; Negotiating Group on Agriculture, Working Group on Sanitary and Phytosanitary Regulations and Barriers, Form and Disposition of the Agreement on Sanitary and Phytosanitary Regulations and Barriers (SPS Measures). Note by the Nordic Delegations, MTN.GNG/ NG5/WGSP/W/10, circulated on 12 February 1990; Negotiating Group on Agriculture, Working Group on Sanitary and Phytosanitary Regulations and Barriers, Harmonization and Transparency: Note by the Nordic Delegations, MTN.GNG/NG5/WGSP/W/9, circulated on 30 January 1990; Negotiating Group on Agriculture, Working Group on Sanitary and Phytosanitary Regulations and Barriers, Dispute Settlement Procedures: Note by the Nordic Delegations, MTN.GNG/NG5/WGSP/W/11, circulated on 12 February 1990; Negotiating Group on Agriculture, Working Group on Sanitary and Phytosanitary Regulations and Barriers, 
and those countries that account for the largest share of agricultural trade, namely the Cairns Group of agriculture exporting countries (at the time of the Uruguay Round negotiations, the Cairns Group was composed of Argentina, Australia, Brazil, Canada, Chile, Colombia, Hungary, Indonesia, Malaysia, New Zealand, the Philippines, Thailand and Uruguay). These countries submitted several written proposals to the Negotiating Group on Agriculture and later the Working Group on Sanitary and Phytosanitary Regulations and Barriers. Other developed countries that also submitted written proposals, as part of their agriculture position papers, were Japan, Israel and Austria. ${ }^{202}$ In addition, proposals on SPS issues were made by developing countries in the context of their positions in the general agriculture negotiations, including by Korea; Morocco; Brazil and Colombia (acting jointly); and Egypt, Jamaica, Mexico and Peru (acting jointly). ${ }^{203}$ An examination of the proposals contained in these submissions provides an indication of the areas of agreement and the points of contention in the negotiations. ${ }^{204}$ It also evinces the extent of participation of the various countries in the negotiation process, and is useful in determining whether the new engagement of developing countries in the Uruguay Round negotiations in general was also carried through to their participation in the negotiations that led to the SPS Agreement. The summaries of the discussions in the meetings of the Working Group on Sanitary and Phytosanitary Regulations and Barriers very often do not specify which country made the various statements referred to, so it is not possible to gauge the extent of active participation in the meetings of various participants, or to identify the positions they supported. However, the content of these discussions does serve to clarify some of the positions taken and the concerns raised. It is therefore referred to where relevant in the description below.

Technical Assistance to Other Parties and Special and Differential Treatment of Developing Countries. Note by the Nordic Delegations, MTN.GNG/NG5/WGSP/W/14, circulated on 20 April 1990; Negotiating Group on Agriculture, Working Group on Sanitary and Phytosanitary Regulations and Barriers, Draft Agreement on Sanitary and Phytosanitary Measures: Note by the Nordic Countries, MTN.GNG/NG5/WGSP/W/21, circulated on 28 May 1990.

202 Japan, Israel and Austria made proposals on SPS issues within their proposals for the agriculture negotiations in general. Negotiating Group on Agriculture, Negotiating Group on Agriculture: Submission by Japan, MTN.GNG/NG5/W/131, circulated on 6 December 1989; Negotiating Group on Agriculture, Supplementary Submission of Japan on Sanitary and Phytosanitary Regulations and Measures, MTN.GNG/NG5/W/156, circulated on 7 March 1990; Negotiating Group on Agriculture, Negotiating Group on Agriculture: Submission by Austria, MTN.GNG/NG5/W/144, 19 December 1989; Negotiating Group on Agriculture, Communication from Israel Expressing Views on Certain Elements in the Negotiation on Agriculture, MTN. GNG/NG5/W/153, 13 February 1990.

${ }^{203}$ Negotiating Group on Agriculture, Proposal for Negotiations on Agriculture: Submitted by the Republic of Korea, MTN.GNG/NG5/W/130, 28 November 1989; Negotiating Group on Agriculture, Negotiating Group on Agriculture: Statement by the Kingdom of Morocco, MTN.GNG/NG5/W/121, 2 November 1989; Negotiating Group on Agriculture, Proposal on Special, Differential and More Favourable Treatment for Developing Countries: Communication from Brazil and Colombia, MTN.GNG/NG5/W/132, 28 November 1989; Negotiating Group on Agriculture, Proposal by Egypt, Jamaica, Mexico and Peru, MTN. GNG/NG5/W/74, circulated on 13 September 1988, available at: http:/www.wto.org/gatt_docs/English/ SULPDF/92050187.pdf, visited on 11 May 2008.

${ }^{204}$ A useful summary of the main proposals relating to key concepts was prepared by the GATT Secretariat, and is referred to here as appropriate. Negotiating Group on Agriculture, Working Group on Sanitary and Phytosanitary Regulations and Barriers, Synoptic Table of Proposals Relating to Key Concepts: Note by the Secretariat. Revision, MTN.GNG/NG5/WGSP/W/17/Rev.1, circulated on 29 May 1990. For a discussion of some of the proposals, see Maury E. Bredahl and Kenneth W. Forsythe, 'Harmonizing Phyto-Sanitary and Sanitary Regulations', The World Economy 12, 1989, 189-206. 


\subsubsection{Positions of the developed-country participants and the Cairns Group}

Most active in the negotiations regarding disciplines on SPS measures were, as mentioned above, several developed countries and the Cairns Group, which included the main developed- and developing-country exporters of agricultural products. While their positions converged in certain areas, in other respects their particular circumstances or concerns resulted in divergent positions. The key components of some of the proposals of these participants are outlined below.

The scope of application of the new disciplines being negotiated on SPS measures was discussed in a few proposals. The product coverage of the new rules was seen as linked to the product coverage of the new Agreement on Agriculture, being negotiated at the same time. However, it was proposed that the products of fisheries and forestry be included, regardless of their inclusion or exclusion in the Agreement on Agriculture. ${ }^{205}$ In addition, there was some debate in the Working Group regarding whether measures aimed at the protection of the environment in general should be covered by the new disciplines. The Cairns Group proposed that as SPS measures may legitimately protect not only commercial products but also natural fauna and flora, such measures should fall under the new disciplines. ${ }^{206}$ It clarified, however, that measures for the conservation of natural resources other than fauna and flora should not be covered by the new rules. Not all participants were of the same view, however, and the 1990 draft text on the SPS Agreement still contained bracketed text with two options, either expressly including or expressly excluding measures aimed at the protection of the environment in the definition of an 'SPS measure'. Both these texts were omitted in the Dunkel Draft, so that the definition of an 'SPS measure' is silent on the question whether measures to protect the environment per se are among the measures covered. Questions also arose with regard to whether health regulations on non-agricultural products, such as pesticides, cigarettes and veterinary drugs, should be covered. ${ }^{207}$ However, overall the prevailing view among negotiators seemed to focus on the link between SPS measures and liberalising trade in agricultural products (in the broad sense), thus limiting the product coverage to primary or processed agricultural products and natural fauna and flora.

More problematic was the question whether regulations addressing PPMs, and especially non-product related PPMs, such as regulations concerning animal welfare, consumer preferences, fair trade and religious concerns, should be covered by the new SPS

\footnotetext{
${ }^{205}$ Negotiating Group on Agriculture, Working Group on Sanitary and Phytosanitary Regulations and Barriers, Synoptic Table of Proposals Relating to Key Concepts: Note by the Secretariat. Revision, MTN.GNG/NG5/ WGSP/W/17/Rev.1, circulated on 29 May 1990, Table 2; Negotiating Group on Agriculture, Working Group on Sanitary and Phytosanitary Regulations and Barriers, Summary of Main Points Raised at the Seventh Meeting of the Working Group on Sanitary and Phytosanitary Regulations and Barriers: Note by the Secretariat, MTN.GNG/NG5/WGSP/W/22, circulated on 31 May 1990, para. 4.

${ }^{206}$ Negotiating Group on Agriculture, Working Group on Sanitary and Phytosanitary Regulations and Barriers, Summary of Main Points Raised at the Sixth Meeting of the Working Group on Sanitary and Phytosanitary Regulations and Barriers: Note by the Secretariat, MTN.GNG/NG5/WGSP/W/18, circulated on 4 May 1990, para. 4.

${ }^{207}$ Negotiating Group on Agriculture, Working Group on Sanitary and Phytosanitary Regulations and Barriers, Summary of Main Points Raised at the Seventh Meeting of the Working Group on Sanitary and Phytosanitary Regulations and Barriers: Note by the Secretariat, MTN.GNG/NG5/WGSP/W/22, circulated on 31 May 1990, para. 4.
} 
disciplines. The Nordic Group and the Cairns Group proposed that the new disciplines should apply equally to SPS measures addressing product characteristics and those addressing product-related PPMs. ${ }^{208}$ The Nordic Group noted that one of the main weaknesses of the Standards Code was its very limited coverage of PPMs, whereas SPS regulations are very often based on PPMs rather than product specifications. ${ }^{209}$ It proposed a discipline providing that, as far as possible, SPS measures should be based on product characteristics rather than PPMs. ${ }^{210}$ The EC proposal, instead, stressed that by contrast to industrial products, for agri-food products the regulation of PPMs plays an important role in ensuring the safety of the resulting product. A simple extension of new disciplines on SPS product requirements to PPM requirements, as proposed by other participants, ${ }^{211}$ would in the view of the EC disregard the different character of the two regulatory systems. While conformity with product requirements can easily be checked by the importer, checking conformity of PPMs, which take place in the exporting country, requires the cooperation of the country concerned. An appropriate framework suited to this special situation should be drafted, according to the EC. ${ }^{212}$ A more vexed question was that of the application of the new disciplines to non-product-related PPMs. The Cairns Group proposal stated that only issues directly related to human, animal or plant life or health should be covered, not consumer preferences, animal welfare, and religious or moral issues. ${ }^{213}$ The EC also distinguished between considerations regarding the protection of life and health, which it considered SPS considerations, and other considerations such as those regarding fair trade, quality and fraud prevention, which it did not regard as SPS considerations. ${ }^{214}$ Similarly, the Nordic Group proposed that regulations based on moral or ethical considerations would fall outside the scope of application of the new rules. ${ }^{215}$

${ }^{208}$ Negotiating Group on Agriculture, Sanitary and Phytosanitary Issues: Supplementary Communication from the Cairns Group, MTN.GNG/NG5/W/164, circulated on 18 April 1990, paras 23-24. The Cairns group saw particular scope for applying the rules on the recognition of equivalence to PPMs.

209 Negotiating Group on Agriculture, Working Group on Sanitary and Phytosanitary Regulations and Barriers, Applicability of the Agreement on Technical Barriers to Trade to Sanitary and Phytosanitary Regulations and Barriers: Note Submitted by the Nordic Delegations, MTN.GNG/NG5/WGSP/W/5, circulated on 22 May 1989, para. 10. As has been seen in Part II. process-based SPS regulations are prevalent in developed countries. Less developed countries tend to rely on product-based regulation as this is easier to control. See above, Part II, Section 1.3.

${ }^{210}$ Negotiating Group on Agriculture, Working Group on Sanitary and Phytosanitary Regulations and Barriers, Note Submitted by the Nordic Delegations with Respect to Some Elements of the Work Programme, MTN. GNG/NG5/WGSP/W/7, circulated on 31 October 1989, para. 1.D.

${ }^{211}$ See for example Negotiating Group on Agriculture, Working Group on Sanitary and Phytosanitary Regulations and Barriers, Summary of Main Points Raised at the Seventh Meeting of the Working Group on Sanitary and Phytosanitary Regulations and Barriers: Note by the Secretariat, MTN.GNG/NG5/WGSP/W/22, circulated on 31 May 1990, para. 13.

212 Negotiating Group on Agriculture, Communication from the European Communities. Working Paper. Drafting of an Appropriate Framework of Rules for Sanitary and Phytosanitary Regulations, MTN.GNG/ NG5/W/56, circulated on 20 April 1988, 3.

${ }^{213}$ Negotiating Group on Agriculture, Sanitary and Phytosanitary Issues: Supplementary Communication from the Cairns Group, MTN.GNG/NG5/W/164, circulated on 18 April 1990, para. 6.

${ }^{214}$ Negotiating Group on Agriculture, Submission of the European Communities on Sanitary and Phytosanitary Regulations and Measures, MTN.GNG/NG5/W/146, circulated on 20 December 1989, 1-2.

${ }^{215}$ Negotiating Group on Agriculture, Working Group on Sanitary and Phytosanitary Regulations and Barriers, Form and Disposition of the Agreement on Sanitary and Phytosanitary Regulations and Barriers (SPS Measures). Note by the Nordic Delegations, MTN.GNG/NG5/WGSP/W/10, circulated on 12 February 1990, 3. 
In response to concerns raised by other participants, in discussions in the Working Group, that it would be a mistake to exclude such measures, which were already being used for protectionist purposes, from the reinforced disciplines being negotiated, it was stated that Article XX(b) could be used to discipline such measures. ${ }^{216}$ The draft text on the SPS Agreement drawn up by the Working Group in 1990 still contained bracketed text with two options, one expressly including measures aimed at consumer preferences and information, animal welfare and ethical and moral considerations from the definition of an 'SPS measure' and another expressly excluding measures aimed at such considerations. ${ }^{217}$ In the Dunkel draft, both were omitted.

The question of the scope of application of the new rules addressed in several proposals also covered the issue of personal scope of application - i.e. to which entities do the new rules apply? This question was regarded as important as it was recognised that SPS standards are often developed by local government bodies (such as states, länder, and cantons), regional bodies (such as regulatory bodies of a customs union) ${ }^{218}$ and non-governmental bodies (such as independent bureaus of standards). The Cairns Group stated that it was necessary to ensure that all levels of government, including national, sub-national and supra-national bodies, be covered by the new rules. ${ }^{219}$ The Nordic proposal noted that the Standards Code applied directly to central government bodies, but its obligations for local and regional government bodies as well as non-government bodies were of a 'best endeavour' or 'second level' nature. It suggested that the latter obligations be strengthened. ${ }^{220}$ In a later proposal, the Nordic Group required parties to ensure compliance with the new disciplines by central and local government bodies, and to take such reasonable measures as may be available to them to ensure compliance by regional and non-governmental bodies, and not to require or encourage such bodies to act inconsistently with these disciplines. ${ }^{221}$ Some participants were concerned that the Nordic proposal was too stringent in this regard and could lead to constitutional difficulties. ${ }^{222}$ Interestingly, the issue

${ }^{216}$ Negotiating Group on Agriculture, Working Group on Sanitary and Phytosanitary Regulations and Barriers, Summary of Main Points Raised at the Eighth Meeting of the Working Group on Sanitary and Phytosanitary Regulations and Barriers: Note by the Secretariat, MTN.GNG/NG5/WGSP/W/24, circulated on 2 July 1990, para. 3. It is not stated in the report which countries participated in this discussion. The assertion that Article $\mathrm{XX}(\mathrm{b})$ would discipline measures aimed at consumer preferences and ethical and religious concerns is not correct as the scope of this exception is limited, as explained above, Part III, Section 1.1.1. Currently, the TBT Agreement would apply to such measures if they take the form of technical regulations or standards. See further below, Part III, Section 2.4.1.

${ }^{217}$ Negotiating Group on Agriculture, Working Group on Sanitary and Phytosanitary Regulations and Barriers, Draft Text for a Decision by the CONTRACTING PARTIES on Sanitary and Phytosanitary Measures, MTN. GNG/NG5/WGSP/W/26, circulated on 1 October 1990, 8.

${ }^{218}$ A current example of a regional SPS regulatory body is Food Standards Australia New Zealand, discussed above, Part II, Section 2.4.2.2.

${ }^{219}$ Negotiating Group on Agriculture, Sanitary and Phytosanitary Issues: Supplementary Communication from the Cairns Group, MTN.GNG/NG5/W/164, circulated on 18 April 1990, 41.

${ }^{220}$ Negotiating Group on Agriculture, Working Group on Sanitary and Phytosanitary Regulations and Barriers, Applicability of the Agreement on Technical Barriers to Trade to Sanitary and Phytosanitary Regulations and Barriers: Note Submitted by the Nordic Delegations, MTN.GNG/NG5/WGSP/W/5, circulated on 22 May 1989, paras 11 and 13.

${ }^{221}$ Negotiating Group on Agriculture, Working Group on Sanitary and Phytosanitary Regulations and Barriers, Draft Agreement on Sanitary and Phytosanitary Measures: Note by the Nordic Countries, MTN.GNG/NG5/ WGSP/W/21, circulated on 28 May 1990, 5.

${ }^{222}$ Negotiating Group on Agriculture, Working Group on Sanitary and Phytosanitary Regulations and Barriers, 
of private sector standards was not raised at all in proposals or discussions concerning the scope of application of the SPS Agreement. ${ }^{223}$ This was due to the fact that, at the time of the negotiations, private-sector standards in the SPS area were not yet as pervasive as they are today. In fact, while private sector standards were then already used extensively in the area of technical specifications, the prevailing view was that safety standards were a matter for government regulation rather than private action. As noted by Digby Gascoine and others, the proliferation of private sector standards to respond to consumer demands with regard to issues such as animal welfare, environmental issues, and food safety is a development that postdates the negotiation of the SPS Agreement, and goes hand-in-hand with the domination of the food market by large supermarket chains. ${ }^{24}$

There was general consensus among the EC, US and Cairns Group on the inclusion of a non-discrimination principle and a requirement that the measure not constitute a disguised restriction on trade, familiar from the existing GATT disciplines, in the disciplines on SPS measures. ${ }^{225}$ However, it was observed that SPS measures often result in differing treatment of products due to differences in SPS conditions in different countries. Therefore, a strict national treatment obligation would not be acceptable. Instead, a prohibition on arbitrary or unjustifiable differences in treatment, as contained in the chapeau of Article XX of the GATT, was deemed more appropriate. ${ }^{226}$ In addition, the idea that SPS measures should be the least-trade-restrictive measures available that ensure the level of health protection chosen by the importing country, taken over from the 'necessary' requirement of Article XX(b) of the GATT, had wide support. ${ }^{227}$

Summary of Main Points Raised at the Eighth Meeting of the Working Group on Sanitary and Phytosanitary Regulations and Barriers: Note by the Secretariat, MTN.GNG/NG5/WGSP/W/24, circulated on 2 July 1990, para. 6.

223 Digby Gascoine et al., Private Voluntary Standards within the WTO Multilateral Framework (United Kingdom Department for International Development, London), March 2006, para. 25 and footnote 13. This report relies upon the recollections of Gretchen Stanton who chaired almost all the negotiations sessions on SPS issues, and Digby Gascoine, who represented Australia throughout the negotiations.

${ }^{224}$ Ibid., para. 25.

${ }^{225}$ The US proposal simply incorporated the national treatment rule of Article III:4 of the GATT Negotiating Group on Agriculture, Submission of the United States on Comprehensive Long-Term Agricultural Reform, MTN.GNG/NG5/W/118, circulated on 25 October 1989, 11. The EC proposal referred to the non-discrimination rule in Articles III:4 of the GATT and in the chapeau of Article XX of the GATT. However, it emphasised the need to work out more precisely how these would apply when different health conditions or systems of protection exist in different countries. Negotiating Group on Agriculture, Communication from the European Communities. Working Paper. Drafting of an Appropriate Framework of Rules for Sanitary and Phytosanitary Regulations, MTN.GNG/NG5/W/56, circulated on 20 April 1988, para. 3. The Cairns group proposed including the national treatment principle in respect of SPS regulations, and extending its application to inspection systems. Negotiating Group on Agriculture, Sanitary and Phytosanitary Issues: Communication from the Cairns Group, MTN.GNG/NG5/W/112, circulated on 2 October 1989, paras 11-12; Negotiating Group on Agriculture, Sanitary and Phytosanitary Issues: Supplementary Communication from the Cairns Group, MTN.GNG/NG5/W/164, circulated on 18 April 1990, para. 25.

${ }^{226}$ Negotiating Group on Agriculture, Working Group on Sanitary and Phytosanitary Regulations and Barriers, Summary of Main Points Raised at the Seventh Meeting of the Working Group on Sanitary and Phytosanitary Regulations and Barriers: Note by the Secretariat, MTN.GNG/NG5/WGSP/W/22, circulated on 31 May 1990, para. 11.

227 Negotiating Group on Agriculture, Communication from the European Communities. Working Paper. Drafting of an Appropriate Framework of Rules for Sanitary and Phytosanitary Regulations, MTN.GNG/ NG5/W/56, circulated on 20 April 1988, 2. The Nordic countries proposed the incorporation of the national treatment and most-favoured-nation obligations and to include under their application to risk assessment procedures and the choice of level of protection. Negotiating Group on Agriculture, Working Group on Sanitary 
From the start of the negotiations, the proposals of the US, the Cairns Group, the Nordic Group, Japan and the EC all supported harmonisation of SPS measures around the standards set by the Codex Alimentarius Commission (CAC), the International Office of Epizootics (OIE) and the International Plant Protection Convention (IPPC) or, for matters not covered by these organisations, around standards set by other relevant international organisations open for full participation by Parties. ${ }^{228}$ However, the proposals differed with respect to the strength of the harmonisation provision. The US and the Cairns Group envisaged a presumption of consistency with either the requirement of sound scientific evidence, ${ }^{229}$ or with the disciplines of Article XX(b) of the GATT, ${ }^{230}$ for SPS measures based on international standards. The Cairns Group went even further, requiring Parties that impose more stringent standards to bear the burden of proving that their measure was consistent with sound scientific evidence or the relevant GATT provisions. ${ }^{231}$ By contrast, the Nordic countries and Japan proposed that parties should adhere to, or base their SPS measures on, international standards unless these were inappropriate, for reasons such as differences in geographical conditions or dietary customs. ${ }^{232}$ Japan suggested that international bodies might more appropriately develop guidelines rather than standards. ${ }^{233}$ Allowing for even more flexibility, the EC saw international standards as constituting only a 'principal source of scientific or technical advice when considering the sanitary and phytosanitary aspects of international trade' and emphasised the need 'to provide for

and Phytosanitary Regulations and Barriers, Draft Agreement on Sanitary and Phytosanitary Measures: Note by the Nordic Countries, MTN.GNG/NG5/WGSP/W/21, circulated on 28 May 1990, 7.

228 Negotiating Group on Agriculture, Submission of the United States on Comprehensive Long-Term Agricultural Reform, MTN.GNG/NG5/W/118, circulated on 25 October 1989, 9; Negotiating Group on Agriculture, Communication from the European Communities. Working Paper. Drafting of an Appropriate Framework of Rules for Sanitary and Phytosanitary Regulations, MTN.GNG/NG5/W/56, circulated on 20 April 1988, para. 1; Negotiating Group on Agriculture, Submission of the European Communities on Sanitary and Phytosanitary Regulations and Measures, MTN.GNG/NG5/W/146, circulated on 20 December 1989, 1; Negotiating Group on Agriculture, Sanitary and Phytosanitary Issues: Supplementary Communication from the Cairns Group, MTN.GNG/NG5/W/164, circulated on 18 April 1990, para. 16; Negotiating Group on Agriculture, Working Group on Sanitary and Phytosanitary Regulations and Barriers, Draft Agreement on Sanitary and Phytosanitary Measures: Note by the Nordic Countries, MTN.GNG/NG5/WGSP/W/21, circulated on 28 May 1990, 7; Negotiating Group on Agriculture, Supplementary Submission of Japan on Sanitary and Phytosanitary Regulations and Measures, MTN.GNG/NG5/W/156, circulated on 7 March 1990, para. 1.

229 Negotiating Group on Agriculture, Submission of the United States on Comprehensive Long-Term Agricultural Reform, MTN.GNG/NG5/W/118, circulated on 25 October 1989, 10. The US proposal envisaged the inclusion into Article XX(b) of a proviso that the measures justified there under be 'consistent with sound science and recognise the principle of equivalency.' Thus, in effect, the US proposal also came down to a presumption of compliance with Article XX(b) of measures conforming to international standards.

${ }^{230}$ Negotiating Group on Agriculture, Sanitary and Phytosanitary Issues: Supplementary Communication from the Cairns Group, MTN.GNG/NG5/W/164, circulated on 18 April 1990, para. 19.

${ }^{231}$ Ibid., para. 20.

${ }^{232}$ Negotiating Group on Agriculture, Working Group on Sanitary and Phytosanitary Regulations and Barriers, Draft Agreement on Sanitary and Phytosanitary Measures: Note by the Nordic Countries, MTN.GNG/NG5/ WGSP/W/21, circulated on 28 May 1990, 7-8; Negotiating Group on Agriculture, Negotiating Group on Agriculture: Submission by Japan, MTN.GNG/NG5/W/131, circulated on 6 December 1989, para. 2. The Japanese proposal noted that where sanitary, dietary and geographic differences had to be considered, harmonisation should be effectuated by guidelines rather than standards. The Nordic proposal required only that parties not basing their SPS measures on international standards must, upon request, explain the reasons therefore. No scientific justification was required.

${ }^{233}$ Negotiating Group on Agriculture, Negotiating Group on Agriculture: Submission by Japan, MTN.GNG/ NG5/W/131, circulated on 6 December 1989, para. 2. 
countries that have reached a high health status to be able to continue to apply standards more stringent than the international standards, where appropriate. ${ }^{234}$ A convergence in positions emerged during the negotiations when the EC was confronted with US restrictions to its wine exports due to the presence of the fungicide procymidone, while an international standard setting a maximum residue level for this pesticide was in the process of adoption by the Codex Alimentarius Commission. ${ }^{235}$ This development led to a realisation by the EC and others of the potential benefits of harmonised standards and a strengthening of support for a stricter provision on harmonisation. ${ }^{236}$ The idea arose that scientific justification should be required for SPS measures that were stricter than international standards. There was disagreement on who should bear the burden of proof in such cases. ${ }^{237}$ It is interesting that in the discussions on the harmonisation proposals, several participants made the point that panels should not be able to question the validity of international standards, but could only review whether the standard was being appropriately applied. ${ }^{238}$

The role of science in SPS regulation was addressed in several proposals, most of which required that SPS measures be based on 'sound science'. ${ }^{239}$ Many proposals stated that measures based on international standards would be deemed to be based on sound

${ }^{234}$ Negotiating Group on Agriculture, Submission of the European Communities on Sanitary and Phytosanitary Regulations and Measures, MTN.GNG/NG5/W/146, circulated on 20 December 1989. In this regard the EC pointed to the fact that international standards have a voluntary character and are intended to apply to a wide range of countries with differing circumstances, and therefore tend not to be very stringent.

235 Marsha A. Echols, 'Sanitary and Phytosanitary Measures', in The World Trade Organization: The Multilateral Trade Framework for the 21st Century and U.S. Implementing Legislation, Terence P. Stewart (ed.) (American Bar Association, Washington, D.C.), 1996, 191-222.

${ }^{236}$ In 1990, in discussions at the Working Group on Sanitary and Phytosanitary Regulations and Barriers, the EC emphasised the importance of harmonisation. It proposed that existing international and regional standards be examined and a list be made of those agreed to for use in a GATT context. Countries complying with such standards would be presumed to comply with their GATT obligations. Countries applying stricter standards could be found in violation of the GATT if the exporting country could prove that the measures were maintained against sound scientific evidence. This EC proposal therefore differs from those of the US and the Cairns group in that it places the burden of proof on the exporting country rather than the regulating country. This allocation of the burden of proof was controversial in the negotiations. In addition, the EC's idea that a list of relevant standards be drawn up was criticised. Negotiating Group on Agriculture, Working Group on Sanitary and Phytosanitary Regulations and Barriers, Summary of Main Points Raised at the Fifth Meeting of the Working Group on Sanitary and Phytosanitary Regulations and Barriers: Note by the Secretariat, MTN. GNG/NG5/WGSP/W/13, circulated on 19 March 1990, paras 8-9.

${ }^{237}$ Negotiating Group on Agriculture, Working Group on Sanitary and Phytosanitary Regulations and Barriers, Summary of Main Points Raised at the Seventh Meeting of the Working Group on Sanitary and Phytosanitary Regulations and Barriers: Note by the Secretariat, MTN.GNG/NG5/WGSP/W/22, circulated on 31 May 1990, para. 8 .

${ }^{238}$ Negotiating Group on Agriculture, Working Group on Sanitary and Phytosanitary Regulations and Barriers, Summary of Main Points Raised at the Third Meeting of the Working Group on Sanitary and Phytosanitary Regulations and Barriers: Note by the Secretariat, MTN.GNG/NG5/WGSP/W/6, circulated on 17 October 1989, para. 9.

${ }^{239}$ See for example Negotiating Group on Agriculture, Negotiating Group on Agriculture: Submission by Austria, MTN.GNG/NG5/W/144, 19 December 1989, para. 5; Negotiating Group on Agriculture, Communication from Israel Expressing Views on Certain Elements in the Negotiation on Agriculture, MTN.GNG/NG5/W/153, 13 February 1990, para. VI; Negotiating Group on Agriculture, Working Group on Sanitary and Phytosanitary Regulations and Barriers, Draft Agreement on Sanitary and Phytosanitary Measures: Note by the Nordic Countries, MTN.GNG/NG5/WGSP/W/21, circulated on 28 May 1990, 4; Negotiating Group on Agriculture, Supplementary Submission of Japan on Sanitary and Phytosanitary Regulations and Measures, MTN.GNG/ NG5/W/156, circulated on 7 March 1990, para. 3. 
scientific evidence, whereas measures not so based would have to be scientifically justified. ${ }^{240}$ The EC proposal required that parties 'consider' available scientific evidence so that their measures are not maintained against sound science. ${ }^{241}$ The EC also proposed that in taking SPS measures a party be obliged to conduct a risk assessment, although it did not explicitly use the term. It proposed a balancing approach to this assessment, between allowing the maximum trade opportunities and ensuring the protection of life and health in a broad sense. ${ }^{242}$ The Nordic Group proposed that SPS measures should be based on adequate risk assessment procedures, 'where appropriate'. ${ }^{243}$ The Cairns Group was more strongly in support of scientific disciplines, in the form of a risk assessment, on SPS measures. ${ }^{244}$ It proposed that SPS measures should be based on verifiable scientific evidence on matters such as risk of entry, establishment or spread of pests and diseases and the potential biological consequences or the risk to human health from excessive contaminants in food In discussions on the factors that could appropriately be taken into account in a risk assessment, many participants supported the view that economic considerations (such as the impact of the introduction of pests or diseases into the importing country) had to be considered. However, it was emphasised that the effect of import competition on domestic production was not a legitimate consideration. ${ }^{245}$ Recognition was also present among negotiators regarding inappropriateness of the strict use of scientific disciplines in situations where the science is not yet conclusive. In discussions in the Working Group it was also observed that sometimes countries need to impose SPS measures in the absence of conclusive scientific evidence. As the 'precautionary principle' was at the time not yet at the forefront of discussions on SPS regulation, it was not expressly mentioned in the negotiations on this point. In the discussions, it was proposed that, to deal with the problem of inconclusive science, instead of requiring that SPS measures be based on scientific evidence, they should not be maintained against scientific evidence. ${ }^{246}$

240 See for example, Negotiating Group on Agriculture, Negotiating Group on Agriculture: Submission by Japan, MTN.GNG/NG5/W/131, circulated on 6 December 1989, para. 2.

${ }^{241}$ Negotiating Group on Agriculture, Submission of the European Communities on Sanitary and Phytosanitary Regulations and Measures, MTN.GNG/NG5/W/146, circulated on 20 December 1989, 2.

${ }^{242} \mathrm{Ibid}$. The EC referred to the requirement to assess the appropriate level of SPS protection, instead of the risk. However the elaboration of the factors that must be considered in this assessment shows that it was in fact referring to a risk assessment. The confusion may be due to the fact that in the discussions negotiators used the terms 'acceptable level of risk' and 'acceptable level of protection' interchangeably.

${ }^{243}$ Negotiating Group on Agriculture, Working Group on Sanitary and Phytosanitary Regulations and Barriers, Draft Agreement on Sanitary and Phytosanitary Measures: Note by the Nordic Countries, MTN.GNG/NG5/ WGSP/W/21, circulated on 28 May 1990, 8.

${ }^{244}$ Negotiating Group on Agriculture, Sanitary and Phytosanitary Issues: Supplementary Communication from the Cairns Group, MTN.GNG/NG5/W/164, circulated on 18 April 1990, para. 8.

${ }^{245}$ Negotiating Group on Agriculture, Working Group on Sanitary and Phytosanitary Regulations and Barriers, Summary of Main Points Raised at the Third Meeting of the Working Group on Sanitary and Phytosanitary Regulations and Barriers: Note by the Secretariat, MTN.GNG/NG5/WGSP/W/6, circulated on 17 October 1989, para. 3 .

${ }^{246}$ Negotiating Group on Agriculture, Working Group on Sanitary and Phytosanitary Regulations and Barriers, Summary of Main Points Raised at the Seventh Meeting of the Working Group on Sanitary and Phytosanitary Regulations and Barriers: Note by the Secretariat, MTN.GNG/NG5/WGSP/W/22, circulated on 31 May 1990, para. 5. This wording is reflected in the EC and Nordic proposals. Negotiating Group on Agriculture, Submission of the European Communities on Sanitary and Phytosanitary Regulations and Measures, MTN. GNG/NG5/W/146, circulated on 20 December 1989, 2; Negotiating Group on Agriculture, Working Group on Sanitary and Phytosanitary Regulations and Barriers, Draft Agreement on Sanitary and Phytosanitary Measures: Note by the Nordic Countries, MTN.GNG/NG5/WGSP/W/21, circulated on 28 May 1990, 8. 
The Cairns Group suggested that where verifiable scientific evidence is insufficient, a temporary level of protection be determined on the basis of all available relevant information, and that parties obtain the necessary information for a more objective assessment of the risk and accordingly review their SPS measures within a reasonable period of time. ${ }^{247}$ This proposal was not controversial and was taken up almost unchanged in the draft text of the SPS Agreement. ${ }^{248}$

Differing views were held on the question of the disciplines that should apply to a country's choice of the appropriate level of protection from SPS risks it wants to ensure on its territory. Some participants were of the view that the although the acceptable level of risk was for the importing country to decide, it should be subject to international scrutiny, and must have a rational basis in the effects of the introduction of the pest or disease into the country. ${ }^{249}$ The Cairns Group proposed that a country's acceptable level of risk should not be different for the same product from different origins or between domestic and imported products. ${ }^{250}$ In addition, it proposed that parties adopt the least stringent level of risk adopted by other parties in similar circumstances. ${ }^{251}$ In early discussions in the Working Group, no clear distinction was made between risk assessment and risk management and the terms 'appropriate level of risk' and 'risk assessment' were sometimes used interchangeably. ${ }^{252}$ Some participants noted that risk assessment is based not only on sound scientific evidence but also on ethical and political considerations. ${ }^{253}$ In later discussions

Further, the Nordic group proposed that where scientific evidence is inconclusive, the burden of proof should shift to the exporting country.

${ }^{247}$ Negotiating Group on Agriculture, Sanitary and Phytosanitary Issues: Supplementary Communication from the Cairns Group, MTN.GNG/NG5/W/164, circulated on 18 April 1990, para. 8.

${ }^{248}$ As noted by Doaa Motaal, if this provision were to be negotiated today, it would be ten times more difficult to reach agreement, due to the scientifically controversial disputes that have been heard at the WTO. Doaa Abdel Motaal, 'The "Multilateral Scientific Consensus" And the World Trade Organisation', Journal of World Trade 38 (5), 2004, 855-876, 863.

${ }^{249}$ Negotiating Group on Agriculture, Working Group on Sanitary and Phytosanitary Regulations and Barriers, Summary of Main Points Raised at the Third Meeting of the Working Group on Sanitary and Phytosanitary Regulations and Barriers: Note by the Secretariat, MTN.GNG/NG5/WGSP/W/6, circulated on 17 October 1989, para. 7.

${ }^{250}$ Negotiating Group on Agriculture, Sanitary and Phytosanitary Issues: Supplementary Communication from the Cairns Group, MTN.GNG/NG5/W/164, circulated on 18 April 1990, para. 9.

251 Ibid.. In addition the Cairns group stated that the acceptable level of SPS risk chosen should allow the maximum trade opportunities consistent with the objective, which seems to embody a least-trade-restrictive requirement. Negotiating Group on Agriculture, Sanitary and Phytosanitary Issues: Supplementary Communication from the Cairns Group, MTN.GNG/NG5/W/164, circulated on 18 April 1990, para. 7.

${ }^{252}$ For example, in discussions in the Working Group, concerns were raised about misunderstandings regarding the meaning of the terms 'acceptable level of risk' and 'risk assessment' and a preference for using instead the term 'acceptable level of protection' was noted. However, risk assessment does not have the same meaning as the other two terms, since the determination of an acceptable level of protection or of risk is a risk management decision, taken on the basis of a risk assessment and other considerations. Negotiating Group on Agriculture, Working Group on Sanitary and Phytosanitary Regulations and Barriers, Summary of Main Points Raised at the Sixth Meeting of the Working Group on Sanitary and Phytosanitary Regulations and Barriers: Note by the Secretariat, MTN.GNG/NG5/WGSP/W/18, circulated on 4 May 1990, para. 4; Negotiating Group on Agriculture, Working Group on Sanitary and Phytosanitary Regulations and Barriers, Summary of Main Points Raised at the Seventh Meeting of the Working Group on Sanitary and Phytosanitary Regulations and Barriers: Note by the Secretariat, MTN.GNG/NG5/WGSP/W/22, circulated on 31 May 1990, para. 9.

${ }^{253}$ Negotiating Group on Agriculture, Working Group on Sanitary and Phytosanitary Regulations and Barriers, Summary of Main Points Raised at the Third Meeting of the Working Group on Sanitary and Phytosanitary 
it was suggested that a distinction be made between the evaluation of risk, which could be carried out on a scientific basis, and the acceptable level of risk (or appropriate level of protection), which was a national sovereign decision for each party to decide for itself, subject to the requirement of non-discrimination. ${ }^{254}$ Japan emphasised that Parties should maintain the right to opt for a 'zero-risk' level of protection. ${ }^{255}$ This was disputed by other participants, which noted that zero-risk is 'virtually impossible and unacceptable'. ${ }^{256}$

Support was present in the proposals of the US, the EC, Japan, the Nordic Countries and the Cairns Group for the inclusion of disciplines regarding the recognition of equivalence of different SPS measures, for cases where harmonisation is not feasible. ${ }^{257}$ The US proposal required that SPS measures that are not identical but have the same effect in ensuring an acceptable level of protection be deemed equivalent. ${ }^{258}$ Likewise, the EC proposal recommended the development of suitable principles of equivalence to enable countries to meet the appropriate level of protection of an importing country using different SPS measures that achieve similar results. ${ }^{259}$ The Cairns Group also proposed the recognition of the principle of equivalence, which it defined as: 'Different parties may use different regulations, techniques and procedures, which are judged to be equal to the extent that they achieve acceptably similar results including meeting the acceptable level of risk.' ${ }^{260}$ It noted that when different possibilities exist for meeting a particular level of protection, a party has the right to choose the approach most suited to its circumstances, provided that it can prove the effectiveness of this approach to the satisfaction of the importing country. ${ }^{261}$ The fact that the burden of proof is on the exporting country to provide scientific information to show equivalence was stressed in Japan's proposal. ${ }^{262}$ The Nordic proposal

Regulations and Barriers: Note by the Secretariat, MTN.GNG/NG5/WGSP/W/6, circulated on 17 October 1989, para. 7.

${ }^{254}$ Negotiating Group on Agriculture, Working Group on Sanitary and Phytosanitary Regulations and Barriers, Summary of Main Points Raised at the Eighth Meeting of the Working Group on Sanitary and Phytosanitary Regulations and Barriers: Note by the Secretariat, MTN.GNG/NG5/WGSP/W/24, circulated on 2 July 1990, para. 7.

${ }^{255}$ Negotiating Group on Agriculture, Working Group on Sanitary and Phytosanitary Regulations and Barriers, Summary of Main Points Raised at the Fifth Meeting of the Working Group on Sanitary and Phytosanitary Regulations and Barriers: Note by the Secretariat, MTN.GNG/NG5/WGSP/W/13, circulated on 19 March 1990, para. 11.

${ }^{256}$ Ibid., para. 12.

257 Negotiating Group on Agriculture, Time for Action. A Proposal for a Framework Approach to Agriculture. Submission by the Cairns Group Comprising Argentina, Australia, Brazil, Canada, Chile, Colombia, Hungary, Indonesia, Malaysia, New Zealand, the Philippines, Thailand and Uruguay, MTN.GNG/NG5/W/69, circulated on 13 July 1988, para. 22, available at: http:/www.wto.org/gatt_docs/English/SULPDF/92050128.pdf, visited on 11 May 2008.

258 Negotiating Group on Agriculture, Submission of the United States on Comprehensive Long-Term Agricultural Reform, MTN.GNG/NG5/W/118, circulated on 25 October 1989, 9.

${ }^{259}$ Negotiating Group on Agriculture, Submission of the European Communities on Sanitary and Phytosanitary Regulations and Measures, MTN.GNG/NG5/W/146, circulated on 20 December 1989, 3.

260 Negotiating Group on Agriculture, Sanitary and Phytosanitary Issues: Communication from the Cairns Group, MTN.GNG/NG5/W/112, circulated on 2 October 1989, para. 10.

${ }^{261}$ Negotiating Group on Agriculture, Sanitary and Phytosanitary Issues: Supplementary Communication from the Cairns Group, MTN.GNG/NG5/W/164, circulated on 18 April 1990, para.22.

${ }^{262}$ Negotiating Group on Agriculture, Supplementary Submission of Japan on Sanitary and Phytosanitary Regulations and Measures, MTN.GNG/NG5/W/156, circulated on 7 March 1990, para. 2. 
required that parties, when appropriate, negotiate bilateral and multilateral agreements on mutual recognition of specific SPS measures. ${ }^{263}$

The idea of 'regionalisation', i.e. adaptation of SPS requirements to the specific pest- or disease-status of region of origin of the product, gained wide support in various proposals. The need to adapt SPS regulations to the specific SPS status of particular areas, rather than an entire country, was noted by the EC. ${ }^{264}$ The Cairns Group proposal also recommended the recognition of pest- or disease- free areas, as well as areas of low pest- or disease-prevalence, based on factors such as geography, epidemiological surveillance, and SPS control and verifiable by scientific evidence. ${ }^{265}$ It stated that the burden of proof that an area is free of a pest or disease (or has low pest/disease prevalence) ${ }^{266}$ is on the party in which the area is located, and that importing parties should have the right to check this by inspection or testing. ${ }^{267}$ It further noted the role of the international organisations in assisting the establishment and recognition of pest- and disease-free areas by developing criteria for such recognition, maintaining lists of countries that have notified their pest- or disease-free status, and nominating experts to provide scientific advice on pest- or disease-free status and the adequacy of controls in place to maintain such status. ${ }^{268} \mathrm{~A}$ similar detailed proposal on regionalisation is contained in the Nordic proposal. ${ }^{269}$

In addition, the importance of ensuring transparency by means of effective notification procedures was strongly supported by the US, EC and the Cairns Group. The EC and US transparency proposals coupled a prior notification obligation with a framework for consultations on SPS measures, to achieve an early resolution of potential disputes on technical level. Suggestions by the US for these notification and consultation procedures included: the requirement of notification of draft SPS measures that could have a significant effect on trade, allowing for a 60-day comment period on such drafts; the creation of a duty on the GATT Secretariat to circulate such notifications, drawing the attention of developing countries to those affecting products of particular interest to them; the obligation to take comments on notified draft measures into account and discuss them upon request; the obligation to establish an enquiry point responsible for notifications and responses to requests for documents and information; a mechanism for consultations on SPS measures with a view to reaching a mutually satisfactory solution, including a pos-

${ }^{263}$ Negotiating Group on Agriculture, Working Group on Sanitary and Phytosanitary Regulations and Barriers, Draft Agreement on Sanitary and Phytosanitary Measures: Note by the Nordic Countries, MTN.GNG/NG5/ WGSP/W/21, circulated on 28 May 1990, 9.

264 Negotiating Group on Agriculture, Communication from the European Communities. Working Paper. Drafting of an Appropriate Framework of Rules for Sanitary and Phytosanitary Regulations, MTN.GNG/ NG5/W/56, circulated on 20 April 1988, para. 3. This was reiterated in Negotiating Group on Agriculture, Submission of the European Communities on Sanitary and Phytosanitary Regulations and Measures, MTN. GNG/NG5/W/146, circulated on 20 December 1989, 2-3.

265 Negotiating Group on Agriculture, Sanitary and Phytosanitary Issues: Communication from the Cairns Group, MTN.GNG/NG5/W/112, circulated on 2 October 1989, para. 8.

${ }^{266}$ Negotiating Group on Agriculture, Sanitary and Phytosanitary Issues: Supplementary Communication from the Cairns Group, MTN.GNG/NG5/W/164, circulated on 18 April 1990, para. 15.

${ }^{267}$ Ibid., para. 12.

${ }^{268}$ Ibid., para. 13.

${ }^{269}$ Negotiating Group on Agriculture, Working Group on Sanitary and Phytosanitary Regulations and Barriers, Draft Agreement on Sanitary and Phytosanitary Measures: Note by the Nordic Countries, MTN.GNG/NG5/ WGSP/W/21, circulated on 28 May 1990, 4-5. 
sibility to request good offices from an appropriate individual or body (in particular the CAC, OIE or IPPC). ${ }^{270}$ The EC proposal also suggested prior notification of draft new or amended SPS measures that do not conform to international standards, except in cases of urgency, and a minimum consultation period, where requested. It recommended that the notification and consultation procedures of the Standards Code be used as a basis, but that ad hoc bilateral negotiations on particular SPS issues should be incorporated into these procedures. ${ }^{271}$ It saw such negotiations as a way to facilitate trade for example by making differing national measures compatible through the recognition of equivalence of alternative measures, and by creating an opportunity to consider providing technical assistance to developing countries to assist their exports. ${ }^{272}$ The Nordic Group supported the creation of a notification system, including prior notification of draft SPS measures limited to 'essential trade issues'. ${ }^{273}$ The Cairns Group proposal on transparency, while supporting 'a high degree of transparency', ${ }^{274}$ was more modest as it was concerned with reducing costs and avoiding duplication with existing transparency mechanisms. It proposed that all parties be required to maintain a central enquiry point, responsible for providing information, upon request, regarding their SPS legislation, pest- and disease-status, inspection and certification systems, and bilateral or regional SPS Agreements. ${ }^{275}$ It regarded that further consideration was needed as to whether a system of notification, and in particular prior notification, was necessary. ${ }^{276}$

Another issue that arose in the negotiations was the discipline that should be applied to national procedures for control, inspection and approval. In discussions in the Working Group, it was stressed that even if SPS regulations are harmonised, procedures for inspection, sampling and testing could create trade barriers, and thus needed to be covered by the new disciplines. ${ }^{277}$ The Nordic Group's proposal addressed conformity assessment procedures, setting out disciplines such as national treatment, the avoidance of undue delay, limitation of requirements to what is reasonable and necessary and respect for confidentiality. This proposal relied on those disciplines in this area contained in the Standards

270 Negotiating Group on Agriculture, Submission of the United States on Comprehensive Long-Term Agricultural Reform, MTN.GNG/NG5/W/118, circulated on 25 October 1989, 9-10.

${ }^{271}$ Negotiating Group on Agriculture, Submission of the European Communities on Sanitary and Phytosanitary Regulations and Measures, MTN.GNG/NG5/W/146, circulated on 20 December 1989, 3.

272 Negotiating Group on Agriculture, Communication from the European Communities. Working Paper. Drafting of an Appropriate Framework of Rules for Sanitary and Phytosanitary Regulations, MTN.GNG/ NG5/W/56, circulated on 20 April 1988, para. 2.

${ }^{273}$ Negotiating Group on Agriculture, Working Group on Sanitary and Phytosanitary Regulations and Barriers, Form and Disposition of the Agreement on Sanitary and Phytosanitary Regulations and Barriers (SPS Measures). Note by the Nordic Delegations, MTN.GNG/NG5/WGSP/W/10, circulated on 12 February 1990, 3.

${ }^{274}$ Negotiating Group on Agriculture, Sanitary and Phytosanitary Issues: Supplementary Communication from the Cairns Group, MTN.GNG/NG5/W/164, circulated on 18 April 1990, para. 33.

275 Ibid., para. 43. This proposal further stated that parties should not impose fees in excess of the actual costs of gathering and reproducing the requested information.

${ }^{276} \mathrm{Ibid}$., para. 36. The Cairns group also added the proviso that the transparency obligations should not require a party to disclose confidential information that would impede law enforcement or affect the legitimate commercial interests of particular enterprises. Ibid., para. 37.

${ }^{277}$ Negotiating Group on Agriculture, Working Group on Sanitary and Phytosanitary Regulations and Barriers, Summary of Main Points Raised at the Seventh Meeting of the Working Group on Sanitary and Phytosanitary Regulations and Barriers: Note by the Secretariat, MTN.GNG/NG5/WGSP/W/22, circulated on 31 May 1990, para. 13. 
Code. ${ }^{278}$ The proposed disciplines were included in the Dunkel Draft version of the SPS Agreement in Annex C. ${ }^{279}$ More problematic, however, were systems requiring prior approval of products before importation. While the Standards Code had covered conformity assessment procedures, it did not extend to systems of prior approval of products. Such systems are, in effect, provisional import bans maintained until the safety of the product is proven and are thus not in line with the proposed disciplines requiring that all SPS measures be based on 'sound science'. The US had complex prior approval systems in place, on federal and state level, for pharmaceuticals and pesticides. It proposed that any Member wishing to challenge such a system be required to first have attempted to obtain approval or certification of their product in accordance with the rules of the system. The only limitations envisaged by the US on such systems were that they use reasonable and science-based procedures and evidentiary standards, and respect the obligation of national treatment. ${ }^{280}$ In the October 1990 draft text of the SPS Agreement, ${ }^{281}$ a bracketed text on prior approval systems is to be found in the main body of the draft Agreement, separate from the remaining disciplines on control, inspection and approval procedures in Annex $\mathrm{C}$ of that draft. ${ }^{282}$ This bracketed text expressly states the right of Contracting Parties to establish and operate systems for the prior approval or registration of substances that are the subject of SPS measures, but stipulates that such systems must be 'non-discriminatory, transparent, based on sound science and result in a timely approval or registration decision. ${ }^{283}$ In addition, it stipulates that if an international standard exists for the product, substance or process subject to prior approval and the exporting country complies with this standard, the Contracting Party imposing the system must bear the entire cost of the approval procedure. However, notwithstanding these requirements, in the absence of the required approval, the text provides that the Contracting Party may restrict market access for the relevant product. Continuing disagreement on this issue is evinced by the December 1990 draft text of the Agreement, which included four bracketed alternatives for the provision on prior approval systems of varying strictness. ${ }^{284}$ One option was to omit the provision entirely. The second option was to include a provision similar to that in the October 1990 text but omitting the reference to international standards. A third alternative was to include the October 1990 text and elaborate its reference to international standards by prohibiting a market access restriction based solely on the absence of

${ }^{278}$ Negotiating Group on Agriculture, Working Group on Sanitary and Phytosanitary Regulations and Barriers, Draft Agreement on Sanitary and Phytosanitary Measures: Note by the Nordic Countries, MTN.GNG/NG5/ WGSP/W/21, circulated on 28 May 1990, 8-9.

${ }^{279}$ John M. Breen, 'Agriculture', in The GATT Uruguay Round: A Negotiating History (1986-1992), Terence P. Stewart (ed.), vol. IV: The End Game (Kluwer, The Hague/London/Boston), 1999, 41-45, 665.

280 Negotiating Group on Agriculture, Submission of the United States on Comprehensive Long-Term Agricultural Reform, MTN.GNG/NG5/W/118, circulated on 25 October 1989, 10.

${ }^{281}$ Negotiating Group on Agriculture, Working Group on Sanitary and Phytosanitary Regulations and Barriers, Draft Text for a Decision by the CONTRACTING PARTIES on Sanitary and Phytosanitary Measures, MTN. GNG/NG5/WGSP/W/26, circulated on 1 October 1990.

${ }^{282}$ In draft negotiating texts, square brackets around a piece of text indicates that the text is still subject to a difference of views among negotiators.

${ }^{283}$ Negotiating Group on Agriculture, Working Group on Sanitary and Phytosanitary Regulations and Barriers, Draft Text for a Decision by the CONTRACTING PARTIES on Sanitary and Phytosanitary Measures, MTN. GNG/NG5/WGSP/W/26, circulated on 1 October 1990, para. 17.

${ }^{284}$ John M. Breen, 'Agriculture', in The GATT Uruguay Round: A Negotiating History (1986-1992), Terence P. Stewart (ed.), vol. IV: The End Game (Kluwer, The Hague/London/Boston), 1999, 41-45, 233-234. 
approval if a relevant international standard exists with which the product conforms and nine months have passed since the complete approval application was submitted and the international standard was adopted. The fourth option was to prohibit a restriction of market access based on the fact that an approval procedure had not been completed, unless that procedure was consistent with the disciplines of the SPS Agreement. Additionally if a relevant international standard existed, the fourth option would prohibit a market access restriction for products conforming to that international standard for longer than four months from the application for approval, unless the importing Member introduced a 'standard' that differed from the international standard in accordance with the harmonisation disciplines of the Agreement. By the time the Dunkel Draft was issued in 1991, this provision had been removed from the main text of the Agreement and replaced by a short paragraph in Annex C, obliging importing Parties that operate systems for prior approval of food additives or for the establishment of tolerances for contaminants to 'consider' basing market access on a relevant international standard until a final determination is made. $^{285}$

In the negotiations, there was widespread recognition of the particular difficulties faced by developing countries in the field of SPS regulation. The US, EC, the Cairns Group and the Nordic countries all indicated the need for technical assistance and special and differential treatment with regard to developing countries. However, these proposals varied in scope and strength. The US proposal suggested that Parties should evaluate its probable impact on developing countries of the enhanced rules on SPS measures, and if warranted should approach the appropriate international organisations (such as the FAO) for technical assistance to strengthen developing countries' SPS regulatory systems. ${ }^{286}$ With regard to special and differential treatment for developing countries, in all agriculture disciplines including SPS, the US proposed that the need for exceptional treatment of a particular less-developed country be demonstrated according to criteria related to its level of agricultural and overall development, and that the flexibility granted to such country be commensurate with the demonstrated needs. ${ }^{287}$ The EC proposal agreed that an assessment of the need of developing countries for technical assistance should proceed without delay and noted that proposed rules on transparency and harmonisation would, in themselves, benefit developing countries. ${ }^{288}$

The Cairns proposal went further in calling for phased introduction of new SPS measures, longer time frames for compliance by developing countries and assistance for SPS dispute settlement. Further, in situations where new SPS measures require substantial investments, it called for developed countries to accord additional market access opportunities for the product involved on a most-favoured-nation basis. ${ }^{289}$ In addition, it suggested that

${ }^{285}$ Ibid., 666.

286 Negotiating Group on Agriculture, Submission of the United States on Comprehensive Long-Term Agricultural Reform, MTN.GNG/NG5/W/118, circulated on 25 October 1989, 11.

${ }^{287} \mathrm{Ibid}$. This proposal comes down to a suggestion for differentiation, on the basis of concrete criteria, between developing countries in granting special and differential treatment. On this issue, see further below, Part V, Section 1.7 .

${ }^{288}$ Negotiating Group on Agriculture, Submission of the European Communities on Sanitary and Phytosanitary Regulations and Measures, MTN.GNG/NG5/W/146, circulated on 20 December 1989, 4.

${ }^{289}$ Negotiating Group on Agriculture, Sanitary and Phytosanitary Issues: Supplementary Communication from the Cairns Group, MTN.GNG/NG5/W/164, circulated on 18 April 1990, para. 26. 
compensation, equivalent to the market loss from the SPS measure, be extended to a developing country where SPS measures more stringent than necessary or not supported by scientific evidence were applied to developing-country products. ${ }^{290}$ In discussions on this compensation proposal, it was suggested that compensation be used as a follow-up to dispute settlement proceedings, to address lost export opportunities. ${ }^{291}$ The Cairns Group proposal stated that parties should actively facilitate the provision of technical assistance to developing countries and other countries that may be in need of such assistance, in the form of advice, credits, donations training and equipment, to adjust and comply with SPS measures on their export markets. ${ }^{292}$

The Nordic countries submitted a detailed and very far-reaching proposal on technical assistance and special and differential treatment for developing countries, based on the provisions contained in the Standards Code. ${ }^{293}$ However, the Nordic countries made an important point in the introduction to their proposal, stating that perhaps more important than special provisions for developing countries was the content of the new disciplines for SPS measures, as this would facilitate trade and minimise conflict to the benefit of all parties, not least the developing countries. The Nordic proposal went on to suggest that an obligation be created on parties to advise other parties, especially developing countries, if requested on the preparation of SPS measures, the establishment of an SPS institutional and legal framework, participation in international standard setting bodies, and compliance with SPS requirements. In addition, an obligation to provide technical assistance on such matters, on mutually agreed terms, was proposed. ${ }^{294}$ Extensive provisions on special

290 Negotiating Group on Agriculture, Sanitary and Phytosanitary Issues: Communication from the Cairns Group, MTN.GNG/NG5/W/112, circulated on 2 October 1989, paras 13-14; Negotiating Group on Agriculture, Sanitary and Phytosanitary Issues: Supplementary Communication from the Cairns Group, MTN.GNG/NG5/W/164, circulated on 18 April 1990, paras 26-28. The call for compensation for the adverse trade effects of SPS measures was already made by the Cairns group in its 1988 proposal. Negotiating Group on Agriculture, Time for Action. A Proposal for a Framework Approach to Agriculture. Submission by the Cairns Group Comprising Argentina, Australia, Brazil, Canada, Chile, Colombia, Hungary, Indonesia, Malaysia, New Zealand, the Philippines, Thailand and Uruguay, MTN.GNG/NG5/W/69, circulated on 13 July 1988, para. 22, available at: http://www.wto.org/gatt_docs/English/SULPDF/92050128.pdf, visited on 11 May 2008. The compensation proposal is much more limited than the early proposals by developing countries in discussions at the Committee on Trade in Agriculture that SPS measures be regarded as a kind of 'safeguard' measure, for which compensatory adjustment must be made by means of concessions in other areas to a level equivalent to the adverse trade effects of the measure. These early proposals were not limited to illegitimate SPS measures, but saw all SPS measures as requiring compensatory adjustment. Committee on Trade in Agriculture, Summary of Points Raised at the Meeting of the Committee Held on 2 - 3 April 1985. Note by the Secretariat, AG/W/13, circulated on 4 September 1985, para. 3.

${ }^{291}$ Negotiating Group on Agriculture, Working Group on Sanitary and Phytosanitary Regulations and Barriers, Summary of Main Points Raised at the Fourth Meeting of the Working Group on Sanitary and Phytosanitary Regulations and Barriers: Note by the Secretariat, MTN.GNG/NG5/WGSP/W/8, circulated on 6 December 1989 , para. 3. This suggested compensation possibility would seem to go further than the current possibility in WTO dispute settlement to provide (agreed) compensation for a measure found to be in violation of WTO rules by a panel or the Appellate Body, pending compliance with the ruling. The proposed compensation covers lost export opportunities and would seem therefore to address past damage.

${ }^{292}$ Negotiating Group on Agriculture, Sanitary and Phytosanitary Issues: Communication from the Cairns Group, MTN.GNG/NG5/W/112, circulated on 2 October 1989, para. 15.

${ }^{293}$ Negotiating Group on Agriculture, Working Group on Sanitary and Phytosanitary Regulations and Barriers, Technical Assistance to Other Parties and Special and Differential Treatment of Developing Countries. Note by the Nordic Delegations, MTN.GNG/NG5/WGSP/W/14, circulated on 20 April 1990.

${ }^{294}$ Ibid., paras A.1-A.2. The Nordic countries also proposed that priority be given to least-developed countries in providing advice and technical assistance. Negotiating Group on Agriculture, Working Group on 
and differential treatment are contained in the Nordic proposal. An obligation to take into account the special development, financial and trade needs of developing countries in the implementation of the new Agreement was proposed. Further, the recognition that developing countries should not be expected to base their SPS measures on international standards which are not appropriate to their development needs was incorporated. ${ }^{295}$ The proposal obliges parties to take reasonable measures to ensure that the international standard-setting bodies operate in a way that facilitates active and representative participation by all parties, taking into account the special problems of developing countries, and that these bodies, upon request of developing countries, examine the possibility of, and if possible prepare, international standards of special interest to developing countries. ${ }^{296}$ Parties, in this proposal, are obliged to provide technical assistance to developing countries to ensure that SPS measures and testing, inspection and approval procedures do not create unnecessary obstacles to the expansion and diversification of trade of developing countries. The terms and conditions for such assistance must take account of the stage of development of the requesting country, thus recognising the need for differentiation. ${ }^{297}$ Implementation problems that developing countries may have are taken into account by providing a possibility for the SPS Committee to grant specified, time-limited exceptions from some or all the obligations of the Agreement, taking into account the particular SPS constraints of the requesting country, its development and trade needs and its stage of technological development. ${ }^{298}$

To ensure the enforcement of the new disciplines, proposals addressed the question of bringing the new Agreement under effective dispute settlement procedures. The need for technical expertise in such procedures was repeatedly raised. The proposal of Austria differed from other proposals in that it suggested that disputes on technical issues be examined by the relevant international organisations, and only if the measure was found to have no sound scientific basis and was not removed in time, a 'trade-related' dispute should be brought before a GATT panel. ${ }^{299}$ The EC, on the contrary, argued that both technical and legal issues in a dispute should be addressed by a single panel. ${ }^{300}$ During the discussion of the Austrian proposal, the CAC, OIE and IPPC pointed out that they had no, or no adequate, dispute settlement system to undertake this task, participants were

Sanitary and Phytosanitary Regulations and Barriers, Technical Assistance to Other Parties and Special and Differential Treatment of Developing Countries. Note by the Nordic Delegations, MTN.GNG/NG5/ WGSP/W/14, circulated on 20 April 1990, para. A.4.

${ }^{295}$ Negotiating Group on Agriculture, Working Group on Sanitary and Phytosanitary Regulations and Barriers, Technical Assistance to Other Parties and Special and Differential Treatment of Developing Countries. Note by the Nordic Delegations, MTN.GNG/NG5/WGSP/W/14, circulated on 20 April 1990, para. B.4. This proposed provision notes that the particular technological and socio-economic conditions in developing countries may necessitate the adoption of particular SPS measures suited to these conditions even where international standards exist.

${ }^{296}$ Ibid., paras B.5 - B.6.

297 Ibid., para. B.7.

${ }^{298}$ Ibid., para. B.8.

299 Negotiating Group on Agriculture, Negotiating Group on Agriculture: Submission by Austria, MTN.GNG/ NG5/W/144, 19 December 1989, 3-4.

${ }^{300}$ Negotiating Group on Agriculture, Submission of the European Communities on Sanitary and Phytosanitary Regulations and Measures, MTN.GNG/NG5/W/146, circulated on 20 December 1989, 3. The EC noted that the separation of technical and legal issues had rendered the dispute settlement procedure under the Standards Code unworkable in certain situations. 
of the view that it was better to submit SPS disputes to strengthened GATT dispute settlement procedures, using the expertise of the relevant international organisations. ${ }^{301}$ In view of the fact that a strengthened and enforceable dispute settlement mechanism was being negotiated at the same time in the Uruguay Round, the Cairns Group proposed that the resolution of SPS disputes be brought under this system. ${ }^{302}$ While convergence was achieved on this point, the importance of providing for technical expertise in the settlement of disputes was repeatedly noted. Thus the need to create a possibility for a panel to consult technical experts from the relevant international organisations or independent experts agreed upon by the parties to a dispute, was stressed in all the relevant proposals. ${ }^{303}$ However, the Cairns Group clarified the supportive role to be given to international organisations and their scientific experts and the final responsibility to resolve a dispute lay with the panel. It stated:

[A]lthough these organizations may be consulted by GATT dispute settlement panels, the GATT is solely responsible for the conduct of its dispute settlement procedures. Additionally, experts nominated by these organizations would be individuals, known because of their expertise in the relevant field, but would not be representing the organizations. ${ }^{304}$

As stated above, few changes were made to the draft text of the SPS Agreement included in the Dunkel Draft in the final stages of the negotiations. However, some limited but crucial changes were needed to secure the agreement of some developed countries. ${ }^{305} \mathrm{In}$

301 The CAC pointed out that it had no dispute settlement mechanism, the OIE reported that it was still in the process of developing a dispute settlement procedure for technical disputes and the IPPC noted that although it had dispute settlement procedures in place, these had never been used by its parties, due to the difficulty of reaching agreement on scientific issues. The discussion on this point is reported in Negotiating Group on Agriculture, Working Group on Sanitary and Phytosanitary Regulations and Barriers, Summary of Main Points Raised at the Fifth Meeting of the Working Group on Sanitary and Phytosanitary Regulations and Barriers: Note by the Secretariat, MTN.GNG/NG5/WGSP/W/13, circulated on 19 March 1990, para. 6. The fact that in the negotiations in the Working Group, most participants preferred bringing SPS disputes under GATT dispute settlement procedures is reported in Negotiating Group on Agriculture, Working Group on Sanitary and Phytosanitary Regulations and Barriers, Summary of Main Points Raised at the Seventh Meeting of the Working Group on Sanitary and Phytosanitary Regulations and Barriers: Note by the Secretariat, MTN.GNG/NG5/WGSP/W/22, circulated on 31 May 1990, para. 16. This report notes also the concerns raised with regard to the fact that a GATT panel would not be able to judge the scientific value of an SPS measure.

302 Negotiating Group on Agriculture, Sanitary and Phytosanitary Issues: Supplementary Communication from the Cairns Group, MTN.GNG/NG5/W/164, circulated on 18 April 1990, paras 38-39.

${ }^{303}$ Ibid., para. 40; Negotiating Group on Agriculture, Submission of the European Communities on Sanitary and Phytosanitary Regulations and Measures, MTN.GNG/NG5/W/146, circulated on 20 December 1989, 4; Negotiating Group on Agriculture, Negotiating Group on Agriculture: Submission by Japan, MTN.GNG/ NG5/W/131, circulated on 6 December 1989, para. 3; Negotiating Group on Agriculture, Working Group on Sanitary and Phytosanitary Regulations and Barriers, Dispute Settlement Procedures: Note by the Nordic Delegations, MTN.GNG/NG5/WGSP/W/11, circulated on 12 February 1990, para. B.4. The Nordic group's proposal outlined a detailed set of rules on a separate dispute settlement mechanism for the SPS Agreement.

${ }^{304}$ Negotiating Group on Agriculture, Sanitary and Phytosanitary Issues: Supplementary Communication from the Cairns Group, MTN.GNG/NG5/W/164, circulated on 18 April 1990, para. 40.

${ }^{305}$ A side-by-side comparison of the draft text of the SPS Agreement in the Dunkel Draft and the final text of the SPS Agreement in the Uruguay Round Final Act can be found in John M. Breen, 'Agriculture', in The GATT Uruguay Round: A Negotiating History (1986-1992), Terence P. Stewart (ed.), vol. IV: The End Game (Kluwer, The Hague/London/Boston), 1999, 41-45, Annex 2. 
particular, the US raised concerns with the possibility that the draft SPS Agreement's harmonisation disciplines could require developed countries to lower their SPS requirements to comply with international standards. ${ }^{306}$ This led to some adjustments to the text of the Agreement. For example, in the Preamble, the paragraph stating the desire of Members to further the use of harmonised measures on the basis of international standards was amended by adding the words: 'without requiring Members to change their appropriate level of protection of human, animal or plant life or health' ${ }^{307}$ In addition, a footnote was added to clarify the requirement in Article 3.3 of the SPS Agreement of scientific justification for SPS measures more stringent than international standards. It specified that such 'scientific justification' exists 'if on the basis of an examination and evaluation of available scientific information ... a Member determines that the relevant international standards ... are not sufficient to achieve its appropriate level of protection. ${ }^{308}$

Another last minute change to the Dunkel Draft version of the SPS Agreement, also in response to concerns of countries with high levels of protection, was with regard to Article 2.2. The original text of Article 2.2 inter alia required SPS measures to be based on scientific principles and not to be maintained against scientific evidence. This was amended by requiring instead that SPS measures not be maintained 'without sufficient scientific evidence' and by the addition of the proviso 'except as provided for in paragraph 7 of Article 5.' Article 5.7 embodies the precautionary principle for purposes of the SPS Agreement. ${ }^{309}$ Thus, this change to Article 2.2 aims to ensure that the scientific disciplines of Article 2.2 do not undermine the extent to which Parties can take provisional measures in situations where scientific evidence is insufficient.

The emphasis of developed countries on the need for additional flexibility in the risk assessment disciplines in cases where human health is at stake, and the need to respect the right of Members to determine for themselves the level of SPS protection that they deem appropriate in their territories, is reflected in another late amendment to the draft text. The provision that is currently Article 5.3 of the SPS Agreement lists certain economic factors that Members must consider when conducting a risk assessment. A change was made to this provision to specify that these economic considerations are only required in the assessment of risks to animal or plant life or health, so not in the assessment of risks to human health. ${ }^{310}$ In addition, it was amended to omit the requirement that these economic factors be considered by a Member when determining its level of SPS protection, and to replace it with the requirement to consider these factors in the choice of SPS measure to be applied to achieve the level of protection deemed appropriate by the Member. Similar reasons motivated the change in the initial requirement in Article 5.6 of the SPS Agreement that SPS measures be least restrictive to trade, to specify that they must be no more trade restrictive than required to achieve a Member's appropriate level of protection. These additional changes secured the agreement of countries with high levels of SPS

306 These concerns were based on arguments of consumer and environmental lobbies claiming that many SPS measures of developed countries would be inconsistent with the draft SPS Agreement. Ibid., 42.

307 Ibid., 44.

${ }^{308}$ Footnote 2 to Article 3.3 of the SPS Agreement. See further below, Part III, Section 4.2.3.

${ }^{309}$ For a discussion of the precautionary principle, see above Part II, Section 1.5. For an analysis of Article 5.7 of the SPS Agreement and the extent to which it reflects the precautionary principle, see below, Part III, Sections 3.2.3.2 and 5.2.5.1.

${ }^{310}$ Article 5.6 of the SPS Agreement is discussed below, Part III, Section 5.2.4. 
protection to the draft text, as they diminished limitations on policy choices made in the exercise of regulatory autonomy.

\subsubsection{Positions of the developing-country participants}

Apart from those developing countries that were members of the Cairns Group at the time of the Uruguay Round negotiations, ${ }^{311}$ developing-country participation in the negotiation of the SPS Agreement was rather limited. Still, although the group of developing countries in the agriculture negotiations was not as identifiable as the Cairns Group, John Breen reports that they still often 'spoke with one voice'. ${ }^{312}$ This group was led by India, Jamaica and Egypt. Other participants in this group were Morocco, Nigeria, Mexico and Peru. This group of developing countries made statements and actively participated in the discussions in the meetings of the Working Group on Sanitary and Phytosanitary Regulations and Barriers and addressed SPS issues as part of their position papers in the Negotiating Group on Agriculture. ${ }^{313}$ Cairns Group members Brazil and Colombia submitted a separate proposal, elaborating on the ideas of the Cairns Group with regard to special and differential treatment for developing countries in agriculture, including in the area of SPS. ${ }^{314}$ They also addressed this issue in their individual proposals. ${ }^{315}$ On behalf of the least-developed countries, Bangladesh touched upon SPS issues in its agriculture proposal. ${ }^{316}$ In addition, Korea, which claimed that despite its industrial strength it had an under-developed agricultural sector, participated as a developing country in these negotiations, calling for special and differential treatment. ${ }^{317}$

311 Negotiating Group on Agriculture, Time for Action. A Proposal for a Framework Approach to Agriculture. Submission by the Cairns Group Comprising Argentina, Australia, Brazil, Canada, Chile, Colombia, Hungary, Indonesia, Malaysia, New Zealand, the Philippines, Thailand and Uruguay, MTN.GNG/NG5/W/69, circulated on 13 July 1988, para. (vi), available at: http://www.wto.org/gatt_docs/English/SULPDF/92050128. pdf, visited on 11 May 2008.

312 John M. Breen, 'Agriculture', in The GATT Uruguay Round: A Negotiating History (1986-1992), Terence P. Stewart (ed.), vol. I: Commentary (Kluwer, Deventer), 1993, 125-254, 191.

${ }^{313}$ Negotiating Group on Agriculture, Proposal by Egypt, Jamaica, Mexico and Peru, MTN.GNG/NG5/W/74, circulated on 13 September 1988, para. II(c), available at: http:/www.wto.org/gatt_docs/English/ SULPDF/92050187.pdf, visited on 11 May 2008. Negotiating Group on Agriculture, Elements for a Proposal by Developing Countries. Communication from Jamaica, MTM.GNG/NG5/W/68, circulated on 11 July 1988, para. 9 (c)(iv); Negotiating Group on Agriculture, Communication from Jamaica, MTN.GNG/ NG5/W/42, circulated on 4 February 1988, para. 13 (vii). See also Negotiating Group on Agriculture, Indian Proposal, MTN.GNG/NG5/W/84, circulated on 14 November 1988; Negotiating Group on Agriculture, Communication from Nigeria on Issues before the Negotiating Group, MTN.GNG/NG5/W/57, circulated on 20 April 1988, para. 7; Negotiating Group on Agriculture, Negotiating Group on Agriculture: Statement by the Kingdom of Morocco, MTN.GNG/NG5/W/121, 2 November 1989, paras 13-18.

${ }^{314}$ Negotiating Group on Agriculture, Proposal on Special, Differential and More Favourable Treatment for Developing Countries. Communication from Brazil and Colombia, MTN.GNG/NG5/W/132, 28 November 1989.

315 Negotiating Group on Agriculture, Statement by Brazil. Special and Differential Treatment, MTN.GNG/ NG5/W/108, circulated on 2 October 1989, para. 7; Negotiating Group on Agriculture, Special and Differential Treatment for Developing Countries. Statement by Colombia, MTN.GNG/NG5/W/110, circulated on 4 October 1989.

${ }^{316}$ Negotiating Group on Agriculture, Proposals on Behalf of the Least-Developed Countries. Communication from Bangladesh, MTN.GNG/NG5/W/126, circulated on 13 November 1989.

${ }^{317}$ Korea pointed to factors such as its overpopulated farmland, small-scale farming, and under-developed infrastructure to support its claim that its agricultural sector was at a very low stage of development. Negotiating Group on Agriculture, Proposal for Negotiations on Agriculture: Submitted by the Republic of Korea, MTN. 
These developing-country proposals generally emphasised the importance of transparency, harmonisation of SPS measures on the basis of standards set by the international standard-setting bodies as well as technical assistance and special and differential treatment for developing countries.

In the proposal of the Developing Country Group in the agriculture negotiations, submitted by Egypt, Jamaica, Mexico and Peru, and supported by Morocco and Nigeria, the issue of SPS measures briefly addressed. ${ }^{318}$ This proposal called for clear rules and disciplines on SPS measures as part of the strengthened GATT disciplines. In addition, it emphasised the importance of improvements in transparency. It proposed that a technical group be convened to identify and analyse those SPS measures that could constitute trade barriers and make recommendations for disciplines on SPS measures, including the possibility for harmonisation and equivalence. However, it expressed concern that 'the immediate application of international standards may serve as unintended barriers to trade among developing countries. ${ }^{319}$ In addition, the establishment of a programme of technical assistance was recommended. Jamaica submitted a more detailed proposal to further clarify these suggestions. It noted the substantial work done in the CAC, United Nations Economic Commission for Europe (UNECE), OECD and others on SPS trade barriers that could be fruitfully used by a GATT technical group to address the issue. It therefore called from prompt commencement of this work. ${ }^{320}$ It again emphasised the importance of special rules on transparency, noting that experience in Jamaica had shown that outdated information on SPS measures was itself an important trade barrier, including between developing countries. It called for a programme of technical assistance and support for developing countries to be defined, to ensure trade expansion, including between developing countries. ${ }^{321}$ On behalf of the Developing Country Group, Jamaica submitted another proposal, noting their concern with the fact that the Working Group on Sanitary and Phytosanitary Regulations and Barriers was focusing on long-term action rather than also on short term measures to address SPS barriers to trade. Although they considered long-term action, for example the creation of disciplines on harmonisation and equivalence, necessary, these countries were convinced of the scope for short term measures to increase the transparency of SPS measures and resolve SPS disputes promptly. They therefore proposed the designation of national enquiry points for information on SPS measures, the identification of existing SPS regulations, a prior notification system for draft SPS measures coupled with consultations with major developing-country suppliers, the negotiation of bilateral or multilateral mutual recognition agreements for products

GNG/NG5/W/130, 28 November 1989, para. 2.

${ }_{318}$ Negotiating Group on Agriculture, Proposal by Egypt, Jamaica, Mexico and Peru, MTN.GNG/NG5/W/74, circulated on 13 September 1988, para. II(c), available at: http://www.wto.org/gatt_docs/English/ SULPDF/92050187.pdf, visited on 11 May 2008. This proposal was taken up from the identical proposal previously made in Negotiating Group on Agriculture, Elements for a Proposal by Developing Countries. Communication from Jamaica, MTM.GNG/NG5/W/68, circulated on 11 July 1988, para. 9 (c)(iv).

${ }^{319}$ Negotiating Group on Agriculture, Elements for a Proposal by Developing Countries. Communication from Jamaica, MTM.GNG/NG5/W/68, circulated on 11 July 1988.

${ }_{320}$ Negotiating Group on Agriculture, Statement by Jamaica, MTN.GNG/NG5/W/72, circulated on 28 July $1988,4$.

${ }^{321}$ Ibid. 
of export interest to developing countries, and training courses for developing-country exporters. ${ }^{322}$

Some individual proposals by Developing Country Group members also touched upon SPS issues. An earlier proposal by Jamaica emphasised the need for harmonisation of SPS measures, as far as possible, and their non-discriminatory application. It stated that SPS measures should be subject to clearly defined multilateral disciplines. ${ }^{323}$ India, in its proposal for a framework for integrating trade in agriculture into a strengthened GATT regime, called for the reduction or elimination of the trade distortive effect of SPS measures. ${ }^{324}$ Nigeria proposed that SPS measures should be harmonised as some of them are 'deliberately created at variance with relevant provisions of the [GATT]', but recognized the need for a 'safety valve for the health of food, plants, animals and the environment' subject to a non-discrimination requirement. ${ }^{325}$ Morocco's proposal recommended harmonisation of SPS measures and risk assessment methods around international standards set by the CAC, OIE and IPPC. At discussions in the Working Group, Morocco clarified that it proposed that Parties exclusively use the methodologies and techniques developed by the OIE and IPPC and the pesticide residue levels established by the CAC. ${ }^{326}$ It further stated that technical assistance to developing countries for the elaboration and implementation of SPS regulations should be a 'central concern' in the negotiations. ${ }^{327}$

Two developing-country members of the Cairns Group, Brazil and Colombia, submitted very similar individual proposals and a joint proposal addressing their concerns with the impact SPS measures on developing countries. All these proposals called for an elimination of the discriminatory SPS treatment of developing countries. ${ }^{328}$ Colombia additionally noted the great importance of establishing procedures for the recognition of pest- and disease free regions. ${ }^{329}$ The joint proposal called for the harmonisation of SPS

322 Negotiating Group on Agriculture, Sanitary and Phytosanitary Regulations and Barriers. Submitted by Jamaica, MTN.GNG/NG5/W/89, circulated on 23 November 1988, 1-2.

${ }^{323}$ Negotiating Group on Agriculture, Communication from Jamaica, MTN.GNG/NG5/W/42, circulated on 4 February 1988, para. 13(vii).

${ }^{324}$ Negotiating Group on Agriculture, Indian Proposal, MTN.GNG/NG5/W/84, circulated on 14 November 1988.

${ }^{325}$ Negotiating Group on Agriculture, Communication from Nigeria on Issues before the Negotiating Group, MTN.GNG/NG5/W/57, circulated on 20 April 1988, para. 7.

${ }^{326}$ Negotiating Group on Agriculture, Working Group on Sanitary and Phytosanitary Regulations and Barriers, Summary of Main Points Raised at the Fourth Meeting of the Working Group on Sanitary and Phytosanitary Regulations and Barriers: Note by the Secretariat, MTN.GNG/NG5/WGSP/W/8, circulated on 6 December 1989, para. 8. Morocco noted the need to increase the resources given to the three standard-setting bodies to permit them to improve their research and expand their work.

${ }^{327}$ Negotiating Group on Agriculture, Negotiating Group on Agriculture: Statement by the Kingdom of Morocco, MTN.GNG/NG5/W/121, 2 November 1989, paras 13-18.

${ }^{328}$ Negotiating Group on Agriculture, Statement by Brazil. Special and Differential Treatment, MTN.GNG/ NG5/W/108, circulated on 2 October 1989, para. 7; Negotiating Group on Agriculture, Special and Differential Treatment for Developing Countries. Statement by Colombia, MTN.GNG/NG5/W/110, circulated on 4 October 1989, 2. Colombia noted that SPS measures were used as a means of discrimination against developing countries, by making them stricter for those countries thereby closing off their access to markets and distorting agricultural trade. Ibid. See also Negotiating Group on Agriculture, Proposal on Special, Differential and More Favourable Treatment for Developing Countries: Communication from Brazil and Colombia, MTN.GNG/NG5/W/132, 28 November 1989, para. 20.

${ }^{329}$ Negotiating Group on Agriculture, Special and Differential Treatment for Developing Countries. Statement by Colombia, MTN.GNG/NG5/W/110, circulated on 4 October 1989, 2. 
measures. ${ }^{330}$ The remainder of both proposals focused on special and differential treatment of developing countries, proposing longer time frames for compliance with SPS measures for developing countries, and compensation of developing countries for export losses caused by SPS measures applied without scientific basis. ${ }^{331}$ In addition, Brazil and Colombia submitted a joint proposal on special and differential treatment clarifying their suggestions further. They pointed out that Parties frequently change their SPS measures, requiring from developing countries considerable resources to adapt to new requirements; and that without sound scientific evidence Parties apply stricter SPS measures to developing-country products than to products from other countries, resulting in a reduction of the market share of developing countries or their exclusion from the relevant market. In such cases they proposed that it should be possible to claim equitable compensation in dispute settlement. ${ }^{332}$ This suggestion reflects early discussions at the Negotiating Group on Agriculture, when several comments made by participants called for the creation of a system of compensation for the adverse effects of SPS measures on developing countries. ${ }^{333}$

Similarly, Honduras, El Salvador and Guatemala proposed longer periods for compliance by developing countries with SPS measures and adequate technical assistance to facilitate compliance. In addition, they suggested compensation for any SPS discrimination against developing countries. ${ }^{334}$

Korea's proposals noted the need to harmonise SPS measures with international standards, and to ensure transparency and national treatment in their application. ${ }^{335}$ However, it called for recognition of the fact that dietary patterns, natural and ecological condi-

${ }^{330}$ Negotiating Group on Agriculture, Proposal on Special, Differential and More Favourable Treatment for Developing Countries: Communication from Brazil and Colombia, MTN.GNG/NG5/W/132, 28 November 1989, para. 17

331 Negotiating Group on Agriculture, Statement by Brazil. Special and Differential Treatment, MTN.GNG/ NG5/W/108, circulated on 2 October 1989, para. 7; Negotiating Group on Agriculture, Special and Differential Treatment for Developing Countries. Statement by Colombia, MTN.GNG/NG5/W/110, circulated on 4 October 1989, 2. Brazil further proposed such compensation for developing countries when export losses resulted from frequent changes in SPS measures. Negotiating Group on Agriculture, Statement by Brazil. Special and Differential Treatment, MTN.GNG/NG5/W/108, circulated on 2 October 1989.

${ }^{332}$ Negotiating Group on Agriculture, Proposal on Special, Differential and More Favourable Treatment for Developing Countries: Communication from Brazil and Colombia, MTN.GNG/NG5/W/132, 28 November 1989, para. 20. This proposal is referred to in Negotiating Group on Agriculture, Working Group on Sanitary and Phytosanitary Regulations and Barriers, Synoptic Table of Proposals Relating to Key Concepts: Note by the Secretariat. Revision, MTN.GNG/NG5/WGSP/W/17/Rev.1, circulated on 29 May 1990, Table 6.

${ }^{333}$ Committee on Trade in Agriculture, Summary of Points Raised at the Meeting of the Committee Held on 2-3 April 1985. Note by the Secretariat, AG/W/13, circulated on 4 September 1985, paras 2 and 10. The idea of rebalancing rights and obligations between Parties applying restrictive SPS measures and those affected thereby was considered to be similar to the existing practice under Article XXIII and Article XXVIII of the GATT 1947, respectively providing for satisfactory adjustment in case of nullification or impairment of benefits accruing under the GATT, and allowing for modification of schedules of concessions subject to negotiated compensatory adjustment) of the GATT 1947.

334 Negotiating Group on Agriculture, Uruguay Round Negotiations on Agriculture. Proposals by CACM Member Countries (Honduras, El Salvador and Guatemala), MTN.GNG/NG5/W/162, circulated on 4 April 1990, para. 7.

335 Negotiating Group on Agriculture, Proposal for Negotiations on Agriculture Submitted by the Republic of Korea, MTN.GNG/NG5/W/80, circulated on 13 October 1988, para. (iv)(a)-(c); Negotiating Group on Agriculture, Proposal for Negotiations on Agriculture: Submitted by the Republic of Korea, MTN.GNG/ NG5/W/130, 28 November 1989, para. 25. 
tions and the level of SPS technologies may differ from country to country. ${ }^{336}$ It further proposed that technical assistance to developing countries be provided by the GATT Secretariat. $^{337}$

Bangladesh submitted a proposal on behalf of the least-developed countries in which it called in general for special consideration for the needs of least-developed countries including for technical assistance within the framework of any agreement on SPS measures. ${ }^{338}$

In discussions in the Working Group on Sanitary and Phytosanitary Regulations and Barriers, the question was raised whether longer compliance periods would not be counter-productive, even in situations where the nature of the SPS risk involved allowed for phased introduction of SPS measures. It was suggested that the impression would be created among consumers in developed countries that products from developing countries generally are less safe, thus affecting consumer acceptance of these products. ${ }^{339}$ The idea that compensation should be provided for the adverse effects of SPS measures was firmly rejected by other negotiators. ${ }^{340}$ It was felt that countries have the right to regulate to protect against SPS risks, and should not have to pay to protect their disease-free status. ${ }^{341}$ In addition, in response to the suggestion that compensation be provided for in case of panel findings of unjustified SPS measures affecting developing countries, the concern was raised that this would create the risk that such panel reports would be unlikely to be adopted. ${ }^{342}$ Instead, it was felt that SPS disputes should not be treated differently from other disputes in this regard.

The lack of capacity of many developing countries to adequately assess risks was raised as a concern when discussing the proposed scientific disciplines at meetings of the Working Group on Sanitary and Phytosanitary Regulations and Barriers. The importance of technical assistance in this regard was emphasised and the role of the international standardsetting bodies in identifying technical assistance needs was noted. ${ }^{343}$ In this regard, the

336 Negotiating Group on Agriculture, Proposal for Negotiations on Agriculture Submitted by the Republic of Korea, MTN.GNG/NG5/W/80, circulated on 13 October 1988, para. (iv)(a)-(c); Negotiating Group on Agriculture, Proposal for Negotiations on Agriculture: Submitted by the Republic of Korea, MTN.GNG/ NG5/W/130, 28 November 1989, para. 26.

337 Negotiating Group on Agriculture, Proposal for Negotiations on Agriculture Submitted by the Republic of Korea, MTN.GNG/NG5/W/80, circulated on 13 October 1988, para. (iv)(a)-(c).

${ }_{338}$ Negotiating Group on Agriculture, Proposals on Behalf of the Least-Developed Countries. Communication from Bangladesh, MTN.GNG/NG5/W/126, circulated on 13 November 1989.

${ }^{339}$ Negotiating Group on Agriculture, Working Group on Sanitary and Phytosanitary Regulations and Barriers, Summary of Main Points Raised at the Sixth Meeting of the Working Group on Sanitary and Phytosanitary Regulations and Barriers: Note by the Secretariat, MTN.GNG/NG5/WGSP/W/18, circulated on 4 May 1990, para. 3 .

${ }^{340}$ Committee on Trade in Agriculture, Summary of Points Raised at the Meeting of the Committee Held on 7-8 July 1986. Note by the Secretariat, AG/W/16, circulated on 9 June 1986, para. 17.

${ }^{341}$ Committee on Trade in Agriculture, Summary of Points Raised at the Meeting of the Committee Held on $2-3$ April 1985. Note by the Secretariat, AG/W/13, circulated on 4 September 1985, para. 9.

342 As these discussions took place before the conclusion of negotiations on the new Dispute Settlement Understanding, they were based on the prevailing dispute settlement system which required a consensus decision among Contracting Parties for the adoption of a panel report.

${ }^{343}$ Negotiating Group on Agriculture, Working Group on Sanitary and Phytosanitary Regulations and Barriers, Summary of Main Points Raised at the Fifth Meeting of the Working Group on Sanitary and Phytosanitary Regulations and Barriers: Note by the Secretariat, MTN.GNG/NG5/WGSP/W/13, circulated on 19 March 
FAO submitted a paper expressing concerns that strict rules requiring sound scientific evidence for regulation would be beyond the compliance capacity of many developing countries, and that very substantial technical assistance would be required. ${ }^{344}$ Again, at a later stage of the negotiations, concerns were raised by some participants regarding the proposed requirement of scientific justification for SPS measures. They noted that developing countries seldom used scientific evidence as a basis for national SPS regulation as they often simply copied the SPS requirements of the EC or US in order to gain access to their markets. They therefore argued that at best, such countries could be asked to provide an explanation for the introduction of SPS measures that were more stringent than international standards, but not scientific evidence. ${ }^{345}$

Nevertheless, the disciplines on SPS measures that were the outcome of these negotiations contained rigorous scientific disciplines for SPS measures, including the requirement of scientific justification for measures stricter than international standards. The draft text's provisions on special and differential treatment and technical assistance, by contrast, were either hortatory or embodied 'best endeavour' commitments. No obligation of compensation for adverse trade effects of SPS measures was included. In the last stages of the negotiations, only one change that was made to the draft text of the SPS Agreement reflects the interests of developing countries. This change is the extension of the transition period granted to least-developed-country Members to implement the provisions of the SPS Agreement from two years to five years.

The lack of broader and more proactive participation from developing countries in the negotiations leading to the drafting of the SPS Agreement can be attributed to their limited resources and the wish to focus these resources on participation in those aspects of the Uruguay Round negotiations that they perceived as being most directly relevant to them (such as the negotiations on agriculture and textiles). The technical nature of the negotiations on disciplines on SPS measures may have further discouraged their participation, as they lacked the necessary technical expertise in this area. They were therefore unable to propose detailed regulatory disciplines that reflected their own capabilities and constraints, and that would thus be workable for them both in respect of meeting their commitments under the new Agreement and in respect of being able to use the new rules to gain market access. Instead, they focused on making proposals for special and differential treatment and technical assistance.

However, the new approach of developing countries to trade negotiations in the Uruguay Round, discussed above, ${ }^{346}$ was reflected also in their proposals on special and differential treatment in the SPS negotiations. Unlike in past negotiating rounds, ${ }^{347}$ in the Uruguay

1990, para. 12.

344 Negotiating Group on Agriculture, Working Group on Sanitary and Phytosanitary Regulations and Barriers, Technical Assistance in the Field of Plant Protection: Paper Submitted by FAO, MTN.GNG/NG5/ WGSP/W/16, circulated on 20 April 1990.

${ }^{345}$ Negotiating Group on Agriculture, Working Group on Sanitary and Phytosanitary Regulations and Barriers, Summary of Main Points Raised at the Eighth Meeting of the Working Group on Sanitary and Phytosanitary Regulations and Barriers: Note by the Secretariat, MTN.GNG/NG5/WGSP/W/24, circulated on 2 July 1990, para. 7. This meeting report does not specify which participants raised this issue, but from its content it would appear to have been raised by developing-country participants in the Working Group.

346 See above, Part I, Section 1.6.

${ }^{347}$ Edwini Kessie notes that developing countries' participation in the negotiation of the Tokyo Round Codes 
Round developing countries did not insist on special and differential treatment in the form of broad exemptions from negotiated disciplines. Instead, they accepted being bound by wide-ranging obligations, including in areas of behind-the-border regulatory policy. To assist them in complying with these new obligations, they called for more limited forms of special and differential treatment and technical assistance, namely longer timeframes for implementation of their obligations and consideration for their special position, as well as improved technical assistance. However, expectations with regard to special and differential treatment and technical assistance have not been met. ${ }^{348}$ As noted by Finger and Schuler:

[T]he developing countries have taken on bound commitments to implement in exchange for unbound commitments of assistance. ${ }^{349}$

In the Uruguay Round, negotiators chose for a 'single undertaking'350 approach to the outcome of the negotiations, contained in the WTO Agreement ${ }^{351}$ and its Annexes. ${ }^{352}$ As explained by the Appellate Body in Brazil-Desiccated Coconut:

The WTO Agreement is fundamentally different from the GATT system which preceded it. The previous system was made up of several agreements, understandings and legal instruments, the most significant of which were the GATT 1947 and the nine Tokyo Round Agreements .... Each of these major

was limited to the last stages, where they demanded the inclusion of special and differential treatment provisions in their favour. Thus the general disciplines in the Codes themselves do not reflect developing-country concerns. Instead, the special constraints faced by developing countries in complying with these new rules were to some extent recognized by means of the special and differential treatment provisions in these Codes. Edwini Kwame Kessie, 'Developing Countries and the World Trade Organization: What Has Changed?' World Competition 22 (2), 1999, 83-110, 91.

${ }^{348}$ As stated by the UNCTAD Secretariat, 'Since the integration into the [international trading system (ITS)] of developing countries has increasingly involved aligning their policies and standards with those of developed countries, there a number of expectations have been implicit in the participation of developing countries in the ITS: (a) that their development, financial and trade needs and circumstances would be fully 'integrated' into the framework of rights and obligations; [and] (b) that adequate international support and assistance, technical and financial, would be readily available, as structural and adjustment support...' United Nations Conference on Trade and Development, UNCTAD XI - the Spirit of Sao Paulo, TD/L.382 (United Nations, Sao Paulo), 17 June 2004, para. 6, available at: www.unctad.org/en/docs/TDL382_en/pdf, visited on 1 June 2005.

349 J. Michael Finger and Philip Schuler, 'Implementation of Uruguay Round Commitments: The Development Challenge', The World Economy 23 (4), 2000, 511-525, 514.

${ }^{350}$ On the single undertaking approach in the Uruguay Round negotiations, see above, Part I, Section 1.6. See also Gabrielle Marceau and Joel P. Trachtman, 'GATT, TBT and SPS: A Map of WTO Law of Domestic Regulation of Goods', in The WTO Dispute Settlement System 1995-2003, F. Ortino and Ernst-Ulrich Petersmann (eds.) (Kluwer Law International, Deventer), 2004, 275-340, footnote 5.

351 'Marrakesh Agreement Establishing the World Trade Organization', in The Results of the Uruguay Round of Multilateral Trade Negotiations: The Legal Texts (World Trade Organization, Geneva), 1994, 6-18. The WTO Agreement contains the institutional and procedural rules of the WTO.

352 The substantive rules of the WTO are contained in the four Annexes to the WTO Agreement. Annex 1A contains all the multilateral agreements on trade in goods, including the GATT 1994, the SPS Agreement, and the TBT Agreement; Annex 1B contains the General Agreement on Trade in Services (GATS); Annex 1C contains the Agreement on Trade-Related Aspects of Intellectual Property Rights (TRIPS Agreement); Annex 2 contains the Understanding on Rules and Procedures Governing the Settlement of Disputes (DSU); Annex 3 contains the Trade Policy Review Mechanism (TPRM); and Annex 4 contains the plurilateral agreements, the only agreements that are still outside the single undertaking. 
agreements was a treaty with different membership, an independent governing body and a separate dispute settlement mechanism. ...

Unlike the previous GATT system, the WTO Agreement is a single treaty instrument which was accepted by the WTO Members as a "single undertaking". Article II:2 of the WTO Agreement provides that the Multilateral Trade Agreements in Annexes 1, 2 and 3 are "integral parts" of the WTO Agreement, binding on all Members. Annex 1A contains thirteen multilateral agreements relating to trade in goods, including the GATT 1994 which was incorporated by reference into that Annex.

Within this framework, all WTO Members are bound by all the rights and obligations in the WTO Agreement and its Annexes 1, 2 and 3. ${ }^{353}$

The 'single undertaking' approach therefore meant that all countries wishing to be Members of the newly-established WTO were obliged to sign on to all the multilateral trade agreements. They could not pick and choose among them, as had been the practice in previous rounds. ${ }^{354}$ As aptly put by Silvia Ostry with regard to the single undertaking:

The deal was pretty much take it or leave it for the Southern countries. So they took it but, it is safe to say, without a full comprehension of the profoundly transformative implications of this new trading system. ${ }^{355}$

The package of agreements resulting from the Uruguay Round included the Dispute Settlement Understanding (DSU), which creates an integrated, strengthened and enforceable dispute settlement system for all disputes arising under any of the 'covered agreements'. The SPS Agreement is among the 'covered agreements' and its obligations are therefore enforceable in binding dispute settlement procedures. Consequently, the new rules on SPS measures negotiated in the Uruguay Round and embodied in the SPS Agreement have far-reaching implications.

\subsection{Conclusion}

The inadequacy of existing rules, both in the GATT 1947 and in the Tokyo Round Standards Code, to deal effectively with trade barriers in the form of SPS measures, as exemplified in the hormones dispute, led GATT Contracting Parties to agree to place this

\footnotetext{
${ }^{353}$ Appellate Body Report, Brazil - Desiccated Coconut, 177.

${ }^{354}$ There were only four plurilateral agreements that did not form part of the 'single undertaking', namely those on civil aircraft, government procurement, dairy and bovine meat. The latter two have since been terminated.

355 Sylvia Ostry, 'The Uruguay Round North-South Grand Bargain: Implications for Future Negotiations', in The Political Economy of International Trade Law. Essays in Honor of Robert E. Hudec, Daniel L. M. Kennedy and James D. Southwick (eds.) (Cambridge University Press, Cambridge), 2002, 285-310, 287. Finger, an economist (previously of the World Bank) who is renown for his work on trade and development issues, agrees with this evaluation. See J. Michael Finger, 'The Uruguay Round North-South Bargain: Will the WTO Get over It?' in The Political Economy of International Trade Law. Essays in Honor of Robert E. Hudec, Daniel L. M. Kennedy and James D. Southwick (eds.) (Cambridge University Press, Cambridge), 2002, 301-310, 308 .
} 
issue on the agenda for the Uruguay Round negotiations. In particular, it was recognised that the use of SPS measures for protectionist purposes threatened to undermine any gains in the liberalisation of agricultural trade that would be achieved in the negotiations. Strengthened disciplines were therefore negotiated, first in the Negotiating Group on Agriculture, and later in a special body established for purposes of this area of negotiation, the Working Group on Sanitary and Phytosanitary Regulations and Barriers. While initially the idea was to improve the provisions in the GATT and/or the Standards Code, in the course of the negotiations the realisation arose that the special character of SPS measures necessitated particular rules. These led to the drafting of a separate agreement, the Agreement on the Application of Sanitary and Phytosanitary Measure (SPS Agreement).

The negotiations on SPS measures were very successful in reaching agreement on new rules. Alone among the various Working Groups negotiating under the auspices of the Negotiating Group on Agriculture, the Working Group on Sanitary and Phytosanitary Regulations and Barriers managed to submit a detailed draft text in November 1990. This text was incorporated into the Dunkel Draft, and eventually, with very few changes, became the final text of the SPS Agreement. The success of these negotiations can largely be ascribed to the proactive approach taken by the key participants in the negotiations, in particular the Nordic Group, the Cairns Group, the EC and the US. Detailed texts were proposed at an early stage of the negotiations and common ground emerged on key issues. In particular, the promotion of harmonisation of SPS measures, subject to the possibility to apply stricter requirements, as well as the focus on science as a justificatory tool, were aspects of the new disciplines strongly supported by the main participants in the negotiations.

While some developing countries, particularly those that were part of the Developing Country Group, participated in the SPS negotiations, it may be questioned whether this participation was effective in ensuring that their interests were adequately reflected in the resulting text. As has been seen above, the input of developing countries, aside from those that were part of the Cairns Group, with regard to disciplines on SPS measures was limited to very general proposals for non-discrimination, harmonisation and transparency. The specific form which these disciplines should take was not addressed. While they agreed with the developed countries on the importance of these issues, they sometimes raised concerns in the discussions noting their capacity constraints, particularly with respect to providing scientific justification for deviation from harmonised standards. However, they did not make concrete proposals that would enable their regulatory realities to be reflected in the new rules. This may have been due to the fact that their national SPS regulatory systems were rather rudimentary and they lacked the technical expertise to contribute effectively to the elaboration of regulatory disciplines. Proposals instead focused on the need for special and differential treatment, especially in the form of longer compliance periods, and technical assistance. The possibility of differentiated provision of technical assistance or special and differential treatment, taking into account stage of development of SPS capacity, was not provided for in these proposals. In addition, many proposals called for compensation for the adverse effects of unjustified SPS measures on developing countries. 
Consequently, as will be seen from the following discussion of the provisions of the SPS Agreement, the final disciplines incorporated into this Agreement closely reflect the more detailed proposals made by the developed countries and the Cairns Group in the Uruguay Round negotiations on SPS issues. As these proposals necessarily embody the concerns of these countries, and mirror their approach to SPS regulation, the disciplines of the SPS Agreement can be said to reflect best regulatory practices in developed countries in this area. To the extent that these proposals, especially those of the Cairns Group and the Nordic Group, took account of developing-country constraints, these are taken up, mostly in hortatory terms, in the rules on special and differential treatment and technical assistance in the SPS Agreement. Little mention is made in the latter provisions of the specific stage of development, trade interests or SPS regulatory regime of the Member concerned, thus excluding the possibility of differentiation.

The rules of the SPS Agreement are binding on all WTO Members as part of the 'single undertaking' resulting from the Uruguay Round negotiations. This means that all multilateral WTO agreements apply equally and are binding on all WTO Members. Developing countries can therefore no longer, as many of them did with the Tokyo Round Standards Code, opt out of the application of one of these agreements. As a result, developing-country Members are bound, equally with all other WTO Members, to comply with the obligations set out in the SPS Agreement and are entitled equally to the rights contained therein. However, unlike the case with obligations on traditional trade barriers such as tariffs and quotas, ${ }^{356}$ the impact of obligations on regulatory systems such as those contained in the SPS Agreement differs according to the particular situation of a Member. More specifically, the stage of development of a Member, including its economic level, the extent of diversification of its exports and the sophistication of its SPS regulatory regime, plays a role in determining the costs and benefits entailed by the SPS Agreement for that Member. This makes a detailed examination of the negotiated provisions of the SPS Agreement, as interpreted in the case law, useful in establishing the consequences of these rules for Members at different levels of development.

\footnotetext{
${ }^{356}$ Finger has pointed out that in the case of tariff reductions, even though from a mercantilist perspective such reductions are seen as 'concessions', there are positive economic effects for both the giver and the receiver of the reduction in real economic terms and there is therefore no need for a cost-benefit analysis of the negotiation results. On the contrary, there are no assurances that the results of negotiations in the new areas covered by the Uruguay Round, involving disciplines on regulatory policy, will bring benefits to the concession-giver as these new obligations result in significant implementation costs and in many cases the policy changes involved have negative impacts. J. Michael Finger, 'The Uruguay Round North-South Bargain: Will the WTO Get over It?' in The Political Economy of International Trade Law. Essays in Honor of Robert E. Hudec, Daniel L. M. Kennedy and James D. Southwick (eds.) (Cambridge University Press, Cambridge), 2002, 301-310, 304 .
} 


\section{CHAPTER 2 \\ Scope of application of the SPS Agreement}

The impact of the new disciplines for SPS measures negotiated in the Uruguay Round and contained in the SPS Agreement is limited to the situations that are within the ambit of the coverage of this Agreement. Therefore, before examining the substantive provisions of the SPS Agreement, it is necessary to determine what falls within the scope of application of this Agreement.

As seen from Chapter 1, the rigorous new disciplines were negotiated in the Uruguay Round to address a particular type of circumstance, involving interaction between two highly sensitive and important policy areas - the protection of human, plant or animal life and health on the one hand, and the liberalisation of agricultural trade, on the other. The new rules attempt to achieve a balance between these two, often conflicting, objectives. As stated in the Preamble to the SPS Agreement, WTO Members:

Reaffirm [ed] that no Member should be prevented from adopting or enforcing measures necessary to protect human, animal or plant life or health, ... [and]

Desir [ed] the establishment of a multilateral framework of rules and disciplines to guide the development, adoption and enforcement of sanitary and phytosanitary measures in order to minimize their negative effects on trade; ... ${ }^{357}$

To demarcate the category of situations to which the SPS Agreement would apply, and limit it to those involving this particular need for balance, detailed provisions on the coverage of the Agreement were drafted. These provisions, contained in Article 1.1 read together with the definition in Annex A.1, address the substantive scope of application of the SPS Agreement. They are discussed in Section 2.1 of this Chapter, in the light of the interpretation given to them in the case law.

A wide array of SPS measures were already in place in WTO Members at the time of coming into force of the SPS Agreement. Section 2.2 therefore examines the question whether these pre-existing measures are covered by the SPS Agreement and have to be brought into conformity with its provisions. Although this issue was not explicitly addressed in the Agreement itself, it has been subject to an Appellate Body ruling. This decision and its implications are briefly discussed in this Section.

In addition, the fact that SPS regulation is very often in the hands of bodies other than central government was recognised in the drafting of the SPS Agreement. To ensure that, as far as possible, the new disciplines would apply to these bodies, a provision on the personal scope of application of the SPS Agreement was included. This is contained in Article 13 of the SPS Agreement, discussed in Section 2.3 of this Chapter.

The SPS Agreement cannot be viewed in isolation. It is part of the indivisible package of agreements resulting from the Uruguay Round negotiations, and is included in the 'single undertaking' agreed to by Members of the WTO. Therefore, Section 2.4 proceeds

\footnotetext{
${ }^{357}$ First and fourth preambular statements to the SPS Agreement.
} 
to examine the relationship between the SPS Agreement and other relevant WTO agreements. In particular, the extent to which the GATT 1994, the TBT Agreement and the Agreement on Agriculture may be relevant to SPS measures is discussed, by briefly examining the scope of application of these agreements and the rules that apply in case a measure falls within the coverage of more than one agreement. It is also interesting to take note of the other relevant WTO agreements since they establish disciplines on measures that fall outside the scope of application of the SPS Agreement. This framework of differing, but complementary, obligations should be borne in mind when examining the SPS Agreement's scope of application.

Section 2.5 concludes by discussing the implications of the coverage of the SPS Agreement for Members at different levels of development.

\subsection{Substantive scope of application}

The substantive scope of application of the SPS Agreement is set out in Article 1.1, which provides that the SPS Agreement applies to 'all sanitary and phytosanitary measures which may, directly or indirectly, affect international trade.'

Thus, as set out by the Panel in EC Hormones, two requirements need to be fulfilled for the SPS Agreement to apply:

(i) the measure in dispute is a sanitary or phytosanitary measure; and

(ii) the measure in dispute may, directly or indirectly, affect international trade. ${ }^{358}$

\subsubsection{The concept of an SPS measure}

Not all measures imposed for the protection of health are SPS measures for purposes of the SPS Agreement. The term SPS measure is defined in Annex A, paragraph 1 of the SPS Agreement, which provides in relevant part that an SPS measure is:

any measure applied:

(a) to protect animal or plant life or health within the territory of the Member from risks arising from the entry, establishment or spread of pests, diseases, disease-carrying organisms or disease causing organisms;

(b) to protect human or animal life or health within the territory of the Member from risks arising from additives, contaminants, toxins or disease-causing organisms in foods, beverages or feedstuffs;

(c) to protect human life or health within the territory of the Member from risks arising from diseases carried by animals, plants or products thereof, or from the entry, establishment or spread of pests; or

(d) to prevent or limit other damage within the territory of the Member from the entry, establishment or spread of pests.

${ }^{358}$ Panel Report, EC - Hormones (US), para. 8.36; Panel Report, EC - Hormones (Canada), para. 8.39. 
Sanitary or phytosanitary measures include all relevant laws, decrees, regulations, requirements and procedures including, inter alia, end product criteria; processes and production methods; testing, inspection, certification and approval procedures; quarantine treatments including relevant requirements associated with the transport of animals or plants, or with the materials necessary for their survival during transport; provisions on relevant statistical methods, sampling procedures and methods of risk assessment; and packaging and labelling requirements directly related to food safety.

As correctly identified by the Panel in EC-Approval and Marketing of Biotech Products, the purpose of the measure, as enumerated in sub-paragraphs (a) to (d), is crucial to the classification of a measure as an SPS measure under this definition. This list is exhaustive, designed to limit the application of the SPS Agreement to a specific category of measures, broadly speaking those that aim to protect human, animal or plant life or health, or the territory of a Member, from specified risks in food or feed or risks from pests or diseases. More specifically, the SPS Agreement applies to measures aimed to protect human or animal life or health from risks in food or feed (from additives, contaminants, toxins or disease-causing organisms); measures aimed to protect animal or plant life or health from risks from pests, diseases or disease-carrying or disease-causing causing organisms; measures aimed to protect human health from risks from pests or diseases carried by plants or animals; ;59 and measures aimed to prevent or limit other damage to the territory of a Member from the entry, establishment or spread of pests. Footnote 4 to Annex A clarifies that the term 'pests' include weeds and the term 'contaminants' includes residues of pesticides and veterinary drugs and extraneous matter. Measures to address other health risks, such as risks from cigarettes, toxic plastics or asbestos fibres, are thus not covered by the SPS Agreement.

While implicit in the definition of an SPS measure is a focus on regulations affecting plants, animals and their products (including processed products such as food, feed and beverages), rather than industrial products (such as pesticides, cigarettes and asbestos) no express limitation on the product coverage of the SPS Agreement is stated in this definition. Instead, there is only a clarification which indicates that the product coverage is not limited to agricultural products as defined for purposes of the Agreement on Agriculture. To give effect to the concern of negotiators to ensure that the new disciplines should include products of fisheries and forestry as well as natural fauna and flora, footnote 4 to the Annex A definitions specifies that in these definitions 'animal' includes fish and wild fauna, and 'plant' includes forests and wild flora. The extension of the product coverage to more than purely agricultural products reflects the realisation of negotiators that measures to protect the wild plants and animals can, as much as measures to protect crops and farm animals, affect agricultural trade.

The definition's focus on the purpose of the relevant measure, reflected in the words 'applied to protect' or 'applied to prevent', makes the determination of such purpose the key

359 Infectious diseases carried by animals that can be transferred to humans are known as zoonoses. Examples of zoonoses are Creutzfeldt-Jakob disease that can be contracted by consuming meat of cattle infected with bovine spongiform encephalopathy (BSE), and highly-pathogenic H5N1 avian influenza (bird flu) that can be transferred from birds to humans through extensive contact with infected birds. 
to the applicability of the SPS Agreement. These words, at first sight, would seem to leave open the possibility that the applicability of the SPS Agreement could be dependent on the purpose ascribed to the measure by the Member using it, in other words, on the subjective intent of the Member. ${ }^{360}$ If this were the case, a Member could avoid the application of the agreement by denying that the purpose of its measure is one of those falling within the Annex A.1 definition. This would be a strange result. ${ }^{361}$ A better interpretation of the definition of SPS measures would be to determine the regulatory goal by looking at the measure itself (for example, at the legislative text) and surrounding circumstances, rather than trying to determine the subjective intent of the regulating Member. This approach would introduce more objectivity into the determination of the aim of the measure for purposes of the application of the SPS Agreement. ${ }^{362}$ It would also be in line with case law under the GATT 1994 where the purpose of a measure is determined by examining its design, structure and architecture rather than by trying to ascertain the subjective intent of the Member. ${ }^{363}$

In Australia - Salmon, the Panel examined whether an Australian ban on imports of dead salmon fell within the definition of an SPS measure under Annex A, paragraph 1(a), or Annex A, paragraph 1(b), as claimed by Australia. Although in either case the SPS Agreement would apply, the classification of the measure as one aimed at risks from food or feed or as one aimed at risks from pests or diseases is important because, as will be discussed later, ${ }^{364}$ the type of risk assessment required in each of these two cases differs. The Panel did not rely purely on Australia's statement of the regulatory objectives of its measure, but examined the legislation at issue and other relevant documents to find:

${ }^{360}$ Dale E. McNiel, 'The First Case under the WTO's Sanitary and Phytosanitary Agreement: The European Union's Hormone Ban', Virginia Journal of International Law 39, 1998, 89-134, 112.

361 Dale McNiel speculates on whether, if the EC had justified its ban on hormone-treated meat in EC Hormones on legitimate grounds other than the protection of public health, such as the harmonisation of regulations within the EC or consumer concerns, it could then have argued that the SPS Agreement did not apply. In this particular case it would have been difficult for the EC to support this argument since it had justified its hormones regime on health grounds for the past 15 years and had established a Scientific Working Group to determine whether the use of the relevant hormones for growth purposes created a threat for human health. McNiel argues that in such a case a Member would be estopped from denying that the purpose of its measure is the protection of health. Ibid., 115.

${ }^{362}$ On the issue of a subjective versus objective test of regulatory purpose, see Joost Pauwelyn, 'The WTO Agreement on Sanitary and Phytosanitary (SPS) Measures as Applied in the First Three SPS Disputes: EC - Hormones, Australia-Salmon and Japan-Varietals', Journal of International Economic Law 2 (4), 1999, 641-664, 641.

${ }^{363}$ In Japan - Alcoholic Beverages II, when addressing the purpose or objective of a measure (in the context of a determination whether a tax measure was applied 'so as to afford protection' under Article III:2 of the GATT 1994), the Appellate Body held that 'although it is true that the aim of a measure may not be easily ascertained, nevertheless its protective application can most often be discerned from the design, the architecture, and the revealing structure of a measure.' Appellate Body Report, Japan - Alcoholic Beverages II, 29. See also Appellate Body Report, Chile - Alcoholic Beverages, paras 62 and 71-72; Appellate Body Report, US - Offset Act (Byrd Amendment), para. 259; Panel Report, Canada-Periodicals, para. 5.38; Panel Report, Korea-Alcoholic Beverages, para. 10.101. In Brazil-Retreaded Tyres, in determining whether Brazil's ban on imports of retreaded tyres fell under Article XX(b), the Panel noted that the design of the measure was 'consistent with Brazil's declared objective of reducing the further accumulation of waste tyres in its territory by avoiding the importation of short-lifespan tyres.' Panel Report, Brazil-Retreaded Tyres, para. 7.331.

${ }^{364}$ See below, Part III, Section 5.1.1. 
In the circumstances at hand, we consider that the definition of a "sanitary measure" in paragraph 1(a) encompasses the coverage sought by Australia under the definition in paragraph 1(b). The definition in paragraph 1(a) deals with risks arising from "the entry, establishment or spread of pests, diseases ... or diseasecausing organisms" in general. In the context of disease-causing organisms, the definition in paragraph $1(\mathrm{~b})$ is limited in the sense that it only addresses risks arising from "disease-causing organisms in foods, beverages or feedstuffs" (hereafter also referred to as food-borne risks). We are of the view that, even though both definitions of a "sanitary measure" invoked by Australia might be applicable to the measure in dispute, the objectives for which that measure is being applied are more appropriately covered by the definition in paragraph 1(a). These objectives have been clearly expressed by Australia on several occasions. ${ }^{365}$

It therefore appears that the Panel conducted an objective examination of the aims of the measure as stated in the legislative text to determine whether the measure fell within the definition in Annex A.1(a) or that in Annex A.1(b) of the SPS Agreement. ${ }^{366}$ It referred to the subjective intent as expressed by the regulating Member only to support its conclusion. This approach has been followed by the Panel in US - Continued Suspension and Canada-Continued Suspension, which examined the stated purpose of the EC ban on hormone-treated meat, as set out in the relevant directive, and concluded that this measure fell within the definition of an SPS measure in Annex A.1(b). ${ }^{367}$

In EC - Approval and Marketing of Biotech Products, the Panel went further in its scrutiny to determine the purpose of the measure at issue. While it began its examination by looking at the stated objectives of the EC legislation at issue, ${ }^{368}$ it then proceeded to verify that this was indeed the objective of the measure by determining whether there

${ }^{365}$ Panel Report, Australia - Salmon, para. 8.34.

${ }^{366}$ As pointed out by Scott, the examination of the Panel did not go beyond the stated objectives in the language of the relevant texts, 'but it did at least seek to ensure that scrutiny would proceed on the basis of the measures' stated objectives, rather than on the basis of expedient governmental whim.' Joanne Scott, The WTO Agreement on Sanitary and Phytosanitary Measures: A Commentary, Oxford Commentaries on the GATT/ WTO Agreements (Oxford University Press, Oxford), 2007, 17.

${ }^{367}$ Panel Report, US - Continued Suspension, paras 7.431-7.432; Panel Report, Canada-Continued Suspension, paras 7.421-7.422. EC Directive 2003/74/EC stated, in Article 1 thereof, that the purpose of the ban on the six hormones at issue was to prevent meat and meat products from cattle treated with such hormones for growth promotion purposes from being placed on the EC market. The Panel recalled the finding in EC-Approval and Marketing of Biotech Products that a substance which a human being or an animal consumes for nutritional reasons may be classified as a 'food' and notes that 'contaminants' are defined in the footnote to Annex A as including veterinary drug residues, such as the residues of the hormones subject to the EC ban.

368 The Panel examined the EC legislation relevant to the approval of biotech products, namely Directives $90 / 220$ and $2001 / 18$, the stated objective of which is the protection of human health and the environment from the adverse effects that might arise from the deliberate release into the environment or the placing on the market of genetically modified organisms. While the Directives do not specifically set out which risks for human health or the environment they aim at, the Panel identified a series of such risks from their provisions on information requirements and risk assessment coverage. It found that all the risks aimed at by the Directives were covered by one or more sub-paragraphs of Annex A.1. With regard to Regulation 258/97, the Panel noted that it had three stated purposes, namely, to prevent novel foods and food ingredients (which include foods and food ingredients containing or consisting of GMOs and those produced from, but not containing, GMOs) from presenting a danger to the consumer, misleading the consumer, and being nutritionally disadvantageous to the consumer. It found the first purpose to fall under Annex A.1(b), but the other two purposes not to be covered by any of the sub-paragraphs of Annex A.1. 
was a 'rational relationship' between the measure and its stated objective. ${ }^{369}$ Similarly, in its examination of the bans applied by certain EC Member States to biotech products that had been approved at EC level (known as safeguard measures) the Panel noted that nothing in the SPS Agreement would 'bar a panel from considering purposes which were not articulated by the member States when they adopted their safeguard measures' ${ }^{370}$ At the same time, it clarified that this did not mean it had to 'accept at face value assertions of purposes which are implausible in the light of all relevant circumstances.' ${ }^{371}$ The Panel referred to the Appellate Body's findings in Japan - Alcoholic Beverages II, ${ }^{372}$ to state:

[O]ur approach is consistent with the view expressed by the Appellate Body that in identifying the purposes of a measure, panels need not seek to determine the subjective intent of the legislators or regulators who adopted the measure. According to the Appellate Body, the purposes of a measure may and should rather be ascertained on the basis of objective considerations, for instance by examining whether there is an objective relationship between the stated purposes and the text and structural features of the relevant measure. ${ }^{373}$

After objectively establishing the purpose of a measure, a Panel must determine whether this purpose falls within the definition of Annex A.1. In order to do so, the panel has to examine, and possibly clarify, the list of relevant purposes contained in sub-paragraphs (a) to (d) of Annex A.1 since this list demarcates the scope of application of the SPS Agreement.

The first time a panel was confronted with the need to clarify the meaning of sub-paragraphs (a) to (d) was in EC-Approval and Marketing of Biotech Products, as in previous cases the purposes of the contested measures clearly fell within the terms of one or more of these sub-paragraphs. ${ }^{374}$ In this dispute, the EC had claimed that the issues arising out of the existence of biotech products and addressed in its approval legislation went 'beyond the risks envisaged and regulated by the SPS Agreement.' ${ }^{375}$ Therefore it argued that the SPS Agreement was relevant to only some issues assessed by EC authorities in the course of approval procedures for biotech products, whereas others fell outside the scope of the Agreement. ${ }^{376}$ The Panel was faced with the task of examining whether all the various objectives of the EC legislation at issue fell within the purposes listed in

369 The Panel stated that where a measure is rationally related to its stated purpose, a panel 'may and should presume that the requirement is intended to serve the purpose articulated in the Directive.' Panel Reports, EC-Approval and Marketing of Biotech Products, para. 7.385.

${ }^{370}$ Panel Reports, EC-Approval and Marketing of Biotech Products, para. 7.2558.

${ }^{371}$ Panel Reports, EC-Approval and Marketing of Biotech Products, footnote 1691.

372 These findings are cited above in this Section, note 7.

${ }^{373}$ Panel Reports, EC - Approval and Marketing of Biotech Products, para. 7.2558.

${ }^{374}$ Although, as stated above, the Panel in Australia - Salmon had to determine whether Australia's measure fell under sub-paragraph (a) or sub-paragraph (b) of Annex A.1, as this measure aimed at preventing the introduction of fish diseases by disease-carrying organisms, it fell squarely within the terms of sub-paragraph (a). Therefore the Panel did not need to clarify the wording used in the relevant subparagraphs.

375 Panel Reports, EC - Approval and Marketing of Biotech Products, para. 7.185.

${ }^{376}$ Panel Reports, EC-Approval and Marketing of Biotech Products, para. 7.186. The EC argued, for example, that a biotech product is not infected nor is it an infection; therefore it cannot be 'a disease'. Neither is a biotech product a 'disease-carrying organism' or a 'pest'. Further, it claimed that biotech seeds destined to be planted cannot be considered as 'food' or 'feed'. Similarly, a biotech crop that is intended to be processed into food or feed is not in itself 'food' or 'feed'. 
sub-paragraphs (a) to (d) of the definition of an 'SPS measure'. ${ }^{377}$ Its interpretation of the coverage of these sub-paragraphs was so wide, however, that the scope of application of the SPS Agreement is thereby significantly extended. ${ }^{378}$

To name but a few examples, the Panel considered that in sub-paragraph (a) the term 'animal or plant life of health' includes non-target micro-organisms; ${ }^{379}$ the term 'establishment or spread of pests' includes risks of the development of resistance in already existing target pests, ${ }^{380}$ and the term 'pests' includes cultivated GM plants if they are growing where they are undesired, cross-breeds that result from unintentional gene-flow between GM plants and other plants if they have undesired introduced traits, and pesticide-resistant target or non-target organisms that result from exposure to pesticide-producing GM plants. ${ }^{381}$ Similarly, in sub-paragraph (b) the Panel regarded the term 'food, beverages or feedstuffs' as including GM crops not intended to be eaten by humans or animals but nevertheless consumed by them, as well as GM plants that are not eaten as such but are processed into food or feed; ${ }^{382}$ the word 'additives' as encompassing genes intentionally added for technological purposes to a GM plant that is eventually eaten or processed into food: ${ }^{383}$ and the term 'contaminants' as including proteins produced by GM plants through the unintended expression of modified genes. ${ }^{384}$ With regard to sub-paragraph (c),

377 The methodology of the Panel in its examination on this point is rather unexpected. Instead of examining whether the various purposes of the measures at issue that it had identified fell within sub-paragraphs (a) to (d) of Annex A.1, the Panel examined the meaning of each of the sub-paragraphs to determine whether their meaning could cover the various risks addressed at by the legislation at issue. Christiane R. Conrad, PPMs, the EC-Biotech Dispute and Applicability of the SPS Agreement: Are the Panel's Findings Built on Shaky Ground?, Research Paper No. 8-06 (International Law Forum of the Hebrew University of Jerusalem, Jerusalem), August 2006, 17, available at: http://papers.ssrn.com/sol3/papers.cfm?abstract_ id=920742\#PaperDownload, visited on 12 May 2008.

378 See further in this respect, Jacqueline Peel, 'A GMO by Any Other Name ... Might Be an SPS Risk! Implications of Expanding the Scope of the WTO Sanitary and Phytosanitary Measures Agreement', European Journal of International Law 17 (5), 2006, 1009-1031; Christiane R. Conrad, PPMs, the ECBiotech Dispute and Applicability of the SPS Agreement: Are the Panel's Findings Built on Shaky Ground?, Research Paper No. 8-06 (International Law Forum of the Hebrew University of Jerusalem, Jerusalem), August 2006, available at: http://papers.ssrn.com/sol3/papers.cfm?abstract_id=920742\#PaperDownload, visited on 12 May 2008.

379 The EC had argued that GMOs could affect ecosystems without affecting animals or plants by affecting micro-organisms in soil or water that are specialised in biophysical or biochemical processes. The Panel considered that the fact that a footnote to Annex A.1 clarifies that the words 'animal' and 'plant' include wild fauna and wild flora indicates that the phrase 'animal or plant life or health' is intended to be comprehensive in coverage, encompassing micro-organisms and non-target organisms. Panel Reports, EC - Approval and Marketing of Biotech Products, paras 7.219-7.220.

380 The Panel considered that the development of resistance could lead to the existing pest becoming established or spreading to new areas. Panel Reports, EC-Approval and Marketing of Biotech Products, para. 7.232.

${ }^{381}$ Panel Reports, EC-Approval and Marketing of Biotech Products, paras 7.241 and 7.244.

382 The EC had argued that food and beverages are things intentionally ingested by humans for nutritional purposes, and a feedstuff is something animals are intentionally permitted to ingest for nutritional purposes. The Panel, instead, held that a GM crop not grown as food for animals but which is nevertheless eaten by animals (including wild animals), or the pollen of which is consumed by insects, can be considered to be feedstuff. Further, it held that GM seeds intended for sowing that are spilt and eaten by birds are also animal feedstuff. Panel Reports, EC-Approval and Marketing of Biotech Products, para. 7.292.

${ }^{383}$ Panel Reports, EC - Approval and Marketing of Biotech Products, paras 7.295-7.301.

${ }^{384}$ Panel Reports, EC-Approval and Marketing of Biotech Products, para. 7.313. 
the Panel regarded 'pests' as covering intentionally cultivated allergenic GM plants that have already been harvested. ${ }^{385}$

Particularly controversial is the Panel's finding that measures aimed at environmental protection, other than plant or animal life or health, are included in the definition of Annex 1.A. ${ }^{386}$ The EC had argued that those aspects of its measures dealing with the effects of biotech products on the non-living components of the environment, such as biogeochemistry, carbon and nitrogen recycling, soil micro-organisms etc., fell outside the scope of the SPS Agreement. It pointed to the negotiating history of the SPS Agreement where discussions took place on whether to include environmental protection measures under the definition of an 'SPS measure', the outcome of which was the omission of the proposed text expressly including such measures. ${ }^{387}$ According to the EC, this indicates that measures to address environmental damage per se do not fall within the scope of the SPS Agreement. ${ }^{388}$ The Panel interpreted 'other damage' in sub-paragraph (d) as a very broad, residual category, which could include not only economic damage or damage to property, but also damage to the non-living components of the environment (i.e. damage other than to the life or health of plants or animals) encompassing adverse effects on biodiversity, population dynamics of species or geochemical cycles. ${ }^{389}$

In coming to its broad interpretations of sub-paragraphs (a) to (d), the Panel often went beyond the internationally-agreed upon definitions of the pertinent terms developed by the relevant international standard-setting bodies referred to in the SPS Agreement. ${ }^{390}$ It

385 At issue here was the potential of GM plants to produce allergenic effects other than as foods, for example in persons working with or otherwise coming into contact with GMOs. The Panel found that pests need not be living, so that GM plants that cause harmful effects in persons handling them during harvesting, transport or processing, can be regarded as pests. Panel Reports, EC-Approval and Marketing of Biotech Products para. 7.351 .

${ }^{386}$ With regard to environmental measures that do, even if indirectly, protect plant or animal life or health as part of their purpose of protecting the environment (such as measures to protect biogeochemical cycles in the soil and thereby prevent threats to soil micro-organisms or measures to protect genetic diversity), the Panel held that these are covered by sub-paragraphs (a) or (b) which address measures to protect animal or plant life of health.

387 Panel Reports, EC - Approval and Marketing of Biotech Products para. 7.199.

${ }^{388}$ According to the EC, those opposed to the inclusion of environmental measures under the coverage of the SPS Agreement stressed that the rules on SPS measures would not necessarily be appropriate to deal with environmental risks as the latter were of a different nature than SPS risks. Here the EC referred to Negotiating Group on Agriculture, Report of the Chairman of the Working Group on Sanitary and Phytosanitary Regulations and Barriers, MTN.GNG/NG5/WGSP/6, circulated on 15 October 1990. This report notes that an area where distinct differences in views remained was whether measures for the protection of, inter alia, the environment be defined as SPS measures and be disciplined under the new agreement. The EC also referred to a GATT Secretariat background note of 16 April 1993, that stated with regard to the draft SPS Agreement that: 'Measures for environmental protection, per se, or to protect the European Communities - Measures Affecting the Approval and Marketing of Biotech Products. Second Written Submission by the European Communities, Geneva), 19 July 2004, para. 58 and footnotes 34-35, available at: http://brode-info.cec.eu.int/ doclib/html/121611.htm, visited on 14 July 2005.

389 Panel Reports, EC - Approval and Marketing of Biotech Products para. 7.369-7.373.

${ }^{390}$ For example, the Panel found the IPPC definition of a pest as something 'injurious' to other plants to be informative but not dispositive of the meaning and scope of the term 'pest' used in the SPS Agreement. Instead, it preferred to refer to the dictionary meaning of pest to find that the term includes not only an animal/ plant that causes harm to the life or health of humans, animals or plants or causes other damage, but also 'a troublesome or annoying animal or plant'. This allowed the Panel to find that a biotech plant that is merely growing where it is undesired is a 'pest'. Panel Reports, EC-Approval and Marketing of Biotech Products 
also did not seem to follow the general rule of treaty interpretation codified in Article 31 of the Vienna Convention on the Law of Treaties, ${ }^{391}$ which requires that the words of a treaty be interpreted according to the ordinary meaning of the words used, in their context and in the light of the object and purpose of the treaty. While relying extensively on dictionary definitions, the meaning given by the Panel to the terms of sub-paragraphs (a) to (d) seems exceedingly strained and inappropriate. The Panel did not seem to take into account the context of provisions examined. Had it done so, one would have expected it to consider the scope of application of the SPS Agreement in the context of the other WTO agreements, in particular the TBT Agreement and the GATT 1994, within whose scope of application some aspects of the EC measure more appropriately fall. ${ }^{392}$ In this regard, the Panel did not explain the implications of the fact that the TBT Agreement expressly mentions environmental protection as a legitimate objective that may be pursued by measures under its coverage, ${ }^{393}$ for the applicability of the SPS Agreement to environmental measures. ${ }^{394}$ Further, the object and purpose of the SPS Agreement as reflected in its Preamble is to respect the right of Members to take measures to protect human, animal or plant life or health while subjecting such measures to disciplines to minimise their negative trade effects. One cannot reasonably argue that it is in accordance with the object and purpose of the SPS Agreement to subject to its disciplines measures aimed at preventing, for example, changes to carbon and nitrogen recycling in the soil due to the presence of transgenes; or changes to genetic diversity in the population of species due to alterations in the competitive advantage of particular plants. Indeed, one may wonder if this extensive interpretation is appropriate, as it results in broadening the application of the exacting disciplines of the SPS Agreement to a range of situations quite far removed from those covered by the ordinary meaning of the words used, in their context, in the light of the object and purpose of the Agreement.

Aside from the stretching of the meaning of the terms in sub-paragraphs (a) to (d), the Panel further expanded the coverage of these sub-paragraphs by establishing a criterion of a 'rational relationship' between the measure at issue and one of the enumerated purposes in the sub-paragraphs i.e. the risk to be averted. For example, in deciding whether

para. 7.238-7.241. For other examples of a similar disregard by the Panel for definitions developed by the international standard-setting bodies of terms that are used in Annex A.1 of the SPS Agreement, see ibid., paras 7.301, 7.277 and 7.313. See further on the Panel's use of international standard reference sources in its interpretation, below, Part IV, Section 2.2.4.

391 Vienna Convention on the Law of Treaties, concluded in Vienna on 23 May 1969, U.N. Doc A/CONF.39/27 (1969), 8 I.L.M. 679. Articles 31 and 32 of this convention, which set out the rules of treaty interpretation, are regarded as having attained the status of customary international law. Article 3.2 of the DSU provides that the WTO dispute settlement system serves to clarify the provisions of the covered agreements 'in accordance with customary rules of interpretation of public international law.' It is established case law that this provision refers to Articles 31 and 32 of the Vienna Convention. Appellate Body Report, US - Gasoline, 16; Appellate Body Report, Japan - Alcoholic Beverages II, 104.

${ }^{392}$ On the scope of application of the TBT Agreement and the GATT 1994, and their relationship with the SPS Agreement see below, Part III, Sections 2.4.1 and 2.4.2.

${ }^{393}$ Article 2.2 of the TBT Agreement. The coverage of the TBT Agreement is not defined according to the purpose of the measures at issue, but rather according to their form (as technical regulations, standards or conformity assessment procedures).

394 The Panel merely stated in response to the EC's argument on this point that this reference to environment in the TBT Agreement did not preclude it from interpreting the term 'other damage' in sub-paragraph (d) to include damage to the environment other than damage to the life or health of plants and animals. Panel Reports, EC-Approval and Marketing of Biotech Products, para. 7.209. 
the EC approval legislation applicable to biotech products could be seen as preventing harm to human, animal or plant life or health from 'pests' under Annex A.1(a), (c) or (d), the Panel did not find it necessary to decide if biotech plants are 'pests'. Instead, it found that cross breeds resulting from unintentional gene transfer from biotech plants to non-biotech plants could be regarded as 'pests' to the extent that they have undesired introduced traits (such as herbicide- or pesticide-resistance). ${ }^{395}$ Recognising that the EC legislation at issue was concerned with biotech products rather than their cross breeds, the Panel found that it is not necessary for the product subject to the SPS measure at issue (for example the biotech plant) to be itself the pest that gives rise to the SPS risk which the measure aims to protect against (e.g. the risk of establishment of cross-breeds with herbicide resistance). Instead, it is sufficient if there is a 'rational relationship' between the measure (e.g. controlling the release into the environment of biotech plants that might cross breed) and the purpose of protecting human, animal or plant life or health from the risk of establishment or spread of pests (in casu the cross breed with undesired traits). ${ }^{396}$ According to the Panel:

[T] he phrase "arising from" in Annex A(1) is broad and unqualified. There is nothing in Annex A(1)(a) which indicates that potential risks to animal or plant life or health must necessarily be the direct or immediate result of, e.g., the spread of a pest. Notably, Annex A(1) does not say that only risks "arising directly and immediately from", e.g., the spread of a pest, are covered. We therefore do not consider that measures taken to protect animal or plant life or health from risks that arise indirectly or in the longer term from pests, diseases, disease-carrying organisms or disease-causing organisms fall outside the scope of Annex A(1) (a). Accordingly, the reference in Annex II of Directive 2001/18 to indirect and delayed adverse effects does not, by itself, remove that Directive from the scope of Annex A(1)(a). ${ }^{397}$

In so doing, the Panel read the words 'directly or indirectly' into the list of purposes in Annex A.1, so that measures that have the indirect effect of preventing a risk that falls under the list of purposes in sub-paragraphs (a) to (d), are also covered by the disciplines of

${ }^{395}$ Panel Reports, EC-Approval and Marketing of Biotech Products, para. 7.255.

${ }^{396} \mathrm{Ibid}$., para. 7.258. The Panel made a similar finding with regard to the situation where pesticide-producing biotech plants lead to the development of pesticide resistance in target and non-target organisms (i.e. insect populations). Although the approval legislation governs biotech plants, not pesticide resistant insects, the Panel held that there was a 'rational relationship' between controlling the release into the environment of biotech plants and protecting animal or plant life or health from risks arising indirectly from the entry, establishment or spread of pests (in casu the pesticide resistant insects). Ibid., para. 7.265. Similar 'rational relationships' were found to exist between the approval legislation and other 'indirect effects' of biotech plants (inter alia, changes in pesticide-use practices and the establishment of antibiotic resistance in pathogens). For these and other examples, see ibid., paras 7.275, 7.284, 7.359. For a critical discussion of the Panel's 'rational relationship' test with regard to the purpose of SPS measures, see Christiane R. Conrad, PPMs, the EC-Biotech Dispute and Applicability of the SPS Agreement: Are the Panel's Findings Built on Shaky Ground?, Research Paper No. 8-06 (International Law Forum of the Hebrew University of Jerusalem, Jerusalem), August 2006, 11-14, available at: http://papers.ssrn.com/sol3/papers.cfm?abstract_id=920742\#PaperDownload, visited on 12 May 2008. See also Joanne Scott, The WTO Agreement on Sanitary and Phytosanitary Measures: A Commentary, Oxford Commentaries on the GATT/WTO Agreements (Oxford University Press, Oxford), 2007, 15 .

${ }^{397}$ Panel Reports, EC - Approval and Marketing of Biotech Products para. 7.226. 
the SPS Agreement. ${ }^{398}$ While it is clear that the product regulated by an SPS measure need not be itself the 'contaminant', 'pest' or 'disease' which the measure aims to prevent (for example, an import ban on mangoes may aim to prevent the introduction of fruit flies), one would expect that there should at least be a close link between the measure and one of the enumerated purposes in order for the measure to be an 'SPS measure'. If a panel is willing to travel far enough down the chain of causality, as the Panel in this case was prepared to do, it is likely to find a risk that is indeed within those listed in sub-paragraphs (a) to (d). ${ }^{399}$ This however, does not mean that the measure at issue was 'applied to protect' against such a risk.

The extension of the scope of application of the SPS Agreement to measures aimed at purposes that are arguably not those it was drafted to cover, has far-reaching consequences. As pointed out by Doaa Motaal, and supported by the negotiating history of the SPS Agreement, the SPS Agreement is 'intended to deal with a limited set of measures' ${ }^{400}$ It is this limited scope of application that enabled Members to agree to the inclusion of strict scientific disciplines. ${ }^{401}$ SPS measures, in the classical sense, most often directly regulate food or agricultural products, thus accounting for the need for strong disciplines to prevent protectionist abuses. Other measures, aimed at broader concerns such as biodiversity and other environmental issues, in many cases have only incidental effects on trade in agricultural products. In addition, such other measures embody societal values of a different nature than those reflected in 'SPS measures' as traditionally understood. Whereas SPS measures address health protection at national level, environmental measures often address harm which has a long-lasting global impact. ${ }^{402}$ Further, the appropriateness of the scientific disciplines of the SPS Agreement for the evaluation of environmental regulation is exceedingly doubtful. As convincingly argued by Jacqueline Peel, in contrast to the strong reliance in SPS regimes on a scientific basis for regulation, 'environmental

${ }^{398}$ The duty of a treaty interpreter is to interpret and apply the words actually used in the treaty, not the words it believes should have been used. A panel is therefore not permitted to read words into an agreement that were not used. On this issue see Appellate Body Report, EC - Hormones, para. 181 and Appellate Body Report, India-Patents (US), paras 46-47. See further below, in this Section, note 67.

399 Conrad argues that this approach of the Panel 'seems to qualify all trade-related environmental measures as SPS measures, since hypothetically, [e]ffects on the environment can easily result at some point in diseases, and certainly environmental regulations intend to prevent those.' Christiane R. Conrad, PPMs, the ECBiotech Dispute and Applicability of the SPS Agreement: Are the Panel's Findings Built on Shaky Ground?, Research Paper No. 8-06 (International Law Forum of the Hebrew University of Jerusalem, Jerusalem), August 2006, 13, available at: http://papers.ssrn.com/sol3/papers.cfm?abstract_id=920742\#PaperDownload, visited on 12 May 2008.

400 Doaa Abdel Motaal, 'The "Multilateral Scientific Consensus" And the World Trade Organisation', Journal of World Trade 38 (5), 2004, 855-876, 856. See also Jacqueline Peel, 'A GMO by Any Other Name ... Might Be an SPS Risk! Implications of Expanding the Scope of the WTO Sanitary and Phytosanitary Measures Agreement', European Journal of International Law 17 (5), 2006, 1009-1031, 1014.

401 Jacqueline Peel, 'A GMO by Any Other Name ... Might Be an SPS Risk! Implications of Expanding the Scope of the WTO Sanitary and Phytosanitary Measures Agreement', European Journal of International Law 17 (5), 2006, 1009-1031, 1016.

${ }^{402}$ Conrad suggests a normative approach which would recognise the existence of 'a different and possibly higher category of value' that an environmental measure seeks to protect. Christiane R. Conrad, PPMs, the ECBiotech Dispute and Applicability of the SPS Agreement: Are the Panel's Findings Built on Shaky Ground?, Research Paper No. 8-06 (International Law Forum of the Hebrew University of Jerusalem, Jerusalem), August 2006, 18, available at: http://papers.ssrn.com/sol3/papers.cfm?abstract_id=920742\#PaperDownload, visited on 12 May 2008. 
regimes invariably couple a requirement for reliance on scientific information with an instruction to act with caution in the face of scientific uncertainty. ${ }^{403}$ This broad acceptance of precautionary action in the field of environmental protection is in marked contrast to the weak and limited scope for precautionary measures in the SPS Agreement. ${ }^{404}$ This variance in the role of science in these two regimes reflects 'the different nature of available scientific knowledge regarding most environmental problems, as opposed to those associated with quarantine pests or diseases, or toxins of concern for human health.' ${ }^{405}$

The implications of the Panel's extremely broad interpretation of the purposes covered by the definition of an SPS measure, and of the relationship between the measure and such purpose, for Members at lower levels of development should not be underestimated. ${ }^{406}$ For example, those developing-country Members that are trying to establish a regulatory regime for biotech products are now faced with the situation that their biotech regulations, often motivated by environmental concerns in general ${ }^{407}$ and, more pragmatically, by the need to ensure that their agricultural products continue to have access to the EC market, may now unexpectedly be subject to the strict scientific disciplines of the SPS Agreement. ${ }^{408}$ For all Members, but particularly for those that face capacity constraints in the area of scientific risk assessment, such a result may have an inhibiting effect on regulatory initiatives. A similar concern can be raised with regard to efforts by developingcountry Members to implement their obligations under multilateral environmental agree-

403 Jacqueline Peel, 'A GMO by Any Other Name ... Might Be an SPS Risk! Implications of Expanding the Scope of the WTO Sanitary and Phytosanitary Measures Agreement', European Journal of International Law 17 (5), 2006, 1009-1031, 1017.

${ }^{404}$ Unlike the SPS Agreement, environmental regimes do not limit the possibility for precautionary measures to cases of insufficient scientific evidence, but cover a broad range of situations of scientific uncertainty. For a brief discussion of the precautionary principle, see above, Part II, Section 1.5. On the scope for precautionary measures under the SPS Agreement, see below, Part III, Sections 3.2.3.2 and 5.2.5.1.

${ }^{405}$ Jacqueline Peel, 'A GMO by Any Other Name ... Might Be an SPS Risk! Implications of Expanding the Scope of the WTO Sanitary and Phytosanitary Measures Agreement', European Journal of International Law 17 (5), 2006, 1009-1031, 1017. Peel points to the extensive and well developed nature of scientific research on food safety risks and risks from quarantine pests or diseases with the potential to cause economic losses to agricultural production, 'knowledge of ecosystems interactions and other environmental problems is more often patchy.' Ibid.

406 This issue has been addressed in Alice Palmer, The WTO GMO Dispute: Implications for Developing Countries and the Need for an Appeal (GeneWatch UK, The RSPB, Forum for Biotechnology and Food Security and the GM Freeze, Buxton), November 2006, available at: http://www.genewatch.org/uploads/f03c6d66a9b354535738483c1c3d49e4/WTO_Biotech_case_dcsummaryfinal_1.pdf, visited on 19 May 2008; Maria Julia Oliva and Simonetta Zarrilli, WTO Panel Report on The "EC-Biotech" Case: Considerations for Trade and Development, TD/B.COM.1/CRP.4 (Trade and Development Board, Commission on Trade in Goods and Services, and Commodities, Geneva), 19-23 March 2007.

407 Gregory Jaffe has pointed out that: 'many developing countries are focusing their Biosafety systems on environmental issues surrounding release of GMOs into the environment and have not established clear pathways for the food-safety assessment and approval process surrounding GMOs.' Gregory Jaffe, 'Biosafety Regulation in the North and South', in Proceedings of the Eighth International Symposium on the Biosafety of Genetically Modified Organisms (International Society for Biosafety Research, Montpellier, France), 2004, 190-194, 191, available at: http://www.isbr.info/symposia/docs/proceedings_montpellier2004.pdf, visited on 19 May 2008.

${ }^{408}$ For example, a regulation on traceability and segregation of biotech products to prevent their adventitious presence in non-biotech food exports to the EC, and thereby secure access for these exports to the EC market, may be deemed, indirectly, to prevent a risk from a 'contaminant' in food if some of those food products are also sold on the domestic market. This despite the fact that such a regulation may not be imposed to prevent food-safety risks at all, but only indirectly have that effect. 
ments, such as the Basel Convention on Hazardous Waste and the Cartagena Protocol on Biosafety. Measures to implement these environmental treaties may have trade effects, and may now fall under the expanded definition of SPS measures. Although poorly suited to this purpose, the SPS Agreement would then discipline these measures. Most Members would be hard pressed to defend such environmental measures from a challenge under the scientific obligations of the SPS Agreement, but this would be even more notably the case for Members at lower levels of development.

Another complicating factor in the determination of whether a measure is an SPS measure is the fact that sometimes a measure has protection of human, plant or animal life or health as only one of several objectives. ${ }^{409}$ Consumer information, environmental protection and ethical concerns are examples of additional objectives which particular measure could pursue. Could the Member imposing the measure argue that the other aims predominate and the measure thus falls outside the definition of SPS measures or is the very existence of one of the listed health objectives sufficient to trigger the application of the SPS Agreement? This question had not received any attention in the case law, until the recent EC-Approval and Marketing of Biotech Products case. In all previous cases, the Member defending its measure claimed that its purpose was the protection of health, or at least did not dispute this fact. ${ }^{410}$ In EC-Approval and Marketing of Biotech Products, however, the EC claimed that its approval procedures for the deliberate release of biotech products into the environment (contained in Directive 90/220 and subsequently Directive 2001/18) and for the approval of novel foods and food ingredients (in Regulation 258/97) fell in part within the scope of the SPS Agreement and in part outside its scope. In particular, the EC argued that the SPS Agreement has a limited scope of application, determined by the objective or purpose of the measure at issue, and therefore that the environmental and related objectives of its approval legislation were not governed by the SPS Agreement but rather by the TBT Agreement. ${ }^{411}$

The Panel in EC-Approval and Marketing of Biotech Products held that a single measure that has more than one autonomous raison d'être which would provide and independent basis for imposing it, can be 'deemed to embody two, if not more, distinct measures which fall to be assessed under different WTO agreements. ${ }^{412}$ Therefore, it agreed with the EC's view and held:

$[\mathrm{T}] \mathrm{o}$ the extent the requirement in the consolidated law is applied for one of the purposes enumerated in Annex A(1), it may be properly viewed as a measure which falls to be assessed under the SPS Agreement; to the extent it is applied for

\footnotetext{
409 See Joost Pauwelyn, 'The WTO Agreement on Sanitary and Phytosanitary (SPS) Measures as Applied in the First Three SPS Disputes: EC-Hormones, Australia-Salmon and Japan-Varietals', Journal of International Economic Law 2 (4), 1999, 641-664, 643.

${ }^{410}$ Panel Report, EC - Hormones (US), para. 8.22; Panel Report, EC - Hormones (Canada), para. 8.25; Panel Report, Australia - Salmon, para. 8.32; Panel Report, Japan - Agricultural Products II, para. 8.12; Panel Report, Japan - Apples, para. 8.73.

411 Panel Reports, EC-Approval and Marketing of Biotech Products, paras 7.151-7.154. According to the EC, where a measure pursues both SPS and non-SPS objectives, the SPS Agreement applies to the extent that SPS objectives are pursued and the TBT Agreement applies to the extent that non-SPS objectives are pursued. It is not clear in what way this argument serves the $\mathrm{EC}$, since it results in subjecting its approval procedures to more than one WTO agreement.

${ }^{412}$ Panel Reports, EC - Approval and Marketing of Biotech Products, para. 7.166.
} 
a purpose which is not covered by Annex A(1), it may be viewed as a separate measure which falls to be assessed under a WTO agreement other than the SPS Agreement. ${ }^{413}$

Such a requirement, according to the Panel, would simultaneously embody an SPS measure and a 'non-SPS measure'. A single requirement would therefore fall under the disciplines of both the SPS Agreement and another WTO agreement, such as the TBT Agreement or the GATT 1994.

It is important to note that the definition in Annex A specifies that the measures must aim to protect human, animal or plant life or health 'within the territory of the Member.' Avoiding the lack of clarity under the GATT with regard to the position of extra-territorial measures, ${ }^{414}$ the SPS Agreement, is explicit in its exclusion of extra-territorial measures from its application. Thus measures aiming at the extra-territorial application of domestic SPS requirements will instead fall under the disciplines of the GATT 1994 or the TBT Agreement. ${ }^{415}$ This issue should be distinguished from the related question of the applicability of the SPS Agreement to product-related PPMs. As noted above, negotiators of the SPS Agreement recognised that in many cases SPS regulations lay down requirements on PPMs rather than requirements on the final product. ${ }^{416}$ Particularly in developed countries with sophisticated SPS regulatory regimes, there has been a movement away from product requirements towards a systems-wide (or farm-to-fork) approach to SPS regulation. ${ }^{417}$ This approach focuses on setting out process requirements, such as the application of HACCP in the production process, ${ }^{418}$ which prevent the introduction of risks at vulnerable stages of this process and thereby ensure the safety of the final product. These PPM requirements can be regarded as 'product-related PPMs' as they aim to ensure that the imported product is risk free, rather than to address non-product related concerns such as animal welfare and labour standards. Therefore, despite the fact that such regulations on PPMs are directed at activities carried out outside the territory of the regulating Member, the health risks they aim to prevent are within the territory of this Member. ${ }^{419}$ These measures therefore meet the territorial requirement in the definition of an SPS measure and thus are not excluded from the scope of application of the SPS Agreement. In fact, among the illustrative list of SPS measures that would fall within the definition in Annex A.1, provided in the second paragraph of this definition, PPMs are explicitly mentioned.

${ }^{413}$ Ibid., para. 7.165.

${ }^{414}$ See the discussion of this issue under the GATT, above, Part III, Section 1.1.1.

415 Note that the lack of clarity regarding the position of extra-territorial measures under the GATT 1994 does not relate to whether these measures are caught by the obligations of the GATT 1994, but rather to whether they can be justified under one of the exceptions in Article XX(b) of the GATT 1994. Thus, it is still correct to say that these measures fall under GATT disciplines. See above, Part III, Section 1.1.1.

416 See above, Part III, Section 1.2.2.

417 This development is discussed in Chapter 2 of Part II of this book. See above, Part II, Section 1.3.

${ }^{418}$ For an explanation of the HACCP system, see above, Part II, Section 1.3.

419 See further on this point Joanne Scott, The WTO Agreement on Sanitary and Phytosanitary Measures: A Commentary, Oxford Commentaries on the GATT/WTO Agreements (Oxford University Press, Oxford), 2007, 11; Gabrielle Marceau and Joel P. Trachtman, 'GATT, TBT and SPS: A Map of WTO Law of Domestic Regulation of Goods', in The WTO Dispute Settlement System 1995-2003, F. Ortino and Ernst-Ulrich Petersmann (eds.) (Kluwer Law International, Deventer), 2004, 275-340, 325. 
The second paragraph of the definition in Annex A.1 states that SPS measures 'include all relevant laws, decrees, regulations, requirements and procedures' and gives an illustrative list of such measures. This provides a broad coverage for different types of legal measures, clearly intended to catch all measures aimed at achieving one of the abovementioned purposes, whether in legislation, administrative regulation or procedural rules.

Contrary to previous cases, which focused on the closed list of purposes to find that the measure at issue was an SPS measure, and recognised the broad coverage of different forms of measures reflected in the illustrative list of the second paragraph of the definition, the Panel in EC-Approval and Marketing of Biotech Products found that there are three elements in the definition of an SPS measure: (1) the purpose of the measure, as enumerated in sub-paragraphs (a) to (d); (2) the legal form of the measure, as described in the second paragraph ('all relevant laws, decrees, [and] regulations'); and (3) the $n a-$ ture of the measure, also set out in the second paragraph ('requirements and procedures, including...'). ${ }^{420}$ According to the Panel, all three elements must be present for a measure to be an 'SPS measure' under Annex A.1. Thus, after its extensive examination of the 'purpose' element of the definition, the Panel proceeded to determine whether the 'form' and 'nature' elements were present.

According to the Panel, the 'form' element, which indicates that SPS measures include 'all relevant laws, decrees [and] regulations', suggests that no particular legal form is prescribed. ${ }^{421}$ Instead, SPS measures may take a variety of legal forms. However, the 'nature' element was seen by the Panel as requiring that all SPS measures have the nature of either a 'requirement' or a 'procedure'.

The Panel's identification of two additional separate elements (form and nature) in the definition of an SPS measure in the second paragraph of Annex A.1 is rather surprising. There seems to be no obvious reason to break the relevant sentence up in this artificial way. In fact, in order to do so, the Panel had to insert the word 'and' between 'decrees' and 'regulations', ${ }^{422}$ which seems contrary to the principle that a treaty interpreter must interpret the words actually used in the treaty, rather than add words it considers should have been used. ${ }^{423}$ It would seem more in line with the natural meaning of the text to regard the second paragraph as providing a broad illustrative list of five types (or in the Panel's word forms) of measures that would be considered SPS measures, namely, all relevant laws, decrees, regulations, requirements and procedures. That this list is non-exhaustive

420 Panel Reports, EC - Approval and Marketing of Biotech Products, para. 7.149. Much of the following discussion on this point is taken from Denise Prévost, 'Opening Pandora's Box: The Panel's Findings in the EC-Biotech Products Dispute', Legal Issues of Economic Integration 34 (1), 2007, 67-101, 71-78.

${ }^{421}$ Panel Reports, EC - Approval and Marketing of Biotech Products, para. 7.1334.

${ }^{422}$ Ibid., para. 7.422 .

${ }^{423}$ As the Appellate Body held in India - Patents (US): 'The duty of a treaty interpreter is to examine the words of the treaty to determine the intentions of the parties. This should be done in accordance with the principles of treaty interpretation set out in Article 31 of the Vienna Convention. But these principles of interpretation neither require nor condone the imputation into a treaty of words that are not there or the importation into a treaty of concepts that were not intended.' Appellate Body Report, India - Patents (US), para. 45. This principle was reiterated in EC-Hormones where the Appellate Body stated, 'The fundamental rule of treaty interpretation requires a treaty interpreter to read and interpret the words actually used by the agreement under examination, not words the interpreter may feel should have been used.' Appellate Body Report, EC - Hormones, para. 181. 
is indicated by the use of the word 'include'. The purpose of the list, rather than to limit the scope of the SPS Agreement by adding specific form and nature requirements, seems to be to make clear the broad reach of the Agreement to all types of measures, whether legislative, administrative or otherwise, once it is established that they are imposed for one of the four purposes listed in the sub-paragraphs. The further list of various measures ('including, inter alia, end product criteria...') is again a non-exhaustive illustration, this time of the types of specific SPS measures that would be regarded as 'laws, decrees, requirements, regulations and procedures' under this definition. ${ }^{424}$

The Panel's approach had practical implications for the application of the SPS Agreement to the measures in dispute. ${ }^{425}$ While the Panel recognised the broad ambit of the 'form' element as encompassing a variety of legal forms, ${ }^{426}$ it relied on the 'nature' element it had read into Annex A.1, and which it regarded as 'key' to its determination, ${ }^{427}$ to find that the EC general de facto moratorium on biotech approvals did not fall under the definition of an SPS measure. The Panel regarded the general de facto moratorium as neither a 'requirement' nor a 'procedure' but rather as the 'application' of approval procedures. ${ }^{428}$

${ }^{424}$ The Panel regarded this illustrative list of specific SPS measures in the last part of Annex A.1 as relating only to the words 'requirements and procedures' and as setting out 'a number of relevant substantive requirements (prescribed end product criteria, prescribed quarantine treatments, certain packaging and labelling requirements, etc.) and procedures (testing procedures, inspection procedures, certification procedures, approval procedures, etc.).' The Panel did note that the term 'requirements' is broad in scope, including both an authorisation to market a particular product and a ban on marketing a particular product. Panel Reports, EC-Approval and Marketing of Biotech Products, para. 7.1334.

${ }_{425}$ The Panel readily found that the EC approval procedures in the relevant Directives and Regulation were SPS measures. As discussed above, the Panel interpreted the objectives laid down in sub-paragraphs (a)-(d) of Annex A.1 broadly to cover the aims of these approval procedures. As the relevant Directives and Regulation were legislative acts that were legally binding and attributable to the EC, the Panel regarded them as 'laws' meeting the 'form' requirement it had identified. Since they laid down approval procedures (as clarified in Annex C.1 to the SPS Agreement), they met the Panel's 'nature' requirement (Panel Reports, EC-Approval and Marketing of Biotech Products, paras 7.422-7.431). However, the Complainants did not challenge the approval procedures as laid down in the Directives and Regulation, but rather challenged the general de facto moratorium, the product specific measures and the Member States safeguard measures. It is interesting that the pre-marketing approval system itself was not challenged (as noted by the Panel more than once, see Panel Reports, EC-Approval and Marketing of Biotech Products, paras 7.1353 and 7.1693) despite the fact that approval procedures are expressly named among the examples of SPS measure listed in Annex A.1 and the fact that pre-marketing approval requirements sit uncomfortably with the disciplines of the SPS Agreement. The SPS Agreement requires that a risk assessment must exist on which the relevant SPS measure (such as a marketing prohibition) is based. A pre-marketing approval system, however, prohibits the marketing of a product until such time as its safety is proven by means of a risk assessment. It can be seen as a provisional ban pending a risk assessment. However, as most countries maintain pre-marketing approval systems for particular products, it is possible that the Complainants wished to avoid opening this can of worms.

426 The Panel noted the use of the word 'include' and found that, 'the reference to "laws, decrees [and] regulations" should not be taken to prescribe a particular legal form'. Panel Reports, EC-Approval and Marketing of Biotech Products, paras 7.422 .

427 Ibid., para. 7.1338 .

${ }_{428}$ The Panel found that the general moratorium should be characterised as a decision to delay the decision on final approval of specific applications until certain conditions were met. It rejected the argument that the moratorium should be seen as an across-the-board marketing ban on biotech products requiring approval, and thus as a 'requirement'. The Panel correctly noted that the pre-marketing approval system itself imposes a provisional ban on biotech products for which approval is sought, pending the final approval decision, yet the Complainants chose not to challenge the pre-marketing approval system. The Panel also disagreed that the moratorium could be seen as itself a 'procedure' by setting out a particular mode or course of action to be followed by the Commission and Group of Five Member States delaying applications. Instead, the Panel 
As the second paragraph of Annex A.1 does not refer to the 'application' of requirements and procedures, the Panel saw its way clear to conclude that the moratorium was not an SPS measure. ${ }^{429}$ Similarly, the Panel regarded the product-specific measures challenged as 'the alleged failure by the [EC] to consider particular applications for final approval., ${ }^{430}$ As this was seen by the Panel to be neither a 'procedure' nor a 'requirement' but rather the 'application' of an approval procedure, it did not meet the Panel's 'nature' criterion and therefore did not fall under the definition of Annex A.1. ${ }^{431}$ This construction served a useful purpose for the Panel in this dispute in that it allowed the Panel to limit its analysis of the moratorium and the product-specific measures at issue to those procedural rules of the SPS Agreement that refer to the 'application' of SPS measures rather than apply the substantive disciplines to these measures. ${ }^{432}$ This permitted the Panel to steer clear of controversial questions such as the scientific basis for the de facto moratorium and product specific measures and the question whether biotech products are 'like' their conventional counterparts. ${ }^{433}$ However, the strained interpretation of the Panel may have unexpected far-reaching effects beyond this dispute.

These unintended effects lie in the consequences of the Panel's approach for future disputes, if not overturned by the Appellate Body in another case. Under the Panel's interpretation of Annex A.1, the determination of whether a measure falls within the SPS Agreement now turns on the rather technical criteria of its form and, more especially, its nature, rather than the more substantive (and arguably more important) criterion of its purpose. The limited list of objectives of SPS measures has been interpreted so broadly as to be practically all encompassing, reducing it to inefficacy as a limitation on the coverage

found that the EC continued to apply its existing approval procedures, but intentionally did not make full use of these procedures to complete the approval process. Panel Reports, EC-Approval and Marketing of Biotech Products, paras 7.1338-7.1378

${ }^{429}$ Ibid., para. 7.1382.

${ }^{430} \mathrm{Ibid}$, para. 7.1690. It should be noted that the Panel did address the substantive disciplines of the SPS Agreement in its examination of the claims regarding the safeguard measures applied by six EC Member States. This examination was less controversial as the scientific committees of the EC itself had evaluated the potential risks prior to granting approval to the biotech products at issue at EC level, and had subsequently reviewed the arguments and scientific evidence submitted by these Member States in support of their safeguard measures and found them insufficient to call into question its earlier conclusions.

${ }^{431}$ The Panel rejected the argument that the failure to consider particular applications for final approval amounted to a ban, and was thus a 'requirement' under Annex A.1. It also disagreed with the allegation that the EC's failure to consider particular applications for final approval was in itself a 'procedure' as it modified the approval procedure with respect to the biotech product in question. Panel Reports, EC-Approval and Marketing of Biotech Products, paras 7.1690-7.1697 (with regard to the US claim). The Panel rejected the claims of Canada and Argentina in this regard on the same reasoning. Ibid., paras 7.1701-7.1704 and 7.1711-17.1712.

${ }^{432}$ However, this result could arguably have been achieved without reading separate form and nature requirements into Annex A.1 by simply finding that the legislation containing approval procedures was covered by the broad description of possible legal forms of SPS measures in the second paragraph of Annex A.1 (specifically an approval procedure), and that the moratorium amounted to an application of such procedures rather than a separate SPS measure (law, decree, regulation, requirement or procedure) itself.

${ }^{433}$ The Panel made sure to point out in its conclusions and recommendations that it had not examined these questions. Panel Reports, EC - Approval and Marketing of Biotech Products, para. 8.3. Other questions which the Panel pointed out it had also not examined in the dispute, such as whether biotech products are safe or not, whether the risk assessments of the EC's scientific committees conformed with the scientific disciplines of the SPS Agreement and whether a Member has a right to have a pre-marketing approval system in place, had not been raised by the parties. 
of the SPS Agreement. By contrast, the Panel seems to disregard the inclusive nature of the illustrative list in the second paragraph of Annex A.1 and, in effect, it requires all SPS measures to have the 'nature' of either 'requirements' or 'procedures.' The result of the focus in interpretation on form rather than substance is that Members may be encouraged to frame their measures in such a way as to avoid having the 'nature' of a requirement or procedure. As discussed above, this approach does not seem to rest comfortably with the text of Annex A.1, which instead appears to restrict the purpose of an SPS measure to only the listed objectives, yet allow for the measures aiming at these objectives to be given a wide range of legal forms, providing only an illustrative list of possibilities to be included. This seems in keeping with the object and purpose of the SPS Agreement. It is entirely unclear what the drafters' objective would have been in excluding measures that do not have the nature of requirements or procedures from the rules of the SPS Agreement. This formalistic criterion would only create incentives to draft legislation in a manner that avoid meeting this 'nature' test. As this Panel Report was not appealed, the Appellate Body has not had the opportunity to consider this interpretation of the Annex 1.A definition. This interpretation has already been followed by the Panel in US - Continued Suspension and Canada - Continued Suspension, which recalled the three-pronged test, read into the definition of an SPS measure by the Panel in EC-Approval and Marketing of Biotech Products, and applied it to the matter before it. ${ }^{434}$

While in the EC - Approval and Marketing of Biotech Products dispute, the broad interpretation of the enumerated purposes under which a measure will be regarded as an 'SPS measure' was tempered by the Panel's unexpected insertion of a 'nature' criterion into the definition, resulting in a limited impact of the substantive disciplines of the SPS Agreement on the measures at issue, this may not be the case in future disputes. SPS measures at issue in future disputes are likely to have the 'nature' of requirements or procedures, particularly in view of the broad interpretation of given by the Panel to the word 'requirements' in its analysis of whether the EC Member States' safeguard measures met the third element of the definition. In this regard the Panel recalled that:

... the reference in [Annex A.1] to "requirements" is broad and unqualified. Hence, both an authorization to market a particular product and a ban on the marketing of a particular product may be considered as "requirements". The second example would constitute a negative requirement. ${ }^{435}$

Noting that each safeguard measure prohibited the marketing of the biotech product at issue, the Panel expressed its view that:

... a prohibition on the marketing of a particular product (within a particular territory) may be considered a "requirement" for the purposes of Annex A(1). ${ }^{436}$

Therefore the nine safeguard measures were found to be 'SPS measures' within the meaning of the definition in Annex A.1 of the SPS Agreement. This was also the case in US-

\footnotetext{
${ }^{434}$ Panel Report, US - Continued Suspension, para. 7.429; Panel Report, Canada - Continued Suspension, para. 7.420 .

${ }^{435}$ Panel Reports, EC-Approval and Marketing of Biotech Products, para. 7.2599. This finding was reiterated with regard to each of the nine safeguard measures.

${ }^{436}$ Ibid., para. 7.2599. Again, this finding was reiterated with regard to each of the nine safeguard measures.
} 
Continued Suspension and Canada-Continued Suspension, where the Panel noted that a ban may be considered a requirement under the 'nature' element of this test to find that the EC's ban on hormone-treated meat was an 'SPS measure'. ${ }^{437}$ Clearly, therefore, normally the 'nature' criterion will often not have much restraining effect on the applicability of the SPS Agreement. ${ }^{438}$ In such cases, an overly broad interpretation of the listed purposes delimiting the concept of an SPS measure may lead to an invasive application of the rigorous disciplines of the SPS Agreement to areas not intended to fall within its ambit. ${ }^{439}$

\subsubsection{Effect on international trade}

The second requirement set in Article 1.1 for the application of the SPS Agreement is that the measure at issue must be a measure that 'may directly or indirectly affect international trade'. This is not an empirical standard, necessitating proof that the measure has led to a reduction in trade flows, but rather a theoretical standard, met by showing that the measure applies to imports and can therefore be presumed to have a negative impact on trade. ${ }^{440}$ This requirement is thus easy to fulfil.

Moreover, as pointed out by the Panel in EC - Approval and Marketing of Biotech Products, Article 1.1 only requires that the measure may affect international trade. Thus, 'it is not necessary to demonstrate that an SPS measure has an actual effect on trade. ${ }^{441}$ In that dispute, the Panel noted that it was uncontested that the EC's approval procedures for biotech applied to biotech products or foods containing or consisting of biotech products produced outside the EC and that would therefore be imported upon approval. These approval procedures were applied to check conformity with SPS requirements the satisfaction of which was necessary to obtain marketing approval. In addition, the procedures themselves, according to the Panel, may have a direct or indirect effect on international trade as their completion takes time and they impose information and documentation requirements. Therefore, the Panel found that the EC's approval procedures were measures that 'may directly or indirectly affect international trade'.

Hygienic practices requirements for street food vendors is arguably an example of an SPS measure which does not fall within the scope of application of the SPS Agreement because it does not, actually or potentially, affect international trade.

${ }^{437}$ Panel Report, US - Continued Suspension, para. 7.443 and Panel Report, Canada - Continued Suspension, para. 7.424.

${ }^{438}$ While this would normally be the case, it should be borne in mind, as argued above, that Members may seek to avoid this broad application of the SPS Agreement by artificially drafting their SPS measures so that they do not meet the formal requirement of having the 'nature' of a requirement or procedure.

${ }^{439}$ Christiane Conrad argues convincingly in this regard that in view of the fact that the SPS Agreement imposes stricter disciplines on health measures than those applicable under the GATT 1994 and the TBT Agreement, the interpretative principle in dubio mitius would require an interpretation of ambiguous terms in the definition of SPS measures in a narrow way so as to limit the applicability of the SPS Agreement in favour of the application of the 'softer' disciplines of the GATT 1994 or TBT Agreement. Christiane R. Conrad, PPMs, the EC-Biotech Dispute and Applicability of the SPS Agreement: Are the Panel's Findings Built on Shaky Ground?, Research Paper No. 8-06 (International Law Forum of the Hebrew University of Jerusalem, Jerusalem), August 2006, 29-30, available at: http://papers.ssrn.com/sol3/papers.cfm?abstract_ id=920742\#PaperDownload, visited on 12 May 2008.

${ }^{440}$ Dale E. McNiel, 'The First Case under the WTO's Sanitary and Phytosanitary Agreement: The European Union's Hormone Ban', Virginia Journal of International Law 39, 1998, 89-134.

${ }^{441}$ Panel Reports, EC - Approval and Marketing of Biotech Products, para. 7.435. 


\subsection{Personal scope of application}

The personal scope of application of the SPS Agreement refers to the question of which entities are covered by its rules. This issue has arisen because the adoption and implementation of SPS requirements is increasingly in the hands of bodies other than central government. Some of these bodies involve governmental action at sub-national level, such as local government regulators (states, provinces, or cantons) or at supra-national level, such as regulatory bodies under regional agreements (for example the FSANZ). ${ }^{442}$ Others may involve both governmental and non-governmental actors, such as national bureaus of standards, which may be public or private bodies that set non-mandatory standards but whose standards are often relied upon by governments in enacting regulations. ${ }^{443} \mathrm{In}$ addition, increasingly SPS requirements are imposed by private sector actors, such as supermarkets. ${ }^{444}$

This development away from central government regulation, towards local, supra-national and private governance structures in the area of SPS should be seen in the context of the broader discussion around the contemporary shifts in the locus of governance, ${ }^{445}$ and the role of the WTO in addressing soft law norms created by different non-state actors. It has been argued that:

The emergence of regional and local governments on the world scene, coupled with an aggressive trade agenda encompassing politically sensitive areas to some degree under the control of these local entities, increases the potential for disguised restrictions on trade and other protectionist measures which could thwart trade liberalization. ${ }^{446}$

${ }^{442}$ The FSANZ (Food Standards Australia New Zealand) is the regulatory body for food established under a regional agreement between Australia and New Zealand. For more details on this body, see above, Part II, Section 2.4.2.1.

${ }^{443}$ Examples of such bodies, with different levels of government involvement, are Standards Australia, the Mauritius Standards Bureau, the Bureau of Standards of Jamaica and the Bangladesh Standards and Testing Institute. See above, Part II, Sections 2.4.2.1, 2.5.2.1, 2.6.2.1 and 2.7.2.1.

${ }^{444}$ Examples of private sector standards imposed by supermarket chains are Tesco's Nature's Choice and the British Retail Consortium Global Standard - Food. For a discussion of the proliferation of private sector standards, see above, Part II, Section 1.3.

445 Joanne Scott refers to the rise of private sector standards as a key element in the 'transformation of the governance landscape'. Joanne Scott, The WTO Agreement on Sanitary and Phytosanitary Measures: A Commentary, Oxford Commentaries on the GATT/WTO Agreements (Oxford University Press, Oxford), 2007, 302. In 1997, Anne-Marie Slaughter developed the theory of the 'disaggregated state' which addresses the idea of the transfer of power from central government authorities to subnational levels of government. Slaughter emphasises the rise of 'global governance' through the networking of functionally distinct parts of the disaggregated state with their counterparts abroad. Anne-Marie Slaughter, 'The Real New World Order', Foreign Affairs 76 (5), 1997, 183-197, 184. An example of the attention currently given in academic research to the move from traditional state-based governance to new forms of governance where public functions are carried out by local, regional and private bodies, is the 'Shifts in Governance' project of the Dutch Organisation for Scientific Research (NWO) which addresses issues of 'governance beyond the state' and 'governance without government'. See the website for this project, available at: http://www.nwo.nl/nwohome.nsf/pages/NWOP 5T8L5H, visited on 25 May 2008.

${ }^{446}$ Edward T. Hayes, 'Changing Notions of Sovereignty and Federalism in the International Economic System: A Reassessment of WTO Regulation of Federal States and the Regional and Local Governments within Their Territories', Northwestern Journal of International Law \& Business 25 (1), 2004, 1-36, 10. 
According to Joost Pauwelyn, in failing to address the increasingly important 'non-traditional' patterns of regulation, such as those reflected in 'soft norms' created by non-state actors, WTO law risks being 'under-inclusive' ${ }^{447}$ The question thus arises whether the SPS Agreement can be applied in such a way as to take account of this shift in governance.

The applicability of the disciplines in the SPS Agreement to bodies other than the central government is addressed in Article 13 of the SPS Agreement. This provision states:

Members are fully responsible under this Agreement for the observance of all obligations set forth herein. Members shall formulate and implement positive measures and mechanisms in support of the observance of the provisions of this Agreement by other than central government bodies. Members shall take such reasonable measures as may be available to them to ensure that non-governmental entities within their territories, as well as regional bodies in which relevant entities within their territories are members, comply with the relevant provisions of this Agreement. In addition, Members shall not take measures which have the effect of, directly or indirectly, requiring or encouraging such regional or non-governmental entities, or local governmental bodies, to act in a manner inconsistent with the provisions of this Agreement. Members shall ensure that they rely on the services of non-governmental entities for implementing sanitary or phytosanitary measures only if these entities comply with the provisions of this Agreement.

Thus, Members are fully responsible for the implementation of the Agreement, which includes a certain level of responsibility for the actions of bodies other than central government. They must enact and implement positive measures to support the observance of its rules by bodies other than central government bodies. In addition, Members must take all reasonable measures available to them to ensure that regional bodies in which their entities are members as well as non-governmental bodies in their territories comply with the SPS Agreement. Further, Members are prohibited from requiring or encouraging noncompliance with the Agreement by local, regional or non-governmental bodies. Members may not rely on non-governmental bodies to implement their SPS measures unless these bodies comply with the SPS Agreement. Thus the rules contained in the SPS Agreement will have an impact not only on the central government bodies of a Member but indirectly also on other bodies under its responsibility which are active in the area of sanitary and phytosanitary protection. It is the task of the Member to promote the compliance by these bodies with the disciplines of the SPS Agreement.

The limits of this responsibility are, however, not clear. In particular, the types of entities that are covered by this provision and the extent of action required of a Member demand clarification. The only dispute in which the interpretation of Article 13 of the SPS Agreement was at issue is Australia - Salmon (Article 21.5-Canada). The Panel in that

447 Joost Pauwelyn, 'Non-Traditional Patterns of Global Regulation: Is the WTO 'Missing the Boat'?' presented at the Conference on Legal Patterns of Transnational Social Regulations and Trade (European University Institute, Florence) 24-25 September 2004, 19-21, available at: http://eprints.law.duke.edu/1311/1/6Sept04. pdf, visited on 25 May 2008. Pauwelyn notes that the WTO exemplifies the traditional focus of international law on hard law, centred on states. However, he points out that today's normative governance patterns are quite different, involving non-state actors and soft law norms. Ibid., 2. 
case held that the sanitary measures taken by the government of Tasmania, an Australian state, fell under the responsibility of Australia, both under WTO law and under general international law, ${ }^{448}$ and were thus subject to the SPS Agreement. It found as follows:

Article 13 of the SPS Agreement provides unambiguously that: (1) 'Members are fully responsible under [the SPS] Agreement for the observance of all obligations set forth herein'; and (2) 'Members shall formulate and implement positive measures and mechanisms in support of the observance of the provisions of this Agreement by other than central government bodies'. Reading these two obligations together, in light of Article 1.1 of the SPS Agreement referred to earlier, we consider that sanitary measures taken by the Government of Tasmania, being an 'other than central government' body as recognized by Australia, are subject to the SPS Agreement and fall under the responsibility of Australia as WTO Member when it comes to their observance of SPS obligations. ${ }^{449}$

This finding is not controversial. It embodies the now generally accepted view that measures by various organs of state, including local government bodies, are considered as measures attributable to a WTO Member and therefore falling under its responsibility. ${ }^{450}$ Under the GATT 1994, this principle is reflected in the Understanding on the Interpretation of Article XXIV of the GATT, ${ }^{451}$ which clarifies that Article XXIV:12 of the

${ }^{448}$ The Panel, inter alia, referred to Article 27 of the Vienna Convention on the Law of Treaties which states that a party may not invoke provisions of its internal law for its failure to perform a treaty. Howard Latin, 'Ideal Versus Real Regulatory Efficiency: Implementation of Uniform Standards And "Fine Tuning” Regulatory Reforms', Stanford Law Review 37, 1985, 1267-1332. It also referred to Article 22.9 of the DSU which states that the dispute settlement provisions of the covered agreements can be invoked in respect of measures by regional or local governments or authorities within the territory of a Member.

${ }^{449}$ Panel Report, Australia - Salmon (Article 21.5 - Canada), para. 7.13. Canada had also made a claim in this case that Australia had violated its obligation under Article 13 of the SPS Agreement to formulate and implement positive measures and mechanisms in support of the observance of the provisions of the Agreement by other than central government bodies. The Panel found that Canada had not substantiated this claim. Ibid., para. 7.162.

${ }^{450}$ A similar finding was recently made by the Panel in Brazil-Retreaded Tyres which found that measures taken by Rio Grande do Sul, a state of the Federative Republic of Brazil, were attributable to Brazil as a WTO Member and therefore should be considered as 'measures' for purposes of Article 3.3 of the DSU. It stated: 'regardless of the relationship between these states [sic] laws and the federal laws based on the jurisdictions covered by the respective law within its domestic legal system, the Brazilian government is ultimately responsible for ensuring that its constituent states respect Brazil's obligations under the WTO...' Panel Report, Brazil-Retreaded Tyres, para. 7.406.

${ }^{451}$ See para. 14 of the 'Understanding on the Interpretation of Article XXIV of the General Agreement on Tariffs and Trade', in The Results of the Uruguay Round of Multilateral Trade Negotiations: The Legal Texts (World Trade Organization, Geneva), 1994, 31-34. Article XXIV:12 of the GATT 1994 requires each Member to 'take such reasonable measures as may be available to it' to ensure observance with the GATT by regional and local governments and authorities in its territory. This could be understood as limiting a Member's responsibility for subnational levels of government, in view of possible constitutional limitations on their authority over such subnational entities. The Understanding clarifies that, instead, a Member can be challenged in dispute settlement in respect of measures taken by regional or local governments or authorities. This is more in line with the approach in international law to the issue of state responsibility for the acts of subnational levels of government. As noted by Edward Hayes, the early doubts as to whether Article XXIV:12 of the GATT reflects an intention to opt out of the customary international law principle of state responsibility for subnational levels of government have been removed by the Understanding and 'there is now no question that federal GATT/WTO Members remain fully responsible for the actions of their component governmental units.' Edward T. Hayes, 'Changing Notions of Sovereignty and Federalism in the International Economic 
GATT 1994 entails that dispute settlement proceedings may be invoked against a Member in respect of measures taken by regional or local government or authorities within its territory. ${ }^{452}$ This principle is embodied in Article 29 of the Vienna Convention on the Law of Treaties, which provides:

Unless a different intention appears from the treaty or is otherwise established, a treaty is binding upon each party in respect of its entire territory.

This has been taken to mean that in federal states, the state party to the treaty is responsible not only for the acts of its central government but also for those of local government bodies in its territory. In addition, Article 27 of the Vienna Convention on the Law of Treaties provides that a party may not invoke provisions of its internal law for its failure to perform a treaty. Thus the constitutional limits of the authority of central government over sub national levels of government cannot be used as an excuse for the violation of treaty obligations by lower levels of government. Similarly, Article 4 of the International Law Commission's (ILC) Articles on Responsibility of States for Internationally Wrongful Acts of 2001 provides that:

The conduct of any State organ shall be considered an act of that State under international law, whether the organ exercises legislative, executive, judicial or any other functions, whatever position it holds in the organization of the State, and whatever its character as an organ of the central Government or of a territorial unit of the State..$^{453}$

The ILC's Commentary to this Article emphasises the long-established nature of the principle of state responsibility for acts of local government bodies. It further notes that:

It does not matter for this purpose whether the territorial unit in question is a component unit of a federal State or a specific autonomous area, and it is equally irrelevant whether the internal law of the State in question gives the federal parliament power to compel the component unit to abide by the State's international obligations. ${ }^{454}$

System: A Reassessment of WTO Regulation of Federal States and the Regional and Local Governments within Their Territories', Northwestern Journal of International Law \& Business 25 (1), 2004, 1-36, 20.

${ }^{452}$ On this issue see further Thomas Cottier and Krista Nadakavukaren Schefer, 'The Relationship between World Trade Organization Law, National Law and Regional Law', Journal of International Economic Law 1 (1), 1998, 83-122, 85-86; Edward T. Hayes, 'Changing Notions of Sovereignty and Federalism in the International Economic System: A Reassessment of WTO Regulation of Federal States and the Regional and Local Governments within Their Territories', Northwestern Journal of International Law \& Business 25 (1), 2004, 1-36.

${ }^{453}$ Article 4 of the Jay Michealson, 'Rethinking Regulatory Reform: Toxics, Politics and Ethics', Yale Law Journal 105, 1996, 1891-1925. These Articles were taken note of in Resolution 56/83 adopted by the General Assembly of the UN on 12 December 2001 and are to be found in the Annex to General Assembly Resolution 56/83 of 12 December 2001, corrected by document A/56/49 (Vol. I)/Corr.4. Official Records of the General Assembly, Fifty-Sixth Session, Supplement No. 10 (A/56/10), chp.IV.E.1. The Articles aim to formulate, through codification and progressive development, the basic international law rules concerning the responsibility of States for their internationally wrongful acts.

${ }^{454}$ Wendy E. Wagner, 'The Science Charade in Toxic Risk Regulation', Columbia Law Review 95, 1995, 1613 1723, para. 9 . 
It is therefore clear that WTO Members will be held directly responsible not only for the acts and omissions of their central government bodies, but also for acts and omissions of lower levels of government. Such local government bodies must therefore comply fully with the SPS Agreement. To facilitate such compliance, the second sentence of Article 13 of the SPS Agreement requires Members to implement positive measures to support compliance by other than central government bodies with the SPS Agreement. ${ }^{455}$ A Member is thus obliged to assist proactively its local government bodies in their compliance.

More contentious is the question whether Article 13 of the SPS Agreement extends the application of the Agreement to private sector standards. While, as discussed above, ${ }^{456}$ this issue did not arise during the negotiation of the SPS Agreement due to the fact that safety regulation was then typically still in the hands of governments, with the proliferation of private sector SPS standards since the mid-1990s, ${ }^{457}$ the issue has come to the forefront of attention. Currently, private sector standards are no longer limited to technical specifications, ethical standards or quality requirements, ${ }^{458}$ but also cover safety issues such as maximum levels for pesticide residues, requirements for the traceability of food products, and process standards such as HACCP. Most often, these private sector standards are stricter than national SPS regulations and lay down complex PPM requirements rather than product specifications. ${ }^{459}$ Although private sector standards are voluntary in

${ }^{455}$ At first sight the applicability of this obligation in respect of 'other than central government bodies' would seem to extend to all bodies that are not central government bodies, thereby including non-governmental bodies and regional bodies in which entities of a WTO Member are members. However, when seen in the context of the rest of Article 13, a narrower interpretation of this provision is clearly called for, limiting it to government bodies other than at central government level. The third sentence of Article 13 addresses a Member's responsibility with regard to compliance by non-governmental and regional bodies. To read both the second and third sentences as covering these types of bodies would not make sense due to the two different obligations contained in each. With respect to government bodies other than at central government level, the second sentence of Article 13 requires positive measures to support compliance. The fact that the acts of local government bodies are considered acts of the relevant Members, and that Members are obliged to comply with the SPS Agreement, explains why Members are not required to take measures to 'ensure' the compliance of local government bodies, but only to support it. Even in the absence of an omission to take positive supportive measures, a Member can be found to violate the SPS Agreement if acts of its subnational levels of government are not in conformity with the SPS Agreement.

${ }^{456}$ See above, Part III, Section 1.2.2.

457 WTO Secretariat notes that there are over 400 private sector standard schemes currently in operation. Some of these are developed by individual firms (for example Tesco Nature's Choice), others are developed collectively by national retailers (for example, the British Retail Consortium Global Standard - Food) or by international consortia (such as GLOBALGAP, which was previously EUREPGAP). Committee on Sanitary and Phytosanitary Measures, Private Standards and the SPS Agreement. Note by the Secretariat, G/SPS/GEN/746, circulated on 24 January 2007, para. 5. As reported by Henson, in 1999 the British Retail Consortium Global Standard was used by less than 500 UK processors, but by 2005 it was in use by 5500 processors in 64 countries. Spencer Henson, 'The Role of Public and Private Standards in Regulating International Food Markets', presented at the IATRC Summer Symposium on Food Regulation and Trade: Institutional Framework, Concepts of Analysis and Empirical Evidence, Bonn) May 28-30 2006, 20, available at: http://www.ilr1.uni-bonn.de/iatrc/iatrc program/Session\%204/Henson.pdf, visited on 27 May 2008.

${ }_{458}$ Note that many private sector standards, such as those addressing animal welfare and fair labour practices, would not meet the definition of an SPS measure since they do not aim to protect human, animal or plant life or health within the territory of the importing Member. However, increasingly food-safety issues are addressed in private standards, making the question of the applicability of the SPS Agreement particularly relevant.

${ }^{459}$ In a 2006 OECD study, Lisa Fulponi notes that over $85 \%$ of leading retailers reported that their required standard was higher than the government regulatory standard, and about $50 \%$ reported that it was significantly 
nature, the wide-scale application of such standards as purchasing requirements by large supermarket chains, which dominate the market for food and agricultural products, ${ }^{460}$ has the effect of excluding non-conforming suppliers from this market. As a result, these standards take on de facto binding force. ${ }^{461}$ Several empirical studies have been carried out that confirm the significant impact of private sector standards on the agri-food sector in general, and on developing-country producers in particular. ${ }^{462}$ It has been noted that the impact of these standards on developing-country producers is disproportionate. ${ }^{463}$ In particular, the challenge of complying with private sector standards has the effect of excluding small-scale producers in developing countries from participating in the export market for high-value agricultural products. ${ }^{464}$

higher. Linda Fulponi, Final Report on Private Standards and the Shaping of the Agro-Food System, AGR/ CA/APM(2006)9/FINAL (Organisation for Economic Co-operation and Development, Paris), 31 July 2006, para. 50, available at: http://www.olis.oecd.org/olis/2006doc.nsf/43bb6130e5e $86 \mathrm{e} 5 \mathrm{fc} 12569 \mathrm{fa} 005 \mathrm{~d} 004 \mathrm{c} / 4 \mathrm{e} 3 \mathrm{a}$ $2945 \mathrm{ffec} 37 \mathrm{eec} 12571 \mathrm{bc00590ce3/ \$ FILE/JT03212398.PDF,} \mathrm{visited} \mathrm{on} 27$ May 2008.

${ }^{460}$ For example, EUREPGAP membership included the 30 largest retailers across 12 EC Member States, accounting for $85 \%$ of the Western European fresh produce market. Grace Chia-Hui Lee, Private Food Standards and Their Impacts on Developing Countries (European Commission, DG Trade, Unit G2, Brussels), 2006, 13, available at: http://trade.ec.europa.eu/doclib/docs/2006/november/tradoc_127969.pdf, visited on 26 May 2008. The fact that the oligopolistic nature of food retailing enables large retailers to require suppliers to be certified for compliance with private standards is noted by Hatanaka et al. Maki Hatanaka et al., "Third-Party Certification in the Global Agrifood System', Food Policy 30, 2005, 354 - 369, 358-359.

${ }^{461}$ As noted by the WTO Secretariat: ' ...the choice of whether or not to comply with a voluntary standard becomes a choice between compliance or exit from the market. In this way, the distinction between private voluntary standards and mandatory "official" or "public" requirements can blur.' Committee on Sanitary and Phytosanitary Measures, Private Standards and the SPS Agreement. Note by the Secretariat, G/SPS/ GEN/746, circulated on 24 January 2007, para. 9. On the blurring distinction between public and private regulation and mandatory and voluntary norms, see also David Vogel, who argues that rather than seeing these as sharp dichotomies, they should be seen as the ends of a continuum to avoid hiding the changing relations of power in international relations. David Vogel, 'Private Global Business Regulation', Annual Review of Political Science, 11, 2008, 261-282, 265.

${ }^{462}$ See for example, Grace Chia-Hui Lee, Private Food Standards and Their Impacts on Developing Countries (European Commission, DG Trade, Unit G2, Brussels), 2006, available at: http://trade.ec.europa.eu/doclib/ docs/2006/november/tradoc_127969.pdf, visited on 26 May 2008; Spencer Henson, 'The Role of Public and Private Standards in Regulating International Food Markets', presented at the IATRC Summer Symposium on Food Regulation and Trade: Institutional Framework, Concepts of Analysis and Empirical Evidence, Bonn) May 28-30 2006, available at: http://www.ilr1.uni-bonn.de/iatrc/iatrc_program/Session\%204/Henson.pdf, visited on 27 May 2008; Linda Fulponi, Final Report on Private Standards and the Shaping of the Agro-Food System, AGR/CA/APM(2006)9/FINAL (Organisation for Economic Co-operation and Development, Paris), 31 July 2006, available at: http://www.olis.oecd.org/olis/2006doc.nsf/43bb6130e5e86e5fc12569fa005d004 c/4e3a2945ffec37eec12571bc00590ce3/\$FILE/JT03212398.PDF, visited on 27 May 2008; Steven Jaffee et al., Food Safety and Agricultural Health Standards: Challenges and Opportunities for Developing Country Exports, 31207 (World Bank, Poverty Reduction \& Economic Management Trade Unit and Agriculture and Rural Development Department, Washington D.C.), 10 January 2005, 26-29, available at: http://www-wds. worldbank.org/external/default/WDSContentServer/WDSP/IB/2005/01/25/000160016_20050125093841/ Rendered/PDF/31207.pdf, visited on 18 May 2008.

${ }^{463}$ Committee on Sanitary and Phytosanitary Measures, Considerations Relevant to Private Standards in the Field of Animal Health, Food, Safety and Animal Welfare: Submission by the World Organization for Animal Health (OIE), G/SPS/GEN/822, circulated on 25 February 2008, paras 5-8.

${ }^{464}$ Spencer Henson et al., 'Private Food Safety and Quality Standards for Fresh Produce Exporters: The Case of Hortico Agrisystems, Zimbabwe', Food Policy 30, 2005, 371 - 384, 373. Henson et al. argue that there is evidence of this exclusionary effect of private standards and refer to the example of the Kenyan fresh vegetable industry. They report that the participation of small-scale producers in the Kenyan export supply chain for fresh vegetables decreased sharply from $45 \%$ of these exports in the mid-1980s, to an estimated $18 \%$ by 1998 . 
Among the main concerns raised by developing countries with regard to private sector standards are the great variety of such standards ${ }^{465}$ and the non-recognition of equivalent standards set by other bodies. ${ }^{466}$ In addition, most often certification of conformity with such standards by a specified independent (or 'third party') body is required. ${ }^{467}$ As usually these conformity assessment bodies are not local but foreign bodies, their rates are not affordable for local producers. ${ }^{468}$ Private sector standards are even more burdensome in cases where they are developed without consultation of producers. ${ }^{469}$ In addition, often there is no scientific justification for the stricter standard. ${ }^{470}$ The ability of private SPS

${ }^{465}$ For example, as reported by Grace Chia-Hiu Lee, in the meat industry alone, many different certification schemes are in place in different countries such as the Dutch Integrale Keten Beheersing, the Belgian Certus, the British Assured British Meat, the French Label Rouge and the German Qualität und Sicherheit. Grace Chia-Hui Lee, Private Food Standards and Their Impacts on Developing Countries (European Commission, DG Trade, Unit G2, Brussels), 2006, 10, available at: http://trade.ec.europa.eu/doclib/docs/2006/november/ tradoc_127969.pdf, visited on 26 May 2008. It should be noted, however, that some effort is being made to coordinate various private sector standards, either through consortia of retailers adopting a harmonised set of private standards (e.g. EUREPGAP) or by the practice of 'benchmarking' which entails setting out key criteria against which various private sector standards are assessed (e.g. the Global Food safety Initiative). Ibid., 13-14. Henson however argues that it is unlikely that a harmonised private sector standard will emerge. He states: 'as fast as collective private standards are evolving, leading food retailers are introducing their own proprietary standards in particular spheres of food safety and/or quality to retain scope of product differentiation.' Spencer Henson, 'The Role of Public and Private Standards in Regulating International Food Markets', presented at the IATRC Summer Symposium on Food Regulation and Trade: Institutional Framework, Concepts of Analysis and Empirical Evidence, Bonn) May 28-30 2006, 17, available at: http://www.ilr1.unibonn.de/iatrc/iatrc_program/Session\%204/Henson.pdf, visited on 27 May 2008.

${ }_{466}$ Since private sector standards are often introduced to create marketplace differentiation between products that are in fact equivalent in sanitary terms, as a means to create a competitive advantage for a product, commercial considerations argue against recognising the standards of other private bodies as equivalent. The issue of the recognition of equivalence between private sector schemes was among those addressed in the recent information session on private standards organised by the Standards and Trade Development Facility. Committee on Sanitary and Phytosanitary Measures, Report of the STDF Information Session on Private Standards (26 June 2008). Note by the Secretariat, G/SPS/50, circulated on 24 July 2008, para. 2.

467 The fact that small-scale producers often find the costs of compliance certification prohibitive was pointed out by the representative of International Certification and Risk Services (CMi), the largest independent certifier of compliance with GLOBALGAP standards for fresh produce, and the sole certifier of Tesco's Nature's Choice, at the information session on private standards organised by the Standards and Trade Development Facility (STDF) in 2008. Ibid., para. 9.

${ }^{468}$ Maki Hatanaka et al., 'Third-Party Certification in the Global Agrifood System', Food Policy 30, 2005,354 - 369, 355 and 364. Hatanaka et al. point out that the drive towards the use of third party certification is based on its 'appeal to technoscientific values such as independence, objectivity and transparency in an attempt to increase trust and legitimacy among ... customers and to limit liability.' However, they note that the high costs of third-party certification requirements have the capacity to exclude small and medium sized suppliers, especially those in developing countries, from global markets. A similar point is made by Gascoine et al. who note further, referring to a 2005 USAID study, that certification costs cannot be passed on by producers down the supply chain because of the competitive environment where there are so few buyers and so many suppliers. Digby Gascoine et al., Private Voluntary Standards within the WTO Multilateral Framework (United Kingdom Department for International Development, London), March 2006, para. 13.

469 This results in private sector standards that ignore variations in production conditions, which accentuates the difficulties of compliance with private sector standards faced by developing countries according to the Managing Director of CMi. This statement was made in the context of his presentation during the information session on private sector standards organised by the STDF in 2008. Committee on Sanitary and Phytosanitary Measures, Report of the STDF Information Session on Private Standards (26 June 2008). Note by the Secretariat, G/SPS/50, circulated on 24 July 2008, para. 9.

${ }^{470}$ Chia-Hui Lee reports that certain major retailers (including Aldi, Lidl, Metro and Rewe) required that all Ivory Coast pineapple producers be EUREPGAP certified by 1 January 2006, but imposed an additional 
standards to escape the disciplines of the SPS Agreement therefore risks undermining the Agreement's achievements in improving market access. ${ }^{471}$

The question here is not whether private actors, such as supermarkets, retail consortia and third party certifiers, can be bound directly to the SPS Agreement. The SPS Agreement, like other WTO agreements, binds only WTO Members. ${ }^{472}$ Therefore only actions (or omissions) by WTO Members, ${ }^{473}$ or attributable to them, ${ }^{474}$ can be challenged in dispute settlement proceedings under the covered agreements. ${ }^{475}$ The question is instead in which cases a Member can be held responsible for the actions of private parties in its territory or of regional bodies in which entities in its territory are members. This question has received some academic attention in recent years. ${ }^{476}$ It has also been extensively discussed at meetings of the SPS Committee, since it was first raised in 2005.

requirement that pesticide residue levels be limited to a third of the maximum levels permitted by the EU. Gascoine et al. point out that either the retailers involved were ignorant of the fact that EU residue levels are established at the lowest level achievable by good agricultural practice, or they intended to deceive consumers by claiming that their products were safer due to this more stringent private standard. Grace Chia-Hui Lee, Private Food Standards and Their Impacts on Developing Countries (European Commission, DG Trade, Unit G2, Brussels), 2006, 27, available at: http:/trade.ec.europa.eu/doclib/docs/2006/november/ tradoc_127969.pdf, visited on 26 May 2008; Digby Gascoine et al., Private Voluntary Standards within the WTO Multilateral Framework (United Kingdom Department for International Development, London), March 2006, footnote 10.

${ }^{471}$ At the meeting of the SPS Committee in 2005, where the issue of private sector standards was first raised, Argentina pointed out that international disciplines have been negotiated to limit the trade restrictive effects of SPS measures and that Members have devoted time and financial and human resources to attending all the international meetings where standards were discussed, developed and implemented. It noted that if the private sector could impose unnecessarily trade restrictive standards, and Members "had no forum in which to advocate some rationalization of these standards, twenty years of discussions in international fora would have been wasted.' Committee on Sanitary and Phytosanitary Measures, Summary of the Meeting Held on 29-30 June 2005. Note by the Secretariat. Revision, G/SPS/R/37/Rev.1, circulated on 18 August 2005, para. 20.

472 As noted by the WTO Secretariat in its not on private standards and the SPS Agreement, while the definition of 'SPS measures' in Annex A.1 of the SPS Agreement is not explicitly limited to government measures, the provisions of the SPS Agreement explicitly refer to the rights and obligations of 'Members'. Committee on Sanitary and Phytosanitary Measures, Private Standards and the SPS Agreement. Note by the Secretariat, G/ SPS/GEN/746, circulated on 24 January 2007, para. 15.

${ }^{473}$ In US - Corrosion Resistant Steel Sunset Review the Appellate Body held that '[i]n principle, any act or omission attributable to a WTO Member can be a measure of that Member for purposes of dispute settlement proceedings.' Appellate Body Report, US - Corrosion Resistant Steel Sunset Review, para. 81.

${ }^{474}$ Referring to the abovementioned finding in US - Corrosion Resistant Steel Sunset Review (although it incorrectly called the dispute US - Carbon Steel) the Panel in EC-Approval and Marketing of Biotech Products noted that for the EC's general de facto moratorium on the approval of biotech products to be a challengeable measure, it must be attributable to the EC. The Panel held that the 'common plan or course of action' followed by the EC Commission and a group of five EC Member States in order to prevent the final approval of applications regarding biotech products was a measure challengeable under the SPS Agreement as, according to the Panel, the Commission and five EC Member States are organs of the EC, from the perspective of international law. Thus, their actions were held to be attributable to the EC. Panel Report, EC-Approval and Marketing of Biotech Products, para. 7.1294.

${ }^{475}$ As held by the Panel in Japan - Film: 'As the WTO Agreement is an international agreement, in respect of which only national governments and separate customs territories are directly subject to obligations, it follows by implication that the term measure in Article XXIII:1(b) [of the GATT 1994] and Article 26.1 of the DSU, as elsewhere in the WTO Agreement, refers only to policies or actions of governments, not those of private parties.' Panel Report, Japan - Film, para. 10.52.

${ }^{476}$ Rex J Zeladis, 'When Do the Activities of Private Parties Trigger WTO Rules?', Journal of International Economic Law 10 (2), 2007, 335-362; Digby Gascoine et al., Private Voluntary Standards within the WTO Multilateral Framework (United Kingdom Department for International Development, London), March 2006. 
An examination of some of the comments by Members on this issue illustrates the lack of clarity that exists with regard to the role of the SPS Agreement in addressing private sector standards. The issue was raised before the SPS Committee for the first time in 2005 by Saint Vincent and the Grenadines with regard to the application of EUREPGAP standards to bananas by UK supermarkets. ${ }^{477}$ Jamaica raised a similar concern with regard to EUREPGAP requirements for fresh fruit and vegetables. ${ }^{478}$ The EC responded that EUREPGAP was not an EC body, and that its standards could not be seen as EC requirements. ${ }^{479}$ Peru then raised the question of the interpretation of the reference in Article 13 of the SPS Agreement to non-governmental entities in the territory of a Member. ${ }^{480}$ Mexico expressed the view that it is only when SPS measures were adopted by governmental authorities that a Member is obliged by Article 13 to ensure that governmental and non-governmental entities implement them properly. Mexico suggested that the SPS Committee look at Annex 3 of the TBT Agreement which establishes a Code of Good Practice applicable to non-governmental standard-setting institutions developing food quality standards. ${ }^{481}$ From these comments it is clear that there is a need for clarification of three main issues. First, it is necessary to examine in which cases actions by private bodies might be regarded as measures by a Member, challengeable under the SPS Agreement. Second, Article 13 of the SPS Agreement must be examined to determine whether, and if so how, Members are required to discipline private sector bodies that develop, impose or implement SPS standards in their territories. ${ }^{482}$ Third, there is a need for an examination of the possible role of a Code of Good Practice such as the one that exists in the TBT Agreement.

The question of when an action by a private entity is deemed an action by a WTO Member is important, as a Member is fully responsible for compliance with all the obligations of the SPS Agreement. Examples of situations where this question might arise, as noted by the WTO Secretariat, are where a government regulator decides to incorporate a standard developed by a private body into its SPS regulation. In addition, a government could condition the granting of import permits on third party certification of compliance with its own, or even private sector, SPS requirements. ${ }^{483}$ If such actions are allowed to escape the disciplines of the SPS Agreement, Members would be encouraged to delegate tasks

See also Santiago M. Villalpando, 'Attribution of Conduct to the State: How the Rules of State Responsibility May Be Applied within the WTO Dispute Settlement System', Journal of International Economic Law 5 (2), 2002, 393-420. On this issue as it relates to private sector standards for environmental protection, see Samir R. Gandhi, 'Regulating the Use of Voluntary Environmental Standards within the World Trade Organization Legal Regime: Making a Case for Developing Countries', Journal of World Trade 39 (5), 2005, 855-880.

${ }^{477}$ Committee on Sanitary and Phytosanitary Measures, Summary of the Meeting Held on 29-30 June 2005. Note by the Secretariat. Revision, G/SPS/R/37/Rev.1, circulated on 18 August 2005, para. 16.

${ }^{478}$ Ibid., para. 17.

${ }^{479}$ Ibid., para. 18.

${ }^{480}$ Ibid., para. 19.

481 Ibid.

${ }^{482}$ In its 2007 paper on the issue of private standards under the SPS Agreement, the WTO Secretariat listed some issues for possible consideration by the SPS Committee in this regard, including what 'positive measures and mechanisms' and what 'reasonable measures' Members can take to ensure compliance with the SPS Agreement by non-governmental entities. Committee on Sanitary and Phytosanitary Measures, Private Standards and the SPS Agreement. Note by the Secretariat, G/SPS/GEN/746, circulated on 24 January 2007, paras 17 and 26.

${ }^{483}$ Ibid., para. 17. 
in this area to private bodies to evade their obligations. ${ }^{484}$ This issue is, however, not limited to the field of SPS regulation, but has arisen under other WTO agreements. ${ }^{485}$ In Japan - Film, the Panel noted that, "what appear on their face to be private actions may nonetheless be attributable to a government because of some governmental connection to or endorsement of those actions. ${ }^{486}$ The Panel further held that private party action may be deemed governmental 'if there is sufficient government involvement with it. ${ }^{\prime 87}$ However, it recognised that no bright-line rules can be established to determine whether there is sufficient government involvement, and a case-by-case examination is necessary. ${ }^{488}$ This idea is to some extent expressly incorporated into Article 13 of the SPS Agreement. Where government involvement takes the form of measures requiring or encouraging non-governmental bodies or regional bodies to act inconsistently with its rules, Article 13 of the SPS Agreement explicitly prohibits such measures. Similarly, Article 13 prohibits reliance by Members on the services of non-complying non-governmental bodies for implementing SPS measures. Such actions by a Member would be, in themselves, a violation of Article 13. However, in the light of the attribution case law developed under the GATT, one could argue that there is likely to be a sufficient nexus between the inconsistent action by the private body and the Member that requires, encourages or relies on such action to attribute the action to the Member involved. As such, the private action becomes a measure by a Member subject to all the disciplines of the SPS Agreement and can be challenged as such, independently of the Article 13 challenge. Similarly, there can be cases beyond those mentioned in the last two sentences of Article 13, where a private body's action is attributable to a Member. For example, where a Member relies on a private body not for the implementation of its SPS measures (as covered by Article 13) but for the elaboration thereof. A typical example is that of independent national bureaus of standards, whose food safety standards are often relied upon by government regulators. As the standard becomes an SPS measure of a Member, the manner in which it was elaborated must comply with the disciplines of the SPS Agreement, for example with regard to its basis in a risk assessment, transparency etc. In this way, Members are prevented from outsourcing their regulatory tasks to private bodies in order to evade their obligations under the SPS Agreement.

\footnotetext{
484 The Panel in Japan - Film noted this risk. Panel Report, Japan - Film, para. 10.328.

${ }^{485}$ Under the GATT 1947, for example, the GATT Panel in Canada - FIRA found that the term 'laws, regulations or requirements' in Article III:4 included a written purchase undertakings by private investors, which once they were accepted, became part of the conditions under which the investment proposals were approved, in which case compliance could be legally enforced. GATT Panel Report, Canada - FIRA, para. 5.4. Under the GATS, the definition of the 'measures by Members' that fall within the scope of application of the Agreement includes 'measures taken by: ... non-governmental bodies in he exercise of powers delegated by central, regional or local governments or authorities.' Article I:3 of the GATS. The issue is also addressed in customary international law. Article 5 of the ILC Draft Articles on Responsibility of States for Internationally Wrongful Acts provides: 'The conduct of a person or entity which is not an organ of the State under article 4 but which is empowered by the law of that State to exercise elements of the governmental authority shall be considered an act of the State under international law, provided the person or entity is acting in that capacity in the particular instance.'

${ }^{486}$ Panel Report, Japan - Film, para. 10.52. The issue was already addressed by the GATT Panel in Review Pursuant to Article XVI:5, which found that private party subsidy schemes that were dependent for their enforcement on some form of government action, were subject to the notification obligation in Article XVI:1 of the GATT 1947. GATT Panel Report, Review Pursuant to Article XVI:5, para. 12.

${ }^{487}$ Panel Report, Japan - Film, para. 10.56.

488 Ibid.
} 
To the extent that actions by private bodies cannot be attributed to a Member, in the absence of a sufficient level of government intervention, the question arises whether Article 13 of the SPS Agreement nevertheless makes Members responsible for ensuring the conformity of such actions with the provisions of the Agreement. This issue is addressed by the third sentence of Article 13, which obliges Members to 'take such reasonable measures as may be available to them' to ensure compliance with the SPS Agreement by non-governmental entities within their territories and by regional bodies in which entities in their territories are members. It must first be determined whether private entities that set, implement or check conformity with SPS standards, either on national level (e.g. the British Retail Consortium) or on regional level (e.g. EUREP) are covered by this provision. If so, it would require WTO Members to take the reasonable measures available to them to ensure that these private bodies in their territories or regional bodies in which entities in their territory participate comply with the SPS Agreement. This raises the additional question of what is meant by 'such reasonable measures as may be available'. ${ }^{489}$

The terms 'non-governmental entities' and 'regional bodies' are not defined in the SPS Agreement. There is also no case law under Article 13 of the SPS Agreement that addresses the question whether this Article's reference to 'non-governmental entities' and 'regional bodies' brings under its scope private sector bodies that set, implement, or check conformity with, SPS standards at national and regional level. In view of the discussion during the negotiation of the SPS Agreement it appears that negotiators wanted to prevent the evasion of the disciplines of the SPS Agreement by Members, through allowing more and more SPS requirements to be developed or implemented through independent agencies or regional networks of regulators. By minimising the level of government intervention in such national or transnational bodies, the Member concerned might be able to avoid the attribution of their actions to it. In light of these concerns to prevent the evasion by Members of the new disciplines, and in view of the fact that at the time of negotiation of the SPS Agreement private sector SPS standards were rare, it is likely that the reference to 'non-governmental entities' in Article 13 of the SPS Agreement was intended by negotiators to refer to bodies such as national standards bureaus, which in many Members operate independently of government, but whose standards in the area of food safety are frequently incorporated in national regulation. Some indication of the meaning of 'regional bodies' is given by the specification in Article 13 that they are bodies in which entities in a Member's territory are members. In other words, unlike the meaning of 'regional' in Article XXIV:12 of the GATT, these are not sub-national government authorities. Instead, they are transnational bodies in which entities within the relevant Member participate. The word 'regional' indicates that these bodies are open for membership by the relevant entities of some but not all WTO Members. This is the same meaning found in the definition of 'regional body or system' in the TBT Agreement, and there seems to be no reason why this meaning would not be apt in the SPS context. It is likely that for purposes of the SPS Agreement this term was intended to refer to SPS regulatory bodies established under regional agreements, such as FSANZ, ${ }^{490}$ or to transnational coopera-

489 Digby Gascoine et al., Private Voluntary Standards within the WTO Multilateral Framework (United Kingdom Department for International Development, London), March 2006, 74-77 and 80-81.

490 Note that the term 'regional bodies' does not encompass the EC for purposes of Article 13 of the SPS Agreement. The EC, in its own right, is a Member of the WTO. It is directly bound by the obligations of the SPS Agreement and its actions are considered analogous to acts of a 'central government body'. Thus no 
tive networks in which SPS regulatory agencies of Members participate. In other words, it would appear that the scope of the third sentence of Article 13, as originally intended, was limited to those bodies that had some link to government regulatory agencies, which while insufficient for attribution of their actions to the Member concerned could provide some possibility for evasion of SPS disciplines.

While this narrow meaning of non-governmental and regional bodies was most likely intended by the drafters of the SPS Agreement, the question arises whether a 'good faith' interpretation of these terms, as required by Article 31 of the Vienna Convention on the Law of Treaties would today require consideration of the changed circumstances in SPS governance. It is to some extent arguable that an evolutive interpretation is called for, ${ }^{491}$ in the light of the fact that private sector bodies at subnational and transnational level (such as Wal-Mart or GLOBALGAP) currently play such an important role in elaborating, implementing and assessing conformity with private sector SPS standards, to the extent that the distinction between public and private sector SPS requirements loses much of its meaning for producers of food and agricultural products. ${ }^{492}$ Such an evolutive interpreta-

reliance on Article 13 is necessary with regard to acts by EC organs. This interpretation is supported by the fact that under the TBT Agreement an explanatory note to the definition of a 'central government body' notes that '[i]n the case of the European Communities the provisions governing central government bodies apply.' This explanatory note clarifies, however, that where regional bodies are created within the EC, these would fall under the provisions on 'regional bodies'. There is no reason to expect a different interpretation under the SPS Agreement. In fact, in the disputes under the SPS Agreement involving the EC, no recourse to Article 13 was needed and the provisions of the SPS Agreement were simply applied to the actions of the EC directly.

${ }^{491}$ A contrary argument is made by Steven Bernstein and Erin Hannah with respect to standards set by 'nonstate market driven governance systems', which they propose should be kept outside the ambit of WTO disciplines, even if they are explicitly adopted or implicitly supported by Members. According to these authors, a 'transnational regulatory space' should be preserved for such systems from WTO disciplines, as they serve to embed societal values in the global marketplace. To open the door for WTO challenges to such systems would threaten the legitimacy of the WTO, in their view. Steven Bernstein and Erin Hannah, 'NonState Global Standard Setting and the WTO: Legitimacy and the Need for Regulatory Space' Journal of International Economic Law, 11(3), 2008, (advance access) 1-34, 4-5. It is argued here, in respect of private sector SPS standards, that while regulatory space should be respected to enable private firms to respond to consumer demands for higher safety levels, some level of procedural discipline is certainly called for. The legitimacy of some private sector SPS standards can be questioned due to the non-participatory and untransparent nature of the standard-setting process. In fact the GLOBALGAP partnership of food retailers has faced criticism regarding the legitimacy of its standards, which are seen as focused on retailer interests and lacking in stakeholder participation and transparency. This differs from the trend among non-state standard setters in the areas of environmental or labour standards, such as the Fairtrade Labelling Organisations and the Rainforest Alliance, which work towards ensuring the legitimacy of their standards by aligning themselves with best practice standards in standard setting as developed by the International Social and Environmental Accreditation and Labelling (ISEAL) Alliance. In view of the absence of such a trend in the area of private sector SPS standards, and their importance as de facto barriers to trade, a certain level of discipline would not be misplaced.

${ }^{492}$ Such an evolutive interpretation goes a step further than that applied by the Appellate Body in US - Shrimp. In the latter dispute, the Appellate Body interpreted the term 'exhaustible natural resources' in Article XX(g) of the GATT 1994 in an 'evolutive' manner to include living resources (such as turtles). In that case, the Appellate Body noted that the treaty provision had been crafted over 50 years before. The 'contemporary concerns of the community of nations' as embodied in international environmental treaties, according to the Appellate Body, showed that both living and non-living resources were to be considered natural resources. The Appellate Body referred to Namibia (Legal Consequences) Advisory Opinion (1971) I.C.J. Rep., p. 31, where the International Court of Justice stated that in the case of concepts embodied in a treaty that are by definition, evolutionary, their 'interpretation cannot remain unaffected by the subsequent development of law... Moreover, an international instrument has to be interpreted and applied within the framework of the 
tion, while going further than the original intention of the drafters, seems justifiable due to the fact that it is in accordance with the ordinary meaning of the terms of Article 13 of the SPS Agreement, which in no way limit the scope of 'non-governmental entities' or 'regional bodies' to bodies with some link to government regulatory agencies. ${ }^{493}$ In addition, it would be in keeping with the purpose of Article 13, namely to take account of the reality of shifts in SPS governance by requiring Members to take reasonable steps to discipline non-governmental and regional actors in the field, to extend its coverage to the new, and arguably most important, actors in these categories. This interpretation would give the third sentence of Article 13 a wide ambit. However, this does not mean that Members would thereby be responsible for every act of a private body that does not conform to the provisions of the SPS Agreement.

It is necessary to examine what are the limits of the obligations of Members under the third sentence of Article 13 of the SPS Agreement. In the first place, the nature of the obligation in this sentence should be noted. It is an obligation of conduct (a so-called 'best-endeavour' obligation) rather than an obligation of result. Members are not required actually to ensure compliance by non-governmental entities and regional bodies, but only to take such reasonable measures as may be available to them to ensure such compliance. As a result, non-compliance with the rules of the SPS Agreement by a non-governmental body will not necessarily entail the responsibility of a Member under Article 13. Only the failure of the Member to take the required reasonable measures would be challengeable. It would seem that such a challenge can be brought independently of a claim of violation by a private entity of a particular provision of the SPS Agreement.

From the cautious terms in which the third sentence of Article 13 is framed, it appears that the extent of the obligations of Members in respect of compliance by non-governmental and regional bodies is rather limited. Members are not obliged to take all measures possible within their legal system to ensure compliance by such bodies, but only to take 'such reasonable measures as may be available' to them to do so. It is useful to examine the ordinary meaning of the words used, in the light of their context and the object and purpose of the Agreement in order to try to obtain clarity as to the meaning of Article $13 .{ }^{494}$ The applicable definition of 'reasonable' in the Concise Oxford Dictionary is 'within the

entire legal system prevailing at the time of the interpretation.' Appellate Body Report, US - Shrimp, paras 129-130 and footnote 109. By contrast, the proposed interpretation of 'non-governmental entities' and 'regional bodies' in Article 13 of the SPS Agreement is based on changes in the normative framework of SPS requirements that occurred over a much shorter period (less than a decade) due to the exponential increase in private sector SPS standards. In addition, these changes do not relate to the 'subsequent development of law' or the 'legal system prevailing at the time of the interpretation', but rather to the development of de facto binding force of private sector standards due to the concentration of large retailers and their dominance of the food and agricultural market.

${ }^{493}$ By way of contrast, see the definition of 'non-governmental body' in Annex 1.7 of the TBT Agreement: 'Body other than a central government body or a local government body, including a non-government body which has legal power to enforce a technical regulation.' See also the definition of 'measures by Members' in Article I:3 of the GATS which refers to measures taken by 'non-governmental bodies in the exercise of powers delegated by central, regional or local governments or authorities.'

${ }^{494}$ Article 31 of the Vienna Convention on the Law of Treaties provides: 'A treaty shall be interpreted in good faith in accordance with the ordinary meaning to be given to the terms of the treaty in their context and in the light of its object and purpose.' As noted by the Panel in US - Section 301 Trade Act, the elements of Article 31 constitute a holistic rule of interpretation rather than a sequence of separate tests to be applied in a hierarchical order. Panel Report, US - Section 301 Trade Act, para. 7.22. 
limits of reason; not greatly less or more than might be expected.' ${ }^{495}$ The same dictionary defines 'available' as 'capable of being used, at one's disposal. ${ }^{496}$ While it is clear that Article 13 does not oblige Members to take all measures at their disposal, these dictionary definitions leave open the question of which measures at a Member's disposal it 'might be expected' to use to discipline the actions of different types of 'non-governmental' and 'regional' bodies. As has been held by the Appellate Body, dictionary definitions are not dispositive of the ordinary meaning of treaty terms but must be seen in the light of the surrounding circumstances. ${ }^{497}$ It seems logical that what is 'reasonable' in one set of circumstances is not necessarily so in another. In particular, while a relatively high level of government intervention may be regarded as reasonable with respect to independent national standards bureaus and regional networks of regulators in which governmental agencies of a Member participate, this is not the case with regard to private economic actors such as supermarkets and retail consortia. In a free market economy, the level of government intervention in normal competitive behaviour of economic actors is limited to what is necessary to pursue public policy objectives such as consumer protection and prevention of anticompetitive practices. It is doubtful whether preventing food companies from responding to consumer demands for a higher level of food safety falls within these limits.

The context for the interpretation of Article 13 of the SPS Agreement includes other WTO agreements. The phrase 'such reasonable measures as may be available' is also found in Article XXIV:12 of the GATT 1947 with regard to local and regional government bodies and was interpreted to require a 'serious, persistent, and convincing effort' by a Contracting Party to ensure compliance. ${ }^{498}$ In addition, it was held that in determining which measures are 'reasonable' for purposes of this Article, the consequences of the non-observance of the provisions of the GATT by local government for trade relations with other Contracting Parties 'are to be weighed against the domestic difficulties of securing compliance.' ${ }^{499}$ These cases dealt with measures by local government bodies,

495 Concise Oxford Dictionary, 9th ed. (Oxford University Press, Oxford), 1995. The definition includes other meanings of reasonable that are not applicable to this context (e.g. having sound judgement or inexpensive). Only the relevant part of the definition is quoted here.

496 Ibid.

497 As noted by the Appellate Body in EC-Chicken Cuts: 'The Appellate Body has observed that dictionaries are a "useful starting point" for the analysis of "ordinary meaning" of a treaty term, but they are not necessarily dispositive. The ordinary meaning of a treaty term must be ascertained according to the particular circumstances of each case. Importantly, the ordinary meaning of a treaty term must be seen in the light of the intention of the parties "as expressed in the words used by them against the light of the surrounding circumstances".' Appellate Body Report, EC-Chicken Cuts, para. 175. Here the Appellate Body referred to its earlier case law in Appellate Body Report, US - Softwood Lumber IV, para. 59; Appellate Body Report,

Us - Offset Act (Byrd Amendment), para. 248; and Appellate Body Report, US - Gambling, para. 166.

498 GATT Panel Report, Canada-Provincial Liquor Boards (US), para. 5.37. Note that this dispute was decided before the Understanding on the Interpretation of Article XXIV of the General Agreement on Tariffs and Trade was adopted in the Uruguay Round, limiting the flexibility allowed by this provision with regard to local and regional government bodies, as discussed above.

${ }^{499}$ GATT Panel Report, Canada - Gold Coins, para. 69. The GATT Panel relied, for its interpretation of 'reasonable', on the Note Ad Article III:1 of the GATT which clarifies what 'reasonable measures' in Article XXIV:12 would mean for purposes of legislation of local governments imposing internal taxes. The Panel stated: 'According to this note the question of whether the repeal of such enabling legislation would be a reasonable measure required by Article XXIV:12 should be answered by taking into account the spirit of the inconsistent local tax laws, on the one hand, and the administrative or financial difficulties to which the repeal of the 
in respect of which it is arguable that much more can be regarded as 'reasonable' than in respect of private economic actors, as discussed above. Examples of reasonable measures that may be available to Members to ensure compliance by national and transnational private bodies with the SPS Agreement could be: ${ }^{500}$ the dissemination of information or provision of training on the Agreement to private sector bodies; agreement of Memoranda of Understanding with private sector bodies in which these bodies commit to comply with the relevant disciplines of the Agreement; ${ }^{501}$ the provision of financial incentives for private sector bodies to comply with these provisions; and the development of a national policy in this regard. It does not seem, however, that the 'reasonable measures as may be available' required of Members extend to the enactment of legislation obliging private sector bodies to comply with the disciplines of the SPS Agreement. ${ }^{502}$ If this was required, it is more likely that the sentence would read 'Members shall take all measures available to them...' or even 'Members shall ensure...' An interpretation of the third sentence of Article13 to require legislative action imposing the rules of the SPS Agreement on private entities would disregard the qualifiers 'reasonable' and 'may be available' entirely, contrary to the principle of effective treaty interpretation. ${ }^{503}$

In fact, such an interpretation would seem to be a step too far. The provisions of the SPS Agreement were clearly not drafted with private sector standards in mind. They apply disciplines pertaining to best regulatory practices that address aspects of the risk analysis process carried out by national regulators. As a result, the extent of intervention in private economic activity that would result if Article 13 were interpreted to require Members actually to ensure that private sector standards comply with all these disciplines seems inappropriate. Of course, arguments based on the negotiating history of the SPS Agreement are not dispositive. ${ }^{504}$ They could be countered by a call for an evolutive interpretation of the Agreement to take account of the current reality where the difference between public and private standards for exporters has blurred. More importantly than the negotiating history, however, the object and purpose of the SPS Agreement militates against an interpretation to the effect that Members would have to ensure compliance with its provisions by private entities through legislative means. The aim of the SPS Agreement is to achieve a balance between the sovereign right of Members to protect health in their territories and the need to prevent protectionism under the guise of SPS regulation. The application of

enabling legislation would give rise, on the other.' Ibid.

${ }^{500}$ These examples are identified, with regard to the TBT Agreement, by Gascoine et al. Digby Gascoine et al., Private Voluntary Standards within the WTO Multilateral Framework (United Kingdom Department for International Development, London), March 2006, paras 11 and 66.

${ }^{501}$ Such a Memorandum of Understanding exists with regard to the TBT Agreement between the Commonwealth of Australia and Standards Australia, an independent national standard-setting agency. See further above, Part II, Section 2.4.2.1.

502 Digby Gascoine et al., Private Voluntary Standards within the WTO Multilateral Framework (United Kingdom Department for International Development, London), March 2006, para. 66.

${ }^{503}$ As held by the Appellate Body in US - Gasoline, a treaty may not be interpreted in such a way that clauses would be reduced to redundancy or inutility. Appellate Body Report, US - Gasoline, 21.

${ }^{504}$ In terms of Article 32 of the Vienna Convention on the Law of Treaties recourse may be had to supplementary means of interpretation of treaties, including the preparatory work of the treaty and the circumstances of its conclusion, in order to confirm the meaning resulting from the application of the general rule of interpretation contained in Article 31. In that function, the negotiating history of the SPS Agreement is useful to consider as it confirms the interpretation arrived at through a consideration of the wording, object and purpose and context of the Agreement. 
its disciplines to private sector bodies would not seem to further this objective. Private sector bodies that develop, impose and assess conformity with private standards are not motivated by a responsibility for health protection, but rather by commercial interests. ${ }^{505}$ Neither can they be accused of protectionism since their activities are in most cases of a global nature and dependant on imports. Rather, their actions raise concerns in the area of anti-competitive practices such as abuse of a dominant position. ${ }^{506}$ This is not a problem that the SPS Agreement is designed to address. Therefore it seems inappropriate to oblige Members to enact legislation to ensure that private sector bodies comply with the SPS Agreement. While legislation directed at private bodies is a tool 'at the disposal' of Members, it does not seem to be a 'reasonable measure' in this context. It is arguably sufficient that a Member provide information and create incentives for private sector bodies at national and transnational level to respect the provisions of the SPS Agreement that are relevant to them.

While the current regulatory disciplines of the SPS Agreement are not suitable for application to private sector standards, the reality of the fact that such standards are a significant obstacle to trade in food and agricultural products cannot be ignored. This is particularly so due to the disproportionate burden these standards place on developing-country producers, and in particular on small-scale producers in these countries. The development impact of private sector standards therefore merits serious attention. The issue is how best this matter can be addressed.

The question then arises whether an approach to private sector standards such as the one embodied in the TBT Agreement would be the best way forward. The TBT Agreement was negotiated in full awareness of the importance of the private sector in setting, applying and assessing conformity with technical standards. It therefore has more elaborate provisions to address actions by non-governmental bodies. The term 'non-governmental body' is defined in Annex 1.8 of the TBT Agreement to mean a '[b]ody other than a central

${ }^{505}$ Even though private SPS standards may aim at food safety and thus at the protection of human health, this cannot be taken to mean that private bodies are responsible, in the way sovereign governments are, for the protection of health. Consequently, the considerations that play a role in the activities of private bodies in this area differ significantly from those that underlie governmental regulatory activity. Government regulation has a normative foundation in the sovereign duty to ensure the rights to life, health and safe food, and incorporate considerations of distributional equity. The standards elaborated or implemented by private bodies are instead a way to increase profits through responding to affluent consumers' willingness to pay a price premium for higher levels of safety, and to reduce costs from liability for damage from unsafe products. To require private bodies to behave as governmental regulators in this area, for example by making sure that there are no arbitrary or unjustifiable distinctions in the level of protection they aim at in similar situations and to harmonise their measures around international standards unless the need for a stricter measure can be scientifically justified, would be to disregard this important difference.

${ }^{506}$ Gascoine et al. recommend, as a possible way forward, an examination of domestic competition issues that arise from the use of private standards as a means of collusion or abuse of a dominant position by retailers. Digby Gascoine et al., Private Voluntary Standards within the WTO Multilateral Framework (United Kingdom Department for International Development, London), March 2006, para. 17(ii). The role of national governments to ensure that private sector standards do not constitute or conceal anti-competitive practices is also noted in Steven Jaffee et al., Food Safety and Agricultural Health Standards: Challenges and Opportunities for Developing Country Exports, 31207 (World Bank, Poverty Reduction \& Economic Management Trade Unit and Agriculture and Rural Development Department, Washington D.C.), 10 January 2005, 9, available at: http://www-wds.worldbank.org/external/default/WDSContentServer/WDSP/IB/2005/0 1/25/000160016_20050125093841/Rendered/PDF/31207.pdf, visited on 18 May 2008. 
government body or a local government body, including a non-governmental body which has legal power to enforce a technical regulation'. A literal reading of this rather vague provision, particularly of the word 'including', seems to indicate that both bodies with and bodies without the power to enforce technical regulations are covered. However, it could also be argued that the specific mention of bodies with enforcement power means, a contrario, that bodies lacking such power are not covered by this term. Such a limited interpretation would negate the possibility to bring private sector standards under the TBT Agreement, a consequence to be avoided.

Similar to the situation under the SPS Agreement, as well as under the Tokyo Round Standards Code, the TBT Agreement contains 'second level' obligations with respect to non-governmental bodies. In particular, Members are required to take such reasonable measures as may be available to them to ensure that these bodies comply with the disciplines of the TBT Agreement with respect to the preparation, adoption and implementation of technical standards and the implementation of conformity assessment procedures. ${ }^{507}$ However, the TBT Agreement goes further than this. In respect of voluntary standards it establishes a Code of Good Practice for the Preparation, Adoption and Application of Standards (the Code of Good Practice). This Code of Good Practice lays down obligations for standardising bodies, whether central or local government bodies, regional bodies or non-governmental bodies. These obligations include non-discrimination, avoidance of unnecessary barriers to trade, the use of international standards as a basis for standards unless they would be ineffective or inappropriate, avoidance of duplication of work, publication of a work programme every six months, prior notification of draft standards with provision of a comment period and a requirement to take into account and respond to comments, and prompt publication of adopted standards. ${ }^{508}$

With regard to non-governmental and regional bodies, Members are obliged to take reasonable measures to ensure that these bodies accept and comply with the Code of Good Practice. ${ }^{509}$ However, whether or not the standardising body has accepted the Code of Good Practice, the Member's obligation to take reasonable measures to ensure compliance therewith applies. This should not create the impression that direct challenges are possible against non-governmental bodies that have accepted but not complied with the Code of Good Practice. The obligations of the TBT Agreement bind Members only, and it is the relevant Member that is responsible if it has not taken the 'reasonable measures' available to it to ensure compliance.

It is arguable that the Code of Good Practice in the TBT Agreement covers also entities that set private sector SPS standards, and that Article 8 thereof covers private entities that assess conformity with SPS standards. If 'non-governmental body' under the TBT Agreement is understood to include non-governmental bodies with no official enforcement power, it would cover private bodies that develop, implement and assess conformity with private SPS standards. In addition, although SPS measures are excluded from

\footnotetext{
${ }^{507}$ Article 3.1 of the TBT Agreement with regard to technical regulations and Article 8.1 of the TBT Agreement with regard to conformity assessment procedures.

${ }^{508}$ It is interesting to note that the ISEAL Alliance's Code of Good Practices for Setting Social and Environmental Standards takes up several elements of the TBT Code of Good Practice.

${ }^{509}$ Article 4.1 of the TBT Agreement.
} 
the scope of application of the TBT Agreement, ${ }^{510}$ it can be argued that this does not apply to private SPS standards as they are not 'SPS measures' for purposes of the SPS Agreement. While the definition of an SPS measure in Annex A.1 of the SPS Agreement is not explicitly limited to governmental measures, unlike the TBT Agreement, the SPS Agreement does not contain any provisions specifically applicable to voluntary standards or conformity assessment procedures carried out by private bodies. It would therefore be strange to view such standards and procedures as SPS measures. This conclusion would be further reinforced if one were to follow the (arguably mistaken) approach of the Panel in EC - Approval and Marketing of Biotech Products, discussed above, requiring that to be an 'SPS measure' a measure must take the 'form' of a law, decree or regulation, all of which are by definition government measures. ${ }^{511}$ This approach to the applicability of the Code of Good Practice and Article 8 of the TBT Agreement has the benefit of bringing some discipline to bodies setting, implementing and assessing conformity with private sector standards, without the need for negotiating new rules or guidelines. Be that as it may, it appears that WTO Members do not regard private SPS standards as falling under the TBT Agreement's disciplines for standards and in particular the Code of Good Conduct. Of all the non-governmental entities that have notified their acceptance of the Code of Good Practice, none are active in the area of SPS standards. ${ }^{512}$ Further, when Members were asked by Chair of the TBT Committee if they wanted to discuss the issue of private SPS standards under the TBT Agreement, they did not indicate any interest to do so. In the view of the Chairman, this was due to the fact that the SPS element of private standards schemes was perceived by Members as more problematic than other elements. ${ }^{513}$ It appears that particular disciplines are regarded as necessary by Members to address private SPS standards, different to those in the TBT Agreement.

The suggestion that a separate Code of Good Practice for the Preparation, Adoption and Application of Standards should be developed for the SPS Agreement, similar to that in Annex 3 to the TBT Agreement, has some merit. This would enable Members to draft disciplines that are appropriate for private sector bodies that set, apply and assess conformity with SPS standards. ${ }^{514}$ In particular, these disciplines could target those practices of

510 The relationship between the SPS Agreement and the TBT Agreement is discussed below, Part III, Section 2.4.1.

511 See above, Part III, Section 2.1.1.

${ }^{512}$ Under Article 4.2 of the TBT Agreement, acceptance must be notified to the ISO/IEC Information Centre in Geneva, not to the WTO. Note, as reported by Gascoine et al. that the list of standardising bodies that notified their acceptance of the Code of Good Practice by January 2006 included no non-governmental standard setting bodies concerned with SPS standards. Digby Gascoine et al., Private Voluntary Standards within the WTO Multilateral Framework (United Kingdom Department for International Development, London), March 2006, para. 24. This was still the case in February 2008, when 160 standardizing bodies from 116 Members had notified acceptance of the Code of Good Practice, including 84 central governmental standardizing bodies, 65 non-governmental standardizing bodies, three statutory bodies, two parastatal bodies, three non-governmental regional bodies, one central governmental/non-governmental body, one central governmental/local governmental body and one autonomous body. The list is updated regularly and the latest version can be found in Committee on Technical Barriers to Trade, List of Standardizing Bodies That Have Accepted the Code of Good Practice for the Preparation, Adoption and Application of Standards since 1 January 1995. Note by the Secretariat. Revision, G/TBT/CS/2/Rev.14, circulated on 20 February 2008.

${ }^{513}$ Committee on Sanitary and Phytosanitary Measures, Summary of the Meeting of 18-19 October 2007. Note by the Secretariat, G/SPS/R/46, circulated on 2 January 2008, para. 140.

514 This suggested Code of Good Practice would therefore extend further than that of the TBT Agreement in that the disciplines for conformity assessment procedures conducted by private bodies would be incorporated 
private bodies that developing-country Members have identified as particularly problematic, such as lack of transparency, ${ }^{515}$ absence of prior consultation to allow for input from producers, ${ }^{516}$ undue burden from costly and complex conformity assessment procedures and non-recognition of equivalence. ${ }^{517}$ This Code of Good Practice should stop short of requiring private sector bodies to base their measures on international standards, conduct risk assessments for their measures, or undertake any other activities inherent to the national regulatory process but inappropriate to the activities of private bodies. Members could then undertake to take reasonable measures available to ensure compliance with the SPS Code of Good Practice. ${ }^{518}$

It should be noted, however, that the agreement needed to adopt such a Code of Good Practice for the SPS Agreement, whether in the form of guidelines adopted by the SPS Committee in terms of its competence under Article 12.1 of the SPS Agreement,${ }^{519}$ or in the form of an amendment to the SPS Agreement agreed to by the Ministerial Conference under Article X of the WTO Agreement, ${ }^{520}$ is very unlikely to be reached. Powerful lobbies of large retail conglomerates and consumer interest groups in developed-country

therein.

${ }^{515}$ Private standards of retail chains are often proprietary as they are part of a firm's competitive strategy. As a result, suppliers not in a relationship with the retailer are not informed of the requirements to be met.

${ }^{516}$ Some private standards, such as EUREPGAP, are developed by technical committees that include representatives not only of retailers but also of suppliers from different countries, thus including broad based stakeholder consultations. However, many others are developed with little producer involvement, resulting in standards compliance with which may be beyond the capacity of producers in developing countries, as they do not take account of local conditions or risk mitigation approaches.

${ }^{517}$ Benchmarking possibilities, such as the one for EUREPGAP, provides a possibility for the recognition of the equivalence of the GAP standards elaborated in developing countries. For example MexicoGAP, developed by the Mexican Ministry of Agriculture, and ChileGAP, developed by a private fruit industry body, have been successfully benchmarked to EUREPGAP. However, as reported by UNCTAD, benchmarking is not a viable option in many developing countries as the national standard, to be recognised, must comply with all control points and compliance criteria in the EUREPGAP standard, not merely result in the same level of safety. Unlike the equivalence regime in the SPS Agreement which depends on the equivalence of outcomes, benchmarking relies on the equivalence of processes. Committee on Sanitary and Phytosanitary Measures, Private Sector Standards and Developing Country Exports of Fresh Fruit and Vegetables. Communication from the United Nations Conference on Trade and Development (UNCTAD), G/SPS/GEN/761, circulated on 26 February 2007, paras 37-40. For a discussion of the equivalence regime of the SPS Agreement, see below, Part IV, Section 1.1.

518 The limited and appropriate nature of such disciplines coupled with the pervasiveness of private standards schemes seems to argue for a stronger interpretation of reasonable measures that may be available as in this case it would be reasonable to take all measures available within the legal system of the Member concerned to ensure compliance.

${ }^{519}$ Article 12.1 of the SPS Agreement mandates the SPS Committee to carry out the functions necessary to implement the provisions of the SPS Agreement and to further its objectives. The SPS Committee has used this competence already to adopt guidelines to further the implementation of other Articles of the SPS Agreement. All decisions of the SPS Committee must be made by consensus. It is important to note that the SPS Committee is not empowered to amend the SPS Agreement or to adopt binding interpretations thereof. Instead, its guidelines are voluntary. Nevertheless, as they embody a 'subsequent agreement between the parties regarding he interpretation of the treaty or the application of its provisions' within the meaning of Article 31.3(a) of the Vienna Convention on the Law of Treaties, they must be taken into account by WTO panels and the Appellate Body when interpreting the relevant provisions of the SPS Agreement together with the context.

${ }^{520}$ Simply put, Article X:1 of the WTO Agreement provides that, if consensus cannot be reached on a proposal to amend a WTO agreement, the Ministerial Conference may take a decision with a two-thirds majority. However, in practice it is very exceptional for WTO bodies to vote. Instead, the GATT practice of decisionmaking by consensus has been continued under the WTO. 
Members can be expected to exert pressure on their governments to oppose any such development. ${ }^{521}$ In such a situation, a next-best solution would be to address private sector standards under the existing TBT Code of Good Practice, and third party conformity assessment procedures under the disciplines of Article 8 of the TBT Agreement, by following the interpretation suggested above. It is to be hoped that a panel confronted by a challenge against the omission by a Member to use the measures reasonably available to it to ensure that private bodies comply with the TBT Code of Good Practice in elaborating and applying private SPS standards, or to ensure that private conformity assessment bodies comply with Article 8 of the TBT Agreement, would be willing to hold that such actions fall within the scope of application of the TBT Agreement.

By disciplining the procedural aspects of the activities of the relevant private bodies, including by requiring prior notification and consultation, and by promoting the recognition of equivalence between different private standards regimes, the provisions of a Code of Good Practice, whether that of the TBT Agreement or in an ideal situation a new one for the SPS Agreement, may go a long way to reducing the trade-restrictive effect of private sector SPS standards. This would, however, still leave private sector entities free to condition market access, de facto, on compliance with standards stricter than those contained in national regulations or international standards, without scientific justification. ${ }^{52}$ It is doubtful whether requiring state intervention in this regard would be reconcilable with the free market system, as stricter private standards may by a legitimate response by economic operators to consumer demands, ${ }^{523}$ and to the shift in liability regimes towards placing the onus for food safety on retailers. ${ }^{524}$

What is needed instead is effective technical assistance to facilitate compliance with private sector standards. ${ }^{525}$ Already examples abound of successful adjustment of develop-

${ }^{521}$ Gascoine et al. note that Digby Gascoine et al., Private Voluntary Standards within the WTO Multilateral Framework (United Kingdom Department for International Development, London), March 2006, para. 7.

${ }^{522}$ Gascoine et al. therefore argue that it can be expected that the improvements at procedural level that could be achieved by a Code of Good Practice would 'ultimately not make much difference to the burden of compliance borne by exporters.' Ibid., para. 44. However, as is argued in Part IV of this book where the procedural arrangements under the SPS Agreement are discussed, it is often the procedural disciplines that achieve most in terms of reducing the trade restrictive effect of SPS requirements and conformity assessment procedures. This is likely to hold true also for procedural disciplines on private sector standards. See below, Part IV, Chapter 1.

${ }^{523}$ Of course, this freedom is not absolute, but is limited in most countries by consumer protection rules, which prohibit misleading consumers, for example by false health claims.

${ }^{524}$ Gascoine et al. report that among the justifications given by supermarket chains for their use of private sector standards are that such standards are a legitimate response to consumer demands for food that is safer than what can be achieved though official regulations; that as the burden of ensuring that food is safe is firmly on retailers, and official regulations may not always be effective, they are justified in applying private standards; and that the large investments they have made in their brand reputation justifies strict measures to protect that reputation from damage caused by food safety problems. Digby Gascoine et al., Private Voluntary Standards within the WTO Multilateral Framework (United Kingdom Department for International Development, London), March 2006, paras 35-37.

${ }_{525}$ Wit reference to the challenges of adjustment to the stricter requirements set by private sector standards, Henson et al. note: 'Indeed, the scale of the challenge faced by small-scale producers in complying with stricter food safety and quality requirements invariably requires some form of external support to not only provide the required expertise and resources, but also to bring about the necessary changes to supply chain organisation and operation. In many cases, this is provided by the exporters, ... while in others non-governmental organisations (NGOs) may play a leading role.' Spencer Henson et al., 'Private Food Safety and 
ing-country producers to private standards where technical and financial assistance has been provided. Most often, this assistance is provided by large export firms that source their products from local producers and therefore have an interest in ensuring that these producers are able to meet the private sector standards of retail conglomerates. ${ }^{526}$

However the current practice with regard to technical assistance leaves much to be desired. Currently much of the assistance provided is dependant on contractual relationships between vertically integrated companies and their preferred suppliers. These arrangements have negative implications in that they create dependant relationships of producers with dominant buyers, which open the door for abuse, and in that they result in the further marginalisation of those small-scale suppliers that are not among the 'preferred suppliers'. This has significant implications for poverty alleviation in rural areas ${ }^{527}$ For example, a recent report of the Danish Institute for International Studies with regard to the organic spice trade of Tanzania points out that although almost all spice production in Tanzania is organic (due to farmers' inability to meet the costs of pesticides and fertilisers) ${ }^{528}$ certified organic farming entails high compliance costs. ${ }^{529}$ In the absence of government services to support organic farming and ensure conformity with organic certification requirements, small spice producers rely on two major vertically integrated companies which buy organic spices for export. These companies undertake organic certification and meet all certification and inspection fees. ${ }^{530}$ However, these companies often do not observe

Quality Standards for Fresh Produce Exporters: The Case of Hortico Agrisystems, Zimbabwe', Food Policy 30, 2005, $371-384,373$.

${ }^{526}$ A case study that illustrates this point is provided in Ibid. Henson et al. examine the practices of the large Zimbabwean fresh produce exporter, Hortico Fresh Produce Ltd., which supplies high-value fresh vegetables to supermarkets in the UK, the Netherlands and South Africa. This exporting company relies on small-scale producers for labour intensive products such as fine beans and baby corn. It has established standards and procedures that the producers it contracts with must meet, in order to comply with the private standards applied by the foreign supermarkets it supplies. In order to ensure that small-scale producers can meet these standards, Hortico provides (through its subsidiary Agrisystems) training and on-going advice regarding production process requirements, pest control, fertiliser application, crop handling etc. It also provides the required inputs on credit to its contracted producers and maintains strict systems of inspection and control at its own cost. Despite an initial step learning curve, small-scale producers have performed as well as largescale producers in meeting the exacting private sector standards applied by Hortico due the financial and technical assistance provided by Hortico.

${ }^{527}$ Uruguay reports that $80 \%$ of agricultural production in Uruguay is in the hands of small, family-run enterprises. Private standards are too burdensome for such producers, thereby excluding them from export markets. Uruguay argues that since economise of scale are necessary for producers to be able to absorb the costs of private standards, these standards result in an imbalance in favour of large-scale producers, thereby displacing small-scale agriculture. Comite De Medidas Sanitarias y Fitosanitarias, Normas Privadas. Declaracion De Uruguay En La Reunion De Los Dias 2 - 3 De Abril De 2008, G/SPS/GEN/843, circulated on 21 May 2008, para.6. This document has not yet been translated.

${ }^{528}$ In addition, there is little need for fertilisers and pesticides due to the high fertility level of the soil and the fact that many spices are natural insect repellents. Adam Akyoo and Evelyne Lazaro, The Spice Industry in Tanzania: General Profile, Supply Chain Structure, and Food Standards Compliance Issues, DIIS Working Paper no 2007/8 (Danish Institute for International Studies, Copenhagen), 2007, 8, available at: http://www. diis.dk/graphics/Publications/WP2007/WP\%202007-8\%20final.web.pdf, visited on 23 May 2008.

${ }_{529}$ Ibid., 22-24. In order to be certified as organic production, rigorous control of the production process is required, including by ensuring the use untreated seed, training farmers with regard to organic requirements, carrying out internal and external inspections and ensuring segregation and traceability of organic produce. Farmers are required to keep careful records.

${ }^{530}$ Cultivation of spices in Tanzania is smallholder-based, almost entirely comprising farms of under one acre. Two major companies, M/S Tazop Ltd. And Zangerm Ltd. dominate the organic market for spices and all 
their contracts with the spice farmers, buying less than the agreed volume of production so that the rest has to be sold at low prices on the domestic market. ${ }^{531}$ In addition, the dominant companies engage in opportunistic behaviour and buyer collusion, with adverse consequences for the spice producers. ${ }^{532}$ The price premium for organic production currently goes to the vertically integrated companies rather than to the spice producers. ${ }^{533}$ Therefore, while the technical and financial assistance provided by the export companies for compliance with the requirements for organic certification allows smallholders to gain access to the European market, this assistance is entirely self-interested. The dependence of smallholders on dominant companies makes them vulnerable to opportunistic behaviour. Clearly, this is not the kind of technical assistance that is needed.

Improvements are necessary to ensure that technical assistance is provided by donors in a coherent and effective manner and results in enabling small-scale producers to participate in export trade in a sustainable manner. An example of such a scheme of relevance to this example is the Export Promotion of Organic Products from Africa (EPOPA) programme, established by the Swedish International Development Agency (SIDA). One of its projects aims to establish internationally recognised local organic certification bodies in Tanzania and Uganda, by working closely with local stakeholders to create systems that are locally accepted and also compatible with international standards. ${ }^{534}$ One important difference between capacity building programmes such as EPOPA and technical assistance through vertically integrated companies is the objective of the assistance given, which is often determinative for its development impact. Unlike the assistance provided by the two dominant exporting companies in Tanzania, the overall objective of EPOPA is poverty alleviation and rural development, and economic growth in favour of the poor. ${ }^{535}$

smallholders that wish to sell certified organic spices do so through one of these two companies. M/S Trazop contracted 320 certified farmers and Zangerm contracted 700 certified farmers in 2005. Both these companies have foreign sister companies (in Germany and Switzerland) with large shareholdings in the local company. The local company ensures conformity with organic certification requirements and availability of a steady volume of the product, whereas the foreign partner meets inspection and certification fees, markets the spices abroad and secures favourable prices. Ibid., 6, 9, 11 .

531 Since local buyers have little interest in organic certified spices, on the domestic market organic producers have to compete with low-cost producers of spices that do not comply with the certification requirements. Akyoo and Lazaro report that the two dominant spice buying companies have often reneged on contract provisions requiring them to buy the farmers' entire crop. For example only $65-70 \%$ of certified organic ginger crop is bought by the relevant company. There is no enforcement of contractual obligations. Ibid., 10 and 28.

${ }^{532}$ Ibid., 14.

533 Ibid., 24.

${ }_{534}$ See the website of EPOPA, available at: http://www.grolink.se/epopa/, visited on 30 June 2008. Another example of a successful technical assistance project is that in Kenya, where assistance from the government, non-governmental organisations and producers associations have enabled small scale producers of fruit and vegetables to apply for EUREPGAP certification. Committee on Sanitary and Phytosanitary Measures, Executive Summary of a Study on Agri-Food Safety and SPS Compliance in Guinea Conakry, Mozambique and Tanzania. Communication from UNCTAD, G/SPS/GEN/567, circulated on 17 June 2005, para. 48.

${ }_{535}$ These objectives are set out in the evaluation of the second phase of implementation of EPOPA. Kim Forss and Mikael Lundström, An Evaluation of the Program "Export Promotion of Organic Products from Africa" - Phase II (Swedish International Development Cooperation Agency, Strängnäs), 15 October 2004, 50, available at: http://www.grolink.se/epopa/Publications/EPOPA-Phase-2-Evaluation-04.pdf, visited on 30 June 2008. This evaluation report further notes that SIDA policy emphasises market-led growth and development. It argues that markets must be made to work for the poor, notes the need for a 'holistic view of development cooperation in relation to economic growth, and particularly for the role that aid can play in creating an enabling environment, not least through institutional development.' Ibid. 
This objective affects the choice of export projects, where they are located, and how they are structured to ensure sustainability and inclusiveness of marginalised groups. More of this type of capacity building programme is called for, but on a wider scale and with more coordination between donors and within projects. ${ }^{536}$

In the meantime, a pragmatic and immediate strategy to address private sector SPS standards is essential. It is suggested that this strategy take the form of using the available, and effective, possibility for multilateral discussion and sharing of experiences that is provided by the forum of the SPS Committee. ${ }^{537}$ Since it was first raised in 2005, there have been two years of 'exploratory discussions' in the SPS Committee on this issue. Various WTO Members and Observers have made use of the opportunity provided by the SPS Committee to report on their experiences with private sector standards and to air their concerns. ${ }^{538}$ Some Members suggested that private sector standards were best discussed in other fora, such as UNCTAD or the WTO Committee on Trade and Development. ${ }^{539}$ This idea was rejected by many other Members who expressed appreciation for the 'rich debate' at the SPS Committee and noted that in view of the important trade implications of the issue, it should not only be examined in development fora. ${ }^{540}$ An information session was organised by the WTO and UNCTAD in 2007 to help Members become familiar

${ }^{536}$ The evaluation of EPOPA notes that delays in projects were mostly caused by SIDA, and relate to uncertainties around finance sources, lack of policy coordination between units, and the inability to take the necessary tendering and contracting decisions. Ibid., 48.

537 The function of the SPS Committee to provide a forum for ad hoc consultations and negotiations among Members on specific SPS issues, under Article 12.2 of the SPS Agreement, is discussed below, Part IV, Section 2.1.2.

${ }^{538}$ For instance, in February 2007, Saint Vincent and the Grenadines submitted a communication pointing to the problems faced by private sector standards for small farmers, and recommending that 'consideration should be given to compliance with the SPS Agreement' when private sector standards are being developed. Committee on Sanitary and Phytosanitary Measures, Private Industry Standards. Communication from Saint Vincent and the Grenadines, G/SPS/GEN/766, circulated on 28 February 2007, para. 6. In June 2007, Ecuador noted the adverse effects posed by private standards to developing-country producers, mentioning the example of traditionally organic production in Ecuador which now has to bear the high costs of certification as such or lose market access. Committee on Sanitary and Phytosanitary Measures, Private and Commercial Standards. Statement by Ecuador at the Meeting of 27 - 28 June 2007, G/SPS/GEN/792, circulated on 5 July 2007.At the SPS Committee meeting in April 2008, highly critical remarks were made by a group of developing-country Members, led by Uruguay and Egypt, on the impact of private sector standards on developing-country trade. The report of this meeting is not yet publicly available. The information on the discussion at the meeting of 2-3 April 2008 is taken by the WTO News Item 'Members set to agree on regionalization, improved SPS transparency’, available at: http://www.wto.org/english/news_e/news08_e/sps_apr08_e.htm, visited on 26 May 2008. The OIE Director-General Bernard Vallat noted that private sector standards could undermine the science based and multilaterally agreed standards set by the 'three sisters'. This statement was made by way of introduction to the OIE submission on private standards. This submission noted that private sector standards are 'developed to meet the needs of commercial parties (especially supermarkets) and consumers and tend towards a non-scientific, zero risk, marketing approach that is not consistent with the disciplines of the SPS Agreement.' Committee on Sanitary and Phytosanitary Measures, Considerations Relevant to Private Standards in the Field of Animal Health, Food, Safety and Animal Welfare: Submission by the World Organization for Animal Health (OIE), G/SPS/GEN/822, circulated on 25 February 2008, para. 2.

${ }^{539}$ Committee on Sanitary and Phytosanitary Measures, Summary of the Meeting of 18-19 October 2007. Note by the Secretariat, G/SPS/R/46, circulated on 2 January 2008, para. 139.

540 Ibid., paras 143 and 153. All the developing-country Members who participated in the discussion at this meeting stated unequivocally that the issue should be kept on the agenda of the SPS Committee. Ibid., paras. 142-172. 
with various private sector standard schemes. ${ }^{541}$ After an impasse was reached on the question whether the SPS Agreement has a role to play in disciplining private standards, Members agreed in April 2008 to consider setting up a small group to work on the issue of private sector standards. ${ }^{542}$ This initiative was discussed at an informal meeting of the SPS Committee meeting in June 2008, on the basis of a proposal by Uruguay on the terms of reference for such a working group. ${ }^{543}$ In the meantime, due to the overwhelming support for keeping the issue on the agenda of the SPS Committee, it will remain there. ${ }^{544}$

At the SPS Committee meeting of 18-19 October 2007, the Chairman noted that discussing private standards in general terms was not a fruitful approach. Instead he proposed that future discussions should address proposals on how to deal with the challenges posed by private sector standards, and should focus on concrete experiences and examples by Members of problems they face with private SPS standards. ${ }^{545}$ This proposal was supported by many Members, both developed-country and developing-country Members. ${ }^{546}$ However, some developing-country Members expressed concerns that this approach risked losing sight of the big picture, and not resolving the issue of the role of the SPS Agreement in addressing this issue. ${ }^{547}$ While the frustration of these Members is understandable, in view of the slim chance that agreement can be reached on the legal frame-

541 This information session was held on 25 June 2007, and involved presentations on various private sector standard schemes and case studies on national experiences with private sector standards. The presentations made are available at: http:/www.wto.org/english/tratop_e/sps_e/private_standards_june07_e/private_ standards_june07_e.htm, visited on 26 May 2008.

${ }^{542}$ The information on the discussion at meeting of 2-3 April 2008 is taken from the WTO News Item 'Members set to agree on regionalization, improved SPS transparency', available at: http:/www.wto.org/english/ news_e/news08_e/sps_apr08_e.htm, visited on 26 May 2008.

${ }^{543}$ Committee on Sanitary and $\bar{P}$ hytosanitary Measures, Terms of Reference for the Working Group on Private Standards. Proposal by Uruguay, G/SPS/W/225, circulated on 18 June 2008. At the informal meeting of the SPS Committee on 23 June, the Uruguayan proposal and other ideas were discussed. The chairperson reported to the formal SPS Committee meeting that there was support by Members for the whole document or certain parts of it. Differences remained on the size of the working group and who should chair it; whether the proposed terms of reference would prejudge the results of the working group's work by seeing private standards as mainly negative; whether the group should focus on concrete examples, examine where private standards deviate from the standards of international governmental bodies, or analyse the legal position of private standards under WTO agreements. To initiate the work, the chairperson and Secretariat will send a list of questions to Members and their replies will be used to discuss how to proceed in informal consultations in October. This information on the discussion at the informal and formal meetings of the SPS Committee in June is taken from the WTO News Item 'Members turn Attention to Improving SPS Mediation', available at: http://www.wto.org/english/news_e/news08_e/sps_24june08_e.htm, visited on 26 June 2008.

${ }^{544}$ Committee on Sanitary and Phytosanitary Measures, Private Standards and the SPS Agreement. Note by the Secretariat, G/SPS/GEN/746, circulated on 24 January 2007, para. 15. See also Committee on Sanitary and Phytosanitary Measures, Summary of the Meeting of 18-19 October 2007. Note by the Secretariat, G/ SPS/R/46, circulated on 2 January 2008, para. 172.

${ }^{545}$ Committee on Sanitary and Phytosanitary Measures, Summary of the Meeting of 18-19 October 2007. Note by the Secretariat, G/SPS/R/46, circulated on 2 January 2008, paras 140-141.

${ }_{546}$ The view that discussions at the SPS Committee on private standards should be concrete and specific was expressed by Australia, the EC, Japan, Canada, and the US. This approach was also regarded as useful by Senegal, Uruguay, Barbados, Bolivia, Bangladesh, Zimbabwe and Argentina although some of these Members felt hat a global systemic debate, in parallel, could be useful. Ibid., paras 145, 149, 150, 152, 153, $156,157,158$ and 165 .

${ }^{547}$ Ibid., paras 143, 155, 165 and 170. In addition, Ecuador noted that obtaining information on concrete examples may prove difficult as producers may be reluctant to share information regarding non-compliance with private standards and thereby lose market share. Ibid., para. 162. 
work within which private standards could be addressed at the WTO, it seems advisable to exploit fully the existing mechanism provided by the SPS Committee to bring about gradual change through the sharing of experiences at technocratic level, and drawing critical attention to problems. As noted by Gascoine et al. large retailers 'acknowledge that there is a business risk associated with the negative reaction of developing countries to their private standards. ${ }^{948}$ Similarly, the EC noted at the relevant SPS Committee meeting that the discussion at the Committee on the issue of private standards had sensitised the private sector bodies to the impact of their measures on developing countries, and that real efforts were being made by these bodies to address the issue. ${ }^{549}$ Several Members that participated in the discussion at the November 2007 meeting pointed to the need for technical assistance to improve capacity for compliance with private standards. It is to be hoped that placing private bodies in the limelight by subjecting their actions to critical attention in a multilateral forum will have the effect of stimulating them to improve their procedures to make them more transparent and inclusive and will spur them and other donors to provide effective technical assistance. ${ }^{550}$

An example of a concrete issue related to private sector standards was promptly raised by Ecuador at the first SPS Committee meeting in 2008. This related to the interplay between the EC's regulatory standard for a plant growth regulator, Ethephon, and the private quality standards set by GLOBALGAP and applied by European retailers, which together have the effect of excluding Ecuadorian pineapples from the European market. ${ }^{551}$ It will be interesting to see what the response of Members will be to this specific example.

548 Digby Gascoine et al., Private Voluntary Standards within the WTO Multilateral Framework (United Kingdom Department for International Development, London), March 2006, para. 5.

${ }^{549}$ Committee on Sanitary and Phytosanitary Measures, Summary of the Meeting of 18-19 October 2007. Note by the Secretariat, G/SPS/R/46, circulated on 2 January 2008, para. 149.

${ }_{550}$ An example of technical assistance by a non-private sector donor in this regard was reported in the information session on private standards organised by the Standards and Trade Development Facility. This was the World Bank grant of US\$750,000 for a three year period to establish the Trade Standards Practitioners Network (TSPN), which aims to build a community of practice to actively promote the adoption of food safety and environmental standards in developing countries and to share experiences and increase learning. The TSPN has as its objectives to better enable developing countries to participate in and take advantage of standards-based markets; to arrange research policy dialogues and create a standards information clearing house; and to facilitate the identification of best practices in standards management. Committee on Sanitary and Phytosanitary Measures, Report of the STDF Information Session on Private Standards (26 June 2008). Note by the Secretariat, G/SPS/50, circulated on 24 July 2008, paras 12-13.

551 In 2008, Ecuador submitted a statement to the SPS Committee in which it expressed its concern that a proposed reduction in the EC's maximum residue levels of Ethephon, a plant growth regulator, in pineapple, would preclude Ecuador from using this substance to control the pineapple ripening process. This was particularly problematic for Ecuador in view of the fact that GLOBALGAP quality standards are applied by purchasers on the EC market, requiring particular quality attributes that would be impossible for Ecuador to meet without the use of Ethephon. Committee on Sanitary and Phytosanitary Measures, MRL for Pineapple - Ethephon, G/SPS/GEN/841/Rev.1, circulated on 9 May 2008. Note that in this case the private sector standard referred to addresses quality requirements, such as the stage of ripeness of fruit, rather than safety requirements. Nevertheless, this example illustrates the fact that when coupled with a mandatory food safety standard, in this case an MRL for chemical residues in food, a private sector quality standard can have the effect of closing off a market for developing-country exports. In view of the debate regarding the role of SPS Agreement in disciplining private standards and the fact that in any case quality standards are not standards falling under the SPS Agreement, in its submission, Ecuador challenged the conformity of the EC's proposed reduction in the MRL for Ethephon rather than the private standards of GLOBALGAP. 


\subsection{Temporal scope of application}

The temporal scope of application of the SPS Agreement also deserves attention here. This issue relates to the question whether the coverage of the SPS Agreement extends to SPS measures that were enacted or applied before its entry into force. In $E C$-Hormones the EC argued that, as its measure predated the entry into force of the SPS Agreement on 1 January 1995, the SPS Agreement was not applicable to it. The Appellate Body agreed with the Panel's finding that the SPS Agreement nevertheless governed the dispute. The Appellate Body held as follows:

If the negotiators had wanted to exempt the very large group of SPS measures in existence on 1 January 1995 from the disciplines of provisions as important as Articles 5.1 and 5.5, it appears reasonable to us to expect that they would have said so explicitly. Articles 5.1 and 5.5 do not distinguish between SPS measures adopted before 1 January 1995 and measures adopted since; the relevant implication is that they are intended to be applicable to both. ${ }^{552}$

The Panel had based its conclusion on Article 28 of the Vienna Convention on the Law of Treaties, ${ }^{553}$ which provides that a treaty cannot apply to acts, facts or situations ceasing to exist before the treaty came into force. As the EC measure continued to exist after the entry into force of the SPS Agreement and since there were no provisions in the SPS Agreement itself limiting its temporal application, the Agreement applied to the measure in question. ${ }^{554}$ The Appellate Body also pointed to Article XVI:4 of the WTO Agreement which obliges Members to ensure the conformity of their laws, regulations and procedures with their obligations under the annexed Agreements. ${ }^{555}$ It noted that, unlike the GATT 1947, the WTO Agreement was accepted definitively by Members, thus there are no longer exceptions for existing legislation (so-called 'grandfather rights'). ${ }^{556}$

This finding that the SPS Agreement governs all existing SPS measures that may affect international trade is not only legally sound; it is also of great practical significance. To find otherwise and exempt pre-existing SPS measures would be to drastically diminish the effectiveness of the SPS Agreement in bringing discipline to the SPS area. By 1995 most Members had functioning SPS regimes in place, encompassing hundreds if not thousands of SPS product requirements, process standards and conformity assessment procedures. To 'grandfather' such SPS measures would be to perpetuate the situation that gave rise to the negotiations on the SPS Agreement in the first place.

However, the flip side of this coin is of course the burden of implementation of the obligations of the SPS Agreement with respect to measures enacted before these obliga-

\footnotetext{
552 Appellate Body Report, EC - Hormones, para. 128.

${ }^{553}$ Howard Latin, 'Ideal Versus Real Regulatory Efficiency: Implementation of Uniform Standards And "Fine Tuning” Regulatory Reforms', Stanford Law Review 37, 1985, 1267-1332. As noted above, Articles 31 and 32 of this convention are regarded as having attained the status of customary international law and must be applied by WTO panels and the Appellate Body by virtue of Article 3.2 of the DSU.

${ }_{554}$ Panel Report, EC-Hormones (Canada), para. 8.28; Panel Report, EC-Hormones (US), para. 8.25.

${ }_{555}$ Appellate Body Report, EC - Hormones, para. 128.

${ }^{556}$ Ibid.
} 
tions existed. ${ }^{557}$ Particularly in less developed Members, where regulation based on risk assessment was not the norm, this entails a wide-scale revision of existing SPS measures. The Appellate Body in EC - Hormones recognised the difficulties that the applicability of the SPS Agreement to pre-existing SPS measures could cause for Members, particularly in the light of the requirement contained in the SPS Agreement that SPS measures be based on risk assessments. In this regard, the Appellate Body pointed to the qualification to the risk assessment obligation contained in Article 5.1 of the SPS Agreement, which provides a degree of flexibility by requiring only a risk assessment 'as appropriate to the circumstances. ${ }^{958}$ It is not entirely clear how this proviso ameliorates the burden of bringing the hundreds of SPS measures that predate the entry into force of the Agreement into conformity with the risk assessment provisions. From the interpretation of Article 5.1 of the SPS Agreement in the case law, ${ }^{559}$ it seems unlikely that the either the fact that a measure predated the SPS Agreement or the fact that a regulating Member faces capacity constraints will be taken into account as a 'circumstance' softening the strict requirements of a risk assessment in terms of the SPS Agreement.

Nevertheless, the value of ensuring the applicability of the SPS Agreement to all existing SPS measures, including those that predated the Agreement, seems to be recognised by all Members. As a result, the question of the temporal application of the SPS Agreement has not been an issue in any dispute since $E C$-Hormones, nor has it been used as a justification by Members against whose measures specific trade concerns have been raised in the SPS Committee. ${ }^{560}$

\subsection{Relationship with other WTO agreements}

The Uruguay Round agreements, embodied in the WTO Agreement including its Annexes, constitute 'an inseparable package of rights and disciplines that have to be considered in conjunction.' ${ }^{561}$ This is because the WTO Agreement is a 'single undertaking'. ${ }^{562}$ Article II:2 of the WTO Agreement provides:

The agreements and associated legal instruments included in Annexes 1, 2 and 3 (hereinafter referred to as "Multilateral Trade Agreements") are integral parts of this Agreement, binding on all Members.

\footnotetext{
${ }^{557}$ Note that the notification obligation of the SPS Agreement does not apply to pre-existing SPS measures. It is limited to proposed (new or amended) SPS measures. See below, Part IV, Section 1.3.2.1.

558 Appellate Body Report, EC-Hormones, para. 129.

${ }^{559}$ For a discussion of the case law on Article 5.1 of the SPS Agreement, in particular the 'as appropriate to the circumstances' qualification, see below, Part III, Section 5.1.2.

${ }^{560}$ On the mechanism for raising specific trade concerns before the SPS Committee, see below, Part IV, Section 2.1.2.

${ }^{561}$ Appellate Body Report, Argentina - Footwear (EC), para. 81. The Appellate Body was citing with agreement the Panel's finding on this point.

${ }^{562}$ Appellate Body Report, Brazil - Desiccated Coconut, 177. The 'single undertaking' nature of the WTO Agreement was reiterated by the Appellate Body in Korea - Dairy, which noted that this is now well-established and that therefore 'all WTO obligations are generally cumulative and Members must comply with all of them simultaneously.' Appellate Body Report, Korea - Dairy, para. 74.
} 
As held by the Appellate Body in Argentina - Footwear (EC), the various multilateral trade agreements 'are all provisions of one treaty, the WTO Agreement. They entered into force as part of that treaty at the same time. They apply equally and are equally binding on all WTO Members. ${ }^{563}$ One therefore cannot analyse the SPS Agreement in isolation. It is important to have regard to the other elements of this 'inseparable package' and their relationship to the SPS Agreement in terms of scope of application and priority in case of conflicts. Only in this way can one ensure that these Agreements, to the extent that they may apply to the same measure, are interpreted 'harmoniously'. ${ }^{564}$

In particular, it is necessary to look at the relationship between the SPS Agreement and other WTO agreements that could be of relevance to measures affecting trade in food and agricultural products. These are the TBT Agreement, the GATT 1994 and the Agreement on Agriculture all of which are part of the Multilateral Agreements on Trade in Goods, contained in Annex 1A to the WTO Agreement. An examination of the relationship between them is useful in sketching the framework of rules applicable to various aspects of this area of trade.

\subsubsection{The TBT Agreement}

As discussed above, during the Tokyo Round, the first steps were taken towards addressing non-tariff barriers to trade in GATT negotiations. One of the outcomes of this Round was the conclusion of the Agreement on Technical Barriers to Trade, commonly referred to as the Standards Code ${ }^{565}$ which applied to all technical regulations and standards, including those aimed at the protection of human, plant or animal life or health. As already explained, this agreement was not very effective and its revision was therefore included on the agenda of the Uruguay Round negotiations. During the Uruguay Round negotiations it was agreed that SPS measures merited special attention, aside from the larger genus of technical measures. ${ }^{566}$ This led to the drafting of two separate agreements addressing technical barriers to trade: the SPS Agreement and the TBT Agreement. ${ }^{567}$ The question therefore arises which of these two Agreements applies in a particular case

The scope of application of the TBT Agreement is determined with reference to the form that a measure takes, irrespective of its purpose or its product coverage. ${ }^{568}$ More specifi-

\footnotetext{
${ }^{563}$ Appellate Body Report, Argentina - Footwear (EC), para. 81.

${ }^{564} \mathrm{Ibid}$. Such harmonious interpretation is particularly necessary due to the fragmented nature of the negotiations which resulted in tensions between provisions in different treaties. Marceau and Trachtman point out that although the WTO Agreement is a single treaty, its provisions, in the various agreements, were negotiated by 15 different working groups. There may have been insufficient coordination between them, leading to difficulty in defining 'clearly and precisely the legal parameters of the relationships among the provisions of the WTO agreements.' Gabrielle Marceau and Joel P. Trachtman, 'GATT, TBT and SPS: A Map of WTO Law of Domestic Regulation of Goods', in The WTO Dispute Settlement System 1995-2003, F. Ortino and ErnstUlrich Petersmann (eds.) (Kluwer Law International, Deventer), 2004, 275-340, 277. This article provides a very useful discussion of the respective scopes of application and disciplines of the SPS Agreement, the TBT Agreement, and the GATT 1994.

${ }^{565}$ Agreement on Technical Barriers to Trade, 26S/154, 1186 UNTS 276, LT/TR/A/5, 12 April 1979.

${ }^{566}$ For a more detailed discussion of the negotiating history, see above, Part III, Section 1.2.

${ }^{567}$ For a graphic representation by the WTO Secretariat of the relative scopes of application of the SPS Agreement and TBT Agreement, see Committee on Sanitary and Phytosanitary Measures, Graphs on the Coverage of the SPS and TBT Agreements. Note by the Secretariat, G/SPS/W/32, circulated on 10 November 1995.

${ }^{568}$ Article 1.4 of the TBT Agreement establishes the comprehensive nature of the product coverage of the TBT
} 
cally, the TBT Agreement applies to three types of measures: technical regulations, standards and conformity assessment procedures. These measures are defined in Annex 1 of the TBT Agreement. A technical regulation is defined in Annex 1.1 as a:

[d] ocument which lays down product characteristics or their related processes and production methods, including the applicable administrative provisions, with which compliance is mandatory. It may also include or deal exclusively with terminology, symbols, packaging, marking or labelling requirements as they apply to a product, process or production method. ${ }^{569}$

Examples of technical regulations are a law requiring that processed food products be labelled as to nutrient content and permissible preservatives, or a law prohibiting the marketing of toys containing toxic plastics. ${ }^{570}$

A standard is defined in Annex 1.2 of the TBT Agreement as a:

[d] ocument approved by a recognised body, that provides, for common and repeated use, rules, guidelines or characteristics for products or related processes and production methods, with which compliance is not mandatory. It may also include or deal exclusively with terminology, symbols, packaging, marking or labelling requirements as they apply to a product, process or production method. 571

In contrast to technical regulations, standards are voluntary in nature. Examples include GLOBALGAP standards for plant propagation material, to ensure the quality of the crop, and standards applied by supermarkets with regard to the size, shape and ripeness level of fresh fruit.

Annex 1.3 of the TBT Agreement defines conformity assessment procedures as:

[a]ny procedure used, directly or indirectly, to determine that relevant requirements in technical regulations or standards are fulfilled.

Examples of conformity assessment procedures are random sampling procedures to ensure that pharmaceuticals conform to safety specifications, or inspection of production facilities to determine whether the requirements for the use of the voluntary label of the FairTrade Foundation are complied with.

Agreement, which extends to include both industrial and agricultural products.

${ }^{569}$ Note that it is debated whether this definition covers measures laying down requirements for non-productrelated PPMs, such as animal welfare standards or minimum labour standards, in view of the fact that it refers to product characteristics 'or their related' PPMs. With regard to labelling requirements, however, it is clear that non-product related PPMs are included by the last sentence of the definition.

570 The definition of a technical regulation was clarified by the Appellate Body in EC-Asbestos which held that to be a technical regulation, a measure must lay down product characteristics (whether in positive or negative form), must do so in a binding manner and must be applicable to an identifiable product or group of products. Appellate Body Report, EC-Asbestos, paras 67-70. This was confirmed in Appellate Body Report, EC-Sardines, para. 176.

${ }^{571}$ The same debate with regard to the coverage of non-product-related PPMs, aside from those set out in labelling standards, exists with regard to this definition. 
Clearly, many SPS measures take the form of technical regulations, standards or conformity assessment procedures. The importance of establishing whether the TBT Agreement or the SPS Agreement applies in such a case comes from the fact that the two agreements apply different disciplines to measures falling within their respective ambits. The rules in the TBT Agreement are arguably less strict; they are primarily aimed at ensuring that technical regulations do not constitute unnecessary barriers to trade, while recognising the right of Members to pursue legitimate objectives by means of technical regulations. In brief, the TBT Agreement prohibits discrimination in the preparation, adoption and application of technical regulations, standards and conformity assessment procedures, sets a Code of Good Practice for public and private standardising bodies, mandates the use of the least-trade-restrictive measure available, obliges transparency in the regulatory process and encourages the adoption of international standards. However, unlike the SPS Agreement, it sets no scientific requirements for the adoption of measures that do not conform to international standards. Instead it allows deviation from international standards where necessary to fulfil a legitimate objective, without requiring scientific justification for the deviation.

The choice of whether to challenge a measure under the SPS Agreement rather than the TBT Agreement is not left to the complaining Member. Instead, the TBT Agreement clearly provides in Article 1.5:

The provisions of this Agreement do not apply to sanitary and phytosanitary measures as defined in Annex A of the Agreement on the Application of Sanitary and Phytosanitary Measures.

As a result, pursuant to Article 1.5 of the TBT Agreement, SPS measures are excluded from the scope of the TBT Agreement, even if they take the form of technical regulations, standards or conformity assessment procedures. SPS measures are instead subject to the distinct disciplines of the SPS Agreement. As noted above, it is primarily the purpose of the measure that qualifies it as a sanitary or phytosanitary measure.

In EC - Hormones, the US and Canada claimed, inter alia, that the EC ban on hormonetreated beef was inconsistent with the TBT Agreement. Referring to Article 1.5 of the TBT Agreement, the Panel found, however, that, since this measure was an SPS measure, the TBT Agreement did not apply to this dispute. ${ }^{572}$

However, as discussed above, ${ }^{573}$ the Panel in EC - Approval and Marketing of Biotech Products has held that a single requirement may simultaneously be both an SPS measure and a 'non-SPS measure', if it is imposed for a purpose that falls within the definition of an SPS measure as well as for a purpose not covered by this definition. ${ }^{574}$ As Article 1.5 of the TBT Agreement does not apply to 'non-SPS measures', it does not operate to exclude from the scope of application of the TBT Agreement requirements that embody 'non-SPS measures'. Thus, if the requirement at issue falls within the definition of a 'technical regulation' as defined in Annex 1.1 of the TBT Agreement, it would fall to be assessed under the TBT Agreement 'to the extent it embodies a non-SPS measure' even if it also embodies

\footnotetext{
572 Panel Report, EC - Hormones (US), para. 8.29; and Panel Report, EC-Hormones (Canada), para. 8.32.

${ }_{573}$ See above, Part III, Section 2.1.1.

${ }^{574}$ Panel Reports, EC-Approval and Marketing of Biotech Products, para. 7.165.
} 
an SPS measure. ${ }^{575}$ Therefore, a single measure may fall within the scope of application of both the SPS Agreement and the TBT Agreement.

It means that a requirement that is an SPS measure may now also be a TBT measure and thus subject to both Agreements. It is important to note that a measure found to be in violation of the SPS Agreement cannot be 'saved' by a finding that it is, at the same time, in conformity with the TBT Agreement. ${ }^{576}$ Instead it will be required to conform to the obligations of both Agreements and may fall foul of either.

\subsubsection{The GATT 1994}

The GATT 1994 applies to all measures affecting trade in goods. As mentioned above, before the Uruguay Round Members could maintain measures necessary for the protection of human, plant and animal life or health that violated other GATT provisions under the exception provided therefore in Article XX(b) of GATT 1947. The insufficiency of this provision to deal with the complexities of SPS measures was one of the factors that led Members to negotiate the SPS Agreement in the Uruguay Round, in an attempt to flesh out Article XX(b) so as to set clear limits on the use of health measures in ways that could affect international trade. However, as already noted above, the resulting SPS Agreement goes further than a mere elaboration of Article XX(b). It also establishes a new, comprehensive set of norms for the adoption and maintenance of SPS measures.

The Panel in EC - Hormones was faced with the question whether a prior finding of violation of the GATT is necessary for the SPS Agreement to apply. The EC had argued that since the Preamble of the SPS Agreement explicitly states as one of its aims the elaboration of rules for the application of the provisions of GATT 1994 relating to SPS measures, particularly Article XX(b), the SPS Agreement is not an independent agreement but only an interpretation of Article XX(b). It thus only applies in cases where Articles I, III or XI of GATT 1994 has been violated and recourse could be had to the Article XX(b) exception. ${ }^{577}$ The Panel rejected this argument, finding that the SPS Agreement is an independent agreement, imposing substantive obligations that go beyond those of the GATT. ${ }^{578}$ It held:

${ }^{575}$ Panel Reports, EC-Approval and Marketing of Biotech Products, para. 7.167. Although the EC Regulation on novel foods was found to be both an SPS measure and a non-SPS measure, the Panel found it unnecessary to decide the claims of Canada and Argentina under the TBT Agreement as the product-specific measures and the safeguard measures challenged under this regulation were all found by the Panel to fall under the SPS Agreement. Ibid., paras 7.2524 and 7.2527 (with regard to the product-specific measures) and paras 7.3412 7.3413 (with regard to the safeguard measures).

576 This fact makes it difficult to understand why in this dispute the EC found it useful to argue that its approval procedures for biotech products were both SPS measures and non-SPS measures.

577 Panel Report, EC - Hormones (US), para. 4.4; Panel Report, EC-Hormones (Canada), para. 4.3.

${ }^{578}$ The Panel based its finding on the following grounds: (1) Under the plain language of Article 1.1, which governs the applicability of the SPS Agreement, the only requirements are that the relevant measure is an SPS measure as defined in Annex A.1 and that it affects international trade. No prior violation of GATT is required; (2) the SPS Agreement does not only elaborate on GATT provisions but establishes its own substantive obligations in order to further, inter alia, the harmonization of SPS measures; (3) under Article 2.4 of the SPS Agreement, measures that conform to the SPS Agreement are deemed to comply with GATT provisions, in particular Art. XX(b); (4) Article 3.2 of the SPS Agreement states that measures conforming to international standards are presumed consistent with GATT 1994. These presumptions imply that the SPS Agreement contains at least as many and probably more obligations than Article XX(b) of the GATT 1994. Panel Report, 
It is clear that some provisions of the SPS Agreement elaborate on provisions already contained in GATT, in particular Article XX(b). The final preambular paragraph of the SPS Agreement provides, indeed, that the Members desired "to elaborate rules for the application of the provisions of GATT 1994 which relate to the use of sanitary or phytosanitary measures, in particular the provisions of Article XX(b)". Examples of such rules are, arguably, some of the obligations contained in Article 2 of the SPS Agreement. However, on this basis alone we cannot conclude that the SPS Agreement only applies, as Article XX(b) of GATT does, if, and only if, a prior violation of a GATT provision has been established. Many provisions of the SPS Agreement impose "substantive" obligations which go significantly beyond and are additional to the requirements for invocation of Article XX(b). These obligations are, inter alia, imposed to "further the use of harmonized sanitary and phytosanitary measures between Members" 579 and to "improve the human health, animal health and phytosanitary situation in all Members". ${ }^{580}$ They are not imposed, as is the case of the obligations imposed by Article XX(b) of GATT, to justify a violation of another GATT obligation (such as a violation of the non-discrimination obligations of Articles I or III).$^{581}$

This finding was not appealed. It establishes that SPS Agreement created an autonomous set of rights and obligations, whose scope of application is independent of a finding of violation of the GATT $1994 .{ }^{582}$ The scope of the SPS Agreement is thus broader than that of the GATT 1994 in that an SPS measure which is neither discriminatory nor a quantitative restriction, ${ }^{583}$ and is thus in compliance with GATT rules, could still fall foul of the disciplines of the SPS Agreement, for example by not being based on a risk assessment. As stated above, the SPS Agreement catches all SPS measures that may have an impact on international trade.

The SPS Agreement, however, did not replace the relevant provisions of the GATT 1947 (now incorporated by reference in the GATT 1994) applicable to SPS measures. Nor is it subordinate to the GATT. Instead the two Agreements now operate in complement to each

EC-Hormones (US), paras 8.36-8.40 and Panel Report, EC-Hormones (Canada), paras 8.39-8.43.

${ }^{579}$ Preambular para. 6 of the SPS Agreement (footnote in original).

${ }^{580}$ Preambular para. 2 of the SPS Agreement (footnote in original).

${ }^{581}$ Panel Report, EC - Hormones (US), para. 8.38 and Panel Report, EC-Hormones (Canada), para. 9.41.

${ }^{582}$ Quick and Blüthner refer, for a contrary approach, to Pierre Pescatore, who argues that the SPS Agreement is subordinate to GATT principles and therefore the first question in a dispute should always be whether there is a violation of GATT rules which can give rise to the application of Article XX(b) and consequently to SPS rules. Pierre Pescatore, Free World Trade and the European Union - The Reconciliation of Interests and the Revision of Dispute Resolution Procedures in the Framework of the WTO, paper presented at the Conference of the Academy of European Law, Trier, in co-operation with the Legal Service of the European Commission, Brussels, 11-12 June 1998, at 23, referred to in Reinhard Quick and Andreas Blüthner, 'Has the Appellate Body Erred? An Appraisal and Criticism of the Ruling in the WTO Hormones Case', Journal of International Economic Law 2 (4), 1999, 603-639.

${ }^{583}$ The SPS Agreement reflects the recognition that a test based on discrimination or quantitative restriction is not an effective tool to distinguish between legitimate SPS measures and those used for protectionist purposes. It is possible for a measure that meet neither of these tests to have a negative impact on international trade, and thereby serve to protect domestic industry from foreign competition. David Hurst makes this observation with regard to the discrimination test. David R. Hurst, 'Hormones: European Communities Measures Affecting Meat and Meat Products', European Journal of International Law 9 (1), 1998, 182-183, 182, available at: http://www.ejil.org/journal/Vol9/No1/sr1g.html, visited on 12 June 2008. 
other and to the TBT Agreement, within their respective scopes of application. Where the measure at issue is an SPS measure as defined in Annex A of the SPS Agreement, it may fall within the scope of application of the SPS Agreement and, to the extent that it is, inter alia, also discriminatory or a quantitative restriction, it may be caught by the GATT 1994 as well. ${ }^{584}$ Since both these Agreements may, in principle, apply to such measure, it is necessary to determine which Agreement would prevail in case of conflict.

The relationship between the GATT 1994 and the other multilateral agreements on trade in goods contained in Annex 1A to the WTO Agreement, including the SPS Agreement, is addressed in general terms by the General Interpretative Note to Annex 1A. It provides:

In the event of conflict between a provision of the GATT 1994 and a provision of another agreement in Annex 1A to the Agreement Establishing the WTO (referred to in the Agreements in Annex 1A as the "WTO Agreement"), the provision of the other agreement shall prevail to the extent of the conflict.

Therefore, in case of conflict between the applicable GATT rules and the SPS Agreement, the latter prevails. It should be borne in mind, however, that in accordance with the general international law presumption against conflicts, ${ }^{585}$ panels and the Appellate Body have interpreted the concept of conflict very strictly, as 'a situation where adherence to one provision will lead to a violation of the other provision...' ${ }^{586}$ In the absence of such conflict, the 'single undertaking' nature of the WTO Agreement dictates that the provisions of the different WTO agreements are generally considered cumulative, and Members must comply with them all. ${ }^{587}$

The possibility for conflict, in this narrow sense, between GATT rules and the disciplines of the SPS Agreement is particularly slim. As will be seen in the following discussion of the SPS Agreement, its provisions take on board the relevant GATT disciplines, as interpreted in the pre-Uruguay Round case law. However, it goes further than this, by both elaborating new disciplines and balancing these against an expressly recognised right of

${ }^{584}$ Note that these are only the most relevant GATT obligations that an SPS measure may fall foul of. Other GATT obligations, such as those in Article X of the GATT 1994 requiring the prompt publication of generally applicable laws, regulations, decisions and rulings affecting the sale, distribution, transportation, inspection etc. of imports or exports; and the uniform, impartial and reasonable administration of these laws, regulations, etc., also catch SPS measures.

${ }^{585}$ The presumption against conflicts was applied, for example, in Appellate Body Report, Canada-Periodicals, 19; and Appellate Body Report, EC-Bananas III, paras 219-222. As held by the Panel in Indonesia-Autos: '[t]his presumption is especially relevant in the WTO context since all WTO agreements, including GATT 1994 which was modified by Understandings when judged necessary, were negotiated at the same time, by the same Members and in the same forum.' Panel Report, Indonesia - Autos, para. 14.28.

586 Appellate Body Report, Guatemala - Cement I, para. 65. The Panel in EC-Bananas III, found that the General Interpretative Note to Annex $1 A$ covers two types of conflicts: (1) conflicts where the obligations are mutually exclusive in the sense that a Member could not comply with both obligations at the same time; and (2) the situation where a rule in one agreement prohibits what a rule in another agreement explicitly permits. Panel Report, EC-Bananas III, para. 7.159.

${ }^{587}$ Appellate Body Report, Korea - Dairy, para. 74, citing with agreement the Panel's statement that: '[i]t is now well established that the WTO Agreement is a "Single Undertaking" and therefore all WTO obligations are generally cumulative and Members must comply with all of them simultaneously...' Panel Report, Korea - Dairy, para. 7.38. On this point, see Joanne Scott, The WTO Agreement on Sanitary and Phytosanitary Measures: A Commentary, Oxford Commentaries on the GATT/WTO Agreements (Oxford University Press, Oxford), 2007, 28. 
Members to regulate against SPS risks. This aims to redress the inability of GATT rules to appropriate deal with the trade/health conflict in this area. It is probably for this reason that the SPS Agreement, unlike the other Annex 1A agreements, contains a presumption of consistency with the GATT 1994 for measures conforming to its provisions. Article 2.4 of the SPS Agreement provides:

Sanitary or phytosanitary measures which conform to the relevant provisions of this Agreement shall be presumed to be in accordance with the obligations of the Members under the provisions of GATT 1994 which relate to the use of sanitary or phytosanitary measures, in particular the provisions of Article XX(b).

The issue of whether this presumption is rebuttable is not addressed in the SPS Agreement, nor has it been examined in the case law. If the presumption were irrebuttable, it would indicate that the relevant disciplines of the GATT, in particular Article XX(b), could be regarded as being subsumed by the SPS Agreement, to the extent that they would apply to SPS measures that are caught by GATT rules (for example SPS measures that are discriminatory or amount to quantitative restrictions). This approach is advocated by some authors. ${ }^{588}$ Others argue, however, that the presumption in Article 2.4 of the SPS Agreement is rebuttable, so that a measure found to be in conformity with the SPS Agreement could still be found in violation of the GATT 1994, if the complainant succeeds in rebutting the presumption of conformity. ${ }^{589}$ Such an interpretation would result in a cumulation of GATT and SPS obligations when an SPS measure is at issue. ${ }^{590}$

This is particularly relevant today, in light of the developments in the case law around Article XX(b) of the GATT 1994, discussed above. ${ }^{591}$ While the old GATT case law's interpretation of the 'necessity' requirement in Article $\mathrm{XX}(\mathrm{b})$ required the imposition of the least trade-restrictive measure reasonably available to achieve the chosen health objective, which requirement was incorporated into Article 5.6 of the SPS Agreement, ${ }^{592}$

${ }^{588}$ Goh and Ziegler claim that where an SPS measure is at issue, the SPS Agreement should apply exclusively, making recourse to the GATT impossible. Gavin Goh and Andreas R. Ziegler, 'A Real World Where People Live and Work and Die: Australian SPS Measures after the WTO Appellate Body's Decision in the Hormones Case', Journal of World Trade 35 (5), 1998, 271-290. This would imply that the presumption of compatibility with the relevant GATT provisions is irrebuttable.

${ }^{589}$ In favour of this position, see Reinhard Quick and Andreas Blüthner, 'Has the Appellate Body Erred? An Appraisal and Criticism of the Ruling in the WTO Hormones Case', Journal of International Economic Law 2 (4), 1999, 603-639, 628; Gabrielle Marceau and Joel P. Trachtman, 'GATT, TBT and SPS: A Map of WTO Law of Domestic Regulation of Goods', in The WTO Dispute Settlement System 1995-2003, F. Ortino and Ernst-Ulrich Petersmann (eds.) (Kluwer Law International, Deventer), 2004, 275-340, 334. Note that the effect of the presumption would be to shift the burden of proof under Article XX(b) from the respondent to the complainant.

${ }^{590}$ Joost Pauwelyn points out that such a cumulation leads to the untenable situation that the obligations of WTO Members are systematically elevated above their rights. This is because a right provided under one agreement can be undermined by an obligation contained in another. He states: 'The obligations of WTO members to liberalize trade cannot systematically prevail over the rights of WTO members to restrict trade. New WTO provisions (such as the TBT, SPS or SCM Agreements) cannot only add obligations to liberalise trade, they may also create new rights to restrict trade.' Joost Pauwelyn, 'Cross-Agreement Complaints before the Appellate Body: A Case Study of the EC-Asbestos Dispute', World Trade Review 1 (1), 2002, 63-87, 80.

591 See above, Part III, Section 1.1.1.

${ }^{592}$ Article 5.6 of the SPS Agreement provides: '...when establishing or maintaining sanitary or phytosanitary measures to achieve the appropriate level of sanitary or phytosanitary protection, Members shall ensure that such measures are not more trade restrictive than required to achieve their appropriate level of protection, 
the current interpretation by the Appellate Body requires a 'weighing and balancing' approach. ${ }^{593}$ Marceau and Trachtman argue that the proportionality test encompassed in this approach is possibly not taken up in Article 5.6 of the SPS Agreement, leaving a measure that complies with Article 5.6 still vulnerable under Article XX(b) of the GATT 1994. ${ }^{594}$ However, it is also arguable that the requirement of 'harmonious' interpretation of the different parts of the WTO Agreement calls for an interpretation of Article 5.6 of the SPS Agreement that reflects the current state of the case law regarding the Article XX(b) necessity test, particularly since the 'reasonably available' wording on which the new case law is based in also found in the footnote ${ }^{595}$ to Article 5.6. ${ }^{596}$ In fact, already much 'crossfertilisation' is occurring in the interpretation of the SPS Agreement and Article XX(b) of the GATT $1994 .{ }^{597}$

Such 'harmonious interpretation' through 'cross fertilisation' is however subject to an important limitation, inherent in the object and purpose of the SPS Agreement. Unlike the GATT, which sees health measures as exceptional and thus to be justified by the Member imposing them, the SPS Agreement aims to achieve an appropriate balance between trade and health. In order to do so, it recognises the right of WTO Members to impose the SPS measures necessary to protect human, animal or plant life or health, ${ }^{598}$ but subjects this

taking into account technical and economic feasibility.'

${ }^{593}$ As discussed above, this approach was introduced by the Appellate Body in Korea - Various Measures on Beef in respect of the necessary requirement in Article XX(d) of the GATT 1994, and was subsequently applied by it in EC-Asbestos to the necessary requirement in Article XX(b) of the GATT 1994. See above, Part III, Section 1.1.1.

${ }^{594}$ Gabrielle Marceau and Joel P. Trachtman, 'GATT, TBT and SPS: A Map of WTO Law of Domestic Regulation of Goods', in The WTO Dispute Settlement System 1995-2003, F. Ortino and Ernst-Ulrich Petersmann (eds.) (Kluwer Law International, Deventer), 2004, 275-340, 334. Of course, as recognised by the authors, the question of conformity with Article XX(b) only arises if the measure violates another GATT provision, such as Article III:4 or Article XI.

${ }^{595}$ Footnote 3 to Article 5.6 of the SPS Agreement provides: 'For purposes of paragraph 6 of Article 5, a measure is not more trade-restrictive than required unless there is another measure, reasonably available taking into account technical and economic feasibility, that achieves the appropriate level of sanitary or phytosanitary protection and is significantly less restrictive to trade.'

${ }^{596}$ Quick and Blüthner argue that an interpretation of those SPS rules which are similar to GATT disciplines (such as those in Articles 2.3 and 5.6 of the SPS Agreement), in a way that diverges from that given to the relevant GATT provision (Article XX(b)), would make it possible for a challenging Member who loses the case under the SPS Agreement, to 'easily' rebut the presumption of compatibility and pursue its challenge under the GATT. This result would go against the aim of the SPS Agreement to clarify and give further meaning to the relevant GATT provisions (while going further than GATT). Thus they argue that the panels and Appellate Body should interpret these SPS rules in the light of existing GATT jurisprudence to avoid this possibility. Reinhard Quick and Andreas Blüthner, 'Has the Appellate Body Erred? An Appraisal and Criticism of the Ruling in the WTO Hormones Case', Journal of International Economic Law 2 (4), 1999, 603-639, 630-632. Scott supports the idea that consistent interpretation between the Article XX(b) of the GATT and the SPS Agreement may be called for in light of the desire expressed in the Preamble to the SPS Agreement to elaborate rules for the application of the relevant GATT rules, in particular Article XX(b). However she considers that it is not clear which of the two Agreements should be considered primary and which secondary (i.e. 'which is to lead and which to follow.') Joanne Scott, The WTO Agreement on Sanitary and Phytosanitary Measures: A Commentary, Oxford Commentaries on the GATT/WTO Agreements (Oxford University Press, Oxford), 2007, 29.

${ }^{597}$ While most of this cross-fertilisation has taken the form of reading into Article XX(b) the more developed disciplines contained in the SPS Agreement, this should not exclude the possibility that evolution in the GATT case law on disciplines relevant to the SPS Agreement, particularly those that have not yet been clarified fully, could be drawn upon in the interpretation of the SPS Agreement where appropriate.

${ }^{598}$ Article 2.2 of the SPS Agreement. See further below, Part III, Section 3.2.1. 
right to disciplines to minimise the negative trade effects of SPS measures. An indispensable aspect of this new approach is the recognition of the right of a Member to choose the level of protection it deems appropriate. ${ }^{599}$ This broader policy space created by the SPS Agreement is further reflected in the fact that the Agreement encourages, but does not oblige Members to 'take into account the objective of minimizing negative trade effects' when determining their appropriate level of protection. ${ }^{600}$ Any interpretation of the SPS Agreement in line with GATT case law is only permissible if it accords with the object and purpose of the SPS Agreement and its respect for the regulatory autonomy of Members with regard to their policy choices on the level of protection. To the extent that a strong proportionality test might undermine this policy space, it cannot be incorporated. ${ }^{601}$ To avoid the situation that might arise in such a case where GATT disciplines may go further than those of the SPS Agreement, allowing for rebuttal of the presumption of conformity, it seems best to regard the presumption in Article 2.4 as irrebuttable. Not to do so would negate the careful balance crafted in the SPS Agreement for the special situation of SPS measures, due to the specific value conflict they entail. ${ }^{602}$

In light of the abovementioned presumption of consistency, even if held to be rebuttable, when an SPS measure is at issue it is logical to examine this measure under the SPS Agreement first, before turning to its conformity with GATT 1994 rules. The SPS Agreement could thus be seen as a kind of lex specialis elaborating rules applicable to SPS measures, aside from the more generally applicable rules of the GATT $1994 .{ }^{603}$ This argument is borne out by the finding of the Panel in EC-Hormones which, when it addressed the question of which of the two Agreements to examine first, held:

The SPS Agreement specifically addresses the type of measure in dispute. If we were to examine GATT first, we would in any event need to revert to the

\footnotetext{
${ }^{599}$ Annex A.5 of the SPS Agreement. See further below, Part III, Section 5.2.1.

${ }^{600}$ Article 5.4 of the SPS Agreement. See further below, Part III, Section 5.2.2.

${ }^{601}$ On the possible limitations on the policy space of Members arising from the strong proportionality requirement read into the necessity test of Article XX(b) of the GATT 1994, see above, Part III, Section 1.1.1.

${ }^{602}$ A different solution to this problem is proposed by Joost Pauwelyn in the context of the relationship between the GATT and the TBT Agreement (which does not contain a presumption of conformity like that in the SPS Agreement). Pauwelyn advocates a broader interpretation of 'conflict' for purposes of the General Interpretative Note to Annex $1 A$ so that it is no longer limited to the unlikely situation where one WTO provision obliges a Member to do something which another provision prohibits. Instead, a conflict should be found to exist 'where one WTO provision prohibits something that another WTO provision explicitly allows for.' Joost Pauwelyn, 'Cross-Agreement Complaints before the Appellate Body: A Case Study of the EC-Asbestos Dispute', World Trade Review 1 (1), 2002, 63-87, 78. Following this approach, the General Interpretative Note would allow the SPS Agreement to prevail in cases where a GATT obligation contradicts an explicit right granted in the SPS Agreement. As the presumption against conflicts in international law argues against such a broadening of this concept in the General Interpretative Note to Annex $1 A$, it may be safer in the case of the SPS Agreement, to rely upon the presumption of conformity in Article 2.4 and interpret it as irrebuttable. In this regard, see Gabrielle Marceau who argues against the expansion of the concept of 'conflict' to ensure that rights within a treaty are respected, noting that other mechanisms are available to resolve conflicts between rights in one treaty and obligations in another, such as the lex specialis derogat generalis principle. Gabrielle Marceau, 'WTO Dispute Settlement and Human Rights', European Journal of International Law 13 (4), 2002, 753-814, 770-772.

${ }^{603}$ Note that where more than one treaty is applicable, although a lex specialis must be examined first, it does not exclude the application of the lex generalis. In the absence of a conflict, both apply. Joost Pauwelyn, 'Cross-Agreement Complaints before the Appellate Body: A Case Study of the EC-Asbestos Dispute', World Trade Review 1 (1), 2002, 63-87, 82.
} 
SPS Agreement: if a violation of GATT were found, we would need to consider whether Article XX(b) could be invoked and would then necessarily need to examine the SPS Agreement; if, on the other hand, no GATT violation were found, we would still need to examine the consistency of the measure with the SPS Agreement since nowhere is consistency with GATT presumed to be consistency with the SPS Agreement. For these reasons, and in order to conduct our consideration of this dispute in the most efficient manner, we shall first examine the claims raised under the SPS Agreement. ${ }^{604}$

In Australia - Salmon, the Panel also examined the SPS Agreement first, holding:

Canada recognizes that the SPS Agreement provides for obligations additional to those contained in GATT 1994, but, nevertheless, first addresses its claim under Article XI of GATT 1994. Australia invokes Article 2.4 of the SPS Agreement, which presumes GATT consistency for measures found to be in conformity with the SPS Agreement, to first address the SPS Agreement. We note, moreover, that (1) the SPS Agreement specifically addresses the type of measure in dispute, and (2) we will in any case need to examine the SPS Agreement, whether or not we find a GATT violation (since GATT consistency is nowhere presumed to constitute consistency with the SPS Agreement). In order to conduct our consideration of this dispute in the most efficient manner, we shall, therefore, first address the claims made by Canada under the SPS Agreement before addressing those put forward under GATT $1994 .{ }^{605}$

An added complication results from the finding of the Panel in EC-Approval and Marketing of Biotech Products that a measure may, in addition to being an SPS measure, also be a 'non-SPS measure' due to the fact that it pursues multiple objectives some of which do not fall within the list in Annex 1.A of the SPS Agreement. Such a measure cannot benefit from the presumption of conformity with Article XX(b) of the GATT 1994 for SPS measures that comply with the SPS Agreement provided for in Article 2.4 of the SPS Agreement. To the extent that such a measure is a 'non-SPS measure' it is thus also vulnerable to a GATT challenge.

\subsubsection{The Agreement on Agriculture}

The relationship between the SPS Agreement and the Agreement of Agriculture is one of complementarity. As explained above, it was clear that to the negotiators of the Agreement on Agriculture the special disciplines for SPS measures were crucial and inherently linked to the attempts to liberalise trade in agricultural products. This link is made explicit in Article 14 of the Agreement on Agriculture, which states:

Members agree to give effect to the Agreement on the Application of Sanitary and Phytosanitary Measures.

\footnotetext{
${ }^{604}$ Panel Report, EC - Hormones (US), para. 8.42; and Panel Report, EC-Hormones (Canada), para. 8.45.

${ }^{605}$ Panel Report, Australia - Salmon, para. 8.39.
} 
This provision is legally speaking redundant, since all WTO Members are bound to give effect to all the multilateral WTO agreements, including the SPS Agreement. However, this provision does serve to emphasise the negotiators' recognition of the importance of the disciplines in the SPS Agreement in securing the gains for agricultural trade liberalisation achieved in the Agreement on Agriculture.

The SPS Agreement and the Agreement on Agriculture can therefore be regarded complementary to each other. Both have the common aim of enhancing liberalisation in the agricultural sector by creating disciplines on trade-restrictive measures. However, the SPS Agreement covers measures affecting not only agricultural products as defined in the Agreement on Agriculture but also products of fisheries and forestry, and processed agricultural products (food, feed and beverages). In addition, the SPS Agreement extends to measures for the protection of wild fauna and flora.

Despite the partial overlap in product coverage of these two Agreements, they apply to different categories of measures. While the Agreement on Agriculture addresses the traditional trade barriers in the agricultural sector, such as tariff barriers, domestic support and export subsidies, the SPS Agreement was negotiated to deal with trade barriers that are not covered by the disciplines of the Agreement on Agriculture, namely SPS measures. ${ }^{606}$ Thus, together these two Agreements represent an important step forward in liberalising trade in food and agricultural products.

\subsection{Conclusion}

The current position of measures for the protection of health under WTO law is determined by the relevant provisions of the SPS Agreement, the TBT Agreement and the GATT 1994 within their respective spheres of application. The measure could thus be caught by any of the three agreements, depending on its objective(s), form and nature and its effect on trade. Which Agreement (or Agreements) applies in a particular case has far-reaching implications for the type of disciplines to which the measure is subjected, and in particular for the extent of policy space left to Members within which to exercise their regulatory autonomy.

The scope of application of the SPS Agreement, as defined in Article 1.1 read together with Annex A.1, reflects its aim to address a particular type of situation involving a conflict between two politically sensitive objectives. These are the liberalisation of trade in food and agricultural products and the protection of human, animal or plant life and health. The SPS Agreement aims to achieve an appropriate balance between these two objectives. The provisions delimiting its coverage therefore address those health risks that may arise from trade in primary and processed agricultural products, such as food safety risks and risks from animal or plant pests and diseases. These provisions consequently primarily focus on the purpose of the measure to determine whether it falls within the

${ }^{606}$ Although Article 4.2 of the Agreement on Agriculture addresses (as defined in footnote 1 to this Article), inter alia, quantitative import restrictions, discretionary import licensing and 'similar border measures', which could cover SPS measures, the footnote goes on to exclude measures maintained under the general, nonagriculture specific provisions of the Multilateral Agreements on Trade in Goods, one of which is the SPS Agreement. 
ambit of the Agreement, while leaving the form that such a measure might take broadly defined by means of an illustrative list of examples.

However, from the discussion in this Chapter it is apparent that the scope of application of the SPS Agreement, as currently interpreted in the case law of the Panel in EC-Approval and Marketing of Biotech Products and followed in the two Continued Suspension cases but not yet vetted by the Appellate Body, is very broad. In particular, it has been held to cover measures aiming at a broad array of purposes beyond the particular situations envisaged by negotiators when drafting its strict scientific disciplines. It therefore now eats into the coverage of the TBT Agreement and the GATT 1994 in situations where the disciplines of those agreements would have been more appropriate. An example of such a situation is that where a measure aims at the protection of the environment per se, not involving a risk to plant or animal life or health. Not only do the scientific obligations of the SPS Agreement inordinately restrict Member's scope for regulatory action in such situations, due to the significant differences in the state of scientific knowledge and extent of uncertainty in the field of environmental protection, but there is also little to be gained for agricultural trade through their application. While many types of measures can be crammed into the definition of Annex 1.A by both stretching its terms, and travelling far down the chain of causality to find a risk with which the measure can be said to be 'rationally related', this does not seem a wise course to take. It reduces to inefficacy the list of enumerated purposes as a tool to limit the scope of application of the SPS Agreement to those situations most likely to entail a conflict between health protection and agricultural trade.

The artificial insertion of a limiting 'nature' element, in addition to the inclusive 'form' element, into the definition of an SPS measure by the Panel in EC-Approval and Marketing of Biotech Products does not ameliorate the problem caused by the expansive interpretation of the enumerated purposes in Annex A.1 (a) to (d). The term 'requirements and procedures' will normally cover most types of measures, doing little to limit the applicability of the SPS Agreement. However, the formalistic character of the nature requirement may create adverse incentives for Members to devise measures of another 'nature' in such a way that they escape the disciplines of the SPS Agreement. For example, a measure that amounts to the application of a requirement or procedure would fail to meet the 'nature' test. The distinction between the types of measures that, under this interpretation, fall within and without the SPS Agreement bears no relation to the objective of the Agreement and only a strained connection to its wording. Instead, the interpretation is artificial, arbitrary and open to abuse. It is to be hoped that when the Appellate Body has an opportunity to address case law it will correct this situation.

It is interesting to examine the implications of the unexpectedly extensive substantive coverage of the SPS Agreement for Members at different levels of development. Here, as in other areas discussed in this book, it is important to avoid the lure of broad generalisations. While it might be tempting to argue that developing-country Members benefit from as wide an application of the SPS Agreement as possible, to extend its strict disciplines to a broad range of situations, this view is too simplistic. It ignores the fact that the positions and interests of developing-country Members are diverse, and that these Members are not only exporters of food and agricultural products, but are also importers of these products. They, like other WTO Members, benefit from the limited application of the disciplines of 
the SPS Agreement to the particular situations they are tailored to address. An inappropriate expansion of the application of this Agreement tilts the balance it aims to achieve and disturbs the relationship between it and the other relevant WTO agreements. It is important to bear in mind that measures not falling under the SPS Agreement are not undisciplined; they are merely disciplined in ways more appropriate to them.

The SPS Agreement together with the other WTO agreements form the 'inseparable package' of rights and disciplines to which Members are bound. For this reason, the SPS Agreement cannot be seen in isolation, but must instead be viewed in relation to the other WTO agreements that may be relevant to the position of SPS measures, namely the TBT Agreement, the GATT 1994 and the Agreement on Agriculture. In order to ensure that these Agreements, to the extent that they may apply to the same measure, are interpreted 'harmoniously', the question of the scope of application of the relevant Agreements and of priority in case of conflicts was addressed.

The scope of application of the TBT Agreement is defined with reference to the form that a measure takes. It applies to technical regulations, standards and conformity assessment procedures, as defined in Annex 1.1-1.3 thereof. In many cases, SPS measures take one of these three forms. However, the TBT Agreement in Article 1.5 expressly excludes SPS measures as defined in Annex A.1 of the SPS Agreement from its scope of application. Once a measure falls within the definition of an SPS measure, therefore, it must be examined under the SPS Agreement to the exclusion of the TBT Agreement. This relationship of mutual exclusivity is not present between the SPS Agreement and the GATT 1994. The GATT 1994 applies to all measures affecting trade in goods, including SPS measures. In principle, therefore, SPS measures may, in addition to being subject to the SPS Agreement, be caught by the disciplines of the GATT, for example the obligations of non-discrimination or the prohibition on quantitative restrictions, and fall to be justified under the requirements of the Article XX(b) exception. The General Interpretative Note to Annex 1A provides that in case of conflict between the GATT 1994 and a provision of another Annex 1A agreement, including the SPS Agreement, the latter prevails. However, in view of the narrow interpretation given to the concept of conflict in WTO law, namely that adherence to one provision would necessarily lead to a violation of another provision, in line with the general international law presumption against conflicts, it is unlikely that a conflict between the GATT 1994 and the SPS Agreement will arise. This is particularly the case because the SPS Agreement incorporates and elaborates upon existing GATT disciplines while adding new rights and disciplines. This conclusion is strengthened by the fact that the SPS Agreement, in Article 2.4 thereof, contains a presumption of conformity with the GATT 1994 for measures complying with its provisions. It is argued in this Chapter that this presumption should be regarded as irrebuttable to avoid the risk that the cumulative application of GATT disciplines and the disciplines of the SPS Agreement would narrow the policy space left to Members in the SPS Agreement, thereby undermining the careful trade/health balance it aims at. The relationship between the SPS Agreement and the Agreement on Agriculture is one of complementarity. Both aim to promote liberalisation of the agricultural sector, but they target different types of traderestrictive measures. While the Agreement on Agriculture focuses on traditional means of agricultural protectionism, such as tariffs, domestic support and export subsidies, the SPS 
Agreement addresses market access barriers for food and agricultural products that take the form of SPS measures.

The situation of the respective scopes of application of the relevant WTO agreements is complicated by the finding of the Panel in EC-Approval and Marketing of Biotech Products that a measure can be both an SPS measure and a 'non-SPS measure' when it has multiple objectives. The fact that such a measure is regarded as both an SPS measure and a 'non-SPS measure' has the effect of subjecting a single measure to multiple, differing disciplines. To the extent that the SPS measure at issue is also a 'non-SPS measure', it is not excluded from the scope of application of the TBT Agreement by Article 1.5 thereof, nor does it benefit from the presumption of conformity with the GATT 1994 for measures in compliance with the SPS Agreement. The result is that the policy space of a Member is even more greatly restricted as its measure is vulnerable to a multitude of challenges under agreements with quite different objectives. Consequently the delicate balance sought by the provisions of the relevant agreements in particular situations is undermined. This cannot be what is meant by a 'harmonious interpretation' of the 'inseparable package' of WTO agreements. It is hoped that the Appellate Body will correct this problem in future cases.

The issue of the applicability of the SPS Agreement to SPS requirements of bodies other than central government is one fraught with difficulty. The increasing shift of SPS norm creation and implementation to subnational and transnational levels in the last decade has brought this issue to the forefront of attention. While the idea that Members are responsible for compliance with WTO obligations by their subnational levels of government is now generally accepted, the same cannot be said for non-governmental entities. The principle of attribution to a Member of acts of private bodies in cases where there is a sufficient level of intervention by the government in the private action, only addresses the problem to a limited degree. A rapidly growing number of SPS requirements are developed and applied by private bodies free of governmental influence, in response to consumer demand, especially in affluent countries. The fact that the market for food and agricultural products, particularly in the high-value sector, is dominated by retail conglomerates which require compliance with specific private standards results in the blurring of the distinction between public and private SPS requirements in terms of their impact on exporters. Private sector standards act as significant barriers to developingcountry exports, particularly those of their small-scale producers. The question thus arises to what extent Article 13 of the SPS Agreement may be relied upon to compel Members to discipline private sector bodies in their territories, or regional bodies in which entities on their territories are members.

It is argued here that the concepts of 'non-governmental entities' and 'regional bodies' in Article 13 should be interpreted to include private sector bodies at subnational and transnational level, to take account of the rapid proliferation of private sector standards. However, the extent of the obligation to take 'such reasonable measures as may be available' must be seen as limited. What is reasonable depends on the circumstances of the case, and in particular on the type of entity involved. The view espoused here is that it would not be appropriate to require Members to impose the existing disciplines of the SPS Agreement on private sector bodies, as they lay down requirements based on best practices of public regulatory authorities, not suitable for private sector bodies. While a 
Code of Good Practice for the SPS Agreement, with appropriate procedural disciplines to promote transparency, consultation and the recognition of equivalence should ideally be drafted, in view of the fact that agreement is unlikely to be reached on this, the Code of Good Practice of the TBT Agreement should be interpreted as applicable to private sector SPS standards.

Even if a Code of Good Practice were in place to discipline the procedural aspects of private sector standards, the burden of compliance with these standards remains high. Current practices with regard to the provision of technical assistance by vertically integrated companies that source their produce in developing countries lead to dependent relationships and the potential for abuse. Instead, effective and disinterested capacity building is called for to achieve sustainable and equitable results. In the meantime, a pragmatic approach to this problem could be the continued use of the multilateral forum provided by the SPS Committee to raise concrete examples of the challenges created by private sector standards, in an effort to stimulate private bodies to be responsive to developing-country Members' needs in the elaboration and implementation of their standards, and to spur donors to provide technical assistance.

Finally, the applicability of the SPS Agreement to all SPS measures still in force, including those enacted before the coming into force of the Agreement, is a double edged sword. On one side, it avoids 'grandfathering' pre-existing measures which would weaken the effectiveness of the SPS Agreement. On the other side, it creates the obligation on Members to revise their SPS measures that predate the SPS Agreement in order to ensure their conformity with its new rules. In Members with less advanced SPS regulatory systems, where the conduct of risk assessments and consideration of international standards was not a matter of course, this may be a heavy burden. On balance, however, this interpretation seems to be the preferable one. It is argued here, as elsewhere in this book, that the capacity constraints of Members at lower levels of development should be addressed through capacity building initiatives rather than by weakening the disciplines of the SPS Agreement, including through creating a wide exemption for pre-existing measures. It is certainly not to the advantage of developing-country Members to create a safe haven for the plethora of SPS measures that were already in place on 1 January 1995, particularly in developed-country Members. The most lucrative markets for agricultural and food products are, at the same time, those on which SPS measures have a long history and a vigorous application. Holding pre-existing SPS measures to the same scientific standards as new SPS measures brings some much-needed discipline to this area. 


\section{CHAPTER 3 \\ Basic principles}

The basic principles of the SPS Agreement are laid down in Article 2 thereof. These rules are then further elaborated on in subsequent Articles. Article 2 clearly embodies the underlying aim of the SPS Agreement, namely to balance the sovereign right of Members to take measures to protect health in their territories against SPS risks, with the goal of promoting free trade and preventing protectionism in the food and agricultural sector. Article 2, under the heading Basic Rights and Obligations, provides, in part, as follows: ${ }^{607}$

1. Members have the right to take sanitary and phytosanitary measures necessary for the protection of human, animal or plant life or health, provided that such measures are not inconsistent with the provisions of this Agreement.

2. Members shall ensure that any sanitary or phytosanitary measure is applied only to the extent necessary to protect human, animal or plant life or health, is based on scientific principles and is not maintained without sufficient scientific evidence, except as provided for in paragraph 7 of Article 5.

3. Members shall ensure that their sanitary and phytosanitary measures do not arbitrarily or unjustifiably discriminate between Members where identical or similar conditions prevail, including between their own territory and that of other Members. Sanitary and phytosanitary measures shall not be applied in a manner which would constitute a disguised restriction on international trade.

Three elements of Article 2 are significant to this discussion. First, the express recognition of the right of Members to take SPS measures in Article 2.1 is a crucial aspect of the SPS Agreement and forms a recognisable thread that runs throughout the rest of the Agreement. Second, the incorporation of familiar GATT disciplines requiring that health measures be limited to what is 'necessary' to achieve their aim in Article 2.2, and prohibiting arbitrary or unjustifiable discrimination and disguised trade restrictions in Article 2.3, provides an early indication of the fact that the SPS Agreement does not ignore but rather builds upon existing GATT rules in this area. Third, the inclusion of new scientific disciplines in Article 2.2 introduces an innovative element of the SPS Agreement, namely the use of science as the touchstone against which SPS measures are to be judged. These three elements will now be discussed further.

\subsection{Right to impose SPS measures}

As mentioned above, Article 2.1 of the SPS Agreement explicitly recognises the right of Members to take SPS measures necessary for the protection of human, plant or animal life or health, provided that they conform to the provisions of the SPS Agreement. This is significant as it represents a movement away from the approach under the GATT 1994

\footnotetext{
${ }^{607}$ Only the first three paragraphs of Article 2 are cited here. The fourth paragraph of Article 2, containing the presumption of conformity of SPS measures that comply with the SPS Agreement with the GATT 1994, has been cited and discussed above, Part III, Section 2.4.2.
} 
where health measures that discriminate against imports or are quantitative restrictions (including bans) are, in principle, prohibited unless they can be justified under the health exception provided in Article XX(b) of the GATT. Thus, under the GATT, the burden of proof rests on the Member imposing the measure to show that it meets the requirements of Article XX(b) and its chapeau. In contrast, in terms of Article 2.1 of the SPS Agreement it is clear that SPS measures are, in principle, allowed and it is for the complaining Member to prove that the relevant SPS measure does not comply with the disciplines of the SPS Agreement. This fact has important consequences for disputes under the SPS Agreement since these disputes typically raise difficult and complex issues of fact and scientific evidence. ${ }^{608}$ Thus, the question of who bears the burden of proof could have a fundamental impact on the outcome of a dispute. ${ }^{609}$

However, the undisputed right of Members to impose SPS measures, as recognised in the SPS Agreement, is not unlimited but is subject to the disciplines set out in the rest of the Agreement. These disciplines can usefully be seen as falling into two categories: first, the familiar GATT trade disciplines, which are reiterated and elaborated upon in the SPS Agreement ${ }^{610}$ and second the new scientific disciplines on the use of SPS measures, introduced by the SPS Agreement.

The disciplines limiting the exercise of the right to impose SPS measures find their first reflection in paragraphs 2 and 3 of Article 2 and are further fleshed out in later provisions. Article 2 can thus be regarded as the basic rule, laying down the scientific disciplines as well as reiterating the usual GATT trade disciplines applicable to SPS measures, both of which are further specified in the rest of the SPS Agreement.

\subsection{Basic limits to the exercise of the right to impose SPS measures}

\subsubsection{Necessity}

The obligation on Members, contained in the first prong of Article 2.2, to ensure that SPS measures are applied 'only to the extent necessary to protect human, animal or plant life or health' reflects the well-known discipline contained in Article XX(b) of the GATT 1994, requiring that a measure be 'necessary to protect human, animal or plant life or health' in order to be justified as an exception to other GATT rules. This requirement of Article 2.2 has not yet been addressed in dispute settlement. In most cases complaining parties in disputes under the SPS Agreement seem to have readily accepted that the SPS measures in dispute meet this requirement, or have addressed their challenges to the later provision of the SPS Agreement which could be regarded as a further specification of this rule, namely Article 5.6. ${ }^{611}$ Article 5.6 embodies the 'least trade-restrictive' test that

\footnotetext{
608 This was recognised in Appellate Body Report, EC-Hormones, para. 97.

${ }^{609}$ The burden of proof under the SPS Agreement is discussed below, Part IV, Section 2.2.2.

${ }^{610}$ The prohibition on arbitrary or unjustifiable discrimination and disguised restrictions on trade is contained in the chapeau of Article XX of GATT 1994 and the necessity test in paragraph (b) of that Article.

${ }^{611}$ Exceptions to this are the complaints of Argentina and Canada in EC-Approval and Marketing of Biotech Products, which did raise challenges to under the 'necessary' requirement of Article 2.2. As the Panel had found the EC's general de facto moratorium and product specific measures not to be 'SPS measures', it found
} 
is characteristic of the interpretation of the 'necessary' requirement in Article XX(b) of the GATT. ${ }^{612}$ However, while the first prong of Article 2.2 refers to the application of SPS measures, Article 5.6 refers to the adoption or maintenance of SPS measures, thus arguably applying the 'necessary' requirement to different aspects of SPS regulation.

It is likely that cases decided under Article XX(b) of the GATT 1994 will usefully be examined by panels and the Appellate Body in future cases dealing with the first prong of Article 2.2 of the SPS Agreement, to find guidance for the interpretation of this discipline, due to the similarity in their wording. ${ }^{613}$ It should, however, be borne in mind that while under the GATT Article XX(b) represents an exception to the normal disciplines, and thus the burden of proof to show that its requirements were met rests on the Member imposing the health measure, under the SPS Agreement this rule-exception relationship is not present. Thus, it is for the complaining Member to prove that the 'necessary' requirement of Article 2.2 of the SPS Agreement has not been complied with. This results in greater respect for the regulatory choices of a Member than is reflected in GATT rules. ${ }^{614}$ In addition, and more importantly, reliance on the interpretation of GATT rules must be tempered by the realisation that the SPS Agreement is more than a mere clarification of Article $\mathrm{XX}(\mathrm{b})$ of the GATT. Instead the object and purpose of the SPS Agreement is to go further than this in creating additional disciplines, while recognising the right of Members to regulate. The careful balance achieved by the provisions of the SPS Agreement must not be disturbed through a wholesale incorporation of interpretations of the relevant GATT rules into the interpretation of its Articles. In each case, the suitability of the GATT interpretation must be assessed in the light of the 'balancing act' that is the object and purpose of the SPS Agreement. As argued above, an appropriate balance between trade and health in the SPS Agreement is in the interest of WTO Members at all levels of development. ${ }^{615}$

From the discussion in Chapter 1 of the requirements to prove that a measure is 'necessary to protect human, animal or plant life or health' in the case law under Article XX(b) of the GATT 1994, ${ }^{616}$ it appears that the policy area addressed by the measure must fall within the ambit of health protection, and a scientifically identifiable risk must be present, to indicate that the measure really is 'designed to protect human, animal or plant life or health' ${ }^{617}$ However, in the SPS Agreement both these elements have been elaborated

that Article 2.2 was not applicable to these measures. With regard to the Member States' safeguard measures, having already found a violation of Article 5.1 of the SPS Agreement, the Panel exercised judicial economy with regard to the Article 2.2 claim. Panel Report, EC-Approval and Marketing of Biotech Products, paras 7.1430-7.1434, 7.1758-7.1759 and 7.3394.

${ }^{612}$ As discussed above, Part III, Section 1.1.1.

${ }^{613}$ The likelihood that a similar interpretation will be followed can be inferred from the presumption in Article 2.4 of the SPS Agreement that measures conforming to the SPS Agreement are in accordance with GATT obligations, in particular Article XX(b), as discussed above, Part III, Section 2.4.2. This shows the intention of the drafters to subsume the existing GATT disciplines into the SPS Agreement.

${ }^{614}$ Frank Garcia states with regard to the shift in burden of proof to the complaining Member in Article 2.2 of the SPS Agreement: 'Shifting the burden in this manner results in a regime that is overall more protective of Member's SPS choices.' Frank J. Garcia, 'The Salmon Case: Evolution of Balancing Mechanisms for NonTrade Values in WTO', in Trade and Human Health and Safety, George A. Bermann and Petros C. Mavroidis (eds.) (Cambridge University Press, Cambridge), 2006, 133-152, 140.

${ }^{615}$ See the discussion in the Introduction to this book, above.

${ }^{616}$ See above, Part III, Section 1.1.1.

${ }^{617}$ Panel Report, EC-Asbestos, para. 8.170. 
upon in other provisions. The definition of SPS measures ${ }^{618}$ ensures that the measures aim at specific health protection objectives before they will fall under the SPS Agreement at all. ${ }^{619}$ The obligation of scientific justification for a measure is contained in the second and third prongs of Article 2.2, in Article 3.3 and in Article 5 of the SPS Agreement. ${ }^{620}$ It would thus seem that the second element of the GATT Article XX(b) requirements, namely the 'necessary' test, is more significant for the interpretation of the obligation in the first prong of Article 2.2 of the SPS Agreement and is useful to examine for purposes of analogous interpretation of Article 2.2 of the SPS Agreement.

The 'weighing and balancing' approach developed in the case law on Article XX of the GATT 1994 in interpreting the 'necessary' requirement is relevant here. As discussed above, ${ }^{621}$ under this approach, the importance of the protected value, the trade restrictiveness of the measure and the extent of the contribution of the measure to the objective to be achieved are weighed and balanced against each other in order to establish whether an alternative, less trade-restrictive measure is reasonably available to achieve the policy objective of the imposing Member. This introduces an element of strong proportionalitytesting into the 'necessary' requirement. The question arises whether such a proportionality test is appropriate in the context of the SPS Agreement. SPS measures, by virtue of their definition, necessarily aim to protect life or health against specified risks. The importance of the objective of the measure in the case of SPS measures is always great, but it can be argued that this would be more the case when human health is at stake, than when risks to animals or plants from pests or diseases are at issue. Further, within these categories, there are also degrees of seriousness of risks. The less serious the health risk, the stricter the measure or the less it contributes to the end sought to be achieved, the easier it would be for a complaining Member to show that the extent of application of the relevant measure is not necessary under a weighing and balancing approach. However, a panel's evaluation of the seriousness of the risk and its weighing of this against the trade restrictiveness of the application of the measure should not be allowed to undermine the policy space left by the SPS Agreement to Members. As will be seen below, the SPS Agreement allows a Member, once a risk is proven, to decide for itself how serious it regards this risk to be, and therefore what level of protection against such risk it deems appropriate on its territory. The measure it adopts is therefore only limited in Article 5.6 to the least

\footnotetext{
${ }^{618}$ See above, Part III, Section 2.1.1.

619 This definition, contained in Annex A.1 of the SPS Agreement, is narrower than the general health policy objective covered by Article XX(b) of the GATT 1994. However, unlike the case with Article XX(b) of the GATT, the fact that a measure is not covered by one of the enumerated objectives in Annex A.1 of the SPS Agreement does not mean the measure is in violation of the Agreement, but only that it falls outside its scope.

${ }^{620}$ The scientific requirement in Article 5.1 of the SPS Agreement goes further than that in Article XX(b) of the GATT, in that it requires that the measure be based on a risk assessment. The Panel in EC-Asbestos prudently refrained from interpreting the proof of risk it read into Article XX(b) of the GATT as requiring a risk assessment, preferring 'to confine itself to the provisions of the GATT 1994 and to the criteria defined by the practice relating to the application of Article XX.' Panel Report, EC-Asbestos, para. 8.180. This approach is to be commended, since the SPS Agreement goes further than the GATT in creating additional disciplines applicable to a discrete set of measures, namely those defined as 'SPS measures' in Annex A.1. To read these additional disciplines into Article XX(b) of the GATT would go against the clear intention of the drafters to limit the scope of application of the SPS Agreement to the defined measures rather than make it generally applicable to all health measures.

${ }^{621}$ See above, Part III, Section 1.1.1.
} 
trade-restrictive measure that achieves the level of protection chosen by the Member. ${ }^{622}$ This has been termed a 'weak proportionality' requirement as this type of proportionality does not open to question a Member's autonomy in establishing its appropriate level of protection. ${ }^{623}$ Similarly, the necessity test of Article 2.2 should be interpreted as requiring that the SPS measure be applied to the least trade-restrictive extent that achieves the level of protection chosen by the Member. Such an interpretation would safeguard the balance between trade and health aimed at by the SPS Agreement. ${ }^{624}$

The relationship between the first prong of Article 2.2 and Article 5.6 was addressed by the Panel in Japan - Agricultural Products II, which found that Article 5.6 should be read together with Article 2.2. ${ }^{625}$ In EC - Approval and Marketing of Biotech Products, the Panel also noted that the two provisions must be read together, Article 5.6 constituting a more specific application of the requirement in the first prong of Article 2.2. ${ }^{626}$ This would entail that a violation of Article 5.6 necessarily implies a violation of the first prong of Article 2.2, but the reverse is not true. ${ }^{627}$ However, as stated above, Article 2.2 makes the 'necessary' requirement applicable to the extent of application of an SPS measure, unlike Article 5.6 which relates to the adoption or maintenance of the measure. Nevertheless, it is clear that Members prefer to challenge SPS measures under the more specific later discipline of Article 5.6 of the SPS Agreement. It is therefore unlikely that the first prong of Article 2.2 will gain more prominence in future disputes under the SPS Agreement.

\footnotetext{
${ }^{622}$ Note that another example of cross fertilisation between the Article XX of the GATT and the SPS Agreement is the recognition that Members are free to choose their own level of protection also under GATT rules. See for example, the Appellate Body's statement in EC-Asbestos that: 'it is undisputed that WTO Members have the right to determine the level of protection of health that they consider appropriate in a given situation.' Appellate Body Report, EC-Asbestos, para. 168.

${ }^{623}$ Joanne Scott, The WTO Agreement on Sanitary and Phytosanitary Measures: A Commentary, Oxford Commentaries on the GATT/WTO Agreements (Oxford University Press, Oxford), 2007, 159. A weak proportionality test entails an examination of the 'suitability' of the measure (i.e. its effectiveness in achieving its objective) and the existence of a less trade restrictive alternative that meets the objective of the measure. By contrast, a strong proportionality test involves an examination of whether the trade restrictive effects of the measure are disproportionate or excessive in relation to the importance of the objective it pursues. On the definition of proportionality and its reflection in WTO law, see Peter Van den Bossche, 'Looking for Proportionality in WTO Law', Legal Issues of Economic Integration 35 (3), 2008, 283-294.

${ }^{624}$ It is useful to recall here that, since the coming into force of the SPS Agreement and in line with its provisions, the 'necessary' test of Article XX(b) of the GATT 1994 has been interpreted not to require a Member to employ any alternative measure that would prevent it from achieving its chosen level of protection. See above, Part III, Section 1.1.1. See also Appellate Body Report, EC-Asbestos, para. 174; and Appellate Body Report, Brazil - Retreaded Tyres, para. 156. However, this may be undermined by the manner in which the weighing and balancing test has been applied, as discussed above, in the abovenmentioned Section.

${ }^{625}$ Panel Report, Japan - Agricultural Products II, para. 8.71.

${ }^{626}$ Panel Reports, EC-Approval and Marketing of Biotech Products, para. 7.1430.

${ }^{627}$ This is deduced by analogy to the finding of the Appellate Body with regard to a similar relationship between Article 2.2, third sentence, and Article 5.1 of the SPS Agreement, set out below, Part III, Section 3.2.3. Appellate Body Report, EC - Hormones, para. 180 and Appellate Body Report, Australia -Salmon, para. 137.
} 


\subsubsection{Prohibition on arbitrary or unjustifiable discrimination or disguised restrictions on trade}

Another familiar trade discipline incorporated into the SPS Agreement is that contained in Article 2.3 of the SPS Agreement, cited above. ${ }^{628}$ This Article embodies a general nondiscrimination rule, combining the most favoured nation treatment and national treatment obligations of Articles I and III of the GATT with the prohibition on arbitrary or unjustifiable discrimination and disguised restrictions on trade of the chapeau of Article XX of the GATT. In this regard, the Appellate Body in Australia - Salmon held:

This provision takes up obligations similar to those arising under Article I:1 and Article III:4 of the GATT 1994 and incorporates part of the "chapeau" to Article XX of the GATT 1994. Its fundamental importance in the context of the SPS Agreement is reflected in the first paragraph of the preamble of the SPS Agreement. ${ }^{629}$

An important difference exists between Article 2.3 and the relevant GATT provisions. A rule-exception relationship exists between Articles I and III:4 of the GATT, on the one hand, and Article XX of the GATT, on the other, whereby discriminatory measures are prohibited in principle but may be justified under an exception provided that they are not applied so as to constitute arbitrary or unjustifiable discrimination or a disguised trade restriction. By contrast, the prohibition of Article 2.3 of the SPS Agreement itself incorporates flexibility for justified measures. Measures that are applied in dissimilar situations or whose discriminatory effects are justified are simply not caught by the Article 2.3 prohibition. The burden of proof is therefore on the complaining party to show that all the requirements for violation of Article 2.3 are met.

The two sentences of Article 2.3 contain separate obligations. The first sentence prohibits SPS measures that arbitrarily or unjustifiably discriminate between Members where identical or similar conditions prevail, whereas the second sentence prohibits the application of an SPS measure in a manner that would constitute a disguised restriction on trade.

It is necessary to examine how a violation of Article 2.3, first sentence, can be established. This issue was raised before the Panel in Australia - Salmon (Article 21.5 - Canada). In that case, Canada claimed that Article 2.3, first sentence, was violated as Australia imposed import requirements for salmonids from Canada but had no internal control measures in place regarding the internal movement of dead, Australian fish, constituting discrimination between Canada and Australia. The compliance Panel identified the requirements for proof of violation of Article 2.3 as follows:

[T]hree elements, cumulative in nature, are required for a violation of this provision:

(1) the measure discriminates between the territories of Members other than the Member imposing the measure, or between the territory of the Member imposing the measure and that of another Member;

\footnotetext{
${ }^{628}$ See above, in the introductory paragraphs of Part III, Chapter 3.

${ }^{629}$ Appellate Body Report, Australia-Salmon, para. 251.
} 
(2) the discrimination is arbitrary or unjustifiable; and

(3) identical or similar conditions prevail in the territory of the Members compared. ${ }^{630}$

In respect of the first of these three elements, the Panel held that, given the finding of the Panel and Appellate Body in the original dispute that discrimination contrary to Article 5.5 by implication entails discrimination contrary to Article 2.3, first sentence; and that under Article 5.5 different situations including different products can be compared, discrimination under Article 2.3, first sentence includes discrimination between different products. In other words, not only discrimination between Canadian salmon and New Zealand salmon or between Canadian salmon and Australian salmon is covered but also discrimination between Canadian salmon and other Australian fish including non-salmonids. ${ }^{631}$

Therefore Article 2.3, first sentence, prohibits not only discrimination between 'like products' but also between different products (in this case salmonids from Canada and other dead fish from Australia). This represents a significant deviation from the position under GATT 1994, which only prohibits discrimination between 'like'632 or 'directly competitive or substitutable ${ }^{933}$ products. The aim of this broader prohibition on discrimination is to take into account the fact that different products can pose the same or similar health risks. One could think here of the possibility that different chemicals may be equally carcinogenic, diverse fruits may be vectors for fruit flies, or various animals can be carriers of foot-and-mouth disease. As a result, one would expect a Member that truly aims to protect against a particular health risk through its SPS measure, to take similar measures to address other similar risks in comparable situations. Not to do so calls into question the reasons behind its measure. The prohibition in Article 2.3 thus does not only aim at ensuring equal opportunities for products that are in a competitive relationship on the market, but is broader, distinguishing health protection from protectionism by filtering out measures whose health protection objectives are doubtful.

The breadth of this prohibition on discrimination is tempered by the second and third cumulative requirements for a violation of the first sentence of Article 2.3, namely that the discrimination must be arbitrary or unjustifiable and that identical or similar conditions must prevail in the territories of the Members subject to different treatment. In line with the interpretation of the term 'arbitrary or unjustifiable discrimination' in the case law on the chapeau of Article XX of the GATT 1994, discussed above, ${ }^{634}$ it is likely that under the second requirement for a violation of Article 2.3, first sentence, different treatment will be considered not to be arbitrary or unjustifiable where it can be explained by a rationale that is directly related to the objective of the measure in addressing SPS risks. ${ }^{635}$

\footnotetext{
${ }^{630}$ Panel Report, Australia - Salmon (Article 21.5 Canada), para 7.111.

${ }^{631}$ Ibid., para. 7.112.

${ }^{632}$ Article I:1 (most favoured nation treatment) and Article III:2, first sentence, and III:4 (national treatment) of the GATT 1994.

${ }^{633}$ Article III:2, second sentence of the GATT 1994, read together with the Ad Note thereto (in respect of taxes).

${ }^{634}$ See above, Part III, Section 1.1.1.

${ }^{635}$ Appellate Body Report, Brazil Retreaded Tyres, para. 227. Although the Appellate Body's assessment of the rationale of the discrimination in this case referred to the contribution of the discrimination to the achievement of the legitimate objective provisionally found to justify the measure at issue under one of the
} 
Likewise, pertinent differences in conditions under the third requirement should be understood in relation to the SPS risk addressed, including those relevant to the disease status of the Members compared. In this regard, the Panel in Australia - Salmon (Article 21.5 - Canada) expressed its doubts whether 'identical or similar conditions' prevailed in the territories of both Canada and Australia in respect of the situations compared, particularly in light of the 'substantial difference in disease status between Canada and Australia'. ${ }^{636}$ Consequently, the Panel found no violation of Article 2.3 in that case. ${ }^{637}$ Other relevant differences are likely to include dissimilar climatic or geographical conditions that affect the incidence or spread of pests and diseases, variations in the regulatory controls in place to minimise the risks, divergent dietary habits etc.

An example of an SPS concern, frequently raised by exporting Members at lower levels of development, that is liable to escape the discipline of the first sentence of Article 2.3 is the fact that importing Members tend to apply more rigorous control and inspection requirements when it comes to products from these exporting Members. If such different treatment can be justified on the basis of the weak SPS regulatory controls in the exporting Member, it cannot be regarded as arbitrary or unjustifiable and neither can the conditions in the Members compared be regarded as 'similar or identical'. While this makes Article 2.3 less useful in these situations, the alternative is unfeasible. SPS measures necessarily distinguish between the territories of different exporting Members or between the territory of the importing Member and other Members, in response to differences in risk. Creating an absolute prohibition on such discrimination is unthinkable, as it would undermine the ability of a Member to ensure the level of SPS protection it deems appropriate. Only where such discrimination is not motivated by factors related to the SPS objective of the measure, and where the conditions in the Members compared relevant to the SPS risk at issue are similar or identical, is the measure in violation of Article 2.3.

The second sentence of Article 2.3 embodies the prohibition on the application of SPS measure in a manner constituting a disguised restriction on trade. Like the chapeau of Article XX of the GATT 1994, this prohibition deals with the manner of application of a measure, rather than the measure itself. In the absence of case law on this provision, the interpretation of the similar requirement in the chapeau of Article XX can shed some light on its meaning. As stated above, ${ }^{638}$ the Appellate Body in US - Gasoline held that the same kind of considerations relevant to the question whether there is arbitrary or unjustifiable discrimination may be taken into account in determining whether there is a disguised restriction on trade. ${ }^{639}$ The purpose of the examination is to ascertain whether the ostensible health objective of the measure is 'only a disguise to conceal the pursuit of trade-restrictive objectives. ${ }^{640}$ This is determined by looking at the design, structure and

paragraphs of Article XX of the GATT 1994, the different structure of the SPS Agreement entails that the rationale of the discrimination at issue should be assessed instead against the relevant SPS objective of the measure as defined in Annex A.1 of the SPS Agreement.

${ }^{636}$ Panel Report, Australia - Salmon (Article 21.5 - Canada), para. 7.113.

${ }^{637}$ Ibid., para. 7.114.

${ }^{638}$ See above, Part III, Section 1.1.1.

${ }^{639}$ Appellate Body Report, US - Gasoline, 23.

${ }^{640}$ Panel Report, EC - Asbestos, para. 8.236. Note however that unlike the chapeau of Article XX of the GATT 1994, which has the role of preventing abuse of the exceptions of Article XX through the application of the measures provisionally justified under one of its paragraphs, the obligations of Article 2.3 apply 
architecture of the measure, rather than by trying to establish the subjective intent of the regulator. ${ }^{641}$

An example of a dispute in which Article 2.3 of the SPS Agreement was raised is that initiated by Ecuador in 2001 against Turkey's application of its import procedures for fresh fruit to bananas. ${ }^{642}$ Ecuador alleged that the manner in which Turkey applied its Control Certificate system to bananas discriminated between domestic and imported bananas and constituted a disguised restriction on trade contrary to Article 2.3. Turkey's import procedures required an importer to obtain a Control Certificate from the Turkish Ministry of Agriculture and Rural Affairs, in order to be able to request the SPS clearance certificate necessary for market access. These Control Certificates were previously issued promptly and for the quantity requested, relying on the correctness of reports of analyses with regard to pesticide residues and phytosanitary conditions submitted by the exporters. However, since November 1999, Turkey issued Control Certificates only for limited quantities, for limited periods and with considerable delays. ${ }^{643}$ Ecuador was of the view that the limited quantities were too small compared to the normal size of a banana shipment, and that the system was applied in a way designed to restrict the entry of Ecuadorian bananas into the Turkish market. ${ }^{644}$ Turkey claimed instead that the new system was motivated by the fact that analyses conducted in Turkey had shown discrepancies with the analysis reports submitted by exporters, thus obliging Turkey to undertake laboratory analyses of imports. According to Turkey, the limited quantities allowed under the Control Certificates were justified by the fact that the Turkish agency with responsibility for inspection and control of food imports had only 15 laboratories at its disposal, only five of which could test for pesticide residues. ${ }^{645}$ These resource constraints meant that Turkey could not verify whole shipments of bananas at once as this would occupy a laboratory for a considerable time and Turkey would face complaints from other food ex-

independently. Like all the disciplines of the SPS Agreement, they aim to balance the right of a Member to enact and apply necessary SPS measures with the need to liberalise trade in food and agricultural products.

${ }^{641}$ Panel Report, EC - Asbestos, para. 8.236. See also above, Part III, Section 1.1.1.

${ }^{642}$ Dispute Settlement Body, Turkey - Certain Import Procedures for Fresh Fruit. Request for Consultations by Ecuador, WT/DS237/1, G/L/472, G/SPS/GEN/276, G/LIC/D/33, G/AG/GEN/48, S/L/101, circulated on 10 September 2001. In its request for consultations, Ecuador also alleged violations of Article 8 and Annexes B and C of the SPS Agreement, as well as certain provisions of the GATT 1994, the Agreement on Import Licensing Procedures, the Agreement on Agriculture, and the GATS.

${ }^{643}$ Whereas previously Control Certificates were issued for shipments of up to a million boxes, under the new system a maximum of 52000 boxes were covered by a Control Certificate. Committee on Sanitary and Phytosanitary Measures, Turkish SPS Measures Applied to Importation of Bananas - Replies from Turkey, G/ SPS/GEN/275, circulated on 24 August 2001, para. 4.

${ }^{644}$ Committee on Sanitary and Phytosanitary Measures, Summary of the Meeting Held on 14-15 March: Note by the Secretariat, G/SPS/R/21, circulated on 22 May 2001, para. 98.

${ }^{645}$ Committee on Sanitary and Phytosanitary Measures, Turkish SPS Measures Applied to Importation of Bananas - Replies from Turkey, G/SPS/GEN/275, circulated on 24 August 2001, para. 4. Turkey clarified that the shipment size limitations in its Control Certificates were not intended to limit import quantities, otherwise it would not have issued many permits to the same firms, which are importing Ecuadorian bananas. In addition, Turkey pointed out that its banana imports had not dropped to a level below the average of previous years. Instead, Turkey stated that the quantities provided for in the Control Certificates were determined according to the infrastructure and capacity of existing laboratories. Committee on Sanitary and Phytosanitary Measures, Turkish SPS Measures Applied to Importation of Bananas - Replies from Turkey, G/ SPS/GEN/275, circulated on 24 August 2001, paras 4 and 7. 
porters due to delays in issuing Control Certificates. ${ }^{646}$ In addition, Turkey stated that additional delays in issuing Control Certificates for Ecuadorian bananas were due to the fact that the pesticide residue reports provided by Ecuador included pesticides not covered by CAC standards or Turkish MRLs, necessitating additional testing. Turkey countered Ecuador's claim of discrimination in favour of domestic producers, ${ }^{647}$ by clarifying that the same requirements with regard to pesticide levels applied to domestic bananas, but these were tested for compliance by laboratory analyses during their production process. Due to the fact that the production stages of imported products could not be monitored by Turkey, it applied controls at the importation stage. As the consultations failed to resolve the dispute, Ecuador requested the establishment of a panel. ${ }^{648}$ However, a panel was never established to hear this dispute as Ecuador and Turkey were able to reach a mutually agreed solution, in which Turkey agreed to issue Control Certificates for the quantities requested by importers and for amended validity periods. ${ }^{649}$ Nevertheless, had a panel heard this dispute, it does not appear from the information available that a violation of Article 2.3 would have been found. The additional requirements applied by Turkey to imported bananas in the face of the unreliable analysis reports submitted by exporters and its inability to carry out controls at foreign production sites seem justifiable. In addition, the limitations on the shipment sizes laid down in its Control Certificates cannot be seen as a disguised restriction on trade since they seem to be a consequence of its limited laboratory capacity. An example of a situation where a trade concern raised under Article 2.3 related to a measure indeed caught by this prohibition, and was successfully pursued, was provided in Part II above. ${ }^{650}$ This example relates to Australia's prohibition on sauces from the Philippines containing benzoic acid. At the core of this trade concern was the Philippines argument that by prohibiting sauces containing benzoic acid from the Philippines, but allowing such sauces from New Zealand, Australia was violating Article 2.3 of the SPS Agreement. Australia justified its discriminatory treatment by pointing to the reason that New Zealand's sauces were granted import permission, despite their benzoic acid content. This was due to the transitional arrangements pending the finalisation of a new joint food code between Australia and New Zealand. ${ }^{651}$ In response, the Philippines stated: 'There is nothing in the [SPS] Agreement which grants a grace period for discriminatory practices under "transitional arrangements". In our view, the only just remedy for this case is the immediate lifting of the ban.' ${ }^{652}$ While Australia did not immediately lift the ban, in 1999 it confirmed that the new Australia New Zealand

${ }^{646}$ Committee on Sanitary and Phytosanitary Measures, Summary of the Meeting Held on 14-15 March: Note by the Secretariat, G/SPS/R/21, circulated on 22 May 2001, para. 98.

${ }^{647}$ Ecuador had alleged that Turkey failed to apply a testing and certification requirement to domestic bananas and to allocate its laboratory capacity appropriately between domestic and foreign banana producers. According to Ecuador, Turkey's procedures were applied in a manner constituting a disguised restriction on trade. Dispute Settlement Body, Turkey - Certain Import Procedures for Fresh Fruit. Request for the Establishment of a Panel by Ecuador, WT/DS237/3, circulated on 14 June 2002.

648 Ibid.

649 Dispute Settlement Body, Turkey - Certain Import Procedures for Fresh Fruit. Notification of Mutually Agreed Solution, WT/DS237/4, circulated on 29 November 2002.

${ }^{650}$ See above, Part II, Section 2.4.2.2.

${ }^{651}$ The joint food code between Australia and New Zealand is discussed above, Part II, Section 2.4.2.1.

${ }^{652}$ Committee on Sanitary and Phytosanitary Measures, Australian Import on Sauces Containing Benzoic Acid: Statement by Philippines at the Meeting of 11-12 November 1998, G/SPS/GEN/106, circulated on 23 November 1998. 
Food Standards Code would allow benzoic acid as an additive in food. In 2000, Australia reported that a tolerance level of $1000 \mathrm{mg} / \mathrm{kg}$ for benzoates in sauces had been laid down in the Code and applied to all products sold on the Australian market, regardless of their origin. The Philippines confirmed that no detention of Philippines sauces had occurred since June $2000 .^{653}$ This example illustrates, as correctly argued by the Philippines, that the grounds for justification of discriminatory treatment under Article 2.3 do not include considerations unrelated to the risk at issue. Therefore, transitional arrangements between Australia and New Zealand cannot be seen as eliminating the 'arbitrary and unjustifiable' nature of the discrimination in place.

As has been stated above, Article 2 lays down core disciplines which are further specified in later Articles. In this way, the prohibition contained in Article 2.3 is reflected again in Article 5.5, which proscribes arbitrary or unjustifiable distinctions in the levels of protection that a Member deems appropriate. The relationship between these two Articles therefore deserves attention here.

The Panel and Appellate Body in EC - Hormones found that Article 5.5 must be read together with the basic obligation of Members to avoid discrimination and disguised restrictions on trade in Article 2.3. ${ }^{654}$ The Appellate Body in EC-Hormones held that an important part of the context for the interpretation of Article 5.5 is Article 2.3 of the SPS Agreement. It stated:

When read together with Article 2.3, Article 5.5 may be seen to be marking out and elaborating a particular route leading to the same destination set out in Article 2.3. ${ }^{655}$

When dealing with Article 5.5, the Appellate Body in EC - Hormones stated the following regarding Article 2.3:

It is well to bear in mind that, after all, the difference in levels of protection that is characterizable as arbitrary or unjustifiable is only an element of (indirect) proof that a Member may actually be applying an SPS measure in a manner that discriminates between Members or constitutes a disguised restriction on international trade, prohibited by the basic obligations set out in Article 2.3 of the SPS Agreement. ${ }^{656}$

In Australia - Salmon, the issue of the relationship between Articles 2.3 and 5.5 was raised before the Appellate Body by Canada, which argued that the Panel had erred in only applying Article 2.3 through Article 5.5 and not independently. The Appellate Body found that the Panel had not intended to deny that Article 2.3 contains an obligation independent of Article $5.5^{657}$ but had merely refrained from addressing Article 2.3 separately

${ }^{653}$ Committee on Sanitary and Phytosanitary Measures, Summary of the Meeting Held on 31 October-1 November 2001. Note by the Secretariat, G/SPS/R/25, circulated on 18 January 2002, para. 36.

${ }^{654}$ Appellate Body Report, EC-Hormones, para. 212.

655 Ibid.

${ }^{656}$ Appellate Body Report, EC-Hormones, para. 240.

${ }^{657}$ Appellate Body Report, Australia - Salmon, para. 248. The Appellate Body here quoted the Panel's finding that 'given the more general character of Article 2.3, not all violations of Article 2.3 are covered by Article 5.5.' Panel Report, Australia - Salmon, para. 8.109. 
on grounds of judicial economy. Further discussing the relationship between Articles 2.3 and 5.5, the Appellate Body in Australia - Salmon held:

We recall that the third - and decisive - element of Article 5.5, discussed above, requires a finding that the SPS measure which embodies arbitrary or unjustifiable distinctions in levels of protection results in "discrimination or a disguised restriction on international trade". Therefore, a finding of violation of Article 5.5 will necessarily imply a violation of Article 2.3, first sentence, or Article 2.3, second sentence. Discrimination "between Members, including their own territory and that of others Members" within the meaning of Article 2.3, first sentence, can be established by following the complex and indirect route worked out and elaborated by Article 5.5. However, it is clear that this route is not the only route leading to a finding that an SPS measure constitutes arbitrary or unjustifiable discrimination according to Article 2.3, first sentence. Arbitrary or unjustifiable discrimination in the sense of Article 2.3, first sentence, can be found to exist without any examination under Article 5.5. ${ }^{658}$

It is therefore clear that Article 2.3 contains disciplines broader than those embodied in Article 5.5 and thus a violation thereof may be found independently of a violation of Article 5.5. In particular, it is useful to note that the discrimination addressed in Article 5.5 is limited to that embodied in the choice of a level of protection, whereas Article 2.3 applies broadly to SPS measures in general.

\subsubsection{Basic scientific disciplines}

As mentioned before, an essential tool used by the SPS Agreement to distinguish between measures that aim at health protection and those that are disguised forms of protectionism is science. The first mention of scientific disciplines in the SPS Agreement is found in the second and third prongs of Article 2.2, which require that SPS measures be based on scientific principles and not be maintained without sufficient scientific evidence, except as provided for in Article 5.7.

As illustration of the potentially devastating effects of SPS measures that are unfounded on scientific evidence, is provided by the example of the EC's measures on Kenyan fish. Until 1996, the EC accounted for 62 percent of Kenya's fish exports. However, from 1997 Kenya was hard hit by a series of SPS measures adopted by the EC with regard to its fish exports. These measures included new testing requirements and bans as a precautionary response to the outbreak of cholera in Mozambique, Kenya, Uganda and Tanzania, ${ }^{659}$ as well as due to the EC's suspicion that Kenyan fishermen were using pesticide chemicals to catch fish by poisoning them. ${ }^{660}$ These EC measures remained in place for extended

\footnotetext{
${ }^{658}$ Appellate Body Report, Australia - Salmon, para. 252. In footnote, the Appellate Body cited its finding in EC - Hormones, para. 212, characterising Article 5.5 as 'marking out and elaborating a particular route leading to the same destination set out in Article 2.3'.

${ }^{659}$ The EC made a statement before the SPS Committee regarding its precautionary measures to address the cholera epidemic in Mozambique, Kenya, Uganda and Tanzania. See Committee on Sanitary and Phytosanitary Measures, Measures in Response to Cholera. Statement by the European Community at the Meeting on 12 and 13 March 1998, G/SPS/GEN/68, circulated on 18 March 1998.

${ }^{660}$ The COMESA Secretariat reports that the EU ban on fish exports from Kenya in 1998, due to the cholera
} 
periods, despite the absence of detectable chemical residues in the Kenyan fish exports, and the statements by the FAO and WHO that the risk of transmission of cholera from commercially imported fish is negligible. ${ }^{661}$ The resulting diversion of fish exports to other markets ${ }^{62}$ led to a sharp decrease in export revenue for the fishing industry, as prices offered on these other markets are significantly lower than those on the EU market. ${ }^{663}$ While, after four years, Kenya was able to meet the new EC requirements and gain market access for its fish exports, there have been significant socio-economic implications in

outbreak, led to a drop in Kenyan Nile perch exports of $66 \%$, corresponding to a $32 \%$ drop in value. The 20-month EU ban on fish exports from Kenya, under EU decision 99/253/EC of April 1999, due to fears of fish poisoning in Lake Victoria led to many fish factories closing down and affected an estimated 40000 artisan fishermen (a similar ban was applied to Uganda and Nigeria, but lifted earlier). A further $68 \%$ decline in fish exports resulted. COMESA Secretariat, Market Access Constraints (Common Market for Southern Africa, Lusaka), 2003, paras 62-64, available at: www.comesa.int/trade/multilateral/epa/Market $\% 20$ Access\%20Constraints/en, visited on 10 January 2008; Richard O. Abila, Food Safety in Food Security and Food Trade. Case Study: Kenyan Fish Exports (International Food Policy Research Institute, Washington D.C.), September 2003.

${ }^{661}$ The Director-General of the WHO, Dr Hiroshi Nakajima, sent a Note Verbale to the WHO member countries in 1998 stressing that although the bacterium that causes cholera is transmissible to humans through food, this usually occurs when individual travellers have transported food, usually seafood, across international borders and that the WHO has not documented an outbreak of cholera resulting from commercially imported food. 'Consequently, the placing of embargoes on the importation of food such as seafood, fresh water fish and vegetables is not an appropriate course of action to prevent the international spread of cholera, and can represent an additional burden on the economy of the affected countries.' 'Director-General Says Food Import Bans Are Inappropriate For Fighting Cholera' Press Release WHO/24, World Health Organization, 16 February 1998, available at: http://www.who.int/inf-pr-1998/en/pr98-24.html, visited on 9 November 2000. Information to this effect was also provided by the WHO to the SPS Committee. Committee on Sanitary and Phytosanitary Measures, Trade Restrictions in Response to Cholera. Submission by the World Health Organization, G/SPS/GEN/53, circulated on 20 February 1998. Similarly, the FAO issued a statement in 1998 noting that it did not consider the ban on fish exports from East African countries the most appropriate response to the cholera outbreak. It noted: 'Epidemiological data suggest that the risk of transmission of cholera from contaminated imported fish is negligible. Only rare and sporadic cases of cholera have occurred in developed countries as a result of eating fish transported across international borders by individuals.' 'FAO: Import Ban On Fish Products From Africa “Not The Most Appropriate Answer"' Press Release 98/21, Food and Agriculture Organization, 25 March 1998, available at: http://www.fao.org/waicent/ois/press_ne/ presseng/1998/pren9821.htm, visited on 9 November 2000.

${ }^{662}$ Israel became the main market for Kenyan fish, followed by other markets such as Japan, Singapore and the United Arab Emirates. Richard O. Abila, Food Safety in Food Security and Food Trade. Case Study: Kenyan Fish Exports (International Food Policy Research Institute, Washington D.C.), September 2003; Spencer Henson et al., 'Food Safety Requirements and Food Exports from Developing Countries: The Case of Fish Exports from Kenya to the European Union', American Journal of Agricultural Economics 82 (5), 2000, 1159-1169, 1164.

${ }^{663}$ Halima Noor, 'Sanitary and Phytosanitary Measures and Their Impact on Kenya', presented at the African Workshop on Standards and Trade (UNCTAD and IDRC, Kampala, Uganda) 13 September 2001, 7, available at: http://r0.unctad.org/trade_env/test1/meetings/standards/kenya3.pdf, visited on 5 January 2002. These lower prices were partly due to the fact that there are few alternative markets for fresh fish fillets and processors had to switch to production of frozen fillets, for which market prices are $60 \%$ lower. Spencer Henson et al., 'Food Safety Requirements and Food Exports from Developing Countries: The Case of Fish Exports from Kenya to the European Union', American Journal of Agricultural Economics 82 (5), 2000, 1159-1169, 1164. In addition, Abila points out that the increased distance of these new markets from Kenya led to reductions in profit margins. Richard O. Abila, Food Safety in Food Security and Food Trade. Case Study: Kenyan Fish Exports (International Food Policy Research Institute, Washington D.C.), September 2003. The report of the Blair Commission for Africa notes that the costs of compliance with EU hygiene requirements in the fisheries sector for Kenya were US\$ 0.5 million. Blair Commission for Africa, Our Common Interest, March 2005, 279, available at: http://213.225.140.43/english/report/thereport/cfafullreport.pdf, visited on 6 June 2005. 
Kenya. Fishermen have had to invest in new boats and cleaning and preservation facilities and many have been driven out of business by the high costs involved. Transporters have had to bear the costs of refrigerated trucks. Processors have been forced to restructure their facilities and production processes and several fish processing plants have been closed. ${ }^{664}$ The government has had to finance training on the new requirements for fishermen and other fisheries workers, set up laboratories and employ inspectors to monitor compliance. ${ }^{665}$ A study on the cost of upgrading a boat single landing site on Lake Victoria estimated this to be US\$1.2 million. ${ }^{666}$ In order to reduce costs of providing the necessary facilities, Kenya has decided that only five out of the previous 300 villages may be landing places for fish destined for export markets, meaning that fishermen from elsewhere bear high costs in bring their fish to the designated villages. ${ }^{667}$ In addition, the high costs in meeting EC standards makes the final product too expensive for the domestic market. Instead, these fish must be exported to recover costs. ${ }^{668}$ As all resources available to the fisheries sector are absorbed in meeting export standards, little effort goes to setting and enforcing safety standards for the domestic market and local consumers are exposed to potentially unsafe fish. ${ }^{669}$ In view of the absence of a scientific basis for the EC measure, one may wonder if these negative consequences could have been avoided by Kenya by reliance on the scientific disciplines of the SPS Agreement. ${ }^{670}$

${ }^{664}$ Henson et al note that this has had significant consequences for persons, mainly women, whose livelihoods depend on processing the skeletons and other waste products produced by processing plants. Spencer Henson et al., 'Food Safety Requirements and Food Exports from Developing Countries: The Case of Fish Exports from Kenya to the European Union', American Journal of Agricultural Economics 82 (5), 2000, 1159-1169, 1166.

${ }_{665}$ Richard O. Abila, Food Safety in Food Security and Food Trade. Case Study: Kenyan Fish Exports (International Food Policy Research Institute, Washington D.C.), September 2003.

${ }^{666}$ Spencer Henson et al., 'Food Safety Requirements and Food Exports from Developing Countries: The Case of Fish Exports from Kenya to the European Union', American Journal of Agricultural Economics 82 (5), 2000, 1159-1169.

${ }^{667}$ Abila notes that this creates room for middlemen to operate between villages and centralised landing points, running counter to the current efforts to reduce the influence of middlemen on the fishing industry. Richard O. Abila, Food Safety in Food Security and Food Trade. Case Study: Kenyan Fish Exports (International Food Policy Research Institute, Washington D.C.), September 2003. Henson et al point out that these changes, while helping to secure longer-term access to the EC market, increase fishermen's dependency on industrial fish processors, directly and via traders, and reduce their ability to negotiate the terms on which they trade. Spencer Henson et al., 'Food Safety Requirements and Food Exports from Developing Countries: The Case of Fish Exports from Kenya to the European Union', American Journal of Agricultural Economics 82 (5), 2000, 1159-1169, 1166.

${ }^{668}$ As Lake Victoria has a near-monopoly of Nile perch, perch prices can be raised to cover some of the costs of meeting EC standards. Richard O. Abila, Food Safety in Food Security and Food Trade. Case Study: Kenyan Fish Exports (International Food Policy Research Institute, Washington D.C.), September 2003.

${ }^{669}$ Ibid.

${ }^{670}$ It is interesting to note that Tanzania, one of the Members affected by the EC's measures in response to the cholera outbreak, raised a concern in this regard at the meeting of the SPS Committee in June 1998, stressing that tests had not found the bacteria concerned in fishery products from the four African countries affected. The EC responded that it had revised its measure, effective probably as of 1 July 1998, and that trade would be restored with the African countries concerned under these new requirements, since the EC was now convinced that the necessary guarantees were in place. The matter was reported 'partially resolved' due to the revision of the EC measure. Committee on Sanitary and Phytosanitary Measures, Specific Trade Concerns. Note by the Secretariat. Addendum. Issues Not Considered in 2007, G/SPS/GEN/204/Rev.8/Add.2, circulated on 27 March 2008, item 40. Notably, Kenya did not indicate its support for the Tanzanian concern, probably due to the fact that, as noted below, Part IV, Section 2.1, Kenya's resource constraints mean that it very rarely sends a delegate to meetings of the SPS Committee. Under the revised EC requirements, Kenya continued 
In an effort to avoid the introduction of SPS measures that are motivated by unfounded fears, or are imposed in response to domestic industry interests, Article 2.2 of the SPS Agreement introduces the use of science as the touchstone against which SPS measures will be judged. The importance of the basic scientific disciplines contained in Article 2.2, and further elaborated in Article 5.1, in mediating between the goals of health protection and the liberalisation of trade was made explicit in $E C$-Hormones, where the Appellate Body stated as follows:

The requirements of a risk assessment under Article 5.1, as well as of 'sufficient scientific evidence' under Article 2.2, are essential for the maintenance of the delicate and carefully negotiated balance in the SPS Agreement between the shared, but sometimes competing, interests of promoting international trade and of protecting the life and health of human beings. ${ }^{671}$

The centrality of science to the operation of the SPS Agreement is thus irrefutable - it is the scale on which the competing values of health protection and trade liberalisation are balanced. It is interesting to examine the way in which the SPS Agreement uses science to strike this balance, and to determine whether this is appropriate to the needs of Members across different levels of development.

The following analysis of the basic scientific discipline in Article 2.2 of the SPS Agreement must be conducted bearing in mind the preceding discussion on the role of science in regulation. ${ }^{672}$

\subsubsection{Meaning of 'scientific principles' and 'sufficient scientific evidence'}

At the crux of the scientific requirements of Article 2.2 is the question of the meaning of the terms 'scientific principles' and 'sufficient scientific evidence', with regard to the required scientific method, quantity of evidence and its quality or scientific validity. ${ }^{673}$ The terms themselves are rather imprecise and leave a lot of scope for interpretation, particularly as to what is entailed by 'scientific' principles or evidence and what would be regarded as 'sufficient'. Must a measure be supported by a preponderance of scientific evidence, or is the existence of any scientific support for the measure sufficient? The interpretation given to these scientific requirements is determinative not only for the intensity of the review to be applied by panels in assessing the scientific basis for a challenged SPS measure, ${ }^{674}$ but also for the level of scientific capacity demanded of Members by this obligation.

The Panel in Japan - Apples was the first to examine the meaning of the words 'scientific evidence' in Article 2.2. It held that in order to be 'scientific' the evidence must be gathered through scientific methods, ${ }^{675}$ and it favoured relying on scientifically produced evi-

to suffer a barrier to market access for another three years, until it was able to demonstrate compliance. The question whether the new EC requirements were scientifically justified was never raised.

${ }^{671}$ Appellate Body Report, EC - Hormones, para. 177.

${ }^{672}$ See above, Part II, Section 1.5.

${ }^{673}$ Dale E. McNiel, 'The First Case under the WTO's Sanitary and Phytosanitary Agreement: The European Union's Hormone Ban', Virginia Journal of International Law 39, 1998, 89-134, 117.

${ }^{674}$ On the issue of the standard of review to be applied by panels, see below, Part IV, Section 2.2.3.

${ }^{675}$ Panel Report, Japan - Apples, para. 8.92. 
dence rather than circumstantial evidence. ${ }^{676}$ In respect of the term 'evidence' the Panel noted that if they had intended that any material could be used, negotiators would have used the term 'information' as they did in Article 5.7 of the SPS Agreement. ${ }^{677}$ It also established that both direct and indirect evidence can be scientific, although the probative value ascribed to each would differ. ${ }^{678}$ According to the Panel, 'evidence' excludes insufficiently substantiated information and non-demonstrated hypotheses. ${ }^{679}$

The question then arises when scientific evidence will be regarded as 'sufficient' for purposes of Article 2.2. This issue arose in EC-Hormones, where the US claimed that the EC ban on hormone-treated beef was not based on scientific principles and was maintained without sufficient scientific evidence. The EC argued that many theories of science and 'scientific method' exist. ${ }^{680}$ According to the EC, SPS measures must be based on scientific principles as opposed to non-scientific ones, such as superstition, ${ }^{681}$ requiring only that the 'minimal attributes of scientific inquiry' be respected. ${ }^{622}$ The Panel in $E C-$ Hormones did not address this issue as it found violations of Articles 3 and 5 and thus did not consider it necessary to decide whether Article 2 was violated also. ${ }^{683}$ The Appellate Body agreed with this application of judicial economy, but expressed its surprise that the Panel did not follow the more 'logically attractive' approach of starting its analysis by focusing on Article 2, which sets out the basic rights and duties, before going on to Article 5 , which sets out more specific rules on risk assessment and the determination of an appropriate level of protection. ${ }^{684}$

The use of judicial economy in this case to avoid deciding on the central question of whether there was 'sufficient scientific evidence' for the EC measure was sharply criticised. ${ }^{685}$ It was argued by some that the Panel had deliberately sidestepped the sensitive

${ }^{676}$ Panel Report, Japan - Apples, para. 8.95, where the Panel quoted a statement to this effect by a panel expert. The Panel held that circumstantial evidence is useful if there is little direct evidence. Where there is a substantial body of direct evidence, circumstantial evidence should be considered in the light of the available scientific evidence.

${ }^{677}$ Ibid., para. 8.93 .

${ }^{678}$ According to the Panel the only difference between direct and indirect evidence is the degree of relationship between the evidence and the facts to be demonstrated. Therefore both may be considered but will have different probative value. Indirect evidence may be scientific even if it does not directly prove the facts. Ibid., paras 8.91 and 8.98-8.99.

${ }^{679}$ Ibid., para. 8.93 .

${ }^{680}$ Panel Report, EC - Hormones (US), para. IV.25. The EC stated that the U.S. definition could have been taken from a 1960s school textbook.

${ }^{681}$ Panel Report, EC - Hormones (US), para. IV.25; Panel Report, EC-Hormones (Canada), para. IV.43.

${ }^{682}$ Panel Report, EC-Hormones(US), para. IV.26; Panel Report, EC-Hormones (Canada), para. IV.50.

${ }^{683}$ Panel Report, EC - Hormones (US), para. 8.271; Panel Report, EC - Hormones (Canada), para. 8.274.

${ }^{684}$ Appellate Body Report, EC - Hormones, para. 250.

${ }^{685}$ Dale McNiel argued that this failure to resolve this crucial issue 'casts a pall on the ability of the WTO dispute settlement system to decide complex cases involving scientific issues.' He pointed to the disregard by the EC of the scientific evidence of its own Scientific Working Group as well as that presented at the 1995 Scientific Conference and in various studies reported in reputable journals as showing beyond dispute that the EC ban was not based on scientific principles or sufficient scientific evidence. He claimed that, due to this decision, neither the fact that evidence overwhelmingly supports the safety of a product, nor the total lack of scientific proof of a health risk would guarantee a finding of a lack of 'sufficient scientific evidence'. Dale E. McNiel, 'The First Case under the WTO's Sanitary and Phytosanitary Agreement: The European Union's Hormone Ban', Virginia Journal of International Law 39, 1998, 89-134, 119-120 and 134. Quick \& Blüthner argue that the Panel's reliance on judicial economy in this instance amounts to a denial of justice, since it does 
issue of panel review of national evaluations of the quality and weight of scientific evidence by deciding the case on the more technical question of whether the requirements for a risk assessment under Article 5.1 were met, casting doubts on the ability of panels to decide this type of issue.

In Japan - Agricultural Products II, the Panel and the Appellate Body were once again faced with the issue of the meaning of 'sufficient' in Article 2.2. In this case they did address the issue, establishing a rather vague test for sufficiency. The Appellate Body stated as follows:

The ordinary meaning of "sufficient" is "of a quantity, extent, or scope adequate to a certain purpose or object". From this, we can conclude that "sufficiency" is a relational concept. "Sufficiency" requires the existence of a sufficient or adequate relationship between two elements, in casu, between the SPS measure and the scientific evidence.

The context of the word "sufficient" or, more generally, the phrase "maintained without sufficient scientific evidence" in Article 2.2, includes Article 5.1 as well as Articles 3.3 and 5.7 of the SPS Agreement. ${ }^{686}$

In examining this context, the Appellate Body first agreed with the Panel that its finding in $E C$-Hormones regarding Article 5.1 provides guidance for the interpretation of Article 2.2. ${ }^{687}$ In the latter case it had held that the requirement in Article 5.1 that a measure be 'based on' a risk assessment, read together with Article 2.2, means that there must be a rational relationship between the measure and the risk assessment. Second, the Appellate Body looked at Article 3.3, which allows Members to introduce or maintain measures resulting in a higher level of protection than those based on the relevant international standard, inter alia if there is sufficient scientific justification. The Appellate Body held that there is sufficient scientific justification if there is a rational relationship between the measure and the available scientific information. ${ }^{68}$ Third, the Appellate Body turned to Article 5.7, which allows Members to adopt provisional measures in case of insufficient scientific evidence. It held that this is a qualified exemption from Article 2.2 and that a too-broad interpretation of Article 2.2 would render it meaningless. ${ }^{689}$

The Appellate Body then concluded as follows:

[W] agree with the Panel that the obligation in Article 2.2 that an SPS measure not be maintained without sufficient scientific evidence requires that there be

not secure a positive resolution of the dispute. Since Article 2.2 is broader than Article 5.1, it would be possible for the EC to comply with the Panel ruling (as confirmed by the Appellate Body) by conducting a proper risk assessment, yet still be subject to a challenge under Article 2.2, "probably necessitating yet another Hormones Case in the future in which the claims which the $\mathrm{AB}$ has refrained from dealing with will be put forward by the complainants.' See Reinhard Quick and Andreas Blüthner, 'Has the Appellate Body Erred? An Appraisal and Criticism of the Ruling in the WTO Hormones Case', Journal of International Economic Law 2 (4), 1999, 603-639, 632-636.

${ }^{686}$ Appellate Body Report, Japan - Agricultural Products II, paras 73-74.

${ }^{687}$ Ibid., para. 76.

${ }^{688}$ Ibid., para. 79.

${ }^{689}$ Ibid., para. 80. 
a rational or objective relationship between the SPS measure and the scientific evidence. Whether there is a rational relationship between an SPS measure and the scientific evidence is to be determined on a case-by-case basis and will depend upon the particular circumstances of the case, including the characteristics of the measure at issue and the quality and quantity of the scientific evidence. ${ }^{690}$

The Appellate Body then proceeded to agree with the Panel that, in the case at hand, Japan's requirement that different varieties of the eight relevant agricultural products, which are potential hosts of codling moth, be tested before importation to ensure the efficacy of the quarantine treatment (the varietal testing requirement) was maintained without sufficient scientific evidence for four of the eight ${ }^{691}$ products at issue. ${ }^{692}$

This 'rational relationship test' does not lay down clear guidelines on what will be regarded as sufficient scientific evidence. Leaving the necessary discretion to panels to make ad hoc decisions based on their evaluation of the circumstances of the case, it also gives panels the mandate to evaluate the quality and quantity of the scientific evidence presented. While some assessment of the scientific evidence is clearly entailed by the discipline of Article 2.2, the limits of this assessment are crucial to establish. If panels were to limit their review of the quality and quantity of the scientific evidence to an assessment whether the regulatory choice made by the Member is reasonable (i.e. that its conclusions based on the evidence are plausible) as seems to be implied by the term 'rational relationship', this would seem an appropriate test. If, however, panels see their task under the 'rational relationship' test as including a reassessment of the quality and quantity of the scientific evidence in order to come to their own conclusions regarding the risk at issue, a task for which these bodies that are primarily composed of trade experts are not qualified, the test is inappropriate. ${ }^{693}$

The approach taken to this issue by the Panel in Japan - Apples, in addressing the meaning of the word 'sufficient' in Article 2.2, does not bode well. Here the Panel had to determine whether Japan's rigorous phytosanitary regime for the importation of apples from the US, ${ }^{694}$ aimed at preventing the introduction of fire blight, was maintained with

${ }^{690}$ Ibid., para. 84.

${ }^{691}$ With respect to the other four products at issue, the Panel found that the US had not adduced any evidence in support of a finding of inconsistency with Article 2.2 of the SPS Agreement. Panel Report, JapanAgricultural Products II, para. 8.45.

${ }^{692}$ The Panel's decision was based on the factual finding of the absence of an actual causal link between varietal differences and test differences regarding the relationship between the fumigant concentration and the time period of fumigation and the level of dose required to kill $50 \%$ of codling moths. The experts advising the panel were of the view that the differences in these values could have been caused by a number of factors not related to varietal differences (e.g. leakage in the fumigation chamber, sorption by the packaging material and experimental errors). Panel Report, Japan - Agricultural Products II, para. 8.42. The Appellate Body understood this finding to indicate the absence of a rational relationship between the varietal testing requirement and the scientific evidence. Appellate Body Report, Japan - Agricultural Products II, para. 83.

${ }^{693}$ The issue of the composition of panels and their use of panel experts is discussed below, Part IV, Section 2.2.5.

${ }^{694}$ Under its Plant Protection Law and the Enforcement Regulations, Japan bans the importation of host plants of 15 quarantine pests, including the bacterium fire blight. This import prohibition can be lifted on a case-bycase basis, subject to certain conditions. Japan lifted its prohibition with respect to apples from the US, subject to a phytosanitary regime consisting of 10 cumulative requirements namely: that the apples be produced in designated fire blight-free orchards; that the orchard be free of fire blight-infected plants and other host 
sufficient scientific evidence. ${ }^{695}$ The Panel followed the interpretation of the Appellate Body in Japan - Agricultural Products II, namely that sufficiency is a relational concept and thus that there must be a sufficient or adequate relationship between the SPS measure and the scientific evidence. The Panel took this to mean an objective or rational relationship. ${ }^{696}$ Going further than the previous case law, the Panel then stated that although the term 'sufficient' is clearly to be considered in relation to the measure itself, 'scientific evidence relates to a risk and is supposed to confirm the existence of a given risk.' ${ }^{697}$ It thus linked the concept of sufficiency in Article 2.2 to the extent to which the scientific evidence indicates the existence of a risk.

After examining the evidence submitted to it, with the assistance of the panel experts, the Panel held that a negligible ${ }^{698}$ risk of transmission of fire blight through apple fruit was shown and thus that there was no sufficient scientific evidence that apple fruit was likely to serve as a pathway for the entry, establishment or spread of fire blight in Japan. ${ }^{699}$ In order to come to this conclusion, the Panel disassembled the sequence of events on the transmission pathway for fire blight, in order to identify the existence and potential of the risk, and then compared the risk so identified with the measure at issue. ${ }^{700}$ In so doing, the Panel, in effect, conducted its own risk assessment. As a result of its characterisation of the risk as negligible, the Panel held that Japan's measure, which consisted of a range of cumulative requirements that had to be met for importation to be allowed, was 'clearly disproportionate' to the risk identified..$^{701}$ The Panel thus introduced a strong proportionality test into the 'rational relationship' requirement in Article 2.2. ${ }^{702}$

plants of fire blight; that the orchard be surrounded by a 500-meter buffer zone; that the orchard and buffer zone be inspected at least three times per year; that the harvested apples, harvesting containers and interior of the packing facility be disinfected; that apples destined for Japan be kept separate from other apples after harvesting; that US officials certify that the apples are not infested or infected with fire blight and were disinfected; and that Japanese officials confirm the certification and carry out inspections themselves.

${ }^{695}$ Fire blight is a bacterium that causes the infected parts of plants to whither, darken and die. It is believed to be native to the US, and since its discovery in 1793 it has been disseminated to Canada, Mexico, the UK, Egypt, New Zealand, Europe and the Mediterranean. Latin America, Large parts of Africa and Asia, including Japan, appear to be fire blight free. Hosts of fire blight are apples, pears, quince, loquats and several garden plants.

${ }^{696}$ Panel Report, Japan - Apples, paras $8.101-8.103$

${ }^{697}$ Ibid., para. 8.104.

${ }^{698}$ One of the experts consulted by the Panel, Dr Hayward, indicated that the standard scientific definition of 'negligible' was a likelihood of between zero and one in one million.

${ }^{699}$ Panel Report, Japan - Apples, paras 8.169 and 8.176.

700 The Panel based this finding on its conclusions on the basis of the evidence available to it with regard to mature symptomless apples and other apples. With regard to mature, symptomless apples, it found that infection with fire blight had not been established; that populations of endophytic bacteria have not been found and epiphytic bacteria are very rare; and that the risk of completion of the transmission pathway is negligible. With regard to apples other than mature, symptomless fruit, it held that infected apples are capable of harbouring populations of bacteria which could survive through the various stages of commercial handling, storage and transportation; that risks of errors of handling or illegal actions could legitimately be taken into account, although the experts considered these risks small or debatable; but that completion of the last stage of the transmission pathway (the transmission of the bacteria to the host plant) was not shown to be likely. This was because only a reduced number of bacteria would survive commercial storage, handling and transportation and the existence of a vector (such as rain splash or bees), which could transmit the bacteria from the imported apples to the host apple plant in Japan, had not been established. Panel Report, Japan - Apples, paras $8.136,8.139,8.153,8.157,8.161$ and 8.168 .

${ }^{701}$ Panel Report, Japan-Apples, paras 8.181 and 8.198.

702 The Panel proceeded to examine two elements of Japan's measure, namely the buffer-zone requirement and the requirement of inspections three times yearly, as instances of elements most obviously maintained 
On appeal, the Appellate Body accepted as appropriate the methodology of the Panel of disassembling the sequence of transmission events and comparing the risk to the measure, in its Article 2.2 analysis, but noted that this does not exhaust the range of possible methodologies and that the circumstances of each case will determine the appropriateness of a given methodology. ${ }^{703}$ The Appellate Body also did not take issue with the Panel's view that 'clear disproportion' between the risk and the measure implies that a 'rational or objective' relationship does not exist. ${ }^{704}$ It rejected Japan's contention that the Panel should have accorded Japan a 'certain degree of discretion' in the way in which it chose, weighed and evaluated the scientific evidence, finding that deference by panels to the findings of national authorities would not be compatible with the standard of review applicable to panels. $^{705}$

The introduction of a strong proportionality test into Article 2.2 gives cause for concern. ${ }^{706}$ While it is certainly true that an SPS measure, and all its individual components, must be supported by the scientific evidence, it goes too far to require the rigour of the measure to be proportional to the gravity of the risk. The balancing paradigm of the SPS Agreement is premised on respect for the policy choices of a Member in the face of proven risk. In other words, once it has been established that a real risk, as opposed to a hypothetical possibility of risk, exists, ${ }^{707}$ it is for the Member to determine how seriously it views this risk, reflected in the level of protection it chooses, and therefore how strict its measures will be to address this risk. ${ }^{708}$ It has been affirmed in the case law that even a 'zero risk' level of protection is permissible, ${ }^{709}$ despite the fact that this is not realistically achievable and would allow for extremely stringent measures. In addition, in the context of the risk assessment obligation in Article 5.1 of the SPS Agreement, it has been established that no threshold level of risk need be shown for a measure to be regarded as based

without sufficient scientific evidence either as such or when applied cumulatively with other elements. Panel Report, Japan - Apples, paras 8.182-8.197.

${ }^{703}$ Appellate Body Report, Japan - Apples, para. 164. Scott notes that this statement seems to indicate a note of caution in the Appellate Body's affirmation of the Panel's approach, although the Appellate Body does not make clear where its concerns lie. Scott speculates that the radical step taken by the Panel in introducing a proportionality test may explain the hesitancy of the Appellate Body. Joanne Scott, The WTO Agreement on Sanitary and Phytosanitary Measures: A Commentary, Oxford Commentaries on the GATT/WTO Agreements (Oxford University Press, Oxford), 2007, 90.

${ }^{704}$ Appellate Body Report, Japan - Apples, para. 163.

${ }^{705}$ Appellate Body Report, Japan - Apples, para. 165. It is well-established case law that the standard of review to be applied by panels is that of an 'objective assessment' of the matter, which implies neither total deference by panels to national authorities' determinations, nor de novo review. The issue of the appropriate standard of review is discussed below, Part IV, Section 2.2.3.

${ }^{706}$ On the difference between strong proportionality and weak proportionality, see above, Part III, Section 1.1.1.

${ }^{707}$ Appellate Body Report, EC - Hormones, para. 186.

${ }^{708}$ Before the Japan - Apples dispute was decided, it was generally accepted that a Member had 'complete freedom to decide on the level of risk it can accept' and that a panel 'cannot therefore, strike down a measure simply because it considers the risk involved to be "minimal".' Joost Pauwelyn, 'Does the WTO Stand for 'Defence to' or 'Interference with' National Health Authorities When Applying the Agreement on Sanitary and Phytosanitary Measures (SPS Agreement)?' in The Role of the Judge in International Trade Regulation: Experience and Lessons for the WTO, T. Cottier and P.C. Mavroidis (eds.) (University of Michigan Press: Ann Arbor, Michigan), 2003, 175-192, 175. See also Catherine Button, The Power to Protect. Trade, Health and Uncertainty in the WTO (Hart Publishing, Oxford and Portland, Oregon), 2004, 47.

${ }^{709}$ Appellate Body Report, Australia - Salmon, para. 125. 
on, or rationally supported by, a risk assessment. ${ }^{710}$ A similar approach could be expected under the more general scientific discipline of Article 2.2. ${ }^{711}$

In casu, the Panel had noted that the parties to the dispute agreed on the ecological and economic impact that the introduction of fire blight into Japan could have. ${ }^{712}$ It recalled the finding in EC-Hormones recognising that responsible governments act with prudence and precaution in case of risks of irreversible damage. ${ }^{713}$ The Panel noted the statements of the panel experts, who while viewing Japan's cumulative requirements as excessive were not comfortable with requiring Japan to remove all aspects of its measure. It recognised that although the scientific evidence showed that apples are highly unlikely to be a pathway for fire blight transmission, the evidence did suggest that 'some slight risk' could not totally be excluded. ${ }^{714}$ In light of a finding of risk, however small, a Member is free to take measures to reduce or eliminate this risk in accordance with its chosen level of protection. An island Member, such as Japan, is likely to choose for a high level of protection against the introduction of phytosanitary risks due to the vulnerability of its ecosystem. This choice is respected by the disciplines of the SPS Agreement. The introduction of a strong proportionality test in Article 2.2 undermines the policy space of a Member in this regard, disturbing the delicate balance between trade liberalisation and health protection in the Agreement.

This policy space is not only important for developed-country Members such as Japan, but also for Members at lower levels of development. For example, like Japan, two of the Members used as illustrative examples in Part II of this book, namely Mauritius and Jamaica, are also island countries with vulnerable ecosystems. In respect of phytosanitary issues deemed particularly important by them, such as the protection against pests and diseases of the sugar crop in Mauritius and the coffee and banana crops in Jamaica, these Members take very strict measures. ${ }^{715}$

It may be argued that introducing a strong proportionality test into Article 2.2 makes it easier for Members at lower levels of development to challenge SPS measures that reflect a high level of protection in the face of a very small risk. An example would be the EC's MRLs for aflatoxins, which are extremely low despite the minimal level of risk arising from the small amount of aflatoxin residues present in the products at issue. ${ }^{716}$ However,

710 Appellate Body Report, EC - Hormones, para. 186; and Appellate Body Report, Australia - Salmon, para. 125. For a discussion of the risk assessment obligation in Article 5.1 of the SPS Agreement, see below, Part III, Section 5.1.5.

711 The relationship between Articles 2.2 and 5.1 is discussed below, Part III, Section 3.2.3.3.

${ }^{712}$ Panel Report, Japan - Apples, paras 8.105.

713 Appellate Body Report, EC-Hormones, para. 124.

714 Panel Report, Japan-Apples, paras 8.181.

${ }^{715}$ See the discussions above with regard to the special phytosanitary protocols in place in Mauritius to reduce the risk of entry of sugar cane white grub, Part II, Section 2.5.2.3; and the various phytosanitary measures applied by Jamaica to prevent the introduction of exotic plant pests, Part II, Section 2.6.2.3.

${ }^{716}$ Tsunehiro Otsuki et al., Saving Two in a Billion: A Case Study to Quantify the Trade Effect of European Food Safety Standards on African Exports (World Bank Development Research Group, Washington D.C.), 2000, available at: http://www1.worldbank.org/wbiep/trade/Standards/aflatoxins.pdf, visited on 5 April 2001. This study estimates that the very strict EU harmonised maximum residue level for aflatoxins (which are substances that can produce liver cancer and occur in stored agricultural products such as peanuts) would reduce health risks by only approximately 1.4 deaths per billion per year (the EU's population is only half a billion), while costing African exporters of cereals, dried fruits and nuts to the EU US\$ 670 million. 
restricting the regulatory autonomy of a Member in the face of real risk, however small, runs the risk of making the disciplines of the SPS Agreement politically unacceptable to Members and of leading to more cases of non-compliance, gradually undermining the value of the Agreement.

\subsubsection{Relevance of the precautionary principle}

Inherent in the SPS Agreement's reliance on science as the key instrument to distinguish legitimate health protection measures from disguised protectionism is the question of how to deal with situations of scientific uncertainty. As explained in Part II, today the uncritical view of science as an objective benchmark for regulatory justification has made way for the recognition of the limits in science. One of these limits lies in the prevalence of uncertainties in scientific evaluations of risk, particularly in areas as complex as human, animal and plant health. It has led to increasing recognition of the need for precautionary action when the available scientific evidence is unable to provide a definite answer regarding the existence or magnitude of a risk. This is commonly known as the precautionary principle in risk regulation. ${ }^{717}$

It is therefore necessary to examine the extent to which the scientific disciplines in the SPS Agreement take account of this current view of the limits of science. In this regard, it is useful to note that Article 2.2 expressly exempts from its requirements situations provided for under Article 5.7, which allows provisional measures in cases of insufficient scientific evidence. ${ }^{718}$ However, in view of the pervasiveness of uncertainty in science, it is necessary to examine whether the precautionary principle has relevance beyond the four corner of Article 5.7, as an interpretative tool to be applied to the scientific disciplines of the SPS Agreement.

In Japan - Agricultural Products II a question arose regarding the applicability of the precautionary principle to the interpretation of Article 2.2. ${ }^{719}$ Japan contended that since it had established that certain products were potential hosts of codling moth (a pest of quarantine significance for Japan), it was entitled to adopt a precautionary attitude and require varietal testing. Thus it argued that Article 2.2's requirement of 'sufficient scientific evidence' must be interpreted in the light of the precautionary principle.

This claim was rejected by the Appellate Body, ${ }^{720}$ which referred back to its decision on the use of the precautionary principle to soften the application of SPS disciplines in EC - Hormones. ${ }^{721}$ In the latter case (with reference to the interpretation of Articles 5.1 and 5.2), the Appellate Body felt that it would be 'unnecessary and probably imprudent' for it to decide whether the precautionary principle now forms part of general customary international law (as opposed to customary international environmental law, where it has gained wide acceptance). ${ }^{722}$ However, it held that even if this were the case, the specific

\footnotetext{
${ }^{717}$ The precautionary principle is discussed above, Part II, Section 1.5.

${ }^{718}$ On the relationship between Article 2.2 and Article 5.7, see below, Part III, Section 5.2.5.

719 For further discussion of the role of the precautionary principle in the SPS Agreement, see David A. Wirth, 'Symposium: The Role of Science in the Uruguay Round and NAFTA Trade Disciplines', Cornell International Law Journal 27, 1994, 817-859, 838-840.

${ }^{720}$ Appellate Body Report, Japan - Agricultural Products II, para. 81.

${ }^{721}$ Appellate Body Report, EC - Hormones, para. 125.

${ }^{722}$ Ibid., para. 123.
} 
agreement on rules for cases of scientific uncertainty in Article 5.7 of the SPS Agreement overrides any such general principle. Thus the precautionary principle cannot be used to justify an otherwise inconsistent measure except to the extent provided for in Article 5.7. ${ }^{723}$ The Appellate Body did, however, recognise that:

[A] panel charged with determining, for instance, whether "sufficient scientific evidence" exists to warrant the maintenance by a Member of a particular SPS measure may, of course, and should, bear in mind that responsible, representative governments commonly act from perspectives of prudence and precaution where risks of irreversible, e.g. life-terminating, damage to human health are concerned. ${ }^{724}$

It is as yet unclear what effect this directive to panels will have in practice on the interpretation of Article 2.2. ${ }^{725}$ It would appear that the Appellate Body is making room for a limited application of the precautionary principle to the interpretation of the requirement of 'sufficient scientific evidence', for extreme cases of risks to human life. Further, the Appellate Body held that Article 5.7 does not exhaust the relevance of the precautionary principle, which it found to be reflected in the sixth preambular paragraph and Article 3.3 of the SPS Agreement as well. ${ }^{726}$ These two provisions refer to the right of Members to set their own level of protection, however cautious. These provisions do not reflect the precautionary principle, however, as before a Member may apply an SPS measure to achieve its chosen level of protection in respect of a particular risk, there has to be 'sufficient scientific evidence' for the measure, and a risk assessment to support it. The precautionary principle is precisely at issue where an insufficiency of scientific evidence hinders the fulfilment of these requirements, yet prompt action is necessary to address suspected risks. Thus the fact that a Member may determine its own level of protection, and apply a measure to achieve this level of protection once the risk has been established does nothing to incorporate the precautionary principle into SPS disciplines. ${ }^{727}$

The Appellate Body's finding on the precautionary principle in EC-Hormones applies not only to the interpretation of Article 5.1, but also to all the science-based rules in the SPS Agreement, (as evinced by the reference thereto in Japan-Agricultural Products II with respect to Article 2.2). When one bears in mind the pervasive nature of uncertainty

${ }^{723}$ The question whether Article 5.7 SPS deals adequately with the issue of lack of certainty in science is discussed below, Part III, Section 5.2.5.1.

${ }^{724}$ Appellate Body Report, EC - Hormones, para. 124.

725 The Appellate Body in Japan-Agricultural Products II did not address the effect of this directive for the interpretation of Article 2.2, probably because what was at stake in that case was a threat to plant health rather than human health whereas the directive is limited to cases of irreversible risks to human health.

${ }^{726}$ Appellate Body Report, EC-Hormones, para. 124.

727 The Appellate Body appears to be confusing the precautionary principle with the protective principle. The latter principle is a forerunner of the precautionary principle, dealing with the duty of governments to provide protection from risks that have been established scientifically. Thus the ability of a government to set a high level of protection once a risk has been proved, falls under this principle. The precautionary principle represents a step forward in that it requires government action in the face of suspected risks that cannot be scientifically proven in the current state of scientific knowledge. It evolved precisely due to the need to address the regulatory paralysis that results from a lack of scientific certainty. See H. Hohmann, Precautionary Legal Duties and Principles of Modern International Environmental Law $1^{\text {st }}$ ed. (Graham \& Trotman/Martinus Nijhoff, London) 1994, 10. 
in scientific analysis and the influence of this factor on most risk assessments and other scientific aspects of the regulatory process, it seems at odds with reality to confine its recognition to a single Article providing for temporary measures. ${ }^{728}$ However, under the current case law, the precautionary principle cannot be used as an interpretative principle to be applied to the scientific disciplines of the SPS Agreement to soften their application in cases of scientific uncertainty. Instead, all situations of insufficient scientific evidence must be dealt with by means of provisional measures under Article 5.7.

This conclusion is supported by the Appellate Body's finding in Japan - Agricultural Products II regarding the relationship between Article 2.2 and Article 5.7, where it stated:

[I]t is clear that Article 5.7 of the SPS Agreement, to which Article 2.2 explicitly refers, is part of the context of the latter provision and should be considered in the interpretation of the obligation not to maintain an SPS measure without sufficient scientific evidence. Article 5.7 allows Members to adopt provisional SPS measures '[i]n cases where relevant scientific evidence is insufficient' and certain other requirements are fulfilled. ${ }^{729}$ Article 5.7 operates as a qualified exemption from the obligation under Article 2.2 not to maintain SPS measures without sufficient scientific evidence. An overly broad and flexible interpretation of that obligation would render Article 5.7 meaningless. ${ }^{730}$

Thus it would appear that the Appellate Body would prefer to limit the scope for deviation from the scientific disciplines of Article 2.2 to the 'qualified exemption' provided for by Article 5.7. Increased flexibility in the interpretation of the provision by means of the use of the precautionary principle is thus rejected by the Appellate Body on the grounds that it would make Article 5.7 'meaningless'. It is consequently necessary to examine the precise nature of the relationship between Article 2.2 and Article 5.7.

\subsubsection{Relationship between Article 2.2 and Article 5.1}

The question of the relationship between the second and third prongs of Article 2.2 and the later, more specific, scientific requirement of Article 5.1 of the SPS Agreement needs to be addressed. Do the scientific requirements of Article 2.2 impose independent obligations on Members, or are their general disciplines subsumed by the specific rules contained in the later Article?

This question arose in EC - Hormones, where the Panel, after finding violations of Articles 3.1, 5.1 and 5.5, applied the principle of judicial economy to refrain from ruling on the Article 2.2 challenge. Appellate Body confirmed the Panel's application of judicial economy. It agreed that Article 5.1 can be seen as 'a specific application of the basic obligations contained in Art. 2.2,731 and thus once a violation of Article 5.1 is established, it is

${ }^{728}$ Article 5.7 of the SPS Agreement is discussed below, Part III, Section 5.2.5. There the question of whether it sufficiently incorporates the precautionary principle is addressed. It should be noted that one of the points raised for negotiation in the failed Seattle Ministerial Conference was the need to strengthen the precautionary principle in the SPS Agreement, as Article 5.7 is perceived as insufficient to give it full effect.

729 The Appellate Body cited the same report. Appellate Body Report, Japan - Agricultural Products II, para. 89.

${ }^{730}$ Ibid., para. 80 .

731 Appellate Body Report, EC - Hormones, para. 180. Note that in EC-Approval and Marketing of Biotech 
unnecessary to determine whether Article 2.2 has also been violated. However, as noted above, the Appellate Body expressed its surprise that the Panel had not followed the more 'logically attractive' route of starting with an analysis of the basic obligations contained in Article 2. ${ }^{732}$ Unfortunately, the Appellate Body did not elaborate further on the relationship between Articles 2 and 5, aside from expressing the view that Articles 2.2 and 2.3 inform Articles 5.1 and 5.5 respectively and these Articles must thus be read together. ${ }^{733}$

In Australia - Salmon the Appellate Body had the opportunity to address this relationship again, and clarified that Article 2 is broader than Articles 3 or 5. It thus agreed with the Panel that, while a violation of the specific rules regarding risk assessment contained in Articles 5.1 and 5.2 necessarily implies a violation of the more general requirements of 'sufficient scientific evidence' and a basis in 'scientific principles' embodied in Article $2.2,{ }^{734}$ due to the more general nature of Article 2.2 not all violations of Article 2.2 are subsumed into Articles 5.1 and 5.2. ${ }^{735}$ Thus a panel should start the analysis with the broader general provisions of Article 2 before proceeding to examine the more specific rules contained in Articles 3 and 5.

In Japan - Agricultural Products $I T^{736}$ the Appellate Body rejected as textually unfounded Japan's proposition that Article 2.2 should only be directly applied in cases where scientific evidence is patently insufficient and that the case at issue should have been dealt with under Article 5.1 instead. It emphasised that the finding in EC-Hormones that Article 5.1 is a specific application of the basic obligation contained in Article 2.2, does not justify limiting the scope of Article 2.2 in favour of Article 5.1. It thus appears that the Appellate Body is at pains to make clear that Article 2 sets disciplines which are broader than those contained in more specific Articles and lays down independent obligations against which measures can be directly challenged, without recourse to other Articles. The precise content of these obligations remains to be determined.

\subsection{Conclusion}

The basic rights and obligations set out in Article 2 of the SPS Agreement set the tone for the rest of the Agreement. They epitomise the trade/health balance aimed at by the SPS Agreement and the manner in which this balance is reflected in the disciplines of the Agreement.

In particular, the express recognition of the right of Members to take SPS measures in Article 2.1 is an innovative aspect of the SPS Agreement. Unlike the situation under the GATT 1994, Members imposing measures covered by the SPS Agreement do not bear the

Products the Panel specified this further by noting that Article 5.1 is a 'specific application of the second and third obligations provided for in Article 2.2.' Panel Reports, EC - Approval and Marketing of Biotech Products, para. 7.1439 .

732 Ibid., para. 250.

733 Ibid., paras 180, 212 and 250. The Appellate Body held that further analysis of the relationship between these Articles 'should await another case.' Ibid., para. 250.

${ }^{734}$ Panel Report Australia - Salmon, para. 8.52.

${ }^{735}$ Appellate Body Report, Australia - Salmon, para. 137.

${ }^{736}$ Appellate Body Report, Japan - Agricultural Products II, para 82. 
burden of justifying their measures under an exception to trade liberalisation disciplines. Instead, a complaining Member wishing to challenge an SPS measure must establish a violation of specific disciplines of the SPS Agreement.

The limits to the right to take SPS measures, first outlined in Article 2.2 and 2.3, recur in more specific form in the rest of the SPS Agreement. These provisions reflect and build upon familiar GATT disciplines, requiring that health measures be limited to what is 'necessary' to achieve their aim (first prong of Article 2.2 of the SPS Agreement), and prohibiting arbitrary or unjustifiable discrimination and disguised trade restrictions (Article 2.3 of the SPS Agreement). In addition, the second and third prongs of Article 2.2 introduce a novel aspect of the SPS Agreement, namely the use of scientific disciplines as the scale on which the competing interests of trade and health are balanced.

While recourse to the case law on the relevant provisions of the GATT 1994 from which the trade disciplines of the SPS Agreement are derived may be useful in elucidating the latter disciplines, care must be taken not to undermine the object and purpose of the SPS Agreement through an indiscriminate transplantation of GATT case law principles to the interpretation of the SPS Agreement. The SPS Agreement was negotiated to address inadequacies in GATT rules in dealing with the specific situation of SPS measures through establishing a careful balance between trade and health. This balance must be respected in the interpretation of its provisions. There is therefore no room for the importation of a strong proportionality test arising from the 'necessary' requirements of Article XX(b) of the GATT 1994 into the 'necessary' requirement of Article 2.2 of the SPS Agreement.

Similarly, the approach of the Panel in Japan - Apples of reading a strong proportionality test into Article 2.2's requirement of 'sufficient scientific evidence' can be criticised. It undermines the policy space left to Members by the SPS Agreement once an SPS risk, however small, has been established. The SPS Agreement does not allocate the assessment of the gravity of a risk to panels, nor does it provide that the strictness of the measure is to be weighed against the gravity of the risk. For panels to do so seems contrary to the balance that is the object and purpose of the Agreement.

The intrusive approach of the Panel in Japan - Apples rests on its understanding that the 'rational relationship' requirement to show that an SPS measure is supported by sufficient scientific evidence, is not limited to an assessment of the relationship between the science and the SPS measure, but also entails an assessment of the relationship between the science and the risk which the measure addresses. This approach put the Panel on a slippery slope on which it easily slid to assessing the available scientific evidence to determine the existence of a risk and the potential of the risk materialising, in other words, to conducting its own risk assessment. On the basis of this assessment, the Panel reviewed the stringency of the SPS measure applied to address the risk and found it disproportional. In so doing, the Panel appropriated for itself competences which the SPS Agreement leaves to national regulatory authorities. This deprives Members of the room to make their own science policy decisions in their assessment of scientific evidence, ${ }^{737}$ and to make policy choices on the seriousness with which they regard the risk and the stringency of the measures they will take to address this risk. In view of the diversity in priorities, economic

${ }^{737}$ On the role of subjective science policy decisions in the risk assessment process, in addressing gaps in data, using assumptions, models, rules of thumb and extrapolations, see above, Part II, Section 1.5. 
resources and risk-averseness of Members at different levels of development, which are reflected in the policy choices inherent to risk regulation, this result is regrettable. 


\section{CHAPTER 4 \\ Disciplines promoting harmonisation}

International rules laying down trade-related and scientific requirements for national SPS regulatory measures are insufficient to achieve full trade liberalisation. Their disciplining effect has clear limits in the sovereign right of national governments to pursue the legitimate societal aim of the protection of health against SPS risks. While requiring that SPS measures be science-based, non-discriminatory and applied only to the extent necessary to protect health, the SPS Agreement leaves much room for Members to make policy choices regarding the level of protection they wish to ensure on their territories. These choices reflect particular conditions in each Member, including consumer preferences, economic considerations and industry interests. The measures Members impose to achieve their chosen level of protection therefore also diverge.

However, as noted above, differences in SPS measures can act as significant trade barriers as exporters are forced to adjust their products or production processes to the requirements of their various export markets, thereby reducing economies of scale. ${ }^{738}$ The promotion of harmonisation of SPS regulations at international level has emerged as a response to this problem.

In the preamble of the SPS Agreement, one of the aims expressed is the promotion of the use of harmonised SPS measures by Members, based on international standards developed by the relevant international organisations, without requiring Members to change their appropriate level of protection. The SPS Agreement therefore attempts to balance the aim of increasing free trade through harmonising SPS measures and thus reducing the trade barriers caused by differing standards, with respect for the right of Members to choose their own level of protection. As a result, harmonisation around international standards is encouraged by means of a presumption of consistency with the GATT 1994 and the SPS Agreement, but it is not actually mandated even though global standards would be most trade efficient. This is in line with the fact that the choice of a level of protection is viewed as a sovereign decision and accorded substantial deference in the SPS Agreement. Thus a government is not obliged to accept an international standard that leads to a level of health protection lower than that which it has established to be appropriate. This strategy is embodied in Article 3 of the SPS Agreement.

In EC-Hormones, the Appellate Body elucidated the aim of Article 3 as follows:

In generalized terms, the object and purpose of Article 3 is to promote the harmonization of the SPS measures of Members on as wide a basis as possible, while recognizing and safeguarding, at the same time, the right and duty of Members to protect the life and health of their people. The ultimate goal of the harmonization of SPS measures is to prevent the use of such measures for arbitrary or unjustifiable discrimination between Members or as a disguised restriction on international trade, without preventing Members from adopting or enforcing measures which are both 'necessary to protect' human life or health

738 The reasons behind international efforts to harmonise SPS regulations are discussed above Part II, Section 3.1.1. 
and 'based on scientific principles', and without requiring them to change their appropriate level of protection. ${ }^{739}$

The question arises whether the SPS Agreement succeeds in this objective. In particular, bearing in mind the severe imbalance in participation in the standard-setting procedures of the three international bodies referenced in the SPS Agreement, discussed in Part II, one may expect that the SPS Agreement's reliance on the resultant standards may have different implications for Members at different levels of development. The provisions of the SPS Agreement that promote harmonisation by reference to the work of the international standard-setting bodies active in the SPS area therefore bear closer examination.

\subsection{International standards, guidelines or recommendations}

As discussed above, ${ }^{740}$ the WTO is not a regulatory body with SPS norm-setting capacity. Thus, it does not set the international standards used as benchmarks by the SPS Agreement itself, but refers instead in Article 3 to 'international standards, guidelines or recommendations'. ${ }^{741}$

It is necessary to start by determining what the term 'standards, guidelines or recommendations' refers to specifically. Annex A.3 of the SPS Agreement defines the term broadly, with reference to the three main international standard-setting bodies active in the area of food safety and plant and animal health, namely the Codex Alimentarius Commission (CAC), the International Office of Epizootics (OIE), ${ }^{742}$ and the Secretariat of the International Plant Protection Convention (IPPC) ${ }^{743}$ For matters not covered by the CAC, OIE or IPPC, the definition of international standards, guidelines and recommendations refers, in Annex A.3(d) of the SPS Agreement, to 'appropriate standards, guidelines and recommendations promulgated by other relevant organizations open for membership to all Members, as identified by the [SPS] Committee.'

The CAC, OIE and IPPC have been discussed in detail in Part II of this book. A brief look is needed at the residual category of standards relevant for purposes of the harmonisation provisions of the SPS Agreement, namely those promulgated by other relevant organisations open for membership to all WTO members, as identified by the SPS Committee.

\subsubsection{Appropriate standards of other relevant organisations}

To date, the SPS Committee has not made any identification under Annex A.3(d) of the SPS Agreement. Neither has the matter come up at all in discussions at SPS Committee meetings. It is nevertheless interesting to consider what could fall under this provision, and to determine the scope of the discretion of the SPS Committee in this regard. While

\footnotetext{
739 Appellate Body Report, EC - Hormones, para. 177.

${ }^{740}$ See above, Part II, Section 3.2.

${ }^{741}$ The term 'international standards' is often used hereinafter as shorthand for 'international standards, guidelines or recommendations', unless otherwise indicated.

${ }^{742}$ Note that, as stated above, the name of this organisation has changed since the coming into force of the SPS Agreement. It is now known as the 'World Organisation for Animal Health'. See above, Part II, Section 3.2.2.

${ }^{743}$ See the discussion of these international standard-setting bodies above, Part II, Section 3.2.
} 
some guidance is provided by the terms of Annex A.3(d), considerable ambiguity remains. The criteria that can be found in this provision are discussed briefly below.

First, the provision limits its applicability to matters not covered by the 'three sisters'. It is not clear whether 'matters not covered' should be taken to mean matters outside the respective mandates of the CAC, OIE and IPPC, or also matters within their mandates that have not been addressed yet in their activities. Ideally, the former interpretation would be the most appropriate, since the 'three sisters' are generally regarded as the most authoritative standard-setting bodies within their areas of competence. ${ }^{74}$ A gap in the coverage of standards within the competence of the referenced international standard-setting bodies is arguably best addressed in that body itself through the initiation of a new standard. ${ }^{745}$

However, this approach does not take into account the reality of the increasing difficulty of setting standards in areas of particular political or economic interest to WTO Members, due to the politicisation of the standard setting processes. Also it disregards the problems of effective participation in the 'three sisters' of Members at lower levels of development, discussed above ${ }^{746}$ which hinder such Members' efforts to exert sufficient influence to obtain standards in their areas of interest. In principle, these problems are better tackled by concerted efforts to reform the standard-setting procedures in the 'three sisters' themselves rather than by adding to the plethora of international bodies to which Members must send delegates in order to promote their interests. Nevertheless, in the absence of sufficient progress in this regard, it may be useful to keep the option open of possible reference to another international body that has managed to set appropriate standards in areas of interest to Members at lower levels of development, either due to simpler, less politicised or more technical decision-making procedures or due to greater or more effective participation of the interested Members. ${ }^{747}$ Of course, care must be taken not to select bodies whose standard-setting procedures are less transparent and participatory than

744 This interpretation is followed by Sandrine Maljean-Dubois and Emilie Etchelar, who argue that the Biosafety Protocol is unlikely to become an international organisation that is competent to set standards with regard to trade in GMOs for purposes of the SPS Agreement 'because this already comes within the competence of organisations referred to in the SPS Agreement...'. Sandrine Maljean and Dubois \& Emilie Etchelar, 'World Trade and International Normalisation: Codex Alimentarius', in WTO Obligations and Opportunities: Challenges of Implementation, Koen Byttebier and Kim Van Der Borght (eds.) (Cameron May, London), 2007, 121-153. It is interesting to note that the Cartagena Protocol nevertheless exerts an influence on the benchmark standards of relevance under Article 3 of the SPS Agreement. As pointed out by Maljean-Dubois and Etchelar, the IPPC Supplement on Phytosanitary Risks for Living Modified Organisms, ISPM 11 (2004) on pest risk analysis for quarantine pests including analysis of environmental risks and living modified organisms, refers repeatedly to the Cartagena Protocol as well as to its Biosafety Clearing House. Similarly, the CAC Ad hoc Intergovernmental task Force on Food Derived from Biotechnology takes into account the content of the Cartagena Protocol and work conducted in its framework. Ibid., 151-152.

${ }^{745}$ A very good example of this is the successful initiation of work on a CAC cinnamon standard by Sri Lanka, discussed below, Part V, Section 2.1.3.

${ }^{746}$ See the discussion above, Part II, Sections 3.2.1.5, 3.2.2.5 and 3.2.3.5.

${ }^{747}$ Steven Bernstein and Erin Hannah argue that pressure could be put on the 'three sisters' to adhere to evolving good practice standards for international standard setting, including inclusiveness in participation and responsiveness to consumer food safety concerns, by demanding recognition by the SPS Committee of more responsive bodies if they are perceived as not doing so. However, they note that in view of the importance of science as legitimating SPS measures under the SPS Agreement, any alternative standard-setter will have to meet the criterion of science-based standard setting. Steven Bernstein and Erin Hannah, 'Non-State Global Standard Setting and the WTO: Legitimacy and the Need for Regulatory Space' Journal of International Economic Law, 11(3), 2008, (advance access) 1-34, 21. 
those of the 'three sisters'. Instead, this possibility could better be seen as an incentive to encourage real efforts at adopting the necessary standards in the CAC, OIE and IPPC.

This interpretation of the 'matters not covered' criterion also reflects the fact that it would be very difficult to find a standard-setting body in the area of SPS regulation whose activities fall outside the mandates of the 'three sisters'. The current functional scopes of the CAC, OIE and IPPC are very broad, and seem to cover the entire ambit of matters falling under the scope of application of the SPS Agreement. ${ }^{748}$ An interpretation of 'matters not covered' that is limited to matters falling outside the mandates of the three sisters would render the option in Annex A.3(d) largely irrelevant. The principle of effective treaty interpretation would therefore seem to require 'matters not covered' to be interpreted to refer to matters currently not dealt with in standards, guidelines or recommendations of the 'three sisters'. The danger that the identification of other bodies active within the areas of competence of the 'three sisters' could result in conflicting standards is avoided by the fact that, even if an international body is identified whose mandate overlaps with those of one of the 'three sisters', the 'appropriate standards' relevant for purposes of the SPS Agreement would be limited to those dealing with matters not covered by the standards set by the CAC, OIE or IPPC. An example of a matter not covered by existing standards, where the absence of standards has been repeatedly raised as a problem by developing-country exporters, is that of maximum residue levels for pesticides and other contaminants across a range of spices. In the absence of international MRLs, importers opt for a 'lowest detectable residue' level, which effectively excludes spices from many developing-country Members. The possibility of referring to the standards set by bodies such as the International Pepper Community, an intergovernmental organisation active in setting standards for microbiological contaminants in pepper and good hygienic practices in pepper production, could alleviate this problem. ${ }^{749}$

Second, it is not clear from Annex A.3(d) whether the SPS Committee is mandated to identify 'other relevant organizations' or only their 'appropriate standards'. At first glance, the qualifying clause could be read to refer either to the organisations themselves or to appropriate standards and other texts promulgated by them. However, the latter interpretation would, in practice, prove unworkable. One must bear in mind the dynamic nature of standard setting. Standards are constantly being elaborated and revised to reflect developments in scientific knowledge, dietary habits, pest control methods etc. Specific standards identified by the SPS Committee would soon become outdated. It makes more sense for the SPS Committee to refer to an organisation and to leave the limitation on the standards of relevance for the SPS Agreement to the first criterion discussed above. This would allay fears of duplication of standards in case of overlapping mandates.

\footnotetext{
${ }^{748}$ A possible exception would be if the broad interpretation of the scope of application of the SPS Agreement applied by the Panel in EC-Approval and Marketing of Biotech Products would be confirmed by the Appellate Body. Such interpretation covers also matters such as environmental damage not affecting humans, plants or animals, and falling outside the mandates of the CAC, OIE and IPPC, for example risks to micro-organisms in soil or water that are specialised in biochemical processes. Panel Reports, EC-Approval and Marketing of Biotech Products, paras 7.197-7.211 and 7.292. On this point, see further above, Part III, Section 2.1.1.

749 The International Pepper Community has set standards for E. coli, salmonella, mould and yeast and aerobic plate count in whole and ground pepper, and has developed guidelines for good hygienic practices in pepper production. Its website is available at: http://www.ipcnet.org/index.php?act=, visited on 15 June 2008.
} 
Third, it is important to note that the international organisation at issue must be open for membership to all WTO Members. This ensures that all Members have at least the possibility of participation in the elaboration of the standards that will be used as benchmarks by the SPS Agreement. Regional organisations that set SPS standards, such as the EC, ${ }^{750}$ would clearly be excluded, as would international organisations where the accession process is subject to the consent of existing members, such as the OECD. ${ }^{751}$ In addition, organisations whose membership does not consist of states but is limited to industry representatives, for example the International Dairy Federation, ${ }^{752}$ or of private economic actors, such as GLOBALGAP, ${ }^{753}$ would not be among the organisations which the SPS Committee may identify. ${ }^{754}$

An example of a body that would meet this requirement is the UNECE. The UNECE has a Working Party on Agricultural Quality Standards, which develops both quality and safety

750 The EC has regulatory competence in the area of SPS protection in terms of Articles 37, 95, 152 and 153 of the EC Treaty. An example of the exercise of this competence is Regulation (EC) No 178/2002 of 28 January 2002 which lays down a comprehensive food policy at EC level. While EC food standards are also of relevance to non-Member States of the EU in some cases through agreements such as the customs union agreement with Turkey or the European Economic Area Agreement with Norway, Iceland and Liechtenstein, only EC institutions and Member States are involved in their elaboration. For a thorough discussion of the European food-safety regime, see Alberto Alemanno, Trade in Food: Regulatory and Judicial Approaches in the EC and WTO (Cameron May, London), 2007, 33-223.

${ }^{751}$ The OECD is engaged to some extent in setting standards and guidelines for its members in the area of food and agriculture. See for example, OECD, Guidance on Objective Tests to Determine Quality of Fruits and Vegetables and Dry and Dried Produce, AGR/CA/FVS(2005)3/REV1, 2006, available at: http://www.oecd. org/dataoecd/32/47/19515719.pdf, visited on 5 February 2008; and OECD, 'Scheme' for the Application of International Standards for Fruit and Vegetables, C(92)184/FINAL, 1992. Although participation in this 'scheme' is open to any member of the UN or one of its specialised agencies or any Member of the WTO that wishes to participate therein, this participation refers to the compliance by exporting countries of the standards adopted by the 'scheme' and the recognition of such standards by importing countries. Therefore, it is not participation in setting the standards under the 'scheme' that is open to all WTO Members. See http://www. oecd.org/document/44/0,3343,en_2649_201185_19507564_1_1_1_1,00.html, visited on 6 February 2008.

${ }^{752}$ The International Dairy Federation (IDF) is a transnational organisation whose members are national committees, made up of the dairy organisations (representing milk production, manufacture, distribution, technology, science, human nutrition, marketing, economics, education and administration) in various countries. It should be noted, however, that although the IDF used to be active in setting standards for dairy products itself, it is now focused on providing input, including in the form of proposals for standards and elaboration of draft standards, to the relevant Codex Committees. See the website of the International Dairy Federation, available at: http://www.fil-idf.org, visited on 5 February 2008.

${ }^{753}$ GLOBALGAP is a consortium of retail companies that set private standards in areas such as good agricultural practice and good warehouse practice. It originated in 2007, after the rebranding of EUREP, the European Retailer Produce Working Group, a consortium of European retailers. See the website of GLOBALGAP, available at: www.globalgap.org, visited on 5 February 2008.

${ }^{754}$ Scott notes the difference in this regard between the SPS Agreement and the TBT Agreement. The latter refers, in Annex 1.4, to international bodies or systems, rather than to international organisations. An international body or system is defined in this provision as a 'body or system whose membership is open to the relevant bodies of at least all Members.' This would include bodies such as the International Organization for Standardisation (ISO). ISO is not an intergovernmental organisation, but rather a network of the national standards institutes of 157 countries. Joanne Scott, The WTO Agreement on Sanitary and Phytosanitary Measures: A Commentary, Oxford Commentaries on the GATT/WTO Agreements (Oxford University Press, Oxford), 2007, 245-246. Contra see Steven Bernstein and Erin Hannah, 'Non-State Global Standard Setting and the WTO: Legitimacy and the Need for Regulatory Space' Journal of International Economic Law, 11(3), 2008, (advance access) 1-34, 20. These authors argue that GLOBALGAP or the International Federation of Organic Agriculture Movements (IFOAM), neither of which are intergovernmental organisations, could be recognised under Annex A.3(d) of the SPS Agreement. 
standards to facilitate trade in agricultural products. ${ }^{755}$ According to the terms of reference of the Working Party, participation in any of its activities is open 'on an equal footing' to any member of the UN or of one of its specialised agencies. ${ }^{756}$ In fact, in a background note prepared by the GATT Secretariat in the context of the Uruguay Round negotiations on the SPS Agreement, regarding the role and work of international organizations relevant in the field of SPS regulation, it expressly identified an UNECE Working Party, alongside the CAC, IPPC and OIE, as a relevant organisation. ${ }^{757}$

Fourth, it is interesting to note that Annex A.3(d) refers to 'international organizations'. This would seem at first sight to suggest that only standard-setting bodies that fulfil the international law criteria for an international organisation would fall under this provision. ${ }^{758}$ However, the term 'international organizations' is used elsewhere in the SPS Agreement to refer, inter alia, to the CAC and the IPPC, neither of which is an international organisation in the legal sense of the term. ${ }^{759}$ Therefore, it would seem that intergovernmental standard-setting bodies that are not necessarily international organisations could be identified by the SPS Committee under Annex A.3(d). One could think, for example, of treaty bodies such as the Conference of the Parties to the Convention on Biological Diversity, taking decisions under the Cartagena Protocol on Biosafety relating to guidelines for the safe handling and transfer of living modified organisms. ${ }^{760}$

The broad interpretation of the criteria for determining the possible international bodies that could be identified as a 'relevant international organization' by the SPS Committee under Annex A.3(d) of the SPS Agreement is tempered by the reality of the decision making process. Decisions by the SPS Committee under this provision, as all its decisions,

${ }^{755}$ The UNECE standards cover a wide spectrum of agricultural products including fresh fruit and vegetables, dry produce, seed potatoes, meat, cut flowers, eggs and egg products. See for example, UNECE standard DDP-18 Concerning the Marketing and Commercial Quality Control of Inshell Almonds, 2007, available at: http://www.unece.org/trade/agr/standard/dry/dry_e/18inalmonds.pdf, visited on 5 February 2008.

${ }^{756}$ Any country that wishes to participate in the work of the Working Party on Agricultural Quality Standards must notify the Executive Secretary of the UNECE, indicating the national focal point for this work and the institution responsible for quality control and a contact person. The Terms of Reference of the Working Party on Agricultural Quality Standards are available at: http://www.unece.org/trade/agr/info/ToR_eng.doc, visited on 5 February 2008.

757 Negotiating Group on Agriculture, Sanitary and Phytosanitary Regulations. Role and Status of Work of Selected Organizations. Note by the Secretariat, circulated on 20 April 1988, 1, available at: http://www. wto.org/gatt_docs/English/SULPDF/92040055.pdf, visited on 11 May 2008. The UN ECE Working Party referred to in the Secretariat Note was an earlier body, namely the Working Party on Standardisation of Perishable Produce, established in 1949.

${ }^{758}$ An international organisation is a subject of international law, capable of having rights and obligations. It is established by a treaty or other international law instrument. It must have its own mandate, and possess its own organs, distinct from its members, capable of fulfilling the functions of the organisation. In this regard, see for example, N.M. Blokker, International Institutional Law, $4^{\text {th }}$ ed. (Martinus Nijhoff, The Hague) 2003, 21-22; Phillippe Sands and Pierre Klein, Bowett's Law of International Institutions, $5^{\text {th }}$ ed. (Sweet and Maxwell, London) 2001, 16; Jan Klabbers, An Introduction to International Institutional Law (Cambridge University Press, Cambridge) 2002, 7-13; and C.F. Amerasinghe, Principles of the Institutional Law of International Organizations $2^{\text {nd }}$ ed. (Cambridge University Press, Cambridge) 2005, 10-11.

${ }^{759}$ For example, see Articles 3.4 and 3.5 of the SPS Agreement.

${ }^{760}$ However, it is very unlikely that this body would, in practice, be identified by the SPS Committee under Annex A.3(d), due to the controversial nature of the regulation of genetically modified organisms among WTO Members. 
must be taken by consensus. ${ }^{761}$ This ensures that all Members have an opportunity to prevent the identification of an international standard-setting body as relevant for purposes of the harmonisation provisions of the SPS Agreement, if they regard this as contrary to their interests. While this may make it difficult to reach decisions on this matter, particularly with regard to controversial bodies, such as that acting under the Cartagena Protocol on Biosafety, it also serves a useful purpose. ${ }^{762}$ It acts as a safeguard against an uncontrolled expansion of the number of international bodies whose standards have relevance as benchmarks for purposes of the SPS Agreement. Such an expansion, while increasing the number of standards available as a basis for harmonisation, also increases the number of bodies in which WTO Members will have to participate in order to protect their interests. The identification of a 'relevant international organisation' under Annex A.3(d) therefore remains a last resort, for cases where Members agree that standards are needed in an area currently not covered by one of the 'three sisters'. These cases are far more likely to relate to areas not currently prioritised by the CAC, OIE or IPPC than to areas where the absence of standards is due to the controversial nature of the matter at issue.

\subsubsection{Nature of the relevant international norms}

A second issue that arises with regard to the definition of 'standards, guidelines and recommendations' in Annex A.3, relates to whether differences in the substantive or procedural nature of various international norms are taken into account by the SPS Agreement in its use of these norms as benchmarks. In particular, this question relates to differences in the substantive types of norms (i.e. standards, guidelines or recommendations) and differences in the procedure that led to the creation of the norm.

No explicit distinction is made in the SPS Agreement between 'standards, guidelines and recommendations'. However, their substantive nature is clearly quite different and they are not intended by the standard-setting bodies themselves to have the same status. As mentioned above, ${ }^{763}$ soon after the coming into force of the SPS Agreement, a question was sent by the CAC to the SPS Committee regarding whether the obligations in Article 3 of the SPS Agreement applied equally and without distinction to standards, guidelines and recommendations set by the CAC. ${ }^{764}$ This was important to CAC members in order to know what effect the differences in the types of norms they adopted would have on their obligations under the SPS Agreement. The answer received from the SPS Committee was

\footnotetext{
${ }^{761}$ Article 12.1 of the SPS Agreement.

${ }^{762}$ Scott argues that the consensus requirement for decision making in the SPS Committee is likely to be an insurmountable obstacle to the identification of other relevant organisations by the SPS Committee. In support of this point she refers to the fact that no agreement could be reached in the SPS Committee even on granting observer status to the Cartagena Protocol on Biosafety. Joanne Scott, The WTO Agreement on Sanitary and Phytosanitary Measures: A Commentary, Oxford Commentaries on the GATT/WTO Agreements (Oxford University Press, Oxford), 2007, 245. While such pessimism is no doubt warranted with regard to bodies active in controversial areas, as are the bodies under the Cartagena Protocol on Biosafety that deals with living modified organisms, other more technical bodies setting standards for particular commodities may not present as many problems.

${ }^{763}$ On this point, see above, Part II, Section 3.2.1.4.

${ }^{764}$ Codex Alimentarius Commission, Report of the Twenty-Second Session, ALINORM 97/37 (Joint FAO/ WHO Food Standards Programme, Geneva), 23-28 June 1997, para. 172.
} 
that the Agreement makes no distinction between the three types of norms and that they are thus equally applicable under the disciplines set by Article 3 of the SPS Agreement. ${ }^{765}$

Although not expressly mentioned in the Annex A.3 definition, the term 'international standards, guidelines and recommendations' includes the requirement that the norms set by the relevant international bodies be 'international' in nature. This would therefore exclude standards set at regional level, intended to address specifically regional SPS concerns. An example would be the standards set by the regional offices of the International Plant Protection Convention, or those adopted by the Codex Alimentarius Commission on proposal by one of the regional Coordination Committees for purposes of that region only. ${ }^{766}$ The omission of the requirement of an international nature would have led to the anomalous situation that Members outside the relevant region for which the standard was set would have to scientifically justify their deviation from a standard or guideline neither intended nor appropriate for their adoption.

There are no explicit qualifications in the definition of 'standards, guidelines and recommendations' with regard to the procedure used to set the norm. Instead, the obligation in Article 3.1 refers broadly to 'international standards, guidelines or recommendations, where they exist' ${ }^{767}$ In particular, there is no requirement as to the degree of support the norm should represent, such as a qualified majority or a consensus in favour. Neither is there any reference to the extent of participation by developing countries in the procedure leading to its adoption. It is only provided that the other relevant international organisations for matters not covered by the 'three sisters' should be 'open for Membership to all Members. ${ }^{768}$ The latter requirement, however, says nothing about the actual participation by all Members in standard setting, or about the effectiveness of the participation that does occur. ${ }^{769}$

This unqualified use of international norms for purposes of the harmonisation disciplines of Article 3 of the SPS Agreement was confirmed by the Panel in EC-Hormones. In that case the EC argued that as the existing Codex standards were not relevant to the dispute as they had been adopted by a very narrow majority indicating their controversial

${ }^{765}$ In the preparatory phase leading towards the Seattle Ministerial Conference, several developing-country Members proposed that the definition of 'international standards, guidelines or recommendations' be amended to distinguish 'mandatory international standards and voluntary international guidelines/recommendations.' WTO Secretariat, Preparations for the 1999 Ministerial Conference. Compilation of Proposals Submitted in Phase 2 of the Preparatory Process. Informal Note by the Secretariat. Revision, JOB(99)/4797/ Rev.3, circulated on 18 November 1999, para. F. While this proposal seems to rest on the mistaken view that standards are mandatory, or are made mandatory by the SPS Agreement, it does serve to indicate the stronger legal status of standards relative to that of guidelines and recommendations, and the wish to have this recognised in the way the SPS Agreement deals with each.

766 This was confirmed in the abovementioned response of the SPS Committee to the CAC. Codex Alimentarius Commission, Report of the Twenty-Second Session (Joint FAO/WHO Food Standards Programme, Geneva), 23-28 June 1997, para. 168.

${ }^{767}$ Note however, that in contrast to the TBT Agreement which refers in Article 2.4 to international standards where they exist or where their completion is imminent, the SPS Agreement does not refer to imminent standards.

${ }^{768}$ The CAC, OIE and IPPC are open to membership by all WTO Members according to their constituent documents, as noted above, Part II, Sections 3.2.1.3, 3.2.2.3 and 3.2.3.3. Thus this requirement only needed to be specified for the 'other relevant international organizations' mentioned in Annex A.3(d).

769 See the discussion on the problems of participation in the CAC, OIE and IPPC, above, Part II, Sections 3.2.1.5, 3.2.2.5 and 3.2.3.5. 
nature; they embodied levels of protection, not measures, and were thus irrelevant to the obligations in the SPS Agreement; and the process leading to their adoption had commenced long before the coming into force of the SPS Agreement so that Codex members were unaware of the effect they would have by virtue of the Agreement. ${ }^{770}$ In response the Panel noted that:

Article 3.1 unambiguously prescribes that “... Members shall base their sanitary ... measures on international standards ... where they exist ..." (emphasis added). Paragraph 3 of Annex A of the SPS Agreement states equally clearly that the international standards mentioned in Article 3:1 are "for food safety, the standards ... established by the Codex Alimentarius Commission relating to ... veterinary drug ... residues ..." (emphasis added). No other conditions are imposed in the SPS Agreement on the relevance of international standards for the purposes of Article 3. Therefore, as a panel making a finding on whether or not a Member has an obligation to base its sanitary measure on international standards in accordance with Article 3.1, we only need to determine whether such international standards exist. For these purposes, we need not consider (i) whether the standards reflect levels of protection or sanitary measures or the type of sanitary measure they recommend, or (ii) whether these standards have been adopted by consensus or by a wide or narrow majority, or (iii) whether the period during which they have been discussed or the date of their adoption was before or after the entry into force of the SPS Agreement. ${ }^{771}$

The Appellate Body did not address this issue as it was not raised by the EC in appeal. A similar approach was taken by the Panel in Australia - Salmon with respect to the applicability of OIE standards. In this case, in the context of the interim review of the Panel Report, Australia stated that the OIE Aquatic Animal Health Code does not set adequate international guidelines since it is under substantial revision, is not representative of global conditions, is not grounded on a scientific basis and is the result of non-transparent decision-making. ${ }^{772}$ The Panel found that:

... the SPS Agreement (paragraph 3(b) of Annex A) explicitly directs us to the OIE and the standards, guidelines and recommendations it develops ... The fact that the OIE Code is subject to revision or the way it has been adopted in our view does not change its validity for our purposes. ${ }^{773}$

This deferential approach to assessing the relevance of the standards set by the three referenced international standard-setting bodies flows from the terms of the SPS Agreement itself. ${ }^{774}$ The absence of procedural or substantive requirements for establishing the relevance of these international standards is indicative of a choice written into the Agreement to allocate the competence for balancing competing trade and health objectives to the in-

\footnotetext{
770 Panel Report, EC - Hormones (Canada), paras 8.69-8.71; Panel Report, EC - Hormones (US), paras 8.66-8.68.

${ }^{771}$ Panel Report, EC - Hormones (Canada), para. 8.72; Panel Report, EC-Hormones (US), para. 8.69.

${ }_{772}$ Panel Report, Australia - Salmon, para. 7.10.

773 Ibid.

${ }^{774}$ For a discussion of the standard of review that this implies, see below, Part IV, Section 2.2.3.
} 
ternational bodies identified in the Agreement in the first place. ${ }^{775}$ However, it is clear that the question of participation in standard-setting in international organisations needs to be addressed if the resultant standards are to constitute credible benchmarks for national authorities. ${ }^{776}$ This issue was raised in the run-up to the Seattle Ministerial Conference, where a group of developing-country Members called for a narrower definition of 'international standards, guidelines and recommendations' to be developed to include only those standards that are developed with the participation of countries at different levels of development and from all geographical regions. ${ }^{777}$ Further, another group of developing-country Members proposed the inclusion of a requirement that such international standards had to have been adopted by consensus in order to fall within the definition. ${ }^{778}$ These proposals evince developing-country concerns with the absence of procedural requirements in the SPS Agreement for the standards used as benchmarks by its provisions.

Naturally, although not expressly stated in the reference to international standards, guidelines or recommendations in Article 3 of the SPS Agreement, the obligations in this Article are only triggered when the existing international norms are relevant to the risk addressed by the SPS measure. ${ }^{779}$ The question arises how closely the international norm must correspond to the issue addressed by he SPS measure in dispute. In EC-Hormones, the EC argued that the existing Codex standards were not relevant to the dispute as they did not apply to the use of hormone growth promoters, as did the EC measure, but rather set MRLs and ADIs. ${ }^{780}$ The Panel noted that Codex standards existed for five of the six hormones at issue, ${ }^{781}$ and proceeded to examine 'the definition and scope of application' of the Codex standards and to determine whether they applied to the EC measure in dispute. ${ }^{782}$ After finding that the 'type' of SPS measure embodied in an international standard is irrelevant, the Panel pointed out that the existing Codex standards related to veterinary drug residues, as referred to in Annex A.3(a), they applied exclusively to cattle and bo-

${ }^{775}$ For a discussion of the idea that harmonisation of SPS requirements around international standards aims to promote the efficient supply of global public goods (free trade and health) by using international negotiations to ensure that costs and benefits of all stakeholders are taken into account at the global level, see above Part II, Section 3.1.1.

776 The problems of participation in international standard-setting procedures are addressed above Part II, Sections 3.2.1.5, 3.2.2.5 and 3.2.3.5.

777 WTO Secretariat, Preparations for the 1999 Ministerial Conference. Compilation of Proposals Submitted in Phase 2 of the Preparatory Process. Informal Note by the Secretariat. Revision, JOB(99)/4797/Rev.3, circulated on 18 November 1999, para. F. This proposal was made by Cuba, the Dominican Republic, Egypt, El Salvador, Honduras, India, Indonesia, Malaysia, Nigeria, Pakistan, Sri Lanka and Uganda.

${ }^{778} \mathrm{Ibid}$., para. H. This proposal was made by Zambia, Jamaica, Kenya, Pakistan, Sri Lanka, Tanzania, Uganda and Zimbabwe.

${ }^{779}$ Article 2.4 of the TBT Agreement explicitly qualifies the international standards it refers to as 'relevant'. This has been interpreted as meaning that the international standard must 'bear upon, relate to, or be pertinent to' the technical regulation at issue. Panel Report, EC - Sardines, para. 7.68; and Appellate Body Report, ECSardines, para. 229.

${ }^{780}$ Panel Report, EC - Hormones (Canada), para. 8.69; Panel Report, EC-Hormones (US), para. 8.66.

${ }^{781}$ With respect to the three natural hormones at issue, oestradiol-17 $\beta$, progesterone and testosterone, the Codex Committee on Residues of Veterinary Drugs in Food found it unnecessary to establish an MRL or ADI as they were considered safe when used in accordance with good veterinary practice. With respect to two of the three synthetic hormones at issue, Zeranol and Trenbolone, the applicable Codex standards were an ADI of $0-0.5$ and $0.02 \mu \mathrm{g} / \mathrm{kg}$ body weight respectively and an MRL of $2 \mu \mathrm{g} / \mathrm{kg}$ in bovine muscle, $102 \mu \mathrm{g} / \mathrm{kg}$ in bovine liver for both.

${ }^{782}$ Panel Report, EC - Hormones (Canada), para.8.61; Panel Report, EC-Hormones (US), para. 8.58. 
vine meat products and they related to five of the six hormones in dispute when used for growth promotion purposes. Similarly, the EC ban applied to bovine meat and meat products in respect of which cattle had been treated with the six hormones for growth promotion purposes. As a result of this correspondence in the product, the risk-causing substance and its technological purpose, the Panel found that international standards existed with respect to the EC measure in dispute in the sense of Article 3.1 and Annex A.3(a). ${ }^{783}$

In Australia - Salmon, the question of the existence of relevant international standards was once again at issue since the guideline that had been drafted by the OIE did not cover all 24 of the fish diseases at which the Australian measure was aimed, nor was it specifically aimed at salmon, the product at issue. The Panel found as follows:

Paragraph 3(b) of Annex A to the SPS Agreement indicates that the international standards, guidelines or recommendations referred to in Article 3 for animal health (the concern at issue in this dispute) are those developed under the auspices of the International Office of Epizooties ('OIE'). Both parties agree that the International Aquatic Animal Health Code adopted by the OIE in 1995 ('OIE Code') provides international guidelines on a disease-by-disease basis. However, they also agree that as of today no relevant OIE guideline exists which deals with salmon on a product specific basis. Moreover, both parties also agree that OIE guidelines do not exist for all of the 24 diseases of concern to Australia. ... In this respect, we are of the view, however, that the fact that in this case no international guidelines exist for all 24 diseases of concern does not mean that an international guideline which applies to only one of these diseases cannot be relevant (or, according to the language of Article 3.1, does not 'exist') for the measure at issue. ${ }^{784}$

Thus, a much lower level of correspondence between the international standard and the SPS measure was accepted in this case to establish the relevance of the international standard.

The lack of concern for the procedural aspects of the international standard that Members are encouraged to adopt is worrying in the light of the problems that exist in the standard-setting procedures followed in the relevant international organisations, as discussed above. ${ }^{785}$ As a result, many international standards reflect the interests and priorities of developed-country members of the standard-setting bodies, and are of limited relevance to developing-country members. This, coupled with the eagerness of the Panel in Australia - Salmon to make the international norms applicable to a case, regardless of whether they really fully cover the situation at hand, gives cause for concern. As aptly stated by Joanne Scott, this means that:

\footnotetext{
${ }^{783}$ Panel Report, EC - Hormones (Canada), para. 8.73; Panel Report, EC - Hormones (US), para. 8.70.

${ }^{784}$ Panel Report, Australia - Salmon, para. 8.46. In this case, however, the Panel noted that as, in the absence of OIE standards for all 24 diseases at issue, it would in any event be obliged to consider whether Australia complied with Articles 2 and 5 of the SPS Agreement, it would begin its analysis with the latter Articles before turning to Article 3. As it found violations of Articles 2 and 5, it exercised judicial economy with respect to the claims under Article 3. Ibid., para. 8.184.

${ }^{785}$ See above, Part II, Sections 3.2.1.5, 3.2.2.5 and 3.2.3.5.
} 
The authority of international standards is 'automatic'. It is not contingent upon the nature of the standard setting process, and that process is not subject to judicial oversight at the WTO. It is not open for Members to seek to justify their departure from international standards on the basis of scientific or due process deficits which characterized their adoption. To the extent that such standards enjoy authority in the WTO, they enjoy authority without judicial contestability. ${ }^{786}$

The unqualified acceptance of all international standards, guidelines and recommendations adopted by the relevant international standard-setting bodies as applicable to the disciplines of Article 3, leads to the question of what exactly is encompassed by these obligations. This will determine the implications of the all-encompassing nature of the reference to international norms for Members at different levels of development.

\subsection{Obligations with regard to international standards}

The particular obligations with regard to the promotion of harmonisation around the international standards set by the CAC, OIE and IPPC are found in Article 3.1, 3.2 and 3.3 of the SPS Agreement. Further, Members are obliged under Article 3.4 to participate in the work of these organisations, to the extent that their resources permit, and to promote development and periodic review of SPS standards. Article 3.5 mandates the SPS Committee to establish a procedure to monitor the process of international harmonisation in co-ordination with the relevant international organisations. ${ }^{787}$

Aside from Article 3, dealing directly with harmonisation and which refers expressly to the CAC, OIE and IPPC, other provisions of the SPS Agreement refer to 'relevant international organizations'. While not directly promoting the harmonisation of SPS measures, as noted by Stewart and Johanson, they do promote increased uniformity by encouraging participation in these organisations and promoting regard for processes and guidelines developed by them or the information gathered by them. ${ }^{788}$ For example, Article 5.1 obliges Members to take account of risk assessment processes developed by the 'relevant

786 Joanne Scott, The WTO Agreement on Sanitary and Phytosanitary Measures: A Commentary, Oxford Commentaries on the GATT/WTO Agreements (Oxford University Press, Oxford), 2007, 275. Here, Scott cites Robert Howse, who refers to the 'automatic' legal force of international standards in the WTO, meaning that 'the Appellate Body does not, apparently, consider it to be of any importance to take into account the intentions or practice of the standard-setting regime in question; it is unconcerned with the intentions of the standard-setting regime or its participants, and uninterested in the practice of that regime. The [Appellate Body] is quite prepared to confer legal force on international standards, without any consideration of the institutional context in which such standards arise.' Robert Howse, 'A New Device for Creating International Legal Normativity: The WTO Technical Barriers to Trade Agreement and "International Standards" in C. Joerges and E. Petersmann (eds) Constitutionalism, Multilevel Trade Governance and Social Regulation, Studies in International Trade Law, 9 (Hart Publishing, Portland) 2006, 383-395.

${ }^{787}$ Article 12.4 of the SPS Agreement reiterates this obligation, stating that the SPS Committee must develop a procedure to monitor the process of international harmonization. On the work of the SPS Committee in this regard, see below, Part IV, Section 2.1.3.

${ }^{788}$ Terence P. Stewart and David S. Johanson, 'The SPS Agreement of the World Trade Organization and International Organizations: The Roles of the Codex Alimentarius Commission, the International Plant Protection Convention, and the International Office of Epizootics', Syracuse Journal of International Law and Commerce 26, 1998, 27-53, 31-32. 
international organizations' ${ }^{789}$ Article 5.7 allows provisional measures to be adopted in cases of scientific uncertainty on the basis of available scientific information 'including that from relevant international organizations'. Article 6.1 obliges Members, in assessing pest- or disease-free areas, to take into account 'guidelines which may be developed by the relevant international organizations' ${ }^{790}$ In Article 9.1 Members agree to facilitate the provision of technical assistance to developing-country Members either bilaterally or through 'the appropriate international organizations'. Article 10.4 provides that Members should encourage the participation of developing-country Members in 'the relevant international organizations'. ${ }^{791}$ Article 11.2 makes it possible for dispute settlement panels to consult 'relevant international organizations' when faced with scientific or technical issues. ${ }^{792}$ These provisions are discussed further below, but it is useful to bear in mind here that the impact of the relevant international standard-setting bodies extends beyond the harmonisation disciplines of Article 3.

The specific provisions of Article 3.1 to 3.3 of the SPS Agreement and their interpretation by panels and the Appellate Body are now examined in detail. Under the heading Harmonization, these provisions state:

1. To harmonize sanitary and phytosanitary measures on as wide a basis as possible, Members shall base their sanitary or phytosanitary measures on international standards, guidelines or recommendations, where they exist, except as otherwise provided for in this Agreement, and in particular in paragraph 3.

2. Sanitary or phytosanitary measures which conform to international standards, guidelines or recommendations shall be deemed to be necessary to protect human, animal or plant life or health, and presumed to be consistent with the relevant provisions of this Agreement and of GATT 1994.

3. Members may introduce or maintain sanitary or phytosanitary measures which result in a higher level of sanitary or phytosanitary protection than would be achieved by measures based on the relevant international standards, guidelines or recommendations, if there is a scientific justification, or as a consequence of the level of sanitary or phytosanitary protection a Member determines to be appropriate in accordance with the relevant provisions of paragraphs 1 through 8 of Article 5. Notwithstanding the above, all measures which result in a level of sanitary or phytosanitary protection different from that which would be achieved by measures based on international standards, guidelines or recommendations shall not be inconsistent with any other provision of this Agreement. (Emphasis added)

In short, Article 3.1 expresses the aim of harmonising SPS measures on as wide a basis as possible, and states the obligation of Members to 'base' their SPS measures on international standards, guidelines or recommendations, where they exist, except as provided for

\footnotetext{
${ }^{789}$ See further on this point below, Part III, Section 5.1.3.

${ }^{790}$ See further on this point below, Part IV, Section 1.2.7.

${ }^{791}$ See further on this point below, Part V, Section 2.4.

${ }^{792}$ See further on this point below, Part IV below, Section 2.2.5.
} 
in Article 3.3. Art 3.2 creates a presumption of consistency with GATT 1994 and the SPS Agreement for measures which 'conform to' international standards. Article 3.3 recognises the right of Members to use SPS measures which result in a higher level of protection than would be achieved by measures 'based on' the relevant international standards and sets certain requirements for this.

The Appellate Body in EC - Hormones identified the various options open for Members under these provisions. It rejected the Panel's approach of seeing Articles 3.1 and 3.2 as the general rule and Article 3.3 as the exception. ${ }^{793}$ Instead it identified three autonomous options available to Members under these provisions. It held as follows:

Under Article 3.2 of the SPS Agreement, a Member may decide to promulgate an SPS measure that conforms to an international standard. Such a measure would embody the international standard completely and, for practical purposes, converts it into a municipal standard. Such a measure enjoys the benefit of a presumption (albeit a rebuttable one) that it is consistent with the relevant provisions of the SPS Agreement and of the GATT 1994.

Under Article 3.1 of the SPS Agreement, a Member may choose to establish an SPS measure that is based on the existing relevant international standard, guideline or recommendation. Such a measure may adopt some, not necessarily all, of the elements of the international standard. The Member imposing this measure does not benefit from the presumption of consistency set up in Article $3.2 ; \ldots$

Under Article 3.3 of the SPS Agreement, a Member may decide to set for itself a level of protection different from that implicit in the international standard, and to implement or embody that level of protection in a measure not 'based on' the international standard. The Member's appropriate level of protection may be higher than that implied in the international standard. The right of a Member to determine its own appropriate level of sanitary protection is an important right. ${ }^{794}$

The nature and implications of each of the three autonomous options identified by the Appellate Body bear closer examination.

\subsubsection{Measures based on international standards}

The first option open to Members, under Article 3.1, is to 'base' their SPS measures on international standards, guidelines or recommendations. The question arises whether this requires that Members conform their measures to international standards, as was found by the Panel in EC-Hormones. ${ }^{795}$ The Panel in this case further held that to be 'based on'

\footnotetext{
793 Appellate Body Report, EC-Hormones, para. 168.

${ }^{794}$ Appellate Body Report, EC-Hormones, paras 170-172.

${ }^{795}$ The Panel had held that Article 3.1 does not define 'based on' but that Article 3.2 equates measures 'based on' international standards with those which 'conform to' these standards. Panel Report, EC - Hormones (US), para. 8.72 and Panel Report EC-Hormones (Canada), para. 8.75.
} 
an international standard, the measure must achieve the same level of sanitary protection as that standard, a conclusion it viewed as implied by Article 3.3. ${ }^{796}$

The Appellate Body rejected this reasoning, finding that the plain meaning of the terms 'based on' and 'conform to' differ. A thing based on another " "stands" or is "founded" or "built" upon or "is supported by" the latter." ${ }^{\text {" } 97}$ By contrast, it held that "conform to' requires much more, namely that the SPS measure "“comply with", "yield or show compliance" with the latter' or correspond 'in form or manner' with, or follow 'in form or nature' the international standard. ${ }^{798}$ It held further:

A measure that 'conforms to' and incorporates a Codex standard is, of course, 'based on' that standard. A measure, however, based on the same standard might not conform to that standard, as where only some, not all, of the elements of the standard are incorporated into the measure. ${ }^{799}$

Noting the fact that the two terms are used in different provisions, the Appellate Body found:

The implication arises that the choice and use of different words in different places in the SPS Agreement are deliberate, and that the different words are designed to convey different meanings. A treaty interpreter is not entitled to assume that such usage was merely inadvertent on the part of the Members who negotiated and wrote that Agreement. Canada has suggested the use of different terms was 'accidental' in this case, but has offered no convincing argument to support its suggestion. We do not believe this suggestion has overturned the inference of deliberate choice. ${ }^{800}$

The Appellate Body also pointed out that the Panel's interpretation was contrary to the object and purpose of Article 3.1, which is ' $[\mathrm{t}] \mathrm{o}$ harmonize [SPS] measures on as wide a basis as possible' ${ }^{801}$ Noting the desire recorded in the preamble to the SPS Agreement to further the use of harmonised measures and the tasks assigned to the SPS Committee in this regard under Article 12 of the SPS Agreement, the Appellate Body stated:

It is clear to us that harmonization of SPS measures of Members on the basis of international standards is projected in the Agreement, as a goal, yet to be realized in the future. To read Article 3.1 as requiring Members to harmonize their SPS measures by conforming those measures with international standards, guidelines and recommendations, in the here and now, is, in effect, to vest such international standards, guidelines and recommendations (which are by the terms of the Codex recommendatory in form and nature) with obligatory force and effect. The Panel's interpretation of Article 3.1 would, in other words, transform those standards, guidelines and recommendations into binding norms. But, as

\footnotetext{
796 Panel Report, EC - Hormones (US), para. 8.73; Panel Report EC-Hormones (Canada), para. 8.76.

797 Appellate Body Report, EC - Hormones, para. 163.

${ }^{798}$ Ibid., para. 163.

799 Ibid.

${ }^{800}$ Ibid., para. 164.

${ }^{801}$ Article 3.1 of the SPS Agreement, cited ibid., para. 165.
} 
already noted, the SPS Agreement itself sets out no indication of any intent on the part of the Members to do so. We cannot lightly assume that sovereign states intended to impose upon themselves the more onerous, rather than the less burdensome, obligation by mandating conformity or compliance with such standards, guidelines and recommendations. To sustain such an assumption and to warrant such a far-reaching interpretation, treaty language far more specific and compelling than that found in Article 3 of the SPS Agreement would be necessary. ${ }^{802}$

The Appellate Body thus made it clear that the voluntary standards set by the relevant international standard-setting bodies do not become mandatory through the operation of the SPS Agreement. ${ }^{803}$

Aside from noting that the requirement for an SPS measure to be 'based on' an international standard is not to be equated with a requirement to 'conform to' such a standard, the Appellate Body further clarified that a measure 'based on' an international standard 'may adopt some, not necessarily all, of the elements of the international standard.' The closeness of the relationship required between the SPS measure and the international standard in order for it to be 'based on' this standard is still not clear. ${ }^{805}$ The Appellate Body refrained from deciding on the correctness of the rest of the Panel's analysis on the meaning of 'based on', including the finding that 'for a sanitary measure to be based on an international standard ..., that measure needs to reflect the same level of sanitary protection as the standard. ${ }^{806}$ Although the question was thus left open by the Appellate Body, it would appear that the Panel was correct in informing the term 'based on' in Article 3.1 with reference to the use of the same term in Article 3.3. Thus in order to be regarded as 'based on' an international standard, the SPS measure must not only adopt at least some of the elements of the international standard but also result in the same level of protection. ${ }^{807}$

Despite the more lenient interpretation of the requirements of Article 3.1 given by the Appellate Body in EC - Hormones than that given by the Panel, the EC ban was obviously not 'based on' the existing Codex standards and did not adopt any elements thereof.

${ }^{802}$ Ibid., para. 165.

${ }^{803}$ Before the Panels, the EC had argued that CAC members were used to adopting voluntary standards and were not aware that the standards for hormones in beef would in effect become mandatory through the operation of the SPS Agreement. Panel Report EC-Hormones (US), para. 8.68; Panel Report EC-Hormones (Canada), para. 8.71.

${ }^{804}$ Appellate Body Report, EC-Hormones, para. 171.

${ }^{805}$ In EC - Sardines, with respect to the requirement in Article 2.4 of the TBT Agreement that international standards be used 'as a basis' for technical regulations, the Appellate Body held that 'there must be a very strong and close relationship' between them and 'at minimum, no such relationship can exist where there is a contradiction' between the regulation and the standard. Appellate Body Report, EC-Sardines, para. 245. It is doubtful whether this interpretation can be applied by analogy to the 'based on' requirement in the SPS Agreement, however, as unlike the SPS Agreement, the TBT Agreement does not contain an alternative 'conform to' option. Therefore it is to be expected that the relationship required by the TBT Agreement between the measure and the international standard in order for the former to be based on the latter is closer than that under the SPS Agreement.

${ }^{806}$ Panel Report, EC - Hormones (Canada), para. 8.76; Panel Report, EC-Hormones (US), para. 8.73.

${ }^{807}$ Appellate Body Report, EC-Hormones, para. 171. 
As stated above, the CAC had set no ADI or MRL ${ }^{808}$ for any of the relevant natural hormones, finding this to be unnecessary as it had determined them to be safe when used in accordance with good veterinary practice, and had set certain ADIs and MRLs ${ }^{809}$ for the two synthetic hormones, which were obviously exceeded by the EC's ban. The Appellate Body thus continued by analysing the EC's measure under the requirements of Article 3.3 for measures that are not based on international standards. ${ }^{810}$

The question arises what the consequences would be of choosing the option under Article 3.1. The Appellate Body in EC-Hormones clarified these consequences as follows:

Under Article 3.1 of the SPS Agreement, a Member may choose to establish an SPS measure that is based on the existing relevant international standard, guideline or recommendation. ... The Member imposing this measure does not benefit from the presumption of consistency set up in Article 3.2; but, as earlier observed, the Member is not penalized by exemption of a complaining Member from the normal burden of showing a prima facie case of inconsistency with Article 3.1 or any other relevant article of the SPS Agreement or of the GATT $1994 .^{811}$

Thus, clearly a Member that merely bases its SPS measures on international standards, without conforming to them, does not enjoy a presumption of compliance of its measures with the SPS Agreement and the GATT 1994. Still, it seems logical that there should be an advantage for a Member which chooses this alternative over that provided under Article 3.3. It has been argued that as a measure based on an international standard is automatically based on a risk assessment (that underlying the standard set by the relevant international standard-setting body), the measure should be deemed to comply with Article 5.1-5.3 of the SPS Agreement. ${ }^{812}$ Thus an evaluation of whether the strict requirements for a risk assessment were met is rendered unnecessary. While not providing a safe haven for SPS measures against challenges under the SPS Agreement and the GATT 1994, as is the case for Article 3.2, the option under Article 3.1 arguably saves SPS measures that are based on international standards from the rigorous scientific disciplines of the Agreement. This would be in line with the SPS Agreement's strong reliance on the expertise and reputable nature of the 'three sisters'. It would also be consistent with the structure of Article 3, in particular the requirement in Article 3.3 of scientific justification for SPS measures that are not based on international standards. SPS measures based on the relevant international standards would then only be vulnerable to challenges under the remaining

${ }^{808}$ Codex standards for veterinary drugs are normally stated in terms of ADI and MRL. ADI constitutes an estimate by the JECFA of the amount of a veterinary drug, expressed on the basis of body weight that can be ingested over a lifetime without appreciable health risks. MRL indicates the maximum concentration of residues, resulting from the use of the veterinary drug, which are recommended to be legally permitted or considered acceptable in food.

${ }^{809}$ These Codex standards, based on the $32^{\text {nd }}$ Report of the JEFCA of 1988 , set an ADI of 0-0.2 ug/ $\mathrm{kg}$ body weight for Trenbolone and $0-0.5 \mathrm{ug} / \mathrm{kg}$ body weight for Zeranol. For both synthetic hormones it set an MRL of $2 \mathrm{ug} / \mathrm{kg}$ (muscle) and $10 \mathrm{ug} / \mathrm{kg}$ (liver).

${ }^{810}$ Appellate Body Report, EC-Hormones, paras 176-177.

811 Appellate Body Report, EC-Hormones, para. 171.

812 David R. Hurst, 'Hormones: European Communities - Measures Affecting Meat and Meat Products', European Journal of International Law 9 (1), 1998, 182-183, available at: http://www.ejil.org/journal/Vol9/ No1/sr1g.html, visited on 12 June 2008. 
trade-related disciplines, such as the non-discrimination and necessity requirements of the Agreement, and its procedural rules. ${ }^{813}$

This approach is partly supported by the findings of the Panels in US - Continued Suspension and Canada - Continued Suspension with regard to the implications of the existence of relevant international standards for the determination of 'insufficiency' of scientific evidence. ${ }^{814}$ Although this finding was made in relation to Article 5.7 of the SPS Agreement it has broader relevance for the relationship between international standards and the scientific disciplines of the SPS Agreement. ${ }^{815}$ The Panels held that the presumption of consistency with the SPS Agreement and the GATT 1994 of measures conforming to international standards, contained in Article 3.2 of the SPS Agreement, implies that such standards are based on risk assessments meeting the requirements of the SPS Agreement, and therefore also that 'sufficient scientific evidence' exists for these standards. ${ }^{816}$ The Panels stressed that 'some meaning' must be given to the role of international standards under the SPS Agreement and in particular the Article 3.2 presumption. ${ }^{817}$

The alternative, providing no advantage to measures based on international standards as compared to measures not so based, would undermine the promotion of harmonisation by the SPS Agreement by eliminating the incentive to use such standards as a basis for SPS measures. It would also mean that the scientific basis of international standards would be open to review by panels and the Appellate Body. As discussed below, panels have difficulty in evaluating scientific evidence and appreciating the limits of science in applying the risk assessment disciplines of the SPS Agreement to national measures. ${ }^{818}$ It can be expected that the same would occur in the evaluation of risk assessments by international expert bodies. Allowing panels to second-guess the work of internationally renowned experts would call into question the authoritative nature of the standards developed by the international standard setting bodies and disturb the relationship between them and the WTO.

More problematically, the latter approach would also have the unfortunate effect of reducing considerably the utility of the first of the 'autonomous options' for developing-country

${ }^{813}$ Contra see Scott, who argues that concerns regarding the scientific basis for decision-making under the $\mathrm{CAC}$ and the politicisation of risk regulation in its context may be addressed through review by WTO panels or the Appellate Body of international standards against the SPS Agreement's rules on risk assessment, least trade restrictive measure, equivalence etc. Joanne Scott, The WTO Agreement on Sanitary and Phytosanitary Measures: A Commentary, Oxford Commentaries on the GATT/WTO Agreements (Oxford University Press, Oxford), 2007, 258. Scott recognises that measures based on international standards have the benefit of providing a Member with 'a reservoir of internationally recognised scientific data upon which to draw in mounting their defence.' But she regards it as 'not inconceivable' that a panel could find that an international standard does not have an adequate basis in science, in view of the mode or operation of the international standard-setting bodies and the mixture of politics and science on which their standards rest. Ibid., 261.

${ }^{814}$ The Panels recalled that Codex Alimentarius standards existed for 4 of the 5 hormones at issue under the Article 5.7 analysis. Panel Report, US - Continued Suspension, para. 7.643; Panel Report, CanadaContinued Suspension, para. 7.621.

${ }^{815}$ These findings are discussed in relation to Article 5.7 of the SPS Agreement below, Part III, Section 5.2.5.

${ }^{816}$ Panel Report, US - Continued Suspension, para. 7.644; Panel Report, Canada - Continued Suspension, para. 7.622 .

${ }^{817}$ Panel Report, US - Continued Suspension, para. 7.646; Panel Report, Canada - Continued Suspension, para. 7.624

${ }^{818}$ See below, Part IV, Section 2.2.3. 
Members. Reliance by these Members on international standards as a basis for their SPS measures is often motivated by the possibility this offers to draw upon the sound scientific basis of these standards, in the face of insufficient scientific capacity at domestic level. At the same time, as the option under Article 3.1 does not require conformity with all aspects of the relevant international standards, it builds in flexibility for developingcountry Members to adjust the international standard to their local needs and technical capacities. While these adjustments are still subject to the non-science-related disciplines of the SPS Agreement, to ensure, inter alia, that the resulting measure is not more trade restrictive than necessary, not a form of arbitrary discrimination and is applied only to the extent necessary, safeguarding its scientific basis from challenge allows international standards to meet an important need of developing-country Members. This need, namely for a reliable scientific basis for their SPS measures, is one of the things the international standard-setting bodies were created to address.

\subsubsection{Measures conforming to international standards}

The second autonomous option open to a Member where international standards, guidelines or recommendations exist, is to adopt an SPS measure that conforms to the relevant international standard, guideline or recommendation under Article 3.2 of the SPS Agreement. It is thus necessary to examine what is required for a measure to 'conform to' an international standard. This issue was addressed by the Appellate Body in ECHormones. As already noted above, the Appellate Body regarded the term 'conform to' as requiring 'correspondence in form or manner', 'compliance with', or 'acquiescence' to 'follow[ing] in form or nature'. ${ }^{819}$ It further clarified that '[s] uch a measure would embody the international standard completely and, for practical purposes, converts it into a municipal standard. ${ }^{920}$

The measure must thus completely embody the international standard. This would seem to mean that the measure and the international standard must be identical in both form and level of protection aimed at.

The SPS Agreement promotes such measures by deeming them to be necessary to protect human, animal or plant life or health and by granting them a presumption of consistency with the SPS Agreement and GATT 1994. The Appellate Body in EC-Hormones addressed the implications of the presumption of consistency, stating as follows:

The presumption of consistency with relevant provisions of the SPS Agreement that arises under Article 3.2 in respect of measures that conform to international standards may well be an incentive for Members so to conform their SPS measures with such standards. It is clear, however, that a decision of a Member not to conform a particular measure with an international standard does not authorize imposition of a special or generalized burden of proof upon that Member, which may, more often than not, amount to a penalty. ${ }^{821}$

\footnotetext{
${ }^{819}$ Appellate Body Report, EC - Hormones, para. 163. This definition draws upon The New Shorter Oxford English Dictionary on Historical Principles, vol. 1 (Clarendon Press), 187.

${ }^{820}$ Ibid., para. 170.

${ }^{821}$ Ibid., para. 102.
} 
The advantage of choosing the option provided by Article 3.2 therefore lies in the safe harbour it creates for measures conforming to international standards. Such measures are not only free from scientific challenges, but are also regarded as meeting the necessity test and all other relevant requirements of the SPS Agreement and the GATT 1994. This wide shelter for measures under this provision is indicative of the high regard reflected in the SPS Agreement for the work of the international standard-setting bodies and the strength of its harmonisation objective.

Article 3.2 of the SPS Agreement does not specify whether its presumption of conformity is rebuttable or not. This is in marked contrast to the TBT Agreement where measures based on international standards are expressly only 'rebuttably presumed' to comply with the necessity requirement of that agreement. ${ }^{822}$ However, the Appellate Body in EC Hormones held nevertheless that the presumption of conformity in Article 3.2 is rebuttable. ${ }^{823}$ It stated:

Such a measure enjoys the benefit of a presumption (albeit a rebuttable one) that it is consistent with the relevant provisions of the SPS Agreement and of the GATT $1994 .{ }^{824}$

Remarkably, this finding of rebuttability, despite its importance, is a mere bracketed afterthought, with no indication of its motivation anywhere in the Appellate Body Report. It can be criticised for taking away much of the advantage for measures conforming to international standards. While the burden of proof on the complainant to show a violation of other provisions of the SPS Agreement would be higher due to the need to overcome the presumption of conformity, this is a small gain for the Member that has taken the effort to embody completely the international standard in its domestic regulation. ${ }^{825}$ This does little to promote harmonisation, contrary to the express objective of the SPS Agreement to 'further to use of harmonized sanitary and phytosanitary measures between Members, on the basis of international standards ..., 826

\footnotetext{
${ }^{822}$ The relative weakness of the harmonisation provision in Article 2.5 of the TBT Agreement as compared to the SPS Agreement is evinced not only in the express rebuttability of its presumption, but also in the fact that the presumption only covers conformity with the necessity requirement and not the entirety of the Agreement and the GATT 1994. In addition, the presumption kicks in when the measure is not only based on an international standard, but also aims at one of the enumerated legitimate objectives listed in Article 2.2 of that Agreement.

${ }^{823}$ Appellate Body Report, EC-Hormones, para. 170. The implications of this presumption for the burden of proof are discussed further below, Part IV, Section 2.2.2.

${ }^{824}$ Appellate Body Report, EC-Hormones, para. 170.

${ }^{825}$ As noted by Scott, this 'does not seem to be a benefit worth having' since in the absence of a rule/exception relationship between Article 3.1 and 3.3 '... it is never incumbent upon a Member to justify its regulatory choices until such a time as another state has entered a complaint, and established a prima facie case of inconsistency. As such, there is no initial burden resting upon the regulating state, such as is susceptible to being reversed in the event of conformity with international standards.' Joanne Scott, 'International Trade and Environmental Governance: Relating Rules (and Standards) in the EU and the WTO', European Journal of International Law 15, 2004, 307-354, 310. On this burden of proof issue, see further below, Part IV, Section 2.2.2.

${ }^{826}$ Sixth preambular paragraph to the SPS Agreement.
} 


\subsubsection{Measures providing a higher level of protection than international standards}

The third option open to Members is to promulgate SPS measures providing a higher level of protection than would measures 'based on' the relevant standards. This provision recognises the right of Members to choose their own level of protection, an important principle in the SPS Agreement. It embodies the clearly expressed proviso in the sixth preambular statement of the SPS Agreement indicating the desire to further harmonisation, 'without requiring Members to change their appropriate level of protection of human, animal or plant life or health'.

In EC-Hormones, as stated above, the Panel regarded Article 3.3 as 'an exception to the general obligation contained in Article 3.1. ${ }^{827}$ Therefore, it stated that if a complainant shows that a relevant international standard exists and that the SPS measure in dispute is not based on the international standard, the burden of proof shifts to the respondent Member to show that it has met the requirements of Article 3.3. ${ }^{828}$ The Appellate Body in EC - Hormones clarified the relationship between Article 3.3 and Article 3.1 and 3.2 as follows:

It appears to us that the Panel has misconceived the relationship between Articles 3.1, 3.2 and 3.3,... which is qualitatively different from the relationship between, for instance, Articles I or III and Article XX of the GATT 1994. Article 3.1 of the SPS Agreement simply excludes from its scope of application the kinds of situations covered by Article 3.3 of that Agreement, that is, where a Member has projected for itself a higher level of sanitary protection than would be achieved by a measure based on an international standard..$^{82}$

Significantly, the Appellate Body held in EC-Hormones that the 'right of a Member to establish its own level of sanitary protection under Article 3.3 of the SPS Agreement is an autonomous right and not an "exception" from a "general obligation" under Article $3.1^{\prime} .^{830}$ Therefore, rather than creating an exception to its disciplines, the words in Article 3.1 'except as otherwise provided in this Agreement, and in particular in paragraph 3' have the effect of carving out a particular type of situation from its scope of application, namely where the level of protection chosen by a Member is higher than that which would result from the international standard. This interpretation is in keeping with the balancing approach of the SPS Agreement, a key element of which is respect for the right of a Member to choose its appropriate level of protection, in accordance with its policy priorities. It would therefore be inappropriate to punish a Member that chooses a higher level of protection by requiring it to bear the burden of proof to justify its measure.

However, as recognised by the Appellate Body, the right of a Member to define its own level of protection is not an 'absolute or unqualified right' ${ }^{831}$ Instead, Article 3.3 sets two science-related conditions in the alternative. Either there must be a scientific justification

\footnotetext{
${ }^{827}$ Panel Report, EC - Hormones (US), para. 8.86; and Panel Report, EC-Hormones (Canada), para. 8.89.

${ }_{828}$ Panel Report, EC-Hormones (US), para. 8.87; and Panel Report, EC-Hormones (Canada), para. 8.90.

829 Appellate Body Report, EC-Hormones, para. 104.

${ }^{830}$ Ibid., para. 172.

${ }^{831}$ Ibid., para. 173.
} 
for the measures, or they must be the result of the higher level of protection chosen by the Member in accordance with Article 5.1-5.8. In both cases the measures must be consistent with all other provisions of the SPS Agreement. In footnote, it is clarified that a 'scientific justification' exists:

...if, on the basis of an examination and evaluation of available scientific information in conformity with the relevant provisions of this Agreement, a Member determines that the relevant international standards, guidelines or recommendations are not sufficient to achieve its appropriate level of sanitary or phytosanitary protection..$^{832}$

The distinction made in Article 3.3 between these two possible situations creates problems of interpretation. In EC-Hormones the EC argued that there was a 'scientific justification' for its measure, so it need not be in accordance with Article 5.1-5.8, which requirement is set for the second situation only. It thus claimed that no risk assessment was required as a basis for its ban on hormone-treated beef, despite the fact that it deviated from Codex standards. The Appellate Body held that 'Article 3.3 is evidently not a model of clarity in drafting and communication' ${ }^{933}$ and that the distinction between the two situations identified in Article 3.3, is more apparent than real. ${ }^{834} \mathrm{In}$ fact both situations require a risk assessment in accordance with Article 5. The Appellate Body in EC-Hormones thus stated as follows:

The use of the disjunctive 'or' does indicate that two situations are intended to be covered. These are the introduction or maintenance of SPS measures which result in a higher level of protection:

(a) 'if there is a scientific justification'; or

(b) 'as a consequence of the level of ... protection a Member determines to be appropriate in accordance with the relevant provisions of paragraphs 1 through 8 of Article 5'.

It is true that situation (a) does not speak of Articles 5.1 through 5.8. Nevertheless, two points need to be noted. First, the last sentence of Article 3.3 requires that 'all measures which result in a [higher] level of ... protection', that is to say, measures falling within situation (a) as well as those falling within situation (b), be 'not inconsistent with any other provision of [the SPS] Agreement'. 'Any other provision of this Agreement' textually includes Article 5. Secondly, the footnote to Article 3.3, while attached to the end of the first sentence, defines 'scientific justification' as an 'examination and evaluation of available scientific information in conformity with relevant provisions of this Agreement ...'. This examination and evaluation would appear to partake of the nature of the risk

\footnotetext{
${ }^{832}$ Footnote 2 to Article 3.3 of the SPS Agreement.

${ }^{833}$ Appellate Body Report, EC-Hormones, para. 175.

${ }^{834} \mathrm{Ibid}$., para. 176. According to the Appellate Body the 'involved and layered language' of Article 3.3 left it with no choice but to interpret the distinction between the two situations in this way. Ibid.
} 
assessment required in Article 5.1 and defined in paragraph 4 of Annex A of the SPS Agreement. ${ }^{835}$

Thus this ruling can be understood as requiring that a Member claiming scientific justification for its deviation from international standards, must base such a claim on a valid risk assessment, in the same way as a Member who justifies its deviation from the international standard on the grounds that it has chosen a different level of protection than that achieved by the international standard. ${ }^{836}$

It is useful to note that the Appellate Body's interpretation is expressly motivated by its consideration of the object and purpose of the SPS Agreement as a whole, recognising the delicate balance between trade and health sought by the Agreement. ${ }^{837}$ In this light, the Appellate Body indicated its 'belief that compliance with Article 5.1 was intended as a countervailing factor in respect of the right of Members to set their appropriate level of protection.' ${ }^{838}$ Thus the requirements of a risk assessment in Article 5.1 and of sufficient scientific evidence in Article 2.2 are regarded by the Appellate Body mediating between the goals of trade liberalisation and the protection of health. The role of science as the scale on which these interests are balanced is striking in this interpretation of this provision.

In Japan - Agricultural Products II, the Appellate Body again faced the question of what a Member needs to show when it claims there is 'scientific justification' for a deviating measure. It held as follows:

In our opinion, there is a 'scientific justification' for an SPS measure, within the meaning of Article 3.3, if there is a rational relationship between the SPS measure at issue and the available scientific information. ${ }^{839}$

This finding clarifies the required relationship between the deviating SPS measure and the scientific information (in the form of a risk assessment). ${ }^{840}$ It logically follows the interpretation of the requirement of Article 5.1 that an SPS measure be 'based on' a risk assessment. For the measure to be justified by the risk assessment required by Article 3.3, it clearly must be based on, i.e. have a rational relationship with, that risk assessment.

${ }^{835}$ Ibid., para. 175. The Appellate Body thus agreed with the Panel that although the EC had established for itself a level of protection higher than that implied in the relevant Codex standards, it was obliged to comply with the risk assessment requirements of Article 5.1. Ibid., para. 176.

${ }^{836}$ Dale E. McNiel, 'The First Case under the WTO’s Sanitary and Phytosanitary Agreement: The European Union's Hormone Ban', Virginia Journal of International Law 39, 1998, 89-134, 126.

${ }^{837}$ Appellate Body Report, EC-Hormones, para. 177. It is useful to recall, as already noted above, the Appellate Body's statement that '[t]he requirements of a risk assessment under Article 5.1, as well as of "sufficient scientific evidence" under Article 2.2, are essential for the maintenance of the delicate and carefully negotiated balance in the SPS Agreement between the shared, but sometimes competing, interests of promoting international trade and protecting the life and health of human beings.' Ibid.

838 Ibid.

${ }^{839}$ Appellate Body Report, Japan - Agricultural Products II, para. 79.

840 The words 'available scientific information' rather than risk assessment in this finding should not be taken to mean that the Appellate Body here stopped short of actually requiring a risk assessment in the case of reliance on a 'scientific justification'. Instead the term used is simply taken from the footnote definition of 'scientific justification' which has already been interested to amount to a requirement of a risk assessment as set out above. 
It has been argued that the reason behind the distinction in Article 3.3 between the two different situations mentioned is to emphasise the difference in the scope of review in each case. ${ }^{841}$ The first situation deals with the Member's judgement, on the basis of scientific information, that the international standards are inadequate to meet its level of protection. This could, for example, be the case where, due to local peculiarities (including dietary practices, climatic conditions etc.) or flaws in the international standard, the standard is ineffective in securing the level of health protection it was aimed at. ${ }^{842}$ The second situation deals with the choice of a different level of protection by a Member, which is a policy choice. One could thus speak of a scientific justification and a policy justification. ${ }^{843}$ In the SPS Agreement scientific justifications are more rigorously reviewed than policy ones. While in both cases the risk assessment underlying the measure must meet the strict test of Article 5.1, harmonisation will be more vigorously promoted in the former case than in the latter.

\subsubsection{Measures providing a lower level of protection than international standards}

Measures that are not based on international standards are of course not limited to those that provide a higher level of protection than these standards; they include also those providing a lower level of protection. However, Article 3 of the SPS Agreement does not expressly deal with the latter situation. It obliges a Member to adopt measures which are 'based on' international standards, that is, achieving the same level of protection, except as provided for in Article 3.3. The latter article allows SPS measures resulting in a higher level of protection under certain conditions. It would therefore seem, at first sight, that Article 3 requires Members to maintain at least the minimum level of SPS protection that is reflected in relevant international standards, while allowing higher, but not lower, levels of protection. ${ }^{844}$

${ }^{841}$ Vern R. Walker, 'Keeping the WTO from Becoming The "World Trans-Science Organization": Scientific Uncertainty, Science Policy, and Factfinding in the Growth Hormones Dispute', Cornell International Law Journal 31, 1998, 251-320, 275-276.

${ }^{842}$ Panel Report, EC - Hormones (Canada), para. 8.84. Here the Panel stated that both Canada and the EC interpreted the first situation as existing where the relevant international standard is outdated, inadequate, faulty or obsolete from a scientific perspective, for example where it in fact does not provide the level of protection it was intended to provide.

${ }^{843}$ Vern R. Walker, 'Keeping the WTO from Becoming The "World Trans-Science Organization": Scientific Uncertainty, Science Policy, and Factfinding in the Growth Hormones Dispute', Cornell International Law Journal 31, 1998, 251-320, 276. On the contrary, Wirth argues that the footnote explaining the meaning of 'scientific justification' might be taken to mean that there are scientific constraints on the choice of the appropriate level of protection. David A. Wirth, 'Symposium: The Role of Science in the Uruguay Round and NAFTA Trade Disciplines', Cornell International Law Journal 27, 1994, 817-859, 827. However, it seems rather that the scientific analysis mandated by that footnote is directed at the question of whether the international standards are effective in achieving the Member's chosen level of protection, rather than at the choice of appropriate level itself.

${ }^{844}$ Although the possibility for measures aimed at a lower level of protection is not expressly mentioned, it is useful to note that the last sentence of Article 3.3 states: 'Notwithstanding the above, all measures which result in a level of sanitary or phytosanitary protection different from that which would be achieved by measures based on international standards, guidelines or recommendations shall not be inconsistent with any other provision of this Agreement.' The reference to SPS measures resulting in a level of protection different from that achieved by international standards is not limited to a higher level of protection but includes measures resulting in a lower level of protection, thereby implicitly recognising this possibility. 
It has consequently been asked whether Article 3 of the SPS Agreement uses international standards 'only as a tool to loosen-up national regulations that go beyond international standards ... or whether those standards could be invoked to tighten national regulations against countries that fall below the minimum of the international standard. ${ }^{845}$ In other words, are the international standards to be seen as only a ceiling beyond which SPS measures will require scientific justification, or are they also a floor below which no measures may sink?

If Article 3 of the SPS Agreement were read to require a harmonised minimum level of SPS protection in all Members, based on international standards, serious questions would arise as to the legitimacy of the international standards used for this purpose and of the WTO's role in requiring compliance therewith. While it may seem laudable to promote minimum levels of health protection, on closer inspection trying to achieve this aim through the WTO, and in particular the SPS Agreement, may lead to undesirable results. The mandate of the WTO is limited to disciplines relating to trade barriers and does not extend to the direct promotion of health objectives. ${ }^{846}$ It has been correctly pointed out that the WTO should no longer maintain the fiction that trade policy has nothing to do with human rights, but instead accept that it is bound by international law to work within a framework of key human rights principles and duties arising from the legally binding human rights obligations of WTO Members. This entails, as discussed above, ${ }^{847}$ that in fulfilling its mandate, the WTO must have full regard for the human rights implications of its work, including with respect to the right to development, the right to health and the right to safe food. This, however, is something different from arguing that the WTO should exceed its mandate and become a global SPS regulator, by requiring a mandatory minimum level of SPS protection based on international standards that were not elaborated with such a role in mind, and whose procedural legitimacy has been called into question. ${ }^{848}$ Instead, the WTO's disciplines, within its area of competence, must be

${ }^{845}$ Joost Pauwelyn, 'Non-Traditional Patterns of Global Regulation: Is the WTO 'Missing the Boat'?' presented at the Conference on Legal Patterns of Transnational Social Regulations and Trade (European University Institute, Florence) 24-25 September 2004, 14, available at: http://eprints.law.duke.edu/1311/1/6Sept04.pdf, visited on 25 May 2008. Pauwelyn argues that if international standards only have a ceiling, not a floor, effect, they do not have a strong harmonising pull as the incentive to harmonise is limited to the safe haven offered by conforming to the standard.

${ }^{846}$ This task is left to other international organisations set up for this purpose, such as the World Health Organisation. However, this single-issue focus of international organisations has been sharply criticised by UN human rights bodies, which call for the full integration of human rights principles and obligations (including the right to health) in future negotiations in the WTO. UN Committee on Economic, Social and Cultural Rights, Statement to the Third Ministerial Conference of the WTO in Seattle, issued in November 1999. This issue falls within the very interesting question of new forms of global governance, which, however, is outside the ambit of this book. See further on this issue Malini Mehra, Human Rights and the WTO: Time to Take on the Challenge, WTO Watch (Institute for Agriculture and Trade Policy, Minneapolis), 22 August 2000, available at: http:www.wtowatch.org/news/index.cfm?ID=1012, visited on 15 January 2001. See also the UNDP's Human Rights Development Report, 2000.

${ }^{847}$ See above, Part I, Section 1.1.

${ }^{848}$ Pauwelyn states that were international standards to be given binding authority as minimum standards, the argument for the Appellate Body 'to exercise closer scrutiny over the procedural qualities and legitimacy of international standards would gain all the more force.' Joost Pauwelyn, 'Non-Traditional Patterns of Global Regulation: Is the WTO 'Missing the Boat'?' presented at the Conference on Legal Patterns of Transnational Social Regulations and Trade (European University Institute, Florence) 24-25 September 2004, 15, available at: http://eprints.law.duke.edu/1311/1/6Sept04.pdf, visited on 25 May 2008. See also Joanne Scott, 
applied in a way that contributes to, rather than undermines, human rights. ${ }^{849}$ It is exactly this objective that is reflected in the SPS Agreement's cautious approach to the policy space of Members, which takes pains to avoid downward harmonisation of SPS protection, while promoting economic growth through trade.

Further, it seems unlikely that a positive obligation in the SPS Agreement to provide a minimum level of SPS protection was intended or would be accepted by WTO Members. Members promote international efforts to improve health protection in international fora other than the WTO. It is hard to imagine one Member challenging another within a trade forum for having a too low level of health protection for its own citizens, a situation which can have no negative trade implications for other Members ${ }^{850}$ In addition, it should be remembered that the Appellate Body in EC - Hormones rejected the Panel's interpretation of Article 3.1 in a way that would give international standards binding force, absent an indication of this intention in the text of the Agreement. ${ }^{851}$ The same reasoning that applies to giving international standards binding force as maximum standards applies to giving them such force as minimum standards, bearing in mind the level of intrusion into national regulatory policy this would entail. In addition, it should be remembered that the respect shown by the harmonisation provisions in the SPS Agreement for the regulatory autonomy of Members by not requiring them to change their appropriate levels of protection is not limited to downward changes. ${ }^{852}$ All indications therefore point to the conclusion that Article 3 of the SPS Agreement does not have the effect of imposing a minimum level of SPS protection on WTO Members on the basis of international standards.

This conclusion is particularly important for developing-country Members. As less influential participants in the standard-setting process at the relevant international bodies, these Members are often confronted with international standards that are beyond their capacity to adopt, or that are ill-suited to their particular conditions. ${ }^{853}$ They are there-

'International Trade and Environmental Governance: Relating Rules (and Standards) in the EU and the WTO', European Journal of International Law 15, 2004, 307-354, 310 and 330.

${ }^{849}$ This is recognised by the preamble to the WTO Agreement in which Members recognise that "their relations in the field of trade and economic endeavour should be conducted with a view to raising standards of living, ensuring full employment and a large and steadily growing volume of real income and effective demand, and expanding the production of and trade in goods and services, while allowing for the optimal use of the world's resources in accordance with the objective of sustainable development, seeking both to protect and preserve the environment and to enhance the means for doing so in a manner consistent with their respective needs and concerns at different levels of economic development'

${ }^{850}$ Pauwelyn notes that seeing international standards as required minimum standards would have the 'odd result' that the WTO would ask a defendant to restrict trade more (i.e. to impose stricter SPS requirements). Joost Pauwelyn, 'Non-Traditional Patterns of Global Regulation: Is the WTO 'Missing the Boat'?' presented at the Conference on Legal Patterns of Transnational Social Regulations and Trade (European University Institute, Florence) 24-25 September 2004, 15, available at: http://eprints.law.duke.edu/1311/1/6Sept04.pdf, visited on 25 May 2008.

${ }^{851}$ Appellate Body Report, EC-Hormones, para. 165.

${ }^{852}$ This point is made in Joanne Scott, The WTO Agreement on Sanitary and Phytosanitary Measures: A Commentary, Oxford Commentaries on the GATT/WTO Agreements (Oxford University Press, Oxford), 2007, 264.

${ }^{853}$ An example of such an international standard is ISPM 15, the IPPC standard for wood packaging materials used in international trade. Several developing-country Members have raised concerns regarding their difficulties in implementing this standard, as noted by Mauritius in 2005. As mentioned in Part II above, the heat treatment requirements for wood packaging material for export in ISPM 15 is difficult for many less developed Members to comply with. Mauritius has sought a 4-year moratorium on the implementation of 
fore more likely to deviate downwards from international standards than are developedcountry Members, which typically pursue higher levels of protection than those reflected in international standards. By contrast to the leeway granted in Article 3.3 of the SPS Agreement for SPS requirements stricter than international standards, interpreting Article 3 as prohibiting SPS requirements that are less demanding than international standards would withhold the very flexibility that developing-country Members need.

\subsection{Conclusion}

Trade would be greatly facilitated by increased harmonisation of SPS measures as this does away with the barriers created by disparate requirements in various importing countries. As a result, Article 3 of the SPS Agreement aims to promote the harmonisation of SPS measures. However, the lack of a rule-making body in the WTO to take on the task of providing generally applicable SPS requirements creates an institutional gap. ${ }^{854}$ Article 3 attempts to fill this gap by making use of other authoritative providers of uniform standards, namely the international standard-setting bodies referenced in Annex A.3. These international standard-setting bodies use recognised risk assessment procedures conducted by scientific expert bodies and discussed in committees to draw up standards. Their standards aim to reflect a large degree of scientific consensus on risk as well as policy agreement on the best way to address such risks. ${ }^{855} \mathrm{WTO}$ Members are therefore encouraged to use these standards through the disciplines of Article 3 of the SPS Agreement.

Ideally, harmonisation around international standards could go a long way to assisting less-developed Members that face capacity constraints in undertaking their own risk assessments as a basis for regulatory decisions. It thus seems imperative to interpret the autonomous options provided by Articles 3.1-3.3 in a manner that rewards Members choosing to base their measures on international standards or to conform their measures to these standards, in contrast to the current interpretation. By regarding a measure that is 'based on' an international standard as complying with the requirement of a scientific basis (in Articles 2.2 and 5.1), as argued above, a less-developed Member which has limited scientific capacity can be given the possibility of relying on the relevant international standard, and in particular the risk assessment that underlies it, while adjusting the aspects of the international standard that are not well-suited to its particular situation. While its measure could still be challenged under the remaining disciplines of the SPS Agreement, such as those relating to necessity, consistency and non-discrimination, it would be safe from scientific challenges. This is a significant advantage for Members

ISPM 15 from the IPPC and from those Members who had adopted the standard, and has requested Members to give positive consideration to the use of phosphine fumigation treatment as an equivalent treatment during the interim period. Committee on Sanitary and Phytosanitary Measures, Procedure to Monitor the Process of International Harmonization. Seventh Annual Report Adopted by the Committee on 30 June 2005, G/SPS/37, circulated on 19 July 2005, para. 8. See above, Part II, Section 2.5.2.3.

${ }^{854}$ This is unlike the situation which exists in the EU, where negative integration (lowering of trade barriers) is accompanied by positive integration (setting of general norms or rules). This is possible due to the normsetting capacity of the EU institutions, which operate on a supranational level, a characteristic which is absent in the WTO.

${ }^{855}$ On the scientific basis of international standards, see above, Part II, Sections 3.2.1.4, 3.2.2.4 and 3.2.3.4 and Part III, Section 4.2.1. 
with weak scientific capacities. Similarly, if the presumption of consistency of measures that 'conform to' international standards with the requirements of the GATT 1994 and the SPS Agreement, contained in Article 3.2 of the SPS Agreement, is interpreted as irrebuttable, it would provide a safe harbour for those Members whose weak regulatory capacity prompts them to fully adopt international standards. An equally important advantage of these interpretations is that they create a stronger impetus for harmonisation around international standards, without calling into question the right of Members to deviate from international standards if this is necessitated by their chosen level of protection. This interpretation therefore furthers the objective of Article 3 as outlined in the Preamble to the SPS Agreement.

These considerations notwithstanding, it is important to recall the concerns raised with regard to international standard-setting procedures in Part II of this book. ${ }^{856}$ The fact that a measure that is in conformity with international standards enjoys a presumption of consistency, even if rebuttable, increases the importance of standard setting on international level. ${ }^{857}$ This is relevant as the distribution of power in international standard-setting organisations is different than on national level due to the fact that certain interests, like those of developing countries, are underrepresented while other groups, such as developed countries and their producer associations, have a lot of influence. ${ }^{858}$ Once it is recognised that the scientific process, on which the standard-setting activities of international organisations are based, rests on value-ridden assumptions which fill gaps in scientific knowledge, and that these assumptions are dictated by the scientific community to which the participating scientists belong, it is easy to see that the bias in participation will result in risk assessment outcomes that reflect developed-country approaches to risk rather than those of developing countries. Even more so, the risk management decisions taken in the international standard-setting bodies will reflect the preferences of those participants which are most actively involved in the standard-setting process and have the most resources to dedicate to ensure the effectiveness of their participation, namely developed countries and industry groups. As these actors, due to the new importance of the resultant standards, increasingly focus attention and resources on the standard-setting activities of the international standard-setting bodies, this problem is exacerbated. Developingcountry Members are at a marked disadvantage in this regard. ${ }^{859}$

\footnotetext{
${ }^{856}$ See above, Part II, Section 3.1.2.

${ }^{857}$ As pointed out by Quick and Blüthner this does not mean that international standards become (either directly or indirectly) binding on WTO Members as a result of SPS disciplines. The standards only give content to the provisions of the SPS Agreement. It is the latter provisions which have binding force. However, the effect of the SPS provisions on harmonisation is to encourage the adoption of international harmonised standards and thus they do increase the status and relevance of these standards for WTO Members. Reinhard Quick and Andreas Blüthner, 'Has the Appellate Body Erred? An Appraisal and Criticism of the Ruling in the WTO Hormones Case', Journal of International Economic Law 2 (4), 1999, 603-639, 613.

${ }^{858}$ See further above, Part II, Section 3.1.2. See also Jeffery Atik, 'Symposium - Institutions for International Economic Integration: Science and International Regulatory Convergence', Journal of International Law and Business 17, 1997, 736-758, 744.

${ }^{859}$ Vinod Rege et al., Influencing and Meeting International Standards: Challenges for Developing Countries. Volume II: Procedures Followed by Selected International Standard-Setting Organisations and Country Reports on TBT and SPS (International Trade Centre UNCTAD/WTO and Commonwealth Secretariat, Geneva), 2004, 148 and 154.
} 
For example, as reported in an ITC/Commonwealth Secretariat study of 2004, Mauritius has very little capacity to conduct risk analyses with respect to the SPS measures it adopts in the absence of relevant international standards. It lacks the substantial empirical data necessary to undertake such analyses and the requisite professional expertise. For this reason, it is of particular importance to Mauritius that international SPS standards be set in areas of relevance to it and that such standards reflect its capabilities and concerns. As mentioned above, ${ }^{860}$ an example of an area where Mauritius faces difficulties in implementing an international standard is that of the IPPC standard for wood packaging material (ISPM 15). Due to its inability to meet the costs of participation, Mauritius does not participate at all in IPPC meetings, but only tries to keep informed of developments at the IPPC through discussions with South Africa's representative to the IPPC. Thus Mauritius was unable to provide an input into the development of this standard.

In addition, in many cases international standards are lacking in areas of importance to developing-country Members. For example, in 2002, Thailand raised a concern before the SPS Committee with regard to Australia's requirements on cooked chicken meat, aimed at the deactivation of infectious bursal disease virus. ${ }^{861}$ Thailand submitted a risk assessment to Australia showing that the risk of introducing this virus to backyard flocks through cooked chicken meat was negligible, but reported that Australia's long and complex risk analysis process resulted in no progress being made to resolve this issue by June 2003. ${ }^{862}$ In 2002 Thailand had expressed its hope that the OIE, under its new food safety mandate, would undertake work to develop a standard in this area. ${ }^{863}$ The OIE took note of Thailand's risk assessment and indicated that it would mandate an EWG to review the OIE standard to address this issue, once data had been received from other Members. However, by June 2003, the OIE had not commenced work on the proposed new standard. It reported that despite its request to members to provide the necessary scientific information, none had been forthcoming. ${ }^{864}$

Some efforts are already underway within the international standard-setting bodies to address the institutional and procedural constraints to developing-country participation, as discussed in Part II of this book. Japan has recently pointed out that systemic improvements have been made at each of these bodies since the previous workshop organised by the WTO Secretariat on this matter in $2001 .^{865}$ It proposed that the SPS Committee organise a new workshop on the standard-setting procedures of the CAC, OIE and IPPC in order for WTO Members to familiarise themselves with these procedures. However, it is clear that much remains to be done to redress the imbalance in participation of Members

\footnotetext{
${ }^{860}$ See above, Part II, Section 2.5.2.3.

${ }^{861}$ Committee on Sanitary and Phytosanitary Measures, Specific Trade Concerns. Note by the Secretariat. Addendum. Issues Not Considered in 2007, G/SPS/GEN/204/Rev.8/Add.2, circulated on 27 March 2008, item 50 .

${ }^{862}$ Committee on Sanitary and Phytosanitary Measures, Summary of the Meeting Held on 24-25 June 2003: Note by the Secretariat, G/SPS/R/30, circulated on 4 September 2003, paras 54-56.

${ }^{863}$ Committee on Sanitary and Phytosanitary Measures, Summary of the Meeting Held on 25-26 June 2002. Note by the Secretariat, G/SPS/R/27, circulated on 2 August 2002, paras 135-137.

${ }^{864}$ Committee on Sanitary and Phytosanitary Measures, Summary of the Meeting Held on 24-25 June 2003: Note by the Secretariat, G/SPS/R/30, circulated on 4 September 2003, paras 54-56.

${ }^{865}$ Committee on Sanitary and Phytosanitary Measures, Relationship between the SPS Committee and Codex, OIE and IPPC. Comments and Proposal by Japan, G/SPS/W/226, circulated on 19 June 2008, para. 4.
} 
at different levels of development in the international standard-setting bodies. Without successful efforts in this regard, the harmonisation disciplines of the SPS Agreement will have a negative impact on development, contrary to their objective. 


\section{CHAPTER 5 \\ Disciplines regarding risk analysis}

In well-developed national SPS systems, the regulatory process by means of which SPS measures are developed typically involves risk analysis. For the purposes of the discussion of the substantive disciplines of the SPS Agreement, two elements of risk analysis are relevant, namely risk assessment and risk management. It is useful to recall here the main aspects of these two aspects of risk analysis, which were explained in Part II above. ${ }^{866}$ As was noted in that Part, the term 'risk assessment' refers to the science-based process of identifying the existence of a risk and establishing the likelihood that the risk may actually materialise according to the measures that could be applied to address the risk. 'Risk management', by contrast, is the policy-based process of determining the level of protection a country wants to ensure in its territory and choosing the measure that will be used to achieve that level of protection. In risk management decision-making, not only are the scientific results of the risk assessment taken into account but also societal values and other policy considerations such as citizens' tolerance of risk, industry interests, relative costs, etc. The distinction between these two elements of the risk analysis process is not absolute. Non-scientific considerations do play some part in risk assessment, in particular in the science policy decisions that inform this process. However, the distinction is a useful tool in enhancing the understanding of the regulatory process.

In the background note on risk analysis prepared by the WTO Secretariat to assist Members in the negotiations in the SPS Committee on guidelines for the implementation of Article 5.5 of the SPS Agreement, ${ }^{867}$ it is expressly stated that different Articles of the SPS Agreement address various aspects of the risk analysis process. In particular, this note distinguishes between the science-based risk assessment process, addressed in Article 5.1, 5.2 and 5.3 and the risk management process, dealt with in Articles 5.4, 5.5 and 5.6.868

It is interesting to note that this Secretariat paper points to the fact that WTO Members find themselves in different situations in terms of their use of formal risk assessment pro-

${ }^{866}$ See for a brief discussion of the risk assessment and risk management aspects of the regulatory process above, Part II, Section 1.5. For a more detailed analysis of this distinction, see Vern R. Walker, "Keeping the WTO from Becoming The "World Trans-Science Organization": Scientific Uncertainty, Science Policy, and Factfinding in the Growth Hormones Dispute', Cornell International Law Journal 31, 1998, 251-320, 256-277.

${ }^{867}$ These guidelines are discussed below, Part III, Section 5.2.3.5. It is important to note that the WTO Secretariat is not competent to develop authoritative interpretations of the WTO agreements. However, the vast experience of the Secretariat staff servicing the SPS Committee with the operation of the SPS Agreement has led Members to entrust the Secretariat with the task of drawing up background documents, such as the one referred to here, to assist them in their negotiations. As such, these documents are useful to examine in view of the light they shed on the provisions of the Agreement.

${ }_{868}$ Note that the risk analysis process, as discussed above, also contains a third element, namely risk communication. In the context of the SPS Agreement some elements of risk communication are addressed in the transparency requirements, including those of publication and notification of SPS measures, provision of information through Enquiry Points and the explanation of reasons for measures upon request. Committee on Sanitary and Phytosanitary Measures, Risk Analysis. Note by the Secretariat, G/SPS/W/80, circulated on 6 March 1997, para. 12. These requirements are addressed in Part IV of this book, dealing with procedural rules in the SPS Agreement. See below, Part IV, Section 1.3. However, it is useful to bear in mind here that risk communication is part of the risk analysis process. 
cedures and in particular the resources and technical expertise they have in this regard. However, with regard to risk management, the Secretariat points out:

[E]ach and every Member nonetheless regularly makes decisions as to whether to permit the imports in question without further restriction, or whether to require some particular treatment to reduce potential risks, or whether to ban altogether the importation of the product concerned. This decision, however unsophisticated methods it may be based on, represents a management of the risks at hand and reflects an inherent decision of what level of risk the Member considers to be acceptable in that particular situation. ${ }^{869}$

The distinction between risk assessment and risk management was recognised by the Panel in EC - Hormones ${ }^{870}$ However, it mistakenly used this distinction to exclude from the scope of a risk assessment certain non-scientific reports as well as opinions of the European Parliament and the Economic and Social Committee, which evaluated reports submitted to them, and the question of risks associated with the problem of control of the use of hormones. It viewed these issues as having to do with social-value judgements and thus as not scientifically based. As a result, it saw them as belonging under risk management rather than risk assessment.

The Appellate Body rejected the Panel's distinction, stating that the SPS Agreement nowhere refers to the term 'risk management' but only to 'risk assessment'. ${ }^{871}$ Thus the Panel's use of the distinction to limit the scope of what falls under risk assessment, was held to have no basis in the text. The Appellate Body stated in this regard:

The Panel observed that an assessment of risk is, at least with respect to risks to human life and health, a 'scientific' examination of data and factual studies; it is not, in the view of the Panel, a 'policy' exercise involving social value judgments made by political bodies. ${ }^{872}$ The Panel describes the latter as 'non-scientific' and as pertaining to 'risk management' rather than to 'risk assessment'. ${ }^{873}$ We must stress, in this connection, that Article 5 and Annex A of the SPS Agreement speak of 'risk assessment' only and that the term 'risk management' is not to be found either in Article 5 or in any other provision of the SPS Agreement. Thus, the Panel's distinction, which it apparently employs to achieve or support what appears to be a restrictive notion of risk assessment, has no textual basis. The fundamental rule of treaty interpretation requires a treaty interpreter to read and interpret the words actually used by the agreement under examination, and not words which the interpreter may feel should have been used. ${ }^{874}$

\footnotetext{
${ }^{869}$ Committee on Sanitary and Phytosanitary Measures, Risk Analysis. Note by the Secretariat, G/SPS/W/80, circulated on 6 March 1997, para. 10.

${ }^{870}$ Panel Report, EC - Hormones (Canada), para. 8.98; Panel Report, EC-Hormones (US), para. 8.95.

${ }^{871}$ Appellate Body Report, EC-Hormones, para. 181.

${ }^{872}$ In the footnote to this sentence, the Appellate Body cited Panel Report, EC-Hormones (US), para. 8.94; Panel Report, EC-Hormones (Canada), para. 8.97.

${ }^{873}$ In the footnote to this sentence, the Appellate Body cited Panel Report, EC - Hormones (US), para. 8.95; Panel Report, EC-Hormones (Canada), para. 8.98.

${ }^{874}$ Appellate Body Report, EC-Hormones, para. 181.
} 
While it is true that the term 'risk management' is not explicitly mentioned in the SPS Agreement, this Agreement clearly deals in different ways with the Members' obligation to base their SPS measures on a risk assessment and their right to establish their own appropriate level of protection and choose an SPS measure to achieve this objective. As will be seen below, risk assessment is subject to strict scientific criteria, whereas the choice of an appropriate level of protection is only reviewable on the basis that it 'take[s] into account' the aim of reducing negative trade effects ${ }^{875}$ and avoids arbitrary or unjustifiable distinctions in different but comparable situations. ${ }^{876}$ The SPS measure established by a Member must be the least trade-restrictive measure that achieves the appropriate level of protection of the Member. The criteria for validity of the choice of level of protection and of the SPS measure recognise the sovereign right of Members to make their own policy choices in the area of public health, taking into account various non-scientific considerations. The choice is ultimately one based on societal value judgements. The latter area of decision-making is commonly known as risk management.

It would perhaps have made more sense for the Appellate Body to take issue with the Panel's classification of the risks of control as non-scientific and thus as not forming part of a risk assessment, rather than denying the de facto different treatment of risk assessment and risk management in the SPS Agreement. The Appellate Body partially recognised this when it overruled the Panel's decision that risks from failure to observe good veterinary practice and problems relating to detection and control of such failure must be rejected a priori because they are unscientific and thus do not fall within Article 5.2. The Appellate Body found that the Panel had misinterpreted the scope of Article 5.2 and that these considerations did, in fact, belong thereunder. ${ }^{877}$

In US/Canada - Continued Suspension, the EC relied upon the Appellate Body's finding in $E C$-Hormones, mentioned above, to argue that 'a risk assessment within in the meaning of Article 5.1 includes a risk management stage which is the responsibility of the regulator to carry out and not of the scientific bodies' ${ }^{878}$ and which involves "weighing policy alternatives in light of the results of risk assessment and, if required, selecting and implementing appropriate control options, including regulatory measures. ${ }^{879}$ The Panel disagreed, clarifying that:

Although the Appellate Body disapproved of the original panel's distinction between "risk assessment" and "risk management" because it had no textual basis in the Agreement, this Panel can find no statement by the Appellate Body confirming that what the European Communities describes as risk management is included within the definition of a risk assessment as set forth in Annex A(4) of the SPS Agreement. ${ }^{880}$

\footnotetext{
${ }^{875}$ Article 5.4 of the SPS Agreement.

${ }^{876}$ Article 5.5 of the SPS Agreement.

877 Appellate Body Report, EC-Hormones, para. 187.

${ }^{878}$ Panel Report, US - Continued Suspension, para. 7.495; Panel Report, Canada-Continued Suspension, para. 7.467.

${ }_{879}$ Panel Report, US - Continued Suspension, para. 7.519; Panel Report, Canada - Continued Suspension, para. 7.492.

${ }^{880}$ Panel Report, US - Continued Suspension, para. 7.519; Panel Report, Canada - Continued Suspension, para. 7.491.
} 
One could therefore argue that the risk assessment/risk management distinction is implicitly taken into account in those disciplines of the SPS Agreement that relate to the risk analysis process contained in Article 5. Therefore, the following sections of this Chapter discuss these two aspects of risk analysis separately. First the strict scientific disciplines for risk assessments on which SPS measures must be based, contained in Articles 5.1 to 5.3 of the SPS Agreement are examined. Second, the rules addressing a Member's choice of an appropriate level of protection contained in Articles 5.4 to 5.5 of the SPS Agreement and its choice of a measure to achieve this level of protection in Articles 5.3 and 5.6 of the SPS Agreement - both aspects of risk management - are set out.

\subsection{Risk assessment}

The risk assessment obligation of the SPS Agreement can be seen as an attempt to ensure rational, science-based decision making in national SPS regulation, and thereby to prevent private-interest capture of the regulatory process. ${ }^{881}$ In particular, in situations where harmonisation is not possible due to the lack of a relevant international standard, or is not feasible due to differences in national conditions or policy preferences, science operates to generate rational regulatory choices. ${ }^{882}$

Article 5.1 of the SPS Agreement contains the obligation of Members with regard to risk assessment. It provides:

Members shall ensure that their sanitary or phytosanitary measures are based on an assessment, as appropriate to the circumstances, of the risks to human, animal or plant life or health, taking into account risk assessment techniques developed by the relevant international organizations.

In all disputes decided under the SPS Agreement thus far, the SPS measures at issue have been found to be in violation of the obligations of Article 5.1, ${ }^{883}$ making this scientific

881 Robert Howse, 'Democracy, Science, and Free Trade: Risk Regulation on Trial at the World Trade Organization', Michigan Law Review 98, 2000, 2329-2357. See further the discussion of the role of science in SPS regulation above, Part II, Section 1.5.

${ }^{882}$ As noted by Jacqueline Peel: 'the very fact of having to take a risk assessment into account and respond to its findings could have the salutary effect of forcing national regulators "to articulate objectives, to assess means, and to rationalize results", a substantial improvement for the regulatory processes of many nations.' Jacqueline Peel, Risk Regulation under the WTO SPS Agreement: Science as an International Normative Yardstick?, Jean Monnet Working Paper 02/04 (NYU School of Law, New York), June 2004, 57, available at: www.jeanmonnetprogram.org/papers/04/040201.pdf, visited on 14 September 2004. The citation referred to by Peel comes from Henrik Horn and Joseph H.H. Weiler, 'European Communities - Trade Description of Sardines: Textualism and Its Discontent', The WTO case law of 2002: The American Law Institute reporter's studies 1, 2003, 248-275.

${ }^{883}$ In Japan - Agricultural Products II, the only SPS dispute in which the Panel found it unnecessary to make a finding under Article 5.1, since it had already found a violation of the scientific discipline of Article 2.2, the Appellate Body completed the legal analysis on this point. The Appellate Body in that case found a violation of Article 5.1 of the SPS Agreement. Appellate Body Report, Japan - Agricultural Products II, para. 114. In EC-Approval and Marketing of Biotech Products, the general de facto moratorium on biotech approvals and the product specific measures were not addressed under Article 5.1 of the SPS Agreement because they were found not to be 'SPS measures'. The EC Member States' safeguard measures were SPS measures and were therefore analysed under Article 5.1 and found to be in violation thereof. 
obligation the discipline on which SPS measures stand or fall. The precise nature of the obligation under Article 5.1, as interpreted in the case law, is therefore crucial to examine.

The Panel in Japan - Apples identified two elements to the obligation of Article 5.1 of the SPS Agreement. According to the Panel, Article 5.1 requires:

(1) an assessment of risk; and

(2) that Members ensure that their SPS measures are 'based on' such an assessment. $^{884}$

These elements are now examined in more detail.

\subsubsection{Definition of a risk assessment}

The first element of the disciplines of Article 5.1 of the SPS Agreement is the requirement of a risk assessment. It is therefore essential to understand what is meant by a risk assessment for purposes of the SPS Agreement. A 'risk assessment' is defined in Annex A.4 of the SPS Agreement as follows:

The evaluation of the likelihood of entry, establishment or spread of a pest or disease within the territory of an importing Member according to the sanitary or phytosanitary measures which might be applied, and of the associated potential biological and economic consequences; or the evaluation of the potential for adverse effects on human or animal health arising from the presence of additives, contaminants, toxins or disease-causing organisms in food, beverages or feedstuffs.

There are thus two types of risk assessment, each with different requirements. The type of risk assessment required in a given case will depend on the objective of the SPS measure at issue. The first type of risk assessment is applicable to SPS measures aimed at risks from pests or diseases; the second to SPS measures aimed at food- or feed-borne risks.

Panels and/or the Appellate Body have examined these definitions in seven disputes. ${ }^{885}$ The interpretation of these definitions is important is assessing what is required of Members which impose SPS measures that deviate from international standards. The rigour of these requirements determines the possibilities for Members at lower levels of development, which often face constraints in respect of scientific capacity, to maintain SPS measures that are not based on international standards, or to challenge the measures of their trading partners for a lack of basis on a risk assessment.

${ }^{884}$ Panel Report, Japan - Apples, para. 8.233.

885 Panel Report, EC - Hormones (US), paras 8.98-8.101 and 8.108-8.111; Appellate Body Report, EC - Hormones (US), paras 178-186; Panel Report, Australia - Salmon, paras 8.68-8.92; Appellate Report, Australia - Salmon, paras 119-135; Panel Report, Australia - Salmon (Article 21.5 - Canada), paras 7.377.71; Appellate Body Report, Japan-Agricultural Products, para. 113 (the Panel in this cases did not address Article 5.1 but the Appellate Body completed the legal analysis in this regard); Panel Report, Japan - Apples, paras 8.245-8.290; Panel Report, Japan - Apples, paras 189-216; Panel Report, Japan - Apples (Article 21.5 - US), paras 8.135-8.147; Panel Reports, EC - Approval and Marketing of Biotech Products, paras 7.3017.3034 and 7.3036-7.3055 (in respect of Austria's measure on T25 maize - an assessment was carried out for all the safeguard measures at issue in this dispute); Panel Report, US - Continued Suspension, paras 7.5047.572; and Panel Report, Canada - Continued Suspension, paras 7.476-7.540. 
The first type of risk assessment, which must be conducted where the risk at issue is from pests or diseases, contains three requirements. Such a risk assessment must:

- identify the pests/diseases whose entry, establishment or spread a Member wants to prevent, as well as the potential biological and economic consequences associated with the entry, establishment or spread of such pests/diseases;

- evaluate the likelihood of entry, establishment or spread of these pests/ diseases and the associated biological and economic consequences; and

- $\quad$ evaluate the likelihood of entry, establishment or spread of these diseases according to the SPS measures that might be applied. ${ }^{886}$

The second type of risk assessment, relevant to risk to human or animal health from food or feed, comprises two requirements, namely that the risk assessment must:

- identify the adverse effects on human [or animal] health (if any) arising from the additive, contaminant, toxin or disease-causing organism in food/ beverages/feedstuffs at issue; and

- $\quad$ if such adverse health effects exist, evaluate the potential or probability of occurrence of these effects. ${ }^{887}$

These detailed requirements immediately raise the question of how less developed Members with weak scientific capacity are to be able to comply. In this respect it is useful to note that the Appellate Body in EC-Hormones clarified that the SPS Agreement is not prescriptive as to who carries out the risk assessment. It stated as follows:

Article 5.1 does not insist that a Member that adopts a sanitary measure shall have carried out its own risk assessment ... The SPS measure might well find its objective justification in a risk assessment carried out by another Member, or an international organization. ${ }^{888}$

This leaves Members free to base their measures on 'borrowed' risk assessments conducted by other Members or international organisations. However, risk assessments relevant to the particular risk at issue, and appropriate to the circumstances of less developed Members do not necessarily exist. In such cases, the Member concerned must conduct its own risk assessment on which to base its measure.

\footnotetext{
${ }^{886}$ This three-pronged test was set out by the Panel and endorsed by the Appellate Body in Australia - Salmon . Appellate Body Report, Australia - Salmon, para. 121. The test was confirmed in Appellate Body Report, Japan - Agricultural Products, para. 113 and used again in Panel Report, Australia - Salmon (Article 21.5 - Canada), para. 7.41.

${ }^{887}$ These requirements are generalised on the basis of the findings of the Panel in EC-Hormones as modified by the Appellate Body in that case. Panel Report, EC-Hormones (Canada), para. 8.101; Panel Report, ECHormones (US), para. 8.98; and Appellate Body Report, EC-Hormones, paras 184-186.

${ }^{888}$ Appellate Body Report, EC - Hormones, para. 190. The Appellate Body did require that proof that a risk assessment supporting the measure does exist, be produced at dispute-settlement proceedings. This finding was reiterated in Panel Report, US - Continued Suspension, para. 7.442; Panel Report, Canada - Continued Suspension, para. 7.431.
} 
The case law dealing with the two definitions of a risk assessment is now examined to elucidate the requirements that have to be met before a risk assessment will fulfil the requirements of Annex A.4. First, some elements common to both types of risk assessment are set out. Thereafter, aspects of the additional third requirement for the first type of risk assessment, relevant to risks from pests or diseases, are examined.

\subsubsection{Specificity}

One of the issues common to both types of risk assessment is the requirement of specificity in the analysis of risk. The first step in both definitions of a risk assessment is the identification of the risk at issue. The second step requires the evaluation of the identified risk. The case law has given great importance to the need for specificity in both these steps. ${ }^{889}$

In $E C$-Hormones, as a food-safety risk was at issue, the second type of risk assessment was relevant. Applying the first requirement of a risk assessment to the case before it, the Panel considered that:

in this dispute, a risk assessment carried out in accordance with the SPS Agreement should (i) identify the adverse effects on human health (if any) arising from the presence of the hormones at issue when used as growth promoters in meat or meat products, ... ${ }^{890}$

Examining the scientific reports and attendant evaluations that the EC invoked as its risk assessment, the Panel found that several of them related to 'the carcinogenic or genotoxic potential of entire categories of hormones or hormones at issue in general, not when used specifically for growth promotion purposes' ${ }^{891}$ Further the Panel noted that these studies did not specifically evaluate the potential for adverse effects arising from the presence of the hormones at issue in food (specifically meat and meat products). As a result, it found that no scientific evidence was available that showed an 'identifiable risk'. ${ }^{892}$ In this regard, the Appellate Body in EC-Hormones stated as follows:

... [the studies submitted by the EC] constitute general studies which do indeed show the existence of a general risk of cancer; but they do not focus on and do not address the particular kind of risk here at stake - the carcinogenic or genotoxic potential of the residues of those hormones found in meat derived from cattle to which the hormones had been administered for growth promotion purposes - as is required by paragraph 4 of Annex A of the SPS Agreement. Those general studies, are in other words, relevant but do not appear to be sufficiently specific to the case at hand. ${ }^{893}$

\footnotetext{
${ }^{889}$ Note that the specificity requirement is not always seen as part of the analysis of whether a risk assessment exists, but is sometimes incorporated in the analysis of whether a Member's measure is 'based on' a risk assessment. However, for purposes of clarity, all the case law on specificity is addressed in this section.

${ }^{890}$ Panel Report, EC - Hormones (Canada), para. 9.101; Panel Report, EC - Hormones (US), para. 8.98.

${ }^{891}$ Panel Report, EC - Hormones (Canada), para.8.133; Panel Report, EC-Hormones (US), para. 8.130.

${ }^{892}$ Panel Report, EC - Hormones (Canada), para. 8.137; Panel Report, EC - Hormones (US), para. 8.134.

${ }^{893}$ Appellate Body Report, EC-Hormones, para. 200.
} 
Further the Appellate Body in EC - Hormones agreed with the Panel that a risk assessment must be comprehensive, i.e. it must cover each of the substances at issue. Thus, the Appellate Body upheld the Panel's finding that 'there was no risk assessment with regard to MGA', ${ }^{894}$ one of the six growth hormones at issue, stating that '[i]n other words, there was an almost complete absence of evidence on MGA in the panel proceedings. ${ }^{895}$ On this point, the Panel explained that 'one of the basic principles of a risk assessment appears to be that it needs to be carried out for each individual substance. ${ }^{896}$

The second type of risk assessment was again at issue in the US-Continued Suspension and Canada - Continued Suspension disputes. These disputes dealt with the question whether the continued suspension of concessions by the US and Canada against the EC for its non-compliance with the rulings in EC-Hormones was illegal due, inter alia, to the fact that the new scientific studies of the EC constituted a risk assessment on which its measure was based, thus bringing its measure into compliance with the SPS Agreement. The Panel in these cases also imposed strict specificity requirements for the risk assessment at issue, to the extent that it inserted an additional first requirement into the second definition. According to the Panel:

... Annex A(4) requires a Member to (a) identify the additives, contaminants, toxins or disease-causing organisms in food, beverages or feedstuffs at issue (if any); (b) identify any possible adverse effect on human or animal health; and (c) evaluate the potential for that adverse effect to arise from the presence of the identified additives, contaminants, toxins or disease-causing organisms in food, beverages or feedstuffs. ${ }^{897}$

Therefore, not only must the adverse effects (or the risk) be identified but also the specific substances causing the adverse effects. The evaluation in the third requirement must therefore address the potential for the specific adverse effects identified to arise from the specific substances identified in the product at issue. Examining the Opinions of the EC's Scientific Committee on Veterinary Measures related to Public Health (SCVPH), the Panel found that they identified the food product and contaminant at issue, namely meat and meat products from cattle treated with oestradiol-17 $\beta$ for growth promotion purposes. Also, the Opinions specified the possible adverse effects on human or animal health, namely neurobiological, developmental, reproductive and immunological effects, as well as immunotoxicity, genotoxicity, and carcinogenicity. ${ }^{898}$ However, examining the Opinions and taking into account the views of the panel experts on this point, the Panel found that no analysis was provided of 'the potential for the adverse effects to arise from the consumption of meat and meat products which contain residues of oestradiol-17 $\beta$ as a result of the cattle they are derived from being treated with the hormone for growth promotion purposes. ${ }^{899}$ Therefore, despite the specificity in identifying the relevant risk,

${ }^{894}$ Ibid., para. 201.

${ }^{895}$ Ibid.

${ }^{896}$ Panel Report, EC - Hormones (US), para. 8.257; Panel Report, EC - Hormones (Canada), para. 8.260.

${ }^{897}$ Panel Report, US - Continued Suspension, para. 7.507; Panel Report, Canada - Continued Suspension, para. 7.279.

${ }^{898}$ Panel Report, US - Continued Suspension, para. 7.508; Panel Report, Canada - Continued Suspension, para. 7.480.

${ }^{899}$ Panel Report, US - Continued Suspension, para. 7.537; Panel Report, Canada - Continued Suspension, 
product and contaminant, the evaluation of the potential for the risk to occur was insufficiently specific.

Similar specificity is required under the first definition of a risk assessment, applicable to risks from pests or diseases. The Panel in Australia - Salmon examined the Australian risk assessment, contained in its 1996 Final Report, and found that it met the first requirement of the three-pronged test under this definition, identified 24 diseases whose establishment or spread Australia was trying to prevent and their potential biological and economic consequences. ${ }^{900}$ Thus it was sufficiently specific in this regard. When dealing with the second element of the three-pronged test, the Panel in Australia - Salmon again emphasised the need for specificity, finding:

$[G]$ iven the definition of risk assessment applicable in this case (the 'evaluation of the likelihood of entry, establishment or spread of a ... disease', in the singular form), a risk assessment for the measure at issue in this dispute at least has to identify risk on a disease specific basis, i.e., it has to identify the risk for any given disease of concern separately, not simply address the overall risk related to the combination of all diseases of concern. ... The experts advising the Panel on this issue confirmed this. In the EC-Hormones case as well, both the panels and the Appellate Body required some degree of specificity for a risk assessment - or a study or report allegedly part thereof - to be in accordance with the requirements imposed in Article 5.1.901

The Appellate Body in Australia - Salmon agreed with the Panel in this regard. ${ }^{902}$ However, the requirement of specificity does not imply that for each product or risk agent at issue, a completely new risk assessment must be carried out. On the relevance of studies on one product category for a risk assessment in respect of another product category, the Panel in Australia - Salmon noted:

We do, however, agree with Australia that some of the evidence, assessments and conclusions contained in the 1996 Final Report might be relevant for the risk assessment to be carried out (or relied upon) for the other categories of salmon products and that, therefore, a completely new risk assessment for these other categories of salmon products might not be necessary. ${ }^{903}$

The issue of specificity was again addressed in Japan-Apples, where the Panel examined Japan's risk assessment which evaluated the risk of entry, establishment and spread of fire blight through a collection of possible hosts, including apples. The Panel found that as Japan's risk assessment did not evaluate the risks in relation to apple fruit separately from those posed by other hosts, whereas scientific evidence showed that the risks vary

para. 7.509.

900 Panel Report, Australia - Salmon, para. 8.73.

901 Ibid., para. 8.74.

902 Appellate Body Report, Australia - Salmon, para. 126. The Appellate Body disagreed with other aspects of the Panel's analysis however, including its identification of the measure at issue as a heat-treatment requirement for salmon rather than the import prohibition on fresh, chilled or frozen salmon. The Appellate Body overturned the Panel's findings in this regard and completed the legal analysis by assessing itself whether the requirements for a risk assessment had been met in respect of the import prohibition.

${ }^{903}$ Panel Report, Australia - Salmon, para. 8.58. This finding was not addressed on appeal. 
significantly depending on the vector (host plant) involved, it did not meet the requirement of specificity. ${ }^{904}$ On appeal, Japan argued that the methodology of a risk assessment is not regulated by the SPS Agreement and a Member may thus decide for itself whether to analyse the risk on the basis of a particular pest or disease, or on the basis of a particular commodity. ${ }^{905}$ The Appellate Body upheld the Panel's finding, holding that it did not limit a Member's choice of risk assessment methodology. Members are free to organise their risk assessments along the lines of pests or diseases, or of the commodity imported, provided that a likelihood of entry, establishment or spread of the disease is attributed to each agent specifically. ${ }^{906}$ The Appellate Body emphasised that, as held in EC-Hormones, the risk to be specified in a risk assessment is the harm concerned as well as the precise agent that may cause the harm. ${ }^{907}$ It stated, in footnote:

Indeed, we are of the view that, as a general matter, 'risk' cannot usually be understood only in terms of the disease or adverse effects that may result. Rather, an evaluation of risk must connect the possibility of adverse effects with an antecedent or cause. For example, the abstract reference to the 'risk of cancer' has no significance, in and of itself, under the SPS Agreement, but when one refers to the 'risk of cancer from smoking cigarettes', the particular risk is given content..$^{908}$

In US - Continued Suspension, the requirement of specificity was the key to the Panel's finding that the EC's risk assessment did not meet the requirements of Annex A.4. After referring to the findings on specificity by the Appellate Body in EC-Hormones and Japan-Apples, the Panel asked the panel experts whether the 'Opinions' of the SCVPH that made up the EC risk assessment 'identified the potential for adverse effects on human health, including the carcinogenic or genotoxic potential, of the residues of oestradiol$17 \beta$ found in meat derived from cattle to which this hormone had been administered for growth promotion purposes in accordance with good veterinary practice and to what extent the Opinions evaluated the potential occurrence of these adverse effects. ${ }^{\prime 909}$ On the basis of the statements of all the experts and an examination of the 'Opinions' the Panel held that the EC:

... has evaluated the potential for the identified adverse effects to be associated with oestrogens in general, but has not provided analysis of the potential for these effects to arise from consumption of meat and meat products which contain residues of oestradiol-17 $\beta$ as a result of the cattle they are derived from being treated with the hormone for growth promotion purposes..$^{910}$

\footnotetext{
904 Panel Report, Japan - Apples, paras 8.268-8.271.

${ }_{905}$ Appellate Body Report, Japan - Apples, para. 204.

906 Ibid.

${ }^{907}$ Ibid., para. 202.

${ }^{908}$ Ibid., footnote 372.

${ }^{909}$ Panel Report, US - Continued Suspension, para. 7.521; Panel Report, Canada - Continued Suspension, para. 7.493 .

910 Panel Report, US - Continued Suspension, para. 7.537; Panel Report, Canada - Continued Suspension, para. 7.509 .
} 
It appears from the above case law that a rather high degree of specificity is required in a risk assessment. It has to identify and address the particular risk arising from the specific risk-causing substance at issue, when present in the relevant product, not just generally establish that the substance is harmful. It must comprehensively cover all pests, diseases or harmful substances at issue and evaluate the risk for each type of pest, disease or harmful substance separately. Although a completely new risk assessment is not required for each product category, a risk assessment for one product cannot be regarded as constituting a risk assessment for related product categories.

While this level of rigour required of risk assessments is useful in ensuring a sound basis for regulatory decisions, it demands a high degree of scientific capacity, which many Members simply do not have. In addition, the possibility for these Members to rely on borrowed risks assessments, identified by the Appellate Body in EC-Hormones, ${ }^{911}$ is severely restricted by the requirement of a high level of specificity in the risk assessment used. ${ }^{912}$ The chance that a Member might find a risk assessment conducted by another Member or an international organisation that deals as specifically with the particular risk at issue as is required in the case law is very slim.

\subsubsection{Quantification and threshold level of risk}

A second significant issue of relevance to both types of risk assessment is whether a quantification of the level of risk is required in a risk assessment in terms of Annex A.4 of the SPS Agreement. A related question is whether a minimum level of risk must be shown in a risk assessment.

In EC - Hormones, addressing the second type of risk assessment, the Panel considered that a risk assessment, if adverse effects have been identified, must 'evaluate the potential or probability of occurrence of these effects. ${ }^{.913}$ The Appellate Body regarded the Panel's use of 'probability' as an alternative for 'potential' as cause for concern as the word implies a higher degree of potentiality and seems to introduce a quantitative element into a risk assessment. ${ }^{914}$ The Appellate Body stated:

The ordinary meaning of 'potential' relates to 'possibility' and is different from the ordinary meaning of 'probability'. 'Probability' implies a higher degree or a threshold of potentiality or possibility. It thus appears that here the Panel introduces a quantitative dimension to the notion of risk. ${ }^{915}$

The Appellate Body addressed the argument of the EC that the Panel by requiring a 'scientifically identified risk' was 'in effect requiring a Member carrying out a risk assessment to quantify the potential for adverse effects on human health', ${ }^{916}$ and found as follows:

\footnotetext{
911 Appellate Body Report, EC - Hormones, paras 189-190. This finding is set out above, Part III, Section 5.1.1.

912 Catherine Button, The Power to Protect. Trade, Health and Uncertainty in the WTO (Hart Publishing, Oxford and Portland, Oregon), 2004, 67.

913 Panel Report, EC-Hormones (Canada), para. 9.101; Panel Report, EC-Hormones (US), para. 8.98.

914 Appellate Body Report, EC-Hormones, paras 184-186.

915 Ibid., para. 184.

916 Ibid., para. 185.
} 
It is not clear in what sense the Panel uses the term 'scientifically identified risk'. ... In one part of its Reports, the Panel opposes a requirement of an 'identifiable risk' to the uncertainty that theoretically always remains since science can never provide absolute certainty that a given substance will not ever have adverse health effects. ${ }^{917}$ We agree with the Panel that this theoretical uncertainty is not the kind of risk which, under Article 5.1, is to be assessed. In another part of its Reports, however, the Panel appeared to be using the term 'scientifically identified risk' to prescribe implicitly that a certain magnitude or threshold level of risk be demonstrated in a risk assessment if an SPS measure based thereon is to be regarded as consistent with Article 5.1. ${ }^{918}$ To the extent that the Panel purported to require a risk assessment to establish a minimum magnitude of risk, we must note that imposition of such a quantitative requirement finds no basis in the SPS Agreement. ${ }^{919}$

Thus it is clear that theoretical uncertainty is not the kind of risk to be assessed under Article 5.1. ${ }^{920}$ Such uncertainty always exists since it is not possible for science to ever completely rule out the possibility of risk. If theoretical uncertainty were to be accepted as a 'risk' under Article 5.1, much room would be left for regulations that are a knee-jerk response to consumer fears regarding purely hypothetical risks. ${ }^{921}$ Instead, Article 5.1 has been interpreted to require proof of an actual risk, not just uncertainty about whether or not a risk exists. ${ }^{922}$ However, no threshold requirement that a certain minimum magnitude of risk be shown is contained in the second definition. Further, the Appellate Body stated that the risk assessment may go beyond the controlled conditions in a scientific laboratory, and take account of the actual potential for adverse effects in the 'real world where people live and work and die. ${ }^{, 923}$

The issue then arises whether the first type of risk assessment, which unlike the second type requires an evaluation of the likelihood of the occurrence of the risk, necessitates a quantitative evaluation of risk, or a minimum threshold level of risk to be demonstrated. This question was addressed in Australia - Salmon. The Panel had examined the Australian risk assessment and found that it evaluated some elements of possibility and probability regarding the likelihood of entry or spread of these diseases and thus that the second element of the three-pronged test was met. Further, the Panel held that the

\footnotetext{
${ }^{917}$ In the footnote to this sentence, the Appellate Body cited Panel Report, EC - Hormones (US), paras. 8.1528.153; and Panel Report, EC-Hormones (Canada), paras. 8.155-8.156

${ }^{918}$ In the footnote to this sentence, the Appellate Body cited Panel Report, EC-Hormones (US), footnote 331; and Panel Report, EC - Hormones (Canada), footnote 437.

919 Appellate Body Report, EC-Hormones, para. 186.

${ }^{920}$ Ibid.

921 Catherine Button, The Power to Protect. Trade, Health and Uncertainty in the WTO (Hart Publishing, Oxford and Portland, Oregon), 2004, 66.

${ }_{922}$ Note, however, that the line between hypothetical risks and real risks is not that easily drawn. Walker argues: 'On the continuum between a merely speculative risk and a conclusively demonstrated one lies a vast stretch of undemonstrated, unquantified, but scientifically plausible risks. Within that zone, the risk of harm is real so long as safety is unproven.' Vern R. Walker, 'Keeping the WTO from Becoming The "World Trans-Science Organization": Scientific Uncertainty, Science Policy, and Factfinding in the Growth Hormones Dispute', Cornell International Law Journal 31, 1998, 251-320, 305.

${ }^{923}$ Appellate Body Report, EC-Hormones, para. 187.
} 
SPS Agreement does not require a quantitative evaluation of risk. ${ }^{924}$ The Appellate Body agreed that the evaluation of the likelihood need not be done quantitatively. It stated:

The likelihood may be expressed either quantitatively or qualitatively. Furthermore, we recall, as does the Panel, that we stated in European Communities - Hormones that there is no requirement for a risk assessment to establish a certain magnitude or threshold level of degree of risk. ${ }^{925}$

While in EC-Hormones the Appellate Body had rejected the use of the term 'probability' due to a concern that it might introduce a quantitative element into the second definition, in Australia - Salmon it found that likelihood or probability in the first definition could be expressed quantitatively or qualitatively. However, Australia's evaluation of the probability as 'low' or 'small' was not deemed sufficient. It is not clear what kind of qualitative determination of probability would satisfy this requirement. Further, the Appellate Body in Australia - Salmon confirmed the finding in EC-Hormones that a risk assessment need not establish a certain magnitude or threshold level of risk. Thus, even a very small, demonstrated probability of risk is sufficientDespite the unexpected finding that, contrary to the suggestion of the Appellate Body in EC-Hormones, also the first type of risk assessment requires no quantification of risk, the Appellate Body in Australia - Salmon did give weight to the different language used in the first and second definitions of risk assessment in Annex A. ${ }^{926}$ It noted that while the second definition calls for an evaluation of the 'potential' for adverse effects, the first requires the evaluation of the 'likelihood' of entry, establishment or spread of pests or diseases. It did 'not believe that it is correct to diminish the substantial differences between these two types of risk assessments' ${ }^{927}$ Noting that the first definition requires the evaluation of 'likelihood' and that in EC-Hormones it has referred to the dictionary meaning of 'probability' as 'degrees of likelihood' and 'a thing that is judged likely to be true', for the purpose of distinguishing the terms 'potential' and 'probability', ${ }^{928}$ the Appellate Body considered that 'likelihood' has the same meaning as 'probability'. ${ }^{929}$ It stated:

On this basis, as well as on the basis of the definition of 'risk' and 'risk assessment' developed by the Office international des épizooties ('OIE') and the OIE Guidelines for Risk Assessment, we maintain that for a risk assessment to fall within the meaning of Article 5.1 and the first definition in paragraph 4 of Annex A, it is not sufficient that a risk assessment conclude that there is a possibility of entry, establishment or spread of diseases and associated biological and economic consequences. A proper risk assessment of this type must evaluate the 'likelihood', i.e., the 'probability', of entry, establishment or spread of diseases

\footnotetext{
${ }_{924}$ Panel Report, EC - Hormones, para. 8.80

${ }_{925}$ Appellate Body Report, Australia - Salmon, para. 124. The Appellate Body referred to the Appellate Body Report, EC-Hormones, para. 186.

${ }_{926}$ Appellate Body Report, Australia - Salmon, para. 123 and note 69.

${ }^{927}$ Appellate Body Report, Australia - Salmon, note 169. Here the Appellate Body rejected the EC's argument that 'the object, purpose and context of the SPS Agreement indicate that no greater level of probability can have been intended for the first type of risk assessment than for the second type, [as b]oth types can apply both to human life or health and to animal or plant life or health'. Ibid.

${ }_{928}$ Appellate Body Report, EC - Hormones, para. 184.

${ }_{929}$ Appellate Body Report, Australia - Salmon, para. 123.
} 
and associated biological and economic consequences as well as the 'likelihood', i.e., 'probability', of entry, establishment or spread of diseases according to the SPS measures which might be applied.

...We do not agree with the Panel that a risk assessment of this type needs only some evaluation of the likelihood or probability. The definition of this type of risk assessment in paragraph 4 of Annex A refers to 'the evaluation of the likelihood' and not to some evaluation of the likelihood. ${ }^{930}$

The Appellate Body distinguished the evaluation of risk, which must show an ascertainable risk, not just a theoretical uncertainty, from the determination of an appropriate level of protection, which may be premised on a zero-risk level. ${ }^{931}$ It is thus possible for a Member, once an actual risk, however small, has been proven to have a certain probability, to choose a zero-risk level of protection and institute strict SPS measures to achieve this level. This respect for the level of protection chosen by a Member is inherent to the delicate balance struck in the SPS Agreement, as discussed above. However, the usefulness of the precise determination of probability required in the case law is thereby called into question, since no matter how small the probability of the risk occurring is proved to be, the state's chosen level of protection cannot be challenged on grounds of proportionality. ${ }^{932}$ The more stringent criterion thus only serves to make it harder to satisfy the risk assessment requirement in cases where risks from pests and diseases are at issue.

In finding that Australia's risk assessment did not meet the requirement of 'an evaluation of likelihood' of the entry, establishment or spread of the fish diseases at issue and their associated potential biological and economic consequences, the Appellate Body relied on the Panel's findings based on statements of the panel experts. ${ }^{933}$ These experts expressed the view that the risk assessment lent more weight to unknown and uncertain elements of the assessment and looked at the possibility of adverse effects occurring rather than assessing the probability thereof. ${ }^{934}$ According to the Appellate Body, the existence of unknown or uncertain elements does not justify a departure from the requirements for a risk assessment. ${ }^{935}$

The same emphasis on the evaluation of probability was exhibited by the Panel in JapanApples, where again the first definition of a risk assessment was at issue. Japan had claimed that it had qualitatively evaluated the probability. The Panel, quoting the Appellate Body's finding in $E C$-Hormones, held that probability requires a higher degree or threshold of potentiality or possibility, although it may be expressed quantitatively or qualitatively. ${ }^{936}$

\footnotetext{
${ }^{930}$ Appellate Body Report, Australia - Salmon, paras. 123-124.

${ }^{931}$ Ibid., para. 125.

${ }^{932}$ The safeguarding of Members' policy space with regard to their chosen level of protection once a risk (however small) has been proven, achieved by this finding of the Appellate Body, is undermined by the strong proportionality requirement read into Article 2.2 by the Panel in Japan - Apples, discussed above, Part III, Section 3.3.3.1. This can be compared to the situation under EC law, where the Article 30 exception for health measures, which requires that the measure be ' necessary' to protect human life or health, has been interpreted by the ECJ to include the requirement that the measure be proportional to the aim it seeks to achieve.

${ }_{933}$ Appellate Body Report, Australia - Salmon, para. 129.

${ }_{934}$ Panel Report, Australia - Salmon, para. 8.83.

935 Appellate Body Report, Australia - Salmon, para. 130. See further below, Part III, Section 5.1.2.

${ }^{936}$ Panel Report, Japan - Apples, para. 8.273.
} 
Japan's risk assessment had used a scale of grades, ranging from 'A' (extremely high) to ' $\mathrm{D}$ ' (extremely low) to rank the risk at issue, and had assessed the overall risk of fire blight as Grade A. ${ }^{937}$ However, aside from the fact that the risk assessment's conclusion did not seem to relate to the risk of fire blight transmission from apple fruit specifically, ${ }^{938}$ the Panel found that, where apple fruit was addressed, no "precise evaluation of the "degree of potentiality" or probability' was suggested. ${ }^{939}$ Although Japan's risk assessment used the term probability, the Panel held that it did not assess the degree of likelihood of the risk occurring. The risk assessment concluded from the cited studies that:

... the mature apple fruit harvested in fire blight occurring orchards can carry E. amylovora and, in addition, the mature fruit not carrying E. amylovora can be contaminated by harvesting operation, etc., in the orchard where there are sources. In particular, when scarred fruit is infected with E. amylovora and becomes rotten, it can be considered to exude bacterial ooze. Such fruit can be the source of transmission after being imported. ${ }^{940}$

In the Panel's view, the emphasised terms indicate the identification of a possibility of entry, establishment and spread of fire blight, but did not evaluate the likelihood thereof as required in the first definition of a risk assessment. ${ }^{941}$ Consequently, Japan's risk assessment was held not to meet the requirements of Annex A.4 and Article 5.1 of the SPS Agreement. ${ }^{942}$ This issue was not addressed on appeal.

The importance of the probability assessment element of the first definition of a risk assessment again came to the fore in EC-Approval and Marketing of Biotech Products, where the Panel had to address whether each of the nine safeguard measures applied by EC Member States to ban biotech products that had already been approved at EC level, were based on risk assessments. For example, when looking at Austria's safeguard measure on T25 maize, the Panel rejected Austria's contention that a scientific report, known as the Hoppichler study, ${ }^{943}$ constituted a risk assessment under Article 5.1. ${ }^{944}$ According to the Panel, the Hoppichler study did not identify the relative probability of the risks it identified, but only referred to the possibilities of the risks, or to the inability to determine probabilities. ${ }^{945}$ It therefore did not meet the requirements of the first definition of a risk

\footnotetext{
${ }^{937}$ Ibid., para. 8.274.

938 The specificity issue is addressed above, Part III, Section 5.1.1.1.

939 Panel Report, Japan-Apples, para. 8.274.

940 This paragraph of the risk assessment was cited by the Panel, which added the emphasis indicated. Ibid., para. 8.275.

${ }_{941}$ Ibid., para. 8.276.

942 Ibid., para. 8.280.

943 The study by Hoppichler, entitled 'Concepts of GMO-free Environmentally Sensitive Areas', was commissioned by the Austrian Federal Ministry of Women's Affairs and Consumer Protection.

${ }_{944}$ The first definition of a risk assessment was at issue to the extent that Austria's measure was aimed at addressing concerns regarding the spread of pollen to surrounding cultivated fields, long-term ecological consequences and the development of resistance to toxins in insects. Panel Reports, EC-Approval and Marketing of Biotech Products, para. 7.3039 .

${ }_{945}$ Ibid., para. 7.3044.
} 
assessment. ${ }^{946}$ Similar findings were made in respect of the studies relied upon as the basis for several of the other safeguard measures at issue in this dispute. ${ }^{947}$

In general, it would appear that by allowing the probability to be established quantitatively or qualitatively, not requiring a minimum level of risk to be shown and finding that the risk to be ascertained is not only that which can be established in science laboratories under controlled conditions but includes that occurring in the 'real world', the Appellate Body is trying to make provision for the reality that scientific evaluations of risk cannot provide absolute, concrete answers to all regulatory questions. This pragmatic approach is to be commended. Unrealistic application of the scientific disciplines of the SPS Agreement would not promote market access. Instead, by resulting in rulings lacking in legitimacy and political acceptability, it would lead to increased instances of noncompliance with the outcome of dispute settlement and undermine the authority of the regime created by the SPS Agreement.

However, the narrow focus on the establishment of a specific probability of entry, establishment or spread of a pest or disease in the first definition of a risk assessment, does not seem useful. It makes it harder to meet the already difficult requirements for a risk assessment, while adding little to the outcome in respect of the SPS measure applied.

It seems possible that the different terminology in the two definitions of risk assessment was intended to set less stringent requirements in cases where human health is more likely to be at risk, namely where food safety is at issue, than in cases where the risk applies to pests or diseases, which are more likely to affect plants or animals. ${ }^{948}$ While recent scares with human health risks from animal diseases, such as avian flu and bovine spongiform

946 ibid., para. 7.3046. Similar findings regarding the lack of an evaluation of likelihood or probability were made in respect of other safeguard measures to which the first definition of a risk assessment applied. See for example ibid., paras. 7.3078 (with regard to Austria's measure on Bt-176 maize), 7.3094 and 7.3098 (with regard to Austria's measure on MON810 maize), paras 7.3145 and 7.3151 (with regard to Germany's measure on Bt-176 maize), para. 7.3170 (with regard to Greece's measure on Topas oilseed rape), para. 7.3186 (with regard to Italy's measure onT25 maize, MON810 maize, MON809 maize and Bt-11 maize) and para. 7.3205 (with regard to Luxembourg's measure on Bt-176 maize).

${ }_{947}$ The lack of an evaluation of likelihood or probability was identified as a defect in the scientific studies relied upon in respect of several other safeguard measures to which the first definition of a risk assessment applied. See for example ibid., paras. 7.3078 (with regard to Austria's measure on Bt-176 maize), 7.3094 and 7.3098 (with regard to Austria's measure on MON810 maize), paras 7.3145 and 7.3151 (with regard to Germany's measure on Bt-176 maize), para. 7.3170 (with regard to Greece's measure on Topas oilseed rape), para. 7.3186 (with regard to Italy's measure onT25 maize, MON810 maize, MON809 maize and Bt-11 maize) and para. 7.3205 (with regard to Luxembourg's measure on Bt-176 maize).

${ }^{948}$ Contrary to the EC's contention, it is not the case that both definitions apply equally to human life or health and plant and animal life or health. In fact the second definition omits plants. While the second definition refers to animal health as well as human, it seems the human health consideration was paramount in the setting of a more lenient criterion to satisfy the obligation to conduct a risk assessment. The first definition, referring to the entry, establishment or spread of pests or diseases is obviously most likely to affect animals and plants, and a stricter requirement was set. It seems that risks to human health were not envisaged as very likely to fall within the first definition. It has since become apparent that pests or diseases that can be spread by cross-border movement of plants or animals not contained in food or beverages (such as BSE and avian flu) can cause serious health risks to humans. It should be noted that the definition of SPS measures in Annex A expressly includes, in paragraph 1(c), measures to protect human health from risks from pests or diseases carried by animals or plants or products thereof. Thus the possibility of risks to humans falling under the first definition of risk assessment must have been foreseen. Therefore the wisdom of interpreting the first definition to lay down a stricter requirement can be questioned. 
encephalitis, have amply shown that not only food imports create risks for human health, it is nevertheless that case that food safety is a much more sensitive issue than risks from pests and diseases, and that risks to human health from the latter are rare.

It is now necessary to examine the additional elements contained in the first definition of a risk assessment relevant to risks from pests and diseases, to determine what exactly is required from Members in such cases.

\subsubsection{Identification and evaluation of potential biological and economic consequences}

Clearly the severity of the consequences of a particular risk occurring differs from situation to situation. These consequences are both economic (such as losses in production or sales of agricultural products and costs of eradication of a pest or disease) and biological (such as damage to biodiversity). It is useful for regulators to establish the severity of the consequences of the risk at issue, as it provides relevant information to be taken into account when making risk management decisions. Regulators are placed in a position where they can consider the costs and benefits of the regulatory options before making a decision. This improves the quality of national risk regulation.

While the consequences of the occurrence of a risk from toxins or contaminants in food and feed also vary, as can be seen by comparing the usually not serious risk of salmonellosis from improperly cooked eggs and poultry infected with salmonellae, ${ }^{949}$ to the serious risk of cancer from dioxin residues in food, as human life or health may be at stake in these cases it is less appropriate to weigh up costs and benefits in such cases. ${ }^{950}$ Therefore, unlike the definition of a risk assessment that applies to risks from food and feed, a risk assessment dealing with risks from pests and diseases must identify and evaluate an additional factor, namely the risk of the 'associated potential biological and economic consequences'.

This requirement was addressed in Australia - Salmon, where the first type of risk assessment was relevant as the risk related to fish diseases that could be introduced through the importation of adult, wild, ocean-caught Pacific salmon from Canada. Referring to the definition in Annex A.4, the Panel clarified which risks have to be evaluated in this type of risk assessment as follows:

[W] consider, first of all, that the risk thus to be assessed includes (1) the risk of 'entry, establishment or spread' of a disease and (2) the risk of the 'associated

${ }^{949}$ While a few strains of salmonella (such as Typhi) are serious and cause typhoid fever, the strains of salmonella currently endemic in commercial chicken populations typically produce diarrhoeal disease with much less severe symptoms and outcome. These cases of salmonellosis are usually self-limiting and do not require antibiotics. Salmonella is currently one of the largest contributors to food-borne disease in many developed countries. This information was taken from the website of the Emerging Pathogens Institute of the University of Florence, available at: http://epi.ufl.edu/food/, visited on 30 June 2008.

${ }^{950}$ Note that not only human but also animal life and health is at stake in risk assessments falling under the second definition which covers risks from food and feed. Nevertheless, it seems that concerns with applying inappropriate requirements to risk assessments involving human health risks predominated in the choice to omit the additional requirements related to the economic and biological consequences of the risk in the second definition. This recognises the fact that any risk to human life or health can legitimately be viewed as very severe in and of itself. 
potential biological and economic consequences'. When we refer hereafter to the risk related to a disease, this risk thus includes the risk of entry, establishment or spread of that disease as well as the biological and economic consequences associated therewith..$^{951}$

The Panel found that Australia's risk assessment, contained in the 1996 Final Report, had properly identified not only the diseases at issue, but also the potential biological and economic consequences associated with them. ${ }^{952}$ However, instead of determining further whether the probability of the risk and associated consequences was evaluated, as mentioned above, the Panel merely assumed that this was the case. ${ }^{953}$ The Appellate Body in this case agreed with the Panel in respect of the elements of a risk assessment under the first definition, ${ }^{954}$ of its finding that the risk assessment at issue identified the risk and its associated consequences. ${ }^{955}$ However, the Appellate Body was of the view that the Panel should have come to the conclusion that the 1996 Final Report did not evaluate likelihood of the associated potential biological and economic consequences as required in the first definition of a risk assessment, as 'some' evaluation is insufficient. ${ }^{956}$

An example of a case where a risk assessment was found to have complied with this requirement is provided in Australia - Salmon (Article 21.5 - Canada). Here the Panel had to assess whether Australia's revised risk assessment, the 1999 PRA, undertaken in support of its new SPS measure, met this requirement. It noted that, for each of the 15 fish diseases identified in the risk assessment as 'high priority' diseases, the risk assessment also determined the 'expected impact or significance of disease establishment' or conducted what it called the 'consequence assessment'. ${ }^{957}$ Using a qualitative scale (catastrophic, high, moderate, low or negligible) it evaluated the severity of the impact of the consequences identified, disease by disease. In each case, it did so with reference to the

${ }^{951}$ Panel Report, Australia - Salmon, para. 8.72. The Panel later reiterated the two aspects of risk to be analysed under the first definition as follows: 'According to this first definition in paragraph 4, such risk assessment has to take into account risks arising not only from the 'entry, establishment or spread of a pest or disease', but also from the 'associated biological and economic consequences'. Panel Report, Australia - Salmon, para. 8.116 .

${ }_{952}$ Ibid., para. 8.73. The Panel here referred in footnote to a section of the 1996 Final Report entitled 'Impact of Salmonid Disease Introduction into Australia' but did not explain further how the information contained therein met the requirement at issue.

953 Ibid., para. 8.83 .

${ }_{954}$ Appellate Body Report, Australia - Salmon, paras 121-122.

955 Ibid., para. 127.

956 Ibid., para. 128. For the same reasons, discussed above, Part III, Section 5.1.1.2, that the Appellate Body regarded the 1996 Final Report as not comprising an evaluation of the risk of entry, establishment or spread of the fish diseases identified, it held that it did not evaluate the associated potential economic or biological consequences. Also in EC-Approval and Marketing of Biotech Products, the question of whether the studies relied upon by some EC Member States as the risk assessments on which their safeguard measures were based met the requirement of identification and evaluation of the associated economic and biological consequences was addressed. For example, the 2001 BEC report on which France relied for its safeguard measure on MSI/RFI oilseed rape (EC-161) was held not to provide any analysis of the associated potential biological and economic consequences of herbicide resistance in oilseed rape varieties, and therefore not to meet the requirements of the first definition of a risk assessment. Panel Reports, EC - Approval and Marketing of Biotech Products, para. 7.3120.

${ }_{957}$ Panel Report, Australia - Salmon (Article 21.5 - Canada), para. 7.54. 
risks related to imports of eviscerated salmonids (the product at issue). ${ }^{958}$ This was found by the Panel to meet the requirement set by the additional factor in the definition of a risk assessment for risks from pests or diseases in Annex A.4 of the SPS Agreement. ${ }^{959}$

The purpose of the additional requirement of the identification and evaluation of the potential economic and biological consequences associated with the risk, in cases where the risks from pests and diseases are at issue, seems to be to ensure that the severity of the risk is considered in the regulatory process. ${ }^{960}$ By obliging Members to undertake this evaluation when they assess risks from pests or diseases, it seems that the SPS Agreement aims to inject greater rationality into the assessment of these risks. Nevertheless, the SPS Agreement stops short of requiring Members to ensure that their SPS measures are proportional to the severity of the risk so identified. A Member remains free to choose its own appropriate level of protection in the face of the identified risk, and to select an SPS measure that will achieve this level of protection. In other words, the additional requirement in the first definition of a risk assessment is purely a procedural one, requiring that the evaluation of consequences be undertaken, rather than a substantive one requiring that the SPS measure based on this assessment be proportional to the consequences of the risk.

\subsubsection{Evaluation according to the SPS measures that might be applied}

The outcome of the risk analysis process, and therefore the aspect of this process of greatest concern to exporting Members, is the choice of an SPS measure to impose in order to address the risk identified in the risk assessment in a manner which achieves the level of protection chosen by the importing Member. In order to ensure that the choice of a particular measure is firmly grounded in the scientific facts, and is necessary to protect health, it is necessary to assess the contribution that different possible SPS measures would make to addressing the risk at issue. For this reason, the first definition of a risk assessment requires, in its third prong, that the risk of entry, establishment or spread of pests or diseases be evaluated 'according to the sanitary or phytosanitary measures which might be applied.'

In Australia - Salmon, the Panel clarified that the term 'those SPS measures which might be applied' refers to those SPS measures that reduce the risks of concern. Australia's 1996 Final Report referred to these measures as the 'risk reduction factors', and examined a large number of them for each of the 24 diseases of concern. ${ }^{961}$ On appeal, the Appellate Body agreed with the Panel's clarification in this regard. ${ }^{962}$ However, it disagreed with the Panel that 'some evaluation of the extent to which these factors could reduce risk'

\footnotetext{
${ }_{958}$ Ibid., para. 7.55.

${ }^{959} \mathrm{Ibid}$., para. 7.58. Note that In Japan - Apples, the additional factor of the biological and economic consequences to be evaluated was not addressed before the original or the compliance Panels, most likely because the evaluation of the first factor (the risk of entry, establishment or spread of the disease at issue) was already found insufficient.

${ }^{960}$ For a discussion of the relationship between the requirement to identify and evaluate associated economic and biological consequences in the first definition of a risk assessment in Annex A.4 and the requirement in Article 5.3 of the SPS Agreement that assessments of risks to animal or plant life or health take into account certain economic factors, see below, Part III, Section 5.1.4.

${ }_{961}$ Panel Report, Australia - Salmon, para. 8.89.

${ }^{962}$ Appellate Body Report, Australia - Salmon, para. 132
} 
was sufficient to justify an assumption that this requirement was met. ${ }^{963}$ It therefore found that the 1996 Final Report did not meet the third requirement of the first definition of a risk assessment. In Australia - Salmon (Article 21.5 - Canada), the compliance Panel had to determine whether Australia's new risk assessment, contained in the 1999 PRA, met this requirement. It found that, contrary to what had been done in the 1996 Final Report, the 1999 PRA identified and discussed, for each disease at issue, a series of 'risk management measures' that might be applied and that would reduce the risk associated with the relevant disease. ${ }^{964}$ Examples of SPS measures discussed were inspection and grading, export certification, controls on waste disposal and restrictions as to the age of the fish. Each measure was discussed and evaluated in the light of the effect that the measures would have on the 'key risk factors' identified in the risk assessment. ${ }^{965}$ On the basis of this evaluation, a list of pre-export and post-import requirements were adopted for each specific disease in order to achieve Australia's appropriate level of protection. ${ }^{966}$ The Panel found that it was not precluded from finding that these steps were sufficient to meet the third prong of the first definition of a risk assessment by the fact that some of the measures actually applied by Australia were not among those assessed. It stated:

[T] he fact that the 1999 IRA would not evaluate the likelihood according to all sanitary measures which may be applied, including some of those that were actually selected, does not, in our view, preclude that the 1999 IRA taken separately meets the definition of risk assessment. Paragraph 4 of Annex A refers to an evaluation "according to the sanitary ... measures which might be applied" tout court. It does not require that all possible measures (of which there could be a very great number) be evaluated nor specify precisely which measures need to be evaluated. ${ }^{967}$

The Panel further rejected the contention that, in order for 1999 PRA to meet the requirements of the third prong of the first definition of a risk assessment, the SPS measure finally applied must be shown to be linked to the risk assessment. It stated as follows:

Canada's claim ... raises the question of whether the definition of risk assessment as such, requiring Members to assess risk 'according to the [sanitary] measures which might be applied', can be construed so as to include the obligation to make the link between the assessment, the measures finally selected and the necessity to use these measures in order to achieve the ALOP. We find it difficult to read such a requirement into paragraph 4 of Annex A.

In our view, the rights and obligations in respect of these linkages are set out not in the definition of risk assessment itself - which logically precedes the selection of measures - but, inter alia, in the obligation to base sanitary measures on a risk assessment in Article 5.1 and to ensure that sanitary measures are not more trade-restrictive than required to achieve the ALOP in the sense of Article 5.6.

\footnotetext{
${ }_{963}$ Panel Report, Australia - Salmon, paras 8.89-8.91; Appellate Body Report, Australia - Salmon, para. 134.

${ }_{964}$ Panel Report, Australia - Salmon (Article 21.5 - Canada), para. 7.64.

965 Ibid., para. 7.65.

966 Ibid.

${ }^{967}$ Ibid., para. 7.70.
} 
To examine these questions of relationship between the risk assessment, the measures selected and the ALOP under the definition of risk assessment - as Canada ... seem[s] to do - would, in our view, run the risk of adding to or diminishing the more specific rights and obligations of Members set out in other SPS obligations, contrary to Article 19.2 of the DSU. ${ }^{968}$

Thus, the third element of the three-pronged test, requiring the evaluation of the likelihood of entry, establishment or spread of the relevant diseases according to the SPS measure which might be applied does not necessitate a determination of the link between the measure applied and the risk assessment or appropriate level of protection, something best left to the evaluation of whether the measure is 'based on' the risk assessment, and whether it is not more trade restrictive than required. ${ }^{969}$ Instead, the first definition of a risk assessment only requires that the risk be determined according to the different options available to mitigate the risk.

In Japan - Apples, the Panel found that Japan had not evaluated the risk according to the measures that might be applied, as its risk assessment had examined only the SPS measure Japan had actually imposed to address the risk from fire blight. According to the Panel, 'consideration should be given not just to those specific measures which are currently in application, but at least to a potential range of relevant measures. ${ }^{970}$ On appeal, the Appellate Body found:

We agree with the Panel that this phrase "refers to the measures which might be applied, not merely to the measures which are being applied." The phrase "which might be applied" is used in the conditional tense. In this sense, "might" means: "were or would be or have been able to, were or would be or have been allowed to, were or would perhaps". We understand this phrase to imply that a risk assessment should not be limited to an examination of the measure already in place or favoured by the importing Member. In other words, the evaluation contemplated in paragraph 4 of Annex A to the SPS Agreement should not be distorted by preconceived views on the nature and the content of the measure to be taken; nor should it develop into an exercise tailored to and carried out for the purpose of justifying decisions ex post facto. ${ }^{971}$

Risk assessments under the first definition must therefore evince an evaluation of a range of possible SPS measures which could be applied to address the risk at issue, and their relative effectiveness, not merely address the measure actually applied. Otherwise they could be regarded as prejudging their own outcome ${ }^{972}$ by showing that the measure actually applied is appropriate and effective, without regard for possible alternatives. Instead,

\footnotetext{
968 Ibid., paras 7.68-7.69.

969 The requirement in Article 5.1 of the SPS Agreement that an SPS measure be 'based on' a risk assessment is discussed below, Part III, Section 5.1.5. The requirement in Article 5.6 of the SPS Agreement that an SPS measure not be more trade restrictive than required to achieve the appropriate level of protection of the relevant Member is discussed below, Part III, Section 5.2.4.

${ }_{970}$ Panel Report, Japan-Apples, para. 8.285.

971 Appellate Body Report, Japan-Apples, para. 208.

972 This comment was made by one of the experts advising the Panel in Japan-Apples. Panel Report, JapanApples, para. 6.177.
} 
Members are required to consider alternative regulatory options. Doing so will make it easier for Members to ensure that the SPS measure they choose is necessary, as required by Article 2.2, and is the least-trade-restrictive SPS measure available that achieves their appropriate level of protection, as required by Article 5.6. However, this does not mean that all possible alternatives must be considered, something that would place an impossible task on risk assessors.

\subsubsection{Risk assessment as appropriate to the circumstances}

The requirement that SPS measures be based on a risk assessment is qualified by the phrase 'as appropriate to the circumstances.' It is therefore necessary to determine what this qualification entails to determine whether circumstances such as scientific uncertainty, or the insufficient economic resources or scientific capabilities of a Member might ease the strict requirements relating to risk assessments. When addressing the applicability of the SPS Agreement to those SPS measures adopted before the entry into force of the WTO Agreement, the Appellate Body in EC-Hormones noted the following:

We are aware that the applicability, as from 1 January 1995, of the requirement that an SPS measure be based on a risk assessment to the many SPS measures already in existence on that date, may impose burdens on Members. It is pertinent here to note that Article 5.1 stipulates that SPS measures must be based on a risk assessment, as appropriate to the circumstances, and this makes clear that the Members have a certain degree of flexibility in meeting the requirements of Article 5.1. ${ }^{973}$

However, what exactly this flexibility would entail in practice is not clear, as the Appellate Body did not relax any of the disciplines in its ensuing assessment of whether the EC had met the requirements for a risk assessment in this case.

The meaning of 'as appropriate to the circumstances' arose again in Australia - Salmon where the Panel had to address Australia's argument that its risk assessment for one product category was equally valid with respect to other product categories which had the same disease agent in common. Referring back to the relevant finding in EC-Hormones, the Panel noted as follows:

As to the product coverage of Article 5.1, the reference contained in Article 5.1 to base sanitary measures on an assessment 'as appropriate to the circumstances' cannot, in our view, annul or supersede the substantive obligation resting on Australia to base the sanitary measure in dispute (irrespective of the products that measure may cover) on a risk assessment. We consider that the reference 'as appropriate to the circumstances' relates, rather, to the way in which such risk assessment has to be carried out. Only Article 5.7 allows for an exception to the obligation to base sanitary measures on a risk assessment. ${ }^{974}$

\footnotetext{
973 Appellate Body Report, EC - Hormones, para. 129.

${ }^{974}$ Panel Report, Australia - Salmon, para. 8.57.
} 
Turning to an examination of Australia's risk assessment, to determine if it constituted a risk assessment in respect of adult, wild, ocean caught salmon, the Panel further stated:

Following Article 5.1, a risk assessment needs to be 'appropriate to the circumstances'. Answering a Panel question in this respect, Canada is of the view that the circumstances thus referred to are the source of the risk (e.g., an animal pathogen or a chemical contaminant) and the subject of the risk (i.e., whether it is to human, animal or plant life or health). For Australia, the phrase 'as appropriate to the circumstances' confers a right and obligation on WTO Members to assess the risk, on a case by case basis, in terms of product, origin and destination, including, in particular, country specific situations. We agree that both interpretations may be covered by the term 'as appropriate to the circumstances'. In our view, also the OIE risk assessment techniques as well as the scientific opinions we gathered, may shed light on what is a risk assessment 'appropriate to the circumstances'. ${ }^{975}$

The Panel, however, did not proceed to evaluate whether Australia's 1996 Final Report met the requirements of a risk assessment, but merely assumed it did so ${ }^{976}$ and went on to determine whether the measure was 'based on' the 1996 Final Report. The Appellate Body in this case did not find it appropriate to base its examination of Article 5.1 on this assumption of the Panel, and thus examined itself the question whether Australia's 1996 Final Report was a risk assessment within the meaning of Article 5.1. In its finding that the second requirement of a risk assessment (the evaluation of the likelihood of the risk) was not met, it stated as follows:

[T]he existence of unknown and uncertain elements does not justify a departure from the requirements of Articles 5.1, 5.2 and 5.3, read together with paragraph 4 of Annex A, for a risk assessment. We recall that Article 5.2 requires that "in the assessment of risk, Members shall take into account available scientific evidence". We further recall that Article 2, entitled "Basic Rights and Obligations", requires in paragraph 2 that "Members shall ensure that any sanitary ... measure ... is based on scientific principles and is not maintained without sufficient scientific evidence, except as provided for in paragraph 7 of Article 5. ${ }^{977}$

Although the Appellate Body was not specifically addressing the question of the meaning of the phrase 'as appropriate to the circumstances', it did not seem to allow the existence of elements of scientific uncertainty to mitigate the requirements for a risk assessment in Article 5.1.

In Japan - Apples, the Panel examined what is meant by a risk assessment 'as appropriate to the circumstances'. It held that this factor, together with the consideration of the risk assessment techniques developed by the relevant international organisations, ${ }^{978}$ pervades the entire risk assessment as defined in Annex A.4 and is therefore relevant to the evaluation of the risk assessment as a whole. It therefore addressed this first, before looking at

${ }^{975}$ Ibid., 8.71.

976 Ibid., paras 8.83 and 8.92 .

977 Appellate Body Report, Australia - Salmon, para. 130.

${ }^{978}$ The latter factor is discussed below, Part III, Section 5.1.3. 
other requirements for a risk assessment. ${ }^{979}$ The Panel first found, rather obviously, that as Japan's measure was a phytosanitary measure, it must focus on risks related to plant life and health. ${ }^{980}$ It then recalled that the term 'as appropriate to the circumstances' has been interpreted, in Australia - Salmon, to provide some flexibility for risk assessments, on a case-by-case basis, including consideration of country-specific situations. It therefore found that Japan's fire blight-free status and its climatic conditions, which were favourable to the spread of fire blight, were relevant 'circumstances' to be taken into account in Japan's risk assessment, and noted that they related to some of the factors required to be considered under Article 5.2..$^{981}$

In Japan - Apples (Article 21.5 - US), the compliance Panel went further in its examination of whether Japan's new 2004 PRA was a risk assessment 'as appropriate to the circumstances'. Recalling that Article 5.1 may be viewed as a specific application of Article 2.2, ${ }^{982}$ it found that the scientific evidence that is being evaluated must support the conclusions of the risk assessment in order for the risk assessment to be 'appropriate to the circumstances'. ${ }^{983}$ In particular, the studies used by Japan had to 'reflect the real production and trade conditions ${ }^{\prime 984}$ in order to support the view that apple fruit were likely to complete the transmission pathway and contaminate host plants in Japan under nonlaboratory conditions. Stating that it was mindful that it was not supposed to conduct its own risk assessment or to impose any scientific opinion on Japan, the Panel stated that it would only examine the scientific evidence in the light of the relevant WTO provisions. ${ }^{985}$ As the Panel experts were of the view that the scientific studies relied upon by Japan in its 2004 PRA did not reflect either natural orchard conditions or commercial practice, the Panel found that these studies did not support the conclusion in the risk assessment that apple fruit were likely complete the transmission pathway. Thus there was no risk assessment 'as appropriate to the circumstances'. ${ }^{986}$

In EC - Approval and Marketing of Biotech Products, the Panel addressed the question whether the term 'as appropriate to the circumstances' allows a Member to take into account as a relevant 'circumstance' the level of protection it has chosen and the uncertainties in science. The EC argued that an importing Member may reject an existing risk assessment as not 'appropriate to [its] circumstances' on the grounds that the risk

\footnotetext{
979 Panel Report, Japan - Apples, para. 8.237.

${ }_{980}$ Ibid., para. 8.238.

${ }^{981}$ Ibid., para. 8.240 and footnote 372. Article 5.2 is discussed below, Part III, Section 5.1.4.

982 The Panel here recalled the finding on this point in Appellate Body Report, EC-Hormones, para. 180

${ }_{983}$ Panel Report, Japan - Apples (Article 21.5 - US), para. 8.136.

${ }^{984}$ Ibid., para. 8.140.

${ }_{985}$ Ibid., para. 8.137. This finding is discussed further in relation to the standard of review applied by panels when assessing the scientific evidence before them. See below, Part IV, Section 2.2.3.

${ }_{986}$ Panel Report, Japan - Apples (Article 21.5 - US), paras 8.141-8.146. In US - Continued Suspension and Canada-Continued Suspension, the Panel relied on this finding to conduct an examination into the question whether the scientific evidence supported the conclusions of the Opinions of the EC Scientific Committee for Veterinary Public Health that excess exposure to oestradiol-17 $\beta$ and its metabolites resulting from the consumption of meat and meat products presents a health risk, especially to pre-pubertal children, and that the hormone is a complete carcinogen. After consulting the Panel experts on this point, the Panel found that the scientific evidence did not support the conclusions reached in the Opinions. Panel Report, US - Continued Suspension, paras 7.538 and 7.552-7.572; and Panel Report, Canada-Continued Suspension, paras 7.510 and 7.520-7.540.
} 
assessment identified constraints or uncertainties such that the risk assessment would not enable the Member to determine with a sufficient degree of precision whether an SPS measure would achieve its appropriate level of protection. ${ }^{987}$ The Panel rejected this argument, finding that the appropriate level of protection of a Member and the uncertainties or constraints identified in a risk assessment do not play a role in determining whether there is a risk assessment as appropriate to the circumstances. Rather, they are factors to be considered by a Member in determining the SPS measure to be applied for achieving its appropriate level of protection. ${ }^{988}$

From the above discussion it appears that the qualifying phrase 'as appropriate to the circumstances' has been interpreted by panels and the Appellate Body to indicate that the manner of conducting a risk assessment may differ, depending on the source of the risk (e.g. chemical or pathogen), subject of the risk (human, plant or animal), product involved, and country-specific situations regarding the country of origin or destination of the product (including risk-free status and climatic conditions). What the appropriate manner of conducting a risk assessment is in a specific case is determined with reference to the opinions of scientific experts, and risk assessment techniques established by international standard-setting organisations in the area at issue. In addition, this term has been interpreted to include a substantive requirement, namely that the scientific evidence that is being evaluated in the risk assessment supports the conclusions of that risk assessment. For example, the risk must be evaluated according to the actual production and trade conditions, rather than laboratory conditions, so that the scientific studies actually support the conclusions come to in the risk assessment.

It seems therefore, that far from providing flexibility to Members at lower levels of development to undertake risk assessments in a manner suitable to their technical and scientific capacities, the criterion of a risk assessment 'appropriate to the circumstances' has been used to further tighten the already strict requirements for a risk assessment. ${ }^{989}$ This makes it even more difficult for Members that lack the capacity to undertake their own risk assessments to 'borrow' risk assessments conducted by other Members or by international organisations. In addition, and rather worryingly, the reading given to this qualifying phrase has opened the door for an intrusive review by panels of the science evaluated in a risk assessment, to determine if the panel, assisted by the panel experts, agrees with the conclusions come to in the risk assessment. ${ }^{990}$ This reading is not supported by the text of Article 5.1 of the SPS Agreement.

\subsubsection{Taking into account the risk assessment techniques developed by the relevant international organisations}

While the SPS Agreement does not mandate a particular methodology for risk assessments, it does promote some convergence in this regard by referring to international

\footnotetext{
${ }_{987}$ Panel Reports, EC-Approval and Marketing of Biotech Products, para. 7.3244.

988 Ibid.

${ }^{989}$ This is also the case with regard to the temporal dimension of the 'appropriate to the circumstances' criterion, identified in Panel Reports, EC - Approval and Marketing of Biotech Products, paras 7.3031-7.3032. On this point, see below, Part III, Section 5.1.5.2.

${ }_{990}$ The intrusive nature of the standard of review applied by some panels to the scientific evidence is discussed below, Part IV, Section 2.2.3.
} 
guidelines for risk assessments. Specifically, Article 5.1 of the SPS Agreement provides that the risk assessment on which a measure is based must be 'tak[e] into account risk assessment techniques developed by the relevant international organizations.'

The first question that arises is which are the 'relevant international organizations' referred to in this provision. This issue arose before the Panel in the US/Canada-Continued Suspension disputes. The Panel noted that the 'relevant international organizations' for purposes of Article 5.1 are not specifically identified in the SPS Agreement. ${ }^{991}$ However, on the basis of references to the 'three sisters' in the Preamble and Annex A.3 to the SPS Agreement and Articles 3.2 and 3.4 of the SPS Agreement, the Panel held that the CAC constitutes a 'relevant organization' within the meaning of Article 5.1. ${ }^{992}$ In addition, the Panel regarded the risk assessment techniques of JECFA as relevant to an analysis of compliance under Article 5.1 because, even though JECFA is not officially part of the CAC structure, it provides independence scientific expert advice to the CAC and its committees. ${ }^{993}$ In particular, the Panel noted that the maximum residue levels adopted by the CAC for five of the hormones at issue in this case were based on JECFA recommendations. It can similarly be deduced that the other two international standard-setting bodies referred to in Annex A.3, namely the OIE and IPPC, are the 'relevant organizations' with regard to risk assessment techniques in the area of animal and plant health, respectively.

In Australia - Salmon, as noted above, the Panel took account of the risk assessment techniques developed by the OIE as part of its consideration of what is covered by the term 'as appropriate to the circumstances'. ${ }^{994}$ In Japan - Apples, however, the Panel examined this issue separately, as one of the two factors which pervade the evaluation of a risk assessment. After noting that Article 5.1 merely requires that these risk assessment techniques be 'taken into account', rather than that a risk assessment be 'based on' or 'in conformity with' them, the Panel found that:

...such techniques should be considered relevant, but that a failure to respect each and every aspect of them would not necessarily, per se, signal that the risk assessment on which the measure is based is not in conformity with the requirements of Article 5.1. Nonetheless, reference to these risk assessment techniques can provide very useful guidance as to whether the risk assessment at issue constitutes a proper risk assessment within the meaning of Article 5.1. ${ }^{995}$

\footnotetext{
991 Panel Report, US - Continued Suspension, para. 7.446; Panel Report, Canada - Continued Suspension, para. 7.435 .

${ }_{992}$ Panel Report, US - Continued Suspension, para. 7.446; Panel Report, Canada - Continued Suspension, para. 7.435 .

${ }_{993}$ Panel Report, US - Continued Suspension, para. 7.447; Panel Report, Canada - Continued Suspension, para. 7.436. On the role of JECFA in the CAC standard-setting procedures see above, Part II, Section 3.2.1.4.

${ }_{994}$ Panel Report, Australia - Salmon, para. 8.71.

995 Panel Report, Japan - Apples, para. 8.241. In this context, the Panel examined two relevant standards set by the International Plant Protection Convention, ISPM 2 on Guidelines for Pest Risk Analysis, and ISPM 11 on Pest Risk Analysis for Quarantine Pests. The parties agreed that both instruments build upon the same framework, thus the Panel focused on the key issue of whether Japan's risk assessment sufficiently identified and assessed the possible pathways for the introduction and spread of fire blight through apple fruit and the likelihood for their being realised, as required by both instruments. Ibid., para. 8.244.
} 
It is thus clear that the risk assessment techniques developed by the relevant international organisations, while useful, are not determinative to the evaluation of whether a risk assessment complies with Article 5.1 of the SPS Agreement.

This issue arose again before the Panel in the US/Canada-Continued Suspension disputes. The panel experts, when questioned on this point, had concluded that the EC's risk assessment, contained in the Opinions of the SCVPH of 1999, 2000 and 2002, was not entirely consistent with the CAC definition of and guidelines for a risk assessment. ${ }^{996}$ Recalling the finding in Japan - Apples cited above, the Panel in US - Continued Suspension stated:

This means that although the risk assessment techniques of Codex and JECFA are relevant and must be considered by the risk assessor, compliance with Codex or JECFA risk assessment techniques is not required by the SPS Agreement. What is required is that the risk assessor takes those techniques into account and that it complies with the other requirements of Article 5 and Annex A of the SPS Agreement with respect to conducting a risk assessment. ${ }^{997}$

As it was undisputed that the EC was aware of the CAC and JECFA guidelines and had considered them in preparing its risk assessment, the Panel concluded that although it had not strictly followed the risk assessment techniques of the relevant international organisations, it had taken them into account as required by Article 5.1.998

The purpose of the obligation to consider the risk assessment techniques developed by the relevant international bodies seems to be to promote regulatory learning and gradual convergence in approaches, by ensuring that Members have regard to the guidelines developed by the international bodies that have particular expertise in regulation for protection against risks from food, pests or diseases. By considering the risk assessment techniques set out in these international guidelines, Members benefit from the regulatory experience of those experts involved in the elaboration of these guidelines. However, bearing in mind that the risk assessment techniques adopted by the CAC, OIE and IPPC are not necessarily feasible for all Members, and respecting the choice of each Member to apply the risk assessment methodology it sees fit, Article 5.1 does not oblige Members to follow international guidelines in this respect.

Regardless of whether a Member finally does or does not follow the risk assessment techniques developed by the relevant international organisations, its risk assessment must still comply with the substantive requirements of Article 5.1 and Annex A.4, discussed above. There is no presumption of conformity for a risk assessment undertaken in conformity

\footnotetext{
${ }_{996}$ Panel Report, US - Continued Suspension, para. 7.463; Panel Report, Canada - Continued Suspension, para. 7.453. The Panels noted that there was considerable debate among the Panel experts and the parties regarding whether all the steps of a risk assessment as defined by the CAC had been followed by the EC, and whether it was in fact necessary to do so in the case of a substance which has genotoxic potential, such as oestradiol-17ß. Panel Report, US - Continued Suspension, para. 7.467; Panel Report, Canada - Continued Suspension, para. 7.457.

${ }_{997}$ Panel Report, US - Continued Suspension, para. 7.468; Panel Report, Canada - Continued Suspension, para. 7.458.

998 Panel Report, US - Continued Suspension, para. 7.469; Panel Report, Canada - Continued Suspension, para. 7.459.
} 
with international guidelines, with the requirements of the SPS Agreement. This is illustrated by the finding of the compliance Panel in Japan - Apples (Article 21.5 - US) that the fact that the panel experts stated that Japan's new 2004 PRA closely followed the procedural steps set out in the relevant IPPC standard, ISPM 11, did not save it from being found in violation of the substantive requirements of Article 5.1.999

\subsubsection{Relevant factors to be considered in assessing risk}

Although the SPS Agreement does not specify a methodology to be used in conducting a risk assessment, it does list the scientific and economic factors that Members must take into account, in Articles 5.2 and 5.3.

Firstly, Article 5.2 provides that Members must take certain factual considerations into account when assessing risks. These are: the available scientific evidence; the relevant processes and production methods; the relevant inspection, sampling and testing methods; the prevalence of specific diseases or pests; the existence of pest- or disease-free areas; the relevant ecological and environmental conditions; and quarantine or other treatment.

In Japan - Apples, the Panel held that Articles 5.1 and 5.2 'directly inform each other, in that paragraph 2 sheds light on the elements that are of relevance in the assessment of risks foreseen in paragraph 1. ${ }^{1000}$ Consequently, 'Article 5.2 imparts meaning to the general obligation contained in paragraph 1 to base measures on an "assessment ...of risks". ${ }^{1001}$ According to the Panel, if a risk assessment that does not take into account the factors listed in Article 5.2 could be found to be in conformity with Article 5.1, Article 5.2 would serve no purpose. The Panel in US - Continued Suspension agreed with this finding and noted that a panel 'must construe the covered agreements in a way that gives meaning to each provision' in accordance with the principle of effective treaty interpretation. ${ }^{1002}$ In EC-Hormones, the Panel had held that the risks relating to detection and control of failure to observe good veterinary practice should be excluded from risk assessment a priori because they are non-scientific and thus do not fall within the scope of Article 5.2's provision on 'relevant inspection sampling and testing methods', but rather are taken into account in risk management. The Appellate Body rejected this finding, holding that the scope of Article 5.2 allowed the taking into account of these risks. The Appellate Body noted:

The listing in Article 5.2 begins with 'available scientific evidence'; this, however, is only the beginning. We note in this connection that the Panel states

\footnotetext{
999 Panel Report, Japan - Apples (Article 21.5 - US), para. 8.147. The Panel therefore found it unnecessary to make a finding on whether the 2004 PRA followed the relevant procedural requirements, once it had concluded that it did not amount to a 'risk assessment' for purposes of Article 5.1 of the SPS Agreement.

1000 Panel Report, Japan-Apples, para. 8.230.

1001 Ibid., para. 8.232.

${ }^{1002}$ Panel Report, US - Continued Suspension, para. 7.441 and footnote 546. The Panel noted that Articles 31.1 and 26 of the Vienna Convention on Law of Treaties, requiring good faith interpretation of treaties and good faith performance of treaty obligations militate against an assumption that 'a provision of a treaty is written without any meaning at all.' It also referred to the statement of the Appellate Body in Japan - Alcoholic Beverages II, that 'a fundamental tenet of treaty interpretation flowing from the general rule of interpretation set out in Article 31 [of the Vienna Convention] is the principle of effectiveness (ut res magis valeat quam pereat)'. Appellate Body, Japan - Alcoholic Beverages II, 12.
} 
that, for purposes of the EC measures in dispute, a risk assessment required by Article 5.1 is 'a scientific process aimed at establishing the scientific basis for the sanitary measure a Member intends to take'. ${ }^{1003}$ To the extent that the Panel intended to refer to a process characterized by systematic, disciplined and objective enquiry and analysis, that is, a mode of studying and sorting out facts and opinions, the Panel's statement is unexceptionable. However, to the extent that the Panel purports to exclude from the scope of a risk assessment in the sense of Article 5.1, all matters not susceptible of quantitative analysis by the empirical or experimental laboratory methods commonly associated with the physical sciences, we believe that the Panel is in error. ${ }^{1004}$

As noted by the Appellate Body, not all the factors listed in Article 5.2 are 'wholly susceptible of investigation according to laboratory methods of, for example, biochemistry or pharmacology. ${ }^{1005}$ In addition, it pointed out that there is nothing in Article 5.2 to indicate that it is intended to contain a closed list of factors. In a memorable and often-quoted statement, the Appellate Body held:

It is essential to bear in mind that the risk that is to be evaluated in a risk assessment under Article 5.1 is not only risk ascertainable in a science laboratory operating under strictly controlled conditions, but also risk in human societies as they actually exist, in other words, the actual potential for adverse effects on human health in the real world where people live and work and die. ${ }^{1006}$

Thus, the Appellate Body is careful to avoid unrealistic limits to the factors that may form part of a risk assessment. It recognises that Article 5.2 does not set out a closed list of factors, thereby making room for Members to incorporate 'real world' considerations into their risk assessments. According to the Appellate Body the reference in Article 5.2 to 'relevant processes and production methods' and 'inspection, sampling and testing methods' read with Article 8 and Annex C: ${ }^{1007}$

... is amply sufficient to authorize the taking into account of risks arising from failure to comply with the requirements of good veterinary practice in the administration of hormones for growth promotion purposes, as well as risks arising from difficulties of control, inspection and enforcement of the requirements of good veterinary practice. ${ }^{1008}$

The Appellate Body qualified its finding, however, by stating that it was not suggesting that risks from potential abuse in the administration of controlled substances or problems of control must be assessed in each and every case. Instead, their relevance must be deter-

\footnotetext{
${ }^{1003}$ Panel Report, EC-Hormones (US), para. 8.107; Panel Report, EC-Hormones (Canada), para. 8.110.

1004 Appellate Body Report, EC-Hormones, para. 187.

1005 Ibid.

1006 Ibid.

${ }^{1007}$ Here the Appellate Body noted that Article 8 of the SPS Agreement requires Members to 'observe the provisions of Annex $\mathrm{C}$ in the operation of control, inspection and approval procedures'. In Annex C, a footnote clarifies that 'control, inspection and approval procedures include, inter alia, procedures for sampling, testing and certification'.

1008 Appellate Body Report, EC-Hormones, para. 205.
} 
mined on a case-by-case basis. What the Appellate Body regarded as 'a fundamental legal error' was the a priori exclusion of such risks from the scope of application of Articles 5.1 and 5.2. ${ }^{1009}$

While Article 5.2 has been held to be an open list, the question arises whether there are any limits to the types of considerations that may be included in a risk assessment. For example, may consumer preferences and industry interests play a role? The Appellate Body's findings cannot be interpreted that broadly. Implicitly, the Appellate Body restricted the scope of Article 5.2 to factors relevant to the assessment of the health risk at issue. It stated:

[T] he SPS Agreement requires assessment of the potential for adverse effects on human health arising from the presence of contaminants and toxins in food. We consider that the object and purpose of the SPS Agreement justify the examination and evaluation of all such risks for human health whatever their precise and immediate origin may be. ${ }^{1010}$

Thus the SPS Agreement requires an assessment of the potential or likelihood for adverse effects on human, animal or plant life or health from food, pests or diseases, regardless of the origin of these risks. Factors that are relevant to assessing these health risks may be taken into account, even if not expressly listed in Article 5.2. However, factors that are not related to the health risk at issue, but rather to extraneous matters such as consumer preferences or other policy considerations, are not among the factors to be considered in a risk assessment. ${ }^{1011}$

The Appellate Body further rejected the risk assessment/risk management distinction made by the Panel, holding that it has no basis in the text of the SPS Agreement. As discussed above, ${ }^{1012}$ it is debatable whether the denial of this distinction is correct, provided that certain risk factors are not artificially excluded for the scope of a risk assessment.

An illustration of the impact of consideration of 'real world' factors, such as problems of control, in assessing the risk from imported products is provided by the EC's prohibition on the use of fishmeal in ruminant feed. In 2001, Peru raised a trade concern before the SPS Committee regarding this measure, which had a very serious impact on the Peruvian economy due to the fact that fishmeal was one of Peru's main export products. ${ }^{1013}$ Peru noted that fishmeal poses no risk from BSE for humans or animals. The EC clarified that its ban on fishmeal in ruminant feeds was due to concerns of cross-contamination of fishmeals with other animal meals that do pose BSE risks, during processing to ruminant feed in the EC. The OIE representative at the meeting drew attention to an expert conference on BSE in 2001, where discussions had highlighted the lack of technical means

\footnotetext{
1009 Ibid., para. 206.

1010 Ibid.

1011 This does not mean that such factors have no role to play in the regulatory process. Instead, they play a role in the policy decisions taken at the risk management stage of SPS regulation. See further below, Part III, Section 5.2.3.1.

1012 See above, in the introductory paragraphs to Part III, Chapter 5.

1013 Committee on Sanitary and Phytosanitary Measures, Specific Trade Concerns. Note by the Secretariat. Addendum. Issues Not Considered in 2007, G/SPS/GEN/204/Rev.8/Add.2, circulated on 27 March 2008, item 97.
} 
to verify the absence of banned products in meals at very low levels, and therefore the risk of cross-contamination. The EC confirmed that its measure reflected failures in the implementation of rules on animal feed. In 2004, a new diagnostic test was developed which permitted mammalian meals to be distinguished from fish meals, eliminating the risk of cross-contamination. While the EC recognised that this new test removed the main scientific barrier to lifting the ban on fishmeal in ruminant feeds, it pointed to the reluctance of the EC Commission to reopen the feed dossier given consumer sensitivities in this area. ${ }^{1014}$ While, prior to the development of the new diagnostic test, the EC's problems of control of implementation of its rules on the use of animal meals in ruminant feed seem legitimate factors be taken into account in its risk assessment, and may reasonably support measures to avoid cross-contamination, the same cannot be said after the new test became available. The continuation of the EC's ban after the control problem was resolved was due to unfounded consumer fears. To allow baseless fears to be considered when making decisions on SPS measures would undermine the scientific disciplines of the SPS Agreement, and disregard the balance it tries to achieve between legitimate health protection and the liberalisation of agri-food trade.

While Article 5.2 can be regarded as an open list, it does set out a mandatory minimum list of factors that must be considered in a risk assessment, as indicated by the words 'shall take into account'. In US - Continued Suspension, the US argued that in drafting its risk assessment the EC had failed to take into account two of the elements listed in Article 5.2, namely the available scientific information and the relevant inspection, sampling, and testing methods. ${ }^{1015}$ According to the US, as the conclusions in the EC's risk assessment were not supported by the scientific evidence, the EC must not have considered the scientific evidence when formulating its risk assessment. The Panel disagreed, holding that whether a risk assessment is supported by the scientific evidence considered is irrelevant to the question whether the relevant scientific evidence was taken into account when formulating the risk assessment as required by Article 5.2. ${ }^{1016}$ It found:

$[\mathrm{I}] \mathrm{n}$ the context of risk assessment techniques, taking available scientific evidence into account does not require that a Member conform its actions to a particular conclusion in a particular scientific study. The available scientific information may contain a multiplicity of views and data on a particular topic. It is the view of the Panel that the requirement in Article 5.2 is to ensure that a Member, when assessing risk with the aim of formulating an appropriate SPS measure, has as wide a range as possible of scientific information before it to ensure that its measure will be based on sufficient scientific data and supported by scientific principles. ${ }^{1017}$

\footnotetext{
1014 Ibid., item 97, para. 234. No solution has been reported to this issue.

1015 Panel Report, US - Continued Suspension, para. 7.470-7.475.

1016 Ibid., para. 7.481.

1017 Ibid., para. 7.480. In casu the Panel noted that the EC's risk assessment specifically addressed the evidence available with regard to the risks at issue, including the very scientific studies that the US alleged were not taken into account. Therefore it found the EC to have taken the available scientific evidence into account as required by Article 5.2. Similarly, with regard to the question whether the EC took into account the relevant sampling, testing and inspection methods, the Panel pointed to the fact that a significant portion of the 1999 Opinion addressed this issue and that the EC had compiled a Working Document on abusive use and difficulties of control of the administration of growth hormones and had conducted on-site inspections and visits to
} 
Clearly, thus, the obligation to 'take into account' the listed factors is quite different from a requirement to ensure that the measure is 'based on' the factors considered. By analogy to the finding of the Panel in Japan - Apples with regard to the requirement in Article 5.1 to take into account the risk assessment techniques of the relevant international organisations, ${ }^{1018}$ or that of the Panel in EC-Approval and Marketing of Biotech Products with regard to the requirement to take into account the special needs of developing-country Members in elaborating SPS measures, ${ }^{1019}$ it can be argued that Article 5.2 merely requires that the listed factors be considered as relevant in the risk assessment.

In addition to the factors to be considered in all risk assessments, set out in Article 5.2, Article 5.3 sets out an additional list of economic factors to be taken into account in assessing risk to animal or plant life or health and in determining which SPS measure should be applied. In particular, Article 5.3 provides:

In assessing the risk to animal or plant life or health and determining the measure to be applied for achieving the appropriate level of sanitary or phytosanitary protection from such risk, Members shall take into account as relevant economic factors: the potential damage in terms of loss of production or sales in the event of the entry, establishment or spread of a pest or disease; the costs of control or eradication in the territory of the importing Member; and the relative costeffectiveness of alternative approaches to limiting risks.

This list of factors reflects the recognition of the fact that risk assessments are not purely science-based but may involve economic considerations as well. In particular, Members are obliged to consider the factors that relate to the 'associated potential ... economic consequences' of the risk, which is an aspect of the risk that must be evaluated under the first definition of a risk assessment, relevant to risks from pests or diseases. ${ }^{1020}$ In addition, Members must consider the cost effectiveness of alternative measures, which assessment is relevant to the requirement in Article 5.6 that Members adopt the least trade-restrictive measure reasonably available, taking into account the 'economic feasibility' of alternative measures. In the Uruguay Round negotiations on the SPS Agreement the need to specify the types of economic considerations relevant to a risk assessment was stressed by some Members, which expressed concern that, in the absence of specification, Members might consider their industry interests as a relevant economic factor in a risk assessment. ${ }^{1021}$

It is significant that human health risks are excluded from this provision, making it clear that Members are entitled to prioritise human health above economic considerations when assessing risks. ${ }^{1022}$ However, it is useful to recall that some human health risks fall within

US regulatory agencies. Therefore it had taken onto account the relevant sampling, testing and inspection methods, regardless of whether the conclusions it reached on this issue were scientifically supported. Panel Report, US - Continued Suspension, para. 7.483.

1018 This finding is discussed above, Part III, Section 5.1.3.

1019 This finding is discussed below, Part V, Section 1.1.

${ }^{1020}$ This requirement in the first definition of a risk assessment is discussed above, Part III, Section 5.1.1.3.

${ }^{1021}$ Negotiating Group on Agriculture, Working Group on Sanitary and Phytosanitary Regulations and Barriers, Summary of Main Points Raised at the Third Meeting of the Working Group on Sanitary and Phytosanitary Regulations and Barriers: Note by the Secretariat, MTN.GNG/NG5/WGSP/W/6, circulated on 17 October 1989, para. 3.

${ }^{1022}$ The exclusion of human health constitutes a significant amendment to the original text of the Dunkel Draft 
the first definition of a risk assessment, relevant to risks from pests or diseases, which requires an evaluation of potential economic consequences of the risk, despite the fact that no examination of the Article 5.3 factors is mandated in such cases. It would seem best to resolve this incongruity, as suggested by Scott, by seeing Article 5.3 as a 'second order' obligation, clarifying the requirement to evaluate the potential economic consequences of a risk in the first type of risk assessment. ${ }^{1023}$

The question arises what the benefit is of the requirement that Members, in their risk assessments, 'take into account' the factors set out in Articles 5.2 and 5.3 of the SPS Agreement, if there is no corresponding obligation to ensure that the final decision on the SPS measure to be adopted reflects these considerations. Are the requirements of Articles 5.2 and 5.3 mere 'empty proceduralism'? ${ }^{1024}$ As noted by Andrew Green and Tracey Epps, procedural rules contain a significant benefit, namely that of increasing information and transparency at the domestic level. By requiring the pertinent factors to be included in the assessment of risk that underlies an SPS measure, Articles 5.2 and 5.3 ensures that regulators have at their disposal a broad range of useful information, thereby improving the possibilities for well-founded and rational decision making. In addition, these requirements place national stakeholders in a position to exert pressure to induce a rational response to the risk at issue, and thereby to counteract protectionist tendencies.

\subsubsection{Requirement that SPS measures be based on a risk assessment}

After examining what is meant by a 'risk assessment' for purposes of the SPS Agreement, it is necessary to consider the import of the obligation in Article 5.1 of the SPS Agreement that SPS measures be 'based on' such a risk assessment. As noted above, the choice of an SPS measure is a risk management decision that is taken on the basis, not only of the scientific assessment of the risk at issue, but also of policy considerations, including the available economic resources and societal value judgements. The meaning of the 'based on' requirement will therefore determine the room left for policy decisions in the choice of an SPS measure.

The meaning of 'based on' was first discussed in EC-Hormones. ${ }^{1025}$ In this case the Panel had read a procedural requirement into the term, obliging Members to actually take a risk assessment into account when enacting or maintaining SPS measures. ${ }^{1026}$ It looked

which referred only to 'assessing the risk'. The final text adds the words 'to animal or plant life or health' after this phrase, to indicate that risks to human health are not intended here. See Terence P. Stewart, The GATT Uruguay Round: A Negotiating History (1986-1994), vol. IV: The End Game (Kluwer, The Hague/ London/Boston), 1999, 44. See further, above Part III, Section 1.2.2.

1023 Joanne Scott, The WTO Agreement on Sanitary and Phytosanitary Measures: A Commentary, Oxford Commentaries on the GATT/WTO Agreements (Oxford University Press, Oxford), 2007, 104. For a detailed discussion of the problem and suggestions to regard Article 5.3 and the definitions in Annex A.4 as cumulative or alternatively as autonomous, see ibid., 102-104.

${ }^{1024}$ The risk that procedural disciplines on risk assessments may amount to 'empty proceduralism', reducing the ability of the WTO to police protectionism, is identified in Andrew Green and Tracey Epps, 'The WTO, Science, and the Environment: Moving Towards Consistency', Journal of International Economic Law 10 (2), 2007, 285-316, 315.

1025 Appellate Body Report, EC-Hormones, paras 188-209.

1026 Thus the panel found that the EC could not rely on new scientific evidence regarding the risks posed by hormone treated beef, published in journals in 1995 and 1996, since it could not have been considered by the EC at the time of imposing the import ban. Panel Report, EC-Hormones (US), para. 8.113; Panel Report 
to preambles of EC Directives for evidence that this was in fact done. ${ }^{1027}$ The Appellate Body in $E C$ - Hormones rejected this subjective procedural requirement as having no basis in the text. It found:

The term 'based on', when applied as a 'minimum procedural requirement' by the Panel, may be seen to refer to a human action, such as particular human individuals 'taking into account' a document described as a risk assessment. Thus, 'take into account' is apparently used by the Panel to refer to some subjectivity which, at some time, may be present in particular individuals but that, in the end, may be totally rejected by those individuals. We believe that 'based on' is appropriately taken to refer to a certain objective relationship between two elements, that is to say, to an objective situation that persists and is observable between an SPS measure and a risk assessment. Such a reference is certainly embraced in the ordinary meaning of the words 'based on' and, when considered in context and in the light of the object and purpose of Article 5.1 of the SPS Agreement, may be seen to be more appropriate than 'taking into account'. We do not share the Panel's interpretative construction and believe it is unnecessary and an error of law as well. ${ }^{1028}$

The Panel had additionally found that Article 5.1 contained a substantive requirement, namely that the scientific conclusions reached in the risk assessment and those implicit in the SPS measure should conform. ${ }^{1029}$ The Appellate Body agreed with the relevance of the relationship between the two sets of conclusions, but emphasised that this is only one of the relevant factors. ${ }^{1030}$ It then held:

We believe that Article 5.1, when contextually read as it should be, in conjunction with and as informed by Article 2.2 of the SPS Agreement, requires that the results of the risk assessment must sufficiently warrant - that is to say, reasonably support - the SPS measure at stake. The requirement that an SPS measure be 'based on' a risk assessment is a substantive requirement that there be a rational relationship between the measure and the risk assessment. ${ }^{1031}$

The conclusion of the Appellate Body that for an SPS measure to be 'based on' a risk assessment there must be an 'objective relationship', or in other words a 'rational relationship', between the risk assessment and the SPS measure leaves open many questions as to what would be considered to constitute such a relationship. ${ }^{1032}$ While the measure needs not 'conform' to the conclusions of the risk assessment, the closeness of the relationship

EC-Hormones (Canada), para. 8.116.

${ }^{1027}$ Panel Report, EC-Hormones, (Canada), paras 8.116-8.119 and Panel Report, EC-Hormones, (US), paras 8.113 and 8.115-8.116.

${ }^{1028}$ Appellate Body Report, EC-Hormones, para. 189. The Appellate Body also rejected the use of preambles as evidence as they are not required by the SPS Agreement and are not normally used to show that a Member has complied with its international obligations.

${ }^{1029}$ Panel Report, EC - Hormones, (Canada), para 8.120 and Panel Report, EC-Hormones, (US), para. 8.117.

${ }^{1030}$ Appellate Body Report, EC-Hormones, para. 193.

1031 Ibid., para. 193.

1032 Note that the requirement that a risk assessment be sufficiently specific was seen by the Appellate Body in EC-Hormones as part of the 'based on' enquiry. Appellate Body Report, EC-Hormones, paras 198-199. 
required is not clearly specified. This has implications for the extent to which a panel may reassess the scientific evidence that forms part of a Member's risk assessment. ${ }^{1033}$

The requirement that an SPS measure be 'based on' a risk assessment was again at issue in Australia - Salmon, but due to several errors made by the Panel, little assistance can be garnered from the findings this dispute. The Panel in this case, after having assumed that Australia's 1996 Final Report was a risk assessment meeting the requirements of Annex A.4, incorrectly identified the measure at issue as a heat-treatment requirement. ${ }^{1034}$ It then found that as the 1996 Final Report made no substantive assessment of the risk or of the risk reduction related to heat-treatment requirements, the heat-treatment requirement was not based on a risk assessment. ${ }^{1035}$ This finding was overturned by the Appellate Body, which held that the 1996 Final Report was not a proper risk assessment, and therefore that Australia's measure, which was in fact its import prohibition on fresh, chilled or frozen salmon, could not be seen as 'based on' a risk assessment. ${ }^{1036}$ Similarly, in Japan - Agricultural Products II, Japan - Apples, and Japan - Apples (Article 21.5 - Canada) the fact that the scientific studies at issue were held not to be proper risk assessments within the meaning of Annex A.4 meant that the SPS measures at issue were held not to be 'based on' a risk assessment, without necessitating analysis of the meaning of 'based on'. ${ }^{1037}$

The compliance Panel in Australia - Salmon (Article 21.5 - Canada) had to address the question whether Australia's revised SPS measure, namely its requirement that salmonids not be released from quarantine unless they were 'consumer-ready', ${ }^{1038}$ was based on its new risk assessment, the 1999 IRA. The 'consumer-ready' requirement aimed to avoid the risk that during commercial processing of imported salmonids in Australia, waste disposal of infected salmon parts could introduce diseases into Australia. However, the Panel noted that none of the panel experts could find a justification in the 1999 IRA for the 'consumer-ready' requirement. The disease agents responsible for the diseases of concern were identified as found in the viscera, head, gills, brain, skin, mucus, blood and

1033 This issue is addressed in the discussion of the standard of review to be applied by panels below, Part IV, Section 2.2.3.

${ }^{1034}$ According to the Panel, '[f]rom a trade perspective ... the measure at issue in effect constitutes an import prohibition on, inter alia, fresh, chilled and frozen salmon.' However, approaching the measure from a sanitary perspective, the Panel found that the measure 'in effect imposes heat-treatment as a sanitary solution to the risk posed by the importation of salmon.' The Panel saw these two perspectives as 'two sides of a single coin' and regarded the sanitary perspective as necessary for an analysis under the SPS Agreement. Panel Report, Australia - Salmon, para. 8.95. The Appellate Body disagreed with this view of the measure at issue, holding that: 'it is not a consequence of the requirement that smoked salmon be heat-treated that imports of fresh, chilled or frozen salmon are prohibited.' Appellate Body Report, Australia - Salmon, para. 104.

1035 Panel Report, Australia - Salmon, paras 8.98-8.100.

1036 Appellate Body Report, Australia - Salmon, para. 136.

${ }^{1037}$ Appellate Body Report, Japan - Agricultural Products II, para. 114; Panel Report, Japan - Apples, para. 8.291; Appellate Body Report, Japan - Apples, para. 216; Panel Report, Japan - Apples (Article 21.5 - US), para. 8.156.

${ }_{1038}$ A consumer-ready product was defined in Australia's measure as: 'a product that is ready for the householder to cook/consume' and this was further specified as including cutlets weighing less than 450g; skinless fillets of any weight; skin-on fillets weighing less than $450 \mathrm{~g}$; eviscerated, headless, pan-size fish weighing less than 450g; and any product that is processed further than the stage described above. Panel Report, Australia-Salmon (Article 21.5 - Canada), para. 7.78. 
kidney remnants. ${ }^{1039}$ The 1999 PRA stated that evisceration, removal of head and gills and thorough washing of the external and internal surfaces of the fish to remove skin, mucus and visceral remnants would 'significantly reduce risk' but went on to propose, in addition, either the requirement that only approved premises (subject to waste disposal controls) be permitted to commercially process imported salmonids in Australia, or that only 'consumer ready' products be released from quarantine. ${ }^{1040}$ The Panel was of the view that as the parts of the salmon that contained disease agents were effectively excluded from importation by the evisceration, beheading, gilling and washing requirements, and no specific explanation for the additional requirements was given in the 1999 PRA, no 'rational relationship' existed between the 'consumer-ready' requirement imposed by Australia and the 1999 PRA. ${ }^{1041}$ As the 1999 PRA specifically recommended the 'consumer-ready' requirement, it is arguable that the SPS measure imposed by Australia was in fact firmly based on the risk assessment. What the Panel takes issue with is the risk assessment itself, and specifically its failure to explain why additional requirements are necessary despite the ability of the other requirements to 'significantly reduce risk' ${ }^{1042}$ Considering Australia's high appropriate level of protection, it seems likely that the conservative measures chosen aim to reduce risks to a very low level. ${ }^{1043}$

In EC-Approval and Marketing of Biotech Products, the Panel had to address the question whether the safeguard measures imposed by six EC Member States banning biotech products that had been approved at EC level, were 'based on' risk assessments. The complainants argued that, although the Member States concerned had offered reasons for their measures, pointing to shortcomings in the risk assessments conducted as part of the EC approval process or expressing general concerns with regard to risks to human health or the environment arising from the relevant biotech products, they had not put forward risk assessments meeting the requirements of Annex A.4. Instead, the only risk assessments available were those conducted by the EC scientific committees and lead competent Authorities, ${ }^{1044}$ which were favourable to the biotech products at issue. Consequently, the safeguard measures could not be said to be 'based on' these risk assessments. ${ }^{1045}$ To the contrary, the EC argued, inter alia, that the risk assessments carried out at the time of approval of the biotech products 'could serve, at least temporarily, as a basis both for the original Community consent, and for the Member States provisional [safeguard] measures.' 1046 This argument was based on the EC's view that as the requirement for a measure to be 'based on' a risk assessment does not mean that the measure must 'conform

\footnotetext{
1039 Ibid., para. 7.80 .

1040 Ibid., para. 7.81 .

1041 Ibid., para. 7.88 .

${ }^{1042}$ Note, however, that in its analysis of whether the requirements for a risk assessment had been met, the Panel expressly rejected Canada's argument that the failure to assess the risk according to the SPS measure actually imposed meant that the third element of the first definition of a risk assessment had not been complied with. See above, Part III, Section 5.1.1.4. It is not clear why the Panel preferred to address this issue under the 'based on' requirement.

${ }^{1043}$ Australia had determined its level of protection to be 'a high or very conservative level of protection aimed at reducing risks to very low levels' Panel Report, Australia - Salmon (Article 21.5 - Canada), para. 7.129

1044 The lead Competent Authorities were the authorities of the Member State to which the application for approval of the relevant biotech product was originally submitted.

${ }^{1045}$ Panel Reports, EC - Approval and Marketing of Biotech Products, paras 7.3012-7.3013.

${ }^{1046}$ Ibid., para. 7.3015 .
} 
to' that risk assessment, the same risk assessment can 'sufficiently warrant' or 'reasonably support' more than one possible SPS measure.

It was common ground between the parties that the assessments conducted by the EC scientific committees and the lead Competent Authorities were risk assessments within the meaning of Annex A.4 and Article 5.1. ${ }^{1047}$ The question was thus whether the safeguard measures were 'based on' these assessments. ${ }^{1048}$ The Panel agreed with the EC that the words 'based on' in Article 5.1 do not mean the same as 'conform to'. ${ }^{1049}$ It accepted that a particular risk assessment can form the basis for different types of measures, in cases where a risk is determined to exist. ${ }^{1050}$ It also acknowledged that the determination of whether a measure is 'based on' a risk assessment may be influenced by the fact that a Member has chosen to follow a precautionary approach in the face of uncertainties or constraints identified in the risk assessment. ${ }^{1051}$ However, the Panel noted that this does not mean that 'Members are free to adopt any kind of SPS measure provided there exists a risk assessment for the product subject to the SPS measure. ${ }^{1052}$ It recalled that the term 'based on' has been interpreted by the Appellate Body to mean 'sufficiently warranted by', 'reasonably supported by' or 'rationally related to'. The Panel held therefore that the 'based on' requirement in Article 5.1 'is plainly a substantive requirement and not simply a formal requirement to accompany an SPS measure by a risk assessment.' ${ }^{1053}$ However, the Member States' safeguard measures at issue simply disregarded favourable risk assessments. ${ }^{1054}$ They did not identify uncertainties or constraints and explain how these justified the safeguard measures. ${ }^{1055}$ According to the Panel, if it were to allow this, it would turn the conduct of risk assessments into 'a mere formality.' 1056

\subsubsection{Problem of differing scientific opinions}

Article 5.1, together with Article 2.2, set science as the touchstone against which SPS measures are judged for validity. However, once one recognises the fallacy inherent in a notion of universal science, it becomes necessary to ask: whose science must measures be tested against? The same factual situation can lead to different scientific conclusions. These different scientific conclusions may be arrived at due to different choices between various scientifically plausible alternatives. This is particularly true when the

1047 Ibid., para. 7.3027. The Panel agreed with the parties on this point.

1048 This question was addressed with regard to each of the safeguard measures at issue. However, as the same arguments were presented by the EC in this regard, the Panel addressed the arguments in respect of the first safeguard measure it addressed, Austria's ban on T25 maize, and referred back to these findings, mutatis mutandis, in its analysis of the other safeguard measures.

1049 Panel Reports, EC-Approval and Marketing of Biotech Products, para. 7.3067.

${ }^{1050}$ Ibid., para. 7.3064.

1051 Ibid.,para. 7.3065. In these cases, the Panel held that the Member might decide to apply an SPS measure even if another Member might not do so on the basis of the same risk assessment; or might decided to apply a stricter SPS measure than that applied by another Member to address the same risk.

${ }^{1052}$ Panel Reports, EC - Approval and Marketing of Biotech Products, para. 7.3067.

1053 Ibid., para. 7.3067.

${ }^{1054}$ At issue here was the safeguard measure imposed by Austria with respect to T25 maize, which was adopted in disregard of the risk assessment conducted by the EC Scientific Committee on Plants and that conducted by the lead Competent Authority.

1055 Panel Reports, EC - Approval and Marketing of Biotech Products, para. 7.3066.

${ }^{1056}$ Ibid., para. 7.3067. 
science-policy decisions inherent in the assumptions, rules-of-thumb and models used to fill gaps in data differ. The science policy choices made in conducting national risk assessments reflect subjective values as risk assessors reflect on how the scientific information before them must be understood. ${ }^{1057}$ Therefore the risk orientation prevalent in a Member will influence the outcome of a risk assessment, leading to the possibility that different conclusions may be drawn from the same scientific data. This situation is sometimes referred to as the problem of 'duelling science.' 1058

The question therefore arises whether, in judging the validity of an SPS measure against the scientific criteria of Articles 2.2 and 5.1, a panel should defer to the choice of scientific view made by the regulatory authorities of the Member imposing the measure, or whether it should substitute its own judgement for that of the Member. ${ }^{1059}$

An illustration of this situation is provided by the statement of one of the panel experts in US - Continued Suspension. ${ }^{1060}$ The panel experts had been asked to evaluate the EC's risk assessment, including its assertion that as the hormone oestradiol-17 $\beta$ has genotoxic potential, the fact that the doses used in growth promotion are low is irrelevant because there is no threshold for genotoxic substances. In response, one of the panel experts explained:

The EC's statement that a threshold cannot be identified reflects their view of genotoxic mechanisms, just as the contrary statement that there is a threshold and that this threshold is above the levels found in meat residues reflects how Canada and the US view genotoxic mechanisms. Neither statement has been demonstrated by the scientific evidence, rather, they are different assumptions that each party uses in their interpretation of the available evidence. ${ }^{1061}$

In such cases, it would seem inappropriate for a panel to set itself up as the arbiter of the scientific merit of the opposing views. The subjective assumptions that are an inherent part of a risk assessment should be seen as within the competence of the regulating Member, and not subject to judicial review. There is no legitimate basis for replacing the science policy choices of a Member with those of a panel. Nevertheless, assessing the Opinions in accordance with the views of the other three panel experts that there is no appreciable risk of cancer from the residues of oestradiol- $17 \beta$ in meat and meat products from cattle treated with the hormone for growth-promotion purposes', ${ }^{1062}$ the Panel came to the conclusion that the science did not support the conclusions in the Opinions of the SCVPH. ${ }^{1063}$

\footnotetext{
${ }^{1057}$ Andrew Green and Tracey Epps, 'The WTO, Science, and the Environment: Moving Towards Consistency', Journal of International Economic Law 10 (2), 2007, 285-316, 304.

${ }^{1058}$ For a more detailed discussion of the problem of 'duelling science' see above, Part II, Section 1.5.

${ }^{1059}$ A discussion on the standard of review to be applied by panels in assessing scientific evidence is found below, Part IV, Section 2.2.3.

${ }^{1060}$ Although this statement was used by the Panel in its analysis under Article 5.1, rather than Article 2.2, of the SPS Agreement, the same considerations with regard to science-policy choices apply in both cases.

1061 Panel Report, US - Continued Suspension, Annex D, para. 186; Panel Report, Canada - Continued Suspension, Annex D, para. 186. This Annex contains the replies by the scientific experts to Panel questions.

1062 Panel Report, US - Continued Suspension, para. 7.569.

${ }^{1063}$ Ibid., para. 7.572.
} 
Differences in scientific opinions exist not only in the varying views on the risk at issue between the parties to the dispute, but may also be found between the scientific experts conducting a particular risk assessment. In EC-Hormones, the Appellate Body addressed the possibility of conflicting scientific opinions in a risk assessment, and the recognised that Members may legitimately choose to rely on minority views. The Appellate Body held:

We do not believe that a risk assessment has to come to a monolithic conclusion that coincides with the scientific conclusion or view implicit in the SPS measure. The risk assessment could set out both the prevailing view representing the 'mainstream' of scientific opinion, as well as the opinions of scientists taking a divergent view. Article 5.1 does not require that the risk assessment must necessarily embody only the view of a majority of the relevant scientific community. ... In most cases, responsible and representative governments tend to base their legislative and administrative measures on 'mainstream' scientific opinion. In other cases, equally responsible and representative governments may act in good faith on the basis of what, at a given time, may be a divergent opinion coming from qualified and respected sources. By itself, this does not necessarily signal the absence of a reasonable relationship between the SPS measure and the risk assessment, especially where the risk involved is life-threatening in character and is perceived to constitute a clear and imminent threat to public health and safety. Determination of the presence or absence of that relationship can only be done on a case-to-case basis, after account is taken of all considerations rationally bearing upon the issue of potential adverse health effects. ${ }^{1064}$

In $E C$ - Hormones, a single scientist, Dr. Lucier, was of the opinion that using oestrogen for growth promotion could raise the risk of breast cancer by up to one in one million. His opinion was deemed, by the Panel and Appellate Body, to be of insufficient weight to overturn the contrary results of the other studies referred to by the EC (which confirmed the safety of the hormones at issue), as it was not based on studies, carried out by him or under his supervision, specifically focused on hormone residues in meat from cattle on which such hormones were used for growth promotion purposes. ${ }^{1065}$ It was rejected for these reasons, rather than because it was a minority opinion. This does not necessarily imply, however, that if his opinion had been sufficiently specific, it would necessarily have been regarded as a rational basis for the EC's measure despite the contrary majority opinion. While the Appellate Body's finding does not make clear within which limits minority opinions may be relied upon, aside from specifying that they must come from 'qualified and respected sources', some further guidelines can be gleaned from later cases.

The compliance Panel in Japan - Apples (Article 21.5 - Canada) considered whether new scientific studies, presented by Japan in support of its revised measure against the risk of fire blight, could be considered a 'minority opinion' on which Japan was entitled to rely. ${ }^{1066}$ Japan argued that the new studies used in its 2004 PRA dealt with all the issues

\footnotetext{
1064 Appellate Body Report, EC-Hormones, para. 194.

1065 Ibid., para. 198.

${ }^{1066}$ Panel Report, Japan - Apples (Article 21.5 - Canada), para. 8.146.
} 
raised by the experts before the original Panel. ${ }^{1067}$ Although the panel experts before the compliance Panel confirmed that these new studies were scientific in nature and closely followed the procedural steps set out by the IPPC in ISPM 11, they did not agree with the conclusions in these studies. In particular, they regarded the studies as reflecting 'laboratory conditions' as opposed to 'real world conditions', namely orchard conditions and commercial practice. ${ }^{1068}$ As a result, the Panel considered that the new studies did not objectively support what Japan wanted to demonstrate, namely that mature apples could be latently infected and that the transmission pathway for fire blight was 'likely to be completed in real conditions. ${ }^{1069}$ As a result, these studies could not 'be assimilated to a minority opinion' in the Panel's view. ${ }^{1070}$

In EC-Approval and Marketing of Biotech Products, the question arose whether an SPS measure could be said to be based on a 'divergent opinion' in a risk assessment if that risk assessment set out a single opinion with which the Member concerned disagreed. The Panel clarified that, to the extent that Members disagree with some or all of the conclusions contained in such a risk assessment:

it would in [the Panel's] view be necessary for Members to explain, by reference to the existing assessment, how and why they assess the risks differently, and provide their revised or supplemental assessment of the risks. ${ }^{1071}$

It is clear, therefore, that the flexibility for divergent opinions read by the Appellate Body into the obligation to base an SPS measure on a risk assessment does not make room for Members to merely disregard those risk assessments they disagree with and consider their own opinion a 'divergent opinion'. Instead, they may offer an alternative risk assessment that diverges from the one they disagree with, and supports their view.

While concerns have been raised that the Appellate Body's approach has left intact the issue of duelling science and has opened the door for the use of 'hired scientists' in future dispute settlement cases, ${ }^{1072}$ this seems unlikely. It should be recognised that the Appellate Body's approach is the only realistic one that could be taken in the light of the lack of consensus that often exists within the scientific community with respect to risks. Respect for Members' right to choose their appropriate levels of protection implicitly includes allowing them to make policy decisions regarding the choice among conflicting scientific views. The careful examination of what has been proffered as a 'minority opinion' in subsequent cases indicates that the scope for misuse is recognised by panels and guarded against. A proper, alternative risk assessment is required, and is subject to the same rigorous review as is usually applied by panels to risk assessments.

Certainly the vigilant approach of panels in this regard is to be applauded. A divergent opinion must meet the normal requirements of a risk assessment to be considered as such. Nevertheless, as is the case with all reviews of scientific evidence by panels, not only in

${ }^{1067}$ Ibid., para. 8.131 .

1068 Ibid., para. 8.140-8.144.

1069 Panel Report, Japan - Apples (Article 21.5 - Canada), para. 8.146.

${ }^{1070}$ Ibid., para. 8.146.

${ }^{1071}$ Panel Report, EC - Approval and Marketing of Biotech Products, para. 7.3062.

1072 Dale E. McNiel, 'The First Case under the WTO's Sanitary and Phytosanitary Agreement: The European Union's Hormone Ban', Virginia Journal of International Law 39, 1998, 89-134, 134. 
the case of divergent opinions, it is argued in this book that care must be taken by panels not to undertake a new risk assessment. It is recommended that a panel should limit its enquiry, also in cases where scientific dissent regarding the issue at hand is present as evinced by the presence of a good faith difference of opinion among scientists, to the plausibility of the view relied upon by the Member imposing the measure. If there is reputable scientific support for the Member's measure, it should be held to be based on a risk assessment, even if the panel might have chosen the opposing scientific view or finds it more convincing. ${ }^{1073}$

In practice, as seen in the previous discussion, the positions taken by panels and the Appellate Body to scientific evidence do not indicate deference to national scientific assessments. While the Appellate Body has shown greater deference to national choices than panels, recognising the right of regulatory health authorities to rely on minority opinions and to act with caution in life-threatening situations, it reserves for panels the ability to rule on the quality and weight of the scientific evidence. As will be seen below, ${ }^{1074}$ this has opened the door for a very intrusive standard of review applied by panels in their assessment of the scientific evidence, undermining the trade/health balance sought by the SPS Agreement.

\subsubsection{Problem of evolving science}

Science is inherently in a state of flux. Scientific conclusions with regard to the existence and extent of SPS risks are continuously being updated in the light of scientific developments. The situation could therefore arise that an SPS measure is based on a risk assessment that is subsequently invalidated by new scientific findings. Similarly, an SPS measure not based on a risk assessment at the time of its adoption could be supported by new risk assessments undertaken later.

It is thus important, first, to determine when the risk assessment needs to have been made in order for a measure to be 'based' thereon. Obviously there are a multitude of SPS measures which were in existence long before the coming into force of the SPS Agreement. ${ }^{1075}$ It is likely that many of these were not based on a risk assessment, particularly in Members whose resources are too scarce to permit them routinely to undertake thorough risk assessments before enacting SPS measures. With respect to the risk assessment requirement for SPS measures enacted before the entry into force of the SPS Agreement, the Panel in EC-Hormones noted:

[Article 5.1] does not prevent that with respect to a sanitary measure enacted before the entry into force of the SPS Agreement, the risk assessment is carried out or invoked after the entry into force of that Agreement (and thus after the enactment of the sanitary measure in question). However, the fact that a sanitary measure may be enacted before the entry into force of the SPS Agreement does

\footnotetext{
1073 See in this regard Vern R. Walker, 'Keeping the WTO from Becoming The "World Trans-Science Organization": Scientific Uncertainty, Science Policy, and Factfinding in the Growth Hormones Dispute', Cornell International Law Journal 31, 1998, 251-320, 280.

1074 See Part IV below, where the intrusive nature of the standard of review currently applied is examined.

1075 The temporal scope of application of the SPS Agreement is discussed above, Part III, Section 2.3.
} 
not mean that, once the SPS Agreement entered into force, there is no obligation for the Member in question to base that measure on a risk assessment. ${ }^{1076}$

The Appellate Body in that case confirmed this finding, ${ }^{1077}$ but recognised the burden that this could impose on Members due to the many SPS measures that were already in existence at the time of entry into force of the SPS Agreement. As stated above, it regarded the stipulation in Article 5.1 that SPS measures must be based on a risk assessment, as appropriate to the circumstances as giving Members 'a certain degree of flexibility in meeting the requirements of Article 5.1.' ${ }^{1078}$ The form this flexibility would take was not specified, however.

A related issue which arises is whether new scientific evidence that comes to light after the adoption of the SPS measure at issue can be taken into account as constituting the risk assessment on which the measure is based. The Appellate Body in EC-Hormones addressed this situation, in an aside. It rejected the Panel's 'minimum procedural requirement' read into the question of whether a measure is 'based on' a risk assessment, which obliged a Member imposing an SPS measure to submit evidence that it actually took into account a risk assessment when it enacted or maintained its SPS measure. ${ }^{1079}$ The Appellate Body stated that this procedural requirement 'could well lead to the elimination or disregard of available scientific evidence that rationally supports the SPS measure being examined.' ${ }^{1080}$ According to the Appellate Body, this risk of exclusion of available scientific evidence could be particularly important for the bulk of SPS measures which were put in place before the entry into force of the SPS Agreement and that have been 'simply maintained thereafter'. ${ }^{1081}$

The question of whether an SPS measure could be regarded as 'based on' a risk assessment finalised after its entry into force was at issue before the compliance Panel in Australia - Salmon (Article 21.5 - Canada). Canada had claimed that the new Australian measure could not be said to be based on a risk assessment, because the publication of the new measure on 19 July 1999, preceded the publication in its final form, on 12 November 1999, of Australia's new risk assessment, the 1999 IRA. The compliance Panel referred back to the finding in the original dispute that it is the scientific and technical content of the studies submitted to the Panel that is relevant, not their administrative status (i.e. as official government reports or not). ${ }^{1082}$ The compliance Panel applied this same approach to the 1999 PRA. It noted that although the 1999 PRA was only edited and published in book form on 12 November 1999, it was announced in July 1999, i.e. before the new measures were adopted. All the substantive elements of the risk assessment were already contained in the draft IRA of July 1999 and the amendments in the final report

\footnotetext{
1076 Panel Report, EC-Hormones (Canada), para. 8.102; Panel Report, EC-Hormones (US), para. 8.99.

1077 The Panel in Australia - Salmon also followed this approach, stating that Article 5.1 places no qualification on the application in time of the substantive obligation on Members to base their sanitary measures on a risk assessment. Panel Report, Australia - Salmon, para. 8.56.

1078 Appellate Body Report, EC-Hormones, para. 129.

1079 Panel Report, EC-Hormones (US), para. 8.113; Panel Report, EC-Hormones (Canada), para. 8.116.

1080 Appellate Body Report, EC-Hormones, para. 190.

1081 Ibid.

${ }^{1082}$ Panel Report, Australia - Salmon, para. 8.136.
} 
did not 'alter the substance or the conclusions of the report as announced on 19 July.' ${ }^{083}$ Therefore the later publication of the final version of the 1999 IRA did not preclude Australia's measures from being 'based on' this IRA. ${ }^{1084}$ A similar situation arose before the compliance Panel in Japan - Apples (Article 21.5 - US), where Japan's 2004 PRA was adopted in September 2004, postdating the adoption of its SPS measure on 30 June 2004. As the Panel found no substantive difference the draft version of the PRA completed in mid-June of that year, i.e. before the adoption of the SPS measure at issue, and the final version adopted in September 2004, it held that the later adoption did not preclude Japan's measure from being 'based on' the 2004 PRA. ${ }^{1085}$

It is thus clear that although the fact that an SPS measure predates the entry into force of the SPS Agreement will not excuse the Member imposing the measure from the obligation of (later) basing the measure on a risk assessment, the final adoption of this risk assessment does not have to precede the enactment of the SPS measure. However, it does appear that a compliance panel will examine whether a risk assessment existed at the time the new SPS measure was adopted in compliance with a DSB ruling, although the final version of the risk assessment need not have been published before the enactment of the measure.

Developments in the scientific evidence regarding a particular risk can operate not only to provide more support for the SPS measure imposed, but also to invalidate the risk assessment on which a measure is based. The question therefore arises whether the scientific disciplines of the SPS Agreement include the obligation to continuously review the scientific basis for SPS measures in the light of advances in scientific evidence. ${ }^{1086} \mathrm{In}$ Japan - Apples, Japan argued that the conformity of its risk assessment, the 1999 PRA, with Article 5.1 should be assessed only in the light of the information available at the time when the PRA was conducted. ${ }^{1087}$ The Panel disagreed, holding that the PRA was already four years old at the time it was reviewed by the Panel. According to the Panel:

[S]ome assessment of the subsequent evolution of the scientific evidence is not only acceptable, it is also necessary, if only to monitor the development of any new evidence which might require a revision of the risk assessment. ${ }^{1088}$

The Panel emphasised the need to bear in mind the purpose of a risk assessment, namely to serve as a basis for regulatory actions. It noted that an evolution in the scientific evidence might be an indication that a review of the risk assessment, or a new risk assess-

\footnotetext{
1083 Ibid., para. 7.77.

1084 Ibid.

${ }^{1085}$ Panel Report, Japan - Apples (Article 21.5 - US), para. 8.155.

${ }^{1086}$ It is interesting to note that the TBT Agreement, unlike the SPS Agreement, explicitly requires regard to changed circumstances with respect to the maintenance of measures. Specifically, Article 2.3 of the TBT Agreement states: 'Technical regulations shall not be maintained if the circumstances or objectives giving rise to their adoption no longer exist or if the changed circumstances or objectives can be addressed in a less trade-restrictive manner.' Such an express reference to changed circumstances is absent from the obligation in Article 2.2 of the SPS Agreement not to maintain SPS measures without sufficient scientific evidence.

1087 Panel Report, Japan - Apples, para. 7.11. This argument was made during the interim review stage of the panel proceedings.

1088 Ibid., para. 7.12.
} 
ment, is needed. ${ }^{1089}$ The Panel also pointed to the legal inconsistency that would arise if the obligation in Article 2.2 to ensure that an SPS measure not be maintained without sufficient scientific evidence would be taken to require a measure to be based on sufficient scientific evidence at the time of the Panel's assessment, yet it would be accepted that risk assessments need not be reviewed in the face of new evidence. ${ }^{1090}$ The Panel was therefore willing to consider evidence subsequent to Japan's 1999 PRA in assessing whether Japan had complied with Article 5.1 of the SPS Agreement. ${ }^{1091}$ On appeal against the Panel's finding that its 1999 PRA was inconsistent with Article 5.1, Japan argued that its 1999 PRA should have been reviewed only against the information available at the time it was conducted. ${ }^{1092}$ However, Japan did not bring evidence to persuade the Appellate Body that the Panel had, in fact, relied on scientific evidence not available to Japan at the time it conducted its risk assessment when analysing the conformity of the 1999 PRA with Article 5.1. ${ }^{1093}$ The Appellate Body therefore found it unnecessary to express its views on the question whether the conformity of a risk assessment with Article 5.1 should be evaluated solely against the scientific evidence available at the time the risk assessment was conducted, or could take into account later scientific developments. ${ }^{1094}$ Whether such an evaluation of a risk assessment in light of the subsequent evolution in science is permissible therefore awaits clarification by the Appellate Body.

The Panel in EC - Approval and Marketing of Biotech Products, ${ }^{1095}$ confused the issue by conflating the question whether risk assessments postdating the adoption of the SPS measure could be relied upon as the scientific basis for the measure with the related question of whether an evolution in science subsequent to a risk assessment can be used to challenge the validity of the risk assessment. When examining whether the various safeguard measures of the EC Member States were based on a risk assessment, the Panel

\footnotetext{
1089 Ibid.

${ }^{1090} \mathrm{Ibid}$. Japan had indicated, in response to the questions of the Panel, that it did support this interpretation with regard to Article 2.2 of the SPS Agreement.

1091 Ibid., para. 8.248.

1092 Appellate Body Report, Japan - Apples, para. 210.

1093 Ibid., paras 213-214.

1094 Ibid., para. 215.

${ }^{1095}$ It is interesting to note that the Panel in EC-Approval and Marketing of Biotech Products also addressed the question of the effect of an evolution in science on the obligation under Article 5.1 in a letter it sent to the parties clarifying the implications of some of its findings. This letter, unprecedented in WTO proceedings, was sent by the Panel due to the fact that the interim Panel report had been leaked to the public, which had led to some of the panel findings 'inadvertently or on purpose' being misconstrued. In this letter, the Panel stated, inter alia, that its findings under Article 5.1 of the SPS Agreement 'preserve the freedom of Members to take prompt protective action in the event that new or additional scientific evidence becomes available which affects their risk assessments.' According to the Panel, if new scientific evidence 'provides grounds for considering that the use or consumption of a product might constitute a risk to human health and/or the environment, a Member might need expeditiously to re-assess the risks to human health and/or the environment. Initially at least, an expedited re-assessment of relevant risks might be "appropriate to the circumstances" and might provide a basis for a different SPS measure or for an SPS measure where none has been applied before.' The Panel stressed, however, that such an expedited re-assessment might later become no longer 'appropriate to the circumstances' in the case that 'further and more thorough and elaborate analysis of the new or additional scientific evidence, as such and together with other available evidence, was possible and indicated, and such analysis would have shown that the conclusions of the initial, expedited re-assessment of relevant risks is no longer valid.' Panel Reports, EC-Approval and Marketing of Biotech Products, Annex K, para. (c). The Panel reports expressly state that this letter of the Panel 'is not part of the Panel's findings and is not intended to modify them in any way.' Ibid., footnote 170.
} 
was faced with the question 'whether the maintenance of the relevant safeguard measures may be justified both by reference to risk assessments which were carried out before these measures were adopted and by reference to risk assessments which were carried out after these measures were adopted. ${ }^{\prime 096}$ It noted that the issue is not specifically addressed in Article 5.1, but found that it is clear that SPS measures must be based on a risk assessment 'throughout the period of time for which these measures are maintained.' 1097 According to the Panel, therefore, the appropriate moment at which to assess whether the SPS measure at issue was based on a risk assessment is the date of the establishment of the panel. ${ }^{1098}$ It further stated:

Also relevant to our inquiry is the requirement that a risk assessment be "appropriate to the circumstances". The phrase "as appropriate to the circumstances" is unqualified as far as its temporal scope is concerned. Notably, Article 5.1 does not say "as appropriate to the circumstances existing at the time of adoption of such measures", or "as appropriate to the circumstances existing at the time of the assessment". We think it may be inferred from the absence of any temporal limitation that at any given time, SPS measures must be based on an assessment of risks which is appropriate to the circumstances existing at that time. Indeed, this is consistent with the fact that relevant circumstances may change over time. A change in relevant circumstances may have an impact on a completed risk assessment and the validity of its conclusions. If and when a change in relevant circumstances affects the continued relevance and validity of a completed risk assessment, that assessment would, in our view, no longer constitute an assessment "appropriate to the circumstances". ${ }^{1099}$

As pointed out by Joanne Scott, there is an obvious flaw in this reasoning. ${ }^{1100}$ While the question set out by the Panel is whether SPS measures can be justified by reference to later risk assessments, the answer it gives allows a measure to be challenged on the basis of a later risk assessment that affects the continued validity of the assessment on which it was originally based. While both of these issues relate to the recognition of the evolving nature of science, they have quite different implications.

To allow a Member to rely on later risk assessments, in existence at the time that its SPS measure is challenged before a panel, provides much needed flexibility, particularly in the light of the manifold of SPS measures in existence before the obligation to base them on a risk assessment came into effect. On the contrary, to permit challenges to an SPS measure that was properly based on a risk assessment at the time of its adoption, but whose reliance on this risk assessment has been called into question by later scientific developments, imposes an onerous obligation on Members to continuously review all

${ }^{1096}$ Panel Reports, EC-Approval and Marketing of Biotech Products, para. 7.3029.

1097 Ibid., para. 7.3030.

1098 Ibid., para. 7.3034. Consequently the Panel was willing to take into account evidence postdating the imposition of the safeguard measures relied upon by the EC, to the extent that it had been published prior to the establishment of the Panel.

1099 Ibid., para. 7.3031.

1100 Joanne Scott, The WTO Agreement on Sanitary and Phytosanitary Measures: A Commentary, Oxford Commentaries on the GATT/WTO Agreements (Oxford University Press, Oxford), 2007, 125. 
their SPS measures in the light of new scientific developments. ${ }^{1101}$ While such a dynamic interpretation of the scientific obligations of the SPS Agreement may induce high-quality risk regulation that is up-to-date with the latest scientific advances at any given point in time, this does not correspond to the reality of the regulatory process. While high-income Members that have significant scientific capacity and financial resources typically do engage in periodic review of their existing SPS measures in response to changes in circumstances, including new scientific understandings, this review is not permanently ongoing for all measures in place. For most other Members, the capacity needed not only to have a sound risk assessment in place for every SPS measure, but also to review this assessment regularly, is a distant hope.

\subsection{Risk management}

Risk management, as explained above, entails policy decision-making regarding the level of protection that a country wants to secure in its territory and the measure it will use to achieve this level of protection. The WTO Secretariat has explained risk management as follows:

Risk management involves a number of steps. These include, inter alia, decisions regarding the acceptable level of risk; identification of possible options to reduce or eliminate the identified risk; evaluation and selection among these options; implementation of the selected measures, as appropriate; and monitoring and control of the effectiveness of the selected measure. ${ }^{1102}$

These choices are based on both scientific evidence and other considerations such as technical and economic feasibility, societal value judgments and the effect on the regulated industry. The SPS Agreement gives national regulators substantial latitude in making risk management decisions, but there are certain non-scientific disciplines in place to ensure that the adverse trade effects of these decisions are limited as much as possible. ${ }^{1103}$

${ }^{1101}$ Joanne Scott argues that while the obligation of Article 5.1 should be interpreted as static, the obligation of Article 2.2 should be regarded as dynamic, requiring Members 'to track new scientific developments, and to revise their measures in so far as these developments threaten to undermine the scientific premises upon which existing measures rest.' Ibid., 126. In other words, she argues that the fact that an SPS measure was based on a risk assessment at the time of its adoption should protect it from challenges under Article 5.1, but not those under Article 2.2. While this would make sense conceptually, due to the fact that Article 2.2 refers to the obligation not to 'maintain' an SPS measure without sufficient scientific evidence, indicating a continuous obligation, in practice it still leads to a heavy compliance burden on Members in respect of monitoring scientific developments and reviewing their measures accordingly.

${ }^{1102}$ Committee on Sanitary and Phytosanitary Measures, Risk Analysis. Note by the Secretariat, G/SPS/W/80, circulated on 6 March 1997, para. 8.

${ }^{1103}$ It should not be forgotten, however, that the scientific disciplines in Articles 2.2 and 5.1 of the SPS Agreement entail a particular relationship between the scientific evidence and the SPS measure applied. In other words, they necessarily have implications for the choice of SPS measure, a risk management decision. While the link required between the measure and the science has been clarified to be that of a 'rational relationship', as discussed above, the strictness with which this criterion has been applied limits the possibilities for consideration of non-science factors in the choice of an SPS measure. 


\subsubsection{Concept of an appropriate level of protection}

A Member's 'appropriate level of protection' is defined in Annex A.5 of the SPS Agreement as ' $[\mathrm{t}] \mathrm{he}$ level of protection deemed appropriate by the Member establishing a sanitary or phytosanitary measure to protect human, animal or plant life or health within its territory." ${ }^{1104}$ Thus, the SPS Agreement recognises Members' right to choose their own appropriate level of protection, or in other words to freely decide what standard of sanitary and phytosanitary protection they will aim at with their SPS measures.

The determination of an appropriate level of protection (risk management) must be clearly distinguished from the evaluation of risk (risk assessment), which is subject to scientific disciplines. This was not done by the Panel in Australia - Salmon which held:

We consider that a risk assessment, on which to base an import prohibition in accordance with Article 5.1, cannot be premised on the concept of 'zero risk' Otherwise, all import prohibitions would be based on a risk assessment since there is a risk (i.e., a possibility of an adverse event occurring), however remote, associated with most (if not all) imports. ${ }^{105}$

The Appellate Body in that case, on the contrary, noted as follows:

[I]t is important to distinguish -- perhaps more carefully than the Panel did -between the evaluation of 'risk' in a risk assessment and the determination of the appropriate level of protection. As stated in our Report in European Communities - Hormones, the 'risk' evaluated in a risk assessment must be an ascertainable risk; theoretical uncertainty is 'not the kind of risk which, under Article 5.1, is to be assessed.' This does not mean, however, that a Member cannot determine its own appropriate level of protection to be 'zero risk'. ${ }^{1106}$

Clearly, once it is established that there is scientific evidence of risk, Members are free to choose their own appropriate level of protection against this risk. The choice of a particular level of protection is what is typically called a risk management decision. Such decisions are taken by national administrations on grounds of societal value judgements on issues such as what level of risk is considered acceptable in society and what is technically and economically feasible, not purely on the basis of scientific analysis of risk. In other words, once it has scientifically been established that an SPS risk exists and what the magnitude of that risk is, by means of a risk assessment, other policy issues come into play in the actual crafting of the regulation. The decision on an appropriate level of

${ }^{1104}$ Emphasis added. A Note to this definition adds that ' $[\mathrm{m}]$ any Members otherwise refer to this concept as the "acceptable level of risk".' As mentioned above, during the negotiations leading to the drafting of the SPS Agreement, there was some disagreement on the best use of terminology on this point. While some Members preferred 'acceptable level of risk', others were of the view that this term creates the impression that risk is acceptable. In addition there was much confusion between the concept of the determination of an 'acceptable level of risk' and a risk assessment, with some Members using the terms interchangeably. In the end, the term 'acceptable level of protection' was chosen for use in the SPS Agreement with the clarification in the Note to the definition of this term with regard to the difference in usage in some Members. See above, Part III, Section 1.2.2.

${ }_{1105}$ Panel Report, Australia - Salmon, para. 8.81.

${ }^{1106}$ Appellate Body Report, Australia - Salmon, para. 125. 
protection is at core a political one, reflecting societal value choices. The SPS Agreement recognises this, by placing no requirement of establishing a scientific basis on the choice of the appropriate level of protection. Neither does it place any restrictions on the types of factors that Members may consider when deciding on their choice of level of protection. Thus divergent national health measures result even where the scientific basis for the measures is same everywhere. ${ }^{1107}$

In some cases, the choice by a Member of a very high level of protection leads to serious adverse economic consequences for its trading partners. This is particularly the case for exporting Members at lower levels of development, which may depend on the affected export product for their foreign revenue. An example of this is provided by the UK's ban on kava-kava from Fiji in 2005. ${ }^{1108}$ The UK's measure was taken in response to a request by the UK Commission on the Safety of Medicines, on the grounds that it had sufficient evidence to show that kava-kava was associated with rare cases of liver toxicity. Fiji pointed out that kava-kava is one of its few tradable crops of economic significance. It pointed to scientific findings that showed that, should toxicity exist, it would occur in an extremely low number of patients. ${ }^{1109}$ The EC pointed out that the ban on kava-kava was in response to reports of rare but serious risks to public health. ${ }^{110}$ In such cases, under the regime of the SPS Agreement, if the risk is scientifically established, a Member is free to choose the level of protection that it deems appropriate, even if this level is very conservative.

However, the choice of an appropriate level of protection is not entirely undisciplined. The rules applicable to the choice of an appropriate level of protection are set out in Articles 5.4 and 5.5 of the SPS Agreement.

\subsubsection{The objective of minimising negative trade effects}

The first provision in the SPS Agreement addressing a Member's choice of an appropriate level of protection is contained in Article 5.4, which provides:

Members should, when determining the appropriate level of sanitary or phytosanitary protection, take into account the objective of minimizing negative trade effects.

The use of the word 'should' rather than 'shall' indicates that this is not a mandatory provision but rather a recommendation. In addition, Members are only encouraged to 'take into account' minimising adverse trade effects as an objective. They are thus not obliged

1107 Jeffery Atik, 'Symposium - Institutions for International Economic Integration: Science and International Regulatory Convergence', Journal of International Law and Business 17, 1997, 736-758, 737.

1108 Committee on Sanitary and Phytosanitary Measures, Specific Trade Concerns. Note by the Secretariat. Addendum. Issues Not Considered in 2007, G/SPS/GEN/204/Rev.8/Add.2, circulated on 27 March 2008, item 220. Kava-kava (Piper methysticum) is made from the root of the kava plant, dried and milled to powder form. It is traditionally used to make a drink with tranquilizing properties. It is now marketed in the developed countries as a herbal medicine against stress and insomnia.

${ }^{1109}$ According to Fiji, out of the 450 million kava-kava pills exported all over the world between 1990 and 2000 , only three cases of liver problems had been reported.

${ }^{1110}$ Committee on Sanitary and Phytosanitary Measures, Summary of the Meeting Held on 29-30 June 2005. Note by the Secretariat. Revision, G/SPS/R/37/Rev.1, circulated on 18 August 2005, paras 72-73. 
to lower their level of protection, even where this would be the most trade efficient option. The Panel in EC-Hormones noted the following in respect of Article 5.4:

Guided by the wording of Article 5.4, in particular the words 'should' (not 'shall') and 'objective', we consider that this provision of the SPS Agreement does not impose an obligation. However, this objective of minimizing negative trade effects has nonetheless to be taken into account in the interpretation of other provisions of the SPS Agreement. ${ }^{111}$

The 'other provisions' where this hortatory provision may be of relevance, seem limited to Article 5.5, discussed below, which is the only other discipline on Members' appropriate level of protection. Still, the effect it may have on the interpretation of this provision is not yet clear.

\subsubsection{Avoidance of arbitrary or unjustifiable distinctions in appropriate levels of protection}

The second discipline contained in the SPS Agreement that applies to a Member's choice of an appropriate level of protection is found in Article 5.5. Unlike Article 5.4, Article 5.5 of the SPS Agreement contains binding obligations on Members. Article 5.5 can be seen as an elaboration of the basic non-discrimination obligation contained in Article 2.3 of the SPS Agreement and must be read together with this provision. ${ }^{112}$ It builds upon the general non-discrimination obligation of Article 2.3 and applies it specifically to the case of the choice by a Member of its appropriate level of protection. Article 5.5 provides:

With the objective of achieving consistency in the application of the concept of appropriate level of sanitary or phytosanitary protection against risks to human life or health, or to animal and plant life or health, each Member shall avoid arbitrary or unjustifiable distinctions in the levels it considers to be appropriate in different situations, if such distinctions result in discrimination or a disguised restriction on international trade. Members shall cooperate in the Committee, in accordance with paragraphs 1,2 and 3 of Article 12, to develop guidelines to further the practical implementation of this provision. In developing the guidelines, the Committee shall take into account all relevant factors, including the exceptional character of human health risks to which people voluntarily expose themselves.

It is necessary to determine what precisely the discipline embodied in Article 5.5 entails. Article 5.5 comprises two distinct elements, namely:

- the goal (for the future) of achieving consistency in the application of the 'concept' of appropriate level of sanitary or phytosanitary protection; ${ }^{1113}$ and

\footnotetext{
1111 Panel Report, EC - Hormones (Canada), para. 8.169; Panel Report, EC-Hormones (US), para. 8.166.

1112 The relationship between Article 5.6 and Article 2.3 is discussed above, Part III, Section 3.2.2.

1113 As set out below, in EC-Hormones the Appellate Body agreed with the Panel that no legal obligation of consistency in levels of protection exists, but that consistency in levels of protection is only a goal for the future. Appellate Body Report, EC-Hormones para. 213.
} 
- the legal obligation to avoid arbitrary or unjustifiable distinctions in the levels of protection deemed appropriate in different situations, if these distinctions lead to discrimination or disguised restrictions on trade.

Members are further obliged to co-operate in the SPS Committee to develop guidelines for the practical implementation of this provision. ${ }^{1114}$ These aspects of Article 5.5 are now discussed in turn.

\subsubsection{Goal of consistency in appropriate levels of protection}

With regard to the first element of Article 5.5, the following clarification was given by the Appellate Body in EC-Hormones:

The objective of Article 5.5 is formulated as the 'achieving [of] consistency in the application of the concept of appropriate level of sanitary or phytosanitary protection'. Clearly, the desired consistency is defined as a goal to be achieved in the future. To assist in the realization of that objective, the Committee on Sanitary and Phytosanitary Measures is to develop guidelines for the practical implementation of Article 5.5, bearing in mind, among other things, that ordinarily, people do not voluntarily expose themselves to health risks. Thus, we agree with the Panel's view that the statement of that goal [consistency] does not establish a legal obligation of consistency of appropriate levels of protection. ${ }^{115}$

The Appellate Body further recognised that Members establish their levels of protection ad hoc as risks arise, thus absolute consistency in levels of protection is not realistic, and also not the goal set forth in Article 5.5. ${ }^{1116}$ Only arbitrary or unjustifiable inconsistencies are to be avoided.

This finding reflects sensitivity by the Appellate Body to the realities of risk regulation and the role of risk management decisions therein. As stated above, the choice of an appropriate level of protection, as an element of the risk management aspect of the regulatory process, is based not only on the outcome of a risk assessment but also on policy considerations. These policy considerations are manifold and involve delicate balancing between the various societal interests involved. Therefore, a level of protection chosen in a particular situation is not simply a function of the identified risk. If this were so, it would make sense to require absolute consistency in levels of protection chosen in the face of similar risks. However, in reality, other considerations, including consumer preferences, economic resources, policy priorities and industry interests play a legitimate role in the choice of a particular level of protection in a specific situation.

A consideration that plays an important role in distinctions in levels of protection applied in the face of comparable risks in Members at lower levels of development is that of the SPS requirements applicable on their export markets. In many cases, the high level of

\footnotetext{
1114 These guidelines have been adopted, and are contained in Committee on Sanitary and Phytosanitary Measures, Guidelines to Further the Practical Implementation of Article 5.5, G/SPS/15, circulated on 18 July 2000. They are discussed further below, Part III, Section 5.2.3.5.

1115 Appellate Body Report, EC-Hormones, para. 213.

${ }^{1116}$ Ibid.
} 
SPS protection aimed at with regard to a particular product, in contrast to much lower levels of protection against similar health risks in other products, is motivated by the exigencies of the export market. These atypically high levels of protection affect not only the domestic industry producing the export products, something which is irrelevant for purposes of the SPS Agreement, but also have implications for the SPS requirements set for imported inputs used in the production process. An example of this situation is provided by Mauritius's requirements in the processed food and fishery products sector. As discussed in Part II above, the export diversification strategy of Mauritius is focused on the potential to become an agri-food processing hub in the region, ${ }^{1117}$ by importing fish and agricultural products from neighbouring countries and processing them for export. ${ }^{1118}$ In order to succeed in this strategy, it needs to apply strict SPS requirements to the imported inputs so that its processed exports achieve the high levels of protection it sets in order to meet the demanding standards of its trading partners. ${ }^{1119}$ Similarly high levels of protection are not aimed at with regard to other food imports not intended for use in the export processing industry. This inconsistency in levels of protection is not motivated by differences in risk, but rather by the intended use of the imported product and in particular by the export interests of the processing industry.

While it is clear that there is no immediate obligation of consistency in appropriate levels of protection, Members are obliged to ensure that the distinctions in the levels of protection they choose meet the requirements of the second element of Article 5.5.

The Appellate Body in EC-Hormones set out the three requirements for a violation the second element of Article 5.5 of the SPS Agreement to be shown. These are that:

- the Member has set different appropriate levels of protection 'in different situations';

- the levels of protection exhibit 'arbitrary or unjustifiable' differences in their treatment of different situations; and

- the measure embodying those arbitrary or unjustifiable differences results in 'discrimination or a disguised restriction' on trade. ${ }^{1120}$

These elements were found by the Appellate Body to be cumulative, thus proof of the arbitrary or unjustifiable character of differences in levels of protection considered ap-

1117 Ministry of Agro-Industry and Fisheries of the Republic of Mauritius, Strategic Options in Crop Diversification and Livestock Sector 2007-2015 (Consultative Draft) (Republic of Mauritius, Port Louis), August 2007, 123, available at: http:/www.areu.mu/files/pub/areunssp.pdf, visited on 10 January 2008.

1118 As previously discussed, the limited suitable land and labour for agricultural production restrict the capacity of Mauritius to produce sufficient agricultural products itself in order to make processing for export economically feasible. Similarly, the small continental shelf of Mauritius limits its local fish production. However, Mauritius has a significant advantage over its neighbouring countries in the area of know-how and technology for processing food and agricultural products. It therefore has the strategy of importing fish and agricultural products from its neighbours and processing them for export. Export diversification is crucial to decreasing Mauritius's dependence on sugar for its export earnings. See further above, Part II, Section 2.5.1.4.

1119 For example, as mentioned in Part II above, the main export market of Mauritius for processed fishery products is the EC, which has very strict sanitary requirements in this sector.

1120 Appellate Body Report, EC - Hormones, para. 214. These elements were reiterated in Panel Report, Australia-Salmon, para. 8.108; and Panel Report, Australia-Salmon (Article 21.5-Canada), para. 7.111. 
propriate in different situations is not sufficient, though it might serve as a warning signal that the measure might be discriminatory or a disguised restriction on trade. ${ }^{1121}$

\subsubsection{Different appropriate levels of protection in comparable situations}

The enquiry under the first element for proving a violation of Article 5.5 clearly requires a 'comparison of several levels of sanitary protection deemed appropriate by a Member'. ${ }^{1122}$ As is the case with Article 2.3, ${ }^{1123}$ the different treatment (in case in the form of differences in appropriate level of protection) at issue does not relate to 'like products' but instead to different 'situations'. This gives Article 5.6 a very broad reach, far beyond that of the GATT non-discrimination rules. ${ }^{1124}$

However, it is obvious that not all health risks can or should be treated the same. Thus, the Appellate Body in EC-Hormones found that to compare the different levels of protection deemed appropriate by a Member, the situations dealt with must be comparable, that is, have some common element or elements 'sufficient to render them comparable.' ${ }^{1125}$ On this issue, the Appellate Body stated as follows:

If the situations proposed to be examined are totally different from one another, they would not be rationally comparable and the differences in levels of protection cannot be examined for arbitrariness. ${ }^{1126}$

The Panel regarded the situations at issue as comparable because they entailed the same substance (hormones) or the same adverse health effect (carcinogenicity). The Appellate Body did not take issue with the Panel's finding that different levels of protection had been established in these different (i.e. comparable) situations. ${ }^{1127}$

Again in Australia - Salmon the question of the comparability of 'different situations' arose. In this case, the two situations assessed for comparability by the Panel were, on the one hand, the import prohibition on Canadian adult, wild, ocean-caught salmon for human consumption and, on the other hand, the admission of imports of: uncooked Pacific herring, cod, haddock, Japanese eel and plaice for human consumption; uncooked Pacific herring, Atlantic and Pacific cod, haddock, European and Japanese eel and Dover sole for human consumption; whole, frozen herring used as bait; and live ornamental finfish. ${ }^{1128}$ According to the Panel, these situations would present sufficient common elements to render them comparable if they involved either a risk of entry, establishment

\footnotetext{
${ }^{1121}$ Appellate Body Report, EC-Hormones, para. 215.

1122 Ibid., para. 217.

${ }^{1123}$ The broad reach of Article 2.3 is discussed above, Part III, Section 3.2.2.

${ }^{1124}$ Charnovitz notes that Article 5.5 exceeds in its reach both the US Commerce Clause and the EC internal market jurisprudence, neither of which prohibit facially neutral regulations from being more stringent than other regulations applied in comparable situations. Steve Charnovitz, 'The Supervision of Health and Biosafety Regulation by World Trade Rules', Tulane Environmental Law Journal 13, 2000, 271-302, 291. By way of example, Charnovitz refers to Maine v. Taylor, 477 U.S. 131, 150 (1986), where the US Supreme Court considered and rejected the argument that Maine's law violated the Commerce Clause because it allowed the importation of salmonids but not baitfish. Ibid, paras 140-152.

${ }^{1125}$ Appellate Body Report, EC-Hormones, para. 217.

1126 Ibid.

${ }^{1127}$ Ibid., para. 218.

${ }^{1128}$ Panel Report, Australia - Salmon, para. 8.113.
} 
or spread of the same or a similar disease, or similar associated biological and economic consequences. ${ }^{1129}$ It found this to be the case in all four comparisons in the two situations. ${ }^{1130}$ Australia appealed this finding, arguing that since the risk to be assessed under Annex A.4 is that of the entry, establishment or spread of the relevant diseases and the associated biological and economic consequences, comparability should be assessed on the basis of both these elements. ${ }^{1131}$ The Appellate Body disagreed, stating:

Situations which involve a risk of entry, establishment or spread of the same or a similar disease have some common elements sufficient to render them comparable under Article 5.5. Likewise, situations with a risk of the same or similar associated potential biological and economic consequences also have some common elements sufficient to render them comparable under Article 5.5. We, therefore, consider that for "different" situations to be comparable under Article 5.5, there is no need for both the disease and the biological and economic consequences to be the same or similar. ${ }^{1132}$

In addition, the Appellate Body stated that for situations to be comparable under Article 5.5 , it was sufficient for them to have in common a risk of entry, establishment or spread of one disease of concern. It was unnecessary that the risk of entry, establishment or spread of all diseases of concern be common to both situations. ${ }^{1133}$ In the case at hand, the situations were deemed comparable as there was a risk of entry, establishment or spread of the same or similar diseases and the risk of associated potential biological and economic consequences was the same or similar, regardless of whether the disease entered Australia via salmon or via other fish. ${ }^{1134}$ However, one could imagine that in other 'different situations' that may arise, the disease of concern may be common to both, yet for reasons related to varying agricultural practices or the different end use of the products at issue, the associated biological and economic consequences may differ. Here the Mauritian example mentioned above comes to mind, where despite similar food-safety risks in imported products intended for domestic consumption and those intended for processing for export, the economic consequences of the risk vary greatly due to the end use of the imported products. The broad reach of Article 5.5, as interpreted in the case law, would mean that also these types of situations are caught by the consistency disciplines of this Article.

In response to Australia's argument that a 'situation' cannot be compared under Article 5.5 if no risk assessment has been made in respect of it, the Panel in Australia - Salmon noted:

... we consider that even though Australia has not yet conducted import risk analyses for the other products compared under Article 5.5, Australia does, nevertheless, have a level of protection it considers to be appropriate for these other products. Australia currently has a sanitary regime, imposing specific

\footnotetext{
${ }^{1129}$ Ibid., para. 8.117.

${ }^{1130}$ Ibid., para. 8.121 and Annex 121.

1131 Appellate Body Report, Australia - Salmon, para. 145.

1132 Ibid., para. 146.

1133 Ibid., para. 152.

1134 Ibid., para. 147. Here the Appellate Body referred to the Panel's findings on this point. Panel Report, Australia-Salmon, para. 8.121.
} 
sanitary measures or refraining from such regulation, for these other products. This sanitary regime (whether or not specific measures are enacted) reflects a level of protection. To have a specific level of protection, there is no need to first complete a risk assessment ...

Article 5.5 directs us to compare for different situations the related levels of protection as they are currently considered to be appropriate by Australia and this whether or not the sanitary measures enacted to achieve that level are based on a risk assessment. Of course, such comparison would be easier and more accurate if for both situations an appropriate risk assessment were available. However, according to Article 5.5 and our mandate set out in Article 11 of the DSU (to make an 'objective assessment of the matter before [us], including an objective assessment of the facts of the case'), we are called upon in this case to make this comparison and to do so on the basis of the evidence before us. ${ }^{1135}$

Therefore, the consistency of a Member's chosen levels of protection will be evaluated even where the risks entailed by the other different situation used in the comparison have not yet been assessed. Otherwise Members could evade the discipline of Article 5.5 by omitting to conduct a risk assessment in other situations involving similar risks. The comparability of the situations could be established in such cases with reference to the fact that the risk causing agent (pest, disease or contaminant/toxin in food) is the same or similar, even though the nature and extent of the risk in the other situations used in the comparison are not yet known and may differ. The fact that the risk of entry, establishment or spread of the pest or disease at issue (e.g. avian influenza) may be affected by differences in, for example, the characteristics of the products concerned (e.g. live canaries as compared to frozen chicken fillets) is not relevant for the determination of comparability under the first element of Article 5.5, but will be considered under the second element, discussed below.

To establish if the first element has been met, it is further necessary to determine whether the Member has imposed different levels of protection in different (but comparable) situations. In EC-Hormones the Panel examined the levels of protection adopted by the EC in five comparable situations, namely the levels of protection in respect of (1) natural hormones administered for growth promotion; ${ }^{1136}$ (2) natural hormones occurring endogenously; ${ }^{1137}$ (3) natural hormones administered for therapeutic or zootechnical purposes; ${ }^{1138}$ (4) synthetic hormones (trenbolone and zeranol) administered for growth promotion; ${ }^{1139}$ and (5) carbadox and olaquindox, two anti-microbial agents used for

\footnotetext{
1135 Panel Report, Australia - Salmon, paras 8.126-8.127.

${ }^{1136}$ The level of protection adopted by the EC for natural hormones used for growth promotion purposes was found to be a 'no residue' level of protection.

1137 The level of protection adopted by the EC for natural hormones occurring endogenously was found to be an 'unlimited residue' level of protection. Panel Report, EC-Hormones (US), para. 8.191; Panel Report, EC-Hormones (Canada), para. 8.194.

${ }^{1138}$ The level of protection adopted by the EC for natural hormones administered for therapeutic or zootechnical purposes was found to be an 'unlimited residue' level of protection. Panel Report, EC - Hormones (US), para. 8.191; Panel Report, EC-Hormones (Canada), para. 8.194.

1139 The level of protection adopted by the EC for synthetic hormones used for growth promotion purposes was found to be a 'no residue' level of protection. Panel Report, EC-Hormones (US), para. 8.212; Panel Report, EC-Hormones (Canada), para. 8.215.
} 
growth promotion in swine. ${ }^{1140}$ The Panel found that different levels of protection were in place in the situations of endogenously-occurring natural hormones and administered anti-microbial agents, on the one hand, and of natural or synthetic hormones administered for growth-promotion purposes on the other. In the former cases an 'unlimited-residue level' was permitted (complete tolerance) whereas in the latter a 'no-residue level' (a ban) was applied.

In Australia - Salmon, the Panel also had to determine whether Australia made a distinction in the levels of protection it deemed appropriate in the situations that had been identified as 'comparable'. It was of the view that it had to examine and compare the SPS measures applied by Australia in the comparable situations. ${ }^{1141}$ The Panel stated:

[W] will for present purposes assume that if there is a difference in the sanitary measures imposed for the different situations we compare under Article 5.5, this difference does reflect a distinction in levels of protection achieved in - and considered to be appropriate by - Australia. ${ }^{1142}$

However (when dealing with the determination of the appropriate level of protection under Article 5.6) the Appellate Body in Australia - Salmon noted that nothing in the SPS Agreement or the DSU permits a panel or the Appellate Body to imply the Member's appropriate level of protection from the SPS measure it applies to attain that level of protection. ${ }^{1143}$ Only if a Member neglects to specify its appropriate level of protection, or does so with insufficient clarity, is it permissible to deduce its level of protection from the SPS measures actually in place. This finding applies equally to the determination of the level of protection under Article 5.5. With regard to diseases from salmon, Australia had explicitly adopted a 'high or "very conservative" level of protection'. With regard to diseases from herring or ornamental finfish no express determination had been made, but from the measures in place the Appellate Body deduced that its level of protection was 'definitely lower'. ${ }^{1144}$ As a result, different levels of protection where found to exist in comparable situations.

In Australia - Salmon (Article 21.5 - Canada), the compliance Panel had to address whether Australia's revised measures complied with the consistency requirements of Article 5.5. Australia had not only made its quarantine measures for salmon imports more lenient but had also tightened its controls on other fish imports. ${ }^{1145}$ Canada claimed that

1140 The level of protection adopted by the EC for the two anti-microbial agents used for growth promotion purposes in swine was found to be an 'unlimited residue' level of protection. Panel Report, EC-Hormones (US), para. 8.226; Panel Report, EC-Hormones (Canada), para. 8.229.

${ }^{1141}$ Panel Report, Australia - Salmon, para. 8.123. In examining the level of protection on the basis of the measure actually applied, the Panel in Australia - Salmon agreed with Australia that imposing the same SPS measure for different situations does not necessarily result in the same level of protection. Different SPS measures might sometimes ensure the same level of protection in comparable situations. The Panel stated that 'one given situation might only represent a small risk for which a lenient sanitary measure will achieve a high level of protection, whereas another situation might pose very high risks requiring a very strict and different sanitary measure in order to meet that same high level of protection.' Ibid.

${ }^{1142}$ Panel Report, Australia - Salmon, para. 8.124. This finding was not appealed.

${ }^{1143}$ Appellate Body Report, Australia - Salmon, paras 199 and 200. This issue is dealt with further below, Part III, Section 5.2.4.3.

1144 Ibid., para. 158.

1145 Following the DSB recommendations and rulings in the original dispute, Australia had conducted risk 
Article 5.5 was violated by the distinctions in the levels of protection applied by Australia in respect of two situations, namely imports of fresh, chilled or frozen salmon from Canada, on the one hand, and imports of non-salmonids and live, ornamental fish and the internal movement of dead Australian fish, on the other hand. According to Canada, the different measures applied by Australia to these different categories of fish indicated different levels of protection. ${ }^{1146}$ Australia did not contest the comparability of the two situations referred to by Canada. However, in respect of the appropriate levels of protection applied in these situations, Australia argued that it applied, in all cases, a 'high or very conservative level of protection, aimed at reducing risk to very low levels, while not based on a zero risk approach'. ${ }^{1147}$

The compliance Panel referred to the reasons given by the Panel and the Appellate Body in the original dispute as support for its finding that the different fish categories referred to by Canada could be compared as 'different situations' under Article 5.5. It referred to the uncontested fact that these situations involved a risk of entry, establishment or spread of the same or a similar disease or a risk of the same or a similar associated biological or economic consequence. ${ }^{1148}$ This despite the fact that the Panel recognised that Canada compared salmonids to 'entire categories of fish ... that include[d] not only a wide variety of different fish but also of different diseases.' ${ }^{1149}$ Also, as noted by the Panel, the diseases associated with the internal movement of dead Australian fish 'are per force already present (i.e. endemic) in Australia' whereas some of the diseases of concern in respect of imports of salmonids 'are, in contrast, not present in (i.e. exotic to) Australia'. ${ }^{150}$ These considerations did not result in a finding by the Panel that the situations at issue were not comparable, but were taken into account instead under the second element of Article 5.5.

In determining whether there were 'distinctions' in the levels of protection applied in the situations found to be comparable, the Panel took account of the generality of Canada's arguments and evidence (with the exception of its arguments on the situation of pilchards), together with the fact of increased convergence in levels of protection applied to different fish categories following Australia's revision of its measures. ${ }^{1151}$ The Panel noted that two of the three panel experts expressed the view that Australia's different treatment of salmonids was scientifically justified and achieved the same or a similar level of protection as its treatment of non-salmonids and live ornamental finfish. ${ }^{1152}$ The Panel found that Canada had not met its burden of proof with regard to the distinctions in appropriate level

assessments also for non-salmonids and live ornamental fish, and on this basis had strengthened its import controls on these products. The question whether the risk assessments on these other categories of products were consistent with the SPS Agreement was not before the compliance Panel. Panel Report, Australia Salmon (Article 21.5 - Canada), para. 7.91 and footnote 203.

1146 Ibid., para. 4.171.

${ }_{1147}$ Ibid., para. 4.191.

1148 Ibid., para. 7.89.

1149 Ibid., para. 7.90 .

1150 Ibid., para. 7.93 .

1151 Ibid., para. 7.91 .

${ }^{1152}$ Ibid., para.7.92. Note that it is not different treatment (i.e. different SPS measures) that is being compared under Article 5.5, but differences in levels of protection. Therefore, if different treatment can be scientifically shown to achieve the same level of protection, the first element for a finding of violation of Article 5.5 is not met. 
of protection, except for in the case of imports of pilchards. ${ }^{1153}$ In the latter case, Canada had substantiated its claim that import restrictions on salmonids were stricter than those applied to pilchards for use as bait or fish feed. ${ }^{1154}$

The very broad reach of the concept of 'different' but comparable situations, as interpreted in the case law under Article 5.5, could lead to an unreasonable obligation to apply consistent levels of protection in situations where differences in the characteristics or use of the products at issue, in the economic or biological consequences of the risk, in societal preferences or in policy priorities for allocation of scarce regulatory resources have led the Member to choose different levels of protection. This possibility is addressed by the two remaining elements of Article 5.5, which set realistic requirements that must be met before the different levels of protection applied in the broadly comparable situations will be found to violate Article 5.5 of the SPS Agreement.

\subsubsection{Arbitrary or unjustifiable distinctions in appropriate levels of protection}

The second element for a finding of violation of Article 5.5 is the existence of 'arbitrary or unjustifiable distinctions' in the appropriate levels of protection compared. To determine whether this element is present, panels and the Appellate Body examine whether reasons exist to justify the differences in levels of protection. The kinds of considerations that may justify different levels of protection are not delimited in Article 5.5. In the case law so far, the Appellate Body has examined:

- whether different levels of risk are at issue in the different situations compared; ${ }^{1155}$

- whether the difficulty of controlling the risk differs in each case, ${ }^{1156}$ or

- whether the degree of government intervention necessary to achieve the same level of protection differs in each situation. ${ }^{1157}$

In particular, the Appellate Body in EC - Hormones disagreed with the Panels' finding that both the added hormones and naturally-occurring hormones pose the same risks and practical difficulties of control, ${ }^{1158}$ and thus that the difference in the level of protection must therefore be arbitrary. The Appellate Body stated as follows:

[W] consider there is a fundamental distinction between added hormones (natural or synthetic) and naturally-occurring hormones in meat and other foods. In respect of the latter, the European Communities simply takes no regulatory action; to require it to prohibit totally the production and consumption of such foods or to limit the residues of naturally-occurring hormones in food, entails

\footnotetext{
${ }^{1153} \mathrm{Ibid}$., para. 7.94. Note that, as was the case in the original dispute, the compliance Panel addressed the question of whether there were distinctions in the appropriate levels of protection not under the first element of Article 5.5, but under the second, together with its examination of whether the distinctions were arbitrary or unjustifiable. Thus some of its reasoning regarding the two elements is somewhat conflated.

1154 Ibid., para. 7.97.

1155 Appellate Body Report, Australia - Salmon, para. 158.

1156 Appellate Body Report, EC-Hormones, paras 221-225.

1157 Ibid., para. 221.

${ }^{1158}$ Panel Report, EC - Hormones (Canada), para. 8.190; Panel Report, EC-Hormones (US), para. 8.187.
} 
such a comprehensive and massive governmental intervention in nature and in the ordinary lives of people as to reduce the comparison itself to an absurdity. ${ }^{1159}$

When comparing the levels of protection for hormones used for growth-promotion purposes and hormones used for therapeutic and zootechnical purposes - a comparison not further pursued by the panels - the Appellate Body, referring to the differences in frequency and scale of the two treatments and the strict mode of administration of the latter treatment, found that the distinction in levels of protection 'is not, in itself, 'arbitrary or unjustifiable'.' ${ }^{1160}$

According to the Panel in Australia - Salmon, differences in the levels of risk are to be taken into account in the second element of Article 5.5 in order to establish whether the different level of protection is arbitrary or unjustifiable. Applying this element to the case before it, the Panel found that the different levels of protection applied by Australia against risks from imports of salmon and from imports of non-salmonids were 'arbitrary or unjustifiable'. It based its finding on the fact that since the level of protection applied in the case of salmon was higher, one could expect that a higher risk was present for salmon than for other fish. However, the evidence pointed to the opposite conclusion, namely that there was 'a higher risk of disease introduction associated with imports of bait fish and live ornamental fish than the risk posed by imports of salmon products for human consumption.' ${ }^{1161}$ The Panel therefore held that the differences in levels of protection applied by Australia were arbitrary and unjustifiable, a finding upheld by the Appellate Body. ${ }^{1162}$ This is the only case thus far where a finding was made of a violation of Article 5.5 .

In Australia - Salmon (Article 21.5 - Canada), the compliance Panel addressed the only situation in which Canada had brought sufficient evidence to show a distinction in the level of protection as compared to that applied to imports of salmonids, namely that of imports of pilchards for use as bait or feed. It also focused on differences in risk to determine whether the distinction in levels of protection was justified under the second element of Article 5.5. It found that whereas 15 'high priority' diseases had been identified in the 1999 IRA for salmonids, only two diseases had been shown by Canada to be associated with pilchards. ${ }^{1163}$ One of these pilchard diseases (herpes virus) was already endemic to Australia and was not associated with salmonids. The other disease (viral haemorrhagic septicaemia virus) was associated with both pilchards and salmonids, but there was no evidence of transmission between pilchards and salmonids. The consequence of the establishment of this disease was determined in the 1999 IRA to be 'low' due to its limited

\footnotetext{
1159 Appellate Body Report, EC - Hormones, para. 121.

${ }^{1160}$ Ibid., paras. 222-225.

${ }^{1161}$ Panel Report Australia - Salmon, para. 8.137. The Panel started its examination with these two categories of non-salmonids (whole, frozen herring used as bait and live ornamental finfish) because it had more evidence on these categories than on the others. Since it found arbitrary and unjustifiable distinctions in the levels of protection applied in respect of these two categories of non-salmonids as compared to the level of protection applied in respect of adult, wild, ocean-caught, Pacific salmon, the Panel found it unnecessary to examine the justifiability of the distinctions in levels of protection in respect of the remaining two categories of nonsalmonids. Ibid., para. 8.143.

1162 Appellate Body Report, Australia - Salmon, para. 158.

${ }^{1163}$ Panel Report, Australia - Salmon (Article 21.5 - Canada), para. 7.97.
} 
impact on salmonids and other finfish in Australia. Two of the three panel experts were of the view that the different treatment accorded to pilchards was scientifically justified. ${ }^{1164}$ The more lenient import conditions for pilchards were therefore found not to be 'arbitrary or unjustifiable' under the second element of Article 5.5. ${ }^{1165}$

It is interesting to note that not only differences in the level of risk or difficulties of controlling the risk may explain differences in the level of protection chosen by a Member in comparable situations. In some cases, differences in the appropriate level of protection are based on subjective consumer preferences. This is particularly the case with regard to the risks to which people voluntarily expose themselves, due to particular cultural practices. Examples include the consumption of traditional foods such as raw fish in Japan, smoked fish in Norway, raw milk cheeses in several European countries including France and Switzerland; as well as the consumption of alcoholic beverages. Article 5.5 recognises that these situations may, exceptionally, justify a lower level of protection by expressly mandating the SPS Committee to take this into account when developing guidelines on the implementation of Article 5.5. ${ }^{1166}$ This exception is significant in that it reflects a policy-based consideration that leads to regulatory divergence. Such divergence is grounded in, often irrational, societal preferences rather than objective differences in risk.

\subsubsection{Discrimination or disguised restriction on trade}

The third requirement for a violation of Article 5.5 is that the measure embodying the arbitrary or unjustifiable distinctions in appropriate levels of protection results in 'discrimination or a disguised restriction on trade'. According to the Appellate Body in EC - Hormones, this is the most important of the three elements. ${ }^{1167}$

While this term is to some extent similar to that found in the chapeau of Article XX of the GATT 1994, there are also important differences in the two provisions which militate against analogous interpretation, as noted by the Appellate Body in EC-Hormones. ${ }^{1168}$ Similarly, the Appellate Body disagreed with the Panel that the findings in Japan Alcoholic Beverages II regarding the impact of large differentials in tax treatment for a finding of a violation of the non-discrimination obligation of Article III:2 of the

\footnotetext{
1164 Ibid., para. 7.96.

$1165 \mathrm{Ibid}$., para. 7.101. It seems that here, again, the Panel is comparing the measures applied in the face of different levels of risk, rather than comparing the appropriate levels of protection applied in different situations. Different measures can achieve the same level of protection (here the high or very conservative level of protection chosen by Australia) if the risk at issue differs. In such cases the first element of Article 5.5 appears not to have been met and it is unnecessary to examine the second element.

1166 These guidelines are discussed below, Part III, Section 5.2.3.5.

1167 Appellate Body Report, EC-Hormones, para. 240.

1168 Ibid., para. 239. In US - Gasoline, the Appellate Body had found that that 'arbitrary discrimination', 'unjustifiable discrimination' and 'disguised restriction on international trade' in the chapeau of Article XX of the GATT 1994 impart meaning to each other and that the fundamental theme is the purpose and object of avoiding abuse or illegitimate use of the exceptions in Article XX. Thus the same considerations used to determine if a measure amounts to arbitrary or unjustifiable discrimination can be used to decide if the measure is a disguised restriction on international trade. Appellate Body Report, US - Gasoline, 22. The Appellate Body in EC-Hormones found that the structural differences between the chapeau of Article XX of GATT 1994 and Article 5.5 of the SPS Agreement are too great for this analogous interpretation to be made. In its arguments, the EC pointed had out that the three elements of the chapeau of Article XX of GATT 1994 are in the alternative, whereas those in Article 5.5 of the SPS Agreement are cumulative.
} 
GATT 1994 can be used as precedents for the interpretation of Article 5.5 of the SPS Agreement. ${ }^{1169}$ It thus reversed the Panels' finding, on the basis of the difference in levels of protection in certain comparable situations, that the EC measure in question constituted discrimination or a disguised restriction on international trade, finding that:

... the degree of difference, or the extent of the discrepancy, in the levels of protection, is only one kind of factor which, along with others, may cumulatively lead to the conclusion that discrimination or a disguised restriction on international trade in fact results from the application of a measure or measures embodying one or more of those different levels of protection. Thus, we do not think that the difference between a 'no residues' level and 'unlimited residues' level is, together with a finding of an arbitrary or unjustifiable difference, sufficient to demonstrate that the third, and most important, requirement of Article 5.5 has been met ... Evidently, the answer to the question whether arbitrary or unjustifiable differences or distinctions in levels of protection established by a Member do in fact result in discrimination or a disguised restriction on international trade must be sought in the circumstances of each individual case. ${ }^{1170}$

In Australia - Salmon, the Panel identified what it called three 'warning signals' i.e., elements which are 'not conclusive in [their] own right', 1171 and three 'other factors more substantial in nature' 1172 taken cumulatively, to support its finding that the third element of Article 5.5 was met. ${ }^{1173}$ The relevance of these warning signals and other factors will depend on the circumstances of each case. ${ }^{1174}$ The 'warning signals' are:

- the arbitrary character of the differences in the levels of protection (i.e., that the second element of Article 5.5 is met) ${ }^{1175}$

- the existence of rather substantial differences in the levels of protection; ${ }^{1176}$ and

\footnotetext{
${ }^{1169}$ In Japan-Alcoholic Beverages II, it was held that a large difference in the taxation applied to imports and that applied to domestic products could be sufficient to prove that it was applied so as to afford protection to domestic products, contrary to Article III of GATT 1994. Appellate Body Report, Japan - Alcoholic Beverages II, 30. The Appellate Body in EC-Hormones, distinguished the reasoning in Japan - Alcoholic Beverages II regarding tax differentials from the different question in this case regarding different levels of health protection. As tax is always expressed quantitatively and affects the competitiveness of imports, a tax differential necessarily protects domestic products. There is no such link between differences in levels of health protection and the issue of discrimination or a disguised restriction on international trade. The extent of the difference is only one factor among others to be taken into account in determining whether there is discrimination or a disguised restriction on trade. Appellate Body Report, EC - Hormones, paras 239- 251. Regard must be had to the circumstances of each case.

1170 Appellate Body Report, EC-Hormones, para. 240.

${ }_{1171}$ Panel Report, Australia - Salmon, para. 8.151.

1172 Ibid., para. 8.152.

1173 Ibid., para. 8.159.

1174 Panel Report, Australia - Salmon paras. 8.149-8.151, as approved by the Appellate Body. Appellate Body Report, Australia - Salmon paras 162, 164 and 166. The first two warning signals had also been relied upon in Appellate Body Report EC-Hormones paras 215 and 240.

1175 Panel Report, Australia - Salmon, para. 8.149.

${ }^{1176}$ Ibid., para. 8.150.
} 
- the absence of scientific justification (based on earlier findings of a violation of Articles 2.2 and 5.1) which indicates that the measure is a disguised restriction on trade. ${ }^{1177}$

The Appellate Body in this case addressed Australia's contention, on appeal, that the Panel had erroneously regarded proof of arbitrary and unjustifiable distinctions in the levels of protection, i.e. the second element of Article 5.5, as evidence that the third element, that of discrimination or a disguised restriction on trade, was met. It clarified that the fact that the second element is established can be one indication (or a 'warning signal') that the third element is also met, although the former cannot be regarded as conclusive proof of the latter. ${ }^{1178}$ This is so even if the distinction in levels of protection is great. Instead, each element must be determined separately and its existence must be determined on a case by case basis, taking into account all relevant circumstances.

The Appellate Body further agreed with the Panel that the rather substantial difference in levels of protection between an import prohibition on ocean-caught Pacific salmon, as opposed to tolerance for imports of herring used as bait and of live ornamental fish, be treated as a separate (second) warning signal. ${ }^{1179}$ It held that the degree of difference in level of protection justified this factor being treated as a separate warning signal, as distinct from the first.

The Appellate Body also agreed with the Panel in respect of the third warning signal, stating:

We note that a finding that an SPS measure is not based on an assessment of the risks to human, animal or plant life or health - either because there was no risk assessment at all or because there is an insufficient risk assessment - is a strong indication that this measure is not really concerned with the protection of human, animal or plant life or health but is instead a trade-restrictive measure taken in the guise of an SPS measure, i.e., a 'disguised restriction on international trade. ${ }^{1180}$

The Appellate Body thus agreed with the Panel's conclusion that Article 5.5, and for that reason also Article 2.3, was violated, ${ }^{1181}$ although it reversed the Panel's finding in respect of one of the additional factors. ${ }^{1182}$ In Australia - Salmon (Article 21.5-Canada),

1177 Ibid., para. 8.151.

1178 Appellate Body Report, Australia - Salmon, para. 162. The Appellate Body found that the Panel had considered the arbitrary or unjustifiable character of differences in levels of protection as a 'warning signal' for, and not as 'evidence' of, a disguised restriction on international trade.

1179 Ibid., para. 164.

1180 Ibid., para. 166.

${ }^{1181}$ Panel Report Australia - Salmon, para. 8.160; Appellate Body Report Australia - Salmon, para. 177.

1182 Appellate Body Report Australia - Salmon, paras 167-169. The 'additional factor' at issue was the fact that two substantially different SPS measures (import prohibitions as opposed to tolerance) were applied, leading to discrimination between salmon on one hand and herring used as bait and ornamental finfish on the other. Thus the Panel viewed 'disguised restriction on international trade' under Article 5.5 as including restrictions amounting to arbitrary or unjustifiable discrimination between products. Australia contended that the Panel's concept of discrimination under Article 5.5 was wrong, as discrimination here refers to discrimination between countries. The Appellate Body agreed with Australia that this 'additional factor' should be excluded from consideration, as all 'arbitrary and unjustifiable distinctions' in levels of protection will logically lead to discrimination between products, whether they are the same or different. Thus this factor is no different 
the compliance Panel applied the same 'warning signals' and 'additional factors' to the case before it and found that none but one of these were present in respect of Australia's revised quarantine regime for fish imports. ${ }^{1183}$ The remaining 'warning signal' namely the fact that Australia's consumer-ready requirements had been found not to be based on a risk assessment in violation of Articles 5.1 and 2.2, was considered insufficient in and of itself to lead to a conclusion that the third element of Article 5.5 was met. ${ }^{1184}$

It is important to establish whether the fact that considerations unrelated to the risk at issue were taken into account by a Member in determining its appropriate level of protection will lead to a finding of discrimination or a disguised trade restriction. In $E C$ - Hormones, in support of its finding that the difference in the level of protection for hormones and that for antimicrobial agents, carbadox and olaquindox, was discriminatory or a disguised restriction on trade, the Panel pointed, among other factors, to the fact that the preambles of the relevant EC directives, the reports of the European Parliament and the opinions of the Social and Economic Committee of the EC indicated that the measure was aimed at harmonisation of laws within the EC, the removal of distortions of competition and barriers to intra-Community trade, the increase of beef consumption and the reduction of internal surpluses. The Appellate Body rejected this conclusion, stating that it did not attach the same importance as the Panel to the multiple objectives of the measure. It pointed to the demonstrated 'depth and extent of the anxieties experienced' within the EC concerning 'the results of the general scientific studies (showing the carcinogenicity of hormones), the dangers of abuse (highlighted by scandals relating to black-marketing and smuggling of prohibited veterinary drugs in the European Communities) ... and the intense concern of consumers within the European Communities over the quality and drug free character of the meat available in its internal market. ${ }^{1185}$ It stated that the harmonisation of regulations was a result of the EC's mandate to establish a Common Market and that the reduction of beef surpluses not only benefited the EC but also other non-hormone beef producers. It thus concluded that it did not share the Panel's inference that the import ban was aimed at restricting beef imports from Canada and the US rather than protecting the EC's population from the risk of cancer. ${ }^{1186}$ The Panel's finding that there was a violation of Article 5.5 was thus reversed. ${ }^{1187}$ The Appellate Body's decision makes it clear that the mere incorporation of various non-scientific considerations in the decision to impose a certain appropriate level of protection is not sufficient to invalidate the chosen level of protection by rendering it a 'disguised restriction on trade'. This decision implies a positive recognition by the Appellate Body of the important role of societal value judgements in the making of risk management decisions.

from the first 'warning signal' and should not be taken into account as a separate factor.

${ }^{1183}$ The Panel had not found an 'arbitrary or unjustifiable distinction' in the levels of protection applied by Australia in comparable situations (first warning signal), nor had it found that the distinctions in level of protection were 'rather substantial (second warning signal). The additional factors considered by the original Panel, relating to the differences in the conclusions of the draft and final risk assessments and the absence of controls on movement of dead Australian fish, has lost their relevance in the compliance dispute. Panel Report, Australia - Salmon (Article 21.5 - Canada), para. 7.104.

${ }^{1184}$ Ibid., para. 7.105.

${ }_{1185}$ Appellate Body Report, EC-Hormones, para. 245.

1186 Ibid.

${ }^{1187}$ Ibid., para. 246. 
The difficulty in evaluating the justifiability of distinctions lies in the problem of explaining why a society accepts some risks but not others or values some goals more than others. ${ }^{1188}$ This fact was explicitly recognised by the drafters of the SPS Agreement in their direction to the SPS Committee to take into account 'the exceptional character of human health risks to which people voluntarily expose themselves' in the SPS Committee's formulation of guidelines for the implementation of this Article.

\subsubsection{Guidelines to further the implementation of} Article $\mathbf{5 . 5}$ of the SPS Agreement

As noted above, Article 5.5 obliges Members to cooperate in the SPS Committee to develop guidelines to further its practical implementation. In doing so, as noted above, the SPS Committee is required to take account of all relevant factors, 'including the exceptional character of risks to which people voluntarily expose themselves.'

Negotiations took place in the SPS Committee in fulfilment of this mandate. ${ }^{1189}$ Steve Suppan reports that when negotiating these guidelines, the US tried to reflect therein the EC-Hormones Panel ruling in its favour with regard to Article 5.5, whereas the EC tried to reflect the Appellate Body's ruling overturning that of the Panel on this point. Suppan further reports that the US was in favour of making the guidelines binding, but was prevented from doing so by the EC and other Members. ${ }^{1190}$

The outcome of the compromise reached is reflected in the Guidelines to Further the Practical Implementation of Article 5.5 (the Guidelines on Article 5.5), provisionally adopted in June 2000 after five years of deliberations. ${ }^{1191}$ Members having objections to the final adoption were asked to make these known by 14 July 2000. Since no objections were raised by that date, the guidelines were regarded as finally adopted on that date. The Guidelines on Article 5.5 are expressly stated to be intended to assist Members in the practical implementation of Article 5.5, and not to add to or detract from the rights and

1188 Vern Walker has therefore suggested that national choice of levels of protection should be respected except in 'the most blatant or unexplainable cases.' Vern R. Walker, 'Keeping the WTO from Becoming The "World Trans-Science Organization": Scientific Uncertainty, Science Policy, and Factfinding in the Growth Hormones Dispute', Cornell International Law Journal 31, 1998, 251-320, 270.

1189 The Chairman of the SPS Committee initiated informal discussions on the best way to proceed to elaborate these guidelines in December 1995 by circulating a questionnaire of pertinent questions to all Members. Committee on Sanitary and Phytosanitary Measures, Consistency: Questions for Consideration: Note by the Chairman, G/SPS/W/45, circulated on 6 December 1995. After identifying common elements in the responses, the Chairman put the issue on the agenda of the meeting of 29-30 May 1996 for general discussion. Committee on Sanitary and Phytosanitary Measures, Consistency: Elaboration of Guidelines: Note by the Chairman, G/SPS/W/59, circulated on 6 May 1996. The report of the Chairman on the comments received evinced a strong focus on procedural aspects, and on the link between risk management decisions and the risk assessments on which they are based. Some Members stressed the importance of applying consistent risk assessment methodologies, and referred to the factors required to be considered in risk assessments, under Articles 5.2 and 5.3, as the 'relevant factors' to be addressed in the SPS Committee in establishing these guidelines.

${ }^{1190}$ Here Suppan refers to: 'WTO Works out New SPS Guidelines without Legal Status', Inside US Trade, 14 April 2000. \{, $2005 \# 4077\}$

${ }^{1191}$ Committee on Sanitary and Phytosanitary Measures, Guidelines to Further the Practical Implementation of Article 5.5, G/SPS/15, circulated on 18 July 2000. 
obligations of Members under the SPS Agreement or to provide any legal interpretation or modification to the Agreement. ${ }^{1192}$

The Guidelines on Article 5.5 focus on recommending procedural tools that should be used to promote consistency in decisions on the appropriate level of protection. Much of the case law on Article 5.5 is reflected in the Guidelines on Article 5.5. In particular, several of the rulings of the Appellate Body on Article 5.5 in Australia - Salmon can be found incorporated in its provisions, including the finding of an implicit obligation on a Member to clearly state its appropriate level of protection, and the ruling on the three 'warning signals' relevant to the determination of discrimination or a disguised restriction on trade. ${ }^{1193}$

In brief, the Guidelines on Article 5.5 are divided into two parts, the first addresses the concept of the appropriate level of protection, and the second relates to the practical implementation of this concept through the adoption of SPS measures. In the first part, after stating that Members should indicate their appropriate level of protection clearly and in so doing should consider the three prongs of Article 5.5, ${ }^{1194}$ the Guidelines on Article 5.5 recommend that Members take certain procedural steps to promote consistency. These are first the establishment of clear and effective communication and information flows between the authorities responsible for determining the appropriate level of protection, so that they can be aware of each others' decisions in comparable cases. ${ }^{1195}$ Second, Members should compare any proposed decision on a level of protection to levels it has previously considered appropriate in previous comparable situations, including those taken in an ad hoc fashion, to ensure that differences between them are justifiable and do not lead to discrimination or a disguised trade restriction. ${ }^{1196}$ Third, Members should review their previous decisions on appropriate levels of protection in the light of the 'objectives and requirements' of Article 5.5, at suitable intervals. ${ }^{197}$ Fourth, it is stated that in determining a new or modified level of protection Members may find it useful to

1192 Ibid., 1.

${ }^{1193}$ Ibid., paras A.2 and B. The Guidelines on Article 5.5 further specify, also in line with the Australia-Salmon ruling, that if a Member is not able to indicate precisely its appropriate level of protection, this may be determined from the level of protection reflected in the SPS measure in place.

${ }^{1194}$ In this respect, the findings in the case law on each of the three prongs are set out, to explain what is required of a Member. Specifically it is stated that the comparison of levels of protection in different situations requires sufficient common elements to render the situations comparable (such as, in the case of risks from pests and diseases, either the risk of the entry establishment or spread of the same or a similar disease or potential biological or economic consequences and in the case of risks from food/feed, the same type of adverse health effect or the same pathogen or substance). Further, the fact that the question whether differences are arbitrary or unjustifiable is decided on a case by case basis and the fact that establishing different levels of protection in the face of similar risks may raise the question as to whether these differences are arbitrary or unjustifiable. Finally, with regard to the third prong the three 'warning signals' are set out, noting that their cumulative occurrence could indicate discrimination or a disguised restriction on trade. Ibid., para. A.2.

1195 Ibid., para. A.3.

${ }^{1196}$ Ibid., para. A.4. Here the Guidelines on Article 5.5 that in the case that there are unjustifiable differences, either the proposed level of protection in the current situation, or the previous level of protection in the comparable situation may need to be modified. It is recommended that Members categorise the risks they examine into groups of similar risks, and that they express possible damage in common terms, whether quantitative or qualitative, although the former is preferable where feasible to facilitate comparisons.

${ }^{1197}$ Ibid., para. A.5. Here it is clarified that unless changes are made to all comparable decisions on level of protection at the same time, temporary unjustifiable differences will be difficult to avoid. 
examine relevant international standards or decisions taken by other Members facing similar risks and situations, while recognising that no obligation to harmonise levels of protection exists. ${ }^{1198}$ Fifth, expert advice is recommended when Members determine new or modified levels of protection. ${ }^{1199}$

With regard to the mandate to consider the exceptional character of risks to which people voluntarily expose themselves, the Guidelines on Article 5.5 note the fact that a significant difference in levels of protection may be justified, in exceptional circumstances, by such voluntarily accepted risks. Examples are the consumption of alcoholic beverages or traditional foods such as smoked fish or raw milk cheeses. The Guidelines on Article 5.5 state that a Member should clearly identify those situations which it considers justify its acceptance of a lower level of protection of human health in this context. ${ }^{1200}$

Part B of the Guidelines on Article 5.5 turns to address the selection and implementation of SPS measures, due to the fact that in practice Members are not always able to precisely indicate their appropriate level of protection, in which case it will be deduced from the SPS measure in place. The same procedural recommendations that were set out in Part A are laid down in Part B, mutatis mutandis. ${ }^{1201}$ The only additional recommendation is that a Member establish common procedures for its authorities for carrying out risk assessments and for the choice of an SPS measure to achieve the appropriate level of protection. ${ }^{1202}$

While useful in setting out the practical steps that Members can take in their regulatory processes in order to promote consistency in appropriate levels of protection, the Guidelines on Article 5.5 seem premised on the existence of a sophisticated and wellfunctioning regulatory system. As argued by Steve Suppan, these guidelines 'have a degree of complexity that favours only those Members with massive SPS bureaucracies capable of setting norms for protecting human, plant and animal health without being accused of trade protectionism.' ${ }^{1203}$

\subsubsection{Least-trade-restrictive measure}

As noted above, the risk management phase of the regulatory process involves not only the choice of an appropriate level of protection, but also the choice of an SPS measure to achieve this level of protection. The SPS measure applied by a Member may be seen as the 'link' between the scientifically-established risk and the policy-based choice of a level of protection. While an SPS measure is applied to achieve the appropriate level of

\footnotetext{
${ }^{1198}$ Ibid., para. A.6.

1199 Ibid., para. A.7.

1200 Ibid., para. A.8.

${ }^{1201}$ Ibid., paras B.1 and B.3-B.7.

1202 Ibid., para. B.2.

1203 Steve Suppan, 'The WTO Agreement on the Application of Sanitary and Phytosanitary Measures (SPS)', in Decision Making in the Global Market: Trade, Standards and the Consumer (Consumers International, London), 2005, 133-148, 142, available at: http://consint.live.poptech.coop/Shared_ASP_Files/ UploadedFiles/1E6FE541-9535-4E43-A86E-D7F66DE4728A_GlobalGovernancefinalpdf.pdf, visited on 9 April 2008. \{, $2005 \# 4077\}\{, 2005 \# 4077\}$
} 
protection chosen by a Member, it must be firmly based, or have a 'rational relationship' with, a risk assessment, as explained above. ${ }^{1204}$

Within the limits set by the need for a scientific basis, a variety of SPS measures may be imposed by Members, reflecting their technological and financial capacities and policy priorities. While as seen above, Members have very broad leeway in their choice of level of protection, subject only to a prohibition on arbitrary or unjustifiable distinctions leading to discrimination or disguised trade restrictions, the choice of measure is disciplined to minimise its adverse trade effects.

The provision in Article 5.3 of the SPS Agreement, discussed above, ${ }^{1205}$ obliging Members to take account of certain economic factors in assessing risks from pests or diseases, also applies to the choice of an SPS measure to address these risks. As noted previously, the obligation in this Article is limited to the requirement that Members 'take account' of, or consider, the listed factors. This is thus an obligation of conduct, rather than of result. It operates to ensure that regulators have useful economic information before them when making a decision regarding what SPS measure to apply, thereby promoting rationality and cost/benefit analysis in regulatory choices regarding SPS measures to address risks from pests and diseases.

One of the factors listed in Article 5.3 is the 'relative cost-effectiveness of alternative approaches to limiting risks'. The consideration of this factor is of relevance to the more rigorous discipline on the choice of an SPS measure set out in Article 5.6. Article 5.6 provides:

Without prejudice to paragraph 2 of Article 3, when establishing or maintaining sanitary or phytosanitary measures to achieve the appropriate level of sanitary or phytosanitary protection, Members shall ensure that such measures are not more trade-restrictive than required to achieve their appropriate level of sanitary or phytosanitary protection, taking into account technical and economic feasibility.

The explicit reference to Article 3.2 in this provision highlights the fact that measures which 'conform to' international standards and are thus are deemed 'necessary' and in conformity with the SPS Agreement and the GATT 1994, under Article 3.2, are also presumed to comply with the least-trade-restrictive requirement of Article 5.6. Legally speaking this reference is redundant, since the presumption of conformity in Article 3.2 extends to the whole of the SPS Agreement (and the GATT), and thus by necessity also Article 5.6. However, its express inclusion may serve to indicate the negotiators' view that international standards are inherently considered to be the least-trade-restrictive means to achieve a Member's appropriate level of protection.

It has been held that Article 5.6 can be seen as a specific elaboration of the 'necessary' requirement in the first prong of Article 2.2. ${ }^{1206}$ However, as noted above, while Article 2.2 refers to the extent of application of the SPS measure at issue, Article 5.6 refers to

\footnotetext{
1204 The requirement that an SPS measure must be 'based on' a risk assessment amounts to a discipline on the choice of SPS measure, in that a 'rational relationship' must exist between the risk assessment and the measure chosen to address the risk. The nature of this relationship is discussed above, Part III, Section 5.1.5.

1205 See above, Part III, Section 5.1.4.

${ }^{1206}$ Panel Reports, EC-Approval and Marketing of Biotech Products, para. 7.1430.
} 
its establishment or maintenance. ${ }^{1207}$ Still, the two provisions are clearly closely related and impart meaning to each other. As a result, Article 5.6 should be read in the light of Article 2.2. ${ }^{1208}$

In a footnote to Article 5.6, what is meant by 'a measure not more trade-restrictive than required' is defined as follows:

For purposes of paragraph 6 of Article 5, a measure is not more trade-restrictive than required unless there is another measure, reasonably available taking into account technical and economic feasibility, that achieves the appropriate level of sanitary or phytosanitary protection and is significantly less restrictive to trade. ${ }^{1209}$

As is clear from the discussion of the GATT case law of relevance to health measures in Chapter 1 above, ${ }^{1210}$ this discipline closely reflects the interpretation of the 'necessary' requirement of Article XX(b) of the GATT 1994. However, the express reference to alternative measures that achieve the appropriate level of protection of the Member concerned indicates the absence of room for strong proportionality testing in respect of the choice of an SPS measure. ${ }^{1211}$

In Australia - Salmon, the Panel set out the three elements of this definition, which it held to be cumulative, namely that a measure is more trade restrictive than required only if there is another SPS measure which:

- is reasonably available taking into account technical and economic feasibility;

- is significantly less trade restrictive than the contested measure; and

- achieves the Member's appropriate level of sanitary protection. ${ }^{1212}$

The Appellate Body in Australia - Salmon agreed with this three-pronged test and confirmed that the three elements are cumulative 'in the sense that, to establish inconsistency with Article 5.6, all of them have to be met. ${ }^{1213}$ It further stated:

Thus, if there is no alternative measure available, taking into account technical and economic feasibility, or if the alternative measure does not achieve the Member's appropriate level of sanitary or phytosanitary protection, or if it is not

\footnotetext{
${ }^{1207}$ On the relationship between Article 2.2 and Article 5.6 see further above, Part III, Section 3.2.1.

${ }^{1208}$ Panel Report, Japan - Agricultural Products II, para. 8.71; and Panel Reports, EC-Approval and Marketing of Biotech Products, para. 7.1430. This relationship has not yet been confirmed by the Appellate Body.

${ }^{1209}$ Footnote 3 to Article 5.5 of the SPS Agreement.

1210 See above, Part III, Section 1.1.1.

1211 Above it is argued that the 'weighing and balancing' test of the 'necessity' requirement of Article XX of the GATT 1994 allows for strong proportionality testing. See above, Part III, Section 1.1.1. See also Marceau and Trachtman, who point out that the necessity test in Article XX GATT requires an actual balancing of the degree to which the measure in dispute contributes to the aim pursued whereas the 'least-trade restrictive' requirement of Article 5.6 of the SPS Agreement does not. Gabrielle Marceau and Joel P. Trachtman, 'GATT, TBT and SPS: A Map of WTO Law of Domestic Regulation of Goods', in The WTO Dispute Settlement System 1995-2003, F. Ortino and Ernst-Ulrich Petersmann (eds.) (Kluwer Law International, Deventer), 2004, 275-340, 296.

1212 Panel Report, Australia - Salmon, para. 8.167.

1213 Appellate Body Report, Australia - Salmon, para. 194.
} 
significantly less trade-restrictive, the measure in dispute would be consistent with Article 5.6. ${ }^{1214}$

It is now useful to examine, in turn, each of the three cumulative requirements for a violation of Article 5.6 of the SPS Agreement.

\subsubsection{Reasonably available taking into account technical and economic feasibility}

The first element of the three-pronged test of Article 5.6, requires that the alternative measure be 'reasonably available, taking into account technical and economic feasibility' of the SPS Agreement.

It should be recalled that the consideration of technical and economic feasibility represents a departure from the previous approach of GATT panels under Article XX(b) of the GATT 1947, which did not take account of economic feasibility when deciding if a measure was more trade restrictive than required. In the Thailand-Cigarettes ${ }^{1215}$ case, the GATT Panel interpreted the requirement of Article XX(b) that the measure be 'necessary' to protect health to mean that it should be the least GATT-inconsistent measure which Thailand could reasonably be expected to employ to achieve its health policy objectives. ${ }^{1216}$ However, in comparing Thailand's ban on cigarette imports to alternative regulatory measures, ${ }^{1217}$ the GATT Panel did not look at the economic impact that the proposed regulatory regimes would have on Thailand. It thus found that alternative GATT-consistent measures were available to Thailand to achieve its health objectives. ${ }^{1218}$ A change in this approach took place after the establishment of the WTO. The Appellate Body has evinced a willingness to consider the technical and economic feasibility of alternative measures as relevant to the 'necessary' test of Article XX of the GATT 1994. ${ }^{1219}$

\footnotetext{
1214 Ibid. This finding was reiterated in Appellate Body Report, Japan-Agricultural Products II, para. 95.

1215 GATT Panel Report, Thailand-Cigarettes, para. 74.

${ }^{1216}$ Ibid., para. 75.

1217 The measure in dispute was Thailand's licensing requirement for cigarette manufacturers and importers. In practice only the licences for the national monopoly were approved. The alternative measures examined by the Panel were labelling and ingredient-disclosure regulations, advertising bans and the maintenance of a government monopoly on the non-discriminatory importation and national sale of cigarettes. GATT Panel Report, Thailand - Cigarettes, paras. 77-79.

${ }^{1218}$ GATT Panel Report, Thailand-Cigarettes, para. 80.

${ }^{1219}$ In US - Gambling, with respect to the 'necessary' requirement in Article XIV(c) of the GATS, the Appellate Body held that: '[a]n alternative measure may be found not to be 'reasonably available' ... where it is merely theoretical in nature, for instance, where the responding Member is not capable of taking it, or where the measure imposes an undue burden on that Member, such as prohibitive costs or substantial technical difficulties.' Appellate Body Report, US - Gambling, para. 308. This finding was recalled by the Appellate Body in Brazil-Retreaded Tyres, which held that in the assessment of whether alternative measures or practices are 'reasonably available' alternatives to a measure, 'the capacity of a country to implement remedial measures that would be particularly costly, or would require advanced technologies' may be relevant. Appellate Body Report, Brazil-Retreaded Tyres, para. 171. In casu the Appellate Body found that the alternative measures proposed by the EC were costly and required advanced technologies and know-how not readily available on a large scale. For this reason, among others, they could not be regarded as 'reasonably available' alternatives to the import ban. Ibid., para. 175.
} 
A clear recognition of the fact that a less trade-restrictive measure could have high regulatory or compliance costs or could be impractical to implement is expressly incorporated in Article 5.6 of the SPS Agreement. ${ }^{1220}$ The determination of whether an alternative measure is technically and economically feasible is of crucial importance to developing-country Members. In many cases, these Members are constrained in their choice of measure by financial and technical limitations. As a result, there may be more sophisticated measures available that achieve the appropriate level of protection of such a Member while being less restrictive of trade. Nevertheless, these alternative measures are not necessarily feasible for the regulating Member. Article 5.6 expressly takes this into account. It seems logical that the question of economic and technical feasibility will be determined on the basis of the characteristics of the importing Member, rather than by looking in the abstract at the alternative measures themselves. This should result in greater flexibility in the application of this discipline to developing-country Members.

In all disputes heard under the SPS Agreement thus far, the respondents were high-income country Members. There has thus not been occasion for a panel to examine the effect of constraints in technical capacity or economic resources on the choice of SPS measure by a less developed Member, and to take this into account in determining the availability of less trade-restrictive alternatives. In the cases where Article 5.6 has been at issue, the panels readily found that the respondent Member had the technical and economic capacity to apply the alternative measures proposed, particularly because these were often less complicated and demanding that the measure actually in place.

In Australia - Salmon, the Panel examined the four regulatory options that were identified in Australia's risk assessment, the 1996 Final Report, and stated as follows in this regard:

[A]11 four alternative options ... were presented in the 1996 Final Report itself as options which merit consideration and this in contrast to two other options removal of all quarantine restrictions and banning the importation of all salmon products - which were thought of as options which could not 'reasonably be considered as appropriate, having regard to associated quarantine risks' and were therefore 'not discussed further'. In our view, this implies that the 1996 Final Report put forward the four alternatives we examine as technically and economically feasible policy options. Nothing in the 1996 Final Report - nor any other evidence before us - implies that any of these four alternatives would be technically or economically unfeasible. ${ }^{1221}$

The compliance Panel in Australia - Salmon (Article 21.5 - Canada), when examining one of the four alternatives proposed by Canada for the Australian 'consumer-ready' requirements for imported salmonids, challenged under Article 5.6, stated that:

${ }^{1220}$ Gavin Goh and Andreas R. Ziegler, 'A Real World Where People Live and Work and Die: Australian SPS Measures after the WTO Appellate Body's Decision in the Hormones Case', Journal of World Trade 35 (5), 1998, 271-290, 280.

1221 Panel Report, Australia - Salmon, para. 8.171. The Appellate Body noted the panel's 'factual finding' in this respect and considered, therefore, that the first element was met. Appellate Body Report, Australia Salmon, para. 195. 
[S]ince one can assume that current Australian requirements are 'reasonably available taking into account technical and economic feasibility', also a regime without the consumer-ready requirements ... would be so. Given that inspection and control to release from quarantine only product that meets the consumerready requirements would no longer be necessary, a regime without the consumer ready requirements would be even more reasonably available in the sense of Article 5.6. ${ }^{1222}$

The Panel was also of the view that another alternative measure requiring different, less onerous, consumer ready-requirements (individual and commercial packaging before release) would be reasonably available as shown by the fact that New Zealand imposed similar requirements. ${ }^{1223}$ While not expressly stated, it seems that the comparison with New Zealand rests on the similarities in income level and technical capacity of this country with Australia. A third alternative, based on end-use conditions, gave rise to difficulties of control. However, as these difficulties were also present with regard to the existing Australian measure, the alternative was found to be technically feasible. ${ }^{1224}$

In Japan - Agricultural Products II, the Panel examined whether testing of agricultural products on a product-by-product basis to determine the efficacy of the quarantine treatment (fumigation) against codling moth was a technically and economically feasible alternative to the measure at issue, namely testing the efficacy for each individual variety of the product. Japan did not contest that this was the case, and the Panel agreed since testing by product is easier to implement than all the various tests and procedural steps required for approval of additional varieties of the agricultural products at issue. ${ }^{1225}$ This issue was not appealed.

The compliance Panel in Japan - Apples (Article 21.5 - US) had to assess whether the measure proposed by the US as an alternative for Japan's revised quarantine requirements for the importation of apples from the US was technically and economically feasible for Japan. The US had suggested that Japan should require 'that only mature, symptomless apples be exported to Japan.' ${ }^{1226}$ The Panel rejected Japan's argument that this could not be seen as an alternative measure since it was a statement of commercial practices rather than an administrative requirement, and it required action by both private operators and public authorities. According to the Panel, this could be seen as a reasonably available alternative provided that sufficient guarantees were in place 'to provide adequate assurances that such practices, whether public or private, will be adhered to.' ${ }^{1227}$ It noted, however, that in considering alternative measures it should determine whether the measure 'would constitute an option reasonably available taking into account technical and economic feasibility in the real world.' ${ }^{1228}$ The risk of incorrect enforcement is, according to the Panel, part of the technical feasibility of the measure. ${ }^{122}$ In view of the fact that

\footnotetext{
1222 Panel Report, Australia - Salmon (Article 21.5 - Canada), paras 7.146.

${ }^{1223}$ Ibid.,para. 7.147.

${ }^{1224}$ Ibid., para. 7.148.

${ }^{1225}$ Panel Report, Japan - Agricultural Products II, para 8.78.

${ }^{1226}$ Panel Report, Japan - Apples (Article 21.5 -US), para. 8.169.

1227 Ibid., para. 8.170.

${ }^{1228}$ Ibid., para. 8.171. Emphasis added.

${ }^{1229}$ Ibid.
} 
the US had indicated that specifications for mature, symptomless apples were laid down in its Apple Export Act, and that it had sufficient quality controls in place to reasonably ensure that the exported product was mature, symptomless apples, the Panel regarded the alternative measure suggested by the US as 'reasonably available, taking into account technical and economic feasibility'. ${ }^{1230}$

The fact that an alternative measure is technically and economically feasible does not necessarily mean that it must be adopted by the regulating Member. The second and third requirements of Article 5.6 specify additional limits to this obligation.

\subsubsection{Significantly less trade restrictive}

With regard to the second requirement, it is notable that the alternative measure must be significantly less trade-restrictive before a Member's measure will be deemed 'more trade-restrictive than required.' Thus a small difference in the trade impacts of the two measures is not sufficient to oblige a Member to adopt the alternative measure.

While Article 5.6 does not define what is meant by 'significantly less restrictive to trade', it is useful to note that a similar term is used in the transparency obligation in Annex B.5 of the SPS Agreement. Members are obliged to notify their proposed SPS measures if they are not substantially the same as an international standard and 'may have a significant effect on trade of other Members'. In the absence of a definition of this term, the SPS Committee has provided guidance in the recommended notification procedures it has adopted for purposes of the SPS Agreement. This guidance states:

To assess whether the sanitary or phytosanitary regulation may have a significant effect on trade, the Member concerned should consider relevant available information such as: the value or other importance of imports to the importing and/or exporting Members concerned, whether from other Members individually or collectively; the potential development of such imports; and difficulties for producers in other Members, particularly in developing country Members, to comply with the proposed sanitary or phytosanitary regulations. The concept of a significant effect on trade of other Members should include both importenhancing and import-reducing effects on the trade of other Members, as long as such effects are significant. ${ }^{1231}$

Particularly helpful in this guidance is its emphasis of the relative nature of the enquiry, taking into account the significance of trade in the product at issue to the Members involved, and the compliance constraints faced by developing countries. This clarifies that the significance of the trade effects of a measure cannot be determined in the abstract, but is a factor of the particular situation of the affected Member. While this guidance seems use-

${ }^{1230}$ Ibid., para. 8.181. The Panel noted that it could not excluded that the US inspection system might sometimes fail to guarantee that all exported apples were mature and symptomless, but Japan had not brought evidence to show that this had occurred with regard to apples in the past.

${ }^{1231}$ The latest version of these guidelines are contained in Committee on Sanitary and Phytosanitary Measures, Recommended Procedures for Implementing the Transparency Obligations of the SPS Agreement (Article 7) as of 1 December 2008. Revision, G/SPS/7/Rev.3, circulated on 20 June 2008, para. 10. They are discussed below, Part IV, Section 1.3.7. 
ful in general terms in elucidating the third requirement of Article 5.6, four qualifications must be borne in mind. First, the SPS Committee is not empowered to adopt authoritative interpretations of the SPS Agreement, but only to further its implementation. ${ }^{1232}$ Thus, these guidelines are not the final word on the meaning of the term, even in the context of Annex B.5. Second, the different object and purpose of the two provisions must be taken into account. While Annex B.5 aims to promote transparency by requiring the notification of measures deviating (upwards or downwards) from international standards if this deviation may have significant trade effects, Article 5.6 aims to limit the trade-restrictive effect of SPS measures imposed by Members by requiring, under the abovementioned conditions, that if a significantly less trade-restrictive alternative measure is reasonably available, it be imposed. Consequently, in the former case both the import-enhancing and import-reducing effects of the deviating measure are relevant, while in the latter only the import-enhancing effects of the alternative measure are pertinent. Third, the notification provision in Annex B.5 refers to an SPS measures that 'may' have a significant effect on trade, whereas Article 5.6 refers to an alternative SPS measure that 'is' significantly less trade-restrictive. Thus, the reference in the notification guidelines to 'potential' trade effects would not apply in the context of Article 5.6. ${ }^{1233}$ Only measures that actually are significantly less trade restrictive must be considered as possible alternatives. Fourth, while Annex B.5 examines the trade effects of the measure per se to determine if they are 'significant', Article 5.6 involves a comparison of the trade effects of the original measure and the alternative measure, to determine if the latter is significantly less than the former. Thus, the relative nature of the criterion in Article 5.6 is determinative.

Panels have typically not had much difficulty in finding that the alternative measures proposed by the complaining Member meet the criterion of being 'significantly less restrictive to trade'. This is a factual examination, depending on the circumstances of each case. An overview of panel findings in this regard gives an idea of the considerations that play a role in this determination.

The requirement that the alternative measures must be 'significantly less restrictive to trade' was examined by the Panel in Australia - Salmon. ${ }^{1234}$ It recalled that Australia's measure prohibited the importation of fresh, chilled or frozen salmon, whereas all four of the alternative options proposed would allow the salmon products to be imported, albeit under specific conditions (e.g. as retail-ready fillets, eviscerated, headless, gilled etc.). ${ }^{1235}$ Consequently, the alternative measures were found to be significantly less trade restrictive.

The compliance Panel in Australia - Salmon (Article 21.5 - US) noted that all the alternative measures proposed by the US 'would result in significantly more salmon product being allowed for direct release from quarantine' (including skin-on salmon weighing more than $450 \mathrm{~g}$, individually or commercially packaged) and that there was demand in

\footnotetext{
${ }^{1232}$ Article 12.1 of the SPS Agreement. Authoritative interpretations are within the exclusive authority of the WTO Ministerial Conference or General Council under Article IX of the WTO Agreement.

1233 Joanne Scott, The WTO Agreement on Sanitary and Phytosanitary Measures: A Commentary, Oxford Commentaries on the GATT/WTO Agreements (Oxford University Press, Oxford), 2007, 162.

1234 Panel Report, Australia - Salmon, para. 8.256.

1235 Ibid., para. 8.182.
} 
Australia for such product. ${ }^{1236}$ Thus, the second requirement of Article 5.6 was held to be met by the proposed alternative measures.

In Japan - Agricultural Products II, Japan did not contest that the alternative measure proposed by the US, namely testing by product, was significantly less restrictive to trade than testing each variety of the product. The Panel agreed, since market access would then be granted automatically to all additional varieties of a product. ${ }^{1237}$ As discussed above, however, as there was insufficient evidence before the Panel to show that testing by product achieved Japan's appropriate level of protection, the three cumulative requirements of Article 5.6 had not been met. The panel experts proposed another alternative measure, namely the determination of the sorption level of additional varieties of a product. Japan also did not contest that this alternative measure was significantly less restrictive to trade. The Panel agreed, since if the sorption level was not higher than that of already approved varieties, no further testing would be required meaning that market access would be obtained significantly more easily than under the existing regime. If the sorption level was higher, further testing could be required, but market access would not be more difficult to obtain than under the existing regime. ${ }^{1238}$ Consequently, the Panel found that this alternative measure met all the requirements of Article 5.6. However, on appeal the Appellate Body overturned the Panel's finding in this regard, since the US had not claimed that the determination of sorption levels was an alternative measure meeting the requirements of Article 5.6, and had thus not made a prima facie case. ${ }^{1239}$

The compliance Panel in Japan - Apples (Article 21.5 - US) readily found that the alternative measure proposed by the US, namely the requirement that only mature, symptomless apple fruit be exported to Japan, would be significantly less trade-restrictive than the combination of quarantine requirements imposed by Japan against fire blight. The Panel noted that the alternative requirement proposed by the US came down to requiring it to do 'what it claims to be already doing under its national legislation'. ${ }^{1240}$ This was found to 'certainly' be significantly less trade-restrictive than Japan's quarantine measures.

Although no express clarification of the meaning of the term 'significantly less restrictive to trade' has been given in the case law, it appears from the findings in the Panel reports discussed above that the main consideration is whether market access would be significantly improved if an alternative measure would be imposed. This criterion has not proved problematic.

\subsubsection{Achieves the Member's appropriate level of protection}

The third element of the three-pronged test under Article 5.6 as clarified by its footnote, requires that the alternative measure 'achieves the appropriate level of sanitary or phytosanitary protection' of the regulating Member. As emphasised by the Panel in Japan

\footnotetext{
${ }^{1236}$ Panel Report, Australia - Salmon (Article 21.5 - Canada), paras 7.150-7.153.

${ }^{1237}$ Panel Report Japan - Agricultural Products II, para. 8.79.

1238 Panel Report Japan - Agricultural Products II, paras 8.95-8.96.

1239 Appellate Body Report, Japan - Agricultural Products II, para. 126. For a discussion on the burden of proof, the role of the panel experts, and the limits to the investigative authority of a panel, see below, Part IV, Sections 2.2.2, 2.2.3 and 2.2.5.

${ }^{1240}$ Panel Report, Japan - Apples (Article 21.5 - US), para. 8.187.
} 
- Agricultural Products II in addressing the US's claim of violation of Article 5.6, the definition of the 'appropriate level of protection' in Annex A.5 to the SPS Agreement makes clear that it is up to the Member imposing the measure, in that case Japan, to determine the level of protection it deems appropriate. ${ }^{1241}$ Therefore, in order to determine whether the third requirement for a violation of Article 5.6 is met, it is necessary to establish what the appropriate level of protection of the relevant Member is.

The Panel in Australia - Salmon had found that the level of protection deemed appropriate by a Member could be implied from the level reflected in the SPS measure it adopts. ${ }^{1242}$ Thus it must be determined whether the alternative measures meet the level of protection achieved by the measure actually imposed. The Appellate Body disagreed, holding as follows:

We do not believe that Article 11 of the DSU, or any other provision of the DSU or of the SPS Agreement, entitles the Panel or the Appellate Body, for the purpose of applying Article 5.6 in the present case, to substitute its own reasoning about the implied level of protection for that expressed consistently by Australia. The determination of the appropriate level of protection, a notion defined in paragraph 5 of Annex A, as 'the level of protection deemed appropriate by the Member establishing a sanitary ... measure', is a prerogative of the Member concerned and not of a panel or of the Appellate Body. ${ }^{1243}$

The Appellate Body distinguished the appropriate level of protection, which is an objective, and the measure used to achieve that level, which is an instrument to attain this objective. It held that the provisions of the SPS Agreement indicate that 'the determination by a Member of the "appropriate level of protection" logically precedes the establishment or decision on maintenance of an "SPS measure".' 1244 The Appellate Body then noted that the correlation between the appropriate level of protection and the relevant SPS measure is most clearly illustrated by Article 5.6 and held:

The words of Article 5.6, in particular the terms 'when establishing or maintaining sanitary ... protection', demonstrate that the determination of the level of protection is an element in the decision-making process which logically precedes and is separate from the establishment or maintenance of the SPS measure. ... To imply the appropriate level of protection from the existing SPS measure would be to assume that the measure always achieves the appropriate level of protection determined by the Member. That clearly cannot be the case. ${ }^{1245}$

Thus, according to the Appellate Body, the appropriate level of protection determines what SPS measure will be used, not vice versa ${ }^{1246}$ Applying this finding to the case at hand, the Appellate Body noted that although the level of protection reflected in Australia's SPS measure (the import prohibition) was 'undisputedly a "zero-risk level" of protection',

\footnotetext{
${ }^{1241}$ Panel Report, Japan - Agricultural Products II, para. 8.81.

1242 Panel Report, Australia - Salmon, para. 8.173.

1243 Appellate Body Report, Australia - Salmon, para. 199.

1244 Ibid., paras 200 and 201.

1245 Ibid., para. 203.

${ }^{1246}$ Ibid.
} 
Australia had determined explicitly that its appropriate level of protection was 'a high or "very conservative" level of sanitary protection aimed at reducing risk to "very low levels", "while not based on a zero-risk approach"., ${ }^{1247}$ As a result, it found:

[T] he appropriate level of protection as determined by Australia is definitely not at least as high as the level of protection reflected in the SPS measure at issue. ${ }^{1248}$

However, as there is no explicit obligation on Members in the SPS Agreement to determine their level of protection, a problem may arise where an importing Member has not done so, or has done so 'with such vagueness or equivocation' 1249 that it becomes impossible to apply the relevant provisions of the SPS Agreement that refer to the level of protection, such as Article 5.6. The Appellate Body recognised this problem, stating that '[i]t would obviously be wrong to interpret the SPS Agreement in a way that would render nugatory entire articles or paragraphs of articles of this Agreement and allow Members to escape from their obligations under this Agreement.' ${ }^{1250}$ It held that an obligation on Members to determine their appropriate level of protection is implicit in Annex B.3, and Articles 4.1, 5.4 and 5.6, which refer to the appropriate level of protection of a Member. ${ }^{1251}$ It found:

[I]n cases where a Member does not determine its appropriate level of protection, or does so with insufficient precision, the appropriate level of protection may be established by panels on the basis of the level of protection reflected in the SPS measure actually applied. Otherwise, a Member's failure to comply with the implicit obligation to determine its appropriate level of protection - with sufficient precision - would allow it to escape from its obligations under this Agreement and, in particular, its obligations under Articles 5.5 and 5.6. ${ }^{1252}$

Thus, if a Member does not determine its appropriate level of protection, or does so with insufficient clarity, panels may deduce the appropriate level from the level reflected in the measure actually applied.

This finding is important in that it prevents the discipline in Article 5.6 from limiting the ability of governments to adopt measures that achieve the level of protection they have chosen. It recognises that the choice of level of protection is the sole prerogative of national decision-makers. Thus alternative measures must always be judged against the Members own chosen level of protection and not simply compared to the measure currently in place. Only in cases where a government does not adequately determine its level of protection, may a panel infer it from the measure applied in order to prevent the avoidance of disciplines under the SPS Agreement.

Panels experience difficulties in applying the discipline of Article 5.6 in cases where the appropriate level of protection has been vaguely or qualitatively expressed. In Australia - Salmon (Article 21.5 - Canada), the Panel expressed 'parenthetically' its view that

${ }^{1247}$ Ibid., para. 197. In footnote here the Appellate Body referred to Panel Report, Australia - Salmon, para. 8.107.

1248 Ibid.

1249 Ibid.

${ }^{1250} \mathrm{Ibid}$., para. 206.

${ }^{1251}$ Ibid.

${ }^{1252}$ Ibid. 
a more explicit, and in particular a quantitative, expression of a Member's appropriate level of protection "would greatly facilitate the consideration of compliance with not only Article 5.6 but with other provisions of the SPS Agreement as well. ${ }^{1253}$ Nevertheless, no such requirement is laid down in the SPS Agreement, nor can it be inferred from its provisions. Consequently, panels dealing with qualitative expressions of levels of protection must face the struggle to ascertain whether alternative measures meet these levels of protection, as did the compliance Panel in Australia - Salmon (Article 21.5-Canada). In that case the Panel took a cautious approach, limited to examining various options without deciding that one of them would necessarily achieve Australia's level of protection. The Panel simply noted after its examination of the alternatives proposed that it was convinced that there were other options available, be it the options it had discussed taken separately or in combination, that would meet Australia's appropriate level of protection. It then stated: 'We leave it up to Australia, preferably in close cooperation with Canada and other trading partners, to select and identify the details of such other measures. ${ }^{1254}$

In Japan - Agricultural Products II, the level of protection deemed appropriate by Japan was clear, expressed quantitatively and undisputed. ${ }^{1255}$ The US argued that an alternative less trade-restrictive measure was available that could achieve this level of protection, namely testing by product instead of testing by variety of each product. According to the US, varietal differences did not affect the efficacy of quarantine treatment for codling moth, and thus varietal testing provided no additional protection. ${ }^{1256}$ Japan countered that data suggests varietal differences in the efficacy of fumigation, so that testing by product would not achieve its level of protection. ${ }^{1257}$ The Panel considered that on the evidence before it, it was impossible 'to state with an appropriate degree of certainty that one and the same treatment would be effective for all varieties of a product. ${ }^{1258}$ It was thus not convinced that testing by product would achieve Japan's level of protection. ${ }^{1259}$ The Appellate Body upheld this finding on appeal. ${ }^{1260}$ Since it is for the complainant to prove that all three cumulative requirements of Article 5.6 are met, no violation will be found if the complainant is unable to establish that the proposed alternative actually meets the level of protection deemed appropriate by the Member imposing the measure.

${ }^{1253}$ Panel Report, Australia - Salmon (Article 21.5 - Canada), para. 7.129.

1254 Ibid., para. 7.144.

${ }^{1255}$ In this case both parties agreed that the level of mortality that Japan was seeking with respect to codling moth could be regarded as Japan's appropriate level of protection. Both parties also agreed that this level was 'complete mortality in large scale tests on a minimum of 30,000 codling moths, with respect to all varieties of that product.' Panel Report, Japan-Agricultural Products II., paras 8.81 and 8.82 .

1256 Ibid., para. 8.65.

1257 Ibid., para. 8.68.

${ }^{1258}$ Ibid., para. 8.83.

${ }^{1259} \mathrm{Ibid}$., para. 8.84. The Panel found that another alternative measure suggested by the panel experts, namely the determination of differences in sorption levels of different varieties of products, would achieve Japan's level of protection. Ibid., para. 8.101. However, as the US had not claimed that the determination of differences in sorption levels was an alternative measure meeting the requirements of Article 5.6, the Appellate Body overturned the Panel's findings in respect of this alternative. Appellate Body Report, Japan - Agricultural Products II, para. 126.

${ }^{1260}$ Appellate Body Report, Japan - Agricultural Products II, paras 97-100. The Appellate Body rejected the US's argument on this point, noting that in essence it challenged the Panel's consideration and weighing of the evidence before it, something which is outside the scope of appellate review. 
In Japan - Apples (Article 21.5 - US), Japan identified its level of protection as 'equivalent to one that would result from an import ban on commercial apples.' The compliance Panel recalled 'that it is for Japan to determine its [appropriate level of protection], and that [the Panel] should not question it. ${ }^{1261}$ However, since the Panel had already found that there was no evidence that mature, symptomless apple fruit could complete the transmission pathway for fire blight, it considered that Japan's level of protection would 'theoretically' be met by the alternative measure proposed by the US, namely the requirement that apples be mature and symptomless. ${ }^{1262}$ It is not clear why the Panel changed the 'real world' approach it used in identifying technically and economically feasible measures for a 'theoretical' approach in establishing whether the appropriate level of protection has been met. Such an approach goes against the respectful approach of the SPS Agreement towards Members' appropriate levels of protection and their right to ensure that these levels are met by imported products. It certainly seems ill-advised and it to be hoped that the Appellate Body will correct this in future cases.

An example of a situation involving developing-country Members where the question arose whether a reasonably available less trade-restrictive measure would achieve the level of protection of the importing Member, is provided by the trade concern raised by Argentina against China's measures against fruit flies. ${ }^{1263}$ Argentina's exports of apples, pears and citrus fruits to China were impeded by China's limitation of imports to those originating from countries that are free of fruit flies, in order to retain China's status as a country free of Medfly and South American fruit fly. Argentina argued that it was using cold treatment to eliminate fruit flies from export products, and requested China to respond to a list of questions regarding its risk assessment. However, China indicated that it required Argentina to provide data on the efficacy of cold treatment in order to demonstrate that it could provide the same level of protection as importation from pestfree areas. If this were so, China was prepared to consider it as an alternative treatment against fruit flies. ${ }^{1264}$

\subsubsection{Rules on provisional measures}

Risk management decisions with regard to the imposition of SPS measures are sometimes taken in situations of scientific uncertainty. In cases where the uncertainty takes the form of insufficiency of scientific evidence, such that the performance of a risk assessment is not possible, Members may be prompted by considerations of precaution to adopt SPS measures despite the absence of a risk assessment basis.

Article 5.7 of the SPS Agreement provides for such cases of insufficient scientific evidence. It states:

\footnotetext{
${ }^{1261}$ Panel Report, Japan - Apples (Article 21.5 - US), para. 8.193.

1262 Ibid.

${ }^{1263}$ Committee on Sanitary and Phytosanitary Measures, Specific Trade Concerns. Note by the Secretariat. Addendum. Resolved Issues, G/SPS/GEN/204/Rev.8/Add.3, circulated on 27 March 2008, item 115.

${ }^{1264}$ It is not entirely clear from the discussion of this trade concern whether Argentina was requesting that China apply the less trade-restrictive measure of requiring cold treatment for imports of products from Members not free of fruit flies, or whether it was requesting the recognition of the equivalence of cold treatment as a measure. In March 2006, the issue was reported resolved, but no indication was given of what the resolution entailed.
} 
In cases where relevant scientific evidence is insufficient, a Member may provisionally adopt sanitary or phytosanitary measures on the basis of available pertinent information, including that from the relevant international organizations as well as from sanitary or phytosanitary measures applied by other Members. In such circumstances, Members shall seek to obtain the additional information necessary for a more objective assessment of risk and review the sanitary or phytosanitary measure accordingly within a reasonable period of time.

The relationship between Article 5.7 and the scientific disciplines contained in Articles 2.2 and 5.1 of the SPS Agreement is useful to examine. As mentioned above, Article 2.2 of the SPS Agreement expressly refers to Article 5.7 and its disciplines apply 'except as provided for in paragraph 7 of Article 5.' The Appellate Body in Japan - Agricultural Products II regarded Article 5.7 as a 'qualified exemption' from Article 2.2, rather than as an exception to this provision. ${ }^{1265}$ Unlike Article 2.2, Article 5.1 does not expressly refer to Article 5.7. However, the Appellate Body in Japan - Apples noted the contextual link between the obligation in Article 5.1 to base an SPS measure on a risk assessment and the first element of Article 5.7, relating to the insufficiency of the scientific evidence. It noted that the scientific evidence will be insufficient for purposes of Article 5.7 if it does not allow the performance of an adequate risk assessment. ${ }^{1266}$

The relationship between Article 5.7 and the scientific obligations of Articles 2.2 and 5.1 was fleshed out further by the Panel in EC-Approval and Marketing of Biotech Products. In this dispute, the EC argued that its Member States' safeguard measures banning biotech products that had already been approved at EC level, fell to be assessed under Article 5.7 rather than Articles 2.2 and 5.1 of the SPS Agreement. The Panel, relying on the test used by the Appellate Body in EC - Tariff Preferences to distinguish between exceptions and exemptions, ${ }^{1267}$ agreed with the EC that Article 5.7 is an autonomous right, and not merely an exception from the general scientific obligation under Article 2.2 and the obligation to base a measure on a risk assessment in Article 5.1. ${ }^{1268}$ Although Article 5.1 does not expressly refer to Article 5.7, the Panel recalled the Appellate Body's finding in Japan-Apples that scientific evidence is 'insufficient' for purposes of Article 5.7 when it is impossible for a Member to conduct a risk assessment on the basis of this evidence. The Panel found it 'unreasonable to assume that Members would accept, even in principle, an obligation with which they cannot comply.' ${ }^{1269}$ Thus, a measure complying with all four

\footnotetext{
${ }^{1265}$ Appellate Body Report, Japan - Agricultural Products II, para. 80.

1266 Appellate Body Report, Japan - Apples, para. 179.

1267 Appellate Body Report, EC - Tariff Preferences, para. 88. Under this test, a provision is an autonomous right, rather than an exception from another provision, where 'one provision permits, in certain circumstances, behaviour that would otherwise be inconsistent with an obligation in another provision, [where] one of the two provisions refers to the other provision, [and] where one of the provisions suggests that the obligation is not applicable to the said measure.' This test was cited in Panel Reports, EC-Approval and Marketing of Biotech Products, para. 7.2985.

${ }^{1268}$ Panel Reports, EC - Approval and Marketing of Biotech Products, paras 7.2969, 7.2976 and 7.2997. This finding is contrary to the finding of the Panel in Japan-Apples, which held that the burden of proof under Article 5.7 is on the respondent. The Appellate Body in Japan - Apples noted that this finding was not appealed, which the Panel in EC-Approval and Marketing of Biotech Products took as expressing the Appellate Body's reservation with regard to this allocation of the burden of proof. Panel Reports, EC-Approval and Marketing of Biotech Products, para. 7.2979.

${ }^{1269}$ Panel Reports, EC-Approval and Marketing of Biotech Products, para. 7.2995.
} 
requirements of Article 5.7 is excluded from the scope of application of both the scientific obligations of the SPS Agreement, contained in Articles 2.2 and 5.1. ${ }^{1270}$

This, as recognised by the Panel, has implications for the burden of proof. ${ }^{1271}$ The party claiming a violation of Articles 2.2 or 5.1 bears the burden of proving that the challenged measure is inconsistent with at least one of the four requirements set out in Article 5.7. Only then will the measure fall within the scope of application of Articles 2.2 or 5.1. ${ }^{1272}$

It is surprising to note that the safe haven from the scientific disciplines of Articles 2.2 and 5.1 of the SPS Agreement has been held to apply only to SPS measures that meet all four requirements of Article 5.7. Japan's argument in Japan-Agricultural Products II, that an SPS measure that is adopted in conformity with the requirements of the first sentence of Article 5.7 (i.e. in a situation of 'insufficient' scientific evidence and on the basis of available pertinent information), is automatically freed from the requirements of Article 2.2 and can only be tested against the obligations of Article 5.7, was rejected by the Appellate Body. It disagreed with Japan that the words 'except as provided for in Article 5.7' in Article 2.2 refer only to the first sentence of Article 5.7, holding that the text of Article 2.2 does not support this proposition as it refers to Article 5.7 as a whole. ${ }^{1273}$ Similarly, the Panel in EC-Approval and Marketing of Biotech Products held that if a challenged SPS measure is not consistent with one of the requirements of Article 5.7, the situation is not 'as provided for in Article 5.7' and thus Article 2.2 applies. ${ }^{1274}$ A similar finding was made by this Panel in respect of Article 5.1, due to its view of Article 5.7 as a 'qualified exemption' from Article 5.1. ${ }^{1275}$ Thus, according to the case law, all four conditions of Article 5.7 must be met in order to avoid the scientific disciplines of Articles 2.2 and 5.1 of the SPS Agreement.

It can be questioned whether this line of case law is correct. A preferable approach, as argued by Andrew Lang, would be to regard the right to take provisional measures as existing in all cases where the scientific evidence is insufficient for the conduct of a risk assessment. In such cases, as explained below, it is impossible for Members to comply with the scientific disciplines of Articles 2.2 and 5.1. The remaining three obligations of Article 5.7 should not be seen as conditions for the existence of the right to take provisional measures, but rather as substantive requirements triggered by the exercise of this

${ }^{1270}$ Despite this finding, the Panel started its analysis with examining whether Article 5.1 was violated, rather than first determining whether the requirements of Article 5.7 were met (in which case Article 5.1 would not be applicable). The Panel explained its choice to follow the same order of analysis than had been applied in previous case law by stating that it considered the 'critical legal issue' in dispute to be whether the EC Member States' safeguard measures met the requirements of Article 5.1. Panel Reports, EC-Approval and Marketing of Biotech Products, paras 7.3006-7.3007.

${ }^{1271}$ On burden of proof issues, see below, Part IV, Section 2.2.2.

1272 Panel Reports, EC - Approval and Marketing of Biotech Products, paras 7.2976 and 7.2996. It is useful to bear in mind that the fact that a particular SPS measure is found to be maintained 'without sufficient scientific evidence' for purposes of Article 2.2 of the SPS Agreement does not necessarily mean that the first requirement, which triggers the application of the Article 5.7 exemption, namely that 'relevant scientific evidence is insufficient', will be met. Panel Report, Japan - Apples, para. 8.215. This is discussed below, Part III, Section 5.2.5.2.

${ }^{1273}$ Appellate Body Report, Japan - Agricultural Products II, para. 90.

1274 Panel Reports, EC - Approval and Marketing of Biotech Products, para. 7.2975.

1275 Panel Reports, EC-Approval and Marketing of Biotech Products, para. 7.2998. 
right. ${ }^{1276}$ If these requirements are not met, the measure is in violation of Article 5.7 of the SPS Agreement. To instead 'send the panel back' to Articles 2.2 and 5.1 in such cases makes no sense, once it is recognised that Article 5.7 applies only in cases where the insufficiency of the scientific evidence is such as to hinder compliance with Articles 2.2 and 5.1. ${ }^{1277}$ In addition, as stated by Lang, 'at the level of principle: there is something objectionable in principle about a situation in which the right to take protective measures can become legally unavailable, even where a clearly legitimate reason exists for such measures.' ${ }^{1278}$

\subsubsection{Relationship with the precautionary principle}

Much of the academic discussion surrounding Article 5.7 of the SPS Agreement relates to the question of the scope it provides for regulating Members to act in accordance with the precautionary principle. ${ }^{1279}$ Although the content and legal status of the precautionary principle are disputed, ${ }^{1280}$ there is increasing recognition of the legitimacy of precautionary approaches to risk regulation in the face of uncertainties in science. ${ }^{1281}$ These precautionary approaches may be reflected in conservative assumptions, safety factors, models, extrapolations and rules of thumb used to fill gaps in scientific knowledge when conducting a risk assessment. They may also be reflected in risk management choices, such as the decision to rely on more risk-averse minority opinions as a basis for an SPS measure in cases where divergent scientific opinions arise from assessments of the scientific data. Precaution may also lead regulators to impose SPS measures in cases where the scientific evidence is insufficient to conduct a risk assessment at all.

1276 Andrew T.F. Lang, Provisional Measures under Article 5.7 of the WTO's Agreement on Sanitary and Phytosanitary Measures: Some Criticisms of the Jurisprudence So Far, LSE Legal Studies Working Paper No. 11/2008 (London School of Economics, London), 30 June 2008, 8, available at: http://ssrn.com/abstract $=1153660$, visited on 18 August 2008 .

1277 The criterion of 'insufficient' scientific evidence to trigger the application of Article 5.7 is discussed below, Part III, Section 5.2.5.2.

1278 Andrew T.F. Lang, Provisional Measures under Article 5.7 of the WTO's Agreement on Sanitary and Phytosanitary Measures: Some Criticisms of the Jurisprudence So Far, LSE Legal Studies Working Paper No. 11/2008 (London School of Economics, London), 30 June 2008, 9, available at: http://ssrn.com/abstract $=1153660$, visited on 18 August 2008.

1279 See for example Joanne Scott and Ellen Vos, 'The Juridification of Uncertainty: Observations on the Ambivalence of the Precautionary Principle within the EU and the WTO', in Good Governance in Europe's Integrated Market, Christian Joerges and Renaud Dehousse (eds.) (Oxford University Press, New York), 2002, 253-286.

${ }^{1280}$ On the debate concerning the status and meaning of the 'precautionary principle' see above, Part II, Section 1.5 .

${ }^{1281}$ It is interesting to note that in the discussion at the SPS Committee following the notification by the EC of its Communication on the Precautionary Principle, Members (including the US, Canada, Mexico, Brazil, Bolivia, Chile and Argentina) did not disagree with the right of Members to act with precaution in regulating against SPS risks. Instead, the point of contention was whether reference to the 'precautionary principle' was appropriate in view of the fact that Article 5.7 of the SPS Agreement already makes provision for action in the face of insufficient scientific evidence. Concerns were expressed that, if the precautionary principle were seen to override the express disciplines of the SPS Agreement, precaution would make room for disguised protectionist measures. Committee on Sanitary and Phytosanitary Measures, Summary of the Meeting Held on 15-16 March 2000: Note by the Secretariat, G/SPS/R/18, circulated on 18 April 2000, paras 3-12. The notification of the EC's Communication on the Precautionary Principle was circulated in Committee on Sanitary and Phytosanitary Measures, Communication by the European Communities on the Precautionary Principle, G/SPS/GEN/168, circulated on 14 March 2000. 
Developing-country Members have expressed concerns regarding reliance on the precautionary principle in SPS regulation to evade the scientific obligations of the SPS Agreement. In discussions in the SPS Committee on this issue, the delegate from Argentina stated that:

[n]o one would disagree about the need to act with precaution. However, it was problematic to introduce this so-called principle that could override SPS obligations; for the sake of precaution, consolidated trade concessions could be removed, impaired or nullified without compensation. He emphasized that this was of much concern to developing countries whose already serious problems in complying with SPS measures in export markets would be made worse by the "blank cheque" of precaution. ${ }^{1282}$

The question arises whether the SPS Agreement makes provision for precaution in regulatory action, and if so, what the limits of this possibility are. This has, in turn, led to an examination of the requirements of Article 5.7 and the question whether this Article is the sole embodiment of the scope for precautionary approaches to risk regulation left in the SPS Agreement.

In $E C$-Hormones, the EC had tried to rely on the precautionary principle outside the framework of Article 5.7, as a general customary rule of international law or at least a general principle of law, applying to both risk assessment and risk management. ${ }^{1283}$ This was because the EC refused to classify its measure as 'provisional' and therefore could not base its arguments on Article 5.7, despite its contention that scientific uncertainty persisted regarding the risks involved in hormone treated meat. After expressing its doubts as to whether the precautionary principle has developed into a principle of general or customary international law, outside the field of international environmental law, the Appellate Body found it unnecessary to decide this issue. ${ }^{1284}$ It stated as follows:

1282 Committee on Sanitary and Phytosanitary Measures, Summary of the Meeting Held on 15-16 March 2000: Note by the Secretariat, G/SPS/R/18, circulated on 18 April 2000, para. 10.

1283 It is interesting to note that the EC Commission's Communication on the Precautionary Principle (COM/2000/001, Brussels, 2 February 2000) adopted partly as a reaction to the Appellate Body decision in $E C$-Hormones, reflects a departure from the view that the precautionary principle applies to both phases of risk analysis. It states that the appropriate role for the precautionary principle is in risk management decisions, where scientific uncertainty precludes a full risk assessment. It distinguishes this situation from the prudential approach which scientists take in their assessment of data, in order to deal with the scientific uncertainties inherent in risk assessment. It identifies (at 15) certain prudential techniques adopted by risk assessors to deal with uncertainties, for example the use of animal models to establish potential effects in humans, adopting a safety factor when evaluating an acceptable daily intake to take account of inter- and intra-species variability, not adopting an acceptable daily intake for recognised carcinogens, etc. It seems that the Commission's change in approach is a reaction to the Appellate Body's refusal in EC - Hormones to see the precautionary principle as allowing deviation from the explicit provisions of Article 5.1 on risk assessment, except as provided for in Article 5.7. It thus cannot influence the application of the risk assessment disciplines. The Commission thus now prefers to view the principle as a risk management tool.

${ }^{1284}$ Appellate Body Report, EC - Hormones, para. 123. The Appellate Body refers to various authors both supporting and denying the claim that the precautionary principle is a principle of customary international law. While the widespread use of this principle in international environmental treaties seems to indicate its emergence as a new norm of customary international environmental law, it is less clear that it has attained this status outside the environmental area. However, emerging practice in the area of health does reflect growing recognition of this principle (see the EC Commission's Communication on the Precautionary Principle, $\mathrm{COM} / 2000 / 001$, as well as the work of the Codex Alimentarius Commission to establish guidelines for the 
The status of the precautionary principle in international law continues to be the subject of debate among academics, law practitioners, regulators and judges. The precautionary principle is regarded by some as having crystallized into a general principle of customary international environmental law. Whether it has been widely accepted by Members as a principle of general or customary international law appears less than clear. We consider, however, that it is unnecessary, and probably imprudent, for the Appellate Body in this appeal to take a position on this important, but abstract, question. We note that the Panel itself did not make any definitive finding with regard to the status of the precautionary principle in international law and that the precautionary principle, at least outside the field of international environmental law, still awaits authoritative formulation. ${ }^{1285}$

The Appellate Body then held that the precautionary principle (presumably whatever its legal status in international law) could not override the explicit requirements of Articles 5.1 and 5.2, in cases of scientific uncertainty. ${ }^{1286}$ On the relationship between the precautionary principle and the SPS Agreement, the Appellate Body noted the following four elements:

First, the principle has not been written into the SPS Agreement as a ground for justifying SPS measures that are otherwise inconsistent with the obligations of Members set out in particular provisions of that Agreement. Secondly, the precautionary principle indeed finds reflection in Article 5.7 of the SPS Agreement. We agree, at the same time, with the European Communities, that there is no need to assume that Article 5.7 exhausts the relevance of a precautionary principle. It is reflected also in the sixth paragraph of the preamble and in Article 3.3. These explicitly recognize the right of Members to establish their own appropriate level of sanitary protection, which level may be higher (i.e., more cautious) than that implied in existing international standards, guidelines and recommendations. Thirdly, a panel charged with determining, for instance, whether 'sufficient scientific evidence' exists to warrant the maintenance by a Member of a particular SPS measure may, of course, and should, bear in mind that responsible, representative governments commonly act from perspectives of prudence and precaution where risks of irreversible, e.g. life-terminating, damage to human health are concerned. Lastly, however, the precautionary principle does not, by itself, and without a clear textual directive to that effect, relieve a panel from the duty of applying the normal (i.e. customary international law) principles of treaty interpretation in reading the provisions of the SPS Agreement. ${ }^{1287}$

implementation of this principle). The Appellate Body also mentions the ICJ decision in Case Concerning the Gabcikovo-Nagaymaros Project (Hungary/Slovakia) ICJ Judgement 25 September 1997, available at: http:/www.icj-cij.org/icjwww/idocket/his/ihsjudgement/his_judgement_970925.html, visited on 25 June 2007. In this case the ICJ recognised that new norms and standards have developed in the field of international environmental law, but did not specifically mention the precautionary principle as being one of those new norms. Appellate Body Report, EC-Hormones, footnotes 92-93.

1285 Appellate Body Report, EC-Hormones, para. 123.

${ }^{1286}$ Appellate Body Report, EC-Hormones, para. 125., where it held, 'We accordingly agree with the finding of the Panel that the precautionary principle does not override the provisions of Article 5.1 and 5.2 of the SPS Agreement.'

${ }^{1287}$ Ibid., para. 124. 
Thus, the Appellate Body in EC - Hormones saw Article 5.7 as incorporating and giving meaning to the precautionary principle for purposes of the SPS Agreement. Although, according to the Appellate Body, Article 5.7 does not necessarily exhaust the relevance of this principle, the other two provisions it referred to as reflections of the precautionary principle do not, in fact, embody the precautionary principle but rather the preventive principle. ${ }^{1288}$

The approach of the Appellate Body in EC-Hormones was followed by the Panel in ECApproval and Marketing of Biotech Products. In response to the European Communities' argument that the precautionary principle has 'by now' become a fully-fledged principle of international law, the Panel noted:

It appears to us from the Parties' arguments and other available materials that the legal debate over whether the precautionary principle constitutes a recognized principle of general or customary international law is still ongoing. Notably, there has, to date, been no authoritative decision by an international court or tribunal which recognizes the precautionary principle as a principle of general or customary international law. ${ }^{1289}$

While agreeing that the precautionary principle has explicitly or implicitly been incorporated into many international conventions and declarations and has been applied by states at the domestic level, the Panel noted that this is mostly in the field of environmental law. It pointed out that questions remain as to the "precise definition and content of the precautionary principle'. ${ }^{1290}$ Moreover, while many authors have expressed the view that the precautionary principle exists as a general principle in international law, at the same time others have expressed scepticism and consider that the precautionary principle has not yet attained this status. ${ }^{1291}$ Therefore the Panel held:

Since the legal status of the precautionary principle remains unsettled, like the Appellate Body before us, we consider that prudence suggests that we not attempt to resolve this complex issue, particularly if it is not necessary to do so. ${ }^{1292}$

However, the matter does not end here. If the precautionary principle can be said to have developed into a principle of customary international law, it has the effect of guiding the interpretation of Articles of the SPS Agreement, where there is room for more than one interpretation. ${ }^{1293}$ It is a customary international law principle of interpretation that, as parties to a treaty are presumed not to have intended to violate norms of customary international law, treaty provisions are interpreted as far as possible in conformity with these norms. ${ }^{1294}$ Thus the Appellate Body's statement that ' ...the precautionary principle

${ }^{1288}$ On the difference between the precautionary principle and the preventive principle, see above, Part II, Section 1.5.

1289 Panel Reports, EC-Approval and Marketing of Biotech Products, para. 7.88.

1290 Ibid.

1291 Ibid.

1292 Ibid., para. 7.89.

${ }^{1293}$ On the role of other international law in the interpretation of WTO agreements, see below, Part IV, Section 2.2.4.

1294 On this point, see Joost Pauwelyn, Conflict of Norms in Public International Law: The Example of the World Trade Organization: Internal Hierarchy and How WTO Law Relates to Other Rules of International Law, 
does not, by itself, and without a clear textual directive to that effect, relieve a panel from the duty of applying the normal (i.e. customary international law) principles of treaty interpretation' ${ }^{1295}$ reveals a misunderstanding of the role of customary international law principles. In fact, it is precisely these 'normal principles of treaty interpretation' ${ }^{1296}$ that require the precautionary principle to be used to guide the interpretation of vague or ambiguous provisions of the SPS Agreement, if it can be shown that this principle is now a customary international law norm. Thus the Appellate Body was wrong to state that it was 'unnecessary' for it to take a position on this question, ${ }^{1297}$ the answer to which is crucial to the determination of the role of the precautionary principle in informing the disciplines of the SPS Agreement. The precautionary principle could be important in giving meaning to vague terms in the SPS Agreement, such as the 'sufficient scientific evidence' requirement in Article $2.2^{1298}$ or the requirement that SPS measures be 'based on' a risk assessment, 'as appropriate to the circumstances' in Article 5.1.

It is useful to recall, however, that despite the Appellate Body's reluctance to consider the precautionary principle as an interpretative tool in guiding the application of the scientific disciplines of the SPS Agreement, it has implicitly done so in some of its findings on these disciplines. The realistic and pragmatic approach followed by the Appellate Body in interpreting Articles 5.1 and 2.2 of the SPS Agreement, discussed above, have made room for precautionary approaches to risk regulation. Examples of this are the Appellate Body's finding that reliance on minority opinions in risk assessments is permissible, ${ }^{1299}$ its rejection of a requirement of a minimum threshold of risk ${ }^{1300}$ and its refusal to limit a risk assessment to 'laboratory science', recognising the need to consider real world conditions, including problems of control, in assessing risk. ${ }^{1301}$ It seems, therefore, that the use

Doctoral Thesis, Faculté de Droit (Université de Neuchâtel, Neuchâtel), 2001, 155.. In footnote, Pauwelyn cites Akehurst, stating: 'just as there is a presumption against the establishment of new customary rules which conflict with pre-existing customary rules, so there is a presumption against the replacement of customary rules by treaties and vice versa.' Michael Akehurst, 'The Hierarchy of the Sources of International Law', 75 British Yearbook of International Law, 1974, 273-285, 275. He also cites Panel Report, Indonesia - Autos, para. 14.28, finding: 'in public international law there is a presumption against conflict'. Ibid., footnote 709 .

1295 Appellate Body Report, EC - Hormones, para. 124.

1296 The normal principles of treaty interpretation that are part of customary international law must be used in the interpretation of the provisions of the WTO agreements, according to Article 3.2 of the DSU. These principles are codified in Articles 31 and 32 of the Vienna Convention on the Law of Treaties. Article 31.3(c) requires regard to 'any relevant rules of international law applicable in the relations between the parties' together with the context when interpreting a treaty provision.

1297 Appellate Body Report, EC-Hormones, para. 123.

1298 It seems that the Appellate Body itself recognised this possibility, in an obiter statement that 'a panel charged with determining, for instance, whether 'sufficient scientific evidence' exists to warrant the maintenance by a Member of a particular SPS measure may, of course, and should, bear in mind that responsible, representative governments commonly act from perspectives of prudence and precaution where risks of irreversible, e.g. life-terminating, damage to human health are concerned.' Appellate Body Report, EC Hormones, para. 124. Although the interpretation of Article 2.2 was not at issue in this case, the Appellate Body seems to have recognised the possibility of interpreting this Article in the light of a rather restrictive formulation of the precautionary principle.

1299 See above, Part III, Section 5.1.5.1.

${ }^{1300}$ See above, Part III, Section 5.1.1.2.

${ }^{1301}$ See above, Part III, Section 5.1.1.2. 
of precautionary approaches in the risk assessment process is not excluded by the rules of the SPS Agreement, as interpreted by the Appellate Body. ${ }^{1302}$

An interesting development in this regard can be found in the obiter statement of the Panel in EC-Approval and Marketing of Biotech Products. In response to the claims by the US, Canada and Argentina that the safeguard measures applied by the EC Member States, at issue in this dispute, were in violation of Article 5.1, the EC argued that these measures were based on the precautionary principle. ${ }^{1303}$ While refraining from referring here to the question whether the 'precautionary principle' has achieved any particular status in international law, the Panel agreed that the fact that a Member chooses to follow 'a precautionary approach' could have a bearing on the assessment by a panel of whether the SPS measure at issue was 'based on' a risk assessment under Article 5.1.1304 More specifically, the Panel considered that if there are factors, such as the limited body of scientific evidence available, that affect scientists' confidence in the risk assessment they have conducted, a Member may in principle take this into account in determining the SPS measure to be applied to achieve its appropriate level of protection. Therefore, when faced with a risk assessment that 'identifies uncertainties or constraints' a Member following a precautionary approach may apply a stricter measure than another Member to address the same risk, or may decide to apply an SPS measure where another Member might decide not to do so. ${ }^{1305}$ However, the SPS measure at issue must still be 'based on' (i.e. reasonably supported by) a risk assessment. ${ }^{1306}$ In this case, the EC had not identified uncertainties or constraints in the risk assessments at issue, nor had it explained how the safeguard measures were reasonably supported by the relevant risk assessments, which were favourable to the biotech products. ${ }^{1307}$ Therefore the argument regarding the 'precautionary approach' of the relevant Member States did not persuade the Panel that this approach had been applied consistently with Article 5.1 .

Although not addressing the precautionary principle as such, this finding seems to indicate a welcome openness of the Panel to interpret the obligation to base an SPS measure on a risk assessment in a manner that respects the right of Members to choose a precautionary approach in their risk management decisions. Notably, this does not mean that the existing scientific obligations of the SPS Agreement are overridden. Instead, in the application of these disciplines, a panel would be guided by the recognition of precaution as a legitimate risk management option, and would therefore not expect as close a correlation between the SPS measure applied and the relevant risk assessment in order for the former to be 'reasonably supported' by the latter as has been the case to date. This is precisely the effect that the use of the precautionary principle as an interpretative tool in disputes under the SPS Agreement could have, were it to be found to have emerged as a

1302 This flexibility may, however, be undermined by the current practice of panels to review the science evaluated in a risk assessment to determine if they agree with the conclusions arrived at. This allows panels to replace the science policy choices of a regulating Member, including those reflecting conservative or precautionary approaches, with their own. This problem relates to the standard of review applied by panels in their assessment of the scientific evidence, and is discussed below, Part IV, Section 2.2.3.

${ }^{1303}$ Panel Reports, EC-Approval and Marketing of Biotech Products, para. 7.3065.

1304 Ibid.

${ }^{1305}$ Ibid.

1306 Ibid.

${ }^{1307}$ Ibid., para. 7.3066 . 
principle of customary international law. The advantage of basing such an interpretation on a principle of international law is that a normative basis is provided for the flexibility inherent in this approach, thereby enhancing its legitimacy. ${ }^{1308}$

However, as the case law now stands, the Appellate Body's decision in EC-Hormones in effect limits the applicability of the precautionary principle to risk management decisions under the SPS Agreement to the situation covered by Article 5.7 of the SPS Agreement. ${ }^{1309}$ It is therefore necessary to examine the provisions of Article 5.7 to determine to what extent they give expression to this principle and deal with the exigencies it was developed to address.

The requirements of Article 5.7 were first set out in Japan - Agricultural Products II. The Appellate Body noted that Article 5.7 lays down four requirements for provisional measures. Two of these requirements relate to the conditions for adoption of provisional measures, and two to the conditions for their maintenance. Under the first sentence, the provisional measure may be adopted if it is: (1) imposed in respect of a situation where 'relevant scientific information is insufficient' and (2) adopted 'on the basis of available pertinent information.' Under the second sentence, the measure may not be maintained unless the Member (1) seeks to 'obtain the additional information necessary for a more objective assessment of risk' and (2) reviews the measure accordingly 'within a reasonable period of time'. ${ }^{1310}$ These requirements have been held to be cumulative. ${ }^{1311}$ Thus, as discussed above, as the case law now stands, all four requirements of Article 5.7 must be met in order for an SPS measure to be exempt from the scientific disciplines of the SPS Agreement.

\subsubsection{Insufficient scientific evidence}

Clearly, the first requirement for the adoption of a provisional measure, namely that 'relevant scientific evidence is insufficient', is what triggers the application of Article 5.7. It is thus crucial to determine in what circumstances this criterion will be met.

In Japan - Agricultural Products II, Japan argued that the meaning of sufficiency in this Article must be the same as that of the same term in Article 2.2. ${ }^{1312}$ This would mean that there is insufficient scientific evidence, and thus Article 5.7 applies, in cases where there is no 'rational relationship' between the available evidence and the SPS measure. The US, on the other hand, averred that the reference to sufficiency in Article 5.7 relates to the sufficiency of the available evidence to enable the conduct of a risk assessment. Thus, at the time of adoption of the provisional measure, the information necessary for an objective risk assessment must be lacking. This is quite different from the case where there is sufficient evidence to conduct a proper risk assessment, but the results of the risk

\footnotetext{
${ }^{1308}$ For a discussion of the importance of international law norms in providing a normative framework for the interpretation of the SPS Agreement, thereby providing a firm foundation for the way in which its trade/ health balance is given effect in dispute settlement, see below, Part IV, Section 2.2.4.

${ }^{1309}$ And possibly, to a limited extent, to the interpretation of Article 2.2 of the SPS Agreement. See above, Part III, Section 3.2.3.2.

${ }^{1310}$ Appellate Body Report, Japan-Agricultural Products II, para. 89. These four requirements were reiterated in Appellate Body Report, Japan - Apples, para. 176.

${ }^{1311}$ Appellate Body Report, Japan - Agricultural Products II, para. 89.

${ }^{1312}$ Ibid., para. 12.
} 
assessment do not reasonably support the measure adopted, as is the case when Article 2.2 is violated. To allow recourse to Article 5.7 in these cases would, according to the US, make the obligation contained in Article 5.1 meaningless. ${ }^{1313}$ In this case the Panel found it unnecessary to decide on this issue for reasons of judicial economy, with which the Appellate Body agreed. ${ }^{1314}$ Nevertheless, it seems that the interpretation given by the US to the requirement in Article 5.7 is logical to the extent that it limits the use of Article 5.7 to cases of where the scientific evidence available does not permit a risk assessment to be conducted, in accordance with its purpose, rather than allowing it to provide a loophole for adopting measures unsupported by the evidence embodied in a risk assessment.

In Japan - Apples, the Panel addressed the relationship between the 'sufficiency' concepts of Articles 2.2 and 5.7 in its examination of the first criterion of Article 5.7. The Panel had found that Japan's quarantine requirements for the importation of apples from the US were maintained without sufficient scientific evidence for purposes of Article 2.2, since the scientific evidence showed that the risk of transmission of fire blight by the importation of apples was negligible. ${ }^{1315}$ The Panel then proceeded to examine Japan's claim, in the alternative, that its measure was justified under Article 5.7. It started by determining whether the first requirement of Article 5.7 was met. In this context, it stated:

We first note that the existence of a situation where "relevant scientific evidence is insufficient" cannot be merely presumed on the basis of the fact that the measure at issue has been found to be maintained "without sufficient scientific evidence" pursuant to Article 2.2. The fact that a particular measure, in this instance the set of requirements applied by Japan to the importation of US apple fruit, is found to be maintained without sufficient scientific evidence may not necessarily dispose of the separate question, under Article 5.7, of whether the situation is one where "relevant scientific evidence" is insufficient. ${ }^{1316}$

The Panel noted that the 'relevant scientific evidence' for purposes of Article 5.7 included 'not only evidence supporting Japan's position, but also evidence supporting other views.' ${ }^{1317}$ This differs from the situation under Article 2.2, where it must be examined whether there is 'sufficient scientific evidence' supporting the views of the Member imposing the measure, in order for there to be a rational relationship between the evidence and the measure imposed. In the case before it, the Panel found that a wealth of scientific evidence was available and had been submitted not only by the parties to the dispute but also by the experts consulted by the Panel. ${ }^{1318}$ It found:

\footnotetext{
1313 Ibid., para. 27.

1314 Ibid., para. 91. While it is clear that, since the requirements of the second sentence of Article 5.7 were not met, Japan could not rely on Article 5.7 to justify its measure and it was unnecessary to go on to investigate whether Japan complied with other two requirements of Article 5.7, it would seem more logical to have started the analysis by determining whether Article 5.7 is applicable to the case at all. For this purpose, it would have been useful to examine the first requirement, which triggers the application of this article when 'scientific evidence is insufficient.' The EC expressed the view in its third party submission in Japan-Agricultural Products II, that both the requirements of the first sentence are the triggers for the operation of Article 5.7 and should therefore be examined first. Appellate Body Report, Japan - Agricultural Products II, para. 64.

1315 This finding is discussed above, Part III, Section 3.2.3.1.

1316 Panel Report, Japan-Apples, para. 8.215.

1317 Ibid., para. 8.216.

1318 It is interesting to note that the Panel in this case found that the insufficiency of the scientific evidence is
} 
The current "situation", where scientific studies as well as practical experience have accumulated for the past 200 years, is clearly not the type of situation Article 5.7 was intended to address. Article 5.7 was obviously designed to be invoked in situations where little, or no, reliable evidence was available on the subject matter at issue. With regard to fire blight, not only a large quantity but a high quality of scientific evidence has been produced over the years that describes the risk of transmission of fire blight through apple fruit as negligible. ${ }^{1319}$ Moreover, this is evidence in which the experts have expressed strong and increasing confidence. We therefore are of the view that the first condition of the first sentence of Article 5.7 is not met. ${ }^{1320}$

The Appellate Body in Japan - Apples endorsed the Panel's approach. It further found that for purposes of Article 5.7, relevant scientific evidence will be insufficient 'if the body of available scientific evidence does not allow, in quantitative or qualitative terms, the performance of an adequate assessment of risks as required under Article 5.1 and as defined in Annex A to the SPS Agreement." ${ }^{1321}$ It noted that it is not 'scientific uncertainty' that triggers the application of Article 5.7, but rather the 'insufficiency of scientific evidence', emphasising that '[t] he two concepts are not interchangeable.' ${ }^{1322}$ This finding demarcates the limits of the situations covered by Article 5.7 to a specific category of cases within the broader concept of 'scientific uncertainty', namely those cases where a risk assessment as required by Article 5.1 and Annex A.4 is rendered impossible by the insufficiency of the available scientific evidence. ${ }^{1323}$

In EC - Approval and Marketing of Biotech Products, the EC argued that the safeguard measures taken by some of its Member States against imports of biotech products could be justified under Article 5.7, as they were provisional measures. The Panel disagreed, finding that the trigger for applicability of Article 5.7 is the insufficiency of the scientific evidence, not the provisional nature of the measure at issue. ${ }^{1324}$ It noted that whether the scientific evidence is insufficient for the performance of a risk assessment must be determined on a case-by-case basis. ${ }^{1325}$ In addition, the Panel disagreed with the EC that

meant to refer to the evidence in general on the SPS question at issue and not to a specific aspect of the SPS problem. It thus rejected Japan's argument that evidence was insufficient on certain aspects of the dissemination of the bacteria. However, it later stated that even if Japan's argument was accepted, there was a large volume of relevant scientific evidence even on the specific questions raised by Japan and thus the first requirement of Article 5.7 was still not met. Ibid., paras 8.217-218.218 and 218.220.

1319 Annex 3, Dr Hale and Dr Smith, paras. 342 and 343 (footnote in the original).

${ }^{1320}$ Panel Report, Japan - Apples, para. 8.219. Emphasis added.

${ }^{1321}$ Appellate Body Report, Japan - Apples, para. 179.

1322 Ibid., para. 184.

${ }^{1323}$ As noted above, other aspects of scientific uncertainty that lead to precautionary approaches, including those of conflicting scientific evidence and of gaps in scientific data, have been dealt with by the pragmatic interpretation of the requirements of for a risk assessment. See above, Part III, Sections 5.1.5.1 and 5.1.5.2. See further Doaa Abdel Motaal, 'Is the World Trade Organization Anti-Precaution?' Journal of World Trade 39 (3), 2005, 483-501, 496.

${ }^{1324}$ The Panel noted that the provisional adoption of an SPS measure is not a precondition for the application of Article 5.7. Instead, the provisional adoption of an SPS measure is permitted by the first sentence of Article 5.7 (if certain conditions are met). Panel Reports, EC-Approval and Marketing of Biotech Products, para. 7.2939 .

${ }^{1325}$ Ibid., para. 7. 1350. This finding was reiterated in Panel Report, US - Continued Suspension, paras 7.6257.626; Panel Report, Canada - Continued Suspension, paras 7.603-7.604. 
the insufficiency of the scientific evidence must be assessed in relation to the appropriate level of protection of the importing Member. ${ }^{1326}$ It held:

The protection goals of a legislator may have a bearing on the question of which risks a Member decides to assess with a view to taking regulatory action, if necessary. And a legislator's protection goals are certainly relevant to the determination of the measure ... to be taken for achieving a Member's level of protection against risk. Yet there is no apparent link between a legislator's protection goals and the task of assessing the existence and magnitude of potential risks. ${ }^{1327}$

In the cases at hand, the Panel found that the scientific evidence was not 'insufficient', as enough evidence was available to permit a risk assessment as required under Article 5.1. This was evinced by the fact that the relevant EC scientific committees had conducted risk assessments prior to approving the biotech products at issue, and had reviewed these risk assessments after the adoption of safeguard measures by the Member States concerned. Both the initial assessments and the review assessments were found by the Panel to constitute 'risk assessments' within the meaning of Article 5.1 and Annex A.4 of the SPS Agreement. ${ }^{1328}$ Thus, according to the Panel, this was not the kind of situation in which Members are allowed to adopt provisional measures.

Interestingly, in an unprecedented move following public criticism on its leaked interim report, the Panel issued a letter to the Parties clarifying some of its findings on the issue of insufficient scientific evidence under Article 5.7. ${ }^{1329}$ It made clear that insufficiency can be quantitative or qualitative. It also emphasised that in applying the concept of insufficiency it had born in mind the Appellate Body's statement in EC-Hormones that the risk to be assessed is real world risk, rather than only risk ascertainable in a laboratory under controlled conditions. Further, it noted that its findings preserve the freedom of Members to take prompt protective action in case new scientific evidence becomes available that affects the relevant risk assessments. It pointed out that the possibility remains open that scientific evidence which is sufficient for a risk assessment at one time may later be considered insufficient. This would be the case if new scientific evidence negates the validity of the existing risk assessment but is itself insufficient to permit the performance of a new risk assessment.

\footnotetext{
1326 The Panel found that 'insufficient' in Article 5.7 relates to the sufficiency of the scientific evidence to permit the performance of a risk assessment as defined in Annex A(4). Panel Reports, EC-Approval and Marketing of Biotech Products, para. 7.3239. In addition, the Panel held that the insufficiency of the scientific evidence must be assessed at the time when the provisional measure was adopted. Ibid., para. 7.3253.

1327 Ibid., para. 7.3238. This finding was cited and followed in Panel Report, US - Continued Suspension, para. 7.609; Panel Report, Canada-Continued Suspension, para. 7.587.

${ }^{1328}$ Panel Report, EC - Approval and Marketing of Biotech Products, para. 7.3260 (in respect of Austria's ban on T25 maize). Similar findings were made for the other safeguard measures challenged in this dispute.

1329 This letter is appended to the Panel Reports in EC-Approval and Marketing of Biotech Products as Annex K. It appears that the Panel was concerned that its findings (in the leaked interim Panel Reports) had been misconstrued, leading to public concern regarding the scope for government action in areas where science is in a state of flux.
} 
This is precisely the type of situation that, according to the EC, was present in US Continued Suspension and Canada-Continued Suspension. ${ }^{1330}$ In this case the EC had replaced its ban on the import of beef from cattle treated with six growth hormones (which had previously been found to be in violation of the SPS Agreement in EC-Hormones) with a provisional ban on beef treated with five of the hormones at issue and a final ban on beef treated with the sixth hormone. The EC argued that its provisional ban was justified under Article 5.7 as 'Article 5.7 of the SPS Agreement is applicable not only when no risk assessment can be made at all, but also when the latest scientific evidence from any credible and objective source raises doubts or puts into question the previously held scientific opinion about the safety or dangerous nature of the substance in question. ${ }^{1331}$ All parties to the dispute agreed that scientific evidence which was previously deemed sufficient could subsequently become insufficient and that there could be situations where new studies could affect the conclusions of existing risk assessments. ${ }^{1332}$ According to the EC, the body of evidence had developed since the EC-Hormones case, and although a complete and definitive risk assessment was still not possible, the evidence 'support[ed] the conclusion that precautionary measures [were] required in order to achieve its chosen level of protection. ${ }^{1333}$ It regarded its high level of protection as relevant to the determination whether the relevant scientific evidence is insufficient, because a Member applying a high level of protection may require more information than that provided and may therefore disagree with an international standard based on such evidence. ${ }^{1334}$

The Panels agreed with the parties that:

...there could be situations where existing scientific evidence can be put in question by new studies and information. There could even be situations where evidence which supported a risk assessment is unsettled by new studies which do not constitute sufficient relevant scientific evidence as such to support a risk

${ }^{1330}$ Note, as stated above, that the Panels' conclusions on all aspects of the analysis under the SPS Agreement (including that under Article 5.7) were made in the context of their evaluation of whether the EC had removed the measure found to be WTO inconsistent in the $E C$-Hormones dispute, and therefore whether the US and Canada violated Article 22.8 of the DSU by maintaining their suspensions of concessions in that case. Consequently, the Panel made no findings with regard to the SPS Agreement in its final conclusions.

1331 Panel Report, US - Continued Suspension, para. 7.615; Panel Report, Canada - Continued Suspension, para. 7.595. Further, the EC argued that: 'due to the dynamic nature of scientific knowledge, a risk assessment that may at one point in time have been based on sufficient scientific evidence may need to be reviewed when new scientific evidence becomes available. In addition, new international risk assessment standards may become available that have to be taken into account in new risk assessments.' Panel Report, US Continued Suspension, para. 7.616; Panel Report, Canada-Continued Suspension, para. 7.596.

1332 Panel Report, US - Continued Suspension, para. 7.597; Panel Report, Canada - Continued Suspension, para. 7.619.

${ }_{1333}$ Panel Report, US - Continued Suspension, para. 7.588; Panel Report, Canada - Continued Suspension, para. 7.557. In particular, the EC argued that although the evidence pointed to a number of risks, it was full of gaps and important contradictions had developed which rendered the JECFA conclusions of 1988, 1999 and 2000 no longer valid. Panel Report, US - Continued Suspension, para. 7.589; Panel Report, CanadaContinued Suspension, para. 7.558.

1334 Panel Report, US - Continued Suspension, para. 7.604; Panel Report, Canada - Continued Suspension, para. 7.579. The EC formulated its level of protection as follows: "no (avoidable) risk, that is a level of protection that does not allow any unnecessary addition from exposure to genotoxic chemical substances that are intended to be added deliberately to food.' Panel Report, US - Continued Suspension, para. 7.607; Panel Report, Canada-Continued Suspension, para. 585. 
assessment but are sufficient to make the existing, previously relevant scientific evidence insufficient. ${ }^{1335}$

According to the Panels, this conclusion is supported by the fact that Article 2.2 of the SPS Agreement provides that sanitary measures must not be 'maintained without sufficient scientific evidence except as provided for in paragraph 7 of Article 5'1336 which 'suggests the possibility of an evolution from a situation of sufficient evidence to perform a risk assessment to one where, in substance, a risk assessment can no longer be performed.' 1337 However, in line with the findings of the Panel in EC-Approval and Marketing of Biotech Products, the Panels disagreed with the EC's contention that its level of protection is a relevant consideration in this regard. According to the Panels, a Member's level of protection is relevant in the choice of an SPS measure to address the risk, but 'should not influence the performance of the risk assessment as such.' 1338

In determining whether the relevant scientific evidence was indeed insufficient for purposes of Article 5.7, the Panels also refused to consider problems in obtaining the necessary evidence on misuse of hormones, despite the fact that the Appellate Body in $E C$ Hormones had recognised that this factor could be part of a risk assessment under Article 5.1. The Panels stated:

We recall that Article 5.7 is applicable when relevant scientific evidence is not sufficient to undertake a risk assessment in conformity with Article 5.1. Whether instances of misuse or abuse in the administration of hormones exist or not is not as such a scientific issue likely to make a risk assessment within the meaning of Article 5.1 and Annex A(4) of the SPS Agreement impossible. In our opinion, the scientific issue is related to the effect of the ingestion of high doses of hormones residues, not to potential or actual misuse or abuse in the administration of hormones. Therefore, we will not address the issue of non compliance with good veterinary practices in our analysis under Article 5.7 of the SPS Agreement. ${ }^{1339}$

The Panels then focused their analysis of the first requirement of Article 5.7 by examining when 'relevant scientific evidence' can become 'insufficient'. Recalling the finding of the Appellate Body in Japan - Apples cited above, ${ }^{1340}$ the Panels noted that while it is always possible to complete formally the four successive steps of a risk assessment, ${ }^{1341}$ this 'does

1335 Panel Report, US - Continued Suspension, para. 7.598; Panel Report, Canada - Continued Suspension, para. 7.620.

${ }^{1336}$ Emphasis added by the Panels.

1337 Panel Report, US - Continued Suspension, para. 7.621; Panel Report, Canada - Continued Suspension, para. 7.599.

1338 Panel Report, US - Continued Suspension, para. 7.609; Panel Report, Canada - Continued Suspension, para. 7.587.

1339 Panel Report, US - Continued Suspension, para. 7.603; Panel Report, Canada - Continued Suspension, para. 7.578.

1340 Appellate Body Report, Japan - Apples, para. 179.

1341 The four steps referred to here are those contained in the definition of a risk assessment in the CAC Procedural Manual, namely hazard identification, hazard characterisation, exposure assessment, and risk characterisation. As noted by the EC, while the CAC risk assessment guidelines are clearly relevant, the risk assessment criteria developed by WTO panels and the Appellate Body with regard to the definition of a risk assessment in the SPS Agreement would seem more relevant to this analysis. Panel Report, US - Continued 
not mean that such a process is equated with a risk assessment within the meaning of Article 5.1 and Annex A(4) of the SPS Agreement.' ${ }^{1342}$ According to the Panels:

Article 5.7 will apply in situations where, in substance, the relevant scientific evidence does not allow the completion of an objective evaluation of the potential for adverse effects on human or animal health arising from the presence of additives, contaminants, toxins or disease-causing organisms in food, beverages or feedstuffs. ${ }^{1343}$

Pointing out that insufficiency should not be confused with uncertainty, as held by the Appellate Body in Japan - Apples, ${ }^{1344}$ the Panels in US - Continued Suspension and Canada-Continued Suspension held that 'the fact that a number of aspects of a given scientific issue remain uncertain may not prevent the performance of a risk assessment. ${ }^{1345}$ In particular, the Panels excluded from the determination of 'insufficiency' under Article 5.7 'theoretical uncertainty' ${ }^{1346}$, uncertainty arising from divergent views on a scientific issue, ${ }^{1347}$ and uncertainties that may be present in the conclusions of a risk assessment despite the fact that there was sufficient evidence to perform the risk assessment. ${ }^{1348}$ Such uncertainty, according to the Panels, does not mean that 'previously sufficient evidence has become insufficient nor should it ipso facto justify the applicability of Article 5.7 of the SPS Agreement. ${ }^{1349}$

The Panels then turned to examine the implications of the existence of relevant international standards for the determination of 'insufficiency' of the scientific evidence. ${ }^{1350}$ The presumption of consistency with the SPS Agreement and the GATT 1994 of measures

Suspension, paras 7.448 and 7.445; Panel Report, Canada-Continued Suspension, paras 7.437 and 7.434.

1342 Panel Report, US - Continued Suspension, para. 7.628; Panel Report, Canada - Continued Suspension, para. 7.606. The Panels called the latter type of risk assessment a risk assessment 'in substance' to distinguish it from merely formally carrying out the four steps of a risk assessment.

1343 Panel Report, US - Continued Suspension, para. 7.628; Panel Report, Canada - Continued Suspension, para. 7.606.

1344 Appellate Body Report, Japan - Apples, para. 184.

1345 Panel Report, US - Continued Suspension, para. 7.637; Panel Report, Canada - Continued Suspension, para. 7.615.

${ }^{1346}$ This term refers to the uncertainty that always remains because science can never provide absolute certainty about the safety of a particular substance. The Panels here referred to the Appellate Body's finding in $E C$ - Hormones that theoretical uncertainty is not the kind of risk to be assessed under Article 5.1 of the SPS Agreement. Appellate Body Report, EC-Hormones, para. 186.

${ }^{1347}$ While noting the Appellate Body's finding in EC - Hormones that divergent views could be a form of scientific uncertainty, the Panels stated that uncertainty arising from divergent views can be factored into the conclusions of a risk assessment. In support of this view the Panels cited the Appellate Body's finding in Australia - Salmon that the existence of unknown or uncertain elements does not justify a departure from the requirements for a risk assessment. Appellate Body Report, Australia - Salmon, para. 130.

${ }^{1348}$ In this regard, the Panels relied upon the finding of the Panel in EC-Approval and Marketing of Biotech Products, which noted that the uncertainties present in a risk assessment may be legitimately taken into account by a Member when determining its SPS measure. Panel Reports, EC-Approval and Marketing of Biotech Products, para. 7.1525. Panel Report, US - Continued Suspension, paras 7.631-7.634; Panel Report, Canada-Continued Suspension, paras 7.609-7.612.

1349 Panel Report, US - Continued Suspension, para. 7.628; Panel Report, Canada - Continued Suspension, para. 7.606 .

${ }_{1350}$ The Panels recalled that Codex Alimentarius standards existed for 4 of the 5 hormones at issue under the Article 5.7 analysis. Panel Report, US - Continued Suspension, para. 7.643; Panel Report, CanadaContinued Suspension, para. 7.621. 
conforming to international standards, contained in Article 3.2 of the SPS Agreement, was held to imply that such standards are based on risk assessments meeting the requirements of the SPS Agreement, and therefore the existence of sufficient scientific evidence. ${ }^{1351}$ Acknowledging that 'science continually evolves' 1352 so that new scientific evidence could call into question existing evidence, the Panels nevertheless held that 'some meaning' must be given to the role of international standards under the SPS Agreement and in particular the Article 3.2 presumption. ${ }^{1353}$ In order to properly take into account the existence of international standards in the case before them, the Panels decided to assess whether scientific evidence has become insufficient by determining 'whether the European Communities has produced any evidence of some sufficient change in the scientific knowledge so that what was once sufficient to perform an adequate risk assessment has now become insufficient (i.e., "deficient in force, quality or amount"). ${ }^{1354}$ Consequently, the Panels concluded:

[I]f relevant evidence already exists, not any degree of insufficiency will satisfy the criterion under Article 5.7 that "relevant scientific evidence is insufficient". Having regard to our reasoning above, particularly with respect to scientific uncertainty and the existence of international standards, we consider that, depending on the existing relevant evidence, there must be a critical mass of new evidence and/or information that calls into question the fundamental precepts of previous knowledge and evidence so as to make relevant, previously sufficient, evidence now insufficient. In the present case where risk assessments have been performed and a large body of quality evidence has been accumulated, this would be possible only if it put into question existing relevant evidence to the point that this evidence is no longer sufficient to support the conclusions of existing risks assessments. $^{1355}$

Examining the alleged insufficiencies identified by the EC, ${ }^{1356}$ and consulting the Panel experts in this regard, the Panels found that the EC had not shown that there was a "criti-

1351 Panel Report, US - Continued Suspension, para. 7.644; Panel Report, Canada - Continued Suspension, para. 7.622.

1352 Panel Report, US - Continued Suspension, para. 7.645; Panel Report, Canada - Continued Suspension, para. 7.623.

1353 Panel Report, US - Continued Suspension, para. 7.646; Panel Report, Canada - Continued Suspension, para. 7.624.

1354 Panel Report, US - Continued Suspension, para. 7.647; Panel Report, Canada - Continued Suspension, para. 7.625. Here the Panels referred to the definition of insufficient in The New Shorter Oxford English Dictionary (1993), 1384.

1355 Panel Report, US - Continued Suspension, para. 7.648; Panel Report, Canada - Continued Suspension, para. 7.626. In footnote, the Panels referred to the European Communities' argument that due to the long latency period of cancer and the numerous confounding factors it was unable to demonstrate the existence of a clear harm. However, the Panels noted that their test did not require the EC to show the existence of a clear harm in order for Article 5.7 to apply to its measure. Instead, the Panels stated; "Under the "critical mass" test, the new scientific information and evidence must be such that they are at the origin of a change in the understanding of a scientific issue.' Panel Report, US - Continued Suspension, footnote 782 to para. 7.648; Panel Report, Canada - Continued Suspension, footnote 730 to para. 7.626.

${ }^{1356}$ In particular the EC considered that the scientific evidence relied upon by JECFA and the CAC was insufficient with respect to the issues of: carcinogenicity; the daily hormone-production rate, particularly in pre-pubertal children; dose response and the lack of a safe threshold; bioavailability; and misuse or abuse of the growth hormones. Panel Report, US - Continued Suspension, para. 7.654; Panel Report, Canada 
cal mass of new evidence' that could make the previously sufficient scientific evidence become 'insufficient' for purposes of Article 5.7 of the SPS Agreement. ${ }^{1357}$

The Panels' requirement of a 'critical mass' of new evidence before evidence previously considered sufficient for risk assessment may become 'insufficient, sets a rather high threshold. This will ensure that once a relevant risk assessment has been performed, including one underlying an international standard, Article 5.7 will not create a broad loophole, allowing a Member to disregard the outcome the risk assessment if it disagrees with the conclusions contained therein. In order to call into question the continued validity of a risk assessment, a Member must show that new scientific evidence exists that leads to a change in the understanding of the scientific issue. ${ }^{1358}$ If this is not the case, the SPS measure at issue does not fall within the scope of application of Article 5.7. ${ }^{1359}$

\subsubsection{Available pertinent information}

The second criterion for the adoption of provisional measures, contained in the first sentence of Article 5.7, requires that the provisional measure be adopted 'on the basis of available pertinent information.' This requirement operates to induce a certain level of rationality in situations in which, by their very nature, an objective risk assessment is not possible. To avoid the arbitrary imposition of provisional measures in response to unfounded consumer fears or purely hypothetical risks, Article 5.7 requires that provisional measures be taken on the basis of 'available pertinent information'. While this logically requires something less than a risk assessment within the meaning of Article 5.1 and Annex A.4, what precisely would be considered 'pertinent information' is not defined. The only guidance given in Article 5.7 is that available pertinent information includes 'that from the relevant international organizations as well as from sanitary or phytosanitary measures applied by other Members.' It seems possible that where a risk assessment has been conducted by another Member or relevant organisation, but the regulating Member cannot rely on it as a 'risk assessment' for purposes of Article 5.1 due to the fact that it is insufficiently specific to the precise risk addressed in its regulation, or it is not 'appropriate to the circumstances' of the regulating Member, this risk assessment may still be relied upon as 'available pertinent information' for purposes of Article 5.7.

This possibility is illustrated by Argentina's BSE risk categorisation scheme. ${ }^{1360}$ In 2002, Canada, supported by the US, raised a trade concern before the SPS Committee regarding this categorisation, according to which Canada had been given a level 2 rating. ${ }^{1361}$ According to Canada, Argentina had copied the EC's risk categorisation scheme for BSE,

- Continued Suspension, para. 7.631.

1357 Panel Report, US - Continued Suspension, para. 7.835; Panel Report, Canada - Continued Suspension, para. 7.821.

${ }_{1358}$ Panel Report, US - Continued Suspension, footnote 782 to para. 7.648; Panel Report, Canada-Continued Suspension, footnote 730 to para. 7.626

1359 This does not mean that the measure is necessarily in violation of the SPS Agreement. It only means that the scientific obligations of the Agreement apply. The regulating Member is still free to rely on divergent scientific opinions embodied in a risk assessment meeting the requirements of the SPS Agreement.

${ }^{1360}$ Committee on Sanitary and Phytosanitary Measures, Specific Trade Concerns. Note by the Secretariat. Addendum. Resolved Issues, G/SPS/GEN/204/Rev.8/Add.3, circulated on 27 March 2008, item 125.

${ }^{1361}$ Committee on Sanitary and Phytosanitary Measures, Summary of the Meeting Held on 25-26 June 2002. Note by the Secretariat, G/SPS/R/27, circulated on 2 August 2002, paras 60-63. 
and had not followed an international standard or conducted its own risk assessment. Argentina argued that its measures were based on the available information. It seems therefore that Argentina made use of the EC's assessment of BSE risks from various countries, and its consequent categorisation of these countries, as pertinent information on which to base its measures. Argentina pointed out that it had had to take urgent action to update its BSE measures and that any delay would have posed unacceptable risks to Argentina's own BSE status. It indicated its willingness to review its BSE categorisation on the basis of risk assessments. ${ }^{1362}$

In Japan - Agricultural Products II, ${ }^{1363}$ Japan - Apples, ${ }^{1364}$ and EC - Approval and Marketing of Biotech Products, ${ }^{1365}$ judicial economy precluded the application of this requirement to the disputes at issue. However, in the latter case the Panel did analyse the meaning of the second requirement as part of its examination of the relationship between Articles 5.1 and 5.7 of the SPS Agreement. ${ }^{1366}$ The Panel in EC-Approval and Marketing of Biotech Products noted that the reference in the third requirement of Article 5.7 to a more objective assessment of risk suggests that provisionally adopted SPS measures must also be based on a risk assessment, namely on a risk assessment that takes into account 'available pertinent information'. Thus, according to the Panel, such a risk assessment:

... would necessarily be different in nature from the kind of risk assessment envisaged in Annex A(4). In other words, any risk assessment which might be required by the first sentence of Article 5.7 would not need to meet the definition of a risk assessment contained in Annex A(4). ${ }^{1367}$

The Panel further supported its conclusion by pointing out that if the right conferred by Article 5.7 arises only when scientific evidence is insufficient for an adequate risk assessment under Article 5.1, as defined in Annex A.4, by definition the risk assessment

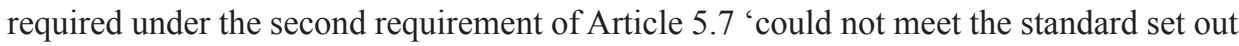
in Annex A(4).' ${ }^{1368}$

The word 'pertinent' indicates that the information must have a bearing upon or be relevant to the suspected risk. It would appear to indicate that the risk must be at least theoretically plausible on the basis of what evidence exists. The term 'pertinent' can be

${ }^{1362}$ This matter was reported resolved when, on the basis of scientific evidence submitted by Canada and the US to Argentina, Argentina undertook to conduct its own BSE risk assessments and to re-categorise the US and Canada on this basis. Committee on Sanitary and Phytosanitary Measures, Summary of the Meeting Held on 2-3 April 2003. Note by the Secretariat, G/SPS/R/29, circulated on 17 June 2003, paras 78-80.

${ }^{1363}$ Panel Report, Japan - Agricultural Products II, para. 8.59. This exercise of judicial economy was supported by the Appellate Body, which held: 'We, therefore, conclude that the Panel did not err in its application of Article 5.7 by first examining whether the varietal testing requirement meets the requirements of the second sentence of Article 5.7. Having established that the requirements of the second sentence of Article 5.7 are not met, there was no need for the Panel to examine the requirements of the first sentence.' Appellate Body Report, Japan - Agricultural Products II, para. 91.

${ }_{1364}$ Panel Report, Japan - Apples, para. 8.222.

1365 Panel Reports, EC - Approval and Marketing of Biotech Products, para. 7.

${ }^{1366}$ In particular, in applying the test set out in EC - Tariff Preferences to determine if these articles are in a relationship of exclusion or of exception to each other, the Panel had to examine whether Article 5.7 permits what Article 5.1 does not allow. For this reason, it examined inter alia the second requirement of Article 5.7.

${ }^{1367}$ Panel Reports, EC - Approval and Marketing of Biotech Products, para. 7.2992.

${ }^{1368}$ Panel Reports, EC-Approval and Marketing of Biotech Products, para. 7.2992. 
further elucidated by reference to the developing concept of the precautionary principle in international law. In earlier treaties embodying the precautionary principle, the available evidence had to relate to threats of serious or irreversible harm before recourse to the precautionary principle was justified. ${ }^{1369}$ However, more recently there has been a tendency to lower this evidentiary threshold or leave it out altogether. ${ }^{1370}$ It would appear that the average evidentiary threshold now required is a non-negligible threat of harm, but beyond that the formulation of the principle in the relevant treaty depends on the relevant circumstances of its negotiation. ${ }^{1371}$ As Article 5.7 in the SPS Agreement incorporates the precautionary principle with respect to health, rather than environmental protection, it seems clear, in the absence of an explicit provision requiring a stricter standard in Article 5.7, that no more than a non-negligible threat should be required to be indicated by the available information. ${ }^{1372}$

The question of when a provisional measure may be considered to be 'based on' the available pertinent information has not been clarified at all in the case law. In the light of the Appellate Body's interpretation of 'based on' in Article 5.1, it could be suggested that under Article 5.7, the SPS measure adopted must be 'reasonably supported' by whatever information exists. In other words, a reasonable concern that harm could result must be able to be derived from the available information. ${ }^{1373}$ Where contradictory information is present, it would appear that the measure need not reflect the preponderance of information, but could be based on a minority view that a potential of harm exists, provided this information comes from qualified and respected sources. ${ }^{1374}$

1369 The Appellate Body seems to support this high evidentiary threshold for the use of the precautionary principle outside the framework of Article 5.7, to interpret the requirement of 'sufficient scientific evidence' in Article 2.2. Appellate Body Report, EC-Hormones, para. 124, quoted above, Part III, Section 3.2.3.2.

${ }^{1370}$ For example, while the Bergen Ministerial Declaration on Sustainable Development in the ECE Region (Bergen, May 1990) required the threat of 'serious or irreversible' damage for the application of the precautionary principle (in art. 7), the Convention on the Ban of Import into Africa and the Control of Transboundary Movement and Management of Hazardous Wastes within Africa (Bamako, 29 January 1991) incorporates the precautionary principle (in art. 4(3)(f)) without requiring the threat of serious or irreparable harm. Similarly, the Cartagena Protocol on Biosafety (UNP/157, adopted 29 January 2000, entry into force 11 September 2003) refers only to 'potential adverse effect.' Both the latter conventions specifically relate to threats to humans as well as the environment, which could explain the lower threshold. See further Sands, P. Principles of International Environmental Law I - Frameworks, Standards and Implementation $1^{\text {st }}$ ed. (Manchester University Press, Manchester) 1995, 210-211.

1371 James Cameron and Juli Abouchar, 'The Status of the Precautionary Principle in International Law', in The Precautionary Principle and International Law: The Challenge of Implementation, David Freestone and Ellen Hey (eds.) (Kluwer Law International), 1996, 29-52, 44.

${ }^{1372}$ It its Communication on the Precautionary Principle, the EC Commission suggests that recourse to the precautionary principle should be allowed when it can be concluded from an evaluation of existing information that the desired level of protection could potentially be jeopardised by inaction. European Commission, Communication from the Commission on the Precautionary Principle, COM/2000/0001 (European Community, Brussels), 2 February 2000, 17

1373 This requirement is embodied in most treaties that incorporate the precautionary principle. See James Cameron and Juli Abouchar, 'The Precautionary Principle: A Fundamental Principle of Law and Policy for the Protection of the Global Environment', Boston College International and Comparative Law Review 14 (1), 1991, 1-27. for a brief discussion of the treaties that incorporate the precautionary principle.

1374 The EC Commission supports this view $(\operatorname{COM}(2000) 1$, at 17), referring to the following statement by the Appellate Body in EC - Hormones at para. 194, 'In some cases, the very existence of divergent views presented by qualified scientists who have investigated the particular issue at hand may indicate a state of scientific uncertainty.' 


\subsubsection{Information necessary for a more objective assessment of risk}

Article 5.7, in its second sentence, lays down two requirements for the maintenance of provisional measures. The first of these prohibits the maintenance of a provisional measure unless a Member 'seeks to obtain the information necessary for a more objective assessment of the risk.' This seems to imply that there must be an original evaluation of the risk before the provisional measure is imposed, although this need not be altogether objective. ${ }^{1375}$

In Japan - Agricultural Products II, Japan argued that the requirement to seek additional information was met by gathering information through the experience of the successful importation of varieties of agricultural products, by requiring exporting countries to submit data when applying for the approval of additional varieties. It claimed that Members are obliged to seek information but no actual results are required. ${ }^{1376}$ The US submitted that the information sought by Japan was not relevant to the question whether different varieties of agricultural products have different sorption levels. It thus did not enable Japan to review its measure and therefore did not meet the third requirement. ${ }^{1377}$ The Appellate Body noted in this regard that no explicit prerequisites are set out Article 5.7 or in any other provision of the SPS Agreement with respect to the 'additional information' to be collected or a specific collection procedure. Neither does Article 5.7 specify 'what actual results must be achieved'. ${ }^{1378}$ However, the Appellate Body noted that:

Article 5.7 states that the additional information is to be sought in order to allow the Member to conduct 'a more objective assessment of risk'. Therefore, the information sought must be germane to conducting such a risk assessment, i.e., the evaluation of the likelihood of entry, establishment or spread of, in casu, a pest, according to the SPS measures which might be applied. ${ }^{1379}$

As in this case the Panel had found that the information collected by Japan did not 'examine the appropriateness' of its SPS measure at issue and did not address the core issue of whether varietal differences caused divergence in quarantine efficacy, the Appellate Body endorsed the Panel's conclusion that Japan had not sought 'to obtain the additional information necessary for a more objective assessment of risk' as required by Article 5.7. ${ }^{1380}$

In EC-Approval and Marketing of Biotech Products, the Panel also examined the third requirement of Article 5.7 of the SPS Agreement. It regarded the term 'a more objective assessment of risk' as referring to a risk assessment within the meaning of Annex A.4, 'or at least which is closer to satisfying the definition in Annex A(4) than consideration of

1375 European Commission, Communication from the Commission on the Precautionary Principle, COM/2000/0001 (European Community, Brussels), 2 February 2000, 12. The EC Commission recommends that the evaluation of existing evidence constitute as complete a scientific evaluation as possible, encompassing both an inventory of existing evidence and an identification of the possible gaps in knowledge as well as the degree of scientific uncertainty at each stage (at 16).

1376 Appellate Body Report, Japan - Agricultural Products II, para. 13.

1377 Ibid., para. 26.

1378 Ibid., para. 92.

1379 Ibid.

1380 Ibid. The Panel pointed out that the information provided by exporting countries was based on studies designed and carried out to comply with Japan's varietal testing requirement. Thus they did not examine the appropriateness of the requirement itself. Panel Report, Japan-Agricultural Products II, para. 8.56. 
"available pertinent information". ' 1381 After noting the Appellate Body's finding in Japan - Apples that 'relevant scientific evidence' will be 'insufficient' within the meaning of Article 5.7 if the body of available scientific evidence does not allow the performance of a proper risk assessment as required under Article 5.1 and defined in Annex A.4, ${ }^{1382}$ the Panel pointed out that:

... if a Member may provisionally adopt an SPS measure on the basis of available pertinent information in situations where the scientific evidence is insufficient for an adequate risk assessment, as required by Article 5.1 and as defined in Annex A(4), it makes sense to require, as the second sentence of Article 5.7 does, that that Member seek to obtain "the additional information necessary" for such a risk assessment. Once a Member has obtained the additional information necessary for a risk assessment which meets the definition of Annex A(4), it will be in a position to comply with its obligation in Article 5.1 to base its SPS measure on a risk assessment which satisfies the definition of Annex A(4). ${ }^{1383}$

The duty to collect additional information is therefore clearly linked to the provisional nature of the measure, pending a final decision on the basis of a proper risk assessment. The obligation to seek the necessary information guards against the indefinite imposition of provisional measures that might result where no efforts are made to generate the data needed to assess the risk.

\subsubsection{Review within a reasonable period of time}

Finally, the second requirement for the maintenance of provisional measures, set out in the second sentence of Article 5.7 of the SPS Agreement, obliges Members to review the provisional SPS measure within a reasonable period of time. This is a reflection of the time-limited nature of such measures under the SPS Agreement. Cooney and Lang note that the requirement in Article 5.7 of review in the light of additional information is well suited to the idea of 'adaptive governance' in the face of pervasive uncertainty. They state:

[A] 'learning' response to uncertainty does not end with the adoption of precautionary approaches, not does it elevate precaution to an over-riding principle on all occasions. ... it is necessarily accompanied by proactive measures to increase our knowledge base through policy experimentation. Furthermore, in learning approaches, policies primarily based on precaution are subject to ongoing review and revision as circumstances change and our state of knowledge advances. ${ }^{1384}$

In line with this approach, Article 5.7 can be seen as creating only a limited exemption from the normal SPS disciplines, pending review of the measure in the light of new evidence. However, as scientific uncertainty may sometimes persist for extended periods of time, artificially linking the requirement of review to a fixed time limit was avoided in

\footnotetext{
${ }^{1381}$ Panel Reports, EC-Approval and Marketing of Biotech Products, para. 7.2988.

1382 Appellate Body Report, Japan - Apples, para. 179.

${ }_{1383}$ Panel Reports, EC - Approval and Marketing of Biotech Products, para. 7.2990.

${ }^{1384}$ Rosie Cooney and Andrew T.F. Lang, 'Taking Uncertainty Seriously: Adaptive Governance and International Trade', European Journal of International Law 18 (3), 2007, 523-551, 542.
} 
the SPS Agreement. Instead, Article 5.7 refers to a 'reasonable period of time'. Thus, the possibility for a Member to maintain a measure as long as necessary for a scientific assessment to establish the presence or absence of a risk, is not compromised.

The Appellate Body in Japan - Agricultural Products II had to decide on what constitutes a 'reasonable period of time' within which to review the measure. The Panel noted that Japan had first applied its varietal testing requirement in 1969, and that since the entry into force of the SPS Agreement in 1995, Japan had been 'under an explicit obligation to collect additional information to enable it to more objectively review the appropriateness of the varietal testing requirement. ${ }^{1385}$ However, the Panel found no evidence that Japan had done so within a reasonable period of time. ${ }^{1386}$ On appeal, regarding this element of Article 5.7, the Appellate Body held:

In our view, what constitutes a 'reasonable period of time' has to be established on a case-by-case basis and depends on the specific circumstances of each case, including the difficulty of obtaining the additional information necessary for the review and the characteristics of the provisional SPS measure. ${ }^{1387}$

As in the case at hand, the Panel had found that it would be 'relatively easy' to collecting the necessary additional information to review the measure, the Appellate Body held that despite the fact that the obligation to review the varietal testing requirement had only existed since 1 January 1995, Japan had not reviewed its varietal testing requirement 'within a reasonable period of time'. ${ }^{1388}$ In Australia - Salmon, although Article 5.7 had not been invoked, the Panel made an obiter statement regarding the temporal dimension of Article 5.7, stating that it did not consider that Article 5.7 applied to the measure in dispute 'given the fact that it was imposed more than 20 years ago and can thus hardly be seen as a measure 'provisionally' adopted.' ${ }^{1389}$ However, it should be recalled that there is no time limit expressed in Article 5.7 on the existence of a 'provisional measure'. While it seems logical that an indirect limit is inherent in the requirement of review within a 'reasonable period' the length of this period is subject to the particular circumstances of the case and cannot be determined in the abstract. Thus it is not the length of time for which a measure has been in existence per se that is crucial to its 'provisional' nature but rather the review thereof, within a reasonable period, which indicates that the measure is not final.

It is interesting to note in this regard that, in its Communication on the Precautionary Principle, ${ }^{1390}$ the European Commission interpreted the requirement of review 'within a reasonable period of time' to include the time needed for completion of the necessary scientific work as well as the time needed for performance of a risk assessment based on the conclusions drawn there from. Thus the provisional nature of measures under Article 5.7

\footnotetext{
${ }^{1385}$ Panel Report, Japan - Agricultural Products II, para. 8.57.

1386 Ibid.

1387 Appellate Body Report, Japan - Agricultural Products II, para. 93.

1388 Ibid.

1389 Panel Report, Australia - Salmon, para. 8.57.

1390 European Commission, Communication from the Commission on the Precautionary Principle, COM/2000/0001 (European Community, Brussels), 2 February 2000. See also Committee on Sanitary and Phytosanitary Measures, Communication by the European Communities on the Precautionary Principle, G/ SPS/GEN/168, circulated on 14 March 2000.
} 
was argued to be dependent on the development of scientific knowledge, rather than on a specific time limit. ${ }^{1391}$ This interpretation is partially supported by the Appellate Body's finding that one of the factors to be considered in the determination of what constitutes a reasonable period of time in a given case is the difficulty of obtaining the additional information necessary for the review. Clearly the state of scientific knowledge has a direct impact on the difficulty of obtaining the required information and would thus affect the determination whether a 'reasonable period' has elapsed. This is significant in that it relativises the temporary nature of measures allowed under Article 5.7 and makes provision for circumstances where scientific uncertainty persists for extended periods or where the risks involved are expected to materialise only in the long term. On the other hand, it is important to note that the difficulty of obtaining information is not the sole criterion. The specific circumstances of the case will be evaluated, including factors such as the characteristics of the SPS measure at stake, amongst others, in order to establish whether this criterion has been met. Nonetheless, it seems important to make sure that the determination of what constitutes a 'reasonable period' in each case be made with particular regard to the reality that the state of scientific knowledge has a decisive influence on whether a 'more objective assessment of risk' can be conducted. Therefore, artificially linking the requirement of review within a 'reasonable period of time' to specific deadlines should be avoided. In this way, Members need not fear that reliance on Article 5.7 to justify their measures will compromise their ability to maintain the measure as long as is necessary for scientific evidence to come up with clear answers. ${ }^{1392}$

When the four requirements of Article 5.7 are met, Members may take provisional measures. If these requirements are interpreted in a flexible way to allow recourse to precautionary measures when the available science does not yet permit a risk assessment within the meaning of Article 5.1 and Annex A.4 of the SPS Agreement, but a plausible case can be made for the existence of a risk on the basis of existing information, Article 5.7 would seem to provide an adequate vehicle for the incorporation of the precautionary principle into the SPS disciplines relating to risk management. By laying down specific requirements for the exercise of the right to take provisional measures, Article 5.7 operates to avoid abuse of this right. It ensures that a framework is in place within which risk management decisions taken in the face of insufficient scientific evidence can be disciplined, to promote rationality.

This does not imply that scientific uncertainty exists only in limited cases of insufficient evidence, which can be dealt with be means of temporary solutions until certainty is achieved. The true state of affairs is that uncertainty is a more common situation than

1391 European Commission, Communication from the Commission on the Precautionary Principle, COM/2000/0001 (European Community, Brussels), 2 February 2000, 21.

${ }^{1392}$ The fact that the EC supports this interpretation of a 'reasonable period of time' could explain why it has changed its approach from the one it followed in EC-Hormones, where it did not rely on Article 5.7 as it refused to classify its ban on hormone treated meat as a 'provisional measure' under Article 5.7, fearing that the temporary nature of such a measure would undermine its hormones regime. Now, in statements claiming that it is now in compliance with the ruling in EC-Hormones, the EC avers that its continued ban on meat treated with the relevant hormones (except 17- $\beta$ oestradiol, for which it has adopted a permanent ban based on conclusions from new studies) is a provisional measure in terms of Article 5.7, pending the results of studies to determine the effects of the relevant hormones on human health. Bridges Weekly Trade News Digest, 30 May 2000. 
certainty in scientific affairs. It is often incorporated into assumptions or rules of thumb used in risk assessments where gaps in evidence exist. In this way, the biases underlying these assumptions remain hidden. It is argued that it would be better to deal openly with the uncertainties inherent in scientific analysis. By recognising the pervasive nature of uncertainty and the gaps in information inherent in scientific analysis and by allowing Members to explicitly take account of these problems through conservative or prudent approaches to risk regulation, using the flexibilities in the SPS Agreement to do so, panels and the Appellate Body could contribute to greater transparency in SPS regulation. The Appellate Body has already taken some steps along this path.

\subsection{Conclusion}

The examination in Chapter 4 of the harmonisation disciplines in Article 3 of the SPS Agreement was instructive in elucidating the role of science in policing the delicate balance between trade liberalisation and health protection. Where no international standards exist or where Members wish to deviate from these standards in the exercise of their sovereign right to choose their appropriate level of protection, 'scientific justification will operate to generate norms and rules. ${ }^{.1393}$

Scientific justification can be seen as counterbalancing the regulatory autonomy of Members, reflected in the policy space reserved to them in the SPS Agreement, by imposing rigorous disciplines. The reason for the choice of science as the tool to bring about this balance is the fact that it was seen to be a universal body of knowledge, based on physical experience, neutral and thus valid for all. Therefore, requiring that national regulations which differ from harmonised standards follow the dictates of science as embodied in risk assessment is intended to result in generally acceptable limits and in greater uniformity of health measures by promoting gradual regulatory convergence across national borders.

However, there is currently broad recognition among scientists and regulators of the limits of science. Science is neither universal nor absolute. Risk assessments are characterised by uncertainties and gaps in knowledge, which are dealt with by means of assumptions, models and rules of thumb which reflect the scientific culture and policy preferences that form the context for the risk assessment. As a result, conflicting scientific opinions may exist with regard to the same factual situation. The Appellate Body has interpreted the scientific obligations of the SPS Agreement to reflect this reality, in order to prevent these obligations from becoming rigid, unworkable restrictions on the regulatory autonomy of Members. In particular, it has allowed Members to consider 'real world' factors that contribute to risk (such as problems of control) in their risk assessments. It has avoided requiring a quantification of risk or a demonstration of a minimum threshold of risk in risk assessments. It has also allowed Members to rely on minority scientific opinions from qualified and respected sources. The Appellate Body has thus been careful to ensure that the use of science as a tool to balance trade and health in the SPS Agreement does not result in a skewed result through the unrealistic application of this tool.

1393 Jeffery Atik, 'Symposium - Institutions for International Economic Integration: Science and International Regulatory Convergence', Journal of International Law and Business 17, 1997, 736-758, 739. 
While this approach has been criticised as opening the door for the inclusion of nonscientific factors within risk assessment and thus making room for regulations based on irrational consumer fears, ${ }^{1394}$ it seems unlikely that the strict definitions of risk assessment, which have been interpreted by the Appellate Body to require proof of actual, not theoretical, risk, would allow for this. Instead, it seems that the Appellate Body's findings are an attempt to take into account factors that are not capable of strict quantifiable analysis, but nonetheless present a real risk for health. This should be seen as a positive development, although it stops short of explicitly recognising the role of science policy in risk assessment, as distinct from risk management decisions.

The fact that a more nuanced understanding of science and the subjective choices inherent in the assessment of risks is emerging does not mean that the reliance on science as a discipline for SPS regulation is completely misplaced. The scientific disciplines of the SPS Agreement have the definite benefit of encouraging rationality in risk regulation and thereby improving the quality of national decision making in this regard. Further, by ensuring that Members, at least in respect of risks from pests and diseases, evaluate the gravity of the potential consequences of the risk occurring, and that they take economic considerations into account, these disciplines increase the range of information available to regulators when making their risk management decisions. They also facilitate the monitoring of regulatory choices by national stakeholders.

However, these disciplines also entail significant costs. The rigorous requirements for a risk assessment necessitate a high level of scientific and technical capacity, something with is lacking in many Members at lower levels of development. Even developed-country Members have never successfully defended their SPS measures under the disciplines of Article 5.1 and Annex A.4 in the disputes under the SPS Agreement to date. It seems very unlikely that less developed Members will succeed in this regard. ${ }^{1395}$ The possibility for these Members to make use of 'borrowed' risk assessments to fill the gap left by their own lack of scientific capacity has been significantly narrowed by the requirement of a great degree of specificity read into the two definitions of 'risk assessment' in Annex A.4, and by the criterion of a risk assessment 'as appropriate to the circumstances'.

The strict scientific rules of the SPS Agreement could be expected to be advantageous to developing-country Members that export agri-food products, since they provide disciplines that can be used to challenge the SPS requirements of their trading partners. However, in order to do so, the complaining Member needs to have sufficient scientific capacity to identify the flaws in the scientific basis for the regulating Member's measure, and to pursue discussions on this basis. This capacity is frequently lacking in Members at lower levels of development.

\footnotetext{
${ }^{1394}$ Warren H. Maruyama, 'A New Pillar of the WTO: Sound Science', The International Lawyer 32 (3), 1998 , $651-677,672$.

1395 Note that, as discussed in Part IV below, the fact that developing-country Members have never yet been challenged in dispute settlement proceedings for non-compliance with the SPS Agreement does not mean that their inability to comply is not a problem. Many disputes regarding SPS issues are resolved through bilateral or multilateral discussions 'in the shadow of the law'. An examination of the compilation of the specific trade concerns raised by Members before the SPS Committee reveals that developing-country Members are increasingly called upon to defend the scientific basis of their SPS measures. See further below, Part IV, Section 2.2.7.
} 
The intrusive review by panels of the scientific evidence evaluated in a risk assessment undermines the scope for national choices in science policy decisions. Despite their assertions to the contrary, panels appear more than eager to conduct their own assessment of the scientific evidence contained in a risk assessment, relying on the opinions of the panel experts, and to replace the assessments of national authorities with their own views. As is discussed in Part IV below, this does not seem an appropriate role for panels. Contrary to what might be expected, an intrusive review by panels of the regulatory determinations of Members in a manner that undermines the room for legitimate policy choices does not lead to increased opportunities for market access. By skewing the balance of the SPS Agreement and thereby resulting in politically unacceptable outcomes of dispute settlement, such review increases the possibilities of non-compliance with the recommendations and rulings resulting from the panel and/or Appellate Body reports. This undermines the legal certainty and predictability of the regime put in place by the SPS Agreement.

While scientific obligations are used to discipline the risk assessment stage of the regulatory process in order to promote trade liberalisation, at the other side of the balance aimed at by the SPS Agreement is the right of Members to embody their own policy choices in their risk management decisions. Risk management decisions include the choice by a Member of the level of protection against SPS risk it wishes to secure on its territory, and its choice of an SPS measure to achieve this level of protection. These choices are based on both scientific evidence and other considerations such as technical and economic feasibility, societal value judgments and the effect on the regulated industry. The SPS Agreement gives national regulators substantial latitude in making risk management decisions, but there are certain non-scientific disciplines in place to ensure that the adverse trade effects of these decisions are limited as much as possible.

In particular, Member are free to choose the level of protection they deem appropriate in their national SPS regulation, provided that they do not make arbitrary or unjustifiable distinctions in comparable situations leading to discrimination or disguised trade restrictions. The latter discipline is contained in Article 5.5 of the SPS Agreement. The case law has given a very broad interpretation to the types of situations that will be considered comparable for purposes of Article 5.5. To avoid the result that an unrealistic constraint would thereby be placed on Members' ability to respond in a dynamic manner to differences in the nature and extent of the risks that arise, the two additional elements of Article 5.5 have been interpreted in a flexible manner. Differences in risks and in the difficulties of controlling risks are taken into account as justificatory factors, so that the resulting differences in the appropriate level of protection do not meet the criterion of 'arbitrary or unjustifiable' distinctions. In addition, the Appellate Body has made clear that the mere incorporation of non-scientific considerations, such as consumer concerns, in the decision to impose a certain appropriate level of protection is not sufficient to invalidate the chosen level of protection by rendering it a 'disguised restriction on trade'. This decision makes room for the important role of societal value judgements in risk management decisions.

In order to facilitate the implementation of Article 5.5, the SPS Committee is mandated to develop practical guidelines. These have been adopted and are known as the Guidelines on Article 5.5. These guidelines elaborate the practical steps that Members can take in their regulatory processes in order to promote consistency in appropriate levels of protection. However, complexity of the guidelines has been criticised as premised on the 
existence of a sophisticated and well-functioning regulatory system. This does little to address the difficulties that less-developed Members face in trying to achieve compliance with Article 5.5.

The risk management phase of the regulatory process involves not only the choice of an appropriate level of protection, but also the choice of an SPS measure to achieve this level of protection. The SPS measure chosen by a Member must have a 'rational relationship' with, a risk assessment, as explained above. In addition, Article 5.6 requires that Members ensure that their SPS measures are not more trade restrictive than required to achieve their appropriate level of protection. This discipline closely reflects the interpretation of the 'necessary' requirement of Article XX(b) of the GATT 1994. However, the express reference to alternative measures that achieve the appropriate level of protection of the Member concerned indicates the absence of room for strong proportionality testing in respect of the choice of an SPS measure. In addition, Article 5.6 recognises the fact that a less trade-restrictive measure could have high regulatory or compliance costs or could be impractical to implement. Therefore it includes a determination of whether the alternative measure proposed is technically and economically feasible for the regulating Member. This may be expected to provide significant flexibility for developing-country Members which may be constrained in their choice of SPS measure by their financial and technical limitations.

An additional manifestation of the respect in the SPS Agreement for the risk management decisions of Members is to be found in Article 5.7, which allows for provisional measures in the case of insufficient scientific evidence. This provision reflects recognition of the fact that Members have the right to act with precaution where there is insufficient scientific evidence to conduct a risk assessment. To prohibit Members from regulating in such cases would be to ignore the reality of gaps in scientific knowledge, to the detriment of SPS protection. The SPS Agreement therefore makes room for provisional measures in such cases, by exempting measures that fall under the terms of Article 5.7 from the scientific disciplines of Articles 2.2 and 5.1. This right is subject to specific conditions to prevent the creation of a broad loophole through which protectionist measures could slip. In the first place, its application is triggered only by cases in which the scientific evidence available does not allow, in quantitative or qualitative terms, the performance of a risk assessment as required under Article 5.1 and Annex A.4 of the SPS Agreement. Situations of theoretical uncertainty, conflicting scientific opinions and disagreement by a Member with the conclusions of a risk assessment are not covered by Article 5.7. Second, some level of rationality is induced, despite the fact that a proper risk assessment is not possible, by the fact that the provisional measure must be based on the available pertinent information. In addition, measures taken under Article 5.7 may only be maintained if the regulating Member makes efforts to obtain the additional information needed for a risk assessment and reviews the measure accordingly in a reasonable period of time. These requirements are in line with the approach of 'adaptive governance' in situations of pervasive uncertainty, in that they promote regulatory learning and ongoing review.

While the exemption provided by Article 5.7 has been interpreted to apply only where all four of its requirements are met, it is argued here that the right to take provisional measures should be available whenever the trigger for the applicability of Article 5.7 exists, namely insufficient scientific evidence. The remaining requirements of Article 5.7 
should rather be seen as requirements for the exercise of this right, than as conditions for its existence. 


\section{Conclusion to Part III}

The analysis in Part III of this books attempts to evaluate the balance struck by the relevant substantive provisions of the SPS Agreement between the competing interests of trade liberalisation in the food and agricultural sector and the protection of health, with specific regard to its development implications. To this end, the appropriateness for Members at different levels of development of the substantive disciplines used in the SPS Agreement to give effect to this balance is examined. In making this examination it is useful to recall the vast differences in trade and health priorities and regulatory capacity illustrated in Part II of this book. As became apparent through the examination of four Members at different income levels in Part II, some Members at high income levels attach great importance and devote enormous resources to SPS regulation. For Members at lower levels of development the available resources are restricted and may be directed to addressing more pressing development priorities. It is in this light that the development implications of the substantive disciplines of the SPS Agreement must be seen.

The criteria used for the evaluation of the relevant substantive disciplines of the SPS Agreement are those set out in the Introduction to this book, namely whether they effectively increase market access opportunities for WTO Members at lower levels of development; and whether they leave these Members sufficient policy space for SPS regulation. Both these criteria are important, as they reflect the values on either side of the scale that the SPS Agreement can be seen to represent. These values are economic growth through increased export opportunities, on the one hand, and the protection of health against SPS risks, on the other. Viewed in the light of the normative framework provided by the concept of the 'right to development', set out in Part I above, the importance of both sides of the balance for developing-country Members, as for all Members, is evident. The development dimension of the SPS Agreement lies in its potential to promote agri-food trade without endangering the protection of health in less developed Members.

The tools used in the SPS Agreement to achieve its balancing objective are best understood in the historical context leading up to the drafting of the Agreement. The inability of the existing rules of the GATT 1947 and the Standards Code to effectively address trade/health conflicts was made evident by the long-running dispute between the EC and the US concerning the EC ban on hormone-treated beef. An awareness of the need to improve these rules in order to avoid undermining the progress made in liberalising the agricultural sector formed the impetus for the negotiations in the Uruguay Round on SPS issues. However, this objective was counterbalanced by the broad recognition of the need to ensure appropriate respect for the ability of Members to meet their legitimate SPS regulatory objectives, to avoid politically unacceptable outcomes. While initially the intention was to amend the existing rules, in the course of the negotiations the recognition of the special character of SPS measures and the sensitivity of the competing interests they entail led to the realisation that a separate agreement was necessary to address this conflict. This agreement came to be called the SPS Agreement.

It is apparent from the overview of the negotiating history set out in Chapter 1 that the regulatory model embodied in the substantive disciplines of the SPS Agreement is that to be found in the proposals of the most active participants in the negotiations. The Agreement 
closely reflects best regulatory practices in developed-country Members. While the ideal of improving the practice of SPS regulation among Members through such best-practice disciplines is, in itself, laudatory, there is a danger of 'putting in place an unrealistic and unachievable model of regulatory practice. ${ }^{\prime 396}$ The examination of the relevant substantive rules of the SPS Agreement, as interpreted in the case law, carried out in Chapters 2 to 5 of this Part aimed to establish whether they embody such an 'unachievable model', or whether they offer workable tools for Members at lower levels of development to effect the trade/health balance.

This examination commenced in Chapter 2 by addressing the scope of application of the new regulatory disciplines contained in the SPS Agreement. Article 1.1 of the SPS Agreement, read together with Annex A.1, gives a clear indication of the type of situations which the new disciplines were intended to address, namely those involving a conflict between the liberalisation of agricultural trade and the protection of human, animal or plant life or health. Consequently, these provisions demarcating the coverage of the SPS Agreement address those health risks that may arise from trade in primary and processed agricultural products, such as food safety risks and risks from pests or diseases of plants or animals. To achieve this coverage, the relevant provisions speak to the purpose of the measure, to establish whether it is an 'SPS measure' falling within the ambit of the SPS Agreement. The variety of forms that such a measure might take is then broadly defined by means of an illustrative list of measures.

As discussed in Chapter 1, the interpretation of Annex A.1 by the Panel in EC-Approval and Marketing of Biotech Products has given the SPS Agreement unexpectedly broad coverage. This coverage now includes environmental protection measures that do not address plant or animal health. It is important to avoid being drawn into making the simplistic assumption that developing-country Members necessarily benefit from the resulting application of the strict scientific disciplines of the SPS Agreement to a wide range of measures. Such an easy generalisation ignores the diversity of positions and interests among developing-country Members, which are both exporters and importers of agrifood products. As such, these Members have the same interest as all other Members in ensuring that the particular disciplines of the SPS Agreement are applied to the specific situations they were crafted to address. The expansion of the application of these disciplines to areas they are ill-suited to is in no-one's interest. Instead, it should be recalled that the SPS Agreement is only one part of an 'inseparable package' of rights and obligations of WTO Members. Measures not covered by the SPS Agreement are not undisciplined. Rather, they are disciplined by the rules of other WTO agreements that address them more appropriately.

An issue of particular concern to many developing-country Members with regard to the applicability of the SPS Agreement is whether private sector SPS standards are covered by its rules. The rapidly increasing trend in recent years towards SPS norm creation and implementation at subnational and transnational levels by private sector actors has brought this issue to the fore. SPS standards are increasingly set and applied by private sector bodies, such as the large retail conglomerates that dominate large sectors of the market

1396 Catherine Button, The Power to Protect. Trade, Health and Uncertainty in the WTO (Hart Publishing, Oxford and Portland, Oregon), 2004, 93. 
for agri-food products. The distinction between binding SPS regulations and private SPS standards has therefore lost much of its meaning for exporters, for whom market access depends on compliance with private sector standards as much as, or sometimes even more than, with SPS regulations. The question thus arises whether the obligation on Members, in Article 13 of the SPS Agreement, to take such reasonable measures as may be available to them to ensure compliance by non-governmental and regional bodies should be interpreted to require them to use legislative means to impose the obligations of the SPS Agreement on private sector bodies that set, apply or check conformity with SPS standards. It is argued here that this would not be appropriate. The substantive disciplines of the SPS Agreement were drafted with national SPS regulators in mind, whose task it is to weigh up competing interests and whose tendency towards protectionism is appropriately constrained by internationally agreed trade disciplines. The aim of the SPS Agreement is to achieve a balance between the sovereign right of Members to protect health in their territories and the need to prevent protectionism under the guise of SPS regulation. The application of its disciplines to private sector bodies would not seem to further this objective. Private economic operators that set, apply or assess conformity with SPS standards have very different objectives from those of public regulators, including profit maximisation through responsiveness to consumer demands. Many of the regulatory disciplines of the SPS Agreement are clearly not appropriate for such private operators.

However, the fact that current regulatory disciplines of the SPS Agreement are not suitable for direct application to private sector standards, does not mean that the reality of the fact that such standards are a significant obstacle to agri-food trade, particularly from developing-country exporters, can be disregarded. The development impact of private sector standards merits serious attention. The question is how best this matter can be addressed. It is argued here that what is ideally needed is a Code of Good Practice, along the lines of that contained in the TBT Agreement, setting out procedural disciplines to address the main problems caused by private sector standards. These disciplines should promote transparency of private sector standards, the institution of consultation mechanisms to ensure participation in standard-setting by the relevant stakeholders, the recognition of equivalent standards, and the reduction of the burden caused by costly and complex conformity assessment procedures. However, this Code of Good Practice should stop short of requiring private sector bodies to base their measures on international standards, conduct risk assessments for their measures, or undertake any other activities inherent to the national regulatory process but inappropriate to the activities of private bodies. Members could then undertake to take reasonable measures available to ensure compliance with the SPS Code of Good Practice.

It seems unlikely, at present, that consensus will be reached on such a Code of Good Practice. It also appears that Members do not regard the Code of Good Practice of the TBT Agreement as relevant to private sector SPS standards. In addition, even if a Code of Good Practice were in place to discipline the procedural aspects of private sector standards, the burden of compliance with these standards remains high. Consequently, it is necessary to ensure the provision of effective and disinterested capacity building to enable developing-country exporters to comply with private sector standards. In the meantime, a pragmatic approach to this problem could be the continued use of the multilateral forum provided by the SPS Committee to raise concrete examples of the challenges created by 
private sector standards, in an effort to stimulate private sector bodies to be responsive to developing-country Members' needs in the elaboration and implementation of their standards, and to spur donors to provide technical assistance.

Within the limits of its scope of application, certain substantive disciplines of the SPS Agreement, as interpreted by panels and the Appellate Body, determine the scope for regulatory action by Members against SPS risks. The basic rights and obligations set out in Article 2 of the SPS Agreement epitomise the trade/health balance aimed at by the Agreement and the manner in which this balance is struck in the Agreement. The express recognition in Article 2.1 of the right of Members to take SPS measures is key in this respect. It has the result that, unlike the situation under the GATT 1994, Members imposing measures covered by the SPS Agreement do not bear the burden of justifying their measures under an exception to trade liberalisation disciplines. Instead, a Member wishing to challenge an SPS measure must establish a violation of specific disciplines of the SPS Agreement. The limits to the right to take SPS measures, first outlined in Articles 2.2 and 2.3, recur in more specific form in the rest of the SPS Agreement. These provisions reflect and build upon familiar GATT disciplines, requiring that health measures be limited to what is 'necessary' to achieve their aim, and prohibiting arbitrary or unjustifiable discrimination and disguised trade restrictions. Further, Article 2.2 introduces an innovative aspect of the SPS Agreement, namely the use of science as the scale on which the competing interests of trade and health are balanced.

This careful balance must be respected in the interpretation of the provisions of the SPS Agreement. There is therefore no room for the importation of a strong proportionality test arising from the 'necessary' requirements of Article XX(b) of the GATT 1994 into the 'necessary' requirement of Article 2.2 of the SPS Agreement. Neither is the strong proportionality test read into the 'sufficient scientific evidence' requirement of Article 2.2 by the Panel in Japan - Apples to be condoned. Requiring an SPS measure to be proportional to the seriousness or magnitude of the risk at issue is contrary to the balance that is the object and purpose of the Agreement. It deprives Members of the room to make their own policy decisions in their responses to risk. In view of the diversity in priorities, economic resources and risk-averseness of Members at different levels of development, reflected in the policy choices inherent to risk regulation, this result is to be avoided.

Harmonisation of SPS measures is promoted by Article 3 of the SPS Agreement in order to reduce the barriers to trade created by disparate requirements in various importing Members. In the absence of a rule-making body in the WTO entrusted with the task of providing generally applicable SPS requirements, Article 3 makes use of other international bodies as authoritative providers of uniform standards, namely the international standard-setting bodies referenced in Annex A.3. These international standard-setting bodies use recognised risk assessment procedures conducted by scientific expert bodies and discussed in committees to draw up standards. Their standards aim to reflect a large degree of scientific consensus on risk as well as policy agreement on the best way to address such risks. WTO Members are therefore encouraged to use these standards through the disciplines of Article 3 of the SPS Agreement.

Harmonisation of SPS measures around international standards has the potential to assist less-developed Members that lack the scientific capacity to undertake their own risk 
assessments as a basis for regulatory decisions. It thus seems imperative to interpret the autonomous options provided by Articles 3.1-3.3 in a manner that provides real benefits to Members that choose to base their SPS measures on international standards or to conform their measures to these standards, in contrast to the current interpretation. If an SPS measure that is 'based on' an international standard would be regarded as complying with the requirement of a scientific basis (in Articles 2.2 and 5.1), less-developed Members with limited scientific capacity could rely on the relevant international standard, and in particular the risk assessment that underlies it, while adjusting the aspects of the international standard that are not well-suited to their particular situations. While such a measure could still be challenged under the remaining disciplines of the SPS Agreement, such as those relating to necessity, consistency and non-discrimination, it would be safe from scientific challenges - a significant advantage for Members with weak scientific capacities. Similarly, if the presumption that SPS measures that 'conform to' international standards are consistent with the GATT 1994 and the SPS Agreement, contained in Article 3.2 of the SPS Agreement, would be interpreted as irrebuttable, it would provide a safe harbour for those Members whose weak regulatory capacity prompts them to fully adopt international standards. Such interpretations create a stronger impetus for harmonisation around international standards, without calling into question the right of Members to deviate from international standards if this is necessitated by their chosen level of protection. This interpretation therefore furthers the objective of Article 3 as outlined in the Preamble to the SPS Agreement.

However, any discussion of the potential benefits of the harmonisation provisions of the SPS Agreement for less-developed Members must be seen against the factual background of the problems of participation of these Members in the international standard-setting process, as set out in Part II. The preferences of the most active participants in the standard-setting process are reflected in both the science policy choices underlying the risk assessments on which international standards are based and risk management decisions taken in the international standard-setting bodies. The most influential participants are those with the most resources to dedicate to ensure the effectiveness of their participation, namely developed countries and industry groups. Efforts are already underway within the international standard-setting bodies to address the institutional and procedural constraints to developing-country participation, as discussed in Parts II and V of this book. However, it is clear that much remains to be done to redress the imbalance in participation of Members at different levels of development in the international standard-setting bodies. Without successful efforts in this regard, the harmonisation disciplines of the SPS Agreement will have a negative impact on development, contrary to their objective.

Harmonisation is not always possible, nor is it always desirable. Diverging SPS measures may be a reflection of the diversity in both capacity and policy priorities that exists in different Members and can be seen as a natural outcome of the exercise of sovereign regulatory authority by their governments. In the absence of harmonisation, the SPS Agreement relies on scientific justification to discipline regulatory decisions. These scientific disciplines counterbalance the regulatory autonomy of Members, reflected in the policy space reserved to them in the SPS Agreement. Science is regarded as a value-neutral benchmark, universally accepted and thus valid for all. As a result, the SPS Agreement requires that 
SPS measures that deviate from harmonised standards are rationally supported by science as embodied in a risk assessment.

A more nuanced understanding of science and the subjective choices inherent in the assessment of risks has emerged, undermining the possibilities for reliance on science as an objective yardstick against which to judge SPS regulation. However, this does not mean that the use of science in the disciplines on SPS measures is completely misplaced. The scientific disciplines of the SPS Agreement have the definite benefit of encouraging rationality in risk regulation and thereby improving the quality of SPS decision making. The Appellate Body has taken steps to prevent the scientific obligations of the SPS Agreement from becoming unrealistic, rigid and unworkable restrictions on the regulatory autonomy of Members. In this way, it has been careful to ensure that the use of science as a tool to balance trade and health in the SPS Agreement does not result in a skewed result through the unrealistic application of this tool.

This realistic approach has unfortunately not been taken by panels in their application of the scientific obligations of the SPS Agreement to the factual situations before them. Instead, panels have seen it as their task to engage in a detailed assessment of the scientific evidence underlying a Member's measure, and to come to an independent conclusion regarding the existence and extent of the risk at issue. The invasive application of the scientific rules of the SPS Agreement by panels might be expected to be advantageous to developing-country Members that export agri-food products, since they provide greater opportunities to challenge the SPS requirements of their trading partners. However, in order to do so, the complaining Member needs to have sufficient scientific capacity to identify the flaws in the scientific basis for the regulating Member's measure, and to pursue challenges on this basis. This capacity is frequently lacking in Members at lower levels of development. In addition, even where the necessary capacity to bring scientific challenges is present, the intrusive approach of panels does not, in fact, lead to increased opportunities for market access. By undermining the scope for national choices in science policy decisions, and thereby skewing the delicate balance of the SPS Agreement, these panel decisions result in politically unacceptable outcomes of dispute settlement. This increases the chances of non-compliance by a regulating Member with the recommendations and rulings of the DSB, thereby undermining the effectiveness of the SPS Agreement.

The scientific disciplines of the SPS Agreement also entail significant compliance costs for Members at lower levels of development. The rigorous requirements for a risk assessment necessitate a high level of scientific and technical capacity, something with is lacking in many Members at lower levels of development. The possibility for these Members to make use of 'borrowed' risk assessments to fill the gap left by their own lack of scientific capacity has been significantly narrowed by the requirement of a great degree of specificity read into the two definitions of 'risk assessment' in Annex A.4, and by the criterion of a risk assessment 'as appropriate to the circumstances'. Consequently, SPS regulations of less-developed Members are often vulnerable to challenges under the scientific obligations of the SPS Agreement.

In contrast to its strict scientific disciplines with regard to risk assessment, the SPS Agreement provides considerable elbow room for Members to give effect to their policy 
choices in their risk management decisions. This policy space left to Members is indicative of the balancing approach of the SPS Agreement. It acknowledges that Members have the right to choose the levels of protection against SPS risks that they deem appropriate. Such decisions are taken by national regulators on grounds of societal value judgements on issues such as what level of risk is considered acceptable in society, not purely on the basis of scientific analysis of risk. The SPS Agreement recognises this, by placing no requirement of establishing a scientific basis on the choice of the appropriate level of protection. Neither does it place any restrictions on the types of factors that Members may consider when deciding on their choice of level of protection. Thus particularised national health measures result even where the scientific basis for the measures is same everywhere

The only real discipline on the choice of a level of protection is the prohibition, in Article 5.5 , on arbitrary or unjustifiable distinctions in levels of protection applied in different but comparable situations, if these distinctions would lead to discrimination or a disguised restriction on trade. The broad ambit given in the case law to the situations that may be considered 'comparable' is tempered by the fact that distinctions in the levels of protection applied are only caught by the prohibition if they are arbitrary or unjustifiable. Panels and the Appellate Body have considered factors relating to the level of risk or difficulties of controlling the risk in the situations compared to determine if the differences in the level of protection chosen by a Member in these situations can be justified. However, in some cases, divergence in the appropriate level of protection is grounded in, often irrational, societal preferences rather than objective differences in risk. This is particularly the case with regard to the risks to which people voluntarily expose themselves, due to particular cultural practices. The SPS Committee is instructed, in Article 5.5, to take this into account in developing guidelines for the implementation of Article 5.5. Room has also been made by the Appellate Body for considerations unrelated to the risk at issue, including consumer concerns, to be factored in to the determination of an appropriate level of protection, by finding that such considerations will not render the chosen level of protection a 'disguised restriction on trade' for purposes of Article 5.5. This decision implies a positive recognition by the Appellate Body of the important role of societal value judgements in the making of risk management decisions.

The choice of an SPS measure to achieve a Member's chosen levels of protection is also disciplined in the SPS Agreement. Not only must these measures bear a rational relationship to a risk assessment, but, according to Article 5.6 of the SPS Agreement, they must also not be more trade-restrictive than required to achieve the appropriate level of protection of the regulating Member. While the least-trade-restrictive discipline is clearly drawn from the 'necessary test' of Article XX of the GATT, unlike the GATT the SPS Agreement excludes the possibility for strong proportionality testing by explicitly providing that any alternative measure proposed must achieve the regulating Member's appropriate level of protection. In addition, the technical and economic feasibility of the alternative measures is expressly considered. This ensures that unrealistic limits on a Member's choice of measure are avoided, in recognition of the fact that resource and capacity constraints play an important role in regulatory decisions. The examination of the space left to Members in the SPS Agreement to carry out their risk management policies is indicative of the balancing approach of the SPS Agreement. 
The SPS Agreement allows for risk management choices in the face of insufficient scientific evidence by providing scope, in Article 5.7, for provisional measures. When the four requirements of Article 5.7 are met, the relevant SPS measure is exempted from the scientific disciplines of Articles 2.2 and 5.1 of the SPS Agreement. Article 5.7 seems to provide an adequate vehicle for the incorporation of the precautionary principle into the SPS disciplines relating to risk management. By laying down specific requirements for the exercise of the right to take provisional measures, Article 5.7 operates to avoid abuse of this right. It ensures that a framework is in place within which risk management decisions taken in the face of insufficient scientific evidence can be disciplined, to promote rationality.

The examination of the relevant substantive disciplines of the SPS Agreement leads to two related conclusions. The first is that the balancing objective of the SPS Agreement is unmistakeably reflected in the way in which these substantive provisions are framed. As identified above, there are aspects of the interpretation of these provisions that do not fully give effect to the careful balance embodied in their terms. Nevertheless, the provisions themselves seem appropriate to address sensitive trade/health conflict in a way that promotes the liberalisation of agri-food trade while respecting the right of Members to regulate against SPS risks. However, the second conclusion that is evident from the discussion of the relevant substantive rules of the SPS Agreement is that these rules impose a regulatory model that is currently not achievable for many Members at lower levels of development. Neither are these Members able to use these substantive rules effectively to procure market access for their products.

The fact that Members at lower levels of development have not been challenged in dispute settlement proceedings to date, should not create the impression that this means that their inability to comply with the disciplines of the SPS Agreement has no real consequences for them. Many instances of non-compliance by these Members with the regulatory obligations of the Agreement have been challenged in the multilateral forum of the SPS Committee, or in bilateral discussions between Members. In these situations, it is often difficult for the regulating Member to justify its measure, other than to refer to its capacity constraints. For example, in response to a trade concern raised in 1996 by the US before the SPS Committee against Korea's import clearance measures and practices, Korea responded that while it had taken several measures to comply with the SPS Agreement it faced problems common to developing-country Members in doing so. These included 'a low level of sanitary infrastructure, lack of experience and information, and lack of relevant international standards. ${ }^{1397}$ Similarly, Venezuela responded to a complaint regarding its seemingly arbitrary practices in granting the SPS certificates necessary for imports by asking Members not to confuse problems of administrative capacity with a policy of discretionary import licensing. ${ }^{1398}$

Aside from the particular aspects of the interpretation of these substantive rules of the SPS Agreement, identified throughout this Part, that leave scope for improvement, it is

1397 Committee on Sanitary and Phytosanitary Measures, Specific Trade Concerns. Note by the Secretariat. Addendum. Resolved Issues, G/SPS/GEN/204/Rev.8/Add.3, circulated on 27 March 2008, item 2, para. 188.

1398 Committee on Sanitary and Phytosanitary Measures, Specific Trade Concerns. Note by the Secretariat. Addendum. Issues Not Considered in 2007, G/SPS/GEN/204/Rev.8/Add.2, circulated on 27 March 2008, item 123, para. 154. 
difficult to see how changes can be made to address developing-country constraints without skewing the careful balance sought by the Agreement. The rules themselves seem appropriate for the fulfilment of their function of allowing sufficient room for Members to regulate in a manner that gives effect to their policy priorities in the area of SPS risk, while disciplining such regulation to eliminate the possibilities for disguised protectionism and to reduce the adverse trade effects of legitimate measures. Nevertheless, the very real problem of the constraints that less-developed Members face in complying with, and benefiting from, these rules cannot be disregarded.

The question arises to what extent the remaining provisions of the SPS Agreement ameliorate this problem by taking account of the capacity constraints of Members at lower levels of development, both in respect of compliance with the disciplines of the Agreement and in respect of enforcement of these disciplines against other Members in order to gain market access. This question is addressed in Parts IV and V of this book. 


\section{Part IV}

Procedural and institutional mechanisms under the SPS Agreement 


\section{Introduction to Part IV}

As seen in Part III of this book, several of the substantive obligations of the SPS Agreement aim to set the limits of the policy space left to Members in the area of SPS regulation, by combining the traditional trade disciplines with new scientific disciplines and by encouraging harmonisation. These disciplines together function as a filter, to distinguish measures legitimately aimed at health protection from measures that are a disguised form of protectionism. In this way, the SPS Agreement tries to balance the often competing interests of trade liberalisation and health protection.

However, alone, these disciplines would not be sufficient to achieve significant gains in market access for food and agricultural products for Members at lower levels of development. These Members often lack the scientific and technical capacity to identify instances of non-compliance with the complex regulatory disciplines of the SPS Agreement and to formulate effective challenges in this regard. In addition, many legitimate SPS regulations that pass muster under the relevant substantive disciplines of the SPS Agreement nevertheless form significant trade barriers. This is particularly so for Members that face capacity constraints in keeping track of new and changed measures, understanding their implications and proving their compliance with SPS requirements (including by demonstrating the equivalence of their own SPS requirements, or by gaining recognition of the pest- or disease-free status of their territories or of regions within their territories). Additionally, substantive disciplines on their own are not useful without effective tools to monitor their implementation, and if necessary enforce compliance therewith. It is important to have additional mechanisms in place that address these institutional and procedural matters.

Therefore the SPS Agreement contains several provisions dealing, in a stronger or weaker fashion, with institutional or procedural matters. These can be divided into two main categories, addressed in Chapters 1 and 2 of this Part. First, Chapter 1 discusses those provisions in the SPS Agreement under which mechanisms creating disciplines of an institutional or procedural nature on Members are established. Often these procedural disciplines are combined with a substantive obligation, yet the procedural mechanism under the provision is key to its potential in improving market access. For example, the substantive obligations on transparency go hand-in-hand with rules requiring Members to follow certain procedures and set up particular institutions with respect to the promotion of transparency of SPS measures. In addition, the substantive obligations to recognise the equivalence of different SPS measures and to adapt SPS measures to regional differences in pest and disease prevalence, are ineffective without procedural disciplines to give effect to these obligations. Due to the weakness of the procedural rules in these provisions, the SPS Committee has developed procedures to further the implementation of the provisions on the recognition of equivalence and regionalisation. There are also disciplines that apply directly to Members' use of procedures, specifically control, inspection and approval procedures, in order to minimise their adverse trade effects and prevent discriminatory application.

A second category of procedural and institutional mechanisms, discussed in Chapter 2, covers those provisions in the SPS Agreement that deal, instead, with the institutions and 
procedures necessary at WTO level for the smooth and effective implementation of the SPS Agreement. These relate to the establishment and functioning of the SPS Committee, the WTO body charged with the administration of the SPS Agreement, and to the institutions and procedures in place to settle disputes between Members concerning claims of violation of the SPS Agreement.

Both categories of institutional and procedural mechanisms have an important impact on the effectiveness of the SPS Agreement in achieving its goals. The procedural disciplines on Members leave undisturbed their policy choices within the bounds of the substantive disciplines of the Agreement, but address the way in which these are achieved in order to minimise as far as possible their trade restrictive effects. The provisions creating institutional and procedural mechanisms at WTO level are essential in promoting and monitoring the implementation of the disciplines of the SPS Agreement, resolving conflicts between Members with regard to these disciplines and, if necessary, enforcing compliance therewith. It is therefore useful to examine these provisions to determine the extent to which they are effective tools for exporting Members at different levels of development to gain market access without endangering the ability of importing Members to protect health in their territories. 


\section{CHAPTER 1 \\ Institutional and procedural obligations on Members}

The substantive disciplines of the SPS Agreement on the adoption and maintenance of SPS measures, which aim to weed out disguised protectionism, can be undermined if Members are free to use procedural means to make it difficult for exporters to access their markets. Examples of such procedural barriers to trade are a Member's lack of transparency with regard to the SPS requirements in place in its territory, its use of costly, burdensome or lengthy procedures to check conformity with its SPS measures, to approve additives or set tolerances for contaminants; and its application of unreasonable requirements and complicated procedures for the recognition of the equivalence of alternative SPS measures that achieve its level of protection or the recognition of pest- and disease-free areas or areas of low pest or disease prevalence in exporting Members.

In order to prevent the misuse of the procedural aspects of SPS regulation to diminish market access, but yet leave the policy room established by the relevant substantive rules untouched, there are certain procedural mechanisms under the SPS Agreement. In particular, there are mechanisms to further the recognition of equivalence and regionalisation of SPS measures (in Articles 4 and 6); to promote the transparency of SPS measures, requiring publication and advance notification (in Article 7 and Annex B); to limit the delays, costs and administrative burden of control, inspection and approval procedures to what is necessary and prevent discriminatory application (in Article 8 and Annex C).

In two cases, those of the recognition of equivalence and regionalisation, the provisions of the SPS Agreement at issue have a strong substantive element, while their procedural aspects are weak. However, it is precisely in disciplining the procedures for the recognition of equivalence and adaptation to regional conditions that the greatest potential for market access gains lies. Steps have been taken to address the procedural weakness of these provisions through decisions of the SPS Committee establishing procedural mechanisms to further the implementation of the substantive obligations. Due to the important potential of the procedural mechanisms under these two provisions, they are discussed in this Part, together with other provisions which contain more detailed procedural obligations on Members.

\subsection{Recognition of equivalence}

Differences between Members with regard to local climatic and geographical conditions, consumer preferences and technical and financial resources, may sometimes make it difficult or even undesirable to harmonise SPS measures. ${ }^{1}$ In such cases, the resulting variety

\footnotetext{
${ }^{1}$ For example, the prevalence of particular pests or diseases may differ, as may climatic conditions that may be more or less conducive to the proliferation of pests or the spread of diseases. In addition, it has been noted that developing countries may face rather different developmental and technological conditions which also result in differences in SPS measures. Simonetta Zarrilli, WTO Sanitary and Phytosanitary Agreement: Issues for Developing Countries, 3 (South Centre, Geneva) 1999, 17, available at: www.southcentre.org/publications/ s\&p/s\&p.pdf, visited 8 November 2001.
} 
of SPS measures, even those that comply with all the substantive provisions of the SPS Agreement, can significantly hinder trade. However, the negative impact of divergent measures can be limited by the recognition that it is possible for different SPS measures to achieve the same level of protection (i.e., be equally effective in reducing risk) and thus by allowing imports of products that comply with different, but equally effective, SPS measures. ${ }^{2}$ As a result, it is possible for importing Members to rely on the standards and control and inspection systems in place in exporting Members, even where these may be different from their own, when they have been demonstrated to achieve the level of protection sought by the importing Member, i.e. to be equally effective in reducing risk. This is known as the recognition or acceptance of equivalence. As noted by Joanne Scott:

Equivalence is key to permitting the maintenance of regulatory diversity, while at the same time promoting market integration. ${ }^{3}$

An important, but often overlooked, benefit from the recognition of equivalence is the opportunity for technical learning and assistance it provides. Efforts towards establishing equivalence are based on close cooperation and exchange of information on technical level by regulatory officials. This enables the regulatory authorities of the exporting Member to gain expertise through obtaining detailed technical information regarding the particular regulatory systems in place in the importing Member. Similarly, the importing Member's officials become thoroughly familiar with the different regulatory system in place in the exporting Member and may learn alternative approaches to risk regulation. In some cases, regulatory cooperation is institutionalised and leads to long-term relationships and sharing of information and best practices. ${ }^{4}$

The recognition of equivalence can take various forms. The Chairperson of the SPS Committee made clear in his 2001 report to the General Council the understanding of Members that equivalence does not necessarily require formal equivalence agreements but can be achieved on different levels. He noted:

In the Committee's discussions in November 2000, Members recognized that there were several different levels of equivalence, which ranged from (i) formal agreements recognizing the equivalence of sanitary and phytosanitary systems; to (ii) agreements of equivalence for specific products; to (iii) acceptance, on an ad hoc basis, of the equivalence of specific technical aspects of certain sanitary and phytosanitary measures. In the March 2001 discussions, it was also

\footnotetext{
${ }^{2}$ Digby Gascoine, 'Harmonisation, Mutual Recognition and Equivalence - How and What Is Attainable?' presented at the Conference on International Food Trade Beyond 2000: Science-Based Decisions, Harmonization, Equivalence and Mutual Recognition (Food and Agriculture Organization of the United Nations, Melbourne Australia) 11-15 October 1999, para. 23, available at: www.fao.org/docrep/meeting/X2808e.htm, visited on 25 June 2007.

3 Joanne Scott, The WTO Agreement on Sanitary and Phytosanitary Measures: A Commentary, Oxford Commentaries on the GATT/WTO Agreements (Oxford University Press, Oxford), 2007, 164.

${ }^{4}$ On this issue see Ibid. Scott notes that equivalence: 'serves to induce a healthy destabilization of the sometimes false premises underpinning established approaches to regulation. It opens up measures to contestation, and encourages ongoing policy learning on the basis of information exchange, and dissemination of best practice.' Ibid.
} 
suggested that equivalence could be considered for either: (i) inspection and control systems; (ii) processing techniques; and (iii) for product standards. ${ }^{5}$

Thus, Members can accept the equivalence of different SPS measures on an ad hoc basis or by means of bilateral or regional equivalence agreements. Acceptance of equivalence on an ad hoc basis commonly occurs with regard to specific products or technical aspects of SPS measures. ${ }^{6}$ In formal equivalence agreements criteria are set out for the acceptance by an importing Member of different SPS requirements as equivalent to its own, on either a systems-wide or product-by-product basis. This can be seen as a 'one-way' recognition of equivalence. ${ }^{7}$ Equivalence agreements can also take the form of a 'two-way' or reciprocal agreement, in which the parties agree that the requirements and food safety systems used by each of them are sufficient to guarantee the level of protection each aims to secure. As a result, they bind themselves to allow each other's products to enter their respective markets despite differences in the SPS measures or control systems applied. The latter type of agreements is known as mutual recognition agreements. Both types of equivalence agreement may be concluded for specific food or agricultural products or all food and agricultural products and may apply to only certain food safety requirements (for example only conformity assessment procedures or only food safety requirements) or to all such requirements.

Article 4 of the SPS Agreement aims to promote the recognition of equivalence, both on an $a d$ hoc basis and by means of formal equivalence agreements and in this way to minimise the trade barriers caused by divergent SPS measures. If effectively implemented, the acceptance of the equivalence of other Members' SPS measures under Article 4 could go a long way in reducing the barriers created by onerous, but legitimate, SPS measures.

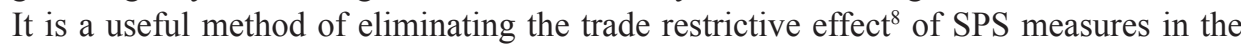
absence of harmonisation. ${ }^{9}$ As has been discussed above, Members are not obliged to

\footnotetext{
${ }^{5}$ Committee on Sanitary and Phytosanitary Measures, Equivalence: Consideration of Article 4 of the SPS Agreement: Summary of Informal Discussions on Equivalence. Second Report by the Chairman, G/L/445, circulated on 21 March 2001, para. 4.

${ }^{6}$ This fact was emphasised in discussions on equivalence in the SPS Committee. This occurs on a technical level and is not reflected in formal bilateral agreements. Committee on Sanitary and Phytosanitary Measures, Equivalence - Note by the Secretariat, G/SPS/W/111, circulated on 4 July 2001.

7 The 'one-way'/'two-way' distinction is made in Bernard O'Connor, Equivalence of SPS Measures in WTO Law, ed. O’Connor and Company, vol. 5, Monographs in Trade Law (Brussels), 2002, 83.

8 See David G. Victor, 'The Sanitary and Phytosanitary Agreement of the World Trade Organization: An Assessment after Five Years', Journal of International Law and Politics 32 (4), 2000, 865-938, 877-878. Victor notes, 'Assuming that exporters have an interest in identifying the least trade restrictive measure, this 'equivalence' requirement could automatically ensure that SPS rules are not more discriminatory than necessary (...)'. It may perhaps be more correct to say that the result would be rules that are least trade restrictive, since SPS measures need not be discriminatory at all to be caught by the SPS Agreement. In this regard, Scott makes the interesting point that Article 4 supplements the least-trade-restrictive-measure obligation by extending it to regulatory alternatives of other Members. Joanne Scott, The WTO Agreement on Sanitary and Phytosanitary Measures: A Commentary, Oxford Commentaries on the GATT/WTO Agreements (Oxford University Press, Oxford), 2007, 163.

9 This may be the case either where no international standards exist in the specific area or where a Member deviates from existing international standards with scientific justification, for example where they do not achieve the level of protection chosen by the importing Member. In these cases, where the SPS Agreement does not result in harmonisation of measures, the principle of equivalence could nevertheless result in open markets. It should be noted that the SPS Committee has emphasised that equivalence does not replace the need
} 
adopt harmonised standards where these do not meet their chosen levels of protection. ${ }^{10}$ However, by recognising divergent SPS measures as equivalent to their own, where these meet their appropriate levels of protection, Members can avoid creating unnecessary trade barriers while continuing to provide the level of protection they deem appropriate. This is of particular importance to developing-country Members, as their SPS measures and food safety systems often differ from those in place in importing developed-country Members, due to the developmental and technological constraints they face. If their measures nonetheless achieve the level of protection aimed at by the importing Member, they should be recognised as equivalent. ${ }^{11}$

Article 4 is now examined more closely to determine if it is effective in meeting its objective of the promotion of the recognition of equivalence.

\subsubsection{Acceptance of equivalence}

Article 4.1 of the SPS Agreement makes provision for the acceptance by WTO Members of equivalence of different SPS measures of exporting Members that achieve the appropriate level of protection chosen by the importing Member. It obliges Members to accept as equivalent different SPS measures that have been proven to achieve their chosen level of SPS protection. This paragraph provides:

Members shall accept the sanitary or phytosanitary measures of other Members as equivalent, even if these measures differ from their own or from those used by other Members trading in the same product, if the exporting Member objectively demonstrates to the importing Member that its measures achieve the importing Member's appropriate level of sanitary or phytosanitary protection. For this purpose, reasonable access shall be given, upon request, to the importing Member for inspection, testing and other relevant procedures.

In order for Members to be obliged to recognise the equivalence of other Members' SPS measures to their own, Article 4 requires that the exporting Member 'objectively demonstrate' to the importing Member that its SPS measures achieve the latter's appropriate level of protection. The burden of proof is therefore clearly on the exporting Member, which must adduce proof of the efficacy of its measure in equally reducing the health risk

\footnotetext{
for the development and use of international standards. Committee on Sanitary and Phytosanitary Measures, Equivalence - Note by the Secretariat, G/SPS/W/111, circulated on 4 July 2001, para. 3. See also David G. Victor, 'The Sanitary and Phytosanitary Agreement of the World Trade Organization: An Assessment after Five Years', Journal of International Law and Politics 32 (4), 2000, 865-938, 878. Victor refers to the similar concept of 'mutual recognition' in the context of the EC single market which 'created a strong market-opening dynamic by allowing legal production from any European country into any other European national market.' In this regard he refers to Linda Horton, 'Mutual Recognition Agreements and Harmonization', Seton Hall Law Review 29, 1998, 692-735, 708-729.

${ }^{10}$ See above, Part III, Section 4.2.

${ }^{11}$ In the meetings of Members in the SPS Committee regarding equivalence, it was stressed that the purpose of equivalence is to facilitate trade and that the recognition of equivalence should enhance developing country access to export markets, including those in developed countries, by allowing them to meet the importer's chosen level of protection by means of alternative measures. Committee on Sanitary and Phytosanitary Measures, Equivalence: Consideration of Article 4 of the SPS Agreement: Summary of Informal Discussions on Equivalence. Second Report by the Chairman, G/L/445, circulated on 21 March 2001, para. 7.
} 
posed by its export. In addition, the exporting Member must allow reasonable access to the importing Member on request, to conduct its own inspections, tests and other procedures to verify that this is in fact the case.

\subsubsection{Agreements on recognition of equivalence}

As mentioned, it is possible for the recognition of equivalence to occur not only on an ad hoc basis but also by means of bilateral, regional or multilateral agreements in which criteria are set out for acceptance of different SPS measures or systems as equivalent. Therefore, the SPS Agreement, in Article 4.2, encourages the conclusion of equivalence agreements between Members by obliging Members to enter into consultations to this end upon request. However, there is no obligation to actually conclude such agreements. Article 4.2 provides:

Members shall, upon request, enter into consultations with the aim of achieving bilateral and multilateral agreements on recognition of the equivalence of specified sanitary or phytosanitary measures.

The weaker requirement in Article 4.2 as compared to that in Article 4.1 attests to the difficulty of negotiating formal equivalence agreements, as opposed to the ad hoc recognition of equivalence with respect to specific products or measures. Very few formal agreements on the recognition of equivalence exist. One example of such an agreement is that between Thailand and Canada with regard to fish inspection and control systems. This equivalence agreement is based on the draft guidelines established by the Codex Committee on Food Import and Export Inspection and Certification Systems. Thailand reports that it would like to conclude equivalence agreements on fish inspection and control systems with the EC, US, South Africa, Australia, New Zealand, Brazil and Korea, but lists several constraints, including the time consuming nature of the document review and comparison entailed, the differences in culture and legal structure in the various countries, the differences in policy, procedures and methods that prevail. ${ }^{12}$

Equivalence agreements that take the form of mutual recognition agreements are most likely to be found between countries that have broadly similar preferences with respect to the appropriate level of protection against particular SPS risks and similar technical capabilities with regard to monitoring and enforcing compliance with SPS requirements. ${ }^{13}$ An example of this is the mutual recognition agreement between the EU and Canada in respect of trade in live animals, fish and their products, mentioned below. ${ }^{14}$

\footnotetext{
${ }^{12}$ Committee on Sanitary and Phytosanitary Measures, Experience with Recognition of Equivalence: Statement by Thailand at the Meeting of 14-15 March 2001, G/SPS/GEN/242, circulated on 6 April 2001.

13 Bernard O'Connor, Equivalence of SPS Measures in WTO Law, ed. O'Connor and Company, vol. 5, Monographs in Trade Law (Brussels), 2002, 82. See also Digby Gascoine, 'Harmonisation, Mutual Recognition and Equivalence - How and What Is Attainable?' presented at the Conference on International Food Trade Beyond 2000: Science-Based Decisions, Harmonization, Equivalence and Mutual Recognition (Food and Agriculture Organization of the United Nations, Melbourne Australia) 11-15 October 1999, 5, available at: www.fao.org/docrep/meeting/X2808e.htm, visited on 25 June 2007. Gascoine points out that mutual recognition is more likely to occur between countries that have a long tradition of food trade with each other, and are in some kind of political or legal association with each other.

${ }^{14}$ See below, Part IV, Section 1.1.4.
} 
Some Members are reluctant to enter into negotiations for the conclusion of formal equivalence agreements due to the lengthy and costly nature of such negotiations. ${ }^{15}$ However, once in place, such formal agreements can make the subsequent recognition of equivalence easier and less costly as the general criteria and conditions for the recognition of equivalence are already established in such agreements. ${ }^{16}$

\subsubsection{Procedure}

While Article 4 sets out substantive obligations on Members, it does not provide detailed procedures for the recognition of equivalence or the conclusion of equivalence agreements. ${ }^{17}$ It is thus left to Members to determine how they will give effect to this provision, in particular what procedures they will lay down and which criteria they will apply for the recognition of equivalence. ${ }^{18}$

All that is stipulated in Article 4 is that an importing Member is obliged to recognise the equivalence of a measure if the exporting Member 'objectively demonstrates' that its measure achieves the appropriate level of protection of the importing Member. What is required for this objective demonstration is not spelled out. As a result, many Members' administrative requirements for the recognition of equivalence are so stringent as to render the benefits of Article 4 unavailable, particularly to developing-country Members. With regard to formal equivalence agreements, Article 4.2 provides only for an obligation to enter into consultations, upon request, with the aim to establish equivalence agreements. No procedural rules are laid down with regard to this consultation process.

The Chairperson of the SPS Committee in his 2001 Report to the General Council reported that Members had stressed that regardless of whether equivalence is recognised ad hoc or in formal agreements, certain obligations exist for both the importing country and the exporting country. These obligations stem from the fact that the SPS measures of the exporting country, in order to be accepted as equivalent, must meet the appropriate level of protection of the importing country. Therefore, the importing country must clearly identify the level of protection its measure aims to achieve and the exporting country must provide appropriate, science-based technical information to demonstrate that its

${ }^{15}$ Committee on Sanitary and Phytosanitary Measures, Equivalence: Submission from the United States, G/ SPS/GEN/212, circulated on 7 November 2000.

${ }^{16}$ Argentina has suggested that all formal equivalence agreements should contain a section establishing general principles, aims and requirements for the recognition of equivalence, and deal with specific products in annexes to the agreement. Committee on Sanitary and Phytosanitary Measures, Equivalence - Article 4 of the Agreement on the Application of Sanitary and Phytosanitary Measures, G/SPS/GEN/268, circulated on 15 August 2001. See also in this regard Simonetta Zarrilli, The SPS Agreement and the Developing Countries (World Bank, Washington D.C.), 2003, 8.

17 Scott argues that the procedural disciplines of Article 8 and Annex C of the SPS Agreement, which deal with control, inspection and approval procedures, apply also to procedures for the recognition of equivalence. Joanne Scott, The WTO Agreement on Sanitary and Phytosanitary Measures: A Commentary, Oxford Commentaries on the GATT/WTO Agreements (Oxford University Press, Oxford), 2007, 165, footnote 101. However, Annex C.1 specifies that its requirements apply 'with respect to any procedure to check and ensure the fulfilment of sanitary and phytosanitary requirements'. The recognition of equivalence, instead, is based on a procedure to check whether alternative SPS requirements (those imposed by an exporting Member) meet the appropriate level of protection of the importing Member. This seems to lie outside the scope of Annex C.

${ }_{18}$ The Decision on Equivalence, discussed below, Part IV, Section 1.1.6, now provides non-binding guidelines with regard to the procedure to be followed. 
alternative measure meets this level of protection. ${ }^{19}$ The WTO Secretariat has noted that, in identifying their appropriate level of protection, Members should take into account the Guidelines to Further the Practical Implementation of Article $5.5,{ }^{20}$ which were adopted by the SPS Committee in June 2000. ${ }^{21}$ The Guidelines incorporate, in paragraph B, the finding by the Appellate Body in Australia - Salmon, that although the SPS Agreement contains no express obligation on a Member to determine its appropriate level of protection, this obligation is implicit in several provisions including Article 4. ${ }^{22}$

Once the appropriate level of protection of the importing Member is known, and the exporting Member must produce evidence to support its claim that its SPS measure achieves this level of protection, and then the importing Member makes its determination of equivalence. The equivalence of different types of SPS measures (such as ban on a potential host of a pest and a requirement of fumigation treatment prior to importation) could be determined by examining the effectiveness of each by means of scientific evidence. In contrast, when different control and inspection systems are compared, a more subjective element is present as the quality of the system and qualifications of personnel are evaluated. ${ }^{23}$

The notification of the recognition of equivalence, whether ad hoc or in formal agreements, is not required by the SPS Agreement. In the informal discussions on equivalence in the SPS Committee, several Members expressed concern regarding the lack of transparency with regard to equivalence agreements. ${ }^{24}$ A notification obligation in this regard, in the view of these Members, would facilitate the recognition of equivalence of SPS measures of developing-country Members by enabling the latter to become party to an existing equivalence agreement if they can show they meet the conditions set therein, or to conclude a similar bilateral agreement with the importing Member. However, it was pointed out in the SPS Committee meeting that all Members' national Enquiry Points ${ }^{25}$ are obliged to respond to questions regarding, inter alia the recognition of equivalence and equivalence agreements. ${ }^{26}$ Nevertheless, the SPS Committee endorsed a conclusion

${ }^{19}$ Committee on Sanitary and Phytosanitary Measures, Equivalence - Note by the Secretariat, G/SPS/W/111, circulated on 4 July 2001, para. 6; Committee on Sanitary and Phytosanitary Measures, Equivalence: Consideration of Article 4 of the SPS Agreement: Summary of Informal Discussions on Equivalence. Second Report by the Chairman, G/L/445, circulated on 21 March 2001.

${ }^{20}$ Committee on Sanitary and Phytosanitary Measures, Guidelines to Further the Practical Implementation of Article 5.5, G/SPS/15, circulated on 18 July 2000. These non-binding guidelines relate to the objective of consistency in the choice of appropriate level of protection and were discussed above, Part III, Section 5.2.3.5.

${ }^{21}$ Committee on Sanitary and Phytosanitary Measures, Equivalence - Note by the Secretariat, G/SPS/W/111, circulated on 4 July 2001, para. 11.

${ }^{22}$ Appellate Body Report, Australia - Salmon, para. 205. In footnote 161 to this paragraph, the Appellate Body stated: 'Articles 4.1 and 4.2 imply, in our view, a clear obligation of the importing Member to determine its appropriate level of protection.'

${ }^{23}$ David S. Johanson and William L. Bryant, 'Eliminating Phytosanitary Trade Barriers: The Effects of the Uruguay Round Agreements on California Agricultural Exports', San Joaquin Agricultural Law Review 6, 1996, 1-26, 6 .

${ }^{24}$ Committee on Sanitary and Phytosanitary Measures, Equivalence - Note by the Secretariat, G/SPS/W/111, circulated on 4 July 2001, para. 19.

${ }^{25}$ The Enquiry Points are discussed further below, Part IV, Section 1.3.4.

${ }^{26}$ This obligation is contained in Annex B.3(d) and was confirmed by the SPS Committee in its meeting of 13 March 2001. Committee on Sanitary and Phytosanitary Measures, Equivalence: Consideration of Article 4 of the SPS Agreement: Summary of Informal Discussions on Equivalence. Second Report by the Chairman, 
stating that Members will inform the SPS Committee of their recognition of the equivalence of the SPS measures of other Members. ${ }^{27}$ The Secretariat proposed a format for the notification of determinations of equivalence and equivalence agreements, where such recognition of equivalence may have a significant effect on the trade of the Member which requested the determination or of other Members. ${ }^{28}$

\subsubsection{Examples}

The absence of notification is not an indication that no recognition of equivalence is taking place at all. Instead, the various examples reported by Members to the SPS Committee in the context of the discussions regarding the implementation of Article 4 show that some practice exists in this area.

In practice, the recognition of equivalence most often takes place informally, on a technical or administrative level for specific products. An example of such recognition of equivalence is that of Australia with regard to Switzerland's measures with respect to hard cheeses. ${ }^{29}$ Australia requires pasteurisation or thermisation of milk in the production of cheeses in order to achieve its 'safe food use' level of protection for cheese consumption. Australia, however, allows the manufacture and importation of raw milk cheeses if these achieve an equivalent level of safety protection. ${ }^{30}$ In 1997, following a review of sanitary requirements, Australia suspended cheese imports from Switzerland. Switzerland sought to demonstrate that its manufacturing process for cheeses achieved Australia's level of protection by means of a risk assessment. ${ }^{31}$ The risk assessment showed, according to Australia, that hard cheeses made following the Swiss process achieved the same level of pathogen destruction as those subject to pasteurisation, but this was not the case with semi-hard cheeses. Australia thus recognised Emmental, Sbrinz and Gruyere as safe due to the equivalence of the Swiss process with regard to hard cheeses. ${ }^{32}$ This led to an amendment to the Australian Food Standards Code to allow hard Swiss cheeses to be imported. ${ }^{33}$

G/L/445, circulated on 21 March 2001, para. 11(ii).

${ }^{27}$ Ibid., para. 11(iii).

${ }^{28}$ Committee on Sanitary and Phytosanitary Measures, Proposed Format for the Notification of Agreements of Equivalence. Note by the Secretariat. Revision, G/SPS/W/114/Rev.1, circulated on 21 May 2002.

29 This example was reported by Australia in response to the request by the WTO Secretariat for information on concrete experiences with the recognition of equivalence as a basis for discussions on improving the implementation of Article 4. Committee on Sanitary and Phytosanitary Measures, An Example of Equivalence: Statement by Australia at the Meeting of 14-15 March 2001, G/SPS/GEN/243, circulated on 9 April 2001.

${ }_{30}$ Australian Standard 4.2.4A Concerning Primary Production and Processing Standard for Specific Cheeses.

${ }^{31}$ Switzerland claimed that an equivalent degree of protection was achieved by 'the combination of heat treating of the milk, continual heating of the curd and the rapid acidification by the added starter cultures as well as the intense brining and long ripening period.' ANZFA Full Assessment Report, 3.

${ }^{32}$ Committee on Sanitary and Phytosanitary Measures, An Example of Equivalence: Statement by Australia at the Meeting of 14-15 March 2001, G/SPS/GEN/243, circulated on 9 April 2001. Other examples of ad hoc recognition of equivalence were provided by New Zealand (see Committee on Sanitary and Phytosanitary Measures, Experience in Recognizing Equivalence of Phytosanitary Measures: Submission by New Zealand, G/SPS/GEN/232, circulated on 28 February 2001.).

${ }^{33}$ For a detailed discussion of this example, see Joanne Scott, The WTO Agreement on Sanitary and Phytosanitary Measures: A Commentary, Oxford Commentaries on the GATT/WTO Agreements (Oxford University Press, Oxford), 2007, 169-170. 
Anther example of ad hoc recognition of equivalence discussed above, is the recognition by the US of Australia's sanitary system for meat as equivalent to its own. ${ }^{34}$ The US Food safety Inspection Service does not enter into equivalence agreements in respect of sanitary requirements for meat and poultry imports. Instead, after conducting an equivalence determination process, it amends US legislation to list the relevant country as eligible to export meat or poultry to the US. ${ }^{35}$ New Zealand provided another example of ad hoc recognition of equivalence, relating to certification requirements. While New Zealand normally requires that cut flower imports be inspected and accompanied by a phytosanitary certificate, it has made an exception for fresh-cut orchids from Singapore that are brought into New Zealand by airline passengers. On the basis of a demonstrated history of compliance by Singapore with New Zealand's phytosanitary requirements, and the low level of pest interceptions related to passenger-carried orchids, New Zealand accepts as equivalent to the required phytosanitary certificates the use of tamper-proof stickers issued by the National Plant Protection Organisation of Singapore. ${ }^{36}$

Currently, the recognition of equivalence by means of formal agreements is taking place in very limited cases. One example, reported by Fiji, is the development of quarantine protocols between Fiji and New Zealand recognising, for specific agricultural products, the use of hot forced air treatment as equivalent to New Zealand's phytosanitary measures. ${ }^{37}$ Donna Roberts reports that some equivalence agreements do exist, particularly in the seafood sector, but that these seem to require 'compliance' rather than equivalence. ${ }^{38}$

Equivalence agreements that take the form of mutual recognition agreements in respect of SPS requirements occur mostly in the context of broader bilateral or regional agreements. In particular, they occur between the Member States of the EU, the Members of NAFTA and between Australia and New Zealand in the context of FSANZ. ${ }^{39}$ In addition, in certain cases Members have negotiated specific agreements laying down the conditions and requirements for the recognition of each other's SPS measures as equivalent for specific products or sectors. An example of such an equivalence agreement is that concluded between the EU and Canada, in respect of trade in live animals, animal products, fish

34 The recognition of equivalence by the US of the new Australian meat inspection system is discussed above, Part II, Section 2.4.2.2. See further, J.J. Kastner and R. K. Pawsey, 'Harmonising Sanitary Measures and Resolving Trade Disputes through the WTO-SPS Framework. Part II. A Case Study of the USA-Australia Determination of Equivalence in Meat Inspection', Food Control 13, 2002, 57-60.

${ }^{35}$ Committee on Sanitary and Phytosanitary Measures, Equivalence: Submission from the United States, G/ SPS/GEN/212, circulated on 7 November 2000, para. 8.

${ }^{36}$ Committee on Sanitary and Phytosanitary Measures, Experience in Recognizing Equivalence of Phytosanitary Measures: Submission by New Zealand, G/SPS/GEN/232, circulated on 28 February 2001, paras 13-14.

${ }^{37}$ Committee on Sanitary and Phytosanitary Measures, Experience On "Equivalence”: Submission by Fiji, G/ SPS/GEN/238, circulated on 13 March 2001, para. 1.

${ }^{38}$ Donna Roberts et al., 'Sanitary and Phytosanitary Barriers to Agricultural Trade: Progress, Prospects and Implications for Developing Countries', in Agriculture and the New Trade Agenda - Creating a Global Trading Environment for Development, M.D. Ingco and L.A.Winters (eds.) (Cambridge University Press, Cambridge), 2004, 329-358, 339. In this respect Roberts cites the following report: 'Major Exporting Countries Seek Help to Comply with US Seafood HACCP Rule', World Food Chemical News, 11 July 1997, 11.

${ }^{39}$ For examples of the recognition of equivalence in the EU and NAFTA and the mutual recognition agreement between Australia and New Zealand (which has since been replaced by a joint food authority, FSANZ), see Simonetta Zarrilli, The SPS Agreement and the Developing Countries (World Bank, Washington D.C.), 2003, 17-18. On equivalence within free trade areas, see also Bernard O'Connor, Equivalence of SPS Measures in WTO Law, ed. O’Connor and Company, vol. 5, Monographs in Trade Law (Brussels), 2002, 91-108. 
and fishery products. ${ }^{40}$ This agreement establishes a mechanism for the mutual recognition of equivalence, laying down criteria and setting out the procedures to be followed. In addition, it lists those sectors that, at the time of the entry into force of the agreement, are recognised as equivalent between the parties. ${ }^{41}$ Similarly, Canada and Australia have signed a Memorandum of Understanding, accepting each others' inspection systems for fish and fishery products as equivalent. ${ }^{42}$

\subsubsection{Problems with implementation}

The implementation of Article 4 of the SPS Agreement to date leaves much to be desired. As stated above, despite the fact that the substantive obligations it lays down for Members are clear and binding, ${ }^{43}$ the procedural aspects of the determination of equivalence are not. This weakness in Article 4 has led to problems with its implementation.

The 'objective' demonstration required by Article 4 for the recognition of equivalence is expressly related to ability of the measure of the exporting Member to meet the level of protection of the importing Member. Article 4 also expressly recognises that different SPS measures can achieve the same level of protection. However, developing-country Members have repeatedly raised the concern that developed-country Members demand 'sameness' rather than equivalence of SPS requirements and control and inspection systems. ${ }^{44}$ This deprives Members of the flexibility in their choice of measures that Article 4 intends to achieve, undermining its effectiveness.

In addition, the difficulty of providing an objective basis for the demonstration of equivalence in the absence of procedural rules has led to lengthy and burdensome equivalence procedures. Often Members have difficulty in ascertaining the level of protection their measures must meet in order to be recognised as equivalent, or cannot meet the level of scientific proof required by the importing Member as objective demonstration of equivalence. Importing Members often do not give clear, scientifically-justified, reasons for rejecting the equivalence of the measures imposed by an exporting Member. Further,

40 Agreement between the European Community and the Government of Canada on Sanitary Measures to Protect Public and Animal Health in Respect of Trade in Live Animals and Animal Products, OJ L 071, 18 March 1999. Other mutual recognition agreements have been concluded between the EU and the US, New Zealand, Switzerland and the Czech Republic.

${ }^{41}$ For a more detailed description of this agreement see Bernard O'Connor, Equivalence of SPS Measures in WTO Law, ed. O'Connor and Company, vol. 5, Monographs in Trade Law (Brussels), 2002, 65-67.

${ }^{42}$ Memorandum of Understanding Concerning the Inspection and Certification of Fish and Fishery Products, Agreement between Australia and Canada, 28 June 1993. Canada has similar agreements with New Zealand (1966), Thailand (1997) and Indonesia (2002). See further Christel Elvestad, Equivalence and Mutual Recognition Agreements in Relation to Technical Measures, Working paper 2002-36 (Norwegian Agricultural Economics Research Institute, Oslo), 2002, 9-11, available at: www.nilf.no/Publikasjoner/Notater/2002/ N200236Hele.pdf, visited on 3 March 2003.

${ }^{43}$ It is interesting to contrast the clear obligation in Article 4 of the SPS Agreement, which actually requires the recognition of equivalence when certain requirements are met, with the weaker equivalence provision in Article 2.7 of the TBT Agreement, which requires only that Members 'give positive consideration' to accepting as equivalent the technical regulations of other Members, if they are satisfied that they adequately fulfil the objectives of their own regulations. The latter is only an obligation of conduct.

${ }^{44}$ Committee on Sanitary and Phytosanitary Measures, Equivalence: Consideration of Article 4 of the SPS Agreement: Summary of Informal Discussions on Equivalence. Second Report by the Chairman, G/L/445, circulated on 21 March 2001, para. 5. 
the procedures and requirements for recognition of equivalence vary between importing Members, making it difficult for an exporting Member to access various markets even if it has obtained recognition of equivalence by one importing Member. For example, Fiji has reported that although New Zealand has accepted hot forced air treatment as an equivalent phytosanitary measure for imports of paw-paws, mangoes and eggplants from Fiji, Australia has refused to do so. Fiji has provided Australia with the requested data on its hot forced air treatment facilities, but AQIS has stated that Fiji must conduct further research on this treatment as it is not satisfied with the data provided. Consequently, Fiji cannot export paw-paw, mangoes and eggplants to Australia. ${ }^{45}$ Fiji has proposed that importing Members should provide the scientific basis for decisions to reject the equivalence of measures of exporting Members. ${ }^{46}$ This would enable exporting Members to take steps to address the problems in their measures that result in non-achievement of appropriate level of protection of the importing Member.

This burdensome nature of procedures for the recognition of equivalence is particularly the case for formal equivalence agreements. As a result, some importing Members, such as the US, are of the opinion that the negotiation of formal equivalence agreements or determinations are too time consuming and resource intensive, imposing administrative burdens on both the importing and the exporting countries, whereas the gains in trade achieved thereby are limited. ${ }^{47}$ They therefore hold the view that recourse to other provisions of the SPS Agreement (such as the rules on risk assessment, transparency, technical assistance and control and inspection procedures) would yield more immediate trade benefits in the form of market access. ${ }^{48}$ However, developing-country Members, such as Argentina, note that although importing Members may view the administrative burden of an equivalence agreement as unjustified with regard to the limited trade benefits it can bring, the improved market access through the formal recognition of equivalence can be very important for developing countries. This is especially the case where the exports of these Members are concentrated in a small number of products and involve few enterprises. The formal recognition that these products meet the level of protection of the importing Member through the use of equivalent measures or procedures would result in significant gains for trade in the exporting Member. ${ }^{49}$

\footnotetext{
${ }^{45}$ Committee on Sanitary and Phytosanitary Measures, Experience On "Equivalence”: Submission by Fiji, G/ SPS/GEN/238, circulated on 13 March 2001, paras 1 and 3.

46 Ibid., para. 8.

${ }^{47}$ See Committee on Sanitary and Phytosanitary Measures, Equivalence: Submission from the United States, G/ SPS/GEN/212, circulated on 7 November 2000, para. 16.

${ }^{48}$ Committee on Sanitary and Phytosanitary Measures, Equivalence - Note by the Secretariat, G/SPS/W/111, circulated on 4 July 2001, para.5. See also Committee on Sanitary and Phytosanitary Measures, Equivalence: Submission from the United States, G/SPS/GEN/212, circulated on 7 November 2000, para. 20.

${ }^{49}$ Committee on Sanitary and Phytosanitary Measures, Equivalence - Note by the Secretariat, G/SPS/W/111, circulated on 4 July 2001, para. 6. Argentina has pointed out that its narrow range of exports and their concentration in a small number of exporters facilitate control of exporting plants and products. It has therefore called for the recognition of equivalence to be focused on these export products rather than on the whole national SPS system. Committee on Sanitary and Phytosanitary Measures, Actions Aimed Implementing the WTO Agreement on the Application of Sanitary and Phytosanitary Measures, G/SPS/GEN/286, circulated on 26 October 2001, 6 .
} 
In its first periodic review of the implementation of the SPS Agreement, ${ }^{50}$ the SPS Committee noted that although there had been an increase in the recognition of equivalence and in the negotiations towards bilateral agreements in this respect, greater efforts in this area were necessary. The Committee pointed in this regard to the importance of the recognition of equivalence for developing-country Members. The Committee requested Members to provide more information on equivalence agreements they have concluded bilaterally. In addition, the work of Codex and other international organisations to promote the recognition of equivalence was welcomed by the SPS Committee. ${ }^{51}$

\subsubsection{The Equivalence Decision}

The concerns of developing-country Members with the lack of implementation of Article 4 , mentioned above, created a strong impetus for discussions to develop guidelines on this issue. At the same time, some developed-country Members supported this initiative as they wished to develop agreed guidelines for the practical implementation of the rather vague obligation in Article 4. Preparatory work was conducted informally on this issue by a small group of developed-country Members. ${ }^{52}$

At its Special Session on Implementation on 18 October 2000, the General Council referred the issue of implementation of Article 4 to the SPS Committee. ${ }^{53}$ The SPS Committee held informal and special meetings on equivalence and also addressed the issue in its regular meetings. ${ }^{54}$ In these discussions it was emphasised that the aim of equivalence is to facilitate trade and enhance developing country access to markets, including those in developed countries, by allowing them to meet the importing country's level of protection by alternative means.$^{55}$ It was also emphasised that equivalence is not a substitute for harmonisation and should not lead to discrimination or additional trade barriers. Discussions in the SPS Committee were based on concrete experiences of Members

\footnotetext{
${ }^{50}$ Committee on Sanitary and Phytosanitary Measures, Review of the Operation and Implementation of the Agreement on the Application of Sanitary and Phytosanitary Measures: Report of the Committee, G/SPS/12, circulated on 11 March 1999, para. 20.

51 Gretchen Stanton, 'A Review of the Operation of the SPS Agreement', presented at the Conference on Agriculture and the New Trade Agenda in the WTO 2000 Negotiations, Geneva, Switzerland) 1-2 October 2000, 5 .

52 Digby Gascoine et al., Private Voluntary Standards within the WTO Multilateral Framework (United Kingdom Department for International Development, London), March 2006, para. 57. Some of this group's preparatory work also took place under the auspices of the Codex Committee on Food Import and Export Inspection and Certification Systems. Gascoine et al report that this work provided the basis for the agreement eventually reached in the SPS Committee.

${ }^{53}$ The General Council requested the SPS Committee "to examine the concerns of developing countries regarding the equivalence of SPS measures and to come up with concrete options as to how to deal with them.' (see General Council Special Session on Implementation, Minutes of Meeting - Held in the Centre William Rappard on 18 October 2000, WT/GC/M/59, circulated on 13 November 2000, para12.).

${ }^{54}$ The informal meetings on equivalence were held on 7 November 2000, 13 March 2001 and 9 July 2001. The formal meetings where equivalence was considered were those of 8-9 November 2000 and 10-11 July 2001. In addition, two Special Meetings on equivalence were held on 18-19 September and 24 October 2001.

${ }_{55}$ Committee on Sanitary and Phytosanitary Measures, Equivalence: Consideration of Article 4 of the SPS Agreement: Summary of Informal Discussions on Equivalence. Second Report by the Chairman, G/L/445, circulated on 21 March 2001, para. 7.
} 
with regard to the recognition of equivalence. ${ }^{56}$ Input was also obtained from the CAC and OIE. ${ }^{57}$

The result of these discussions was the adoption, in November 2001, of the Decision on the Implementation of Article 4 of the Agreement on the Application of Sanitary and Phytosanitary Measures (the Equivalence Decision) by the SPS Committee. ${ }^{58}$ It was adopted under the authority of the SPS Committee to carry out the functions necessary to implement and further the objectives of the SPS Agreement under Article 12.1 of the SPS Agreement. ${ }^{59}$

At its meeting of 19-21 March 2002, the SPS Committee adopted a work programme for further work on equivalence, setting out the main issues for discussion in 2002 and 2003. The work programme included discussions regarding the clarification of specific paragraphs of the Equivalence Decision. These discussions culminated in the adoption of clarifying texts, incorporated into the revised versions of the Equivalence Decision. ${ }^{60}$ In addition, the issue of equivalence remains a standing agenda item for meetings of the SPS Committee.

In its preamble, the Equivalence Decision recognises that equivalence 'can be applied between all Members, irrespective of their level of development.' It further takes account of the specific concerns raised by developing-country Members regarding their difficulties in having the equivalence of their SPS measures recognised by other Members. It states the desire to make operational the provisions of Article 4.

The Equivalence Decision starts in its first paragraph by stating in mandatory terms that a Member, when so requested, 'shall seek to accept' the equivalence of a measure related

${ }^{56}$ Members were asked to provide specific information with regard to their experiences with the recognition of equivalence. Responses were received from Argentina, Australia, Chile, Egypt, the EC, Fiji, India, New Zealand, the Philippines (on behalf of ASEAN countries), Thailand, the US and the CAC. The responses are summarised in Committee on Sanitary and Phytosanitary Measures, Equivalence - Note by the Secretariat, G/ SPS/W/111, circulated on 4 July 2001.

57 Committee on Sanitary and Phytosanitary Measures, Draft Paper on the Judgement of Equivalence of Sanitary Measures Relating to International Trade in Animals and Animal Products. Submission by the Office International Des Epizooties (OIE), G/SPS/W/119, circulated on 18 March 2002; Committee on Sanitary and Phytosanitary Measures, Relevant Codex Documents on Equivalence of Sanitary Measures: Information Submitted by the Codex Alimentarius Commission (Codex), G/SPS/GEN/210, circulated on 6 November 2000; Committee on Sanitary and Phytosanitary Measures, Relevant Codex Documents on Equivalence of Sanitary Measures: Information Submitted by the Codex Alimentarius Commission (Codex), G/SPS/GEN/211, circulated on 6 November 2000.

${ }^{58}$ Committee on Sanitary and Phytosanitary Measures, Decision on the Implementation of Article 4 of the Agreement on the Application of Sanitary and Phytosanitary Measures, G/SPS/19, circulated on 24 October 2001. This decision was adopted ad referendum. The Ministerial Conference at Doha took note of this Decision. Ministerial Conference, Implementation-Related Issues and Concerns. Decision of 14 November 2001, WT/MIN(01)/17, circulated on 20 November 2001, para. 3.3.

${ }^{59}$ On the legal status of the Equivalence Decision, see below, Part IV, Section 2.1.1.

${ }^{60}$ Committee on Sanitary and Phytosanitary Measures, Decision on the Implementation of Article 4 of the Agreement on the Application of Sanitary and Phytosanitary Measures. Decision by the Committee. Addendum, G/SPS/19/Add.1, circulated on 15 November 2002; Committee on Sanitary and Phytosanitary Measures, Decision on the Implementation of Article 4 of the Agreement on the Application of Sanitary and Phytosanitary Measures - Revision, G/SPS/19/Rev.2, circulated on 23 July 2004; Committee on Sanitary and Phytosanitary Measures, Decision on the Implementation of Article 4 of the Agreement on the Application of Sanitary and Phytosanitary Measures. Decision by the Committee - Addendum, G/SPS/19/Add.3, circulated on 26 March 2004. 
to a product or category of products. It further provides that Members 'may' seek more comprehensive and broad ranging agreements on equivalence. ${ }^{61}$ While noting that in the former case an evaluation of product-related infrastructure and programmes may be necessary, this is clarified in footnote to refer to 'testing, inspection and other relevant requirements specific to product safety. ${ }^{92}$ This footnote was added to secure agreement with the Equivalence Decision by some Members that were concerned by the possibility that non-product related PPMs could be regarded as relevant to the consideration of equivalence. ${ }^{63}$ Further, the distinction between $a d$ hoc recognition of equivalence with regard to specific products, and more comprehensive recognition of equivalence reflected in agreements seems based on concerns raised by Members with regard to the burdensome nature of the latter category. While product-related equivalence allows flexibility to exporting Members to use different means to achieve the same level of product safety, systems-based equivalence is far more intrusive and costly to demonstrate. In this regard it is useful to recall Argentina's argument that while a developing-country Member could easily show equivalence in respect of export products, it would be most unlikely to be able to show systems-wide equivalence. Further, the costs of such a global equivalence demonstration would be too high, bearing in mind the relatively small number of products exported by developing counties. ${ }^{64}$

In subsequent paragraphs, the Equivalence Decision sets out procedural guidelines for any Member who requests the recognition of equivalence of their SPS measures and for the importing Member who is the addressee of such a request. These requirements reflect the recognition in the preamble of the Equivalence Decision that 'transparency, exchange of information and confidence-building by both the importing and exporting Member are essential to achieving an agreement on equivalence.' In particular, the Decision states that the importing Member should, on request, supply information regarding the aim and rationale of its SPS measure, clearly identify the risks it addresses and indicate the appropriate level of protection chosen by the Member ${ }^{65}$ The explanation should be accompanied by a copy of the underlying risk assessment for the measure or a technical justification not based on a relevant international standard, guideline or recommendation. ${ }^{66}$ The importing Member must respond in a timely manner to the request for recognition of equivalence, normally within six months. ${ }^{67}$ The exporting Member must provide science-based and

${ }^{61}$ Para. 1 of the Equivalence Decision.

${ }^{62}$ Footnote 1 to the Equivalence Decision.

${ }^{63}$ As noted below, the Equivalence Decision, like several other decisions of the SPS Committee, was adopted on an ad referendum basis, meaning that a decision is provisionally adopted pending the expiry of a specified period during which Members may still raise objections to the decision. As concerns were raised with regard to para. 1 of the Equivalence Decision, the Chairperson of the SPS Committee undertook discussions to resolve these concerns, culminating in the inclusion of footnote 1 clarifying this paragraph. See further Joanne Scott, The WTO Agreement on Sanitary and Phytosanitary Measures: A Commentary, Oxford Commentaries on the GATT/WTO Agreements (Oxford University Press, Oxford), 2007, 48, footnote 20.

${ }^{64}$ Committee on Sanitary and Phytosanitary Measures, Equivalence: Article 4 of the Agreement on the Application of Sanitary and Phytosanitary Measures. Communication from Argentina, G/SPS/GEN/268, circulated on 15 August 2001, Annex, para. 4 (c) and (d).

${ }^{65}$ Para. 2 of the Equivalence Decision. Further, this paragraph states that the importing Member should provide any additional information which may assist the exporting Member to provide an objective demonstration of the equivalence of its own measure.

${ }^{66}$ Ibid.

${ }^{67}$ Para. 3 of the Equivalence Decision. 
technical information to show that its measure achieves the appropriate level of protection identified by the importing Member and provide reasonable access for testing and inspection. ${ }^{68}$ The importing Member should evaluate the scientific and technical information with a view to determining if the SPS measure of the exporting Member achieves the level of protection provided by its own SPS measure. ${ }^{69}$ It is clear that there is a variance between these last two provisions. While the exporting Member must demonstrate that its measure achieves the appropriate level of protection identified by the importing Member, the latter is asked to evaluate whether the exporting Member's measure achieves the same level of protection as its own SPS measure. As established in the case law on Article 5.5, a Member's level of protection is not to be inferred from its SPS measure unless it fails to adequately identify its level of protection. To do so would undermine a Member's right to determine for itself the level of protection it deems appropriate and would assume that SPS measures applied necessarily succeed in achieving the level they aim at. ${ }^{70}$ As stated above, Article 4.1 of the SPS Agreement expressly makes the obligation to recognise equivalence dependent on the objective demonstration that the exporting Member's measures achieve the appropriate level of protection of the importing Member. As the Equivalence Decision cannot amend the provisions of the SPS Agreement, ${ }^{71}$ this provision of the Decision must be read as requiring the importing Member to evaluate the information provided with a view to establishing whether the exporting Member's measure achieves its appropriate level of protection.

In view of the technical constraints that developing-country Members face in using Article 4, the Equivalence Decision provides that Members shall give full consideration to requests for technical assistance for the implementation of Article 4, in accordance with Article 9 of the SPS Agreement. ${ }^{72}$ This technical assistance may be in the form of help in identifying and implementing equivalent measures, otherwise enhancing market access opportunities or the development and provision of science-based information to support the recognition of equivalence request.

To address Members' concerns that requests for the recognition of equivalence may have adverse effects on trade, the Equivalence Decision provides that the consideration of equivalence shall not be a reason to disrupt or suspend on-going imports of the

${ }^{68}$ Para. 4 of the Equivalence Decision. This paragraph provides that such information may include, inter alia, relevant risk assessments or relevant international standards.

${ }^{69}$ Para. 7 of the Equivalence Decision.

${ }^{70}$ The Appellate Body in Australia - Salmon has noted that this is not the case. See above, Patr III, Section 5.2.4.3. Scott argues, however, that reading Article 4.1 in accordance with existing case law would be problematic in that it results in denial of recognition of equivalence of measures that achieve the same, or a higher, level of protection than the SPS measures actually in place in the importing Member, but do not achieve the appropriate level of protection identified by a Member. While this is undoubtedly the case, another reading of Article 4 seems excluded by the fact that it specifically requires that the measure achieve the appropriate level of protection of the importing Member, which is defined as the level deemed appropriate by a Member in establishing its SPS measure. If Article 4 was intended to provide for a comparison of the level of protection achieved by the measure of the importing country and that achieved by the measure of the exporting country, it could have easily been phrased to reflect this objective. Joanne Scott, The WTO Agreement on Sanitary and Phytosanitary Measures: A Commentary, Oxford Commentaries on the GATT/WTO Agreements (Oxford University Press, Oxford), 2007, 166-167.

${ }^{71}$ On the competence of the SPS Committee and the legal status of its decisions, see below, Part IV, Section 2.1.1.

${ }^{72}$ Para. 8 of the Equivalence Decision. 
relevant product from the exporting Member. ${ }^{73}$ In addition, the procedure for determining equivalence should be accelerated for products historically imported from the exporting Member. $^{74}$

In view of the potential usefulness of international guidelines on the recognition of equivalence, the Decision provides that Members should actively participate in the work of the international standard-setting bodies on equivalence and should consider facilitating the participation of developing-country Members in these bodies. ${ }^{75}$ These bodies are further formally encouraged by the SPS Committee to elaborate guidelines on the recognition of equivalence or complete ongoing work in this respect. ${ }^{76}$

In order to promote transparency in this area, the Equivalence Decision states that the SPS Committee shall revise its Recommended Transparency Procedures to provide for the notification of equivalence agreements, and to reinforce the obligation in Annex B.3(d) of the SPS Agreement for Enquiry Points to provide information on bilateral or multilateral equivalence agreements. ${ }^{77}$ The SPS Committee adopted the revised notification format and procedures in 2002. ${ }^{78}$ These cover not only the recognition of equivalence of specific measures related to a certain product or product category, but also on a systemswide basis. ${ }^{79}$ Significant changes to existing equivalence arrangements, including their suspension or rescission should also be notified. ${ }^{80}$ Members are further encouraged to notify bilateral equivalence agreements to the SPS Committee and to regularly provide it with information on their experiences with the implementation of Article 4 of the SPS Agreement, under a standing agenda item in SPS Committee meetings. ${ }^{81}$

The Equivalence Decision mandates the creation of a specific work programme to further the implementation of Article 4, with particular consideration of the problems of developing-country Members, and provides that the SPS Committee shall review the Decision in the light of Members' experiences and the work of the CAC, OIE and IPPC. ${ }^{82}$ The results of the additional work programme on the Equivalence Decision, now incorporated into its provisions, clarify paragraph 5 (regarding accelerated steps for determining equivalence for products historically imported from the exporting Member); paragraph 6 (with respect to the relationship between current imports and potential compliance problems) and para-

\footnotetext{
${ }^{73}$ Para. 6 of the Equivalence Decision.

${ }^{74}$ Para. 5 of the Equivalence Decision.

${ }^{75}$ Para. 9 of the Equivalence Decision.

${ }^{76}$ Para. 10 of the Equivalence Decision.

${ }^{77}$ Para. 11 of the Equivalence Decision.

78 Committee on Sanitary and Phytosanitary Measures, Notification of Determination of the Recognition of Equivalence of Sanitary and Phytosanitary Measures. Decision by the Committee. Addendum, G/SPS/7/ Rev.2/Add.1, circulated on 25 July 2002.

${ }^{79}$ Ibid., 3.

${ }^{80} \mathrm{Ibid}$. The proposed format stated that notification should be made not only of formal equivalence agreements but also less formal arrangements, provided that the recognition of equivalence 'may have a significant effect on trade' of the exporting Member or other Members. Committee on Sanitary and Phytosanitary Measures, Proposed Format for the Notification of Agreements of Equivalence. Note by the Secretariat, G/SPS/W/114, circulated on 19 February 2002, paras 3-4. However this language was not taken up in the final version of the notification procedures and format.

${ }^{81}$ Para. 12 of the Equivalence Decision.

${ }^{82}$ Para. 13 of the Equivalence Decision.
} 
graph 7 (regarding the examination of scientific and technical information to determine equivalence of SPS measures) of the Decision.

Despite the inclusion of equivalence agreements in the revised Recommended Transparency Procedures, there have been only two notifications of the recognition of equivalence to date, both involving a developing-country Member's recognition of an aspect of the SPS system of a developed-country Member. The first-ever notification of the recognition of equivalence was made by Panama in 2007. Panama notified that it recognises all of the US's SPS systems and related regulatory systems for meat, poultry and processed food for human or animal consumption. ${ }^{83}$ Subsequently, the Dominican Republic notified its recognition of the inspection system of the US Food Safety Inspection Service with respect to imports of beef, pork and poultry products as equivalent to the Dominican inspection system. ${ }^{84}$ It remains to be seen if developed-country Members will similarly notify their recognition of the equivalence of developing-country Members' SPS systems or measures.

In their responses to the questionnaire circulated by the WTO Secretariat in preparation for the Workshop on Transparency held in 2007, Members indicated quite diverse reasons for the poor use of the procedure for notification of equivalence, namely that Members are unable to reach agreement on equivalence; that Members are using mechanisms other than equivalence to gain market access; and that the Equivalence Decision's procedures are being used but not being notified. ${ }^{85}$ The reluctance of importing Members to notify equivalence determinations has been ascribed by Joanne Scott to the possibility that transparency in this area would encourage more Members to request notifying importing Members to recognise the equivalence of their SPS measures, creating the associated heavy resource demands. In addition, she notes that exporting Members who have been successful in obtaining recognition of the equivalence of their SPS measures from importing Members may be reluctant to share the trade advantage this signifies by notifying this to other Members. ${ }^{86}$

\subsubsection{International guidelines on equivalence}

Since the SPS Agreement itself does not lay down specific substantive criteria for the recognition of equivalence, and the Equivalence Decision is limited to procedural rules, international guidelines in this regard are useful. ${ }^{87}$ International guidelines also reduce the

${ }^{83}$ Committee on Sanitary and Phytosanitary Measures, Notification of Determination of the Recognition of Equivalence of Sanitary and Phytosanitary Measures, G/SPS/N/EQV/PAN/1, circulated on 9 August 2007.

${ }^{84}$ Committee on Sanitary and Phytosanitary Measures, Notification of Determination of the Recognition of Equivalence of Sanitary and Phytosanitary Measures, G/SPS/N/EQV/DOM/1, circulated on 19 June 2008.

${ }^{85}$ Committee on Sanitary and Phytosanitary Measures, Analysis of Replies to the Questionnaire on the Operation of Enquiry Points and National Notification Authorities. Note by the Secretariat. Revision, G/SPS/ GEN/751/Rev.1, circulated on 18 June 2007, para. 29.

${ }^{86}$ Joanne Scott, The WTO Agreement on Sanitary and Phytosanitary Measures: A Commentary, Oxford Commentaries on the GATT/WTO Agreements (Oxford University Press, Oxford), 2007, 176.

${ }^{87}$ In discussions on equivalence in the SPS Committee, Members noted with regard to the concern about the time and resources needed to conclude equivalence agreements, that international guidelines for systemic application of the principle would be useful. The progress made by the CAC in this regard was noted. Committee on Sanitary and Phytosanitary Measures, Equivalence: Consideration of Article 4 of the SPS Agreement: Summary of Informal Discussions on Equivalence. Second Report by the Chairman, G/L/445, circulated on 
costs of equivalence negotiations by providing a framework against which equivalence can be judged. ${ }^{88}$ In fact, the Equivalence Decision itself draws upon work in the international standard-setting bodies on the issue of equivalence. ${ }^{89}$

In order to lend impetus to the development of international guidelines for the recognition of equivalence, as stated above, the Equivalence Decision mandates the SPS Committee to formally encourage the $\mathrm{CAC}$ to complete its work with regard to equivalence as expeditiously as possible, and to formally encourage the OIE and IPPC to elaborate guidelines on equivalence as appropriate. ${ }^{90}$ All three standard-setting bodies have now done so.

In order to facilitate the recognition of equivalence among trading partners, ${ }^{91}$ the CAC has established international guidelines on the development of equivalence agreements ${ }^{92}$ and on the design, operation, assessment and accreditation of food import and export inspection and certification systems ${ }^{93}$ as well as guidelines for the judgement of equivalence of sanitary measures associated with food inspection and certification systems. ${ }^{94}$

The OIE's Terrestrial Animal Health Code recognises the possibility that different sanitary measures can achieve the same level of protection, by recommending alternative measures to address several diseases or pathogenic agents addressed in its provisions. ${ }^{95}$

21 March 2001, para. 7.

${ }^{88}$ It has been noted that in the absence of guidelines on the methodology for judging equivalence, specific bilateral issues are more likely to arise and the methodological concerns of developing countries are more likely to be neglected. See Simonetta Zarrilli, The SPS Agreement and the Developing Countries (World Bank, Washington D.C.), 2003, 8.

${ }^{89} \mathrm{Scott}$ notes that the acknowledgement of the relevance of historic trade in equivalence determinations and the recognition of the need to prevent equivalence applications from being used as an excuse to disrupt existing trade are both informed by the Codex Guidelines on food import and export inspection and certification (CAC/ GL 17, CAC/GL 20 and CAC/GL 26).

${ }^{90}$ Committee on Sanitary and Phytosanitary Measures, Decision on the Implementation of Article 4 of the Agreement on the Application of Sanitary and Phytosanitary Measures - Revision, G/SPS/19/Rev.2, circulated on 23 July 2004, para. 10.

${ }^{91}$ One of the recommendations resulting from an FAO conference in 1999, under the heading 'Food trade and implementation of WTO Agreements,' was the recognition of the urgency of the development of Codex guidelines on the judgement of equivalence, initially in a generic sense and subsequently in relation to specific topics such as equivalence of inspection and certification systems and food hygiene measures. Food and Agriculture Organization, 'Report of the Conference on International Food Trade Beyond 2000: ScienceBased Decisions, Harmonization, Equivalence and Mutual Recognition', presented at the Conference on International Food Trade Beyond 2000: Science-Based Decisions, Harmonization, Equivalence and Mutual Recognition, Melbourne Australia) 11-15 October 1999, Appendix II A.2, available at: www.fao.org/docrep/ meeting/X4015e.htm, visited on 25 June 2007.

92 Codex Alimentarius Commission, Guidelines for the Development of Equivalence Agreements Regarding Food Import and Export Inspection and Certification Systems, CAC/GL34-1999 (Joint FAO/WHO Food Standards Programme, Rome), 1999.

93 Codex Alimentarius Commission, Guidelines for the Design, Operation, Assessment and Accreditation of Food Import and Export Inspection and Certification Systems, CAC/GL 26-1997 (Joint FAO/WHO Food Standards Programme, Rome), 1997.

94 These guidelines were referred to the $24^{\text {th }}$ Session of the CAC on 2-7 July 2001 for adoption at step 5 or 8 (ALINORM 01/30A para. 98 and Appendix III). Due to the fact that several countries raised concerns regarding these guidelines, the CAC decided to adopt them at step 5 only so that they could be considered further by the Codex Committee on Food Import and Export Inspection and Certification Systems. These guidelines were finally adopted at the $26^{\text {th }}$ Session of the CAC in 2003. Codex Alimentarius Commission, Report of the Twenty-Sixth Session, ALINORM 03/41 (Joint FAO/WHO Food Standards Programme, Rome), 30 June - 7 July 2003, Appendix I.

95 Committee on Sanitary and Phytosanitary Measures, Equivalence - Article 4. Update from the World 
In response to the SPS Committee's call to develop specific guidelines on the recognition of equivalence, the OIE in 2002 submitted draft guidelines on procedures for the recognition of equivalence of animal health measures to the SPS Committee. ${ }^{96}$ In 2005, the OIE notified the SPS Committee that it had adopted guidelines for reaching a judgement of equivalence of sanitary measures. ${ }^{97}$ These guidelines provide substantive criteria and procedural steps to help OIE members to establish whether measures forming part of different animal health and production systems provide the same level of sanitary protection. These guidelines apply whether equivalence is being determined at a measure-specific or systems-wide level, and whether it is established for a particular product or for trade in general. $^{98}$

The IPPC also generally recognises the principle of equivalence, as reflected in several ISPMs. ${ }^{99}$ In response to the SPS Committee's request that it develop guidelines for the recognition of equivalence, the IPPC notified the SPS Committee in 2002 of the view of the ICPM that a prerequisite for the development of guidelines on equivalence was the establishment of guidance on the concept of efficacy of phytosanitary measures. ${ }^{100}$ In 2003, the IPPC reported that an EWG was established to address this issue, including the factors to be taken into account when determining equivalence of measures. ${ }^{101}$ The ICPM work program in 2003 identified both efficacy of phytosanitary measures and equivalence as priorities for ISPMs. The EWG on efficacy of measures produced a draft ISPM which was submitted to the Standards Committee. ${ }^{102}$ The Standards Committee returned the draft to the EWG due to additional issues that had to be addressed in its view. ${ }^{103}$ The revised draft ISPM was resubmitted to the Standards Committee in May 2004, but work on this ISPM is currently still pending, until completion of work on the draft ISPMs on sampling of consignments and the appropriate level of protection. ${ }^{104}$ In September 2003,

Organization for Animal Health Organization (OIE), G/SPS/GEN/767, circulated on 1 March 2007.

${ }^{9}$ Committee on Sanitary and Phytosanitary Measures, Draft Paper on the Judgement of Equivalence of Sanitary Measures Relating to International Trade in Animals and Animal Products. Submission by the Office International Des Epizooties (OIE), G/SPS/W/119, circulated on 18 March 2002.

${ }^{97}$ Committee on Sanitary and Phytosanitary Measures, Guidelines for Reaching a Judgement of Equivalence of Sanitary Measures. Submission by the Office International Des Épozooties., G/SPS/GEN/406, circulated on 19 June 2003.

${ }^{98}$ Guidelines for Reaching a Judgement of Equivalence of Sanitary Measures, Chapter 1.3.6 of the OIE Terrestrial Animal Health Code of 2007, available at: http://www.oie.int/eng/normes/mcode/en_chapitre_1.3.6.htm, visited on 29 June 2008.

${ }^{99}$ For example, in ISPM 1 equivalence is listed as one of the general principles of plant quarantine. ISPM 5, which is a glossary of phytosanitary terms, defines equivalence. In addition, ISPM 11 which deals with pest risk analysis for quarantine pests addresses equivalence in its section on risk management options. Interim Commission on Phytosanitary Measures, Equivalence, ICPM 03/INF/3, Fiat Panis, March 2003, paras 1-3.

${ }^{100}$ Committee on Sanitary and Phytosanitary Measures, Summary of the Meeting Held on 25-26 June 2002. Note by the Secretariat, G/SPS/R/27, circulated on 2 August 2002, para. 89.

${ }^{101}$ Committee on Sanitary and Phytosanitary Measures, Equivalence. Statement by the International Plant Protection Convention (IPPC) at the Meeting of 28 - 30 October 2003, G/SPS/GEN/439, circulated on 27 October 2003.

${ }^{102}$ Interim Commission on Phytosanitary Measures, Equivalence, ICPM 03/INF/3 (Fiat Panis, March 2003.

103 Committee on Sanitary and Phytosanitary Measures, Equivalence. Statement by the International Plant Protection Convention (IPPC) at the Meeting of 28 - 30 October 2003, G/SPS/GEN/439, circulated on 27 October 2003, para. 4.

${ }^{104}$ Committee on Sanitary and Phytosanitary Measures, International Plant Protection Convention (IPPC) Standard Setting Work Programme (up-to-Date June 2008), G/SPS/GEN/848, circulated on 18 June 2008, para. 6.4. 
an EWG was convened to develop an ISPM on equivalence. The report of the EWG was presented to the Standards Committee for review in May 2004. ${ }^{105}$ In 2005, the CPM adopted the guidelines for the determination and recognition of equivalence of phytosanitary measures. ${ }^{106}$

\subsection{Regionalisation}

SPS conditions, and in particular the incidence of pests and diseases, are not determined by national borders, and may differ between various regions within a country. This may be the case due to variations in climatic, environmental or geographic conditions within a country and/or due to the efforts of the regulatory authorities to eradicate a pest or disease from specific areas. If importing Members were to adapt their SPS measures to the pest or disease conditions prevailing in the region of origin of the product, this could greatly improve market access possibilities. Such adaptation of SPS measures to regional conditions in the exporting Member is especially significant for large developing countries, where conditions vary greatly from region to region, as the costs of eradicating a pest or disease or keeping pest- or disease-free status can be limited by focusing on specific areas.

In practice, however, it is common to ban products from an entire country where it has been established that a pest or disease of significance for the importing country occurs, even if its prevalence is limited to certain regions. ${ }^{107}$ In addition, sometimes importing Members do not adapt their measures to the pest- or disease status of an exporting Member and impose SPS restrictions against exporting Members that are in fact free of the pest or disease at issue. An example of this is the failure of the EC to recognise the status of South Africa as free of food and mouth disease, despite the fact that this status was officially recognised by the OIE. ${ }^{108}$

SPS characteristics in importing Members are also of importance to take into account in establishing SPS measures. Some importing Members are already infested by the pest or disease their import restriction aims to keep out. However, it frequently occurs that the pest or disease status of the importing Member is not taken into account in applying

${ }^{105}$ Committee on Sanitary and Phytosanitary Measures, Equivalence. Statement by the International Plant Protection Convention (IPPC) at the Meeting of 28 - 30 October 2003, G/SPS/GEN/439, circulated on 27 October 2003, para. 5 .

106 Guidelines for the Determination and Recognition of Equivalence of Phytosanitary Measures, ISPM 24 (2005) Committee on Sanitary and Phytosanitary Measures, International Plant Protection Convention (IPPC) Standard Setting Work Programme (up-to-Date June 2008), G/SPS/GEN/848, circulated on 18 June 2008, para. 1.

${ }^{107}$ For example, in 1995 Ecuador banned the importation of fruit hosts of the oriental fruit fly from the US after a few oriental fruit flies had been detected in Southern California. This example was noted in David S. Johanson and William L. Bryant, 'Eliminating Phytosanitary Trade Barriers: The Effects of the Uruguay Round Agreements on California Agricultural Exports', San Joaquin Agricultural Law Review 6, 1996, 1-26, 7.

${ }^{108}$ Committee on Sanitary and Phytosanitary Measures, The Failure of the European Communities to Amend EC Directive 2001/661/EC Allowing the Import of Bone in Meat from Ovine/Caprine Species from Countries Zoned Free from Foot and Mouth Disease without Vaccination. Communication from South Africa, G/SPS/ GEN/373, circulated on 26 February 2003. 
import restrictions. For example, the US maintains import restrictions on goat imports due to the risk of scrapie, while the presence of scrapie in US sheep is currently widespread. ${ }^{109}$ In addition, the climactic and geographical conditions in the importing Member may reduce the threat of introduction of a particular pest or disease, rendering their SPS measure superfluous. A good example of the reduction in trade barriers that results from the recognition of this type of SPS condition in the importing Member is provided by the situation of the US ban on hass avocado imports from Mexico due to concerns of potential importation of pests (fruit flies, weevils and seed moth), which for several years formed the subject of one of the most contentious SPS disputes between these two Members. ${ }^{110}$ Mexico argued that its main avocado-producing region has low prevalence of pests of quarantine significance, and that its systems approach to risk management in this area eliminates the threat of transmission of pests in any event. The US avocado industry strongly contests this. After four years of negotiations on this point, the US Department of Agriculture partially eased its ban by allowing hass avocado imports from Mexico into its north-eastern states in the winter months, when the risk of establishment of pests is mitigated by the winter weather.

In order to promote the adaptation of SPS measures to national or regional SPS conditions (commonly termed 'regionalisation') Article 6 of the SPS Agreement lays down substantive obligations coupled with procedural requirements. Article 6.1 requires, in general terms, that Members ensure that their sanitary or phytosanitary measures are adapted to the sanitary or phytosanitary characteristics of the area from which the product originated and to which the product is destined, taking into account specific factors. Article 6.2 is more specific, requiring the recognition of pest- or disease-free areas and areas of low pest or disease prevalence. Finally, Article 6.3 outlines some procedural requirements to give effect to the obligation of adaptation to regional conditions. These are discussed in more detail below.

\subsubsection{Adaptation to regional conditions}

The basic obligation of regionalisation is set out in Article 6.1 of the SPS Agreement. It provides:

Members shall ensure that their sanitary or phytosanitary measures are adapted to the sanitary or phytosanitary characteristics of the area - whether all of a country, part of a country, or all or parts of several countries - from which the product originated and to which the product is destined. In assessing the sanitary or phytosanitary characteristics of a region, Members shall take into account, inter alia, the level of prevalence of specific diseases or pests, the existence of

\footnotetext{
${ }^{109}$ European Commission, Report on United States Barriers to Trade and Investment (European Commission, Brussels), December 2003, 33, available at: http://rade-info.cec.eu.int/doclib/docs/2003/december/tradoc 115383.pdf, visited on 3 January 2004.

110 This dispute is discussed in David Orden et al., 'Least Trade-Restrictive SPS Policies: An Analytic Framework Is There but Questions Remain', in The Economics of Quarantine and the SPS Agreement, Kym Anderson, et al. (eds.) (Centre for International Economic Studies, Adelaide), 2001, 183-215, 188; Council of the Organisation for Economic Co-Operation and Development, A Synthesis of Empirical Studies of SPS Regulations and a Proposal for Future Work, COM/AGR/TD/WP/(2002)72, OECD, 27 August 2002.
} 
eradication or control programmes, and appropriate criteria or guidelines which may be developed by the relevant international organizations.

Some guidance is provided in Article 6.1 as to the criteria to be taken into account in adaptation to regional conditions, unlike the situation in Article 4 with respect to the recognition of equivalence. In determining what the sanitary or phytosanitary characteristics of a region are, Article 6.1 obliges Members to take into account the level of prevalence of specific pests or diseases, the existence of eradication or control programmes and guidelines developed by international organisations. This is not a closed list of factors, as indicated by the term 'inter alia'. Thus Members may consider additional relevant factors in decisions on regionalisation.

The reference to the guidelines developed by international organisations would seem to require consideration of OIE or IPPC guidelines on pest- or disease- prevalence and in particular on the recognition of pest- or disease-free areas. In this light, it can be argued that the official recognition of the pest-free status of a Member by the OIE and the publication of this in the official Bulletin of the OIE should be taken into account as an important part of the necessary evidence for an objective demonstration of disease-free status. Similarly, the self-declaration of a Member of its pest- or disease free status in accordance with the specific OIE guidelines for the disease at issue should be among the factors considered when adapting an SPS measure to regional conditions. However, this is not the same as requiring Members to automatically accept the pest- or disease-free status of a Member that has established such status according to the relevant international guidelines. Other factors, such as the reliability of the competent authorities of the exporting Member and the veterinary or phytosanitary structures in place to maintain the status, including monitoring and verification also play a role. ${ }^{11}$

\subsubsection{Recognition of pest- or disease-free areas or areas of low pest or disease prevalence}

The regionalisation obligation of Article 6 is made more concrete in paragraph 2 thereof. This paragraph deals with the most controversial aspect of adaptation to regional conditions, namely the recognition of areas that are free of pests of diseases and areas where the prevalence of pests or diseases is low. Article 6.2 states:

Members shall, in particular, recognize the concepts of pest- or disease-free areas and areas of low pest or disease prevalence. Determination of such areas shall be based on factors such as geography, ecosystems, epidemiological surveillance, and the effectiveness of sanitary or phytosanitary controls.

Once again, an open list of factors that Members must consider is provided. Further, Annex A.6 of the SPS Agreement defines a pest- or disease-free area as an area, which can be all or part of a country or of several countries, as identified by the competent authorities, in which a pest or disease does not occur. This area may adjoin an area where the

111 Committee on Sanitary and Phytosanitary Measures, Comments on the Background Document on Issues in the Application of Article 6 of the SPS Agreement (G/SPS/GEN/640). Communication from the European Communities, G/SPS/W/190, circulated on 30 May 2006, para. 6. 
pest or disease does occur, but is subject to regional control measures such as protection, surveillance or buffer zones that confine or eradicate the pest or disease. An area of low pest- or disease prevalence is defined as an area, which can be all or part of a country or of several countries, as identified by the competent authorities, in which a pest or disease occurs at low levels and is subject to effective surveillance, control or eradication measures.

\subsubsection{Procedure}

To give effect to the regionalisation obligations in Article 6.1 and 6.2, some procedural requirements are outlined in Article 6.3. It provides:

Exporting Members claiming that areas within their territories are pest- or diseasefree areas or areas of low pest or disease prevalence shall provide the necessary evidence thereof in order to objectively demonstrate to the importing Member that such areas are, and are likely to remain, pest- or disease-free areas or areas of low pest or disease prevalence, respectively. For this purpose, reasonable access shall be given, upon request, to the importing Member for inspection, testing and other relevant procedures.

Clearly, the limited procedural requirements of Article 6.3 are very similar to those provided in Article 4.1 on the recognition of equivalence. In terms of Article 6.3, an exporting Member that claims that regions within its territory are pest- or disease-free or have low pest or disease prevalence must provide the necessary evidence to 'objectively demonstrate' this fact to the importing Member. For this purpose, it must give the importing Member reasonable access for inspection, testing and other relevant procedures. The criteria set out in Article 6.1 and 6.2 give some content to what must be considered in a regionalisation decision in general, and more specifically in a decision regarding the recognition of pest- or disease-free areas or areas of low pest- or disease prevalence, and therefore by implication to what information a Member should bring to 'objectively demonstrate' this status. However, no further procedural disciplines are set out in Article 6, leaving it open to Members to maintain complex and lengthy procedures in this regard. ${ }^{112}$

\subsubsection{Examples}

The case of an avian influenza outbreak in Chile offers a good example of regionalisation. ${ }^{113}$ In May 2002, Chile was confronted with the first-ever outbreak of avian influenza

\footnotetext{
${ }^{112}$ As with procedures for the recognition of equivalence, also with procedures to adapt to regional conditions Scott argues that the procedural disciplines of Article 8 and Annex C of the SPS Agreement, which deal with control, inspection and approval procedures, apply. Joanne Scott, The WTO Agreement on Sanitary and Phytosanitary Measures: A Commentary, Oxford Commentaries on the GATT/WTO Agreements (Oxford University Press, Oxford), 2007, 185, footnote 198. However, as stated above, Annex C.1 specifies that its requirements apply 'with respect to any procedure to check and ensure the fulfilment of sanitary and phytosanitary requirements'. The adaptation of SPS measures to regional conditions, instead, is based on a procedure to ascertain the SPS characteristics of the relevant area, including the prevalence of pests and diseases, in order to change the SPS measure applied to products from that area accordingly. This seems to lie outside the scope of Annex C.

${ }^{113}$ See C. Orozco, 'The SPS Agreement and Crisis Management: The Chile-EU Avian Influenza Experience', in: P. Gallagher, P. Low and A.L. Stoler, Managing the Challenges of WTO Participation, (Cambridge University Press, 2005), pp. 150-168.
} 
on its territory. In response to this, the European Commission adopted an import ban on 23 July 2002. Three months later, when the Chilean government had the disease under control, it requested the Commission to consider the 'regionalisation of the Chilean territory' for the purposes of imports in accordance with Article 6 of the SPS Agreement. After the Chilean authorities presented sufficient evidence, the Commission adopted a decision on 14 October 2002 allowing for the temporary regionalization of Chile for the purposes of imports and allowed for importation of areas which were designated disease-free.

Another example is that of Ecuador's phytosanitary restrictions to prevent the introduction of oriental fruit flies. ${ }^{114}$ In November 1995, following the detection of a limited number of these flies outside growing areas in Southern California, Ecuador imposed an import ban on all potential hosts, mainly fruit, from the US. The US promptly initiated informal bilateral consultations with Ecuador on the basis of Article 6 of the SPS Agreement. Ecuador agreed to revise its measure and allow importation of non-Californian fruit. ${ }^{115}$

A third example of regionalisation is that discussed in Part II above, ${ }^{116}$ in respect of Indonesia's fumigation and cold-treatment requirements to prevent the introduction of fruit flies through imports of fresh fruit and vegetables. To address the problem caused by these measures to its fruit industry, Australia promptly and successfully conducted highlevel technical discussions with the Indonesian authorities, leading to the recognition by Indonesia of three regions and one State in Australia as fruit-fly free regions. ${ }^{117}$

The use of international guidelines in regionalisation decisions is illustrated by the lifting by Mauritius of its bans on chilled, processed pork products from France and live cattle, sheep and goats from certain regions in South Africa. In April 2001, Mauritius had imposed a ban on all meat products from the EC, except poultry and canned pork, due to the outbreak of foot-and-mouth disease. ${ }^{118}$ In the same month it imposed a temporary suspension on imports of live cattle, sheep and goats from Zimbabwe and South Africa, due to the prevalence of foot-and-mouth disease in these countries. ${ }^{119}$ However, in November of that year, Mauritius notified that, following the September 2001 report of the OIE on the foot-and-mouth disease situation in different countries, it would lift its ban on chilled,

114 A similar example exists with regard to China's restrictions to prevent the introduction of Mediterranean fruit fly. Due to detections of this pest in the Los Angeles area, China imposed an import restriction on all citrus, apples, table grapes and cherries from the US. The US raised this issue in 1994, the context of China's negotiations towards accession to the WTO and the requirement that it bring its SPS measures into conformity with WTO rules. In March 1995, China agreed to evaluate the risk of introduction of Mediterranean fruit fly on a commodity basis, and to allow regions outside the fruit fly quarantine area in California to export to China. David S. Johanson and William L. Bryant, 'Eliminating Phytosanitary Trade Barriers: The Effects of the Uruguay Round Agreements on California Agricultural Exports', San Joaquin Agricultural Law Review $6,1996,1-26,7$.

${ }^{115} \mathrm{Ibid}$. In addition fresh fruit from California was permitted if fumigated with methyl bromide before leaving customs.

116 See above, Part II, Section 2.4.2.4.

117 Australian Government Department of Agriculture Fisheries and Forestry, Annual Report 2006-07: Growing Australia through Sustainable, Innovative and Profitable Agriculture, Fisheries and Forestry (Commonwealth of Australia, Canberra), September 2007, 109, available at: http://www.daff.gov.au/_data/ assets/pdf_file/0005/439493/2_AR_06-07_ROP_WEB.pdf, visited on 17 January 2008.

${ }^{118}$ Committee on Sanitary and Phytosanitary Measures, Notification of Emergency Measures, G/SPS/N/MUS/4, circulated on 10 April 2001.

${ }^{119}$ Committee on Sanitary and Phytosanitary Measures, Notification of Emergency Measures, G/SPS/N/MUS/5, circulated on 23 April 2001. 
processed pork products from France, and on live cattle from foot-and-mouth disease free zones in South Africa. ${ }^{120}$ In April 2002, based on the same OIE report, Mauritius extended the lifting of its ban to all pork and pork products from the EC, except the UK, and to all live cattle, sheep and goats from foot-and-mouth disease free zones in South Africa. ${ }^{121}$

An example of the successful use of regionalisation between two developing-country Members, at different levels of development, was reported by Trinidad and Tobago in 2006. ${ }^{122}$ In this example, Trinidad and Tobago conducted a pest risk analysis to determine the risks associated with importation of fresh fruit from Argentina, and established that the main risk related to the Mediterranean fruit fly in respect of which the most effective quarantine treatment was cold treatment. The literature also indicated that there were fruit-fly free production areas in Argentina. However, Trinidad and Tobago had no expertise in the application of cold treatment and had insufficient data to establish the pest-free status of fruit production areas in Argentina. It therefore requested technical assistance from Argentina to help it to determine first hand the pest-free status of the relevant regions; to evaluate the data on the pest-free status of these regions; to evaluate the pest-free status of the harvested fruits; and to use cold treatment as a quarantine measure. Argentina responded by sponsoring the visit of an Argentine scientist to Trinidad and Tobago, and the visit of two Crop Protection Officers from Trinidad and Tobago to Argentina. The latter officials visited production sites in the Patagonia area of Argentina where natural barriers prevent the entry of fruit flies. They observed in practice several phytosanitary measures applied by Argentina against the spread of fruit flies. ${ }^{123}$ They also examined fruit fly trapping records for the Patagonia valley. In addition they were given a demonstration of cold treatment. On the basis of this visit, the officials verified that the strict phytosanitary system in place in Argentina was effective in ensuring the fruit-fly free status of the Patagonia region. ${ }^{124}$ A recommendation was therefore issued to the Plant Protection Committee of Trinidad and Tobago to allow the importation of apples, grapes and pears from the Patagonia region of Argentina when accompanied by a phytosanitary certificate indicating the region of origin and adherence to Trinidad and Tobago's phytosanitary requirements. This fruit will not be subject to cold treatment, due to its pest-free status. However, Argentina must bear the costs of an annual audit visit by crop protection personnel of Trinidad and Tobago.

120 Committee on Sanitary and Phytosanitary Measures, Notification, G/SPS/N/MUS/7, circulated on 8 November 2001. The same lifting of the ban was notified again in 2002. Committee on Sanitary and Phytosanitary Measures, Notification, G/SPS/N/MUS/8, circulated on 8 April 2002.

121 Committee on Sanitary and Phytosanitary Measures, Notification, G/SPS/N/MUS/9, circulated on 8 April 2002.

122 Committee on Sanitary and Phytosanitary Measures, Some Experiences of Trinidad and Tobago in the Application of the SPS Agreement. Communication from Trinidad and Tobago, G/SPS/GEN/680, circulated on 31 March 2006.

${ }^{123}$ For example, they participated in fruit cutting in the field, observed fruit-fly trapping in rural and urban areas, observed the breeding and release of sterile male fruit flies, visited quarantine checkpoints and observed physical checks, visited a freight inspection facility and observed export fruit inspection and sampling for fruit flies, visited a packing house to observe the preparation, storage and packing of export fruits.

${ }^{124}$ Committee on Sanitary and Phytosanitary Measures, Some Experiences of Trinidad and Tobago in the Application of the SPS Agreement. Communication from Trinidad and Tobago, G/SPS/GEN/680, circulated on 31 March 2006, para. 6. 


\subsubsection{Problems with implementation}

Despite the potential of regionalisation to limit the trade restrictive effect of SPS measures by facilitating the lifting of unnecessary SPS requirements with respect to pest- or disease free regions, as illustrated by the successful examples above, or by adjusting strict requirements to take account of low pest- or disease prevalence, to date implementation of Article 6 of the SPS Agreement has been very limited. This has been attributed not to a problem with the substantive obligations in Article 6 but rather to the weakness of its procedural rules. Therefore Members have proposed strengthening the operation of this provision through developing administrative procedures for its implementation. ${ }^{125}$ In addition, Members have addressed the need to further specify the criteria to be taken into account in regionalisation decisions, and in particular the role to be played by international recognition of pest- or disease-free status, and the importance of trust in the competent authority of the exporting Member. ${ }^{126}$

There are many examples of situations were the failure to adapt SPS requirements to the particular pest or disease status of the area of origin of the product (whether a country, part of a country or parts of several countries) has caused unnecessary trade restrictions. They are often raised as specific trade concerns in SPS Committee meetings. ${ }^{127}$

One such example is that raised by South Africa before the SPS Committee in 2003. ${ }^{128}$ It concerned the EC's restrictions on meat imports due to the risk of introduction of footand-mouth disease (FMD). South Africa and Namibia are officially recognised as zones free of FMD by the OIE. While the EC Directive at issue allowed fresh meat imports from South Africa, except from within the FMD control zone, ${ }^{129}$ it imposed additional sanitary requirements for ovine and caprine meat from zones recognised as FMD free without vaccination. These requirements were that the meat be deboned, mature, with the lymph nodes removed and that importation take place only three weeks after slaughter. South Africa argued that these additional requirements were contrary to the OIE Terrestrial Animal Health Code, which does not require deboning if the meat originates from FMDfree countries or zones where vaccination is not practiced. ${ }^{130}$ The EC agreed to review its measure in light of the FMD situation in South Africa after its new Directive came into force in January 2005. ${ }^{131}$ However, no solution to this problem has been reported to date.

${ }^{125}$ For a summary of the procedural steps proposed by various Members in this regard, see Committee on Sanitary and Phytosanitary Measures, Issues on the Application of Article 6 of the Agreement on the Application of Sanitary and Phytosanitary Measures. Background Document. Note by the Secretariat. Revision, G/SPS/ GEN/640/Rev.1, circulated on 14 September 2006, paras 27-47.

126 Ibid., para. 8 .

${ }^{127}$ Ibid., para. 4. Further, the SPS Committee has reported that also outside the context of its specific trade concerns mechanism, in general Committee discussions, Members have specifically highlighted difficulties in obtaining prompt recognition of their pest- or disease-free status by importing Members.

${ }^{128}$ Committee on Sanitary and Phytosanitary Measures, The Failure of the European Communities to Amend EC Directive 2001/661/EC Allowing the Import of Bone in Meat from Ovine/Caprine Species from Countries Zoned Free from Foot and Mouth Disease without Vaccination. Communication from South Africa, G/SPS/ GEN/373, circulated on 26 February 2003.

${ }^{129}$ Council Directive 2001/661.

${ }^{130}$ Committee on Sanitary and Phytosanitary Measures, Specific Trade Concerns. Note by the Secretariat. Addendum. Issues Not Considered in 2007, G/SPS/GEN/204/Rev.8/Add.2, circulated on 27 March 2008, para. 247.

${ }^{131}$ Council Directive 99/2002, which updated EC legislation to reflect the fact that certain virus strains (SAT and 
During discussions at the SPS Committee with regard to the inadequate implementation of Article 6 of the SPS Agreement, ${ }^{132}$ Members have identified various problems. ${ }^{133}$ In particular, national administrative procedures applied by importing Members in respect of regionalisation have been criticised as being often untransparent, complex, lengthy and expensive, and lacking clearly defined time-limits for a response to a request. ${ }^{134}$ This is illustrated by the example provided in Part II above regarding Jamaica's still-pending request for the recognition by the US of the existence of areas free of weevils, in order to lift fumigation requirements for yam exports from these regions. ${ }^{135}$ In addition, the lack of consistency in the various administrative procedures applied by different importing Members for the acceptance of regionalisation has been identified as a problem. ${ }^{136}$ Further, it has been noted that inconsistencies exist in the application of regionalisation

Asiat 1) were no longer considered differently from FMD.

${ }^{132}$ In 2004, New Zealand provided a useful summary of the implementation problems raised by Members. In 2006, the WTO Secretariat circulated a similar summary covering the submissions made until September 2006. These two documents been drawn upon for the discussion in this section. Committee on Sanitary and Phytosanitary Measures, Monitoring of International Harmonization: Regionalization. Submission by New Zealand, G/SPS/W/151, circulated on 29 September 2004, paras 5-6; Committee on Sanitary and Phytosanitary Measures, Issues on the Application of Article 6 of the Agreement on the Application of Sanitary and Phytosanitary Measures. Background Document. Note by the Secretariat. Revision, G/SPS/ GEN/640/Rev.1, circulated on 14 September 2006.

${ }^{133}$ For examples of specific submissions in this regard, see Committee on Sanitary and Phytosanitary Measures, Implementation of Regionalization Principle: Communication by Argentina, G/SPS/GEN/433, circulated on 22 October 2003; Committee on Sanitary and Phytosanitary Measures, Decision on the Implementation of Article 6 of the Agreement on the Application of Sanitary and Phytosanitary Measures - Proposal by Canada, G/SPS/W/145, circulated on 16 March 2004; Committee on Sanitary and Phytosanitary Measures, Comments on Chapter 6 of the SPS Agreement - Regionalization. Communication by Chile, G/SPS/W/129, circulated on 21 March 2003; Committee on Sanitary and Phytosanitary Measures, Draft Decision on the Implementation of Article 6 of the Agreement on the Application of Sanitary and Phytosanitary Measures: Proposal by Chile: Revision, G/SPS/W/140/Rev.1, circulated on 30 October 2003; Committee on Sanitary and Phytosanitary Measures, Additional Comments on Article 6 of the SPS Agreement - Regionalization. Communication by Chile, G/SPS/GEN/381, circulated on 1 April 2003; Committee on Sanitary and Phytosanitary Measures, Review of the SPS Agreement. Update on Adaptation to Regional Conditions. Submission by the European Communities, G/SPS/GEN/461, circulated on 12 December 2003; Committee on Sanitary and Phytosanitary Measures, Draft Decision on the Implementation of Article 6 of the Agreement on the Application of Sanitary and Phytosanitary Measures - Comments by the European Communities on the Proposal of Chile (G/ SPS/W/140/Rev.1), G/SPS/W/144, circulated on 11 March 2004; Committee on Sanitary and Phytosanitary Measures, Comments on Article 6 of the SPS Agreement - Regionalization. Communication by Mexico, G/ SPS/GEN/388, circulated on 1 May 2003; Committee on Sanitary and Phytosanitary Measures, Article 6 of the Agreement on the Application of Sanitary and Phytosanitary Measures. Adaptation to Regional Conditions, Including Pest- or Disease-Free Areas of Low Pest or Disease Prevalence. Proposal by Peru, G/ SPS/W/148, circulated on 7 July 2004; Committee on Sanitary and Phytosanitary Measures, Articles 6(2), 6(3) and Annex A(3)(B): Recognition of the Concept of Pest-or Disease-Free Areas as an International Standard, Guideline or Recommendation: Submission by South Africa, G/SPS/GEN/139, circulated on 2 November 1999; Committee on Sanitary and Phytosanitary Measures, Regionalization - Communication by the United States, G/SPS/GEN/477, circulated on 16 March 2004.

${ }^{134}$ See for example Committee on Sanitary and Phytosanitary Measures, Peru Initiates a Process for the Declaration and Recognition of Areas Free from and of Low Prevalence of Fruit Flies Certitis Capitata and Anastrepha Spp. Communication from Peru, G/SPS/GEN/417, circulated on 1 August 2003. It has been stated that the time taken to recognise an area free from a certain pest or disease can vary from a few months to several years.

${ }^{135}$ See above, Part II, Section 2.6.2.3.

${ }_{136}$ While some Members have no established guidelines, other Members have procedures with a number of stages. 
to different exporting Members. This may be due to factors that 'can either generate or erode importing Members' trust' ${ }^{\prime 37}$ in the exporting Member's regulatory system, which influence an importing Member's acceptance of pest- or disease-free areas. This has often proved a difficulty for exporting Members at lower levels of development, in cases where their SPS regulatory regimes are underdeveloped and do not inspire confidence in importing Members.

Members have noted that the uncertainties in the national procedures to obtain recognition of pest- or disease-free areas for market access threatens the sustainability of such areas. In view of the significant investments required to establish and maintain pest- or disease-free areas, the maintenance of these areas depends on the commercial gains that producers can achieve from trade resulting from pest- or disease-free status. ${ }^{138}$ Therefore, market access is the main objective for investing in the establishment and maintenance of pest- or disease-free areas.

In the discussions on this issue, importing Members have stressed the need for confidence in the SPS status of exporting Members and for the provision of accurate information in their evaluation of requests for recognition of free status. ${ }^{139}$ One way to address these challenges that has been suggested is the consideration of the relationship between the work of the SPS Committee and the work of the international standards setting bodies. ${ }^{140}$ However, in their early submissions to the SPS Committee, Members pointed to the then non-existence of international guidelines by the OIE or IPPC for national administrative procedures for the recognition of pest- or disease-free areas or areas of low pest or disease prevalence, including the absence of specified time-limits for a response to a request for such recognition. In addition, with regard to the possibilities that could be provided by the official recognition for pest- or disease-free areas or areas of low pest or disease prevalence by the IPPC and by the OIE, it was noted that there is limited provision of official recognition by the OIE and none by the IPPC. The OIE conducts evaluations, upon request, and grants recognition of sanitary status in respect of only four animal diseases. ${ }^{141}$ However, Members have expressed concerns that some importing Members

${ }^{137}$ Committee on Sanitary and Phytosanitary Measures, Issues on the Application of Article 6 of the Agreement on the Application of Sanitary and Phytosanitary Measures. Background Document. Note by the Secretariat. Revision, G/SPS/GEN/640/Rev.1, circulated on 14 September 2006, para. 7.

138 Committee on Sanitary and Phytosanitary Measures, Regionalisation. Communication by Peru, G/SPS/ GEN/607, circulated on 6 December 2005.

${ }^{139}$ Committee on Sanitary and Phytosanitary Measures, Issues on the Application of Article 6 of the Agreement on the Application of Sanitary and Phytosanitary Measures. Background Document. Note by the Secretariat. Revision, G/SPS/GEN/640/Rev.1, circulated on 14 September 2006, paras 4-5. The EC has stated in this regard that: 'the ultimate decision to recognize remains with the importing Member and very much depends on the trust in the competent authority of the exporting Member. This trust builds on the veterinary/phytosanitary system in place and previous experience with the exporting Member. Consequently, the recognition process varies from one case to another, hence the need for predictability and transparency.' Committee on Sanitary and Phytosanitary Measures, Comments on the Background Document on Issues in the Application of Article 6 of the SPS Agreement (G/SPS/GEN/640). Communication from the European Communities, G/SPS/W/190, circulated on 30 May 2006, para. 6.

${ }^{140}$ In particular, a suggestion was made that the eradication measures applied to establish a pest- or disease free area follow the provisions of the OIE Terrestrial Animal Health Code concerning the declaration of a disease free area. While the IPPC does not have pest-specific eradication guidelines, ISPM 9 provides more general Guidelines for Pest Eradication Programmes.

141 As previously mentioned, these are foot-and-mouth disease, rinderpest, BSE and contagious bovine 
do not automatically or promptly accept such OIE recognition. Reasons given for this are the fact that the procedures and information required for OIE verification do not fully meet the concerns of some Members; and that the lack of transparency in the international procedure for verification of disease free status makes it difficult to determine if the conditions for recognition of disease-free status applied by the importing Member have been met. ${ }^{142}$ The IPPC does not grant recognition of pest- or disease-free areas or areas of low pest or disease prevalence but has developed standards for Members to use to in national determinations of pest-free areas.

\subsubsection{Regionalisation Decision}

The abovementioned problems were raised in the context of the first review of the implementation of the SPS Agreement, concluded in 1999. As a result, the report of the SPS Committee on this review noted that while adaptation to regional conditions, including the recognition of pest- or disease-free areas or areas of low pest or disease prevalence, was of great importance for trade in agricultural products, Members faced difficulties in the implementation of Article 6 of the Agreement. ${ }^{143}$ In June 2003, discussions between WTO Members in the SPS Committee were initiated regarding the operationalisation of Article 6 of the SPS Agreement. Some Members suggested that a work programme, along the lines of that undertaken with regard to equivalence, be set up regarding the regionalisation provision. Informal meetings were held on this matter from 2003 to $2006 .{ }^{144} \mathrm{In}$ its second review of the implementation of the SPS Agreement, concluded in 2005, the SPS Committee agreed to develop a proposal for a decision on the effective application of Article 6, on the basis of the various proposals submitted by Members and the discussions in the Committee. ${ }^{145}$

pleuropneumonia. Further, OIE members can also declare themselves free of other diseases by following the requirements set out for this in the OIE Terrestrial Animal Health Code chapter dealing with the specific disease.

${ }^{142}$ Committee on Sanitary and Phytosanitary Measures, Issues in the Application of Article 6 of the Agreement on the Application of Sanitary and Phytosanitary Measures. Japanese Comments and Proposals, circulated on 30 May 2006, G/SPS/W/192, para. 7(a). In this respect, Japan argues that the fact that there is a disclaimer in the official recognition of disease-free status by the OIE indicates a probability of inaccuracy. Further, Japan states that in order to use official recognition as a basis for a decision to speed up the procedure on the recognition of disease-free status it is important that not only the data submitted to the OIE is shared with the importing Member, but also that details of the discussion in the OIE leading to the granting of official recognition are accessible to the importing Member.

${ }^{143}$ Committee on Sanitary and Phytosanitary Measures, Review of the Operation and Implementation of the Agreement on the Application of Sanitary and Phytosanitary Measures: Report of the Committee, G/SPS/12, circulated on 11 March 1999, para. 21. Some problems mentioned here were: 'divergences in interpretation and implementation of international guidelines; an excessively lengthy administrative process in importing countries for recognizing pest- or disease-free areas or areas of low pest or disease prevalence; and the complexities often involved in risk assessment.' Ibid.

${ }_{144}$ The relevant meeting reports are the following: October 2003 (G/SPS/R/31, paras 90-103); March 2004 (G/ SPS/R/33, paras 108-119); June 2004 (G/SPS/R/34, paras 83-97); October 2004 (G/SPS/R/35, paras 120 137); March 2005 (G/SPS/R/36, paras 115-136); June 2005 (G/SPS/R/37, paras 98-114); February 2006 (G/ SPS/R/38 and Corr.1 and G/SPS/R/39 and Corr.1, paras 121 146), March 2006 (G/SPS/R/40, paras 72-78 and June 2006 (G/SPS/R/42).

${ }^{145}$ Committee on Sanitary and Phytosanitary Measures, Review of the Operation and Implementation of the Agreement on the Application of Sanitary and Phytosanitary Measures. Report Adopted by the Committee on 30 June 2005, G/SPS/36, circulated on 11 July 2005, Attachment, para. 23. 
At the SPS Committee meeting of 9-10 March 2005, a draft decision on regionalisation was circulated by the Secretariat, setting out a proposed work programme in this area. This work programme would make regionalisation a standing agenda item for SPS Committee meetings, and would mandate information gathering through questions to Members regarding the implementation of Article 6. In 2006, the WTO Secretariat drafted a compilation of the issues involved in the regionalisation discussion, ${ }^{146}$ and a small group of interested WTO Members, led by New Zealand, commenced work on a compromise text. Input into this work has been provided by Members, in the form of papers reporting on their experiences, ${ }^{147}$ and by the IPPC and the OIE in the form of reports on their activities in providing guidance for Members who wish to establish, or to be recognised for pest- or disease-free status. ${ }^{148}$

After five years of discussion within the SPS Committee and one year of work by the group of WTO Members working on this issue, provisional agreement was reached on non-binding guidelines for implementing Article 6 of the SPS Agreement, known as the Regionalisation Decision. ${ }^{149}$ This Decision was provisionally adopted at the SPS Committee meeting on 2-3 April 2008, under the authority of the SPS Committee in terms of Article 12.1 of the SPS Agreement. ${ }^{150}$ Some members of the group charged with work on the guidelines expressed their disappointment at the weakness of the compromise text in avoiding undue delay in the recognition of a region's status. ${ }^{151}$ However, they were urged by others to accept the compromise so that what has been agreed so far can be implemented, with the understanding that the guidelines can be revised in the future on the basis of experience. These Members therefore did not raise objections and Regionalisation Decision was finally adopted on 15 May $2008 .^{152}$

The Regionalisation Decision expressly states that the guidelines it provides are aimed at improving transparency, exchange of information, predictability, confidence and cred-

${ }^{146}$ Committee on Sanitary and Phytosanitary Measures, Issues on the Application of Article 6 of the Agreement on the Application of Sanitary and Phytosanitary Measures. Background Document. Note by the Secretariat. Revision, G/SPS/GEN/640/Rev.1, circulated on 14 September 2006.

${ }^{147}$ Some of these papers were already submitted in 1998 and predate the formal initiation of discussions on ways to address the problems of implementation of Article 6.

${ }^{148}$ A compendium of all these submissions is provided in Committee on Sanitary and Phytosanitary Measures, Compendium of Documents Regarding Article 6 of the SPS Agreement - Regionalization, G/SPS/GEN/636/ Rev.1, circulated on 30 October 2006.

${ }^{149}$ On the legal status of the Regionalisation Decision, see below, Part IV, Section 2.1.1.

${ }^{150}$ Committee on Sanitary and Phytosanitary Measures, Guidelines to Further the Practical Implementation of Article 6 of the Agreement on the Application of Sanitary and Phytosanitary Measures: Submission by New Zealand on Behalf of the Small Group Process on Article 6, G/SPS/W/218, circulated on 22 February 2008.

${ }^{151}$ This is reported in the WTO news item on this development, at an informal meeting on regionalisation held on 1 April 2008. 'Members set to Agree on Regionalization, Improved SPS Transparency' WTO News Items 2008, available at: http://www.wto.org/english/news_e/news08_e/sps_apr08_e.htm, visited on 8 April 2008.

152 The SPS Committee had formally agreed that if no Member objected by 15 May 2008, the guidelines would be adopted. This is officially termed adoption 'ad referendum' (see discussion below, Part IV, Section 2.1). As no objections were received, the guidelines were considered finally adopted on 15 May 2008. They are contained in Committee on Sanitary and Phytosanitary Measures, Guidelines to Further the Practical Implementation of Article 6 of the Agreement on the Application of Sanitary and Phytosanitary Measures, G/ SPS/48, circulated on 16 May 2008. 
ibility between importing and exporting Members, and are not intended to duplicate the technical and administrative guidance provided to Members by the IPPC and OIE. ${ }^{153}$

The Regionalisation Decision starts by setting out some general principles that Members should comply with in respect of their procedures to recognise pest- or disease-free areas or areas of low pest or disease prevalence, namely transparency; ${ }^{154}$ avoidance of undue delays; ${ }^{155}$ non-discrimination in the application of the recognition process; ${ }^{156}$ and consideration of relevant factors such as the strength and credibility of the veterinary or phytosanitary infrastructure of the exporting Member, ${ }^{157}$ any relevant knowledge of and prior experience with the authorities of the exporting Member, ${ }^{158}$ and in cases where the request is being resubmitted, all information previously provided, if the continuing validity of the information has been verified by the exporting Member. ${ }^{159}$ In addition, the Decision states that the importing Member, upon request, should provide information on the stage of the exporting Member's request in its recognition process, and that, in the case of multiple requests by the same exporting Member, that Member's indication of priority among these requests must be taken into account. ${ }^{160}$

Thereafter, the Regionalisation Decision addresses the initial discussions regarding a request for the recognition of pest- or disease-free areas or areas of low pest or disease prevalence. It provides that the importing Member should, upon request, engage in discussions with the exporting Member to clarify the general procedure and the information requirements it applies. ${ }^{161}$ These initial discussions should take place within a reasonable period of time, normally 90 days from the request unless otherwise mutually agreed. ${ }^{162}$ However, discussions may be postponed for a reasonable period if the importing Member has limited resources to undertake work on new requests for recognition. ${ }^{163}$

153 Ibid., para. 1.

${ }_{154}$ Paragraph 4 of the Regionalisation Decision provides that Members should publish the basis for recognition of pest- or disease-free areas and areas of low pest or disease prevalence, as well as a description of the general procedures, including the information generally required to evaluate requests and a contact point to which requests can be addressed. Paragraph 7 provides more generally that 'Members should endeavour to maintain transparency in all aspects of the recognition process'.

${ }^{155}$ Regionalisation Decision, para. 5.

${ }^{156}$ Regionalisation Decision, para. 6.

${ }^{157}$ Regionalisation Decision, para. 8. This provision further states that the exporting Member's veterinary or phytosanitary authorities should be able to 'demonstrate their ability to maintain freedom from specified pests or diseases to encourage confidence on the part of the importing Member.'

${ }^{158}$ Regionalisation Decision, para. 9.

159 Regionalisation Decision, para. 10.

${ }^{160}$ Regionalisation Decision, paras 11 and 12.

161 Specifically, the discussions should clarify the importing Member's general process for the evaluation of requests for the recognition of pest- or disease-free areas and areas of low pest or disease prevalence; its general information requirements to evaluate the request; the information-exchange process relating to the request (including a contact point); and if possible, an anticipated timeframe for completion of the recognition process. Regionalisation Decision, para. 14 (a)-(d). Clarifications should be appropriately recorded to avoid misunderstandings. Regionalisation Decision, para. 16.

162 Regionalisation Decision, para. 15.

${ }^{163}$ Regionalisation Decision, para. 17. Postponement decisions should take into account the number of requests the importing Member has received; the priority indication of the exporting Member where it has submitted multiple requests, and the capacity to undertake work on new requests. If postponement occurs, the importing Member should inform the exporting Member and provide an explanation in writing for the delay. Regionalisation Decision, para. 18. 
While recognising the right of Members to determine their own administrative procedures for the evaluation of requests for recognition of pest- or disease-free areas or areas of low pest or disease prevalence, the Regionalisation Decision sets out nine steps that are typically part of such procedures. ${ }^{164}$ These are the following. First, the exporting Member requests information about the importing Member's requirements and procedures for the evaluation of requests for recognition of pest- or disease-free areas or areas of low pest or disease prevalence. ${ }^{165}$ A request for recognition may be accompanied by supporting scientific and technical information, including international recognition of the area as a pest- or disease-free area or an area of low pest or disease prevalence. ${ }^{166}$ Second, the importing Member explains its requirements and procedures. ${ }^{167}$ Third, the exporting Member sends the required documentation demonstrating compliance with the importing Member's requirements as well as any further information that could assist in the determination. ${ }^{168}$ Fourth, the importing Member acknowledges the receipt of documentation, evaluates it, and gives feedback to the exporting Member, which may include an indication that additional information or an on-site verification is necessary, where justified. ${ }^{169}$ Fifth, the exporting Member responds to the feedback by providing any requested clarifications, additions or modifications. ${ }^{170}$ Sixth, the importing Member evaluates the additional information provided and gives further feedback. ${ }^{171}$ Seventh, if applicable, the importing Member conducts an on-site verification of the information provided. ${ }^{172} \mathrm{~A}$ report on the on-site verification is provided to the exporting Member. Eighth, if requested in the inspection report, the exporting Member provides further clarifications, additions or modifications. ${ }^{173}$ Ninth, the importing Member makes a determination on whether or not to recognize the pest- or disease-free area or area of low pest or disease prevalence. In case of a negative determination, the importing Member provides the technical grounds for this decision to enable the exporting Member to modify its system with a view to future requests. ${ }^{174}$ If the determination is positive, the importing Member takes the necessary administrative or legal steps to facilitate trade from the exporting Member. ${ }^{175}$

The Regionalisation Decision expressly provides the possibility for an importing Member to apply an expedited process for the recognition of pest- or disease-free areas or ar-

164 Regionalisation Decision, paras 20-31 setting out steps A to I.

165 This request may be made prior to formally requesting recognition of an area as a pest- or disease-free area or an area of low pest or disease prevalence, or at the time of the request for recognition. Regionalisation Decision, para. 20.

${ }^{166}$ Regionalisation Decision, para. 21.

${ }^{167}$ Regionalisation Decision, para. 22. For example, the importing Member may require answers to a specific questionnaire.

${ }^{168}$ Where relevant the exporting Member provides information showing that the procedures it used to identify that area as pest- or disease-free or of low pest or disease prevalence are based on an international standard, guideline or recommendation. Regionalisation Decision, para. 23.

169 Regionalisation Decision, para. 24.

${ }^{170}$ Regionalisation Decision, para. 25.

${ }^{171}$ If further clarification is needed the fifth and sixth steps are repeated. Regionalisation Decision, para. 26.

172 This site visit examines the administrative structure of the regulatory bodies and their sanitary or phytosanitary programmes and evaluates the strength and credibility of the veterinary or phytosanitary infrastructure of the exporting region. Regionalisation Decision, para. 26.

173 Regionalisation Decision, para. 29.

174 Regionalisation Decision, para. 30.

${ }^{175}$ Where necessary, the importing Member modifies its sanitary or phytosanitary regulations or elaborates new ones to give effect to its determination. Regionalisation Decision, para. 31. 
eas of low pest or disease prevalence. ${ }^{176}$ The decision on whether to apply an expedited process should involve consideration of factors including: when there has been official recognition by a relevant international organisation of an area as a pest- or disease-free area or an area of low pest of disease prevalence; if after an outbreak in an area previously recognised as a pest- or disease-free area or an area of low pest or disease prevalence, the area is restored to its former status as determined by the importing Member in accordance with the relevant international standards, guidelines or recommendations; if as a result of existing trade relations the importing Member is familiar with the infrastructure and operation of the responsible veterinary or phytosanitary service of the exporting Member; and if no previously notified occurrence of the pest or disease exists in the exporting Member and the importing Member agrees that the surveillance procedures and other measures of the exporting Member establish the non-existence of the pest or disease on its territory. ${ }^{177}$

The Regionalisation Decision requires the SPS Committee to monitor the implementation of Article 6 under a standing agenda item. ${ }^{178}$ To facilitate this, Members are encouraged to notify the SPS Committee of their requests for, and determinations of, the recognition of pest- or disease-free areas or areas of low pest or disease prevalence. It also encourages Members to provide information on their experiences in the implementation of Article 6 and to provide relevant background information on their decisions to other interested Members upon request. ${ }^{179}$ In June 2008, Chile submitted a communication to the SPS Committee, in terms of the Regionalisation Decision as well as under the permanent agenda item on regionalisation in meetings of the SPS Committee. ${ }^{180}$ In this communication, Chile notifies its preliminary recognition of the whole of the US, except the state of Arkansas, as free of avian influenza. ${ }^{181}$ This recognition will become final once the US submits the additional information required by Chile. In addition, Chile notifies its final decision on the recognition of three states of Brazil as free of Newcastle disease, based on the certification of the disease-free status of these states by the competent authority in Brazil, as confirmed by an inspection visit. ${ }^{182}$ In this communication, Chile emphasises that while it is a country free of the main pests and diseases identified by the OIE and IPPC and that it maintains a high appropriate level of protection, in conformity with the SPS Agreement it bases its SPS measures on scientific evidence. ${ }^{183}$

\footnotetext{
${ }^{176}$ An expedited process is stated to involve exclusion of one or more stages or some parts of a stage of the importing Member's general process for the recognition of pest- or disease-free or areas of low pest or disease prevalence.' Regionalisation Decision, para. 32.

${ }_{177}$ Regionalisation Decision, para. 32(a)-(d).

${ }_{178}$ Regionalisation Decision, para. 34.

${ }^{179}$ Regionalisation Decision, para. 34.

180 Committee on Sanitary and Phytosanitary Measures, Recognition of Areas Free of Pests or Diseases. Communication by Chile to the SPS Committee Meeting of 24-25 June 2008, G/SPS/GEN/862, circulated on 7 July 2008.

${ }^{181}$ Ibid., paras 2-3. Chile states that the result of this recognition is that day-old chicks and fertilised eggs are not effected by trade restrictions. With regard to Arkansas, where avian influenza was detected, chilled or frozen poultry exports to Chile are prohibited, but boneless processed poultry products that have been subjected to heat-treatment are permitted.

182 Ibid., para. 4.

${ }^{183}$ Ibid., para. 5.
} 


\subsubsection{International guidelines on regionalisation}

It is significant that international guidelines are mentioned in Article 6 of the SPS Agreement as a factor that must be had regard to in assessing the SPS characteristics of a region for purposes of regionalisation. Both the OIE and the IPPC have been active in drawing up guidelines on this issue.

The OIE has specific procedures in place according to which it officially recognises the disease free status of a country or region with regard to only four animal diseases, namely FMD, ${ }^{184}$ rinderpest ${ }^{185}$ contagious bovine pleuropneumonia and BSE after an investigation and evaluation of evidence. Country status is evaluated under the auspices of the Technical Commission of the OIE and recommendations are forwarded to the International Committee for adoption. The Director-General of the OIE publishes a list of countries that meet the requirements for disease free status. ${ }^{186}$ With regard to these and other diseases the OIE lays down guidelines according to which a country can declare itself or a zone or compartment within the country free of a particular disease ${ }^{187}$ In such a case, the country must provide epidemiological information that conforms to the standards laid down in the Terrestrial Animal Health Code, to the importing country in support of its declaration. ${ }^{188}$ In May 2006, the International Committee of the OIE adopted new texts on zoning and compartmentalisation, and revised a chapter of the Terrestrial Animal Health Code to incorporate the concept of compartmentalisation. ${ }^{189}$ In 2008, a new text was adopted for inclusion in the Terrestrial Animal Health Code containing general guidelines on compartmentalisation and the concept of a 'containment zone' as a trade facilitation mechanism in the event of a disease incursion. ${ }^{190}$ The OIE expressly notes the

${ }^{184}$ OIE International Committee, Establishment of a list of foot and mouth disease (FMD) free countries where vaccination is not practised, Resolution XI. 63rd General Session, (1995).

185 OIE International Committee, Procedure for the recognition of the foot and mouth disease status of Member Countries, Resolution XII, 63rd General Session, (1995). It should be noted that with regard to rinderpest, only whole countries and not regions can be officially recognised as rinderpest-free by the OIE.

186 The evaluation and approval procedure applied by the OIE in this regard are set out in Committee on Sanitary and Phytosanitary Measures, Official OIE Recognition of Member Countries' Health Status. Communication from the World Organization for Animal Health (OIE). Addendum, G/SPS/GEN/542/Add.1, circulated on 2 March 2005.

${ }^{187}$ A zone is a clearly defined part of a country containing an animal sub-population with a distinct health status with respect to a particular disease. A compartment refers to premises where animals are kept under a biosecurity management system containing an animal sub-population with a distinct health status with respect to a particular disease. Thus a zone is defined on a geographical basis (by reference to natural, artificial or legal boundaries) whereas a compartment is defined by reference to risk management practices Committee on Sanitary and Phytosanitary Measures, Update on Activities Relating to Disease Regionalisation. 39th Meeting of the SPS Committee. Communication from the World Organisation for Animal Health (OIE), G/ SPS/GEN/789, circulated on 26 June 2007, paras 1-2.

188 The Terrestrial Animal Health Code contains recommendations for zones or compartments for those diseases for which the concept are appropriate. The recommendations reflect the epidemiology of the disease, environmental factors, biosecurity measures that are required and feasible, and the conduct of required disease surveillance. Ibid., para. 11.

${ }^{189}$ Committee on Sanitary and Phytosanitary Measures, Procedure to Monitor the Process of International Harmonization. Eight Annual Report Adopted by the Committee on 28 June 2006, G/SPS/42, circulated on 4 August 2006, para. 23.

${ }^{190}$ Committee on Sanitary and Phytosanitary Measures, Report on OIE Activities to the Meeting of the SPS Committee to Be Held on 24-25 June 2008, G/SPS/GEN/853, circulated on 20 June 2008, para. 10. A containment zone is a mechanism to facilitate rapidly regaining disease-free status after an incursion of a disease into a previously disease-free country or zone. Specific technical criteria are specified for a containment zone. 
dependence of zoning and compartmentalisation on the existence in the exporting country of the necessary veterinary infrastructure to develop, implement and certify the relevant zone or compartment. Without this, an importing country will not agree to recognise the zone or compartment for trade purposes. ${ }^{191}$ As noted above, a lack of confidence exists in the SPS regulatory systems of many less-developed countries, making the recognition of zones and compartments in their territories by other countries unlikely.

While the IPPC does not have a mechanism in place to officially recognise pest- and disease-free areas itself, it has laid down guidelines for national authorities in the establishment of pest free areas ${ }^{192}$ and for the determination of pest status in an area. ${ }^{193}$ Further, it has set out guidelines for the establishment of pest free production sites and areas of production, ${ }^{194}$ and for the establishment of areas of low pest prevalence. ${ }^{195}$ In addition, guidelines have been adopted for the establishment of pest free areas for fruit flies specifically. ${ }^{196}$ In its seventh session in April 2005, the Interim Commission on Phytosanitary Measures (ICPM), which was then the governing body of the IPPC as mentioned above, convened a working group to address possible ways to recognise pest-free regions. ${ }^{197}$ The report of this working group recommended that guidelines for the recognition of pestfree regions be urgently developed. This process commenced with a meeting of the IPPC Standards Committee on 25 April 2005. ${ }^{198}$ In March 2007, guidelines for the bilateral recognition of pest-free areas and areas of low pest prevalence were adopted by the CPM. ${ }^{199}$ They contain a useful flow chart outlining the procedure set out in the guidelines. ${ }^{200}$ The CPM has also adopted terms of reference to assess the feasibility of undertaking international recognition of pest-free areas. ${ }^{201}$

${ }^{191}$ Committee on Sanitary and Phytosanitary Measures, Update on Activities Relating to Disease Regionalisation. 39th Meeting of the SPS Committee. Communication from the World Organisation for Animal Health (OIE), G/SPS/GEN/789, circulated on 26 June 2007, para. 17.

${ }^{192}$ International Plant Protection Convention, Requirements for the Establishment of Pest Free Areas, ISPM 4, (FAO, Rome) 1996.

${ }^{193}$ International Plant Protection Convention, Determination of Pest Status in an Area, ISPM 8, (FAO, Rome) 1998.

194 International Plant Protection Convention, Requirements for the Establishment of Pest Free Places of Production and Pest Free Production Sites, ISPM 10, (FAO, Rome) 1999.

195 International Plant Protection Convention, Requirements for the Establishment of Areas of Low Pest Prevalence, ISPM 22, (FAO, Rome) 2005.

${ }^{196}$ International Plant Protection Convention, Requirements for the Establishment of Pest Free Areas for Fruit Flies (Tephritidea), ISPM 26, (FAO, Rome) 2006.

197 Interim Commission on Phytosanitary Measures, Report of the Seventh Interim Commission on Phytosanitary Measures, ICPM-7(2005)/Report (Food and Agriculture Organization, Rome), 4-7 April 2005, available at: https://www.ippc.int/servlet/BinaryDownloaderServlet/75067_Report_ICPM7_E. pdf?filename=1132938412531_ICPM7_Report_En_REV_list_part.pdf\&refID=75067, visited on 10 March 2008.

${ }^{198}$ Committee on Sanitary and Phytosanitary Measures, Decisions from the Seventh Interim Commission on Phytosanitary Measures. Communication from the International Plant Protection Convention Secretariat (IPPC), G/SPS/GEN/573, circulated on 22 June 2005. See also 'Regionalisation Identified as Top Priority by ICPM', Bridges Trade Biores, 15 April 2005.

${ }^{199}$ Committee on Sanitary and Phytosanitary Measures, ISPM 29: Recognition of Pest-Free Areas and Areas of Low Pest Prevalence. Submission by the Secretariat of the International Plant Protection Convention (IPPC), G/SPS/GEN/782, circulated on 19 June 2007.

${ }^{200}$ Ibid., Appendix 1.

201 These terms of reference are set out in Committee on Sanitary and Phytosanitary Measures, Update of Activities of the International Plant Protection Convention (IPPC) June 2006. Pest- and Disease-Free Areas 
The abovementioned international guidelines should facilitate the implementation of Article 6 , as they clarify what is meant by a pest- or disease-free country or region and how this can be established by means of specific technical criteria. This creates an objective basis for the recognition of the pest or disease status of an area. However, concerns have been raised that pest- and disease-free areas established, through the investment of significant resources, in accordance with international guidelines are often not recognised by importing Members. In fact, even the official recognition of a Member as disease-free by the OIE is in practice not considered at all by other Members as an element of the 'objective demonstration' of disease-free status and the exporting Member is required to supply anew all the evidence it has in support of its claim of disease-free status to the importing country. ${ }^{202}$ This situation seems to be contrary to the aim of Article 6 .

\subsection{Transparency obligations}

An important, and perhaps underestimated, aspect of the SPS Agreement is its insistence on transparency of SPS measures. The significance of transparency disciplines lies in two main areas, which could be called the ex ante and the ex post effects of transparency.

The ex ante effect of transparency can be described as follows. Exporters of food and agricultural products are affected by regulatory decisions taken in foreign jurisdictions, yet they traditionally have no say in the decision-making process involved. Foreign regulators take into account national priorities and interests when making SPS decisions. This raises the problem which Robert Keohane has called the 'external accountability gap'203 which term describes the situation which arises in a globalising world where the impact of the actions of a state no longer coincide with its jurisdiction but go beyond it, affecting the lives of persons outside it. ${ }^{204}$ Imposing ex ante transparency obligations on regulating countries ensures that exporting countries are informed of proposed new or amended SPS measures and that affected foreign traders have the opportunity, through their governments, to raise concerns regarding these proposals and to have these comments taken into account in the regulatory process.

- Article 6. Statement by the IPPC at the Meeting of 27-28 June 2006, G/SPS/GEN/707, circulated on 26 June 2006, Annex 1. Committee on Sanitary and Phytosanitary Measures, Issues on the Application of Article 6 of the Agreement on the Application of Sanitary and Phytosanitary Measures. Background Document. Note by the Secretariat. Revision, G/SPS/GEN/640/Rev.1, circulated on 14 September 2006, para. 22.

${ }^{202}$ Committee on Sanitary and Phytosanitary Measures, Articles 6(2), 6(3) and Annex a(3)(B): Recognition of the Concept of Pest- or Disease-Free Areas as an International Standard, Guideline or Recommendation: Submission by South Africa, G/SPS/GEN/139, circulated on 2 November 1999.

${ }^{203}$ Robert Keohane, 'Global Governance and Democratic Accountability', in Taming Globalization: Frontiers of Governance, David Held and Mathias Koenig-Archibugi (ed.) (Polity Press, Cambridge), 2003, 130-159, 141.

${ }^{204}$ Scott addresses the question whether judicial review of SPS regulations in the WTO could be seen as a way to mitigate the accountability gap identified by Keohane, 'and hence to reinforce democracy in an age where the concept of statehood no longer captures all dimensions of power.' See Joanne Scott, European Regulation of GMOs: Thinking About 'Judicial Review' in the WTO, Jean Monnet Working Paper 04/04 (Jean Monnet Program, New York), 2004, 13, available at: www.jeanmonnetprogram.org/papers/04/040401.pdf, visited on 14 September 2004. 
The second important aspect of transparency, lies in its ex post effects. A significant hurdle to exporters of food and agricultural products is the paucity of information that is available regarding the SPS measures that they must comply with on their export markets. SPS measures are often complex and subject to change; as a result of which exporters have no certainty that their products will have access to the markets of the country of destination. Obtaining necessary information regarding the SPS measures they have to comply with is often a costly and burdensome process for exporters. Transparency obligations requiring publication of adopted SPS measures are crucial in facilitating market access for exports from Members by greatly reducing the cost and difficulty of obtaining information on their trading partners' SPS measures.

Not only is the ex post effect of transparency important for traders, but it is also essential in enabling WTO Members to exercise their rights and police the implementation of the obligations of the SPS Agreement. ${ }^{205}$ Lack of information regarding the existence, content and scientific basis of SPS measures makes it difficult for Members whose exporters are faced with SPS barriers to trade to determine whether they have legal grounds to challenge these measures in terms of the disciplines of the SPS Agreement. Transparency with regard to SPS measures aims to ensure that Members obtain full information about these measures in order to identify whether they are consistent with the SPS Agreement or not. It also makes it possible for traders to be well informed as to SPS measures affecting their exports and to lobby their governments to take action in this regard. Consequently, Members can try to resolve their trade concerns in bilateral discussions with the relevant Member, ${ }^{206}$ in multilateral discussions at SPS Committee meetings, ${ }^{207}$ or in formal dispute-settlement proceedings. ${ }^{208}$

For the reasons mentioned above, the SPS Agreement has rules in place to promote transparency in SPS regulation. There are contained in Article 7, Annex B and Article 5.8 of the SPS Agreement. ${ }^{209}$ In particular, Article 7 of the SPS Agreement, under the heading 'Transparency', provides:

Members shall notify changes in their sanitary or phytosanitary measures and shall provide information on their sanitary or phytosanitary measures in accordance with the provisions of Annex B.

Annex B contains detailed provisions with regard to publication of adopted SPS measures and prior notification of proposed new SPS measures or changes in existing SPS

${ }^{205}$ Scott refers to this as the 'all-important accountability function' of transparency, which operates to enable other Members to evaluate and contest proposed SPS regulation. Joanne Scott, The WTO Agreement on Sanitary and Phytosanitary Measures: A Commentary, Oxford Commentaries on the GATT/WTO Agreements (Oxford University Press, Oxford), 2007, 192-193.

206 Wolfe notes that the WTO Secretariat 'knows that the real reason many experts attend [SPS] Committee meetings is to hold private unrecorded bilateral meetings with each other.' Robert Wolfe, 'See You in Geneva? Legal (Mis)Representations of the Trading System', European Journal of International Relations 11 (3), 2005, 339-364, 353.

${ }^{207}$ The mechanism for raising specific trade concerns at SPS Committee meetings is discussed below, Part IV, Section 2.1.2.

${ }^{208}$ The dispute settlement system is discussed below, Part IV, Section 2.2.

${ }^{209}$ Note that transparency is also required in Annex C.1 with respect to control, inspection and approval procedures. See further below, Part IV, Section 1.4.5. 
measures. Annex B is an integral part of the SPS Agreement, as are all the Annexes, in terms of Article 1.3 of the SPS Agreement. Article 7 expressly refers to Annex B. Therefore Article 7 must be read together with Annex B, and a violation of the latter necessarily entails a violation of the former.

An additional transparency obligation is contained in Article 5.8 of the SPS Agreement, which states:

When a Member has reason to believe that a specific sanitary or phytosanitary measure introduced or maintained by another Member is constraining, or has the potential to constrain, its exports and the measure is not based on the relevant international standards, guidelines or recommendations, or such standards, guidelines or recommendations do not exist, an explanation of the reasons for such sanitary or phytosanitary measure may be requested and shall be provided by the Member maintaining the measure.

Thus, these provisions comprise, broadly speaking, three categories of transparency obligations: the obligation to publish all adopted SPS measures, the obligation to notify, in advance, draft SPS regulations to the WTO and the requirement to provide, upon request, an explanation for the reasons behind an SPS measure. These transparency obligations have different implications for Members at different levels of development, both in terms of the compliance burden they impose and in terms of the potential benefits they offer. The content of these obligations will be examined in more detail below.

\subsubsection{Publication obligation}

Publication of SPS requirements is one way to give effect to the ex post benefits of transparency, discussed above. The publication obligation is first reflected in Article 7 of the SPS Agreement. Article 7 obliges Members, inter alia, to provide information on their SPS measures in accordance with Annex B. In terms of Annex B.1:

Members shall ensure that all sanitary and phytosanitary regulations which have been adopted are published promptly in such a manner as to enable interested Members to become acquainted with them.

The Appellate Body in Japan - Agricultural Products II addressed the object and purpose of Annex B.1, and noted that it is 'to enable interested Members to become acquainted with' the SPS regulations adopted or maintained by other Members and 'thus to enhance transparency regarding these measures.' ${ }^{210}$

\subsubsection{Scope of application}

It is useful to start by identifying the scope of application of this publication requirement. Annex B.1 requires the prompt publication of 'SPS regulations which have been adopted'. The meaning of 'SPS regulations' is clarified in a footnote to Annex B.1 which defines them as 'sanitary and phytosanitary measures such as laws, decrees or ordinances

${ }^{210}$ Appellate Body Report, Japan - Agricultural Products II, para. 106. 
which are applicable generally. ${ }^{211}$ On the basis of these provisions, the Panel in Japan Agricultural Products II identified three requirements for a measure to be subject to the publication requirement in Annex B namely:

(1) the measure '[has] been adopted'; (2) the measure is a 'phytosanitary regulation, namely a phytosanitary measure such as a law, decree or ordinance, which is (3) 'applicable generally'. 212

The first requirement has not been addressed in the case law thus far. ${ }^{213}$ Adoption seems to require an action by the government of a Member, but should not be taken to mean that the measure must be legally enforceable. The Panel in Japan - Agricultural Products II emphasised that neither Annex B.1 nor Annex A.4 require the measures falling there under to be mandatory or legally enforceable. ${ }^{214}$ It noted the fact that terms such as 'measure', 'requirement' and 'restriction' in other WTO agreements (which form the context for interpretation of the SPS Agreement) as interpreted in the case law, indicate that a non-mandatory government measure is also subject to WTO disciplines, 'in the event compliance with this measure is necessary to obtain an advantage from the government or, in other words, if sufficient incentives or disincentives exist for that measure to be abided by. ${ }^{215}$

The second requirement for the application of Annex B.1 raises the question of the relationship between an 'SPS regulation' and an 'SPS measure'. It is surprising that Annex B.1 refers to SPS regulations rather than SPS measures, despite the fact that the obligation in Article 7 explicitly applies to SPS measures. The question thus arises whether SPS measures that do not take the form of SPS regulations are covered by the publication requirement. ${ }^{216}$ What is clear from the wording of Annex B. 1 and its footnote is that the publication applies to a narrower category of measures than those covered by the definition of SPS measures in Annex A.1. This was found by the Panel in EC-Approval and Marketing of Biotech Products, which saw SPS regulations for purposes of Annex B.1 as a 'sub-category' of the wider concept of SPS measures. ${ }^{217}$ The fact that the publication obligation does not apply to all SPS measures is indicated by three factors. First there is the fact that the illustrative list of measures in the footnote is different from, and seem-

${ }^{211}$ Footnote 1 to Annex B of the SPS Agreement.

${ }^{212}$ Panel Report, Japan - Agricultural Products II, para. 8.109.

${ }^{213}$ In Japan - Agricultural Products II it was undisputed that this requirement had been met. In EC-Approval and Marketing of Biotech Products it was unnecessary to address this requirement since the measures at issue fell outside the scope of application of Article B.1 for other reasons, discussed below.

${ }^{214}$ Panel Report, Japan - Agricultural Products II, para. 8.111.

215 Ibid. Here the Panel referred to Panel Report, Japan - Film, para. 10.49; GATT Panel Report, EEC - Parts and Components, para. 5.21; and GATT Panel Report, Japan - Semi-Conductors, para. 109.

216 The confusion caused by this difference in terminology and its impact on the implementation of the transparency obligations was pointed out by Canada, which recalled the need identified in the second review of the operation of the SPS Agreement to clarify the relevant terms. Committee on Sanitary and Phytosanitary Measures, Second Review of the Operation and Implementation of the Agreement on the Application of Sanitary and Phytosanitary Measures. Clarification of the Terms "Measures" and "Regulations" as contained in the SPS Agreement. Submission by Canada, G/SPS/W/186, circulated on 20 March 2006.

${ }^{217}$ Panel Reports, EC -Approval and Marketing of Biotech Products, para. 7.1455. According to the Panel, the fact that under Article 1.3 of the SPS Agreement Annexes are an integral part of the Agreement means that the reference to 'SPS measures' in the footnote to Annex B.1 must be interpreted in the light of the Annex A.1 definition of 'SPS measures'. 
ingly more limited than, that in Annex A.1. ${ }^{218}$ Second, there is the additional requirement in the footnote Annex B.1 that the SPS measures relevant to the publication requirement are only those 'which are applicable generally.' Third, Annex B.1 is limited to SPS regulations 'that have been adopted'. ${ }^{219}$

The Appellate Body in Japan - Agricultural Products II noted that the scope of application of the transparency provision must be interpreted in the light of the object and purpose of Annex B.1, mentioned above. ${ }^{220}$ It therefore stated with regard to the definition of SPS regulations:

We consider that the list of instruments contained in the footnote to paragraph 1 of Annex B is, as is indicated by the words 'such as', not exhaustive in nature. The scope of application of the publication requirement is not limited to 'laws, decrees or ordinances', but also includes, in our opinion, other instruments which are applicable generally and are similar in character to the instruments explicitly referred to in the illustrative list of the footnote to paragraph 1 of Annex B. ${ }^{221}$

As a result, the Appellate Body found that the measure at issue, Japan's varietal testing requirement, was covered by the publication obligation in Annex B.1, despite the fact that the Panel had found the measure to be "not mandatory - in that exporting countries can demonstrate quarantine efficiency by other means'. ${ }^{222}$ In EC - Approval and Marketing of Biotech Products, however, the Panel noted that even a purposive interpretation of Annex B.1 does not entitle a panel to 'expand the scope of the publication requirement negotiated by Members' even if the panel were to consider that 'it might in principle be desirable to do so. ${ }^{223}$ At issue in this dispute was the question whether the EC was obliged to publish its general de facto moratorium on the approval of biotech products. As the Panel had found the moratorium not to be an SPS measure itself but rather to amount to the administration or operation of an SPS measure, something not falling within the text of Annex B.1, it was therefore outside the scope of application of the publication requirement. ${ }^{224}$ Thus, for Annex B.1 to apply there must first be an 'SPS measure', similar in character to the instruments mentioned in the illustrative list, although it does not have to take the form of one of the instruments expressly mentioned.

The third requirement, namely general applicability, was addressed by the Panel in EC - Approval and Marketing of Biotech Products. It held that 'general applicability is a

218 The waters are muddied in this respect by the fact that, while in Annex A.4 'regulations' are listed together with other instruments including laws and decrees as examples of SPS measures, in the footnote to Annex B.1 laws and decrees are examples of SPS regulations. Joanne Scott, The WTO Agreement on Sanitary and Phytosanitary Measures: A Commentary, Oxford Commentaries on the GATT/WTO Agreements (Oxford University Press, Oxford), 2007, 196.

219 This last requirement has not been addressed in dispute settlement yet.

${ }^{220}$ See above, Part IV, Section 1.3.1.

${ }^{221}$ Appellate Body Report, Japan - Agricultural Products II, para. 105.

${ }^{222}$ Ibid., para. 103.

${ }^{223}$ Panel Reports, EC - Approval and Marketing of Biotech Products, para. 7.1461.

${ }^{224}$ Ibid. Here the Panel compared the text of Annex B.1 and Article 7 of the SPS Agreement to the text of Article 18.5 of the Anti-Dumping Agreement, which requires notification by a Member of 'any changes in its laws and regulations relevant to this Agreement and in the administration of such laws and regulations' (emphasis added). The extension of the publication requirement to the administration of regulations would have been made explicit in the SPS Agreement if it had been intended, according to the Panel. Ibid., para. 7.1460. 
necessary definitional element of the term "SPS regulations".' 225 The term 'applicable generally' has not been clearly defined in the case law under Annex B of the SPS Agreement thus far. However, it does not seem to mean that the SPS regulation must apply to all WTO Members. ${ }^{226}$ Such a requirement would not make sense as SPS measures are directed at specific health risks which most often are found in products from one or more particular Member/s. Guidance can be drawn from the interpretation of the term 'of general application' used in Article X of the GATT 1994 with regard to the publication and administration of measures, which has been fleshed out in the jurisprudence. In US - Underwear, the Appellate Body agreed with the Panel that the fact that a measure is country-specific does not exclude the possibility of it being a measure of general application. To the extent that the measure affected 'an unidentified number of economic operators, including domestic and foreign producers' it was held to be a measure of general application. ${ }^{27}$ In this line, the Recommended Transparency Procedures adopted by the SPS Committee, which although not an authoritative interpretation of the transparency obligations does reflect the agreement of Members on their application, clarify the scope of application of the publication requirement to encompass not only 'generic' measures but also measures affecting bilateral or plurilateral trade. This indicates agreement that to be generally applicable a measure does not have to affect all Members. The example given in the Recommended Transparency Procedures is of a restriction imposed by Colombia on fresh fruit from Brazil.

What would seem to be excluded by the requirement of general applicability are individual instances of application of SPS measures. This is in line with case law on the 'general application' condition for the applicability of the publication obligation in Article $\mathrm{X}$ of the GATT 1994. ${ }^{228}$ In EC - Approval and Marketing of Biotech Products the Panel found that the 'product specific measures' at issue in that dispute, namely the individual instances of the application of the EC's approval procedures to particular requests for approval, fell outside the publication requirement of Annex B.1 due to a failure to meet the requirement of general applicability. ${ }^{229}$ As noted by the Panel with regard to the product specific measures:

${ }^{225}$ Panel Reports, EC-Approval and Marketing of Biotech Products, para. 7.1776.

${ }^{226}$ In Japan - Agricultural Products II the meaning of 'generally applicable' was not addressed as it was undisputed that the measure at issue was generally applicable. Appellate Body Report, Japan - Agricultural Products II, para. 107.

${ }^{227}$ Panel Report, US - Underwear, para.7.65 as upheld in Appellate Body Report, US - Underwear, 21. The Panel and Appellate Body in this case held that administrative rulings may be measures of general application. In Japan - Film the Panel further clarified the scope of Article X as follows: '[ I]t stands to reason that inasmuch as the Article X:1 requirement applies to all administrative rulings of general application, it also should extend to administrative rulings in individual cases where such rulings establish or revise principles or criteria applicable in future cases.' Panel Report, Japan - Film, para. 10.388.

${ }^{228}$ With regard to the 'general application' condition in Article X of the GATT 1994, in US - Underwear the Appellate Body agreed with the Panel's finding that: 'If, for instance, the restraint was addressed to a specific company or applied to a specific shipment, it would not have qualified as a measure of general application.' Panel Report, US - Underwear, para.7.65 as upheld in Appellate Body Report, US - Underwear, 21. In EC - Poultry, the Appellate Body stated: 'Article X:1 of the GATT 1994 makes it clear that Article X does not deal with specific transactions, but rather with rules "of general application". ... Although it is true, as Brazil contends, that any measure of general application will always have to be applied in specific cases, nevertheless, the particular treatment accorded to each individual shipment cannot be considered a measure 'of general application' within the meaning of Article X.' Appellate Body Report, EC-Poultry, paras 111 and 113.

${ }^{229}$ Panel Reports, EC-Approval and Marketing of Biotech Products, para. 7.1775-7.1776. Although, elsewhere, 
[E]ach of these measures affects an application concerning a specific biotech product. None of these measures is applicable to all biotech products generally, or at least to all biotech products that fall within the scope of the relevant EC approval procedures and require approval. ${ }^{230}$

By contrast, the general applicability criterion was regarded as met by the general de facto moratorium on approvals, as it was 'applicable to all applications which were pending between June 1999 and August 2003. ${ }^{231}$ However, as the moratorium was found not to be an SPS measure, as stated above, it was not subject to the publication requirement. Instead, the Panel noted that the transparency requirements contained in Annex C.1(b), applicable to control, inspection and approval procedures, were relevant to the de facto moratorium. ${ }^{232}$

\subsubsection{Prompt publication}

Once it is established that an SPS measure constitutes an SPS regulation falling under the scope of application of Annex B.1, the Member adopting the measure is required to publish it 'promptly in such a manner as to enable interested parties to become acquainted with [it].' This obligation has not been clarified in the case law thus far. ${ }^{233}$

In the Transparency Handbook drawn up by the WTO Secretariat to assist Members in implementing their transparency obligations, Members are encouraged to publish their SPS regulations on the Internet, if possible. ${ }^{234}$ This preference is explained with reference to the greater transparency this offers and the ease of access to documents provided thereby, minimising the work involved in requesting documents and processing these requests. ${ }^{235}$ This suggestion has been taken up in the Recommended Transparency Procedures adopted by the SPS Committee in 2002. ${ }^{236}$ However, as both of these documents establish non-binding guidelines, rather than obligations, it is clear that it is up to Members to decide how to give effect to the publication obligation in Annex B.1,

the Panel found that the product-specific measures were not 'SPS measures' at all, as discussed above, Part III, Section 2.1.1, in respect of its finding under Annex B.1 the Panel found it unnecessary to address this issue.

${ }^{230}$ Panel Reports, EC-Approval and Marketing of Biotech Products, para. 7.1775.

${ }^{231}$ Ibid., para. 7.1775.

${ }^{232}$ Ibid., para. 7.1464. In this dispute, only the US had alleged a violation of Annex C.1(b) by the de facto moratorium. The obligations of Annex C.1 are discussed below, Part IV, Section 1.4.

${ }^{233}$ Note that the publication obligation is a general obligation on Members and does not relate specifically to the work of the National Notification Authority or the Enquiry Point of a Member. Committee on Sanitary and Phytosanitary Measures, Recommended Procedures for Implementing the Transparency Obligations of the SPS Agreement (Article 7) as of 1 December 2008. Revision, G/SPS/7/Rev.3, circulated on 20 June 2008, para. 57. The National Notification Authority and the Enquiry Point are discussed below, Part IV, Section 1.3.4.

234 WTO Secretariat, How to Apply the Transparency Provisions of the SPS Agreement (World Trade Organization, Geneva), September 2002, para. 92, available at: http://www.wto.org/english/tratop_e/sps_e/ spshand_e.doc, visited on 25 June 2007.

${ }_{235}$ Ibid., para. 92(a)-(c).

236 Committee on Sanitary and Phytosanitary Measures, Recommended Procedures for Implementing the Transparency Obligations of the SPS Agreement (Article 7). Revision, G/SPS/7/Rev.2, circulated on 2 April 2002, para. 47. The Recommended Transparency Procedures are discussed further below, Part IV, Section 1.3.7. 
provided that the manner that they choose meets the requirement of enabling interested parties to become acquainted with the SPS regulation.

This requirement is somewhat undermined by the stipulation, in the 'General Reservations' provision of Annex B.11, that nothing in the SPS Agreement shall be construed as requiring the publication of texts 'other than in the language of the Member'. In practice, many Members publish their SPS measures, particularly those that take the form of legislation or administrative regulations, in their Government Gazettes in their own official languages. This may mean that many exporting Members at lower levels of development that lack the resources to undertake translations, and the producers of such Members, are not in a position to 'become acquainted' with the published regulation in a timely manner. ${ }^{237}$

An example of a complaint regarding non-implementation of the publication requirement in Annex B.1 of the SPS Agreement, is that brought by Nicaragua with respect to Mexico's measures restricting the importation of black beans. ${ }^{238}$ According to Mexican officials, these restrictions were imposed in order to address the 'associated risk' with imports of dried beans. ${ }^{239}$ However, Mexico failed to publish the specific phytosanitary requirements for the importation of black beans from Nicaragua and its officials refused to furnish importers with the document containing these requirements. In March 2003, Nicaragua officially initiated dispute settlement proceedings against Mexico in this regard, by requesting consultations with Mexico. ${ }^{240}$ A year later Nicaragua notified the DSB of the withdrawal of its request for consultations since a mutually agreed solution had been found between the two Members. ${ }^{241}$

\subsubsection{Reasonable adaptation period}

An important benefit from improved transparency, as noted above, is the opportunity it provides for early adaptation to new SPS requirements. However, for this to be effective, exporters need to be given a period, before the new requirements come into force, to adapt their products or production processes. In Members at lower levels of development, an adequate adaptation period may be particularly important as it may be difficult

\footnotetext{
${ }^{237}$ The exception to this provision in Annex B.8 of the SPS Agreement, requiring developed-country Members, upon request, to provide translations in one of the three WTO working languages (English, French or Spanish) applies only to documents covered by a specific notification. This means that while requesting Members may gain access to a proposed draft SPS measure in a language they understand, they cannot oblige the Member imposing the measure to publish the final adopted SPS regulation in a language other than its own language.

${ }^{238}$ Committee on Sanitary and Phytosanitary Measures, Specific Trade Concerns. Note by the Secretariat. Addendum. Resolved Issues, G/SPS/GEN/204/Rev.8/Add.3, circulated on 27 March 2008, item 164.

239 The issue was first raised before the SPS Committee by the US, which requested that Mexico provide an explanation for the reasons for its measure. Committee on Sanitary and Phytosanitary Measures, Mexican Restrictions on US Dry Beans - Request for Explanation (Article 5.8). Submission by the United States, G/ SPS/GEN/379, circulated on 31 March 2003.

240 Dispute Settlement Body, Mexico-Certain Measures Preventing the Importation of Black Beans from Nicaragua, WT/DS284/1, G/L/614, G/LIC/D/37, G/SPS/GEN/375, circulated on 20 March 2003.

241 Dispute Settlement Body, Mexico - Certain Measures Preventing the Importation of Black Beans from Nicaragua. Communication from Nicaragua, WT/DS284/4, circulated on 11 March 2004. This communication indicates that the 'excellent political and trade relations' between the two Members had enabled them to find a positive solution through periodic talks on the matter. It is rather unusual to notify a withdrawal of a request for consultations, since this has no legal purpose. Instead, it would be more logical to notify the mutually agreed solution itself.
} 
for producers to access the necessary technology and the financial resources for its implementation that may be entailed by the new SPS requirements. ${ }^{242}$ In order to enable producers in exporting Members to adjust to new or changed SPS requirements without losing market access during the adjustment period, Annex B. 2 provides:

Except in urgent circumstances, Members shall allow a reasonable interval between the publication of a sanitary or phytosanitary regulation and its entry into force in order to allow time for producers in exporting Members, and particularly in developing country Members, to adapt their products and methods of production to the requirements of the importing Member.

To take into account the fact that delaying the entry into force of new SPS regulations is not always possible, due to the urgent nature of some of these regulations in the face of serious threats to heath, Annex B.2 creates an exception for 'urgent circumstances'. However, it does not define urgency. This, together with the lack of guidance as to what a 'reasonable interval' for adaptation is, has led to implementation problems with regard to this provision. ${ }^{243}$

In view of the often-heard complaint that little or no adaptation period was provided with respect to new SPS measures, in the Implementation Decision adopted at the Doha Ministerial Conference in 2001, it was agreed that the 'reasonable interval' between publication of an SPS measure and its entry into force shall be no less than six months, except if the new or changed measure has a trade liberalising effect. ${ }^{244}$

\subsubsection{Notification obligation}

The ex ante benefit of transparency in enabling producers in exporting Members to respond to draft SPS measures before they are adopted, is given effect in the notification obligations of the SPS Agreement. To this purpose, Article 7 of the SPS Agreement requires not only the publication of adopted SPS measures, but also the prior notification of changes in SPS measures, in accordance with Annex B. The notification requirement is further worked out in Annex B.5-10. As already noted, a violation of Annex B automatically entails a violation of Article 7 .

\subsubsection{Scope of application}

It is first necessary to examine in what situations the notification obligation applies. Annex B.5 provides that Members must notify proposed 'SPS regulations' according to its requirements:

\footnotetext{
${ }^{242}$ The SPS Agreement encourages, in Article 10.2, the provision of a longer period for compliance in respect of products of interest to developing-country Members. This SDT provision is discussed below, Part V, Section 1.2 .

${ }^{243}$ On the implementation problems with regard to the transparency obligations of the SPS Agreement, see below, Part IV, Section 1.3.6.

${ }^{244}$ Ministerial Conference, Implementation-Related Issues and Concerns. Decision of 14 November 2001, WT/ $\mathrm{MIN}(01) / 17$, circulated on 20 November 2001, para. 3.2. The reasonable adaptation period is discussed further below, Part V, Section 1.3.
} 
[w] henever an international standard, guideline or recommendation does not exist or the content of a proposed sanitary or phytosanitary regulation is not substantially the same as the content of an international standard, guideline or recommendation, and if the regulation may have a significant effect on trade of other Members, ...

Although the term 'SPS regulation' is not clarified in this provision, there seems to be no reason to interpret it differently to the same term in Annex B.1. ${ }^{245}$ As a result, the same considerations regarding the type of instrument and the general applicability of the SPS measure apply, as discussed above. ${ }^{246}$ Logically, as Annex B.5 deals with 'proposed' SPS regulations, there is no notification obligation with respect to existing SPS regulations.

The applicability of the notification obligation to an SPS regulation is subject to two further requirements, namely: (1) that its content is not 'substantially the same' as an international standard, or no such standard exists; and (2) that it 'may have a significant effect on trade'. These requirements need to be examined.

The question arises whether an SPS regulation that is 'substantially the same' as an international standard for purposes of Annex B.5 (and thus does not fall within the scope of application of the prior notification requirement) is the same as an SPS measure that is 'based on' an international standard under Article 3.1, or instead as an SPS measure that 'conforms to' an international standard under Article 3.2 of the SPS Agreement. Although the reason for the difference in terminology used in Annex B.5 as compared to Article 3 is not clear, it would appear that a measure 'not substantially the same' as an international standard is a measure that does not 'conform to' the international standard under Article 3.2. The case law clarifying the meaning of 'based on' under Article 3.1 establishes that this refers to a measure that stands, is founded or is built upon an international standard, and incorporates some but not all elements of the international standard. ${ }^{247}$ This seems to suggest something much less than a measure that is 'substantially the same' as international standard. The term 'substantially the same' is more likely to refer to measures that 'conform to' international standards. This view is supported by the fact that measures which do 'conform to' international standards benefit from a presumption of consistency with the SPS Agreement and thus also with its Annexes including the transparency provisions of Annex B, whereas measures which are simply 'based on' international standards do not. Therefore, if a measure is merely 'based on' an international standard, it seems likely that it will be regarded as 'not substantially the same' as the international standard for purposes of Annex B.5 and will have to be notified.

In 2004, New Zealand suggested that the SPS Committee amend its notification guidelines to encourage Members to notify all new SPS measures, including those that are substantially the same as international standards so as to enable the SPS Committee to fully

\footnotetext{
${ }^{245}$ As noted by Scott, the term is defined in Annex B.1 which is the first place it occurs in the Annex, and the identical term is used throughout the Annex, indicating that the definition is applicable throughout the Annex. Joanne Scott, The WTO Agreement on Sanitary and Phytosanitary Measures: A Commentary, Oxford Commentaries on the GATT/WTO Agreements (Oxford University Press, Oxford), 2007, 195.

${ }^{246}$ See above, Part IV, Section 1.3.1.1.

${ }^{247}$ For the discussion on the meaning of 'based on' in Article 3.1 of the SPS Agreement, see above, Part III, Section 4.2.1.
} 
monitor the process of international harmonisation. ${ }^{248}$ The EC and Canada made similar submissions. The EC convincingly argued that the lack of notification of the adoption of a new SPS measure identical to an international standard has the result that other Members are faced, without warning, with obstacles to their trade without having time to adapt their production to the new requirements. ${ }^{249}$ This is particularly the case in view of the absence of a mechanism in the CAC, OIE or IPPC to notify adoption of their international standards. General support for this suggestion led to it being taken up in the third revision to the Recommended Transparency Procedures adopted by the SPS Committee at its meeting on 2-3 April 2008. ${ }^{250}$ It should be noted, however, that this revision does not create an obligation on Members to make such notifications as this would amount to an amendment of the SPS Agreement, the notification obligation of which is expressly limited to SPS regulations 'not substantially the same' as international standards. ${ }^{251}$

In addition, the notification procedures of Annex B.5 apply only if the relevant SPS measure 'may have a significant effect on trade of other Members'. This is a stricter criterion than that which is used in Article 1.1 to demarcate the scope of application of the SPS Agreement. In the latter case, it is only required that a measure 'may, directly or indirectly, affect international trade'. Clearly the notification obligation has narrower application.

The SPS Committee has established non-binding guidelines for what is meant by a 'significant effect on trade' in its Recommended Transparency Procedures. ${ }^{252}$ According to these guidelines, this term may refer to the import-enhancing or import-reducing effect on trade in a specific product, group of products or products in general of a single SPS measure or various SPS measures in combination, between two or more Members. The guidelines further set out various factors that Members should take into account when determining if there is a significant effect on trade. These are the value or importance of the imports in respect of the importing or exporting Members concerned; the potential development of such imports; and the difficulties for producers in other Members to comply with the proposed SPS regulations.

In Japan - Apples, the US claimed that Japan had violated Article 7 and Annex B.5 and B.7 of the SPS Agreement due to its failure to notify changes that had been made to its fire blight measures since the entry into force of the SPS Agreement in 1995. The Panel thus had to determine whether the relevant changes constituted changes which were required to be notified under Article 7 because, inter alia, they 'may have a significant effect on

${ }^{248}$ Committee on Sanitary and Phytosanitary Measures, The Second Review of the Operation and Implementation of the SPS Agreement. Further Elaboration of Issues for Consideration by New Zealand, G/SPS/W/157, circulated on 12 October 2004, para. 10.

${ }^{249}$ Committee on Sanitary and Phytosanitary Measures, Review of the Operation and Implementation of the SPS Agreement. Submission by the European Communities, G/SPS/W/159, circulated on 14 October 2004, paras 7 and 9.

250 The SPS Committee formally agreed that if no Member objected by 30 May 2008, the revised guidelines would be adopted. Officially, this is termed adoption ' ad referendum'. See further below, Part IV, Section 2.1.

${ }^{251}$ Amendments to WTO agreements can only be made by the Ministerial Conference by means of the procedure for amendments in Article X of the WTO Agreement, and not by decisions of subsidiary organs. See further below, Part IV, Section 2.1.1 and note 44.

252 Committee on Sanitary and Phytosanitary Measures, Recommended Procedures for Implementing the Transparency Obligations of the SPS Agreement (Article 7). Revision, G/SPS/7/Rev.2, circulated on 2 April 2002, para. 6 . 
trade of other Members' in the context of the introductory paragraph to Annex B.5. The Panel referred to the guidelines on this concept adopted by the SPS Committee in its Recommended Transparency Procedures and held that:

...the most important factor in this regard is whether the change affects the conditions for market access for the product concerned, that is, would the exported product (apple fruit from the United States in this case) still be permitted to enter Japan if they complied with the prescription contained in the previous regulations. If this is not the case, then we must consider whether the change could be considered to potentially have a significant effect on trade of other Members. In this regard it would be relevant to consider whether the change has resulted in any increase in production, packaging and sales costs, such as more onerous treatment requirements or more time-consuming administrative formalities. ${ }^{253}$

The crux of the issue is therefore whether the changes have an actual or potential significant effect on the conditions for market access. If so, the changes must be notified.

When all the conditions of Annex B.5 are met, Members have to comply with the notification procedure set out in the rest of the Annex.

\subsubsection{Notification procedures}

Paragraphs 5 to 10 of Annex B set out the prior publication and notification procedure to be followed when proposed SPS regulations fall within the scope of application of the notification obligation. In terms of this procedure, the proposal to introduce an SPS regulation must be published at an early stage and in such a manner as to allow other Members to become acquainted with the proposal. ${ }^{254}$ In addition, the products to be covered and the objective and rationale for the proposed SPS regulation must be notified to other Members through the WTO Secretariat. ${ }^{255}$ This notification must occur at an early stage when comments can still be taken into account and amendments introduced to the draft measure. ${ }^{256}$ Upon request, copies of the proposed regulation must be provided, identifying where possible the parts that deviate in substance from international standards, guidelines or recommendations. ${ }^{257}$ It is recommended that requested documents be provided within five working days. ${ }^{258}$ The notifying Member must allow a 'reasonable time' for comments in writing from other Members. According to the Recommended Transparency Procedures adopted by the SPS Committee, the comment period should be normally at

${ }^{253}$ Panel Report, Japan - Apples, para. 8.314. After comparing the two existing measures (which predated the SPS Agreement) with the two new measures, the Panel did not consider that the changes in one measure could have a significant effect on the trade of other Members, and was unable to determine if the changes to the second measure were strictly editorial or introduced substantial changes. It therefore found that the US had failed to make a prima facie case of violation of Article 7 of the SPS Agreement. Ibid., paras. 8.324 and 8.326.

${ }^{254}$ Annex B.5(a) of the SPS Agreement.

${ }_{255}$ Annex B.5(b) of the SPS Agreement.

${ }^{256}$ Annex B.5(b) of the SPS Agreement.

${ }^{257}$ Annex B.5(c) of the SPS Agreement.

258 Committee on Sanitary and Phytosanitary Measures, Recommended Procedures for Implementing the Transparency Obligations of the SPS Agreement (Article 7) as of 1 December 2008. Revision, G/SPS/7/ Rev.3, circulated on 20 June 2008, para. 19. 
least 60 days, except if the proposed measure facilitates trade or is substantially the same as an international standard. ${ }^{259}$ The comments must be discussed upon request and must be taken into account by the Member imposing the SPS measure. ${ }^{260}$

In emergency situations, namely where 'urgent problems of health protection arise or threaten to arise', Members may follow a shorter procedure under Annex B.6. ${ }^{261}$ They must, however, immediately notify other Members, through the Secretariat of the regulation, its rationale and product coverage and the nature of the urgent problem. ${ }^{262}$ Copies of the regulation must be provided upon request and written comments on the regulation must be allowed, discussed and taken into account. ${ }^{263}$ The frequency with which some Members, particularly developing-country Members, use the emergency notification procedure, including in cases where the urgency of the problem is not apparent, is problematic. ${ }^{264}$ In some cases it seems that the emergency procedure is used in order to reduce the administrative burden of notification, or to omit the comment period when the notification has been made too late and the measure has already come into force by the time the notification is made. This concern is reflected in the Recommended Transparency Procedures, which expressly state that the late notification of an SPS regulation is not a sufficient reason for the use of the emergency procedure. ${ }^{265}$ Concerns have been raised in discussions in the SPS Committee that SPS regulations notified as emergency measures simply became permanent measures. It was suggested that notifications under the emergency procedure indicate the period of application, including the end date, of the notified measure. ${ }^{266}$

${ }^{259} \mathrm{Ibid}$., para. 13. It is useful to recall here that although SPS regulations that are substantially the same as an international standard are not covered by the notification obligation in Annex B.5 of the SPS Agreement, the revised Recommended Transparency Procedures adopted by the SPS Committee encourage Members to notify these measures as well, if they are expected to have a significant effect on trade of other Members. Ibid., para. 8. The Recommended Transparency Procedures are discussed below, Part IV, Section 1.3.7.

${ }^{260}$ Annex B.5(d) of the SPS Agreement.

${ }^{261}$ Annex B.6 allows Members to omit such steps of the notification procedure in Annex B.5 as it finds necessary, where urgent problems of health protection arise or threaten to arise.

${ }^{262}$ Annex B.6(a) of the SPS Agreement.

${ }^{263}$ Annex B.6(b)-(c) of the SPS Agreement.

264 The notification practice of the developing-country Members that were used as examples in Part II of this book, provides a practical illustration of this. Mauritius has submitted 12 notifications of proposed SPS measures, 6 of which were notified under the emergency procedure. Jamaica has notified 11 proposed SPS measures, 8 of which are notified as emergency measures and provide no comment period. While some of these measures, such as those taken in response to outbreaks of BSE or foot-and-mouth disease are clearly emergency measures, others, such as Jamaica's fumigation requirement for wooden pallets (G/SPS/N/JAM/6), are more difficult to categorise as such. See further below, Part IV, Section 1.3.5.

265 Committee on Sanitary and Phytosanitary Measures, Recommended Procedures for Implementing the Transparency Obligations of the SPS Agreement (Article 7) as of 1 December 2008. Revision, G/SPS/7/ Rev.3, circulated on 20 June 2008, para. 15.

${ }^{266}$ Committee on Sanitary and Phytosanitary Measures, Workshop on Transparency Held on 15 - 16 October 2007. Note by the Secretariat, G/SPS/R/47, circulated on 8 January 2008, para. 36. It should be noted, however, that the fact that a regulation is notified under the emergency procedure due to the need for quick action does not necessarily imply that it is a provisional measure not based on a risk assessment as a result of insufficiency of the scientific information regarding the risk at issue. Where a proper risk assessment already exists and is used as the basis for the measure, it may be maintained indefinitely despite the fact that it was notified under the shorter procedure for urgent measures. 
Notifications must be made in one of the three working languages of the WTO, namely English, French or Spanish. ${ }^{267}$ However, particulars and the documents relating to the notification are not required to be provided in a language other than that of the notifying Member. ${ }^{268}$ An exception is provided in case of developed-country Members, which are required, upon request, to provide the documents relating to their notifications in English, French or Spanish except in the case of voluminous documents in which case a summary in one of these languages suffices. ${ }^{269}$ Members are not obliged to disclose confidential information that could hamper the enforcement of their SPS measures or prejudice the legitimate interests of enterprises. ${ }^{270}$

The Recommended Transparency Procedures adopted by the SPS Committee make provision for Members to provide supplementary information, in addition to their original notifications, in three different forms. ${ }^{271}$ First, Members may submit addenda to provide additional information or notify changes in the status of a notified draft measure (such as extensions of the comment period, the adoption or coming into force of the notified regulation; the withdrawal of the notified regulation; or changes to the content or scope of application of a notified draft regulation). Second, corrigenda may be used to correct an error in the original notification. Third, revisions may be submitted to replace an original notification if the draft regulation was substantially redrafted or if the notification contained a large number of errors. Specific formats are provided for these three additional forms of notification. ${ }^{272}$

Notifications received by the WTO Secretariat are circulated to Members and interested international organisations, as required by Annex B.9 of the SPS Agreement, including by electronic mail. ${ }^{273}$ In 1999, the WTO Secretariat decided to circulate, in addition, a monthly list of all notifications received in a particular month with a brief summary of the products covered by the notification, the country or regions identified as likely to be affected by the notified measure (where provided), the nature of the measure notified, and the deadline for the submission of comments on the notification. ${ }^{274}$ This decision was taken in terms of the obligation on the WTO Secretariat in Annex B.9 to draw the attention of developing-country Members of notifications relating to products of particular interest to them. ${ }^{275}$

As of 31 August 2007, WTO Members had submitted 5,621 routine notifications (and 1,401 addenda or corrigenda thereto); and 986 emergency notifications (and 193 addenda or corrigenda thereto). ${ }^{276}$ In addition, two notifications of the recognition of equivalence

\footnotetext{
${ }^{267}$ Annex B.7 of the SPS Agreement.

${ }_{268}$ Annex B.11(a) of the SPS Agreement.

${ }^{269}$ Annex B.8 of the SPS Agreement.

${ }^{270}$ Annex B.11(b) of the SPS Agreement.

271 Committee on Sanitary and Phytosanitary Measures, Recommended Procedures for Implementing the Transparency Obligations of the SPS Agreement (Article 7) as of 1 December 2008. Revision, G/SPS/7/ Rev.3, circulated on 20 June 2008, paras 35-42.

${ }^{272}$ Ibid., Annex A and B.

${ }^{273}$ They are circulated in the official document series G/SPS/N/*.

${ }^{274}$ Committee on Sanitary and Phytosanitary Measures, Electronic Transmission of Notifications to National Enquiry Points. Note by the Secretariat, G/SPS/GEN/136, circulated on 9 August 1999.

275 This is discussed further in Part V of this book.

${ }^{276}$ Committee on Sanitary and Phytosanitary Measures, Overview Regarding the Level of Implementation of
} 
had been submitted, as mentioned above. ${ }^{277}$ By the same date, of the then-151 Members, 94 (62 percent) had submitted at least one notification. ${ }^{278}$ Developed-country Members submitted 57.4 percent of the notifications received by 31 August $2007,{ }^{279}$ developingcountry Members had submitted a further 42.3 percent, ${ }^{280}$ and least-developed-country Members the remaining 0.3 percent. ${ }^{281}$ The Secretariat has pointed out that the upward trend in the number of notifications submitted over the years does not necessarily indicate the extent to which actual new or changed SPS regulations are being notified to the WTO. The specific trade concerns raised at SPS Committee meetings still often refer to failures to notify SPS regulations. ${ }^{282}$ In addition, the number of notifications says nothing about the conformity of their content with the requirements of Annex B.5. Several problems remain in this area, as discussed below. ${ }^{283}$

A good example of the potential of the prior notification and comment mechanism for facilitating the discussion and resolution of trade concerns with SPS measures at technical level is provided by the EC's notification of its draft amendments to its regulation laying down health rules concerning animal by-products not intended for human consumption. ${ }^{284}$ The regulation only allowed imports when the country or region of origin is free from certain diseases without vaccination; furthermore it excluded imports of blood from animals treated with certain substances having a hormonal or thyrostatic action and of $\beta$-agonists. The EC received numerous comments concerning the aspects of its regulation dealing with trade on blood and blood fractions for uses other than human consumption such as animal feed or technological uses. ${ }^{285}$ In response to the comments received and consequent to more recent risk analysis, the EC changed its draft amendment. In particular, it deleted the condition that blood products of ruminants are allowed only if the region of origin is eligible for the import of live animals into the Community. The changed draft measure also now allows imports of untreated blood products of ruminants

the Transparency Provisions of the SPS Agreement: Note by the Secretariat, G/SPS/GEN/804, circulated on 11 October 2007, para. 7.

${ }^{277}$ See above, Part IV, Section 1.1.6.

${ }^{278}$ Committee on Sanitary and Phytosanitary Measures, Overview Regarding the Level of Implementation of the Transparency Provisions of the SPS Agreement: Note by the Secretariat, G/SPS/GEN/804, circulated on 11 October 2007, para. 12.

279 The US alone was responsible for $28.8 \%$ of all notifications received by 31 August 2007 (2,367 notifications). It was followed by the EC with $6.3 \%$ (517 notifications), New Zealand with $5.6 \%$ (464 notifications) and Canada with 5.5\% (449 notifications). Ibid., Table 1.

${ }^{280}$ The developing-country Member submitting the greatest number of notifications by 31 August 2007 was Brazil, with $5.4 \%$ of all notifications (446 notifications); followed by Chile with $3.6 \%$ (292 notifications); China with 3.2\% (261 notifications) and Mexico with 2.9\% (236 notifications). Ibid.

${ }^{281}$ Ibid., para. 13. The categorisation of countries into levels of development used by the Secretariat to develop these statistics relies on WTO working definitions as identified in the Integrated Database for analytical purposes. Ibid., footnote 8 .

${ }^{282}$ Ibid., para. 10.

${ }^{283}$ See below, Part IV, Section 1.3.6.

${ }^{284}$ Regulation (EC) No.1774/2002 of the European Parliament and of the Council of 3 October 2002 laying down health rules concerning animal by-products not intended for human consumption, Official Journal L273, 10 October 2002 pp.1-95, notified in G/SPS/N/EEC/103, circulated on 24 November 2000. The regulation provides for rules concerning the means of disposal and uses of animal by-products, including milk for animal feed.

${ }^{285}$ As regards to heat-treated blood fractions from non-ruminant animals which have undergone ante-mortem inspection, the draft amendment is contained in Document SANCO/10586/2006 Rev.6, notified in G/SPS/N/ EEC/103/Add.20, circulated on 21 November 2007. 
from countries or regions which are free from foot-and-mouth disease with vaccination under the condition that imported blood is channelled to the place of destination under secure conditions for further processing. Further it extends the lists of third countries authorised to export blood products intended for technical purposes, to include countries which are able to comply with the EC treatment requirements. It allows the import into the Community of blood derived from animals treated with certain substances having a hormonal or thyrostatic action and of B-agonists; and updates the requirements related to the import of blood products from poultry and other avian species by referring to the international standards laid down in the Terrestrial Animal Health Code of the OIE. ${ }^{286}$ The much revised draft is expected to be adopted soon.

Compliance with the notification procedures set out in Annex B.5-8 are the responsibility of the National Notification Authority that each Member is required to designate under Annex B.10. This institutional obligation is discussed below. ${ }^{287}$

\subsubsection{Explanation of reasons for SPS measures}

As pointed out above, effective enforcement by Members of their rights under the SPS Agreement necessitates information beyond that on the existence and content of SPS measures. It also requires information regarding the scientific basis of the measure and other aspects of the reasons for its imposition. Lack of this information makes it difficult for exporting Members to determine whether they have legal grounds to challenge the relevant SPS measures in terms of the disciplines of the SPS Agreement. However, notifications and publication of SPS measures rarely contain more than the briefest statement of the purpose of the particular measure. To address this problem, an additional transparency provision has been included, namely Article 5.8 of the SPS Agreement. According to this provision, a Member may request another Member to provide the reasons for the latter's SPS measure where it is not based on international standards and it constrains or could potentially constrain the former Member's exports. The importing Member is then obliged to provide such reasons to the requesting Member.

\subsubsection{Scope of application}

The obligation contained in Article 5.8 of the SPS Agreement is not generally applicable to all SPS measures. Instead, it applies only when three conditions are met.

First, the obligation to provide reasons only applies upon request by an exporting Member. It is therefore up to the Member whose exporters are facing problems due to the SPS measure at issue to proactively seek information from the importing Member. This may mean that Members who lack the capacity to keep track of all published SPS measures, and whose channels of communication with its export industries are not effective, may not be in a position to make full use of the potential offered by this provision. As discussed above, this will often be the case for Members at lower levels of development.

\footnotetext{
${ }^{286}$ Committee on Sanitary and Phytosanitary Measures, Notification. Addendum, G/SPS/N/EEC/103/Add.21, circulated on 3 April 2008.

${ }^{287}$ See below, Part IV, Section 1.3.4.
} 
Second, similar to the situation with the prior notification obligation, the obligation to provide reasons only applies to SPS measures that are not based on the relevant international standards, guidelines or recommendations or where no relevant standards, guidelines or recommendations exist. Measures based on international standards are thus not covered by this obligation. Note, however, that whereas the notification provision in Annex B.5 of the SPS Agreement refers to SPS measures that are not 'substantially the same' as international standards, which was argued above to cover those measures that do not 'conform to' international standards, Article 5.8 refers to SPS measures that are not 'based on' such standards. This means that in respect of SPS measures that adopt some but not necessarily all the elements of the international standard, Members are exempt from the obligation to provide reasons. ${ }^{288}$ This is in line with the idea, discussed above, ${ }^{289}$ that the scientific justification for an SPS measure 'based on' an international standard is to be found in the risk assessment relied upon by the relevant international standard-setting body when elaborating the standard. Thus it has been argued above that SPS measures that are based on international standards are saved from challenges under the rigorous scientific disciplines of the Agreement. Therefore also, the Member imposing a measure based on an international standard does not have to provide, upon request, the justification for such a measure.

Third, the obligation to provide reasons applies only when the exporting Member has reason to believe that the SPS measure at issue 'is constraining or has the potential to constrain' its exports. This requirements clearly sets a lower threshold than that the measure 'may have a significant effect on trade' as required in the notification obligation. ${ }^{290}$ The extent to which exports are, or may be, constrained is not specified in this provision, thereby extending the obligation to provide reasons, upon request, to SPS measures with any actual or potential trade restrictive effect. The term 'has reason to believe' rather than just 'believes' indicates that there must be an objective basis for the belief of the exporting Member that this is in fact the case. This condition can easily be met by showing that the SPS measure at issue applies to specific exports of the requesting Member and sets requirements which these exports currently do not meet.

\subsubsection{Obligation to provide an explanation of reasons}

The obligation contained in Article 5.8 is an informational requirement. It should not be understood as shifting the burden of proof to the Member imposing the SPS measure to justify its measure in dispute settlement proceedings. Overturning a ruling of the Panel to that effect, the Appellate Body in EC-Hormones held:

\footnotetext{
${ }^{288}$ For the meaning of an SPS measure 'based on' international standards, see above, Part III, Section 4.2.1.

289 See the discussion of the consequences of choosing to base an SPS measure on an international standard, above, Part III, Section 4.2.1.

${ }^{290}$ The reason for this different threshold seems to lie in the difference in the administrative burden imposed by each of the two provisions. While all draft SPS measures meeting the requirements of Annex B.5 must be notified in advance and comments thereon considered and responded to, the obligation in Article 5.8 is limited to SPS measures in respect of which an exporting Member requests reasons. Therefore a lower threshold for the required trade effect under Article 5.8 will not result in an overwhelming administrative burden on importing Members.
} 
Article 5.8 of the SPS Agreement does not purport to address burden of proof problems; it does not deal with a dispute settlement situation. To the contrary, a Member seeking to exercise its right to receive information under Article 5.8 would, most likely, be in a pre-dispute situation, and the information or explanation it receives may well make it possible for that Member to proceed to dispute settlement proceedings and to carry the burden of proving on a prima facie basis that the measure involved is not consistent with the SPS Agreement. ${ }^{291}$

Thus, despite the fact that it does not address the burden of proof, the obligation contained in Article 5.8 can play a significant role in dispute settlement proceedings by assisting a Member in establishing a prima facie case that another Member's SPS measure is not based on a risk assessment or sufficient scientific evidence. This possibility was addressed in Japan - Agricultural Products II, where the US argued that the Panel had imposed an impossible burden of proof on it by requiring it to prove a negative under Article 2.2 of the SPS Agreement:, namely that there were no relevant studies supporting Japan's measure. The Appellate Body disagreed with the US, noting that the US only had to raise a presumption that there were no such relevant studies. As pointed out by the Appellate Body, the US could have raised a prima facie case that there was insufficient scientific evidence for Japan's measure in the following way:

The United States could have requested Japan, pursuant to Article 5.8 of the SPS Agreement, to provide 'an explanation of the reasons' for its varietal testing requirement, in particular, as it applies to apricots, pears, plums and quince. Japan would, in that case, be obliged to provide such explanation. The failure of Japan to bring forward scientific studies or reports in support of its varietal testing requirement as it applies to apricots, pears, plums and quince, would have been a strong indication that there are no such studies or reports. ${ }^{292}$

This, once again, elucidates the ex post benefits of transparency in enabling Members to enforce their rights under the SPS Agreement by ensuring that they have the means at their disposal to obtain the necessary information regarding the SPS measures of their trading partners. Several Members have made use of this possibility. For example, in 1999, Argentina submitted a series of questions to Korea under Article 5.8 of the SPS Agreement regarding Korea's restrictions on fresh bovine meat from Argentina due to concerns regarding foot-and-mouth disease, despite Argentina's status as free from that disease without vaccination. Among these questions, circulated to the SPS Committee for the information of other Members, ${ }^{293}$ Argentina asked Korea to indicate the scientific basis for its ban, which was not based on OIE recommendations and to provide full information regarding the risk analysis carried out in terms of Article 5 of the SPS Agreement. Korea responded that its measure was consistent with OIE recommendations and with the SPS Agreement. Korea stated that it had been free of foot-and-mouth disease for 60 years, and only imported from countries free of foot-and-mouth disease without vaccination for

\footnotetext{
291 Appellate Body Report, EC-Hormones, para. 102.

292 Appellate Body Report, Japan-Agricultural Products II, para. 137.

${ }^{293}$ Committee on Sanitary and Phytosanitary Measures, Restrictions on the Exportation of Fresh Bovine Meat to the Republic of Korea: Statement by Argentina at the Meeting of 7-8 July 1999, G/SPS/GEN/130, circulated on 21 July 1999.
} 
at least 12 months. At the time of Korea's review of Argentina's sanitary status in April 1996, Argentina did not meet this requirement. Korea indicated that the matter should be discussed and resolved bilaterally. ${ }^{294}$ The matter has not been reported resolved, but may be so since it has not been raised again. ${ }^{295}$

Compliance with the obligation under Article 5.8 is among the responsibilities of the Enquiry Point which each Member is required to have under Annex B.3 of the SPS Agreement. This institutional obligation is discussed below.

\subsubsection{Infrastructure for transparency}

Members are required by the SPS Agreement to create the necessary institutional infrastructure for the implementation of their transparency obligations. Under Annex B.10, Members must designate a single authority, commonly known as the National Notification Authority, as responsible for implementing the notification procedures in Annex B.58 at national level. This authority must be a central government body. As noted in the Handbook on Transparency most often Members designate as their National Notification Authority an existing government department or agency with responsibilities in sanitary or phytosanitary matters, or a government department responsible for disseminating information. ${ }^{296}$ Even if SPS responsibilities are divided among several government departments, only one National Notification Authority may be designated. The National Notification Authority need not have SPS experts on its staff, but it must have access to or relationships with the technical experts responsible for drafting SPS regulations. ${ }^{297}$ The WTO Secretariat should be informed of the designation or change of a Member's National Notification Authority, ${ }^{298}$ and it regularly updates and circulates lists of these authorities to all Members. ${ }^{299}$

The responsibilities of the National Notification Authority include ensuring that a notice of proposed regulations is published at an early stage; notifying other Members through the WTO Secretariat of proposed SPS regulations at an early stage, preferably using the

\footnotetext{
${ }^{294}$ Committee on Sanitary and Phytosanitary Measures, Summary of the Meeting Held on 7-8 July 1999: Note by the Secretariat, G/SPS/R/15, circulated on 20 September 1999, paras 13-14.

295 Committee on Sanitary and Phytosanitary Measures, Specific Trade Concerns. Note by the Secretariat. Addendum. Issues Not Considered in 2007, G/SPS/GEN/204/Rev.8/Add.2, circulated on 27 March 2008, item 65.

296 WTO Secretariat, How to Apply the Transparency Provisions of the SPS Agreement (World Trade Organization, Geneva), September 2002, para. 9, available at: http://www.wto.org/english/tratop_e/sps_e/ spshand_e.doc, visited on 25 June 2007.

${ }^{297}$ Ibid., para. 11.

298 The SPS Agreement does not expressly oblige Members to notify the Secretariat of this designation. However, this seems logical to read the 'designation' obligation as including the requirement that the WTO Secretariat be informed of such designation. In this line, the Recommended Transparency Provisions encourage Members to do so, and specify further that it would be useful to include particular contact information of the designated authorities. Committee on Sanitary and Phytosanitary Measures, Recommended Procedures for Implementing the Transparency Obligations of the SPS Agreement (Article 7) as of 1 December 2008. Revision, G/SPS/7/Rev.3, circulated on 20 June 2008, para. 5.

${ }^{299}$ These can be found in the G/SPS/NNA/* series of official WTO documents.
} 
recommended format; ${ }^{300}$ providing copies of the proposed regulations, upon request; and ensuring that comments received on notified regulations are handled correctly. ${ }^{301}$

Also as part of the infrastructure necessary for transparency, the Annex B.3 of the SPS Agreement obliges each Member to ensure that one national Enquiry Point exists. The aim of the Enquiry Point is to provide a single contact point to enable Members to easily obtain information regarding SPS matters without having to identify and approach the agency responsible for the relevant matter. ${ }^{302}$ This Enquiry Point need not be a government body, but may also be an independent agency. It must be able, however, to obtain the necessary answers from the relevant national bodies in order to reply to the requests for information received. Therefore, it needs to have established relationships with the relevant sanitary and phytosanitary officials to facilitate prompt access to the requested information. As noted in the Handbook on Transparency, most commonly Members designate an existing standards information office or the government department that is most concerned with responsibilities falling under the SPS Agreement as their Enquiry Point. ${ }^{303}$ Once again, the WTO Secretariat should be kept informed of the designated authority, ${ }^{304}$ and it maintains an updated list of Enquiry Points, which it circulates to Members. ${ }^{305}$

The responsibilities of a Member's Enquiry Point are to provide answers to all reasonable questions from other Members as well as provide relevant documents regarding: any adopted or proposed SPS regulations in its territory; the risk assessment basis for the measure; the determination of the appropriate level of protection; control and inspection procedures, production and quarantine treatment, pesticide tolerance and food additive approval procedures in its territory; and the Member's (or its relevant bodies') membership of and participation in international or regional SPS systems as well as bilateral or multilateral agreements within the scope of the SPS Agreement. ${ }^{306}$ Requested copies of documents must be supplied to other Members at the same price as to nationals. ${ }^{307}$ In the Handbook on Transparency prepared by the WTO Secretariat, Members are encouraged

300 The Recommended Transparency Procedures adopted by the SPS Committee contain recommended formats for routine and emergency notifications. See further below, Part IV, Section 1.3.7.

301 WTO Secretariat, How to Apply the Transparency Provisions of the SPS Agreement (World Trade Organization, Geneva), September 2002, para. 8, available at: http://www.wto.org/english/tratop_e/sps_e/ spshand e.doc, visited on 25 June 2007.

${ }^{302}$ Ibid., para. 15.

303 Ibid., para. 18

${ }^{304}$ As is the case with the National Notification Authorities, there is no express obligation in the SPS Agreement to keep the WTO Secretariat informed as to which body has been designated as the Enquiry Point of a Member. However, as the aim of an Enquiry Point is to provide a single contact point to which questions and requests for documentation can be addressed, making available the contact details of the designated Enquiry Point is essential to the fulfilment of this objective. Effective treaty interpretation therefore seems to require notification of the designated Enquiry Point and its contact details to other Members, most easily done by notifying the WTO Secretariat which will circulate the information to all Members. To this end, the Recommended Transparency Provisions encourage Members to inform the Secretariat of their designated Enquiry Point and its contact information. Committee on Sanitary and Phytosanitary Measures, Recommended Procedures for Implementing the Transparency Obligations of the SPS Agreement (Article 7) as of 1 December 2008. Revision, G/SPS/7/Rev.3, circulated on 20 June 2008, para. 5.

${ }^{305}$ These can be found in the G/SPS/ENQ/* series of official WTO documents.

${ }^{306}$ Annex B.3 (a)-(d) of the SPS Agreement.

${ }^{307}$ Annex B.4 of the SPS Agreement. Delivery costs may however differ from those charged to nationals. 
not to charge for requested documents, as a gesture of goodwill, taking into account that it is not very cost effective to recover the small amounts involved. ${ }^{308}$

The resources needed for the operation of the Enquiry Point and the National Notification Authority have been identified by the WTO Secretariat as being, at a minimum, office facilities with some form of word-processing capability, a photocopier and access to postal facilities and a telephone. Existing office infrastructure and services may be utilised. ${ }^{309}$ If possible, a fax machine is recommended as it speeds up communication with the WTO Secretariat and other Members. In order to ensure more efficient operation of the infrastructure for transparency, Members are encouraged to obtain and use e-mail and Internet resources. These speed up communication and allow documents to be sent and received electronically, eliminating the delay between the making of a notification and its receipt by the Secretariat. Internet access enables Members to download all documents circulated on the WTO website and all SPS regulations that have been published by Members on their own websites. Thus, although the minimum resources needed are small, the additional resources that will ensure that the Enquiry Point and National Notification Authority operate speedily and efficiently may be difficult to obtain for Members where computer facilities and Internet access are not readily available or are too costly for the budget they have to work with. Added to the infrastructure resources identified above are the human resources needed to process and distribute SPS notifications and answer requests for information. As noted by the WTO Secretariat, while this workload is not particularly onerous, 'depending on the size and workload of the existing body, this could put an additional strain on already finite resources.' ${ }^{310}$

Some Members have decided to designate the same body as both their National Notification Authority and their Enquiry Point. This minimises the financial and physical resources needed and allows building up trade policy expertise in a single dedicated body. ${ }^{311}$ It also removes the need for coordination between two separate bodies. Other Members have allocated these roles in two different bodies. Still others have designated more than one Enquiry Point to address different areas of SPS regulation (food safety, and animal and plant health), ${ }^{312}$ despite the obligation to 'ensure that one enquiry point exists' (emphasis added) in Annex B.3. ${ }^{313}$

308 WTO Secretariat, How to Apply the Transparency Provisions of the SPS Agreement (World Trade Organization, Geneva), September 2002, para. 85, available at: http://www.wto.org/english/tratop_e/sps_e/ spshand_e.doc, visited on 25 June 2007.

${ }^{309}$ Ibid., para. 21.

310 Ibid., para. 17.

311 Ibid.

${ }^{312}$ For example, India and Kenya have designated three Enquiry Points each, one for food safety issues, one for animal health issues and one for phytosanitary issues, within the three different government departments with responsibilities in these areas. Committee on Sanitary and Phytosanitary Measures, National Enquiry Points. Note by the Secretariat, G/SPS/ENQ/23, circulated on 27 March 2008, 26 and 28-29.

313 Committee on Sanitary and Phytosanitary Measures, Recommended Procedures for Implementing the Transparency Obligations of the SPS Agreement (Article 7) as of 1 December 2008. Revision, G/SPS/7/Rev.3, circulated on 20 June 2008, footnote 1. In practice, more than one Enquiry Point is tolerated but not more than one National Notification Authority. Committee on Sanitary and Phytosanitary Measures, Workshop on Transparency Held on 15 - 16 October 2007. Note by the Secretariat, G/SPS/R/47, circulated on 8 January 2008, para. 25 . 
By October 2007, of the then 151 WTO Members, 131 had designated National Notification Authorities and 139 had designated Enquiry Points. ${ }^{314}$ Other than Kuwait, all the Members not having established an Enquiry Point and/or National Notification Authority were either developing-country Members, or least-developed-country Members. ${ }^{315}$

\subsubsection{Implementation of transparency obligations by selected Members}

An illustration of the varying degrees of implementation of the transparency provisions of the SPS Agreement by Members at different levels of development can be provided by looking at the notification practice of the four Members selected as examples in Part II of this book.

Australia has established a single dedicated agency as both its National Notification Authority and its Enquiry Point under Article 7 and Annex B of the SPS Agreement. This is the Australian SPS Contact Point, an agency within the Department of Agriculture, Forestry and Fisheries. ${ }^{316}$ Australia reports that it has a dedicated administrative officer to collect and distribute all SPS notifications received and to transmit Australia's comments back to other national Enquiry Points. ${ }^{317}$ It maintains electronic address lists to ensure that notifications are distributed promptly to the relevant national agencies and other stakeholders. ${ }^{318}$ As a result, interested parties receive notifications quickly, allowing them the maximum time for review of and comment on notified documents. The Enquiry Point also coordinates responses to requests from other Members for further information under Article 5.8 of the SPS Agreement. ${ }^{319}$ Australia uses e-mail as an efficient means of communication, which it states 'enables SPS Enquiry Points to act as effective conduits for communicating information to the relevant national authorities. ${ }^{320}$ Australia notes that frequently a notification indicates the website where full documentation on the proposed SPS measure can be found. ${ }^{321}$ However, when the relevant documents are very large, some Members experience difficulty in downloading them. Australia has adopted

${ }^{314}$ Committee on Sanitary and Phytosanitary Measures, Implementation of the Transparency Obligations as of 8 October 2007: Note by the Secretariat, G/SPS/GEN/27/Rev.17, circulated on 9 October 2007.

315 The following Members had established neither an Enquiry Point nor a National Notification Authority as of 8 October 2007: Burundi, Cambodia, Central African Republic, Chad, Congo, Democratic Republic of the Congo, Guinea, Guinea Bissau, Lesotho, Rwanda, Sierra Leone and Togo. On that date, an Enquiry Point, but no National Notification Authority had been established by: Burkina Faso, Côte d'Ivoire, Former Yugoslav Republic of Macedonia, Ghana, Kuwait, Maldives, Namibia, Nepal and Niger. Only Georgia had established a National Notification Authority but no Enquiry Point. As noted by the Secretariat, of the Members that had not designated a National Notification Authority, 12 were least-developed-country Members and 7 were developing-country Members. Of the Members that had not established an Enquiry Point, 11 were leastdeveloped-country Members and one was a developing-country Member.

316 Committee on Sanitary and Phytosanitary Measures, National Notification Authorities. Note by the Secretariat, G/SPS/NNA/13, circulated on 27 March 2008, 13; Committee on Sanitary and Phytosanitary Measures, National Enquiry Points. Note by the Secretariat, G/SPS/ENQ/23, circulated on 27 March 2008, 13.

317 Committee on Sanitary and Phytosanitary Measures, Special Meeting of the SPS Committee on Enquiry Points - 31 October 2003: Comment by Australia, G/SPS/GEN/429, circulated on 14 October 2003, para. 3.

318 The distribution lists operate through self-nomination, ensuring that interested parties receive relevant notifications. Ibid.

319 Ibid.

${ }^{320}$ Ibid., para. 6.

${ }^{321}$ Ibid., para. 4. 
the approach suggested in the Recommended Transparency Procedures of including an executive summary of the relevant information on the same site as larger documents and has also initiated the provision of compact disc copies of larger documents to facilitate their distribution, especially abroad. It also provides hard copies by mail, but notes that this significantly reduces the period available for comment. ${ }^{322}$

To date Australia has submitted 226 notifications of 225 draft regulations, ${ }^{323}$ only 14 of which were notifications of emergency measures with no comment period. Australia usually provides a sixty-day comment period for routine notifications, the expiry of which is well before the expected date of adoption of the measure and its entry into force. ${ }^{324}$ However, there are instances of routine notifications in which Australia has not provided a comment period. ${ }^{325}$ Usually, Australia indicates the website where the draft documents related to the notification can be found, and indicates the postal address where they can be requested. Australia notifies both draft risk analysis reports ${ }^{326}$ and the outcome of the risk analysis process. ${ }^{327}$ Australia has also notified its proposed changes to the IRA process for

322 Ibid.

${ }^{323}$ See G/SPS/N/AUS/1-226. One notification (G/SPS/N/AUS/141) was mistakenly resubmitted (as G/SPS/N/ AUS/142) and was then withdrawn by means of an addendum.

${ }^{324}$ For example, Australia's notification of a draft assessment report regarding an application to amend the Australia New Zealand Food Standards Code to approve the use of steviol glycosides as intense sweeteners and flavour enhancers in a range of foods, which was circulated on 25 May 2007 (G/SPS/N/AUS/213), provided a comment period ending on 27 July 2007. It indicated in the box for the proposed date of adoption that a notification to its government was anticipated in December 2007 with adoption (gazettal) to follow, pending Government consideration. The proposed date of entry into force was indicated as being the date of Gazettal pending Government consideration.

${ }^{325}$ For example, Australia's most recent routine notification (G/SPS/N/AUS/226) was circulated on 25 July 2008, but was adopted and came into force on 14 July 2008, thus providing no comment period and no adaptation period. This measure relates to amendments in Australia's quarantine system for imports of horses to prevent the reintroduction of equine influenza after its successful eradication. The notification states that a formal horse import risk analysis will be undertaken, during which comments will be accepted from stakeholders, including WTO Members. It appears therefore that this is a provisional measure, pending a full risk assessment, and should have been notified as an emergency measure.

${ }^{326}$ An example of this is Australia's notification of the report of an assessment regarding an application seeking to amend the Australia New Zealand Food Standards Code to increase the current maximum level of cadmium in peanuts from $0.1 \mathrm{mg} / \mathrm{kg}$ to $0.5 \mathrm{mg} / \mathrm{kg}$ (G/SPS/N/AUS/223, circulated on 6 May 2008). Australia's notification states that all applications to change the Australia New Zealand Food Standards Code, 'must be assessed in the context of the following objectives: (a) the protection of public health and safety; (b) the provision of adequate information relating to food to enable consumers to make informed choices; and (c) the prevention of misleading or deceptive conduct.' It states the website and postal address where the assessment report can be obtained and provides a comment period until 20 June 2008.

${ }^{327}$ For example, in May 2007 Australia notified a draft policy review open for public comment in respect of salt and heat treated eggs and alkalized eggs of ducks from Chinese Taipei (G/SPS/N/AUS/212). On 4 October 2007, Australia's Director of Animal and Plant Quarantine made a policy determination in respect of these eggs, based on the conclusions and recommendations of the final policy review that included consideration of comments received on the draft policy review. The outcome of the final determination, namely that salt and heat-treated duck eggs do not require risk management while alkalised duck eggs require risk management for four diseases of quarantine concern (notifiable avian influenza viruses, Newcastle disease virus, and Salmonella enteritidis and multi-drug resistant S. typhimurium), was notified as an addendum to the original notification on 18 October 2007 (G/SPS/N/AUS/212/Add.1). Australia's practice of notifying both draft IRAs and the outcome of the IRA process is reported in Trade Policy Review Body, Trade Policy Review: Australia - Report by the Secretariat. Revision, WT/TPR/S/178/Rev.1, circulated on 1 May 2007, Section IV para. 57. 
plant and animal health, and the coming into force of these changes. ${ }^{328}$ Where the content or scope of the draft regulation changes, Australia follows the recommended practice of submitting an addendum to the original notification. ${ }^{329}$ It also submits revisions to its notifications in case of significant changes, ${ }^{330}$ and corrigenda in case of small errors. ${ }^{331}$

Mauritius reports that it has achieved a 'reasonable level of compliance'332 with the transparency provisions of the SPS Agreement. It has designated an Enquiry Point within the Division of Plant Pathology and Quarantine, namely the Principal Research \& Development Officer of the National Plan Protection Office, Ministry of Agro- Industry and Fisheries. ${ }^{333}$ The Enquiry Point receives and responds to requests for information regarding national SPS measures. ${ }^{334}$ It has also been effective in promptly circulating the notifications of other WTO Members of their SPS measures to interested parties in Mauritius. ${ }^{335}$ This has facilitated the formulation of Mauritian positions on these notifications, which are sent to the SPS Committee as appropriate. ${ }^{336}$ The Enquiry Point is an

${ }^{328}$ On 27 October 2006, Australia notified proposed reforms to its Import Risk Analysis (IRA) process (G/ SPS/N/AUS/203). On 17 September 2007, Australia notified that the Quarantine Amendment Regulation 2007 (No.1) came into force on 5 September 2007. Its notification stated: 'These regulations are an important part of the legal framework for the reforms to Australia's IRA system and include the regulation of the key steps, and overall time frames, for IRAs. The commencement of the new regulations was accompanied by the release of an updated IRA Handbook 2007 which provides detailed information regarding the new IRA process' (G/SPS/N/AUS/203/Add.1).

${ }^{329}$ For example, Australia submitted an addendum to its notification of emergency measures to suspend imports of fresh produce and nursery stock of tomatoes, capsicum, eggplant, pepino, potato and chilli from New Zealand to manage the risk of introduction to and spread in Australia of an undescribed species of the genus Candidatus Liberibacter (G/SPS/N/AUS/224) in order to include a further three potential hosts of Candidatus Liberibacter: tamarillo, cape gooseberry and tomatillos (G/SPS/N/AUS/224/Add.1).

${ }^{330}$ An example of a revision can be found in G/SPS/N/AUS/199/Rev.1, circulated on 4 December 2006, revising Australia's quarantine measures on fresh corm taro (Colocasia esculenta) (previously notified in G/SPS/N/AUS/199) to ensure the suspension on the importation the antiquorum variety of this plant can be effectively enforced. The revision was necessary due to the indication in available scientific literature Colocasia esculenta var. antiquorum has a high capacity to propagate even when topped and free from all foliage including petiole bases and therefore presents an increased risk of introducing pests and diseases of quarantine concern to Australia.

${ }^{331}$ For example, Australia submitted a corrigendum to notification G/SPS/N/AUS/192 soon after the original notification was made, to indicate that the notification concerned an amendment to the conditions for importation of hatching eggs of domestic turkeys from approved countries, rather than eggs of domestic hens as the original notification incorrectly stated (G/SPS/N/AUS/192/Corr.1).

${ }^{332}$ Committee on Sanitary and Phytosanitary Measures, The Mauritian Experience with the SPS Agreement from the Indian Ocean Perspective, G/SPS/GEN/526, circulated on 25 October 2004, para. 8.

${ }^{333}$ Committee on Sanitary and Phytosanitary Measures, National Enquiry Points. Note by the Secretariat, G/ SPS/ENQ/23, circulated on 27 March 2008, 33.

${ }^{334}$ Committee on Sanitary and Phytosanitary Measures, The Mauritian Experience with the SPS Agreement from the Indian Ocean Perspective, G/SPS/GEN/526, circulated on 25 October 2004, para. 8.

${ }^{335}$ In the private sector of Mauritius, among farmers and other producers, there is little understanding of the SPS Agreement, as a result of which one may expect that few producers will lobby the relevant authorities to take steps under this Agreement to address export barriers they face. Exceptions to this are representative bodies such as the Chamber of Commerce and Industry and the Chamber of Agriculture, as well as representatives of producers of certain commodities such as sugar and pineapples, which are reported to be well informed as to the disciplines of the SPS Agreement. Vinod Rege et al., Influencing and Meeting International Standards: Challenges for Developing Countries. Volume II: Procedures Followed by Selected International StandardSetting Organisations and Country Reports on TBT and SPS (International Trade Centre UNCTAD/WTO and Commonwealth Secretariat, Geneva), 2004, 152.

${ }^{336} \mathrm{Ibid}$., 151. However, it is interesting to note that Mauritius has, to date, never raised a specific trade concern at a meeting of the SPS Committee or supported any concern raised by another Member. See further below, 
active participant in all SPS-related national decision-making. The head of the Enquiry Point used to attend meetings of the SPS Committee in Geneva at least once a year. This required substantial financial resources so at other meetings Mauritius is represented by its Permanent Mission in Geneva. ${ }^{337}$ In 2006, however, Mauritius reported that resource constraints prevented the participation of capital-based representatives at SPS Committee meetings. ${ }^{338}$

Notification to the WTO of Mauritian SPS measures is carried out by the Secretary for Foreign Affairs of the Ministry of Foreign Affairs, International Trade and Regional Cooperation (its designated National Notification Authority) ${ }^{339}$ and coordinated by the Division of Plant Pathology and Quarantine. Mauritius has made 12 notifications so far, of which six were emergency measures. ${ }^{340}$

Jamaica has established the infrastructure necessary for transparency in SPS matters, but its operation leaves much to be desired. The Plant Quarantine/Produce Inspection (PQ/PI) Unit of the Ministry of Agriculture and Lands has been designated as Jamaica's Enquiry Point and the Ministry of Foreign Affairs and Foreign Trade as its National Notification

Part IV, Section 2.1.2.

${ }^{337}$ Ibid., 151.

338 Committee on Sanitary and Phytosanitary Measures, Experience with the Implementation of the SPS Agreement. Information for the Workshop on 31 March 2006. Communication from Mauritius, G/SPS/ GEN/657, circulated on 27 March 2006, para. 2. The representation of Mauritius at SPS Committee meetings is discussed below, Part IV, Section 2.1.

339 Committee on Sanitary and Phytosanitary Measures, National Notification Authorities. Note by the Secretariat, G/SPS/NNA/13, circulated on 27 March 2008, 18.

${ }^{340} \mathrm{See}$ WT/SPS/N/MUS/1-12. The first notification of Mauritius in September 1999 was rather unusual in that, instead of notifying a specific proposed SPS regulation, it set out a series of steps taken prior to the notification to address concerns with dioxin contamination, following the dioxin detection in Belgium. It notified that on 5 June 1999 a ban with immediate effect had been imposed on all food products from Belgium, followed by a ban imposed on 18 June 1999 on all meat products from the EC. On 25 June, the ban was lifted for meat and poultry products from the EC excluding Belgium, if the exports were accompanied by a veterinary certificate from the exporting Member's competent authority certifying that the product was not contaminated by dioxin. As of 30 July, food products from the EC, excluding Belgium, were allowed to be imported into Mauritius if accompanied by the required certification. All these steps, including the adoption of the final measure predated the notification and thus no comment period was provided. The second, third, fourth, fifth and sixth notifications of Mauritius all related to emergency measures, whose entry into force predated the circulation of the notification thus providing for no comment or adaptation period. These measures were: a temporary ban on fish and fish products from South Africa due to cholera outbreaks and four temporary bans to prevent the introduction of foot-and mouth disease (namely a ban on all livestock and livestock products from the UK; a ban on all meat products from the EC, except poultry and canned pork; a temporary ban on live cattle, sheep and goats from Zimbabwe and South Africa; and a temporary ban on imports of horses and other equidae from the UK). The seventh, eighth and ninth notifications of Mauritius related to the lifting of some of these bans, following the OIE report of 2001 on the foot-and-mouth disease situation in different countries. Normally, as set out in the Recommended Transparency Provisions discussed above, this type of change in a measure should be notified as an addendum to the original notification rather than as a new notification. Mauritius's tenth notification is also rather unusual in that it does not relate to a proposed SPS regulation of Mauritius that may affect trade of other Members, but rather notifies an agreement between Mauritius and Madagascar to eliminate the risk of BSE transmission through animal feed exports to Madagascar, by ensuring that no meat meal or bone meal would be used as animal feed ingredients in Mauritius. The eleventh and twelfth notifications of Mauritius are of emergency measures, one temporarily banning imports of fruit and vegetables from Kenya due to the detection of fruit flies on the Kenyan coastal region; and the other banning imports of live poultry and pigs as well as their frozen or chilled products from South Africa following reports of highly-pathogenic avian influenza in ostriches in South Africa. 
Authority. ${ }^{1}$ While hard copies of SPS notifications are received by the Ministry of Foreign Affairs and Trade, it does not have the resources to sort and prioritise them or distribute them to stakeholders for comments. Jamaica's Enquiry Point, the PQ/PI Unit, has taken over the responsibility for this. However, Reid has noted that while the PQ/PI Unit is already on the WTO's list of Enquiry Points, all that has happened is that one officer from the Unit has been trained and the Enquiry Point has been given the necessary software by the US Department of Agriculture. ${ }^{2}$ The software downloads new notifications, without any sorting or prioritisation, and distributes them as a newsletter to 18 persons in the Jamaican government. ${ }^{3}$ Problems with the software following changes to the WTO website resulted in no newsletters being produced between May 2001 and February 2002, until the software was amended. Inadequate computer access and human resource constraints have also hindered Jamaica in benefiting from notifications. The PQ/ PI Unit has made a request for a person with a computer dedicated to the task of monitoring notifications alone. ${ }^{4}$ There is no system in place to manage the flow of information between technocrats, SPS policy makers and producers in Jamaica. In addition, problems have been identified with internal communication between the various government departments and agencies dealing with SPS issues, ${ }^{5}$ making the operation of the Enquiry Point inefficient. ${ }^{6}$ Reid points out that Jamaica 'needs much more in terms of managing the Enquiry Point and the information systems needed to support it."7

Jamaica has notified eleven SPS measures to the WTO, in terms of the transparency requirements of the SPS Agreement. Eight of these notifications relate to emergency measures and provide no comment period. In addition, one routine notification provides no comment period, and adaptation periods are either not provided or not specified. ${ }^{8}$

\footnotetext{
${ }^{1}$ Committee on Sanitary and Phytosanitary Measures, National Enquiry Points. Note by the Secretariat, G/ SPS/ENQ/23, circulated on 27 March 2008, 27; Committee on Sanitary and Phytosanitary Measures, National Notification Authorities. Note by the Secretariat, G/SPS/NNA/13, circulated on 27 March 2008, 14.

2 Janice Reid, Needs Analysis of the Readiness of Jamaican Institutions for WTO-SPS: Executive Summary (Inter-American Institute for Cooperation on Agriculture, Kingston), April 2000, 7, available at: www.agroinfo.org/caribbean/iicacarc/jamaica/summary.pdf, visited on 7 January 2008.

${ }^{3}$ Vinod Rege et al., Influencing and Meeting International Standards: Challenges for Developing Countries. Volume II: Procedures Followed by Selected International Standard-Setting Organisations and Country Reports on TBT and SPS (International Trade Centre UNCTAD/WTO and Commonwealth Secretariat, Geneva), 2004, 115.

4 Ibid.

5 Ibid.

${ }^{6}$ The ITC/Commonwealth Secretariat report notes that by September 2001, the PQ/PI Unit had received three requests for information following notifications by Jamaica (from the US, Canada and Mexico) but had been unable to respond to any due to difficulties in obtaining the necessary information. Ibid., 116.

7 Janice Reid, Needs Analysis of the Readiness of Jamaican Institutions for WTO-SPS: Executive Summary (Inter-American Institute for Cooperation on Agriculture, Kingston), April 2000, 7, available at: www.agroinfo.org/caribbean/iicacarc/jamaica/summary.pdf, visited on 7 January 2008.

${ }^{8}$ See G/SPS/N/JAM/1-11. Jamaica's first notification related to standards for jerk seasoning (including chemical and microbiological specifications). The deadline for comments was given in the same month (July 1996) in which the notification was made but specifies no date, and the date of adoption and entry into force were both October 1996, thus providing no adaptation period. The second notification was of the proposed adoption of the HACCP system for the production of canned ackee in brine. A two-month comment period was given, and the dates of adoption and entry into force of the new requirements were not specified. Jamaica's eighth notification related to draft regulations laying down import conditions for fruits, vegetables, plants and plant parts. A comment period of almost two months was given. The proposed date of adoption of the regulations, however, coincided with the end of the comment period, meaning that no time was provided for consideration
} 
Bangladesh has designated the Director-3 WTO Cell of its Ministry of Commerce as both its Enquiry Point and its National Notification Authority under the SPS Agreement. ${ }^{9}$ However, Bangladesh experiences difficulties meeting its notification obligations under WTO rules, including those under the SPS Agreement.${ }^{10}$ In fact, it has, to date, never notified an SPS measure to the WTO. As a least-developed-country Member, Bangladesh benefited from a five-year transition period for implementation of the SPS Agreement, including its transparency obligations. However, Bangladesh is of the view that this transition period was too short.

\subsubsection{Problems with implementation}

The inadequate implementation of the transparency provisions of the SPS Agreement was among the implementation concerns raised in the run-up to the Seattle Ministerial Conference. India emphasised the problems caused by this poor implementation for developing-country Members. ${ }^{11}$ It noted that SPS measures are often developed in a nontransparent manner and that developing-country Members invariably are not given an adequate opportunity to respond to the proposed measures. Further, referring to the obligations in the SPS Agreement to provide a reasonable interval between the publication of an SPS measure and its entry into force (Annex B.2), and to grant 'longer time-frames for compliance' for developing-country Members (Article 10.2), it pointed out that:

The basic purpose of these provisions is to provide sufficient time to producers in developing countries to adopt their products to the requirements of new regulations. In practice, compliance of these provisions by countries introducing new measures has been largely non-existent. ${ }^{12}$

\footnotetext{
of comments received. The actual adoption of the regulations, however, was notified by Jamaica almost a year later, by means of an addendum to its eighth notification (G/SPS/N/JAM/8/Add.1). All the remaining notifications related to emergency measures. The third and fourth notifications were of precautionary measures restricting imports of certain animal products (including untreated milk) and straw/fodder from Uruguay and from the UK, Ireland, France, the Netherlands and Argentina due to outbreaks of FMD. The fifth notification was of a precautionary measure against imports of beef and beef products from the EC due to concerns with regard to BSE. Jamaica's sixth notification was of a measure laying down fumigation and certification requirements on wood pallets from Trinidad and Tobago to prevent the importation of two quarantine pests. Three months later, Jamaica submitted an addendum to that notification, stating that one of the pests addressed in its notification was already present in Jamaica and thus not considered a quarantine pest. Jamaica's seventh notification, related to a temporary suspension of imports of beef and beef products and bovine-derived pharmaceuticals from the US due to BSE risks. Jamaica's ninth, tenth and eleventh notifications related to emergency measures on wooden pallets used as packaging for floor tiles, to prevent the introduction of a wood boring pest from India, Thailand and Indonesia. All these emergency notifications post-dated the entry into force of the measure involved and therefore did not provide for any comment period.

${ }^{9}$ Committee on Sanitary and Phytosanitary Measures, National Enquiry Points. Note by the Secretariat, G/ SPS/ENQ/23, circulated on 27 March 2008; Committee on Sanitary and Phytosanitary Measures, National Notification Authorities. Note by the Secretariat, G/SPS/NNA/13, circulated on 27 March 2008, 3.

${ }^{10}$ Trade Policy Review Body, Trade Policy Review: Bangladesh - Report by the Secretariat, WT/TPR/S/68, circulated on 3 April 2000, Part II para. 25 and Table II.23.

${ }^{11}$ General Council, Preparations for the 1999 Ministerial Conference. Proposals Regarding the Agreement on Sanitary and Phytosanitary Measures in Terms of Paragraph 9(a)(I) of the Geneva Ministerial Declaration. Communication from India, WT/GC/W/202, circulated on 14 June 1999.

${ }^{12}$ Ibid., para. 1.
} 
The Implementation Decision adopted in 2001 at the Doha Ministerial Conference, as discussed above, aims to address the problem of short compliance periods by providing that each of these two periods should be at least six-months. ${ }^{13}$ However, problems remain with the inadequate implementation of these and other transparency obligations, as highlighted by China in 2003, when it submitted an analysis of the SPS notifications submitted in $2002 .{ }^{14}$ This analysis showed that of the 374 routine notifications submitted in that year only 14 notifications ( 3.7 percent of routine notifications) provided an adaptation period of at least 6 months, 128 notifications ( 34.2 percent) provided an adaptation period of less than 6 months and 232 notifications (62.1 percent) did not specify the date of adoption and/or the date of entry into force. ${ }^{15}$

The analysis conducted by China also identified problems in the provision of a 'reasonable time' for comments as required by Annex B.5(d) and specified as normally at least 60 days in the Recommended Transparency Procedures. As noted by China, in view of the major difficulties faced by many developing-country Members in keeping track of the flood of notifications, a too short comment period may make it impossible for these Members to make use of this possibility to have their concerns taken into account. Of the 374 routine notifications submitted in 2002, only 79 (21.1 percent) allowed at least 60 days for comments, and 230 notifications (61.5 percent) allowed a comment period of less than 60 days. The final dates for comments for 11 notifications (2.9 percent) were earlier than the dates of circulation of the notification, depriving Members of their right to comment on the notifications altogether. In 54 notifications (14.5 percent) no final dates for comments were specified. ${ }^{16}$ An additional problem identified by China, aside from the too short comment periods provided in most notifications, is that time is needed between the date of submission of a notification and its circulation to Members by the WTO Secretariat for the review and translation of the document by the Secretariat. This eats into the comment period. ${ }^{17}$ In addition, China pointed out that the requirement in Annex B.5(d) that comments shall be taken into account is undermined by the fact that

\footnotetext{
${ }^{13}$ Ministerial Conference, Implementation-Related Issues and Concerns. Decision of 14 November 2001, WT/ MIN(01)/17, circulated on 20 November 2001, paras 3.1 and 3.2. The reasonable adaptation period and the longer compliance period for developing-country Members are discussed further below, Part V, Sections 1.2 and 1.3 .

${ }^{14}$ Committee on Sanitary and Phytosanitary Measures, Report of the Analysis on SPS Notifications in 2002. Submission by China, G/SPS/GEN/378, circulated on 31 March 2003.

${ }^{15}$ As the notification format provided to Members in the second revision of the Recommended Transparency Procedures provided boxes for the date of adoption and the date of entry into force of a measure but not for the date of publication, this calculation was made on the assumption that the measure was published on the date of its entry into force. Ibid., para. 12. This omission has been corrected in the latest revision of the Recommended Transparency Procedures.

${ }^{16}$ Ibid., para. 10.

${ }^{17}$ Consequently, China has proposed that the comment period not be indicated by means of a specific deadline for comments, but rather by an indication of the number of days from the date of circulation of the notification by the Secretariat (normally 60 days) provided for comments. Committee on Sanitary and Phytosanitary Measures, Proposal for Amending the Recommended Transparency Procedures Relating to the Comment Period of SPS Notifications. Submission by China, G/SPS/W/131, circulated on 31 March 2003. However, several Members, including Australia and the US, stated that their domestic regulatory procedures require them to specify the date at which the comment period expires. New Zealand emphasised that the determination of when a comment period begins or ends is the sovereign right of a Member and cannot be left to the Secretariat to determine. Further Japan pointed out that the date of circulation is unpredictable and was thus not an appropriate date from which to calculate the comment period.
} 
no period is provided for between the last day for comments and the date of adoption of the measure. Of the 374 routine notifications examined by China, only 67 notifications (17.9 percent) provided at least one day between the expiry of the comment period and the date of adoption for the consideration of comments from other Members. The remaining 307 notifications ( 82.1 percent) did not provide any interval for the consideration of comments, or the final date for comments and/or the proposed date of adoption were not available. It was even the case in 38 notifications that the date of adoption was earlier than the final date for comments. ${ }^{18}$

More recently, in 2007, the WTO Secretariat undertook a similar, though more limited, review of the level of implementation of the transparency obligations of the SPS Agreement. This review indicated that in the period June-August 2007, while 73 percent of notifications submitted provided a comment period, the average period they allowed was only 40 days. In addition, 22 percent of notifications submitted did not provide a comment period at all. A remaining five percent provided a comment period which ended before the date of circulation of the notification. ${ }^{19}$

Not only are the comment periods and adaptation periods provided by Members often inadequate, but other aspects of notifications are also in need of improvement. Members are required to indicate the products covered by their notifications under Annex B.5(b). According to the Recommended Transparency Procedures, in order to ensure a clear indication of the product, this should be done by indicating the tariff item number of the product as contained in the notifying Member's national schedule of commitments. ${ }^{20}$ However, Members rarely do so. ${ }^{21}$ In addition, very few notifications identify the Members or regions most likely to be affected by the notified regulation, despite the encouragement to do so in the Recommended Transparency Procedures. ${ }^{22}$ In addition, contrary to the obligation in Annex B.5(c) of the SPS Agreement to identify the parts of the proposed regulation that deviate in substance from international standards, where possible, very few notifications do so. ${ }^{23}$

Another problem that has been raised with regard to transparency relates to language. As noted above, while the notification of a proposed SPS regulation must be made in one of

${ }^{18}$ Committee on Sanitary and Phytosanitary Measures, Report of the Analysis on SPS Notifications in 2002. Submission by China, G/SPS/GEN/378, circulated on 31 March 2003, para. 14.

${ }^{19}$ Committee on Sanitary and Phytosanitary Measures, Overview Regarding the Level of Implementation of the Transparency Provisions of the SPS Agreement: Note by the Secretariat, G/SPS/GEN/804, circulated on 11 October 2007, Table 3.

${ }^{20}$ The national schedule of commitments of each Member contains its tariff bindings, usually classified according to the Harmonised System of Tariff Classification (HS) developed by the World Customs Organisation. In such cases the HS chapter and heading number of the products covered should be provided in the notification of an SPS regulation.

${ }^{21}$ Committee on Sanitary and Phytosanitary Measures, Overview Regarding the Level of Implementation of the Transparency Provisions of the SPS Agreement: Note by the Secretariat, G/SPS/GEN/804, circulated on 11 October 2007, para. 16.

${ }^{22} \mathrm{Ibid}$. This report indicates that in June-August 2007, only $16 \%$ of notifications identified a group of countries or region affected. Others refer generally to 'all countries' or 'all trading partners'.

${ }^{23} \mathrm{Ibid}$., Figure 5. This overview indicates that $13.3 \%$ of notifications refer to CAC standards, $9 \%$ to OIE standards, $8 \%$ to IPPC standards and the remaining $69.8 \%$ do not refer to international standards at all. In some cases this may be due to the fact that no relevant international standards exist, but it is unlikely that this is the situation in almost $70 \%$ of cases. 
the three WTO official languages,${ }^{24}$ the obligation to provide translations of documents relating to notified regulations (or in the case of voluminous documents summaries thereof) in one of the official languages of the WTO is limited to developed-country Members, and then only upon request. ${ }^{25}$ No translation obligation at all exists in respect of the publication of the final measure. As a result, many Members that lack the resources to undertake translations of the relevant documentation, are unable to familiarise themselves with the content of the proposed SPS regulation and benefit from the ex ante effects of transparency. ${ }^{26}$ Other Members that do have the capacity to undertake translations but have insufficient resources to do so promptly may find that the comment period has expired by the time they have the notified draft regulation in a language they can understand. Once again, this undermines their ability to benefit from the transparency disciplines of the SPS Agreement. China suggested that Members submit to the WTO Secretariat, with their notifications, the draft SPS regulation being notified and that the Secretariat translate the draft when it translates the notification. This was rejected as placing an unmanageable translation burden on the Secretariat. ${ }^{27}$

Implementation problems relate not only to notifications and publication of measures, but also to requests for information. The inadequate implementation of Article 5.8, evinced by the frequent lack of responses to the requests by Members for information under this Article, was highlighted by the EC in $1999 .{ }^{28}$ In addition, there are often lengthy delays in responding to requests for information. In 2007, a survey by the Secretariat indicated that the time taken to respond to queries varied between one and 60 days. ${ }^{29}$ Members have

${ }^{24}$ Annex B.7 of the SPS Agreement. Notifications are translated into the other two WTO official languages by the WTO Secretariat and are circulated to all Members.

${ }^{25}$ The Recommended Transparency Procedures adopted by the SPS Committee suggest that where a translation of a requested document or its summary exists in the WTO working language used by the requesting Member, it should automatically be sent with the original of the document requested. If such translation does not exist, the notifying Member should inform the requesting Member of any other Members that have requested a copy of the document so that the requesting Member can approach them to determine if they are willing to share any translation that they have or will be making. Committee on Sanitary and Phytosanitary Measures, Recommended Procedures for Implementing the Transparency Obligations of the SPS Agreement (Article 7) as of 1 December 2008. Revision, G/SPS/7/Rev.3, circulated on 20 June 2008, paras 25 and 27.

${ }^{26}$ This problem was pointed to already in October 1996, when Argentina expressed its regret that the regulations notified by Japan and Korea were not available in one of the three WTO working languages. The Chairman of the SPS Committee recalled the obligation on developed-country Members in Annex B.8 of the SPS Agreement to provide documents (or summaries thereof) in a WTO working language, if requested to do so by another Member. Committee on Sanitary and Phytosanitary Measures, Specific Trade Concerns. Note by the Secretariat. Addendum. Issues Not Considered in 2007, G/SPS/GEN/204/Rev.8/Add.2, circulated on 27 March 2008, item 13.

27 Committee on Sanitary and Phytosanitary Measures, Summary of the Meeting Held on 24-25 June 2003 : Note by the Secretariat, G/SPS/R/30, circulated on 4 September 2003, para. 83. The Secretariat noted, in addition, that this translation burden would relate to documents that were only draft regulations and not final texts. A mechanism has instead been created to enable Members to make available the unofficial translations of the documents relating to a notification that they may have made. On this mechanism, see below, Part IV, Section 1.3.7.

${ }^{28}$ Committee on Sanitary and Phytosanitary Measures, Implementation of the SPS Agreements - Trade Concerns. Submission by the European Communities at the Meeting of 7 - 8 July 1999, G/SPS/GEN/132, circulated on 21 July 1999. In this document, the EC lists eighteen requests for information it made under Article 5.8 of the SPS Agreement, some made on bilateral basis and some in the form of documents circulated to all Members to draw the attention of the SPS Committee to its questions to a particular Member. Of the listed requests, only two had received an answer.

${ }^{29}$ This data was taken from 58 responses by Members to a questionnaire circulated by the Secretariat. Committee 
indicated difficulty in obtaining access to full texts of regulations. While it was recognised that national SPS websites could facilitate such access, the costly nature of this option for certain developing-country Members and least-developed-country Members was noted. Some Members suggested that the Secretariat provide assistance in this regard. ${ }^{30}$

The challenges faced by Members at lower levels of development in the operation of National Notification Authorities and Enquiry Points have been pointed to as an implementation problem. ${ }^{31}$ The Enquiry Points of some Members do not have access to the necessary facilities in order to function effectively. ${ }^{32}$ Some Enquiry Points do not have established contacts with the relevant government bodies from which answers must be obtained in order to be able to reply to requests for information. They are thus unable to respond to requests within the recommended five days. In addition, not all National Notification Authorities have effective links with the technical officials that are responsible for drafting and amending SPS measures. This makes it difficult for them to provide accurate information in the notification of a proposed measure, and to ensure that the comments they receive from interested Members with regard to the notified measures are properly taken into account. In 2006, the US, Australia and New Zealand noted the need to address the question of how the SPS Committee can best assist the Members that have not designated an Enquiry Point or National Notification Authority in doing so, and how it can better ensure that the Enquiry Points that have been identified are operational and working to further the full implementation of the Agreement. ${ }^{33}$ They urged the Committee to initiate a detailed study of these and other transparency-related problems. ${ }^{34}$ In their responses to the Secretariat's questionnaire on the operation of Enquiry Points and National Notification Authorities, Members indicated a strong preference for enhanced interaction between Members' bodies, to facilitate information sharing and the development of best practices. Twinning ${ }^{35}$ or mentoring arrangements were suggested. ${ }^{36}$

on Sanitary and Phytosanitary Measures, Analysis of Replies to the Questionnaire on the Operation of Enquiry Points and National Notification Authorities. Note by the Secretariat. Revision, G/SPS/GEN/751/Rev.1, circulated on 18 June 2007, para. 23.

${ }^{30}$ Committee on Sanitary and Phytosanitary Measures, Workshop on Transparency Held on 15 - 16 October 2007. Note by the Secretariat, G/SPS/R/47, circulated on 8 January 2008, para. 34

31 On the difficulties of Malawi, an LDC Member, in upgrading the facilities of the Malawi Bureau of Standards to cope with the additional function of being an SPS Enquiry Point, see Committee on Sanitary and Phytosanitary Measures, Establishment of National WTO TBT/SPS Enquiry Point. Project Proposal. Submission by Malawi, G/SPS/GEN/349, circulated on 24 October 2002.

${ }^{32}$ For example, Malawi reports that its Bureau of Standards, which will function as its Enquiry Point, currently has a small technical paper library for national, foreign national, regional and international standards, as well as other publications. It receives over 10,000 documents in a year, which creates problems for its limited space. In addition, some documents, mainly national standards, are stored and retrieved on three outdated IBM computers, subject to frequent breakdowns and lack of spare parts. This has led to loss of information or the inability to access information. The computers also process data slowly, rendering computer services ineffective and inefficient. Ibid., para. 3.

${ }^{33}$ Committee on Sanitary and Phytosanitary Measures, Second Review of the Operation and Implementation of the SPS Agreement. Review of the Implementation of Transparency Provisions. Communication from Australia, New Zealand and the United States, G/SPS/W/197, circulated on 13 June 2006, paras 4-5.

${ }^{34}$ For a description of the work undertaken by the SPS Committee in this regard, see below, Part IV, Section 1.3.7.

35 Twinning refers to an arrangement whereby an Enquiry Point or National Notification Authority in a lessdeveloped Member is paired with the corresponding body in a developed-country Member, in order to benefit from technical advice and knowledge sharing from the latter.

${ }^{36}$ Committee on Sanitary and Phytosanitary Measures, Analysis of Replies to the Questionnaire on the 
Some of the 'implementation problems' relating to the transparency provisions of the SPS Agreement do not relate, strictly speaking, to the difficulty of enforcing or complying with these provisions, but rather to the capacity constraints that limit the benefits that Members at lower levels of development can derive from them. Among these constraints are institutional problems, such as the insufficient coordination between government ministries, ${ }^{37}$ limiting the flow of information regarding notified draft SPS regulations and undermining the possibilities for framing responses that reflect national positions. Also, capacity constraints in managing the great inflow of notifications have been identified. ${ }^{38}$ In addition, weak links with private sector stakeholders have been recognized as a challenge, ${ }^{39}$ having the effect that information on new or changed SPS measures is not promptly communicated to producers ${ }^{40}$ reducing their opportunities to adjust to the new requirements in a timely manner, or to communicate their concerns with the new measure to their government so that these may be taken on board in discussions with the notifying Member. Some transparency problems have their source in deeper capacity problems going to the core of the SPS Agreement, namely the weakness of scientific capacity in some less-developed Members. As noted by Wolfe:

Without a scientific establishment at home able to understand the technical basis of another country's notification, it is hard to know whether it should be challenged in the committee, especially when hundreds of new notifications arrive every year. ${ }^{41}$

This indicates that efforts to address implementation problems relating to the transparency obligations of the SPS Agreement by improving the institutions and procedures for transparency, while necessary, will not be sufficient on their own. They must be supported by concerted efforts to address underlying problems with inadequate SPS regulatory capacity. ${ }^{42}$

Operation of Enquiry Points and National Notification Authorities. Note by the Secretariat. Revision, G/SPS/ GEN/751/Rev.1, circulated on 18 June 2007, para. 11(a). A mentoring mechanism was developed in 2008, as discussed below, Part V, Section 2.7.

${ }^{37}$ Committee on Sanitary and Phytosanitary Measures, Summary of the Meeting of 18-19 October 2007. Note by the Secretariat, G/SPS/R/46, circulated on 2 January 2008, para. 41(b).

${ }^{38}$ Ibid., para. 41(e). As indicated in the Secretariat's analysis of replies to its questionnaire on the operation of Enquiry Points and National Notification Authorities, this area is one where Members have strongly indicated the need for technical assistance and guidance from best practices. Committee on Sanitary and Phytosanitary Measures, Analysis of Replies to the Questionnaire on the Operation of Enquiry Points and National Notification Authorities. Note by the Secretariat. Revision, G/SPS/GEN/751/Rev.1, circulated on 18 June 2007, para. 11(b). This has also been identified as a problem in Vinod Rege et al., Influencing and Meeting International Standards: Challenges for Developing Countries. Volume I: Background Information, Findings from Case Studies and Technical Assistance Needs (International Trade Centre UNCTAD/WTO and Commonwealth Secretariat, Geneva), 2003, 66.

${ }^{39}$ Committee on Sanitary and Phytosanitary Measures, Summary of the Meeting of 18-19 October 2007. Note by the Secretariat, G/SPS/R/46, circulated on 2 January 2008, para. 41(c).

${ }^{40}$ Vinod Rege et al., Influencing and Meeting International Standards: Challenges for Developing Countries. Volume I: Background Information, Findings from Case Studies and Technical Assistance Needs (International Trade Centre UNCTAD/WTO and Commonwealth Secretariat, Geneva), 2003, 66.

${ }^{41}$ Robert Wolfe, 'Regulatory Transparency, Developing Countries and the WTO', World Trade Review 2 (2), 2003, 157-182, 169.

${ }^{42}$ The issue of SPS-related technical assistance and capacity building is addressed below, Part V, Section 2.5. 


\subsubsection{Work on improving the implementation of the transparency provisions}

In 1996 the SPS Committee established detailed Recommended Notification Procedures, to facilitate compliance by Members with their notification obligations. ${ }^{43}$ These recommended procedures contain guidelines for notifications under both the normal and the urgent procedure, including specific formats to be used for routine and emergency notifications. The formats are useful in that they specify the information that a Member should provide in each notification, and present this in a standardised form. The Recommended Notification Procedures explicitly do not add to or detract from the rights and obligations of Members under the SPS Agreement, nor do they provide a legal interpretation or modification of the Agreement. ${ }^{44}$ These guidelines have been revised three times to address Members' concerns regarding issues such as the period for comments on notified measures, the timing of notifications, the provision of documents relating to a notification, the handling of comments on notifications, the use of addenda, corrigenda and revisions to notifications, and the notification of measures that conform to international standards. ${ }^{45}$

More specifically, the second revision extends the coverage of the recommended procedures to cover not only notification, but also the other transparency obligations of the SPS Agreement. It is therefore known as the Recommended Transparency Procedures. This revision states that where previously notified measures are changed so as to apply to new Members or new products they should be re-notified by means of the submission of a Revision. An additional sixty days are allowed for comments in such cases. The revision was originally proposed by New Zealand in response to an implementation proposal of Brazil ${ }^{46}$ that called for the re-notification of measures if they may have negative trade effects on trade opportunities of developing countries. ${ }^{47}$ An addendum to the second revision incorporates into procedures for the notification of the recognition of equivalence, and a special format for such notifications. ${ }^{48}$

${ }^{43}$ Committee on Sanitary and Phytosanitary Measures, Recommended Notification Procedures, G/SPS/7, circulated on 11 June 1996.

44 Committee on Sanitary and Phytosanitary Measures, Recommended Procedures for Implementing the Transparency Obligations of the SPS Agreement (Article 7) as of 1 December 2008. Revision, G/SPS/7/Rev.3, circulated on 20 June 2008, para. 3. On the legal status of the Recommended Transparency Procedures, see below, Part IV, Section 2.1.1.

45 Committee on Sanitary and Phytosanitary Measures, Recommended Notification Procedures. Revision, G/SPS/7/Rev.1, circulated on 26 November 1999; Committee on Sanitary and Phytosanitary Measures, Recommended Procedures for Implementing the Transparency Obligations of the SPS Agreement (Article 7). Revision, G/SPS/7/Rev.2, circulated on 2 April 2002; Committee on Sanitary and Phytosanitary Measures, Recommended Procedures for Implementing the Transparency Obligations of the SPS Agreement (Article 7) as of 1 December 2008. Revision, G/SPS/7/Rev.3, circulated on 20 June 2008.

46 Committee on Sanitary and Phytosanitary Measures, Agreement on the Application of Sanitary and Phytosanitary Measures. Proposal by Brazil, G/SPS/W/108, circulated on 22 June 2001.

${ }^{47}$ Brazil's proposal followed a dispute with Canada in February 2001 due to a ban by Canada of Brazilian beef imports due to BSE concerns. The ban was based on a previously notified regulation and was therefore not notified to the WTO although it was applied to Brazil for the first time. Bridges Weekly Trade News Digest, 26 March 2002.

${ }^{48}$ Committee on Sanitary and Phytosanitary Measures, Notification of Determination of the Recognition of Equivalence of Sanitary and Phytosanitary Measures. Decision by the Committee. Addendum, G/SPS/7/ Rev.2/Add.1, circulated on 25 July 2002. As noted above, to date two notifications of the recognition of equivalence have been received. 
The third revision, adopted in April 2008, includes new procedures and forms for notifications and details of new on-line databases where notifications of SPS measures and other relevant information are compiled. ${ }^{49}$ It also encourages WTO Members also to notify when they adopt SPS measures that are based on, conform to or are substantially the same as international standards. ${ }^{50}$ To address the problem that the comment period is shortened due to delays in circulating notifications, the revised procedures provide that, where domestic regulatory mechanisms allow, the comment period should start at the date of circulation of the notification by the WTO Secretariat. ${ }^{51}$ If the guidelines on regionalisation, discussed above, were not adopted, their transparency provisions were to be inserted into the revised text of the guidelines on notification. However, with the adoption of the Regionalisation Decision its own transparency provisions apply. ${ }^{52}$ The third revision of the Recommended Transparency Procedures was adopted ad referendum in April $2008,{ }^{53}$ and as no objections were received the adoption was confirmed on 30 May $2008 .{ }^{54}$

In addition, as discussed below, in order to improve transparency regarding the provision of SDT to developing-country Members, in November 2004, the SPS Committee adopted a Procedure to Enhance Transparency of SDT. ${ }^{55}$ This non-binding Decision essentially follows the Recommended Transparency Procedures, but adds new actions to make provision for raising compliance difficulties in comments on notified draft SPS regulations or adopted regulations; the discussion of these comments; and the notification of the decision taken on SDT by means of an Addendum to the original notification. The Recommended Transparency Procedures encourage Members to make use of the

49 Committee on Sanitary and Phytosanitary Measures, Recommended Procedures for Implementing the Transparency Obligations of the SPS Agreement (Article 7) as of 1 December 2008. Revision, G/SPS/7/Rev.3, circulated on 20 June 2008, para. 63.

${ }^{50} \mathrm{Ibid}$., para. 8. The Secretariat's analysis of the responses to its questionnaire on the operation of Enquiry Points and National Notification Authorities indicates that the large majority of respondents prefer WTO Members to notify all new or changed SPS regulations, whether or not based on international standards. However, some warn about the excessive number of notifications that this may generate, when Members are already struggling to handle the existing volume of notifications. Committee on Sanitary and Phytosanitary Measures, Analysis of Replies to the Questionnaire on the Operation of Enquiry Points and National Notification Authorities. Note by the Secretariat. Revision, G/SPS/GEN/751/Rev.1, circulated on 18 June 2007, para. 11(f).

51 Committee on Sanitary and Phytosanitary Measures, Recommended Procedures for Implementing the Transparency Obligations of the SPS Agreement (Article 7) as of 1 December 2008. Revision, G/SPS/7/Rev.3, circulated on 20 June 2008, para. 13.

${ }^{52}$ As noted above, the Regionalisation Decision encourages Members to notify the SPS Committee of their requests for, and determinations of, the recognition of pest- or disease-free areas or areas of low pest or disease prevalence. One such notification has been received thus far. See further above, Part IV, Section 1.2.6.

${ }^{53}$ The term 'ad referendum' means that a decision is provisionally adopted, and the adoption becomes final if no Member objects by a certain deadline, in casu 30 May 2008. On adoption ad referendum, see further below, Part IV, Section 2.1.

${ }^{54}$ The recommendations will come into effect on 1 December 2008 as time is needed to prepare the new notification formats, and for the WTO Secretariat to adapt the electronic system it uses to manage and circulate the notifications to the rest of the membership. The recommendations were circulated to Members in Committee on Sanitary and Phytosanitary Measures, Recommended Procedures for Implementing the Transparency Obligations of the SPS Agreement (Article 7) as of 1 December 2008. Revision, G/SPS/7/Rev.3, circulated on 20 June 2008 .

${ }^{55}$ Committee on Sanitary and Phytosanitary Measures, Procedure to Enhance Transparency of Special and Differential Treatment in Favour of Developing Country Members. Decision by the Committee of 27 October 2004, G/SPS/33, circulated on 2 November 2004. This Decision is discussed below, Part V, Section 1.8. 
procedures in the Procedure to Enhance Transparency of SDT. ${ }^{56}$ By 31 August 2007, no notification had been submitted under this new procedure. In their responses to a questionnaire circulated by the WTO Secretariat, a significant number of Members indicated as a reason for the lack of use of this procedure the difficulties faced by developing-country Members in screening notifications quickly enough to identify compliance difficulties that could be addressed through SDT. However, some Members stated that although the steps set out in this procedure for raising and discussing compliance difficulties were being followed, the use of the procedure and its outcome was not being notified. ${ }^{57}$

In 2000, the WTO Secretariat drafted a clear explanation of the rules in the SPS Agreement on transparency, contained in the handbook How to Apply the Transparency Provisions of the SPS Agreement (referred to as the Handbook on Transparency). ${ }^{58}$ These are particularly aimed at providing practical guidance to help developing-country Members comply with their transparency obligations, in response to requests from several developing- and least-developed-country Members.

The WTO Secretariat has organised three workshops for Members on the transparency provisions of the SPS Agreement. The first of these was held in November 1999, ${ }^{59}$ just prior to the expiry of the transitional period granted in the SPS Agreement to LDC Members, ${ }^{60}$ to assist these and other Members to address problems and concerns relating to notification obligations and the functioning of Enquiry Points and National Notification Authorities. Officials from the Enquiry Points and National Notification Authorities of all Members were invited. The Secretariat, using a Trust Fund provided by Norway, funded the participation of officials from the eight LDC Members that had notified either their Enquiry Point or their National Notification Authority (or both) to the WTO. ${ }^{61}$

56 Committee on Sanitary and Phytosanitary Measures, Recommended Procedures for Implementing the Transparency Obligations of the SPS Agreement (Article 7) as of 1 December 2008. Revision, G/SPS/7/Rev.3, circulated on 20 June 2008, para. 34.

57 Committee on Sanitary and Phytosanitary Measures, Analysis of Replies to the Questionnaire on the Operation of Enquiry Points and National Notification Authorities. Note by the Secretariat. Revision, G/SPS/ GEN/751/Rev.1, circulated on 18 June 2007, para. 11(i). Other respondents indicated that developing-country Members are using other channels to request SDT.

${ }^{58}$ New Zealand made a significant contribution to developing the first draft, introduced in 1999 at the first workshop on transparency organised by the WTO Secretariat. The Handbook was published in 2000 after comments had been taken into account. It has since been revised and the latest version of the handbook is contained in: WTO Secretariat, How to Apply the Transparency Provisions of the SPS Agreement (World Trade Organization, Geneva), September 2002, available at: http://www.wto.org/english/tratop_e/sps_e/spshand_e. doc, visited on 25 June 2007. The guidelines are non-binding and are not intended as a legal interpretation of the relevant provisions of the SPS Agreement.

${ }^{59}$ Committee on Sanitary and Phytosanitary Measures, Summary of the Special Meeting of the SPS Committee on the Transparency Provisions of the SPS Agreement, 9 November 1999. Note by the Secretariat, G/SPS/R/16, circulated on 20 January 2000.

${ }^{60}$ Article 14 of the SPS Agreement. The transition period for least-developed-country Members expired on 31 December 1999, after which they were obliged to comply with all the disciplines of the SPS Agreement, including those on transparency. The transition period for other developing-country Members excluded the transparency provisions in Article 7 and Annex B.5 of the SPS Agreement, which were required to be implemented immediately. On the transition periods, see further below, Part V, Section 1.4.

${ }^{61}$ These LDC Members were Bangladesh, Burkina Faso, Djibouti, Madagascar, Malawi, Tanzania, Uganda and Zambia. Committee on Sanitary and Phytosanitary Measures, Summary of the Special Meeting of the SPS Committee on the Transparency Provisions of the SPS Agreement, 9 November 1999. Note by the Secretariat, G/SPS/R/16, circulated on 20 January 2000, para. 3 . 
In October 2003, the SPS Committee held a special meeting regarding the operation of Enquiry Points, organised by the WTO Secretariat. To facilitate participation by Members, the workshop was organised back-to-back with the SPS Committee meeting. Two Members provided funding for the participation of ten officials from Enquiry Points of developing-country Members. The purpose of this meeting was to identify the specific problems faced by developing-country Members that restrict the effective operation of their Enquiry Points and to suggest possible solutions. Prior to the meeting a questionnaire was circulated by the WTO Secretariat among Members regarding the operation of Enquiry Points and National Notification Authorities, ${ }^{62}$ leading to the submission of information by several Members on their experiences in this regard. Selected developingcountry Members gave presentations on the constraints they face in this regard and others presented the mechanisms they had found to overcome their constraints. ${ }^{63}$

In October 2007, the WTO Secretariat organised a third workshop on the transparency provisions of the SPS Agreement, to enhance the implementation of transparency provisions and identify best practices to enable Members to benefit fully from these provisions. Again, participation was facilitated by organising the workshop back-to-back with the SPS Committee meeting. As a result, almost 100 Members were present, with more than 163 total participants. Prior to the workshop, the Secretariat circulated, and analysed responses to, a revised questionnaire on the operation of Enquiry Points and National Notification Authorities. ${ }^{64}$ At the workshop Members identified several concrete actions to improve the implementation of the transparency provisions. ${ }^{65}$ Further, New Zealand and Australia conducted a practical workshop on how to manage an Enquiry Point and National Notification Authority. ${ }^{66}$ They subsequently prepared a draft step-by-step procedural manual on this issue. ${ }^{67}$

${ }^{62}$ Committee on Sanitary and Phytosanitary Measures, Questionnaire on the Operation of SPS Enquiry Points and National Notification Authorities, G/SPS/W/103/Rev.1, circulated on 15 September 2003.

${ }^{63}$ The presentations of the participants have been compiled and are available in Committee on Sanitary and Phytosanitary Measures, Special Meeting of the SPS Committee on the Operation of Enquiry Points, 31 October 2003. Presentations by Participants, G/SPS/GEN/458, circulated on 12 December 2003.

${ }^{64}$ Committee on Sanitary and Phytosanitary Measures, Questionnaire on the Operation of SPS Enquiry Points and National Notification Authorities. Note by the Secretariat. Revision, G/SPS/W/103/Rev.2, circulated on 8 December 2006. The 58 responses received are analysed in Committee on Sanitary and Phytosanitary Measures, Analysis of Replies to the Questionnaire on the Operation of Enquiry Points and National Notification Authorities. Note by the Secretariat. Revision, G/SPS/GEN/751/Rev.1, circulated on 18 June 2007.

${ }^{65}$ Brief presentations were given by the Secretariat and the Enquiry Point of Chile, after which participants worked in break-out sessions to identify concrete actions which could be taken at the national and international level to enhance the use and usefulness of the transparency provisions. This resulted in the identification of several recommendations for follow-up action at different levels. Committee on Sanitary and Phytosanitary Measures, Workshop on Transparency Held on 15 - 16 October 2007. Note by the Secretariat, G/SPS/R/47, circulated on 8 January 2008, para. 4.

${ }^{66}$ Ibid., paras 6-7.

${ }^{67}$ Committee on Sanitary and Phytosanitary Measures, Availability of Draft Procedural Manual on the Operation of SPS Enquiry Points and National Notification Authorities. Note by the Secretariat G/SPS/GEN/824, circulated on 11 March 2008. The draft manual itself is contained in Ministry of Agriculture and Forestry (MAF) Biosecurity New Zealand, Department of Agriculture Fisheries and Forestry of the Government of Australia and Ministry of Commerce and Industry of the Sultanate of Oman, Procedural Manual for National Notification Authority \& National Enquiry Point, Version 1-2007, World Trade Organization, Geneva, 2007, 80, available at: http://members.WTO.org/WTO_resources/SPS/files/Draft_Procedural_Manual.doc, visited on 26 March 2008. 
As noted above, only developed-country Members are obliged, upon request, to provide translations of documents relating to a notification in one of the official languages of the WTO. ${ }^{1}$ In order to facilitate access to documents relating to a notification in the working language of the requesting Member where no such official translation exists, a new mechanism was created by the WTO Secretariat in 2004. Under this mechanism, any Member possessing an unofficial translation of such a document, after informing the notifying Member, should submit a supplement to the original notification. ${ }^{2}$ This supplement should indicate the address at which the unofficial translation can be requested or the website at which it can be found. ${ }^{3}$ By 31 August 2007, 12 supplementary notifications of the availability of unofficial translations had been made, by the US and Canada. ${ }^{4}$ No further translations have been notified. A format for such a supplement was added to the Recommended Transparency Procedures in 2008. ${ }^{5}$ It is to be hoped that developedcountry Members that have the necessary resources to translate notified SPS measures and frequently do so when the measure is of interest to them, will make fuller use of the mechanism to circulate information on the availability of these unofficial translations.

Due to the problem of identification of the product coverage of notified SPS regulations, in the absence of an indication of the HS code of the product by the notifying Member, the WTO's Central Registry of Notifications has taken the task of assigning HS codes upon itself. ${ }^{6}$

To address the challenge faced by the Secretariat and Members in managing the vast increase in SPS-related documents and information, the WTO Secretariat has made available to Members an extensive database on SPS-related information known as the SPS Information Management System (SPS IMS). This facility includes all SPS notifications, all SPS-related official WTO documents, all trade concerns raised at the SPS Committee, and the contact details of Members Enquiry Points and National Notification Authorities. The SPS IMS has advanced searching and reporting functions to make it easer for Members to find quickly the specific information they need. ${ }^{7}$ Since 2003, the WTO's Central Registry of Notifications has been assigning around 60 predefined keywords (such as avian influenza, pesticides, zoonoses etc.) to notifications to facilitate searching in the SPS IMS. The public website version of the SPS IMS was launched during the 2007 workshop, with hands-on demonstrations to introduce its functions and

\footnotetext{
${ }^{1}$ Annex B.8 of the SPS Agreement. This requirement was discussed above, Part IV, Section 1.3.6.

${ }^{2}$ Committee on Sanitary and Phytosanitary Measures, Unofficial Translation: Note by the Secretariat, G/SPS/ GEN/487, circulated on 23 April 2004.

3 This notification should clearly indicate the unofficial nature of the translation.

${ }^{4}$ Committee on Sanitary and Phytosanitary Measures, Overview Regarding the Level of Implementation of the Transparency Provisions of the SPS Agreement: Note by the Secretariat, G/SPS/GEN/804, circulated on 11 October 2007, para. 8.

5 Committee on Sanitary and Phytosanitary Measures, Recommended Procedures for Implementing the Transparency Obligations of the SPS Agreement (Article 7) as of 1 December 2008. Revision, G/SPS/7/Rev.3, circulated on 20 June 2008, para. 28 and Annex D.

${ }^{6}$ Committee on Sanitary and Phytosanitary Measures, Overview Regarding the Level of Implementation of the Transparency Provisions of the SPS Agreement: Note by the Secretariat, G/SPS/GEN/804, circulated on 11 October 2007, para. 16.

7 Committee on Sanitary and Phytosanitary Measures, Workshop on Transparency Held on 15 - 16 October 2007. Note by the Secretariat, G/SPS/R/47, circulated on 8 January 2008, paras 20-21.
} 
capabilities to interested participants. ${ }^{8}$ Discussions held at the launch of the SPS IMS indicated that many Members expected to use the system to filter and assess incoming notifications more easily and to alert relevant stakeholders promptly. ${ }^{9}$ In addition, the importance of complementarities between the SPS IMS and other databases, such as the FAO's International Portal on Food Safety, Animal and Plant Health, and the International Phytosanitary Portal of the IPPC were noted.

In response to a need identified during the 2007 Workshop on Transparency, the WTO Secretariat created a new facility to facilitate access to notified draft SPS measures. This facility enables Members who wish to do so to provide an electronic version of their notified proposed SPS measure as an attachment to the notification. ${ }^{10}$ These attachments will be stored on a WTO server and be accessible through a hyperlink in the notification itself. ${ }^{11}$

Finally, in 2008, to meet the need identified by several Members in the context of transparency discussions in the SPS Committee, to clarify the times frames between the various steps involved in drafting, notifying and adopting SPS measures, the Secretariat developed useful guidelines. ${ }^{12}$ These guidelines, presented in the form of a chart, set out the Secretariat's understanding of the relevant periods on the basis of the obligations in the SPS Agreement, the specifications in the Doha Implementation Decision, and the Recommended Transparency Procedures adopted by the SPS Committee. The relevant time frames are laid down for the notification of a draft proposed measure, the provision of a comment period, the adoption of the measure, its publication, its entry into force, and the period of time for compliance. Only non-urgent SPS measures are considered, since time frames are not specified in the SPS Agreement or the transparency procedures where urgent measures are at issue.

\subsection{Rules regarding control, inspection and approval procedures}

In order to ensure that their SPS requirements are complied with, Members usually have control, inspection and approval procedures in place. If these procedures are complex, lengthy or costly, they may effectively restrict market access.

An illustration of the problems that can arise for exporters of a developing-country Member in such cases is provided by the pre-shipment inspection requirements imposed on Costa Rican fish exports. Costa Rica's testing facilities are limited, ${ }^{13}$ but its trading

\footnotetext{
${ }^{8}$ This website is available at: http://spsims.wto.org, visited on 25 June 2008.

${ }^{9}$ Committee on Sanitary and Phytosanitary Measures, Workshop on Transparency Held on 15 - 16 October 2007. Note by the Secretariat, G/SPS/R/47, circulated on 8 January 2008, para. 21.

${ }^{10}$ Ibid., para. 34.

${ }^{11}$ Committee on Sanitary and Phytosanitary Measures, Attachments to SPS Notifications. Note by the Secretariat, G/SPS/GEN/818, circulated on 29 January 2008. This possibility was already in place for draft measures notified under the TBT Agreement.

${ }^{12}$ Committee on Sanitary and Phytosanitary Measures, Time-Frames Relating to the Introduction of New SPS Measures. Note by the Secretariat, G/SPS/GEN/819, circulated on 13 February 2008.

${ }^{13}$ Valverde reports that Costa Rica faces equipment problems with regard to national testing for heavy metals. The single machine for mercury testing is malfunctioning. It is expected that lead testing will begin soon. Max Valverde, Sanitary and Environmental Trade Barriers in Costa Rican Fisheries, Project on Standards
} 
partners impose a large number of mandatory tests leading to large cost increases for exporters. While Costa Rican regulations require fish processing plants to conducts 16 histamine tests per year, which costs around US\$ 500 a year, the US FDA requires at least two tests per ton of exported fish, which would cost a large plant exporting 15000 kilograms of fish per week about US\$52 000 per year, in histamine tests only. ${ }^{14}$ This problem is compounded by the fact that testing procedures differ between countries. ${ }^{15}$ While the EU accepts national methods of analysis that are equivalent to those mandated in EC Directives, Costa Rican technicians are unfamiliar with EU methods and thus cannot assess if their own methods are equivalent. Offers of exchange opportunities from the EU to Costa Rican laboratory technicians have never materialised. ${ }^{16}$

To address the trade restrictive effects of control, inspection and approval procedures, Article 8 of the SPS Agreement provides:

Members shall observe the provisions of Annex $\mathrm{C}$ in the operation of control, inspection and approval procedures, including national systems for approving the use of additives or for establishing tolerances for contaminants in foods, beverages or feedstuffs, and otherwise ensure that their procedures are not inconsistent with the provisions of this Agreement.

Annex $\mathrm{C}$ contains detailed rules on control inspection and approval procedures, which broadly aim to ensure that procedures are not more lengthy and burdensome than is reasonable and necessary and that they do not discriminate against imports. As stated above, Article 1.3 of the SPS Agreement provides that the Annexes are an integral part of the Agreement. In addition, Article 8 expressly refers to Annex C. It is therefore essential to read Article 8 together with Annex C. A violation of Annex $\mathrm{C}$ automatically results in a violation of Article 8 of the SPS Agreement. ${ }^{17}$

In particular, Annex C.1 contains a list of nine requirements in subparagraphs (a) to (i) applicable to procedures to check and ensure the fulfilment of SPS measures. In an additional unnumbered subparagraph, Annex C.1 addresses prior approval systems. The remaining two paragraphs of Annex $\mathrm{C}$ are rather limited in scope, dealing with two specific situations in a facultative way, imposing no obligations on importing Members. In particular, Annex C.2 addresses the situation where SPS measures specify control at the level of production, and requires Members in whose territory the production takes place (i.e. the exporting Member) to facilitate such control as well as the work of the control-

\footnotetext{
and Trade, Strengthening Developing Countries' Capacity to Respond to Health Sanitary and Environmental Requirements (UNCTAD and IDRC, Geneva), 16-17 May 2001, para. 93, available at: http://r0.unctad.org/ trade_env/test1/meetings/standards/mariacostarica1.doc, visited on 10 June 2008.

14 Ibid.

${ }^{15}$ Valverde relates that a shipment of Costa Rican fish was rejected by US authorities, on the grounds that sampling and testing had detected histamine presence. The shipment was re-imported to Costa Rica and tested at public and private facilities, revealing no histamine presence. Valverde suggests that a possible explanation for this divergence in test results may be that the samples were sent by US officials to testing facilities by mail, under inappropriate temperature conditions, resulting in the development of histamine. Ibid., para. 94. An alternative explanation could be that the testing methods used in the US are more advanced and detect lower levels of histamine than do those of Costa Rica.

${ }^{16}$ Ibid., para. 95.

${ }^{17}$ Panel Reports, EC-Approval and Marketing of Biotech Products, para. 7.1569.
} 
ling authorities. Annex C.3 provides that nothing in the SPS Agreement shall prevent Members from carrying out reasonable inspection in their own territories.

As the substantive disciplines on control, inspection and approval procedures are to be found in Annex C.1, this provision is now addressed in more detail.

\subsubsection{Scope of application}

The first issue to be examined is the precise coverage of the disciplines of Annex C.1. A footnote to the title of Annex $\mathrm{C}$ specifies that:

Control, inspection and approval procedures include, inter alia, procedures for sampling, testing and certification. ${ }^{18}$

Further, the introductory sentence of Annex C.1 states that its obligations apply "with respect to any procedure to check and ensure the fulfilment of sanitary or phytosanitary measures'. However, these procedures are themselves SPS measures in their own right as evinced by the fact that among the illustrative list of SPS measures in Annex A.1 is 'testing, inspection, certification and approval procedures'. As a result, such procedures are subject not only to Article 8 and Annex C, but also to all the relevant rules of the SPS Agreement. This is expressly stated in Article 8, as cited above. ${ }^{19}$

It would therefore seems that control, inspection and approval procedures are a particular category of SPS measures, which take the form of procedures to check compliance with other SPS measures, and are subject to the additional requirements of Article 8 as specified in Annex C.

Other SPS measures of a substantive nature are not subject to Article 8 and Annex C. This was found in Australia - Salmon (Article 21.5 - Canada), where Canada invoked a violation by Australia of Annex C.1(c) of the SPS Agreement. The Australian measure at issue was its requirement that Canada prove that: the exported fish were from a population for which there was a documented health monitoring and surveillance system; the fish were not juveniles or sexually mature adults; and the fish were not derived from a population slaughtered as an official disease control measure. The Panel thus had to address the question whether the measure at issue fell within the scope of application of Annex C.1. It noted that only 'procedures to check and ensure the fulfilment of sanitary or phytosanitary measures' fall under the scope of Annex C.1. The Panel considered that the three Australian information requirements were 'substantive sanitary measures in their own right' and not 'procedures to check and ensure the fulfilment of sanitary or phytosanitary measures'. The Panel thus concluded that Annex C.1 was not applicable and consequently no violation of paragraph 1 (c) could be found. ${ }^{20}$ The Panel clearly distinguished

\footnotetext{
${ }^{18}$ Footnote 7 to Annex C of the SPS Agreement.

${ }^{19}$ It is interesting to note that the US in Japan - Apples did not challenge the inspection and control requirements that formed part of Japan's phytosanitary regime for apples under the disciplines of Annex C.1. Instead, it challenged their scientific basis as part of a cumulative set of requirements, under Articles 2.2 and 5.1 of the SPS Agreement. This did not present any problems since control and inspection procedures are, as just explained, themselves SPS measures and subject to all the relevant disciplines of the SPS Agreement.

${ }^{20}$ Panel Report, Australia - Salmon (Article 21.5 - Canada), paras 7.154-7.157.
} 
substantive SPS measures from procedural SPS measures for purposes of determining the applicability of Annex C.1. ${ }^{21}$

The question whether the application of control, inspection and approval procedures that are not themselves challenged, can be examined under Annex C.1 was addressed by the Panel in EC-Approval and Marketing of Biotech Products. The complainants did not challenge the EC's prior approval system for biotech products itself, ${ }^{22}$ but instead claimed that the general de facto moratorium on the approval of biotech products and the productspecific measures in place in the EC, were inconsistent, inter alia, with Annex C.1. The Panel found that the EC's prior approval procedures for biotech products were SPS measures in the form of 'procedures to check and ensure the fulfilment of SPS measures' as referred to in Annex C.1. ${ }^{23}$ However, it found that the challenged de facto moratorium and product specific measures were not themselves SPS measures, ${ }^{24}$ but only the 'application' of approval procedures. As Annex C.1 disciplines approval procedures, the Panel found that the EC was obliged to comply with the provisions of Annex C.1 in its 'application' of its approval procedures. ${ }^{25}$

It is now necessary to examine the disciplines which Annex C. 1 sets out for control, inspection and approval procedures. These are contained in subparagraphs (a) to (i) of Annex C.1, as well as in a final, unnumbered subparagraph thereof. This final subparagraph will be examined first, before proceeding to look at the obligations contained in the numbered subparagraphs of Annex C.1.

\subsubsection{Systems of prior approval and tolerance determination}

Stuck at the end of Annex C.1, after its list of disciplines, in subparagraphs (a) to (i), on procedures to check and ensure fulfilment of SPS measures, almost as an afterthought, is a provision dealing with systems for prior approval and the establishment of tolerance levels for contaminants. This unnumbered subparagraph states:

Where an importing Member operates a system for the approval of the use of food additives or for the establishment of tolerances for contaminants in food, beverages or feedstuffs which prohibits or restricts access to its domestic markets for products based on the absence of an approval, the importing Member shall consider the use of a relevant international standard as the basis for access until a final determination is made.

\footnotetext{
${ }^{21}$ Scott criticises this distinction as unnecessary on the basis that whether the SPS measures are substantive or procedural, they still have to meet the science-based requirements of the SPS Agreement. If they fail to do so, judicial economy could be used so as not to turn to Annex C. Joanne Scott, The WTO Agreement on Sanitary and Phytosanitary Measures: A Commentary, Oxford Commentaries on the GATT/WTO Agreements (Oxford University Press, Oxford), 2007, 220. However, the distinction seems to retain its relevance to the question whether Article C is applicable at all. Even if no violation of the science-based rules of the SPS Agreement is found, a measure that takes the form of a substantive SPS measure rather than a procedure to check compliance with another SPS measure cannot be tested under the requirements of Annex C.

${ }^{22}$ On this issue, see below, Part IV, Section 1.4.2.

${ }^{23}$ Panel Reports, EC-Approval and Marketing of Biotech Products, para. 7.1491.

${ }^{24}$ On the Panel's interpretation of the term 'SPS measures' in this case, see above, Part III, Section 2.1.1.

${ }_{25}$ Panel Reports, EC - Approval and Marketing of Biotech Products, para. 7.1492 (with regard to the de facto moratorium) and para. 7.1785 (with regard to the product specific measures).
} 
While the rest of Annex C.1 deals with conformity assessment procedures in relation to other SPS measures in general, this subparagraph addresses a more specific situation. This is the situation where the procedures in place condition market access for food or feed $^{26}$ on prior approval of the relevant additives by the importing Member or restrict access pending the determination of a tolerance level for the relevant contaminants. This amounts to a provisional import ban or import restriction, pending the decision on approval or tolerance level. Such a ban or restriction is not based on an assessment of risk, but is rather a precautionary measure.

Two situations can be distinguished in this regard. The first is where the regulating Member maintains the import ban or restriction temporarily, while an assessment is made of whether the food additive is safe, or what level of contaminants are safe and should be tolerated. In some cases, the complex risk assessment procedures in place in the regulating Member may result in long delays before a final decision is taken on approval or on the tolerance level. Examples of this situation abound in the area of food-safety. One illustration is that mentioned in Part II of this book with regard to Australia's application of a 'limit of determination' level for residues of agricultural or veterinary chemicals in food, pending the conduct of a risk assessment to determine the safe residue level. Another example is the ban in place in Australia on novel foods, irradiated foods, and genetically-modified foods until such time as their safety has been established by means of a risk assessment. ${ }^{27}$ In principle, the importing Member will proceed to obtain the necessary evidence to carry out a risk assessment on which to base its final determination.

However, a second type of situation arises where an importing Member does not have a strong interest in the product involved, for example with respect to exotic fruits which are imported in small quantities, or the harmful substance at issue, for example outdated pesticides, and is therefore unwilling to commit the necessary resources to conduct a risk assessment on the basis of which to decide on approval or tolerance levels. In such a situation, the market access restriction remains in place indefinitely, or until the exporting Member can bring sufficiently convincing scientific evidence assessing the risk and establishing its safety to the satisfaction of the importing Member. Examples have been mentioned in Part II of the significant problems faced by Mauritius and Jamaica due to the application of a 'limit of determination' residue level on their traditional products such as tropical fruits, yams and callaloo, due to the absence of commercial support to conduct the experimental trials necessary to establish tolerance levels for pesticides on these products. ${ }^{28}$ In 2003, a number of developing-country Members indicated their concerns

\footnotetext{
${ }^{26}$ It is interesting to note that the obligation of Annex C.1 to consider conditioning market access on the relevant international standards is limited to food or feed and does not apply to risks from pests or diseases that are not food-related. However, prior approval systems are often in place for imports of plants, animals or their products. For example it is very common to require that the exporting Member submit a pest risk assessment showing the absence of risk from the proposed import, as a condition for the granting of an import permit. The exclusion of this situation from Annex C.1 may be due to the fact that international standards are not of much help in the case of prior approval systems relating to pests or diseases that are not food-related, since these are based on the specific pest or disease prevalence in the exporting country involved and thus involve a factual country-specific determination. An exception to this may be the case of officially recognised diseasefree status by the OIE.

${ }^{27}$ See above, Part II, Section 2.4.2.2.

${ }^{28}$ See above, Part II, Sections 2.5.2.1 (Mauritius) and 2.6.2.1 (Jamaica).
} 
with regard to the EC's new approach to the determination of tolerance levels for pesticides. ${ }^{29}$ The EC had notified Members of a new draft regulation, according to which 325 chemical substances would be reassessed to update the available information and to set new MRLs. ${ }^{30}$ In all cases where a particular pesticide had not been not authorised on a particular product or when no data was available to prove that its residues posed no danger to consumer health, the MRL was set at $0.01 \mathrm{mg} / \mathrm{kg}$, which is the enforceable default for zero. Many developing-country Members expressed concerns, noting their lack of technological and analytical capacity to comply with this MRL and its serious adverse effects on their agri-food exports. ${ }^{31}$ They enquired as to the risk assessment basis for this measure. The EC indicated that the re-assessment of risks was being conducted on the basis of scientific information provided by the pesticide industry. However, the industry was no longer interested in marketing some of the older pesticides and was not keen to fund research in this regard. As a result, no data was available for a risk assessment and the default MRL was applied to these substances.

The last subparagraph of Annex C.1 applies a very weak discipline to prior approval systems. It establishes only that Members 'shall consider' conditioning market access in such cases on the relevant international standard, until a final determination is made. This is a far cry from the disciplines in the rest of the SPS Agreement which require that a measure must either be based on an international standard, or on a risk assessment meeting the requirements in the relevant provisions of the Agreement. ${ }^{32}$ Provisional measures are only allowed where scientific evidence is insufficient to permit a risk assessment, and where the imposing Member has complied with the remaining requirements of Article 5.7, including the obligation to seek to obtain the necessary information for a proper risk assessment and to review the measure within a reasonable period. ${ }^{33}$

Systems of prior approval and tolerance determination sit uncomfortably with these disciplines of the SPS Agreement. This is because the SPS Agreement is premised on the idea that the need for precaution is exceptional, arising only in situations of insufficient scientific evidence. In other cases, measures must be firmly based on science, embodied in either an international standard or a risk assessment. However, in the second situation mentioned above, systems of prior approval and tolerance determination adopt a precautionary approach not due to the insufficiency of available scientific evidence, but due to the limited resources a Member has to dedicate to conducting risk assessments on the basis of the available evidence prior to adopting an SPS measure. To ensure safety in the absence of a risk assessment and a final determination, Members impose provisional bans on such products or adopt very restrictive measures, such as 'limit of determination'

\footnotetext{
29 Committee on Sanitary and Phytosanitary Measures, Specific Trade Concerns. Note by the Secretariat. Addendum. Issues Not Considered in 2007, G/SPS/GEN/204/Rev.8/Add.2, circulated on 27 March 2008, item 169

30 Proposal for a Regulation of the European Parliament and of the Council on Maximum Residue Levels of Pesticides in Products of Plant and Animal Origin, COM/2003/117 Final, 2003/0052 (COD).

31 Concerns were raised by Argentina and China and supported by Bolivia, Brazil, Chile, Colombia, Cuba, Honduras, Mexico, Paraguay and Uruguay. Committee on Sanitary and Phytosanitary Measures, Specific Trade Concerns. Note by the Secretariat. Addendum. Issues Not Considered in 2007, G/SPS/GEN/204/Rev.8/ Add.2, circulated on 27 March 2008, item 169, para 169.

32 These disciplines are discussed above, Part III, Sections 4.2 and 5.1.

${ }^{33}$ On the requirements under Article 5.7 of the SPS Agreement, see above, Part III, Section 5.2.5.
} 
residue levels. In cases falling under the second situation mentioned above, Members choose not to prioritise the assessment of risks from products that are not significant for them, perhaps because they are not produced domestically or are imported in very small amounts. As a result, approval or tolerance decisions may be delayed for extended periods (or even indefinitely) even where scientific evidence is available or can be obtained on which a risk assessment could be conducted. In other cases, falling under the first situation mentioned above, provisional bans or very restrictive measures, such as 'limit of determination' residue levels are imposed pending a future risk assessment and final determination. However, lengthy delays may result from the complexity of the risk analysis procedure operated by a Member, as is the case with Australia. ${ }^{34}$

The question of the relationship between the last subparagraph of Annex C.1 and the rest of the SPS Agreement is problematic. As stated above, Annex $\mathrm{C}$ is an integral part of the SPS Agreement and must be read together with it. The way in which the SPS Agreement is drafted results in all SPS measures falling within its scope of application, also those covered by the last subparagraph of Annex C.1, being subject to all the disciplines of the SPS Agreement relevant to them. This is also made explicit in Article 8, as stated above.

The object and purpose of Annex C.1, as seen from its remaining provisions, appears to be to bring discipline to control, inspection and approval procedures to prevent them undermining the gains from the substantive disciplines of the SPS Agreement. This is in keeping with the overall balancing objective of the SPS Agreement, which aims to reduce the trade restrictive effects of legitimate SPS measures by disciplining those aspects that can unnecessarily increase their negative impact on trade. Consequently, reading the last subparagraph of Annex C.1 in the context of Article 8, and in the light of the object and purpose of Annex C.1 and the balancing objective of the SPS Agreement as a whole, this subparagraph should be seen as establishing an additional discipline on the types of systems covered by it, rather than creating a wide loophole for such systems. In this light, the last subparagraph of Annex C.1 can be regarded as aiming to reduce the great trade restrictive effect of the use of systems of prior approval and tolerance determination by encouraging reference to international standards to fill the gap pending the final approval or tolerance determination on the basis of scientific risk assessment.

However, the application of all the relevant disciplines of the SPS Agreement to systems for prior approval and tolerance determination would make redundant the Annex 1.C provision dealing specifically with these systems. The flexibility allowed by its weak discipline would effectively be eliminated entirely by the application of the normal SPS disciplines on harmonisation and risk assessment. Such a result is contrary to the principle of effective treaty interpretation. In view of the fact that this absurdity would result from the application of the normal rules of interpretation to this provision, regard may be had to the negotiating history of the SPS Agreement.

As discussed above, the disciplines to be applied to prior approval systems were a contentious aspect of the negotiations towards the SPS Agreement, and various options were considered to address the trade restrictive effect of such systems, while recognising the

\footnotetext{
${ }^{34}$ See the discussion of the lengthy risk analysis procedures of Australia, with repeated stakeholder consultations and technical reviews of data, above Part II, Section 2.4.2.
} 
right of Members operating them to restrict market access pending a final approval. ${ }^{35}$ Some of the options imposed a strong obligation to rely on international standards, where they existed, pending the approval decision, or to comply with the rest of the obligations in the SPS Agreement in the operation of approval procedures. In the end, however, agreement was reached to include only the very watered-down discipline we currently find in the last subparagraph of Annex C.1. Nevertheless, no explicit carve-out was provided for prior approval systems.

This seems to indicate an instance of 'constructive ambiguity' ${ }^{36}$ resulting from a compromise reached in the negotiations on this contentious issue. This is borne out by the subsequent practice in this regard, whereby Members have not challenged prior approval systems under the substantive disciplines of the SPS Agreement, despite the widespread use of such systems by developed-country Members and the great trade restrictive effect they have.

A treaty interpreter, faced with a challenge to a system of prior approval or tolerance determination under the last subparagraph of Annex C.1, would be obliged to give some meaning to this provision, in light of the principle of effective treaty interpretation. In view of all the considerations mentioned above, it is proposed here that this provision could best be interpreted as providing a (rather weak) additional discipline to prior approval and tolerance determination systems in the first situation mentioned above. In this situation, during the reasonable period of time allowed by Article 5.7 for seeking additional information to review a provisional measure, Annex C.1 would oblige Members to consider allowing market access for products conforming to relevant international standards. The normal requirements of Article 5.7 would continue to apply as well. However, measures that do not meet the requirements of Article 5.7, due to the fact that they are taken in the second type of situation mentioned above, where scientific evidence is not 'insufficient' or there are no efforts to seek additional information or to conduct a risk assessment, would, under the proposed interpretation, not be 'saved' from the operation of the relevant substantive disciplines of the SPS Agreement by the weak discipline of the last subparagraph of Annex C.1. Instead, such systems would fall foul of the scientific obligations of the SPS Agreement and not meet the requirements of Article 5.7 for exemption from these disciplines, leaving no room for the application of Annex C.1.

The disconnect between the general disciplines of the SPS Agreement and the position of systems of prior approval is illustrated by the EC-Approval and Marketing of Biotech Products dispute. As repeatedly noted by the Panel in that case, the complainants chose not to challenge the pre-marketing approval system of the EC for biotech products as such. ${ }^{37}$ It would appear that this decision by the complainants was motivated by their desire to avoid opening this can of worms in view of the general prevalence of priorapproval systems in many Members and the fact that they jar with the general regime

\footnotetext{
${ }^{35}$ For a discussion of the four options considered during the negotiations on the SPS Agreement, see above, Part III, Section 1.2.2.

${ }^{36}$ As noted by former WTO Director-General Mike Moore, WTO negotiators resorted to what has been called 'constructive ambiguity' in framing controversial treaty provisions as a diplomatic means of enabling consensus on WTO rules. Mike Moore, A World Without Walls - Freedom, Development, Free Trade and Global Governance, (Cambridge University Press, Cambridge), 2003, 111.

${ }^{37}$ Panel Reports, EC-Approval and Marketing of Biotech Products, paras 7.1353 and 7.1693.
} 
of the SPS Agreement. As stated by the Panel, one of the consequences of the EC's prior approval system is that the marketing of the biotech products for which approval is sought is provisionally banned pending the final approval decision. In the absence of a challenge to this system, the Panel was obliged to assume for purposes of the dispute that both the prior approval system and the provisional ban were WTO consistent. ${ }^{38}$ As a result, the Panel could only address the complainants' challenges to the EC's decision to delay the approval procedures, as evinced in its general de facto moratorium and the product specific measures. As set out above, this decision to delay was seen by the Panel as not constituting an 'SPS measure' ${ }^{39}$ but only the 'application' of an approval procedure which was itself an SPS measure. ${ }^{40}$ The Panel therefore addressed both the general de facto moratorium and the product specific measures only under the procedural disciplines of Annex C.1, to the exclusion of the substantive disciplines of the SPS Agreement. Due to the lack of independent challenges to the approval system, not only were the substantive disciplines of the SPS Agreement found inapplicable in the absence of a challenge to an 'SPS measure', but also the procedural rules of Annex C.1 were difficult to apply. The way the challenge was framed meant that only the prohibition on undue delays in Annex C.1 could be applied.

The last subparagraph of Annex C.1 was not at issue in this case since the complainants did not allege a violation thereof. It is unlikely that relevant international standards existed for the biotech products at issue, and in any case the weakness of the obligation in this provision makes it ineffectual in bringing discipline to prior approval systems. The complainants therefore preferred to base their claims of violation on the stronger procedural disciplines in numbered subparagraphs of Annex C.1. These are discussed below.

\subsubsection{Undue delay}

Lengthy control, inspection and approval procedures can have an important trade restrictive effect, especially in the case of perishable products. ${ }^{41}$ In addition, in Members operating prior approval systems based on complex risk analysis procedures, as is the case with Australia as seen above, ${ }^{42}$ procedures may go on for several years, during which market access is provisionally denied. The first obligation imposed by Annex C.1, contained in paragraph (a), seeks inter alia to avoid undue delays in the operation of control, inspection and approval procedures. It provides:

Members shall ensure, with respect to any procedure to check and ensure the fulfilment of sanitary or phytosanitary measures, that:

\footnotetext{
${ }^{38}$ Ibid., para. 7.1353 .

${ }^{39}$ For a discussion on this point, with regard to the scope of application of the SPS Agreement, see above, Part III, Section 2.1.1.

${ }^{40}$ Panel Reports, EC-Approval and Marketing of Biotech Products, para. 7.1382 (with regard to the general de facto moratorium) and para. 7.1690 (with regard to the product specific measures).

${ }^{41}$ For example, in 2003, the EC reported that a variety of its exports to the US had experienced problems due to lengthy delays in US customs sampling and inspection procedures, leading to damage to the products and commercial losses. It expressed the view that adequate steps should be taken to ensure that perishable goods are dealt with expeditiously in US control and inspection procedures. European Commission, Report on United States Barriers to Trade and Investment (European Commission, Brussels), December 2003, 35, available at: http://trade-info.cec.eu.int/doclib/docs/2003/december/tradoc_115383.pdf, visited on 3 January 2004.

${ }^{42}$ See above, Part II, Section 2.4.2.2.
} 
(a) such procedures are undertaken and completed without undue delay and in no less favourable manner for imported products than for like domestic products;

In EC - Approval and Marketing of Biotech Products, the complainants claimed that the EC's approval procedures for biotech products were carried out in a manner inconsistent with Annex C.1(a). The Panel thus had to examine whether the measures at issue were 'undertaken and completed without undue delay'.

The Panel noted that what matters for purposes of this obligation is not the length of the delay, but rather whether there is a legitimate reason or justification for it. ${ }^{43}$ This must be determined on a case-by-case basis. Logically, a Member is only responsible for delays that are attributable to it (thus not for delays caused by the applicant). The Panel considered that Members applying approval procedures must be allowed to take the time reasonably needed to determine with adequate confidence that their SPS requirements are met. The Panel examined and rejected the EC's arguments that the delays were justified by the perceived inadequacy of its existing legislation and the prudent and precautionary approach it applied due to the fact that the relevant science was evolving and in a state of flux. ${ }^{44}$ The Panel then examined a particular approval procedure to determine if the EC's de facto moratorium had led to undue delay and readily found this to be the case ${ }^{45}$ It therefore found that the general de facto moratorium constituted a violation of the procedural prohibition in Annex C.1(a) and consequently of Article 8 of the SPS Agreement. ${ }^{46}$ Similarly, with respect to the product-specific measures challenged in this dispute, the Panel examined the procedures followed with regard to the 27 products specified by the complainants and determined that there had been 'undue delay' in 24 of the 27 cases, contrary to Article 8 and Annex C.1(a). ${ }^{47}$

\subsubsection{Less favourable treatment}

Not only undue delays, but also discriminatory application of control, inspection and approval procedures are a cause for concern. Discriminatory treatment of imports is addressed in the second clause of Annex C.1(a), cited above, by means of a prohibition on less favourable treatment of imported products than of like domestic products.

In EC - Approval and Marketing of Biotech Products, Argentina claimed that the EC's product-specific measures were inconsistent with the second clause of Annex C.1(a), It argued that the EC had undertaken approval procedures in a less favourable manner for the biotech products that were the subject of the product-specific measures challenged by Argentina than for 'like' novel, non-biotech products. Argentina averred that undue

${ }^{43}$ Panel Reports, EC - Approval and Marketing of Biotech Products, paras 7.1496-7.1498.

44 Panel Reports, EC - Approval and Marketing of Biotech Products, paras 7.1511-7.1530. While the Panel agreed that limited availability of scientific evidence may mean that deferring decisions might allow for better decisions to be taken, it pointed out that the core obligation of Annex C.1(a) is for Members to come to a substantive decision. This decision need not give 'a straight yes or no answer to applicants'. Instead, a Member, for example, may reject an application subject to later review, or give a time-limited approval. Ibid., para. 7.1527.

${ }^{45}$ Ibid., para. 7.1567.

46 Ibid., para. 7.1567.

${ }^{47}$ The analysis was carried out for large number of approval procedures (ibid., paras. 7.1779-7.2389). The Panel then summarised its conclusions in the form of a table. See ibid, para. 7.2391. 
delays had taken place only in the processing of applications concerning biotech products, not in those concerning non-biotech products.

According to the Panel, in order to establish a violation of the second clause of Annex C.1(a), it is necessary to establish:

(i) that imported products have been treated in a "less favourable manner" than domestic products in respect of the undertaking and completion of approval procedures, and (ii) that the imported products which are alleged to have been treated less favourably are "like" the domestic products which are alleged to have been treated more favourably. ${ }^{48}$

Turning to the first requirement, the Panel noted that it clearly lays down a national treatment obligation, and it therefore considered it useful to 'look to the jurisprudence on Articles III:1 and III:4 of the GATT 1994 for appropriate interpretative guidance.'49 Reading Article C.1(a), second clause, in the light of this jurisprudence, it considered that:

... in undertaking and completing its approval procedures, a Member may, in principle, differentiate between products that have been found to be like because this would not, by itself, mean that the relevant approval procedures have been undertaken or completed in less favourable manner for the group of like imported products than for the group of like domestic products. In particular, a mere showing that a Member has undertaken or completed a particular approval procedure in a manner which is unfavourable for a given imported product would not be sufficient to establish a "less favourable manner" of undertaking or completing approval procedures if the relevant Member's conduct is explained by factors or circumstances unrelated to the foreign origin of the product. ${ }^{50}$

Turning to examine Argentina's arguments, it noted that Argentina had not alleged that the manner of processing applications under the relevant legislation differed depending on the origin of the products. It therefore found that it was 'not self-evident' that the alleged less favourable manner of processing applications regarding the imported biotech products at issue was explained by the foreign origin of these products rather than, for instance, by a 'perceived difference between biotech products and novel non-biotech products in terms of the required care in their safety assessment, risk for the consumer, etc. ${ }^{51}$ According to the Panel, Argentina had not succeeded in raising a presumption that the alleged less favourable treatment was explained by the foreign origin of the relevant biotech products. ${ }^{52}$ It thus found no violation of the second clause of Annex C.1(a).

This, while in line with the recent finding of Appellate Body in Dominican Republic - Import and Sale of Cigarettes, ${ }^{53}$ seems to depart from the previous case law on the

\footnotetext{
${ }^{48}$ Ibid., para. 7.2400 .

${ }^{49}$ Ibid., para. 7.2401. The Panel examined the findings regarding the national treatment obligation in Appellate Body Report, EC - Asbestos, para. 100 and Appellate Body Report, Dominican Republic - Import and Sale of Cigarettes, para. 96. These findings are discussed above, Part III, Section 1.1.1.

${ }^{50}$ Panel Reports, EC - Approval and Marketing of Biotech Products, para. 7.2408.

${ }^{51}$ Ibid., para. 7.2411.

52 Ibid., para. 7.2411.

${ }^{53}$ As mentioned above, Part III, Section 1.1.1, the Appellate Body held in Dominican Republic - Import and
} 
national treatment obligation, in that it allows different treatment of like products if this is explained by something other than their foreign origin (in this case by a 'perceived difference'). ${ }^{54}$ It seems that the Panel requires the complainant to show that the reason behind the difference in treatment is related to the foreign origin of the product, rather than merely that the structure, design and architecture of the measure are such that predominantly imported products are subject to the delays and predominantly domestic products are approved without delay.

In view of the fact that, different from the situation under the GATT 1994, there is no general exception in the SPS Agreement that could justify discriminatory treatment, and the less favourable treatment in Annex C.1(a) is not qualified by the requirement that it be arbitrary or unjustifiable, the Panel's examination of the possible justification for the different treatment in its examination of the 'less favourable treatment' criterion may be understandable. ${ }^{55}$

\subsubsection{Operation of procedures}

Annex C.1(b) sets out rules that aim at due process in the operation of control, inspection and approval procedures. It requires that, with respect to any procedure to check and ensure the fulfilment of SPS measures:

... the standard processing period of each procedure is published or that the anticipated processing period is communicated to the applicant upon request; when receiving an application, the competent body promptly examines the completeness of the documentation and informs the applicant in a precise and complete manner of all deficiencies; the competent body transmits as soon as possible the results of the procedure in a precise and complete manner to the applicant so that corrective action may be taken if necessary; even when the application has deficiencies, the competent body proceeds as far as practicable with the procedure if the applicant so requests; and that upon request, the applicant is informed of the stage of the procedure, with any delay being explained;

Two of the complainants in the EC - Approval and Marketing of Biotech Products dispute, namely the US and Argentina, claimed a violation of Annex C.1(b). ${ }^{56}$ According to

\footnotetext{
Sale of Cigarettes that there is no less favourable treatment if the detrimental effect of the measure on imports can be explained by factors unrelated to the foreign origin of the product. Appellate Body Report, Dominican Republic - Import and Sale of Cigarettes, para. 96.

${ }^{54}$ Note that this finding was made in the context of the less-favourable treatment analysis, and not the like product analysis under Article C.1(a). It therefore does not follow that perceived differences, particularly those unrelated to the product itself (here the care required in assessing the risks), may now be taken into account when determining whether products are 'like' for purposes of the SPS Agreement.

${ }_{55}$ Joanne Scott sees this finding as coming close to endorsing a 'quasi-exception within the [national treatment] rule itself' similar to the 'mandatory requirements' doctrine in the EC. She notes that this exception is broader than that in Article XX of the GATT, as it makes room for new and diverse concerns. However, she regards the allocation of the burden of proof on the complainant to demonstrate that the differential treatment is explained by factors other than the foreign origin of the products as 'less than appropriate'. Joanne Scott, The WTO Agreement on Sanitary and Phytosanitary Measures: A Commentary, Oxford Commentaries on the GATT/ WTO Agreements (Oxford University Press, Oxford), 2007, 230.

${ }^{56}$ Only the US claimed that the general de facto moratorium violated Annex C.1(b). Both the US and Argentina claimed that the product-specific measures that they challenged violated this provision.
} 
the Panel, this provision contains 'five separate, but related, obligations to be observed by Members in the operation of approval procedures. ${ }^{57}$ These it identified as relating to:

(i) the publication or communication to applicants of the processing period of each procedure;

(ii) the examination of the completeness of the documentation and the communication to applicants of deficiencies;

(iii) the transmission of the results of the procedure;

(iv) the processing of applications which have deficiencies; and

(v) the provision of information about the stage of a procedure and the provision of an explanation of any delay. ${ }^{58}$

With respect to the first obligation (publication or communication of the processing period) the US argued that, due to the EC's de facto moratorium as well as its failure to consider the product specific applications for final approval, the 'standard' processing period published in the EC approval legislation was not followed. According to the US, the actual 'effective' processing period was neither published nor communicated to the applicants. ${ }^{59}$ The Panel disagreed, holding that the processing period to be published 'is the period which is intended to be the norm for all approval procedures of a particular type. ${ }^{60}$ With respect to the product-specific measures, the Panel held that deviation from the published period in a single approval procedure would not justify the conclusion that there was a new, unpublished, effective 'standard' processing period. ${ }^{61}$ Even if there was a new standard processing period, the Panel regarded the failure to publish this period as not due to the de facto moratorium or the product-specific measures, but rather as an independent failure by the EC to publish its processing period. ${ }^{62}$ The Panel further noted that communication of the anticipated processing period is only required 'upon request', and the US had not shown that such a request had been made and that it had been denied by the EC. ${ }^{63}$ Therefore no violation of the first obligation of Annex C.1(b) was found.

${ }^{57}$ Panel Reports, EC - Approval and Marketing of Biotech Products, para. 7.1574.

${ }^{58}$ Ibid., para. 7.1574.

${ }^{59}$ Ibid., paras 7.1584 and 7.1589 (with regard to the de facto moratorium) and paras 7.2439 and 7.2443 (with regard to the product specific-measures). Argentina made no arguments in relation to the first obligation of Annex C.1(b).

${ }^{60}$ Ibid., para. 7.2440. According to the Panel, the word 'standard' in this context should be understood as meaning 'normal'. Ibid.

${ }^{61}$ Ibid., para. 7.2440. The Panel recalled (in footnote 1660) that the measures at issue were the individual product-specific measures, and not the product-specific measures taken collectively or the general de facto moratorium. Still, it seems strange that this narrow focus was applied, in disregard for the fact that the EC's failure to proceed to final approval of applications was the norm, as evinced not only in each of the product specific measures but also the general de facto moratorium. This factual context seems relevant to the assessment of the 'standard processing period', even where the claim related to a specific measure.

${ }^{62}$ Ibid., para. 7.1587 (with regard to the de facto moratorium) and para. 7.2441 (with regard to the productspecific measures).

${ }^{63}$ Ibid., para. 7.1592 (with regard to the de facto moratorium) and para. 7.2443 (with regard to the productspecific measures). The US had brought arguments regarding the failure of the EC Regulatory Committee and of the Commission at the post-Regulatory Committee stage, to inform the applicant of deficiencies in the documentation. However, the competent body that received the application was the lead Member State to which the application was submitted for initial assessment. In any event, the Panel found no proof that deficiencies in the documentation had been identified by the Regulatory Committee or the Commission. Ibid., 
With regard to the second obligation of Annex C.1(b), regarding the examination of the completeness of the documentation, the Panel held that it is when the 'competent body' receives an application that the applicant must be informed of deficiencies in the documentation, not during the evaluation later in the approval process. ${ }^{64}$ As no concrete evidence was brought by the US or Argentina in this regard, the Panel found no violation of this obligation.

The third obligation of Annex C.1(b), requiring the prompt transmission of the results of the procedure, was held to be inapplicable to the case at hand by the Panel in $E C$ Approval and Marketing of Biotech Products. This was due to the fact that the de facto moratorium and the product specific measures had the effect that no final results of the procedures were achieved. Thus there were no results to be promptly transmitted. ${ }^{65}$ Therefore, clearly in the Panel's view the only results to be communicated are the final results of the procedure. The results of interim stages of the procedure were not regarded as falling within this obligation. Considering that this obligation applies 'so that corrective action may be taken if necessary' ${ }^{\prime} 6$ it seems odd to wait until a final decision, when it may no longer be possible to allow for corrective action, to transmit the results. At this late stage, any corrective action could only be taken into account in a new control, inspection or approval procedure, thereby delaying the possibility to gain market access. Obliging the transmission of the outcome of interim stages in the procedure would be preferable in that it allows the applicant to promptly address any problems and thus influence the outcome of the final decision.

With regard to the fourth obligation of Annex C.1(b), namely that the competent body must proceed as far as practicable with the procedure even if the application has deficiencies, and the fifth obligation, namely that the applicant must be informed of the stage of the procedure and any delay must be explained, the Panel pointed out that both these obligations expressly apply only 'if the applicant so requests' or 'upon request'. As no evidence had been brought that such a request had been made, and had been denied by the EC, the Panel found no violation of this obligation. ${ }^{67}$

With regard to each of the obligations of Annex C.1(b), the Panel in EC-Approval and Marketing of Biotech Products emphasised that any possible violation thereof, even if one were found to exist, would not be a necessary result of the general de facto moratorium or the product-specific measures, but would be a result of a separate and independent failure of the EC to comply with the obligation at issue. Consequently, the Panel held that in this case the complainants had not brought sufficient evidence to show a violation of the obligations of Annex C.1(b). ${ }^{68}$

paras 7.2449-2450.

${ }^{64}$ Ibid., para. 7.1595 (with regard to the de facto moratorium) and para. 7.2641 (with regard to the productspecific measures).

${ }^{65}$ Ibid., para. 7.1589 (with regard to the de facto moratorium) and para. 7.2448 (with regard to the productspecific measures).

${ }^{66}$ Annex C.1(b) of the SPS Agreement, cited above in this Section.

${ }^{67}$ Panel Reports, EC-Approval and Marketing of Biotech Products, paras 7.1598 and 7.1601 (with regard to the de facto moratorium) and paras 7.2466 and 7.2469 (with regard to the product-specific measures).

${ }^{68} \mathrm{Ibid}$., para. 7.1604 (with regard to the US's claim in respect of the general de facto moratorium) and para. 7. 2474 (with regard to the claims of the US and Argentina in respect of the product-specific measures). 


\subsubsection{Information requirements}

One important cause of delays in control, inspection and approval procedures is the information requirements imposed on an exporter, in order to demonstrate compliance with the SPS requirements of the importing Member. Annex C.1(c) addresses this situation by requiring that:

... information requirements are limited to what is necessary for appropriate control, inspection and approval procedures, including for approval of the use of additives or for the establishment of tolerances for contaminants in food, beverages or feedstuffs.

In EC - Approval and Marketing of Biotech Products, Argentina argued that the EC had acted inconsistently with this provision through its undue delays in the consideration of particular applications, by requiring excessive submissions of information. In particular, Argentina challenged the EC's requirement that applications made under Directive 90/220 had to be resubmitted under the subsequent legislation, Directive 2001/18 which resulted in numerous requests for additional information in the approval procedures. ${ }^{69}$ The EC countered that if Argentina considered the requirement in its new approval legislation to resubmit an updated dossier upon entry into force of Directive 2001/18, it should have challenged this Directive under the SPS Agreement. ${ }^{70}$

The Panel noted that the product-specific measures challenged by Argentina were the undue delays of the EC in considering particular approval applications. This delay, according to the Panel, did not itself impose information requirements which were not necessary. ${ }^{71}$ As Argentina had not challenged the information requirements in the new legislation, but only the undue delays in the application of approval procedures, no inconsistency with Annex C.1(c) could be established. In any event, Argentina had not explained why the information requirements imposed were 'excessive' and thus not necessary. ${ }^{72}$ Consequently, the claim regarding Article C.1(c) had not been proven. ${ }^{73}$

It appears that, had Argentina challenged the approval procedures themselves, rather than the delays in their application, under Annex C.1(c), and brought arguments to show why the numerous requests for additional information were in fact not necessary for 'appropriate' approval procedures, it would have had a chance of success. This seems likely if the requests for additional information could be shown to have formed part of a concerted plan by the European Commission and certain EC Member States to delay the approval procedures. However, as noted above, Members are reluctant to open a can of worms by challenging prior approval systems per se under the rules of the SPS Agreement, due to the fact that, while they are maintained by many Members, they jar with the regime created by the Agreement.

\footnotetext{
${ }^{69}$ Panel Reports, EC-Approval and Marketing of Biotech Products, para. 7.2478.

${ }^{70}$ Panel Reports, EC - Approval and Marketing of Biotech Products, para. 7.2479.

${ }^{71}$ Panel Reports, EC-Approval and Marketing of Biotech Products, para. 7.2482.

${ }^{72}$ Panel Reports, EC-Approval and Marketing of Biotech Products, para. 7.2483.

${ }^{73}$ Panel Reports, EC-Approval and Marketing of Biotech Products, para. 7.2485.
} 


\subsubsection{Requirements on individual specimens}

There are situations when procedures for control and inspection, for example sampling and testing requirements, are applied in an excessive manner to individual specimens of the product involved. This may unnecessarily raise the cost and administrative burden of the procedure for exporters. To address this problem, in subparagraph (e), Annex C.1 obliges Members to ensure that requirements for control, inspection and approval of 'individual specimens' of a product are 'limited to what is reasonable and necessary'.

In EC - Approval and Marketing of Biotech Products Argentina claimed, with respect to the product-specific measures, that the application of the EC's approval procedures was not limited to what was reasonable and necessary, in violation of Annex C.1(e). ${ }^{74}$ However, the Panel clarified that this measure entailed the failure to complete the approval procedures for specific biotech products without undue delay. It therefore does not impose any requirements on individual specimens of the relevant biotech products. As a result, the product specific measures cannot give rise to an inconsistency with Annex C.1(e). ${ }^{75}$

It seems that the type of procedural measure intended to be caught by Annex C.1(e) is of the type that was at issue in a specific trade concern raised by Thailand against Australia in $2000 .^{76}$ This measure was a pre-shipment inspection requirement for durian fruit. Australia required that for shipments of less than 1000 fruits, random samples of 450 fruits be cut open to check for the presence of seed borers, and for shipments of more than 1000 fruits, samples of 600 fruits be thus opened. The result of these requirements was that in many cases for each fruit to be exported to Australia, a pre-shipment volume of two fruits was necessary, in effect doubling the cost of each shipment. Thailand raised its concerns regarding this measure with reference to Annex C.1(e). ${ }^{77}$

\subsubsection{Remaining obligations}

The remaining obligations contained in subparagraphs (d) and (f) to (i) of Annex C.1 have not yet been addressed in dispute settlement proceedings. A brief look at the disciplines contained therein is taken to complete the picture of the manner in which the SPS Agreement tries to minimise the trade-restrictive impact of control, inspection and approval procedures.

\footnotetext{
${ }^{74}$ Panel Reports, EC-Approval and Marketing of Biotech Products, para. 7.2491.

${ }^{75}$ Panel Reports, EC - Approval and Marketing of Biotech Products, para. 7.2494.

${ }^{76}$ Committee on Sanitary and Phytosanitary Measures, Australia's Import Restrictions on Durian: Statement by Thailand at the Meeting of 8-9 November 2000, G/SPS/GEN/217, circulated on 22 November 2000.

77 In response, Australia noted that its requirement was in conformity with the internationally accepted approach, but amended its requirement to allow culled fruits to be included in samples taken from the shipment to reduce its economic impact. Committee on Sanitary and Phytosanitary Measures, Australia's Import Restrictions on Durian: Response by Australia to Thailand's Statement at the Meeting of 8-9 November 2000, G/SPS/GEN/218, circulated on 22 November 2000. Thailand continued to reiterate its concern with the cutting requirement and the excessive sample size, in response to which Australia indicated that it was willing to consider alternatives to destructive sampling if their efficacy is shown. Joint trials with x-ray technology were undertaken. Committee on Sanitary and Phytosanitary Measures, Summary of the Meeting Held on 25-26 June 2002. Note by the Secretariat, G/SPS/R/27, circulated on 2 August 2002, paras 133-134.
} 
Subparagraph (d) of Annex C.1 contains a non-discrimination rule, requiring no less favourable respect for the confidentiality of information about imported products provided in the context of control, inspection and approval procedures than is applied for domestic products. Further, this respect must be in such a manner as to protect legitimate commercial interests. This obligation takes account of the fact that control procedures may require the submission of proprietary information such as the disclosure of ingredients and processing methods.

In subparagraph (f) of Annex C.1 is found a requirement of equitable application of fees imposed for the procedures at issue. What is equitable is stated in relation to the fees charged to domestic producers and other Members. The criterion of equity rather than no less favourable treatment in respect of fees seems to be intended to reflect the fact that actual costs of procedures may differ depending on the origin of the products (for example, if inspectors have to travel further to inspect a production site in a particular Member, or if the SPS status of a Member necessitates more controls and testing than that of another). Further, subparagraph (f) provides that the fees 'should' be no higher than the actual cost of the service. This is purely hortatory and thus allows higher fees when considerations of equity would not prevent this. Read in the light of Article 10.1 of the SPS Agreement that obliges Members to take account of developing-country Members' needs in applying their SPS measures, equity could be seen to require Members to consider applying differential fees for Members at different levels of development. ${ }^{78}$

Subparagraphs (g) and (h) of Annex C.1 contain disciplines to minimise the trade effects of procedures. In particular, subparagraph $(\mathrm{g})$ requires Members to minimise inconvenience to applicants, importers, exporters and their agents by using the same criteria for imported and domestic products when it comes to decisions on the selection of product samples and the location of the facilities used for the relevant procedures. Subparagraph (h) addresses the situation where a product's specifications have been changed after it has been through control and inspection procedures. The new procedure for the modified product may not exceed what is necessary to establish whether adequate confidence exists that the product still meets the applicable SPS requirements.

Finally, subparagraph (i) contains due process requirements. It mandates the existence of a review procedure for complaints regarding the operation of control, inspection and approval procedures and a procedure for corrective action where such complaints are justified.

\subsection{Conclusion}

The balance struck in the relevant substantive rules of the SPS Agreement in order to distinguish legitimate health protection from disguised protectionism can be undermined if the procedures used in SPS regulation are undisciplined. These procedures may be abused to throw down practical barriers that restrict the possibilities for exporters to access the markets of their trading partners. In other words, in many cases it is not what is done

78 Joanne Scott, The WTO Agreement on Sanitary and Phytosanitary Measures: A Commentary, Oxford Commentaries on the GATT/WTO Agreements (Oxford University Press, Oxford), 2007, 221-222. 
but the way in which it is done that creates problems. These problems may be especially burdensome for Members at lower levels of development, due to their lack of resources to devote to compliance with complex procedural requirements.

The SPS Agreement contains some rules dealing directly with procedures imposed by Members to check compliance with their SPS measures. These are contained in Article 8 and Annex C, which address control, inspection and approval procedures. Annex C.1 sets out a list of disciplines on various aspects of control, inspection and approval procedures, which broadly speaking aim to ensure that procedures are not more lengthy and burdensome than is reasonable and necessary, and that they do not discriminate against imports. A few of these disciplines have been clarified by the Panel in EC-Approval and Marketing of Biotech Products. Further clarification and a rigorous application of these rules are called for, to give full effect to the potential of Annex C.1 to discipline the relevant procedures. Further, Annex C.1 contains a weak additional discipline for systems of prior approval of additives and establishment of tolerances for contaminants, requiring consideration of the use of international standards pending a final determination. While these systems sit uncomfortably with the general regime established by the SPS Agreement, they do fall within the definition of SPS measures and are covered by all the disciplines of the Agreement, not just Annex C.1. Members are, however, reluctant to challenge prior approval systems as such under the SPS Agreement. This is evinced by the fact that the only challenge relating to a prior approval system to date is that in EC-Approval and Marketing of Biotech Products, which did not challenge the system itself but only the delays in its application, as reflected in the de facto moratorium and product-specific measures.

The additional procedural arrangements under the SPS Agreement aim to operationalise certain of its substantive obligations. The substantive obligations on Members in respect of the recognition of equivalence, the adaptation of their SPS measures to regional conditions and transparency in respect of their SPS measures would achieve little without procedural arrangements to give effect to them. Yet, the procedural aspects of the provisions on these matters in the SPS Agreement, aside from the provisions on transparency, are extremely weak. This has led to very poor implementation of the obligations on equivalence and regionalisation, rendering ineffective these provisions despite the very significant potential they hold for market access improvements.

These potential benefits are of particular relevance for Members at lower levels of development. As discussed above, the recognition of equivalence, unlike harmonisation rules, allows for differences between Members, including those relating to consumer preferences and technical and financial resources, that lead to divergent SPS measures. Yet it limits the trade restrictive effect of the divergent measures by acknowledging that it is possible for different SPS measures to achieve the same level of protection. Thus by recognising equivalence an importing Member would allow imports of products that comply with different, but equally effective, SPS measures. This leaves flexibility for Members at lower levels of development to apply SPS measures suited to their capacities and still gain market access, provided the measures achieve the importing Member's chosen level of protection. Similarly, regionalisation holds great potential by recognising that SPS conditions, and in particular the incidence of pests and diseases, are not determined by national borders, and may differ between various regions within a country. In some large 
developing countries, conditions may vary greatly from region to region, due to variations in climate, environmental or geographic conditions within the country and/or due to the efforts of the regulatory authorities to eradicate a pest or disease from specific areas. Adaptation of SPS measures of importing Members to the pest or disease conditions of the region of origin of the product could greatly improve market access possibilities. This enables the exporting Member to limit the costs of eradicating a pest or disease or keeping pest- or disease-free status by focusing on specific areas.

In order to realise the potential of the obligations on the recognition of equivalence and adaptation to regional conditions, the SPS Committee has developed procedural arrangements. These procedures do not amend the substantive obligations, but instead provide guidelines for their effective implementation. Developed on the basis of concrete information provided by Members on their experiences in the relevant areas, and elaborated in technical discussions among SPS regulatory officials, these procedures illustrate the potential of the SPS Committee to find cooperative solutions to implementation problems, as discussed further below. ${ }^{79}$

The substantive transparency obligations regarding prior notification of changes to SPS measures, publication of adopted measures and the explanation, upon request, of reasons for SPS measures also hold great potential to improve market access possibilities. Prior notification enables exporting Members to be informed of proposed new or amended SPS measures and to transmit this information to their exporters. This gives Members, and through them their exporters, the opportunity to make comments regarding these proposals at an early stage and to have these comments taken into account in the regulatory process. They can also raise concerns on notified measures in multilateral discussions at SPS Committee meetings, as discussed below. ${ }^{80}$ The publication requirement for adopted SPS measures is crucial in facilitating market access for exports from Members by greatly reducing the cost and difficulty of obtaining information on their trading partners' SPS measures. It also enables exporting Members to exercise their rights and police the implementation of the obligations of the SPS Agreement, by ensuring that Members obtain full information on the content of the SPS measures of importing Members in order to identify whether they are consistent with the SPS Agreement. The provision of an adaptation period before the entry into force of a published measure is of particular importance to developing-country Members as their exporters may need more time to adjust to new requirements. The obligation to provide reasons supplements the other transparency provisions by enabling Members to obtain information beyond that on the existence and content of SPS measures, such as that regarding the scientific basis of the measure, the level of protection it seeks to achieve and other aspects of the reasons for its imposition. This information enables an exporting Member to raise its concerns regarding the measure in a focused manner, by pointing to specific inconsistencies with the SPS Agreement in bilateral discussions or in the multilateral forum of the SPS Committee. It can also play a useful role in dispute settlement proceedings by assisting an exporting Member in establishing a prima facie case, for example, that an importing Member's SPS measure is not based on a risk assessment or sufficient scientific evidence. To give effect

\footnotetext{
${ }^{79}$ See below, Part IV, Section 2.1.1.

${ }^{80}$ See below, Part IV, Section 2.1.2.
} 
to these transparency obligations, the SPS Agreement, in Annex B, contains some procedural rules, particularly in respect of notification. However, these procedural rules are not sufficiently detailed and have given rise to difficulties of implementation, undermining the effect of the substantive obligations.

The impact of the transparency obligations for Members at different levels of development varies, both in terms of the compliance burden they impose and in terms of the potential benefits they offer. Both the implementation of transparency obligations and managing the inflow of information resulting from increased transparency require institutional infrastructure and human and financial resources. This is illustrated by an examination of the greatly varying transparency practice of the four Members selected as examples in this book. To facilitate compliance with the transparency obligations and to assist Members to derive full benefits from them, the SPS Committee has adopted recommended transparency procedures and formats for notifications. The procedures, while not binding, are commonly followed by Members, and have resulted in great improvements in transparency. On the basis of experience with their use and new suggestions for improvement, the procedures have been revised three times and they can be regarded as a 'work in progress'. Transparency procedures have also been adopted by the SPS Committee in respect of determinations on equivalence and regionalisation, as well as with regard to requests for SDT and responses to such requests. The Recommended Transparency Procedures currently also incorporate references to mechanisms designed by the WTO Secretariat, on the initiative of Members, to address constraints faced by developing-country Members. Examples are the mechanisms to improve access to unofficial translations of documents; to provide access to a database, known as the SPS IMS, where notifications of SPS measures and other relevant sources of information are compiled; and to facilitate access to notified draft SPS measures by storing documents electronically on the WTO server and enabling access to these documents through hyperlinks in notifications. In this way, the work of the SPS Committee, supported by the WTO Secretariat, with regard to improving the procedural arrangements for transparency under the SPS Agreement has been instrumental in furthering the realisation of the benefits of transparency while reducing some of its costs. 


\title{
CHAPTER 2 \\ Institutional and procedural arrangements for administration and enforcement
}

\begin{abstract}
As noted above, crucial to the effectiveness of the SPS Agreement are its provisions to create institutions and procedures at WTO level to facilitate and promote its proper implementation and to enable Members to enforce its provisions. These two aspects are addressed in detail in this Chapter. First, the provisions relating to the establishment and functions of the SPS Committee contained in Article 12 of the SPS Agreement, are discussed. Second, this Chapter proceeds to examine the rules, contained in Article 11 of the SPS Agreement, read together with the Dispute Settlement Understanding, setting out the procedure for the settlement of disputes arising under the SPS Agreement.
\end{abstract}

\subsection{The SPS Committee}

The Committee on Sanitary and Phytosanitary Measures (the SPS Committee) is established under Article 12.1 of the SPS Agreement to carry out the functions necessary to implement the provisions of the SPS Agreement and to further its objectives.

The SPS Committee is composed of representatives of all WTO Members. Members are free to determine the composition of their delegations to the meetings of the SPS Committee as they see fit. Members at higher levels of development tend to send technocrats from the relevant national ministries, such as officials from their food safety authorities or veterinary or plant health officials to meetings of the SPS Committee. ${ }^{1}$ Through creating a forum for regular interaction between key regulatory officials, the SPS Committee promotes regulatory learning and creates possibilities for building professional networks. The importance of continuous regulatory learning through monitoring and feedback mechanisms, such as those provided by the SPS Committee, has been identified as a key aspect of the type of governance needed in areas relating to complex systems, including SPS systems. ${ }^{2}$

However, many Members are not in a position to make full use of the opportunities provided by the SPS Committee for regulatory learning. Those Members that do not have the resources to send an SPS expert from their capital are represented in meetings of the SPS Committee by diplomats from their mission in Geneva, lacking in the necessary technical

\footnotetext{
1 Until 2005, the Secretariat provided a list of representatives to the SPS Committee. See for example, Committee on Sanitary and Phytosanitary Measures, List of Representatives, G/SPS/INF/16, circulated on 8 June 2005. No such list has been circulated subsequently.

${ }^{2}$ Rosie Cooney and Andrew T.F. Lang, 'Taking Uncertainty Seriously: Adaptive Governance and International Trade', European Journal of International Law 18 (3), 2007, 523-551, 524. Rosie Cooney and Andrew Lang develop a model of 'adaptive governance' that is necessary to respond to the pervasive uncertainty facing regulators in areas of SPS regulation. They point out that complex systems require a dynamic and responsive regulatory approach, based on learning, monitoring and feedback, and pluralism, through the identification of alternative regulatory options. This adaptive governance is made possible through 'open forums for discursive and communicative interaction - discussion, mutual sharing of information, problem centred negotiation - in the formulation of policy.' Ibid., 538
} 
knowledge. ${ }^{3}$ There are also some Members that are unable to send any representative to most SPS Committee meetings. ${ }^{4}$ For example, Kenya rarely sends a representative. On a few occasions, staff from Kenya's permanent mission in Geneva has attended SPS Committee meetings. ${ }^{5}$ Most often, however, Kenya is not represented at meetings of the SPS Committee at all. ${ }^{6}$ Unusually, in 2001 and 2002 a Kenyan official from the capital attended the SPS Committee meetings where EC requirements regarding cut flowers were on the agenda, as this product is of significant export interest to Kenya. The Kenyan official supported expressions of concern raised by other Members regarding measures notified by the EC with regard to cut flowers. ${ }^{7}$ While the attendance of African Members, aside from Egypt, in meetings of the SPS Committee is weak, the attendance of South and Central American and Caribbean countries has improved greatly due to a technical assistance initiative of the Inter-American Institute for Agricultural Cooperation (IICA) ${ }^{8}$ Costa

${ }^{3}$ For example, Zimbabwe reports that it is represented by its Geneva-based trade representatives or other international officials in SPS Committee meetings, but that its veterinary experts from the capital have not been involved in SPS Committee meetings. Committee on Sanitary and Phytosanitary Measures, Implementation of the SPS Agreement: Information for the Workshop on 31 March. Communication from Zimbabwe, G/SPS/ GEN/663, circulated on 28 March 2006, para. 2. Similarly, Uganda states that its attendance of SPS Committee meetings is irregular, and that when it does attend it is represented by Geneva-based trade representatives without any technical data or input from the capital. Committee on Sanitary and Phytosanitary Measures, Implementation of the SPS Agreement. Information for the Workshop on 31 March 2006. Communication from Uganda, G/SPS/GEN/673, circulated on 31 March 2006, para. 1.

${ }^{4}$ In 2006, the Gambia reported that the March 2006 meeting was the first SPS Committee meeting to which it had sent a representative. Committee on Sanitary and Phytosanitary Measures, Implementation of the SPS Agreement. Information for the Workshop on 31 March 2006. Communication from Gambia, G/SPS/GEN/664, circulated on 28 March 2006, para. 2.

${ }^{5}$ It should be noted that Kenya's mission in Geneva has only three persons working on WTO issues, all of whom have economic or business degrees. There is no legal expert among them, despite the fact that the WTO is a rules-based system and an understanding of legal issues is indispensable to ensure that Kenya enforces the market access rights available to it under WTO law. These three persons not only have to deal with all WTO issues, including negotiations, attendance of meetings etc, but also have to cover matters related to the World Intellectual Property Organization, the EU, bilateral donors, investors in Kenya and Kenyan investors in Europe. James Gathii, 'A Critical Appraisal of the Nepad Agenda in Light of Africa's Place in the World Trade Regime in an Era of Market Centred Development', Transnational Law and Contemporary Problems 13, 2003, 179-210, 202.

${ }^{6}$ Vinod Rege et al., Influencing and Meeting International Standards: Challenges for Developing Countries. Volume II: Procedures Followed by Selected International Standard-Setting Organisations and Country Reports on TBT and SPS (International Trade Centre UNCTAD/WTO and Commonwealth Secretariat, Geneva), 2004, 130.

7 Committee on Sanitary and Phytosanitary Measures, Specific Trade Concerns. Note by the Secretariat. Revision, G/SPS/GEN/204/Rev.3, circulated on 26 March 2003, paras 217-218. The EC notification addressed four harmful non-native organisms that were often found on certain products including cut flowers: Amauromyza maculosa, Bemisia tabaci, Liriomyza sativae and Thrips palmi. As most cut flowers were not subject to plant health checks but were a pathway for the organisms in question, the EC believed that control measures needed to be strengthened. Ecuador and Israel raised trade concerns on this matter at the SPS Committee meeting of 31 October - 1 November 2001. Kenya asked to receive a copy of the EC response to Ecuador's questions. The issue was raised again by Israel at the SPS Committee meeting of November 2002 and Kenya expressed its hope that a solution would be found to the problem. The European Communities agreed to bilateral consultations with Israel and Kenya. There has been no notification of an agreed solution resulting from such consultations thus far. See also Committee on Sanitary and Phytosanitary Measures, paras 45-48; Committee on Sanitary and Phytosanitary Measures, Summary of the Meeting Held on 7-8 November 2002. Note by the Secretariat, G/SPS/R/28, circulated on 5 February 2003, para. 178.

${ }^{8}$ Since October 2002, IICA's SPS Initiative for the Americas has facilitated participation in SPS Committee meetings of a total of 223 capital-based experts from 32 countries. This initiative is not limited to attendance 
Rica reports that due to this initiative it has been able to send at least one expert delegate from capital to all SPS Committee meetings since 2004 and two since 2005 (one from its Ministry of Trade and the other from its Ministry of Agriculture). In addition, its Geneva mission includes one person responsible for SPS issues, amongst other areas or responsibility, who provides support to the capital-based experts. Costa Rica has expressed its concern with the phasing out of financial assistance by IICA from 2006 onwards. It argues that, if no alternative funding is found, the efforts and achievements that participation in the Committee has brought the Initiative's beneficiary countries may be wasted. ${ }^{9}$ Costa Rica notes that in its experience, the ideal level of participation is the presence of at least one person responsible for trade and one person responsible for agriculture at all SPS Committee meetings. ${ }^{10}$

In respect of the four Members used as illustrative examples in this book, it is useful to note the differences in their representation. Australia is represented at meeting of the SPS Committee by several ministry officials with specific expertise on trade-related SPS issues. Its delegation includes representatives from the International Division of the Department of Agriculture, Fisheries and Forestry and officials from the Department of Foreign Affairs and Trade. ${ }^{11}$ These delegates participate very actively in both formal and informal SPS Committee meetings. Not only do they make use of the possibility provided by the SPS Committee to discuss trade concerns, but they have also played a key role in the elaboration of Committee decisions, for example the Decision on Regionalisation. ${ }^{12}$ By contrast, Mauritius's participation in the informal and formal meetings of the SPS Committee is rather poor. Representation by capital-based officials has decreased due to local economic constraints. While this used to occur once or twice yearly, Mauritius reports that its government is currently unable to fund the participation of capital-based

\footnotetext{
of meetings but also promotes the establishment of offices at national level to follow the activities of SPSrelated international bodies, particularly the SPS Committee. In view of the aim of gradually transferring financial responsibility to the supported Members, the financial assistance granted is being progressively reduced. Currently only air travel is funded. As a result, of the 28 Members that are part of the Initiative, 15 (53\%) sent capital-based experts to the SPS Committee meeting of March 2008. Committee on Sanitary and Phytosanitary Measures, Actions for Implementing the WTO Agreement on Sanitary and Phytosanitary Measures. Information Presented by the Inter-American Institute for Agricultural Cooperation (IICA), G/SPS/ GEN/835, circulated on 27 March 2008, paras 2-4. Scott reports that due to the role of the US in funding this Initiative, Venezuela and Cuba are excluded from benefiting. Joanne Scott, The WTO Agreement on Sanitary and Phytosanitary Measures: A Commentary, Oxford Commentaries on the GATT/WTO Agreements (Oxford University Press, Oxford), 2007, 49.

${ }^{9}$ Committee on Sanitary and Phytosanitary Measures, Implementation of the SPS Agreement. Information for the Workshop on 31 March 2006. Communication from Costa Rica, G/SPS/GEN/679, circulated on 31 March 2006, paras 2-3.

${ }_{10}$ Ibid., para. 3.

11 Australian Government Department of Agriculture Fisheries and Forestry, Annual Report 2006-07. Growing Australia through Sustainable, Innovative and Profitable Agriculture, Fisheries and Forestry (Commonwealth of Australia, Canberra), September 2007, 107, available at: http://www.daff.gov.au/_data/ assets/pdf_file/0005/439493/2_AR_06-07_ROP_WEB.pdf, visited on 17 January 2008. In 2005, Australia was represented at meetings of he SPS Committee by the General Manager and one other official of Technical Market Access Strategy Division, of the Australian Government Department of Agriculture, Fisheries and Forestry, and two officials from the Office for Trade Negotiations of the Australian Government Department of Foreign Affairs and Trade. Committee on Sanitary and Phytosanitary Measures, List of Representatives, G/ SPS/INF/16, circulated on 8 June 2005.

${ }^{12}$ See above, Part II, Section 2.4.3.
} 
experts to the SPS Committee. ${ }^{13}$ Instead, Mauritius is represented at SPS Committee meetings by the technical advisor to its Permanent Mission to the UN in Geneva. ${ }^{14}$ However given the technical/scientific nature of discussions of the SPS Committee, this representative finds it difficult to contribute to the SPS Committee effectively and to initiate follow-up action. ${ }^{15}$ Jamaica's attendance of meetings of the SPS Committee is sporadic at best due to resource constraints. ${ }^{16}$ At those meetings that Jamaica has attended, it has been represented by its permanent mission in Geneva, under instruction from the ministries involved in SPS and trade matters. ${ }^{17}$ On one occasion, a FSPID official from the capital attended a meeting of the SPS Committee. ${ }^{18}$ The representation of Bangladesh at SPS Committee meetings is better. SPS Committee meetings are regularly attended by officials from the Ministry of Commerce or from the permanent mission of Bangladesh in Geneva. ${ }^{19}$ However, depending on the issues being discussed at a particular meeting, an official from a different ministry may participate in the meeting. In particular, SPS Committee meetings where measures on shrimp products are on the agenda are attended by officials from the Ministry of Fisheries and Livestock. ${ }^{20}$

The SPS Committee meets formally at least three times a year, with additional informal meetings as the need arises. ${ }^{21}$ In March 1995, the SPS Committee adopted working procedures for the conduct of its meetings.22 In March 1997, the SPS Committee agreed that the Rules of Procedure for meetings of the General Council ${ }^{23}$ shall apply mutatis mutandis to its meetings, except as otherwise provided in the Working Procedures. ${ }^{24}$ Meetings of the

13 Committee on Sanitary and Phytosanitary Measures, Experience with the Implementation of the SPS Agreement. Information for the Workshop on 31 March 2006. Communication from Mauritius, G/SPS/ GEN/657, circulated on 27 March 2006, para. 2.

${ }^{14}$ Committee on Sanitary and Phytosanitary Measures, List of Representatives, G/SPS/INF/16, circulated on 8 June 2005.

15 Committee on Sanitary and Phytosanitary Measures, Experience with the Implementation of the SPS Agreement. Information for the Workshop on 31 March 2006. Communication from Mauritius, G/SPS/ GEN/657, circulated on 27 March 2006, para. 2.

${ }^{16}$ Constraints identified in the report by the ITC and Commonwealth Secretariat are the small size of Jamaica's mission in Geneva and the lack of funds to send capital-cased officials to Geneva. Vinod Rege et al., Influencing and Meeting International Standards: Challenges for Developing Countries. Volume II: Procedures Followed by Selected International Standard-Setting Organisations and Country Reports on TBT and SPS (International Trade Centre UNCTAD/WTO and Commonwealth Secretariat, Geneva), 2004, 116.

${ }^{17}$ It is interesting to note, however, that Scott reports that the Jamaican delegate is particularly voluble and effective. Joanne Scott, The WTO Agreement on Sanitary and Phytosanitary Measures: A Commentary, Oxford Commentaries on the GATT/WTO Agreements (Oxford University Press, Oxford), 2007, footnote 25.

18 Vinod Rege et al., Influencing and Meeting International Standards: Challenges for Developing Countries. Volume II: Procedures Followed by Selected International Standard-Setting Organisations and Country Reports on TBT and SPS (International Trade Centre UNCTAD/WTO and Commonwealth Secretariat, Geneva), 2004, 116.

${ }^{19}$ Committee on Sanitary and Phytosanitary Measures, Implementation of the SPS Agreement. Information for the Workshop on 31 March 2006. Communication from Bangladesh, G/SPS/GEN/676, circulated on 31 March 2006.

20 Ibid.

${ }^{21}$ In 2007, the SPS Committee held three formal meetings. World Trade Organization, Report (2007) on the Activities of the Committee on Sanitary and Phytosanitary Measures, G/L/842, circulated on 20 November 2007, para. 2 .

${ }^{22}$ Committee on Sanitary and Phytosanitary Measures, Working Procedures of the Committee - Adopted by the Committee at Its Meeting of 29-30 March 1995, G/SPS/1, circulated on 4 April 1995.

${ }^{23}$ General Council Chairman.

${ }^{24}$ Committee on Sanitary and Phytosanitary Measures, Rules of Procedure for Meetings of the Committee 
SPS Committee are chaired by an annually appointed Chairperson. ${ }^{25}$ The SPS Committee is supported by officials of the Agriculture and Commodities Division of the WTO Secretariat. Reports of the meetings of the SPS Committee are published promptly on the WTO website, and a yearly summary of its activities is drawn up by the Chairperson for submission to the General Council. ${ }^{26}$

Observer status in the SPS Committee is accorded to non-Member governments that have been granted Observer status in higher WTO bodies, ${ }^{27}$ as well as to certain international inter-governmental organisations with a mandate in the area of sanitary or phytosanitary issues. ${ }^{28}$ After initially agreeing to grant Observer status to the CAC, OIE, IPPC, FAO, WHO, ISO, ITC, and UNCTAD, ${ }^{29}$ in 1999, the SPS Committee agreed to adopt criteria for deciding on requests for observer status. These are: the mandate, scope and area of work of the applicant organisation; its contribution to the work of the SPS Committee; and reciprocity with regard to the grant of observer status to the WTO. ${ }^{30}$ However, due to concerns by Members with regard to granting Observer status to other intergovernmental organisations, the Committee agreed, as an interim step, to apply these criteria on an $a d$ hoc, meeting-by-meeting basis with regard to other requests for Observer status. The SPS Committee conducts informal consultations with various international intergovernmental organisations regarding the recognition of their Observer status at meetings of the SPS Committee. Observer status on an ad hoc meeting-by-meeting basis was granted in November 1999 to the ACP Group, the European Free Trade Area (EFTA), the IICA, the OECD, the Regional International Organization for Plant Protection and Animal Health (OIRSA), and the Latin American Economic System (SELA). ${ }^{31}$ In practice, all of these organizations have been invited to attend all SPS Committee meetings since November

on Sanitary and Phytosanitary Measures: Approved by the Council for Trade in Goods on 11 June 1997, G/L/170, circulated on 20 June 1997. The Committee on Trade in Goods approved the rules of procedure for the SPS Committee on 11 June 1997.

${ }_{25}$ The Council for Trade in Goods selects the Chairperson of the SPS Committee, in consultation with the Committee. The selection is preceded by the submission by the SPS Committee of a list of candidates to the Council for Trade in Goods. The Chairperson does not have to be selected from amongst persons on this list. The Chairperson does not participate in meetings of the SPS Committee as a representative of a Member. Joanne Scott, The WTO Agreement on Sanitary and Phytosanitary Measures: A Commentary, Oxford Commentaries on the GATT/WTO Agreements (Oxford University Press, Oxford), 2007, footnote 23.

${ }^{26}$ For the 2007 report, see World Trade Organization, Report (2007) on the Activities of the Committee on Sanitary and Phytosanitary Measures, G/L/842, circulated on 20 November 2007.

${ }^{27}$ Observer status is granted to countries that are in the process of accession to the WTO.

${ }^{28}$ Committee on Sanitary and Phytosanitary Measures, Criteria for Observer Status. Note by the Secretariat, G/SPS/GEN/229, circulated on 23 February 2001. For an example of the information provided under these three criteria in the recent application for observer status of the Gulf Cooperation Council Standardization Organization, see Committee on Sanitary and Phytosanitary Measures, Applicants for Observer Status: Note by the Secretariat (Addendum), G/SPS/GEN/121/Add.3, circulated on 5 October 2007.

${ }^{29}$ At its first meeting, in line with the Working Procedures, the SPS Committee granted observer status to the CAC, OIE and IPPC. In June 1995, Observer status was granted to FAO and WHO; in November 1995 to ISO and ITC; and in March 1996 to UNCTAD.

${ }^{30}$ Committee on Sanitary and Phytosanitary Measures, Consideration of Requests for Observer Status. Note by the Secretariat, G/SPS/W/98, circulated on 19 February 1999, para. 7. These criteria were adopted at the meeting of the SPS Committee of March 1999. Committee on Sanitary and Phytosanitary Measures, Summary of the Meeting Held on 10-11 March 1999: Note by the Secretariat, G/SPS/R/14, circulated on 7 May 1999.

31 Committee on Sanitary and Phytosanitary Measures, International Intergovernmental Organisations. Requests for Observer Status in the Committee on Sanitary and Phytosanitary Measures. Revision, G/ SPS/W/78/Rev.3, circulated on 3 July 2007. 
1999, with the decision being renewed at each meeting. ${ }^{32}$ Requests for Observer status from the Asian and Pacific Coconut Community (APCC), the Convention on Biological Diversity (CBD), Gulf Cooperation Council Standardization Organization (GSO) and the International Vine and Wine Office (OIV) have proved controversial and are still pending. Observers may be invited to speak and may table papers but do not participate in decision-making in the Committee.

Decisions of the SPS Committee are taken by consensus of the Members, as required by Article 12.1 of the SPS Agreement. Interestingly, the procedure for adoption of decisions practiced by the SPS Agreement, known as adoption 'ad referendum', provides an opportunity for Members not present at the relevant SPS Committee meeting where adoption is decided upon, to participate in decision-making. This practice entails that a decision is provisionally adopted if there is consensus in favour of adoption among the Members present at the relevant SPS Committee meeting. However, final adoption is dependant on the absence of objections to the decision by a specified deadline. This provides the opportunity for Members not present at the meeting where provisional adoption took place to consider the proposed decision and raise objections, preventing the final adoption of the decision. Where objections have been raised by Members to decisions adopted ad referendum their concerns have been addressed in further discussions in the SPS Committee, as with the decision on transparency of SDT, or through proactive consultations conducted by the Chairperson of the SPS Committee, as with the Equivalence Decision. ${ }^{33}$ In doing so, this practice ensures broad support for the decisions adopted by the SPS Committee, which is particularly important to secure implementation thereof in view of their legal status. ${ }^{34}$

The SPS Committee is entrusted with various tasks under Article 12. ${ }^{35}$ These tasks will now be discussed with particular attention to the work the Committee has undertaken in fulfilment of its mandate.

\subsubsection{Furtherance of the implementation of the SPS Agreement}

Article 12.1 gives the SPS Committee the general mandate to carry out the functions necessary to implement the SPS Agreement and to further its objectives. The SPS Committee has undertaken a broad range of activities under this mandate.

In particular, the norm-creating role of the SPS Committee in fulfilment of this mandate is significant. Rosie Cooney and Andrew Lang refer, in this regard, to the SPS Committee's 'softer or more informal modes of revision' of the SPS Agreement than could occur through amendment or authoritative interpretations thereof. They state:

${ }^{32}$ Committee on Sanitary and Phytosanitary Measures, Criteria for Observer Status. Note by the Secretariat, G/ SPS/GEN/229, circulated on 23 February 2001, para. 5.

33 See above, Part IV, Section 1.1.6. The proactive role of the Chairperson is noted by Joanne Scott. Joanne Scott, The WTO Agreement on Sanitary and Phytosanitary Measures: A Commentary, Oxford Commentaries on the GATT/WTO Agreements (Oxford University Press, Oxford), 2007, 48, footnote 20.

${ }^{34}$ On the legal status of the decisions of the SPS Committee, see below, Part IV, Section 2.1.1.

${ }^{35}$ The SPS Committee also has a task relating to SDT of developing countries in terms of Article 10.3 of the SPS Agreement, which is discussed below, Part V, Section 1.5. 
It is important to remember that the WTO legal system is more than just the WTO texts as interpreted by the Appellate Body and Panels - these rules are embedded within, and shaped by, a wide variety of informal understandings and social norms at play within the trading system. Particularly where legal texts are ambiguous, little known or poorly understood ... normative guidance is provided, not so much by the rules themselves, but by semi-formal consensus concerning how they are to be implemented, and how they apply in particular circumstances. The point is that the SPS Committee is one venue in which such semi-formal norms are generated and revised... ${ }^{36}$

As already discussed, several decisions have been adopted by the SPS Committee to promote the implementation of the provisions of the SPS Agreement. The decisions of the SPS Committee do not lay down enforceable obligations, but instead provide guidelines to facilitate the implementation of specific provisions. In particular, in order to promote the implementation of the transparency obligations in the SPS Agreement (Article 7 and Annex B), the SPS Committee adopted and revised three times the Recommended Transparency Procedures for SPS measures, which set out guidelines for compliance with the notification and publication obligations of the SPS Agreement, including formats for the notification of routine and emergency measures. In addition, as stated above the SPS Committee has adopted non-binding guidelines for the implementation of Article 5.5 (on consistency in the appropriate level of protection), Article 4 (on equivalence) and Article 6 (on regionalisation) of the SPS Agreement. ${ }^{37}$ As discussed below, it has also adopted a decision to enhance the transparency of SDT. ${ }^{38}$ Wolfe points out that:

most 'clarification' of the SPS agreement seems to come, not from Appellate Body decisions, but from how officials understand the WTO 'aquis' through their ongoing negotiations with each other... ${ }^{39}$

The decisions of the SPS Committee, as has been seen above, are typically based on technical discussions based on concrete experiences of Members regarding specific provisions of the SPS Agreement. These discussions may take place in furtherance of an express mandate in the SPS Agreement, such as that contained in Article 5.5, which requires the development by the SPS Committee of guidelines for the practical implementation of that Article; or that in Articles 3.5 and 12.4 which mandate the development of procedures to monitor the process of international harmonisation. Discussions leading to a decision may also occur in response to a mandate provided by the General Council, for example that with regard to the implementation problems arising with regard to the provision on the recognition of equivalence. Further, these discussions may be initiated by Members, for example, the discussions that led to the adoption of the decision on transparency of SDT, discussed below, that originated in proposals of Egypt and Canada. ${ }^{40}$ Finally, as

\footnotetext{
${ }^{36}$ Rosie Cooney and Andrew T.F. Lang, 'Taking Uncertainty Seriously: Adaptive Governance and International Trade', European Journal of International Law 18 (3), 2007, 523-551, 548.

${ }^{37}$ See above, Part III, Section 5.2.3.5 and Part IV, Sections 1.1.6 and 1.2.6.

${ }^{38}$ See below, Part V, Section 1.8.

${ }^{39}$ Robert Wolfe, 'See You in Geneva? Legal (Mis)Representations of the Trading System', European Journal of International Relations 11 (3), 2005, 339-364, 353.

${ }^{40}$ See below, Part V, Section 1.8.
} 
was the case with the guidelines to further the practical implementation of Article 6 on regionalisation, the discussions in the SPS Committee may be initiated by the Committee itself. ${ }^{41}$ As input into the discussions, Members are encouraged to provide information on their practical experiences in respect of the relevant provision under discussion. This process of information sharing promotes regulatory learning between Members and ensures that the decisions of the SPS Committee are congruent with the practices of those actors whose conduct they aim to guide. ${ }^{42}$ The practice of adopting decisions ad referendum, as discussed above, improves the opportunities for participation by Members at lower levels of development that may lack the resources to send a delegate with sufficient expertise on the subject matter of the decision, or any delegate at all, to the relevant SPS Committee meetings. In addition, the fact that the SPS Committee maintains the subjects of its decisions, such as transparency, equivalence, regionalisation and SDT, as agenda items at its meetings and often revises its decisions on the basis of ongoing discussion, ensures responsiveness to evolving practice, and allows for 'learning by doing'. ${ }^{43}$

The legal status of the various decisions adopted by the SPS Committee brings up interesting questions. As stated above, these decisions were adopted under the authority of the SPS Committee to carry out the functions necessary to implement and further the objectives of the SPS Agreement under Article 12.1 of the SPS Agreement. The authority of the SPS Committee does not extend to amending, or making authoritative interpretations of, the provisions of the SPS Agreement. ${ }^{44}$ Therefore, the decisions expressly state that they do not add to or detract from the existing rights and obligations of Members under the SPS Agreement or any other WTO agreement, and that they do not provide an authoritative interpretation or modification to the SPS Agreement itself.

${ }^{41}$ The initiation of these discussions in 2003, flowed from the recognition, at the conclusion of the first review of the SPS Agreement in 1999, "that adaptation to regional conditions, including the recognition of pest- or disease-free areas or areas of low pest or disease prevalence, was of significant importance for trade in agricultural products'and that 'Members faced difficulties in the implementation of Article 6 of the Agreement.' This is stated in the preamble to the Regionalisation Decision.

${ }^{42}$ Robert Wolfe notes that in order to ensure the legitimacy of the results of decision-making at the WTO, "the process needs to engage the actors whose conduct will be regulated. The effect of the most elegantly drafted agreement will be minimal if it is incongruent with the informal practices and mutual expectations of actors in the trading system.' Robert Wolfe, 'Decision-Making and Transparency in the 'Medieval' WTO: Does the Sutherland Report Have the Right Prescription?' Journal of International Economic Law 8 (3), 2005, 631645,633 .

43 The need for review is often provided for in the Decisions themselves. See Committee on Sanitary and Phytosanitary Measures, Decision on the Implementation of Article 4 of the Agreement on the Application of Sanitary and Phytosanitary Measures, G/SPS/19, circulated on 24 October 2001, para. 13; Committee on Sanitary and Phytosanitary Measures, Guidelines to Further the Practical Implementation of Article 6 of the Agreement on the Application of Sanitary and Phytosanitary Measures, G/SPS/48, circulated on 16 May 2008, para. 3; Committee on Sanitary and Phytosanitary Measures, Procedure to Enhance Transparency of Special and Differential Treatment in Favour of Developing Country Members. Decision by the Committee of 27 October 2004, G/SPS/33, circulated on 2 November 2004, para. 4.

44 Authoritative interpretations of the WTO agreements lie in the exclusive authority of the Ministerial Conference and the General Council, in terms of Article IX:2 of the WTO Agreement. The authority to amend WTO agreements is reserved for the Ministerial Conference under Article X of the WTO Agreement. The SPS Committee is authorised under Article 12.7 of the SPS Agreement to make proposals to the Council for Trade in Goods for amendments to the SPS Agreement, following the periodic review of the Agreement. Such proposals may be submitted by the Council for Trade in Goods to the Ministerial Conference under Article $\mathrm{X}: 1$ of the WTO Agreement. However, neither of the two periodic reviews of the SPS Agreement conducted so far have led to proposals for amendments. On the periodic reviews, see further below, Part IV, Section 2.1.4. 
However, this does not detract from the fact that the SPS Committee has been given the authority to make decisions within its area of competence. Decisions of the SPS Committee cannot be enforced directly in dispute settlement proceedings, since they are not 'covered agreements' for purposes of the DSU, and only claims under a 'covered agreement' fall within the jurisdiction of panels or the Appellate Body. ${ }^{45}$ However, arguably the decisions of the SPS Committee must be had regard to in the interpretation of the relevant Articles of the SPS Agreement in dispute settlement proceedings. This is because they can be seen as constituting subsequent agreements between WTO Members regarding the interpretation of the SPS Agreement in terms of Article 31.3(a) of the Vienna Convention on the Law of Treaties, which reflects customary international law with regard to treaty interpretation. ${ }^{46}$ As stated by the International Law Commission in its Commentary on Article 31.3(a):

An agreement as to the interpretation of a provision reached after the conclusion of the treaty represents an authentic interpretation by the parties which must be read into the treaty for purpose of its interpretation. ${ }^{47}$

As such subsequent agreements, the decisions of the SPS Committee must be considered together with the context for interpreting the SPS Agreement, despite the fact that they do not constitute 'authoritative interpretations' of the SPS Agreement under Article IX:2 of the WTO Agreement.

Reference has been made to decisions of the SPS Committee in dispute settlement proceedings twice thus far. In Japan - Apples, in interpreting the meaning of the term 'significant effect on trade' in Annex B.5 of the SPS Agreement, the Panel referred in footnote to the Recommended Transparency Provisions ${ }^{48}$ adopted by the SPS Committee, which clarify this concept. ${ }^{49}$ In EC - Approval and Marketing of Biotech Products, the Panel relied on the SPS Committee's Guidelines on Article 5.5 for its interpretation of the scope of application of Article 5.5 of the SPS Agreement ${ }^{50}$ This use of the decisions of the SPS Committee is to be commended, as it makes it possible for Members, through technical discussions among their delegates to the SPS Committee, to reach agreements 'fleshing

\footnotetext{
45 Article 3.1 and 3.2 of the DSU.

${ }^{46}$ It is useful to note that the Appellate Body in US - Shrimp, in support of its interpretation of the chapeau of Article XX of the GATT 1994 to require serious efforts to negotiate a multilateral solution before imposing a unilateral measure, referred to a report of the Committee on Trade and Environment, which was also part of the report of the General Council to the Singapore Ministerial Conference. It used this report to show that WTO Members endorsed and supported the idea that multilateral solutions based on international cooperation are the best solution to transboundary environmental problems. Appellate Body Report, US - Shrimp, para. 168.

${ }^{47}$ International Law Commission, 'Commentary on the draft Vienna Convention', Yearbook of the International Law Commission, 1966, II, 221.

48 Specifically, the Panel referred to Committee on Sanitary and Phytosanitary Measures, Recommended Procedures for Implementing the Transparency Obligations of the SPS Agreement (Article 7). Revision, G/ SPS/7/Rev.2, circulated on 2 April 2002, para. 7.

${ }^{49}$ Panel Report, Japan-Apples, para. 8.314, footnote 422.

${ }^{50}$ Panel Reports, EC - Approval and Marketing of Biotech Products, para. 7.1415. In particular, the Panel relied on the provision in para. B.1 of the Guidelines on Article 5.5 (stating that the concept of appropriate level of protection is applied in practice through SPS measures) for its finding that although Article 5.5 does not expressly refer to SPS measures, for it to apply there must be an SPS measure imposed to achieve a particular appropriate level of protection. Ibid., para. 7.1416.
} 
out' the weaker provisions of the SPS Agreement thereby operationalising them. Such agreements are far more likely to be reached at this technical level than through more political negotiations at the General Council or Ministerial Conference under the procedures for authoritative interpretations or amendments. Of course, however, the decisions made by the SPS Committee cannot amend the provisions of the SPS Agreement or alter the rights and obligations contained therein. ${ }^{51}$

This limit to the legal status of the decisions of the SPS Committee is in fact useful, in that it facilitates consensus decision-making in the SPS Committee. As argued by Joanne Scott, if the decisions of the SPS Committee were to be given specific authority in dispute settlement proceedings, the activities of the SPS Committee would be impeded as Members might be reluctant to adopt decisions that would later be subject to interpretation and enforcement by panels or the Appellate Body. ${ }^{52}$ Currently the SPS Committee has proved an effective decision-maker, enabling Members to effect much-needed improvements to the regime of the SPS Agreement, particularly through the development of appropriate procedures for the operationalisation of its provisions. In addition, the opportunity for review of the decisions of the SPS Committee means that they can be revised and improved on the basis of Members' experiences with their use.

It would thus be mistaken to view the importance of the decisions of the SPS Committee as limited to their possible role in dispute settlement proceedings. Instead, their main achievement lies in the facilitation of the implementation by Members of their obligations. For example, despite the fact that non-compliance with the Recommended Transparency Procedures of the SPS Committee cannot be challenged directly in dispute settlement, these procedures and the notification formats contained therein are commonly used by Members in the fulfilment of their transparency obligations.

\subsubsection{Forum for consultations}

An important advantage arising from the establishment of the SPS Committee is the opportunity it offers for regular information exchange between regulatory officials with regard to specific issues that arise with regard to SPS matters, in order to achieve cooperative solutions. To make full use of this opportunity, Article 12.2 mandates the SPS Committee to 'encourage and facilitate ad hoc consultations or negotiations among Members on specific sanitary or phytosanitary issues.' Coupled with the transparency obligations, this provision goes a long way towards helping Members to solve SPS conflicts in a low-cost manner, without necessarily having to resort to dispute settlement. This has particularly important potential benefits for developing-country Members.

\footnotetext{
${ }^{51}$ As noted by Rosie Cooney and Andrew Lang, the activities of the SPS Committee (in respect of guidance regarding and clarification of the provisions of the SPS Agreement) are 'carefully circumscribed so as not to change the formal rights and obligations under the SPS Agreement, and they are certainly not authoritative interpretations in the sense of Article IX:2. Nevertheless they perform crucial functions of norm generation and revision, which some have described as quasi-legislative in nature.' Rosie Cooney and Andrew T.F. Lang, 'Taking Uncertainty Seriously: Adaptive Governance and International Trade', European Journal of International Law 18 (3), 2007, 523-551, 549.

52 Joanne Scott, The WTO Agreement on Sanitary and Phytosanitary Measures: A Commentary, Oxford Commentaries on the GATT/WTO Agreements (Oxford University Press, Oxford), 2007, 74.
} 
The SPS Committee has carried out its task under this provision in three main ways. Namely, through the creation of a permanent agenda item for the discussion of specific trade concerns with regard to notified measures at meetings of the SPS Committee; through discussions at SPS Committee meetings of specific issues that arise (such as the issue of private standards and the problems faced by Members arising from the IPPC standard on wood packaging material); and through the development of a mechanism for making use of the good offices of the Chairperson of the SPS Committee to facilitate the resolution of disputes between Members..$^{53}$ These are now discussed in more detail.

To give effect to Article 12.2, at each of its regular meetings, the SPS Committee maintains a standing agenda item for the specific trade concerns of Members regarding SPS measures of other Members. The specific trade concerns are often raised in response to notifications of new or amended SPS measures received and circulated by the WTO Secretariat under the transparency provisions of Article 7 and Annex B. These specific trade concerns are compiled into a document by the Secretariat, by means of periodic revisions. $^{54}$

Members raising specific trade concerns are required to notify the Secretariat and the Member concerned in advance. ${ }^{55}$ They must also provide an outline of the trade concern. They do so in practice by giving the Secretariat copies of their correspondence with the Member concerned regarding the inclusion of the item on the agenda, or by providing the Member concerned with a copy of their request to the Secretariat for inclusion of the specific trade concern on the agenda. ${ }^{56}$ However, sometimes Members do not provide the required outline of their specific concerns.

Most often, bilateral discussions on trade concerns placed on the agenda are held in the margins of SPS Committee meetings. When sufficient progress is made bilaterally on resolving the matter, the concern may be withdrawn from the agenda of the SPS Committee meeting. If no solution is achieved bilaterally, discussions take place in the SPS Committee with regard to the specific trade concerns raised. The exporting Member raising the concern is first given the floor, after which other interested Members are

53 Committee on Sanitary and Phytosanitary Measures, Ad Hoc Consultations and Resolution of Trade Concerns, G/SPS/GEN/781, circulated on 15 June 2007, para. 3.

${ }^{54}$ The revisions since 2005 follow a different format, in that they are divided into several parts to facilitate information retrieval and the circulation of the document. See Committee on Sanitary and Phytosanitary Measures, Specific Trade Concerns. Note by the Secretariat. Addendum: Part 4, G/SPS/GEN/204/Rev.5/Add.3, circulated on 25 February 2005; Committee on Sanitary and Phytosanitary Measures, Specific Trade Concerns. Note by the Secretariat. Revision: Part 1, G/SPS/GEN/204/Rev.5, circulated on 25 February 2005; Committee on Sanitary and Phytosanitary Measures, Specific Trade Concerns. Note by the Secretariat. Addendum: Part 2, G/SPS/GEN/204/Rev.5/Add.1, circulated on 25 February 2005; Committee on Sanitary and Phytosanitary Measures, Specific Trade Concerns. Note by the Secretariat. Addendum: Part 3, G/SPS/GEN/204/Rev.5/ Add.2, circulated on 25 February 2005. In 2007, 16 new trade concerns were raised.

${ }^{55}$ Although the Working Procedures of the SPS Committee do not make express provision for raising specific trade concerns, the SPS Committee applies the procedure for matters relating to notifications also to the raising specific trade concerns at Committee meetings. According to this procedure, matters relating to notifications can be raised in the course of any meeting. A Member proposing to raise a matter relating to a particular notification in a meeting must notify this intention to the relevant notifying Member and the Secretariat, together with an outline of its concerns, as far as possible in advance of the meeting.

${ }^{56}$ Where it does not appear that the other Member concerned has been duly informed, the Secretariat may remind the requesting Member of this requirement. Committee on Sanitary and Phytosanitary Measures, $\mathrm{Ad}$ Hoc Consultations and Resolution of Trade Concerns, G/SPS/GEN/781, circulated on 15 June 2007, para. 7. 
invited to comment. Often several other interested Members may join in supporting the specific trade concern raised, increasing the pressure on the Member involved to address the problems identified. Finally, the floor is given to the Member maintaining the measure, so that it can respond. ${ }^{57}$ The discussions could lead to the revision of the notified measure or to further bilateral consultations between the Members involved. Sometimes technical or financial assistance may be provided to facilitate compliance with the contested measure. ${ }^{58}$ Through the use of the specific trade concerns mechanism, disputes can often be resolved without recourse to the expensive and time-consuming process of formal dispute settlement. In addition, Members learn from each other and obtain clarity with regard to the operation of the different SPS regimes in place in other Members. As aptly put by Joanne Scott:

In a significant number of cases, the back and forth contestation and reasoned justification leads to a change in behaviour of Member States. Not only does it serve to induce compliance in situations where this was otherwise lacking, but it also serves to elucidate what it is that compliance demands. ${ }^{59}$

In addition to the direct benefits of the specific trade concerns mechanism in relation to the resolution of disputes, indirect benefits are reaped from this mechanism. These flow from increased familiarity of Members with each other's regulatory systems due to the regular contact and sharing of experiences between Members' officials. Members may gain confidence in the regulatory capacity of the alternative SPS regimes maintained by other Members. This confidence has an impact on issues such as the recognition of equivalence and of pest- or disease free areas. Another indirect benefit relates to improvements in SPS governance. Cooney and Lang view the specific trade concern mechanism as well-suited to problem-centred information exchange. This is valued by the adaptive approaches to governance that are necessitated in respect of complex systems, such as SPS systems. ${ }^{60}$

An example of the direct and indirect benefits of this mechanism is provided by the specific trade concern against the EC's notification of a proposed reduction in its MRL for aflatoxins. This concern was raised by Australia, Argentina, Bolivia, Brazil, Gambia, India, Indonesia, Malaysia, the Philippines, Senegal and Thailand and supported by Canada, Colombia, Mexico, Pakistan, Paraguay, Peru, South Africa, Turkey, the US and Uruguay. ${ }^{61}$ These Members argued that the proposed MRL would drastically affect trade

\footnotetext{
${ }^{57} \mathrm{Ibid}$., para. 9. It is open to Members who wish to do so to circulate documents with more detailed information on the matter at issue, either in advance of or at the time of the Committee meeting.

${ }^{58}$ As noted by Joanne Scott: 'The readiness of States to cooperate in problem-solving in the [SPS] committee, including in the provision of technical assistance to developing country Members, stands in contrast to the difficulties associated with formal attempts to re-draw the parameters of special and differential treatment for developing countries within the SPS frame.' Joanne Scott, The WTO Agreement on Sanitary and Phytosanitary Measures: A Commentary, Oxford Commentaries on the GATT/WTO Agreements (Oxford University Press, Oxford), 2007, 46. On the attempts to operationalise special and differential treatment, see below, Part V, Section 1.7.

${ }^{59}$ Ibid., 75.

${ }^{60}$ Rosie Cooney and Andrew T.F. Lang, 'Taking Uncertainty Seriously: Adaptive Governance and International Trade', European Journal of International Law 18 (3), 2007, 523-551, 550. These adaptive approaches are called for in respect of complex systems due to the prevalence of uncertainty.

${ }^{61}$ Committee on Sanitary and Phytosanitary Measures, Specific Trade Concerns. Note by the Secretariat.
} 
but would have insignificant health benefits. ${ }^{62}$ They also claimed that no risk assessment seemed to have been conducted and that the sampling procedure was unduly costly and burdensome. ${ }^{63}$ At the time, the Codex Committee on Food Additives and Contaminants was considering an aflatoxin standard but while many members supported the proposed standard, the EC did not. The US encouraged the EC to take account of the FAO/WHO risk assessments regarding MRLs for consumer-ready products. ${ }^{64}$ Bolivia stressed the effect of the proposed MRL on its nut exports and requested to see the risk assessment on which it was based. In response to the comments of Bolivia and other Members, the EC extended the comment period and revised its proposal, raising the MRL for nuts. However, Bolivia remained concerned with the trade effect of the EC measure. In November 1998, the Chairperson of the SPS Committee reported that bilateral consultations between the EC and Bolivia, which he had been asked to facilitate, had been fruitful. ${ }^{65}$ Bolivia was better able to understand the rationale behind the EC measure and the procedures to be followed. The EC's understanding of the effect of its measure on Bolivia was improved. ${ }^{66}$ Following this exchange, Bolivia presented a plan to improve its production of Brazil nuts, a specific type of nut, and indicated that this would be a good case for the application of SDT. ${ }^{67}$ An EC expert visited Bolivia in May 2000 and a EuropeAid project was initiated to address weaknesses in the production chain and the equipment used in Bolivia. In addition, the EC proposed a certification procedure to allow three Bolivian laboratories to issue internationally recognised certificates. After some delays in the implementation of the promised technical assistance, in June 2003, Bolivia reported that a favourable outcome had been reached and Bolivia would soon be granted permission to export its nuts to the EC. ${ }^{68}$

From 1995 until the end of 2007, 261 specific trade concerns had been raised by Members. ${ }^{69}$ The greatest number of concerns raised relate to measures addressing animal health issues including zoonoses, ${ }^{70}$ accounting for 42 percent of the total. 28 percent of

\footnotetext{
Addendum. Resolved Issues, G/SPS/GEN/204/Rev.8/Add.3, circulated on 27 March 2008, item 39.

${ }^{62}$ See further on this issue Tsunehiro Otsuki et al., Saving Two in a Billion: A Case Study to Quantify the Trade Effect of European Food Safety Standards on African Exports (World Bank Development Research Group, Washington D.C.), 2000, available at: http://www1.worldbank.org/wbiep/trade/Standards/aflatoxins.pdf, visited on 5 April 2001.

${ }^{63}$ Committee on Sanitary and Phytosanitary Measures, Summary of the Meeting Held on 12-13 March 1998, G/ SPS/R/10, circulated on 30 April 1998, paras 24-31.

${ }^{64}$ Committee on Sanitary and Phytosanitary Measures, Specific Trade Concerns. Note by the Secretariat. Addendum. Resolved Issues, G/SPS/GEN/204/Rev.8/Add.3, circulated on 27 March 2008, para. 118.

${ }^{65}$ Committee on Sanitary and Phytosanitary Measures, Summary of the Meeting Held on 10-11 November 1998. Note by the Secretariat, G/SPS/R/13, circulated on 15 January 1999, para. 26. On the possibility to make use of the good offices of the Chairperson, see further below, in this Section.

${ }^{66}$ Committee on Sanitary and Phytosanitary Measures, Specific Trade Concerns. Note by the Secretariat. Addendum. Resolved Issues, G/SPS/GEN/204/Rev.8/Add.3, circulated on 27 March 2008, para. 120.

${ }^{67}$ Committee on Sanitary and Phytosanitary Measures, Summary of the Meeting Held on 10-11 March 1999: Note by the Secretariat, G/SPS/R/14, circulated on 7 May 1999, paras 64-66.

${ }^{68}$ Committee on Sanitary and Phytosanitary Measures, Summary of the Meeting Held on 24-25 June 2003: Note by the Secretariat, G/SPS/R/30, circulated on 4 September 2003, para. 66.

${ }^{69}$ Committee on Sanitary and Phytosanitary Measures, Specific Trade Concerns. Note by the Secretariat. Revision, G/SPS/GEN/204/Rev.8, circulated on 27 March 2008, para. 7. In 2007 alone, 16 new trade concerns were raised.

${ }^{70}$ Of these concerns, $36 \%$ relate to transmissible spongiform encephalopathy, $23 \%$ to food and mouth disease, $9 \%$ to avian influenza and the remaining $32 \%$ to a variety of other animal health concerns. Ibid.
} 
the total number of concerns raised related to measures addressing plant health issues and 26 percent to food-safety measures. The remaining four percent of concerns concern other issues such as certification requirements or translation. ${ }^{71}$

To establish the extent of the impact of the specific trade concern mechanism on WTO Members at different levels of development, it is interesting to examine a breakdown of the participation of WTO Members at each of the different income levels in this mechanism. In particular, the extent to which specific trade concerns are raised or supported by WTO Members at each of the different income levels, and the extent to which trade concerns are raised against measures maintained by Members at the different income levels is set out below.

\section{Graph 40: Specific Trade Concerns: Participation by WTO Members by Income Level, 1995-2007}

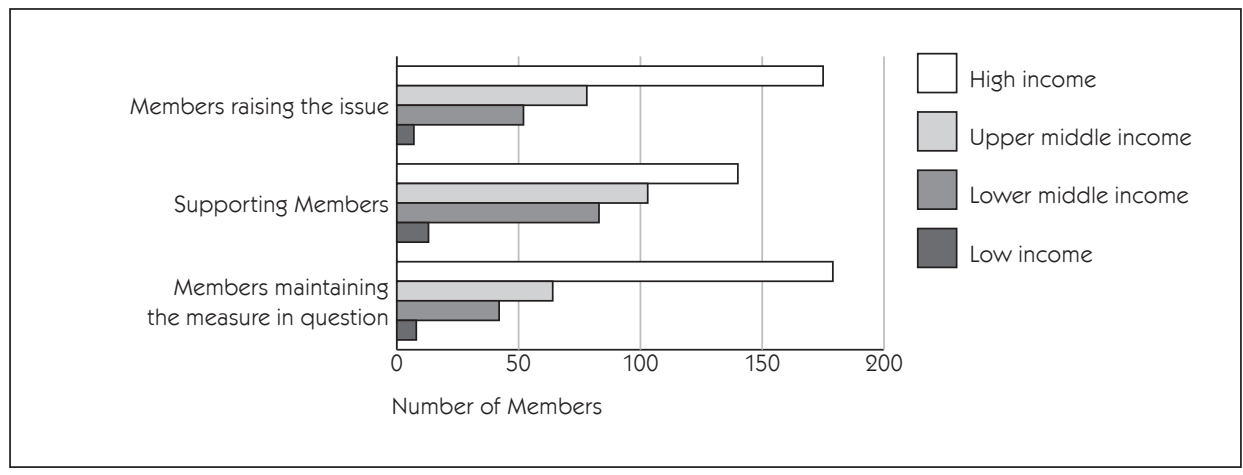

Source: Committee on Sanitary and Phytosanitary Measures, Specific Trade Concerns. Note by the Secretariat. Revision, G/SPS/GEN/204/Rev.8, circulated on 27 March 2008.

Often more than one Member has raised or supported a specific trade concern. Similarly, sometimes more than one Member has maintained the measures complained of. ${ }^{72}$ By the end of 2007, in respect of the 261 trade concerns raised, ${ }^{73}$ the Members raising the concern were high-income Members 175 times, ${ }^{74}$ they were upper-middle-income Members 78 times, they were lower-middle-income Members 52 times and they were low-income Members seven times, two of which were least-developed-country Members. ${ }^{75}$

\footnotetext{
71 Ibid.

${ }^{72}$ For example, Switzerland has raised a single concern regarding measures maintained in relation to BSE by Argentina, Australia, Austria, Belgium, Brazil, Canada, Chile, the Czech Republic, France, Germany, Italy, the Netherlands, Poland, Romania, Singapore, the Slovak Republic, Slovenia, Spain and the US.

${ }^{73}$ The number of Members raising a trade concern exceeds the number of trade concerns raised as a single trade concern is sometimes raised by more than one Member. In total Members were involved in raising specific trade concerns 307 times. The number of Members indicated here does not refer to 307 different WTO Members, as in many cases a single Member raises several trade concerns and is then counted separately in respect of each trade concern raised.

${ }^{74}$ The European Communities was counted as one Member, but if one or more Member States of the European Communities individually raised a concern, they were counted separately.

75 Committee on Sanitary and Phytosanitary Measures, Specific Trade Concerns. Note by the Secretariat. Revision, G/SPS/GEN/204/Rev.8, circulated on 27 March 2008, para. 8.
} 
High-income Members have supported other Members raising a specific trade concern 140 times, compared to 103 times for upper-middle-income Members, 83 times for lower-middle-income Members and 13 times for low-income Members, one of which was a least-developed-country Member. Most often by far, trade concerns relate to measures of high-income Members, these accounting for 179 of the concerns raised, compared to 64 concerns with regard to measures of an upper-middle-income Member, 42 with regard to measures of a lower-middle-income Member, and 8 with regard to measures of a lowincome Member (India). No trade concerns have been raised with regard to measures of least-developed-country Members. ${ }^{76}$

The latest report of the WTO Secretariat regarding specific trade concerns states that developing countries have featured strongly in the SPS Committee discussions, both as initiators or supporters of issues raised, and as subjects of concerns raised. However, closer examination shows that the number of different developing countries raising SPS issues to date has been limited. They are mainly members of the Cairns group of the main agriculture exporting countries. ${ }^{77}$ Thus, the statistics reflect that fact that a limited number of (larger) developing countries is quite active in raising specific trade concerns, rather than that developing countries in general are making active use of the possibility to raise trade concerns at SPS Committee meetings. ${ }^{78}$ Similarly, the number of different WTO Members that supported trade concerns raised by other Members, which occurred 339 times, is limited to 14 high-income Members (140 times), 14 upper-middle-income Members (103 times), 19 lower-middle-income Members (83 times) and 5 low-income Members (13 times). ${ }^{79}$ The Members maintaining SPS measures that are the subject of concerns raised are also limited to a relatively small number of different Members. These are 30 high-income Members (179 times), 17 upper-middle-income Members (64

\footnotetext{
${ }^{76}$ Ibid., para. 8.

${ }^{77}$ Michael Friis Jensen points out, in 2002, that almost all developing-country trade concerns came from the developing countries that are part of the Cairns group of agricultural exporting Members and from India and Mexico, while African and least-developed-country trade concerns are almost non-existent. Michael Friis Jensen, Reviewing the SPS Agreement: A Developing Country Perspective, CDR Working Paper 02.3 (Centre for Development Research, Copenhagen), February 2002. Currently, the Cairns Group accounts for 84 of the trade concerns raised by non-high-income Members.

78 The concentration of the use of the specific trade concerns mechanism in a limited number of different Members occurs on all income levels. At most income levels, except high-income, Cairns Group members as well as China and India are most active in raising specific trade concerns. The 175 times that specific trade concerns were raised by high-income Members, they were in fact raised by only 14 high-income Members ( 3 of which are Cairns Group members accounting for 33 of the concerns raised). 17 upper-middle-income Members were responsible for the 78 times that an upper-middle-income Member raised a trade concern (with 7 Cairns Group members accounting for 59 of these concerns); 14 lower-middle-income Members were responsible for the 52 times that a lower-middle-income Member raised a trade concern (with 6 Cairns Group members accounting for 25 of these concerns and China for a further 18); and 5 low-income Members were responsible for the 7 times that a low-income Member raised a trade concern (with India as the most active Member in this category). Committee on Sanitary and Phytosanitary Measures, Specific Trade Concerns. Note by the Secretariat: Revision, G/SPS/204/Rev.8, circulated on 27 March 2008, 6.

${ }^{79}$ Committee on Sanitary and Phytosanitary Measures, Specific Trade Concerns. Note by the Secretariat. Addendum. Issues Considered in 2007, G/SPS/GEN/204/Rev.8/Add.1, circulated on 27 March 2008, Committee on Sanitary and Phytosanitary Measures, Specific Trade Concerns. Note by the Secretariat Addendum. Issues Not Considered in 2007, G/SPS/GEN/204/Rev.8/Add.2, circulated on 27 March 2008; Committee on Sanitary and Phytosanitary Measures, Specific Trade Concerns. Note by the Secretariat. Addendum. Resolved Issues, G/SPS/GEN/204/Rev.8/Add.3, circulated on 27 March 2008.
} 
times), 12 lower-middle-income Members (42 times) and 1 low-income Member (India) (8 times). ${ }^{80}$

To see these statistics in a factual context, it is useful to look specifically at the four Members used as illustrative examples in this book, of which the specific situation is known. Australia has raised only eight specific trade concerns to date, two of which were later reported resolved. ${ }^{81}$ In most cases, Australia's proactive approach in dealing promptly with problems arising from the SPS measures of its trading partners through bilateral technical discussions has enabled it to resolve these problems without the need to raise specific trade concerns. ${ }^{82}$ Australia has supported another 21 trade concerns raised by other Members. Australia has also had 16 trade concerns raised against SPS measures maintained by it, six of which were reported resolved. ${ }^{83}$ For example, in 2004, a concern was raised by Chile, and supported by the EC and New Zealand, regarding undue delays experienced by exporters of table grapes pending the completion of an IRA by Australia. Australia clarified that Biosecurity Australia had become the responsible agency for IRAs in December 2004, and had shortly thereafter reissued several draft IRAs. The final IRA for table grapes was notified in September 2005 and Chilean table grapes were authorised under certain conditions. In March 2006, Chile reported that a joint work plan had been agreed to resolve the issue. ${ }^{84}$ Another trade concern, raised by New Zealand in 2005, against an Australian measure was that discussed above concerning Australia's quarantine measures on apples aimed at avoiding the transmission of fire blight. ${ }^{85}$ The lack of success in resolving this matter in discussions led to the initiation of formal dispute settlement proceedings by New Zealand. ${ }^{86}$

By contrast, Mauritius, Jamaica and Bangladesh have never raised a specific trade concern, nor have they ever had a specific trade concern raised against a measure maintained by them. However, there has been at least one occasion when Mauritius has 'actively considered' raising a trade concern at an SPS Committee meeting. ${ }^{87}$ This trade concern

${ }^{80}$ Committee on Sanitary and Phytosanitary Measures, Specific Trade Concerns. Note by the Secretariat: Revision, G/SPS/204/Rev.8, circulated on 27 March 2008, 6.

${ }^{81}$ The resolved trade concerns related to Korea's shelf life requirements and the EC's MRLs for aflatoxins in food. Committee on Sanitary and Phytosanitary Measures, Specific Trade Concerns. Note by the Secretariat. Addendum. Resolved Issues, G/SPS/GEN/204/Rev.8/Add.3, circulated on 27 March 2008, items 1 and 39. The remaining trade concerns raised by Australia related to the EC's BSE-related measures on cosmetics; Indonesia's restrictions on fresh fruit and vegetables; measures of Japan and Korea regarding living modified organisms; the EC's measures on live animals and animal products; and the EC's measures on certification requirements for live fish. Committee on Sanitary and Phytosanitary Measures, Specific Trade Concerns. Note by the Secretariat. Addendum. Issues Not Considered in 2007, G/SPS/GEN/204/Rev.8/Add.2, circulated on 27 March 2008, items 17, 21, 49, 50, 173 and 174.

${ }^{82}$ See the discussion on this point above, Part II, Sections 2.4.2.2, 2.2.2.4 and 2.3.

${ }^{83}$ Committee on Sanitary and Phytosanitary Measures, Specific Trade Concerns. Note by the Secretariat. Addendum. Resolved Issues, G/SPS/GEN/204/Rev.8/Add.3, circulated on 27 March 2008, items 4, 8, 45, 49, 86 and 194.

${ }^{84}$ Ibid., item 194.

${ }^{85}$ Committee on Sanitary and Phytosanitary Measures, Specific Trade Concerns. Note by the Secretariat. Addendum. Issues Considered in 2007, G/SPS/GEN/204/Rev.8/Add.1, circulated on 27 March 2008, item 217. See further above, Part II, Section 2.4.2.4.

${ }^{86}$ Dispute Settlement Body, Australia - Measures Affecting the Importation of Apples from New Zealand. Request for Consultations by New Zealand, WT/DS367/1, G/L/825, G/SPS/GEN/796, circulated on 4 September 2007.

${ }^{87}$ This example is reported in Vinod Rege et al., Influencing and Meeting International Standards: Challenges 
related to a Kenyan ban on the import of day-old chicks from Mauritius, due to concerns regarding avian encephalomyelitis. According to Mauritius, no risk assessment had been conducted, no testing had been done, and the measure was not notified to the WTO. The Mauritian authorities, in consultation with the Mauritian mission in Geneva, therefore considered raising a trade concern at the next meeting of the SPS Committee. The matter was however resolved bilaterally, and Kenya withdrew its ban.

Of the three Members discussed here, only Jamaica has supported trade concerns of other Members, which it has done on four occasions. In particular, it supported a concern raised by Brazil, with regard to the EC's new MRLs for dimetholate, ${ }^{88}$ a chemical used in fruit production, which exceeded Codex standards. ${ }^{89}$ Jamaica also supported a concern raised by Canada seeking clarifications regarding the EC's new Food and Feed Hygiene Rules, ${ }^{90}$ and one raised by the US on the issue of the EC's deviation from the IPPC standard for wood packing material. ${ }^{91}$ Finally, Jamaica supported the concern raised by St. Vincent and the Grenadines regarding EUREPGAP's private sector standards for fresh fruit and vegetables, required by UK supermarkets. ${ }^{92}$ None of these trade concerns was reported resolved.

In general, however, the mechanism of specific trade concerns has been quite effective in resolving trade concerns. Of the 261 trade concerns raised, 75 have been reported resolved, two of which in $2007 . .^{93}$ A partial solution has been reported to 18 trade concerns, meaning that market access may have been provided for selected products or by some of the importing Members imposing the relevant SPS measure. For the remaining 168 trade concerns, 152 of which are over a year old, no solutions have been reported..$^{94}$ However, as solutions are not always reported, some of these concerns may have been resolved already without the knowledge of the SPS Committee..$^{95}$ It is interesting to examine how successful Members at different income levels are in resolving disputes through the specific trade concern mechanism.

for Developing Countries. Volume II: Procedures Followed by Selected International Standard-Setting Organisations and Country Reports on TBT and SPS (International Trade Centre UNCTAD/WTO and Commonwealth Secretariat, Geneva), 2004, 151.

${ }^{88}$ These new MRLs were contained in Directive 2002/71/EC of 19 August 2002, notified in G/SPS/N/EEC/160.

${ }^{89}$ This new MRL, set at the level of analytical detection, was argued by the EC to be due to the fact that the existing MRL was inadequate to protect health. The EC noted that Codex had been asked to withdraw its MRL for dimethoate a number of years previously. The EC was at the time evaluating the safety of several hundred chemicals used in plant protection due to the fact that they were in use without having been properly evaluated. In the absence of toxicological data for a chemical, the EC would use the level of analytical detection as the MRL. See Committee on Sanitary and Phytosanitary Measures, Specific Trade Concerns. Note by the Secretariat. Addendum. Issues Not Considered in 2007, G/SPS/GEN/204/Rev.8/Add.2, circulated on 27 March 2008, item 144.

${ }^{90}$ In particular, clarification was sought on the traceability provisions of the new rules. The EC pointed to a document it had circulated explaining its new traceability requirements (G/SPS/GEN/539) and reported that a seminar would be held in Brussels to explain the new rules. Ibid., item 208.

${ }^{91}$ Ibid., item 199. The EC Directive required the debarking of wood in addition to the IPPC requirement of fumigation and heat treatment.

${ }_{92}$ Ibid., item 219. This issue has been discussed above, Part III, Section 2.6.2.3.

${ }_{93}$ Committee on Sanitary and Phytosanitary Measures, Specific Trade Concerns. Note by the Secretariat. Revision, G/SPS/GEN/204/Rev.8, circulated on 27 March 2008, para. 9.

${ }^{94}$ Ibid.

${ }^{95}$ Ibid. 


\section{Graph 41: Resolved Specific Trade Concerns Raised by WTO Members by Income Level, 1995-2007}
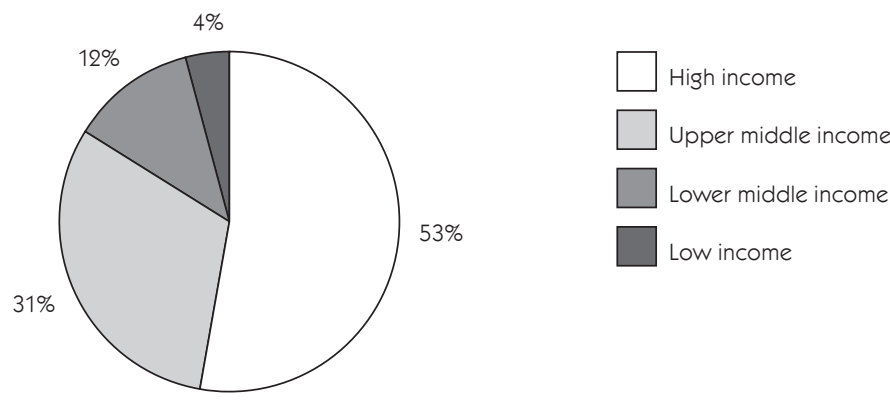

The 75 specific trade concerns that have been reported resolved were raised by 94 Members. ${ }^{96}$ An examination of the income level of the Members raising the trade concerns that have been reported as resolved indicates that these are overwhelmingly high-income Members, and again concentrated in a limited number of different Members. More specifically, in 50 cases the Members raising the resolved concern were high-income Members (6 different Members), in 29 cases they were upper-middle-income Members ( 8 different Members), in 11 cases they were lower-middle-income Members ( 7 different Members) and in 4 cases they were low-income Members ( 3 different Members). It is interesting to note that in all cases where low-income Members were involved in raising a specific trade concern that was successfully resolved, the relevant trade concern was jointly raised with high-income or upper-middle-income Members.

An examination of the current status of all specific trade concerns raised thus far indicates that for all income categories of Members except low-income Members, the number of concerns not reported resolved exceeds those resolved or partially resolved. ${ }^{97}$

\footnotetext{
${ }^{96}$ Note, again, that this figure does not refer to 94 different Members. Instead it counts separately the number of times Members have been involved in raising trade concerns, even if the same Member was involved in raising several trade concerns.

${ }^{97}$ For low-income Members, four specific trade concerns raised by them are reported resolved, whereas one is partially resolved. For three of the concerns raised by low-income Members, no solution has been reported.
} 


\section{Graph 42: Status of Specific Trade Concerns Raised by WTO Members by Income Level, 1995-2007}

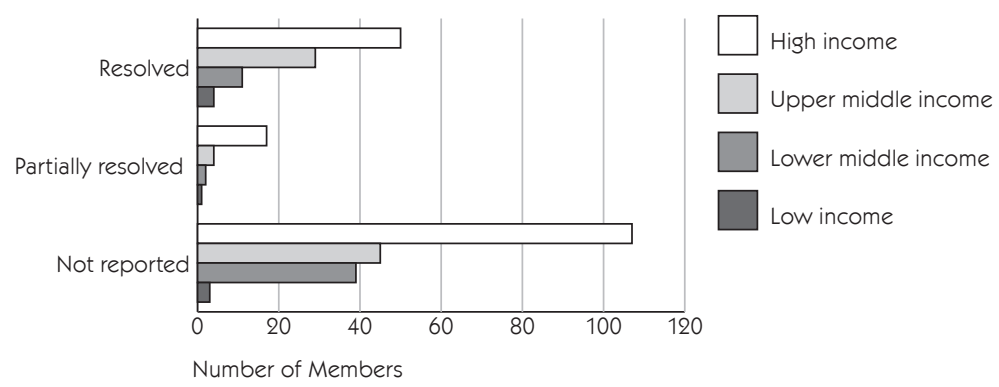

The possibility of resolving a dispute through discussions at the SPS Committee, among technocrats, rather than through formal dispute settlement, has practical implications. As noted by Wolfe,

[E]xpertise is never neutral; every choice of forum privileges some set of actors. Trade lawyers displace microbiologists and regulators once a food problem moves from the SPS Committee to a dispute panel. ${ }^{98}$

The weak participation of some Members at lower levels of development in the specific trade concern mechanism does not seem to be due to flaws in the mechanism itself. In fact, the threshold for raising and supporting trade concerns is very low. The costs involved are minimal and there are almost no procedural requirements to be met, as set out above. It seems that the reason for the limited use of this mechanism by these Members lies rather in their national capacity constraints. Effective use of the mechanism is dependent on systematic monitoring of notified SPS measures in order to identify problems in a timely manner. It also requires good coordination with national export industries, which are best placed to pinpoint the problematic aspects of particular measures. Further, coordination between national ministries is important, to ensure that an effective strategy for raising the problem is developed. In addition, the attendance of SPS Committee meetings by at least one delegate with expertise in the relevant area is crucial. This is not only the case for the meeting where the Member involved wants to raise a trade concern, but for all meetings, so that the delegate is well-placed to see opportunities to support trade concerns raised by other Members where these are of importance to its own exports. Without assistance to build capacity in these areas, an improvement in the extent to which Members at lower levels of development use the specific trade concerns mechanism are unlikely.

As mentioned above, the specific trade concerns mechanism is not the only way in which the SPS Committee gives effect to its mandate under Article 12.2. The second way in which it does so, is by creating a forum for discussion of issues related to SPS matters of broader relevance, in SPS Committee meetings. Any Member may propose that the

\footnotetext{
${ }_{98}$ Robert Wolfe, 'See You in Geneva? Legal (Mis)Representations of the Trading System', European Journal of International Relations 11 (3), 2005, 339-364, 347.
} 
SPS Committee consider, as part of its agenda, any specific SPS-related issue unrelated to a specific trade concern. A number of specific issues have been considered in this way, including implementation problems regarding certain provisions of the SPS Agreement (including those on equivalence, regionalisation, special and differential treatment and technical assistance). The discussions taking place through this mechanism have led in some cases to the decisions of the SPS Committee discussed above. ${ }^{99}$ Other SPS issues discussed include those of private sector SPS standards, approaches to risk assessment, and the practice on setting pesticide limits.

No formal procedure has been adopted in this regard. In practice, a Member wishing to add a specific issue to the agenda of an SPS Committee meeting submits a proposal to the Committee, with an explanation of the reasons this request. The item will be added to the agenda for the next meeting. ${ }^{100}$ Either the Member making the proposal or the Secretariat will normally prepare a background document on the matter in advance of the meeting where the issue will be discussed, to help focus the Committee's discussions. ${ }^{101}$ Following the discussions, the SPS Committee decides what further steps, if any, it will take on the specific issue. ${ }^{102}$

The task of the SPS Committee under Article 12.2, as stated above, has also been understood to include a third mechanism. This mechanism entails the role of the Chairperson of the SPS Committee in providing good offices for the resolution of specific trade concerns raised under the SPS Agreement, also known as the 'good offices of the Chair'. This is provided for in the Working Procedures of the SPS Committee. ${ }^{103}$ In 1998, the US reminded the SPS Committee of this mechanism of informal consultations between the Chairperson and Members involved in a trade concern. ${ }^{104}$ It noted that these consultations are not necessarily a precursor to formal dispute settlement proceedings but could, in fact, be used by Members to avoid costly and lengthy dispute settlement. This issue was raised by New Zealand in the context of the second review of the SPS Agreement, where it suggested that the SPS Committee remind Members of the availability of this option and encourage them to make use thereof. ${ }^{105}$ The WTO Secretariat invited the SPS Committee

\footnotetext{
${ }^{99}$ See above, Part IV, Sections 1.1.6 and 1.2.6 and Part V, Section 1.8.

${ }^{100}$ Committee on Sanitary and Phytosanitary Measures, Ad Hoc Consultations and Resolution of Trade Concerns, G/SPS/GEN/781, circulated on 15 June 2007, para. 14.

102 This approach is being used to discuss specific issues identified in the Second Review of the operation and implementation of the SPS Agreement (such as the use of ad hoc consultations and the relationship between the SPS Committee and Codex, IPPC and OIE).

${ }^{103}$ Committee on Sanitary and Phytosanitary Measures, Working Procedures of the Committee - Adopted by the Committee at Its Meeting of 29-30 March 1995, G/SPS/1, circulated on 4 April 1995, para. 6. This provision states: 'With respect to any matter which has been raised under the Agreement, the Chairperson may, at the request of the Members directly concerned, assist them in dealing with the matter in question. The Chairperson shall normally report to the Committee on the general outcome with respect to the matter in question.'

104 See Committee on Sanitary and Phytosanitary Measures, Facilitation of Informal Consultations on Specific SPS Issues: Submission by the United States, G/SPS/GEN/74, circulated on 5 June 1998.

${ }^{105}$ Committee on Sanitary and Phytosanitary Measures, The Second Review of the Operation and Implementation of the SPS Agreement. Further Elaboration of Issues for Consideration by New Zealand, G/SPS/W/157, circulated on 12 October 2004, para. 12.
} 
to consider whether more explicit guidance on the use of 'good offices' would be helpful, or whether other mechanisms for ad hoc consultations should be developed. ${ }^{106}$

In March 2008, Argentina noted the underutilisation of the possibility to make use of the 'good offices' of the Chairperson, which had then been used only three times. ${ }^{107}$ Argentina expressed the view that the lack of detailed guidelines on access to and the operation of this mechanism contributed to its underutilisation and therefore it supported the suggestion of the WTO Secretariat that such guidelines be drafted. ${ }^{108}$ In June 2008 the US similarly supported the Secretariat's suggestion for the elaboration of guidelines on this process. ${ }^{109}$ The proposals of Argentina and the US are similar overall but do have some important differences. An important difference is that while the Argentine proposal deals only with a procedure for the use of the 'good offices' of the Chairperson, the US proposal stresses that the best forum for addressing concerns on SPS measures and related technical issues is the SPS Committee, coupled with bilateral discussions. ${ }^{110}$ It creates a procedure for consultations between Members, which includes the possibility to agree on using the 'good offices' of the Chairperson. The US said its proposal emphasises technical consultations rather than legal procedures. In the US proposal the Chairperson (or person designated by him/her) is prohibited from expressing an opinion about whether the measure under discussion is legal or not under WTO agreements. ${ }^{111}$ Similarities in the proposals include the provision that participation in the consultations is voluntary and without prejudice to the rights and obligations of Members under WTO agreements or in further proceedings; the requirement that a written request for consultations be addressed to another Member identifying the measure at issue and the concerns that the requesting Member has with the measure; ${ }^{112}$ the notification of the initiation and termination of the

106 The Secretariat's suggestion is contained in Job(07)/14, para. 30.

107 The first use of the good offices of the Chairperson of the SPS Committee was in 1998 by Argentine, Chile, South Africa and Uruguay with regard to the EC's measures with respect to citrus canker (see G/SPS/ GEN/204/Rev.6/Add.3, item 27, paras 25-88). The second use of this mechanism was by the US with regard to Poland's restrictions on wheat and oil seeds in November 1998 (see G/SPS/GEN/204/Rev.6/Add.2, item 25, paras 444-445). The third use of this mechanism was by Canada with regard to India's restrictions on imports of bovine semen in March 2001 (see G/SPS/GEN/204/Rev.6/Add.2, item 61, paras 327-335).

${ }^{108}$ Argentina's communication containing its proposal for guidelines for the operation of the mechanism of good offices of the Chairperson of the SPS Committee are contained in Committee on Sanitary and Phytosanitary Measures, Good Offices of the Chairperson. Communication from Argentina, G/SPS/W/219, circulated on 17 March 2008.

${ }^{109}$ Committee on Sanitary and Phytosanitary Measures, Article 12.2 - Consultations. Proposal by the United States, G/SPS/W/227, circulated on 23 June 2008, para. 7.

${ }^{110}$ The US calls this a 'Committee first' approach, which it has also taken in its informal response to a proposal with regard to non-tariff barriers in non-agricultural market access (NAMA) negotiations which includes the possibility of mediation by a facilitator. Negotiating Group on Market Access, Market Access for NonAgricultural Products. Ministerial Decision on Procedures for the Facilitation of Solutions to Non-Tariff Barriers. Proposal by the African Group, Canada, European Communities, LDC Group, NAMA-11, the Group of Developing Countries, New Zealand, Norway, Pakistan and Switzerland, TN/MA/W/106, circulated on 9 May 2008. The Group of Developing Countries consists of Argentina, Bolivarian Republic of Venezuela, Brazil, Egypt, India, Indonesia, Namibia, Philippines, South Africa and Tunisia. SPS measures are one of the non-tariff barriers addressed in this proposal (to the extent that they apply to non-agricultural products such as processed food).

${ }^{111}$ Committee on Sanitary and Phytosanitary Measures, Article 12.2 - Consultations. Proposal by the United States, G/SPS/W/227, circulated on 23 June 2008, para. 20.

${ }^{112}$ While the US proposal refers only to the requesting Member's questions and concerns regarding the measure, the Argentine proposal is more formal requiring an identification of the legal basis for the concerns with 
proceedings to the WTO Secretariat; the possibility to request the participation of the secretariat of the CAC, OIE or IPPC where an international standard is at issue; the confidentiality of the proceedings; and the requirement that the Chairperson report back on the general outcome of the consultations to the SPS Committee. Argentina and the US have agreed to discuss combining their papers before the next meeting, in October 2008. ${ }^{113}$

\subsubsection{Monitoring and promotion of international harmonisation}

The SPS Committee is allocated various tasks regarding the process of international harmonisation of SPS standards by Article 12 of the SPS Agreement. According to Article 12.2 it must encourage the use of international standards, guidelines and recommendations by all Members, and sponsor technical consultation and study in this regard. As required by Article 12.3, it must also maintain close contact with the three main international standard-setting organisations in order to obtain the best possible scientific advice for the administration of the SPS Agreement and avoid duplication of effort. In the exercise of this function, the SPS Committee maintains close working relationships with the CAC, OIE and IPPC Secretariat and receives regular updates of their activities.

Further, Article 12.5 allows the SPS Committee to avoid unnecessary duplication by using information generated by the procedures, particularly those relating to notification, in place in the international organisations. In 2008, the IPPC reported to the SPS Committee that the CPM had initiated the development of a system to monitor the use of IPPC standards, under the responsibility of a standards implementation officer. ${ }^{114}$ The OIE indicated that it has no monitoring mechanism in place for the implementation of its standards and no plans to develop such a mechanism. ${ }^{115}$ The CAC acceptance procedure, whereby members notified the CAC of their intention to apply the CAC standard at issue, ${ }^{116}$ was abolished in $2005 .{ }^{117}$ The CAC currently has no procedure in place to

reference to the applicable Articles of the SPS Agreement.

113 As the report of the discussion at the June 2008 meeting of the SPS Committee has not been circulated yet, this information is taken from the WTO News Item 'Members turn Attention to Improving SPS Mediation', available at: http://www.wto.org/english/news_e/news08_e/sps_24june08_e.htm, visited on 26 June 2008.

114 Committee on Sanitary and Phytosanitary Measures, Decisions from the Third Session of the Commission on Phytosanitary Measures (Rome, 7-11 April 2008). Submission from the International Plant Protection Convention, G/SPS/GEN/849, circulated on 18 June 2008. Under the new mechanism, a database will be created allowing the identification of the IPPC standards that are being used. The IPPC has noted that in some cases non-use of standards is due to the fact that they may not be relevant to the particular situation of an individual country.

${ }^{115}$ Committee on Sanitary and Phytosanitary Measures, Procedure to Monitor the Process of International Harmonization. Tenth Annual Report Adopted by the Committee on 25 June 2008, G/SPS/49, circulated on 14 July 2008 , para. 8 .

${ }^{116}$ Under the CAC acceptance procedure, members could indicate their acceptance of CAC standards in three different ways: (1) full acceptance, which entailed the obligation to ensure that conforming products could circulate freely and that non-conforming products could not bear the name or description set out in the standard; (2) acceptance with specific deviations, which obliged members to allow free circulation of conforming products, except under the derogations specified by the member and to ensure that products complied with the standard as qualified by the derogations; and (3) acceptance by means of a declaration of free distribution, which required that the member allow free circulation of conforming products within its territory. For a detailed explanation of the acceptance procedure, see Mariëlle Masson-Matthee, The Codex Alimentarius Commission and Its Standards, Doctoral Thesis, Maastricht University, Faculty of Law (T.M.C. Asser Press, Maastricht), 2007, 83-85.

${ }^{117}$ Codex Alimentarius Commission, Report of the Twenty-Eighth Session, ALINORM 05/28/41 (Joint FAO/ 
monitor the implementation of its standards. ${ }^{118}$ Therefore, except in the case of phytosanitary standards once the proposed IPPC mechanism is in operation, the burden of gathering information on implementation of international standards remains squarely on the SPS Committee.

Article 12.4 of the SPS Agreement requires that the SPS Committee develop a procedure to monitor the process of international harmonisation and the use of international standards. This duty is also provided for in Article 3.5 of the SPS Agreement. To give effect to this obligation, a provisional procedure was established by the SPS Committee in $1997,{ }^{119}$ and extended three times. ${ }^{120}$ In October 2004, the procedure was modified to facilitate the consideration of new issues at each meeting, by changing the deadline for identifying issues from 30 days to 10 days in advance of Committee meetings. ${ }^{121}$ Finally, in 2006, the SPS Committee agreed to extend the provisional procedure indefinitely. ${ }^{122}$

The monitoring procedure currently applies only to the standards set by the CAC, OIE or IPPC, but if the need arises it may be extended to the standards of other relevant international organisations. ${ }^{123}$ In terms of the monitoring procedure, only the use or non-use of international standards with a 'major trade impact' is monitored. ${ }^{124}$ A standing agenda

WHO Food Standards Programme, Rome), 4 - 9 July 2005, para. 36, available at: http://www.codexalimentarius.net/web/ archives.jsp?year=05, visited on 14 May 2008.

118 Committee on Sanitary and Phytosanitary Measures, Procedure to Monitor the Process of International Harmonization. Ninth Annual Report Adopted by the Committee on 28 June 2007, G/SPS/45, circulated on 10 July 2007, para. 6. At the SPS Committee meeting of October 2006, the CAC representative informed the SPS Committee of the ongoing discussion in the CAC regarding the introduction of a mechanism to monitor the use of Codex standards. The CAC Secretariat had sent a questionnaire to all CAC members relating to: (1) the use of Codex standards and related texts at the national and regional level; (2) non-use of Codex standards and related texts; (3) any difficulties encountered by Codex members in using Codex standards and related texts; (4) relevance of Codex standards as a basis for harmonization; and (5) any other health and trade problems related to standardization. Committee on Sanitary and Phytosanitary Measures, Submission to the 37th Meeting of the SPS Committee (Geneva, 11-13 October 2006). Information on Activities of the Codex Alimentarius Commission. Submission by the Codex Alimentarius Commission, G/SPS/GEN/727, circulated on 9 October 2006, para. 9.

119 Committee on Sanitary and Phytosanitary Measures, Procedure to Monitor the Process of International Harmonization: Decision of the Committee, G/SPS/11, circulated on 22 October 1997.

120 Committee on Sanitary and Phytosanitary Measures, Decision to Extend the Provisional Procedure to Monitor the Process of International Harmonization. Decision of the Committee of 8 July 1999, G/SPS/14, circulated on 12 July 1999; Committee on Sanitary and Phytosanitary Measures, Decision to Extend the Provisional Procedure to Monitor the Process of International Harmonization, G/SPS/17, circulated on 19 July 2001; Committee on Sanitary and Phytosanitary Measures, Decision to Modify and Extend the Provisional Procedure to Monitor the Process of International Harmonization. Adopted by the Committee on 25 June 2003, G/SPS/25, circulated on 1 July 2003.

121 Committee on Sanitary and Phytosanitary Measures, Revision of the Procedure to Monitor the Process of International Harmonisation. Decision of the Committee. Revision, G/SPS/11/Rev.1, circulated on 15 November 2004.

122 Committee on Sanitary and Phytosanitary Measures, Decision to Modify and Extend the Provisional Procedure to Monitor the Process of International Harmonization. Adopted on 28 June 2006, G/SPS/40, circulated on 5 July 2006.

${ }^{123}$ Recall here the possibility set out in Annex A.3(d) for other international organisations to be identified as relevant by the SPS Committee for matters not covered by the CAC, OIE or IPPC. See above, Part III, Section 4.1.1.

${ }^{124}$ Committee on Sanitary and Phytosanitary Measures, Procedure to Monitor the Process of International Harmonization: Decision of the Committee, G/SPS/11, circulated on 22 October 1997, para. 5. Trade impact is determined on the basis of the extent to which Members use the relevant standard and the frequency/ 
item for all SPS Committee meetings exists in this regard, allowing Members to raise problems with regard to international standards at any meeting. Members should do so in advance, indicating the nature of the trade problem. Members may submit comments with regard to trade problems resulting from the non-use of appropriate standards or the non-existence or inappropriateness of international standards. ${ }^{125}$ On the basis of the submissions of Members and the discussion in the SPS Committee, a list of international standards with a major impact on trade is drawn up, and reviewed at each SPS Committee meeting. The SPS Committee may, on this basis, invite the relevant standard-setting body to consider reviewing the standard at issue or to provide information on the standard, including with regard to amendments or ongoing work. Members participating in the standard-setting bodies should take this into account in priority setting activities. ${ }^{126}$ The SPS Committee adopts annual reports, drawn up by the Secretariat, based on information and comments from Members and international standard-setting organisations regarding the use of existing international standards, the need for new international standards and work on the adoption of such standards. ${ }^{127}$ Ten annual reports have been adopted thus far. ${ }^{128}$

When used, this procedure can be effective in resolving concerns of Members in the area of harmonised standards. It allows for discussion of these concerns among WTO Members and may result in a recommendation by the SPS Committee, under Article 12.6 of the SPS Agreement, inviting the international standard-setting organisation involved to address the issue. More specifically, Article 12.6 allows the SPS Committee, on the

severity of trade problems experienced with regard to the products covered by the standard.

${ }^{125}$ For example, in 2001 South Africa requested the monitoring of the OIE standard for African horse sickness under this procedure, on the grounds that the standard was outdated in terms of the epidemiology of the disease and created an impediment to international trade in horses. Committee on Sanitary and Phytosanitary Measures, Monitoring/Revision of an International Standard: African Horse Sickness - Request by South Africa, G/SPS/GEN/289, Geneva, circulated on 29 October 2001.

126 Committee on Sanitary and Phytosanitary Measures, Revision of the Procedure to Monitor the Process of International Harmonisation. Decision of the Committee. Revision, G/SPS/11/Rev.1, circulated on 15 November 2004, para. 10.

127 Committee on Sanitary and Phytosanitary Measures, Procedure to Monitor the Process of International Harmonization: Decision of the Committee, G/SPS/11, circulated on 22 October 1997, para. 6.

${ }^{128}$ Committee on Sanitary and Phytosanitary Measures, Procedure to Monitor the Process of International Harmonization: First Annual Report Adopted by the Committee on 8 July 1999, G/SPS/13, circulated on 12 July 1999; Committee on Sanitary and Phytosanitary Measures, Procedure to Monitor the Process of International Harmonization. Second Annual Report, G/SPS/16, circulated on 10 July 2000; Committee on Sanitary and Phytosanitary Measures, Procedure to Monitor the Process of International Harmonization. Third Annual Report, G/SPS/18, circulated on 19 September 2001; Committee on Sanitary and Phytosanitary Measures, Procedure to Monitor the Process of International Harmonization. Fourth Annual Report, G/ SPS/21, circulated on 27 June 2002; Committee on Sanitary and Phytosanitary Measures, Procedure to Monitor the Process of International Harmonization. Fifth Annual Report, G/SPS/28, circulated on 7 July 2003; Committee on Sanitary and Phytosanitary Measures, Procedure to Monitor the Process of International Harmonization. Sixth Annual Report. Adopted by the Committee on 23 June 2004, G/SPS/31, circulated on 24 June 2004; Committee on Sanitary and Phytosanitary Measures, Procedure to Monitor the Process of International Harmonization. Seventh Annual Report Adopted by the Committee on 30 June 2005, G/SPS/37, circulated on 19 July 2005; Committee on Sanitary and Phytosanitary Measures, Procedure to Monitor the Process of International Harmonization. Eighth Annual Report Adopted by the Committee on 28 June 2006, G/SPS/42, circulated on 4 August 2006; Committee on Sanitary and Phytosanitary Measures, Procedure to Monitor the Process of International Harmonization. Ninth Annual Report Adopted by the Committee on 28 June 2007, G/SPS/45, circulated on 10 July 2007; Committee on Sanitary and Phytosanitary Measures, Procedure to Monitor the Process of International Harmonization. Tenth Annual Report Adopted by the Committee on 25 June 2008, G/SPS/49, circulated on 14 July 2008. 
initiative of one Member, to use appropriate channels to invite the relevant international organisations or their subsidiary bodies to examine specific matters relating to a particular standard, guideline or recommendation. Among these specific matters, the reasons for non-use of international standard provided by Members under Article 12.4 are expressly included.

By 2005, Members had raised 11 issues under this procedure and these concerns were promptly addressed by the standard-setting bodies. ${ }^{129}$ Six new issues were raised between 2005 and 2006. In the context of the second periodic review of the SPS Agreement, New Zealand noted that this procedure was successfully used by the US to achieve the development of a definition and guidelines on the issue of 'official control' by the IPPC's Interim Committee on Phytosanitary Measures. ${ }^{130}$ In addition, this possibility was used to facilitate progress in the discussion in the SPS Committee on regionalisation, as proposed by New Zealand at the SPS Committee meeting of October 2004. ${ }^{131}$ According to New Zealand, this could lead to the incorporation of the best available scientific and technical advice into the work of the SPS Committee on this matter, thereby avoiding unnecessary duplication of work. In accordance with Article 12.6 of the SPS Agreement, New Zealand requested the SPS Committee to invite OIE and IPPC Secretariats to examine the specific matters concerning regionalisation relevant to their international standards, guidelines or recommendations. ${ }^{132}$ In particular, New Zealand proposed that the SPS Committee invite the OIE and IPPC to consider the appropriateness of developing administrative procedures for the recognition of pest- or disease-free areas or areas of low pest prevalence and including them in their international standards, recommendations or guidelines. ${ }^{133}$

The successful use of the possibilities provided by the procedure under Article 12.4 and 12.6 is best illustrated by the following example involving Sri Lanka. Sri Lanka has faced significant problems with regard to its exports of cinnamon due to the absence of a CAC standard setting an MRL for sulphur dioxide in cinnamon. In February 2006, Sri Lanka raised this concern under the SPS Committee's procedure for monitoring harmonisation. The SPS Committee, in view of the importance of this matter for the exports of a devel-

129 This was reported by the WTO Secretariat. Committee on Sanitary and Phytosanitary Measures, Review of the Operation and Implementation of the SPS Agreement. Background Document. Note by the Secretariat. Revision, G/SPS/GEN/510/Rev.1, circulated on 23 February 2005, para. 24.

${ }^{130}$ Committee on Sanitary and Phytosanitary Measures, The Second Review of the Operation and Implementation of the SPS Agreement. Further Elaboration of Issues for Consideration by New Zealand, G/SPS/W/157, circulated on 12 October 2004, para. 16.

131 Committee on Sanitary and Phytosanitary Measures, Monitoring of International Harmonization: Regionalization. Submission by New Zealand, G/SPS/W/151, circulated on 29 September 2004.

${ }^{132}$ Committee on Sanitary and Phytosanitary Measures, Procedure to Monitor the Process of International Harmonization. Seventh Annual Report Adopted by the Committee on 30 June 2005, G/SPS/37, circulated on 19 July 2005, para. 5. Although New Zealand refers to the OIE Secretariat, it may be assumed that it means the OIE Bureau.

${ }^{133}$ In addition, New Zealand suggested that the CAC and OIE address the issue of the recognition of pestor disease-free status, in particular the process for acceptance by members of OIE recognition of diseasefree status; the question whether OIE recognition constitutes a determination under Article 6.2 of the SPS Agreement; and whether it would be feasible under the IPPC to provide recognition of pest or disease free status for a limited number of pests or diseases which have a significant impact on international trade of Members. Committee on Sanitary and Phytosanitary Measures, Monitoring of International Harmonization: Regionalization. Submission by New Zealand, G/SPS/W/151, circulated on 29 September 2004, para. 8. 
oping-country Member, immediately brought the matter to the attention of the CAC. ${ }^{134}$ In July 2006, the CAC informed the SPS Committee that, pursuant to the latter's request, a Codex standard had been adopted setting an MRL for sulphites in herbs and spices. ${ }^{135}$ In his letter, the Chairperson of the CAC expressly noted that this rapid action on the part of the CAC 'would not have been possible without the proactive intervention made by the Delegation of Sri Lanka in the Codex Committee on Food Additives and Contaminants, and without the support of other Codex members on the proposal made by Sri Lanka.' ${ }^{136}$

Another example of the use of the procedure to monitor harmonisation, this time to report a problem in the implementation of an international standard, is the concern raised by Mauritius under this agenda item in 2005 before the SPS Committee with regard to the IPPC guidelines on wood packaging material (ISPM 15). ${ }^{137}$ As noted above, Mauritius lacks the capacity to set up the heat-treatment plant for wood packaging material required by the relevant IPPC standard. ${ }^{138}$ It therefore sought, through this procedure, a four-year moratorium for the implementation of this standard from the IPPC and from Members imposing the IPPC standard, while it developed the necessary capacity. Mauritius also requested Members to give positive consideration to recognising the equivalence of the use of phosphine fumigation treatment as a treatment for wood packaging materials in the interim period. ${ }^{139}$

A third example of the use of the Article 12.4 procedure is that by Argentina's at the SPS Committee meeting of June 2007. Argentina raised its concerns regarding the fact that several importing Members set MRLs for pesticides that are stricter than CAC MRLs without scientific justification. ${ }^{140}$ As noted by Argentina, these Members set MRLs exceeding Codex standards based on studies conducted exclusively with national data. This causes problems in cases where a product is not grown in the importing Members or where the relevant pesticide is not used in that Member. In such cases, Members tend to automatically set MRLs at the 'limit of detection' level, creating significant compliance problems for developing-country Members. ${ }^{141}$ Further, as noted by Argentina, Codex MRLs are

${ }^{134}$ For a discussion of the international standard setting bodies and their procedures, see above, Part II, Section 3.2 .

${ }^{135}$ Committee on Sanitary and Phytosanitary Measures, Sulphur Dioxide in Cinnamon, G/SPS/GEN/716, circulated on 25 July 2006. The standard was adopted at the $29^{\text {th }}$ Session of the CAC, held on 3-7 July 2006. It sets a maximum level for use of $150 \mathrm{mg} / \mathrm{kg}$ for sulphites (including sulphur dioxide) in the food category 'herbs and spices' of the Codex General Standard for Food Additives (GSFA) Codex STAN 192-1995, Rev. 7 (2006) (available at www.codexalimentarius.net/gsfaonline/index.html, visited on 25 June 2007).

136 Ibid.

137 This example was mentioned above, Part II, Section 2.5.2.3.

138 Committee on Sanitary and Phytosanitary Measures, Implementation of International Standards. Communication by Mauritius, G/SPS/GEN/547, circulated on 2 March 2005.

139 Committee on Sanitary and Phytosanitary Measures, Procedure to Monitor the Process of International Harmonization. Seventh Annual Report Adopted by the Committee on 30 June 2005, G/SPS/37, circulated on 19 July 2005, para. 8 .

140 Committee on Sanitary and Phytosanitary Measures, Maximum Residue Levels for Pesticides: Impact on Exports from Developing Countries. Communication from Argentina, G/SPS/W/211, circulated on 26 June 2007. This concern was reported in Committee on Sanitary and Phytosanitary Measures, Procedure to Monitor the Process of International Harmonization. Ninth Annual Report Adopted by the Committee on 28 June 2007, G/SPS/45, circulated on 10 July 2007.

${ }^{141}$ Committee on Sanitary and Phytosanitary Measures, Maximum Residue Levels for Pesticides: Impact on Exports from Developing Countries. Communication from Argentina, G/SPS/W/211, circulated on 26 June 
lacking for many of the products of export interest to developing-country Members. Of the 345 active substances registered to treat Argentina's various export crops, only 110 (31.8 percent) have Codex MRLs. ${ }^{142}$ In addition, Argentina stated that some Members 'remove active substances from their national registries of permitted products not for scientific reasons but for purely commercial reasons. ${ }^{143}$ Argentina recognised that the scientific justification requirement for SPS measures not based on international standards aims to ensure objectivity. However, it stressed that, "in the event of a dispute it implies an almost insurmountable restriction for developing countries, which do not have the necessary resources or scientific analyses to demonstrate the inconsistency of a measure that has been imposed on them unfairly.' ${ }^{144}$

Argentina proposed, inter alia, that the SPS Committee set up appropriate mechanisms to ensure that the CAC undertakes or hastens work on the establishment of MRLs for pesticides on products of interest to agricultural exporting Members, and that it urge Members to provide the scientific data at their disposal to facilitate this work. ${ }^{145}$ Several Members supported Argentina's position. The CAC representative pointed out that Codex pesticide standards were established on the basis of the best available scientific data by the JMPR, but that this necessitated a commitment by members to generate the necessary data and to provide this to JMPR. ${ }^{146}$ Further, the CAC representative stated that the issue raised by Argentina would be considered by the CAC at its July 2007 meeting, with a view to determining how to proceed. ${ }^{147}$ At that meeting the CAC noted that the enforcement of CAC standards, including MRLs fell outside its mandate and could better be addressed in the SPS Committee. ${ }^{148}$ In addition, the CAC noted that the lack of capacity of developing countries to generate scientific data, especially with regard to pesticide MRLs, had been discussed at the Fifty-Ninth Session of the CAC Executive Committee on the basis of a proposal made by the representative for the Latin American and the Caribbean region to include an activity in the draft CAC Strategic Plan 2008-2013 to promote the strengthening of scientific advisory groups, with regard to their efficiency and necessary resources, particularly in the area of pesticide residues. However, the CAC Executive Committee stated that some of these concerns might best be addressed outside the CAC, including through international FAO/WHO workshops on pesticide residues. ${ }^{149}$ The FAO representative, on behalf of the FAO and WHO, clarified that both organizations had assisted member states to enhance their capacity on data provision, ${ }^{150}$ and expressed the

2007, para. 15 .

142 Ibid., para. 19.

${ }^{143}$ Ibid., para. 21.

144 Ibid., para. 20.

145 Committee on Sanitary and Phytosanitary Measures, Procedure to Monitor the Process of International Harmonization. Ninth Annual Report Adopted by the Committee on 28 June 2007, G/SPS/45, circulated on 10 July 2007, para. 4(a).

${ }^{146}$ Ibid., para. 6.

${ }^{147}$ Ibid.

${ }^{148}$ Codex Alimentarius Commission, Report of the Thirtieth Session, ALINORM 07/30/REP (Joint FAO/WHO Food Standards Programme, Rome), 2-7 July 2007, paras 205-209, available at: http://www.codexalimentarius.net/web/ archives.jsp?year=07, visited on 8 February 2008.

${ }^{149}$ Ibid., para. 209.

${ }^{150}$ One initiative mentioned was the FAO/WHO Meeting on Enhancing Developing Country Participation in Scientific Advice Activities, 12-15 November 2005, held in Belgrade, Serbia and Montenegro, which had led to several recommendations in this regard. 
willingness of the FAO and WHO to continue efforts to fulfil their mandate by means of enhancing the provision scientific advice. ${ }^{151}$

Despite these examples of the possibilities provided by this monitoring procedure to raise awareness of specific issues relating to international standards and to create momentum for work to address these issues, to date, this possibility is generally poorly used and Members seldom provide information for the annual reports on harmonisation. In June 2008, a number of Members expressed their concern that the existing procedure was not providing for an effective monitoring of the use of international standards. ${ }^{152}$ In addition, monitoring is currently limited to cases where international standards are lacking, inadequate, or not being used. In the abovementioned paper submitted by New Zealand, it proposed that the monitoring be extended to include also all new SPS measures that are based on international standards, to enable the SPS Committee to fully monitor harmonisation and the use of international standards. ${ }^{153}$ Useful information may be provided if the recommendation in the recent revision of the transparency procedures that Members notify new or modified SPS measures that are based on international standards is given effect. ${ }^{154}$

\subsubsection{Periodic review of the SPS Agreement}

The SPS Committee is obliged by Article 12.7 to review the operation and implementation of the SPS Agreement three years after its entry into force, and thereafter as the need arises. Where appropriate, the SPS Committee may make proposals to the Council for Trade in Goods regarding amendments to the SPS Agreement. The SPS Committee established a procedure for this review ${ }^{155}$ and the first review was conducted in 1998, resulting in a report of the SPS Committee. ${ }^{156}$ This report identified various problems with the implementation of the SPS Agreement. Among these were deficiencies in the operation of the transparency requirements, which the Committee stressed could be addressed by improvements in Members' compliance with the Recommended Notification Procedures as well as through revisions to these procedures to deal with new concerns. The need

${ }^{151}$ Executive Committee of the Codex Alimentarius Commission, Report of the Fifty-Ninth Session, ALINORM 07/30/3 (Joint FAO/WHO Food Standards Programme, Rome), 26-29 June 2007, para. 81.

${ }^{152}$ Committee on Sanitary and Phytosanitary Measures, Procedure to Monitor the Process of International Harmonization. Tenth Annual Report Adopted by the Committee on 25 June 2008, G/SPS/49, circulated on 14 July 2008, para. 6.

${ }^{153}$ Committee on Sanitary and Phytosanitary Measures, The Second Review of the Operation and Implementation of the SPS Agreement. Further Elaboration of Issues for Consideration by New Zealand, G/SPS/W/157, circulated on 12 October 2004, paras 8 and 10. New Zealand proposed that this should be done by means of amendments to the SPS Committee's Recommended Procedures for Implementing the Transparency Obligations of the SPS Agreement (Article 7), (G/SPS/7/Rev.2), as was done with regard to transparency of the recognition of equivalence.

154 This point was made by Members at the SPS Committee meeting of June 2008, where the procedure to monitor international harmonisation was discussed. Committee on Sanitary and Phytosanitary Measures, Procedure to Monitor the Process of International Harmonization. Tenth Annual Report Adopted by the Committee on 25 June 2008, G/SPS/49, circulated on 14 July 2008, para. 6.

${ }^{155}$ Committee on Sanitary and Phytosanitary Measures, Procedure to Review the Operation and Implementation of the Agreement, G/SPS/10, circulated on 21 October 1997.

${ }^{156}$ Committee on Sanitary and Phytosanitary Measures, Review of the Operation and Implementation of the Agreement on the Application of Sanitary and Phytosanitary Measures: Report of the Committee, G/SPS/12, circulated on 11 March 1999. 
for improvements in the provision of technical assistance and the lack of information on the extent to which SDT was accorded to developing-country Members was pointed to. The potential importance of the obligations on equivalence and regionalisation was noted and the contributions of the CAC, OIE and IPPC through their work in these areas was welcomed. However, no amendments were proposed as a result of this review. The SPS Committee noted that the review had not been comprehensive and recognised that Members could raise any issue for the consideration of the Committee at any time. ${ }^{157}$

In the Decision on Implementation adopted at the Doha Session of the Ministerial Conference in 2001, the SPS Committee is instructed to review the operation and implementation of the SPS Agreement at least once every four years. ${ }^{158}$ The next review was required to result in a report for the Sixth Session of the Ministerial Conference. In order to meet this goal, the SPS Committee adopted a decision, at its meeting on 22-23 June 2004, setting out the procedure for the second review process. ${ }^{159}$ On request of the Members, the WTO Secretariat prepared and revised a background document for purposes of the review. ${ }^{160}$

The outcome of the second review reflected a positive assessment by Members regarding the achievement of the SPS Agreement of its purpose, which was seen as benefiting both importing and exporting Members. ${ }^{161}$ It also noted the importance of the SPS Committee in providing a regular forum for national officials to make contacts, engage in consultations and explore solutions to trade problems. However, it pointed to the fact that, despite improvements in participation, many developing-country Members and LDC Members still faced difficulties in participating effectively, including in adequate preparation for meetings and timely follow-up. ${ }^{162}$ After commending the progress made on a number of issues by the SPS Committee through its decisions on transparency, consistency in appropriate level of protection, equivalence and monitoring of harmonisation, it was noted that more could be done by the SPS Committee to ensure the effective implementation of the SPS Agreement. The second review was completed in June 2005, and resulted in a 47-page report, including 40 recommendations and a programme for further work. ${ }^{163}$ Many of the recommendations relate to maintaining as standing agenda items for SPS Committee meetings the various issues addressed in the review (including consistency, equivalence, regionalisation, transparency, monitoring of international standards, technical assistance, SDT and specific trade concerns) and continuing work on these issues. In

${ }^{157}$ Ibid., para. 26.

${ }^{158}$ Ministerial Conference, Implementation-Related Issues and Concerns. Decision of 14 November 2001, WT/ MIN(01)/17, circulated on 20 November 2001, para. 3.4.

159 Committee on Sanitary and Phytosanitary Measures, Process for the Review of the Operation and Implementation of the Agreement. Decision by the Committee, G/SPS/32, circulated on 25 June 2004.

${ }^{160}$ Committee on Sanitary and Phytosanitary Measures, Review of the Operation and Implementation of the SPS Agreement. Background Document. Note by the Secretariat, G/SPS/GEN/510, circulated on 20 September 2004; Committee on Sanitary and Phytosanitary Measures, Review of the Operation and Implementation of the SPS Agreement. Background Document. Note by the Secretariat. Revision, G/SPS/GEN/510/Rev.1, circulated on 23 February 2005.

${ }^{161}$ Committee on Sanitary and Phytosanitary Measures, Review of the Operation and Implementation of the Agreement on the Application of Sanitary and Phytosanitary Measures. Report Adopted by the Committee on 30 June 2005, G/SPS/36, circulated on 11 July 2005, para. 8.

162 Ibid., para. 7.

163 The report of the Second Review was adopted at the SPS Committee meeting of 29-30 June 2005. Ibid. 
addition, the SPS Committee agreed to pursue work on new issues, based on information provided by Members regarding their experiences and on specific suggestions submitted by Members to the Committee. These new issues were the need to clarify the relationship between the SPS Committee and the CAC, OIE and IPPC; the need to clarify the relationship between the terms 'SPS measures' and 'SPS regulations' for purposes of the transparency provisions; the need to examine the relationship between Articles 2.1 and 5.6 of the SPS Agreement; the need to address undue delays in respect of various provisions of the SPS Agreement (including in respect of equivalence, regionalisation, risk assessments prior to granting market access, and the operation of control, inspection and approval systems); the need to develop guidelines on good regulatory practices; and the need to clarify ambiguities and develop common practices with regard to control and inspection procedures, in particular with regard to who should bear the costs of inspection visits. ${ }^{164}$

It is interesting to note that, despite the express option given to the SPS Committee under Article 12.7 of the SPS Agreement to submit proposals to the Council for Trade in Goods for amendments to the SPS Agreement where appropriate, having regard to the experience gained in the implementation of the Agreement, neither review proposed any amendments. No suggestion was made that the work of the Committee in developing procedural guidelines for the operationalisation of the provisions of the SPS Agreement be incorporated in the form of amendments. Instead, it is apparent that Members wish to continue the current successful modus operandi of working towards the resolution of implementation problems through decisions of the Committee, based on technical discussions and shared experiences, and reviewing these decisions as needed. As noted above, the weak legal status of decisions of the SPS Committee, as compared to the binding status of an amendment, makes it easier for Members to reach consensus on new norms.

\subsection{Dispute settlement procedures}

While the mechanism established by the SPS Committee to address specific trade concerns through multilateral discussions is very useful in facilitating cooperative solutions to SPS conflicts where bilateral initiatives have failed, Members do not always succeed in finding agreed solutions. In such cases, it is important to have a well-functioning, enforceable system for the settlement of disputes.

While a very small proportion of the conflicts between Members with regard to the rules of the SPS Agreement result in the initiation of dispute settlement proceedings, and even fewer actually proceed to adjudication, as set out below, ${ }^{165}$ this does not mean that the dispute settlement system is of limited importance to SPS disputes. The very existence of the dispute settlement system creates an incentive for Members against whose SPS measures concerns are raised to address these concerns through negotiated solutions. In addition, the clarifications developed by panels and the Appellate Body with regard to the provisions of the SPS Agreement play a key role in establishing the normative framework

\footnotetext{
${ }^{164}$ Ibid., paras 91, 93, 95, 97, 99, and 101.

${ }^{165}$ See the discussion of the use of the dispute settlement system to resolve SPS-related disputes, below, Part IV, Section 2.2.7.
} 
within which Members address their SPS conflicts. ${ }^{166}$ These clarifications are taken up in decisions of the SPS Committee that elaborate procedural guidelines for the operationalisation of provisions of the SPS Agreement. Equally importantly, they form the backdrop against which discussions between Members, bilaterally but even more so in the multilateral forum of the SPS Committee, take place to resolve trade concerns. ${ }^{167}$ These have been referred to as 'settlements negotiated in law's shadow'. ${ }^{168}$

The manner in which panels and the Appellate Body have applied the disciplines of the SPS Agreement to the disputes before them has had important implications for the balance achieved by the Agreement between the competing objectives of health protection and trade liberalisation, and its effect on Members at different levels of development, as is seen from the discussion of the case law in this book. ${ }^{169}$ The sensitive nature of this balance has meant that the disputes under the SPS Agreement, although few, 'have been among the most closely watched and carefully critiqued' ${ }^{170}$ of all WTO disputes to date. Much of the criticism relates not so much to the disciplines of the SPS Agreement as such, but rather to the way in which they have been clarified and applied in dispute settlement. While the substantive clarifications are discussed elsewhere in this book, a closer look at procedural aspects of the work of panels and the Appellate Body in disputes under the SPS Agreement is now called for. This work takes place within the framework of the WTO rules applicable to dispute settlement proceedings.

In order to enforce their rights under the SPS Agreement, Members can have recourse to the dispute settlement system of the WTO, as embodied in the Dispute Settlement Understanding (DSU). ${ }^{171}$ In terms of Article 11.1 of the SPS Agreement, Articles XXII

166 Victor Mosoti notes, with regard to the need for improving developing (and especially African) country participation in WTO dispute settlement, the importance of ensuring that these Members contribute to the evolving corpus of international trade law principles and jurisprudence arising from cases that 'will govern multi-lateral trade relations for years to come.' Victor Mosoti, 'Does Africa Need the WTO Dispute Settlement System?' in Towards a Development-Supportive Dispute Settlement System in the WTO, Gregory Shaffer, et al. (eds.) (International Centre for Trade and Sustainable Development, Geneva), 2003, 67-88, 7374, available at: www.ictsd.org/pubs/ictsd_series/resource_papers/DSU_2003.pdf, visited on 30 June 2008.

${ }^{167}$ As noted by Wolfe, several authors have argued that the decisions of WTO adjudicatory bodies affect how Members bargain before they get to court, and that knowledge of what a court would do shapes the bargaining between Members. Here Wolfe refers, inter alia, to Richard H. Steinberg, 'In the Shadow of Law or Power? Consensus-Based Bargaining and Outcomes in the GATT/WTO', International Organization 56 (2), 2002, 339-374. However, Wolfe advocates a contrary understanding, which he calls 'law in the shadow of bargaining', arguing that law arises from human interaction rather than through dispute settlement outcomes. Robert Wolfe, 'See You in Geneva? Legal (Mis)Representations of the Trading System', European Journal of International Relations 11 (3), 2005, 339-364.

${ }^{168}$ Gregory Shaffer, 'Recognising Public Goods in WTO Dispute Settlement: Who Participates? Who Decides? The Case of TRIPS and Pharmaceutical Patent Protection', Journal of International Economic Law 7 (2), 2004, 459-482, 471.See also Gregory Shaffer, 'Power, Governance, and the WTO: A Comparative Institutional Approach', in Power in Global Governance, Michael Barnett and Raymond Duvall (eds.) (Cambridge University Press, Cambridge), 2005, 130-160, 136.

169 The case law on specific substantive disciplines of the SPS Agreement is discussed in Part III above; that on the procedural arrangements under this Agreement in Chapter 1 of Part IV, above; and that on the special provisions for developing-country Members in Part V, below.

${ }^{170}$ Andrew T.F. Lang, Provisional Measures under Article 5.7 of the WTO's Agreement on Sanitary and Phytosanitary Measures: Some Criticisms of the Jurisprudence So Far, LSE Legal Studies Working Paper No. 11/2008 (London School of Economics, London), 30 June 2008, 2, available at: http://ssrn.com/abstract $=1153660$, visited on 18 August 2008 .

171 'Understanding on the Rules and Procedures Governing the Settlement of Disputes', in The Results of the 
and XXIII of GATT 1994, as elaborated by the DSU apply to consultations and settlement of disputes under the SPS Agreement, unless otherwise provided in the Agreement.

This Chapter starts by briefly outlining the general rules on the WTO dispute settlement procedure. It proceeds to pay particular attention to certain aspects of these rules of special relevance to dispute settlement under the SPS Agreement, namely the question of which party bears the burden of proof, the standard of review to be applied by panels, and the role of international law in the interpretation of the Agreement.

In addition to the normal rules of the DSU, the SPS Agreement contains a special provision with regard to dispute settlement. This is contained in Article 11.2, dealing with the authority of panels to seek expert advice. ${ }^{172}$ This Chapter therefore proceeds to examine the use of experts by panels when resolving disputes under the SPS Agreement.

Article 11.3 preserves the rights of Members under other international agreements, including the right to avail themselves of the good offices or dispute settlement mechanisms of other international organisations or created by any international agreement. Particularly relevant here are the dispute settlement mechanisms of the OIE and IPPC. These mechanisms are briefly outlined in this Chapter.

Finally, this Chapter examines the practice of dispute settlement under the SPS Agreement to date. Specific reference is made to the use made of the dispute settlement system by Members at different levels of development to resolve SPS disputes. An effort is made to identify some of the constraints faced by developing-country Members in participating in this system, and the implications their weak participation may have for the effect of the SPS Agreement on their trade/health interests. In addition, the implementation problems arising in respect of certain SPS disputes are addressed.

\subsubsection{Overview of the WTO dispute settlement system}

The DSU, negotiated in the Uruguay Round and seen as one of its main achievements, sets out the rules and procedures of the dispute settlement system of the WTO. The WTO dispute settlement system aims to provide security and predictability to the multilateral trading system. ${ }^{173}$ It builds upon the dispute settlement practice that developed under the GATT 1947, and addresses the major shortcomings of that system. One of these shortcomings, as mentioned above, was the requirement of consensus for the establishment of a panel to hear a dispute and for the adoption of the report of this panel. ${ }^{174}$ The consensus requirement for these decisions has been replaced by decision-making by reverse consensus (i.e. the decision is taken unless there is a consensus against it). In this way, there has

Uruguay Round of Multilateral Trade Negotiations: The Legal Texts (World Trade Organization, Geneva), 1994, 404-433.

${ }^{172}$ Article 11.2 of the SPS Agreement. Article 1.2 of the DSU provides that its rules and procedures apply subject to such additional rules and procedures on dispute settlement as are identified in Annex 2 to the DSU. Article 11.2 of the SPS Agreement is one of the provisions identified in Annex 2 of the DSU.

${ }^{173}$ Article 3.2 of the DSU.

${ }^{174}$ See the discussion of the shortcomings of the existing legal framework for the resolution of disputes concerning trade/health conflicts prior to the Uruguay Round, above Part III, Section 1.1.3. 
been a movement away from a political/diplomatic system of resolving disputes towards a 'quasi-judicial' dispute settlement system. ${ }^{175}$

However, the preference for negotiated solutions to disputes, rather than adjudicated solutions, remains and is evident in several provisions of the DSU. Article 3.7 of the DSU declares the aim of the dispute settlement system to be 'to secure a positive solution to a dispute' and expresses the preference for 'a solution mutually acceptable to the parties to a dispute'. As a result, parties to a dispute are obliged to engage in consultations, normally for a minimum of 60 days, before resorting to adjudication. ${ }^{176}$ Any agreed solution must be in accordance with the rights and obligations established by the covered agreements. ${ }^{177}$ The possibility to make use of good offices, mediation and conciliation to resolve disputes is also provided for, in an attempt to increase the chances for a negotiated solution. ${ }^{178}$

Under Article 4.7 of the DSU, if attempts to resolve a dispute by means of consultations between the parties fail, a complaining party may request the Dispute Settlement Body to establish a panel to hear the dispute. ${ }^{179}$ There is no standing panel body at the WTO, so a new panel must be established $a d$ hoc for each dispute that proceeds to adjudication. A panel is normally composed of three persons, agreed upon by the parties to the dispute or, if no agreement can be reached within 20 days of the establishment of the panel, chosen by the WTO Director-General. ${ }^{180}$ Where the dispute is between a developingcountry Member and a developed-country Member, if the developing-country Member so requests at least one panellist shall be from a developing-country Member. ${ }^{181}$ Article 10 makes provision for the participation, as a third party, of any Member having a substantial interest in the matter before a panel. This possibility is frequently used by Members that have a systemic interest in the dispute, for example with regard to the interpretation of the obligations in the relevant agreement, to have their views heard by the panel.

Panels have the right to seek information from any individual or body they deem appropriate and to consult experts to obtain their opinion on certain aspects of the matter before them. ${ }^{182}$ During the panel process, the panel should continue to consult with the parties

${ }^{175}$ For a detailed discussion of the WTO dispute settlement system, see Peter Van den Bossche, The Law and Policy of the World Trade Organization: Text, Cases and Materials, $2^{\text {nd }}$ ed. (Cambridge University Press, Cambridge), 2008, 168-311.

${ }^{176}$ Article 4.7 of the DSU provides a minimum 60-day period for consultations, unless both parties agree during the 60-day period that consultations have failed to settle the dispute. The consultation period may also be less than 60 days if the respondent does not reply to the request for consultations within 10 days of the request, or does not enter into consultations within 30 days. In both these situations, the complainant can proceed directly to request the establishment of a panel, under Article 4.3 of the DSU. The consultation period may also be shortened in cases of urgency, including those involving perishable goods, under Article 4.8 of the DSU.

${ }^{177}$ Article 3.4 of the DSU.

${ }^{178}$ Article 5 of the DSU.

179 Article 4.7 provides that if consultations have failed, the complaining party may request the Dispute Settlement Body to establish a panel to hear the dispute. Article 6.1 of the DSU provides that the requested panel shall be established at the latest at the DSB meeting following that at which the request first appears on the agenda, unless there is a consensus in the DSB not to establish a panel (known as a 'reverse consensus'). Since the complaining party would logically never join such a reverse consensus, a panel is always established to hear a dispute.

${ }^{180}$ Article 8.5 and 8.7 of the DSU.

${ }^{181}$ Article 8.10 of the DSU.

${ }^{182}$ Article 13.1 and 13.2 of the DSU. 
and give them an opportunity to develop a mutually agreed solution. ${ }^{183}$ If no mutually agreed solution has been reached, the panel circulates its findings in the form of a written report, within a period that should not exceed nine months from the date of establishment of the panel. ${ }^{184}$ In practice, this period is very often exceeded. The report of the panel, where one or more of the parties to a dispute is a developing-country Member, must indicate the form in which any SDT provisions raised have been taken into account. ${ }^{185}$ The report of the panel is adopted by the DSB by reverse consensus within 60 days of its circulation, unless a party to the dispute notifies the DSB of its intention to appeal. ${ }^{186}$

Appeals are heard by the Appellate Body, which, unlike panels, is a permanent body. The Appellate Body is composed of seven members, who sit in divisions of three to hear appeals from panel reports. ${ }^{187}$ Only issues of law and legal interpretations covered in the panel report may be appealed. ${ }^{188}$ Appellate Body proceedings may not exceed 90 days. ${ }^{189}$ In all but a few cases, the Appellate Body has managed to keep to this time limit. ${ }^{190}$ The report of the Appellate Body is adopted by reverse consensus within 30 days of its circulation. ${ }^{191}$

Where a panel or the Appellate has found that a challenged measure is inconsistent with a WTO agreement, it must recommend that the Member concerned bring its measure into conformity with that agreement. ${ }^{192}$ The first objective of the DSU, in such a case, is to secure the withdrawal of the inconsistent measure. ${ }^{193}$ Prompt compliance with the recommendations and rulings of the DSB is preferred. ${ }^{194}$ If this is impracticable, the respondent Member shall have a reasonable period of time to comply. ${ }^{195}$ This period may be agreed to between the parties, or be determined through binding arbitration. If the recommendations and rulings of the DSB are not implemented within the reasonable period of time, the DSU provides for the temporary remedies of agreed compensation, ${ }^{196}$ or as a last resort, authorised retaliation through the suspension by the complaining Member of concessions or other obligations towards the respondent Member of a level equivalent to the nullification or impairment of benefits suffered from non-compliance. ${ }^{197}$ Members

\footnotetext{
${ }^{183}$ Article 11 of the DSU.

${ }^{184}$ Articles 12.7 and 12.9 of the DSU.

${ }_{185}$ Article 12.11 of the DSU.

${ }^{186}$ Article 16.4 of the DSU.

${ }^{187}$ Article 17.1 of the DSU.

${ }^{188}$ Article 17.6 of the DSU.

189 Article 17.5 of the DSU.

${ }^{190}$ An example of a case where this time limit was exceeded is the appeal against the panel reports in US - Continued Suspension and Canada-Continued Suspension, which was initiated on 29 May 2008. The Appellate Body has indicated that, due to the numerous and complex issues it has to address and the increased burden on translation services, it is unable to meet the deadline, and expects to circulate its report in October 2008.

191 Article 17.14 of the DSU.

${ }^{192}$ Article 19.1 of the DSU.

193 Article 3.7 of the DSU.

194 Article 21.1 of the DSU.

195 Article 21.3 of the DSU.

196 Article 22.2 of the DSU.

${ }^{197}$ Article 22.2 and 22.4 of the DSU. Authorisation to suspend concessions or other obligations must be requested from the DSU, which grants this request by reverse consensus. Disagreements as to the level of retaliation shall be referred to arbitration, by the original panel if possible, under Article 22.6 of the DSU.
} 
may not unilaterally determine non-compliance with the recommendations and rulings of the DSB. If there is disagreement regarding the existence, or consistency with a covered agreement, of measures taken to comply, this dispute must be decided by recourse to the dispute settlement procedures of the DSU. ${ }^{198}$ Where possible, resort is had to the original panel to hear this dispute.

The WTO dispute settlement system is characterised by the confidentiality of the proceedings. Consultations, and - as a rule - panel and Appellate Body proceedings take place behind closed doors, ${ }^{199}$ and the submission of parties and third parties are confidential unless the party involved decides to make its own submission available to the public. ${ }^{200}$ In view of the fact that disputes under the SPS Agreement, particularly those dealing with food safety issues such as the EC-Hormones dispute and EC-Approval and Marketing of Biotech Products dispute, have been the subject of much public concern, the confidential nature of dispute settlement proceedings has given rise to distrust in the manner in which disputes are addressed. In a surprising, and welcome, move, the Panels and the Appellate Body in the US/Canada-Continued Suspension disputes agreed to the parties' request to open the panel meetings with the parties and the Appellate Body's oral hearing to the public through a closed-circuit television broadcast. ${ }^{201}$ This was also done by the Panel in the Australia-Apples dispute, in respect of its first substantive meeting with the parties and third parties. ${ }^{202}$

After this very brief overview of the dispute settlement process, it is necessary to look in more detail at certain aspects thereof that have an impact on the way in which the trade/ health balance written into the provisions of the SPS Agreement plays out in disputes. Some of these aspects have a particular effect on the possibilities for Members at lower levels of development to participate effectively in the dispute settlement system.

198 Article 21.5 of the DSU. A shorter time-frame (90 days) is laid down for compliance panel proceedings. Appeal from the report of an Article 21.5 panel is possible.

199 Articles 4.6 and 17.10 and Appendix 3 para. 2 of the DSU.

${ }^{200}$ Articles 18.2 and 17.10 and Appendix 3 para. 3 of the DSU.

${ }^{201}$ Dispute Settlement Body, United States-Continued Suspension of Obligations in the EC-Hormones Dispute (WT/DS320); Canada-Continued Suspension of Obligations in the EC-Hormones Dispute (WT/DS321). Communication from the Chairman of the Panels, WT/DS320/8, WT/DS321/8, circulated on 2 August 2005. The WTO Secretariat was asked by the Panels to make the necessary arrangements for the broadcast. To ensure full transparency and non-discriminatory access to the broadcast by all, the Panels also requested the Secretariat to ensure that each Member has at least two seats available in the room where the broadcast would be shown. As the third parties in this case did not all agree to opening up proceedings to the public, meetings with third parties remained closed. The Appellate Body's decision to open its oral hearing to observation via simultaneous closed circuit broadcast was reported on the WTO website, available at: http://www.wto.org/ english/tratop_e/dispu_e/public_hearing_july08_e.htm, visited on 15 July 2008. The hearing was held on 28-29 July 2008. Two other panels in non-SPS disputes have followed suit, by allowing public observation in different forms, namely through allowing actual presence of the public at the panel meeting in a public gallery (EC-Bananas III (Article 21.5 - US)) and through the broadcasting of an edited video tape of the panel meeting (EC and Certain Member States - Large Civil Aircraft).

202 'WTO Hearings on Apple Dispute Open to the Public'WTO News Item, 11 August 2008, available at: http:// www.wto.org/english/news_e/news08_e/hearing_11aug08_e.htm, visited on 11 August 2008. This meeting will take place on 2-3 September 2008. 


\subsubsection{Burden of proof}

The allocation of the burden of proof in dispute settlement reflects a particular choice, which is of relevance to the balance struck between the competing interests at issue in disputes. It has been argued that it 'serves to allocate of the risk of error between the disputing Members and to indicate the relative importance that is attached to the ultimate decision. ${ }^{203}$ The question of which party bears the burden of proof is particularly significant in the case of SPS disputes due to the difficult and intricate factual issues involved in this area. In $E C$ - Hormones the Appellate Body emphasised the importance of the issue of burden of proof, in the light of the 'multiple and complex issues of fact' that may arise under the SPS Agreement. ${ }^{204}$

The Appellate Body first set out the burden of proof rules for WTO disputes in US - Wool Shirts and Blouses. ${ }^{205}$ There it recognised that various international tribunals and most national jurisdictions apply the rule that the party who asserts a fact, whether plaintiff or respondent, must prove it. Once a party has adduced sufficient evidence to create a presumption that what is claimed is true, in other words established a prima facie case, the evidentiary burden shifts to the other party who must rebut the presumption or lose the case. In EC-Hormones the Appellate Body held that this rule applies equally to disputes under the SPS Agreement. It rejected the Panel's finding that the SPS Agreement allocates the burden of proof to the Member imposing the SPS measure. ${ }^{206}$ Instead, the Appellate Body allocated the burden of proof as follows:

The initial burden lies on the complaining party, which must establish a prima facie case of inconsistency with a particular provision of the SPS Agreement on the part of the defending party, or more precisely, of its SPS measure or measures complained about. When that prima facie case is made, the burden of proof moves to the defending party, which must in turn counter or refute the claimed inconsistency. ${ }^{207}$

This finding was reiterated by the Panels in Australia - Salmon, ${ }^{208}$ Japan - Agricultural Products II ${ }^{209}$ and Australia - Salmon (Article 21.5 - Canada). ${ }^{210}$ The importance of this approach to the burden of proof lies in its recognition of the difference in the regime

${ }^{203}$ Theofanis Christoforou, 'Settlement of Science-Based Trade Disputes in the WTO: A Critical Review of the Developing Case Law in the Face of Scientific Uncertainty', New York University Environmental Law Journal 8, 2000, 622-648, 641.

${ }^{204}$ Appellate Body Report, EC - Hormones, para. 97.

${ }^{205}$ Panel Report, US - Wool Shirts and Blouses, 14-16.

206 The Appellate Body in EC-Hormones dealt with the grounds for the Panel's finding in turn. Firstly, it rejected the Panel's conclusion that the fact that many SPS provisions are worded 'Members shall ensure that...' has any logical connection to the allocation of the evidentiary burden. Secondly, it held that Article 5.8, under which Members may ask for an explanation of the reasons for an SPS measure from another Member and the latter is obliged to comply with the request, does not purport to address burden of proof issues, contrary to the Panel's finding. Instead this Article is most likely to be used in pre-dispute situations in order to enable a Member to acquire information which it could later use to meet its burden of proof in dispute settlement proceedings. Appellate Body Report, EC-Hormones, paras 102-105

${ }^{207}$ Appellate Body Report, EC - Hormones, para. 98.

${ }^{208}$ Panel Report, Australia - Salmon, para. 8.40.

${ }^{209}$ Panel Report, Japan - Agricultural Products II, para. 8.13.

${ }^{210}$ Panel Report, Australia - Salmon (Article 21.5 - Canada), para. 7.37. 
created by the SPS Agreement to balance trade and health objectives, from the regime applicable to health measures under the GATT 1994. As discussed above, the GATT approach was premised on the idea that health protection measures were exceptional, and therefore once a complainant Member had shown a violation of one of the GATT disciplines by the health measure at issue, the burden of justifying the measure under the relevant exception of Article XX(b) of the GATT was on the Member imposing the measure. ${ }^{211}$ The new approach of the SPS Agreement is to recognise that Members have the right to regulate to the extent necessary to address SPS risks, but to subject such regulation to disciplines to minimise its trade effects and the possibilities for disguised protectionism. It is therefore for the complaining Member to prove, prima facie, that the SPS measure complained of violates the disciplines of the SPS Agreement.

In EC-Hormones, the Appellate Body clarified what is meant by a 'prima facie case', stating:

[A] prima facie case is one which, in the absence of effective refutation by the defending party, requires a panel, as a matter of law, to rule in favour of the complaining party presenting the prima facie case. ${ }^{212}$

A complicating issue regarding the burden of proof under the SPS Agreement has to do with the question whether, in view of the scientific requirements in the Agreement, a complaining Member is required to prove the absence of scientific evidence to back the challenged measure. This issue arose in Japan - Agricultural Products II. ${ }^{213}$ In this case, the Panel had found that Japan's varietal testing requirement was maintained without 'sufficient scientific evidence' contrary to Article 2.2, with regard to apples, cherries, nectarines and walnuts. ${ }^{214}$ However, it did not consider that there was sufficient evidence before it to extend this finding to apricots, pears, plums and quince. This was due to the fact that the parties had not submitted any evidence for the latter products. The Panel had also asked the experts advising it whether their statements with regard to the former group of products applied to the latter as well. The experts affirmed this but did not elaborate at all. Thus the Panel found that the US had not adduced sufficient evidence to raise a presumption (i.e. make a prima facie case) that the measure was maintained without sufficient scientific evidence with regard to apricots, pears, plums and quince.

The US appealed this ruling, arguing that the Panel's interpretation imposed on it an impossible burden of proof, requiring it to prove a negative (namely that there were no relevant studies or reports supporting Japan's measure). The US contended that the Panel's finding amounted to holding that because there was insufficient evidence of the existence or relevance of varietal differences, it could not find that there was insufficient evidence to support the measure. ${ }^{215}$ The Appellate Body rejected this argument, finding that the US was not being required to prove a negative, but merely to raise a presumption that there were no relevant studies or reports. According to the Appellate Body, this is not an

${ }^{211}$ See the discussion of the relevant GATT rules above, Part III, Section 1.1.1.

212 Appellate Body Report, EC - Hormones, para. 104, referring to Appellate Body Report, US - Wool Shirts and Blouses, 14.

213 Appellate Body Report, Japan - Agricultural Products II, paras 132-139.

${ }^{214}$ Panel Report, Japan - Agricultural Products II, para. 8.45.

${ }^{215}$ Appellate Body Report, Japan - Agricultural Products II, para. 38. 
impossible burden. The US could have requested Japan, under Article 5.8, ${ }^{216}$ to provide an 'explanation of the reasons' for its measure as it related to the products at issue. The failure of Japan to do so would have amounted to a strong indication that such studies or reports did not exist. Further, the US could have questioned the Panel's experts or submitted an opinion of its own experts on the question whether such reports exist. Instead, the US submitted no evidence on the point. Therefore, the Appellate Body agreed with the Panel's refusal to find a violation of Article 2.2 with regard to the products at issue.

This decision is significant as it establishes clearly that it is the complaining Member's duty to make a prima facie case for the absence of scientific evidence in support of the SPS measure. Only once this has occurred does the defending Member have to submit evidence to rebut this presumption. A mere contention that scientific evidence is lacking without the submission of any evidence in support of this claim is insufficient to create a duty of rebuttal. It would be too onerous to require Members to have to defend their many SPS measures on the basis of scientific evidence, without any indication having to be shown that the measures violate the SPS Agreement in the first place. Complaining Members are assisted in their task by the possibility created in Article 5.8 of the SPS Agreement to request information on the SPS measures of other Members.

The allocation of the burden of proof on the complaining Member to make a prima facie case of violation of the SPS Agreement, does not absolve the respondent Member from proving its case. In Japan - Apples, the Appellate Body clarified its finding in EC Hormones as follows:

[T]he Appellate Body statement in EC - Hormones does not imply that the complaining party is responsible for providing proof of all facts raised in relation to the issue of determining whether a measure is consistent with a given provision of a covered agreement. In other words, although the complaining party bears the burden of proving its case, the responding party must prove the case it seeks to make in response. ${ }^{217}$

The issue of the burden of proof of the respondent Member arose also in Japan - Apples. In that case, the US had argued that there was insufficient scientific evidence, for purposes of Article 2.2, that mature, symptomless apples could form a transmission pathway for fire blight. To counter these arguments, Japan averred that, due to failures in export control systems, infected or immature apples could be exported, and these apples could serve as a pathway for fire blight. The US limited its arguments to the issue of mature, symptomless apples. On the basis of the scientific evidence presented to it, the Panel agreed with the US that Japan's measure, as it applied to mature, symptomless apples, was maintained without sufficient scientific evidence and concluded that it had not been established with sufficient scientific evidence that infected or immature apples could serve as a pathway for the transmission of fire blight. ${ }^{218}$ On appeal, Japan argued that the

${ }^{216}$ See the discussion of the transparency obligation contained in Article 5.8 of the SPS Agreement, above, Part IV, Section 1.3.3.

217 Appellate Body Report, Japan - Apples, para. 154. This finding was referred to by the Panel in US Continued Suspension, para. 7.329; Canada-Continued Suspension, para. 7.329.

${ }^{218}$ This was due to the fact that Japan did not present sufficient scientific evidence that the last stage of the transmission pathway of fire blight from the infected imported apple to the host plant, was likely to be completed. 
Panel had erred in shifting the burden of proof to Japan in respect of infected or immature apples before the US had made a prima facie case in that regard. The Appellate Body rejected Japan's contention, holding:

It is important to distinguish, on the one hand, the principle that the complainant must establish a prima facie case of inconsistency with a provision of a covered agreement from, on the other hand, the principle that the party that asserts a fact is responsible for providing proof thereof. In fact, the two principles are distinct. In the present case, the burden of demonstrating a prima facie case that Japan's measure is maintained without sufficient scientific evidence, rested on the United States. Japan sought to counter the case put forward by the United States by putting arguments in respect of apples other than mature, symptomless apples being exported to Japan as a result of errors of handling or illegal actions. It was thus for Japan to substantiate those allegations; it was not for the United States to provide proof of the facts asserted by Japan. Thus, we disagree with Japan's assertion that "the shift of the burden of proof to Japan was made prematurely before the demonstration of a prima facie case by the United States." There was no "shift of the burden of proof "with respect to allegations of fact relating to apples other than mature, symptomless apples, for Japan was solely responsible for providing proof of the facts it had asserted. Moreover, it was only after the United States had established a prima facie case that Japan's measure is maintained without sufficient scientific evidence, that the Panel had to turn to Japan's attempts to counter that case. ${ }^{219}$

This finding is useful in clarifying the issue of the burden of proof in cases where there are several hypotheses regarding the alleged risks underlying an SPS measure. It is not necessary for the complainant to address all possible hypotheses and establish that there is insufficient evidence of risk for each. ${ }^{220}$ According to the Appellate Body in Japan Apples, the Panel had evidently found it sufficient for the US to address whether mature symptomless apples could serve as a transmission pathway for fire blight. It noted, referring to its previous finding in US - Wool Shirts and Blouses that 'the nature and scope of evidence required to establish a prima facie case "will necessarily vary from measure to measure, provision to provision, and case to case." ${ }^{221}$ Once a prima facie case is established, the respondent will bear the burden of proving the assertions it makes to refute the complainant's case.

The difficulty of finding the scientific evidence necessary to prove a case under the SPS Agreement has raised questions regarding whether the availability of the necessary information should affect the allocation of the burden of proof. In Japan - Apples, Japan argued that the US, as the exporting country affected by the disease, would naturally have more information regarding the fire blight bacterium. Therefore it should bear a greater burden of proof. The Panel disagreed, noting that it did not see the greater expertise of the

Panel Report, Japan - Apples, para. 8.168.

219 Appellate Body Report, Japan - Apples, para. 157.

220 This was argued by Japan but rejected by the Appellate Body. Ibid., para. 159.

${ }^{221}$ Appellate Body Report, Japan - Apples, para. 160. In footnote, the Appellate Body referred to Appellate Body Report, US - Wool Shirts and Blouses, 335. 
exporting Member as a factor automatically justifying a different allocation of the burden of proof or the imposition of a heavier burden on one party. ${ }^{222}$ While acknowledging that certain pieces of scientific evidence may be more readily available in some Members than others (for example, a disease-free Member may have less-developed evidence on that disease than a Member with direct exposure to the disease), the Panel did not see this as relevant to the burden of proof issue, noting the possibility for Japan to commission research in third countries. It pointed out that, in fact, many developing-country Members affected by a pest or disease may not have the resources to gather information on that pest or disease and may have to rely on information gathered in other countries. ${ }^{223}$ However, the Panel noted that all Members have the duty to cooperate in the dispute settlement proceedings including with respect to the gathering of information relevant to the Panel's assessment. ${ }^{224}$ While the Panel's finding on the allocation of the burden of proof seems correct, it does highlight the difficulty encountered by Members in accessing the necessary scientific data to prove their cases. If Japan, a high-income Member, faced difficulties in this regard, how much more so will less-developed Members. These Members may not have the resources to commission third country research and will therefore depend on the chance that there are already existing studies of relevance to their situation. It can be doubted whether the duty to cooperate in dispute settlement proceedings will lead Members, in an adversarial system, to provide data supporting of the position of the opposing party.

Aside from the issue of the burden of proof under the SPS Agreement generally, two provisions of the Agreement, namely Articles 3 and 5.7, present interesting specific burden of proof issues. The question of the allocation of the burden of proof under the harmonisation provision contained in Article 3 of the SPS Agreement arose in the EC-Hormones dispute. The Appellate Body's ruling on this issue is particularly important in the light of the problematic aspects, discussed above, of standard-setting by international bodies. ${ }^{225}$ In EC - Hormones the Panel had derived, from the presumption in favour of a measure that conforms to an international standard in Article 3.2 and from its finding of a rule/exception relationship between Articles 3.1 and 3.3, a burden of proof for the respondent Member whose SPS measure deviates from the relevant international standard. ${ }^{226}$ The Appellate Body rejected this finding as having no textual basis. It denied that Article 3.3 embodies an exception to the general rule contained in Article 3.1, finding that the relationship between Articles 3.1, 3.2 and 3.3 is qualitatively different from that between Articles I or III (non-discrimination obligations) and Article XX (exceptions) of the GATT 1994. Instead, it held that Article 3.1 of the SPS Agreement merely excludes from its scope situations falling under Article 3.3. Article 3.3 contains an autonomous option available to Members and it is for the challenging Member to prove non-compliance with the conditions laid down in this Article for SPS measures not based on international standards. ${ }^{227}$ To hold otherwise would result in penalising a Member who chooses a higher level of protection than that aimed at by the international standard, a right expressly

\footnotetext{
${ }^{222}$ Panel Report, Japan - Apples, para. 8.44.

${ }^{223}$ Panel Report, Japan - Apples, para. 8.45.

${ }^{224}$ Ibid., para. 8.48.

${ }^{225}$ See above, Part II, Sections 3.2.1.4, 3.2.2.4 and 3.2.3.4.

${ }^{226}$ Panel Report, EC - Hormones (US), para. 8.54.; Panel Report, EC - Hormones (Canada), para. 8.57.

${ }^{227}$ Appellate Body Report, EC-Hormones, para. 104.
} 
recognised in the Preamble to the SPS Agreement. ${ }^{228}$ The Appellate Body held as following in respect of the presumption in Article 3.2:

The presumption of consistency with relevant provisions of the SPS Agreement that arises under Article 3.2 in respect of measures that conform to international standards may well be an incentive for Members so to conform their SPS measures with such standards. It is clear, however, that a decision of a Member not to conform a particular measure with an international standard does not authorize imposition of a special or generalized burden of proof upon that Member, which may, more often than not, amount to a penalty. ${ }^{229}$

While it is not likely that developing-country Members will often choose a level of protection higher than that reflected in international standards, the problems of participation they face in international standard setting procedures means that the adopted standards are often technically inappropriate for them or do not take into account scientific data on the risk at issue as it occurs in their particular circumstances. This may lead a developingcountry Member to adopt a different SPS measure than that embodied in an international standard, as done by Mauritius in adopting a fumigation treatment for wood packaging material rather than the heat treatment laid down in the relevant IPPC standard, ISPM 15. If a Member would wish to challenge Mauritius's measure, that Member would bear the burden of proof to show a violation of the requirements of Article 3.3 of the SPS Agreement.

A second question raised by Article 3 is that of the consequences of the presumption of consistency with the SPS Agreement and GATT 1994, for measures that conform to the relevant international standards, contained in Article 3.2. Clearly, this provision is intended to encourage Members to adopt international standards, thus resulting in increasing harmonisation of SPS measures and promoting free trade. However, in EC-Hormones, the Appellate Body held this presumption to be rebuttable. ${ }^{230}$ One could question the practical benefit of a rebuttable presumption for the defending Member, since in any case the burden of proving a violation of the SPS Agreement and GATT 1994 rests on the challenging Member, even in the absence of this presumption. Thus the efficacy of this presumption in promoting harmonisation around international standards would seem questionable. It would seem preferable to view the Article 3.2 presumption as irrebuttable.

In any case, as suggested above, ${ }^{231}$ a Member whose measure conforms to an international standard under Article 3.2, just as one whose measure is based on such a standard under Article 3.1, would arguably be immune to challenges on grounds of violation of the obligation to conduct a risk assessment under Articles 5.1-5.3 of the SPS Agreement, since the international standard-setting procedure of all three of the relevant international bodies is founded on risk assessments by scientific expert groups. Bearing in mind the difficulties

\footnotetext{
${ }^{228}$ Para. 6 of the Preamble to the SPS Agreement provides: 'Desiring to further the use of sanitary and phytosanitary measures between Members, on the basis of international standards, guidelines and recommendations developed by international organisations ... without requiring Members to change their appropriate level of protection of human, animal or plant life or health.'

${ }^{229}$ Appellate Body Report, EC-Hormones, para. 102.

${ }^{230}$ Ibid., para. 170.

${ }^{231}$ See above, Part III, Sections 4.2.1 and 4.2.2.
} 
of proving that the requirements for a risk assessment have been met, particularly for developing-country Members which often lack the necessary expertise, this would constitute a considerable advantage and thus a strong incentive to adopt international standards.

The question of the burden of proof under Article 5.7 of the SPS Agreement was first addressed in Japan - Apples ${ }^{232}$ where the Panel held that the burden of proof under Article 5.7 is on the respondent. ${ }^{233}$ This finding, as expressly pointed out by the Appellate Body, was not appealed. ${ }^{234}$ When the issue arose again in EC - Approval and Marketing of Biotech Products, the Panel took this remark by the Appellate Body as expressing the Appellate Body's reservations with regard to this allocation of the burden of proof. ${ }^{235}$ In EC - Approval and Marketing of Biotech Products, the EC argued that its Member States' safeguard measures banning biotech products that had already been approved at EC level, fell to be assessed under Article 5.7 rather than under Articles 2.2 and 5.1 of the SPS Agreement. As discussed above, ${ }^{236}$ the Panel agreed with the EC that Article 5.7 is an autonomous right, and not merely an exception from the scientific obligations under Articles 2.2 and 5.1. ${ }^{237}$ Thus, the Panel held that a measure falling under Article 5.7 is excluded from the scope of application of the scientific obligations in Article 2.2 and Article 5.1, in the same way that a measure falling under Article 3.3 is excluded from the scope of application of Article 3.1 $1^{238}$ The Panel pointed out the implications of this finding for the burden of proof, namely that the party claiming a violation of Articles 2.2 or 5.1 bears the burden of proving that the challenged measure is inconsistent with at least one of the four requirements set out in Article 5.7. ${ }^{239}$ Only then will the measure fall within the scope of application of Articles 2.2 and 5.1.

The result for the burden of proof of viewing Article 5.7 as an autonomous right rather than as an exception to Articles 2.2 and 5.1 reflects the leeway, to take into account scientific realities, provided to regulating Members by the Appellate Body in its interpretation of the SPS Agreement. By allocating the burden of proof to the complaining Member, the Appellate Body ensures that the policy space left to Members by the SPS Agreement is not undermined by an unrealistic application of its scientific disciplines in the face of insufficiencies in science.

An issue repeatedly raised regarding the burden of proof is that of the relationship between the burden of proof on a Member to show a prima facie case and the investigative authority of a panel. Regarding the role of panels (in this case with regard to the determination whether an SPS measure is based on a risk assessment), the Panel in EC - Hormones stated as follows:

\footnotetext{
${ }^{232}$ The burden of proof under Article 5.7 was also relevant in Japan-Agricultural Products II, the first case in which Article 5.7 was at issue. However, the Panel did not expressly address the burden of proof under this Article but merely referred back to its general statement on the allocation of the burden of proof as set out in EC-Hormones. Panel Report, Japan - Agricultural Products II, para. 59.

${ }^{233}$ Panel Report, Japan-Apples, para. 8.212. Here, Japan had invoked Article 5.7 to justify its measure, which explains the Panel's approach.

234 Appellate Body Report, Japan - Apples, para. 175 and footnote 316.

${ }^{235}$ Panel Reports, EC - Approval and Marketing of Biotech Products, para. 7.2979.

${ }^{236}$ See above, Part III, Section 5.2.5.

${ }^{237}$ Panel Reports, EC-Approval and Marketing of Biotech Products, paras 7.2969 and 7.3004.

${ }^{238}$ Ibid., paras 7.2969 and 7.3007.

239 Panel Reports, EC - Approval and Marketing of Biotech Products, paras 7.2976 and 7.3007.
} 
It is for the European Communities to submit evidence before the Panel that its measures are based on a risk assessment; it is not for the Panel itself to conduct its own risk assessment on the basis of scientific evidence gathered by the Panel or submitted by the parties during the Panel proceedings. ${ }^{240}$

This issue is closely related to the issue of the standard of review to be applied by a panel in evaluating the evidence before it, and the question of the role of the experts advising the panel. These issues are discussed further below. ${ }^{241}$

\subsubsection{Standard of review}

The issue of the appropriate standard of review to be applied in dispute settlement proceedings is an important one, as it has a significant role to play in the allocation of authority to make policy choices balancing competing trade and health interests. The particular standard of review applied determines the extent to which the WTO adjudicatory bodies are entitled to interfere in Members' regulatory determinations. On either end of the spectrum of possible standards of review are deference to national regulatory decisions and de novo review, allowing the adjudicator to replace national regulatory decisions with its own assessment. The question of where on this spectrum the appropriate standard of review lies in SPS disputes is crucial to the limits of policing national regulatory choices in favour of trade liberalisation, and therefore to the trade/health balance achieved in the implementation of the rules of the SPS Agreement.

As noted by Shaffer, through its determination of the applicable standard of review, the 'Appellate Body can effectively allocate decision making over policy matters brought before it to alternative decision-making processes, each of which favours different actors to varying extents. ${ }^{242}$ A deferential approach effectively allocates the competence to balance the competing interests of trade liberalisation and health protection to national authorities. This has the advantage of giving greater policy space to domestic regulators, enabling them to give effect to democratically determined preferences. ${ }^{243}$ In view of the wide divergences between Members at different levels of development in respect of priorities, consumer preferences and regulatory capacity, such respect for policy space seems wise. However, this approach also holds dangers. It allows for regulatory capture by powerful domestic industry lobbies. ${ }^{244}$ It also neglects the fact that the interests of foreign stakeholders, including producers and exporters, are not taken into account in the balancing of interests that underlies national regulation. The application of a de novo standard of review would instead allocate the balancing competence to the adjudicatory

\footnotetext{
${ }^{240}$ Panel Report, EC - Hormones (Canada), para. 8.104.; Panel Report, EC-Hormones (US), para. 8.101.

${ }^{241}$ See below, Part IV, Sections 2.2.3 and 2.2.5.

${ }^{242}$ Gregory Shaffer, 'Power, Governance, and the WTO: A Comparative Institutional Approach', in Power in Global Governance, Michael Barnett and Raymond Duvall (eds.) (Cambridge University Press, Cambridge), 2005, 130-160, 159. Shaffer analyses the US - Shrimp dispute and identifies five different options for the standard of review that could have been applied. These overlap to some extent with some of the discussion below.

${ }^{243}$ Shaffer notes that participation in democratic decision-making is of a higher quality at national level than at international level due to the closer relation between the citizen and the state, the sense of a common identity and communal cohesiveness, and the reduced costs f organisation and participation. Ibid., 143.

${ }^{244}$ See the discussion of private interest capture of national SPS regulation, above, Part II, Section 1.2.
} 
body itself, replacing the regulatory choices of the national regulator with its own. While this has the benefit of incorporating the trade interests of the exporting Member, as reflected in WTO disciplines, in the balancing exercise, it creates legitimacy problems. ${ }^{245}$ There are many subjective elements to the risk analysis process, in particular with regard to the evaluation of scientific evidence and the choice amongst equally plausible alternative risk assessments, that are best left to democratic decision-making processes. In addition, due to the imbalance in effective participation in WTO dispute settlement by Members at different levels of development, ${ }^{246}$ de novo review may skew the outcome of judicial review in favour of developed-country Members that have the resources to bring convincing scientific evidence and persuasive legal arguments in support of their positions. ${ }^{247}$ It would therefore seem that neither complete deference nor de novo review is the appropriate standard of review to be applied by WTO adjudicators. Some have suggested that, instead, a process-based review would be best, limited to establishing whether the procedural requirements have been complied with. ${ }^{248}$ As the SPS Agreement does not lay down procedures for the conduct of a risk assessment or the establishment of sufficient scientific evidence, such a limited review seems inappropriate. ${ }^{249}$ Instead, it is proposed here that a panel should limit its examination to the question whether the regulatory disciplines of the SPS Agreement have been complied with, including that requiring that an SPS measure be based on a risk assessment as defined in the Agreement, stopping short of assessing quality and weight of the scientific evidence itself. In other words, panels should apply a strict standard of review to legal questions, but should show more defer-

${ }^{245}$ In respect of the US - Shrimp dispute, involving a conflict between trade and environmental objectives, Shaffer notes that the Appellate Body was 'reluctant to allocate substantive decision-making authority to itself' due to the realisation that 'it lacked the legitimacy to engage in a delicate balancing of the priorities of constituencies from countries of widely disparate levels of development under open-ended standards. Although, as any court, WTO judicial bodies are not elected, they are even more subject to legitimacy challenges than domestic courts because of the more fragile social acceptance of their decisions.' Gregory Shaffer, 'Power, Governance, and the WTO: A Comparative Institutional Approach', in Power in Global Governance, Michael Barnett and Raymond Duvall (eds.) (Cambridge University Press, Cambridge), 2005, 130-160, 153.

${ }^{246}$ See below, Part IV, Section 2.2.7.

${ }^{247}$ Shaffer notes that participation in dispute settlement 'is far from neutral'. He points out that in contrast to developed countries that are repeat players in WTO dispute settlement and thus are able to mobilise legal resources cost-effectively, developing countries (such as Malaysia in the US - Shrimp (Article 21.5 - Malaysia) dispute) may fail to bring convincing factual and legal arguments in their WTO challenges. Gregory Shaffer, 'Power, Governance, and the WTO: A Comparative Institutional Approach', in Power in Global Governance, Michael Barnett and Raymond Duvall (eds.) (Cambridge University Press, Cambridge), 2005, 130-160, 152.

${ }^{248}$ Rosie Cooney and Andrew T.F. Lang, 'Taking Uncertainty Seriously: Adaptive Governance and International Trade', European Journal of International Law 18 (3), 2007, 523-551, 544. Cooney and Lang advocate procedural rather than substantive review, not primarily to ensure against interference with democratic decisions at national level but rather in order to use the trade regime in a positive way to facilitate and encourage appropriate governance frameworks on national level by promoting transparent, accountable and reasoned use of science and risk assessment.

${ }^{249}$ Claus-Dieter Ehlermann and Nicolas Lockhart, 'Standard of Review in WTO Law', in A True European: Essays for Judge David Edwards, Mark Hoskins and William Robinson (eds.) (Hart Publishing, Portland), 2003, 267-296, 291. These authors note that while the SPS Agreement identifies the substantive issues to be considered in a risk assessment, it does not lay down procedures for how the risk assessment is to be conducted. There is no requirement to carry out an investigation, engage in formal fact-finding or publish a report explaining the justification for the SPS measure adopted. See further on this point Catherine Button, The Power to Protect. Trade, Health and Uncertainty in the WTO (Hart Publishing, Oxford and Portland, Oregon), 2004, 182-185. 
ence to national regulatory authorities in factual determinations. ${ }^{250}$ Such a review ensures that the regulating Member respects the balance struck in the rules of the SPS Agreement between its health concerns and the trade interests of other Members, but the review does not intrude too far into the regulatory competence of Members by interfering in their assessment of scientific evidence. Considering the fact that SPS disputes largely turn on determinations regarding the scientific disciplines of the Agreement, the importance of ensuring that the standard of review applied reflects the balance aimed at by the Agreement cannot be overstated. The proposed type of review would also reduce the disadvantage at which Members that lack scientific capacity find themselves in challenging or defending measures under the SPS Agreement.

Despite its importance, the standard of review to be applied by panels is not explicitly addressed in the SPS Agreement or in the DSU. It has therefore been elaborated in the case law. In EC-Hormones, ${ }^{251}$ the question of the appropriate standard of review for SPS disputes was first dealt with. The EC argued that the Panel had failed to apply the appropriate standard of review, which it asserted to be a 'deferential reasonableness standard', as exists for the WTO Anti-Dumping Agreement. ${ }^{252}$ Under such a standard, the Panel should not interfere in the investigation conducted on national level which led to the establishment of the measure. If the Member has properly established the facts and conducted an objective, unbiased examination thereof, its conclusions should be deferred to by the Panel, even if it would have come to a different conclusion on the facts. Instead, the EC argued that the Panel had undertaken a de novo standard of review, under which it has complete freedom to examine the factual and procedural validity of the decision and to come to a different conclusion.

The Appellate Body rejected the proposed extension of the standard of review set in the Anti-Dumping Agreement to the SPS Agreement, ${ }^{253}$ holding that this standard is textually specific to the former Agreement and there is no evidence of an intention to adopt it in the latter Agreement. ${ }^{254}$ It stated:

In so far as legal questions are concerned - that is, consistency or inconsistency of a Member's measure with the provisions of the applicable agreement - a standard not found in the text of the SPS Agreement itself cannot absolve a panel (or the Appellate Body) from the duty to apply the customary rules of interpretation of public international law ... Nevertheless, it is appropriate to stress that here

${ }^{250}$ Catherine Button criticises the Appellate Body's articulation of the standard of review to be applied under the SPS Agreement for disregarding the distinction between issues of fact and issues of law. Catherine Button, The Power to Protect. Trade, Health and Uncertainty in the WTO (Hart Publishing, Oxford and Portland, Oregon), 2004, 179-181.

${ }^{251}$ Appellate Body Report, EC - Hormones, para. 133.

${ }^{252}$ Agreement on Implementation of Article VI of the General Agreement on Tariffs and Trade 1994, (reprinted in The Results of the Uruguay Round of Multilateral Trade Negotiations: The Legal Texts (1994) GATT Secretariat, Geneva at 168-196) [hereinafter referred to as the Anti-Dumping Agreement] at Article 17.6(i).

${ }^{253}$ This refusal to extend the standard of review laid down in the Anti-Dumping Agreement to other WTO agreements was affirmed in Appellate Body Report US - Lead and Bismuth II, para. 51, where the Appellate Body held that Article 11 of the DSU sets the standard of review for disputes under the Agreement on Subsidies and Countervailing Measures.

${ }^{254}$ Further, this standard applies only to the factual assessment of the matter and not to the legal analysis applied thereto. 
again Article 11 of the DSU is directly on point, requiring a panel to "make an objective assessment of the matter before it, including an objective assessment of the facts of the case and the applicability of and conformity with the relevant covered agreements ... 255

Thus, instead of adopting the deferential standard proposed by the EC, the Appellate Body focused on the need to maintain the balance between the competences WTO Members retain and those they transferred to the WTO, as reflected in the SPS Agreement itself. The Appellate Body stated as follows:

The standard of review appropriately applicable in proceedings under the SPS Agreement, of course, must reflect the balance established in that Agreement between the jurisdictional competences conceded by the Members to the WTO and the jurisdictional competences retained by the Members for themselves. To adopt a standard of review not clearly rooted in the text of the SPS Agreement itself, may well amount to changing that finely drawn balance; and neither a panel nor the Appellate Body is authorized to do that. ${ }^{256}$

The Appellate Body then expressed its view that the standard of review applicable to 'both the ascertainment of facts and the legal characterization of such facts' in disputes under the SPS Agreement is to be found in Article 11 of the DSU. According to the Appellate Body, this provision 'articulates with great succinctness but with sufficient clarity the appropriate standard of review'. ${ }^{257}$ Article 11 of the DSU provides that 'a panel should make an objective assessment of the matter before it, including an objective assessment of the facts of the case and the applicability of and conformity with the relevant covered agreements. ${ }^{, 258}$ Examining this provision, the Appellate Body held:

So far as fact-finding by panels is concerned, their activities are always constrained by the mandate of Article 11 of the DSU: the applicable standard is neither de novo review as such, nor 'total deference', but rather the 'objective assessment of the facts'. Many panels have in the past refused to undertake de novo review, wisely, since under current practice and systems, they are in any case poorly suited to engage in such a review. On the other hand, 'total deference to the findings of the national authorities', it has been well said, 'could not ensure an 'objective assessment' as foreseen by Article 11 of the DSU'. 259

\footnotetext{
255 Appellate Body Report, EC - Hormones, para. 118.

${ }^{256}$ Ibid., para. 115.

257 Ibid.

${ }^{258}$ The utility of this 'objective assessment' standard has been criticised on the grounds that it far from clarifies the required standard of review. See Axel G. Desmedt, "Hormones: "Objective Assessment" And (or as) Standard of Review', Journal of International Economic Law 1 (4), 1998, 695-698, 698. See also David Palmeter, 'The WTO Standard of Review in Health and Safety', in Trade and Human Health and Safety, George A. Bermann and Petros C. Mavroidis (eds.) (Cambridge University Press, Cambridge), 2006, 224$234,229$.

${ }^{259}$ Appellate Body Report, EC - Hormones, para. 117. A footnote to this sentence refers to Panel Report on US - Underwear, para. 7.10.
} 
The Appellate Body's finding that neither a panel nor the Appellate Body is authorised to change the balance of jurisdictional competences agreed to by the Members and embodied in the SPS Agreement is undoubtedly correct. However, it could be argued that where this balance lies is not always made explicit in the SPS Agreement and there is thus room for interpretation. It is precisely here that the panel's role lies, and its approach to the standard of review will have important consequences for the allocation of the authority to make policy choices balancing competing trade and health interests. ${ }^{260}$ The extent to which a panel may examine the substantive choices made by a Member, including in its assessment of scientific evidence, is crucial in establishing the nature of this balance. The possibility of limiting a panel's authority to conducting a purely procedural review is excluded by the terms of the provisions of the SPS Agreement, many of which contain enforceable obligations of a substantive nature. According to the Appellate Body in $E C$-Hormones, the question whether a panel's analysis is purely procedural or also substantive depends on the specific provision at issue. ${ }^{261}$ Where the provision in question contains substantive elements, a panel must conduct a substantive analysis. For example, in addressing a claim under the requirement in Article 5.1 that an SPS measure be 'based on' a risk assessment, a panel does not only look at the procedural requirements for a risk assessment, but also determines substantively whether a risk assessment is 'rationally related to' or 'reasonably supports' the measure. However, this should not amount to a panel conducting its own risk assessment, which would amount to a de novo review. An examination of panel practice is called for in this regard.

As noted above, the Panel in EC - Hormones, in its determination of whether the SPS measure at issue was based on a risk assessment, noted that 'it is not for the Panel itself to conduct its own risk assessment on the basis of scientific evidence gathered by the Panel or submitted by the parties during the Panel proceedings.' ${ }^{262}$ In Japan - Agricultural Products II, in examining the claim under Article 2.2, the Panel made a similar finding, noting that it needed to refer to the opinions of experts advising the Panel regarding the evidence submitted by the parties, but stating: 'We are not empowered, nor are the experts advising the Panel, to conduct our own risk assessment. ${ }^{263}$ The Panel in Australia Salmon similarly stressed: '[I]n examining this case we did not attempt (nor are we, in our view, allowed) to conduct our own risk assessment or to impose any scientific opinion on Australia.' ${ }^{264}$ The Panel in this case further stated, in respect of Australia's contention that

\footnotetext{
${ }^{260}$ Natalie McNelis argues that regardless of the expressed terminology for the standard of review to be applied by an adjudicator, the real standard of review is determined by the relationship between the adjudicator and the actor that is judged (as reflected by the different standards of review applied when WTO adjudicators judge the acts of WTO Members, when the ECJ judges an act of a European institution, and when the ECJ judges an act of an EU Member State). She cautions that as the WTO adjudicators do not have the same legitimacy with regard to WTO Members as the ECJ has with regard to EU Member States, WTO adjudicators should be less interventionist in reviewing health measures or will risk strident opposition from citizens. Natalie McNelis, 'The Role of the Judge in the EU and WTO: Lessons from the BSE and Hormones Cases', in The Role of the Judge in International Trade Regulation: Experience and Lessons for the WTO, T. Cottier and P.C. Mavroidis (eds.) (University of Michigan Press: Ann Arbor, Michigan), 2003, 225-246, 234 and 237-239.

${ }^{261}$ Hurst, David R., 'Hormones: European Communities - Measures Affecting Meat and Meat Products', European Journal of International Law 9 (1), 1998, 27.

${ }^{262}$ Panel Report, EC - Hormones (Canada), para. 8.104.; Panel Report, EC-Hormones (US), para. 8.101.

${ }^{263}$ Panel Report, Japan - Agricultural Products II, para. 8.32.

264 Panel Report, Australia - Salmon, para. 8.41. The Panel further stated: 'We only examined and evaluated
} 
for 'different situations' to be compared under Article 5.5, a risk assessment in respect of each situation must have been carried out:

We cannot conduct our own risk assessment. Nor do we attempt to do so in this report. ... Our mandate is different. We are not asked to make a scientific risk comparison nor to state with scientific certainty that one product is riskier than the other. We can only weigh the evidence put before us and, on the basis of the rules of burden of proof we adopted, including the use of factual presumptions, decide whether sufficient evidence is before us - evidence which has not been rebutted - in order to state that it can be presumed that one product is riskier than the other. ${ }^{265}$

In the same line, the Panels in US/Canada-Continued Suspension, recalled that:

[I]t is not the appropriate role of the Panel to conduct its own risk assessment based on scientific evidence gathered by the Panel or submitted by the parties during the Panel proceedings. Similarly, the Panel believes that it is not its role to impose any scientific opinion on the European Communities. The Panel must objectively measure the Opinions against the relevant standard for whether a risk assessment has been conducted, which can be found in the texts of Articles 5.1 (including an examination of Article 5.2) as well as Annex A(4) of the SPS Agreement. ${ }^{266}$

From this line of case law it appears that panels are well-aware of the limits to their competence in respect of the standard of review to be applied in assessing the scientific evidence before them. This assessment, they recognise, cannot extend to undertaking a risk assessment themselves, and imposing their evaluation of the risk at issue on the respondent Member. However, a close examination of what panels actually do indicates that, despite their statements to the contrary cited above, panels increasingly assess the scientific evidence before them, relying on the opinions of the panel experts, to determine for themselves the likelihood or potential of the adverse effects materialising. In effect, therefore, they go ever further along the path to conducting their own risk assessments, and often impose the scientific views of the panel experts on the respondent Member.

The relevant scientific disciplines of the SPS Agreement, namely Articles 2.2 and 5.1, as interpreted in the case law, are limited to requiring a 'rational relationship' between an SPS measure and the scientific evidence, as discussed above, ${ }^{267}$ implying some space for regulatory autonomy in the assessment of the evidence. ${ }^{268}$ This more deferential approach is illustrated by the manner in which the Panel in Australia - Salmon (Article 21.5 - Canada) addressed the question of whether the new risk assessment submitted by

the evidence - including the information we received from the experts advising the Panel - and arguments put before us in light of the relevant WTO provisions and, following the rules on burden of proof set out above, based our findings on this evidence and these arguments.' Ibid.

${ }^{265}$ Panel Report, Australia - Salmon, para. 8.126.

266 Panel Report, US - Continued Suspension, para. 7.443; Panel Report, Canada - Continued Suspension, para. 7.432 .

${ }^{267}$ See above, Part III, Sections 3.2.3.1 and 5.1.5.

${ }^{268}$ M. Gregg Bloche, 'WTO Deference to National Health Policy: Toward an Interpretative Principle', Journal of International Economic Law 5 (4), 2002, 825-848, 837. 
Australia, the 1999 IRA, met the requirements for a risk assessment. The Panel stated that what it was looking for was a level of objectivity in the risk assessment such that 'one can have reasonable confidence in the evaluation made, in particular, in the levels of risk assigned. ${ }^{269}$ Although Canada and one of the panel experts, Dr. Wooldridge, pointed out certain methodological flaws and alleged inconsistencies in the 1999 IRA, arguing that it did not fully take into account all information available, and that a possible bias might arise due to the way the information was presented, the Panel did not regard these flaws as serious enough to call into question the validity of the risk assessment. It held that although the alleged flaws, if absent, 'might have led to a lower level of assessed risk, [it had] not been convinced that this would be so, at least not to such an extent that [it] would no longer have reasonable confidence in the levels of risk currently assigned in the 1999 IRA.' ${ }^{270}$ The Panel thus seemed reluctant to interfere in the choices of methodology and presentation of information made by Australia in conducting its risk assessment, in the absence of proof that these had undermined the objectivity of the assessment in a manner preventing reasonable confidence in its results.

However, most panels have gone considerably further than this and adopted a rather intrusive approach. ${ }^{271}$ They consider themselves mandated to 'examine and weigh' ${ }^{272}$ all the evidence submitted to them and to come to their own conclusions regarding the risk at issue. This approach has relied upon the finding by the Appellate Body that the 'rational relationship' test that is part of Articles 2.2 and 5.1 depends, inter alia, on 'the quality and quantity of the scientific evidence'. ${ }^{273}$ This reading of the 'rational relationship' requirement entailed by the scientific disciplines of the Agreement opens the door for an intrusive review. ${ }^{274}$

The most glaring example of the assessment of scientific evidence by a panel in a manner constituting a risk assessment is to be found in the Japan - Apples case. ${ }^{275}$ In this case the Panel had to address whether Japan's cumulative requirements on apple imports for the prevention of the introduction of fire blight were maintained without 'sufficient scientific evidence' under Article 2.2 of the SPS Agreement. As discussed above, ${ }^{276}$ the Panel in

${ }^{269}$ Panel Report, Australia - Salmon (Article 21.5 - Canada), para. 7.51.

${ }^{270}$ Ibid., para. 7.57.

${ }^{271}$ Andrew T. Guzman, 'Food Fears: Health and Safety at the WTO', Virginia Journal of International Law 45 (1), 2004, 1-40.

${ }^{272}$ Panel Report, Japan - Agricultural Products II, para. 7.10.

${ }^{273}$ Appellate Body Report, Japan - Agricultural Products II, para. 84.

${ }^{274}$ Alberto Alemanno, Trade in Food: Regulatory and Judicial Approaches in the EC and WTO (Cameron May, London), 2007, 339. Alberto Alemanno argues that there is greater scope for an intrusive review in cases decided under Article 2.2 than those under Article 5.1 due to the former provision's lack of specific guidance for how a panel should verify whether a measure is based on scientific principles (or maintained without sufficient scientific evidence). Ibid., 341 .

${ }^{275}$ Button states with regard to the Panel's approach to the 'sufficient scientific evidence' requirement in the Japan - Apples dispute: 'It is difficult to discern in the panel's consideration of these and other scientific questions any point at which the panel did not conduct a de novo assessment. In evaluating these scientific questions, the panel engaged closely with the studies cited (going as far as to point out flaws in a study's methodology), relied heavily on the panel-appointed experts' views, engaged in interpretation of the results and implications of the studies, and arrived at its own conclusions on specific scientific questions.' Catherine Button, 'The WTO's 'Objective Assessment' Standard of Review and Panel Review of Health Measures', in Challenges and Prospects for the WTO, Andrew D. Mitchell (ed.) (Cameron May, London), 2005, 99.

276 The Panel's findings on this point are discussed in more detail above, Part III, Section 3.2.3.1. 
Japan-Apples considered that the 'sufficiency' requirement entailed not only a rational relationship between the scientific evidence and the SPS measure, but also between the evidence and the risk at issue. In so finding, the Panel allocated to itself the competence to assess the available scientific evidence to determine whether it convincingly established the risk addressed by Japan's measure. In coming to its decision, the Panel disassembled the sequence of events on the transmission pathway of the fire blight bacterium. It then assessed the divergent scientific evidence brought by the parties with regard to whether each step of the transmission pathway could be completed, and relying on the advice of the panel experts it came to its own conclusion on the likelihood of the risk of transmission. ${ }^{277}$ Although it was of the view that 'some slight risk of contamination cannot be totally excluded' it relied on the opinion of the panel experts that all the risks were 'negligible' to find that Japan's measure was maintained without 'sufficient scientific evidence' contrary to Article 2.2. ${ }^{278}$

Not only in an analysis under Article 2.2, but also under Article 5.1, panels have appropriated to themselves, with the assistance of the panel experts, the task of reassessing the scientific evidence that forms the basis of the risk assessment at issue, to determine the existence of a risk and the likelihood or potential of the risk occurring. In other words, they have conducted a risk assessment. This is shown, for example, in the report of the Panel in Japan - Apples (Article 21.5 - US), where it examined Japan's revised 2004 Pest Risk Assessment, which assessed the probability of infection of US apple fruit and the question whether fire blight could survive handling, storage, shipment and finally complete the transmission pathway. The Panel referred to the opinions of its experts that the studies relied upon in the 2004 Pest Risk Assessment did not support the conclusion that mature symptomless apples can be latently affected, since they did not address real orchard conditions and actual commercial practice. ${ }^{279}$ Consequently the Panel found the new studies relied upon by Japan not to support the conclusions in the 2004 Pest Risk Assessment. Therefore, despite the confirmation by the panel experts that Japan's Pest Risk Assessment closely followed the steps set out in the IPPC's standard for pest risk analysis (ISPM 11), the Panel found that it did not constitute a 'risk assessment' because, in the Panel's view, its conclusions were not supported by the scientific evidence relied upon therein. ${ }^{280}$

A similar approach was subsequently followed by the Panels in the US/Canada Continued Suspension disputes when addressing the question whether Article 5.1 was violated by the EC's measure. They did not stop at determining whether the Opinions of

${ }^{277}$ For example, in respect of the question whether mature, symptomless apples could host endophytic bacterial, Japan relied on a 1990 study by Van der Zwet et al., confirmed in 1998 by Roberts et al, which recorded fire blight on harvested fruit, but did not specify if this fruit was mature or symptomless. The US pointed to other studies which found that endophytic bacteria do not occur in mature, symptomless apple fruit. The panel experts indicated that they were not convinced by the evidence in papers describing the presence of endophytic bacteria. The Panel followed the views of the experts and concluded that there was not sufficient scientific evidence to conclude that mature symptomless apples could harbour endophytic populations of bacteria. Panel Report, Japan - Apples, paras 8.123-8,128.

278 On the additional problem of the strong proportionality requirement read into Article 2.2 of the SPS Agreement by this finding, see above, Part III, Section 3.2.3.1.

${ }^{279}$ Panel Report, Japan-Apples (Article 21.5 - US), paras 8.140-8.144. These same studies had been examined under the Article 2.2 claim and found to be insufficient to support the measure.

${ }^{280}$ Ibid., paras 8.147. 
the SCVPH relied upon by the EC constituted a risk assessment within the meaning of Annex A.4, and whether the EC's measure was based on these Opinions, but proceeded to address the question whether the conclusions arrived at in these risk assessments were sufficiently supported by the scientific evidence referred to therein. ${ }^{281}$ In so doing they examined the divergent scientific evidence brought by the US and Canada on the one hand and that contained in the EC's Opinions on the other regarding the genotoxicity of oestradiol-17 $\beta$. Recognising that they were not in a position to evaluate the scientific data reviews by the SCVPH, the Panels consulted the panel experts and asked them to evaluate the Opinions and the underlying science. ${ }^{282}$ It is significant that one panel expert, Dr. Cogliano, noted with respect to a particular divergence in views between the EC and Canada and the US regarding threshold in genotoxic potential, that neither was scientifically demonstrated but rather reflected different assumptions used by the parties in the interpretation of the available evidence. ${ }^{283}$ Nevertheless, in response to direct questioning, the panel experts expressed the view that while a zero risk could not be guaranteed, the level of risk of cancer was so small as to not be calculable. The Panels consequently stated:

The Panel's evaluation of the expert views and the plain language of the Opinions themselves leads the Panel to conclude that the scientific evidence referred to in the Opinions does not support the European Communities' conclusion that for oestradiol-17 $\beta$ genotoxicity had already been demonstrated explicitly, nor does it support the conclusion that the presence of residues of oestradiol-17 $\beta$ in meat and meat products as a result of the cattle being treated with the hormone for growth promotion purposes leads to an increased cancer risk. ${ }^{284}$

As can be seen from these examples, in practice most panels do not merely police the trade/health balance as established by the rules of the SPS Agreement, including its requirements for a rational relationship between the SPS measure and sufficient scientific evidence and a risk assessment, but instead they appropriate one of the aspects of this balance left by the Agreement in the competence of Members, namely the competence to evaluate the scientific evidence in a way that reflects the science policy choices of that Member, provided that the requirements set out in the Agreement are met. ${ }^{285}$ Instead of reviewing Member's science-based risk assessments for compliance with the requirements of the SPS Agreement, panels directly review the basis in science of a Members' SPS measures. ${ }^{286}$ In doing so, the relevant panels have gone further than allowed by the

${ }^{281}$ Panel Report, US - Continued Suspension, para. 7.538; Panel Report, Canada - Continued Suspension, para. 7.510.

${ }^{282}$ Panel Report, US - Continued Suspension, para. 7.553; Panel Report, Canada - Continued Suspension, para. 7.521. The Panel expressly noted that the experts were asked not to make their own scientific conclusions but rather to evaluate the Opinions to assess wither the evidence relied on by the SCVPH supports the conclusions in the Opinions.

${ }^{283}$ Panel Report, US - Continued Suspension, para. 7.559; Panel Report, Canada - Continued Suspension, para. 7.527.

${ }^{284}$ Panel Report, US - Continued Suspension, para. 7.572; Panel Report, Canada - Continued Suspension, para. 7.499

${ }^{285}$ On the subjective elements inherent to a risk assessment that reflect science policy choices, see above, Part II, Section 1.5.

286 Jacqueline Peel, Risk Regulation under the WTO SPS Agreement: Science as an International Normative 
'objective assessment' standard of review, and have allocated to themselves the competence to conduct a risk assessment by evaluating the scientific evidence and determining the likelihood or potential of the risk at issue.

As the failure to conduct an objective assessment under Article 11 of the DSU is an issue of law, it is subject to appeal. Not surprisingly, all appeals from panel reports in SPS disputes have included claims of violation of Article 11 of the DSU, due to the failure of the relevant panel to properly assess, interpret or take into account the scientific evidence provided by the parties.

However, the Appellate Body has set a very high threshold for a finding that a panel has failed to make an objective assessment of the matter, thereby limiting the impact of the discipline of Article 11 of the DSU. ${ }^{287}$ In EC-Hormones, in addressing a claim that the Panel had failed to make an objective assessment, the Appellate Body held:

$[\mathrm{N}]$ ot every error in the appreciation of the evidence (although it may give rise to a question of law) may be characterized as a failure to make an objective assessment of the facts ... The duty to make an objective assessment of the facts is, among other things, an obligation to consider the evidence presented to a panel and to make factual findings on the basis of that evidence. The deliberate disregard of, or refusal to consider, the evidence submitted to a panel is incompatible with a panel's duty to make an objective assessment of the facts. The wilful distortion or misrepresentation of the evidence put before a panel is similarly inconsistent with an objective assessment of the facts. "Disregard" and "distortion" and "misrepresentation" of the evidence, in their ordinary signification in judicial and quasi-judicial processes, imply not simply an error of judgment in the appreciation of evidence but rather an egregious error that calls into question the good faith of a panel. ${ }^{288}$

Only this type of egregious error will prompt the Appellate Body to find that a panel has exceeded the bounds of its discretion as a trier of facts. The narrow interpretation by the Appellate Body of what is meant by a failure to make an objective assessment has meant that in no case has the overreaching of panels in the cases decided under the SPS Agreement been corrected. The problematic consequences can be seen by looking at the Appellate Body's rulings on this issue in the SPS disputes where the standard of review applied by panels has been challenged.

Yardstick?, Jean Monnet Working Paper 02/04 (NYU School of Law, New York), June 2004, 19, available at: www.jeanmonnetprogram.org/papers/04/040201.pdf, visited on 14 September 2004.

287 The reason for this very high threshold lies in the Appellate Body's view that an allegation that a panel has failed to conduct an objective assessment is very serious and 'goes to the very core of the integrity of the WTO dispute settlement process itself.' Appellate Body Report, EC - Poultry, para. 133. In addition, as explained by the Appellate Body in US - Carbon Steel, its deference to panels' evaluation of the evidence is motivated by its recognition of the distinction in the respective roles of the Appellate Body and panels. In the WTO dispute settlement process it is the panel that is the trier of facts, and the appreciation of evidence therefore falls within the bounds of its discretion. The Appellate Body will thus not find a violation of Article 11 merely because it would have reached a different factual finding from that reached by the panel. Appellate Body Report, US - Carbon Steel, para. 142.

288 Appellate Body Report, EC - Hormones, para. 133. 
In EC - Hormones, the Appellate Body found that although the Panel had misquoted and misinterpreted the evidence, including the statements of its own expert advisors, its actions had not been deliberate or grossly negligent and there had thus been no failure to make an objective assessment of the facts. ${ }^{289}$ This trend continued in Australia - Salmon ${ }^{290}$, Japan - Agricultural Products II, ${ }^{291}$ and Japan - Apples ${ }^{292}$ where errors of the Panels in the appreciation of evidence were not characterised by the Appellate Body as failures to make an objective assessment of the facts, due to their lack of an egregious nature. ${ }^{293}$ It thus seems that the only limitation on the powers of review of a panel is its obligation not to make mistakes so serious that they call into question its good faith.

289 The Appellate Body in EC-Hormones, agreed with the EC that the Panel had misquoted the evidence of an EC expert, Dr. Lucien but it held that this mistake did not constitute 'a deliberate disregard of evidence or gross negligence amounting to bad faith.' Appellate Body Report, EC-Hormones, para. 138. Further, in response to the EC's contention that the Panel had distorted the views of a panel expert, Dr. André, by stating that they supported those of the other panel experts when, in fact, they rather supported the views of EC scientists, the Appellate Body stated: 'Whether or not the views of Dr. André support the statements made by the other Panel experts or the opinions expressed by the EC scientists may be an issue of fact; it does require some technical expertise to deal with it. However, even if the Panel has interpreted the views of Dr. Andre incorrectly, we see no reason, and no reason was advanced, to consider this mistake as a deliberate disregard or distortion of evidence.' Appellate Body Report, EC-Hormones, para. 139. A similar finding was made in respect of the Panel's inaccurate representation of the statements of the panel exports on the potential for abuse in a regime where the use of hormones was allowed, as compared to a regime where they were banned. Ibid., para. 144. It would appear that the Appellate Body gives a certain leeway for the lack of 'technical expertise' of the panel to deal with scientific evidence, provided the mistake is not deliberate. When one bears in mind that cases under the SPS Agreement often turn on scientific evidence, this is a worrying approach.

${ }^{290}$ In Australia - Salmon, Australia claimed on appeal that the Panel had 'partially or wholly ignored the relevant evidence placed before it, or misrepresented the evidence in a way that went beyond a mere question of the weight attributed to it, but constituted an egregious error amounting to an error of law' and had 'failed to accord due deference to matters of fact put forward by the parties.' Appellate Body Report, Australia Salmon, para. 262. The Appellate Body dealt very shortly with this claim, finding only that the Panel had not deliberately disregarded, refused to consider, wilfully distorted or misrepresented the evidence, nor had Australia proved an 'egregious error that calls into question the good faith' of the Panel. It added that panels are not required to accord the same meaning or weight to factual evidence as do the parties. Consequently, no violation of Article 11 was found. Appellate Body Report, Australia - Salmon, paras 266-267.

291 Similarly, the Appellate Body in Japan - Agricultural Products II responded to Japan's claim that the Panel had not properly examined the evidence, had cited the views of the experts in an arbitrary manner and had evaluated the evidence in a contradictory way, by stressing the egregious nature of the errors required for a finding of violation of Article 11 of the DSU, and holding that Japan had not demonstrated errors of that gravity. Appellate Body Report, Japan - Agricultural Products II, paras 140-142.

${ }^{292}$ In Japan - Apples, Japan argued before the Appellate Body, inter alia, that the Panel had made a material factual error in characterising the experimental evidence underlying its conclusion that fire blight was unlikely to complete the transmission pathway to infect apple fruit. The Appellate Body found no violation of Article 11 of the DSU in this respect as the Panel had relied on factual evidence in addition to that allegedly mischaracterised for its findings. Further, Japan claimed that the Panel's conclusion covered infected apple fruit although the evidence before it centred on mature symptomless apple fruit, leading to a lack of connection between the evidence considered and the findings of the Panel, in violation of Article 11. The Appellate Body, instead, found that the Panel had simply been unclear in its findings in this respect. In addition, Japan argued that the Panel's conclusion regarding the likelihood of the completion of the transmission pathway was inconsistent with its recognition that the risk identified by the experts was not merely a theoretical risk. In response, the Appellate Body found that the Panels finding that the risk from infected fruit, identified in the scientific prudence expressed by the experts, was 'real' did not contradict its finding that the risk of transmission was 'negligible'. As a result, no violation of Article 11 of the DSU was found. Appellate Body Report, Japan-Apples paras. 218-242.

${ }^{293}$ Appellate Body Report, Australia - Salmon, para. 266 and Appellate Body Report, Japan - Agricultural Products II, para. 142. 
Further, it seems that a panel is free to substitute its own judgement, even if its appreciation of the scientific evidence before it is incorrect, for that of the Member government without any real limits beyond that of not committing an egregious error. One wonders whether this was the 'balance' in competences intended by the Members to be embodied in the SPS Agreement.

Due to the limited interpretation given by the Appellate Body to the obligation to conduct an objective assessment, it is clear that the parties are to a large degree at the mercy of the relevant panel when it comes to its review of the evidence before it. This is problematic when one bears in mind the composition of panels and their lack of expertise in scientific matters. Despite a lack of bad faith or gross negligence on the part of the panel, it could still (and does) sometimes substantially misunderstand or mischaracterise evidence before it. This is not surprising, when one sees the extremely technical and complex nature of the evidence submitted in SPS disputes. This complexity and the difference of opinions that often exists in the scientific arena mean that the panel's possibility to consult experts does not constitute a real safeguard against the possibility of mistakes. While the discretion of panels as the triers of fact to decide on the meaning and weight to be given to the factual evidence before them is not disputed, this should not extend to allowing panels to evaluate for themselves the scientific evidence that forms part of a Member's risk assessment and make their own conclusions as to the likelihood or potential of the risk, in effect conducting their own risk assessments. Otherwise the likelihood of panels 'getting the science wrong' is greatly increased. ${ }^{294}$

In sum, the current case law on the standard of review has two problematic aspects. Firstly, the decision that the applicable standard of review is an 'objective assessment' of the factual and legal aspects of the case, without a precise definition of what this standard entails, gives cause for concern. ${ }^{295}$ While this was held to mean neither complete deference nor de novo review, what it does entail is not clear aside from the fact that a panel must not commit egregious errors such that its good faith is called into question. While expressly recognising that their task is not to conduct their own risk assessments or impose a particular scientific view on the respondent Member, it appears that panels in practice do substitute their judgements for that of the respondent Member in the evaluation of scientific evidence, despite their lack of 'technical expertise' in reviewing such evidence and their possible miscomprehension of the advice of the panel experts. This could lead to

294 Jacqueline Peel, Risk Regulation under the WTO SPS Agreement: Science as an International Normative Yardstick?, Jean Monnet Working Paper 02/04 (NYU School of Law, New York), June 2004, 19, available at: www.jeanmonnetprogram.org/papers/04/040201.pdf, visited on 14 September 2004. It is interesting to note that similar difficulties confront judicial organs at national level when faced with the task of reviewing risk regulation. As noted by Jacqueline Peel in her analysis of the case law of the EC and the US in this regard, despite different rhetoric, there are striking similarities in the approaches of adjudicators in both Members to this issue. In particular, both bodies of jurisprudence feature deference to the judgement of regulators to select the appropriate risk management policies on the basis of the scientific evidence. Ibid., 50 .

295 Claus-Dieter Ehlermann and Nicolas Lockhart, 'Standard of Review in WTO Law', in A True European: Essays for Judge David Edwards, Mark Hoskins and William Robinson (eds.) (Hart Publishing, Portland), 2003, 267-296, 271. Ehlermann and Lockhart point out that the 'objective assessment' standard of review 'is couched in rather broad terms that do little to provide substantive guidance on the nature and intensity of the review which panels should apply to national measures.' They note that 'the requirement for an "objective assessment" must function with another, more detailed, underlying standard of review' and they suggest that the scope and intensity of review differs for different issues in dispute. 
arbitrary results when one bears in mind the complexity of scientific evidence in the area of health and the conflicting opinions that often exist. Secondly, since only 'wilful distortion' or 'deliberate disregard' of evidence will constitute a failure to make an 'objective assessment' of the facts, the situation could arise that a case is incorrectly decided on the basis of a good faith misunderstanding of scientific evidence by a panel, without this mistake constituting a ground for overturning the panel decision. This is problematic since the disciplines of the SPS Agreement are primarily science-based, and thus cases decided under its provisions will most likely turn on the evaluation of scientific evidence. Since the Appellate Body may not review issues of fact on appeal, an appeal will not be able to correct this situation but will instead be decided on the basis of this mistaken understanding of the facts. Also, a panel that does go as far as undertaking a de novo evaluation of the scientific evidence, in disregard of the scientific choices made by national authorities, will not have its finding overruled on the basis of a failure to conduct an 'objective assessment' since this action does not fall within the narrow definition given by the Appellate Body to the failure to conduct an objective assessment.

In order to avoid this unacceptable situation, it seems imperative that the question of the appropriate standard of review under the SPS Agreement be reassessed to allow for some deference to national decisions regarding the quality and weight of scientific evidence in conducting a risk assessment. This does not imply that a panel should conduct a purely procedural review. ${ }^{296}$ Neither does it mean that a panel must respect a national authority's assessment of the evidence, no matter what. Instead, it requires that the panel start with 'the Member's evaluations and approach by asking whether they are reasonable. ${ }^{297}$ This means that provided that the scientific support for a measure is plausible and a Member has met all the requirements of the SPS Agreement relating to the conduct of a risk assessment and has based its measure on this risk assessment, a panel should refrain from evaluating the risk on the basis of the scientific evidence itself, a task for which it is demonstrably poorly suited. Ensuring that panels stay within the bounds of the proposed standard of review not only ensures that the balance of competences written into the SPS Agreement is respected, but also makes room for the diversity of priorities, consumer preferences and regulatory capacity between Members at different levels of development to be reflected in the science policy choices incorporated into national risk assessments. The Appellate Body, while respecting the role of panels as the triers of facts, should be willing to shoulder its responsibility to keep watch over the standard of review applied by panels.

\footnotetext{
${ }^{296}$ An alternative approach, suggested by Joost Pauwelyn, is to set out explicitly the procedural steps that national authorities have to take when conducting a risk assessment (the factors to be examined, the type and source of scientific evidence to be considered etc) and to limit review by panels to the question whether the Member concerned has followed the required steps and made an unbiased and objective evaluation of the facts (in line with the deferential approach followed under the Anti-Dumping Agreement). Joost Pauwelyn, 'Does the WTO Stand for 'Defence to' or 'Interference with' National Health Authorities When Applying the Agreement on Sanitary and Phytosanitary Measures (SPS Agreement)?' in The Role of the Judge in International Trade Regulation: Experience and Lessons for the WTO, T. Cottier and P.C. Mavroidis (eds.) (University of Michigan Press: Ann Arbor, Michigan), 2003, 175-192, 186.

297 Catherine Button, The Power to Protect. Trade, Health and Uncertainty in the WTO (Hart Publishing, Oxford and Portland, Oregon), 2004, 112. Button calls this the 'reasonable regulator' standard of review.
} 
An additional issue which arises with regard to the standard of review to be applied is whether the precautionary principle should guide a panel's evaluation of the evidence before it. This issue arose in Japan - Apples. Japan argued, on appeal, that the Panel had failed to adequately take into account the precautionary principle in its evaluation of the evidence, leading to a violation of Article 11 of the DSU. The panel experts in this case had recognized the need for caution with respect to the elimination of the phytosanitary measures protecting Japan from fire blight. According to Japan, this fact should have been given greater weight by the Panel in considering the evidence regarding the completion of the transmission pathway for fire blight. ${ }^{298}$ The Appellate Body noted that Japan did not argue that the precautionary principle should have been applied as distinct from the provisions of the SPS Agreement, nor did it argue that the Panel should have used the precautionary principle as part of its interpretative analysis of the Agreement. Instead, it understood Japan to argue that the principle was embodied in the cautionary opinions of the experts and should have been given greater weight in the Panel's conclusions on the completion of the pathway. The Appellate Body then noted that it is established case law that the credibility and weight to be properly ascribed to a particular piece of evidence is in the discretion of a panel as the trier of facts. This discretion is limited only by a panel's duty to make an 'objective assessment' of the facts. Since Japan made no argument challenging the objectivity of the Panel's assessment, it failed to establish a violation of Article 11.299

This finding of the Panel reinforces the conclusion that the possible relevance of the precautionary principle for purposes of the SPS Agreement is limited to the particular formulation it has been given in Article 5.7.300 Outside this Article, the precautionary principle plays no role, according to the case law, in guiding the interpretation of the SPS Agreement or the evaluation of the evidence. The standard of review to be applied by panels remains an 'objective assessment' of the matter, even in cases of scientific uncertainty. Once again, it is argued here that the assessment of scientific evidence, including the weight to be given to particular scientific opinions, is best left to the Member imposing the SPS measure. This would allow the Member to take a precautionary approach in the science policy choices incorporated in its risk assessment. The assessment of the scientific evidence by a panel should be limited to establishing whether the risk assessment meets the conditions of the SPS Agreement, and its conclusions are plausible.

\subsubsection{Role of international law in interpretation}

It is also interesting to examine the approach taken in WTO case law to the role of international law in the interpretation of the SPS Agreement. This will determine the scope for taking into account development-oriented norms of the international legal order in the interpretation of the SPS Agreement. ${ }^{301}$ It also establishes the possibility for consideration of

\footnotetext{
${ }^{298}$ This evidence was considered for purposes of the Panel's finding under Article 2.2 of the SPS Agreement.

${ }^{299}$ Appellate Body Report, Japan - Apples, para. 283.

${ }^{300}$ See further on this issue, above, Part III, Section 5.2.5.1.

301 Asif H. Qureshi, 'Interpreting World Trade Organization Agreements for the Development Objective', Journal of World Trade 37 (5), 2003, 847-882, 301. Qureshi points out that international law norms that could be of relevance to the interpretation of WTO agreements are not limited to environmental or human rights norms, as feared by some developing-country Members. Instead they include development-oriented norms, since '[d] evelopment is an imperative of the international economic order.' Ibid.
} 
international law norms on the protection of human life and health and the environment in addressing the rights and obligations laid down in the SPS Agreement. Such consideration of the international law context within which the SPS Agreement functions, could operate to provide the much-needed normative framework to guide WTO adjudicators in striking a balance between the competing goals of trade liberalisation and health protection. ${ }^{302}$

Article 3.2 of the DSU requires provides that the dispute settlement system of the WTO serves, inter alia, to clarify the provisions of WTO agreements 'in accordance with customary rules of interpretation of public international law'. However, in doing so panels and the Appellate Body may not 'add to or diminish the rights and obligations provided in the covered agreements.' ${ }^{303}$

As acknowledged in previous WTO case law, the customary rules of interpretation, referred to in Article 3.2 of the DSU, are reflected in Articles 31 and 32 of the Vienna Convention on the Law of Treaties. ${ }^{304}$ Article 31.3(c) deals with the relevance of other international law rules for the interpretation of a treaty. It provides:

There shall be taken into account, together with the context:

...(c) any relevant rules of international law applicable in the relations between the parties.

Further, as held by the Panel in Korea-Procurement:

Article 3.2 of the DSU requires that we seek within the context of a particular dispute to clarify the existing provisions of the WTO agreements in accordance with customary rules of interpretation of public international law. However, the relationship of the WTO Agreements to customary international law is broader than this. Customary international law applies generally to the economic relations between the WTO Members. Such international law applies to the extent that the WTO agreements do not 'contract out' from it. To put it another way, to the extent there is no conflict or inconsistency, or an expression in a covered WTO agreement that implies differently, we are of the view that the customary rules of international law apply to the WTO treaties and to the process of treaty formation under the WTO. ${ }^{305}$

\footnotetext{
302 Jacqueline Peel identifies the absence of a normative framework for this balancing as the reason why WTO adjudicators, different from adjudicators in the US and EC, when reviewing SPS regulations conduct such a rigorous review of the scientific basis. Jacqueline Peel, Risk Regulation under the WTO SPS Agreement: Science as an International Normative Yardstick?, Jean Monnet Working Paper 02/04 (NYU School of Law, New York), June 2004, 3, available at: www.jeanmonnetprogram.org/papers/04/040201.pdf, visited on 14 September 2004.

${ }^{303}$ Article 19.2 of the DSU. Similarly, Article 3.2 of the DSU provides that the recommendations and rulings of the SDB cannot add to or diminish the rights and obligations provided in the covered agreements. The term 'covered agreements' refers to all the WTO agreements that are covered by the dispute settlement mechanism set out in the DSU, as listed in Appendix 1 to the DSU. This includes all the multilateral agreements on trade in goods, of which the SPS Agreement is one.

${ }^{304}$ Appellate Body Report, US - Gasoline, 16 (in respect of Article 31 of the Vienna Convention on the Law of Treaties); and Appellate Body Report, Japan - Alcoholic Beverages II, 104 (in respect of Article 32 of the Vienna Convention on the Law of Treaties).

${ }^{305}$ Panel Report, Korea-Procurement, para. 7.96. This panel report was not appealed.
} 
Considerable debate has arisen regarding the question of the extent to which international law must be had regard to by WTO panels and the Appellate Body in adjudicating claims under the WTO agreements. While there is widespread support for the idea that, in line with the presumption against conflicts in international law, WTO agreements should as far as possible be interpreted in conformity with other international law rules, ${ }^{306}$ disagreement persists with regard to situations of irreconcilable conflict between a rule of WTO law and another international law rule. The debate centres on the question of what WTO adjudicators should do when faced with such a conflict. Should they necessarily give precedence to WTO law rules, due to the prohibition on adding to or diminishing the rights or obligations contained in WTO agreements that is part of their mandate? ${ }^{307}$ Or can WTO adjudicators refuse to apply a WTO law rule that conflicts with a non-WTO rule of international law that has precedence due to the application of the rules on conflicts of laws $?^{308}$ Irreconcilable conflicts are, however, rare and the question most often before a panel is to what extent non-WTO law should inform the interpretation of WTO provisions rather than whether it should override the express terms of WTO law. ${ }^{309}$

This issue of the role of other international law norms in the interpretation of the SPS Agreement arose already in the first SPS dispute, EC-Hormones. As discussed above, ${ }^{310}$ in this case the EC relied on the 'precautionary principle' which it argued had attained the status of customary international law, or at least of a general principle of law, to guide the interpretation of Article 5.1 of the SPS Agreement. The Appellate Body found it unnecessary to decide whether the precautionary principle now forms part of general customary international law. ${ }^{311}$ However, it held that even if this were the case, the specific agreement on rules for cases of scientific uncertainty in Article 5.7 of the SPS Agreement overrides any such general principle. ${ }^{312}$ This approach was also followed by the Appellate

306 Gabrielle Marceau, 'Conflicts of Norms and Conflicts of Jurisdictions. The Relationship between the WTO Agreement and MEAs and Other Treaties', Journal of World Trade 35 (6), 2001, 1081-1131, 1086-1090; Joost Pauwelyn, 'The Role of Public International Law in the WTO: How Far Can We Go?', The American Journal of International Law 95, 2001, 535-578, 542.

307 Gabrielle Marceau supports this view, arguing that the applicable law in WTO disputes is limited to the covered agreements and the institutional actions pursuant to these agreements. She states that it is difficult to imagine a situation where a provision of other international law, such as a human rights provision, would supersede a WTO provision without, in effect, adding to or diminishing the rights or obligations of the two disputing Members under the covered agreements. Gabrielle Marceau, 'WTO Dispute Settlement and Human Rights', European Journal of International Law 13 (4), 2002, 753-814.

308 Joost Pauwelyn is the main proponent of this view, arguing that although the jurisdiction of WTO adjudicators is limited to claims brought under WTO agreements, the law applicable in deciding such claims is not limited to WTO law, but includes other rules of international law. Therefore, international law rules that bind both parties to a dispute may be invoked in dispute settlement proceedings with regard to a claim of violation of WTO law. Joost Pauwelyn, 'The Role of Public International Law in the WTO: How Far Can We Go?', The American Journal of International Law 95, 2001, 535-578, 560-561 and 566.

${ }^{309}$ On the narrow interpretation of the concept of 'conflict' in WTO law (referring to situations where compliance with one obligation necessarily entails violation of the other), see above, Part III, Section 2.4.2. Note, however, that Pauwelyn advocates a broader interpretation of 'conflict' to include situations where one norm permits something which the other norm prohibits. Joost Pauwelyn, Conflict of Norms in Public International Law: The Example of the World Trade Organization: Internal Hierarchy and How WTO Law Relates to Other Rules of International Law, Doctoral Thesis, Faculté de Droit (Université de Neuchâtel, Neuchâtel), 2001, 107-110.

310 See above, Part III, Section 5.2.5.1.

311 Appellate Body Report, EC - Hormones, para. 123.

312 Ibid., para. 125. 
Body in Japan - Agricultural Products II when addressing the role of the precautionary principle in the interpretation of Article 2.2 of the SPS Agreement. ${ }^{313}$ This view seems rather limited. The question of the relationship between a norm of international law and a WTO provision is not limited to which one prevails, but instead, as mentioned above, is most often a question of whether a harmonious interpretation is possible that would avoid a conflict. In this light it would seem appropriate for the Appellate Body to have addressed the question whether the precautionary principle has attained the status of a rule of customary international law or a general principle of law, in order to ascertain its relevance in interpreting the scientific disciplines of the SPS Agreement. As was discussed above, there are various aspects of the scientific disciplines, including the meaning of the 'rational relationship' requirement read into Articles 2.2 and 5.1, that could usefully be informed by reference to the precautionary principle, should it have achieved this status. ${ }^{314}$

In EC-Approval and Marketing of Biotech Products, the EC raised the question of the relevance of other rules of international law to the interpretation of the applicable WTO agreements in this dispute, including the SPS Agreement. It relied on Article 31.3(c) of the Vienna Convention on the Law of Treaties requiring a treaty interpreter to take account of relevant rules of international law. In particular, the EC referred to the precautionary principle and relevant multilateral environmental agreements (MEAs), especially the Convention on Biological Diversity (CBD) of 1992 and the Cartagena Protocol on Biosafety of $2000,{ }^{315}$ as international law rules to which the Panel must have regard. It further made reference in some of its arguments to definitions of terms developed by international standard-setting bodies. ${ }^{316}$

The Panel noted that Article 3.2 of the DSU requires it to interpret WTO agreements 'in accordance with customary rules of interpretation of public international law' which are reflected in Articles 31 and 32 of the Vienna Convention on the Law of Treaties. The Panel focused on Article 31.3(c) of the Vienna Convention on the Law of Treaties, cited above. It noted that the use of the word 'shall' indicates that Article 31.3(c) mandates a treaty interpreter to take account of other international law rules, rather than merely gives

${ }^{313}$ Appellate Body Report, Japan-Agricultural Products II, para. 81.

${ }^{314}$ For an example of the recognition of the possibility to make room for a 'precautionary approach' in applying the requirement of Article 5.1 to base an SPS measure on a risk assessment, see Panel Reports, EC-Approval and Marketing of Biotech Products, para. 7.3065. This finding is discussed above, Part III, Section 5.2.5.1.

315 The Cartagena Protocol on Biosafety is a protocol to the UN Convention on Biological Diversity. It deals with transboundary movement of living modified organisms. It contains provisions dealing with approval procedures, laying down a time line and addressing factors that could cause delays in such procedures (in Articles 9-11 thereof). It contains provisions on risk assessment (in Article 15 and Annex III) and the precautionary approach (Articles 1, 10.6 and 11.8 and Annex III). It currently has 147 contracting parties (as of 30 June 2008). The EC argued that the Cartagena Protocol and the SPS Agreement should be interpreted and applied consistently as far as possible. It claimed that there are no a priori inconsistencies between the two treaties, and that the Cartagena Protocol's provisions on risk assessment and the precautionary principle inform the meaning and effect of the relevant provisions in the SPS Agreement. Panel Reports, EC-Approval and Marketing of Biotech Products, para. 7.55.

316 The EC pointed to the strong relationship between the SPS Agreement and these international bodies, which are expressly referred to in Annex A.3 of the SPS Agreement as the relevant standard-setting bodies for purposes of the harmonisation obligations in Article 3. Further, it noted that Article 12.3 of the SPS Agreement refers to the objective of securing from the relevant international organisations the best available scientific and technical advice for the administration of the SPS Agreement (by the SPS Committee). Panel Reports, EC-Approval and Marketing of Biotech Products, para. 4.749. 
the interpreter the option of doing so. ${ }^{317}$ Thereby, this Article enhances the consistency of international law rules applicable to the relevant States parties and contributes to avoiding conflicts between those rules. ${ }^{318}$

The Panel examined the term 'rules of international law' in Article 31.3(c) and noted that it is broad enough to encompass 'all generally accepted sources of public international law' including treaties and customary international law rules. ${ }^{319}$ Further, it noted that in US - Shrimp, the Appellate Body had made clear that general principles of international law also fall under Article 31.3(c). ${ }^{320}$ Thus, if the precautionary principle is a general principle of public international law, it could also be considered to fall under this provision. ${ }^{321}$

However, the Panel pointed out that Article 31.3(c) of the Vienna Convention on the Law of Treaties contains an important limitation, namely that only those rules of international law 'applicable in the relations between the parties' are to be taken into account. ${ }^{322}$ The Panel held 'the parties' to mean those states that have consented to be bound by the treaty being interpreted (i.e. all WTO Members). ${ }^{323}$ After examining the MEAs at issue, the Panel found that while the EC, Argentina and Canada are parties to the CBD (having signed and ratified it), the US is not. ${ }^{324}$ Further, the Cartagena Protocol has been signed and ratified by the EC only. Argentina and Canada have signed but not ratified it, and the US has neither signed nor ratified it. ${ }^{325}$ Thus, according to the Panel, these two treaties cannot be regarded as falling within the scope of 31.3(c) of the Vienna Convention on the Law of Treaties. This finding would seem to practically exclude the possibility of a Panel being obliged to have regard to other treaties in the interpretation of WTO agreements, since it is improbable that all 153 WTO Members would be parties to another treaty. As is stated in the report of the Study Group set up by the United Nations International Law

317 Panel Reports, EC-Approval and Marketing of Biotech Products, para. 7.69. The Panel pointed out that although this obligation is limited to taking account of other international law rules and no particular outcome is prescribed, the principle of good faith would require that where more than one interpretation is possible, the treaty interpreter applying Article 31.3(c) of the VCLT must choose the alternative that is more in accord with the other rules of international law.

318 Ibid., para. 7.70 .

319 Ibid., para. 7.67.

${ }^{320}$ The Panel here referred to the finding in Appellate Body Report, US - Shrimp, para.158 and note 157.

${ }^{321}$ Panel Reports, EC-Approval and Marketing of Biotech Products, para. 7.67.

${ }^{322}$ Ibid., para. 7.68 .

${ }^{323} \mathrm{Ibid}$., para. 7.67. To support its finding, the Panel noted that Article 31.3(c) does not refer to 'one or more parties' or 'the parties to the dispute'. Further, it pointed to the definition of 'party' in Article 2.1(g) of the Vienna Convention on the Law of Treaties as 'a State that has consented to be bound by the treaty and for which the treaty is in force' and derived from this definition the conclusion that 'parties' in Article 31.3(c) refers to states which have consented to be bound by the treaty that is being interpreted and for which that treaty is in force.

${ }^{324}$ The US signed the CBD in 1993 but never ratified it. Note, however, that Article 18 of the Vienna Convention on the Law of Treaties establishes the obligation on states that have signed but not yet ratified a treaty to refrain from acts that would defeat the object and purpose of the treaty.

${ }^{325}$ Although the Panel limited its examination to the four Parties to this dispute, this should not give the impression that it had departed from its view that the other rules of international law must be applicable to all WTO Members. Instead, the Panel stated that if a rule of international law is not applicable to one of the four Parties to this dispute, it is not applicable to the relations between all WTO Members. Thus, although the Panel declined to take a position on this, it appears that even if the relevant international law rules raised in this dispute had been applicable to all four Parties, but had not been applicable to another WTO Member, they would still not have to be taken into account by the Panel under Article 31.3(c) of the Vienna Convention on the Law of Treaties. Panel Reports, EC-Approval and Marketing of Biotech Products, paras 7.71-7.72. 
Commission (ILC) to address the issue of the fragmentation of international law (expressly criticising this finding by the Panel in EC-Approval and Marketing of Biotech Products): ${ }^{326}$

Bearing in mind the unlikeliness of a precise congruence in the membership of most important multilateral conventions, it would become unlikely that any use of conventional international law could be made in the interpretation of such conventions. This would have the ironic effect that the more the membership of a multilateral treaty such as the WTO covered agreements expanded, the more those treaties would be cut off from the rest of international law. In practice, the result would be the isolation of multilateral agreements as "islands" permitting no references inter se in their application. ${ }^{327}$

The ILC Study Group finds it a better solution to permit reference to another treaty under Article 31.3(c), provided that the parties in dispute are also parties to that other treaty. ${ }^{328}$ The resulting possibly divergent interpretations would respect party will, which is inherently divergent according to the Study Group. Further, it advocates taking into account the extent to which the other treaty can be regarded as implicitly accepted or tolerated by other parties in the sense that it can be considered to reflect the common understanding of Members as to the meaning of the relevant term. ${ }^{329}$ In the same vein, in the conclusions of the Study Group, the particular relevance of other treaty-based rules to the interpretation of a treaty under Article 31.3(c) of the Vienna Convention on the Law of Treaties is noted, inter alia where "they provide evidence of the common understanding of the parties as to the object and purpose of a treaty under interpretation or as to the meaning of a particular term.' ${ }^{330}$

${ }^{326}$ International Law Commission, 58th Session, Fragmentation of International Law: Difficulties Arising from the Diversification and Expansion of International Law, Report of the Study Group of the International Law Commission, finalised by Martti Koskenniemi, A/CN.4/L.682, 13 April 2006. This report contains an analytical study finalised by the Chairman of the ILC Study Group. A set of 42 conclusions adopted by the Study Group is published separately as an appendix. The ILC took note of the conclusions and commended them to the UN General Assembly. The Study Group emphasised that conclusions are based on the analytical study and must be read together with it. It is interesting that this report expressly addresses the findings of the Panel in EC-Approval and Marketing of Biotech Products although at that stage only the interim Panel reports had been issued and were officially confidential.

${ }^{327}$ International Law Commission, 58th Session, Fragmentation of International Law: Difficulties Arising from the Diversification and Expansion of International Law, Report of the Study Group of the International Law Commission, finalised by Martti Koskenniemi, A/CN.4/L.682, 13 April 2006, para. 471.

328 Ibid., para. 472. This approach to the meaning of 'the parties' is also taken by David Palmeter and Petros Mavroidis, 'The WTO Legal System: Sources of Law', The American Journal of International Law 92, 1998, 398-413, 411. Contra, see Michael Lennard, 'Navigation by the Stars: Interpreting the WTO Agreements', Journal of International Economic Law 5 (1), 2002, 17-89, 35-39.

${ }^{329}$ International Law Commission, 58th Session, Fragmentation of International Law: Difficulties Arising from the Diversification and Expansion of International Law, Report of the Study Group of the International Law Commission, finalised by Martti Koskenniemi, A/CN.4/L.682, 13 April 2006, para. 472. Here the ILC refers to the approach taken in Appellate Body Report, US - Shrimp, para. 130.

${ }^{330}$ These conclusions are contained in the following document: International Law Commission, 58th Session, Fragmentation of International Law: Difficulties Arising from the Diversification and Expansion of International Law, Report of the Study Group of the International Law Commission, A/CN.4/L.702, 18 July 2006, para. 21. 
The Panel's finding in EC-Approval and Marketing of Biotech Products seems to be a step backwards from the progressive approach of the Appellate Body in US - Shrimp. In that case, the Appellate Body reaffirmed that WTO law is not to be read 'in clinical isolation from public international law'. ${ }^{331}$ It followed an evolutionary interpretation of the relevant treaty terms, taking into account the 'contemporary concerns of the community of nations ${ }^{\prime 332}$ as reflected in other treaties. In so doing, it relied on treaties that were not binding on all the parties to the dispute, let alone all WTO Members. ${ }^{333}$ However, the Panel in EC-Approval and Marketing of Biotech Products considered that its approach was consistent with that followed by the Appellate Body in US - Shrimp. According to the Panel, the Appellate Body in the latter case 'drew on other rules of international law because it considered that they were informative and aided it in establishing the meaning and scope of the term...' ${ }^{334}$ rather than because it was obliged to refer to these other rules under Article 31.3(c) of the Vienna Convention on the Law of Treaties.

The Panel pointed out that under Article 31.1 of the Vienna Convention on the Law of Treaties, a treaty must be interpreted in accordance with the ordinary meaning of its terms, in their context and in the light of its object and purpose. It regarded, in addition to dictionaries, other relevant rules of international law as aids for a treaty interpreter to establish the ordinary meaning of words in their context. Thus, the treaty interpreter may rely on such other rules when he/she considers them informative, but need not do so, particularly if the ordinary meaning of the treaty terms can be otherwise ascertained. ${ }^{335}$ In this case, the Panel apparently did not regard the CBD or Cartagena Protocol to be 'informative' for the interpretation of the SPS Agreement. ${ }^{336}$

With regard to the precautionary principle, as discussed above, the Panel rejected the EC's argument that it has 'now become a fully-fledged and general principle of international law' ${ }^{337}$ It referred to the Appellate Body's finding in January 1998, in the EC-Hormones case, that the status of the precautionary principle was still subject to debate, and that it was 'unnecessary and probably imprudent' for the Appellate Body to take a position on that question. ${ }^{338}$ The Panel noted that this legal debate is still ongoing and that, despite its incorporation in numerous international conventions and declarations, mainly in the area of the environment, its precise definition, content and legal status remains an open question. Due to considerations of prudence, the Panel declined to resolve this complex issue, noting further that it was unnecessary to do so. ${ }^{339}$

331 This finding reiterates that of the Appellate Body in US - Gasoline, 16.

332 The Appellate Body was interpreting the term 'exhaustible natural resources', which it regarded as by definition evolutionary, necessitating regard to modern environmental treaties. Appellate Body Report, US Shrimp, paras 129-130.

${ }^{333}$ It is interesting that in US - Shrimp, the Appellate Body referred to the CBD in support of the arguments of the US, which had itself neither signed nor ratified that convention.

334 Panel Reports, EC-Approval and Marketing of Biotech Products, para. 7.94.

335 Ibid., para. 7.92-7.93.

336 Ibid., para. 7.95. The Panel stated that it 'did not find it necessary or appropriate' to rely on the CBD or Cartagena Protocol in interpreting the WTO agreements at issue.

${ }^{337}$ The EC pointed to several international instruments incorporating the precautionary principle and noted that the approval systems in many countries are based on the need to take precautionary action. Ibid., para. 7.78.

338 Appellate Body Report, EC-Hormones, para. 121, cited in Panel Reports, EC-Approval and Marketing of Biotech Products, para. 7.87.

339 According to the Panel, it was not necessary for it to take a position on the question of whether the 
While one can understand the Panel's reluctance to rule upon this controversial issue, it is difficult to see how it could be regarded as 'unnecessary' in this dispute. As pointed out by the Panel itself, if the precautionary principle has become a general principle of law, or a rule of customary international law, it must be taken into account in the interpretation of the SPS Agreement under Article 31.3(c) of the Vienna Convention on the Law of Treaties. It therefore seems imperative for the Panel to decide whether the precautionary principle has achieved this status, in order for it to know whether it is obliged to have regard to this principle.

It is also interesting to examine the approach of the Panel in EC-Approval and Marketing of Biotech Products to internationally agreed-upon definitions of terms used in the SPS Agreement. The Panel itself had invited several international organisations to identify appropriate standard references (such as technical dictionaries, glossaries, standards and guidelines) which might be useful to it in determining the meaning of terms in the SPS Agreement. ${ }^{340}$ In its arguments regarding the scope of application of the SPS Agreement, the EC repeatedly relied on definitions of terms used in Annex A(1), which have been developed by the international standard-setting bodies expressly referred to in the SPS Agreement, namely the CAC, OIE and IPPC.

For example, the EC argued that the definition of a 'pest' in the IPPC of 1997 as a 'plant, animal or pathogenic agent injurious to plants or plant products' provides a context for the interpretation of the term in the SPS Agreement, requiring that a pest be a living organism and that it cause injury to a plant. ${ }^{341}$ Similarly, it relied on the definition of 'additives' of the Codex, which refers to a substance intentionally added to food in the manufacture thereof for a technological purpose, for its argument that the substance must be added to food and not to a plant that may later find its way into food. ${ }^{342}$ It also pointed to the Codex definition of 'contaminants' as 'any substance not intentionally added to food, which is present in the food as a result of the production....of such food...' to argue that as GMOs and the proteins they produce will be intentionally present in food, they cannot be contaminants. ${ }^{343}$ The OIE definition of a 'disease' as 'the clinical and/or pathological manifestation of infection' was further pointed to by the EC in support of its contention that a GMO is not a disease..$^{34}$

The Panel found that while these internationally agreed upon definitions are informative, ${ }^{345}$ they are not dispositive of the meaning of the relevant terms in the SPS Agreement since the international standard-setting bodies are not referred to in Annex A.1. It therefore felt

precautionary principle 'is a recognized principle of general or customary international law', in order for it to dispose of the legal claims before it. Panel Reports, EC-Approval and Marketing of Biotech Products, para. 7.89 .

${ }^{340}$ Panel Reports, EC - Approval and Marketing of Biotech Products, paras 7.19 and 7.31. The Panel consulted the Parties on the choice of organisations and decided to seek information from the secretariats of the CBD, Codex, FAO, IPPC, OIE, UNEP and WHO.

${ }^{341}$ Ibid., para. 7.241.

342 Ibid., para. 7.295.

343 Ibid., para. 7.314.

344 Ibid., para. 7.276

${ }^{345}$ The Panel, in its findings on the relevance of other international law as evidence of the ordinary meaning of terms used in a treaty, noted that the reference materials obtained from the relevant international organisations had been 'taken into account by [the Panel] as appropriate.' Ibid., para. 7.96. 
free to deviate from these definitions and come to a more expansive interpretation of the relevant terms. ${ }^{346}$ The Panel appeared to prefer to rely on definitions in the New Shorter Oxford English Dictionary to determine the 'ordinary meaning' of the terms used in the SPS Agreement. ${ }^{347}$ This approach does not seem in line with the SPS Agreement's reliance on the work of the relevant international standard-setting bodies as establishing standards and guidelines that Members are encouraged to adopt. ${ }^{348}$ It seems strange to promote the use of these international standards by Members, while the Panel can freely disregard them in applying the provisions of the SPS Agreement.

The narrow view of the Panel in EC - Approval and Marketing of Biotech Products regarding the role of other international law in the interpretation of WTO agreements is lamentable. The Panel fruitfully could have had recourse to relevant multilateral environmental agreements, general principles of international law (if found to exist) and internationally agreed definitions of terms to inform certain terms in the SPS Agreement, such as 'pests', 'contaminants', 'undue delay' and 'insufficient scientific evidence'. In this way, the Panel would have promoted the coherence of the international law system, in line with the progressive approach of the Appellate Body in US - Shrimp. ${ }^{349}$ The concern may be voiced that, as developed countries can afford higher levels of regulatory protection, and may prioritise these above economic goals, some MEAs negotiated by these Members would not be appropriate to refer to in the interpretation of the SPS Agreement in disputes involving developing-country Members not party to the particular MEA. This danger is averted by the very terms of Article 31.3(c) of the Vienna Convention on the Law of Treaties, which even under the proposed wider interpretation limits the international agreements that may be used in the interpretation of WTO agreements to those between the parties to the dispute.

${ }^{346}$ On this expansive interpretation and its impact on the scope of application of the SPS Agreement, see above, Part III, Section 2.1.1.

${ }^{347}$ For example, the Panel noted that the IPPC definition did not support part of its interpretation of the term 'pest' but as it did not regard the IPPC's definition as dispositive, it did not regard it as detracting from the Panel's view that plants may be considered pests even if they are not injurious to other plants. Panel Reports, EC-Approval and Marketing of Biotech Products, para. 7.241. Likewise, the Panel, while noting that the word 'manufacture' in the Codex definition of 'additives' does not fit well with the situation where GM plants are grown for food purposes and the gene is added in the development of the seeds, preferred to rely on the dictionary definition of this term. It thus held that genes intentionally added to food for a technological purpose are to be considered 'additives in food'. Ibid., para. 7.301. Further, the Panel preferred to make use of the wider definition of 'disease' in the New Shorter Oxford English Dictionary rather than rely on that of the OIE, although it refrained from finding that GMOs are themselves diseases. Ibid., para. 7.277. Similarly, with regard to 'contaminants', after examining the New Shorter Oxford English Dictionary, the Panel agreed that intentionally added genes and the proteins produced by GM plants that are intended, are not contaminants. However, it regarded proteins that are an unintended expression of the intentionally added genes as contaminants if they infect or pollute the food product. Ibid., para. 7.313.

${ }^{348}$ Many of the definitions at issue are contained in actual 'standards' developed by the relevant standard-setting bodies. As discussed above, Part III, Section 4.2, while Article 3 of the SPS Agreement does not oblige Members to adopt international standards, guidelines or recommendations, it provides a strong incentive for doing so by providing a presumption of conformity with the SPS Agreement and GATT 1994 for measures conforming to international standards and requiring that deviation be justified by means of a risk assessment.

${ }^{349}$ For an in-depth critique of the findings on this issue by the Panel in EC-Approval and Marketing of Biotech Products, see Margaret A. Young, 'The WTO's Use of Relevant Rules of International Law: An Analysis of the Biotech Case', International \& Comparative Law Quarterly 56 (4), 2007, 907-930. 
The limited interpretative approach applied by the Panel in EC-Approval and Marketing of Biotech Products does not only have effects on the possibility to interpret the SPS Agreement in a manner coherent with the obligations of Members under international environmental law. It also does not bode well for the possibilities to interpret the SPS Agreement in light of the normative framework that is provided by international human rights law. The various human rights conventions and customary international law rules regarding the protection of the rights to life, health and safe food clearly have relevance for the way that the regulatory disciplines of the SPS Agreement should be interpreted, so as not to undermine the protection of these rights. ${ }^{350}$ Due regard by panels, policing the regulatory disciplines of the SPS Agreement, for the duties of states under international human rights law would ensure that the flexibilities inherent in the Agreement, for example in the requirement of a 'rational relationship' between an SPS measure and the scientific evidence, are applied in a way that is supportive of the protection of these rights.

In addition, the emerging recognition of a 'right to development' as reflected in the UN Declaration on the Right to Development of 1986 and the Vienna Declaration and Programme of Action of 1993 may arguably be seen as reflecting a customary international law principle. This principle recognises the link between economic growth and human rights as inherent parts of development, and establishes the responsibility of states and international organisations that are part of the international trade regime to act in a way that is supportive of development. ${ }^{351}$ This principle, if found to have attained the status of customary international law, could inform the interpretation of the SPS Agreement, and especially the trade/health balance it aims to achieve. Such an interpretative tool would set the limits for the interpretation of the SPS Agreement in that its promotion of economic growth through trade cannot come at the cost of the ability of an importing Member to protect human life and health in its territory. Panels would be called upon to use the flexibilities inherent in the SPS Agreement, such as the requirement of a risk assessment 'as appropriate to the circumstances', to take account of the particular situation of Members at different levels of development in order to ensure that the regulatory disciplines of the Agreement do not operate to undermine health protection in less-developed Members. Reliance on the right to development as an interpretative tool would also be useful in redressing the currently weak interpretation of SDT under the SPS Agreement. ${ }^{352}$

However, for this to be possible, a panel faced with this issue would have to be willing to rule on whether the right to development has emerged as a customary international law

${ }^{350}$ For a brief discussion of the relevant human rights framework, see above Part I, Section 1.1 and Part II, Section 1.1. No attempt is made in this book to analyse the question of whether all these human rights obligations have attained the status of customary international law rules, or to set out their content in precise terms. Instead, only the aspects of these rights, as set out by authoritative bodies, that are of particular relevance to the SPS Agreement are highlighted above. The argument here is limited to the idea that WTO adjudicators in interpreting the SPS Agreement should examine whether the relevant international law norms, either as customary international law rules or as treaty obligations binding on the parties to the dispute, are among those rules which they are required to take into account together with the context of the SPS provision under interpretation. If so, these international human rights norms should inform the meaning of the relevant provisions, thereby contributing to the achievement of an appropriate trade/health balance by the SPS Agreement.

${ }^{351}$ See the discussion of the relevance of the right to development for the world trading system above, Part I, Section 1.1 .

352 The interpretation of the only one of these provisions that has been raised in dispute settlement to date (Article 10.1) is discussed below, Part V, Section 1.1. 
principle, and to use it in its interpretation of the relevant provisions of the Agreement. Similarly, a panel would have to be willing to have regard to international human rights treaties where the parties to the dispute, even if not all WTO Members, are parties to the relevant treaties. In addition, it would need to consider whether the human rights to life, health and safe food have developed into customary international law rights, and if so, to inform its interpretation of the regulatory disciplines of the SPS Agreement with reference to these rights. This would be a salutary development, providing a clear normative basis for the trade/health balance pursued in the interpretation of the rules of the SPS Agreement.

As argued by Jacqueline Peel, the 'normative vacuum' in which the SPS Agreement is currently interpreted, has led panels to rely heavily on science as a default criterion. ${ }^{353}$ Science provides a seemingly universal and objective benchmark against which to judge Member's SPS measures. However, in reality this benchmark is far from neutral and the increasingly intrusive review of the scientific assessments underlying Members' regulatory choices simply allows adjudicators to replace Member's policy choices in the assessment of evidence with their own. If, instead, WTO adjudicators were to acknowledge the relevance of international law norms, particularly those relating to the rights to life, health, safe food and development, in their interpretation of the SPS Agreement, this normative backdrop for interpretation would enable panels to achieve a more appropriate balance between recognising the policy space left in the Agreement for Members to regulate and policing the disciplines on this space to promote trade liberalisation and economic growth. They may then be less inclined to adopt an invasive approach to the review of the scientific basis for Member's SPS measures. In other words, in applying the scientific disciplines of the SPS Agreement, reliance on international human rights law to provide a normative framework for interpretation would operate to moderate panels' dependence on the supposed neutrality of science as the arbiter of the legitimacy of SPS measures.

\subsubsection{Expertise of panellists and the use of panel experts}

As noted above, there is no permanent panel body in the WTO dispute settlement system. Instead, panels are created ad hoc for each dispute. Panels must be composed of wellqualified governmental or non-governmental individuals according to Article 8.1 of the DSU. No further specification is given regarding what these individuals must be well qualified in, aside from an illustrative list of possible panellists Specifically, the DSU includes the following among possible panellists: persons who have previously served on a panel, persons who have presented a case before a panel, persons who have represented their governments at the GATT or the WTO or in any Council or Committee of a covered agreement or in the Secretariat, persons who served as senior trade policy officials of Members and finally persons who have taught or published in the area of international trade law or policy. ${ }^{354}$

353 Jacqueline Peel, Risk Regulation under the WTO SPS Agreement: Science as an International Normative Yardstick?, Jean Monnet Working Paper 02/04 (NYU School of Law, New York), June 2004, 9, available at: www.jeanmonnetprogram.org/papers/04/040201.pdf, visited on 14 September 2004.

${ }^{354}$ An indicative list is kept by the WTO Secretariat, with the names of persons suggested by Member governments who meet the requirements of Article 8.1 of the DSU. Members may suggest new persons for inclusion on this list, providing information on their expertise in the area of international trade and the subject matter 
Although this list is not exclusive, it seems that the primary focus of this provision is on the trade expertise of panellists. No express reference is made to persons with non-trade fields of expertise that are nonetheless relevant to disputes under WTO rules, such as experts in the fields of phytosanitary protection, animal health or food safety. However, the reference in Article 8.1 of the DSU to persons who have represented a Member in a WTO committee leaves open the possibility that representatives at the SPS Committee could be called upon to act as panellists. A recent example of this is the composition of the Panel to hear the latest SPS dispute, namely Australia - Apples. ${ }^{355}$ The Chairperson of this Panel is Attie Swart, Chief Programmes Officer at the South African National Department of Agriculture, formerly South Africa's delegate to the SPS Committee in 1996-2000 and later Chairperson of the SPS Committee.

Nevertheless, it is clear that panellists are primarily trade experts. Although it is possible that persons with additional knowledge in the area of SPS protection may be included among them, there is no requirement that panels hearing cases on health measures include such persons. Bearing in mind the often complex scientific issues that are involved in health regulation, it seems likely that persons without scientific expertise in this area would experience difficulty in making judgements evaluating the often-conflicting scientific evidence before them. ${ }^{356}$ This seems particularly problematic when one has regard to the vague limits on the standard of review applied by panels to the regulatory determinations of Member governments, as discussed above. ${ }^{357}$

An attempt to deal with the lack of scientific expertise of panellists is reflected generally in Article 13 of the DSU and for disputes under the SPS Agreement more specifically in Article 11.2 of the SPS Agreement. Article 13.1 of the DSU authorises panels to seek information and technical advice from any individual or body. Article 13.2 of the DSU allows panels to seek information from any source and to consult experts or request advisory reports from expert review. ${ }^{358}$ Article 11.2 of the SPS Agreement states:

In a dispute under this Agreement involving scientific or technical issues, a panel should seek advice from experts chosen by the panel in consultation with the parties to the dispute. To this end, the panel may, when it deems it appropriate, establish an advisory technical experts group, or consult the relevant international organizations, at the request of either party to the dispute or on its own initiative.

The views of panel experts are not binding on a panel, but are purely advisory. In all disputes under the SPS Agreement to date, panels have chosen to consult experts in their individual capacities, rather than establish an expert review group. ${ }^{359}$ This choice is partly

of the covered agreements. Article 8.4 of the DSU.

355 Dispute Settlement Body, Australia - Measures Affecting the Importation of Apples from New Zealand. Request for Consultations by New Zealand, WT/DS367/1, G/L/825, G/SPS/GEN/796, circulated on 4 September 2007.

356 There have been calls for reform in this area. It has been argued that the primary focus on the trade expertise of panellists leads to a definite slant towards free trade goals in panel decisions, which results in inadequate attention being paid to the equally important aim of the protection of health against SPS risks. It has been suggested that a more balanced composition of panels, including experts in both trade and health, is needed.

357 See above, Part IV, Section 2.2.3.

${ }^{358}$ These groups are set up in terms of Appendix 4 of the Dispute Settlement Understanding.

${ }^{359}$ Panel Report, EC-Hormones, para. 6.10 (the same experts were appointed for both Panels); Panel Report, 
motivated by the panels' wish to hear all scientific views on the matter at hand, rather than only the consensus position arrived at by an expert review group. As noted by Joost Pauwelyn, the fact that an expert review group must produce a report under Appendix 6.4 of the DSU 'may be perceived as transforming the expert group into a form of "tribunal within a tribunal". '360 By questioning independent experts, a panel has the flexibility obtain a range of individual opinions rather than a consensus view. ${ }^{361}$ In EC-Hormones, the Panel stressed that it had 'made clear to the experts advising the Panel that [it was] not seeking a consensus position among the experts but wanted to hear all views.' ${ }^{362}$

The Appellate Body in EC - Hormones affirmed the right of panels to appoint individual experts rather than expert review groups. ${ }^{363}$ It held that:

in disputes involving scientific or technical issues, neither Article 11.2 of the SPS Agreement, nor Article 13 of the DSU prevents panels from consulting with individual experts. Rather, both the SPS Agreement and the DSU leave to the sound discretion of a panel the determination of whether the establishment of an expert review group is necessary or appropriate. ${ }^{364}$

The same approach was followed by all the other panels hearing disputes under the SPS Agreement. In US - Continued Suspension, ${ }^{365}$ the Panel addressed the EC's argument that Article 13.2 and Appendix 4 of the DSU, Article 11.2 of the SPS Agreement and Article 14.2 of the TBT Agreement all refer to the possibility to establish expert review groups, and that this 'normal procedure' was clearly preferred by the drafters of the WTO agreements. According to the EC, establishing an expert review group would reduce ${ }^{366}$ the risk of the Panel having to decide between competing scientific views among the experts. The Panel disagreed, holding that neither Article 13.2 of the DSU nor Article 11.2 of the SPS Agreement sets a preference for expert review groups, but instead they mention consultation of expert review groups as only one option. It stressed that Article 13.2 of the DSU only says that panels 'may' request an advisory report from expert review groups,

Australia - Salmon, para. 6.6; Panel Report, Australia - Salmon (Article 21.5 - Canada), para. 6.5 (where all but one of the experts appointed were different to those in the original dispute); Panel Report, Japan Agricultural Products II, para. 6.4; Panel Report, Japan - Apples, para. 6.4; Panel Report, Japan - Apples (Article $21.5-U S$ ), para. 6.2 (appointing the same experts as in the original dispute); Panel Reports, EC Approval and Marketing on Biotech Products, para. 7.25; Panel Report, US - Continued Suspension, paras 7.86 and 7.88; Panel Report, Canada - Continued Suspension, paras 7.84 and 7.86 (the same experts were appointed by the latter two Panels).

360 Joost Pauwelyn, 'The Use of Experts in WTO Dispute Settlement', International and Comparative Law Quarterly 51 (2), 2002, 325-364, 328.

${ }^{361}$ Pauwelyn notes that while the report of an expert review group is advisory only, it may be harder for a panel to overrule a consensus position of such a group than it is to disregard the views of single experts. Ibid.

${ }^{362}$ Panel Report, EC-Hormones (Canada), 8.9.; Panel Report, EC-Hormones (US), 8.9.

${ }^{363}$ Appellate Body Report, EC-Hormones, para. 147.

364 Ibid., para. 142.

${ }^{365}$ Although this dispute was not strictly speaking a dispute under the SPS Agreement since the terms of reference of the Panel did not refer to the SPS Agreement. However, the Panel was of the view that since, in order to address the EC's claim of violation of Article 22.8 of the DSU, it had to examine whether the EC had complied with its obligations under the SPS Agreement, the dispute was 'at least indirectly "under [the SPS] Agreement".' Panel Report, US - Continued Suspension, para. 7.63; Panel Report, Canada-Continued Suspension, para. 7.61.

${ }^{366}$ Panel Report, US - Continued Suspension, para. 7.66; Panel Report, Canada-Continued Suspension, para. 7.64 . 
and that Article 11.2 of the SPS Agreement states that a panel 'may, when it deems it appropriate' establish an advisory technical experts group. The Panel read these provisions as leaving a wide margin of discretion to the Panel. ${ }^{367}$

Explaining its choice to consult experts in their individual capacity rather than as part of an expert review group, the Panel in US-Continued Suspension gave the following two reasons:

Firstly, the fields of competence proposed by the parties were quite varied, rendering it difficult to find individual experts with competence in most or all of these fields to serve in an expert review group. The fact that no expert would have a comprehensive knowledge of all the relevant subjects made it even more important for the Panel to seek advice from the experts on an individual basis on their respective fields of expertise. Secondly, the Panel wished to hear any dissenting or minority views among the experts rather than receiving a consensus text from an expert review group. The Panel did not consider that the risk that experts may have diverging opinions would generate difficulties as serious as those alleged by the European Communities. The Panel rather saw the risk that an expert review group would only agree on a minimum common position, thus depriving the Panel of a full picture of the problems. It was also worth noting that so far, all WTO panels had preferred to consult scientific and/or technical experts on an individual basis. ${ }^{368}$

Referring to the consequence of its choice to consult experts individually rather than as an expert review group, the Panel in US - Continued Suspension recognised that sometimes diverging views were expressed by the experts. It considered this situation to be similar to that addressed by the Appellate Body in EC-Hormones when the Appellate Body considered that both mainstream and divergent views may be set out in a risk assessment. ${ }^{369}$ Recognising that it was not carrying out its own risk assessment, the Panel in US - Continued Suspension nevertheless felt that:

...it may benefit from hearing the full spectrum of experts' views and thus obtain a more complete picture both of the mainstream scientific opinion and of any divergent views. ${ }^{370}$

However, once it has the full spectrum of divergent views before it, problems may arise with regard to the way in which a panel deals with the various viewpoints. In US Continued Suspension, the Panel explained its approach as follows

While, on some occasions, we followed the majority of experts expressing concurrent views, in some others the divergence of views were such that we could not follow that approach and decided to accept the position(s) which appeared,

\footnotetext{
${ }^{367}$ Panel Report, US - Continued Suspension, paras 7.72-7.75; Panel Report, Canada-Continued Suspension, paras $7.70-7.73$.

${ }^{368}$ Panel Report, US - Continued Suspension, para. 7.71 and Panel Report, Canada - Continued Suspension, para. 7.69.

${ }^{369}$ Appellate Body Report, EC-Hormones, para. 194, discussed further above, Part III, Section 5.1.5.1.

${ }^{370}$ Panel Report, US - Continued Suspension, para. 7.418 and Panel Report, Canada - Continued Suspension, para. 7.409 .
} 
in our view, to be the most specific in relation to the question at issue and to be best supported by arguments and evidence. As we have told the parties and the experts during these proceedings, this Panel is not composed of scientists. ${ }^{371}$

This seems a perilous approach. ${ }^{372}$ The difference between the role of a panel in assessing whether an SPS measure has a rational relationship with the scientific evidence, including diverging scientific opinions, and the role of a regulatory authority in assessing the, also sometimes diverging, scientific evidence before it should be borne in mind. While it is the responsibility of a regulatory agency to make policy choices with regard to which of the diverging scientific opinions it will follow, a task for which it has both the mandate and the expertise, it is not the task of a WTO panel to make such policy choices. Instead, a panel is tasked with assessing whether a Member's measure is in conformity with the relevant provisions of the SPS Agreement, inter alia by determining whether the scientific evidence on which the measure is based meets the requirements of Articles 2.2 and 5.1. It is here that the experts play a role, in assisting the panel to understand the scientific evidence before it.

In this regard, contrary to the view of the Panel, it has been argued that scientists consulted individually are unlikely to provide a clear picture of the state of scientific knowledge on an issue. Scientists' views reflect the scientific tradition of which they are part. ${ }^{373}$ Individual scientists may therefore offer a range of possibly competing opinions, leaving it to the panel to decide between them. As stated by Pauwelyn, this 'would exceed [panels'] competence and stain the legitimacy that is traditionally linked to science-based outcomes. It increases the risk of panels "getting it wrong"... ${ }^{374}$ In addition, reliance on individual opinions enables a panel to attach undue weight to a single expert's opinion. ${ }^{375}$ An expert review group is regarded as more conducive to understanding the range of possible interpretations of scientific data. An expert review group is not obliged to come to a monolithic conclusion, but could present the various possible views in a more authoritative way since these would no longer be purely individual opinions but rather the alternative views on the scientific evidence that the expert group regards as plausible.

${ }^{371}$ Panel Report, US - Continued Suspension, para. 7.420 and Panel Report, Canada - Continued Suspension, para. 7.411.

${ }^{372}$ For a strong view that it would be preferable for panels $t$ appoint expert review groups and thus avoid the situation that 'untrained and inexperienced panelists' have to assess competing scientific opinions by different panel experts, see Theofanis Christoforou, 'Settlement of Science-Based Trade Disputes in the WTO: A Critical Review of the Developing Case Law in the Face of Scientific Uncertainty', New York University Environmental Law Journal 8, 2000, 622-648, 638.

${ }^{373}$ According to Atik, scientists are more likely to recognise a scientific justification for a measure where the scientific assertion is accepted in the scientific community to which they belong. Jeffery Atik, 'Symposium - Institutions for International Economic Integration: Science and International Regulatory Convergence', Journal of International Law and Business 17, 1997, 736-758, 757.

374 Joost Pauwelyn, 'The Use of Experts in WTO Dispute Settlement', International and Comparative Law Quarterly 51 (2), 2002, 325-364, 329.

${ }^{375}$ Alberto Alemanno, Trade in Food: Regulatory and Judicial Approaches in the EC and WTO (Cameron May, London), 2007, 355-356. Alemanno gives the example in EC-Hormones, where the Panel dismissed the argument of the EC that no alternative existed to Carbadox with the same therapeutic effect, by relying on the opinion of a single expert who stated that Oxytetracycline was a readily available alternative. Panel Report, EC-Hormones, para. 8.234. 
In addition, an expert group, through discussions, could find common ground between scientific views that may at first appear contradictory. ${ }^{376}$

In respect of the nomination of panel experts, it should be noted that both Article 13.2 and Appendix 4 of the DSU and Article 11.2 of the SPS Agreement require the Panel to consult the parties to the dispute in the selection of experts. No further rules are provided for the selection of individual experts. However, with regard to expert groups, Appendix 4 of the DSU requires that experts be 'persons of professional standing and experience in the field in question, ${ }^{377}$ and that they serve in their individual capacities and not as government representatives. ${ }^{378}$ Citizens of parties to the dispute may not be selected as expert group members except in exceptional circumstances. ${ }^{379}$ These guidelines could be applied, by analogy, to the selection of individual experts. However, in EC-Hormones the Appellate Body held:

The rules and procedures set forth in Appendix 4 of the DSU apply in situations in which expert review groups have been established. However, this is not the situation in this particular case. Consequently, once the panel has decided to request the opinion of individual scientific experts, there is no legal obstacle to the panel drawing up, in consultation with the parties to the dispute, ad hoc rules for those particular proceedings. ${ }^{380}$

In EC-Hormones, the Panels gave the parties the right to nominate one scientific expert each, and the Panel selected three additional experts (from a list drawn up for it by the $\mathrm{CAC}$ and the International Agency for Cancer Research (IARC)), taking into account the comments of the parties. ${ }^{381}$ Among the experts chosen were nationals of the parties to the dispute. However, since these experts were chosen in terms of procedures agreed upon by the parties, the Appellate Body in EC-Hormones found that the Panel had not acted inconsistently with Articles 11, 13.2 and Appendix 4 of the DSU and Article 11.2 of the SPS Agreement. ${ }^{382}$

In contrast, in Australia - Salmon, the panel did not give the parties the right to nominate experts, although it did invite them, together with the OIE, to submit names of individuals with expertise on the matter before the Panel. Parties were given the opportunity to comment on the suggested experts and to raise compelling objections if any. ${ }^{383}$ This practice was followed in later cases. ${ }^{384}$ An example of the complexity of the expert

376 Joost Pauwelyn, 'The Use of Experts in WTO Dispute Settlement', International and Comparative Law Quarterly 51 (2), 2002, 325-364, 329.

377 Appendix 4.2 of the DSU.

378 Appendix 4.3 of the DSU.

${ }^{379}$ Appendix 4.3 of the DSU. The exceptional circumstance referred to is where the panel considers that the need for specialised scientific expertise cannot otherwise be fulfilled. An example suggested by Pauwelyn is where expertise is needed on a very country-specific disease. Joost Pauwelyn, 'The Use of Experts in WTO Dispute Settlement', International and Comparative Law Quarterly 51 (2), 2002, 325-364, 340.

${ }^{380}$ Panel Report, EC - Hormones (Canada), 148.

381 Appellate Body Report, EC-Hormones, para. 148.

382 Ibid.

${ }^{383}$ Panel Report, Australia - Salmon, paras 6.2-6.3. Parties were given the opportunity to comment on the potential experts and state any compelling objections before the Panel selected four individuals from the list of persons proposed.

${ }^{384}$ See Panel Report, Japan - Agricultural Products II, para.6.2. Here the Panel set out a procedure for the 
selection process is provided by the US-Continued Suspension and Canada-Continued Suspension disputes. Here the Panel requested the Secretariats of the CAC, JECFA and the IARC to recommend names of candidate experts in the relevant fields. ${ }^{385}$ Of the 22 suggested experts, 11 were available and willing to participate. However, as the positions of parties to the disputes differed significantly on these experts, the Panel requested the parties to suggest additional names of experts. ${ }^{386}$ An additional 49 experts were suggested by the parties. Of all the experts proposed, all but one was objected to by at least one party. ${ }^{387}$ Finally the Panel selected six experts, on the following basis:

The Panel excluded experts with close links with governmental authorities directly involved in policy-making regarding the six hormones and experts with close links to pharmaceutical companies or involved in public advocacy activities. The Panel chose not to exclude a priori experts who had participated in the preparation and drafting of JECFA's risk assessments because this would deprive the Panel and the parties of the benefit of the contribution of internationally recognized specialists and because the Panel was of the opinion that experts familiar with the JECFA reports would be well-placed to assist the Panel in understanding the work of JECFA extensively referred to by the parties in their submissions, in particular by the European Communities. Moreover, the Panel, who was fully aware of the fields of competence of these experts, considered that they would be competent to answer questions with respect to risk assessment regarding the hormones at issue. The Panel also decided not to exclude a priori all experts who were current or past governmental employees unless a potential conflict of interests could reasonably be assumed from their official functions. In selecting the experts, the Panel also had in mind the need to choose experts with expertise to cover all the fields identified as at issue in the dispute. ${ }^{388}$

selection and questioning of experts, indicating that it would request suggestions from the IPPC and the parties and allow parties to comment or raise compelling objections to suggested experts. The Panel indicated that it did not intend to appoint nationals of the parties unless the need for specialised scientific expertise could otherwise not be fulfilled. See also Panel Report, Australia - Salmon (Article 21.5 - Canada), para. 6.2. Although the Panel in this case initially considered appointing two of the four experts appointed in the original dispute and a third expert specialised in the application of sanitary measures, after the parties had the opportunity to comment on this proposal the Panel decided to appoint only one of the experts in the original dispute and two others. A similar procedure was set out in Panel Report, Japan - Apples, para. 6.2. See further Panel Reports, EC-Approval and Marketing of Biotech Products, paras 7.21-7.30. Here the Panel noted that it would request suggestions from the CBD, CAC, FAO, WHO, IPPC and OIE as well as from the parties to identify appropriate experts. Parties were invited to comment and raise compelling objections to the suggestions, which they did in many cases. The Panel then selected four experts. As two issues were identified on which the selected experts were unlikely to be able to provide advice, the parties were invited to submit names of experts on these issues. After allowing for comments and compelling objections, the Panel selected two additional experts.

${ }^{385}$ Panel Report, US - Continued Suspension, para. 7.79 and Panel Report, Canada - Continued Suspension, para. 7.77 .

386 Panel Report, US - Continued Suspension, para. 7.80 and Panel Report, Canada - Continued Suspension, para. 7.78.

387 Objections were made on the grounds that a proposed expert either lacked scientific expertise in the relevant areas; was affiliated with a government of a party to the dispute; was affiliated with JECFA; had received funding from the pharmaceutical industry; or had been involved in the regulatory approval of one or more of the six hormones at issue. Panel Report, US - Continued Suspension, para. 7.84 and Panel Report, CanadaContinued Suspension, para. 7.82.

${ }^{388}$ Panel Report, US - Continued Suspension, para. 7.85 and Panel Report, Canada - Continued Suspension, 
In addition to authorising panels to seek information from selected experts, Article 11.2 of the SPS Agreement allows a panel to consult relevant international organisations. ${ }^{389}$ In EC - Approval and Marketing of Biotech Products, the Panel, after consulting the parties, decided to seek information from the secretariats of the CBD, CAC, FAO, IPPC, OIE, UNEP and WHO. These organisations were invited to identify standard references that could assist the Panel in determining the meaning of certain terms and concepts. ${ }^{390}$ In US - Continued Suspension and Canada - Continued Suspension, the Panel sought information from three international organisations, the CAC, JECFA and the IACR, particularly with regard to institutional and procedural issues, and definitions relevant to the dispute. ${ }^{391}$

The procedures used to obtain scientific advice from experts are also described in the panel reports. ${ }^{392}$ In general, in parallel to the expert selection procedure, a panel draws up a list of written questions and submits them to the parties for comment. Then the panel finalises the questions and sends them, together with the submissions and scientific evidence, to the experts with the request that they address the questions that are within their competence. Parties have the opportunity to comment in writing on the experts' answers. A joint meeting is then held with the parties and the experts, where discussion takes place on the views of the experts, and the panel can ask additional questions and allows questions by the parties. A transcript of the hearing is attached to the panel report. As noted by Pauwelyn, the publication of the experts' answers in this way is of great importance as '[i]t ensures peer pressure which, in turn, constitutes an incentive for experts to be neutral and truthful..., 393

para. 7.83. Footnote omitted.

389 The reliance on the international standard-setting organisations to suggest relevant experts and to provide information to the panels has been criticised by Theofanis Christoforou. According to this author, scientists coming from these organisations may be 'unfairly biased in favour of maintaining their organizations standards and recommendations. Theofanis Christoforou, 'Settlement of Science-Based Trade Disputes in the WTO: A Critical Review of the Developing Case Law in the Face of Scientific Uncertainty', New York University Environmental Law Journal 8, 2000, 622-648, 630. On the other hand, Pauwelyn notes that the relevant international organisations bring together the best scientists in the world in working groups and committees. In addition, the names they provide are often those of independent scientists working at universities, research institutes or public authorities, rather than their own staff. Peer pressure operates to prevent these persons from expressing 'bogus positions.' Joost Pauwelyn, 'The Use of Experts in WTO Dispute Settlement', International and Comparative Law Quarterly 51 (2), 2002, 325-364, 343.

${ }^{390}$ Panel Reports, EC-Approval and Marketing of Biotech Products, para. 7.31.

${ }^{391}$ Panel Report, US - Continued Suspension, para. 7.79; and Panel Report, Canada - Continued Suspension, para. 7.77. See also Working Procedures for Consultations with Scientific and/or Technical Experts in Annex A-5 to each of these Panel Reports, and the letter from the Panel to parties on 25 November 2005, in Annex A-5 to each of these Panel Reports. At its meeting with the experts in the presence of the parties, the Panel met with six experts and four representatives from the three international organisations mentioned above. One of these persons served as both an individual scientific expert and as the representative of the IARC. Panel Report, US - Continued Suspension, para. 7.98; and Panel Report, Canada-Continued Suspension, para. 7.95 .

${ }^{392}$ Panel Report EC-Hormones, paras. 6.8-6.9; Panel Report, Australia - Salmon, paras. 6.4-6.5; Panel Report, Japan - Agricultural Products II, paras 6.2-6.3; Panel Report, Australia - Salmon (Article 21.5 - Canada), paras 6.3-6.4; Panel Report, Japan - Apples, paras 6.2-6.3; and Panel Reports, EC-Approval and Marketing of Biotech Products, para. 7.29.

393 Joost Pauwelyn, 'The Use of Experts in WTO Dispute Settlement', International and Comparative Law Quarterly 51 (2), 2002, 325-364, 347. 
A panel can also make use of scientific reports as part of its mandate to seek information from any source. In Australia - Salmon, the Panel noted that 'for purposes of our examination the scientific and technical content of ... reports and studies is relevant, not their administrative status (i.e., whether they are official government reports or not)'.${ }^{394}$ When examining certain reports under Article 5.5, it further stated:

We note that these reports do not form part of Australia's formal risk assessment nor represent Australia's official government policy. However, to the extent they constitute relevant available scientific information which was submitted to the Panel, we consider it our task to take this evidence into account. We consider that, for purposes of our examination, the scientific and technical content of these reports and studies is relevant, not their administrative status (i.e., whether they are official government reports or not).

... Whether or not this evidence is part of official Australian government policy does not, in our mind, change the scientific weight to be given to it. ${ }^{395}$

In respect of the use of the various sources of scientific advice and information available to panels, it is very important to set the limits. These limits lie in the interaction between the obligation of a party to prove a prima facie case of inconsistency and the investigative authority of a panel. This issue was examined by the Appellate Body in Japan Agricultural Products II. ${ }^{396}$ In this case, the US had argued that Japan's varietal testing requirement was more trade restrictive than required to meet Japan's appropriate level of protection, contrary to Article 5.6 of the SPS Agreement. It claimed that testing by product was an alternative measure, meeting the Article 5.6 requirements. The Panel found that this measure would not meet Japan's appropriate level of protection. However, it went on to deduce another alternative measure, neither claimed nor argued by the US, from the opinions given by the panel experts. ${ }^{397}$ Although the Panel acknowledged that the US had not argued that this measure, the determination of sorption levels, met any of the three requirements of Article 5.6, it held that it could be presumed that the requirements were met and that the US had offered views consistent with this.

This finding was appealed and the Appellate Body found that the US was obliged to establish a prima facie case that an alternative measure exists meeting all three requirements of Article 5.6. As the US had not even claimed that determination of sorption levels was such a measure, it did not comply with this obligation. The Appellate Body stated as follows:

Article 13 of the DSU and Article 11.2 of the SPS Agreement suggest that panels have a significant investigative authority. However, this authority cannot be used by a panel to rule in favour of a complaining party which has not established a prima facie case of inconsistency based on specific legal claims asserted by it. A panel is entitled to seek information and advice from experts and from any other relevant source it chooses, pursuant to Article 13 of the DSU and, in an SPS

\footnotetext{
394 Panel Report, Australia - Salmon, para. 7.5.

395 Ibid., paras. 8.136-8.137.

${ }^{396}$ Appellate Body Report, Japan - Agricultural Products II, para. 121-131.

${ }^{397}$ Panel Report, Japan - Agricultural Products II, para. 8.74.
} 
case, Article 11.2 of the SPS Agreement, to help it to understand and evaluate the evidence submitted and the arguments made by the parties, but not to make the case for a complaining party. ${ }^{398}$

This makes clear that the expert advice sought by a panel is intended to help it understand and evaluate the evidence submitted and arguments made by the parties, not to make the complaining party's case for it.

In Japan - Apples, Japan referred to this finding by the Appellate Body to challenge on appeal the Panel's use of experts. Japan argued that the US had not made claims or submitted evidence in respect of the risk of transmission of fire blight by apples other than mature symptomless apples, yet the Panel had made findings of fact with regard to these 'other' apples. Japan claimed that the Panel had thus exceeded the bounds of its investigative authority. ${ }^{399}$ The Appellate Body rejected Japan's argument, finding that the Panel had acted within the limits of its investigative authority, as 'it did nothing more than assess the relevant allegations of fact asserted by Japan, in the light of the evidence submitted by the parties and the opinions of the experts. ${ }^{400}$ It thus clarified that a panel may use the evidence of its experts to assist it in assessing not only the claims of the complaining Member, but also the allegations of the responding Member. In doing so, it cannot be said to be exceeding its authority under Article 11.2.

These findings are important in clarifying the respective roles of the panel, its experts and the parties before it in the proceedings. It establishes that the panel procedure is adversarial, with the panel acting as an impartial arbiter, rather than inquisitorial, where the panel would have a more active role in the investigation of the facts and establishment of a case. The panel's investigative authority, including its reliance on panel experts, is meant only to help its own understanding and evaluation of the factual case presented by each of the parties before it.

However, panels have not always stayed within these boundaries in their use of panel experts. In some cases, they have put questions to the experts that entail analysis that is not purely scientific but rather falls within the role of the panel in applying WTO law to the facts before it. For example, in Japan - Agricultural Products II, the Panel asked its experts whether 'in their expert opinion, there is a rational or objective relationship between, on the one hand, the varietal testing requirement imposed by Japan, and, on the other hand, any evidence submitted by the parties. ${ }^{401}$ The concept of a 'rational relationship' has a particular legal significance in the context of the SPS Agreement. The question thus addresses an issue of law that is for the panel, as the arbitrator, to determine. A similar legal question was put to the panel experts in Japan - Apples, namely whether Japan's 1999 Report was a proper risk assessment. ${ }^{402}$ Once again, what is a proper 'risk assessment' for purposes of the SPS Agreement is legally defined. It is beyond the competence of panel experts to address this question. Instead, their role should be strictly limited to assisting the panel in understanding the scientific evidence brought by the parties. In other

\footnotetext{
${ }^{398}$ Appellate Body Report, Japan-Agricultural Products II, para. 129.

${ }^{399}$ Appellate Body Report, Japan - Apples, para. 158.

400 Ibid.

${ }^{401}$ Panel Report, Japan-Agricultural Products II, para. 8.35.

${ }^{402}$ Panel Report, Japan-Apples, para. 6.27, question 2.
} 
cases, the questions put to the panel experts were not related to their scientific expertise but required a personal opinion. For example, in EC-Hormones, the Panel asked the experts whether the conditions imposed by the EC for the therapeutic or zootechnical use of hormones could 'achieve its aim of avoiding any potential adverse effects on human health' arising from their residues in meat. One of the experts, Dr André, responded that this question was 'not related to a scientific expertise' and that he could therefore only give a personal opinion. ${ }^{403}$ In addition, the experts in this case were asked about the feasibility of labelling with respect to hormone-treated meat. As pointed out by Dr. André, this is again not a question related to scientific expertise, but requires rather a 'political decision' ${ }^{404}$ Dr. Ritter, another of the panel experts, noted that labelling is an issue subject to intense public debate and to which there was no easy resolution. ${ }^{405}$

While the use of panel experts is to be welcomed as it assists panels to understand the highly complex factual evidence before them, and thereby lends scientific authority to the decision, the prevailing use of panel experts clearly leaves much to be desired. Reliance on panel experts should avoid the assessment and choice between competing scientific views by a panel. However, the practice of reliance on individual experts rather than expert groups has the effect of adding to the competing scientific opinions before a panel. It allows a panel to pick and choose between the various opinions, ${ }^{406}$ which is troubling in view of the lack of scientific expertise of panellists to undertake this task. It is recommended that panels make use of expert review groups, in order to ensure that the scientific basis for their decisions is authoritative. In addition, the fact that there are no standard guidelines for the process of nomination of individual panel experts, or for the procedures by which expert advice is sought, is problematic. While the current practice in this regard is converging, established guidelines, such as those contained in Appendix 4 of the DSU, lend transparency and legitimacy to the process while allowing sufficient flexibility to take account of the different circumstances of the cases at issue. It is also recommended that these guidelines be amended by providing that, in cases involving a developingcountry Member, an expert from a developing-country Member be included in the review group. As experts' views reflect the scientific traditions of which they are part, this step is necessary to ensure that the assessments provided by the group incorporate developingcountry realities. Finally, it is important that panels take more seriously the distinction between the respective roles of the panel, its experts and the parties before it in the proceedings. While the temptation is there to expand the role of the experts to providing the evidence in support of the position of one of the parties, or, even more so, to addressing the legal questions before the panel that require a basis in scientific assessments, such use of experts undermines the legitimacy of the outcome of dispute settlement.

\footnotetext{
403 Panel Report, EC-Hormones (US), para. 6.189.

${ }^{404}$ Panel Report, EC-Hormones (US), para. 6.234.

${ }^{405}$ Ibid., para. 6.238 .

${ }^{406}$ Alberto Alemanno, Trade in Food: Regulatory and Judicial Approaches in the EC and WTO (Cameron May, London), 2007, 356. Alemanno points out that the practice of consulting individual experts entrusts panels 'with an even more demanding task: to assess the merits of the expert opinions formulated on the plausibility of the scientific evidence brought by the parties and to verify whether there exists common ground among the diverging opinions of individual experts, thus legitimising and even more complex involvement in scientific matters.' Ibid.
} 


\subsubsection{Resort to other dispute resolution mechanisms}

While the jurisdiction to hear disputes under the SPS Agreement lies exclusively with the WTO's adjudicatory bodies, disputes regarding other SPS-related matters may be properly addressed through resort to other mechanisms for the resolution of disputes. The SPS Agreement makes provision for this possibility, in Article 11.3, which states:

Nothing in this Agreement shall impair the rights of Members under other international agreements, including the right to resort to the good offices or dispute settlement mechanisms of other international organizations or established under any international agreement.

Of particular relevance here are the non-binding mechanisms in place in the OIE and IPPC to resolve disputes between their members or contracting parties. ${ }^{407}$ Both these mechanisms focus on finding technical solutions to sanitary or phytosanitary issues.

The OIE has a voluntary dispute settlement system in place. ${ }^{408}$ It takes the form of the possibility for disputing countries to request Director-General of the OIE to arrange for mediation by a panel of scientific experts. ${ }^{409}$ The experts are recommended by the Director-General of the OIE, usually from the relevant OIE Reference Laboratories, and agreed upon by the parties. The discussions by the panel experts take place on a technical basis. ${ }^{410}$ This procedure has been argued to have certain advantages as compared to WTO dispute settlement in that it is less resource-intensive and allows for face-saving solutions, for example by finding technical measures to resolve the disputes that had not yet considered. ${ }^{411}$ The recommendations of the OIE panel are communicated by the DirectorGeneral to both parties, and are non-binding. Although the OIE dispute settlement process is confidential, the documentation from this mediation and the experts conducting the

\footnotetext{
${ }^{407}$ For a description of mandate, institutional structure and procedures of the OIE and IPPC, see above, Part II, Sections 3.2.2 and 3.2.3.

${ }^{408}$ This mechanism is provided for in Article 1.3.1.3 of the Animal Health Code (2006 Edition). The Aquatic Animal Health Code has contained similar provisions since its creation in 1995 (in Article 1.4.1.3 of the 2006 Edition).

409 The agreement of both parties is required to initiate the process and the outcomes are not legally binding unless both parties agree to this in advance. The parties must also agree on the terms of reference and the work program. Committee on Sanitary and Phytosanitary Measures, OIE Dispute Mediation Process. Communication from the World Organization for Animal Health (OIE), G/SPS/GEN/731, circulated on 12 October 2006, para 5 .

${ }^{410}$ Ibid., para 4. This communication stresses the fact that the 'role of the OIE is to help the parties find a resolution of their differences strictly based on scientific elements and with facilitation by OIE experts'. It contrasts this with the WTO dispute settlement system which is based on the application of legal provisions.

${ }^{411}$ Alex B. Thiermann, The Role of Animal Health and Zoonoses Standards on Disease Control and Trade (OIE, Paris), February 2003, available at: http:/www.oie.int/eng/edito/en_thiermann.htm, visited on 6 February 2008. Thiermann is the president of the Animal Health Code Commission. See also on this point Committee on Sanitary and Phytosanitary Measures, Implementing the Standards of the OIE. Communication from the OIE, G/SPS/GEN/437, circulated on 28 October 2003, paras 33-34.
} 
mediation are available to WTO panels should the dispute eventually result in a formal case at the WTO. ${ }^{412}$ The OIE dispute settlement mechanism has been used twice to date. ${ }^{413}$

The IPPC also has dispute settlement procedures in place, ${ }^{414}$ under the authority of the SBDS. The seven members of the SBDS are phytosanitary experts from each of the FAO regions. ${ }^{415}$ Under the IPPC dispute settlement mechanism, measures prohibiting or restricting imports of plants or plant products may be challenged as unjustified. ${ }^{416}$ The contracting parties concerned are required to engage in consultations to resolve the dispute. ${ }^{417}$ If these are unsuccessful, the parties concerned may request the Director-General of the FAO to establish a committee of experts to consider the issue in dispute, in terms of the rules and procedures established by the CPM and administered by the SBDS. ${ }^{418}$ The dis-

412 Thiermann further compares the OIE dispute settlement procedure to the possibilities provided under Article 12.2 of the SPS Agreement to resolve disputes through discussions in the SPS Committee. He notes, 'While this is simple and does not require extensive legal preparation and it encourages parties to examine options which may have not been fully considered, it has the disadvantage that it does not focus as much on the technical aspects of the dispute, as it lacks the technical experts in the panel.' See Alex B. Thiermann, The Role of Animal Health and Zoonoses Standards on Disease Control and Trade (OIE, Paris), February 2003, available at: http://www.oie.int/eng/edito/en_thiermann.htm, visited on 6 February 2008. The possibilities under Article 12.2 of the SPS Agreement are discussed above, Part IV, Section 2.1.2.

${ }^{413}$ The first dispute in 2002, between Japan and the US, related to avian influenza. The second dispute was rather atypical, in that the EC and the US jointly requested the OIE's assistance in facilitating bilateral consultations on the interpretation and implementation of the BSE provisions in the Terrestrial Animal Health Code. In both cases, the mechanism was effective in facilitating technical discussions that significantly narrowed initial differences and provided a basis for the disputing parties to better understand their respective positions. Committee on Sanitary and Phytosanitary Measures, OIE Dispute Mediation Process. Communication from the World Organization for Animal Health (OIE), G/SPS/GEN/731, circulated on 12 October 2006, paras 7-9.

${ }^{414}$ The original IPPC of 1951 included an article on the settlement of disputes (providing for a conciliation mechanism whereby contracting parties could request the FAO Director-General to establish a committee to consider issues in dispute). This was unchanged by the 1979 amendments to the IPPC. The $1997 \mathrm{New}$ Revised Text of the IPPC expanded on this mechanism to include consultation requirements before establishing an IPPC dispute settlement committee. The conciliation mechanism was maintained in revised form. The revised dispute settlement mechanism of the IPPC is set out in Article XIII of the New Revised Text of 1997.

${ }^{415}$ The Terms of Reference and Rules of Procedure for the Subsidiary Body on Dispute Settlement are to be found in International Plant Protection Convention, Report of the First Session of the Commission on Phytosanitary Measures, CPM-1 (2006)/Report (Food and Agriculture Organization, Rome), 3-7 April 2006, Appendix V, available at: https://www.ippc.int/servlet/BinaryDownloaderServlet/133571_CPM_1_report_2006. pdf?filename=1151505665852_CPM_1_report.pdf\&refID=133571, visited on 28 July $200 \overline{6}$. The SBDS replaces the interim Subsidiary Body on Dispute Settlement that was in place pending the entry into force of the New Revised Text of the IPPC. The composition of the SBDS was described above Part II, Section 3.2.3.2.

${ }^{416}$ The dispute settlement mechanism of the IPPC under Article XIII of the New Revised Text of the IPPC may be relied upon if there is any dispute regarding the interpretation or application of the New Revised Text of the IPPC or if a contracting party considers that any action by another contracting party is in conflict with its obligations under Articles V and VII of the New Revised Text. These obligations relate to phytosanitary certification and requirements in relation to imports. Committee on Sanitary and Phytosanitary Measures, IPPC Dispute Settlement Manual. Submission by the Secretariat of the International Plant Protection Convention (IPPC), G/SPS/GEN/787, circulated on 22 June 2007.

${ }^{417}$ Article XIII.1 of the New Revised Text of the IPPC.

${ }^{418}$ Article XIII.2 of the New Revised Text of the IPPC. The CPM was instructed to develop rules and procedures for the settlement of disputes, as well as rules and procedures for IPPC expert committees and their reports established under the dispute settlement system (Articles XI.2(c) and XIII of the New Revised $T e x t)$. For details on the rules and procedures for IPPC dispute settlement, see Committee on Sanitary and Phytosanitary Measures, IPPC Dispute Settlement Manual. Submission by the Secretariat of the International Plant Protection Convention (IPPC), G/SPS/GEN/787, circulated on 22 June 2007. The Subsidiary Body on Dispute Settlement (SBDS) was established by the Third Session of the ICPM in 2001 and its first members 
pute settlement process under the IPPC offers an alternative for examining controversial issues at a technical level. The dispute settlement process in the IPPC is non-binding, but forms the basis for renewed consideration by the parties of the matter at issue. ${ }^{419}$ The results of the process can be expected to have an influence in disputes that may be raised at the WTO level under the SPS Agreement. The possibility of providing WTO panels or the Appellate Body with the report of the SBDS is expressly stated in Article XIII.3 of the New Revised Text. ${ }^{420}$ To date, there have been only two requests under the IPPC dispute settlement procedure, both in 2007.421

\subsubsection{Use of the dispute settlement mechanism}

The question whether Members at lower levels of development have been able to use the WTO dispute settlement system to enforce their rights under the SPS Agreement requires attention. Several studies have examined the participation of developing-country Members in WTO dispute settlement in general, ${ }^{422}$ and have proposed various explanations for the low level of participation found to exist. ${ }^{423}$ Among the reasons for the

confirmed by the Fourth Session of the ICPM in 2002.

${ }^{419}$ Article XIII.4 of the New Revised Text of the IPPC provides: 'The contracting parties agree that the recommendations of such a committee, while not binding in character, will become the basis for renewed consideration by the contracting parties concerned of the matter out of which the disagreement arose.'

${ }^{420}$ Article XIII.3 of the New Revised Text of the IPPC provides that the report of the committee hearing the dispute 'may also be submitted, upon its request, to the competent body of the international organization responsible for resolving trade disputes.' This is clearly a reference to the WTO.

421 One request was dropped and in the second discussions are still ongoing. Committee on Sanitary and Phytosanitary Measures, Summary of the Work of the International Plant Protection Convention (IPPC) October 2007-February 2008. Communication from the IPPC Secretariat, G/SPS/GEN/833, circulated on 26 March 2008, para. 13

${ }^{422}$ It is beyond the scope of this book to examine in detail the issue of developing-country participation in WTO dispute settlement. A wealth of literature exists on this important issue. See for example Victor Mosoti, 'Does Africa Need the WTO Dispute Settlement System?' in Towards a Development-Supportive Dispute Settlement System in the WTO, Gregory Shaffer, et al. (eds.) (International Centre for Trade and Sustainable Development, Geneva), 2003, 67-88, available at: www.ictsd.org/pubs/ictsd_series/resource_papers/DSU_2003.pdf, visited on 30 June 2008; Chad P. Bown and Bernard M. Hoekman, 'WTO Dispute Settlement and the Missing Developing Country Cases: Engaging the Private Sector', Journal of International Economic Law 8 (4), 2005, 861-890; Chad P. Bown, 'Developing Countries as Plaintiffs and Defendants in GATT/WTO Trade Disputes', The World Economy 27 (1), 2004, 59-80; James Smith, 'Inequality in International Trade? Developing Countries and Institutional Change in WTO Dispute Settlement', Review of International Political Economy 11 (3), 2004, 542-573; Mary E. Footer, 'Developing Country Practice in the Matter of WTO Dispute Settlement', Journal of World Trade 35 (1), 2001, 55-98; Chakravarthi Raghavan, The World Trade Organization and Its Dispute Settlement System: Tilting the Balance against the South, Trade and Development Series no. 9 (Third World Network, Geneva), 2002, available at: www. twnside.org.sg/title/tilting-cn.htm, visited on 6 June 2003; Valentina Delich, 'Developing Countries and the WTO Dispute Settlement System', in Development, Trade and the WTO: A Handbook, Philip English, et al. (eds.) (World Bank, Washington D.C.), 2002, 71-80, available at: http://publications.worldbank.org/ catalog/product-detail?product_id=1525978\&, visited on 5 June 2003; Robert E. Hudec, 'The Adequacy of WTO Dispute Settlement Remedies. A Developing Country Perspective', in Development, Trade and the WTO: A Handbook, Philip English, et al. (eds.) (World Bank, Washington D.C.), 2002, 81-91, available at: http://publications.worldbank.org/catalog/product-detail?product_id=1525978\&, visited on 5 June 2003; Gregory Shaffer, 'How to Make the WTO Dispute Settlement System Work for Developing Countries: Some Proactive Developing Country Strategies', in Towards a Development-Supportive Dispute Settlement System in the WTO, Gregory Shaffer, et al. (eds.) (International Centre for Trade and Sustainable Development, Geneva), 2003, 1-65, available at: http://ictsd.net/i/dsu/11342/, visited on 30 June 2008.

${ }^{423}$ Chad Brown and Bernard Hoekman report that between 1995 and 2006, of the 352 disputes brought in 
relatively few complaints initiated by developing-country Members are financial hurdles due to the high costs of WTO litigation; ${ }^{424}$ the small trade volumes in the affected developing-country exports, ${ }^{425}$ which lower the absolute benefits from participation in dispute settlement; ${ }^{426}$ and the absence of partnerships with private sector actors that have the resources and incentives to support Members in bringing disputes at the WTO. ${ }^{427}$ Also, the reliance of developing-country Members on development assistance or preferential market access from the potential respondent Members makes them hesitant to risk these benefits by bringing a challenge against these respondents. ${ }^{428}$ In addition, lack of legal expertise in WTO law often means that less-developed Members are unaware of potential claims they could bring against the measures of their trading partners, or of how to use the procedural mechanisms available for them to do so. Of relevance to SPS-related disputes

that period by 380 complainants, 235 were brought by high-income Members, 59 by upper-middle-income Members, 65 by lower-middle-income Members ( 22 of which by Brazil and 12 by Thailand), and 21 by lowincome Members (17 of which by India). Chad P. Bown and Bernard M. Hoekman, 'Developing Countries and Enforcement of the Trade Agreements: Why Dispute Settlement in Not Enough', Journal of World Trade 42 (1), 2008, 177-203, Table 1.

${ }^{424}$ Chad P. Bown and Bernard M. Hoekman, 'WTO Dispute Settlement and the Missing Developing Country Cases: Engaging the Private Sector', Journal of International Economic Law 8 (4), 2005, 861-890, 863. See also Gregory Shaffer, 'How to Make the WTO Dispute Settlement System Work for Developing Countries: Some Proactive Developing Country Strategies', in Towards a Development-Supportive Dispute Settlement System in the WTO, Gregory Shaffer, et al. (eds.) (International Centre for Trade and Sustainable Development, Geneva), 2003, 1-65, 9-10, available at: http://ictsd.net/i/dsu/11342/, visited on 30 June 2008. Shaffer points out that the greater legalisation of the WTO dispute settlement system, and the rapid increase in case law has led to a skyrocketing of the human resource demands of dispute settlement. He states: 'Just to read through and understand the hundreds of WTO panel and Appellate Body decisions is an immense task, even for specialised academics. Actually deploying the legal system to defend a country's interests through marshalling facts and legal arguments that take account of WTO case law is a daunting enterprise. If developing countries are unable to mobilize the requisite legal resources, they do not stand a chance.' Gregory Shaffer, 'How to Make the WTO Dispute Settlement System Work for Developing Countries: Some Proactive Developing Country Strategies', in Towards a Development-Supportive Dispute Settlement System in the WTO, Gregory Shaffer, et al. (eds.) (International Centre for Trade and Sustainable Development, Geneva), 2003, 1-65, 10, available at: http://ictsd.net/i/dsu/11342/, visited on 30 June 2008.

${ }^{425}$ Shaffer notes, in addition, that although developing countries' stakes in trade disputes are often higher than those of the EC or US, relative to the small size of their economies, their aggregate stakes in the trading system are smaller. As a result they are less likely to be repeat players who benefit from economies of scale in bringing disputes. Gregory Shaffer, 'Power, Governance, and the WTO: A Comparative Institutional Approach', in Power in Global Governance, Michael Barnett and Raymond Duvall (eds.) (Cambridge University Press, Cambridge), 2005, 130-160, 137.

${ }^{426}$ Chad P. Bown and Bernard M. Hoekman, 'WTO Dispute Settlement and the Missing Developing Country Cases: Engaging the Private Sector', Journal of International Economic Law 8 (4), 2005, 861-890, 863.

${ }^{427}$ Gregory Shaffer, 'Power, Governance, and the WTO: A Comparative Institutional Approach', in Power in Global Governance, Michael Barnett and Raymond Duvall (eds.) (Cambridge University Press, Cambridge), 2005, 130-160, 136. Shaffer points out that multinational corporations are the world's largest traders, and thus have the greatest stake in the 'interpretative nuances of WTO rules'. They have the necessary resources to dedicate to supporting Members in WTO litigation, and are willing to do so due to the stakes involved. As a result, they engage in partnerships with US or EC authorities and hire economists and lawyers to work on the dispute.

${ }^{428}$ Chad P. Bown and Bernard M. Hoekman, 'WTO Dispute Settlement and the Missing Developing Country Cases: Engaging the Private Sector', Journal of International Economic Law 8 (4), 2005, 861-890, 863. See also Victor Mosoti, 'Does Africa Need the WTO Dispute Settlement System?' in Towards a DevelopmentSupportive Dispute Settlement System in the WTO, Gregory Shaffer, et al. (eds.) (International Centre for Trade and Sustainable Development, Geneva), 2003, 67-88, 80, available at: www.ictsd.org/pubs/ictsd_series/resource_papers/DSU_2003.pdf, visited on 30 June 2008. 
is the lack of the necessary SPS regulatory capacity to analyse the SPS measures of other Members for compliance with the disciplines of the SPS Agreement, particularly those relating to the scientific basis of a measure.

Aside from these constraints to bringing disputes, the inability of Members with small economies to use the retaliation mechanism to induce compliance by larger Members with the outcome of dispute settlement has been identified as a disincentive to participation. ${ }^{429}$ Chad Bown points out that while the Uruguay Round reforms to the mechanism for resolving trade disputes may have reduced many barriers to the initiation of disputes by developing-country Members, ${ }^{430}$ problems with enforcement of compliance by economically stronger respondents with the outcome of dispute settlement remain deterrents to the use of the system. In this light, the increasing participation of developing-country Members as complainants in dispute settlement proceedings can be explained by examining the respondents against which they bring disputes. As reported by Bown, the evidence suggests that developing-country Members increasingly initiate disputes against respondents against which they can make credible retaliatory threats. ${ }^{431}$

As pointed out above, another way for Members to make their views heard in dispute settlement proceedings is by acting as third parties in a dispute between other Members. Any Member having a 'substantial interest' in a dispute may participate as a third party, by notifying its interest to do so to the DSB. This is a low-cost way to participate in a dispute, as it enables 'piggy-backing' on the efforts of the parties to the dispute, in what have been dubbed 'me too' cases. ${ }^{432}$ Third parties have the opportunity to make written submissions to a panel and to be heard by the panel, and their submissions must be reflected in the panel report. ${ }^{43}$ In addition to the advantages of participation for advancing a Member's interests in a particular dispute, third party participation enables a Member to gain experience with the workings of dispute settlement system. This familiarity with the system will stand them in good stead by lowering the threshold for future participation as parties in dispute settlement. While some developing-country Members make use of this possibility, in practice the EC and US are the most frequent participants as third parties in disputes between other Members. ${ }^{434}$ They use this opportunity to defend their systemic interests in the interpretation of WTO rules through the case law.

${ }^{429}$ Chad P. Bown and Bernard M. Hoekman, 'WTO Dispute Settlement and the Missing Developing Country Cases: Engaging the Private Sector', Journal of International Economic Law 8 (4), 2005, 861-890, 863. An empirical analysis of the way in which the retaliation capacity of the complaining Member affects the market access outcome of a dispute is presented in Chad P. Bown, 'Developing Countries as Plaintiffs and Defendants in GATT/WTO Trade Disputes', The World Economy 27 (1), 2004, 59-80, 68-73.

${ }^{430}$ As discussed above, these reforms include the elimination of the possibility for respondents to prevent the establishment of a panel to hear a dispute or the adoption of the resulting panel report (and possibly Appellate Body report).

${ }^{431}$ Chad P. Bown, 'Developing Countries as Plaintiffs and Defendants in GATT/WTO Trade Disputes', The World Economy 27 (1), 2004, 59-80, 78.

${ }^{432}$ Gregory Shaffer, 'Recognising Public Goods in WTO Dispute Settlement: Who Participates? Who Decides? The Case of TRIPS and Pharmaceutical Patent Protection', Journal of International Economic Law 7 (2), 2004, 459-482, 472.

${ }^{433}$ Article 10.2 of the DSU. In practice third parties are invited to present their views to the panel in a special session of the first substantive meeting of the panel with the parties.

${ }^{434}$ Shaffer reports that by 2003, among developing-country Members, only India, Brazil and Mexico had participated as third parties in more than 8 of the 273 disputes raised by then. In contrast, Japan had done so 42 times, the EC 41 times and the US 32 times. Gregory Shaffer, 'How to Make the WTO Dispute Settlement 
The capacity constraints of developing-country Members in bringing disputes at the WTO were the impetus for the creation, in 2001, of the Advisory Centre on WTO Law (ACWL). ${ }^{435}$ The ACWL is an independent organisation, created to help developing countries improve their participation in the multilateral trading system. It, inter alia, ${ }^{436}$ provides direct support in WTO dispute settlement proceedings at low-cost to its developingcountry members and to LDCs that are Members of the WTO or in the process of accession. ${ }^{437}$ It is funded by its members, with membership fees determined on the basis of share in world trade and per capita income. ${ }^{438}$ The dispute settlement support provided by the ACWL is of a very high quality, but its resource constraints limit the number of cases that it can take on. ${ }^{439}$ The ACWL has a staff of only eight lawyers, two junior lawyers under a secondment programme and three administrative officers. By the end of 2007, the ACWL had provided support to developing countries and LDCs in 29 WTO dispute settlement proceedings. In 22 of these cases, the support was provided to the complainant, ${ }^{440}$ in 11 of these cases against a developing-country respondent. ${ }^{441}$

A Technical Expertise Fund has been created for ACWL members that are developing countries, customs territories or economies in transition to bear some of the costs of the technical expertise needed to prepare the information required in fact-intensive dispute settlement proceedings, including those under the SPS Agreement. ${ }^{442}$ To date, Denmark,

System Work for Developing Countries: Some Proactive Developing Country Strategies', in Towards a Development-Supportive Dispute Settlement System in the WTO, Gregory Shaffer, et al. (eds.) (International Centre for Trade and Sustainable Development, Geneva), 2003, 1-65, 14, available at: http://ictsd.net/i/ $\mathrm{dsu} / 11342 /$, visited on 30 June 2008.

${ }^{435}$ At the Seattle Session of the WTO Ministerial Conference in 1999, 29 Members signed the Agreement establishing the Advisory Centre on WTO Law, which entered into force on 15 July 2001. Membership of the ACWL is open to all WTO Members and any state or separate customs territory in the process of acceding to the WTO. The ACWL is administered by its developing-country Members, LDCs and by the developed countries that fund its activities. Its administrative and financial roles are separate from its legal services to ensure the independence of its legal advice and services.

${ }^{436}$ In addition the ACWL provides free legal advice on all substantive and procedural aspects of WTO law, not limited to cases where dispute settlement is contemplated, as well as training services.

${ }^{437}$ The fees payable by developing-country Members are CHF324 per hour for Category A members, CHF243 per hour for Category B members, and CHF162 per hour for Category C members. LDCs pay CHF40 per hour. LDCs do not have to be members of the ACWL to benefit from its free legal assistance. Currently 27 developing-country members and 42 LDCs are entitled to the services of the ACWL.

438 Each of the developed-country members of the ACWL (Canada, Denmark, Finland, Ireland, Italy, the Netherlands, Norway, Sweden, Switzerland and the UK) has contributed US\$1 million or more to the Endowment Fund and/or has committed to pay US\$1,250,000 in multiyear contributions to finance expenditures in the first five years. It is notable that the US is not among these members and neither is the EC in its own name. Developing-country members are divided into three categories according to their share of world trade and income per capita, according to which their contributions are determined (CHF486,000 for Category A members, CHF162,000 for Category B members and CHF81,000 for Category C members). LDCs are not required to contribute. They have priority in the provision of the ACWL's services.

${ }^{439}$ Bown and Hoekman note that the reluctance of certain high-income Members, such as the US, Japan, France, Germany and the EC, to fund the ACWL may be due to the fact that the ACWL provides litigation assistance to Members that may be used in direct challenges to the measures of the donor Members. Chad P. Bown and Bernard M. Hoekman, 'WTO Dispute Settlement and the Missing Developing Country Cases: Engaging the Private Sector', Journal of International Economic Law 8 (4), 2005, 861-890, 875.

${ }^{440}$ In the remaining 7 cases the ACWL provided support to the respondent or a third party.

${ }^{441}$ Advisory Centre on WTO Law, Report on Operations 2007, available at: http://www.acwl.ch/pdf/Oper_2007. pdf, visited on 30 June 2008.

${ }^{442}$ This information is provided on the ACWL's website, available at: http://www.acwl.ch/e/dispute/technical_e. 
Norway and the Netherlands have contributed or pledged contributions to this fund. ${ }^{443}$ The fund has been used in two disputes involving claims under the SPS Agreement. ${ }^{444}$

Not only does the level of participation of Members as complainants in dispute settlement vary with their level of development, but a similar pattern can be seen with regard to the participation of Members as respondents. Much fewer cases are brought against developing-country Members than against developed-country Members. ${ }^{445}$ Several reasons have been suggested for this, among which is the fact that the small market size of many Members at lower levels of development means that the potential gains in terms of increased market access to be obtained from winning a case may be too small to compensate for the costs of litigation. Also, politically, high-income Members may be hesitant to 'be seen as picking on a poor country for WTO violations.' 446

As the WTO dispute settlement system is a Member-to-Member system, depending on the initiative of Members for the enforcement of the rules, the limited number of disputes brought against Members at lower levels of development results in weak incentives for compliance with their commitments. ${ }^{447}$ With regard to WTO disciplines on domestic regulation, as contained in the SPS Agreement, this may be seen as creating the advantage of securing for these Members additional de facto policy space, to take measures supportive of their development objectives, even if these are WTO-inconsistent. This is particularly the case where the relevant rules are not appropriate for Members at lower levels of development. However, as pointed out by Bown and Hoekman, the appropriate remedy for badly designed rules or commitments is 'to renegotiate the rules or seek waivers, and not to rely on the low probability of being confronted with a dispute. ${ }^{448}$ Reliance on non-enforcement creates uncertainty and unpredictability with regard to the limits of the policy space available to the relevant Members, and leaves them vulnerable to pressure

aspx, visited on 30 June 2008 .

443 Their contributions total over CHF 1 million.

${ }^{444}$ Advisory Centre on WTO Law, The ACWL after Four Years. A Progress Report by the Management Board, ACWL/GA/2005/1, ACWL/MB/2005/1, 5 October 2005, 18, available at: www.acwl.ch/misc/getfile. aspx?id=008b453f-b440- 4995-be50-1e536f5f8477, visited on 30 June 2008.

445 Bown and Hoekman report that between 1995 and 2006, of the 352 disputes brought, 217 were brought against high-income Members, 69 against upper-middle-income Members, 46 against lower-middle-income Members 913 of which against Brazil) and 20 against low income Members (18 of which against India and the remaining 2 against Pakistan). Chad P. Bown and Bernard M. Hoekman, 'Developing Countries and Enforcement of the Trade Agreements: Why Dispute Settlement in Not Enough', Journal of World Trade 42 (1), 2008, 177-203, Table 1.

${ }_{446}$ Ibid., 179. Other reasons for the low level of challenges against developing-country Members mentioned by Bown and Hoekman, which are less relevant to disputes under the SPS Agreement, are the fact that Members at lower levels of development have made fewer market access commitments, thereby creating fewer possibilities for challenges. In addition, developing countries can invoke SDT provisions in some cases with regard to the application of specific rules.

447 With respect to basic trade disciplines, such as tariff concessions, the prohibition on quotas and the rules on non-discrimination, implementation of commitments is welfare enhancing for Members at all levels of development. In these cases, as argued by Bown and Hoekman, weak enforcement of compliance reduces the economic gains from WTO membership due to: 'welfare economic losses die to continued import protection within developing economies; diminished incentives for the country to take on additional WTO commitments such as reducing tariff bindings to meaningful levels ...; as well as externality costs to other developing countries.' Ibid. These economic losses from non-compliance are not equally present with regard to WTO disciplines on behind-the-border areas of regulatory policy, as discussed above, Part I, Section 1.6.

${ }^{448}$ Ibid., 180. 
from threats of dispute settlement action. In some cases, this pressure may lead the noncomplying Member to accept unfavourable settlements in respect of trade concerns they have with regard to the measures of other Members. To avoid this undesirable situation, it is important to ensure that in cases where the regulatory disciplines laid down in the SPS Agreement are beyond the capacity of certain less-developed Members to comply with, and the disciplines themselves cannot be amended without tilting the delicate trade/ health balance sought by the Agreement, an effective mechanism is in place to allow for temporary waivers from specific disciplines in response to the development needs of the relevant Member. ${ }^{449}$ In addition, an effective mechanism for the delivery of technical assistance in order to build the capacity of the Member to comply with the obligations at issue is essential. ${ }^{450}$

It is now useful to examine the practice of dispute settlement under the SPS Agreement. This analysis aims to establish the extent to which the dispute settlement system is used by Members to resolve their SPS-related conflicts. It pays particular attention to the participation of Members at different levels of development in this dispute settlement practice to determine whether, and to what extent, the factors mentioned above have played a role in inhibiting developing-country Members' participation in the system. An overview of the disputes involving claims under the SPS Agreement that have been initiated to date, the Members participating and the status of the disputes, is provided in table form in the Appendix to this book. ${ }^{451}$

\footnotetext{
${ }^{449}$ For a discussion of the waiver mechanism in Article 10.3 of the SPS Agreement, see below, Part V, Section 1.5 .

${ }^{450}$ On technical assistance and capacity building, see below, Part V, Section 2.1.

${ }^{451}$ See below, Appendix.
} 
To date, there have been 31 formal disputes ${ }^{452}$ under the SPS Agreement regarding 27 sep-

${ }^{452}$ Dispute Settlement Body, Korea-Measures Concerning the Testing and Inspection of Agricultural Products. Request for Consultations by the United States, WT/DS3/1, circulated on 6 April 1995; Dispute Settlement Body, Korea - Measures Concerning the Shelf-Life of Products - Request for Consultations by the United States, WT/DS5/1, circulated on 5 May 1995; Dispute Settlement Body, Australia - Measures Affecting Importation of Salmon. Request for Consultations by Canada, WT/DS18/1, G/L/28, G/SPS/W/29, circulated on 11 October 1998; Dispute Settlement Body, Korea-Measures Concerning Bottled Water. Request for Consultations by Canada, WT/DS20/1, G/L/33, G/SPS/W/35, G/TBT/D/4, G/MA/3, G/AG/W/14, circulated on 22 November 1995; Dispute Settlement Body, Australia - Measures Affecting the Important of Salmonids. Request for Consultations by the United States, WT/DS21/1, G/L/39, G/SPS/W/40, circulated on 23 November 1995; Dispute Settlement Body; Dispute Settlement Body; Dispute Settlement Body, Japan - Measures Affecting Agricultural Products. Request for Consultations by the US, WT/DS76/1, G/L/167, G/SPS/GN/15, G/SG/GEN/1, circulated on 9 April 1997; Dispute Settlement Body, India - Quantitative Restrictions on Imports of Agricultural, Textile and Industrial Products. Request for Consultations by the European Communities, WT/DS96/1, G/L/178, G/AG/GEN/10, G/LIC/D/11, G/SPS/GEN/25, circulated on 24 July 1997; Dispute Settlement Body, United States - Measures Affecting Imports of Poultry Products. Request for Consultations by the EC, WT/DS100/1, G/SPS/GEN/28, G/TBT/D/14, circulated on 25 August 1997; Dispute Settlement Body, Slovak Republic - Measures Concerning the Importation of Dairy Products and the Transit of Cattle. Request for Consultations by Switzerland, WT/DS133/1, G/L/243, G/SPS/GEN/71, G/LIC/D/22, circulated on 18 May 1998; Dispute Settlement Body, European Communities - Restrictions on Certain Import Duties on Rice. Request for Consultations by India, WT/DS134/1, G/L/245, G/VAL/D/1, G/LIC/D/23, G/AG/GEN/24, G/TBT/D/16, G/SPS/GEN/73, circulated on 8 June 1998; Dispute Settlement Body, EC - Measures Affecting Asbestos and Products Containing Asbestos: Request for Consultations by Canada, WT/DS135/1, G/SPS/GEN/72, G/TBT/D/15, circulated on 3 June 1998; Dispute Settlement Body, EC-Measures Affecting Imports of Wood of Conifers from Canada: Request for Consultations by Canada, WT/DS137/1, G/L/246, G/SPS/GEN/84, G/TBT/D/17, circulated on 24 June 1998; Dispute Settlement Body, United States - Certain Measures Affecting the Import of Cattle, Swine and Grain from Canada. Request for Consultations from Canada, WT/DS144/1, G/L/260, G/SPS/W/90, G/TBT/D/18, G/AG/ GEN/27, circulated on 29 September 1998; Dispute Settlement Body, Mexico - Measures Affecting Trade in Live Swine. Request for Consultations by the United States, WT/DS203/1, G/L/389, G/ADP/D25/1, G/ SPS/GEN/196, G/AG/GEN/43, G/TBT/D/20, circulated on 13 July 2000; Dispute Settlement Body, EgyptImport Prohibition on Canned Tuna with Soybean Oil. Request for Consultations by Thailand, WT/DS205/1, G/L/392, G/SPS/GEN/203, circulated on 27 September 2000; Dispute Settlement Body, Turkey - Certain Import Procedures for Fresh Fruit. Request for Consultations by Ecuador, WT/DS237/1, G/L/472, G/SPS/ GEN/276, G/LIC/D/33, G/AG/GEN/48, S/L/101, circulated on 10 September 2001; Dispute Settlement Body, Japan - Measures Affecting the Importation of Apples: Request for Consultations by the US, WT/ DS245/1, G/L/520, G/SPS/GEN/299, G/AG/GEN/50, circulated on 6 March 2002; Dispute Settlement Body, Turkey - Import Ban on Pet Food from Hungary. Request for Consultations by Hungary, WT/DS256/1, G/L/538, G/SPS/GEN/316, G/AG/GEN/51, circulated on 7 May 2002; Dispute Settlement Body, Australia Certain Measures Affecting the Importation of Fresh Fruit and Vegetables. Request for Consultations by the Philippines, WT/DS270/1, G/L/575, G/SPS/GEN/345, G/LIC/D/34, circulated on 23 October 2002; Dispute Settlement Body, Australia - Certain Measures Affecting the Importation of Fresh Pineapple. Request for Consultations by the Philippines, WT/DS271/1, G/L/576, G/SPS/GEN/346, circulated on 23 October 2002; Dispute Settlement Body, India - Import Restrictions Maintained under the Export and Import Policy $2002-$ 2007. Request for Consultations by the EC, WT/DS279/1, G/L/600, G/AG/GEN/57, G/LIC/D/36, G/SPS/ GEN/367, G/TBT/D/26, circulated on 9 January 2003; Dispute Settlement Body, Australia - Quarantine Regime for Imports. Request for Consultations by the European Communities, WT/DS287/1, G/L/618, G/ SPS/GEN/384, circulated on 9 April 2003; Dispute Settlement Body, European Communities - Measures Affecting the Approval and Marketing of Biotech Products. Request for Consultations by the United States, WT/DS291/1, G/L/627, G/SPS/GEN/397, G/AG/GEN/60, G/TBT/D/28, circulated on 20 May 2003; Dispute Settlement Body, European Communities - Measures Affecting the Approval and Marketing of Biotech Products. Request for Consultations by Canada, WT/DS292/1, G/L/628, G/SPS/GEN/398, G/AG/GEN/61, G/TBT/D/29, circulated on 20 May 2003; Dispute Settlement Body, European Communities - Measures Affecting the Approval and Marketing of Biotech Products. Request for Consultations by Argentina, WT/ DS293/1, G/L/629, G/SPS/GEN/399, G/AG/GEN/62, G/TBT/D/30, circulated on 21 May 2003; Dispute Settlement Body, Croatia - Measure Affecting Imports of Live Animals and Meat Products. Request for 
arate issues. Five of the 31 complaints only involved minor SPS issues. ${ }^{453}$ Consultations are still pending with regard to ten complaints. ${ }^{454}$ A mutually agreed solution has been reached in 14 cases, eight of which before a panel was established; ${ }^{455}$ three after a panel

Consultations by Hungary, WT/DS297/1, G/L/636, G/SPS/GEN/411, circulated on 14 July 2003; Dispute Settlement Body, Mexico - Certain Measures Preventing the Importation of Black Beans from Nicaragua, WT/DS284/1, G/L/614, G/LIC/D/37, G/SPS/GEN/375, circulated on 20 March 2003.

${ }^{453}$ Dispute Settlement Body, India - Quantitative Restrictions on Imports of Agricultural, Textile and Industrial Products. Request for Consultations by the European Communities, WT/DS96/1, G/L/178, G/AG/GEN/10, G/LIC/D/11, G/SPS/GEN/25, circulated on 24 July 1997; Dispute Settlement Body, European Communities - Restrictions on Certain Import Duties on Rice. Request for Consultations by India, WT/DS134/1, G/L/245, G/VAL/D/1, G/LIC/D/23, G/AG/GEN/24, G/TBT/D/16, G/SPS/GEN/73, circulated on 8 June 1998; Dispute Settlement Body, EC - Measures Affecting Asbestos and Products Containing Asbestos: Request for Consultations by Canada, WT/DS135/1, G/SPS/GEN/72, G/TBT/D/15, circulated on 3 June 1998; Dispute Settlement Body, Mexico - Measures Affecting Trade in Live Swine. Request for Consultations by the United States, WT/DS203/1, G/L/389, G/ADP/D25/1, G/SPS/GEN/196, G/AG/GEN/43, G/TBT/D/20, circulated on 13 July 2000; Dispute Settlement Body, India - Import Restrictions Maintained under the Export and Import Policy 2002-2007. Request for Consultations by the EC, WT/DS279/1, G/L/600, G/AG/GEN/57, G/ $\mathrm{LIC/D} / 36, \mathrm{G} / \mathrm{SPS} / \mathrm{GEN} / 367, \mathrm{G} / \mathrm{TBT} / \mathrm{D} / 26$, circulated on 9 January 2003.

${ }^{454}$ Dispute Settlement Body, United States - Measures Affecting Imports of Poultry Products. Request for Consultations by the EC, WT/DS100/1, G/SPS/GEN/28, G/TBT/D/14, circulated on 25 August 1997; Dispute Settlement Body, European Communities - Restrictions on Certain Import Duties on Rice. Request for Consultations by India, WT/DS134/1, G/L/245, G/VAL/D/1, G/LIC/D/23, G/AG/GEN/24, G/TBT/D/16, G/SPS/GEN/73, circulated on 8 June 1998; Dispute Settlement Body, EC - Measures Affecting Imports of Wood of Conifers from Canada: Request for Consultations by Canada, WT/DS137/1, G/L/246, G/SPS/ GEN/84, G/TBT/D/17, circulated on 24 June 1998; Dispute Settlement Body, United States - Certain Measures Affecting the Import of Cattle, Swine and Grain from Canada. Request for Consultations from Canada, WT/DS144/1, G/L/260, G/SPS/W/90, G/TBT/D/18, G/AG/GEN/27, circulated on 29 September 1998; Dispute Settlement Body, Mexico - Measures Affecting Trade in Live Swine. Request for Consultations by the United States, WT/DS203/1, G/L/389, G/ADP/D25/1, G/SPS/GEN/196, G/AG/GEN/43, G/TBT/D/20, circulated on 13 July 2000; Dispute Settlement Body, Egypt - Import Prohibition on Canned Tuna with Soybean Oil. Request for Consultations by Thailand, WT/DS205/1, G/L/392, G/SPS/GEN/203, circulated on 27 September 2000; Dispute Settlement Body, Australia - Certain Measures Affecting the Importation of Fresh Fruit and Vegetables. Request for Consultations by the Philippines, WT/DS270/1, G/L/575, G/ SPS/GEN/345, G/LIC/D/34, circulated on 23 October 2002; Dispute Settlement Body, Australia - Certain Measures Affecting the Importation of Fresh Pineapple. Request for Consultations by the Philippines, WT/ DS271/1, G/L/576, G/SPS/GEN/346, circulated on 23 October 2002; Dispute Settlement Body, India Import Restrictions Maintained under the Export and Import Policy 2002-2007. Request for Consultations by the EC, WT/DS279/1, G/L/600, G/AG/GEN/57, G/LIC/D/36, G/SPS/GEN/367, G/TBT/D/26, circulated on 9 January 2003; and Dispute Settlement Body, Croatia - Measure Affecting Imports of Live Animals and Meat Products. Request for Consultations by Hungary, WT/DS297/1, G/L/636, G/SPS/GEN/411, circulated on 14 July 2003.

${ }^{455}$ Four mutually agreed solutions were notified to the DSB, namely Dispute Settlement Body, Korea - Measures Concerning the Shelf-Life of Products. Notification of Mutually Agreed Solution, WT/DS5/5, G/SPS/W/27, G/TBT/D/3, G/AG/W/8, circulated on 31 July 1995; Dispute Settlement Body, Korea-Measures Concerning Bottled Water. Notification of Mutually Agreed Solution, WT/DS20/6, G/L/33/Add.1, G/SPS/W/35/Add.1, G/ TBT/D/4/Add.1, G/MA/3/Add.1, G/AG/W/14/Add.1, circulated on 6 May 1996; Dispute Settlement Body, India - Quantitative Restrictions on Imports of Agricultural, Textiles and Industrial Products. Notification of Mutually Agreed Solution, WT/DS96/8, G/L/234, G/AG/GEN/23, G/LIC/D/21, G/SPS/GEN/70, circulated on 6 May 1998; Dispute Settlement Body, Mexico - Certain Measures Preventing the Importation of Black Beans from Nicaragua. Communication from Nicaragua, WT/DS284/4, circulated on 11 March 2005. The remaining four mutually agreed solutions were reported to the SPS Committee but not notified to the DSB. They concerned the following disputes: Turkey - Import Ban on Pet Food From Hungary, WT/DS256; Slovak Republic - Measures Concerning the Importation of Dairy Products and the Transit of Cattle, WT/ DS133; Korea - Measures Concerning Inspection of Agricultural Products. Request for Consultations by the United States, WT/DS41/1; Korea - Measures Concerning Inspection of Agricultural Products, WT/ DS4; and Korea - Measures Concerning the Testing and Inspection of Agricultural Products, WT/DS3. 
had been established but before it had adjudicated the dispute, ${ }^{456}$ and three of which with regard to implementation of the outcome of adjudication of the dispute. ${ }^{457}$ Thirteen complaints resulted in the establishment of a panel. ${ }^{458}$ Nine complaints, ${ }^{459}$ regarding five separate issues, were actually (or are currently being) adjudicated by a panel under the SPS Agreement and eight panel reports have thus far been issued. ${ }^{460}$ All these panel reports,

See Committee on Sanitary and Phytosanitary Measures, Specific Trade Concerns. Note by the Secretariat. Addendum. Resolved Issues, G/SPS/GEN/204/Rev.8/Add.3, circulated on 27 March 2008, items 1 and 4.

456 Dispute Settlement Body, Australia - Measures Affecting the Importation of Salmonids. Notification of Mutually Agreed Solution, WT/DS21/10, G/L/39/Add.1, G/SPS/W/40/Add.1, circulated on 1 November 2000; Dispute Settlement Body, Turkey - Certain Import Procedures for Fresh Fruit. Notification of Mutually Agreed Solution, WT/DS237/4, circulated on 29 November 2002 and Dispute Settlement Body, AustraliaQuarantine Regime for Imports. Notification of Mutually Agreed Solution, WT/DS287/8, G/L/618/Add.1, G/ SPS/GEN/384/Add.1, circulated on 13 March 2007.

${ }^{457}$ Dispute Settlement Body, Japan - Measures Affecting Agricultural Products. Communication from Japan and the United States, WT/DS76/12, circulated on 30 August 2001; Dispute Settlement Body, Japan Measures Affecting the Importation of Apples. Notification of Mutually Agreed Solution, WT/DS245/21; G/L/520/Add.1; G/SPS/GEN/299/Add.1; G/AG/GEN/50/Add.1, circulated on 2 September 2005. At the DSB meeting of 18 May 2000, Australia and Canada reported that they had reached a mutually agreed solution on the implementation by Australia of the conclusions and recommendations adopted by the DSB in the case Australia - Salmon. However, the details of this solution have not yet been formally notified to the DSB.

${ }^{458}$ Not all of these thirteen Panels actually adjudicated the relevant dispute, or did not do so under the SPS Agreement. One of these Panels, namely the Panel in Australia - Measures Affecting the Importation of Salmonids (Complaint by the United States), WT/DS21, did not adjudicate the dispute before it as it was instructed to suspend its work by the US, the complainant in the case, pending the outcome of the Article 21.5 Panel Report in the related case Australia - Salmon (Article 21.5 - Canada), and consultations between the US and Australia. A mutually agreed solution was notified in November 2000. Dispute Settlement Body, Australia - Measures Affecting the Importation of Salmonids. Notification of Mutually Agreed Solution, WT/ DS21/10, G/L/39/Add.1, G/SPS/W/40/Add.1, circulated on 1 November 2000. Further, two separate Panels were established with regard to each of the disputes Australia-Certain Measures Affecting the Importation of Fresh Fruit and Vegetables (Complaint by the Philippines) (WT/DS270) and Australia -Quarantine Regime for Imports (Complaint by the European Communities) (WT/DS287), on 29 August 2003 and 7 November 2003 respectively. See Dispute Settlement Body, Minutes of Meeting Held in Centre William Rappard on 29 August 2003, WT/DSB/M/155, circulated on 7 November 2003, para. 26; Dispute Settlement Body, Minutes of Meeting Held in the Centre William Rappard on 7 November 2003, WT/DSB/M/157, circulated on 18 December 2003, para. 40. The disputes deal with the same matter, so it was expected that (in terms of Article 9.3 of the DSU) the two panels would be composed of the same panellists and follow a harmonised timetable. However, the panels were not composed as the parties suspended discussions on the composition of the panels. In 2007 a mutually agreed solution was notified in the second of these disputes. Dispute Settlement Body, Australia - Quarantine Regime for Imports. Notification of Mutually Agreed Solution, WT/DS287/8, G/L/618/Add.1, G/SPS/GEN/384/Add.1, circulated on 13 March 2007. The dispute in EC - Asbestos also proceeded to adjudication by a Panel and the Appellate Body, but the claims under the SPS Agreement were not pursued in the adjudication process.

${ }^{459}$ These nine complaints are the separate complaints by the US and Canada in EC-Hormones that were heard by separate panels, composed of the same panellists, which issued separate but largely identical reports; the complaint by the US in Japan - Agricultural Products II; the complaint by Canada in Australia - Salmon; the complaint by the US in Japan - Apples; the separate complaints by the US, Canada and Argentina in EC - Approval and Marketing of Biotech Products which were heard by a single Panel that issued three reports in a single document; and the complaint by New Zealand against Australia in Australia - Apples which is currently before a Panel.

${ }^{460}$ Panel Report, EC - Hormones (Canada); Panel Report, EC - Hormones (US); Panel Report, Australia - Salmon; Panel Report, Japan - Agricultural Products II; Panel Report, Japan - Apples; Panel Reports, EC-Approval and Marketing of Biotech Products. The findings in these cases were discussed in previous chapters where relevant. 
except the three reports of the Panel in EC-Approval and Marketing of Biotech Products, have been appealed, resulting in four Appellate Body reports. ${ }^{461}$

Aside from the cases decided under the SPS Agreement, the SPS Agreement has also been addressed in the Canada - Continued Suspension and US - Continued Suspension disputes, brought by the EC. These disputes concern the refusal of Canada and the US to lift their retaliatory measures against EC exports imposed due to the EC's non-compliance with the recommendations and rulings of the DSB in the EC-Hormones dispute. The EC's claim that the continued suspension of concessions against it was inconsistent with the DSU was based on its argument that it had brought its measure into conformity with the SPS Agreement. Therefore, the Panel had to examine the EC measure against the relevant provisions of the SPS Agreement, although its findings were limited to the claims under the DSU. ${ }^{462}$ This Panel report was appealed, but at time of writing was still before the Appellate Body. ${ }^{463}$

The varying levels of participation of Members at different levels of development in these disputes is now examined.

\section{Graph 43: Participation in Initiating SPS-related Dispute Settlement Proceedings: WTO Members by Income Level, 1995-2008}

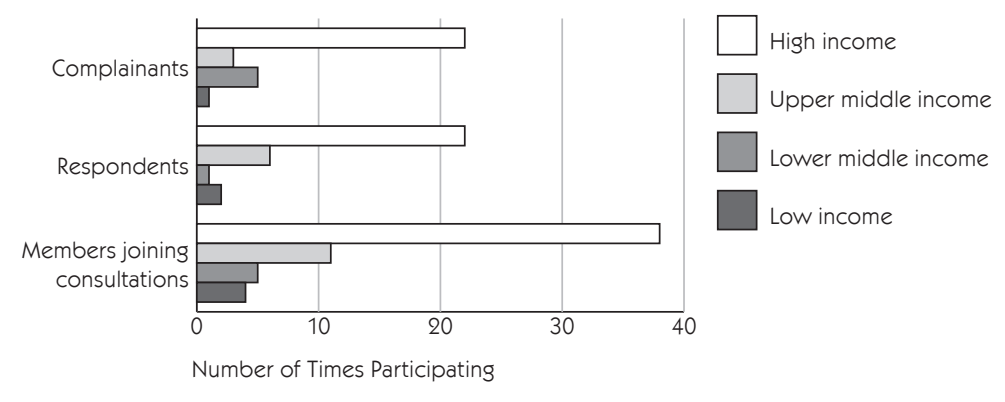

No African country or LDC has initiated a complaint under the SPS Agreement. India is the only low-income country to have done so, in one complaint against the EC on import duties on rice, involving a minor SPS claim. ${ }^{464}$ Upper-middle-income Members have been complainants in three of the dispute settlement proceedings initiated under

\footnotetext{
${ }^{461}$ Appellate Body Report, EC - Hormones; Appellate Body Report, Australia - Salmon; Appellate Body Report, Japan - Agricultural Products II; Appellate Body Report, Japan - Apples. The appeals against the panel reports in EC - Hormones (US) and EC - Hormones (Canada) were heard together and a single Appellate Body report was issued.

${ }^{462}$ Panel Report, US - Continued Suspension, paras 7.375-7.379; Panel Report, Canada-Continued Suspension, para. 7.372-7.376.

${ }^{463}$ Consequently, the Appellate Body's rulings in this case are not addressed in this book.

${ }^{464}$ EC - Restrictions on Certain Import Duties on Rice (Complaint by India), WT/DS134. The only SPS claim in this dispute was of a violation of Article 2.2 of the SPS Agreement.
} 
the SPS Agreement, ${ }^{465}$ and lower-middle-income Members in five. ${ }^{466}$ This is in marked contrast to the involvement of high-income Members, which have been complainants in the remaining 22 disputes. Five of the disputes brought by upper- and lower-middle-income Members, have involved other upper-and lower-middle-income respondents, which seems to support Bown's view regarding the role of a credible retaliation possibility in decisions to bring disputes. Of the four disputes brought by middle- or low-income complainants against high-income respondents, three were brought in parallel to high-income Member complaints on the same or a similar issue. It is interesting to note that in four cases, the disputes brought by non-high-income Members were supported by the ACWL. ${ }^{467}$

By far the greatest number of complaints under the SPS Agreement has been brought against high-income Members, accounting for 22 of the respondents. Upper-middleincome Members have been respondents in six disputes, ${ }^{468}$ a lower-middle-income Member in one dispute ${ }^{469}$ and a low-income Member in two disputes. ${ }^{470}$

It is also interesting to examine the participation of Members at different levels of development in dispute settlement proceedings by joining consultations in disputes brought by other Members under the SPS Agreement. Of the 58 times that Members have joined consultations in the 31 disputes relating to the SPS Agreement, 65 percent (38) were joinders by high-income Members, 19 percent (11) by upper-middle-income Members, 8.5 percent (5) by lower-middle income Members and 7.5 percent (4) by a low-income Member. This form of participation is, however, concentrated in a limited number of Members, namely seven high-income Members, four upper-middle-income Members, four lower-middle income Members and one low-income Member. ${ }^{471}$

465 Croatia - Measure Affecting Imports of Live Animals and Meat Products (Complaint by Hungary), WT/ DS297; European Communities - Measures Affecting the Approval and Marketing of Biotech Products (Complaint by Argentina), WT/DS293; and Turkey - Import Ban on Pet Food from Hungary (Complaint by Hungary), WT/DS256.

${ }^{466}$ Mexico - Certain Measures Preventing the Importation of Black Beans from Nicaragua (Complaint by Nicaragua), WT/DS284; Australia - Certain Measures Affecting the Importation of Fresh Pineapple (Complaint by the Philippines), WT/DS271; Australia - Certain Measures Affecting the Importation of Fresh Fruit and Vegetables (Complaint by the Philippines), WT/DS270; Turkey - Certain Import Procedures for Fresh Fruit (Complaint by Ecuador), WT/DS237; and Egypt - Import Prohibition on Canned Tuna with Soybean Oil (Complaint by Thailand), WT/DS205.

${ }^{467}$ These were the following four disputes: Mexico - Certain Measures Preventing the Importation of Black Beans from Nicaragua (Complaint by Nicaragua), WT/DS284; Australia - Certain Measures Affecting the Importation of Fresh Pineapple (Complaint by the Philippines), WT/DS271; Australia - Certain Measures Affecting the Importation of Fresh Fruit and Vegetables (Complaint by the Philippines), WT/DS270; and Turkey - Certain Import Procedures for Fresh Fruit (Complaint by Ecuador), WT/DS237. The ACWL is discussed above, Part IV, Section 2.2.7.

${ }^{468}$ Croatia - Measures Affecting Imports of Live Animals and Meat Products (Complaint by Hungary), WT/ DS297; Mexico - Certain Measures Preventing the Importation of Black Beans from Nicaragua (Complaint by Nicaragua), WT/DS284; Turkey - Import Ban on Pet Food from Hungary (Complaint by Hungary), WT/DS256; Turkey - Certain Import Procedures for Fresh Fruit (Complaint by Ecuador), WT/DS237; Mexico - Measures Affecting Trade in Live Swine (Complaint by the United States), WT/DS203; and Slovak Republic-Measures Concerning the Importation of Dairy Products and the Transit of Cattle (Complaint by Switzerland), WT/DS133.

${ }^{469}$ Egypt - Import Prohibition on Canned Tuna with Soy Oil (Complaint by Thailand), WT/DS205.

${ }^{470}$ India - Import Restrictions Maintained Under the Export and Import Policy 2002-2007 (Complaint by the European Communities), WT/DS279; and India - Quantitative Restrictions on Imports of Agricultural, Textile and Industrial Imports (Complaint by the European Communities), WT/DS96.

${ }^{471}$ The 7 high-income Members that have joined consultations in these disputes are the US ( 9 times), Canada ( 8 
The extent to which Members at different levels of development have participated in the 13 disputes that proceeded to the establishment of a panel, is also useful to examine.

\section{Graph 44: Participation in SPS-related Dispute Settlement Proceedings in which a Panel was Established: WTO Members by Income Level, 1995-2008}

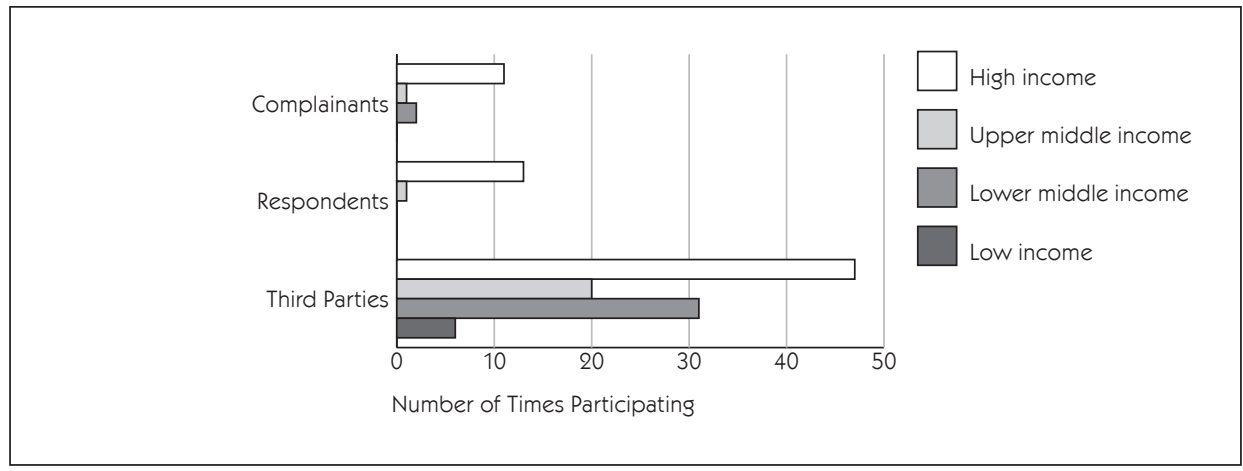

The complainants in 10 of these 13 disputes were high-income Members. In addition, one upper-middle-income Member and two lower-middle-income Members were complainants in the remaining three disputes. In only one of the disputes involving a nonhigh-income Member as complainant has the dispute actually been heard by a panel, namely EC-Approval and Marketing of Biotech Products where Argentina was one of the complainants, together with the US and Canada. ${ }^{472}$ In all but one case the disputes that proceeded to the establishment of a panel were brought against high-income respondents. ${ }^{473}$ In these disputes, of the 104 times that Members joined as third parties in panel proceedings, high-income Members accounted for 45 percent (47); upper-middle-income Members for 19 percent (20); lower-middle-income Members for 30 percent (31) and low-income Members 6 percent (6). ${ }^{474}$

times), Australia (6 times), New Zealand (6 times), the EC (5 times), Japan (3 times) and Switzerland (once). The 4 upper-middle-income Members that have done so are Brazil (4 times), Mexico (3 times), Argentina (twice), and Chile (twice). The 4 lower-middle-income Members that have joined consultations are Thailand (twice), Colombia (once), the Philippines (once) and Peru (once). The only low-income Member to have joined consultations is India (4 times).

${ }^{472}$ In the two other cases involving non-high-income complainants, panels were requested (and in one of these cases actually established). In Turkey - Certain Import Procedures for Fresh Fruit (Complaint by Ecuador), WT/DS237, a panel request was submitted by Ecuador on 14 June 2002, but a mutually agreed solution was subsequently reached. In Australia - Certain Measures Affecting the Importation of Fresh Fruit and Vegetables (Complaint by the Philippines), WT/DS270, the Philippines' first panel request, on 10 July 2003, was blocked by Australia. The Philippines's second panel request led to the establishment of a panel on 29 August 2003. However, as mentioned above, this panel was never composed as parties suspended discussions on the composition of the panel.

${ }^{473}$ The only exception is Turkey - Certain Import Procedures for Fresh Fruit (Complaint by Ecuador), WT/ DS237.

474 The 10 high income Members that have joined as third parties in these disputes are the US ( 9 times), the EC and Norway (7 times each), New Zealand and Australia (6 times each), Canada (5 times), Chinese Taipei (4 times) and Hong Kong, China, Iceland and Japan (once each). The 6 upper-middle-income Members that have done so are Brazil (6 times), Chile (5 times), Mexico and Uruguay (3 times each), Argentina (twice), and Hungary (once). The 9 lower-middle-income Members that have done so are China (7 times), Thailand (6 times), Colombia (5 times), El Salvador, Honduras, Paraguay and Peru (3 times each), and the Philippines 
The significance of the weak participation of Members at lower levels of development in SPS-related dispute settlement should not be underestimated. The constraints these Members face in enforcing their rights through dispute settlement proceedings affects their ability to pursue their interests successfully through negotiated solutions. As pointed out by Gregory Shaffer:

WTO law casts a weaker shadow over settlement negotiations for countries that lack lawyers conversant in WTO law. When developing countries are unable to mobilize legal resources cost-effectively, their threats to invoke WTO legal procedures lack credibility. They thus wield less bargaining leverage in WTO law's shadow. ${ }^{475}$

\subsection{Conclusion}

The proper implementation and operation of the SPS Agreement is ensured through two institutional and procedural avenues, that provided by the bargaining forum of the SPS Committee and that provided by the adjudicatory mechanism of the dispute settlement system.

The question of whether Members' trade concerns with respect to the SPS measures of other Members are dealt with through multilateral discussions at SPS Committee meetings or through formal adjudication is not without significance. It is highly relevant for the manner in which the trade/health balance is struck, which is closely tied to the questions of who participates in framing the issues under discussion and who decides on the outcome of the dispute. These questions are particularly pertinent when one bears in mind the differences in opportunities for effective participation available to Members at different levels of development under each of the two alternatives. As stated by Shaffer:

Balancing concerns over competing public goods and defining the means of production of these goods involve tradeoffs over preferences and priorities that vary in a world of divergent levels of development and limited public finances. The dynamics of participation in national, regional and international decisionmaking over the production of public goods thus becomes decisive. ${ }^{476}$

The discussion of the role and functioning of the SPS Committee has shown much greater possibilities for participation of Members at lower levels of development than exist currently in the dispute settlement system. The specific trade concern mechanism of the SPS Committee has proved very effective in providing opportunities for Members to address the problems they face regarding the SPS measures of their trading partners

and Ecuador (once each). The low-income Members that have participated as third parties are India (4 times) and Pakistan and Zimbabwe (once each).

${ }^{475}$ Gregory Shaffer, 'Power, Governance, and the WTO: A Comparative Institutional Approach', in Power in Global Governance, Michael Barnett and Raymond Duvall (eds.) (Cambridge University Press, Cambridge), 2005, 130-160, 137.

${ }^{476}$ Gregory Shaffer, 'Recognising Public Goods in WTO Dispute Settlement: Who Participates? Who Decides? The Case of TRIPS and Pharmaceutical Patent Protection', Journal of International Economic Law 7 (2), 2004, 459-482, 464. 
in an inexpensive and constructive way. Most often, bilateral discussions on trade concerns placed on the agenda are held in the margins of SPS Committee meetings, and may resolve the matter. If not, discussions are held in the multilateral forum of the SPS Committee, which enables other Members to comment on the issue and support the trade concern raised. This could lead to the revision of the notified measure or to further bilateral consultations between the Members involved. It may also facilitate compliance by the Member raising the concern with the SPS measure at issue, through increased clarity on the requirements and ways to meet them, and in some cases by means of the provision of technical or financial assistance by the importing Member. In this way disputes can be resolved without recourse to the expensive, time-consuming and confrontational process of formal dispute settlement. Indirect benefits of the specific trade concerns mechanism also exist, including increased familiarity of Members with each other's regulatory systems due to the regular contact and sharing of experiences between Members' officials. Members may gain confidence in the regulatory capacity of the alternative SPS regimes maintained by other Members. This confidence has an impact on issues such as the recognition of equivalence and of pest- or disease free areas.

As shown by the examination of participation by Members at different levels of development in the specific trade concerns mechanism, while developing countries have featured strongly, both as initiators or supporters of issues raised, and as subjects of concerns raised, the number of different developing countries participating to date has been limited. The statistics reflect the fact that a relatively small number of (larger) developing countries, particularly Cairns Group members as well as China and India, has been quite active in raising and supporting specific trade concerns. While participation in the specific trade concerns mechanism is certainly broader than in dispute settlement, there is still room for improvement. The constraints to the use of this mechanism seem to lie, not in the mechanism itself but rather in the capacity of Members at lower levels of development to keep track of notified measures, consult with their export industries to identify specific trade concerns arising from these measures, understand the extent to which these concerns can be addressed under the rules of the SPS Agreement, and send a national expert to the meetings of the SPS Committee to raise the concern. This is an area where capacity building is sorely needed. Efforts such as IICA's SPS Initiative for the Americas are to be applauded. It not only funds participation in SPS Committee meetings by capitalbased experts but also promotes the establishment of offices at national level to follow the activities of SPS-related international bodies, particularly the SPS Committee. As the support provided by this initiative is being phased out, new and more broadly-applicable efforts along the same lines are essential.

The SPS Committee not only provides a forum for the discussion and resolution of specific trade concerns, but it also promotes regulatory learning and creates possibilities for building professional networks. It provides a mechanism for the monitoring of harmonisation that allows concerns regarding the lack of international standards or problems with existing standards to be raised and forwarded to the relevant international standard setting body. In addition, it plays a crucial role in addressing broader SPS concerns by promoting the implementation of particular disciplines in the SPS Agreement through developing and adopting procedural guidelines. The disciplines addressed, such as those on equivalence, regionalisation, SDT and transparency, are particularly important for developing-country 
Members in that they hold great potential for market access gains while fully respecting the level of protection chosen by importing Members.

Attendance and effective participation by Members at different levels of development in meetings of the SPS Committee varies greatly. As illustrated by the four Members used as examples in this book, high-income Members tend to participate actively and effectively in SPS Committee meetings and are represented by experts from their relevant ministries. However, some Members at lower levels of development do not have the resources to send an SPS expert from their capital, and are represented in meetings of the SPS Committee by diplomats from their missions in Geneva, lacking in the necessary technical knowledge. There are also some Members that are unable to send any representative to most SPS Committee meetings.

The problems this situation creates for effective participation by Members at lower levels of development in the decisions of the SPS Committee are ameliorated by two practices of the Committee. The first is its practice to canvass all Members, by means of questionnaires, to submit their practical experiences with regard to the issue under discussion and to compile these experiences as the basis for the development of the new guidelines. The second practice that addresses participation problems is that of ad referendum decision making. This entails that a decision is only provisionally adopted at a meeting of the SPS Committee, and a period is provided for Members to raise objections to the provisional decision. This enables Members that were not present at the relevant meeting, or those that were represented by delegates lacking the necessary expertise to evaluate the impact of the provisional decision, to have the decision examined by their ministry officials and to raise objections if necessary. Objections are addressed and the agreement of the objecting Member is obtained before the provisional decision is finally adopted. This practice ensures broad participation in the decisions of the SPS Committee, increasing their legitimacy and the 'ownership' of the decision by Members. This is important in view of the fact that decisions of the SPS Committee are not directly enforceable in dispute settlement proceedings. Implementation of decisions of the SPS Committee therefore relies upon the willingness of Members to follow the procedural guidelines set out therein.

The dispute settlement mechanism of the WTO, through which non-compliance with the obligations of the SPS Agreement can be challenged by Members, is a great improvement above that existing under the GATT 1947. While a very small proportion of the SPSrelated conflicts between Members result in the initiation of WTO dispute settlement proceedings, and even fewer actually proceed to adjudication, the importance of the dispute settlement system to SPS disputes should not be underestimated. The very existence of the dispute settlement system creates an incentive for Members against whose SPS measures concerns are raised to address these concerns through negotiated solutions. In addition, the clarifications developed by panels and the Appellate Body with regard to the provisions of the SPS Agreement are essential in establishing the normative framework within which Members address their SPS conflicts. These clarifications are taken up in decisions of the SPS Committee that elaborate procedural guidelines for the operationalisation of provisions of the SPS Agreement. Equally importantly, they inform discussions between Members, bilaterally but even more so in the multilateral forum of the SPS 
Committee, to resolve trade concerns. As noted above, these have been referred to as 'settlements negotiated in law's shadow'. ${ }^{477}$

The question of which party bears the burden of proof in dispute settlement proceedings is particularly significant in the case of SPS disputes due to the difficult and intricate factual issues involved in this area. The approach to the burden of proof in complaints under the SPS Agreement, as clarified by the Appellate Body, reflects the difference in the regime created by the SPS Agreement to balance trade and health objectives, from the regime applicable to health measures under the GATT 1994, where health measures were seen as exceptional and needing justification. The new approach of the SPS Agreement, is to recognise that Members have the right to regulate to the extent necessary to address SPS risks, but to subject such regulation to disciplines. It is for the complaining Member to bring a prima facie case to show that the SPS measure complained of violates the disciplines of the SPS Agreement. Complaining Members are assisted in their task by the possibility created in Article 5.8 of the SPS Agreement to request information on the SPS measures of other Members. The Appellate Body's view of Articles 3.3 and Article 5.7 of the SPS Agreement as autonomous rights rather than as exceptions to the harmonisation discipline in Article 3.1 and the scientific disciplines in Articles 2.2 and 5.1, respectively, results in maintaining the burden of proof firmly on the complaining Member. This reflects the leeway provided to regulating Members by the Appellate Body in order to ensure that the policy space left to Members by the SPS Agreement is not undermined.

Many developing-country Members may not have the resources to gather the scientific information necessary to bring a challenge under the SPS Agreement, or to defend their measures. High-income Members have faced serious difficulties in this regard in the SPS disputes heard thus far. For less-developed Members the hurdle seems almost insurmountable. These Members may not have the resources to commission the necessary research and will therefore depend on the chance that there are already existing studies of relevance. The duty to cooperate in dispute settlement proceedings, identified by the Panel in Japan - Apples, is unlikely to lead Members, in an adversarial system, to provide data supportive of the position of the opposing party.

The issue of the burden of proof on Members in dispute settlement proceedings is closely linked with the question of the investigative authority of a panel, the standard of review it applies when assessing the facts before it and the question of the appropriate role of experts advising the Panel.

The question of the appropriate standard of review to be applied in dispute settlement proceedings plays a significant role in the allocation of authority to make policy choices balancing competing trade and health interests. The particular standard of review applied determines the extent to which the WTO adjudicatory bodies are entitled to interfere in Members' regulatory determinations. Currently, while panels customarily state that they will not conduct their own risk assessment or impose a particular scientific view on the regulating Member in reviewing the scientific evidence, in practice this is increasingly what they do. This is in part due to the interpretation given to the 'rational relationship' requirement entailed by the scientific disciplines of the Agreement as involving an

${ }^{477}$ Ibid., 471. 
assessment of the quality and weight of the scientific evidence, which opens the door for an intrusive review. It is proposed here that a panel should limit its examination to the question whether the regulatory disciplines of the SPS Agreement, including that an SPS measure is based on a risk assessment as defined in the Agreement, have been complied with, stopping short of reassessing the scientific evidence itself to determine the existence and extent of a risk. Limiting the factual assessment to the question whether the regulatory determination by the Member is plausible on the scientific evidence before it, allows some deference to national authorities' scientific determinations. Such a review ensures that the regulating Member respects the balance struck in the rules of the SPS Agreement between its health concerns and the trade interests of other Members, but the review does not intrude too far into the regulatory competence of Members by interfering in their assessment of scientific evidence. This would make room for the diversity of priorities, consumer preferences and regulatory capacity between Members at different levels of development to be reflected in the science policy choices incorporated into national risk assessments. This type of review would also reduce the disadvantage at which Members that lack scientific capacity find themselves in challenging or defending measures under the SPS Agreement. The current intrusive approach may skew the outcome of judicial review in favour of developed-country Members that have the resources to bring convincing scientific evidence and persuasive legal arguments in support of their positions.

The standard of review currently applied by panels is made even more problematic by the practice with regard to the consultation of experts by panels. While the use of panel experts is essential in assisting panels, which are usually composed of trade specialists rather than SPS experts, to understand the highly complex scientific evidence before them, it is important to ensure that appropriate regard is had to the role of experts in dispute settlement. The use of panel experts aims to ensure that the assessment and choice between the competing scientific views presented by the parties is not made by a panel on its own, but rather that the panel is advised on this by persons with the necessary expertise. The prevailing practice of panels of appointing individual experts rather than expert groups has the contrary effect, adding to the competing scientific opinions before a panel. It allows a panel to pick and choose between the various opinions, which is troubling in view of the lack of scientific expertise of panellists to undertake this task. It is recommended that panels make use of expert review groups, in order to ensure that the scientific basis for their decisions is authoritative. In cases involving a developing-country Member, the expert review group should include at least one expert from a developing-country Member to ensure that the assessments provided by the group incorporate developing-country realities. In addition, it is important that panels respect the distinction between the respective roles of the panel, its experts and the parties before it in the proceedings. They should resist the temptation to expand the role of the experts to providing the evidence in support of the position of one of the parties, or to address the legal questions before the panel that require a basis in scientific assessments. Such inappropriate use of experts undermines the legitimacy of the outcome of dispute settlement.

It has been argued that the 'normative vacuum' in which the SPS Agreement is currently interpreted has led to the strong focus on science, and the concomitant heavy reliance on the opinions of panel experts in assessing the science, by panels in reviewing the SPS measures of Members. Science is seen as providing a neutral and universal benchmark 
against which SPS measures can be tested to distinguish SPS protection from disguised protectionism. It is submitted here that consideration of the international law context within which the SPS Agreement functions, in particular international human rights norms relating to the rights to life, health, safe food and development, in addressing the rights and obligations laid down in the SPS Agreement could operate to provide the urgently needed normative framework to guide WTO adjudicators in striking a more appropriate balance between the competing goals of trade liberalisation and health protection. The recognition of this normative basis for interpretation, on which they can rely to enhance the legitimacy of their decisions, may make panels less inclined to continue their current invasive approach to the review of the scientific basis for Member's SPS measures. It may also make them more willing to use the flexibilities in the SPS Agreement to allow for the consideration of developing-country Members' constraints in the application of the scientific disciplines on regulation, to ensure that the SPS Agreement does not operate to undermine the protection of health in these Members.

The weak use of the dispute settlement system by Members at lower levels of development attests to high political and financial costs of dispute settlement for these Members and the limited chance of success they foresee. The ACWL is a welcome development in providing much-needed assistance in dispute settlement. However, without concerted efforts to build SPS capacity in developing countries, these Members are unlikely to overcome the remaining hurdles to participation in dispute settlement and thereby to influence the normative framework within which negotiations to address SPS issues occur. 


\section{Conclusion to Part IV}

The difficulties and failures with reliance by less-developed Members on formal dispute settlement procedures to ensure compliance with the SPS Agreement 'imply a need to reconsider alternative mechanisms that induce compliance with [its] obligations. ...Greater transparency is critical to prevent capture of policies by interest groups, to make policies contestable, and to give both winners and losers a greater voice in policy formation.'

The discussion in this Part makes it abundantly clear that currently 'alternative mechanisms' to dispute settlement represent the best way forward in ensuring that developingcountry Members benefit as fully as possible from the benefits offered by the disciplines of the SPS Agreement. This is recognised by the concerted efforts of the SPS Committee in this regard.

First and foremost, from the earliest days of the SPS Agreement, the SPS Committee has worked to promote the implementation of the transparency provisions of the SPS Agreement, by drafting the Recommended Notification Procedures and by revising and extending them to cover all aspects of the transparency rules. These procedural guidelines have been successful in increasing the number of SPS measures being notified, and improving greatly the content of notifications. It is impossible to determine how many potential trade disputes have been resolved to date through informal bilateral consultations following the notification of draft measures, or by making use of the other transparency mechanisms created by the SPS Agreement, such as the possibility to request information from the national Enquiry Point. However, it seems likely that the majority of SPS issues between trading partners are addressed in this way, with greater or lesser degrees of success.

The transparency provisions are essential for the functioning of the specific trade concerns mechanism of the SPS Committee. This mechanism can be regarded as second in order of importance for the resolution of problems between trading partners with regard to SPS measures. Members can engage in discussions on these concerns both in the multilateral forum of the SPS Committee and bilaterally on the margins of meetings in an effort to find a mutually acceptable solution in a constructive manner. The current work to strengthen the role for the Chair of the SPS Committee in providing good offices for the resolution of specific trade concerns raised under the SPS Agreement is aimed at increasing the possibilities for agreed solutions to SPS-related trade concerns. The statistics presented in this Part indicate the importance of non-adjudicatory methods of resolving SPS conflicts, and therefore also of the value of transparency as an instrument to facilitate these processes.

The 'alternative mechanisms' to promote compliance with the SPS Agreement, however, are not limited to tools to address specific trade concerns. More mundane and prone to be underestimated, is the mechanism provided by the SPS Committee, in the fulfilment of

\footnotetext{
1 This statement is made by Bown and Hoekman with regard to the use of dispute settlement procedures to enforce developing-country compliance with WTO rules. However, in the context of the SPS Agreement it applies more broadly to mechanisms to induce compliance with the SPS Agreement by all Members. Chad P. Bown and Bernard M. Hoekman, 'Developing Countries and Enforcement of the Trade Agreements: Why Dispute Settlement in Not Enough', Journal of World Trade 42 (1), 2008, 177-203, 194.
} 
its mandate to further the implementation of the SPS Agreement and the attainment of its objectives, by creating a forum for discussion on SPS matters of broader relevance to the implementation of specific provisions of the Agreement. A number of issues have been considered in this way, including implementation problems regarding provisions of the SPS Agreement that hold great potential benefits for developing-country Members, such as those on equivalence, regionalisation and special and differential treatment. In addition, specific issues of particular importance to developing-country Members, including the issues of private sector standards, approaches to risk assessment and pesticide MRLs, have received attention. The discussions taking place through this mechanism have led in some cases to decisions of the SPS Committee laying down procedural guidelines to further the implementation of the provision at issue. The inclusive nature of the process leading up to the elaboration of these guidelines, based on the collection of practical experiences of Members with the issue under discussion and discussions in formal and informal sessions of the Committee, is crucial to the value of the resulting guidelines. In addition, the practice of ad referendum decision-making of the SPS Committee is to be applauded for its effort to ensure the broadest participation possible. While clearly far from all implementation problems have been removed by the procedural guidelines developed by the SPS Committee, these guidelines are 'works in progress' and make provision for periodic reassessment and review.

The positive light in which Members view this role of the SPS Committee is evinced by the outcome of the second review of the SPS Agreement. Many of the recommendations coming out of this review relate to maintaining as standing agenda items for SPS Committee meetings the various issues currently addressed by the Committee (such as equivalence, regionalisation, transparency, monitoring of international standards, technical assistance, SDT and specific trade concerns) and continuing work on these issues. In addition, the second review mandates the SPS Committee to pursue work on new issues, based on information provided by Members regarding their experiences and on specific suggestions submitted by Members to the Committee. None of the recommendations suggest that proposals for amendments to the SPS Agreement be submitted to the Council for Trade in Goods, as allowed by Article 12.7 of the SPS Agreement. This despite the fact that it would be possible to give the procedural guidelines developed by the SPS Committee binding force in this way. It is apparent that Members wish to continue the current successful modus operandi of working towards the resolution of implementation problems through decisions of the Committee, based on technical discussions and shared experiences, and reviewing these decisions as needed.

In view of the current problems with the use of the dispute settlement system faced by Members at lower levels of development that lack the scientific capacity essential to mounting an effective challenge, there is little to be gained by converting the procedural guidelines of the SPS Committee into enforceable rules, and much to be lost. As noted above, the weak legal status of decisions of the SPS Committee, as compared to the binding status of an amendment, makes it easier for Members to reach consensus on new norms. In addition, the flexibility to respond to new problems and to improve the existing procedures that is provided by their 'soft law' nature is highly valued by Members.

It is nevertheless necessary to address the hurdles faced by less-developed Members in using the dispute settlement system to enforce their rights under the SPS Agreement. As 
emphasised above, the bargaining that takes place at the SPS Committee, both with regard to specific trade concerns and with regard to broader implementation issues, takes place 'in the shadow' of dispute settlement. This brings us once again to the need for effective initiatives to build the capacity of Members at lower levels of development to make use of the dispute settlement system to resolve their SPS disputes. An essential component of the capacity needed in this regard relates to the SPS regulatory systems and scientific competence in these Members. 


\section{Part V}

Special provisions for developing countries in the SPS Agreement 


\section{Introduction to Part V}

WTO agreements creating disciplines for behind-the border regulatory regimes, such as the SPS Agreement, necessitate the recognition of differences in SPS capacity of Members across different levels of development. As noted in Part I of this book, the expansion of trade rules beyond issues of tariffs and quotas into areas of regulatory activity, brings with it new problems. The ability of countries to comply with, and benefit from, such rules depends on their 'starting position.' ${ }^{1}$ In other words, the existing situation in a country, such as the strength of its regulatory system, its infrastructure and its human and financial resources will affect the impact of regulatory disciplines on that Member, and its ability to use those disciplines against other Members to gain market access. ${ }^{2}$

It is therefore necessary to find ways to ensure that WTO agreements laying down regulatory disciplines, such as the SPS Agreement, are development friendly. ${ }^{3}$ To meet this objective, they should leave sufficient space for countries to pursue their development policies through national regulation, while at the same time create clear and workable rules that developing countries can use to gain market access. This difficult balance is not only achieved in the substantive and procedural disciplines, but is contributed to by provisions in WTO agreements providing special treatment for developing-country Members.

In the current discussion on SDT in the WTO, there is wide recognition of the fact that 'one size does not fit all' when it comes to regulatory disciplines in trade rules. ${ }^{4}$ Stevens sees the primary purpose of SDT as being:

to provide a framework for development in cases where it is not possible to agree a standard rule, applicable to all Members, that achieves this objective. ${ }^{5}$

\footnotetext{
${ }^{1}$ Hoekman notes that the adjustment burden of resource-intensive WTO agreements containing regulatory disciplines falls mostly on developing countries, since the rules in such agreements mostly reflect best practices in developed countries. Bernard Hoekman, 'Operationalizing the Concept of Policy Space in the WTO: Beyond Special and Differential Treatment', Journal of International Economic Law 8 (2), 2005, 405-424.

${ }^{2}$ Low reports that 24 WTO Members have no representation in Geneva, and many others have too few staff to deal adequately with all the issues on the agenda at the WTO. Patrick Low, 'Is the WTO Doing Enough for Developing Countries?' in WTO Law and Developing Countries, George A. Bermann and Petros C. Mavroidis (eds.) (Cambridge University Press, Cambridge), 2007, 324-358, 339.

3 Stevens argues that this is particularly the case now that the improved dispute settlement system has eliminated much of the flexibility that characterized the GATT. As a result, 'in order to avoid adverse, unintended consequences from dispute settlement (or the threat thereof), the WTO needs new mechanisms to balance precise rules and appropriate flexibility...' See Christopher Stevens, 'Recognising Reality: Balancing Precision and Flexibility in WTO Rules', presented at the Joint ICTSD - GP International Dialogue: Making Special \& Differential Treatment More Effective and Responsive to Development Needs (International Centre for Trade and Sustainable Development, Chavannes-de-Bogis, Switzerland) 6 and 7 May 2003, 3, available at: www. ictsd.org/dlogue/2003-05-06/STEVENS_S\&DT_final.pdf, visited on 6 July 2003.

${ }^{4}$ Hamwey notes that: '.. the playing field resulting from international trade agreements that have ostensibly equivalent rules for all contracting parties, may provide a much smaller policy space for developing than developed countries because of differences in initial conditions and national policy implementation capacities'. Robert M. Hamwey, Expanding National Policy Space for Development: Why the Multilateral Trading System Must Change, T.R.A.D.E. Working Paper 25 (South Centre, Geneva), September 2005, i, available at: http://129.3.20.41/eps/ dev/papers/0511/0511005.pdf, visited on 6 June 2008.

${ }^{5}$ Christopher Stevens, 'Recognising Reality: Balancing Precision and Flexibility in WTO Rules', presented at the Joint ICTSD - GP International Dialogue: Making Special \& Differential Treatment More Effective and Responsive to Development Needs (International Centre for Trade and Sustainable Development, Chavannes-de-Bogis, Switzerland) 6 and 7 May 2003, 3 (emphasis omitted), available at: www.ictsd.org/
} 
These general observations are particularly on point with regard to the SPS Agreement. WTO Members at lower levels of development face particular problems with regard to the SPS Agreement, as has become clear from preceding Parts of this book.

Broadly speaking, these problems relate to two main areas. The first concerns the disciplines of the SPS Agreement itself, which are the tools it uses to achieve a balance between trade and health. In particular, some less developed Members experience difficulties with compliance with the resource-intensive obligations of the SPS Agreement. The fact that this non-compliance is infrequently challenged does not ameliorate the situation. ${ }^{6}$ As argued by Low, there is no substitute for viable rules and legal certainty. ${ }^{7}$ Further, many developing-country Members lack the capacity to enforce their rights under the SPS Agreement to gain market access for their exports. The problem area relating to the disciplines of the SPS Agreement encompasses also many developing-country Members' frustration at their inability to participate effectively in international standard setting and thereby influence the content of the benchmark standards created in this process. The second problem area goes beyond the SPS Agreement and relates to the constraints on the ability of less developed Members to meet the SPS requirements of their trading partners, even when these are consistent with the SPS Agreement. ${ }^{8}$ Both these areas need to be addressed.

It is important to ensure that developing-country Members are in a position to reap the benefits of the SPS Agreement without these benefits being outweighed by its significant implementation costs. At the same time, many developing-country Members need assistance in overcoming their supply-side constraints in respect of the ability to meet the SPS requirements imposed on their export markets. ${ }^{9}$ It is important to ensure that the

dlogue/2003-05-06/STEVENS_S\&DT_final.pdf, visited on 6 July 2003.

${ }_{6}$ As reported above, Part IV, Section 2.2.7, there have been only nine challenges to developing-country Members alleged non-compliance with the SPS Agreement to date in dispute settlement proceedings, none of which have led to adjudication by a panel. More often, the 'specific trade concerns' mechanism of the SPS Committee is used to address problems with non-implementation by developing-country Members of their obligations under the SPS Agreement.

${ }^{7}$ Low points out that while many instances of non-compliance with their obligations under the SPS Agreement by developing-country Members are not challenged by other Members as this non-compliance is not regarded as sufficiently serious to warrant a dispute settlement procedure, this cannot be seen as a mechanism to redefine the de facto obligations of Members. It has systemic implications in that it opens the door to arbitrariness or directed pressure that would render some countries unduly vulnerable. Low emphasises that there is no substitute for viable rules and legal certainty. Patrick Low, 'Is the WTO Doing Enough for Developing Countries?' in WTO Law and Developing Countries, George A. Bermann and Petros C. Mavroidis (eds.) (Cambridge University Press, Cambridge), 2007, 324-358, 338.

${ }^{8}$ Patrick Low, 'Is the WTO Doing Enough for Developing Countries?' in WTO Law and Developing Countries, George A. Bermann and Petros C. Mavroidis (eds.) (Cambridge University Press, Cambridge), 2007, 324-358, 334. Low points out that these concerns of developing countries, while undoubtedly legitimate, 'are poorly addressed by seeking an exemption from the application of the standards regime.'

${ }^{9}$ Supply-side constraints are those that limit the ability of a country to take advantage of market access opportunities. Special treatment of developing countries in this area would be aimed at enabling them to implement active policies to take advantage of market access, for example by taking measures to ensure their exports meet the SPS requirements of their trading partners. For the distinction between demand-side SDT and supply-side SDT, see Werner Corrales-Leal et al., "'Spaces for Development Policy": Revisiting Special and Differential Treatment', presented at the Joint ICTSD - GP International Dialogue: Making Special \& Differential Treatment More Effective and Responsive to Development Needs, Chavannes-de-Bogis, Switzerland) 6-7 May 2003, available at: www.ictsd.org/dlogue/2003-05-06/ICTSD_SDT_wkgdraft-16-May.pdf, visited on 6 June 
regulatory disciplines of the SPS Agreement do not have the effect of forcing developingcountry Members to divert resources from other areas of public spending which may be more crucial to their development needs, such as the provision of health and education services. For this reason, special consideration is needed with regard to the compliance obligations of developing countries. The extent to which this is provided for in the SPS Agreement, whether in the form of special flexibilities in the rules for developing-country Members or in the form of provisions on technical assistance to support developingcountry Members' compliance efforts, bears examination.

At the same time, despite some proposals to the contrary, it is widely recognised by WTO Members that any mechanisms to deal with developing-country concerns should not jeopardise the right of a Member to impose scientifically-justified measures necessary to prevent risks to human, plant or animal life or health that they consider unacceptable. ${ }^{10}$ To do so would not only lead to risks of harmful effects on human health and agricultural production, contrary to the obligations of governments, but would also be counterproductive. It would fuel consumer fears, leading to a decrease in demand for products originating in developing countries, and harm the reputation of such exporting countries by casting doubts on their regulatory capacities. ${ }^{11}$ Similarly, difficulties with implementation of the regulatory disciplines of the Agreement should not be dealt with by means of wholesale relaxation of the rules. Creating loopholes though which measures that are disguised forms of protectionism can slip, would undermine the market access gains achieved by the SPS Agreement. Thus, it is important to find ways of helping developing countries to overcome their constraints without weakening legitimate SPS measures or watering down the disciplines of the Agreement. The extent to which the SPS Agreement achieves this difficult objective needs to be examined.

The general disciplines on SPS measures contained in the SPS Agreement apply equally to developed and developing countries. However, the SPS Agreement does recognise the financial and technical resource constraints that developing countries face. This consideration finds its first reflection in the Preamble to the SPS Agreement, which recognises that:

... developing country Members may encounter special difficulties in complying with sanitary and phytosanitary measures of importing Members, and as a consequence in access to markets, and also in the formulation and application of sanitary and phytosanitary measures in their own territories, and desiring to assist them in their endeavors in this regard; ${ }^{12}$

The degree to which this recognition is given effect in the operational provisions of the SPS Agreement is examined in this Part.

Although in general WTO-parlance, the term 'special and differential treatment' is understood to mean all special provisions in favour of developing countries, and covers both additional flexibilities in the rules and the provision of technical assistance, the

\footnotetext{
2008.

${ }_{10}$ Committee on Sanitary and Phytosanitary Measures, Report on Proposals for Special and Differential Treatment. Adopted by the Committee on 30 June 2005, G/SPS/35, circulated on 7 July 2005, para. 5.

${ }^{11}$ Ibid.

${ }^{12}$ See the $7^{\text {th }}$ preambular recital of the SPS Agreement.
} 
SPS Agreement deals with SDT and technical assistance in separate Articles. The SPS Committee also regards them as separate agenda items in its meetings. For that reason, a distinction will be made in this Part between SDT in the form of additional flexibilities for developing countries, and provisions regarding technical assistance to comply with the obligations of the SPS Agreement or the SPS measures of other Members. Only the former category will be termed 'SDT' in this book. ${ }^{13}$

The analysis in this Part therefore proceeds as follows. In Chapter 1, those provisions in the SPS Agreement allowing additional flexibility for developing-country Members through SDT are addressed. Chapter 2 examines the provisions in the SPS Agreement relating to technical assistance. In both these Chapters, first the relevant provisions are set out and analysed. Then, each Chapter identifies some of the problems with the implementation of the SDT or technical assistance provisions discussed. Finally, each Chapter discusses the ongoing work and progress made in finding solutions to those problems in the context of the Doha Round negotiations and elsewhere, and examines the possibilities for operationalising SDT and technical assistance provisions. With regard to technical assistance, a few selected examples of actual initiatives in place to provide technical assistance to developing countries, on bilateral and multilateral level, are briefly set out and evaluated. The Conclusion to Part V evaluates the current role and potential of the rules on special treatment and technical assistance for developing-country Members in the SPS Agreement as a mechanism to make the Agreement workable for these Members without disturbing the careful balance achieved by its disciplines.

\footnotetext{
13 This approach is also followed in the current Doha Round negotiations, where SDT is treated separately from technical assistance. Ministerial Conference, Doha Ministerial Declaration. Adopted on 14 November 2001, WT/MIN(01)/DEC/1, circulated on 20 November 2001, paras 38-41 and 44.
} 


\section{CHAPTER 1 \\ Special and differential treatment of developing-country Members}

Specific provisions exist in the SPS Agreement to take into account the special constraints of developing-country Members by providing them with some flexibility with regard to both their implementation of the obligations of the SPS Agreement and their compliance with the SPS measures of other Members. These SDT provisions can be found not only in Article 10 of the SPS Agreement, entitled 'Special and Differential Treatment', but also in Article 14 and in Annex B.2 and 8.

It should be noted that, as discussed in Part III above, some of the substantive disciplines in the SPS Agreement also contain elements of flexibility that can be used to the benefit of developing-country Members. ${ }^{1}$ However, as these flexibilities are available to all Members, they cannot be regarded as a form of SDT in the strict sense and will consequently not be discussed in this Chapter.

\subsection{Consideration of the special needs of developing-country Members}

Developing countries, especially those at lower levels of development, with weaker regulatory systems and lower levels of health protection, find it hard to meet the SPS requirements of their trading partners. A new or stricter SPS measure affecting a product of export interest to such countries can therefore have a significant economic effect on them. This is even more the case where the SPS measure does not prescribe the characteristics of the final product, something which could be achieved in a variety of ways, but instead sets requirements for the production process. For example, the application of HACCP requirements by the EC and US to the entire production chain in the fisheries sector, ${ }^{2}$ has created huge compliance problems for Kenya and Costa Rica, whose fisheries industries are largely composed of artisanal fishermen. ${ }^{3}$

\footnotetext{
${ }^{1}$ For example, Article 5.1 requires a risk assessment 'as appropriate to the circumstances' and Article 5.6 allows technical and economic feasibility to be taken into account in assessing the existence of a less-trade-restrictive alternative SPS measure. These flexibilities have been discussed above, Part III, Sections 5.1.2 and 5.2.4.1.

${ }^{2}$ The EC legislation applying HACCP to fish products is Council Directive Laying down the Health Conditions for the Production and the Placing on the Market of Fishery Products, No. 91/493/EEC (22 July 1991). The basic US legislation making mandatory the HACCP system for fish and fishery products is US Food and Drug Administration, 21 Code of Federal Regulations Parts 123 and 1240 Procedures for the Safe and Sanitary Processing and Importing of Fish and Fishery Products: Final Rule. US Fed. Regist. 61, 65096-65202 (18 December 1995).

${ }^{3}$ Max Valverde, Sanitary and Environmental Trade Barriers in Costa Rican Fisheries, Project on Standards and Trade, Strengthening Developing Countries' Capacity to Respond to Health Sanitary and Environmental Requirements (UNCTAD and IDRC, Geneva), 16-17 May 2001, para. 96 and 106, available at: http://r0.unctad. org/trade_env/ test1/meetings/standards/mariacostarica1.doc, visited on 10 June 2008; Food and Agriculture Organization, Fortalecimiento De Los Comites Nacionales Del Codex y Aplicacion De Las Normas Del Codex Alimentarius, Project TCP/RLA/0065 (FAO, San Jose, Costa Rica), 24 September - 5 October 2001; Richard O. Abila, Food Safety in Food Security and Food Trade. Case Study: Kenyan Fish Exports (International Food Policy Research Institute, Washington D.C.), September 2003. Henson et al note that in Kenya this has had significant consequences for persons, mainly women, whose livelihoods depend on processing the skeletons and other waste products produced by processing plants. Spencer Henson et al., 'Food Safety Requirements and Food Exports from Developing Countries: The Case of Fish Exports from Kenya to the European Union',
} 
Similarly, the way in which an SPS requirement is applied by an importing country may create particular difficulties for countries at lower levels of development. Some countries may not have the resources or institutional structures in place to deal with strict or inflexible implementation mechanisms. For example, the authorisation procedure for importation of plant products that may be hosts of pests may require lengthy and complex pest risk assessments that, while routine for more developed Members, are beyond some developing countries' capabilities. Another example is the application of rigid mandatory testing requirements, such as the US requirement that two histamine tests be carried out per ton of fish, which creates prohibitive costs for Costa Rica. ${ }^{4}$

Very often, the regulatory process in importing countries through which SPS measures are prepared, does not involve consideration of the effect of proposed measures on developing-country exporters. Neither are developing-country constraints commonly taken into account in the application of the resulting SPS measures. This despite the fact that active consideration of developing-country circumstances could lead to the framing of measures and the application thereof in ways that facilitate compliance by developing countries, without endangering the level of SPS protection sought.

For this reason, Article 10.1 of the SPS Agreement provides:

In the preparation and application of sanitary or phytosanitary measures, Members shall take account of the special needs of developing country Members, and in particular of the least-developed country Members.

This is the only SDT provision in Article 10 of the SPS Agreement that is couched in mandatory terms, and would seem to create an obligation for Members. ${ }^{5}$

However, the strength of this obligation, as interpreted in dispute settlement, leaves much to be desired. It was raised as a challenge for the first time ever by Argentina in the EC - Approval and Marketing of Biotech Products dispute. ${ }^{6}$ In support of its reliance on this provision, Argentina claimed that the general moratorium had important implications for its economic development, due to the fact that Argentina is highly dependant on agricultural exports. Argentina pointed out that it is the world's second-largest producer of biotech products and is the world's leading developing-country producer of biotech products. It further noted that it has a great interest in the integrated EC market. Therefore, it argued, the EC was obliged to take into account Argentina's special needs in

American Journal of Agricultural Economics 82 (5), 2000, 1159-1169, 1166.

${ }^{4}$ Max Valverde, Sanitary and Environmental Trade Barriers in Costa Rican Fisheries, Project on Standards and Trade, Strengthening Developing Countries' Capacity to Respond to Health Sanitary and Environmental Requirements (UNCTAD and IDRC, Geneva), 16-17 May 2001, paras 93-95, available at: http://r0.unctad.org/ trade_env/test1/meetings/standards/mariacostarica1.doc, visited on 10 June 2008.

${ }^{5}$ In the WTO Secretariat's review of SDT provisions in WTO agreements for purposes of the discussions in the Committee on Trade and Development on strengthening SDT, this Article is classified as a mandatory provision, creating an 'obligation of conduct', in that it does not prescribe a particular result. Committee on Trade and Development, Implementation of Special and Differential Treatment Provisions in WTO Agreements and Decisions. A Review of Mandatory Special and Differential Treatment Provisions. Note by the Secretariat. Addendum, WT/COMTD/W/77/Rev.1/Add.2, circulated on 21 December 2001, 9.

${ }^{6}$ Much of the following discussion is taken from a previously published article, namely Denise Prévost, 'Opening Pandora's Box: The Panel's Findings in the EC-Biotech Products Dispute', Legal Issues of Economic Integration 34 (1), 2007, 67-101, 93-97. 
the preparation and application of its SPS measure. ${ }^{7}$ Argentina emphasised the mandatory nature of Article 10.1 and claimed that it requires more than mere attention to developingcountry problems. Instead, it requires 'positive action', in this case 'preferential market access' for developing-country products or implementation of the Member's obligations in a manner that is 'beneficial, or less detrimental, to the interests of developing country Members. ${ }^{9}$ According to Argentina, the EC failed to comply with this obligation.

The EC countered these arguments by stating that it does 'bear [SDT provisions] in mind when developing and applying its legislation, including, where relevant, its GMO legislation'. ${ }^{9}$ It further argued that Argentina's claim amounted to 'nothing more than saying that since the European Communities has violated other provisions of the agreements and this affects Argentina, a developing country, it has consequently also failed to comply with its obligations of special and differential treatment towards developing countries. ${ }^{10}$ Finally, the EC disputed the factual assertion that developing-country exports were restricted by its measure, but averred that trade statistics showed that its imports from developing countries that have widely adopted biotechnology in agriculture have increased since 1995/1996. ${ }^{11}$ In response, Argentina disputed the EC's view, implicit in its arguments, that Article 10.1 is discretionary and a Member can thus have regard to developing-country needs when it deems it 'relevant'. ${ }^{12}$ Secondly, Argentina pointed out that the obligation contained in Article 10.1 is separate, and not consequential on the violation of other provisions of the SPS Agreement. ${ }^{13}$ Finally, Argentina questioned how data on trade flows can be an indication that developing-country needs have been taken into account. ${ }^{14}$

The Panel took a conservative approach to the interpretation of Article 10.1, in keeping with previous case law on SDT provisions in other WTO agreements. ${ }^{15}$ It held that the

\footnotetext{
7 The Panel considered that it seemed that Argentina intended to claim that the general de facto moratorium constituted the SPS measure at issue for purposes of its Article 10.1 claim. As the Panel regarded the general moratorium not to be an SPS measure but rather the application of an SPS measure, it did not find Article 10.1 of the SPS Agreement applicable to it (otherwise Article 10.1 would impose an obligation with regard to the 'application' of the application of an SPS measure, which would be illogical and contrary to the obligation on a treaty interpreter to give effect to all the terms of a treaty provision). However, while the Panel regarded Argentina's claim as less than precisely clear, in light of its status as a developing country, the Panel was willing to consider the alternative possibility that Argentina regarded the EC legislation as the SPS measure at issue. Panel Reports, EC-Approval and Marketing of Biotech Products, para. 7.1611.

${ }^{8}$ Panel Reports, EC - Approval and Marketing of Biotech Products, para. 7.1607

${ }^{9}$ European Communities - Measures Affecting the Approval and Marketing of Biotech Products. First Written Submission by the European Communities, Geneva, 17 May 2004, para. 666, available at: http://www.tradeenvironment.org/output/theme/tewto/EC submission biotech.pdf, visited on 14 July 2005.

${ }^{10}$ Ibid., para. 667.

${ }^{11}$ Ibid., paras 670-671.

${ }^{12}$ European Communities - Measures Affecting the Approval and Marketing of Biotech Products (WT/Ds293) Written Rebuttal of the Republic of Argentina, Geneva), 19 July 2004, paras 113-115, available at: www.genewatch.org/WTO/Submissions/Argentina/rebutal.pdf, visited on 14 July 2005.

${ }^{13}$ Ibid., para. 117.

${ }^{14}$ Ibid., para. 122.

${ }^{15}$ For example, in $E C$-Bed Linen, the Panel addressed a claim of violation of the SDT provision contained in Article 15 of the Anti-Dumping Agreement, which like Article 10.1 of the SPS Agreement, is framed in mandatory terms. Article 15 of the Anti-Dumping Agreement provides: 'It is recognized that special regard must be given by developed country Members to the special situation of developing country Members when considering the application of anti-dumping measures under this Agreement. Possibilities of constructive remedies
} 
obligation to 'take account' of developing-country needs merely requires Members 'to consider along with other factors before reaching a decision" ${ }^{16}$ the needs of developing countries. This obligation, according to the Panel, does not prescribe a particular result to be achieved, and notably does not provide that the importing Member must invariably accord SDT where a measure may lead to a decrease, or slower increase, in developingcountry imports. ${ }^{17}$ In fact, it is conceivable, according to the Panel, that the EC did take account of Argentina's needs, but at the same time took account of other legitimate interests (such as those of its consumers and environment) and gave priority to the latter. ${ }^{18}$

This finding, like that in case law on SDT in other WTO agreements, leads to the conclusion that, to be effective, SDT provisions must not only be framed in mandatory language, but must also specify the action required of Members. ${ }^{19}$ This result is particularly problematic when one takes into account the purpose of SDT, which is to provide the flexibility to respond to the special needs of developing countries. ${ }^{20}$ What the needs of particular developing countries are varies from case to case. As has been highlighted several times in previous Chapters, developing countries are not a homogenous group. Instead, there are vast differences in their levels of economic and human development, export

provided for by this Agreement shall be explored before applying antidumping duties where they would affect the essential interests of developing country Members.' (Emphasis added). The Panel in EC-Bed Linen noted that both parties in that dispute, the EC and India, had agreed that the first sentence of Article 15 imposes no legal obligations on developed-country Members. Thus, the Panel expressed no views on this matter. Focusing on the second sentence, the Panel held that it creates an obligation to consider actively, with an open mind, the possibility of constructive remedies before imposing an anti-dumping duty that would affect the essential interests of a developing-country Member. Panel Report, EC-Bed Linen, para. 6.233. This issue was not appealed. Subsequently, with regard to the same provision, the Panel in US - Steel Plate held, 'Members cannot be expected to comply with an obligation whose parameters are entirely undefined. In our view, the first sentence of Article 15 imposes no specific or general obligation on Members to undertake any particular action.' Panel Report, US - Steel Plate, para. 7.110. This Panel Report was not appealed. Similarly, on the same issue, the Panel in EC-Tube or Pipe Fittings held, '...even assuming that the first sentence of Article 15 imposes a general obligation on Members, it clearly contains no operational language delineating the precise extent or nature of that obligation or requiring a developed country Member to undertake any specific action.' Panel Report, EC-Tube or Pipe Fittings, para. 7.68. This finding was not appealed. It appears from these cases that the use of mandatory language in SDT provisions is not sufficient to make them enforceable. Such SDT provisions must additionally contain specific obligations to undertake a particular action before a claim of violation can succeed. The discussion in this footnote is taken from Denise Prévost, “Operationalising' Special and Differential Treatment in the SPS Agreement', South African Yearbook of International Law 30, 2005, 82-111.

16 This finding was based on the definition of the expression 'take account' in the Concise Oxford Dictionary.

${ }^{17}$ Panel Reports, EC-Approval and Marketing of Biotech Products, para. 7.1620.

18 Ibid., para. 7.1621.

19 An example of such a specific obligation in an SDT provision is that in Article 9.1 of the Safeguards Agreement which sets a de minimis threshold below which Members shall not impose safeguard measures on imports from developing-country Members. In US - Line Pipe, both the Panel and the Appellate Body found this provision to be legally enforceable. Panel Report, US - Line Pipe, paras 7.180-7.181 and Appellate Body Report, US - Line Pipe, para. 133.

${ }^{20}$ An example of a request by a developing-country Member for the application of Article 10.1 of the SPS Agreement to provide additional flexibility in particular circumstances is the following. In 2005, Sri Lanka requested that the EC suspend its ban on Sri Lankan cinnamon containing sulphur dioxide, and establish instead a maximum residue level of 150 parts per million, pending the development of an international standard. The EC's ban was in place not because it held the view that all sulphur dioxide residues in cinnamon are harmful, but because it had not yet evaluated the risks of sulphur dioxide in cinnamon. According to Sri Lanka, the proposed provisional MRL would satisfy the EC's obligations under Article 10.1. Committee on Sanitary and Phytosanitary Measures, Trade Difficulties Encountered in the Export of Sri Lankan Cinnamon to the European Communities. Communication by Sri Lanka, G/SPS/GEN/597, circulated on 10 October 2005. 
diversification, ability to absorb costs from trade restrictive measures and to adapt to new economic circumstances, and therefore also in their 'special situation'. To require that an SDT provision, to be effective, must specify the required action to be taken in response to developing-country needs undermines the very flexibility that characterises SDT.

Even if one were to accept the Panel's restrictive view of the nature of the obligation in Article 10.1, one might take issue with its approach to the burden of proof on this issue. In keeping with the normal rules on burden of proof followed in WTO disputes, ${ }^{21}$ the Panel found that it was incumbent on Argentina as the Complainant to adduce prima facie evidence that the EC failed to take account of Argentina's needs, in violation of Article 10.1.22 However, the Panel made it very difficult for Argentina to meet this burden. Argentina had argued that there is no reference in the EC approval legislation to the special needs of developing countries. Neither could any evidence be found in the entire period of application of the general moratorium that the EC had taken account of Argentina's special needs. Further, the EC had not provided any evidence that it had taken account of Argentina's needs as a developing-country Member. The Panel found these arguments insufficient. According to the Panel, the absence of reference to developingcountry needs in the approval legislation does not demonstrate a failure to take account of those needs in the adoption or application of that legislation. ${ }^{23}$ Further, the Panel found the absence of evidence supporting the conclusion that the EC took Argentina's needs into account insufficient to indicate that Argentina had met its burden of proof. The Panel noted that Article 10.1 does not require a Member to document how it has complied with this Article. ${ }^{24}$ In addition, the Panel stated that Argentina had noted the absence of relevant evidence without specifying what efforts it had made to collect such evidence. ${ }^{25}$ While recognising that Argentina may not have ready access to information regarding whether and to what extent the EC took its special needs as a developing country into account, the Panel found no evidence to show that Argentina had approached the EC for such information. ${ }^{26}$ Consequently, the Panel did not consider that Argentina had met its burden of proof and thus found that a violation of Article 10.1 had not been shown.

It is unclear from these findings what a developing country would have to do to meet its burden of proof under Article 10.1. Aside from seeming to require that the Complainant set out what steps it has taken to collect evidence regarding whether its needs as a developing country have been considered, and approach the opposing party for such information, the Panel does not provide guidance as to how a developing country can make a prima facie case under Article 10.1. Given the absence of an obligation on Members to

${ }^{21}$ The first WTO case dealing with the issue of burden of proof was US - Wool Shirts and Blouses where the Appellate Body held it is a generally-accepted rule applied by international courts and tribunals as well as in civil law, common law and most jurisdictions, '...that the burden of proof rests upon the party, whether complaining or defending, who asserts the affirmative of a particular claim or defence. If that party adduces evidence sufficient to raise a presumption that what is claimed is true, the burden then shifts to the other party, who will fail unless it adduces sufficient evidence to rebut the presumption.' Appellate Body Report, US Wool Shirts and Blouses, 14. The issue of burden of proof is discussed above, Part IV, Section 2.2.2.

${ }^{22}$ Panel Reports, EC-Approval and Marketing of Biotech Products, para. 7.1622.

${ }^{23}$ Ibid., para. 7.1623.

${ }^{24}$ Panel Reports, EC - Approval and Marketing of Biotech Products, para. 7.1624.

${ }^{25}$ Ibid., para. 7.1624.

${ }^{26}$ Ibid., para. 7.1625. The Panel explained that it did not mean to suggest that there is a duty on developing countries to specifically request that their needs as developing countries are considered. 
document how developing-country needs have been taken into account, it seems particularly difficult for a developing country to meet its burden of proof regarding a claim of violation of Article 10.1. A request for information from the Member imposing the measure could be met by the mere assertion that due regard was had to developing-country needs. This finding makes ineffectual the SDT obligation in Article 10.1 of the SPS Agreement. This is an unfortunate outcome. ${ }^{27}$

On a more hopeful note, it should be recalled that the SPS Committee in 2004 adopted a decision amending the Recommended Transparency Procedures for SPS measures in order to improve the transparency of SDT, as discussed above. ${ }^{28}$ New steps have been added to the notification procedure, requiring a Member that has notified a new or revised SPS measure to submit an addendum to its notification in the case that SDT is requested. This addendum must set out what SDT was requested and specify the SDT that was provided, or if none was provided, it must give reasons why not. Although this procedure has rarely been used to date, in the future it may assist developing countries in meeting their burden of proof under Article 10.1. The lack of submission of an addendum on SDT in cases where SDT was requested might be taken to indicate an absence of consideration of developing-country needs. However, since the procedure only applies where a developing country has requested SDT from a notifying Member, it will not fully cover the situations where a developing-country complainant may seek to rely upon the obligation in Article 10.1. ${ }^{29}$

If the approach taken by the Panel in EC-Approval and Marketing of Biotech Products to the interpretation of Article 10.1 of the SPS Agreement and its evidentiary requirements is not rejected by the Appellate Body in later cases, the risk exists that Article 10.1 may turn out to be, for practical purposes, a dead letter. Militating against this result is the principle of effective treaty interpretation, which requires that effect be given to all provisions of a treaty. In US - Gasoline, the Appellate Body held:

One of the corollaries of the 'general rule of interpretation' in the Vienna Convention is that interpretation must give meaning and effect to all the terms of a treaty. An interpreter is not free to adopt a reading that would result in reducing whole clauses or paragraphs of a treaty to redundancy or inutility.58

This principle has been consistently followed in subsequent cases. It is therefore likely that the Appellate Body, when interpreting Article 10.1 will consider itself bound to give some effect thereto, even if the provision itself is not regarded as enforceable. One way of

\footnotetext{
${ }^{27}$ Scott proposes that Article 10.1 of the SPS Agreement should be interpreted to encompass a procedural obligation to maintain a record of how developing-country interests have been taken into account, against which later claims can be assessed. In the alternative she suggests a reversal of the burden of proof with respect to Article 10.1. This seems to imply that a developed-country Member that prepares or applies an SPS measure that is challenged by a developing-country Member will have to show that it took account of developingcountry needs in order for its measures to be in conformity with the SPS Agreement. Joanne Scott, The WTO Agreement on Sanitary and Phytosanitary Measures: A Commentary, Oxford Commentaries on the GATT/ WTO Agreements (Oxford University Press, Oxford), 2007, 286-287.

${ }_{28}$ This notification procedure for SDT is discussed below, Part V, Section 1.8.

${ }^{29}$ This obligation requires Members to take developing-country needs into account regardless of whether SDT has been requested or not, and applies not only to the development of (new or amended) measures, but also to the application of existing measures.
} 
doing so, appears to be by seeing it as reflecting the 'general policy' with regard to SDT in the SPS Agreement, and therefore using it to inform related provisions, which give its general exhortation more concrete effect. Such an approach has been taken in the case law under Article 15 of the Anti-Dumping Agreement, which like Article 10.1 of the SPS Agreement, is couched in mandatory terms. ${ }^{30}$ It provides in its first sentence that special regard 'must' be given to the special situation of developing countries when considering the application of anti-dumping duties and in its second sentence that the possibilities of constructive remedies 'shall' be explored where essential interests of developing countries are at stake. In EC - Tube or Pipe Fittings, Brazil argued that the first sentence of Article 15 of the Anti-Dumping Agreement contains 'a general obligation to pay particular attention to the special situation of developing Members, while the second sentence concerns one possible way of fulfilling this obligation'. ${ }^{31}$ The Panel in this case found that:

even assuming that the first sentence of Article 15 imposes a general obligation on Members, it clearly contains no operational language delineating the precise extent or nature of that obligation or requiring a developed country Member to undertake any specific action. The second sentence serves to provide operational indications as to the nature of the specific action required. ${ }^{32}$

Thus, according to the Panel, compliance with the obligations in the second sentence would necessarily 'constitute fulfilment of any general obligation that might arguably be contained in the first sentence'. ${ }^{33}$ The Panel's interpretation of Article 15 was not appealed. In EC-Bed Linen, the Panel examined the second sentence of Article 15 of the Anti-Dumping Agreement and held that despite the difficulty in determining the precise parameters of this obligation, and the fact that no particular outcome is required by its provisions, 'taken in its context and in the light of the object and purpose of Article 15, 34 the second sentence imposes an obligation to actively consider, with an open mind, the possibility of a constructive remedy. Therefore, it appears that effect can be given to a mandatory SDT provision that does not itself contain operational language by regarding it as reflecting the 'general policy' with regard to SDT in the relevant agreement, and therefore using it to inform related provisions, which give it concrete effect.

It is now necessary to examine the remaining SDT provisions in the SPS Agreement to determine if they can be regarded as giving effect to the obligation contained in Article 10.1, in the same way that the second paragraph of Article 15 of the Anti-Dumping Agreement, 'operationalises' the first paragraph. However, in doing so it is necessary to keep in mind that while both the first and second sentences of Article 15 of the Anti-Dumping Agreement contain mandatory language, the remaining SDT provisions of the SPS Agreement do not.

\footnotetext{
${ }^{30}$ Article 15 of the Anti-Dumping Agreement is quoted above, in this Section, note 15.

${ }^{31}$ Brazil's claim was based on the argument that the EC had not had regard to the special situation of Brazil as a developing-country Member (in particular the specificity of the Brazilian tax rebate system which is unlike the sophisticated VAT systems in developed countries and the devaluation of the Brazilian currency) and conducted itself in the same way as it would have done when dealing with a developed-country Member. Panel Report, EC - Tube or Pipe Fittings, para. 7.57.

${ }^{32}$ Ibid., para. 7.68.

33 Ibid.

${ }^{34}$ Panel Report, EC-Bed Linen, para. 6.233.
} 


\subsection{Longer time frames for compliance for developing-country Members}

As already mentioned, compliance with new SPS measures, especially those drafted and applied without regard to developing-country constraints, often entails considerable changes to production and processing systems. Particularly where the existing domestic SPS regime is very different from the new requirements on foreign markets, and supporting public services and infrastructure are weak, compliance may require substantial efforts and investments. Thus, time is needed to find the necessary resources and to make the required changes. If exports from developing countries are immediately subject to the new SPS measures, they risk being excluded from their export markets while producers are adapting to the new measure. This would result not only in loss of export revenue, but possibly also in loss of market share.

To address this problem, Article 10.2 of the SPS Agreement makes provision for the phased introduction of new SPS measures. It provides:

Where the appropriate level of sanitary or phytosanitary protection allows scope for the phased introduction of new sanitary or phytosanitary measures, longer time-frames for compliance should be accorded on products of interest to developing country Members so as to maintain opportunities for their exports

This provision is aimed at allowing developing countries to maintain their export opportunities while adjusting to the new measures, in cases where this would not undermine the SPS protection sought by the importing Member. However, it would appear from the hortatory wording of this provision, that it encourages, rather than obliges, Members to grant developing countries extended compliance periods. ${ }^{35}$

The legal effect of Article 10.2 of the SPS Agreement has not yet been established in the case law. Therefore, once again, guidance may be sought from the interpretation of similarly worded SDT provisions in other WTO agreements. The Panel in EC-Bed Linen (Article 21.5 - India) was faced with the question whether there was a violation of Article 21.2 of the DSU, which provides that special attention 'should' be applied to matters affecting developing-country Members with respect to measures that have been the subject of dispute settlement. It found that this Article contains no obligation to take any particular action, noting the use of the hortatory word 'should' and the fact that Article 21.2 does not set out any specific action. ${ }^{36}$ However, the Panel stated that Article 21.2 is not devoid

\footnotetext{
${ }^{35}$ In its review of SDT provisions conducted for the Committee on Trade and Development, the WTO Secretariat categorised this provision as a non-mandatory provision. It noted that the provision could be made mandatory by replacing the word 'should' with 'shall'. Alternatively it suggested that an authoritative interpretation of this provision could be adopted (pursuant to Article IX:2 of the WTO Agreement) clarifying that 'should' in Article 10.2 must be read to express a duty rather than an exhortation. Committee on Trade and Development, Non-Mandatory Special and Differential Treatment Provisions in WTO Agreements and Decisions. Note by the Secretariat. Addendum, WT/COMTD/W/77/Rev.1/Add.3, circulated on 4 February 2002, 6.

${ }^{36}$ The Panel held, '[W]e find nothing in that provision which explicitly requires a Member to take any particular action in any case. Nor has India pointed to any contextual element which would suggest that the hortatory word "should" must nonetheless be understood, in Article 21.2 of the DSU, to have the mandatory meaning of "shall". ... In addition, the fact that there is no specific action set out in Article 21.2 makes it unlikely that Members intended the provision to be mandatory - the lack of specificity in this regard implies rather a hortatory use of should.' Panel Report, EC - Bed Linen (Article 21.5 - India), para. 2.667.
} 
of meaning but 'clearly reflects the concern of Members with ensuring that appropriate attention is given the interests of developing Members, and thus states an important general policy. ${ }^{37}$ It thus found it appropriate that the Arbitrator in another case had found guidance in this provision in his interpretation of Article 21.3 of the DSU with regard to the determination of a reasonable period of time to comply with the recommendations and rulings of the DSB. ${ }^{38}$ It further held:

There may be any number of ways in which the policy set forth in Article 21.2 might be effectuated. However, nothing in that provision obliges any Member actually to effectuate that general policy, or to do so in any particular way in any particular case. ${ }^{39}$

By contrast, outside the context of SDT provisions, the Appellate Body in Canada Aircraft has been prepared to interpret the word 'should' in Article 13.1 of the $\mathrm{DSU}^{40}$ as implying an obligation. It held:

Although the word "should" is often used colloquially to imply an exhortation, or to state a preference, it is not always used in those ways. It can also be used "to express a duty [or] obligation". ${ }^{41}$

It justified this finding by reference to the context of the provision, and the consequences of denying obligatory effect to this provision. The Appellate Body noted the fact that Article 13.1 gives panels a right to seek information, which right would be rendered illusory if parties had no duty to respond to requests for information. Further, Members would be free to prevent a panel from carrying out its duties and thereby undermine the negotiated dispute settlement procedures. ${ }^{42}$ To avoid these far-reaching consequences, the Appellate Body saw fit to interpret the word 'should' as creating an obligation. ${ }^{43}$

\footnotetext{
${ }^{37}$ Ibid., para. 2.669.
}

${ }^{38}$ Award of the Arbitrator, Indonesia - Autos (Article 21.3(c)), para. 24. In this award, relating to the period of time to be granted to Indonesia to implement the recommendations and ruling of the DSB, the Arbitrator noted that the language of Article 21.2 of the DSU 'is rather general and does not provide a great deal of guidance'. However, the Arbitrator held: 'Indonesia is not only a developing country; it is a developing country that is currently in a dire economic and financial situation. Indonesia itself states that its economy is "near collapse". In these very particular circumstances, I consider it appropriate to give full weight to matters affecting the interests of Indonesia as a developing country pursuant to the provisions of Article 21.2 of the DSU.' Therefore the Arbitrator granted Indonesia an additional period of six months, over and above the six-month period needed for its domestic rule-making process to be completed, for implementation of the recommendations and rulings of the DSB. Ibid.

${ }^{39}$ Panel Report, EC-Bed Linen (Article 21.5 - India), para. 2.669. This issue was not appealed.

${ }^{40}$ Article 13.1 of the DSU, with regard to the right of a panel to seek information, provides, 'A Member should respond promptly and fully to any request by a panel for such information as the panel considers necessary and appropriate.' (Emphasis added.)

${ }^{41}$ Appellate Body Report, Canada-Aircraft, para. 187

${ }^{42}$ In this regard, the Appellate Body stated, 'So to rule would be to reduce to an illusion and a vanity the fundamental right of Members to have disputes arising between them resolved through the system and proceedings for which they bargained in concluding the DSU. We are bound to reject an interpretation that promises such consequences.' Ibid., para. 189.

${ }^{43}$ Another example of where the Appellate Body gave binding force to a provision in which 'should' rather than 'shall' is used, is Article 11 of the DSU which provides that, '... a panel should make an objective assessment of the matter before it...' While it did not expressly address the issue of the use of the word 'should' in this Article, the Appellate Body referred several times to the 'duty' of a panel to make an objective assessment, 
What guidance can we find in these cases for the interpretation of Article 10.2 of the SPS Agreement? It appears that in certain specific cases the Appellate Body is willing to interpret a provision containing the word 'should' as mandatory. However, this seems limited to cases where the context of the provision indicates that an obligation was intended, without which negotiated rights would be made illusory. In other cases, panels would seem reluctant to give binding force to a provision containing the word 'should', particularly if it does not set out any specific action. Article 10.2 of the SPS Agreement would seem to fall closer to the first than the second situation. Its context includes Article 10.1, which is framed in mandatory terms. While the lack of operational language delineating the precise extent or nature of the obligation in Article 10.1 means that it is unlikely to be interpreted as requiring a developed-country Member to do anything besides 'consider alongside other factors' developing-country needs, it cannot be 'devoid of meaning.' It would seem logical that it should be seen as reflecting 'the concern of Members with ensuring that appropriate attention is given the interests of developing Members, and thus [as stating] an important general policy. ${ }^{44}$ As a result, it should guide the interpretation of the rest of Article 10, ${ }^{45}$ including Article 10.2. Otherwise, the right of developing-country Members to rely on this negotiated obligation would be illusory.

Unlike Article 10.1, and contrary to the situation in Canada-Aircraft, Article 10.2 does set out specific actions to give effect to its provisions. It concretely calls on Members to allow longer time frames for compliance with new SPS measures on products of interest to developing-country Members, where the level of SPS protection allows. Thus, Article 10.2 , it is argued here, should be interpreted as providing the operational indications for compliance with the obligation in Article 10.1; in much the same way as Article 15.2 of the Anti-Dumping Agreement is regarded as setting out obligations operationalising the provisions of Article 15.1 of that Agreement. ${ }^{46}$ It therefore lays down an obligation on Members to provide longer compliance periods to developing countries so as to maintain their export opportunities, in all cases where such phased introduction of new SPS measures would not threaten the level of protection sought by the importing Member.

Concerns regarding the lack of implementation of this provision were raised in the run-up to the Doha Ministerial Conference. ${ }^{47}$ As a result of discussions on this issue, agreement was reached to include a provision in the Doha Implementation Decision specifying that:

and called this an 'obligation'. Appellate Body Report, EC-Hormones, para. 133.

${ }^{44}$ As set out above, this finding was made with regard to Article 21.2 of the DSU, which also does not set out concrete action, and further contains the word 'should' rather than 'shall'. Panel Report, EC - Bed Linen (Article 21.5 - India), para. 2.669.

${ }^{45}$ This includes Article 10.4 of the SPS Agreement, which is discussed below, Part V, Section 2.4.

46 The argument here goes one step further than the approach followed with respect to Article 15 of the AntiDumping Agreement in that, unlike Article 15.2, Article 10.2 of the SPS Agreement is not couched in mandatory terms. However, in light of the fact that non-mandatory language is not seen by the Appellate Body as an impediment to the creation of obligations in cases where the context so demands, it would seem that such an interpretation is a logical extension of this line of reasoning.

${ }^{47}$ A group of developing countries (Cuba, the Dominican Republic, Egypt, El Salvador, Honduras, India, Indonesia, Malaysia, Nigeria, Pakistan, Sri Lanka and Uganda) proposed that Article 10.2 of the SPS Agreement be modified to include a mandatory period of at least twelve months between the date of notification of the measure and its entry into force for products from developing countries. Committee on Sanitary and Phytosanitary Measures, Special and Differential Treatment: Note by the Secretariat, G/SPS/W/105, circulated on 9 May 2000, para. 7. 
... the phrase 'longer time-frame for compliance' referred to in Article 10.2 [of the SPS Agreement], shall be understood to mean normally a period of not less than 6 months. Where the appropriate level of sanitary and phytosanitary protection does not allow scope for the phased introduction of a new measure, but specific problems are identified by a Member, the Member applying the measure shall upon request enter into consultations with the country with a view to finding a mutually satisfactory solution to the problem while continuing to achieve the importing Member's appropriate level of protection. ${ }^{48}$

While not directly enforceable in dispute settlement, it may be expected that this provision in the Implementation Decision will be taken into account be panels and the Appellate Body in interpreting the term 'longer time frame for compliance' in Article 10.2 of the SPS Agreement as a 'subsequent agreement between the parties regarding the interpretation of the treaty or the application of its provisions' under Article 31.3(a) of the Vienna Convention on the Law of Treaties. It serves the purpose of setting a guideline of 6 months for the additional compliance period, and adding a procedural obligation of consultations for cases where no phased introduction of the measure is possible.

The currently poor implementation of Article 10.2 is illustrated by China's request, in 2005, that Japan provide a two-year additional period for compliance to developingcountry Members in respect of its MRL for pesticides. This MRL sets a standard limit of 0.1 ppm for over 700 different pesticides. ${ }^{49}$ In November 2005, Japan indicated that a sixmonth transition period would be granted to all Members before the new MRL would be officially enforced. China argued that developing-country Members needed an additional two years to adjust their application of agricultural chemicals, train farmers and prepare their laboratories for the necessary tests. In addition, two years would be needed in order to allow pesticide residue levels in the soil and air to decline after their use had ceased. China noted that in view of the large number of pesticides affected by the new MRL, a phased introduction of the measure was called for. However, Japan considered that a sixmonth implementation period was sufficient for all Members. ${ }^{50}$

\subsection{Reasonable adaptation period}

Another provision in the SPS Agreement that aims to allow sufficient time for producers to adapt to new SPS measures can be found in paragraph 2 of Annex B. It provides:

Except in urgent circumstances, Members shall allow a reasonable interval between the publication of a sanitary or phytosanitary regulation and its entry into force in order to allow time for producers in exporting Members, and particularly in developing country

\footnotetext{
${ }^{48}$ Ministerial Conference, Implementation-Related Issues and Concerns. Decision of 14 November 2001, WT/ MIN(01)/17, circulated on 20 November 2001, para. 3.1.

49 Committee on Sanitary and Phytosanitary Measures, Specific Trade Concerns. Note by the Secretariat. Addendum. Issues Not Considered in 2007, G/SPS/GEN/204/Rev.8/Add.2, circulated on 27 March 2008, item 212.

${ }^{50}$ Ibid., item 212 para. 361.
} 
Members, to adapt their products and methods of production to the requirements of the importing Member.

This provision differs from Article 10.2 of the SPS Agreement in three main respects. First, its binding nature is beyond doubt, as it is both worded in a mandatory fashion and specifically identifies the action required. ${ }^{51}$ Second, it provides for delaying the entry into force of an SPS measure, rather than just extending the period of time for compliance therewith. Third, as the reasonable adaptation period must be granted equally to both developed and developing-country exporting Members, this provision is not an SDT provision in the strict sense of the term.

However, this provision does hold particular advantages for developing countries. As developing countries often face more difficulties in adapting to new SPS measures than do their developed counterparts, the provision makes specific reference to developing countries. This implies that in determining the reasonable adaptation period to be provided for compliance with new SPS measures, a Member should have particular regard to the time needed by the affected developing-country Members to adapt to the new requirements. For this reason, it can be seen as an SDT provision in the broader sense of the term. ${ }^{52}$

Despite the strong indications of the enforceability of the requirement of a reasonable adaptation period, lack of implementation of this provision has persisted. Concerns in this regard led developing-country Members to raise this as an implementation issue to be addressed before launching the Doha Round of negotiations. Following discussions in this regard, the reasonable adaptation period, for purposes of Annex B.2, was specified in the Doha Implementation Decision to mean normally a period of not less than six months. However, in each specific case, regard must be had to the circumstances of the measure and actions necessary for its implementation. The Implementation Decision further notes that the entry into force of trade liberalising measures should not be unnecessarily delayed..$^{53}$ This takes into account the fact that some new SPS measures may establish lower or easier requirements than existing ones. Despite the six-month specification in the Implementation Decision, statistics for $2002^{54}$ show that only 3.7 percent of routine notifications ${ }^{55}$ provided for an adaptation period of at least six months. A further 34.2 percent of notifications provided an adaptation period shorter than six months, and 62.1 percent did not state the date of adoption and/or entry into force. This situation showed

${ }^{51}$ In its review of SDT provisions, the WTO Secretariat classifies this provision as a mandatory provision containing an 'obligation of result'. Committee on Trade and Development, Implementation of Special and Differential Treatment Provisions in WTO Agreements and Decisions. A Review of Mandatory Special and Differential Treatment Provisions. Note by the Secretariat. Addendum, WT/COMTD/W/77/Rev.1/Add.2, circulated on 21 December 2001, 10.

52 An indication that Annex B.2 is regarded as an SDT provision is the fact that it is included in the WTO Secretariat's review of SDT provisions, conducted for purposes of the Doha Round negotiations on SDT. Ibid., 9-10.

${ }_{53}$ Ministerial Conference, Implementation-Related Issues and Concerns. Decision of 14 November 2001, WT/ MIN(01)/17, circulated on 20 November 2001, para. 3.2.

${ }_{54}$ These statistics were developed by China, on the basis of an analysis of all notifications submitted

in 2002. Committee on Sanitary and Phytosanitary Measures, Report of the Analysis on SPS Notifications in 2002. Submission by China, G/SPS/GEN/378, circulated on 31 March 2003, para. 13.

${ }_{55}$ As discussed above, routine notifications are those that are not 'emergency notifications', which have a different notification format. Emergency notifications relate to measures adopted in situations of urgency, for which a reasonable adaptation period is not required. See further above, Part IV, Section 1.3.2.2. 
only slight improvement in 2003. ${ }^{56}$ The frequent failures to comply with Annex B.2 have never been challenged in dispute settlement proceedings, notwithstanding its apparently binding and enforceable nature. This may be due to the fact that the enforcement thereof is hindered by a loophole, namely the proviso that a reasonable adaptation period need not be granted in 'urgent circumstances'.

There is no further clarification of what types of situation would be deemed urgent. ${ }^{57}$ The risk therefore exists that Members may interpret urgency broadly and thus be disinclined to grant the required adaptation period. In the absence of any criteria for the determination of urgency, developing-country Members may be reluctant to incur the costs of challenging a refusal to grant an adaptation period before a panel due to the uncertainty regarding what a panel might regard as 'urgent'. There is a risk that a panel will readily find that urgency exists in most cases where SPS measures comply with the remaining requirements of the SPS Agreement, since such measures address scientifically proven risks to human, plant or animal life or health. A panel may be hesitant to interfere with the determination by the importing Member in such a sensitive policy area. This may result in an overly broad interpretation of 'urgency', which would diminish the utility of the provision for reasonable adaptation periods in Annex B.2.

Instead, it is recommended that panels, if and when such an issue is raised before them, shoulder their responsibility to interpret and apply this provision, in order to guard the negotiated balance reflected in the SPS Agreement between the right of Members to protect health in their territories, and the goal of increasing market access for food and agricultural products, including through SDT of developing countries. While this task is not an easy one, it is nevertheless one which panels are obliged to carry out under Article 11 of the DSU. As discussed above, this Article requires that panels carry out an 'objective assessment' of the matter before them, which has been interpreted to mean neither de novo review of the matter, nor complete deference to the determination of a Member..$^{58}$ Therefore, when addressing claims under Annex B.2, a panel must not simply defer to the determination by a member that the situation was urgent, but must objectively examine the facts and the applicability of the legal requirements of this provision to such facts. ${ }^{59}$

\footnotetext{
${ }^{56}$ On analysis of all notifications submitted in 2003, China calculated that $9.2 \%$ of routine notifications provided at least 6 months adaptation period, $41.4 \%$ provided a period of less than 6 months, and $49.4 \%$ did not specify the date of adoption and/or entry into force of the measure. Committee on Sanitary and Phytosanitary Measures, Report of the Analysis on SPS Notifications in 2003. Submission by China, G/SPS/GEN/498, circulated on 18 June 2004, para. 15.

${ }^{57}$ The concept of 'urgency' is also found in article 4.8 and 4.9 of the DSU, which allow for shorter consultation periods and the acceleration of dispute settlement proceedings in cases of urgency, including those concerning perishable goods. This issue came before a Panel in Canada-Patent Term where the US requested expedited consideration of the dispute under Article 4.9 of the DSU on the grounds that premature expiration of patents during the dispute settlement procedure caused irreparable harm to the patent owners. The Panel did not examine the requirement of urgency, but noted that due to other demands on panellists' time, it could not accelerate the timetable prior to the first substantive meeting. It then fixed its timetable according to the minimum periods of the proposed timetable provided in Working Procedures in Appendix 3 to the DSU, since Canada did not object to such a timetable. Panel Report, Canada-Patent Term, para. 1.5.

${ }^{58}$ Appellate Body Report, EC-Hormones, para. 116.

${ }^{59}$ It is useful to recall here that between total deference and de novo review is a wide spectrum of possibilities. The lack of guidance for panels in this respect gives cause for concern in a field such as that of SPS regulation, where disputes turn on the evaluation of complex scientific facts. The issue of the 'objective assessment' standard of review is discussed further above, Part IV, Section 2.2.3.
} 
Such policing of compliance with this provision, including the urgency requirement justifying deviation, would encourage members to take the obligation to provide a reasonable adaptation period seriously.

\subsection{Delayed compliance with the SPS Agreement}

Not only is compliance with SPS measures imposed by importing Members a problem for many developing-country-Members, also the implementation of the obligations contained in the SPS Agreement may be costly and burdensome for them.

As discussed above, many of the disciplines of the SPS Agreement reflect the 'best practices' of developed countries with regard to SPS regulation. For example, currently in developed countries scientific risk assessments are an inherent part of the regulatory process. Similarly, it is common practice in these countries to invite public comments on regulatory proposals and to publish new regulations promptly. While often the adoption of such regulatory practices by developing countries has long-term benefits, they lack the resources to do so immediately.

A certain level of regulatory capacity, infrastructure and skilled human resources is necessary in order to meet the requirements of the SPS Agreement. In countries in which wellfunctioning SPS regulatory systems are not in place, administrative systems are poor, or sufficient scientific capacity, both in the form of properly equipped laboratories and trained scientific staff, is lacking, complying with the SPS Agreement requires significant adjustments. For this reason, such countries need additional time for the implementation of their obligations under the SPS Agreement.

The SPS Agreement, in Article 14, makes provision for delayed implementation of the obligations under the Agreement for developing and least-developed-country Members. Least-developed-country Members were granted a five-year transitional period, from the entry into force of the WTO Agreement on 1 January 1995, for delayed implementation of all their obligations. Other developing Members were given a two-year transitional period, where lack of technical expertise, infrastructure or resources prevented immediate implementation of their obligations. ${ }^{60}$ However, this possibility did not extend to their notification and information obligations under Articles 5.8 and 7 of the SPS Agreement. This cut-out can be attributed to the fact that transparency of SPS measures is crucial to the operation of the SPS Committee as a forum for consultations on SPS issues. It is also of key importance for exporting firms, as it creates a predictable trading environment. Therefore, developing-country Members, unlike least-developed-country Members, were, in principle, obliged to comply immediately with the transparency provisions in the SPS Agreement.

The transitional period expired in January 2000 for least-developed-country Members and in January 1997 for other developing-country Members. As one might expect, not all

\footnotetext{
${ }^{60}$ An example of the use of this possibility can be found in the notification of Honduras to the SPS Committee, in March 1995, of its decision to reserve the right to make use of the two-year transitional period. See Committee on Sanitary and Phytosanitary Measures, Communication from the Republic of Honduras, G/SPS/W/2, circulated on 24 March 1995.
} 
developing-, and least-developed-country Members have been able to comply fully with their obligations under the SPS Agreement within the transition periods. Some obligations, such as those relating to risk assessments, may require far-reaching reforms and institutional capacity. In addition, such reforms are often not a priority for government spending in countries with more urgent development needs. Further, although the transitional period for developing-country Members does not apply to the transparency obligations, it can be envisioned that immediate compliance would be impossible for some of these Members.

An example of an LDC for which the transition periods were not sufficient is Bangladesh. ${ }^{61}$ As set out in Part II above, Bangladesh is currently not in a position to comply with its notification obligations, and despite having set up its required National Notification Authority and Enquiry Point, it has never notified an SPS measure.

Therefore, although the transitional periods in Article 14 represented one of the most operational forms of SDT since their application was automatic and did not depend on implementation by other Members, they were not sufficient to address fully developingcountry constraints with regard to meeting their obligations under the SPS Agreement. An indefinite exemption for developing-country Members from obligations under the SPS Agreement is clearly not the answer, as it would reintroduce the unfavourable situation that existed under the Tokyo Round Standards Code, where most developing countries opted out of the Code. As around two-thirds of WTO Members are currently developingcountry Members, exempting them from the obligations of the SPS Agreement would leave this area largely undisciplined, to the detriment of trade not only between developed- and developing-country Members, but also between developing-country Members themselves. Instead, the constraints faced by developing-country Members in meeting their obligations under the SPS Agreement must be addressed in a constructive fashion that entails flexibility but not exemption.

\subsection{Time-limited exemptions from specific obligations}

To create additional flexibility for developing-country Members that have difficulties with compliance with their obligations under the SPS Agreement after the lapse of the transitional periods, Article 10.3 of the SPS Agreement provides:

With a view to ensuring that developing country Members are able to comply with the provisions of this Agreement, the Committee is enabled to grant to such countries, upon request, specified, time-limited exceptions in whole or in part from obligations under this Agreement, taking into account their financial, trade and development needs.

This provision aims to enable developing-country Members to comply with their obligations by giving them extra time to adjust to their new obligations, where necessitated by their financial, trade and development needs.

${ }^{61}$ Trade Policy Review Body, Trade Policy Review: Bangladesh - Report by the Secretariat, WT/TPR/S/68, circulated on 3 April 2000, Part II para. 25 and Table II.23. 
While the SPS Committee is enabled to grant requested exemptions, it has no obligation to do so. ${ }^{62}$ Neither are concrete criteria laid down according to which the SPS Committee should evaluate developing-country requests under Article 10.3. The only guidance for the Committee in this Article is the provision that the Committee is enabled to grant such requests from developing countries 'taking into account their financial, trade and development needs.' While the introduction of criteria based on the specific needs of the requesting Member, rather than purely its self-selected developing-country status, allows for differentiated decisions tailored to the concrete situation of a specific developingcountry Member, the provision leaves very broad discretion to the SPS Committee in this regard. ${ }^{63}$ As decisions of the SPS Committee, as discussed above, are taken by consensus according to Article 12.1 if the SPS Agreement, any exemptions requested under Article 10.3 would need at minimum the tacit approval of all Members.

It is difficult to determine whether Members within the SPS Committee would be disposed to grant requests under Article 10.3 easily or instead be reluctant to do so, as to date no developing-country or LDC Member has requested such an exemption. This despite the fact that some remain in breach of certain obligations under the SPS Agreement, such as the obligation to establish a National Notification Authority and Enquiry Point, to publish and notify all new SPS measures, or to base their SPS measures on either an international standard or a risk assessment. It seems possible that the hesitation of developingcountry Members to make use of this exemption possibility is due to their uncertainty regarding the likelihood that their requests will be granted, given the broad discretion of the SPS Committee in this regard coupled with the consensus requirement, and their unwillingness to draw attention to their non-compliance in the face of this uncertainty. If the SPS Committee were to refuse to grant an exemption, the requesting country has exposed itself to the risk of challenges for violation of the SPS Agreement, either through the specific trade concerns mechanism of the SPS Committee or in dispute settlement proceedings. ${ }^{64}$

Some developing countries have proposed that Article 10.3 of the SPS Agreement be amended to oblige the SPS Committee to grant requests for time-limited exemptions for developing countries. However, this would have the effect of creating an automatic waiver, excusing developing-country Members from any of the obligations under the SPS Agreement, upon request. When one bears in mind that intra-developing-country trade in food and agricultural products is significant, the creation of such a loophole in the obligations would be to the detriment of developing-country Members themselves by reducing

${ }^{62}$ It is useful to bear in mind, as noted above, that there is no possibility to challenge the action of a WTO organ in dispute settlement proceedings, as these are limited to disputes between members. Thus the issue of enforceability of Article 10.3 of the SPS Agreement does not arise.

${ }^{63}$ The actions of WTO Members acting within the SPS Committee under Article 10.3 of the SPS Agreement are not guided by the general policy contained in Article 10.1 requiring consideration of the needs of developingcountry Members, as exemptions cannot be regarded as covered by its reference to the "preparation and application' of SPS measures by Members.

${ }^{64}$ While the risk of dispute settlement challenges to non-compliance of less developed Members is very small, in view of the limited interest in access to their markets, as discussed in Part IV of this book, weak enforcement does not obviate the need to ensure that there is sufficient flexibility in WTO obligations to accommodate the constraints of LDC Members and developing-country Members. Instead, it merely creates an undesirable lack of certainty and predictability and makes the non-complying Member vulnerable to pressure from other Members. See further above, Part IV, Sections 2.2.7 and 2.3. 
their possibilities to enforce the market access achievements of the SPS Agreement against other developing-country Members making use of such a waiver. Instead, the creation of clear and concrete criteria to determine when the 'financial, trade and development needs' of developing countries preclude immediate compliance with specific obligations may be more useful. It would give guidance to the SPS Committee in taking decisions on exemptions, providing a degree of security and predictability for Members. The development of criteria would require Members to accept the possibility of differentiation between developing countries, on the basis of their specific needs, in the provision of this form of SDT.

\subsection{Special provisions in the notification obligations}

As stated above, compliance with the transparency obligations of the SPS Agreement can be particularly costly and onerous for developing-country Members. Nevertheless, due to their fundamental importance to the functioning of the SPS Agreement, immediate compliance therewith is required, except by LDC Members. However, some aspects of the transparency obligations are less crucial than others to the operation of the Agreement and may create an unnecessary burden for developing-country Members.

One such obligation is that contained in paragraph 8 of Annex B, with regard to documentation for notified measures. This provision contains an obligation to provide, upon request, copies of the documents, or in case of lengthy documents, summaries of the documents covered by a specific notification in one of the official languages of the WTO. Developing-country Members are exempt from these obligations of translation and summarising. This is clearly an attempt to reduce the burden on developing countries that results from compliance with some of the transparency provisions. Once again, as was the case with the transitional periods, this SDT provision is automatic in its application and requires no implementation. It can thus be regarded as an effective, albeit very limited, form of SDT.

Developing countries do not only have difficulties in complying with certain transparency obligations. They also face constraints in fully benefiting from increased transparency if they do not have the skilled human resources to monitor the notifications and identify those of interest to them. For this reason, under paragraph 9 of Annex B, the WTO Secretariat is obliged to draw the attention of developing countries to any notifications relating to products of interest to them. This aims to enable developing countries to take full advantage of the increased transparency resulting from the disciplines of the SPS Agreement despite the fact that they may lack the resources to keep track of all notifications.

The question of enforceability of this provision through dispute settlement does not arise, as the WTO dispute settlement system is limited to disputes between Members. Thus, claims can only be brought by a WTO Member against measures taken by another Member and not against acts or omissions of the WTO Secretariat. Nevertheless, the Secretariat takes its task under Annex B.9 seriously and has made every effort to give effect to this provision. 
In practice, it is difficult to determine which notifications may be of interest to each developing-country Member. This was particularly the case initially when notifications were rudimentary and provided little information. The Secretariat thus revised the notification format to be used by Members, to include a box on which countries are most likely to be affected by the notification. ${ }^{65}$ In addition, the Secretariat decided to implement its obligation under Article B.9 by circulating lists of all notified SPS measures to all WTO Members. Initially these periodic lists contained merely the official document number of the notification and the date in which it was issued, ${ }^{66}$ and were therefore not very useful for developing-country Members. Following consultations with Members on this issue, the Secretariat decided, in 1999, to draw up a monthly document identifying all notifications received that month, with a short summary of the products covered by each notification, the countries or regions identified in the notification as likely to be affected, the nature of the measure, and the deadline for the submission of comments. ${ }^{67}$ This additional information facilitates the monitoring of relevant notifications by developing-country authorities. The summary document is sent by electronic mail to each Member's Enquiry Point, and in paper form to all Members' permanent missions to the WTO. The actual notifications received are transmitted to all Members in the same way. ${ }^{68}$

These efforts indicate that this SDT provision, addressed to the WTO Secretariat, is implemented effectively, within the limits of what is possible given the information provided by Members in their notifications of SPS measures. ${ }^{69}$

\subsection{Work on improving implementation of SDT provisions}

The weakness of the SDT provisions in the SPS Agreement and the consequent inadequate implementation thereof has been the subject of much criticism by developingcountry Members. In its review of the utilisation of SDT provisions in WTO agreements, the WTO Secretariat reported that no information was available on the extent to which the special and differential treatment provided for in Articles 10.1 and 10.2 had been accorded to developing-country Members, nor on the extent to which developing-country Members had made use of any special and differential treatment accorded to them. ${ }^{70}$

${ }^{65}$ The notifications received by the WTO Secretariat are transmitted by electronic mail to each Member's enquiry point, and in paper form to all Members' permanent missions to the WTO. The Secretariat sends all SPS-related documents to Members in English as well as the other WTO working languages of their choice (French or Spanish). The WTO Secretariat has created a self-subscribing e-mail list to receive SPS notifications and other non-restricted SPS documents. WTO Members and interested public can subscribe to this list.

${ }^{66}$ See for example, Committee on Sanitary and Phytosanitary Measures, List of Notifications - Note by the Secretariat, G/SPS/W/19, circulated on 19 June 1995.

${ }^{67}$ Committee on Sanitary and Phytosanitary Measures, Electronic Transmission of Notifications to National Enquiry Points. Note by the Secretariat, G/SPS/GEN/136, circulated on 9 August 1999. These lists can be found in the series G/SPS/GEN/* by searching under the keyword 'notifications'.

${ }^{68}$ The Secretariat sends all SPS-related documents to Members in English as well as the other WTO working language of their choice (French or Spanish).

${ }^{69}$ The work done to improve the content and timeliness of notifications by Members has been discussed above, Part IV, Section 1.3.7.

${ }^{70}$ Committee on Trade and Development, Information on the Utilisation of Special and Differential Treatment Provisions. Note by the Secretariat. Addendum, WT/COMTD/W/77/Rev.1/Add.4, circulated on 7 February 2002, Section D. 
While some developed-country Members have used this lack of information as a basis for the claim that strengthening SDT provisions is not useful since developing-country Members do not utilise the available SDT in any case, ${ }^{71}$ this superficial argument has been effectively countered. As noted by Mexico and Uganda, the under-utilisation of the SDT provisions can be ascribed to their vague and weak terms and it is precisely this that needs to be addressed. ${ }^{72}$ Further, as pointed out by Egypt and Uganda, the lack of reported use of the SDT provisions does not mean they are not utilised. In fact, they are often relied upon informally on a bilateral basis. ${ }^{73}$

Concerns regarding poor implementation of SDT are not limited to the SPS Agreement. They form part of the broader discussion on implementation of the WTO agreements, which as discussed above, has been going on since the Seattle Ministerial Conference and, in a more concrete fashion, during the preparations for the Doha Ministerial Conference and ever since. ${ }^{74}$ Developing-country Members regard SDT as the quid pro quo for the extensive obligations they undertook in the Uruguay Round, and therefore regard the inadequate implementation thereof as cause for concern. As part of the effort to bring developing-country Members back on board after the failed Seattle Ministerial Conference in 1999, these implementation concerns received increased attention, resulting in the adoption of the Implementation Decision at the Doha Ministerial Conference in 2001. ${ }^{75}$

The Implementation Decision represents a step towards the strengthening of the provisions in the SPS Agreement in favour of developing-country Members. As stated above, this decision set out guidelines for the adaptation period and additional compliance period for developing-country Members provided for in Article 10.2 and Annex B.8 of the SPS Agreement ${ }^{76}$ However, much remains to be done if the SDT provisions are to be fully operationalised. For this reason, the Implementation Decision sets out a work programme on SDT. The Doha Ministerial Declaration, adopted at the same time as the Implementation Decision, recognises that SDT provisions are 'an integral part of the WTO Agreements'

${ }^{71}$ Committee on Sanitary and Phytosanitary Measures, Procedure to Enhance Transparency of Special and Differential Treatment in Favour of Developing Country Members. Decision by the Committee of 27 October 2004, G/SPS/33, circulated on 2 November 2004, para. 15.

${ }^{72}$ Ibid., paras 18 and 26.

${ }^{73}$ Ibid., paras 19 and 26. Egypt pointed to Pakistan's comments on its unsuccessful attempts to rely on SDT as well as to the discussion in the SPS Committee on SDT with regard to the EC aflatoxin standards.

${ }^{74}$ See the discussion above, Part I, Sections 1.7 and 1.8 .

${ }^{75}$ Ministerial Conference, Implementation-Related Issues and Concerns. Decision of 14 November 2001, WT/ MIN(01)/17, circulated on 20 November 2001. This Decision was adopted having regard to Articles IV:1, IV:5 and IX of the WTO Agreement. The Implementation Decision does not only address the SPS Agreement, but embodies decisions to address the concerns of developing-country Members regarding the implementation of various provisions in the WTO agreements, including those providing SDT, and sets out a work programme on SDT.

${ }^{76}$ Aside from the issue of SDT, it is useful to recall that the Implementation Decision also contains other provisions of relevance to the SPS Agreement, which have been referred to above where relevant. In particular, it took note of the Equivalence Decision and mandated the SPS Committee to expeditiously develop its work programme on that issue. It also instructed the SPS Committee to review the operation of the SPS Agreement every 4 years. Further, it took note of the Director-General's efforts to facilitate the increased participation of Members at different levels of development in international standard setting organizations and to coordinate with these organizations and financial institutions in identifying SPS-related technical assistance needs and how best to address them; and it urged him to continue these efforts. Finally it urged Members to provide to the extent possible, technical and financial assistance to LDC Members to help them to comply with new SPS measures and to implement the SPS Agreement. Ibid., paras 3.1-3.6. 
and mandates the review of SDT provisions, '... with a view to strengthening them and making them more precise, effective and operational. ${ }^{17}$ The Doha Ministerial Declaration endorses the Work Programme on special and differential treatment set out in the Implementation Decision.

Work is ongoing in the Special Session of the Committee on Trade and Development with respect to the identification of ways to make the special and differential treatment provisions in WTO agreements more effective. ${ }^{78}$ Proposals in this regard have addressed both agreement-specific SDT provisions and cross-cutting issues, including questions of eligibility criteria and differentiation between developing countries.

As noted above, some developing countries have opposed negotiations on cross-cutting issues, before agreement-specific issues have been resolved. ${ }^{79}$ However, at the meeting of 28 October 2004, the polarisation between developed and developing countries reportedly diminished and some progress was made regarding the process for negotiations in the Special Session of the CTD. ${ }^{80}$ It was decided that it was necessary to address the underlying development challenges when examining the agreement-specific proposals (other than those forwarded to other WTO bodies) in the Committee. ${ }^{81}$

As discussed above, 88 agreement-specific proposals have been made by Members. ${ }^{82}$ It is useful to recall that these proposals were informally divided into three categories. Category I is composed of those proposals on which agreement is likely in the short-term, including those 28 proposals which were agreed upon in principle before the Cancun Ministerial. Category II consists of those 38 proposals that were forwarded to those WTO bodies that deal with the specific agreements involved for further work. Category III refers to the most controversial proposals on which negotiations have not yet been conducted. Five proposals have been made containing 12 specific recommendations that relate to Articles 9 and 10 of the SPS Agreement. ${ }^{83}$

Three recommendations relevant to SDT deal with Article 10.1 of the SPS Agreement and are regarded as Category II proposals. These proposals were referred to the SPS Committee by the General Council in May 2003. One of these is a proposal by a group

\footnotetext{
${ }^{77}$ Ministerial Conference, Doha Ministerial Declaration. Adopted on 14 November 2001, WT/MIN(01)/DEC/1, circulated on 20 November 2001, para. 44.

${ }^{78}$ In early 2002, the Trade Negotiations Committee established the Special Session of the Committee on Trade and Development to be the body responsible for carrying out the Doha mandate with regard to special and differential treatment negotiations.

${ }^{79}$ See above, Part I, Section 1.8 .

80 'WTO S\&D Talks Focus on Process In "Positive" Session', Bridges Weekly Trade News Digest, 3 November 2004.

${ }^{81}$ Ibid. Switzerland reportedly proposed the clustering of proposals around specific themes, such as technical assistance or capacity constraints, and approaching the cross-cutting issues in a more focused manner so that the two aspects of the negotiations are complementary.

${ }^{82}$ See above, Part I, Section 1.8 .

${ }^{83}$ These proposals are contained in: Committee on Trade and Development Special Session, Special and Differential Treatment Provisions. Joint Communication from Cuba, Dominican Republic, Egypt, Honduras, India, Indonesia, Kenya, Mauritius, Pakistan, Sri Lanka, Tanzania and Zimbabwe, TN/CTD/W/2, circulated on 14 May 2002; Committee on Trade and Development, Special and Differential Treatment Provisions Joint Communication from the African Group in the WTO. Revision, TN/CTD/W/3/Rev.2, circulated on 17 July 2002; Committee on Trade and Development Special Session, Special and Differential Treatment Provisions. Communication from India, TN/CTD/W/6, circulated on 17 June 2002.
} 
of Members referred to as the 'Like-Minded Group' suggests an addition to Article 10.1 to require consultations, upon request, if a developing-country Member identifies specific problems in complying with SPS measures of a developed-country Member. This addition specifies that the 'special needs' of developing countries referred to should be interpreted to include securing and enhancing export levels and maintaining market share, as well as developing technological and infrastructural capabilities ${ }^{84}$ The African group has made two proposals in its submission regarding the interpretation of Article 10.1. It suggests that the requirement to 'take account of the special needs' of developing- and leastdeveloped-country Members be understood to mean that an importing Member must either withdraw measures that adversely affect such exporting Members or must provide the technical and financial resources necessary for compliance. ${ }^{85}$ Further it proposes that this requirement be interpreted to mean that Members are obliged to initiate consultations in the SPS Committee if they intend to take measures that are likely to affect developingor least-developed-country exporting Members. These consultations aim to determine whether the proposed measures, if in conformity with the SPS Agreement, adversely affect such exporting Members. ${ }^{86}$

In addition, two SDT recommendations deal with Article 10.3 of the SPS Agreement and are regarded as Category I proposals. One of these is a proposal by Egypt to amend Article 10.3 of the SPS Agreement to make obligatory the granting of time-limited exemptions by the SPS Committee to developing-country Members that request such exemptions. ${ }^{87}$ New Zealand submitted a compromise proposal in this regard, proposing a specification in Article 10.3 that the SPS Committee should take a decision on an exemption request no later than at the third meeting of the Committee following the meeting where the request was tabled. The remaining proposal is in Category III. It is the Indian proposal for a revision of Article 10.2, to make mandatory the additional time frame of at least six months for developing-country Members to comply with new or amended SPS measures, with the exception of emergency measures. ${ }^{88}$

From November 2002 onwards, the Special Session of the CTD has been discussing the Category I and III proposals. ${ }^{89}$ India's proposal to establish a mandatory additional time

\footnotetext{
${ }^{84}$ Committee on Trade and Development Special Session, Special and Differential Treatment Provisions. Joint Communication from Cuba, Dominican Republic, Egypt, Honduras, India, Indonesia, Kenya, Mauritius, Pakistan, Sri Lanka, Tanzania and Zimbabwe, TN/CTD/W/2, circulated on 14 May 2002. Further, the importing Member is required to indicate the systems and/or equivalent systems that can be used to comply with its SPS measure and the names of the developing- and least-developed-country Members that could be affected by the measure.

${ }^{85}$ Committee on Trade and Development Special Session, Special and Differential Treatment Provision: Joint Communication from the African Group in the WTO, TN/CTD/W/3, circulated on 24 May 2002.

${ }^{86}$ Ibid.

${ }^{87}$ The proposal states that the SPS Committee 'shall grant' such exemptions upon request. 'Friends of the Chair Looking to Save WTO’s S\&D Review', Bridges Weekly Trade News Digest, 12 June 2003.

${ }^{88}$ The two proposals with regard to Article 10.3 of the SPS Agreement were considered to be proposals on which recommendations were more likely to be made by the General Council, and were therefore discussed in the Special Sessions of the CTD. The proposal with regard to Article 10.2 was characterised as a proposal where a wide divergence of views existed and on which progress was unlikely without redrafting the original text. This proposal is also discussed in the Special Sessions of the CTD. Committee on Sanitary and Phytosanitary Measures, Special and Differential Treatment Proposals - Schedule of Work: Proposal by the Chairman, G/ SPS/W/135, circulated on 13 June 2002, para. 1.

${ }^{89}$ Committee on Trade and Development Special Session, Note on the Meeting of 6 November 2002, TN/
} 
frame for developing countries to comply with SPS measures under Article 10.2 was rejected by many developed-country Members, who felt that it would undermine their right to set science-based SPS measures and implement them in accordance with the identified risk. ${ }^{90}$ These Members noted that an obligatory minimum period disregards the fact that the possibilities for extended compliance periods can only be assessed on a case-by-case basis depending on the nature or the risk. ${ }^{91}$ While India tabled a revised proposal, taking into account informal discussions, it remained of the view that a specific time frame is necessary to prevent Article 10.2 remaining a 'non-implementable best endeavour clause' ${ }^{92}$ India, supported by Pakistan, China sand Egypt, felt that alternatives proposals made would dilute the strength of its proposal..$^{93}$ China pointed out that developed-country Members' concerns are already reflected in the fact that Article 10.2 contains the condition that extended compliance periods are only accorded when the appropriate level of SPS protection allows. ${ }^{94}$ As noted by the Chair, significant divergences remain and no agreement seems likely. ${ }^{95}$

As was to be expected, there is also no support from developed-country Members for Egypt's proposal to make mandatory the granting by the SPS Committee of an exemption from specific obligations in the SPS Agreement under Article 10.3. ${ }^{96}$ While the US, Canada, Australia, Switzerland, Japan and Hungary have expressly opposed the automatic nature of the proposed exemption, the EC supported changing the wording of Article 10.3 from 'is enabled to grant' to 'shall positively consider' ${ }^{97}$ A revised text was submitted by Egypt, indicating that the 'eligibility' of developing-country Members for an exemption refers to their right to request an exemption, not their right to have an exemption granted. ${ }^{98}$ As these Members are already eligible to request exemptions, this does not add anything to Article 10.3. Further, the revised proposal incorporates the EC's suggestion by creating an obligation of 'positive and expeditious consideration' by the SPS Committee to exemption requests. To indicate that the word 'positive' does not prejudge

CTD/M/10, circulated on 21 January 2002.

90 Special Session Committee on Trade and Development, Note on the Meeting of 7 December 2007, TN/ CTD/M/32, circulated on 9 January 2008, para. 6 .

${ }^{91}$ Ibid., paras 10, 13, 14 and 15. This comment was first made by Australia, which then called for more creative thinking in this regard, to ensure that the nature and purpose of the SPS Agreement is respected. Similar comments were made by the US, Canada and the EC.

92 Ibid., para. 7. India pointed out that the objective of its proposal was to address the practical problems faced by developing-country exporters with short time frames for compliance with new and onerous SPS measures, resulting in virtual denial of market access.

${ }^{93} \mathrm{Ibid}$., paras 6, 8, 11 and 12. Pakistan gave concrete examples of where non-compliance with new SPS measures has resulted not only in a rejection of its exports but also in their confiscation. It has attempted to resolve these issues bilaterally rather than through the use of Article 10.2 due to the uncertainty that results can be achieved through this avenue, and the need to resolve issues promptly to minimise the damage suffered by exporters.

94 Ibid., para. 17.

95 Ibid., para. 6. The assessment of the Chair was agreed with by Australia and the US.

${ }^{96}$ It is therefore surprising that this proposal was classified as a Category I proposal, which are those on which agreement seems likely in the short term.

${ }_{97}$ This discussion took place at the meeting of the General Council Chair and the Heads of Delegations of Members on 5 June 2003, where, inter alia, Article 10.3 of the SPS Agreement was on the table. 'Friends of the Chair Looking to Save WTO's S\&D Review', Bridges Weekly Trade News Digest, 12 June 2003.

98 Special Session Committee on Trade and Development, Note on the Meeting of 7 December 2007, TN/ CTD/M/32, circulated on 9 January 2008, para. 5. 
the outcome of the decision, Egypt added that the decision would be taken 'as appropriate'. Finally, Egypt added a sentence specifying that assistance can be provided either bilaterally or through the appropriate international organisations. Egypt clarified that the proposal does not aim to make technical assistance mandatory, but only seeks to ensure that it is targeted and linked to the request. ${ }^{99}$ Despite these broad concessions, there were still some Members that remained concerned and sought further revisions. The Chair noted the considerable progress on this issue and urged Members to show flexibility. ${ }^{100}$

The SPS Committee has set up a work programme of formal and informal meetings to address the Category II SDT proposals referred to it by the General Council. ${ }^{101}$ In particular, the two proposals on Article 10.1 were discussed. Some Members opposed the Like-Minded Group's proposal for the creation of a legally binding obligation to enter into consultations if a developing-country Member identifies problems in complying with an SPS measure, on the basis that if no mutually satisfactory solution could be reached in consultations, the proposal might lead to 'other legal solutions' with other effects on the SPS Agreement. ${ }^{102}$ Further, Canada indicated that its proposal on transparency procedure for SDT, subsequently adopted in revised form, reflected the same concerns as the LikeMinded Group's proposal. ${ }^{103}$ However, Egypt pointed out that the Canadian proposal did not contain the requirement to ensure and enhance current export levels, as embodied in the Like-Minded Group's proposal. This requirement was strongly opposed by Norway and New Zealand, as it would oblige Members to maintain market access in disregard of national SPS requirements. ${ }^{104}$ Pakistan and Sri Lanka clarified that importing Members were not being asked to surrender their right to regulate, but only to compensate for the resulting loss of export revenue, or to assist developing-country Members to acquire the infrastructure and capacity to comply with the SPS requirements of the importing Members. A revised proposal by the Africa Group suggested that before a new SPS requirement is adopted by a developed-country Member, it must carry out an impact assessment to establish whether an adverse effect on developing-country trade is likely to result. ${ }^{105}$ In the event that such adverse effects are identified, the new measure may not

${ }^{99}$ Ibid.

100 Ibid.

${ }^{101}$ Committee on Sanitary and Phytosanitary Measures, Special and Differential Treatment Proposals Schedule of Work. Decision by the Committee., G/SPS/26, circulated on 2 July 2003.

102 Committee on Sanitary and Phytosanitary Measures, Proposals and Progress on Special and Differential Treatment. Note by the Secretariat, G/SPS/GEN/543, circulated on 28 February 2005, para 26.

103 The SDT transparency procedure is discussed below, Part V, Section 1.8.

${ }^{104}$ Committee on Sanitary and Phytosanitary Measures, Proposals and Progress on Special and Differential Treatment. Note by the Secretariat, G/SPS/GEN/543, circulated on 28 February 2005, para. 30.

${ }^{105}$ Committee on Trade and Development, Special and Differential Treatment Provisions Joint Communication from the African Group in the WTO. Revision, TN/CTD/W/3/Rev.2, circulated on 17 July 2002. Scott supports the idea of prior impact assessment, referring to the 2005 World Bank report that recommends that industrialised countries include in their SPS regulatory assessments the prospective impact of their measures on developing countries, and inform developing countries of these effects. Steven Jaffee et al., Food Safety and Agricultural Health Standards: Challenges and Opportunities for Developing Country Exports, 31207 (World Bank, Poverty Reduction \& Economic Management Trade Unit and Agriculture and Rural Development Department, Washington D.C.), 10 January 2005, 34, available at: http://www-wds.worldbank. org/external/default/WDSContentServer/WDSP/IB/2005/01/25/000160016_20050125093841/Rendered/ PDF/31207.pdf, visited on 18 May 2008. Naturally, Scott does not support the idea that SPS measures must be delayed pending the establishment of the ability of the affected Members to comply with the new measure. Joanne Scott, The WTO Agreement on Sanitary and Phytosanitary Measures: A Commentary, Oxford 
come into force until it is established that the affected Members have acquired the capacity to comply. In June 2007, Egypt informally tabled a new proposal on Article 10.1, with a view to making it an obligation of result, rather than of conduct. ${ }^{106}$ The same objections were raised.

During these discussions, developing-country Members complained that the provisions on technical assistance and special and differential treatment are either couched in nonmandatory language or constitute at most 'best-endeavour' obligations without being fully operational. ${ }^{107}$ In particular, they noted that additional time for compliance with new SPS measures has seldom been granted. In addition, their continued problems with regard to effective participation in international standard setting were pointed out. A number of developing-country Members indicated their concern with ensuring that proposed changes did not result in discrimination among developing countries. ${ }^{108}$ In its 2005 report, the SPS Committee noted a strong resistance by many Members to changes in the text of the SPS Agreement and indicated an emerging broad consensus to actively seek alternative, concrete avenues to fulfil the mandate before undertaking specific changes in the text of the SPS Agreement. It reiterated the major concern repeatedly raised that modification could result in changes to the balance of rights and obligations established by the SPS Agreement. This could result in changes in the text of other provisions. ${ }^{109}$

The common thread running through many of the responses of developed-country Members to the SDT proposals is the concern with disturbing the balance between trade and health achieved in the SPS Agreement. ${ }^{110}$ For example, the US expressed the view that SDT under the SPS Agreement is fundamentally different than under other WTO agreements, and that some of the proposals for mandatory SDT put at risk the balance of the SPS Agreement. ${ }^{111}$ The EC pointed out that as health protection is at stake, some of the SDT proposals are unfeasible. ${ }^{112}$ Similarly, Australia stated that once a risk has been scientifically established, the risk is not diminished by virtue of the exporting Member being

Commentaries on the GATT/WTO Agreements (Oxford University Press, Oxford), 2007, 293.

${ }^{106}$ Committee on Sanitary and Phytosanitary Measures, Special and Differential Treatment: Report by the Chairman to the General Council, G/SPS/46, circulated on 29 October 2007, para. 5.

107 Committee on Trade and Development Special Session, Note on the Meeting of 6 November 2002. Corrigendum, TN/CTD/M/10/Corr.1, circulated on 21 February 2002, para. 8.

${ }^{108}$ Committee on Sanitary and Phytosanitary Measures, Implementation and Special and Differential Treatment. Report by the Chairman to the General Council, G/SPS/27, circulated on 4 July 2003, para. 13.

${ }^{109}$ Committee on Sanitary and Phytosanitary Measures, Report on Proposals for Special and Differential Treatment: Adopted by the Committee on 30 June 2005, G/SPS/35, circulated on 7 July 2005, para. 4.

${ }^{110}$ Low notes that some of the proposals made for reform of SDT, such as those regarding the reduction of SPS requirements in importing countries in order to meet the development needs of developing countries, would be 'difficult to accommodate'. Patrick Low, 'Is the WTO Doing Enough for Developing Countries?' in WTO Law and Developing Countries, George A. Bermann and Petros C. Mavroidis (eds.) (Cambridge University Press, Cambridge), 2007, 324-358.

111 Committee on Trade and Development Special Session, Note on the Meeting of 6 November 2002, TN/ CTD/M/10, circulated on 21 January 2002, para. 5. Argentina rejected the idea that SDT in the SPS Agreement is different from that under any other WTO agreement. Committee on Trade and Development Special Session, Note on the Meeting of 6 November 2002. Corrigendum, TN/CTD/M/10/Corr.1, circulated on 21 February 2002, para. 7.

112 Committee on Trade and Development Special Session, Note on the Meeting of 6 November 2002, TN/ $\mathrm{CTD} / \mathrm{M} / 10$, circulated on 21 January 2002, para. 6. In the same line, Switzerland argued that it did not see how it would be possible to reconcile the right to maintain the desired level of health protection with an obligation to maintain a certain market share for developing-country exporting Members. Ibid., para. 11. 
a developing or developed country. Therefore, to make SDT mandatory would deny the sovereign right of an importing Member, enshrined in the SPS Agreement, to determine its own level of protection. ${ }^{113}$ It noted that efforts to strengthen special provisions for developing countries are more likely to take the form of stronger commitments to provide technical assistance under Article 9 of the SPS Agreement, than making mandatory the SDT provisions of Article 10. Many of the comments of developing-country Members in this discussion recognised the right of other Members to impose SPS measures, and emphasised that they were not attempting to change the balance in the SPS Agreement. ${ }^{114}$ Instead, they stressed the need to address the capacity constraints of developing-country Members in complying with these measures through technical assistance. In addition, several Members supported work on procedural issues improving the transparency of SDT and the development of guidelines on the recognition of equivalence. ${ }^{115}$

The SDT discussions bring to light the difficulty inherent in attempts to reform the SDT provisions of the SPS Agreement in a manner that does not threaten the delicate balance achieved by its provisions between trade and health. Although the regulatory disciplines of the SPS Agreement, unlike traditional trade liberalisation rules, entail real costs for developing-country Members, the solution does not lie in weakening the disciplines when it comes to developing countries. Neither can it lie in greater limitations to the right of developed-country Members to regulate or to maintain their chosen level of protection. A different solution must be sought.

In the academic and policy discussion on how to strengthen SDT, the possibility of differentiation between developing-country Members is increasingly raised. ${ }^{116}$ Developed-country

113 Ibid., para. 9.

114 See for example the remarks made by the representatives of Pakistan, India and Kenya. Committee on Sanitary and Phytosanitary Measures, Procedure to Enhance Transparency of Special and Differential Treatment in Favour of Developing Country Members. Decision by the Committee of 27 October 2004, G/ SPS/33, circulated on 2 November 2004, paras 10, 12 and 13.

115 Ibid., paras 4, and 6-8.

${ }^{116}$ Some authors argue for a revision of the current groupings in the WTO, away from self-selection of developing-country status towards more objective criteria. For instance, Hoekman et al. suggest the development of criteria to identify an LDC+ group of small and poor developing-country Members to capture those Members most in need of SDT for all WTO agreements. Bernard Hoekman et al., Special and Differential Treatment for Developing Countries: Towards a New Approach in the WTO (World Bank, Washington D.C.), 4 April 2003. Kasteng proposes a more advanced country classification system, based on mutually exclusive indicators. The criteria examined are based on food security, rural development, and significance of net exports of agricultural products. Jonas Kasteng et al., Differentiation between Developing Countries in the WTO, Report 2004:14 E (Swedish Board of Agriculture, International Affairs Division, Jönköping), June 2004, available at: http://www.sjv.se/webdav/files/SJV/trycksaker/ Pdf rapporter/ra04 14E.pdf, visited on 15 July 2004. Prowse recommends an 'issues-based' approach, assessing a Member's overall development strategy and transition requirements to determine the sequencing for implementation of WTO agreements. Susan Prowse, 'The Role of the International and National Agencies in the Trade-Related Capacity Building', The World Economy 25 (9), 2002, 1235-1261. Others, such as Keck and Low, argue for the need to move way from classification of countries but instead disaggregate SDT by means of agreement-specific criteria. Susan Prowse, 'The Role of the International and National Agencies in the Trade-Related Capacity Building', The World Economy 25 (9), 2002, 1235-1261. For example, Stevens argues for the development of criteria or indicators, on the basis of an analysis of what is supportive of development, to establishment the readiness of Members to commit to certain obligations. Graduation would then automatically be triggered for specific Members with regard to specific obligations at a time established by the development process itself. Christopher Stevens, The Future of the Special and Differential Treatment (SDT) for Developing Countries in the WTO, IDS Working Paper 163 (Institute for Development Studies, Brighton), September 2002. An ICTSD policy 
Members have suggested that strengthening SDT will not be achieved unless it is possible to differentiate between developing-country Members at different levels of development, so that these Members could progressively graduate from SDT eligibility. Developingcountry Members, however, have consistently refused to engage in any discussion of differentiation and graduation. ${ }^{117}$ As noted by Thomas Cottier, while improving SDT by means of progressive application, or phasing-in, of prescriptive rules may be a solution for other WTO agreements, it is not the case for the SPS Agreement. ${ }^{118}$ This is due to the special the nature of the conflict it mediates, involving both a particularly crucial area of trade liberalisation, namely agricultural trade, and a highly important societal value, namely health.

Consequently, while effective solutions to the problems of developing countries are essential, they will not be found in changing the substantive rights and obligations through strengthening and differentiating the SDT provisions. Instead, progress can be, and to some extent already has been, made in resolving the problems that underlie the SDT proposals by improving the implementation of the procedural rules (for example, those on transparency, equivalence and regionalisation). The remaining concerns that form the basis for the SDT proposals can only be addressed through technical assistance.

This conclusion is reflected in the outcome of the work on SDT in the SPS Committee. The work programme of the SPS Committee did not result in any decisions on the Category II proposals. ${ }^{119}$ However, SDT remains an agenda item at each of the regular meetings of the SPS Committee. In this regard, the SPS Committee has taken a two pronged approach. ${ }^{120}$ Not only does the Committee continue to discuss the SDT proposals, ${ }^{121}$ but it usefully

paper of 2007 focuses on distinctions in SDT provision based on differences in 'development situations', i.e. the special needs or constraints of particular countries in specific situations. This avoids an 'all-or-nothing' approach to differentiation and graduation. International Centre for Trade and Sustainable Development, $A n$ Approach to Special and Differential Treatment Based On "Development Situations" (International Centre for Trade and Sustainable Development, May 2007, available at: http://www.ictsd.org/issarea/S\&DT/Docs/ Policy\%20Paper\%20FT2\%20(2).pdf, visited on 11 June 2008.

${ }^{117}$ Patrick Low, 'Is the WTO Doing Enough for Developing Countries?' in WTO Law and Developing Countries, George A. Bermann and Petros C. Mavroidis (eds.) (Cambridge University Press, Cambridge), 2007, 324358,334 . Low regards this as a major impediment to progress in the SDT discussions.

${ }^{118}$ Cottier develops the idea of a new type of graduation in SDT, through progressive application of substantive prescriptive rules to developing countries, commensurate to their divergent levels of development, based on economic factors within the substantive rules (rather than through exemptions from the rules). This is analogous to the idea of progressive liberalisation, which historically underlies the GATT, and now the WTO, framework. However, Cottier points out that this approach is not possible in the area of SPS regulation, since health protection is 'indivisible'. Therefore the only solution in this area is technical assistance. T. Cottier, 'From Progressive Liberalization to Progressive Regulation in WTO Law', Journal of International Economic Law 9 (4), 2006, 779-821, 794 and 800.

119 The report at the end of the initial work programme indicates the absence of decisions. Committee on Sanitary and Phytosanitary Measures, Implementation and Special and Differential Treatment: Report by the Chairman to the General Council, G/SPS/30, circulated on 20 November 2003. In August 2004 the General Council again referred the agreement-specific proposals to the relevant WTO bodies, with the instruction to expeditiously complete work on these proposals and report back with clear recommendations for a decision by July 2005. The SPS Committee was again unable to develop any recommendations on the proposals by this date. Committee on Sanitary and Phytosanitary Measures, Report on Proposals for Special and Differential Treatment. Adopted by the Committee on 30 June 2005, G/SPS/35, circulated on 7 July 2005, para. 41.

${ }^{120}$ Committee on Sanitary and Phytosanitary Measures, Special and Differential Treatment. Report by the Chairman to the General Council, G/SPS/44, circulated on 23 April 2007, para. 1.

${ }^{121}$ In 2006 and 2007, discussions centred on the revised proposal of the African Group and the new informal 
identifies possible pragmatic and concrete actions that could address the concerns that underlie the SDT proposals made. ${ }^{122}$ One example of this approach is the concerted attention currently given in the SPS Committee to the question of how to improve technical assistance provision, addressed further below. Other examples are the outcomes of the work done in the SPS Committee to improve compliance with the procedural rules on transparency, equivalence and regionalisation, discussed above. Finally, the recent agreement reached in the SPS Committee regarding transparency of special and differential treatment falls into this category.

The latter agreement, although not directly based on the proposals forwarded to the Committee, was mentioned by Canada at the October 2004 meeting of the Special Session of the CTD as a positive result achieved with regard to Category II proposals. ${ }^{123}$ It deserves further attention and is therefore discussed below.

\subsection{Transparency in the provision of SDT}

During discussions on the Recommended Transparency Procedures at the SPS Committee meeting of March 2002, Egypt made a last minute proposal with the objective of improving transparency with regard to the operation of the SDT provisions of the SPS Agreement. Egypt proposed the inclusion in the SPS notification form of a box for countries to state what special and differential treatment they were applying to assist compliance with the notified measure. This proposal was supported by many developing-country Members as they believed it would encourage developed-country Members to build in leniency for developing countries such as longer time periods for compliance. Developed countries (in particular the EC, Canada and the US), while agreeing broadly with the need to promote transparency in the operation of SDT provisions in the SPS Agreement, questioned whether the Egyptian proposal would be effective in ensuring SDT. The difficulty of determining, ex ante, the specific Members that would need SDT to comply with a notified measure and what type of SDT would be appropriate was raised.

A Canadian proposal, building upon the Egyptian proposal, was submitted in October 2002. ${ }^{124}$ This proposal required notifying Members to submit an Addendum to their original notification ex post, regarding the provision or non-provision of SDT after consultations had been held on concerns raised by affected Members. Discussions arose around

proposal of Egypt, discussed above.

${ }^{122}$ Committee on Sanitary and Phytosanitary Measures, Special and Differential Treatment. Report by the Chairman to the General Council, G/SPS/44, circulated on 23 April 2007, paras 7 and 20-24. In this regard, the SPS Committee has formulated a list of 5 elements for discussion. It is interesting to note that all of these concern either procedural improvements or technical assistance. None of these elements address SDT in the sense of special flexibilities for developing-country Members. Committee on Sanitary and Phytosanitary Measures, Report on Proposals for Special and Differential Treatment. Adopted by the Committee on 30 June 2005, G/SPS/35, circulated on 7 July 2005, para. 43. These elements for discussion are set out below, Part $\mathrm{V}$, Section 2.7 .

123 'WTO S\&D Talks Focus on Progress In "Positive” Session', Bridges Weekly Trade News Digest, 3 November 2004.

${ }^{124}$ Committee on Sanitary and Phytosanitary Measures, Enhancing Transparency of Special and Differential (S\&D) Treatment within the SPS Agreement. Submission by Canada, G/SPS/W/127, circulated on 30 October 2002. 
the Canadian proposal at the SPS Committee meeting of 7-8 November $2002,{ }^{125}$ resulting in amendments.

The amended Canadian proposal ${ }^{126}$ was adopted, in principle, in April 2003, pending further elaboration. However, adoption of the subsequent proposal of the WTO Secretariat ${ }^{127}$ for the elaboration of the original proposal was prevented by the US, which opposed the idea of an unlimited consultation period and proposed modifications in this regard. ${ }^{128}$ The SPS Committee reverted to this issue in its meeting in March of 2004 and a revised version of the Secretariat proposal was adopted. ${ }^{129}$

However, this revised proposal was not finally adopted at the meeting of 22-23 June 2004, as Malaysia expressed objections. Malaysia argued that the onus should not be on developing-country Members to request SDT but rather on developed-country Members introducing new measures to provide SDT to affected countries. Certain Members disagreed with Malaysia, noting that without the comments from the affected exporting Member, importing Members have difficulty in assessing what SDT they need. Canada noted that SPS Agreement already obliges developed countries to provide SDT and that its proposal addressed instead the developing-country concern that SDT does not meet their needs. Therefore the proposal allows them to specify the additional SDT they seek. Several other countries (Jamaica, Nicaragua, Ecuador, Cuba, Peru, Brazil, and the US) urged Malaysia to join the consensus in support of the revised proposal. After a compromise between Canada and Malaysia on this issue, the SPS Committee finally reached agreement on a procedure for the transparency of SDT and this procedure was adopted in October 2004. ${ }^{130}$

The new procedure, known as the Procedure to Enhance Transparency of SDT, was adopted without prejudice to Members' rights under Article 10.1 of the SPS Agreement. ${ }^{131}$ It expressly recognises that it does not fully resolve the SDT issue, but is only one step to-

${ }^{125}$ Egypt submitted written comments on the Canadian proposal. See Committee on Sanitary and Phytosanitary Measures, Comments on the Canadian Proposal. Statement by Egypt at the Meeting of 7-8 November 2002, G/SPS/GEN/358, circulated on 15 November 2002.

${ }^{126}$ Committee on Sanitary and Phytosanitary Measures, Enhancing Transparency of Special and Differential (S\&D) Treatment within the SPS Agreement. Submission by Canada, G/SPS/W/127, circulated on 30 October 2002.

${ }^{127}$ Committee on Sanitary and Phytosanitary Measures, Elaboration of the Proposal to Enhance Transparency of Special and Differential Treatment in Favour of Developing Country Members, G/SPS/W/132/Rev.1, circulated on 8 July 2003.

${ }^{128}$ Committee on Sanitary and Phytosanitary Measures, Elaboration of the Proposal to Enhance Transparency of Special and Differential Treatment in Favour of Developing Country Members: Proposal by the United States, G/SPS/W/141, circulated on 27 October 2003.

${ }^{129}$ Committee on Sanitary and Phytosanitary Measures, Elaboration of the Proposal to Enhance Transparency of Special and Differential Treatment in Favour of Developing Country Measures. Note by the SecretariatRevision, G/SPS/W/132/Rev.2, circulated on 19 March 2004. According to the revision, Members are obliged to engage in bilateral consultations if an exporting Member identifies significant difficulties in complying with the SPS measure of the importing Member. Thereafter the notifying Member must inform the WTO, by means of an addendum to the original notification, of the SDT requested and provided, or reasons for its non-provision.

${ }^{130}$ Committee on Sanitary and Phytosanitary Measures, Procedure to Enhance Transparency of Special and Differential Treatment in Favour of Developing Country Members. Decision by the Committee of 27 October 2004, G/SPS/33, circulated on 2 November 2004.

131 Ibid. 
wards addressing the problem of SDT implementation. ${ }^{132}$ In spite of its title, the Procedure to Enhance Transparency of SDT is not limited to transparency aspects, but instead and perhaps more importantly, it sets out procedural steps for the identification of SDT needs and discussion of these needs between the Members involved, and suggests possible actions to provide SDT. In this respect it resembles the procedures for the recognition of equivalence and regionalisation adopted by the SPS Committee. ${ }^{133}$ The Procedure to Enhance Transparency of SDT comprises seven steps, still requiring bilateral consultations if an exporting Member identifies significant difficulties with a proposed SPS measure. In particular, the procedure provides that an exporting Member that identifies a concern with the content of a proposed SPS measure should contact the notifying Member, preferably within the comment period. ${ }^{134}$ Where requested by an exporting Member, and particularly where there have been delays in receiving or translating documents or where the notified measure needs further clarification, the importing Member 'should' extend the comment period 'wherever practicable', usually by 30 days. ${ }^{135}$ The notifying Member should acknowledge receipt of the request, and explain to any Member from which it has received comments how it will take these comments into account. ${ }^{136}$ If the exporting Member identifies significant difficulties with the notified measure, it may request an opportunity to discuss and resolve the potential difficulty with the notifying Member. The latter will contact the appropriate officials of the exporting Member and enter into bilateral discussions to attempt resolve the problem. If the exporting Member is a developing country, its special needs will be taken into account in determining how to best address the problem. ${ }^{137}$ Possible ways in which concerns raised by Members could be resolved are set out in the procedure, including the provision of SDT (applied equally to all developing-country Members), a change in the measure on most-favoured-nation basis or the provision of technical assistance to the affected Member. A similar consultation obligation applies, upon request, where following the entry into force of a new or modified SPS measure, including an emergency measure, significant difficulties in compliance are identified by an exporting Member. ${ }^{138}$ The notifying Member is obliged to subsequently submit an Addendum to its original notification where the SDT treatment requested and provided is specified, or reasons are given why SDT was not provided and information is given regarding whether technical assistance or any other solution was found to address the identified concern. ${ }^{139}$ The Decision provided for a review of the Procedure to Enhance Transparency of SDT within a year of its adoption. ${ }^{140}$

132 Ibid., para. 3.

${ }^{133}$ These procedures are discussed above, Part IV, Sections 1.1.6 and 1.2.6.

${ }^{134}$ Committee on Sanitary and Phytosanitary Measures, Procedure to Enhance Transparency of Special and Differential Treatment in Favour of Developing Country Members. Decision by the Committee of 27 October 2004, G/SPS/33, circulated on 2 November 2004, Step 3. Steps 1 and 2 are the usual requirements of prior notification of new or modified SPS measures, with a reasonable comment period of normally not less than 6 months, and circulation of the notification by the WTO Secretariat.

135 Ibid.

136 Ibid., Step 4.

137 Ibid., Step 5.

${ }^{138}$ Ibid., Step 6. This applies especially if no time, or an insufficient time has been provided for comments.

${ }^{139}$ Committee on Sanitary and Phytosanitary Measures, Procedure to Enhance Transparency of Special and Differential Treatment in Favour of Developing Country Members. Decision by the Committee of 27 October 2004, G/SPS/33, circulated on 2 November 2004, Step 7.

${ }^{140}$ Ibid., para. 2. 
The SPS Committee noted in February 2006 that the Procedure to Enhance Transparency of SDT had only been used a few times. Therefore, it was unable to review its procedures and assess its implementation in order to evaluate whether changes are needed, as required under paragraph 4 of that procedure. As more experience with its application was necessary for an appropriate assessment, the SPS Committee decided to extend the procedure until 2008, and to conduct a review at that time. ${ }^{141}$ In June 2008, the Secretariat pointed out that the use of the Procedure to Enhance Transparency of SDT had never been notified. ${ }^{142}$ This is rather ironic since the stated objective of the procedure is to promote transparency. Following the revision of the general Recommended Transparency Procedures, adopted in April 2008, ${ }^{143}$ and in light of an additional informal proposal by Egypt $^{144}$ and discussions in the SPS Committee, the WTO Secretariat proposed a revision to the SDT transparency procedures for consideration by the SPS Committee. ${ }^{145}$ The proposed revisions aim to make the SDT transparency procedure easier to use and reflect the recent changes to the overall transparency procedures. These revisions were considered at the SPS Committee meeting in June 2008, but as no agreement could be reached Members decided to revert to the matter at the following meeting.

The lack of notification of SDT may be misleading as to the usefulness of the Procedure to Enhance Transparency of SDT. The apparent contradiction between the 2006 report of the SPS Committee that the procedure had been used a few times and the 2008 statement by the Secretariat indicating the absence of notifications under this procedure can be explained with reference to the responses of Members to the questionnaire on transparency circulated by the Secretariat. Some Members have indicated that they have used the Procedure to Enhance Transparency of SDT, to raise their compliance concerns regarding notified or published measures, and to initiate discussions with the notifying Member, but the outcome of these discussions has not been notified as an Addendum to the original notification as required by this procedure. ${ }^{146}$ In the absence of notifications it is difficult to judge to what extent the procedure has proved useful. ${ }^{147}$ However, a tentative conclu-

141 Committee on Sanitary and Phytosanitary Measures, Decision to Extend the Procedure to Enhance Transparency of Special and Differential Treatment in Favour of Developing Countries. Decision by the Committee of 1 February 2006. Addendum, G/SPS/33/Add.1, circulated on 6 February 2006.

${ }^{142}$ As the report of the discussion at the June meeting of the SPS Committee has not been circulated yet, this information is taken from the WTO News Item 'Members turn Attention to Improving SPS Mediation', available at: http://www.wto.org/english/news e/news08 e/sps 24june08 e.htm, visited on 26 June 2008.

${ }^{143}$ Committee on Sanitary and Phytosanitary Measures, Recommended Procedures for Implementing the Transparency Obligations of the SPS Agreement (Article 7) as of 1 December 2008. Revision, G/SPS/7/Rev.3, circulated on 20 June 2008. This was adopted ad referendum. As no objections were received, the revision was finally on 30 April 2008, but will come into force only on 1 December 2008 to give the Secretariat time to make the necessary changes to the SPS Information Management System.

$144 \mathrm{Job}(07) / 104$.

145 Committee on Sanitary and Phytosanitary Measures, Proposed Revision of the Procedure to Enhance Transparency of Special and Differential Treatment in Favour of Developing Country Members (G/SPS/33), $\mathrm{G} / \mathrm{SPS} / \mathrm{W} / 224$, circulated on 6 June 2008. The changes in this revision mostly entail an incorporation of the changes to the general notification procedures. In addition, the provision of information at Step 4 is expressly extended to testing and inspection procedures, and the word 'would' is changed to 'will' in Steps 5 and 6 to reflect that this is no longer a proposed procedure, but an adopted procedure.

146 Committee on Sanitary and Phytosanitary Measures, Analysis of Replies to the Questionnaire on the Operation of Enquiry Points and National Notification Authorities. Note by the Secretariat. Revision, G/SPS/ GEN/751/Rev.1, circulated on 18 June 2007, para. 28.

${ }^{147}$ It should be noted that other respondents to the Secretariat's questionnaire indicated that the lack of 
sion can be drawn that despite the continued reluctance of Members to notify their actions in the area of SDT, the progress made by the Procedure to Enhance Transparency of SDT in setting out procedural guidelines for requests for SDT and the discussions on these requests may represent a first step towards operationalising SDT under the SPS Agreement.

\subsection{Conclusion}

If developing-country Members are to benefit fully from the rules of the SPS Agreement, without being overwhelmed by the costs of compliance, appropriate flexibilities are necessary to take account of their special constraints. These flexibilities are necessary with regard to compliance not only with the resource intensive obligations of the SPS Agreement but also with new or modified SPS measures imposed by their trading partners. It is therefore important that the provision of SDT in this agreement not remain at the level of rhetoric, but be effective and operational.

The main form of SDT in the SPS Agreement actually applied in favour of developing countries was the provision for transitional periods, as a result of which most disciplines of the SPS Agreement only became binding on developing countries in January 1997, and on least-developed countries in January $2000 .{ }^{148}$ It has been pointed out in the 2005 report by the SPS Committee on SDT proposals that the SPS Agreement is, consequently, still fairly new for developing-country Members, which are still in the process of adjusting to its rules. Other SDT provisions are not very far-reaching or effective and have proved of limited use in helping developing countries adjust to their new obligations.

Although implementation of SDT in the SPS Agreement has been disappointing to date, the examination in this Chapter of the various forms of SDT provided for in the SPS Agreement indicates that real possibilities exist for panels and the Appellate Body to take a more progressive approach than that adopted by the Panel in the EC-Approval and Marketing of Biotech Products dispute, to operationalise SDT provisions through effective treaty interpretation. These possibilities arguably allow for the recognition that several provisions contain enforceable obligations that give effect to the general policy of consideration for the special needs of developing countries, thereby ensuring that the negotiated rights enshrined in these provisions are not rendered illusory. The WTO adjudicatory bodies should shoulder their responsibility to apply the SDT provisions effectively, in the light of the circumstances of each case. However, the possibilities for strengthening SDT through effective treaty interpretation are restricted - they have their bounds in the terms of the provisions themselves, which respect the right of importing Members to secure the level of health protection on their territories that they deem appropriate, and in the object and purpose of the SPS Agreement. No interpretation of SDT can go beyond these limitations without undermining the balance in the SPS Agreement.

notification is because developing-country Members are using other channels to request SDT or because developing-country Members lack resources to screen notifications quickly enough to identify compliance difficulties that could be addressed through SDT. Ibid.

148 This point is made in Committee on Sanitary and Phytosanitary Measures, Report on Proposals for Special and Differential Treatment. Adopted by the Committee on 30 June 2005, G/SPS/35, circulated on 7 July 2005, para. 6. 
This conclusion has implications for the ongoing Doha Round negotiations on SDT and technical assistance, at least as they relate to the SPS Agreement. Very little has been achieved by way of operationalising SDT, aside from the Procedure to Enhance Transparency of SDT, which has almost never been used. The deadlocked negotiations reflect an impasse between two opposing positions. On the one side are developing-country Members, who view the operationalisation of SDT and technical assistance provisions through amendments or clarifications to strengthen them and make them enforceable, as merely ensuring the implementation of existing negotiated rules. They are therefore not prepared to make concessions in other areas to get, as quid pro quo, the agreement of developed countries to these amendments. On the other side are several developed-country Members, who regard the strengthening of SDT and technical assistance provisions as the creation of new rights and obligations, and thus as something developing countries should 'pay' for by means of concessions in other areas. In the area of SPS, the additional complication arises that many of the proposals on SDT would have the effect of either requiring developed-country Members to lower their levels of SPS protection when it comes to developing-country products, or would create exemptions from the disciplines of the SPS Agreement for developing-country Members. Developed-country Members are extremely hesitant to agree to any amendments of the SPS Agreement which might disturb its balance.

If Members recognise that most of the existing SDT provisions could be operationalised by effective treaty interpretation in dispute settlement proceedings, the basis for this deadlock falls away. Members are then left with two options. They can leave the fleshing out of SDT provisions to panels and the Appellate Body, on a case-by-case basis as they are faced with claims such as that of Argentina in EC-Approval and Marketing of Biotech Products, or instead they can reach political agreement on the nature and extent of these obligations.

Nevertheless, the limits of SDT should not be forgotten. New or strengthened SDT provisions cannot be framed in a way that would undermine the careful balance between trade and health objectives that is the core purpose of the SPS Agreement. This would be the case both if Members were obliged to allow market access to developing-country products that do not meet their chosen level of protection, thus compromising Members' policy autonomy in the area of SPS protection and if SPS disciplines on SPS regulation were relaxed for developing countries allowing protectionist SPS measures taken by developing-country Members to slip through. The need to avoid such undesirable results means that SDT, even if strengthened within these limits, will in many cases be an insufficient instrument to resolve the problems that developing countries face. Thus, technical assistance assumes greater importance as a tool to help developing-country Members overcome their constraints. 


\section{CHAPTER 2 Technical assistance for developing countries}

It is currently widely acknowledged that technical assistance is crucial for developingcountry Members to be able to implement those WTO agreements requiring regulatory capacity and infrastructure, such as the SPS Agreement. Without such assistance, the costs of compliance with such agreements could outweigh the benefits from trade liberalisation gains. For this reason, secure, predictable and effective provision of technical and financial assistance is indispensable in the case of trade rules involving regulatory disciplines. ${ }^{1}$

The recognition of this fact is most clearly reflected in the explicit link in the Doha mandate between the negotiations on new trade facilitation rules, ${ }^{2}$ and the provision of technical assistance. Rules on trade facilitation resemble rules on SPS regulation in the sense that both aim to improve market access through disciplines on national regulatory and administrative systems, thus requiring investment in infrastructure and human resources for implementation. The mandate for trade facilitation negotiations spells out:

$\ldots$ it is recognized that negotiations could lead to certain commitments whose implementation would require support for infrastructure development on the part of some Members. In these limited cases, developed-country Members will make every effort to ensure support and assistance directly related to the nature and scope of the commitments in order to allow implementation. It is understood, however, that in cases where required support and assistance for such infrastructure is not forthcoming, and where a developing or least-developed

\footnotetext{
${ }^{1}$ Finger points out that while traditional trade liberalisation concessions, in the form of tariff reductions or the removal of quotas, benefit both the country making the concession and the countries receiving the concession in real economic terms, this is not the case for 'New Area' concessions. By 'New Area' Finger means concessions that involve significant implementation costs for policy and institutional reform. Real economics provides no guarantee that the concession giver will benefit from 'new area' concessions. Finger notes that, 'to make development sense, New Area reforms must be packaged with capacity-building. Not just the capacity to participate in WTO business in Geneva, capacity as well for the relevant commercial activities. ... This point was clearly made by an African whose government had been provided with technical assistance on Sanitary and Phytosanitary (SPS) implementation by one of the WTO's powerful members: they want us to understand SPS so that we will import more chicken.' J. Michael Finger, 'The Uruguay Round North-South Bargain: Will the WTO Get over It?' in The Political Economy of International Trade Law. Essays in Honor of Robert E. Hudec, Daniel L. M. Kennedy and James D. Southwick (eds.) (Cambridge University Press, Cambridge), 2002, 301-310, 305.

2 Trade facilitation is one of the four so-called 'Singapore issues' (competition, investment, trade facilitation and transparency in government procurement) on which, according to the Doha Ministerial Declaration, negotiations would be launched after 'explicit consensus' had been reached on the modalities for negotiation at the Cancun Ministerial Conference. Most developing-country Members opposed the launching of these negotiations. After their experience with implementation difficulties regarding Uruguay Round agreements creating regulatory obligations, and the lack of provision of the expected technical assistance, developing countries were understandably reluctant to negotiate more such agreements. The Doha Round negotiations deadlocked on this point at the Cancun Ministerial Conference in 2003. As part of the 'July Package' agreed to in August 2004 in order to get the Doha Round negotiations back on track, Members decided to drop the other three Singapore issues and launch negotiations only on trade facilitation. General Council, Doha Work Programme. Decision Adopted by the General Council on 1 August 2004, WT/L/579, circulated on 2 August 2004.
} 
Member continues to lack the necessary capacity, implementation will not be required. ${ }^{3}$

Along the same lines, the 2004 report of the Consultative Board, which was established by the WTO Director-General to address the challenges currently facing the WTO, recognises that the implementation burdens of new WTO obligations will fall heavily on least-developed Members. It therefore advises that:

... least-developed countries should have a contractual entitlement to capacity building support to implement new commitments in the WTO. It is not good enough for advanced Members merely to express their political intent to provide support - it should be part and parcel of the new agreements. ${ }^{4}$

The Consultative Board therefore recommends the inclusion of provisions in new agreements containing such a contractual right, including the necessary funding arrangements. ${ }^{5}$

This recognition of the need to couple regulatory disciplines with the provision of technical assistance was lacking during the Uruguay Round negotiations leading to the SPS Agreement. Instead, the technical assistance provisions of the SPS Agreement are loosely framed and no direct link is made between the obligation on Members to implement resource-intensive commitments and the provision of technical assistance to do so.

This Chapter will examine the adequacy of the technical assistance provisions in the SPS Agreement and their implementation in practice. In order to do so, however, it is necessary to begin by identifying the needs of developing-country Members in this area. Only with these needs in mind can the sufficiency of the relevant provisions and of technical assistance initiatives be evaluated properly.

\subsection{Technical assistance needs of developing-country Members}

In a 2004 report prepared by Joseph Stiglitz and Andrew Charlton for the Commonwealth Secretariat, they note that although the Doha Development Round has re-emphasised 'the importance of sharing the benefits of trade reform fairly between developed and developing countries. ... there has been less attention to the distribution of adjustment costs among countries " ${ }^{\prime 6}$ With regard to the SPS Agreement, these adjustment costs relate not only to the reforms necessary to implement the obligations set out in this Agreement, but also to those necessary to overcome constraints to fully benefiting from its poten-

\footnotetext{
${ }^{3}$ Ibid., Annex D, para. 6.

${ }^{4}$ Peter Sutherland et al., The Future of the WTO: Addressing Institutional Challenges in the New Millennium. Report by the Consultative Board to the Director-General Supachai Panitchpakdi (World Trade Organization, Geneva), 2004, para. 306, available at: http://www.wto.org/english/thewto_e/10anniv_e/future_wto_e.pdf, visited on 5 January 2005.

5 Ibid., para. 311.

${ }^{6}$ Joseph E. Stiglitz and Andrew Charlton, The Development Round of Trade Negotiations in the Aftermath of Cancun (Commonwealth Secretariat and Initiative for Policy Dialogue, June 2004, 3, available at: http://www. thecommonwealth.org/shared_asp_files/uploadedfiles/\{F1997C23-BC54-44D0-8E66-7D1166FC9937\}_ StiglitzPaperComsec.pdf, visited on 6 December 2004.
} 
tial for increased market access. ${ }^{7}$ The latter type of adjustment costs would necessitate improvements in the ability of developing-country Members to enforce their rights under the SPS Agreement when confronted with non-compliant measures as well as actions to address supply-side constraints with regard to meeting legitimate SPS requirements. ${ }^{8}$

The differences in the technical assistance needs of specific Members at different levels economic and human development became apparent from the case studies conducted in Part II of this book. Much depends on the existing SPS regulatory system in the country, its administrative institutional capacity, the importance of agricultural and food trade for its economy, and the availability of human and financial resources. Nevertheless, in broad terms, certain common elements can be found, which necessitate concerted efforts to provide effective technical assistance. A thorough study of the problems of developing countries in the area of SPS regulation, carried out under the auspices of the International Trade Centre (ITC) and the Commonwealth Secretariat points out that:

Particularly having regard to those needs being common to many developing countries, very substantial long-term technical assistance requirements exist. ${ }^{9}$

Some of the common needs identified in various studies will now be briefly set out.

Training and information is needed to improve developing-country Members' understanding of the disciplines of the SPS Agreement. ${ }^{10}$ Such training is essential to assist

\footnotetext{
${ }^{7}$ In his overview of UNCTAD's Least Developed Country Report 2004, UNCTAD Secretary-General Rubens Ricupero has identified the need for international assistance for developing production and trade capacities in least-developed countries as one of the three pillars necessary for effective poverty reduction. In this regard he noted, 'Building productive and supply capacities at the national level will contribute to both trade expansion and poverty reduction and play a central role in improving the trade-poverty relationship in the LDCs. There is a need for massive investment in enhancing the supply capacities of the LDCs and improving their competitiveness. In the approach being advocated here, trade capacity building is central to that process. ... The need for international financial and technical assistance arises because of the limited domestic resources available for doing this, the short-term trade-off between domestic resource mobilization and poverty reduction, and also limits to the potential of private capital inflows to meet many of the investment needs.' United Nations Conference on Trade and Development, The Least Developed Countries Report 2004: Linking International Trade with Poverty Reduction, UNCTAD/LDC/2004 (UNCTAD, Geneva), 27 May 2004, 29-30, available at: http://www.unctad.org/en/docs/ldc2004_en.pdf, visited on 7 June 2008.

8 In more general terms, Stiglitz and Charlton note, 'Assistance is required not only to help bear the often large costs associated with trade reform, but also to enable developing countries to avail themselves of the new opportunities provided by a more integrated global economy.' Joseph E. Stiglitz and Andrew Charlton, The Development Round of Trade Negotiations in the Aftermath of Cancun (Commonwealth Secretariat and Initiative for Policy Dialogue, June 2004, 4, available at: http://www.thecommonwealth.org/shared_asp_ files/uploadedfiles/\{F1997C23-BC54-44D0-8E66-7D1166FC9937\}_StiglitzPaperComsec.pdf, visited on $\overline{6}$ December 2004.

${ }^{9}$ Vinod Rege et al., Influencing and Meeting International Standards: Challenges for Developing Countries. Volume I: Background Information, Findings from Case Studies and Technical Assistance Needs (International Trade Centre UNCTAD/WTO and Commonwealth Secretariat, Geneva), 2003, 88. This study notes that technical assistance needs are country-specific and cannot simply be seen as the gap between developed and developing countries. It notes, in particular, the differences in level of industrial development between countries, and the differences in priorities between food-importing and food-exporting countries. It stresses the importance of identifying, evaluating and quantifying the specific needs of each country. Ibid., 86.

10 This need is emphasised in Gonzalo K. Ríos 'Technical Assistance Needs of Developing Countries and Mechanisms to Provide Technical Assistance', presented at the Conference on International Food Trade Beyond 2000: Science-Based Decisions, Harmonization, Equivalence and Mutual Recognition (Food and Agriculture Organization of the United Nations, Melbourne, Australia) 11-15 October 1999, para. 42,
} 
developing countries to comply with their obligations under the Agreement. Further, it would help developing-country Members to enforce their rights and make use of the opportunities the SPS Agreement provides for enhanced market access, for example by challenging an SPS measure of another Member before the SPS Committee or in dispute settlement proceedings. The need for improved understanding of the SPS Agreement was underlined several times in the case studies set out in Part II above. In addition, training is needed to improve the SPS regulatory capacity of developing countries, particularly when it comes to setting up complex systems such as HACCP and conducting pest risk

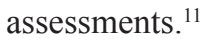

Although such training programmes are necessary in many countries, technical assistance needs do not stop here. Developing-country Members have often pointed to the fact that the recent proliferation of workshops on SPS issues cannot bear fruit without accompanying resources to implement reforms. In the report of the in-depth study conducted jointly by the ITC and the Commonwealth Secretariat, it is stated with regard to the provision of training without resources:

This can be compared to training a carpenter, but that carpenter then having no tools (equipment) or timber (financial resources) to actually work with. ${ }^{12}$

For this reason, technical assistance must extend to addressing resource constraints and improving supply-side capacity. As repeatedly noted above, the SPS Agreement is resource-intensive, as it requires the creation of institutional structures for transparency and the creation of an SPS regulatory system reflecting best practices in developed countries. Technical assistance is needed by developing-country Members to alleviate the burden of compliance with their obligations under the SPS Agreement.

This entails, inter alia, support for the establishment of a well functioning National Notification Authority and Enquiry Point. Although most Members, including developing countries, have now designated bodies to fulfil these functions, there are many shortcomings in their operation. ${ }^{13}$ Developing-country Members often lack the capacity to issue timely and complete notifications of their SPS measures, provide the relevant documentation, and create procedures for receipt and consideration of comments on notified measures. Similarly, with regard to the notifications of their trading partners, developing-country Members may not have the resources to keep track of all notifications and identify those of interest to them, even with the help of the improved Secretariat lists of notifications. ${ }^{14}$ They may also not have mechanisms in place for the circulation of notifications to interested private parties who are in a position to identify problems with notified measures. As a result, they may fail to make use of the opportunity to provide

\footnotetext{
available at: www.fao.org/docrep/meeting/ X2674e.htm, visited on 6 November 1999.

${ }^{11}$ With regard to the problems with existing training programmes, see below, Part V, Sections 2.5.2.1 and 2.6.

12 Vinod Rege et al., Influencing and Meeting International Standards: Challenges for Developing Countries. Volume I: Background Information, Findings from Case Studies and Technical Assistance Needs (International Trade Centre UNCTAD/WTO and Commonwealth Secretariat, Geneva), 2003, 88. The report, in this context, makes mention of the considerable amount of training provided to African and Pacific countries on pest risk analysis by various agencies, the effectiveness of which could not be maximised due to a lack of resources.

13 These implementation problems are discussed further above, Part IV, Section 1.3.6.

${ }^{14}$ See further on the notification procedure above, Part IV, Section 1.3.2.2.
} 
comments on draft measures in order that their interests may be considered by regulators in the relevant importing Members.

Many developing-country Members also need assistance to improve their effective participation in international standard-setting bodies. ${ }^{15}$ The new importance of the harmonised standards set by these bodies since the coming into force of the SPS Agreement, as discussed above ${ }^{16}$ is of particular consequence for developing-country Members. Often, these Members do not have the capacity to provide the required scientific justification for deviation from harmonised standards. They must thus conform their measures to the relevant international standards or face the possibility of a challenge under the SPS Agreement. It is therefore essential that developing-country interests and circumstances be properly reflected in all stages of the international standard-setting process, including the initiation of new standards, the technical drafting of standards, and the adoption of the resulting standards. ${ }^{17}$ This can be achieved only if the technical, financial and human resources are available to allow not only attendance of meetings of the international standard-setting bodies, but also the collection of relevant data and the formulation of national positions in advance. ${ }^{18}$ This requires technical assistance. ${ }^{19}$

Further, several developing-country Members experience difficulties with the adoption or implementation of internationally harmonised standards. For example, as set out in Part II above, ${ }^{20}$ the implementation of international standards is difficult for Bangladesh, Bangladesh points to the lack of domestic expertise and institutional structures for the adoption of these standards and the additional financial burden these standards place on its exporters. ${ }^{21}$ Without technical assistance to overcome these constraints, countries like Bangladesh cannot comply with Article 3 of the SPS Agreement, nor benefit from the adoption of harmonised SPS measures by its trading partners.

Closely linked to the above, is the fact that developing countries need help to strengthen their national SPS regulatory systems, through legislative and institutional reforms. Well-functioning SPS systems would make it easier for developing countries to be able to comply with international standards, or to justify deviating measures. One particular area of SPS regulatory capacity for which technical assistance is needed, is risk assess-

15 This conclusion is also come to in Vinod Rege et al., Influencing and Meeting International Standards: Challenges for Developing Countries. Volume I: Background Information, Findings from Case Studies and Technical Assistance Needs (International Trade Centre UNCTAD/WTO and Commonwealth Secretariat, Geneva), 2003, 72 .

${ }^{16}$ See above, Part III, Section 4.3.

${ }^{17}$ With regard to the extent of participation by developing-country Members in the various stages of international standard setting procedures, see above, Part II, Sections 3.2.1.5, 3.2.2.5 and 3.2.3.5.

18 Gonzalo K. Ríos, 'Technical Assistance Needs of Developing Countries and Mechanisms to Provide Technical Assistance', presented at the Conference on International Food Trade Beyond 2000: Science-Based Decisions, Harmonization, Equivalence and Mutual Recognition (Food and Agriculture Organization of the United Nations, Melbourne, Australia) 11-15 October 1999, para. 27, available at: www.fao.org/docrep/meeting/X2674e.htm, visited on 6 November 1999.

${ }^{19}$ The initiatives to provide such assistance to facilitate developing-country participation in international standard-setting are discussed below, Part V, Section 2.4.

${ }^{20}$ See above, Part II, Section 2.7.2.1.

${ }^{21}$ Trade Policy Review Body, Trade Policy Review: Bangladesh - Report by the Government, WT/TPR/G/68, circulated on 3 April 2000, para. 19. 
ment. ${ }^{22}$ Support for building the capacity to conduct scientific analysis is necessary for developing-country Members to be able to meet the scientific requirements of the SPS Agreement for their SPS measures, on the one hand, and to be able to challenge SPS measures of other Members lacking the required scientific basis, on the other. For this, expertise must be developed, risk analysis units must be established in government bodies, laboratory facilities must be upgraded, channels must be created for the involvement of universities and the private sector in data collection and analysis, and coordination mechanisms must be set up between the responsible government authorities. ${ }^{23}$

Assistance is further needed to improve developing countries' ability to comply with the applicable SPS requirements for their export products. This necessitates both development of private sector capacity to implement the required reforms and enhancement of public sector facilities to support such compliance. The new trend in many developed countries towards laying down systems-wide SPS requirements, for example HACCP, GAP and GMP, ${ }^{24}$ necessitates far-reaching reforms and substantial investments for compliance by developing countries. The additional increasing application of 'zero tolerance' or 'lowest achievable level' requirements for certain contaminants or toxins by some importing Members exacerbates compliance problems.

As has been previously noted, it is not sufficient to be able to comply with the SPS requirements of trading partners. It is also necessary to be able to prove such compliance, in order to gain market access. Although most importing countries have effective import control systems in place to ensure compliance with their requirements, it is important for exporting countries to have strong export control systems in place as well. This would, inter alia, serve to reduce delays from inspection and testing at the point of entry, ensure that decisions on what to do with non-complying products can be taken by the exporting rather than importing Member, ${ }^{25}$ protect the reputation of the exporting country as a source of safe products, ${ }^{26}$ and eliminate the risk of rejection. ${ }^{27}$ Developing-country

22 Gonzalo K. Ríos 'Technical Assistance Needs of Developing Countries and Mechanisms to Provide Technical Assistance', presented at the Conference on International Food Trade Beyond 2000: Science-Based Decisions, Harmonization, Equivalence and Mutual Recognition (Food and Agriculture Organization of the United Nations, Melbourne, Australia) 11-15 October 1999, para. 40, available at: www.fao.org/docrep/meeting/X2674e.htm, visited on 6 November 1999.

${ }^{23}$ Ibid., para. 53. Ríos further points to the need to implement GAP and GMP in developing countries.

${ }^{24}$ This trend towards systems-wide requirements is discussed above, Part II, Section 1.3.

${ }^{25}$ For example, the exporter, with the approval of the export control authority, could send the non-complying product to another country with less strict SPS requirements. If the decision is left to the importing country, non-complying products are often destroyed or at best sent back to the exporting country, possibly causing spoilage due to delays in getting the product onto the market.

${ }^{26}$ The WHO Regional Office for Africa has noted that, 'Losses from export rejection not only rob countries of critical revenues but also of credibility as reliable trading partners.' WHO Regional Office for Africa, 'Developing and Maintaining Food Safety Control Systems for Africa - Current Status and Prospects for Change', presented at the FAO/WHO Second Global Forum of Food Safety Regulators, Conference Room Document 32 (Food and Agriculture Organization and World Health Organization, Bangkok, Thailand) 12-14 October 2004, 2, available at: ftp://ftp.fao.org/ docrep/fao/meeting/008/ae144e/ae144e00.pdf, visited on 24 June 2008.

27 These advantages are listed, among others, in Shashi Sareen, 'Food Export Control and Certification', presented at the FAO/WHO Second Global Forum of Food Safety Regulators, GF 02/8a (Food and Agriculture Organization and World Health Organization, Bangkok, Thailand) 12-14 October 2004, available at: ftp://ftp. fao.org/docrep/fao/meeting/008/ j2747e.pdf, visited on 6 November 2004. 
Members therefore need help to establish reliable quality control systems for conformity assessment (such as product testing and certification). ${ }^{28}$ These require well-equipped and adequately staffed laboratories, ${ }^{29}$ which are accredited according to international standards. ${ }^{30}$ For example, as we have seen above, the new EC chemicals regime resulting in setting permissible level of pesticide residues at zero (or the lowest detection level) has raised considerable concerns in Mauritius, which would require substantial laboratory capacity in order to be able to test for all relevant residues. ${ }^{31}$ In addition, a well-functioning export control programme must be in place, involving official inspection and certification bodies $^{32}$ that can undertake inspections, sampling, examinations of records, and audits of establishments and are competent to issue certificates of compliance. ${ }^{33}$

From the above discussion, it appears that technical assistance should be seen broadly. In keeping with this, the WTO Secretariat has developed a typology of technical assistance for purposes of the SPS Agreement including: the provision of information to enhance Members' understanding of their rights and obligations under the SPS Agreement; the provision of practical and detailed training on the operation of the SPS Agreement; the provision of 'soft' infrastructure (training and formation of technical and scientific personnel and the development of national regulatory frameworks); and 'hard' infrastructure (laboratories, equipment, veterinary services and the establishment of disease free areas)..$^{34}$

As recently noted by the UNCTAD Secretariat with regard to technical assistance in the context of the WTO in general:

Developing countries require concrete assistance to build supply capacity... Targeted, comprehensive and high-quality technical assistance and deeper

${ }^{28}$ See Gonzalo K. Ríos 'Technical Assistance Needs of Developing Countries and Mechanisms to Provide Technical Assistance', presented at the Conference on International Food Trade Beyond 2000: Science-Based Decisions, Harmonization, Equivalence and Mutual Recognition (Food and Agriculture Organization of the United Nations, Melbourne, Australia) 11-15 October 1999, para. 39, available at: www.fao.org/docrep/meeting/X2674e.htm, visited on 6 November 1999.

${ }^{29}$ The WHO Regional Office for Africa reports that most public sector laboratories in that region do not have the capacity to test for naturally occurring toxins and chemical contaminants. It notes that 'this may be due to lack of financial resources for the development and maintenance of equipment and manpower.' WHO Regional Office for Africa, 'Developing and Maintaining Food Safety Control Systems for Africa - Current Status and Prospects for Change', presented at the FAO/WHO Second Global Forum of Food Safety Regulators, Conference Room Document 32 (Food and Agriculture Organization and World Health Organization, Bangkok, Thailand) 12-14 October 2004, 5, available at: ftp://ftp.fao.org/docrep/fao/meeting/008/ae144e/ ae144e00.pdf, visited on 24 June 2008.

${ }^{30}$ The International Standardisation Organisation (ISO) has developed standard ISO 17025 for laboratory accreditation. Such internationally recognised standards ensure that the results of laboratory tests are accepted as reliable.

31 The EU's technical assistance efforts, under the Cotonou Agreement, to enable Mauritius to meet the new requirements are noted above Part II, Section 2.5.2.1.

${ }^{32}$ ISO also lays down standards for accreditation of inspection bodies (ISO 17020) and certification bodies (ISO guides 62 and 65). See Shashi Sareen, 'Food Export Control and Certification', presented at the FAO/WHO Second Global Forum of Food Safety Regulators, GF 02/8a (Food and Agriculture Organization and World Health Organization, Bangkok, Thailand) 12-14 October 2004, 11, available at: ftp://ftp.fao.org/docrep/fao/ meeting/008/j2747e.pdf, visited on 6 November 2004.

${ }^{33}$ These and other elements of a good export control system are discussed in Ibid., 3-5.

${ }^{34}$ Committee on Sanitary and Phytosanitary Measures, Technical Assistance Typology: Note by the Secretariat, G/SPS/GEN/206, circulated on 18 October 2000. 
institutional and structural capacity building are important components. They need to be enhanced and to go beyond traditional technical cooperation directed at implementing World Trade Organization (WTO) Agreements by providing for, inter alia, deeper institutional and structural capacity building. ${ }^{35}$

The abovementioned report of the ITC and Commonwealth Secretariat project states:

Without targeted technical assistance based on a sound strategy, and in-country commitment to support the efforts made, it is highly unlikely that developing countries will be able to extract benefits from the existence of the [SPS Agreement]. ${ }^{36}$

Whether the relevant technical assistance provisions of the SPS Agreement meet these needs, must now be examined. Technical assistance provisions are found not only in Article 9, which is entitled 'Technical Assistance', but also in Article 10.4 of the SPS Agreement. ${ }^{37}$ These provisions will now be discussed in turn.

\subsection{Facilitation of provision of technical assistance}

The first general provision addressing technical assistance in the SPS Agreement is found in Article 9.1. Its terms are remarkably weak. Under this provision, Members 'agree to facilitate' the bilateral or multilateral provision of technical assistance to other Members, especially developing countries. According to this Article, such assistance may take various forms, including advice, credits, and grants and donations, and may be in the areas of processing technologies or research and infrastructure, including the creation of national regulatory bodies. Such assistance may also aim at helping developing countries adjust to and comply with SPS measures necessary to achieve the appropriate level of protection in their export markets.

It is difficult to determine what the agreement to facilitate the provision of technical assistance entails. It does not seem to require the actual provision of technical assistance. Instead, it would seem to imply a 'best endeavour' commitment by Members, acting both individually and within international organisations, with regard to a broad range of possible assistance initiatives. Such an open-ended commitment is unlikely to be enforceable through dispute settlement proceedings. As aptly stated by Joanne Scott:

The anaemic quality to the language would seem to be matched by the inadequacy of the provision of technical assistance to date. ${ }^{38}$

35 United Nations Conference on Trade and Development, UNCTAD XI - the Spirit of Sao Paulo, TD/L.382 (United Nations, Sao Paulo), 17 June 2004, para. 3, available at: www.unctad.org/en/docs/TDL382_en/pdf, visited on 1 June 2005.

${ }^{36}$ Vinod Rege et al., Influencing and Meeting International Standards: Challenges for Developing Countries. Volume I: Background Information, Findings from Case Studies and Technical Assistance Needs (International Trade Centre UNCTAD/WTO and Commonwealth Secretariat, Geneva), 2003, 88.

${ }^{37}$ As previously pointed out, despite the fact that Article 10 is entitled 'Special and Differential Treatment' paragraph 4 thereof deals with technical assistance rather than SDT in the narrow sense, as it is used in this Chapter. Thus this paragraph fits better into the discussion in this Section.

38 Joanne Scott, The WTO Agreement on Sanitary and Phytosanitary Measures: A Commentary, Oxford 
Concerns with lack of implementation of technical assistance, particularly for least-developed-country Members, in the run-up to the Doha Ministerial Conference led to the inclusion in the Doha Implementation Decision of a provision urging Members to ensure that technical assistance is provided to least-developed countries to respond to the special problems they face in implementing the SPS Agreement. ${ }^{39}$ This exhortation evinces the importance of the issue but does nothing to operationalise Article 9.1.

\subsection{Technical assistance for compliance with SPS measures}

A more concrete obligation with regard to the provision of technical assistance is contained in Article 9.2 of the SPS Agreement. It refers specifically to the case where the SPS measures put in place by an importing Member necessitate substantial investments in order for a developing-country exporting Member to be able to comply with these measures. In such a case, the importing Member 'shall consider providing' technical assistance that will enable the developing-country Member to maintain and expand its market access opportunities for that product. This provision is therefore framed in mandatory terms. However, the obligation contained therein stops short of requiring Members actually to provide technical assistance.

Instead, in light of the case law on SDT provisions in other agreements discussed above, the obligation in Article 9.2 would seem to be limited to the requirement that the Member imposing the SPS measure requiring substantial investments 'actively consider with an open mind' and 'with a willingness to reach a positive outcome' 40 the provision of technical assistance to allow the affected developing country to maintain of expand its market share in the product. In line with the approach of the Panel in EC-Bed Linen, one could argue that this obligation would be violated by pure passivity on the part of the Member imposing the measure, or the failure of that Member to respond to a request for technical assistance other than by mere rejection of the request. ${ }^{41}$ Such an interpretation would

Commentaries on the GATT/WTO Agreements (Oxford University Press, Oxford), 2007, 297.

${ }^{39}$ Ministerial Conference, Implementation-Related Issues and Concerns. Decision of 14 November 2001, WT/ $\mathrm{MIN}(01) / 17$, circulated on 20 November 2001.

${ }^{40}$ As set out above, Part V, Section 1.1, note 15, the Panel in EC-Bed Linen found that the SDT provision in the Article 15 of the Anti-Dumping Agreement providing that Members 'shall' explore the possibilities of constructive remedies, does not imply a particular outcome. Instead, taken in its context, and in light of its object and purpose, the Panel found the obligation in Article 15 to require that the exploration of possibilities be actively undertaken by the developed-country authorities 'with a willingness to reach a positive outcome'. In other words, it imposes 'an obligation to actively consider, with an open mind, the possibility of such a remedy prior to imposition of an anti-dumping measure that would affect the essential interests of a developing country.' Panel Report, EC-Bed Linen, para. 6.233.

${ }^{41}$ In $E C$ - Bed Linen, the Panel held, '... In our view, the European Communities simply did nothing different in this case, than it would have done in any other anti-dumping proceeding (...) nothing that would demonstrate that the European Communities actively undertook the obligation imposed by Article 15 of the AD Agreement. Pure passivity is not sufficient, in our view, to satisfy the obligation to "explore" possibilities of constructive remedies (...) Thus, we consider that the failure of the European Communities to respond in some fashion other than bare rejection, particularly once the desire to offer undertakings had been communicated to it, constituted a failure to "explore possibilities of constructive remedies", and therefore conclude that the European Communities failed to act consistently with its obligations under Article 15 of the AD Agreement.' Ibid., para. 6.238. This issue was not appealed. 
contribute to the effectiveness of Article 9.2, by ensuring that Members at least give their attention to the possibilities for technical assistance, or risk exposing themselves to challenges under Article 9.2 in dispute settlement proceedings. Still, this remains an obligation of conduct rather than of result.

In an effort to spur implementation of this provision, at least with respect to least-developed-country Members, the Doha Implementation Decision urges Members to provide, to the extent possible, technical and financial assistance to least-developed countries to enable them to respond to new SPS measures that may have significant negative effects on their trade. ${ }^{42}$ Once again, this does little more than focus the attention of Members on the importance of this issue.

\subsection{Technical assistance for participation in international standard-setting}

The issue of developing-country participation in international standard setting is currently at the forefront of policy discussions and reforms in the standard-setting bodies. As noted above, participation in the numerous committees of the international bodies where harmonised standards are initiated, developed and proposed for adoption is onerous. It requires not only financial and human resources for attendance of meetings, but also scientific data and technical capabilities for the formulation of national positions regarding standards of interest to the country. An actively involved private sector is also crucial to provide important inputs for the identification of areas where standards are needed, and the formulation of standards that are feasible and appropriate for national conditions. Deficient developing-country participation in international standard setting, since the coming into force of the SPS Agreement and its use of international standards as benchmarks, has significant implications for developing-country Members. These Members assert that, due to their inability to participate effectively, the standards set by the relevant international bodies do not sufficiently cover areas of interest to them, and do not reflect a level of protection that is realistic or desirable for them.

Although in recent years, the number of developing-country delegates attending meetings of the standard-setting bodies has increased and their participation has been more active, considerable room for improvement remains. This has led to assertions that the standards set by the international bodies do not cover areas of interest for developing countries and do not reflect a level of protection that is realistic or desirable for developing countries.

Already at the time of drafting the SPS Agreement, the importance of improving developing-country participation in international standard setting was recognised. This concern is reflected in Article 10.4, which provides that Members 'should' encourage and facilitate the active participation of developing countries in the relevant international organisations. The 'relevant international organizations' would seem to be a reference to the international standard-setting bodies. ${ }^{43}$ Although it falls under Article 10, which is entitled

${ }^{42}$ Ministerial Conference, Implementation-Related Issues and Concerns. Decision of 14 November 2001, WT/ $\operatorname{MIN}(01) / 17$, circulated on 20 November 2001, para. 3.6(i).

${ }^{43}$ Not all these international standard setting bodies are international organizations in the strict sense of the term. However, the SPS Agreement does seem to regard them as such, as evinced by the wording of Annex A paragraph 3, which in its definition of international standards, guidelines and recommendations, lists the 
'Special and Differential Treatment', this paragraph seems to fit more comfortably into the category of technical assistance provisions. It does not create flexibilities for developing countries, but rather calls for assistance to promote the participation of developing countries in standard setting.

Article 10.4 is addressed to WTO Members, rather than to the international standard setting bodies themselves. This is logical since the WTO agreements can only create obligations for WTO Members and organs. Despite the fact that the SPS Agreement makes use of the standards set by the relevant international standard-setting bodies, these bodies are not under the authority of the WTO but are independent institutions. ${ }^{44}$ Any WTO provisions relating to improving developing-country participation in the standard-setting process in these international bodies must therefore be addressed to WTO Members. These Members may give effect to Article 10.4 in their individual capacities through bilateral technical assistance initiatives, or through efforts undertaken within the relevant standard-setting bodies, in their capacities as members of these bodies.

Like Article 10.2, discussed above, Article 10.4 is couched in hortatory language and the question arises whether any binding obligations can be derived from its terms. The same argument developed above would apply here, to support the interpretation of Article 10.4 in the light of the guiding principle, laid down in Article 10.1, that developing countries interests 'shall' be taken into account in the development and application of SPS measures. International SPS standards can be seen as part of the process of development of SPS measures, as they are required to form the basis of SPS measures adopted by Members, unless deviation can be scientifically justified. Consequently, Article 10.4 should be seen as one concrete indication of the specific action required by the general obligation in Article 10.1. ${ }^{45}$ However, it is unlikely that an enforceable obligation will be derived from the terms of Article 10.4, calling on Members to 'encourage and facilitate' active developing-country participation in standard setting. Since no concrete action is specified, it is to be expected that panels will see this provision as unable to create an obligation for Members as 'Members cannot be expected to comply with an obligation whose parameters are entirely undefined.' ${ }^{46}$

Nevertheless, it should be noted that both individual WTO Members and international organisations, including the standard-setting bodies themselves, are taking steps to address the problem of developing-country participation. ${ }^{47}$ Such efforts seem motivated by the need to ensure the legitimacy and acceptability of the international standards, in the light of the changed situation since the coming into force of the SPS Agreement, rather

three main standard-setting bodies (CAC, OIE, and IPPC) and then provides that 'for matters not covered by the above organizations...' regard may be had to standards, guidelines and recommendations 'promulgated by other relevant international organizations, open for membership to all Members, as identified by the Committee' (emphasis added).

${ }^{44}$ See further on this point above, Part II, Section 3.2.

${ }^{45}$ This would be in line with the approach of the Panel in EC-Tube or Pipe Fittings, where the second sentence of Article 15 was held to provide 'operational indications as to the nature of the specific action required [by the first sentence]'. Panel Report, EC - Tube or Pipe Fittings, para. 7.68.

${ }^{46}$ Panel Report, US - Steel Plate, para. 7.110. This is also in line with the approach of the Panel in EC-Pipe Fittings, discussed above. See Panel Report, EC-Tube or Pipe Fittings, para. 7.68.

${ }^{47}$ Some of these initiatives are set out below, Part V, Section 2.5.2.2. Others are discussed above, Part II, Sections 3.2.1.4, 3.2.1.5, 3.2.2.4, 3.2.3.4 and 3.2.3.5. 
than by any perception of an obligation to do so by Members under Article 10.4 of the SPS Agreement.

The Implementation Decision adopted at the Doha Ministerial Conference, mentioned above, addresses the issue of participation of developing-country Members in international standard setting. In particular, it takes note of the efforts of the WTO DirectorGeneral 'to facilitate the increased participation of members at different levels of development in the work of the relevant international standard setting organizations' and to coordinate with these organisations and financial institutions on the identification and addressing of technical assistance needs. ${ }^{48}$ This refers to the work of the Director General following the request of the General Council in October 2000, ${ }^{49}$ which led, in part, to the establishment of trust funds under the auspices of the three standard-setting bodies, to improve developing-country participation. ${ }^{50}$ The Implementation Decision urges the Director-General to continue his work in this regard, giving priority to LDCs therein. ${ }^{51}$

In this respect, it is important to note the declaration, at the Doha Ministerial Conference, by the Director-Generals of the WTO, FAO, and OIE and the President of the World Bank of their commitment to promote the participation of developing countries in international standard setting. ${ }^{52}$ This work has led to the establishment of the Standards and Trade Development Facility (STDF), a significant achievement which is discussed further below. ${ }^{53}$

\subsection{Provision of technical assistance}

The question arises to what extent WTO Members give effect to the exhortations in Article 9 of the SPS Agreement to provide technical assistance. This issue has particular significance in view of the conclusions drawn from the analysis conducted in the previous Chapter of this book. These indicate that the serious problems faced by developingcountry Members, which make the SPS Agreement of limited benefit to them, cannot be

\footnotetext{
${ }^{48}$ Ministerial Conference, Implementation-Related Issues and Concerns. Decision of 14 November 2001, WT/ MIN(01)/17, circulated on 20 November 2001, para. 3.5(i).

49 The Director-General submitted three reports outlining his work in this area. General Council Special Session on Implementation, Actions to Increase the Participation of Developing Country Members in the Work of Relevant Sanitary and Phytosanitary International Standard-Setting Organizations: Second Report by the Director General, WT/GC/45, circulated on 7 March 2001; General Council, Actions to Increase the Participation of Developing Country Members in the Work of Relevant International Standard-Setting Organizations - Information from Financial Institutions, WT/GC/46/Rev.1, circulated on 16 July 2001; General Council, Actions to Increase the Participation of Developing Country Members in the Work of Relevant Sanitary and Phytosanitary International Standard-Setting Organizations, WT/GC/54, circulated on 7 November 2001. See further Committee on Sanitary and Phytosanitary Measures, Proposals and Progress on Special and Differential Treatment. Note by the Secretariat, G/SPS/GEN/543, circulated on 28 February 2005, para. 49

${ }^{50}$ On the trust funds, see below, Part V, Section 2.5.2.2.

${ }^{51}$ Ministerial Conference, Implementation-Related Issues and Concerns. Decision of 14 November 2001, WT/ MIN(01)/17, circulated on 20 November 2001, para. 3.5(ii).

52 Ministerial Conference, Participation of Developing Countries in the Development and Application of International Standards, Guidelines and Recommendations on Food Safety, Animal and Plant Health, WT/ $\mathrm{MIN}(01) / \mathrm{ST} / 97$, circulated on 11 November 2001.

${ }^{53}$ See below, Part V, Section 2.5.2.4.
} 
addressed through changes to the substantive rules through SDT. Consequently, technical assistance becomes the crucial aspect of any solution to these problems.

A rigorous analysis of the extent and nature of SPS-related technical assistance is currently not possible, due to the fact that data is only partially available. Although efforts have been made to collect data from donors and recipients of technical assistance through questionnaires and to compile such data in technical assistance databases, as discussed below, these efforts are constrained by serious problems of under-reporting. Not only do many instances of technical assistance go unreported, but even reported initiatives suffer from incomplete information. This problem has been highlighted in a recent review of SPS-related technical assistance carried out in the context of the review of the Aidfor-Trade initiative. ${ }^{54}$ Similarly, the WTO Secretariat's most recent overview of reported SPS-related technical assistance mentions under-reporting as a major difficulty it encountered in its efforts to identify accurately SPS-related technical assistance flows. ${ }^{55}$

The provision of technical assistance to developing countries involves several actors, including other WTO Members, the WTO Secretariat, as well as other international organisations and bodies such as the FAO (including with respect to Codex and the IPPC), the WHO, the OIE and the World Bank. A brief overview is provided here of selected technical assistance initiatives at both bilateral and multilateral level. No attempt is made to address all the work currently being done in this area. Instead the objective of the discussion in this section is limited to an effort to illustrate the range and diversity of such initiatives by looking at selected examples.

\subsubsection{Bilateral provision of technical assistance}

Many WTO Members provide SPS-related technical assistance to developing-country Members. Regular reports to the SPS Committee in this regard reflect the diversity of initiatives in this regard. Particular donors tend to focus on regions of particular interest to them. ${ }^{56}$ For example, the US is the largest provider of SPS-related technical assistance to Central American countries accounting for 50 percent of all such assistance granted in 2002-2006. The EC focuses on the ACP region, accounting for 74 percent of SPS-related technical assistance to that region in the same period (or 97 percent if aid by EC Member

\footnotetext{
${ }^{54}$ Committee on Sanitary and Phytosanitary Measures, Background Document from the Standards and Trade Development Facility for the Global Review of Aid for Trade: Note by the Secretariat, G/SPS/GEN/812, circulated on 22 November 2007, paras 16-17.

${ }^{55}$ Committee on Sanitary and Phytosanitary Measures, Overview of SPS-Related Technical Assistance Reported to the WTO/OECD Trade Capacity Building Database. Note by the Secretariat, G/SPS/GEN/726, circulated on 4 October 2006, paras 1-2.

${ }^{56}$ In addition, it is interesting to note that various donors seem to target different categories of beneficiaries in general. For instance, countries with a colonial past, such as the UK and the Netherlands, have been shown to direct a large part their assistance to their former colonies. They also direct much of their bilateral assistance to the poorest countries. In contrast, Japan and the US show a preference for small but relatively well-off countries. Bob Baulch, Aid for the Poorest? The Distribution and Maldistribution of International Development Assistance, CPRC Working Paper No 35 Institute of Development Studies, 2003, available at: http://www. chronicpoverty.org/pdfs/35Baulch.pdf, visited on 10 June 2008.
} 
States is included). ${ }^{57}$ Australia and Canada are the main suppliers of SPS-related technical assistance to certain ASEAN countries. ${ }^{58}$

Donors also tend to concentrate their efforts on particular areas of SPS capacity, sometimes leading to an unbalanced outcome. For example, the assistance provided by Denmark to the fisheries sector in Viet Nam accounted for 27 percent of all SPS-related technical assistance to the region as a whole in 2002-2006. ${ }^{59}$ In some cases, the area of focus relates to the donor's concerns, as an importing country, with particular risks. For instance, Australia's technical assistance tends to focus on plant health issues, whereas Japan and the US concentrate on food safety. ${ }^{60}$ In other cases, donors give priority to projects that help address the SPS restrictions that they themselves impose on access to their markets. ${ }^{61}$ For example, the EC gives most attention to certain thematic areas, namely pesticides, fisheries and animal health. In fact, one of the most successful capacity building projects in Senegal was the upgrading of fisheries production processes to meet EC HACCP requirements. ${ }^{62}$ It has been noted with regard to trade capacity building in general that: '[a] $\mathrm{s}$ the development objectives of developed countries (as donors) overlap with their commercial interests (as trading powers) they may be prone to decide what type of assistance to provide according to their own interests rather than those of the recipient countries. ${ }^{93}$

Another difficulty that arises from bilateral technical assistance, particularly in the area of training for participation in negotiations (for example discussions in the SPS Committee of at the standard-setting bodies), is the indirect influence that may be exerted on the recipient's own goals. ${ }^{64}$ While effective capacity building in this respect should result in the recipient Member being able to formulate and defend its own policy interests, in practice training strongly emphasises issues that are priorities for the donor country. ${ }^{65}$ Further, it is

${ }^{57}$ Committee on Sanitary and Phytosanitary Measures, Background Document from the Standards and Trade Development Facility for the Global Review of Aid for Trade: Note by the Secretariat, G/SPS/GEN/812, circulated on 22 November 2007, paras 18 and 20.

${ }^{58} \mathrm{Ibid}$., para. 24. This study examined ASEAN members Cambodia, Lao PDR and Viet Nam only. Other important bilateral donors to this region are the EC, Japan and Norway.

${ }^{59}$ Ibid., para. 22.

${ }^{60} \mathrm{Ibid}$., para. 24. Wiig and Kolstad note that one of the criteria used by the US in choosing between technical assistance projects is whether the project will improve US public health by increasing the ability to control public health risks associated with products exported to the US. Arne Wiig and Ivar Kolstad, 'Lowering Barriers to Agricultural Exports through Technical Assistance', Food Policy 30, 2005, 185 - 204, 189.

${ }^{61}$ Henri-Bernard Solignac Lecomte and Kathleen Van Hove, Building Capacity to Trade: A Road Map for Development Partners. Insights from Africa and the Caribbean, ECPDM Discussion Paper 33 (European Centre for Development Policy Management and Overseas Development Institute, Maastricht), July 2001, 21, available at: http://www.ecdpm.org/Web_ECDPM/Web/Content/FileStruc.nsf/index.htm?ReadForm\&0F 344E30651892B0C1256C8B0035F9AA, visited on 12 June 2008.

62 Ibid.

63 Ibid.

${ }^{64}$ For example, in April 2007 the US sponsored a workshop for large scale African farmers, policy makers and seed trade association representatives in South Africa to promote the acceptance and development of agricultural biotechnology in Africa. This initiative is reported in the US overview of its technical assistance activities contained in Committee on Sanitary and Phytosanitary Measures, Technical Assistance to Developing Countries Provided by the United States. Submission by the United States. Addendum, G/SPS/ GEN/181/Add.7, circulated on 18 June 2008, 47. The resistance of many African countries to the introduction of biotechnology has been an ongoing concern for the US, whose biotechnology industry needs to recoup large investments in developing biotech products.

${ }^{65}$ Henri-Bernard Solignac Lecomte and Kathleen Van Hove, Building Capacity to Trade: A Road Map for 
difficult for a recipient to defend interests that are in contradiction to those of the donor, when the donor is sitting at the same negotiating table. ${ }^{66}$

As an illustration of bilateral provision of SPS-related technical assistance, Australia's efforts are discussed here. Australia is chosen for practical reasons, since it is the developed-country Member used as an example elsewhere in this book. As a result, some background already exists to the particular SPS concerns and trade interests of Australia.

\subsubsection{Technical assistance by Australia}

In its report on technical assistance submitted to the SPS Committee, Australia states that in the period January 2006 to December 2007, its has provided technical assistance amounting to over $\mathrm{A} \$ 31.4$ million. ${ }^{67}$ This technical assistance took the form of training, information, and the development of both soft and hard infrastructure. ${ }^{68}$

This assistance was provided to 36 individual countries, most of which were Asia-Pacific countries, but a few African and Middle Eastern countries were also included. ${ }^{69}$ Some assistance was also provided to groups of countries or regional organisations, such as the Pacific Island group of countries, ASEAN and APEC.

In its report, Australia lists 90 technical assistance projects. Of these, 50 percent relate to phytosanitary protection. In addition, 16 percent of the projects relate to animal health, 14 percent to food safety, and the remaining 20 percent involve a combination of two or all three of these objectives.

In Australia, technical assistance provision is mainly in the hands of the Commonwealth Government and the State and Territory governments. Within the Commonwealth government, the departments responsible for the provision of SPS-related technical assistance are the same ones who are in charge of SPS protection in Australia, namely the Department of Agriculture, Fisheries and Forestry, the Department of Health and Aging and the Department of Foreign Affairs and Trade. ${ }^{70}$ The technical assistance work of these departments is managed primarily by the Australian Agency for International Development (AusAID), an administratively autonomous agency, and the Australian Centre for International Agricultural Research (ACIAR), a statutory agency. Both of these agencies fall under the foreign affairs and trade portfolio of Australia. AusAID manages about 75 percent of Australia's official development assistance, including its

Development Partners. Insights from Africa and the Caribbean, ECPDM Discussion Paper 33 (European Centre for Development Policy Management and Overseas Development Institute, Maastricht), July 2001, 22, available at: http://www.ecdpm.org/Web_ECDPM/Web/Content/FileStruc.nsf/index.htm?ReadForm\&0F 344E30651892B0C1256C8B0035F9AA, visited on 12 June 2008.

${ }^{66}$ Ibid.

${ }^{67}$ Committee on Sanitary and Phytosanitary Measures, Technical Assistance to Developing Countries Provided by Australia. Addendum, G/SPS/GEN/717/Add.1, circulated on 11 October 2007, para. 2.

${ }^{68}$ Ibid., para. 4. These four categories are taken from the WTO Secretariat's typology of technical assistance. Committee on Sanitary and Phytosanitary Measures, Technical Assistance Typology: Note by the Secretariat, G/SPS/GEN/206, circulated on 18 October 2000.

${ }^{69}$ Committee on Sanitary and Phytosanitary Measures, Technical Assistance to Developing Countries Provided by Australia. Addendum, G/SPS/GEN/717/Add.1, circulated on 11 October 2007, para. 3.

${ }^{70}$ The work of these departments, and the agencies within them, in ensuring SPS protection within Australia has been discussed above, Part II, Section 2.4.2. 
contributions to the Doha Development Agenda Global Trust Fund (which covers also SPS-related activities). ${ }^{71}$

Some examples of technical assistance initiatives undertaken by Australia in 2002-2006 are the following. Research funding has been provided to Bangladesh for plant health management for faba bean, lentils and chickpeas. This aims to enable the examination of diseases, biology and host resistance in these plants through screenings to identify new sources of disease resistance. ${ }^{72}$ Funding research has also been provided to the Philippines to assist in detection surveys for mango seed and pulp weevils. This project aims to increase the areas of mango production in the Philippines certified as free from seed and pulp weevils, to increase export opportunities. ${ }^{73}$ Technical expertise and training has been provided to Papua New Guinea for fruit fly management so as to improve the yield and quality of capsicums, tomatoes, mangoes, papaya, bananas and cucurbits. ${ }^{74}$ In addition, a seminar has been given to developing-country members of the Codex with regard to issues being discussed at the Codex Committee on Food Import and Export Inspection and Certification Systems. ${ }^{75}$

\subsubsection{Multilateral provision of technical assistance}

Many multilateral agencies are involved in the provision of SPS-related technical assistance. The nature and extent of the technical assistance provided at multilateral level varies widely. In order to illustrate the diversity of initiatives in this area, a few examples have been selected here.

The nature of the relevant multilateral agency, its mandate and its technical assistance budget play a role in the type technical assistance provided. Some of these multilateral agencies provide SPS related technical assistance as part of more general trade-related technical assistance activities, as in the case of the WTO. Others, whose work focuses on an SPS-related area, provide technical assistance within their specific area of activity, such as the CAC. In both these cases, technical assistance is not the main activity of the agency involved and therefore has a limited budget and is focused on assisting developing countries to participate effectively in the work of the multilateral body involved, rather than to build SPS capacity in general.

In addition, cooperative initiatives exist between several multilateral agencies which make use of complementarities in their areas of expertise to provide more coherent SPSrelated technical assistance, for example the STDF and the International Portal for Food Safety, Animal and Plant Health (IPFSAPH). These initiatives both have as their focus the improvement of SPS capacity, but they differ greatly in their scope of activity and tools used to build capacity. While the IPFSAPH is an information tool, available to all, but with a particular interest in improving its utility for developing-country users, the STDF is a financing and coordination mechanism for SPS-related capacity building projects.

\footnotetext{
${ }^{71}$ Committee on Sanitary and Phytosanitary Measures, Technical Assistance to Developing Countries Provided by Australia. Addendum, G/SPS/GEN/717/Add.1, circulated on 11 October 2007, para. 13.

${ }^{72}$ Ibid., Table 1.

73 Ibid.

${ }^{74}$ Ibid.

${ }^{75}$ Ibid.
} 
A brief overview of these multilateral initiatives is given below to provide a practical illustration of the nature and extent of some of the SPS-related technical assistance efforts that currently exist at multilateral level.

\subsubsection{Technical assistance by the WTO}

The Doha Development Agenda recognises the importance of technical assistance and capacity building for developing countries in order to enable these Members to benefit fully from the multilateral trading system. For this reason, a Doha Development Agenda Global Trust Fund has been established, to which donor countries pledged CHF 30 million.

The WTO Secretariat regularly provides technical assistance to developing-country Members for the implementation of the SPS Agreement, in particular through training programs organized by the WTO or through WTO participation in training programs organised by other organisations or institutions. ${ }^{76}$ The main objective of SPS technical assistance by the WTO Secretariat is to increase the awareness of participants of their rights and obligations under the SPS Agreement and its implications for their national policies. ${ }^{77}$ Typically, training courses last 3 days, but to meet demands for more advanced SPS training, a three-week SPS Specialised Trade Policy Course has been developed. ${ }^{78}$ From 1 September 1994 to 31 December 2007, the Secretariat has carried out 158 SPS technical assistance and training activities. These have been conducted at national and regional level, and were organised in close cooperation with the three international standard setting bodies, WTO Members and regional organisations where appropriate. ${ }^{79} \mathrm{~A}$ further 37 activities are planned for $2008 .^{80}$

To ensure that the officials that participate in these training activities are the persons responsible for SPS activities within their national administrations and have the expertise to be able to benefit from the training, the Secretariat has developed the practice sending the invitations to the CAC, OIE and IPPC contact points of Members and to their SPS Enquiry Points. ${ }^{81}$ By December 2007, 6,040 persons had received training by the WTO Secretariat on the SPS Agreement, 24 percent of which were from least-developedcountry Members. ${ }^{82}$

${ }^{76}$ For a list of SPS-related technical assistance activities in 2007, see Committee on Sanitary and Phytosanitary Measures, SPS Technical Assistance Activities in 2007. Information from the Secretariat G/SPS/GEN/797, circulated on 5 September 2007.

77 Committee on Sanitary and Phytosanitary Measures, SPS Technical Assistance and Training Activities (1 September 1994 to 31 December 2007). Note by the Secretariat. Revision, G/SPS/GEN/521/Rev.3, circulated on 9 June 2008, para. 2. These workshops are adapted to reflect the level of development of the participants, their familiarity with the SPS Agreement and any specific concerns they may have relating to the implementation of the Agreement.

${ }^{78}$ Ibid., para. 8. The first SPS Specialised Trade Policy Course was held in 2005, and since then one such course has been organised each year.

${ }^{79}$ Of the 158 technical assistance activities, the CAC participated in 65, the OIE in 62 and the IPPC in 52. Ibid., para. 6.

${ }^{80}$ Committee on Sanitary and Phytosanitary Measures, SPS Technical Assistance Activities in 2008. Information from the Secretariat, G/SPS/GEN/851, circulated on 18 June 2008.

${ }^{81}$ Committee on Sanitary and Phytosanitary Measures, SPS Technical Assistance and Training Activities (1 September 1994 to 31 December 2007). Note by the Secretariat. Revision, G/SPS/GEN/521/Rev.3, circulated on 9 June 2008, para. 7.

${ }^{82}$ Ibid., paras 13-14. 
The Secretariat has also developed a number of tools to facilitate developing-country Members' compliance with the SPS Agreement. These include the Handbook on Transparency which provides guidance on the application of the transparency provisions of the SPS Agreement, the booklet on the SPS Agreement published as volume 4 in the WTO Agreements Series, and an interactive CD-rom providing detailed information of the provisions of the SPS Agreement, and dealing in particular implementation, transparency, SDT and dispute settlement issues.

The WTO Secretariat has further attempted to improve its compliance with the technical assistance task laid down for it in Annex B.9. In the context of the second periodic review of the SPS Agreement, New Zealand indicated its support for a Secretariat proposal in June 2004 for the creation of a user-friendly database on notified SPS measures, which it felt could form a meaningful implementation of the Secretariat's obligations under Annex B.9. ${ }^{83}$ The report of the SPS Committee on the second review of the SPS Agreement states that the Secretariat has initiated such an SPS IMS. ${ }^{84}$ The SPS IMS is a comprehensive source for searching for information on SPS measures.$^{85}$ It allows users to obtain information on SPS measures that Members have notified to the WTO, specific trade concerns raised in the SPS Committee, official WTO documents circulated by the SPS Committee, and details of Members' national enquiry points and national notification authorities.

The WTO's work on technical assistance in general also has an impact on SPS-related technical assistance. The new WTO work programme on Aid-for-Trade, ${ }^{86}$ launched in the Hong Kong Ministerial Conference in $2005,{ }^{87}$ points to the challenges posed by developing countries' supply side constraints for their ability to benefit from the multilateral trading system and implement the WTO agreements. It notes the need for aid-for-trade to address this problem, as a valuable complement to the Doha Development Agenda. A task force was created to provide recommendations on how to operationalise aid-for-trade and to increase financial resources for aid-for-trade. This task force recommended that the WTO fulfil a monitoring and evaluation role consisting of annual reviews and debates on aid-for-trade. ${ }^{88}$ The Global Review of Aid-for-Trade conducted in November 2007 aimed to take stock of what is - and what is not - happening in the delivery of aid-for-trade, ${ }^{89}$

${ }^{83}$ Committee on Sanitary and Phytosanitary Measures, The Second Review of the Operation and Implementation of the SPS Agreement. Further Elaboration of Issues for Consideration by New Zealand, G/SPS/W/157, circulated on 12 October 2004, para. 7.

${ }^{84}$ Committee on Sanitary and Phytosanitary Measures, Review of the Operation and Implementation of the Agreement on the Application of Sanitary and Phytosanitary Measures. Report Adopted by the Committee on 30 June 2005, G/SPS/36, circulated on 11 July 2005, para. 31.

${ }^{85}$ The SPS IMS is available at: http://spsims.wto.org, visited on 12 June 2008

${ }^{86}$ For more information on the Aid-for-Trade work programme, see the dedicated page on the WTO website, available at: http://www.wto.org/english/tratop_e/devel_e/a4t_e/aid4trade_e.htm, visited on 10 June 2008.

${ }^{87}$ Ministerial Conference, Doha Work Programme. Ministerial Declaration Adopted on 18 December 2005, WT/MIN(05)/DEC, circulated on 22 December 2005, para 57.

${ }^{88}$ The monitoring takes place at three levels: global monitoring by the OECD; donor monitoring, in the form of self-evaluations; and in-country monitoring, also in the form of self-assessments. These aspects are brought together in an annual report and an Aid-for-Trade debate in the WTO General Council.

${ }^{89}$ In terms of financial resources, the OECD and the WTO assessed that donors have committed US\$21 billion per year to the aid categories more closely associated with aid-for-trade in 2002-2005. Of this, around US\$11.2 billion was allocated to building economic infrastructure, US\$8.9 billion to promoting productive capacities (including US\$2 billion for trade development), and US\$0.6 billion to increasing the understanding and implementation of trade policy and regulations. At the Hong Kong Ministerial Conference in 2005, the EU, the 
to identify the next steps and to improve monitoring and evaluation by the WTO. It is expected that the Aid-for-Trade initiative will improve the effectiveness and coherence of technical assistance and increase beneficiary ownership of assistance projects. ${ }^{90}$ This work programme will have implications for SPS-related technical assistance.

To improve transparency with regard to the provision of technical assistance, the Doha Development Agenda Trade Capacity Building Database (TCBDB) has been created by the WTO jointly with the OECD. ${ }^{91}$ It aims to promote information-sharing so as to improve coordination and coherence in capacity building projects and avoid duplication of efforts. The projects covered are not limited to SPS-related technical assistance but extend to all trade-related technical assistance and capacity building projects, both at national and at regional level. Data is obtained from reports of bilateral donors and multilateral/regional agencies. However, as noted above, under-reporting is a serious problem. The WTO Secretariat has noted that, for example, data reported for one Member in the TCBDB showed only 8 SPS-related technical assistance projects in 2001-2003, whereas it had notified the SPS Committee of 115 projects in 2000-2002.92 As a result of this discovery, the TCDBD has been extended by additional entries on the basis of the submissions of Members and Observers to the SPS Committee.

The Secretariat's work in the area of SPS-related technical assistance is very useful, particularly due to its extensive expertise in substantive and institutional aspects of WTO law. It is therefore particularly well-placed to assist developing-country Members to understand their rights and obligations under the SPS Agreement and to develop mechanisms, such as the SPS IMS, to promote the sharing of information among WTO Members. However, the early technical assistance efforts of the Secretariat were criticised as being focused on quantity rather than quality and lacking coordination with national capitals. ${ }^{93}$ In addition, at first the technical assistance work of the Secretariat was largely dependant on ad hoc extra-budgetary contributions, undermining its sustainability and predictability. ${ }^{94}$ In 2001, a 'new strategy' for WTO technical assistance was announced, to address

US, and Japan committed themselves to increasing aid-for-trade spending, which they reaffirmed later. 'WTO Global Review puts 'Spotlight' on Aid-for-Trade', Bridges Weekly Trade New Digest, 28 November 2007.

${ }^{90}$ However, it is reported that Anne-Laure Constantin, of the Institute for Agriculture and Trade Policy, was critical about the WTO's work on aid-for-trade, stating: 'After two years, there is still no clearly accepted definition of what counts as an aid-for-trade initiative, no guidelines for accessing funds, only a questionable list of priorities, no effective monitoring and evaluation mechanisms, and none of the promised additional money.' 'WTO Global Review puts 'Spotlight' on Aid-for-Trade', Bridges Weekly Trade New Digest, 28 November 2007.

${ }^{91}$ The TCBDB is available at: http://tcbdb.wto.org/index.aspx?lg=EN, visited on 13 June 2008.

${ }^{92}$ Committee on Sanitary and Phytosanitary Measures, Overview of SPS-Related Technical Assistance Reported to the WTO/OECD Trade Capacity Building Database. Note by the Secretariat, G/SPS/GEN/726, circulated on 4 October 2006, para. 2.

${ }_{93}$ Committee on Trade and Development, Technical Cooperation Audit Report for 2002: Note by the Secretariat, WT/COMTD/W/111, circulated on 28 March 2003, para. 49.

${ }^{94}$ Kostecki points out that this situation encourages a 'hit-and-run' approach, with too much emphasis on one-off seminars and insufficient efforts to ensure the sustainability of the capacities created. In addition, sometimes the donors of extra-budgetary funds determine the allocation of the resources they provide, making it difficult to apply a coherent technical assistance strategy. Michel Kostecki, Technical Assistance Services in Trade-Policy: A Contribution to the Discussion on Capacity-Building in the WTO, Resource Paper No. 2 (International Centre for Trade and Sustainable Development, Geneva), November 2001, 18, available at: www.ictsd.org/pubs/respaper/TApaper5-12-01.pdf, visited on 12 May 2002. 
the prevailing problems. ${ }^{95}$ This strategy aims at moving from traditional 'technical assistance' towards 'capacity building' by becoming more demand driven, coherent and flexible. The financial stability needed to undertake projects in a predictable manner, ${ }^{96}$ has improved with the creation of the Doha Development Agenda Global Trust Fund in 2002. ${ }^{97}$ However, it is still insufficient to undertake large-scale projects. The Hong Kong Ministerial Declaration calls on strengthening the WTO Secretariat structures for traderelated capacity building and enhancing its resources. It reaffirms the commitment of Members to secure and adequate funding for trade-related capacity building, including in the Doha Development Agenda Global Trust Fund, to complete the Doha work programme and to implement its results. ${ }^{98}$

However, it should be noted that the role of the WTO Secretariat in the provision of SPS-related technical assistance is necessarily limited, even if its resources were to be sufficiently increased. As argued by Gregory Shaffer, this limitation lies in the manner in which the Secretariat sees its role in the context of the WTO's view of itself as a 'memberdriven' institution. Traditionally, this has meant that the Secretariat's task is limited to servicing the Member's activities in the various WTO organs and promoting implementation of the agreed rules, rather than policy formulation. This approach filters through to the Secretariat's technical assistance activities, which aim to promote compliance with WTO disciplines rather than to assist beneficiary Members to 'critically engage with the rules in light of their perceptions of their national interests. ${ }^{\text {'99 }}$ Even the 'new strategy' for technical assistance reiterates the traditional approach, stating: 'The core mandate of the WTO is trade liberalization ... WTO technical assistance is a key component of the development dimension of the multilateral trading system ... It provides enabling assistance for Members to undertake trade liberalization... It involves support by the Secretariat ... to assist them in understanding WTO rules and disciplines.' ${ }^{100}$

While the Secretariat's work in providing training with regard to the implementation and operation of the SPS Agreement is invaluable, other multilateral bodies, in particular the three international standard-setting bodies (CAC, OIE and IPPC) as well as the World

95 Committee on Trade and Development, A New Strategy for WTO Technical Cooperation: Technical Cooperation for Capacity Building, Growth and Integration. Note by the Secretariat, WT/COMTD/W/90, circulated on 21 September 2001.

96 The WTO Technical Assistance Plan costs around CHF 30 million to implement. Of this CHF 6 million is financed from the regular WTO budget and CHF24 million from extra budgetary funding.

${ }_{97}$ The Doha Development Agenda Global Trust Fund receives the extra-budgetary contributions of Members and uses them towards implementation of the Technical Assistance Plan. It is operated against periodic benchmarks, under the strict supervision of the Committee on Budget Finance and Administration and the Committee and Trade and Development.

98 Ministerial Conference, Doha Work Programme. Ministerial Declaration Adopted on 18 December 2005, WT/MIN(05)/DEC, circulated on 22 December 2005, para. 54.

99 Gregory Shaffer, 'Can WTO Technical Assistance and Capacity-Building Serve Developing Countries?' Wisconsin International Law Journal, 2005, 656. Shaffer states that if WTO Secretariat officials in their technical assistance activities simply promote existing WTO rules, '[t]hey cut off what could be a valuable discussion, in meetings with those most up-to-date about WTO developments, as to how developing countries can shape the rules through implementation and renegotiation in order to advance trade related development objectives.' Ibid.

100 Committee on Trade and Development, A New Strategy for WTO Technical Cooperation: Technical Cooperation for Capacity Building, Growth and Integration. Note by the Secretariat, WT/COMTD/W/90, circulated on 21 September 2001, para. 1. 
Bank, FAO and WHO, with which the WTO cooperates closely, and regional organisations (such as IICA and OIRSA) ${ }^{101}$ are better suited to the provision of technical assistance in areas requiring scientific or technical expertise, such as building regulatory systems or strengthening infrastructure in the SPS sector. ${ }^{102}$ Improved national SPS capacity empowers Members not only to implement and enforce the existing rules of the SPS Agreement but also to engage as active participants in framing the norms within which this system operates. ${ }^{103}$

\subsubsection{Technical assistance by the Codex Alimentarius Commission}

The FAO/WHO Project and Fund for Enhanced Participation in Codex (commonly known as the Codex Trust Fund) was launched in February 2003 during the $25^{\text {th }}$ (Extraordinary) Session of the Codex Alimentarius Commission. It was created to help developing countries and countries with transition economies improve their level of effective participation in Codex standard setting. ${ }^{104}$ Further, such active participation was recognised by CAC members as enhancing the ability of countries to develop their food safety systems and thereby improve public health and promote food trade. ${ }^{105}$

The Codex Trust Fund seeks funding from national governments, multilateral organisations, private foundations and trusts that do not create conflicts of interests. It requires an estimated US\$40 million over a 12-year period to meet its objectives. It became operational in March 2004, upon reaching the agreed minimum level of funding (US\$ 500 000), ${ }^{106}$ and has since received additional contributions. ${ }^{107}$ The funding is administered by the WHO on behalf of both the WHO and FAO. ${ }^{108}$

${ }^{101}$ IICA is the Inter-American Institute for Cooperation on Agriculture and OIRSA is the International Regional Organization for Plant and Animal Health.

102 On this point, see also Michel Kostecki, Technical Assistance Services in Trade-Policy: A Contribution to the Discussion on Capacity-Building in the WTO, Resource Paper No. 2 (International Centre for Trade and Sustainable Development, Geneva), November 2001, 12, available at: www.ictsd.org/pubs/respaper/ TApaper5-12-01.pdf, visited on 12 May 2002.

${ }^{103}$ Here it is useful to recall the opportunities to participate in developing relevant norms in the form of international standards relevant to the SPS Agreement, as discussed above, Part II, Sections 3.2.1.5, 3.2.2.5 and 3.2.3.5; and in the form of non-binding procedural rules drafted by the SPS Committee for the operationalisation of provisions of the SPS Agreement, as discussed above, Part IV, Section 2.1.1.

${ }^{104}$ In the Codex Alimentarius Commission's Strategic Framework, adopted at its $24^{\text {th }}$ Session in 2001, the issue of improving developing-country participation was included as an objective. See Codex Alimentarius Commission, Report of the Twenty-Fourth Session, ALINORM 01/41 (Joint FAO/WHO Food Standards Programme, Geneva), 2-7 July 2001, Appendix II, 16. The objectives of the Strategic Framework were to be implemented through a Medium Term Plan for 2003-2007.

105 FAO/WHO Project and Fund for Participation in Codex, Annual Report for 2004 (Food and Agriculture Organization and World Health Organization, Geneva), December 2004, 1.

106 Codex Alimentarius Commission, FAO/WHO Project and Fund for Enhanced Participation in Codex. Second Progress Report to the 26th Session of the Codex Alimentarius Commission, 30 June - 7 July 2003, ALINORM 03/26/12 (Joint FAO/WHO Food Standards Programme, Rome), May 2003, para. 17, available at: http://www.who.int/ foodsafety/codex/en/prog2e.pdf, visited on 25 June 2007.

${ }^{107}$ During the period from January 2003 to December 2007, a total of US\$ 5,485,396 was received as contributions from 12 high-income CAC member countries and the European Community. For the first time in 2008, a Codex member classified as an upper middle income economy, Malaysia made a contribution (US\$10 000) to the Codex Trust Fund. It has benefited from the Codex Trust Fund support in the past.

108 The administration of funding is conducted through the WHO's Voluntary Fund for Health Promotion, but separate financial records and reporting are maintained for the Codex Trust Fund. See FAO/WHO Project and Fund for Participation in Codex, Annual Report for 2004 (Food and Agriculture Organization and World 
Guidance for the operation of the Codex Trust Fund is in the hands of a Consultative Group on the Trust Fund (CGTF), composed of senior officials of the FAO and WHO. ${ }^{109}$ The CGTF gives strategic guidance to the Fund, establishes guidelines and criteria for its activities, and monitors their implementation. ${ }^{110}$ Further, the CGTF is responsible for ensuring coherence and complimentarity between the Codex Trust Fund and other international funding mechanisms in the area, including the Standards and Trade Development Facility, the FAO Trust Fund for Food Security and Food Safety and the FAO Integrated Programme for Building Capacity for Biotechnology, Food Quality and Safety and Phyto- and Zoosanitary Standards. The CGTF also annually reviews eligibility of Codex members to apply for support from the Codex Trust Fund.

The eligibility of Codex members for support is based on three official classifications: ${ }^{111}$ the list of LDCs produced by the UN Economic and Social Council; ${ }^{112}$ the World Bank classification of countries according to income level; ${ }^{113}$ and the UN Human Development Index. ${ }^{14}$ Since not all Codex members appear on each of these lists, the CGTF drew up a list combining the three classifications. ${ }^{115}$ The financial resources of the Fund are

Health Organization, Geneva), December 2004, 1. The internal and external auditing procedures provided for in the WHO Financial Regulations and Rules apply to the Codex Trust Fund. See Codex Alimentarius Commission, FAO/WHO Project and Fund for Enhanced Participation in Codex. First Progress Report to the 25th (Extraordinary) Session of the Codex Alimentarius Commission, 13-15 February 2003, ALINORM 03/25/4 (Joint FAO/WHO Food Standards Programme, Geneva), January 2003, para. 6, available at: http:// www.who.int/foodsafety/codex/en/progle.pdf, visited on 25 June 2007.

${ }^{109}$ Codex Alimentarius Commission, FAO/WHO Project and Fund for Enhanced Participation in Codex. First Progress Report to the 25th (Extraordinary) Session of the Codex Alimentarius Commission, 13-15 February 2003, ALINORM 03/25/4 (Joint FAO/WHO Food Standards Programme, Geneva), January 2003, para. 5, available at: http://www.who.int/foodsafety/codex/en/prog1e.pdf, visited on 25 June 2007.

110 Ibid., para. 11.

111 The original proposal by the CGTF was to use only the World Bank income classification. However, in response to comments made by Codex members regarding the desirability of taking into account factors other than purely economic ones, this was revised to include the three classifications mentioned below.

112 As set out above, Part I, Section 1.2, note 54, this classification lists countries regarded as LDCs based on criteria reflecting low income, weak human resources and economic vulnerability.

113 The World Bank classification of countries on the basis of GNI per capita into low-income, lower-middle income, upper-middle income and high-income countries is set out above Part II, Section 2.1. The CGTF reconsidered the use of the World Bank income classification, on the basis of comments received regarding other comparable classifications (such as the OECD's DAC list of recipients), and noted in its second progress report that there were no significant differences in these lists, and that the World Bank list was more appropriate for use in the context of the UN system. It was further decided that countries in the categories low-income, lower-middle income and upper-middle income would be considered eligible for support from the Codex Trust Fund, but low-income countries would be favoured as donors both wish to increase the participation of low-income countries and to improve the representativeness of Codex as an institution. See Codex Alimentarius Commission, FAO/WHO Project and Fund for Enhanced Participation in Codex. Second Progress Report to the 26th Session of the Codex Alimentarius Commission, 30 June - 7 July 2003, ALINORM 03/26/12 (Joint FAO/WHO Food Standards Programme, Rome), May 2003, paras 3-4, available at: http://www.who.int/foodsafety/codex/en/prog2e.pdf, visited on 25 June 2007.

${ }^{114}$ The Human Development Index of the UNDP divides countries into the categories low, medium and high human development based on the criteria of life expectancy, adult literacy rate and educational enrolment ratio, and standard of living as reflected by per capita GDP. This is further elaborated above, Part II, Section 2.2.

115 This list divides Codex members into three groups, two of which as subdivided, as follows: Group 1A: LDCs; Group 1B: Other low-income countries, listed as low-income countries by the World Bank or as low human development countries by the UNDP; Group 2: Countries listed as lower-middle income countries by the World Bank or as medium human development countries by the UNDP; Group 3A: Countries listed as upper-middle income countries by the World Bank and medium human development by the UNDP; and 
distributed among the resulting three groups according to an agreed ratio. ${ }^{116}$ Between applicant countries within the same group, funds are distributed equitably. ${ }^{117}$ In 2008 , 133 of the 176 Codex members were considered eligible for support, including all three developing countries selected as case studies in this book. ${ }^{118}$

In addition, all applicants for funding must meet the following four basic requirements: ${ }^{119}$ (1) the country must be a Codex member; (2) the country must have identified a Codex Contact Point; ${ }^{120}$ (3) the application must outline national objectives in the framework of Codex; ${ }^{121}$ and (4) coordination between government entities must be demonstrated. ${ }^{122}$ For applications for continued funding, an additional requirement applies: (5) the country must have submitted a written report and evaluation of progress towards the objectives identified in (3) above, within two months of the relevant meeting. It has been recog-

Group 3B: Countries listed as upper-middle income countries by the World Bank. All other countries (i.e. those listed as either high-income countries by the World Bank or high human development countries by the UNDP are not eligible for support from the Codex Trust Fund. See Codex Alimentarius Commission, FAO/ WHO Project and Fund for Enhanced Participation in Codex. Third Progress Report to the 53rd Session of the Executive Committee of the Codex Alimentarius Commission, 4-6 February 2004, CX/EXEC 04/53/3 (Joint FAO/WHO Food Standards Programme, Geneva), December 2003, paras 9-10, available at: http:// www.who.int/foodsafety/codex/en/prog3e.pdf, visited on 25 June 2007.

${ }^{116}$ Available funds will be allocated as follows: Group 1: 60\%, Group 2: 30\% and Group 3: 10\%. See Ibid., Table 1. Originally a further allocation was made according to the category of output for which the funding was requested. However, this element was dropped from the application form due to the difficulty experienced by applicant countries in organising their requests according to output categories. See Codex Alimentarius Commission, FAO/WHO Project and Fund for Enhanced Participation in Codex. Fourth Progress Report to the 27th Session of the Codex Alimentarius Commission, 28 June - 3 July 2004, ALINORM 02/27/10F (Joint FAO/WHO Food Standards Programme, Geneva), May 2004, para. 17, available at: http://www.who. int/foodsafety/codex/en/prog4e.pdf, visited on 25 June 2007.

117 Making choices between various group members was regarded as undesirable, and all eligible applicant countries should obtain at least their priority request, depending on the availability of funding.

118 FAO/WHO Project and Fund for Participation in Codex, Countries Eligible to Apply for Support in 2006 (Food and Agriculture Organisation and World Health Organization, Rome), 17 June 2005.

${ }^{119}$ Codex Alimentarius Commission, FAO/WHO Project and Fund for Enhanced Participation in Codex. Third Progress Report to the 53rd Session of the Executive Committee of the Codex Alimentarius Commission, 4-6 February 2004, CX/EXEC 04/53/3 (Joint FAO/WHO Food Standards Programme, Geneva), December 2003, Annex 1, available at: http://www.who.int/foodsafety/codex/en/prog3e.pdf, visited on 25 June 2008.

${ }^{120}$ The identification of a Codex Contact Point is considered crucial as it is the only point of access to the country that can be used by the Trust Fund Secretariat, due to the fact that Codex issues cut across sectors and areas of responsibility of government ministries. For this reason, for funding requests for 2005 and onwards, only applications submitted by a Codex Contact Point will be considered. Codex Alimentarius Commission, FAO/WHO Project and Fund for Enhanced Participation in Codex. Fourth Progress Report to the 27th Session of the Codex Alimentarius Commission, 28 June - 3 July 2004, ALINORM 02/27/10F (Joint FAO/WHO Food Standards Programme, Geneva), May 2004, para. 10, available at: http://www.who. int/foodsafety/codex/en/prog4e.pdf, visited on 25 June 2007.

121 The CGTF has outlined certain requirements for funding of suitable activities, other than travel to Codex meetings, which must be met if a country wishes to be eligible for support for that activity from the Codex Trust Fund. It has dropped the requirement that activities fall within the three 'output level' categories initially identified, due to the difficulty applicants experienced in organising their requests according to these categories. See Ibid., paras 12-17.

${ }^{122}$ Compliance with this requirement is strictly enforced, and may in no case be waived. This is due to the fact that one of the major objectives of the Codex Trust Fund is the improvement of coordination and communication between the relevant stakeholders and increasing multidisciplinarity. This has proved to be the most difficult requirement to meet, and in some cases several funding applications were received from different government bodies, listing different proposed participants. Ibid., para. 8 . 
nised that some countries may need financial support to enable them to meet the basic requirements mentioned above. Such countries only have to meet requirement (1).

In 2007, the Codex Trust Fund was used to support the attendance of a total of 224 participants from 96 countries of 16 Codex meetings. ${ }^{123}$ For the period January to December 2008, the participation in CAC meetings by 314 participants from 96 countries is being supported by the Fund. Of the latter participants, 64 percent are from LDCs and other low-income countries, 33 percent from lower-middle income countries and 3 percent from upper-middle income countries. ${ }^{124}$

From its inception until the end of 2007, the Codex Trust Fund enabled around 750 participants from almost 100 developing countries to attend over than $60 \mathrm{CAC}$ meetings. ${ }^{125}$ Further, 111 persons from 72 countries participated in the Codex training programme. ${ }^{126}$ This is expected to assist them to participate more actively in CAC meetings. Leastdeveloped countries and other low-income countries have received about 60 percent of the support provided. ${ }^{127}$ As noted in a recent evaluation of the Trust Fund, their delegates would probably have been unable to participate in these meetings without its support. ${ }^{128}$ In respect of the three developing-country Members used as illustrations in this book, applications for funding have been received by all three and the Codex Trust Fund has funded the attendance of participants from Jamaica to three meetings of various Codex committees. ${ }^{129}$ No participants from Mauritius or Bangladesh have been supported thus far. $^{130}$

Countries that are beneficiaries of the Codex Trust Fund are expected to conduct national consultations and research prior to the relevant meeting, be present and participate in the whole meeting, report back to interested parties at the national level after the meeting, and, as set out above, are required, as a precondition for further funding, to submit a written report following a prescribed format to the Trust Fund Secretariat, as well as their national Codex Contact Point and interested parties, within two months of the meeting.

${ }^{123}$ Codex Alimentarius Commission, FAO/WHO Project and Trust Fund for Enhanced Participation in Codex. Report Prepared by the WHO Secretariat for the Trust Fund, ALINORM 08/31/9F (Joint FAO/WHO Food Standards Programme, Geneva), May 2008, 2. These were selected from 103 applications, of which eight could not be retained, three were received after the deadline (Egypt, Guyana, Romania), three were from countries that were not Codex members (Comoros, Palau and Tajikistan) and two were from noneligible countries (Cyprus and Qatar). The remaining 95 applications included applications from Mauritius, Bangladesh and Jamaica, and were considered for funding in 2004.

124 Ibid., 18.

${ }^{125}$ Stuart A. Slorach, Enquiry Concerning the FAO/WHO Project and Trust Fund for Enhanced Participation in Codex ("Codex Trust Fund") (Swedish International Development Cooperation Agency, Stockholm), 12 October 2007, ix, available at: http://www.who.int/foodsafety/codex/Slorach_report.pdf, visited on 10 June 2008.

126 Ibid.

127 Ibid.

${ }^{128}$ Ibid., 19.

${ }^{129}$ Codex Alimentarius Commission, FAO/WHO Project and Trust Fund for Enhanced Participation in Codex. Report Prepared by the WHO Secretariat for the Trust Fund, ALINORM 08/31/9F (Joint FAO/WHO Food Standards Programme, Geneva), May 2008, 13-16, 21.

${ }^{130}$ Stuart A. Slorach, Enquiry Concerning the FAO/WHO Project and Trust Fund for Enhanced Participation in Codex ("Codex Trust Fund") (Swedish International Development Cooperation Agency, Stockholm), 12 October 2007, 51, available at: http://www.who.int/foodsafety/codex/Slorach_report.pdf, visited on 10 June 2008 . 
As of 31 December 2007, 73 reports had been submitted by beneficiary countries (a compliance rate of 76 percent). The standard of reporting is variable. Only a few countries submit high quality reports that follow the standard reporting format. Other countries do not follow the reporting format and/or do not provide sufficient information that would allow the Codex Trust Fund to exploit this information to track progress in enhancing participation in the CAC. Member countries that did not comply with reporting obligations are not eligible for support in 2008. ${ }^{131}$

In 2004, being the first year of operation of the Codex Trust Fund, it was decided to fund only participation in Codex meetings. However, it has been recognised that other activities that contribute to improved participation should be eligible for funding as well. The CGTF set out an initial list of suitable activities, including training, guidance on setting up a Codex Contact Point, and support for taking on regional responsibilities. ${ }^{132}$ Aside from applications for support to attend Codex meetings, some countries have requested support for capacity building by means of training. A Codex Training Package was developed using contributions from Canada and Switzerland and it was field tested in Tanzania in March 2004. It was used to conduct regional training courses on the Codex. ${ }^{133}$ In the period from its establishment in 2004 until 2007, 80 percent of the resources of the Trust Fund have been used to fund participation in Codex meetings, eight percent to fund Codex training activities and 12 percent for administrative costs. ${ }^{134}$

The operation and impact of the Codex Trust Fund can be evaluated on the basis of the comments made in the reports received from beneficiaries. These were summarised by the Codex Secretariat in 2004. ${ }^{135}$ Several of these reports indicated that the relevant delegate was a first-time participant in Codex meetings, and that much work remained to be done in his or her country as a result of lack of experience in CAC work, weak national food-safety legislation and infrastructure, lack of political awareness of the importance of the CAC for international trade, and capacity constraints with regard to implementation of Codex standards. ${ }^{136}$ Other reports reflected significant existing understanding of and participation in CAC work, and highlighted the contribution of the Trust Fund support

${ }^{131}$ Codex Alimentarius Commission, FAO/WHO Project and Trust Fund for Enhanced Participation in Codex. Report Prepared by the WHO Secretariat for the Trust Fund, ALINORM 08/31/9F (Joint FAO/WHO Food Standards Programme, Geneva), May 2008, 3.

132 Codex Alimentarius Commission, FAO/WHO Project and Fund for Enhanced Participation in Codex. Fourth Progress Report to the 27th Session of the Codex Alimentarius Commission, 28 June - 3 July 2004, ALINORM 02/27/10F (Joint FAO/WHO Food Standards Programme, Geneva), May 2004, paras 12-16, available at: http://www.who.int/foodsafety/codex/en/prog4e.pdf, visited on 25 June 2007.

${ }^{133}$ Codex Alimentarius Commission, FAO/WHO Project and Fund for Enhanced Participation in Codex. Fifth Progress Report (January-June 2005), to the 28th Session of the Codex Alimentarius Commission, 4-9 July 2005, CAC/28 INF/12 (Joint FAO/WHO Food Standards Programme, Rome), June 2005, para. 5, available at: http://www.who.int/foodsafety/codex/en/prog5e.pdf, visited on 25 June 2007.

${ }^{134}$ Stuart A. Slorach, Enquiry Concerning the FAO/WHO Project and Trust Fund for Enhanced Participation in Codex ("Codex Trust Fund") (Swedish International Development Cooperation Agency, Stockholm), 12 October 2007, 11, available at: http://www.who.int/foodsafety/codex/Slorach_report.pdf, visited on 10 June 2008.

135 FAO/WHO Project and Fund for Participation in Codex, Reported Issues Drawn from 24 Supported Participants' Reports (March - July 2004) (Food and Agriculture Organisation and World Health Organization, Geneva), 2004.

${ }^{136}$ FAO/WHO Project and Fund for Participation in Codex, Annual Report for 2004 (Food and Agriculture Organization and World Health Organization, Geneva), December 2004, 3. 
to increasing broad government participation and improving the level of coordination of country positions. ${ }^{137}$ Other benefits of Codex Trust Fund support identified in beneficiary reports included better understanding of $\mathrm{CAC}$ work and the roles and responsibilities of member countries; improved understanding of CAC documents and of the positions of different countries; the opportunity to establish networks with technically experienced colleagues from other countries; the possibility to interact with other countries and within regions to establish common positions; increased knowledge of how standards impact on food safety and trade; and increased impetus for the development of national food safety legislation based on Codex standards. ${ }^{138}$

Three issues emerge from beneficiaries' reports as requiring attention. First, timely approval of applications is crucial to enable participants to make the necessary practical arrangements. Last minute approvals have led to problems with visas and travel arrangements. Second, and related to the above, participants need sufficient time before a meeting to prepare properly and develop a national position, including the collection of the necessary scientific and factual data. Third, the need has been identified to link Trust Fund support to support for policy development, capacity building and training activities, regional activities, and implementation of Codex standards. ${ }^{139}$

Two studies evaluating the Codex Trust Fund were undertaken in 2007. One, entitled Initiative to Explore Linkages between Increased Participation in Codex and Enhanced International Food Trade Opportunities was financed by Department for International Development (DFID) of the UK. ${ }^{140}$ Its preliminary findings and recommendations were circulated at the 30th Session of the Codex Alimentarius Commission in July 2007. This report found that the Codex Trust Fund has contributed significantly to increased participation of persons from eligible countries in Codex standard-setting. However, the report notes that it is too early to tell if countries will be able to sustain their participation in Codex activities that address health and economic issues that are priorities for them. ${ }^{141}$ Some progress has been made through ensuring the delivery of Codex training to strengthen participation in Codex. The study recommends, however, more in-country support before and after Codex meetings to strengthen the capacity of the regulatory system. The Trust Fund has been weak in enhancing the scientific or technical ability of countries to participate in Codex. ${ }^{142}$ Without effective participation on technical level,

${ }^{137}$ Ibid.

138 FAO/WHO Project and Fund for Participation in Codex, Reported Issues Drawn from 24 Supported Participants' Reports (March - July 2004) (Food and Agriculture Organisation and World Health Organization, Geneva), 2004, para. 1.

139 Ibid., para. 2.

${ }^{140}$ Robert J. Connor, Initiative to Explore Linkages between Increased Participation in Codex and Enhanced International Food Trade Opportunities. Final Report, Project number RNRAT 012 (Department for International Development, Geneva), August 2007, available at: http:/www.who.int/foodsafety/codex/ Connor report.pdf, visited on 10 June 2008.

${ }^{141}$ The report notes: 'It is unlikely that small island developing states (SIDS) would sustain funding the routine participation of their national delegates in Codex meetings because of the proportional high cost to their national budgets.' Ibid., 15.

${ }^{142}$ The report states; 'Although it is an important objective of the Codex Trust Fund to assist the generation of scientific data to support the development of new Codex standards, there was a widespread view that there had been negligible progress in this area. A number of respondents mentioned the lack of support from the Codex Trust Fund for the development of national food control systems or national position papers, although 
including through submission of relevant scientific data, developing countries cannot obtain Codex standards in areas they need. The report notes the following example:

Australian maximum permissible concentration (MPC) for arsenic in foods has been set for total arsenic only - at $1 \mathrm{mg} / \mathrm{kg}$ - which does not take into account the great differences in toxicity between organic and inorganic arsenic species. Clearly, this represents an opportunity for developing countries to become engaged in data generation and collection as part of the standard setting process. Similarly, the continuing debate on methyl mercury levels in fish is of relevance to many developing countries' exports. ${ }^{1}$

A second review of the Codex Trust fund entitled Enquiry Concerning the FAO/WHO Project and Trust Fund for Enhanced Participation in Codex ("Codex Trust Fund") was commissioned by the SIDA and undertaken between August and October 2007.2 The functioning and progress of the Trust Fund in achieving its objectives and expected outputs were assessed. The study also gave particular attention to the African region. Many of its findings confirmed those of the first report mentioned above. In particular, the report notes that while the Trust Fund has successfully widened participation in Codex activities; it has not yet deepened the level of this participation. Developing countries that benefit from the Trust Fund still do not yet take an active part in the discussions at Codex meetings. This may be due to their inexperience with Codex terminology and procedures as well as to the often late arrival of working documents in a language with which the participant is familiar. In addition, sometimes a country position had not been developed on the issues under discussion, resulting in poor preparation for meetings. ${ }^{3}$ In addition, the report notes that very little progress has been made in increasing developing countries' scientific and technical input into Codex standard-setting work. This can be ascribed to these countries' lack of technical and scientific infrastructure and resources, making it impossible or very difficult for them to produce reliable data, for example, on the levels of residues of pesticides and veterinary drugs and other contaminants in food. ${ }^{4}$ This requires technical assistance to build technical capacity. The Codex Trust Fund role in capacity

other initiatives had made valuable contributions to such developments (e.g., the FAO in Cambodia, Viet Nam and Uganda; and Swedish International Development Agency (SIDA) and UNIDO in Uganda).' Ibid., 18.

${ }^{1}$ Ibid., 41. Further examples mentioned are the fact that discussions with a food processor in showed its interest in developing a standard for passion fruit syrup for export. Viet Nam and Thailand need a standard for fish sauce.

2 Stuart A. Slorach, Enquiry Concerning the FAO/WHO Project and Trust Fund for Enhanced Participation in Codex ("Codex Trust Fund") (Swedish International Development Cooperation Agency, Stockholm), 12 October 2007, available at: http://www.who.int/foodsafety/codex/Slorach_report.pdf, visited on 10 June 2008. Sweden, through the Swedish International Development Cooperation Agency (SIDA), has been the largest single contributor to the Codex Trust Fund so far (more than $30 \%$ of the total of contributions). Before deciding on further contributions SIDA commissioned this enquiry.

${ }^{3}$ Ibid., 19. However, some progress is starting to be made in this area. The report notes a 'growing number of examples of countries supported by the CTF making important contributions to Codex debates, e.g. the interventions of Samoa in the discussions at CCGP in 2007 on the Code of Ethics. At the CAC meeting in July 2007, Paraguay made several interventions on the issue of a natural sweetener which is of particular interest to that country.'

${ }^{4}$ Ibid., 20. 
building is very limited and specialised. It complements the wider programmes of FAO and WHO that are aimed at building the capacity of national food safety control systems. ${ }^{5}$

Although not discussed in detail here, it is useful to note that not only the CAC but also the OIE and IPPC have trust funds in place to assist developing countries in improving their sanitary and phytosanitary capacities or to facilitate their participation in the standard-setting work.

The OIE created the World Animal Health and Welfare Fund on 28 May 2004, ${ }^{6}$ from which its capacity building activities are financed. It aims to strengthen the capacity of developing-country OIE members to deal with animal health and welfare. In particular, it supports implementation of training programmes and action programmes; the organisation of seminars, workshops and conferences; the development of information media; the editing and distribution of scientific and technical publications; the implementation of scientific research programmes; the OIE Strategic Plans; and the activities of developing countries in all these areas. ${ }^{7}$ In October 2006, the OIE held a meeting with its newly created 'Advisory Committee' for the Fund, consisting of high level representatives of the WTO, FAO, WHO and World Bank and possible donor countries (the US, the EC, Australia, Japan and France).$^{8}$ The fund has received US\$ 13 million and is being used to conduct economic studies, identify areas for priority investments, train developingcountry trainers and evaluate the veterinary services in 15 pilot countries. ${ }^{9}$ Aside from this trust fund, the OIE continues its existing practice of funding the participation of the Chief Veterinary Officers of its members in OIE standard-setting work. ${ }^{10}$

The IPPC established a Trust Fund in 2004, under FAO rules, to facilitate the participation of developing-country contracting parties in all IPPC activities. These include the meetings of the CPM and EWG as well as regional workshops on draft standards. ${ }^{11}$ There have been no indications from any contracting party of an intention to contribute to this Trust Fund in 2008. ${ }^{12}$ The IPPC also provides technical assistance to build phytosanitary capacity under the FAO Technical Cooperation Programme. ${ }^{13}$

${ }^{5}$ Ibid., 21.

${ }^{6}$ OIE International Committee, Resolution No. XVII , 28 May 2004.

${ }^{7}$ Committee on Sanitary and Phytosanitary Measures, Capacity-Building Tools and Activities. Communication from the World Organization for Animal Health (OIE), G/SPS/GEN/830, circulated on 27 March 2008, para 32.

${ }^{8}$ OIE Director General, Dr Bernard Vallat stated with regard to this meeting: 'When dealing with animal health governance and emergencies, it is crucial to have a mechanism between partner international organisations and donors for synergies and better routing of limited resources.' 'International bodies join forces to advise OIE animal health and welfare fund', 1 November 2006, WTO Press Release Press/456, available at: http://www. wto.org/english/news_e/pres06_e/pr456_e.htm, visited on 10 June 2008.

${ }^{9}$ Ibid.

${ }^{10}$ Committee on Sanitary and Phytosanitary Measures, Proposals and Progress on Special and Differential Treatment. Note by the Secretariat, G/SPS/GEN/543, circulated on 28 February 2005, para. 29.

${ }^{11}$ Ibid., para. 28.

${ }^{12}$ Committee on Sanitary and Phytosanitary Measures, Decisions from the Third Session of the Commission on Phytosanitary Measures (Rome, 7-11 April 2008). Submission from the International Plant Protection Convention, G/SPS/GEN/849, circulated on 18 June 2008, para. 31.

${ }^{13}$ Committee on Sanitary and Phytosanitary Measures, Technical Assistance and Cooperation. Planned Activities to Be Undertaken by the IPPC under the FAO Technical Cooperation Programme-2008. Communication from the International Plant Protection Convention Secretariat (IPPC), G/SPS/GEN/834, circulated on 26 March 2008. 


\subsubsection{The International Portal for Food Safety, Animal and Plant Health (IPFSAPH)}

IPFSAPH was set up through an initiative led by the FAO, in partnership with the CBD, OIE, WHO and WTO. It has been active since May 2004. This is an internet-based resource, through which users can search for national SPS regulations; international SPS standards, guidelines and codes of practice; risk analyses; and national contact points for the Codex, OIE, IPPC, SPS Committee and CBD. It aims to facilitate trade in food and agricultural products and support the implementation of the SPS Agreement by providing a reliable single access point for official international and national SPS-related information. $^{14}$

This portal integrates data sources maintained by the Codex, CBD, FAO, IAEA, IPPC, OIE, WHO and WTO as well as some national data sources (currently mainly from the US and EC). As of April 2008, it contains over 35000 records. ${ }^{15}$ By linking through to locally-managed sources, it makes it possible for users to find a wide range of SPS information and official documents through a single portal without duplicating the work of identifying and uploading documents. At the same time, the IPFSAPH is often more user-friendly than the source site and provides a one-stop search tool.

A unique feature of the IPFSAPH is that 'cross-sectoral' searches are possible, as information uniformly 'described' through appropriate keywords. ${ }^{16}$ It facilitates accurately comparison of information within the IPFSAPH system that originally derives from different sources. Information can be searched relating to specific commodities (such as dairy, nuts etc.), countries, sources, information types (such as official texts, supporting materials, contacts etc.) and cross-sectoral issues (such as equivalence, HACCP, accreditation, specific pathogens, pests or diseases, etc.). ${ }^{17}$ The information is updated each month.

To facilitate the use of the IPFSAPH by persons in developing countries with limited Internet access, a CD-Rom version of the portal has been created. ${ }^{18}$ This makes it possible to search offline and download all main Codex, OIE and IPPC documents. Connecting to the Internet is then only necessary to download a document that is not available on the CD.

The IPFSAPH is useful both in creating awareness among officials of important international SPS standards and national measures taken to implement them, and in providing information on SPS requirements on export markets to actual or potential trading partners. ${ }^{19}$ It makes use of partnerships in order to reach as wide a range of users as possible. ${ }^{20}$

${ }^{14}$ Animal \& Plant Health International Portal on Food Safety, IPFSAPH Users Guide (Food and Agriculture Organization, Rome), 2008, 1, available at: http://www.ipfsaph.org/En/Help/IPFSAPH_UserGuide_EN.pdf, visited on 30 June 2008.

15 Ibid. $\{$ Codex Alimentarius Commission, 2005 \#4065\} \{Codex Alimentarius Commission, 2005 \#4065\}

${ }^{16}$ Ibid., 5.

${ }^{17}$ See the website of the IPFSAPH, available at: http://www.ipfsaph.org/En/default.jsp, visited on 10 June 2008.

${ }_{18}$ The CD-Rom was distributed in May-June 2005 by means of a news item on the FAO website. See Codex Alimentarius Commission, The International Portal for Food Safety, Animal and Plant Health. Submission from the FAO, CAC/28 INF/4 (Joint FAO/WHO Food Standards Programme, Rome), June 2005, para. 6, available at: http://www.ipfsaph.org/En/default.jsp, visited on 10 June 2008.

19 Ibid., para. 9.

${ }^{20}$ For example, it collaborated in JTTAP projects with regard to briefing national SPS Enquiry Points and 
The figures on the use of the IPFSAPH to date indicate that it has proved to be a valuable resource..$^{21}$ In order to further improve its operation, the IPFSAPH conducted a user survey. It has extended its data to include up to eight additional major importing countries in Asia and Latin America, and to refine existing data on the US and EC. Countries are encouraged to take the initiative to make their own legislation and other information available to the portal.

The major challenge faced by the IPFSAPH is to promote its wider use among key target groups in developing countries. Workshops run jointly with the CAC in 2006 have introduced this tool to academics teaching courses on food safety, biological risk assessment, international trade and consumer protection. The long term vision is that national stakeholders should be able to draw on the IPFSAPH for core SPS-related information. ${ }^{22}$

\subsubsection{The Standards and Trade Development Facility}

As mentioned above, the STDF was established in 2002 by five organisations: the FAO, the World Bank, the WHO, the OIE and the WTO, following a commitment made at the Doha Ministerial Conference in 2001. It is both a financing and a coordination mechanism. ${ }^{23}$

The STDF is administered by a Secretariat, under the responsibility of the WTO. ${ }^{24}$ It has a Policy Committee composed of high-level representatives of the five partners and other stakeholders responsible for overseeing its activities. A Working Group, made up of representatives of the partner organisations and standard-setting bodies, is tasked with approving the STFD work programme, approving grants, overseeing the Secretariat, and appointing committees for special tasks.

The STDF was established with seed funding from the World Bank Development Grant Facility and a contribution from the WTO Doha Development Agenda Global Trust Fund, ${ }^{25}$ and since then 11 WTO Members have made contributions. ${ }^{26}$ The STDF has thus

provided training materials for programmes run by others (e.g. the World Bank and the WTO Secretariat) regarding the use of the portal. Ibid., para. 11.

${ }^{21}$ Just after its launch, the portal averaged 5000 page views a day, which increased to 11000 by May 2007. Over 600 documents are downloaded from the site each day, and an increasing number of queries are being received by the helpdesk and Webmaster. Codex Alimentarius Commission, The International Portal on Food Safety, Animal and Plant Health: Progress in 2006/7. Submission from FAO, CAC/30 INF/11 (Joint FAO/ WHO Food Standards Programme, Rome), May 2007, para. 6.

22 Ibid., para. 15.

${ }^{23}$ Committee on Sanitary and Phytosanitary Measures, Update on the Operation of the Standards and Trade Development Facility, G/SPS/GEN/748, circulated on 2 February 2007, Annex, para. 11.

${ }^{24}$ The Secretariat is responsible for public relations, project screening, project management and financial management of the STDF. The Secretariat's staff consists of one full-time WTO Secretariat staff member and the part-time services of another. These staff resources are insufficient as the STDF has grown, and there is a need to establish separate management unit ether at the WTO or at one of the partner agencies. Committee on Sanitary and Phytosanitary Measures, Update on the Operation of the Standards and Trade Development Facility. Note by the Secretariat, G/SPS/GEN/648, circulated on 24 March 2006, para. 8.

25 The World Bank Development Grant Facility contributed US\$300 000 per year for 3 years (ending in June 2005) and the WTO committed to contributing CHF100 000 in 2003 and 2004, and CHF225 000 in 2005 and 2006 from the Doha Development Agenda Global Trust Fund.

${ }^{26}$ The fund grew from US\$1.4 million in 2004 to US\$5.3 million in September 2005. Since then additional contributions were received from Sweden (12 million Swedish Kronor), the US (US\$100 000) and Denmark 
proved to be quite successful in attracting one-off donor funds. However, the STDF faces challenges in obtaining sustained commitments to donor funding. Only two Members have made formal multi-annual funding commitments thus far.

The STDF aims to help developing countries build their capacity to analyse and implement SPS requirements, and thereby to gain and maintain market access. Public or private entities in developing countries may request financing. The STDF provides both project preparation grants and project grants. ${ }^{27}$ To date the STDF has approved funding for 27 projects and 25 project preparation grants. ${ }^{28}$

In addition, the STDF aims to act as a vehicle for coordination among providers of technical assistance, for the mobilisation of funds, the exchange of experience and the dissemination of good practices with regard to SPS-related technical assistance. Its partner institutions have extensive experience and skills in the areas of SPS and technical assistance, and are thus extremely well-suited to assist developing countries to build capacity in this area. The STDF benefits from this collective expertise. It does not compete with or replace existing technical assistance activities conducted by its partners, but is complementary to them..$^{29}$ In December 2006, a new medium-term strategy (2007-2011) was agreed for the STDF by its Policy Committee. This strategy puts more focus on the STDF's function as a vehicle for co-ordination, fund mobilization and the identification and dissemination of best practices in SPS-related technical assistance. ${ }^{30}$ While funding will still be provided for technical assistance projects, tighter eligibility criteria will be imposed and there will be more emphasis on project preparation grants. ${ }^{31}$

The new strategy aims at achieving an annual funding target of US\$5 million. The project preparation grants are expected to attract funds from both the STDF itself and the wider donor community. ${ }^{32}$ Synergies are expected between the STDF and the Integrated Framework for Trade-Related Technical Assistance to Least-Developed Countries (IF) ${ }^{33}$

(2.5 million Danish Kronor). Committee on Sanitary and Phytosanitary Measures, Update on the Operation of the Standards and Trade Development Facility. Note by the Secretariat, G/SPS/GEN/648, circulated on 24 March 2006, para. 3.

27 Ibid., para. 1.

${ }^{28}$ Committee on Sanitary and Phytosanitary Measures, Update on the Operation of the Standards and Trade Development Facility. Note by the Secretariat, G/SPS/GEN/829, circulated on 25 March 2008, para. 19. Of the 27 projects, 11 projects have been completed, 12 were in progress and 4 are awaiting contracting. Of the 25 project preparation grants, 17 have been completed and 8 are being implemented.

${ }^{29}$ For example, the STDF does not fund participation in the international standard-setting bodies but instead the capacity built through STDF projects is expected to improve the ability of developing countries to participate effectively in these international bodies. Committee on Sanitary and Phytosanitary Measures, Update on the Operation of the Standards and Trade Development Facility, G/SPS/GEN/748, circulated on 2 February 2007, para. 17.

${ }^{30}$ Ibid., para. 1.

${ }^{31}$ Ibid., para. 2 and Annex, para. 4. Projects funded should be innovative, sustainable, preventative and replicable; address gaps in SPS information and training materials; or aim to improve coordination between SPS technical assistance providers.

${ }^{32}$ Ibid., Annex, para. 3.

33 The IF is a multi-agency, multi-donor initiative. It was launched based on the commitment of ministers at the 1996 Singapore Ministerial Conference to address the increasing marginalisation of least-developedcountries in world trade, and to improve the coherence of technical assistance activities. A Plan of Action was developed, which led to the establishment of the IF in 1997 under the joint responsibility of the WTO, World Bank, UNDP, UNCTAD, IMF and ITC. The IF process is comprised of four steps, namely (1) the creation of 
and the Joint Integrated Technical Assistance Programme for selected least-developed and other African countries (JITAP). ${ }^{34}$ In particular, the needs identified in the national diagnostic studies conducted in the IF framework will be addressed by inviting the partners to assist in developing a project preparation grant. ${ }^{35}$ Forty per cent of STDF resources are committed for least-developed countries and other low income economies. ${ }^{36}$

The STDF does not only fund national and regional capacity building initiatives, such as the project to support compliance with regulatory and private SPS export standards in the fruit and vegetable sector in Guinea. It also undertakes global initiatives. For example, the STDF has completed a project establishing a database on SPS-related technical assistance and capacity building projects, including national and regional projects. ${ }^{37}$ This electronic resource compiles data reported by the five partner institutions, multilateral agencies, and regional and bilateral donors. It draws upon the existing WTO/OECD Trade-Related Technical Assistance and Capacity Building Database. ${ }^{38}$ This database has been criticised for the overwhelming mass of information it contains on technical assistance initiatives, many of which are limited to one-time capacity building events, while only a fraction entail sustained capacity building efforts. ${ }^{39}$ Another global initiative is the workshop on SPS capacity evaluation tools organised by the STDF on 31 March $2008 .{ }^{40}$ The various

awareness regarding the importance of trade for the promotion of development; (2) the conduct of a Diagnostic Trade Integration Study (DTIS) to identify areas of greatest export potential and constraints in these areas, and establish a plan of action; (3) the integration of the plan of action into national development plans such as the Poverty Reduction Strategy Process; and (4) the implementation of the plan of action together with the development cooperation community. Funding for implementation comes primarily from bilateral donors, but the IF Trust Fund has been established to finance the preparation of the DTIS and to provide some bridging funds for capacity building projects that are part of the action plan. In the context of the DTIS, SPS-related issues have sometimes been identified as forming constraints to the export potential of a country. These have been compiled by the WTO Secretariat. See Committee on Sanitary and Phytosanitary Measures, Review of Standards Related Issues Identified in the Integrated Framework Diagnostic Trade Integration Studies. Note by the Secretariat, G/SPS/GEN/545, circulated on 28 February 2005. More information is to be found on the IF website, available at: http://www.integratedframework.org/, visited on 30 June 2008.

34 The JITAP aims to develop human and institutional capacity of selected African countries to support their integration in the multilateral trading system. It was launched by the heads of the WTO, UNCTAD and the ITC in 1996. Initially 8 beneficiary countries were selected to participate. With the launch of JITAP II in 2002 another 8 beneficiaries were included. JITAP is designed to enhance synergies among the WTO, UNCTAD and ITC and to ensure efficient use of resources, through economies of scale and scope in management and programme implementation. A key feature is the role of JITAP as a framework for catalyzing other trade-related technical assistance, including that provided under the Integrated Framework. This information is drawn from the JITAP website, available at: http://www.jitap.org/info-e.htm, visited on 30 June 2008.

${ }^{35}$ Committee on Sanitary and Phytosanitary Measures, Update on the Operation of the Standards and Trade Development Facility, G/SPS/GEN/748, circulated on 2 February 2007, Annex, para. 13.

${ }^{36}$ Ibid., Annex, para. 3.

37 This database is available at: http://stdfdb.wto.org, visited on 1 June 2008.

${ }^{38}$ Committee on Sanitary and Phytosanitary Measures, Update on the Operation of the Standards and Trade Development Facility. Note by the Secretariat, G/SPS/GEN/648, circulated on 24 March 2006, para. 12.

39 Steven Jaffee et al., Food Safety and Agricultural Health Standards: Challenges and Opportunities for Developing Country Exports, 31207 (World Bank, Poverty Reduction \& Economic Management Trade Unit and Agriculture and Rural Development Department, Washington D.C.), 10 January 2005, footnote 69, available at: http://www-wds.worldbank.org/external/default/WDSContentServer/WDSP/IB/2005/01/25/00016 0016_20050125093841/Rendered/PDF/31207.pdf, visited on 18 May 2008. This criticism is reiterated by Scott. Joanne Scott, The WTO Agreement on Sanitary and Phytosanitary Measures: A Commentary, Oxford Commentaries on the GATT/WTO Agreements (Oxford University Press, Oxford), 2007, 301.

${ }^{40}$ Committee on Sanitary and Phytosanitary Measures, Overview of SPS Capacity Evaluation Tools. Note by the Secretariat, G/SPS/GEN/821, circulated on 18 February 2008. 
capacity evaluation tools were assessed and the possibilities for collaboration and cooperation between organisations in the development and use of such tools were discussed. ${ }^{41}$ In addition, on 26 June 2008, the STDF organised an information session on private standards, in which representatives of the World Bank, the Africa Observer Project, the Global Food Safety Initiative and the International Certification and Risk Services made presentations. The issues addressed included how to make developing countries' voices heard in the area of private standards; how to reduce the costs of certification; how to promote dialogue between private standard holders, suppliers, certifiers and other interested parties; and advancements with respect to the recognition of equivalence between various schemes. ${ }^{42}$

A mid-term review of the STDF was commissioned in $2005 .{ }^{43}$ While it was too early to determine if STDF projects had been effective, since none had yet reached their end, the report of this review was positive about the profile of the projects funded by the STDF. The STDF was judged to have been successful in attracting considerable donor interest as well as many projects from a range of beneficiaries. However, to sustain such interest and funding it is important to show demonstrable results. It is recommended that procedures be established for the monitoring and measurement of the results of projects. The review finds that the STDF has been a learning experience for the partner institutions. It fills a niche in the "crowded market of development assistance in support of trade development by focusing on a highly technical area neglected by donors. ${ }^{44}$ It has been a successful forum for knowledge sharing on SPS and for building coherence in technical assistance. ${ }^{45}$ However, more attention must be given to the coherence of the STDF's actions with the IF and other capacity building activities. ${ }^{46}$ The review warns that due to lack of administrative capacity, the STDF could 'become asphyxiated by its own success' ${ }^{47}$ The creation of a project management unit is recommended.

\subsection{Problems with the implementation of technical assistance}

There are many flaws in the current implementation of technical assistance. Although from the description provided above of technical assistance initiatives it would appear that donor countries allocate substantial financial resources to SPS technical assistance, in practice often the amount actually provided is much less than that committed to. While the amount of technical assistance granted has increased since the launch of the Doha Development Round, ${ }^{48}$ it is still inadequate. In fact, a report by the World Bank

\footnotetext{
${ }^{41}$ Information on this workshop is available at: http://www.wto.org/english/tratop_e/sps_e/wkshop_march08_e/ wkshop_marc, visited on 3 June 2008.

${ }^{42}$ Committee on Sanitary and Phytosanitary Measures, Report of the STDF Information Session on Private Standards (26 June 2008). Note by the Secretariat, G/SPS/50, circulated on 24 July 2008, paras 1-2.

${ }^{43}$ Triple Line Consulting, Review of the STDF: Report, STDF 76 Add. 1 (Standards and Trade Development Facility, London), 1 December 2005, available at: http://www.standardsfacility.org/files/Review_of_STDF. pdf, visited on 4 October 2006. This review led to the new Medium term Strategy discussed above.

${ }^{44}$ Ibid., para. 47.

${ }^{4}$ Ibid., paras 54-55.

46 Ibid., para. 61.

${ }^{47}$ Ibid., para. 57.

48 The Hong Kong Ministerial Declaration notes with appreciation 'the substantial increase in trade-related
} 
characterises the level of technical assistance in the area of SPS capacity building as 'extremely modest given the significance of the challenges (and opportunities) facing developing countries. ${ }^{49}$ In the implementation discussions at the WTO, developing-country Members have complained that they most often do not receive technical assistance to facilitate adjustment to SPS measures that affect their trade. Further, the prevalent reactive approach to technical assistance, where assistance is only provided once an exporting Member has already lost market access due to an SPS trade barrier, has been criticised by Members. ${ }^{50}$ In addition, long delays between allocation of funds and their actual provision are common, frustrating attempts at long term planning..$^{51}$ The lack of certainty and predictability in the provision of technical assistance aggravates this problem. ${ }^{52}$

Another often-heard complaint is that bilateral technical assistance is frequently geared towards furthering the interests of the donor country. ${ }^{53}$ This perception was given voice in an aptly-worded comment by a representative of an African country that received SPSrelated technical assistance: '[T]hey want us to understand SPS so that we will import more chicken.' ${ }^{54}$ This remark powerfully captures the prevailing idea that the strategic interests of developed countries, rather than real needs in developing countries, underlie decisions on bilateral technical assistance. ${ }^{55}$ A 2005 report by the World Bank confirms this view. ${ }^{56}$ Even where donor-driven technical assistance does not directly conflict with

technical assistance since [its] Fourth Session, which reflects the enhanced commitment of Members to address the increased demand for technical assistance, through both bilateral and multilateral programmes. Ministerial Conference, Doha Work Programme. Ministerial Declaration Adopted on 18 December 2005, WT/MIN(05)/DEC, circulated on 22 December 2005, para. 52.

49 Steven Jaffee et al., Food Safety and Agricultural Health Standards: Challenges and Opportunities for Developing Country Exports, 31207 (World Bank, Poverty Reduction \& Economic Management Trade Unit and Agriculture and Rural Development Department, Washington D.C.), 10 January 2005, 119, available at: http://www-wds.worldbank.org/external/default/WDSContentServer/WDSP/IB/2005/01/25/000160016_200 50125093841/Rendered/PDF/31207.pdf, visited on 18 May 2008.

50 Committee on Sanitary and Phytosanitary Measures, Report on Proposals for Special and Differential Treatment. Adopted by the Committee on 30 June 2005, G/SPS/35, circulated on 7 July 2005, para. 21.

${ }^{51}$ Vinod Rege et al., Influencing and Meeting International Standards: Challenges for Developing Countries. Volume I: Background Information, Findings from Case Studies and Technical Assistance Needs (International Trade Centre UNCTAD/WTO and Commonwealth Secretariat, Geneva), 2003, 70.

52 Committee on Sanitary and Phytosanitary Measures, Report on Proposals for Special and Differential Treatment. Adopted by the Committee on 30 June 2005, G/SPS/35, circulated on 7 July 2005, para. 21. This is the underlying concern leading to the calls for mandatory technical assistance provisions in the SPS Agreement, discussed below, Part V, Section 2.7.

${ }^{53}$ In the discussions in the SPS Committee on strengthening technical assistance, Members characterised much of the technical assistance received as 'supply-driven' and 'determined to a greater extent by the policy interests of the donor than the specific needs of the recipient'. Ibid.

${ }^{54}$ J. Michael Finger, 'The Uruguay Round North-South Bargain: Will the WTO Get over It?' in The Political Economy of International Trade Law. Essays in Honor of Robert E. Hudec, Daniel L. M. Kennedy and James D. Southwick (eds.) (Cambridge University Press, Cambridge), 2002, 301-310, 306.

${ }_{55}$ This concern is also reflected in United Nations Development Programme, Human Development Report 2005. International Cooperation at a Crossroads: Aid, Trade and Security in an Unequal World (United Nations, New York), 2005, 11, available at: http://hdr.undp.org/en/media/hdr05_complete.pdf, visited on 2 January 2008. While emphasizing the importance of capacity building for trade, this report notes that ' $[\mathrm{u}] \mathrm{nfortunately}$, there is an unhealthy concentration on capacity building in areas that rich countries consider strategically useful.'

${ }^{56}$ Steven Jaffee et al., Food Safety and Agricultural Health Standards: Challenges and Opportunities for Developing Country Exports, 31207 (World Bank, Poverty Reduction \& Economic Management Trade Unit and Agriculture and Rural Development Department, Washington D.C.), 10 January 2005, 116, available at: 
the interests of the recipient Member, 'in a world of limited resources, technical assistance in one area can divert human and material resources from others that may be of greater priority. ${ }^{57}$ It is interesting to note that the Hong Kong Ministerial Declaration urges the WTO Director-General 'to ensure that [technical assistance] programmes focus accordingly on the needs of beneficiary countries and reflect the priorities and mandates adopted by Members.' 58

There is therefore a need to ensure that technical assistance is demand-driven, focusing on the priorities of the beneficiary country. As recommended by the World Bank study mentioned above, developing countries need to be assisted in making their own strategic decisions with regard to how to respond to new SPS measures, including possibly challenging those measures or negotiating changes. ${ }^{59}$ In order to effectuate this, there needs to be a willingness on the part of donor countries to look beyond their own interests in providing technical assistance. As noted by Michel Kostecki, 'ownership' by the beneficiary is the most important feature of the new approach to technical assistance. This new approach focuses on the idea of partnership between the donor and the beneficiary. To distinguish it from traditional donor-driven technical assistance, this is referred to as 'capacity building'. ${ }^{60}$

A precondition for needs-driven capacity building is the determination by developingcountry Members of their capacity needs. It has been noted that the paucity of demanddriven requests for technical assistance is partly due to institutional capacity constraints. ${ }^{61}$ In addition, there is a need for 'effective prioritizing and planning mechanisms within developing countries. ${ }^{62}$ The input of various relevant government agencies and the private sector is essential in the determination of national priorities. As many developing countries do not have effective channels in place for inter-agency coordination or for communication with the private sector, ${ }^{63}$ assistance may be needed already at this level. It

http://www-wds.worldbank.org/external/default/WDSContentServer/WDSP/IB/2005/01/25/000160016_200 50125093841/Rendered/PDF/31207.pdf, visited on 18 May 2008.

${ }^{57}$ Gregory Shaffer, 'Can WTO Technical Assistance and Capacity-Building Serve Developing Countries?' Wisconsin International Law Journal, 2005, 651.

${ }_{58}$ Ministerial Conference, Doha Work Programme. Ministerial Declaration Adopted on 18 December 2005, WT/MIN(05)/DEC, circulated on 22 December 2005, para. 53.

59 Steven Jaffee et al., Food Safety and Agricultural Health Standards: Challenges and Opportunities for Developing Country Exports, 31207 (World Bank, Poverty Reduction \& Economic Management Trade Unit and Agriculture and Rural Development Department, Washington D.C.), 10 January 2005, 120, available at: http://www-wds.worldbank.org/external/default/WDSContentServer/WDSP/IB/2005/01/25/000160016_200 50125093841/Rendered/PDF/31207.pdf, visited on 18 May 2008.

${ }^{60}$ Michel Kostecki, Technical Assistance Services in Trade-Policy: A Contribution to the Discussion on Capacity-Building in the WTO, Resource Paper No. 2 (International Centre for Trade and Sustainable Development, Geneva), November 2001, 6, available at: www.ictsd.org/pubs/respaper/TApaper5-12-01.pdf, visited on 12 May 2002.

${ }^{61}$ Committee on Sanitary and Phytosanitary Measures, Report on Proposals for Special and Differential Treatment. Adopted by the Committee on 30 June 2005, G/SPS/35, circulated on 7 July 2005, para. 21.

${ }^{62}$ Vinod Rege et al., Influencing and Meeting International Standards: Challenges for Developing Countries. Volume I: Background Information, Findings from Case Studies and Technical Assistance Needs (International Trade Centre UNCTAD/WTO and Commonwealth Secretariat, Geneva), 2003, 89.

${ }^{63}$ The problem of lack of internal communication and coordination between the various experts and bodies active in the area of SPS was highlighted in Gonzalo K. Ríos 'Technical Assistance Needs of Developing Countries and Mechanisms to Provide Technical Assistance', presented at the Conference on International Food Trade Beyond 2000: Science-Based Decisions, Harmonization, Equivalence and Mutual Recognition 
is important to do the groundwork in this regard, since without it the assistance provided may be a wasted effort. The ITC/Commonwealth Secretariat report mentioned above notes:

For example sophisticated laboratory equipment may have been provided even though the recipient country does not have the means or is unwilling to commit to provide the skilled human resources to operate it, essential maintenance, consumables and so forth. Indeed it is possible for export capacity to be developed that is beyond the needs of developing country exporters. Not only does this waste scarce technical assistance, but it can tie developing countries into longer term resource demands to maintain this capacity. This underlines the need for technical assistance to be 'appropriate' and problem-focused. ${ }^{64}$

Efforts made to address this problem through the development of capacity evaluation tools, discussed below, ${ }^{65}$ have resulted in a considerable body of research work on capacity needs. However, the evaluation of SPS-related technical assistance conducted by the STDF in the context of the Aid-For-Trade review points put that a 'single common analysis of SPS-related technical cooperation needs shared between donors, international organisations and beneficiaries is missing. ${ }^{66}$ It points out the danger of duplication of efforts in the absence of greater coordination.

Further, the effectiveness of the technical assistance provided has been questioned by several developing-country Members. Much of the assistance received has not had the desired result of enabling recipient Members to maintain or expand market access for their products when faced with new SPS requirements. ${ }^{67}$ This has partly been ascribed to the fact that decisions on the allocation of technical assistance are driven by the political considerations of the funding agency rather than based on systematic criteria to determine where technical assistance will have most practical effect. ${ }^{68}$ The STDF evaluation of technical assistance in 2007, in the context of the Aid-for-Trade review, notes that 'a strong conclusion which emerged related to the difficulty of translating the need for strengthening SPS functions into concrete actions which will have a tangible impact, in particular in the area of market access. ${ }^{69}$

(Food and Agriculture Organization of the United Nations, Melbourne, Australia) 11-15 October 1999, para. 9, available at: www.fao.org/docrep/ meeting/X2674e.htm, visited on 6 November 1999.

${ }^{64}$ Vinod Rege et al., Influencing and Meeting International Standards: Challenges for Developing Countries. Volume I: Background Information, Findings from Case Studies and Technical Assistance Needs (International Trade Centre UNCTAD/WTO and Commonwealth Secretariat, Geneva), 2003, 89.

${ }^{65}$ See below, Part V, Section 2.7.

${ }^{66}$ Committee on Sanitary and Phytosanitary Measures, Background Document from the Standards and Trade Development Facility for the Global Review of Aid for Trade: Note by the Secretariat, G/SPS/GEN/812, circulated on 22 November 2007.

${ }^{67}$ Committee on Sanitary and Phytosanitary Measures, Report on Proposals for Special and Differential Treatment. Adopted by the Committee on 30 June 2005, G/SPS/35, circulated on 7 July 2005, para. 22.

${ }^{68}$ Arne Wiig and Ivar Kolstad, 'Lowering Barriers to Agricultural Exports through Technical Assistance', Food Policy 30, 2005, 185 - 204. Wiig and Kolstad conducted a survey of the major providers of SPS-related technical assistance (US, EC, WTO, FAO, and World Bank) which found that even in those cases where a set of formal criteria for the allocation of SPS-related assistance exists, their application is weak and in practice the allocation of funds is politically driven.

${ }^{69}$ Committee on Sanitary and Phytosanitary Measures, Background Document from the Standards and Trade Development Facility for the Global Review of Aid for Trade: Note by the Secretariat, G/SPS/GEN/812, 
The provision of technical assistance is characteristically fragmented, focusing on particular projects rather than system-wide improvements. The STDF evaluation of technical assistance initiatives concludes that 'capacity building is being undertaken on an ad hoc basis with specific donors looking at specific interventions, rather than as part of an over-arching development plan which includes a clear vision of national SPS strategy.' ${ }^{70}$ It notes, for example, the rapid rise in technical assistance related to highly pathogenic avian influenza (bird flu) in Asian countries and the provision by the EC of assistance with regard to very large thematic projects on pesticides, fisheries and animal health. These areas of assistance are closely related to the particular interests of the donors. The type and nature of assistance provided varies widely between different regions, between countries in the same region, and between different sectors within the same country. ${ }^{71}$

Another problem that is prevalent with regard to technical assistance initiatives is the lack of coherence and coordination between various projects. This shortcoming is reflected in the discussion of technical assistance activities above. As noted in the abovementioned STDF evaluation, the importance of greater coordination between donor activities is further underlined by the fact that donor funding in the area of SPS-related technical assistance is growing due to increasing attention of donors to SPS issues. The multiplicity of projects leads to frequent overlaps and duplication of efforts to address particular capacity needs. ${ }^{72}$ This leads to wasted resources. At the same time, other needs are neglected, leading to gaps in SPS capacity. An integrated approach is called for.

\subsection{Efforts to improve the implementation of technical assistance}

High-level as well as technical meetings have been held between the WTO and other international organisations to coordinate the provision of technical assistance. In addition, regular updates on technical assistance activities are provided to the SPS Committee by the three international standard setting bodies, international organisations (such as the FAO, the World Bank, OIRSA, IICA, and UNCTAD) and some Members. While this should lead to greater coherence, in fact an examination of the submissions reveals that fragmentation and duplication are still prevalent.

The Hong Kong Ministerial Declaration has reaffirmed the priorities set out in the Doha Ministerial Declaration with regard to technical assistance. It invites the Director-General to reinforce the cooperation with other agencies in the design and implementation of

circulated on 22 November 2007, para. 27.

${ }^{70}$ Ibid.

${ }^{71}$ Ibid., para. 26.

${ }^{72}$ These problems were identified in the ITC/Commonwealth Secretariat report, based on concrete case studies. Vinod Rege et al., Influencing and Meeting International Standards: Challenges for Developing Countries. Volume I: Background Information, Findings from Case Studies and Technical Assistance Needs (International Trade Centre UNCTAD/WTO and Commonwealth Secretariat, Geneva), 2003, 88. This report mentions the example of the overlap between its own country papers and those drafted with the assistance of funding from the German technical cooperation through the SADC Secretariat for the SADC SPS/Food Safety Conference in 2000, on similar issues. Further, it mentions USAID funding for SPS capacity building in SADC countries, and the World Bank's intention to fund a similar study, covering the many of the same countries. The 2003 World Bank report in this regard is contained in John S. Wilson and Victor O. Abiola, eds., Standards and Global Trade: A Voice for Africa (World Bank, Washington D.C.), 2003. 
technical assistance programmes, 'so that all dimensions of trade-related capacity building are addressed, in a manner coherent with the programmes of other providers.'

The WTO Secretariat makes concerted efforts to help Members identify problems in the delivery of technical assistance and to find solutions through shared experiences. Already in 1999 and 2001 the Secretariat undertook a survey of technical assistance needs and activities by means of questionnaires, ${ }^{2}$ and has drawn up a technical assistance typology to help Members identify the most appropriate type of technical assistance. ${ }^{3}$ In November 2002, prior to the SPS Committee meeting, the WTO Secretariat organised a seminar on SPS-related technical assistance and capacity building. At this seminar, information was presented by international and regional organisations as well as developing-country Members regarding their experiences with technical assistance in the SPS area. ${ }^{4}$

Technical assistance has been a standing item on the agenda of SPS Committee meetings since 1995, where Members are encouraged to identify specific technical assistance needs and report on technical assistance activities. ${ }^{5}$ In addition, informal discussions on technical assistance and co-operation have been held in the SPS Committee. In these discussions, concrete proposals were put forward to improve the effectiveness of the technical assistance provisions, including creating a coherent program for the provision of technical assistance, regardless of the source of the assistance, and placing emphasis on the development of human resources. ${ }^{6}$

1 Ministerial Conference, Doha Work Programme. Ministerial Declaration Adopted on 18 December 2005 ,
WT/MIN(05)/DEC, circulated on 22 December 2005, para. 53 .

${ }^{2}$ In July 1999, a questionnaire was circulated to Members by the Secretariat, to gather information on technical assistance requested, received or provided under the SPS Agreement but few developing countries replied. Committee on Sanitary and Phytosanitary Measures, Questionnaire on Technical Assistance: Note by the Secretariat, G/SPS/W/101, circulated on 23 July 1999. A summary of the responses is contained in Committee on Sanitary and Phytosanitary Measures, Summary of the Replies to the Questionnaire on Technical Assistance - Note by the Secretariat, G/SPS/GEN/143/Rev.1/Add.3, circulated on 3 July 2001. In October 2001 a second questionnaire was circulated regarding technical assistance needs to which 37 Members have responded to date (of the Members selected as illustrative examples in this book, only Mauritius responded to the questionnaire). Committee on Sanitary and Phytosanitary Measures, Committee on Sanitary and Phytosanitary Measures, Questionnaire on Technical Assistance, G/SPS/W/113, circulated on 15 October 2001. For the responses, see the addenda to Committee on Sanitary and Phytosanitary Measures, Technical Assistance - Responses to the Questionnaire. Note by the Secretariat, G/SPS/GEN/295, circulated on 6 February 2002.

${ }^{3}$ Committee on Sanitary and Phytosanitary Measures, Technical Assistance Typology: Note by the Secretariat, G/SPS/GEN/206, circulated on 18 October 2000.

${ }^{4}$ See for example, 'Technical Assistance and Capacity Building Related to SPS Agreement. The Contribution of the Food and Agriculture Organization of the United Nations', presented at the WTO Seminar on technical assistance and capacity building related to the SPS Agreement, Geneva) 5 November 2002, available at: www. wto.org/english/tratop_e/sps_e/sem_nov02_e/programme_e.htm. The PowerPoint presentations delivered at this seminar are available at: www.wto.org/english/tratop_e/sps_e/sem_nov02_e/programme_e.htm, visited on 3 December 2002.

5 Committee on Sanitary and Phytosanitary Measures, Proposals and Progress on Special and Differential Treatment. Note by the Secretariat, G/SPS/GEN/543, circulated on 28 February 2005, para. 37. A compilation of all documents submitted to and drafted by the SPS Committee on this issue was circulated to all Members in 2002. Committee on Sanitary and Phytosanitary Measures, Technical Assistance and Capacity Building in the Context of the SPS Committee. Note by the Secretariat, G/SPS/GEN/332, circulated on 24 June 2002.

${ }^{6}$ The first meeting was held in July 2001. Committee on Sanitary and Phytosanitary Measures, Discussion on Technical Assistance and Cooperation - Informal Meeting of the SPS Committee of 9 July 2001, G/SPS/ GEN/267, circulated on 16 July 2001. The second was held on 18 March 2002 (report not yet derestricted). 
This work gathered momentum in the context of the Doha Round work programme on implementation issues. Among the Category II proposals referred to the SPS Committee by the General Council in 2003, were several proposals on strengthening Article 9 of the SPS Agreement. In addition, some of the proposals made with regard to Article 10 in fact deal with technical assistance. An examination of these proposals and of the discussions in this regard provides an indication of the current positions of WTO Members on the possibilities for strengthening an operationalising technical assistance under the SPS Agreement.

Relevant to Article 9.1, the African Group has proposed the establishment of a facility within the Global Trust Fund to ensure that developing countries and LDCs: (i) have the technical and financial capacity to meet the requirements of the SPS Agreement; (ii) can send delegations and effectively participate in meetings of the SPS Committee and the relevant international standard-setting bodies; (iii) can effectively utilise the flexibilities under the SPS Agreement; and (iv) have their rights protected against contravention by measures adopted under the SPS Agreement. ${ }^{7}$ In addition, this proposal suggests that it be understood that technical and financial assistance as well as transfer of technology to developing countries and LDCs shall be cost free. ${ }^{8}$

Two proposals have been received with regard to Article 9.2 of the SPS Agreement, which deals with the situation where compliance with an SPS measure requires substantial investments from a developing-country Member. The Group of Like-Minded Countries has suggested replacing the words 'shall consider providing' with 'shall provide', making the provision of technical assistance obligatory in such cases. This proposal further extends the obligation to provide technical assistance to cases where a developing-country Member identifies specific problems of inadequate technology and infrastructure to meet the SPS requirements of an importing developed-country Member. ${ }^{9}$ The African Group's proposal suggests that the phrase 'substantial investments' in Article 9.2 be interpreted in relation to the resources of the government departments of the affected Members and their development needs. Any changes to SPS requirements that would necessitate additional resources (greater expenditure, restructuring, additional staff or training) would be considered to require 'substantial investments'. This proposal further specifies that 'technical assistance' shall be understood as fully funded technical assistance, not entailing financial obligations on the part of the beneficiaries. In addition, the African Group proposes to add to Article 9.2, for cases where no technical assistance is provided, the obligation to withdraw the measures immediately and unconditionally, or to compensate the exporting developing-country Members for the losses arising directly or indirectly from the measures. Finally, this proposal, as already mentioned above, calls for the WTO to recommend prior impact assessments with regard to the likely effects of draft SPS measures on developing- and least-developed-country trade. Where adverse effects are

\footnotetext{
7 This proposal was made in connection with Art. 10 of the SPS Agreement, but seems to relate more to the issue of technical assistance. Committee on Trade and Development, Special and Differential Treatment Provisions. Joint Communication from the African Group in the WTO. Revision, TN/CTD/W/3/Rev.1, circulated on 24 June 2002, para. 54(c).

${ }^{8}$ Ibid., para. 54(d).

${ }^{9}$ Committee on Trade and Development Special Session, Special and Differential Treatment Provisions. Joint Communication from Cuba, Dominican Republic, Egypt, Honduras, India, Indonesia, Kenya, Mauritius, Pakistan, Sri Lanka, Tanzania and Zimbabwe, TN/CTD/W/2, circulated on 14 May 2002.
} 
identified, SPS requirements would not be applicable until affected Members have acquired the capacity to comply with the requirements.

With regard to Article 10.4 of the SPS Agreement, which deals with facilitation of developing-country Members in the international standard setting bodies, India has proposed that the word 'should' be read as a duty rather than an exhortation. It recommends the adoption of an authoritative interpretation under Article IX:2 of the WTO Agreement to this effect. ${ }^{10}$ The African Group's proposal regarding the use of its proposed Trust Fund facility to enable developing- and least-developed-country Members to participate effectively in international standard setting bodies is also relevant to Article 10.4. ${ }^{11}$

Discussions on these proposals indicated some receptivity to the idea that technical assistance must be made more effective and needs-driven. ${ }^{12}$ While many Members pointed to the various existing technical assistance initiatives, ${ }^{13}$ at bilateral and multilateral level, they also indicated their willingness to take the underlying concerns of developing-country Members seriously, and to address the problems with existing technical assistance. ${ }^{14}$ Australia, as mentioned above, indicated that firm commitments in the area of technical assistance were more likely than agreement on mandatory SDT. In particular, Australia was willing to consider India's proposal that Article 10.4 be read as mandatory, obliging Members to encourage developing-country participation in international standard-setting bodies. ${ }^{15}$ However, the idea that the application of SPS measures would be conditional on granting cost-free technical assistance or compensation was firmly rejected. ${ }^{16}$ Similarly, developed-country Members did not see mandatory technical assistance as a feasible option, due to its unlimited budgetary implications. ${ }^{17}$ Further, the paucity of concrete technical assistance requests from developing countries was noted. Developing-country Members countered that without binding technical assistance, they could not be assured that requests would actually be honoured. In addition, the capacity constraints they face in undertaking specific needs assessments should be borne in mind. Developing-country Members sought a clear commitment that technical assistance would be provided when an SPS requirement caused compliance difficulties.

${ }^{10}$ Committee on Trade and Development Special Session, Special and Differential Treatment Provisions. Communication from India, TN/CTD/W/6, circulated on 17 June 2002.

${ }^{11}$ Committee on Trade and Development, Special and Differential Treatment Provisions. Joint Communication from the African Group in the WTO. Revision, TN/CTD/W/3/Rev.1, circulated on 24 June 2002, para. 54(c).

${ }_{12}$ Committee on Trade and Development Special Session, Note on the Meeting of 6 November 2002, TN/ CTD/M/10, circulated on 21 January 2002, para. 30.

${ }^{13}$ For example, Canada pointed to the mechanism run by the Standards Council of Canada to assist developing countries to participate in the international standard setting bodies. The US drew attention to a programme funded by it and other developed-country Members to assist 32 Latin American and Caribbean countries to participate in SPS Committee meetings since 2002. Committee on Sanitary and Phytosanitary Measures, Proposals and Progress on Special and Differential Treatment. Note by the Secretariat, G/SPS/GEN/543, circulated on 28 February 2005, paras 33-34.

${ }^{14}$ Ibid., para. 23.

15 Committee on Trade and Development Special Session, Note on the Meeting of 6 November 2002, TN/ CTD/M/10, circulated on 21 January 2002, para. 9.

16 Ibid.

17 Committee on Sanitary and Phytosanitary Measures, Proposals and Progress on Special and Differential Treatment. Note by the Secretariat, G/SPS/GEN/543, circulated on 28 February 2005, para. 22. 
The failure of the discussions on technical assistance to lead to recommendations for operationalising the relevant provisions of the SPS Agreement has been ascribed to a number of constraints faced by the SPS Committee. One of these is the fact that few concrete proposals have been made in this regard, and those that have been made require actions outside the sphere of competence of the SPS Committee. For example, they involve actions at bilateral level, at the level of the international standard-setting bodies, and at the level of the WTO as a whole. Further, discussions on the proposals only became specific and concrete very late in the process. In addition, the 'expectations gap' between Members on the issue of technical assistance has proven intractable. ${ }^{18}$

In view of this deadlock, the SPS Committee has undertaken to discuss further work that could address the concerns that underlie the proposals made. As mentioned above, the initial elements for discussion identified by the SPS Committee in this regard relate to improvements in the procedural mechanisms provided by the SPS Agreement, to make them better suited to resolve the SPS problems faced by developing-country Members. These include the identification of best practices in transparency procedures to ensure timely receipt by these Members of information on SPS measures relevant to their trade; the identification of mechanisms for efficient and early evaluation by developing-country Members of potential trade problems in notified measures; and the consideration of ways for these Members to make greater use of the opportunities provided by the SPS Committee to resolve specific trade concerns. In addition, two elements are identified with regard to technical assistance, namely the establishment of an effective mechanism to monitor the demand for and supply of technical assistance, in order to improve its predictability, timeliness and effectiveness relative to developing-country Members' needs; and the development of best practices for SPS technical assistance under the WTO Doha Development Agenda Global Trust Fund. ${ }^{19}$

Work on some of these elements is underway. In January 2008, the WTO Secretariat requested Members to provide information on SPS-related technical capacity building projects that could be regarded as 'good practice', by means of the provided questionnaire. ${ }^{20}$ On the basis of responses, field research will be undertaken in the beneficiary and a separate questionnaire circulated to determine the beneficiary's assessment of the project. The information gathered in this way will be used to identify best practices in technical assistance and presented in a workshop.

In October 2007, at a special workshop on transparency issues, New Zealand proposed the establishment of a voluntary 'mentoring' system to help developing-country Members implement and fully benefit from the transparency obligations of the SPS Agreement. ${ }^{21}$

18 Committee on Sanitary and Phytosanitary Measures, Report on Proposals for Special and Differential Treatment. Adopted by the Committee on 30 June 2005, G/SPS/35, circulated on 7 July 2005, paras 37-40.

19 Ibid., para. 43.

20 As only seven Members responded to this request (Australia, Canada, Chinese Taipei, Costa Rica, the EC, Sweden and Switzerland) the deadline for the request for information was extended to 30 April 2008. Committee on Sanitary and Phytosanitary Measures, Request for Information on Good Practice in SPSRelated Technical Cooperation. Note by the Secretariat, G/SPS/GEN/816, circulated on 18 January 2008; Committee on Sanitary and Phytosanitary Measures, Request for Information on Good Practice in SPSRelated Technical Cooperation. Extension of Deadline. Note by the Secretariat. Addendum, G/SPS/GEN/816/ Add.1, circulated on 20 March 2008.

${ }^{21}$ Committee on Sanitary and Phytosanitary Measures, Technical Assistance for Operating the SPS Notification 
Members showed interest in this proposal and it was developed further by the WTO Secretariat. ${ }^{22}$ In terms of this proposal, Members who need assistance in operating their national notification agency or enquiry point would request help..$^{23}$ Developed and developing-country Members that have experience in this area would volunteer to be 'mentors' by registering with the WTO Secretariat, which would have the task of matching mentors and mentees. This proposal envisages a 'long term, positive and proactive relationship' between the officials involved, which is 'based on trust, which requires thoughtful interaction and a commitment to providing ongoing assistance and support to those being mentored.' ${ }^{24}$ The 'mentor' Member could provide support in a variety of ways, including through the provision of information by telephone or email; by giving guidance on the development of legislation and the operation of procedures; by providing in-house training or hands-on workshops; by assisting with resources or translations. ${ }^{25}$ The mentoring system is expressly stated not to imply any commitment to provide financial or other types of assistance and does not replace other technical assistance activities. ${ }^{26}$

Efforts are also being undertaken in the international standard-setting bodies to address problems in the provision of technical assistance. Particularly useful are the initiatives to develop tools to assist developing countries in evaluating their current capacities and needs in the area of SPS regulation. As noted above, this evaluation is a crucial first step in the technical assistance process if such assistance is to be driven by the needs of beneficiaries rather than by donor interests. In this regard it is useful to note the OIE's Evaluation of Performance of Veterinary Services Tool (commonly referred to as the PVS Tool). ${ }^{27}$ This tool was developed with STDF funding in collaboration with IICA, and builds on capacity building experiences of both organisations. It aims to establish the capacity of a country to meet the standards set out in the OIE Terrestrial Animal Health Code. The OIE trains and certifies experts to carry out PVS evaluations and feedback from experienced assessors is used to further refine the PVS Tool. ${ }^{28}$ In addition, in collaboration with international donors, the OIE is undertaking PVS evaluations of 105 countries over a three-year period. ${ }^{29}$ Similarly, a Phytosanitary Capacity Evaluation Tool

Authority and SPS Enquiry Point. Proposal by New Zealand, G/SPS/W/214, circulated on 1 October 2007.

22 Committee on Sanitary and Phytosanitary Measures, Proposal for A "Mentoring” System of Assistance Relating to the Transparency Provisions of the SPS Agreement. Note by the Secretariat, G/SPS/W/217, circulated on 20 February 2008.

${ }^{23}$ In view of the General Council's decision on measures to assist small economies to meet their obligations under the SPS Agreement (WT/COMTD/SE/5 and WT/COMTD/SE/W/16), this mentoring system makes it possible to request that the assistance be provided via a relevant international secretariat, rather than to a national official. Ibid., para. 4.

${ }^{24}$ Committee on Sanitary and Phytosanitary Measures, Technical Assistance for Operating the SPS Notification Authority and SPS Enquiry Point. Proposal by New Zealand, G/SPS/W/214, circulated on 1 October 2007, para.7.

${ }_{25}$ Committee on Sanitary and Phytosanitary Measures, Proposal for A "Mentoring” System of Assistance Relating to the Transparency Provisions of the SPS Agreement. Note by the Secretariat, G/SPS/W/217, circulated on 20 February 2008, para. 3(a)-(g).

${ }^{26}$ Ibid., para.4.

27 The PVS Tool may be downloaded from the OIE website, available at: http://www.oie.int/eng/oie/ organisation/EN_update2007_pvs_out.pdf, visited on 10 June 2008.

${ }^{28}$ For a recent update on the PVS Tool, see Committee on Sanitary and Phytosanitary Measures, CapacityBuilding Tools and Activities. Communication from the World Organization for Animal Health (OIE), G/SPS/ GEN/830, circulated on 27 March 2008, paras 10-21.

${ }^{29} \mathrm{Ibid}$., paras 22-24. By the end of May 2008, PVS evaluation missions had been conducted in 56 OIE members, 
(PCE Tool) has been developed by the FAO, under the auspices of the IPPC. ${ }^{30}$ It aims to establish the capacity of an National Plant Protection Organisation to implement the international phytosanitary standards elaborated by the IPPC. The application of the PCE Tool is built into many of FAO's Technical Cooperation Programme Projects funded in response to requests for assistance in developing phytosanitary systems. The PCE tool has been applied in over 60 countries worldwide, including Jamaica. ${ }^{31}$ Finally, in 2006 the FAO, in collaboration with the WHO, developed a set of guidelines for capacity needs assessment in the area of food safety, contained in the publication Strengthening National Food Control Systems: Guidelines to Assess Capacity Building Needs. ${ }^{32}$ The Guidelines aim to assist governments to assess their capacity in the core elements of a national food control system and identify their related capacity building needs. Unlike other assessment tools which are used to verify whether particular regulations or standards are met by the food industry, these Guidelines focus on the role of government agencies within a comprehensive system for food safety and quality. They are unique in that they establish a methodology for self-assessment of capacity building needs and as well as internationally accepted benchmarks and principles for each of the core components of a food-safety regulatory system. ${ }^{33}$ These three tools have been broadly applied and have resulted in various sector-specific assessments of needs. ${ }^{34}$ The Hong Kong Ministerial Declaration on the Doha Work Programme endorses the application of appropriate needs assessment mechanisms and supports the efforts to enhance ownership by beneficiaries, in order to ensure the sustainability of trade related capacity building. ${ }^{35}$

These concrete initiatives are commendable and are likely to have real benefits for developing-country Members. However, more is needed if real progress is to be made in addressing the capacity constraints that make it difficult for developing countries to benefit from the SPS Agreement. The question arises whether the proposals to make technical

with the support of international donors. Committee on Sanitary and Phytosanitary Measures, Report on OIE Activities to the Meeting of the SPS Committee to Be Held on 24-25 June 2008, G/SPS/GEN/853, circulated on 20 June 2008 , para. 3 .

${ }^{30}$ This tool is based on a pilot project conducted in 1999 in 6 countries (Cook Islands, Fiji, Solomon Islands, Indonesia, Bangladesh and Viet Nam) with funding from New Zealand. The IPPC Secretariat, after a field evaluation on 30 countries, recommended the inclusion of new components to the PCE. At the Fourth Session of the ICPM, the PCE was adopted as the preferred tool for phytosanitary needs assessment. Committee on Sanitary and Phytosanitary Measures, FAO Evaluation Tools for Safety, Biosecurity and Plant Protection, G/ SPS/GEN/831, circulated on 27 March 2008, para. 29.

${ }^{31}$ For a discussion of the SPS capacity problems of Jamaica, see above, Part II, Sections 2.6.2 and 2.6.3.

${ }^{32}$ Marlynne Hopper and Ezzedine Boutrif, Strengthening National Food Control Systems: Guidelines to Assess Capacity Building Needs (Food and Agriculture Organization, Rome), 2006, available at: ftp://ftp.fao.org/ docrep/fao/009/a0601e/a0601e00.pdf, visited on 12 June 2008. A condensed version, entitled Strengthening National Food Control Systems: A Quick Guide to Assess Capacity Building Needs, has been developed for use in situations that require a faster assessment.

33 Ibid., xii. See also Committee on Sanitary and Phytosanitary Measures, FAO Evaluation Tools for Safety, Biosecurity and Plant Protection, G/SPS/GEN/831, circulated on 27 March 2008, para. 7.

${ }^{34}$ For a review of the capacity evaluation studies conducted in three pilot regions (Central America, the East African Community and some ASEAN countries, in the context of the review of the Aid-for-Trade initiative, see Committee on Sanitary and Phytosanitary Measures, Background Document from the Standards and Trade Development Facility for the Global Review of Aid for Trade: Note by the Secretariat, G/SPS/GEN/812, circulated on 22 November 2007, paras 5-14.

${ }^{35}$ Ministerial Conference, Doha Work Programme. Ministerial Declaration Adopted on 18 December 2005, WT/MIN(05)/DEC, circulated on 22 December 2005, para. 53. 
assistance mandatory under the SPS Agreement would contribute to resolving some of the current inadequacies in its provision. Hoekman has argued that an obligation to compensate developing-country Members for the adoption of new measures would be at the expense of donor country support for the recipient's own development priorities. ${ }^{36}$ In addition, in light of the fact that currently there is no differentiation among developing countries, creating an obligation to grant technical assistance whenever a developingcountry Member has to make substantial investments to comply with an SPS measure is simply not feasible. As noted above, this would require developed-country Members to undertake a financial obligation of unlimited proportions. Further, while obligatory technical assistance may result in a greater number of technical assistance projects, it would do nothing to ensure that these project amount to real 'capacity building'.

\subsection{Conclusion}

As noted from the start of the analysis of the provisions of the SPS Agreement conducted in this book, ${ }^{37}$ technical assistance is not a magic bullet solution to all developing-country concerns with WTO obligations. It certainly does not obviate the need for a rigorous analysis of substantive and procedural rules to ensure that they are appropriate for all Members as tools to achieve the agreed objectives of a particular agreement. It also does not preclude the need to take seriously the provisions on SDT negotiated as a quid pro $q u o$ for the extensive obligations taken on by developing countries in the Uruguay Round.

Previous Parts and Chapters of this book have examined these issues in detail. This examination has led to the conclusion that, in view of the delicate balance struck by the provisions of the SPS Agreement between trade and health, it is difficult to adjust those aspects of its substantive disciplines that create problems for developing-country Members without doing damage to its ability to meet its objectives. Similarly, there is limited scope for strengthening SDT in the SPS Agreement, beyond operationalising the current rules through interpretation or negotiated clarification. While very useful work has been done, and is continuing, by the SPS Committee in developing procedural guidelines to facilitate the implementation of certain provisions of the SPS Agreement of particular importance to less-developed Members, significant problems remain. Consequently, while far from being a panacea, technical assistance assumes a crucial role in addressing the very real problems that Members at lower levels of development face in implementing their obligations, and enforcing their rights under this Agreement.

The current provisions on technical assistance in the SPS Agreement are loosely worded and difficult to enforce. As a result, the provision of SPS-related technical assistance leaves much to be desired. Discussions on ways to strengthen these provisions have proved fruitless. In many cases this can be ascribed to the unrealistic nature of the proposals made, making the imposition of SPS requirements with adverse effects on developingcountry Members' exports conditional on granting cost-free technical assistance upon request. This would have enormous budgetary implications, impossible to determine in

\footnotetext{
${ }^{36}$ J. Michael Finger and Philip Schuler, 'Implementation of Uruguay Round Commitments: The Development Challenge', The World Economy 23 (4), 2000, 511-525.

37 See above, Introduction to Part III.
} 
advance, and would risk undermining the regulatory autonomy of importing Members. Nevertheless, the concerns underlying these proposals cannot be discounted. The experience of developing-country Members with the voluntary provision of technical assistance has been disheartening. It is therefore not surprising that they are seeking real commitments from their developed trading partners in the area of technical assistance.

An examination of a few illustrative examples of technical assistance initiatives in place has shown that the current approach is fragmented and lacking in coherence. Bilateral technical assistance tends to reflect donor interests and areas of concern, resulting in a disregard for the priorities of beneficiaries. Recent efforts to develop tools to assist developing countries to identify their capacity needs are useful, but must be coupled with the appropriate response to ensure that the project truly builds capacity in the beneficiary in a sustainable manner. Currently, political considerations rather than objective criteria determine which technical assistance projects are supported by donors. The lack of predictability resulting from the voluntary nature of assistance provided currently makes long-term planning difficult.

Multilateral efforts are characterised by inefficiencies and overlaps. The limited mandate of some organisations in the area of technical assistance means that additional efforts in the area of technical assistance result in widening its reach but not deepening its impact. Concerted efforts are needed not only in the areas of training and funding of participation in SPS-related fora, but also in respect of building technical and scientific capacity and infrastructure. Without the latter, participation will not bring the desired results.

The STDF represents and important step forward in coordinating the plethora of technical assistance initiatives. It creates a cooperative framework of partners with a wide range of high-level technical expertise and significant financial resources. In addition, making use of complementarities with needs-assessment mechanisms such as those in the IF and JITAP, it ensures that the priorities and capacity needs of beneficiary countries are an integral part of the framing of a project. Consequently, it is in a position to provide needs-driven and expert assistance. The STDF's new approach is to reduce its focus on actually funding projects and turn its attention to the coordination aspect of its mandate. It aims to use its project preparation grants to facilitate the securing of funds and assistance from its partner institutions and other donors. This may indeed be a more efficient use of its unique capacities to promote coordination in technical assistance. It is to be hoped that the work of the STDF will fulfil the potential it has for turning ad hoc technical assistance projects into coherent and needs-driven capacity building programmes in developing countries. For this to occur, however, donors must show a new willingness to make multi-annual commitments to funding the STDF. Without such commitment, the lack of certainty regarding sustained funding makes the development of a long-term strategy difficult.

It is clear that more work is needed in this area. It is beyond the scope of this book to examine the possibilities for developing a useful mechanism for effective, needs-driven and coherent capacity building in the SPS area. This seems to be a field where multidisciplinary research could make a significant contribution. 


\section{Conclusion to Part V}

Undoubtedly, the problems faced by developing-country Members in enforcing their rights and complying with their obligations under the SPS Agreement need to be urgently addressed. However, it has been argued here that the answer does not lie in broad exemptions from the obligations contained in this Agreement. Allowing the undisciplined use of SPS measures by developing-country Members will result in disguised protectionism and will not contribute to the development of competitive food and agricultural industries in these Members. ${ }^{1}$ Equally, the solution cannot lie in requiring importing Members to allow the importation of unsafe products, if they originate in developing-country Members. As discussed above, such solutions would be counterproductive and damaging to developing-country Members themselves. Forcing a lowering of SPS requirements in importing Members will not only endanger health in such countries, but also not achieve increased market access. Importers will continue to respond to consumer demands by laying down private standards that their suppliers must comply with. Thus, other more constructive solutions must be found that do not upset the balance achieved by the SPS Agreement between health protection and trade liberalisation.

It is argued here that the answer lies in a new, more effective approach to SPS-related assistance that is more in line with the current conception of 'capacity building'. In other words, what is needed is effective, predictable and needs-driven assistance that creates capacity in a sustainable manner. Real commitments must be made to the provision of such assistance. While this is unlikely to happen at bilateral level, where the interests and limited resources of donors lead to ad hoc projects, multilateral cooperative initiatives such as the STDF show promise. The acceptability of binding commitments towards financing a new technical assistance mechanism, will in turn depend on the willingness of developing-country Members to accept differentiation across levels of development, reflecting differences in regulatory capacity and dependence on agricultural exports. This would mirror the reality of development, which is a continuum.

Innovative research is urgently needed to identify the necessary conditions for such a mechanism. While research in this area lies beyond the scope of this book and the expertise of its author, there is much room for useful contributions to thinking in this respect from other disciplines. Here an important input can be made by rigorous study, based on empirical research and economic analysis and taking into account the lessons of political science.

\footnotetext{
${ }^{1}$ The Consultative Board noted in its report that many least-developed-country governments actively use WTO disciplines to 'secure internal reform and integrate into the global trading economy.' See Peter Sutherland et al., The Future of the WTO: Addressing Institutional Challenges in the New Millennium. Report by the Consultative Board to the Director-General Supachai Panitchpakdi (World Trade Organization, Geneva), 2004, para. 310.
} 
Conclusion 
This book analysed the implications of the rules of the SPS Agreement for WTO Members at different levels of development. More specifically, it evaluated whether the tools used by the SPS Agreement to achieve a balance between the often competing goals of trade liberalisation and health protection are appropriate also for Members at lower levels of development.

In doing so, it aimed to elucidate what can be seen as the 'development dimension' of the SPS Agreement. This analysis has two aspects, namely first, a consideration of the limits on policy space defined by the general disciplines of the SPS Agreement, and its effect of developing-country Members as agri-food exporters and SPS regulators; and second, an examination of the special provisions for developing-country Members in the SPS Agreement.

\section{The SPS Agreement as a product of historical developments forming its background}

The analysis conducted in this book takes place against the background of the delicate position of the SPS Agreement on the interface between two aspects of the process of globalisation, namely the globalisation of trade and the globalisation of health. This background was set out in Part I.

The term 'globalisation of trade', as discussed in Chapter 1 of Part I, refers to the process of increasing involvement of countries at lower levels of development in the multilateral trading system. This process must be seen in its normative context, which is to be found in the growing recognition of the right to development. This right encompasses not only economic growth but also the progressive realisation of all human rights. In this light, it is clear that it is necessary to ensure that the participation of countries at lower levels of development in the international trade regime is supportive of their development, so that trade fulfils its potential to be an engine for growth, without endangering the attainment of other human rights including the rights to life, health and safe food. This necessitates the recognition of the special position of countries at lower levels of development in the rules of the international trading system. If developing-country Members of the WTO are to benefit fully from the market access gains that can be derived from its rules and not bear excessive implementation costs to the detriment of their development objectives, mechanisms must be found to ensure that their constraints are taken into account by the rules of the system. In particular, the right to development encompasses the responsibility of the international community to work towards an appropriate enabling environment at international level for the realisation of this right. In the context of the international trading system this, inter alia, requires the provision of flexibility in the applicable disciplines to make them workable for developing-country Members and the creation of mechanisms for assistance of these Members.

Thus two main conclusions can be derived from the normative framework established by international human rights law of relevance to the analysis of the SPS Agreement. First, international trade rules must balance the important objective of economic growth through trade liberalisation with the equally important objective of human rights protection. In the 
context of the SPS Agreement this means that its disciplines to promote market access for food and agricultural products, a sector of vital importance to the economies of many developing countries, must not undermine the ability of its Members to take measures to protect health in their territories. Therefore any evaluation of the SPS Agreement must be fully cognisant of the fundamental importance of its trade/health balance. Second, the normative context establishes the need to ensure that trade liberalisation objectives are achieved by disciplines that are responsive to the special position of developing countries in order to be truly supportive of development. As mentioned above, this entails not only the requirement that the rules be workable for developing countries but also the need to provide flexibility in the rules, where appropriate, and to promote assistance of developing countries to address their supply-side constraints. The assessment of the development dimension of the SPS Agreement therefore requires an evaluation of both the appropriateness of its general disciplines for developing-country Members and the effectiveness of its provisions giving special treatment to developing-country Members.

The overview of the historical developments in the international trading system with respect to the progressive integration of developing countries, sketched in Chapter 1, indicates a changing approach to the concept of special treatment for these countries. The early demands of developing countries for exemptions from the rules of the trading system are in marked contrast to their approach by the time the Uruguay Round negotiations were launched. Developing countries then showed a new willingness to bind themselves to extensive obligations contained in the Uruguay Round agreements, including those imposing regulatory disciplines that entailed high compliance costs, such as the SPS Agreement. The calls of developing countries for special treatment were limited to the provision of longer transition periods, the consideration for their special position and the provision of technical assistance. The latter types of provisions can be found in the SPS Agreement. However, the lack of implementation by developed-country Members of the special provisions for developing-country Members in WTO agreements, coupled with the high compliance costs for developing-country Members of implementing the disciplines of agreements creating disciplines for behind-the-border areas of regulatory policy, results in asymmetry in the costs and benefits of the multilateral trading system. The new assertiveness shown by developing-country Members in the run-up to the Seattle Ministerial Conference and since then, has convinced developed-country Members of the need to take their concerns seriously, as reflected in the development focus of the Doha Round of negotiations. However, as indicated in this Chapter, negotiations in the context of the Doha Round to address implementation problems have borne little fruit thus far.

This discussion forms the background for the assessment of the development dimension of the SPS Agreement. It indicates that the approach taken in the SPS Agreement is characteristic of the new Uruguay Round agreements aimed at addressing non-tariff barriers to trade through disciplines on regulatory activities. In spite of the high implementation costs entailed by these disciplines, the SPS Agreement contains weak provisions on special and differential treatment and technical assistance for developing countries. In analysing the development dimension of the SPS Agreement it is therefore important to assess both the appropriateness of its general disciplines for Members at lower levels of development and the effectiveness of its special provisions for developing-country Members. 
For trade to be supportive of development, it is crucial that developing-country Members be fully integrated into the international trading system so that they are in a position to benefit from the increased market access achieved by its rules without bearing high implementation costs. This necessitates a re-evaluation of the Uruguay Round agreements that require regulatory investments, on the basis of thorough agreement-specific research to identify concretely both the problems with the general disciplines and the weaknesses in the special provisions for developing countries. This book conducted such analysis with respect to one WTO agreement, namely the SPS Agreement. This detailed and technical review aims to provide useful input to help Members move away from their current polarised positions in the implementation discussions and engage in seeking constructive solutions. This goal informed the analysis conducted in this book.

The second, and related, aspect of the globalisation process forming the background to the discussion of the SPS Agreement is the globalisation of health. This results from the exponential increase in the movement of food, plants, animals and their products across borders so that national strategies are no longer sufficient to address the health risks arising there from. A historical overview of this process, provided in Chapter 2 of Part I, indicated the growing realisation of the need for international cooperation in addressing SPS risks as well as the limitations of such an international approach. In particular, it is instructive to note the role played in this process by achievements in the use of science as a tool for risk regulation.

Scientific developments in the late nineteenth century led to a better understanding of the way in which certain substances in food as well as pests and diseases affect health, which initially facilitated international consensus on risk mitigation mechanisms. Science provided a possibility to avoid trade conflicts arising from the effect of SPS measures on imports, by establishing a seemingly objective and universally valid basis for international harmonisation of SPS requirements. However, advances in science in the first half of the twentieth century lead to a 're-nationalisation' of SPS regulation in developed countries. These countries used scientific advances to develop a strong national regulatory and institutional infrastructure to deal with SPS risks, including those from imported products. International cooperation was no longer seen as a priority. This complacent attitude was shaken in the second half of the twentieth century, when the rapid increase in trade with developing countries where SPS risks were endemic led to new threats from imported products, challenging the capacity of national SPS systems. Renewed international cooperation, firmly based on science, took the form of the creation of formalised international arrangements and institutions to promote common action against SPS risks while facilitating trade. Examples of these are the creation of the OIE to prevent the spread of animal diseases through trade, the establishment of the CAC by the FAO and WHO in order to administer their Joint Food Standards Programme, and the adoption of the IPPC by the FAO to formalise international cooperation in the field of plant health.

While these international efforts were a significant achievement, they failed to take account of the vast differences in national SPS conditions and regulatory capacities. These differences often meant that developed countries chose for risk management strategies that were stricter than the harmonised standards developed at international level. They also meant that several developing countries were unable to meet the minimum requirements reflected in the international harmonised standards. This led to a rethinking of the 
strategy needed to address the globalisation of SPS risks in the face of the exponential growth in trade. Currently, a multifaceted approach is followed with regard to the challenges posed by globalised health risks. It continues to rely on international cooperation, based on scientific risk assessment and information-sharing by experts. Through this cooperation, harmonised standards and guidelines are developed for the management of SPS risks, in order to facilitate trade. However, the emphasis has shifted to national sovereignty in policy decisions regarding SPS risks, to allow for particularised approaches that are responsive to national differences, within the framework of international cooperation. In addition, especially in developed countries, a crisis of confidence in the ability of national regulators to provide effective SPS protection (among other factors) has led to increasing involvement of local, transnational and private governance structures in laying down SPS requirements.

The SPS Agreement must be understood against this complex regulatory background, which has had an important effect on the framing of its disciplines. As a product of the late twentieth century, the SPS Agreement embodies the multifaceted approach to risk regulation prevailing since that time in developed countries. Acknowledging the achievements made at international level in setting science-based harmonised SPS standards, the SPS Agreement incorporates these standards into its rules as benchmarks for SPS measures in order to facilitate trade. However, in recognition of the need to allow for different policy choices based on national priorities and capacities, the SPS Agreement allows for deviation from harmonised standards. It reflects the focus on science as a neutral and universally valid touchstone for SPS regulation that prevailed at the time of its negotiation in developed countries, and requires scientific justification for non-harmonised measures. The background sketched in Chapter 2 thus elucidated the manner in which the SPS Agreement tries to achieve a balance between trade and health, and provided an indication of the developed-country regulatory concerns embedded in its disciplines.

Chapter 3 of Part I completed the background discussion by situating the SPS Agreement on the interface between globalised trade and globalised health. It pointed out that the globalisation of trade, in the sense of the full integration of developing countries into the international trading system, is greatly affected by measures to deal with globalised health risks, in the form of both national and international SPS regulations and standards. This is due to the importance of agricultural and food exports for the foreign revenue earnings of many developing countries, and the effect of the proliferation of SPS regulations and standards on such exports.

In particular, Chapter 3 established the importance of food and agricultural trade to the economies of many developing-country Members, not only in terms of income generation but also in terms of both formal and informal employment of the poorest sector of the population. The great potential of trade in food and agricultural products to contribute to poverty alleviation and development is constrained not only by traditional barriers to agricultural trade (such as tariff peaks, tariff escalation, domestic support and export subsidies) but also increasingly by SPS measures. SPS measures are particularly prevalent with respect to high-value perishable products, such as fish, fresh flowers, fruit and vegetables, and processed agri-food products. This diminishes the possibilities for developing-country Members to diversify from bulk agricultural commodities to highvalue and processed products. 
As discussed in this Chapter, SPS requirements continue to increase in number and strictness, in response to factors such as elevated consumer demands due to increased affluence, well-publicised food-safety scares and fears regarding new technologies in agricultural production; growing pressure from domestic agricultural lobbies in the face of increased competition; scientific developments that make it possible to regulate ever-more strictly and to control compliance accurately; and the increased sourcing of products from suppliers in developing countries where national SPS regulation and infrastructure is weak. By limiting market access for food and agricultural products, these SPS measures undermine the hard-won steps towards liberalising the agricultural sector and are a real obstacle to development.

While legitimate SPS regulation to address SPS risks from traded products must be allowed, disguised protectionist measures in the form of unfounded SPS requirements must be effectively disciplined if the full integration of developing countries into the international trading system is to be achieved. It is here, on the interface between globalised trade and globalised risk, that the SPS Agreement plays a role. In this book, its impact on developing-country Members is evaluated in this light.

\section{The factual context of national and international SPS}

\section{systems within which the SPS Agreement operates}

The evaluation of the 'development dimension' of the SPS Agreement conducted in this book is fully cognisant of the fact that developing-country Members are not a monolithic group. Instead, development takes place on a continuum, along which there may be great divergences in economic resources, regulatory capacity, export interests and health status. All these factors play a role in determining the impact of the SPS Agreement on particular Members, and the question of how workable its rules are for the relevant Member. An analysis of the implications of the SPS Agreement for developing-country Members must therefore take into account these divergences.

In order to do so, Part II of this book examined the factual context for the operation of the SPS Agreement as embodied in national and international systems for SPS regulation and standard setting, with a particular focus on the impact of differences in the levels of development of Members for the functioning of these systems.

Chapter 1 of Part II set out the underlying normative rationale for national SPS regulatory systems, embodied in international human rights law. It is widely recognised that among the fundamental duties of states, and an integral part of both the right to life and the right to development, is the obligation to ensure safe food and to protect human health. This creates a normative framework that informs the discussion of SPS protection and, therefore, also of international rules that limit the ability of governments to regulate in this area. The analysis of this framework in Chapter 1 established that a government has an obligation to take steps, to the maximum of its available resources, to progressively realise the human rights to adequate food and the highest attainable standard of health, and to address threats to the agricultural sector in the form of pests and diseases. Further, it made clear that assistance from the international community in this regard is essential. 
Trade plays an important role as an engine for growth and development. The role of trade, however, is tempered by the recognition, in the understanding of the right to development, that economic growth may not be achieved at the cost of other rights, such as the right to life, adequate food and the highest attainable standard of health.

The way in which governments carry out their responsibilities with regard to SPS protection varies greatly across different levels of development. As elucidated by the law-andeconomics analysis conducted in Chapter 1, national SPS regulation is necessitated by the failure of the market in providing public goods, including SPS protection. This requires domestic regulators to step in to correct the deficiencies in the market to ensure that an optimal level of SPS protection is provided, as explained by the public interest theory of regulation. This entails a weighing up of the various costs and benefits of SPS regulation in a particular risk situation. The costs and benefits of SPS regulation differ significantly depending on the particular situation of a country, including its regulatory capacity, resources and health and trade priorities. In this light, the differences in domestic SPS regulation can be ascribed to legitimate regulatory choices that are responsive to differences in national conditions. However, the public choice theory of regulation indicates that regulators are vulnerable to pressure from private interest groups, including industry lobbies, and may enact inefficient, or protectionist, regulations. There is therefore a need for disciplines to distinguish legitimate SPS regulation from disguised protectionism.

Due to the cost and difficulty of obtaining all the necessary information to conduct a cost/ benefit analysis of SPS regulation as a tool to differentiate between legitimate measures for the protection of health on the one hand, and disguised protectionist measures on the other, regulatory systems in developed countries rely on science as a proxy for the variables that would ideally be considered. The SPS Agreement has taken over this reliance on science as the touchstone against which to evaluate SPS measures. However, care must be taken not to adopt a simplistic view of science as a neutral and universally valid tool to depoliticise SPS regulation. In fact, science is characterised by value-ridden assumptions and subjective choices that reflect particular paradigms and ideologies of the scientific community generating the science. While science remains a useful tool, a nuanced and realistic view must be taken of its justificatory capacity. In particular, account must be taken of the fact that diverging scientific opinions on the same set of factual data may be equally valid. In addition science cannot always resolve uncertainties with regard to the existence and magnitude of a particular SPS risk. In response to the realisation of the prevalence of uncertainties in science, many regulators take a precautionary approach to risk regulation.

Both the use of science as a tool, albeit an inherently limited one, to discipline and legitimate regulatory action and the attendant emergence of precautionary approaches to deal with situations of scientific uncertainty are developments rooted in advances in the regulatory regimes of developed countries. They entail a high level of human and financial resources devoted to risk regulation and reflect best practices in dealing with the complexities of SPS risks. It should be borne in mind that these best practices do not present an accurate picture of the regulatory systems with regard to SPS risks in countries at lower levels of development. In fact, many less developed countries lack the capacity to staff and operate the scientific committees and regulatory agencies necessary to enact SPS regulations in a manner that conforms to these best practices. In addition, their particular development priorities and health concerns may dictate the use of their scarce 
resources in areas other than SPS regulation, for example, the provision of safe drinking water, basic sanitation and primary health care.

The understanding of the great differences in national SPS systems, and the link to differences in trade and health priorities, is facilitated by an examination, in Chapter 2 of Part II, of four illustrative examples of WTO Members in different income categories and in different geographical regions, namely Australia, Mauritius, Jamaica and Bangladesh. These examples show that while vast differences exist in SPS regulatory systems between developed and developing countries, there are also significant differences among developing-country Members. Clearly, some developing countries have been more successful than others in upgrading their SPS systems and securing access to the markets of their trading partners.

In addition, it has been shown that differences are also prevalent between different sectors within certain Members. Some sectors are operating at high levels of SPS safety, while others remain underdeveloped in this regard. This reflects national priorities with regard to export promotion as well as technical and financial assistance received in a particular area. Generally, the Members studied have in place relatively strong SPS controls over the most important SPS risks they face in economically significant areas. There is therefore clearly a need for a more nuanced understanding of the SPS problematique than to see it merely in terms of a developed country versus developing country issue.

Nevertheless, two general conclusions can be drawn regarding differences in SPS regimes according to the level of development as discussed in Chapter 2. First, the level of SPS protection exhibits marked differences, being substantially higher in more developed countries due to better technological capacity, higher consumer demands, and a more developed regulatory infrastructure. Second, the regulatory focus differs. Less developed countries tend to rely on product requirements, which are enforced by means of testing and inspections by government authorities at the point of exit or entry. Product requirements are easier to comply with as they leave the means of compliance up to the producer and are usually based on objective, testable properties that can more readily be ascertained. By contrast, developed countries are increasingly, especially in the area of food safety, moving towards process requirements, such as those embodied in the Hazard Analysis and Critical Control Point (HACCP) system, which require the producers themselves to take responsibility for ensuring that the entire chain, 'from farm to fork' meets certain standards of hygiene and safety. These process requirements entail a systems-wide approach to SPS issues, which necessitates significant technical expertise, supporting infrastructure and control systems.

These differences in SPS regimes have notable consequences for the impact both of SPS measures themselves and of the SPS Agreement on Members at different levels of development. The illustrative examples provided identify, by means of the discussion of practical situations, various problems faced by developing-country Members in complying with SPS measures in developed-country markets. These problems reflect the fact that the difficulty and costs of compliance are directly related to the extent of the gap between the existing domestic SPS regime and the SPS requirements in foreign markets. Several factors play a role here, such as weak domestic SPS regulation, inadequate public infra- 
structure, unreliable compliance assessment and certification, insufficient dissemination of information on SPS requirements abroad, and poor laboratory equipment and staff.

However, it would be an over-generalisation to state that middle- and low-income Members are entirely incapable of meeting SPS requirements on their export markets, or of upgrading their SPS systems to protect their territories from SPS risks. Examples were provided in Chapter 2 of success stories in this respect, such as the lifting of the fumigation requirement for Jamaica's hot pepper exports to the US, after its implementation of an integrated pest management system. It is, nevertheless, important to note the central role played by technical and financial support from the importing Member in some of these situations. In the Jamaican example just mentioned, the achievements were made possible by a collaborative effort with USAID. In many of the examples given in Chapter 2 , it is unlikely that, without the necessary technical assistance, the exporting Member would have been able to resolve the SPS problems facing its industry. This puts those Members that face capacity constraints in the area of SPS regulation in a very dependent position.

The differences in the legal and institutional capacity for SPS regulation between Members at different levels of development, illustrated by the selected Members used as examples in Chapter 2, have a bearing on the way in which the SPS Agreement impacts on them. These examples of divergent SPS regulatory systems therefore provide the factual context for the discussion of the provisions of the SPS Agreement in Parts III to V of this book.

The factual context within which the SPS Agreement operates also includes international systems for the elaboration of SPS standards. These were discussed in Chapter 3 of Part II. As explained in this Chapter, divergence in national SPS regulations impedes trade by reducing the possibilities to exploit economies of scale. Therefore harmonisation around international standards is promoted by free trade regimes, including by the WTO in the SPS Agreement. However, internationally-set standards cannot mirror the diversity of circumstances in countries around the world. Instead, they reflect a compromise position accepted by the delegates of those countries present and active in the standard-setting process, and developed according to the procedures of the relevant standardising body. An examination of the institutional structure and standard-setting procedures of the international bodies referenced in the SPS Agreement, namely the Codex Alimentarius Commission, the International Office of Epizootics and the Secretariat of the International Plant Protection Convention, shows that they are such that the participation of developing-country Members is limited. This is due to the fact that the structures and procedures do not sufficiently take into account the resource and capacity constraints of countries at lower levels of development. For example, in some cases the number and location of the committee meetings in which standards are developed may make regular participation difficult for countries with resource constraints.

Chapter 3 noted improvements that have been made in this situation in recent years, due to the realisation by developing-country Members of the increased importance of international standards under the SPS Agreement, and the efforts of the abovementioned three international standard-setting bodies to enhance their participation. Nevertheless, as seen from the data presented in this Chapter, developing-country Members still tend to 
be most widely represented in plenary sessions of the relevant standard-setting bodies, where standards are initiated and adopted. However, their participation in technical committees where scientific evidence is discussed and standards are prepared, and even more so in the scientific bodies that conduct the risk assessments on which standards are based, often leaves much to be desired. This is a significant problem as it is at this technical level that participation can be most effective. This inadequate participation is often due to the lack of human and financial resources necessary to ensure attendance of the plethora of committee meetings by well-prepared specialists in the areas in which standards are set. In addition, the lack of effective national infrastructures for the evaluation of draft standards and the formulation of positions was identified as a problem.

International standard-setting is therefore dominated by developed-country Members, resulting in standards that are often not appropriate for Members at lower levels of development. This is problematic as these are the Members that most depend on international standards as a basis for national regulation. More work is needed, not only in the form of simplification and improvement of the standard-setting procedures of the relevant bodies, but also in the form of efforts to build the capacity of Members at lower levels of development to participate effectively in these procedures. Here, once again, technical assistance has an important role to play.

The factual context provided by an examination of national SPS regulation and international SPS standard setting in Part II showed the great need for technical assistance of developing-country Members in order to build SPS capacity. However, there is a danger in seeing technical assistance as a magic bullet solution, assuming that developing-country Members can and should meet any obligation as long as they are provided with technical assistance to do so. Technical assistance is not an alternative to analysing whether a rule is appropriate for developing-country Members to implement. While it can address some of the costs of implementation, it cannot take away the long term disadvantages of the application of inappropriate disciplines. Consequently, it is essential to begin by assessing, on the basis of the detailed examination conducted in Parts III and IV of this book, whether the substantive and procedural rules of the SPS Agreement are appropriate for developing-country Members. To facilitate this assessment, the legal analysis of the regulatory disciplines and procedural arrangements under the SPS Agreement conducted in Parts III and IV of this book takes place against the factual background and regulatory context sketched in Parts I and II.

\section{The relevance of the history of the SPS Agreement}

Part III of this book turned to examine the SPS Agreement. In Chapter 1, this Part discussed the history of the Agreement, which has its roots in the inadequacy of the previously existing rules, contained in the GATT 1947 and the Tokyo Round Standards Code, to deal with SPS measures. This inadequacy was highlighted by the unresolved dispute between the EC and US with regard to the EC ban on beef from cattle treated with growth hormones. The SPS Agreement was negotiated in the Uruguay Round to address the fraught situation of the conflicting objectives of liberalisation of trade in food and agricultural products, on the one hand, and the protection of health against SPS risks, on the 
other. Its disciplines take on board the existing GATT rules applicable to health measures, as interpreted in the early case law, but do not stop here. Instead, the SPS Agreement builds upon the existing rules and creates novel disciplines. In addition, it balances the disciplines on SPS measures with an express recognition of the right of Members to regulate to protect against SPS risks. This balancing objective pervades the SPS Agreement and informs the choice of disciplines it contains.

However, the disciplines of the SPS Agreement are also a reflection of the fact that the most active participants in the negotiations towards this Agreement were developed countries and the Cairns Group of agriculture-exporting countries, as apparent from the discussion of the negotiating history set out in Chapter 1 of Part III. As a result of the differences in the extent and effectiveness of participation of countries at different levels of development in the negotiations, the disciplines of the SPS Agreement can be said to embody a regulatory model that reflects best practices in developed-country Members with regard to SPS regulation. The illustrative examples of different WTO Members set out in Part II showed that the reality in many developing-country Members is quite different. While disciplines reflecting a best-practice regulatory model could have the salutary effect of improving the quality of SPS regulation worldwide, it is important to ensure that these disciplines are achievable for all Members.

It may be expected that compliance with the requirements in the SPS Agreement for SPS regulation, in terms of both scientific basis and procedural mechanisms, is more difficult and costly for less-developed Members. Many of these Members have to make significant investments to upgrade their SPS systems in order to be able to comply with the disciplines of the SPS Agreement. In addition, institutional and scientific capacity constraints are likely to affect the possibilities that less-developed Members have to use the substantive rules and procedural mechanisms of the SPS Agreement to gain access to foreign markets. Whether this is, in fact, the case is the question addressed in the subsequent analysis of those substantive rules that limit the scope for regulation in this area and the procedural arrangements under the SPS Agreement, in the rest of Part III and in Part IV of this book.

\section{The limits of the coverage of the SPS Agreement}

The disciplines of the SPS Agreement were negotiated to deal with a specific type of situation, involving a conflict between two particularly politically sensitive objectives, namely the liberalisation of agri-food trade and the protection of health against SPS risks. The SPS Agreement aims to achieve an appropriate balance between these two objectives. This limited objective is reflected in the SPS Agreement by its careful demarcation of its scope of application in Article 1.1 read together with Annex A.1, as discussed in Chapter 2 of Part III.

The provisions delimiting the coverage of the SPS Agreement encompass measures to address those risks to human, animal or plant life or health that may arise from trade in primary and processed agricultural products. These include, for example, food safety risks and risks from pests and diseases of animals or plants. The provisions of the SPS 
Agreement dealing with its scope of application consequently primarily focus on the purpose of the measure to determine whether it falls within the ambit of the Agreement, while leaving the form that such a measure might take broadly defined by means of an illustrative list of possible types of measures.

However, the discussion in Chapter 2 of Part III demonstrated that the current interpretation of the scope of application of the SPS Agreement in the case law, since the EC - Approval and Marketing of Biotech Products dispute, is very broad. In particular, the Agreement has been held by the Panel in that case to cover measures aiming at a broad array of purposes beyond the particular situations that seem to have been envisaged by negotiators when drafting its strict scientific disciplines. It now eats into the coverage of the TBT Agreement and the GATT 1994 in situations where the disciplines of those Agreements would have been more appropriate. An example of such a situation is where a measure aims at the protection of the environment per se, not involving a risk to plant or animal life or health. Not only do the scientific obligations of the SPS Agreement inordinately restrict Members' scope for regulatory action in such situations, due to the significant differences in the state of scientific knowledge and extent of uncertainty in the field of environmental protection, but there is also little to be gained for agricultural trade through their application. While many types of measures can be crammed into the definition of Annex A.1 to the SPS Agreement by both stretching its terms, and travelling far down the chain of causality to find a risk to which the measure can be said to be 'rationally related', this does not seem a wise course to take. It reduces to inefficacy the list of enumerated purposes in Annex A.1(a) to (d) as a tool limiting the scope of application of the SPS Agreement to those situations most likely to entail a conflict between health protection and agricultural trade.

The artificial insertion, by the Panel in EC-Approval and Marketing of Biotech Products, of a limited 'nature' element, in addition to the inclusive 'form' element, into the definition of an SPS measure does not ameliorate the problem caused by its expansive interpretation of the enumerated purposes in Annex A.1 (a) to (d). The term 'requirements and procedures' in Annex A.1 would normally cover most types of measures, doing little to limit the applicability of the SPS Agreement. However, the formalistic character of the Panel's 'nature' requirement may create adverse incentives for Members to devise measures of another 'nature' in such a way that they escape the disciplines of the SPS Agreement. For example, a measure that amounts to the application of a requirement or procedure would fail to meet the 'nature' test and thus fall outside the scope of application of the SPS Agreement. The distinction between the types of measures that, under this interpretation, fall within and without the SPS Agreement bears no relation to the objective of the Agreement and only a strained connection to its wording. Instead, the interpretation is artificial, arbitrary and open to abuse.

The unexpectedly extensive substantive coverage of the SPS Agreement under the abovementioned Panel's approach is not necessarily to the benefit of developing-country Members. It would be too simplistic to think that these Members automatically benefit from as wide an application of the SPS Agreement as possible, extending its strict disciplines to a broad range of situations. It must be recognised, as discussed in Part II, that the positions and interests of developing-country Members are diverse, and that these Members are not only exporters of food and agricultural products, but are also importers 
of these products. They, like other WTO Members, benefit from the limited application of the disciplines of the SPS Agreement to the particular situations these are tailored to address. An inappropriate expansion of the application of this Agreement tilts the balance it aims to achieve and disturbs the relationship between it and the other relevant WTO agreements. It is important to bear in mind that measures not falling under the SPS Agreement are not undisciplined; they are merely disciplined in ways more appropriate to them by other WTO agreements.

The finding by the Panel in EC - Approval and Marketing of Biotech Products that a measure can be both an 'SPS measure' and a 'non-SPS measure' when it has multiple objectives, further complicates the situation. It has the effect of subjecting a single measure to multiple, differing, disciplines. The result is that the policy space of a Member is even more greatly restricted as its measure is vulnerable to a multitude of challenges under agreements with quite different objectives. Consequently the particular objectives sought by the provisions of the relevant agreements in specific situations are undermined. This cannot be what is meant by a 'harmonious interpretation' of the 'inseparable package' of WTO agreements. It is hoped that the Appellate Body will correct this problem in future cases.

Chapter 2 of Part III further addressed the difficult issue of the applicability of the SPS Agreement to the SPS requirements of bodies other than central government. The increasing shift of SPS norm creation and implementation to subnational and transnational levels in the last decade has brought this issue to the forefront of attention. While the idea that Members are responsible for compliance with WTO obligations by their subnational levels of government is now generally accepted, the same cannot be said for nongovernmental entities. The principle of attribution to a Member of acts of private bodies in cases where there is a sufficient level of intervention by the government in the private action, only addresses the problem to a limited degree. A rapidly growing number of SPS requirements are developed and applied by private bodies free of governmental influence, in response to consumer demand, especially in affluent Members. The fact that the market for food and agricultural products, particularly in the high-value sector, is dominated by retail conglomerates which require compliance with specific private sector standards results in the blurring of the distinction between public and private SPS requirements in terms of their impact on exporters. Private sector standards act as significant barriers to developing-country exports, particularly those of their small-scale producers. The question thus arises to what extent Article 13 of the SPS Agreement may be relied upon to compel Members to discipline private sector bodies in their territories, or regional bodies in which entities on their territories are members.

It was argued in Chapter 2 that the concepts of 'non-governmental entities' and 'regional bodies' in Article 13 of the SPS Agreement should be interpreted to include private sector bodies at subnational and transnational level, to take account of the rapid proliferation of private sector standards. However, the extent of the obligation to take 'such reasonable measures as may be available' must be seen as limited. What is 'reasonable' depends on the circumstances of the case, and in particular on the type of entity involved. The view espoused here is that it would not be appropriate to require Members to enact legislation to impose the existing disciplines of the SPS Agreement on private sector bodies, such as supermarkets, as these disciplines lay down best regulatory practice requirements not 
suitable for such bodies. A Code of Good Practice for the SPS Agreement, with appropriate procedural disciplines to promote transparency, consultation and the recognition of equivalence should ideally be drafted. However, in view of the fact that agreement is unlikely to be reached on this, it is recommended that the Code of Good Practice of the TBT Agreement be interpreted as applicable to private sector SPS standards.

Even if a Code of Good Practice were in place to discipline the procedural aspects of private sector standards, the burden of compliance with these standards remains high due to their demanding nature. Current practices with regard to the provision of technical assistance by vertically integrated companies that source their produce in developing countries lead to dependent relationships and the potential for abuse. Instead, effective and disinterested capacity building is called for to achieve sustainable and equitable results. In the meantime, a pragmatic approach to this problem could be the continued use of the multilateral forum provided by the SPS Committee to raise concrete examples of the challenges posed by private sector standards, in an effort to stimulate private bodies to be responsive to developing-country Members' needs in the elaboration and implementation of their standards, and to spur donors to provide technical assistance.

Finally, Chapter 2 noted the applicability of the SPS Agreement to all SPS measures still in force, including those enacted before the coming into force of the Agreement. This has the benefit of avoiding the creation of an exemption for all pre-existing measures, something that would weaken the effectiveness of the SPS Agreement. However, its downside is the heavy burden it imposes by creating an obligation on Members to revise SPS measures that predate the SPS Agreement in order to ensure their conformity with its new rules. In Members with less advanced SPS regulatory systems, where the conduct of risk assessments and consideration of international standards was not a matter of course, this may be a difficult and costly task. On balance, however, this interpretation seems to be the preferable one. It is argued here, as elsewhere in this book, that the capacity constraints of Members at lower levels of development should be addressed through capacity building initiatives rather than by weakening the disciplines of the SPS Agreement, including through creating a wide exemption for pre-existing measures. It is certainly not to the advantage of developing-country Members to create a safe haven for the plethora of SPS measures that were already in place on 1 January 1995, particularly in developed-country Members. The most lucrative markets for agricultural and food products are, at the same time, those on which SPS measures have a long history and a vigorous application. Holding pre-existing SPS measures to the same scientific standards as new SPS measures brings some much-needed discipline to this area.

As set out in Chapter 2, the current position of measures for the protection of health under WTO law is determined by the relevant provisions of the SPS Agreement, the TBT Agreement and the GATT 1994 within their respective spheres of application. The measure could thus be caught by any of the three agreements, depending on its objective(s), form and nature and its effect on trade. Which agreement (or agreements) applies in a particular case has far-reaching implications for the type of disciplines to which the measure is subjected, and in particular for the extent of policy space left to Members within which to exercise their regulatory autonomy. 


\section{The delicate trade/health balance in the regulatory disciplines}

Within the limits of the applicability of the SPS Agreement, certain of its substantive disciplines, as interpreted by panels and the Appellate Body, determine the scope for regulatory action by Members against SPS risks. The basic rights and obligations set out in Article 2 of the SPS Agreement epitomise the trade/health balance aimed at by the Agreement and the manner in which this balance is struck in its substantive rules. These were discussed in Chapter 3 of Part III.

The express recognition in Article 2.1 of the right of Members to take SPS measures is key in this respect. It has the result that, unlike the situation under the GATT 1994, Members imposing measures covered by the SPS Agreement do not bear the burden of justifying these measures under an exception to trade liberalisation disciplines. Instead, a Member wishing to challenge an SPS measure must establish a prima facie case of violation of specific disciplines of the SPS Agreement. The limits to the right to take SPS measures, first outlined in Articles 2.2 and 2.3, recur in more specific form in the rest of the SPS Agreement. These provisions reflect and build upon familiar GATT disciplines, requiring that health measures be limited to what is 'necessary' to achieve their aim, and prohibiting arbitrary or unjustifiable discrimination and disguised trade restrictions. Further, Article 2.2 introduces an innovative aspect of the SPS Agreement, namely the use of science as the scale on which the competing interests of trade and health are balanced.

The careful balance aimed at by these substantive disciplines of the SPS Agreement must be respected in their interpretation. There is therefore no room for the importation of a strong proportionality test arising from the 'necessary' requirement of Article XX(b) of the GATT 1994 into the 'necessary' requirement of Article 2.2 of the SPS Agreement. Neither is the strong proportionality test read into the 'sufficient scientific evidence' requirement of Article 2.2 by the Panel in Japan - Apples to be condoned. Requiring an SPS measure to be proportional to the seriousness or magnitude of the risk at issue is contrary to the balance that is the object and purpose of the Agreement. It deprives Members of the room to make their own policy decisions in their responses to risk. In view of the diversity in priorities, economic resources and risk-averseness of Members at different levels of development, reflected in the policy choices inherent to risk regulation, this result is to be avoided.

Harmonisation of SPS measures is promoted by Article 3 of the SPS Agreement in order to reduce the barriers to trade created by disparate SPS requirements in various importing Members. Chapter 4 of Part III examined this provision. In the absence of a rule-making body in the WTO entrusted with the task of providing generally applicable SPS requirements, Article 3 of the SPS Agreement makes use of other international bodies as authoritative providers of uniform standards, namely the international standard-setting bodies referenced in Annex A.3 thereof. These bodies use recognised risk assessment procedures conducted by scientific expert groups and discussed in committees to draw up standards. Their standards aim to reflect a large degree of scientific consensus on risk as well as policy agreement on the best way to address such risks. WTO Members are therefore encouraged to use these standards through the disciplines of Article 3 of the SPS Agreement. 
Harmonisation of SPS measures around international standards has the potential to assist less-developed Members that lack the scientific capacity to undertake their own risk assessments as a basis for regulatory decisions. It thus seems imperative to interpret the autonomous options provided by Articles 3.1 to 3.3 of the SPS Agreement in a manner that provides real benefits to Members that choose to base their SPS measures on international standards or to conform their measures to these standards, in contrast to the current interpretation in the case law. If an SPS measure that is 'based on' an international standard would be regarded as complying with the requirement of a scientific basis (in Articles 2.2 and 5.1), less-developed Members with limited scientific capacity could rely on the relevant international standard, and in particular on the risk assessment that underlies it, while adjusting the aspects of the international standard that are not well-suited to their particular situations. While such a measure could still be challenged under the remaining disciplines of the SPS Agreement, such as those relating to necessity, consistency and non-discrimination, it would be safe from scientific challenges - a significant advantage for Members with weak scientific capacities. Similarly, if the presumption that SPS measures that 'conform to' international standards are consistent with the GATT 1994 and the SPS Agreement, contained in Article 3.2 of the SPS Agreement, would be interpreted as irrebuttable, it would provide a safe harbour for those Members whose weak regulatory capacity prompts them to fully adopt international standards. Such interpretations create a stronger impetus for harmonisation around international standards, without calling into question the right of Members to deviate from international standards if this is necessitated by their chosen level of protection. This interpretation therefore furthers the objective of Article 3 as outlined in the Preamble to the SPS Agreement. Such an interpretation is proposed here as preferable to the one currently followed in the case law.

However, any discussion of the potential benefits of the harmonisation provisions of the SPS Agreement for less-developed Members must be seen against the factual background of the problems of participation of these Members in the international standardsetting process, as set out in Part II. The preferences of the most active participants in the standard-setting process are reflected both in the science policy choices underlying the risk assessments on which international standards are based and in the risk management decisions taken in the international standard-setting bodies. The most influential participants are those with the most resources to dedicate to ensure the effectiveness of their participation, namely developed countries and industry groups. Efforts are already underway within the international standard-setting bodies to address the institutional and procedural constraints to developing-country participation, as discussed in Parts II and $\mathrm{V}$ of this book. However, it is clear that much remains to be done to redress the imbalance in participation of Members at different levels of development in the international standard-setting bodies. Without successful efforts in this regard, the harmonisation disciplines of the SPS Agreement will have a negative impact on development, contrary to their objective.

Harmonisation is not always possible, nor is it always desirable. Diverging SPS measures may be a reflection of the diversity in both capacity and policy priorities that exists in different Members and can be seen as a natural outcome of the exercise of sovereign regulatory authority by their governments. In the absence of harmonisation, the SPS Agreement relies on scientific justification to discipline regulatory decisions. These 
scientific disciplines, discussed in Chapter 5 of Part III, counterbalance the regulatory autonomy of Members, reflected in the policy space reserved to them in the SPS Agreement. Science is regarded as a value-neutral benchmark, universally accepted and thus valid for all. As a result, the SPS Agreement requires that SPS measures that deviate from harmonised standards are rationally supported by science as embodied in a risk assessment.

A more nuanced understanding of science and the subjective choices inherent in the assessment of risks has emerged since the negotiation of the SPS Agreement, undermining the possibilities for reliance on science as an objective yardstick against which to judge SPS regulation. However, this does not mean that the use of science in the disciplines on SPS measures is completely misplaced. The scientific disciplines of the SPS Agreement have the definite benefit of encouraging rationality in risk regulation and thereby improving the quality of SPS decision making. The Appellate Body has taken steps to prevent the scientific obligations of the SPS Agreement from becoming rigid and unworkable restrictions on the regulatory autonomy of Members. In this way, it has been careful to ensure that the use of science as a tool to balance trade and health in the SPS Agreement does not result in a skewed outcome through the unrealistic application of this tool.

This realistic approach has unfortunately not been taken by panels in their application of the scientific obligations of the SPS Agreement to the factual situations before them. Instead, panels have seen it as their task to engage in a detailed assessment of the scientific evidence underlying a Member's measure, and to come to an independent conclusion regarding the existence and extent of the risk at issue. The invasive application of the scientific rules of the SPS Agreement by panels might be expected to be advantageous to developing-country Members that export agri-food products, since it provides greater opportunities to challenge the SPS requirements of their trading partners. However, in order to do so, the complaining Member needs to have sufficient scientific capacity to identify the flaws in the scientific basis for the regulating Member's measure, and to pursue challenges on this basis. This capacity is frequently lacking in Members at lower levels of development. In addition, even where the necessary capacity to bring scientific challenges is present, the intrusive approach of panels does not, in fact, lead to increased opportunities for market access. By undermining the scope for national choices in science policy decisions, and thereby skewing the delicate balance of the SPS Agreement, these panel decisions result in politically unacceptable outcomes of dispute settlement. This increases the chances of non-compliance by a regulating Member with the recommendations and rulings of the DSB, thereby undermining the effectiveness of the SPS Agreement.

The scientific disciplines of the SPS Agreement also entail significant compliance costs for Members at lower levels of development. The rigorous requirements for a risk assessment necessitate a high level of scientific and technical capacity, something which is lacking in many less-developed Members. The possibility for these Members to make use of 'borrowed' risk assessments to fill the gap left by their own lack of scientific capacity has been significantly narrowed by the requirement of a great degree of specificity read into the two definitions of 'risk assessment' in Annex A.4, and by the additional restrictions read into the criterion of a risk assessment 'as appropriate to the circumstances' in the case law. Consequently, the SPS regulations of less-developed Members are often vulnerable to challenges under the scientific obligations of the SPS Agreement. 
In contrast to its strict scientific disciplines with regard to risk assessment, the SPS Agreement provides considerable latitude for Members to give effect to their policy choices in their risk management decisions, as discussed in Chapter 5 of Part III. This policy space left to Members is indicative of the balancing approach of the SPS Agreement. It acknowledges that Members have the right to choose the levels of protection against SPS risks that they deem appropriate. Such decisions are taken by national regulators on grounds of societal value judgements on issues such as what level of risk is considered acceptable in society, not purely on the basis of scientific analysis of risk. The SPS Agreement recognises this, by placing no requirement of establishing a scientific basis on the choice of the appropriate level of protection. Neither does it place any restrictions on the types of factors that Members may consider when deciding on their choice of level of protection. Thus divergent, particularised national health measures result even where the scientific basis for the measures is the same everywhere.

The only real discipline on the choice of a level of protection is the prohibition, in Article 5.5 of the SPS Agreement, on arbitrary or unjustifiable distinctions in levels of protection applied in different but comparable situations, if these distinctions would lead to discrimination or a disguised restriction on trade. The broad ambit given in the case law to the situations that may be considered 'comparable' is tempered by the fact that distinctions in the levels of protection applied are only caught by the prohibition if they are arbitrary or unjustifiable. Panels and the Appellate Body have considered factors relating to the level of risk and difficulties of controlling the risk in the situations compared, to determine if the differences in the level of protection chosen by a Member in these situations can be justified. However, in some cases, divergence in the appropriate level of protection is grounded in (often irrational) societal preferences rather than objective differences in risk. This is particularly the case with regard to the risks to which people voluntarily expose themselves, due to particular cultural practices. The SPS Committee is instructed, in Article 5.5, to take this into account in developing guidelines for the implementation of Article 5.5. Room has also been made by the Appellate Body for considerations unrelated to the risk at issue, including consumer concerns, to be factored into the determination of an appropriate level of protection, by finding that such considerations will not render the chosen level of protection a 'disguised restriction on trade' for purposes of Article 5.5. This decision implies a positive recognition by the Appellate Body of the important role of societal value judgements in the making of risk management decisions.

The choice of an SPS measure to achieve a Member's appropriate level of protection is also disciplined in the SPS Agreement. Not only must these measures bear a rational relationship to a risk assessment, but they must also not be more trade-restrictive than required to achieve the appropriate level of protection of the regulating Member. While the least-trade-restrictive discipline is clearly drawn from the 'necessary' test of Article XX of the GATT, unlike the GATT the SPS Agreement clearly excludes the possibility for strong proportionality testing by explicitly providing that any alternative measure proposed must achieve the regulating Member's appropriate level of protection. In addition, the technical and economic feasibility of the alternative measures is expressly considered. This ensures that unrealistic limits on a Member's choice of measure are avoided, in recognition of the fact that resource and capacity constraints play an important role in regulatory decisions. The examination of the space left to Members in the SPS Agreement 
to carry out their risk management policies is indicative of the balancing approach of the SPS Agreement.

The SPS Agreement allows for risk management choices in the face of insufficient scientific evidence by providing scope, in Article 5.7, for provisional measures. When the four requirements of Article 5.7 are met, the relevant SPS measure is exempted from the scientific disciplines of Articles 2.2 and 5.1 of the SPS Agreement. Article 5.7 seems to provide an adequate vehicle for the incorporation of the precautionary principle into the SPS disciplines relating to risk management. By laying down specific requirements for the exercise of the right to take provisional measures, Article 5.7 operates to avoid abuse of this right. It ensures that a framework is in place within which risk management decisions taken in the face of insufficient scientific evidence can be disciplined, to promote rationality.

The examination of the relevant substantive disciplines of the SPS Agreement leads to two related conclusions. The first is that the balancing objective of the SPS Agreement is unmistakeably reflected in the way in which these substantive provisions are framed. As identified above, there are aspects of the interpretation of these provisions that do not fully give effect to the careful balance embodied in their terms, and leave room for improvement. Nevertheless, the provisions themselves seem appropriate to address the sensitive trade/health conflict in a way that promotes the liberalisation of agri-food trade while respecting the right of Members to regulate against SPS risks. However, the second conclusion that is evident from the discussion of the relevant substantive rules of the SPS Agreement is that these rules impose a regulatory model that is currently not achievable for many Members at lower levels of development. Neither are these Members able to use these substantive rules effectively to procure market access for their products.

The fact that the SPS measures of Members at lower levels of development have rarely been challenged in dispute settlement proceedings to date, should not create the impression that this means that their inability to comply with the disciplines of the SPS Agreement has no real consequences for them. Many instances of non-compliance by these Members with the regulatory obligations of the Agreement have been challenged in the multilateral forum of the SPS Committee, or in bilateral discussions between Members. In these situations, it is often difficult for the regulating Member to justify its measure, other than to refer to its capacity constraints. This situation leaves less-developed Members vulnerable to pressure by other Members to settle other SPS conflicts in ways unfavourable to them.

Aside from the particular aspects of the interpretation of the substantive rules of the SPS Agreement, identified throughout Part III, that leave scope for improvement, it is difficult to see how changes can be made to address developing-country constraints without skewing the careful balance sought by the Agreement. The rules themselves seem appropriate for the fulfilment of their function of allowing sufficient room for Members to regulate in a manner that gives effect to their policy priorities in the area of SPS risk, while disciplining such regulation to eliminate the possibilities for disguised protectionism and to reduce the adverse trade effects of legitimate measures. Nevertheless, the very real problem of the constraints that less-developed Members face in complying with, and benefiting from, these rules cannot be disregarded. 
The question arises to what extent the remaining provisions of the SPS Agreement ameliorate this problem by taking account of the capacity constraints of Members at lower levels of development, both in respect of compliance with the disciplines of the Agreement and in respect of enforcement of these disciplines against other Members in order to gain market access. This question is addressed in Parts IV and V of this book.

\section{The underestimated benefits of the procedural}

\section{and institutional arrangements}

Alone, the substantive disciplines of the SPS Agreement discussed above would not be sufficient to achieve significant gains in market access for food and agricultural products from developing-country Members. As was pointed out, these Members lack the scientific and technical capacity to identify instances of non-compliance with the complex regulatory disciplines of the SPS Agreement, and to formulate effective challenges in this regard. In addition, many legitimate SPS regulations that pass muster under the relevant substantive disciplines of the SPS Agreement nevertheless form significant trade barriers. This is particularly so for Members that face capacity constraints in keeping track of new and changed measures, understanding their implications and proving their compliance with SPS requirements (including by demonstrating the equivalence of their own SPS requirements, or by gaining recognition of the pest- or disease-free status of their territories or of regions within their territories). Additionally, substantive disciplines on their own are not useful without effective tools to monitor their implementation, resolve conflicts between Members with regard to these disciplines and if necessary enforce compliance therewith. The rules of the SPS Agreement that address these institutional and procedural matters were discussed in Part IV. These institutional and procedural provisions have an important impact on the effectiveness of the SPS Agreement in achieving its goals. The examination of these provisions aimed to determine the extent to which they are effective tools for exporting Members at lower levels of development to gain market access without endangering the ability of importing Members to protect health in their territories.

First, Chapter 1 discussed those provisions in the SPS Agreement under which mechanisms creating disciplines of an institutional or procedural nature on Members are established. These institutional or procedural disciplines leave undisturbed Members' policy choices within the bounds of the relevant substantive disciplines of the Agreement, but address the way in which these policies are achieved in order to minimise as far as possible their trade-restrictive effects. Often the procedural obligations in the SPS Agreement are combined with a substantive discipline, yet the procedural mechanism under the provision is key to its potential in improving market access. It is useful to note that procedures may be abused to prevent the achievement of the goals of the relevant substantive disciplines, thereby undermining the trade/health balance of the Agreement. In other words, in many cases it is not what is done but the way in which it is done that creates problems. These problems may be especially burdensome for Members at lower levels of development, due to their lack of resources to devote to compliance with complex procedural requirements. 
The SPS Agreement contains some rules dealing directly with procedures imposed by Members to check compliance with their SPS measures. These are contained in Article 8 and Annex C, which address control, inspection and approval procedures. Annex C.1 sets out a list of disciplines, which broadly speaking aim to ensure that these procedures are not more lengthy and burdensome than is reasonable and necessary, and that they do not discriminate against imports. A few of these disciplines have been clarified by the Panel in EC-Approval and Marketing of Biotech Products. Further clarification and a rigorous application of these rules are called for, to give full effect to the potential of Annex C.1 to discipline the relevant procedures.

Further, Annex C.1 contains a weak additional discipline for systems of prior approval of additives and establishment of tolerances for contaminants, requiring consideration of the use of international standards pending a final determination. While these systems sit uncomfortably with the general regime established by the SPS Agreement, they do fall within the definition of SPS measures and are covered by all the disciplines of the Agreement, not just Annex C.1. Members are, however, reluctant to challenge prior approval systems as such under the SPS Agreement. This is evinced by the fact that the only challenge relating to a prior approval system to date is that in EC-Approval and Marketing of Biotech Products, where the challenge did not address the system itself but only the delays in its application, as reflected in the de facto moratorium and product-specific measures.

The additional procedural mechanisms under the SPS Agreement aim to operationalise certain of its substantive obligations. The substantive obligations on Members in respect of the recognition of equivalence, the adaptation of their SPS measures to regional conditions and transparency in respect of their SPS measures would achieve little without procedural arrangements to give effect to them. Yet, the procedural aspects of the provisions on these matters in the SPS Agreement, aside from the provisions on transparency, are extremely weak. This has led to very poor implementation of the obligations on equivalence and regionalisation, rendering ineffective these provisions despite the very significant potential they hold for market access improvements.

These potential benefits are of particular relevance for Members at lower levels of development. The recognition of equivalence, unlike harmonisation rules, allows for differences between Members, including those relating to consumer preferences and technical and financial resources, that lead to divergent SPS measures. Yet it limits the trade-restrictive effect of the divergent measures by acknowledging that it is possible for different SPS measures to achieve the same level of protection. Thus by recognising equivalence an importing Member would allow imports of products that comply with different, but equally effective, SPS measures. This leaves flexibility for Members at lower levels of development to apply SPS measures suited to their capacities and still gain market access, provided that the measures achieve the importing Member's chosen level of protection. Similarly, regionalisation holds great potential by recognising that SPS conditions, and in particular the incidence of pests and diseases, are not determined by national borders, and may differ between various regions within a country. In some large developing countries, conditions may vary greatly from region to region, due to variations in climate, environmental or geographic conditions within the country and/or due to the efforts of the regulatory authorities to eradicate a pest or disease from specific areas. Adaptation of SPS measures of importing Members to the pest or disease conditions of the region of 
origin of the product could greatly improve market access possibilities. This enables the exporting Member to limit the costs of eradicating a pest or disease or keeping pest- or disease-free status by focusing on specific areas.

In order to realise the potential of the obligations on the recognition of equivalence and adaptation to regional conditions, the SPS Committee has adopted decisions setting out procedural mechanisms. These decisions do not amend the substantive obligations on equivalence and regionalisation, but instead provide guidelines for their effective implementation. Developed on the basis of concrete information provided by Members on their experiences in the relevant areas, and elaborated in technical discussions among SPS regulatory officials, these procedures illustrate the potential of the SPS Committee to find cooperative solutions to implementation problems.

The substantive transparency obligations of the SPS Agreement regarding prior notification of changes to SPS measures, publication of adopted measures and the explanation, upon request, of reasons for SPS measures also hold great potential to improve market access possibilities. Prior notification enables exporting Members to be informed of proposed new or amended SPS measures and to transmit this information to their exporters. This gives Members, and through them their exporters, the opportunity to make comments regarding these proposals at an early stage and to have these comments taken into account in the regulatory process. Members can also raise concerns on notified measures in multilateral discussions at SPS Committee meetings. The publication requirement for adopted SPS measures is crucial in facilitating market access for exports from less-developed Members by greatly reducing the cost and difficulty of obtaining information on their trading partners' SPS measures. It also enables exporting Members to exercise their rights and police the implementation of the obligations of the SPS Agreement, by ensuring that these Members obtain full information on the content of the SPS measures of importing Members in order to identify whether they are consistent with the SPS Agreement. The provision of an adaptation period before the entry into force of a published measure is of particular importance to developing-country Members as their exporters may need more time to adjust to new requirements. The obligation to provide reasons supplements the other transparency provisions by enabling Members to obtain information beyond that on the existence and content of SPS measures, such as that regarding the scientific basis of the measure, the level of protection it seeks to achieve and other aspects of the reasons for its imposition. This information enables an exporting Member to raise its concerns regarding the measure in a focused manner, by pointing to specific inconsistencies with the SPS Agreement in bilateral discussions or in the multilateral forum of the SPS Committee. It can also play a useful role in dispute settlement proceedings by assisting an exporting Member in establishing a prima facie case, for example, that an importing Member's SPS measure is not based on a risk assessment or sufficient scientific evidence. To give effect to these transparency obligations, the SPS Agreement, in Annex B, contains some procedural rules, particularly in respect of notification. However, these procedural rules are not sufficiently detailed and have given rise to difficulties of implementation, undermining the effect of the substantive obligations.

The impact of the transparency obligations for Members at different levels of development varies, both in terms of the compliance burden they impose and in terms of the potential benefits they offer. Not only the implementation of transparency obligations 
but also the need to manage the inflow of information from other Members resulting from increased transparency require institutional infrastructure and human and financial resources. This was illustrated by an examination of the greatly varying transparency practice of the four Members selected as examples in this book. To facilitate compliance with the transparency obligations and to assist Members to derive full benefits from them, the SPS Committee has adopted recommended transparency procedures and formats for notifications. The procedures and formats, while not binding, are commonly followed by Members, and have resulted in great improvements in transparency. On the basis of experience with their use and new suggestions for improvement, the transparency procedures have been revised three times and they can be regarded as a 'work in progress'. Transparency procedures have also been adopted by the SPS Committee in respect of determinations on equivalence and regionalisation, as well as with regard to requests for special and differential treatment and responses to such requests. The Recommended Transparency Procedures currently also incorporate references to mechanisms designed by the WTO Secretariat, on the initiative of Members, to address constraints faced by developing-country Members. Examples are the mechanisms to improve access to unofficial translations of documents; to provide access to a database, known as the SPS IMS, where notifications of SPS measures and other relevant sources of information are compiled; and to facilitate access to notified draft SPS measures by storing documents electronically on the WTO server and enabling access to these documents through hyperlinks in notifications. In this way, the work of the SPS Committee, supported by the WTO Secretariat, with regard to improving the procedural arrangements for transparency under the SPS Agreement has been instrumental in furthering the realisation of the benefits of transparency while reducing some of its costs.

A second category of procedural and institutional mechanisms, discussed in Chapter 2 of Part IV, covers those provisions in the SPS Agreement that deal with the institutions and procedures necessary at WTO level for the smooth and effective implementation of the SPS Agreement. The proper implementation and operation of the SPS Agreement is ensured through two institutional and procedural avenues, that provided by the bargaining forum of the SPS Committee and that provided by the adjudicatory mechanism of the dispute settlement system. The provisions relating to the SPS Committee and to dispute settlement are essential in promoting and monitoring the implementation of the disciplines of the SPS Agreement, resolving conflicts between Members with regard to these disciplines and, if necessary, enforcing compliance therewith.

The question of whether Members' trade concerns with respect to the SPS measures of other Members are dealt with through multilateral discussions at SPS Committee meetings or instead through formal adjudication is not without significance. It is highly relevant for the manner in which the trade/health balance is struck, which, in turn, is closely tied to the questions of who participates in framing the issues under discussion and who decides on the outcome of the dispute. These questions are particularly pertinent when one bears in mind the differences in opportunities for effective participation available to Members at different levels of development under each of the two mechanisms. The discussion in Part IV made abundantly clear that, currently, alternative mechanisms to dispute settlement represent the best way forward in ensuring that developing-country 
Members benefit as fully as possible from the advantages offered by the disciplines of the SPS Agreement.

In particular, the discussion of the role and functioning of the SPS Committee showed much greater possibilities for participation of Members at lower levels of development than exist currently in the dispute settlement system. The specific trade concern mechanism of the SPS Committee has proved very effective in providing opportunities for Members to address the problems they face regarding the SPS measures of their trading partners in an inexpensive and constructive way. Most often, bilateral discussions on trade concerns placed on the agenda are held in the margins of SPS Committee meetings and may resolve the matter. If not, discussions are held in the multilateral forum of the SPS Committee, which enables other Members to comment on the issue and support the trade concern raised. This could lead to the revision of the notified measure or to further bilateral consultations between the Members involved. It may also facilitate compliance with the SPS measure complained of by the Member raising the concern, through increased clarity on the requirements and ways to meet them, and in some cases by means of the provision of technical or financial assistance by the importing Member. In this way disputes can be resolved without recourse to the expensive, time-consuming and confrontational process of formal dispute settlement.

The specific trade concerns mechanism of the SPS Committee also has indirect benefits, including increased familiarity of Members with each other's regulatory systems due to the regular contact and sharing of experiences between Members' officials. Members may gain confidence in the regulatory capacity of the alternative SPS regimes maintained by other Members. This confidence has an impact on issues such as the recognition of equivalence and of pest- or disease free areas.

As shown by the examination of participation by Members at different levels of development in the specific trade concerns mechanism, while developing-country Members have featured strongly, both as initiators or supporters of issues raised, and as subjects of concerns raised, the number of different developing countries participating to date has been limited. Participation in the specific trade concerns mechanism is certainly broader than in dispute settlement, yet there is still room for improvement. The constraints to the use of this mechanism seem to lie, not in the mechanism itself but rather in the capacity of Members at lower levels of development to keep track of notified measures, consult with their export industries to identify specific trade concerns arising from these measures, understand the extent to which these concerns can be addressed under the rules of the SPS Agreement, and send a national expert to the meetings of the SPS Committee to raise a trade concern. This is an area where capacity building is sorely needed. Efforts such as IICA's SPS Initiative for the Americas are to be applauded. It not only funds participation in SPS Committee meetings by capital-based experts but also promotes the establishment of offices at national level to follow the activities of SPS-related international bodies, particularly the SPS Committee. As the support provided by this initiative is being phased out, new and more broadly-applicable efforts along the same lines are essential.

The SPS Committee not only provides a forum for the discussion and resolution of specific trade concerns, but it also promotes regulatory learning and creates possibilities for building professional networks. It provides a mechanism for the monitoring of harmonisation 
that allows concerns regarding the lack of international standards, or problems with existing standards, to be raised and forwarded to the relevant international standard setting body. In addition, it plays a crucial role in addressing broader SPS concerns by promoting the implementation of particular disciplines in the SPS Agreement through developing and adopting procedural guidelines. The disciplines addressed, such as those on equivalence, adaptation to regional conditions, special and differential treatment and transparency, are particularly important for developing-country Members, as already noted, in that they hold great potential for market access gains while fully respecting the level of protection chosen by importing Members.

As noted, the SPS Committee provides much greater possibilities for participation than the adjudicatory system. Nevertheless, currently attendance and effective participation by Members at different levels of development in meetings of the SPS Committee varies greatly. As illustrated by the four Members used as examples in this book, high-income Members tend to participate actively and effectively in SPS Committee meetings and are represented by experts from their relevant ministries. However, many Members at lower levels of development do not have the resources to send an SPS official from their capitals, and are represented in meetings of the SPS Committee by diplomats from their missions in Geneva, often lacking the necessary technical knowledge. There are also some Members that are unable to send any representative to most SPS Committee meetings.

The problems this situation creates for effective participation by Members at lower levels of development in the decisions of the SPS Committee are mitigated by two practices of the Committee. The first is its practice to canvass all Members, by means of questionnaires, to submit their practical experiences with regard to the issue under discussion and to compile these experiences as the basis for the development of the new guidelines. The second practice that addresses participation problems is that of ad referendum decision making. This entails that a decision is only provisionally adopted at a meeting of the SPS Committee, and a period is then provided for Members to raise objections to the provisional decision. This enables Members that were not present at the relevant meeting, or those that were represented by delegates lacking the necessary expertise to evaluate the impact of the provisional decision, to have the decision examined by their ministry officials and to raise objections if necessary. Objections are addressed through revisions and the agreement of the objecting Member is obtained before the provisional decision is finally adopted. This practice ensures broad participation in the decisions of the SPS Committee, increasing their legitimacy and the 'ownership' of the decision by Members. This is important in view of the fact that decisions of the SPS Committee are not directly enforceable in dispute settlement proceedings. Implementation of decisions of the SPS Committee therefore relies upon the willingness of Members to follow the procedural guidelines set out therein. In view of the current problems with the use of the dispute settlement system faced by Members at lower levels of development that lack the scientific capacity essential to mounting an effective challenge, set out below, there is little to be gained by converting the procedural guidelines of the SPS Committee into enforceable rules, and much to be lost. The weak legal status of decisions of the SPS Committee, as compared to the binding status of an amendment, makes it easier for Members to reach consensus on new norms. In addition, the flexibility to respond to new problems and to 
improve the existing procedures that is provided by their 'soft law' nature is highly valued by Members.

The positive light in which Members view the role of the SPS Committee is evinced by the outcome of the second review of the SPS Agreement. Many of the recommendations coming out of this review relate to maintaining as standing agenda items for SPS Committee meetings the various issues addressed in the decisions of the Committee and to continuing work on these issues. In addition, the second review mandates the SPS Committee to pursue work on new issues, based on information provided by Members regarding their experiences and on specific suggestions submitted by Members to the Committee. None of the recommendations suggest that proposals for amendments to the SPS Agreement be submitted to the Council for Trade in Goods, as allowed by Article 12.7 of the SPS Agreement. This despite the fact that it would be possible in this way to initiate discussions on giving the procedural guidelines developed by the SPS Committee binding force. It is apparent that Members wish to continue the current successful modus operandi of working towards the resolution of implementation problems through decisions of the Committee, based on technical discussions and shared experiences, and reviewing these decisions as needed.

The dispute settlement mechanism of the WTO, through which non-compliance with the obligations of the SPS Agreement can be challenged by Members, is a great improvement above that existing under the GATT 1947. While a very small proportion of the SPSrelated conflicts between Members result in the initiation of WTO dispute settlement proceedings, and even fewer actually proceed to adjudication, the importance of the dispute settlement system to SPS disputes should not be underestimated. The very existence of the dispute settlement system creates an incentive for Members against whose SPS measures concerns are raised to address these concerns through negotiated solutions. In addition, the clarifications developed by panels and the Appellate Body with regard to the provisions of the SPS Agreement are essential in establishing the legal framework within which Members address their SPS conflicts. These clarifications are taken up in decisions of the SPS Committee that elaborate procedural guidelines for the operationalisation of provisions of the SPS Agreement. Equally importantly, they inform discussions between Members, bilaterally but even more so in the multilateral forum of the SPS Committee, to resolve trade concerns. These have been referred to as 'settlements negotiated in law's shadow'. ${ }^{1}$ It was therefore necessary to examine specific aspects of the dispute settlement system that are of particular relevance to SPS disputes, and to determine the opportunities for effective participation by Members at lower levels of development.

The question of which party bears the burden of proof in dispute settlement proceedings is particularly significant in the case of SPS disputes due to the difficult and intricate factual issues involved in this area. The approach to the burden of proof in complaints under the SPS Agreement, as clarified by the Appellate Body, reflects the difference in the regime created by the SPS Agreement to balance trade and health objectives, from the regime applicable to health measures under the GATT 1994, where health measures were

\footnotetext{
${ }^{1}$ Gregory Shaffer, 'Recognising Public Goods in WTO Dispute Settlement: Who Participates? Who Decides? The Case of TRIPS and Pharmaceutical Patent Protection', Journal of International Economic Law 7 (2), 2004, 459-482, 471.
} 
seen as exceptional and needing justification. The new approach of the SPS Agreement is to recognise that Members have the right to regulate to the extent necessary to address SPS risks, but to subject such regulation to disciplines. It is therefore for the complaining Member to bring a prima facie case to show that the SPS measure complained of violates the disciplines of the SPS Agreement. Complaining Members are assisted in their task by the possibility created in Article 5.8 of the SPS Agreement to request information on the SPS measures of other Members. The Appellate Body's view of Articles 3.3 and Article 5.7 of the SPS Agreement as autonomous rights rather than as exceptions to the harmonisation discipline in Article 3.1 and the scientific disciplines in Articles 2.2 and 5.1, respectively, results in maintaining the burden of proof firmly on the complaining Member. This reflects the leeway provided to regulating Members by the Appellate Body in order to ensure that the policy space left to Members by the SPS Agreement is not undermined.

As noted, many developing-country Members may not have the resources to gather the scientific information necessary to bring a challenge under the SPS Agreement, in order to make a prima facie case of violation. In addition, the difficulties they face in complying with the regulatory disciplines of the Agreement mean that these Members are unlikely to be able to defend their SPS measures in case of a challenge. High-income Members have experienced serious difficulties in this regard in the SPS disputes heard thus far. For less-developed Members the hurdle seems almost insurmountable. These Members may not have the resources to commission the necessary research and will therefore depend on the chance that there are already existing studies of relevance. The duty to cooperate in dispute settlement proceedings, identified by the Panel in Japan - Apples, is unlikely to lead Members, in an adversarial system, to provide data supportive of the position of the opposing party.

The issue of the burden of proof on Members in dispute settlement proceedings is closely linked with the question of the investigative authority of a panel, the standard of review it applies when assessing the facts before it and the question of the appropriate role of experts advising the Panel.

The question of the appropriate standard of review to be applied in dispute settlement proceedings plays a significant role in the allocation of authority to make policy choices balancing competing trade and health interests. The particular standard of review applied determines the extent to which the WTO adjudicatory bodies are entitled to interfere in Members' regulatory determinations. Currently, while panels customarily state that they will not conduct their own risk assessment or impose a particular scientific view on the regulating Member in reviewing the scientific evidence, in practice this is increasingly what they do. This is in part due to the interpretation given to the 'rational relationship' requirement entailed by the scientific disciplines of the SPS Agreement as involving an assessment of the quality and weight of the scientific evidence. This opens the door for an intrusive review. It is proposed here that a panel should limit its examination of the scientific evidence to the question whether the regulatory disciplines of the SPS Agreement, including that an SPS measure is based on a risk assessment as defined in the Agreement, have been complied with. It should stop short of completely reassessing the scientific evidence itself to determine the existence and extent of a risk. Limiting the factual assessment to the question whether the regulatory determination by the Member is plausible on the scientific evidence before it, allows some deference to national authorities' scientific 
determinations. Such a review ensures that the regulating Member respects the balance struck in the rules of the SPS Agreement between its health concerns and the trade interests of other Members, but the review does not intrude too far into the regulatory competence of Members by interfering unduly in their assessment of scientific evidence. This would make room for the diversity of priorities, consumer preferences and regulatory capacity between Members at different levels of development to be reflected in the science policy choices incorporated into national risk assessments. This type of review would also reduce the disadvantage at which Members that lack scientific capacity find themselves in challenging or defending measures under the SPS Agreement. The current intrusive approach may skew the outcome of judicial review in favour of developedcountry Members that have the resources to bring convincing scientific evidence and persuasive legal arguments in support of their positions.

The standard of review currently applied by panels is made even more problematic by the practice with regard to the consultation of experts by panels. While the use of panel experts is essential in assisting panels, which are usually composed of trade specialists rather than SPS experts, to understand the highly complex scientific evidence before them, it is important to ensure that appropriate regard is had to the role of such experts in dispute settlement. The use of panel experts aims to ensure that the assessment and choice between the competing scientific views presented by the parties is not made by a panel on its own, but rather that the panel is advised on this by persons with the necessary expertise. The prevailing practice of panels of appointing individual experts rather than expert review groups has the contrary effect, adding to the competing scientific opinions before a panel. It allows a panel to pick and choose between the various opinions, which is troubling in view of the lack of scientific expertise of panellists to undertake this task. It is recommended that panels make use of expert review groups, in order to ensure that the scientific basis for their decisions is authoritative. In cases involving a developing-country Member, the expert review group should include at least one expert from a developing-country Member to ensure that the assessments provided by the group incorporate developing-country realities. In addition, it is important that a panel respects the distinction between the respective roles of the panel, its experts and the parties before it in the proceedings. Panels should resist the temptation to expand the role of the experts to providing the evidence in support of the position of one of the parties, or to address the legal questions before the panel that require a basis in scientific assessments. Such inappropriate use of experts undermines the legitimacy of the outcome of dispute settlement.

The argument has been made that the 'normative vacuum' in which the SPS Agreement is currently interpreted has led to the strong focus on science, and the concomitant heavy reliance on the opinions of panel experts in assessing this science, by panels in reviewing the SPS measures of Members. Panels see science as providing a neutral and universal benchmark against which SPS measures can be tested to distinguish SPS protection from disguised protectionism. It is submitted here that consideration of the international law context within which the SPS Agreement functions, in particular international human rights norms relating to the rights to life, health, safe food and development, in addressing the rights and obligations laid down in the SPS Agreement could operate to provide the urgently needed normative framework to guide WTO adjudicators in striking a more appropriate balance between the competing goals of trade liberalisation and health protection. 
The recognition of this normative basis for interpretation, on which they can rely to enhance the legitimacy of their decisions, may make panels less inclined to continue their current intrusive approach to the review of the scientific basis for Member's SPS measures. It may also make them more willing to use the flexibilities in the SPS Agreement to allow for the consideration of developing-country Members' constraints in the application of the scientific disciplines on regulation, to ensure that the SPS Agreement does not operate to undermine the protection of health in these Members.

The weak use of the dispute settlement system by Members at lower levels of development attests to high political and financial costs of dispute settlement for these Members and the limited chance of success they foresee. The Advisory Centre on WTO Law is a welcome development in providing much-needed assistance in dispute settlement. However, without concerted efforts to build SPS capacity in developing countries, these Members are unlikely to overcome the remaining hurdles to participation in dispute settlement. It is essential to address these hurdles, as the bargaining that occurs at the SPS Committee, both with regard to specific trade concerns and with regard to broader implementation issues, takes place 'in the shadow' of dispute settlement. Without participation in dispute settlement, less-developed Members are unable to influence the normative framework within which negotiations to address SPS issues occur.

This brings us once again to the need for effective initiatives to build the capacity of Members at lower levels of development to make use of the dispute settlement system to resolve their SPS disputes. An essential component of the capacity needed in this regard relates to the SPS regulatory systems and scientific competence in these Members.

\section{The limits of special and differential treatment for developing-country Members in the SPS Agreement}

The SPS Agreement, as one of the WTO agreements creating disciplines for behind-theborder regulatory regimes, necessitates special recognition of differences in SPS capacity of Members across different levels of development. As has been seen from the discussion thus far, the ability of Members to comply with, and benefit from, the disciplines of the SPS Agreement depends on their 'starting position.' In other words, the existing situation in a Member, such as the strength of its regulatory system, its infrastructure and its human and financial resources will affect the impact of regulatory disciplines of the SPS Agreement on that Member, and its ability to use those disciplines against other Members to gain market access. To be 'development-friendly' it is important that the SPS Agreement leaves sufficient space for less-developed Members to pursue their development policies through national SPS regulation, while at the same time creates clear and workable rules that these Members can use to gain market access. This difficult balance is not only achieved in the substantive and procedural disciplines, but is contributed to by provisions in the SPS Agreement providing special treatment for developing-country Members. These provisions, discussed in Part V, take the form of rules on special and differential treatment (SDT) of developing-country Members and rules on the provision of technical assistance. 
The rules on SDT were examined in Chapter 1 of Part V. These rules aim to ensure that developing-country Members benefit fully from the rules of the SPS Agreement, without being overwhelmed by the costs of compliance. To achieve this objective, appropriate flexibilities are necessary to take account of the special constraint faced by these Members. These flexibilities are needed with regard to compliance not only with the resource intensive obligations of the SPS Agreement but also with new or modified SPS measures imposed by their trading partners.

The current provisions on SDT of developing-country Members are, however, mostly hortatory and ineffective. This problem has been exacerbated by the unwillingness of panels to interpret SDT provisions, even those phrased in mandatory language, as imposing any enforceable obligations. While this could be improved by a more progressive interpretation of the relevant provisions in dispute settlement, to ensure that developedcountry Members take seriously their commitments to take account of developing-country constraints, this possibility has clear limits. Members cannot be obliged to import risky products simply because not to do so would restrict developing-country trade. Differential treatment of developing-country Members with regard to the imposition of SPS measures would be counterproductive, leading to consumer concerns regarding the safety of products from developing-country Members.

Work in the SPS Committee on operationalising SDT has been unsuccessful, aside from the adoption of the Decision to Enhance Transparency of SDT in 2004. The discussions in the SPS Committee on the SDT proposals forwarded to it in the context of the Doha Round negotiations remain polarised. It is unlikely that a constructive solution to strengthen SDT for developing-country Members would take the form of the current proposals. These proposals amount to a limitation on the right of Members to apply SPS measures to achieve the level of protection they deem appropriate if this entails market access restrictions for developing-country Members; or to the possibility for broad exemptions for developingcountry Members from the disciplines of the SPS Agreement. It is widely recognised by WTO Members that any mechanisms to deal with developing-country concerns should not jeopardise the right of a Member to impose scientifically-justified measures necessary to prevent risks to human, plant or animal life or health that they consider unacceptable. To do so would not only lead to risks of harmful effects on human health and agricultural production, contrary to the obligations of governments, but would also be counterproductive. It would fuel consumer fears, leading to a decrease in demand for products originating in developing-country Members, and harm the reputation of such exporting Members by casting doubt on their regulatory capacities. Similarly, difficulties with implementation of the regulatory disciplines of the SPS Agreement should not be dealt with by means of a wholesale relaxation of its rules in respect of developing-country Members. Creating loopholes through which measures that are disguised forms of protectionism can slip, would undermine the market access gains achieved by the SPS Agreement. The proposed solutions would skew the delicate balance between trade liberalisation and health protection achieved in the SPS Agreement. This would be contrary to the normative framework established by the right to development which recognises both the importance of trade as an engine for growth and the obligation to ensure that such growth does not come at the cost of the protection of human rights, including the rights to life, health and safe food. Nevertheless, the rejection of the current proposals does not diminish the need to 
recognise the reality of the underlying concerns of developing-country Members and to address them urgently.

Thus, it is important to find more constructive ways of helping developing-country Members to overcome their constraints without weakening legitimate SPS measures or watering down the disciplines of the SPS Agreement. The question therefore arises whether the second category of special rules for developing-country Members contained in the SPS Agreement, those on technical assistance, provides a more effective solution.

\section{The need to turn technical assistance into capacity building}

As noted from the start of the analysis conducted in this book, technical assistance is not a magic bullet solution to all developing-country Members' concerns with regard to the obligations of the SPS Agreement. It certainly does not obviate the need for a rigorous analysis of substantive and procedural rules to ensure that they are appropriate for all Members as tools to achieve the agreed objectives of the Agreement. It also does not preclude the need to take seriously the provisions on SDT negotiated as a quid pro quo for the extensive obligations taken on by developing countries in the SPS Agreement.

Parts III and IV and Chapter 1 of Part V have examined these issues in detail. This examination has led to the conclusion that, in view of the delicate balance struck by the provisions of the SPS Agreement between trade and health, it is difficult to adjust those aspects of its substantive disciplines that create problems for developing-country Members without doing damage to its ability to meet its objectives. Similarly, there is limited scope for strengthening SDT in the SPS Agreement, beyond operationalising the current rules through interpretation or negotiated clarification. While very useful work has been done, and is continuing, by the SPS Committee in developing procedural guidelines to facilitate the implementation of certain provisions of the SPS Agreement of particular importance to less-developed Members, significant problems remain. Consequently, while far from being a panacea, technical assistance assumes a crucial role in addressing the very real problems that Members at lower levels of development face in implementing their obligations, and enforcing their rights under this Agreement.

In particular, technical assistance is needed to ensure that the regulatory disciplines of the SPS Agreement do not have the effect of forcing developing-country Members to divert resources from other areas of public spending which may be more crucial to their development needs, such as the provision of basic health and sanitation services. In addition, it is essential to address the fact that many legitimate SPS measures of importing Members present significant compliance problems for developing-country Members. The extent to which the rules on technical assistance in the SPS Agreement provide the means to effectively support developing-country Members' compliance efforts, was examined in Chapter 2 of Part V.

This examination showed that the current provisions on technical assistance in the SPS Agreement are loosely worded and difficult to enforce. As a result, the provision of SPSrelated technical assistance leaves much to be desired. Discussions in the SPS Committee on ways to strengthen and operationalise the provisions on technical assistance in the SPS 
Agreement have proved fruitless. In many cases this can be ascribed to the unrealistic nature of the proposals made, such as making the imposition of SPS requirements with adverse trade effects for developing-country Members conditional on granting cost-free technical assistance upon request. This would have enormous budgetary implications for importing Members, impossible to determine in advance, and would risk undermining their regulatory autonomy. Nevertheless, the concerns underlying these proposals cannot be discounted. The experience of developing-country Members with the voluntary provision of technical assistance has been disheartening. It is therefore not surprising that they are seeking real commitments from their developed trading partners in the area of technical assistance.

The discussion of illustrative examples of technical assistance initiatives currently in place highlighted the insufficiencies of the current approach, which is fragmented and lacking in coherence. Bilateral technical assistance tends to reflect donor interests and areas of concern, resulting in a disregard for the priorities of beneficiaries. Recent efforts to develop tools to assist developing countries to identify their own capacity needs are useful, but must be coupled with the appropriate response to ensure that the project truly builds capacity in the beneficiary in a sustainable manner. Currently, political considerations rather than objective criteria determine which technical assistance projects are supported by donors. The lack of predictability resulting from the voluntary nature of assistance provided currently makes long-term planning difficult.

Multilateral efforts are characterised by inefficiencies and overlaps. The limited mandate of some organisations in the area of technical assistance means that additional efforts in the area of technical assistance result in widening its reach but not deepening its impact. Concerted efforts are needed not only in the areas of training and funding of participation in SPS-related fora, but also in respect of building technical and scientific capacity and infrastructure. Without the latter, participation will not bring the desired results.

The Standards and Trade Development Facility (STDF) represents and important step forward in coordinating the plethora of technical assistance initiatives. It creates a cooperative framework of partners with a wide range of high-level technical expertise and significant financial resources. In addition, making use of complementarities with needsassessment mechanisms (such as those in the Integrated Framework for Trade-Related Technical Assistance to Least-Developed Countries and the Joint Integrated Technical Assistance Programme for selected least-developed and other African countries), the STDF ensures that the priorities and capacity needs of beneficiary countries are an integral part of the framing of a project. Consequently, it is in a position to provide needsdriven and expert assistance. The STDF's new approach is to reduce its focus on actually funding projects and turn its attention to the coordination aspect of its mandate. It aims to use its project preparation grants to facilitate the securing of funds and assistance from its partner institutions and other donors. This may indeed be a more efficient use of its unique capacities to promote coordination in technical assistance. It is to be hoped that the work of the STDF will fulfil the potential it has for turning ad hoc technical assistance projects into coherent and needs-driven capacity building programmes in developing countries. However, the unwillingness of donors to make multi-year commitments to funding the STDF results in budgetary unpredictability and the inability to undertake long term projects. 
It is argued here that an important part of the solution to the problems that less-developed Members face in implementing their obligations and enforcing their rights under the SPS Agreement, lies in a new, more effective approach to SPS-related technical assistance that reflects the current conception of 'capacity building'. In other words, what is needed is effective, predictable and needs-driven assistance that creates capacity in a sustainable manner. While this is unlikely to happen at bilateral level, where the interests and limited resources of donors lead to ad hoc projects, multilateral cooperative initiatives such as the STDF show promise. However, real commitments must be made to fund the provision of such assistance in a predictable and sustainable manner. The acceptability of binding commitments towards financing a new technical assistance mechanism, will in turn depend on the willingness of developing-country Members to accept differentiation across levels of development, reflecting differences in regulatory capacity and dependence on agricultural exports. This would mirror the reality of development, which occurs along a continuum.

\section{Concluding remarks}

This book examined the 'development dimension' of the SPS Agreement by evaluating the impact of the disciplines used in this Agreement on WTO Members at lower levels of development. In particular, it assessed whether the balance achieved by these disciplines between the often competing goals of trade liberalisation and health protection is 'appropriate' for less-developed Members in the sense that it effectively increases their market access opportunities while leaving these Members sufficient policy space for SPS regulation. The analysis conducted to address this question in Parts I to $\mathrm{V}$ of this book gave rise to the following conclusions.

The globalisation of trade, including the growth in the participation of less-developed countries, has brought with it increased threats of international spread of risks to human, animal and plant life and health. Acting on the interface between the parallel processes of the globalisation of trade and the globalisation of health, the SPS Agreement is best seen as a negotiated instrument embodying new ways to mediate the trade/health conflict. The normative framework provided by the emerging 'right to development' establishes the importance of ensuring that, in doing so, the SPS Agreement promotes agri-food trade without endangering the protection of health.

The question whether this objective is achieved cannot be answered with easy generalisations regarding the impact of the SPS Agreement on market access and regulatory autonomy in developing-country Members. A factual examination of the SPS regulatory systems of selected WTO Members at different income levels, and with different trade and health priorities, makes clear that any analysis of the impact of the SPS Agreement on developing-country Members must be informed by a realisation of the heterogeneity of this group. A similar conclusion flows from a factual examination of the institutions and procedures through which the international standards used as benchmarks in the SPS Agreement are developed, and the participation of Members at different income levels therein. Consequently, while specific difficulties can be identified as deriving from the level of development of certain Members, linked to their SPS regulatory capacity and 
their financial and technical constraints, these difficulties do not affect all developingcountry Members or not all to the same extent.

With this caveat in mind, the legal analysis of those substantive provisions of the SPS Agreement that discipline the way in which WTO Members exercise their SPS regulatory autonomy leads to two main conclusions. First, although these disciplines reflect a regulatory model currently not achievable for many less-developed Members, the solution to this problem does not seem to lie in weakening the rules. To do so would skew the delicate trade/health balance in the SPS Agreement, to the detriment of all Members. Second, the opportunities that do present themselves to ameliorate the difficulties with the relevant substantive disciplines faced by various Members at lower levels of development seem to lie most often in addressing the problems of interpretation and application of these rules in dispute settlement. Most importantly, it is recommended that panels, in interpreting the SPS Agreement, relinquish their heavy reliance on science as a seemingly objective and universal touchstone for distinguishing SPS protection from trade protectionism, and their accompanying intrusive approach to the review of the scientific basis for Members' SPS measures. Instead, it is suggested that panels would do better to recognise the normative basis for interpretation of the SPS Agreement provided by international human rights law, on which they can rely to enhance the legitimacy of their decisions. This may make panels more inclined to use the flexibilities inherent in disciplines of the SPS Agreement in order to achieve the trade/health balance aimed at by the Agreement in a manner more appropriate to the capacities of less-developed Members.

Greater opportunities for enhancing the benefits of the SPS Agreement for less-developed Members, while reducing its costs, arise from the institutional and procedural rules contained in the Agreement and those developed by the SPS Committee to operationalise its provisions. These procedural arrangements address several of the implementation problems faced by many less-developed Members, yet do so without undermining the trade/ health balance achieved by the relevant substantive disciplines. Great strides have been taken in this regard by the SPS Committee and this work is continuing. Yet many hurdles remain to the full realisation of the potential benefits of the SPS Agreement by Members at lower levels of development. These hurdles are rooted in the capacity constraints of these Members, which limit their ability to enforce their rights and comply with their obligations under the Agreement.

The special provisions in the SPS Agreement that aim to take account of developing-country constraints, namely the rules on SDT and those on technical assistance leave much to be desired. Both their weak terms and the ineffectual interpretation given to them in dispute settlement have contributed to the disappointing implementation of these provisions to date. In the case of the SDT provisions, the possibilities for strengthening them through negotiated revisions or interpretation are clearly limited by the need to avoid skewing the trade/health balance of the SPS Agreement. Consequently, SDT is an inadequate instrument to resolve the problems that developing countries face. Instead, technical assistance takes on greater importance as a tool to help developing-country Members overcome their constraints. What is needed is a new, more effective approach to SPS-related assistance that is more in line with the current understanding of 'capacity building', which refers to a mechanism for effective, predictable and needs-driven assistance that creates 
capacity in a sustainable manner. Here the academic community can play an essential role in identifying the necessary conditions for such a mechanism. 


\section{Summary}

\section{Introduction}

The link between free trade and measures for the protection of health is not new, but has been recognised since the commencement of trading activities between newly emerged city-states in the fourteenth century. Today, however, the proliferation of health measures, on the one hand, and the great advancements in trade liberalisation, on the other, mean that the interaction between these two policy areas has assumed critical importance.

The exponential increase in the speed and volume of trade and in the diversity of traded products in the last fifty years, and the accompanying proliferation of health risks and SPS measures, has meant that the international trade regime, currently embodied in the rules of the World Trade Organisation (WTO), has had to find new ways of mediating the conflict between free trade and health protection. Acting on the interface of globalised trade and globalised health risks, is the WTO's Agreement on the Application of Sanitary and Phytosanitary Measures (SPS Agreement). It reflects a negotiated balance between the competing goals of the liberalisation of trade in the food and agricultural sector and the protection of health by national governments.

Developing-country Members of the WTO have a significant interest in the way in which these two competing societal aims are balanced in the SPS Agreement. On one side, as agricultural products often form an important part of the merchandise export trade of developing-country Members, they are concerned with gaining market access in this sector in order to earn the foreign revenue necessary to meet their development needs. Hardwon achievements in liberalising trade in agricultural products can easily be undermined by the misuse of SPS measures for protectionist purposes. Developing-country Members thus depend on effective disciplines in international trade rules to prevent this. On the other side, one should not forget the fact that developing-country Members are also important importers of food and agricultural products, and face sanitary and phytosanitary risks from imported products. In this respect, they have an interest in being allowed sufficient flexibility by international trade rules to enact SPS regulations appropriate to their needs and capabilities. It is therefore important to recognise that the interests balanced in the SPS Agreement are those of conflicting societal goals of importance to both developed and developing-country Members, rather than competing developed and developing country interests. Nevertheless, the mechanisms used to achieve this balance in the SPS Agreement may have a disparate impact on Members at different levels of development.

This book analyses the implications of the rules of the SPS Agreement for WTO Members at different levels of development. More specifically, it evaluates the tools used by the SPS Agreement to achieve a balance between the often competing goals of trade liberalisation and health protection from the perspective of Members at lower levels of development. In doing so, it elucidates what can be seen as the 'development dimension' of the SPS Agreement. The 'development dimension' of this Agreement can be seen as composed of two distinct, but interrelated elements, which are determinative for the impact of the SPS Agreement on the trade and health interests of Members at different levels of development. These two complementary elements are: (1) the limits of policy space 
defined by the general disciplines of the SPS Agreement, and their effect on developingcountry Members as agri-food exporters and SPS regulators; and (2) special treatment for developing-country Members in the SPS Agreement.

\section{The SPS Agreement on the interface between globalised trade and globalised health}

Understanding the impact of the disciplines used in the SPS Agreement to achieve a balance between trade and health objectives on Members at different levels of development necessitates a grasp of the context within which this Agreement functions. This context encompasses the twin processes of the globalisation of trade and the globalisation of health. Therefore, Part I of this book provides the background necessary for a full understanding of the research problem, and the development focus adopted therein, by examining the parallel processes of globalisation in the area of trade and in the area of health, in order to situate the SPS Agreement in this context.

It does so firstly by examining, in Chapter 1, the changing role of developing countries in the world trading system to determine why an examination of the development dimension of international trade rules, and more specifically on the SPS Agreement, is urgently needed. The progressive integration of developing countries into the trading system is referred to as the globalisation of trade for purposes of this book. This process has to be seen in the normative framework provided by the emerging recognition of the 'right to development'. This framework serves to establish, on the one hand, the importance of trade as an engine for economic growth in the service of development and the responsibility of the international community to create favourable conditions to facilitate this growth. On the other hand, the right to development clarifies that development is more than economic growth. Instead, development entails the progressive realisation of all human rights. This means that mechanisms to promote development, including through trade liberalisation, may not come at the cost of other human rights such as the right to life, health and safe food. Consequently, the SPS Agreement, which plays an important role in liberalising agricultural trade, cannot achieve its trade objectives through disciplines that would undermine the ability of Members to protect life and health in their territories.

Secondly, Chapter 2 of Part I sketches the historical developments relating to the recognition of the globalisation of health in the face of transboundary health risks and the initiatives for international cooperation in this regard. The globalisation of trade has brought with it the international spread of threats to human, animal and plant life and health. The evolution in the strategies to deal with this problem has been determined to some extent by developments in scientific understandings of risk. Science has formed the basis both for common understandings that support international cooperation, and for national strategies to mitigate risk. The failure of purely national approaches as well as international regulatory approaches to provide an effective strategy in the face of globalised risk, has led to a new, multifaceted approach to risk management. This involves both national and international initiatives in both public and private arenas. These complex governance structures for the protection against SPS risk form the backdrop for the operation of the SPS Agreement. Acknowledging the achievements made on international level in setting 
voluntary harmonised standards, the SPS Agreement incorporates these standards into its rules, while allowing for deviation. Reflecting the view of science as a neutral and universally valid benchmark for SPS regulation that prevailed at the time of its negotiation, the SPS Agreement requires scientific justification for non-harmonised measures.

The dual aspects of the process of globalisation discussed in Chapters 1 and 2 are brought together, and related to the core theme of this book, in Chapter 3 of Part I by means of an examination of the importance for developing country trade of regulations and standards imposed to address globalised health risks. The proliferation of SPS requirements to mitigate risks from traded products has important implications for trade in the agri-food sector, particularly for countries at lower levels of development. These countries are often largely dependent on agricultural exports for their foreign revenue earnings. Hard-won gains in the liberalisation of agricultural trade achieved through rules on traditional trade barriers can be undermined by the trade restrictive effects of SPS measures. As these measures predominate in the areas of high-value fresh produce and processed food products, the possibilities for developing countries to diversify their exports to these lucrative markets are greatly restricted. While many SPS measures are legitimate efforts to address health risks, they may be more trade restrictive than is necessary to achieve their objectives. In addition, the danger exists that SPS measures may be misused for protectionist purposes.

The SPS Agreement acts to address this problem. Situated on the interface of globalised trade and globalised health, this Agreement aims to balance the often conflicting goals of trade liberalisation and health protection. The mechanisms it uses to do so are a reflection of the historical developments outlined above.

\section{National and international SPS regulation and standard setting}

The evaluation of the 'development dimension' of the SPS Agreement conducted in this book is fully cognisant of the fact that developing-country Members are not a monolithic group. Instead, development takes place on a continuum, along which there may be great divergences in economic resources, regulatory capacity, export interests and health status. All these factors play a role in determining the impact of the SPS Agreement on particular Members, and the question of how workable its rules are for the relevant Member. An analysis of the implications of the SPS Agreement for developing-country Members must therefore take into account these divergences.

In order to do so, Part II of this book examines the factual context for the operation of the SPS Agreement as embodied in national and international systems for SPS regulation and standard setting, with a particular focus on the impact of differences in levels of development of Members for the functioning of these systems.

Chapter 1 of Part II introduces SPS regulation by addressing specific issues that are necessary to grasp for a full understanding of the thesis of this book. It starts by setting out the normative framework within which SPS regulation occurs, as reflected in international human rights law. Then, in order to facilitate understanding of the role played by the level of development of a country in its regulatory choices, this Chapter undertakes a 
brief law-and-economics analysis of SPS regulation. This analysis highlights the divergent costs and benefits of SPS regulation for countries at different levels of development. Finally, Chapter 1 sets out the role and limits of science in the SPS regulatory process. This theoretical discussion sets the stage for the factual analysis conducted in the following Chapters of Part II.

Chapter 2 of Part II examines the great differences in national SPS systems by means of four illustrative examples of WTO Members in different income categories and in different geographical regions, namely Australia, Mauritius, Jamaica and Bangladesh. These examples show that while vast differences exist in SPS regulatory systems between developed and developing countries, there are also significant differences among developing-country Members. Clearly, some developing countries have been more successful than others in upgrading their SPS systems and securing access to the markets of their trading partners. Nevertheless, two general conclusions can be drawn regarding differences in SPS regimes according to level of development. First, the level of SPS protection exhibits marked differences, being substantially higher in more developed countries due to better technological capacity, higher consumer demands, and more developed regulatory infrastructure. Second, the regulatory focus differs. Less developed countries tend to rely on product requirements, which are enforced by means of testing and inspections by government authorities at the point of exit or entry. Product requirements are usually easier to comply with as they leave the means of compliance up to the producer and are typically based on objective, testable properties that can be more readily ascertained. By contrast, developed countries are increasingly, especially in the area of food safety, moving towards process requirements, such as those embodied in the Hazard Analysis and Critical Control Point (HACCP) system. Process requirements oblige the producers themselves to take responsibility for ensuring that the entire production chain, 'from farm to fork' meets certain standards of hygiene and safety. These process requirements entail a systems-wide approach to SPS issues, which necessitates significant technical expertise, supporting infrastructure and control systems.

These differences in SPS regimes have notable consequences for the impact both of SPS measures themselves and of the SPS Agreement on Members at different levels of development. The illustrative case studies provided identify, by means of the discussion of practical examples, various problems faced by developing-country Members in complying with SPS measures in developed-country markets. These problems reflect the fact that the difficulty and costs of compliance are directly related to the extent of the gap between the existing domestic SPS regime and the SPS requirements in foreign markets. Several factors play a role here, such as weak domestic SPS regulation, inadequate public infrastructure, unreliable compliance assessment and certification, insufficient dissemination of information on SPS requirements abroad, and poor laboratory equipment and staff. However, it would be an over-generalisation to state that middle- and low-income Members are entirely incapable of meeting SPS requirements on their export markets, or of upgrading their SPS systems to protect their territories from SPS risks. Examples are provided in Chapter 2 of success stories in this respect. It is, nevertheless, important to note the central role played by technical and financial support from the importing Member in some of these situations. This puts those Members that face capacity constraints in the area of SPS regulation in a very dependent position. 
The differences in the legal and institutional capacity for SPS regulation between Members at different levels of development, illustrated by the selected Members used as examples in Chapter 2, have a bearing on the way in which the SPS Agreement impacts on them. These examples of divergent SPS regulatory systems therefore provide the factual context for the later discussion of the provisions of the SPS Agreement.

The factual context within which the SPS Agreement operates also includes international systems for the elaboration of SPS standards. These are discussed in Chapter 3 of Part II. Divergence in national SPS regulations is an impediment to trade as it reduces the possibilities to exploit economies of scale. Therefore harmonisation around international standards is promoted by free trade regimes, including by the WTO in the SPS Agreement. However, internationally-set standards cannot mirror the diversity of circumstances in countries around the world. Instead, they reflect a compromise position accepted by the delegates of the countries present and active in the standard-setting process, and developed according to the procedures of the relevant standardising body. An examination of the institutional structure and standard-setting procedures of the international bodies referenced in the SPS Agreement shows that they are such that the participation of developing-country Members is limited. This is due to the fact that the structures and procedures do not sufficiently take into account the resource and capacity constraints of countries at lower levels of development. While improvements have been made in this situation in recent years, developing-country Members still tend to be most widely represented in plenary sessions of the relevant standard-setting bodies, where standards are initiated and adopted. However, their participation in technical committees where scientific evidence is discussed and standards are prepared, and even more so in the scientific bodies that conduct the risk assessments on which standards are based, often leaves much to be desired. This is a significant problem as it is at this technical level that participation can be most effective. This inadequate participation is often due to the lack of human and financial resources necessary to ensure attendance of the plethora of committee meetings by well-prepared specialists in the areas in which standards are set. In addition, the lack of effective national infrastructures for the evaluation of draft standards, the collection of information from national stakeholders and the formulation of positions is identified as a problem.

International standard-setting is therefore dominated by developed-country Members, resulting in standards that are often not appropriate for Members at lower levels of development. This is problematic as the latter Members depend most on international standards as a basis for national regulation. More work is needed, not only in the form of simplification and improvement of the standard-setting procedures of the relevant bodies, but also in the form of efforts to build the capacity of Members at lower levels of development to participate effectively in these procedures. Here, once again, technical assistance has an important role to play.

The factual context provided by an examination of national SPS regulation and international SPS standard setting in Part II shows the great need for technical assistance of developing-country Members in order to build SPS capacity. However, there is a danger in seeing technical assistance as a magic bullet solution, assuming that developingcountry Members can and should meet any SPS-related obligation as long as they are provided with technical assistance to do so. Technical assistance is not an alternative to 
analysing whether the disciplines of the SPS Agreement are appropriate for developingcountry Members to implement. It can address some of the costs of implementation, but cannot take away the long term disadvantages of the application of inappropriate disciplines. Consequently, it is essential to begin by assessing whether the substantive rules and procedural mechanisms of the SPS Agreement are appropriate for developing-country Members. This is the aim of the detailed examination conducted in Parts III and IV of this book.

\section{The rules balancing trade and health in the SPS Agreement}

Several of the substantive obligations of the SPS Agreement aim to set the limits of the policy space left to Members in the area of SPS regulation, by combining the traditional trade disciplines found in the GATT 1994 with new scientific disciplines and by encouraging harmonisation. These disciplines together function as a filter, to distinguish measures legitimately aimed at health protection from measures that are a disguised form of protectionism. In this way, the SPS Agreement tries to balance the often competing interests of trade liberalisation and health protection.

The question arises whether the substantive rules in the SPS Agreement that aim to achieve this balance are appropriate for Members at lower levels of development. The criteria used to answer this question are those set out in the Introduction to this book, namely whether the relevant rules effectively increase market access opportunities for WTO Members at lower levels of development; and whether they leave these Members sufficient policy space for SPS regulation. Viewed in the light of the normative framework provided by the concept of the 'right to development', set out in Part I, the importance of assessing the ability of the SPS Agreement to promote agri-food trade without endangering the protection of health in less developed Members is evident. Herein lies the development dimension of the SPS Agreement.

It is apparent from the overview of the negotiating history set out in Chapter 1 of Part III that the regulatory model embodied in the substantive disciplines of the SPS Agreement is that to be found in the proposals of the most active participants in the negotiations, namely key developed-country Members and the Cairns Group. The Agreement closely reflects best regulatory practices in developed-country Members. While the ideal of improving the practice of SPS regulation among Members through such best-practice disciplines is, in itself, laudatory, there is a danger that a model of regulatory practice that is unworkable for less-developed Members has been created.

The examination, in Chapters 2 to 5 of Part III, of the relevant substantive disciplines of the SPS Agreement that define the limits of policy space available to Members for SPS regulation leads to two related conclusions. The first is that the balancing objective of the SPS Agreement is unmistakeably reflected in the way in which these substantive provisions are framed. While there are aspects of the interpretation of these provisions that do not fully give effect to the careful balance embodied in their terms, and leave room for improvement, the provisions themselves seem appropriate to address the sensitive trade/health conflict in a way that promotes the liberalisation of agri-food trade while 
respecting the right of Members to regulate against SPS risks. However, the second conclusion that is evident from the discussion of the relevant substantive rules of the SPS Agreement is that these rules impose a regulatory model that is currently not achievable for many Members at lower levels of development. Neither are these Members able to use these substantive rules effectively to procure market access for their products.

The fact that most Members at lower levels of development have not been challenged in dispute settlement proceedings under the SPS Agreement to date, should not create the impression that their inability to comply with some of the disciplines of the SPS Agreement has no real consequences for them. Many instances of non-compliance by these Members with the regulatory obligations of the Agreement have been challenged in the multilateral forum of the SPS Committee, or in bilateral discussions between Members. In these situations, it is often difficult for the regulating Member to justify its measure, other than to refer to its capacity constraints. This leaves less-developed Members vulnerable to pressure by other Members to settle other SPS conflicts in ways unfavourable to them.

Aside from the particular aspects of the interpretation of the substantive rules of the SPS Agreement, identified throughout Part III, that leave scope for improvement, it is difficult to see how changes can be made to address developing-country constraints without skewing the careful balance sought by the Agreement. The rules themselves seem appropriate for the fulfilment of their function of allowing sufficient room for Members to regulate in a manner that gives effect to their policy priorities in the area of SPS risk, while disciplining such regulation to eliminate the possibilities for disguised protectionism and to reduce the adverse trade effects of legitimate measures. Nevertheless, the very real problem of the constraints that less-developed Members face in complying with, and benefiting from, these rules cannot be disregarded.

The question arises to what extent provisions of the SPS Agreement other than those discussed above ameliorate this problem by taking account of the capacity constraints of Members at lower levels of development, both in respect of compliance with the disciplines of the Agreement and in respect of enforcement of these disciplines against other Members in order to gain market access. This question is addressed in Parts IV and V of this book.

\section{Procedural and institutional mechanisms under the SPS Agreement}

Alone, the substantive disciplines of the SPS Agreement discussed above would not be sufficient to achieve significant gains in market access for food and agricultural products from developing-country Members. These Members lack the scientific and technical capacity to identify instances of non-compliance with the complex regulatory disciplines of the SPS Agreement, and to formulate effective challenges in this regard. In addition, many legitimate SPS regulations that pass muster under the relevant substantive disciplines of the SPS Agreement nevertheless form significant trade barriers. This is particularly so for Members that face capacity constraints in keeping track of new and changed measures, understanding their implications and proving their compliance with SPS requirements (including by demonstrating the equivalence of their own SPS requirements, or by gaining 
recognition of the pest- or disease-free status of their territories or of regions within their territories). Additionally, substantive disciplines on their own are not useful without effective tools to monitor their implementation, resolve conflicts between Members with regard to these disciplines and, if necessary, enforce compliance therewith. The rules of the SPS Agreement that address these institutional and procedural matters are discussed in Part IV. These institutional and procedural provisions have an important impact on the effectiveness of the SPS Agreement in achieving its goals.

First, Chapter 1 of Part IV discusses those provisions in the SPS Agreement under which mechanisms creating disciplines of an institutional or procedural nature on Members are established. These institutional or procedural disciplines leave undisturbed Members' policy choices within the bounds of the relevant substantive disciplines of the Agreement, but address the way in which these policies are achieved in order to minimise as far as possible their trade-restrictive effects. Often the procedural obligations in the SPS Agreement are combined with a substantive discipline, yet it is the procedural mechanism under the provision that is key to its potential in improving market access. It is useful to note that national procedures may be abused to prevent the achievement of the goals of the relevant substantive disciplines, thereby undermining the trade/health balance of the Agreement. In other words, in many cases it is not what is done but the way in which it is done that creates problems. These problems may be especially burdensome for Members at lower levels of development, due to their lack of resources to devote to compliance with complex procedural requirements on their export markets.

The SPS Agreement contains some rules dealing directly with procedures imposed by Members to check compliance with their SPS measures. These are contained in Article 8 and Annex $\mathrm{C}$, which address control, inspection and approval procedures. The additional procedural mechanisms under the SPS Agreement aim to operationalise certain of its substantive obligations. The substantive obligations on Members in respect of the recognition of equivalence; the adaptation of their SPS measures to regional conditions; and transparency in respect of their SPS measures would achieve little without procedural arrangements to give them effect. Yet, the procedural aspects of the provisions on these matters in the SPS Agreement, aside from the provisions on transparency, are extremely weak. This has led to very poor implementation of the obligations on equivalence and regionalisation, rendering ineffective these provisions despite the significant potential they hold for market access improvements.

In order to realise the potential of the obligations on transparency, the recognition of equivalence and adaptation to regional conditions, the SPS Committee has adopted decisions setting out detailed procedural mechanisms. These decisions do not amend the substantive obligations, but instead provide guidelines for their effective implementation. Developed on the basis of concrete information provided by Members regarding their experiences in the relevant areas, and elaborated in technical discussions among SPS regulatory officials, these procedures illustrate the ability of the SPS Committee to find cooperative solutions to implementation problems.

A second category of procedural and institutional mechanisms, discussed in Chapter 2 of Part IV, covers those provisions in the SPS Agreement that deal with the institutions and procedures necessary at WTO level for the smooth and effective implementation of 
the SPS Agreement. The proper implementation and operation of the SPS Agreement is ensured through two institutional and procedural avenues, that provided by the bargaining forum of the SPS Committee and that provided by the adjudicatory mechanism of the dispute settlement system. The provisions relating to the SPS Committee and to dispute settlement are essential in promoting and monitoring the implementation of the disciplines of the SPS Agreement, resolving conflicts between Members with regard to these disciplines and, if necessary, enforcing compliance therewith.

The question of whether Members' trade concerns with respect to the SPS measures of other Members are dealt with through multilateral discussions at SPS Committee meetings or instead through formal adjudication is not without significance. It is highly relevant for the manner in which the trade/health balance is struck, which is closely tied to the questions of who participates in framing the issues under discussion and who decides on the outcome of the dispute. These questions are particularly pertinent when one bears in mind the differences in opportunities for effective participation available to Members at different levels of development under each of the two mechanisms. The discussion in Part IV makes clear that, currently, alternative mechanisms to dispute settlement represent the best way forward in ensuring that developing-country Members benefit as fully as possible from the benefits offered by the disciplines of the SPS Agreement.

In particular, the discussion of the role and functioning of the SPS Committee shows much greater possibilities for participation of Members at lower levels of development than exist currently in the dispute settlement system. The specific trade concern mechanism of the SPS Committee has proved very effective in providing opportunities for Members to address the problems they face regarding the SPS measures of their trading partners in an inexpensive and constructive way. Most often, bilateral discussions on trade concerns placed on the agenda are held in the margins of SPS Committee meetings, and may resolve the matter. If not, discussions are held in the multilateral forum of the SPS Committee, which gives publicity to the trade concern, enables other Members to comment on the issue and support the trade concern raised. This could lead to the revision of the notified measure or to further bilateral consultations between the Members involved. It may also facilitate compliance with the SPS measure complained of by the Member raising the concern, through increased clarity on the requirements and ways to meet them, and in some cases by means of the provision of technical or financial assistance by the importing Member. In this way disputes can be resolved without recourse to the expensive, time-consuming and confrontational process of formal dispute settlement.

The SPS Committee not only affords Members with a forum for the discussion and resolution of specific trade concerns, but it also promotes regulatory learning and creates possibilities for building professional networks. It provides a mechanism for the monitoring of harmonisation that allows concerns regarding the lack of international standards or problems with existing standards to be raised and forwarded to the relevant international standard setting body. In addition, it plays a crucial role in addressing broader SPS concerns by promoting the implementation of particular disciplines in the SPS Agreement through developing and adopting non-binding procedural guidelines. The disciplines addressed, such as those on equivalence, adaptation to regional conditions, special and differential treatment and transparency, are particularly important for developing-country Members, as discussed above, in that they hold great potential for market access gains 
while fully respecting the level of protection chosen by importing Members. The inclusive nature of the process leading up to the elaboration of these procedural guidelines, based on the collection of practical experiences of Members with the issue under discussion and discussions in formal and informal sessions of the Committee, is crucial to the value of the resulting guidelines. In addition, the practice of ad referendum decisionmaking of the SPS Committee is to be applauded for its effort to ensure the broadest participation possible, including by Members who are unable to attend the meeting where the guidelines are adopted.

Attendance and effective participation by Members at different levels of development in meetings of the SPS Committee varies greatly. As illustrated by the four Members used as examples in this book, high-income Members tend to participate actively and effectively in SPS Committee meetings and are represented by experts from their relevant ministries. However, many Members at lower levels of development do not have the resources to send an SPS official from their capitals, and are represented in meetings of the SPS Committee by diplomats from their missions in Geneva, lacking in the necessary technical knowledge. There are also some Members that are unable to send any representative to most SPS Committee meetings. This diminishes the potential of the SPS Committee to be a mechanism though which less-developed Members can resolve their trade concerns.

The dispute settlement mechanism of the WTO, through which non-compliance with the obligations of the SPS Agreement can be challenged by Members, is a great improvement above that existing under the GATT 1947 . While a very small proportion of the SPSrelated conflicts between Members result in the initiation of WTO dispute settlement proceedings, and even fewer actually proceed to adjudication, the importance of the dispute settlement system to SPS disputes should not be underestimated. The very existence of the dispute settlement system creates an incentive for Members against whose SPS measures concerns are raised to address these concerns through negotiated solutions. In addition, the clarifications developed by panels and the Appellate Body with regard to the provisions of the SPS Agreement are essential in establishing the legal framework within which Members address their SPS conflicts. These clarifications are taken up in decisions of the SPS Committee that elaborate procedural guidelines for the operationalisation of provisions of the SPS Agreement. Equally importantly, they inform discussions between Members, bilaterally but even more so in the multilateral forum of the SPS Committee, to resolve trade concerns. These have been referred to as 'settlements negotiated in law's shadow'.

The relatively weak participation in the dispute settlement system by Members at lower levels of development with respect to SPS issues attests to the high political and financial costs of dispute settlement for these Members and the limited chance of success they foresee. Constraints to effective participation arise in respect of both bringing an SPS dispute and mounting a successful defence in case of a challenge under the SPS Agreement. On the one hand, many developing-country Members may not have the resources to gather the scientific information necessary to bring a challenge under the SPS Agreement, in order to make a prima facie case of violation. On the other hand, the difficulties they face in complying with the regulatory disciplines of the Agreement mean that these Members are unlikely to be able to defend their SPS measures in case they are faced with a challenge. High-income Members have experienced serious difficulties in this regard in the 
SPS disputes heard thus far. For less-developed Members the hurdle seems almost insurmountable. These Members may not have the resources to commission the necessary research and will therefore depend on the chance that there are already existing studies of relevance. The Advisory Center on WTO Law is a welcome development in providing much-needed assistance for developing-country Members' participation in WTO dispute settlement. However, without concerted efforts to build SPS capacity in developing countries, these Members are unlikely to overcome the remaining hurdles to effective participation in dispute settlement and thereby to influence the normative framework within which negotiations to address SPS issues occur.

Aside from the problems of participation, another aspect of the dispute settlement process that deserves special attention is that of the standard of review applied by the adjudicatory bodies. The standard of review in dispute settlement proceedings plays a significant role in the allocation of the authority to make policy choices balancing competing trade and health interests. It determines the extent to which the WTO adjudicatory bodies are entitled to interfere in Members' regulatory determinations. Currently, while panels customarily state that they will not conduct their own risk assessment or impose a particular scientific view on the regulating Member in reviewing the scientific evidence before them, in practice this is increasingly what they do. It is proposed in this book that a panel should limit its examination of the scientific evidence to the question whether the regulatory disciplines of the SPS Agreement, including the requirement that an SPS measure is based on a risk assessment as defined in the Agreement, have been complied with. It should stop short of completely reassessing the scientific evidence itself to determine the existence and extent of a risk. Such a limited review ensures that the regulating Member respects the balance struck in the rules of the SPS Agreement between its health concerns and the trade interests of other Members, but the review does not intrude too far into the regulatory competence of a Member by interfering unduly in its assessment of scientific evidence. This would make room for the diversity of priorities, consumer preferences and regulatory capacity that exists between Members at different levels of development to be reflected in the science policy choices incorporated into national risk assessments. This type of review would also reduce the disadvantage at which Members that lack scientific capacity find themselves in challenging or defending measures under the SPS Agreement. The current intrusive approach may skew the outcome of judicial review in favour of developed-country Members that have the resources to bring convincing scientific evidence and persuasive legal arguments in support of their positions.

It has been argued that the 'normative vacuum' in which the SPS Agreement is currently interpreted has led to the strong focus on science, and the concomitant heavy reliance on the opinions of panel experts in assessing the science, by panels in reviewing the SPS measures of Members. Science is seen as providing a neutral and universal benchmark against which SPS measures can be tested to distinguish SPS protection from disguised protectionism. It is submitted here that consideration of the international law context within which the SPS Agreement functions, in particular international human rights norms relating to the rights to life, health, safe food and development, in addressing the rights and obligations laid down in the SPS Agreement is essential. It could operate to provide the urgently needed normative framework to guide WTO adjudicators in striking a more appropriate balance between the competing goals of trade liberalisation and 
health protection. The recognition of this normative basis for interpretation, on which they can rely to enhance the legitimacy of their decisions, may make panels less inclined to continue their current intrusive approach to the review of the scientific basis for Member's SPS measures. It may also make them more willing to use the flexibilities in the SPS Agreement to allow for the consideration of developing-country Members' constraints in the application of the scientific disciplines on regulation, to ensure that the SPS Agreement does not operate to undermine the protection of health in these Members.

\section{Special provisions for developing countries in the SPS Agreement}

WTO agreements creating disciplines for behind-the-border regulatory regimes, such as the SPS Agreement, necessitate the recognition of differences in capacity of Members across different levels of development. As noted in Part I of this book, the expansion of trade rules beyond issues of tariffs and quotas into areas of regulatory activity, brings with it new problems. The ability of Members to comply with, and benefit from, such rules depends on their 'starting position.' In other words, the existing situation in a Member, such as the strength of its regulatory system, its infrastructure and its human and financial resources will affect the impact of regulatory disciplines on that Member, and its ability to use those disciplines against other Members to gain market access. It is therefore necessary to find ways to ensure that WTO agreements laying down regulatory disciplines, such as the SPS Agreement, are development friendly. To meet this objective, they should leave sufficient space for countries to pursue their development policies through national regulation, while at the same time create clear and workable rules that developing countries can use to gain market access. This difficult balance is not only achieved in the generally applicable substantive disciplines and procedural arrangements under the SPS Agreement, but is also contributed to by provisions providing special treatment for developing-country Members.

The extent to which the SPS Agreement addresses developing-country constraints, either through providing special flexibilities in the rules for developing-country Members or in the form of provisions on technical assistance to support developing-country Members' compliance efforts is examined in Chapters 1 and 2 of Part IV.

Chapter 1 looks at the special and differential treatment (SDT) provisions of the SPS Agreement. It establishes that, although implementation of SDT in the SPS Agreement has been disappointing to date, real possibilities exist for panels and the Appellate Body to take a more progressive approach than that adopted by the Panel in the EC-Approval and Marketing of Biotech Products dispute, to operationalise SDT provisions through effective treaty interpretation. These possibilities arguably allow for the recognition that several provisions contain enforceable obligations that give effect to the general policy of consideration for the special needs of developing countries, thereby ensuring that the negotiated rights enshrined in these provisions are not rendered illusory. The WTO adjudicatory bodies should shoulder their responsibility to apply the SDT provisions effectively, in the light of the circumstances of each case. 
If Members recognise that most of the existing SDT provisions could be operationalised by effective treaty interpretation in dispute settlement proceedings, the basis for the current deadlock in the Doha Development Round negotiations to strengthen the SDT provisions in the SPS Agreement falls away. Members are then left with two options. They can leave the fleshing out of SDT provisions to panels and the Appellate Body, on a caseby-case basis as they are faced with claims such as that of Argentina in EC-Approval and Marketing of Biotech Products, or instead they can reach political agreement on the nature and extent of these obligations.

Nevertheless, the limits of SDT should not be forgotten. New or strengthened SDT provisions cannot be framed in a way that would undermine the careful balance between trade and health objectives that is the core purpose of the SPS Agreement. This would be the case both if Members were to be obliged to allow market access to developingcountry products that do not meet their chosen level of protection, thus compromising these Members' policy autonomy in the area of SPS protection; and if the disciplines of the SPS Agreement were to be relaxed for developing-country Members allowing protectionist SPS measures taken by these Members to slip through. The need to avoid such undesirable results means that SDT, even if strengthened within these limits, will in many cases be an insufficient instrument to resolve the problems that developing countries face. Thus, technical assistance assumes greater importance as a tool to help developing-country Members overcome their constraints.

It is currently widely acknowledged that technical assistance is crucial for developingcountry Members to be able to implement those WTO agreements requiring regulatory capacity and infrastructure, such as the SPS Agreement. Without such assistance, the costs of compliance with such agreements could outweigh the benefits from trade liberalisation gains. For this reason, secure, predictable and effective provision of technical and financial assistance is indispensable in the case of trade rules involving regulatory disciplines. The extent to which the technical assistance provisions in the SPS Agreement contribute to securing this result is examined in Chapter 2 of Part V.

The current provisions on technical assistance in the SPS Agreement are loosely worded and difficult to enforce. As a result, the provision of SPS-related technical assistance leaves much to be desired. Discussions on ways to strengthen these provisions have proved fruitless. In many cases this can be ascribed to the unrealistic nature of the proposals made, making the imposition of SPS requirements with adverse effects on developingcountry Members' exports conditional on granting cost-free technical assistance upon request. This would have enormous budgetary implications, impossible to determine in advance, and would risk undermining the regulatory autonomy of importing Members. Nevertheless, the concerns underlying these proposals cannot be discounted. The experience of developing-country Members with the voluntary provision of technical assistance has been disheartening. It is therefore not surprising that they are seeking real commitments from their developed trading partners in the area of technical assistance.

An examination of a few illustrative examples of technical assistance initiatives in place shows that the current approach is fragmented and lacking in coherence. Bilateral technical assistance tends to reflect donor interests and areas of concern, resulting in a disregard for the priorities of beneficiaries. Recent efforts to develop tools to assist developing 
countries to identify their capacity needs are useful, but must be coupled with the appropriate response to ensure that the project truly builds capacity in the beneficiary in a sustainable manner. Currently, political considerations rather than objective criteria determine which technical assistance projects are supported by donors. The lack of predictability resulting from the voluntary nature of assistance provided currently makes long-term planning difficult. Multilateral efforts are characterised by inefficiencies and overlaps. The limited mandate of some organisations in the area of technical assistance means that additional efforts in the area of technical assistance result in widening its reach but not deepening its impact. Concerted efforts are needed not only in the areas of training and funding of participation in SPS-related fora, but also in respect of building technical and scientific capacity and infrastructure. Without the latter, participation will not bring the desired results.

The Standards and Trade Development Facility (STDF) represents an important step forward in coordinating the plethora of technical assistance initiatives. It creates a cooperative framework of partners with a wide range of high-level technical expertise and significant financial resources. In addition, making use of complementarities with needsassessment mechanisms, it ensures that the priorities and capacity needs of beneficiary countries are an integral part of the framing of a project. Consequently, it is in a position to provide needs-driven and expert assistance. The STDF's new approach is to reduce its focus on actually funding projects and turn its attention to the coordination aspect of its mandate. It aims to use its project preparation grants to facilitate the securing of funds and assistance from its partner institutions and other donors. This may indeed be a more efficient use of its unique capacities to promote coordination in technical assistance. It is to be hoped that the work of the STDF will fulfil the potential it has for turning ad hoc technical assistance projects into coherent and needs-driven capacity building programmes in developing countries. For this to occur, however, donors must show a new willingness to make multi-annual commitments to funding the STDF. Without such commitment, the lack of certainty regarding sustained funding makes the development of a long-term strategy difficult.

It is argued in this book that the answer lies in a new, more effective approach to SPSrelated assistance that is more in line with the current understanding of 'capacity building'. In other words, what is needed is effective, predictable and needs-driven assistance that creates capacity in a sustainable manner. Real commitments must be made to the provision of such assistance. The acceptability of binding commitments towards financing a new technical assistance mechanism will, in turn, depend on the willingness of developing-country Members to accept differentiation across levels of development, reflecting differences in regulatory capacity and dependence on agricultural exports. This would mirror the reality of development, which is a continuum.

Innovative research is urgently needed to identify the necessary conditions for such a mechanism. While research in this area lies beyond the scope of this book and the expertise of its author, there is much room for useful contributions to thinking in this respect from other disciplines. Here an important input can be made by rigorous study, based on empirical research and economic analysis and taking into account the lessons of political science. 


\section{Conclusion}

This book examines the 'development dimension' of the SPS Agreement by evaluating the impact of the disciplines used in this Agreement on WTO Members at lower levels of development. In particular, it assesses whether the balance achieved by these disciplines between the often competing goals of trade liberalisation and health protection is 'appropriate' for less-developed Members in the sense that it effectively increases their market access opportunities while leaving these Members sufficient policy space for SPS regulation. The analysis conducted to address this question in Parts I to V gives rise to the following conclusions.

The globalisation of trade, including the growth in the participation of less-developed countries, has brought with it increased threats of international spread of risks to human, animal and plant life and health. Acting on the interface between the parallel processes of the globalisation of trade and the globalisation of health, the SPS Agreement is best seen as a negotiated instrument embodying new ways to mediate the trade/health conflict. The normative framework provided by the emerging 'right to development' establishes the importance of ensuring that, in doing so, the SPS Agreement promotes agri-food trade without endangering the protection of health.

The question whether this objective is achieved cannot be answered with easy generalisations regarding the impact of the SPS Agreement on market access and regulatory autonomy in developing-country Members. A factual examination of the SPS regulatory systems of selected WTO Members at different income levels, and with different trade and health priorities, makes clear that any analysis of the impact of the SPS Agreement on developing-country Members must be informed by a realisation of the heterogeneity of this group. A similar conclusion flows from a factual examination of the institutions and procedures through which the international standards used as benchmarks in the SPS Agreement are developed, and the participation of Members at different income levels therein. Consequently, while specific difficulties can be identified as deriving from the level of development of certain Members, linked to their SPS regulatory capacity and their financial and technical constraints, these difficulties do not affect all developingcountry Members or not all to the same extent.

With this caveat in mind, the legal analysis of those substantive provisions of the SPS Agreement that discipline the way in which WTO Members exercise their SPS regulatory autonomy leads to two main conclusions. First, although these disciplines reflect a regulatory model currently not achievable for many less-developed Members, the solution to this problem does not seem to lie in weakening the rules. To do so would skew the delicate trade/health balance in the SPS Agreement, to the detriment of all Members. Second, the opportunities that do present themselves to ameliorate the difficulties with the relevant substantive disciplines faced by various Members at lower levels of development seem to lie most often in addressing the problems of interpretation and application of these rules in dispute settlement. Most importantly, it is recommended that panels, in interpreting the SPS Agreement, relinquish their heavy reliance on science as a seemingly objective and universal touchstone for distinguishing SPS protection from trade protectionism, and their accompanying intrusive approach to the review of the scientific basis for Members' SPS measures. Instead, it is suggested that panels would do better 
to recognise the normative basis for interpretation of the SPS Agreement provided by international human rights law, on which they can rely to enhance the legitimacy of their decisions. This may make panels more inclined to use the flexibilities inherent in disciplines of the SPS Agreement in order to achieve the trade/health balance aimed at by the Agreement in a manner more appropriate to the capacities of less-developed Members.

Greater opportunities for enhancing the benefits of the SPS Agreement for less-developed Members, while reducing its costs, arise from the institutional and procedural rules contained in the Agreement and the procedural arrangements developed by the SPS Committee to operationalise its provisions. These procedures address several of the implementation problems faced by many less-developed Members, yet do so without undermining the trade/health balance achieved by the relevant substantive disciplines. Great strides have been taken in this regard by the SPS Committee and this work is continuing. Yet many hurdles remain to the full realisation of the potential benefits of the SPS Agreement by Members at lower levels of development. These hurdles are rooted in the capacity constraints of these Members, which limit their ability to enforce their rights and comply with their obligations under the Agreement.

The special provisions in the SPS Agreement that aim to take account of developing-country constraints, namely the rules on SDT and those on technical assistance leave much to be desired. Both their weak terms and the ineffectual interpretation given to them in dispute settlement have contributed to the disappointing implementation of these provisions to date. In the case of the SDT provisions, the possibilities for strengthening them through negotiated revisions or interpretation are clearly limited by the need to avoid skewing the trade/health balance of the SPS Agreement. Consequently, SDT is an inadequate instrument to resolve the problems that developing countries face. Instead, technical assistance assumes greater importance as a tool to help developing-country Members overcome their constraints. What is needed is a new, more effective approach to SPS-related assistance that is more in line with the current understanding of 'capacity building', which refers to a mechanism for effective, predictable and needs-driven assistance that creates capacity in a sustainable manner. Here the academic community can play an essential role in identifying the necessary conditions for such a mechanism. 


\section{Samenvatting}

\section{Inleiding}

In de laatste vijftig jaar zijn de snelheid en omvang van de handel exponentieel toegenomen en is ook de diversiteit van de verhandelde producten gegroeid. Dat heeft een verdere verspreiding van gezondheidsrisico's met zich meegebracht. Het internationale handelsregime, dat is neergelegd in de regels van de Wereldhandelsorganisatie (WTO), heeft daarom nieuwe manieren moeten vinden om het belang van vrije handel en het belang van bescherming van de gezondheid tegen elkaar af te wegen. De WTO Agreement on the Application of Sanitary and Phytosanitary Measures (Overeenkomst inzake sanitaire en fytosanitaire maatregelen - SPS Overeenkomst) bevindt zich op het raakvlak van de geglobaliseerde handel en geglobaliseerde gezondheidsrisico's. De overeenkomst weerspiegelt een onderhandeld evenwicht tussen concurrerende doelen: liberalisering van de handel in de voedsel- en landbouwsector en bescherming van de gezondheid door nationale overheden.

Ontwikkelingslanden die Lid van de WTO zijn (hierna: 'ontwikkelingslanden') hebben een aanzienlijk belang bij de manier waarop deze twee concurrerende maatschappelijke belangen in de SPS Overeenkomst met elkaar in evenwicht worden gebracht. Aangezien landbouwproducten niet zelden een aanzienlijk deel van de uitvoerhandel in goederen van ontwikkelingslanden vormen, proberen deze landen toegang te krijgen tot de markt van deze sector om buitenlands kapitaal ter verwerven dat nodig is om hun ontwikkelingsbehoeften te bevredigen. Hard bevochten verworvenheden behaald bij het liberaliseren van de handel in landbouwproducten kunnen gemakkelijk worden aangetast door misbruik van SPS maatregelen voor protectionistische doeleinden. Om dit te verhinderen zijn ontwikkelingslanden afhankelijk van effectieve regels in internationaal handelsrecht. Anderzijds moet niet worden vergeten dat ontwikkelingslanden ook belangrijke importeurs van voedsel en landbouwproducten zijn en worden geconfronteerd met sanitaire en fytosanitaire risico's die geïmporteerde producten met zich meebrengen. In dit opzicht hebben ontwikkelingslanden er belang bij dat internationaal handelsrecht voldoende flexibiliteit biedt voor het vaststellen van SPS regelgeving die aansluit bij de behoeften en capaciteiten van die landen. Het is daarom belangrijk te onderkennen dat de belangen die in de SPS Overeenkomst in evenwicht zijn gebracht, belangen zijn van strijdige maatschappelijk doelen die zeer relevant zijn voor zowel ontwikkelde landen als ontwikkelingslanden. Niettemin kan het mechanisme dat wordt gebruikt om dit evenwicht in de SPS Overeenkomst te bereiken van uiteenlopende invloed zijn al naar gelang het ontwikkelingsniveau van de WTO Leden.

Dit onderzoek analyseert de gevolgen van de regels van de SPS Overeenkomst voor WTO Leden met verschillende ontwikkelingsniveaus. Het evalueert meer in het bijzonder de instrumenten die door de SPS Overeenkomst worden gebruikt om een evenwicht te bereiken tussen gezondheid en handel, zodat kan worden bepaald of zij geschikt zijn voor minder ontwikkelde WTO Leden. De “ontwikkelingsdimensie" van de SPS Overeenkomst wordt zo verduidelijkt. 


\section{De SPS Overeenkomst op het snijvlak van}

\section{geglobaliseerde handel en gezondheid}

De SPS Overeenkomst functioneert binnen de context van de parallel lopende globaliseringprocessen van handel en gezondheid. In Deel I wordt de SPS Overeenkomst in deze context geplaatst. In Hoofdstuk 1 van Deel I wordt de veranderende rol van ontwikkelingslanden in het wereldhandelssysteem onderzocht om zo te kunnen vaststellen waarom een onderzoek van de ontwikkelingsdimensie van de SPS Overeenkomst dringend noodzakelijk is. Het normatieve kader dat wordt geboden door de opkomende erkenning van het recht op ontwikkeling dient er enerzijds toe het belang vast te stellen van handel als de motor van economische groei ten dienste van ontwikkeling en van de verantwoordelijkheid die de internationale gemeenschap draagt om gunstige voorwaarden te scheppen om deze groei mogelijk te maken. Anderzijds maakt het recht op ontwikkeling duidelijk dat ontwikkeling niet alleen economische groei, maar tevens een geleidelijke realisering van alle mensenrechten, met inbegrip van het recht op leven, gezondheid en veilig voedsel, met zich mee brengt. De SPS Overeenkomst, die een belangrijke rol speelt in de liberalisering van de handel in landbouwproducten, kan dus zijn handeldoeleinden niet realiseren met behulp van regels die het vermogen van WTO Leden tot het beschermen van leven en gezondheid op hun grondgebied nadelig beïnvloeden.

Hoofdstuk 2 van Deel I schetst de historische ontwikkeling van de erkenning van de globalisering van gezondheid in het licht van grensoverschrijdende gezondheidsrisico's en initiatieven op het gebied van internationale samenwerking in dit verband. In dit Hoofdstuk staat de rol van wetenschappelijke ontwikkelingen op het totstandkoming van nieuwe veelzijdige benaderingen ten aanzien van risicobeheer in ontwikkelingslanden, waarmee complexe bestuursstructuren zowel op nationaal als op internationaal niveau gemoeid zijn, centraal. Dit vormt de achtergrond voor de werking van de SPS Overeenkomst. De SPS Overeenkomst erkent de vorderingen die zijn gemaakt op internationaal niveau met betrekking tot de vrijwillige harmonisatie van normen. Deze normen zijn opgenomen in de regels van de SPS Overeenkomst, maar afwijking van de norm is mogelijk. De SPS Overeenkomst weerspiegelt de ten tijde van de onderhandelingen heersende opvatting dat wetenschap een onpartijdige (neutrale) universele maatstaf biedt voor SPS regulering en schrijft wetenschappelijke onderbouwing voor als het gaat om niet-geharmoniseerde maatregelen. De twee aspecten van dit globaliseringproces die werden besproken in Hoofdstukken 1 en 2, worden in Hoofdstuk 3 samen in verband gebracht met het kernthema van het boek met de bestudering hierin van het belang van regulering en normering inzake geglobaliseerde gezondheidsrisico's voor de handel van ontwikkelingslanden.

\section{Nationale en internationale SPS regulering en normstelling}

Bij de evaluatie van de ontwikkelingsdimensie van de SPS Overeenkomst, wordt rekening gehouden met het feit dat ontwikkelingslanden geen monolithische groep vormen. Ontwikkeling vindt plaats in een continuüm, waarin er grote verschillen kunnen zijn in economische middelen, regelgevingscapaciteit, exportbelangen en gezondheidsniveaus. 
Al deze factoren spelen een rol bij het vaststellen van de invloed van de SPS Overeenkomst op bepaalde WTO Leden en op de vraag hoe werkbaar de regels voor het betreffende Lid zijn. Bij de analyse van de gevolgen van de SPS Overeenkomst voor ontwikkelingslanden dient daarom met deze verschillen rekening te worden gehouden.

Het is om die reden dat in Deel II van dit boek de feitelijke context van de werking van de SPS Overeenkomst zoals neergelegd in nationale en internationale SPS reguleringen normeringstelsels wordt onderzocht, waarbij bijzondere aandacht wordt besteed aan de invloed van niveauverschillen tussen de WTO Leden op het functioneren van deze stelsels.

Hoofdstuk 1 van Deel II beschrijft het normatieve kader waarbinnen SPS regulering plaatsvindt, namelijk het internationale recht inzake de rechten van de mens. Vervolgens wordt in dit Hoofdstuk een korte rechtseconomische analyse van SPS regulering gemaakt voor een beter begrip van de rol die het ontwikkelingsniveau van een land speelt bij de keuze van regulering. Tot slot worden de rol en de grenzen van de wetenschap in het SPS reguleringsproces uiteengezet. Deze theoretische bespreking bereidt de weg voor de feitelijke analyse die in de daaropvolgende hoofdstukken van Deel II wordt uitgevoerd.

Hoofdstuk 2 van Deel II onderzoekt de aanzienlijke verschillen tussen de nationale SPS stelsels aan de hand van vier illustratieve voorbeelden van WTO Leden in verschillende geografische gebieden: Australië, Mauritius, Jamaica en Bangladesh. Uit deze voorbeelden blijkt dat, hoewel er enorme verschillen bestaan tussen de SPS reguleringstelsels van ontwikkelde landen en die van ontwikkelingslanden, er ook significante verschillen op dit gebied zijn tussen ontwikkelingslanden onderling. Deze verschillen in SPS regimes hebben aanmerkelijke gevolgen voor de impact van zowel SPS maatregelen als de SPS Overeenkomst zelf op WTO Leden met verschillende ontwikkelingsniveaus. Zij vormen daarom de feitelijke context voor de latere bespreking van de bepalingen van de SPS Overeenkomst.

Tot de feitelijke context waarbinnen de SPS Overeenkomst functioneert, behoren eveneens de internationale stelsels voor de uitwerking van SPS normen. Deze worden besproken in Hoofdstuk 3 van Deel II. De normen die gesteld worden op internationaal niveau, kunnen de diversiteit aan omstandigheden die onder de landen in alle delen van de wereld bestaat, niet weergeven, maar in plaats daarvan laten zij het compromis zien dat werd gesloten door de afgevaardigden van de landen die actief waren bij de totstandkoming van de normen. Onderzoek naar de institutionele structuur en normstellingsprocedures van de internationale organen waarnaar in de SPS Overeenkomst wordt verwezen, laat zien dat zij van dien aard zijn dat deelname door ontwikkelingslanden beperkt is. Dit is te wijten aan het feit dat deze structuren en procedures onvoldoende rekening houden met de beperkte middelen en capaciteit in landen met een lager ontwikkelingsniveau. Internationale normstelling wordt daardoor gedomineerd door de ontwikkelde landen, hetgeen heeft geleid tot normen die vaak niet geschikt zijn voor WTO Leden met een lager ontwikkelingsniveau.

De feitelijke context die een onderzoek naar SPS regulering op nationaal niveau en SPS normstelling op internationaal niveau biedt, toont een grote behoefte bij ontwikkelingslanden aan technische ondersteuning bij het opbouwen van SPS capaciteit. Het is echter gevaarlijk om ondersteuning te zien als een wondermiddel door aan te nemen dat 
ontwikkelingslanden in staat zijn elke SPS-gerelateerde verplichting na te komen en dat ook zouden moeten doen zolang zij daarbij maar worden voorzien van de nodige ondersteuning. Die technische ondersteuning is geen alternatief voor het uitvoeren van een analyse met betrekking tot de vraag of de regels van de SPS Overeenkomst geschikt zijn voor implementatie door ontwikkelingslanden. Het is daarom essentieel te beginnen met de vraag of de materieelrechtelijke regels en de procedurele mechanismen van de SPS Overeenkomst geschikt zijn voor ontwikkelingslanden. Dit is het doel van het gedetailleerde onderzoek dat ten grondslag ligt aan Delen III en IV.

\section{Regels in de SPS Overeenkomst die evenwicht aanbrengen tussen handel en gezondheid}

Verscheidene materieelrechtelijke verplichtingen in de SPS Overeenkomst hebben tot doel grenzen te stellen aan de beleidsruimte van WTO Leden waar het SPS regulering betreft door middel van het samenvoegen van de traditionele handelsdisciplines van GATT 1994 en nieuwe wetenschappelijke disciplines, en door harmonisatie te stimuleren. Al deze regels samen fungeren als een filter waarmee gezondheidsbeschermende maatregelen kunnen worden afgescheiden van maatregelen die een verhulde vorm van protectionisme zijn. Op die manier tracht de SPS Overeenkomst een evenwicht bereiken tussen de - vaak tegengestelde - belangen van handelsliberalisering enerzijds en bescherming van de gezondheid anderzijds.

De vraag of deze materieelrechtelijke regels in de SPS Overeenkomst die dit evenwicht trachten te bewerkstelligen, geschikt zijn voor WTO Leden met een lager ontwikkelingsniveau, wordt behandeld aan de hand van de vraag of de toepasselijke regels daadwerkelijk de kansen op markttoegang vergroten voor minder ontwikkelde WTO Leden en of ze deze Leden voldoende beleidsruimte laten voor SPS regulering. Gezien in het licht van het normatieve kader dat door het begrip 'recht op ontwikkeling' wordt gevormd, zoals is uiteengezet in Deel I, is het belang van het evalueren van het vermogen van de SPS Overeenkomst om de handel in landbouw- en voedsel producten te stimuleren zonder de bescherming van de gezondheid in minder ontwikkelde landen in gevaar te brengen, evident. Daarin ligt de ontwikkelingsdimensie van de SPS Overeenkomst besloten.

Uit het overzicht van de onderhandelingsgeschiedenis besproken in Hoofdstuk 1 van Deel III blijkt duidelijk dat het reguleringsmodel als neergelegd in de materieelrechtelijke regels van de SPS Overeenkomst kan worden teruggevonden in de voorstellen van de meest actieve deelnemers aan die onderhandelingen: de belangrijkste ontwikkelde landen en de Cairns Group. De Overeenkomst weerspiegelt de ‘best regulatory practices' in ontwikkelde landen vrij precies, zodat het gevaar bestaat dat een model van een reguleringspraktijk is opgesteld dat niet werkbaar is voor minder ontwikkelde WTO Leden.

Zoals te lezen is in Hoofdstukken 2 tot 5 van Deel III, laat de analyse van de toepasselijke materieelrechtelijke regels van de SPS Overeenkomst die de grenzen bepalen van de beleidsruimte van WTO Leden voor het reguleren van SPS aangelegenheden, zien dat de doelstelling van de SPS Overeenkomst evenwicht aan te brengen, duidelijk zichtbaar is in de manier waarop deze materieelrechtelijke bepalingen zijn geformuleerd. Hoewel er 
aspecten zijn aan de interpretatie van deze bepalingen die het zorgvuldige evenwicht dat besloten ligt in hun voorwaarden niet volledig tot zijn recht laten komen, lijken de bepalingen zelf geschikt om het gevoelige conflict tussen handel en gezondheid aan te pakken op een manier die liberalisering van de handel in landbouw- en voedselprodukten stimuleert en tegelijkertijd het recht van WTO Leden eerbiedigt om regelgeving op te stellen met betrekking tot SPS risico's. De regels laten echter een reguleringsmodel zien dat op dit moment niet haalbaar is voor vele WTO Leden op een lager ontwikkelingsniveau. Evenmin zijn deze WTO Leden in staat om deze materieelrechtelijke regels te gebruiken om daadwerkelijk toegang tot de markt te verkrijgen voor hun producten.

Afgezien van de specifieke interpretatieaspecten van de materieelrechtelijke regels in de SPS Overeenkomst, die in Deel III worden geïdentificeerd en die voor verbetering vatbaar zijn, lijkt het niet mogelijk om veranderingen aan te brengen ten einde de problemen van ontwikkelingslanden te verhelpen zonder het evenwicht dat door de Overeenkomst wordt nagestreefd, te verstoren. Niettemin verdient het zeer reële probleem van de beperkingen waarmee de minder ontwikkelde landen kampen bij de nakoming van deze regels en het genieten van de voordelen ervan, meer aandacht.

De vraagt rijst in hoeverre andere bepalingen van de SPS Overeenkomst dan die hierboven besproken dit probleem kunnen verminderen. Deze vraag wordt behandeld in de Delen IV en V van dit boek.

\section{Procedurele en institutionele mechanismen op grond van de SPS Overeenkomst}

Op zichzelf genomen kunnen de materieelrechtelijke regels van de SPS Overeenkomst die hierboven werden besproken, niet voldoende zijn om aanzienlijke vorderingen te maken ten aanzien van toegang tot de markt voor voedsel- en landbouwproducten afkomstig uit ontwikkelingslanden. Dit is te wijten aan hun beperkte vermogen deze regels toe te passen. Daar komt bij dat materieelrechtelijke regels op zich geen nut hebben als er geen effectieve instrumenten bestaan voor het toezicht op de implementatie ervan, voor het oplossen van geschillen tussen WTO Leden over deze regels én, waar nodig, voor het afdwingen van de naleving ervan. De regels uit de SPS Overeenkomst die deze institutionele en procedurele zaken beheersen, worden besproken in Deel IV.

Hoofdstuk 1 van Deel IV beschrijft de bepalingen in de SPS Overeenkomst krachtens welke de mechanismen worden vastgesteld die regels van institutionele of procedurele aard opleggen aan WTO Leden. Deze institutionele en procedurele regels laten het beleid van WTO Leden ongemoeid zolang het blijft binnen de grenzen van de toepasselijke materieelrechtelijke regels van de Overeenkomst; zij zijn gericht op de manier waarop dit beleid wordt uitgevoerd, met het oog op het zo klein mogelijk houden van de handelsbeperkende gevolgen van dat beleid. Het verdient te worden opgemerkt dat nationale procedures misbruikt kunnen worden om te voorkomen dat de doelen die door de toepasselijke materieelrechtelijke regels worden gesteld, worden bereikt, waardoor het in de Overeenkomst aangebrachte evenwicht tussen handel en gezondheid wordt verstoord. De SPS Overeenkomst bevat een aantal regels die rechtstreeks betrekking hebben 
op procedures die door de WTO Leden worden opgelegd om naleving van hun SPS maatregelen te controleren. Voorts bevat de SPS Overeenkomst procedurele mechanismen die bedoeld zijn om bepaalde materieelrechtelijke verplichtingen te operationaliseren, namelijk die met betrekking tot erkenning van gelijkwaardigheid, aanpassing van SPS maatregelen aan regionale omstandigheden en transparantie. Gezien de rudimentaire aard van deze procedurele regels, heeft de SPS Commissie niet-bindende besluiten genomen die gedetailleerde aanvullende procedurele mechanismen bevatten. Deze procedures, die werden ontwikkeld aan de hand van door WTO Leden verstrekte specifieke informatie over hun ervaring op relevante gebieden en die werden bewerkt in besprekingen van technische aard tussen SPS regelgevingsambtenaren, zijn een voorbeeld van het vermogen van de SPS Commissie om in gezamenlijk oplossingen voor uitvoeringsproblemen te vinden.

In Hoofdstuk 2 van Deel IV worden vervolgens de bepalingen in de SPS Overeenkomst besproken met betrekking tot de organen en procedures die nodig zijn om op WTO-niveau de SPS Overeenkomst zonder al te veel problemen effectief te kunnen implementeren. De bepalingen aangaande de SPS Commissie en geschillenbeslechting zijn essentieel voor het bevorderen en bewaken van de implementatie van de regels uit de SPS Overeenkomst, het oplossen van geschillen tussen WTO Leden aangaande deze regels, en waar nodig het afdwingen van de naleving van deze regels.

De bespreking van de rol en het functioneren van de SPS Commissie laat veel ruimere mogelijkheden zien voor deelname van WTO Leden met een lager ontwikkelingsniveau dan er tot op heden zijn in het kader van geschillenbeslechting. Het specifieke bezwaarmechanisme van de SPS Commissie is zeer effectief gebleken in de zin dat het mogelijkheden voor WTO Leden schept hun problemen met SPS maatregelen die door hun handelspartners werden genomen op een goedkope, constructieve manier aan te pakken. De discussies in de SPS Commissie verruimen de kennis van regelgevingtechnieken bij nationale ambtenaren. Bovendien schept de SPS Commissie de mogelijkheid professionele netwerken op te bouwen en speelt zij een cruciale rol waar het de meer algemene SPS bezwaren betreft door implementatie van bepaalde regels uit de SPS Overeenkomst te stimuleren door middel van het ontwikkelen en aannemen van niet-bindende procedurele richtlijnen. Er zijn echter grote verschillen onder de WTO Leden, al naar gelang hun ontwikkelingsniveau, voor wat betreft hun aanwezigheid bij en daadwerkelijke deelname aan bijeenkomsten van de SPS Commissie. Dit verkleint het potentieel van de SPS Commissie om als mechanisme te fungeren voor minder ontwikkelde WTO Leden bij het oplossen van hun handelsproblemen.

Het geschillenbeslechtingssysteem van de WTO, dat het mogelijk maakt voor WTO Leden te klagen over niet-nakoming van de verplichtingen vervat in de SPS Overeenkomst, is een hele verbetering ten opzichte van het systeem dat bestond onder de GATT 1947. Weliswaar wordt voor een zeer klein gedeelte van de geschillen over SPS maatregelen tussen WTO Leden overgegaan tot het instellen van een WTO geschillenbeslechtingsprocedure, en nog minder vaak komt het tot een rechterlijke beoordeling, maar het belang van het geschillenbeslechtingssyteem voor SPS geschillen moet echter niet worden onderschat. Het motiveert WTO Leden tegen wier SPS maatregelen bezwaren zijn gerezen, om deze bezwaren op te lossen door middel van onderhandelingen. Voorts is de uitleg van bepalingen uit de SPS Overeenkomst door WTO panels en de Beroepsinstantie essentieel 
voor het vaststellen van het juridische kader waarbinnen de WTO Leden hun SPS geschillen behandelen. Deze uitleg wordt niet alleen meegenomen in de besluiten van de SPS Commissie die een uitwerking bevatten van procedurele richtlijnen voor de operationalisering van de bepalingen uit de SPS Overeenkomst, zij zijn ook een uitgangspunt bij discussies tussen WTO Leden rondom SPS-gerelateerde handelsproblemen. Men spreekt in dit verband ook van 'settlements negotiated in law's shadow'.

De betrekkelijk bescheiden deelname van WTO Leden met een lager ontwikkelingsniveau aan het geschillenbeslechtingssysteem voor SPS zaken is een indicatie van de hoge politieke en financiële kosten die geschillenbeslechting met zich meebrengt voor deze Leden en van hun opvatting dat de kans op een goede afloop beperkt is. Een ontwikkeling met betrekking tot de zeer nodige hulpverlening aan ontwikkelingslanden in WTO geschillenbeslechting die moet worden toegejuicht, is het Advisory Center on WTO Law. Zonder een gezamenlijke inspanning om de SPS regelgevingscapaciteit in ontwikkelingslanden op te bouwen, zullen deze WTO Leden echter naar alle waarschijnlijkheid de overige belemmeringen voor effectieve deelname niet kunnen overwinnen.

Afgezien van de problemen met deelname, is er een ander geschillenbeslechtingsaspect dat bijzondere aandacht verdient. Dat is het aspect van de toetsingsnorm die wordt gehanteerd door de rechtsprekende organen. Tegenwoordig is het zo dat, hoewel panels als regel verklaren dat zij zelf geen risicobeoordeling zullen uitvoeren of een specifieke wetenschappelijke opvatting van reguleren zullen opleggen aan het regulerende WTO Lid bij het beoordelen van het voorliggende wetenschappelijke bewijsmateriaal, zij dit in de praktijk in toenemende mate toch doen. Voorgesteld wordt dat panels zich bij de bestudering van het wetenschappelijk bewijsmateriaal beperken tot de vraag of de reguleringsverplichtingen van de SPS Overeenkomst, met inbegrip van de eis dat een SPS maatregel gebaseerd moet zijn op een risicobeoordeling als omschreven in de Overeenkomst, in acht zijn genomen. Wat een panel niet zou moeten doen, is het wetenschappelijk bewijsmateriaal zelf volledig opnieuw beoordelen om het bestaan van een risico en de grootte ervan te kunnen vaststellen. Een dergelijke beperkte toetsing zorgt ervoor dat het regulerende WTO Lid het evenwicht eerbiedigt dat in de regels van de SPS Overeenkomst is aangebracht tussen zijn eigen zorgen betreffende de gezondheid en de handelsbelangen van andere WTO Leden. Zo'n toetsing, die een te grote bemoeienis met de beoordeling van het wetenschappelijk bewijsmateriaal vermijdt, beperkt de regelgevende bevoegdheid van een WTO Lid in mindere mate. Dit zou er voor zorgen dat de diversiteit aan prioriteiten, consumentenvoorkeuren en regelgevend vermogen onder de WTO Leden met verschillende ontwikkelingsniveaus tot uitdrukking worden gebracht in de keuzes voor wetenschapsbeleid neergelegd in nationale risicobeoordelingen. Een dergelijke toetsing zou tevens de nadelige positie verminderen van WTO Leden die niet beschikken over de nodige wetenschappelijk capaciteit bij het neerleggen van een klacht over of het verdedigen van maatregelen die zijn genomen in het kader van de SPS Overeenkomst. De huidige ingrijpende aanpak kan het resultaat van een rechterlijke toetsing doen uitvallen ten gunste van ontwikkelde landen die beschikken over de middelen om met overtuigend wetenschappelijk bewijs en sterke juridische argumenten hun standpunt te onderbouwen.

Er is wel aangevoerd dat het 'normatieve vacuüm' waarbinnen de SPS Overeenkomst momenteel wordt geïnterpreteerd, er toe heeft geleid dat er door panels die de SPS maatregelen van WTO Leden toetsen nogal wordt geconcentreerd op wetenschappelijk onderzoek 
en zij in grote mate afgaan op de opvattingen van panel-deskundigen bij de beoordeling van maatregelen die door WTO Leden zijn genomen. De wetenschap wordt in te sterke mate gezien als een onpartijdige, universele maatstaf aan de hand waarvan SPS maatregelen kunnen worden beoordeeld teneinde SPS bescherming van verhulde vormen van protectionisme te onderscheiden. Het is van essentieel belang dat bij de behandeling van de rechten en verplichtingen uit de SPS Overeenkomst, de internationaal-rechtelijke context waarbinnen de SPS Overeenkomst functioneert, in aanmerking wordt genomen en in het bijzonder de normen die in het internationale mensenrechtenrecht met betrekking tot het recht op leven, gezondheid, veilig voedsel en ontwikkeling worden gehanteerd. Dit recht zou het zo dringend noodzakelijke normatieve kader kunnen vormen dat als leidraad kan dienen voor de rechterlijke instanties van de WTO bij het vinden van een geschikter evenwicht tussen de strijdige belangen van liberalisering van de handel en bescherming van de gezondheid.

\section{Bijzondere bepalingen voor ontwikkelingslanden in de SPS Overeenkomst}

In de Hoofdstukken 1 en 2 van Deel IV wordt onderzocht in welke mate de SPS Overeenkomst de beperkingen van ontwikkelingslanden aanpakt, hetzij door middel van het inbouwen van toegesneden flexibiliteit in de regels met betrekking tot ontwikkelingslanden of in de vorm van bepalingen met betrekking tot technische ondersteuning om zo de ontwikkelingslanden te helpen bij de naleving.

Hoofdstuk 1 behandelt de bepalingen uit de SPS Overeenkomst over bijzondere en gedifferentieerde behandeling van ontwikkelingslanden (special and differential treatment - SDT). Hoewel de implementatie van SDT bepalingen in de SPS Overeenkomst tot nu toe teleurstellend is geweest, bestaan er reële mogelijkheden voor de panels en de Beroepsinstantie om een meer vooruitstrevende houding aan te nemen dan die van het Panel in EC - Approval and Marketing of Biotech Products bij het operationaliseren van SDT bepalingen door middel van een effectieve verdragsuitleg. De rechtsprekende organen van de WTO moeten hun verantwoordelijkheid dragen en de SDT bepalingen effectief toepassen in het licht van de omstandigheden van de zaak. Nochtans moeten de grenzen van SDT niet uit het oog worden verloren. SDT kan niet zodanig worden toegepast dat dit het zorgvuldig aangebrachte evenwicht tussen handel en gezondheid -het hoofddoel van de SPS Overeenkomst- aan het wankelen brengt. SDT zal dus in vele gevallen een onvolledig instrument zijn om problemen waar ontwikkelingslanden mee kampen, op te lossen. En zo gaat technische ondersteuning een grotere plaats innemen als instrument om ontwikkelingslanden te helpen bij het overwinnen van hun beperkingen. De mate waarin bepalingen over technische ondersteuning uit de SPS Overeenkomst bijdragen tot het behalen van een resultaat, wordt onderzocht in Hoofdstuk 2 van Deel V.

De thans geldende bepalingen in de SPS Overeenkomst aangaande technische ondersteuning zijn vaag geformuleerd en lastig af te dwingen, met als gevolg dat het verschaffen van SPS-gerelateerde technische assistentie nogal wat te wensen overlaat. Onderhandelingen over manieren om deze bepalingen wat steviger te maken zijn op niets uitgelopen. Dit kan in vele gevallen worden toegeschreven aan het niet-realistische karakter van de gedane voorstellen. Niettemin moeten de zorgen die aan deze voorstellen ten grondslag liggen, 
serieus worden genomen. De ervaring van ontwikkelingslanden met het op vrijwillige basis verlenen van technische ondersteuning is ontmoedigend te noemen. Het hoeft daarom niet te verbazen dat zij van hun ontwikkelde handelspartners verlangen dat zij zich daadwerkelijk committeren om technische ondersteuning te verlenen.

Onderzoek naar enkele voorbeelden van reeds genomen initiatieven op het gebied van technische ondersteuning laat zien dat er thans sprake is van een versnipperde aanpak zonder enige samenhang. Bilaterale technische ondersteuning weerspiegelt over het algemeen de belangen en aandachtsgebieden van het hulpverlenende land, waardoor er geen aandacht is voor de prioriteiten van de ontvangers. Onlangs gedane pogingen om instrumenten te ontwikkelen om ontwikkelingslanden bij te staan bij het identificeren van hun capaciteitsbehoeften zijn weliswaar nuttig, maar dienen te worden gerelateerd aan de gewenste reactie om te verzekeren dat het project werkelijk duurzame capaciteit opbouwt in het ontvangende land. Overwegingen van politiek aard in plaats van objectieve criteria bepalen heden ten dage wat voor soort technische assistentie wordt onderschreven door de donors. Het gebrek aan voorspelbaarheid dat voortkomt uit het vrijwillige karakter van de ondersteuning die thans wordt verleend, maakt lange-termijn planning moeilijk. Multilaterale pogingen worden gekenmerkt door inefficiëntie en overlap. Een gezamenlijke inspanning is vereist, niet alleen op het gebied van scholing en financiering van deelname in fora voor SPS aangelegenheden, maar ook met betrekking tot het ontwikkelen van technische en wetenschappelijke capaciteit en infrastructuur. Zonder dat laatste zal deelname niet het gewenste resultaat opleveren.

Er is behoefte aan een nieuwe, effectievere aanpak van SPS-gerelateerde ondersteuning die meer aansluit bij de huidige invulling van het begrip 'capacity building'. Met andere woorden, effectieve, voorspelbare, op behoefte gerichte ondersteuning, die capaciteit op duurzame wijze tot stand brengt, is essentieel. Er moet sprake zijn van een daadwerkelijk verplichting tot het verschaffen van zulke bijstand. De aanvaardbaarheid van zulke verplichtingen, zal dan weer afhangen van de bereidheid van ontwikkelingslanden differentiatie naar ontwikkelingsniveau te aanvaarden, waarin de verschillen in regelgevingscapaciteit en afhankelijkheid van de export in landbouwproducten tot uitdrukking komen. Dit zou een afspiegeling zijn van het feit dat ontwikkeling een continuüm is. 


\section{Appendix:}

Table of Disputes initiated under the SPS Agreement

\begin{tabular}{|c|c|c|c|c|c|c|c|c|}
\hline & Dispute & $\begin{array}{l}\text { DS } \\
\text { No. }\end{array}$ & Complainant(s) & $\begin{array}{l}\text { Members } \\
\text { Joining } \\
\text { Consultations }\end{array}$ & Third Parties & $\begin{array}{l}\text { Date } \\
\text { Initiated }\end{array}$ & Agreements & $\begin{array}{l}\text { Status of } \\
\text { dispute }\end{array}$ \\
\hline 1 & $\begin{array}{l}\text { Australia - } \\
\text { Measures } \\
\text { affecting the } \\
\text { importation of } \\
\text { apples from } \\
\text { New Zealand }\end{array}$ & 367 & New Zealand & $\begin{array}{l}\text { European } \\
\text { Communities; } \\
\text { United States }\end{array}$ & $\begin{array}{l}\text { Chile; European } \\
\text { Communities; } \\
\text { Japan; Pakistan; } \\
\text { Chinese Taipei; } \\
\text { United States }\end{array}$ & 31.18 .2007 & SPS & $\begin{array}{l}\text { Pending } \\
\text { before the } \\
\text { Panel }\end{array}$ \\
\hline 2 & $\begin{array}{l}\text { Croatia - } \\
\text { Measures } \\
\text { affecting } \\
\text { imports of live } \\
\text { animals and } \\
\text { meat products }\end{array}$ & 297 & Hungary & & & 09.07 .2003 & SPS, GATT & $\begin{array}{l}\text { Pending } \\
\text { consultations }\end{array}$ \\
\hline 3 & $\begin{array}{l}\text { EC - } \\
\text { Measures } \\
\text { affecting the } \\
\text { approval and } \\
\text { marketing } \\
\text { of biotech } \\
\text { products }\end{array}$ & 293 & Argentina & $\begin{array}{l}\text { Canada; } \\
\text { Mexico; } \\
\text { United States; } \\
\text { Australia, } \\
\text { New Zealand; } \\
\text { India; Brazil }\end{array}$ & $\begin{array}{l}\text { Australia; } \\
\text { Brazil; Canada; } \\
\text { Chile; China; } \\
\text { Chinese Taipei; } \\
\text { Colombia; } \\
\text { El Salvador; } \\
\text { Honduras; } \\
\text { Mexico; New } \\
\text { Zealand; } \\
\text { Norway; } \\
\text { Paraguay; } \\
\text { Peru; Thailand; } \\
\text { Uruguay; } \\
\text { United States }\end{array}$ & 21.05 .2003 & $\begin{array}{l}\text { SPS, GATT, } \\
\text { TBT, } \\
\text { Agriculture }\end{array}$ & $\begin{array}{l}\text { Panel Report } \\
\text { adopted by } \\
\text { DSB on } 21 \\
\text { November } \\
2007\end{array}$ \\
\hline 4 & \begin{tabular}{|l|} 
EC - \\
Measures \\
affecting the \\
approval and \\
marketing \\
of biotech \\
products
\end{tabular} & 292 & Canada & \begin{tabular}{|l} 
Argentina; \\
Mexico; \\
United States; \\
Australia; \\
New Zealand; \\
India; Brazil
\end{tabular} & $\begin{array}{l}\text { Argentina; } \\
\text { Australia; } \\
\text { Brazil; Chile; } \\
\text { China; Chinese } \\
\text { Taipei; } \\
\text { Colombia; } \\
\text { El Salvador; } \\
\text { Honduras; } \\
\text { Mexico; New } \\
\text { Zealand; } \\
\text { Norway; } \\
\text { Paraguay; } \\
\text { Peru; Thailand; } \\
\text { Uruguay; } \\
\text { United States }\end{array}$ & 20.05 .2003 & $\begin{array}{l}\text { SPS, GATT, } \\
\text { TBT, } \\
\text { Agriculture }\end{array}$ & $\begin{array}{l}\text { Panel Report } \\
\text { adopted by } \\
\text { DSB on } 21 \\
\text { November } \\
2006\end{array}$ \\
\hline 5 & $\begin{array}{l}\text { EC - } \\
\text { Measures } \\
\text { affecting the } \\
\text { approval and } \\
\text { marketing } \\
\text { of biotech } \\
\text { products }\end{array}$ & 291 & United States & $\begin{array}{l}\text { Peru; } \\
\text { Colombia; } \\
\text { Chile; Brazil; } \\
\text { Argentina; } \\
\text { Mexico; } \\
\text { Australia; } \\
\text { New Zealand; } \\
\text { Canada; India }\end{array}$ & $\begin{array}{l}\text { Argentina; } \\
\text { Australia; } \\
\text { Brazil; Canada; } \\
\text { Chile; China; } \\
\text { Chinese Taipei; } \\
\text { Colombia; } \\
\text { El Salvador; } \\
\text { Honduras; } \\
\text { Mexico; New } \\
\text { Zealand; } \\
\text { Norway; } \\
\text { Paraguay; } \\
\text { Peru; Thailand; } \\
\text { Uruguay }\end{array}$ & 20.05 .2003 & $\begin{array}{l}\text { SPS, GATT, } \\
\text { TBT, } \\
\text { Agriculture }\end{array}$ & $\begin{array}{l}\text { Panel Report } \\
\text { adopted by } \\
\text { DSB on } 21 \\
\text { November } \\
2007\end{array}$ \\
\hline
\end{tabular}




\begin{tabular}{|c|c|c|c|c|c|c|c|c|}
\hline & Dispute & $\begin{array}{l}\text { DS } \\
\text { No. }\end{array}$ & Complainant(s) & $\begin{array}{l}\text { Members } \\
\text { Joining } \\
\text { Consultations }\end{array}$ & Third Parties & $\begin{array}{l}\text { Date } \\
\text { Initiated }\end{array}$ & Agreements & $\begin{array}{l}\text { Status of } \\
\text { dispute }\end{array}$ \\
\hline 6 & $\begin{array}{l}\text { Australia - } \\
\text { Quarantine } \\
\text { regime for } \\
\text { Imports }\end{array}$ & 287 & $\begin{array}{l}\text { European } \\
\text { Communities }\end{array}$ & $\begin{array}{l}\text { Canada; } \\
\text { India; Chile; } \\
\text { Philippines }\end{array}$ & $\begin{array}{l}\text { Canada; Chile; } \\
\text { China; India; } \\
\text { Philippines; } \\
\text { Thailand; } \\
\text { United States }\end{array}$ & 09.04 .2003 & SPS & 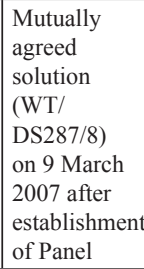 \\
\hline 7 & $\begin{array}{l}\text { Mexico } \\
\text { - Certain } \\
\text { measures } \\
\text { preventing the } \\
\text { importation } \\
\text { of black } \\
\text { beans from } \\
\text { Nicaragua }\end{array}$ & 284 & Nicaragua & $\begin{array}{l}\text { United States; } \\
\text { Canada }\end{array}$ & & 20.03 .2003 & $\begin{array}{l}\text { SPS, GATT, } \\
\text { Licensing }\end{array}$ & \begin{tabular}{|l} 
Mutually \\
agreed \\
solution \\
(WT/ \\
DS284/4) \\
on 11 March \\
2004
\end{tabular} \\
\hline 8 & $\begin{array}{l}\text { India - Import } \\
\text { restrictions } \\
\text { maintained } \\
\text { under the } \\
\text { export and } \\
\text { import policy } \\
\text { 2002-2007 }\end{array}$ & 279 & $\begin{array}{l}\text { European } \\
\text { Communities }\end{array}$ & United States & & 23.12 .2002 & $\begin{array}{l}\text { SPS, GATT, } \\
\text { TBT, } \\
\text { Agriculture, } \\
\text { Licensing }\end{array}$ & $\begin{array}{l}\text { Pending } \\
\text { consultations }\end{array}$ \\
\hline 9 & $\begin{array}{l}\text { Australia } \\
\text { - Certain } \\
\text { measures } \\
\text { affecting the } \\
\text { importation } \\
\text { of fresh } \\
\text { pineapple }\end{array}$ & 271 & Philippines & $\begin{array}{l}\text { European } \\
\text { Communities; } \\
\text { Thailand }\end{array}$ & & 18.10 .2003 & $\begin{array}{l}\text { SPS, GATT, } \\
\text { Licensing }\end{array}$ & \begin{tabular}{|l|} 
Pending \\
consultations
\end{tabular} \\
\hline 10 & $\begin{array}{l}\text { Australia } \\
\text { - Certain } \\
\text { measures } \\
\text { affecting the } \\
\text { importation of } \\
\text { fresh fruit and } \\
\text { vegetables }\end{array}$ & 270 & Philippines & $\begin{array}{l}\text { European } \\
\text { Communities; } \\
\text { Thailand }\end{array}$ & $\begin{array}{l}\text { Chile; China; } \\
\text { European } \\
\text { Communities; } \\
\text { Ecuador; India; } \\
\text { Thailand; } \\
\text { United States }\end{array}$ & 18.10 .2002 & $\begin{array}{l}\text { GATT, } \\
\text { Licensing, } \\
\text { SPS }\end{array}$ & $\begin{array}{l}\text { Pending } \\
\text { consultations } \\
\text { Panel } \\
\text { established } \\
\text { on } 29 \\
\text { August 2003, } \\
\text { but never } \\
\text { composed }\end{array}$ \\
\hline 11 & $\begin{array}{l}\text { Turkey - } \\
\text { Import ban } \\
\text { on pet food } \\
\text { from Hungary }\end{array}$ & 256 & Hungary & $\begin{array}{l}\text { European } \\
\text { Communities }\end{array}$ & & 03.05 .2002 & $\begin{array}{l}\text { SPS, GATT, } \\
\text { Agriculture }\end{array}$ & $\begin{array}{l}\text { Mutually } \\
\text { agreed } \\
\text { solution } \\
\text { reported } \\
\text { to SPS } \\
\text { Committee } \\
\text { in June } \\
\text { 2004, but } \\
\text { not reported } \\
\text { to DSB }\end{array}$ \\
\hline
\end{tabular}




\begin{tabular}{|c|c|c|c|c|c|c|c|c|}
\hline & Dispute & $\begin{array}{l}\text { DS } \\
\text { No. }\end{array}$ & Complainant(s) & $\begin{array}{l}\text { Members } \\
\text { Joining } \\
\text { Consultations }\end{array}$ & Third Parties & $\begin{array}{l}\text { Date } \\
\text { Initiated }\end{array}$ & Agreements & $\begin{array}{l}\text { Status of } \\
\text { dispute }\end{array}$ \\
\hline 12 & $\begin{array}{l}\text { Japan - } \\
\text { Measures } \\
\text { affecting the } \\
\text { importation } \\
\text { of apples }\end{array}$ & 245 & United States & & $\begin{array}{l}\text { Australia; } \\
\text { Brazil; China; } \\
\text { Chinese Taipei; } \\
\text { European } \\
\text { Communities; } \\
\text { New Zealand }\end{array}$ & 06.03 .2002 & $\begin{array}{l}\text { SPS, GATT, } \\
\text { Agreement } \\
\text { on } \\
\text { Agriculture }\end{array}$ & $\begin{array}{l}\text { Mutually } \\
\text { agreed } \\
\text { solution } \\
\text { (WT/ } \\
\text { DS245/21) } \\
\text { on } 2 \\
\text { September } \\
\text { 2004. Article } \\
\text { 21.5 Panel } \\
\text { Report } \\
\text { adopted by } \\
\text { DSB on 20 } \\
\text { July 2005. } \\
\text { Panel Report } \\
\text { and Appellate } \\
\text { Body Report } \\
\text { adopted by } \\
\text { DSB on } 10 \\
\text { December } \\
\text { 2003. }\end{array}$ \\
\hline 13 & $\begin{array}{l}\text { Turkey - } \\
\text { Certain import } \\
\text { procedures } \\
\text { for fresh fruit }\end{array}$ & 237 & Ecuador & & $\begin{array}{l}\text { Colombia; } \\
\text { European } \\
\text { Communities; } \\
\text { United States }\end{array}$ & 10.09 .2001 & $\begin{array}{l}\text { SPS, GATT, } \\
\text { GATS, } \\
\text { Licensing, } \\
\text { Agriculture }\end{array}$ & $\begin{array}{l}\begin{array}{l}\text { Mutually } \\
\text { agreed } \\
\text { solution } \\
\text { (WT/ } \\
\text { DS237/4) on } \\
\text { 29 November } \\
2002 \text { after } \\
\text { establishment } \\
\text { of Panel }\end{array} \\
\end{array}$ \\
\hline 14 & $\begin{array}{l}\text { Egypt - } \\
\text { Import } \\
\text { prohibition } \\
\text { on canned } \\
\text { tuna with } \\
\text { soybean oil } \\
\end{array}$ & 205 & Thailand & & & 22.09 .2000 & SPS, GATT & $\begin{array}{l}\text { Pending } \\
\text { consultations }\end{array}$ \\
\hline 15 & \begin{tabular}{|l|} 
Mexico - \\
Measures \\
affecting trade \\
in live swine \\
\end{tabular} & 203 & United States & & & 10.07 .2000 & $\begin{array}{l}\text { SPS, GATT, } \\
\text { TBT, AD, } \\
\text { Agriculture }\end{array}$ & $\begin{array}{l}\text { Pending } \\
\text { consultations }\end{array}$ \\
\hline 16 & $\begin{array}{l}\text { United States } \\
\text { - Certain } \\
\text { measures } \\
\text { affecting the } \\
\text { import of } \\
\text { swine, cattle } \\
\text { and grain } \\
\text { from Canada }\end{array}$ & 144 & Canada & & & 25.09 .1998 & $\begin{array}{l}\text { SPS, TBT, } \\
\text { GATT, } \\
\text { Agriculture }\end{array}$ & $\begin{array}{l}\text { Pending } \\
\text { consultations }\end{array}$ \\
\hline 17 & $\begin{array}{l}\text { EC - } \\
\text { Measures } \\
\text { affecting } \\
\text { imports of } \\
\text { wood of } \\
\text { conifers from } \\
\text { Canada }\end{array}$ & 137 & Canada & & & 17.07 .2003 & $\begin{array}{l}\text { SPS, GATT, } \\
\text { TBT }\end{array}$ & $\begin{array}{l}\text { Pending } \\
\text { consultations }\end{array}$ \\
\hline
\end{tabular}




\begin{tabular}{|c|c|c|c|c|c|c|c|c|}
\hline & Dispute & $\begin{array}{l}\text { DS } \\
\text { No. }\end{array}$ & Complainant(s) & $\begin{array}{l}\text { Members } \\
\text { Joining } \\
\text { Consultations }\end{array}$ & Third Parties & $\begin{array}{l}\text { Date } \\
\text { Initiated }\end{array}$ & Agreements & $\begin{array}{l}\text { Status of } \\
\text { dispute }\end{array}$ \\
\hline 18 & \begin{tabular}{|l} 
EC - \\
Measures \\
affecting \\
Asbestos \\
and products \\
containing \\
asbestos
\end{tabular} & 135 & Canada & Brazil & $\begin{array}{l}\text { Brazil; } \\
\text { Zimbabwe; } \\
\text { United States }\end{array}$ & 03.06 .1998 & $\begin{array}{l}\text { SPS, GATT, } \\
\text { TBT } \\
\text { (SPS not } \\
\text { invoked in } \\
\text { reports) }\end{array}$ & $\begin{array}{l}\text { Panel Report } \\
\text { and Appellate } \\
\text { Body Report } \\
\text { adopted by } \\
\text { DSB on } 5 \\
\text { April } 2001\end{array}$ \\
\hline 19 & $\begin{array}{l}\text { EC - } \\
\text { Restrictions } \\
\text { on certain } \\
\text { import duties } \\
\text { on rice }\end{array}$ & 134 & India & & & 25.05 .1998 & $\begin{array}{l}\text { SPS, GATT, } \\
\text { Customs, } \\
\text { Agriculture, } \\
\text { TBT, } \\
\text { Licensing }\end{array}$ & $\begin{array}{l}\text { Pending } \\
\text { consultations }\end{array}$ \\
\hline 20 & $\begin{array}{l}\text { Slovak } \\
\text { Republic - } \\
\text { Measures } \\
\text { concerning the } \\
\text { importation of } \\
\text { dairy products } \\
\text { and the transit } \\
\text { of cattle }\end{array}$ & 133 & Switzerland & United States & & 11.05 .1998 & \begin{tabular}{|l} 
SPS, GATT, \\
Licensing
\end{tabular} & 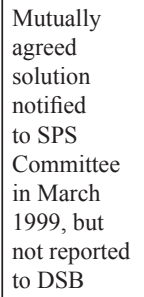 \\
\hline 21 & \begin{tabular}{|l} 
United States \\
- Measures \\
affecting \\
imports \\
of poultry \\
products \\
\end{tabular} & 100 & $\begin{array}{l}\text { European } \\
\text { Communities }\end{array}$ & & & 18.08 .1997 & $\begin{array}{l}\text { SPS, GATT, } \\
\text { TBT }\end{array}$ & $\begin{array}{l}\text { Pending } \\
\text { consultations }\end{array}$ \\
\hline 22 & $\begin{array}{l}\text { India - } \\
\text { Quantitative } \\
\text { restrictions } \\
\text { on imports of } \\
\text { agricultural, } \\
\text { textile and } \\
\text { industrial } \\
\text { products }\end{array}$ & 96 & \begin{tabular}{|l} 
European \\
Communities
\end{tabular} & $\begin{array}{l}\text { Japan; United } \\
\text { States; } \\
\text { Switzerland; } \\
\text { Australia; } \\
\text { Canada; New } \\
\text { Zealand }\end{array}$ & & 27.07.1997 & $\begin{array}{l}\text { SPS, GATT, } \\
\text { Agriculture, } \\
\text { Licensing }\end{array}$ & \begin{tabular}{|l} 
Mutually \\
agreed \\
solution \\
(WT/ \\
DS96/8) on \\
6 May 1998
\end{tabular} \\
\hline 23 & \begin{tabular}{|l} 
Japan - \\
Measures \\
affecting \\
agricultural \\
products
\end{tabular} & 76 & United States & & \begin{tabular}{|l} 
Brazil; \\
European \\
Communities; \\
Hungary
\end{tabular} & 09.04.1997 & $\begin{array}{l}\text { SPS, GATT, } \\
\text { Agriculture }\end{array}$ & 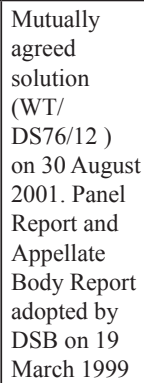 \\
\hline
\end{tabular}




\begin{tabular}{|c|c|c|c|c|c|c|c|c|}
\hline & Dispute & $\begin{array}{l}\text { DS } \\
\text { No. }\end{array}$ & Complainant(s) & $\begin{array}{l}\text { Members } \\
\text { Joining } \\
\text { Consultations }\end{array}$ & Third Parties & $\begin{array}{l}\text { Date } \\
\text { Initiated }\end{array}$ & Agreements & $\begin{array}{l}\text { Status of } \\
\text { dispute }\end{array}$ \\
\hline 24 & $\begin{array}{l}\text { EC - } \\
\text { Measures } \\
\text { affecting } \\
\text { livestock } \\
\text { and meat } \\
\text { (hormones) }\end{array}$ & 48 & Canada & $\begin{array}{l}\text { New Zealand; } \\
\text { Australia; } \\
\text { United States }\end{array}$ & $\begin{array}{l}\text { Australia; } \\
\text { New Zealand; } \\
\text { Norway; } \\
\text { United States }\end{array}$ & 08.07 .1996 & $\begin{array}{l}\text { SPS, GATT, } \\
\text { TBT, } \\
\text { Agriculture }\end{array}$ & 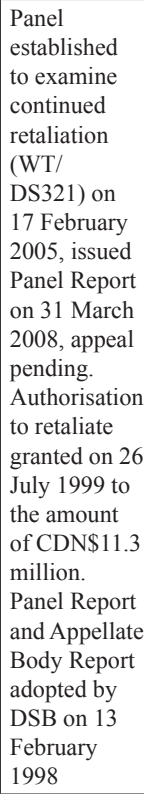 \\
\hline 25 & \begin{tabular}{|l|} 
Korea - \\
Measures \\
concerning \\
inspection of \\
agricultural \\
products
\end{tabular} & 41 & United States & & & 24.05 .1996 & $\begin{array}{l}\text { SPS, GATT, } \\
\text { TBT, } \\
\text { Agriculture }\end{array}$ & 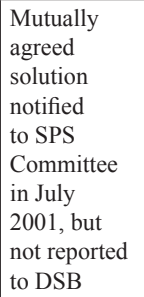 \\
\hline
\end{tabular}




\begin{tabular}{|c|c|c|c|c|c|c|c|c|}
\hline & Dispute & $\begin{array}{l}\text { DS } \\
\text { No. }\end{array}$ & Complainant(s) & $\begin{array}{l}\text { Members } \\
\text { Joining } \\
\text { Consultations }\end{array}$ & Third Parties & $\begin{array}{l}\text { Date } \\
\text { Initiated }\end{array}$ & Agreements & $\begin{array}{l}\text { Status of } \\
\text { dispute }\end{array}$ \\
\hline 26 & \begin{tabular}{|l|} 
EC - \\
Measures \\
concerning \\
meat and \\
meat products \\
(hormones)
\end{tabular} & 26 & United States & $\begin{array}{l}\text { Australia; } \\
\text { New Zealand; } \\
\text { Canada }\end{array}$ & $\begin{array}{l}\text { Australia; } \\
\text { Canada; New } \\
\text { Zealand; } \\
\text { Norway }\end{array}$ & 31.01 .1996 & $\begin{array}{l}\text { SPS, GATT, } \\
\text { TBT, } \\
\text { Agriculture }\end{array}$ & $\begin{array}{l}\text { Panel } \\
\text { established } \\
\text { to examine } \\
\text { continued } \\
\text { retaliation } \\
\text { (WT/ } \\
\text { DS320) on } \\
17 \text { February } \\
2005 \text {, issued } \\
\text { Panel Report } \\
\text { on } 31 \text { March } \\
\text { 2008, appeal } \\
\text { pending. } \\
\text { Authorisation } \\
\text { to retaliate } \\
\text { granted on } 26 \\
\text { July } 1999 \text { to } \\
\text { the amount } \\
\text { of US } \$ 116.8 \\
\text { million. } \\
\text { Panel Report } \\
\text { and Appellate } \\
\text { Body Report } \\
\text { adopted by } \\
\text { DSB on } 13 \\
\text { February } \\
1998\end{array}$ \\
\hline 27 & $\begin{array}{l}\text { Australia - } \\
\text { Measures } \\
\text { affecting the } \\
\text { importation } \\
\text { of salmonids }\end{array}$ & 21 & United States & Canada & $\begin{array}{l}\text { Canada; } \\
\text { European } \\
\text { Communities; } \\
\text { Hong Kong, } \\
\text { China; Iceland; } \\
\text { India; Norway }\end{array}$ & 23.11 .1995 & SPS, GATT & \begin{tabular}{|l}
$\begin{array}{l}\text { Mutually } \\
\text { agreed } \\
\text { solution } \\
\text { (WT/ } \\
\text { DS21/10) on } \\
1 \text { November } \\
\text { 2000, after } \\
\text { establishment } \\
\text { of the Panel }\end{array}$ \\
\end{tabular} \\
\hline 28 & $\begin{array}{l}\text { Korea - } \\
\text { Measures } \\
\text { concerning } \\
\text { bottled water }\end{array}$ & 20 & Canada & $\begin{array}{l}\text { United States; } \\
\text { European } \\
\text { Communities }\end{array}$ & & 22.11 .1995 & $\begin{array}{l}\text { SPS, GATT, } \\
\text { TBT }\end{array}$ & \begin{tabular}{|l} 
Mutually \\
agreed \\
solution \\
(WT/ \\
DS20/6) on \\
6 May 1996 \\
\end{tabular} \\
\hline
\end{tabular}




\begin{tabular}{|c|c|c|c|c|c|c|c|c|}
\hline & Dispute & $\begin{array}{l}\text { DS } \\
\text { No. }\end{array}$ & Complainant(s) & $\begin{array}{l}\text { Members } \\
\text { Joining } \\
\text { Consultations }\end{array}$ & Third Parties & $\begin{array}{l}\text { Date } \\
\text { Initiated }\end{array}$ & Agreements & $\begin{array}{l}\text { Status of } \\
\text { dispute }\end{array}$ \\
\hline 29 & $\begin{array}{l}\text { Australia - } \\
\text { Measures } \\
\text { affecting the } \\
\text { importation } \\
\text { of salmon }\end{array}$ & 18 & Canada & & \begin{tabular}{|l|} 
European \\
Communities; \\
India; Norway; \\
United States
\end{tabular} & 10.10 .1995 & SPS, GATT & $\begin{array}{l}\text { Mutually } \\
\text { agreed } \\
\text { solution } \\
\text { reported } \\
\text { to SPS } \\
\text { Committee } \\
\text { in May } \\
\text { 2000, but } \\
\text { not reported } \\
\text { to DSB. } \\
\text { Article } 21.5 \\
\text { Panel Report } \\
\text { adopted by } \\
\text { DSB on 20 } \\
\text { March 2000. } \\
\text { Panel Report } \\
\text { and Appellate } \\
\text { Body Report } \\
\text { adopted by } \\
\text { the DSB on } \\
6 \text { November } \\
\text { 1998 }\end{array}$ \\
\hline 30 & $\begin{array}{l}\text { Korea - } \\
\text { Measures } \\
\text { concerning } \\
\text { the shelf-life } \\
\text { of products }\end{array}$ & 5 & United States & Japan; Canada & & 05.05 .1995 & $\begin{array}{l}\text { SPS, GATT, } \\
\text { TBT, } \\
\text { Agriculture }\end{array}$ & $\begin{array}{l}\text { Mutually } \\
\text { agreed } \\
\text { solution } \\
\text { (WT/DS5/5 } \\
\text { and Add.1- } \\
\text { 5) on } 31 \\
\text { July } 1995\end{array}$ \\
\hline 31 & \begin{tabular}{|l|} 
Korea - \\
Measures \\
concerning \\
the testing and \\
inspection of \\
agricultural \\
products
\end{tabular} & 3 & United States & Japan & & 04.04 .1995 & $\begin{array}{l}\text { SPS, GATT, } \\
\text { TBT, } \\
\text { Agriculture }\end{array}$ & $\begin{array}{l}\text { Mutually } \\
\text { agreed } \\
\text { solution } \\
\text { notified } \\
\text { to SPS } \\
\text { Committee } \\
\text { in July } \\
2001, \text { but } \\
\text { not reported } \\
\text { to DSB }\end{array}$ \\
\hline
\end{tabular}




\section{List of Abbreviations}

AAHL: $\quad$ Australian Animal Health Laboratory

ABARE: Australian Bureau of Agricultural and Resource Economics

ACIAR: Australian Centre for International Agricultural Research

ACP: $\quad$ African, Caribbean and Pacific

ACWL: $\quad$ Advisory Centre on WTO Law

ADI: $\quad$ Acceptable Daily Intake

AHC: $\quad$ Animal Health Committee of the OIE

ALARA: As low as reasonably achievable

ANZCERTA: Australia-New Zealand Closer Economic Relations Trade Agreement of 1983

ANZFA: $\quad$ Australia New Zealand Food Authority

APCC: $\quad$ Asian and Pacific Coconut Community

APEC: $\quad$ Asia Pacific Economic Cooperation

APHIS: Animal and Plant Health Inspection Service of the US

APO: $\quad$ Associate Professional Officer

AQIS: $\quad$ Australian Quarantine and Inspection Service

ASEAN: Association of Southeast Asian Nations

ASTP: $\quad$ Australian System of Tariff Preferences

AusAID: Australian Agency for International Development

AUSFTA: Australia-United States Free Trade Agreement of 2005

BSE: $\quad$ Bovine Spongiform Encephalopathy

BSJ: $\quad$ Bureau of Standards of Jamaica

BSTI: Bangladesh Standards and Testing Institute

CAC: $\quad$ Codex Alimentarius Commission

CARIBCAN: Caribbean-Canada Trade Agreement

CARICOM: Caribbean Community

CBD: $\quad$ Convention on Biological Diversity of 1992

CEPM: Committee of Experts on Phytosanitary Measures of the IPPC

CGTF: Consultative Group on the Codex Trust Fund

COLEACP: Committee for Liaison for Europe and the African Caribbean and Pacific countries

COMESA: Common Market for Eastern and Southern Africa

COPs: $\quad$ Codes of Practice

CPM: Commission on Phytosanitary Measures of the IPPC

CROSQ: CARICOM Regional Organisation for Standards and Quality

CRVDF: Codex Committee on Residues of Veterinary Drugs in Food 
CSIRO: Commonwealth Scientific and Industrial Research Organisation

DAFF: $\quad$ Australian Government Department of Agriculture, Fisheries and Forestry

DFID: $\quad$ Department for International Development of the UK

DSB: $\quad$ Dispute Settlement Body

DSU: $\quad$ Dispute Settlement Understanding

EC: $\quad$ European Communities

EFSA: $\quad$ European Food Safety Authority

EFTA: $\quad$ European Free Trade Area

EPA: $\quad$ Economic Partnership Agreement

EPOPA: Export Promotion of Organic Products from Africa

EU: $\quad$ European Union

EUREPGAP: Euro-Retailer Produce Working Group's Good Agricultural Practice Standards

EWG: $\quad$ Expert Working Group of the IPPC

FAO: $\quad$ United Nations Food and Agricultural Organization

FDA: $\quad$ Food and Drug Administration of the US

FMD: $\quad$ Foot and Mouth Disease

FSANZ: $\quad$ Food Standards Australia New Zealand

FSPID: $\quad$ Food Storage and Prevention of Infestation Division of Jamaica

G-20: $\quad$ Group of 20 (developing country coalition of varying membership)

G-77: $\quad$ Group of 77 (developing county coalition originating in UNCTAD)

G-90: $\quad$ Group of 90 (developing country coalition at Cancun consisting of ACP, AU and LDC countries, not all of which are WTO Members)

GAP: $\quad$ Good Agricultural Practice

GATT: General Agreement on Tariffs and Trade

GDP: $\quad$ Gross Domestic Product

GFSI: Global Food Safety Initiative

GIFSA: Global Initiative for Food-Related Scientific Advice

GLOBALGAP: Global Partnership for Good Agricultural Practices

GMOs: $\quad$ Genetically Modified Organisms

GMP: $\quad$ Good Manufacturing Practices

GNI: Gross National Income

GSO: Gulf Cooperation Council Standardization Organization

HACCP: Hazard Analysis and Critical Control Point

HDI: Human Development Index of the UNDP

IAEA: International Atomic Energy Agency

IARC: International Agency for Cancer Research

ICPM: Interim Committee on Phytosanitary Measures of the IPPC 
IC: International Committee of the OIE

ICCPR: International Covenant on Civil and Political Rights

ICESCR: International Covenant on Economic, Social and Cultural Rights

IDRC: International Development Research Centre

IF: Integrated Framework for Trade-Related Technical Assistance to LeastDeveloped Countries

IFAS: $\quad$ International Food and Agriculture Service of Australia

IHR: International Health Regulations

IICA: Inter-American Institute for Agricultural Cooperation

ILC: $\quad$ International Law Commission

INFOSAN: International Food Safety Authorities Network

IPFSAPH: International Portal for Food Safety, Animal and Plant Health

IPM CRSP: Pest Management Collaborative Research Support Program

IPP: International Phytosanitary Portal

IPPC: International Plant Protection Convention

IRA: Import Risk Analysis

ISC: $\quad$ Interim Standards Committee of the IPPC

ISPM: International Standards for Phytosanitary Measures

ITC: $\quad$ International Trade Centre

JECFA: Joint FAO/WHO Expert Committee on Food Additives

JEMRA: Joint FAO/WHO Expert Meetings on Microbiological Risk Assessment

JITAP: Joint Integrated Technical Assistance Programme

JMPR: Joint FAO/WHO Expert Meetings on Pesticide Residues

LDCs: $\quad$ Least Developed Countries

LOD: $\quad$ Limit of determination

MAURITAS: Mauritius Accreditation Service

MEAs: Multilateral Environmental Agreements

MFN: $\quad$ Most-Favoured Nation

MOE: $\quad$ Margin of Exposure

MSB: $\quad$ Mauritius Standards Bureau

MTAs: $\quad$ Multilateral Trade Agreements

MRL: $\quad$ Maximum Residue Level

NAHFSCC: National Agricultural Health and Food Safety Coordinating Committee of Jamaica

NAMA: Non-Agricultural Market Access

NAFTA: North American Free Trade Agreement

NASA: National Aeronautical and Space Administration of the US 
NATA: National Association of Testing Authorities

NAPPO: $\quad$ North American Plant Protection Organization

NGOs: Non-Governmental Organisations

NIEO: New International Economic Order

NPPO: $\quad$ National Plant Protection Organization

OCPPO: $\quad$ Office of the Chief Plant Protection Officer of Australia

OCVO: Office of the Chief Veterinary Officer of Australia

OECD: Organisation for Economic Cooperation and Development

OIE: $\quad$ International Office of Epizootics (now the World Animal Health Organisation)

OIRSA: Regional International Organization for Plant Protection and Animal Health

OIV: $\quad$ International Vine and Wine Office

PCE: $\quad$ Phytosanitary Capacity Evaluation

PCE Tool: Phytosanitary Capacity Evaluation Tool

PHC: $\quad$ Plant Health Committee of Australia

PIAPH: $\quad$ Product Integrity, Animal and Plant Health Division of the Australian

Government Department of Agriculture, Fisheries and Forestry

PPM: $\quad$ Process and Production Method

PQ/PI: $\quad$ Plant Quarantine/Produce Inspection

PRA: $\quad$ Pest Risk Assessment

PVS Tool: OIE Evaluation of Performance of Veterinary Services Tool

rBST: Recombinant Bovine Somatotrophin

REIO: Regional Economic Integration Organisation

RPPO: Regional Plant Protection Organization

SAARC: $\quad$ South Asian Association for Regional Cooperation (consisting of

Bangladesh, Bhutan, India, the Maldives, Nepal, Pakistan and Sri Lanka)

SABS: $\quad$ South African Bureau of Standards

SADC: $\quad$ Southern African Development Community (consisting of Angola, Botswana, Democratic Republic of Congo, Lesotho, Malawi, Mauritius, Mozambique, Namibia, Seychelles, South Africa, Swaziland, Tanzania, Zambia and Zimbabwe)

SAFTA: $\quad$ Singapore-Australia Free Trade Agreement of 2005

SBDS: $\quad$ Subsidiary Body on Dispute Settlement of the IPPC

SC: $\quad$ Standards Committee of the IPPC

SCVPH: $\quad$ Scientific Committee on Veterinary Measures relating to Public Health

SELA: Latin American Economic System

SDC: $\quad$ Standards Development Committee of Australia and New Zealand

SDT: $\quad$ Special and differential treatment 
SIDA: $\quad$ Swedish International Development Agency

SIDS: $\quad$ Small-Island Developing States

SPARTECA: South Pacific Region Trade and Economic Cooperation Agreement

SPS: $\quad$ Sanitary and phytosanitary

SPS IMS: $\quad$ SPS Information Management System

SPTA: $\quad$ Strategic Planning and Technical Assistance

STDF: $\quad$ Standards and Trade Development Facility

SVES: $\quad$ Small Vulnerable Economies

TAFTA: Thailand-Australia Free Trade Agreement of 2005

TBT: $\quad$ Technical Barriers to Trade

TCBDC: Doha Development Agenda Trade Capacity Building Database

TCP: Technical Cooperation Programme

TP: $\quad$ Technical Panel of the IPPC

TRTA: $\quad$ Trade Related Technical Assistance

UK: $\quad$ United Kingdom

UN: $\quad$ United Nations

UNCTAD: United Nations Conference on Trade and Development

UNDP: $\quad$ United Nations Development Programme

UNECE: United Nations Economic Commission for Europe

US: $\quad$ United States of America

USAID: US Agency for International Development

USDA: $\quad$ United States Department of Agriculture

WHO: World Health Organization

WTO: World Trade Organization 


\section{Table of Cases}

\section{GATT Panel Reports}

\author{
Australia-Ammonium \\ Sulphate \\ Canada - Gold Coins
}

Canada-FIRA

Canada-Provincial Liquor

Canada - Provincial Liquor

Canada/Japan - Tariff on

Imports of Spruce, Pine, Fir

EEC - Animal Feed Proteins

EEC - Minimum Import Prices

Italy-Agricultural

Machinery

Japan-Semi-Conductors

Japan - SPF Dimension

Lumber
GATT Working Party Report, The Australian

Subsidy on Ammonium Sulphate, adopted 3 April 1950, BISD II/188

GATT Panel Report, Canada-Measures Affecting the Sale of Gold Coins, circulated on 17 September 1985 (unadopted), L/5863

GATT Panel Report, Canada-Administration of the Foreign Investment Review Act, adopted 7 February 1984, BISD 30S/140

GATT Panel Report, Canada - Import, Distribution and Sale of Boards (EEC) Alcoholic Drinks (EEC )by Canadian Provincial Marketing Agencies, adopted 22 March 1988, BISD 35S/37

GATT Panel Report, Canada - Import, Distribution and Sale of Boards (US) Alcoholic Drinks (US) by Canadian Provincial Marketing Agencies, adopted 18 February 1992, BISD 39S/27

GATT Panel Report, Canada/Japan - Tariff on Imports of Spruce, Pine, Fir (SPF), adopted 19 July 1998, BISD 36S/167

GATT Panel Report, EEC - Measures on Animal Feed Proteins, adopted 14 March 1978, BISD $25 \mathrm{~S} / 49$

GATT Panel Report, EEC - Programme of Minimum Import Prices, Licences and Surety Deposits for Certain Processed Fruits and Vegetables, adopted 18 October 1978, BISD 25S/68

GATT Panel Report, Italian Discrimination against Imported Agricultural Machinery, adopted 23 October 1958, BISD 7S/60

GATT Panel Report, Japan - Trade in Semi-Conductors, adopted 4 May 1988, BISD $35 \mathrm{~S} / 116$

GATT Panel Report, Canada/Japan - Tariff on Imports of Spruce, Pine, Fir (SPF) Dimension Lumber, adopted 19 July 1989, BISD 36S/167 
Spain-Unroasted Coffee

Thailand-Cigarettes

US - Malt Beverages

US - Section 337

US - Spring Assemblies

US - Taxes on Automobiles

US - Tuna (Canada)

US - Tuna (EEC)

US - Tuna (Mexico)

Certificates of origin, marks of origin and consular formalities

\section{WTO Panel Reports}

Argentina - Footwear (EC)
GATT Panel Report, Spain - Tariff Treatment of Unroasted Coffee L/5135, adopted 11 June 1981, BISD 28S/102

GATT Panel Report, Thailand - Restrictions on Importation of and Internal Taxes on Cigarettes, adopted 7 November 1990, BISD 37S/200

GATT Panel Report, United States - Measures Affecting Alcoholic and Malt Beverages, adopted 19 June 1992, BISD 39S/206

GATT Panel Report, United States Section 337 of the Tariff Act of 1930, adopted 7 November 1989, BISD $36 \mathrm{~S} / 345$

GATT Panel Report, United States - Imports of Certain Automotive Spring Assemblies, adopted 26 May 1983, BISD 30S/107

GATT Panel Report, United States - Taxes on Automobiles, 11 October 1994, unadopted, DS31/R GATT Panel Report, United States - Prohibition of Imports of Tuna and Tuna Products from Canada, adopted 22 February 1982, BISD 29S/91611

GATT Panel Report, United States - Restrictions on Imports of Tuna, 16 June 1994, unadopted, DS29/R

GATT Panel Report, United States - Restriction on Imports of Tuna, 3 September 1991, unadopted, BISD 39S/155

Report of the Working Party on Trade and Customs Regulations Certificates of Origin, Marks of Origin and Consular Formalities, 15 November 1956, $\mathrm{L} / 595$.

Panel Report, Argentina - Safeguard Measures on Imports of Footwear, WT/DS121/R, adopted 12 January 2000, as modified by Appellate Body Report, WT/DS121/AB/R, DSR 2000:II, 575 
Argentina-Hides and Leather

Australia-Salmon

Australia - Salmon

(Article 21.5 - Canada)

Brazil-Desiccated Coconut

Brazil-Retreaded Tyres

Canada-Autos

Canada-Continued

Suspension

Canada-Patent Term

Canada-Periodicals
Panel Report, Argentina - Measures Affecting the Export of Bovine Hides and Import of Finished Leather, WT/DS155/R and Corr.1, adopted 16 February 2001, DSR 2001:V, 1779

Panel Report, Australia-Measures Affecting Importation of Salmon, WT/DS18/R and Corr.1, adopted 6 November 1998, as modified by Appellate Body, WT/DS18/AB/R, DSR 1998:VIII, 3407

Panel Report, Australia - Measures Affecting Importation of Salmon-Recourse to Article 21.5 by Canada, WT/DS18/RW, adopted 20 March 2000, DSR 2000:IV, 2031

Panel Report, Brazil-Measures Affecting

Desiccated Coconut, WT/DS22/R, adopted 20

March 1997, upheld by Appellate Body Report, WT/ DS22/AB/R, DSR 1997:I, 189

Panel Report, Brazil - Measures Affecting Imports of Retreaded Tyres, WT/DS332/R, adopted 17 December 2007, as modified by Appellate Body Report, WT/ $\mathrm{DS} 332 / \mathrm{AB} / \mathrm{R}$

Panel Report, Canada-Certain Measures Affecting the Automotive Industry, WT/DS139/R, WT/ DS142/R, adopted 19 June 2000, as modified by Appellate Body Report, WT/DS139/AB/R, WT/ DS142/AB/R, DSR 2000:VII, 3043

Panel Report, Canada - Continued Suspension of Obligations in the EC-Hormones Dispute, WT/ DS321/R, adopted 14 November 2008, as modified by Appellate Body Report, WT/DS321/AB/R

Panel Report, Canada-Term of Patent Protection, WT/DS170/R, adopted 12 October 2000, upheld by Appellate Body Report, WT/DS170/AB/R, DSR 2000:XI, 5121

Panel Report, Canada-Certain Measures Concerning Periodicals, WT/DS31/R and Corr.1, adopted 30 July 1997, as modified by Appellate Body Report, WT/DS31/AB/R, DSR 1997:I, 481 
Canada-Wheat Exports and Grain Imports

Dominican Republic Import and Sale of Cigarettes

EC-Approval and Marketing of Biotech Products

EC-Asbestos

EC-Bananas III

EC-Bed Linen

$E C-$ Bed Linen

(Article 21.5 - India)
Panel Report, Canada-Measures Relating to Exports of Wheat and Treatment of Imported Grain, WT/DS276/R, adopted 27 September 2004, upheld by Appellate Body Report, WT/DS276/AB/R, DSR 204:VI, 2817

Panel Report, Dominican Republic - Measures Affecting the Importation and Internal Sale of Cigarettes, WT/DS302/R, adopted 19 May 2005, as modified by Appellate Body Report, WT/DS302/ AB/R, DSR 2005:XV, 7425

Panel Reports, European Communities - Measures Affecting the Approval and Marketing of Biotech Products, WT/DS291/R, WT/DS292/R, WT/ DS293/R, Corr.1 and Add.1, 2, 3, 4, 5, 6, 7, 8 and 9, adopted 21 November 2006

Panel Report, European Communities - Measures Affecting Asbestos and Asbestos-Containing Products, WT/DS135/R and Add.1, adopted 5 April 2001, as modified by Appellate Body Report, WT/ DS135/AB/R, DSR 2001:VIII, 3305

Panel Report, European Communities - Regime for the Importation, Sale and Distribution of Bananas, WT/DS27/R/GTM, WT/DS27/R/HND, WT/DS27/R/ MEX, WT/DS27/R/USA, WT/DS27/R/ECU adopted 25 September 1997, as modified by Appellate Body Report, WT/DS27/AB/R, DSR 1997:II, 695, 803, 943; DSR 1997:III,1085

Panel Report, European Communities - AntiDumping Duties on Imports of Cotton-Type Bed Linen from India, WT/DS141/R, adopted 12 March 2001, as modified by Appellate Body Report, WT/ DS141/AB/R, DSR 2001:VI, 2077

Panel Report, European Communities - AntiDumping Duties on Imports of Cotton-Type Bed Linen from India-Recourse to Article 21.5 of the DSU by India, WT/DS141/RW, adopted 24 April 2003, as modified by Appellate Body Report, WT/ DS141/AB/RW, DSR 2003:IV, 1269 

EC-Hormones (Canada)
EC-Hormones (US)
EC-Sardines
Panel Report, EC Measures Concerning Meat and Meat Products (Hormones), Complaint by Canada, WT/DS48/R/CAN, adopted 13 February 1998, as modified by Appellate Body Report, WT/DS26/ AB/R, WT/DS48/AB/R, DSR 1998:II, 235
Panel Report, EC Measures Concerning Meat and Meat Products (Hormones), Complaint by the United States, WT/DS26/R/USA, adopted 13 February 1998, as modified by Appellate Body Report, WT/ DS26/AB/R, WT/DS48/AB/R, DSR 1998:III, 699
Panel Report, European Communities - Trade Description of Sardines, WT/DS231/R and Corr.1, adopted 23 October 2002, as modified by Appellate Body Report, WT/DS231/AB/R, DSR 2002:VIII, 3451

EC-Tariff Preferences
EC-Trademarks and
Geographical Indications
(Australia)

EC-Tube or Pipe Fittings

Guatemala-Cement I

India-Autos
Panel Report, European Communities - Conditions for the Granting of Tariff Preferences to Developing Countries, WT/DS246/R, adopted 20 April 2004, as modified by Appellate Body Report, WT/ DS246AB/R, DSR 2004:III, 1009

Panel Report, European Communities - Protection of Trademarks and Geographical Indications for Agricultural Products and Foodstuffs, Complaint by Australia, WT/DS290/R, adopted 20 April 2005, DSR 2005:X-XI, 4603

Panel Report, European Communities - AntiDumping Duties on Malleable Cast Iron Tube or Pipe Fittings from Brazil, WT/DS219/R, adopted 18 August 2003, as modified by Appellate Body Report, WT/DS219/AB/R, DSR 2003:VI, 2701

Panel Report, Guatemala-Anti-Dumping Investigation Regarding Portland Cement from Mexico, WT/DS60/R, adopted 25 November 1998, as modified by Appellate Body Report, WT/DS60/ AB/R, DSR 1998:IX, 3797

Panel Report, India-Measures Affecting the Automotive Sector, WT/DS146/R, WT/DS175/R and Corr.1, adopted 5 April 2002, DSR 2002:V, 1827 
India-Patents (EC)

Indonesia-Autos

Japan-Agricultural

Products II

Japan-Alcoholic

Beverages II

Japan-Apples

Japan-Apples

(Article 21.5 - US)

Japan - Film

Korea-Alcoholic Beverages

Korea-Dairy
Panel Report, India - Patent Protection for

Pharmaceutical and Agricultural Chemical Products,

Complaint by the European Communities, WT/

DS79/R, adopted 22 September 1998, DSR 1998:VI, 2661

Panel Report, Indonesia - Certain Measures

Affecting the Automobile Industry, WT/DS54/R,

WT/DS55/R, WT/ DS59/R, WT/DS64/R and Corr.1, 2, 3 and 4, adopted 23 July 1998, DSR 1998:VI, 2201

Panel Report, Japan - Measures Affecting

Agricultural Products, WT/DS76/R, adopted 19

March 1999, as modified by Appellate Body Report, WT/ DS76/AB/R, DSR 1999:I, 315

Panel Report, Japan - Taxes on Alcoholic

Beverages, WT/DS8/R, WT/DS10/R, WT/DS11/R, adopted 1 November 1996, as modified by Appellate Body Report, WT/DS8/AB/R, WT/DS10/AB/R, WT/DS11/AB/R, DSR 1996:I,125

Panel Report, Japan - Measures Affecting the Importation of Apples, WT/DS245/R, adopted 10 December 2003, upheld by Appellate Body Report, WT/DS245/AB/R, DSR 2003:IX, 4481

Panel Report, Japan - Measures Affecting the Importation of Apples - Recourse to Article 21.5 of the DSU by the United States, WT/DS245/RW, adopted 20 July 2005, DSR 2005:XVI, 7911

Panel Report, Japan - Measures Affecting Consumer Photographic Film and Paper, WT/DS44/R, adopted 22 April 1998, DSR 1998:IV, 1179

Panel Report, Korea - Taxes on Alcoholic Beverages, WT/DS75/R, WT/DS84/R, adopted 17 February 1999, as modified by the Appellate Body Report, WT/ DS75/AB/R, WT/DS84/AB/R, DSR 1999:I, 44

Panel Report, Korea - Definitive Safeguard Measure on Imports of Certain Dairy Products, WT/DS98/R and Corr.1, adopted 12 January 2000, as modified by Appellate Body Report, WT/DS98/AB/R, DSR 2000:I, 49 

Korea-Procurement Panel Report, Korea-Measures Affecting
Government Procurement, WT/DS163/R, adopted
19 June 2000, DSR 2000:VIII, 3541
Mexico - Corn Syrup
Panel Report, Mexico - Anti-Dumping Investigation of High Fructose Corn Syrup (HFCS) from the United States, WT/DS132/R and Corr.1, adopted 24 February 2000, DSR 2000:III, 1345

Mexico - Taxes on Soft

Drinks

US - Continued Suspension

US - Corrosion Resistant

Steel Sunset Review

US-Gasoline

US-Line Pipe

US - Section 301 Trade Act

US - Shrimp

(Article 21.5 - Malaysia)
Panel Report, Mexico - Tax Measures on Soft Drinks and Other Beverages, WT/DS308/R, adopted 24 March 2006, as modified by Appellate Body Report, WT/DS308/AB/R 49

Panel Report, US - Continued Suspension of Obligations in the EC-Hormones Dispute, WT/ DS320/R, adopted 14 November 2008, as modified by Appellate Body Report, WT/DS320/AB/R

Panel Report, United States - Sunset Review of AntiDumping Duties on Corrosion-Resistant Carbon Steel Flat Products from Japan, WT/DS244/R, adopted 9 January 2004, as modified by Appellate Body Report, WTDS244/AB/R, DSR 2004:I, 85

Panel Report, United States - Standards for Reformulated and Conventional Gasoline, WT/ DS2/R, adopted 20 May 1996, as modified by the Appellate Body Report, WT/DS2/ AB/R, DSR 1996:I, 29

Panel Report, United States - Definitive Safeguard Measures on Imports of Circular Welded Carbon Quality Line Pipe from Korea, WT/DS202/R, adopted 8 March 2002, as modified by Appellate Body Report, WT/DS202/AB/, DSR 2002:IV, 1473

Panel Report, United States - Section 301-310 of the Trade Act of 1974, WT/DS152/R, adopted 27 January 2000, DSR 2000:II, 815.

Panel Report, United States - Import Prohibition of Certain Shrimp and Shrimp Products, Recourse to Article 21.5 of the DSU by Malaysia, WTDS58/ RW, adopted 21 November 2001, as upheld by the Appellate Body Report, WT/DS58/AB/RW, DSR 2001:XIII, 6539 


\author{
US - Steel Plate \\ US - Underwear \\ US - Wool Shirts and \\ Blouses \\ Panel Report, United States - Anti Dumping and \\ Countervailing Measures on Steel Plate from India, \\ WT/DS206/R and Corr.1, adopted 29 July 2002, \\ DSR 2002:VI, 2073 \\ Panel Report, United States - Restrictions on Imports \\ of Cotton and Man-made Fibre Underwear, WT/ \\ DS24/R, adopted 25 February 1997, as modified \\ by Appellate Body Report, WT/DS24/AB/R, \\ DSR 1997:I, 31 \\ Panel Report, United States - Measure Affecting \\ Imports of Woven Wool Shirts and Blouses from \\ India, WT/DS33/R, adopted 23 May 1997, upheld \\ by Appellate Body Report, WT/DS33/AB/R, \\ DSR 1997:I, 343
}

\section{Appellate Body Reports}

Argentina - Footwear (EC)

Australia-Salmon

Brazil-Desiccated Coconut

Brazil-Retreaded Tyres

Canada-Aircraft

Canada-Patent Term

Canada-Periodicals
Appellate Body Report, Argentina - Safeguard Measures on Imports of Footwear, WT/DS121/AB/R, adopted 12 January 2000, DSR 2000:I, 515

Appellate Body Report, Australia - Measures Affecting Importation of Salmon, WT/DS18/AB/R, adopted 6 November 1998, DSR 1998:VIII, 3327

Appellate Body Report, Brazil - Measures Affecting Desiccated Coconut, WT/DS22/AB/R, adopted 20 March 1997, DSR 1997:I, 167

Appellate Body Report, Brazil - Measures Affecting Imports of Retreaded Tyres, WT/DS332/AB/R, adopted 17 December 2007

Appellate Body Report, Canada-Measures Affecting the Export of Civilian Aircraft, WT/DS70/AB/R, adopted 20 August 1999, DSR 1999:III, 1377

Appellate Body Report, Canada - Term of Patent Protection, WT/DS170/AB/R, adopted 12 October 2000, DSR 2000:X, 5093

Appellate Body Report, Canada-Certain Measures Concerning Periodicals, WT/DS31/AB/R, adopted 30 July 1997, DSR 1997:I, 449 
Chile-Alcoholic Beverages

EC-Asbestos

EC-Bananas III

EC-Chicken Cuts

EC-Hormones

EC-Poultry

EC-Sardines

EC-Tariff Preferences

Guatemala-Cement I

India-Patents (US)
Appellate Body Report, Chile - Taxes on Alcoholic Beverages, WT/DS87/AB/R, WT/DS110/AB/R, adopted 12 January 2000, DSR 2000:I, 281

Appellate Body Report, European Communities Measures Affecting Asbestos and Asbestos-Containing Products, WT/DS135/AB/R, adopted 5 April 2001, DSR 2001:VII, 3243

Appellate Body Report, European Communities Regime for the Importation, Sale and Distribution of Bananas, WT/DS27/AB/R, adopted 25 September 1997, DSR 1997:II, 591

Appellate Body Report, European Communities Customs Classification of Frozen Boneless Chicken Cuts, WT/DS269/AB/R, WT/DS286/AB/R and Corr. 1, adopted 27 September 2005, DSR 2005: XIX, 9157

Appellate Body Report, European Communities - Measures Concerning Meat and Meat Products (Hormones), WT/DS26/AB/R, WT/DS48/AB/R, adopted 13 February 1998, DSR 1998:I, 135

Appellate Body Report, European Communities Measures Affecting the Importation of Certain Poultry Products, WT/DS69/AB/R, adopted 23 July 1998, DSR 1998:V, 2031

Appellate Body Report, European Communities Trade Description of Sardines, WT/DS231/AB/R, adopted 23 October 2002, DSR 2002:VIII, 3359

Appellate Body Report, European Communities Conditions for the Granting of Tariff Preferences to Developing Countries, WT/DS246/AB/R, adopted 20 April 2004, DSR 2004:III, 925

Appellate Body Report, Guatemala-Anti-Dumping Investigation Regarding Portland Cement from Mexico, WT/DS60/AB/R, adopted 25 November 1998, DSR 1998:IX, 3767

Appellate Body Report, India - Patent Protection for Pharmaceutical and Agricultural Chemical Products, WT/DS50/AB/R, adopted 16 January 1998, DSR 1998:I, 9 
Japan-Agricultural

Products II

Japan-Alcoholic

Beverages II

Japan-Apples

Korea-Dairy

Korea-Various Measures on Beef

US - Carbon Steel

US - Corrosion Resistant

Steel Sunset Review

US - FSC (Article 21.5-EC)

US - Gambling

US - Gasoline
Appellate Body Report, Japan - Measures Affecting Agricultural Products, WT/DS76/AB/R, adopted 19 March 1999, DSR 1999:I, 277

Appellate Body Report, Japan - Taxes on Alcoholic Beverages, WT/DS8/AB/R, WT/DS10/AB/R, WT/ DS11/AB/R, adopted 1 November 1996, DSR 1996:I, 97

Appellate Body Report, Japan - Measures Affecting the Importation of Apples, WT/DS245/AB/R, adopted 10 December 2003, DSR 2003:IX, 4291

Appellate Body Report, Korea - Definitive Safeguard Measure on Imports of Certain Dairy Products, WT/ DS98/AB/R, adopted 12 January 2000, DSR 2000:I, 3

Appellate Body Report, Korea-Measures Affecting Imports of Fresh, Chilled and Frozen Beef, WT/ DS161/AB/R, WT/DS169/AB/R, adopted 10 January 2001, DSR 2001:I, 5

Appellate Body Report, United States Countervailing Duties on Certain Corrosion-Resistant Carbon Steel Flat Products from Germany, WT/ DS213/AB/R and Corr.1, adopted 19 December 2002, DSR 2002:IX, 3779

Appellate Body Report, United States - Sunset Review of Anti-Dumping Duties on CorrosionResistant Carbon Steel Flat Products from Japan, WT/DS244/AB/R, adopted 9 January 2004

Appellate Body Report, United States - Tax Treatment for "Foreign Sales Corporations" Recourse to Article 21.5 of the DSU by the European Communities, WT/DS108/AB/RW, adopted 29 January 2002, DSR 2002:I, 55

Appellate Body Report, United States - Measures Affecting the Cross-Border Supply of Gambling and Betting Services, WT/DS285/AB/R and Corr.1, adopted 20 April 2005, DSR 2005:XII, 5663

Appellate Body Report, United States - Standards for Reformulated and Conventional Gasoline, WT/DS2/ AB/R, adopted 20 May 1996, DSR 1996:I, 3 
US - Lead and Bismuth II

US-Line Pipe

US - Offset Act

(Byrd Amendment)

US - Shrimp

US - Shrimp

(Article 21.5 - Malaysia)

US - Softwood Lumber IV

US - Stainless Steel (Mexico)

US - Wool Shirts and

Blouses
Appellate Body Report, United States - Imposition of Countervailing Duties on Certain Hot-Rolled Lead and Bismuth Carbon Steel Products Originating in the United Kingdom, WT/DS138/AB/R, adopted 7 June 2000, DSR 2000: V, 2595

Appellate Body Report, United States - Definitive Safeguard Measures on Imports of Circular Welded Carbon Quality Line Pipe from Korea, WT/DS202/ AB/R, adopted 8 March 2002, DSR 2002:IV, 1403

Appellate Body Report, United States - Continued Dumping and Subsidy Offset Act of 2000, WT/DS217/ AB/R, WT/DS234/AB/R, adopted 27 January 2003, DSR 2003:I, 375

Appellate Body Report, United States - Import Prohibition of Certain Shrimp and Shrimp Products, WT/DS58/AB/R, adopted 6 November 1998, DSR 1998:VII, 2755

Appellate Body Report, United States - Import Prohibition of Certain Shrimp and Shrimp Products - Recourse to Article 21.5 of the DSU by Malaysia, WT/DS58/AB/RW, adopted 21 November 2001, DSR 2001:XIII, 6481

Appellate Body Report, United States - Final Countervailing Duty Determination with Respect to Certain Softwood Lumber from Canada, WT/DS257/ AB/R, adopted 17 February 2004, DSR 2004:II, 571

Appellate Body Report, United States - Final AntiDumping Measures on Stainless Steel from Mexico, WT/DS344/AB/R, adopted 20 May 2008

Appellate Body Report, United States - Measure Affecting Imports of Woven Wool Shirts and Blouses from India, WT/DS33/AB/R and Corr.1, adopted 23 May 1997, DSR 1997:I, 323

\section{Awards/Decisions of Arbitrators}

Australia - Salmon

(Article 21.3(c))
Award of the Arbitrator, Australia - Measures Affecting Importation ofSalmon - Arbitration under Article 21.3(c) of the DSU, WT/DS18/9, 23 February 1999, DSR 1999:I, 267 
EC-Hormones

(Article 21.3(c))

EC-Hormones (US)

(Article 22.6-EC)

Indonesia-Autos

(Article 21.3(c))
Award of the Arbitrator, EC Measures Concerning Meat and Meat Products (Hormones) - Arbitration under Article 21.3(c) of the DSU, WT/DS26/15, WT/ DS48/13, 29 May 1998, DSR 1998:V, 1833

Decision by the Arbitrators, European Communities - Measures Concerning Meat and Meat Products (Hormones), Original Complaint by the United States - Recourse to Arbitration by the European Communities under Article 22.6 of the DSU, WT/ DS26/ARB, 12 July 1999, DSR 1999:III, 1105

Award of the Arbitrator, Indonesia - Certain Measures Affecting the Automobile IndustryArbitration under Article 21.3(c) of the DSU, WT/ DS54/15, WT/DS55/14, WT/DS59/13, WT/DS64/12, 7 December 1998, DSR 1998:IX, 4029 


\section{Bibliography}

\section{Articles, Books and Reports}

Abila, Richard O., Food Safety in Food Security and Food Trade. Case Study: Kenyan Fish Exports, International Food Policy Research Institute, Washington D.C., September 2003.

Ad Hoc Group on Food Safety, Compendium of National Food Safety Systems and Activities, SG/ADHOC/FS(2000)5/ANN/FINAL, Organisation for Economic Co-operation and Development, Paris, 12 May 2000, 331, available at: http:// www.olis.oecd.org/olis/2000doc.nsf/LinkTo/sg-adhoc-fs(2000)5-ann-final, visited on 12 January 2008.

Advisory Centre on WTO Law, The ACWL after Four Years. A Progress Report by the Management Board, ACWL/GA/2005/1, ACWL/MB/2005/1, 5 October 2005, 18, available at: www.acwl.ch/misc/getfile.aspx?id=008b453f-b440-4995-be501e536f5f8477, visited on 30 June 2008.

Ahmed, Nazneen, Ad Hoc Expert Meeting in Preparation for the Mid-Term Review of the Programme of Action for the Least Developed Countries for the Decade 2001-2010: Case Study on Bangladesh UNCTAD/LDC/MISC/2006/4, United Nations Conference on Trade and Development, May 2006.

Akehurst, Michael, 'The Hierarchy of the Sources of International Law', 75 British Yearbook of International Law, 1974, 273-285.

Akyoo, Adam and Lazaro, Evelyne The Spice Industry in Tanzania: General Profile, Supply Chain Structure, and Food Standards Compliance Issues, DIIS Working Paper no 2007/8, Danish Institute for International Studies, Copenhagen, 2007, available at: http://www.diis.dk/graphics/Publications/WP2007/WP\%20 2007-8\%20final.web.pdf, visited on 23 May 2008.

Alauddin, Mohammad and Hamid, M. Akhter, 'Shrimp Culture in Bangladesh with Emphasis on Social and Economic Aspects', in Towards Sustainable Shrimp Culture in Thailand and the Region: Proceedings of a Workshop, edited by Paul Smith, Australian Centre for International Agricultural Research, Canberra, 1999, 53-62, available at: http://www.aciar.gov.au/web.nsf/doc/JFRN-5J473M/\$file/ PR90\%20Chapter\%2009.pdf, visited on 13 May 2000.

Alemanno, Alberto, Trade in Food: Regulatory and Judicial Approaches in the EC and WTO, Cameron May, London, 2007.

Amerasinghe, C.F., Principles of the Institutional Law of International Organizations $2^{\text {nd }}$ ed., Cambridge University Press, Cambridge, 2005.

Araya, M., WTO Negotiations on Environmental Goods and Services: Maximizing Opportunities, Global Environmental and Trade Study, Yale Center for Environmental Law and Policy, June 2003. 
Arcuri, Alessandra, The Case for a Procedural Version of the Precautionary Principle Erring on the Side of Environmental Preservation, Global Law Working Paper 09/04, Hauser Global Law School, New York, 2004, available at: www. nyulawglobal.org/workingpapers/documents/GLWP0904Arcuri.pdf, visited on 12 May 2005.

Atik, Jeffery, 'Symposium - Institutions for International Economic Integration: Science and International Regulatory Convergence', Journal of International Law and Business 17, 1997, 736-758.

Avery, Natalie, Drake, Martine and Lang, Tim, Cracking the Codex: An Analysis of Who Sets World Food Standards, National Food Alliance, London, 1993.

Babcock, S., 'Animal Welfare and International Trade', Revue Scientifique et Technique Office International des Epizooties, 2005.

Bach, Christian Friis, Larsen, Arne, Kaegaard, Niels, Pinstrup-Andersen, Per and Tarp, Finn, Free Trade Is Not Enough: A New Vision for the World's Poorest Farmers, Mellemfolkeligt Samvirke, Copenhagen, Denmark, October 2003.

Bäckstrand, Karin, 'Precaution, Scientisation or Deliberation? Greening Environmental Decision-Making', presented at the End of Environmentalism Workshop, European Consortium for Political Research, Turin, 22-27 March 2002, available at: http://www.essex.ac.uk/ecpr/events/jointsessions/paperarchive/turin/ws10/ Backstrand.pdf, visited on 10 June 2003.

Baulch, Bob, Aid for the Poorest? The Distribution and Maldistribution of International Development Assistance, CPRC Working Paper No 35, Institute of Development Studies, 2003, available at: http://www.chronicpoverty.org/pdfs/35Baulch.pdf, visited on 10 June 2008.

Barrieu, Pauline and Sinclair-Desgagne, Bernard, The Paradox of Precaution, CIRANO, Montreal, October 2003, available at: www.cirano.qc.ca/pdf/ publication/2003s-63.pdf, visited on 15 June 2004.

Berdeguë, Julio A., Balsevich, Fernando, Flores, Luis, Mainville, Denise and Reardon, Thomas, Food Safety in Food Security and Food Trade: Case Study: Supermarkets and Quality and Safety Standards for Produce in Latin America, International Food Policy Research Institute, Washington D.C., September 2003, available at: http://www.ifpri.org/2020/focus/focus10/focus10_12.pdf, visited on 23 January 2008.

, 'Central America Supermarkets' Private Standards of Quality and Safety in Procurement of Fresh Fruits and Vegetables', Food Policy 30, 2005, 254-269.

Bernstein, Steven and Hannah, Erin, 'Non-State Global Standard Setting and the WTO: Legitimacy and the Need for Regulatory Space' Journal of International Economic Law, 11(3), 2008, (advance access) 1-34.

Blair Commission for Africa, Our Common Interest, March 2005, available at: http://213.225.140.43/english/report/thereport/cfafullreport.pdf, visited on 30 November 2005. 
Bloche, M. Gregg, 'WTO Deference to National Health Policy: Toward an Interpretative Principle', Journal of International Economic Law 5 (4), 2002, 825-848.

Blokker, N.M., International Institutional Law, $4^{\text {th }}$ ed., Martinus Nijhoff, The Hague, 2003.

Boehmer-Christiansen, S., 'The Precautionary Principle in Germany - Enabling Government' in T. O'Riordan and J. Cameron (eds), Interpreting the Precautionary Principle, Cameron May, London, 1994, 31-60.

Boutros-Gali, Boutros, An Agenda for Development, U.N. Doc. A/48/935, United Nations, 6 May 1994.

Bown, Chad P. 'Developing Countries as Plaintiffs and Defendants in GATT/WTO Trade Disputes', The World Economy 27 (1), 2004, 59-80.

Bown, Chad P. and Bernard M. Hoekman, 'WTO Dispute Settlement and the Missing Developing Country Cases: Engaging the Private Sector', Journal of International Economic Law 8 (4), 2005, 861-890.

, 'Developing Countries and Enforcement of the Trade Agreements: Why Dispute Settlement in Not Enough', Journal of World Trade 42 (1), 2008, 177-203.

Bredahl, Maury E. and Forsythe, Kenneth W., 'Harmonizing Phyto-Sanitary and Sanitary Regulations', The World Economy 12, 1989, 189-206.

Breen, John M., 'Agriculture', in The GATT Uruguay Round: A Negotiating History (1986-1992), edited by Terence P. Stewart, vol. I: Commentary, Kluwer, Deventer, 1993, 125-254.

, 'Agriculture', in The GATT Uruguay Round: A Negotiating History (1986-1992), edited by Terence P. Stewart, vol. IV: The End Game, Kluwer, The Hague/ London/Boston, 1999, 41-45.

Brückner, Gideon, Implementation of OIE Standards in the Framework of the SPS Agreement, 73 SG/9, World Organization for Animal Health, Paris, 22-27 May 2005, 11, available at: http://www.oie.int/downld/SG/2005/A_73\%20SG_9.pdf, visited on 12 September 2005.

Brusick, Philippe, Alvarez, Ana Maria and Horna, Pierre, Strengthening Institutions and Capacities in the Area of Competition and Consumer Protection Policies in Latin America: Cases of Bolivia, Costa Rica, El Salvador, Honduras, Guatemala, Nicaragua and Peru, UNCTAD/DITC/CPL/2004/3, United Nations Conference on Trade and Development, New York and Geneva, 2005, available at: http:// www.unctad.org/en/docs/ditcclp20043_en.pdf, visited on 14 September 2006.

Button, Catherine, The Power to Protect. Trade, Health and Uncertainty in the WTO, Hart Publishing, Oxford and Portland, Oregon, 2004.

, 'The WTO's 'Objective Assessment' Standard of Review and Panel Review of Health Measures', in Challenges and Prospects for the WTO, edited by Andrew D. Mitchell, Cameron May, London, 2005. 
Calvin, Linda, and Krissof, Barry, 'Technical Barriers to Trade: A Case Study of Phytosanitary Barriers and U.S.-Japanese Apple Trade', Journal of Agricultural and Resource Economics 23 (2), 1998, 351-366.

Camerer, Colin, Issacharoff, Samuel, Loewenstein, George, O'donoghue, Ted and Rabin , Matthew, 'Regulation for Conservatives: Behavioral Economics and the Case for 'Asymmetric Paternalism'.' University of Pennsylvania Law Review 151, 2003, 101-144.

Cameron, James, 'The Precautionary Principle', in Trade, Environment, and the Millennium, edited by Gary P. Sampson and W. Bradnee Chambers, United Nations University Press, Tokyo, 1999, 239-269.

Cameron, James and Abouchar, Juli, 'The Precautionary Principle: A Fundamental Principle of Law and Policy for the Protection of the Global Environment', Boston College International and Comparative Law Review 14 (1), 1991, 1-27.

, 'The Status of the Precautionary Principle in International Law', in The Precautionary Principle and International Law: The Challenge of Implementation, edited by David Freestone and Ellen Hey, Kluwer Law International, 1996, 29-52.

Casella, Alessandra, 'Free Trade and Evolving Standards', in Fair Trade and Harmonisation: Prerequisites for Free Trade?, edited by Jagdish N. Bhagwati and Robert E. Hudec, 2 vols., vol. 1, MIT Press, Cambridge, 1997, 119-156.

Cato, J.C. and Lima Dos Santos, C.A., 'European Union 1997 Seafood Safety Ban: The Economic Impact on Bangladesh Shrimp Processing', Marine Resource Economics 13 (3), 1998, 215-227.

, 'Costs to Upgrade the Bangladesh Frozen Shrimp Processing Sector to Adequate Technical and Sanitary Standards and to Maintain a HACCP Program', presented at the Conference on the Economics of HACCP: New Studies of Costs and Benefits, Washington D.C., 15-16 June 1998, available at: www.umass.edu/ ne165/haccp1998/cato.html, visited on 25 June 2007.

Cato, James C. and Subasinge, S., Food Safety in Food Security and Food Trade: Case Study: The Shrimp Export Industry in Bangladesh, International Food Policy Research Institute, Washington D.C., September 2003.

Chadha, Rajesh, Hoekman, Bernard, Martin, Will, Oyejide, Ademola, Pangestu, Mari, Tussie, Diana and Zarrouk, Jamel, 'Developing Countries and the Next Round of WTO Negotiations', The World Economy 23 (4), 2000, 431-436.

Chang, Howard F., Risk Regulation, Endogenous Public Concerns, and the Hormones Dispute: Nothing to Fear but Fear Itself?, Research Paper 03-25, University of Pennsylvania Law School, Institute for Law and Economics, Pennsylvania, August 2003, 38, available at: http://ssrn.com/abstract_id=432220, visited on 12 June 2006.

Charnovitz, Steve, 'Environment and Health under WTO Dispute Settlement', The International Lawyer 32 (3), 1998: 901-921. 
, 'The Supervision of Health and Biosafety Regulation by World Trade Rules', Tulane Environmental Law Journal 13, 2000, 271-302.

COMESA Secretariat, Market Access Constraints, Common Market for Southern Africa, Lusaka, 2003, available at: www.comesa.int/trade/multilateral/epa/ Market\%20Access\%20Constraints/en, visited on 10 January 2008.

Connor, Robert J., Initiative to Explore Linkages between Increased Participation in Codex and Enhanced International Food Trade Opportunities. Final Report, Project number RNRAT 012, Department for International Development, Geneva, August 2007, available at: http://www.who.int/foodsafety/codex/ Connor_report.pdf, visited on 10 June 2008.

Consumers International, Comments in Response to Alinorm 99/8 by Consumers International, Position Paper, Consumers International, 29 January 1999, available at: http://www.consumersinternational.org/campaigns/food/codex/ alinorm0699.html, visited on 16 May 2000.

, Position of Consumers International for the Twenty-Second Session of the Codex Alimentarius Commission Re: Involvement of Non-Governmental Organizations in the Work of the Codex Alimentarius Commission, June 1997.

Conrad, Christiane R., PPMs, the EC-Biotech Dispute and Applicability of the SPS Agreement: Are the Panel's Findings Built on Shaky Ground?, Research Paper No. 8-06, International Law Forum of the Hebrew University of Jerusalem, Jerusalem, August 2006, available at: http://papers.ssrn.com/sol3/papers. cfm?abstract_id=920742\#PaperDownload, visited on 12 May 2008.

Cooney, Rosie and Lang, Andrew T.F., 'Taking Uncertainty Seriously: Adaptive Governance and International Trade', European Journal of International Law 18 (3), 2007, 523-551.

Corrales-Leal, Werner, Sugathan, Mahesh and Primack, David, "“Spaces for Development Policy": Revisiting Special and Differential Treatment', presented at the Joint ICTSD - GP International Dialogue: Making Special \& Differential Treatment More Effective and Responsive to Development Needs, Chavannes-de-Bogis, Switzerland, 6-7 May 2003, available at: www.ictsd.org/ dlogue/2003-05-06/ICTSD_SDT_wkgdraft-16-May.pdf, visited on 6 June 2008.

Cottier, Thomas and Schefer, Krista Nadakavukaren, 'The Relationship between World Trade Organization Law, National Law and Regional Law', Journal of International Economic Law 1 (1), 1998, 83-122.

Cottier, Thomas, 'From Progressive Liberalization to Progressive Regulation in WTO Law', Journal of International Economic Law 9 (4), 2006, 779-821.

Council of the Organisation for Economic Co-Operation and Development, A Synthesis of Empirical Studies of SPS Regulations and a Proposal for Future Work, COM/ AGR/TD/WP/(2002)72, OECD, 27 August 2002.

Coutrelis, Nicole, Le Principe De Precaution: Aspects Juridiques, 16 May 2000. 
Craddock, Neville, 'Risk, Precaution, and the Food Business', in Governing Food: Science, Safety and Trade, edited by Peter W.B. Phillips and Robert Wolfe, McGill-Queen's University Press, Montreal, 2001, 75-88.

Christoforou, Theofanis, 'Settlement of Science-Based Trade Disputes in the WTO: A Critical Review of the Developing Case Law in the Face of Scientific Uncertainty', New York University Environmental Law Journal 8, 2000, 622-648

Cross, Frank B., 'Paradoxical Perils of the Precautionary Principle', Wash \& Lee Law Review 53 (3), 1996, 1, available at: www.wlu.edu/ lawrev/abs/bradshaw.htm, visited on 25 June 2007.

DaSilva, Edgar J. and Taylor, Mary, 'Island Communities and Biotechnology ', Electronic Journal of Biotechnology 1 (1), 1998, 1-10, available at: http://www. ejbiotechnology.info/content/vol1/issue1/full/1/1.pdf, visited on 14 April 2008.

De Feyter, Koen, World Development Law: Sharing Responsibility for Development, Intersentia, Antwerp, 2001.

De Feyter, Koen, 'Contracting for Human Development: International Law and Development Revisited', Asia Pacific Law Review 10 (1), 2002, 49-74.

Delich, Valentina, 'Developing Countries and the WTO Dispute Settlement System', in Development, Trade and the WTO: A Handbook, edited by Philip English, Bernard M. Hoekman and Aaditya Matoo, World Bank, Washington D.C., 2002, 71-80, available at: http://publications.worldbank.org/catalog/productdetail?product_id=1525978\&, visited on 5 June 2003.

Desmedt, Axel G., 'Hormones: "Objective Assessment" and (or as) Standard of Review', Journal of International Economic Law 1 (4), 1998, 695-698.

Diaz Rios, Luz B., and Jaffee, Steven, Barrier, Catalyst, or Distraction? Standards, Competitiveness, and Africa's Groundnut Exports to Europe, Agriculture and Rural Development Discussion Paper 39, World Bank, Washington D.C., January 2008, available at: http://siteresources.worldbank.org/ INTARD/825826-1111055015956/21663468/ARDDiscussionPaper39.pdf, visited on 5 March 2008.

Dolan, Catherine and Humphrey, John, Governance and Trade in Fresh Vegetables: The Impact of UK Supermarkets on the African Horticulture Industry, World Bank, Washington DC, 147-176, available at: http://www.colorado.edu/geography/ class_homepages/geog_3662_s06/uk.pdf, visited on 23 January 2008.

Douma, Wybe Th., The Precautionary Principle, T.M.C Asser Institute, The Hague, 2000, 1-12, available at: http://www.eel.nl/virtue/precprin.htm, visited on 20 March 2002.

Dowlah, C.A.F., 'Agriculture and the New WTO Round - Economic Analysis of Interests and Options for Bangladesh', presented at the Workshop on a New WTO Round on Agriculture, SPS, and the Environment: Capturing the Benefits for South Asia, World Bank, UNCTAD and SAARC Secretariat, New Delhi, India, 
31 December 2000, available at: http://r0.unctad.org/trade_env/test1/meetings/ standards/NewDelhi.doc, visited on 7 July 2001.

Drahos, Peter, 'The Regulation of Public Goods', Journal of International Economic Law 7 (2), 2004, 321-339.

Dubey, Muchkund, An Unequal Treaty - World Trading Order after GATT, New Age International, India, 1996.

Echols, Marsha A., 'Sanitary and Phytosanitary Measures', in The World Trade Organization: The Multilateral Trade Framework for the 21st Century and U.S. Implementing Legislation, edited by Terence P. Stewart, American Bar Association, Washington, D.C., 1996, 191-222.

Eide, Asbjorn, Oshaug, Arne and Eide, Wenche Barth, 'Food Security and the Right to Food in International Law and Development', Transnational Law and Contemporary Problems 1, 1991, 415-467.

Ehlermann, Claus-Dieter and Lockhart, Nicolas, 'Standard of Review in WTO Law', in A True European: Essays for Judge David Edwards, edited by Mark Hoskins and William Robinson, Hart Publishing, Portland, 2003, 267-296.

Elvestad, Christel, Equivalence and Mutual Recognition Agreements in Relation to Technical Measures, Working paper 2002-36, Norwegian Agricultural Economics Research Institute, Oslo, 2002, available at: www.nilf.no/ Publikasjoner/Notater/2002/N200236Hele.pdf, visited on 3 March 2003.

Epstein, Samuel S., Codex Alimentarius Decided to Support Rbgh Moratorium, Cancer Prevention Coalition, 18 August 1999, available at: www.psrast.org/bghcodex. htm, visited on 28 January 2008.

Eurostep, GAWU, DHS, CIECA, ABEID and GRAPAD, New ACP-EU Trade Arrangements: New Barriers to Eradicating Poverty?, Eurostep, Brussels, March 2004, 132, available at: www.eurostep.org/pubs/trade_study.pdf, visited on 25 June 2007.

Farber, Daniel A. and Frickey, Philip P., 'The Jurisprudence of Public Choice', Texas Law Review 65 (5), 1987, 873-928.

Farina, Elizabeth M.M.Q., Gutman, Graciela E., Lavarello, Pablo J., Nunes, Rubens and Readon, Thomas, 'Private and Public Milk Standards in Argentina and Brazil', Food Policy 30, 2005, 302 - 315.

Faure, Michael G., 'Environmental Regulation', in Encyclopedia of Law and Economics. Vol. II: Civil Law and Economics, edited by Boudewijn Bouckaert and Gerrit De Geest, 5 vols., vol. 2, Edward Elgar, Cheltenham, 2000, 443-519, available at: www.allserv.rug.ac.be/ /gdegeest/2300book.pdf, visited on 25 June 2007.

Fidler, David P., 'Return of the Fourth Horseman: Emerging Infectious Diseases and International Law', Minnesota Law Review 81, 1997, 771-868. 
, 'Microbialpolitik: Infectious Diseases and International Relations', American University International Law Review 14, 1998, 1-52.

, 'The Globalization of Public Health: Emerging Infectious Diseases and International Relations', Indiana Journal of Global Legal Studies 5 (2), 1997, available at: http://www.law.indiana.edu/glsj/vol5/no1/fidler.html, visited on 25 June 2007.

, 'Symposium on Globalization at the Margins: Perspectives on Globalization from Developing States: Neither Science nor Shamans: Globalization of Markets and Health in the Developing World', Indiana Journal of Global Legal Studies 7, 1999, 191-224.

Fidler, David P., Heymann, David L., Ostroff, Stephen M. and O’Brien, Terry P., 'Emerging and Re-Emerging Infectious Diseases: Challenges for International, National, and State Law', The International Lawyer 31, 1997, 773-813.

Finger, J. Michael, 'The Uruguay Round North-South Bargain: Will the WTO Get over It?' in The Political Economy of International Trade Law. Essays in Honor of Robert E. Hudec, edited by Daniel L. M. Kennedy and James D. Southwick, Cambridge University Press, Cambridge, 2002, 301-310.

, The Doha Agenda and Development: A View from the Uruguay Round, Asian Development Bank, Manila, August 2002, available at: http://www.adb.org/ Economics/pdf/doha/J_Michael_Finger.pdf, visited on 29 June 2008.

Finger, J. Michael and Schuler, Philip, 'Implementation of Uruguay Round Commitments: The Development Challenge', The World Economy 23 (4), 2000, 511-525.

Finger, J. Michael and Nogués, Julio J., The Unbalanced Uruguay Round Outcome: The New Areas in Future WTO Negotiations, December 2001.

Fisher, Elizabeth, 'Precaution, Precaution Everywhere: Developing a Common Understanding of the Precautionary Principle in the European Community', Maastricht Journal of European and Comparative Law 9 (1), 2002, 7-28.

Fitzgerald, Jim, A\$34 Billion Reasons to Access the US Seafood Market: A Guide to Exporting Australia's Fisheries Products to the United States, Department of Agriculture, Fisheries and Forestry of the Government of Australia and Australian Seafood Industry Council, Canberra, November 2002, available at: http://www.daff.gov.au/_data/assets/pdf_file/0017/6047/34billion.pdf, visited on 22 January.

Fitzgerald, Jim and Kowalski, Shelley, The FishBook II: A Guide to Australian Government Programs, Grants and Services for the Australian Seafood Industry, Department of Agriculture, Fisheries and Forestry of the Government of Australia, Canberra, 2006, available at: http://www.daff.gov.au/_data/assets/ pdf_file/0019/6049/fishbook_2.pdf, visited on 13 January 2008.

Footer, Mary E., 'Developing Country Practice in the Matter of WTO Dispute Settlement', Journal of World Trade 35 (1), 2001, 55-98. 
Forss, Kim and Lundström, Mikael, An Evaluation of the Program "Export Promotion of Organic Products from Africa" - Phase II, Swedish International Development Cooperation Agency, Strängnäs, 15 October 2004, available at: http://www. grolink.se/epopa/Publications/EPOPA-Phase-2-Evaluation-04.pdf, visited on 30 June 2008.

Fox, Eleanor M., 'The Prospective Role of Economic and Social Human Rights in the Law of International Trade Liberalization and Economic Integration: Globalization and Human Rights: Looking out for the Welfare of the Worst Off', NYU Journal of International Law and Politics 35, 2002, 201-220.

Freestone, David, 'The Road to Rio: International Environmental Law after the Earth Summit', Journal of Environmental Law 6, 1994, 193-218.

Freestone, David and Hey, Ellen, 'Implementing the Precautionary Principle:

Challenges and Opportunities', in The Precautionary Principle and International Law: The Challenge of Implementation, edited by David Freestone and Ellen Hey, Kluwer Law International, 1996, 249-268.

Fulponi, Linda, Final Report on Private Standards and the Shaping of the Agro-Food System, AGR/CA/APM(2006)9/FINAL, Organisation for Economic Cooperation and Development, Paris, 31 July 2006, available at: http://www.olis. oecd.org/olis/2006doc.nsf/43bb6130e5e86e5fc12569fa005d004c/4e3a2945ffec3 7eec12571bc00590ce3/\$FILE/JT03212398.PDF, visited on 27 May 2008.

Funtowicz, Silvio O. and Ravetz, Jerome R., 'Science for the Post-Normal Age', Futures 25 (7), 1993, 739-755.

Funtowicz, Silvio O. and Ravetz, Jerome R., 'Three Types of Risk Assessment and the Emergence of Post-Normal Science', in Social Theories of Risk, edited by S. Krimsky and D. Golding, Praeger, Westport, 1992.

Gandal, Niel, 'Quantifying the Trade Impact of Compatibility Standards and Barriers - an Industrial Organization Perspective', presented at the Workshop on Quantifying the Trade Effect of Standards and Regulatory Barriers: Is it possible? , World Bank, Washington D.C., 27 April 2000, available at: http:// www.worldbank.org/research/trade/conference/gandal.pdf, visited on 25 October 2000 .

Gandhi, Samir R., 'Regulating the Use of Voluntary Environmental Standards within the World Trade Organization Legal Regime: Making a Case for Developing Countries', Journal of World Trade 39 (5), 2005, 855-880.

Ganslandt, Mattias and Markusen, James R., 'Standards and Related Regulations in International Trade: A Modeling Approach', presented at the Workshop on Quantifying the Trade Effect of Standards and Regulatory Barriers: Is it possible?, World Bank, Washington D.C., 27 April 2000, available at: http:// www.worldbank.org/research/trade/conference/markusen.pdf, visited on 25 October 2000. 
Garcia, Frank J., 'The Salmon Case: Evolution of Balancing Mechanisms for Non-Trade Values in WTO', in Trade and Human Health and Safety, edited by George A. Bermann and Petros C. Mavroidis, Cambridge University Press, Cambridge, 2006, 133-152.

Gascoine, Digby, 'Harmonisation, Mutual Recognition and Equivalence - How and What Is Attainable?' presented at the Conference on International Food Trade Beyond 2000: Science-Based Decisions, Harmonization, Equivalence and Mutual Recognition, Food and Agriculture Organization of the United Nations, Melbourne Australia, 11-15 October 1999, available at: www.fao.org/docrep/ meeting/X2808e.htm, visited on 25 June 2007.

Gascoine, Digby, Vergano, Paolo and Carreño, Ignacio, Private Voluntary Standards within the WTO Multilateral Framework, United Kingdom Department for International Development, London, March 2006, 110.

Gathii, James, 'A Critical Appraisal of the Nepad Agenda in Light of Africa's Place in the World Trade Regime in an Era of Market Centred Development', Transnational Law and Contemporary Problems 13, 2003, 179-210.

Geistfeld, Mark, Implementing the Precautionary Principle, Working Paper 33, New York University School of Law, New York, Fall 2001, 9, available at: www. papers.ssrn.com/abstract $=289146$, visited on 25 June 2007.

Godard, Olivier, 'Social Decision-Making under Conditions of Scientific Controversy, Expertise and the Precautionary Principle', in Integrating Scientific Expertise into Regulatory Decision-Making: National Traditions and European Innovations, edited by Christian Joerges, Karl-Heinz Ladeur and Ellen Vos, Nomos, Baden-Baden, 1997, 39-73.

Goh, Gavin and Ziegler, Andreas R., 'A Real World Where People Live and Work and Die: Australian SPS Measures after the WTO Appellate Body's Decision in the Hormones Case', Journal of World Trade 35 (5), 1998, 271-290.

Goklany, Indur M., The Precautionary Principle. A Critical Appraisal of Environmental Risk Assessment, CATO Institute, Washington D.C., 121 pp., 2001.

Golt, Sidney, Developing Countries in the GATT System, Trade Policy Research Centre, London, 1978.

Greater Access to Trade Expansion Project, A Pro-Poor Analysis of the Shrimp Sector in Bangladesh, United States Agency for International Development Arlington, February 2006, 93, available at: http://www.usaid.gov/our_work/cross-cutting programs/wid/pubs/Bangladesh_Shrimp_Value_Chain_Fe b_ 2006.pdf, visited 13 January 2008.

Green, Andrew and Epps, Tracey, 'The WTO, Science, and the Environment: Moving Towards Consistency', Journal of International Economic Law 10 (2), 2007, 285-316.

Griffin, R., 'Introduction to the International Plant Protection Convention (IPPC)', in Multilateral Trade Negotiations on Agriculture: A Resource Manual. 
Agreement on the Application of Sanitary and Phytosanitary Measures (SPS) and Agreements on Technical Barriers to Trade (TBT), edited by Food and Agriculture Organization, vol. III, Food and Agriculture Organization, Rome, 2000, available at: www.fao.org/docrep/003/x7354e/X7354e01.htm, visited on 27 June 2001.

Gujadhur, Shyam K., 'Technical Assistance for SPS Measures: Protect Health, Not Trade', International Trade Forum (3), 2002, 31-35, available at: http://www. tradeforum.org/news/fullstory.php/aid/460/Technical_Assistance_for_SPS_ Measures:_Protect_Health,_Not_Trade.html, visited on 28 June 2003.

Gutiérrez, Maria, Nuengsigkapian, Prisna and Schipper, Lisa, Summary Report of the Conference on Assuring Food and Nutrition Security in Africa by 2020: 1-3 April 2004, International Institute for Sustainable Development, Winnipeg, 5 April 2004, 1-10, available at: www.iisd.ca/download/pdf/sd/sdvol58num6e.pdf, visited on 30 June 2008.

Guzman, Andrew T., 'Food Fears: Health and Safety at the WTO', Virginia Journal of International Law 45 (1), 2004, 1-40.

Hammer, W.C.K., 'Food Trade and Implementation of the SPS and TBT Agreements: Current Status of Food Trade, Including Food Quality and Safety Problems', presented at the Conference on International Food Trade Beyond 2000: ScienceBased Decisions, Harmonization, Equivalence and Mutual Recognition (Food and Agriculture Organization of the United Nations, Melbourne Australia) 11-15 October 1999, available at: www.fao.org/docrep/meeting/X2636e.htm, visited on 28 June 2008.

Hamwey, Robert M., Expanding National Policy Space for Development: Why the Multilateral Trading System Must Change, T.R.A.D.E. Working Paper 25, South Centre, Geneva, September 2005, 30, available at: http://129.3.20.41/eps/dev/ papers/0511/0511005.pdf, visited on 6 June 2008.

Hatanaka, Maki, Bain, Carmen and Busch, Lawrence, 'Third-Party Certification in the Global Agrifood System', Food Policy 30, 2005, 354 - 369.

Hayes, Edward T., 'Changing Notions of Sovereignty and Federalism in the International Economic System: A Reassessment of WTO Regulation of Federal States and the Regional and Local Governments within Their Territories', Northwestern Journal of International Law \& Business 25 (1), 2004, 1-36.

Henson, Spencer, 'Consumer Perceptions of Food Safety: Survey Research in Economics and Social Psychology', in Governing Food: Science, Safety and Trade, edited by Peter W.B Phillips and Robert Wolfe, McGill-Queen's University Press, Montreal, 2001, 91-111.

'The Role of Public and Private Standards in Regulating International Food Markets', presented at the IATRC Summer Symposium on Food Regulation and Trade: Institutional Framework, Concepts of Analysis and Empirical Evidence, Bonn, May 28-30 2006, available at: http://www.ilr1.uni-bonn.de/iatrc/iatrc program/Session\%204/Henson.pdf, visited on 27 May 2008. 
Henson, Spencer and Loader, Rupert, 'Barriers to Agricultural Exports from Developing Countries: The Role of Sanitary and Phytosanitary Requirements', World Development 29 (1), 2001, 85-102.

Henson, Spencer, Loader, Rupert, Swinbank, Alan and Bredahl, Maury E., 'How Developing Countries View the Impact of Sanitary and Phytosanitary Measures on Agricultural Exports', in Agriculture and the New Trade Agenda: Creating a New Global Trading Environment for Development, edited by M.D. Ingco and L.A. Winters, Cambridge University Press, Cambridge, 2004, 359-375.

Henson, Spencer, Masakure, Oliver and Boselie, David, 'Private Food Safety and Quality Standards for Fresh Produce Exporters: The Case of Hortico Agrisystems, Zimbabwe', Food Policy 30, 2005, 371-384.

Henson, Spencer, Brouder, Ann-Marie and Mitullah, Winnie, 'Food Safety Requirements and Food Exports from Developing Countries: The Case of Fish Exports from Kenya to the European Union', American Journal of Agricultural Economics 82 (5), 2000, 1159-1169.

Henson, Spencer, Preibisch, Kerry and Masakure, Oliver, Review of Developing Country Needs and Involvement in International Standards Setting Bodies, Centre for Food Economics Research, Department of Agricultural and Food Economics, University of Reading, 2001, available at: http://www.dfid.gov.uk/ pubs/files/issb.pdf, visited on 12 May 2008.

Henson, Spencer and Jaffee, Steve, Jamaica's Trade in Ethnic Foods and Other Niche Products: The Impact of Food Safety and Plant Health Standards, Agriculture and Rural Development Discussion Paper, World Bank, Washington D.C., 2005, available at: http://siteresources.worldbank.org/INTARD/Resources/ JamaicaStandardsF_final.pdf, visited on 7 January 2008.

Henson, Spencer and Reardon, Thomas, 'Private Agri-Food Standards: Implications for Food Policy and the Agri-Food System', Food Policy 30, 2005, 241-253.

Hepworth, Lorne H., 'Industry Stewardship as a Response to Food Safety Concerns', in Governing Food: Science, Safety and Trade, edited by Peter W.B Phillips and Robert Wolfe, McGill-Queen's University Press, Montreal, 2001, 63-74.

Herath, Anura, 'Cost of Compliance of Sanitary and Phytosanitary Requirements in Beverages and Spices in Sri Lanka', presented at the Workshop on a new WTO Round on Agriculture, SPS and the Environment: Capturing the Benefits for South Asia, World Bank, UNCTAD, SAARC Secretariat, New Delhi, India, 11-13 January 2001, available at: http://r0.unctad.org/trade_env/test1/meetings/ standards/anura\%20herath.doc, visited 20 June 2008.

Hey, Ellen, 'The Precautionary Concept in Environmental Policy and Law: Institutionalizing Caution', Georgetown International Environmental Law Review 4, 1992, 303-318. 
Hoekman, Bernard, 'Operationalizing the Concept of Policy Space in the WTO: Beyond Special and Differential Treatment', Journal of International Economic Law 8 (2), 2005, 405-424.

, Cancún: Crisis or Catharsis?, World Bank, Washington D.C., 20 September 2003, 4, available at: http://siteresources.worldbank.org/INTRANETTRADE/ Resources/Hoekman-CancunCatharsis-092003.pdf, visited on 5 December 2003.

Hoekman, Bernard, Michalopoulos, Constantine and Winters, Alan L., 'Special and Differential Treatment of Developing Countries in the WTO: Moving Forward after Cancún', The World Economy 27 (4), 2004, 481-506.

, More Favorable Differential Treatment of Developing Countries: Towards a New Approach in the WTO, World Bank Policy Research Working Paper 3107, World Bank, Washington D.C., August 2003, 30, available at: www.econ.worldbank. org/files/28991_wps3107.pdf, visited on 11 November 2004.

, Special and Differential Treatment for Developing Countries: Towards a New Approach in the WTO, World Bank, Washington D.C., 4 April 2003.

Hoekman, Bernard and Prowse, Susan, 'More Favourable Treatment for Developing Countries in the WTO: Policy Options for a Way Forward', presented at the High-Level Meeting on Trade and Development, Copenhagen, 27 May 2003, available at: http://www.um.dk/udenrigspolitik/handel\&udvikling/background/ SDT-paper.pdf, visited on 6 June 2003.

Hohmann, H., Precautionary Legal Duties and Principles of Modern International Environmental Law, ${ }^{\text {st }}$ ed., Graham \& Trotman/Martinus Nijhoff, London, 1994.

Holland, Ian and Kellow, Aynsley, 'Trade and Risk Management: Exploring the Issues', in Globalization and the Environment. Risk Assessment and the WTO, edited by David Robertson and Aynsley Kellow, Edward Elgar, Cheltenham, 2001, 229-248.

Hood, Christopher, Rothstein, Henry and Baldwin, Robert, The Government of Risk: Understanding Risk Regulation Regimes, Oxford University Press, Oxford, 2001.

Hopper, Marlynne and Boutrif, Ezzedine, Strengthening National Food Control Systems: Guidelines to Assess Capacity Building Needs, Food and Agriculture Organization, Rome, 2006, available at: ftp://ftp.fao.org/docrep/fao/009/a0601e/ a0601e00.pdf, visited on 12 June 2008.

Horn, Henrik and Weiler, Joseph.H.H., 'European Communities - Trade Description of Sardines: Textualism and Its Discontent', The WTO Case Law of 2002: The American Law Institute Reporter's Studies 1, 2003, 248-275.

Horton, Linda R., 'Food from Developing Countries: Steps to Improve Compliance', Food and Drug Law Journal 53, 1998, 139-171.

, 'Mutual Recognition Agreements and Harmonization', Seton Hall Law Review 29, 1998, 692-735. 
Howse, Robert, 'Democracy, Science, and Free Trade: Risk Regulation on Trial at the World Trade Organization', Michigan Law Review 98, 2000, 2329-2357.

Howse, Robert and Regan, Donald, 'The Product/Process Distinction - an Illusory Basis for Disciplining Unilateralism in Trade Policy', European Journal of International Law 11 (2), 2000, 249-289.

Howse, R., van Bork, P. and Hedebrand, C., 'WTO Disciplines and Biofuels, Opportunities and Constraints in the Creation of a Global Marketplace', IPC Discussion Paper, October 2006.

Howse, Robert and Teitel, Ruti G. , Beyond the Divide: The Covenant on Economic, Social and Cultural Rights and the World Trade Organization, Occasional Paper No.30, Friedrich Ebert Stiftung, Geneva, April 2007, available at: http://library. fes.de/pdf-files/iez/global/04572.pdf, visited on 15 June 2008.

Hudec, Robert E., 'GATT/WTO Constraints on National Regulation: Requiem for An “Aim and Effects" Test', in Essays on the Nature of International Trade Law, Cameron May, London, 1999, 359-393.

, 'The Product-Process Doctrine in GATT/WTO Jurisprudence', in New Directions in International Economic Law. Essays in Honour of John H. Jackson, edited by M. Bronckers and R. Quick, Kluver Law International, The Hague, 2000, 187-217.

, Developing Countries in the GATT Legal System, Gower, London, 1987.

, 'The Adequacy of WTO Dispute Settlement Remedies. A Developing Country Perspective', in Development, Trade and the WTO: A Handbook, edited by Philip English, Bernard M. Hoekman and Aaditya Matoo, World Bank, Washington D.C., 2002, 81-91, available at: http://publications.worldbank.org/catalog/ product-detail?product_id=1525978\&, visited on 5 June 2003.

Hunt, Paul, Report Submitted by the Special Rapporteur on the Right of Everyone to the Enjoyment of the Highest Attainable Standard of Physical and Mental Health, UN Doc. E/CN.4/2003/58, United Nations Commission on Human Rights, Geneva, 13 February 2003.

, Report of the Special Rapporteur on the Right of Everyone to the Enjoyment of the Highest Attainable Standard of Physical and Mental Health. Mission to the World Trade Organization, UN Doc. E/CN.4/2004/49/Add.1, United Nations Commission on Human Rights, Geneva, 1 March 2004.

Hurst, David R., 'Hormones: European Communities - Measures Affecting Meat and Meat Products', European Journal of International Law 9 (1), 1998, 182-183.

Hussain, Mohammed, 'World Trade Organization and the Right to Health: An Overview’, Indian Journal of International Law 43 (2), 2003, 279-313.

Hussain, Sahadad M. and Rahman, S.M. Khalilur, 'Sanitary and Phytosanitary Measures and Environmental Management in Bangladesh', presented at the Workshop on a New WTO Round on Agriculture, SPS, and the Environment: Capturing the 
Benefits for South Asia, World Bank, UNCTAD and SAARC Secretariat, New Delhi, India, 11-13 January 2001, available at: http://r0.unctad.org/trade_env/ test1/meetings/standards/BARC.doc, visited on 7 July 2001.

Immordino, Giovanni, Looking for a Guide to Protect the Environment: The Development of the Precautionary Principle, GREMAQ, Université de Toulouse and Universita di Palermo, December 1999.

International Centre for Trade and Sustainable Development, An Approach to Special and Differential Treatment Based On "Development Situations", International Centre for Trade and Sustainable Development, May 2007, 43, available at: http://www.ictsd.org/issarea/S\&DT/Docs/Policy\%20Paper\%20FT2\%20(2).pdf, visited on 11 June 2008.

, Export Quality - an Introduction to HACCP, Bulletin No. 71, UNCTAD and WTO, December 2002.

, ed. Environmental Regulation and Food Safety: Studies of Protection and Protectionism, Edward Elgar and International Development Research Centre, Ottawa, 232 pp., 2005.

International Centre for Trade and Sustainable Development and International Institute for Sustainable Growth, Doha Round Briefing Series. Developments since the Fourth WTO Ministerial Conference: Implementation-Related Issues and Concerns, Vol. 1 No.1, Geneva, February 2003.

, Doha Round Briefing Series. Cancun Update: Implementation-Related Issues and Concerns, Vol. 2 No. 1, Geneva, August 2003.

International Trade Centre of UNCTAD/WTO, Trade Competitiveness Map, Exports of Mauritius, 2005, available at: http://www.intracen.org/appli1/TradeCom/TP_EP CI.aspx?RP $=480 \& Y R=2005$, visited on 11 January 2008.

Islam, Roumeen, and Zanini, Gianni, World Trade Indicators 2008: Benchmarking Policy and Performance, World Bank, Washington D.C., 2008, available at: http://info.worldbank.org/etools/wti2008/docs/mainpaper.pdf, visited on 7 June 2008.

Jackson, John H., 'Comments on Shrimp/Turtle and the Product/Process Distinction', European Journal of International Law 11 (2), 2000, 303-307.

, The World Trading System: Law and Policy of International Economic Relations, Second edition, MIT Press, Cambridge, 1997.

, World Trade and the Law of GATT: A Legal Analysis of the General Agreement on Tariffs and Trade, Bobbs Merrill, Indianapolis, 1969.

Jackson, John H., Davey, William J. and Sykes Jr., Alan O., Legal Problems of International Economic Relations: Cases, Materials and Text on the National and International Regulation of Transnational Economic Relations, Fourth ed., American Casebook Series, West Group, St. Paul, 1245 pp., 2002. 
Jaffe, Gregory, 'Biosafety Regulation in the North and South', in Proceedings of the Eighth International Symposium on the Biosafety of Genetically Modified Organisms, International Society for Biosafety Research, Montpellier, France, 2004, 190-194, available at: http://www.isbr.info/symposia/docs/proceedings_ montpellier2004.pdf, visited on 19 May 2008.

Jaffee, Steven, and Henson, Spencer, Standards and Agro-Food Exports from Developing Countries: Rebalancing the Debate, 3348, World Bank, Geneva, June 2004, available at: http://econ.worldbank.org/external/default/main?pagePK $=64165259 \&$ theSitePK $=469382 \&$ piPK $=64165421 \&$ menuPK $=64166093 \&$ entity ID $=000112742 \_20040722152604$, visited 28 June 2008 .

Jaffee, Steven, Van Der Meer, Kees, Henson, Spencer, De Haan, Cees, Sewadeh, Mirvat, Ignacio, Laura, Lamb, John and Bergovoy Lisazo, Mariana Food Safety and Agricultural Health Standards: Challenges and Opportunities for Developing Country Exports, 31207, World Bank, Poverty Reduction \& Economic Management Trade Unit and Agriculture and Rural Development Department, Washington D.C., 10 January 2005, available at: http://www-wds. worldbank.org/external/default/WDSContentServer/WDSP/IB/2005/01/25/0001 60016_20050125093841/Rendered/PDF/31207.pdf, visited on 18 May 2008.

Jaffee, Steve and Masakure, Oliver, 'Strategic Use of Private Standards to Enhance International Competitiveness: Vegetable Exports from Kenya and Elsewhere', Food Policy 30, 2005, 316-333.

Jasanoff, Sheila, The Fifth Branch: The Science Advisers as Policymakers, Harvard University Press, Cambridge and London, 291 pp., 1990.

Javelosa, Josyline and Schmitz, Andrew, 'Costs and Benefits of a WTO Dispute: Philippine Bananas and the Australian Market', The Estey Centre Journal of International Law and Trade Policy 7 (1), 2006, 58-83.

Jensen, Michael Friis, Reviewing the SPS Agreement: A Developing Country Perspective, CDR Working Paper 02.3, Centre for Development Research, Copenhagen, February 2002.

Jha, Veena, 'South Asia', in Environmental Regulation and Food Safety: Studies of Protection and Protectionism, edited by Veena Jha, Edward Elgar and International Development Research Centre, Ottawa, 2005, 39-69, available at: http://www.idrc.ca/openebooks/185-X/, visited on 5 January 2006.

Jha, Veena, ed. Environmental Regulation and Food Safety: Studies of Protection and Protectionism, Edward Elgar and International Development Research Centre, Ottawa, 232 pp., 2005.

Joerges, Christian, 'Scientific Expertise in Social Regulation and the European Court of Justice: Legal Frameworks for Denationalized Governance Structures', in Integrating Scientific Expertise into Regulatory Decision-Making: National Traditions and European Innovations, edited by Christian Joerges, Karl-Heinz Ladeur and Ellen Vos, Nomos, Baden-Baden, 1997, 295-323. 
Johanson, David S. and Bryant, William L., 'Eliminating Phytosanitary Trade Barriers: The Effects of the Uruguay Round Agreements on California Agricultural Exports', San Joaquin Agricultural Law Review 6, 1996, 1-26.

Kaferstein, F.K., Motarjemi, Y. and Bettcher, D.W., 'Foodborne Disease Control: A Transnational Challenge', Emerging Infectious Diseases 3 (4), 1997, 503-510.

Karki, Tika, 'Issues on SPS and Food Standards for Nepal', presented at the Workshop on a New WTO Round on Agriculture, SPS, and the Environment: Capturing the Benefits for South Asia, World Bank, UNCTAD, SAARC Secretariat, New Delhi, India, 11-13 January 2001, available at: http://r0.unctad.org/trade_env/test1/ meetings/standards/nepal.doc, visited on 28 June 2008.

Kasteng, Jonas, Karlsson, Arne and Lindberg, Carina Differentiation between Developing Countries in the WTO, Report 2004:14 E, Swedish Board of Agriculture, International Affairs Division, Jönköping, June 2004, 58, available at: http://www.sjv.se/webdav/files/SJV/trycksaker/Pdf_rapporter/ra04_14E.pdf, visited on 15 July 2004.

Kastner, J.J. and Pawsey, R. K., 'Harmonising Sanitary Measures and Resolving Trade Disputes through the WTO-SPS Framework. Part II. A Case Study of the USAAustralia Determination of Equivalence in Meat Inspection', Food Control 13, 2002, 57-60.

Kennedy, Kevin C., 'Resolving International Sanitary and Phytosanitary Disputes in the WTO: Lessons and Future Directions', Food and Drug Law Journal 55 (1), 2000, 81-104.

Keohane, Robert, 'Global Governance and Democratic Accountability', in Taming Globalization: Frontiers of Governance, edited by David Held and Mathias Koenig-Archibugi, Polity Press, Cambridge, 2003, 130-159.

Kessie, Edwini Kwame, 'Developing Countries and the World Trade Organization: What Has Changed?' World Competition 22 (2), 1999, 83-110.

Keyzer, Michiel and Merbis, Max, 'SPS-Standards and Developing Countries: The Need for Differentiation', presented at the Capaciteitsopbouw in Ontwikkelingslanden in verband met Niet-Tarifaire Handelsbelemmeringen (SPS), Dutch Ministry of Agriculture and Ministry of Foreign Affairs (DGIS), The Hague, 20 June 2001.

Khachatourians, George G., 'How Well Understood Is The "Science” Of Food Safety?' in Governing Food: Science, Safety and Trade, edited by Peter W.B Phillips and Robert Wolfe, McGill-Queen's University Press, Montreal, 2001, 13-23.

Kithu, Charles J., 'Issues on SPS and Environmental Standards for India', presented at the Workshop on a New WTO Round on Agriculture, SPS, and the Environment: Capturing the Benefits for South Asia, World Bank, UNCTAD, SAARC Secretariat, New Delhi, India, 11-13 January 2001, available at: http://R0.unctad. org/trade_env/test1/meetings/standards/charles.doc, visited on 27 June 2008. 
Klabbers, Jan, An Introduction to International Institutional Law, Cambridge University Press, Cambridge, 2002.

Koichi, Jackson, John H., Lafer, Celso and De Montbrial, Thierry, The Future of the WTO: Addressing Institutional Challenges in the New Millennium. Report by the Consultative Board to the Director-General Supachai Panitchpakdi, World Trade Organization, Geneva, 2004, available at: http://www.wto.org/english/ thewto_e/10anniv_e/future_wto_e.pdf, visited on 5 January 2005.

Kostecki, Michel, Technical Assistance Services in Trade-Policy: A Contribution to the Discussion on Capacity-Building in the WTO, Resource Paper No. 2, International Centre for Trade and Sustainable Development, Geneva, November 2001, available at: www.ictsd.org/pubs/respaper/TApaper5-12-01.pdf, visited on 12 May 2002.

Lamy, Pascal, 'The Emergence of Collective Preferences in International Trade: Implications for Regulating Globalisation', presented at the Conference on Collective Preferences and Global Governance: What Future for the Multilateral Trading System?, European Commission, Brussels, 15 September 2004, available at: http://ec.europa.eu/archives/commission_1999_2004/lamy/speeches_articles/ spla242_en.ht, visited on 7 June 2008.

, 'Result of the WTO Ministerial Conference in Cancun', presented at the Plenary Session of the European Parliament, Strasbourg, 24 September 2003, available at: http://europa.eu.int/comm/commissioners/lamy/speeches_articles/spla192_ en.htm, visited on 7 November 2003.

, 'The EU, Cancun and the Future of the Doha Development Agenda', presented at the Annual Lecture of the Journal for Common Market Studies, London, 28 October 2003, available at: http://europa.eu.int/comm/commissioners/lamy/ speeches_articles/spla195_en.htm, visited on 6 December 2003.

Lang, Andrew T.F., Provisional Measures under Article 5.7 of the WTO's Agreement on Sanitary and Phytosanitary Measures: Some Criticisms of the Jurisprudence So Far, LSE Legal Studies Working Paper No. 11/2008, London School of Economics, London, 30 June 2008, available at: http://ssrn.com/ abstract $=1153660$, visited on 18 August 2008.

Lee, Grace Chia-Hui, Private Food Standards and Their Impacts on Developing Countries, European Commission, DG Trade, Unit G2, Brussels, 2006, available at: http://trade.ec.europa.eu/doclib/docs/2006/november/tradoc_127969.pdf, visited on 26 May 2008.

Leebron, David W., 'Lying Down with Procrustes: An Analysis of Harmonization Claims', in Fair Trade and Harmonization: Prerequisites for Free Trade?, edited by Jagdish N. Bhagwati and Robert E. Hudec, 2 vols., vol. 1, MIT Press, Cambridge, 1997, 41-117.

Lennard, Michael, 'Navigation by the Stars: Interpreting the WTO Agreements', Journal of International Economic Law 5 (1), 2002, 17-89. 
Loppacher, Laura J. and Kerr, William A., 'The Efficacy of World Trade Organization Rules on Sanitary Barriers: Bovine Spongiform Encephalopathy in North America', Journal of World Trade 39 (3), 2005, 427-443.

Low, Patrick, 'Is the WTO Doing Enough for Developing Countries?' in WTO Law and Developing Countries, edited by George A. Bermann and Petros C. Mavroidis, Cambridge University Press, Cambridge, 2007, 324-358.

Lynedjian, Marc, 'Le Principe De Précaution En Droit International Public', Revue de droit international, de sciences diplomatiques et politiques 3, 2000.

Maclaren, Donald, Some Issues in the Economic Analysis of Technical Barriers to International Trade in Agri-Food Products, Research Paper Number 663, University of Melbourne, Department of Economics, Melbourne, December 1998.

McNelis, Natalie, 'The Role of the Judge in the EU and WTO: Lessons from the BSE and Hormones Cases', in The Role of the Judge in International Trade Regulation: Experience and Lessons for the WTO, edited by T. Cottier and P.C. Mavroidis, University of Michigan Press: Ann Arbor, Michigan, 2003, 225-246.

Maljean, Sandrine and Etchelar, Dubois \& Emilie, 'World Trade and International Normalisation: Codex Alimentarius', in WTO Obligations and Opportunities: Challenges of Implementation, edited by Koen Byttebier and Kim Van Der Borght, Cameron May, London, 2007, 121-153.

Malloch-Brown, Mark, 'Human Security and Human Development in the 21st Century: A Post-September 11 Agenda', presented at the London School of Economics, Centre for the Study of Global Governance, London, 25 October 2001, available at: www.lse.ac.uk/collections/globalDimensions/lectures/ humanSecurityAndHumanDevelopment, visited on 5 November 2001.

Marceau, Gabrielle and Trachtman, Joel, 'GATT, TBT and SPS: A Map of WTO Law of Domestic Regulation of Goods', in The WTO Dispute Settlement System 1995-2003, edited by F. Ortino and E-U Petersmann, vol. 18, Kluwer Law International, Deventer, 2004, 275-340.

, 'Conflicts of Norms and Conflicts of Jurisdictions. The Relationship between the WTO Agreement and MEAs and Other Treaties', Journal of World Trade 35 (6), 2001, 1081-1131.

, 'WTO Dispute Settlement and Human Rights', European Journal of International Law 13 (4), 2002, 753-814.

Marks, Stephen, 'The Human Right to Development: Between Rhetoric and Reality', Harvard Human Rights Journal 17, 2004, 137-168, available at: http://www. law.harvard.edu/students/orgs/hrj/current/marks.shtml\#Heading160, visited on 3 June 2005.

Martin, Peter, Van Mellor, Thuy and Hooper, Stephen, Australian Beef. Live Cattle Export Trade: Importance to Northern and Southern Australian Beef Industries ABARE 07.1, Australian Bureau of Agricultural and Resource Economics, 
February 2007, 11, available at: http://www.abareconomics.com/publications html/livestock/livestock_07/Beef07.pdf, visited on 16 January 2008.

Maruyama, Warren H., 'A New Pillar of the WTO: Sound Science', The International Lawyer 32 (3), 1998, 651-677.

Maskus, Keith E. and Wilson, John S., 'Quantifying the Impact of Technical Barriers to Trade: A Review of Past Attempts and the New Policy Context', presented at the World Bank Workshop on Quantifying the trade effect of standards and technical barriers: Is it possible?, World Bank, Washington D.C., 27 April 2000, available at: http://www.worldbank.org/research/trade/conference/maskus.pdf, visited on 25 October 2000.

Maskus, Keith E., Wilson, John S. and Otsuki, Tsunehiro, Quantifying the Impact of Technical Barriers to Trade: A Framework for Analysis, Report No. 2512, World Bank, Washington D.C., December 2000, 51, available at: http://econ.worldbank. org/files/1324_wps2512.pdf, visited on 5 April 2001.

Masson-Matthee, Mariëlle, The Codex Alimentarius Commission and Its Standards, Doctoral Thesis, Maastricht University, Faculty of Law, T.M.C. Asser Press, Maastricht, 352 pp., 2007.

Matsushita, Mitsuo, Schoenbaum, Thomas J. and Mavroidis, Petros C., The World Trade Organization: Law, Practice, and Policy 1st ed, Oxford University Press, Oxford, 776 pp., 2003.

Mattli, Walter and Büthe, Tim, 'Setting International Standards: Technological Rationality or Primacy of Power', World Politics 56 (1), 2003, 1-42.

Mayeda, Graham, 'Developing Disharmony? The SPS and TBT Agreements and the Impact of Harmonization on Developing Countries', Journal of International Economic Law 7 (4), 2004, 737-764.

Mbengue, Makane Moïse and Thomas, Urs P., 'The Precautionary Principle's Evolution in the Light of the Four SPS Disputes', EcoLomic Policy and Law (3), 2004, 1-15, available at: http://www.ecolomics-international.org/epal_2004_3_mmm upt_pp2_evolution_four_sps_disputes.pdf, visited on 5 January 2005.

McIntyre, Owen and Mosedale, Thomas, 'The Precautionary Principle as a Norm of Customary International Law', Journal of Environmental Law 9 (2), 1997, 221-241.

McNiel, Dale E., 'The First Case under the WTO's Sanitary and Phytosanitary Agreement: The European Union's Hormone Ban', Virginia Journal of International Law 39, 1998, 89-134.

Mehra, Malini, Human Rights and the WTO: Time to Take on the Challenge, WTO Watch, Institute for Agriculture and Trade Policy, Minneapolis, 22 August 2000, available at: http:www.wtowatch.org/news/index.cfm?ID=1012, visited on 15 January 2001. 
Michalopolous, Constantine, 'The Developing Countries in the WTO', The World Economy 22, 1999, 117-143.

Mitchell, Lorraine, 'Economic Theory and Conceptual Relationships between Food Safety and International Trade', in International Trade and Food Safety: Economic Theory and Case Studies, edited by Jean C. Buzby, Agricultural Economic Report No. 828, USDA Economic Research Service, Washington D.C., 2003, 10-27, available at: http://ers.usda.gov/publications/aer828.pdf, visited on 4 January 2004.

Moore, Mike, A World Without Walls - Freedom, Development, Free Trade and Global Governance, Cambridge University Press, Cambridge, 2003.

Mosoti, Victor, 'Does Africa Need the WTO Dispute Settlement System?' in Towards a Development-Supportive Dispute Settlement System in the WTO, edited by Gregory Shaffer, Victor Mosoti and Asif Qureshi, International Centre for Trade and Sustainable Development, Geneva, 2003, 67-88, available at: www.ictsd.org/ pubs/ictsd_series/resource_papers/DSU_2003.pdf, visited on 30 June 2008.

Motaal, Doaa Abdel, "The "Multilateral Scientific Consensus" And the World Trade Organization', Journal of World Trade 38 (5), 2004, 855-876.

, 'Is the World Trade Organization Anti-Precaution?' Journal of World Trade 39

(3), 2005, 483-501.

Mujeri, Mustafa K., Rural Development Priorities for Poverty Reduction in Bangladesh, Bangladesh Resident Mission of the Asian Development Bank, Dhaka, November 2001, 51, available at: www.adb.org/documents/epps/ban/rural development/rural_development.pdf, visited on 6 December 2002.

Murphy, Sophia, Securing Enough to Eat, International Institute for Sustainable Development, Winnipeg, January 2005, 11, available at: http://www.iisd.org/ pdf/2005/trade_securing_enough_to_eat.pdf, visited on 6 February 2005.

Nairn, M.E., Allen, P.G., Inglis, A.R. and Tanner, C., Australian Quarantine: A Shared Responsibility, Australian Quarantine Review Secretariat, Canberra, 1996, available at: http://www.daff.gov.au/__data/assets/pdf_file/0009/111969/nairn_ report.pdf, visited on 24 January 2008.

Neumann, Jan and Türk, Elisabeth, 'Necessity Revisited: Proportionality in World Trade Organization Law after Korea-Beef, EC-Asbestos and EC-Sardines', Journal of World Trade 37 (1), 2003, 199-233.

Noor, Halima, 'Sanitary and Phytosanitary Measures and Their Impact on Kenya', presented at the African Workshop on Standards and Trade, UNCTAD and IDRC, Kampala, Uganda, 13 September 2001, available at: http://r0.unctad.org/ trade_env/test1/meetings/standards/kenya3.pdf, visited on 5 January 2002.

Norton, George W., Sanchez, Guillermo E., Clarke-Harris, Dionne and Traore, Halimatou Kone, Food Safety in Food Security and Food Trade: Case Study: Reducing Pesticide Residues on Horticultural Crops, in 2020 Vision for Food, 
Agriculture and the Environment, Focus 10 International Food Policy Research Institute, Washington D.C., September 2003.

Nowak, Manfred, Introduction to the International Human Rights Regime, Vol. 14, Martinus Nijhoff Publishers, Leiden/Boston, 153 pp., 2003.

O'Connor, Bernard, Equivalence of SPS Measures in WTO Law, Edited by O'Connor and Company, Vol. 5, Monographs in Trade Law, Brussels, 142 pp., 2002.

Ogus, Anthony, Regulation: Legal Form and Economic Theory, Clarendon Press, Oxford, 355 pp., 1994.

Okechukwu Ibeanu, Report of the Special Rapporteur on the Adverse Effects of the Illicit Movement and Dumping of Toxic and Dangerous Products and Wastes on the Enjoyment of Human Rights, UN Doc. E/CN.4/2006/42, UN Commission on Human Rights, Geneva, 20 February 2006.

Oliva, Maria Julia and Zarrilli, Simonetta, WTO Panel Report on The "EC-Biotech" Case: Considerations for Trade and Development, TD/B.COM.1/CRP.4, Trade and Development Board, Commission on Trade in Goods and Services, and Commodities, Geneva, 19-23 March 2007.

Orden, David, Narrod, Clair and Glauber, Joseph W., 'Least Trade-Restrictive SPS Policies: An Analytic Framework Is There but Questions Remain', in The Economics of Quarantine and the SPS Agreement, edited by Kym Anderson, Cheryl Mcrae and David Wilson, Centre for International Economic Studies, Adelaide, 2001, 183-215.

Organization for Economic Co-operation and Development, 'Scheme'for the Application of International Standards for Fruit and Vegetables, C(92)184/ FINAL, 1992.

, Guidance on Objective Tests to Determine Quality of Fruits and Vegetables and Dry and Dried Produce, AGR/CA/FVS(2005)3/REV1, 2006, available at: http:// www.oecd.org/dataoecd/32/47/19515719.pdf, visited on 5 February 2008.

, Food Agriculture and Fisheries Directorate, Measurement of Sanitary, Phytosanitary and Technical Barriers to Trade, 17-18 September 2001, available at: www.oecd.org/dataoecd/1/36/1816774.pdf, visited on 22 June 2008.

Orozco, Claudia, 'The SPS Agreement and Crisis Management: The Chile-EU Avian Influenza Experience', in Managing the Challenges of WTO Participation: 45 Case Studies, edited by Peter Gallagher, Patrick Low and Andrew L. Stoler, World Trade Organization, Geneva, 2005, available at: http://www.wto.org/ english/res_e/booksp_e/casestudies_e/case10_e.htm, visited on 6 January 2006.

Ostry, Sylvia, 'The Uruguay Round North-South Grand Bargain: Implications for Future Negotiations', in The Political Economy of International Trade Law. Essays in Honor of Robert E. Hudec, edited by Daniel L. M. Kennedy and James D. Southwick, Cambridge University Press, Cambridge, 2002, 285-310. 
Otsuki, Tsunehiro, Wilson, John S. and Sewadeh, Mirvat, Saving Two in a Billion: A Case Study to Quantify the Trade Effect of European Food Safety Standards on African Exports, World Bank Development Research Group, Washington D.C., 2000, available at: http://www1.worldbank.org/wbiep/trade/Standards/aflatoxins. pdf, visited on 5 April 2001.

Otsuki, Tsunehiro, Wilson, John S. and Sewadeh, Mirvat, 'Measuring the Effect of Food Safety Standards on African Exports to Europe', in The Economics of Quarantine and the SPS Agreement, edited by Kim Anderson, Cheryl Mcrae and David Wilson, Centre for International Economic Studies, Adelaide, 2001.

Otsuki, Tsunehiro, Wilson, John and Sewadeh, Mirvat, A Race to the Top? A Case-Study of Food Safety Standards and African Exports, Report No. 2563, World Bank, Washington D.C., 2000, available at: http://econ.worldbank.org/files/1424 wps2563.pdf, visited on 15 April 2001.

Otway, Harry, 'Public Wisdom, Expert Flexibility: Toward a Contextual Theory of Risk', in Social Theories of Risk, edited by S. Krimsky and D. Golding, Praeger, Westport, 1992, 412.

Oyejide, T. Ademola, Ogunkola, E Olawale and Bankole, S. Abiodun, 'Quantifying the Trade Impact of Sanitary and Phytosanitary Standards: What Is Known and Issues of Importance for Sub-Saharan Africa', presented at the Workshop on Quantifying the Trade Effect of Standards and Regulatory Barriers: Is it possible?, World Bank, Washington D.C., 27 April 2000, available at: http:// www.worldbank.org/research/trade/conference/oyeyide1.pdf, visited on 25 October 2000.

Page, Sheila, Davenport, Michael and Hewitt, Adrian, The GATT Uruguay Round: Effects on Developing Countries, 2 ed, Chameleon Press, London, 1992.

Palmer, Alice, The WTO GMO Dispute: Implications for Developing Countries and the Need for an Appeal, GeneWatch UK, The RSPB, Forum for Biotechnology and Food Security and the GM Freeze, Buxton, November 2006, 13, available at: http://www.genewatch.org/uploads/f03c6d66a9b354535738483c1c3d49e4/ WTO_Biotech_case_dcsummaryfinal_1.pdf, visited on 19 May 2008.

Palmeter, David and Mavroidis, Petros, 'The WTO Legal System: Sources of Law', The American Journal of International Law 92, 1998, 398-413.

Pardo Quintillán, Sara, 'Free Trade, Public Health Protection and Consumer Information in the European and WTO Context: Hormone Treated Beef and Genetically Modified Organisms', Journal of World Trade 33 (6), 1999, 147-197.

Patterson, Eliza, 'International Efforts to Minimize the Adverse Trade Effects of National Sanitary and Phytosanitary Regulations', Journal of World Trade 24 (2), 1990, 91-102.

Patton, Michael Quinn, Qualitative Research and Evaluation Methods, 3rd ed, Sage, Thousand Oaks, 2002. 
Paul, Joel R., 'Do International Trade Institutions Contribute to Economic Growth and Development?', Virginia Journal of International Law 44 (1), 2003, 284-340.

Pauwelyn, Joost, 'WTO Dispute Settlement: Of Sovereign Interests, Private Rights and Public Goods', in International Public Goods and Transfer of Technology under a Globalized Intellectual Property Regime, edited by Keith E. Maskus, Cambridge University Press, Cambridge, 2005, 817-830.

, 'The WTO Agreement on Sanitary and Phytosanitary (SPS) Measures as Applied in the First Three SPS Disputes: EC-Hormones, Australia-Salmon and JapanVarietals', Journal of International Economic Law 2 (4), 1999, 641-664.

, 'Cross-Agreement Complaints before the Appellate Body: A Case Study of the EC-Asbestos Dispute', World Trade Review 1 (1), 2002, 63-87.

, 'Non-Traditional Patterns of Global Regulation: Is the WTO 'Missing the Boat'?' presented at the Conference on Legal Patterns of Transnational Social Regulations and Trade, European University Institute, Florence, 24-25 September 2004, available at: http://eprints.law.duke.edu/1311/1/6Sept04.pdf, visited on 25 May 2008.

, Conflict of Norms in Public International Law: The Example of the World Trade Organization: Internal Hierarchy and How WTO Law Relates to Other Rules of International Law, Doctoral Thesis, Faculté de Droit, Université de Neuchâtel, Neuchâtel, 2001.

, 'The Role of Public International Law in the WTO: How Far Can We Go?', The American Journal of International Law 95, 2001, 535-578.

, 'Does the WTO Stand for 'Defence to' or 'Interference with' National Health Authorities When Applying the Agreement on Sanitary and Phytosanitary Measures (SPS Agreement)?' in The Role of the Judge in International Trade Regulation: Experience and Lessons for the WTO, edited by T. Cottier and P.C. Mavroidis, University of Michigan Press: Ann Arbor, Michigan, 2003, 175-192.

, 'The Use of Experts in WTO Dispute Settlement', International and Comparative Law Quarterly 51 (2), 2002, 325-364.

Peel, Jacqueline, 'A GMO by Any Other Name ... Might Be an SPS Risk! Implications of Expanding the Scope of the WTO Sanitary and Phytosanitary Measures Agreement', European Journal of International Law 17 (5), 2006, 1009-1031.

Peel, Jacqueline, Risk Regulation under the WTO SPS Agreement: Science as an International Normative Yardstick?, Jean Monnet Working Paper 02/04, NYU School of Law, New York, June 2004, 99, available at: www. jeanmonnetprogram.org/papers/04/040201.pdf, visited on 14 September 2004.

Perez, Oren, 'Multiple Regimes, Issue Linkage, and International Cooperation: Exploring the Role of the WTO', University of Pennsylvania Journal of International Economic Law 26 (4), 2005, 735-778. 
Petersmann, Ernest-Ulrich, 'Time for a United Nations" "Global Compact” For Integrating Human Rights into the Law of Worldwide Organizations: Lessons from European Integration Law for Global Integration Law', in Trade and Human Health and Safety, edited by George A. Bermann and Petros C. Mavroidis, Columbia Studies in WTO Law and Policy, Cambridge University Press, Cambridge, 2006, 271-326.

Phillips, Peter W.B., 'Food Safety, Trade Policy and International Institutions', in Governing Food: Science, Safety and Trade, edited by Peter W.B Phillips and Robert Wolfe, McGill-Queen's University Press, Montreal, 2001, 27-48.

Picker, Colin B., 'Neither Here nor There - Countries That Are Neither Developing nor Developed in the WTO: Geographic Differentiation as Applied to Russia and the WTO', George Washington International Law Review 36, 2004, 147-171.

Poli, Sara, 'The European Community and the Adoption of International Food Safety Standards within the Codex Alimentarius Commission', European Law Journal 10 (5), 2004, 613-630.

Porges, Amelia and Trachtman, Joel, 'Robert Hudec and Domestic Regulation: The Resurrection of Aim and Effects', Journal of World Trade 27 (4), 2003, 783-799.

Post, Diahanna L., 'The Diffusion of International Food Safety Policies: What's the Motivation?' presented at the 2003 Annual Convention of the International Studies Association, Portland, Oregon, 25 February - 1 March 2003.

, 'Standards and Regulatory Capitalism: The Diffusion of Food Safety Standards in Developing Countries', The ANNALS of the American Academy of Political and Social Science (598), 2005, 168-183, available at: http://ann.sagepub.com/cgi/ reprint/598/1/168, visited on 12 June 2008.

Potts, Jason, The Legality of the PPMs under the GATT: Challenges and Opportunities for Sustainable Trade Policy, International Institute for Sustainable Development, Manitoba, 2008, available at: http://www.iisd.org/pdf/2008/ppms gatt.pdf, visited on 9 April 2008.

Prakash, J., 'Plant Tissue Culture: Concept to Commercialisation in South East Asia', International Society for Horticultural Science Acta Horticulturae 560 (IV), 2001, 571-574, available at: http://www.actahort.org/books/560/560_117.htm, visited on 15 April 2008.

Prévost, Denise, “Operationalising' Special and Differential Treatment in the SPS Agreement', South African Yearbook of International Law 30, 2005, 82-111.

, 'Opening Pandora's Box: The Panel's Findings in the EC-Biotech Products Dispute', Legal Issues of Economic Integration 34 (1), 2007, 67-101.

Prowse, Susan 'The Role of the International and National Agencies in the TradeRelated Capacity Building', The World Economy 25 (9), 2002, 1235-1261. 
Public Citizen, Harmonization Handbook: Accountable Governance in the Era of Globalization: The WTO, NAFTA, and International Harmonization of Standards, Public Citizen, Washington D.C., 2000.

Quick, Reinhard and Blüthner, Andreas, 'Has the Appellate Body Erred? An Appraisal and Criticism of the Ruling in the WTO Hormones Case', Journal of International Economic Law 2 (4), 1999, 603-639.

Qureshi, Asif H., 'Interpreting World Trade Organization Agreements for the Development Objective', Journal of World Trade 37 (5), 2003, 847-882.

Raffensperger, Carolyn and Tickner, Joel, 'To Foresee and to Forestall', in Protecting Public Health and the Environment: Implementing the Precautionary Principle, edited by Carolyn Raffensperger and Joel Tickner, Island Press, Washington D.C., 1999, 1-12.

Raghavan, Chakravarthi, Recolonization - GATT, the Uruguay Round and the Third World, Third World Network, Penang, 1990.

, The World Trade Organization and Its Dispute Settlement System: Tilting the Balance against the South, Trade and Development Series no. 9, Third World Network, Geneva, 2002, 22, available at: www.twnside.org.sg/title/tilting-cn. htm, visited on 6 June 2003.

Rahman, Mustafizur, 'EU Ban on Shrimp Imports from Bangladesh: A Case Study on Market Access Problems Faced by LDCs', presented at the Workshop on a New WTO Round on Agriculture, SPS, and the Environment: Capturing the Benefits for South Asia, World Bank, UNCTAD and SAARC Secretariat, New Delhi, India, 11-13 January 2001, available at: http://r0.unctad.org/trade_env/test1/ meetings/standards/mustafizur.doc, visited 6 March 2001.

Ravallion, Martin, Competing Concepts of Inequality in the Globalization Debate, Working Paper 3243, World Bank, Washington D.C., March 2004.

, Pro-Poor Growth: A Primer, Working Paper 3242, World Bank, Washington D.C., March 2004.

Rayner, Steve, 'Cultural Theory and Risk Analysis', in Social Theories of Risk, edited by S. Krimsky and D. Golding, Praeger, Westport, 1992.

Regan, Donald H., 'Further Thoughts on the Role of Regulatory Purpose under Article III of the General Agreement on Tariffs and Trade. A Tribute to Bob Hudec', Journal of World Trade 27 (4), 2003, 737-760.

Rege, Vinod, Gujadhur, Shyam K. and Franz, Roswitha, Influencing and Meeting International Standards: Challenges for Developing Countries. Volume I: Background Information, Findings from Case Studies and Technical Assistance Needs, International Trade Centre UNCTAD/WTO and Commonwealth Secretariat, Geneva, 2003.

, Influencing and Meeting International Standards: Challenges for Developing Countries. Volume II: Procedures Followed by Selected International 
Standard-Setting Organisations and Country Reports on TBT and SPS, International Trade Centre UNCTAD/WTO and Commonwealth Secretariat, Geneva, 2004.

Regmi, Anita, Gehlhar, Mark, Waino, John, Vollrath, Thomas, Johnston, Paul and Kathuria, Nitin, Market Access for High-Value Foods, Agricultural Economic Report No. 840, United States Department of Agriculture, Washington D.C., February 2005, 45, available at: http://www.ers.usda.gov/publications/aer840/ aer840.pdf, visited on 30 June 2008.

Reid, Janice, Needs Analysis of the Readiness of Jamaican Institutions for WTO-SPS: Executive Summary, Inter-American Institute for Cooperation on Agriculture, Kingston, April 2000, 18, available at: www.agroinfo.org/caribbean/iicacarc/ jamaica/summary.pdf, visited on 7 January 2008.

Renn, Ortwin, 'Concepts of Risk: A Classification', in Social Theories of Risk, edited by S. Krimsky and D. Golding, Praeger, Westport, 1992.

Ríos, Gonzalo K., 'Technical Assistance Needs of Developing Countries and Mechanisms to Provide Technical Assistance', presented at the Conference on International Food Trade Beyond 2000: Science-Based Decisions, Harmonization, Equivalence and Mutual Recognition, Food and Agriculture Organization of the United Nations, Melbourne, Australia, 11-15 October 1999, available at: www.fao.org/docrep/meeting/X2674e.htm, visited on 6 November 1999.

Rizki, Rudi Muhammad, Report of the Independent Expert on Human Rights and International Solidarity. Note by the United Nations High Commissioner for Human Rights, A/HRC/4/8, UN Human Rights Council, Geneva, 7 February 2007.

Rogers, M. D. and Wiener, Jonathan B., 'Comparing Precaution in the United States and Europe', Journal of Risk Research 5 (4), 2002, 317-349.

Roberts, Donna, 'Sanitary and Phytosanitary Risk Management in the Post-Uruguay Round Era: An Economic Perspective', in Incorporating Science, Economics, and Sociology in Developing Sanitary and Phytosanitary Standards in International Trade: Proceedings of a Conference, edited by National Research Council Board on Agriculture and Natural Resources, National Academy Press, Washington D.C., 2000, 33-50, available at: www.nap.edu/ openbook/0309070902/html/199.html, visited on 25 June 2007.

Roberts, Donna, Orden, David and Josling, Tim, 'Sanitary and Phytosanitary Barriers to Agricultural Trade: Progress, Prospects and Implications for Developing Countries', in Agriculture and the New Trade Agenda - Creating a Global Trading Environment for Development, edited by M.D. Ingco and L.A.Winters, Cambridge University Press, Cambridge, 2004, 329-358.

Robinson, M., 'Making the Global Economy Work for Human Rights', edited by Gary P. Sampson, The Role of the WTO in Global Governance, United Nations University Press, 2001. 
Roesseler, Frieder, 'Beyond the Ostensible. A Tribute to Professor Robert Hudec's Insights on the Determination of the Likeness of Products under the National Treatment Provisions of the General Agreement on Tariffs and Trade', Journal of World Trade 27 (4), 2003, 771-781.

Rosas, Alan, 'The Right to Development', in Economic, Social and Cultural Rights: A Textbook, edited by Asbjorn Eide, Catarina Krause and Allan Rosas, Martinius Nijhoff publishers, Dordrecht, Boston, London, 2001, 119-130.

Rowley, Charles K., Tollison, Robert D. and Tullock, Gordon, eds. The Political Economy of Rent Seeking, Kluwer, Dordrecht, 512 pp., 1988.

Schepsle, Kenneth A., 'Congress Is A “They," Not An "It": Legislative Intent as an Oxymoron', International Review of Law and Economics 12 (2), 1992, 239-256.

Sally, Razeen, Whither the World Trading System? Trade Policy Reform, the WTO and Prospects for the New Round, No. 76, Timbro, Stockholm, 2002, 65, available at: http://www.timbro.se/pdf/whither.pdf, visited on 28 January 2008.

, Whither the World Trading System? Trade Policy Reform, the WTO and Prospects for the New Round, IGD Occasional Paper No. 36, Institute for Global Dialogue, Braamfontein, January 2003, available at: www.idgd.org.za/pub/OP/OP36.rtf, visited on 6 November 2003.

Sands, Phillippe, Principles of International Environmental Law I - Frameworks, Standards and Implementation $1^{\text {st }}$ ed., Manchester University Press, Manchester, 1995.

Sands, Phillippe and Klein, Pierre, Bowett's Law of International Institutions, $5^{\text {th }}$ ed., Sweet and Maxwell, London, 2001.

Sareen, Shashi, 'Food Export Control and Certification', presented at the FAO/ WHO Second Global Forum of Food Safety Regulators, GF 02/8a, Food and Agriculture Organization and World Health Organization, Bangkok, Thailand, 12-14 October 2004, available at: ftp://ftp.fao.org/docrep/fao/meeting/008/ j2747e.pdf, visited on 6 November 2004 .

Scott, Joanne, The WTO Agreement on Sanitary and Phytosanitary Measures: A Commentary, Oxford Commentaries on the GATT/WTO Agreements, Oxford University Press, Oxford, 340 pp., 2007.

, European Regulation of GMOs: Thinking About 'Judicial Review' in the WTO, Jean Monnet Working Paper 04/04, Jean Monnet Program, New York, 2004, 29, available at: www.jeanmonnetprogram.org/papers/04/040401.pdf, visited on 24 November 2004.

, 'International Trade and Environmental Governance: Relating Rules (and Standards) in the EU and the WTO', European Journal of International Law 15, 2004, 307-354.

Scott, Joanne and Vos, Ellen, 'The Juridification of Uncertainty: Observations on the Ambivalence of the Precautionary Principle within the EU and the WTO', in 
Good Governance in Europe's Integrated Market, edited by Christian Joerges and Renaud Dehousse, Oxford University Press, New York, 2002, 253-286.

Segerson, Kathleen, 'Mandatory vs. Voluntary Approaches to Food Safety', Agribusiness 15 (1), 1999, 53-70.

Sen, Amartya, Development as Freedom, 1st ed., Knopf, New York, 1999.

Sengupta, Arjun, The Right to Development. Report of the Independent Expert on the Right to Development, UN Doc. E/CN.4/2000/WG.18/CRP.1, UN Commission on Human Rights, Geneva, 11 September 2000.

, Review of Progress and Obstacles in the Promotion, Implementation, Operationalization, and Enjoyment of the Right to Development. Consideration of the Sixth Report of the Independent Expert on the Right to Development: Implementing the Right to Development in the Current Global Context, UN Doc. E/CN.4/2004/WG.18/2, UN Commission on Human Rights, Geneva, 17 February 2004.

, Report of the Independent Expert UN Doc. E/CN.4/2006/43, UN Commission on Human Rights, Geneva, 2 March 2006.

Shaffer, Gregory, 'Can WTO Technical Assistance and Capacity-Building Serve Developing Countries?’ Wisconsin International Law Journal, 2005.

'Recognising Public Goods in WTO Dispute Settlement: Who Participates? Who Decides? The Case of TRIPS and Pharmaceutical Patent Protection', Journal of International Economic Law 7 (2), 2004, 459-482.

'How to Make the WTO Dispute Settlement System Work for Developing Countries: Some Proactive Developing Country Strategies', in Towards a Development-Supportive Dispute Settlement System in the WTO, edited by Gregory Shaffer, Victor Mosoti and Asif Qureshi, International Centre for Trade and Sustainable Development, Geneva, 2003, 1-65, available at: http://ictsd.net/i/ dsu/11342/, visited on 30 June 2008.

, 'Power, Governance, and the WTO: A Comparative Institutional Approach', in Power in Global Governance, edited by Michael Barnett and Raymond Duvall, Cambridge University Press, Cambridge, 2005, 130-160.

Shapiro, Martin, 'The Frontiers of Science Doctrine: American Experiences with the Judicial Control of Science-Based Decision-Making', in Integrating Scientific Expertise into Regulatory Decision-Making: National Traditions and European Innovations, edited by Christian Joerges, Karl-Heinz Ladeur and Ellen Vos, Nomos, Baden-Baden, 1997, 325-342.

Shubber, Sami, 'The Codex Alimentarius Commission under International Law', International and Comparative Law Quarterly 21, 1972, 631-655.

Sikes, Lucinda, 'FDA's Consideration of Codex Alimentarius Standards in Light of International Trade Agreements', Food and Drug Law Journal 53, 1998, 327-335. 
Skogstad, Grace, 'The WTO and Food Safety Regulatory Policy Innovation in the European Union', Journal of Common Market Studies 39 (3), 2001, 485-505.

Slaughter, Anne-Marie, 'The Real New World Order', Foreign Affairs 76 (5), 1997, 183-197.

Slorach, Stuart A., Enquiry Concerning the FAO/WHO Project and Trust Fund for Enhanced Participation in Codex ("Codex Trust Fund"), Swedish International Development Cooperation Agency, Stockholm, 12 October 2007, available at: http://www.who.int/foodsafety/codex/Slorach_report.pdf, visited on 10 June 2008 .

Slovic, Paul, Finucane, Melissa L., Peters, Ellen and Macgregor, Donald, 'Risk as Analysis and Risk as Feelings: Some Thoughts About Affect, Reason, Risk and Rationality', presented at the Workshop on Conceptualizing and Measuring Risk Perceptions, National Cancer Institute, Washington D.C., 13-14 February 2003.

Smith, James, 'Inequality in International Trade? Developing Countries and Institutional Change in WTO Dispute Settlement', Review of International Political Economy 11 (3), 2004, 542-573.

Solignac Lecomte, Henri-Bernard and Van Hove, Kathleen, Building Capacity to Trade: A Road Map for Development Partners. Insights from Africa and the Caribbean, ECPDM Discussion Paper 33, European Centre for Development Policy Management and Overseas Development Institute, Maastricht, July 2001, 44, available at: http://www.ecdpm.org/Web_ECDPM/Web/Content/FileStruc.nsf/ index.htm?ReadForm\&0F344E30651892B0C1256C8B0035F9AA, visited on 12 June 2008.

Southern African Development Community, SADC SPS and Food Safety Issues: An Agenda for Action, SADC Consultative Forum on SPS/Food Safety, Windhoek, Namibia, 20-22 November 2000, 61, available at: www1.worldbank.org/wbiep/ trade/Stds_Africa/SADC_SPS.pdf, visited on 1 February 2001.

Srinivasan, T.N., Developing Countries and the Multilateral Trading System - from GATT to the Uruguay Round and the Future, Westview, Boulder, Colorado, 1998.

Stanton, Gretchen, Food Safety and the SPS Agreement, Standards and Trade Development Facility, Geneva, 2000, 4, available at: www.standardsfacility.org/ files/foodsafety\&sps.pdf, visited on 13 December 2000.

, 'A Review of the Operation of the SPS Agreement', presented at the Conference on Agriculture and the New Trade Agenda in the WTO 2000 Negotiations, Geneva, Switzerland, 1-2 October 2000.

, Codex and International Trade, Standards and Trade Development Facility, Geneva, 2002, 60, available at: www.standardsfacility.org/files/codex\&intltrade. pdf, visited on 3 August 2006.

Stark, John D., 'An Overview of Risk Assessment', in Incorporating Science, Economics, and Sociology in Developing Sanitary and Phytosanitary Standards 
in International Trade: Proceedings of a Conference, edited by National Research Council Board on Agriculture and Natural Resources, National Academy Press, Washington D.C., 2000, 51-64, available at: www.nap.edu/ openbook/0309070902/html/199.html, visited on 6 September 2001.

Steinberg, Richard H., 'In the Shadow of Law or Power? Consensus-Based Bargaining and Outcomes in the GATT/WTO', International Organization 56 (2), 2002, 339-374

Stevens, Christopher, 'Recognising Reality: Balancing Precision and Flexibility in WTO Rules', presented at the Joint ICTSD - GP International Dialogue: Making Special \& Differential Treatment More Effective and Responsive to Development Needs, International Centre for Trade and Sustainable Development, Chavannesde-Bogis, Switzerland, 6 and 7 May 2003, available at: www.ictsd.org/ dlogue/2003-05-06/STEVENS_S\&DT_final.pdf, visited on 6 July 2003.

, The Future of the Special and Differential Treatment (SDT) for Developing Countries in the WTO, IDS Working Paper 163, Institute for Development Studies, Brighton, September 2002.

Stewart, Terence P., ed. The GATT Uruguay Round. A Negotiating History (1986-1992), Vol. I - IV, Kluwer Law and Taxation Publishers, Deventer, 1993.

Stewart, Terence P. and Johanson, David S., 'The SPS Agreement of the World Trade Organization and International Organizations: The Roles of the Codex Alimentarius Commission, the International Plant Protection Convention, and the International Office of Epizootics', Syracuse Journal of International Law and Commerce 26, 1998, 27-53.

Stiglitz, Joseph E. and Charlton, Andrew, The Development Round of Trade Negotiations in the Aftermath of Cancun, Commonwealth Secretariat and Initiative for Policy Dialogue, June 2004, 62, available at: http://www. thecommonwealth.org/shared_asp_files/uploadedfiles/\{F1997C23-BC54-44D08E66-7D1166FC9937\}_StiglitzPaperComsec.pdf, visited on 6 December 2004.

Subramanian, Arvind and Shang-Jin, Wei, The WTO Promotes Trade, Strongly but Unevenly, WP/03/185, International Monetary Fund, September 2003, available at: www.inf.org/external/pubs/cat/longres.cfm?sk=16822.0, visited on 26 November 2003.

Sunstein, Cass R., 'Probability Neglect: Emotions, Worst Cases, and Law', Yale Law Journal 112, 2002, 61-107.

, Beyond the Precautionary Principle, Working Paper no. 38, University of Chicago, Chicago, January 2003, 48, available at: http://www.law.uchicago. edu/academics/publiclaw/resources/38.crs.precautionary.pl-lt.pdf, visited on 16 February 2003.

Sutherland, Peter, Bhagwati, Jagdish, Botchwey, Kwesi, Fitzgerald, Niall, Hamada, Koichi, Jackson, John H., Lafer, Celso and De Montbrial, Thierry, The Future of the WTO: Addressing Institutional Challenges in the New Millennium. Report by 
the Consultative Board to the Director-General Supachai Panitchpakdi, World Trade Organization, Geneva, 2004, 86, available at: http://www.wto.org/english/ thewto_e/10anniv_e/future_wto_e.pdf, visited on 25 June 2008.

Suppan, Steve, 'The WTO Agreement on the Application of Sanitary and Phytosanitary Measures (SPS)', in Decision Making in the Global Market: Trade, Standards and the Consumer (Consumers International, London), 2005, 133-148, available at: http://consint.live.poptech.coop/Shared_ASP_ Files/UploadedFiles/1E6FE541-9535-4E43-A86E-D7F66DE4728A_ GlobalGovernancefinalpdf.pdf, visited on 9 April 2008.

Suppan, Steve and Leonard, Rod, Comments Submitted to the Independent Evaluation of the Codex Alimentarius and Other FAO-WHO Work on Food Standards, 14 May 2002, available at: http://www.tradeobservatory.org/library.cfm?RefID=25513, visited on 12 June 2008.

Technical Centre for Agricultural and Rural Cooperation ACP-EU, Study of the Consequences of the Application of Sanitary and Phytosanitary (SPS) Measures on ACP Countries, CTA, Wageningen, May 2003, 108, available at: http:// www.tcd.ie/iiis/policycoherence/index.php/iiis/content/download/371/1446/file/ CTA\%20Impact\%20of\%20SPS\%20Measures\%20on\%20ACP\%20countries.pdf., visited on 23 January 2008.

Thiermann, Alex B., The Role of Animal Health and Zoonoses Standards on Disease Control and Trade OIE, Paris, February 2003, available at: http://www.oie.int/ eng/edito/en_thiermann.htm, visited on 6 February 2008.

Thornsbury, Suzanne, Sanitary and Phytosanitary Issues: Where Does the WTO Go from Here?, Working Paper, Center for International Business Education and Research, Gainesville, Florida, 2000.

Tietje, Christian, 'Process-Related Measures and Global Environmental Governance', in Multilevel Governance of Global Environmental Change: Perspectives from Science, Sociology and the Law, edited by Gerd Winter, Cambridge University Press, Cambridge, 2006, 254-274.

Toebes, Brigit, The Right to Health as a Human Right in International Law, IntersentiaHart, Groningen, 417 pp., 1999.

, 'The Right to Health', in Economic, Social and Cultural Rights: A Textbook, edited by Asbjorn Eide, Catarina Krause and Allan Rosas, Martinius Nijhoff, Dordrecht, Boston, London, 2001, 169-190.

Trebilcock, Michael J. and Giri, Shiva K., 'The National Treatment Principle in International Trade Law', in Handbook of International Trade, edited by Choi E. Kwan, Blackwell, Malden MA, 2005, 185-238.

Triple Line Consulting, Review of the STDF: Report, STDF 76 Add. 1, Standards and Trade Development Facility, London, 1 December 2005, 52, available at: http:// www.standardsfacility.org/files/Review_of_STDF.pdf, visited on 4 October 2006. 
Trouwborst, Arie, Precautionary Rights and Duties of States, Doctoral Thesis, Utrecht University, Faculty of Law, Martinus Nijhoff Publishers, Leiden/Boston, 360 pp., 2006.

Trouwborst, Arie, Evolution and Status of the Precautionary Principle in International Law (Kluwer Law International, The Hague/Boston/London, 2002.

Turvey, Calum G. and Mojduszka, Eliza M., 'The Precautionary Principle and the Law of Unintended Consequences', Food Policy 30, 2005, 145-161.

Tussie, Diana, The Less Developed Countries and the World Trading System - a Challenge to the GATT, Pinter, London, 1987.

Valverde, Max, Sanitary and Environmental Trade Barriers in Costa Rican Fisheries, Project on Standards and Trade, Strengthening Developing Countries' Capacity to Respond to Health Sanitary and Environmental Requirements, UNCTAD and IDRC, Geneva, 16-17 May 2001, 41, available at: http://r0.unctad.org/trade_env/ test1/meetings/standards/mariacostarica1.doc, visited on 10 June 2008.

Vallat, Bernard, The New Mandates of the OIE, International Office of Epizootics, Paris, November 2002, available at: http://www.oie.int/eng/Edito/en_edito_nov02.htm, visited on 5 February 2008.

Van den Bossche, Peter, The Law and Policy of the World Trade Organization: Text, Cases and Materials, $2^{\text {nd }}$ ed., Cambridge University Press, Cambridge, 917 pp., 2008.

, 'Looking for Proportionality in WTO Law', Legal Issues of Economic Integration 35 (3), 2008, 283-294.

Verhoosel, Gaëtan, National Treatment and WTO Dispute Settlement: Adjudicating the Boundaries of the Regulatory Autonomy, Hart Publishing, Oxford, 124 pp., 2002.

Victor, David G., 'Risk Management and the World Trading System: Regulating International Trade Distortions Caused by National Sanitary and Phytosanitary Policies', in Incorporating Science, Economics, and Sociology in Developing Sanitary and Phytosanitary Standards in International Trade: Proceedings of a Conference, edited by National Research Council Board on Agriculture and Natural Resources, National Academy Press, Washington D.C., 2000, 118-169, available at: www.nap.edu/openbook/0309070902/html/199.html, visited on 20 June 2001.

, 'The Sanitary and Phytosanitary Agreement of the World Trade Organization: An Assessment after Five Years', Journal of International Law and Politics 32 (4), 2000, 865-938.

Villalpando, Santiago M., 'Attribution of Conduct to the State: How the Rules of State Responsibility May Be Applied within the WTO Dispute Settlement System', Journal of International Economic Law 5 (2), 2002, 393-420. 
Vogel, David, 'Food Safety and International Trade', in Trading Up: Consumer and Environmental Regulation in a Global Economy, Harvard University Press, Cambridge/London, 1995, 150-195.

, Trading up, Consumer and Environmental Regulation in the Global Economy, Harvard University Press, Cambridge/London, 322 pp., 1995.

, 'Ships Passing in the Night: GMOs and the Politics of Risk Regulation in Europe and the United States', presented at the Regulatory Issues of Genetically Modified Organisms, Maastricht, 24-25 June 2002.

Von Moltke, Konrad, 'The Relationship between Policy, Science, Technology, Economics and Law in the Implementation of the Precautionary Principle', in The Precautionary Principle and International Law: The Challenge of Implementation, edited by David Freestone and Ellen Hey, Kluwer Law International, 1996, 97-108.

, The Vorzorgeprinzip in West German Environmental Policy, $12^{\text {th }}$ Report, Royal Commission on Environmental Policy, London, 1998.

Walker, Vern R., 'Keeping the WTO from Becoming The "World Trans-Science Organization": Scientific Uncertainty, Science Policy, and Factfinding in the Growth Hormones Dispute', Cornell International Law Journal 31, 1998, 251-320.

, 'The Myth of Science as A "Neutral Arbiter” For Triggering Precautions', International \& Comparative Law Quarterly 26, 2003, 197-228.

Wehr, H. Micheal, 'Update on Issues before the Codex Alimentarius', Food and Drug Law Journal 52, 1997, 531-536.

Welte, V., 'Introduction to the Office International Des Epizooties (OIE)', in Multilateral Trade Negotiations on Agriculture: A Resource Manual. Agreement on the Application of Sanitary and Phytosanitary Measures (SPS) and Agreements on Technical Barriers to Trade (TBT), edited by Food and Agriculture Organization, vol. III, Food and Agriculture Organization, Rome, 2000, 13, available at: www.fao.org/docrep/003/x7354e/X7354e01.htm visited on 6 November 2001.

Wibisana, Muhamad Ramdan Andri Gunawan Law and Economics Analysis of the Precautionary Principle, Doctoral Thesis, Maastricht University, Faculty of Law, Universitaire Pers, Maastricht, 2008.

Wiener, Jonathan B., 'Whose Precaution after All? A Comment on the Comparison of Civil Justice Systems', Duke Journal of Comparative and International Law 13, 2003.

Wiig, Arne and Kolstad, Ivar, 'Lowering Barriers to Agricultural Exports through Technical Assistance', Food Policy 30, 2005, 185-204.

Wilson, John S., International Trade: Standards, Technical Regulations, and Global Reform, World Bank, Economic Development Institute, Washington D.C., 1997, 
available at: http://www1.worldbank.org/wbiep/trade/Standards/diplomacy.pdf, visited on 24 June 2000.

, The Post-Seattle Agenda of the World Trade Organization in Standards and Technical Barriers to Trade: Issues for Developing Countries, World Bank, Washington D.C., 1999, available at: http://www1.worldbank.org/wbiep/trade/ Standards/Position_TBT_SPS.pdf, visited on 25 October 2000.

Wilson, John S. and Otsuki, Tsunehiro, Food Safety in Food Security and Food Trade: Balancing Risk Reduction and Benefits from Trade in Setting Standards, International Food Policy Research Institute, Washington D.C., September 2003.

Wilson, John S., Otsuki, Tsunehiro and Orden, David, Agriculture in the WTO - the Role of Product Attributes in the Agricultural Negotiations, Commissioned paper no. 17, International Agricultural Trade Research Consortium, Washington D.C., 2001, available at: www1.worldbank.org/wbiep/trade/Standards/Product Attributes.pdf, visited on 10 November 2001.

Wilson, John S. and Abiola, Victor O., eds. Standards and Global Trade: A Voice for Africa, World Bank, Washington D.C., 24 pp., 2003.

Wirth, David A., 'Symposium: The Role of Science in the Uruguay Round and NAFTA Trade Disciplines', Cornell International Law Journal 27, 1994, 817-859.

, 'International Trade Agreements: Vehicles for Regulatory Reform?' The University of Chicago Legal Forum, 1997, 331-373.

Wolfe, Robert, 'See You in Geneva? Legal (Mis)Representations of the Trading System', European Journal of International Relations 11 (3), 2005, 339-364.

, 'Regulatory Transparency, Developing Countries and the WTO', World Trade Review 2 (2), 2003, 157-182.

, 'Decision-Making and Transparency in the 'Medieval' WTO: Does the Sutherland Report Have the Right Prescription?' Journal of International Economic Law 8 (3), 2005, 631-645.

Wood, Roslyn, Peat, Alistair and Galeano, David, Australian Fisheries Statistics 2006, Australian Bureau of Agricultural and Resource Economics, Canberra, June 2007, available at: http://www.abareconomics.com/publications_html/fisheries/ fisheries_07/07_fishstats.pdf, visited on 13 January 2008.

Young, Margaret A., 'The WTO's Use of Relevant Rules of International Law: An Analysis of the Biotech Case', International \& Comparative Law Quarterly 56 (4), 2007, 907-930.

Zalaquette, José, 'The Relationship between Development and Human Rights', in Food and Human Rights, edited by Asbjorn Eide, Wenche Barth Eide, Susantha Goonatilake, Joan Gussow and Omawale, The United Nations University, Tokyo, 1984, 141-151.

Zarrilli, Simonetta, The SPS Agreement and the Developing Countries, World Bank, Washington D.C., 2003. 
, WTO Sanitary and Phytosanitary Agreement: Issues for Developing Countries, 3, South Centre, 1999, 28, available at: www.southcentre.org/publications/s\&p/ s\&p.pdf, visited on 8 November 2001.

Zaring, David, Informal Procedure, Hard and Soft, in International Administration, IILJ Working Paper 2004/6, Institute for International Law and Justice, New York University School of Law, New York, 2004, 46, available at: http://www.iilj.org/ publications/documents/2004.6\%20Zaring.pdf, visited on 28 January 2008.

Zeladis, Rex J, 'When Do the Activities of Private Parties Trigger WTO Rules? ' Journal of International Economic Law 10 (2), 2007, 335-362.

Ziegler, Jean, Report Submitted by the Special Rapporteur on the Right to Food, UN Doc. E/CN.4/2001/53, United Nations Commission on Human Rights, Geneva, 7 February 2001.

, Report Submitted by the Special Rapporteur on the Right to Food, UN Doc. E/ CN.4/2003/54, United Nations Commission on Human Rights, Geneva, 10 January 2003.

, Report Submitted by the Special Rapporteur on the Right to Food, UN Doc. E/CN.4/2004/10, United Nations Commission on Human Rights, Geneva, 9 February 2004.

, Interim Report of the Special Rapporteur on the Right to Food. Note by the Secretary General, A/60/350, UN General Assembly, Geneva, 12 September 2005.

Zoelink, Robert, 'America Will Not Wait', in Where Next for the WTO? After Cancún: Views, Ideas and Proposals by Trade Ministers, Federal Trust for Education and Research and Commonwealth Business Council, London, 2003.

\section{Official Documents of WTO Members}

\section{Argentina}

European Communities - Measures Affecting the Approval and Marketing of Biotech Products (WT/DS293). Written Rebuttal of the Republic of Argentina, Geneva, 19 July 2004, 54, available at: www.genewatch.org/WTO/Submissions/Argentina/ rebuttal.pdf, visited on 14 July 2005.

\section{Australia}

Agreement between the Government of Australia and the Government of New Zealand Establishing a System for the Development of Joint Food Standards, 5 December 1995, available at: http://www.foodstandards.gov.au/_srcfiles/NZ_Treaty.pdf, visited on 28 January 2008. 
Food Regulation Agreement, between the Commonwealth of Australia and its States and Territories, adopted on 6 December 2002, available at: http://www.coag.gov. au/ig_agreements/food_regulation_agreement_2002.htm, visited on 12 January 2008 .

Memorandum of Understanding Concerning the Inspection and Certification of Fish and Fishery Products, Agreement between Australia and Canada, 28 June 1993.

Australian Bureau of Agricultural and Resource Economics, Australian Farm Survey Results 2004-05 to 2006-07, Commonwealth of Australia, Canberra, March 2007, 22, available at: http://www.abareconomics.com/publications_html/ economy/economy_07/fsr_07.pdf, visited on 13 January 2008.

Australian Bureau of Statistics, 2007 Year Book Australia: A Comprehensive Source of Information About Australia, ABS Catalogue No. 1301.0, Commonwealth of Australia, Canberra, 2007, available at: http://www.ausstats.abs.gov.au/Ausstats/ subscriber.nsf/0/D6C6B02D31617DA4CA25726D000467A6/\$File/13010_2007. pdf, visited on 12 January 2008.

Australia New Zealand Food Safety Authority, 'The Development and Implementation of the New Australian Food Safety Standards', presented at the FAO/WHO Global Forum of Food Safety Regulators, Food and Agriculture Organization and World Health Organization, Marrakesh, 28-30 January 2002, available at: www.foodsafetyforum.org/global/, visited on 6 November 2002.

Australian Government Department of the Attorney General, Food Standards Australia New Zealand Act No. 118 of 1991, as Amended, Commonwealth of Australia, Canberra, 1991, available at: http://www.comlaw.gov.au/ComLaw/Legislation/ ActCompilation1.nsf/0/FE55337FDCFAA567CA25735B0001D93D/\$file/ FoodStandAusNZ1991.pdf, visited on 20 January 2008.

, Imported Food Control Regulations, Statutory Rules No. 100 of 1993, as Amended, Commonwealth of Australia, Canberra, 1 July 2005, available at: http:/www.comlaw.gov.au/ComLaw/Legislation/ LegislativeInstrumentCompilation1.nsf/0/50F611D12A8F4B2CCA25702E007D FC1E?OpenDocument, visited on 29 January 2008.

, Quarantine Act of 1908, Act No. 3 of 1908, as Amended, Commonwealth of Australia, Canberra, 4 October 2007, available at: http://www.comlaw.gov.au/ ComLaw/Legislation/ActCompilation1.nsf/0/71DD1F7D48D8CEA8CA25736E 001978EC/\$file/Quarantine1908_WD02.doc, visited on 25 January 2008.

, Quarantine Proclamation of 1998, as Amended, Made under Section 13 of the Quarantine Act of 1908, Commonwealth of Australia, Canberra, 1 November 2007, available at: http://www.comlaw.gov.au/ ComLaw/Legislation/LegislativeInstrumentCompilation1.nsf/all/search/ AA0B4452ED7BBD44CA25737F00157097, visited on 24 January 2008.

, Quarantine Regulations of 2000, Statutory Rules No. 129 of 2000, as Amended, Made under the Quarantine Act 1908, Commonwealth of Australia, Canberra, 15 December 2007, available at: http://www.comlaw.gov.au/ComLaw/legislation/ 
legislativeinstrumentcompilation1.nsf/0/3DE4AB6D94856101CA2573AA00197 491/\$file/QuarantineRegs2000.doc, visited on 25 January 2008.

Australian Government Department of Agriculture Fisheries and Forestry, National Food Industry Strategy: An Action Agenda for the Australian Food Industry, Commonwealth of Australia, Canberra, June 2002, available at: http://www.daff. gov.au/_data/assets/pdf_file/0017/183320/strategy_statement_final.pdf, visited on 13 January 2008.

, Annual Report 2004-05, Commonwealth of Australia, Canberra, October 2005, available at: http://www.daff.gov.au/_data/assets/word_doc/0016/5704/200405_annual_report_exc_fin_statements.doc, visited on 17 January 2008.

, Import Risk Analysis Handbook 2007, Commonwealth of Australia, Canberra, September 2007, 47, available at: http://www.daff.gov.au/ biosecuritycoordination/import_risk_analysis_handbook_2007, visited on 15 January 2008.

, Annual Report 2006-07: Growing Australia through Sustainable, Innovative and Profitable Agriculture, Fisheries and Forestry, Commonwealth of Australia, Canberra, September 2007, available at: http:/www.daff.gov.au/_data/assets/ pdf_file/0005/439493/2_AR_06-07_ROP_WEB.pdf, visited on 17 January 2008.

, Australian Food Statistics 2006, Commonwealth of Australia, Canberra, 2007, 40, available at: http://www.abareconomics.com/publications_html/crops/crops_07/ fstats_main.pdf, visited on 15 January 2008.

, The OCVO - Who We Are and What We Do, Commonwealth of Australia, Canberra, available at: http://www.daff.gov.au/_ data/assets/pdf_ file/0020/361541/about-ocvo.pdf, visited on 22 January 2008.

Australian Government Department of Health and Ageing and Food Standards Australia New Zealand, 'Enhancing Surveillance of Foodborne Diseases in Australia to Control Disease and Improve Food Safety', presented at the FAO/WHO Second Global Forum of Food Safety Regulators, Conference Room Document 6, Food and Agriculture Organization and World Health Organization, Bangkok, Thailand, 12-14 October 2004, available at: ftp://ftp.fao.org/docrep/fao/ meeting/008/ae019e.pdf, visited on 22 January 2008.

, 'Emerging Chemical and Microbiological Issues - Importance of Surveillance and International Cooperation and Information Sharing', presented at the FAO/ WHO Second Global Forum of Food Safety Regulators, Conference Room Document 8, Food and Agriculture Organization and World Health Organization, Bangkok, Thailand, 12-14 October 2004, available at: ftp://ftp.fao.org/docrep/ fao/meeting/008/ae081e.pdf, visited on 22 January 2008.

Australian Government Department of Foreign Affairs and Trade, Trade Topics: A Quarterly Review of Australia's International Trade. Spring 2007, Commonwealth of Australia, Canberra, September 2007, available at: http:// www.dfat.gov.au/publications/stats-pubs/downloads/trade_topics_spring_07.pdf, visited on 12 January 2008. 
, Composition of Trade Australia: 2006-07, Commonwealth of Australia, Canberra, November 2007, available at: http://www.dfat.gov.au/publications/stats-pubs/ downloads/COT_FY2007.pdf, visited on 12 January 2008.

, Exports of Primary and Manufactured Products Australia: 2006-07, Commonwealth of Australia, Canberra, December 2007, available at: http:// www.dfat.gov.au/publications/stats-pubs/downloads/pmp_2006_07.pdf, visited on 12 January 2008.

Australian Quarantine and Inspection Service, Salmon Import Risk Analysis: An Assessment by the Australian Government of Quarantine Controls on Uncooked, Wild, Ocean-Caught Pacific Salmonid Products Sourced from the United States of America and Canada, Final Report, December 1996.

Biosecurity Australia, Plant Biosecurity Policy Memorandum, 2000/22, Commonwealth of Australia, Canberra, 17 October 2000, available at: http://www.daff.gov.au/ data/assets/word_doc/0017/22904/2000-22.doc, visited on 25 January 2008.

, Import Risk Analysis (IRA) on Fresh Banana Fruit from the Philippines: Issues Paper, Commonwealth of Australia, Canberra, 2 May 2001, available at: http:// www.daff.gov.au/_data/assets/word_doc/0018/22941/2001-10a.doc, visited on 25 January 2008.

, Plant Biosecurity Policy Memorandum 2002/08, Canberra, 4 March 2002, available at: http://www.daff.gov.au/_data/assets/word_doc/0003/18930/200208.doc, visited on 25 January 2008.

, Importation of Fresh Bananas from the Philippines: Draft IRA Report, Commonwealth of Australia, Canberra, June 2002, available at: http://www.daff. gov.au/_data/assets/pdf_file/0012/164001/draft-ira.pdf, visited on 25 January 2008 .

, Plant Biosecurity Memorandum, 2003/30, Commonwealth of Australia, Canberra, 22 October 2003, available at: http://www.daff.gov.au/_data/assets/word_ doc/0015/14082/2003-30.doc, visited on 25 January 2008.

, Importation of Fresh Bananas from the Philippines: Revised Draft IRA Report, Commonwealth of Australia, Canberra, February 2004, available at: http://www. daff.gov.au/_data/assets/pdf_file/0006/22866/banana_rev_draft.pdf, visited on 28 January 2008 .

, Importation of Fresh Bananas from the Philippines: Addendum to Revised Draft IRA Report of February 2004, Commonwealth of Australia, Canberra, June 2004, available at: http://www.daff.gov.au/_data/assets/pdf_file/0003/22881/ ban_add.pdf, visited on 25 January 2008.

, Revised Draft Import Risk Analysis Report for the Importation of Cavendish Bananas from the Philippines, Commonwealth of Australia, Canberra, February 2007, available at: http://www.daff.gov.au/_data/assets/pdf_ file/0005/157964/2007-06a.pdf, visited on 25 January 2008. 
, Plant Biosecurity Memorandum, 2007/12, Commonwealth of Australia, Canberra, 16 May 2007, available at: http://www.daff.gov.au/_data/assets/word doc/0010/243982/2007_12.doc, visited on 25 January 2008.

, Import Risk Analysis for Bananas from the Philippines - Status Report, Advice 2008/13, available at: http://www.daff.gov.au/_data/assets/word doc/0020/661403/2008-13.doc, visited on 28 June 2008.

Food Standards Australia New Zealand, Australia New Zealand Food Standards Code, Commonwealth of Australia, Canberra, available at: http://www.foodstandards. gov.au/thecode/foodstandardscode.cfm, visited on 17 January 2008.

, Australia New Zealand Food Standards Code. Commentary, Commonwealth of Australia, Canberra, available at: http://www.foodstandards.gov.au/_srcfiles/ Commentary_v95.pdf, visited on 18 January 2008.

, A Short History of NFA/ANZFA/FSANZ, Commonwealth of Australia, Canberra, available at: http://www.foodstandards.gov.au/aboutfsanz/historyoffsanz.cfm, visited on 17 January 2008.

, Fact Sheet 2003: Imported Food. The Imported Food Inspection Scheme in Australia, Commonwealth of Australia, Canberra, May 2003, available at: http://www.foodstandards.gov.au/newsroom/factsheets/factsheets2003/ importedfoodinspecti1985.cfm, visited on 20 January 2008.

, Application Handbook, Issue 1, Commonwealth of Australia, Canberra, October 2007, available at: http://www.foodstandards.gov.au/_srcfiles/Application $\% 20$ Handbook\%20as\%20at\%201\%20Oct\%2007.pdf, visited on 21 January 2008.

, 'Science for the Post-Normal Age', Futures 25 (7), 1993, 739-755.

National Health Priority Action Council, National Chronic Disease Strategy, Department of Health and Aging of the Commonwealth of Australia, Canberra, 2006 available at: http://www.health.gov.au/internet/wcms/publishing.nsf/Conte nt/7E7E9140A3D3A3BCCA257140007AB32B/\$File/stratal3.pdf, visited on 12 January 2008.

OzFoodNet Working Group, Burden and Causes of Foodborne Disease in Australia: Annual Report of the OzFoodNet Network, 2005, Commonwealth of Australia, Canberra, 2006, available at: http:/www.health.gov.au/internet/wcms/Publishing. nsf/Content/cda-cdi3003-pdf-cnt.htm/\$FILE/cdi3003b.pdf, visited on 14 January 2008 .

\section{European Communities}

Agreement between the European Community and the Government of Canada on Sanitary Measures to Protect Public and Animal Health in Respect of Trade in Live Animals and Animal Products, OJ L 071, 18 March 1999. 
Council of the European Union, Council Decision 2007/627/EC of 28 September 2007 denouncing on behalf of the Community Protocol 3 on ACP sugar appearing in the ACP-EEC Convention of Lomé and the corresponding declarations annexed to that Convention, contained in Protocol 3 attached to Annex V to the ACP-EC Partnership Agreement, with respect to Barbados, Belize, the Republic of Congo, the Republic of Cote d'Ivoire, the Republic of the Fiji Islands, the Republic of Guyana, Jamaica, the Republic of Kenya, the Republic of Madagascar, the Republic of Malawi, the Republic of Mauritius, the Republic of Mozambique, the Federation of Saint Kitts and Nevis, the Republic of Suriname, the Kingdom of Swaziland, the United Republic of Tanzania, the Republic of Trinidad and Tobago, the Republic of Uganda, the Republic of Zambia and the Republic of Zimbabwe OJ L 255, 29 September 2007.

, Council Regulation applying the arrangements for products originating in certain states which are part of the African, Caribbean and Pacific (ACP) Group of States provided for in agreements establishing, or leading to the establishment of, Economic Partnership Agreements, 14970/1/07 REV 1, Brussels, 18 December 2007, available at: http://www.mcci.org/photos/news/EPARegulation. pdf, visited on 10 January 2008.

European Communities - Measures Affecting the Approval and Marketing of Biotech Products. First Written Submission by the European Communities, Geneva, 17 May 2004, 221, available at: http://www.trade-environment.org/output/theme/ tewto/EC_submission_biotech.pdf, visited on 14 July 2005.

European Communities - Measures Affecting the Approval and Marketing of Biotech Products. Second Written Submission by the European Communities, Geneva, 19 July 2004, 103, available at: http://brode-info.cec.eu.int/doclib/html/121611.htm, visited on 14 July 2005.

European Council of Ministers, Council Directive 85/649 Prohibiting the Use in Livestock Farming of Certain Substances Having a Hormonal Action of 31 December 1985, OJ L.382.

,Council Directive Laying down the Health Conditions for the Production and the Placing on the Market of Fishery Products, No. 91/493/EEC, 22 July 1991.

, Regulation (EC) No.1774/2002 of the European Parliament and of the Council of 3 October 2002 laying down health rules concerning animal by-products not intended for human consumption, OJ L 273, 10 October 2002.

European Commission, Commission Decision of 13 February 1998 Laying Down Special Conditions Governing Imports of Fishery and Aquaculture Products Originating in Bangladesh, (EC) 98/147/EC, European Commission, Brussels, 13 February 1998.

, Communication on the Precautionary Principle, COM/2000/0001, Brussels, adopted on 2 February 2000.

, Communication from the Commission to the Council, to the European Parliament, and to the Economic and Social Committee: Reviving the DDA Negotiations - the 
EU Perspective, European Union, Brussels, 26 November 2003, available at: hrrp://trade-info.cec.eu.int/doclib/html/114259.htm, visited on 1 December 2003.

, Report on United States Barriers to Trade and Investment, European

Commission, Brussels, December 2003, available at: http://trade-info.cec.eu.int/ doclib/docs/2003/december/tradoc_115383.pdf, visited on 10 December 2004.

, Report on United States Barriers to Trade and Investment, European

Commission, Brussels, December 2003, available at: http://trade-info.cec.eu.int/ doclib/docs/2003/december/tradoc_115383.pdf, visited on 3 January 2004

, Joint Press Communiqué of the Meeting between the G-20 Ministers and the EU Trade Commissioner Pascal Lamy, Brasilia, 12 December 2003, available at: http://europa.eu.int/comm/trade/issues/newround/doha_da/jpc121203_en.htm, visited on 30 June 2008.

, 20th Commission Directive 97/1/EC of 10 January 1997 Adapting to Technical Progress Annexes II, III, VI and VII of Council Directive 76/768/EEC on the Approximation of the Laws of the Member States Relating to Cosmetic Products, 97/1/EC, European Community, Brussels, 10 January 1997, available at: http:// eur-lex.europa.eu/LexUriServ/LexUriServ.do?uri=CELEX:31997L0001:EN:HT ML, visited on 28 January 2008.

European Commission, Directorate-General for Trade, The Doha Development Agenda after Cancun (European Union, Brussels), 25 September 2003, available at: http://www.ictsd.org/ministerial/cancun/docs/COMMISSION-Cancun-andBeyond-Sept-03.pdf, visited on 3 December 2003.

, Economic Partnership Agreements: Questions and Answers, Brussels, 2 October 2007, available at: http://trade.ec.europa.eu/doclib/docs/2007/october/ tradoc_136230.pdf, visited on 21 December 2007.

, Update: Interim Economic Partnership Agreements', Trade Policy in Practice, 19 December 2007, available at: http://trade.ec.europa.eu/doclib/docs/2007/ november/tradoc_136959.pdf, visited on 21 December 2007.

, Note on the State of Play in the EPAs Negotiations, Brussels, 20 December 2007, available at: http://trade.ec.europa.eu/doclib/docs/2007/december/ tradoc_137364.pdf, visited on 22 December 2007.

European Court of Justice, Case 178/84 Commission v Germany (Reinheitsgebot) [1987] ECR 1227.

, Case 68/86 United Kingdom v. Council [1988] ECR 855.

European Parliament and Council of the European Union, Directive Amending Council Directive 96/22/EC Concerning the Prohibition on the Use in Stockfarming of Certain Substances Having a Hormonal or Thyrostatic Action and of BetaAgonists, EC No. 2003/74 OJ L 262/17, European Community, Brussels, 22 September 2003. 


\section{Jamaica}

Jamaica, Catalogue of Jamaican Standards of the BSJ (as updated in 2001), available at: http://www.jbs.org.jm/standards/section_one(sectional_list_of_jamaican_ standards)(part1).pdf, visited on 8 January 2008.

Jamaica, Proposal for the Coordination of the Activities of Agricultural Health and Food Safety Agencies in Jamaica, May 2005, Memorandum of Understanding, Ministry of Health, Ministry of Agriculture and Lands and Ministry of Industry, Commerce and Technology of Jamaica setting up a single Food Safety Authority for Jamaica, available at: http://www.mct.gov.jm/FINAL\%20COORDINATION\%20PROPOSAL\%20-Signed1.pdf, visited on 27 December 2007.

Ministry of Agriculture and Lands, Policies Being Developed for the Financial Year 2006/2007, Synopsis Table, available at: http://www.moa.gov.jm/agripp/pol/ index.php, visited on 28 December 2007.

\section{Mauritius}

Government of Mauritius, Mauritian Standard MS 30-1984 on the Labelling of Prepackaged Foods, General Notice No. 1058 of 1983. , Mauritius Standards Bureau Act of 1993.

, Multifunctional Role of Agriculture in Small Island Developing States, AIE/51, dated 10 March 1999, cited in Committee on Agriculture, Non-Trade Concerns - Issues Raised by Members in AIE Papers and Pre-Seattle Submissions, G/AG/ $\mathrm{NG} / \mathrm{S} / 17$, circulated on 16 October 2000.

Ministry of Agriculture Food Technology \& Natural Resources of the Republic of Mauritius, A Sustained Programme for Agricultural Diversification: A NonSugar Sector Strategic Plan 2003-2007, Republic of Mauritius, Port Louis, 2003, available at: http://www.gov.mu/portal/sites/moasite/download/nsssplan.pdf, visited on 11 January 2008.

Ministry of Agro-Industry and Fisheries of the Republic of Mauritius, Multi-Annual Adaptation Strategy Sugar Sector Action Plan 2006-2015: Safeguarding the Future through Consensus, Republic of Mauritius, Port Louis, 2006, available at: http://www.gov.mu/portal/sites/moasite/download/Multi\%20Annual\%20 Adaption\%20Strategy.pdf, visited on 10 January 2008.

, Strategic Options in Crop Diversification and Livestock Sector 2007-2015

(Consultative Draft), Republic of Mauritius, Port Louis, August 2007, available at: http://www.areu.mu/files/pub/areunssp.pdf, visited on 10 January 2008.

, Fisheries \& Marine Resources Bill (Second Reading), available at: http://www. gov.mu/portal/site/moa?content_id=fc3edalef2f36110VgnVCM1000000a04a8c0 RCRD, visited on 10 January 2008. 
Ministry of Health and Quality of Life, Republic of Mauritius, White Paper on Health Sector Development and Reform, December 2002, 56, available at: http://www. gov.mu/portal/goc/moh/file/whitepap.doc, visited on 10 January 2008.

\section{United Kingdom}

International Development Committee House of Commons, Trade and Development at the WTO: Learning the Lessons of Cancún to Revive a Genuine Development Round. First Report of Session 2003-04, HC92-I (House of Commons, London), 4 December 2003, available at: www.publications.parliament.uk/pa/cm200304/ cmselect/cmintdev/92/92.pdf, visited on 10 June 2008.

United States

US Food and Drug Administration, Procedures for the Safe and Sanitary Processing and Importing of Fish and Fishery Products: Final Rule. US Fed. Regist. 61, 65096-65202, 21 Code of Federal Regulations, Parts 123 and 1240, 18 December 1995.

\section{Official Documents of the World Trade Organization}

Committee on Agriculture, Non-Trade Concerns - Issues Raised by Members in AIE Papers and Pre-Seattle Submissions, G/AG/NG/S/17, circulated on 16 October 2000.

, Fourth Special Session of the Committee on Agriculture. Statement by Jamaica, World Trade Organization, 6 December 2000.

, WTO Negotiations on Agriculture: Proposals by Small Island Developing States (SIDS): Communication from Barbados, Cuba, Dominica, Jamaica, Mauritius, St. Kitts and Nevis, St. Lucia, St. Vincent and the Grenadines, and Trinidad and Tobago, G/AG/NG/W/97 and Corr.1, adopted on 29 December 2000.

,WTO Negotiations on Agriculture - Market Access: Negotiating Proposal on Behalf of the Members of the Caribbean Community (CARICOM), G/AG/ NG/W/100, adopted on 15 January 2001.

, Special Session, Negotiations on Agriculture. Overview, TN/AG/6, circulated on 18 December 2002.

Committee on Sanitary and Phytosanitary Measures, Communication from the Republic of Honduras, G/SPS/W/2, circulated on 24 March 1995.

, Notification (of Emergency Measures). Australia, G/SPS/N/AUS/1-226, circulated between 14 July 1995 and 25 July 2008.

, Working Procedures of the Committee - Adopted by the Committee at Its Meeting of 29-30 March 1995, G/SPS/1, circulated on 4 April 1995. 
, List of Notifications - Note by the Secretariat, G/SPS/W/19, circulated on 19 June 1995.

, Graphs on the Coverage of the SPS and TBT Agreements. Note by the Secretariat, G/SPS/W/32, circulated on 10 November 1995.

, Consistency: Questions for Consideration: Note by the Chairman, G/SPS/W/45, circulated on 6 December 1995.

, Consistency: Elaboration of Guidelines: Note by the Chairman, G/SPS/W/59, circulated on 6 May 1996

, Draft Agreement between the World Trade Organization and the Office International Des Epizooties, G/SPS/W/61, circulated on 22 May 1996.

, Recommended Notification Procedures, G/SPS/7, circulated on 11 June 1996.

, Notification (of Emergency Measures). Jamaica, G/SPS/N/JAM/1-11, circulated between 12 July 1996 and 12 October 2007.

, Risk Analysis. Note by the Secretariat, G/SPS/W/80, circulated on 6 March 1997.

, Notification, G/SPS/N/EEC/43, circulated on 7 March 1997.

, Summary of the Meeting Held on 19-20 March 1997. Note by the Secretariat, G/ SPS/R/7, circulated on 29 April 1997.

, Rules of Procedure for Meetings of the Committee on Sanitary and Phytosanitary Measures. Approved by the Council for Trade in Goods on 11 June 1997, G/L/170, circulated on 20 June 1997.

, Procedure to Review the Operation and Implementation of the Agreement, G/ SPS/10, circulated on 21 October 1997.

, Procedure to Monitor the Process of International Harmonization: Decision of the Committee, G/SPS/11, circulated on 22 October 1997.

, Trade Restrictions in Response to Cholera. Submission by the World Health Organization, G/SPS/GEN/53, circulated on 20 February 1998.

, Measures in Response to Cholera. Statement by the European Community at the Meeting on 12 and 13 March 1998, G/SPS/GEN/68, circulated on 18 March 1998.

, Facilitation of Informal Consultations on Specific SPS Issues. Submission by the United States, G/SPS/GEN/74, circulated on 5 June 1998.

, Summary of the Meeting Held on 10-11 June 1998. Note by the Secretariat, G/ SPS/R/11, circulated on 17 August 1998.

, Australia's Quarantine Requirements for the Importation of Cooked Chicken Meat (G/SPS/N/AUS/72). Submission by Thailand, G/SPS/GEN/90, circulated on 7 September 1998. 
, Australian Import on Sauces Containing Benzoic Acid. Statement by Philippines at the Meeting of 11-12 November 1998, G/SPS/GEN/106, circulated on 23 November 1998.

, Summary of the Meeting Held on 10-11 November 1998. Note by the Secretariat, G/SPS/R/13, circulated on 15 January 1999.

, Review of the Operation and Implementation of the Agreement on the Application of Sanitary and Phytosanitary Measures. Report of the Committee, G/SPS/12, circulated on 11 March 1999.

, Procedure to Monitor the Process of International Harmonization. First Annual Report Adopted by the Committee on 8 July 1999, G/SPS/13, circulated on 12 July 1999.

, Decision to Extend the Provisional Procedure to Monitor the Process of International Harmonization. Decision of the Committee of 8 July 1999, G/ SPS/14, circulated on 12 July 1999.

, Restrictions on the Exportation of Fresh Bovine Meat to the Republic of Korea. Statement by Argentina at the Meeting of 7-8 July 1999, G/SPS/GEN/130, circulated on 21 July 1999.

, Implementation of the SPS Agreements - Trade Concerns. Submission by the European Communities at the Meeting of 7 - 8 July 1999, G/SPS/GEN/132, circulated on 21 July 1999.

, Questionnaire on Technical Assistance. Note by the Secretariat, G/SPS/W/101, circulated on 23 July 1999.

, Electronic Transmission of Notifications to National Enquiry Points. Note by the Secretariat, G/SPS/GEN/136, circulated on 9 August 1999.

, Notification (of Emergency Measures). Mauritius, G/SPS/N/MUS/1-12, circulated between 1 September 1999 and 15 September 2004.

, Summary of the Meeting Held on 7-8 July 1999. Note by the Secretariat, G/

SPS/R/15, circulated on 20 September 1999.

, Articles 6(2), 6(3) and Annex A(3)(B). Recognition of the Concept of

Pest- or Disease-Free Areas as an International Standard, Guideline or

Recommendation: Submission by South Africa, G/SPS/GEN/139, circulated on 2 November 1999.

, Recommended Notification Procedures. Revision, G/SPS/7/Rev.1, circulated on 26 November 1999.

, Summary of the Special Meeting of the SPS Committee on the Transparency

Provisions of the SPS Agreement, 9 November 1999. Note by the Secretariat, G/

SPS/R/16, circulated on 20 January 2000.

, Communication by the European Communities on the Precautionary Principle, G/ SPS/GEN/168, Geneva, circulated on 14 March 2000. 
, Special and Differential Treatment. Note by the Secretariat, G/SPS/W/105, circulated on 9 May 2000.

, Procedure to Monitor the Process of International Harmonization. Second Annual Report, G/SPS/16, circulated on 10 July 2000.

, Guidelines to Further the Practical Implementation of Article 5.5, G/SPS/15, circulated on 18 July 2000.

, Summary of the Meeting Held on 21-22 June 2000. Note by the Secretariat, G/ SPS/R/19, circulated on 1 August 2000.

, Technical Assistance Typology. Note by the Secretariat, G/SPS/GEN/206, circulated on 18 October 2000.

, Relevant Codex Documents on Equivalence of Sanitary Measures. Information Submitted by the Codex Alimentarius Commission (Codex), G/SPS/GEN/210, circulated on 6 November 2000.

, Relevant Codex Documents on Equivalence of Sanitary Measures. Information Submitted by the Codex Alimentarius Commission (Codex), G/SPS/GEN/211, circulated on 6 November 2000.

, Equivalence. Submission from the United States, G/SPS/GEN/212, circulated on 7 November 2000.

, Australia's Import Restrictions on Durian. Statement by Thailand at the Meeting of 8-9 November 2000, G/SPS/GEN/217, circulated on 22 November 2000.

, Australia's Import Restrictions on Durian: Response by Australia to Thailand's Statement at the Meeting of 8-9 November 2000, G/SPS/GEN/218, circulated on 22 November 2000.

, Notification by Australia, G/SPS/N/AUS/124, circulated on 23 November 2000.

, Notification by Australia, G/SPS/N/AUS/126, circulated on 19 February 2001.

, Criteria for Observer Status, G/SPS/GEN/229, circulated on 23 February 2001.

, Experience in Recognizing Equivalence of Phytosanitary Measures: Submission by New Zealand, G/SPS/GEN/232, circulated on 28 February 2001.

, Specific Trade Concerns: Note by the Secretariat. Revision, G/SPS/GEN/204/ Rev.1, circulated on 5 March 2001.

, Note on Developing Country Participation in Codex Bodies. Submission by the FAO/WHO Codex Alimentarius Commission, G/SPS/GEN/236, circulated on 9 March 2001.

, Experience On “Equivalence”: Submission by Fiji, G/SPS/GEN/238, circulated on 13 March 2001.

, Experience with Recognition of Equivalence: Statement by Thailand at the Meeting of 14-15 March 2001, G/SPS/GEN/242, circulated on 6 April 2001. 
, Notification of Emergency Measures, G/SPS/N/MUS/4, circulated on 10 April 2001.

, Notification of Emergency Measures, G/SPS/N/MUS/5, circulated on 23 April 2001.

, Equivalence: Consideration of Article 4 of the SPS Agreement: Summary of Informal Discussions on Equivalence. Second Report by the Chairman, G/L/445, circulated on 21 March 2001.

, Summary of the Meeting Held on 14-15 March. Note by the Secretariat, G/ SPS/R/21, circulated on 22 May 2001.

, An Example of Equivalence: Statement by Australia at the Meeting of 14-15 March 2001, G/SPS/GEN/243, circulated on 9 April 2001.

, Summary Report of the Workshop on the International Standard-Setting Organizations: Process and Participation, G/SPS/GEN/250, circulated on 14 May 2001.

, Agreement on the Application of Sanitary and Phytosanitary Measures. Proposal by Brazil, G/SPS/W/108, circulated on 22 June 2001.

, Summary of the Replies to the Questionnaire on Technical Assistance - Note by the Secretariat, G/SPS/GEN/143/Rev.1/Add.3, circulated on 3 July 2001.

, Equivalence - Note by the Secretariat, G/SPS/W/111, circulated on 4 July 2001.

, Discussion on Technical Assistance and Cooperation - Informal Meeting of the SPS Committee of 9 July 2001, G/SPS/GEN/267, circulated on 16 July 2001.

, Decision to Extend the Provisional Procedure to Monitor the Process of International Harmonization, G/SPS/17, circulated on 19 July 2001.

, Equivalence - Article 4 of the Agreement on the Application of Sanitary and Phytosanitary Measures, G/SPS/GEN/268, circulated on 15 August 2001.

, Turkish SPS Measures Applied to Importation of Bananas. Replies from Turkey, G/SPS/GEN/275, circulated on 24 August 2001.

, Procedure to Monitor the Process of International Harmonization. Third Annual Report, G/SPS/18, circulated on 19 September 2001.

, Questionnaire on Technical Assistance, G/SPS/W/113, circulated on 15 October 2001.

, Decision on the Implementation of Article 4 of the Agreement on the Application of Sanitary and Phytosanitary Measures, G/SPS/19, circulated on 24 October 2001 .

, Actions Aimed Implementing the WTO Agreement on the Application of Sanitary and Phytosanitary Measures, G/SPS/GEN/286, circulated on 26 October 2001.

, Monitoring/Revision of an International Standard: African Horse Sickness Request by South Africa, G/SPS/GEN/289, circulated on 29 October 2001. 
, Notification, G/SPS/N/MUS/7, circulated on 8 November 2001

, Summary of the Meeting Held on 31 October-1 November 2001. Note by the Secretariat, G/SPS/R/25, adopted on 18 January 2002.

, Technical Assistance - Responses to the Questionnaire. Note by the Secretariat, G/SPS/GEN/295, circulated on 6 February 2002.

, Proposed Format for the Notification of Agreements of Equivalence. Note by the Secretariat, G/SPS/W/114, circulated on 19 February 2002.

, Draft Paper on the Judgement of Equivalence of Sanitary Measures Relating to International Trade in Animals and Animal Products. Submission by the Office International Des Epizooties (OIE), G/SPS/W/119, circulated on 18 March 2002.

, Equivalence-Programme for Further Work. Decision by the Committee, G/ SPS/20, circulated on 21 March 2002.

, Recommended Notification Procedures for Implementing the Transparency

Obligations of the SPS Agreement (Article 7). Revision, G/SPS/7/Rev.2, circulated on 2 April 2002.

, Notification, G/SPS/N/MUS/8, circulated on 8 April 2002.

, Notification, G/SPS/N/MUS/9, circulated on 8 April 2002.

, Proposed Format for the Notification of Agreements of Equivalence. Note by the Secretariat. Revision. G/SPS/W/114/Rev.1, circulated on 21 May 2002.

, Special and Differential Treatment Proposals - Schedule of Work: Proposal by the Chairman, G/SPS/W/135, circulated on 13 June 2002.

, Technical Assistance and Capacity Building in the Context of the SPS Committee. Note by the Secretariat, G/SPS/GEN/332, circulated on 24 June 2002.

, Procedure to Monitor the Process of International Harmonization. Fourth Annual Report, G/SPS/21, circulated on 27 June 2002.

, Notification of Determination of the Recognition of Equivalence of Sanitary and Phytosanitary Measures. Decision by the Committee. Addendum, G/SPS/7/Rev.2/ Add.1, circulated on 25 July 2002.

, Summary of the Meeting Held on 25-26 June 2002. Note by the Secretariat, G/ SPS/R/27, circulated on 2 August 2002.

, Establishment of National WTO TBT/SPS Enquiry Point. Project Proposal.

Submission by Malawi, G/SPS/GEN/349, circulated on 24 October 2002.

, Enhancing Transparency of Special and Differential (S\&D) Treatment within the SPS Agreement. Submission by Canada, G/SPS/W/127, circulated on 30 October 2002.

, Comments on the Canadian Proposal. Statement by Egypt at the Meeting of 7-8

November 2002, G/SPS/GEN/358, circulated on 15 November 2002. 
, Decision on the Implementation of Article 4 of the Agreement on the Application of Sanitary and Phytosanitary Measures. Decision by the Committee. Addendum, G/SPS/19/Add.1, circulated on 15 November 2002.

, Notification of Emergency Measures. Jamaica. Wooden pallets, G/SPS/N/JAM/6, circulated on 10 January 2003.

, Summary of the Meeting Held on 7-8 November 2002. Note by the Secretariat, G/ SPS/R/28, circulated on 5 February 2003.

, The Failure of the European Communities to Amend EC Directive 2001/661/EC Allowing the Import of Bone in Meat from Ovine/Caprine Species from Countries Zoned Free from Foot and Mouth Disease without Vaccination. Communication from South Africa, G/SPS/GEN/373, circulated on 26 February 2003.

, Comments on Chapter 6 of the SPS Agreement - Regionalization. Communication by Chile, G/SPS/W/129, circulated on 21 March 2003.

, Specific Trade Concerns. Note by the Secretariat. Revision, G/SPS/GEN/204/ Rev.3, circulated on 26 March 2003.

, Report of the Analysis on SPS Notifications in 2002. Submission by China, G/ SPS/GEN/378, circulated on 31 March 2003.

, Mexican Restrictions on US Dry Beans - Request for Explanation (Article 5.8). Submission by the United States, G/SPS/GEN/379, circulated on 31 March 2003.

, Proposal for Amending the Recommended Transparency Procedures Relating to the Comment Period of SPS Notifications. Submission by China, G/SPS/W/131, circulated on 31 March 2003.

, Additional Comments on Article 6 of the SPS Agreement - Regionalization. Communication by Chile, G/SPS/GEN/381, circulated on 1 April 2003.

, Comments on Article 6 of the SPS Agreement - Regionalization. Communication by Mexico, G/SPS/GEN/388, circulated on 1 May 2003.

, Guidelines for Reaching a Judgement of Equivalence of Sanitary Measures. Submission by the Office International Des Épozooties, G/SPS/GEN/406, circulated on 19 June 2003.

, Decision to Modify and Extend the Provisional Procedure to Monitor the Process of International Harmonization. Adopted by the Committee on 25 June 2003, G/ SPS/25, circulated on 1 July 2003.

, Special and Differential Treatment Proposals Schedule of Work. Decision by the Committee, G/SPS/26, circulated on 2 July 2003.

, Implementation and Special and Differential Treatment. Report by the Chairman to the General Council, G/SPS/27, circulated on 4 July 2003.

, Procedure to Monitor the Process of International Harmonization. Fifth Annual Report, G/SPS/28, circulated on 7 July 2003. 
, Elaboration of the Proposal to Enhance Transparency of Special and Differential Treatment in Favour of Developing Country Members, G/SPS/W/132/Rev.1, circulated on 8 July 2003.

, Peru Initiates a Process for the Declaration and Recognition of Areas Free from and of Low Prevalence of Fruit Flies Certitis Capitata and Anastrepha Spp. Communication from Peru, G/SPS/GEN/417, circulated on 1 August 2003.

, Summary of the Meeting Held on 24-25 June 2003. Note by the Secretariat, G/ SPS/R/30, circulated on 4 September 2003.

, Questionnaire on the Operation of SPS Enquiry Points and National Notification Authorities, G/SPS/W/103/Rev.1, circulated on 15 September 2003.

, Special Meeting of the SPS Committee on Enquiry Points - 31 October 2003: Comment by Australia, G/SPS/GEN/429, circulated on 14 October 2003.

, Implementation of Regionalization Principle: Communication by Argentina, G/ SPS/GEN/433, circulated on 22 October 2003.

, Elaboration of the Proposal to Enhance Transparency of Special and Differential Treatment in Favour of Developing Country Members: Proposal by the United States, G/SPS/W/141, circulated on 27 October 2003.

, Equivalence. Statement by the International Plant Protection Convention (IPPC) at the Meeting of 28 - 30 October 2003, G/SPS/GEN/439, circulated on 27 October 2003.

, Implementing the Standards of the OIE. Communication from the OIE, G/SPS/ GEN/437, circulated on 28 October 2003.

, Draft Decision on the Implementation of Article 6 of the Agreement on the Application of Sanitary and Phytosanitary Measures: Proposal by Chile: Revision, G/SPS/W/140/Rev.1, circulated on 30 October 2003

, Implementation and Special and Differential Treatment: Report by the Chairman to the General Council, G/SPS/30, circulated on 20 November 2003.

, Notification of Emergency Measures, G/SPS/N/MUS/11, circulated on 3 December 2003.

, Special Meeting of the SPS Committee on the Operation of Enquiry Points, 31 October 2003. Presentations by Participants, G/SPS/GEN/458, circulated on 12 December 2003.

, Review of the SPS Agreement. Update on Adaptation to Regional Conditions. Submission by the European Communities, G/SPS/GEN/461, circulated on 12 December 2003.

, Summary of the Meeting Held on 29 - 30 October 2003. Note by the Secretariat, G/SPS/R/31, circulated on 23 December 2003.

, Specific Trade Concerns. Note by the Secretariat: Revision, G/SPS/GEN/204/ Rev.4, circulated on 2 March 2004. 
, Draft Decision on the Implementation of Article 6 of the Agreement on the Application of Sanitary and Phytosanitary Measures - Comments by the European Communities on the Proposal of Chile (G/SPS/W/140/Rev.1), G/ SPS/W/144, circulated on 11 March 2004.

, Decision on the Implementation of Article 6 of the Agreement on the Application of Sanitary and Phytosanitary Measures. Proposal by Canada, G/SPS/W/145, circulated on 16 March 2004.

, Regionalization. Communication by the United States, G/SPS/GEN/477, circulated on 16 March 2004.

, Elaboration of the Proposal to Enhance Transparency of Special and Differential Treatment in Favour of Developing Country Measures. Note by the Secretariat Revision, G/SPS/W/132/Rev.2, circulated on 19 March 2004.

, Decision on the Implementation of Article 4 of the Agreement on the Application of Sanitary and Phytosanitary Measures. Decision by the Committee Addendum, G/SPS/19/Add.3, circulated on 26 March 2004.

, Summary of the Meeting Held on 17 - 18 March 2004. Note by the Secretariat, G/ SPS/R/33, circulated on 7 May 2004.

, Unofficial Translation: Note by the Secretariat, G/SPS/GEN/487, circulated on 23 April 2004.

, Report of the Analysis on SPS Notifications in 2003. Submission by China, G/ SPS/GEN/498, circulated on 18 June 2004.

, Implementation of the Transparency Obligations as of 18 June 2004. Note by the Secretariat - Revision, G/SPS/GEN/27/Rev.13, circulated on 21 June 2004.

, Procedure to Monitor the Process of International Harmonization. Sixth Annual Report. Adopted by the Committee on 23 June 2004, G/SPS/31, circulated on 24 June 2004.

, Process for the Review of the Operation and Implementation of the Agreement. Decision by the Committee, G/SPS/32, circulated on 25 June 2004.

, Article 6 of the Agreement on the Application of Sanitary and Phytosanitary Measures. Adaptation to Regional Conditions, Including Pest- or Disease-Free Areas of Low Pest or Disease Prevalence. Proposal by Peru, G/SPS/W/148, circulated on 7 July 2004.

, Decision on the Implementation of Article 4 of the Agreement on the Application of Sanitary and Phytosanitary Measures - Revision, G/SPS/19/Rev.2, circulated on 23 July 2004.

, Summary of the Meeting. Note by the Secretariat, G/SPS/R/34, circulated on 16 August 2004. 
, Review of the Operation and Implementation of the SPS Agreement. Background Document. Note by the Secretariat, G/SPS/GEN/510, circulated on 20 September 2004.

, Monitoring of International Harmonization: Regionalization. Submission by New Zealand, G/SPS/W/151, circulated on 29 September 2004.

, The Second Review of the Operation and Implementation of the SPS Agreement. Further Elaboration of Issues for Consideration by New Zealand, G/SPS/W/157, circulated on 12 October 2004.

, Review of the Operation and Implementation of the SPS Agreement. Submission by the European Communities, G/SPS/W/159, circulated on 14 October 2004.

, The Mauritian Experience with the SPS Agreement from the Indian Ocean Perspective, G/SPS/GEN/526, circulated on 25 October 2004.

, Procedure to Enhance Transparency of Special and Differential Treatment in Favour of Developing Country Members. Decision by the Committee of 27 October 2004, G/SPS/33, circulated on 2 November 2004.

, Report (2004) on the Activities of the Committee on Sanitary and Phytosanitary Measures, G/L/709, circulated on 8 November 2004.

, Revision of the Procedure to Monitor the Process of International Harmonisation. Decision of the Committee. Revision, G/SPS/11/Rev.1, circulated on 15 November 2004.

, National Enquiry Points. Note by the Secretariat, G/SPS/ENQ/18, circulated on 20 December 2004.

, National Notification Authorities. Note by the Secretariat, G/SPS/NNA/8, circulated on 20 December 2004.

, Summary of the Meeting Held on 27 - 28 October 2004. Note by the Secretariat, G/SPS/R/35, circulated on 13 January 2005.

, Review of the Operation and Implementation of the SPS Agreement. Background Document. Note by the Secretariat. Revision, G/SPS/GEN/510/Rev.1, circulated on 23 February 2005.

, Specific Trade Concerns. Note by the Secretariat. Addendum: Part 2, G/SPS/ GEN/204/Rev.5/Add.1, circulated on 25 February 2005.

, Specific Trade Concerns. Note by the Secretariat. Addendum: Part 3, G/SPS/ GEN/204/Rev.5/Add.2, circulated on 25 February 2005.

, Specific Trade Concerns. Note by the Secretariat. Addendum: Part 4, G/SPS/ GEN/204/Rev.5/Add.3, circulated on 25 February 2005.

, Specific Trade Concerns. Note by the Secretariat. Revision: Part 1, G/SPS/

GEN/204/Rev.5, circulated on 25 February 2005. 
, Proposals and Progress on Special and Differential Treatment. Note by the Secretariat, G/SPS/GEN/543, circulated on 28 February 2005.

, Review of Standards Related Issues Identified in the Integrated Framework Diagnostic Trade Integration Studies. Note by the Secretariat, G/SPS/GEN/545, circulated on 28 February 2005.

, Official OIE Recognition of Member Countries' Health Status. Communication from the World Organization for Animal Health (OIE). Addendum, G/SPS/ GEN/542/Add.1, circulated on 2 March 2005.

, Implementation of International Standards. Communication by Mauritius, G/SPS/ GEN/547, circulated on 2 March 2005.

, Summary of the Meeting Held on 9 - 10 March 2005. Note by the Secretariat, G/ SPS/R/36, circulated on 4 May 2005.

, List of Representatives, G/SPS/INF/16, circulated on 8 June 2005.

, Executive Summary of a Study on Agri-Food Safety and SPS Compliance in Guinea Conakry, Mozambique and Tanzania. Communication from UNCTAD, G/ SPS/GEN/567, circulated on 17 June 2005.

, Decisions from the Seventh Interim Commission on Phytosanitary Measures. Communication from the International Plant Protection Convention Secretariat (IPPC), G/SPS/GEN/573, circulated on 22 June 2005.

, Report on Proposals for Special and Differential Treatment. Adopted by the Committee on 30 June 2005, G/SPS/35, circulated on 7 July 2005.

, Procedure to Monitor the Process of International Harmonization. Seventh Annual Report Adopted by the Committee on 30 June 2005, G/SPS/37, circulated on 19 July 2005.

, Review of the Operation and Implementation of the Agreement on the Application of Sanitary and Phytosanitary Measures. Report Adopted by the Committee on 30 June 2005, G/SPS/36, circulated on 11 July 2005.

, Summary of the Meeting Held on 29 - 30 June 2005. Note by the Secretariat, G/ SPS/R/37, circulated on 11 August 2005.

, Summary of the Meeting Held on 29-30 June 2005. Note by the Secretariat. Revision, G/SPS/R/37/Rev.1, circulated on 18 August 2005.

, Trade Difficulties Encountered in the Export of Sri Lankan Cinnamon to the European Communities. Communication by Sri Lanka, G/SPS/GEN/597, circulated on 10 October 2005.

, Regionalisation. Communication by Peru, G/SPS/GEN/607, circulated on 6 December 2005.

, Decision to Extend the Procedure to Enhance Transparency of Special and Differential Treatment in Favour of Developing Countries. Decision by the 
Committee of 1 February 2006. Addendum, G/SPS/33/Add.1, circulated on 6 February 2006.

, Summary of the Special Meeting on Article 6 (Regionalization) Held on 30 - 31 January 2006. Note by the Secretariat, G/SPS/R/38, circulated on 27 February 2006.

, Second Review of the Operation and Implementation of the Agreement on the Application of Sanitary and Phytosanitary Measures. Clarification of the Terms "Measures" and "Regulations" as contained in the SPS Agreement. Submission by Canada, G/SPS/W/186, circulated on 20 March 2006.

, Update on the Operation of the Standards and Trade Development Facility. Note by the Secretariat, G/SPS/GEN/648, circulated on 24 March 2006.

, Experience with the Implementation of the SPS Agreement. Information for the Workshop on 31 March 2006. Communication from Mauritius, G/SPS/GEN/657, circulated on 27 March 2006.

, Implementation of the SPS Agreement: Information for the Workshop on 31 March. Communication from Zimbabwe, G/SPS/GEN/663, circulated on 28 March 2006.

, Implementation of the SPS Agreement. Information for the Workshop on 31 March 2006. Communication from Gambia, G/SPS/GEN/664, circulated on 28 March 2006.

, Summary of the Meeting of 24 October 2005, Resumed on 1 - 2 February 2006. Note by the Secretariat, G/SPS/R/39, circulated on 28 March 2006.

, Implementation of the SPS Agreement. Information for the Workshop on 31 March 2006. Communication from Uganda, G/SPS/GEN/673, circulated on 31 March 2006.

, Implementation of the SPS Agreement. Information for the Workshop on 31 March 2006. Communication from Bangladesh, G/SPS/GEN/676, circulated on 31 March 2006.

, Implementation of the SPS Agreement. Information for the Workshop on 31 March 2006. Communication from Costa Rica, G/SPS/GEN/679, circulated on 31 March 2006.

, Some Experiences of Trinidad and Tobago in the Application of the SPS Agreement. Communication from Trinidad and Tobago, G/SPS/GEN/680, circulated on 31 March 2006.

, Specific Trade Concerns. Note by the Secretariat. Issues Not Considered in 2005. Addendum, G/SPS/GEN/204/Rev.6/Add.2, circulated on 19 May 2006.

, Specific Trade Concerns. Note by the Secretariat. Resolved Issues. Addendum, G/ SPS/GEN/204/Rev.6/Add.3, circulated on 19 May 2006. 
, Summary of the Meeting of 29 - 30 March 2006. Note by the Secretariat, G/ SPS/R/40, 26 May 2006.

, Comments on the Background Document on Issues in the Application of Article 6 of the SPS Agreement (G/SPS/GEN/640). Communication from the European Communities, G/SPS/W/190, circulated on 30 May 2006.

, Issues in the Application of Article 6 of the Agreement on the Application of Sanitary and Phytosanitary Measures. Japanese Comments and Proposals, G/ SPS/W/192, circulated on 30 May 2006.

, Second Review of the Operation and Implementation of the SPS Agreement. Review of the Implementation of Transparency Provisions. Communication from Australia, New Zealand and the United States, G/SPS/W/197, circulated on 13 June 2006.

, Update of Activities of the International Plant Protection Convention (IPPC) June 2006. Pest- and Disease-Free Areas - Article 6. Statement by the IPPC at the Meeting of 27-28 June 2006, G/SPS/GEN/707, circulated on 26 June 2006.

, Decision to Modify and Extend the Provisional Procedure to Monitor the Process of International Harmonization. Adopted on 28 June 2006, G/SPS/40, circulated on 5 July 2006.

, Sulphur Dioxide in Cinnamon, G/SPS/GEN/716, circulated on 25 July 2006.

, Membership in WTO and International Standard-Setting Bodies, G/SPS/GEN/49/ Rev.7, circulated on 26 July 2006.

, Procedure to Monitor the Process of International Harmonization. Eight Annual Report Adopted by the Committee on 28 June 2006, G/SPS/42, circulated on 4 August 2006.

, Notification of Emergency Measures. Jamaica. Beef and Beef Products, Bovine Derived Pharmaceuticals, Meat and Bone Meal Premixes and Feed Additives. Addendum, G/SPS/N/JAM/8/Add.1, circulated on 18 August 2006.

, Issues on the Application of Article 6 of the Agreement on the Application of Sanitary and Phytosanitary Measures. Background Document. Note by the Secretariat. Revision, G/SPS/GEN/640/Rev.1, circulated on 14 September 2006.

, Summary of the Meeting of 27 - 28 June 2006. Note by the Secretariat, G/ SPS/R/42, circulated on 25 September 2006.

, Overview of SPS-Related Technical Assistance Reported to the WTO/OECD Trade Capacity Building Database. Note by the Secretariat, G/SPS/GEN/726, circulated on 4 October 2006.

, Submission to the 37th Meeting of the SPS Committee (Geneva, 11-13 October 2006). Information on Activities of the Codex Alimentarius Commission. Submission by the Codex Alimentarius Commission, G/SPS/GEN/727, circulated on 9 October 2006. 
, OIE Dispute Mediation Process. Communication from the World Organization for Animal Health (OIE), G/SPS/GEN/731, circulated on 12 October 2006.

, Compendium of Documents Regarding Article 6 of the SPS Agreement Regionalization, G/SPS/GEN/636/Rev.1, circulated on 30 October 2006.

, Questionnaire on the Operation of SPS Enquiry Points and National Notification Authorities. Note by the Secretariat. Revision, G/SPS/W/103/Rev.2, circulated on 8 December 2006.

, Summary of the Meeting of 11-12 October 2006. Note by the Secretariat, G/ SPS/R/43, circulated on 3 January 2007.

, Private Standards and the SPS Agreement. Note by the Secretariat, G/SPS/ GEN/746, circulated on 24 January 2007.

, Update on the Operation of the Standards and Trade Development Facility, G/ SPS/GEN/748, circulated on 2 February 2007.

, Specific Trade Concerns. Note by the Secretariat. Revision, G/SPS/GEN/204/ Rev.7, circulated on 6 February 2007.

, Specific Trade Concerns. Note by the Secretariat. Addendum: Issues Considered in 2006, G/SPS/GEN/204/Rev.7/Add.1, circulated on 6 February 2007.

, Specific Trade Concerns. Note by the Secretariat. Addendum: Issues Not Considered in 2006, G/SPS/GEN/204/Rev.7/Add.2, circulated on 7 February 2007.

, Specific Trade Concerns. Note by the Secretariat. Addendum: Resolved Issues, G/ SPS/GEN/204/Rev.7/Add.3, circulated on 7 February 2007.

, Private Sector Standards and Developing Country Exports of Fresh Fruit and Vegetables. Communication from the United Nations Conference on Trade and Development (UNCTAD), G/SPS/GEN/761, circulated on 26 February 2007.

, Private Industry Standards. Communication from Saint Vincent and the Grenadines, G/SPS/GEN/766, circulated on 28 February 2007.

, Equivalence - Article 4. Update from the World Organization for Animal Health Organization (OIE), G/SPS/GEN/767, circulated on 1 March 2007.

, Special and Differential Treatment. Report by the Chairman to the General Council, G/SPS/44, circulated on 23 April 2007.

, Summary of the Meeting of 28 February - 1 March 2007. Note by the Secretariat, G/SPS/R/44, circulated on 30 May 2007.

, Ad Hoc Consultations and Resolution of Trade Concerns, G/SPS/GEN/781, circulated on 15 June 2007.

, Analysis of Replies to the Questionnaire on the Operation of Enquiry Points and National Notification Authorities. Note by the Secretariat. Revision, G/SPS/

GEN/751/Rev.1, circulated on 18 June 2007. 
, ISPM 29: Recognition of Pest-Free Areas and Areas of Low Pest Prevalence, G/ SPS/GEN/782, circulated on 19 June 2007.

, IPPC Dispute Settlement Manual. Submission by the Secretariat of the International Plant Protection Convention (IPPC), G/SPS/GEN/787, circulated on 22 June 2007.

, Maximum Residue Levels for Pesticides: Impact on Exports from Developing Countries. Communication from Argentina, G/SPS/W/211, circulated on 26 June 2007.

, Update on Activities Relating to Disease Regionalisation. 39th Meeting of the SPS Committee. Communication from the World Organisation for Animal Health (OIE), G/SPS/GEN/789, circulated on 26 June 2007.

, International Intergovernmental Organisations. Requests for Observer Status in the Committee on Sanitary and Phytosanitary Measures. Revision, G/SPS/W/78/ Rev.3, circulated on 3 July 2007.

, Australia's Revised Import Risk Analysis and Measures on Prawns and Prawn Products. Statement by Vietnam at the Meeting of 27-28 June 2007, G/SPS/ GEN/791, circulated on 4 July 2007.

, Private and Commercial Standards. Statement by Ecuador at the Meeting of 27 28 June 2007, G/SPS/GEN/792, circulated on 5 July 2007.

, Procedure to Monitor the Process of International Harmonization. Ninth Annual Report Adopted by the Committee on 28 June 2007, G/SPS/45, circulated on 10 July 2007.

, Notification. Addendum, G/SPS/N/AUS/204/Add.1, circulated on 2 August 2007.

, Notification of Determination of the Recognition of Equivalence of Sanitary and Phytosanitary Measures, G/SPS/N/EQV/PAN/1, circulated on 9 August 2007.

, SPS Technical Assistance Activities in 2007. Information from the Secretariat G/ SPS/GEN/797, circulated on 5 September 2007.

, Summary of the Meeting of 27-28 June 2007. Note by the Secretariat, G/ SPS/R/45, circulated on 12 September 2007.

, Technical Assistance for Operating the SPS Notification Authority and SPS Enquiry Point. Proposal by New Zealand, G/SPS/W/214, circulated on 1 October 2007.

, Applicants for Observer Status: Note by the Secretariat (Addendum), G/SPS/ GEN/121/Add.3, circulated on 5 October 2007.

, Membership in WTO and International Standard-Setting Bodies. Note by the Secretariat. Revision, G/SPS/GEN/49/Rev.8, circulated on 9 October 2007.

, Implementation of the Transparency Obligations as of 8 October 2007: Note by the Secretariat, G/SPS/GEN/27/Rev.17, circulated on 9 October 2007. 
, Technical Assistance to Developing Countries Provided by Australia. Addendum, G/SPS/GEN/717/Add.1, circulated on 11 October 2007.

, Overview Regarding the Level of Implementation of the Transparency Provisions of the SPS Agreement: Note by the Secretariat, G/SPS/GEN/804, circulated on 11 October 2007.

, Special and Differential Treatment: Report by the Chairman to the General Council, G/SPS/46, circulated on 29 October 2007.

, Notification.European Communities. Animal by-product. Addendum, G/SPS/N/ EEC/103/Add.20, circulated on 21 November 2007

, Background Document from the Standards and Trade Development Facility for the Global Review of Aid for Trade: Note by the Secretariat, G/SPS/GEN/812, circulated on 22 November 2007.

, Summary of the Meeting of 18-19 October 2007. Note by the Secretariat, G/ SPS/R/46, circulated on 2 January 2008.

, Workshop on Transparency Held on 15 - 16 October 2007. Note by the Secretariat, G/SPS/R/47, circulated on 8 January 2008.

, Request for Information on Good Practice in SPS-Related Technical Cooperation. Note by the Secretariat, G/SPS/GEN/816, circulated on 18 January 2008.

, Attachments to SPS Notifications. Note by the Secretariat, G/SPS/GEN/818, circulated on 29 January 2008.

, Time-Frames Relating to the Introduction of New SPS Measures. Note by the Secretariat, G/SPS/GEN/819, circulated on 13 February 2008.

, Overview of SPS Capacity Evaluation Tools. Note by the Secretariat, G/SPS/ GEN/821, circulated on 18 February 2008.

, Proposal for A "Mentoring” System of Assistance Relating to the Transparency Provisions of the SPS Agreement. Note by the Secretariat, G/SPS/W/217, circulated on 20 February 2008.

, Guidelines to Further the Practical Implementation of Article 6 of the Agreement on the Application of Sanitary and Phytosanitary Measures. Submission by New Zealand on Behalf of the Small Group Process on Article 6, G/SPS/W/218, circulated on 22 February 2008.

, Considerations Relevant to Private Standards in the Field of Animal Health, Food, Safety and Animal Welfare. Submission by the World Organization for Animal Health (OIE), G/SPS/GEN/822, circulated on 25 February 2008.

, Availability of Draft Procedural Manual on the Operation of SPS Enquiry Points and National Notification Authorities. Note by the Secretariat G/SPS/GEN/824, circulated on 11 March 2008.

, Good Offices of the Chairperson. Communication from Argentina, G/SPS/W/219, circulated on 17 March 2008. 
, List of Codex Alimentarius Commission Standards, Guidelines, Codes of Practice and Other Texts in Force as of 4 March 2008, G/SPS/GEN/828, circulated on 19 March 2008.

, Request for Information on Good Practice in SPS-Related Technical Cooperation. Extension of Deadline. Note by the Secretariat. Addendum, G/SPS/GEN/816/ Add.1, circulated on 20 March 2008.

, Update on the Operation of the Standards and Trade Development Facility. Note by the Secretariat, G/SPS/GEN/829, circulated on 25 March 2008.

, Summary of the Work of the International Plant Protection Convention (IPPC) October 2007-February 2008. Communication from the IPPC Secretariat, G/ SPS/GEN/833, circulated on 26 March 2008.

, Technical Assistance and Cooperation. Planned Activities to Be Undertaken by the IPPC under the FAO Technical Cooperation Programme-2008. Communication from the International Plant Protection Convention Secretariat (IPPC), G/SPS/GEN/834, circulated on 26 March 2008.

, Specific Trade Concerns. Note by the Secretariat. Addendum. Issues Considered in 2007, G/SPS/GEN/204/Rev.8/Add.1, circulated on 27 March 2008.

, Specific Trade Concerns. Note by the Secretariat. Addendum. Issues Not Considered in 2007, G/SPS/GEN/204/Rev.8/Add.2, circulated on 27 March 2008.

, Specific Trade Concerns. Note by the Secretariat. Addendum. Resolved Issues, G/ SPS/GEN/204/Rev.8/Add.3, circulated on 27 March 2008

, Capacity-Building Tools and Activities. Communication from the World Organization for Animal Health (OIE), G/SPS/GEN/830, circulated on 27 March 2008.

, FAO Evaluation Tools for Safety, Biosecurity and Plant Protection, G/SPS/

GEN/831, circulated on 27 March 2008.

, Actions for Implementing the WTO Agreement on Sanitary and Phytosanitary

Measures. Information Presented by the Inter-American Institute for Agricultural Cooperation (IICA), G/SPS/GEN/835, circulated on 27 March 2008.

, National Enquiry Points. Note by the Secretariat, G/SPS/ENQ/23, circulated on 27 March 2008.

, National Notification Authorities. Note by the Secretariat, G/SPS/NNA/13, circulated on 27 March 2008.

, Notification. Addendum, G/SPS/N/EEC/103/Add.21, circulated on 3 April 2008.

, Recommended Procedures for Implementing the Transparency Obligations of the SPS Agreement (Article 7). Note by the Secretariat. Revision, G/SPS/W/215/ Rev.2, circulated on 22 April 2008. 
, MRL for Pineapple - Ethephon, G/SPS/GEN/841/Rev.1, circulated on 9 May 2008.

, Guidelines to Further the Practical Implementation of Article 6 of the Agreement on the Application of Sanitary and Phytosanitary Measures, G/SPS/48, circulated on 16 May 2008.

, Normas Privadas. Declaracion De Uruguay En La Reunion De Los Dias 2 - 3 De Abril De 2008, G/SPS/GEN/843, circulated on 21 May 2008.

, Proposed Revision of the Procedure to Enhance Transparency of Special and Differential Treatment in Favour of Developing Country Members (G/SPS/33), G/SPS/W/224, circulated on 6 June 2008 .

, SPS Technical Assistance and Training Activities (1 September 1994 to 31 December 2007). Note by the Secretariat. Revision, G/SPS/GEN/521/Rev.3, circulated on 9 June 2008.

, Technical Assistance to Developing Countries Provided by the United States.

Submission by the United States. Addendum, G/SPS/GEN/181/Add.7, circulated on 18 June 2008.

, SPS Technical Assistance Activities in 2008. Information from the Secretariat, G/ SPS/GEN/851, circulated on 18 June 2008.

, International Plant Protection Convention (IPPC) Standard Setting Work Programme (up-to-Date June 2008), G/SPS/GEN/848, circulated on 18 June 2008.

, Decisions from the Third Session of the Commission on Phytosanitary Measures (Rome, 7-11 April 2008). Submission from the International Plant Protection Convention, G/SPS/GEN/849, circulated on 18 June 2008.

, Terms of Reference for the Working Group on Private Standards. Proposal by Uruguay, G/SPS/W/225, circulated on 18 June 2008.

, Notification of Determination of the Recognition of Equivalence of Sanitary and Phytosanitary Measures, G/SPS/N/EQV/DOM/1, circulated on 19 June 2008.

, Relationship between the SPS Committee and Codex, OIE and IPPC. Comments and Proposal by Japan, G/SPS/W/226, circulated on 19 June 2008,

, Recommended Procedures for Implementing the Transparency Obligations of the SPS Agreement (Article 7) as of 1 December 2008. Revision, G/SPS/7/Rev.3, circulated on 20 June 2008.

, Report on OIE Activities to the Meeting of the SPS Committee to be Held on 2425 June 2008, G/SPS/GEN/853, circulated on 20 June 2008.

, Article 12.2 - Consultations. Proposal by the United States, G/SPS/W/227, circulated on 23 June 2008. 
, Recognition of Areas Free of Pests or Diseases. Communication by Chile to the SPS Committee Meeting of 24-25 June 2008, G/SPS/GEN/862, circulated on 7 July 2008.

, Procedure to Monitor the Process of International Harmonization. Tenth Annual Report Adopted by the Committee on 25 June 2008, G/SPS/49, circulated on 14 July 2008.

, Report of the STDF Information Session on Private Standards (26 June 2008). Note by the Secretariat, G/SPS/50, circulated on 24 July 2008.

Committee on Technical Barriers to Trade, List of Standardizing Bodies That Have Accepted the Code of Good Practice for the Preparation, Adoption and Application of Standards since 1 January 1995. Note by the Secretariat. Revision, G/TBT/CS/2/Rev.14, circulated on 20 February 2008.

Committee on Trade and Development, A New Strategy for WTO Technical Cooperation: Technical Cooperation for Capacity Building, Growth and Integration. Note by the Secretariat, WT/COMTD/W/90, circulated on 21 September 2001.

, Implementation of Special and Differential Treatment Provisions in WTO Agreements and Decisions. A Review of Mandatory Special and Differential Treatment Provisions. Note by the Secretariat. Addendum, WT/COMTD/W/77/ Rev.1/Add.2, circulated on 21 December 2001.

, Non-Mandatory Special and Differential Treatment Provisions in WTO Agreements and Decisions. Note by the Secretariat. Addendum, WT/ COMTD/W/77/Rev.1/Add.3, circulated on 4 February 2002.

, Information on the Utilisation of Special and Differential Treatment Provisions. Note by the Secretariat. Addendum, WT/COMTD/W/77/Rev.1/Add.4, circulated on 7 February 2002.

, Special and Differential Treatment Provisions. Joint Communication from the African Group in the WTO. Revision, TN/CTD/W/3/Rev.1, circulated on 24 June 2002.

, Special and Differential Treatment Provisions Joint Communication from the African Group in the WTO. Revision, TN/CTD/W/3/Rev.2, circulated on 17 July 2002.

, Technical Cooperation Audit Report for 2002: Note by the Secretariat, WT/ COMTD/W/111, circulated on 28 March 2003.

, Non-Paper on the Need for Urgent Action in WTO to Deal with the Crisis Situation Created by the Long-Term Trend Towards Decline in Prices of Primary Commodities to the Trade and Development of Developing Countries Which Are Heavily Dependant on Their Exports. Communication from Kenya, Uganda and Tanzania, WT/COMTD/W/113, circulated on 19 May 2003. 
Committee on Trade and Development, Special Session, Note on the Meeting of 6 November 2002, TN/CTD/M/10, circulated on 21 January 2002.

, Note on the Meeting of 6 November 2002. Corrigendum, TN/CTD/M/10/Corr.1, circulated on 21 February 2002.

, Special and Differential Treatment Provisions. Joint Communication from Cuba, Dominican Republic, Egypt, Honduras, India, Indonesia, Kenya, Mauritius, Pakistan, Sri Lanka, Tanzania and Zimbabwe, TN/CTD/W/2, circulated on 14 May 2002.

, Special and Differential Treatment Provision: Joint Communication from the African Group in the WTO, TN/CTD/W/3, circulated on 24 May 2002.

, Special and Differential Treatment Provisions. Communication from India, TN/ CTD/W/6, circulated on 17 June 2002.

, Proposals Submitted by the Landlocked Developing Countries - Work Programme on Small Economies: Communication by Paraguay on Behalf of the Delegations of Bolivia, Mongolia, and Paraguay, WT/COMTD/SE/W/10, circulated on 27 April 2004

, Note on the Meeting of 7 December 2007, TN/CTD/M/32, circulated on 9 January 2008.

Committee on Trade in Agriculture, Special Session, Revised Draft Modalities for Agriculture, TN/AG/W/4/Rev.2, circulated on 19 May 2008, 134-135.

Dispute Settlement Body, Korea - Measures Concerning the Testing and Inspection of Agricultural Products. Request for Consultations by the United States, WT/ DS3/1, circulated on 6 April 1995.

, Korea-Measures Concerning the Shelf-Life of Products. Request for Consultations by the United States, WT/DS5/1, circulated on 5 May 1995. , Korea-Measures Concerning the Shelf-Life of Products. Notification of Mutually Agreed Solution, WT/DS5/5, G/SPS/W/27, G/TBT/D/3, G/AG/W/8, circulated on 31 July 1995.

, Korea-Measures Concerning Bottled Water. Request for Consultations by Canada, WT/DS20/1, G/L/33, G/SPS/W/35, G/TBT/D/4, G/MA/3, G/AG/W/14, circulated on 22 November 1995.

, Australia-Measures Affecting the Important of Salmonids. Request for Consultations by the United States, WT/DS21/1, G/L/39, G/SPS/W/40, circulated on 23 November 1995.

, European Communities - Measures Concerning Meat and Meat Products (Hormones). Request for Consultations by the United States, WT/DS26/1, G/L/62, G/SPS/W/46, G/AG/W/17, circulated on 31 January 1996. 
, Korea-Measures Concerning Bottled Water. Notification of Mutually Agreed Solution, WT/DS20/6, G/L/33/Add.1, G/SPS/W/35/Add.1, G/TBT/D/4/Add.1, G/MA/3/Add.1, G/AG/W/14/Add.1, circulated on 6 May 1996.

, Korea-Measures Concerning Inspection of Agricultural Products. Request for Consultations by the United States, WT/DS41/1, G/L/76, G/SPS/W/64, G/ TBT/D/6, G/AG/W/25, circulated on 31 May 1996.

, European Communities - Measures Affecting Livestock and Meat (Hormones). Request for Consultations by Canada, WT/DS48/1, G/L/91, G/SPS/W/71, G/ TBT/D/7, G/AG/W/26, circulated on 8 July 1996.

, Japan - Measures Affecting Agricultural Products. Request for Consultations by the US, WT/DS76/1, G/L/167, G/SPS/GN/15, G/SG/GEN/1, circulated on 9 April 1997.

, India - Quantitative Restrictions on Imports of Agricultural, Textile and Industrial Products. Request for Consultations by the European Communities, WT/DS96/1, G/L/178, G/AG/GEN/10, G/LIC/D/11, G/SPS/GEN/25, circulated on 24 July 1997.

, India - Quantitative Restrictions on Imports of Agricultural, Textile and Industrial Products. Request to Join Consultations, WT/DS96/5, circulated on 5 August 1997.

, United States - Measures Affecting Imports of Poultry Products. Request for Consultations by the EC, WT/DS100/1, G/SPS/GEN/28, G/TBT/D/14, circulated on 25 August 1997.

, India - Quantitative Restrictions on Imports of Agricultural, Textiles and Industrial Products. Notification of Mutually Agreed Solution, WT/DS96/8, G/L/234, G/AG/GEN/23, G/LIC/D/21, G/SPS/GEN/70, circulated on 6 May 1998.

, Slovak Republic - Measures Concerning the Importation of Dairy Products and the Transit of Cattle. Request for Consultations by Switzerland, WT/DS133/1, G/L/243, G/SPS/GEN/71, G/LIC/D/22, circulated on 18 May 1998.

, EC-Measures Affecting Asbestos and Products Containing Asbestos: Request for Consultations by Canada, WT/DS135/1, G/SPS/GEN/72, G/TBT/D/15, circulated on 3 June 1998.

, European Communities - Restrictions on Certain Import Duties on Rice. Request for Consultations by India, WT/DS134/1, G/L/245, G/VAL/D/1, G/LIC/D/23, G/ AG/GEN/24, G/TBT/D/16, G/SPS/GEN/73, circulated on 8 June 1998.

, Turkey-Certain Import Procedures for Fresh Fruit. Request for the Establishment of a Panel by Ecuador, WT/DS237/3, circulated on 14 June 2002.

, EC-Measures Affecting Imports of Wood of Conifers from Canada: Request for Consultations by Canada, WT/DS137/1, G/L/246, G/SPS/GEN/84, G/TBT/D/17, circulated on 24 June 1998. 
, United States - Certain Measures Affecting the Import of Cattle, Swine and Grain from Canada. Request for Consultations from Canada, WT/DS144/1, G/L/260, G/SPS/W/90, G/TBT/D/18, G/AG/GEN/27, circulated on 29 September 1998.

, Australia - Measures Affecting Importation of Salmon. Request for Consultations by Canada, WT/DS18/1, G/L/28, G/SPS/W/29, circulated on 11 October 1998.

, United States - Section 306 of the Trade Act of 1974 and Amendments Thereto. Request to Join Consultations, WT/DS200/3, circulated on 22 June 2000.

, Minutes of Meeting Held in the Centre William Rappard on 18 May 2000, WT/ DSB/M/80, circulated on 26 June 2000.

, Mexico - Measures Affecting Trade in Live Swine. Request for Consultations by the United States, WT/DS203/1, G/L/389, G/ADP/D25/1, G/AG/GEN/43, G/ TBT/D/20, circulated on 13 July 2000.

, Egypt - Import Prohibition on Canned Tuna with Soybean Oil. Request for Consultations by Thailand, WT/DS205/1, G/L/392, G/SPS/GEN/203, circulated on 27 September 2000.

, Australia - Measures Affecting the Importation of Salmonids. Notification of Mutually Agreed Solution, WT/DS21/10, G/L/39/Add.1, G/SPS/W/40/Add.1, circulated on 1 November 2000.

, Japan - Measures Affecting Agricultural Products. Communication from Japan and the United States, WT/DS76/12, circulated on 30 August 2001.

, Turkey - Certain Import Procedures for Fresh Fruit. Request for Consultations by Ecuador, WT/DS237/1, G/L/472, G/SPS/GEN/276, G/LIC/D/33, G/AG/ GEN/48, S/L/101, circulated on 10 September 2001.

, United States - Rules of Origin for Textiles and Apparel Products. Request to Join Consultations. Communication from Bangladesh, WT/DS243/2, circulated 5 February 2002.

, Japan - Measures Affecting the Importation of Apples: Request for Consultations by the US, WT/DS245/1, G/L/520, G/SPS/GEN/299, G/AG/GEN/50, circulated on 6 March 2002.

, Turkey - Import Ban on Pet Food from Hungary. Request for Consultations by Hungary, WT/DS256/1, G/L/538, G/SPS/GEN/316, G/AG/GEN/51, circulated on 7 May 2002.

, Australia - Certain Measures Affecting the Importation of Fresh Fruit and Vegetables. Request for Consultations by the Philippines, WT/DS270/1, G/L/575, G/SPS/GEN/345, G/LIC/D/34, circulated on 23 October 2002.

, Australia - Certain Measures Affecting the Importation of Fresh Pineapple. Request for Consultations by the Philippines, WT/DS271/1, G/L/576, G/SPS/ GEN/346, circulated on 23 October 2002. 
, Turkey - Certain Import Procedures for Fresh Fruit. Notification of Mutually Agreed Solution, WT/DS237/4, circulated on 29 November 2002.

, Turkey - Certain Import Procedures for Fresh Fruit. Notification of Mutually Agreed Solution, WT/DS237/4, circulated on 29 November 2002.

, India - Import Restrictions Maintained under the Export and Import Policy 2002-2007. Request for Consultations by the EC, WT/DS279/1, G/L/600, G/AG/ GEN/57, G/LIC/D/36, G/SPS/GEN/367, G/TBT/D/26, circulated on 9 January 2003.

, Mexico - Certain Measures Preventing the Importation of Black Beans from Nicaragua, WT/DS284/1, G/L/614, G/LIC/D/37, G/SPS/GEN/375, circulated on 20 March 2003.

, Australia - Quarantine Regime for Imports. Request for Consultations by the European Communities, WT/DS287/1, G/L/618, G/SPS/GEN/384, circulated on 9 April 2003.

, European Communities - Measures Affecting the Approval and Marketing of Biotech Products. Request for Consultations by Canada, WT/DS292/1, G/L/628, G/SPS/GEN/398, G/AG/GEN/61, G/TBT/D/29, circulated on 20 May 2003.

, European Communities - Measures Affecting the Approval and Marketing of Biotech Products. Request for Consultations by the United States, WT/DS291/1, G/L/627, G/SPS/GEN/397, G/AG/GEN/60, G/TBT/D/28, circulated on 20 May 2003.

, European Communities - Measures Affecting the Approval and Marketing of Biotech Products. Request for Consultations by Argentina, WT/DS293/1, G/L/629, G/SPS/GEN/399, G/AG/GEN/62, G/TBT/D/30, circulated on 21 May 2003.

, Australia - Certain Measures Affecting the Importation of Fresh Fruit and Vegetables. Request for the Establishment of a Panel by the Philippines. Revision, WT/DS270/5/Rev. 1, circulated on 11 July 2003.

, Croatia - Measure Affecting Imports of Live Animals and Meat Products. Request for Consultations by Hungary, WT/DS297/1, G/L/636, G/SPS/GEN/411, circulated on 14 July 2003.

, Minutes of Meeting Held in Centre William Rappard on 29 August 2003, WT/ DSB/M/155, circulated on 7 November 2003.

, Minutes of Meeting Held in the Centre William Rappard on 7 November 2003, WT/DSB/M/157, circulated on 18 December 2003.

, India-Anti-dumping Measure on Batteries from Bangladesh. Request for Consultations by Bangladesh, WT/DS306/1, circulated on 2 February 2004. , European Communities - Measures Affecting the Approval and Marketing of Biotech Products. Constitution of the Panel Established at the Requests of the 
United States, Canada and Argentina. Note by the Secretariat, WT/DS291/24, WT/DS292/18, WT/DS293/18, circulated on 5 March 2004.

, United States - Continued Suspension of Obligations in the EC-Hormones

Dispute. Request for Consultations by the European Communities, WT/DS320/1, G/L/713, adopted on 10 November 2004.

, Canada-Continued Suspension of Obligations in the EC-Hormones Dispute.

Request for Consultations by the European Communities, WT/DS321/1, G/L/714, circulated on 10 November 2004.

, United States - Continued Suspension of Obligations in the EC-Hormones Dispute. Request for the Establishment of a Panel by the European Communities, WT/DS320/6, circulated on 14 January 2005.

, Canada-Continued Suspension of Obligations in the EC-Hormones Dispute. Request for the Establishment of a Panel by the European Communities, WT/ DS321/6, circulated on 14 January 2005.

, Mexico - Certain Measures Preventing the Importation of Black Beans from Nicaragua. Communication from Nicaragua, WT/DS284/4, circulated on 11 March 2005.

, United States - Continued Suspension of Obligations in the EC-Hormones Dispute. Constitution of the Panel Established at the Request of the European Communities. Note by the Secretariat, WT/DS320/7, circulated on 7 June 2005.

, Canada-Continued Suspension of Obligations in the EC-Hormones Dispute. Constitution of the Panel Established at the Request of the European Communities. Note by the Secretariat, WT/DS321/7, circulated on 7 June 2005.

, United States - Continued Suspension of Obligations in the EC-Hormones Dispute (WT/DS320); Canada-Continued Suspension of Obligations in the EC-Hormones Dispute (WT/DS321). Communication from the Chairman of the Panels, WT/DS320/8, WT/DS321/8, circulated on 2 August 2005.

, Japan - Measures Affecting the Importation of Apples. Notification of Mutually Agreed Solution, WT/DS245/21; G/L/520/Add.1; G/SPS/GEN/299/Add.1; G/ AG/GEN/50/Add.1, circulated on 2 September 2005.

, Australia - Quarantine Regime for Imports. Notification of Mutually Agreed Solution, WT/DS287/8, G/L/618/Add.1, G/SPS/GEN/384/Add.1, circulated on 13 March 2007.

, Australia-Measures Affecting the Importation of Apples from New Zealand. Request for Consultations by New Zealand, WT/DS367/1, G/L/825, G/SPS/ GEN/796, circulated on 4 September 2007.

, Australia-Measures Affecting the Importation of Apples from New Zealand. Request for the Establishment of a Panel by New Zealand, WT/DS367/5, circulated on 7 December 2007. 
General Council, Preparations for the 1999 Ministerial Conference. Proposals

Regarding the Agreement on Sanitary and Phytosanitary Measures in Terms of

Paragraph 9(a)(I) of the Geneva Ministerial Declaration. Communication from India, WT/GC/W/202, circulated on 14 June 1999.

, Preparations for the 1999 Ministerial Conference. Special and Differential

Treatment and the Spaces for Policies in WTO: Two Elements of the

Development Dimension in the Multilateral Trading System, WT/GC/W/279, circulated on 29 July 1999.

, Preparations for the 1999 Ministerial Conference - Agreement on Agriculture, WT/GC/W/370, circulated on 13 October 1999.

, Doha Work Programme. Decision Adopted by the General Council on 1 August 2004, WT/L/579, circulated on 1 August 2004.

General Council, Special Session on Implementation, Minutes of Meeting - Held in the Centre William Rappard on 18 October 2000, WT/GC/M/59, circulated on 13 November 2000.

, Actions to Increase the Participation of Developing Country Members in the Work of Relevant Sanitary and Phytosanitary International Standard-Setting Organizations: Second Report by the Director General, WT/GC/45, circulated on 7 March 2001.

, Actions to Increase the Participation of Developing Country Members in the Work of Relevant International Standard-Setting Organizations - Information from Financial Institutions, WT/GC/46/Rev.1, circulated on 16 July 2001.

, Actions to Increase the Participation of Developing Country Members in the Work of Relevant Sanitary and Phytosanitary International Standard-Setting Organizations, WT/GC/54, circulated on 7 November 2001.

, Implementation of Paragraph 6 of the Doha Declaration on the TRIPS Agreement and Public Health. Decision of the General Council of 30 August 2003, WT/L/540 and Corr.1, circulated on 1 September 2003.

High-Level Meeting on Integrated Initiatives for Least-Developed Countries' Trade Development, Country-Specific Round Tables: Documentation - Bangladesh: Addendum, WT/LDC/HL/12/Add.1, circulated on 24 October 1997.

, Market Access for Least Developed Countries, WT/LDC/HL/14, circulated on 23 October 1997.

Ministerial Conference, Second Session, Ministerial Declaration, WT/MIN(98)/DEC/1, Geneva: World Trade Organization, adopted 20 May 1998.

Ministerial Conference, Fourth Session, Doha Ministerial Declaration. Adopted on 14 November 2001, WT/MIN(01)/DEC/1, Doha, circulated on 20 November 2001. , Implementation-Related Issues and Concerns. Decision of 14 November 2001, WT/MIN(01)/17, Doha, circulated on 20 November 2001. 
, Participation of Developing Countries in the Development and Application of International Standards, Guidelines and Recommendations on Food Safety, Animal and Plant Health, WT/MIN(01)/ST/97, circulated on 11 November 2001.

Ministerial Conference, Fifth Session, Mauritius: Statement Circulated by the Honourable Jaya Krishna Cuttaree Minister of Industry and International Trade, WT/MIN(03)/ST/70, circulated on 12 September 2003.

, Fifth Session, Ministerial Statement. Adopted on 14 September 2003, WT/ MIN(03)/20, circulated on 23 September 2003.

Ministerial Conference, Sixth Session, Mauritius: Statement of the Honourable Madan Murlidhar Dulloo Minister of Foreign Affairs, International Trade and Cooperation, WT/MIN(05)/ST/120, circulated on 16 December 2005.

, Doha Work Programme. Ministerial Declaration Adopted on 18 December 2005, WT/MIN(05)/DEC, Hong Kong, circulated on 22 December 2005.

Ministry of Agriculture and Forestry (MAF) Biosecurity New Zealand, Department of Agriculture Fisheries and Forestry of the Government of Australia and Ministry of Commerce and Industry of the Sultanate of Oman, Procedural Manual for National Notification Authority \& National Enquiry Point, Version 1-2007, World Trade Organization, 2007, available at: http://members.WTO.org/WTO_ resources/SPS/files/Draft_Procedural_Manual.doc, visited on 26 March 2008.

Negotiating Group on Market Access, Market Access for Non-Agricultural Products. Ministerial Decision on Procedures for the Facilitation of Solutions to Non-Tariff Barriers. Proposal by the African Group, Canada, European Communities, LDC Group, NAMA-11, the Group of Developing Countries, New Zealand, Norway, Pakistan and Switzerland, TN/MA/W/106, circulated on 9 May 2008.

Panitchpakdi, Supachai and Oshima, Shotaro, Doha Work Programme. Draft General Council Decision of [...] July 2004, JOB(04)/96, circulated on 16 July 2004.

Sub-Committee on Least-Developed Countries, Report on the Seminar by the Integrated Framework Core Agencies, WT/LDC/SWG/IF/15/Rev.1, circulated on 17 April 2001.

Trade Policy Review Body, Trade Policy Review: Australia - Report by the Secretariat. Revision, WT/TPR/S/178/Rev.1, circulated on 1 May 2007.

, Trade Policy Review: Australia - Report by the Secretariat, WT/TPR/S/178, circulated on 29 January 2007.

, Trade Policy Review: Bangladesh - Report by the Government, WT/TPR/G/68, circulated on 3 April 2000.

, Trade Policy Review: Bangladesh - Report by the Secretariat, WT/TPR/S/68, circulated on 3 April 2000.

, Trade Policy Review: Bangladesh - Report by the Government, WT/TPR/G/168, circulated on 9 August 2006. 
, Trade Policy Review: Bangladesh - Report by the Secretariat, WT/TPR/S/168, circulated on 9 August 2006.

, Trade Policy Review: Jamaica - Report by the Secretariat, WT/TPR/S/139, circulated on 11 October 2004.

, Trade Policy Review: Jamaica - Report by the Government, WT/TPR/G/139, circulated on 15 December 2004.

, Trade Policy Review: Jamaica - Minutes of Meeting, WT/TPR/M/139, circulated on 28 February 2005.

, Trade Policy Review: Jamaica - Minutes of Meeting. Addendum, WT/ TPR/M/139/Add.1, circulated on 2 March 2005.

, Trade Policy Review: Jamaica - Report by the Secretariat. Revision, WT/ TPR/S/139/Rev.1, adopted on 9 March 2005.

, Trade Policy Review: Mauritius - Report by the Secretariat, WT/TPR/S/90, circulated on 5 October 2001.

, Trade Policy Review: Mauritius - Report by the Government, WT/TPR/G/90, circulated on 5 October 2001.

, Trade Policy Review: Mauritius - Report by the Secretariat, WT/TPR/S/198, circulated on 19 March 2008.

Working Group on Trade, Debt and Finance, Market Access for Developing Country Exports-Selected Issues. Paper Prepared Jointly by the Staff of the International Monetary Fund and the World Bank, WT/WGTDF/W/14, 18 October 2002, 51.

World Trade Organization, Report (2007) on the Activities of the Committee on Sanitary and Phytosanitary Measures, G/L/842, circulated on 20 November 2007.

WTO Secretariat, Development Division, Developing Countries and the Multilateral Trading System: Past and Present. Background Document for the High Level Symposium on Trade and Development, World Trade Organization, Geneva, 17-18 March 1999, available at: http://www.wto.org/english/tratop_e/devel_e/ tr_dvbadoc_e.doc, visited on 25 June 2007.

WTO Secretariat, Analytical Index: Guide to GATT Law and Practice, 6th ed, Vol. 2, World Trade Organization, 1152 pp., 1995.

, Analytical Index: Guide to GATT Law and Practice, 6th ed, Vol. 1, World Trade Organization, Geneva, 610 pp., 1995.

, Understanding the World Trade Organization Agreement on Sanitary and Phytosanitary Measures (SPS). Revision 1, Export Quality Bulletin no. 46 Rev. 1, International Trade Centre, November 1996, available at: www.intracen.org/ eqm/eqb/eq46eng.pdf, visited on 5 April 1999.

, Preparations for the 1999 Ministerial Conference. Compilation of Proposals Submitted in Phase 2 of the Preparatory Process. Informal Note by the Secretariat. Revision, JOB(99)/4797/Rev.3, circulated on 18 November 1999. 
, How to Apply the Transparency Provisions of the SPS Agreement, World Trade Organization, Geneva, November 2000.

, How to Apply the Transparency Provisions of the SPS Agreement, World Trade Organization, Geneva, September 2002.

, Second LDC Trade Ministers' Meeting, Dhaka, Bangladesh. Communication from Bangladesh, WT/L/521, circulated on 26 June 2003.

, World Trade Report 2004: Exploring the Linkage between the Domestic Policy Environment and International Trade, World Trade Organization, Geneva, 11 June 2004, available at: www.wto.org/english/news_e/pres04_e/press378_ annex_e.pdf, visited on 26 June 2008.

, World Trade Report 2005: Exploring the Links between Trade, Standards and the WTO, World Trade Organization, Geneva, 30 June 2005, 333, available at: http:// www.wto.org/english/res_e/booksp_e/anrep_e/world_trade_report05_e.pdf, visited on 4 June 2007.

, Trade Profiles 2007, World Trade Organization, Geneva, October 2007, 192, available at: http://www.wto.org/english/res_e/booksp_e/anrep_e/trade_ profiles07_e.pdf, visited on 8 January 2008.

WTO, 'Lamy: "We Have Resumed Negotiations Fully Across the Board"' WTO News Item, 7 February 2007, available at: http://www.wto.org/english/news_e/ news07_e/gc_dg_stat_7feb07_e.htm, visited on 8 June 2008.

WTO, 'Talks Suspended: Today there are Ony Losers', WTO News Item, 24 July 2006, available at: http://www.wto.org/english/news_e/news06_e/mod06 summary_24july_e.htm, visited on 6 June 2008.

WTO, 'Lamy Urges “Maximum Effort” for July Meeting of Ministers', WTO News Item, 27 June 2008, available at: http:/www.wto.org/english/news_e/news08_e/ tnc_dg_stat_june08_e.htm, visited on 29 June 2008.

WTO, 'International Bodies Join Forces to Advise OIE Animal Health and Welfare Fund', WTO Press Release Press 456, 1 November 2006, available at: http:// www.wto.org/english/news_e/pres06_e/pr456_e.htm, visited on 10 June 2008.

WTO, 'Members set to Agree on Regionalization, Improved SPS Transparency', WTO News Item, April 2008, available at: http://www.wto.org/english/news_e/ news08_e/sps_apr08_e.htm, visited on 8 April 2008.

WTO, 'Members turn Attention to Improving SPS Mediation', WTO News Item, 24 June 2008, available at: http://www.wto.org/english/news_e/news08_e/ sps_24june08_e.htm, visited on 26 June 2008.

WTO, 'WTO Hearings on Apple Dispute Open to the Public', WTO News Item, 11 August 2008, available at: http://www.wto.org/english/news_e/news08_e/ hearing_11aug08_e.htm, visited on 11 August 2008. 


\section{Official Documents of the GATT 1947}

GATT, Trends in International Trade, Geneva: 1958, Sales No. GATT/1958-3.

Agriculture Committee, Report to the Council, L/3472, circulated on 18 December 1970.

, Working Group on Techniques and Modalities. Report to the Agriculture Committee, COM.AG/W/88, Geneva, circulated on 4 August 1972.

Committee on Trade in Industrial Products, Examination of Part 3 of the Inventory of Non-Tariff Barriers (Spec(69)51) - Standards Involving Imports and Domestic Goods - Note by the Secretariat, COM.IND/W/13, circulated on 19 October 1969.

, Report to the Council, L/3496 Geneva, circulated on 10 February 1971.

, Report to the Council, L/3756, circulated on 24 October 1972.

, Working Group 5, Examination of the Inventory of Non-Tariff Barriers Supplemental and Replacement Cards, COM.IND/W/20, Geneva, circulated on 9 January, 20 March and 9 November 1970.

Committee on Trade and Development, Report Presented to the CONTRACTING PARTIES, BISD 32S/21 L/5913, circulated on 28 November 1985.

Committee on Trade in Agriculture, Summary of Points Raised at the Meeting of the Committee Held on 2-3 April 1985. Note by the Secretariat, AG/W/13, circulated on 4 September 1985.

, Summary of Points Raised at the Meeting of the Committee Held on 7-8 July 1986. Note by the Secretariat, AG/W/16, circulated on 9 June 1986.

GATT Secretariat, Expansion of Trade-Agricultural Policy-Report of Committee II on the Consultation with Australia, L/1055, circulated on 7 October 1959.

, Notifications of Import Restrictions Applied Inconsistently with the Provisions of GATT and Not Covered by Waivers - Addendum - France, L/3212/Add.12, circulated on 22 August 1969.

, EEC - Imports of Poultry from the United States - Recourse to Article XXIII:2 by the United States, L/5033, circulated on 29 September 1980.

GatT Contracting Parties, Twentieth Session, Report of the Panel on Uruguayan Recourse to Article XXIII, L/1923 and Corr.1 and 2, circulated on 15 November 1962.

, Ministerial Meeting, 20S/19 (1974), MIN(73)1, Declaration of Ministers approved at Tokyo, 14 September 1974.

, Decision on Procedures for Modification and Rectification of Schedules of Tariff Concessions L/4962, BISD 27S/26, circulated on 26 March 1980. 
, Fortieth Session, Trade in Agriculture. Action Taken on 30 November 1984,

L/5753, circulated on 20 December 1984.

, Special Session, Ministerial Declaration on the Uruguay Round of 20 September 1986, GATT MIN.DEC, BISD 33S/19, Punta del Este, Uruguay, circulated on 25 September 1986.

, Declaration on Trade Measures Taken for Balance-of-Payment Purposes, BISD 26S/205 (1980), L/4904, 28 November 1979.

, Decision on Differential and More Favourable Treatment, Reciprocity and Fuller Participation of Developing Countries, L/4903, LT/TR/D/1, BISD 26S/203 (1980), circulated on 28 November 1979.

, Action by the CONTRACTING PARTIES on the Multilateral Trade Negotiations. Decision of 28 November 1979, L/4905, circulated on 3 December 1979.

, Decision on Safeguard Action for Development Purposes, LT/TR/D/2, L/4904, BISD 26S/205, decision of 28 November 1979.

Negotiating Group on Agriculture, Communication from Jamaica, TN.GNG/NG5/W/42, circulated on 4 February 1988.

, Communication from the European Communities. Working Paper. Drafting of an Appropriate Framework of Rules for Sanitary and Phytosanitary Regulations, MTN.GNG/NG5/W/56, circulated on 20 April 1988.

, Communication from Nigeria on Issues before the Negotiating Group, MTN. GNG/NG5/W/57, circulated on 20 April 1988.

, Sanitary and Phytosanitary Regulations. Role and Status of Work of Selected Organizations. Note by the Secretariat, circulated on 20 April 1988, available at: http://www.wto.org/gatt_docs/English/SULPDF/92040055.pdf, visited on 11 May 2008.

, Elements for a Proposal by Developing Countries. Communication from Jamaica, MTN.GNG/NG5/W/68, circulated on 11 July 1988.

, Statement by Jamaica, MTN.GNG/NG5/W/72, circulated on 28 July 1988.

, Communication from the United States on a Health and Sanitary Working Group, MTN.GNG/NG5/77, circulated on 13 September 1988.

, Proposal for Negotiations on Agriculture Submitted by the Republic of Korea, MTN.GNG/NG5/W/80, circulated on 13 October 1988.

, Indian Proposal, MTN.GNG/NG5/W/84, circulated on 14 November 1988.

, Sanitary and Phytosanitary Regulations and Barriers. Submitted by Jamaica, MTN.GNG/NG5/W/89, circulated on 23 November 1988.

, Background Note by the Secretariat, MTN.GNG/NG5/W/41, circulated on 2 February 1988 available at: http://www.wto.org/gatt_docs/English/ SULPDF/92030210.pdf, visited on 11 May 2008. 
, Time for Action. A Proposal for a Framework Approach to Agriculture.

Submission by the Cairns Group Comprising Argentina, Australia, Brazil, Canada, Chile, Colombia, Hungary, Indonesia, Malaysia, New Zealand, the Philippines, Thailand and Uruguay, MTN.GNG/NG5/W/69, circulated on 13 July 1988 available at: http://www.wto.org/gatt_docs/English/ SULPDF/92050128.pdf, visited on 11 May 2008.

, Proposal by Egypt, Jamaica, Mexico and Peru, MTN.GNG/NG5/W/74, circulated on 13 September 1988 available at: http://www.wto.org/gatt_docs/ English/SULPDF/92050187.pdf, visited on 11 May 2008.

, Statement by Brazil. Special and Differential Treatment, MTN.GNG/NG5/W/108, circulated on 2 October 1989.

, Sanitary and Phytosanitary Issues: Communication from the Cairns Group, MTN.GNG/NG5/W/112, circulated on 2 October 1989.

, Special and Differential Treatment for Developing Countries. Statement by Colombia, MTN.GNG/NG5/W/110, circulated on 4 October 1989.

, Submission of the United States on Comprehensive Long-Term Agricultural Reform, MTN.GNG/NG5/W/118, circulated on 25 October 1989.

, Statement by the Kingdom of Morocco, MTN.GNG/NG5/W/121, 2 November 1989.

, Proposal for Negotiations on Agriculture: Submitted by the Republic of Korea, MTN.GNG/NG5/W/130, circulated on 28 November 1989.

, Proposal on Special, Differential and More Favourable Treatment for Developing Countries: Communication from Brazil and Colombia, MTN.GNG/NG5/W/132, circulated on 28 November 1989.

, Submission by Japan, MTN.GNG/NG5/W/131, circulated on 6 December 1989.

, Proposals on Behalf of the Least-Developed Countries. Communication from Bangladesh, MTN.GNG/NG5/W/126, circulated on 13 November 1989.

, Submission by Austria, MTN.GNG/NG5/W/144, circulated on 19 December 1989.

, Submission of the European Communities on Sanitary and Phytosanitary Regulations and Measures, MTN.GNG/NG5/W/146, circulated on 20 December 1989.

, Communication from Israel Expressing Views on Certain Elements in the Negotiation on Agriculture, MTN.GNG/NG5/W/153, circulated on 13 February 1990.

, Supplementary Submission of Japan on Sanitary and Phytosanitary Regulations and Measures, MTN.GNG/NG5/W/156, circulated on 7 March 1990. 
, Uruguay Round Negotiations on Agriculture. Proposals by CACM Member Countries (Honduras, El Salvador and Guatemala), MTN.GNG/NG5/W/162, circulated on 4 April 1990.

, Sanitary and Phytosanitary Issues: Supplementary Communication from the Cairns Group, MTN.GNG/NG5/W/164, circulated on 18 April 1990.

, Report of the Chairman of the Working Group on Sanitary and Phytosanitary Regulations and Barriers, MTN.GNG/NG5/WGSP/6, circulated on 15 October 1990.

, Sanitary and Phytosanitary Regulations Affecting Trade in Agriculture.

Trade Negotiations Committee, Mid-Term Meeting, MTN.TNC/11, circulated on 21 April 1989.

, Draft Final Act Embodying the Results of the Uruguay Round of Multilateral Trade Negotiations, MTN.TNC/W/FA, circulated on 20 December 1991.

Working Group on Sanitary and Phytosanitary Regulations and Barriers, Negotiating Group on Agriculture, Summary of Main Points Raised at the First Meeting of the Working Group on Sanitary and Phytosanitary Regulations and Barriers: Note by the Secretariat, MTN.GNG/NG5/WGSP/W/1, circulated on 28 October 1988.

, Summary of Main Points Raised at the Second Meeting of the Working Group on Sanitary and Phytosanitary Regulations and Barriers: Note by the Secretariat, MTN.GNG/NG5/WGSP/W/2, circulated on 14 November 1988.

, Statement by the Representative of the Codex Alimentarius Commission at the Second Meeting of the Working Group (3 November 1988), MTN.GNG/NG5/ WGSP/W/3, circulated on 30 November 1988.

, Statement by the Representative of the International Plant Protection Convention at the Second Meeting of the Working Group (3 November 1988), MTN.GNG/ NG5/WGSP/W/4, circulated on 30 November 1988.

, Applicability of the Agreement on Technical Barriers to Trade to Sanitary and Phytosanitary Regulations and Barriers: Note Submitted by the Nordic Delegations, MTN.GNG/NG5/WGSP/W/5, circulated on 22 May 1989.

, Summary of Main Points Raised at the Third Meeting of the Working Group on Sanitary and Phytosanitary Regulations and Barriers: Note by the Secretariat, MTN.GNG/NG5/WGSP/W/6, circulated on 17 October 1989.

, Note Submitted by the Nordic Delegations with Respect to Some Elements of the Work Programme, MTN.GNG/NG5/WGSP/W/7, circulated on 31 October 1989.

, Summary of Main Points Raised at the Fourth Meeting of the Working Group on Sanitary and Phytosanitary Regulations and Barriers: Note by the Secretariat, MTN.GNG/NG5/WGSP/W/8, circulated on 6 December 1989. 
, Harmonization and Transparency: Note by the Nordic Delegations, MTN.GNG/

NG5/WGSP/W/9, circulated on 30 January 1990.

, Form and Disposition of the Agreement on Sanitary and Phytosanitary

Regulations and Barriers (SPS Measures). Note by the Nordic Delegations,

MTN.GNG/NG5/WGSP/W/10, circulated on 12 February 1990.

, Dispute Settlement Procedures: Note by the Nordic Delegations, MTN.GNG/

NG5/WGSP/W/11, circulated on 12 February 1990.

, Communication from the United States Regarding the International Office of Epizootics, MTN.GNG/NG5/WGSP/W/12, circulated on 16 February 1990.

, Summary of Main Points Raised at the Fifth Meeting of the Working Group on Sanitary and Phytosanitary Regulations and Barriers: Note by the Secretariat, MTN.GNG/NG5/WGSP/W/13, circulated on 19 March 1990.

, Technical Assistance to Other Parties and Special and Differential Treatment of Developing Countries. Note by the Nordic Delegations, MTN.GNG/NG5/ WGSP/W/14, circulated on 20 April 1990.

, Technical Assistance in the Field of Plant Protection: Paper Submitted by FAO, MTN.GNG/NG5/WGSP/W/16, circulated on 20 April 1990.

, Summary of Main Points Raised at the Sixth Meeting of the Working Group on Sanitary and Phytosanitary Regulations and Barriers: Note by the Secretariat, MTN.GNG/NG5/WGSP/W/18, circulated on 4 May 1990.

, Comments by the International Office of Epizootics (OIE): Meeting of 2-3 April 1990, MTN.GNG/NG5/WGSP/W/19, circulated on 4 May 1990.

, Draft Agreement on Sanitary and Phytosanitary Measures: Note by the Nordic Countries, MTN.GNG/NG5/WGSP/W/21, circulated on 28 May 1990.

, Synoptic Table of Proposals Relating to Key Concepts: Note by the Secretariat. Revision, MTN.GNG/NG5/WGSP/W/17/Rev.1, circulated on 29 May 1990.

, Summary of Main Points Raised at the Seventh Meeting of the Working Group on Sanitary and Phytosanitary Regulations and Barriers: Note by the Secretariat, MTN.GNG/NG5/WGSP/W/22, circulated on 31 May 1990.

, Summary of Main Points Raised at the Eighth Meeting of the Working Group on Sanitary and Phytosanitary Regulations and Barriers: Note by the Secretariat, MTN.GNG/NG5/WGSP/W/24, circulated on 2 July 1990.

, Draft Text for a Decision by the CONTRACTING PARTIES on Sanitary and Phytosanitary Measures, MTN.GNG/NG5/WGSP/W/26, circulated on 1 October 1990.

, Draft Text on Sanitary and Phytosanitary Measures, MTN.GNG/NG5/WGSP/7, circulated on 20 November 1990. 


\section{Official Documents of Other International Organisations}

\section{Codex Alimentarius (FAO/WHO Food Standards Programme)}

Codex Ad Hoc Intergovernmental Task Force on Foods Derived from Biotechnology, Report of the Fifth Session, ALINORM 06/29/34, Joint FAO/WHO Food Standards Programme, Chiba, 19-23 September 2005, available at: http://www. codexalimentarius.net/web/archives.jsp?year=06, visited on 1 April 2008.

Codex Alimentarius Commission, Report of the Sixth Session, Joint FAO/WHO Food Standards Programme, Geneva, 4-14 March 1969, available at: http://www.fao. org/docrep/meeting/005/87246e/87246e00.htm, visited on 14 May 2008.

, Recommended International Code of Practice for the Processing and Handling of Quick Frozen Foods, CAC/RCP 8-1976.

, Report of the Nineteenth Session, ALINORM 91/40, Joint FAO/WHO Food Standards Programme, Rome, 1-10 July 1991, available at: http://www.fao.org/ docrep/meeting/005/t0490e/t0490e00.htm, visited on 13 May 2008.

, Guideline Procedures for the Visual Inspection of Lots of Canned Foods, CAC/ GL 17-1993.

, Report of the Twentieth Session, ALINORM 93/40, Joint FAO/WHO Food Standards Programme, Geneva, 28 June -7 July 1993, available at: http://www. fao.org/docrep/meeting/005/t0817e/t0817e00.htm, visited on 13 May 2008.

, Report of the Twenty-First Session, ALINORM 95/37, Joint FAO/WHO Food Standards Programme, Rome, 3-8 July 1995, available at: http:/www.fao.org/ docrep/meeting/005/v7950e/v7950e00.htm, visited on 13 May 2008.

, Principles for Food Import and Export Certification and Inspection, CAC/GL 20-1995.

, Guidelines for the Design, Operation, Assessment and Accreditation of Food Import and Export Inspection and Certification Systems, CAC/GL 26-1997, Joint FAO/WHO Food Standards Programme, 1997.

, The Application of Risk Analysis Principles in Codex, ALINORM 97/7, Joint FAO/WHO Food Standards Programme, 16 May 1997.

, Report of the Twenty-Second Session, ALINORM 97/37, Joint FAO/WHO Food Standards Programme, Geneva, 23-28 June 1997.

, Code of Hygienic Practice for Refrigerated Packaged Foods with Extended ShelfLife, CAC/RCP 46-1999.

, Report of the Twenty-Third Session, ALINORM 99/37, Joint FAO/WHO Food Standards Programme, Rome, 28 June - 3 July 1999, 124.

, Guidelines for the Development of Equivalence Agreements Regarding Food Import and Export Inspection and Certification Systems, CAC/GL34-1999, Joint FAO/WHO Food Standards Programme, Rome, 1999. 
, Maximum Residue Limits (MRLs) for Pesticides, CAC/MRL 1-2001.

, Consideration of Codex Standards and Related Texts. Part III: Proposals to Elaborate New Standards and/or Related Texts, ALINORM 01/21, Part III, Joint FAO/WHO Food Standards Programme, Geneva, 2-7 July 2001, available at: ftp://ftp.fao.org/codex/ALINORM01/al0121ce.pdf, visited on 20 February 2008.

, Report of the Twenty-Fourth Session, ALINORM 01/41, Joint FAO/WHO Food Standards Programme, Geneva, 2-7 July 2001.

, Conclusions and Recommendations of the Joint FAO/WHO Evaluation of the Codex Alimentarius and Other FAO and WHO Work on Food Standards, ALINORM 03/25/3, Joint FAO/WHO Food Standards Programme, Rome, December 2002.

, FAO/WHO Project and Fund for Enhanced Participation in Codex. First Progress Report to the 25th (Extraordinary) Session of the Codex Alimentarius Commission, 13-15 February 2003, ALINORM 03/25/4, Joint FAO/WHO Food Standards Programme, Geneva, January 2003, 10, available at: http://www.who. int/foodsafety/codex/en/progle.pdf.

, Report of the Twenty-Fifth (Extraordinary) Session, ALINORM 03/25/5 (Joint FAO/WHO Food Standards Programme, Rome), 13-15 February 2003.

, Scientific Advice to Codex and FAO/WHO Member Countries (Submitted by FAO and WHO). Selection of Experts and Working Procedures of the Expert Committees and Expert Consultations: 2002-2003, CAC/26 INF/4, Food and Agriculture Organization and World Health Organization, Rome, 30 June - 7 July 2003.

, Report of the Twenty-Sixth Session, ALINORM 03/41, Joint FAO/WHO Food Standards Programme, Rome, 30 June - 7 July 2003.

, List of Proposals for the Elaboration for the New Standards and the Related Texts and for the Discontinuation of Work, ALINORM 05/28/8, Joint FAO/WHO Food Standards Programme, Rome, 4-9 July 2005, available at: ftp://ftp.fao.org/codex/ cac/cac28/al28_08e.pdf, visited on 20 February 2008.

, General Principles of the Codex Alimentarius, published in Joint FAO/WHO Food Standards Programme, Codex Alimentarius Commission: Procedural Manual, Food and Agriculture Organization and World Health Organization, Rome, 2006, available at: ftp://ftp.fao.org/codex/Publications/ProcManuals/ Manual_16e.pdf, visited on 25 June 2007.

, Maximum Residue Limits for Veterinary Drugs in Food, CAC/MRL 2-2006.

, Information Guide for First-Time Delegates to a Codex Session, Joint FAO/WHO Food Standards Programme, Geneva, February 2006, available at: ftp://ftp.fao. org/codex/Information_for_delegates/Info_leaflet_en.pdf, visited on 25 July 2006 . 
, Report of the Twenty-Eighth Session, ALINORM 05/28/41, Joint FAO/WHO Food Standards Programme, Rome, 4-9 July 2005, available at: http://www. codexalimentarius.net/web/archives.jsp?year=05, visited on 14 May 2008.

, Report of the Twenty-Ninth Session ALINORM 06/29/41, Joint FAO/WHO Food Standards Programme, Geneva, 3-7 July 2006.

, List of Proposals for the Elaboration of New Standards and Related Texts (Including Project Documents Submitted) and for the Discontinuation of Work, ALINORM 06/29/8, Joint FAO/WHO Food Standards Programme, Geneva, 3-7 July 2006, available at: ftp://ftp.fao.org/codex/CAC/CAC29/al29_08e.pdf, visited on 20 February 2008.

, List of Proposals for the Elaboration of New Standards and Related Texts (Including Project Documents Submitted) and for the Discontinuation of Work, ALINORM 07/30/8, Joint FAO/WHO Food Standards Programme, Rome, 2-7 July 2007, available at: ftp://ftp.fao.org/codex/CAC/CAC30/al30_08e.pdf, visited on 20 February 2008.

, Report of the Thirtieth Session, ALINORM 07/30/REP, Joint FAO/WHO Food Standards Programme, Rome, 2-7 July 2007, available at: http://www. codexalimentarius.net/web/archives.jsp?year=07, visited on 8 February 2008.

, Codex Alimentarius Commission: Procedural Manual, 15th ed. (Food and Agriculture Organization and World Health Organization, Rome), 2005.

, Procedural Manual, Seventeenth Edition, Joint FAO/WHO Food Standards Programme, Rome, 2007, available at: ftp://ftp.fao.org/codex/Publications/ ProcManuals/Manual_17e.pdf, visited on 21 February 2008.

, FAO/WHO Project and Trust Fund for Enhanced Participation in Codex. Report Prepared by the WHO Secretariat for the Trust Fund, ALINORM 08/31/9F, Joint FAO/WHO Food Standards Programme, Geneva, May 2008.

Codex Alimentarius Commission, Information Guide for First-Time Delegates to a Codex Session, Joint FAO/WHO Food Standards Programme, Geneva, February 2006, available at: ftp://ftp.fao.org/codex/Information_for_delegates/Info_ leaflet_en.pdf, visited on 25 July 2006.

Codex Committee on Contaminants in Foods, Report of the First Session, ALINORM 07/30/41, Joint FAO/WHO Food Standards Programme, Beijing, 16-20 April 2007, available at: http://www.codexalimentarius.net/web/archives.jsp?year=07, visited on 8 February 2008.

Codex Committee on Fats and Oils, Report of the Nineteenth Session, ALINORM 05/28/17, Joint FAO/WHO Standards Food Programme, London, 21-25 February 2005, available at: http://www.codexalimentarius.net/web/archives.jsp?year $=05$, visited on 1 April 2008.

, Report of the Twentieth Session, ALINORM 07/30/17, Joint FAO/WHO Food Standards Programme, London, 19-23 February 2007, available at: http://www. codexalimentafrius.net/web/archives.jsp?year=07, visited on 8 February 2008. 
Codex Committee on Fish and Fishery Products, Report of the Twenty-Seventh Session, ALINORM 05/28/18, Joint FAO/WHO Food Standards Programme, Cape Town, 28 February - 4 March 2005, available at: http://www.codexalimentarius.net/ web/archives.jsp?year=05, visited on 1 April 2008.

, Report of the Twenty-Eighth Session, ALINORM 07/30/18, Joint FAO/WHO Food Standards Programme, Beijing, 18 - 20 September 2006, available at: http://www.codexalimentarius.net/web/archives.jsp?year=07, visited on 8 February 2008.

Codex Committee on Food Additives and Contaminants, Report of the Thirty-Seventh Session, ALINORM 05/28/12, Joint FAO/WHO Food Standards Programme, The Hague, 25-29 April 2005, available at: http://www.codexalimentarius.net/ web/archives.jsp?year=05, visited on 1 April 2008.

, Report of the Thirty-Eighth Session, ALINORM 06/29/12, Joint FAO/WHO Food Standards Programme, The Hague, 24-28 April 2006, available at: http://www. codexalimentarius.net/web/archives.jsp?year=06, visited on 1 April 2008.

Codex Committee on Food Additives, Report of the Thirty-Ninth Session, ALINORM 07/30/12 Rev., Joint FAO/WHO Food Standards Programme, Beijing, 2428 April 2007, available at: http://www.codexalimentarius.net/web/archives. jsp?year=07, visited on 8 February 2008.

Codex Committee on Food Hygiene, Report of the Thirty-Third Session, ALINORM 01/13A, Joint FAO/WHO Food Standards Programme, Washington, 23-28 October 2000, available at: http:/www.codexalimentarius.net/web/archives. jsp?year=01, visited on 1 April 2008.

, Report of the Thirty-Ninth Session, ALINORM 08/31/13, Joint FAO/WHO Food Standards Programme, New Delhi, 30 October - 4 November 2007, available at: http://www.codexalimentarius.net/web/archives.jsp?year=08, visited on 8 February 2008.

Codex Committee on Food Import and Export Inspection and Certification Systems, Report of the Ninth Session, ALINORM 01/30A, Joint FAO/WHO Food Standards Programme, Perth, 11-15 December 2000, available at: http://www. codexalimentarius.net/web/archives.jsp?year=01, visited on 1 April 2008.

, Report of the Sixteenth Session ALINORM 08/31/30, Joint FAO/WHO Food Standards Programme, Surfers Paradise, Queensland, 26-30 November 2007, available at: http://www.codexalimentarius.net/web/archives.jsp?year=08, visited on 8 February 2008.

Codex Committee on Food Labelling, Report of the Thirty-Fourth Session, ALINORM 06/29/22, Joint FAO/WHO Food Standards Programme, Ottawa, 1-5 May 2006, available at: http://www.codexalimentarius.net/web/archives.jsp?year=06, visited on 1 April 2008 
, Report of the Thirty-Fifth Session, ALINORM 07/30/22, Joint FAO/WHO Food Standards Programme, Ottawa, 30 April-4 May 2007, available at: http://www. codexalimentarius.net/web/archives.jsp?year=07, visited on 8 February 2008.

Codex Committee on Fresh Fruits and Vegetables, Report of the Twelfth Session, ALINORM 05/28/35, Joint FAO/WHO Food Standards Programme, Mexico City, 16-20 May 2005, available at: http:/www.codexalimentarius.net/web/ archives.jsp?year=05, visited on 1 April 2008.

, Report of the Thirteenth Session, ALINORM 07/30/35, Joint FAO/WHO Foods Standards Programme, Mexico City, 25-29 September 2006, available at: http:// www.codexalimentarius.net/web/archives.jsp?year $=07$, visited on 8 February 2008 .

Codex Committee on General Principles, Report of the Twenty-Fourth Session, ALINORM 07/30/33, Joint FAO/WHO Food Standards Programme, Paris, 2-6 April 2007, available at: http://www.codexalimentarius.net/web/archives. jsp?year=07, visited on 8 February 2008.

Codex Committee on Methods of Analysis and Sampling, Report of the Twenty-Seventh Session, ALINORM 06/29/23, Joint FAO/WHO Food Standards Programme, Budapest, 15-19 May 2006, available at: http://www.codexalimentarius.net/web/ archives.jsp?year=06, visited on 1 April 2008.

, Report of the Twenty-Eighth Session, ALINORM 07/30/23, Joint FAO/WHO Food Standards Programme, Budapest, 5-9 March 2007, available at: http:// www.codexalimentarius.net/web/archives.jsp?year=07, visited on 8 February 2008.

Codex Committee on Milk and Milk Products, Report of the Seventh Session, ALINORM 06/29/11, Joint FAO/WHO Food Standards Programme, Queenstown, 27 March-1 April 2006, available at: http://www. codexalimentarius.net/web/archives.jsp?year=06, visited on 8 February 2008.

Codex Committee on Nutrition and Foods for Special Dietary Uses, Report of the Twenty-Ninth Session, ALINORM 08/31/26, Joint FAO/WHO Food Standards Programme, Bad Neuenahr-Ahrweiler, 12 - 16 November 2007, available at: http://www.codexalimentarius.net/web/archives.jsp?year $=08$, visited on 8 February 2008.

Codex Committee on Processed Fruits and Vegetables, Report of the Twentieth Session, ALINORM 01/27, Joint FAO/WHO Food Standards Programme, Washington, 11-15 September 2000, available at: http://www.codexalimentarius.net/web/ archives.jsp?year $=01$, visited on 2 April 2008.

, Report of the Twenty-Third Session, ALINORM 07/30/27, Joint FAO/WHO Food Standards Programme, Arlington, Washington D.C., 16-21 October 2006, available at: http://www.codexalimentarius.net/web/archives.jsp?year=07, visited on 8 February 2008. 
Codex Committee on Pesticide Residues, Report of the Thirty-Ninth Session, ALINORM 07/30/24 - Rev. 1, Joint FAO/WHO Food Standards Programme, Beijing, 7-12 May 2007, available at: http://www.codexalimentarius.net/web/ archives.jsp?year=07, visited on 8 February 2008.

Codex Committee on Residues of Veterinary Drugs in Foods, Report of the Seventeenth Session, ALINORM 08/31/31, Joint FAO/WHO Food Standards Programme, Breckenridge, Colorado, 3-7 September 2007, available at: http://www. codexalimentarius.net/web/archives.jsp?year=08, visited on 8 February 2008.

FAO/WHO Coordinating Committee for Africa, Report of the Seventeenth Session, ALINORM 07/30/28, Joint FAO/WHO Food Standards Programme, Rabat, 2326 January 2007, available at: http://www.codexalimentarius.net/web/archives. jsp?year $=07$, visited on 8 February.

FAO/WHO Coordinating Committee for Asia, Report of the Fourteenth Session, ALINORM 05/28/15, Joint FAO/WHO Food Standards Programme, Jeju-Do, 7-10 September 2004, available at: http:/www.codexalimentarius.net/web/ archives.jsp?year=05, visited on 1 April 2008.

FAO/WHO Coordinating Committee for Asia, Report of the Fifteenth Session, ALINORM 07/30/15, Joint FAO/WHO Food Standards Programme, Seoul, 21-24 November 2006, available at: http://www.codexalimentarius.net/web/ archives.jsp?year=07, visited on 8 February 2008.

FAO/WHO Coordinating Committee for Europe, Report of the Twenty-Fifth Session, ALINORM 07/30/19, Joint FAO/WHO Food Standards Programme Vilnius, 15-18 January 2007, 16, available at: http://www.codexalimentarius.net/web/ archives.jsp?year=07, visited on 1 March 2008.

FAO/WHO Coordinating Committee for Latin America and the Caribbean, Report of the Fifteenth Session, ALINORM 07/30/36, Joint FAO/WHO Food Standards Programme, Mar del Plata, 13-17 November 2006, available at: http://www. codexalimentarius.net/web/archives.jsp?year=07, visited on 8 February 2008.

FAO/WHO Coordinating Committee for the Near East Region, Report of the Fourth Session, ALINORM 07/30/40, Joint FAO/WHO Food Standards Programme, Amman, 26 February - 1 March 2007, available at: http://www. codexalimentarius.net/web/archives.jsp?year=07, visited on 8 February 2008.

FAO/WHO Coordinating Committee for North America and South West Pacific, Report of the Ninth Session, ALINORM 07/30/32, Joint FAO/WHO Food Standards Programme, Apia, 10-13 October 2006, available at: http://www. codexalimentarius.net/web/archives.jsp?year=07, visited on 8 February 2008.

Food and Agriculture Organization and World Health Organization, Understanding the Codex Alimentarius, United Nations, Rome, 2005, available at: http:/www.fao. org/docrep/008/y7867e/y7867e00.HTM, visited on 28 July 2006.

Food Safety Unit of the Programme of Food Safety and Food Aid, Guidance on Regulatory Assessment of HACCP. Report of a Joint FAO/WHO Consultation on 
the Role of Government Agencies in Assessing HACCP, WHO/FSF/FOS/98.5, World Health Organization and Food and Agriculture Organization, Geneva, 2-6 June 1998.

Food Quality and Standards Service of the FAO and Department of Food Safety, Zoonoses and Foodborne Diseases and International Programme on Chemical Safety of the WHO, FAO/WHO Framework for the Provision of Scientific Advice on Food Safety and Nutrition (to Codex and Member Countries), Food and Agriculture Organization and World Health Organization, Rome/ Geneva, 2007, available at: http://www.fao.org/ag/agn/agns/files/Final_Draft EnglishFramework.pdf, visited on 1 February 2008.

International Food Safety Authorities Network, Acrylamide in Food Is a Potential Health Hazard, INFOSAN Information Note No. 2/2005, Food and Agriculture Organization and World Health Organization, Rome/Geneva, 1 March 2005, available at: http://www.who.int/foodsafety/fs_management/en/No_02_ Acrylamide_Mar05_en.pdf, visited on 26 June 2008.

Joint FAO/WHO Food Standards Programme, Codex Alimentarius Commission: Procedural Manual, 12th ed, Food and Agriculture Organization and World Health Organization, Rome, 2001.

, Report of the Evaluation of the Codex Alimentarius and Other FAO and WHO Food Standards Work, Food and Agriculture Organization and World Health Organization, Rome, 15 November 2002, 113, available at: http://www.fao.org/ docrep/meeting/005/y7871e/y7871e00.htm, visited on 4 August 2006, Geneva, January 2003, 10, available at: http://www.who.int/foodsafety/codex/en/progle. pdf, visited on 25 June 2007.

, FAO/WHO Project and Fund for Enhanced Participation in Codex. Second Progress Report to the 26th Session of the Codex Alimentarius Commission, 30 June - 7 July 2003, ALINORM 03/26/12, Joint FAO/WHO Food Standards Programme, Rome, May 2003, available at: http://www.who.int/foodsafety/ codex/en/prog2e.pdf, visited on 25 June 2007.

, FAO/WHO Project and Fund for Enhanced Participation in Codex. Third Progress Report to the 53rd Session of the Executive Committee of the Codex Alimentarius Commission, 4-6 February 2004, CX/EXEC 04/53/3, Joint FAO/ WHO Food Standards Programme, Geneva, December 2003, available at: http:// www.who.int/foodsafety/codex/en/prog3e.pdf, visited on 25 June 2007.

, FAO/WHO Project and Fund for Enhanced Participation in Codex. Fourth Progress Report to the 27th Session of the Codex Alimentarius Commission, 28 June - 3 July 2004, ALINORM 02/27/10F, Joint FAO/WHO Food Standards Programme, Geneva, July 2004.

, Report of the Joint FAO/WHO Workshop on the Provision of Scientific Advice to Codex and Member Countries, Held on 27-29 January 2004, Food and Agriculture Organization and World Health Organization, Geneva, 2004, 45, 
available at: http://www.who.int/foodsafety/codex/en/workshop_report.pdf, visited on 20 June 2008.

, FAO/WHO Project and Fund for Enhanced Participation in Codex. Fifth Progress Report (January-June 2005), to the 28th Session of the Codex Alimentarius Commission, 4-9 July 2005, CAC/28 INF/12, Rome, June 2005, available at: http://www.who.int/foodsafety/codex/en/prog5e.pdf, visited on 25 June 2007.

, The International Portal for Food Safety, Animal and Plant Health. Submission from the FAO, CAC/28 INF/4, Joint FAO/WHO Food Standards Programme, Rome, June 2005, available at: http://www.ipfsaph.org/En/default.jsp, visited on 28 June 2008.

, The International Portal on Food Safety, Animal and Plant Health: Progress in 2006/7. Submission from FAO, CAC/30 INF/11, Joint FAO/WHO Food Standards Programme, Rome, May 2007.

, Conclusions of the Consultative Process on the Provision of Scientific Advice and Global Initiative for Food-Related Scientific Advice (GIFSA), Food and Agriculture Organization and World Health Organization, Rome, 6 July 2007, available at: http://www.fao.org/ag/agn/agns/files/GIFSA_SideEvent_July2007. pdf, visited on 12 June 2008.

Joint FAO/WHO Expert Committee on Food Additives, Summary and Conclusions of the Thirty Second Meeting, Food and Agriculture Organization and World Health Organization, Rome, 15-23 June 1987.

Joint FAO/WHO Expert Committee on Food Safety, The Role of Food Safety in Health and Development, WHO Technical Report Series 705, Geneva: World Health Organization, 1984.

Joint FAO/WHO Project and Fund for Participation in Codex, Annual Report for 2004, Food and Agriculture Organization and World Health Organization, Geneva, December 2004.

, Reported Issues Drawn from 24 Supported Participants'Reports (March - July 2004), Food and Agriculture Organisation and World Health Organization, Geneva, 2004.

, Funds Received 2003-2005 (as at 20 June 2005), Food and Agriculture Organization and World Health Organization, Geneva, June 2005, available at: http://www.who.int/foodsafety/codex/funds_04_05_en.pdf, visited on 25 June 2007.

, Countries Eligible to Apply for Support in 2006, Food and Agriculture Organization and World Health Organization, Rome, 17 June 2005.

FAO/WHO, Instituto Panamericano De Proteccion De Alimentos y Zoonosis, 'International Cooperation on Food Contamination Monitoring and Foodborne Disease Surveillance. A Case Study in the Amro Region', presented at the FAO/WHO Second Global Forum of Food Safety Regulators, Conference Room Document 66, Food and Agriculture Organization and World Health 
Organization, Bangkok, Thailand, 12-14 October 2004, available at: ftp://ftp.fao. org/docrep/fao/meeting/008/ae196e.pdf, visited on 26 June 2008.

FAO/WHO Secretariat, 'Strengthening Official Food Safety Control Services', presented at the FAO/WHO Second Global Forum of Food Safety Regulators, GF 02/3, Food and Agriculture Organization and World Health Organization, Bangkok, Thailand, 12-14 October 2004, available at: ftp://ftp.fao.org/docrep/ fao/meeting/008/j2951e.pdf, visited on 26 June 2008.

FAO/WHO, Enhancing Participation in Codex Activities. An FAO/WHO Training Package, 2005, available at: ftp://ftp.fao.org/docrep/fao/008/y5884e/y5884e00. pdf, visited on 16 April 2008.

FAO/WHO, Enhancing Developing Country Participation in FAO/WHO Scientific Advice Activities. Report of a Joint FAO/WHO Meeting, FAO Food and Nutrition Paper 88, Food and Agriculture Organization and World Health Organization, Rome, December 2006, available at: ftp://ftp.fao.org/docrep/fao/meeting/010/ j7630e.pdf, visited on 4 October 2006.

\section{Food and Agriculture Organization}

Food and Agriculture Organization, 'Report of the Conference on International Food Trade Beyond 2000: Science-Based Decisions, Harmonization, Equivalence and Mutual Recognition', presented at the Conference on International Food Trade Beyond 2000: Science-Based Decisions, Harmonization, Equivalence and Mutual Recognition, Melbourne Australia, 11-15 October 1999, available at: www.fao.org/docrep/meeting/X4015e.htm, visited on 25 June 2007.

, Fortalecimiento De Los Comites Nacionales Del Codex y Aplicacion De Las Normas Del Codex Alimentarius, Project TCP/RLA/0065, FAO, San Jose, Costa Rica, 24 September - 5 October 2001.

, Rise of Supermarkets across Africa Threatens Small Farmers: Opportunities and Challenges in a Changing Market, FAO, Rome, 8 October 2003, available at: http://www.fao.org/english/newsroom/news/2003/23060-en.html, visited on 23 January 2008.

, Animal Disease Outbreaks Hit Global Meat Exports, Food and Agriculture Organization, Rome, 2 March 2004, available at: http://www.fao.org/newsroom/ en/news/2004/37967/index.html, visited on 25 June 2007.

FAO Commodities and Trade Division, Commodity Market Review 1999-2000, Food and Agriculture Organization, Rome, 2000.

, Agriculture, Trade and Food Security: Issues and Options in the WTO

Negotiations from the Perspective of Developing Countries. Volume I: Issues and Options, Food and Agriculture Organization, Geneva, 2000, available at: www. fao.org/docrep/003/X4829e/X4829e00.htm, visited on 29 June 2008. 
, Agriculture, Trade and Food Security: Issues and Options in the WTO

Negotiations from the Perspective of Developing Countries. Volume II: Country

Case Studies, Food and Agriculture Organization, Geneva, 2000, available at: www.fao.org/docrep/003/X8731e/X8731e00.htm, visited on 7 January 2008.

, The State of Agricultural Commodity Markets, United Nations, Rome, 2004, available at: ftp://ftp.fao.org/docrep/fao/007/y5419e/y5419e00.pdf, visited 27 June 2008.

FAO Conference, Resolution No. 12/61, adopted at the 11th Session of the FAO Conference, 4-24 November 1961.

FAO, 'Technical Assistance and Capacity Building Related to SPS Agreement. The Contribution of the Food and Agriculture Organization of the United Nations', presented at the WTO Seminar on Technical Assistance and Capacity Building related to the SPS Agreement, Geneva, 5 November 2002.

\section{International Plant Protection Convention (FAO)}

Commission on Phytosanitary Measures, Business Plan 2007-2011, International Plant Protection Convention, Rome, 29 March 2007, available at: https:// www.ippc.int/servlet/BinaryDownloaderServlet/184265_CPMBusinessPlan. pdf?filename $=1180093785157$ Latest_Business_Plan___Revised-1196537010. pdf\&refID $=184265$, visited on 2 April 2008.

, Improvement of Transparency in the Development of International Standards for Phytosanitary Measures. Proposal of Brazil, Chile and Paraguay, CPM 2007/31, International Plant Protection Convention, Rome, 23-30 March 2007, available at: https://www.ippc.int/servlet/BinaryDownloaderServlet/182254 CPM2007_31.pdf?filename=1173975771673_CPM_2007_31. pdf\&refID=182254, visited on 11 April 2008.

, Report by the Secretariat, CPM 2007/21, Food and Agriculture Organization, Rome, 26 - 30 March 2007, available at: https://www. ippc.int/servlet/BinaryDownloaderServlet/177435_CPM2007_21. pdf?filename $=1169452364803$ _CPM2007_21r.pdf\&refID $=17 \overline{7} 435$, visited on 27 March 2008.

, Report of the Second Session of the CPM: Standard Setting Work Programme, CPM 2007/24, International Plant Protection Convention, Rome, 26-30 March 2007, available at: https://www. ippc.int/servlet/BinaryDownloaderServlet/177411_CPM2007_24. pdf?filename $=1169219668797$ CPM2007_24.pdf\&refID $=17 \overline{74} 11$, visited on 11 April 2008.

CPM Informal Working Group on Strategic Planning and Technical Assistance, Report of the First Meeting International Plant Protection Convention, Rome, 2-6 October 2006, available at: https://www.ippc. int/servlet/BinaryDownloaderServlet/176987_SPTA_Report_2006. 
pdf?filename=1168261796553_SPTA_2006_Final_Report.pdf\&refID=176987, visited on 1 April 2008.

, Report of the Second Meeting International Plant Protection Convention, Rome, 1-5 October 2007, available at: https:/www.ippc.int/servlet/BinaryDownloade rServlet/190812_9th_SPTA_Report_2007.pdf?filename=1196340302166_9th SPTA_Report_2007.pdf\&refID=190812, visited on 1 April 2008.

Expert Working Group on Debarking of Wood and Bark Freedom, Report of the Expert Working Group on Debarking of Wood and Bark Freedom, International Plant Protection Convention, Aas, 6-10 June 2005, available at: https://www. ippc.int/servlet/BinaryDownloaderServlet/124443_EWG_report_Debarking. doc?filename $=1146746850877$ Report_EWG_DEBARKED_AND_ BARK_F-1150223015.doc\&refID=124443, visited on 9 April 2008.

Expert Working Group on Guidelines for Regulating Potato Micropropagation, Report of the Expert Working Group on Guidelines for Regulating Potato Micropropagation, International Plant Protection Convention, Edinburgh, 12-16 September 2005, available at: https://www.ippc.int/servlet/ BinaryDownloaderServlet/107323_Report.doc.doc?filename=1135789491954 Potatoes_EWG_Report.doc\&refID=107323, visited on 9 April 2008.

Expert Working Group on Post-Entry Quarantine Facilities, Report on Expert Working Group on Post-Entry Quarantine Facilities, International Plant Protection Convention, Clermont Ferrand, 23-27 May 2005, available at: https://www.ippc.int/servlet/BinaryDownloaderServlet/107175_quarantine. doc.doc?filename $=1135691355617$ EWG_Report_post_entry_quarantine. doc\&refID=107175, visited on 9 April 2008.

Expert Working Group on Sampling of Consignments, Report of the Expert Working Group on Sampling of Consignments, International Plant Protection Convention, Ottawa, 18-22 July 2005, available at: https://www.ippc. int/servlet/BinaryDownloaderServlet/183951_Report_EWG_Sampling. doc?filename $=1178634852520 \_E W G \_r e p o r t$ Sampling_of_consignments FINAL.doc\&refID=183951, visited on 9 April 2008.

Expert Working Group on Appropriate Level of Protection, Report of the Expert Working Group on Appropriate Level of Protection, International Plant Protection Convention, Ottawa, 23 August - 1 September 2006, available at: https://www.ippc.int/servlet/BinaryDownloaderServlet/184106_Report_EWG ALOP.doc?filename $=1179214789083$ _Report_EWG_ALOP_2007_04_24_final. doc\&refID=184106, visited on 9 April 2008.

Expert Working Group on Classification of Commodities into Phytosanitary Risk Categories, Report of the Expert Working Group on Classification of Commodities into Phytosanitary Risk Categories, International Plant Protection Convention, Kleinmachnow, 18-22 September 2006, available at: https://www. ippc.int/servlet/BinaryDownloaderServlet/183948_Report_EWG_Classific. doc?filename=1178634754538_Report_EWG_Classification_of_c-390496381. doc\&refID=183948, visited on 9 April 2008 . 
Expert Working Group on Alternatives to Methyl Bromide, Report of the Expert Working Group on Alternatives to Methyl Bromide, International Plant Protection Convention, Orlando, 30 October - 3 November 2006, available at: https://www. ippc.int/servlet/BinaryDownloaderServlet/183954_Report_EWG_Methyl_ br.doc?filename $=1178634989508$ EWG_report_Methyl_bromide_FINAL. doc\&refID $=183954$, visited on 9 April 2008 .

Expert Working Group on Pest Risk Management for Plants for Planting in International Trade, Report of the Second Meeting of the Expert Working Group on Pest Risk Management for Plants for Planting in International Trade, International Plant Protection Convention, Vancouver, 26 February - 2 March 2007, available at: https://www.ippc.int/servlet/BinaryDownloaderServlet/201554_2007 Report_Pest_ris.doc?filename $=1207143261816$ REPORT_EWG_Pest_risk managemen1364784651.doc\&refID=201554, visited on 9 April 2008.

Expert Working Group on Pest Risk Management for Plants for Planting in International Trade, Report of the Second Meeting of the Expert Working Group on Pest Risk Management for Plants for Planting in International Trade, International Plant Protection Convention, Vancouver, 26 February - 2 March 2007, available at: https://www.ippc.int/servlet/BinaryDownloaderServlet/201554_2007 Report_Pest_ris.doc?filename $=1207143261816$ REPORT_EWG_Pest_risk_ managemen1364784651.doc\&refID=201554, visited on 9 April 2008.

Focus Group on the Review of IPPC Standard Setting Procedures, Report of the Focus Group, International Plant Protection Organization, Rome, 16-20 July 2007, available at: https://www.ippc.int/servlet/BinaryDownloaderServlet/189350 Report_FG_2007.pdf?filename $=1193215805220$ Report_2007_FG_on_ standard_set-1163088563.pdf\&refID $=189350$, visited on 9 April 2008.

ICPM Informal Working Group on Strategic Planning and Technical Assistance, Final Report of the Fifth Meeting, International Plant Protection Convention, Rome, 13-17 October 2003, available at: https:/www. ippc.int/servlet/BinaryDownloaderServlet/30461_SPTA2003_report. pdf?filename $=1073570691417$ FINAL_REPORT_SPTA.pdf\&refID $=30461$, visited on 1 April 2008.

, Report of the Sixth Meeting, International Plant Protection Convention, Rome, 11-15 October 2004, available at: https:/www.ippc.int/ servlet/BinaryDownloaderServlet/41717_Report_SPTA2004. pdf?filename $=1107531893932$ SPTA2004_Final_Report.pdf\&refID $=41717$, visited on 1 April 2008.

, Report of the Seventh Meeting, Rome, 11-14 October 2005, available at: https:// www.ippc.int/servlet/BinaryDownloaderServlet/116839_Report_SPTA_2005. pdf?filename $=1141372703272$ SPTA_report_2005.pdf\&refID $=116839$, visited on 1 April 2008.

, Report of the Second Meeting, International Plant Protection Convention, Rome, 1-5 October 2007, available at: https://www.ippc.int/servlet/ BinaryDownloaderServlet/190812_9th_SPTA_Report_2007. 
pdf?filename=1196340302166_9th_SPTA_Report_2007.pdf\&refID=190812, visited on 1 April 2008.

Informal Working Group on Technical Assistance and Phytosanitary Capacity Evaluation, Draft Report of the Informal Working Group on Technical Assistance and Phytosanitary Capacity Evaluation, International Plant Protection Organization, Nairobi, 29 July - 3 August 2007, available at: https:// www.ippc.int/servlet/BinaryDownloaderServlet/188573_Draft_Report IWG_TA_.doc?filename $=1191582430687$ TA_PCE_IWG_Draft_report v4.doc\&refID=188573, visited on 21 April 2008.

Interim Commission on Phytosanitary Measures, Report of the Second Interim Commission on Phytosanitary Measures, ICPM-2(1999)/Report Food and Agriculture Organization, Rome, 4-8 October 1999, available at: https://www. ippc.int/servlet/BinaryDownloaderServlet/13804_ICPM_Report_1999_E. PDF?filename=/publications/13804.Report_of_the_Second_Meeting_of_the ICPM_1999.2001-3-27.PDF\&refID=13804, visited on 10 March 2008.

, Equivalence, ICPM 03/INF/3, International Plant Protection Convention, Fiat Panis, March 2003.

, Developing Country Participation in IPPC Standard-Setting and Listing of Experts for IPPC Working Groups 2000-2002, ICPM 03/INF/2, International Plant Protection Convention, Rome, 7-11 April 2003, available at: https://www.ippc.int/servlet/BinaryDownloaderServlet/21133_English. pdf?filename $=1051088293796$ ICPM03_INF2.pdf\&refID $=21133$, visited on 18 April 2008.

, Fifth Session: Topics and Priorities for Standards, ICPM 03/14, Food and Agriculture Organization, Rome, 7-11 April 2003.

, Report of the Fifth Interim Commission on Phytosanitary Measures, ICPM5(2003)/Report, Food and Agriculture Organization, Rome, 7-11 April 2003, available at: https://www.ippc.int/servlet/BinaryDownloaderServlet/21899 ICPM5_2003_en.pdf.pdf?filename=1053957860772_ICPM5Report_final_ en.pdf\&refID=21899, visited on 10 March 2008.

, Report of the Sixth Interim Commission on Phytosanitary Measures, ICPM-6 (2004) / Report, Food and Agriculture Organization, Rome, 29 March - 2 April 2004, available at: https://www.ippc. int/servlet/BinaryDownloaderServlet/34062_ICPM6_2004_ en.pdf?filename=1085664580297_ICPM6_Report_final.pdf\&refID=34062, visited on 26 March 2008.

, Report of the Seventh Interim Commission on Phytosanitary Measures, ICPM7(2005)/Report Food and Agriculture Organization, Rome, 4-7 April 2005, available at: https://www.ippc.int/servlet/BinaryDownloaderServlet/75067 Report_ICPM7_E.pdf?filename=1132938412531_ICPM7_Report_En_REV list_part.pdf\&refID=75067, visited on 10 March 2008 . 
International Plant Protection Convention, Requirements for the Establishment of Pest Free Areas, ISPM 4, Food and Agriculture Organization, Rome, 1996.

, Determination of Pest Status in an Area, ISPM 8, Food and Agriculture Organization, Rome, 1998.

, Requirements for the Establishment of Pest Free Places of Production and Pest Free Production Sites, ISPM 10, Food and Agriculture Organization, Rome, 1999.

, Requirements for the Establishment of Areas of Low Pest Prevalence, ISPM 22, Food and Agriculture Organization, Rome, 2005.

, Requirements for the Establishment of Pest Free Areas for Fruit Flies (Tephritidea), ISPM 26, Food and Agriculture Organization, Rome, 2006.

, Report of the First Session of the Commission on Phytosanitary Measures, CPM1 (2006)/Report, Food and Agriculture Organization, Rome, 3-7 April 2006, available at: https://www.ippc.int/servlet/BinaryDownloaderServlet/133571 CPM_1_report_2006.pdf?filename $=1151505665852 \_C P M \_1$ report. pdf\&refID=133571, visited on 28 July 2006.

, Terms of Reference and Rules of Procedure for the Standards Committee, CPM1 (2006)/Report, Food and Agriculture Organization, Rome, 2006, available at: https://www.ippc.int/servlet/BinaryDownloaderServlet/142427_TORs ROPs_SC.doc?filename $=1155309920830 \_C P M \_1$ _Terms_of_reference_ and_R-221799051.doc\&refID=142427, visited on 10 March 2008.

, Report of the Second Session of the Commission on Phytosanitary Measures, CPM-2 (2007)/Report, Food and Agriculture Organization, Rome, 26-30 March 2007, available at: https://www.ippc.int/ servlet/BinaryDownloaderServlet/184215_CPM_2_report. pdf?filename $=1179929463410 \_$CPM_2_report.pdf\&refID $=184215$, visited on 20 February 2008.

, Procedural Manual, Food and Agriculture Organization, Rome, 1 June 2007, 180, available at: https://www.ippc.int/servlet/BinaryDownloaderServlet/159931 Procedural_manual_20.pdf?filename $=1188388585480 \_$ProceduralManual2007. pdf\&refID $=159931$, visited on 10 March 2008.

, Report of the Second Meeting of the CPM Informal Working Group on Strategic Planning and Technical Assistance (SPTA), Food and Agriculture Organization, Rome, 1-5 October 2007, available at: https://www.ippc. int/servlet/BinaryDownloaderServlet/190812_9th_SPTA_Report 2007. pdf?filename $=1196340302166$ 9th_SPTA_Report_2007.pdf\&refID=190812, visited on 27 March 2008.

, Technical Panel for the Glossary (TPG), Food and Agriculture Organization, Rome, 2007, available at: https://www.ippc.int/ servlet/BinaryDownloaderServlet/184138_TPG_membership. 
doc?filename $=1179394983426 \_$Members_TPG_contact_info_09_2006. doc\&refID=184138, visited on 10 March 2008 .

, Technical Panel on Forest Quarantine (TPFQ), Food and Agriculture

Organization, Rome, 2007, available at: https://www.ippc.int/ servlet/BinaryDownloaderServlet/184132_TPFQ_membership. doc?filename $=1179394878295$ _Members_TPFQ_contact_info_2007_05. doc\&refID=184132, visited on 10 March 2008 .

, Technical Panel on Pest Free Areas and Systems Approaches for Fruit Flies (TPFF), Food and Agriculture Organization, Rome, 2007, available at: https:// www.ippc.int/servlet/BinaryDownloaderServlet/184135_TPFF_membership. doc?filename $=1198056074829$ Members_TPFF_contact_info_2007_12. doc\&refID=184135, visited on 10 March 2008 .

, Technical Panel on Phytosanitary Treatments (TPPT), Food and Agriculture Organization, Rome, 2007, available at: https:/www.ippc. int/servlet/BinaryDownloaderServlet/184141_TPPT_membership. doc?filename $=1195228322930 \_$Members_TPPT_contact_info_2007_11_16. doc\&refID $=184141$, visited on 10 March 2008 .

, Technical Panel to Develop Diagnostic Protocols for Specific Pests (TPDP), Food and Agriculture Organization, Rome, 2007, available at: https://www.ippc.int/ servlet/BinaryDownloaderServlet/186512_08.do.doc?filename=1186745673624 Members_TPDP_contact_info_2007_08.doc\&refID=186512, visited on 10 March 2008.

, Standards Committee Membership, International Plant Protection Convention, Rome, 23 January 2008, available at: https://www.ippc. int/servlet/BinaryDownloaderServlet/179715_SC_members_contact_i. doc?filename $=1201075805403$ _SC_members_contact_info_2008_01_23. doc\&refID=179715, visited on 10 March 2008.

IPPC Secretariat, A Summary of the IPPC, International Plant Protection Convention, Rome, 30 June 2006, available at: https://www.ippc.int/ servlet/BinaryDownloaderServlet/14258_IPPC_History_Member_. doc?filename $=1152100003077$ Handout00_IPPC_History Member_-610767244.doc\&refID=14258, visited on 28 July 2006.

FAO Programme Committee, Independent Evaluation of the Working of the International Plant Protection Convention and Its Institutional Arrangements, Food and Agriculture Organization, Rome, 17-21 September 2007, available at: https://www.ippc.int/servlet/BinaryDownloaderServlet/184229_IPPC_ Evaluation_Repo.doc?filename $=1180006371650$ 1_IPPC_Final_Evaluation Report.doc\&refID=184229, visited on 10 March 2008 .

Standards Committee, Report of the Standards Committee, Food and Agriculture Organization, Rome, November 2006, available at: https:/www.ippc. int/servlet/BinaryDownloaderServlet/174127_SC_report_Nov_2006. 
pdf?filename $=1164985290005$ Report_SC_November_2006_FINAL_with ISPMs.pdf\&refID=174127, visited on 27 March 2008.

, Report of the Standards Committee, Food and Agriculture Organization, Rome, 30 April - 4 May 2007, available at: https://www.ippc.int/servlet/CDSServlet?stat us=ND0xMzQwMiY2PWVuJjMzPSomMzc9a29z, visited on 1 April 2008.

, Report of the Standards Committee, Food and Agriculture Organization, Rome, 5-9 November 2007, available at: https://www.ippc.int/ servlet/BinaryDownloaderServlet/191801_Report_SC_Nov_2007. doc?filename $=1197908679365$ Report_SC_Nov_2007_FINAL_with_ISPMs. doc\&refID $=191801$, visited on 2 April 2008.

Third Interim Commission on Phytosanitary Measures, Report of the Third Interim Commission on Phytosanitary Measures, ICPM 01/REPORT, Food and Agriculture Organization, Rome, 2-6 April 2001, available at: https://www. ippc.int/servlet/BinaryDownloaderServlet/14320_ICPM_Report_2001_E. PDF?filename $=1079019159579$ ICPM3e.PDF\&refID $=14320$, visited on 2 April 2008.

\section{United Nations}

Commission on Human Rights, Resolution 72 U.N. ESCOR, $44^{\text {th }}$ Sess., Supp. No. 3, at 229, UN Doc. E/CN.4/1998/177, 1998.

, Concept Document on the Right to Development. Working Paper Submitted by Florizelle O'Connor, E/CN.4/Sub.2/2005/23, Sub-Commission on the Promotion and Protection of Human Rights, Geneva, 24 June 2005.

Committee on Economic Social and Cultural Rights, General Comment No. 3 on the Nature of States Parties' Obligations, UN Doc. E/1991/23, United Nations, Geneva, 14 December 1990.

, Statement to the Third Ministerial Conference of the WTO in Seattle, issued in November 1999.

, General Comment No. 12 on the Right to Adequate Food, UN Doc. E/2000/22, United Nations, Geneva, 2000.

Committee on Economic Social and Cultural Rights, General Comment No. 12 on the Right to Adequate Food, UN Doc. E/2000/22, United Nations, Geneva, 2000.

, General Comment No. 14 on the Right to the Highest Attainable Standard of Health, UN Doc. E/C.12/2000/4, United Nations, Geneva, 11 August 2000.

Department of Economic and Social Affairs, UN World Economic and Social Survey, United Nations, December 2003, available at: www.un.org/esa/analysis/wess/ wess2003chap1.pdf.

Economic and Social Council, Voluntary Guidelines to Support the Progressive Realization of the Right to Adequate Food in the Context of National Food 
Security, adopted by the 127th Session of the FAO General Council in November 2004, UN Doc. E/CN.4/2005/131, United Nations Commission on Human Rights, Geneva, 28 February 2005.

Boutros-Ghali, Boutros An Agenda for Development, UN Doc. A/48/935, United Nations, 6 May 1994, available at: www.un.org/Docs/SG/agdev.html.

General Assembly, Declaration on the Right to Development, G.A. Resolution 41/128 U.N. GAOR, 41st Sess., Supp. No. 53, at 186, U.N. Doc. A/41/53, United Nations, Geneva, December 1986, available at: www.unhchr.ch/html/ menu3/b/74.htm, visited on 25 June 2007.

General Assembly, Declaration on the Right to Development, G.A. Resolution 41/128 U.N. GAOR, 41 ${ }^{\text {st }}$ Sess., Supp. No. 53, U.N. Doc A/41/54, 4 December 1986. , Resolution 48/141 of 1993, G.A. Res. 48/141, U.N. GAOR, 48th Sess., Supp. No. 49, at 261, U.N. Doc. A/48/141, 1993.

, Fifty-Fifth Session of the General Assembly. Letter Dated 5 May 2000 from the Permanent Representative of Nigeria to the United Nations Addressed to the President of the General Assembly, A/55/74, United Nations, New York, 12 May 2000, available at: www.G77.org/main/docs/summitfinaldocs_english.pdf, visited on 28 January 2008.

, Report of the Meeting of Eminent Persons on Commodity Issues: Note by the Secretary General, A/58/402, United Nations, 2 October 2003, available at: www.un.org/ga/58/documentation/list4.html, visited on 25 June 2008.

Human Rights Council, Mandate of the Special Rapporteur on the Right to Food, UN Doc. A/HRCRES/6/2, United Nations, Geneva, 27 September 2007.

Human Rights Committee, ICCPR General Comment No. 6 on Article 6 (the Right to Life), United Nations, Geneva, 30 April 1982, available at: http://www.unhcr.org/ cgi-bin/texis/vtx/refworld/rwmain?docid=45388400a, visited on 3 January 2008.

ICCPR General Comment No. 6 on Article 6 (the Right to Life), United Nations, Geneva, 30 April 1982, available at: http://www.unhcr.org/cgi-bin/texis/vtx/ refworld/rwmain?docid=45388400a, visited on 3 January 2008.

International Law Commission, 'Commentary on the Draft Vienna Convention', Yearbook of the International Law Commission, 1966, II, 221.

, 'Commentary on Article 4 of Draft Articles on Responsibility of States for Internationally Wrongful Acts', in ILC Annual Report 2001, Ch. IV, available at: http://untreaty.un.org/ilc/texts/instruments/english/commentaries/9_6_2001.pdf, visited on 27 May 2008.

, Fragmentation of International Law: Difficulties Arising from the Diversification and Expansion of International Law. Report of the Study Group of the International Law Commission, A/CN.4/L.682, United Nations General Assembly, Geneva, 13 April 2006. 
Open-Ended Working Group on the Right to Development, The Right to Development,

UN Doc. E/CN.4/2001/26, United Nations Commission on Human Rights, Geneva, 20 March 2001.

Office of the United Nations High Commissioner for Human Rights, Human Rights and Poverty Reduction: A Conceptual Framework, HR/PUB/04/1, UN Office of the United Nations High Commissioner for Human Rights, Geneva, 2004.

, Principles and Guidelines for the Human Rights Approach to Poverty Reduction Strategies, HR/PUB/06/12, United Nations, Geneva, 2006.

Office of the High Representative for the Least Developed Countries, Landlocked Developing Countries and Small Island Developing States, 'No more an LDC, Cape Verde looks to build on economic gains', 19 February 2008, available at: http://www.unohrlls.org/en/orphan/590/, visited on 8 June 2008

United Nations Conference on Trade and Development, The Least Developed Countries Report 2002: Escaping the Poverty Trap, UNCTAD/LDC/2002, UNCTAD, Geneva,18 June 2002, available at: http://www.unctad.org/en/docs/ldc2002 en.pdf, visited on 7 June 2008.

, Economic Development in Africa: Trade Performance and Commodity Dependence, UNCTAD/GDS/AFRICA/2003/1,United Nations, Geneva, 2003, available at: http://www.unctad.org/en/docs/gdsafrica20031_en.pdf, visited on 20 June 2008.

, Development and Globalisation: Facts and Figures, United Nations, Geneva and New York, 2004, available at: www.unctad.org/Templates/WebFlyer. asp?intItemID=3096\&lang=1, visited on 21 June 2008 .

, The Least Developed Countries Report 2004: Linking International Trade with Poverty Reduction, UNCTAD/LDC/2004, UNCTAD, Geneva, 27 May 2004, available at: http://www.unctad.org/Templates/WebFlyer. asp?intItemID=3074\&lang=1, visited on 20 June 2008 .

, Eleventh Session, 13-18 June 2004. Draft São Paulo Consensus, TD/L.380 (United Nations, Sao Paulo), 16 June 2004, available at: www.unctad.org/en/ docs/tdl380_en.pdf, visited on 21 June 2007.

, UNCTAD XI - the Spirit of Sao Paulo, TD/L.382, United Nations, Sao Paulo, 17 June 2004, available at: www.unctad.org/en/docs/TDL382_en/pdf, visited on 1 June 2005.

, Assuring Development Gains from the International Trading System and Trade Negotiations. Background Note by the UNCTAD Secretariat for the 11th Session, 13-18 June 2004, TD/397, United Nations, São Paulo, 4 May 2004.

, The Least Developed Countries Report 2007: Knowledge, Technological Learning and Innovation for Development, UNCTAD/LDC/2007, UNCTAD, Geneva, 2007, available at: http://www.unctad.org/en/docs/ldc2007_en.pdf, visited on 7 June 2008. 
United Nations Development Programme, Human Development Report 2005.

International Cooperation at a Crossroads: Aid, Trade and Security in an Unequal World, United Nations, New York, 2005, available at: http://hdr.undp. org/en/media/hdr05_complete.pdf, visited on 2 January 2008.

, Human Development Report 2005. International Cooperation at a Crossroads: Aid, Trade and Security in an Unequal World, United Nations, New York, 2005, available at: http://hdr.undp.org/en/media/hdr05_complete.pdf, visited on 2 January 2008.

, Human Development Report 2007/2008. Fighting Climate Change: Human Solidarity in a Divided World, Palgrave Macmillan, New York, 2007, available at: http://hdr.undp.org/en/media/hdr_20072008_en_complete.pdf, visited on 10 December 2007.

United Nations Population Fund, Draft Country Programme Document for Bangladesh, DP/FPA/DCP/BGD/7, United Nations, New York, 7 April 2005, available at: http://www.unfpa.org/exbrd/2005/annualsession/bangladesh-final-draft.doc, visited on 9 January 2008.

UN Millennium Project, Investing in Development: A Practical Plan to Achieve the Millennium Development Goals, United Nations Development Programme, New York, 2005, available at: http://www.unmillenniumproject.org/reports/fullreport. htm, visited on 7 January 2008.

United Nations, World Conference on Human Rights, Vienna Declaration and Programme of Action, UN Doc. A/CONF.157/23, Vienna, 25 June 1993.

United Nations, Third UN Conference on Least-Developed Countries, Programme of Action for the Least-Developed Countries, A/CONF.191/11, United Nations, 1420 May 2001.

United Nations, Report of the International Conference on Financing for Development, UN Doc. A/CONF.198/11, United Nations, Monterrey, 18-22 March 2002.

\section{World Bank}

World Bank, Bangladesh. A Proposed Rural Development Strategy, World Bank, Dhaka, 1999.

, Global Economic Prospects 2004: Realizing the Development Promise of the Doha Agenda, World Bank, Washington D.C., 2003.

, World Development Report 2008: Agriculture for Development, World Bank, Washington D.C., 2008, 1, available at: http://siteresources.worldbank.org/ INTWDR2008/Resources/WDR_00_book.pdf, visited on 27 June 2008.

, The World Development Report of 2008 notes: 'Cross-country estimates show that GDP growth originating in agriculture is at least twice as effective in reducing poverty as GDP growth originating outside agriculture.' World 
Bank, World Development Report 2008: Agriculture for Development, World Bank, Washington D.C., 2008, available at: http://siteresources.worldbank.org/ INTWDR2008/Resources/WDR_00_book.pdf, visited on 27 June 2008.

, Global Economic Prospects 2004: Realizing the Development Promise of the Doha Agenda, 0-8213-5582-1, World Bank, Washington D.C., 2003, available at: http://www.worldbank.org/prospects/gep2004/full.pdf, visited on 30 June 2008.

World Bank, Poverty Reduction \& Economic Management Trade Unit and Agriculture and Rural Development Department, Food Safety and Agricultural Health Standards: Challenges and Opportunities for Developing Country Exports, Report no. 31207, World Bank, Washington D.C., 10 January 2005, available at: http://siteresources.worldbank.org/INTRANETTRADE/Resources/Topics/ Standards/standards_challenges_synthesisreport.pdf, visited on 27 June 2008.

\section{World Health Organization}

World Health Organization, International Health Regulations, adopted by the $22^{\text {nd }}$ World Health Assembly (1969) and amended in 1973 and 1981 ( $3^{\text {rd }}$ annotated ed.) Geneva 1983, available at, http://policy.who.int/cgi-bin/om_isapi.dll?infobas $\mathrm{e}=$ Ihreg\&softpage=Browse_Frame_Pg42, visited on 25 June 2007.

Food Safety Unit of the Programme of Food Safety and Food Aid, HACCP: Introducing the Hazard Analysis and Critical Control Point System, WHO/FSF/FOS/97.2, World Health Organization, Geneva, 1997.

WHO Regional Office for Africa, 'Developing and Maintaining Food Safety Control Systems for Africa - Current Status and Prospects for Change', presented at the FAO/WHO Second Global Forum of Food Safety Regulators, Conference Room Document 32, Food and Agriculture Organization and World Health Organization, Bangkok, Thailand, 12-14 October 2004, available at: ftp://ftp.fao. org/docrep/fao/meeting/008/ae144e/ae144e00.pdf, visited on 24 June 2008.

World Health Organization, Human Rights, Health and Poverty Reduction Strategies, WHO/ETH/HDP/05.1 World Health Organization, Geneva, April 2005.

World Health Assembly, Resolution 16.42, adopted at the 16th Session World Health Assembly, Geneva, 7-23 May 1963, Off. Rec.

\section{World Organisation for Animal Health (OIE)}

Aquatic Animal Health Standards Commission, Report of the Meeting, 76 SG/12/CS4 B, World Organization for Animal Health, Paris, 3-7 March 2008.

Biological Standards Commission, Report of the Meeting, 76 SG/12/CS2 B, World Organization for Animal Health, Paris, 22-24 January 2008. 
International Office of Epizootics, Widening Consultation Mechanisms in the Development of OIE Standards. Press Release, 3 October 2005, available at: http://www.oie.int/eng/press/en_051003.htm, visited on 24 August 2006.

International Committee of the OIE, Establishment of a list of foot and mouth disease (FMD) free countries where vaccination is not practised, Resolution XI. 63rd General Session, 1995.

, Procedure for the recognition of the foot and mouth disease status of Member Countries, Resolution XII, 63rd General Session, 1995.

, Resolutions adopted by the International Committee of the OIE during its 72 General Session, 72/GS/FR, OIE, Paris, 23-28 May 2004, available at: http:// www.oie.int/downld/SG/2004/A_RESO_2004_WP.pdf, visited on 26 June 2008.

, Final Report of the 71st General Session, 71/GS/FR, OIE, Paris, 18-23 May 2003, available at: ftp://ftp.oie.int/A_RFinal_2003\%20wp.pdf, visited on 24 August 2006.

, Final Report of the 73rd General Session, 73/GS/FR, OIE, Paris, 22-27 May 2005, available at: http://www.oie.int/downld/SG/2005/A_RF_2005.pdf, visited on 5 February 2008.

World Organisation for Animal Health, Transparency in the OIE StandardSetting Process, OIE, Paris, 2005, available at: http:/www.oie.int/eng/oie/ transparency\%20_eng.pdf, visited on 5 February 2008. , Terrestrial Animal Health Code, 16th edition 2007, OIE, Paris, 2007. , Aquatic Animal Health Code, 10th edition 2008, OIE, Paris, 2008. , The OIE International Standards, World Organisation for Animal Health, Paris, 2007, available at: http://www.oie.int/eng/normes/guide\%20to\%20OIE\%20 intl\%20standards\%20v6.pdf, visited on 1 June 2008.

OIE Working Group on Animal Production Food Safety, Report of the Seventh Meeting, 76 SG/12/CS1 B, World Organisation for Animal Health, Paris, 6-8 November 2007.

OIE Working Group on Animal Welfare, Report of the Sixth Meeting, World Organisation for Animal Health, Paris, 5-7 September 2007.

OIE Working Group on Wildlife Diseases, Report to 76th General Session of the International Committee, $76 \mathrm{SG} / 13 / \mathrm{GT}$, World Organisation for Animal Health, Paris, 28-31 January 2008.

Terrestrial Animal Health Standards Commission, Report of the Meeting, 76 SG/12/CS1 B World Organization for Animal Health, Paris, 10-14 March 2008.

\section{Other Publications}

‘Argentina and EU Sign SPS Agreement', Animal Pharm 351, 1996, 14. 
'Major Exporting Countries Seek Help to Comply with US Seafood HACCP Rule', World Food Chemical News, 11 July 1997.

'WTO Works out New SPS Guidelines without Legal Status', Inside US Trade, 14 April 2000.

'Friends of the Chair Looking to Save WTO's S\&D Review', Bridges Weekly Trade News Digest, 12 June 2003.

'S\&D Talk Adjourn Early Amidst Disagreement', Bridges Weekly Trade News Digest, 13 April 2004

'Work on Development Sees Limited Progress at WTO', Bridges Weekly Trade News Digest, 3 August 2004.

'WTO S\&D Talks Focus on Progress In "Positive” Session', Bridges Weekly Trade News Digest, 3 November 2004.

'Regionalisation Identified as Top Priority by ICPM', Bridges Trade Biores, 15 April 2005.

'WTO Members Move Forward on S\&D Negotiations', Bridges Weekly Trade News Digest, 9 February 2005.

'No Results on S\&D Despite Marathon Negotiations', Bridges Weekly Trade News Digest, 27 July 2005

'Codex Considers Role of Precaution in Risk Standard', Bridges Trade Biores, 15 April 2005, International Centre for Trade and Sustainable Development, Geneva, available at: http://www.ictsd.org/biores/05-04-15/story2.htm, visited on 3 August 2006.

'WTO Members “Open” to Talks on S\&D Monitoring Mechanism', Bridges Weekly Trade News Digest, 12 April 2006.

'WTO Global Review puts 'Spotlight' on Aid-for-Trade', Bridges Weekly Trade New Digest, 28 November 2007.

A New Approach to Special and Differential Treatment, IPC position paper, International Food and Agricultural Trade Policy Council, Washington D.C., 15 September 2004, 2, available at: www.agritrade.org/Publications/Position\%20Papers/13\%20 SND.pdf, visited on 25 June 2007.

Page, Sheila, 'Making Doha a Better Deal for Poor Countries', Financial Times, 26 July 2004.

Wolf, Martin, 'Growth Makes the Poor Richer', Financial Times, 24 January 2001.

\section{Treaties, Conventions and Legal Texts}

Agenda 21, adopted at the United Nations Conference on Environment and Development, Rio de Janeiro, Brazil, 3-14 June 1992, adopted 12 August 1992. 
African Charter on Human and People's Rights, 1520 UNTS 363, adopted 27 June 1981, entry into force 21 October 1986.

Agreement establishing the CARICOM Regional Organisation for Standards and Quality (CROSQ) signed at Belize City on 4 February 2002.

Agreement on Technical Barriers to Trade, 26S/154, 1186 UNTS 276, LT/TR/A/5, 12 April 1979.

'Agreement on Agriculture', in The Results of the Uruguay Round of Multilateral Trade Negotiations: The Legal Texts, World Trade Organization, Geneva, 1994, 39-68.

'Agreement on Government Procurement', LT/TR/PLURI/2, dated 12 April 1979, BISD $26 \mathrm{~S} / 33$.

'Agreement on Import Licensing Procedures', LT/TR/A/4, dated 12 April 1979, BISD 26S/154.

'Agreement on Implementation of Article VI of the General Agreement on Tariffs and Trade 1994', in The Results of the Uruguay Round of Multilateral Trade Negotiations: The Legal Texts, World Trade Organization, Geneva, 1994, 168-196.

'Agreement on Implementation of Article VII of the General Agreement on Tariffs and Trade', LT/TR/A/2, dated 12 April 1979, BISD 26S/116.

'Agreement on Interpretation and Application of Articles VI, XVI and XXIII of the General Agreement on Tariffs and Trade', LT/TR/A/3, dated 12 April 1979, BISD 26S/56.

'Agreement on the Application of Sanitary and Phytosanitary Measures', in The Results of the Uruguay Round of Multilateral Trade Negotiations: The Legal Texts, World Trade Organization, Geneva, 1994, 69-84.

'Agreement on Subsidies and Countervailing Measures', in The Results of the Uruguay Round of Multilateral Trade Negotiations: The Legal Texts, World Trade Organization, Geneva, 1994, 264-314.

'Agreement on Technical Barriers to Trade', in The Results of the Uruguay Round of Multilateral Trade Negotiations: The Legal Texts, World Trade Organization, Geneva, 1994, 138-162.

'Agreement on Textiles and Clothing', in The Results of the Uruguay Round of Multilateral Trade Negotiations: The Legal Texts, World Trade Organization, Geneva, 1994, 85-137.

American Convention on Human Rights, OAS Treaty Series No. 36, adopted 22 November 1969, entry into force 18 July 1978.

Additional Protocol to the American Convention on Human Rights in the Area of Economic, Social and Cultural Rights, "Protocol of San Salvador," O.A.S. Treaty Series No. 69, 1988, adopted 17 November 1988, entry into force 16 
November, 1999, reprinted in Basic Documents Pertaining to Human Rights in the Inter-American System, OEA/Ser.L.V/II.82 doc.6 rev.1, 1992.

Additional Protocol to the European Social Charter Providing for a System of Collective Complaints, (ETS No. 158), adopted 9 November 1995, entry into force 7 January 1998.

Articles on Responsibility of States for Internationally Wrongful Acts, adopted by the International Law Commission at its Fifty-Third Session.

Bergen Ministerial Declaration on Sustainable Development in the ECE Region, adopted in Bergen, May 1990.

Cartagena Protocol on Biosafety, UNP/157, adopted 29 January 2000, entry into force 11 September 2003.

Convention for the Protection of Human Rights and Fundamental Freedoms, ETS

No. 5, Protocol 11, ETS No. 155, adopted 4 November 1950, entry into force 3 September 1953 (as amended, in force 1 November 1998).

Convention on the Ban of Import into Africa and the Control of Transboundary

Movement and Management of Hazardous Wastes within Africa, adopted in

Bamako on 29 January 1991.

Convention on the Elimination of All Forms of Discrimination against Women, G.A. res. 34/180, 34 U.N. GAOR Supp. (No. 46) at 193, U.N. Doc. A/34/46, adopted 18

December 1979, entry into force 3 September, 1981.

Convention on the Rights of the Child, U.N. General Assembly, Document A/

RES/44/25, 12 December 1989, entry into force 2 September 1990.

European Social Charter, Turin, 18.X.1961, signed 18 October 1961, entry into force 26 February, 1965, European Social Charter, (Revised), Strasbourg, 3.V.1996.

Framework Convention on Climate Change, 199231 I.L.M. 849, adopted 9 May 1992, entry into force 21 March 1994.

Havana Charter for an International Trade Organization, UN Doc. E/Conf.2/78, United Nations Conference on Trade and Employment, 28 March 1948.

International Covenant on Civil and Political Rights, General Assembly Resolution 2200A (XXI), UN Doc. A/6316 (1966), adopted 16 December 1966, entry into force 23 March 1976.

International Covenant on Economic, Social and Cultural Rights (ICESCR), UN Doc. A/6316, 1966, adopted within the UN framework.

'Marrakesh Agreement Establishing the World Trade Organization', in The Results of the Uruguay Round of Multilateral Trade Negotiations: The Legal Texts, World Trade Organization, Geneva, 1994, 6-18.

Partnership Agreement between the Members of the African, Caribbean and Pacific Group of States of the One Part and the European Community and Its Member States, of the Other Part, signed in Cotonou, Benin, on 23 June 2000. 
Rio Declaration on Environment and Development, A/CONF.151/26 (Vol. I), Rio de Janeiro, Brazil, 3-14 June 1992, adopted 12 August 1992

'Trade Policy Review Mechanism', in The Results of the Uruguay Round of Multilateral Trade Negotiations: The Legal Texts, World Trade Organization, Geneva, 1994, 434-437.

'Understanding on the Interpretation of Article XXIV of the General Agreement on Tariffs and Trade', in The Results of the Uruguay Round of Multilateral Trade Negotiations: The Legal Texts, World Trade Organization, Geneva, 1994, 31-34.

'Understanding on the Rules and Procedures Governing the Settlement of Disputes', in The Results of the Uruguay Round of Multilateral Trade Negotiations: The Legal Texts, World Trade Organization, Geneva, 1994, 404-433.

Universal Declaration on Human Rights, General Assembly Resolution 217A (III), UN Doc. A/810 (1848), adopted 10 December 1948.

Revision of the International Health Regulations, WHA58.3, Fifty-Eighth World Health Assembly, 23 May 2005.

The Limburg Principles on the Implementation of the International Covenant on Economic, Social and Cultural Rights, UN Doc. E/CN.4/1987/17, International Commission of Jurists, the Urban Morgan Institute on Human Rights and the Centre for Human Rights of Limburg University, Maastricht, 6 June 1986.

The Maastricht Guidelines on Violations of Economic, Social and Cultural Rights, International Commission of Jurists, the Urban Morgan Institute on Human Rights and the Centre for Human Rights of Maastricht University, Maastricht, 26 January 1997.

Vienna Convention on the Law of Treaties, U.N. Doc A/CONF.39/27, 8 I.L.M. 679, concluded in Vienna 23 May 1969. 


\section{Curriculum Vitae}

Marie Denise Prévost was born on 6 March 1971, in La Paz, Bolivia and immigrated to South Africa in 1974. She matriculated with distinction from Clapham High School in 1988. Supported by the Attorney's Fidelity Fund Merit Bursary, she studied law at the University of Pretoria, South Africa (BLC cum laude 1992, LL.B cum laude 1994). In 1995 and 1996, she worked as a researcher at the University of South Africa, where she also obtained an LL.M degree with a focus on international economic law. She was admitted as an advocate of the High Court of South Africa in December 1996. Subsequently, she followed the Magister Iuris Communis programme at Maastricht University (LL.M summa cum laude, 1998).

Since August 2007, Denise Prévost is Assistant Professor (universitair docent) in international economic law at Maastricht University. She is also the Academic Coordinator of the Institute for Globalisation and International Regulation. Previously (2004-2007) she worked as Assistant Professor in international economic law at Utrecht University, where she coordinated and lectured courses in this field at Bachelor's and Master's level and conducted research on WTO law issues. From 1998 to 2004, she worked as a research associate in the Department of International and European Law, at Maastricht University, where she lectured courses on the external relations of the European Union, legal English and international trade law, and conducted research towards her $\mathrm{PhD}$.

In 2001, Denise Prévost interned at the Legal Affairs Division of the Secretariat of the World Trade Organization. She has also done consulting work for the European Commission and the Brussels law firm Vermulst, Waer and Verhaeghe on WTO law matters. She regularly gives capacity-building workshops for the European Commission, the Asser Institute, UNCTAD and the Trade Law Centre for Southern Africa on sanitary and phytosanitary issues and WTO dispute settlement. 


\section{Index}

Adaptation to regional conditions (see Regionalisation)

Agricultural trade

Australia, of

Bangladesh, of.

Impact of SPS measures on

$102-110$

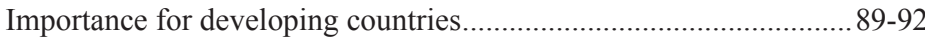

Jamaica, of.

Mauritius, of

235-240

Problems regarding.

92-99

Australia

Agricultural sector, significance of.

$181-187$

Animal health system

206-214

Development indicators

174-175

Food-safety system

194-206

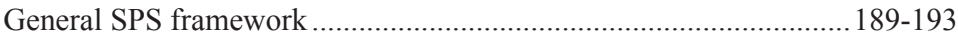

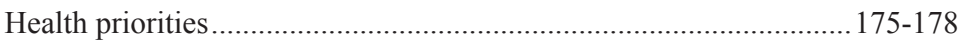

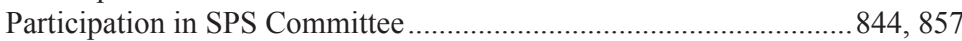

Plant health system..................................................................214-226

Technical assistance, provision of ....................................................992-993

Trade priorities ........................................................................... 178-181

Transparency of SPS measures ................................................... 806-808

Bangladesh

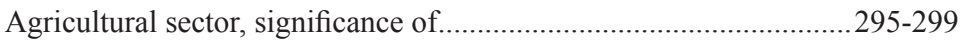

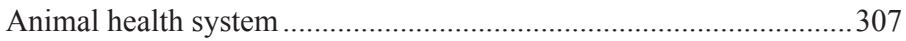

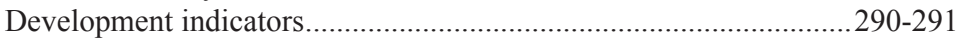

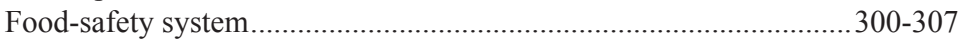

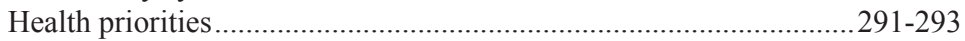

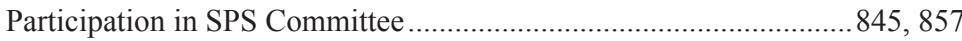

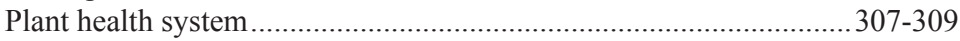

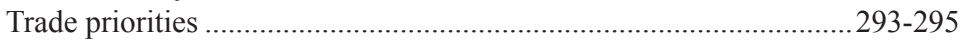

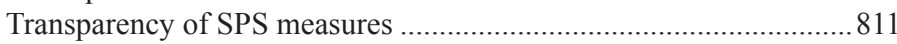

Codex Alimentarius Commission

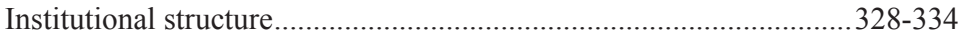

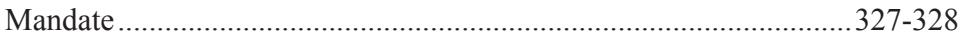

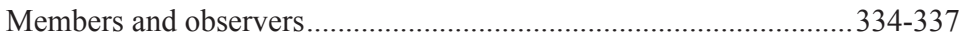

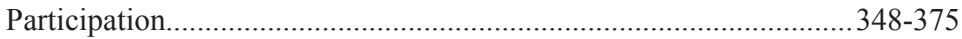

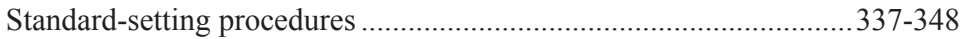

Trust fund for participation in ..................................................... 998-1005

Control, inspection and approval procedures............................................ 822-838

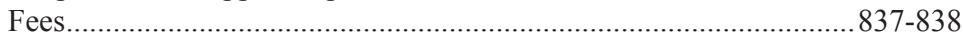

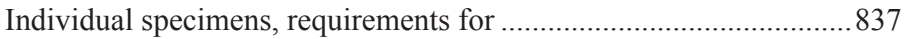

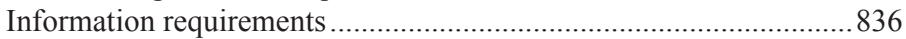

Non-discrimination in application, requirement of .......................... 831-833, 837-838

Operation of procedures, disciplines on ........................................... 833-835

Prior approval systems ................................................................... 825-830

Undue delay, prohibition on ...........................................................8 830-831

Developing-country Members

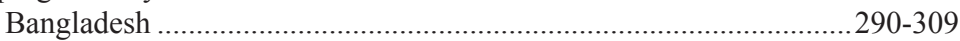

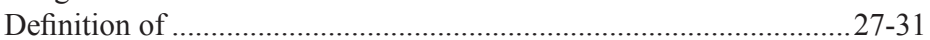


Differentiation between

27-31, 42-48,

59-75, 143,

310-312, 960-962,

963-972, 1014-1021,

1021-1022

Under the GATT 1947

31-39

Impact of SPS measures on.

$102-110$

Importance of agri-food sector for

89-92

Jamaica

252-290

Mauritius

228-252

Participation in SPS-related dispute settlement

920-932

Participation in SPS Committee $842-847,851-863$

Participation in international standard-setting. 348-375, 388-392,

Problems in agri-food trade 419-436 .92-99

Dispute settlement system

871-932

Burden of proof

$877-884$

International law, role of

$897-907$

Interpretation, rules on

$897-907$

IPPC dispute settlement mechanism

918-920

OIE dispute settlement mechanism...

918-920

Overview of WTO dispute settlement systems

873-876

Role of panel experts $907-917$

Standard of review. 884-897

Use of dispute settlement system .920-932

Doha Development Round (see Negotiations)

Enabling Clause $42-48$

Equivalence, recognition of

Acceptance of equivalence

.753-754

Equivalence agreements

754-755

Equivalence Decision

761-766

Examples of.

$757-759$

Importance of ....

.750

Problems of implementation ............................................................ 759-761

Procedure for .755-757, 761-765

International guidelines on

.766-769

Harmonisation of SPS requirements

Failings of.

$318-322$

Reasons for

Disciplines of the SPS Agreement promoting 614-629

International standards, guidelines or recommendations (see International standards guidelines or recommendations) Option to base SPS measure on international standard .........616-621 Option to conform SPS measure to international standard....621-622 Option to deviate from international standard .623-626, 626-629

International Office of Epizootics

Institutional structure.

Mandate 376-377

Members and observers 383

Participation.

Standard-setting procedures .384-388 
Trust fund for participation in

1005

International Plant Protection Convention

Institutional structure.

$397-408$

Mandate

394-397

Contracting parties and observers

409-410

Participation

419-436

Standard-setting procedures

411-419

Trust fund for participation in 1005

International human rights law

Relevance in interpretation of SPS Agreement

$18-27,897-907$

Right to development

Right to health

Right to life $116-126$

Right to safe food $116-126$

International standards, guidelines or recommendations

Concept of 604-614

Obligations in the SPS Agreement with regard to

Measures based on

616-621

Measures conforming to

621-622

Measures providing a higher level of protection than

623-626

Measures providing a lower level of protection than

626-629

Participation of developing countries in elaboration of 348-375, 388-392,

419-436

Procedures for development of. 337-348, 348-388, 411-419

Jamaica

Agricultural sector, significance of.

257-263

Animal health system

277-279

Development indicators

252-253

Food-safety system

264-277

Health priorities

253-254

Participation in SPS Committee

$845,857-858$

Plant health system

279-287

Trade priorities

254-257

Transparency of SPS measures

809-810

Mauritius

Agricultural sector, significance of.

235-240

Animal health system

245-247

Development indicators

228-229

Food-safety system

241-245

Health priorities

229-231

Participation in SPS Committee $844-845,857-858$

Plant health system 248-251

Trade priorities 231-235

Transparency of SPS measures 808-809

Negotiations

Doha Development Round 59-75

Implementation discussion 59-75

Special and differential treatment 59-75, 963-972, 1014-1021

Seattle Ministerial Conference, run-up to 55-59 


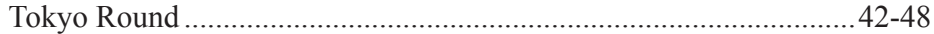

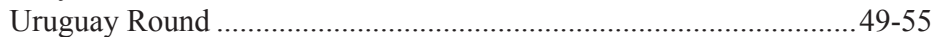

Negotiations towards SPS Agreement ...................................481-512

Role of developed countries and Cairns Group .........488-505

Role of developing countries ...............................................505-512

Approach of developing countries .......................................................49-55

Precautionary principle

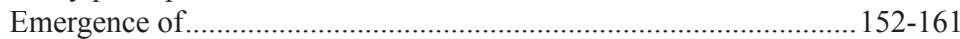

Reflection in Article 5.7 of the SPS Agreement .................................. 712-718

Relation to Article 2.2 of the SPS Agreement.....................................597-600

Relation to Article 5.1 of the SPS Agreement....................................597-600

Private sector standards

Problems for Jamaica of ...............................................................279-287

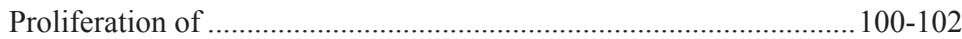

Extent of coverage by the SPS Agreement.........................................534-558

Protocol Adding Part IV to the GATT 1947 .....................................................39-42

Provisional measures

Precautionary principle, relationship with......................................712-718

Requirements for, in Article 5.7 of the SPS Agreement

Available pertinent evidence, on the basis of ........................726-728

Information necessary for a risk assessment, obligation to seek

Insufficient scientific evidence ...........................................718-726

Review within a reasonable period.......................................730-733

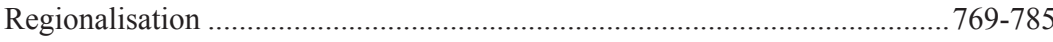

Adaptation to regional conditions ..................................................770-771

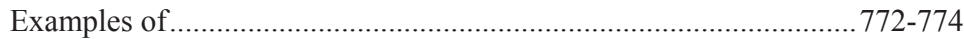

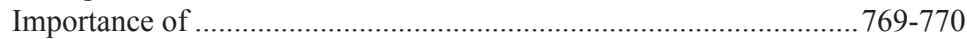

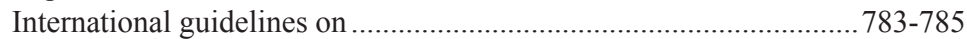

Problems of implementation ............................................................ 775-778

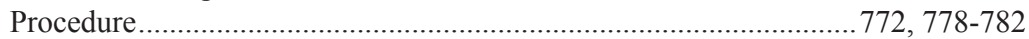

Recognition of pest- or disease status .............................................. 771-772

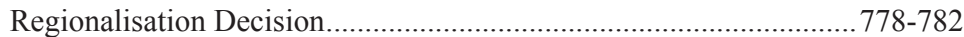

Risk analysis

633-737

Elements of.

$152-161$

Risk assessment

According to SPS measures that might be applied

$651-654$

As appropriate to the circumstances

Biological and economic consequences, identification and evaluation of ............................................649-651

Concept of ......

Defintions of, in SPS Agreement

Factors to be considered in ...............................................660-665

Precaution, scope for .......................................................709-733

Quantification of risk in ........................................................643-649

Requirement that SPS measures be based on ..........................665-678

Diverging scientific opinions, problem of..................669-673

Evolving science, problem of.....................................673-678

Risk assessment techniques of international organisations, role of 
Risk management

$636-678$

Choice of appropriate level of protection .............................679-680

Avoiding arbitrary/unjustifiable distinctions in.........681-697

Arbitrary or unjustifiable distinctions............689-691

Comparable situations ..................................684-689

Different levels of protection..........................684-689

Goal of consistency .......................................682-684

Discrimination or disguised restriction

on trade ..................................................691-695

Minimising negative trade effects .............................680-681

Choice of SPS measure...................................................697-709

Least-trade restrictive measure ................................697-709

Achieves appropriate level of protection...... 705-709

Reasonable availability............................... 700-703

Significantly less trade-restrictive ................703-705

Precautionary measures (see Provisional measures)

Concept of.

$152-161,633-636$

Science

Role in international cooperation on health risks..............................79-80

Role in sanitary and phytosanitary regulation...................................152-161

Special and differential treatment

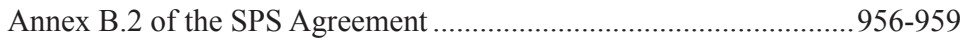

Annex B.8 of the SPS Agreement ...................................................... 962-963

Article 10.1 of the SPS Agreement ............................................... 946-952

Article 10.2 of the SPS Agreement .................................................953-956

Article 10.3 of the SPS Agreement ................................................. 960-962

Article 14 of the SPS Agreement ...................................................959-960

Consideration of special needs of developing countries ....................946-952

Decision to Promote Transparency of SDT

Doha Development Round negotiations...........................................59-75

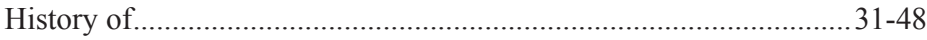

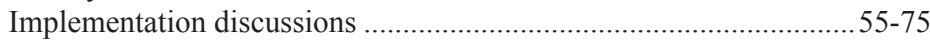

Longer time frames for compliance .................................................953-956

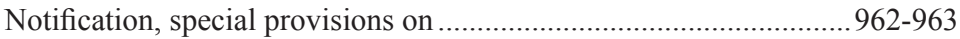

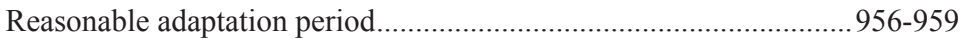

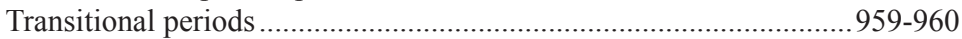

Transparency in the provision of...................................................972-976

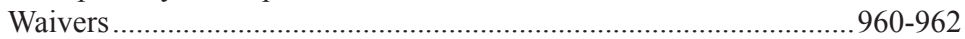

Work on improving implementation of ............................................. 963-972

SPS Agreement

Basic principles

Article 2

$.576-602$

Basic limits to the right to take SPS measures .....................577-600

Necessity ......................................................... 577-580

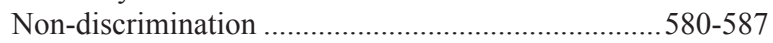

Scientific disciplines............................................... 58

Right to take SPS measures .................................................. 576-577

Harmonisation, promotion of

Article 3 (see Harmonisation)

Negotiation history

Background to the negotiations 
Insufficiency of existing rules $.473-481$

Positions of developed country participants and

Cairns Group 488-505

Positions of developing country participants $505-512$

Procedural and institutional arrangements .747-940

Control inspection and approval procedures, rules on Article 8 and Annex C (see Control, inspection and approval procedures)

Dispute settlement procedures

Article 11 (see Dispute settlement)

Recognition of equivalence, procedures for

Article 4 (see Equivalence)

Adaptation to regional conditions, procedures for

Article 6 (see Regionalisation)

SPS Committee

Article 12 (see SPS Committee)

Transparency, procedures for

Articles 5.8 and 7 and Annex B (see Transparency)

Provisional measures 709-733

Article 5.7 (see Provisional measures)

Precautionary principle, relation to (see Precautionary principle)

Relationship with other WTO agreements

Agreement on Agriculture $.570-571$

GATT 1994 $.564-570$

TBT Agreement $.561-564$

Risk assessment obligations 636-678

Articles 5.1 to 5.3 and Annex A.1 (see Risk analysis)

Risk management obligations $.678-733$

Articles 5.4 to 5.7 and Annex A.5 (see Risk analysis)

Scope of application, Articles 1.1 and 13

Personal scope of application $534-558$

Local government bodies $534-558$

Private sector bodies $534-558$

Substantive scope of application $516-533$

SPS measure, concept of $516-533$

Effect on international trade

Temporal scope of application $559-560$

Special and differential treatment provisions

Article 10.1 to $10.3,14$ and Annex B.2 and B.8

(see Special and differential treatment)

Technical assistance provisions

Articles 9.1, 9.2 and 10.4 (see Technical assistance)

SPS Committee $842-871$

Decision-making $842-847$

Mandate of

Forum for discussion $.851-863$

Furtherance of implementation of SPS Agreement

Monitoring of harmonisation $863-869$

Periodic review of the SPS Agreement $869-871$

Participation in $842-847,851-863$

SPS measures

Definition of 
SPS regulation

Cost/benefit analyis of.

$150-152$

Differences at different levels of development

310-312

Impact on developing country trade

102-110

Law-and-economics analysis of

Nature of.

134-142

Normative framework for.

Proliferation of

Reasons for

Role of scientific analysis in 152-161

TBT Agreement

Relationship with SPS Agreement

Code of Good Practice

Technical assistance

Article 9.1 of the SPS Agreement 985-986

Article 9.2 of the SPS Agreement 986-987

Article 10.4 of the SPS Agreement 987-989

Compliance with SPS measures, for 986-987

Facilitation of provision of. 985-986

Need for 979-985

Participation in international standard setting, for 987-989

Problems with implementation 1010-1014

Provision of 989-1010

Bilateral...... 990-993

Australia 992-993

Multilateral 993-1010

Codex Alimentarius Commission 998-1005

International Portal for Food Safety, Animal and Plant Health 1006-1007

Standards and Trade Development Facility $1007-1010$ WTO. 994-998

Work on improving implementation of 1014-1021

Tokyo Round Standards Code 470-473

Transboundary health risks $78-88$

International cooperation

Origins of $78-79$

Return to

Multi-level approach to $84-87$

National approach to $80-81$

Role of scientific developments ..................................................... 79-80 Transparency $785-822$

Implementation of Transparency Obligations

Australia 806-808

Bangladesh 811

Jamaica 809-810

Mauritius 808-809

Importance of $785-787$

Infrastructure for 803-806

Obligations in the SPS Agreement

Explanation of reasons.

Implementation by selected Members 
Notification

$793-800$

Publication

$.787-793$

Problems of implementation ...............................................................811-816

Recommended Transparency Procedures..........................................817-822

Special and Differential Treatment, of

972-976

Uruguay Round negotiations (see Negotiations)

World Animal Health Organisation (see International Office of Epizootics) 